UNIVERSITAT
POLITÉCNICA
DE VALËNCIA
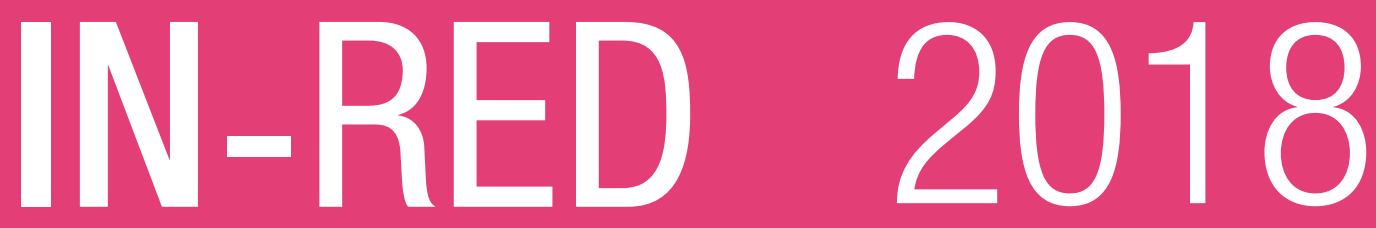

\title{
IV Congreso Nacional de Innovación Educativa y Docencia en Red
}

\section{inred.blogs.upv.es}

Vicerrectorado de Recursos Digitales y Documentación Vicerrectorado de Estudios, Calidad y Acreditación 


\section{Colección Congresos UPV}

Los contenidos de esta publicación han sido evaluados por el Comité Científico que en ella se relaciona y según el procedimiento que se recoge en http://ocs.editorial.upv.es/index.php/INRED/INRED2018/about/editorialPolicies

\section{Editores}

Virginia Vega Carrero

Eduardo Vendrell Vidal

\section{Editado por}

Editorial Universitat Politècnica de València, 2018

www.lalibreria.upv.es / Ref.: 6490_01_01_01

ISBN: 978-84-9048-750-1 (versión impresa)

DOI: http://dx.doi.org/10.4995/INRED2018.2018.8894

\section{(c) $(\Theta \Theta \Theta$}

In-Red 2018 - IV Congreso Nacional de Innovación Educativa y Docencia en Red se distribuye bajo una licencia de Creative Commons Reconocimiento-NoComercial-SinObraDerivada 4.0 Internacional. Basada en una obra en http://ocs.editorial.upv.es/index.php/INRED/INRED2018 


\section{Prólogo}

Innovar, aprender y enseñar con las TIC, motivar, activar... son palabras que suenan constantemente en las tendencias actuales de la educación, en los docentes que cada día intentan mejorar y responder a unas necesidades de cambio.

INRED 2018 pretende hacerse eco de estas inquietudes y tendencias, siendo una invitación abierta a todos aquellos docentes creativos, innovadores, emprendedores... que quieran inspirar, y ser inspirados, con su trabajo, experiencia e investigación en la educación superior.

En su cuarta edición, INRED tratará el aprendizaje en movimiento, tecnologías móviles, aulas abiertas, competencias, recursos tecnológicos, proyectos colaborativos en red... todo ello con la finalidad de mejorar el proceso de enseñanza-aprendizaje en los centros universitarios. Se proponen pues distintas áreas temáticas a las que esperamos se unan muchos miembros de la comunidad docente en la educación superior. 


\section{Objetivos}

- Compartir experiencias de producción de recursos tecnológicos en el aula, con el fin de servir de modelo y ayuda para la comunidad docente.

- Animar al profesorado a experimentar estrategias innovadoras que reviertan en la mejora del proceso de enseñanza-aprendizaje en la formación universitaria.

- Debatir sobre los retos actuales planteados a la universidad como institución directamente implicada en la mejora de los procesos de formación.

- Favorecer la creación de redes de trabajo e investigación conjunta de procesos innovadores en la docencia universitaria. 


\title{
Editores
}

\author{
Prof. Virginia Vega Carrero \\ Vicerrectora de Recursos Digitales y Documentación de la \\ Universitat Politècnica de València \\ Prof. Eduardo Vendrell Vidal \\ Vicerrector de Estudios, Calidad y Acreditación de la \\ Universitat Politècnica de València
}

\section{Comité Ejecutivo}

Presidente: Prof. Dr. Francisco Mora Más

Rector Magnífico de la Universitat Politècnica de València

Prof. Virginia Vega Carrero

Vicerrectora de Recursos Digitales y Documentación de la Universitat Politècnica de València

Prof. Eduardo Vendrell Vidal

Vicerrector de Estudios, Calidad y Acreditación de la

Universitat Politècnica de València

\section{Comité Científico}

CoPresidente: Francisco Javier Oliver Villarroya (Universitat Politècnica de València)

CoPresidente: Rubén Ruiz García (Universitat Politècnica de València)

$\mathrm{D}^{\mathrm{a}}$. Ana Rosa Abadía Valle (Universidad de Zaragoza)

D. Jesús Alba Fernández (Universitat Politècnica de València)

D. José Álvarez Teruel (Universitat d'Alacant)

$D^{a}$. Eva Antonino Daviu (Universitat Politècnica de València)

D. Rafael Balart Gimeno (Universitat Politècnica de València)

$D^{a} . M^{a}$ Pilar Bonet Espinosa (Universitat Politècnica de València)

D. Ignacio Bosch Roig (Universitat Politècnica de València)

D. Juan Luis Bravo Ramos (Universidad Politécnica de Madrid)

$D^{a}$. Concepción Bueno García (Universidad de Zaragoza)

$D^{a}$. Pilar Aurora Cáceres González (Universitat Politècnica de València)

$\mathrm{D}^{\mathrm{a}}$. Ángeles Calduch Losa (Universitat Politècnica de València)

D. Andrés Camacho García (Universidad Politécnica de València)

D. Francisco Javier Camacho Torregrosa (Universitat Politècnica de València)

D. David Carabantes Alarcón (Universidad Complutense de Madrid)

D. Enrique Castaño Perea (Universidad de Alcalá de Henares)

D. David de Andrés Martínez (Universitat Politècnica de València)

D. Joan Domingo Peña (Universitat Politècnica de Catalunya) 
$\mathrm{D}^{\mathrm{a}}$. Eva Emmanuel Martínez (Universidad del País Vasco)

$\mathrm{D}^{\mathrm{a}}$.Tomas Escudero Escorza (Universidad del Zaragoza)

$D^{a}$. Vicente Estruch Fuster (Universitat politècnica de València)

D. Jaume Fabregat Fillet (Universitat Politècnica de Catalunya)

D. Miguel Ferrando Bataller (Universitat Politècnica de València)

D. Miguel Ángel Fortea Bagán (Universitat Jaume I)

D. Eduardo García Giménez (Universidad de Sevilla)

D. Ester Giménez Carbó (Universitat Politècnica de València)

D. José Luis Giménez López (Universitat Politècnica de València)

D. María Esther Gómez Martín (Universitat Politénica de València)

Da . Vanessa González Fernández (Universidad de Sevilla)

$D^{a}$. Fuensanta Hernández Pina (Universidad de Murcia)

$D^{a}$. José Ignacio Herranz Herruzo (Universitat Politècnica de València)

D. Adolfo Hilario Caballero (Universitat Politècnica de València)

D. Francisco Javier Hoyuelos Álvaro (Universidad de Burgos)

$\mathrm{D}^{\mathrm{a}}$. Sara Ibáñez Asensio (Universitat Politècnica de València)

$D^{a}$. Noelia Ibarra Rius (Universitat de València)

D. Miguel Leiva Brondo (Universitat Politècnica de València)

$\mathrm{D}^{\mathrm{a}}$. Victoria Lizama Abad (Universitat Politècnica de València)

D. Martín Llamas Nistal (Universidad de Vigo)

D. Salvador Llinares Ciscar (Universitat d'Alacant)

D. Carmen Llinares Millán (Universitat Politècnica de València)

D. Faraón Llorens Largo (Universitat d'Alacant)

$D^{a}$. $M^{a}$ Gracia López Patiño (Universitat Politècnica de València)

$D^{\mathrm{a}}$. Mercedes López Santiago (Universitat Politècnica de València)

D. Juan Antonio Marín García (Universitat Politècnica de València)

D. José Luís Martínez de Juan (Universitat Politècnica de València)

D. Víctor Martínez Gómez (Universitat Politècnica de València)

$D^{a}$. $\mathrm{M}^{\mathrm{a}}$ Asunción Martínez Mayoral (Universidad Miguel Hernández)

$D^{a}$. Susana Martínez Naharro (Universitat Politècnica de València)

$\mathrm{D}^{\mathrm{a}}$. Ma Jesús Martínez Usurralde (Universitat de València)

D. Germán Moltó Martínez (Universitat Politècnica de València)

D. Carmen Monreal Gimeno(Universidad Pablo Olavide de Sevilla)

$\mathrm{D}^{\mathrm{a}}$. Llucia Monreal Mengual (Universitat Politècnica de València)

D. Juan Antonio Monsoriu Serra (Universitat Politècnica de València)

D. Juan Carlos Morales Sánchez (Universitat Politècnica de València)

$\mathrm{D}^{\mathrm{a}}$. Josefa Mula Bru (Universitat Politècnica de València)

$D^{a}$. Juan Navarro Gregori (Universitat Politècnica de València)

$D^{a}$. Teresa Pages Costas (Universidad de Barcelona)

$D^{a}$. Teresa Pardo Vicente (Universitat Politècnica de València)

$\mathrm{D}^{\mathrm{a}}$. Esther Pérez Martell (Universidad de Las Palmas de Gran Canaria)

$\mathrm{D}^{\mathrm{a}}$. $\mathrm{M}^{\mathrm{a}}$ Asunción Pérez Pascual (Universitat Politècnica de València)

$\mathrm{D}^{\mathrm{a}}$. $\mathrm{M}^{\mathrm{a}}$ José Pérez Peñalver (Universitat Politècnica de València)

D. José Manuel Prats Montalbán (Universitat Politècnica de València)

$\mathrm{D}^{\mathrm{a}}$ Mari Paz Prendes Espinosa (Universidad de Murcia)

D. Israel Quintanilla García (Universitat Politècnica de València) 
D. Miguel Rebollo Pedruelo (Universitat Politècnica de València)

$\mathrm{D}^{\mathrm{a}}$. Amparo Ribes Greus (Universitat Politècnica de València)

D. Luis José Rodríguez Muñiz (Universidad de Oviedo)

$\mathrm{D}^{\mathrm{a}}$. Rosabel Roig Villa (Universidad de Alicante)

$\mathrm{D}^{\mathrm{a}}$. Francesca Romero Forteza (Universitat Politècnica de València)

D. Sixto Romero Sánchez (Universidad de Huelva)

D. José Vicente Salcedo Romero de Ávila (Universitat Politècnica de València)

D. José Antonio Sánchez Nuñez (Universidad Politécnica de Madrid)

D. Raúl Santiago Campión (Universidad de la Rioja)

$\mathrm{D}^{\mathrm{a}}$. Carla Sentieri Omarrementeria (Universitat Politècnica de València)

D. Jordi Vidal Perona (Universitat de València)

D. Emilio Vivancos Rubio (Universitat Politècnica de València)

D. Víctor Yepes Piqueras (Universitat Politècnica de València)

\title{
Comité Organizador
}

\author{
$D^{a}$. Pilar Bonet Espinosa \\ Da . Pilar Aurora Cáceres González \\ $D^{a}$. Jasmina Carralero Herráiz \\ $\mathrm{D}^{\mathrm{a}}$. Carolina Ros Dolz \\ $D^{a}$. Susana Martínez Naharro \\ D. Juan Carlos Morales Sánchez
}




\section{1 \\ Recursos tecnológicos para la docencia}




\title{
Mejora de la autoeficacia, el nivel de ansiedad y el rendimiento en la redacción y la defensa oral del Trabajo Fin de Máster a través del uso de las Nuevas Tecnologías de la Información y la Comunicación
}

Silvia Collado ${ }^{\text {a }}$, Camino Fidalgo ${ }^{\text {a }}$ y Juan Senís ${ }^{b}$

aDepartamento de Psicología y Sociología, Universidad de Zaragoza, scollado@unizar.es; alvarezcamino@unizar.es y bepartamento de Didáctica de las Lenguas y las Ciencias Humanas y Sociales,jsenis@unizar.es

\begin{abstract}
Master's students face the writing and the oral examination of the Final Master's Project (TFM) with anxiety, and with a low level of competencies necessary for its correct execution. This work shows the results of a teaching innovation project aiming at increasing the self-efficacy and performance of students in the writing and oral examination of the TFM at University of Zaragoza. For this purpose, four seminars and a spefic class have been designed to cover the key competences to be acquired by the students. Through a pre-post experimental procedure, we have evaluated students' self-efficacy, their level of anxiety and their writing and oral performance. The project has been supported by Moodle platform, so that all the material was accessible to the students through this platform and the evaluation and co-evaluation of the participants was done through it. The results show statistically significant differences in students' self-efficacy, level of anxiety and the performance before and after participating in the program. Thus, participants are more effective in the writing and oral examination of their TFM at the end of the program, show lower levels of anxiety and higher performance in completing the task.
\end{abstract}

Keywords:Self-Efficacy, Moodle, Master, Anxiety, Master thesis, Academic performance, Co-evaluation, Formative Evaluation, Oral skills

\footnotetext{
Resumen

Los alumnos de Máster se enfrentan a la redacción y la defensa oral del Trabajo Fin de Máster (TFM) con ansiedad, y con un nivel bajo de competencias necesarias para su correcta realización. El presente trabajo muestra los resultados de un proyecto de innovación docente que tiene por objetivo aumentar la autoeficacia y el rendimiento del alumnado en la redacción del TFM en la Universidad de Zaragoza. Para ello, se han diseñado cuatro seminarios y una asignatura especifica que cubren las competencias clave a adquirir por el alumnado para la redacción del TFM, y se ha evaluado la autoeficacia, el nivel de ansiedad y el nivel de redimiento de los alumnos mediante un procedimiento experimental pre-post. El
} 
proyecto ha estado apoyado por la plataforma Moodle, de manera que todo el material era accesible a los alumnos a través de dicha plataforma y la evaluación y co-evaluación de los participantes se hizo a través de la misma. Los resultados muestran que existen diferencias estadísticamente significativas en la autoeficacia, el nivel de ansiedad y el rendimiento de los sujetos antes y después de participar en el programa. Así, los sujetos se consideran más eficaces en la redacción y defensa oral del TFM al finalizar el programa, muestran menores niveles de ansiedad y mayor rendimiento.

Palabras clave: Autoeficacia, Moodle, Máster, Trabajo Fin de Máster, Rendimiento, Coevaluación, Evaluación Formativa, Habilidades comunicativas

(cc) EY-NG-ND 2018, Universitat Politècnica de València 


\section{Introducción}

En el Máster de Profesorado de enseñanza secundaria obligatoria, bachillerato, formación profesional y enseñanza de idiomas, artísticas y deportivas de la Universidad de Zaragoza (a partir de ahora, Máster de profesorado), la realización y defensa del Trabajo Fin de Máster (TFM) es una asignatura obligatoria del segundo cuatrimestre. Ésta consiste en la realización de una memoria, un trabajo de innovación o de investigación que será presentado y evaluado en su totalidad por un Tribunal. La importancia de esta asignatura para la obtención del título del Máster queda recogida en la guía docente de la misma, donde se indica que "esta asignatura es la que confiere sentido a todo el diseño del máster. Al superar esta asignatura, tenemos indicios fiables de que nos encontramos ante un buen profesional" (Universidad de Zaragoza, 2017, p. 4). A pesar de la relevancia que la realización del TFM tiene para la superación del Máster, este trabajo supone un desafío para el alumnado que accede al Máster de profesorado en el Campus de Teruel de la Universidad de Zaragoza (UNIZAR). En este campus se imparte la especialidad de Dibujo y Artes Plásticas y el alumnado que accede a este Máster, en contraposición a otros Másteres impartidos en el Campus de Teruel, se caracteriza por su diversidad, convergiendo personas de titulaciones dispares tales como Bellas Artes, Arquitectura, Biología, Veterinaria, y diversas ingenierías, entre otras. Además, la media de edad de las personas que acceden al Máster es superior a la de otras titulaciones (ej., arquitectos, escultores, artistas, etc., que han perdido su trabajo debido a la crisis económica), lo que en general conlleva una mayor dificultad del uso de las Tecnologías de la Información y de la Comunicación (TIC). Todo ello da lugar a que gran parte de los alumnos muestren serias dificultades en el proceso de enseñanza-aprendizaje del Máster. Éstas pueden resumirse en:

1. Dificultad para utilizar la plataforma Moodle para el correcto seguimiento de las distintas asignaturas que componen el Máster y

2. Dificultad para llevar a cabo con eficacia cada una de las actividades para superar con éxito la defensa del TFM. Más concretamente, el desempeño de los estudiantes es relativamente bajo en actividades consideradas necesarias para la superación del Máster. Estas incluyen las siguientes:

- Capacidad de síntesis.

- Búsqueda de información bibliográfica relevante para tema de análisis.

- Seguimiento de la normativa APA (American Psychological Association, 2010)para la redacción de documentos científicos.

- Redacción de un texto científico en un correcto y adecuado registro académico.

- Defensa oral de la memoria final en un correcto y adecuado registro académico, y con un uso pertinente de los recursos de apoyo audiovisuales.

Así, los resultados de las encuestas de evaluación pasadas por el profesorado del Máster a los alumnosque cursaron la asignatura de TFM en el curso 2016/17 muestran la frustración del alumnado ante un trabajo que consideran difícil de completar en el tiempo destinado para ello. Esto se debe, principalmente, a la percepción de lejanía entre lo que se exige para la redacción y defensa oral de un texto científico y lo que el alumnado sabe una vez se enfrenta a la redacción y exposición pública del mismo. Todo esto hace que el proceso del Máster en general, y de redacción y defensa del TFM en particular, sea percibido por el alumnado como un ardua tarea, donde en lugar de "activar los procesos de reflexión y de autoevaluación del profesional de la actividad docente en los diferentes contextos para los que capacita este Máster" (Universidad de Zaragoza, 2017, p.3) se busque la mínima calificación para obtener el título profesionalizante. Estas dificultades conllevan, aparte del perjuicio para el proceso de enseñanza-aprendizaje del alumnado, que el profesorado 
emplee un tiempo de supervisión y revisión del TFM muy superior al establecido por la normativa.

Partiendo de esta base, se presenta un trabajo de innovación educativa que pretende la mejora de las competencias requeridas para la correcta realización del TFM. En concreto, el trabajo se centra en la autoeficacia del alumnado en cuanto a la realización de su TFM, el nivel de ansiedad generado al enfrentarse a dicho trabajo y cómo estas dos variables pueden relacionarse con el rendimiento escrito y oral.

\subsection{Autoeficacia, rendimiento y habilidades comunicativas}

La autoeficacia ha sido definida como la capacidad percibida de hacer frente a situaciones concretas (Bandura, 1986). Así, la autoeficacia está referida a una tarea específica, de manera que una persona puede sentirse autoeficaz en una determinada tarea (p.ej., cocinar) y no eficaz en otra (p.ej., montar en bicicleta).

En el ámbito educativo, existen numerosas evidencias empíricas que demuestran una relación positiva entre el nivel de autoeficacia y el rendimiento del alumno (DoménechBetoret, Abellán-Roselló, y Gómez-Artiga, 2017; Galleguillos, 2017; Lane \& Lane, 2001; Pajares, 2001). Es decir, cuanto más eficaz se percibe un alumno, mayor es su rendimiento académico.

A su vez, la autoeficaca ha sido relacionada con distintas emociones, tanto positivas como negativas. Así, Bandura (2000) expone que una mayor autoeficacia promueve reacciones emocionales favorables. Por el contrario, se ha encontrado que una baja percepción de eficacia se relaciona positivamente con el nivel de ansiedad del sujeto (Contreras, Espinosa, Esguerra, Haikal, Polanía, Rodríguez, 2005; Pervin, 1997).

Asimismo, la importancia del adiestramiento en habilidades comunicativas orales ha sido desarrollada en investigaciones de diverso tipo, que ponen de relieve su importancia en la formación en estudiantes universitarios y futuros docentes (Bain, 2007; Castellà, Comelles, Cros \& Vilà, 2007; Cros, 1996; Morales y Navarro, 2013; Orejudo, Fernández Turrado y Briz, 2012; Sánchez Miguel, 1993; Sánchez Miguel, Rosales y Cañedo, 1994; Sanjuán, Senís y Del Moral, 2017; Vázquez, 2001; Vilà, 2005).

\section{Objetivos}

Partiendo de estos antecedentes, el trabajo tiene como objetivo evaluar los niveles de ansiedad y de autoeficacia ante la realización del TFM del alumnado del Máster en profesorado antes y después de llevar a cabo un programa de innovación, y la relación de estas dos variables con el rendimiento académico. Este programa de innovación forma parte de la Convocatoria de proyectos de innovación docente 2017/18 de UNIZAR.

\subsection{Hipótesis}

Las hipótesis del estudio son las siguientes:

Hipótesis 1 (H1). El alumnado mostrará mayores niveles de autoeficacia hacia el TFM tras la participación en el programa.

Hipótesis 2 (H2). El alumnado mostrará menores niveles de ansiedad hacia el TFM tras la participación en el programa.

Hipótesis 3 (H3). El alumnado mejorará el rendimiento en la redacción y la defensa oral de textos científicos tras la participación en el programa.

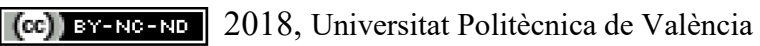

Congreso IN-RED (2018) 


\section{Desarrollo de la innovación}

El proyecto de innovación se llevó a cabo a través de una serie de actividades cuyo fin es la adquisición de varias de las competencias marcadas en la guía docente del TFM a lo largo del primer cuatrimestre del curso académico 2017/18. Partiendo de los criterios de evaluación el TFM que figuran en la guía docente de la asignatura, se diseñaron una serie de actividades destinadas a la correcta superación de la asignatura de TFM. Los criterios de evaluación, el peso en la nota de los mismos y las actividades desarrolladas se detallan a continuación:

\section{Criterio de evaluación:}

A. Competencias para sintetizar e integrar los aprendizajes adquiridos y aportar ideas propias $(60 \%)$

B. Competencias de comunicación escrita (20\%)

C. Competencias de comunicación escrita (20\%):

Actividades a desarrollar:

1. Seminario introductorio sobre el TFM (estructura, uso de registro académico, síntesis de ideas, etc.).

2. Seminario sobre búsqueda bibliográfica, selección de información, uso de la normativa APA y cómo citar de manera adecuada

3. Seminario sobre plagio

4. Seminario introductorio sobre habilidades comunicativas orales.

5. Asignatura optativa "Habilidades comunicativas para profesores" (4 créditos).

Teniendo en cuenta las dificultades encontradas por el alumnado a la hora de usar la plataforma Moodle, todas las actividades enfocadas a la adquisición de competencias para la superación del TFM han sido apoyadas por el uso de dicha plataforma. Así, el material utilizado en los seminarios es accesible para los alumnos a través de Moodle. A su vez, se estableció un sistema de evaluación continua y de co-evaluación a través de la plataforma, de manera que el alumnado la utilizase activamente. Esto se llevó a cabo mediante la herramienta "cuestionarios" de Moodle, lo cual permitió un seguimiento individual del proceso de aprendizaje del alumnado. Así el alumno pudo ser partícipe de su proceso de enseñanza-aprendizaje y además está en línea con la normativa de la Universidad de Zaragoza (artículo 9 del Acuerdo de 22 de diciembre de 2010, del Consejo de Gobierno de la Universidad, por el que se aprueba el Reglamento de Normas de Evaluación del Aprendizaje). Esto permitió llevar a cabo una evaluación formativa del alumnado en contraposición a la evaluación sumativa de la mayoría de las asignaturas del Máster.

\subsection{Participantes}

Formaron parte de dicho proyecto 16 estudiantes (3 hombres y 13 mujeres) del Máster de profesorado de la Universidad de Zaragoza, de edades comprendidas entre los 22 y los 42 años.

\subsection{Método de estudio}

Se utilizó un diseño experimental intrasujeto pre-post, donde la variable independiente es la participación en los distintos seminarios y actividades propuestas, y las variables dependientes son: autoeficacia, nivel de ansiedad y rendimiento. Antes de llevar a cabo los seminarios (condición pre-experimental) se realizó una evaluación de la percepción de autoeficacia y nivel de ansiedad ante la redacción y defensa oral del TFM del alumnado. 
Posteriormente, se pidió a los sujetos que llevaran a cabo un "simulacro de TFM", de manera que cumpliera con los requisitos del TFM que deben desarrollar a final de curso. Es decir, el alumnado debía ser capaz de citar artículos científicos siguiendo la normativa APA, de sintetizar ideas, y de argumentar los objetivos de su trabajo con una base teórica, entre otros. A este trabajo se le denominó Simulacro de TFM_1. Además, los alumnos grabaron una exposición oral defendiendo su Simulacro de TFM__1, la cual fue subida ala plataforma Moodle.

Posteriomente, los alumnos asistieron a los seminarios expuestos en la sección anterior y realizaron ejercicios prácticos para la correcta adquisición de conocimientos. Una vez terminados los seminarios, el alumnado debía, en la primera fase:

1) Co-evaluar el Simulacro de TFM_1 escrito de uno de sus compañeros siguiendo las pautas estrablecidas por el profesor. Dichas pautas correspondían a los conocimientos y habilidades adquiridas en los seminarios. La co-evaluación se llevó a cabo a través de Moodle.

2) Recibir el feedback del profesor, siguiendo los mismos criterios que para la coevaluación, sobre su propio Simulacro de TFM_1.

3) Corregir su propio Simulacro de TFM_2, rehaciéndolo y entregándolo de nuevo a través de Moodle.

Una vez realizadas estas tareas, se llevó a cabo la segunda fase (Habilidades comunicativas orales), en la que el alumnado debía:

4) Co-evaluar el Simulacro de exposición oral de TFM_1 de uno de sus compañeros siguiendo las pautas estrablecidas por el profesor. Dichas pautas correspondían a los conocimientos y habilidades adquiridas en el seminario sobre comunicación oral. La co-evaluación se llevó a cabo a través de Moodle.

5) Recibir el feedback del profesor, siguiendo los mismos criterios que para la coevaluación, sobre su propio Simulacro de exposición oral de TFM_1.

6) Realizar un segundo simulacro de exposición oral de TFM (Simulacro de exposición oral de TFM_2) después de que el profesor encargado de impartir la asignatura "Habilidades comunicativas para profesores" expusiera en clase los principales contenidos y competencias de la misma.

7) Recibir el feedback del profesor,siguiendo los mismo criterios del Simulacro de exposición oral de TFM_1, para el Simulacro de exposición oral de TFM_2.

El diseño experimental queda reflejado en la Tabla 1. 
Tabla 1. Diseño experimental

Fase 1: habilidades de redacción

\begin{tabular}{llll}
\hline \multicolumn{1}{c}{ Pre intervención } & \multicolumn{1}{c}{ Tiempo 0 (T0) } & \multicolumn{1}{c}{ Intervención } & Coevaluación \\
\hline $\begin{array}{l}\text { Seminario 1: Breve } \\
\text { introducción al TFM }\end{array}$ & Cuestionario Autoeficacia & Seminario uso normativa APA & $\begin{array}{l}\text { Co-evaluación del trabajo de un } \\
\text { compañero a través de Moodle }\end{array}$ \\
$\begin{array}{l}\text { (competencias a alcanzar, } \\
\text { plazos, necesidad de uso de }\end{array}$ & Cuestionario Ansiedad & Seminario plagio & Cuestionario Autoeficacia \\
normativa APA, etc.) & Entrega de simulacro de TFM_1 & Seminario adecuada redacción de TFM & Entrega simulacro TFM corregido \\
& & Feedback resultados propio TFM & (TFM_2) \\
& & & \\
& & & \\
& & & \\
\end{tabular}

Fase 2: habilidades comunicativas orales

\begin{tabular}{|c|c|c|c|c|}
\hline Pre-intervención & Tiempo 0 (T0) & Intervención & Coevaluación & Tiempo 1 (T1) \\
\hline $\begin{array}{l}\text { Seminario 1: introducción a las } \\
\text { competencias orales (competencias } \\
\text { orales básicas, etc.) }\end{array}$ & $\begin{array}{l}\text { Cuestionario Autoeficacia } \\
\text { Cuestionario Ansiedad } \\
\text { Entrega de simulacro exposición oral } \\
\text { de TFM_1 }\end{array}$ & $\begin{array}{l}\text { Asignatura "Habilidades } \\
\text { comunicativas para profesores" } \\
\text { Feedback con los alumnos sobre los } \\
\text { resultados y la puntuación de la } \\
\text { exposición oral (TFM_1) }\end{array}$ & $\begin{array}{l}\text { Co-evaluación de los trabajos de } \\
\text { compañeros a través de Moodle }\end{array}$ & $\begin{array}{l}\text { Entrega simulacro TFM_2 } \\
\text { Cuestionario Autoeficacia } \\
\text { Cuestionario Ansiedad }\end{array}$ \\
\hline
\end{tabular}

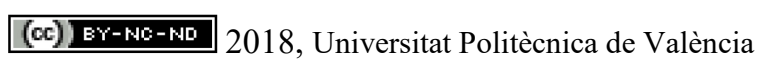
Congreso In-Red (2018) 


\subsubsection{Intrumentos}

a) Cuestionario de autoeficacia en redacción de TFM. Basándonos en la creación de cuestionarios de autoeficacia de Bandura (2006), se creó un cuestionario de percepción de autoeficacia que reflejara las competencias a adquirir por el alumnado presentes en la guía docente del Máster. Éste está compuesto por los siguientes ítems: "Puedo: 1. buscar fuentes bibliográficas con rigor científico (actualizadas, en castellano e inglés, contrastadas, etc.).; 2. sintetizar e integrar ideas obtenidas de diversos textos científicos para apoyar mis argumentos en lenguaje escrito; 3 . manejar la normativa APA; 4. escribir y estructurar un texto científico; 5. escribir un texto científico con la seguridad de no estar cometiendo plagio.". El formato de respuesta fue del 1 (no puedo) al 5 (estoy seguro de que puedo hacerlo). La fiabilidad interna del instrumento fue adecuada $(\alpha \mathrm{T} 1=.70 ; \alpha \mathrm{T} 1=.70)$.

b) Cuestionario de ansiedad ante la redacción de TFM. Se creó un cuestionaro ad hoc para medir el grado de ansiedad del alumnado. El cuestionario consta de los mismo ítems que el cuestionario de autoeficacia y los alumnos debían indicar cuánta ansiedad les produciría cada una de las tareas descritas (ej., Buscar fuentes bibliográficas con rigor científico (actualizadas, en castellano e inglés, contrastadas, etc.), desde 1 (no me produciría ninguna ansiedad) hasta 5 (me generaría mucha ansiedad). La fiabilidad interna del instrumento fue adecuada $(\alpha \mathrm{T} 1=.88 ; \alpha \mathrm{T} 1=.78)$

c) Cuestionario de evaluación de los simulacros escritos de TFM. El rendimiento académico en relación a la redacción del TFM se midió evaluando la calidad de los simulacros de TFM (pre y post intervención). Ésta fue evaluados mediante 9 ítems en los que se analiza la correcta utilización de la normativa APA, el uso adecuado de bibliografía y una adecuada redacción del trabajo. Concretamente, los ítems son: 1. Indique el número de citas presentes en el texto que no se han citado siguiendo la normativa APA; 2. Indique el número de trabajos presentes en las referencias bibliográficas que no siguen la normayiva APA; 3. ¿Aparecen todas las citas en las referencias? ; 4. ¿Hay más trabajos en las referencias bibliográficas de los citados en el texto? ; 5. ¿Hay un uso excesivo de citas textuales? ; 6. ¿Presenta la introducción un uso suficiente de la bibliografía?; 7. ¿Se utiliza bibliografía de calidad científica?; 8. ¿Se ha utilizado un lenguaje científico para la redacción del trabajo? Puntúe del 1 al 5 siendo 1 la puntuación más baja y 5 la más alta ; 9 . ¿Se ha cometido plagio en este trabajo? La calificación del alumno se obtuvo haciendo el sumatorio de la calificación obtenida en todos los ítems, sobre una escala de 0 a 5 .

d) Cuestionario de co-evaluación del simulacro escrito de TFM antes de la intervención: Este cuestionario es similar al anterior pero la evaluación es llevada a cabo por los propios alumnos. Para ello, cada alumno fue adjudicado el trabajo de un compañero.

e) Cuestionario de autoeficacia en defensa oral del TFM. Al igual que en el caso del instrumento de autoeficacia en la redacción del TFM, para este cuestionario nos vasamos en la creación de cuestionarios de Bandura (2006). El cuestionario refleja las competencias a adquirir por el alumnado presentes en la guía docente del Máster. Éste está compuesto por los siguientes ítems: "Puedo: 1. Hacer una presentación oral siguiendo un registro científico.; 2. Ajustarme al tiempo establecido para una presentación oral, sin atropellar las palabras y sin dejarme ideas y 3 . Contestar y argumentar de manera adecuada las preguntas de los miembros del Tribunal. El formato de respuesta fue del 1 (no puedo) al 5 (estoy seguro de que puedo hacerlo). La fiabilidad interna del instrumento fue adecuada ( $\alpha \mathrm{T} 1=$ $.76 ; \alpha \mathrm{T} 1=.79)$.

f) Cuestionario de ansiedad ante la defensa oral del TFM. Se creó un cuestionaro ad hoc para medir el grado de ansiedad del alumnado ante la defensa del TFM. El cuestionario consta de los mismo ítems que el cuestionario de autoeficacia para la defensa oral y los alumnos debían indicar cuánta ansiedad les produciría cada una de las tareas descritas (ej., 
Contestar de manera adecuada las preguntas del tribunal), desde 1 (no me produciría ninguna ansiedad) hasta 5 (me generaría mucha ansiedad). La fiabilidad interna del instrumento fue adecuada $(\alpha \mathrm{T} 1=.82 ; \alpha \mathrm{T} 1=.80)$

g) Cuestionario de evaluación de los simulacros orales de TFM. El rendimiento académico se midió evaluando la calidad de los simulacros orales de TFM (pre y post intervención). Ésta fue evaluados mediante 10 ítems: 1. Postura erguida y un poco inclinada hacia delante; 2. Uso de marcadores no vernales para los aspectos más importantes del discurso; 3 . Expresión facial agradable (no tensa ni seria, dirigida al interlocutor); 4. Tono de voz claro, con buena vocalización, modulación (sin monotonía) y ritmo de habla adecuado; 5 . Respeto del tiempo establecido para la exposición; 6. Uso de un léxico adecuado a la situación comunicativa y una terminología precisa y ligada al tema; 7. Uso de un registro académico y formal, evitando en todo momento los coloquialismos, los vulgarismos y las muletillas (ehhhh, bueno, pues, entonces...); 8. Discurso ordenado, con un desarrollo claro y bien estructurado, sin digresiones ni reiteraciones innecesarias; 9. Uso adecuado y pertinente de los conectores para marcar las distintas partes; 10. Uso pertinente de la presentación, con una selección adecuada y coherente de la información incluida, acorde con el discurso oral. La calificación del alumno se obtuvo haciendo el sumatorio de la calificación obtenida en todos los ítems, sobre una escala de 0 a 5 .

h) Cuestionario de co-evaluación del simulacro oral de TFM antes de la intervención. Este cuestionario es igual al anterior pero la evaluación es llevada a cabo por los propios alumnos. Para ello, a cada alumno le fue adjudicado el trabajo de un compañero.

\section{Resultados}

\subsection{Efectos de la intervención en los niveles de autoeficacia y ansiedad ante la redacción del TFM}

En primer lugar, se calcularon las medias en cada una de estas variables antes de la intervención y después de la misma, y se llevaron a cabo pruebas t de Student para muestras relacionadas para evaluar si las diferencias de medias encontradas son estadísticamente significativas. Las medias (M) y el error estándar (ES) de los participantes en cada una de estas variables pueden observarse en las Figuras 1, 2 y 3.

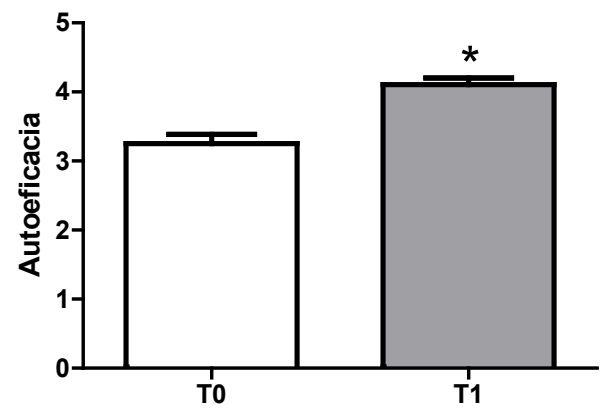

Fig. 1 Niveles de autoeficica ante la redacción del TFM pre-post intervención. En la figura se muestran las medias \pm ES del rendimiento a tiempo 0 (T0) y a tiempo 1 (T1). * $p \leq 0.05$

Como se puede observar en la Figura 1, la autoeficacia ante la redacción del TFM aumenta tras el paso de los estudiantes por la intevención siendo $M=3.25(E S=0.13)$ en el tiempo 0 
(pre-intervención) y $M=4.10(E S=0.01)$ en el tiempo 1 (post-intervención). Estas diferencias son estadísticamente significativas, siendo $\mathrm{t}_{15}=-5.82, p<.001$.

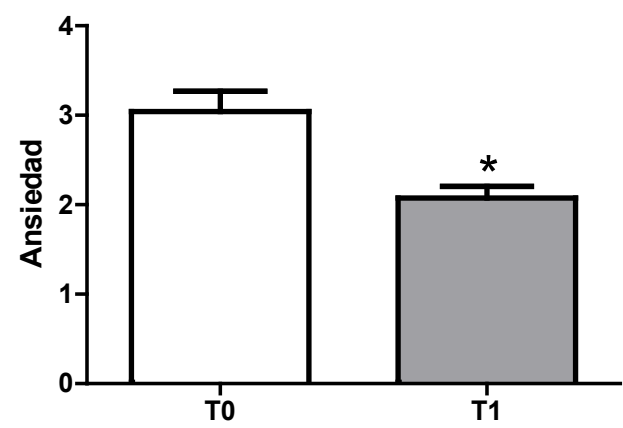

Fig. 2 Niveles de ansiedad ante la redacción del TFM pre-post intervención. En la figura se muestran las medias \pm ES del nivel de ansiedad a tiempo 0 (T0) y a tiempo 1 (T1). * ${ }^{*} \leq 0.05$

Como se puede observar en la Figura 2, la ansiedad ante el TFM disminuye tras el paso por la intervención, siendo $M=3.03(E S=0.22)$ en el tiempo 0 y $M=2.07(E S=0.13)$ en el tiempo 1. Estas diferencias son significativas siendo $\mathrm{t}_{15}=6.026, p<.001$.

\subsection{Efectos de la intervención en la calidad de la redacción del simulacro de TFM y relación con la co-evaluación}

En primer lugar, se calcularon las medias en la evaluación llevada a cabo por el profesor antes y después de la intervención. Los resultados muestran que la calidad del Simulacro de redacción de TFM antes de la intervención (T0) es peor $(M=2,39, E S=0,24)$ que después de la misma $(M=3,7, E S=0,31)$, siendo estas diferencias estadísticamente significativas $\left(\mathrm{t}_{15}=-4,41, p<.01\right)$. Véase Figura 3A.

A

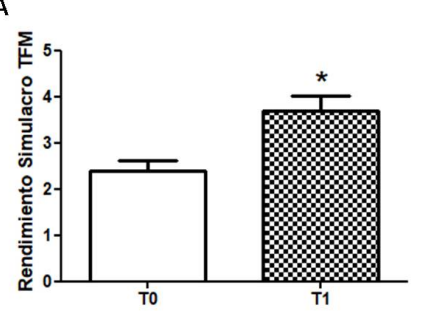

B

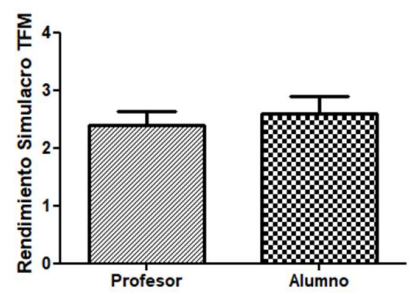

Fig. 3 Calidad de redacción del simulacro de TFM pre-post intervención. A.En la figura se muestran las medias \pm ES del rendimiento a tiempo 0 (T0) y a tiempo 1 (T1) * ${ }^{*} \leq 0.05$ ). B. Se muestran las medias \pm ES del rendimientodel simulacro del TFM cuando este fue evaluado por el profesor respecto a cuando lo evaluaron los alumnos. No se observaron diferencias significativas entre los distintos grupos. 
En relación a la co-evaluación, la correlación entre la evaluación del simulacro de redacción del TFM en T0 y la co-evaluación llevada a cabo por los alumnos es de $.842, p<$ .01 , siendo esta una correlación alta. Además, los resultados de la prueba de t de Student para muestras relacionadas indican que las diferencias entre las medias otrogadas por el profesor $(M=2.39 E S=0.24)$ y las otrogadas por los alumnos $(M=2.60, E S=0.30)$ no son estadísticamente significativas, siendo $\mathrm{t}_{15}=-1,176, p=.26$, Véase Figura 3B. Estos resultados sugieren que los alumnos entendieron la forma de redactar un TFM y fueron capaces de evaluar con exactitud el simulcro de TFM de sus compañeros.

4.3. Efectos de la intervención en la percepción de eficacia y niveles de ansiedad ante la defensa oral del TFM

Para evaluar si existe un aumento de la percepción de eficacia de los sujetos en cuanto a la defensa oral del TFM entre antes y después de participar en el proyecto de innovación docente, se llevó a cabo una $\mathrm{T}$ de student de medias relacionadas. Los resultados muestran que existen diferencias significativas entre la percepción de autoeficacia de los sujetos en el T1(Media $(M)=3,04$; Error estándar de la muestra $(E S)=0,11)$ y T2 $(M=4,37 ; E S=$ $0,11)$, siendo $t(15)=10,05, p<.001$. Véase Figura 4 .

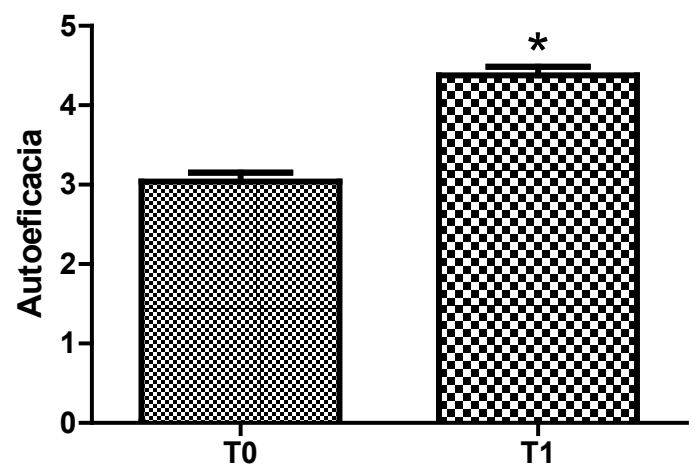

Fig. 4 Niveles de autoeficica en la defensa oral pre-post intervención. En la figura se muestran las medias $\pm E S$ de autoeficacia a tiempo 0 (T0) y a tiempo 1 (T1). *p $\leq 0.05$

En relación al nivel de ansiedad de los sujetos ante la defensa oral del TFM, el análisis de medidas repetidas muestra que la ansiedad de los sujetos ante la exposición oral disminuyó después de su participación en el programa, siendo el nivel medio de ansiedad en T0 $=3,45$ $(E S=0,27)$ y en $\mathrm{T} 1=2,39(E S=0,20)$. Esta disminución es estadísticamente significativa, $t$ $(15)=5,95, p<.001$. Véase Figura 5 . 


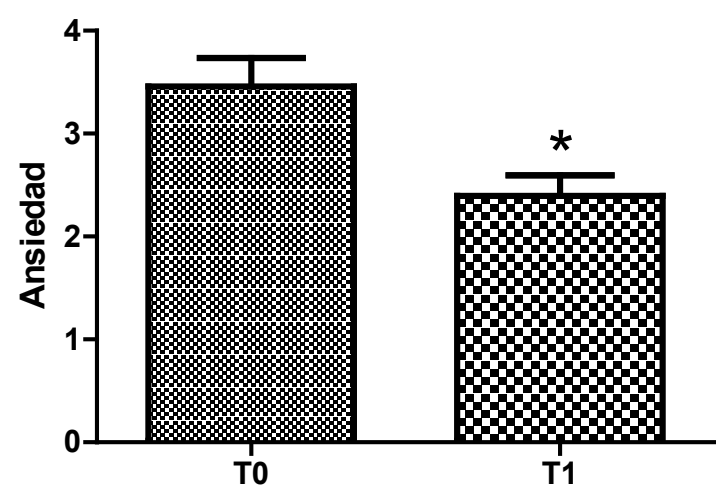

Fig. 5 Niveles de ansiedad ante la defensa oral del TFM pre-post intervención. En la figura se muestran las medias \pm ES de ansiedad a tiempo 0 (T0) y a tiempo 1 (T1). * ${ }^{*} \leq 0.05$

\subsection{Calidad del simulacro oral de TFM y relación con la co-evaluación}

En primer lugar, se calcularon las medias en la evaluación llevada a cabo por el profesor antes y después de la intervención, para ello se realizó una prueba t de student para muestras relacionadas. Los resultados muestran que la calidad del simulacro oral de TFM antes de la intervención (T0) es peor $(M=2,39, E S=0,24)$ que después de la misma $(M=$ $3,7, E S=0,31)$, siendo estas diferencias estadísticamente significativas $\left(\mathrm{t}_{15}=3,74, p<.01\right)$. Véase Figura 6A.

A

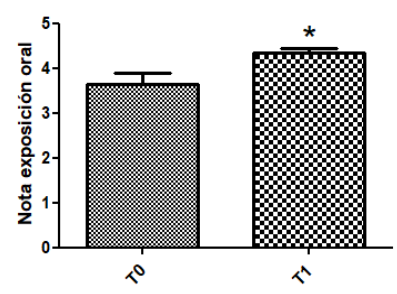

B

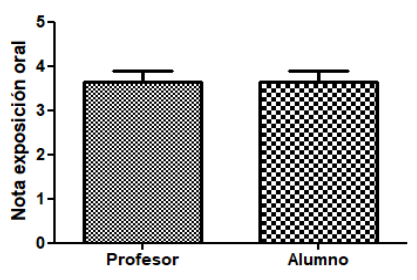

Fig. 6 Calidad del simulacro oral de TFM pre-post intervención. A. En la figura se muestran las medias $\pm E S$ del rendimiento a tiempo 0 (T0) y a tiempo 1 (T1) $\left.{ }^{*} p \leq 0.05\right)$. B. Se muestran las medias \pm ES del rendimiento del simulacro del TFM cuando este fue evaluado por el profesor respecto a cuando lo evaluaron los alumnos. No se observaron diferencias significativas entre los distintos grupos.

Para estudiar la relación entre la evaluación llevada a cabo por el profesor en T1 y la coevaluación, se llevó a cabo una prueba de t de Student para muestras independientes. Los resultados muestran que no existen diferencias estadísticamente significativas entre las medias otorgadas por el profesor $(M=3,65, E S=0,22)$ y la media otorgadas por el alumnado $(M=3,63, E S=0,26)$, siendo $\mathrm{t}_{12}=0,05, p=.95$. Véase Figura 6B. Estos 
resultados sugieren que los alumnos entendieron la forma correcta de realizar una presentación oral de un trabajo científico y fueron capaces de evaluar con exactitud a sus compañeros.

\section{Conclusiones}

En este trabajo se han evaluado los efectos de un proyecto de innovación docente en la autoeficacia, niveles de ansiedad y rendimiento de alumnos del Máster de profesorado de UNIZAR frente a la redacción y defensa oral de su TFM. En consonancia con la hipótesis 1 , el nivel de autoeficacia de los sujetos aumenta después de asistir a los seminarios del proyecto de innovación. Así, los alumnos sienten que son capaces de afrontar eficazmente las tareas requeridas para una correcta redacción y defensa oral del TFM, como por ejemplo sintetizar ideas, buscar información relevante, seguir el formato APA o ajustarse al tiempo requerido en la exposición oral. Además, tras los seminarios, los alumnos muestran menores niveles de ansiedad ante la redacción y defensa del TFM (hipótesis 2). Cabe también destacar que, tal y como se esperaba, los sujetos mejoraron la calidad de su trabajo (simulacro de TFM escrito y oral) después de su participación en los seminarios (Hipótesis 3).

Como conclusión, puede decirse que la intervención de innovación educativa ha tenido los efectos deseados, dado que ha aumentado la autoeficacia y el nivel de rendimiento de los alumnos frente a la redacción y la defensa oral del TFM y ha disminuido su ansiedad ante el mismo. Se considera que el proyecto puede servir de precedente para ser utilizado con alumnos que deban realizar trabajos similares, tales como TFM en otras titulaciones y Trabajos Fin de Grado.

\section{Referencias}

AMERICAN PSYCHOLOGICAL ASSOCIATION (2010). Publication Manual of the American Psychological Association $6^{\text {th }}$ Ed. Washington: American Psychological Association, 2010.

BANDURA, A. (1986). Social Fundations of Thoughts and Action. A social cognitive theory. Englewood Cliffs, NJ: Prentice Hall.

CASTEllÁ, J.M., COMELlES, S., CROS, A. \& VILÀ, M. (2007). Enterder(se) en clase. Las estrategias comunicativas de los docentes bien valorados. Barcelona: Graó.

CONTRERAS, F., ESPINOSA, J. C., ESGUERRA, G., HAIKAL, A., POLANÍA, A., Y RODRÍGUEZ, A. (2005). "Aueficacia, ansiedad y rendimiento académico en adolescents" en Perspectivas en Psicología, 2, 184-194.

CROS, A. (1996). "La clase magistral. Aspectos discursivos y utilidad didáctica", en Signos, 17, 22-29

DOMÉNECH-BETORET F, ABELLÁN-ROSELLÓ L AND GÓMEZ-ARTIGA A (2017). "Self-Efficacy, Satisfaction, and Academic Achievement: The Mediator Role of Students' Expectancy-Value Beliefs". In Front. Psychol. 8:1193. doi: 10.3389/fpsyg.2017.01193 
GALLEGUILLOS, P. (2017). “Autoeficacia académica y rendimiento escolar: un estudio metodológico y correlacional en escolares.” en Reidocrea, 6, 156-169.

LANE, J., \& LANE, A. M. (2001). "Self-efficacy and academic performance." in Social Behavior and Personality, 29, 687-694.

MORALES, Z. \& NAVARRO (20139. "Evaluación de la competencia comunicativa "Hablar en público" en un grupo de estudiantes universitarios tras un curso sobre habilidades interpresonales". en Revista de Enseñanza Universitaria 39, 1-10.

OREJUDO, S. SÁNCHEZ, M. T. y BRIZ, E. (2012). "Resultados de un programa parareducir el miedo y aumentar la autoeficacia para hablar en público en estudiantes universitarios de primer año". en Estudios sobre educación 22, 199-217.

PERVIN, L. (1997). La ciencia de la personalidad. Madrid: McGraw-Hill

SÁNCHEZ MIGUEL, E.; ROSALES, E. \& CAÑEDO, I. (1994). "El discurso expositivo: una comparación entre profesores principiantes y novatos", en Infancia y Aprendizaje, 67, $51-74$.

SANJUÁN, M., SENÍS, J. y DEL MORAL, C. (2017). "Diseño y evaluación de un proceso de formación en habilidades comunicativas para la docencia". en Porta Linguarum, monográfico II, 57-71.

UNIVERSIDAD DE ZARAGOZA (2017). Guía docente asignatura 68500. Zaragoza.

VÁZQUEZ, G. (coord.) (2001). El discurso académico. Madrid: Edinumen.

VILÀ, M. (2005). "El discurso explicativo oral: estrategias comunicativas", en M. Vilà (coord.), El discurso oral formal. Barcelona: Graó, 37-56.

\section{Agradecimientos}

Este trabajo se ha podido llevar a cabo gracias al apoyo del Vicerrectorado de Política Académica de la Universidad de Zaragoza titulado "Aprender a investigar: el uso de las TIC en la adquisición de competencias clave para la realización y defensa de Trabajos Fin de Máster en el Máster de profesorado (PIIDUZ_17_047)”. 


\title{
Razones para el uso de blogs por maestros en formación
}

\section{Jesús García Laborda ${ }^{\mathrm{a}}$}

${ }^{a}$ Universidad de Alcalá; Departamento de Filología Moderna; Calle Trinidad, 3, 28801 Alcalá de Henares (Madrid), email: jesus.garcialaborda@uah.es

\begin{abstract}
Although information technologies have been used in the university classroom since the early 1980s, their diffusion and depth is very different in Spain. In the careers of Humnidades and Social Science of the University of Alcalá they have been limited by resources certainly limited. Hence the need to obtain simple and accessible resources free of charge. Blogs are an excellent opportunity to develop the ability of future teachers to develop or combine their own creations and classroom tasks to give them maximum possible dissemination. This work succinctly presents the results of the reasons and use of blogs in teacher training. To do this, after the students of the Magisterium elaborated their blogs in groups, they were asked for their opinions regarding their use and functionality. Among the results, the combination of ludic and formative aspects stands out. This indicates that the use of blogs favors not only creativity, the ability to write, but is also highly motivating.
\end{abstract}

Keywords: blogs, teacher training, motivation, play elements, survey.

\section{Resumen}

Aunque las tecnologías de la información han sido utilizadas en el aula universitaria desde principios de los 80 , su difusión y profundidad es muy diferente en España. En las carreras de Humanidades y Ciencia Sociales de la Universidad de Alcalá se han visto limitadas por unos recursos ciertamente limitados. De ahí la necesidad de obtener recursos sencillos y accesibles gratuitamente. Los blogs constituyen una excelente oportunidad para desarrollar la capacidad de los futuros maestros de elaborar o combinar sus propias creaciones y tareas del aula para darles la máxima difusión posible. Este trabajo presenta sucintamente los resultados de las razones y uso de blogs en la formación de profesores. Para ello, tras elaborar los estudiantes de Magisterio sus blogs en grupos, se les solicitó sus opiniones respecto a su uso y funcionalidad de los mismos. Entre los resultados destaca la combinación de aspectos lúdicos y formativos. Esto indica que el uso de blogs favorece no sólo la creatividad, la capacidad de escritura sino que es, además, altamente motivador.

Palabras clave: blogs, formación del profesorado, motivación, elementos lúdicos, encuesta. 


\section{Introducción}

El uso de blogs se ha incrementado durante los últimos años debido al interés que suscitan tanto en profesores como en alumnos (MacDonald, 2015; Hughes, Liu \& Lim, 2016). Asimismo, los blogs permiten el uso de los mismos para desarrollar distintos estilos de competencia escrita y leída tanto de manera individual como colectiva (Morgan, 2015). Para muchos, los blogs, además, son la viva representación de una comunicación multimodal realista (Sandlin \& Peña, 2014).

Dentro de las competencias requeridas para los estudiantes en el siglo 21, los blogs permiten potenciar muchas de las áreas de desarrollo, especialmente el uso de la tecnología, conocimiento de lenguas extranjeras (figura 1) de manera interaccionista (Yang, 2018).

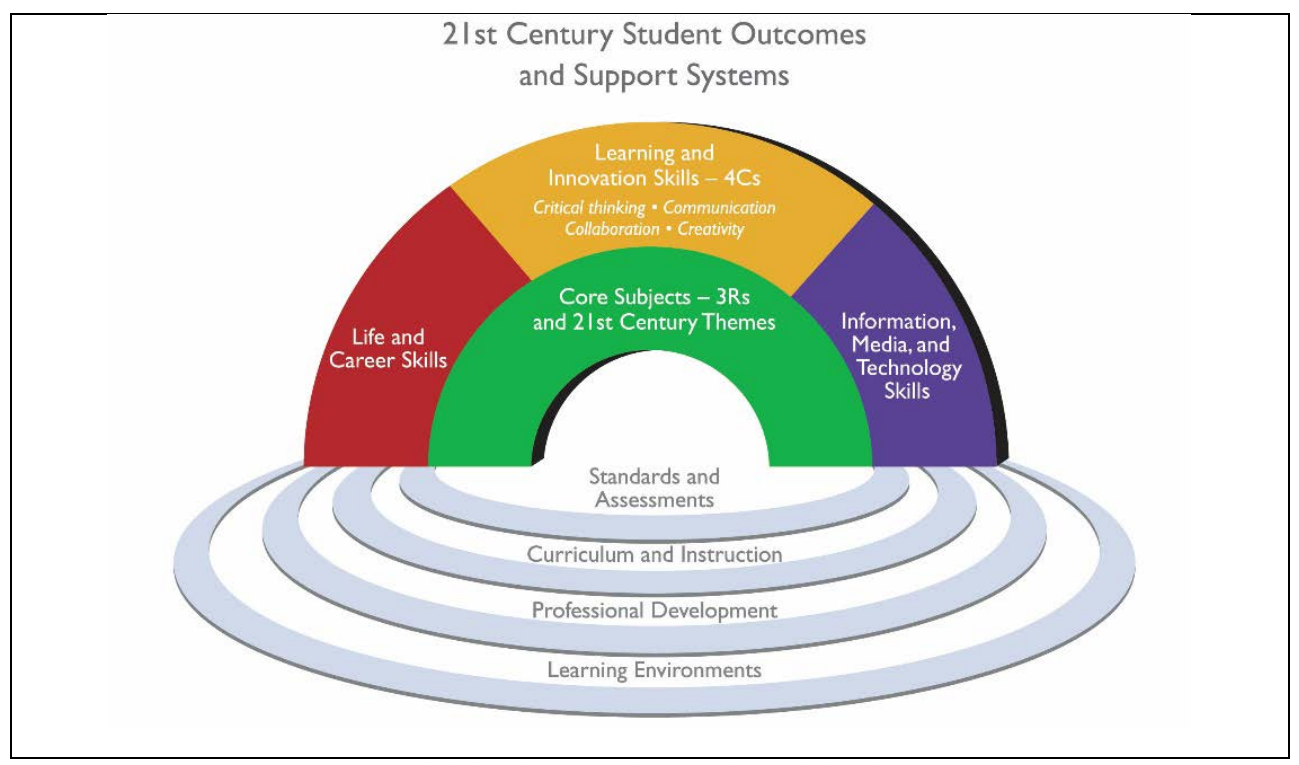

Fig. 1 Marco conceptual de las destrezas de aprendizaje del siglo 21 (fuente: www.P21.org)

\section{Objetivos}

El objetivo general del proyecto de innovación docente "Web 2.0 para maestros de inglés en formación (UAH/EV891)” era la incorporación de blogs como método de formación de profesores (Khan, 2017) para incorporar contenidos didácticos que sirviesen en su desarrollo profesional como docentes en la asignatura de Didáctica del inglés ( $4^{\circ}$ curso, Grado de Maestro de Primaria) con una participación de 23 alumnos (6 blogs en grupos de 3-4 alumnos). La creación de los blogs era una parte obligatoria evaluable (40\%) de la asignatura. Los objetivos de este proyecto son:

1) Familiarización a los alumnos con tecnología social;

2) Búsqueda de aplicaciones directas e indirectas de la tecnología para su docencia formal al graduarse;

3) Creación de objetos de aprendizaje; 
4) Adaptación de contenidos curriculares de Primaria para los trabajos en el propio aula; $\mathrm{y}$

5) La presentación como mini clases de cara a su práctica efectiva con audiencia en el aula.

Para conseguir estos objetivos deberían incluir una serie de módulos en el propio blog. García Laborda y Litzler (2017) describen un uso de blogs similar en la facultad de Ciencias Económicas de la Universidad de Alcalá. Según la propia instrucción del profesorado participante el blog debería incluir una serie de aplicaciones usadas específicamente con el fin de desarrollar su uso como parte de la enseñanza de lenguas. Los principios que regirían la selección de herramientas sería la que sugiere el American Council on the Teaching of Foreign Languages (ACTFL) para el uso de la tecnología según las habilidades lingüísticas a adquirir en el siglo XXI:

1) Comunicación: Ya que es importante que los niños del siglo 21 deben ser capaces de comunicar a través de redes sociales (Facebook, Storify, ejejot, Blogger, etc.);

2) Trabajo cooperativo: Puesto que deberán usar su lengua materna y las adquiridas adicionalmente para trabajar con otras personas de distinta lengua y cultura como miembros de equipos interdisciplinares usando Google sheets, diigo, PBWorks, etc.;

3) Pensamiento crítico: para ser capaces de conceptualizar, analizar y sintetizar así como negociar a través comunicaciones efectivas para resolver problemas y avanzar en sus relaciones personales y/o conocimiento (bubbl.us, lino-it, spycynodes);

4) Creatividad e innovación usando el lenguaje de manera original y creativa para realizar contribuciones adecuadas a través de Storyfy, PicMonkey, Big Huge labs...;

5) Alfabetización tecnológica, digital y de media usando paper.li, hootsuite, newsmap, animoto, netvibes o CC; $\mathrm{y}$

6) A éstos se añadirían otras facetas como flexibilidad y adaptabilidad, iniciativa y autodirectividad, habilidades sociales e interculturales y capacidad de responsabilidad y liderazgo.

\section{Desarrollo de la innovación}

Con el fin de que estos valores se practicasen y se pudiesen utilizar como una primera aproximación al uso de la tecnología para transmitir estos valores en primaria se pidió un blog que no sólo debería estar integrado por elementos electrónicos sino que tenía que ser acompañado por otras actividades no digitales como juegos, teatros de marionetas, etc. Para alcanzar este objetivo, el blog constaría de las siguientes partes:

1) Página web no dinámica con un tema de contenido y una explicación teórica;

2) Creación de dos videos para enseñar a alumnos de primaria materias relacionadas con el tema central;

3) Presentaciones realizadas en Power Point u otras aplicaciones de presentación;

(cc) EY-NC-ND 2018, Universitat Politècnica de València

Congreso In-Red (2018) 
4) Diseño de aplicaciones sociales para la promoción profesional (generalmente Linkedin); y

5) Enlaces a aplicaciones útiles para la enseñanza.

La figura 1 muestra la composición final de la interfaz principal de uno de estos blogs diseñados por los alumnos.

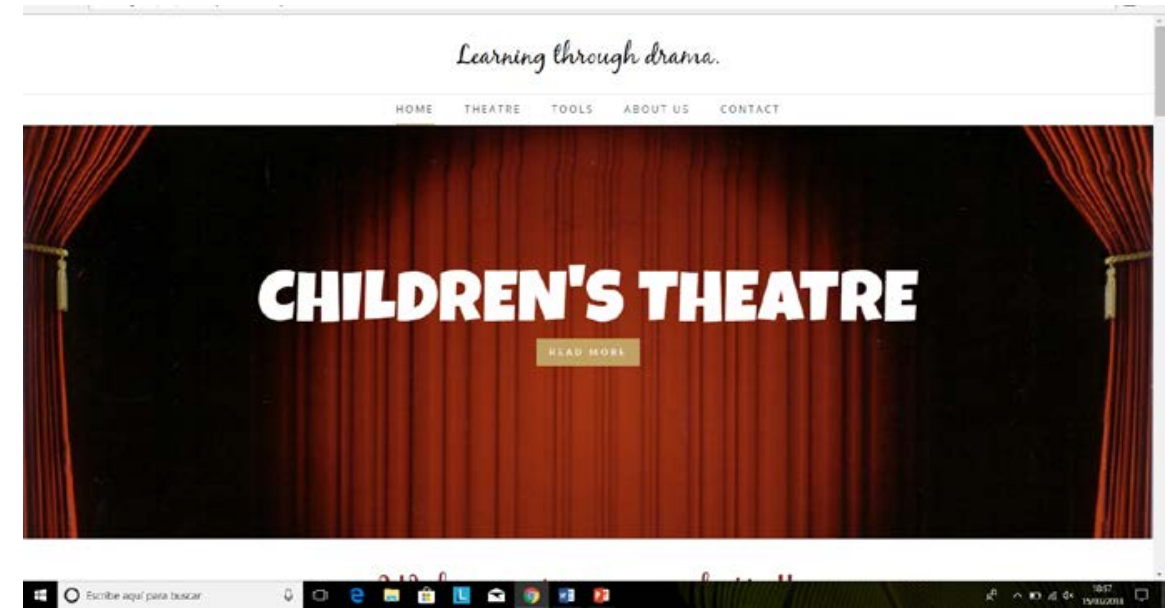

Fig. 1 Blog "Children's Theater" (https://funnytheatre.weebly.com/)

Este blog muestra de manera efectiva sus distintas partes. El objetivo último de la instrucción en educación sería la comunicación por tanto debemos considerar en nuestro constructo dicho objetivo último. En el diagrama dos se presenta el flujo direccional del constructo con el fin de llegar desde el input inicial hasta el output (figura 2).

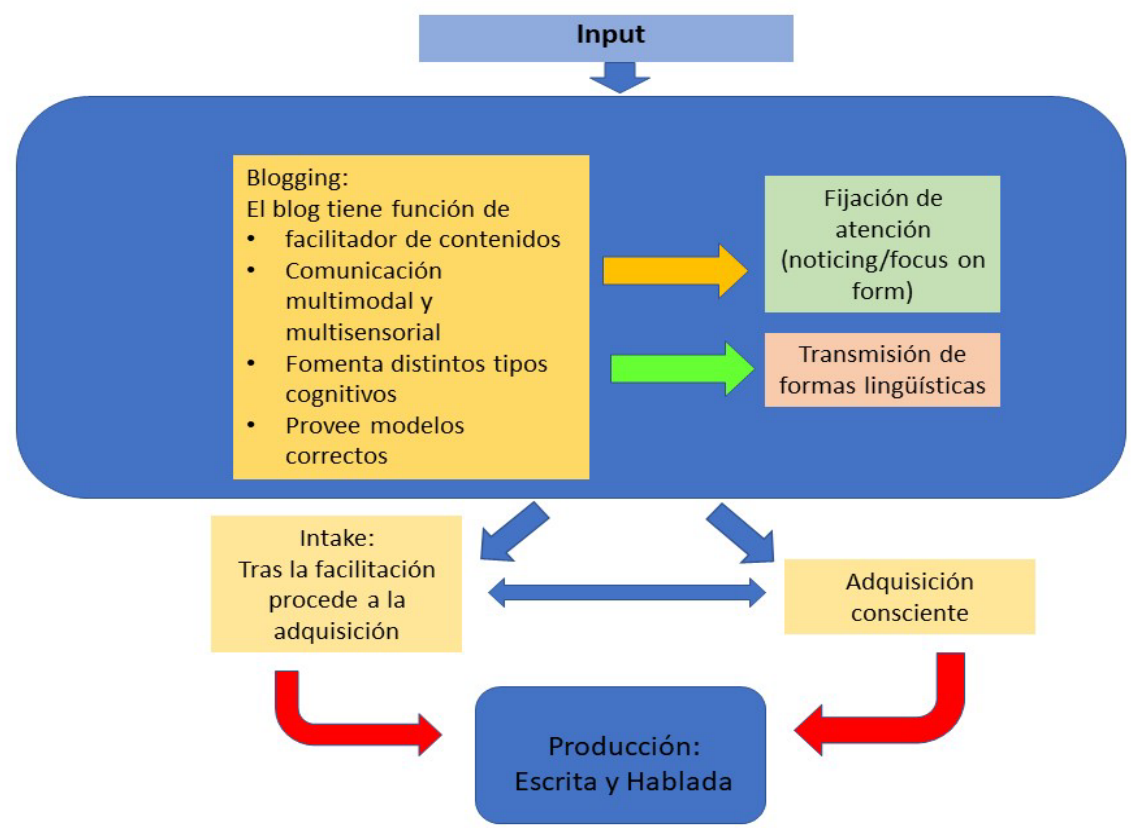

Fig. 2 Proceso de aprendizaje de la lengua a través de blogs (fuente propia)

(cc) EY-Nc-No 2018, Universitat Politècnica de València

Congreso IN-RED (2018) 
Como se ve en la figura 2, el blog sirve como medio de transmisión comunicativa no sólo de la lengua, sino que tiene una función de motivación. En el ejemplo señalado más arriba esta función la cumplen parcialmente los dos vídeos que, además, transmiten los contenidos lingüísticos de forma multimodal facilitando el aprendizaje de acuerdo a los distintos estilos cognitivos del alumno. Asimismo, puesto los estudiantes producen formas escritas, el alumno es capaz de crear y recibir modelos lingüísticos específicos especialmente porque los alumnos deben editar su producción, lo que, a su vez, requiere un proceso de monitorización y edición del propio trabajo que tiene un efecto en la fijación y en la atención a la forma y también un esfuerzo en la transmisión de las formas correctas. En nuestro ejemplo la variedad de estilos discursivos escritos se hace porque los futuros profesores crean lecturas que, a su vez, deben servir de lectura para potenciales alumnos (Yakut \& Aydin, 2017). Bien es cierto que, aunque en el blog sugerido el tema es muy elevado para los alumnos, en general, lo que se puede introducir una vez en el ejercicio de la enseñanza en educación primaria pueden ser cuentos con distintos estilos de letras (mayúscula, grande, pequeña, itálica, script) y colores que fomenten la creatividad de sus alumnos. Una vez los alumnos han percibido, entendido y fijados los contenidos se produce tanto una adquisición consciente como no consciente que, en última instancia, llevan al aprendizaje. Posteriormente los alumnos podrán producir ejercicios escritos para sus compañeros (y en el futuro para sus alumnos potenciales).

\section{Resultados}

En primera instancia el producto del blog mismo es un resultado ya que los alumnos han desarrollado un objeto (o varios) de aprendizaje que es transferible a su realidad profesional y, por consiguiente, debe ser valorado por sí mismo. Los alumnos, también, reconocen que tiene otros efectos que se reflejan en la figura 3. Para ello realizaron una encuesta libre a través de Survey Monkey que respondieron demanera voluntaria y que trataba de encontrar beneficios y problemas de la implementación del proyecto. 


\section{¿Cuál cree que podría ser el beneficio si se usasen blogs creados por los alumnos en enseñanza primaria?}

Respondidas: 15 Omitidas: 0

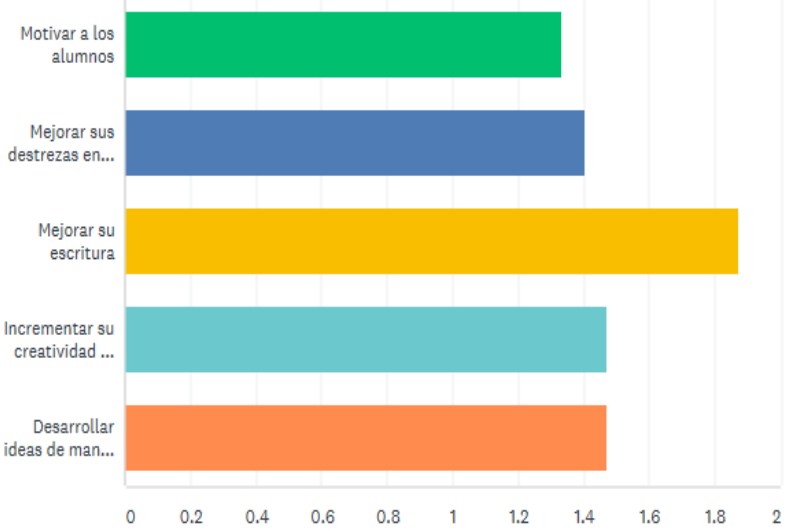

Fig. 3 Proceso de aprendizaje de la lengua a través de blogs

La figura 3 muestra que los alumnos encuentran una transferencia directa del trabajo realizado que además tiene un efecto significativo en la motivación, en la mejora de destrezas lingüísticas y, por supuesto, muy especialmente en la escritura (también Akdag \& Özcan, 2017). Así los alumnos muestran sus opiniones valorando con 2 su afirmación absoluta y un 0 su negativa absoluta. Así pues, su máxima valoración se va a la mejora de la escritura. Asimismo, sirve para fomentar la creatividad en el aula (azul claro) y el desarrollo de ideas y la mejora de destrezas escritas (azul oscuro).

\section{Conclusiones}

La creación de blogs representa una inmensa cantidad de beneficios en la formación de futuros maestros que se forman en el desarrollo de competencias exigibles y necesarias en el siglo XXI. Como se ha visto es un excelente medio para aprendizaje de lenguas extranjeras tanto para los creadores como para los receptores potenciales.

Este trabajo ha mostrado el proceso de aprendizaje y desarrollo lingüístico ejemplificado en un blog desarrollado para la asignatura de Didáctica de la Lengua Inglesa correspondiente al Grado de Maestro de Educación primaria de la Universidad de Alcalá. Obviamente, las propias limitaciones del estudio estriban en su eminente practicidad contrastada con otros trabajos en el ámbito del uso de blogs por maestros y, por supuesto, en la propia limitación de la aplicación ya que las clases en la escuela de Magisterio de la UAH nunca tienen más de 25 alumnos y ésta específicamente tan solo 20.

Por tanto, futuros trabajos deberían basarse en una muestra mucho más amplia de alumnos y en el análisis de sus propias dificultades. También se podría estudiar el efecto de la 
creación de esos blogs en los propios estudiantes y en su uso fuera y dentro de clase. En resumen, ésta es una primera aproximación que tiene una diferencia en la aplicabilidad inmediata del objeto desarrollado y en la propia percepción de su utilidad por los propios maestros en formación.

\section{Referencias}

AKDAG, E., \& ÖZKAN, Y. (2017). Enhancing writing skills of EFL learners through blogging. Reading Matrix: An International Online Journal, 17(2), 79-95.

García LABORDA, J., \& LitZler, M. F. (2017). English for business: Student responses to language learning through social networking tools. EST Today: Journal of English for Specific Purposes at Tertiary Level, 5(1), 91-107.

HughES, J. E., LiU, S., \& LiM, M. (2016). Technological modeling: Faculty use of technologies in preservice teacher education from 2004 to 2012. Contemporary Issues in Technology and Teacher Education (CITE Journal), 16(2) Retrieved from https://search-proquestcom.ezproxy.uned.es/docview/1871576920?accountid=14609

KHAN, A. (2017). Blog-based professional development of English teachers in Mumbai: The potential of innovative practice under scrutiny.Australasian Journal of Educational Technology, 33(4), 88-106.

MACDONALD, D. (2015). Teacher-as-knowledge-broker in a futures-oriented health and physical education. Sport, Education and Society, 20(1), 27-41.

Morgan, H. (2015). Creating a class blog: A strategy that can promote collaboration, motivation, and improvement in literacy. Reading Improvement, 52(1), 27-31.

SANDLIN, J. K., \& PEÑA, E. V. (2014). Building authenticity in social media tools to recruit postsecondary students. Innovative Higher Education, 39(4), 333-346.

SEJDIU, S. (2017). Are listening skills best enhanced through the use of multimedia technology. Digital Education Review, (32), 60-72.

YAKUT, A. D., \& AYdin, S. (2017). An experimental study on the effects of the use of blogs on EFL reading comprehension. Innovation in Language Learning and Teaching, 11(1), 1-16.

YANG, S. J. (2018). Language learners' perceptions of having two interactional contexts in eTandem. Language Learning \& Technology, 22(1), 42-51. 


\title{
Uso de recursos $y$ rendimiento en las actividades evaluación: análisis y comparación de resultados en el Grado en Ingeniería de Tecnologías Industriales ${ }^{1}$
}

\section{Begoña Peña ${ }^{a}$}

a Universidad de Zaragoza - Departamento de Ingeniería Mecánica (España) e-mail: bpp@unizar.es.

\begin{abstract}
Virtual Learning Environments such as Moodle register a large amount of information about student activity that is normally hidden for both the teacher and the student. This paper presents a simple analysis of this information from the data processing in a spreadsheet, without the help of tools that automate processing. In order to evaluate its usefulness, a comparison of the activity and the learning results is here presented for the last three courses on the subject Engineering Thermodynamics and Fundamentals of Heat Transmission of the Degree in Engineering of Industrial Technologies at the University of Zaragoza. The results show the patterns of the different groups of students, allowing to detect deviations and to predict in some extent the success in the final exams.
\end{abstract}

Keywords: Moodle, Learning Analytics, High Education Innovation, Engineering.

\begin{abstract}
Resumen
Las plataformas digitales educativas como Moodle recogen una gran cantidad de información sobre la actividad del estudiante que normalmente queda oculta tanto para el profesor como para el alumno. En este trabajo se presenta un análisis sencillo de dicha información a partir del tratamiento de datos en una hoja de cálculo, sin ayuda de herramientas que automaticen el procesamiento. Con el fin de evaluar su utilidad, se ha realizado la comparativa de la actividad y de los resultados de aprendizaje de los tres últimos cursos para la asignatura de Termodinámica Técnica y Fundamentos de Transmisión de Calor del Grado en Ingeniería de Tecnologías Industriales de la Universidad de Zaragoza. Los resultados muestran los patrones de los diferentes grupos de estudiantes, permitiendo detectar desviaciones e incluso predecir en cierta medida el éxito en los exámenes finales.
\end{abstract}

Palabras clave: Moodle, Learning Analytics, Innovación Universitaria, Ingeniería.

\footnotetext{
1 Este trabajo se ha desarrollado dentro del proyecto PIIDUZ_17_299 de innovación docente (Programa de Proyectos de Innovación Docente para Grupos de Profesores del Vicerrectorado de Política Académica de la Universidad de Zaragoza).
} 


\section{Introducción}

Las plataformas educativas se han convertido para la Universidad en un entorno habitual de comunicación entre alumnos y profesores, en donde se encuentran disponibles los recursos de las asignaturas. Además, gracias a las nuevas funcionalidades, como foros, wikis o cuestionarios, se utlizan cada vez más como herramienta de aprendizaje y de evaluación. Esto hace que cada usuario deje una huella digital de sus actividades que se puede analizar y procesar para establecer patrones de conducta o de aprendizaje, informar al estudiante y al profesor de los progresos y predecir el éxito final (Boyer, 2016). Todo esto ha abierto un nuevo campo de investigación, las analíticas del aprendizaje (Learning Analytics, LA) cuyo potencial solo se empieza a vislumbrar.

Reino Unido es pionero en la implementación de estas herramientas a nivel nacional (Sclater, 2016), pero no es el único país que está convencido del potencial de LA. La Comisión Europea está trabajando en este sentido para desarrollar guías y medios que faciliten la adaptación de LA en la Universidad Europea con el fin de asegurar la calidad (Ferguson, 2016). En otros países como Estados Unidos o Australia, también se lleva años desarrollando herramientas y modelos predictivos basados en LA que ayuden a mejorar los resultados de aprendizaje (Wanli, 2015).

En este sentido, parece demostrado que puede utilizarse como herramienta a nivel institucional para asegurar y mejorar la calidad, para monitorizar el seguimiento y el progreso en el aprendizaje de una asignatura, para reducir las tasas de abandono identificando a tiempo los casos de riesgo y como precursor del, tan perseguido, aprendizaje adaptativo o personalizado.

El presente trabajo se ha desarrollado siguiendo esta prometedora línea de investigación educativa con el fin de utilizar el potencial de LA para mejorar los resultados de aprendizaje en el Grado en Ingeniería de Tecnologías Industriales de la Universidad de Zaragoza. Concretamente, en esta ponencia, se presentan los datos recogidos de la plataforma Moodle en la asignatura de Termodinámica Técnica y Fundamentos de Transmisión de Calor para los tres últimos cursos académicos. Puesto que se han ido incorporando materiales y actividades durante este tiempo, la comparativa no puede ser completa y se realizará en base a aquellas actividades que son comunes al menos a dos cursos académicos.

\section{Objetivos}

Este trabajo ha surgido de las diferencias encontradas en las calificaciones finales para una misma asignatura de dos cursos académicos consecutivos en los que se ha seguido la misma metodología de aprendizaje y evaluación con el mismo profesor. Este hecho ha planteado la necesidad de obtener más información sobre el proceso de aprendizaje para encontrar los factores que más influyen en los resultados de aprendizaje. 
Los objetivos específicos de este trabajo son:

- Recopilar datos almacenados en cada curso en la plataforma Moodle.

- Procesar los datos para obtener indicadores promediados de dedicación y esfuerzo del estudiante en la asignatura.

- Comparar dichos indicadores para los diferentes cursos académicos.

- Obtener patrones y seleccionar los parámetros que pueden ser útiles para predecir el éxito en la asignatura.

\section{Desarrollo de la innovación}

El presente estudio se ha llevado a cabo con alumnos del Grado en Ingeniería de Tecnologías Industriales de la Universidad de Zaragoza, concretamente en la asignatura "Termodinámica Técnica y Fundamentos de Transmisión de Calor", que se imparte durante el primer cuatrimestre del segundo curso. La asignatura cuenta con 6 ECTS, equivalentes a 150 horas de trabajo, correspondientes a 45 horas de clases presenciales de teoría y resolución de problemas, 15 horas de prácticas de laboratorio y 90 horas de trabajo personal del alumno (estudio individual, resolución de problemas y cuestiones con o sin la supervisión y evaluación del profesor). Concretamente, se van a comparar los datos de los cursos académicos 2015-2016, 2016-2017 y 2017-2018.

Las actividades planificadas en la asignatura con fines de aprendizaje y evaluación han ido cambiando con el tiempo. En esencia, han aumentado las actividades realizadas por los estudiantes a través de la plataforma Moodle, con el fin de tener una corrección automática con feedback más rápido para los alumnos. El siguiente cuadro resume el trabajo del estudiante en la asignatura, tanto en lo que se refiere las sesiones presenciales de prácticas como de clases magistrales, indicándose en rojo las actividades con peso en la calificación final.

Tabla 1. Actividades planificadas dentro y fuera del aula

\begin{tabular}{|c|c|c|}
\hline & Sesiones prácticas & Clases \\
\hline Trabajo previo & $\begin{array}{l}\text { - Estudio de guion y apuntes } \\
\text { - Visualización de videos } \\
\text { - Cuestionario previo }\end{array}$ & $\begin{array}{ll}\text { - } & \text { Estudio con textos } \\
\text { - } & \text { Visualización de videos } \\
\text { - } & \text { Cuestionario tras cada video }\end{array}$ \\
\hline $\begin{array}{l}\text { Trabajo } \\
\text { presencial }\end{array}$ & $\begin{array}{l}\text { - Resumen del profesor } \\
\text { - Resolución de dudas } \\
\text { - Resol. de problemas complejos } \\
\text { - Aprendizaje del uso de software } \\
\text { - Entrega de resultados }\end{array}$ & $\begin{array}{l}\text { - Explicación del profesor } \\
\text { - } \text { Resolución de dudas } \\
\text { - Aprendizaje basado en problemas } \\
\text { - Gamificación con Kahoot! }\end{array}$ \\
\hline $\begin{array}{l}\text { Trabajo } \\
\text { posterior }\end{array}$ & & $\begin{array}{l}\text { - } \text { Cuestionarios de auto-evaluación } \\
\text { - } \text { Resol. problemas complejos } \\
\text { - } \\
\text { - } \\
\text { - }\end{array}$ \\
\hline
\end{tabular}

(c)) EY-NG-ND 2018, Universitat Politècnica de València

Congreso In-Red (2018) 
La metodología seguida en las clases se enmarca bajo el modelo de clase inversa en gran medida y se encuentra más detallada en las referencias (Peña, 2017a-b). Esencialmente, para las clases prácticas, se proporcionan una serie de materiales (guion, apuntes, videos) con los que el estudiante prepara la práctica y resuelve un cuestionario que en los cursos 2015-2017 se entregaba en papel al comienzo de la práctica y el presente curso se realiza a través de la plataforma Moodle. En la sesión, el profesor realiza un breve resumen, resuelve las dudas y deja el resto del tiempo para que los estudiantes por parejas reuelvan un problema más complejo. Si han trabajado adecuadamente, entregan los resultados al final de la sesión y no tienen que realizar tareas adicionales.

Con respecto a las sesiones magistrales, el profesor proporciona apuntes, bibliografía y videos con el fin de que el alumno prepare las clases (Zabalza, 2016-2017). Para el presente curso académico, tras cada video el alumno puede afianzar los conceptos más importantes mediante la resolución de un cuestionario breve que le sirve como autoevaluación. Una vez en clase, dependiendo del tema, el profesor explica en mayor o menor medida los conceptos y procedimientos teóricos para luego resolver problemas, bien el profesor, bien los alumnos en pequeños grupos bajo la guía y supervisión del profesor. Al finalizar cada tema, se realiza una gamificación con Kahoot!, cuyos resultados quedan fuera del alcance del presente artículo (Peña, 2018). También se proporciona al estudiante un cuestionario en Moodle con 3 intentos (contando en la nota sólo el último) y un trabajo que consiste en resolver varios problemas similares a los del examen, cuyos resultados debe entregar tanto en papel como a través de la plataforma Moodle para una corrección automatizada. Tras revisar la versión en papel se mantiene o se modifica la calificación obtenida de la corrección automática del trabajo.

Puesto que una buena parte de la evaluación y bastantes actividades de aprendizaje se realizan a través de Moodle, se dispone de una gran cantidad de información almacenada en la plataforma que puede servir para hacer seguimiento del proceso de enseñanzaaprendizaje. En la sección siguiente se presentan y comparan los datos registrados durante los 3 últimos cursos académicos, pero antes de eso, se detallan de forma concreta las diferencias en las actividades y recursos disponibles en la plataforma digital con el fin de que se pueda realizar una correcta interpretación de los resultados .

\section{Diferencias y novedades en cada curso analizado}

- El número de alumnos matriculados en cada curso ha sido 51 en 2015-2016, 70 en 2016-2017 y 52 en el curso actual.

- Las fechas del examen de la convocatoria de febrero, que pueden interesar a efectos de la actividad temporal en Moodle, fueron: 27/01/16, 02/02/17, 05/02/2018.

- Encuestas: durante los cursos 2015-2016 y 2016-2017 se realizaron encuestas sobre metodología y sobre su opinión acerca de los videos docentes, cuyos resultados se encuentran detallados en (Zabalza, 2016) y en (Zabalza, 2017).

- Cuestionarios de evaluación y de autoevaluación: han ido aumentando en número con el tiempo (5 en el curso 2015-2016, 7 en el curso 2016-2017 y 8 en el curso actual).

(cc) EY-NC-ND 2018, Universitat Politècnica de València

Congreso IN-RED (2018) 
- Videos docentes: los videos de la lección 2 mencionada a lo largo del documento se desarrollaron entre diciembre y julio de 2016, por lo que no estuvieron disponibles durante la impartición de esa lección (en octubre) y sólo los dos primeros estuvieron disponibles para la convocatoria de febrero.

- Clase inversa: innovación introducida en el curso 2016-2017.

- Cuestionarios tras cada video: innovación introducida en el curso 2017-2018.

- Formularios para introducir los resultados de los trabajos tutorados: innovación introducida en el curso 2017-2018.

\section{Resultados}

La plataforma digital utilizada en la Universidad de Zaragoza es Moodle, concretamente, es la versión 3 desde el curso 2016-2017 (curso 16-17 Moodle 3.1 y curso 17-18 Moodle 3.3). Hasta la fecha no se ha instalado ningún módulo para el análisis del aprendizaje, del tipo SmartKlass o Calam, por lo que en este trabajo se ha extraído directamente la información de cada curso y se ha analizado en hojas de cálculo. De la información almacenada en el curso de la asignatura, se presentan concretamente el análisis y la comparación de los siguientes datos:

- Actividad global del estudiante: número de vistas totales y número de mensajes intercambiados.

- Visualización de los videos y acceso a los cuestionarios correspondientes.

- Actividad asociada a los cuestionarios de evaluación: tiempo invertido, número de intentos, calificación.

- Uso de los cuestionarios de autoevaluación y de otros recursos colgados en Moodle.

\subsection{Actividad global en la plataforma}

La información sobre la actividad global puede encontrarse en el menú Administración, Informes, Estadísticas. Se contabilizan tanto el número de Vistas (“views”) de cualquier elemento del curso, como lo que Moodle denomina Mensajes ("posts”) (Moodle, 2013). Las Vistas incluyen actividades pasivas del usuario, como el acceso o visualización de recursos, lecturas o descargas. Los Mensajes engloban respuestas activas del usuario, como participación en foros, envío de tareas, resolución de cuestionarios o encuestas.

En las gráficas de la Figura 1 se muestran los resultados de los tres últimos cursos a lo largo del semestre (septiembre-febrero). Se observa un patrón de uso completamente diferente. Durante el curso 2015-2016, la actividad en general fue mucho más baja que en lo dos cursos posteriores, del orden de la mitad de accesos totales, mostrando un pico durante el mes de febrero, asociado a la proximidad del examen final. Esto puede deberse a un menor número de tareas encomendadas a través de la plataforma. 

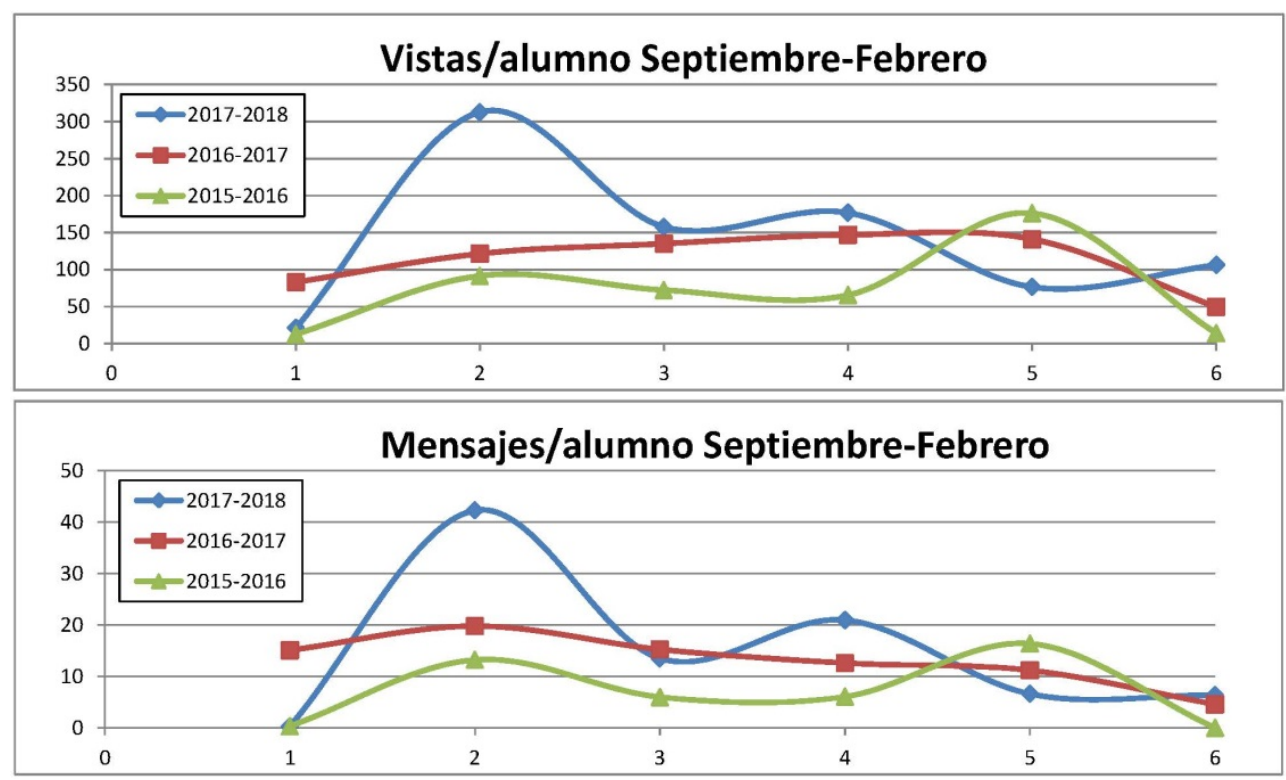

Fig. 1 Actividad general por alumno registrada en el curso de Moodle.

Entre los cursos 2016-2017 y 2017-2018 también existen diferencias significativas. El perfil de accesos durante el curso 2016-2017 es muy plano, mantiendo el nivel hasta el mes de enero en que se realizó el examen. Por el contrario, en el curso 2017-2018 observa una gran actividad durante el mes de octubre para luego tomar una tendencia decreciente con un repunte en el mes de diciembre. Llama la atención la baja actividad durante los meses de enero y febrero en que está la banda de preparación y realización del examen final.

\subsection{Visualización de videos docentes}

Un total de 20 videos docentes se están utilizando actualmente en la asignatura: 7 de ellos para la preparar las sesiones de prácticas, 6 para preparar las clases de la lección 2 que se ha impartido como clase inversa (Flipped Classroom Model, FCM) durante los cursos 20162017 y 2017-2018, y 7 videos más disponibles en el canal de YouTube de la Universidad Politécnica de Valencia. Los resultados obtenidos de las encuestas de opinión realizadas a los alumnos fueron muy positivos y se analizaron con detalle en publicaciones previas (Zabalza, 2016-2017).

Como ya se ha explicado en la Sección 2, no todos ellos han estado disponibles para todos los cursos académicos, hecho que se refleja en las gráficas de la Figura 2. Se ha representado el número de visualizaciones totales, el número de estudiantes que han visto al menos una vez el video y el porcentaje que ese número representa frente al número de matriculados en la asignatura. Nótese la diferencia de escala en el eje de abscisas: [0, 140], $[0,450]$ y $[0,300]$. 


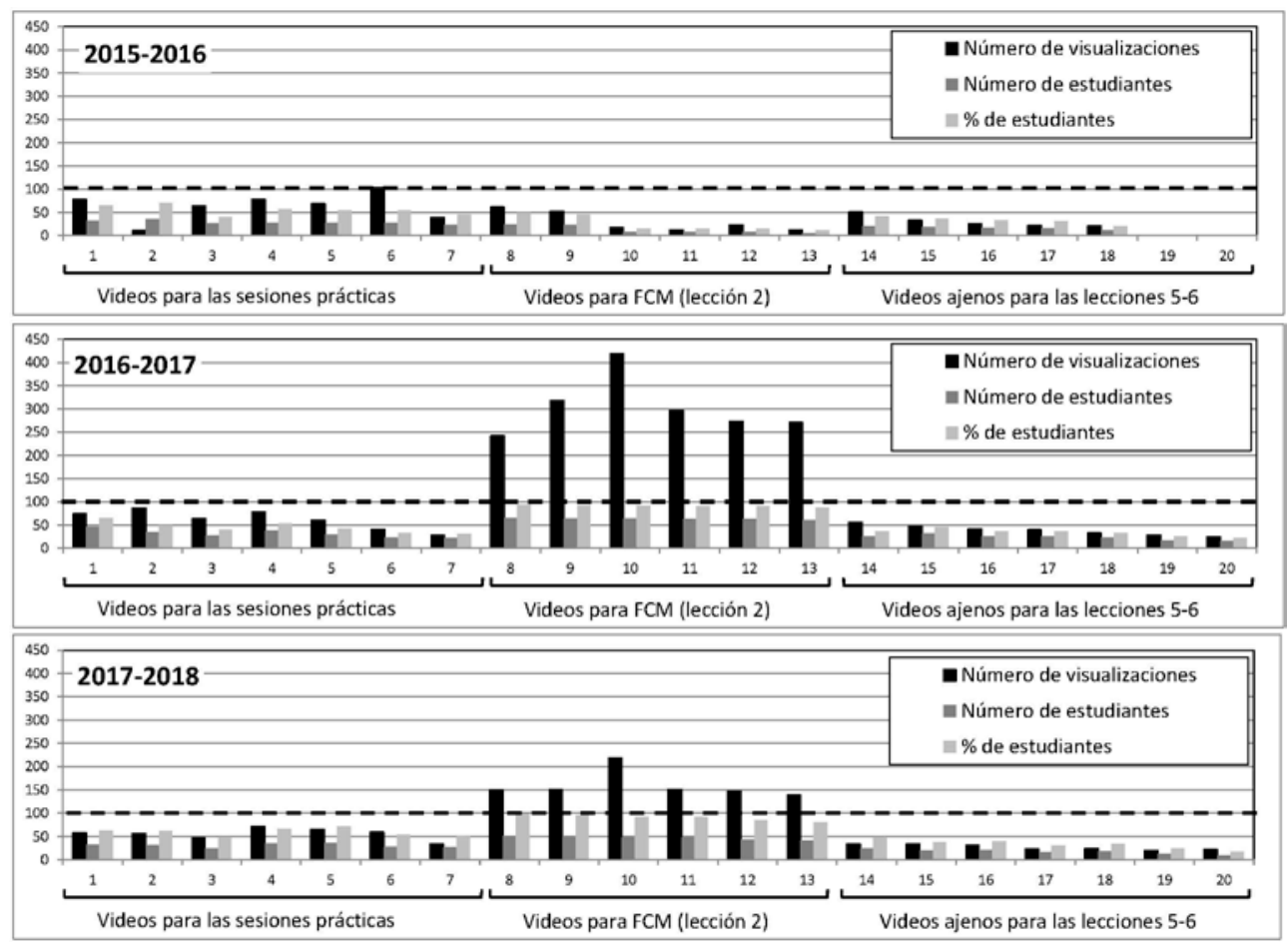

Fig. 2 Uso de los videos docentes.

Por ser de una escala mucho menor, no se ha representado el número de visualizaciones por alumno en la figura anterior. Los datos para cada bloque de videos (B1-prácticas, B2-FCM y B3-ajenos) se recogen en la Tabla 2:

Tabla 2. Resumen sobre la visualización de videos docentes

\begin{tabular}{ccccccc}
\hline \multirow{2}{*}{ Curso } & \multicolumn{3}{c}{ Estudiantes (\%) } & \multicolumn{3}{c}{ Vistas/alumno } \\
& B1 & B2 & B3 & B1 & B2 & B3 \\
\hline $2015-2016$ & 55,54 & 25,49 & 23,53 & 1,24 & 1,10 & 0,60 \\
$2016-2017$ & 45,20 & 91,67 & 34,08 & 0,89 & 4,34 & 0,56 \\
$2017-2018$ & 59,62 & 90,71 & 33,24 & 1,07 & 3,07 & 0,52 \\
\hline
\end{tabular}

Durante el primer curso, los videos más vistos fueron los destinados a prácticas. Por el contrario para los dos últimos cursos, aunque se mantienen niveles parecidos en el bloque B1, los videos más vistos fueron los de la lección 2. El porcentaje de alumnos que han visto los videos del bloque B2 es similar en los cursos 2016-2017 y 2017-2018, pero el número de visualizaciones ha disminuido en un $30 \%$ en el último curso, a pesar de tener asociado un cuestionario para ser respondido a continuación. 
Los videos del tercer bloque han mantenido cifras muy similares durante los tres cursos analizados. Aunque son videos de gran calidad y el profesor los considera de gran interés para los temas finales, los alumnos hacen un bajo uso de los mismos. El hecho de que estén desarrollados por un profesor externo a la Universidad de Zaragoza parece dar la impresión de que son complementarios, no esenciales para la asignatura.

Para el presente curso se han desarrollado cuestionarios específicos que le sirvan a estudiante para saber si ha aprendido lo más importante de cada video. Para este primer año, hay un cuestionario por cada dos videos de contenido relacionado y su resolución es requisito imprescindible para acceder a los videos siguientes. En la siguiente tabla se resume la actividad recogida a este respecto. La notación utilizada es la siguiente: Estudiantes, I-ntentos, T-iempo.

Tabla 3. Resumen sobre los cuestionarios asociados a cada video para el curso 2017-2018

\begin{tabular}{ccccc}
\hline Curso & E (\%) & I/E & T/I (min) & Nota media \\
\hline Videos 1-2 & 96,2 & 1,2 & 9 & 8,3 \\
Videos 3-4 & 88,5 & 1,1 & 10 & 9.2 \\
Videos 5-6 & 76,9 & 1,1 & 9 & 9,8 \\
\hline
\end{tabular}

A priori, un elevado porcentaje de alumnos ha completado al menos una vez el cuestionario, obteniendo una nota elevada. Dado que no había videos posteriores, no existía ninguna medida coercitiva para la realización del último cuestionario, reduciéndose el porcentaje de estudiantes que accedieron a él.

\subsection{Cuestionarios de evaluación}

Los cuestionarios de evaluación consisten en un conjunto de preguntas de diversos tipos (verdadero/falso, elección múltiple, calculadas) cuya nota promedio constituye un 5\% de la nota final. En los tres cursos analizados, el alumno dispone de 3 intentos contándose únicamente la nota del último. Durante los dos primeros cursos analizados, tras cada intento el alumno podía ver la calificación final pero no la puntuación de cada pregunta. A petición de los estudiantes esto se modificó para el presente curso, pudiéndose ver ahora si una respuesta es o no correcta tras completar cada intento. El número de preguntas y cuestionarios se ha ampliado con el tiempo, de ahí que con fines comparativos se haya calculado el tiempo dedicado por pregunta. 
Tabla 4. Resumen sobre los cuestionarios de evaluación

\begin{tabular}{cccccc}
\hline Curso & E (\%) & I/E & T/I (min) & T/P (min) & Nota media \\
\hline $2015-2016$ & 71,4 & 1,7 & 24 & 2,4 & 5,3 \\
$2016-2017$ & 73,3 & 1,7 & 22 & 1,9 & 6,6 \\
$2017-2018$ & 77,4 & 1,8 & 15 & 1,0 & 7,3 \\
\hline
\end{tabular}

En la Tabla 4 se ha utilizado la siguiente notación: E-studiantes, I-ntentos, T-iempo, Pregunta. Puede verse que la participación en esta actividad en cuanto a la proporción de estudiantes y al número de intentos es similar en todos los cursos. Sin embargo, el tiempo dedicado a su resolución ha disminuido con el tiempo, a la vez que ha aumentado considerablemente la nota media. Esto puede deberse en cierta medida a que ahora pueden saber si una respuesta es correcta o no tras cada intento. Aunque en ciertas preguntas hay una pequeña penalización por respuesta incorrecta, no se aplica a todas ellas y puede contribuir a conseguir una calificación más alta.

\subsection{Cuestionarios de autoevaluación y otros recursos de feedback}

Los cuestionarios de evaluación se convierten en herramientas de autoevaluación para que el alumno los realice tantas veces como considere oportuno. Siguiendo la notación de tablas anteriores, en la Tabla 5 se recoge el número total de intentos, el porcentaje de estudiantes que ha realizado al menos un intento y el promedio de intentos por alumno.

Tabla 5. Resumen sobre los cuestionarios de autoevaluación

\begin{tabular}{cccc}
\hline Curso & I & E (\%) & I/E \\
\hline $2015-2016$ & 303 & 29,9 & 2,5 \\
$2016-2017$ & 285 & 35,3 & 1,6 \\
$2017-2018$ & 140 & 25,2 & 1,3 \\
\hline
\end{tabular}

El número de intentos ha ido disminuyendo con el tiempo, así como parece estar disminuyendo también el porcentaje de alumnos que los resuelve. Esto puede deberse a fluctuaciones naturales entre grupos de estudiantes diferentes, pero también puede ser que el aumento en las actividades obligatorias en la asignatura reduzca el interés por recursos de uso no obligatorio.

A partir del curso 2016-2017, junto con la calificación de cada trabajo tutorado se cuelga un resumen de los errores más comunes/importantes detectados en las diferentes entregas. A pesar de los recordatorios enviados por el profesor, estos documentos han tenido una baja acogida por parte de los estudiantes. Tan sólo un $27 \%$ de los estudiantes lo consultó en el curso 2016-2017 y un 18\% en el curso actual.

(c)) EY-NC-ND 2018, Universitat Politècnica de València

Congreso In-Red (2018) 


\subsection{Comparativa de resultados}

Una vez presentada la información obtenida de la plataforma Moodle, se quiere discutir en este apartado final su posible uso para correlacionar o predecir con dicha información los resultados en el examen final. En la siguiente tabla se recoge el número de estudiantes matriculados en cada curso, las calificaciones promedio en diferentes actividades y el porcentaje de estudiantes aprobados en la primera convocatoria.

Tabla 6. Comparación de resultados de aprendizaje

\begin{tabular}{lccc}
\hline Curso & 2015-2016 & 2016-2017 & 2017-2018 \\
\hline Número de alumnos matriculados & 42 & 69 & 52 \\
Nota en cuestionarios de Moodle & 5,3 & 6,6 & 7,3 \\
Nota de trabajos tutorados & 6,8 & 7,4 & 7,7 \\
Nota media del examen final & 6,5 & 6,2 & 6,4 \\
Estudiantes presentados (\%) & 90,7 & 91,3 & 90,4 \\
Estudiantes aprobados (\%) & 48,7 & 66,7 & 45,8 \\
\hline
\end{tabular}

La nota media de los estudiantes aprobados es muy parecida durante los tres cursos académicos, así como el porcentaje de alumnos presentados, que es muy elevado. Las calificaciones en los cuestionarios de Moodle y en los trabajos tutorados ha ido aumentando en cada curso, pero no ha ocurrido lo mismo con el porcentaje de éxito en el examen final. En el curso 2016-2017 la tasa de aprobados supera en prácticamente 20 puntos porcentuales a los otros dos grupos.

\section{Conclusiones}

Revisando los datos presentados sobre la actividad en Moodle, se puede relacionar la tasa de éxito con ciertos indicadores de buen uso de los recursos recomendados por el profesor.

- Para el curso 2016-2017 se observa un uso continuado y estable, sin picos al comienzo o al final del cuatrimestre.

- El número de visualizaciones de los vídeos de la lección 2 es más alto durante este curso, a pesar de que dicho año no se encontraban disponibles los cuestionarios para afianzar lo aprendido con cada video.

- Con respecto a los cuestionarios de evaluación, el tiempo dedicado a cada pregunta se ha reducido desde $2.4 \mathrm{~min}$ hasta $1.0 \mathrm{~min}$, pero la nota media ha subido 2 puntos. Teniendo en cuenta los resultados del examen, podría decirse que han existido malas prácticas durante la realización de los mismos. Igual que se han detectado muchos más casos de copia fraudulenta en los trabajos tutorados durante el presente curso, podría pensarse que ha ocurrido lo mismo en los cuestionarios de evaluación de la parte teórica.

(cc) EY-NC-ND 2018, Universitat Politècnica de València

Congreso IN-RED (2018) 
- En cuanto a los cuestionarios de autoevaluación, el porcentaje de estudiantes que realizó al menos un intento es superior en 10 puntos porcentuales durante el curso 2016-2017, aunque el número de intentos por estudiante es menor que en el curso previo.

- También la consulta de los errores frecuentes en los trabajos tutorados fue superior durante el curso 2016-2017 en 10 puntos porcentuales con respecto al curso actual.

Hay que añadir que existen factores externos a la asignatura que influyen notablemente en la dedicación del estudiante y que pueden variar de un curso a otro, pero que no son completamente conocidos por el profesor y de ninguna manera controlables por él. La existencia de exámenes intermedios y de entrega de trabajos exigentes hace que descienda notablemente la asistencia a clase y el seguimiento continuo de la asignatura.

De todo esto, se pueden obtener varias conclusiones:

- Conviene reducir las posibilidades de copia en los cuestionarios de evaluación, reduciendo por ejemplo el número de intentos, eliminando la opción de saber si una pregunta es correcta, limitando el tiempo para su resolución o seleccionando preguntas de forma aleatoria de un banco de preguntas.

- Para un mejor aprovechamiento de las sesiones de prácticas, será útil realizar una breve evaluación (diferente para cada grupo de prácticas) al comienzo de la sesión, pudiendo realizar la práctica únicamente los alumnos que realmente la han preparado.

- Sobre los trabajos tutorados, el uso de formularios para introducir los resultados durante este curso para automatizar la corrección, parece haber fomentado la copia fraudulenta, ya que se han detectado bastantes más casos que en el curso anterior. Convendrá tomar medidas coercitivas o diseñar casos múltiples (aunque es complicado implementar preguntas múltiples calculadas en Moodle) para reducirlo, ya que este comportamiento sólo le proporciona al alumno una falsa sensación de llevar bien la asignatura y reduce su tasa de éxito en el examen final.

- Aunque realmente no es el cometido del profesor, parece necesario recordar al estudiante la utilidad de recursos como videos, cuestionarios de autoevaluación o resúmenes para realizar un aprendizaje significativo y eficaz.

- Implementar una evaluación por rúbricas para que el estudiante tenga claros sus avances en el curso, puede ser motivador pero hay que encontrar una forma eficiente de gestionarlas, ya que la herramienta de Moodle no es una opción asumible en grupos tan grandes como los que existen en este grado (Peña, 2018).

Para finalizar, cabe señalar que el estudio resultaría más eficaz a efectos de predicción de la tasa de éxito si el análisis de los datos se hubiera realizado por estudiante, en lugar de utilizar valores promedio. Sin embargo, esta tarea es muy costosa si no se dispone de herramientas que automaticen el análisis. En este sentido, resultará útil disponer en próximos cursos de la nueva versión Moodle 3.4 que incorpora un módulo de analíticas del aprendizaje (Moodle, 2018). 
Uso de recursos y rendimiento en las actividades evaluación: análisis y comparación de resultados en el Grado en Ingeniería de Tecnologías Industriales

\section{Referencias}

BOYER, A. y BONNIN, G. (2016) Higher Education and the Revolution of Learning Analytics. Report of the International Council for Open and Distance Education (ICDE). Disponible en: $<$ https://icde.memberclicks.net/assets/RESOURCES/anne_la_report\%20cc\%20licence.pdf> [Consulta: 15 de marzo de 2018].

FERGUSON, R., et al. (2016). Research Evidence on the Use of Learning Analytics - Implications for Education Policy. R. Vuorikari, J. Castaño Muñoz (Eds.). Joint Research Centre Science for Policy Report; EUR 28294 EN; doi:10.2791/955210.

MOODLE (2013). Course overview report. Documentación de Moodle.org. $<$ https://docs.moodle.org/25/en/Course_overview_report > [Consulta: 9 de marzo de 2018].

MOODLE (2018). Analytics. Documentación de Moodle.org. $<$ https://docs.moodle.org/34/en/Analytics> [Consulta : 15 de mayo de 2018].

PEÑA, B. et al. (2017a) "Pilot experience for the application of the flipped classroom in subjects of the field of Thermal Engineering”. En: INTED17 Proceedings of the $11^{\text {th }}$ annual International Technology, Education and Development Conference, Valencia, IATED Academy, pp. 3601-3610. Doi: 10.21125/inted.2017.0887.

PEÑA, B. et al. (2017b) “Experiencia piloto de aula invertida para mejorar el proceso de enseñanzaaprendizaje en la asignatura de Termodinámica Técnica”. En: Actas del congreso INRED 2017, Valencia, Editorial Universitat Politècnica de València. Doi: 10.4995/INRED2017.2017.6868. Disponible en: < http://ocs.editorial.upv.es/index.php/INRED/INRED2016/paper/view/4430>.

PEÑA, B. (2018) “Defining quantitative and automated rubrics from assessment activities scores” En: INTED18 Proceedings of the $12^{\text {th }}$ annual International Technology, Education and Development Conference, Valencia, IATED Academy, pp. Doi:

SCLATER N., PEASGOOD A. y MULLAN J. (2016) "Learning Analytics in Higher Education: A review of UK and international practice” Full Report: JISC. Disponible en: $<$ https://www.jisc.ac.uk/reports/learning-analytics-in-higher-education> [Consulta:11 de marzo de 2018].

ZABALZA, I., PEÑA, B., LLERA, E.M. y USÓN, S. (2016) "Improving the teaching-learning process using educational videos as reusable learning objects in the field of thermal engineering”, Proceedings of the $8^{\text {th }}$ International Conference on Education and New Learning Technologies (EDULEARN 2016), Barcelona, IATED Academy, pp. 363-372. Doi: 10.21125/edulearn.2016.1068.

ZABALZA, I., et al. (2017) "Development of educational videos as reusable learning objects for their integration into an Open Courseware on fundamentals of thermodynamics and thermal engineering”, En: INTED17 Proceedings of the $11^{\text {th }}$ annual International Technology, Education and Development Conference, Valencia, IATED Academy, pp. 4453-4461. Doi: 10.21125/inted.2017.1055.

WANLI X., RUI G., EVA P. y SEAN G. (2015) "Participation-based student final performance prediction model through interpretable Genetic Programming: Integrating learning analytics, educational data mining and theory" Computers in Human Behavior 47 (2015) 168-181.

(cc) EY-NC-ND 2018, Universitat Politècnica de València

Congreso IN-RED (2018) 


\title{
Detección de copiones con "pinganillos magnéticos" y experimentos sobre magnetismo
}

\author{
Ismael Ripoll $^{1}$, Hector Marco-Gisbert ${ }^{2}$, Víctor Martinez-Fernandez ${ }^{1}$ y \\ Pedro Gil ${ }^{1}$ \\ ${ }^{1}$ Universitat Politècnica de València. [\{iripoll,vicmarfe,pgil\}.upv.es] \\ ${ }^{2}$ University of the West of Scotland. [Hector.Marco@uws.ac.uk]
}

\begin{abstract}
Technological advances affect to all fields of the society, which includes the methods used by some individuals cheat on exams. This work presents an effective detection system against the well known invisible earpiece cheating gadget. In addition to the main use for which the detector has been designed, the project also serves as a demonstrator (in laboratory activities) of the basic principles of electromagnetism and electronics. Which, in turn, will server as a deterrent against possible cheaters by demonstrating how ease they can be discovered.
\end{abstract}

Keywords: examn, cheating, handset, magnet.

\section{Resumen}

Los avances tecnológicos se aplican a todos los campos de la sociedad, incluyendo los métodos utilizados por algunos individuos para copiar en los exámenes. Este trabajo presenta un efectivo sistema de detección contra el sistema de copia conocido comúnmente como pinganillos magnéticos o invisibles. Aparte del uso principal para el que ha sido diseñado el detector, el proyecto también sirve como demostrador (en sesiones de laboratorio) de los principios básicos de electromagnetismo y electrónica. Lo que a su vez, servirá como medida disuasoria contra posibles copiones al demostrar la facilidad con la que pueden ser descubiertos.

Keywords: examen, copia, auricular, imán. 


\section{Introducción}

En los últimos años estamos asistiendo a un aumento del número de actuaciones irregulares en los actos de evaluación por parte de los alumnos (Adams 2018; Pascual 2015). Al igual que la mayoría de problemas de índole social, no es lógico atribuirlos a una única causa, sino que es la combinación de la múltiples factores. Sin ánimo de ser exhaustivos $^{1}$, podemos citar entre otros: la falta de sanciones, la pérdida de autoridad de los docentes, pero sobre todo, la mejora de las técnicas de copia.

Una rápida búsqueda en internet nos permite apreciar la magnitud del problema:

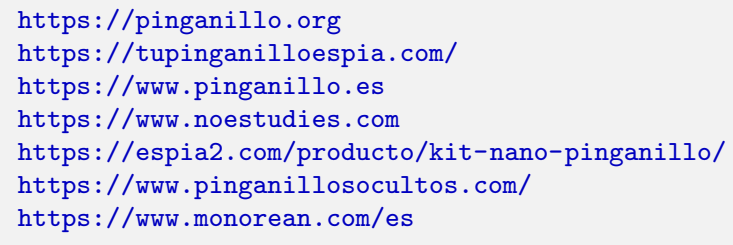

En este trabajo nos centraremos en solventar el retraso tecnológico que parece existir por parte de los docentes. En concreto, daremos una solución a lo que se conoce como la técnica del pinganillo magnético, que según se anuncia en multitud de web es el método de copia perfecto: "Los pinganillos que en esta pagina web son TODOS ABSOLUTAMENTE INDETECTABLES"2 . Como se puede apreciar, el nivel gramatical y científico de estos vendedores está a la par que el de sus clientes.

Demostraremos que es posible detectarlos mediante un sencillo dispositivo electrónico de fácil construcción. También presentaremos el marco legal que nos permitirá utilizar el detector con seguridad jurídica.

\section{Terminología}

La RAE define el término "pinganillo" como "carámbano (pedazo de hielo)". Pero comúnmente se utiliza para referirse al artefacto que se coloca bien en el exterior de la oreja o bien en el conducto auditivo con el fin de reproducir sonido, y que no cuenta con conexión física con otros elementos exteriores. Por otra parte, Pinganillo ${ }^{\circledR}$ es una marca registrada cuyo titular es Hernando de Liñan Eduardo Jose, para referirse en exclusiva a la gama de auriculares inalámbricos que comercializa. En adelante, para evitar confusiones con los productos de este fabricante, utilizaremos "pinganillo magnético" para referirnos a los dispositivos objeto de este estudio.

Utilizaremos el término "copión" para referirnos al individuo que trata de superar una prueba de evaluación mediante engaños. Es comprensible que algunos alumnos sientan la tentación de mejorar sus notas recurriendo a pequeños engaños cuando las circunstancias lo permiten y de forma esporádica. Pero la compra de material, la logística de uso y la determinación necesarias para la copia con auriculares sitúan a estos individuos fuera de la categoría de alumno o estudiante.

\footnotetext{
${ }^{1} \mathrm{Ni}$ posiblemente acertados.

${ }^{2}$ Frase literal de la web: http://pinganillomania.es/preguntas-frecuentes/
} 
Por economía del lenguaje, utilizaremos el término examen para referirnos a cualquier acto de evaluación en el que el alumno deba realizar una prueba por sí mismo sin ayuda de terceros.

Aparte del cambiazo o la suplantación de identidad, donde la prueba la realiza otro individuo, la "copia" requiere que el copión reciba información desde el exterior de su cerebro. Los canales principales son el oído y la vista. Las chuletas, el examen de un compañero, las anotaciones en la mesa, en las manos, mirar el móvil o más recientemente, el reloj inteligente, son los métodos visuales más usados. Por otra parte, los métodos que usan el canal auditivo, por lo general, necesitan de la colaboración de un "compinche" que esté cerca del copión. Es aquí donde la tecnología entra en juego para ampliar notablemente las posibilidades.

Finalmente, llamaremos "cuidador" al profesor o ayudante responsable del correcto desarrollo del examen.

\section{Copia con auricular inalámbrico}

Actualmente el copión ya no necesita disponer de una posición privilegiada cerca del compinche más espabilado. Utilizando dispositivos electrónicos camuflados dentro del oído es posible recibir ayuda de muy buena calidad desde el exterior. Varios compinches con acceso a internet y toda la documentación de la asignatura, permiten asegurar una buena nota al copión.

El pinganillo magnético requiere los siguientes elementos:

1. Enunciado del examen en manos del compinche.

2. Comunicación desde el exterior del examen al interior: intercomunicador.

3. Comunicación desde el intercomunicador al oído del copión.

4. (Opcional) Elemento de retorno o de salida desde copión hacia el compinche.

La principal limitación de los pinganillos magnéticos es que son unidireccionales. El copión puede escuchar las respuestas del compinche, pero no puede exfiltrar información con facilidad. Por regla general, el compinche necesita tener el enunciado del examen, cosa que se puede conseguir de distintas formas dependiendo de las normas del examen y/o las capacidades económicas de los copiones: un compinche podría sacar las preguntas del examen, abandonando o finalizando la prueba con antelación; existen bolígrafos con cámara bluetooth que se pueden conectar al móvil, otro método equivalente, pero más burdo y arriesgado es hacer fotos con el móvil; también está la posibilidad de utilizar un micrófono (bien en la manga o en un bolígrafo por bluetooth) que podría utilizar el copión, pero evidentemente no es la mejor opción. El micrófono es útil para sincronizar al copión con el compinche pero no para dictar el enunciado del examen.

La copia con pinganillo magnético permite que un solo compinche dicte las respuestas a múltiples copiones. Esto aumenta el rendimiento del sistema. Desde un punto de vista organizativo la copia con pinganillo requiere de:

- Uno o más copiones. 
- Un compinche que saque el examen, o algún método de extracción electrónica del examen.

- Un compinche que resuelva y transmita el examen.

El compinche que extrae el examen y el que lo resuelve podrían ser la misma persona. En este caso, dispondría de bastante menos tiempo para responder a su propio examen, en caso de tener que aprobarlo.

La comunicación desde el exterior hacia los copiones se suele hacer con un teléfono móvil. También se podría usar una pareja de walkie talkies, pero es una opción mucho menos flexible y cara. En adelante asumiremos que se utilizan móviles.

Queda por resolver el problema de la comunicación entre el móvil y el oído del copión. Evidentemente, utilizar un auricular con cable no es una opción aceptable. Existen dos opciones inalámbricas:

Radio: El auricular miniaturizado contiene un receptor de radio, una batería y un altavoz. Los más utilizados son los bluetooth. A pesar del alto grado de miniaturización, este tipo de auriculares se denominan "semi-invisibles" porque una parte queda visible desde el exterior del conducto auditivo.

Imán de neodimio: Este dispositivo no es realmente un auricular, sino una parte de un altavoz convencional. Este dispositivo sí que es completamente invisible desde el exterior.

A diferencia de los otros métodos de copia, que son principalmente individuales, el uso de pinganillos necesita de un grupo coordinado. Cuanto más numeroso sea el grupo mayor será la tasa de aprobados y mejor nota sacarán en conjunto.

En este trabajo asumimos que el examen requiere que el alumno elaboré las respuestas, como así sucede en la mayoría de las materias tecnológicas, incluso en ocasiones se permite llevar apuntes o libros. Por otra parte, en exámenes donde se ponga a prueba la capacidad de retención memorística, el copión podría grabar todos los temas en distintas pistas o ficheros y acceder secuencialmente con un pequeño botón camuflado, por lo que no necesitaría al compinche. En cualquier caso, el dispositivo de detección que se presenta sirve tanto si se necesita compinche como si no.

\section{Pinganillos de imán}

El altavoz dinámico o (de bobina móvil) es, con diferencia, el tipo de transductor acústico más utilizado; es económico, eficiente, compacto y robusto. La figura 1 muestra todos los elementos de un altavoz.

Por regla general, el imán se fija a la carcasa, este bloque debe tener una gran inercia mecánica, esto es, no deben moverse; mientras que la bobina está unida solidariamente a la membrana, ambos se pueden mover libremente respecto al imán fijo. Cuando se hace pasar una corriente por la bobina, está induce un campo magnético con la consiguiente fuerza de repulsión o atracción respecto del imán fijo. La membrana recibe ese movimiento y lo transforma en ondas de presión, sonido. 


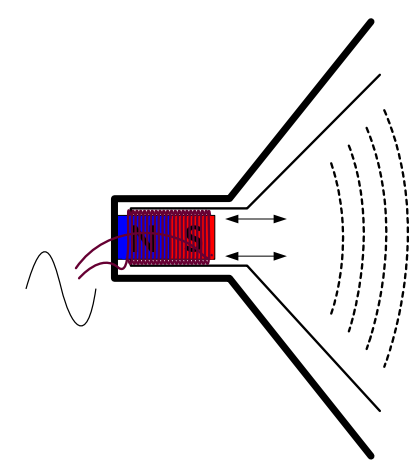

Fig. 1: Esquema de un altavoz

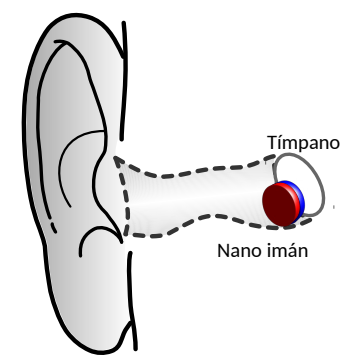

Fig. 2: Imán en el canal auditivo.

El funcionamiento de un pinganillo magnético es similar al del altavoz dinámico, pero en lugar de ser la bobina el elemento móvil (siendo el imán el que queda fijo), es el imán el que se mueve respecto una bobina fija. El imán se coloca dentro del canal auditivo en contacto o muy próximo al tímpano (ver figura 2); la bobina se coloca lo más cerca posible del oído pero en un lugar que se pueda camuflar fácilmente, como puede ser el cuello del copión o debajo de la mesa. Puesto que el imán está en contacto directo con el tímpano, el más mínimo movimiento del imán será detectado por el oído.

Como se puede apreciar en la figura 3, el imán es un cilindro de 1x2mm, aunque también se puede utilizar de mayor tamaño. Se pueden adquirir este tipo de imanes por internet en lotes de 100 unidades por menos de un euro (aunque la calidad de los mismos deja mucho que desear). Son preferibles los imanes niquelados, un poco más caros pero mucho más resistentes a la oxidación.

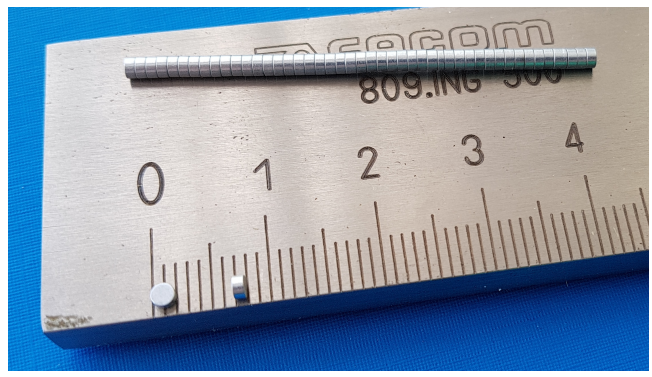

Fig. 3: Foto del imán de neodimio.

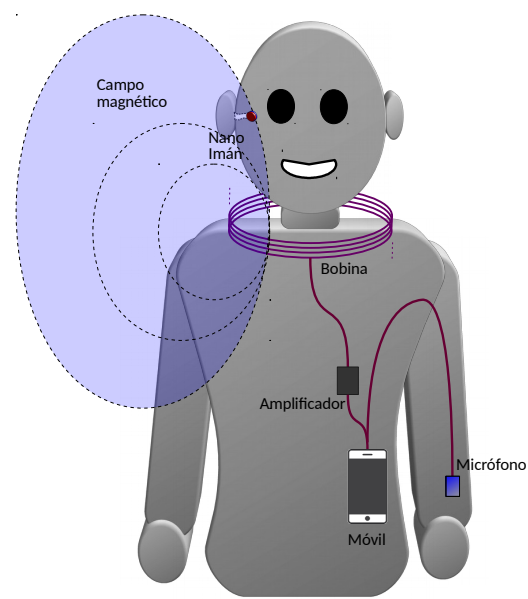

Fig. 4: Instalación del dispositivo para copiar.

La figura 4 representa una posible instalación del equipo completo. Toda la instalación se realiza por debajo de la ropa con lo que es imposible ver o escuchar desde el fuera. Esta es la principal diferencia entre el pinganillo de imán y el resto de auriculares (bluetooth y radio), y lo que los hace tan atractivos para la copia. 


\section{Contramedidas}

En esta sección presentaremos las opciones que tienen los cuidadores de los exámenes para detectar estos timos.

\section{Confiscar los móviles}

Puesto que el móvil está conectado a varios elementos distribuidos por el cuerpo del copión, el móvil está escondido en algún bolsillo interior. Por tanto, recoger los móviles o incluso las mochilas durante el examen es completamente inútil, a no ser que se pueda "cachear" a los sospechosos. Claramente, un cacheo es una medida extraordinaria de difícil implementación y de todavía más dudosa legalidad.

\section{Confiscar los bolígrafos}

Aunque no es el objeto central de este trabajo, es recomendable observar los bolígrafos utilizados por los alumnos. Siempre podemos llevarnos unos cuantos bolis BIC ${ }^{\circledR}$ para dárselos a los sospechosos a cambio de los bolígrafos que estén utilizando. Esto nos permitiría estudiarlos detenidamente sin interrumpir la realización del examen. En cualquier caso, recordemos que los bolígrafos con cámara o micrófono son elementos accesorios para el uso de los pinganillos magnéticos.

\section{Inhibición de señal del teléfono móvil}

La siguiente idea que se suele barajar es bloquear la comunicación del teléfono móvil, esto es, utilizar inhibidores de señal móvil. Estos dispositivos emiten señales en las bandas utilizadas por la red de telefonía que interfieren e impiden la comunicación entre el terminal y la estación base.

Esta medida se utilizó en varias universidades (ABC 2013), pero por desgracia, es ilegal (Cid 2016) y tuvo que ser retirada. Las bandas de frecuencias utilizadas para la telefonía móvil están alquiladas a las operadoras, y solo ellas pueden utilizarlas. La cuestión quedó zanjada en el informe que el Ministerio del Interior publicó al efecto (Trueba 2010):

"Los dispositivos inhibidores de frecuencia sólo pueden ser usados por las Fuerzas y Cuerpos de Seguridad y Administraciones Públicas autorizadas, por lo que, en la actualidad, todos aquellos que se estén utilizando fuera de esta excepción, y sin la autorización expresa de la Secretaría de Estado de Telecomunicaciones, se encuentran al margen de la legislación vigente, pudiendo aplicarse, en consecuencia, previa denuncia, el correspondiente régimen sancionador por parte del organismo competente." 


\section{Interferencia de baja frecuencia}

Otra opción consiste en bloquear la señal magnética para que no pueda excitar (mover) el imán del oído. De forma similar a cómo funcionan los inhibidores de señal móvil, podríamos generar una señal de ruido magnético en la misma banda que la generada por la bobina del copión.

El resultado de nuestra señal solo sería percibido por el copión. Nadie más, ni el propio cuidador del examen que está operando el dispositivo de interferencia, podría apreciar qué está oyendo el copión. Lo cual supone un grave problema. El imán del copión está en contacto con el tímpano y un campo magnético excesivamente potente podría dañarlo irreversiblemente. Por otra parte, aún siendo capaces de ajustar la potencia de la interferencia generada, tanto la disposición del imán dentro del oído, como la distancia entre nuestro emisor a su imán producen una gran variación en la intensidad de la señal que llega al oído del copión.

Evidentemente, esta contramedida queda descartada.

\section{Detección}

Llegamos a la opción de detección perfecta. El objetivo consiste en "escuchar" la misma señal que excita el imán del copión. El desarrollo completo de esta solución se presenta en la siguiente sección.

\section{Detección de pinganillos magnéticos}

La idea es utilizar una bobina, que hace la función de antena, conectada a un pequeño amplificador de señal de baja frecuencia, a cuya salida se conecta un auricular o un altavoz. Dada la relativamente elevada potencia de emisión que necesita la bobina del copión y la posibilidad de acercarnos tanto como queramos al mismo, el diseño de la bobina detectora y el amplificador admiten amplios margenes de tolerancia.

A continuación se propone el diseño de un amplificador con componentes discretos que funciona satisfactoriamente. Pero queda a la libertad del lector modificarlo para adaptarlo a los recursos que tenga disponibles.

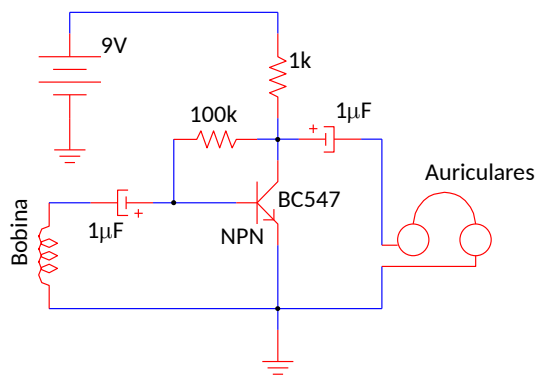

Fig. 5: Esquemático del detector.

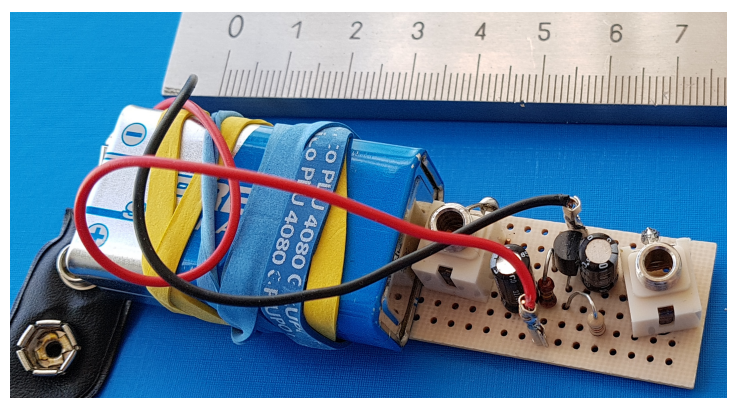

Fig. 6: Circuito soldado sobre placa perforada para prototipos.

Los condensadores son para eliminar la componente de continua y para evitar cortocircuitar la entrada del transistor, dada la baja impedancia de entrada que tiene 
la bobina (por las pocas espiras que tiene). Cualquier par de condensadores a partir de $1 \mu F$ servirán. Igualmente, se puede utilizar cualquier transistor NPN con una ganancia por encima de $\beta=100$. Dado el reducido número de componentes y la sencillez del circuito, este se puede realizar directamente sobre una placa perforada para prototipos, sin necesidad de preparar una $\mathrm{PCB}$, tal como se muestra en la figura 6 .

La bobina (figura 7) es de hilo esmaltado a partir de $0.2 \mathrm{~mm}$ de grosor; el número de espiras puede estar comprendido entre 30 y varios cientos; con un diámetro de entre 3 y $10 \mathrm{~cm}$. Cuanto mayor sea el número de espiras mayor será la sensibilidad, en especial a las frecuencias altas. La cantidad total de cable necesaria no es muy grande, y se puede obtener fácilmente de un transformador estropeado. Incluso es posible utilizar directamente el devanado de entrada de un transformador de $220 \mathrm{v}$.

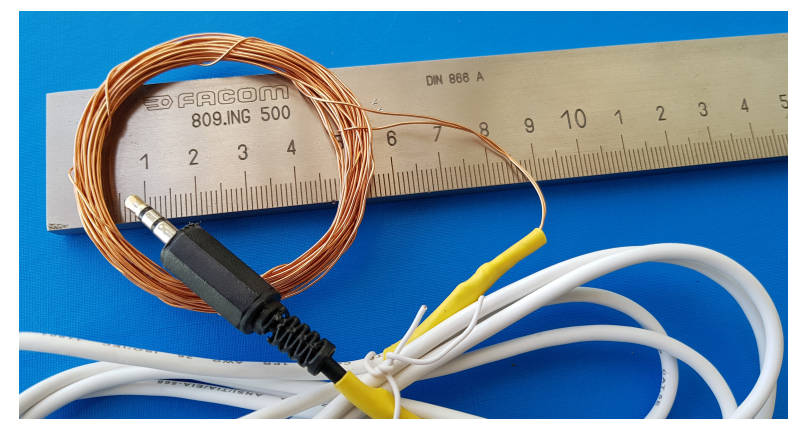

Fig. 7: Detalle de la bobina detectora.

Este circuito detector (bobina y amplificador) es completamente pasivo en lo relativo a la emisión de campos magnéticos. Por tanto, no puede genera ninguna interferencia con ningún equipo electrónico ni orgánico. Es totalmente seguro para la salud de cualquiera que lo utilice.

\section{Instalación y operativa}

Para poder detectar el campo magnético creado por la bobina del copión, el cuidador debe situar la bobina detectora a una distancia de entre $20 \mathrm{~cm}$ y 2 metros (dependiendo del número de espiras). Para poder discriminar con facilidad la procedencia de la señal y distinguir correctamente al copión, es interesante poder mover con facilidad la bobina por el campo creado por el copión. La opción más fácil es situar la bobina de detección en el extremo del brazo, debajo de la manga. Dada la baja frecuencia de la señal, el cuerpo humano no produce ninguna interferencia importante. Recordemos hay que mantener la bobina de detección en el mismo plano que la bobina del copión para que sea atravesada por el máximo número de líneas de campo.

Otro elemento a tener en cuenta es que cuando no hay campo magnético no se escucha nada (quizás un poco de estática). Por tanto no es posible identificar si se ha desconectado algún cable (la batería, la bobina detectora o el auricular) o es que no hay ningún copión. La solución pasa por acercar la mano (bobina) a un interruptor de la luz. La red eléctrica opera a $50 \mathrm{~Hz}$ (en España), y los cables de potencia no están apantallados, por lo que radian una pequeña señal de baja frecuencia que es detectada 


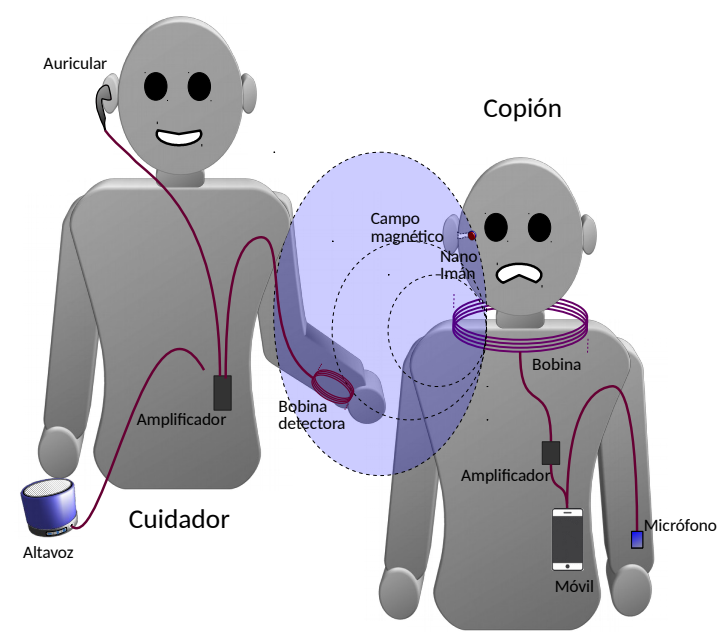

Fig. 8: Instalación del dispositivo detector.

fácilmente por nuestro amplificador. Si oímos el clásico zumbido de alterna conforme acercamos la mano, entonces nuestro detector continua funcionando correctamente.

Como se puede observar, es muy sencillo de usar y no supone ninguna interferencia con el normal desarrollo del examen. Tampoco representa mayor problema ni sobrecarga para el cuidador ya que la instalación es trivial.

\section{Toma de pruebas y levantamiento del acta}

En caso de tener un copión entre los alumnos, y haberlo escuchado por el auricular, es necesario levantar un acta lo más completa posible del incidente. A pesar de que a los profesores somos autoridad pública y tenemos la presunción de veracidad (BOE-A2010-15028 2010) en el desarrollo de nuestras labores, es conveniente recoger muestras del hecho. No sería la primer vez que un copión "niega la mayor".

Para ello, nos ayudaremos de un pequeño altavoz a baterías con entrada de audio, que se puede adquirir en cualquier tienda o por internet. En lugar de conectar la salida de nuestro amplificador a los auriculares, lo conectaremos al altavoz para que pueda ser escuchardo claramente por todos los alumnos. Antes de realizar esto, preparamos un grabador de audio (por ejemplo, la aplicación de grabación de nuestro teléfono móvil), y grabamos el sonido que está oyendo el copión a la vez que hacemos una descripción verbal del incidente. Es importante no realizar grabaciones de vídeo para evitar problemas legales (ver sección 6) de captación de imágenes sin autorización. Sin embargo, grabar audio en una situación donde debería reinar el silencio y donde no puede interferir con ninguna actividad privada (los alumnos deben guardar silencio durante la realización de la prueba y son sabedores de ello), es más que razonable de cara a poder exponer el hecho a terceros.

No se debe olvidar tomar nota del nombre del copión y verificar la identidad mediante el DNI o el carné de estudiante.

La toma de muestras es un hecho que por necesidad interrumpe el normal desarrollo del examen. Tener claros los pasos exactos a realizar ayudará a reducir las molestias a 
la clase. En cualquier caso, con una visión más amplia de la educación con mayúsculas, podemos convertir este momento en una excelente lección para todos los alumnos:

1. Los buenos estudiantes aprecien la buena labor de lo cuidadores que velan por una correcta evaluación, impidiendo que individuos de baja moral puedan obtener injustamente mejores notas.

2. Aquellos estudiantes que podrían caer en la tentación de ser copiones, al ver que el delito no queda impune, se lo pensarán dos veces antes de tomar este camino.

Finalmente, en una situación como esta es donde se debe mostrar y demostrar la autoridad del profesorado. No debemos tratar de airear ni minimizar el hecho (más allá de reducir las molestias a los buenos estudiantes). Un exceso de sigilo o cautela, quizás movido por la corrección política ${ }^{3}$, hacia los copiones puede ser entendido como un signo de debilidad o miedo por parte del cuidador.

\section{Limitaciones técnicas y mejoras}

El sistema descrito solo tiene una pequeña limitación, si el copión puede comunicarse con el compinche mediante un pequeño micrófono, entonces puede indicarle que deje de hablar cuando ve que se acerca el profesor. Cuando no hay señal magnética, no se puede detectar nada.

La solución a esta limitación pasa por aumentar el rango de detección del dispositivo, lo que evitaría que el copión supiera si está siendo objeto de análisis o no. Para aumentar el rango de detección se tiene que aumentar la sensibilidad, que se puede conseguir realizando las siguientes modificaciones:

1. Aumentar el número de espiras y el diámetro de la bobina, lo que mejora la sensibilidad.

2. Aumentar la ganancia del amplificador, lo cual se puede conseguir bien mejorando circuito original (añadiendo más componentes o etapas), utilizando un amplificador operacional, o bien utilizando un circuito. Existen multitud del circuitos ya montados y a muy bajo precio basados en el operacional LM368, preparados para utilizar con circuitos Arduino.

3. En caso de tener un amplificador de alta ganancia también sería necesario añadir un filtro pasobanda que solo deje pasar la banda de la voz (entre los $100 \mathrm{~Hz}$ y $\operatorname{los} 4 \mathrm{kHz})$.

\footnotetext{
${ }^{3}$ Lenguaje, ideas políticas o comportamientos con los que se procura minimizar la posibilidad de ofensa a grupos de personas pertenecientes a cierta etnia, cultura, nacionalidad, género o religión...
} 


\section{Aspectos legales}

La Ley Orgánica de Protección de Datos (BOE-A-1999-23750 1999), junto con la nueva RGDP (EU-2016-679 2016), son el marco jurídico que regula los derechos y libertades en relación con nuestros datos personales. El Artículo 6, puntos 1 y 2 de la LOPD indica que:

1. El tratamiento de los datos de carácter personal requerirá el consentimiento inequívoco del afectado, salvo que la Ley disponga otra cosa.

2. No será preciso el consentimiento cuando los datos de carácter personal se recojan para el ejercicio de las funciones propias de las Administraciones Públicas en el ámbito de sus competencias; [...]

La jurisprudencia indica que la imagen (grabación de vídeo) tiene el tratamiento de dato de carácter personal. Así como también lo tienen las comunicaciones electrónicas. Es por ello importante, limitar la captura de datos solo a aquellos que sean estrictamente necesarios para dejar constancia de la infracción. Un exceso de celo en el acopio de pruebas puede acabar en un problema legal para el cuidador por extralimitarse en su obligación de cuidar diligentemente el examen. Recordemos que las sanciones previstas en la LOPD en lo relativo a la violación de los datos personales son (a juicio de los autores) desproporcionadas en relación con otro tipo de delitos. Sin miedo a equivocarnos podemos decir que la LOPD es la norma más garantista de todos de países de la EU.

Por otra parte, recordemos que los profesores tenemos la presunción de veracidad, esto es, nuestras declaraciones en acto de servicio se consideran veraces a no ser que se demuestre lo contrario. Si el examen es vigilado por más de un cuidador, bastará con que otro cuidador ${ }^{4}$ de fe de lo sucedido para tener suficientes elementos probatorios para sancionar al copión de acuerdo a la normativa de cada centro educativo.

Obsérvese que no se aconseja buscar físicamente los dispositivos electrónicos instalados en el cuerpo o mochila del copión. También se podría pensar en tener otro imán de neodimio de mayores dimensiones para realizar la extracción del imán interno. Podemos pensar que tener el imán que estaba alojado en el oído del copión es una prueba irrefutable. Sin embargo no es necesario realizar acciones físicas sobre el copión, ni por otra parte es conveniente molestar en exceso al resto de estudiantes que sí que están realizando el examen con honestidad y corrección; podríamos entrar en el terreno de dimes y diretes con el copión, con el consiguiente alboroto. Hemos de considerar que la catadura moral de los individuos que realizan estas acciones (con toda la preparación y logística necesarias) no es la de un ciudadano modelo. Nos podemos encontrar con respuestas y actitudes chulescas fuera de tono, que en absoluto tienen porqué sufrir el resto de estudiantes. Por otro lado, si el copión considera que necesitamos sus dispositivos de copia para poder acusarlo de copia, entonces creerá que impedir su recogida le asegurará la impunidad.

\footnotetext{
${ }^{4}$ En este paso el cuidador debe tener la categoría de profesor o equivalente para poder ejercer la presunción de veracidad.
} 
En esta línea, podríamos caer en la problemática que existe en los aeropuertos con el equipaje. La normativa dicta que el propietario de una maleta es responsable de su contenido. De forma similar, cada estudiante debe ser responsable de sus emisiones magnéticas.

La cobertura legal que regula las acciones que puede/debe realizar el cuidador es como poco difusa cuando no inexistente. La "Normativa de Régimen Académico y Evaluación del Alumnado Universitat Politècnica de València", Título III, Artículo 1 , punto primero ${ }^{5}$ manifiesta que:

1.- Los alumnos tienen derecho a ser evaluados con garantías de equidad, objetividad y justicia de acuerdo con el nivel de enseñanza impartida.

A pesar de que en el texto se determina que los alumnos tienen derecho a una evaluación equitativa y justa (lo que está en contra de que haya copiones), sería deseable que en la citada normativa se hiciera mención expresa a las obligaciones de los estudiantes respecto a su comportamiento ético, así como la aceptación explícita (en el momento de formalizar la matricula) del uso de medidas de control, proporcionales, para la salvaguarda de la equidad en los exámenes. Tal como marca la LOPD, el consentimiento debe ser: 1) libre, 2) específico, 3) informado y 4) inequívoco. Por lo que se debe introducir en la documentación de matriculación una casilla donde el alumno manifieste (marque afirmativamente) que ha leído, comprende y acepta la normativa de régimen académico y evaluación. Con este formalismo legal, los docentes estaríamos cubiertos por el punto 1 del artículo 6 de la LOPD, lo que a buen seguro reduce el número de posibles problemas con alumnos copiones.

La normativa también debería especificar las sanciones aplicables en función de la gravedad, tal como hacen las universidades más prestigiosas (Stanford University 2018):

Violations of the Honor Code

Examples of conduct that have been regarded as being in violation of the Honor Code include:

- Copying from another's examination paper or allowing another to copy from one's own paper

- Unpermitted collaboration

- Plagiarism

- Revising and resubmitting a quiz or exam for regrading, without the instructor's knowledge and consent

- Giving or receiving unpermitted aid on a take-home examination

- Representing as one's own work the work of another

- Giving or receiving aid on an academic assignment under circumstances in which a reasonable person should have known that such aid was not permitted

\footnotetext{
${ }^{5}$ Un texto similar debe aparecer en la totalidad de las reglamentaciones universitarias.
} 
Sanctions for Violating the Honor Code

In recent years, most student disciplinary cases have involved Honor Code violations; of these, the most frequent arise when a student submits another's work as his or her own, or gives or receives unpermitted aid. The standard sanction for a first offense includes a one-quarter suspension from the University and 40 hours of community service. In addition, most faculty members issue a "No Pass" or "No Credit" for the course in which the violation occurred. The standard sanction for multiple violations (e.g. cheating more than once in the same course) is a three-quarter suspension and 40 or more hours of community service.

La normativa española data de tiempos predemocráticos, concretamente el "Decreto de 8 de septiembre de 1954 por el que se aprueba el Reglamento de disciplina académica de los Centros oficiales de Enseñanza Superior y de Enseñanza Técnica dependientes del Ministerio de Educación Nacional" (BOE-A-1954-17807 1954). El capítulo III, artículos 5 y 6 :

\section{Artículo 5.}

Las faltas de los escolares serán:

a) Graves:

1. Las manifestaciones contra la Religión y moral católicas o contra los principios e instituciones del Estado.

2. La injuria, ofensa o insubordinación contra las autoridades académicas o contra los Profesores.

3. La ofensa grave, de palabra u obra, a compañero, funcionarios y personal dependiente del Centro.

4. La suplantación de personalidad en actos de la vida docente y la falsificación de documentos.

5. La falta de probidad ${ }^{a}$ y las constitutivas de delito.

6. La reiteración de faltas menos graves.

[...] Artículo 6.

Las correcciones aplicables a las faltas de los escolares, serán:

a) De las graves:

1. Inhabilitación temporal o perpetua para cursar estudios en todos los Centros docentes.

2. Expulsión temporal o perpetua de los Centros comprendidos en el Distrito Universitario.

3. Expulsión temporal o perpetua del Centro.

$[\ldots]$

${ }^{a}$ RAE] Probidad: 1. f. honradez.

Un análisis más pormenorizado de las soluciones legales adoptadas por las distintas universidades excedería la extensión y el objeto de este trabajo. El lector interesado puede consultar el interesante artículo (La Información 2016).

\section{Otros usos docentes}

El detector que hemos construido es un amplificador para campos magnéticos de baja frecuencia que convierte la señal magnética en sonido. En el ámbito puramente pedagógico es una excelente herramienta para introducir a los alumnos en el magnetismo. En muchas ocasiones el magnetismo se asocia con el movimiento: motores, dinamos, solenoides que lanzan imanes al conectarlos a una pila, etc. Con este circuito unimos el magnetismo con el sonido lo que permite realizar, entre otros, los siguientes experimentos: 


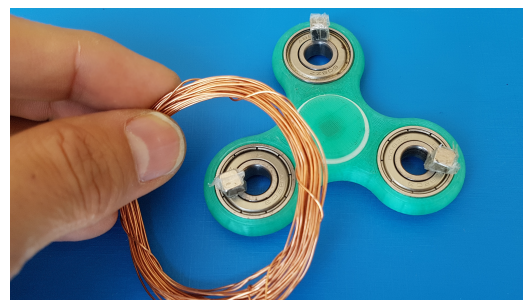

Fig. 9: Spinner con 3 imanes para generar una señal de unos pocos Herzios.

- Escuchar el altavoz de un móvil. Aunque la bobina que forma el altavoz del móvil es pequeña y muy eficiente, no toda la energía magnética que genera se transfiere a la membrana y se transforma en sonido. Una mínima parte de ese campo magnético escapa al exterior del móvil, y ese lo podremos detectar (escuchar). Ponemos el móvil a reproducir una canción y tapamos con un dedo la salida del altavoz interno para reducir la señal sonora; luego ponemos nuestra bobina sobre la zona de móvil donde está el altavoz y podremos escuchar la canción claramente amplificada por nuestro dispositivo.

- Escuchar los cables eléctricos que pasan por dentro de las paredes de los edificios, siempre que haya corriente circulando por ellos. Con solo acercar la bobina a la pared es posible oír perfectamente el campo creado por los cables de la luz. Se puede seguir su recorrido partiendo de un interruptor de luz en dirección ascendente.

- Escuchar las emisiones electromagnéticas de baja frecuencia de todos los aparatos que funcionan con electricidad, un ventilador, el ordenador y todos sus periféricos, los tubos fluorescentes, etc.

- Otra experiencia consiste en producir sonido a partir del movimiento mecánico de imanes. Para ello utilizaremos 3 imanes pequeños y un spinner. Se colocan los 3 imanes en los rodamientos exteriores (ver figura 9), se hace girar el spinner y se acerca la bobina al lateral del spinner. Si la velocidad de giro supera las 10 vueltas por segundo, se podrá escuchar la inducción que produce cada uno de los imanes al pasar cerca de la bobina como pequeños golpes de tambor. Incluso los imanes de mejor calidad (bañados con una gruesa capa de níquel) pueden romperse si chocan con fuerza entre ellos, por lo que es aconsejable envolverlos con cinta adhesiva. Que amortigua los impactos y evita que se desprendan fragmentos.

\section{Conclusiones}

Los avances tecnológicos no tienen ninguna implicación ética por sí mismos, sino por el uso que de ellos se hace. Los nuevos materiales magnéticos (imanes de neodimio) han abierto la puerta a métodos de copia cada vez más sofisticados y difíciles de detectar si no se cuentan con las herramientas necesarias. Este trabajo presenta una eficaz y barata solución contra uno de los métodos de copia más baratos y efectivos, los pinganillos magnéticos. El mismo dispositivo desarrollado se puede también utilizar para mostrar conceptos fundamentales de física. El resultado es un material docente que 
a buen seguro captará la atención de todos los estudiantes. Los "malos" estudiantes al ser descubiertos tratando de copiar en los exámenes y a los "buenos" estudiantes podrán disfrutar de experiencias divertidas y sorprendentes que les permitirán acercarse a materias tan ásperas para algunos como el magnetismo, la electricidad y la electrónica a través del sonido. El bajo coste económico, la facilidad de montaje y la seguridad hacen de este montaje una buena actividad de laboratorio.

También se han presentado los aspectos legales que surgen cuando ciertos individuos (los copiones) tratan de violentar el marco legal y la normal convivencia de la mayoría de los estudiantes. Por regla general, los individuos que optan por copiar en los exámenes suelen ser de una baja catadura moral, por lo que los responsables de la correcta realización de los exámenes deben seguir escrupulosamente la normativa y la legalidad para evitar cualquier tipo de resquicio legal que puedan utilizar los copiones para evitar la sanción.

A los autores nos ha sorprendido el contraste que hay entre el gran interés que despiertan estos temas en los medios de comunicación generalistas, mientras que la comunidad académica parece quedarse al margen: falta de debate, artículos docentes al respecto, normativa institucional, etc. Si queremos salir al paso del grave desprestigio que esta problemática supone en al sistema educativo, en especial a las universidades, debemos abordarlo y resolverlo con seriedad y profesionalidad, en lugar de evitarlo o minimizarlo.

\section{Referencias bibliográficas}

EU-2016-679 (2016). Reglamento (UE) 2016/679 del Parlamento Europeo y del Consejo. Diario Oficial de la Unión Europea.

ABC (2013). "Inhibidores de frecuencia para no copiar en los exámenes de medicina de la Complutense". En: $A B C$.

Adams, Richard (2018). More than 1,000 pupils penalised for phones in GCSE and A-level exams. The Guardian, International Edition.

BOE-A-1954-17807 (1954). Decreto de 8 de septiembre de 1954 por el que se aprueba el Reglamento de disciplina académica de los Centros oficiales de Enseñanza Superior y de Enseñanza Técnica dependientes del Ministerio de Educación Nacional. Boletín Oficial del Estado.

BOE-A-1999-23750 (1999). Ley Orgánica 15/1999, de 13 de diciembre, de Protección de Datos de Carácter Personal. Boletín Oficial del Estado.

BOE-A-2010-15028 (2010). Ley 2/2010, de 15 de junio, de Autoridad del Profesor. Boletín Oficial del Estado.

Cid, Mikel (2016). "Cómo funcionan los inhibidores de frecuencia y por qué está prohibido su uso". En: Xataka.

La Información (2016). “¿Cuáles son las consecuencias de copiar en un examen?” En: La Informacion.

Pascual, Juan Antonio (2015). "Los nuevos trucos tecnológicos para copiar en los exámenes". En: Computer Hoy.

Stanford University (2018). Honor Code and Fundamental Standard. Office of Community Standards Student Affairs.

Trueba, Esteban Gándara (2010). "Inhibidores de Frecuencia, Informe UCSP No: 2010/009". En: Ministerio del Interior. 


\title{
Aprende a Experimentar en Física sobre un Entorno Virtual 3.0.
}

\section{José Daniel Sierra Murillo}

a Universidad de La Rioja, Departamento de Química, Área de Física Aplicada; Complejo

Científico-Tecnológico, C/ Madre de Dios 51 26006-Logroño, daniel.sierra@unirioja.es.

\begin{abstract}
The objective of this Teaching Innovation Project, "Learn to Experiment in Physics on a Virtual Environment 3.0", is to generate audiovisual resources that allow teachers and students to enjoy physical phenomena permanently. Besides the improvement of the learning of the Physics, it is of great interest the acquisition on the part of the student of competences on autonomous and collaborative work, as well as of computer skills, fundamental in the science and technology of the 21st century.
\end{abstract}

\section{Keywords:}

Experiment in Physics, Virtual Environment 3.0, audiovisual resources, competences on autonomous and collaborative work, computer skills, 21st century.

\section{Resumen}

El objetivo de este Proyecto de Innovación Docente, "Aprende a Experimentar en Física sobre un Entorno Virtual 3.0”, es generar recursos audiovisuales que permitan a profesores y alumnos disfrutar de los fenómenos físicos de forma permanente. Además de la mejora del aprendizaje de la Física, es de gran interés la adquisición por parte del alumno de competencias sobre trabajo autónomo y colaborativo, así como de habilidades informáticas, fundamentales en la ciencia y tecnología del siglo XXI.

\section{Palabras clave:}

Experimentar en Física, Entorno Virtual 3.0, recursos audiovisuales, competencias sobre trabajo autónomo y colaborativo, habilidades informáticas, siglo XXI.

\section{Introducción}

Las demostraciones experimentales de Física están asociadas al desarrollo de la ciencia moderna y fueron utilizadas desde el siglo XVII en sociedades científicas, academias, salones y conferencias para todo tipo de público. También han sido empleadas de forma generalizada como herramientas docentes en instituciones educativas y universidades 
constituyéndose como prácticas docentes habituales en diferentes países. A pesar de que su uso está recogido explícitamente en el proyecto europeo “Tuning” (González y Wagenaar, 2003) de Física para la armonización de titulaciones universitarias, en nuestro país no forma parte de las prácticas docentes generalizadas. A este respecto, en la Facultad de Ciencias Físicas de la Universitat de València existe un proyecto docente que ha incorporado el uso de las demostraciones experimentales como herramienta habitual en sus clases, y que dicho proyecto ha obtenido resultados altamente satisfactorios (Ferrer 2012).

Algunos de los estudiantes que llegan a la universidad no han cursado Física durante la enseñanza secundaria y, la mayoría de quienes sí lo han hecho, no han realizado prácticas de laboratorio o visto demostraciones experimentales. Por lo que, por lo general, desconocen las causas/consecuencias experimentales de los fenómenos físicos más básicos. Por ello, el uso de demostraciones experimentales permite articular un proceso de observación racional en el que se emitan conclusiones en términos de los modelos físicos estudiados en el ámbito teórico, algo esencial en la comprensión del método científico; además de ofrecer la posibilidad de involucrar de forma activa a los alumnos en su propio proceso de aprendizaje. (Aparicio, F., González, R.M. y Sobrevila, M.A., 2005) (Calvo, I., Lopez-Guede, J.M. y Zulueta, E., 2010) (Alba, J., Torregrosa, C. y Del Rey, R., 2015).

Como hemos descrito previamente, la propia naturaleza intrínseca de las demostraciones experimentales hace que sea posible involucrar a los alumnos de forma activa y en primera persona en el proceso de aprendizaje. Esto permite pasar de un planteamiento centrado en el profesor a uno más orientado al estudiante.

En otro orden de cosas, la educación superior ha experimentado un gran cambio dentro del sistema educativo de la sociedad actual en diferentes ámbitos (Ortega, 2004; González, 2008) como, por ejemplo:

- La evolución de los procesos de formación desde entornos presenciales convencionales hacia otros ámbitos más amplios.

- La demanda generalizada para que los estudiantes adquieran competencias específicas y transversales (Bolonia, 2009), así como ciertas habilidades necesarias para su aprendizaje continuo.

Para ello, pueden apoyarse en las nuevas Tecnologías de la sociedad de la Información y de la Comunicación (TIC), sin olvidar hacer énfasis en la docencia. Cambios de estrategias didácticas de los profesores y alumnos para acceder, buscar, compartir y gestionar toda la información referida a diferentes materiales objeto de estudio y aprendizaje, es decir, en los procesos de innovación docente. (Mora Mora H., Signes Pont, M. T., De Miguel Casado, G. y Gilart Iglesias, V., 2015)

En cuanto al EV-3.0, se considera como un estado en el que Internet proporciona condiciones de gran interés para que los individuos y las organizaciones puedan compartir información independientemente de las redes y dispositivos que utilicen. (Mora Mora H., Azorín López, J., Jimeno Morenilla, A., Sánchez Romero, J. L., Pujol López, F., García Rodríguez, J., Serra Pérez, J. A., Morell Giménez, V., Rives Pérez, M. F., Saval Calvo, M., García García, A. y Orts Escolano, S., 2016) Las Webs 3.0 (Figura 1) también se han 
venido a denominar Webs semánticas (Berners-Lee, 2001; W3C, 2001). Este nuevo concepto de Web semántica constituye esencialmente una extensión de la Web tradicional en la que la información se coloca de forma estructurada para permitir su fácil consulta y acceso tanto por interlocutores humanos como por sistemas automáticos (Silva, J. M., Mahfujur, A. S. Md. y El Saddik, A., 2008; Nacer y Aissani, 2014).

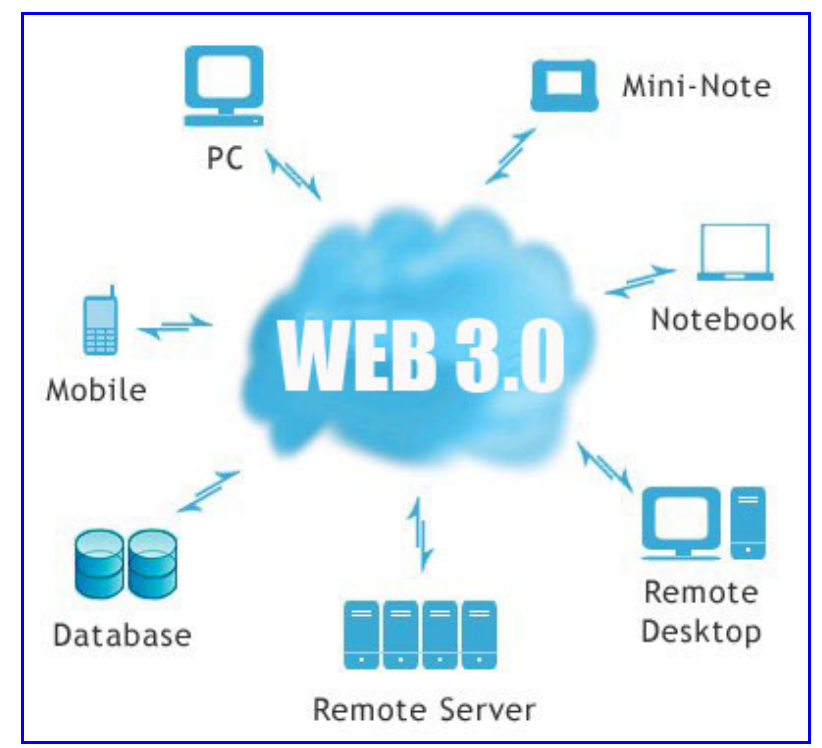

Fig. 1 Visión esquemática de la Web 3.0.

En el ámbito educativo esas herramientas adquieren más relevancia debido a que contribuyen a revisar los planteamientos docentes actuales. Los estudiantes, ya no solo tienen que ser buenos conocedores de cada materia en cuestión, sino también deben desarrollar otras actitudes como la creatividad, el espíritu crítico y la capacidad para el aprendizaje continuo que la sociedad les demanda. Todo ello, en línea con la Declaración Mundial para la Educación Superior en el siglo XXI (Granados, 2011) y la Declaración de Bolonia 2020 (Bolonia, 2009).

Seguidamente se describen brevemente los apartados de los que consta este artículo. A continuación (Sección "Objetivos"), se exponen los objetivos que se pretenden alcanzar a través de este proyecto innovador. Posteriormente, y dentro de la Sección "Desarrollo de la innovación”, se describe el desarrollo de la metodología utilizada en este proyecto mediante una planificación en tres Fases. Por lo que respecta a la Sección titulada "Resultados", en ella se exponen brevemente los logros obtenidos mediante el desarrollo del presente proyecto de innovación. Finalmente, se exhiben unas conclusiones que reafirman el gran valor del uso racional de las TIC en el estudio/aprendizaje Teórico/Experimental de la Física. 


\section{Objetivos}

El principal objetivo de este trabajo es preparar los primeros recursos audiovisuales asociados al Proyecto de Innovación Docente titulado: “Aprende a Experimentar en Física sobre un Entorno Virtual 3.0”, así como poner de manifiesto el carácter multidisciplinar que puede presentar este tipo de herramientas en un EV-3.0.

El desarrollo de estas demostraciones experimentales en formato audiovisual conlleva la generación de nuevos recursos multimedia tales como guías descriptivas, mini-vídeos y memorias que permitan a profesores y estudiantes planificar, grabar, almacenar e intercambiar en un E.V-3.0 las diferentes experiencias sobre diversos fenómenos físicos de forma permanente, más allá del uso instantáneo del material en el aula presencial. Esta colección (o banco audiovisual) se está desarrollando de forma colaborativa con otros profesores que participan o no en el proyecto. Conviene recordar que, aunque de gran interés en el proceso educativo, las metodologías activas basadas en el Aprendizaje Basado en Proyectos (ABP o PBL, Project-Based Learning) suponen una mayor carga/dedicación docente para el profesor (Alba, Torregrosa, del Rey, 2015).

El carácter multidisciplinar de este trabajo presenta importantes ventajas de cara al acercamiento a una temática fundamental (Física) no solo desde la perspectiva de las habituales titulaciones científico-tecnológicas, sino desde otras con un marcado carácter más didáctico/divulgativo.

Otro objetivo no menos importante consiste en conseguir involucrar a más profesores en un futuro cercano y consolidar un grupo de trabajo de innovación docente con aquellos participantes que demuestren un interés para participar activamente en la consecución de este proyecto inicial.

Por otra parte, dado que es un proyecto innovador sobre Experiencias de Física en un EV3.0, otros objetivos fundamentales son la mejora de las competencias del trabajo autónomo y colaborativo del alumno, entre los alumnos de los Grupos de Laboratorio (GL) y de estos con el profesor (Mazur, 1997). Ambas, apoyadas en la Metodología "Flipped Learning" (MFL), (Prieto, 2015) y dentro del EV-3.0. Además de la mejora en el aprendizaje de la Física, es de gran interés la adquisición por parte del alumno de habilidades informáticas, muy importantes en un entorno científico-tecnológico del siglo XXI. (Karpicke and Blunt, 2011; Deslauriers, L., Schelew, E. and Wieman C., 2011; Freeman, S., Eddy, S. L., McDonough, M., Smith M. K., Okoroafor N., Jordt, H. and Wenderoth, M. P., 2014)

\section{Desarrollo de la innovación}

Este proyecto pretende utilizar cualquier plataforma virtual con el objetivo de compatibilizar los trabajos autónomos y colaborativo de los alumnos en la preparación de Experiencias en Física mediante la utilización de un EV-3.0. Este entorno puede ser, desde la Plataforma Virtual de la Universidad de La Rioja (UR) (Figura 2), hasta cualquier sistema de intercambio de información virtual: WhatsApp (foros, grupos, etc.), redes sociales, etc. La innovación reside en utilizar como herramienta de intercambio de 
información multimedia, debate crítico y aprendizaje estos nuevos entornos virtuales que forman parte de los usos y costumbres de la sociedad actual, siglo XXI.

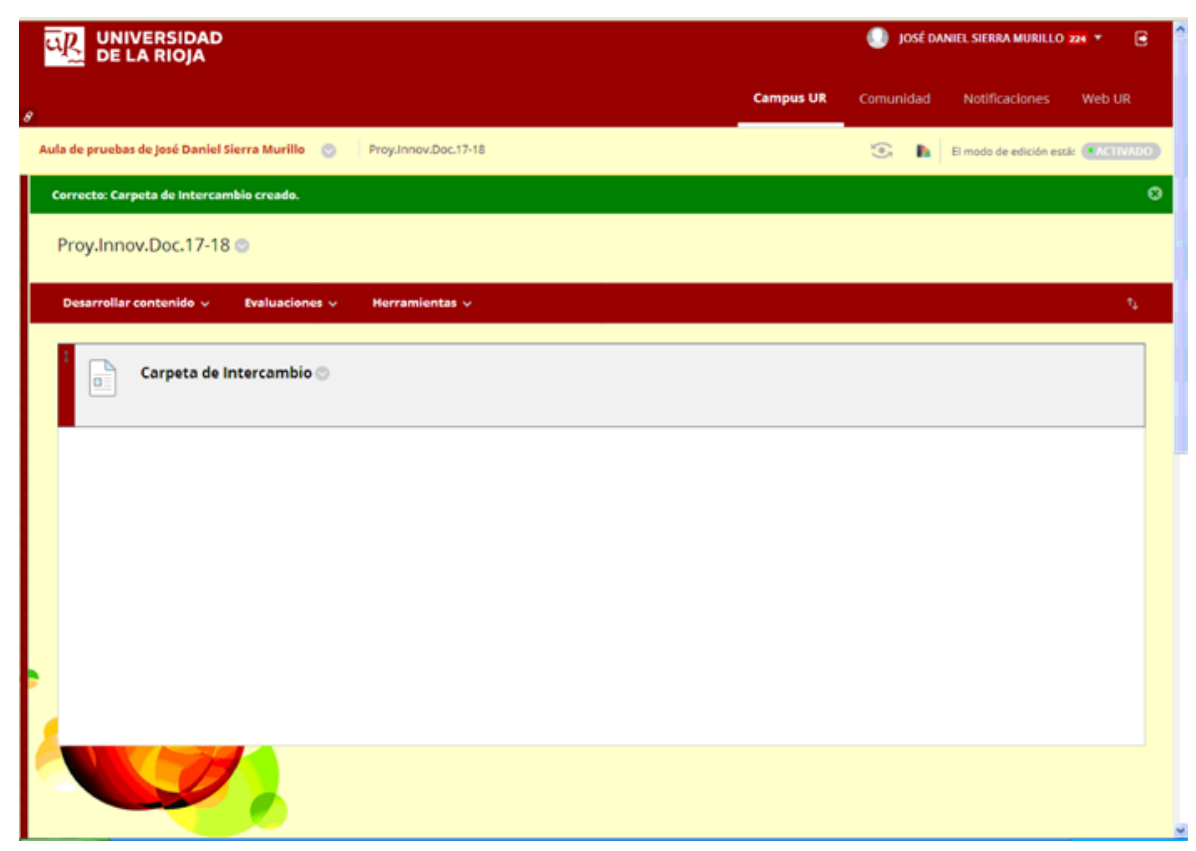

Fig. 2 Plataforma Virtual de la Universidad de La Rioja.

La planificación de la metodología utilizada en este proyecto consta de tres fases.

\section{Primera Fase}

En la primera fase, se pretende evolucionar la enseñanza tradicional (centrada en el protagonismo del profesor que explica todo a sus alumnos) hacia otro tipo de enseñanza en la que el protagonismo se reparta más entre el profesor y sus alumnos. Para que sean estos los que profundicen en el estudio de los temas objeto de investigación teórico-experimental a partir de los materiales y/o referencias proporcionados previamente por el profesor. Todo ello, a través de un trabajo autónomo-colaborativo dentro de un EV-3.0. El trabajo autónomo y colaborativo del alumno en la preparación de Experiencias de Física a través de la MFL y la utilización de un EV-3.0 es sumamente interesante. Por ello, el objetivo fundamental de esta fase es buscar la eficacia autónoma y colaborativa de cada alumno en dicho trabajo de preparación como miembro activo.

Segunda Fase

La optimización de la primera fase, con un posible asesoramiento complementario del profesor, promueve una mejora sustancial en el buen desarrollo posterior de la experimentación (fase 2), que necesita un trabajo constructivo/eficiente de los equipos de alumnos en el desarrollo de las mencionadas experiencias. Por otra parte, su grabación en soporte audiovisual requiere una claridad de ideas sobre el proceso experimental tanto en su realización como en su descripción. (Figura 3) 


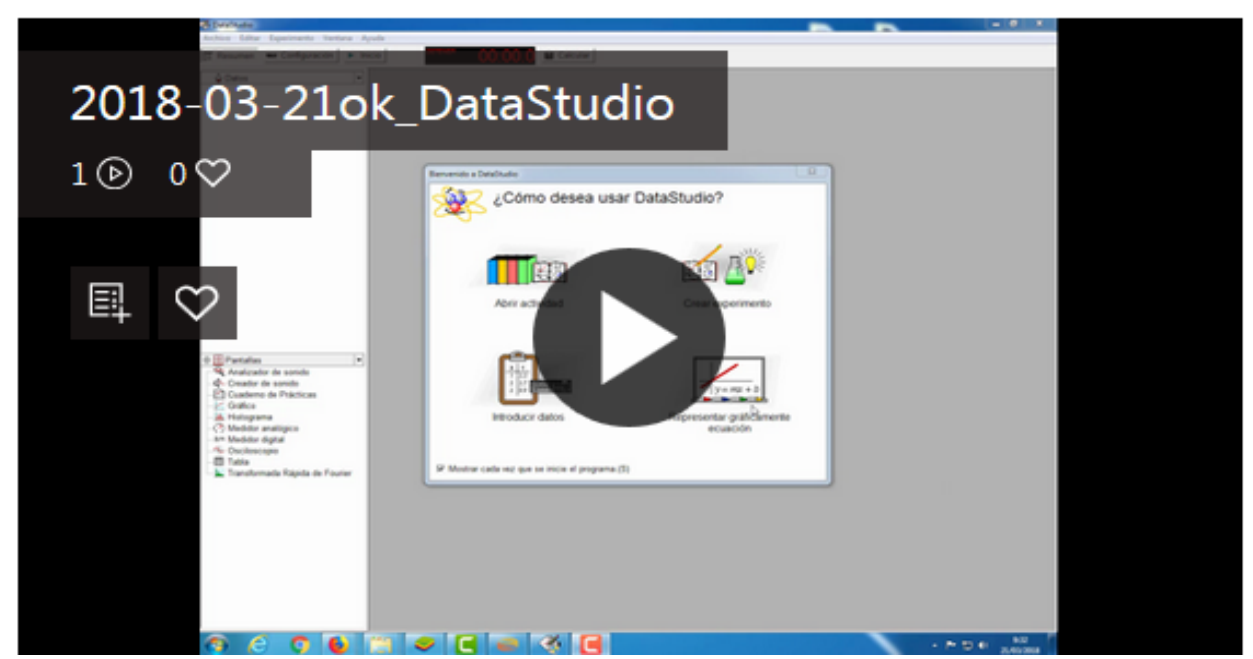

Fig. 3 Carátula del mini-vídeo de una de las Experiencias de Física.

Una vez trabajada con suficiencia las experiencias, y ya dentro del Laboratorio de Física (LF):

a) Comenzará el montaje experimental, para su realización y filmación. Se hará uso de las observaciones anotadas por los alumnos a lo largo del proceso de preparación anteriormente indicado (Fase 1) serán de gran ayuda. Se debe recordar a los alumnos:

- Que es muy importante un correcto montaje del sistema experimental para evitar posibles errores sistemáticos.

- La correcta utilización del hardware y software disponible en el LF con el fin de que consolide unas muy útiles habilidades informáticas necesarias en su posterior dedicación discente/docente, investigadora y profesional en general.

b) Con el sistema experimental correctamente montado, se procederá a la toma de las medidas experimentales y su filmación.

- Hacerles notar a los alumnos la importancia de anotar/(comentar en la filmación) todas las vicisitudes observadas en el transcurso del proceso de medidas: dificultades conceptuales surgidas en el proceso de medida, eventualidades técnicas, etc.. Esta información multimedia compartida en el EV-3.0 mejora el crecimiento consolidado en el aprendizaje científico-tecnológico.

c) Finalmente, se realizará el análisis de las medidas experimentales.

- Recalcar en una buena interpretación física de los resultados de tales análisis, así como en los razonamientos pertinentes que justifiquen el correcto uso del Método Científico sobre el experimento objeto de estudio.

\section{Tercera Fase}

La tercera fase permite la posibilidad de transmitir/compartir la información multimedia obtenida/generada en todo el proceso de aprendizaje a través de los mencionados entornos virtuales crea hábitos de transparencia y superación entre los alumnos. 


\section{Resultados}

Alguno de los resultados que se obtienen con este proyecto son, entre otros, corroborar la importancia de la utilización de las nuevas tecnologías de la sociedad de la información y de la comunicación, no solo en la transmisión de información multimedia, sino también en los procesos de aprendizaje universitario, todo ello, dentro de un EV-3.0. Este perfil del proyecto conjuga con la filosofía de Bolonia 2020 relativas a los cambios en los modelos de docencia-aprendizaje.

Dentro de los resultados perseguidos a lo largo de la puesta en práctica del proyecto de innovación aquí presentado, se exponen a continuación los más significativos:

Se produce una evidente mejoría del trabajo autónomo y colaborativo entre los alumnos, y también entre alumnos-profesor, principalmente a través del EV-3.0.

Además, es significativo el progreso del alumnado en la utilización de:

- La conexión entre plataformas informáticas (hardware y software) con sistemas experimentales donde la adquisición de datos se realiza de forma automática.

- Las plataformas informáticas (hardware y software) para el análisis de los resultados experimentales por parte del alumno.

- Diferentes entornos virtuales utilizados para la transmitir y compartir la información multimedia utilizada y generada en todo el proceso por los mismos alumnos y entre alumnos-profesor.

* Un resultado sumamente importante es la creación de un banco de información multimedia del que se podrá disponer en todo momento para consultas de tipo TeóricoExperimental en Física por parte del alumnado matriculado/inscrito en la Plataforma Virtual de la Universidad de La Rioja. Así como poderlo utilizar para entablar debates sobre aspectos relacionados con la docencia impartida y/o cuestiones afines vinculadas con la investigación y el desarrollo científico-tecnológico.

* Y, ante todo, existe una muy apreciable mejora cualitativa y cuantitativa en el proceso de aprendizaje Teórico-Experimental en Física por parte de los alumnos, así como de sus resultados académicos. Es muy satisfactorio para el profesor, recibir un feedback tan positivo por parte de la mayoría del alumnado (>80\%), para el cual, este proyecto innovador crea hábitos muy positivos en la preparación previa del trabajo experimental en el laboratorio, sobre todo, porque son usuarios habituales de recursos multimedia. De hecho, ese porcentaje está en consonancia con la mejora experimentada en sus resultados académicos, en los cuales se producen aumentos en sus notas de prácticas en laboratorio de forma significativa: Notable (16\%) y Sobresaliente (43\%). 


\section{Conclusiones}

Las conclusiones que pueden extraerse de los resultados obtenidos a lo largo del desarrollo de este proyecto de innovación docente confirman un potencial real de la utilización racional de las TIC y la MFL. En un proceso sólido y fiable de aprendizaje TeóricoExperimental de la Física de los Sistemas Naturales y Artificiales $(\mathrm{I}+\mathrm{D}+\mathrm{i})$, y con la inestimable ayuda de un EV-3.0.

Una óptima preparación previa del trabajo teórico-experimental que va a desarrollar el GL mediante la MFL, así como la puesta en común de este proceso a través del mencionado EV-3.0, hacen de dicha metodología una herramienta muy interesante para obtener una mejora, tanto en el aprendizaje consolidado de la Física como los resultados académicos.

Por otra parte, su grabación en soporte audiovisual requiere una claridad de ideas sobre el proceso experimental tanto en su realización como en su descripción. Además, el intercambio a través del EV-3.0 de toda esta información multimedia, mejora sustancialmente el análisis de los procesos experimentales, los resultados obtenidos a partir de ellos y el debate constructivo entre alumnos y entre alumnos-profesor, generando un rico caldo de cultivo que alimenta un progreso científico-tecnológico sólido y transparente.

Sobra decir que todo el proceso está embebido en una praxis en torno a las TIC, que mejora las habilidades del alumnado respecto a todo aquello relacionado con esta nueva realidad virtual que ya está instalada entre nosotros.

\section{Referencias}

ALBA J., TORREGROSA C. y DEL REY R. (2015) Aprendizaje basado en proyectos: Primera experiencia en la asignatura de Física del Grado en Ingeniería de Telecomunicación, Sonido e Imagen. Universitat Politècnica de València Congreso IN-RED (2015).

APARICIO, F., GONZALEZ, R. M. y SOBREVILA, M. A. (2005). Formación de Ingenieros. Objetivos, métodos y estrategias. Instituto de Ciencias de la Educación, UPM.

BERNERS-LEE, T., HENDLER, J. y LASSILA, O. (2001). The Semantic Web: A new form of Web content that is meaningful to computers will unleash a revolution of new possibilities. Scientific American, Vol. 284: pp. 35-43.

BOLONIA. (2009). The Bologna Process 2020 - The European Higher Education Area in the new decade. Communiqué of the Conference of European Ministers Responsible for Higher Education.

CALVO, I., LOPEZ-GUEDE, J.M. y ZULUETA, E. (2010). Aplicando la metodología Project Based Learning en la docencia de Ingeniería Técnica en Informática de Gestión, Revista de Formación e Innovación Educativa Universitaria. Vol. 3, No 4, 166-181. 
CURY, A. (2007). Padres Brillantes, Maestros Fascinantes. Brasil, Planeta. ISBN: 9788408063605.

DESLAURIERS, L., SCHELEW, E. y WIEMAN C.. (2011). Improved Learning in a LargeEnrollment Physics Class, Science, Vol. 332, pp. 862-864. DOI: 10.1126/science.1201783.

DIAZ M. (2007) fq-experimentos. Experimentos caseros de Física y Química. <http://fq.experimentos.blogspot .com.es/> [Consulta: 29 de mayo de 2017]

FERRER C. (2012) Demostraciones experimentales de Física para el aula. <http://fisicademos.blogs.uv.es/?page_id=29> [Consulta: 12 de marzo de 2018]

FREEMAN, S., EDDY, S. L., MCDONOUGH, M., SMITH M. K., OKOROAFOR N., JORDT, H. y WENDEROTH, M. P. (2014). Active learning increases student performance in science, engineering, and mathematics, Proc. Natl. Acad. Sci. USA, Vol. 111, pp. 8410-8415.

GONZÁLEZ, J. y WAGENAAR, R. (2003): Tuning Educational Structures in Europe. Informe Final - Proyecto Piloto, Fase 1, Bilbao, Universidad de Deusto.

GONZÁLEZ MARIÑO, J. C. (2008). TIC y la transformación de la práctica educativa en el contexto de las sociedades del conocimiento. Revista de Universidad y Sociedad del Conocimiento (RUSC). Vol. 5, n. ${ }^{\circ} 2$.

GRANADOS, J. (2011). The Challenges of Higher Education in the 21st Century, GUNi Newsletter, 5/11. (http://www.guninetwork.org/articles/challenges-higher-education-21st-century).

KARPICKE, J. D. y BLUNT, J. R. (2011). Retrieval Practice Produces More Learning than Elaborative Studying with Concept Mapping, Science, Vol. 331, pp. 772-775. DOI: 10.1126/science.1199327.

MAZUR, E. (1997). Peer Instruction: A User's Manual. New York: Prentice Hall Series in Educational Innovation.

MORA MORA H., AZORÍN LÓPEZ, J., JIMENO MORENILLA, A., SÁNCHEZ ROMERO, J. L., PUJOL LÓPEZ, F., GARCÍA RODRÍGUEZ, J., SERRA PÉREZ, J. A., MORELL GIMÉNEZ, V., RIVES PÉREZ, M. F., SAVAL CALVO, M., GARCÍA GARCÍA, A. y ORTS ESCOLANO, S. (2016). Nuevas tendencias web 3.0 para la mejora de los procesos docencia-aprendizaje. Innovaciones metodológicas en docencia universitaria: resultados de investigación (pp.1543-1558). Alicante: Universidad de Alicante, Vicerrectorado de Estudios, Formación y Calidad, Instituto de Ciencias de la Educación.

MORA MORA H., SIGNES PONT, M. T., DE MIGUEL CASADO, G. y GILART IGLESIAS, V. (2015). Management of social networks in the educational process, Computers in Human Behavior, Vol. 51, Part B, pp. 890-895. doi:10.1016/j.chb.2014.11.010.

NACER, H. y AISSANI, D. (2014). Semantic web services: Standards, applications, challenges and solutions, Journal of Network and Computer Applications, Vol. 44, pp. 134-151. DOI: 10.1016/j.jnca.2014.04.015.

ORTEGA CARRILLO, J. A.. (2004). Redes de aprendizaje y curriculum intercultural. Actas del XIII Congreso Nacional y II Iberoamericano de Pedagogía. Ed. Sociedad Española de Pedagogía. Valencia. 
PRIETO MARTÍN, A. (2017-03-12). Decálogo de innovación metodológica para que los alumnos aprendan más y mejor en las asignaturas universitarias. Blog Profesor 3.0. http://profesor3punto0.blogspot.com.es/2015/12/decalogo-de-innovacion-metodologica.html.

SALINAS, J. (2004). Innovación docente y uso de las TIC en la enseñanza universitaria. Revista Universidad y Sociedad del Conocimiento. Vol. $1, \mathrm{n} .^{\circ} 1$.

SILVA, J. M., RAHMAN, A. S. y EL SADDIK, A. (2008). Web 3.0: a vision for bridging the gap between real and virtual. Paper presented at the 1st ACM international workshop on Communicability design and evaluation in cultural and ecological multimedia system, Vancouver British Columbia, Canada.

VILAPLANA, R. GOMIS O. y HYDER A. (2011) "Working in terms of competences: activities designed using active methodologies”. Safeeullah Soomro New Achievements in Technology, Education and Development. Croatia: In-Tech. Cap. 22, Pags: 352-372.

W3C. (2001). W3C Semantic Web Activity. URL: http://www.w3.org/2001/sw/, Acceso: mayo 2016. 


\title{
Diseño tecnopedagógico de un e-portafolio en educación superior para la mejora de las competencias transversales y la inserción socioprofesional
}

\section{Vanessa Soria ${ }^{a}$}

aUniversidad Pompeu Fabra, Centro para la Innovación en Aprendizaje y Conocimiento (CLIK), Barcelona, vanessa.soria@upf.edu

\begin{abstract}
This article shows how UPF implemented the use of e-portfolios in some of its degrees. The e-portfolio is a document designed with the Mahara tool that compiles all the educational and job-related competences that students acquire throughout their studies. At UPF, students elaborate their e-portfolios in tutoring sessions. The competences included in them help teachers identify what specific aspects must be tackled during their courses. The goal of the eportfolio is to help students acquire the competences they lack while they create a useful resource exportable in and outside the University.
\end{abstract}

Keywords: transversal skills, employability, e-portfolio, portfolio, Mahara, higher education

\section{Resumen}

El presente artículo muestra como se ha diseñado un e-portafolio a través de la plataforma Mahara, aunque el modelo es compatible con otros dispositivos. Este portafolio pretende recoger, mostrar y promover la adquisición de competencias transversales así como de competencias para la inserción socioprofesional durante el tiempo que el alumnado realizada el grado. Así mismo, este e-portafolio se desarrolla paralelamente al programa de tutorías de la UPF, permitiendo la integración de dichas temáticas en la formación específica de los futuros profesionales. El objetivo es mejorar la adquisición de las competencias transversales a la vez que facilitar la creación de un producto final que se pueda mostrar dentro y fuera de la universidad.

Palabras clave: competencias transversales, inserción laboral, e-portafolio, portfolio, Mahara, educación superior 
Diseño tecnopedagógico de un e-portafolio en educación superior para la mejora de las competencias transversales y la inserción socioprofesional.

\section{Introducción}

Uno de los supuestos de la nueva situación del Espacio Europeo de Educación Superior (EEES) es el fomento de las competencias transversales de los estudiantes. Así, los alumnos además de las competencias específicas de sus respectivos grados deberían lograr las competencias transversales definidas para su profesión y formación.

\section{Competencias transversales y evaluación formativa}

La definición de competencia transversales como comentan Aguado, González, Antúnez y Dios, 2017: 130 es: "se entienden las competencias como repositorios de conducta diferenciales que llevan a las personas a desarrollar con mayor eficiencia su trabajo (Sparrow, 1997) y que se componen del conjunto de comportamientos que son instrumentales para la consecución de un desempeño exitoso en el puesto (Bartram, 2005)". Estos mismos autores señalan que dichas competencias son aquellas generales que se pueden aplicar a cualquier puesto de trabajo, ello lo derivan del proyecto Turning Education Structures in Europe de González y Wagenaar (2003). En el marco español, así como las competencias básicas están definidas por el Ministerio de Educación en el real decreto 1393/2007, de 29 de octubre, por el que se establece la ordenación de las enseñanzas universitarias oficiales, en el caso de las competencias generales y transversales suele ser más flexible y se define por la universidad desde cada grado teniendo en cuenta el perfil profesional. Éstas suelen ir relacionadas con aspectos instrumentales (cognitivos, metodológicos, tecnológicos y lingüísticos), interpersonales (interacción social y cooperación) y sistemáticos (uso de las competencias instrumentales e interpersonales) según Aguado, González, Antúnez y Dios (2017: 131). Este enfoque basado en competencias ha permitido mejorar los procesos de enseñanza-aprendizaje y evaluación en la universidad (Vivel-Búa et al. 2015 en Aguado, González, Antúnez y Dios, 2017). Aún asi, como indican los mismos autores, para una implementación exitosa de las competencias son necesarios dos aspectos fundamentales "El desarrollo de un marco común de competencias transversales para los universitarios, y de otro, el desarrollo de instrumentos de medición de dichas competencias" (Aguado, González, Antúnez y Dios, 2017:132). En esa línea de medición o evaluación, hablamos de diferentes tipos, es decir, evaluación diagnóstica o inicial, formativa y sumativa. En el marco del plan Bolonia, se ha equilibrado la evaluación sumativa con la formativa, de este modo, ya no solo se evalúa al final del proceso, sino también durante el mismo para un mayor logro de las competencias, los objetivos y los resultados de aprendizaje. Por tanto, podríamos concluir señalando que la incorporación, específicamente, de la evaluación formativa ha sido y es un valor añadido en la formación, ya que diseña procesos de enseñanza-aprendizaje constantes y activos desde un enfoque constructivista (García-Carpintero, Siles,

(cc) EY-NC-ND 2018, Universitat Politècnica de València

Congreso IN-RED (2018) 
Martínez, Martínez, Manso y Álvarez, 2017) lo que mejora notablemente dichos procesos. Como indican los mismos autores y autoras, esto se da con el cambio de un modelo clásico centrado en el profesor a otro que emplea nuevas metodologías y donde el estudiante es autónomo y responsable de su aprendizaje. Para ello, se debe fomentar la capacidad de autoaprendizaje con el acompañamiento de expertos/as (García-Carpintero, Siles, Martínez, Martínez, Manso y Álvarez, 2017) y en ese contexto deben variarse las metodologías y los sistemas de evaluación que van más allá de los exámenes finales.

\section{El portafolio electrónico}

Dentro de los sistemas de evaluación, encontramos el portafolio: "una colección útil del trabajo de los estudiantes que ilustra los esfuerzos, progresos y logros en una o más áreas" (Barret, 2006 en Soria y Carrió, 2016:385). Cuando hablamos de portafolios electrónicos, esto se refiere al uso de la tecnología como plataforma para desarrollarlos (Soria y Carrió, 2016). El portafolio es un instrumento que se basa tanto en el producto final como en el proceso, por ello se caracterizan por ser herramientas de evaluación formativa y sumativa, o final, de las más empleadas en educación superior en la actualidad. El portafolio como indica López-Pastor (2009) es un instrumento que fomenta una evaluación orientada al aprendizaje y lo que se busca es que:

Los estudiantes sean conscientes de los cambios producidos a lo largo de su proceso de aprendizaje, que autorregulen su forma de aprender y reflexionen sobre los beneficios y dificultades encontradas para poder así ayudarles y estimularles. Esto supone un proceso de aprendizaje que toma en cuenta los conocimientos previos de los estudiantes, su involucramiento en la construcción de su propio aprendizaje y su implicación motivacional, adquiriendo así un aprendizaje más significativo (García-Carpintero, Siles, Martínez, Martínez, Manso y Álvarez, 2017:26).

En esta idea, se le da mucha importancia a la evaluación formativa por: 1) revisión de las actividades del portafolio antes de la entrega final, 2) detección y corrección de las deficiencias del proceso de enseñanza-aprendizaje a lo largo del curso, y 3) evaluación final de la experiencia para mejorar los procesos de enseñanzaaprendizaje para el siguiente curso académico (Pérez Gutiérrez, M. 2017:84). En conclusión, como indican García-Carpintero, Siles, Martínez, Martínez, Manso y Álvarez, (2017:27) el portafolio es una herramienta educativa potente ya que incide en la enseñanza, en el aprendizaje y en la evaluación:

- Enseñanza: retroactividad, centrado en el aprendizaje, interés en el proceso.

- Aprendizaje: crítico-reflexivo, autónomo, responsable, significativo. 
- Evaluación: formativa y sumativa, multidimensional, individualizada y autoevaluativa.

En resumen, como señala (Veytia, 2017:123) el uso de portafolio electrónico integra el diseño tecnopedagógico, la evaluación reflexiva y el desarrollo de competencias, lo que hace de él una herramienta muy completa y pertinente en la Educación Superior actual.

Cabe destacar, que el e-portafolio, como evidencia formativa y evaluativa, muestra las competencias adquiridas pero también puede ayudar especialmente en el proceso de inserción socioprofesional, demostrando a las entidades externas el perfil del estudiante. Es decir, aquello que saeb hacer de una forma visual y práctica.

\section{La inserción socioprofesional}

Así mismo y para concluir, destacar que la formación de los estudiantes universitarios suele ir encaminada a facilitarles, una vez finalizados sus estudios, la inserción sociprofesional, aspecto que como destacan Ruiz y Molero, 2002 (en Jiménez, 2009:1) es cada vez más transcendental para "jóvenes, empresas, universidad y sociedad" ya que:

La flexibilización del mercado de trabajo, los avances tecnológicos, económicos y demográficos junto a la democratización de la universidad y el aumento de otras posibilidades formativas, ha originado que la preocupación por la búsqueda de un empleo adecuado a una cualificación determinada sea una constante en las personas que obtienen una titulación. (Jiménez, 2009:1)

Por tanto, una de las competencias a trabajar es el acceso al mundo profesional. Éste es un aspecto que aunque fundamental, no se trabaja en asignaturas concretas pero si de forma transversal durante el grado en algunos caso. Aun así, es necesario que la universidad ofrezca herramientas y estrategias para encarar el futuro profesional más allá de las competencias específicas sino también teniendo en cuenta las competencias generales y transversales. Es decir, "el nuevo modelo de educación superior destaca por la importancia concedida a las competencias profesionales y la empleabilidad como elemento de cambio.". Siguiendo con el mismo tema citan "los estudiantes esperan que las universidades los apoyen, no solo en su desarrollo intelectual y académico, sino también estableciendo una plataforma para el empleo y el desarrollo de la carrera". (García-Álvarez, Vázquez-Rodríguez, Mella-Núñez, 2017:45). 


\section{Objetivos}

El objetivo de esta experiencia es mejorar la adquisición de dichas competencias (transversales y socioprofesionales) a la vez que facilitar la creación de un producto final que se pueda mostrar dentro y fuera de la universidad.

\section{Desarrollo de la innovación}

Durante el curso 2017-2018 se ha implementado un e-portafolio en el Grado en Global Studies de la Universidad Pompeu Fabra. Para ello durante el tercer trimestre del cuso 2016-2017 se realizó un diseño previo, posteriormente validado por los coordinadores del grado. A continuación se expone el diseño pedagógico y algunes detalles de la implementación.

\section{- El diseño pedagógico}

\section{Contextualización:}

La Universidad Pompeu Fabra cuenta con un centro de apoyo al profesorado en temas pedagógicos y de innovación docente. Este es denominado Centro para la Innovación en Aprendizaje y Conocimiento (CLIK) (www.upf.edu/web/clik). El CLIK ofrece recursos de apoyo al profesorado en diferentes áreas: formación, multilingüismo, nuevas metodologías, innovación tecnológica,entre otros temas. Así, es habitual que el profesorado de los diferentes estudios, solicite asesoramiento para la implementación de nuevas propuestas que mejoren los procesos de enseñanza-aprendizaje. Concretamente, en este caso hablamos de la incorporación de un portafolio electrónico para la mejora y visibilización de las competencias transversales de un grado específico.

Como se ha comentado con anterioridad, señalar que un portafolio es una recopilación de información y documentación representativa de un proceso de aprendizaje. Así, el e-portafolio (portafolio electrónico) se diferencia por tener las mismas carácterísticas pero además es digital y utiliza plataformas en línea. En el caso de la UPF, desde el curso 2016-2017, se hace uso del portafolio electrónico Mahara, ya que está integrado en la plataforma virtual de la universidad (denominada Aula Global).

El grado específico, objeto de la implementación, es el Global Studies (Grado en Estudios Globales), que se imparte en su mayoritariamente en inglés. Éste tiene una duración de 3 años, se organiza desde la Facultad de Humanidades y su objetivo es "Estos estudios están pensados como una oferta docente abierta a estudiantes de todo el mundo interesados en entender aquellos fenómenos — culturales, económicos, jurídicos, medioambientales, políticos, sociales y tecnológicos- que nos afectan 
Diseño tecnopedagógico de un e-portafolio en educación superior para la mejora de las competencias transversales y la inserción socioprofesional.

con independencia de nuestra precisa ubicación territorial y cuya comprensión precisa de una aproximación transdisciplinar y una visión global del ser humano."

A continuación destacamos algunos de los recursos audiovisuales de difusión sobre dicho grado:

- Información general: https://www.upf.edu/web/graus/grau-en-estudisglobals

- Video de presentación: https://www.youtube.com/watch?time continue $=12 \& v=t$ cuAcylhPp0

- Video informativo: https://www.youtube.com/watch?v=GJQsn3TLwyM

Cabe destacar que, aunque la propuesta de diseñar el e-portafolio tanto a nivel de contenido como de forma, se inició en dichos estudios, la propuesta es extrapolable a cualquier grado ya que hablamos de competencias que deben adquirir todos los estudiantes universitarios y que no dependen de la titulación ya que son transversales.

En esa línea, en la UPF ya partíamos de un portafolio de éxito implementado durante años en el grado de Biología Humana de la Facultad de Ciencias Experimentales y de la Salud (CEXS) (https://www.upf.edu/web/biomed/grau-en-biologia-humana). Éste se caracterizaba por desarrollarse durante los 4 años del grado. En el primer curso se presentaba y se empezaba a trabajar en él y a partir del segundo a través de las tutorías trimestrales. Apuntar que el programa de tutorías de la UPF (ACTE) también es una seña de calidad y éxito. El ACTE se basa en que cada estudiante, al iniciar sus estudios, tiene asignado un tutor/a que es profesor/a de su grado. Con este tutor se reúnen una vez al trimestre para comentar como van sus estudios y si necesitan algún tipo de apoyo. Por ello, trabajar el portafolio en este contexto es ideal y se mantiene este diseño/sistema para el portafolio del Global Studies. La presentación del portafolio se realiza a través de una sesión específica informativa para tutores y estudiantes por separado, asimismo se les envía una guía muy práctica con toda la información. Dicha guía ofrece una serie de recursos, además de informaciones clave, como unas fichas para ir evaluando las competencias tutoría a tutoría y una muestra del producto final que se pide. El trabajo en las tutorías se realiza a través de revisar las competencias transversales estipuladas, en este grado: trabajo en grupo, comunicación oral, comunicación escrita y búsqueda de información. Para ello, en una de las tutorías del año se revisa como van estas competencias haciendo uso de la ficha anteriormente citada. Éstas fichas se basan en analizar qué potencialidades y dificultades tienen en cada competencia, cómo pueden mejorar y en qué acciones concretas van a hacerlo. Las fichas son firmadas por el tutor/a y el tutorando/a y son evidencias para el portafolio que se presenta al final. El producto final es una página de reflexión por competencia, haciendo asociaciones

(c)) EY-NC-ND 2018, Universitat Politècnica de València

Congreso IN-RED (2018) 
entre la evolución de los diferentes cursos y las fichas que lo demuestran, así como con muestras de tres trabajos por competencia que denoten la evolución. Finalmente, si el portafolio es apto tienen la suma 0.5 de la nota de una asignatura del último año del grado.

Este modelo de éxito nos permitió mantener algunos aspectos para la nueva propuesta:

- Desarrollo durante todos los cursos del grado

- Enlazar el portafolio con el programa de tutorías

- Trabajar las competencias transversales indicadas, aunque se le añadieron algunas más específicas del grado en Global Studies

- Mantener la guía, las fichas y el producto final, con algunas mejoras y traducida al inglés

- Sumar un pequeño porcentaje en la nota de una asignatura del último año de grado.

Aspectos a mejorar:

- Modificar el formato del portafolio: pasarlo de papel a digital para permitir nuevos productos a añadir, por ejemplo videos, también para recoger los feedbacks de los tutores durante todo el desarrollo y para mostrarlo en entrevistas de trabajo.

- Añadir competencias transversales relacionadas con el grado específico como se ha indicado: intercultura y acceso a la profesión

- Incorporar aspectos de inserción laboral

- Mejorar las fichas de seguimiento, partiendo de las existentes, pero añadiéndole aspectos del coaching educativo, rúbricas y otros elementos para un análisis más profundo.

- Facilitar los comentarios del tutor en cada uno de los productos del portafolio para mejorar el feedback y el aprendizaje

- Colaborar con el serviciode carreras profesionales de la universidad, para entender el portafolio como un proyecto integral del grado y de la universidad.

\section{El portafolio y su contenido}

En resumen, el e-portafolio del grado en Global Studies está orientado en dos líneas: un bloque demostrativo del logro de las competencias transversales destinado al curriculum laboral y otro bloque para la inserción socioprofesional.

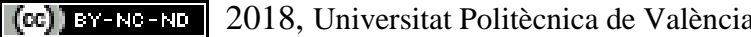


Concretamente, por lo que respecta a las competencias transversales finalmente a trabajar en el e-portafolio de Global Studies, y siguiendo la clasificación del programa Turning, son:

- Competencias transversales instrumentales: comunicación oral y comunicación escrita.

- Competencias transversales interpersonales: trabajo en grupo e intercultural

- Competencias transversales sistemáticas: búsqueda de información y acceso a la ocupación.

Estos bloques se traducen en el siguiente contenido demostrativo del perfil del estudiante:

a) Video curricular de presentación del estudiante (bloque inserción socioprofesional)

b) Carta de presentación del estudiante (bloque inserción socioprofesional)

c) Carta de recomendación del tutor u otras que pueda tener durante el grado(bloque inserción socioprofesional)

d) Curricular en formato infografía (bloque inserción socioprofesional)

e) Carpetas de cada competencia transversal con las fichas, la hoja resumen de la evolución durante el grado y productos como evidencias de la adquisición de las competencias. También se le añadió un extra "otras" por si algún alumno quería añadir más evidencias. (bloque competencias transversales)

f) Además, se le añadió un apartado con datos de contacto.

\section{El portafolio electrónico y el uso de Mahara}

Como se ha indicado, el contenido del portafolio recibió pequeñas mejoras en cuanto a las competencias, siguiendo el modelo del Grado en Biología Humana pero añade una parte de inserción profesional hasta ahora inédito en la universidad. Aunque la mayor disrupción tiene que ver con su formato, el paso de papel a digital. Básicamente, esto ofrece:

- Recibir feedback a través de comentarios que pueden ser públicos o privados en cada una de las piezas del portafolio.

- Consultar el portafolio en cualquier momento por parte del alumnado, profesorado, compañeros o personas externas.

- Incorporar nuevos productos más visuales y atractivos. Por ejemplo, videos o infografías.

- Facilitar la muestra desde cualquier dispositivo a agentes internos y externos. 
- Utilizar las piezas o productos del portafolio de manera separada o subiéndolos en otras aplicaciones: LinkeIn, blogs, etc.

- Tener en cuenta aspectos de protección de datos, en una versión de Mahara cerrada para la UPF e incorporada e integrada en la plataforma virtual.

- Ser más sostenibles reduciendo el uso de papel.

A continuación, mostramos el portafolio que hicimos como plantilla para el alumnado. Pueden acceder todos los estudiantes a Mahara y adquirir la plantilla o empezar a elaborar una propia (ver imagen 1).

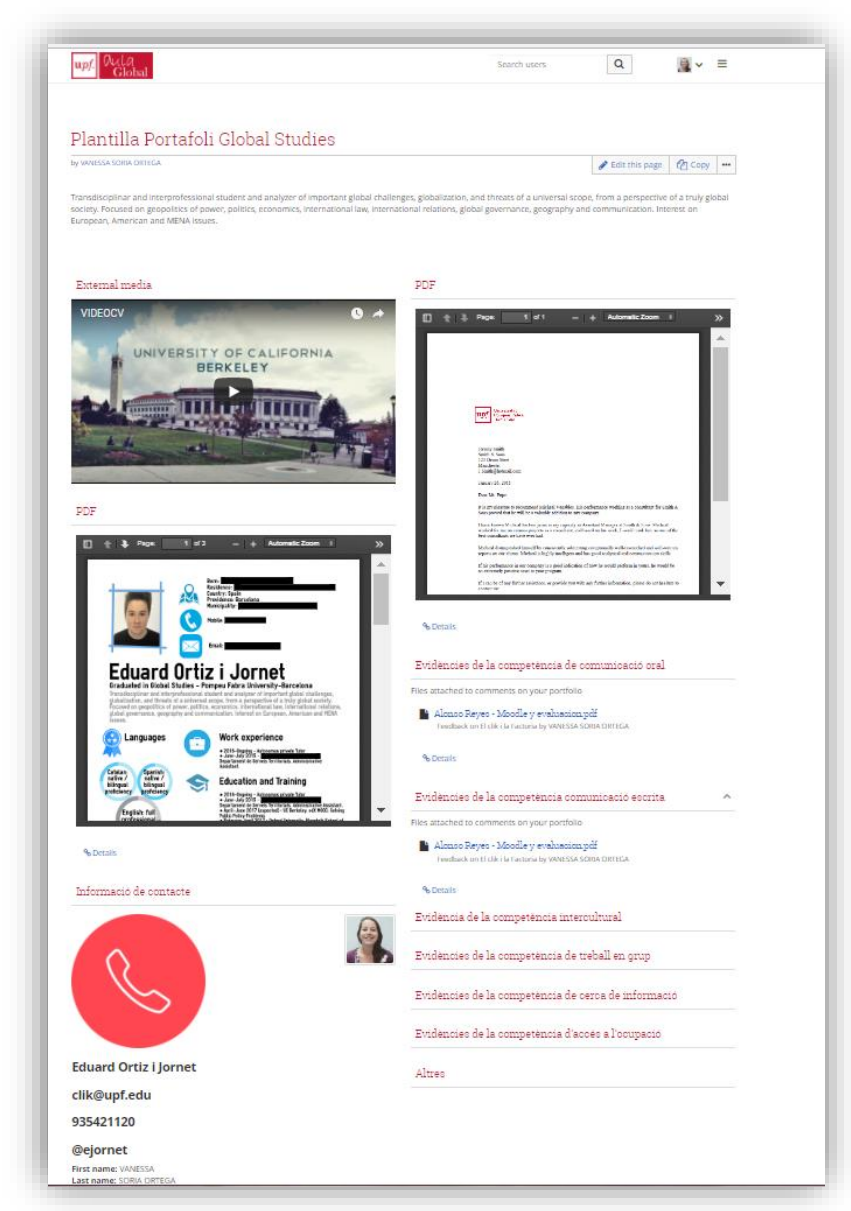

Imagen 1. Plantilla del e-portafolio del Grado de Global Studies de la UPF

\section{Las fichas para realizar el seguimiento de las competencias}

Por lo que respecta a la ficha, partíamos de un documento donde habían los títulos de los temas a trabajar "puntos fuertes, puntos débiles, propuesta de mejora y 
Diseño tecnopedagógico de un e-portafolio en educación superior para la mejora de las competencias transversales y la inserción socioprofesional.

actividad donde aplicar la mejora". Se decidió diseñar un modelo más atractivo, incorporando preguntas basadas en el coaching educativo, así como una rúbrica para analizar la adquisición de la competencia de una manera más detalla, sencilla y profunda. Así mismo, se preparó una ficha didáctica para el profesorado con el objetivo de informar y dar recomendaciones para usarla de la forma más eficaz posible y también decidimos ofrecer la ficha en versión PDF de autorelleno para colgarla en el e-portfafolio. A continuación se muestra un ejemplo de ficha de competencias.

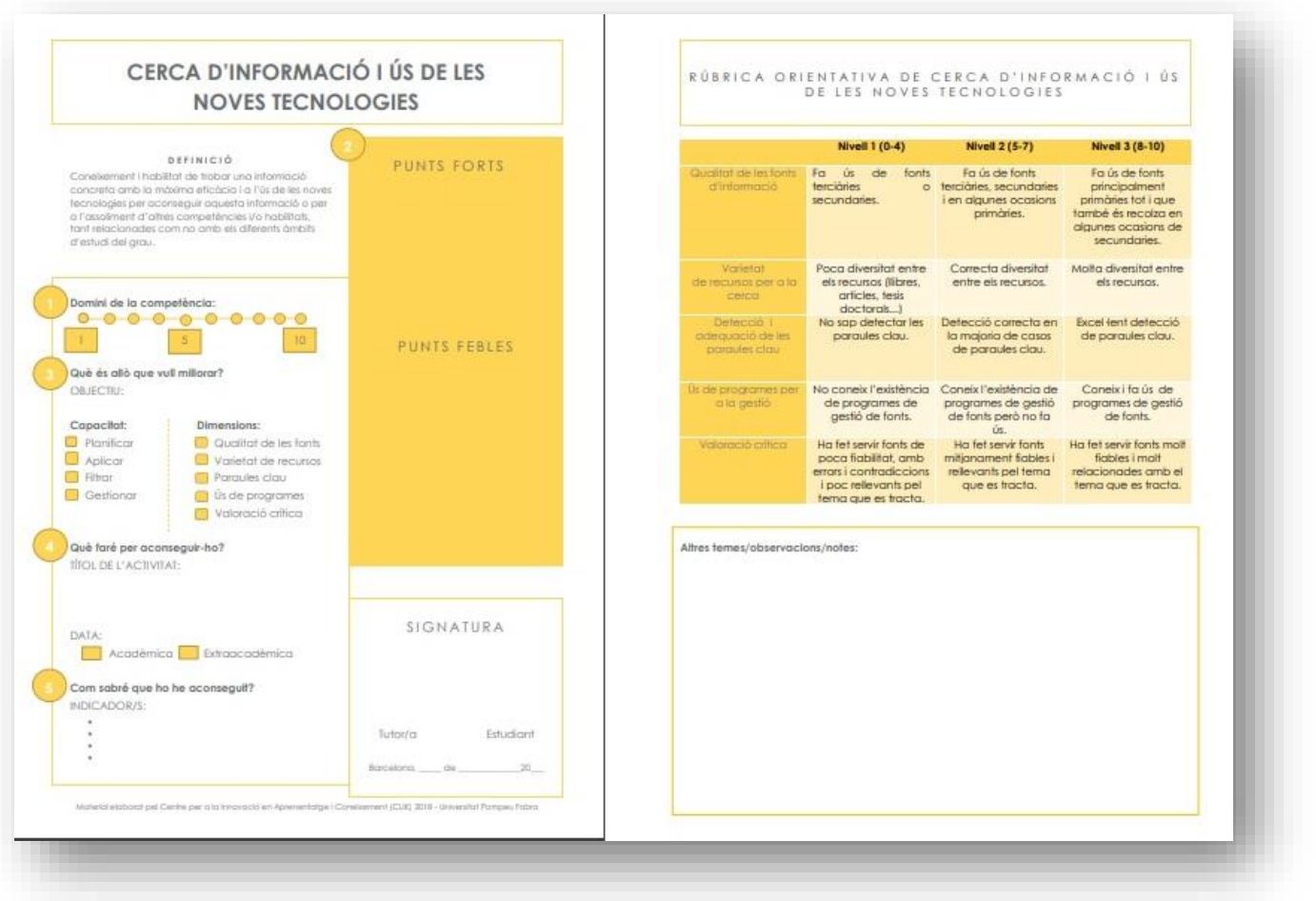

Imagen 2. Ficha de competencia oral.

\section{El proceso de validación e implementación:}

Para aplicación del portafolio, seguimos los pasos detallados a continuación:

1. Diseño junto a un estudiante del grado y la coordinación de los estudios

(cc) EY-NC-ND 2018, Universitat Politècnica de València

Congreso IN-RED (2018) 
2. Propuesta de diseño y validación, tanto de contenido como de formato

3. Elaboración de la plantilla modelo y guía para estudiantes

4. Sesiones informativas para alumnado y profesorado

5. Inicio de la elaboración del portafolio en las tutorías

6. Curso 2018-2019 evaluación del primer curso como prueba piloto.

\section{Resultados}

Por ahora podemos valorar la acogida de profesorado y alumnado, la cual ha sido muy positiva. El diseño además ha permitido enlazar cursos relacionados con el acceso a la ocupación que están desarrollando desde el servicio de carreras profesionales de la universidad. Por lo que respecta a las limitaciones podemos indicar que destacamos las siguientes:

- Limitaciones a la hora de mantener el portafolio una vez se gradúen los estudiantes, ya que va asociado al correo de alumno. Estamos trabajando para buscar modos de solucionar este aspecto. Por ahora hemos logrado que lo tengan un año más después de graduarse.

- La capacidad de espacio de Mahara es muy limitada, así requiere de usar otros lugares de hospedaje: YouTube. Drive, Dropbox, entre otros. Por tanto, ofrecemos una guía de como usar Mahara complementado con otras aplicaciones para aprovechar los megas reducidos que ofrece Mahara. También se contempla pedir una ampliación de espacio.

- El diseño del portafolio en cuanto a estética es común para todos los estudiantes y no permite customización.

\section{Conclusiones}

En cuanto al diseño, podemos valorar que éste da respuesta a las necesidades educativas actuales, a las competencias transversales, así como a la formación en materia de inserción profesional, algo que ayuda enormemente a la incorporación en el mercado laboral de nuestros futuros ingresados.

Aun así, y aunque partíamos de un modelo de éxito ya testado, faltarán varias generaciones de estudiantes del grado en Global Studies para realizar mejoras específicas y adaptar la propuesta de portafolio electrónico a sus necesidades educativas, formativas y laborales. La versión digital es una mejora, pero seguro que en los próximos años se desarrollan formatos más diruptivos de portafolios electrónicos que respondan a las necesidades educativas y profesionales. 
Diseño tecnopedagógico de un e-portafolio en educación superior para la mejora de las competencias transversales y la inserción socioprofesional.

\section{Referencias}

Aguado, D.; González, A.; Antúnez,M. y Dios, T. (2017). Evaluación de Competencias Transversales en Universitarios. Propiedades Psicométricas Iniciales del Cuestionario de Competencias Transversales. REICE. Revista Iberoamericana sobre Calidad, Eficacia y Cambio en Educación, 2017, 15(2), 129-152.

García-Álvarez, J.; Vázquez-Rodríguez, A.; y Mella-Núñez, I. (2017). La empleabilidad de los universitarios en Europa. Contribuciones de la educación no formal. Revista de estudios e investigación en psicología y educación. Vol. Extr. $N^{\circ} 7$. ISSN: 2386-7418.

García-Carpintero, E.; Siles, J.; Martínez, M.E.; Martínez, E.; Manso, C. y Álvarez, B. (2017). Metodologías de enseñanza-aprendizaje en enfermería: ¿es el portafolio una metodología acorde con el Espacio Europeo de Educación Superior?. Revista Enfermería Docente; enero-junio (108): 24-28 ISSN 2386-8678.

Jímenez, A. (2009). Reflexiones sobre la necesidad de acercamiento entre la universidad y mercado laboral. Revista Iberoamericana de Educación. N50/1- 25 de julio. ISSN: 1681-5653.

López-Pastor, V.M. (coord.). (2009). Evaluación formativa y compartida en Educación Superior. Propuestas, técnica, instrumentos y experiencias. Madrid: Narcea

Pérez Gutierréz, M. (2017). Diseño de una experiencia de evaluación formativa mediante portafolio en el grado en magisterio de educación infantil en la Universidad de Cantabria. Infancia, educación y Aprendizaje (IEYA). Vol.2, N $N^{\circ}$ (edición especial), pp.82-87- ISSN:0719-6202

Soria, V. y Carrió, M. (2016). Pedagogías disruptivas para la formación inicial de profesorado: usando blogs como e-portafolio. Revista de currículum y formación del profesorado. Vol. 20, nº2 (mayo-agosto). ISSN 1138-414X

Veytia, M.G. (coord..). (2017). Diferentes miradas sobre el empleo de las tecnologías de la información y la comunicación en educación. Durango: México 


\title{
Influencia de la gamificación en diferentes cursos y tipos de alumno
}

Rafael R. Sola-Guirado ${ }^{\text {; }}$ Sergio Castro-Garcia ${ }^{\text {; }}$ Emilio Gonzalez-Sanchez ${ }^{a}$

${ }^{a}$ E.T.S.I.A.M. Universidad de Córdoba. Ed. Leonardo Da Vinci, Ctra. N IV, km. 396. 14014. Córdoba.

\begin{abstract}
Resumen
La gamificación web abre nuevas oportunidades en la enseñanza, especialmente en materias relacionadas con agricultura donde existe una desmotivación general en el aprendizaje de contenidos teóricos. En este trabajo se ha diseñado un test con Kahoot! como evaluación intermedia, sobre los contenidos de un mismo módulo de enseñanza, impartido en diferentes cursos (extensión, grado y postgrado). Se ha evaluado su impacto sobre el proceso de aprendizaje de diferentes tipos de alumnos (edad, estudios previos, experiencia profesional...) y su valoración según un cuestionario. Los resultados muestran que la herramienta es aún desconocida y que aumentó su motivación, especialmente para aquellos con estudios no universitarios. El 56\% percibe la herramienta de gran utilidad en el aula y el 48\% que debería usarse mucho en casa. Sin embargo, no la utilizarían para evaluación final. A mayor rango académico del curso impartido, peor fueron los aciertos en el test. Esto estuvo relacionado con su experiencia como agricultores, y señala la importancia de la práctica en el aprendizaje. Hubo una ligera relación negativa entre el número de aciertos con el tiempo de respuesta. En los bloques no tecnológicos, hubo diferencias entre los tipos de cursos.
\end{abstract}

Keywords: gamificación, agricultura, autoevaluación, tipo alumno

\begin{abstract}
The gaming tools opens up new opportunities in teaching, especially in subjects related to agriculture where there is a general demotivation for theoretical contents. A test has been designed by Kahoot! as an intermediate self-assessment, based on the same teaching module, for different courses (extension, university and master) It has been assessed the tool impact on the learning process of different types of students (age, previous studies, professional experience ...) and it has been evaluated according to a questionnaire. The results show that the tool is still unknown and that it increased its motivation, especially for those with non-university studies. $56 \%$ looked at the tool very useful in the classroom and $48 \%$ would use it at home. However, they would not use it to final evaluation purposes. The higher the academic rank of the course was, the lower were the successes in the test. This was related to their experience as farmers, and this point out the importance of the practice in the learning. There was a slight negative
\end{abstract}


relationship between the number of hits and the response time. In the nontechnological blocks, there were differences between the different courses.

Palabras clave: gaming, agriculture, self-assessment, student profile. 


\section{Introducción}

Los métodos de aprendizaje están en continua evolución, condicionados en gran parte por el modo de vida de la sociedad. Este hecho conlleva a la necesidad de innovación pedagógica para la actualización y mejora de la calidad de la enseñanza. Las metodologías empleadas por los docentes deben ir alineadas con las necesidades de los alumnos y del mercado que los demanda (Rompelman, 2000). En este sentido y en este momento, las nuevas tecnologías de la información y la comunicación habilitan unas potentes herramientas de fácil uso para alumnado.

Las técnicas de gamificación tecnológicas parecen ser un buen aliado en el actual paradigma de la Educación Superior. Entre las posibilidades que ofrecen, puede tener gran utilidad en uno de los grandes problemas docentes: despertar el interés del alumno y dotarle de motivación (Lee y Hammer, 2011). Para ello, el uso de estas herramientas en el aula debe adecuarse para que el alumno pueda sentir logros a medida que progresa (Fitz-Walter,. Tjondronegoro y Peta, 2011). Con ello, se conseguirá mantener su interés y hacerlo formar parte activa del aprendizaje, no sólo como elemento de escucha del docente.

Además, para que este aprendizaje se desempeñe con éxito es importante que alumno sepa comprender su evolución, mediante evaluaciones intermedias en el desempeño de las competencias que se pretende que alcancen (Christoforou y Yigit, 2008). La realización de exámenes tradicionales intermedios en clase puede llegar a ser un elemento desmotivador para el alumno y que requiere una gran labor de corrección para el docente. Sin embargo, las nuevas herramientas de gamificación permiten que el alumno pueda autoevaluarse en tiempo real y a su vez, el profesor pueda detectar la incidencia de aquellas partes que han de reforzarse y poder ayudar a aquellos alumnos que tenga mayores necesidades.

La combinación de estas autoevaluaciones con las nuevas tecnológicas existentes de gamificación en el aula, puede se llevada a cabo con herramientas como "Socrative", "Pinnion" o "Polleveryway". En este trabajo, se ha utilizado "KAHOOT!" por su uso sencillo y gratuita en la creación y aplicación de cuestionarios. El alumno responde en tiempo real y recibe instantáneamente los resultados junto con una puntuación, de modo similar a una competición, para generar una adecuada retroalimentación con el alumno o el docente.

Existen numerosos estudios de utilización de este tipo de herramientas en diversos ámbitos tan variados como la informática (Jaume-i-Capó et al., 2016), actividades físicas (PérezLópez et al. (2017), odontología (Pintor et al., 2014), idiomas (Zarzycka, 2014), etc. Sin embargo, su aplicación en materias relacionadas con la agricultura es muy escasa. En este campo, el modo de enseñanza difiere mucho por la falta de una tipología de alumnado y su diversidad en cuanto a edad, formación, experiencia y nacionalidad. De entre los cursos más extendidos en agricultura, se encuentran los de extensión agraria, de grado o de postgrado. Debido a su orientación final aplicada y práctica, el alumando tiene una desmotivación en la impartición de los contenidos teóricos. Esto deriva a que tengan un rendimiento bajo en los exámenes finales debido a la falta de estudio. 


\section{Objetivos}

Por todo ello, parece interesante introducir la gamificación informática en el aula en estos cursos de formación agraria y evaluar su incidencia en el alumnado. Así pues, proponemos la aplicación de un test gamificado, como autoevaluación intermedia, en una serie de cursos, tanto desde una perspectiva universitaria como de extensión agraria, con contenidos comunes de mecanización agrícola. El objetivo es evaluar el impacto de la herramamienta y el test sobre las diferentes tipologías de alumnado en los diferentes tipos de cursos.

\section{Desarrollo de la innovación}

Se ha impartido un módulo de enseñanza en español en diferentes modalidades, todos relacionados con la mecanización agraria del olivar: 1) Curso para técnicos en Instituto de Formación Agraria, 2) asignatura de Grado (Ingeniería Agroalimentaria y del Medio Rural) y 3) Asignatura de Máster (Olivicultura). En cada curso hubo 15 alumnos (45 en total) con diferentes características en formación previa (universitaria y no universitaria), edades, experiencia previa como agricultores (sí y no), grado de asistencia a clase (más de 75\%, entre $50-75 \%$ y menos de 50\%) y lengua materna (española y extranjera de otros países mediterráneos como Egipto, Italia, Israel, Irán y Turquía).

Se elaboró un test que contiene preguntas relacionadas con los contenidos que se han explicado en un módulo concreto de "mecanización agraria del olivar" (5 horas de clase). El test está basado en 5 bloques de 5 preguntas por bloque con los ámbitos costes olivar, mecanización del olivar, conceptos técnicos, maquinaria e innovación. Para cada pregunta dispusieron de 30 segundos y los enunciados de las mismas estaban equilibrados para resolverlos en un tiempo similar. El test se aplicó a través de la plataforma "KAHOOT!" que aplica los test como un juego colaborativo en tiempo real y de manera virtual mediante los Smartphones de los alumnos. El test permitía 4 respuestas posibles, de las cuales una de las mismas era claramente errónea para un experto en la materia. Al final de cada test la plataforma emitió un informe que permitió evaluar el rendimiento individual y grupal.

Por otro lado, para estudiar la influencia de esta herramienta en la docencia, los estudiantes completaron un cuestionario sobre el uso de la herramienta. Se ha estudiado el conocimiento previo de la herramienta, el grado de motivación que ha supuesto en ellos, el uso de la herramienta en la enseñanza y aprendizaje, la frecuencia que se estima adecuada para usarla, sus posibilidades en otro ámbito, su utilidad para el estudio y su comparación como herramienta de evaluación respecto a un test ordinario.

\section{Resultados obtenidos y discusión}

\section{Valoración de la herramienta por el alumno}

La edad de los alumnos estuvo entre 20 y 58 años con una mediana 24 años y una media de 27 años. 15 alumnos no tenían el español como lengua materna. 15 de los alumnos no tenían ninguna experiencia previa como agricultores. El 77\% de los mismos acudió a más de $4 \mathrm{~h}$ de las $5 \mathrm{~h}$ impartidas, el $20 \%$ a más de la mitad de las horas impartidas y el 3\% restante a menos de la mitad. El 20\% de los alumnos no tenía ningún tipo de estudios universitarios.

(c) ) EY-NC-ND 2018, Universitat Politècnica de València

Congreso IN-RED (2018) 
Los resultados del cuestionario reflejan que esta herramienta era muy desconocida en el ámbito de enseñanza agrario, no habiéndola utilizado nada en más del 75\% de los alumnos encuestados. A la mayoría de los estudiantes les pareció muy o bastante adecuada para despertar su atención, siendo aquellos a los que motivó mucho principalmente aquellos sin estudios universitarios (77,8 \%). En este ámbito de motivación, ninguno de los encuestados respondió de manera negativa coincidiendo con otros autores (Lee y Hammer, 2011, Teixes, 2015).

El 57\% de los alumnos considera muy útil el uso de la herramienta en el aula en este tipo de contenidos, siendo mejor la valoración en los cursos de extensión agraria $(3,8 / 4)$ que en los de ámbito universitario $(3,4 / 4)$. Sin embargo, el $64 \%$ consideran que su uso en el aula podría aumentar para utilizarla con bastante frecuencia, pero no mucho, especialmente en el grupo de cursos universitarios, donde este porcentaje sube al 75\%. Además, el 58\% de los alumnos de cursos no universitarios creen la gamificación les ha ayudado mucho para afianzar los conocimientos aprendidos frente al 34\% los cursos universitarios. Ello, indica que podría ser utilizada a la finalización de alguna unidad específica para afianzar conocimientos como señala Yapıcı y Karakoyun (2017). El hipotético uso de la herramienta fuera de clase como complemento al estudio, es considerado de bastante utilidad por el 55\% de los alumnos y de mucho potencial por el $45 \%$ restante. Esto sugiere el uso de la herramienta para el trabajo fuera del aula, permitiéndole estudiar o repasar de un modo más ludifico.

En el apartado del uso de la herramienta para la evaluación final frente a un examen test tradicional, se obtuvo una nota media más baja. El $44 \%$ de los alumnos de los cursos no universitarios piensan que este tipo de evaluación les ha perjudicado mucho o bastante en su rendimiento, con un porcentaje mayor en los cursos universitarios (56,7\%). En los grupos de grado, fue donde se obtuvo una peor nota de 2,2/4. Esto es explicado por otros autores por el efecto negativo de la competitividad y del tiempo en la realización del test (Glover, 2013.

En general, en ninguna de las respuestas ha habido una relación ni en el factor edad, ni en el factor lengua materna, con la valoración del cuestionario. Ello determina, que el uso de la gamificación no está influenciado por la edad, ni la generación de la que provenga, pudiendo extenderse su uso a cualquier ámbito en la enseñanza.

\section{Resultados del test en el ámbito agrícola entre los grupos de estudio.}

Los resultados de los test realizados a los alumnos muestran diferentes resultados para distintos grupos de alumnos (Figura 1). En primer lugar, el nivel de estudios no repercute positivamente en el número de aciertos, es más, alumnos con niveles universitarios obtuvieron una media de 2,6 aciertos menos que aquellos con estudios no universitarios. Sin embargo, hay que señalar que esto se explica puesto que el grupo sin estudios universitarios estaba compuesto por agricultores, con experiencia en el sector. La variable experiencia tiene un peso muy importante en los aciertos con diferencias significativas ( $\mathrm{p}<0,05$, t-student) entre los aciertos de los alumnos con experiencia previa $(\mathrm{n}=25)$ y $\sin$ ella. De esta manera, el número aciertos medios fue de 19,14 para los estudiantes sin 
estudios universitarios y agricultores ( $\mathrm{n}=10), 17,16$ para aquellos con niveles universitarios y agricultores $(n=19)$, y 15,64 para los universitarios sin experiencia previa $(n=15)$.

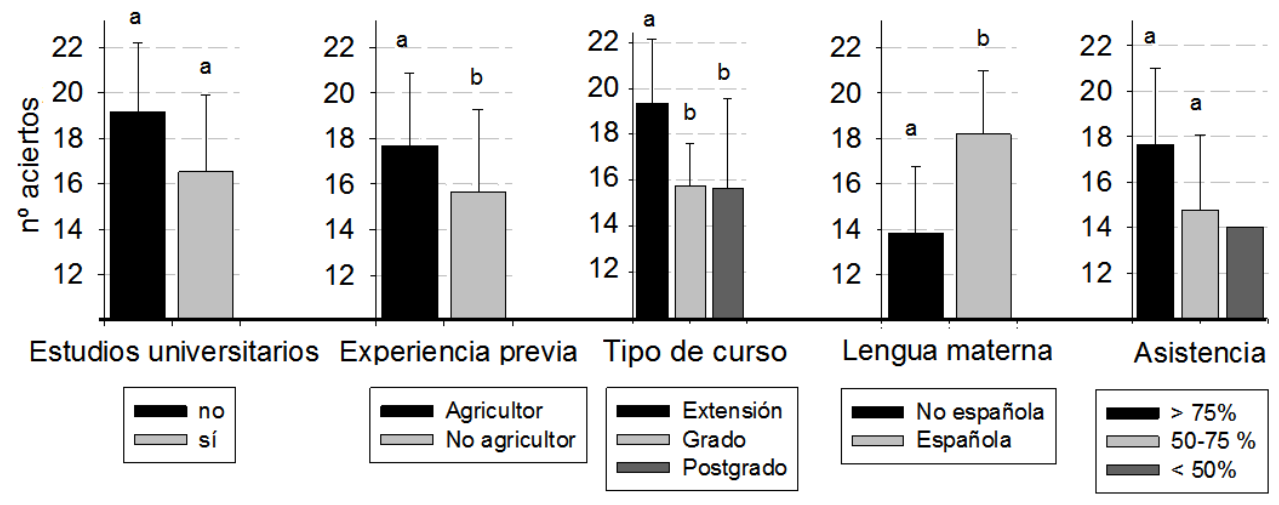

Fig. 1 Aciertos de los alumnos en el test según agrupación en diferentes categorías. Letras diferentes indican diferencias significativas entre barras para cada categoría ( $p<0.05$, test de Duncan para "Tipo de curso" y “Asistencia” y test $t$-student para el resto..

Se observa una tendencia decreciente del número de aciertos desde los cursos de mayor grado, con diferencias significativas entre los cursos de extensión y los universitarios ( $<<0.05$, Duncan test). De nuevo, la variable experiencia previa tiene cierta relación ya que, por lo general, el número de agricultores es mayor en cursos de menor rango académico: extensión $(n=16)$, grado $(n=6)$, postgrado $(n=6)$. Ha sido estudiado que la elección del alumno de una formación está altamente influenciada por su ámbito familiar (Esquivel, 1994; Martinez, 1993), siendo los alumnos provenientes de un ámbito rural los prefieren cursos de extensión y manifiestan mayor experiencia.

Entre cursos de grado y postgrado no se observan diferencias entre el número de aciertos, pero en postgrado la desviación es mayor. Ello puede ser en parte explicados por la variable lingüística, ya que en los cursos de postgrado había un mayor número de alumnos con lengua extranjera $(n=9)$ frente a los de grado $(n=2)$. Esta variable muestra diferencias significativas ( $<<0,001$, $t$-student) entre los aciertos de los grupos con habla española y extranjera. Esto refleja la barrera lingüística en la enseñanza (Sawir, E. (2005).

La relación entre el número de aciertos del alumno con su asistencia a clase, parece indicar una relación positiva (Figura 1), ya que los alumnos que asistieron que asistieron a más del $75 \%$ de las clases obtuvieron más de 2,9 aciertos con respecto a los que no lo hicieron. Ello refuerza la creencia de que la asistencia es un importante predictor del rendimiento del alumno (Credé et al., 2010).

El tiempo medio de los distintos estudiantes para responder fue de $12,89 \pm 2,85 \mathrm{~s}$. Si se analiza la influencia de los aciertos con el tiempo de respuesta, se observan ligeras diferencias entre los grupos estudiados. No existen diferencias entre las variables de agrupación, ya que sólo muestran diferencias entre grupos de menos de $1 \mathrm{~s}$, excepto en la variable lengua, donde existe una diferencia de casi 2,9 s. Existe una ligera tendencia que indica que el número de aciertos medio es inversamente al tiempo medio de respuesta

(cc) EY-NC-ND 2018, Universitat Politècnica de València

Congreso IN-RED (2018) 
(pendiente de $-11^{\circ}, \mathrm{R} 2=0,04$ ) y esto denota que el acierto puede estar relacionado con la seguridad del alumno al responder a la pregunta.

Finalmente, se observa que no existe una relación directa entre la edad del alumnado ni con el número de aciertos ni con el tiempo medio empleado en responder.

\section{Resultados de los alumnos por bloques}

El análisis de los aciertos entre los diferentes bloques del test indica diferencias entre los grupos estudiados (Figura 2). En el factor estudios universitarios no se observa ninguna diferencia significativa entre bloques. Esta tendencia es similar si los aciertos se agrupan por la experiencia previa, señalando en este caso, que en el bloque 4 de maquinaria, sí existe una diferencia significativa ( $\mathrm{p}<0,05$, $\mathrm{t}$-student) entre aquellos con y sin experiencia como agricultores. Las preguntas de este bloque, que versaron sobre identificar diferentes tipos de máquinas, reflejan cómo puede ser más eficaz iteractuar de manera práctica con una máquina, que sólo estudiarla apoyándose en fotografías. En la agrupación por tipo de curso, el número de aciertos en los bloques 1 y 4 (costes de olivar y maquinaria de olivar) fue significativamente diferentes ( $\mathrm{p}<0,05$, Duncan test) entre el curso de extensión y los de grado y postgrado, quizás debido a su carácter más generalista al igual que el planteamiento de los cursos de extensión. Sin embargo, en la agrupación por lengua materna, fueron los bloques 2 y 3 (mecanización y conceptos técnicos) los que supusieron diferencias significativas ( $\mathrm{p}<0,05$, t-student) entre los estudiantes de habla española, pudiendo explicarse a que el carácter más específico de estos bloques cuesta más su entendimiento en otra lengua.

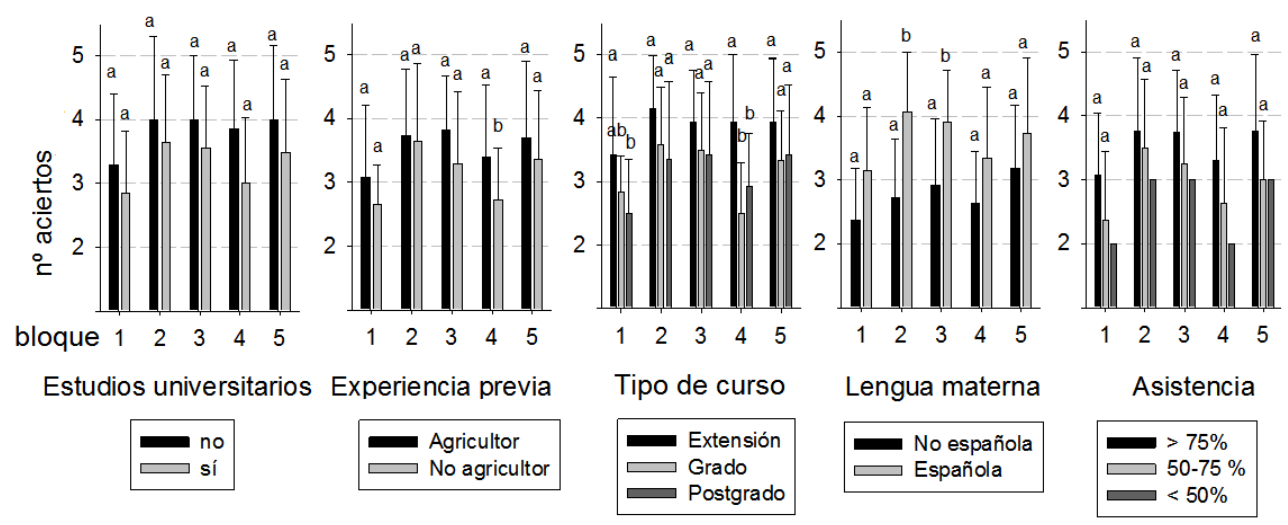

Fig. 2 Aciertos de los alumnos en el test según los distintos bloques (1 costes del olivar, 2 mecanización del olivar, 3 conceptos técnicos, 4 maquinaria e 5 innovación según agrupación en diferentes categorías. Letras diferentes indican diferencias significativas entre barras para cada categoría $(p<0.05$, test de Duncan para “Tipo de curso" y "Asistencia” y test $t$-student para el resto.

Si se analiza la incidencia del tiempo de respuesta según el bloque de preguntas (Figura 3) se observa un tiempo medio de $14,1 \pm 4,5 \mathrm{~s}$ para el bloque de costes de olivar, $15,2 \pm 3,71 \mathrm{~s}$ para el bloque de mecanización general, 13,4 $\pm 3,5 \mathrm{~s}$ para el bloque de conceptos técnicos, 11,3 \pm 3,6 s para el bloque de maquinaria y 10,46 \pm 3,3 s para el bloque de innovación. En general, el bloque 4 de maquinaria requirió menor tiempo que el resto, significativamente diferente ( $<<0,05$, Duncan test) entre el tipo de curso de extensión y el de postgrado. 
Igualmente, el bloque 5 de innovación requirió menos tiempo que el resto, coincidiendo además con el bloque con el mayor número de aciertos medios 3,7/5. Este último dato podría indicar que el alumno presta más atención a aquellos contenidos que hacen referencia al presente y futuro.

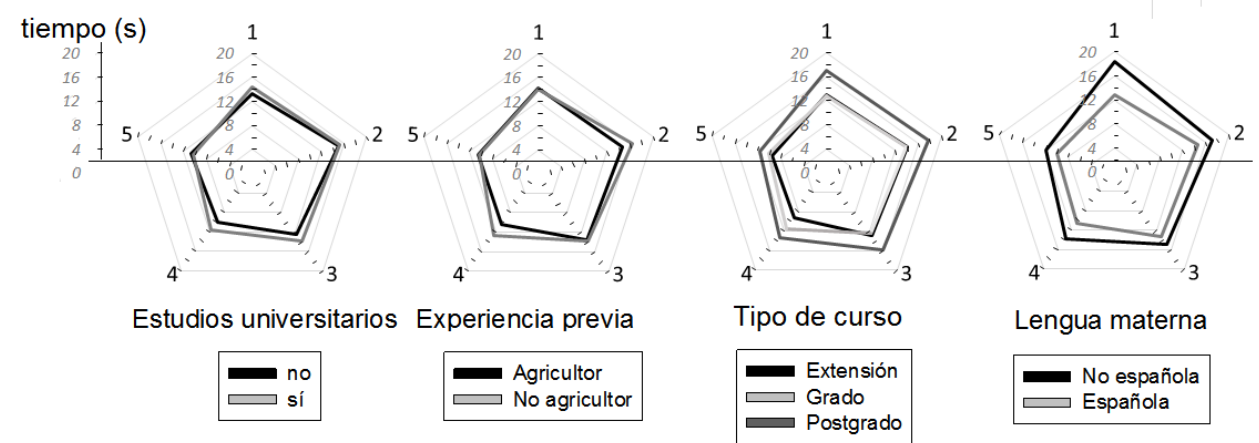

Fig. 3 Tiempo medio empleado de los alumnos en responder a las preguntas del test según los distintos bloques (1 costes del olivar, 2 mecanización del olivar, 3 conceptos técnicos, 4 maquinaria e 5 innovación según agrupación en diferentes categorías.

\section{Conclusiones}

La utilización de la gamificación en el aula de contenidos de agricultura ha tenido una fuerte aceptación a pesar de su desconocimiento previo. Los alumnos consideran que es un elemento motivador, que debería usarse frecuentemente como complemento a la enseñanza y que sirve de ayuda a la comprensión, especialmente los alumnos de cursos no universitarios. En general, no consideran adecuado su uso para la evaluación en exámenes finales.

Se ha puesto de manifiesto que la experiencia como agricultor es uno de los factores de mayor influencia para la resolución del test, y que en los cursos de extensión agraria es donde mayor número de alumnos existe con este perfil. La asistencia a clase también se muestra como indicador de buenos resultados. Existe un escollo con el idioma que repercute en peores resultados en los aciertos, donde en los bloques muy técnicos tienen un significativo menor número de aciertos con respecto a los alumnos de igual lengua a la de impartición de las clases.

Existe una ligera relación inversa entre el tiempo medio de contestación y el número de aciertos. No existen grandes diferencias entre las poblaciones de los diferentes grupos estudiados, pero parece que los bloques de maquinaria requieren de menor tiempo para la respuesta. Los bloques más generalistas de costes y maquinaria tienen mayor número de aciertos por los cursos más genéricos de extensión.

\section{Referencias}

CHRISTOFOROU, A. P., Y YIGIT, A. S. (2008). "Improving teaching and learning in engineering education through a continuous assessment process en European Journal of Engineering Education, 33(1), 105-116.

(cc) EY-NC-ND 2018, Universitat Politècnica de València

Congreso IN-RED (2018) 
CREDÉ, M., ROCH, S. G., KIESZCZYNKA, U. M. (2010). “Class attendance in college: A meta-analytic review of the relationship of class attendance with grades and student characteristics” en Review of Educational Research, 80(2), 272-295.

ESQUIVEL, L. (1994). " Toma de decisiones: Autoreporte de los factores que influyen en la elección de una carrera profesional." En Educación y ciencia, 39( 9), 37-53.

FITZ-WALTER Z., TJONDRONEGORO D. W. Y WYETH P. “Orientation Passport: using gamification to engage university students” en OzCHI 2011, Canberra, Australia. 2011.

GLOVER, I. (2013). "Play As You Learn: Gamification as a Technique for Motivating Learners" en World Conference on Educational Multimedia, Hypermedia and Telecommunications. Chesapeake: AACE.

JAUME-I-CAPÓ, A., LERA, I., VIVES, F. J., MOYÀ-ALCOVER, B., GUERRERO TOMÉ, C. (2016). "Experiencia piloto sobre el uso de la gamificación en estudios de grado de ingeniería en informática” en Simposio-Taller XXII JENUI, Universidad de Almería.

LEE J. Y HAMMER J. (2011). “Gamification in Education: What, How, Why Bother?” en Academic Exchange Quarterly, 15( 2).

MARTINEZ, T. (1993). "Familia y elección de carrera" en Perfiles educativos. Redalyc, 60,79-82.

PÉREZ-LÓPEZ, I. J., RIVERA GARCÍA, E., DELGADO-FERNÁNDEZ, M. (2017). "Mejora de hábitos de vida saludables en alumnos universitarios mediante una propuesta de gamificación” en Nutrición Hospitalaria, 34(4).

PINTOR HOLGUÍN, E., GARGANTILLA MADERA, P., HERREROS RUIZ VALDEPEÑAS, B., LÓPEZ DEL HIERRO CASADO, M. (2014). "Kahoot en docencia: una alternativa practica a los clickers” en XI Jornadas Internacionales de Innovación Universitaria.

ROMPELMAN, O. (2000). "Assessment of student learning: evolution of objectives in engineering education and the consequences for assessment" en European Journal of Engineering Education, 25(4), 339-350.

SAWIR, E. (2005). "Language difficulties of international students in Australia: The effects of prior learning experience” en International Education Journal, 6(5), 567-580.

TEIXES, F. (2015) Gamificación. Motivar jugando. Barcelona: Editorial UOC.

ZARZYCKA-PISKORZ, E. (2016). "Kahoot It or Not? Can Games Be Motivating in Learning Grammar?” in Teaching English with Technology, 16(3), 17-36. 


\title{
Material multimedia para aumentar la motivación y el aprendizaje en el aula universitaria
}

Eva Serna $^{a}$, Javier Megías ${ }^{b}$, Gloria Olaso ${ }^{a}$, María Dolores Mauricio ${ }^{\text {a }}$ y Teresa SanMiguel $^{\mathrm{b}}$

a Departamento de Fisiología, Universitat de Valencia. Eva.serna@uv.es, ํDepartamento de Patología, Universitat de Valencia. Teresa.Miguel@uv.es

\begin{abstract}
The multimedia material used as a teaching medium in the classroom can help the teaching-learning process of the students. It also helps the teacher in his work of transmitting information from another point of view more striking and entertaining. This would cause an enlargement and enrichment in the recipient's experience to assimilate more quickly, dynamically and fluidly. In this study we analyze the grades obtained with and without the help of a multimedia material prepared by teachers. Subsequently, the opinion of the students is collected through an anonymous and voluntary survey allowing the teachers to collect the information necessary for the search to improve the quality of teaching.
\end{abstract}

Keywords: multimedia material, evaluation, quality of university education.

\footnotetext{
Resumen

El material multimedia usado como medio didáctico en el aula puede ayudar al proceso enseñanza-aprendizaje del alumnado. Además le sirve de apoyo al profesor en su labor de trasmitir la información desde otro punto de vista más llamativo y entretenido. Esto provocaría una ampliación y enriquecimiento en la experiencia del receptor para asimilar el contenido didáctico de manera más rápida, dinámica y fluida. En este estudio se analizan las calificaciones obtenidas con y sin ayuda de un material multimedia elaborado por profesores. Posteriormente, se recoge la opinión del alumnado mediante una encuesta anónima y voluntaria permitiendo al profesorado recoger la información necesaria para a partir de ésta, elaborar unos objetivos de mejora de la calidad de la enseñanza.
}

Palabras clave: material multimedia, evaluación, calidad enseñanza universitaria. 


\section{Introducción}

La enseñanza universitaria necesita de nuevos recursos o medios para transmitir y presentar la información. Por ello el uso de material multimedia podría ser una de las estrategias didácticas que ayudarían en este sentido (Marquès, 2000). Al término material multimedia lo entendemos como el medio que utiliza conjunta y simultánemanete diversos medios, como imágenes, sonidos y texto en la transmisión de la información.

La motivación es un factor determinante del rendimiento académico (Roncel, 2007). Entendemos la motivación como un "incentivo, necesidad o deseo que el alumno siente de aprender y alcanzar un nivel elevado en la meta", concepto en que intervienen cuatro componentes: fijarse un objetivo, el deseo de alcanzarlo, actitudes favorables hacia una actividad particular y esfuerzo. Se trata de un concepto, en el que las variables psicosociales, la motivación y la actitud hacia el aprendizaje son mucho más decisivas que otros factores como la inteligencia, ya que las primeras son más susceptibles de modificación (Luján-García, 1999). Además, para la mayoría de investigadores, es la imagen animada, un entorno gráfico atractivo para el educando, el elemento motivador por excelencia, habiéndose demostrado que favorece la retención (Salinas, 1996).

Además de proporcionar información, el material multimedia puede orientar al estudiante, remarcando los conceptos más importantes, reforzando los puntos más conflictivos o aumentando la motivación, uno de los principales motores del aprendizaje (Polanco, 2005).

A la hora de incorporar estos recursos a la educación superior, es necesario o bien formar a los docentes para que sepan crear su propio material multimedia o bien ofrecer un servicio de calidad que se encargue de la parte técnica y oriente al profesor en la elaboración del mismo. En la Universitat de València existen convocatorias anuales de proyectos de innovación educativa, que en una de sus modalidades ofrecen la ayuda técnica para elaborar un material multimedia. Nuestro equipo docente desarrolló un proyecto a cargo de la mencionada convocatoria durante el curso académico 2015-2016 (Projectes innovació Código proyecto: UV-SFPIE_RMD15-377257). En nuestro caso el material elaborado entraría dentro de la definición de presentación multimedia.

Este tipo de recurso multimedia apoyaría al profesor en su labor de estimular el deseo de aprender y aumentar la autoestima del alumno y es, por tanto, una buena opción para ayudar en el proceso enseñanza-aprendizaje obteniendo mejores resultados. Por ello, "entender mediante conceptos y entender a través de la vista se combinan en una suma positiva reforzándose o al menos integrándose el uno en el otro" (Sartori, 1998), lo que viene a reforzar la tesis de que la cultura escrita y la cultura audiovisual dan lugar a una síntesis armoniosa.

(cc) EY-NC-ND 2018, Universitat Politècnica de València

Congreso IN-RED (2018) 


\section{Objetivos}

El objetivo general es la valoración de un material multimedia de elaboración propia sobre el aprendizajey la motivación del alumnado.

Objetivos específicos:

1. Comparar las calificaciones obtenidas por los equipos del curso 2016-2017 que realizaron la actividad sin la ayuda del material multimedia, con las obtenidas por los equipos del curso 2017-2018 que han tenido a su disposición el material multimedia.

2. Analizar la encuesta anónima y voluntaria sobre el material multimedia proporcionado.

3. Recopilar la opinión del alumnado sobre el impacto del material multimedia.

\section{Desarrollo de la innovación}

La experiencia se llevó a cabo con el alumnado matriculado en la asignatura de Biología Celular y Tisular de $1^{\text {er }}$ Curso del Grado de Podología de la Universitat de València en el curso académico 2017-2018 (Código de Asignatura: 34324 con 6 ECTS y con carácter de formación básica). El número total de alumnos fue 55 de 67 matriculados.

Mediante el uso del microscopio óptico podemos describir los componentes que integran la célula y que son descritos en la parte teórica de la asignatura. Así, podemos ayudar al alumnado a consolidar sus conocimientos teóricos y permitir familiarizarse con su uso para distinguir y caracterizar las estructuras celulares.

La elaboración del material multimedia se dividió en tres partes:

1. Descripción y manejo óptimo de las partes del microscopio óptico.

Se detalla el nombre y función de cada parte, tanto mecánica como óptica, y se explica su manejo adecuado dentro de un laboratorio.

MMEDIA: http://mmedia.uv.es/buildhtml/45978

RODERIC: http://roderic.uv.es/handle/10550/62959

YOUTUBE: https://youtube/86RmR6Lpo1c

2. Obtención de un frotis sanguíneo y tinción de Giemsa.

Esta etapa es fundamental para que el alumnado que nunca ha trabajado en un laboratorio pueda ver cómo se procede a la obtención de una preparación biológica. Además la tinción de Giemsa es el método habitual para el examen de frotis sanguíneos, cortes histológicos, y otros tipos de muestras biológicas. Por tanto, se explica una técnica básica para que en el futuro sea puesta en práctica en su carrera profesional.

MMEDIA: http://mmedia.uv.es/buildhtml/46889

(c) ) EY-NC-ND 2018, Universitat Politècnica de València

Congreso In-Red (2018) 
RODERIC: http://roderic.uv.es/handle/10550/56145

YOUTUBE: https://youtube/rmKx5JWmo4I

3. Observación de tipos celulares.

En esta parte, procedemos a observar al microscopio óptico, mediante la ayuda de un proyector, la preparación realizada en la etapa 2 . En esta fase les enseña a diferenciar los tres tipos celulares que van a encontrar en la sangre: eritrocitos, leucocitos y plaquetas.

MMEDIA: http://mmedia.uv.es/buildhtml/46662

RODERIC: http://roderic.uv.es/handle/10550/62960

YOUTUBE: https://youtube/gQwqS5xEEhE

Este material multimedia fue realizado gracias a la concesión de un proyecto de Innovación Docente titulado "Elaboración de material docente multimedia para la realización de prácticas de laboratorio enfocadas al uso de microscopio óptico y observación de tipos celulares” con Código: UV-SFPIE_RMD15-377257 y coordinado por Eva Serna García.

La encuesta que se les proporcionó, tras la visualización del material multimedia, para realizarla de forma anónima y voluntaria fue la que se muestra en la Figura 1. 


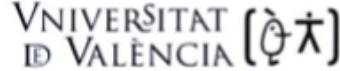 \\ Facultat de Medicina i Odontologia \\ Departament de Patologia}

\section{Encuesta sobre el material multimedia proporcionado por la Unidad de Biología}

1-¿'Te ha gustado?

\begin{tabular}{|l|l|l|l|l|l|}
\hline Nada & Poco & Indiferente & Bastante & Mucho & NS/NC \\
\hline & & & & & \\
\hline
\end{tabular}

2-¿Resulta ameno?

\begin{tabular}{|l|l|l|l|l|l|}
\hline Nada & Poco & Indiferente & Bastante & Mucho & NS/NC \\
\hline & & & & & \\
\hline
\end{tabular}

3-¿Resulta largo?

\begin{tabular}{|l|l|l|l|l|l|}
\hline Nada & Poco & Indiferente & Bastante & Mucho & NS/NC \\
\hline & & & & & \\
\hline
\end{tabular}

4-¿Aprecias tener este material de apoyo?

\begin{tabular}{|l|l|l|l|l|l|}
\hline Nada & Poco & Indiferente & Bastante & Mucho & NS/NC \\
\hline & & & & & \\
\hline
\end{tabular}

5-¿Te ha servido para reforzar la parte práctica y entender mejor la parte teórica de la asignatura

\begin{tabular}{|l|l|l|l|l|l|}
\hline Nada & Poco & Indiferente & Bastante & Mucho & NS/NC \\
\hline & & & & & \\
\hline
\end{tabular}

6-Propón alguna sugerencia de mejora o algún tema que te gustaría tener mediante esta metodología multimedia. (Respuesta libre).

Fig. 1 Encuesta anónima para la valoración de los alumnos sobre el material multimedia distribuido

\section{Resultados}

Los resultados obtenidos sobre las calificaciones del alumnado se recogen en la Tabla 1. Como se puede apreciar, se obtuvo un incremento de más de $5 \%$ en las calificaciones de su examen referidas al contenido de prácticas, y por tanto, al contenido que el material multimedia complementaba en la formación del alumnado. 
Tabla 1. Porcentaje de respuestas acertadas en las preparaciones de sangre humana y de anguila de las dos poblaciones de estudio.

\begin{tabular}{cccc}
\hline Población & $\begin{array}{c}\text { \% Respuestas correctas } \\
\text { en preparaciones de } \\
\text { sangre humana }\end{array}$ & $\begin{array}{c}\text { \% Respuestas } \\
\text { correctas en } \\
\text { preparaciones de } \\
\text { sangre de anguila }\end{array}$ & $\begin{array}{c}\text { Cantidad total de } \\
\text { respuestas } \\
\text { computadas y \% } \\
\text { acertado }\end{array}$ \\
\hline $\begin{array}{c}\text { Sin MM (Curso 2016- } \\
\text { 2017) }\end{array}$ & $80,0 \%$ & $83,8 \%$ & 67 (82,1\% acertado) \\
Con MM (Curso 2017- & $88,9 \%$ & $86,1 \%$ & 72 (87,5\% acertado) \\
2018) & & & \\
\hline
\end{tabular}

Sin MM: estudiantes que no tuvieron el material multimedia.

Con MM: estudiantes que tuvieron el material multimedia.

Tras pasar la encuesta al alumnado, el 65,45\% (36 alumnos/as) valoró la experiencia como que le había gustado bastante la visualización de los 3 videos (Figura 2), al 54,55\% (30 alumnos/as) les resultó bastante amena (Figura 3), el 65,45\% (36 alumnos/as) apreció mucho disponer de este tipo de material multimedia (Figura 4). Además al 32,73\% (18 alumnos/as) les parecía un formato adecuado ya que no les pareció que fuera largo (Figura 5), y el 47,27\% (26 alumnos/as) valoraba que el material mutimedia ayudaba a reforzar el contenido teórico-práctico dado en la asignatura (Figura 6).

\section{Te ha gustado}

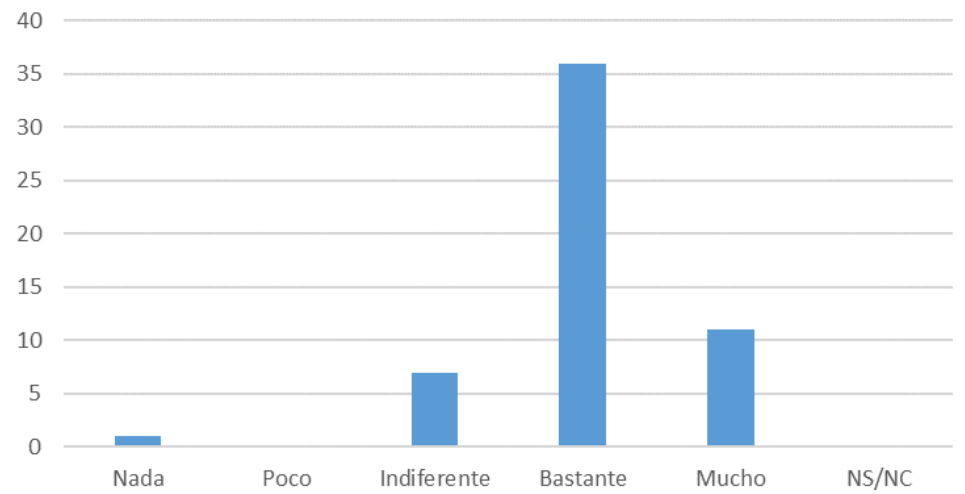

Fig. 2. Valoración del material multimedia a la pregunta de si "les ha gustado" de los 55 participantes. 


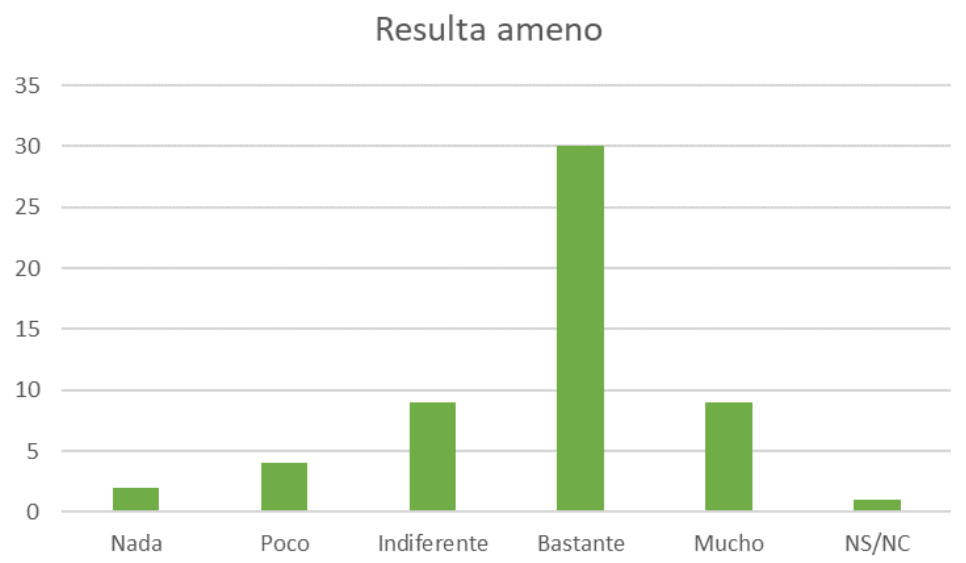

Fig. 3. Valoración del material multimedia a la pregunta de si "les ha resultado ameno" de los 55 participantes.

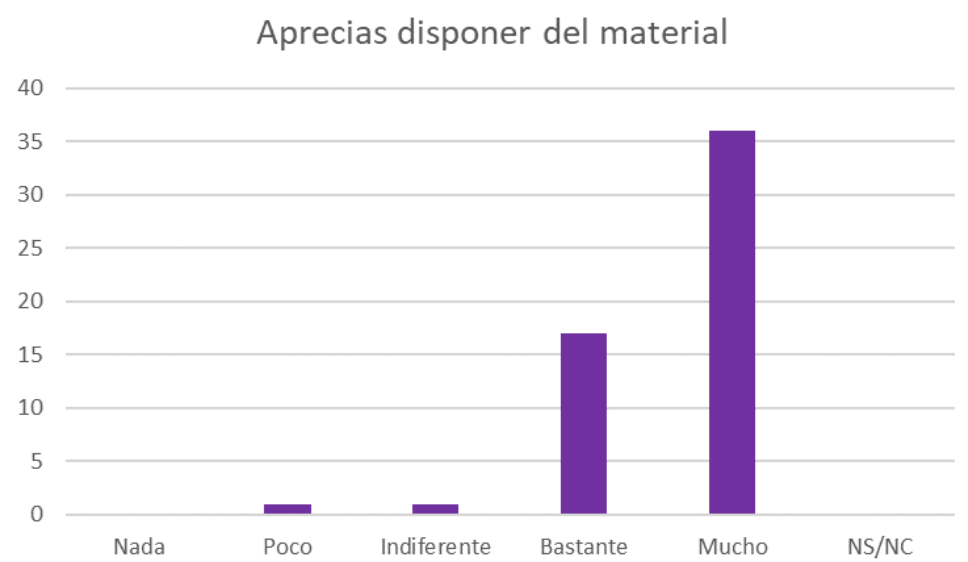

Fig. 4. Valoración del material multimedia a la pregunta de si "aprecias disponer del material” de los 55 participantes. 
Resulta largo

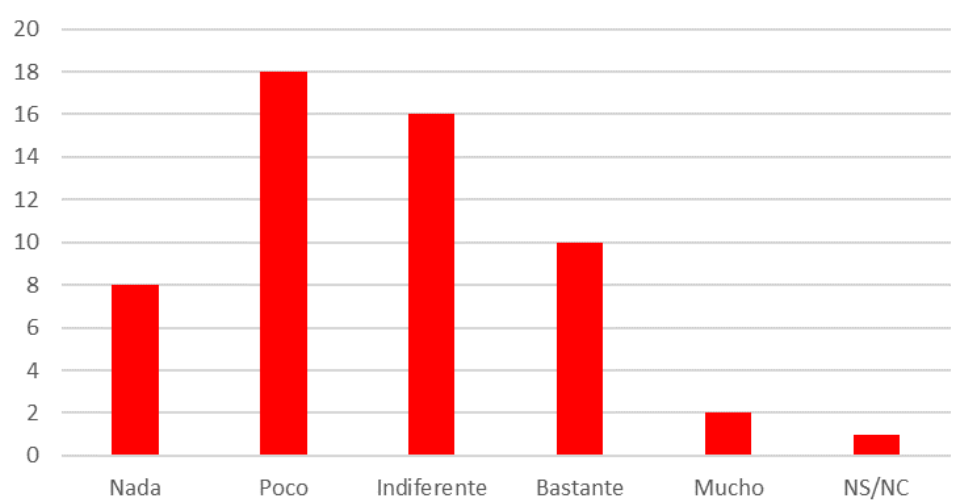

Fig. 5. Valoración del material multimedia a la pregunta de si "resulta largo" de los 55 participantes.

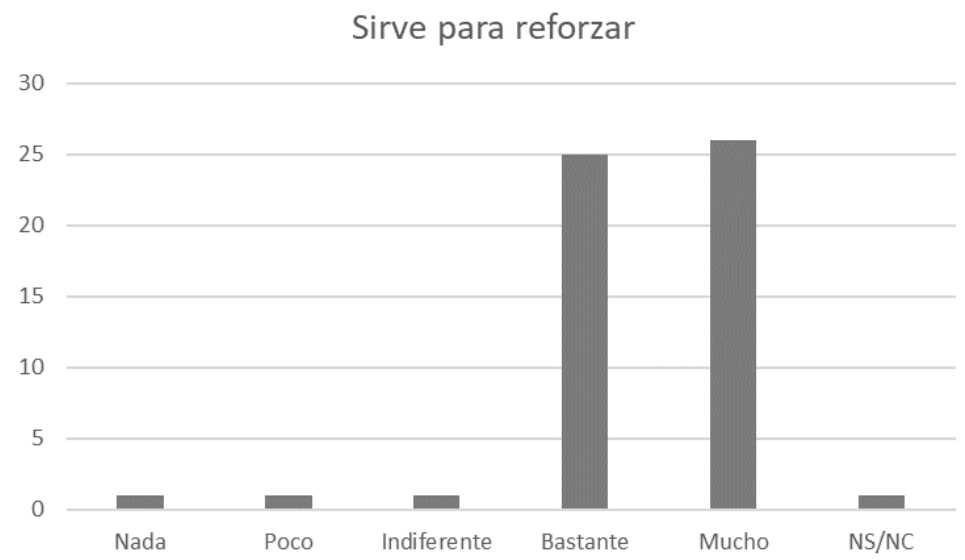

Fig. 6. Valoración del material multimedia a la pregunta de si "sirve para reforzar" de los 55 participantes.

Sobre la opinión libre de los alumnos (punto 6 de la encuesta proporcionada) obtuvimos un total de 19 aportaciones. De las cuales, destacamos que 8 opiniones que eran para pedir más material similar al elaborado y que también se realizara en el área, no solo de microscopia óptica, sino también de la electrónica. Tres opiniones estaban encaminadas a la interactividad a posteriori de la visualización del material, 2 pedían un cambio de música, y otros dos participantes opinaban que la duración fuera menor.

Además, contabilizamos la cantidad de visualizaciones de los tres vídeos realizados por las tres plataformas utilizadas para su divulgación (MMEDIA, RODERIC y YOUTUBE). La plataforma youtube fue la más utilizada, siendo el material mutimedia 2: “ Obtención de un frotis sanguíneo y tinción de Giemsa” el más exitoso, con más de 3.000 visitas.

(c)) EY-NC-ND 2018, Universitat Politècnica de València

Congreso IN-RED (2018) 


\section{Número de visualizaciones en la plataforma de youtube}

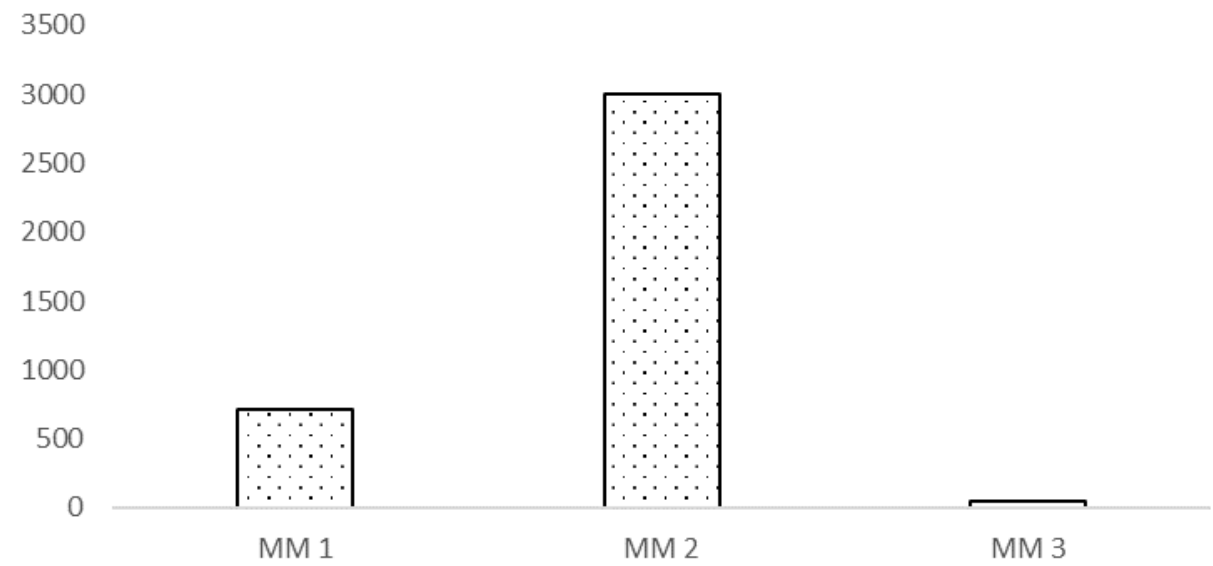

Fig. 7. Número de visualizaciones en la plataforma de youtube del material multimedia (MM) de cada uno de los vídeos elaborados (última actualización 13-03-2018.)

\section{Conclusiones}

La finalidad de nuestra experiencia es comprobar si con el uso de material multimedia, además de proporcionar al alumnado un recurso más atractivo desde el punto de vista del profesorado, si es interesante y aprovechoso para el alumnado y además si le potencia en su proceso de aprendizaje.

Desde un punto de vista de análisis de calificaciones, se pudo observar que el uso del material multimedia ayuda a mejorar significativamente el rendimiento del alumnado, ya que el aumento fue de más de $5 \%$.

La opinión del material multimedia realizado por el equipo de profesores y profesoras fue muy bien valorado, siendo para la mayoría del alumnado un recurso que gusta, es ameno, con el formato adecuado, y que es apreciado tenerlo para reforzar sus contenidos. Cabe destacar que este material introduce un factor de tipo motivacional que necesariamente favorece el aprendizaje.

De los tres videos generados, el que más éxito tiene, tanto para el alumnado como para los seguidores de la plataforma youtube, es el material multimedia correspondiente a la realización de un frotis sanguíneo y tinción de Giemsa (Material Multimedia 2). Este contenido se suele dar desde un punto de vista teórico y con la generación de este recurso se adentra al alumnado en un laboratorio real y le permite visualizar cada paso de manera detallada y relajada.

Como conclusión final podemos afirmar que el material multimedia es una herramienta que se debería usar en la docencia universitaria ya que tiene muy buena acogida por el alumnado y mejora en el rendimiento de su aprendizaje.

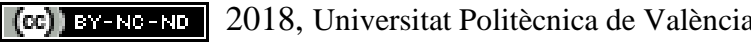




\section{Referencias}

LUJÁN-GARCÍA, C.I. (1999). La motivación: Un factor relevante en el proceso de enseñanza/aprendizaje de lenguas extranjeras. Boletín Millares Carlo, (18), 269-278.

MARQUÈS, P. (2000). Ventajas e inconvenientes del material multimedia educativo. Departamento de Pedagogía Aplicada, Facultad de Educación, UAB $<$ http://peremarques.net/ventajas.htm> [Consulta: 20 de marzo de 2018].

POLANCO, A. (2005). "La motivación en los estudiantes universitarios". Revista Electrónica "Actualidades Investigativas en Educación. Vol. 5, núm. 2, pp. 1-13 $<$ http://www.redalyc.org/articulo.oa?id=44750219 > [Consulta: 18 de marzo de 2018]

RONCEL VEGA, V. M. (2007). El rendimiento en ELE en la enseñanza reglada: un modelo explicativo. MarcoELE: Revista De Didáctica, (5).

SALINAS, J. (1996): "Multimedia en los procesos de enseñanza - aprendizaje: Elementos de discusión”. Ponencia en el Encuentro de Computación Educativa. Santiago de Chile, 2-4 mayo.

SARTORI, G. (1998) “Homo Videns, La sociedad teledirigida”. Ed. Aguilar, Altea, Taurus, Alfaguara, S.A., México. 


\title{
Desarrollo y aplicación de software docente en prácticas de psicrometría
}

\author{
Emilio José Sarabia Escriva a , Víctor Soto Francés ${ }^{\mathrm{b}}$ y Jose Manuel Pinazo Ojer ${ }^{c}$ \\ ${ }^{a}$ Universitat Politècnica de València(emsaes@upvnet.upv.es), Universitat Politècnica de \\ València(vsoto@ter.upv.es) y ${ }^{\mathrm{c}}$ Universitat Politècnica de València(jmpinazo@upvnet.upv.es)
}

\begin{abstract}
The article describes the motivation for the development of a friendly software for the students and their integration in the laboratory practices of different subjects related to air conditioning, in which the psychrometric processes are explained.

The software allows to simulate psychrometric processes without having to make costly calculations, and with that, students can better understand the functioning of different equipment.

The text describes the characteristics required for the software in order to improve the learning process and the design of a practice session with it.

Keywords: air conditioning, psychrometry, software

Resumen

El artículo describe la motivación por el desarrollo de un software amigable para los alumnos y su integración en las prácticas de laboratorio de diferentes asignaturas relacionadas con la climatización, en las que se explican los procesos psicrométricos.

El software permite simular procesos psicrométricos sin necesidad de hacer costosos cálculos, con ello, el alumno puede entender mejor el funcionamiento de los diferentes equipos.

En el texto se describen las características requeridas al programa para poder atender a las necesidades docentes y el diseño de una sesión de prácticas con el mismo.
\end{abstract}

Palabras clave: climatización, psicrometría, software

\section{Introducción}

El uso de programas informáticos es una actividad extendida en las sesiones prácticas de muchas asignaturas. Este tipo de actividad permite a los alumnos emplear los conocimientos teóricos vistos en clase en la resolución de casos reales utilizando herramientas que ayudan a realizar los cálculos de forma automática. En muchos casos, el software empleado es de tipo profesional, es decir, no tiene carácter docente. Por ejemplo, en el caso de programas informáticos para selección de equipos, el programa, en base a 
unos datos de entrada te indica el resultado óptimo, sin especificar la metodología de cálculo empleada, los criterios utilizados o las posibles soluciones alternativas. De alguna manera, el programa actúa como una caja negra que responde a unos datos de entrada. Esto puede ser suficiente a nivel profesional, pero a nivel docente esa laguna de información no es adecuada.

En este artículo se describe el desarrollo de un software de carácter docente para la realización de cálculos psicrométricos en asignaturas de climatización. El software también puede emplearse de forma profesional, pero el diseño del mismo ha tenido en cuenta una aplicación docente para su empleo por parte de alumnos en prácticas de climatización.

La psicrometría estudia las propiedades termodinámicas del aire húmedo y el comportamiento de éste ante diferentes procesos como: calentamiento, enfriamiento, humectación, mezcla de diferentes corrientes, etc. De esta forma, se modeliza el comportamiento del aire, con el fin de predecir el estado final del mismo al aplicar uno u otro proceso. Esto requiere conocer las diferentes variables que definen el estado del aire (variables psicrométricas), así como la relación existente entre las mismas (Atecyr, 2009) (Pinazo, 1995).

El estudio de esta materia es un tema básico en aquellas asignaturas relacionadas con la climatización. Existen diferentes grados y másters en la Universitat Politècnica de València (UPV) en los que se imparten asignaturas relacionados con la climatización (Grado de Mecánica, Grado de Energía, Grado de Química, Máster de Tecnologías industriales, Máster de Edificación, Máster de Instalaciones industriales, etc.) por lo que es una asignatura ampliamente extendida.

Los cálculos psicrométricos son necesarios para el diseño de equipos o unidades de tratamiento de aire (UTA). Con ello se diseñan los equipos de clima que son capaces de contrarrestar las cargas térmicas de los edificios (Pinazo, 1996). De ahí la importancia de este tema en cualquier asignatura de climatización. Los cálculos psicrométricos nos permiten, por un lado, determinar las condiciones de impulsión de aire necesarias para compensar las cargas térmicas y por otro, determinar la potencia necesaria que deben tener las baterías de frío y de calor de los sistemas para poder desempeñar este trabajo.

El software implementado está registrado como una patente de software en la oficina del CTT de la UPV con el nombre de SICRO_V2 (código R-18126-2016). En la actualidad, el software es utilizado también por diferentes ingenierías para realizar sus cálculos y se incluye dentro de un paquete de herramientas que ofrece la Asociación de Técnicos de Climatización y Refrigeración para los técnicos del sector de forma gratuita a través de la plataforma (Atecyr, 2016).

El artículo se ha dividido en los apartados: objetivos, en el que se plantea la necesidad de una herramienta docente para la explicación y práctica de conceptos de psicrometría; una sección de desarrollo de la aplicación, en la que se enumeran las características necesarias del software que se desea desarrollar además de su puesta en práctica; una sección de resultados, en la que se comenta cómo ha sido la introducción de la innovación en el aula; y filamente una sección en la que se exponen las conclusiones del trabajo.

(cc) EY-NC-ND 2018, Universitat Politècnica de València 


\section{Objetivos}

El objetivo planteado en el trabajo ha sido desarrollar una herramienta informática de carácter docente para su aplicación en prácticas informáticas de asignaturas de climatización, en concreto para la realización de cálculos psicrométricos. De esta forma, se pueden realizar tareas de diseño de unidades de tratamiento de aire y hacerlo empleando tiempos de cálculo razonables. Además, se preparan una serie de ejercicios, para la sesión de prácticas, que el alumno deberá resolver utilizando la herramienta como apoyo a la hora de realizar cálculos. En el mercado no existe software similar, al menos de carácter docente, por lo que el desarrollo resulta ser innovador en el campo especificado. De hecho, es utilizado en otros centros formativos en que se imparten asignaturas de climatización.

La práctica diseñada se adapta a cualquier asignatura de climatización que contenga el tema de psicrometría. De esta manera, es una tarea que se puede emplear en diferentes asiganturas y cursos, además se puede emplear en cursos presenciales o a distancia. Para las clases de asignaturas presenciales, el profesor hace una explicación básica del funcionamiento de la misma y comenta la actividad que los alumnos deben realizar. En el caso de cursos online, la explicación profesor se substituye por unos videos tutoriales que explican el funcionamiento de la aplicación (Atecyr, 2016). En ambos casos, la entrega de la tarea es un documento con los cálculos realizados en la aplicación y la respuesta a una serie de cuestiones que requieren el análisis de los resultados obtenidos.

\section{Desarrollo de la innovación}

\subsection{Características docentes de la aplicación}

Para el desarrollo de la herramienta se ha utilizado el lenguaje de programación C++ y el compilador de la compañía Borland C++ Builder versión 5 (Schildt ,2001). La herramienta es un ejecutable que funciona en el sistema operativo Windows y el modo de instalación del programa consiste en descomprimir un archivo zip que contiene toda la información del mismo. De esta manera, el programa no requiere ninguna instalación especial y puede ejecutarse incluso desde una unidad USB, esto resulta especialmente útil en aulas informáticas en las que hay que tener permisos especiales para la instalación de software. Esta característica permite también que el alumno pueda tener la aplicación en su propio ordenador y pueda realizar las tareas en cualquier lugar y momento.

A continuación se enumeran aquellas características que hemos considerado interesantes incluir en la herramienta con el fin de conseguir una adecuada función docente:

- Interface sencilla, de manera que el aprendizaje del manejo del programa no suponga una dedicación excesiva del alumno. Para ello el programa contiene únicamente dos pantallas, una principal en la que se definen los procesos psicrométricos y se representan directamente sobre el diagrama psicrométrico y otra en la que se resumen en dos tablas los procesos definidos y las propiedades termodinámicas de las variables en cada punto (Fig. 1). 


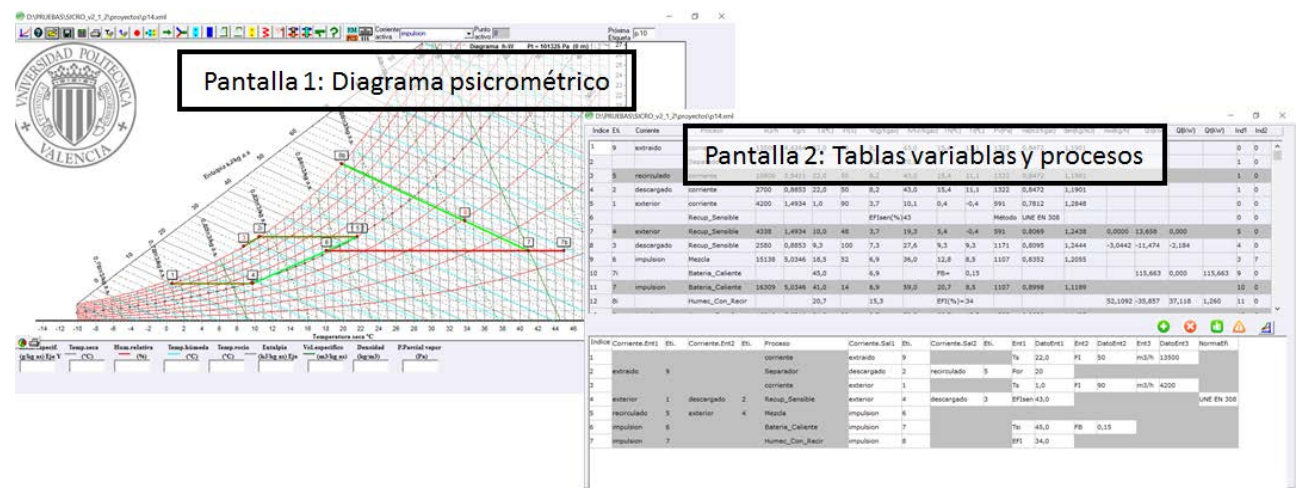

Fig. 1. Pantallas de la aplicación SICRO_V2

- Deglose de los resultados parciales en cada uno de los procesos psicrométricos que se calculan. Esta información permite a los alumnos observar las características de cada uno de los procesos y el efecto que tienen las propiedades de los equipos. Por ejemplo, el paso del aire por una batería caliente proporciona solamente potencia sensible, mientras que el paso por una batería fría puede hacer que exista también una reducción de la humedad del mismo, potencia latente.

- Detalle del valor de todas las variables psicrométricas en cada uno de los puntos de los procesos definidos.

- Posibilidad de modificación de propiedades ya definidas y recálculo del proceso para observar las consecuencias y efectos que producen (Figura 2).

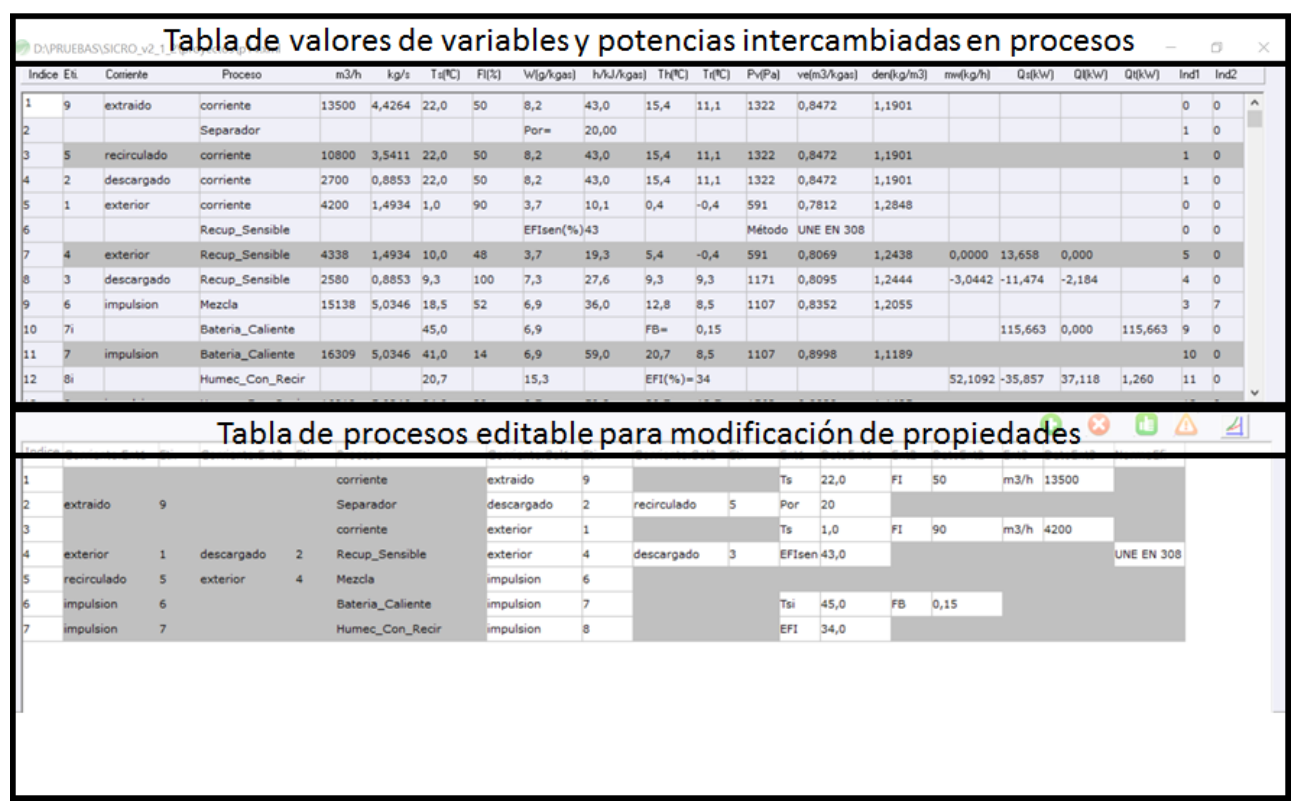

Fig. 2. Tabla de propiedades de los puntos del ciclo y tabla de edición de datos de los procesos.

- Representación gráfica de resultados en el diagrama psicrométrico, con el fin de visualizar de forma clara el proceso general. La representación del proceso sobre

(cc) EY-NC-ND 2018, Universitat Politècnica de València

Congreso IN-RED (2018) 
el diagrama psicrométrico facilita el entendimiento del mismo y de los resultados que se obtienen (Figura 3).

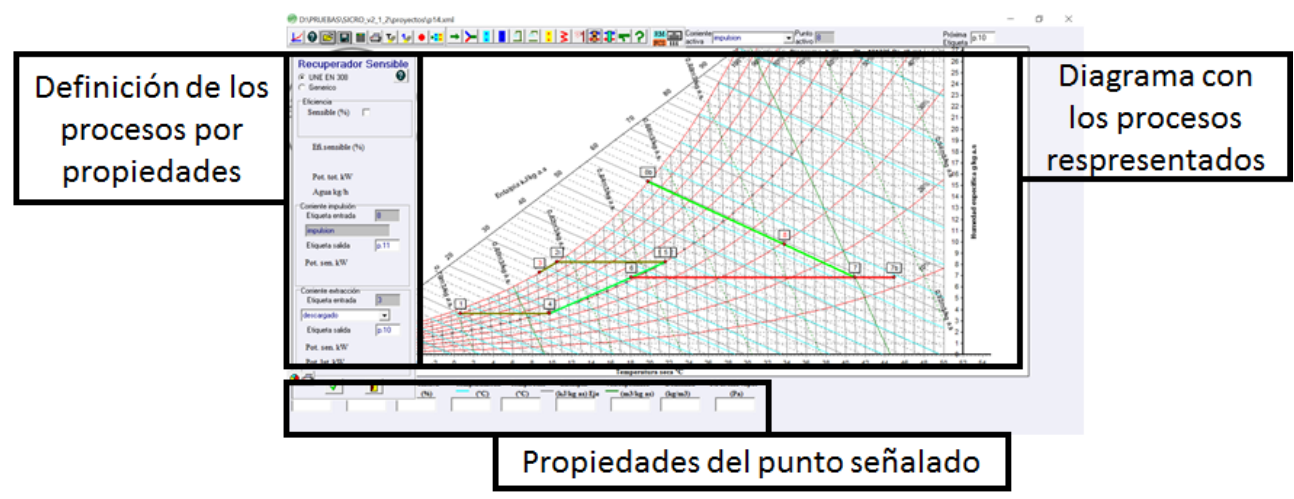

Fig. 3. Diagrama psicrométrico con los procesos representados.

- Informe de resultados de salida en el que se especifiquen los caudales y las propiedades termodinámicas del aire en cada punto. Como formato de salida de resultados se ha decidido emplear html por ser un archivo de texto que se puede visualizar en cualquier editor de texto y navegador.

- Posibilidad de definir los procesos psicrométricos de diferentes formas, incluso de modo gráfico.

- Creación de tutoriales explicativos del manejo de la instalación para que los alumnos presenciales puedan volver a ver algunas características del programa y para que los alumnos de cursos a distancia puedan aprender el manejo de la aplicación. Los tutoriales consisten en videos cortos de entre 5 y diez minutos en los que se explican detalles concretos del programa (Atecyr, 2016).

- Versión del programa en inglés para poder utilizarla con alumnos extranjeros o con los grupos asignados a esta lengua.

\subsection{Diseño de una práctica informática con la aplicación}

A continuación se describe una sesión práctica de tres horas de duración dedicada al análisis del funcionamiento de dos UTAs (unidades de tratamiento de aire) utilizando el programa SICRO_V2 para la resolución y discusión de resultados. La práctica se ha diseñado a modo de análisis de dos casos de equipos de climatización. Una situación que el alumno debería entender como motivadora, lo cual ayuda a la implicación del alumno en la resolución de la misma y facilita el aprendizaje. (Cabrero, 2006) especifican las variables que deben tenerse en cuenta para que la actividad sea percibida como útil por parte de los alumnos.

El esquema de la sesión práctica es sencillo, una primera hora se dedica a la explicación del manejo del programa por parte del profesor y con ello se repasan algunos conceptos ya vistos en las sesiones teóricas. En el caso de los cursos online, esta hora está dedicada por 
parte del alumno a la visualización de los videos tutoriales de la aplicación que muestran el funcionamiento de la misma (Atecyr, 2016).

Las siguientes dos horas están dedicadas al trabajo individual del alumno para la resolución de dos modos de funcionamiento que se plantean para una equipo de climatización. Cada uno de los ejercicios tiene una duración de una hora. La tabla 1 refleja el ajuste de tiempos asignados a cada actividad.

Tabla 1. Esquema de práctica informática con el programa SICRO

\begin{tabular}{cc}
\hline Tareas & Duración \\
\hline $\begin{array}{c}\text { Caso presencial: Explicación del } \\
\text { funcionamiento del programa. }\end{array}$ & 1 hora \\
Caso online: Visualización videos \\
tutoriales del manjo de la aplicación \\
$\begin{array}{c}\text { Tarea 1. Análisis funcionamiento de } \\
\text { una UTA en modo verano }\end{array}$ \\
$\begin{array}{c}\text { Tarea 2. Análisis funcionamiento de } \\
\text { una UTA en modo invierno }\end{array}$ \\
\hline
\end{tabular}

Las tareas 1 y 2 consisten en el análisis del funcionamiento de unos equipos de climatización, uno para modo verano y otro para modo invierno. La figura 4 muestra el esquema de estas UTAs que el alumno deberá definir en la aplicación SICRO_V2 y responder a una serie de cuestiones para identificar que entiende los resultados que la aplicación muestra y que es capaz de utilizarlos para realizar otros análisis.
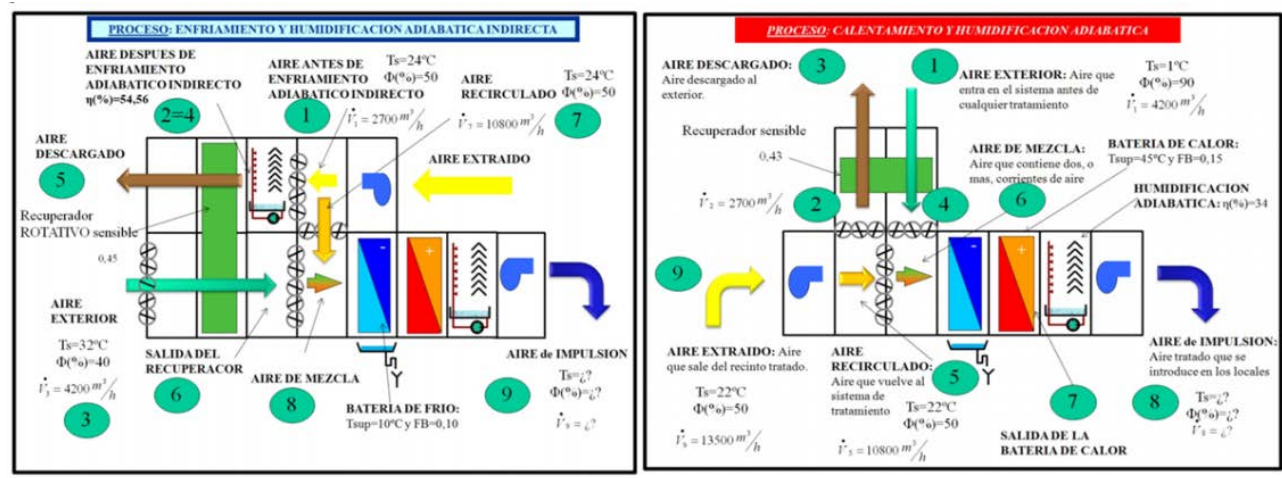

Fig. 4. Equipos de climatización cuyo comportamiento el alumno debe modelizar en la aplicación.

El alumno deberá definir cada uno de los procesos psicrométricos que existen en las diferentes corrientes de aire definidas en las figuras para responder a las siguientes cuestiones:

- Cuestiones conceptuales: 
o Conocer las propiedades termodinámicas de cada uno de los puntos indicados en los equipos.

o Determinar la potencia intercambiada con el aire por cada uno de los equipos.

- Cuestiones de análisis:

o Indicar el significado de los valores positivos y negativos en las potencias.

o Calcular las cargas térmicas que pueden contrarrestar estos equipos en un edificio.

o Indicar qué consecuencias tiene si no existe humectador en el aire de extracción para la UTA que trabaja en modo verano.

o Indicar qué pasa cuando el recuperador sensible tiene una eficiencia del $60 \%$ en ambos casos.

Las primeras dos cuestiones se resuelven identificando los datos correctos sobre los resultados de la aplicación, son cuestiones conceptuales. Mientras que para el resto de cuestiones, el alumno hace uso de los resultados obtenidos para llegar a otras conclusiones, se trata de cuestiones de análisis.

La evaluación de la práctica se especifica en la Tabla 2. A modo de resumen, se valora en un $30 \%$ el diseño de los equipos en el programa SICRO_V2 y un 30\% conocer dónde identificar las variables del proceso y los resultados obtenidos. El 40\% restante corresponde a la resolución de las cuestiones de análisis propuestas.

Tabla 2. Evaluación de la práctica

\begin{tabular}{ccc}
\hline Tareas & Actividad & Valor \\
\hline \multirow{2}{*}{$\begin{array}{c}\text { Tarea 1. Análisis funcionamiento de } \\
\text { una UTA en modo verano }\end{array}$} & Diseño de la UTA & $15 \%$ \\
\cline { 2 - 3 } & Cuestiones conceptuales & $15 \%$ \\
\hline \multirow{2}{*}{$\begin{array}{c}\text { Tarea 2. Análisis funcionamiento de } \\
\text { una UTA en modo invierno }\end{array}$} & Cuestiones de análisis & $20 \%$ \\
\cline { 2 - 3 } & Cuseño de la UTA & $15 \%$ \\
\cline { 2 - 3 }
\end{tabular}

\section{Resultados}

El uso del programa informático SICRO_V2 ha permitido desarrollar una práctica exclusivamente informática sobre la materia. Este tema se complementa en las asignaturas de clima con otra sesión de prácticas en el laboratorio, sobre equipos reales. Las sesiones de laboratorio con equipos reales permiten que el alumno pueda ver in situ cómo es y funciona una instalación real, lo cual les motiva y mejora el proceso de aprendizaje. Pero esta sesión práctica en el laboratorio se aprovecha mucho más cuando el alumno llega con los conceptos teóricos claros, si no es así, el profesor debe invertir mucho tiempo en repasar 
parte del contenido teórico para que los alumnos entiendan adecuadamente lo que está pasando en los equipos.

Se ha observado que la sesión de laboratorio se aprovecha más cuando la sesión informática se realiza previamente, ya que ésta le permite al alumno entender mejor cada uno de los procesos psicrométricos y el funcionamiento de los equipos. El programa informático permite modificar el valor de algunas propiedades de equipos y ver qué consecuencias tiene eso sobre el proceso final. En el laboratorio, en cambio, los equipos tienen menor posibilidad de variabilidad y cuando se realizan cambios, los resultados no son tan inmediatos ni fáciles de entender. Esto se comprueba al analizar los diferentes trabajos de prácticas presentados por los alumnos. Aquellos grupos que han trabajado la sesión informática previamente son capaces de entender mejor el comportamiento de los equipos del laboratorio cuando obtienen los datos.

Por tanto, la sesión informática con el programa SICRO_V2 permite a los alumnos entender mejor los procesos psicrométricos y con ello el funcionamiento de los equipos de climatización. Por otro lado, se considera necesario también para el correcto aprendizaje de la materia una sesión de laboratorio en la que los alumnos pueden visualizar los equipos y tomar ellos los datos para la realización de cálculos.

\section{Conclusiones}

Para concluir enumeramos algunos de los aspectos más significativos del trabajo que se ha realizado:

- Se ha desarrollado una aplicación informática de carácter docente para las asignaturas de climatización. En concreto para el tema de psicrometría.

- La herramienta cumple con las especificaciones que se han indicado en el apartado de desarrollo y que se han considerado interesantes para un trabajo adecuado con los alumnos.

- Se ha diseñado una sesión de prácticas informáticas de una duración de tres horas que puede ser impartida tanto en clases presenciales como en cursos online.

- El uso de la herramienta no tiene por qué limitarse a la sesión de prácticas, también se puede utilizar en las sesiones de teoría y de problemas de las asignaturas con el fin de ilustrar mejor las explicaciones.

- Cuando los alumnos trabajan primero la sesión informática entienden mejor el comportamiento de los equipos en las sesiones de laboratorio, como se comprueba al comparar los trabajos de prácticas.

\section{Referencias}

ATECYR (2009), Psicrometría DTIE 3.01. Madrid, Atecyr

ATECYR (2016). Calcula con Atecyr. <http://www.calculaconatecyr.com/> [Consulta: 16 de mayo de 2018]

(cc) EY-NC-ND 2018, Universitat Politècnica de València

Congreso IN-RED (2018) 
ATECYR (2016). Tutorial SICRO_V2. http://www.calculaconatecyr.com/tutoriales-psicro.php [Consulta: 16 de mayo de 2018]

CABRERO, J., ROMAN, P (2006). E-actividades: un referente básico para la formación en internet. Editorial MAD.

PINAZO, JM (1995) Manual de climatización. Tomo I:Transformaciones sicrométricas. Editorial UPV

PINAZO, JM (1996) Manual de climatización.Tomo II:Cargas Térmicas. Editorial UPV

SCHILDT, H., GUNTLE, GL (2001) Borland C++ Builder: The Complete Reference. Editorial Osborne/McGraw-Hill 


\title{
Entorno Virtual de Aprendizaje en el marco de la formación Dual Universidad-Empresa
}

\author{
Urcola Carrera, Leire ${ }^{a}$; Azkue Irigoyen, Itziar ${ }^{b}$ y Allur Aranburu, Erlantz \\ aDepartamento de Economía Aplicada V (UPV/EHU, leire.urcola@ehu.eus), \\ bepartamento de Economía Financiera I (UPV/EHU, itziar.azkue@ehu.eus) y ${ }^{\mathrm{c} D e p a r t a m e n t o ~ d e ~}$ \\ Organización de Empresas (UPV/EHU, erlantz.allur@ehu.eus).
}

\begin{abstract}
In the context of the implementation of the dual training itinerary in the degree of Business Administration and Management of the Faculty of Economics and Business of the University of the Basque Country (UPV/EHU), this paper presents the design and use proposal of the electronic portfolio (ePortfolio) as a tool to support the teaching and learning process of this itinerary.

The pilot scheme carried out by the Virtual Campus of the UPV/EHU (EHUfolio), has served as a reference to test the application that allows the use of the electronic portfolio (MAHARA) integrating it into an interoperable environment. This environment opens the possibility to the use of virtual classrooms with other approaches. More specifically, the use of teaching and learning spaces directed from a competence and student-centered approach.

In the following sections the use of the ePortfolio is developed in the context of the dual training itinerary. Likewise, the functionalities of the integrated platforms in the virtual learning environment are addressed. The paper ends with the main conclusions and future lines of research.
\end{abstract}

Keywords: ePortfolio, electronic portfolio, dual itinerary, training evaluation

\section{Resumen}

En el marco de la implantación del itinerario de formación Dual en el grado de Administración y Dirección de Empresas de la Facultad de Economía y Empresa de la Universidad del País Vasco (UPV/EHU), el presente artículo expone la propuesta de diseño y uso del portafolio electrónico (ePortfolio) como herramienta de soporte al proceso de enseñanza y aprendizaje de este itinerario.

El proyecto piloto llevado a cabo por el Campus Virtual de la UPV/EHU (EHUfolio), ha servido de referencia para probar la aplicación que permite el uso del portafolio electrónico (MAHARA) integrándolo en un entorno interoperable. Este entorno abre la posibilidad a la utilización de las aulas virtuales con otros enfoques. Más concretamente, al uso de espacios de enseñanza y aprendizaje dirigidos desde un enfoque competencial y centrado en el estudiante.

En los siguientes apartados se describe el uso del ePortfolio en el contexto del itinerario de formación Dual. Asimismo, se abordan las funcionalidades de las plataformas integradas en el entorno virtual de aprendizaje. El artículo finaliza con las principales conclusiones y líneas de trabajo futuras.

(cc) EY-NC-ND 2018, Universitat Politècnica de València 
Palabras clave: ePortfolio, portafolio electrónico, itinerario dual, evaluación formativa

\section{Introducción}

En el presente trabajo se presenta el entorno virtual en el que se integra la propuesta de diseño de un portafolio electrónico (ePortfolio) que sirva como herramienta de seguimiento en la tutorización de los estudiantes que optan por la formación del itinerario Dual que ofrece la Facultad de Economía y Empresa de la Universidad del País Vasco (Sección Gipuzkoa) en el curso 2017-18.

Esta propuesta viene motivada por la necesidad de disponer de modelos y estrategias integradas de evaluación, acreditación y demostración de las competencias desarrolladas a lo largo de la vida, ya sea en el ámbito educativo como profesional en el seno de una sociedad que demanda permanente formación y alta flexibilidad para un desempeño satisfactorio en contextos laborales heterogéneos (Guárdia et al., 2014).

En el contexto de la educación superior, los portafolios han demostrado su utilidad como herramientas y metodologías para la evaluación y seguimiento del proceso de aprendizaje de los estudiantes (Castañeda y Adell, 2013), pudiendo materializarse este proceso en una amplia colección del trabajo del estudiante que muestra su esfuerzo, progreso y logros a lo largo del tiempo.

Su uso, cada vez más extendido y sencillo, permite proponer nuevas metodologías docentes en las que el estudiante es considerado como el centro del proceso de aprendizaje.

En el contexto particular de la formación Dual (universidad-empresa), planteamos el uso del ePortfolio haciendo especial hincapié en el desarrollo de competenicas. Más concretamente, como un método de presentación de evidencias de aprendizaje por parte de los estudiantes con el fin de que el docente pueda realizar un seguimiento y evaluación del desarrollo de las competencias contempladas en el currículo formativo en un periodo de tiempo determinado (Karsten, 2012). Además de lo anterior, nuestra aportación va más allá al sugerir la integración de esta herramienta en un espacio virtual interoperable, en convivencia con distintas plataformas cuyas funcionalidades permitan explotar al máximo su potencialidad.

En los siguientes apartados, primeramente, se describe el propósito del uso del ePortfolio en el contexto formativo del itinerario Dual. Seguidamente, se explica el entorno virtual donde interoperan distintas plataformas y que sirve de canal de comunicación entre los participantes de este itinerario formativo. También se abordan las tecnologías de soporte de este entorno y sus principales funcionalidades. Posteriormente, se exponen algunas consideraciones sobre el proceso de la evaluación de este itinerario. Por último, se recogen las principales conclusiones extraídas y se indican las líneas de trabajo futuras.

(cc) EY-NC-ND 2018, Universitat Politècnica de València

Congreso IN-RED (2018) 


\section{Propósito del ePortfolio para el itinerario de Formación Dual}

Se plantea el uso del ePortafolio como una herramienta de acompañamiento del proceso de enseñanza y aprendizaje del estudiante durante su andadura Dual y que recogerá su desarrollo competencial a través de un itinerario progresivo tanto formativo como profesional.

Según la configuración del plan de estudios de la titulación, el itinerario Dual se imbrica en el módulo denominado "Avance en Administración y Dirección de Empresas" que corresponde al tercer y cuarto curso del grado, donde se combina la formación obligatoria con la optatividad y la alternancia en la empresa. Así, a lo largo del módulo se profundiza en materias más específicas de la administración y dirección de empresas, con un grado creciente de especialización.

En el marco del itinerario Dual, el estudiante se incorpora a la empresa en el segundo cuatrimestre de tercer curso y a lo largo del siguiente, compaginando su actividad profesional con la académica. La figura 1 recoge la estructura organizativa del itinerario Dual.

\begin{tabular}{|c|c|c|c|c|c|}
\hline \multicolumn{6}{|c|}{ PROCESO DE ENSEÑANZA-APRENDIZAJE DUAL } \\
\hline & & \multicolumn{2}{|c|}{40 curso - Itinerario Dual } \\
\hline \multicolumn{3}{|c|}{ 1er Cuatrimestre } & 2o Cuatrimestre & 1er Cuatrimestre & 20 Cuatrimestre \\
\hline UPV/EHU & $\begin{array}{l}\text { Régimen fiscal de la empresa } \\
\text { Análisis contable } \\
\text { Dirección estratégica } \\
\text { Macroeconomía } \\
\text { Econometría }\end{array}$ & & $\begin{array}{l}\text { Consolidación de Estados } \\
\text { Contables } \\
\text { Dirección estratégica }\end{array}$ & $\begin{array}{l}\text { Dirección financiera: } \\
\text { inversiones } \\
\text { Derecho de la empresa } \\
\text { Sistemas informáticos de } \\
\text { Gestión Empresarial }\end{array}$ & \\
\hline \multirow{2}{*}{\multicolumn{2}{|c|}{$\begin{array}{c}\text { UPV/EHU } \\
+ \\
\text { Empresa }\end{array}$}} & \multirow{3}{*}{ 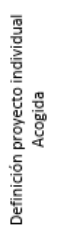 } & $\begin{array}{l}\text { Orientación a la empresa I } \\
\text { (5 ECTS) }\end{array}$ & $\begin{array}{l}\text { Orientación a la empresa II } \\
\text { (5 ECTS) }\end{array}$ & $\begin{array}{l}\text { Reconocimiento de } \\
\text { créditos }\end{array}$ \\
\hline & & & $\begin{array}{l}\text { Memoria (Posicionamiento)y } \\
\text { Evaluación }\end{array}$ & $\begin{array}{l}\text { Memoria (Diagnóstico) y } \\
\text { Evaluación }\end{array}$ & $\begin{array}{l}\text { Trabajo Fin de Grado } \\
\text { (12ECTS) (en empresa) }\end{array}$ \\
\hline & EMPRESA & & $\begin{array}{l}\text { Estancia en la empresa } 1 \\
\text { (13 ECTS) }\end{array}$ & $\begin{array}{l}\text { Estancia en la empresa } 2 \\
\text { ( } 9 \text { ECTS) }\end{array}$ & $\begin{array}{l}\text { Estancia en la empresa } 3 \\
\text { (11 ECTS) }\end{array}$ \\
\hline
\end{tabular}

Fig. 1 Estructura organizativa del itinerario Dual

El estudiante que opte por este itinerario ha de cursar entre 43 y 48 créditos optativos, para lo cual cuenta con una oferta de asignaturas especializadas de orientación a la empresa, de 5 ECTS cada una y, las distintas estancias que se desarrollarán en la empresa en distintos periodos y con una duración distinta.

El estudiante de este itinerario debe demostrar capacidad de aplicar los conocimientos adquiridos a la práctica empresarial para resolver problemas en los distintos ámbitos funcionales de la empresa.

Para ello, en la definición del proyecto profesional, se establecerán distintos tipos de estancia, en función de los niveles de dificultad y de responsabilidad que se tendrán que adecuar con los niveles de adquisición de competencias.

En este sentido, se establecen los siguientes niveles o fases de participación en la empresa: 
- Fase 1 "Observación”. Conocimiento de la empresa.

- Fase 2 "Aplicación”. Funciones y objetivos de la empresa.

- Fase 3 “Toma de responsabilidad”. Intervención.

En este contexto, el portafolio puede emplearse como repositorio de evidencias que permita demostrar el progreso del aprendizaje del estudiante durante su trayectoria Dual y como un espacio de reflexión personal de su experiencia de aprendizaje.

Desde la perspectiva del estudiante, utilizar este instrumento puede tener una doble utilidad. De una parte, a modo de DAFO personal, donde realizará una auto-reflexión sincera de su experiencia tanto académica como profesional, así como del grado de avance de las competencias que ha ido adquiriendo y de aquellos aspectos en los que debería mejorar. De otra parte, el ePortafolio puede tener una utilidad de cara al exterior, como carta de presentación para un puesto laboral.

Desde la perspectiva del docente, el ePortafolio le va a facilitar el seguimiento y la evaluación progresiva basada en competencias.

Desde la perspectiva de la empresa, disponer de un espacio de comunicación con la universidad, así como herramientas que le permiten realizar el seguimiento del estudiante al que supervisa pudiendo consultar su progreso durante su estancia en la empresa, le va a facilitar una comunicación más ágil y un acercamiento al ámbito universitario, pudiendo conocer de primera mano, el programa académico que siguen los estudiantes, los resultados de aprendizaje esperados y los sistemas de evaluación, entre otros aspectos. Sin duda, esta información ayuda a la empresa a la hora de plantear las funciones y tareas que puede desempeñar un estudiante de esta titulación en la definición de su perfil profesional.

\section{Entorno Virtual de Aprendizaje para el itinerario Dual}

La Universidad del País Vasco (UPV/EHU) a través de su Campus Virtual (eCampus) pone a disposición de toda la comunidad universitaria, una plataforma de enseñanza telemática soportada a través de un sistema de gestión de contenidos basado en Moodle.

Esta plataforma se habilita y se configura en función del propósito de su uso. De una parte, se proporciona una plataforma como herramienta de apoyo a la docencia reglada (para las asignaturas de grado y máster oficial). De otra parte, se ofrece otra plataforma como herramienta de formación complementaria a otras actividades de docencia no reglada, así como herramienta colaborativa para grupos de investigación y actividades de gestión.

Las plataformas que prestan estos servicios a la comunidad universitaria se soportan en una nueva versión de Moodle (v2.7) que trae cambios en la apariencia, navegación y gestión de archivos con respecto a versiones anteriores. Asimismo, esta versión ofrece nuevas funcionalidades en todo lo que concerniente a la asignación de tareas y a su evaluación, incorporando nuevas opciones para crear rúbricas y guías de evaluación basadas en el desarrollo de competencias. Sin duda, estos sistemas ofrecen multitud de ventajas, principalmente para su gestión, al facilitar una administración centralizada de todo el sistema desde la perspectiva del profesor.

(cc) EY-NC-ND 2018, Universitat Politècnica de València

Congreso IN-RED (2018) 
Sin embargo, presentan limitaciones de cara a la utilización como herramientas enfocadas en el aprendizaje continuo del estudiante y en su evaluación formativa. Además, normalmente son espacios habilitados para uso y acceso exclusivo de los miembros que forman parte de la comunidad universitaria (únicamente pueden formar parte de las aulas virtuales usuarios que dispongan de cuenta LDAP o correo electrónico institucional con el dominio: ehu.eus).

Esto plantea una limitación importante a la hora de utilizar estos espacios con otros enfoques y propósitos. En el contexto de la formación Dual, sería deseable que pudieran participar e intervenir distintos actores, tanto del ámbito académico como del ámbito profesional para realizar el seguimiento de todo el proceso, tal y como se refleja en la figura 2.

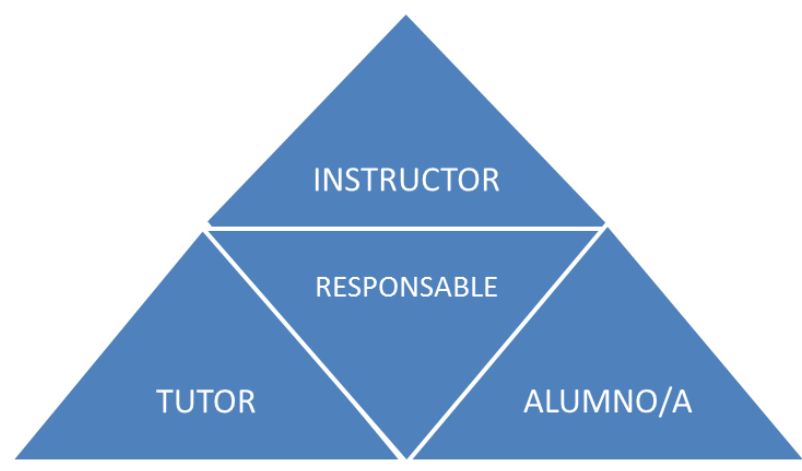

Fig. 2. Agentes que participan en el itinerario Dual

Por su parte, disponer de un portafolio electrónico responde a la necesidad del estudiante de contar con un medio digital donde poder volcar toda su experiencia de aprendizaje de su estancia en la empresa y paralelamente, poder compartir sus avances y logros con su tutor académico y empresarial, así como con otros miembros.

Para esta finalidad, el entorno virtual configurado presentaría la siguiente estructura:

De una parte, un aula virtual o plataforma de gestión de aprendizaje (LMS), con un enfoque tradicional centrado en el docente $y$, de otra parte, una plataforma que soporta el ePortfolio con un enfoque centrado en el estudiante. La figura 3 ilustra la estructura del entorno virtual que soporta el proceso formativo Dual. 


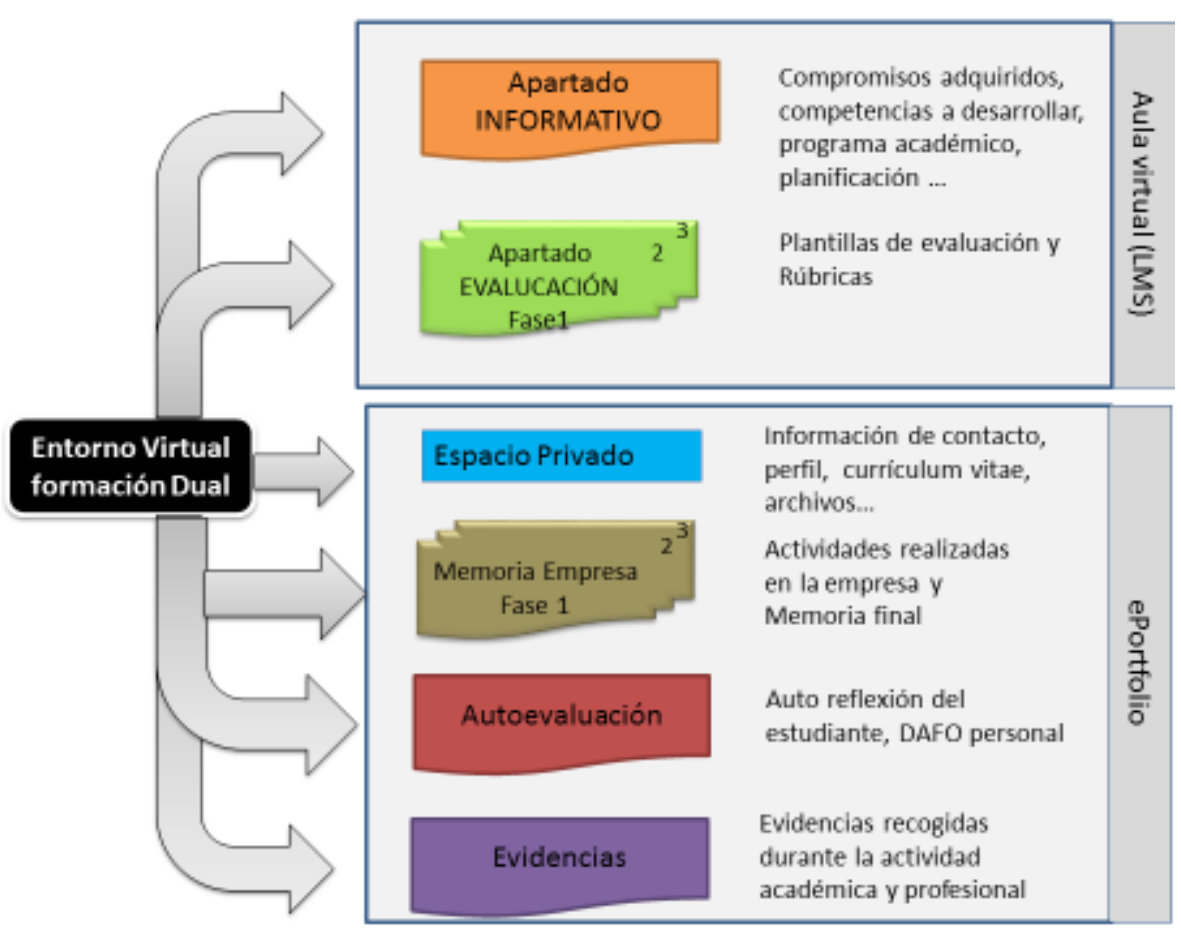

Fig. 3 Estructura del Entorno Virtual para el proceso formativo Dual

Es importante notar que mediante el aula virtual se gestiona todo el proceso, mientras que el ePortfolio servirá para crear el producto, es decir, una colección del trabajo del estudiante que muestra su esfuerzo, progreso y logros.

\section{Tecnologías de soporte.}

A la hora de seleccionar las tecnologías de soporte, de acuerdo con Coromina (2011), cada centro educativo podrá seleccionar las soluciones que mejor satisfagan sus necesidades y prácticas educativas a partir de una lista de criterios útiles.

Pero con independencia de la solución tecnológica elegida, parece del todo deseable que los diferentes sistemas o plataformas que se utilizan desde el espacio virtual universitario puedan comunicarse entre sí, sobre todo en beneficio de los propios usuarios (Barberá, Gewerc y Rodríguez, 2009).

En este sentido, el Campus Virtual de la UPV/EHU ha realizado un proyecto piloto (EHUfolio) orientado a la integración de la herramienta ePortflio en el entorno virtual de aprendizaje de la universidad. Este proyecto tiene por objetivo facilitar un entorno virtual que sustente la interoperabilidad de distintas plataformas (Ovelar y Pizarro, 2017).

En la figura 4 se presenta el prototipo creado que integra el ePortfolio dentro del entorno virtual de aprendizaje.

2018, Universitat Politècnica de València

Congreso IN-RED (2018) 
De un lado, la plataforma de enseñanza y aprendizaje (LMS) soportada en Moodle, de otra parte, la aplicación MAHARA (https:IImahara.org), que el Campus Virtual ha escogido para poner a disposición de los estudiantes un servicio que les permita conservar una copia de las evidencias y los resultados obtenidos a lo largo de su proceso de aprendizaje.

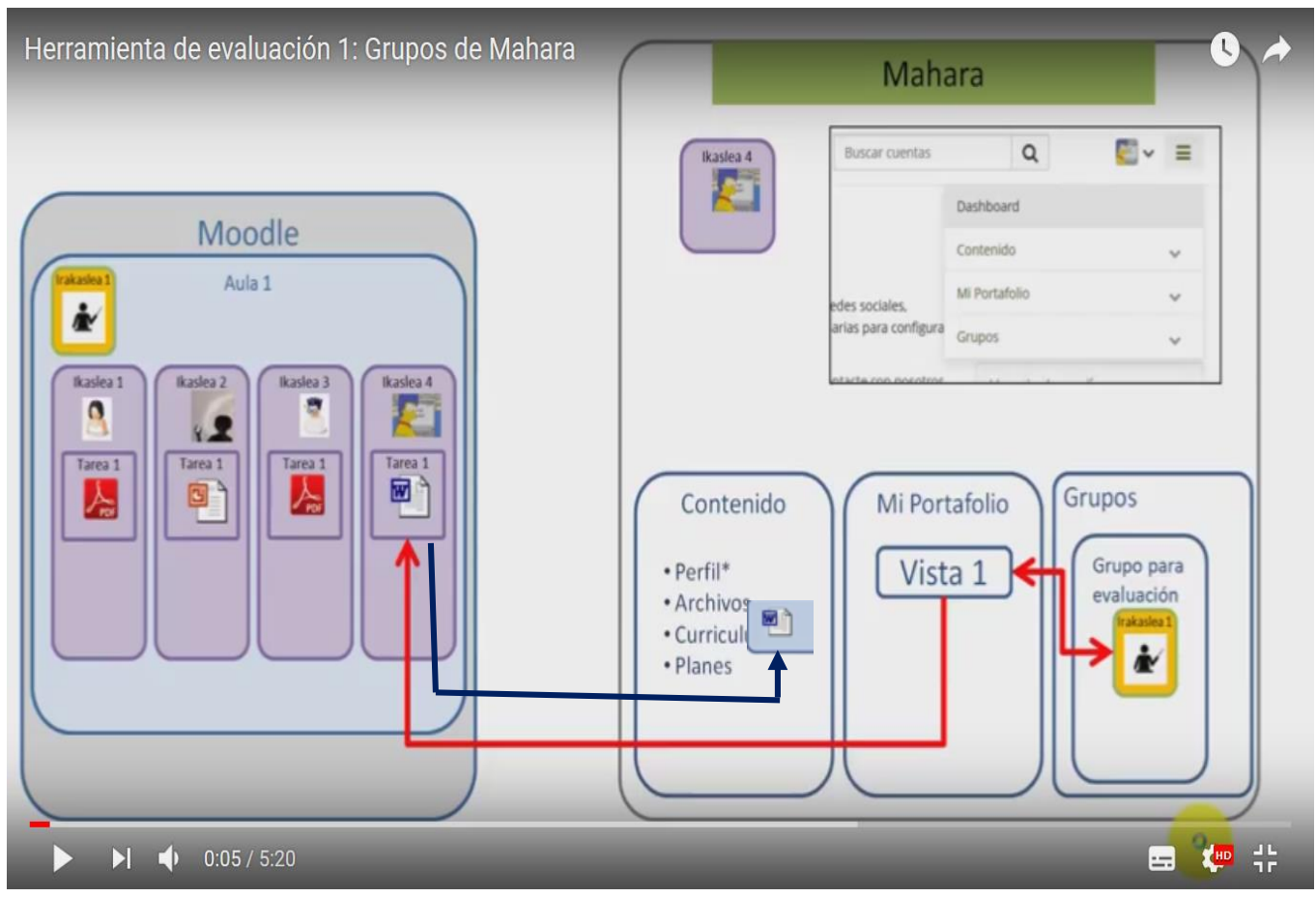

Figura 4. Prototipo del espacio que integra el ePortfolio (Ovelar y Pizarro, 2017)

La aplicación MAHARA ofrece al estudiante un espacio donde puede gestionar su propio contenido, crear "colecciones" y "vistas" con las evidencias almacenadas en la propia aplicación o en otras aplicaciones externas, así como gestionar grupos con el objetivo de compartir y de establecer redes de contactos.

Tal y como se aprecia en la figura 4, los archivos pueden haber sido exportados del aula virtual (Moodle) que esté conectado a MAHARA mediante los estándares IMS ePortfolio y LEAP2A. De la misma manera, también se pueden exportar "vistas" o páginas creadas en la sección "Mi portafolio" de MAHARA a Moodle.

Además, los perfiles de usuarios de ambas aplicaciones pueden estar conectados, pudiéndose importar algunos datos del perfil existente en Moodle a MAHARA (como, por ejemplo, el nombre de usuario, la imagen del perfil y su rol, entre otros datos).

De cara a la publicación de contenidos, es importante notar que se pueden configurar distintos niveles de visibilidad de las "vistas" o colecciones de páginas creadas. 


\section{El procedimiento de la evaluación}

En el proceso de la evaluación, las figuras del tutor académico, del instructor de la empresa y del responsable del itinerario formativo, constituyen un elemento clave. Entre ellos, se debe consensuar un proyecto formativo que tenga en consideración los diferentes niveles o fases de participación en la empresa (observación, aplicación y toma de responsabilidades), así como el perfil profesional y las actividades o tareas a realizar. A partir de este proyecto formativo, se traza un plan de trabajo inicial que estará sujeto a posibles modificaciones y a una mayor concreción posterior.

Durante su estancia en la empresa, el tutor académico y el instructor de la empresa realizarán un seguimiento continuo del trabajo del estudiante y se establecerán reuniones presenciales entre los actores implicados (al menos tres reuniones, al inicio de la estancia, en una fase intermedia y al final de la misma) para evaluar su desarrollo. De esta manera, se realiza una evaluación progresiva y reflexiva de todo el proceso.

Durante la estancia en la empresa, el estudiante junto con el tutor académico y el instructor, elaborarán un informe de seguimiento competencial que estará refrendado por las evidencias y evaluaciones realizadas en las distintas etapas (inicial, intermedia y final). Al finalizar el periodo, el estudiante realizará una apreciación general de toda la experiencia formativa en la empresa, realizando un ejercicio reflexivo que le permita interiorizar su proceso de aprendizaje. Asimismo, el estudiante elaborará una Memoria que será objeto de evaluación tras una defensa ante el tutor académico y responsable universitario y el instructor (empresa). Tras la defensa, se evaluarán los resultados obtenidos, analizándose las dificultades identificadas y estableciéndose nuevos objetivos para el periodo siguiente.

Todas las "tareas" que serán objeto de evaluación, se configurarán en el aula virtual o plataforma de gestión de contenidos (Moodle). En la tabla 1 se incluyen las "tareas" a las que se les otorgará una calificación. Hay que notar que los entregables pueden ser productos elaborados con distintas aplicaciones (procesador de texto, hoja de cálculo, "vistas" o colecciones del portafolio digital) y tendrán una ponderación determinada en la calificación final.

Tabla 1. Instrumentos y métodos de evaluación

\begin{tabular}{|lcc|c|l|l|l|}
\hline \multicolumn{2}{|c|}{ Tareas } & Peso & $\begin{array}{l}\text { Evidencias } \\
\text { entregadas }\end{array}$ & $\begin{array}{l}\text { Instrumento } \\
\text { de evaluación }\end{array}$ & Evaluador \\
\hline $\begin{array}{l}\text { Seguimiento } \\
\text { Inicial }\end{array}$ & Fase $\quad$ I- & $\%$ & $\begin{array}{l}\text { Informe } \\
\text { empresa. } \\
\text { Reunión } \\
\text { empresa } \\
\text { Cuaderno de } \\
\text { trabajo del } \\
\text { estudiante }\end{array}$ & Rúbrica & Tutor+Instructor \\
\hline $\begin{array}{l}\text { Seguimiento } \\
\text { Intermedia }\end{array}$ Fase $\quad$ I- & $\%$ & $\begin{array}{l}\text { Informe } \\
\text { empresa. } \\
\text { Reunión } \\
\text { empresa }\end{array}$ & Rúbrica & Tutor+Instructor \\
\hline
\end{tabular}

(c)) EY-NC-ND 2018, Universitat Politècnica de València

Congreso IN-RED (2018) 


\begin{tabular}{|c|c|c|c|c|}
\hline & & $\begin{array}{lr}\text { Cuaderno } & \text { de } \\
\text { trabajo } & \text { del } \\
\text { estudiante } & \\
\end{array}$ & & \\
\hline $\begin{array}{l}\text { Seguimiento Fase I - } \\
\text { Final }\end{array}$ & $\%$ & $\begin{array}{ll}\text { Informe } & \\
\text { empresa } & \\
\text { Reunión } & \\
\text { empresa } & \\
\text { Cuaderno } & \text { de } \\
\text { trabajo } & \text { del } \\
\text { estudiante } & \\
\end{array}$ & Rúbrica & Tutor+Instructor \\
\hline Memoria Final & $\%$ & $\begin{array}{l}\text { Informe } \\
\text { memoria o } \\
\text { Portfolio } \\
\text { elaborado por } \\
\text { el estudiante }\end{array}$ & Rúbrica & Tutor+Instructor \\
\hline $\begin{array}{l}\text { Autoevaluación } \\
\text { Estancia I }\end{array}$ & $\%$ & $\begin{array}{l}\text { Informe, } \\
\text { Portfolio o } \\
\text { encuesta } \\
\text { entregada por } \\
\text { el estudiante }\end{array}$ & Rúbrica & $\begin{array}{l}\text { Tutor+Instructor } \\
+ \text { Estudiante }\end{array}$ \\
\hline $\begin{array}{l}\text { Evidencias aportadas } \\
\text { de la estancia }\end{array}$ & $\%$ & $\begin{array}{l}\text { Evidencias en } \\
\text { cualquier tipo } \\
\text { de soporte } \\
\text { (pueden } \\
\text { incluirse } \\
\text { también en el } \\
\text { Portfolio) }\end{array}$ & Rúbrica & Tutor+Instructor \\
\hline
\end{tabular}

A la hora de realizar la evaluación del itinerario Dual, el control se llevará a cabo desde el aula virtual (Moodle). Desde este espacio, el docente configurará las tareas que el estudiante debe entregar y cuya calificación quedará registrada en el libro de calificaciones de esta plataforma. Para la evaluación de la primera fase en la empresa, se decide "ceder" el control de la evaluación a la plataforma de gestión de contenidos (aula virtual soportada en Moodle), dado que es un espacio conocido por el equipo docente y, además, todas las calificaciones otorgadas se registrarían en el libro de calificaciones del aula virtual junto con el resto de las calificaciones otorgadas en las asignaturas específicas de orientación a la empresa que se imparten en este itinerario. Esta manera de proceder, proporcionaría una visión de conjunto de los resultados obtenidos.

\section{Conclusiones}

En el marco de actuación del itinerario de formación Dual, a caballo entre el ámbito académico y profesional, cobra una especial relevancia la evaluación basada en el desarrollo competencial de unos aprendizajes autónomos, realizados dentro y, fundamentalmente, fuera del aula.

El uso de nuevos espacios de aprendizaje supone importantes desafíos para profesores y estudiantes, ya que demanda el replanteamiento de roles hacia una perspectiva de colaboración en el proceso de aprendizaje con una responsabilidad también compartida. En este contexto, el 
uso de portafolios electrónicos, va a requerir una fuerte implicación que asumirán los estudiantes al tener que profundizar en el conocimiento sobre su propio proceso de aprendizaje. La reflexión ocupa aquí un lugar sustancial, porque provee al sujeto de herramientas para autoevaluarse.

Tras probar las funcionalidades del prototipo creado en la primera fase del piloto (EHUfolio), podemos asegurar que este servicio integrado en el propio entorno virtual universitario puede aportar importantes beneficios en el marco del itinerario Dual. Además, esta integración puede resolver cuestiones complejas desde el punto de vista técnico y organizacional, si bien otras interrogantes referentes a la confidencialidad de datos, vigencia de estos espacios y el empleo de los mismos como herramientas de soporte en las actividades de tutorización y evaluación de las asignaturas del grado requerirían de reflexiones más profundas.

En relación con los aspectos concernientes a la evaluación, es importante señalar que, para realizar el seguimiento de la primera fase de estancia en la empresa, se ha considerado más adecuado llevar a cabo la gestión y el control del proceso desde el aula virtual soportada en Moodle, mientras que el producto (colecciones de trabajos, logros y la actividad reflexiva del estudiante) se desarrollará a través de la aplicación MAHARA.

El entorno de la aplicación que se pone a disposición de los estudiantes presenta un diseño atractivo e intuitivo, con una estructura de contenidos sencilla, cuya funcionalidad cubre adecuadamente los requerimientos deseables de estas soluciones.

Tras finalizar la primera fase del itinerario Dual y una vez valorados los resultados de la experiencia de uso del nuevo espacio de aprendizaje y de las tecnologías soportadas, se estudiará la posibilidad de realizar una adaptación mayor de sus posibilidades a las necesidades concretas del itinerario Dual de cara a las subsiguientes fases.

\section{Referencias}

BARBERÁ, E.; GeWERC, A. y RodríGUEZ, J.L. (2009). "Portafolios electrónicos y educación superior en España: Situación y tendencias". RED. Revista de Educación a Distancia. Número monográfico VIII.

CASTAÑEDA, L y ADELL, J. (2013). "Entornos Personales de Aprendizaje: claves para el ecosistema educativo en la red". Alcoy: Marfil.

Coromina, J.; SABATe, F.; Romeu, J. y Ruiz, F. (2011). "Portafolio digital de aprendizaje: Un nuevo medio de comunicación en la educación”. Intangible Capital, Vol. 7, núm. 1. Universitat Politècnica de Catalunya.

GUÂRDIA, L.; MAINA, M.; BARBERÁ, E. y ALSINA, I. (2014). "Matriz conceptual sobre usos y propósitos de los eportfolios". Social and Behavioral Sciences, 196.

KARSTEN, K. (2012). "Using ePortfolio to demonstrate competence in associate degree nursing studentes". Teaching and Learning in Nursing, 7.

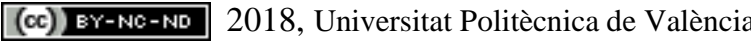

Congreso IN-RED (2018) 
Urcola, L., Azkue, I. y Allur, E.

Ovelar, R. y PIZARRO, J.L. (2017). "Experiencia EHUfolio: nuevos escenarios de aprendizaje basados en el portafolio electrónico del estudiante". CINTE'17. Congreso Internacional de Nuevas Tecnologías y Tendencias en la Educación, Universidad del País Vasco / Euskal Herriko Unibertsitatea.

(cc) BY-NC-ND 2018, Universitat Politècnica de València

Congreso In-Red (2018) 


\title{
PluriTAV: desarrollo de las competencias plurilingües mediante el uso de la traducción audiovisual ${ }^{1}$
}

\author{
Anna Marzàa , Gloria Torralba Miralles ${ }^{\mathrm{b}}$, Beatriz Cerezo Merchán ${ }^{\mathrm{c}}$ y Juan José Martínez \\ Sierrad $^{\mathrm{d}}$
}

a'Universitat Jaume I, amarza@edu.uji.es, 'bniversitat Jaume I, gtorralb@edu.uji.es, 'Universitat de València, beatriz.cerezo@uv.es y ${ }^{\mathrm{d}}$ Universitat de València, juan.j.martinez@uv.es.

\begin{abstract}
This piece of work introduces the PluriTAV (Audiovisual Translation as a Tool for the Development of Multilingual Competences in the Classroom) research project. This project is staked on one of the most recent approaches of foreign language teaching, the multilingual approach, in which not only the language being studied (or taught) but also the linguistic repertoire of the classroom are taken into account. The project, focused on the teaching and perfecting of language, is based on the said approach and draws on a field related to foreign language teaching, audiovisual translation, so that through it, one can learn a foreign language, perfect mother tongue abilities and develop multilingual abilities. The fundamental objective of this project consists in the creation of a free web platform (PluriTAV) that allows the exploration and exploitation of the methodological possibilities that the implementation of the multilingual approach and the tools of different audiovisual translation modes can offer in the teaching of a foreign language and in the perfecting of mother tongues in the university environment. The hypothesis is that the proposed approach will allow improvement in foreign language acquisition, perfection of first languages and promotion of multilingual skills.
\end{abstract}

Keywords: didactics, foreign/mother tongue, audiovisual translation, multilingual approach, competences, multimedia resources

\section{Resumen}

En este trabajo se presenta el proyecto de investigación PluriTAV. La traducción audiovisual como herramienta para el desarrollo de competencias plurilingües en el aula. Se trata de un proyecto que apuesta por uno de los enfoques más recientes de enseñanza de lenguas extranjeras (LE), el multilingüe, en el que se tienen en cuenta no solo la lengua que se estudia, sino también el repertorio lingüístico del aula. El proyecto, centrado en la didáctica

\footnotetext{
${ }^{1}$ Esta investigación se enmarca en el proyecto de investigación PluriTAV. La traducción audiovisual como herramienta para el desarrollo de competencias plurilingües en el aula (ref. FFI2016-74853-P, 2017-2019), financiado por la Agencia Estatal de Investigación (AEI) y el Fondo Europeo de Desarrollo Regional (FEDER).
} 
y el perfeccionamiento de lenguas, se basa en dicho enfoque y recurre a un campo que tiene su espacio dentro de la didáctica de LE, la traducción audiovisual, para, a partir de ella, aprender una LE, perfeccionar competencias de las lenguas propias y desarrollar competencias plurilingües. El objetivo fundamental consiste en la creación de una plataforma web libre y gratuita (PluriTAV) que permita explorar y explotar las posibilidades metodológicas que la aplicación del enfoque multilingüe y de herramientas basadas en diferentes modalidades de traducción audiovisual pueden ofrecer a la enseñanza de lenguas extranjeras y al perfeccionamiento de las maternas en el ámbito universitario. La hipótesis es que el enfoque propuesto permitirá mejorar la adquisición de LE, perfeccionar las maternas y potenciar las competencias plurilingües.

Palabras clave: didáctica, lengua extranjera/materna, traducción audiovisual, enfoque multilingüe, competencias, recursos multimedia

\section{Introducción}

Vivimos en una sociedad cada vez más globalizada y multilingüe, algo que, unido a la importancia internacional del inglés, la profusión de las situaciones multilingües en entornos laborales y académicos y el mejorable nivel de lenguas extranjeras (LE), propicia un claro reto de mejora de las competencias plurilingües. La didáctica de lenguas debe seguir ofreciendo nuevas perspectivas interdisciplinarias para la adquisición de LE y para la mejora de las maternas, y el proyecto que aquí se presenta pretende buscar nuevos enfoques desde campos afines y nuevas herramientas para ampliar y mejorar los conocimientos lingüisticos.

Este proyecto apuesta por uno de los enfoques más recientes de enseñanza de LE, el multilingüe, en el que se tienen en cuenta no solo la lengua que se estudia, sino también el repertorio lingüístico del aula, para el diseño de los objetivos, las tareas y la evaluación. El proyecto, centrado en la didáctica y el perfeccionamiento de lenguas, se basa en dicho enfoque y recurre a un campo que tiene su espacio dentro de la didáctica de LE, la traducción audiovisual (TAV), para, a partir de ella, aprender una LE, perfeccionar competencias de las lenguas propias y desarrollar competencias plurilingües.

El objetivo fundamental consiste en la creación de una plataforma web libre y gratuita (PluriTAV) que permita explorar y explotar las posibilidades metodológicas que la aplicación del enfoque multilingüe y de herramientas basadas en diferentes modalidades de TAV (como doblaje, subtitulación, voice over, audiodescripción o SPS) pueden ofrecer, inicialmente, a la enseñanza de la lengua inglesa y al perfeccionamiento del catalán y el español en el ámbito universitario. La hipótesis es que el enfoque propuesto permitirá mejorar la adquisición de LE, perfeccionar las lenguas maternas y potenciar las competencias plurilingües.

Como principal resultado figurará PluriTAV, una plataforma de didáctica de la lengua inglesa, española y catalana desde un enfoque multilingüe, destinada a docentes y estudiantes y que tendrá, como rasgo distintivo, la aplicación de las herramientas propias de diversas 
modalidades de TAV dirigidas a la enseñanza de lenguas, con el Marco Común Europeo de Referencia para las Lenguas (MCER) y el Marco de Referencia para los Enfoques Plurales de las Lenguas y de las Culturas (MAREP) como guías.

Como se verá, a diferencia de otros proyectos que también han conectado la TAV y la didáctica de lenguas, este se centra en la práctica totalidad de modalidades de TAV, y adopta el enfoque multilingüe para evaluar su impacto en todas las lenguas implicadas en el intercambio lingǘstico y, en especial, para explorar la influencia que la transferencia interlingüística propia de la tarea traductora puede ejercer en las competencias plurilingües de los alumnos. Asimismo, se dará relevancia a la figura del docente.

\section{Objetivos e hipótesis}

Como ya se ha mencionado, el objetivo fundamental de este proyecto consiste en la creación de una plataforma web de acceso libre en la que los docentes de lenguas podrán encontrar fundamentación teórica y recursos didácticos para la aplicación de diferentes modalidades de TAV en la enseñanza de lenguas, con una perspectiva multilingüe. Todo esto partiendo del convencimiento de que el enfoque propuesto permitirá mejorar la adquisición de ciertas competencias lingüísticas específicas y desarrollar la competencia multilingüe por parte del alumnado, con la ventaja añadida de que los resultados obtenidos podrán ser fácilmente extrapolables y aplicables a otras lenguas y a otros niveles de formación. Entre otras cuestiones se pretende, a partir de un repaso inicial a las diferentes teorías de enseñanza de lenguas extranjeras y del papel que la traducción ha tenido en ellas, definir propuestas de uso didáctico de la TAV para el desarrollo de competencias específicas y llevar a cabo un proyecto eminentemente aplicado, con experimentación directa en el aula, de modo que los resultados obtenidos no sean fruto de abstracciones o suposiciones, sino de la previa comprobación empírica de las líneas de trabajo propuestas. Todo ello en un contexto social en el que existe una clara apuesta por el aprendizaje de idiomas y por la movilidad en todos los niveles educativos en el ámbito europeo, contexto en el que este proyecto busca encontrar nuevas vías para llevar a cabo dicha pretensión.

El actual contexto lingüístico, cultural, comercial, político, social y económico, con una destacada movilidad de ciudadanos que gestionan, además del inglés, una elevada diversidad lingüística, requiere nuevos planteamientos que contribuyan a aumentar el nivel de lenguas que los profesionales precisen, sea cual sea el fin que le den a esas segundas (o terceras) lenguas (familiar, profesional, escolar, social, comunidades concretas...). La didáctica de lenguas extranjeras, como ya se ha dicho, está obligada a seguir buscando fórmulas que contribuyan a avanzar en el objetivo general de formar a futuros profesionales cada vez más capacitados lingüísticamente.

A la hora de reflexionar sobre la viabilidad didáctica y pedagógica del proyecto es importante plantearse también cuál será la direccionalidad traductora que se requerirá en la implementación de los materiales. Hoy en día se reconoce la utilidad de la traducción inversa $(\mathrm{L} 1 \rightarrow \mathrm{LE})$ como herramienta para el aprendizaje de lenguas (Yuste Frías, 2005: 155). El hecho de traducir a una lengua extranjera suele conllevar una mayor dificultad que hacerlo hacia la 
materna, aunque esto también puede resultar un aliciente que fomente el esfuerzo. Lertola (2012: 200), por su parte, cree que la traducción directa es una actividad que resulta más útil para detectar los problemas y errores más comunes entre el alumnado, mientras que la traducción inversa resulta más adecuada desde un punto de vista pedagógico. La vasta profusión de material audiovisual y las facilidades de acceso a este que ofrecen las nuevas tecnologías hacen posible contar con recursos tanto en L1 como en LE, y esto permite una infinidad de usos dependiendo del nivel del alumnado y de los objetivos de la tarea. Además, cabe destacar que el enfoque adoptado por los citados autores, tanto para el diseño de la investigación como para el análisis de resultados, no es multilingüe y, por tanto, faltan estudios que evalúen de forma global los beneficios de una traducción directa o inversa en el aprendizaje de las dos lenguas utilizadas en el intercambio lingüístico.

Así, partimos de la hipótesis general de que será posible encontrar en el campo de la TAV conceptos, planteamientos y herramientas (desde actividades hasta software) que nos permitan analizar, delimitar y describir un recurso didáctico poco explorado hasta la fecha y que puede contribuir a la mejora de las capacidades comunicativas en tres ámbitos: la mejora de la lengua extranjera (inglés, en este proyecto), el perfeccionamiento de algunas competencias de las lenguas maternas o de instrucción general (español o catalán en el contexto en el que se lleva a cabo este proyecto) y el desarrollo de determinadas competencias plurilingües que se activan al trabajar simultáneamente en dos lenguas del repertorio.

\section{Antecedentes y estado actual}

\subsection{Consideraciones generales}

En una sociedad cada vez más globalizada, los intercambios de información entre distintos países en sus correspondientes lenguas son continuos, si bien la lengua inglesa sigue imperando como lingua franca en numerosos ámbitos ${ }^{2}$. Sin embargo, la tendencia en el mundo empresarial y académico es la de ir incluyendo el uso progresivo de más lenguas, lo cual refleja la realidad de unas sociedades cada vez más multilingües. De hecho, autores como Janssens y Steyaert (2014) destacan que en los mercados internacionales coexisten diversas lenguas y que más que de una lingua franca, es preciso hablar de una multilingua franca ${ }^{3}$. Esto encaja con la visión del proyecto, puesto que el inglés será la lengua común en todos o la mayoría de los ejercicios (también porque es la que forma parte del currículo español), pero a través del uso de esta lengua y de las propias (español y catalán), nos centraremos en las competencias que necesitarán desarrollar los alumnos para un futuro decididamente

\footnotetext{
${ }^{2}$ Por ejemplo, el inglés es el idioma oficial en más de 50 países, y está presente en ámbitos tan variados como la Unión Europea, Naciones Unidas o el Comité Olímpico Internacional, siendo además la lengua utilizada con más frecuencia en los intercambios comerciales entre países. Es, además, el idioma oficial de comunicación aeronáutica y marítima.

${ }^{3}$ Es igualmente relevante mencionar el estudio ELAN.cat: http://noticias.universia.es/vidauniversitaria/noticia/2010/04/08/654445/multilingismo-instrumento-negocio.html.
} 
multilingüe en el que puede que no haya una única lingua franca, sino que los fenómenos de alternancia de lenguas sean la norma en la empresa, como ya lo son en la sociedad.

Pese a esta realidad lingüística, la sociedad española sigue presentando como una asignatura pendiente la mejora del dominio de idiomas. Tomando el inglés como ejemplo, según datos facilitados en 2015 por la EF Índice de Nivel de Inglés, la primera y más completa clasificación de las destrezas del idioma inglés en adultos alrededor del mundo, España aparece en un puesto intermedio (23) en el ámbito internacional. Ahora bien, en el marco europeo nuestro país cae hasta las últimas posiciones. De manera similar, según la Encuesta sobre la Participación de la Población Adulta elaborada por el Instituto Nacional de Estadística (INE) de 2011, el 47,24\% de la población no sabe ninguna lengua además de la materna, un $34,78 \%$ habla una lengua extranjera, un $13,45 \%$ dos y solo un $4,54 \%$ tres o más. Esto nos conduce de nuevo a un escenario multilingüe en el que la lengua inglesa figura como primera lengua extranjera (LE) ${ }^{4}$ en cuanto a uso, conocimiento y presencia en el currículo educativo.

Por tanto, si triangulamos 1) el actual entorno globalizado (medios de comunicación, formación, negocios...); 2) la importancia de la lengua inglesa en el ámbito internacional y el empuje de las situaciones multilingües en entornos laborales; y 3) el mejorable porcentaje de conocimientos de lenguas extranjeras, la conclusión palmaria que obtenemos es que nuestra sociedad tiene como un claro reto el fomento o mejora de las competencias plurilingües, con objeto de no perder las diferentes oportunidades, fundamentalmente de mercado y profesionales, que el ámbito internacional le brinda.

A partir de esta consideración, y como se sugería, la didáctica de lenguas tiene la obligación de ofrecer de manera insistente nuevas perspectivas y metodologías que permitan seguir dando pasos en la dirección señalada. Entendemos que la interdisciplinariedad es un valor que dicha didáctica ha de aprovechar. Por tanto, merece la pena seguir evolucionando y dirigir nuestra mirada a otros campos afines en busca de nuevos enfoques y herramientas que nos permitan enseñar lenguas y desarrollar competencias multilingües de una manera cada vez más eficiente y completa. Uno de dichos campos afines, como se apuntaba, lo constituye la traducción, más concretamente, la TAV. El interés por este ámbito y sus posibilidades de aplicación y explotación por parte de la didáctica de lenguas extranjeras se encuentra en una fase relativamente inicial, aunque ha dejado ya entrever un sinfín de posibilidades. En esta línea se enmarca el proyecto que aquí se presenta, aunque con un enfoque claramente diferenciador: el aprovechamiento del contacto entre lenguas que permite de forma natural la traducción, para explotar el desarrollo de las competencias multilingües de los alumnos, que se añadiría a la mejora de las competencias específicas en cada lengua, y la generación de una plataforma que posibilite la explotación de dicho contacto.

\footnotetext{
${ }^{4}$ A menudo, cuando se utiliza el concepto segunda lengua (L2), se hace referencia al estudio de cualquier lengua a parte de la materna (L1). Sin embargo, en contextos bilingües, tales como aquel en el que se desarrolla este proyecto, es necesario distinguir entre segunda lengua y lengua extranjera (LE). Así pues, utilizamos la nomenclatura L1 o L2 para apelar al español o al catalán, dependiendo de cuál sea la lengua materna del alumno, y con LE nos referiremos a la lengua inglesa.
} 
Como antes se apuntaba, la principal finalidad de este proyecto consiste en generar una plataforma que permita evaluar el uso de la traducción como herramienta para el aprendizaje de lenguas desde una perspectiva multilingüe, tomando como base la aplicación de enfoques y herramientas (así como software) relacionados con las diferentes modalidades de TAV. De manera paralela, se busca ahondar en la investigación y aplicación del enfoque multilingüe, e implementar una serie de actividades en línea que vinculen las competencias de la adquisición lingüística a dichas modalidades de TAV, así como utilizar software libre para TAV que facilite este aprendizaje. Para ello, y dada la naturaleza interdisciplinaria del proyecto, se hace necesario un repaso de los antecedentes en este campo.

Respecto al proyecto propiamente dicho, no podemos dejar de mencionar las investigaciones cuya temática está relacionada con la de la que aquí se presenta. Los dos antecedentes más claros son los proyectos europeos LeViS y ClipFlair. El primero, ejecutado en 2008, partió de la premisa, aquí compartida, de que cada vez es más evidente para profesores e investigadores de lenguas extranjeras que no existe un único método garantizado de enseñanza y que es preciso combinar en clase varios recursos técnicos y metodológicos. Pretendía, fundamentalmente, generar herramientas y métodos para contrarrestar la pasividad que se puede producir al trabajar con material audiovisual; es decir, fomentar el papel activo del estudiante mediante el aprendizaje activo, haciendo uso de los multimedia de manera productiva como núcleo de la actividad (principalmente, centrada en la subtitulación) y no como un mero elemento complementario (http://levis.cti.gr/). Por su parte, y en una línea similar, ClipFlair, ejecutado en 2015, tenía como punto de partida el hecho de que los docentes que usan recursos audiovisuales se encuentran con la dificultad de encontrar tareas activas que hagan participar a los estudiantes y disuadan la observación pasiva. Por ello, se postulaba la idea de que una forma de trabajar con material audiovisual de manera productiva y motivadora es pidiendo a los estudiantes que doblen o subtitulen un vídeo (http://clipflair.net/).

El presente proyecto, si bien comparte diferentes características con los dos citados en el párrafo anterior, posee una serie de elementos distintivos. Por un lado, no se centra en una única modalidad de TAV (como el subtitulado, en el caso de LeViS), sino en la práctica totalidad de modalidades con mayor presencia en nuestro país (atendiendo a su pertinencia en nuestro contexto social más cercano e incluyendo, por ejemplo, la audiodescripción o las voces superpuestas). Por otro, y de manera esencial, a diferencia de lo que se presenta en LeViS y Clipflair, en este proyecto trasladamos la realidad bilingüe de la tarea que llevarán a cabo los alumnos al diseño de la investigación y adoptamos el enfoque multilingüe propuesto por Cenoz y Gorter (2011), según el cual la investigación no debería centrarse en una única lengua, sino en el repertorio lingüístico del alumnado y en las relaciones entre las lenguas de dicho repertorio. Este enfoque da respuesta a la exigencia del MCER de transformar el objetivo de la enseñanza de lenguas para lograr desarrollar un único repertorio lingüístico y ofrecer al alumnado la posibilidad de ampliar su competencia plurilingüe. Así pues, y teniendo en cuenta el contexto en el que se desarrolla, en este proyecto evaluaremos empíricamente el impacto que la TAV tiene en las dos lenguas entre las que se producirá el intercambio lingüístico (inglés y español o catalán) y, además, exploraremos la influencia que la transferencia interlingüística propia de la tarea traductora puede ejercer en las competencias plurilingües de los alumnos, unas competencias que no van ligadas a ninguna lengua concreta, sino a las

(cc) EY-NC-ND 2018, Universitat Politècnica de València

Congreso IN-RED (2018) 
relaciones entre estas. Finalmente, mientras que los dos proyectos citados se centraban en el estudiante, el nuestro tiene también en consideración la figura del docente, puesto que no se trata únicamente de generar un catálogo de actividades, sino también de (re)elaborar unos fundamentos investigadores, teóricos y metodológicos que permitan a dicho docente hacer uso de la plataforma para, por ejemplo, crear sus propias actividades y utilizar los instrumentos de evaluación de desarrollo de competencias elaborados en el proyecto para medir su efectividad.

\subsection{Principales teorías de la didáctica de lenguas y su relación con la traducción}

A lo largo del siglo XX hemos sido testigos de la aplicación de un variado número de métodos y enfoques para el aprendizaje de idiomas. La traducción ha jugado distintos papeles a lo largo de la evolución de la didáctica de lenguas. En la actualidad todavía son muchos los que la relacionan con el método Gramática-Traducción, el cual se impuso en el campo de la enseñanza de lenguas hasta mediados del siglo XX, y consistía, básicamente, en enseñar una lengua combinando la explicación de normas gramaticales con la traducción directa e inversa de frases. La artificialidad de esta metodología y la poca atención que le dedicaba a aspectos como las destrezas orales, conllevaron que se viera desplazada por otras que abogaban por la inmersión lingüística en el aula y el monolingüismo en la lengua estudiada, realidad que ocasionó la total ausencia de traducción, salvo como ejercicio literario para estudiantes de nivel avanzado (Zaro, 1999: 533).

Hubo que esperar hasta principios de la década de los ochenta del pasado siglo para que, gracias a metodologías como los enfoques comunicativos (en los que la comunicación es el objetivo final en el aprendizaje de idiomas) y los enfoques basados en tareas (que presentan situaciones familiares a los alumnos a través de tareas, para que así aprendan a utilizar el lenguaje adecuado en situaciones reales concretas), la traducción volviera a utilizarse como recurso didáctico y se valorara su carácter de actividad comunicativa auténtica.

El final del siglo XX trajo consigo algunas críticas a la rigidez de los enfoques y métodos de enseñanza de lenguas que se estaban adoptando. Muchos enseñantes se encontraban ante situaciones en las que, a pesar de haber apostado por un enfoque o método concretos, las circunstancias del aula les obligaban a adaptarlo o a combinarlo con otros. Esta búsqueda de eclecticismo favoreció el nacimiento del Postmétodo, una nueva postura que reclamaba una revisión de la pedagogía en términos de estrategias de aula, objetivos curriculares, materiales docentes y evaluación (Kumaravadivelu, 2001), algo que, a su vez, contribuyó a que se volviera a introducir la actividad de traducción en la enseñanza de lenguas extranjeras. En este sentido, autores como Cook recuerdan que si lo que se buscan son tareas reales en las que prime el significado y la comunicación sea el objetivo último, la traducción cumple todos los requisitos, dado que es "a real-world activity outside the classroom". El autor añade que "It is outcome-orientated: a successful translation is one that works. It promotes a focus on form as an offshoot of a communicative need, rather than as an end in itself" (2010: 30).

La perspectiva multilingüe ha acabado de situar a la traducción en un lugar destacado en la enseñanza de lenguas, desde que Manyak (2004) observó que la traducción desde su lengua materna promovía la adquisición del inglés como lengua extranjera, el desarrollo de la lectura 
y la escritura bilingüe y la afirmación de la propia identidad entre los alumnos. Autores como Cummins (2014) o Malakoff y Hakuta (1991) también defienden el uso de la traducción en el aula no solo para promover la adquisición de la lengua extranjera, sino también para desarrollar o afianzar la lengua materna. Con este proyecto, como antes se apuntaba, se pretende contribuir a esta línea de investigación con una metodología experimental, para determinar qué competencias mejoran gracias al uso de la traducción.

En nuestro caso, todos los elementos positivos que incluye la traducción como herramienta para el aprendizaje de lenguas extranjeras son extrapolables a la especialidad de la TAV, aunque la naturaleza polisemiótica del texto audiovisual hace necesario tener en consideración aspectos que no están presentes en la traducción general.

\subsection{El MCER y el MAREP}

Nuestro proyecto se desarrolla dentro del actual contexto europeo, en lo que a los niveles de lenguas se refiere. Por tanto, no podemos obviar el marco común del que se ha dotado. Según explica el Centro Virtual Cervantes, el MCER proporciona una base común para la elaboración de programas de lenguas, orientaciones curriculares, exámenes, manuales... en toda Europa. Describe de forma integradora lo que tienen que aprender a hacer los estudiantes de lenguas con el fin de utilizar una lengua para comunicarse, así como los conocimientos y destrezas (saber hacer) que tienen que desarrollar para poder actuar de manera eficaz. La descripción también comprende el contexto cultural donde se sitúa la lengua. El MCER define, asimismo, niveles de dominio de la lengua que permiten comprobar el progreso de los alumnos en cada fase del aprendizaje y a lo largo de su vida.

Por último, el MCER coloca a la traducción entre las destrezas (saber hacer) que un hablante competente debe poseer, al incluir la mediación entre las actividades que activan la competencia lingüística comunicativa de dicho hablante. Según este documento, el objetivo de la enseñanza de lenguas para los ciudadanos de la Unión Europea no es la competencia comunicativa en una lengua concreta, sino una competencia plurilingüe y pluricultural que permita no solo la comunicación, sino también la intermediación entre diferentes lenguas y culturas (es decir, la comunicación intercultural).

Desde esta perspectiva, la finalidad de la educación en una lengua queda profundamente modificada. Ya no se contempla como el simple logro del dominio de una o dos (o incluso tres) lenguas, cada una considerada de forma aislada, con el hablante nativo ideal como modelo fundamental. Por el contrario, el objetivo es el desarrollo de un repertorio lingüístico en el que tengan lugar todas las capacidades lingüísticas. Esto supone, naturalmente, que las lenguas que se ofrecen en las instituciones educativas tienen que diversificarse y que a los alumnos debe dárseles la posibilidad de desarrollar una competencia plurilingüe, lo cual exige ciertas modificaciones metodológicas que aboguen por una mayor integración en la didáctica de lenguas y por un enfoque más multilingüe en el diseño de las tareas y la evaluación, ambos aspectos considerados en este proyecto.

Aun así, en el MCER las competencias se encuentran divididas por lenguas y no se especifica con detalle las características de dicha competencia plurilingüe. Por esta razón, desde el Centro 
Europeo de Lenguas Modernas (ECML, por sus siglas en inglés), perteneciente al Consejo de Europa, se ha propuesto un marco de referencia complementario al MCER y específico para las competencias plurilingües: el MAREP.

Dicho marco describe una serie de competencias globales propias de los hablantes plurilingües, válidas para toda lengua y toda cultura y también para las relaciones entre lenguas y entre culturas. Asimismo, propone una serie de recursos como elementos que pueden ejercitarse en clase y contribuir a desarrollar dichas competencias. Este marco nos servirá como referencia para la elaboración de las actividades y los instrumentos de evaluación referidos a las competencias plurilingües, entendiendo por competencia "un savoir-agir complexe résultant de l'intégration, de la mobilisation et de l'agencement d'un ensemble de capacités et d'habiletés (pouvant être d'ordre cognitif, affectif, psychomoteur ou social) et de connaissances (connaissances déclaratives) utilisées efficacement, dans des situations ayant un caractère commun” (Lasnier, 2000: 32).

\subsection{La traducción audiovisual}

Podemos definir la TAV como una variedad de traducción que se ocupa de los textos audiovisuales, los cuales se caracterizan, fundamentalmente, por transmitir información a través de dos canales simultáneos y complementarios (el acústico y el visual) y por presentar una combinación de varios códigos de significación (lingüístico, paralingüístico, visual, etc.) cuyos signos interactúan y construyen el entramado semántico del texto. Muestra una serie de características propias que la definen frente a la traducción escrita y a la interpretación y que tienen que ver, principalmente, con los condicionantes o restricciones que presenta y las estrategias que requiere.

El doblaje y la subtitulación son las principales modalidades de TAV, al menos cuantitativamente. Las voces superpuestas están también presentes en nuestro contexto más inmediato (por ejemplo, documentales). Ahora bien, existen otras modalidades a las que deseamos prestar especial atención por su relevancia en nuestro contexto social y que merecen ser visibilizadas con el fin de evitar la sensación de que la actividad traductora audiovisual se reduce a la práctica del doblaje y de la subtitulación.

La subtitulación para sordos difiere de la convencional en que incluye información referente a la banda sonora (música, efectos especiales...) y también suprasegmental, como la entonación de los actores a la hora de hablar, a la cual las personas con deficiencias auditivas no tienen acceso. Incluye, además, otras características como un uso de léxico y de estructuras sintácticas más sencillas de lo habitual. Por su parte, la audiodescripción para ciegos, que implica una traducción de naturaleza semiótica, tiene como principal objetivo convertir en palabras la información visual de un texto audiovisual. En esta modalidad se intercalan comentarios sobre los aspectos más significativos de la imagen en los huecos entre los diálogos de producciones como pueden ser una película, una obra de teatro o una ópera.

A estas modalidades, más habituales en los medios, cabe añadir otras como el comentario libre, el rehablado, el sobretitulado o la traducción para el teatro. Por último, merece la pena nombrar otras manifestaciones de TAV que escapan al paraguas oficial de modalidades, y que 
son, básicamente, variantes de prácticas como el doblaje o la subtitulación llevadas a cabo no por profesionales. Se trata de los fandubs y los fansubs, doblajes y subtitulaciones hechas por amateurs y de gran popularidad entre el público más joven.

\subsection{La TAV y la didáctica de lenguas}

Nuestro proyecto se basa en la utilización de la traducción pedagógica como instrumento didáctico al servicio de la adquisición de competencias plurilingües. Se han constatado diferencias entre los niveles de competencia lingüística de los distintos países europeos, si se agrupan según la tendencia predominante en términos de TAV. En un informe relativamente reciente de la Comisión Europea (2012) sobre el aprendizaje de lenguas extranjeras en Europa, el porcentaje de encuestados capaces de hablar al menos una lengua diferente a la suya era, en el caso de España (país doblador), de un 48\%, lejos de los porcentajes de países subtituladores como Holanda (94\%), Suecia (91\%) o Dinamarca (89\%)

La mayoría de estudios sobre TAV y enseñanza de lenguas se han centrado en la subtitulación, quizá porque se ha considerado como la modalidad más adecuada de la TAV para el aprendizaje de una lengua extranjera. No obstante, como explica Chaume (2004: 147), las aplicaciones de otras modalidades de TAV y, en especial, del doblaje, constituyen un campo aún prácticamente virgen. El experimento de Danan (2010) y el trabajo de von Flotow (2009) apuntan a la posibilidad del uso del doblaje como instrumento totalmente válido para la enseñanza de lenguas. Con el enfoque adoptado en este proyecto, en el cual también se analiza el efecto de la TAV en la mejora de las competencias en las lenguas curriculares (español y catalán), se abren las posibilidades de aprovechamiento de las distintas combinaciones lingüísticas que ofrecen las diversas modalidades de TAV.

Este es, pues, un aspecto innovador del presente proyecto, puesto que pretende explorar las posibilidades de otras modalidades de TAV hasta la fecha ignoradas o apenas consideradas en el contexto de la didáctica de lenguas extranjeras, como pueden ser las voces superpuestas, la audiodescripción o el comentario libre (con un gran potencial para la redacción creativa), por ejemplo.

Por otro lado, como también señala Talaván (2013: 34), la gran multitud de medios audiovisuales de los que disponemos en la actualidad ayudan a crear un entorno de enseñanzaaprendizaje de una lengua extranjera activo, multisensorial y participativo, en el que los materiales audiovisuales se pueden utilizar de un modo productivo, eficiente y motivador. Por ello, resulta crucial analizar el papel que juegan las nuevas tecnologías de la información y la comunicación (TIC) y el vídeo (el medio audiovisual por excelencia) en la enseñanzaaprendizaje de una lengua extranjera. Si al recurso semiótico del producto audiovisual se le

\footnotetext{
${ }^{5}$ Países cuyo nivel de inglés es, sin embargo, más bajo que el nivel acreditado en España. Por tanto, quizá no se deba establecer necesariamente una relación entre subtitulación y alto nivel de inglés, puesto que hay países subtituladores cuyo nivel de inglés es bajo. Sin duda, influyen otros factores, como la inversión e investigación en la enseñanza de lenguas. De ahí la necesidad de proyectos como este.
} 
añade el elemento de la autenticidad (del que disponemos con gran facilidad en entornos multimedia de internet), se obtienen contextos de aprendizaje bastante realistas. A pesar de que el vídeo es uno de los ejemplos más representativos de este tipo de materiales auténticos necesarios, desgraciadamente se ha utilizado de un modo limitado durante años (Baltova, 1994; Canning-Wilson, 2000; Mayer, 2002; o Talaván, 2007). En la actualidad, la presencia de los medios audiovisuales es altamente notable, si bien no es tan frecuente su uso para llevar a cabo tareas activas (y no pasivas, como sí se hace con el contenido multimedia ${ }^{6}$ ). Por otro lado, tampoco es habitual usar los audiovisuales para llevar a cabo situaciones reales de comunicación, como se plantea en este proyecto. Los alumnos ejercerán el rol de fansubbers y fandubbers, puesto que llevarán a cabo todo el proceso: desde el borrador de traducción hasta la sincronización y ajuste de voces (y locución de diálogos) o subtítulos, dando como resultado un producto audiovisual acabado.

Una idea influyente que también justifica el uso de las TIC y del vídeo y que ha dominado el pensamiento occidental de las últimas décadas es el concepto de las inteligencias múltiples, que explica que la inteligencia no es una facultad mental monolítica, sino que tiene más de un nivel. Tanto las TIC como el vídeo son recursos idóneos para activar distintos tipos de inteligencia (más allá de la puramente lingüística) de modo simultáneo, por lo que un mayor número de aprendices se puede beneficiar plenamente de su utilización.

Para finalizar este apartado, no podemos dejar de mencionar la importancia que ha adquirido la investigación en enseñanza de lenguas a través de la TAV desde un punto de vista activo, especialmente de la subtitulación. Tal y como se ha comentado, en la última década hemos asistido a la realización de experimentos que han involucrado a los sujetos en la práctica de la traducción y la subtitulación. Así, en sus tesis, Talaván (2009), Bravo (2008) y Lertola (2013) recurrieron a esta modalidad para investigar su grado de relevancia en la mejora de conocimientos relacionados con la comprensión oral, las expresiones idiomáticas y el vocabulario, respectivamente. A estos trabajos, llevados a cabo con estudiantes de lengua extranjera, hay que sumar el de Torralba (2016), que también se centra en la adquisición de léxico a través de la subtitulación activa, pero en este caso con estudiantes del grado de Maestro como sujetos.

Conscientes de la reciente profusión de publicaciones que, de una manera dispersa, ahondan en el campo de la adquisición de lenguas, otra de las aportaciones de este proyecto será la sistematización del estudio de las posibilidades de la TAV en la enseñanza de lenguas, con un enfoque holístico que aborde todas las posibilidades de manera conjunta, cohesionada y completa. En todo caso, en la fase de revisión del estado de la cuestión, además de la de otros estudios publicados por los propios miembros del equipo, es precisa la lectura de trabajos como, por citar algunos, los de 1) doblaje en el aprendizaje de lenguas (AL): Kumai (1996),

\footnotetext{
${ }^{6}$ Como podemos leer en la web de Clipflair, "Using audiovisual material in the foreign language classroom is a common resource for teachers since it introduces variety, provides exposure to nonverbal cultural elements and, most importantly, presents linguistic and cultural aspects of communication in their context. However, teachers using this resource face the difficulty of finding active tasks that would engage learners and discourage passive viewing" (http://clipflair.net/).
} 
Burston (2005), Wagener (2006), Chiu (2012), Navarrete (2013), Martínez Sierra (2014) o Talaván y Ávila-Cabrera (2015); 2) subtitulación en el AL: Williams y Thorne (2000), Vermeulen (2003), Sokoli (2006), Wagener (2006), Bravo (2008), Incalcaterra (2009), Borghetti (2011), Sokoli, Zabalbeascoa y Fountana (2011), Martínez Sierra (2014), Incalcaterra y Lertola (2011 y 2014) o Lertola (2012); o 3) audiodescripción en el AL: Clouet (2005), Martínez Martínez (2012) o Ibáñez Moreno y Vermeulen (2013a y 2013b).

\section{Resultados futuros}

Como antes se avanzaba, entre los resultados palpables del proyecto figurará una plataforma virtual interdisciplinaria, única en su género, de didáctica de lenguas en contextos multilingües basada en la TAV y dirigida al desarrollo de las competencias plurilingües con el MCER y el MAREP como guías. Este sitio web, denominado PluriTAV, será de acceso libre y gratuito y contendrá, entre otros, recursos didácticos (incluyendo actividades y software para el trabajo guiado ${ }^{7}$ ), y estará ideado como plataforma de referencia para profesores y de práctica para estudiantes. PluriTAV (http://citrans.uv.es/pluritav/) incluirá contenidos multimedia de naturaleza didáctica sobre la enseñanza de lenguas desde una perspectiva multilingüe basada en la aplicación de la TAV. Esta plataforma, creada en las tres lenguas propias del contexto de este proyecto (inglés, español y catalán), estará estructurada en distintas secciones que incluirán, entre otros, una explicación de los fundamentos teóricos en los que se engloba la investigación y un apartado de bibliografía (ya disponible), la presentación de los resultados de la misma (como los instrumentos de evaluación), la aplicación de dichos resultados a la actividad docente (catálogo de actividades), el calendario de congresos (incluido el que se celebrará en la Universidad de Valencia, cuya página web se incluirá en este sitio), seminarios y talleres pensados para la difusión de los resultados, software para la traducción y el aprendizaje de lenguas, galería de vídeos clasificados por modalidades de traducción, por competencias específicas y por dificultades, manuales de uso en formato audiovisual y un foro abierto pensado para el intercambio de ideas, además de información sobre el programa que ha subvencionado la investigación y sobre los miembros de los equipos.

Dicho producto supondrá el siguiente beneficio: una mejor comprensión de las posibilidades de los enfoques multilingües y un enriquecimiento de los recursos didácticos de la enseñanza de lenguas, siempre dentro del contexto del MCER, que proporcionará un abanico de novedosas opciones metodológicas para la labor del personal docente.

\footnotetext{
${ }^{7}$ Fruto de la Declaración de la Sorbona (1998) y de la Declaración de Bolonia (1999), Europa comenzó su andadura hacia la creación de un Espacio Europeo de la Educación Superior (EEES). La creación del EEES es ya una realidad, y las universidades europeas se centran ahora en su consolidación. Una de las principales apuestas de este espacio educativo europeo es el cambio de paradigma del proceso de enseñanza-aprendizaje: pasamos de un sistema conductista a un sistema cognitivo-constructivista del conocimiento, en el que el estudiante es el protagonista de su propio proceso de aprendizaje y el profesor actúa como guía o facilitador.
} 
PluriTAV se encuentra en el inicio de su segundo año de vigencia, periodo durante el cual se va a llevar a cabo el diseño y aplicación del experimento pretendido, por lo que aún no dispone de conclusiones que poder aportar.

\section{Referencias}

Baltova, I. (1994). "Impact of video on the comprehension skills of core French students" en Canadian Modern Language Review, 50, 3, p. 506-531.

BorghetTI, C. (2011). "Intercultural Learning through Subtitling: The Cultural Studies Approach” en Incalcaterra, L., Biscio, M., Ní Mhainnín, M. Á. Audiovisual Translation Subtitles and Subtitling. Theory and Practice. Berna: Peter Lang. 111-137.

BRAVO, C. (2008). Putting the reader in the picture: Screen translation and foreign-language learning. Tesis doctoral. Tarragona: Universitat Rovira i Virgili.

BURSTON, J. (2005). "Video dubbing projects in the foreign language curriculum” en CALICO Journal, 23, p. 79-92.

CANNING-Wilson, C. (2000). "Practical Aspects of Using Video in the Foreign Language Classroom” en The Internet TESL Journal, 6, 11.

CENOz, J., GORTER, D. (2011). "Focus on multilingualism: A study of trilingual writing” en Modern Language Journal, 95, p. 356-369.

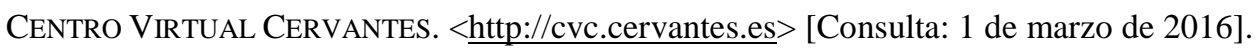

Chaume, F. (2004). Cine y traducción. Madrid: Cátedra.

CHIU, Y. H. (2012). “Can film dubbing projects facilitate EFL learners’ acquisition of English pronunciation?” en British Journal of Educational Technology, 43, 1, p. 24-27.

CLOUET, R. (2005). "Estrategia y propuestas para promover y practicar la escritura creative en una clase de inglés para traductores". En Actas del IX Simposio Internacional de la Sociedad Española de Didáctica de la Lengua y la Literatura. 319-326.

СоoK, G. (2010). Translation in Language Teaching. Oxford: Oxford University Press.

Cummins, J. (2014). "Rethinking pedagogical assumptions in Canadian French immersion programs" en Journal of Immersion and Content-Based Language Education, 2, 1, 3-22.

DANAN, M. (2010). "Dubbing projects for the language learner: a framework for integrating audiovisual translation into task-based instruction” en Computer Assisted Language Learning, 23, 5, p. 441-456.

FLOTOW, L. VON (2009). "Frenching the feature film twice: Or le synchronien au débat" en Díaz Cintas, J. New Trends in Audiovisual Translation. Bristol: Multilingual Matters. 8399.

IBÁÑEZ Moreno, A., Vermeulen, A. (2013a). "La audiodescripción como técnica aplicada a la enseñanza y aprendizaje de lenguas para promover el desarrollo integrado de 
competencias” en Orozco, R. New Directions on Hispanic Linguistics. Baton Rouge: Cambridge Scholars Publishing. 258-287.

--- (2013b). “Audio Description as a tool to improve lexical and phraseological competence in Foreign Language Learning” en Floros, G., Tsigari, D. Translation in Language Teaching and Assessment. Newcastle: Cambridge Scholars Publishing. 41-64.

INCALCATERRA, L. (2009). "Inter-semiotic Translation in Foreign Language Acquisition: The Case of Subtitles” en Witte, A., Harden, T., Ramos de Oliveira Harden, A. Translation in Second Language Learning and Teaching. Berna: Peter Lang. 227-244.

INCALCATERRA, L., LERTOLA, J. (2011). "Learn through subtitling: Subtitling as an aid to language learning” en Incalcaterra, L., Biscio, M., Ní Mhainnín, M. Á. Audiovisual Translation Subtitles and Subtitling. Theory and Practice. Berna: Peter Lang. 243-263.

--- (2014). “Audiovisual translation in second language acquisition. Integrating subtitling in the foreign-language curriculum” en The Interpreter and Translator Trainer, 8, 1, p. 70-83.

JAnssens, M., SteyaerT, C. (2014). "Re-considering language within a cosmopolitan understanding: Toward a multilingual franca approach in international business studies” en Journal of International Business Studies, 45, p. 623-639.

KUMAI, W. (1996). “Karaoke movies: Dubbing movies for pronunciation” en The Language Teacher Online, 20, 9.

Kumaravadivelu, B. (2001). “Toward a Postmethod Pedagogy” en TESOL Quartely, 35, 4, p. 537-560.

LASNIER, F. (2000). Réussir la formation par compétences. Montréal: Guérin.

LertolA, J. (2012). "The effect of subtitling task on vocabulary learning” en Pym, A., Orrego-Carmona, D. Translation research projects 4. Tarragona: Intercultural Studies Group. 61-70.

--- (2013). Subtitling New Media: Audiovisual Translation and Second Language Acquisition. Tesis doctoral. Galway: National University of Ireland.

MALAKOFF, M., HAKUTA, K. (1991). "Translation skill and metalinguistic awareness in bilinguals” en Language Processing in Bilingual Children, p. 141-166.

MANYAK, P. C. (2004). “'What did she say?' Translation in a primary-grade English immersion class” en Multicultural Perspectives, 6, p. 12-18

MARTínEZ MARTínEZ, S. (2012). "La audiodescripción (AD) como herramienta didáctica: Adquisición de la competencia léxica” en Cruces, S., del Pozo, M., Luna, A., Álvarez, A. Traducir en la Frontera. Granada: Atrio. 87-102.

MARTínez Sierra, J. J. (2014). “The Use of Audiovisual Translation Software in Second Language Teaching” en Journal of Foreign Language Teaching and Translation Studies, 3, 1, p. 74-85.

MAYER, R. E. (2001). Multimedia learning. Nueva York: Cambridge University Press.

(cc) EY-NC-ND 2018, Universitat Politècnica de València

Congreso IN-RED (2018) 
NAVARRETE, M. (2013). "El doblaje como herramienta de aprendizaje en el aula de español y desde el entorno de CLIPFLAIR” en MarcoELE, 16.

SOKOLI, S. (2006). "Learning via Subtitling (LvS). A tool for the creation of foreign language learning activities based on film subtitling”, ponencia presentada en Multidimensional translation: Audiovisual translation scenarios, Copenhague.

Sokoli, S., Zabalbeascoa, P., Fountana, M. (2011). "Subtitling Activities for Foreign Language Learning: What Learners and Teachers Think” en Incalcaterra, L., Biscio, M., Ní Mhainnín, M. Á. Audiovisual Translation Subtitles and Subtitling. Theory and Practice. Berna: Peter Lang. 219-242.

TALAVÁN, N. (2009). Aplicaciones de la traducción audiovisual para mejorar la comprensión oral del inglés. Tesis doctoral. Madrid: Universidad Nacional de Educación a Distancia.

--- (2007). "Learning Vocabulary through Authentic Video and Subtitles" en TESOL-SPAIN Newsletter, 31, p. 5-8.

--- (2013). La subtitulación en el aprendizaje de lenguas extranjeras. Barcelona: Octaedro.

Talaván, N., Ávila-Cabrera, J. (2015). "First insights into the Combination of Dubbing and Subtitling as L2 didactic tools" en Gambier, Y., Caimi, A., Mariotti, C. Subtitles and Language Learning. Berna: Peter Lang. 149-172.

TORRALBA, G. (2016). L'aprenentatge de llengües a través de la traduccio audiovisual: la subtitulació com a eina per a l'adquisició de lèxic en llengua estrangera. Tesis doctoral. Castellón: Universitat Jaume I.

Vermeulen, A. (2003). "La traducción audiovisual en la enseñanza de idiomas”. En Actas del Segundo Congreso Internacional de Español para Fines Específicos. 159-168.

WAGENER, D. (2006). "Promoting independent learning skills using video on digital language laboratories” en Computer Assisted Language Learning, 19, 4-5, pp. 279-286.

WiLliams, H., THORNE, D. (2000). "The value of teletext subtitling as a medium for language learning” en System, 28, 2, p. 217-228.

YUSTE FRÍAS, J. (2005). "Didáctica de la traducción inversa español-francés: el fin justifica los medios” en Yuste Frías, J., Álvarez Lugrís, A. Estudios sobre traducción, teoría, didáctica, profesión. Vigo: Universidad de Vigo. 147-170.

ZARO, J. J. (1999). "La traducción, estrategia y objeto de aprendizaje” en Salaberri, R., Sagrario, M. Lingüística aplicada a la enseñanza de lenguas extranjeras. Almería: Universidad de Almería. 531-555. 


\title{
Preferencias y rendimiento de los alumnos en el aprendizaje de Investigación Operativa con videos
}

\author{
Marina Segura, Concepción Maroto, Concepción Ginestar, José Ramón Navarro \\ Departamento de Estadística e Investigación Operativa Aplicadas y Calidad. Universitat \\ Politècnica de València. E-mail: masema@upvnet.upv.es; cmaroto@eio.upv.es; \\ cginesta@upvnet.upv.es; jonacer@upvnet.upv.es
}

\begin{abstract}
The increasing supply of videos as an online resource has changed the performance of students who study degrees based on face-to-face learning. The objectives of this paper are to elicit current preferences for different types of learning resources, especially videos, developed to teach Operations Research in Business Administration and Management degree, as well as analysing the relation between the videos use and students' performance. The methodology is based on a survey using the Likert scale and the multicriteria method AHP.

While all available resources are used to learn the subject, the results show a predominant preference for exam answers and videos, although more than one third of the students also use books and slides. Detailed exam answers improve learning and decrease tutorial appointments. There are significant differences in the use of learning resources among groups and resources affect students' behaviour and performance. The videos with teaching modules decrease face-to-face class attendance, while the videos with interactive case studies affect performance positively. Therefore, we think that moving forward in this line would improve effective learning.
\end{abstract}

Keywords: learning, videos, students' preferences, teaching resources, active learning, autonomous learning

\footnotetext{
Resumen

La creciente oferta de videos como recurso online ha modificado el comportamiento de los alumnos que cursan titulaciones con docencia presencial. Los objetivos de este trabajo son cuantificar las preferencias actuales por los diversos tipos de materiales, y en particular los videos, elaborados para la docencia de Investigación Operativa en el Grado en Administración y Dirección de Empresas, así como analizar la relación entre el uso de videos y el rendimiento de los alumnos. La metodología se basa en una encuesta con la escala de Likert y la técnica AHP.
} 
Si bien todos los recursos disponibles se utilizan para preparar la materia, los resultados muestran una preferencia mayoritaria por los exámenes resueltos y videos, aunque más de un tercio de los alumnos también utilizan libros y presentaciones. Los exámenes resueltos mejoran el aprendizaje y reducen las tutorías. Se han encontrado diferencias significativas en el uso de los recursos por grupo y los medios utilizados también afectan al comportamiento y al rendimiento de los alumnos. Los videos con unidades didácticas reducen la asistencia a clase presencial, mientras que los videos de casos prácticos interactivos afectan positivamente al rendimiento. Por tanto, creemos que avanzar en esta última línea mejoraría el aprendizaje efectivo.

Palabras clave: aprendizaje, videos, preferencias, recursos, enseñanza, aprendizaje activo, aprendizaje autónomo.

\section{Introducción}

La creciente oferta de formación online y semipresencial en las universidades ha generado una gran cantidad y diversidad de recursos docentes. Esta tendencia también se ha constatado en los estudios de gestión y administración de empresas (Arbaugh et al., 2009). La Universitat Politècnica de València (UPV) tiene una larga trayectoria en este sentido y en particular en el desarrollo de videos como recursos de aprendizaje, que son cada vez más demandados por los alumnos de docencia presencial.

En estudios previos hemos constatado que los alumnos de docencia inversa son los que mayor preferencia muestran por los videos para aprender Investigación Operativa y los que más valoran este recurso, que está influyendo en el comportamiento de los alumnos de docencia presencial. Así, los videos inicialmente grabados para apoyar la docencia inversa amplían las oportunidades de aprendizaje y contribuyen a adquirir la competencia de aprendizaje autónomo también del alumno presencial (Bas et al., 2017). Por una parte, la disponibilidad de videos reduce la necesidad de tutorías al poder visualizarlos varias veces, tomar notas y en definitiva adaptarlos a las necesidades personales. Por otra, los videos pueden reducir la asistencia a clase tal y como se ha observado también en otros trabajos, que analizan el impacto de los videos como material complementario a las clases presenciales (Winch y Cahn, 2015; Sharkey y Nurre, 2016). Además, en Bas et al. (2017) se encontró una relación negativa entre utilización de videos y rendimiento en la asignatura, que se consideró debido a la carencia de videos con casos prácticos, que sí se trabajan en el aula y no se resolvían de forma autónoma por los alumnos que utilizan más los videos. Para comprender los conceptos de Investigación Operativa es esencial que el alumno los aplique a casos prácticos, bien en clase o de forma autónoma.

Mejorar estos resultados y las sugerencias de los alumnos nos animaron a solicitar un Proyecto de Innovación y Mejora Educativa en la UPV (PIME B01) para el curso 2017-18, titulado "Casos y aplicaciones de toma de decisiones: vídeos y obtención de preferencias de los alumnos mediante técnicas multicriterio", cuyos primeros resultados presentamos en este trabajo.

(cc) EY-NC-ND 2018, Universitat Politècnica de València

Congreso IN-RED (2018) 


\section{Objetivos}

Teniendo en cuenta la experiencia previa comentada en la introducción los objetivos del presente trabajo son los siguientes:

1. Cuantificar las preferencias de los alumnos por los distintos tipos de materiales elaborados para la docencia de Investigación Operativa en el Grado en Administración y Dirección de Empresas y en particular los videos.

2. Analizar la relación entre el grado de utilización de videos y el rendimiento de los alumnos.

Para alcanzar el primer objetivo se ha realizado y analizado una encuesta a los alumnos que incluye tanto la escala de Likert, metodología habitual en este tipo de estudios, como la técnica multicriterio Analytic Hierarchy Process (AHP), muy empleada para elicitar las preferencias en toma de decisiones colaborativa y que representa un enfoque novedoso en educación (Saaty y Vargas, 2001; Saaty y Peniwati, 2008). Para alcanzar el segundo objetivo se han utilizado test estadísticos adecuados como Chi-cuadrado de Pearson en las tablas de contingencia, test de Kruskal-Wallis y test de Mann-Whitney para el análisis de variables cuantitativas.

En los siguientes apartados se presenta el contexto y el material docente previo al desarrollo de nuevos videos con casos prácticos y aplicaciones reales, la metodología y los principales resultados de la encuesta realizada a los alumnos la última semana del curso (adjunta como anexo). Por último, se incluyen las conclusiones del estudio y futuras líneas de mejora educativa.

\section{Desarrollo de la innovación}

\subsection{Contexto}

La Investigación Operativa es una materia de naturaleza cuantitativa que se imparte en $3^{\circ}$ curso del Grado en ADE (Facultad de Administración y Dirección de Empresas, UPV). En síntesis, los resultados de aprendizaje son que los alumnos sean capaces de formular modelos de optimización para resolver problemas reales de toma de decisiones, aplicar los conceptos y algoritmos para resolver modelos de programación lineal, entera, no lineal, multiobjetivo y multicriterio mediante software profesional e interpretar los resultados para mejorar las decisiones empresariales.

La asignatura tiene 3 créditos de teoría y 3 créditos de prácticas, 1 de prácticas de aula y 2 de prácticas informáticas. Se utiliza una metodología orientada hacia el aprendizaje, que tiene su origen en varios Planes de Innovación Educativa desarrollados en la UPV (Maroto et al., 1997; Alcaraz et al., 2003; Alcaraz et al., 2004).

El sistema de evaluación se basa en la evaluación continua de las prácticas informáticas (20\%) y 2 exámenes ( $40 \%$ cada uno). Los alumnos que no superan la asignatura pueden realizar un examen de recuperación. La media de la tasa de rendimiento de los estudiantes 
en los 6 últimos cursos es 90\%. El porcentaje medio de suspensos es 7,8\% y el de no presentados $2,2 \%$.

\subsection{Material docente}

El material docente básico consiste en un libro de texto diseñado para impartir la asignatura en el grado en ADE, las presentaciones del profesor en Powerpoint, videos con la voz del profesor explicando las presentaciones utilizadas en clase presencial y todos los exámenes resueltos (6 cursos). Tanto el libro como las presentaciones y los exámenes están en castellano y en inglés, ya que un grupo -Alto Rendimiento Académico (ARA)- se imparte en inglés. El libro está disponible en formato papel y electrónico (Maroto et al., 2012, Maroto et al., 2014). Los alumnos tienen acceso a 17 vídeos en castellano de toda la asignatura con una duración entre 8 min y 55 (grabados en 2015 para un proyecto piloto de docencia inversa) y a 3 en inglés (https://media.upv.es).

Dado que el material incluye casos prácticos a desarrollar y resolver en el aula y en el laboratorio informático, los alumnos no disponen de la solución, siendo ésta una demanda constatada en estudios previos (Bas et al., 2017), que se ha tratado de cubrir con nuevos videos en el curso 2017-18.

Durante el curso 2017-18 se han elaborado 12 nuevos videos con casos prácticos y aplicaciones reales (https://media.upv.es). Estos videos cumplen los requerimientos que exige el programa Docencia en Red de la UPV. Concretamente, son interactivos, indivisibles e independientes y duran 10 minutos. Aunque se han diseñado para cubrir las necesidades de la asignatura Investigación Operativa en ADE, no están contextualizados y pueden utilizarse en otras titulaciones y universidades.

\subsection{Metodología}

Para conocer las preferencias de los alumnos por los videos comparados con otros recursos docentes y su utilidad para mejorar su aprendizaje y rendimiento se ha diseñado la encuesta que figura en el anexo. La encuesta se ha realizado a todos los alumnos de Investigación Operativa del grado en ADE durante el curso académico 2017-2018, que se distribuyen en 4 grupos (Mañanas, Tardes, ARA y Doble Titulación ADE-Telecomunicaciones).

Se ha preguntado por el grado de utilización del material docente en el aprendizaje de Investigación Operativa utilizando la escala de Likert de 1 a 5. También aplicamos el método AHP basado en comparaciones por pares y la escala de 1 a 9 para conocer las preferencias de los estudiantes, que es una técnica multicriterio contrastada para conocer y agregar las preferencias de grupos, muy utilizada en toma de decisiones colaborativa y con mayor poder discriminante que la escala de Likert (Bas et al. 2017).

La encuesta, realizada la última semana de curso, también pregunta por calificación obtenida en la asignatura (nota primer parcial), si asiste regularmente a las clases y la meta personal en cuanto a la puntuación final para estudiar la posible influencia de los videos en el comportamiento y rendimiento de los alumnos. Por último, la encuesta incluye una pregunta abierta sobre sugerencias de mejora de los materiales docentes.

(cc) EY-NC-ND 2018, Universitat Politècnica de València

Congreso IN-RED (2018) 


\section{Resultados}

La tabla 1 recoge el número de alumnos matriculados en cada grupo y el porcentaje de los que han respondido la encuesta, que a nivel global es del $82,2 \%$. Se puede afirmar que tenemos una elevada representatividad tanto a nivel global como en todos los grupos.

Tabla 1. Número de alumnos matriculados y porcentaje de respuesta por grupos

\begin{tabular}{|l|c|c|c|}
\hline \multicolumn{1}{|c|}{ Grupo } & Matriculados & Respuesta & \% Respuesta \\
\hline Mañanas & 68 & 54 & 79,4 \\
\hline Doble ADE_Teleco & 16 & 14 & 87,5 \\
\hline ARA & 31 & 20 & 64,5 \\
\hline Tardes & 37 & 32 & 86,4 \\
\hline TOTAL & 152 & 125 & 82,2 \\
\hline
\end{tabular}

Arbaugh et al. (2009) y Cochran (2012) defienden la utilización y complementariedad de metodologías cualitativas y cuantitativas en estudios de educación. Por una parte, existe una gran controversia sobre la naturaleza cualitativa o cuantitativa de la escala de Likert, mientras que los resultados que se obtienen con AHP son cuantitativos. Autores como Garuti (2017) defienden el carácter cualitativo de la escala de Likert. Sin embargo, en la literatura también se encuentran resultados de la escala de Likert con análisis propios de variables cuantitativas.

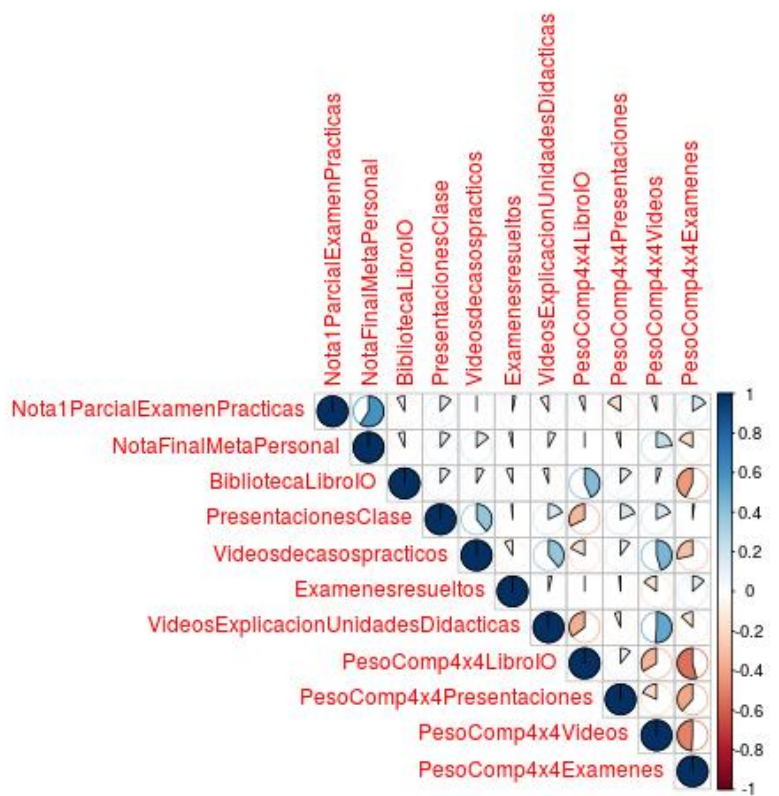

Fig. 1 Gráfico de correlaciones del rendimiento de los alumnos y grado de utilización de los recursos docentes

A nivel ilustrativo la figura 1 presenta un gráfico de correlaciones de las variables consideradas en la encuesta que muestra la elevada correlación entre la nota que han

(c) EY-NC-ND 2018, Universitat Politècnica de València

Congreso In-Red (2018) 
obtenido los estudiantes (primer parcial, 50\% de la calificación) y la meta personal que tienen para su calificación final, pudiendo ser éste un factor importante en la explicación del rendimiento, en especial para las notas más altas como sobresalientes y matrículas de honor. Además, destaca la inexistencia de correlación entre la utilización de los exámenes resueltos con ninguna otra variable.

Si evaluamos el grado de utilización de los diferentes tipos de materiales con el porcentaje de alumnos que los utiliza bastante o mucho, medido con la escala de Likert, el resultado de la encuesta refleja que el recurso más utilizado son los exámenes resueltos (92,00\%), seguido de los videos con explicación de las unidades didácticas $(54,17 \%)$ y videos de casos prácticos (50,41\%). El porcentaje de alumnos que utiliza bastante o mucho el libro de texto $(37,40 \%)$ y las presentaciones que utiliza el profesor en las clases $(37,19 \%)$ es menor, aunque importante porque representa más de un tercio del alumnado. En síntesis, se puede afirmar que todos los recursos disponibles se utilizan para preparar la asignatura.

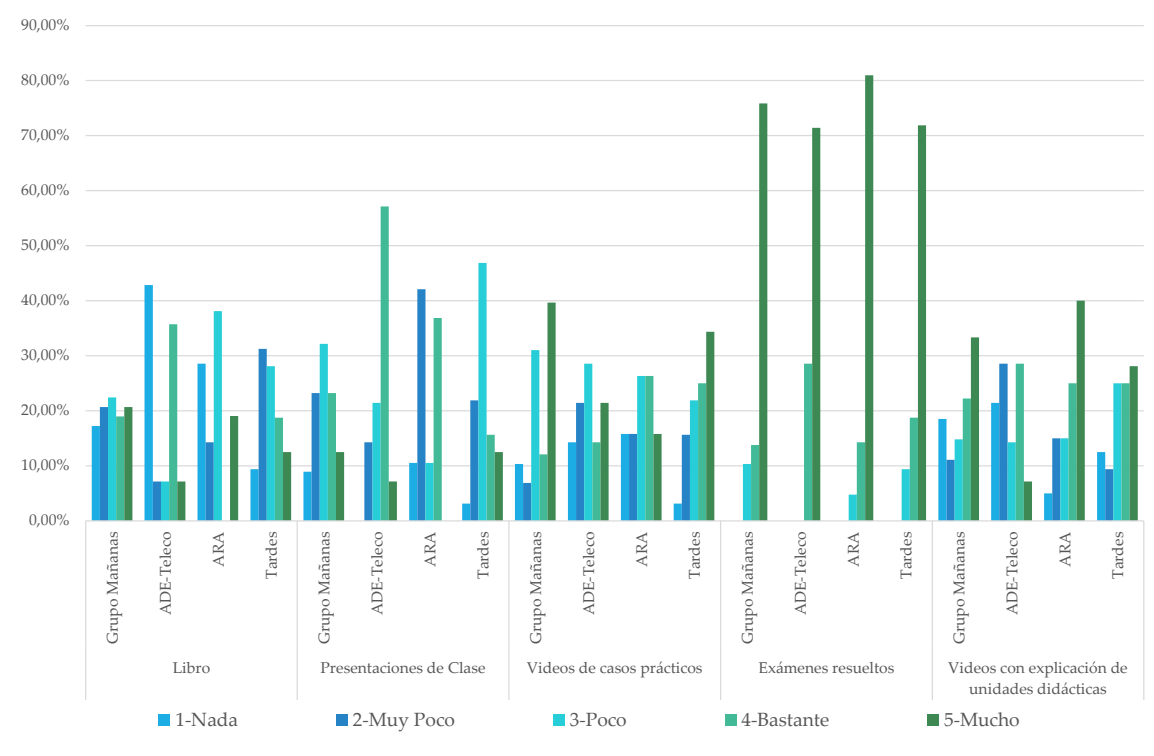

Fig. 2 Utilización del material docente en el aprendizaje de Investigación Operativa en porcentaje de alumnos por grupo. Escala de Likert.

Las diferencias por grupo se pueden observar en la figura 2, que se han analizado mediante tablas de contingencia, como herramienta adecuada para variables cualitativas. Mediante el test Chi-Cuadrado de Pearson se han encontrado diferencias significativas en el caso del libro y las presentaciones al $94 \%$ y $95 \%$ de confianza respectivamente. Los alumnos que cursan doble titulación ADE y Telecomunicación (DAT) destacan por ser los que en mayor proporción utilizan bastante o mucho el libro y a la vez no lo usa nunca en una proporción similar (42\%). Las diferencias en el uso de las presentaciones también se debe al distinto comportamiento de los alumnos de la doble titulación respecto a los demás, que son los que aprovechan más este recurso.

(cc) EY-NC-ND 2018, Universitat Politècnica de València

Congreso IN-RED (2018) 
Respecto a los exámenes y los videos, tanto de unidades didácticas como de casos prácticos las diferencias entre grupos no son significativas. Destaca que entre el 90 y 100\% de los alumnos utilizan bastante o mucho los exámenes resueltos. En cuanto a los videos la mitad de los estudiantes indican que los han utilizado bastante o mucho, siendo más empleados que el libro y las presentaciones.

Para obtener las preferencias de los alumnos por los diferentes materiales de Investigación Operativa en ADE utilizando la técnica multicriterio AHP en primer lugar se ha calculado la consistencia de las respuestas tanto de la matrices $4 \times 4$, como de las matrices $3 \times 3$, eliminando del análisis los exámenes. El porcentaje de encuestas consistentes del total de alumnos es 58\% de la matriz 3x3 y 62\% de la matriz 4x4, siendo mayor en DAT ( $79 \%$ en ambos casos), y menor en el grupo más numeroso de la mañana (52\% en ambos casos).

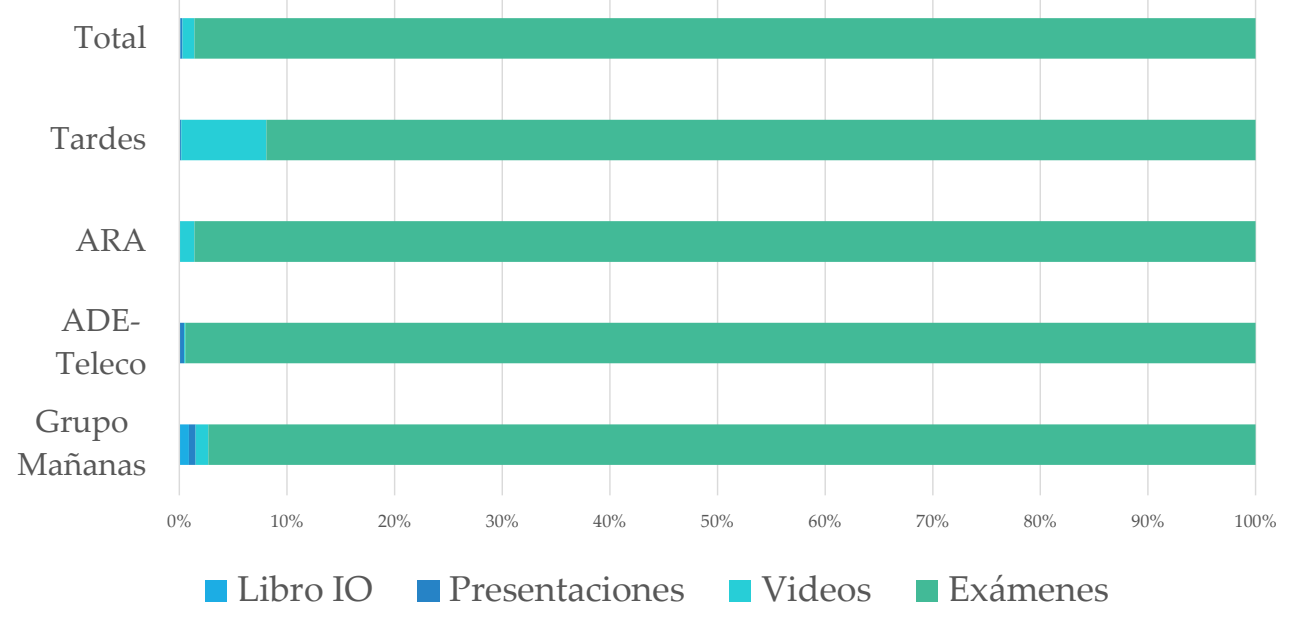

Fig. 3 Preferencias agregadas de los alumnos por el material docente en el aprendizaje de Investigación Operativa obtenidas con AHP. El porcentaje indica el peso relativo de cada uno de los 4 recursos.

Utilizando sólo las respuestas con consistencia aceptable (índice de inconsistencia menor o igual a 0,10 ) se han obtenido los resultados que se presentan en la figuras 3 y 4 . Los pesos de cada grupo para los recursos se han calculado agregando las comparaciones por pares realizadas por los alumnos mediante la media geométrica y de esta manera determinar la preferencia del grupo. La media geométrica mantiene la consistencia de las preferencias del grupo cuando las respuestas individuales son consistentes.

Dado que el método AHP discrimina más que la escala de Likert el peso que los alumnos atribuyen a los exámenes resueltos domina a todos los demás, tal y como se observa en la figura 3. Para analizar si las diferencias por grupos son significativas hemos realizado el test de Kruskal-Wallis. En caso afirmativo el test de Mann-Whitney nos permite detectar entre qué grupos existen diferencias significativas.

Cuando los alumnos comparan los cuatro tipos de recursos sólo es significativo el libro, debido al diferente comportamiento del grupo DAT con los grupos de mañana y tarde. En 
el análisis de las comparaciones sin incluir exámenes, resulta significativo el diferente comportamiento del grupo DAT con los otros tres grupos por el mayor uso de las presentaciones tal y como muestra la figura 4 .

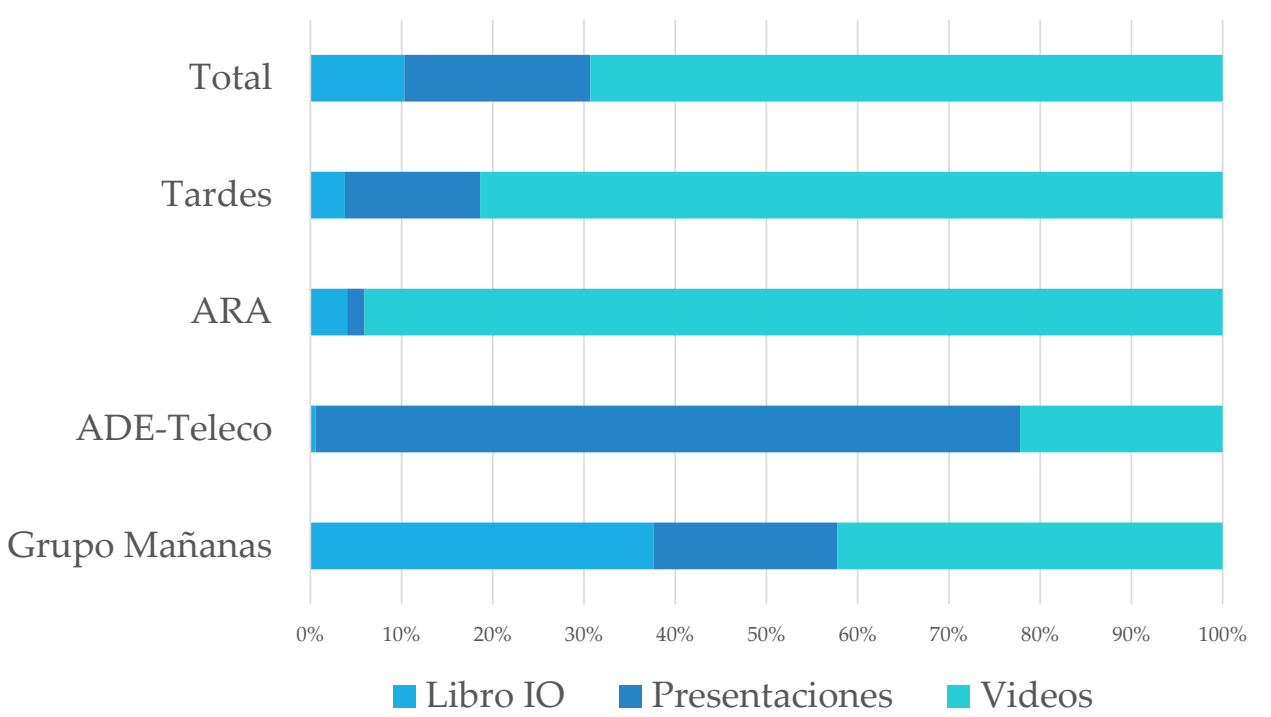

Fig. 4 Preferencias agregadas de los alumnos por el material docente en el aprendizaje de Investigación Operativa obtenidas con AHP. El porcentaje indica el peso relativo de cada uno de los 3 recursos.

También se han encontrado diferencias significativas entre las comparaciones por pares de matrices consistentes, cuando los alumnos comparan los videos con presentaciones y los videos con exámenes. En ambos casos el comportamiento del grupo de la doble titulación presenta un comportamiento distinto a los demás, dando menor preferencia a los videos que a las presentaciones cuando se comparan entre sí y también cuando se comparan con los exámenes.

Analizando la relación entre la calificación obtenida en la primera mitad de la asignatura y los materiales utilizados sólo son significativas las diferencias con los videos de unidades didácticas al 99 \% y con los videos de casos prácticos al 95\%. En el primer caso, el mayor porcentaje de alumnos que utilizan bastante o mucho los videos está en los que sacan notable, seguido de los aprobados. Asimismo, destaca que el 57\% de los sobresalientes no ven este tipo videos.

En cuanto a los videos de casos prácticos, un tercio de los suspensos los ha usado, mientras que la proporción sube al $56 \%$ en los aprobados y al $64 \%$ en los notables. Por otra parte, sólo los han visto el 28,6 \% de los sobresalientes. Atendiendo a este resultado se puede decir que los videos de casos prácticos son útiles para alcanzar un conocimiento mínimo y medio, aunque para alcanzar el mayor grado de aprendizaje y aprovechamiento se necesitan otras estrategias. 
También resulta significativo al 98\% la relación entre la meta personal en la calificación de la asignatura y la utilización de exámenes. Entre los que tienen una meta de notable un $85 \%$ utiliza mucho los exámenes, siendo este porcentaje menor en los demás casos.

El 72\% de las encuestas corresponden a alumnos que asisten regularmente a clase de teoría y prácticas de aula, ya que prácticamente todos asisten al laboratorio, que no siendo obligatorio, el trabajo que se realiza representa la evaluación continua del curso. El grado de utilización del libro presenta un comportamiento diferente y significativo dependiendo de si el alumno asiste o no a la clase presencial. Los que no van a clase usan el libro bastante o mucho (41,1\%) algo más que los que asisten (35,6\%). Sin embargo, la diferencia más importante está en que 1 de cada 3 de los que no van a clase no utilizan el libro, mientras este comportameinto sólo se da en el $17 \%$ de los que van a las clases presenciales.

La asistencia o no a clase presencial resulta significativa al 99\% de confianza con la visualización de videos con las explicaciones de las unidades didácticas. Un 74,3\% de los que no asisten a clase utilizan bastante o mucho estos videos y todos los ven, aunque sea muy poco. Por otra parte, el $45,8 \%$ de los que asisten a clase regularmente ven bastante o mucho estos videos y un $22 \%$ no los usa.

Por último, la asistencia regular a clase también está relacionada con la nota de la asignatura. Casi la mitad de los que no van a clase no han superado la primera parte de la asignatura (47,1\%), mientras que este dato es del $22 \%$ para los que sí asisten, que además de aprobar tienen mejores notas. En cuanto a los motivos por los que no asisten regularmente a clase, dos de cada tres contestan que prefieren ver los videos con las explicaciones de los temas, mientras que sólo la cuarta parte indica su preferencia por las presentaciones. El trabajo o realizar prácticas en empresas es el motivo de no asistir a clase en el 8,5\% de los casos.

Los resultados anteriores pueden estar relacionados con el comportamiento de muchos alumnos de dejar el trabajo para el final, como se ha podido comprobar con la evolución de las visualizaciones de los videos de casos prácticos. La figura 5 muestra que la mitad de las visitas se concentra en la semana anterior al examen, comportamiento general en todos los videos y documentado también por otros autores (Aljarrah et al. 2018).

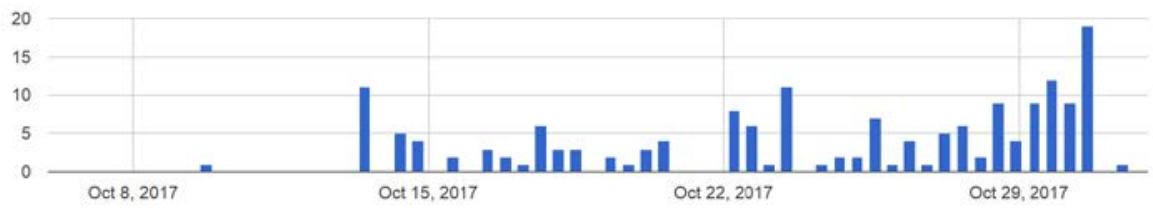

Fig. 5 Evolución del número de visitas (171) de un caso práctico (Algoritmo del simplex: método de las dos fases).

En cuanto a las sugerencias de mejora del material docente lo más destacable es que aproximadamente el $20 \%$ de los encuestados proponen disponer de más casos prácticos resueltos, incluyendo tanto los que especifican en formato video como los que no indican nada al respecto. El 2\% de los alumnos proponen incluir más casos reales en la asignatura. 


\section{Conclusiones}

Se ha constatado que todos los recursos disponibles para aprender Investigación Operativa que incluyen libros, presentaciones, videos y exámenes resueltos se utilizan por un número importante de alumnos. En general, los estudiantes muestran una clara preferencia por los exámenes resueltos, que utilizan y priorizan sobre videos, libros y presentaciones. Éste es un resultado que se ha obtenido con las dos metodologías, la escala de Likert y el método multicriterio AHP y además no está relacionado ni con el grupo ni con el rendimiento de los alumnos. Los exámenes resueltos con explicaciones detalladas mejoran el aprendizaje de los alumnos y reducen las tutorías.

El recurso preferido en segundo lugar son los videos, que utilizan bastante o mucho la mitad de los estudiantes y en una proporción mayor que el libro y las presentaciones del profesor, que no por esto dejan de ser relevantes. Las diferencias significativas por grupos se encuentran entre los alumnos de cursan la doble titulación con los demás grupos, tanto en los resultados de la escala de Likert como en los de AHP. Una mayor formación matemática, mayor regularidad en la asistencia y trabajo en clase y laboratorio, así como menor número de alumnos pueden estar en el origen de su menor empleo de videos para el aprendizaje.

Otra conclusión relevante es que la existencia de videos con las explicaciones de las unidades didácticas reducen la asistencia a clase, que está positivamente relacionada con el rendimiento académico. Por otra parte, reducen la necesidad de tutorías y favorecen el aprendizaje autónomo del alumno presencial. Sin embargo, los videos de casos prácticos interactivos presentan un uso más general por todos los alumnos y presentan una relación positiva con el rendimiento.

Por último, los resultados obtenidos no se pueden generalizar a cualquier titulación, pero consideramos que pueden ser representativos para los grados de ADE. La creciente demanda de contenidos online y de videos en particular sugieren que debemos seguir avanzando en el desarrollo de recursos especialmente diseñados para mejorar el aprendizaje y rendimiento de los alumnos, tales como sistemas de evaluación y videos interactivos de corta duración centrados en casos prácticos, vinculados entre sí ya que juegan un papel destacado en las preferencias y en el aprendizaje efectivo.

\section{Referencias}

ALCARAZ, J. et al. (2003). “Autonomous web-based learning of Operations Research” en International Conference on Engineering Education ICEE2003. Abstracts. Valencia.

ALCARAZ, J. et al. (2004). “Teaching Innovation of Operations Research Through a Web-Based System” en 7th Internacional Workshop on Higher Education and its Perspectives. Actas. Havana (Cuba).

ALJARRAH, A. et al. (2018). "Investigating temporal access in a flipped classroom: procrastination persists” en International Journal of Educational Technology in Higher Education 15:1, 1-18.

(cc) EY-NC-ND 2018, Universitat Politècnica de València

Congreso IN-RED (2018) 
ARBAUGH, J.B. et al. (2009). "Research in online and blended learning in the business disciplines: Key findings and possible future directions” en Internet and Higher Education 12, 71-87.

BAS, M.C. et al. (2017). "Preferencias en el aprendizaje de Investigación Operativa: Docencia inversa y presencial” en Congreso Nacional de Innovación Educativa y Docencia en Red (IN-RED 2017). Valencia, Spain: Editorial UPV. DOI:10.4995/INRED2017.2017.6806

COCHRAN, J.J. (2012). "You want them to remember? Then make it memorable! Means for enhancing operations research education” en European Journal of Operational Research 219, 659670.

GARUTI, C. (2017). "Reflections on scales from measurement, not measurements from scales” en International Journal of the Analytic Hierarchy Process 9, 349-361.

MAROTO, C. et al. (2012). Investigación Operativa en Administración y Dirección de Empresas. Valencia: Editorial UPV. Disponible en papel y libro electrónico.

MAROTO, C. et al. (2014). Operations Research in Business Administration and Management. Valencia: Editorial UPV. Disponible en papel y libro electrónico.

MAROTO, C. et al. (1997). "Operational Research Teaching in Computer Science through Six Years of Innovative Education Experience” en XV EURO and XXXIV INFORMS Joint International Meeting: OR/MS for the New Millennium. Abstracts.

SAATY, T.L. y PENIWATI, K. (2008). Group decision making: drawing out and reconciling differences. RWS Publications.

SAATY, T.L. y VARGAS, L.G. (2001). Models, methods, concepts \& applications of the analytic hierarchy process. Kluwer Academic Publishers.

SHARKEY, T.C. y NURRE, S.G. (2016). "Video Tutorials Within an Undergraduate Operations Research Course: Student Perception on Their Integration and Creating A Blended Learning Environment” en INFORMS Transactions on Education 17(1):1-12.

WINCH, J.K y CAHN, E.S. (2015). "Improving Student Performance in a Management Science Course With Supplemental Tutorial Videos” en Journal of Education for Business, 90:7, 402-409. 


\title{
ANEXO. CUESTIONARIO
}

\author{
Proyecto de Innovación y Mejora Educativa
}

PIME B01- curso 2017-18

\section{Preferencias sobre el material docente de Investigación Operativa}

El objetivo esta encuesta es conocer las preferencias de los alumnos por los diferentes tipos de materiales docentes disponibles para la asignatura Investigación Operativa.

1. Indica el grupo en el que estás matriculado/a:

Grupo Mañanas

Grupo Tardes

Grupo ARA

Grupo Doble ADE-Teleco

2. Grado de utilización del material docente en el aprendizaje de Investigación Operativa.

\begin{tabular}{|l|l|l|l|l|l|}
\hline \multicolumn{1}{|c|}{ Material docente } & Nada & $\begin{array}{c}\text { Muy } \\
\text { poco }\end{array}$ & Poco & Bastante & Mucho \\
\hline Biblioteca/Personal & & & & & \\
\hline Libro: Investigación Operativa en ADE & & & & & \\
\hline Book: Operations Research in BAM & & & & & \\
\hline En Poliforma T/Recursos: & & & & & \\
\hline Presentaciones de clase & & & & & \\
\hline Videos de casos prácticos & & & & & \\
\hline Exámenes resueltos & & & & & \\
\hline Videos Temas 2 y 3 (English) & & & & & \\
\hline PoliformaT/Contenidos: & & & & & \\
\hline $\begin{array}{l}\text { Videos con explicación de unidades } \\
\text { didácticas }\end{array}$ & & & & & \\
\hline
\end{tabular}


3. Indica tus preferencias por los distintos tipos de materiales docentes aplicando el método AHP basado en comparaciones por pares y la escala de 1 a 9 .

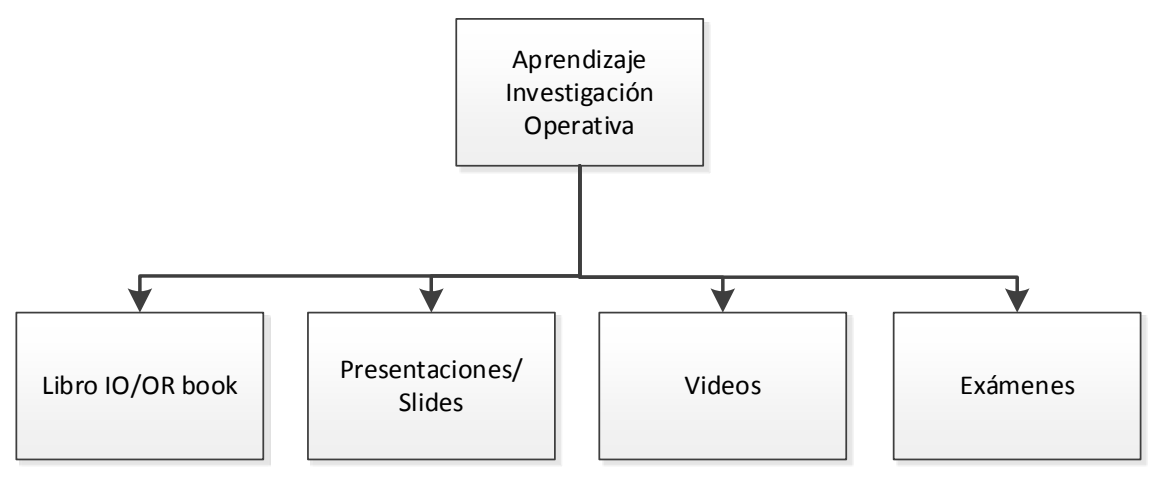

Compara la importancia relativa del material docente indicado en la fila de la matriz de comparaciones con el de la columna utilizando la escala del método AHP.

\section{Escala:}

1 igual importancia, 3 importancia moderada, 5 importancia fuerte, 7 mucha mayor importancia y 9 importancia extrema del primer elemento sobre el segundo.

Si el material de la columna tiene para ti mayor importancia que el de la fila: $1 / 3,1 / 5,1 / 7$ y $1 / 9$.

Rellena sólo las casillas en blanco.

\begin{tabular}{|c|c|c|c|c|}
\hline Material docente & Libro 10 & Presentaciones & Videos & Exámenes \\
\hline \multicolumn{5}{|l|}{ Libro IO } \\
\hline \multicolumn{5}{|l|}{ Presentaciones } \\
\hline \multicolumn{5}{|l|}{ Videos } \\
\hline Exámenes & & & & \\
\hline
\end{tabular}

Si tienes dudas sobre cómo rellenar esta matriz de comparaciones, contesta a las preguntas de la página siguiente. 


\begin{tabular}{|c|c|}
\hline Libro IO/OR book & Presentaciones/Slides \\
\hline $\begin{array}{ll}\circ & \circ \\
\circ & \text { Moderada }=3 \\
\circ & 4 \\
\circ & \text { Fuerte }=5 \\
\circ & 6 \\
\circ & \text { Mucha mayor = }=7 \\
\circ & 8 \\
\circ & \text { Extrema }=9\end{array}$ & $\begin{array}{l}\circ \mathbf{2} \\
\circ \text { Moderada = } 3 \\
\circ 4 \\
\circ \text { Fuerte }=5 \\
\circ 6 \\
\circ \text { Mucha mayor = } 7 \\
\circ 8 \\
\circ \text { Extrema = 9 }\end{array}$ \\
\hline
\end{tabular}

¿Cual de los dos materiales docentes tiene para ti más importancia en el aprendizaje de Investigación Operativa?

\begin{tabular}{|c|c|}
\hline Libro IO/OR book & Exámenes \\
\hline $\begin{array}{ll}\circ & \mathbf{2} \\
\circ & \text { Moderada = } 3 \\
0 & 4 \\
\text { - } & \text { Fuerte = } 5 \\
0 & 6 \\
\text { - Mucha mayor = } 7 \\
\text { - } 8 \\
\text { - Extrema }=9\end{array}$ & $\begin{array}{l}\circ \mathbf{2} \\
\circ \text { Moderada = } 3 \\
\circ \mathbf{4} \\
\text { - } \text { Fuerte = } 5 \\
\circ \mathbf{6} \\
\circ \text { Mucha mayor = } 7 \\
\circ \mathbf{8} \\
\circ \text { Extrema = 9 }\end{array}$ \\
\hline
\end{tabular}

4. Calificación en la primera parte de la asignatura (Examen + Prácticas laboratorio):

No presentado

Suspenso

Aprobado

Notable

Sobresaliente

Teóricas y Prácticas de aula

SI

NO
¿Cuál de los dos materiales docentes tiene para ti más importancia en el aprendizaje de Investigación Operativa?

\begin{tabular}{|c|c|c|}
\hline Libro IO/OR book & & Videos \\
\hline$\circ 2$ & o Igual = 1 & $\circ 2$ \\
\hline - Moderada $=\mathbf{3}$ & & - Moderada $=\mathbf{3}$ \\
\hline$\circ 4$ & & $\circ 4$ \\
\hline ○ Fuerte $=\mathbf{5}$ & & ○ Fuerte $=\mathbf{5}$ \\
\hline$\circ 6$ & & $\circ 6$ \\
\hline ○ Mucha mayor $=7$ & & - Mucha mayor $=\mathbf{7}$ \\
\hline$\circ 8$ & & $\circ 8$ \\
\hline ○ Extrema $=\mathbf{9}$ & & ○ Extrema $=\mathbf{9}$ \\
\hline
\end{tabular}

¿Cuál de los dos materiales docentes tiene para ti más importancia en el aprendizaje de Investigación Operativa?

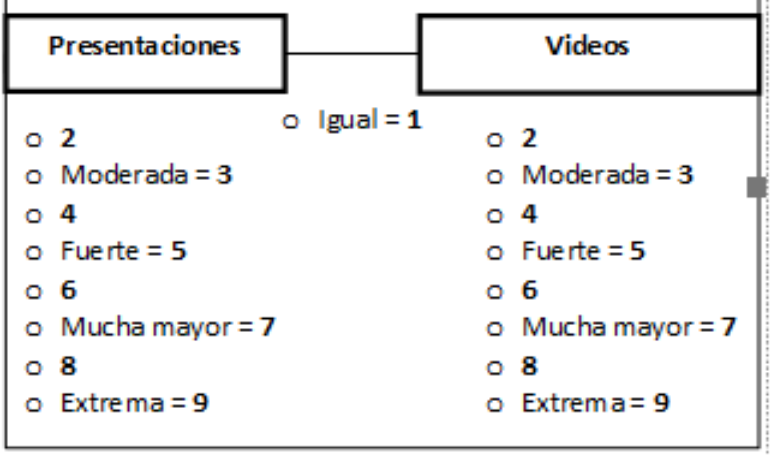

\begin{tabular}{|c|c|c|c|c|}
\hline $\begin{array}{l}\text { ¿Cuál c } \\
\text { importa }\end{array}$ & \multicolumn{4}{|c|}{$\begin{array}{l}\text { ¿Cuál de los dos materiales docentes tiene para ti más } \\
\text { importancia en el aprendizaje de Investigación Operativa? }\end{array}$} \\
\hline Presel & Videos & & & Exámenes \\
\hline 02 & 02 & lgual = 1 & o & $2^{h}$ \\
\hline o Modi & - Moderada $=\mathbf{3}$ & & 0 & Moderada $=\mathbf{3}$ \\
\hline$\circ 4$ & $\circ 4$ & & 0 & 4 \\
\hline - Fuert & - Fuerte $=\mathbf{5}$ & & o & Fuerte $=\mathbf{5}$ \\
\hline$\circ 6$ & $\circ 6$ & & 0 & 6 \\
\hline - Muct & - Mucha mayor $=7$ & & 0 & Mucha mayor $=7$ \\
\hline 08 & $\circ 8$ & & 0 & 8 \\
\hline - Extre & - Extrema $=\mathbf{9}$ & & 0 & Extrema $=\mathbf{9}$ \\
\hline
\end{tabular}

5. Asisto regularmente a las clases:

2018, Universitat Politècnica de València

Congreso IN-RED (2018) 


\section{Prácticas Informáticas}

En caso de NO asistencia indica el motivo:

SI

Prácticas de empresa

NO

Prefiero ver los videos con explicación de los temas

Prefiero preparar la asignatura con el libro

Prefiero estudiar con las presentaciones de clase

Otros:

6. Meta personal para la calificación final de la asignatura Investigación Operativa

Aprobado

Notable

Sobresaliente

Sobresaliente $10 \mathrm{MH}$

7. Sugerencias de mejora para la elaboración de materiales docentes: 


\title{
Redes sociales en la enseñanza superior
}

\author{
Alícia Martí Climent, Pilar Garcia Vidal
}

Universitat de València, alicia.marti@uv.es, pilar.garcia-vidal@uv.es

\begin{abstract}
In this communication we expect to show project work experiences using social networks (Facebook, Twitter, Instagram and Youtube) as an educational resource in higher education to share, create, inform and communicate. In this way, educational innovation has been promoted with new work methods improving university students' motivation and academic results in classroom work.
\end{abstract}

Keywords: TIC, Social Networks, Higher Education, Educational Innovation.

\begin{abstract}
Resumen
En esta comunicación pretendemos mostrar experiencias realizadas con proyectos de trabajo que emplean las redes sociales (Facebook, Twitter, Instagram y Youtube) como recurso educativo en la enseñanza superior para compartir, crear, informar y comunicar. De esta manera, se favorece la innovación educativa con nuevos medios que suponen diferentes metodologías y mejoran la motivación del alumnado universitario y el resultado del trabajo en el aula.
\end{abstract}

Palabras clave: TIC, redes sociales, educación superior, innovación educativa.

\section{Introducción}

Esta comunicación tiene como objetivo presentar el uso de las redes sociales como recurso educativo en la enseñanza superior con el fin de animar al profesorado a la utilización de este tipo de medios en su práctica didáctica.

Actualmente la universidad acoge alumnado de la llamada generación en red (Generation red, Tapscott, 2009) o millenials ${ }^{1}$, que está acostumbrado a la interactividad que promueven

\footnotetext{
${ }^{1}$ Como apuntan Meso Ayerdi, Pérez Dasilva y Mendiguren Galdospin (2011), las nuevas generaciones han recibido varias etiquetas, como Generation Red (Tapscott, 1998), e-
} 
las redes sociales. La influencia del audiovisual y de Internet está muy presente en estos nativos digitales (Prensky, 2001). Al estar más familiarizados con el uso de las TIC tienen un concepto positivo sobre su utilidad en el aprendizaje.

Las herramientas tecnológicas que les permiten compartir, crear, informar y comunicarse son múltiples. Las redes sociales se han convertido en esenciales en sus vidas. Actualmente, los jóvenes las utilizan con frecuencia (sobre todo Twitter e Instagram) con fines diversos. Así pues, a partir de este hecho nace nuestra propuesta didáctica: el uso de las redes sociales como recurso educativo en la enseñanza superior.

Nuestra experiencia se basa en la aplicación de este recurso de las nuevas tecnologías de la información y la comunicación (TIC) desde la perspectiva pedagógica de las técnicas del aprendizaje colaborativo y la creación de conocimiento en red, es decir, de las tecnologías para el aprendizaje y el conocimiento (TAC). El uso de estas herramientas tecnológicas debe seguir siempre principios pedagógicos didácticos con el fin de conseguir la innovación educativa adecuada en los procesos formativos. La innovación y la mejora de las prácticas educativas mediante las tecnologías depende del buen uso en su aplicación didáctica. La renovación metodológica debe tener en cuenta los avances en didáctica de la lengua y la literatura y debe incorporar las posibilidades de la red para investigar, reflexionar y compartir (Manresa, Durán y Ramada, 2012).

Concretamente, hemos utilizado las redes sociales en la asignatura Complementos para la formación disciplinar de la especialidad de lengua y literatura catalana dentro del Máster universitario en profesorado de educación secundaria de la Universitat de València. A partir de los datos recogidos en unos cuestionarios realizados por el alumnado del Máster desde el curso 2011-12 hasta el 2017-18, constatamos el tipo de recursos TIC que emplean los alumnos para la elaboración y la presentación de trabajos académicos de diferentes géneros. Observamos un aumento evidente en los últimos años de la diversidad de herramientas utilizadas por el alumnado para trabajar diferentes géneros académicos. Las plataformas digitales más utilizadas para publicar y difundir los trabajos multimedia son: blogs (Blogger, Wordpress), wiki (Wikispaces), webquest (Google Sites), redes sociales (Twitter, Facebook, Instagram, Tuenti), servidores para alojar presentaciones (Slideshare, Scribd), edición de revistas digitales (Issuu), participación en una enciclopedia digital (Wikipedia), elaboración de rutas en un mapa digital (Goggle Maps), compartir vídeos en red (Youtube) y presentaciones en línea (Prezi).

En este trabajo nos centraremos en el uso de las redes sociales en proyectos realizados por los alumnos del Màster de Secundaria con una finalidad didáctica, como ejemplos de experiencias que pueden servir como modelos de trabajos académicos con un buen uso de este tipo de recursos.

Generation, Millennial Generation, Generación Interactiva (Bringué y Sadaba, 2008) o Generación Einstein (Piscitelli, 2009).

(cc) EY-NC-ND 2018, Universitat Politècnica de València

Congreso IN-RED (2018) 


\subsection{Las redes sociales}

Las redes sociales son sitios web que permiten compartir de manera virtual lo que hacemos cotidianamente (actividades diversas) y también lo que creamos encontramos en la red (vídeos, música, imágenes, etc). Como señala Macías (2016: 228), "Las redes sociales, entendidas como comunidad abierta y no jerarquizada, se basan en el principio de las tres ces: contenido, construcción y colaboración (content, construction, colaboration)".

De entre las diversas redes sociales en línea, Área (2008) distingue tres tipos: redes de masas (Facebook, Twitter,...) en que las personas usuarias comparten un perfil, fotos, comentarios, etc.; redes abiertas para compartir archivos en diferentes formatos (YouTube, Slideshare, Flickr...) y redes temáticas o comunidades de aprendizaje con un objetivo común o un interés específico (Ning, Elgg...). En el uso de las redes sociales en el Máster de Secundaria han ido apareciendo cambios desde el curso 2010-11 al 2017-18 por lo que se refiere al tipo de plataformas utilizadas. Han ido subtituyéndose las que se utilizaban como redes temáticas para el seguimiento del trabajo de clase, desde Ning, Wikispaces a Google Sites; han augmentado el uso de las redes de masas, como Facebook, Twitter, Instagram; y en las redes abiertas, ha predominado YouTube.

\subsection{El uso académico de las redes sociales}

Cualquier red social permite mantener el contacto entre las personas. El uso de las redes sociales favorece el desarrollo de las habilidades lingüísticas y comunicativas mediante el hipertexto que se configura con la combinación de códigos verbales gráficos y sonoros, y la interacción comunicativa que se genera a través de la conversación y el debate en la red. Cada usuario se convierte en emisor y receptor de textos diversos. La utilización de las tecnologías de la información y la comunicación resulta un elemento esencial para informarse, aprender y comunicarse. (Garcia y Martín, 2010)

Posiblemente una de las redes usadas con fines educativos más habitual sea Ning, como podemos ver en las experiencias de Haro (2009) y García y Martí (2010), aunque ha disminuido su uso desde que dejó de ser gratuita. Últimamente encontramos destacadas aplicaciones didácticas para el trabajo de la lectura social y colaborativa mediante Twitter (Lluch, 2014; Rovira, 2015). La lectura se comparte, se comenta y se muestra. Según Lluch (2014), la clave del éxito radica en "su carácter social, público, interactivo y global que permite socializar la lectura, compartirla con cualquier otro adolescente de cualquier lugar del mundo y a cualquier hora" (Lluch, 2014: 19).

Así pues, las redes sociales o, según los expertos, servicios 2.0 con características de red social, en el ámbito educativo presentan diferentes posibilidades didácticas. De acuerdo con Haro $(2009,2010)$ y Orihuela (2009), las redes sociales en línea permiten generar nuevas sinergias entre los miembros de una comunidad educativa, ya que favorecen la comunicación bidireccional entre el alumnado y el profesorado, y por tanto el efecto de proximidad y el aumento de la fluidez y sencillez de la comunicación. Pero, además, proyectan y consolidan las relaciones interpersonales una vez que han terminado los estudios. También facilitan la circulación de información, la organización de eventos, el 
compartir recursos y la coordinación y trabajo de varios grupos de aprendizaje (clase, asignatura, grupo de alumnos de una asignatura, etc.) mediante la creación de los grupos apropiados.

Sobre el uso las redes sociales en la educación, Pérez García (2013) señala que es recomendable su uso ya que favorecen la adquisición de las competencias tecnológicas, fundamentales tanto en el ámbito educativo como en el laboral. Garcia y Martí (2016) apuntan que éstas facilitan una planificación didáctica eficaz y motivadora para el alumnado, potencian la creatividad y la originalidad, fomentan el trabajo colaborativo, refuerzan el aprendizaje individual y permiten la difusión de propuestas de trabajo innovadoras.

El uso de las redes sociales presenta una ventaja fundamental: el acercamiento del aprendizaje formal y el informal. Sin embargo, este aspecto conlleva al mismo tiempo la necesidad de enseñar a los alumnos a participar, ya que pueden tender a utilizarlos sólo de forma personal. Es necesario, por lo tanto, enseñar a a usar la red como herramienta para el trabajo académico y para potenciar la colaboración (Garcia y Martí, 2010).

Gómez, Roses y Farias (2012) señalan que entre las actividades que realiza el alumnado en las redes sociales encontramos: resolver dudas sobre la materia, mantenerse informados del ritmo de las clases y realizar trabajos en grupo; si bien, ninguna de estas tareas es demasiado frecuente. Los autores apuntan también que las redes sociales resultan más rentables en contextos en que se utilizan las metodologías activas y participativas, que consiguen, entre otros, fomentar el trabajo colaborativo, el aprendizaje continuo, la cohesión del grupo, el aprendizaje autónomo, el diálogo y la comunicación entre los alumnos y entre éstos y el profesor, el pensamiento crítico.

Por otra parte, el estudio de Gómez, Roses y Farias (2012) sobre el uso académico que hacen los universitarios de las redes sociales, a partir de una encuesta a una muestra representativa de estudiantes de la Universidad de Málaga, plantea una paradoja: aunque los alumnos utilizan frecuentemente las redes sociales, su uso para actividades académicas es escaso y entre sus contactos no suelen tener a ningún profesor.

En nuestro trabajo, nos llama la atención la escasa formación en TIC que demuestra la mayoría de los estudiantes del Máster, salvo en el caso de los que han cursado una especialidad que incluye trabajar con varias tecnologías, como en el caso de los grados en comunicación audioviosual o periodismo. De ello se deduce que la incorporación de las TIC no tiene la relevancia que debería tener en la formación universitaria de algunas especialidades, por lo que conviene considerarla para completar la formación de los futuros docentes, que deben saber utilizar las TIC como herramientas de trabajo habituales e incorporarlas en el aprendizaje continuo a lo largo de la vida, tanto personal como profesional (Martí y Garcia, 2014). Hay que añadir que uno de los obstáculos para el uso de las redes sociales en la enseñanza son también las restricciones en el acceso a las redes sociales en algunos centros educativos.

(c)) EY-NC-ND 2018, Universitat Politècnica de València

Congreso IN-RED (2018) 


\section{Objetivos}

Nos proponemos potenciar el uso de las redes sociales en trabajos académicos de enseñanza superior con el objetivo de suplir estos obstáculos que hemos observado durante nuestra experiencia académica como profesoras del ámbito universitario y de enseñanza secundaria. El poco uso que aún se hace de estas herramientas con fines didácticos supone que no se aproveche suficientemente su potencial a nivel de motivación e implicación del alumnado, de posibilidades para aumentar el grado de interacción y de colaboración entre profesorado y alumnado, de difusión y publicación inmediata del trabajo realizado en el aula.

Además, planteamos como objetivos específicos facilitar la innovación en proyectos con redes sociales que permitan nuevos planteamientos para trabajar con una metodología más colaborativa y participativa, que aprovechen de manera más efectiva los recursos más actualizados de la red.

Por otra parte, aprender a hacer un uso adecuado de las redes sociales permite tener en cuenta estos recursos que pueden resultar muy productivos desde el punto de vista educativo para el aprendizaje y la comunicación. Las redes sociales permiten desarrollar la capacidad lectora, la expresión oral y la creación de textos escritos multimedia del alumnado.

Finalmente, con nuestro trabajo pretendemos mostrar experiencias realizadas con proyectos de trabajo que emplean las redes sociales con buenos resultados a nivel académico.

\section{Desarrollo de la innovación}

Presentamos ejemplos de proyectos realizados con algunas de las redes más utilizadas en educación, como Facebook, Twitter, Instagram y YouTube, que forman parte de experiencias que hemos llevado a cabo en el aula con el alumnado del Máster de Secundaria.

\subsection{Facebook}

Esta red es un punto de encuentro colectivo y atemporal. El muro de Facebook permite a cada usuario disponer de un espacio para difundir contenidos textuales, visuales, audiovisuales y de audio entre los miembros de la red con los que el usuario ha aceptado compartir estos contenidos. Ahora bien, Facebook no está concebido como una plataforma docente. Encontramos diversas dificultades para su uso en la docencia, como no poder hacer un seguimiento personalizado de la actividad de cada usuario y la imposibilidad de compartir documentos en PDF.

Sin embargo, un estudio de Gómez, Roses y Farias (2012) apunta que la red social más adecuada para el uso académico es Facebook, por la cantidad de funciones que presenta (textos, vídeos, foros, chats, etc.) y por la creación de contenidos. De hecho, los autores 
recomiendan la creación de un grupo en Facebook con el nombre de la asignatura por parte del profesor/a.

Como ejemplo de experiencia educativa de uso de esta red, tenemos la creación en el Máster de Secundaria del programa de radio El redolí que dispone de perfiles del programa en las redes sociales Facebook y Twitter. El objetivo de emplear estas redes es ayudar a difundir el programa y potenciar la interacción con el oyente. Además, existe la voluntad de construcción de una comunidad de aprendizaje alrededor del programa, un objetivo para el que es necesario potenciar la participación. En este sentido, y sólo a título de ejemplo, podemos destacar la propuesta de llevar a cabo la participación en un concurso que se realiza en el programa mediante estas dos redes sociales.

Otro proyecto que emplea las redes sociales Facebook y Twitter es la creación del periódico L'Interrogant que, además de una edición de papel, tiene una edición digital en una web y interacciona con sus lectores mediante estas redes sociales.

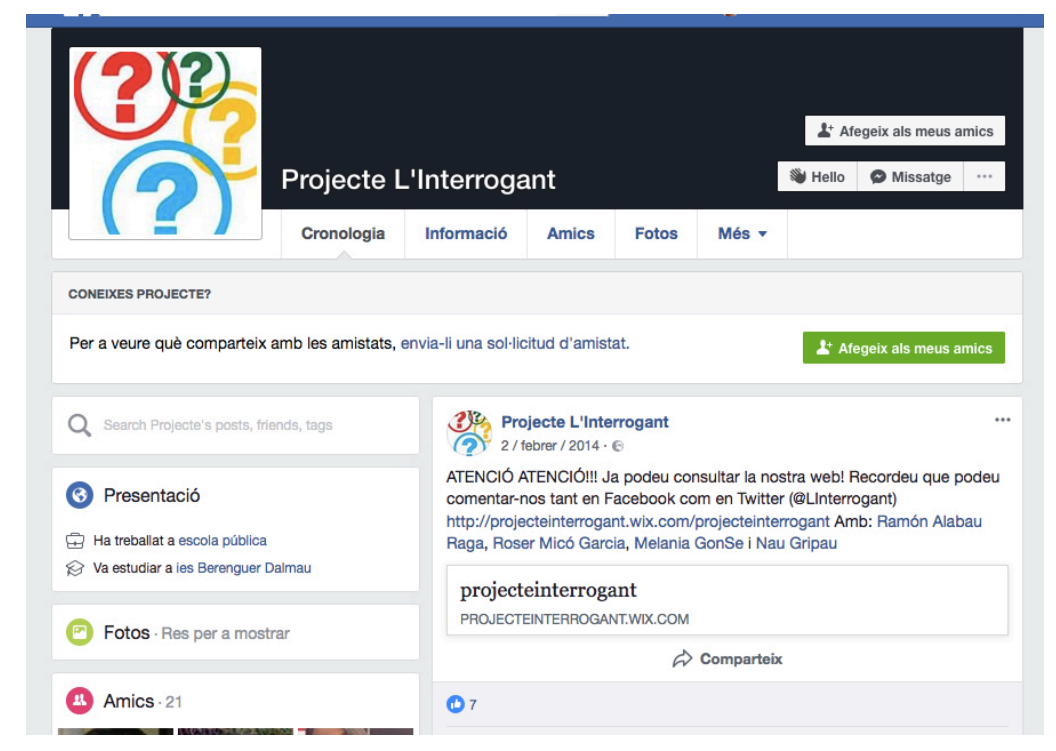

Fig. 1 Pàgina de Facebook del periódico L'Interrogant

\subsection{Twitter}

Con respecto a esta red, encontramos la ventaja de la limitación en el uso de caracteres que desarrolla la capacidad de síntesis. Sobre Twitter, Lluch (2012) apunta su uso como espacio de comunicación en torno a libros, autores o lecturas. Según la autora, podemos aprovechar las características de Twitter para:

- informar sobre el libro que leemos: los avances que hacemos, las partes que nos gustan, escribir una frase que en guste, etc. 
- iniciar una conversación sobre un libro, una temática o un autor

- comentar noticias relacionadas con la lectura o los libros que leeremos

- compartir enlaces de Internet que nos informan sobre los temas lectores que nos interesan

- pedir ayuda sobre un libro que no encontramos, un capítulo que no entendemos, etc.

(Lluch, 2012: 203)

En relación al uso académico de Twitter, Lluch y Nicolás (2015) hacen algunas recomendaciones a partir de los trabajos de Torres (2011), Zayas (2012), Sáez (2013), Millán (2013) y Lluch (2014), como la importancia de aportar valor a la comunicación, de interactuar con los usuarios que comparten intereses y etiquetas y de hacer un uso adecuado, correcto y normativo de la lengua, entre otros. Usar Twitter "de manera adecuada, con registro formal y propósito académico" para "aprender y ampliar los horizontes del espacio académico en cualquier lugar o momento" (Lluch, Nicolás, 2015: 201-261).

Sobre el uso que se hace de la red Twitter a nivel educativo, encontramos ejemplos para trabajar lecturas, como la experiencia desarrollada por la Universitat de València Diàleg entre l'escriptor $i$ els lectors joves, organizado desde 2002 por la profesora Carme Gregori. El profesor Ignasi Moral participa con las tertulias literarias de sus alumnos mediante Twitter mientras se lleva a cabo la lectura (Lluch, 2012: 155-159), utilizando una etiqueta para compartir sus comentarios sobre el libro y consensuando una serie de normas sobre el tipo de comentarios, la forma, los plazos de lectura, etc.

Este tipo de tertulia literaria con Twitter está implementado también en el Máster de Secundaria para hacer comentarios, citas, reflexiones, enlaces a documentos, webs, etc. sobre el libro que se lee. Se parte de una cuestión antes de la lectura para incluir impresiones previas que se insertan en una etiqueta con el fin de interactuar entre los alumnos y el profesor durante la lectura. Posteriormente, se destacan los tuits de interés y se realiza un debate sobre las ideas comentadas por los lectores. 


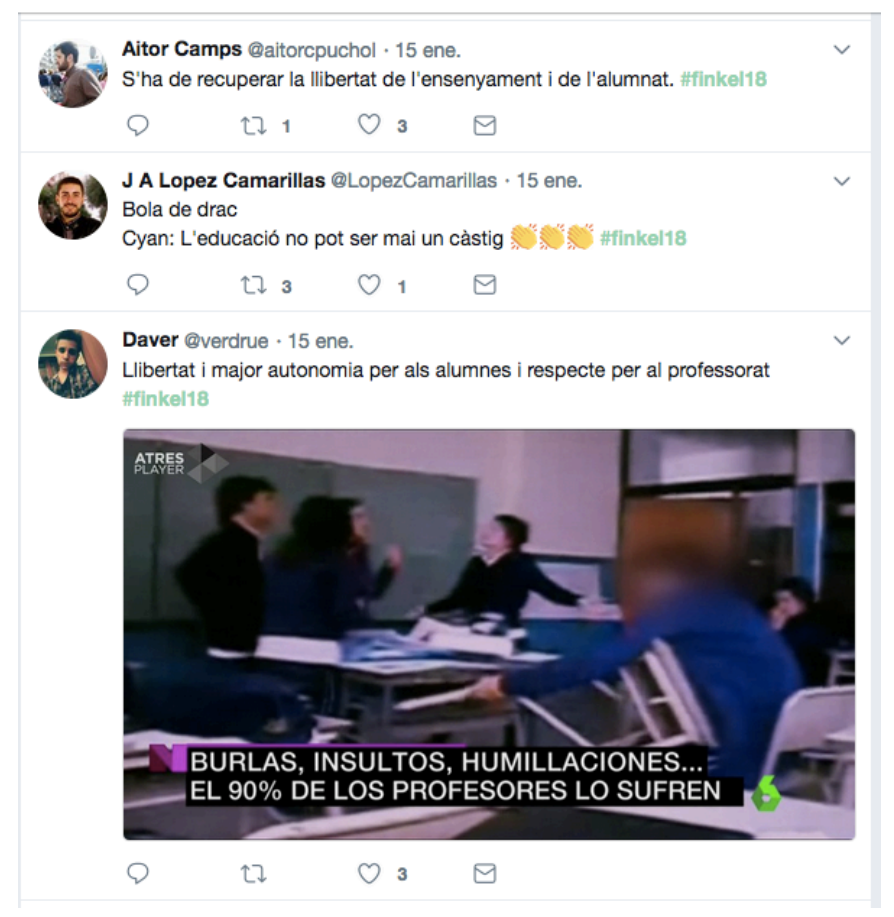

Fig.2 Tuits con la etiqueta del libro comentado por el alumnado del Máster

Otra experiencia para trabajar la lectura con Twitter, propuesta en el Máster de Secundaria, consiste en seguir la lectura de la obra Aloma de Mercè Rodoreda mediante tuits con aquellas palabras y frases de la obra que les resultan más impactantes al alumnado y les provocan algún sentimiento, emoción o pensamiento, tanto en relación a la variedad dialectal como con la manera de expresarse de los personajes, lo que sienten y lo que hacen sentir y reflexionar a los lectores. Se utilizarían tres tipos de etiquetas: una para el léxico, como \#LèxicAloma; otra para los pensamientos y las visiones de los personajes, como \#PensemAloma; y otra para los pensamientos, emociones y opiniones que les sorprenden a los alumnos mientras leen, o para hacer de amigos de Aloma, a quien aconsejan, como \#JoSócAloma. La elección de etiquetas se dejará en manos del alumnado. El profesorado tiene acceso directo a la cronología de publicaciones de la actividad.

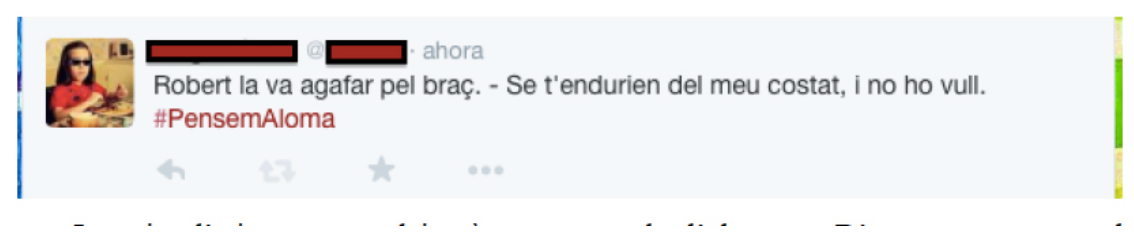

Fig. 3 Tuit con la etiqueta del comentario de los alumnos sobre la novela Aloma 


\subsection{Instagram}

Esta red permite hacer fotografías, modificarlas con efectos especiales y compartirlas, y, además, desde hace poco tiempo, podemos hacer vídeos de un máximo de 15 segundos de duración, a los que se les puede aplicar diferentes filtros. Actualmente es una de las redes sociales con más éxito, por lo que se podría aprovechar desde la enseñanza.

Un ejemplo de su uso en el ámbito educativo es el World Mobile City Project (WMCP), un proyecto colaborativo innovador, impulsado por la Red Lacenet, con el objetivo de que el alumnado conozca la ciudad con herramientas de geolocalización (Google Maps), códigos QR y realidad aumentada, mediante el uso del móvil, en el que se utiliza Instagram. La Asociación de profesorado lentretants organiza desde hace años la Valencianada (\#VLCda) en la ciudad de Valencia, una actividad multidisciplinar dirigida preferentemente a alumnos de $2^{\circ}$ ciclo de secundaria y de bachillerato que, en grupos reducidos, deben localizar, mediante sus dispositivos móviles y el uso de determinadas aplicaciones, varios puntos de interés social, literario, científico, artístico, histórico... de la ciudad de València. Simultáneamente, deben responder cuestiones relacionadas con los lugares que visitan y hacer difusión a través de diversas redes sociales, concretamente deben aportar en Instagram cuatro imágenes y un breve vídeo, cubriendo todos los puntos, todas ellas con explicaciones de calidad.

Otro ejemplo de utilización didáctica lo tendríamos en algunos proyectos desarrollados en el Máster de Secundaria, como el llamado \#Instacacera, que tiene como objetivo principal introducir al alumnado del segundo ciclo de Educación Secundaria Obligatoria en el aprendizaje y la identificación de neologismos, préstamos léxicos y barbarismos. La secuencia didáctica propuesta consiste en la elaboración de un álbum digital en la red social Instagram. Cada alumno deberá realizar una búsqueda de neologismos, barbarismos y préstamos léxicos. Con estas palabras tendrá que hacer una fotografía con la palabra en concreto que en el momento puntual está trabajando para analizarla y encontrar su equivalente al catalán siguiendo la siguiente estructura:

- Pie de foto: explicación del error que ha encontrado y su corrección.

- Inclusión del enlace donde ha encontrado la corrección (diccionario en línea, libro, gramática, vocabulario, etc.).

- Especificación del lugar donde ha encontrado la palabra analizada adjuntando la localización. 


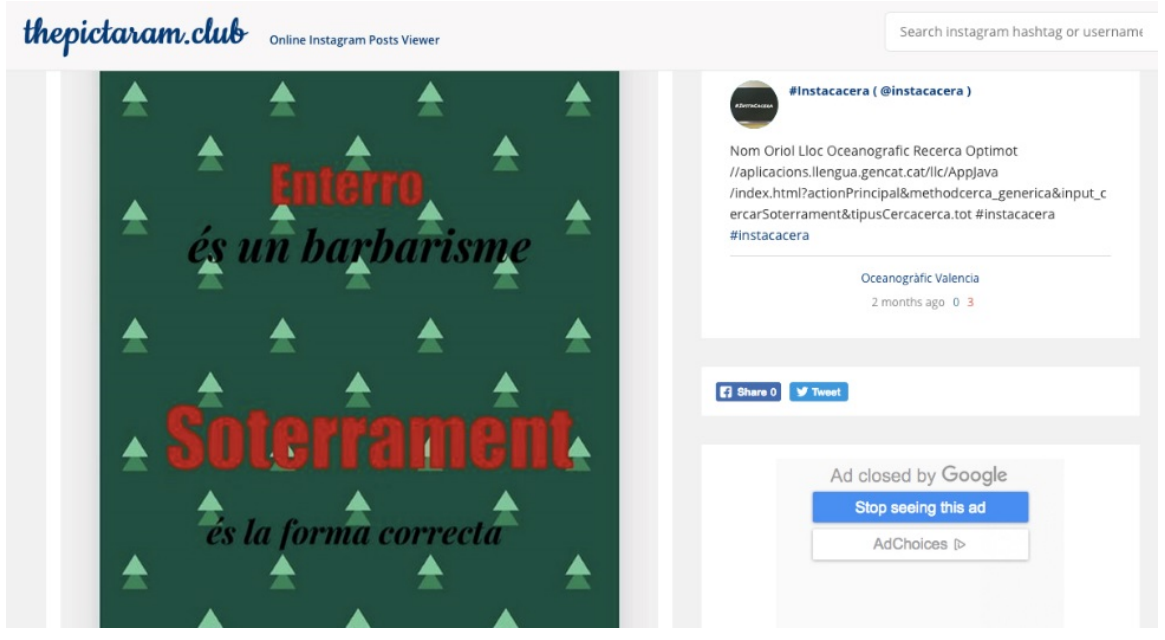

Fig. 4 Imagen de Instagram del proyecto \#Instacacera

\subsection{YouTube}

Como señala Martí (2018), Internet se ha convertido en uno de los principales medios de difusión de contenidos y concretamente Youtube es uno de los portales que ha aumentado más su uso en los últimos años gracias a su utilización por muchos jóvenes como medio de comunicación, plataforma de expresión sobre temas diversos, lo que ha llevado al nacimiento del fenómeno conocido como YouTubers, algunos de los cuales podríamos decir que son estrellas mediáticas, incluso de alcance mundial. A la sombra de esta figura ha crecido la comunidad de los booktubers o bibliotubers, jóvenes que quieren compartir su pasión por los libros haciendo vídeos divertidos.

También destaca la proliferación del booktrailer para potenciar la lectura en educación, como en el caso del concurso de booktrailer Martí Sorolla, con el objetivo de promover la lectura utilizando la creatividad y el uso de las TIC para elaborar un vídeo-resumen del libro que han leído, acercando la lectura con un formato más próximo a nuestros adolescentes; o la convocatoria que se hace en los premios Sambori, entre otros.

Desde hace tiempo el vídeo está presente en las aulas pero, como apunta García García (2014), su utilización como recurso educativo ha vivido una evolución vertiginosa en los últimos años. Según el autor, el uso educativo del vídeo debería enfocarse más hacia la producción que no al simple visionado o consumo: "deberíamos aprovechar todo el potencial multimedia de los dispositivos móviles y el potencial creativo de nuestro alumnado, y potenciar su papel como prosumidor y generador de contenidos audiovisuales" (García García, 2014: 117).

Como ejemplo de uso de esta red, tomamos el proyecto Dialectes en xarx@, desarrollado en el Máster de Secundaria. Lo que se pretende con esta secuencia didáctica es introducir las principales variedades diatópicas del catalán de la forma más amena posible, con la 
ayuda de las nuevas tecnologías. En este proyecto los alumnos deben registrar en el canal de Youtube, creado para la clase, la lectura de los fragmentos en la variedad dialectal que han trabajado.

Otro ejemplo de proyecto desarrollado por el alumnado del Máster de Secundaria donde se emplea la difusión de una producción audiovisual en Youtube, es la creación de un "videoling" (vídeo lingüístico), que consiste en crear un noticiario didáctico para trabajar cuestiones lingüísticas. El noticiario consta de tres partes, en que los alumnos tienen que grabar una serie de vídeos simulando las diferentes secciones de los informativos. La primera se explicará a partir de la sección del tiempo y tratará de cuestiones de sintaxis con el análisis de una serie de titulares. En segundo lugar, se dedica unos minutos a un "anuncio-denuncia", en el que se destaca algún tema de problemática social y se trabaja el eslogan publicitario. Por último, se corrigen errores ortográficos de algunos textos que aparecen en fotografías de lugares de la ciudad donde los alumnos han encontrado estos errores.

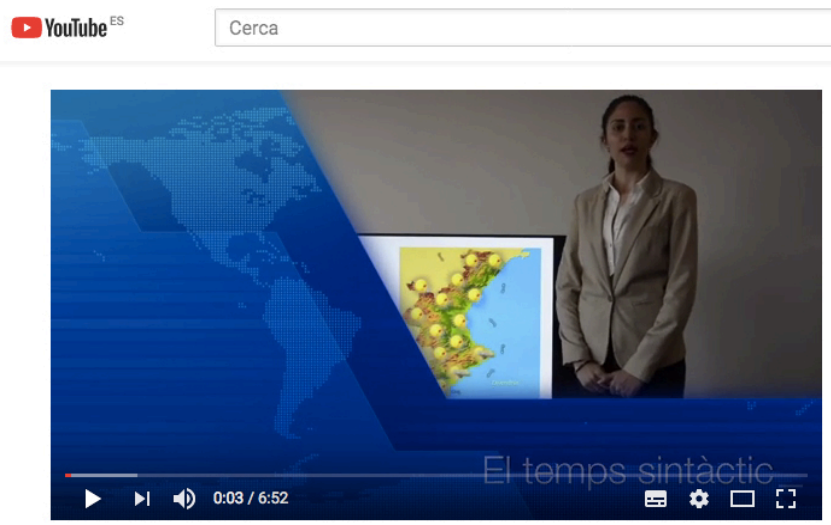

VIDEOLING

53 visualitzacions

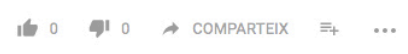

Fig. 5 Imagen del noticiario didáctico realizado por los alumnos del Máster

\section{Resultados}

Hemos comprobado, a partir de los cuestionarios contestados por los alumnos y de los proyectos realizados desde el curso 2011-12 hasta el 2017-18, un aumento del interés de los estudiantes por usar las redes sociales en proyectos para trabajar la lengua y la literatura en Secundaria. Con estas herramientas se ha favorecido la innovación educativa proponiendo nuevas formas de trabajar que mejoran la motivación y el resultado del trabajo en el aula. 
El alumnado cada vez tiene un mayor grado de conocimiento de recursos TIC y la posibilidad de incluir las redes sociales en la docencia favorece el trabajo colaborativo y la posibilidad de compartir documentos en diferentes formatos. Por otra parte, destacamos las aportaciones de las redes sociales a la escritura académica ya que suponen la aparición de nuevos géneros que implican:

- nuevas formas de escritura más sintética e inmediatez en la difusión de los textos: el post en Facebook, el tuit en Twitter, el pie de foto en Instagram,

- un carácter más público, lo que implica la posibilidad de compartir, revisar y cuidar más la presentación de los textos,

- una mayor exigencia en la elaboración de los proyectos ya que tienen más difusión,

- una necesaria coordinación que potencia el trabajo colaborativo, la interacción y la reflexión entre los estudiantes.

\section{Conclusiones}

Con el uso de las redes sociales se favorece el desarrollo de diferentes competencias (comunicativa, lingüística, digital, tratamiento de la información, aprender a aprender, autonomía y iniciativa personal), como ya señalábamos en un estudio anterior sobre la utilización de las TIC en trabajos académicos (Martí y Garcia, 2014).

También ha sido muy positiva la valoración del alumnado puesto que las TIC les motivan más a participar en las actividades propuestas en la materia, les facilitan acceder a los contenidos del currículo, interaccionar entre ellos y con las profesoras, y compartir otros actividades de interés cultural, referentes musicales y cinematográficos, vídeos, fotografías, etc.

Por otra parte, las redes sociales posibilitan la escritura colaborativa de manera que los estudiantes interactúan y reflexionan con las herramientas apropiadas, como dice Castelló (2009). Además, estos textos tienen un carácter público que supone un mayor nivel de exigencia en la elaboración y presentación de los trabajos. Por lo tanto, las redes sociales presentan nuevas posibilidades didácticas y su uso académico supone una innovación educativa durante el proceso de aprendizaje del alumnado que se debería tener más en cuenta en la enseñanza superior.

En este estudio hemos revisado ejemplos de trabajos académicos con el uso de redes sociales que el alumnado valora muy positivamente para mejorar el trabajo colaborativo y la motivación en proyectos de lengua y literatura. Consideramos importante, pues, favorecer la difusión de este tipo de trabajos que ponen en evidencia las ventajas del uso de las redes sociales con el fin de contribuir a aumentar la interacción entre el alumnado y el profesorado, el aprendizaje de las diferentes habilidades lingüísticas y la difusión de trabajos académicos más allá de los límites del aula y del entorno educativo.

(cc) EY-NC-ND 2018, Universitat Politècnica de València

Congreso IN-RED (2018) 


\section{Referencias}

ÁreA MoreirA, M. (2008). La innovación pedagógica con TIC y el desarrollo de las competencias informacionales y digitales. Investigación en la Escuela, 64, 5-17. $<$ http://www.investigacionenlaescuela.es/articulos/64/R64_1.pdf $>$ [Consulta: 8 de septiembre de 2017]

CAstelló, M. (2009). Aprender a escribir textos académicos: ¿copistas, escribas, compiladores o escritores?. En J.I. Pozo; Pérez Echevarría, M.P. (coords.) Psicología del aprendizaje universitario: la formación en competencias. Madrid: Morata, 120-133.

García GarcíA, D. (2014). Creación y edición de vídeo. En Trujillo, F. (coord.) Artefactos digitales. Una escuela digital para la educación de hoy. Barcelona: Graó, 114-117.

GARCiA VidAl, P.; MARTí Climent, A. (2010). Les xarxes socials com a recurs educatiu. Quaderns Digitals.net, 65.

Garcia Vidal, P.; Martí Climent, A. (2016). Treballem llengua i literatura amb les TIC. Aplicació didàctica en la formació del futur professorat de secundària. Quaderns digitals.net, 82 .

Gómez, M.; Roses, S.; Farias, P. (2012). El uso académico de las redes sociales en universitarios. Comunicar. Revista Científica de Comunicación y Educación. DOI: 10.3916/C38-2011-03-04, <https:/www.revistacomunicar.com/pdf/preprint/38/14-PRE13426.pdf> [Consulta: 23 de octubre de 2017]

HARO, J.J.. (2009). Las redes sociales aplicadas a la práctica docente. Didáctica, Innovación y Multimedia, 13, 1-8.

HARO, J.J. (2010). Redes Sociales para la educación. Madrid: Anaya.

HARO, J.J. (2010). Las redes sociales en educación. $<$ http://jjdeharo.blogspot.com.es/2008/11/la-redes-sociales-en-educacin.html $>$ [Consulta: 18 de septiembre de 2017]

Lluch, G. (2012). La lectura al Centre. Llegir (i escriure) llibres, pantalles, documents al Pla de Lectura de Centre. Alzira: Editorial Bromera.

LLUCH, G. (2014). Jóvenes y adolescentes hablan de lectura en la red. Ocnos, 11, 7-20. $<$ https://www.revista.uclm.es/index.php/ocnos/article/view/ocnos_2014.11.01> [Consulta: 27 de noviembre de 2017]

Lluch, G.; Nicolás, M. (2015). Escriptura acadèmica. Planificació, documentació, redacció, citació i models. Barcelona: UOC.

MACÍAS, C. (2016). Las redes sociales como herramientas de aprendizaje: algunas consideraciones. Revista de Estudios Latinos (RELat) 16, 225-256.

MAnReSA, M.; Duran, C. I RAMADA, L. (2012). Les TIC en les seqüències didàctiques de llengua i literatura, en Projectes de treball per ensenyar i aprendre llengua i literatura. Articles de Didàctica de la Llengua i la Literatura, 57, 36-48.

MARTí Climent, A. (2018). Booktubers en valencià. [en prensa]

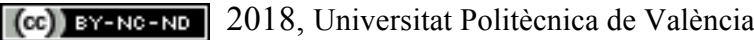
Congreso In-Red (2018) 
Martí Climent, A. ; Garcia Vidal, P. (2014). El treball per projectes amb les TIC a l'àrea de Llengua i Literatura. Una experiència didàctica en la formació del professorat de Secundària. Articles de Didàctica de la Llengua i la literatura, 64.

Meso Ayerdi K.; Pérez Dasilva J. Y.; Mendiguren Galdospin, T. (2011). La implementación de las redes sociales en la enseñanza superior universitaria. Tejuelo, 12 (2011), 137-155.

ORIHUELA, J. L. (2009). Redes sociales y educación. $<$ http://www.ecuaderno.com/2009/03/10/redes-sociales-y-educacion/ $>$ [Consulta: 15 de enero de 2018]

PÉREZ GARCíA, A. (2013). Redes Sociales y Educación. Una reflexión acerca de su uso $\begin{array}{llllll}\text { didáctico } & \mathrm{y} & \text { creativo. } & \text { Creatividad } & y & \text { sociedad, }\end{array}$ $<$ http://www.creatividadysociedad.com/articulos/21/12.\%20Redes $\% 20$ Sociales $\% 20 y \% 20 \mathrm{e}$ ducacion. $\% 20$ Una $\% 20$ reflexion $\% 20$ acerca $\% 20 \mathrm{de} \% 20 \mathrm{su} \% 20 \mathrm{uso} \% 20$ didactico $\% 20 \mathrm{y} \% 20 \mathrm{cre}$ ativo.pdf> [Consulta: 26 de febrero de 2018]

PRENSKY, M. (2001). Digital Natives, Digital Immigrants. On the Horizon. MCB University Press, Vol. 9 No. 5. <https://www.marcprensky.com/writing/Prensky\%20\%20Digital\%20Natives,\%20Digital\%20Immigrants\%20-\%20Part1.pdf $>$ [Consulta: 15 de octubre de 2017]

Rovira Collado, J. (2015). Redes sociales de lectura: del libro de caras a la LIJ 2.0. Investigaciones sobre Lectura, 3, 106-122. 


\title{
Utilización de Wolfram Mathematica la resolución de problemas de Ingeniería
}

\author{
Samuel Sánchez Caballero ${ }^{1}$, Miguel Ángel Sellés Cantó ${ }^{1}$, Rafael Pla \\ Ferrando $^{1}$ y Sergi Montava Jordà ${ }^{1}$ \\ ${ }^{1}$ Escuela Politécnica Superior de Alcoy. Universitat Politècnica de València
}

\begin{abstract}
Machine Design teaching has been traditionally related with the use of lots of calculation formulae, graphs and tables whose manipulation involves a human error. The use of Mathematica in teaching allows the students to replace this mathematical apparatus with a few code lines. This lets the professor to be focused in the main design concepts, allowing him to assess the student competence instead if its calculator or reading skills. As a result of this experience, not only the students grades have been improved, but also the exams have become a way to discriminate the students that have reached the problem-solving competence.
\end{abstract}

\section{Resumen}

La enseñanza del Diseño de Máquinas ha estado tradicionalmente ligada a la utilización de numerosas fórmulas de cálculo, gráficas y tablas cuya manipulación conlleva un error humano inherente. La introducción de Mathematica en la docencia permite a los estudiantes reemplazar todo este aparato matemático, con unas pocas líneas de código. Esto posibilita que el profesor se centre en las cuestiones fundamentales del diseño, permitiéndole evaluar realmente la competencia del alumno a la hora de resolver problemas y no su habilidad para teclear una calculadora o leer en gráficas y tablas. Como resultado de esta experiencia, no solo se ha logrado una mejora en los resultados de los alumnos, sino que los exámenes se han convertido realmente en un sistema que discrimina a los alumnos que han adquirido la competencia de resolución de problemas de los que no.

Keywords: Mathematica, Diseño de Máquinas, Resolución de Problemas, Ingeniería. 


\section{Introducción}

El presente trabajo se desarrolla a partir de la experiencia adquirida en la docencia de la asignatura de Teoría y Diseño de Máquinas (Diseño de Máquinas en los planes antiguos) durante los últimos dieciocho años. Dicha asignatura pertenece al grado de Ingeniería Mecánica y es obligatoria y anual, con un peso total de 9 créditos, estando repartidos al $50 \%$ entre las clases de teoría y prácticas. La asignatura es a su vez punto de control de la competencia de Resolución de problemas"Resolución de problemas" del citado grado, por lo tanto se trata de una asignatura donde los alumnos hacen de un uso intensivo de la calculadora en los exámenes.

La experiencia adquirida durante los primeros doce años de docencia de la asignatura mostraba que los resultados obtenidos por los alumnos en el apartado de problemas eran especialmente malos, pese a haberse planteado diferentes estrategias de mejora. Dichas estrategias de mejora estuvieron orientadas fundamentalmente a la ampliación del abanico de problemas resueltos disponible, y al planteamiento de problemas con resolución autónoma por parte del alumno. Pese a estas acciones, la tasa de abandono se mantenía especialmente elevada (por encima del $40 \%$ ), a la vez que la nota media se mantenía por debajo del tres, a lo largo de los años.

Partiendo de esta situación, este trabajo analiza inicialmente las posibles causas de estos malos resultados para plantear como innovación docente la introducción del software Wolfram Mathematica en la resolución del apartado de problemas de la asignatura. Se analizan diferentes etapas seguidas en la introducción del software, desde la más elemental donde se reproducía el esquema de resolución manual, hasta la más avanzada con el empleo de paquetes y funciones recursivas. Como resultado de este trabajo se ha logrado una reducción significativa de la tasa de abandono, así como una mejora creciente en la nota media obtenida por los alumnos.

\section{Objetivos}

El objetivo principal de este trabajo es la reducción de la elevada tasa de abandono, así como la mejora de los resultados obtenidos en el apartado de problemas de la asignatura de Teoría y Diseño de Máquinas.

\section{Desarrollo de la innovación}

Análisis de las causas

La ausencia de mejoras en los resultados provocó que a finales del curso 2012/13 se decidiera hacer un análisis de la problemática asociada a la asignatura. La Figura 1 muestra los resultados obtenidos entre los cursos 2009 y 2012. Como puede apreciarse, las estrategias de mejora seguidas durante estos años elevaron la nota media de los alumnos aprobados. Sin embargo, la tasa de alumnos que no superaban el examen de problemas era muy significativa, siendo especialmente remarcable la tasa de alumnos que o bien obtenían menos de un punto, o bien ni siquiera se presentaban al examen. Esta tasa se situaba entre el 40 y el $50 \%$, sin que se se apreciase ningún efecto de las estrategias aplicadas sobre la misma. En base a estos resultados se decidió realizar un análisis de las posibles causas, determinando entre ellas las siguientes: 

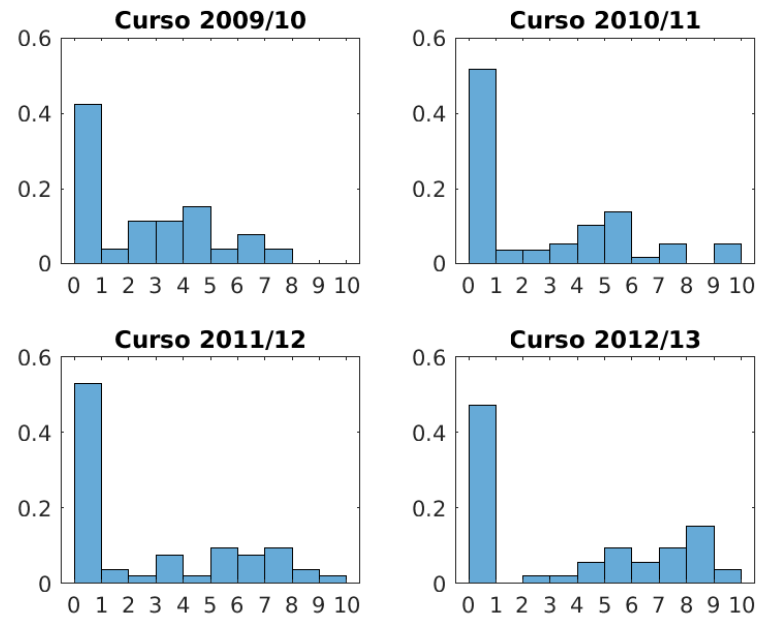

Fig. 1: Distribución de notas entre los cursos 2009 y 2012

1. La cantidad de formulación que deben manejar es muy elevada por lo que existe una probabilidad bastante grande de que los alumnos cometan errores en la transcripción de las fórmulas.

2. la resolución de problemas requiere de múltiples cálculos concatenados y dependientes entre sí, de forma que un resultado erróneo provoca un error en cascada en la solucion.

3. La resolución de problemas a mano requiere de mucho tiempo y hay una gran posibilidad de equivocarse. Si, por ejemplo, nuestra tasa de error en un cálculo simple es del $1 \%$, cuando encadenamos 20 cálculos, la probabilidad de error se incrementa al 18,2\%. De este modo resulta bastante difícil obtener la máxima puntuación.

4. Existen otras fuentes adicionales de error, como el manejo de tablas o gráficos.

5. La resolución de determinados apartados como la obtención de tensiones principales, el calculo de holgura en cojinetes o la distancia entre centros de engranajes, requiere de la utilización de métodos numéricos de resolución de ecuaciones ya que no tienen solución algebraica.

6. En el mundo laboral, los cálculos se raramente se realizan a mano.

7. De algún modo, estamos evaluando su habilidad para manejar la calculadora, no su competencia para resolver problemas. 
Estrategias de mejora. Primera etapa: 2013-2014

A partir de estas observaciones, así como de la experiencia obtenida durante una estancia en el verano del curso 2011/12 en la Universidad de Notre Dame (IN, USA) donde los alumnos utilizaban el software Wolfram Mathematica como herramienta de resolución de problemas (Cheah y col. 2016; Vetyukov 2016; Vinogradov 2000; Rus, Veresiu y Mereuta 2014), se decidió empezar a emplear este software como herramienta de apoyo en la resolución de problemas de la asignatura. Con objeto de poder comparar los resultados obtenidos, el sistema de evaluación, el tipo de examen y el peso de los diferentes apartados se ha mantenido estable a lo largo de los cursos, antes y después de la incorporación de la herramienta en la docencia. Sin embargo, la forma de utilizar el software dentro de la asignatura ha variado durante los diferentes cursos. Seguidamente se describen las acciones seguidas en cada una de las etapas. En una primera etapa, nos centramos en los apartados de mayor complejidad como el cálculo de tensiones principales, diferentes factores de fatiga, el cálculo generalizado de diferentes elementos de máquinas. A modo de ejemplo, se muestra el desarrollo del cálculo de tensiones principales empleando Wolfram Mathematica.

El cálculo de tensiones principales es uno de los primeros cálculos requeridos en la resolución de problemas y requiere de la diagonalización del tensor de tensiones $\mathbf{T}$ :

$$
\boldsymbol{\sigma}=\left[\begin{array}{ccc}
\sigma_{x} & \tau_{x y} & \tau_{x z} \\
\tau_{x y} & \sigma_{y} & \tau_{y z} \\
\tau_{x z} & \tau_{y z} & \sigma_{z}
\end{array}\right] \cdot\left[\begin{array}{c}
\mathbf{i} \\
\mathbf{j} \\
\mathbf{k}
\end{array}\right]=\mathbf{T} \cdot \mathbf{u}
$$

De donde se obtiene la ecuación característica:

$$
\sigma^{3}-I_{1} \sigma^{2}+I_{2} \sigma-I_{3}=0
$$

Cuyos coeficientes son:

$$
\begin{aligned}
& I_{1}=\sigma_{x}+\sigma_{y}+\sigma_{z} \\
& I_{2}=\sigma_{x} \sigma_{y}+\sigma_{x} \sigma_{z}+\sigma_{y} \sigma_{z}-\left(\tau_{x y}^{2}+\tau_{x z}^{2}+\tau_{y z}^{2}\right) \\
& I_{3}=\|T\|
\end{aligned}
$$

La resolución de esta ecuación característica requiere de utilizar métodos numéricos, o bien una compleja solución algebraica derivada del cambio de sistema de referencia al espacio de Haigh-Westergaard.

Por contra, el cálculo con Mathematica es mucho más simple y solo requiere de una sencilla instrucción:

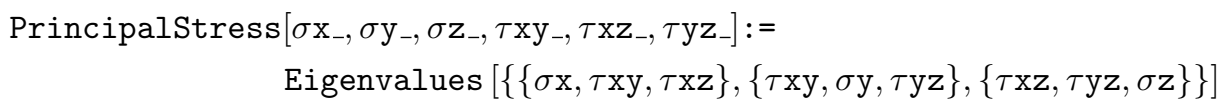

De este modo, el programa se empleaba a modo de herramienta que permitía calcular los apartados más complejos del problema. 
Estrategias de mejora. Segunda etapa: 2014-2015

Durante esta etapa se desarrolla la formulación completa de la asignatura, a excepción de los factores que aparecían en tablas o gráficas. Los ejercicios se desarrollaban en la pizarra mediante el método tradicional para ser posteriormente resueltos siguiendo los mismos pasos que en la resolución manual y comparando los resultados. Durante esta etapa se inician dos sesiones de prácticas introductorias al programa dadas las carencias de formación detectadas en la etapa anterior. También se introduce el desarrollo de talleres virtuales y representaciones tridimensionales que han resultado muy útiles para ilustración de los diferentes conceptos teóricos. A continuación se muestran varios de ellos.

1. Teorias de fallo bajo estado tensional plano para materiales frágiles: el que el alumno puede determinar, para cualquier estado tensional plano, si las tensiones principales asociadas generarán la rotura del material gráfica y numéricamente. También proporciona los valores de las tensiones equivalentes y los coeficientes de seguridad.

http://labmathematica.upvnet.upv.es/eslabon/Ejercicio.asp?do=Teorias_fallo_fragil

2. Teorias de fallo bajo estado tensional plano para materiales dúctiles: el alumno puede determinar, para cualquier estado tensional plano, si las tensiones principales asociadas generarán la fluencia del material gráfica y numéricamente. También proporciona los valores de las tensiones equivalentes y los coeficientes de seguridad.

http://labmathematica.upvnet.upv.es/eslabon/Ejercicio.asp?do=Teorias_fallo_ductil

3. Determinación de la tensión alternante pura equivalente a un estado tensional compuesto: el alumno puede determinar, en función de las componentes medias y alternante de tensión, la tensión equivalente pura gráfica y numéricamente. http://labmathematica.upvnet.upv.es/eslabon/Ejercicio.asp?do=Tension_alternate_pura

4. Teorías de fallo por fatiga: el alumno puede determinar, en función de las componentes medias y alternante de tensión, si estas generarán la rotura del material gráfica y numéricamente.

http://labmathematica.upvnet.upv.es/eslabon/Ejercicio.asp?do=Teorias_fallo_fatiga

Estrategias de mejora. Tercera etapa: 2015-2016

En base a los buenos resultados obtenidos en las etapas anteriores se continúa profundizando en la herramienta y se introduce el empleo de funciones recursivas. Como se ha indicado anteriormente, el cálculo requiere en muchos casos del cálculo de diversos factores intermedios para obtener el factor final, el cual es el realmente interesante. El cálculo de factores intermedios requiere de la ejecución de instrucciones intermedias que requieren de tiempo y pueden inducir a cierto error en caso de olvidar el cálculo de alguno de estos factores. A modo de ejemplo se muestra uno de estos cálculos.

El cálculo del concentrador de tensiones corregido a fatiga requiere el cálculo previo de las constantes de Neuber y la sensibilidad a la entalla, las cuales se calculan tradicionalmente de la siguiente forma:

La constante de Neuber (Neuber 2001) se calcula mediante la fórmula: 


$$
\sqrt{a}=\left\{\begin{array}{cl}
-0,32865+34,5452 S_{u t}^{-0,60977} & \text { para el acero } \\
-0,29486+77,4708 S_{u t}^{-0,78374} & \text { para el aluminio recocido } \\
0,0634+101,97946 S_{u t}^{-0,81409} & \text { para el aluminio endurecido }
\end{array}\right.
$$

La sensibilidad a la entalla se calcula en función de la constante de Neuber mediante la ecuación:

$$
q=\frac{1}{1+\frac{\sqrt{a}}{\sqrt{r}}}
$$

Finalmente, y a partir del valor de $K_{t}$, obtenido mediante gráficas (Peterson 1966): se el valor del concentrador de tensiones corregido a fatiga $K_{f}$ mediante la expresión:

$$
K_{f}=1+q\left(K_{t}-1\right)
$$

El desarrollo de las siguientes funciones recursivas, permite el cálculo del factor $K_{f}$ mediante una única llamada a la función (la última) y sin tener que calcular los valores intermedios de la constante de Neuber y la sensibilidad a la entalla:

$$
\begin{aligned}
& \text { Fneubercons [material_, Sut_] : =Which[acero == material, } \\
& -0,32865+34,5452 \mathrm{Sut}^{\wedge}-0,60977 \text {, aluminio }==\text { material, } \\
& -0,29486+77,4708 \mathrm{Sut}^{\wedge}-0,78374 \text {, duraluminio }==\text { material, } \\
& \left.0,0634+101,97946 \text { Sut }^{\wedge}-0,81409\right] \\
& \text { Fq[material } \left., \text { Sut }_{-}, \mathbf{r}_{-}\right]:=1 /(1+\text { Fneubercons[material, Sut] } / \text { Sqrt }[\mathrm{r}]) \\
& \text { FKf } \left.\left[\text { material_,Kt_,Sut,_, } \text { Kt }_{-}\right]:=1+\text { Fq[material,Sut,r }\right](\text { Kt-1) }
\end{aligned}
$$

Estrategias de mejora. Cuarta etapa: 2016-2017

Mientras que en la etapa anterior se siguió utilizando el esquema de resolución de problemas tradicional, pese a la introducción de algunas funciones recursivas, en esta etapa se extiende el uso de funciones recursivas a la resolución de problemas. La introducción de esta metodología de cálculo supone un cambio de paradigma ya que la resolución de problemas deja de seguir los pasos tradicionales, requiriendo un nivel de abstracción mayor por parte de los alumnos. Durante esta etapa se inicia también la conversión a forma de función de las diferentes tablas y gráficas empleadas, ya que los resultados de la etapa anterior muestra que la mayoría de los errores cometidos por parte de los alumnos se centra en el manejo de tablas o la lectura de gráficas. 
Estrategias de mejora. Quinta etapa: 2017-2018

Durante el curso actual se ha introducido el empleo de aplicaciones en Wolfram Mathematica desarrollados expresamente para la asignatura. Las aplicaciones de Mathematica constan por una parte de todo el conjunto de funciones necesarias para realizar los diferentes cálculos, así como de un sistema de ayuda donde se describen las diferentes funciones, sus parámetros y limitaciones de uso. La Figura 2 muestra un ejemplo de la aplicación para el cálculo de concentradores de tensiones.

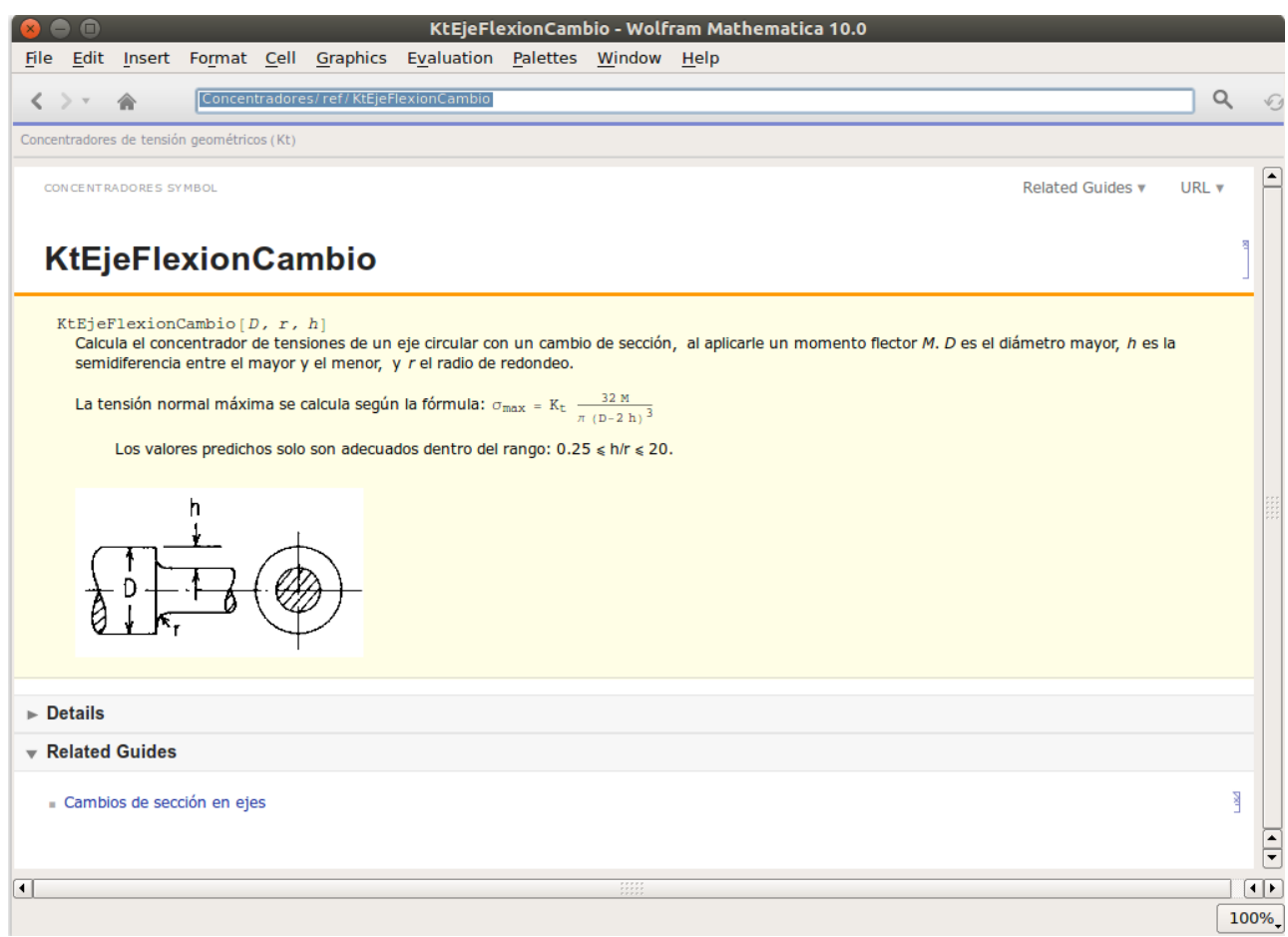

Fig. 2: Ejemplo de la ayuda de la aplicación para el cálculo de concentradores de tensiones

\section{Resultados}

La Figura 3 muestran la distribución de notas la asignatura durante los últimos cuatro cursos. Como puede apreciarse, el porcentaje de alumnos con una nota inferior a uno o que no se presentan disminuye significativamente desde el primer curso, pasando del $40 \%$ existente antes de la introducción del programa, al $10 \%$ en los dos últimos cursos. Así mismo, puede apreciarse como los alumnos que aprueban la asignatura, obtienen notas significativamente más altas.

Por otro lado, la Figura 4 y la Tabla 1 muestran la evolución de la nota media durante los últimos ocho años. Como puede observarse, la nota media de la asignatura se incrementa año tras año, pasando de 2,44 a 6,72 puntos durante el último curso, siendo 
especialmente significativo el incremento de la misma a partir del curso 2013/14, coincidiendo con la introducción del software en la asignatura.
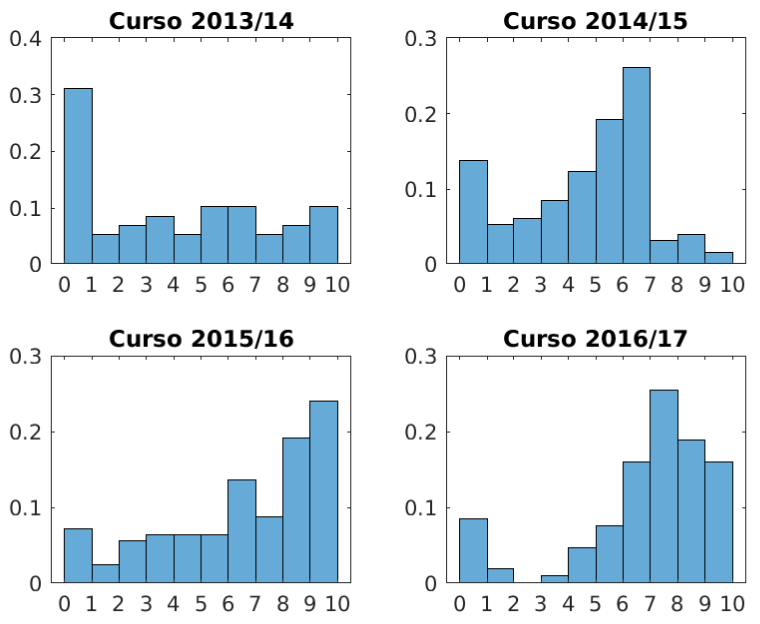

Fig. 3: Distribución de notas entre los cursos 2013 y 2016

Tabla 1: Evolución de la media y la desviación típica

\begin{tabular}{lcccccccc} 
Curso & $09 / 10$ & $10 / 11$ & $11 / 12$ & $12 / 13$ & $13 / 14$ & $14 / 15$ & $15 / 16$ & $16 / 17$ \\
\hline Media & 2,44 & 2,50 & 2,54 & 3,49 & 4,00 & 4,50 & 6,41 & 6,72 \\
Desv. Típica & 2,47 & 2,98 & 3,13 & 3,58 & 3,41 & 2,46 & 2,92 & 2,59 \\
\hline
\end{tabular}

Finalmente, los resultados de la implantación de los aplicaciones y paquetes durante este curso no se encuentran actualmente disponibles, aunque se prevee sean mejores debido a que se reduce la posibilidad de cometer errores al eliminar la lectura de gráficas o la interpolación en tablas.

\section{Conclusiones}

Después de cuatro cursos utilizando Wolfram Mathematica como herramienta de resolución de problemas, el resultado ha sido mas que satisfactorio, no solo porque se ha conseguido mejorar los resultados de la asignatura, sino porque los mismos alumnos proporcionan un feed-back positivo al respecto. La gran mayoría siguen utilizando el programa en otras asignaturas o en el desarrollo de sus Trabajos de Fin de Grado. Así mismo, en vista de los resultados obtenidos, otros profesores del grado se han implicado en la utilización del programa en sus asignaturas. Finalmente, la experiencia se ha hecho extensiva al resto de profesores de la escuela, programándose varios cursos de formación sobre el programa con más de veinticinco profesores implicados.

Evidentemente, la experiencia también ha presentado varios aspectos negativos que deben también ser remarcados. Uno de ellos es que los alumnos que no dominan la asignatura, tampoco lo hacen con el programa, lo cual les supone una piedra de tropiezo, obteniendo resultados incluso inferiores. Normalmente estos alumnos tienen 


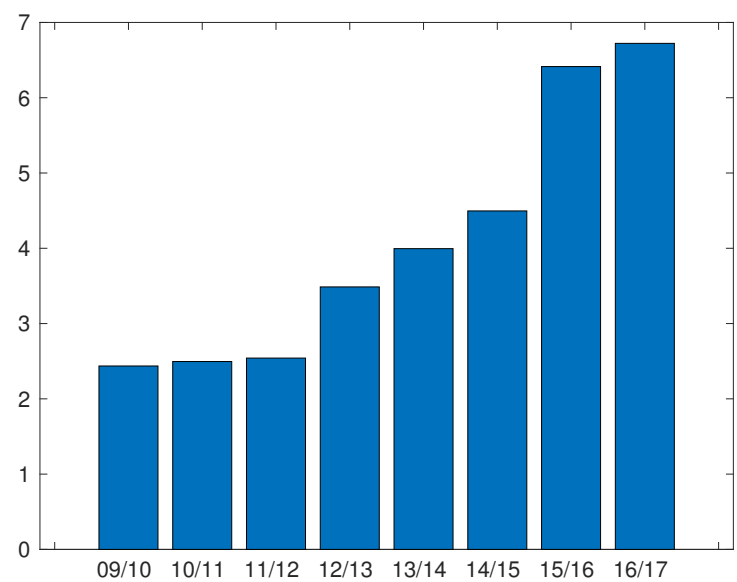

Fig. 4: Evolución de la nota media desde el curso 2009/10 al 2016/17

la falsa impresión de que el programa resuelve los problemas por si mismo. Finalmente, una pequeña proporción estudiantes intentan copiar. Evidentemente, cuando se utiliza un soporte electrónico esta opción parece más tentadora, por lo cual requiere de un esfuerzo extra por parte del profesor para evitarlo. A este respecto, el propio programa incorpora un historial donde se registra temporalmente todos y cada uno de los cambios realizados en la hoja, lo cual puede servir para revisar estos casos cuando existan dudas.

\section{Agradecimientos}

Los autores desean agradecer al equipo de Wolfran Mathematica Europa y en especial a Maria Dimitrova su labor de soporte y colaboración con el programa.

\section{Referencias bibliográficas}

Cheah, C. T. y col. (2016). "Selection of software for mechanical engineering undergraduates". En: AIP Conference Proceedings 1754.1, pág. 060002. DOI: 10.1063/1. 4958443. eprint: https://aip.scitation.org/doi/pdf/10.1063/1.4958443.

Neuber, Heinz. (2001). Kerbspannungslehre : Theorie der Spannungskonzentration ; genaue Berechnung der Festigkeit. Berlin: Springer.

Peterson, Rudolph Earl (1966). Stress concentration design factors; charts and relations useful in making strength calculations for machine parts and structural elements. New York: Wiley. 
Rus, M., S. Veresiu y E. Mereuta (2014). "Using mathematica program in teaching mechanisms". En: vol. 17. cited By 0, págs. 531-540. DOI: 10.1007/978-3-31901845-4_53.

Vetyukov, Yury. (2016). Nonlinear Mechanics Of Thin-Walled Structures : asymptotics, direct approach and numerical analysis. Springer.

Vinogradov, Oleg. (2000). Fundamentals of kinematics and dynamics of machines and mechanisms. Boca Raton; London: CRC Press. 


\title{
Nos divertimos y aprendemos con Kahoot! en las clases de Estadística
}

\section{R.M. Alcover, A. Calduch-Losa, S. Vidal-Puig}

Departamento de Estadística e Investigación Operativa Aplicadas y Calidad

Universitat Politècnica de València

\{ralcover, mcalduch, svidalp\}@eio.upv.es

\begin{abstract}
In this work we propose the use of different educational gaming strategies as a tool for learning and working the different generic skills competences. These methodologies have been applied in several statistics subjects delivered in different engineering degrees at the Universitat Politècnica de València (UPV). In order to design the different innovation activities we have chosed the game-based platform Kahoot! based on his straightforward and versatile use. The activities developed by the authors allow to improve the students assistance, the autonomus learning of the students and generic skills development.
\end{abstract}

Keywords: Statistics; Gaming; Educational Innovation; Active Learning; Soft skills; Kahoot!.

\begin{abstract}
Resumen
En el trabajo se aborda la utilización de las estrategias de juego como herramientas de aprendizaje y de trabajo de competencias en varias asignaturas de Estadística impartidas en diferentes Grados de Ingeniería de la Universitat Politècnica de València (UPV). Para el diseño de las actividades de innovación propuestas se ha utilizado la plataforma Kahoot!, por su sencillez y versatilidad de uso. Estas actividades desarrolladas por los autores permiten establecer diferentes dinámicas de trabajo de los alumnos, motivar la asistencia y el trabajo autónomo de los estudiantes, así como desarrollar diferentes competencias.
\end{abstract}

Palabras clave: Estadística; Gamificación; Innovación educativa; Dinamización de aula; Competencias transversales; Kahoot!.

\section{Introducción}

Una de las preocupaciones actuales del profesorado universitario es conseguir y mantener la motivación e interés de los estudiantes en sus clases. Esta preocupación se incrementa en aquellas asignaturas que cumplen estas dos condiciones: están ubicadas en los primeros cursos de las titulaciones y no están directamente relacionadas con la titulación en la que se imparten. Son las asignaturas que constituyen las materias básicas de los actuales Grados. Este es el caso de las asignaturas de la materia Estadística, impartida en primer o segundo curso de los diferentes Grados de Ingeniería en la Universitat Politècnica de València (UPV). 
En algunas clases de estas asignaturas es difícil mantener la atención del estudiante durante toda la sesión (90 minutos), sobre todo cuando en los horarios establecidos por las correspondientes Escuelas (ERT) estas sesiones tienen lugar a últimas horas de la tarde. Los alumnos, tras realizar diferentes actividades durante la mañana (algunos de ellos desempeñan trabajos en empresas y llegan a clase con una jornada laboral ya cumplida), están algo cansados. Como profesorado, no debemos plantearnos estas cirscunstancias como un problema, sino como un reto que nos motive y estimule a organizar nuestras clases de la mejor manera posible para adaptarnos a las diferentes situaciones que se nos puedan plantear. Debemos actualizarnos constantemente tanto en conocimientos de nuestra área, como en la metodología empleada para conseguir desarrollar en nuestros alumnos las competencias que les conducirán, a su vez, a ser buenos profesionales (GIMA, 2008).

La introducción en el aula de elementos o actividades de juego es un tipo de gamificación (Kapp, 2012), esto es, una técnica de aprendizaje que traslada la mecánica de los juegos al ámbito educativo con el fin de conseguir mejores resultados, constituyendo una experiencia positiva para el alumno y el profesor (EDUCACIÓN 3.0). Numerosos trabajos confirman los buenos resultados obtenidos tras introducir estrategias de juego en el ámbito docente, como ejemplo Del Cerro (2015), Villalustre y Moral (2015), Rodriguez-Fernández (2017).

Por otra parte, en los últimos años con el desarrollo de las TIC (Tecnologías de la información y comunicación), se han introducido en la docencia sistemas que intentan estimular la participación activa de los alumnos mediante sistemas de respuesta personal (Personal Response System o PRS). Estos sistemas, inicialmente denominados “clickers", son unos dispositivos con unos mandos electrónicos que pueden utilizarse para la realización de preguntas e interpretación de resultados en tiempo real. El avance de la tecnología y la proliferación de los dispositivos móviles ha dejado obsoletos los anteriores sistemas, siendo los teléfonos inteligentes o smartphones (también puede utilizarse cualquier tableta o PC) los elementos clave en la introducción de las TIC en el proceso educativo. Actualmente todos los alumnos disponen de uno de estos teléfonos, que se han convertido en potentes herramientas educativas y que nos pueden proporcionar múltiples ventajas (Fuertes, 2016). La disponibilidad en las aulas de internet y plataformas como Kahoot!, Socrative, QuestionPress, Google forms, Brainscape, Cerebriti, Knowre, etc... combinan la facilidad y rapidez de uso de estos dispositivos, bajo mantenimiento y coste nulo.

Para la innovación que presentamos en este trabajo, el grupo de profesores implicado ha seleccionado la plataforma on line Kahoot! (https://kahoot.com), desarrollada en 2013 por el profesor Alf Inge Wang de la Norwegian University Of Science And Technology. Son numerosos los trabajos que hacen referencia a esta herramienta, como ejemplo Dellos (2015), Johns (2015) y Plump y LaRosa (2017). En nuestro caso, las actividades que introducimos en el aula desde las diferentes asignaturas de Estadística en la UPV programadas con Kahoot! nos van a permitir, además de las ventajas ya referidas de este tipo de sistemas, el poder trabajar y hacer hincapié en las diferentes competencias que nuestras asignaturas tienen establecidas. No perdamos de vista que la introducción de las 
TIC facilita al profesorado múltiples actividades didácticas, permitiendo adaptarse más fácilmente al tipo de alumnado y mejorar su aprendizaje.

En nuestra opinión, este tipo de estrategias de juego combinadas con las nuevas tecnologías, posee un gran potencial como herramientas para mejorar el aprendizaje e incrementar el trabajo competencial en el aula, como mostramos con la descripción de las actividades que presentamos en este trabajo. De forma análoga queremos incidir en la facilidad y versatilidad del uso de Kahoot!, lo que incrementa su capacidad de establecer diferentes dinámicas de trabajo activas en el aula, generando múltiples posibilidades y redundando todo ello en una valiosa herramienta de aprendizaje significativo, tal como mostramos en los siguientes apartados.

\section{Objetivos}

El propósito general de nuestro trabajo ha sido explorar el uso de la plataforma Kahoot! para realizar diferentes tipos de actividades en el aula que involucren activamente al alumnado y fomenten el aprendizaje. Algunas de las actividades que hemos diseñado se han llevado a cabo por primera vez en la docencia de las asignaturas del área de Estadística en nuestra universidad. Más en detalle, los objetivos que se pretenden con nuestra propuesta son los siguientes:

- Utilizar un juego como herramienta de trabajo en el aula, implicando y motivando al alumno en el proceso de aprendizaje.

- Captar la atención del alumno, incrementar su participación y conseguir un aprendizaje activo.

- Trabajar con el juego algunas competencias transversales.

- Implicar en el seguimiento de la clase a los alumnos más tímidos y/o con ciertas minusvalías.

- Reforzar el aprendizaje resumiendo y resaltando conceptos relevantes de cada unidad didáctica.

- Evaluar algunos contenidos de conocimiento de las unidades didácticas.

Los profesores implicados pretendemos conseguir estos objetivos involucrando al alumno en el "juego" (actividad), de tal manera que él piense que está jugando en lugar de estudiando. Es decir, que no sea consciente de que está trabajando, simplemente con este tipo de actividades el estudiante se divierte, como un niño. La mecánica del juego, las imágenes que presentamos junto con las preguntas, el formato de elección de las respuestas...., transforma una tarea o evaluación, digamos formal, en una actividad lúdica en la que los alumnos interactúan, comentan, se mueven, ríen y en defintiva, se divierten aprendiendo. Como docentes, es reconfortante ver a nuestros estudiantes trabajando activamente los contenidos. 


\section{Desarrollo de la innovación}

Las actividades con la plataforma Kahoot! se han llevado a cabo en asignaturas de Estadística de diferentes Grados impartidos en la Universitat Politècnica durante el curso académico 2017-2018: Grado de Ingeniería Informática (GII), Grado en Ciencia y Tecnología de los Alimentos (GCTA), Grado en Ingeniería en Diseño Industrial y Desarrollo de Productos (GIDDP), Grado en Ingeniería Forestal y del Medio Natural (GIFMN).

\subsection{Innovación 1}

En la asignatura de Estadística (primer curso del GII) la plataforma se ha utilizado diseñando actividades con diferentes objetivos. Uno de ellos ha consistido en utilizar Kahoot! como refuerzo de aprendizaje al final de la clase. En el GII todas las sesiones impartidas tienen una duración de 90 minutos. Tras 60 minutos de trabajo y dedicación del alumno a las explicaciones del profesor, disminuye su nivel de atención. El cambio de actividad y la novedad del juego permite de nuevo recuperar la atención del alumno. Este tipo de actividades que hemos llevado a cabo ha tenido una duración aproximada de 30 minutos en cada sesión.

Por ejemplo, en la unidad didáctica de Introducción al Cálculo de Probabilidades del temario de la asignatura, se ha planteado un cuestionario (Figura 1) con el fin de revisar conceptos, reforzar conocimientos y trabajar diferentes competencias. Especialmente relevantes resultan las competencias transversales (http: //www.upv.es/contenidos/COMPTRAN) .

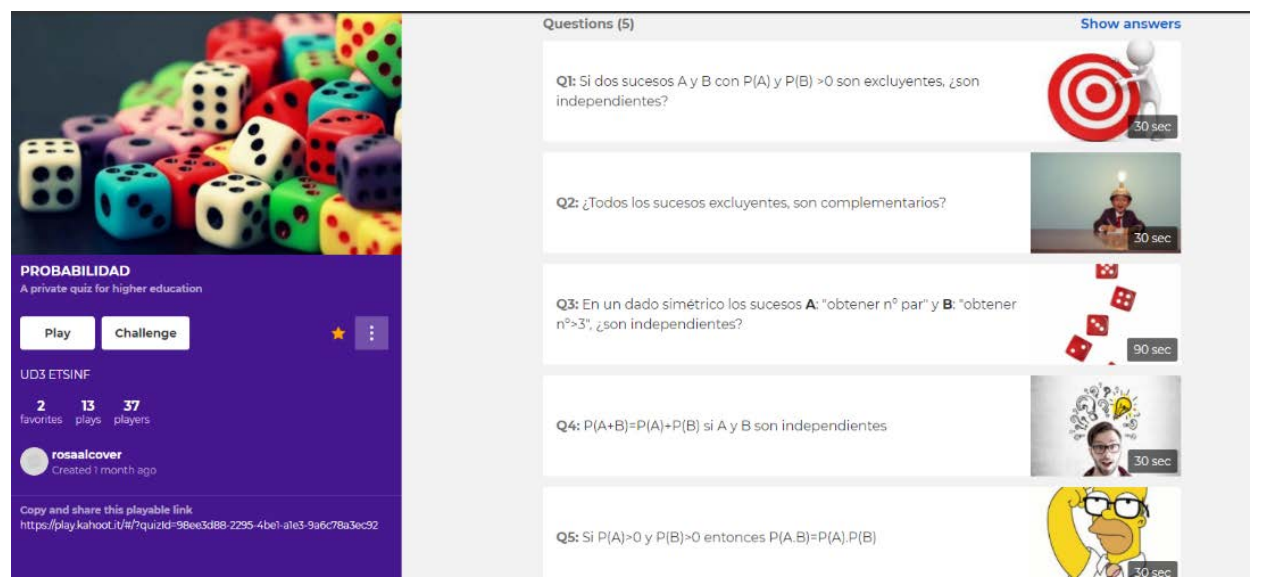

Fig. 1 Cuestionario con cinco preguntas de la Unidad de Cálculo de Probabilidades

Los alumnos, de manera individual se conectan a través de sus teléfonos móviles a la plataforma. Tras ir respondiendo las preguntas y obtener las puntuaciones finales de cada uno de ellos, el alumno ganador es ovacionado y recibe el reconocimiento por parte del resto de sus compañeros. A continuación se revisa cada una de las preguntas del cuestionario y entre aquellos que han acertado la respuesta a cada pregunta un alumno, voluntariamente, justifica al resto por qué cada una de las respuestas alternativas es correcta o incorrecta. Se trata de una exposición de los argumentos del alumno, con su lenguaje y

(cc) EY-NC-ND 2018, Universitat Politècnica de València

Congreso IN-RED (2018) 
vocabulario, al resto de los compañeros, generándose un debate productivo. En este caso el profesor actúa de moderador, regulando el turno de las intervenciones entre ellos y gestionando el tiempo.

Además de utilizar esta actividad como refuerzo de aprendizaje (cada alumno reflexiona sobre cada pregunta del cuestionario dos veces) y trabajar en ella diferentes competencias según la naturaleza de la pregunta, se incide especialmente en desarrollar las habilidades de comunicación oral por parte de los alumnos. Este tipo de actividad se ha trabajado de forma sistemática a lo largo de un semestre con un grupo de 26 alumnos matriculados en el turno de tarde.

La competencia transversal de comunicación efectiva (CT-08, Proyecto institucional de las competencias transversales UPV) se trabaja con frecuencia en el aula, en forma escrita: ejercicios, memorias, informes de prácticas, exámenes. Sin embargo, en su dimensión oral se incide con menor frecuencia, por lo menos en primer curso. Con la actividad propuesta intentamos que el alumno transmita "conocimientos" de la manera lo más clara posible, esforzándose en construir correctamente las frases aunque utilice su propio lenguaje. Además, el alumno debe saber responder a las preguntas que durante las explicaciones le formulan sus compañeros. La mayoría de ellos utiliza el lenguaje gestual para apoyar sus explicaciones. Finalmente, con el debate los alumnos elaboran sus propios argumentos, los exponen y los defienden, trabajando esta competencia de manera más compleja.

\subsection{Innovación 2}

La siguiente actuación se realizó también con alumnos de primer curso de GII, pero en otros grupos diferentes al que realizó la actividad de innovación 1 que se acaba de exponer. Estos grupos constan de 20 y 37 alumnos matriculados en el turno de mañana. En este caso se cambió la manera de utilizar Kahoot!, proponiendo a los alumnos que fueran ellos quienes plantearan posibles preguntas para realizar un Kahoot! con posterioridad. Así, los alumnos invertían más tiempo en la experiencia en su casa que en el aula. Lo que se pretende con esta actuación es un aprendizaje activo, al que llamamos ACL (ACtive Learning), ya que se ha conseguido que los alumnos participantes en la experiencia profundizaran en los conocimientos teóricos de la materia, al revisar los contenidos de las unidades temáticas para plantear las cuestiones. Se ha constatado que las preguntas propuestas por los alumnos eran más complicadas que las que normalmente plantea la profesora, ya que parece que los estudiantes "quieren cazar" a sus compañeros, poniendo adrede cuestiones más complicadas. Esto ha provocado un aumento del nivel de los conocimientos en el aula.

La actividad se propone como voluntaria, y los estudiantes que así lo desean envían sus preguntas por correo electrónico a la profesora. En la Figura 2 se muestra una imagen compartida por un estudiante: 


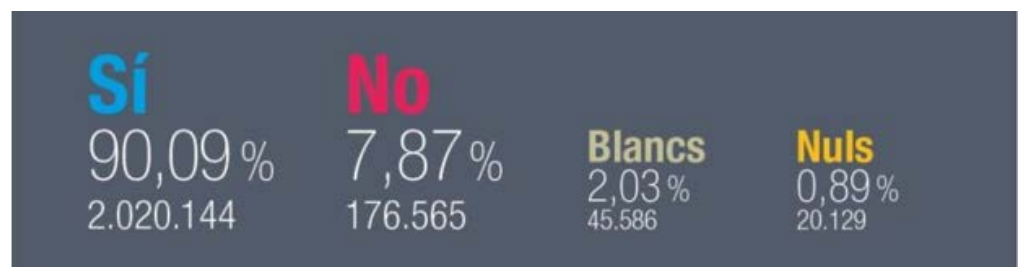

Fig. 2 Imagen presentada por un alumno

La pregunta que hacía el alumno en cuestión era: “¿Cuál es el problema de este porcentaje de resultados?”, y las posibles respuestas que daba el estudiante eran: a) Los porcentajes no suman $100 \%$, b) Solo está bien el porcentaje de nulos, c) Las dos anteriores.

En esta ocasión, la pregunta y las respuestas proporcionadas nos indican que el alumno que las ha enviado tiene claros los conceptos que pregunta y ha buscado o calculado los números adecuados.

Al presentar la pregunta en clase, sirvió para repasar dos temas de la asignatura: Estadística descriptiva y Probabilidad condicional. Por lo tanto, vemos cómo con esta modalidad de Kahoot!, los alumnos comparten conocimiento y tienen un doble refuerzo: cuando piensan e investigan para proponer las preguntas y cuando las responden. Además, hay que destacar que en esta acción se está trabajanado la CT-01 de la UPV, Comprensión e integración, ya que un alumno tiene que comprender las unidades didácticas para proponer sus preguntas (Proyecto institucional de las competencias transversales de la UPV).

\subsection{Innovación 3}

En los grados de GIDDP (asignatura: Matemáticas II), GCTA (asignatura: Bioestadística) y GIFMN (asignatura: Métodos Estadísticos) también se utilizó como una herramienta de refuerzo del aprendizaje de las diferentes unidades temáticas, pero de forma diferente al tipo de innovación 1, anteriormente expuesto. Para ello se realizaban unas 10-15 preguntas al final de cada unidad temática y se daba entre 20 y 30 segundos para responder a cada una de las preguntas, dependiendo de la dificultad de las mismas. Al final de cada pregunta y con la información del número de respuestas obtenido en cada una de las opciones propuestas, y antes de pasar a la pregunta siguiente, se procedía a revisar los fallos más importantes y numerosos, de modo que el alumno pudiera reforzar los conceptos y relaciones más importantes vistas en la unidad temática. Este enfoque permite al alumno darse cuenta de sus errores y se situaría, por tanto, dentro del campo de las evaluaciones con carácter formativo. La actividad venía a tener una duración total de entre 15 y 20 minutos y a parte de potenciar el aprendizaje servía para proporcionar un final de la clase más competitivo y motivador.

A diferencia de la innovación 1, en este caso los cuestionarios presentados a los alumnos son más largos, no se trabaja la competencia de comunicación efectiva y los resultados son tenidos en cuenta en la calificación final del alumno. 


\section{Resultados}

Los resultados presentados corresponden a las asignaturas de Bioestadística (recogidas: 34 encuestas de 69 alumnos), Matemáticas II (recogidas: 20 de 55 alumnos) y Métodos Estadísticos (Met. Estadísticos) (recogidas: 16 encuestas de 32 alumnos). A partir de los resultados de las encuestas pasadas a los alumnos en estas asignaturas, obtenidos al final del primer cuatrimestre, podemos afirmar que el uso del Kahoot! ha tenido muy buena acogida, con una opinión de más del 80\% que consideraba el uso de la herramienta como adecuado o muy adecuado (Figura 3).

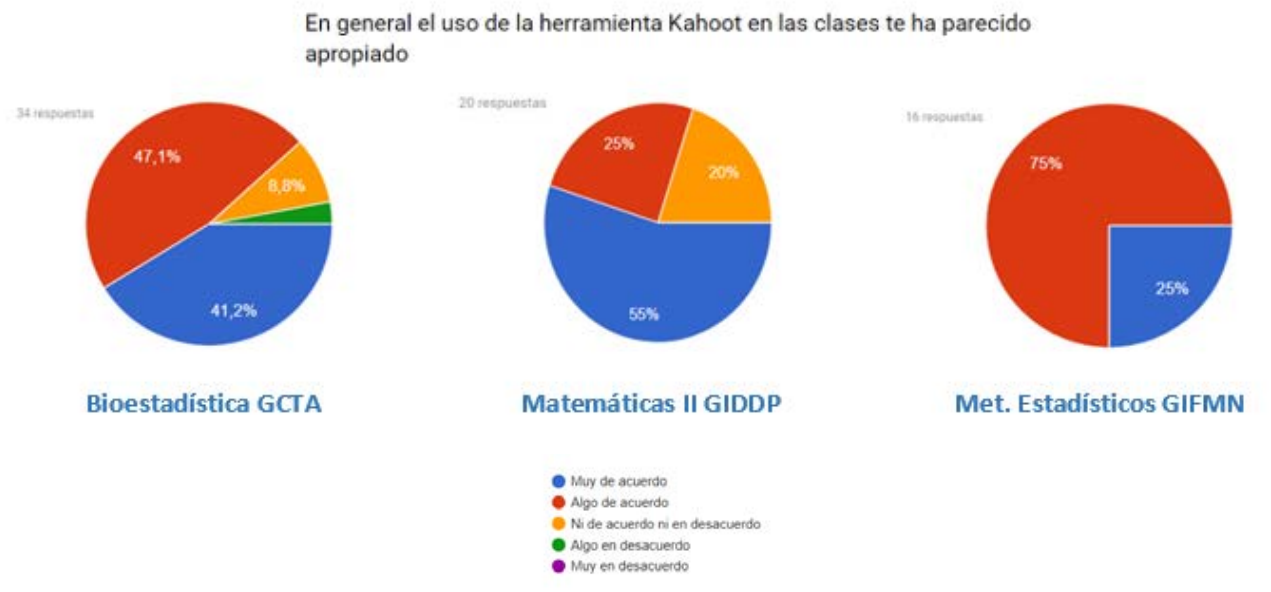

Fig. 3 Resultados de Ia cuestion 1 de la encuesta

En cuanto a la motivación (Figura 4), de nuevo más del 80\% de los alumnos consideraba que mejoraba su motivación.

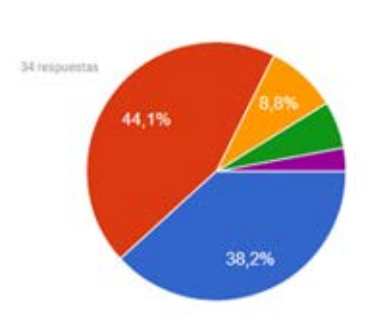

Bioestadística GCTA

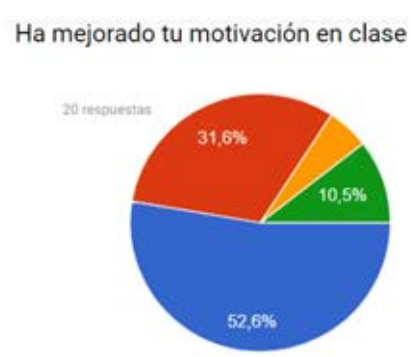

Matemáticas II GIDDP

- Agro de acuerdo

Ans acuerdo ni en desacuerdo

- Algo en dessaverdo

Fig. 4 Resultados de la Cuestión 2 de la encuesta

En relación a la pregunta sobre si se habían divertido con la actividad, más del 85\% de los alumnos estaban de acuerdo en los tres grupos (Figura 5). 


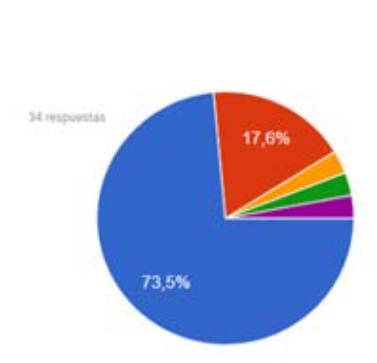

Bioestadística GCTA
Te has divertido con el Kahoot

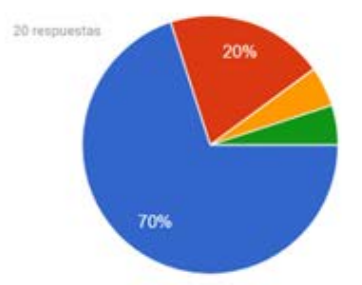

Matemáticas II GIDDP

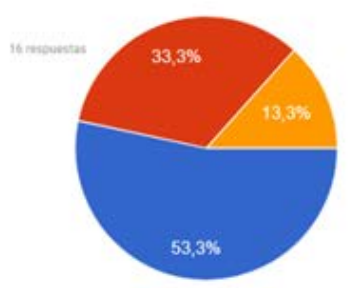

Met. Estadísticos GIFMN

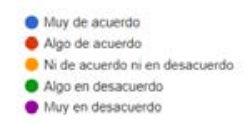

Fig. 5 Resultados de la Cuestión 3 de la encuesta

Respecto a la dificultad de las preguntas realizadas, el 35\% de los alumnos de Matemáticas II, el 52\% de Bioestadística y el 7\% de los de Met. Estadísticos estaban de acuerdo o muy de acuerdo con que eran difíciles (Figura 6).

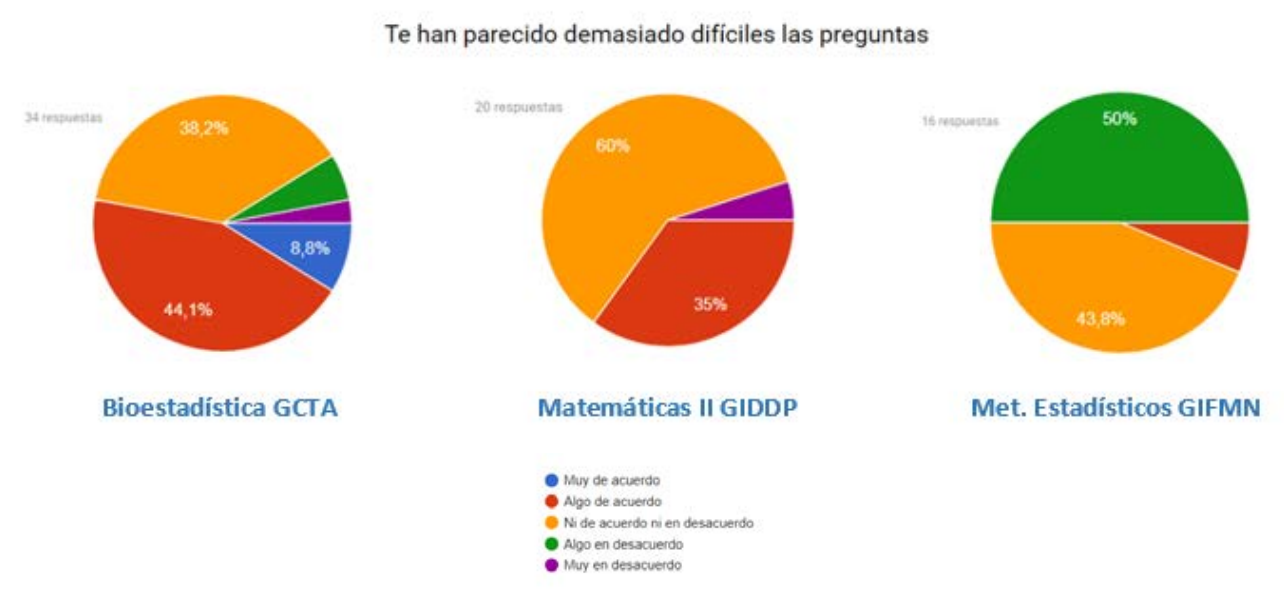

Fig. 6 Resultados de la Cuestión 4 de la encuesta

Respecto a la posible falta de tiempo, un 50\% de los alumnos de Matemáticas II, un 73.5\% de los de Bioestadística y un 62\% de los de Met. Estadísticos estaban de acuerdo (Figura 7).

(cc) BY-NC-ND 2018, Universitat Politècnica de València 
Te ha agobiado la falta de tiempo al contestar

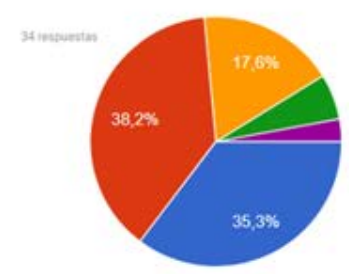

Bioestadística GCTA

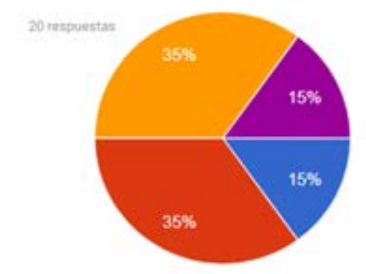

Matemáticas II GIDDP

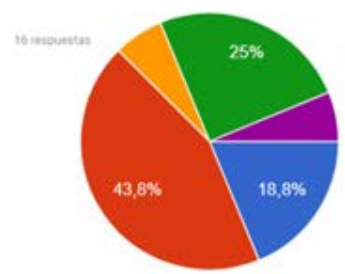

Met. Estadísticos GIFMN

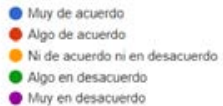

Fig. 7 Resultados de la Cuestión 5 de la encuesta

Hay que indicar que los Kahoot! realizados en Bioestadística eran de mayor dificultad y centrados en herramientas de Inferencia Estadística frente a los de Matemáticas II que estaban centrados en Estadística Descriptiva y Probabilidad. Los alumnos de Met. Estadísticos son los que realizaron más pruebas con Kahoot!, cubriendo Estadística Descriptiva e Inferencia.

Respecto a la opinión de los alumnos en relación el refuerzo del aprendizaje (objetivo principal de la metodología empleada), cabe señalar (Figura 8) que en el caso de Matemáticas II un 65\% de los alumnos estuvo de acuerdo o muy de acuerdo con que la metodología reforzaba su aprendizaje y un $10 \%$ estaba en ligero desacuerdo. En el caso de Bioestadística, un $47.1 \%$ de los alumnos estuvo de acuerdo o muy de acuerdo frente a un 29.4\% que estaba en desacuerdo y, por último, en Met. Estadísticos un 56\% de los alumnos estuvo de acuerdo o muy de acuerdo frente a un $12.5 \%$ que estaba en ligero desacuerdo.

Te ha servido de refuerzo de aprendizaje al acabar los temas

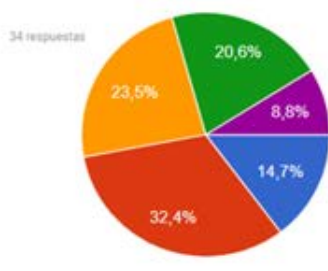

Bioestadística GCTA

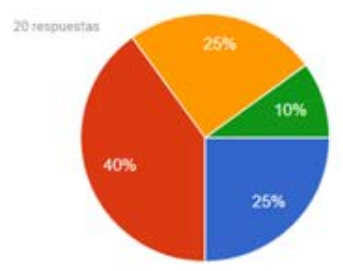

Matemáticas II GIDDP

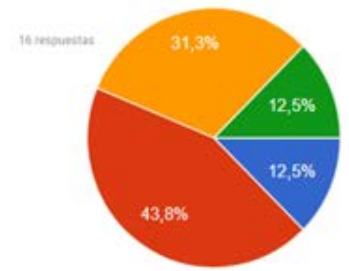

Met. Estadísticos GIFMN

- Mago de acuerdo

Ni de acuerdo ni en desacuerdo

- Algo en desacuerdo

Fig. 8 Resultados de la Cuestión 6 de la encuesta

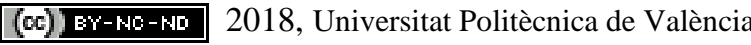

Congreso In-Red (2018) 
Finalmente, en relación a la pregunta sobre si estaban de acuerdo con que se utilizara sus resultados en el Kahoot! para valorar su participación en clase (Figura 9), había más variación en las opiniones, estando en el caso de Matemáticas II el 60\% de los alumnos a favor frente a un $20 \%$ en contra, en Bioestadística del $41.1 \%$ a favor frente al $41.2 \%$ en contra y en Met. Estadísticos el 49.9\% de los alumnos a favor frente a un 31\% en contra.

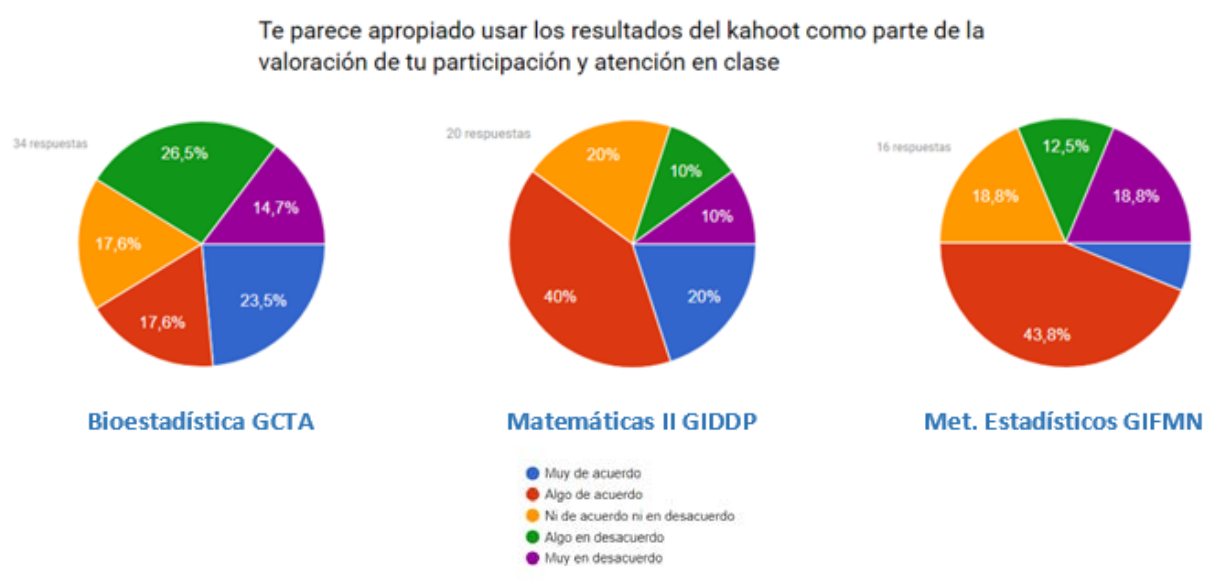

Fig. 9 Resultados de la Cuestión 7 de la encuesta

\section{Conclusiones}

En los últimos años, con el desarrollo de las TIC se han introducido en la docencia sistemas que intentan fomentar la participación activa del alumno en el proceso de enseñanzaaprendizaje. Por otra parte, los resultados de estrategias de juego en las aulas han proporcionado resultados positivos, como han mostrado diversas experiencias previas.

En este trabajo combinamos ambas modalidades utilizando la plataforma Kahoot! con el fin de introducir dinámicas de juego en el aula que estimulen y fomenten la participación activa y el trabajo autónomo de los estudiantes. Para ello, se han propuesto tres actividades de innovación educativa, que además de conseguir estos objetivos generales, han proporcionado las siguientes evidencias: alto grado de motivación y diversión ; el tiempo de respuesta, la dificultad de las preguntas y la posible evaluación de la actividad se perfila globalmente como una cuestión muy relevante para los estudiantes. Señalar que esta cuestión no afecta negativamente a la valoración que hacen los alumnos sobre la idoneidad de las metodologías propuestas.

En la actividad de innovación 3, los resultados ponen de manifiesto que la actividad ha servido realmente para reforzar el aprendizaje de los contenidos de las asignaturas.

Respecto a las actividades de innovación 1 y 2, están actualmente en desarrollo y no se dispone de la valoración final de los alumnos, pero de momento y tras aplicarlo desde el inicio del cuatrimestre, la opinión de los estudiantes y su participación en estas actividades es muy buena. Los resultados provisionales confirman todas las conclusiones expuestas 
hasta el momento. Consideramos interesante encuestar a los alumnos involucrados en estas dos innovaciones y, una vez acabado el curso, comparar los resultados con los obtenidos en la innovación 3. Esta es nuestra próxima tarea.

\section{Referencias}

DEL CERRO GÓMEZ, G. (2015). “Aprender jugando, resolviendo: diseñando experiencias positivas de aprendizaje“. En XII Jornadas Internacionales de Innovación Universitaria (20-21 Julio 2015. Villaviciosa de Odón). Madrid: Universidad Europea de Madrid. 237-244.

DELLOS, R. (2015). "Kahoot! A digital game resource for learning" en International Journal of Instructional Technology and Distance Learning, vol. 12, issue 4, p. 49-52.

EDUCACIÓN 3.0. ¿Qué es la gamificación y cuáles son sus objetivos? https://www.educaciontrespuntocero.com/noticias/gamificacion-que-es-objetivos/70991.html [Consulta: 17 de marzo de 2018].

FUERTES, A. et al. (2016). "Uso de herramientas de respuesta de audiencia en la docencia presencial universitaria. Un primer contacto“. En XXII Jenui (6-8 Julio 2016. Almería) Editorial Universidad de Almería. 261-268.

GIMA (2008). Metodologías activas. Valencia: Universitat Politècnica de València, Editorial UPV.

JOHNS, K. (2015). "Engaging and Assessing Students with Technology: A Review of Kahoot!“ en Delta Gamma Bulletin, vol. 81, issue 4, p. 89

KAPP, K.M. (2012). The gamification of Learning and Instruction : game based Methods and Starategies for Training and Education. Ed. Pfeiffer-Wiley. New York.

PLUMP, C. y LAROSA, J. (2017). "Using Kahoot! in the Classroom to Create Engagement and Active learning: A Game-Based Technology Solution for eLearning Novices“ en Management Teaching Review, vol. 2, issue 2, p. 151-158.

RODRIGUEZ-FERNÁNDEZ, L. (2017). "Smartphone y aprendizaje : el uso de Kahoot en el aula universitaria“ en Revista Mediterránea de Comunicación. Universidad de Alicante (2017, vol.8, núm. 1, pp. 181-190).

UPV, Universidad Politécnica de Valencia. Proyecto institucional de las competencias transversales. http://www.upv.es/contenidos/COMPTRAN/) [Consulta: 14 de marzo de 2018].

VILlALUSTRE, M. L. y MORAL, P. E. (2015). "Gamificación: Estrategia para optimizar el proceso de aprendizaje y la adquisición de competencias en contextos universitarios“. En Digital Education. Revistes Cientifiques de la Universitat de Barcelona (2015, núm. 27, pp. 13-31). http://greav.ub.edu/der [Consulta: 18 de Marzo de 2018] 


\title{
Cellusim: Un simulador 3D en entorno videojuego para la docencia del laboratorio de cultivos celulares
}

\author{
Daniel Monléon $^{\mathrm{a}, *}$, Javier Megias ${ }^{\mathrm{a}}$, Teresa San Miguel $^{\mathrm{a}}$, Consuelo Borrás ${ }^{\mathrm{b}}$, Rosario Gil- \\ Benso $^{a}$, Concha López-Ginés ${ }^{a}$ \\ àpepartamento de Patología, Universitat de Valencia, bepartamento de Fisiología, Universitat de \\ Valencia, *Autor de correspondencia: daniel.monleon@uv.es
}

\begin{abstract}
Cell cultures allow the maintenance of living cells outside the body. This technique is fundamental to study the biological, biochemical and physiological properties of cells and can be used as an experimental model in vitro in the field of biomedical research. The teaching in the laboratory of this technique presents numerous difficulties at a practical, logistical and economic level. On the other hand, the learning of cell culture protocols is an important part of the student's training in Cell Biology. Based on the routine practices carried out within a cell culture laboratory, we have developed the virtual 3D simulator of a cell culture laboratory "Cellusim". In "Cellusim" you can perform basic tasks of the cell culture of an established cell line of your own (Mel-RC08, Gil-Benso et al., 2012). To make Cellusim more attractive and intuitive to students, it has been developed in the Unity graphic environment, commonly used for the development of video games. The system includes the simulator in Unity, a mysql server with users, passwords and logs and a web of help and explanatory videos. In the simulator the student can virtually execute the essential tasks that are performed in a cell culture laboratory, such as thawing cells, seeding the cells, preparing and changing culture media and making cell subcultures. Cellusim is a training tool that allows users to discover the basics of cell culture techniques in a simple and fast way and without the economic costs or time consumption derived from doing the same work in a real laboratory. In order to evaluate the students' learning, Cellusim can be executed in training mode and in evaluation mode, allowing the student to perform all the processes as many times as necessary to become familiar with the protocols and when be able to execute them in evaluation mode. In evaluation mode, Cellusim records student errors in order to score the acquired training. In this communication we present the Cellusim project and the results of the first experiences with volunteer students of Master's Degrees in the School of Medicine.
\end{abstract}

Keywords: cell biology, virtual laboratory, 3D simulator, teaching health sciences, unity, video games for teaching

\section{Resumen}

Los cultivos celulares permiten el mantenimiento de células vivas fuera del organismo. Esta técnica es fundamental para estudiar las propiedades biológicas, bioquímicas y fisiológicas de las células y puede ser utilizada como 
modelo experimental in vitro en el ámbito de la investigación biomédica. La enseñanza en el laboratorio de esta técnica presenta numerosas dificultades a nivel práctico, logístico y económico. Por otra parte, el aprendizaje de los protocolos del cultivo celular resultan una parte importante de la formación del alumno de Biología Celular. Basándonos en las prácticas rutinarias llevadas a cabo dentro de un laboratorio de cultivos celulares, hemos desarrollado el simulador virtual 3D de un laboratorio de cultivos celulares "Cellusim". En "Cellusim" se pueden realizar tareas básicas del cultivo celular de una línea celular establecida propia (Mel-RC08, Gil-Benso y cols., 2012). Para hacer Cellusim más atractivo e intuitivo a los alumnos, ha sido desarrollado en el entorno gráfico Unity, utilizado habitualmente para el desarrollo de videojuegos. El sistema incluye el simulador en Unity, un servidor mysql con usuarios, contraseñas y registros y una web de ayuda y videos explicativos. En el simulador el alumno puede ejecutar de modo virtual las tareas esenciales que se realizan en un laboratorio de cultivos celulares, tales como la descongelación de células, el sembrado de las células, la preparación y el cambio de medios de cultivo y el subcultivo celular o técnica de doblaje. Cellusim es una herramienta formativa que permite a los usuarios descubrir los fundamentos de las técnicas básicas de cultivo celular de una manera sencilla, rápida y sin los costes económicos ni el consumo de tiempo derivados de realizar el mismo trabajo en un laboratorio real. Para poder evaluar el aprendizaje de los alumnos, Cellusim puede ser ejecutado en modo entrenamiento y en modo evaluación, permitiendo que el alumno realice todos los procesos las veces que sea necesario para familiarizarse con los protocolos y que cuando esté en condiciones pueda ejecutarlas en modo evaluación. En modo evaluación, Cellusim registra los errores del alumno para poder puntuar la formación adquirida. En esta comunicación presentamos el proyecto Cellusim y los resultados de las primeras experiencias con alumnos voluntarios de Master de la Facultad de Medicina.

Palabras clave: biología celular, laboratorio virtual, simulador 3D, docencia en ciencias de la salud, unity, videojuegos para docencia

\section{Introducción}

Se entiende por cultivo celular al conjunto de técnicas que permite el mantenimiento de células vivas fuera de un organismo, preservando en la medida de lo posible sus propiedades fisiológicas, bioquímicas y genéticas. Las condiciones ambientales controladas que se aplican para el mantenimiento de un cultivo celular reciben el nombre de condiciones in vitro, término latino que alude al uso inicial de recipientes de vidrio como soporte para la vida de las células aisladas del organismo.

En la actualidad, los cultivos celulares son muy utilizados en el ámbito de investigación biomédica, debido a sus múltiples aplicaciones entre las que destacan: la fecundación in vitro,

(cc) BY-NC-ND 2018, Universitat Politècnica de València

Congreso IN-RED (2018) 
terapia génica, estudios farmacológicos, fabricación de vacunas, estudios citogenéticos, microbiología, cartografía génica, tratamiento de quemados, obtención de anticuerpos monoclonales e investigación básica en biología molecular.

La Unidad de Biología del Departamento de Patología de la Universidad de Valencia imparte una práctica sobre Cultivos Celulares en las asignaturas de Biología de los grados de Medicina, Odontología, Podología e Ingeniería Biomédica. En esta práctica se abordan los fundamentos, técnicas y aplicaciones de los cultivos celulares, y se observan preparaciones microscópicas de diversos cultivos celulares; de procedencia animal y de células tumorales humanas.

Este tipo de docencia, pese a tener un éxito pedagógico contrastado, adolece de una limitación principal: que los alumnos no pueden acceder a las instalaciones de un laboratorio de cultivos celulares real, ni trabajar con células vivas. Esta limitación implica que el conocimiento adquirido sobre las técnicas de mantenimiento de cultivos celulares sea únicamente teórico y, por tanto, alejado de la realidad del laboratorio.

Por otro lado, se descarta plantear una práctica de laboratorio real. Esto se debe a cuatro limitaciones insalvables: (a) el elevado número de alumnos matriculados en las asignaturas de Biología, (b) el tiempo limitado disponible para las prácticas, (c) el tamaño reducido de los laboratorios de cultivos celulares y (d) el gasto de material específico de laboratorio de alto coste.

Por las razones expuestas, se requiere la fabricación de una herramienta pedagógica que mejore la docencia en las técnicas de cultivo celular, sin suponer un elevado coste, ni un exceso en las horas de docencia establecidas.

\section{Objetivos}

El objetivo general del presente trabajo es el desarrollo de nuevos métodos de aprendizaje de los protocolos de cultivos celulares para acercar al alumno al entorno y complejidad de esta técnica. En concreto los objetivos particulares han sido:

1) Desarrollar el simulador virtual "Cellusim"; una herramienta pedagógica que reproduce el trabajo rutinario de un laboratorio de cultivos celulares. El uso del simulador permitirá un acercamiento por parte de los usuarios al trabajo de laboratorio, sin el elevado coste que supondría el mismo trabajo en un laboratorio real. "Cellusim” contribuye a la formación de nuevos investigadores y de alumnos pertenecientes a grados de carácter biomédico o sanitario.

2) Dar a "Cellusim" un enfoque docente con el fin de evaluar de una manera objetiva los conocimientos del alumno de grado sobre el manejo virtual de cultivos celulares, gracias al sistema de penalización de errores incorporado.

\section{El simulador Cellusim}

Se accede al simulador ejecutando el programa instalado de modo local. Tras ello se muestra la pantalla inicial que muestra el acceso al sistema virtual en la que se debe ingresar el correo electrónico y contraseña del usuario que fue previamente registrado en la página web de administración. 


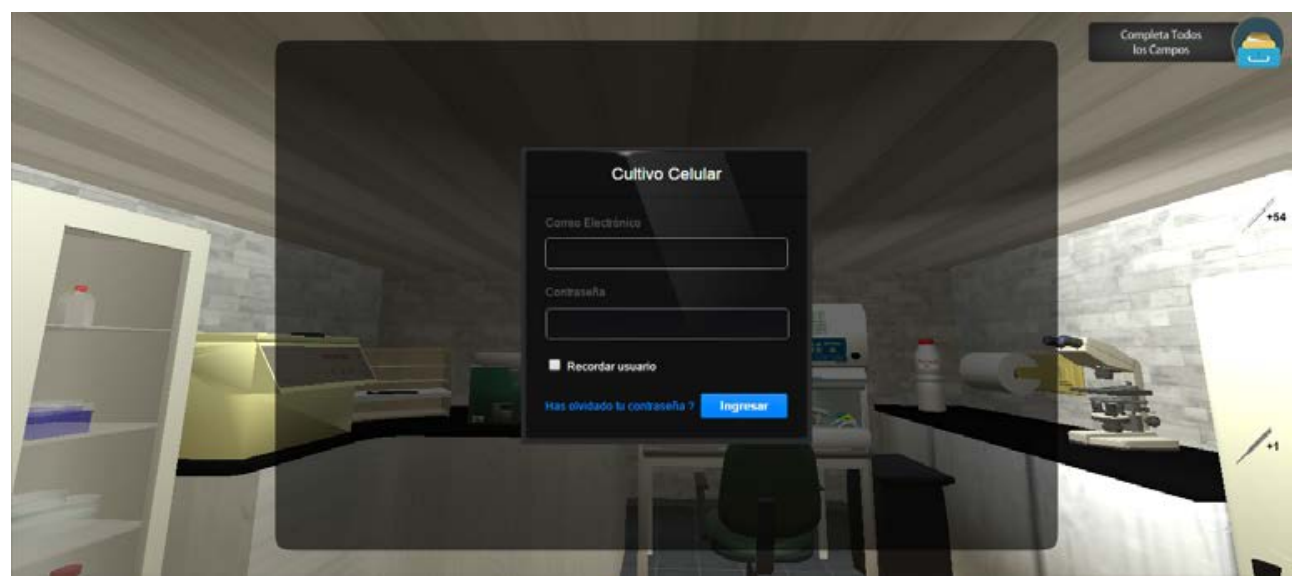

Figura 1: Ventana de acceso al sistema virtual de cultivo celular

Dentro del sistema virtual, tal y como se realiza en el laboratorio real, se tendrá que configurar la Temperatura y el 『CO $\rrbracket \_2$ de la incubadora que es el paso fundamental para el resto de actividades en el cultivo celular.

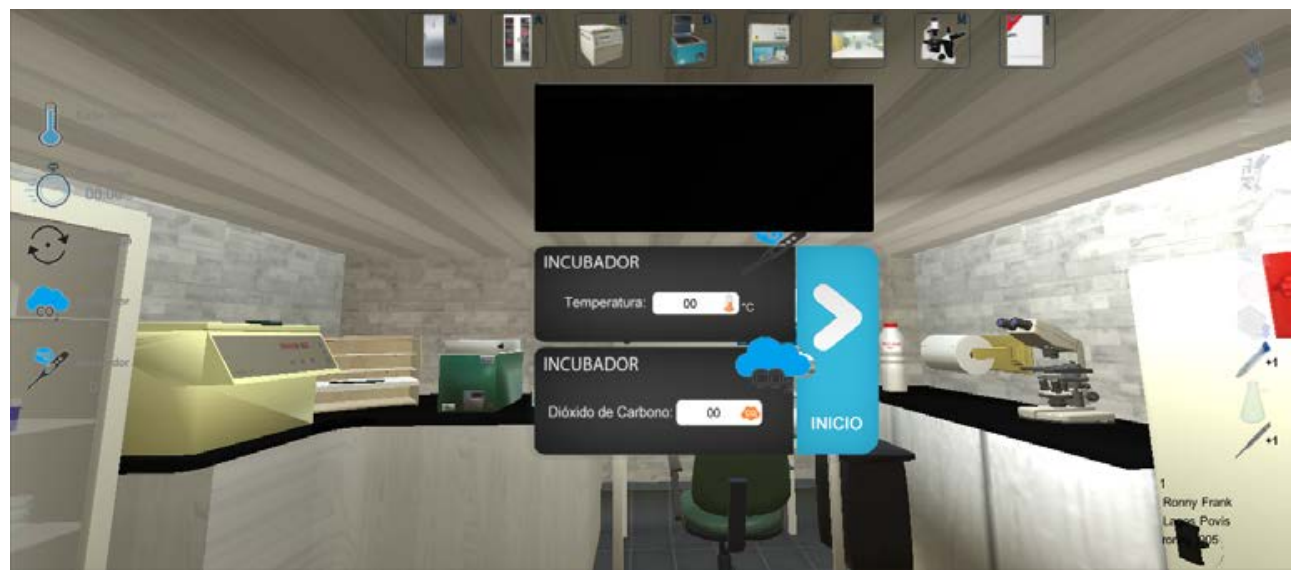

Figura 2: Establecer la Temperatura y el 『CO』_2 de la incubadora.

A partir de aquí, nos encontramos en medio del laboratorio y podemos acceder a diferentes estaciones de trabajo (congelador, nevera, microscopia, estufa, campana de cultivos, centrífuga, etc) cada una con sus controladores y protocolos de trabajo definidos. En el laboratorio el alumno tiene que realizar 4 tareas básicas del laboratorio de cultivos con su protocolo de pasos definidio y explicado previamente en clase (descongelado de células, sembrado de células, cambio de medio de cultivo y realización de un subcultivo o pase). A modo ilustrativo exponemos los pasos a seguir para las tareas a realizar. 


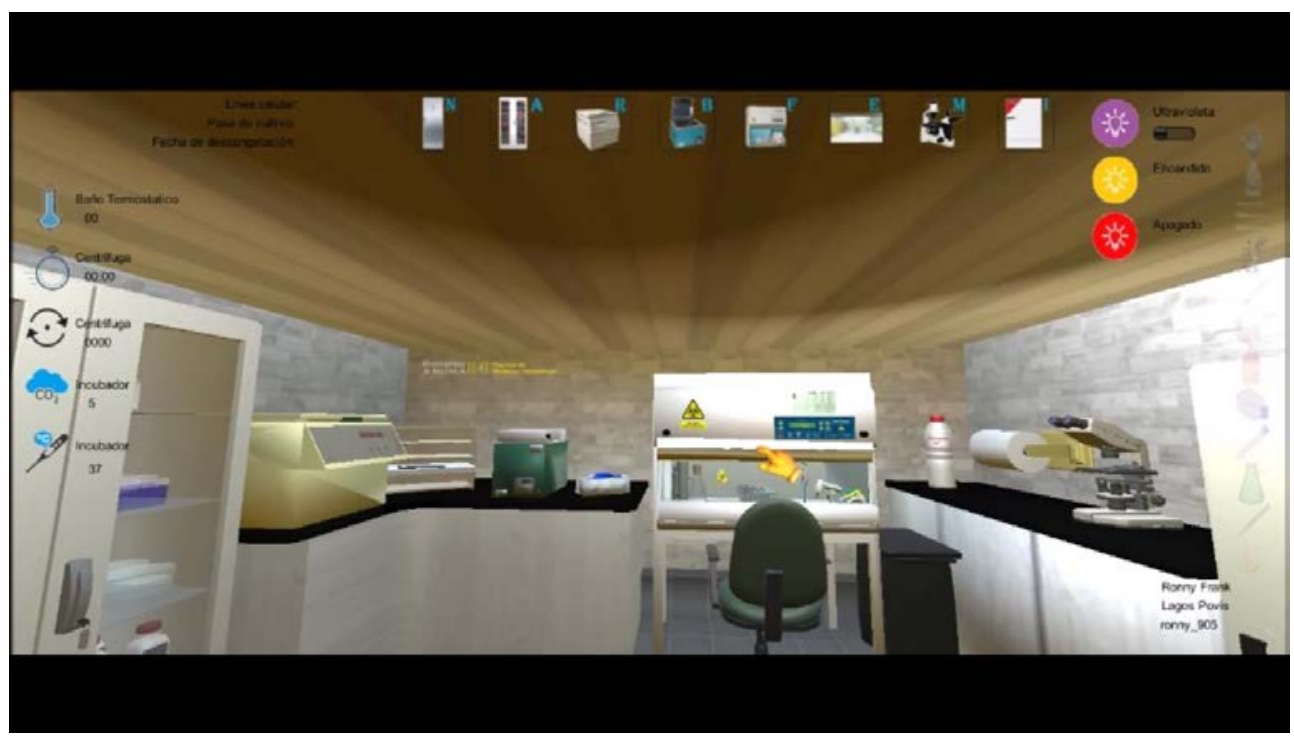

Figura 3. Visión general del laboratorio Cellusim con las diferentes estaciones de trabajo en la parte superior a las que se puede acceder mediante el ratón o mediante atajos de teclado.

Para el proceso de descongelación de las células contenidas en un criovial y sembrado de las mismas se realizan los siguientes pasos: 1) Ponerse guantes de látex antes de comenzar a trabajar; 2) Poner en marcha la cabina de flujo laminar y limpiarla con alcohol al 70\%; 3) Establecer la temperatura del baño termostático a $37^{\circ} \mathrm{C}$; 4) Obtener el medio de cultivo de la nevera y colocar en el baño termostático; 5) Obtener el criovial con células congeladas y colocar en el baño termostático, hasta que el medio de congelación con la suspensión celular se descongele completamente; 6) Llevar el medio de cultivo y el criovial del baño termostático a la cabina de flujo laminar; 7) Añadir $5 \mathrm{ml}$ de medio de cultivo a un tubo estéril de $15 \mathrm{~mL}$; 8) Añadir el contenido del criovial (suspensión celular) al tubo estéril; 9) Centrifugar las células a 1200 rpm durante 5 minutos; 10) Eliminar el sobrenadante del tubo por medio de una pipeta Pasteur y la bomba de vacío; 11) Resuspender el precipitado celular y transferir a un frasco de cultivo. Añadir $5 \mathrm{ml}$ de medio de cultivo en el frasco; 12) Observar las células en el microscopio óptico invertido; 13) Guardar las células en el incubador. 


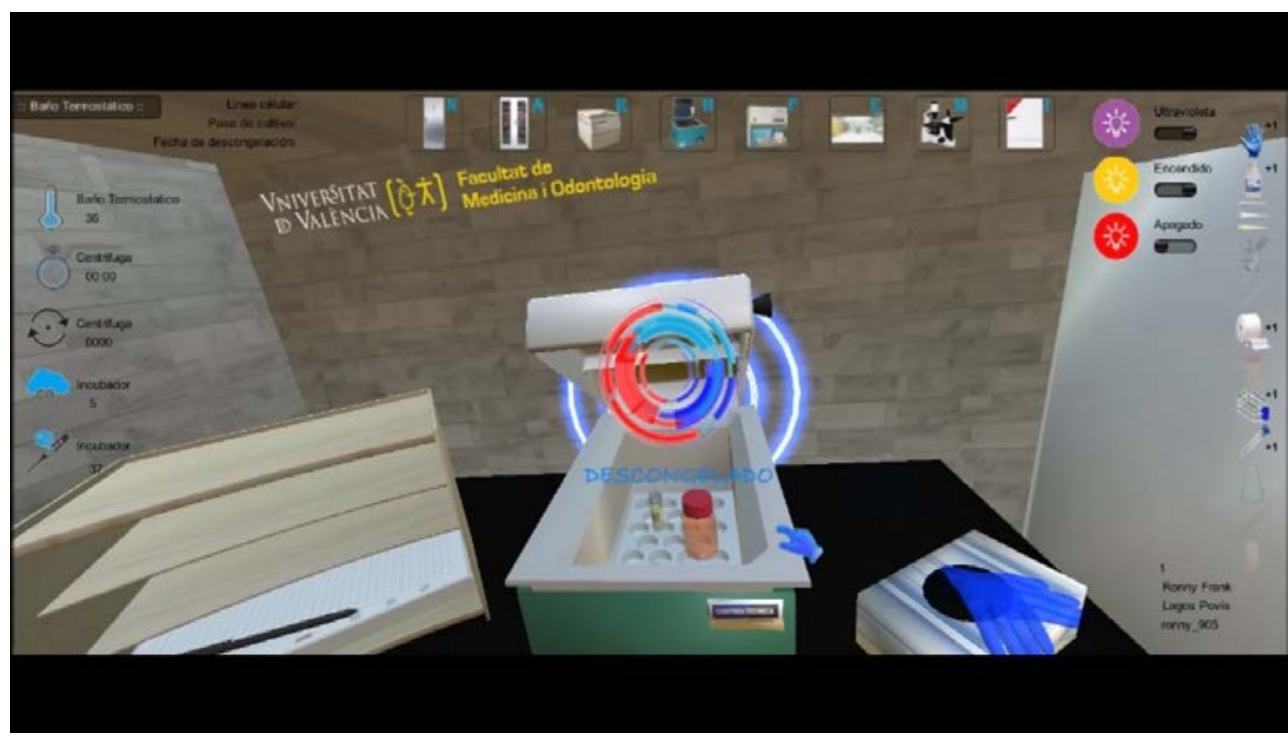

Figura 4. Descongelación de las células en el baño termostático. El proceso en el laboratorio real lleva alrededor de 15 minutos pero en el simulador se ha acelerado a algunos segundos y se indica el progreso del tiempo mediante avance de barras circulares.

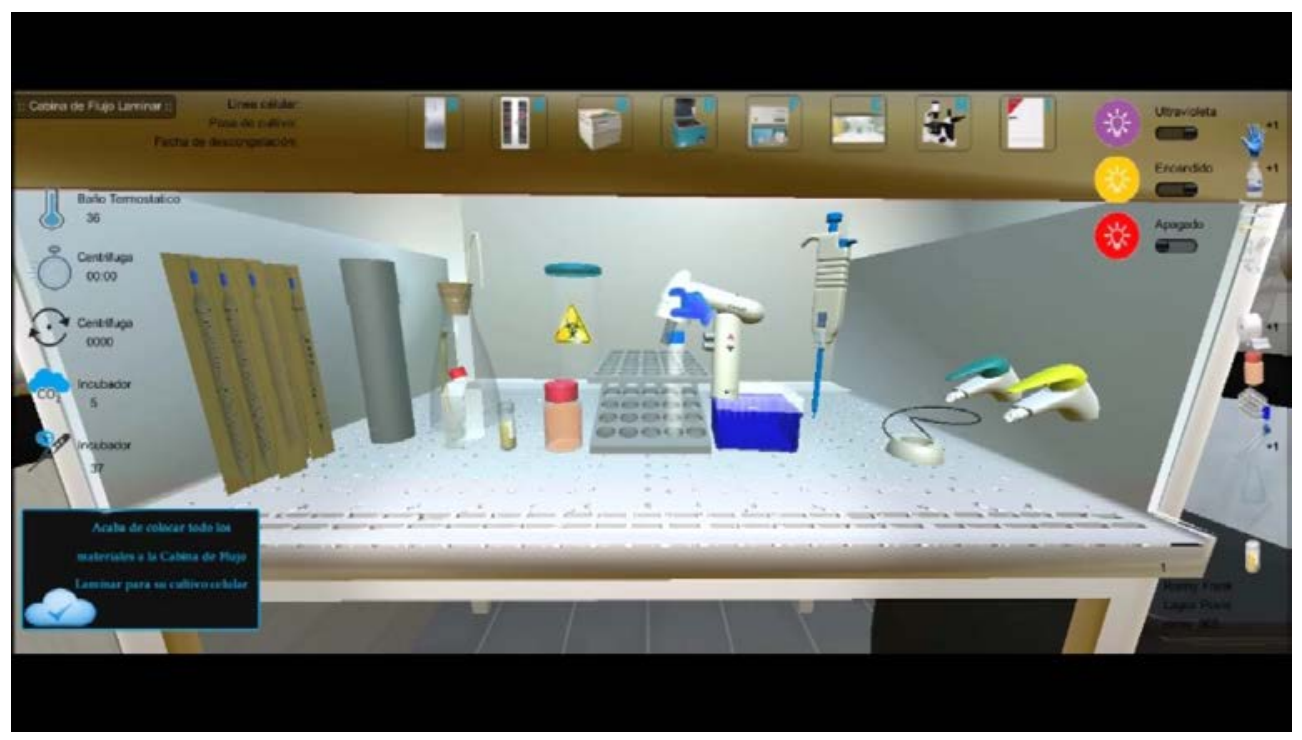

Figura 5. Visión de la cabina de cultivos celulares de Cellusim en que se pueden apreciar los distintos elementos e instrumental para realizar las operaciones especificadas en el protocolo de trabajo. Una nota de aviso en la esquina inferior izquierda informa al alumno cuando se alcanzan hitos relevantes en el protocolo. En la esquina superior derecha se encuentran los controles de la cabina. En el lateral izquierdo el alumno tiene permanentemente la información sobre el estado de los diferentes sistemas del laboratorio (baño termostático, estufa, etc).

Para la realización del cambio de medio de cultivo los pasos a seguir son los siguientes: 1) Ponerse guantes de látex antes de comenzar a trabajar; 2) Poner en marcha la cabina de flujo 
laminar y limpiarla con alcohol al 70\%; 3) Establecer la temperatura del baño termostático a $37^{\circ} \mathrm{C}$; 4) Obtener el medio de cultivo de la nevera y colocar en el baño termostático; 5) Sacar el frasco con las células del incubador; 6) Observar el estado de las células y su confluencia al microscopio óptico invertido; 7) Eliminar el medio de cultivo del frasco con una pipeta Pasteur y la bomba de vacío; 8) Añadir $5 \mathrm{~mL}$ de medio de cultivo completo al frasco; 9) Observar nuevamente las células al microscopio óptico invertido; 10) Depositar las células en el incubador.

Para el proceso de realización de un subcultivo celular o pase los pasos a seguir en el simulador son: 1)Ponerse guantes de látex antes de comenzar a trabajar; 2) Poner en marcha la cabina de flujo laminar y limpiarla con alcohol al 70\%; 3) Establecer la temperatura del baño termostático a $37^{\circ} \mathrm{C}$; 4) Obtener el medio de cultivo de la nevera y colocar en el baño termostático; 5) Sacar el frasco con las células del incubador; 6) Observar el estado de las células y su confluencia al microscopio óptico invertido; 7) Eliminar el medio de cultivo del frasco con una pipeta Pasteur y la bomba de vacío; 8) Lavar las células añadiendo $5 \mathrm{~mL}$ de PBS; 9) Eliminar el PBS por medio de una pipeta Pasteur y la bomba de vacío; 10) Añadir 2 $\mathrm{mL}$ de tripsina e incubar a 37oC durante 5 minutos; 11) Añadir $5 \mathrm{~mL}$ de medio completo al frasco y recoger la suspensión celular en un tubo estéril de $15 \mathrm{~mL}$; 12) Centrifugar las células a 1200 rpm durante 5 minutos; 13) Eliminar el sobrenadante del tubo por medio de una pipeta Pasteur y la bomba de vacío; 14) Resuspender el precipitado celular y transferir a dos frascos de cultivo. Añadir $5 \mathrm{ml}$ de medio de cultivo en cada frasco; 15) Observar las células en el microscopio óptico invertido; 16) Guardar las células en el incubador.

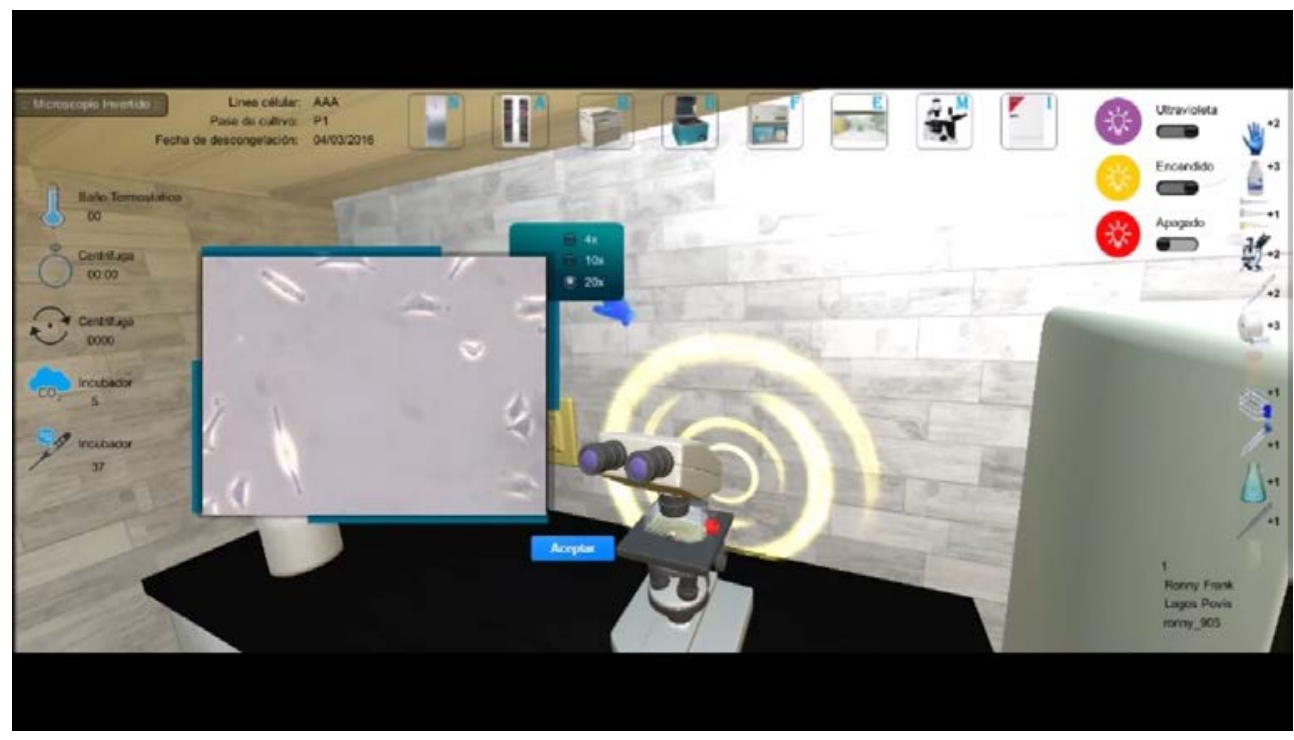

Figura 6. Observación de células en cultivo en el microscopia en el entorno del simulador Cellusim.

Durante la etapa en que el alumno utiliza el simulador en mod entrenamiento, el alumno se familiariza con la ubicación de los diferentes elementos en el laboratorio (viales, crioviales, pipetas, guantes, estaciones de trabajo, etc). A partir de ahí, el trabajo en este laboratorio 
virtual es mucho más fluido y el alumno puede pasar a ser evaluado cambiando el modo a evaluación.

El proceso completo dura alrededor de 20 minutos ya que los tiempos de crecimiento de las células y de operaciones largas como la descongelación o la centrifugación han sido reducidos a segundos. En el video del enlace http://www.uv.es/dmonleon/cellusim/videodemo.avi es posible observar todo el proceso. La sensación para el alumno es siempre la de estar participando en un videojuego interactivo 3D con lo que la motivación para el uso y aprendizaje es muy alta.

\section{Experiencia con los alumnos}

Los alumnos de diversos estudios de Máster en la Facultad de Medicina han mostrado interés en el simulador y lo han podido probar. La experiencia en general ha sio muy positiva e incluso algunos profesores e investigadores jefe de grupo han pedido acceso al simulador para que sus doctorandos y el personal que se va a iniciar en los cultivos celulares reales en entornos de investigación experimenten antes con el simulador para acelerar su cirva de aprendizaje. Tras estos ensayos voluntarios hemos recibido numerosas sugerencias de mejora (una libreta de laboratorio virtual que acompañe a las operaciones, barra de vida remanente que disminuya al cometer errores, etc) que esperamos incluir en la versión 2.0 del simulador.

\section{Conclusiones}

Cellusim es el primer simulador 3D construido con un motor de videojuegos para el aprendizaje de las técnicas de cultivos celulares y la evaluación de conocimientos del alumno. Existen otros simuladores con un fin parecido pero carecen de los componentes de ellusim más atractivos para los alumnos (entorno 3D, motor de videojuego, posibilidad de entrenamiento) y para los profesores (posibilidad de monitorización del alumno, posibilidad de evaluación interna en el simulador). Las primeras experiencias con voluntarios han superado en mucho nuestras expectativas y ha suscitado mucho interés tanto para la docencia en los grados relacionados con Ciencias de la Salud como en entornos de enseñanza postgrado y formación en investigación.

\section{Referencias}

Gil-Benso R, Monteagudo C, Cerdá-Nicolás M, Callaghan RC, Pinto S, Martínez-Romero A, Pellín-Carcelén A, San-Miguel T, Cigudosa JC, López-Ginés C. Characterization of a new human melanoma cell line with CD133 expression. Hum Cell. 2012 Jun; 25(2): 61-7.

(c) EY-NC-ND 2018, Universitat Politècnica de València

Congreso IN-RED (2018) 


\title{
GoKoan: Una plataforma e-learning de apoyo al estudio en estudiantes universitarios
}

\author{
María José Náchera, Laura Badenes-Ribera ${ }^{b}$, Clara Torrijos ${ }^{c}$, Miguel Ángel Ballesteros ${ }^{\mathrm{d}} \mathbf{y}$ \\ Elena Cebadera ${ }^{\mathrm{e}}$
}

${ }^{a}$ Profesora Titular de Universidad adscrita al Departamento de Psicología Básica de la Facultad de Psicología de la Universitat de València. Email: mjnacher@uv.es, ${ }^{b}$ Profesora Ayudante Doctora de la Facultad de Psicología adscrita al Departamento de Metodología de las Ciencias del Comportamiento de la Facultad de Psicología de la Universitat de València. Email: Laura.Badenes@uv.es, ${ }^{\mathrm{c}} \mathrm{CEO}$ (Chief Executive Officer) GoKoan. Calle Serpis, 68, entresuelo, Valencia. Teléfono: 636284938. Email: clara.torrijos@gokoan.com, ${ }^{\mathrm{d}} \mathrm{CTO}$ (Chief Technical Officer) GoKoan. Calle Serpis, 68, entresuelo, Valencia. Email: ma.ballesteros@gokoan.com y ${ }^{\mathrm{E}} \mathrm{UX} / \mathrm{UI}$ (User Experience/User Interface) GoKoan. Calle Serpis, 68, entresuelo, Valencia. Email: elena.cebadera@gokoan.com

\begin{abstract}
In this paper GoKoan is presented as an e-learning platform which supports in-person education in the university. In the present study, a total of 175 students on the "Psychology of Memory" course from the Psychology Degree of the Universitat de Valencia participated, 88 of them were part of the control group and 87 of the experimental group. The experimental group conducted the study in two phases: 1) Learning phase: the content of the course was presented fragmented for study, with evaluations of each content until they were learned. 2) Review phase: multiple choice exams were done to review of the whole subject. The reviews were progressively grouped into blocks with a higher content load and ended with a mock exam. To achieve a greater optimization of the learning process, a series of factors are considered: personalized study planning, distributed study over time, comprehensive analysis of errors, continuous progress reports, collaborative learning, etc. At this time there are no results available, because the academic year has not ended, but it is expected that the experimental group will obtain better results than the control group.
\end{abstract}

Keywords: Information and Communications Technologies, ICT, Blended learning, B-learning, E-learning tool, Academic achievement, Educational innovation, Koan Algorithm, Teaching-learning process, Higher Education.

\section{Resumen}

En este trabajo se presenta GoKoan, una plataforma e-learning de apoyo a la formación presencial en la enseñanza universitaria. Han participado un total de 175 estudiantes de la asignatura de "Psicología de la Memoria" del Grado de Psicología de la Universitat de València, 88 forman parte del grupo control y 87 del grupo experimental. El grupo experimental realizó el estudio 
de la asignatura en dos fases: 1) Fase de aprendizaje: los contenidos se presentaron fragmentados para su estudio con evaluaciones del nivel de adquisición de cada contenido hasta conseguir su aprendizaje. 2) Fase de repaso: se realizaron repasos de toda la asignatura mediante preguntas tipo test. Los repasos se fueron agrupando de forma progresiva en bloques con mayor carga de contenido, y acababan con un simulacro de examen. Para lograr una mayor optimización del proceso de aprendizaje, se tiene en cuenta una serie de factores: planificación personalizada del estudio, estudio distribuido en el tiempo, análisis exhaustivo de los errores, reportes continuos del progreso, aprendizaje colaborativo, etc. En estos momentos no se disponen de resultados por no haber finalizado el curso académico pero se espera que el grupo experimental obtenga mejor rendimiento en la asignatura que el grupo control.

Palabras clave: Tecnologías de la Información y de la Comunicación, TIC, Aprendizaje mixto o combinado, Herramienta e-learning, Rendimiento académico, Innovación educativa, Algoritmo Koan, Proceso de enseñanza-aprendizaje, Educación Superior.

\section{Introducción}

La entrada en vigor del Espacio Europeo de Educación Superior (EEES) (Ministerio de Educación y Ciencia, MEC, 2006) ha supuesto el marco idóneo de implantación de las Tecnologías de la Información y de la Comunicación (TICs) en el contexto de la formación Universitaria puesto que ha permitido la adaptación de nuevas metodologías virtuales a las competencias transversales (comunes a todas las titulaciones) y a las específicas de cada titulación.

Ello ha generado un cambio de paradigma a la hora de abordar el proceso de enseñanza-aprendizaje que tradicionalmente priorizaba la figura del profesor como único agente transmisor de conocimientos para centrarse en las necesidades de aprendizaje de los estudiantes, propiciando, además, un cambio en el espacio de aprendizaje que ya no se limita al espacio físico del aula sino que se amplía a otros entornos virtuales.

En la actualidad, se puede constatar la utilización generalizada en las universidades públicas españolas de numerosas plataformas educativas (plataformas e-learning) que se combinan con la enseñanza en la clase presencial (enseñanza mixta o b-learning) (Britain y Liber, 2004) y que tienen como objetivo fundamental la creación y gestión de los espacios de enseñanza y aprendizaje en Internet dirigidos a la adquisición de una o varias competencias (Griffiths et al., 2004; López Alonso et al., 2008), donde el profesorado y el alumnado puedan interaccionar durante su proceso de formación (Fernández-Pampillón, 2009). 
De hecho, según el informe emitido por la Conferencia de Rectores de las Universidades Españolas (CRUE, 2008), desde el año 2005 prácticamente la totalidad de universidades españolas cuentan con algún producto para impartir docencia virtual, pues posibilitan la creación de entornos virtuales de aprendizaje de forma sencilla (Zapata, 2003) y, sobre todo, permiten ampliar la oferta educativa bajo las modalidades semipresencial o no presencial (virtual) (SCOPEO, 2011).

Siguiendo la clasificación ofrecida por Fernández-Pampillón (2009), las plataformas e-learning que se están aplicando en el ámbito universitario son de dos tipos: de carácter general y específico.

Las plataformas educativas genéricas son "pedagógicamente neutras", es decir no están orientadas hacia el aprendizaje de una materia concreta o hacia la adquisición de una competencia en particular, pero permiten crear múltiples espacios diferentes a partir de una plantilla y un conjunto de herramientas, como por ejemplo, los sistemas de gestión del aprendizaje (Learning Management Systems, LMS).

Las plataformas LMS de software libre ${ }^{1}$ como plataformas de contenidos abiertos son las más utilizadas por las universidades españolas de carácter presencial, entre ellas destacan (Prendes, 2009):

1) Moodle la plataforma más utilizada en las universidades españolas ${ }^{2}$, concretamente en 39 universidades ${ }^{3}$.

2) Sakai: en la Universitat de Lleida, la Universitat de Barcelona y la Universitat Politècnica València.

3) Claroline: en la Universidad de Vigo, en Ilias de la Universidad de Jaén.

4) Dokeos: en la Universidad de Nebrija (Universidad Privada en Madrid).

5) dotLRN: utilizado por la UNED y hasta el año 2016 por la Universitat de València.

Según, Fernández-Pampillón (2009) y el equipo SCOPEO (2011), estas plataformas ofrecen múltiples herramientas y funcionalidades, como por ejemplo:

\footnotetext{
${ }^{1}$ La Free Software Fundation (FSF) define el concepto de software libre como "la libertad de los usuarios para ejecutar, copiar, distribuir, estudiar, cambiar y mejorar el software". Que el software sea libre, no quiere decir que sea gratuito, sino que el usuario es libre de adaptarlo a sus necesidades (SCOPEO, 2011).

${ }^{2}$ Universitat de València, Internacional de Andalucía, Valladolid, Ramón Llull, León, Pontificia de Salamanca, San Jorge, Católica de Valencia, San Vicente Mártir, Salamanca, Extremadura, Huelva, Granada, Córdoba, Castilla-La Mancha, Mondragón, Unibersitatea, País Vasco, Politécnica de Madrid, Rovira i Virgili, Pompeu Fabra, Complutense de Madrid, Oviedo, Internacional de Catalunya, Barcelona, Illes Balears, Politécnica de Catalunya, Oberta de Catalunya, Politécnica de Cartagena, Católica Santa Teresa de Jesús de Ávila, Cádiz, Jaume I de Castellón, Autónoma de Madrid, Europea de Madrid, Carlos III de Madrid, Universidad a Distancia de Madrid, La Laguna, Las Palmas de Gran Canaria, Málaga, Deusto, Camilo José Cela y Zaragoza.

${ }^{3}$ Se incluye también la Universitat de Valencia que en el año 2016 pasó de la plataforma dotLRN a Moodle.
}

(c)) EY-NC-ND 2018, Universitat Politècnica de València

Congreso In-Red (2018) 
- Herramientas de administración del espacio de enseñanza-aprendizaje (EA) en relación con la gestión de usuarios y del propio espacio EA.

- Herramientas de comunicación de los participantes mediante correo electrónico, foros, chats, calendarios, noticias o tablón de anuncios.

- Herramientas de gestión y creación de contenidos: agendas, tareas y ejercicios, contenido compartido y herramientas de diseño instruccional.

- Herramientas de evaluación y seguimiento: libros de calificaciones online y métodos de evaluación.

- Herramientas de soporte: autentificación, registro y ayuda.

Entre las ventajas de estas plataformas LMS destacan: la mejora del aprendizaje, la organización y la distribución de contenidos, el seguimiento y responsabilización del alumno, un soporte no presencial, o la compatibilidad con experiencias previas de uso de las TIC en la docencia. Debido a las ventajas que ofrece a nivel pedagógico, es en el ámbito universitario donde más extendido está el uso de este tipo de plataformas.

Estas plataformas dan soporte a los campus virtuales de las universidades, concebidos como un sistema de información (que incluye usuarios, datos, procesos y herramientas software) encargado exclusivamente del apoyo a los procesos de enseñanza-aprendizaje e investigación (Britain y Liber, 2004; Fernández-Valmayor et al., 2008).

Además de las plataformas educativas de carácter genérico, hay plataformas educativas específicas (LMS específicos) cuyo objetivo es el de mejorar la eficacia y eficiencia académica de una determinada área de conocimiento o la funcionalidad de las plataformas genéricas. Estas plataformas están especializadas en una materia o tarea concreta o una metodología de aprendizaje específico. Utilizan herramientas que permiten la comunicación síncrona multimedia (por ejemplo, videoconferencia), el almacenamiento de recursos didácticos digitalizados, (por ejemplo, repositorios de archivos de vídeo, sonido, hipertextos $\mathrm{y}$ textos), diccionarios y tesauros, materiales educativos multimedia e interactivos, trabajo colaborativo (por ejemplo, blogs, wikis, podcasting), soporte multilingüe (como interfaz en múltiples lenguas) o definición de los perfiles de los participantes, de votación, y de publicación de trabajos de alumnos (López Alonso y Séré, 2005; Monti, et al., 2006).

Ejemplos de este tipo de plataformas serían las de aprendizajes de lenguas o plataformas e-learning síncronas como Elluminate Live donde profesores y alumnos interaccionan en tiempo real, viéndose y escuchándose como si de una clase presencial se tratara con herramientas como pizarras electrónicas para la lectura y escritura participativa, o audios, vídeos o chats para la comunicación síncrona, con espacios de intercambio de archivos, bloc de notas personales, gestión de grupos y evaluación (Fernández-Pampillón, 2009).

En el contexto universitario y con el objetivo de adaptar el funcionamiento de los campus virtuales a los requisitos institucionales y didácticos, a las plataformas e-learning genéricas se integran LMS específicos que incluyen nuevas capacidades y recursos al LMS genérico como aplicaciones web, bases de datos o repositorios de recursos didácticos digitalizados. Así por ejemplo, la Universitat de València cuenta con el Repositorio Institucional 
RODERIC $^{4}$ destinado a recoger y difundir la producción digital generada por los miembros de la comunidad universitaria en materia de cultura, docencia, colecciones digitalizadas, e investigación. Los contenidos abarcan todas las materias científicas que se imparten en la Universidad y recoge todo tipo de materiales digitales, tanto preprints como postprints, comunicaciones a congresos, documentos de trabajo, materiales docentes y objetos de aprendizaje, revistas editadas por la Universidad, así como documentos y materiales resultantes de la actividad institucional realizada por sus centros, unidades y servicios.

Por último, en la docencia universitaria también se empiezan a utilizar algunas aplicaciones como el Kahoot!, Socrative e Infuse Learning, que se engloban dentro del aprendizaje móvil electrónico y de la ludificación entendida como la incorporación de elementos, mecanismos y dinámica de los juegos en las actividades de aprendizaje (Díaz-Martínez y Lizárraga-Celaya, 2013).

En definitiva, en la actualidad nos encontramos con la expansión cada vez mayor de las tecnologías de la información y la comunicación (TICs) como una nueva manera de concebir la docencia universitaria, un nuevo paradigma favorecido por la Declaración de Bolonia (1999), de Berlín (2003), y el documento marco para la convergencia de la universidad española en el espacio europeo (2003), donde las TICs son consideradas prioritarias en las líneas de acción de las universidades (Alba y Carballo, 2005).

Dentro de este contexto de expansión de las TICs, las tendencias educativas actuales involucran cada vez más el uso combinado de entornos tecnológicos/sociales (Blended-Learning o b-learning) para mejorar el aprendizaje. El término Blended-learning se usa para nombrar el enfoque que combina instrucción cara a cara con instrucción mediada por computadora en un escenario de aprendizaje único. Las nuevas tecnologías web ofrecen muchas características on-line para usar en un curso: demostraciones interactivas, exámenes y cuestionarios de autoaprendizaje, tutoriales, laboratorios remotos y virtuales, educación a distancia, etc. De hecho, en la mayoría de las universidades e instituciones educativas se usan cursos virtuales que utilizan herramientas web colaborativas como aLF, Moodle o WebCT.

En estos cursos híbridos, los educadores combinan las ventajas del aprendizaje on-line con los beneficios de la instrucción presencial. Los beneficios de usar nuevas herramientas tecnológicas para promover el aprendizaje ya han sido probados. Diferentes estudios indican que los estudiantes logran una mejor comprensión, retienen la información por más tiempo y disfrutan las clases de manera más efectiva cuando se emplean las metodologías de e-learning, potenciando y mejorando su construcción de un entendimiento más cohesivo con las facetas interconectadas de una disciplina (e.g., Álvarez et al., 2013; Fernandez-Aleman et al., 2011; Hassner y Bayaz, 2012; López et al., 2011; Regueras et al., 2009). En este sentido, Regueras et al. (2009) en una muestra de estudiantes universitarios de telecomunicaciones utilizaron una herramienta de e-learning (llamada QUEST) para

${ }^{4}$ https://www.uv.es/uvweb/servicio-informatica/es/repositorio-institucional-roderic-1285904072947.html 
analizar los efectos del aprendizaje competitivo sobre la satisfacción y el rendimiento académico. Los resultados de este estudio señalan que los estudiantes universitarios que utilizaron la herramienta de e-learning obtuvieron mejores calificaciones en los exámenes finales que el grupo control. Si bien, éstas calificaciones finales no correlacionaron con los puntos obtenidos en la herramienta e-learning.

Por otra parte, Woods et al. (2004) argumentan que una combinación de enfoque presencial y de instrucción on-line es superior a un curso totalmente presencial o completamente on-line, ya que ofrece a los estudiantes una experiencia de aprendizaje intelectualmente más interesante; dado que estas herramientas web (e-Learning) permite a los docentes desarrollar aplicaciones para reforzar los conceptos que los estudiantes ya han aprendido de los libros de texto o conferencias (González-Gómez et al., 2015).

\section{Objetivos}

Desde esta realidad, en el presente trabajo se ofrece una nueva herramienta de enseñanza y aprendizaje on-line para la Comunidad Universitaria, denominada GoKoan.

Con el objetivo de conseguir que el aprendizaje de contenidos académicos sea lo más efectivo posible, GoKoan se apoya en una serie de principios y leyes de la memoria humana que se desarrollaron a partir de los trabajos pioneros de Ebbinghaus $(1885,1913)$ en el campo de la psicología experimental. De sus resultados se derivan aspectos importantes a tener en cuenta en el contexto educativo: el estudio del material espaciado en el tiempo y la importancia del repaso tanto en la adquisición como en el mantenimiento y consolidación de la información a largo plazo.

Teniendo en cuenta las principales conclusiones que se derivan de la investigación experimental sobre la memoria y el aprendizaje, la plataforma GoKoan desarrolla un algoritmo que permite:

- El estudio distribuido en el tiempo de todo el material.

- La fragmentación del material y los repasos en los momentos "críticos" de olvido. Por ejemplo, inmediatamente tras el aprendizaje y a las 24 horas.

- La agrupación del material en contenidos mayores y espaciado en el tiempo de los repasos. Es decir, el estudiante hace repasos periódicos con menor cantidad de información, $\mathrm{y}$, conforme se produce la consolidación de la huella de memoria, los repasos se van distanciando en el tiempo con más carga de contenido.

- Aprendizaje significativo. La herramienta permite la elaboración por parte del estudiante de materiales propios (esquemas, mapas mentales, etc.) junto con la propuesta, por parte de la herramienta, de estrategias y técnicas de memoria que permitan un procesamiento más profundo y elaborado del material y por tanto, una mayor consolidación y recuperación del mismo a largo plazo.

- Repasos a partir de preguntas tipo test, con feedback al estudiante de los errores cometidos y del lugar del temario donde se ha producido el error. De forma, que la plataforma vuelve

(c) EY-NC-ND 2018, Universitat Politècnica de València

Congreso IN-RED (2018) 
a agendar el estudio y el repaso del contenido relacionado con el error para asegurar su correcto aprendizaje.

Para validar científicamente tanto la metodología que sustenta a GoKoan como el algoritmo de planificación desarrollado, la herramienta se ha puesto a prueba en una asignatura universitaria. Un total de 175 estudiantes de $2^{\circ}$ curso del Grado de Psicología de la Universitat de València que están cursando la asignatura de "Psicología de la Memoria" participan en esta investigación, 88 forman parte del grupo control y 87 del grupo experimental. Ambos grupos disponen de los mismos contenidos y materiales de la asignatura, sin embargo, el grupo experimental cuenta también con el apoyo de la herramienta GoKoan para la preparación de la asignatura.

La hipótesis principal de la investigación es que los participantes del grupo experimental que empleen la herramienta GoKoan para el estudio obtendrán mejor rendimiento y por tanto mejores calificaciones en la asignatura Psicología de la Memoria que los participantes del grupo control que no han tenido acceso a la misma.

\section{Desarrollo de la innovación}

\section{Participantes}

En el estudio han participado, de forma voluntaria, un total de 175 estudiantes de la asignatura "Psicología de la Memoria" correspondiente al segundo curso del Grado de Psicología de la Universitat de València. La edad media de los participantes fue de 21.46 años $(\mathrm{DT}=4.55)$, de los cuales el $82.9 \%$ fueron mujeres, $16.6 \%$ hombres y $0.6 \%$ no especificó su sexo.

Los participantes fueron asignados de forma aleatoria a las dos condiciones de investigación: el grupo experimental que recibió el apoyo de la plataforma GoKoan para el estudio de la asignatura, y el grupo control que no pasó por ella. De esta forma, el grupo experimental estuvo compuesto por 87 participantes con una edad media de 21.55 años (DT $=4.80$ ), de los cuales el $88.5 \%$ fueron mujeres, y el $11.5 \%$ hombres. Y el grupo control estuvo formado por 88 participantes con una edad media de 21.37 años (DT = 4.32), de los cuales el $77.3 \%$ fueron mujeres, el $21.6 \%$ hombres y el $1.1 \%$ no especificó su sexo.

\section{Gokoan: Una herramienta de aprendiazaje e-learning}

A nivel tecnológico, GoKoan ha desarrollado un complejo algoritmo basado en inteligencia artificial a través del cual consigue crear una planificación totalmente personalizada para el usuario. El estudiante le dice a GoKoan qué ha de estudiar, para cuándo necesita tenerlo aprendido y cuál es su disponibilidad, entonces, el algoritmo resuelve este problema ofreciendo una planificación acorde a las características personales del usuario, pero 
también teniendo en cuenta los hallazgos obtenidos en investigación científica sobre memoria y aprendizaje humano.

\section{Algoritmo GoKoan}

En base a estos estudios sobre la memoria, el algoritmo GoKoan se fundamenta en los principios del repaso espaciado, ya que es posible implementarlo en el aprendizaje e-learning. De este modo, el ritmo de aprendizaje se adapta a las necesidades individuales de cada usuario: su disponibilidad temporal y la capacidad o nivel de retención deseado (porcentaje de información que se quiere recordar); permitiendo optimizar la experiencia de aprendizaje.

Cuando un usuario accede GoKoan, se encuentra con un material que debe aprender. Para ello, el usuario específica cuál es su disponibilidad horaria, cuál es la fecha límite en la que quiere tener el temario aprendido y a qué grado de retención quiere aprenderlo. Entonces, el algoritmo calcula y ofrece una planificación teniendo en cuenta tanto las fases de estudio, como de repaso y evaluación.

\section{Descripción del software}

GoKoan emplea una arquitectura software basada en la nube, con servidores sin estado bajo el paraguas de un balanceador que reparte la carga.

GoKoan es una aplicación web desarrollada sobre la tecnología Angular JS la cual accede a los servidores mediante una interfaz de comunicación HTTP. Los servidores corren sobre la máquina virtual Java, siendo Kotlin el lenguaje con el que está montado toda la lógica de negocio. La base de datos está basada en la tecnología PostgreSQL, que nos ofrece transaccionalidad en las operaciones y consulta estándar para el cruce de datos.

En el núcleo del sistema, encontramos los algoritmos principales del método GoKoan:

a) El algoritmo de scoring que parte de las puntuaciones del usuario en cada uno de los apartados y construye una visión agregada de la posición global del estudiante, incluyendo su avance total y parcial en cada sección (Figuras 1 y 2).

(c) EY-NC-ND 2018, Universitat Politècnica de València

Congreso IN-RED (2018) 

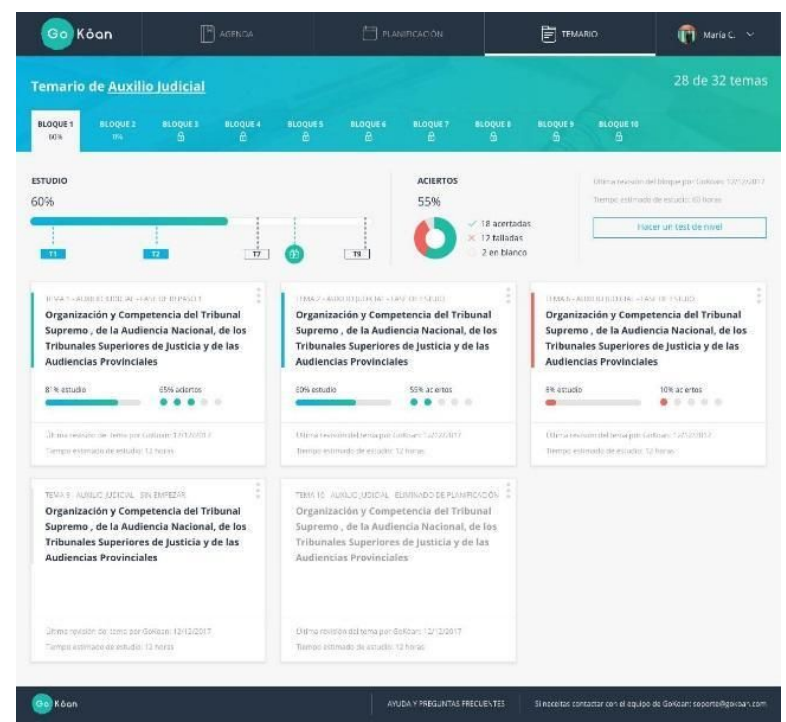

Fig. 1 Puntuación global y por unidades

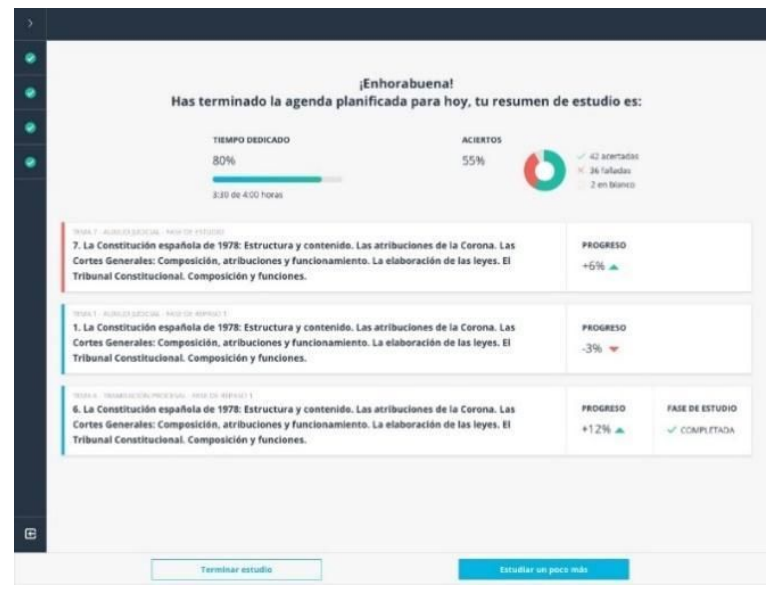

Fig. 2 Feeedback sobre el progreso al final de sesión

b) El algoritmo de secuenciación de contenidos en función del scoring previo, que determina qué contenido debe trabajarse a continuación, y qué tareas le corresponde hacer al usuario (estudiar, hacer un test, etc.) (Figura 3). 


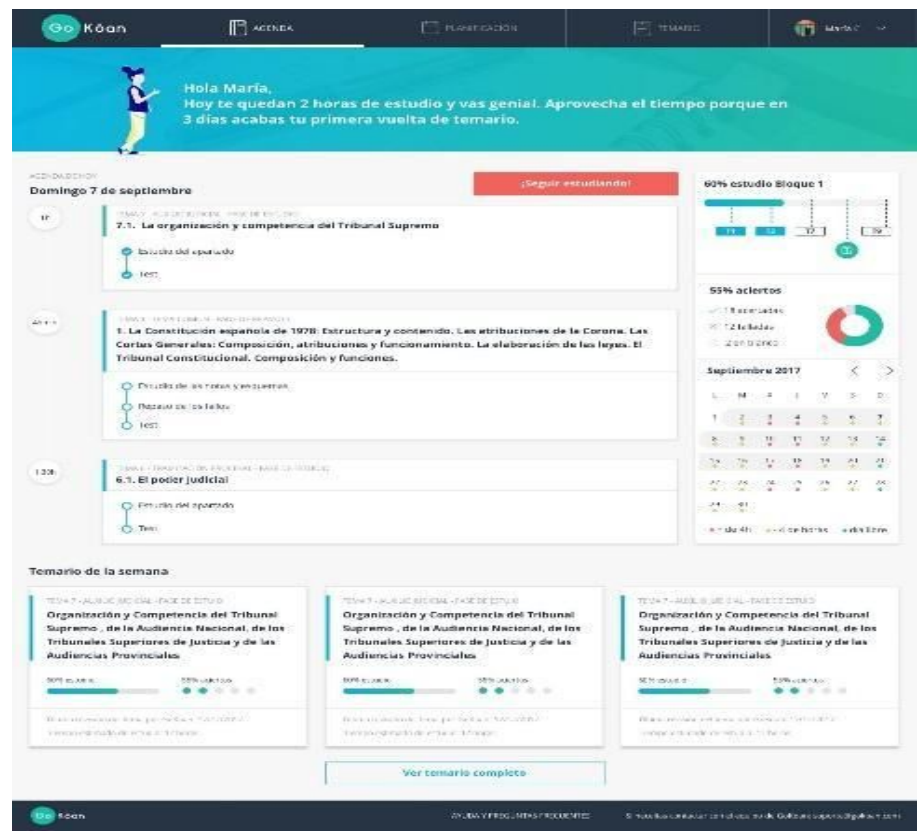

Fig. 3 Agenda del día con información al detalle de contenidos a estudiar y actividades propuestas

c) El algoritmo de planificación, que cruza disponibilidad horaria/diaria y la secuenciación, generando un calendario único y personal que reparte en el tiempo de la forma más óptima posible todo el trabajo dependiente (Figura 4).

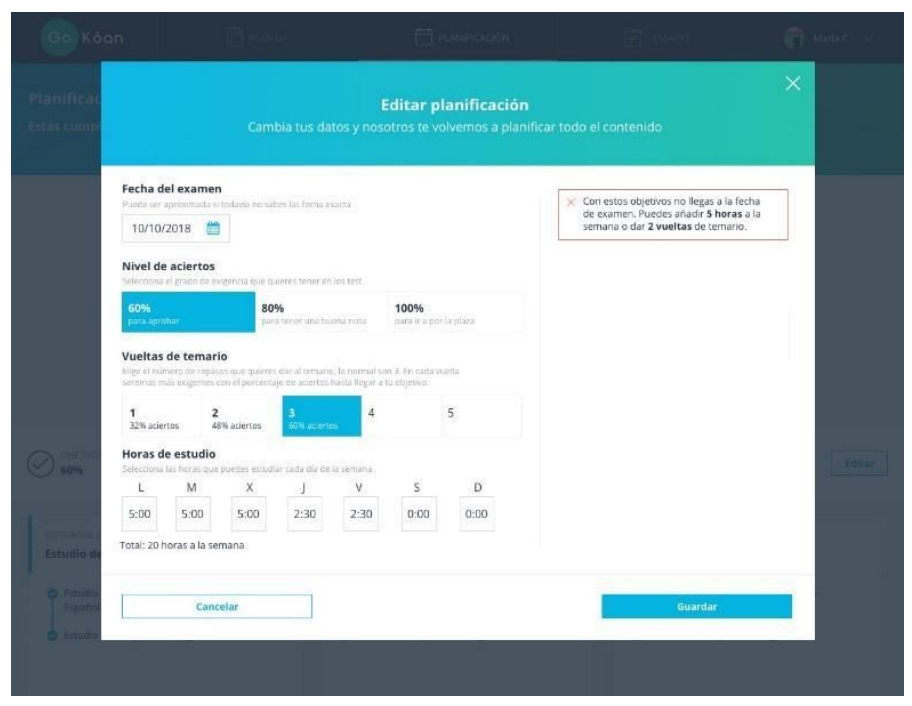

Fig. 4 Editor de planificación personal

d) El algoritmo de construcción de tests, que analiza los puntos débiles del usuario incidiendo en ellos para detectar puntos de olvido y elige preguntas según el nivel del usuario (Figura 5).

(c) EY-NC-ND 2018, Universitat Politècnica de València 


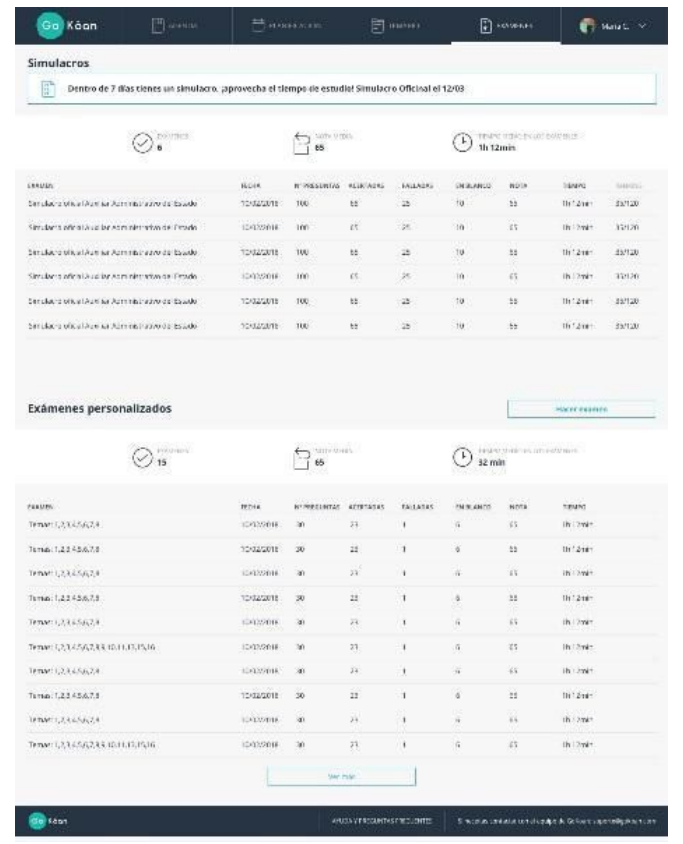

Fig. 5 Feedback de los resultados de las evaluaciones

e) El algoritmo de coaching, basado en árboles de decisión, que cruza el scoring, la planificación y los objetivos para dar un feedback "humano" sobre cómo optimizar el tiempo de estudio (Figura 6).

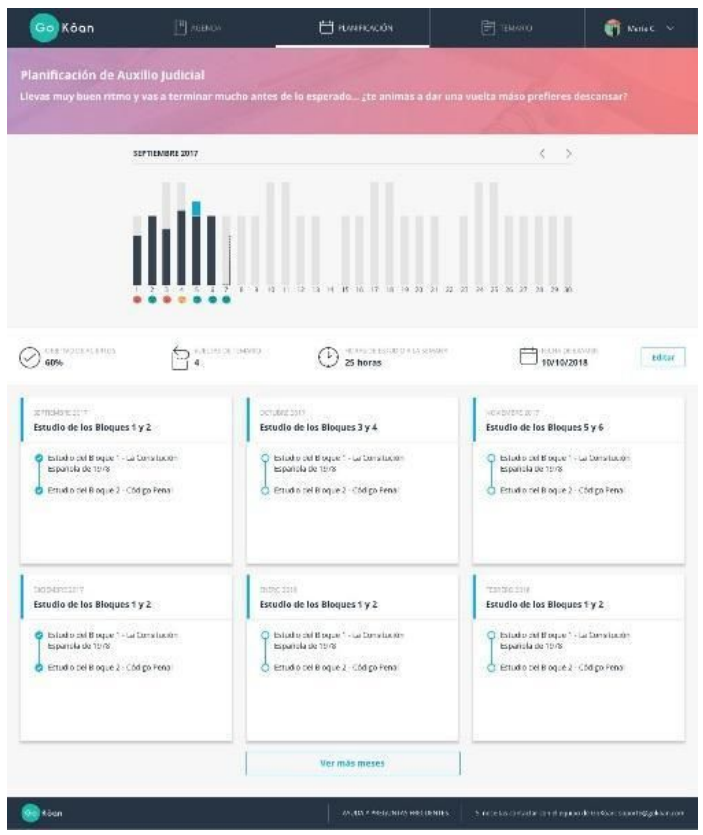

Fig. 6 Banner con mensajes que mejoran la motivación, y gráfica emocional

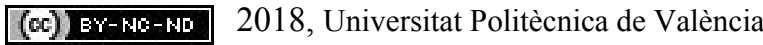




\section{Resultados esperados}

En estos momentos, la herramienta se encuentra en fase experimental de validación científica a la espera de la realización de los exámenes oficiales de la asignatura en los meses de junio y julio. No obstante, en la línea de los resultados obtenidos por otras Universidades (e.g., Universidad de Granada, del País Vasco, etc.) que han desarrollado metodologías aprendizaje on-line, demostrando que la incorporación de estas plataformas a la enseñanza presencial produce mejoras en el rendimiento académico de los estudiantes, en su nivel de motivación y en el grado de satisfacción con los docentes (Álvarez et al., 2013; López et al., 2011), esperamos que el grupo experimental obtenga mejores calificaciones en la asignatura, así como puntuaciones más altas en su percepción sobre la utilidad de la herramienta en su proceso de aprendizaje.

Por último, cabe destacar que el uso de la plataforma puede ofrecer una serie de beneficios tanto a los estudiantes como los docentes:

Por una parte, entre los beneficios a los estudiantes se encontrarían:

- Una planificación totalmente personalizada a las necesidades del estudiante y que además, se va ajustando en base a su progreso.

- Adquisición de material de calidad así como la posibilidad de enriquecerlo mediante notas, enlaces, mapas mentales, esquemas, etc. para favorecer, de este modo, un aprendizaje activo y significativo.

- Una evaluación a través de test, que reporta al estudiante un análisis exhaustivo de los errores cometidos. De este modo, sabe en qué está fallando y en qué lugar del temario se produce el olvido. GoKoan vuelve a agendar el repaso de estos errores para asegurarse que se aprenden correctamente.

- Un reporte continuo y en tiempo real del progreso obtenido, así como una comparativa con el resto de estudiantes.

- Una comunidad en la que compartir dudas y material de estudio, de modo que se favorezca el aprendizaje colaborativo.

Por otra parte, entre los beneficios que la herramienta puede reportar a los docentes cabría destacar:

- Permite delegar el aprendizaje de los contenidos más teóricos en la plataforma y así aprovechar el horario del aula para llevar a cabo actividades que faciliten un aprendizaje más significativo: experienciales, simulaciones, que fomenten el debate y la reflexión, el pensamiento crítico, etc. En definitiva, lo que a nivel pedagógico se conoce como "aula invertida" (flipped classroom).

- Conocimiento en tiempo real de los errores más habituales que cometen cada uno de los alumnos, lo que permite llevar a cabo estrategias preventivas que eviten el fracaso.

(cc) EY-NC-ND 2018, Universitat Politècnica de València

Congreso IN-RED (2018) 
- Fomento del aprendizaje colaborativo a través de la comunidad, compartiendo materiales y resolviendo dudas.

- Más tiempo para dedicar a la atención a la diversidad y a estudiantes con necesidades educativas especiales.

- Mayor accesibilidad de los contenidos, importante sobre todo en casos de bajas y ausencias temporales.

- Permite el aprendizaje a partir de errores.

- Permite a los profesores intercambiar métodos tradicionales con nuevas metodologías más innovadoras; favoreciendo la motivación e interés por el estudio y enriqueciendo la práctica educativa por parte del docente.

- Favorece un aprendizaje constructivista en el que el profesor tiene un rol de guía y el estudiante tiene un rol más protagonista y responsable en su proceso de aprendizaje.

\section{Conclusiones}

En pleno siglo XXI resulta indudable la presencia de las nuevas tecnologías en todos los ámbitos de la vida del ser humano, abriéndose nuevos escenarios de actuación en el contexto de la Educación Superior que están generando profundas transformaciones en la actividad docente y en los mismos procesos de enseñanza aprendizaje.

En este trabajo se presenta GoKoan como una nueva herramienta on-line de apoyo a la docencia universitaria que complementa y refuerza la formación presencial en el aula con el objetivo final de lograr niveles más altos en el rendimiento de los estudiantes.

Si bien nos encontramos en una fase de validación experimental de la herramienta, son muchos los beneficios que puede aportar tanto para los estudiantes como para el profesorado: planificación del estudio en función de la disponibilidad y progresos del estudiante, aprendizaje colaborativo, estrategias preventivas de fracaso, aprendizaje a partir de los errores, atención a la diversidad y disponibilidad de contenidos, entre otros.

De hecho, la integración del aprendizaje virtual en el contexto tradicional del aula universitaria ha demostrado tener efectos positivos tanto en el éxito académico, como en los niveles de motivación de los estudiantes y en el grado de satisfacción de los docentes (Álvarez et al., 2013; López et al., 2011). Por ello, consideramos que la herramienta, que se presenta en este trabajo, puede suponer un elemento de optimización de los procesos de enseñanza-aprendizaje en el ámbito universitario.

\section{Referencias}

ALBA, C. y CARBALLO, F. (2005). "Viabilidad de las propuestas metodológicas para la aplicación del crédito europeo por parte del profesorado de las universidades españolas, vinculadas a la utilización de las TIC en la docencia y la investigación" en Revista de Educación, 337, p. 71-97. 
$<$ http://www.mecd.gob.es/revista-de-educacion/numeros-revista-educacion/numeros-anteriores/2005/ re337/re337_05.html> [Consulta: 15 de marzo de 2018].

ÁlVAREZ, A., MARTIN, M., FERNÁNDEZ-CASTRO, I., y URRETAVIZCAYA, M. (2013). "Blended traditional teaching methods with learning environments: experience, cyclical evaluation process and impact with MAgAdI" en Computers \& Education, 68, pp. 129-140.

BRITAIN, S. y LIBER, O. (2004). "A Framework for the Pedagogical Evaluation of eLearning Environment" en JISC-commissioned report.

$<$ http://www.cetis.ac.uk/members/pedagogy/files/4thMeet_framework/VLEfullReport> [Consulta: 10 de marzo de 2018].

CRUE (2008). Las TIC en el sistema universitario español. Resumen ejecutivo.

$<$ http://www.crue.org> [Consulta: 15 de marzo de 2018].

DECLARACIÓN DE BERLÍN (2003). Declaración conjunta de los Ministros Europeos de Educación.

<http://oa.mpg.de/files/2010/04/Berlin-I-2.pdf> [Consulta: 16 de marzo de 2018].

DECLARACIÓN DE BOLONIA (1999). Declaración conjunta de los Ministros Europeos de Educación.

$<$ http://www.universia.es/contenidos/universidades/documentos/Universidadesdocum bolonia.htm $>$ [Consulta: 10 de marzo de 2018].

DÍAZ-MARTINEZ, S. y LIZÁRRAGA-CELAYA, C. (2013). "Un acercamiento a un plan de ludificación para un curso de física computacional en Educación Superior" en XIV Encuentro internacional Virtual Educa. Colombia. Disponible en $<$ https://reposital.cuaed.unam.mx:8443/xmlui/bitstream/handle/123456789/3901/VE13.509.pdf?seque nce $=1 \&$ isAllowed $=y>$ [Consulta: 9 de marzo de 2018] .

EBBINGHAUS, H. (1885). "Über das Gedächtnis. Untersuchungen zur experimentellen Psychologie" en Ebbingahaus, H. (1913): Memory: A Contribution to Experimental Psychology. Nueva York: Teachers College, Columbia University.

EBBINGHAUS, H. (1913). Memory: A Contribution to Experimental Psychology. H.A. Ruger y C.E. Bussenius (trads.). Nueva York: Teachers College, Columbia University.

FERNANDEZ-ALEMAN, J. L., CARRILLO DE GEA, J. M., y RODRÍGUEZ-MONDEJAR, J. J. (2011). "Effects of competitive computer-assisted learning versus conventional teaching methods on the acquisition and retention of knowledge in medical surgical nursing students" en Nurse Education Today, 31, vol. 8, pp. 866-871

FERNÁNDEZ-PAMPILLÓN, A. (2009). "Las plataformas e-learning para la enseñanza y el aprendizaje universitario en Internet" en , López Alonso, C., y Matesanz del Barrio, M. Las plataformas de aprendizaje. Del mito a la realidad. Madrid: Biblioteca Nueva

FERNÁNDEZ-VALMAYOR, A., CRISTÓBAL, J., NAVARRO, A., FERNÁNDEZ-PAMPILLÓN, A., Merino Granizo, J., Peralta, M. y Roldán, Y. (2008). "El campus virtual en la universidad Complutense de Madrid" en PixelBit, revista de Medios y Comunicación, 32, pp. 55-65.

GONZÁlEZ-GÓMEZ, D., AIRADO, D., CAÑADA-CAÑADA, F., y SU-JEONG, J. (2015). "A Comprehensive Application to Assist in Acid-Base Titration Self-Learning: An Approach for High School and Undergraduate Students” en Jounal of Chemical Education, 92, pp. 855-863.

GRIFFITHS, D., BLAT, J., GARCÍA, R. y SAYAGO, S. (2004). "La aportación de IMS Learning Design a la creación de recursos pedagógicos reutilizables" en Simposio SPDECE: Alcalá de Henares.

HASSNER, T., y BAYAZ, I. (2012). "Teaching computer vision: Bringing research benchmarks to the classroom" en ACM Transactions on Computing Education, 14, vol. 4, 22.

(c) EY-NC-ND 2018, Universitat Politècnica de València

Congreso IN-RED (2018) 
LÓPEZ-ALONSO, C., MIGUEL, E. D. y FERNÁNDEZ-PAMPILLÓN, A. (2008). "Propuesta de integración de LAMS en el marco conceptual del espacio de aprendizaje socio-constructivista E-Ling” en European LAMS Conference.

LÓPEZ, M. V., PÉREZ, M. C. Y RODRIGUEZ, L. (2011). "Blended learning in higher education: Students' perceptions and their relation to outcomes" en Computers \& Education, 56, pp. 818-826.

LÓPEZ-ALONSO, C. y SÉRÉ, A. (2005). "GALANET: una plataforma de enseñanza multimedia interactiva para la intercomprensión en lenguas románicas" en Santos-Rios, L. Palabras, norma, discurso: en memoria de Fernando Lázaro Carreter. Salamanca: Universidad de Salmanca.

MINISTERIO DE EDUCACIÓN, CULTURA Y DEPORTES (2003). La integración del sistema universitario español en el espacio europeo de enseñanza superior. Documento Marco.

$<$ http://www.eees.ua.es/conferencias/Documento-Marco_10_Febrero.doc $>$ [Consulta: 23 de marzo de 2018].

MINISTERIO DE EDUCACIÓN Y CIENCIA (2006). Propuestas para la Renovación de las Metodologias Educativas.

$<$ http://univ.micinn.fecyt.es/univ/ccuniv/html/metodologias/docu/PROPUESTA_RENOVACION.pdf $>$ [Consulta: 23 de marzo de 2018].

MONTI, S., SAN VICENTE, F. y PRETI, V. (2006). "Characteristics and Capacity of elearning platforms for learning languages" en eLearning papers, 1.

$<$ http://www.elearningpapers.eu/index.php> [Consulta: 10 de marzo de 2018].

PRENDES, M.P. (Dir.) (2009). "Plataformas de campus virtual de software libre: Análisis comparativo de la situación actual en las universidades españolas". Informe del Proyecto EA-2008-0257 de la Secretaría de Estado de Universidades e Investigación.

$<$ http://www.um.es/campusvirtuales/informe.html > [Consulta: 10 de marzo de 2018].

REGUERAS, L. M., VERDU, E., MUNOZ, M. F., PEREZ, M. A., DE CASTRO, J. P., y VERDU, M. J. (2009). "Effects of competitive E-Learning tools on higher education students: A case study" en IEEE Trans. Educ., 52, vol. 2, pp. 279-285.

SCOPEO (2011). “Aproximación pedagógica a las plataformas open source en la universidad española", Marzo de 2011. Monográfico SCOPEO, nº 2.

$<$ http://scopeo.usal.es/wp- content/uploads/2013/04/scopeom002.pdf $>$ [Consulta: 20 de marzo de 2018].

WOODS, R., JASON, D. B., y HOPPER, D., (2004). "Hybrid structures: faculty use and perception of web-based courseware as a supplement to face-face instruction" en The Internet and Higher Education, 7, pp. 281-297.

ZAPATA, M. (2003). "Sistemas de gestión del aprendizaje - Plataformas de teleformación". Revista de Educación a Distancia, [S.1.].

$<$ http://revistas.um.es/red/article/view/25661>> [Consulta: 23 de marzo de 2018].

(c)) EY-NC-ND 2018, Universitat Politècnica de València

Congreso In-Red (2018) 


\title{
Imagen digital en Anatomía Patológica: desde el diágnóstico a la docencia y la investigación
}

\author{
Luis Alfaro Ferreres ${ }^{\text {a b c }}$, M $^{\mathrm{a}}$ José Roca Estellés $^{\mathrm{b}}$ y Carlos Pascual Roca \\ ${ }^{\mathrm{a}}$ Universidad CEU-Cardenal Herrera. Castellón, ${ }^{\mathrm{b}}$ Hospital 9 de Octubre. Valencia y ${ }^{\mathrm{c}}$ FISABIO \\ Oftalmología Médica. Valencia
}

\begin{abstract}
Pathology is the part of medicine performing diagnosis of diseases from the study of samples of patients' injuries. The basis of the diagnosis is the recognition and interpretation of the morphological alterations that diseases induce in the tissues and in the cells of the organism. There is an initial part, with the macroscopic study of the excised samples: biopsies and surgical specimens and a second with the microscopic analysis of the lesions. This process can now be done from the study of the digitized images of macroscopic and microscopic lesions. Pathology laboratories with a digital organization generate a huge amount of images with great value in teaching and research. To transfer these images from a hospital environment we have developed a web-based query system from hospital databases that are exported to MySQL and available from an Apache web server (XAMPP) where query forms are generated, through which students and researchers access all images of different pathologies. The system allows continuous updating and the potential integration of images from different sources
\end{abstract}

Keywords: digital image, pathological anatomy, image biobank, portability.

\section{Resumen}

La Anatomía Patológica se encarga del diagnóstico de las enfermedades a partir del estudio de muestras de la lesiones de los pacientes. La base del diagnóstico es el reconocimiento y la interpretación de las alteraciones morfológicas que las enfermedades inducen en los tejidos y en las células del organismo. Hay una parte inicial, con el estudio macroscópico de las muestras extirpadas: biopsias y piezas quirúrgicas y una segunda con el análisis microscópico de las lesiones. Este proceso en la actualidad se puede realizar a partir del estudio de las imágenes digitalizadas de las lesiones macroscópicas y microscópicas. Los servicios hospitalarios de Anatomía Patológica con una organización digital generan una enorme cantidad de imágenes con gran valor en la docencia y en la investigación. Para transferir estas imágenes desde entorno hospitalario hemos generado una un sistema de consulta en formato web a partir de las bases de datos hospitalarias que son exportadas a MySQL y accesibles desde un servidor web Apache (XAMPP) donde se generan los formularios de consulta a través de los cuales los 
estudiantes e investigadores acceden a la imágenes de las diferentes patologías. El sistema permite la actualización continua y la incorporación potencial de imágenes de diferente procedencia.

Palabras clave: imagen digital, anatomía patológica, bancos de imágenes, portabilidad.

\section{Introducción}

Los servicios hospitalarios de Anatomía Patológica están inmersos en un proceso progresivo de digitalización (Salas, 2009) que afecta diferentes ámbitos como la trazabilidad de las muestras, el diágnótico remoto (Alfaro, 2008), el control de calidad (Wei, 2014) y la sustitución de los microscopios por ordenadores que proyectan imágenes escaneadas a máximo aumento de las preparaciones microscópicas. El estudio macroscópico de las biopsias y piezas quirúrgicas está evolucionando, desde las clásicas descripciones narrativas en textos adjuntos a los informes, hacia la documentación fotográfica completa de todos los especímenes. Esta organización digital genera bancos de imágenes, que tienen un gran valor docente $\mathrm{y}$ un potencial aprovechamiento en investigación (ESR, 2015).

Por otro lado, la docencia universitaria en Anatomía Patológica ha adoptado sistemas digitales incluso con anterioridad a los hospitales (Poblet, 2013). La organización de seminarios y prácticas se ve agilizada cuando las salas de microscopios en las universidades se sustituyen por salas de ordenadores. Los estudiantes se manejan con facilidad en el uso de imágenes digitales, mientras que el aprendizaje del uso de los microscopio requiere un tiempo muy superior. Las preparaciones microscópicas tradicionales en portaobjetos de cristal tienen riesgo de rotura, pierden con el tiempo parcialmente la intensidad de tinción y requieren un elevado número de cortes en función del número de estudiantes y de microscopios. La imágenes digitales solucionan estos problemas y facilitan la interacción con el profesor.

Para los investigadores el acceso a patologías concretas, la identificación de procesos degenerativos, infecciosos o neoplásicos se facilita cuando existen bancos de imágenes digitales (Martínez, 2017) que permiten una clasificación exacta de las lesiones. El empleo de tejidos para técnicas moleculares de detección de mutaciones o secuenciación, requiere una selección precisa del tipo de lesión e incluso identificación exacta del área afecta, que las imágenes digitales aportan con detalle. Incluso en el propio proceso asistencial de diagnóstico primario, el acceso a imágenes de lesiones infrecuentes agiliza y facilita dicho diagnóstico.

En los últimos 10 años los servicios de Anatomía Patológica de los hospitales Vithas-Nisa 9 de Octubre y Virgen del Consuelo de Valencia y Rey don Jaime de Castellón han generado 
en el curso de su actividad asistencial un banco de imágenes digitales macro y microscópicas superior a las 500.000 .

\section{Objetivos}

El aprovechamiento en docencia e investigación de este banco de imágenes hospitalarias se planteó con las siguientes premisas:

- El sistema debía desarrollarse en un entorno web para la máxima facilidad de acceso.

- La imágenes deben estar anonimizadas sin información de filiación de los pacientes.

- Las imágenes deben estar relacionadas con la información clínica de las bases de datos hospitalarias con indicación del diagnóstico anatomopatológico, topografía de las lesiones y datos de edad y sexo de los pacientes.

- El sistema debe ser capaz de importar imágenes de diferentes hospitales con una actualización continua

- $\quad$ El sistema debe ser preferiblemente portable para su traslado e incorporación de imágenes externas

- Las consultas a las bases de datos deben hacerse a través de un formulario que incorpora los datos tabulados en las bases de datos

- La respuestas a las búsquedas del formulario deben aportar las imágenes que cumplan los criterios solicitados y presentarse en forma de iconos de pequeño tamaños enlazados con las imágenes a alta resolución.

\section{Desarrollo de la Innovación}

El sistema de información de Anatomía Patológica de nuestros hospitales cuenta con dos bases de datos. El sistema de información hospitalario (HIS) y el sistema de información propio del servicio. La primera de ellas por su propia naturaleza global no es adecuada para ser la fuente de conexión al banco de imágenes. La base de datos del servicio de Anatomía Patológica tiene la ventajas de incorporar todos los diagnósticos anatomopatológicos que lógicamente se generan en el propio servicio. Integra una numeración propia que comparte con el número de identificación de las imágenes. Está diseñada en tablas Access por lo que su manejo no requiere elevados conocimientos informáticos. A partir de esta base de datos Access se obtenían tablas html a las que se incorporaba un sencillo sistema de búsquedas basado en javascript:

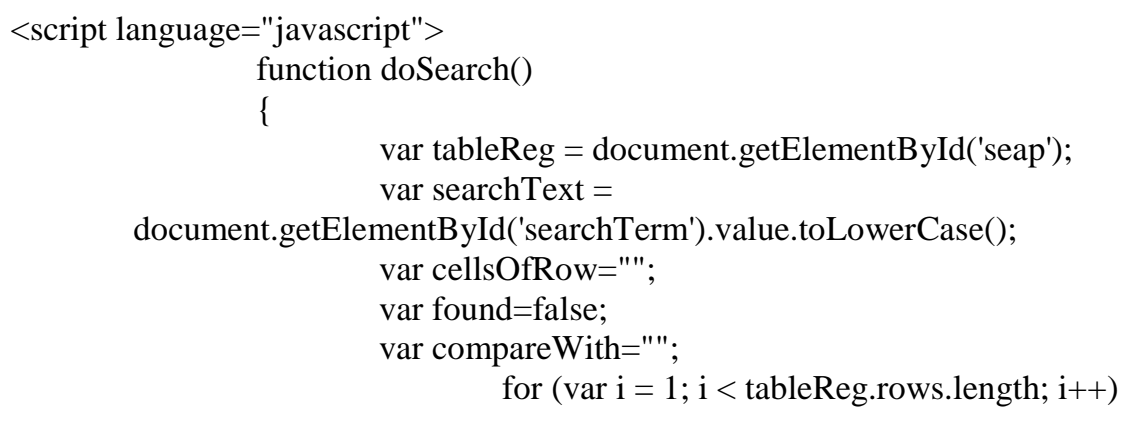


tableReg.rows[i].getElementsByTagName('td');

$$
\text { cellsOfRow }
$$

$$
\text { found = false; }
$$

for (var $\mathrm{j}=0$; $\mathrm{j}<$ cellsOfRow.length \&\& !found; $\mathrm{j++}$ )

\{

compareWith = cellsOfRow[j].innerHTML.toLowerCase();

if ( searchText.length $==0 \|($ compareWith.indexOf(searchText) $>-1)$ )

found = true;

\}

\}

$$
\text { found = true; }
$$

if(found)

\{

tableReg.rows[i].style.display = ";

\} else \{

tableReg.rows[i].style.display = 'none'; \}

\}

\}

$</$ script $>$

La tabla incorpora un pequeño cuadro de búsqueda con esta definición en HTML:

$<$ form $>$ $</$ form $>$

Buscar <input id="searchTerm" type="text" onkeyup="doSearch()" />

En un entorno médico, con bajo nivel de conocimiento en tecnologías de información, la sencillez del código de búsqueda, aunque no sea creado por los propios patólogos, es aprovechable de una manera directa sin necesidad de depender de personal especialidado.

El crecimiento del banco de imágenes limitó esta funcionalidad a subgrupos del total de imágenes con características determinadas. Para el manejo simultáneo de todas las imágenes se hizo necesario contar con una base de datos tipo MySQL (Roca, 2017). La conversión de las tablas de Access a MySQL se hizo con el software Access to MySQL de Bullzip. Durante el procedimiento se seleccionaban los campos de interés, excluyéndose el nombre de los pacientes.

Con la idea de conseguir un sistema completamente portable se utilizo un disco duro externo de 2,5" con una capacidad de 4 TB que permite almacenar la totalidad de las 500.000 imágenes y los thumbnails de cada una de ellas asi compo el servidor Apache en una versión portable (XAMPP). Los thumbnails de las imágenes se crearon con el programa XnView y con un tamaño de 250x150 pixeles (Fig. 1).

(cc)) EY-NC-ND 2018, Universitat Politècnica de València 


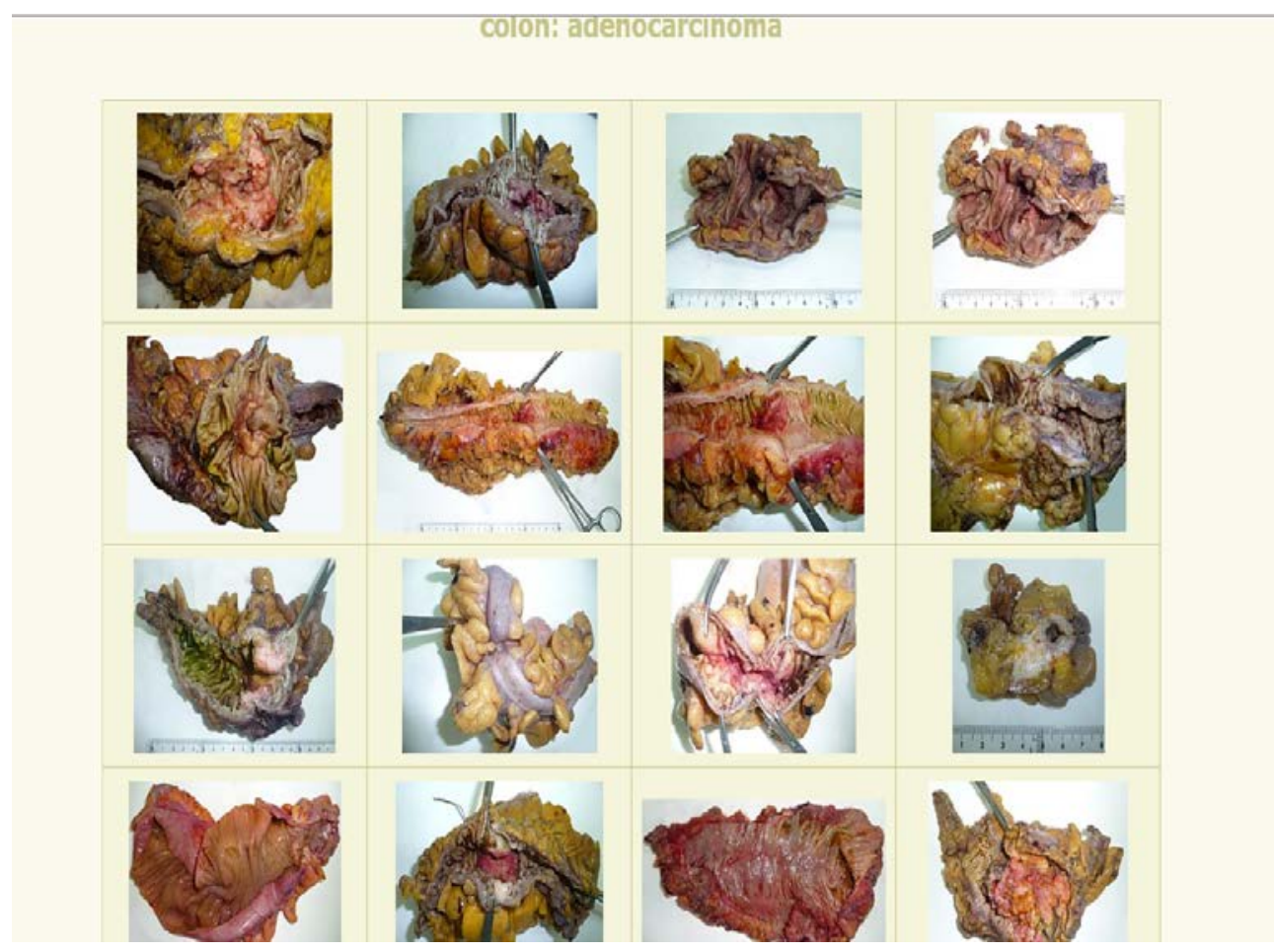

Fig. 1.- Ejemplo de presentación de imágenes macroscópicas de adenocarcinoma de colon.

El formulario de consulta a la bases de datos fue generado por uno de nosotros (C.P.R.) utilizando php como lenguaje de programación (Fig. 2). Para ello se tuvo en cuenta la ubicación de la imágenes en carpetas distribuidas por años y en subcarpetas que almacenan cada una un millar de casos. Por convención las imágenes macroscópicas se numeran con dos dígitos correspondiste al año seguido de un guión y el número del caso. Cuando hay más de una imagen por caso se añaden secuencialmente letras de manera alfabética. Las imágenes microscópicas se numeran de la misma manera pero anteponiendo el número del caso y la letra de número de orden, seguidas de un guión y los dos dígitos del año. Las imágnes de técnicas especiales de histoquimia, inmunohistoquímica, fluorescencia, etc. conservan el número del caso, al que se añade un sufijo que indica el tipo de técnica que expresan 


\section{Imágenes Anatomopatológicas}

Formulario de consulta

Conected to database

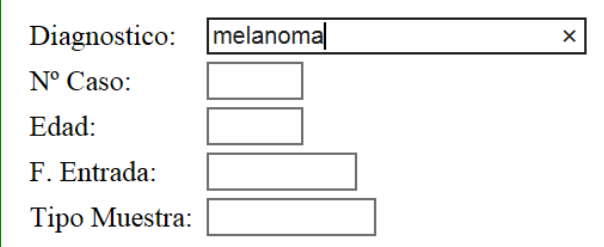

Tipo Muestra:

Fig. 2.- Formulario web de consulta al banco de imágnes.

\section{Resultados}

La presentación de resultados a partir del formulario de consulta muestra la colección de imágenes que cumplen los criterios de búsqueda en una pagina web con los thumbnails de cada caso, el diagnóstico completo de la lesión, el hospital de origen y el tipo de lesión (Fig. 3). Cuando el número de casos/imágenes es muy elevado, se generan automáticamente diversas páginas web ordenadas, conteniendo una distribución parcial de las imágenes en cada una de ellas hasta completar la totalidad. Cada thumbnail presentado está enlazado y muestra al pulsar sobre él la imagen original a alta resolución. 


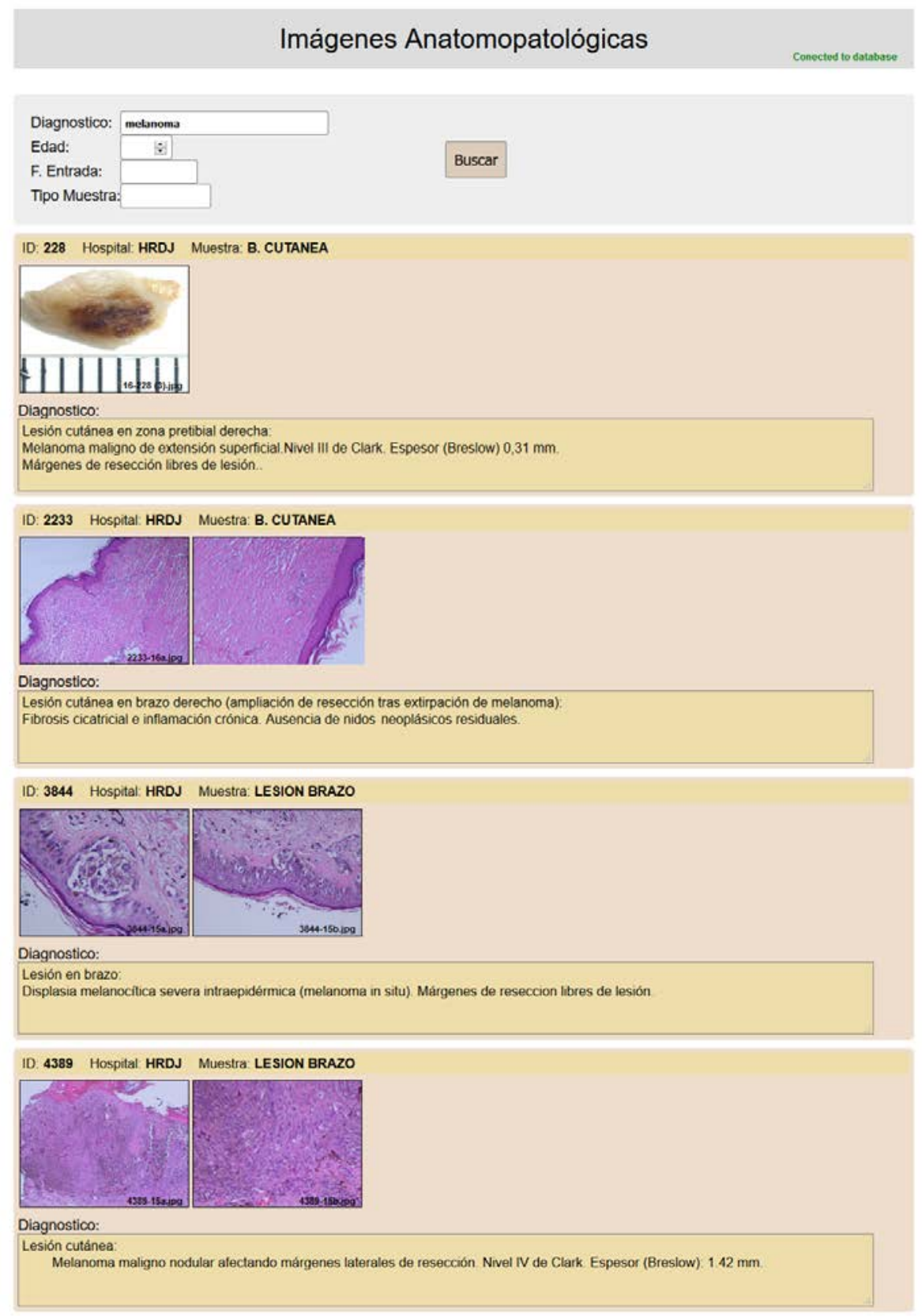

Fig. 3. Resultados de un ejemplo de busqueda de imágenes de melanoma cutáneo.

\section{Conclusiones}

El sistema descrito de gestión de imágenes permite aprovechar el enorme valor de nuestros archivos gráficos.

(c) ) EY-NC-ND 2018, Universitat Politècnica de València 
En la práctica diaria para un patólogo la revisión de las imágenes de casos previos es más informativa que la revisión del texto del informe ya que muestra los datos morfológicos que sustentan el diagnóstico, en lugar de la información orientada a los clínicos donde priman los criterios de categorización con información pronóstica y orientación terapéutica.

El aprovechamiento docente tanto para técnicos (macroscopía, citología...), (Gallardo, 2017) como para estudiantes pregrado justifica por sí solo la creación de estas colecciones. El gran número de casos disponibles abarca prácticamente la totalidad de las patologías, mostrando de cada categoría diagnóstica el espectro de variación morfológica posible. Los estudiantes tienen posibilidad de familiarizarse con las diferentes patologías accediendo a un gran número de lesiones de todas las ramas de la patología.

Nuestra experiencia aplicada progresivamente en los 6 últimos años en Anatomía Patológica en el grado de Medicina en la Universidad CEU Cardenal Herrera de Castellón, nos confirma la excelente adaptación de los estudiantes, el incremento de número de casos que pueden ser explicados en los seminarios y las prácticas, en relación con la metodología clásica de aulas con microscopios y proyectores, y el gran valor adicional para los estudiantes que representa el acceso a las imágenes desde cualquier ubicación y en cualquier horario.

El estudio retrospectivo de casos en investigación permite la revisión de un elevado número de casos en un tiempo muy reducido. La aplicación de nuevas tecnologías permite seleccionar con precisión los casos concretos que cumplen los criterios diseñados para cada investigación y seleccionar subcategorias con rasgos que van más allá de los que tienen interés clínico para ser mencionados en los informes de diagnóstico anatomopatológico. La selección retrospectiva de bloques de tejido en los estudios de biología molecular para extraer ADN/ARN permite seleccionar exactamente las neoplasias de más interés conociendo con más precisión la de carga tumoral en relación al estroma tisular, el componente inflamatorio o el grado de necrosis, que son factores que pueden alterar el resultado de las técnicas moleculares, si no se escogen las zonas concretas representativas de la celularidad tumoral.

El diseño portable y el entorno web hace posible exportar el sistema a cualquier banco de imágenes en un tiempo muy reducido. Basta con reconfigurar la distribución de las imágenes, hacer compatible la numeración de las mismas con los criterios de búsqueda programados y exportar la bases de datos original a MySQL.

\section{Referencias}

ALFARO FERRERES, L. y ROCA ESTELLÉS, M.J. (2008). "Portable Telepathology: Methods and Tools". Diagnostic Pathology, Vol. 3 (Suppl. 1), p. 19-21.

European Society of Radiology (ESR). (2015). “ESR Position Paper on Imaging Biobanks. Insights”. Imaging. 2015. Vol. 6, issue 4, p. 403-10.

$<$ https://www.ncbi.nlm.nih.gov/pmc/articles/PMC4519817/> [Consulta: 20 de marzo de 2018].

GALlARDO SANZ, B., ALFARO FERRERES, L., DOMÍNGEZ RECOBERT, M. y HUART PERIS, M.C., (2017) "Beneficios de la fotografía microscópica en la mejora del diagnóstico en la

(cc) EY-NC-ND 2018, Universitat Politècnica de València

Congreso IN-RED (2018) 
citología ginecológica” en $28^{\circ}$ Congreso Nacional de la Sociedad Española de Anatomía Patológica. Valencia.

MARTÍNEZ, J. (2017). "Biobancos con fines de investigación biomédica y Bancos de imágenes“ en VI Curso de Patología Digital. Valencia FISABIO Oftalmología Médica $<$ http://digipat.org> [Consulta: 20 de marzo de 2018].

POBLET MARTÍNEZ, E., MORO RODRÍGUEZ, E., ALFARO FERRERES, L. (2013). “Patología digital y docencia” en: Libro Blanco de la Anatomía Patológica en España (C) SEAP, págs. 105-109.

ROCA ESTELLÉS, M.J., ALFARO FERRERES, L. y PASCUAL ROCA, C. (2017).

"Bancos de imágenes digitales en anatomía patológica. Metodología y aplicaciones" en $28^{\circ}$ Congreso Nacional de la Sociedad Española de Anatomía Patológica. Valencia.

SALAS VALIEN, J.S., GARCÍA ROJO, M. y ALFARO FERRERES, L. (2009).

“Tecnología de la Información en los Servicios de Anatomía Patológica” en: Libro Blanco de la Anatomía Patológica en España @ SEAP; págs: 185-194.

WEI B.R. y SIMPSON R.M. (2014). "Digital pathology and image analysis augment biospecimen annotation and biobank quality assurance harmonization”. Clin Biochem. vol, 47 issue 4-5, p. 274-9 https://www.ncbi.nlm.nih.gov/pmc/articles/PMC4975042/ [Consulta: 20 de marzo de 2018]. 


\title{
Padlet: el uso de la pizarra colaborativa on-line en estudios de grado
}

\section{Francesc A. Esteve-Turrillas, Sergio Armenta}

Departamento de Química Analítica, Universitat de València, Edificio Jeroni Muñoz, c/ Dr. Moliner 50, 46100 Burjassot, España (francesc.a.esteve@uv.es, sergio.armenta@uv.es)

\begin{abstract}
This communication shows two applications of the padlet virtual board to develop both specific and transversal skills in the study of Degree in Chemistry and Degree in Food Science and Technology. The use of virtual walls allows students to select and expand content related to the subject, as well as facilitate the divulgation and comment of these in a common place to all students of the subject. Finally, data on the utility and degree of satisfaction obtained through an opinion survey were included.
\end{abstract}

\section{Keywords: Padlet, virtual wall, collaborative blackboard, active learning.}

\section{Resumen}

En la presente comunicación se muestran dos aplicaciones del empleo de la pizarra virtual padlet para desarrollar competencias tanto específicas como transversales en estudio de Grado en Química y Grado en Ciencia y Tecnología de los Alimentos. El empleo de pizarras virtuales permite el alumno seleccionar y ampliar contenidos relacionados con la asignatura, así como facilitar la divulgación y el comentario de estos en un lugar común a todos los alumnos de la asignatura. Finalmente, se incluyen datos de la utilidad y grado de satisfacción obtenidos a través de una encuesta de opinión.

Palabras clave: Padlet, muro virtual, pizarra colaborativa, aprendizaje activo.

\section{Introducción}

El desarrollo tecnológico y las nuevas formas de comunicación obligan a un replanteamiento de la práctica docente. Cada vez aumenta en mayor grado el espacio dedicado a las tecnologías digitales de la información y la comunicación en los procesos educativos universitarios, siendo necesarias una readaptación continua de los procesos de enseñanza aprendizaje, así como nuevas funciones y roles para el profesorado y los estudiantes (Palomo-López, 2007). Con todo ello, no se pretende, de ninguna forma, introducir procesos más sofisticados y/o complejos, sino de adaptarse a la forma de pensar y actuar de los estudiantes actuales a la vez que se valoran las posibilidades didácticas de diferentes herramientas didácticas disponibles en la actualidad. Debemos por tanto, plantearnos la siguiente reflexión ¿Qué se entiende por aprendizaje, cómo se produce y cómo podemos mejorarlo mediante el uso de herramientas tecnológicas? Está claro, que el 
estudiante universitario actual, gracias a internet, tiene a su disposición (inmediata) más información de la que puede procesar, por tanto, los procesos de enseñanza/aprendizaje no deberían estar tan centrados en facilitar la información sino dotar al estudiante de las herramientas adecuadas para procesar dicha información, consiguiendo que los estudiantes tengan un espíritu crítico que les permita seleccionar, procesar, analizar y sacar conclusiones de la información que tiene a su alcance. Este cambio en los objetivos supone un cambio del papel del profesor y también del alumno. El primero deja de ser un mero transmisor de conocimiento y pierde protagonismo en favor del estudiante, que deja de ser un sujeto pasivo, con un papel puramente receptivo, para tener ahora un papel mucho más activo en el proceso de enseñanza aprendizaje. En este sentido desplazamos el foco de la enseñanza y nos centramos en el aprendizaje (Bergman et al., 2014).

Una de las herramientas digitales que facilita este cambio de visión es el uso de murales o pizarras digitales. Estas pizarras virtuales se construyen empleando una metodología socioconstructivista en la que se promueve la colaboración frente a la competencia, las redes de trabajo (networks) frente al individualismo, que les permita alcanzar las competencias básicas y además las trasversales. De esta forma se pretende fomentar el aprendizaje activo, por descubrimiento y significativo que permita adaptarse a las necesidades educativas del alumnado.

Existen varias herramientas en la actualidad para realizar murales o pizarras virtuales entre las que podemos destacar Prezi, Smore, Pooplet, Mural.ly, Padlet, Lino o Glogster (Hernández et al., 2014).

En esta comunicación se ha utilizado Padlet como herramienta educativa para crear pizarras virtuales, brindando la posibilidad de cargar y compartir diversos contenidos multimedia como esquemas, imágenes, audios y videos en un muro de entorno digital. La herramienta contribuye a la creación de contenidos de forma colaborativa, funcionando como pizarra virtual (Gonzalez-Frías et al., 2015). La aplicación ofrece un panel en blanco fácilmente configurable en función de las necesidades y propósitos docentes de cada asignatura. En dicho panel, tanto profesor como alumnos pueden puede seleccionar los elementos que desean guardar, que pueden ser de diferentes formatos: imágenes, videos, caricaturas, archivos doc o pdf, etc. de creación propia o encontrados en internet. Por tanto, padlet puede considerarse una herramienta de edición abierta orientada a la construcción colaborativa de contenidos.

Una de las ventajas claras que aporta padlet es la generación de contenidos mediante trabajo coordinado y su facilidad de actualización y revisión permanente. Además de ser un espacio de trabajo colaborativo, las pizarras creadas en padlet pueden considerarse como objetos de múltiple autoría, de forma que los propios estudiantes sean los creadores de conocimiento.

\section{Objetivos}

El objetivo principal de esta comunicación es crear una pizarra virtual en la que tanto estudiantes como profesor puedan intercambiar información, ideas, imágenes y videos 
fomentando el aprendizaje activo y colaborativo. En dicha pizarra interactiva los estudiantes tendrán a su disposición información generada por ellos mismos que les facilitará alcanzar los resultados de aprendizaje definidos en las guías docentes de las asignaturas. Este objetivo principal se puede dividir en los siguientes objetivos específicos:

- Saber utilizar Internet para buscar información y recursos en la preparación de las clases y complementar los contenidos de la asignatura.

- Conocer páginas de Internet (portales, páginas web, revistas electrónicas, diccionarios, buscadores...) relativos a su especialidad y compartirlos con sus compañeros para crear un temario específico de la asignatura en la que ellos contribuyen en la búsqueda de contenidos.

- Fomentar el empleo de nuevas herramientas disponibles en Internet para comunicarse con sus compañeros (correo electrónico, listas de distribución, foros...) y crear un entorno educativo común con sus compañeros.

\section{Desarrollo de la innovación}

\subsection{Química General II - Grado en Química}

\subsubsection{Contexto de aprendizaje}

La asignatura de Química General II se imparte en el segundo cuatrimestre del primer curso del grado en Química. El número de estudiantes matriculados es de 220-240 divididos en cuatro grupos de 60 estudiantes aproximadamente. Respecto a los resultados académicos cabe destacar que el porcentaje de estudiantes aprobados respecto a matriculados es de $56 \%$ en el periodo comprendido entre 2010-17, siendo el 59\% el correspondiente al año 20162017. La asignatura incluye 51 horas de clases de teoría, 9 horas de tutorías regladas, 12 horas de elaboración de trabajos en grupo, 54 horas de estudio y trabajo autónomo y 24 horas de preparación de actividades de evaluación.

\subsubsection{Contenidos de la asignatura}

La descripción de los contenidos de la asignatura Química General II es la siguiente, conforme se indica en la Guía Docente de la asignatura:

Tema 1. Energía de las reacciones químicas

Tema 2. La dirección del cambio químico

Tema 3. El equilibrio en las reacciones químicas

Tema 4. Cambios de estado de sustancias puras

Tema 5. Disoluciones

Tema 6. Equilibrio ácido-base

Tema 7. Equilibrios de formación de complejos

Tema 8. Equilibrios de solubilidad 
Tema 9. Equilibrios de oxidación-reducción

Tema 10. La velocidad del cambio químico

\subsubsection{Descripción de la tarea}

Se ha creado una pizarra virtual usando Padlet para almacenar, visualizar y comentar videoresúmenes, de dos minutos de duración, creados por los propios estudiantes (distribuidos en grupos) de los diferentes temas de la asignatura. Esta tarea se ha realizado siguiendo el esquema propuesto:

- Clases magistrales participativas (dependiendo del tema seleccionado el número de sesiones puede variar entre 3-6).

- Seminario, donde el docente explica el interés de la creación de un mural virtual para añadir los video-resúmenes de los diferentes temas de la asignatura y la posibilidad de comentar y discutir los videos generados. En esta sesión, se explica y se definen claramente los objetivos de la tarea y los resultados esperados junto con la evaluación de dichos video resúmenes.

- Tutorías grupales (mínimo 2/3 sesiones), seguimiento del proceso de realización del video y comentario de las discusiones generadas en la pizarra virtual.

- Seminario, visionado y evaluación de los video-resúmenes finales.

La evaluación del/los objeto/s generados se realizará mediante rúbricas. De esta forma se pretende que los alumnos sean conocedores de los diferentes niveles de cumplimiento de la actividad o de parte de ella, desde lo considerado como insuficiente hasta lo excelente. La evaluación de dicha actividad forma parte de la evaluación de las sesiones de tutorías grupales, seminarios y elaboración de trabajos. El porcentaje en el que la actividad expuesta contribuye a la nota final es un 25 \%, que se obtendrá como media de la evaluación del profesor y la evaluación del resto de grupos (compañeros de clase).

Adicionalmente, se han realizado encuestas tanto a los estudiantes como a los docentes para establecer el grado de satisfacción con la pizarra creada así como la utilidad de los materiales elaborados.

\subsubsection{Resultados de la actividad y grado de satisfacción}

A continuación se muestran parte de los resultados obtenidos durante la preparación del material definitivo, junto con el número de alumnos implicados en la actividad y su grado de participación.

En el Padlet creado por los estudiantes de la asignatura Química General II (ver Figura 1) se ha optado por crear un mural distribuido en columnas en los que debajo de cada columna se pueden encontrar los video-resúmenes creados por los estudiantes de los diferentes cursos (2016/17 y 2017/18), además de otra columna en los que se han añadido ejemplos representativos de la actividad en cuestión obtenidos de YouTube.

Los alumnos han realizado un total de 9 video-resúmenes; 2 del tema 1 (Energía de las reacciones químicas), 2 del tema 2 (La dirección del cambio químico), 1 del tema 3 (El

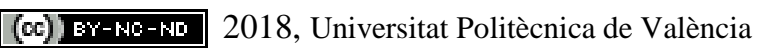

Congreso IN-RED (2018) 
equilibrio en las reacciones químicas), 1 del tema 4 (Cambios de estado de sustancias puras) y 3 del tema 5 (Disoluciones).

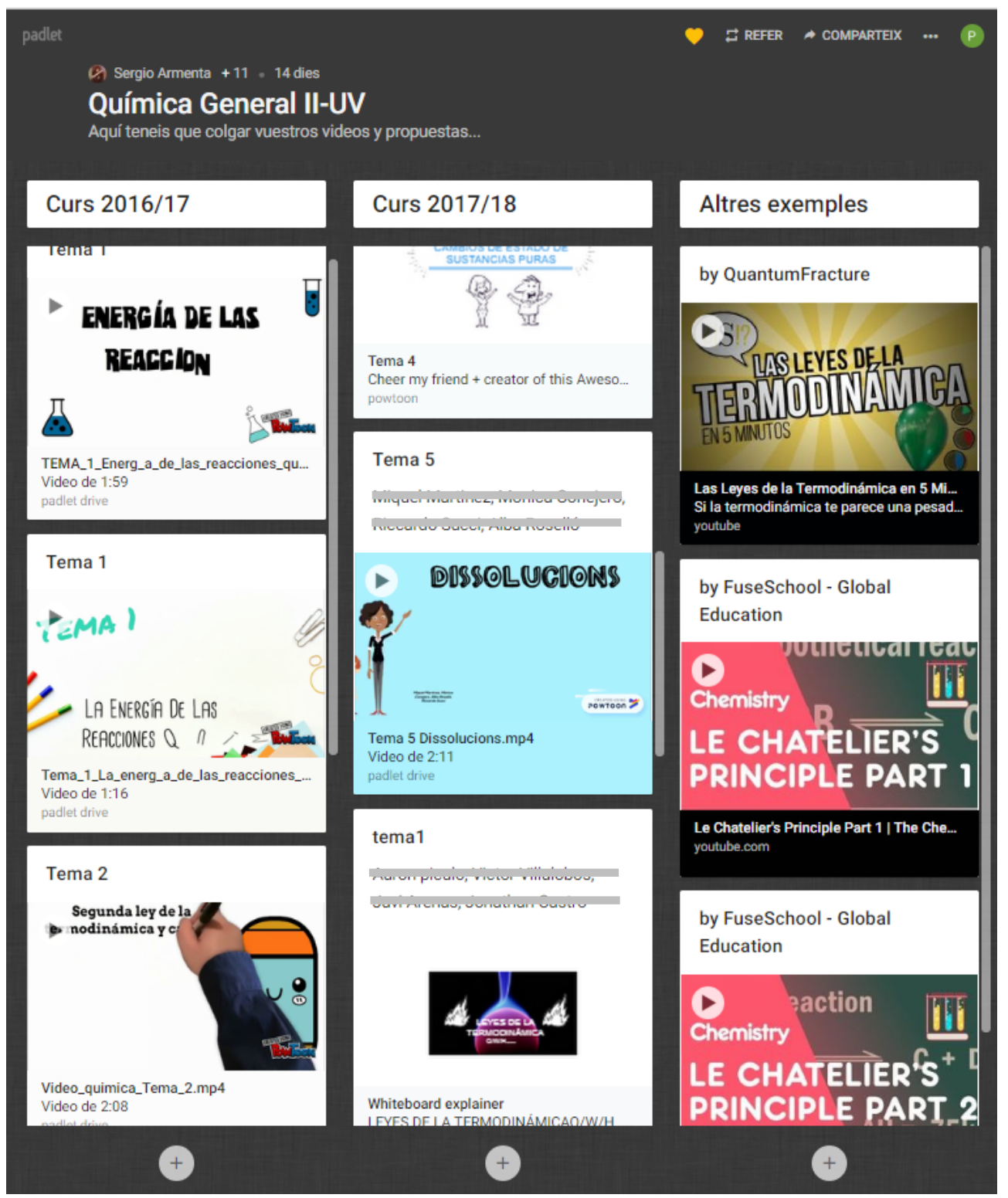

Fig. 1 Esquema de los diferentes video-resúmenes generados ordenados en función del curso.

Para conocer el grado de satisfacción de los estudiantes con la actividad realizada se les pasó al final de la misma una encuesta de evaluación con las preguntas que se pueden observar en la Tabla 1.

El tiempo dedicado por la mayoría de los alumnos (72\%) para la realización de los microvideos fue de 5 a 10 horas, mientras que un $22 \%$ empleó de 2 a 5 horas y un 6 \% más de 10 horas. En cuanto al tiempo dedicado al visionado de videos realizados por sus 
compañeros la mayoría de los alumnos emplearon de 10 a 30 min (50\%) y entre 30 y 60 min (22\%), mientras que un leve 3\% dedicó más de 1 hora al visionado de videos de compañeros. Sin embargo un 25 \% manifestó haber empleado menos de 10 minutos indicando un mínimo interés por la participación en dicha actividad. Respecto a la utilidad de los videos disponibles en el padlet de la asignatura, la gran mayoría de los alumnos indicaron que les había ayudado algunas veces (50\%) y muchas veces (38\%) en la mejor comprensión del tema correspondiente. La encuesta realizada indicó que el estudiante percibe muchas veces (23\%) y algunas veces (61\%) que la información está más accesible a través del empleo de pizarras virtuales, mientras que un $16 \%$ de los estudiantes no percibió mejora en la accesibilidad. El 57 \% de los alumnos encuestados nunca o casi nunca (23 \%) había utilizado pizarras electrónicas tipo padlet en alguna otra asignatura y el 80\% de ellos se muestra de acuerdo o totalmente de acuerdo en utilizarlas en otras asignaturas.

Tabla 1. Porcentaje de respuestas obtenidas en la encuesta realizada sobre la actividad.

\begin{tabular}{|c|c|c|c|c|}
\hline & $>10 h$ & $5-10 h$ & $2-5 h$ & $<2 h$ \\
\hline \multicolumn{5}{|l|}{$\begin{array}{l}\text { ¿Cuánto tiempo has dedicado a la } \\
\text { realización de vídeo? }\end{array}$} \\
\hline & $>1 \mathrm{~h}$ & $30-60 \mathrm{~min}$ & 10-30min & $<10$ min \\
\hline \multicolumn{5}{|l|}{$\begin{array}{l}\text { ¿Cuánto tiempo has dedicado al } \\
\text { visionado de vídeos de compañeros } \\
\text { publicado en padlet? }\end{array}$} \\
\hline & $\begin{array}{l}\text { Totalmente } \\
\text { de acuerdo }\end{array}$ & De acuerdo & En desacuerdo & $\begin{array}{c}\text { Muy en } \\
\text { desacuerdo }\end{array}$ \\
\hline \multicolumn{5}{|l|}{$\begin{array}{c}\text { ¿Crees que el microvideo ayuda a } \\
\text { comprender mejor este tema de la } \\
\text { asignatura? }\end{array}$} \\
\hline \multicolumn{5}{|l|}{$\begin{array}{l}\text { ¿Crees que la información está más } \\
\text { accesible en el muro virtual de padlet? }\end{array}$} \\
\hline \multicolumn{5}{|l|}{$\begin{array}{c}\text { ¿Emplearías pizarras electrónicas tipo } \\
\text { padlet en alguna otra asignatura? }\end{array}$} \\
\hline & $\begin{array}{l}\text { Muchas } \\
\text { veces }\end{array}$ & $\begin{array}{l}\text { Algunas } \\
\text { veces }\end{array}$ & Casi nunca & No nunca \\
\hline $\begin{array}{l}\text { ¿Has empleado con anterioridad algún } \\
\text { tipo de pizarra electrónica? }\end{array}$ & & & & \\
\hline
\end{tabular}

\subsection{Transformación y Conservación - Grado en Ciencia y Tecnología de los Alimentos}

\subsubsection{Contexto de aprendizaje}

Transformación y conservación es una asignatura obligatoria anual que se imparte en el segundo curso del Grado de Ciencia y Tecnología de los Alimentos que se imparte en la Facultad de Farmacia de la Universitat de València. La asignatura incluye 72 créditos ECTS distribuidos en 82 horas de teoría, 25 horas de prácticas de laboratorio, 4 horas de seminarios coordinados y 4 horas de tutorías presenciales. La asignatura se imparte con una frecuencia de 4 horas semanales en el primer semestre y 5 horas semanales en el segundo. El número de alumnos en el curso 2016-2017 fue de 38. La asignatura se imparte en un aula con asientos y mesas fijos con una capacidad de 120 personas.

\subsubsection{Contenidos de la asignatura}

2018, Universitat Politècnica de València

Congreso IN-RED (2018) 
Los contenidos que refleja la guía docente de la asignatura Transformación y Conservación se distribuyen en 8 bloques con un total de 27 temas.

Bloque 1. Introducción

Tema 1. Introducción a la tecnología de los alimentos

Tema 2. Causas de alteración de los alimentos

Tema 3. Las industrias de producción de alimentos

Tema 4. Operaciones de acondicionamiento de materias primas

Bloque 2. Operaciones de transformación de alimentos

Tema 5. Modificación de tamaño. Mezclado. Emulsificación

TEMA 6. Operaciones de separación

TEMA 7. Operaciones de modificación de la textura

Bloque 3. Métodos térmicos de conservación

Tema 8. Bases de la conservación de alimentos por el calor

Tema 9. Cálculo y ajuste del tratamiento térmico

Tema 10. Instalaciones para el tratamiento térmico y su aplicación

Bloque 4. Conservación de alimentos por frío

Tema 11. La refrigeración de los alimentos

Tema 12. Conservación de alimentos por congelación

Tema 13. Métodos y equipos de congelación de alimentos

Bloque 5. Conservación por depresión de la actividad de agua

Tema 14. Fundamentos sobre la depresión de la actividad de agua

Tema 15. Deshidratación de alimentos

Tema 16. Equipos e instalaciones de deshidratación de alimentos

Tema 17. Conservación por concentración

Bloque 6. Tecnologías emergentes de conservación

Tema 18. Conservación por atmósferas modificadas

Tema 19. Conservación por radiaciones ionizantes

Tema 20. Altas presiones hidrostáticas

Tema 21. Pulsos eléctricos de alto voltaje

Tema 22. Nuevas tecnologías de conservación

Bloque 7. Tecnología culinaria

Tema 23. El horneado y el asado

Tema 24: La fritura y el tostado

Tema 25. Microondas

Bloque 8. Envasado de alimentos

Tema 26. Sistemas de llenado y envasado de alimentos

Tema 27. Envases activos

(cc) EY-NC-ND 2018, Universitat Politècnica de València

Congreso In-Red (2018) 


\subsubsection{Descripción de la tarea}

En esta asignatura se ha empleado padlet como medio para publicar información relativa al procesado de alimentos en una pizarra virtual común a todos los estudiantes. Durante el desarrollo de la asignatura en las clases teóricas se imparten conocimientos relacionados con las operaciones necesarias para el acondicionamiento, conservación, cocinado y envasado de alimentos. En los últimos meses en que se imparte la asignatura resulta muy adecuado mostrar a los alumnos vídeos que muestren el proceso de elaboración de distintos alimentos, para indicar las variadas operaciones que se incluyen en el proceso completo y discutir su idoneidad y las ventajas o inconvenientes que presentan. En este sentido, el empleo de pizarras virtuales, como padlet, permite a los alumnos compartir videos (obtenidos principalmente a través de YouTube) relacionados con el procesado de alimentos. De esta forma los alumnos participan activamente en la elección del tipo de alimento a estudiar, lo que constituye una motivación extra a la hora de relacionar los contenidos de la asignatura con la fabricación de alimento propuesto. Adicionalmente, la plataforma padlet no solo permite incluir material multimedia, sino que también permite incluir comentarios de los videos que se han añadido, lo que permite al profesor proporcionar un feedback rápido al alumno y fomentar la discusión de los aspectos más relevantes.

El desarrollo de esta actividad se temporaliza en el segundo semestre, donde se realizan dos tutorías de una hora de duración cada una. En la primera tutoría se explica al alumno cual es el fundamento de la actividad propuesta, explicando detenidamente el funcionamiento de la herramienta padlet y las ventajas que presenta. A partir de ese momento, el profesor cuelga videos en el padlet común para que el alumno se familiarice con el empleo de esta pizarra electrónica y se fomenta que los alumnos realicen comentarios acerca de la temática expuesta en los videos. En esta etapa es donde se incita al alumno a participar activamente en la búsqueda y publicación de videos adicionales. Esto permite al profesor hacer referencia directa a los videos publicados por los alumnos, durante la impartición de las clases de teoría, relacionándolos con los contenidos teóricos que se imparten. La Figura 2 muestra el contenido de la pizarra electrónica padlet creada para la asignatura Transformación y Conservación en el curso 2017-2018.

\subsubsection{Resultados de la actividad y grado de satisfacción}

La evaluación del trabajo realizado en las tutorías del segundo semestre presenta un 5 \% de la nota final. La evaluación de esta actividad se centrará en la participación del alumno, tanto en la publicación de videos, como en el comentario de videos publicados por otros compañeros. Para obtener un aprobado en la actividad propuesta el alumno debe publicar al menos un vídeo y comentar un video de un compañero. La nota máxima se otorgará a aquellos alumnos que publiquen más de un video y realicen más de un comentario de videos de compañeros. En este caso el profesor puede actuar de moderador de la pizarra electrónica, eliminando aquellos videos improcedentes y comentando aquellos que no se ajusten al objetivo propuesto. Adicionalmente, se ha realizado una encuesta opcional (ver

(cc) EY-NC-ND 2018, Universitat Politècnica de València

Congreso IN-RED (2018) 
Tabla 1) para establecer el grado de evolución y el grado de satisfacción de los alumnos relacionado con el empleo de la pizarra electrónica padlet como medio de difusión de contenidos multimedia, siendo el número de encuestas recogidas 34 .

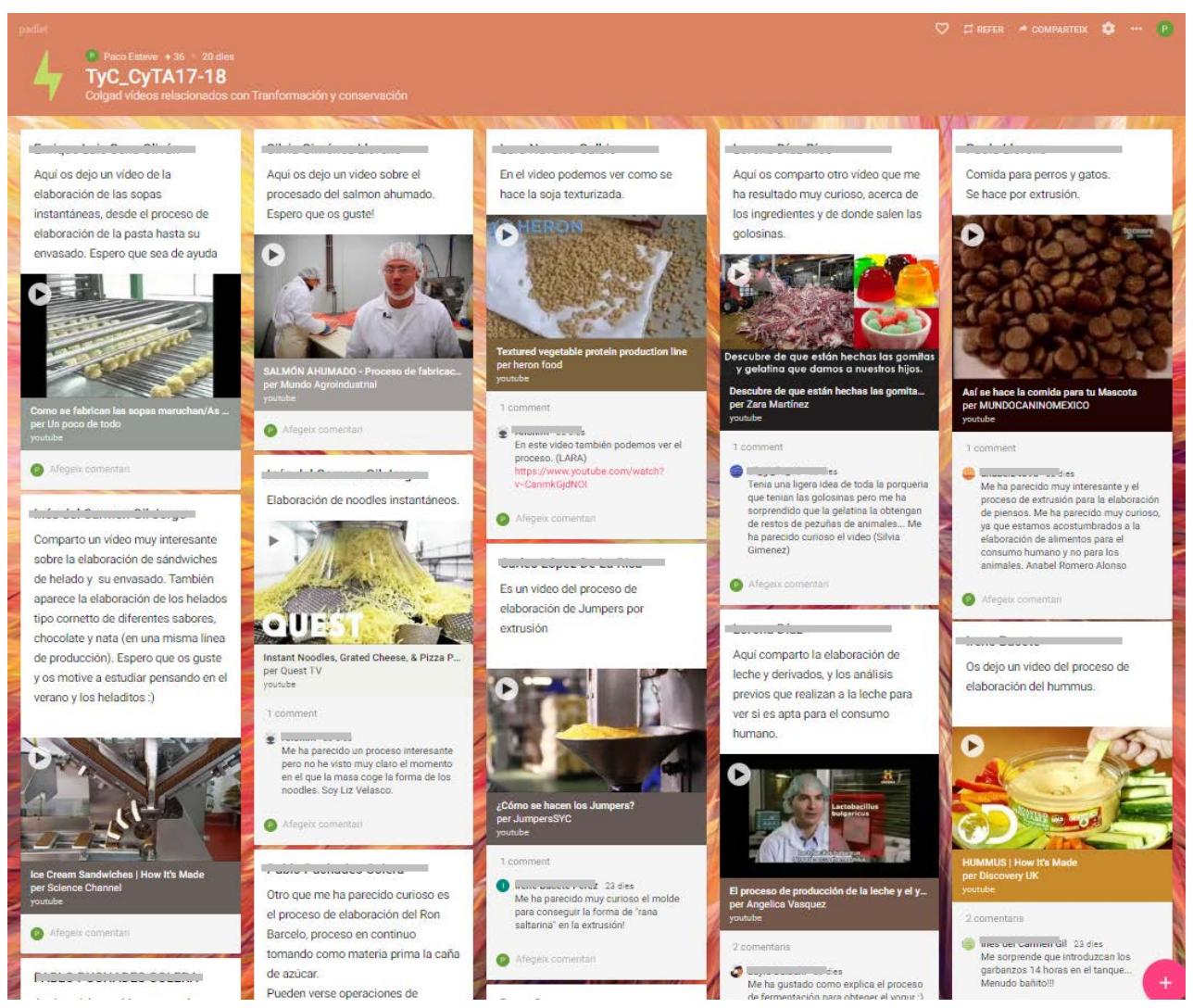

Fig. 2 Pizarra electrónica padlet creada para la asignatura Transformación y Conservación (https://es.padlet.com/paco_esteve_turrillas/TyC1718).

En primer lugar se observa que los tipos de dispositivos electrónicos más frecuentemente empleados para buscar contenidos en internet fueron el ordenador portátil y el Smartphone, siendo el Smartphone más empleado en la búsqueda de contenidos generales (45\%) y el portátil en la búsqueda de contenidos relacionados con el Grado en Ciencia y Tecnología de Alimentos (71\%). Respecto al lugar donde se buscan contenidos en internet cabe destacar el elevado porcentaje obtenido en casa tanto para las búsquedas de contenidos generales (70\%) como de contenidos relacionados con la asignatura (66\%); mientras en segundo lugar figura la Universidad (19 y 29 \%, respectivamente). El tiempo dedicado a la búsqueda de vídeos en internet relacionados con la fabricación de alimentos es menos de una hora para el 33\%, entre 1 y 2 horas para el 48\%, y más de 2 horas para el $18 \%$. Tiempos ligeramente inferiores se han dedicado al visionado de vídeos publicados en padlet por compañeros, menos de una hora para el 55\%, entre 1 y 2 horas para el $42 \%$, y más de 2 horas para solo un $3 \%$. Los alumnos también autoevaluaron su propio trabajo indicando tanto el número de videos publicados en el padlet como el número de comentarios de videos de compañeros. La gran mayoría publicó un video (76 \%) y un comentario (62 \%), 
mientras que un 24 \% publicó más de un video y un 33\% hizo más de un comentario. Cabe destacar que 2 alumnos (6\%) no hicieron ningún comentario a videos de compañeros, a pesar que era obligatorio para obtener el aprobado en esta actividad.

Tabla 2. Encuesta de grado de satisfacción de la actividad propuesta para la asignatura Transformación y Conservación.

\begin{tabular}{|c|c|c|c|c|}
\hline & PC & PC portátil & Tablet & Smartphone \\
\hline \multicolumn{5}{|l|}{$\begin{array}{l}\text { ¿Qué dispositivo electrónico empleas más } \\
\text { frecuentemente para buscar contenidos } \\
\text { generales en internet? }\end{array}$} \\
\hline \multicolumn{5}{|l|}{$\begin{array}{l}\text { ¿Qué dispositivo electrónico empleas más } \\
\text { frecuentemente para buscar contenidos en } \\
\text { internet relacionados con Tecnología de } \\
\text { Alimentos? }\end{array}$} \\
\hline & Casa & Universidad & $\begin{array}{l}\text { Medio de } \\
\text { transporte }\end{array}$ & Calle \\
\hline \multicolumn{5}{|l|}{$\begin{array}{l}\text { ¿Dónde buscas contenidos generales en } \\
\text { internet? }\end{array}$} \\
\hline \multicolumn{5}{|l|}{$\begin{array}{l}\text { ¿Dónde buscas contenidos en internet } \\
\text { relacionados con Tecnología de Alimentos? }\end{array}$} \\
\hline & $<\mathbf{1 h}$ & $1-2 h$ & $2-5 h$ & $>5 h$ \\
\hline \multicolumn{5}{|l|}{$\begin{array}{l}\text { ¿Cuánto tiempo has dedicado a la } \\
\text { búsqueda de vídeos en internet? }\end{array}$} \\
\hline \multicolumn{5}{|l|}{$\begin{array}{l}\text { ¿Cuánto tiempo has dedicado al visionado } \\
\text { de vídeos de compañeros publicado en } \\
\text { padlet? }\end{array}$} \\
\hline & 0 & 1 & 2 & $>2$ \\
\hline \multicolumn{5}{|l|}{$\begin{array}{l}\text { ¿Cuántos videos has publicado en el padlet } \\
\text { de la asignatura? }\end{array}$} \\
\hline \multicolumn{5}{|l|}{$\begin{array}{c}\text { ¿Cuántos comentarios has realizado en el } \\
\text { padlet de la asignatura? }\end{array}$} \\
\hline & $\begin{array}{l}\text { Totalmente } \\
\text { de acuerdo }\end{array}$ & De acuerdo & $\begin{array}{c}\text { En } \\
\text { desacuerdo }\end{array}$ & $\begin{array}{c}\text { Muy en } \\
\text { desacuerdo }\end{array}$ \\
\hline \multicolumn{5}{|l|}{$\begin{array}{c}\text { ¿Los videos publicados en el padlet están } \\
\text { relacionados con los contenidos teóricos de } \\
\text { la asignatura? }\end{array}$} \\
\hline \multicolumn{5}{|l|}{$\begin{array}{l}\text { ¿Te han resultado útiles los comentarios } \\
\text { realizados a tu publicación? }\end{array}$} \\
\hline \multicolumn{5}{|l|}{$\begin{array}{c}\text { ¿Ha sido satisfactorio el desarrollo de la } \\
\text { actividad propuesta? }\end{array}$} \\
\hline \multicolumn{5}{|l|}{$\begin{array}{c}\text { ¿Has empleado con anterioridad algún tipo } \\
\text { de pizarra electrónica? }\end{array}$} \\
\hline $\begin{array}{c}\text { ¿Emplearías pizarras electrónicas tipo } \\
\text { padlet en alguna otra asignatura? }\end{array}$ & & & & \\
\hline
\end{tabular}

Los resultados obtenidos en la encuesta acerca del grado de satisfacción de la actividad propuesta se muestran en la Figura 3. Como se observa en la figura, tanto el grado de satisfacción, como la utilidad de los videos y comentarios ha sido muy positiva para los alumnos. De hecho los alumnos afirman que considerarían positivo el empleo de pizarras electrónicas en futuras asignaturas.

Para concluir, el grado de satisfacción del profesor con la actividad propuesta fue muy elevado, ya que aumentó la motivación de los estudiantes para buscar contenidos audiovisuales relacionados con la asignatura impartida, además fue habitual durante el desarrollo de la clase hacer comentarios a algunos de los videos publicados en el padlet por 
los alumnos. A pesar que la participación fue bastante elevada durante el desarrollo de la actividad por la mayor parte de los alumnos, aproximadamente un 30\% del alumnado se esperó hasta el última día antes de finalizar el plazo para colgar el video y comentario correspondiente, indicando una baja motivación por cierta parte del alumnado que no se refleja en las encuestas realizadas. Finalmente, el ambiente generado fue positivo, ya que aumentó tanto la interrelación entre los estudiantes, como la relación estudiante alumno, y habitualmente se generaban debates antes del comienzo de la clase sobre los videos subidos a la pizarra electrónica.

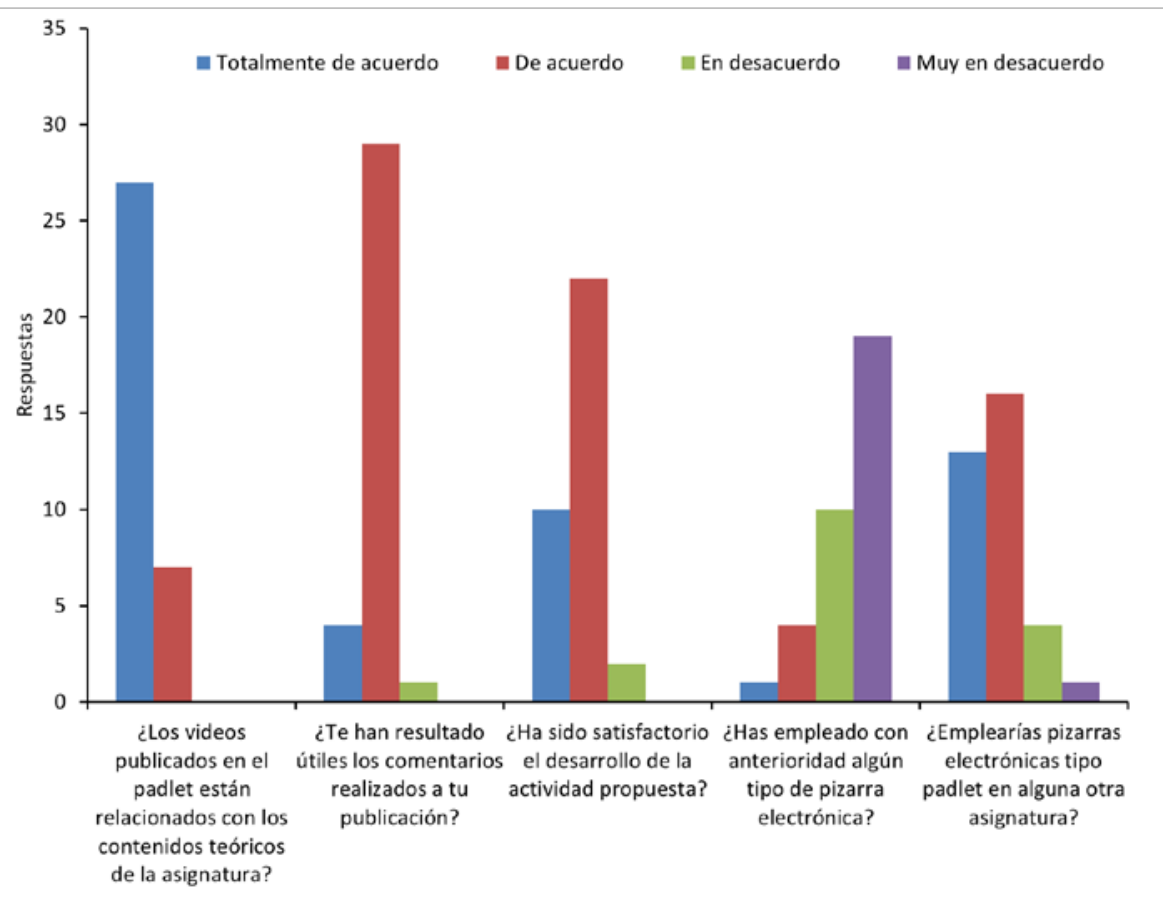

Fig.3 Resultado de la encuesta de grado de satisfacción de la actividad propuesta.

\section{Conclusiones}

Como conclusión, la experiencia ha resultado muy positiva, tanto para los alumnos como para el profesorado. Por una parte, se ha fomentado el trabajo colaborativo en lugar de fomentar un excesivo individualismo o competitividad. Por otra parte, se fomenta el interés por la asignatura y que sean los propios estudiantes los creadores de conocimiento, dejando su tradicional papel pasivo receptivo y adoptando una actitud más activa en el proceso de enseñanza/aprendizaje.

El haber creado un muro virtual en padlet ha brindado la posibilidad de cargar y compartir diversos contenidos multimedia como esquemas, imágenes, audios y videos en un muro de entorno digital y que estén fácilmente disponibles para los estudiantes pudiendo ser visualizados en cualquier momento. 
Los resultados obtenidos son preliminares. Para extraer conclusiones más realistas, se desarrollará esta actividad en cursos futuros y se podrá evaluar cuantitativamente su impacto a largo plazo en el proceso de enseñanza/aprendizaje de los alumnos.

\section{Referencias}

BERGMANN, J., SAMS, A. (2014). Dale la vuelta a tu clase: lleva tu clase a cada estudiante, en cualquier momento y cualquier lugar, Madrid: Biblioteca innovación educativa, Fundación Santa María-Ediciones SM.

GONZALEZ FRIAS, M.T., CRESPO-CABUTO, A., RIVERA-IRIBARREN, M. (2015). "Estudio de la percepción de los estudiantes sobre el uso de PADLET como apoyo a clases presenciales”, en Pizá Gutiérrez, R.I., Mortis Lozoya, S.V., González Román, M., Orduño Acosta, B.E. Resultados de interacción educativa. Méjico: Altexto, México.

HERNÁNDEZ, E., MEDINA, F. (2014). "La atención a la diversidad con la herramienta de innovación educativa GLOG” en Navarro, J., Gracia, M.D., Lineros, R., Soto, F.J. Claves para una educación diversa. Murcia: Consejería de Educación, Cultura y Universidades.

PALOMO LÓPEZ, R., RUIZ PALMERO, J., SÁNCHEZ RODRIGUEZ, J. (2007). Las TIC como agentes de innovación educativa. Sevilla: Junta de Andalucía, Consejería de Educación. 


\title{
Materiales audiovisuales para el estudio de cuestiones de Derecho de Familia y Sucesiones a partir de la jurisprudencia de Estrasburgo $^{1}$
}

\author{
Catalina Pons-Estel Tugores. Profesora Contratada Doctora interina de Derecho Civil \\ Universidad de las Islas Baleares \\ E-mail: catalina.pons-estel@uib.es
}

Marcos González Sánchez. Profesor Titular de Derecho Eclesiástico del Estado

Universidad Autónoma de Madrid

E-mail: marcos.gonzalez@uam.es

\begin{abstract}
This paper presents the teaching innovation project in which we have opted for the promotion of active learning methodologies. The reverse pedagogy has been used and the students have been the ones who have assumed the elaboration of audiovisual material that will support them and their future colleagues (we want these tools to be available and can be used during several academic courses) to address the study of current issues of Family Law and Inheritance and Donations. In particular, the jurisprudence of Strasbourg has been studied since it is the main current instrument for the legal protection of human rights at the international level.
\end{abstract}

Keywords: audiovisual, jurisprudence, methodology, learning, coordination, family, successions.

\begin{abstract}
Resumen
En el proyecto de innovación docente que presentamos se ha optado por el impulso de las metodologías activas de aprendizaje. Se ha usado la pedagogía inversa y los alumnos han sido quienes han asumido la elaboración de material audiovisual que les servirá de apoyo a ellos y a sus compañeros futuros (pues tenemos intención de que estas herramientas tengan perdurabilidad y las podamos usar a lo largo de varios cursos académicos) para abordar el estudio de cuestiones actuales del Derecho de
\end{abstract}

\footnotetext{
${ }^{1}$ Comunicación realizada en el marco del Proyecto de Innovación Docente "Materiales audiovisuales para el estudio de cuestiones de Derecho de Familia y Sucesiones a partir de la jurisprudencia de Estrasburgo" (PID 171817) perteneciente a los proyectos de innovación y mejora de la calidad docente de la Universidad de las Islas Baleares (2017-2018), siendo la investigadora principal la Dra. Catalina Pons-Estel Tugores y formando parte del Proyecto el Dr. Marcos González Sánchez, el Dr. Pedro A. Munar Bernat, el Dr. Salvador Pérez Álvarez, la Dra. Beatriz Verdera y la Dra. Francisca $\mathrm{M}^{\mathrm{a}}$ Rosselló Rubert.
} 
Familia y de Sucesiones y Donaciones. Especialmente, se ha estudiado la jurisprudencia de Estrasburgo al ser el principal instrumento actual para la tutela jurídica de los derechos humanos en el plano internacional.

Palabras clave: audiovisual, jurisprudencia, metodología, aprendizaje, coordinación, familia, sucesiones.

\section{Introducción}

La configuración actual de los planes de estudios exige una innovación continua en la metodología docente que se aplica en nuestras aulas. No solo los profesores, sino también los alumnos y la sociedad en general, demandamos unas mejoras y evolución constantes en la manera de "enseñar-aprender". Quienes integramos el proyecto de Innovación Docente que ahora presentamos somos profesores de Facultades de Derecho y nuestra propuesta se basa en los siguientes elementos: a) El estudio de la jurisprudencia de Estrasburgo en tres cuestiones concretas del Derecho de Familia y Sucesiones: derecho a contraer matrimonio, adopción y custodia. Hay que tener en cuenta que el TEDH es probablemente el principal instrumento actual para la tutela jurídica de los derechos humanos en el plano internacional y su influencia va mucho más allá del Consejo de Europa y su repercusión es cada vez mayor en la modificación del Derecho interno de los Estados sometidos a su jurisdicción. Las sentencias del TEDH relativas al derecho al respeto a la vida privada y familiar (artículo 8 del CEDH) son cada vez más abundantes; b) El impulso de las metodologías activas de aprendizaje, ya que en una parte de nuestra propuesta hemos usado la pedagogía inversa y han sido nuestros alumnos quienes han asumido la elaboración del material audiovisual; c) el uso de herramientas TIC; y, d) la interdisciplinariedad de la materia, pues colaboraremos en el proyecto profesores de tres áreas de conocimiento, trabajando en equipo y coordinando nuestra labor docente.

\section{Contexto en el que se ha desarrollado el proyecto}

El equipo que ha desarrollado la experiencia docente que detallamos está integrado por profesores de Derecho Civil, Derecho Eclesiástico del Estado y Derecho Mercantil de tres Universidades distintas (Universidad de las Islas Baleares, Universidad Autónoma de Madrid y Universidad Nacional de Educación a Distancia), que imparten diversas asignaturas de sus disciplinas. Se ha trabajado coordinadamente logrando una comparativa de los diversos grupos y del aprendizaje conseguido por los alumnos.

En la Universidad de las Islas Baleares el proyecto se ha desarrollado en un grupo de Persona y Familia ( $2^{\circ}$ de Grado en Derecho) con 84 alumnos matriculados impartido por la Dra. Catalina Pons-Estel Tugores, profesora de Derecho Civil; un grupo de Derecho Eclesiástico del Estado (asignatura optativa de $4^{\circ}$ curso) con 50 alumnos matriculados, también impartido por la Dra. Pons-Estel; dos grupos de Donaciones y Sucesiones ( $4^{\circ} \mathrm{de}$ Grado en Derecho) con 60 y 45 alumnos matriculados, impartido por el Dr. Pedro A. Munar Bernat, Catedrático de Derecho Civil; un grupo de Persona y Familia (2 $2^{\circ}$ de Grado 
en Administración y Dirección de Empresas y Derecho) con 45 alumnos matriculados impartido por la Dra. Beatriz Verdera, profesora de Derecho Civil y un grupo de Nociones básicas de Derecho ( $1^{\circ}$ de Grado en Economía) con 10 alumnos matriculados impartido por la Dra. Francisca $\mathrm{M}^{\mathrm{a}}$ Rosselló Rubert, Ayudante de Derecho Mercantil. En la Universidad Autónoma de Madrid se ha trabajado con 5 alumnos de Trabajo Fin de Grado tutorizados por el Dr. Marcos González Sánchez, Profesor Titular de Derecho Eclesiástico del Estado. Por su parte, en la Universidad Nacional de Educación a Distancia se ha trabajado con el Dr. Salvador Pérez Álvarez, Profesor Titular de Derecho Eclesiástico del Estado y organizador de un Seminario celebrado en su Universidad con la finalidad de compartir y transferir los resultados logrados con el Proyecto.

Los conocimientos en materia de Persona y Familia, Donaciones y Sucesiones y Jurisprudencia del Tribunal Europeo de Derechos Humanos son muy distintos en un grupo o en otro, debido -fundamentalmente- al curso concreto que están estudiando los alumnos. Precisamente por eso, el estudio de estas materias se ha realizado de forma progresiva, según los conocimientos jurídicos del alumnado. Ello ha supuesto que los resultados alcanzados han sido diversos dependiendo del curso académico; pero, en todos ellos se ha pretendido fomentar el razonamiento lógico y el espíritu crítico.

Persona y Familia es una asignatura que, por un lado introduce en el estudio del Derecho de la Persona (personalidad jurídica, capacidad natural, capacidad de obrar, modificaciones judiciales de la capacidad de obrar, representación, etc.); y, por otro, aborda el Derecho de Familia (instituciones jurídicas que regulan las relaciones personales y patrimoniales entre los miembros de la familia y en sus relaciones con terceros). Precisamente el concepto de Familia ha sufrido una auténtica revolución en los últimos tiempos y en ella nos encontramos con familias "tradicionales", monoparentales, uniones heterosexuales u homosexuales (inscritas y no inscritas), familias reconstituidas, familias ocasionales, etc. Además, también a día de hoy hay instituciones que están viviendo una etapa crítica a la espera de una nueva regulación, como es el caso de la filiación y la dificultad que conlleva en ocasiones cohonestar la realidad biológica y la realidad jurídica de la misma.

El Derecho Eclesiástico del Estado es una rama especializada del ordenamiento jurídico que se ocupa de cómo el Derecho del Estado regula la exteriorización del fenómeno religioso en la sociedad (tanto en su dimensión individual como en la colectiva). También se pretende la familiarización del alumnado con las fuentes, los principios informadores, la legislación específica y la jurisprudencia propia del Derecho Eclesiástico, con el objetivo de poder profundizar en aquellas cuestiones que resulten de interés, especialmente interrelacionando los conocimientos de esta materia con el resto de las del ordenamiento jurídico.

Para ello, los contenidos temáticos que se trabajan son: a) concepto, evolución histórica y fuentes del Derecho Eclesiástico; b) concepto, contenido, límites, titularidad y protección jurídica del derecho fundamental de libertad religiosa; c) la dimensión individual del derecho de libertad religiosa (enseñanza, asistencia religiosa, objeción de conciencia, matrimonio canónico y acatólico -junto con su eficacia civil-); y, d) la dimensión colectiva del derecho de libertad religiosa (personalidad jurídica de las entidades religiosas, 
patrimonio cultural de las confesiones religiosas, financiación y régimen fiscal de las confesiones religiosas, etc.).

La asignatura Donaciones y Sucesiones se imparte en cuarto curso del grado en Derecho y en ella se analizan instituciones de gran arraigo social como son las derivadas del Derecho sucesorio, que llevan a concretar el destino y consecuencias del patrimonio de una persona después de su fallecimiento. En dicha asignatura se estudian distintas instituciones como pueden ser el título sucesorio, el concepto mismo de herencia y el estudio de todo el proceso que lleva a la adquisición de la misma. Y, respecto al Derecho de Donaciones se trata de concretar el procedimiento a seguir para determinar la transmisión voluntaria de bienes sin que medie un precio. Por tanto, se estudian las donaciones remuneratorias, modales, las mortis causa, con cláusula de reversión, las liberalidades de uso, etc.

Por su parte, Nociones básicas de Derecho es una asignatura de formación básica cuya función es ofrecer una panorámica de la regulación jurídica de la vida cotidiana. Sirve para tener una visión previa y general de todo aquello que, a lo largo de la carrera, se estudiará con mayor profundidad. Fundamentalmente pretende que se conozcan y comprendan -en un nivel básico- las principales nociones, instituciones y principios jurídicos.

Los Trabajos Fin de Grado son una materia globalizadora que pretende la evaluación integrada de las competencias específicas y transversales del Grado en Derecho. El objetivo es conseguir que los alumnos sean aptos para realizar un trabajo de forma autónoma e individual aplicando e integrando las competencias adquiridas durante la carrera.

\section{Objetivos}

El objetivo principal es conseguir que los alumnos adquieran conciencia del papel que juega la jurisprudencia del TEDH en el ámbito privado familiar y sucesorio. A su vez, queremos que se familiaricen con los criterios seguidos hasta la fecha por el citado Tribunal y que valoren el impacto de sus resoluciones. En otro orden de cosas, sabemos por experiencia propia, que la mejor forma de estudiar cualquier temática es teniéndola que explicar. Es por eso que estamos convencidos de que al pedir a nuestros estudiantes que preparen una cuestión muy concreta para elaborar el material audiovisual que servirá de apoyo a sus compañeros actuales y futuros (pues tenemos intención de que estas herramientas tengan perdurabilidad y las podamos usar a lo largo de varios cursos académicos), en realidad, les estamos empujando a conocer a fondo los temas que van a trabajar. Además, al recibir las explicaciones de sus propios compañeros, los estudiantes muestran una mejor predisposición a escuchar y a aprender. Incluso, más curiosidad y participación activa.

El objetivo secundario es elaborar un material de apoyo audiovisual, que quedará a disposición del alumnado, a través del Aula digital. Creemos que mediante las distintas actividades que hemos planteado durante el curso 2017-2018, hemos logrado trabajar las distintas competencias propias del Grado en Derecho. Así, queremos contribuir a la formación integral de los alumnos como juristas y a posibilitarles que en un futuro gocen de total autonomía, de forma que sean capaces de enfrentarse a nuevos problemas y de 
encontrar la forma de solucionarlos. Para ello, es básico que puedan conseguir información jurídica (ya sea derecho positivo, doctrina, jurisprudencia, etc.), a través de las fuentes instrumentales, incluidas las electrónicas. De este modo, será necesario que, a nivel de usuario, manejen las herramientas electrónicas básicas. Con nuestra propuesta, les ayudaremos -mediante la ejemplificación- a comprender, analizar y sistematizar la jurisprudencia de Estrasburgo en la materia concreta del Derecho de familia, así como a conocer de qué forma se aplica. Y no solo para resolver conflictos actuales, sino también para prever las potenciales consecuencias jurídicas de la ejecución de un determinado acto. La idea de que sean los propios alumnos quienes elaboren los recursos audiovisuales nace de la convicción de los miembros de este Proyecto de la importancia capital de la comunicación. Así, hay que saber exponer ideas, propuestas, soluciones jurídicas y hacerlo de forma ordenada, precisa, concisa -ya sea oralmente, ya sea por escrito- adaptando nuestro discurso a las circunstancias. Pensamos que la preparación y exposición por parte de los alumnos, de cuestiones muy concretas, no solo apoyará estas competencias, sino que, además, potenciará la actitud crítica, el ser capaz de contrastar cualquier información jurídica, analizando las consecuencias políticas, económicas y sociales. Por cuanto venimos indicando, este proyecto promueve especialmente la metodología activa de aprendizaje; la coordinación entre diversas materias de un mismo Grado; el uso de herramientas TIC en la metodología de enseñanza-aprendizaje; la evaluación de la calidad docente y de los procesos de evaluación y aprendizaje de los alumnos; la orientación tutorial; la realización de actividades de formación complementaria; e incluso el uso de lenguas extranjeras, por cuanto las resoluciones del TEDH aparecen en inglés y en francés y -lógicamente- la promoción de la elaboración de material didáctico.

\section{Desarrollo de la innovación}

\subsection{Metodología}

Nuestro planteamiento metodológico consta de varias fases, que, cronológicamente han seguido el siguiente desarrollo: A) De cada cuestión que hemos trabajado con los alumnos hemos elaborado una carpeta con material (normativo, doctrinal, jurisprudencial, pericial, etc.) que está disponible online, en la página de nuestras asignaturas en el Aula digital, a fin de que puedan trabajarlo con anterioridad y posterioridad a nuestras explicaciones en clase; B) Hemos abordado los temas mediante el sistema tradicional de clase magistral; C) Hemos propuesto unas palabras clave e ideas básicas de cada tema; D) Hemos formulado preguntas relacionadas con la temática trabajada para que activaran el espíritu crítico de los alumnos; E) Hemos realizado prácticas; F) Hemos planteado foros de debate; G) Hemos pedido a los alumnos que, individualmente, elaboraran un vídeo del tema asignado, de una duración comprendida entre 1.5-3.5 minutos; $\mathrm{H}$ ) Hemos subido este material audiovisual a la plataforma, a fin de que todos puedan disponer de él; I) Realizaremos un Mesa redonda abierta al público en general, pues pensamos que así será más enriquecedora- sobre las cuestiones más candentes que hemos trabajado y lo haremos mediante exposiciones breves (15 minutos aprox.) y sugerentes, a fin de potenciar el debate ulterior entre todos los asistentes y los ponentes, pues los alumnos estarán muy formados acerca de las cuestiones 
que se expondrán y estamos convencidos de que disfrutarán de participar. A lo largo de todo el íterin, los alumnos han contado con unas tutorías específicas para hacer un seguimiento de su proceso de aprendizaje, así como para orientarles en todo aquello que hayan necesitado.

\subsection{Plan de trabajo}

El plan de trabajo en el que han participado todos los profesores implicados en el proyecto ha sido el siguiente:

a) Selección, bajo la dirección de su tutor, de 25 sentencias del TEDH sobre derecho a contraer matrimonio, adopción, custodia y ajuste a derecho de las sentencias de nulidad matrimonial canónica y posterior elaboración de una breve síntesis de cada una de ellas por parte de los alumnos de TFG de la Universidad Autónoma de Madrid. Posteriormente, este material se transfirió a los alumnos de la Universidad de las Islas Baleares de los grupos implicados en el proyecto que nos ocupa.

b) Explicación por parte de los profesores al alumnado de la Universidad balear de la trascendencia e influencia de la jurisprudencia del Tribunal de Estrasburgo en la modificación del Derecho interno de los Estados sometidos a su jurisdicción, haciendo especial hincapié en la materia específica de cada docente (persona y familia, derecho de libertad religiosa, etc.).

c) Elaboración por parte del profesorado de un dossier con material sobre la jurisprudencia del Tribunal de Estrasburgo (artículos doctrinales, sentencias, etc.).

d) Elaboración de la propuesta de los trabajos y actividades a realizar por los alumnos.

e) Puesta a disposición del alumnado de la Universidad de las Islas Baleares del material proporcionado por los alumnos de TFG de la Universidad Autónoma de Madrid, así como del dossier con material y la propuesta de trabajos y actividades a realizar.

f) Estudio por parte de los alumnos del material recibido y selección de un tema.

g) Elaboración por parte de los estudiantes de un borrador de trabajo.

h) Realización de tutorías individualizadas para evaluar la viabilidad de las propuestas de los alumnos y para guiar la realización de los trabajos (tanto las fichas como el material audiovisual) hasta su culminación.

i) Celebración de una sesión tutorizada por el personal de Campus Extens a los alumnos de los grupos de Persona y Familia y de Derecho Eclesiástico del Estado para resolver las dudas técnicas que hubieran podido surgir en la elaboración del material audiovisual.

j) Acceso a todo el alumnado implicado en el proyecto a las fichas y a los materiales audiovisuales realizados.

k) Valoración en clase de las actividades desarrolladas. 


\section{Resultados}

En el marco de este proyecto de innovación se ha realizado una Mesa redonda en el Aula de Grados de la Facultad de Derecho de la Universidad de las Islas Baleares -moderada por el Dr. Munar Bernat, miembro del equipo docente del proyecto- en la que han intervenido los Dres. González Sánchez y Pons-Estel Tugores -también miembros de dicho proyecto de innovación- y se ha tratado la cuestión de la Jurisprudencia del TEDH en el reconocimiento de efectos civiles a los matrimonies religiosos. Además, se ha celebrado un Seminario en la UNED con la finalidad de compartir y transferir los resultados logrados con el Proyecto.

Por otro lado, en el ámbito de la docencia, las actividades realizadas con el alumnado han sido:

a) Explicaciones teóricas en dos sesiones de clase.

b) Incorporación de una carpeta específica de la temática (legislación, doctrina, jurisprudencia, prensa, etc.) en la página de la asignatura en el Aula digital, poniendo a su disposición una carpeta con abundante material formativo, que hemos ido ampliando y actualizando a medida que avanzaba el curso.

c) Prácticas en una clase.

d) Asistencia a la mesa redonda en la que participaron como ponentes dos miembros del equipo docente del proyecto.

e) Foro a través de la página de la asignatura en el Aula digital -abierto durante 21 días-, en el que los alumnos han tenido que reflexionar y responder individualmente sobre cuál es el papel que juega la jurisprudencia del TEDH en relación a la jurisprudencia española relativa al Derecho de Familia y Sucesiones. Precisamente las intervenciones en este Foro han generado un intenso debate entre los participantes y tenemos que subrayar que la participación del alumnado ha sido masiva y la interactuación entre los distintos miembros del foro, continua.

f) Y como colofón, se ha logrado el objetivo de la elaboración de materiales audiovisuales. Concretamente, esta actividad constó de dos partes:

A) Una primera, en la que cada alumno escogió el tema y la sentencia del TEDH que deseó (siempre que fuera de la materia de Derecho de Familia o de Donaciones y Sucesiones) y completó una ficha al respecto en la que debían constar:

-Los datos de la sentencia: Tribunal, fecha de la sentencia y sujetos (recurrente y recurrido).

-El tema principal. Objeto del recurso.

-El tema o temas secundarios.

-El resumen de los antecedentes fácticos.

-El resumen de la fundamentación jurídica.

-Las disposiciones legales aplicadas.

-El fallo de la sentencia.

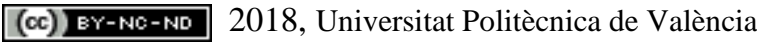

Congreso In-Red (2018) 
-La valoración personal.

-La ubicación del material audiovisual elaborado por el alumno, a fin de que todos los participantes del grupo pudieran acceder al mismo.

-La relación de fuentes de información manejadas.

La extensión de la ficha no debía superar las 3 páginas. Lógicamente, con anterioridad el alumno habrá tenido que subir la grabación a la red, pues en la ficha ya tenía que indicarse la ubicación del material audiovisual elaborado por el alumnado.

B) Una segunda en la que cada alumno llevó a cabo una grabación (utilizando su teléfono móvil o su tablet) en la que abordó la explicación del tema que había escogido, así como el planteamiento jurisprudencial del TEDH acerca del mismo. La duración de la grabación abarcó desde un minuto y medio (duración mínima) hasta tres minutos y medio (duración máxima).

Como resultado final, hemos conseguido 54 grabaciones que suponen un material valiosísimo no solo para los alumnos que han participado en este proyecto, sino también para las futuras promociones que podrán beneficiarse de este gran trabajo. Además, la aceptación por los propios alumnos participantes en este proyecto ha sido muy satisfactoria, por cuanto el 82\% de ellos así lo han manifestado en una encuesta realizada.

\section{Conclusiones}

Tras la finalización de las distintas actividades llevadas a cabo en el marco del proyecto de innovación que ahora presentamos, los profesores integrantes del mismo nos reunimos para hacer una valoración del mismo y, muy brevemente, podemos reseñar las siguientes conclusiones:

a) Esta iniciativa ha resultado muy enriquecedora para los alumnos, fundamentalmente por dos motivos: porque ha supuesto una toma de contacto con compañeros de otra Universidad y porque ha posibilitado una relación de trabajo y complemento entre alumnos de distintos cursos.

b) La elaboración del material audiovisual ha sido muy motivadora porque ha supuesto que en el parte final del trabajo han podido utilizar instrumentos tan propios de su día a día y tan populares como el teléfono móvil o la tableta.

c) El hecho de que los alumnos hayan tenido que elaborar material didáctico útil para sus compañeros les ha obligado a tener que estudiar y comprender en profundidad una temática que, de entrada, es muy compleja. En cambio, se han metido tanto en su papel de “docentes” que ni siquiera se han percatado de la cantidad de horas que han invertido en la consecución del objetivo final que era el material audiovisual.

d) La multidisciplinariedad del proyecto por la participación en el mismo de profesores de tres disciplinas distintas ha proporcionado una riqueza supletoria durante todo el proceso de trabajo y, sin duda, también en el resultado final. El intercambio de opiniones entre 
profesionales que se centran en aspectos distintos, hace que tengamos una perspectiva más amplia.

e) De entrada, trescientos alumnos han participado en la elaboración de este material audiovisual y, por tanto, se benefician del mismo de forma directa. Pero, este trabajo va más allá, pues estos recursos audiovisuales serán utilizados durante los próximos cursos como material de apoyo. Por esto, resulta difícil cuantificar el número total de alumnos que de forma más o menos inmediata podrán usar estos recursos. Lo que sí tenemos claro es que serán muchos.

f) Para los profesores implicados en el proyecto esta iniciativa ha supuesto muchísimo trabajo extra. No obstante, también nosotros nos hemos sentido muy motivados al ver a los alumnos tan implicados en el mismo y con tantas ansias de hacer las cosas bien.

\section{Referencias}

AA.VV. (1993). Marriage and religion in Europe. Milano: Giuffrè Editore.

AlCARAZ Ramos, M. (2000). "Familia y matrimonio en las constituciones de los Estados de la Unión Europea” en AA.VV. Estudios en homenaje al Profesor Martínez Valls. Alicante: Universidad de Alicante, vol. II, pp. 749-760.

CAÑAMARES ARRIBAS, S. (2014). "El derecho al matrimonio en la jurisprudencia del TEDH” en Derecho y Religión. vol. 9, pp. 245-260.

COOPER, S.L. (2010). "Marriage, Family, Discrimination \& Contradiction: An Evaluation of the Legacy and Future of the European Court of Human Rights' Jurisprudence on LGBT Rights” en German Law Journal. vol. 12, pp. 1747-1761.

FARNÓs AMORÓs, E. (2015). "La reproducción asistida ante el Tribunal de Estrasburgo margen de apreciación v. necesidad de armonización” en AA.VV. Treinta años de reproducción asistida en España Recurso electrónico una mirada interdisciplinaria a un fenómeno global y actual. Madrid: Ministerio de Justicia, pp. 175-202.

GonZÁLEZ SÁNCHEZ, M. (2008). La incidencia de los acuerdos internacionales sobre derechos fundamentales en la jurisprudencia de Derecho Eclesiástico del Tribunal Constitucional. Navarra: Civitas.

NANClARES VALLE, J. (2015). "Convivencia entre personas del mismo sexo e interés público en la jurisprudencia del Tribunal Europeo de Derechos Humanos” en Persona y Derecho, vol. 72, 2015, pp. 109-132.

NOVALES AlquÉZAR, M.A. (2015). "La filiación de matrimonio homosexual en España en el contexto europeo”, en AA.VV. Nuevas orientaciones del derecho civil en Europa. Navarra: Dykinson.

Paniza Fullana, A. (2017), Realidad biológica versus realidad jurídica: el necesario replanteamiento de la filiación. Navarra: Aranzadi. 
Polo Sabau, J.R. (2006). Matrimonio y Constitución ante la Reforma del Derecho de Familia. Navarra: Civitas.

SANZ CABALLERO, S. (2004/2005). "Unmarried cohabiting couples before the European court of Human Rights; parity with marriage?” en Columbia Journal of European Law. pp. 151 y ss.

(cc) EY-NC-ND 2018, Universitat Politècnica de València 


\title{
Aplicación del KAHOOT para la mejora de la adquisición de los objetivos del aprendizaje en el alumnado de Fisiología de los órganos del lenguaje y la audición
}

Jose Ignacio Priego Quesada ${ }^{\mathrm{ab}}$, Irene Jiménez Pérez ${ }^{\mathrm{ab}}$, Rosa $\mathrm{M}^{\mathrm{a}}$ Cibrián Ortiz de Anda $^{a}$, Rolando González-Peña ${ }^{a}$, Rosario Salvador Palmer ${ }^{a}$

${ }^{a}$ Grupo de Investigación en Física Médica (GIFIME), Departamento de Fisiología, Facultad de Medicina y Odontología, Universitat de València ${ }^{\text {}}$ Grupo de Investigación en Biomecánica aplicada al Deporte (GIBD), Departamento de Educación Física y Deportiva, Facultad de Ciencias de la Actividad Física y el Deporte, Universitat de València. Emails: j.priego.gibd@gmail.com; i.jimenez.gibd@gmail.com; rosa.m.cibrian@uv.es; Rolando.J.Gonzalez@uv.es; Rosario.Salvador@uv.es.

\begin{abstract}
One of the most used applications as a strategy of gamification in the classroom for the improvement of the learning process is KAHOOT. However, there are not many studies that have evaluated the repercussion of the application of sessions of this game at the end of the subject in the results of the final evaluation. In this way, the application of two complete sessions of KAHOOT was carried out at the end of the subject "Physiology of the Organs of Language and Hearing" of the Degree in Speech Pathology of the Universitat de València (course 2016-2017), with the objective of reviewing the contents related to the learning objectives of the subject. Two questionnaires, one for each session, were created consisting of 24 test questions with a duration of 1 and a half hour. The approval number of students of the subject was compared with the implementation of the KAHOOT session with respect to the two previous courses without innovation, observing an increase of $8 \%$. More specifically, the percentage of students with higher qualifications increased, while that of lower qualifications decreased. The analysis of this implementation in the qualifications of the present and future results will corroborate the results of this work.
\end{abstract}

Keywords: Gamification; web application; learning process; questionnaire; contents; motivation; evaluation results. 
Aplicación del KAHOOT para la mejora de la adquisición de los objetivos del aprendizaje en el alumnado de Fisiología de los órganos del lenguaje y la audición

\section{Resumen}

Una de las aplicaciones más utilizadas como estrategia de gamificación en el aula para la mejora del proceso de aprendizaje es el KAHOOT. Sin embargo, no existen muchos estudios que hayan evaluado la repercusión de la aplicación de sesiones de este juego al final de la asignatura en los resultados de la evaluación final. De esta forma, se llevó a cabo la aplicación de dos sesiones completas de KAHOOT al final de la asignatura “Fisiología de los órganos del lenguaje y la audición” del Grado de Logopedia de la Universitat de València (curso 2016-2017), con el objetivo de repasar los contenidos relacionados con los objetivos del aprendizaje de la asignatura. Se desarrolló en cada sesión un cuestionario compuesto de 24 preguntas tipo test con una duración de 1 hora y media. Se comparó el número de aprobados con la implementación de la sesión de KAHOOT respecto a los dos cursos anteriores sin innovación, observándose un aumento de un 8\%. De forma más específica, el porcentaje de alumnado con calificaciones altas aumentó, mientras que el de calificaciones bajas disminuyó. El análisis de dicha implementación en los resultados del presente y futuros cursos permitirá corroborar los resultados de este trabajo.

Palabras clave: gamificación, aplicación web, proceso de aprendizaje, cuestionario, contenidos, motivación, resultados de evaluación. 


\section{Introducción}

Para cualquier docente, uno de los objetivos principales de su proceso de enseñanza es conseguir que el máximo número de su alumnado alcance los objetivos de aprendizaje de la asignatura. Si el proceso de evaluación está correctamente diseñado, cuanto mayor sea el nivel alcanzado por el alumnado, se obtendrán mejores cualificaciones finales. En este sentido, diferentes estrategias se han explorado en las últimas décadas con el objetivo de mejorar el proceso de aprendizaje, siendo una de estas la gamificación.

La gamificación tiene como objetivo utilizar dinámicas del juego en contextos que no son propios del juego (empresas, aulas, etc.) (Deterding et al. 2011). Uno de los contextos en los que más se ha aplicado es en la educación, en la que se busca introducir elementos del juego en el diseño de los procesos de enseñanza (Bellotti et al. 2013). Se ha observado que la aplicación de la gamificación en las aulas propicia mejoras en los comportamientos cognitivos, afectivos y sociales dentro de la clase (Lee y Hammer 2011). Además, estos juegos suelen tener un componente de competición que aumenta el nivel de atención del alumnado (Bicen y Kocakoyun 2017). Entre los diferentes juegos de gamificación utilizados en las aulas, el KAHOOT es uno de los más empleados por la comunidad docente.

El KAHOOT es una aplicación web con la que el docente puede crear cuestionarios tipo test para que el alumnado conteste durante la clase utilizando sus teléfonos móviles, ordenadores o "tablets". Algunos aspectos positivos del KAHOOT es que es una aplicación gratuita, divertida, e intuitiva. El KAHOOT ha sido utilizado para reforzar contenidos impartidos en clases anteriores o para repasar al final de la clase los conceptos clave enseñados durante la sesión. Sin embargo, no existen muchos estudios que hayan evaluado la aplicación del KAHOOT al final de la asignatura, para repasar los contenidos relacionados con los objetivos del aprendizaje.

\section{Objetivos}

El objetivo del presente trabajo fue analizar los resultados en la evaluación final del alumnado de la asignatura "Fisiología de los órganos del lenguaje y la audición” del Grado de Logopedia de la Universitat de València, tras la aplicación de dos sesiones completas de KAHOOT al final de la asignatura, con el objetivo de repasar los contenidos relacionados con los objetivos del aprendizaje de la asignatura.

\section{Desarrollo de la innovación}

\subsection{Alumnado sobre el que se ha desarrollado la innovación}

La innovación se llevó a cabo en el curso 2016-2017 en la asignatura "Fisiología de los órganos del lenguaje y la audición” del Grado de Logopedia, de la Universitat de València. Dicha asignatura se imparte en el primer curso del grado. Todo el alumnado del curso, es decir, 80 estudiantes matriculados en la asignatura, participaron en la innovación. 


\subsection{Diseño de la innovación}

La innovación se llevó a cabo al final de la impartición teórica, siendo las dos últimas prácticas de la asignatura. Se desarrollaron dos sesiones de 1 hora y media de KAHOOT. Una de las sesiones estuvo dedicada a las bases de la audición y la fonación y la otra a las bases de la electrofisiología, cubriendo así el temario de la asignatura. Se utilizó la subdivisión en grupos de prácticas (unos 20 estudiantes en el aula). El cuestionario para ambas sesiones estuvo compuesto de 24 preguntas tipo test con entre 2 y 4 posibles respuestas (Fig. 1), cubriendo entre las dos sesiones el temario de la asignatura. Antes de la sesión se insistió al alumnado que era de gran importancia que estudiasen el temario y apuntes de la asignatura de cara a cada una de las sesiones. Las preguntas fueron confeccionadas conjuntamente por el profesorado de la asignatura teniendo en cuenta los siguientes aspectos:

a) Debían tratar contenidos y conceptos clave que tuviesen que ver con los objetivos de aprendizaje desarrollados en la guía docente de la asignatura.

b) Cada pregunta fue confeccionada para poderse responder con claridad en 30 segundos, que fue el tiempo máximo estipulado en la aplicación.

c) En ningún caso debían ser preguntas semejantes a las que aparecerían en el examen final de la asignatura.

Durante la sesión, se llevó a cabo el siguiente orden de acciones:

a) Dividir a la clase en 5 grupos de 4 estudiantes cada uno. La elección de 5 grupos vino motivada por la componente de juego que tiene esta modalidad de enseñanza. Como se indicará posteriormente en "visualización de los resultados", a lo largo del cuestionario va apareciendo un ranking de mejores resultados pero sólo se visualizan 5 grupos. Por lo tanto, para que los estudiantes vean su evolución no interesa más de estos 5 grupos.

b) Se utiliza para cada grupo un pseudónimo y se trabaja en grupo con lo que ningún estudiante queda explícitamente señalado si no resulta ganador.

c) Para cada una de las preguntas, el protocolo fue:

- Tiempo para mostrar la pregunta y que el alumnado la discutiera y respondiera.

- Visualización de la respuesta correcta y las respuestas erróneas. En este tiempo, el/la profesor/a debía aprovechar para aclarar la respuesta correcta. Si el/la profesor/a detectaba un déficit por parte de los estudiantes en algún concepto o contenido, se procedía a una explicación más detallada.

- Visualización de los resultados. La aplicación permite mostrar en cada pregunta el ranking de los estudiantes teniendo en cuenta haber acertado la pregunta, así como el tiempo empleado en contestar. Tras este ranking por preguntas, también se mostraba el ranking del cómputo total de preguntas contestadas hasta el momento. En este tiempo, se fomentaba la competición para aumentar la motivación del alumnado. También se aprovechaba para utilizar el humor como herramienta de motivación, y para que los grupos que

(c) EY-NC-ND 2018, Universitat Politècnica de València

Congreso IN-RED (2018) 
fallasen no se sintiesen avergonzados y entendiesen que el objetivo de la sesión era mejorar su proceso de aprendizaje.
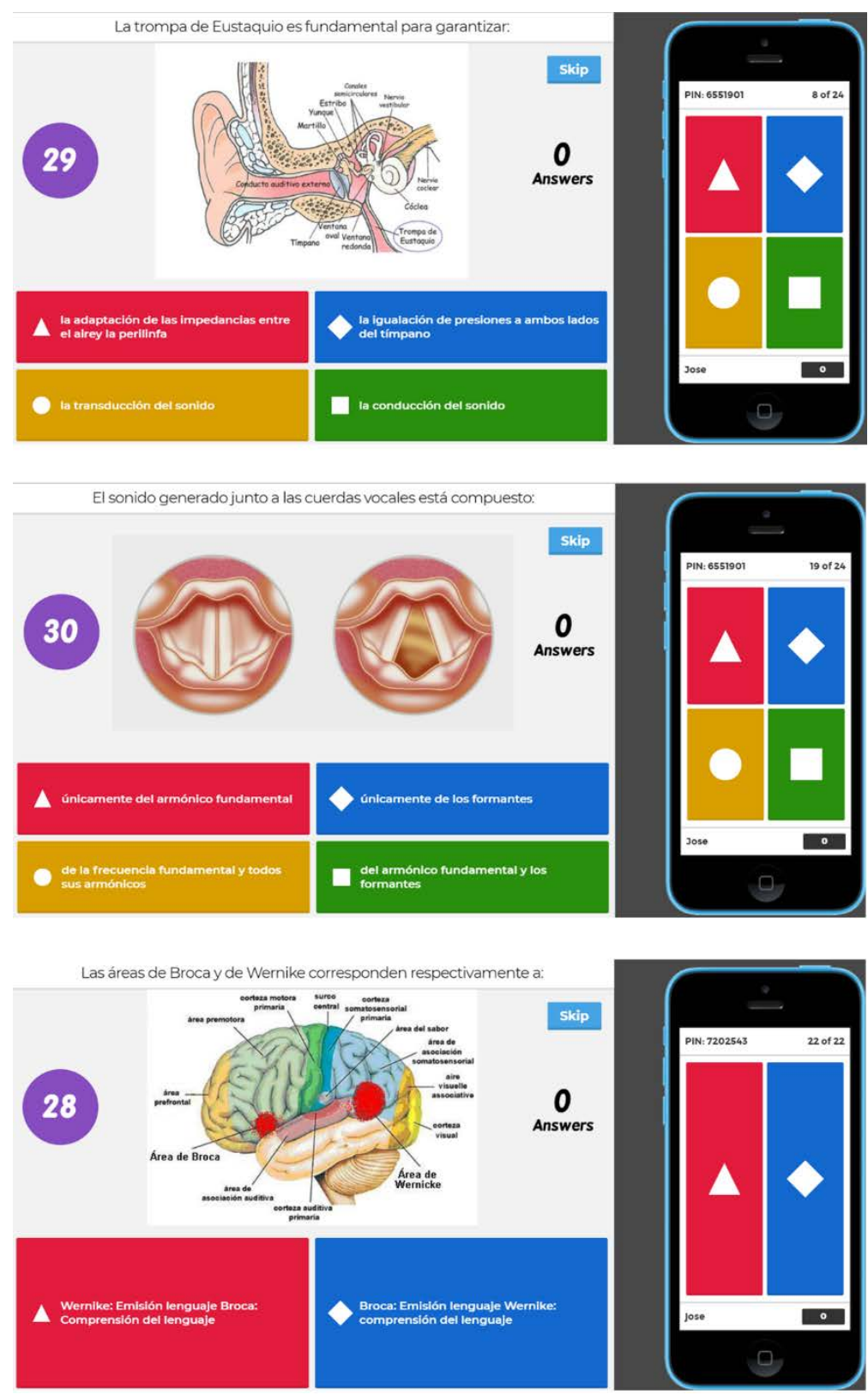

Fig. 1 Ejemplos del cuestionario KAHOOT empleado.

\subsection{Análisis de los datos}

Con el objetivo de analizar la eficacia de la innovación implementada, se compararon los resultados de la evaluación final de los estudiantes del curso 2016-2017, con los resultados 
de los dos cursos anteriores en los que no se realizaba la sesión KAHOOT. En los dos cursos previos, la asignatura tuvo 74 estudiantes matriculados en cada curso, y en el curso 2016-2017 el número de estudiantes matriculados fue de 80. Para dicho análisis, se tuvo en cuenta tanto el porcentaje de aprobados total, el porcentaje de presentados en la primera convocatoria, así como el porcentaje para cada una de las calificaciones: suspenso, aprobado, notable, sobresaliente/matrícula. La dificultad del examen de la evaluación final fue similar en los tres cursos evaluados.

\section{Resultados}

La implementación de las sesiones de KAHOOT al final de la asignatura, con el objetivo de repasar los contenidos relacionados con los objetivos del aprendizaje, aumentó en aproximadamente un $8 \%$ los estudiantes aprobados respecto a los dos cursos anteriores (Fig. 2).

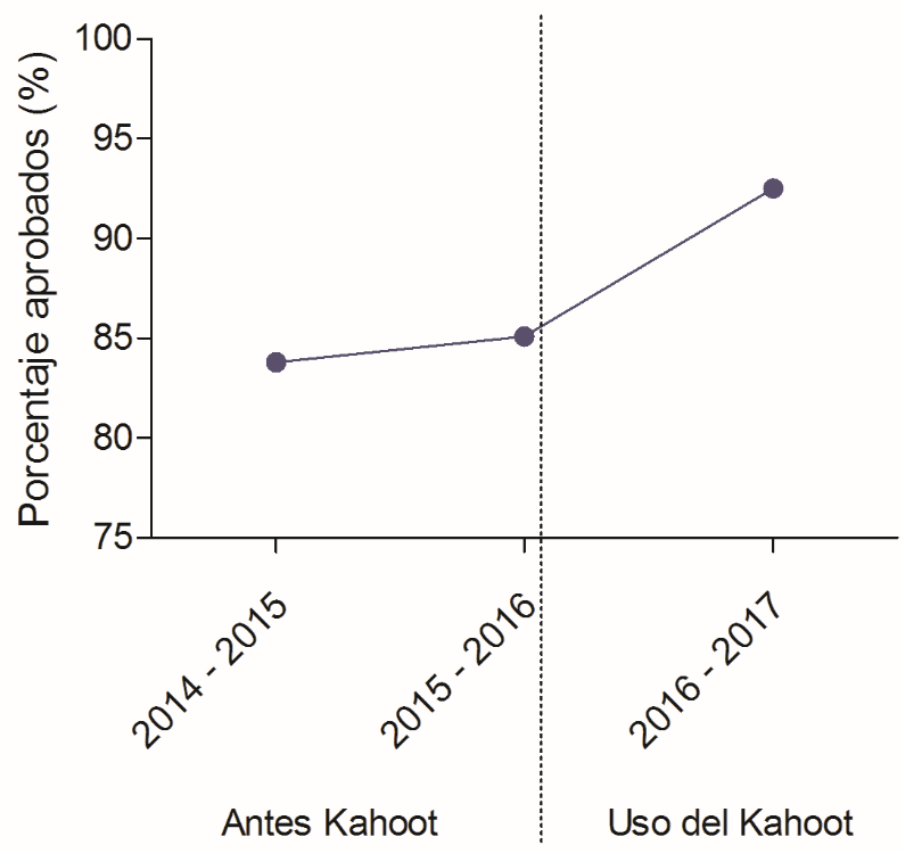

Fig. 2 Porcentaje de aprobados en los dos cursos anteriores a la implementación de la sesión de KAHOOT y en el curso en el que fue implementado.

De manera más específica, se puede observar como la implementación de las sesiones de KAHOOT cambió la distribución de los estudiantes en las diferentes calificaciones (Fig. 3). El porcentaje de alumnado que obtuvo calificaciones altas aumentó (notables y sobresalientes/matrículas) y el porcentaje que obtuvo calificaciones bajas disminuyó (suspensos y aprobados). De esta forma, el porcentaje de estudiantes que obtuvieron notable aumentó con la implementación de la sesión de KAHOOT en aproximadamente un

(cc) EY-NC-ND 2018, Universitat Politècnica de València

Congreso IN-RED (2018) 
20\%, y los que obtuvieron sobresaliente/matrícula en un $8 \%$. Mientras que el porcentaje de estudiantes que suspendían la asignatura se redujo en aproximadamente un $8 \%$, y los que obtenían aprobado se redujo en un $20 \%$ en comparación con los dos cursos anteriores. Estos resultados además son muy positivos si se tiene en cuenta el porcentaje de estudiantes presentados en la primera convocatoria. El porcentaje de estudiantes presentados en la primera convocatoria fue del 81\% en el curso 2014-2015, del 85\% en el curso 2015-2016, y del 89\% en el curso 2016-2017. Por lo tanto, la mejora del porcentaje de calificaciones altas estuvo acompañada de un aumento del porcentaje de estudiantes presentados en primera convocatoria.

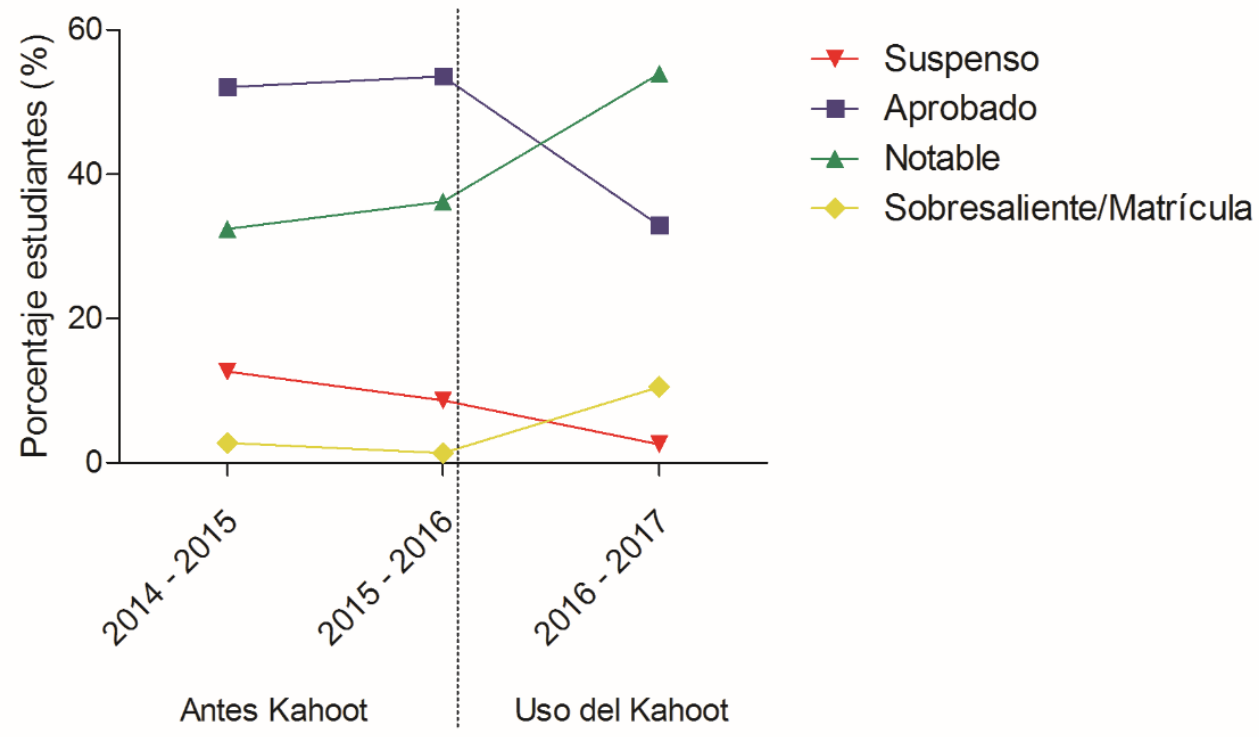

Fig. 3 Porcentaje de estudiantes que obtuvieron las diferentes calificaciones específicas en los dos cursos anteriores a la implementación de la sesión de KAHOOT y en el curso en el que fue implementado.

\section{Conclusiones}

La utilización de KAHOOT al final de la asignatura "Fisiología de los órganos del lenguaje y la audición” con el objetivo de aclarar, repasar y fijar los contenidos relacionados con los objetivos del aprendizaje resultó beneficiosa aumentando, tanto el porcentaje de estudiantes aprobados en un $8 \%$, como los porcentajes correspondientes a las calificaciones más altas (notable en un $20 \%$ y sobresaliente/matrícula en un $8 \%$ ).

El análisis de dicha implementación en los resultados del presente y futuros cursos permitirá corroborar los resultados de este trabajo.

\section{Referencias}

BELlOtTI, F., BERTA, R., DE GLORIA, A., LAVAGNino, E., ANTONACI, A., DAGNiNO, F.M., y OTT, M. (2013). “A gamified short course for promoting entrepreneurship among ICT 
Aplicación del KAHOOT para la mejora de la adquisición de los objetivos del aprendizaje en el alumnado de Fisiología de los órganos del lenguaje y la audición

engineering students”. En: 13 th International Conference on Advanced Learning Technologies (ICALT). IEEE, 31-32.

BICEN, H. y KOCAKOYUN, S. (2017). "Determination of University Students’ Most Preferred Mobile Application for Gamification” en World Journal on Educational Technology: Current Issues, 9, 1, 18-23.

DETERDING, S., DIXON, D., KHALED, R., y NACKE, L. (2011). "From game design elements to gamefulness: defining gamification”. En: Proceedings of the 15th international academic MindTrek conference: Envisioning future media environments. ACM, 9-15.

LEE, J.J. y HAMMER, J. (2011). “Gamification in education: What, how, why bother?” en Academic exchange quarterly, 15, 2, 146.

(cc) EY-NC-ND 2018, Universitat Politècnica de València 


\title{
Uso de dispositivos móviles para el desarrollo de las prácticas de laboratorio utilizando una herramienta on line
}

\author{
Santiago Lillo ${ }^{a}$, María del Mar Camachob y Nuria Martínez-Navarrete ${ }^{\mathrm{c}}$ \\ ${ }^{a}$ Departamento de Expresión Gráfica Arquitectónica (Universitat Politècnica de València, \\ sanlilgi@ega.upv.es), bepartamento de Tecnología de Alimentos (Universitat Politècnica de \\ València, mdmcamvi@tal.upv.es) y ${ }^{c}$ Departamento de Tecnología de Alimentos (Universitat \\ Politècnica de València,nmartin@tal.upv.es)
}

\begin{abstract}
Laboratory practices allow students to learn concepts and develop competencies that contribute to making sense of the theory of the subject in question. That is why, in many cases, they play a primary role in the overall teaching load of the subject, so that their assessment may become very important in the final grade. Thus, its monitoring and evaluation acquire significant relevance. In this sense, it would be of great interest to implement the use of a tool that would guide the student in the development of the work and help him to systematically collect the relevant data for further treatment, in addition to facilitating the final evaluation by the teacher. It would also be desirable that, at the same time, the tool facilitate the final evaluation by the teacher. Based on these premises, the use of mobile devices as a pedagogical tool is proposed, since its infinite applications allow to complement the learning process taking into account some of its advantages. One of them may be the increased motivation of the students when incorporating to their academic tasks a tool with which they are fully familiar. The objective of the present work is to implement a new methodology that guides the student in the realization of the practices through the incorporation of mobile devices. Its use in laboratory practices allowed to provide order to the data obtained from the development of the work and greater accessibility to information by all students. At the same time, it allowed the teacher a simple control of the attendance to the practice and facilitated the evaluation of the practical work of the student.
\end{abstract}

Keywords: Mobile devices, surveys, evaluation, laboratory practices.

\begin{abstract}
Resumen
Las prácticas de laboratorio permiten a los estudiantes aprender conceptos y desarrollar competencias que contribuyen a dar sentido a la teoría del tema en cuestión. Es por esto que, en muchos casos, tienen un peso determinante en la carga docente global de la asignatura, de forma que su valoración puede llegar a ser muy importante en la nota final. Así, su seguimiento y evaluación adquieren una relevancia significativa. En este sentido, sería de gran interés implementar el uso de alguna herramienta que permitiese guiar
\end{abstract}


al alumno en el desarrollo del trabajo y le ayudase a recoger sistemáticamente los datos pertinentes para su posterior tratamiento, además de facilitar la evaluación final por parte del profesor. En base a estas premisas, se propone el uso de los dispositivos móviles como herramienta pedagógica, puesto que sus infinitas aplicaciones permiten complementar el proceso de aprendizaje aprovechando algunas de sus ventajas. Una de ellas puede ser el aumento de la motivación por parte de los alumnos, al incorporar a sus tareas académicas una herramienta con la que se encuentran plenamente familiarizados. El objetivo del presente trabajo es implementar una nueva metodología que guíe al alumno en la realización de las prácticas a través de la incorporación de los dispositivos móviles. Su uso en las prácticas de laboratorio permitió proporcionar orden a los datos obtenidos del desarrollo del trabajo y una mayor accesibilidad a la información por parte de todos los alumnos. Al mismo tiempo, al profesor le permitió un sencillo control de la asistencia a la práctica y le facilitó la evaluación del trabajo práctico del alumno.

Palabras clave: Dispositivos móviles, encuestas, evaluación, prácticas de laboratorio.

\section{Introducción}

El rol de los profesores como facilitadores del aprendizaje debe llevarnos al uso de una variedad de recursos. Bain (2007) presenta una interesante investigación sobre profesores excelentes y muestra que muchos de estos profesores ayudan a sus alumnos con muy buenas clases magistrales, pero otros se apoyan más en otras estrategias didácticas y en otros recursos. Se pueden diseñar tareas de aprendizaje muy variadas (para clase y para fuera de clase) que literalmente responden a un enfoque didáctico centrado en lo que hace el alumno y que constituyen a su vez un eficaz sistema de evaluación (Morales Vallejo, 2008). Hay que destacar la necesidad de fomentar la pluralidad metodológica para atender la diversidad de personas, situaciones y ámbitos de conocimiento que existen. Entre las estrategias didácticas pueden utilizarse métodos de transmisión (lección magistral), métodos de enseñanza comprensiva no lineal (clases de resolución de problemas, prácticas en aula informática, prácticas de laboratorio, entre otros) y métodos de enseñanza no formal (los que surgen en contextos de intercambio, foros, seminarios abiertos, etc). De todos ellos, tradicionalmente la lección magistral ha sido el foco de atención desde el punto de vista de acciones de mejora. Sin embargo, las prácticas de laboratorio constituyen una parte imprescindible de la estructura de muchas asignaturas, ya que intervienen en la formación de los alumnos complementando la parte teórica. En particular permiten a los estudiantes aprender conceptos y desarrollar competencias en la aplicación de conocimientos, habilidades y actitudes en situaciones reales. De esta forma dan sentido a la teoría, al llevarla a la práctica, y aprenden a reconocer los aspectos más importantes y los problemas inherentes a ella. Una de las herramientas más utilizadas para la evaluación del aprendizaje en las prácticas de laboratorio es el informe, que se suele presentar días después de la 
realización de la práctica y que acaba siendo muy laborioso, en algunos casos, y un mero plagio entre alumnos, en otros. En este sentido, alguna herramienta que permita la recogida sistemática de datos durante la ejecución de las prácticas, para su posterior tratamiento en relación con los conceptos adquiridos en las sesiones de teoría, sería de gran interés. En la bibliografía se han descrito tareas que permiten este tipo de actividades, como la presentación de cuestionarios o tablas que deben completarse (Noguera, Tortajada, Atienza \& Herrero, 2011) y que pueden ayudar al profesor a la evaluación global de las prácticas, pero que, por otra parte, podrían ser susceptibles de mejora si se combinan con la utilización de nuevas tecnologías (Muñoz et al., 2016).

A pesar de la plena integración en la sociedad actual de los dispositivos móviles y, en mayor medida si cabe, en el colectivo universitario, su uso como herramienta pedagógica no se encuentra en la actualidad tan extendido en virtud de las posibilidades que puede ofrecer, a pesar de que existen, sin embargo, algunos precedentes tales como el m-learning (mobile learning). Se trata de una metodología que complementa el proceso de aprendizaje, a través de instrumentos móviles, computadoras portátiles, tablets, lectores de MP3, teléfonos inteligentes (smartphones) y teléfonos móviles y tiene infinitas aplicaciones, dependiendo de la creatividad del docente (Gisbert \& Esteve, 2011). Éstos pueden incidir de forma negativa en la atención de los alumnos durante las clases, sin embargo, de su utilización como herramienta pedagógica en el ámbito académico se derivan algunas ventajas a nivel global. Una de las más inmediatas es el aumento, por parte de los alumnos, de la motivación y de la predisposición al proceso de aprendizaje, al incorporar a sus tareas académicas una herramienta con la que se encuentran plenamente familiarizados y que, por tanto, pueden incorporar a su flujo de trabajo de una manera rápida (Andrés-Ferre, AlfaroCid, Lillo, Pérez de los Cobos \& Rodrigo, 2013).

\section{Objetivo}

El objetivo del presente trabajo es implementar una nueva metodología que guíe al alumno en la realización de las prácticas, a través de la incorporación de los dispositivos móviles. Esta metodología debe permitir generar bases de datos que serán utilizadas, a su vez, en fases posteriores de la práctica para su análisis y posible relación con los conocimientos teóricos adquiridos en la asignatura.

\section{Desarrollo de la innovación}

Como ejemplo para la aplicación de la propuesta de mejora se ha seleccionado una asignatura del Máster Universitario en Ciencia e Ingeniería de los Alimentos, Tecnología de los alimentos en polvo, impartido en la Escuela Técnica Superior de Ingeniería Agronómica y del Medio Natural en la Universitat Politècnica de València. Es una asignatura optativa de 2,5 créditos, con pocos alumnos ( $<25)$ y con una carga práctica importante $(1,25$ créditos), por lo que la valoración de las prácticas de laboratorio tiene un peso significativo en la nota final de la asignatura (40\%). Las sesiones de prácticas se organizan de manera que los 
alumnos trabajan cada uno con una muestra diferente, de forma que la última sesión se dedica a la puesta en común de todos los resultados.

Durante el curso pasado 2016-2017, para el seguimiento y evaluación de las prácticas de esta asignatura, se sustituyó el clásico informe por una serie de tablas y cuestionarios que los alumnos debían ir completando durante las sesiones prácticas hasta elaborar una especie de dossier con todos los datos recogidos y su tratamiento en relación con los conceptos teóricos adquiridos. La innovación en el curso 2017-2018 ha consistido en la utilización de encuestas a través de dispositivos móviles, como sustitutas de las tablas y cuestionarios. La aplicación utilizada para ello ha sido la herramienta gratuita de Google Formularios de Google. La selección de esta herramienta se hizo en base a su accesibilidad y facilidad de uso. Además, es compatible con todos los sistemas operativos móviles (IOS y Android) y con cualquier navegador de internet. Por otra parte, no es necesaria ninguna instalación previa, tan solo un dispositivo con acceso a internet.

Teniendo como base el material utilizado en el curso anterior, se han elaborado las preguntas que deberán incluirse en las encuestas que se responderán a través del móvil. Estas preguntas, que el alumno debe responder de forma individual, sirven además como una guía que facilita el proceso global de la práctica, estableciendo un orden lógico de las etapas que deberá ir completando hasta su resolución final. Una vez elaboradas las encuestas, se facilita a los alumnos la url previamente acortada, con el fin de que el proceso de introducción de la dirección electrónica en el móvil sea más rápido y con menos errores.

A pesar de que la toma de datos se lleva a cabo de forma grupal (en parejas o tríos) la encuesta debe ser respondida individualmente. Para ello, el primer campo que deben rellenar los alumnos es el nombre, de forma que sirva además como comprobante de la asistencia a las prácticas (Figura 1).

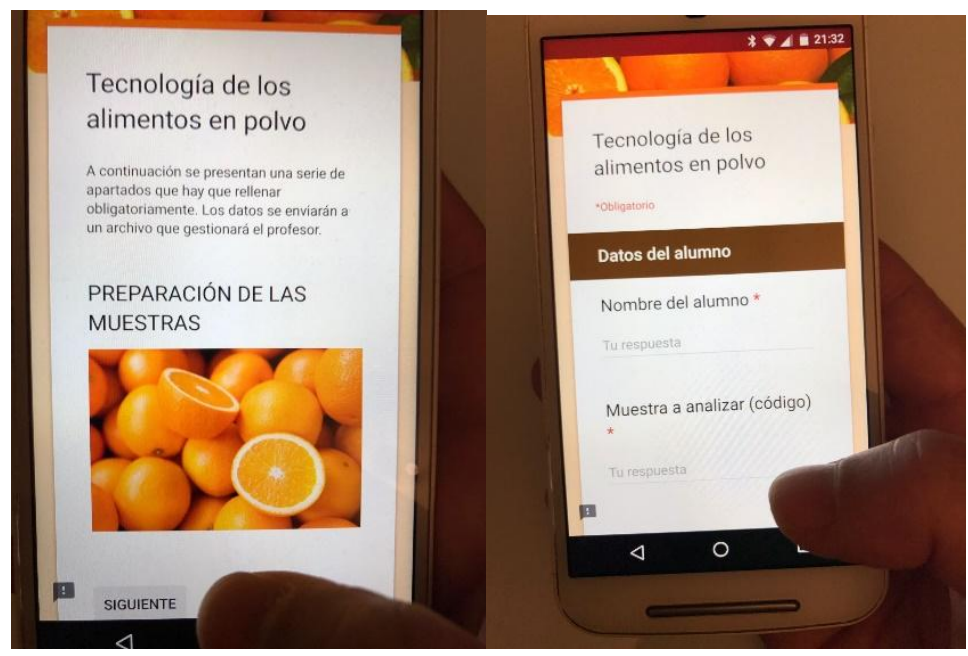

Fig. 1 Ejemplo del inicio de una de las encuestas y primer campo a rellenar por el alumno. Campo obligatorio. 
Se planteó en un principio añadir a cada pregunta la opción "respuesta obligatoria" que incluye el formulario Google, con el fin de garantizar que todas quedan respondidas, lo cual es fundamental para el correcto desarrollo de la práctica. Sin embargo, esta opción exige un desarrollo excesivamente lineal de la práctica, puesto que no ofrece la posibilidad de volver atrás y corregir las respuestas ya introducidas, en el caso de que se detecte algún error, lo cual suele ser bastante habitual. Para solventar este tipo de incidencias se eliminó la obligatoriedad de la respuesta y se incluyó una pregunta final del tipo "¿has rellenado todos lo campos de la encuesta?” . Esta pregunta, si bien no garantiza que no quede ningún campo sin completar, sí estimula al menos a que el alumno compruebe que, efectivamente, se ha respondido por completo a la encuesta (Figura 2). En este sentido, hemos echado en falta algún tipo de opción que impidiera enviar el resultado definitivo de la encuesta en el caso de que algún campo hubiera quedado sin completar, o bien, que todas las respuestas fueran de carácter obligatorio pero con la posibilidad de alterar el orden de su resolución.

Una vez terminada la sesión de prácticas, los alumnos han debido completar la encuesta correspondiente $\mathrm{y}$, automáticamente, se genera una tabla de resultados exportable como documento de hoja de cálculo. Esta hoja se pone a diposición delos alumnos a través de la plataforma propia de la UPV, poliformaT, para su tratamiento, en el caso de que sean datos, o para su comparación con los de los demás compañeros, en el caso de que ya sean resultados del tratamiento de dichos datos. Además, estas tablas generadas servirán para la evaluación de la parte práctica de la asignatura por parte del profesor.

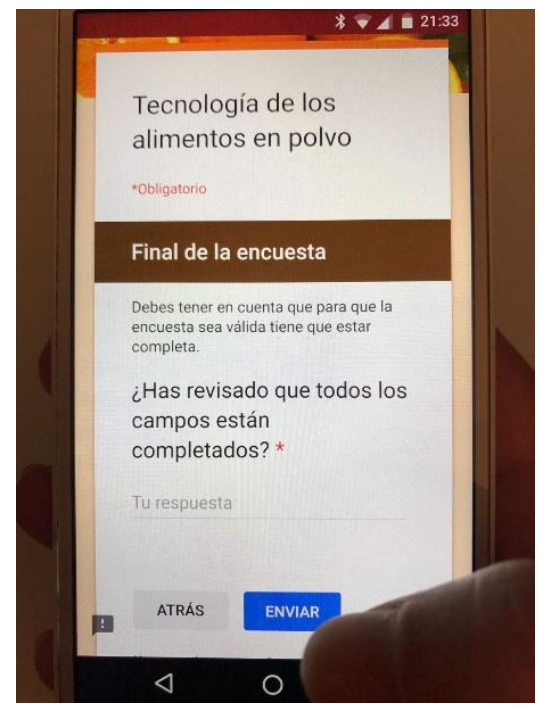

Fig. 2. Final de la encuesta. Campo obligatorio.

Por último y para conocer la opinión de los alumnos en cuanto a esta nueva metodología de aprendizaje, se realizó una encuesta de satisfacción en la que se preguntó sobre la contribución del móvil a organizar la toma de datos en las prácticas de laboratorio, su uso 
como guía o facilitando el aprendizaje de la materia. Por otra parte, también se les preguntó si su utilización había aumentado el interés en la asignatura y si pensaban que su uso era más eficaz que el uso del sistema “tradicional” (lápiz y papel). Por último, se les instó a sugerir mejoras en el sistema.

\section{Resultados}

A lo largo del curso, en las sesiones prácticas, se enviaron varios tipos de encuestas: de adquisición de datos, de cálculos y de razonamiento (Figura 3).

En la Figura 4 se presenta un momento de las prácticas en que los alumnos completan las encuestas in situ. El tipo de respuesta, numérica o corta, facilitó su cumplimentación. Así, las encuestas fueron enviadas al finalizar cada una de las sesiones prácticas.

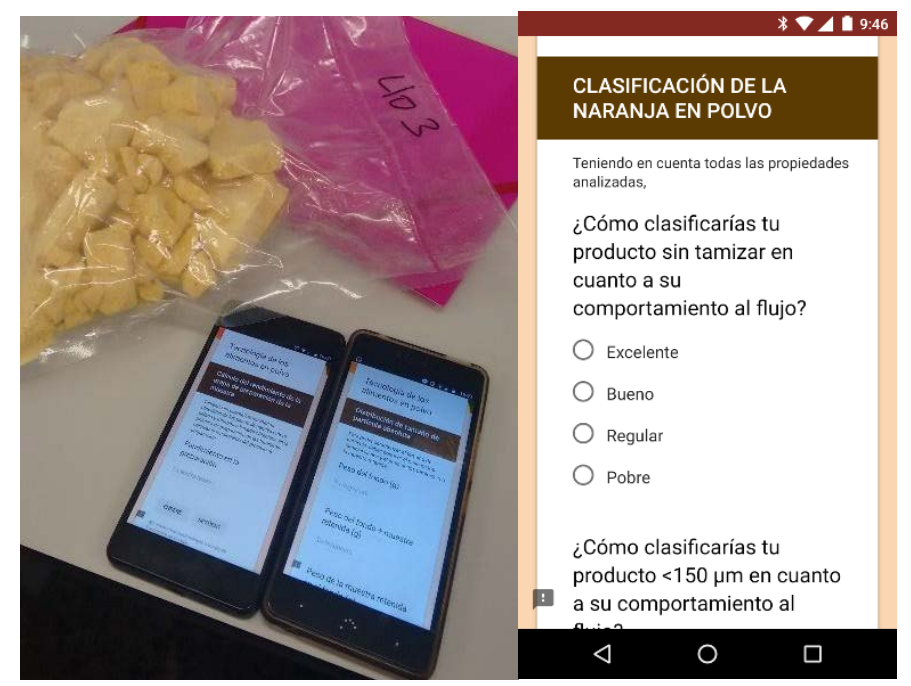

Fig. 3. Ejemplo de algunas de las cuestiones presentadas en las diferentes clases de encuestas: de adquisición de datos, de cálculos y de razonamiento. 


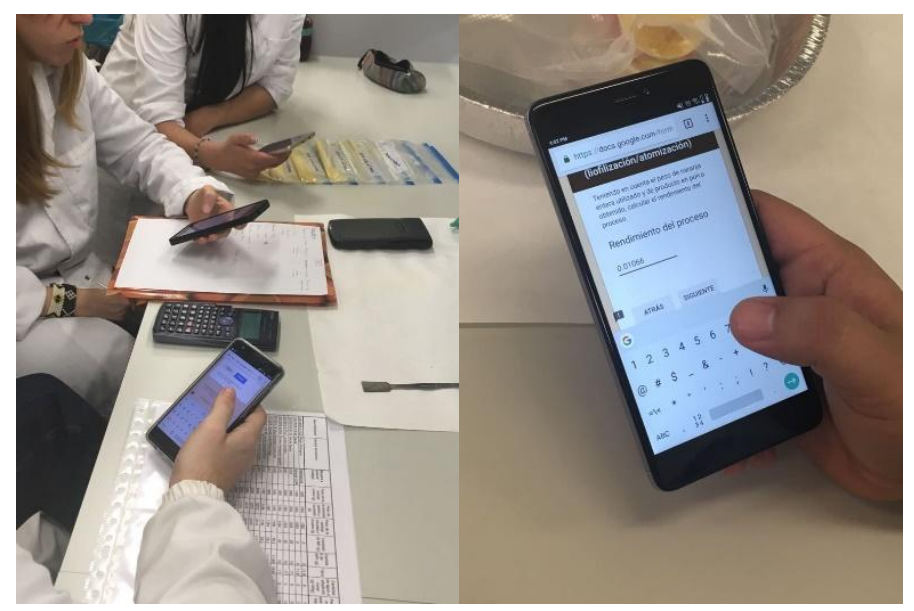

Fig. 4. Cumplimentación de las encuestas por parte del alumnado en el laboratorio.

En la Figura 5 se muestra, como ejemplo, una de las tablas de datos generada a partir de la introducción de éstos mediante el dispositivo móvil. Si se compara con la tabla de datos presentada en papel del curso 2016-17, después de haber sido revisa por el profesor (Figura 6), es evidente la diferencia. La presentación de la primera permite tener los datos más ordenados, haciendo más cómoda la tarea del profesor a la hora de comprobar que están bien para poderlos poner a disposición de los alumnos a través de la plataforma de la UPV poliformaT. Para los alumnos, la información está también más clara y ordenada. En las prácticas de esta asignatura, en concreto, cada grupo de alumnos trabaja con una muestra diferente que tiene que comparar con las de los demás compañeros, por lo que es también interesante tener todos los datos a disposición de todos en todo momento. Esto no ocurría cuando se utilizó la metodología del curso 16-17, ya que sólo estaba disponible una sola tabla para todos los alumnos que iba circulando de mano en mano hasta ser completada.

Encuesta 1 Preparación Muestra (respuestas).xlsx ty the

Archivo Editar Ver Insertar Formato Datos Herramientas Complementos Ayuda Todos los cambios se han guardado en Drive

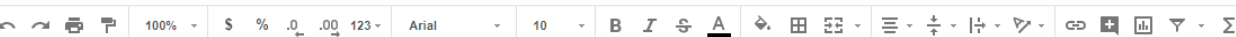

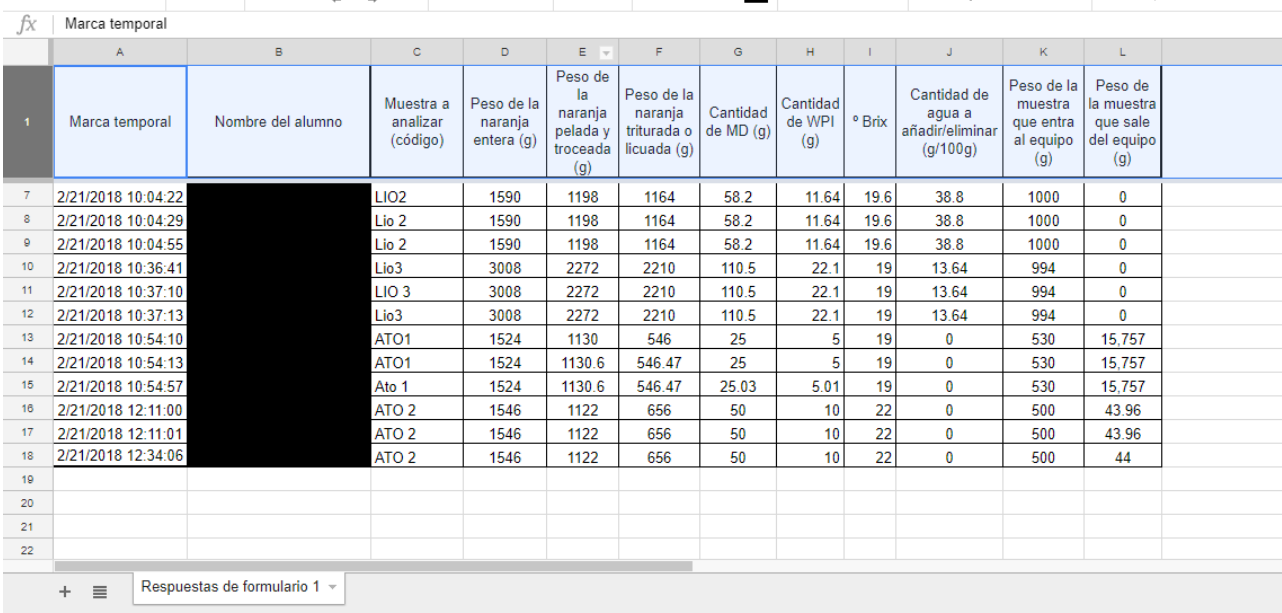

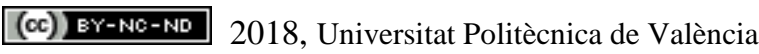

Congreso In-Red (2018) 
Fig. 5. Hoja de cálculo generada tras el envío de las encuestas cumplimentadas por los alumnos en las prácticas del curso 2017-18.

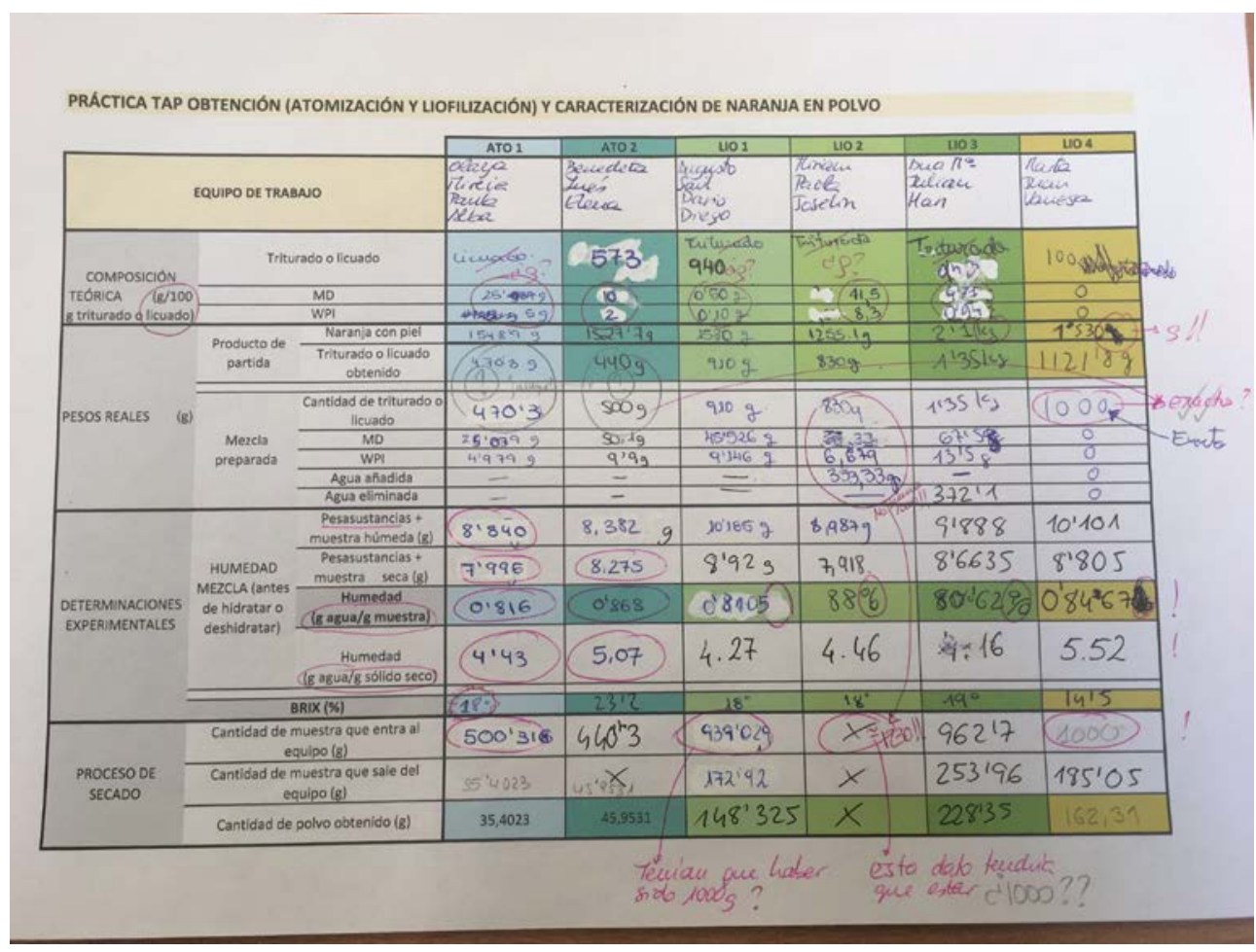

Fig. 6. Documento generado por los alumnos tras la toma de datos en las prácticas del curso 2016-17.

Estos datos son necesarios para la continuación de la práctica ya que a partir de ellos se tendrán que realizar cálculos que formarán parte de las respuestas de las encuestas siguientes. Las figuras 7 y 8 muestran los documentos generados en los cursos 2016-17 y 2017-18, respectivamente, con los resultados obtenidos a partir del tratamiento de los datos anteriormente recopilados.

(c)) EY-NC-ND 2018, Universitat Politècnica de València 


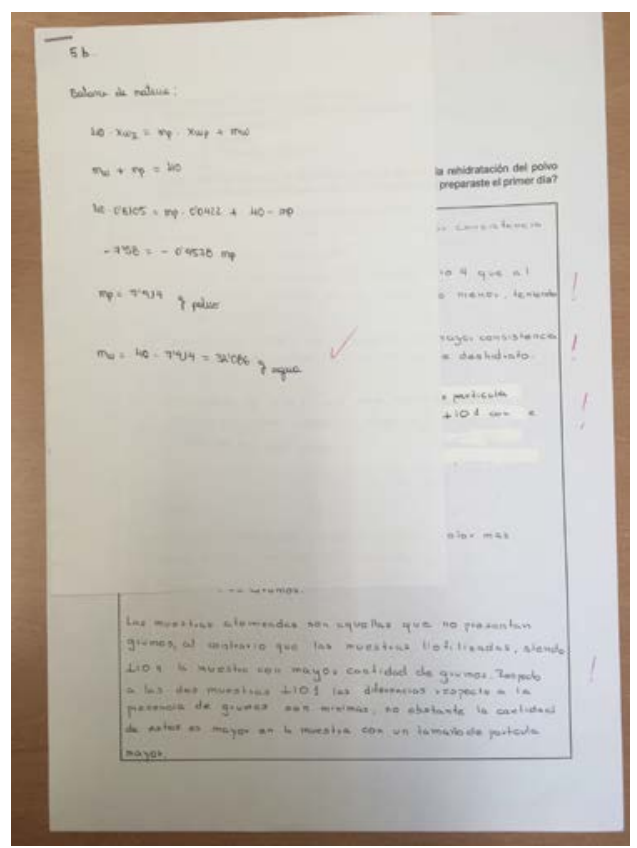

Fig. 7. Documento generado en el curso 2016-17 con los resultados obtenidos a partir del tratamiento de los datos anteriormente recopilados en el laboratorio.

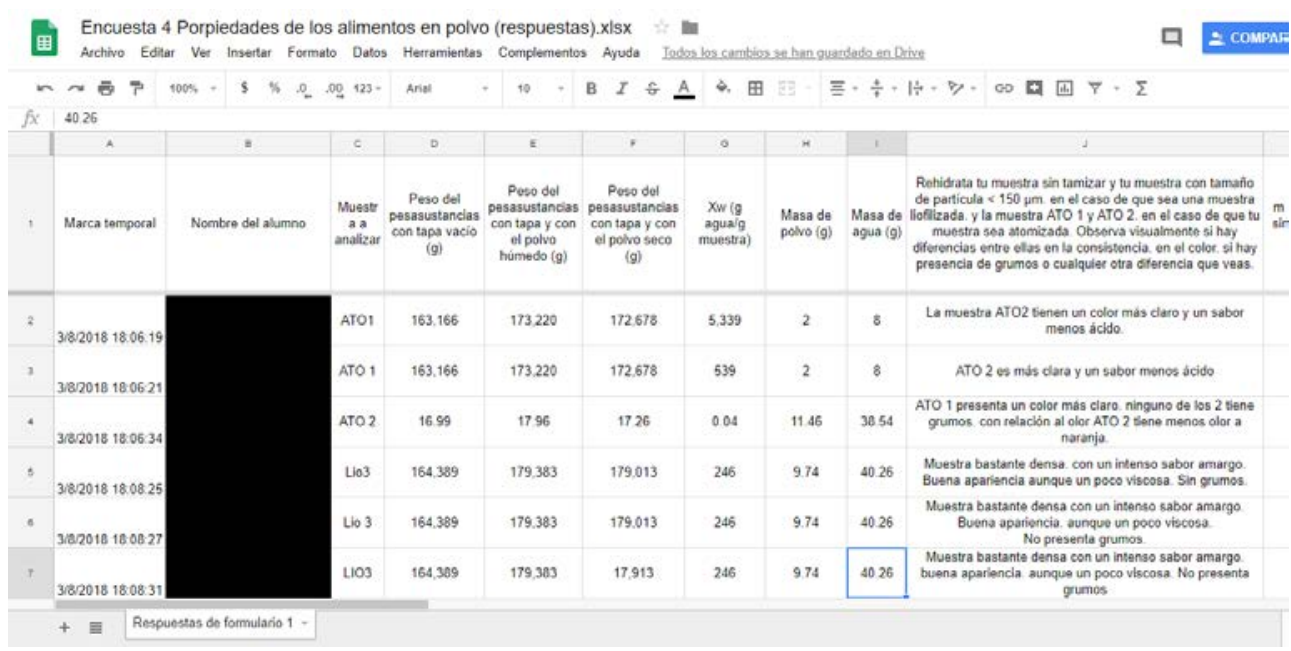

Fig. 8. Documento generado en el curso 2017-18 con los resultados obtenidos a partir del tratamiento de los datos anteriormente recopilados en el laboratorio.

En la última sesión práctica, la puesta en común de resultados, en la encuesta se presentan una serie de cuestiones para que el alumno analice los resultados obtenidos a lo largo de todas las prácticas y los relacione con los conceptos aprendidos en teoría. Las figuras 9 y 10 muestran un ejemplo de los documentos de los cursos 2016-17 y 2017-18, respectivamente.

(c)) EY-NC-ND 2018, Universitat Politècnica de València 


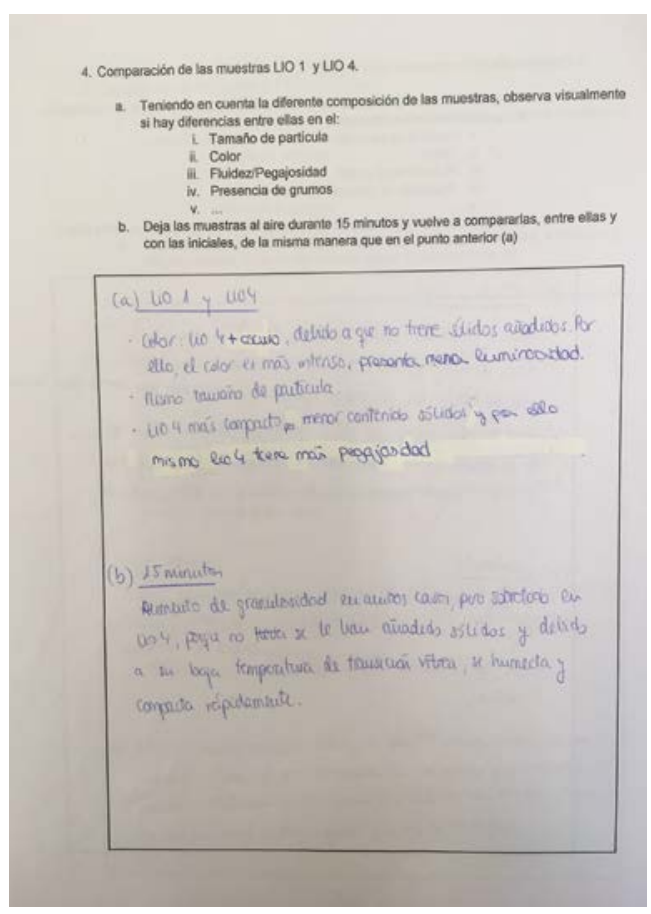

Fig. 9. Documento generado de la puesta en común de los resultados de las prácticas de laboratorio en el curso 2016-17.

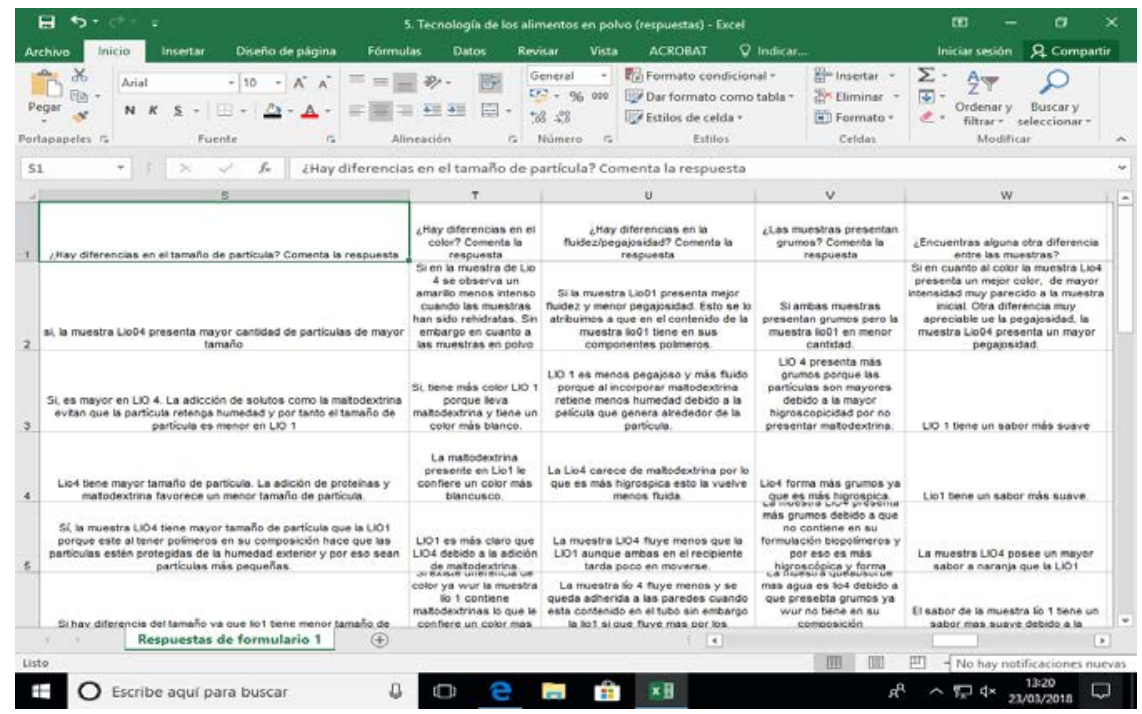

Fig. 10. Documento generado de la puesta en común de los resultados de las prácticas de laboratorio en el curso 2017-18.

Finalmente, los resultados obtenidos de la encuesta de satisfacción con la nueva metodología por parte de los alumnos muestran que el $75 \%$ de los alumnos valoraron positivamente el uso del móvil como herramienta para la ayuda a organizar la toma de datos en las prácticas de laboratorio y como facilitador del aprendizaje de la materia, mientras

(cc)) EY-NC-ND 2018, Universitat Politècnica de València

Congreso IN-RED (2018) 
que un $25 \%$ lo valoran negativamente. Por otra parte, parece que la utilización del móvil como guía les parece adecuada siendo valorado positivamente por el 81.3\% de los alumnos. Otro resultado interesante es que el $68.8 \%$ piensa que el uso del móvil ha aumentado su interés en la materia. Sin embargo, cuando se les pregunta si creen que el uso del móvil es más eficaz que el uso del sistema "tradicional" (lápiz y papel), el 31.3\% contestan que sí, el $31.3 \%$ que no y hay un $37.4 \%$ que contestan que tal vez. Esto puede ser debido a los problemas que encontraron y que quedaron plasmados en las sugerencias de mejora. En concreto echaron en falta la posibilidad de guardar la información, para evitar la pérdida de datos cuando se cerraba el programa (algo que ocurrió en algunos casos), y el consumo de batería del móvil. Por otra parte, comentaron que la utilización del móvil les había parecido interesante y útil pero que también era necesaria la toma de datos en papel y el uso de protocolos en las prácticas.

\section{Conclusiones}

La metodología docente debe adaptarse a la tecnología disponible en cada momento. En este sentido, hoy en día las tecnologías móviles están cambiando el panorama educativo, aportando movilidad, conectividad y permanencia. Estas interesantes características pueden favorecer, en un momento dado, al aprendizaje del alumno, ya que la generación de conocimiento depende de una adecuada gestión de la información y estos dispositivos ayudan a ello. Se trata, en cierta medida, de permitirles contar con una suerte de "aliado" que les ayude en la realización de las tareas que prescribe el profesor para la realización de la práctica. Algunos de los factores positivos que se derivaron del uso de los dispositivos móviles en el aula, como consecuencia de su implementación en el desarrollo de las prácticas de laboratorio, fueron el registro ordenado de los datos y la accesibilidad a la información en todo momento. Además, para el profesor, supuso una ventaja, a la hora de comprobar la asistencia y evaluar las prácticas. Por otra parte, se concluye que no se debe dejar de lado por completo la metodología “tradicional”, además de que es necesario mantener actualizada cualquier tecnología utilizada, para hacerla sostenible en el tiempo y cómoda en el manejo diario.

\section{Referencias}

ANDRES-FERRER, J. ALFARO-CID, E. LILLO, S. PEREZ DE LOS COBOS CASSINELLO, M. RODRIGO, A. (2013). El uso de encuestas rápidas a través del móvil en la enseñanza universitaria. Actas del XXI Congreso Universitario de Innovación Educativa en las Enseñanzas Técnicas. 1082-1092.

BAIN, K. (2007). Lo que hacen los mejores profesores universitarios. Valencia, Universitat de València.

GISBERT, M., ESTEVE, F. (2016). Digital Leaners: la competencia digital de los estudiantes universitarios. La Cuestión Universitaria, 7, 48-59.

2018, Universitat Politècnica de València

Congreso In-Red (2018) 
MORALES VALLEJO, P. (2008). Nuevos roles de profesores y alumnos, nuevas formas de enseñar y aprender. En, L. Prieto Navarro (coordinadora), La enseñanza universitaria centrada en el aprendizaje. Estrategias útiles para el profesorado. Barcelona, Octaedro-ICE.

MUÑOZ, M.J., BLASCO, E., BES, M.A., GARCÍA, J., SANCHIS, P., VIDAL, B., FENOLLOSA, M.L., RIBAL, F.J., TORTAJADA, L.A., NOGUERA, P. (2012). "Evaluación de las prácticas mediante rúbricas: experiencia multidisciplinar". Proceedings. Jornada de Innovación ICE-UPV. Valencia: Editorial UPV.

NOGUERA, P, TORTAJADA, L.A. ATIENZA, J, HERREERO, M.A. (2011). Autoevaluación previa a las prácticas de laboratorio químico: introducción al autoaprendizaje” en ARBOR Ciencia, Pensamiento y Cultura .Vol. 187 - Extra 3 diciembre. 267-272. 


\title{
Kahoot como herramienta de autoevaluación en la universidad
}

Francisca Sempere Ferre

Universidad Politécnica de Valencia. Camino de Vera s/n. 46022-Valencia. España.

frasemfe@upvnet.upv.es

\begin{abstract}
The present study addresses the use of Kahoot as a self-assessment tool in the university classroom. The experiment was conducted in the subject of Bromatology of the Degree in Human Nutrition and Dietetics (San Vicente Mártir Catholic University of Valencia) during the academic year 2016-2017 with a population sample of 45. At the end of each thematic block test questions were designed linked to the contents and the students answered them through the mobile phone.

The students valued the application in a very positive way as a tool to improve learning. The percentage of questions answered correctly exceeded $50 \%$ in all the questionnaires. In addition, they rated the methodology as very good to excellent.

In summary, the use of Kahoot according to the results obtained suggests that it could be a good method to motivate student study and as a selfevaluation system.
\end{abstract}

Keywords: self-evaluation, gamification, TICs, Kahoot, smarthphone

\section{Resumen}

El presente estudio aborda la utilización de Kahoot como herramienta de autoevaluación el aula universitaria. El experimento se realizó en la asignatura de Bromatología del Grado de Nutrición Humana y Dietética (Universidad Católica de Valencia San Vicente Mártir) durante el curso académico 2016-2017 con una muestra poblacional de 45. Al final de cada bloque temático se diseñaron preguntas tipo test vinculadas con los contenidos y los alumnos las contestaron a través del teléfono móvil.

Los estudiantes valoraron de forma muy positiva la aplicación como herramienta para mejorar el aprendizaje. El porcentaje de preguntas contestadas correctamente superó en todos los cuestionarios el 50\%. Además, valoraron la metodología como muy buena a excelente.

En resumen, el uso de Kahoot según los resultados obtenidos, sugiere que podría ser un buen método para motivar el estudio del alumnado y como sistema de autoevaluación.

Palabras clave: autoevaluación, gamificación, TICs, Kahoot, smarthphone 


\section{Introducción}

Los estudiantes que actualmente ingresan en la universidad son jóvenes que han nacido, han crecido y han sido educados en ambientes dónde la tecnología ha jugado un papel fundamental (Ibáñez, Cuesta, Taglibaue y Zangaro, 2008). En este sentido, las metodologías docentes necesitan cambiar y el proceso de enseñanza-aprendizaje debe apoyarse en esta.

Dentro de este contexto, la inclusión de dispositivos móviles y herramientas de gamificación en la enseñanza ha dado lugar a nuevas posibilidades para los docentes que si las usan correctamente pueden ser una fuente de innovación, favoreciendo el aprendizaje del estudiante del siglo XXI.

Aunque existen diferentes conceptos, la gamificación consiste en la utilización de las mecánicas del juego, su estética y sus estrategias para involucrar a la gente, motivar a la acción, promover el aprendizaje y resolver problemas (Kapp, 2012).

Kahoot es una herramienta web gratuíta que conjuga el uso de ambos elementos: dispositivos móviles y gamificación. Permite crear encuestas, cuestionarios y discusiones, obteniendo feedback de los alumnos en tiempo real.

El uso de Kahoot en diferentes ámbitos educativos con diversos objetivos ha sido estudiado previamente y siempre se han obtenido resultados muy positivos (Grinias, J.P, 2017; Iwamoto, Hargis, Taitano y Vuong, 2017; Mu y Paparas, 2015; RodriguezFernandez, 2017; Varannai, Sasvari y Urbanovics, 2017). Las investigaciones concluyen que Kahoot es una buena herramienta para realizar actividades en el aula, contribuye a mejorar la participación del alumno fomentando una relación positiva entre el grupo de alumnos, aumenta la tasa de asistencia a clase y el alumno lo percibe como un juego.

La aplicación de esta herramienta se aplicó en la Universidad Católica de Valencia durante el curso académico 2016-2017 con una muestra poblacional de 45 alumnos en la asignatura de Bromatología de segundo del Grado de Nutrición Humana y Dietética.

\section{Objetivos}

Objetivo general:

- Estimular el aprendizaje de la asignatura.

Objetivos especifícos:

- Fomentar el hábito de estudio entre los estudiantes universitarios.

- Motivar al alumno a través de la competitividad.

\section{Desarrollo de la innovación}

Durante el cuatrimestre en el que se impartió la asignatura, se crearon 12 cuestionarios tipo test vinculados con los diferentes temas impartidos.

El número de preguntas de cada cuestionario fue variable. Cada pregunta constaba de cuatro opciones de respuesta con una de ellas verdaderas.

(cc) EY-NC-ND 2018, Universitat Politècnica de València

Congreso IN-RED (2018) 


\subsection{Valoración de la herramienta}

Después de impartir cada uno de los temas, los alumnos disponían de cuatro días para prepararlo.

Las preguntas se proyectaron en el aula y el alumno a través de su smartphone, tablet u ordenador, respondían a las mismas ajustándose al tiempo marcado (20 segundos).

Cada pregunta mostraba el respectivo ganador y los puntos se iban acumulando para ofrecer un ranking final, como si se tratase de una competición.

Los resultados se consideraron dentro de la evaluación de la asignatura como evaluación sumativa dándole un peso de $0,5 \%$.

Para conocer la opinión de los alumnos, al final de cada test, se realizó una encuesta cuantitativa. El modelo de encuesta aplicado recogía los siguientes ítems:

- $\quad$ ¿Os ha servido como herramienta de aprendizaje? Valoración (0-100)

- ¿ ¿Os ha parecido divertido? Valoración 1: Insuficiente, 2: Regular, 3: Bueno, 4: Muy bueno, 5: Excelente.

- ¿¿Lo recomendarías? (0-100)

De los resultados obtenidos en las doce encuestas se realizaron las medias para interpretar los resultados.

Además, se evaluaron los porcentajes de respuestas correctas e incorrectas respondidas a lo largo del periodo académico.

\section{Resultados}

\subsection{Respuestas correctas en los cuestionarios}

El porcentaje de respuestas correctas en los 12 cuestionarios realizados durante el periodo académico superó al porcentaje de respuestas incorrectas (Tabla 1). Las respuestas acertadas en todos los casos, fue superior al 50\% de las preguntas planteadas, siendo el valor mínimo del $68 \%$ y el valor máximo de $84 \%$.

Respecto a las respuestas no acertadas, este no superó el 32\% (Tabla 1).

Tabla 1. Resultado de los cuestionarios tipo test realizados.

\begin{tabular}{|l|c|c|c|c|c|c|}
\cline { 2 - 7 } \multicolumn{1}{l|}{} & Kahoot 1 & Kahoot 2 & Kahoot 3 & Kahoot 4 & Kahoot 5 & Kahoot 6 \\
\hline \% de respuestas correctas & 82 & 68 & 81 & 75 & 68 & 69 \\
\hline $\begin{array}{l}\text { \% de respuestas } \\
\text { incorrectas }\end{array}$ & 18 & 32 & 19 & 25 & 32 & 31 \\
\hline \% de respuestas correctas & 74 & 72 & 80 & 84 & 78 & 79 \\
\hline $\begin{array}{l}\text { \% respuestas } \\
\text { incorrectas }\end{array}$ & 26 & 28 & 20 & 16 & 22 & 21 \\
\hline
\end{tabular}


En las 12 encuestas realizadas, un $90 \%$ de los estudiantes valoraron de forma muy positiva la aplicación como herramienta para mejorar el aprendizaje (Figura 1).

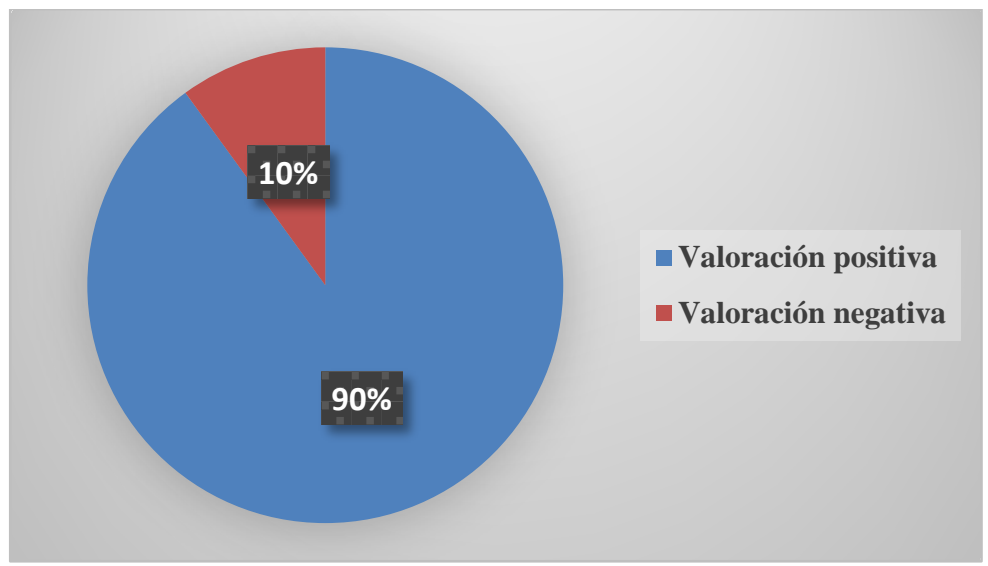

Fig. 1 Valoración de Kahoot por parte del estudiante.

Considerando el aspecto divertido de la aplicación, se obtuvo un valor medio de 4,25. Según la interpretación de los items estipulados, los alumnos consideraron que kahoot es una aplicación de muy buena a excelente (Figura 2).

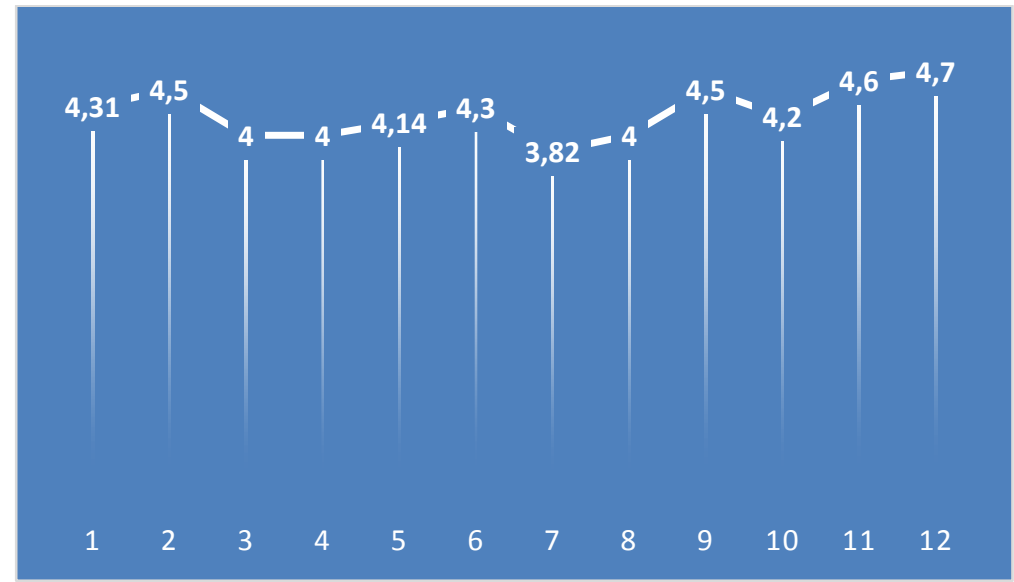

Fig. 2. Grado de valoración del aspecto divertido de Kahoot de los 12 cuestionarios realizados. 1: Insuficiente. 2: Regular. 3: Buena. 4: Muy buena. 5: Excelente.

Finalmente a la pregunta si recomendarían la aplicación, la mayoría de alumnos lo harían, obteniendo un resultado promedio del $80 \%$.

(c) EY-NC-ND 2018, Universitat Politècnica de València

Congreso IN-RED (2018) 


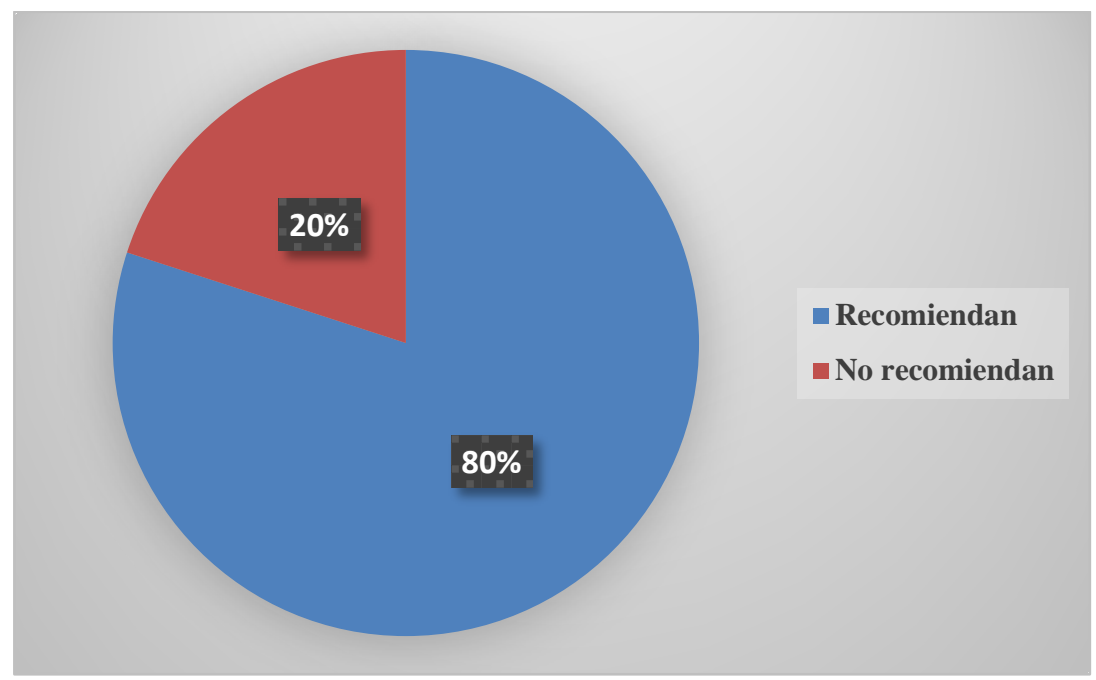

Fig. 3. Recomendación de la herramienta.

\section{Conclusiones}

Kahoot se perfila como una herramienta de autoevaluación dentro del aula que integra la gamificación y el uso del teléfono móvil y que permite según los resultados obtenidos:

- Mejorar el aprendizaje de la asignatura

- Fomentar el hábito de estudio entre los estudiantes universitarios.

- Motivar a los alumnos a través de la competitividad.

Además es una herramienta valorada de forma positiva por la mayoría de los estudiantes.

Como aspectos negativos cabe resaltar:

- $\quad$ Se necesita conexión wifi.

- La herramienta a veces falla y algunos alumnos se quedan a la mitad del cuestionario.

- A la hora de formular las preguntas, limita el uso de palabras.

- $\quad$ No se pueden imprimir los test realizados.

Por otra parte, se ha observado también que utilizar Kahoot como herramienta de autoevaluación:

- Aumenta la asistencia clase y la participación del alumnado en el aula. Los días estipulados para la realización de las pruebas, se registró una asistencia del 100\%.

- Incrementa el tiempo de estudio de la asignatura. Ya que los alumnos tenían que estudiar para aprobar el test. La nota formaba parte de la evaluación sumativa.

- Facilita al docente información relevante sobre el alumnado; como por ejemplo, aquellos conceptos no asimilados. Una vez realizado el cuestionario el profesor podia observar que preguntas tenían un mayor porcentaje de fallo.

- Ayuda al docente a reformular preguntas mal planteadas.

- Mejora los resultados académicos de los alumnos. 
Es necesario en este sentido, realizar futuros estudios al respecto. En esta línea se sugiere la ampliación de las preguntas de las encuestas que recojan aspectos que mejora el uso de la aplicación y que no se han podido constatar por no haberse evaluado, como algunos citados anteriormente. Se necesita además diseñar estudios que describan una correlación positiva entre la puntuación obtenida en los Kahoot y la obtenida en el examen parcial, ya que se ha observado que aquellos alumnos que mayor puntuación consiguieron en el juego, también lo hicieron en este examen.

\section{Bibliografía}

Grinias, J.P. (2017). Making a game out of it: using web-based competitive quizzes for cuantitative analysis content review. Journal of Chemical Education, 94 (9), 13631366.

Ibañez, E., Cuesta, M., Taglibaue, R y Zangaro, M. (2008). La generación actual en la universidad: el impacto de los millennials. V Jornadas de Sociología de la UNLP. Universidad Nacional de La Plata. Facultad de Humanidades y Ciencias de la Educación. Departamento de Sociología. La Plata. Recuperado de https://www.aacademica.org/000-096/261.pdf.

Iwamoto, D.H., Hargis, J., Taitano, E.J. y Vuong, K. (2017). Analizing the efficacy of te testing effect using Kahoot (TM) on student performance. Turkish Online Journal of Distance Education, 18 (2), 80-93.

Kaap, K.M. (2012). The gamification of learning and instruction: game-based methods and strategies for training and education.San Francisco: John Wiley \& Sons.

$\mathrm{Mu}$, H.R y Paparas, D. (2015). Incorporating the advantages of clickers and mobile devices to teach economics to non-economist. Congent Economics \& Finance,. 3 (1), 1-10.

Rodríguez-Fernández, R. (2017). Smartphones y aprendizaje: el uso de Kahoot en el aula universitaria. Revista Mediterránea de Comunicación, 8(1),181-189.

Varannai, I., Sasvari, P. y Urbanovics, A. (2017). The use of gamification in higher education: an empirical study. International Journal of Advanced Computer Science and Applications, 8 (10), 1-6. 


\title{
Monitorización de instrumentación avanzada para docencia en red.
}

Juan Bta. Talens, José Pelegrí-Sebastià, Fco José Ibáñez y Tomás Sogorb.

Universitat Politècnica de Valéncia, jpelegri@upv.es.

\begin{abstract}
Due to university internationalization, learning's concept is not linked to a specific geographical place. This document describes the methods used to visualize the laboratory's instruments (oscilloscope Tektronix TDS 210 and the generator Agilent 33120A) monitored remotely. Being able to generalize to any instrument that has an interface for remote connection regardless of the type of bus technology.
\end{abstract}

Keywords: LabVIEW, Osciloscope, Tektronix, Function Generator, Agilent.

\begin{abstract}
Resumen
Debido a la internacionalización universitaria, el concepto aprendizaje no está vinculado a un lugar geográfico específico. Este documento describe los métodos utilizados para visualizar en el laboratorio los instrumentos (osciloscopio Tektronix TDS 210 y el generador Agilent 33120A) monitorizados de forma remota. Pudiéndose generalizar a cualquier instrumento que tenga interfaz para conexión remota independientemente del tipo de tecnología bus.
\end{abstract}

Palabras clave: LabVIEW, Osciloscopio, Tektronix, Generador de funciones, Agilent.

\section{Introducción}

La asignatura de Instrumentación Avanzada estudia con detalle diferentes instrumentos básicos en un laboratorio de telecomunicaciones y el control de estos a través de diferentes buses de instrumentación (GPIB, VXI, Ethernet, USB). Estos contenidos cubren un amplio rango de conceptos prácticos de un instrumento convencional y las herramientas que hacen posible realizar un instrumento virtual y su control. El internet de las cosas nos brinda la oportunidad de convertir algunas computadoras alrededor del mundo en sofisticados laboratorios (Yang-Mei and Bo, 2014) o donde simplemente un alumno o alumna pueda hacer sus prácticas como p. ej. (Amer et al., 2015), (Selangor, 2017) y (Kamensky et al., 2017). El presente artículo detalla el diseño y desarrollo de una aplicación capaz de mostrar en pantalla el estado de los instrumentos del laboratorio de electrónica. En concreto el osciloscopio y el generador de funciones, elementos básicos en la realización de prácticas con LabVIEW. Esta aplicación surge con la imposibilidad de algunos alumnos acceder al laboratorio por encontrarse ocupado o por incompatibilidad de horarios. Así pues, se recogen las observaciones de los alumnos que han cursado la asignatura desde el curso 
académico 2012-2013 hasta el curso 2016-2017 y que han tenido la posibilidad de utilizarla.

\section{Objetivo}

El objetivo de la monitorización de instrumentación en red es favorecer el acceso remoto al laboratorio de los alumnos que por incompatibilidad de horarios o por encontrarse desplazados les es imposible acceder físicamente.

\section{Desarrollo de la innovación}

\subsection{Especificaciones}

Se requiere el diseño y desarrollo de una aplicación capaz de mostrar en pantalla el estado de los instrumentos del laboratorio de electrónica. La aplicación debe proporcionar el control de errores y no debe permitir desde la misma el control WYSIWYG de los mismos p. ej. cambios de escala, señal etc. El usuario únicamente podrá controlar el instrumento mediante el uso de LabVIEW (National Instruments, 2016) u otro software. Por tanto, la aplicación únicamente debe mostrar el estado de los mismos.

Se establecen tres condiciones:

- El alumno debe acceder respetando un determinado control horario de acceso al equipo informático y la sesión activa tiene un máximo de dos horas. Si el alumno deja inactiva la sesión se debe desconectar automáticamente a los 10 minutos. Si otro usuario alumno, accede fuera de su horario marcado podrá acceder si la sesión está libre. Por el contrario, si está siendo usada la sesión, el sistema pedirá permiso al usuario activo para permitir el acceso o denegarlo.

- Para el control y evaluación del profesor, se requiere de registro de control de acceso a los equipos, en que se pueda realizar una auditoría del usuario que se conecta, la hora de inicio y la hora de finalización.

- Para que el sistema sea sostenible desde la perspectiva económica y medioambiental los equipos tanto informáticos como instrumental se deben enchufar en el horario de trabajo, quedando totalmente apagados fuera de ese horario.

\subsection{Tecnologías utilizadas}

\subsubsection{Condiciones iniciales del entorno}

Se dispone de un laboratorio con equipos informáticos en un entorno WINDOWS, versión para empresas (WINDOWS 7 ENTERPRISE ED., WINDOWS 10, etc.) conectados en red y unidos a un dominio (GANDIELAB2008) de ACTIVE DIRECTORY bajo WINDOWS 2008 SERVER o posterior. En cada puesto de trabajo hay un equipo informático y un osciloscopio digital Tektronix TDS210 y un generador de funciones HP33120A ambos 
controlados por GPIB. Además, dispone de una fuente de alimentación regulable y cortocircuitable Promax FA-662B y otras herramientas y componentes.

\subsubsection{Escritorio remoto}

Escritorio remoto (Meneses Wong, 2008) conecta dos equipos a través de una red o de Internet. Una vez establecida la conexión, se observa el escritorio del PC remoto como si se estuviese sentado frente a él, y se tiene acceso a todos sus programas y archivos. Dado que los equipos del laboratorio de electrónica poseen el S.O. WINDOWS y que esta función está incluida en todas las ediciones. Esta tecnología ofrece de una forma rápida y sencilla una solución a la conectividad entre equipos remotos.

\subsubsection{LabVIEW}

Es una plataforma propietaria para programación a gran escala que permite el desarrollo de aplicaciones generalmente orientadas al control de la Instrumentación, además de estar presente con una carga alta en los contenidos de las asignaturas de Instrumentación Avanzada de la titulación Grado en Ingeniería de Telecomunicación, Sonido e imagen de la Escuela Politécnica Superior de Gandia.

\subsubsection{MAX (Measurement \& Automation Explorer)}

Measurement \& Automation Explorer (National Instruments, 2016) proporciona acceso a los instrumentos conectados a los periféricos de la computadora, permitiendo su monitorización y detección de fallos. Aunque ofrece amplias posibilidades el uso de este software se ha limitado a la depuración de errores en el análisis de etapas tempranas de diseño.

\subsubsection{GPIB}

El Hewlett-Packard Instrument Bus (HP-IB) es un estándar bus de datos digital de corto rango desarrollado por Hewlett-Packard en los años 1970 para conectar dispositivos de test y medida p. ej. multímetros, osciloscopios, etc, con dispositivos que los controlen como un ordenador. Otros fabricantes copiaron el HP-IB, llamando a su implementación General Purpose Instrumentation Bus (GPIB). En 1978 el bus fue estandarizado por el Institute of Electrical and Electronics Engineers (IEEE) como el IEEE-488 (488.1).

El IEEE-488 permite que hasta 15 dispositivos inteligentes compartan un simple bus paralelo de 8 bits, mediante conexión en cadena, con el dispositivo más lento determinando la velocidad de transferencia. La máxima velocidad de transmisión está sobre 1 Mbps en el estándar original y en 8 Mbps con IEEE-488.1-2003 (HS-488).

\subsection{Soluciones}

\subsubsection{LabVIEW}

La captura de imagen mediante el uso del comando HARDCopy proporciona la ventaja que no se deben obtener otros parámetros y traducirlos a un lenguaje visual para su 
interpretación por el usuario. Este hecho hace que se descarte la opción de copiar los puntos ya que implica el envío de 10 MS y además las cabeceras de toda la configuración que llevan a la saturación del bus. Por otra parte, la implementación al lenguaje visual requiere de una elevada complejidad en la aplicación.

\subsubsection{Elección del BUS}

El uso de dos buses, soportado en el caso del osciloscopio, nace en previsión que el usuario reciba constantemente actualizaciones de la imagen. Se comprueba que esto es inviable ya que el bus se bloquea y por lo tanto no es posible enviar ni recibir comandos. Por lo que se decidió restringir la captura a petición del usuario. Este sólo recibe cuando pulsa el botón actualizar. No obstante, la idea del uso del RS232 para la captura de la imagen sigue siendo interesante porque permite mayor velocidad que el GPIB. Se puede configurar el osciloscopio hasta 19200 baudios, aunque requiere de una configuración previa del instrumento que pudiera no ser compatible con el reseteo del mismo e inducir al usuario a errores de interpretación, o en el peor de los casos, a imposibilitar la conexión.

\subsubsection{Control de errores}

La monitorización por parte del IOtrace se descarta ya que los errores que muestra no están codificados como en los manuales de los instrumentos por lo que sacar del mismo información para después mostrarla en la aplicación supone una carga computacional adicional que ejecutar el MAX en la misma máquina. Se decide incorporar en la aplicación la información de errores a petición del usuario

\subsubsection{Configuración del sistema}

Usuarios y grupos: Desde la consola de Active Directory Users and Computers del dominio informático WINDOWS, en nuestro caso GANDIELAB2008, se crea un Grupo de Seguridad de tipo Dominio Local, GrupoEscritorioRemotoIns. También se crean tantos usuarios como alumnos deben conectarse por Escritorio Remoto. Cada usuario debe ser miembro del grupo.

El equipo del laboratorio debe tener activado el Servicio de Escritorio Remoto desde la configuración del sistema, apartado Escritorio Remoto. Además, se debe agregar el grupo de dominio "GrupoEscritorioRemotoIns" desde la consola de Administración de Equipo (local) al grupo "Usuarios de Escritorio Remoto" ubicado en Herramientas del sistema > Usuarios y Grupos Locales > Grupos

Igualmente se deben revisar las reglas del firewall y del antivirus para verificar que está permitida la conexión externa desde Escritorio Remoto.

Tiempos: Para el control tiempos debemos ir a la pestaña sesiones dentro de las propiedades del usuario tal como vemos en la figura 1. 


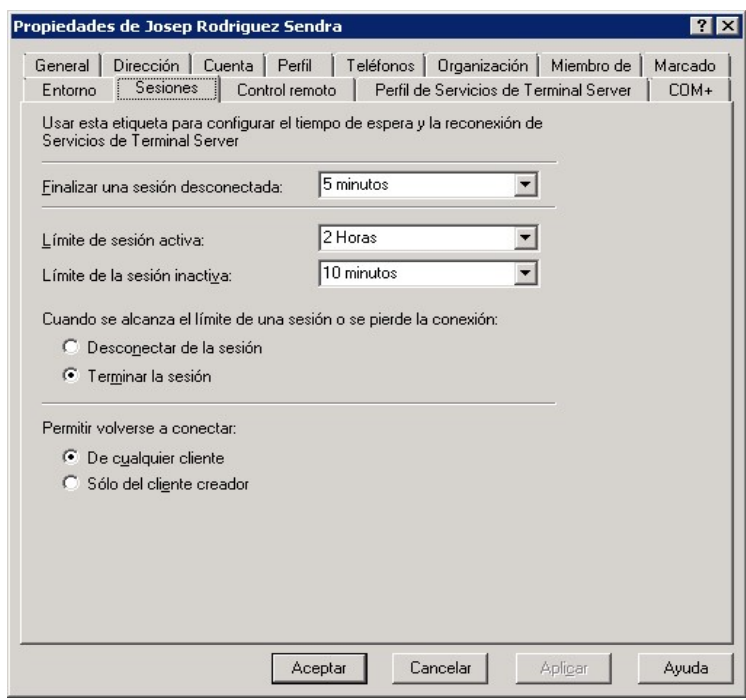

Figura 1. Datos para el control de tiempo.

Auditoría: Para abordar la segunda condición correspondiente al registro de actividad y acceso al equipo se realiza un doble sistema de auditoría. Una activando la auditoría del sistema operativo y la otra desde un fichero de texto accesible a través de red que refleje inicio o cierre, nombre de equipo, usuario fecha y hora.

Para la primera auditoría se activa desde la directiva de grupo de controlador de dominio (GPO) que el sistema refleje automáticamente en los Registros del Sistema. Estos son accesibles desde la consola del Visor de Sucesos del controlador de dominio como los siguientes eventos:

- Auditar eventos de inicio de sesión

- Auditar eventos de inicio de sesión de cuenta

Con esta auditoría queda almacenada una gran cantidad de información respecto a los inicios y cierres de sesión de usuario. Esta información es demasiado pesada de manejar para los fines docentes que se persiguen y por ello, se establece la segunda forma de registro de actividad que es más sencilla, quedando la primera con fines de resolución de conflictos y redundancia.

La segunda forma de registro de actividad y acceso consta de unos Scripts que se ejecutan en el equipo de laboratorio al inicio y cierre de sesión de usuario remoto y que escriben una línea de texto con la siguiente información para cada evento de inicio o cierre:

Inicio, nombre equipo, usuario, fecha y hora tal y como puede verse en la figura 2. 


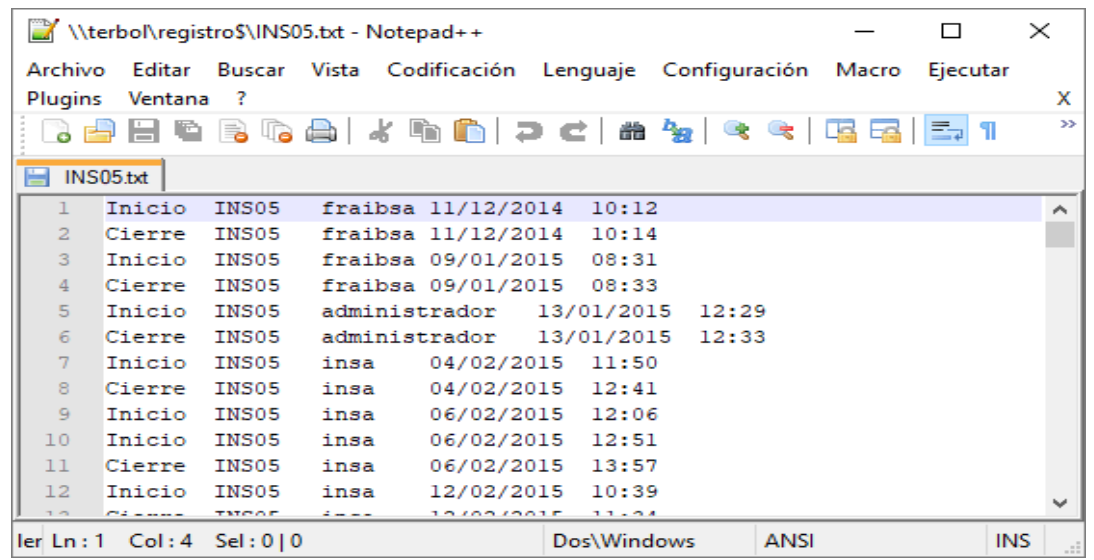

Figura 2. Registro de actividad.

Para implementar este registro se debe generar un recurso compartido oculto en el controlador de dominio, p. ej. Iterbollregistro\$; . Los administradores de sistema y el profesorado deben tener permisos de acceso. En esta carpeta se crean dos ficheros de texto vacíos con el nombre de los equipos informáticos que se pretende registrar. Por ejemplo INS05.txt y INS06.txt y se les asigna permisos de "escritura" para el usuario "todos".

También requiere dejar en este recurso los scripts que deberemos lanzar al inicio y cierre de sesión para registrar los accesos; inicio.cmd, cierre.cmd y control_insa.cmd.

\section{- Inicio.cmd}

Este script será lanzado al inicio de la sesión y llamará al control_insa.cmd para que registre el evento. Lanza en siguiente comando:

call \\terbol\registro\$\control_insa.cmd Inicio

- $\quad$ cierre.cmd

Este script se lanza al cierre de la sesión

call \} \backslash \text { terbol\registro\$\control_insa.cmd Cierre }

- control_insa.cmd

Este es el script principal que permite escribir cada una de las filas del fichero de texto con la información solicitada y lo realiza de la siguiente manera:

echo off

set dia=\%DATE\%

FOR /F "tokens=*" \%\%A IN ('TIME/T') DO SET hora=\%\%A

if \%computername\%==INS05 echo \%1 \%computername\% \%username\%

$\%$ dia\%

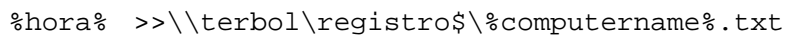

if \%computername\%==INS06 echo \%1 \%computername\% \%username\% \%dia\%

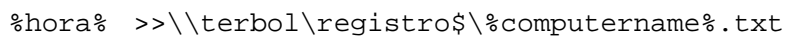

2018, Universitat Politècnica de València

Congreso IN-RED (2018) 
Para mejorar su privacidad, es interesante que estos ficheros se les active el atributo de "ocultos". Para lanzar estos scripts se requiere de una directiva GPO del dominio. Para ello, a través de la consola de "Administración de Directivas de Grupo" del dominio WINDOWS, se activan las políticas de ejecución de scripts requeridas tal y como podemos ver en la figura 3. En dicha consola se crea un GPO en dicho dominio i.e. "Auditoria acceso inicio-cierre sesión" y se vincula. En la ruta "Configuración de usuario > directivas > Configuración de Windows > Scripts" se requiere agregar para el elemento "Iniciar sesión" el fichero "inicio.cmd" y para el elemento "Cerrar sesión" el fichero "cierre.cmd".

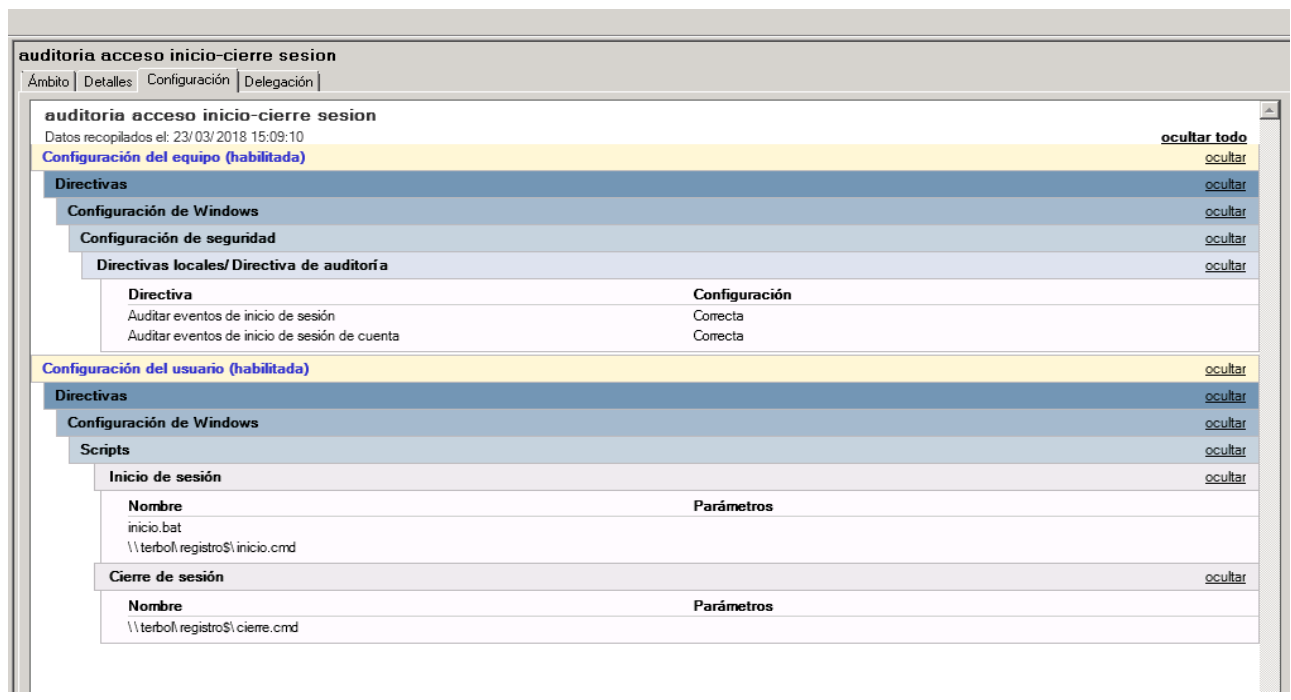

Figura 3. Configuración de políticas de ejecución.

A cada usuario se les proporciona un archivo ejecutable para realizar la conexión.

\section{Contenido del archivo para la conexión:}

ConexinER(pass=insa).rdp

screen mode id:i:2 use multimon:i:0 desktopwidth:i:800 desktopheight:i:600 session bpp:i:32

winposstr:s:0,3,0,0,800,600 compression:i:1 keyboardhook:i:2 audiocapturemode:i:0 videoplaybackmode:i:1 connection type:i:7 networkautodetect:i:1 bandwidthautodetect:i:1 displayconnectionbar:i:1 username:s:gandielab2008linsa4 enableworkspacereconnect:i:0 disable wallpaper:i:0

allow font smoothing:i:0 allow desktop composition:i:0 disable full window drag:i:1 disable menu anims:i:1 disable themes:i:0

disable cursor setting:i:0 bitmapcachepersistenable:i:1 full address:s:ins06.gnd.upv.es audiomode:i:0 redirectprinters:i:1 redirectcomports:i:0 redirectsmartcards:i:1 redirectclipboard:i:1 redirectposdevices:i:0 autoreconnection enabled:i:1 authentication level:i:2

prompt for credentials:i:0 negotiate security layer:i:1 remoteapplicationmode:i:0 alternate shell:s:

shell working directory:s: gatewayhostname:s: gatewayusagemethod:i:4 gatewaycredentialssource:i:4 gatewayprofileusagemethod:i:0 promptcredentialonce:i:0 gatewaybrokeringtype:i:0

use redirection server name:i:0 rdgiskdcproxy:i:0 kdcproxyname:s:

(cc)) EY-NC-ND 2018, Universitat Politècnica de València

Congreso In-Red (2018) 


\subsubsection{Sostenibilidad}

Para el ahorro energético y sostenibilidad se ha configurado la BIOS del equipo informático de tal manera que se despierte automáticamente a una determinada hora usando el "Wake Up" de las opciones de la pestaña "Power Management”. Para el apagado del equipo se utiliza las funciones de ahorro de energía propias del sistema operativo local. Mediante el uso de un controlador horario programable Orbis Tempo+ como el de la figura se optimiza el control del consumo energético.

\subsection{Detalles de implementación}

La implementación del sistema en LabVIEW se desarrolla por separado para luego unirse en un proyecto. Como puede verse en la figura 4 la aplicación consiste en dos subprogramas, uno para el osciloscopio y otro para el generador de señales. Tanto el osciloscopio como el generador realizan dos procesos, captura de la imagen y captura de errores. El generador dependiendo de que haya seleccionado el usuario únicamente muestra dicha selección. Por lo que los subprocesos de este último, como son error, frecuencia, amplitud, offset y forma de onda derivan de una única petición al instrumento.

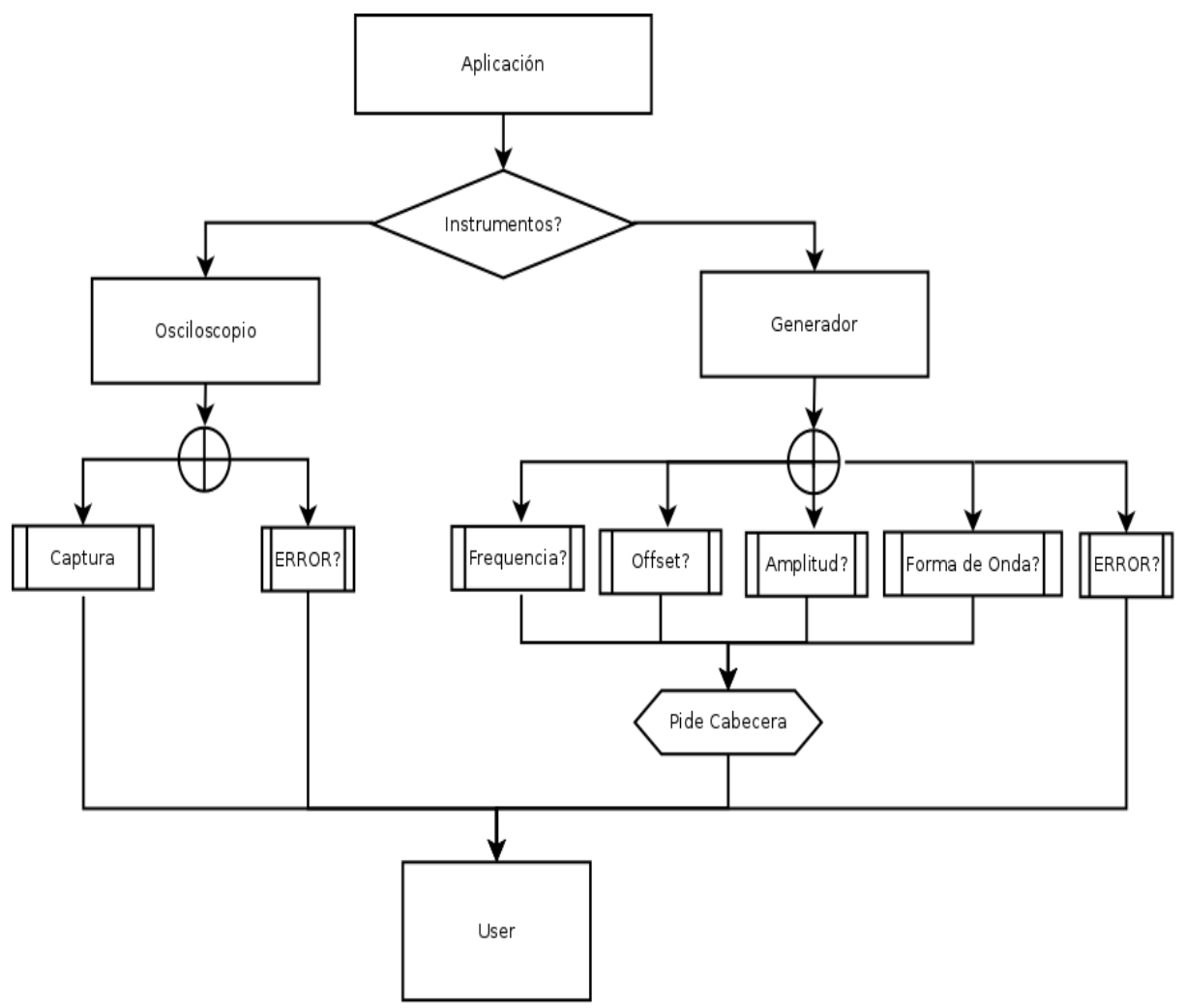

Figura 4. Diagrama de flujo de la aplicación.

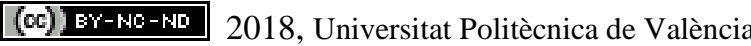

Congreso IN-RED (2018) 


\subsubsection{Búsqueda de Instrumentos}

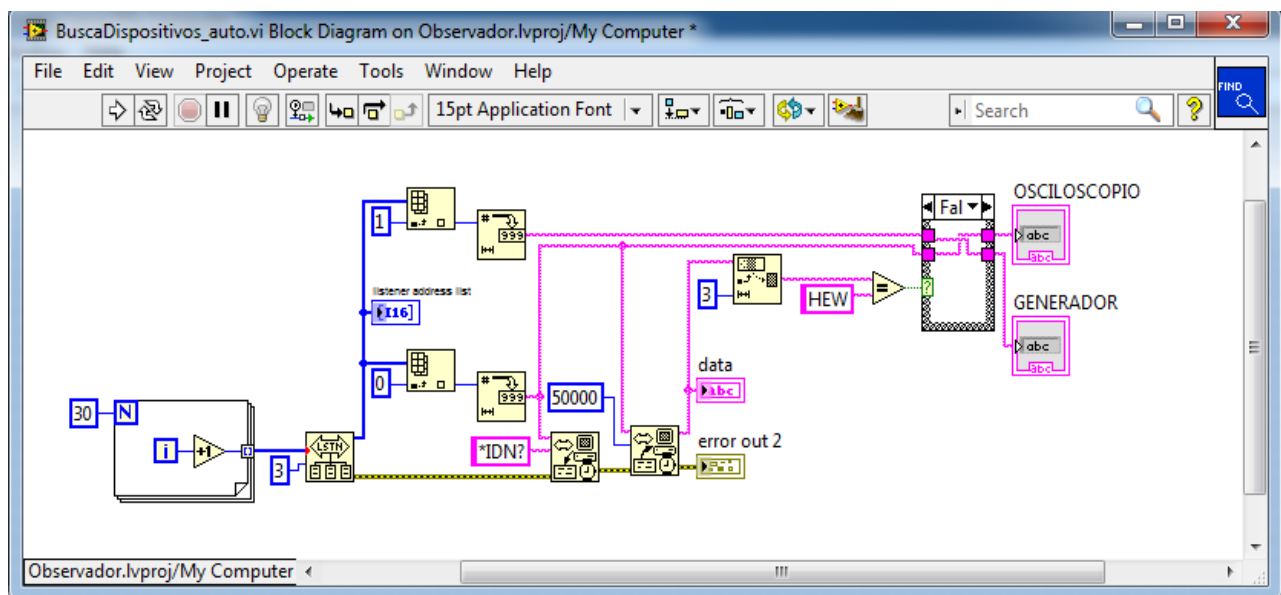

Figura 5. Diagrama de Bloques BuscaDispositivos auto.vi

Para que la aplicación sea universal a todos los PC's del laboratorio se incluye un *.vi que se encarga de buscar los dispositivos e identificarlos para su uso en los otros *.vi's. En la figura 5 se puede observar el diagrama de bloques del código. Si se observa el código se intuye como se está pidiendo que se identifiquen los instrumentos y se compara con las tres primeras letras que corresponden a la denominación del generador de funciones 'HEWLETT-PACKARD,33120A,0,10.0-5.0- 1.0'. Una vez identificado o descartado el generador resulta trivial asignar a los indicadores correspondientes el valor de la dirección del instrumento

\subsubsection{Osciloscopio}

El osciloscopio sigue dos secuencias. Inicialmente se encuentra el instrumento y se crea un archivo *.bmp en la carpeta de recursos temporales. Se registra un path que utilizara el *.vi para convertir los datos en imagen. En la segunda secuencia previa pulsación del botón “Actualizar” se envían los comandos vistos en la figura 6 y se bloquea el cursor hasta que se capturan los datos. Con los datos se genera la imagen que se envía al visor. El *.vi reacciona a petición del usuario mediante la captura de eventos. Los eventos posibles dependen de los tres botones que existen; Error, Actualizar y ON/OFF.

(c) EY-NC-ND 2018, Universitat Politècnica de València 


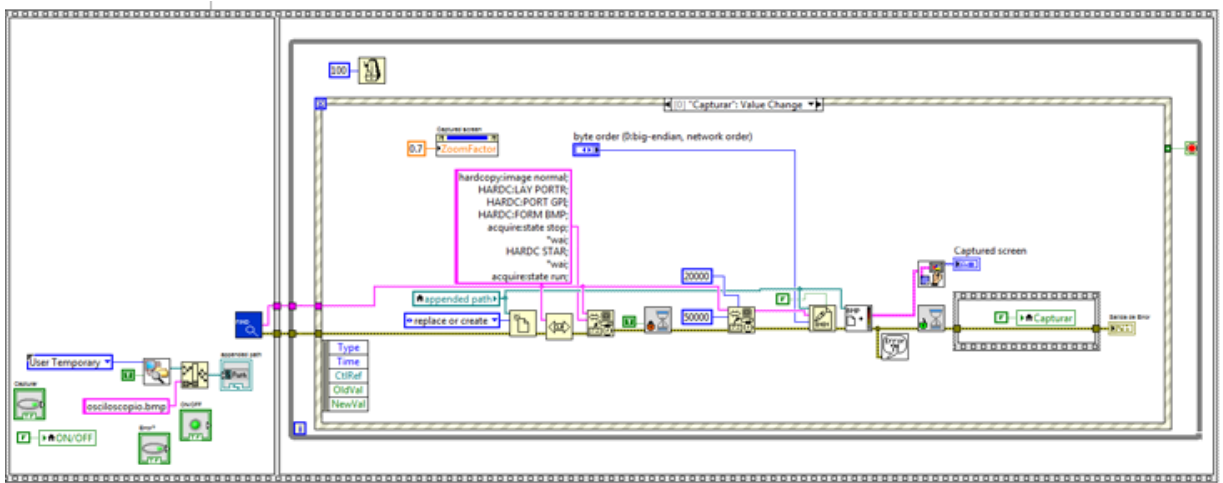

Figura 6. Diagrama de bloques archivo Osciloscopio.vi.

\subsubsection{Generador de funciones}

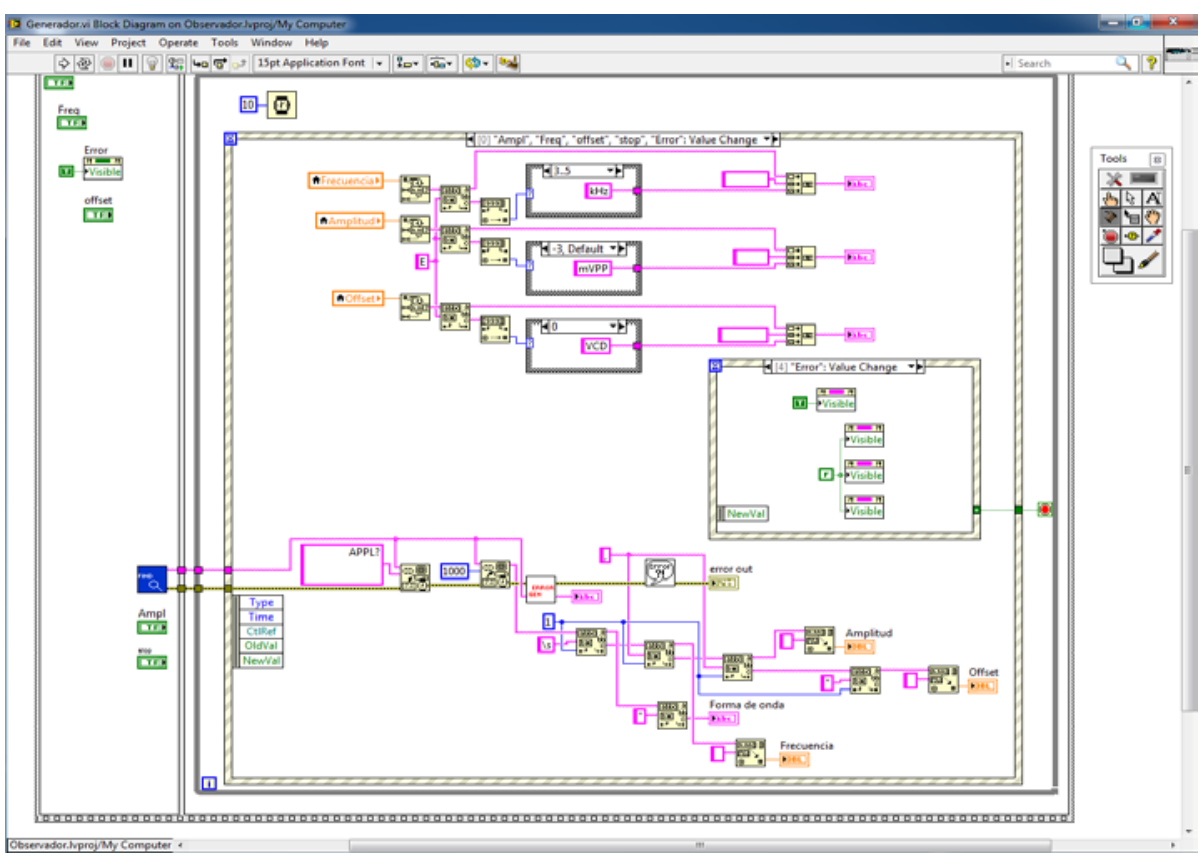

Figura 7. Diagrama de bloques archivo Generador.vi.

El generador de funciones sigue una secuencia donde en una primera fase se encuentra el dispositivo mediante el *.vi visto en $\mathrm{V}$-A y en la segunda se queda en un bucle mientras no se actúe sobre el botón de "OFF". Es en dicho bucle donde se pide al instrumento el estado del mismo mediante el comando APPL? y, dependiendo del botón pulsado se muestra el texto requerido en pantalla. En la figura 7 puede verse un detalle de la implementación.

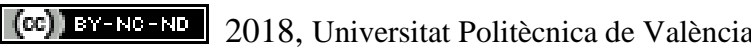

Congreso IN-RED (2018) 


\subsubsection{Errores del generador de funciones}

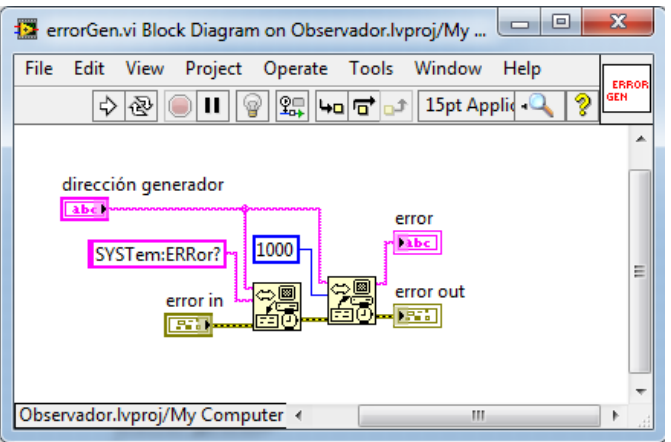

Figura 8. Diagrama de bloques archivo errorGen.vi

Tal y como se deduce del diagrama de bloques del *.vi, visto en la figura 8, se recoge la respuesta del instrumento al comando 'SYSTem:ERRor?'.

\subsubsection{Coma decimal}

En el sistema anglosajón no se utiliza la coma para indicar que empieza la mantisa de un número, en lugar de eso, se utiliza el punto. Este hecho obliga al programador a tener en cuenta un posible error de interpretación en el sistema operativo según la configuración regional establecida. LabVIEW permite tener en cuenta el uso de la coma para la separación decimal, pero en la compilación del proyecto se observó que no se disponen de la compatibilidad con el idioma español y por tanto al compilar resultó imposible establecer dicha configuración. Por lo que se optó por utilizar en el equipo destinado al uso de la aplicación la configuración anglosajona.

\subsection{INSTALACIÓN Y USO}

\subsubsection{Conexión remota}

Tras configurar la conexión VPN necesaria para acceder a equipos fuera de la Universidad Politécnica de Valencia, explicado paso a paso en (UPV- Área de Sistemas de la Información y las Comunicaciones) sección de información de la UPV. Se debe ejecutar el archivo 'Conexion ER (PASS=insa).rdp' para que realice la petición de conexión remota al equipo ins06.gnd.upv.es, el cual debe estar iniciado. Se selecciona la opción 'Usar otra cuenta', y se introduce el usuario y la contraseña proporcionada, por ejemplo, 'gandielab2008\insa4' e 'insa4'. Una vez en el escritorio remoto, se accede a la ruta donde se encuentra la aplicación y se ejecuta el acceso directo 'Observador.lnk'. Tras el inicio se debería poder visualizar en el escritorio dos ventanas como en la figura 9.

2018, Universitat Politècnica de València

Congreso In-Red (2018) 


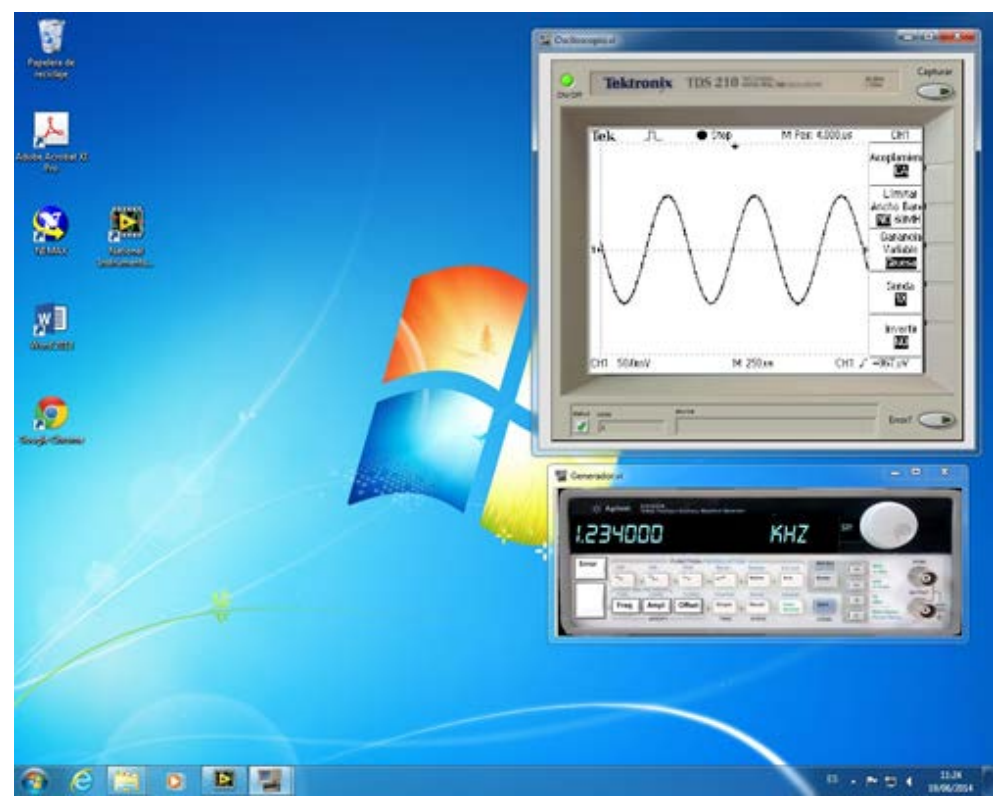

Figura 9. Captura Aplicación Observador abierta mediante Escritorio remoto.

\subsubsection{Uso del Observador}

Osciloscopio: Una vez iniciada la aplicación el usuario podrá acceder al botón de Error para visualizar si existe algún error en el dispositivo o bien al botón de Actualizar. Este último bloquea el cursor hasta que la captura se muestre en pantalla. El tiempo aproximado dependerá del equipo y la conexión siendo como mínimo de 17s.

En el caso que el instrumento no se encuentre activo o el bus esté saturado aparecerá un mensaje de error y aparecerá en la parte inferior izquierda un tick de color rojo que indica que el dispositivo no se ha encontrado y/o no se ha listado correctamente. Es posible la detención del subprograma cerrando la ventana o bien mediante el botón de ON/OFF.

Generador: Una vez iniciada la aplicación se tienen varios botones disponibles; 'Freq', 'Ampl' y 'Offset', que permiten que se muestre en el display del generador virtual los valores de frecuencia, amplitud y offset, respectivamente, que el generador real está suministrando en ese momento.

Mediante el botón 'Error' se mostrarán en pantalla los errores que haya tenido el generador al introducir los comandos u otros parámetros, en caso que los tuviera.

En el caso que el dispositivo muestre todos los valores a cero y que no existen errores o no muestre ningún valor podría significar que el instrumento está apagado o el bus saturado o desconectado, no obstante, debería aparecer un mensaje del sistema indicando el suceso. Se recomienda consultar el horario de funcionamiento del sistema. Se requiere reiniciar la aplicación con los instrumentos encendidos. Es posible la detención del subprograma cerrando la ventana o bien mediante el botón de ON/OFF. 


\section{Resultados}

La media de alumnado que ha cursado la asignatura desde la implantación del sistema descrito, en el curso escolar 2012-2013 hasta el curso 2016-2017, es de 8.2. El porcentaje de uso se mantuvo los tres primeros cursos entorno un 15\%. La disponibilidad del laboratorio junto con escasez de matrícula; 6, 7 y 6 matriculados, facilitó una atención más personalizada y propició la realización íntegra de las prácticas en el mismo sin que hubiese la necesidad imperativa de realizarlas en remoto.

En el curso académico 2015-2016 la tasa de uso alcanzó en 100\% ya que se determinó una práctica obligatoria mediante el uso de la misma. Se realizó un cuestionario donde se recoge el grado de satisfacción del alumnado con los siguientes resultados.

Tabla 1. Resultados grado de satisfacción.

\begin{tabular}{|l|c|c|c|c|c|}
\hline Curso académico & $2012-2013$ & $2013-2014$ & $2014-2015$ & $2015-2016$ & $2016-2017$ \\
\hline$N^{\circ}$ Matriculados. & 6 & 7 & 6 & 12 & 10 \\
\hline Tasa de uso de la plataforma. & $16.67 \%$ & $14.29 \%$ & $16.67 \%$ & $100 \%$ & $100 \%$ \\
\hline Acceso a la aplicación. & 5 & 5 & 5 & 4 & 4 \\
\hline Dificultad de instalación y uso. & 5 & 5 & 5 & 5 & 5 \\
\hline Horario de disponibilidad y uso. & 5 & 5 & 5 & 5 & 5 \\
\hline Aplicabilidad a la asignatura. & 5 & 3 & 5 & 5 & 5 \\
\hline Aplicabilidad a la carrera. & 5 & 3 & 4 & 5 & 5 \\
\hline
\end{tabular}

\section{Conclusiones}

El grado de utilización ha sido forzado para que tuviese un efecto considerable y se pudiese evaluar la aplicación. No obstante, la aplicabilidad y su utilidad resultan satisfactorias para el $100 \%$ de los usuarios y en entornos semipresenciales o a distancia podría ser de utilidad.

Algunas de las sugerencias responden a la activación de los equipos que por mantenimiento podrían quedar desconectados de la red y precisan de la intervención del técnico del laboratorio. Una mejora que se prevé es introducir un circuito que active un relé cuando el ordenador arranque, tomando la señal de arranque desde cualquiera de los conectores de la fuente de alimentación ATX del equipo informático o del USB. Así los instrumentos sólo estarán encendidos el tiempo que el ordenador esté activo. 


\section{Referencias bibliográficas.}

AMER, M.A., CORTINA-PUIG, M., MARTÍNEZ, V., CRUZ, J., AND MORRAL, J. (2015). "Implementation of a LabVIEW-based virtual laboratory". 2015 IEEE International Conference on Industrial Technology (ICIT), Seville, 2015, pp. 3274-3277.

JOHARI, J., AHMAD, A., MADZHI, N. K., BUNIYAMIN, N. AND KASSIM, R. A., "LabVIEW as an effective tool for problem-based learning in undergraduate engineering education," 2017 IEEE 9th International Conference on Engineering Education (ICEED), Kanazawa, 2017, pp. 169-173.

KAMENSKÝ, M., KRÁlIKOVÁ, E., ČERVEŇOVÁ, J. AND KOVÁČ, K., "Interfacing of measuring devices in educational software system for remote access," 2017 11th International Conference on Measurement, Smolenice, 2017, pp. 175-178.

MENESES WONG, L.E. Administración de escritorio remoto. Comuniquiti, 2008, pp. 1-8.

NATIONAL INSTRUMENTS (2016). LabVIEW System Design Software.

SELANGOR, S.A. (2017). LabVIEW as an Effective Tool for Problem-Based Learning in Undergraduate Engineering Education. 169-173.

UNIVERSITAT POLITÉCNICA DE VALENCIA, Área de Sistemas de la Información y las Comunicaciones "Infoacceso: Upv".

YANG-MEI, L. AND BO, C. "Electronic Circuit Virtual Laboratory Based on LabVIEW and Multisim," 2014 7th International Conference on Intelligent Computation Technology and Automation, Changsha, 2014, pp. 222-225. 


\title{
Valoración del alumnado de los experimentos virtuales frente a los experimentos tradicionales
}

Juan José Serrano-Pérez ${ }^{\mathrm{a}^{*}}$, Lorena González-García ${ }^{b^{*}}$, Alida Taberner-Cortés ${ }^{\mathrm{a}}$, Nicla Flacco ${ }^{\text {a }}$ Isabel García-Arnandis ${ }^{\text {a }}$, Gonzalo Pérez-López .

a Universidad Europea de Valencia, Departamento de Ciencias Biomédicas, c/General Elío, 8, 46010 Valencia. ' Universidad Europea de Valencia, Departamento de Psicología, c/General Elío, 8, 46010 Valencia.

*juanjose.serrano@universidadeuropea.es, lorena.gonzalez@universidadeuropea.es

\begin{abstract}
Traditional laboratory experiments are critical to the learning process across all areas and levels of study in science subjects. However, along with hands-on experiments, virtual labs have received considerable attention over the past several years due to the popularisation of ICT tools in Education, which may help teachers consider multiple learning styles to pursue meaningful learning. In this regard, studies concerning pupils' experiences with both approaches are needed.

The main aim of this study is to analyse the impact of the use of both virtual and hands-on labs in basic science subjects (BSS) in Health Sciences university degrees. For this reason, we have analysed different variables: general assessment, level of satisfaction, increase in motivation and increase in academic performance concerning BSS, as well as gender differences in the perception of both methodologies.
\end{abstract}

A total of 129 undergraduate students from one Spanish university (degree in Dentistry) participated in the study. The results point out to statistically significant differences in favour of traditional labs in all the considered parameters.

In conclusion, the results point out the importance of carrying out hands-on experiments to boost students' motivation and performance.

Keywords: laboratory, ICT, simulation, interactivity, active learning.

\footnotetext{
Resumen

Las prácticas de laboratorio tradicionales juegan un papel protagonista en la enseñanza de las ciencias en todas las áreas y niveles. Sin embargo, en los últimos años la popularidad de los laboratorios virtuales ha aumentado significativamente, debido a que la aplicación de las herramientas TIC en educación permite atender adecuadamente a la diversidad del alumnado y fomentar el aprendizaje activo. En este sentido, resulta necesario estudiar las experiencias del alumnado con ambos enfoques.
} 
El principal objetivo de este estudio es analizar el impacto de los laboratorios virtuales y tradicionales en asignaturas de Ciencias Básicas (CCBB) en un grado de Ciencias de la Salud en el contexto universitario. Para ello se ha estudiado la valoración del alumnado, su grado de satisfacción general, su motivación y su rendimiento en las asignaturas de CCBB, así como la existencia de posibles diferencias de género.

Los participantes del estudio fueron 129 estudiantes del grado en Odontología de una universidad española. Los resultados indican que existen diferencias significativas a favor de las prácticas tradicionales en todas las variables estudiadas.

Como conclusión, se resalta la importancia de fomentar las prácticas tradicionales en grados de Salud para potenciar la motivación y el rendimiento del alumnado.

Palabras clave: laboratorio, TIC, simulación, interactividad, aprendizaje activo.

\section{Introducción}

En la enseñanza del siglo XXI, las TIC (Tecnologías de la Información y Comunicación) aplicadas a la educación (es decir, las TAC, Tecnologías del Aprendizaje y del Conocimiento) ocupan un lugar protagonista. Con su uso, se pretende fomentar una mayor implicación por parte del alumnado, lo cual constituye la base del constructivismo (Coll, 2007; Hyslop-Margison, 2007; Phillips, 1995; Pozo, 2006; Spencer, 1999), que fomenta el aprendizaje activo y significativo (Freeman, 2014; Michael, 2006; Pinto, 2008; Prince, 2004). Esta corriente es especialmente importante en las orientaciones metodológicas que los expertos proponen a los docentes de las asignaturas de Ciencias (Pinto, 2008; Pozo, 2006; Rocard, 2007; Sanmartí, 2009), fomentando la comprensión frente a la mera memorización, esto es, desarrollando habilidades cognitivas de orden superior, de acuerdo con la taxonomía de Bloom de los objetivos didácticos (Cook, 2013; Krathwohl, 2002).

Con el auge de Internet y las TIC (Livingstone, 2012), no sólo la enseñanza presencial tradicional está siendo complementada con otras modalidades como e-learning, b-learning y m-learning (Franco, 2013), sino que se ha asentado en las modernas corrientes pedagógicas un cambio de paradigma en el proceso de enseñanza-aprendizaje: pasar de un sistema educativo basado en la enseñanza a otro distinto basado en el aprendizaje, alejándose de la perspectiva tradicional según la cual "contar" algo en clase equivalía a “enseñar”. En otras palabras, la típica clase magistral se está convirtiendo en un concepto anacrónico.

En definitiva, se trata de fomentar el aprendizaje activo mediante el uso de estrategias metodológicas centradas en el estudiante (Coll, 2007), dando cada vez menos importancia a las clases magistrales (Mazur, 2009) y fomentando el uso de actividades que constituyan un

(cc) BY-NC-ND 2018, Universitat Politècnica de València

Congreso IN-RED (2018) 
reto abordable para los estudiantes, teniendo en cuenta sus competencias actuales y su potencial, permitiendo que desarrollen sus capacidades dentro de la zona de desarrollo próximo (Coll, 2007; Pozo, 2006; Smagorinsky, 1995; Sanmartí, 2009), que es la distancia entre el nivel de desarrollo efectivo del alumno (aquello que es capaz de hacer por sí mismo) y su nivel de desarrollo potencial (aquello que sería capaz de hacer con la ayuda del docente o de un compañero más capaz). Este enfoque es crucial para incentivar la competencia de "aprender a aprender". Básicamente, cuanto más implicado está un estudiante en una actividad dada, más y mejor aprenderá, tal y como pone de manifiesto el cono de la experiencia de Dale (Herreid, 2012; Sprawls, 2008).

La realización de prácticas de laboratorio en las ciencias experimentales es esencial para motivar al alumnado y para la adquisición de contenidos procedimentales importantes en su formación académica y en su futuro ejercicio profesional (ACS, 2013; Domin, 1999; Elliott, 2008; Hofstein, 2003; NSTA, 2013). Sin duda, las prácticas de laboratorio constituyen una herramienta fundamental en las carreras científicas. Sin embargo, como alternativa y complemento a las prácticas de laboratorio, el uso de aplicaciones informáticas de simulación está actualmente en boga.

Los laboratorios virtuales son plataformas interactivas que se adaptan a diferentes estilos y ritmos de aprendizaje, y que suelen estár disponibles gratuitamente para todas las Ciencias Básicas, como Física, Química y Biología. Su uso presenta muchas ventajas (Bortnik, 2017; Chan, 2009; Climent-Bellido, 2003; Cobb, 2009; De Jong, 2013; Franco, 2013; García Armada, 2016; Heradio, 2016; Jensen, 2013): fomentan el trabajo en equipo, son motivantes, implican menos costes que los laboratorios tradicionales, fomentan la creatividad y un aprendizaje más autónomo, se pueden repetir las experiencias tantas veces como sea necesario, disminuyen el miedo al error y al fracaso por parte del discente, facilitan la visualización de procesos y conceptos abstractos, y permiten al docente llevar a cabo actividades de laboratorio sin tener que cambiar de aula. Además, ofrecen alternativas para la enseñanza híbrida y a distancia.

El impacto de los laboratorios virtuales, y la disyuntiva entre experimentos tradicionales y virtuales, han sido objeto de un considerable interés por parte de la comunidad educativa en los últimos años en diferentes áreas de conocimiento: Física (Deutsch, 2014; Finkelstein, 2005; Finkelstein, 2006; Franco, 2013; Perkins, 2006; Wieman, 2008), Química (Bortnik, 2017; Climent-Bellido, 2003; García Armada, 2016; Jensen, 2013; Moore, 2014; Tatli, 2010), Biología y Ciencias de la Vida (Lewis, 2014; Sanz, 2005; Stuckey-Mickell, 2007) e Ingeniería (Chan, 2009; Heradio, 2016; Ma, 2006; Potkonjak, 2016).

En general, diferentes estudios, tanto de Ciencias Experimentales como de Ciencias de la Salud, muestran niveles similares de éxito con ambos enfoques en cuanto a calificaciones, adquisición de contenidos y/o valoración (Cobb, 2009; Darrah, 2014; De Jong, 2013; Hawkins, 2013; Klar, 2007; Lewis, 2014; Makransky, 2016; Pyatt, 2012; Spernjak, 2017; Triona, 2003; Tsihouridis, 2013; Winkelmann, 2014; Winkelmann, 2017), aunque recientes estudios comparativos sobre la eficacia de laboratorios tradicionales (LT) y laboratorios virtuales (LV) muestran que con los segundos los estudiantes adquieren el mismo nivel de aprendizaje, e incluso superior (Brinson, 2015; Faour, 2018; Herga, 2012; Martínez- 
Jiménez, 2003; Tatli, 2010; Toth, 2014; Zacharia, 2007), y una valoración general muy positiva (Bozkurt, 2010; McKagan, 2008; Olakanmi, 2015; Pyatt, 2012; Stuckey-Mickell, 2007; Tatli, 2010) en relación con diferentes variables (conocimiento y comprensión de contenidos, razonamiento científico, habilidades prácticas experimentales, interés y apreciación por la Ciencia, habilidades analíticas de investigación, manejo de datos, comunicación científica y trabajo en equipo, visualización de fenómenos microscópicos, etc.). De hecho, Merchant (2014) señala la gran utilidad didáctica de simulaciones, juegos y mundos virtuales. También se destaca el hecho de poder realizar prácticas de laboratorio muy complicadas o que requerirían medios muy costosos (Heradio, 2016; Lewis, 2014; Muhamad, 2010). Asimismo, diferentes estudios señalan que el alumnado que llevó a cabo simulaciones por ordenador adquirió un mayor dominio de los contenidos conceptuales en Física e incluso desarrolló una mayor destreza en la manipulación de componentes reales (Finkelstein, 2006; Tarekegn, 2009).

Por otro lado, también hay estudios que apuntan a que el aprendizaje en ciertas áreas como Química, Biología y Farmacología es más productivo con LT (es decir, las calificaciones son superiores o se recuerdan mejor los detalles experimentales) y/o más apreciado por el alumnado, mientras que en Física los resultados son similares con LT y LV (Brinson, 2015; Colorado DOHE, 2012; Hughes, 2001; Quinn, 2009). Sin embargo, estudiantes que realizaron experimentos tradicionales y virtuales análogos valoraron más positivamente, en ocasiones, la experiencia tradicional (Engum, 2003; Chan, 2009; Spernjak, 2017), lo que unido a las ventajas intrínsecas de la experiencia virtual debería conducir a la sinergia más que al debate en la comunidad educativa.

En este sentido, tal y como han señalado diferentes autores (Bortnik, 2017; Brinson, 2015; Cheesman, 2014; Chiu, 2015; Climent-Bellido, 2003; De Jong, 2013; Engum, 2003; Karpen, 2014; Kocijancic, 2004; Limniou, 2007; Liu, 2006; Makransky, 2016; Tsihouridis, 2014; Tsihouridis, 2015; Tsihouridis, 2017; Winkelmann, 2017; Zacharia, 2007; Zacharia, 2008), la clave para un aprendizaje significativo puede estar en la combinación de ambos tipos de experiencias: tradicionales y virtuales. En materias como Física y Química puede resultar muy útil que los estudiantes se percaten de las semejanzas y diferencias entre ambos enfoques en lo que respecta a resultados y a protocolos de trabajo, y que simultáneamente se beneficien de la combinación sinérgica de ambos tipos de experimentos:

$\checkmark \quad$ Los laboratorios tradicionales acercan al estudiante al trabajo de un científico, pero los laboratorios virtuales son más adecuados para discentes inexpertos porque, al no existir error experimental, los resultados son siempre los esperados de acuerdo con la teoría vista en clase.

$\checkmark \quad$ Los laboratorios tradicionales permiten mejorar la destreza de trabajo en equipo en un período corto de tiempo (la sesión de laboratorio), mientras que los laboratorios virtuales permiten la colaboración en línea entre los diferentes miembros del equipo durante un tiempo indefinido.

$\checkmark \quad$ Los laboratorios tradicionales permiten concienciar al alumnado de la importancia de la optimización del tiempo, del esfuerzo y de los recursos, mientras que los

(cc) EY-NC-ND 2018, Universitat Politècnica de València

Congreso IN-RED (2018) 
laboratorios virtuales permiten repetir las experiencias siempre que sea necesario y a un ritmo adecuado para cada estudiante.

$\checkmark$ Se pone de manifiesto la importancia del error experimental en experimentos tradicionales al comparar los resultados obtenidos con la práctica virtual, fomentando así la reflexión acerca de la diferencia entre situaciones ideales (a través del LV) y situaciones reales (a través del LT).

$\checkmark$ Muchos laboratorios virtuales están diseñados en modo "abierto” y flexible, de modo que el usuario puedes utilizarlos de formas muy diferentes, realizando experiencias "a la carta”, lo que puede servirle para alcanzar un amplio abanico de objetivos didácticos.

\section{Objetivos}

El principal objetivo de este estudio es analizar el impacto de los laboratorios virtuales y tradicionales en asignaturas de Ciencias Básicas (CCBB) en un grado de Ciencias de la Salud.

En este trabajo nos hemos centrado en la percepción del alumnado como herramienta fundamental para distinguir la experiencia de los discentes con ambas aproximaciones didácticas. Esto puede ser crucial, puesto que, en general, los estudios que muestran un mayor éxito de los LT ponen más énfasis en los contenidos y la comprensión conceptual (por lo que utilizan exámenes y pruebas de conocimiento como herramientas de evaluación), mientras que los estudios que inclinan la balanza en favor de los LV se apoyan preferentemente en datos cualitativos relacionados con la percepción del profesorado y/o del alumnado (Brinson, 2015). Sin embargo, hemos de considerar que encontramos muchas excepciones en la literatura científica, y además no son iguales todas las asignaturas de Ciencias ni tampoco son iguales los diferentes perfiles de estudiantes que estudian uno u otro grado.

Para evaluar la percepción del alumnado con respecto a ambos tipos de laboratorios hemos analizado cinco variables: valoración general, grado de satisfacción, aumento de motivación y aumento del rendimiento, investigándose también las posibles diferencias de género.

\section{Desarrollo de la innovación}

Los participantes del estudio fueron 129 estudiantes del grado en Odontología $\left(n_{\text {hombres }}=59\right.$; $\left.n_{\text {mujeres }}=70\right)$ entre 18 y 46 años $(M=20.73 ; D T=0.72)$ de una universidad española. Todos los participantes firmaron un consentimiento informado antes de su participación en el estudio. Los estudiantes universitarios que participaron en el estudio estaban distribuidos en grupos diferentes, algunos de los cuales recibieron docencia en español, y otros en inglés. Los estudiantes procedían de 20 países, principalmente de Italia (50.4\%), Francia (17.1\%), Alemania (7\%) y España (6.2\%), aunque también de Reino Unido (3.9\%) y Marruecos (2.3\%). La media de edad fue de $20.73 \pm 3.09$ años (rango 18-46), con un $54.3 \%$ de mujeres 
y un $45.7 \%$ de varones. A lo largo del curso académico los alumnos recibieron diversas prácticas equivalentes en formato tradicional y en formato virtual en dos asignaturas de CCBB: bioquímica y microbiología.

El enfoque de este estudio es longitudinal y cuantitativo. Al principio del curso los estudiantes respondieron a un primer cuestionario con diferentes ítems para valorar tanto sus conocimientos previos (las asignaturas científicas que habían estudiado en la etapa preuniversitaria, si estaban acostumbrados a trabajar con ordenadores, de qué asignaturas habían hecho prácticas de laboratorio y a qué nivel creían dominar las materias de CCBB pre-universitarias) como su apreciación e interés hacia las CCBB, tanto de forma individual como el conjunto de las mismas (importancia para su grado, importancia para su profesión, motivación...). Asimismo, también se analizó su implicación académica y los diferentes tipos de motivación al cursar sus estudios actuales. Dicho cuestionario estaba compuesto mayoritariamente por ítems que se podían valorar mediante una escala de Likert. Análogamente, al final del curso académico los alumnos completaron un paquete de cuestionarios para evaluar la valoración y el impacto de ambos enfoques (LT y LV), por un lado, y también para analizar la variación en los ítems anteriores que aparecían en el primer cuestionario.

Este análisis está en progreso en la actualidad, por lo que en el presente estudio abordaremos únicamente la valoración de los diferentes tipos de prácticas de laboratorio una vez terminado el curso académico. El análisis de datos (Greasley, 2008; Muijs, 2014; Pardo, 2015) se llevó a cabo con el programa SPSS (IBM Corp. Released 2013. IBM SPSS Statistics for Windows, Version 22.0. Armonk, NY: IBM Corp).

\section{Resultados}

En este estudio piloto nos hemos centrado en una serie de variables para evaluar la apreciación de los estudiantes hacia ambos tipos de experimentos: LT y LV. La valoración general de las prácticas se midió analizando la media de las respuestas de una serie de adjetivos positivos (i.e. "interesantes”, “útiles”, “divertidas”, “fáciles” y "curiosas”) valorados a través de una escala de Likert de 1 (muy bajo) a 5 (muy alto). La satisfacción con la realización de las prácticas se evaluó a través de un único ítem, mientras que el aumento de la motivación hacia las CCBB y el aumento del rendimiento en las asignaturas de $C C B B$ resultan de la media aritmética de las apreciaciones del alumnado (evaluadas a través de una escala tipo Likert desde 1 muy bajo a 5 muy alto) de las diferentes asignaturas cursadas.

Como puede observarse en la Figura 1, los alumnos que participaron en este estudio indicaron que estaban más satisfechos con los laboratorios tradicionales que con los virtuales. Estos resultados se observan tanto al analizar la muestra conjuntamente como al analizar la muestra de hombres y mujeres por separado. Asimismo, los resultados indican que existen diferencias significativas en la satisfacción de los universitarios a favor de los laboratorios tradicionales $(t=-6.937 ;$ g.l. $=112 ; p=.000)$.

(cc) BY-NC-ND 2018, Universitat Politècnica de València

Congreso IN-RED (2018) 


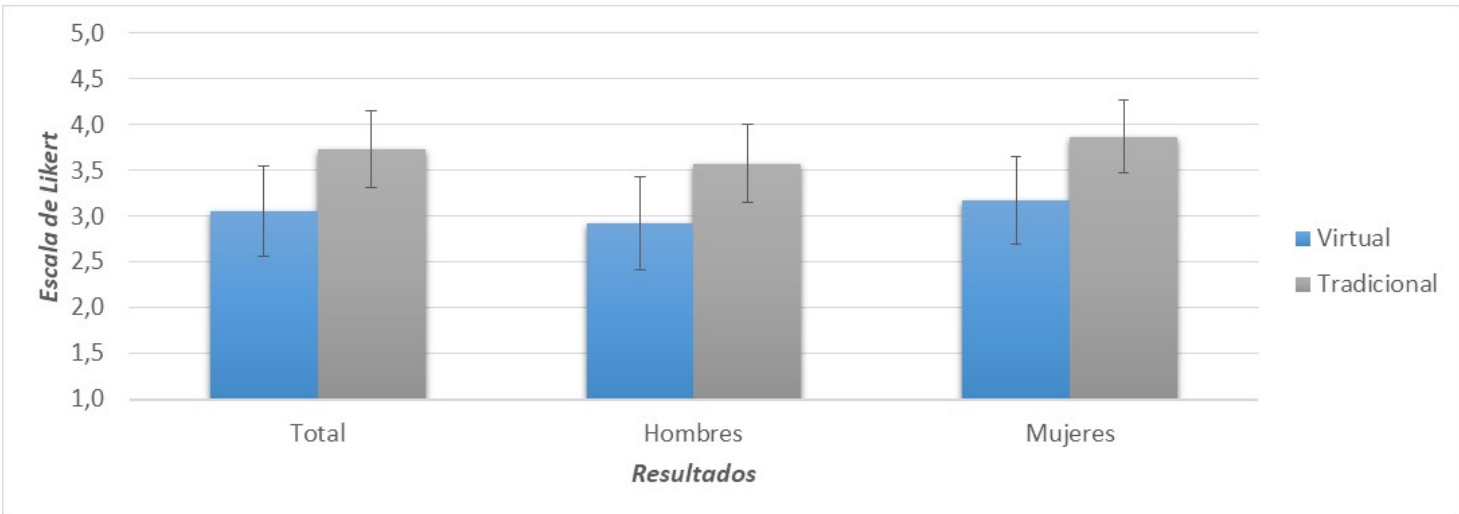

Fig. 1. Satisfacción del alumnado con las prácticas virtuales y tradicionales.

En la misma línea, los resultados del estudio muestran que los universitarios valoraban más positivamente los laboratorios tradicionales que los laboratorios virtuales realizados en las asignaturas de CCBB (véase Figura 2). Al comparar la media de ambos tipos de prácticas, los resultados indican que existen diferencias significativas en la valoración general de las prácticas a favor de los laboratorios tradicionales $(t=-6.981$; g.l. $=127 ; p=.000)$.

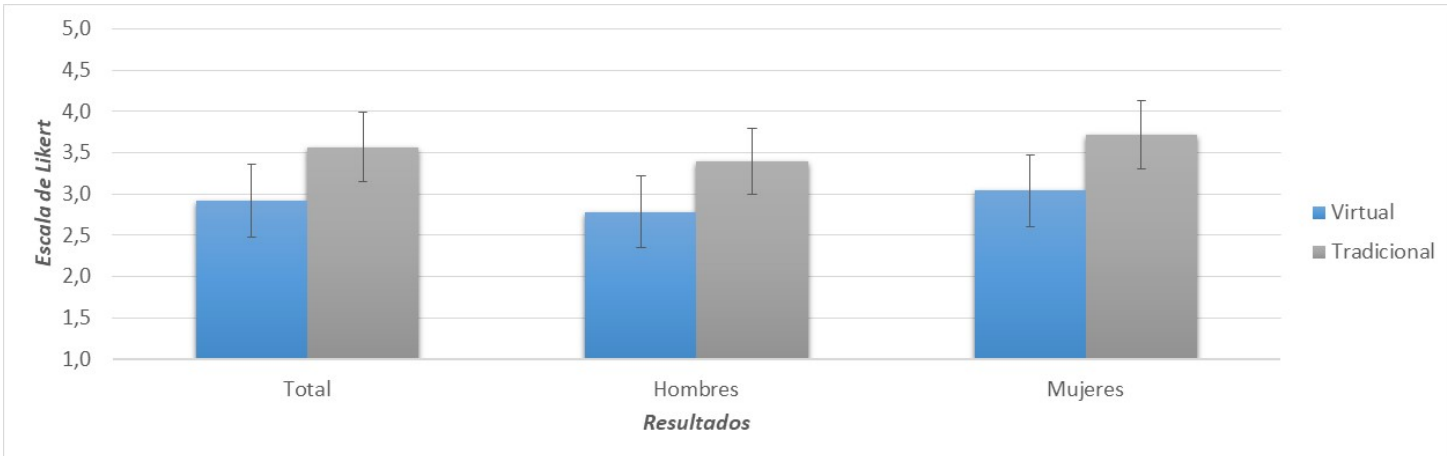

Fig. 2. Valoración positiva del alumnado de las prácticas virtuales y tradicionales.

En relación al rendimiento del alumnado en las asignaturas de CCBB, los resultados del estudio indican que los participantes percibían que su rendimiento aumentaba más a través de la realización de prácticas tradicionales (véase Figura 3). Estos resultados mantenían la misma tendencia tanto analizando las respuestas de hombres y mujeres por separado como evaluando sus respuestas conjuntamente. Al analizar la existencia de diferencias significativas, los resultados confirman la existencia de dichas diferencias $(t=-6.228$; g.l. $=128 ; p=.000$ ) a favor de las prácticas tradicionales. 


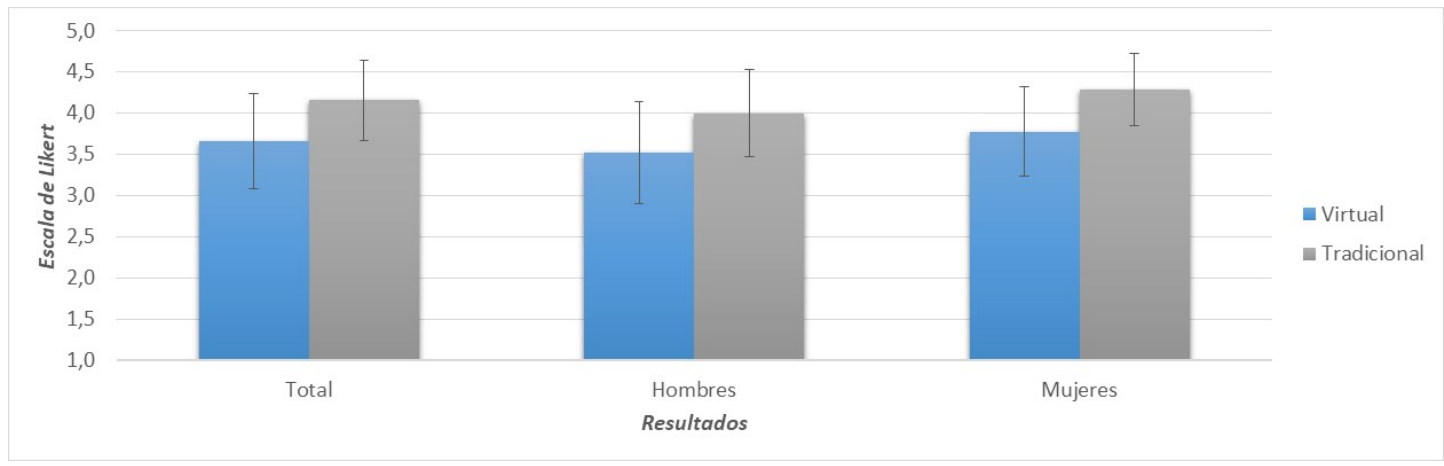

Fig. 3. Aumento del rendimiento en las asignaturas de CCBB tras la realización de prácticas virtuales y tradicionales

Por otro lado, en relación a la motivación de los universitarios respecto a las asignaturas de CCBB, en la Figura 4 se puede observar que los participantes del presente estudio indicaron que su motivación hacia las asignaturas de CCBB aumentaba más tras la realización de prácticas tradicionales. Estas diferencias resultaron ser significativas $(t=-5.016 ;$ g.l. $=127$; $p=.000)$.

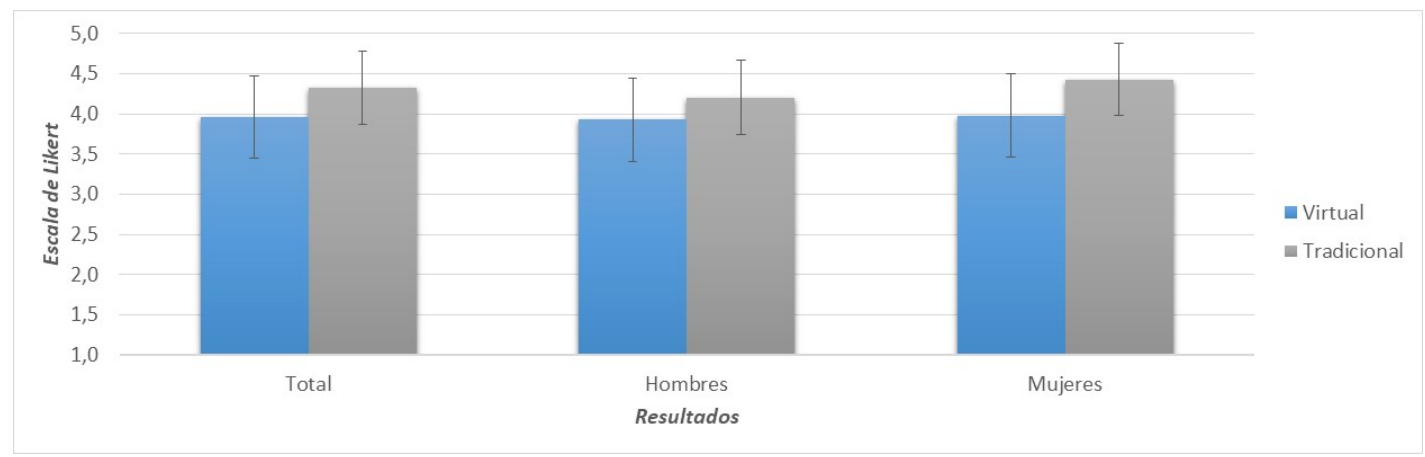

Fig. 4. Aumento de la motivación en las asignaturas de CCBB tras la realización de prácticas virtuales y tradicionales.

En relación con las diferencias de género, los resultados indicaron que las mujeres valoraban significativamente mejor las prácticas tradicionales $(t=-2.227$; g.l. $=124 ; p=$ .028), y referían una mayor satisfacción general con este tipo de prácticas $(t=-2.027 ;$ g.l. $=$ $127 ; p=.045)$.

Además, es importante destacar que tanto los LT como los LV condujeron a un aumento de la motivación hacia las CCBB y a una mejor valoración de las mismas, así como una mejora del rendimiento académico, siempre desde la perspectiva de apreciación de los discentes. En la Tabla 1 pueden observarse las medias y las desviaciones típicas de la percepción de aumento de motivación y percepción de mejora del rendimiento en las asignaturas de CCBB a través de la realización de ambos tipos de prácticas. Estos

(cc) EY-Nc-No 2018, Universitat Politècnica de València

Congreso IN-RED (2018) 
resultados muestran una mayor percepción en el aumento de la motivación y del rendimiento en todas las asignaturas a través de la realización de los laboratorios tradicionales.

Tabla 1. Resultados de valoración de las experiencias con LT y LV en diferentes asignaturas.

\begin{tabular}{lccccc}
\hline Materia & Rango & $\begin{array}{c}\text { Aumento de } \\
\text { motivación } \\
\text { con LV }\end{array}$ & $\begin{array}{c}\text { Aumento de } \\
\text { motivación } \\
\text { con LT }\end{array}$ & $\begin{array}{c}\text { Mejora de } \\
\text { rendimiento } \\
\text { con LV }\end{array}$ & $\begin{array}{c}\text { Mejora de } \\
\text { rendimiento } \\
\text { con LT }\end{array}$ \\
\hline Bioquímica & $1-5$ & $3.80(1.27)$ & $4.14(1.23)$ & $3.71(1.34)$ & $4.09(1.21)$ \\
Microbiología & $1-5$ & $4.43(1.06)$ & $4.57(1.00)$ & $3.98(1.17)$ & $4.43(1.01)$ \\
\hline
\end{tabular}

En lo referente a los adjetivos positivos, y en concordancia con los resultados anteriores, los LT siempre son mejor valorados que los LV, tal y como se puede observar en la Tabla 2:

Tabla 2. Valoración positiva de las prácticas virtuales y tradicionales.

\begin{tabular}{lccc}
\hline \multicolumn{1}{c}{ Adjetivos } & Rango & $\begin{array}{c}\text { LV } \\
\text { M (DT) }\end{array}$ & $\begin{array}{c}\text { LT } \\
\text { (DT) }\end{array}$ \\
\hline Interesantes & & $3.02(0.99)$ & $3.78(0.94)$ \\
Útiles & $1-5$ & $2.96(1.10)$ & $3.75(0.88)$ \\
Divertidas & $1-5$ & $2.61(1.14)$ & $3.44(1.11)$ \\
Fáciles & $1-5$ & $3.01(1.06)$ & $3.18(0.92)$ \\
Curiosas & $1-5$ & $3.02(1.11)$ & $3.68(1.03)$ \\
\hline
\end{tabular}

Por otro lado, tal y como se puede ver en la Figura 5, el alumnado prefiere hacer preferentemente LT (49.6\%) o incluso hacer solo LT (21.7\%) frente a hacer el mismo número de LT y de LV (14.7\%), hacer preferentemente LV (12.4\%) o hacer solo LV (0.8\%). Este resultado está en la línea de los hallazgos de Engum (2003), Chan (2009), Quinn (2009) o Stuckey-Mickell (2007), aunque difiere de otros estudios en los que se valoraban de forma similar ambos tipos de prácticas (Lewis, 2014; Tatli, 2010; Winkelmann, 2014; Faour, 2018), o en los que se apuntaba a una mejor valoración de los LV (Bozkurt, 2010; Pyatt, 2012). En este sentido, hemos de tener en cuenta el perfil del alumnado: por un lado, se trata de personas acostumbradas a trabajar y a divertirse con herramientas digitales, por lo que el LT puede suponer una novedad respecto al LV; por otro lado, son estudiantes de grados de Ciencias de la Salud en cuyo futuro trabajo los 
contenidos procedimentales serán cruciales. Este interés por mejorar sus destrezas podría motivarles más, de entrada, hacia los LT en CCBB.

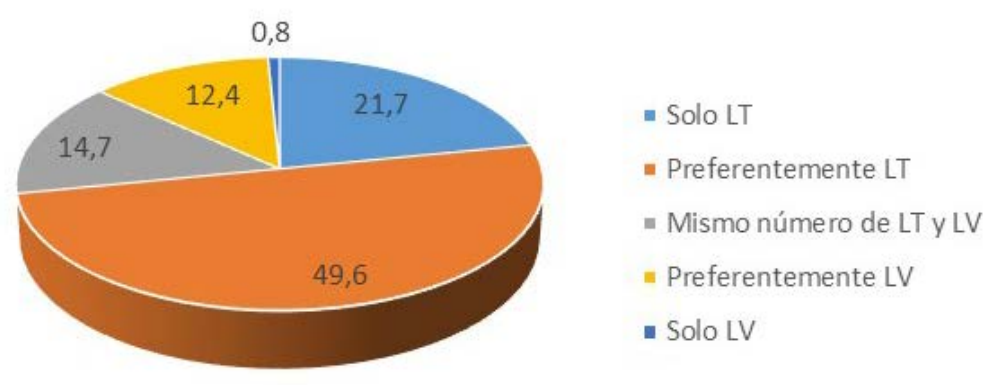

Fig. 5. Preferencias del alumnado en cuanto a la realización de experimentos virtuales y experimentos virtuales durante el curso.

\section{Conclusiones}

Los resultados obtenidos muestran que los estudiantes prefieren las prácticas tradicionales a las virtuales en todos los aspectos: valoración general, grado de satisfacción, aumento de motivación y aumento del rendimiento. Estos resultados resaltan la importancia de mantener un número considerable de prácticas tradicionales en los grados en Ciencias de la Salud para potenciar la motivación y el rendimiento del alumnado en las asignaturas de CCBB. Esto es importante puesto que son asignaturas que los discentes tienden a percibir como alejadas de su futura práctica profesional, por lo que su motivación suele ser inferior a la de otras asignaturas del grado.

Sin embargo, el rol de los laboratorios virtuales en la educación del presente y del futuro no debe subestimarse. En este sentido, la clave es conseguir que el estudiante no se muestre pasivo en el aula, sino que participe y actúe, e incluso que explore y descubra cosas motu proprio, objetivo que se puede conseguir más fácilmente con aplicaciones virtuales on-line.

En futuros trabajos consideraremos los diferentes tipos de motivación del alumnado, su apreciación de la importancia de las ciencias básicas para su grado y para su futuro profesional, así como los conocimientos previos respecto a actividades de laboratorio y a conocimientos informáticos. Asimismo, se está valorando la opción de estudiar cualitativamente las apreciaciones del alumnado mediante entrevistas aleatorias con la finalidad de llevar a cabo una triangulación de los datos obtenidos. Por último, también se intentará contar con una muestra $n$ de mayor tamaño, teniendo en cuenta además a estudiantes de diferentes grados de Ciencias de la Salud (no solo de Odontología, sino también de Fisioterapia y de Enfermería).

(c) EY-NC-ND 2018, Universitat Politècnica de València

Congreso IN-RED (2018) 


\section{Referencias}

AMERICAN CHEMICAL SOCIETY. ACS position statement: Importance of hands-on laboratory

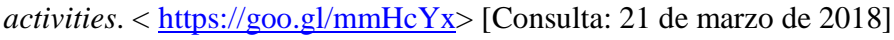

BORTNIK, B., STOZHKO, N., PERVUKHINA, I., TCHERNYSHEVA, A. y BELYSHEVA, G. (2017). "Effect of virtual analytical chemistry laboratory on enhancing student research skills and practices" en Research in Learning Technology Research in Learning Technology, 25, 1-20.

BOZKURT, E. e ILIK, A. (2010). “The effect of computer simulations over students' beliefs on physics and physics success” en Procedia - Social and Behavioral Sciences, 2, 4587-4591.

BRINSON, J. R. (2015). "Learning outcome achievement in non-traditional (virtual and remote) versus traditional (hands-on) laboratories: A review of the empirical research” en Computers \& Education, 87, Supplement C, 218-237.

CHAN, C., y FOK, W. (2009). "Evaluating learning experiences in virtual laboratory training through student perceptions: a case study in Electrical and Electronic Engineering at the University of Hong Kong” en Engineering Education, 4, 2, 70-75.

CHEESMAN, M.J., CHEN, S., MANCHADI, M.-L., JACOB, T., MINCHIN, R.F. y TREGLOAN, P.A. (2014). "Implementation of a Virtual Laboratory Practical Class (VLPC) module in pharmacology education” en Pharmacognosy Communication, 4, 2-10.

CHIU, J. L., DEJAEGHER, C. J. y CHAO, J. (2015). “The effects of augmented virtual science laboratories on middle school students' understanding of gas properties” en Computers \& Education, 85, 59-73.

CLIMENT-BELLIDO, M. S., MARTÍNEZ-JIMÉNEZ, P., PONTES-PEDRAJAS, A., y POLO, J. (2003). "Learning in Chemistry with Virtual Laboratories" en Journal of Chemical Education, 80, 3, 346352.

COBB, S., HEANEY, R., CORCORAN, O. y HENDERSON-BEGG, S. (2009). "The Learning Gains and Student Perceptions of a Second Life Virtual Lab” en Bioscience Education, 13, 1-9.

COLL, C., MARTÍN, E., MAURI, T., MIRAS, M., ONRUBIA, J., SOLÉ, I., et al. (2007). El constructivismo en el aula (18 ${ }^{\mathrm{a}}$ ed.). Barcelona: Editorial Graó.

COLORADO DOHE (Department of Higher Education, 2012). “Online versus traditional learning: A comparison study of Colorado community college science classes”. <https://goo.gl/E3j2Yf> [Consulta: 21 de marzo de 2018].

COOK, E., KENNEDY, E., y MCGUIRE, S. Y. (2013). "Effect of Teaching Metacognitive Learning Strategies on Performance in General Chemistry Courses” en Journal of Chemical Education, 90, 8, 961-967.

DARRAH, M., HUMBERT, R., FINSTEIN, J., SIMON, M. y HOPKINS, J. (2014). “Are Virtual Labs as Effective as Hands-on Labs for Undergraduate Physics? A Comparative Study at Two Major Universities” en Journal of Science Education and Technology, 23, 803-814.

DE JONG, T., LINN, M. C. y ZACHARIA, Z. C. (2013). "Physical and Virtual Laboratories in Science and Engineering Education” en Science, 340, 305-308.

DEUTSCH, J. M. (2014). “Biophysics software for interdisciplinary education and research” en American Journal of Physics, 82, 5, 442-450.

(c) 2018, Universitat Politècnica de València

Congreso In-Red (2018) 
DOMIN, D. S. (1999). “A Review of Laboratory Instruction Styles” en Journal of Chemical Education, 76, 4, 543.

ELLIOTT, M. J., STEWART, K. K. y LAGOWSKI, J. J. (2008). “The Role of the Laboratory in Chemistry Instruction” en Journal of Chemical Education, 85, 145-149.

ENGUM, S. A., JEFFRIES, P., y FISHER, L. (2003). “Intravenous catheter training system: Computerbased education versus traditional learning methods” en The American Journal of Surgery, 186, 1, 6774.

FAOUR, M. A. y AYOUBI, Z. (2018). "The Effect of Using Virtual Laboratory on Grade 10 Students' Conceptual Understanding and their Attitudes towards Physics” en Journal of Education in Science, Environement and Health, 4, 54-68.

FINKELSTEIN, N. D., ADAMS, W. K., KELLER, C. J., KOHL, P. B., PERKINS, K. K., PODOLEFSKY, N. S., et al. (2005). "When learning about the real world is better done virtually: A study of substituting computer simulations for laboratory equipment” en Physical Review Special Topics Physics Education Research, 1, 1, 010103.

FINKELSTEIN, N. D., ADAMS, W. K., PERKINS, K. K., y WIEMAN, C. (2006). "HighTech Tools for Teaching Physics: the Physics Education Technology Project” en Journal of Online Learning and Teaching, 2, 3, 110-121.

FRANCO, A., BELÉNDEZ, A., y ABLANQUE, J. (2013). "Recursos multimedia para la enseñanza on-line de la Física” en Revista Española de Física, 27, 1, 49-56.

FREEMAN, S., EDDY, S. L., MCDONOUGH, M., SMITH, M. K., OKOROAFOR, N., JORDT, H., et al. (2014). “Active learning increases student performance in science, engineering, and mathematics” en Proceedings of the National Academy of Sciences, 111, 23, 8410-8415.

GARCIA ARMADA, M. P., y FERNANDEZ-AVILES PEDRAZA, D. (2016). "Prácticas de Química Orgánica posibles gracias a las nuevas tecnologías” en M. González, A. Baratas y A. Brandi (Eds.). IV Congreso de Docentes de Ciencias (pp. 229-238). Madrid: Santillana.

GREASLEY, P. (2008). Quantitative Data Analysis Using SPSS: An Introduction for Health \& Social Science. New York: McGraw-Hill Open University Press.

HAWKINS, I. \& PHELPS, A. J. (2013). "Virtual laboratory vs. traditional laboratory: which is more effective for teaching electrochemistry?” en Chem. Educ. Res. Pract., 14, 516-523.

HERADIO, R., DE LA TORRE, L., GALAN, D., CABRERIZO, F. J., HERRERA-VIEDMA, E., y DORMIDO, S. (2016). "Virtual and remote labs in education: A bibliometric analysis"en Computers \& Education, 98, Supplement C, 14-38.

HERGA, N. y DINEVSKI, D. (2012). "Virtual Laboratory in Chemistry - Experimental Study of Understanding, Reproduction and Application of Acquired Knowledge of Subject's Chemical Content” en Organizacija, 45, 3, 108-116.

HERREID, C. F. (2012). "ConfChem Conference on Case-Based Studies in Chemical Education: The Future of Case Study Teaching in Science” en Journal of Chemical Education, 90, 2, 256-257.

HOFSTEIN, A., y LUNETTA, V. N. (2004). “The laboratory in science education: Foundations for the twenty-first century” en Science Education, 88, 1, 28-54.

HYSLOP-MARGISON, E. J., y STROBEL, J. (2007). “Constructivism and education: misunderstandings and pedagogical implications” en The Teacher Educator, 43, 1, 72-86.

(cc) EY-NC-ND 2018, Universitat Politècnica de València

Congreso IN-RED (2018) 
HUGHES, I. E. (2001). “Do computer simulations of laboratory practicals meet learning needs?” en Trends in Pharmacological Sciences, 22, 71-74.

JENSEN, J. H., y KROMANN, J. C. (2013). “The Molecule Calculator: A Web Application for Fast Quantum Mechanics-Based Estimation of Molecular Properties” en Journal of Chemical Education, 90, 8, 1093-1095.

KARPEN, M. E., HENDERLEITER, J., y SCHAERTEL, S. A. (2004). "Integrating Computational Chemistry into the Physical Chemistry Laboratory Curriculum: A Wet Lab/Dry Lab Approach” en Journal of Chemical Education, 81, 4, 475-477.

KLAR, D., TRIONA, L.M. y CAMERON, W. (2007). "Hands on what? The relative effectiveness of physical versus virtual materials in an engineering design project by middle school children” en Journal of Research in Science Teaching, 44, 183-203.

KRATHWOHL, D. R. (2002). “A Revision of Bloom's Taxonomy: An Overview” en Theory Into Practice, $41,4,212-264$.

KOCIJANCIC, S., y O'SULLIVAN, C. (2004). "Real or Virtual Laboratories in Science Teaching -is this Actually a Dilemma? ” en Informatics in Education, 3, 2, 239-250.

LEWIS, D. I. (2014). “The pedagogical benefits and pitfalls of virtual tools for teaching and learning laboratory practices in the biological sciences”. Higher Education Academy, Vol. 4, pp. 22-30.

LIMNIOU, M., PAPADOPOULOS, N., GIANNAKOUDAKIS, A., ROBERTS, D. \& OTTO, O. (2007). "The integration of a viscosity simulator in a chemistry laboratory" en Chemistry Education Research and Practice, 8, 220-231.

LIU, X. (2006). "Effects of Combined Hands-on Laboratory and Computer Modeling on Student Learning of Gas Laws: A Quasi-Experimental Study” en Journal of Science Education and Technology, 15, 1, 89-100.

LIVINGSTONE, S. (2012). "Critical reflections on the benefits of ICT in education”. Oxford Review of Education, Vol. 38(1), pp. 9-24.

MA, J., y NICKERSON, J. V. (2006). "Hands-on, simulated, and remote laboratories: A comparative literature review” en ACM Computing Surveys, 38, 3.

MAKRANSKY, G., THISGAARD, M. W. y GADEGAARD, H. (2016). "Virtual simulations as preparation for lab exercises: Assessing learning of key laboratory skills in microbiology and improvement of essential non-cognitive skills” en Plos One, 11, 1-11.

MAZUR, E. (2009). “Farewell, Lecture? ” en Science, 323, 5910, 50-51.

MERCHANT, Z., GOETZ, E. T., CIFUENTES, L., KEENEY-KENNICUTT, W. y DAVIS, T. J. (2014). "Effectiveness of virtual reality-based instruction on students' learning outcomes in K-12 and higher education: A meta-analysis” en Computers \& Education, 70, 29-40.

MCKAGAN, S. B., PERKINS, K. K., DUBSON, M., MALLEY, C., REID, S., LEMASTER, R., et al. (2008). "Developing and researching PhET simulations for teaching quantum mechanics" en American Journal of Physics, 76, 4, 406-417.

MICHAEL, J. (2006). "Where's the evidence that active learning works? ” en Advances in Physiology Education, 30, 4, 159-167.

MOORE, E. B., CHAMBERLAIN, J. M., PARSON, R., y PERKINS, K. K. (2014). "PhET Interactive Simulations: Transformative Tools for Teaching Chemistry” en Journal of Chemical Education, 91, 8, 1191-1197. 
MUHAMAD, M., ZAMAN, H. B., Y AHMAD, A. (2010). "Virtual laboratory for learning biology - a preliminary investigation” en World Academy of Science, Engineering and Technology, 71, 572-575.

MUIJS, D. (2004). Doing quantitative research in education with SPSS. London: SAGE Publications Ltd.

NATIONAL SCIENCE TEACHERS ASSOCIATION. NSTA position statement: The integral role of laboratory investigations in science instruction. < https://goo.gl/CgL67b $>$ [Consulta: 21 de marzo de 2018].

OLAKANMI, E. E. (2015). "The Effects of a Web-Based Computer Simulation on Students' Conceptual Understading of rate of reaction and attitude towards chemistry"en Journal of Baltic Science Education, 14(5). 627-641.

PARDO, A., RUIZ, M. Á., y SAN MARTÍN, R. (2015). Análisis de datos en ciencias sociales y de la salud I (2a ed.). Madrid: Editorial Síntesis.

PERKINS, K., ADAMS, W., DUBSON, M., FINKELSTEIN, N., REID, S., WIEMAN, C., et al. (2006). "PhET: Interactive Simulations for Teaching and Learning Physics" en The Physics Teacher, 44, 1823.

PHILLIPS, D. C. (1995). “The Good, the Bad, and the Ugly: The Many Faces of Constructivism” en Educational Researcher, 24, 7, 5-12.

PINTO, G., ESCUDERO, P., y MARTIN, M. (2008). "Aportaciones sobre el aprendizaje activo de la química” en Anales de Química, 104, 3, 211-214.

POTKONJAK, V., GARDNER, M., CALlAGHAN, V., MATTILA, P., GUETL, C., PETROVIC, V. M., et al. (2016). "Virtual laboratories for education in science, technology, and engineering: A review" en Computers \& Education, 95, Supplement C, 309-327.

POZO, J. I., y GOMEZ, M. A. (2006). Aprender y enseñar ciencia: del conocimiento cotidiano al conocimiento científico ( $7^{\mathrm{a}}$ ed.). Madrid: Ediciones Morata.

PRINCE, M. (2004). “Does Active Learning Work? A Review of the Research” en Journal of Engineering Education, 93, 3, 223-231.

PYATT, K. y SIMS, R. (2012). "Virtual and Physical Experimentation in Inquiry-Based Science Labs: Attitudes, Performance and Access” en Journal of Science Education and Technology, 21, 133-147.

ROCARD, M., CSERMELY, P., JORDE, D., LENZEN, D., WALBERG-HENRIKSSON, H., y HEMMO, V. (2007). "Science education now: a renewed pedagogy for the future of Europe". Brussels: European Commission: Directorate-General for Research.< https://goo.gl/vhVrvv> [Consulta: $21 \mathrm{de}$ marzo de 2018].

SANMARTI, N. (2009). Didáctica de las ciencias en la educación secundaria obligatoria (7ª ed.). Madrid: Editorial Síntesis.

SANZ, A., Y MARTINEZ, J. (2005). "El uso de los laboratorios virtuales en la asignatura Bioquímica como alternativa para la aplicación de las tecnologías de la información y la comunicación” en Tecnología Química, 25, 1, 5-17.

SMAGORINSKY, P. (1995). "The Social Construction of Data: Methodological Problems of Investigating Learning in the Zone of Proximal Development” en Review of Educational Research, 65, 3, 191-212.

SPENCER, J. N. (1999). "New Directions in Teaching Chemistry: A Philosophical and Pedagogical Basis" en Journal of Chemical Education, 76(4), 566-569.

(cc) EY-NC-ND 2018, Universitat Politècnica de València

Congreso IN-RED (2018) 
ŠPERNJAK, A. y ŠORGO, A. (2018). "Differences in acquired knowledge and attitudes achieved with traditional, computer-supported and virtual laboratory biology laboratory exercises” en Journal of Biological Education, 52, 206-220.

SPRAWLS, P. (2008). "Evolving models for medical physics education and training: a global perspective" en Biomedical imaging and intervention journal, 4, 1, e16-e16.

STUCKEY-MICKELL, T. A., y STUCKEY-DANNER, B. D. (2007). "Virtual Labs in the Online Biology Course: Student Perceptions of Effectiveness and Usability” en Journal of Online Learning and Teaching, 3, 2, 105-111.

TAREKEGN, G. (2009). “Can computer simulations substitute real laboratory apparatus?” en LatinAmerican Journal of Physics Education, 3, 3, 506-517.

TOTH, E. E., LUDVICO, L. R. y MORROW, B. L. (2014). "Blended inquiry with hands-on and virtual laboratories: the role of perceptual features during knowledge construction” en Interactive Learning Environments, 22, 614-630.

TRIONA, L. M., y KLAHR, D. (2003). Point and Click or Grab and Heft: Comparing the Influence of Physical and Virtual Instructional Materials on Elementary School Students' Ability to Design Experiments en Cognition and Instruction, 21(2), 149-173.

TSIHOURIDIS, C., VAVOUGIOS, D. y IOANNIDIS, G. S. (2013). “The effectiveness of virtual laboratories as a contemporary teaching tool in the teaching of electric circuits in Upper High School as compared to that of real labs" en 2013 International Conference on Interactive Collaborative Learning (ICL), 25-27 Sept. 2013, Kazan, 816-820.

TSIHOURIDIS, C., VAVOugios, D., IOANnidis, G. S., AlEXIAS, A., ARGYROPOUlOS, C. y POULIOS, S. (2014). "Using sensors and data-loggers in an integrated mobile school-lab setting to teach Light and Optics” en 2014 International Conference on Interactive Collaborative Learning (ICL), 3-6 Dic. 2014, Dubai, 439-445.

TSIHOURIDIS, C., VAVOugios, D., IOANNIDIS, G. S., AlEXIAS, A., ARGYROPOUlOS, C. y POULIOS, S. (2015). "The effect of teaching electric circuits switching from real to virtual lab or vice versa; A case study with junior high-school learners” en 2015 International Conference on Interactive Collaborative Learning (ICL), 20-24 Sept. 2015, Florencia, 643-649.

TSIHOURIDIS, C. A., VAVOUGIOS, D. y IOANNIDIS, G. S. (2017). “The Effect of Switching the Order of Experimental Teaching in the Study of Simple Gravity Pendulum - Study with Junior High-school Learners” en International Journal of Emerging Technologies in Learning, 12, 128-141.

WIEMAN, C. E., PERKINS, K. K., y ADAMS, W. K. (2008). “Oersted Medal Lecture 2007: Interactive simulations for teaching physics: What works, what doesn't, and why” en American Journal of Physics, 76, 4, 393-399.

WINKELMANN, K., SCOTT, M. y WONG, D. (2014). “A Study of High School Students’ Performance of a Chemistry Experiment within the Virtual World of Second Life” en Journal of Chemical Education, 91, 1432-1438.

WINKELMANN, K., KEENEY-KENNICUTT, W., FOWLER, D. y MACIK, M. (2017). "Development, Implementation, and Assessment of General Chemistry Lab Experiments Performed in the Virtual World of Second Life” en Journal of Chemical Education, 94, 849-858.

ZACHARIA, Z.C. (2007). "Comparing and combining real and virtual experimentation: an effort to enhance students' conceptual understanding of electric circuits” en Journal of Computer Assisted Learning, 23, 120-132.

ZACHARIA, Z.C., OLYMPIOU, G.. y PAPAEVRIPIDOU, M. (2008). "Effects of experimenting with physical and virtual manipulatives on students' conceptual understanding in heat and temperature" en Journal of Research in Science Teaching, 45, 1021-1035.

(c) 2018, Universitat Politècnica de València

Congreso In-Red (2018) 


\title{
Flipped Teaching y Redes Sociales
}

\section{María-Ángeles Carabal-Montagud ${ }^{\mathrm{a}}$, Virginia Santamarina-Campos ${ }^{\mathrm{b}}$, María-Victoria Esgueva-López ${ }^{\mathrm{c}}$, María de-Miguel-Molina ${ }^{\mathrm{d}}$}

${ }^{a}$ Departamento de Conservación y Restauración de Bienes Culturales, Universitat Politècnica de València, macamon@crbc.upv.es bepartamento de Conservación y Restauración de Bienes Culturales, Universitat Politècnica de València, virsanca@crbc.upv.es ${ }^{\circ}$ Departamento de Dibujo, Universitat Politècnica de València, maeslo2@dib.upv.es y ${ }^{\mathrm{d}}$ Departamento de Organización de Empresas, Universitat Politècnica de València, mademi@omp.upv.es

\begin{abstract}
The "Flipped Teaching" or "Flipped Classroom" can be given from multiple channels. We usually share the information through institutional channels, in fact PoliformaT, within the UPV, is key in any teaching methodology. The present work intends to explore other access ways to information to complement those that we use in a habitual way. Social networks have become protagonists in any type of communication. In this article we present social media from the perspective of their innovative teaching capacity, which adds a playful perception to learning, is attractive to students and favors the acquisition of content with easy access.
\end{abstract}

Keywords: flipped teaching, flipped classroom, training, metodology, innovation, social media

\footnotetext{
Resumen

La "Docencia Inversa", "Flipped Teaching" o "Flipped Classroom" puede darse desde multiples canales. Habitualmente compartimos la información a través de canales institucionales, de hecho PoliformaT, dentro de la UPV, es clave en cualquier metodología docente. El presente trabajo pretende explorar otras vías de acceso a la información para complementar a los que empleamos de modo habitual. Las redes sociales se han convertido en protagonistas en cualquier tipo de comunicación. En el presente artículo presentamos las redes sociales desde la perspectiva de su capacidad docente innovadora, que añade una percepción lúdica al aprendizaje, resulta atractivo al alumnado y favorece la adquisición de contenidos con un fácil acceso.
}

Palabras clave: docencia inversa, flipped teaching, flipped classroom, formación, metodología, innovación, redes sociales 


\section{Introducción}

Las redes sociales son un canal de comunicación común para el alumnado, que les resulta familiar, cómodo, asequible, intuitivo y, sobre todo, lúdico, ya que suelen utilizarlo para comunicarse entre sí. Desde plataformas como WhatsApp, con 1.200 millones de usuarios a nivel mundial y con un 93,4\% de usuarios españoles de mensajería instantánea, según el Centro de Investigaciones Sociológicas (CIS, 2017).

La participación en diferentes redes sociales, como Facebook, Twitter o Instagram, según la misma fuente, asciende al 72,4\% de la población española, con un 93,3\% en la franja de edad de 18 a 24 años, y con un 94,7\% en la franja de 25 a 34 años, con una participación decreciente en franjas de edad superiores (CIS, 2017).

Teniendo en cuenta estos datos, el alumnado de nuestras aulas, salvo alguna excepción, suele estar en estas franjas de edad, con lo que la gran mayoría de los mismos hace uso de las redes sociales a nivel cotidiano.

Ahora bien, las redes sociales son canales que se amoldan a sus necesidades, a sus inquietudes, les resultan intuitivas, rápidas, sencillas y, sin apenas ser conscientes de ello, de manera lúdica, realizan aprendizaje en múltiples aspectos... entonces ¿por qué no utilizarlas para la docencia universitaria?

La presente innovación no se plantea como un canal único o se compara con otras plataformas existentes, sobre todo las institucionales de cada universidad, ya que son el mejor medio para transferir la información. La siguiente innovación se plantea teniendo en cuenta que el alumnado ya realiza un trabajo de docencia inversa a través de PoliformaT en el caso de la UPV- con la lectura previa de apuntes, textos, etc., pero todo ello se puede complementar mediante el uso de las redes sociales.

Según el estudio de Haro "Las redes sociales permiten el uso masivo por parte de miles de alumnos y cientos de profesores [...]. De este modo se favorece la incorporación generalizada de las TIC en los centros educativos, algo que ya se está empezando a producir en algunos de ellos” (Haro, 2009). En la presente investigación se plantea el uso de las mismas para exponer al alumnado las prácticas a efectuar en el laboratorio, empleando estas apps, fundamentalmente Instagram o YouTube para flipped classroom, haciendo uso de imágenes y audiovisuales, que resultan atractivas y se adaptan a su código visual. Se expondrá la experiencia en la asignatura "Técnicas Instrumentales de la Restauración de Dorados y Policromías”, optativa de tercer curso del Grado en Conservación y Restauración de Bienes Culturales, para posteriormente analizar el resultado de su implantación mediante encuestas de opinión del alumnado, además de la valoración de los resultados objetivos de las prácticas.

(cc) EY-NC-ND 2018, Universitat Politècnica de València

Congreso IN-RED (2018) 


\section{Objetivos}

El objetivo principal de la presente innovación se centra en la búsqueda de canales, paralelos a los institucionales, en los que desarrollar la docencia inversa de modo que el alumno realice el aprendizaje con una percepción lúdica.

Los objetivos específicos:

- Implementar apps en la docencia inversa, que faciliten el acceso a la información.

- Generar contenidos en otros medios que sean asequibles y familiares para el alumnado.

- Analizar la respuesta del alumnado mediante las encuestas de opinión con la plataforma SurveyMonkey®.

- Contribuir a un aprendizaje virtual colaborativo, mediante plataformas de ocio.

- Acceder a la realidad empresarial, mediante sus redes sociales, enlazando los contenidos de la asignatura con su futuro laboral.

\section{Desarrollo de la innovación}

\subsection{Justificación}

Como se ha citado con anterioridad, el desarrollo de la innovación se ha llevado a cabo en la asignatura “Técnicas Instrumentales de la Restauración de Dorados y Policromías”, del Grado en Conservación y Restauración de Bienes Culturales.

La mencionada asignatura consta de 6 créditos ECTS en el actual Grado, mientras que en la anterior licenciatura, contaba con 12 créditos presenciales. El tiempo en el aula se ha reducido a la mitad, pero los contenidos deben mantenerse, e incluso ampliarse, independientemente de este cambio. De ahí surge la necesidad de implementar el flipped teaching en la docencia, y más teniendo en cuenta que la práctica ocupa casi la totalidad del tiempo en el laboratorio.

Las prácticas a efectuar suelen estar relacionadas con procesos que deben llevarse a cabo en el aula, dado que es el espacio para trabajar la resolución de problemas ante situaciones complejas que se puedan presentar, y ante la dificultad de alguna de las técnicas a desarrollar. Con ello, el tiempo de la teoría se tiene que ver considerablemente reducida para dar paso a la realidad de la práctica. El flipped teaching ha dado una nueva perspectiva para poder desarrollar esta docencia.

En este punto nos encontramos ante una dualidad, dado que el alumnado presenta alta carga de trabajo fuera del aula, para completar sus créditos ECTS, pero por otro lado tenemos la necesidad de que asimilen ciertos contenidos de modo previo a efectuar la práctica. En ocasiones, el trabajo no presencial, unido a la totalidad de asignaturas que cursa, genera en el alumnado una percepción de falta de tiempo para completar todas las tareas. Una herramienta básica para llevar a cabo la docencia inversa consiste en subir en las plataformas institucionales, como PoliformaT en la UPV, los apuntes, textos, o documentos, bien como archivos adjuntos o bien con la propia herramienta Lessons, que 
permite generar apuntes, incorporando imágenes, texto, vídeos, etc. También la UPV oferta a su profesorado una gran cantidad de posibilidades a la hora de acceder a la información audivisual a modo de screencasts, polimedia, videoapuntes, vídeos didácticos, cursos MOOC, registro de voz, etc. (UPV, 2018).

No obstante, las plataformas públicas que analizaremos en el presente estudio han sido analizadas durante este curso debido a que los jóvenes son la población que mayor uso hace de las diferentes plataformas, o apps, como se ha expuesto con anterioridad, según datos del CIS de noviembre de 2017 (CIS, 2017).

Los dispositivos móviles forman parte de nuestro sistema social actual "Para el alumnado, en el siglo XXI, estar conectado, de manera ininterrumpida, con los estímulos provenientes de las redes sociales, es la realidad a la que nos enfrentamos en las aulas universitarias" (Carabal et al., 2017).

Según Terrasa y Andreu: “Adaptarse al nuevo carácter de nuestros estudiantes implica un cambio en las metodologías docentes utilizadas” (Terrasa, Andreu, 2015). A la hora de escoger las plataformas adecuadas, se ha tenido en cuenta que éstas no tuviesen una finalidad específica, que diesen la posibilidad de versatilidad, ya que "La diversidad de las redes sociales lleva a hacer distinciones entre ellas. Por un lado, encontramos las redes sociales genéricas, cuya temática no está definida, como son Facebook, Twitter, YouTube e Instagram” (Espinosa et al., 2017).

Las plataformas escogidas han sido fundamentalmente Instagram y YouTube en menor medida. El motivo de la selección es debido a que el alumnado, en una encuesta de opinión a través de la plataforma SurveyMonkey®, ha valorado que su preferencia a la hora de conocer las prácticas, previamente a efectuarlas, es mediante el uso de audiovisuales, con un porcentaje del $79,49 \%$. Los textos obtuvieron un $15,38 \%$ de porcentaje y las encuestas un 5,13\%.

\section{¿Qué clase de material me resulta más útil?}

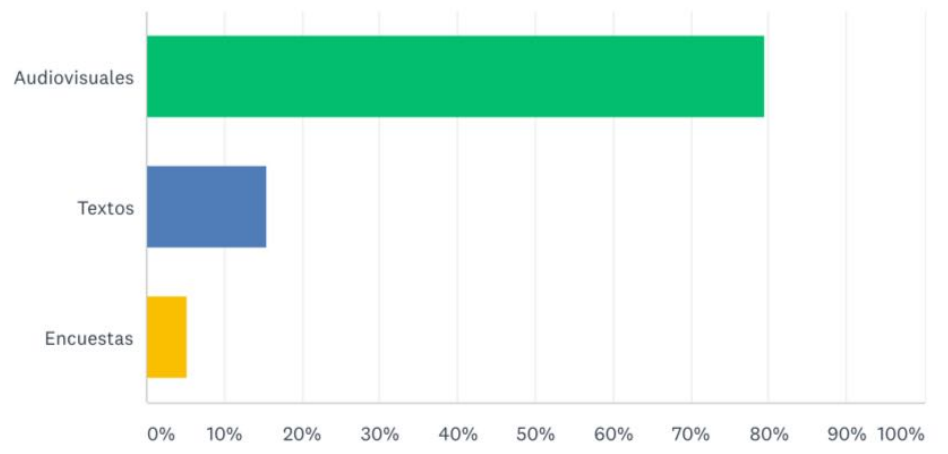

Fig.1. Resultados de la encuesta con la plataforma SurveyMonkey®

(cc) EY-NC-ND 2018, Universitat Politècnica de València

Congreso IN-RED (2018) 
Cabe destacar que el uso de audiovisuales resultan muy útiles en nuestra área, dada la carga informativa que conlleva y la facilidad que otorgan de fijar procesos y contenidos.

Analizaremos la citada encuesta (Carabal, 2018), que ha sido planteada al alumnado para valorar de modo instantáneo sus preferencias u opiniones, mediante una plataforma sencilla e inmediata. En ella se recogen una serie de preguntas relacionadas con el uso de las aplicaciones mencionadas con anterioridad, en los que se valora su percepción al respecto de la utilidad del flipped classroom, de los canales de acceso a la información y de las redes sociales, con sus ventajas y desventajas.

\subsection{Metodología docente}

La metodología llevada a cabo se ha desarrollado en dos sentidos, que han sido:

\subsubsection{Elaborar material y "subirlo" a Instagram o YouTube}

La metodología ha consistido en efectuar imágenes y vídeos, de modo previo a la práctica. Obviamente conlleva trabajo para el profesor, dado que hay que efectuarlo con previsión y conlleva una minuciosa planificación de los tiempos del aula, para que la imagen o el vídeo sea planteado en el momento oportuno. No obstante, las ventajas que presenta son mayores a los inconvenientes, dado que en un amplio porcentaje es visualizado por el alumnado, como puede valorarse en el aula, mediante el planteamiento de dudas y el debate previo a la práctica, en el que la inmensa mayoría ha cumplido el objetivo de la docencia inversa.

Previamente se hace un sondeo anónimo, acerca de la predisposición del alumnado al uso de redes, dado que tampoco se pretende invadir su privacidad. La totalidad del alumnado suele estar de acuerdo con el uso de las mismas, dado el carácter que otorgan estos canales de adaptación a sus necesidades. 


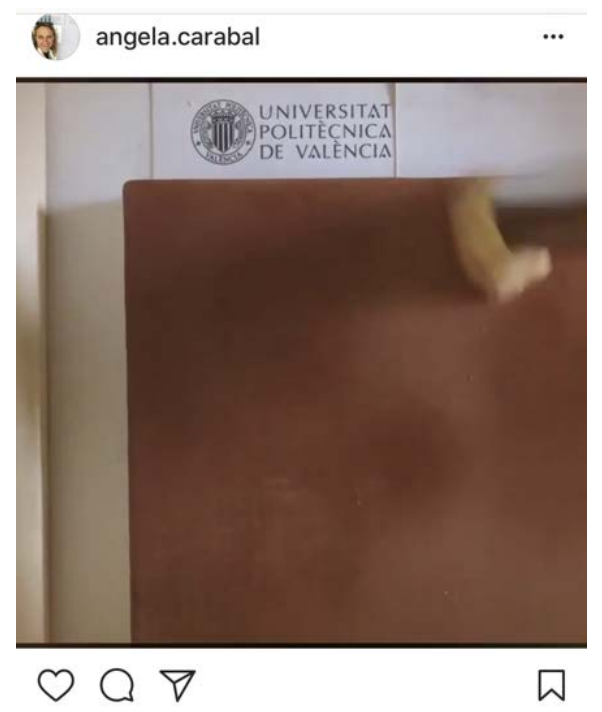

173 views $\cdot$ Liked by andreaacantos and aira_restaura

angela.carabal Preparando la superficie \#embolada con una lija fina o un pincel de cerda gruesa \#perrillo para que cerrar algo el poro y quede sin residuos para recibir la

\#coladepescado \#fishglue y el \#pandeoro \#goldleaf \#flippedteaching \#docenciainversa \#upv

Fig. 2. Vídeo de flipped teaching en la plataforma Instagram, con uno de los procesos de la práctica, previo a su ejecución en el aula.

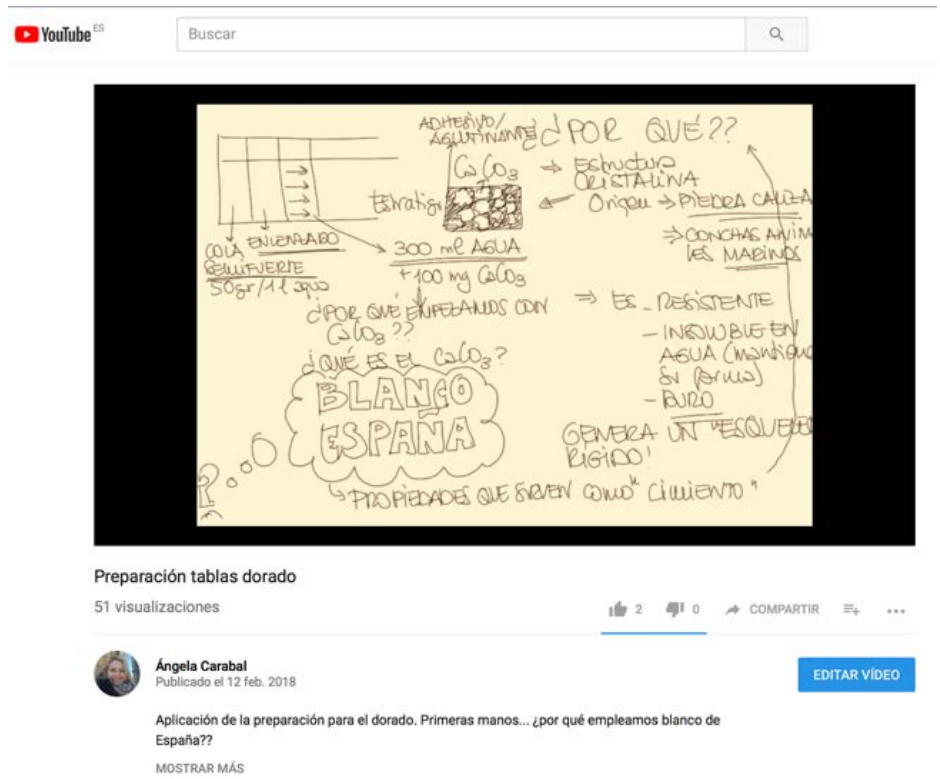

Fig. 3. Vídeo de flipped teaching en la plataforma Youtube, con la exposición de los materiales de uno de los procesos de la práctica, previo a su ejecución en el aula.

(cc) EY-Nc-No 2018, Universitat Politècnica de València 
María-Ángeles Carabal-Montagud, Virginia Santamarina-Campos, María-Victoria Esgueva-López, María de-Miguel-Molina

Cabe destacar que a través de la información enviada, se tiene constancia de los usuarios que han accedido a la información, o bien mediante la interacción directa con la imagen, o bien mediante el uso de una de las herramientas de la aplicación, consistentes en visualizar los usuarios que han accedido a la reproducción de los vídeos. Instantáneamente se reciben notificaciones con en número de reproducciones, en tiempo real, y los usuarios que lo han visualizado. En la figura 2 se puede observar el número de vistas y de interacciones.

También está la posibilidad de almacenar la información mediante una herramienta de archivo, que permite únicamente publicar durante el tiempo que se considere adecuado, resguardando los contenidos para emplearlos o bien en cursos posteriores o bien para tener una base y sustituirlos por otros, que se consideren más apropiados en posteriores cursos académicos. De este modo se va generando un repositorio, que el profesor puede utilizar, dependiendo de las necesidades de cada parte del temario o de la práctica.

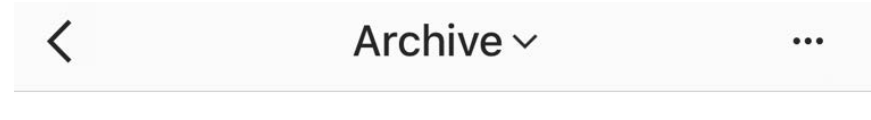

Only you can see the posts you've archived

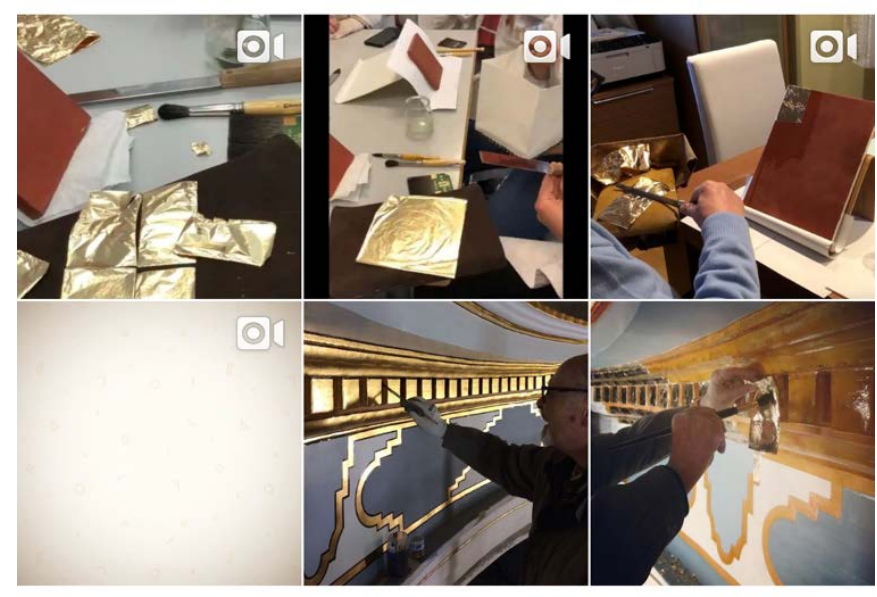

Fig. 4. Imágenes y vídeos de flipped teaching, archivados para cursos posteriores, una vez ya han cumplido su objetivo en el tiempo estipulado.

\subsubsection{Realizar una búsqueda de contenidos, seleccionar el material docente y compartirlo con el alumnado}

Con ello, se han ido subiendo imágenes y vídeos relacionados con la práctica durante el avance de la asignatura. Pero paralelamente, también se ha procedido a la búsqueda y selección de materiales generados y publicados por otros usuarios de dichas redes sociales y se han intercalado dependiendo de los contenidos de la asignatura.

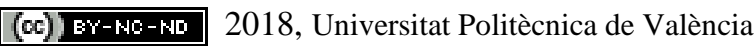

Congreso In-Red (2018) 


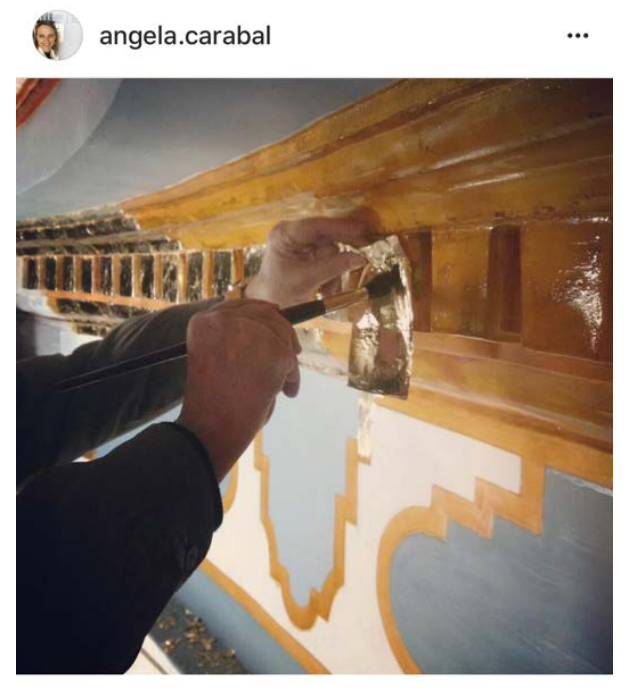

00

Liked by elisamartisa, art_conservation_studio and 69 others

angela.carabal \#procesos \#aplicación de los \#panesdeoro Foto que me envían directa desde la \#iglesia de \#banyeresdemariola \#gilding \#goldensurfaces \#flippedteaching angela.carabal

Universitat Politècnica de València UPV

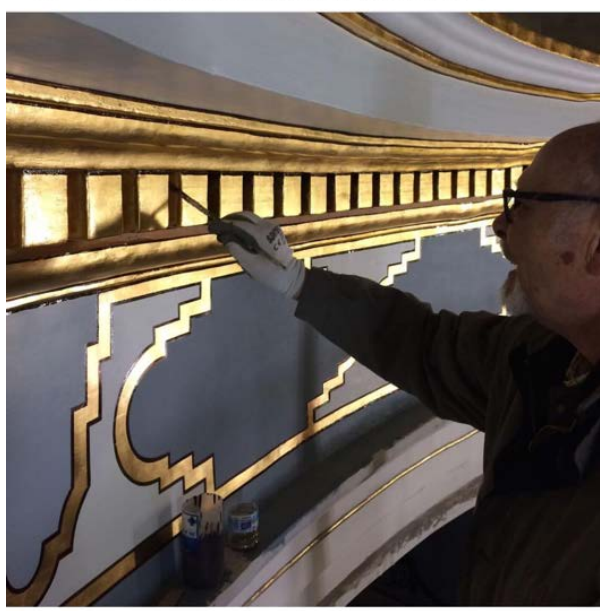

$\mathrm{OO}$

Liked by elisamartisa, andreaacantos and 53 others

angela.carabal Me envían el último proceso de \#dorado Observadlo y reforzamos contenidos en clase \#doradoypolicromía \#procesodorado \#flippedteaching \#gilding \#gildengsurfaces

Figs. 5,6. Imágenes de flipped teaching en la plataforma Instagram, con uno de los procesos de la práctica efectuado en empresas, previo a su ejecución en el aula.

La posibilidad que ofertan de compartir, facilita la tarea de puesta a disposición de la información al alumnado. En algunas ocasiones se ha compartido a través de dichas plataformas los enlaces, o directamente las imágenes y vídeos, pero en el caso de YouTube se ha procedido al empleo de PoliformaT para compartir la información del enlace URL para que los alumnos pudieran acceder. Este procedimiento responde al principal objetivo del presente estudio, que pretende sumar las plataformas activas institucionales junto con la redes sociales, de manera colaborativa.

En el caso de la citada asignatura, se ha realizado una compilación de todo el material que hay en la red, teniendo en cuenta que es cambiante y que cada día aparecen más recursos, lo cual genera en el alumno una visión de inmediatez, de actualidad, que suma valor la docencia inversa. Para ello, en Instagram, se han buscado imágenes de prácticas efectuadas o bien en empresas o bien en otro tipo de usuarios, realizando tareas como el dorado, la preparación de las tablas, el bruñido y el estofado, entre otros procesos. Al ser una 
María-Ángeles Carabal-Montagud, Virginia Santamarina-Campos, María-Victoria Esgueva-López, María de-Miguel-Molina

información pública, en ocasiones se ha compartido, o en otras ocasiones, se ha dado la referencia para que ellos acudan a la fuente de información.

También se han compartido imágenes de procesos previos, como el procesado del oro o como las diferentes aleaciones metálicas del pan de oro o plata, que pueden encontrar en el mercado, a través de búsqueda de empresas que utilicen la redes sociales y se dedican a la fabricación del oro, por poner un ejemplo.

De este modo, en este caso no solamente se utiliza para la consecución de las prácticas, sino también para entender de una manera visual la teoría y ayudar a la consecución de las competencias requeridas en la asignatura.

\section{Resultados}

Los datos recopilados de la innovación docente se van a clasificar teniendo en cuenta los diversos ámbitos que abarca y teniendo en cuenta la opinión de los receptores de la innovación docente, analizando por porcentajes los resultados obtenidos de la encuesta realizada a través de la plataforma SurveyMonkey ${ }^{\circledR}$.

\subsection{Encuesta de opinión del alumnado}

Con la finalidad de analizar los resultados obtenidos hasta el momento, con el empleo de las redes sociales como plataformas paralelas a las institucionales, se ha propuesto una encuesta en la citada plataforma, con contenidos que serán representativos para valorar la opinión de los destinatarios de la innovación. La encuesta consta de siete preguntas, acerca del flipped classroom en general y del uso de las redes sociales en particular.

\subsubsection{Valoración del uso de flipped classroom}

El 97,50\% del alumnado ha valorado como positiva la implantación, en términos de utilidad, de la docencia inversa para entender las prácticas y así agilizar su consecución. Con ello se corrobora que el alumnado entiende la implantación progresica de esta innovación metodológica. 


\section{Me resulta útil tener la información de modo previo a la} práctica a efectuar

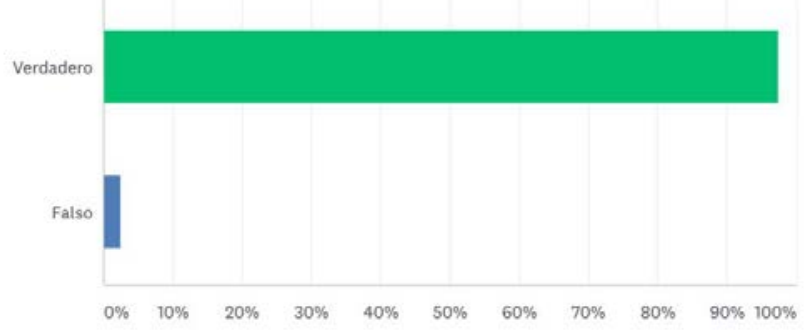

Fig. 7. Resultados de la encuesta con la plataforma SurveyMonkey®

Este porcentaje de respuesta resulta algo diferente cuando se pregunta acerca de la conveniencia de implantación de la docencia inversa en todas las asignaturas. La respuesta es afirmativa en el 77,50\% de los encuestados, mientas que el 22,50\% no valoran de modo positivo el flipped teaching para todas las asignaturas. Nuestra hipótesis al respecto es que, aunque sea de modo lúdico, ven incrementar con esta herramienta docente, el tiempo de dedicación no presencial.

\section{Creo que la docencia inversa (ver en casa cosas que nos hace ganar tiempo en clase) debería implantarse en todas las asignaturas}

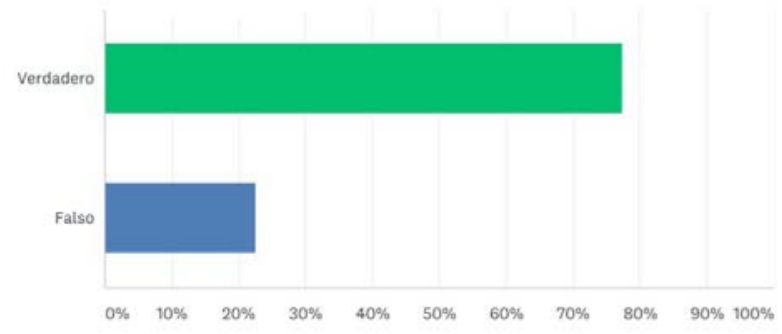

Fig. 8. Resultados de la encuesta con la plataforma SurveyMonkey®

Con todo, atendiendo a los porcentajes, es obvio que la docencia inversa es percibida por el alumnado como una herramienta útil, que ayuda a ganar tiempo en el aula.

\subsubsection{Valoración del uso de redes sociales para docencia inversa}

En general, la valoración del alumnado del uso de redes sociales y de sus preferencias de canales, también ha sido analizada en la presente investigación.

(cc)) EY-NC-ND 2018, Universitat Politècnica de València

Congreso IN-RED (2018) 
María-Ángeles Carabal-Montagud, Virginia Santamarina-Campos, María-Victoria Esgueva-López, María de-Miguel-Molina

Podemos concluir que en un $92,50 \%$ se valora de modo positivo el uso de redes sociales para la docencia inversa (Fig.9). A la hora de responder qué canales son más cómodos para ellos (Fig.10), para acceder a la información, un 40\% prefiere complementar los canales institucionales con las redes sociales, mientras que el 22,50\% prefiere el uso único de PoliformaT, y un 35\% refiere que le resulta indiferente uno u otro canal complementario. Un 2,5\% prefiere el uso de correo electrónico.

Al sondear al alumnado acerca del resultado obtenido, reseñan que para acceder a las plataformas institucionales el alumno tiene que insertar sus claves y suele hacerlo, en mayor medida, a través de tabletas u ordenadores, con lo cual, complementarlo con el uso de las redes sociales les da una visión más familiar y asequible de las tareas, dado que éstas responden mediante la entrada en una app, siendo más rápido y en un solo click.

La redes sociales me parecen un buen canal para comunicar con el alumnado

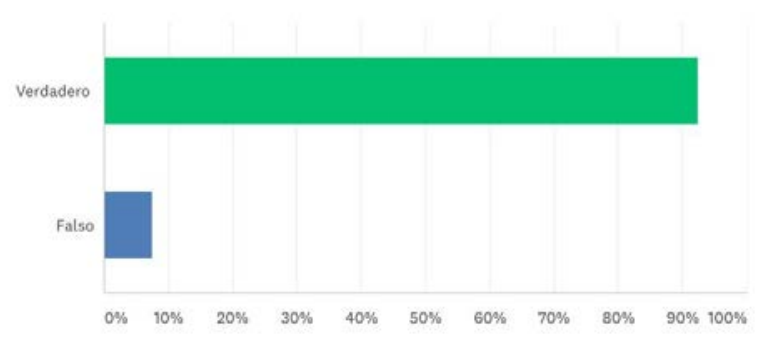

¿Qué canales son más cómodos para mi a la hora de acceder a la información?

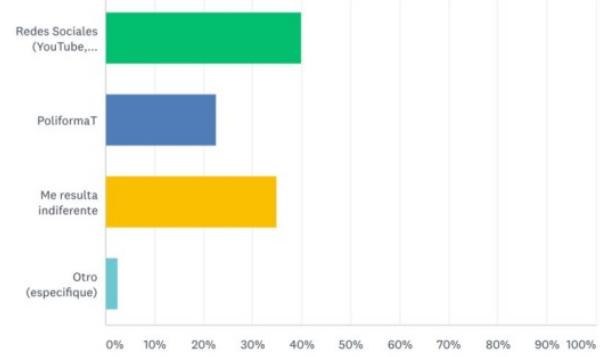

Figs. 9,10. Resultados de la encuesta con la plataforma SurveyMonkey®

Asimismo, cuando se les pregunta acerca de la percepción lúdica que añade el uso de redes sociales a la docencia inversa, un 90\% del alumnado opina de modo afirmativo (Fig.11). Con lo cual, el resultado principal de esta implementación se está cumpliendo de manera positiva.
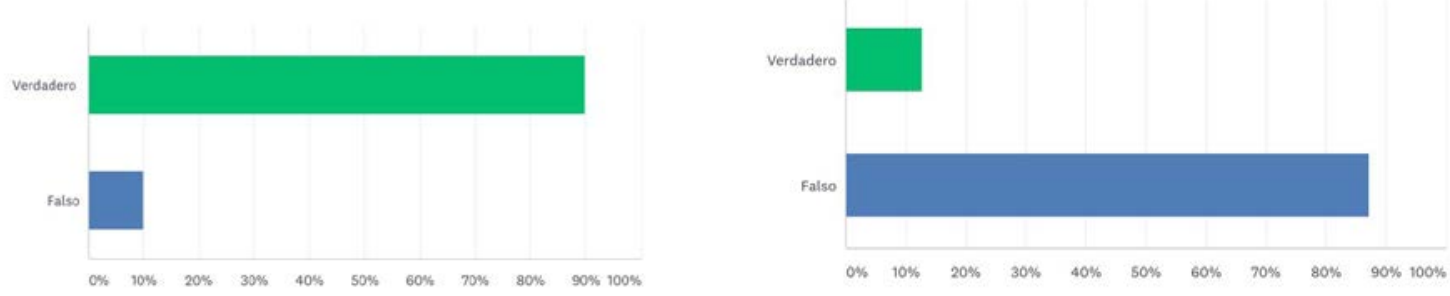

Figs. 11, 12. Resultados de la encuesta con la plataforma SurveyMonkey®

(c) ) EY-Nc-No 2018, Universitat Politècnica de València

Congreso In-Red (2018) 
No obstante, mientras se ha efectuado esta innovación docente se ha tenido en cuenta, como se ha citado con anterioridad, que el alumnado no sienta que los contenidos educativos invadan su parcela personal. Para averiguar si les produce cierta incomodidad el encontrar materiales docentes en sus redes, se les ha preguntado su percepción al respecto. Un 87,18\% niega que le resulte incómodo la implementación de la docencia inversa en las redes.

\subsection{Desarrollo y resultado de las prácticas}

Se ha observado una mejora en la planificación de las actividades prácticas, una mayor predisposición, por la seguridad que otorga el saber a qué se van a enfrentar, además de una mayor participación, un nivel cognitivo superior de la práctica, que se traduce en que cada vez presentan dudas más técnicas y complejas, además de suplirse problemas cotidianos relacuionados por el desconocimiento previo de la metodología a llevar a cabo.

Los resultados a nivel práctico, han sido también positivos, teniendo en cuenta que las consecuencias positivas obtenidas de la práctica han conllevado un aumento colaborativo y han favorecido la resolución de problemas, conducentes a un buen resultado final.

\section{Conclusiones}

En el presente estudio, fundamentalmente se analizan los resultados de la docencia inversa mediante dos vías: directamente en la consecución de las prácticas, en el modo de trabajar en el aula y en la mejora de los resultados. Al mismo tiempo se ha establecido otro tipo de valoración, mediante encuestas para validar la fiabilidad de los datos, a través de la correlación de los resultados.

El alumnado demanda una inmediatez, una fácil accesibilidad a la información mediante el uso de apps, un mayor uso de sus dispositivos móviles, que les otorgan la sensación de comodidad de acceso. Se trata de acercar la docencia a sus canales y códigos cotidianos, de modo que les resulte más asequible el acceder a los contenidos docentes.

Mediante el presente estudio se ha verificado que las redes sociales son bien valoradas por el alumnado y pueden emplearse, como canal complementario, para la docencia inversa. Refuerzan no sólo contenidos prácticos del aula, sino que también sirven para exponer la teoría, extrapolando la tarea o lo aprendido en el aula con la realidad empresarial fuera de la universidad, a modo de baño de realidad. De este modo se enlazan los contenidos de la asignatura con su futuro laboral, cumpliéndose uno de los objetivos más importantes de la presente metodología.

Otra de las conclusiones del presente estudio es la interactividad y la inmediatez de las redes sociales. Respecto a la plataforma YouTube, cabe destacar que el acceso a vídeos

(cc) BY-Nc-ND 2018, Universitat Politècnica de València

Congreso IN-RED (2018) 
María-Ángeles Carabal-Montagud, Virginia Santamarina-Campos, María-Victoria Esgueva-López, María de-Miguel-Molina

relacionados, a otros contenidos subidos por otros usuarios, resulta de gran utilidad a los alumnos. En Instagram la información es inmediata en los dos sentidos, tanto para el alumnado que la consulta, como para el profesorado, dado que las visualizaciones van ascendiendo en un corto espacio temporal, así como las interacciones con los contenidos, generándose un espacio virtual colaborativo.

Si bien es cierto que el uso de audiovisuales resulta muy útil en nuestra área, dada la carga visual que conlleva, cada uno tendría que valorar la implantación en su ámbito.

Supone un esfuerzo para el profesor y mayor tiempo de trabajo, además de que en ocasiones el mismo material no es aprovechable, suponiendo una práctica de innovación constante, porque en las redes se valora la inmediatez, pero los resultados obtenidos apuntan a que los alumnos lo prefieren, al acercarse a su realidad cotidiana.

\section{Referencias}

CARABAL, M.A. (2018) Flipped Classroom, encuesta en la plataforma SurveyMonkey®

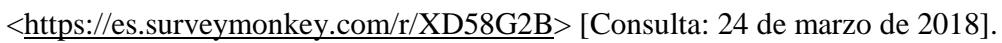

CARABAL MONTAGUD, MARÍA ÁNGELES (@angela.carabal). [Instagram]. $<$ www.instagram.com> [Consulta: 20 de marzoi de 2018].

CARABAL MONTAGUD, "Preparación tablas dorado". Youtube $<$ https://www.youtube.com/watch?v=wEZ-46TO4Cw > [Consulta: 23 de enero de 2018]

CARABAL-MONTAGUD, M.A., SANTAMARINA-CAMPOS, V., DE MIGUEL-MOLINA, M., DE MIGUEL-MOLINA, M.B., (2017). “Uso del Phubbing como estrategia de aprendizaje” UPV. En Comunica2. Valencia: Editorial UPV. Pp 107-121. ISBN 978-84-945855-3-1. Disponible en $<$ https://datos.comunica2.webs.upv.es/uploads/2018/02/Actas-7Comunica2-2017.pdf> [Consulta: 3 de marzo de 2018]

CIS. Participación en diferentes redes sociales durante los últimos tres meses. Barómetro de Noviembre de 2017. <http://www.analisis.cis.es/cisdb.jsp> [Consulta: 2 de febrero de 2018].

ESPINOSA MOLINA, M.A., CALCUCH-LOSA, A., SERRANO-COBOS, J. (2017). "Patrones de contenidos sociales en youtubers de moda española” UPV. En Comunica2. Valencia: Editorial UPV. Pp 133-148. ISBN 978-84-945855-3-1. Disponible en $<$ https://datos.comunica2.webs.upv.es/uploads/2018/02/Actas-7Comunica2-2017.pdf> [Consulta: 3 de marzo de 2018]

HARO, J.J., (2009). Las redes sociales aplicadas a la práctica docente. Spain: DIM. Didáctica, Innovación y Multimedia

< http://www.raco.cat/index.php/DIM/article/view/138928/189972 > [Consulta: 15 de enero de 2018].

(c)) EY-NC-ND 2018, Universitat Politècnica de València

Congreso In-Red (2018) 
TERRASA BARRENA, S., ANDREU GARCÍA, G. (2015) Cambio a metodología de clase inversa en una asignatura obligatoria.Actas del simposio-taller sobre estrategias y herramientas para el aprendizaje y la evaluación. Andorra La Vella. Pp.32-37. Disponible en <http://bioinfo.uib.es/ joemiro/aenui/procJenui/Jen2015/Tte_camb.pdf> [Consulta: 14 de marzo de 2018]

UPV. Página web de la Universitat Politècnica de València <www.upv.es> [Consulta: 23 de marzo de 2018]. 


\title{
Diseño y evaluación de un laboratorio virtual para visualizar momentos de un vector deslizante en 3D
}

\author{
José A. Gómez-Tejedor ${ }^{\mathrm{a}, \mathrm{b}}$, Juan A. Monsoriu ${ }^{\mathrm{a}, \mathrm{c}}$, Isabel Salinas ${ }^{\mathrm{a}, \mathrm{d}}$, Juan A. Sans ${ }^{\mathrm{a}, \mathrm{e}}$, \\ Vanesa P. Cuenca-Gotor ${ }^{\mathrm{a}, \mathrm{f}}$ y Marcos H. Giménez ${ }^{\mathrm{a}, \mathrm{g}}$ \\ ${ }^{a}$ ETS de Ingeniería del Diseño, Universitat Politècnica de València, bjogomez@fis.upv.es,

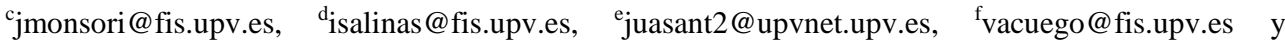 \\ gmhgimene@fis.upv.es.
}

\begin{abstract}
The use of multimedia tools for the development and implementation of teaching material is considered of paramount importance for first degree courses. Thus, we have observed, in fundamentals of Physics subjects, how the use of this kind of didactic material increases the motivation and the learning curve of the student. In this work, we present a virtual lab for the calculation of moments that allow multiple selections such as the vector representation, its action line and the moment in a $3 D$ environment. This applet allows the user modifying the point of view and the scale in an interactive way. Besides the visualization, this virtual lab allows the calculation of the moment of a sliding vector with respect to an axis and perform different operation between them. Additionally, it helps to understand the relation between the velocity at a point and the angular velocity of the rigid body in rotation to whom it belongs, the moment of a force with respect to an axis, and the way that this force affects the rotation. All of this supports the development of several transversal skills.
\end{abstract}

Keywords: Virtual laboratory, Physics, Easy Java, Sliding vector, moment.

\footnotetext{
Resumen

El uso de herramientas multimedia para el desarrollo e implementación de material didáctico se considera de una importancia capital para los primeros cursos de grado. Así, en las asignaturas de fundamentos de Física hemos observado cómo el uso de esta clase de material aumenta tanto la satisfacción como el aprendizaje del alumno. En este trabajo, presentamos un laboratorio virtual para el cálculo de momentos que permite múltiples opciones como la representación del vector, su línea de acción y su momento en un entorno 3D. Este applet permite al usuario modificar tanto el punto de vista como la escala de forma interactiva. Además de la visualización, este laboratorio virtual permite calcular el momento del vector deslizante respecto a un eje y realizar operaciones entre ellos. Asimismo, ayuda a comprender la relación entre la velocidad de un punto y la velocidad angular del sólido rígido en rotación al que pertenece, el momento de una fuerza
} 
respecto a un eje, y la forma en que dicha fuerza afecta a una rotación. Todo esto sustenta el desarrollo de diversas competencias transversales.

Palabras clave: Laboratorio Virtual, Física, Easy Java, Vector deslizante, momento.

\section{Introducción}

En la actualidad, las Tecnologías de la Información y la Comunicación (TICs) son ampliamente utilizadas en la enseñanza de las ciencias. Los métodos tradicionales de enseñanza, como es la lección magistral, están siendo reemplazados o compaginados con metodologías más activas enfocadas en los estudiantes. En este contexto, el docente actúa como un guía, brindando a los estudiantes las herramientas y mostrándoles las diferentes maneras en que pueden aplicarse al proceso de aprendizaje. El docente debe elegir la mejor manera de permitir que el alumno construya y comprenda la solución a problemas prácticos (Duffy, 1992). El docente no transfiere el conocimiento a los estudiantes, sino que los ayuda a construir, o al menos a interpretar, la realidad del cuerpo de conocimiento basado en sus experiencias.

En este contexto, los procesos de aprendizaje basados en simulaciones digitales han demostrado ofrecer varias ventajas (Jimoyainni, 2001; Gómez Tejedor, 2008), aunque su eficacia pedagógica está condicionada a una integración completa de la simulación en el plan de instrucción global (Vidaurre, 2002). La introducción de las TICs para la enseñanza tiene la ventaja de ofrecer la posibilidad de mostrar el tema de estudio desde diferentes puntos de vista. Concretamente, los laboratorios virtuales proporcionan a los estudiantes herramientas con las que controlar los parámetros relevantes de un fenómeno físico y visualizar las consecuencias (Depcik, 2005; Daineko, 2017; Lynch 2017).

En este trabajo presentamos un nuevo laboratorio virtual VISUALIZADOR DE MOMENTOS DE UN VECTOR DESLIZANTE. El laboratorio permite que el usuario introduzca las componentes de un vector deslizante y las coordenadas de un punto de su línea de acción. La aplicación calcula el momento del vector respecto a un punto seleccionado por el usuario. El vector, su línea de acción y su momento se muestran en una representación 3D en la que el usuario puede modificar de forma interactiva tanto el punto de vista como la escala. El laboratorio virtual también permite calcular el momento del vector deslizante respecto a un eje, además de representarlo gráficamente.

\section{Objetivos}

Con este laboratorio virtual, se pretende que los alumnos adquieran conocimientos y comprensión de diferentes conceptos relacionados con el cálculo del momento de un sistema de vectores respecto a un punto y respecto a un eje. En particular, los principales objetivos que el alumno puede alcanzar mediante la utilización de este laboratorio virtual son:

- Comprender y analizar cómo afectan a los momentos de un vector deslizante:

(cc) EY-NC-ND 2018, Universitat Politècnica de València

Congreso IN-RED (2018) 
José A. Gómez-Tejedor, Juan A. Monsoriu, Isabel Salinas, Juan A. Sans, Vanesa P. Cuenca-Gotor y Marcos H. Giménez

- El módulo, la orientación y la posición del vector.

- El desplazamiento del punto de aplicación del vector a lo largo de su línea de acción.

- El desplazamiento del punto respecto al que se calcula de forma paralela, radial o circular respecto a la línea de acción del vector deslizante.

- Analizar cómo afecta al momento respecto a un eje el desplazamiento del punto de dicho eje utilizado para el cálculo.

- Comprender la relación entre los momentos de la velocidad angular y las velocidades de los diferentes puntos de un sólido rígido en rotación.

- Comprender la relación entre el momento de una fuerza respecto a un eje y la forma en que dicha fuerza afecta a una rotación.

Estos objetivos se alcanzan tanto con la ayuda del profesor en el aula, como mediante un aprendizaje autónomo del alumno fuera de clase, trabajando así algunas de las competencias transversales establecidas por la Universitat Politècnica de València (UPV), como son: comprensión e integración; aplicación y pensamiento práctico; análisis y resolución de problemas; pensamiento crítico; y aprendizaje permanente.

\section{Desarrollo de la innovación}

\subsection{Definiciones}

Antes de entrar en la explicación del laboratorio virtual, es necesario realizar una serie de definiciones que se utilizan a lo largo de este trabajo y en el applet. Son definiciones que se explican en clase y que el alumno conoce, ya que este laboratorio virtual se utiliza precisamente para que el alumno trabaje y profundice en dichos conceptos.

Se define el momento de un vector deslizante $\vec{v}$ respecto a un punto $Q, \vec{M}(Q)$, como:

$$
\vec{M}(Q)=\overrightarrow{Q P} \times \vec{v}
$$

donde $P$ es un punto cualquiera de la línea de acción del vector $\vec{v}$ (Figura 1a).
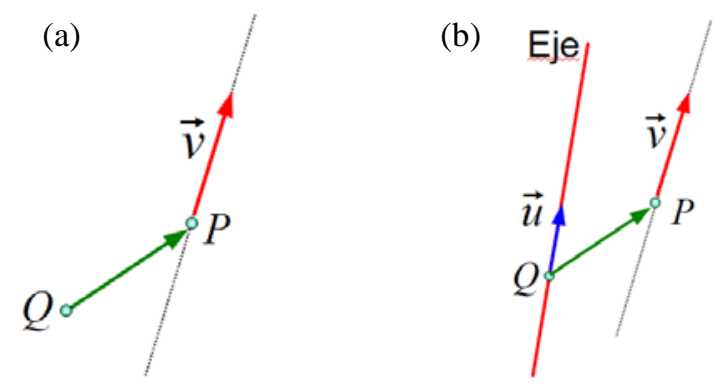

Fig. 1 (a) Momento de un vector respecto a un punto. (b) Momento de un vector respecto a un eje

Dado un eje definido mediante un punto $Q$ y un vector $\vec{w}$, se define el momento de un vector deslizante $\vec{v}$ respecto a dicho eje (momento áxico), $M(Q ; \vec{w})$, como:

$$
M(Q ; \vec{w})=\vec{M}(Q) \cdot \vec{u}=(\overrightarrow{Q P} \times \vec{v}) \cdot \vec{u}
$$


donde en esta expresión, $\vec{u}$ es un vector unitario en la dirección de $\vec{w}$, y define por tanto la dirección del eje (Figura 1b).

\subsection{Laboratorio virtual para la visualización de momentos de un vector deslizante}

Para alcanzar los objetivos descritos anteriormente, se ha desarrollado un laboratorio virtual VISUALIZADOR DE MOMENTOS DE UN VECTOR DESLIZANTE mediante la herramienta EASY JAVA SIMULATIONS, que se distribuye gratuitamente bajo la licencia de código abierto GNU GENERAL PUBLIC LICENSE. Dicha herramienta permite desarrollar aplicaciones basadas en el lenguaje de programación Java.

El applet permite que el usuario introduzca las componentes de un vector deslizante y las coordenadas de un punto de su línea de acción. La aplicación calcula el momento del vector respecto a un punto seleccionado por el usuario. El vector, su línea de acción y su momento se muestran en una representación 3D en la que el usuario puede modificar de forma interactiva tanto el punto de vista como la escala. Se puede acceder a la aplicación a través de la dirección web http://hdl.handle.net/10251/30531.

En la interfaz de la aplicación podemos destacar en primer lugar el menú Herramientas (Figura 2), que dispone de dos opciones: Restaurar vista 3D, que permite que el usuario pueda recuperar la perspectiva y escala iniciales; y Reiniciar, que devuelve el applet a su estado inicial.

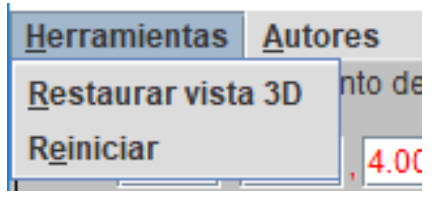

Fig. 2 Menú Herramientas.

En el panel Vector deslizante y punto de aplicación el estudiante puede introducir las tres componentes del vector deslizante $\vec{v}$ del cual se calcula el momento, y las coordenadas del punto de aplicación $P$ de dicho vector, utilizando para ello los cuadros de texto correspondientes (Figura 3). El programa calcula el módulo del vector, que se muestra a la derecha de sus componentes.

Conviene mencionar que la herramienta de desarrollo no permite poner flechas sobre los caracteres. Por este motivo, el laboratorio virtual muestra los vectores en negrita.

La aplicación calcula el momento de dicho vector respecto a un punto y/o un eje. En el panel Punto / eje para el cálculo de momentos, el usuario tiene que introducir las coordenadas del punto $Q$ respecto al que se quiere calcular el momento del vector, o un punto $Q$ y un vector $\vec{w}$ que definen la línea respecto a la cual se calcula el momento áxico (Figura 3). El programa calcula y muestra también el brazo $d$ del vector $\vec{v}$ respecto al punto $Q$. 
José A. Gómez-Tejedor, Juan A. Monsoriu, Isabel Salinas, Juan A. Sans, Vanesa P. Cuenca-Gotor y Marcos H. Giménez

A la hora de introducir los valores en los cuadros de texto anteriores hay que tener en cuenta que, al teclear cualquier entrada, dicho cuadro se muestra con fondo amarillo. Es obligatorio pulsar la tecla INTRO para validar la entrada, tras lo cual el fondo pasa a ser blanco. Si el valor introducido no es un número válido, el fondo cambia a color rojo, pudiendo entonces corregir la entrada.

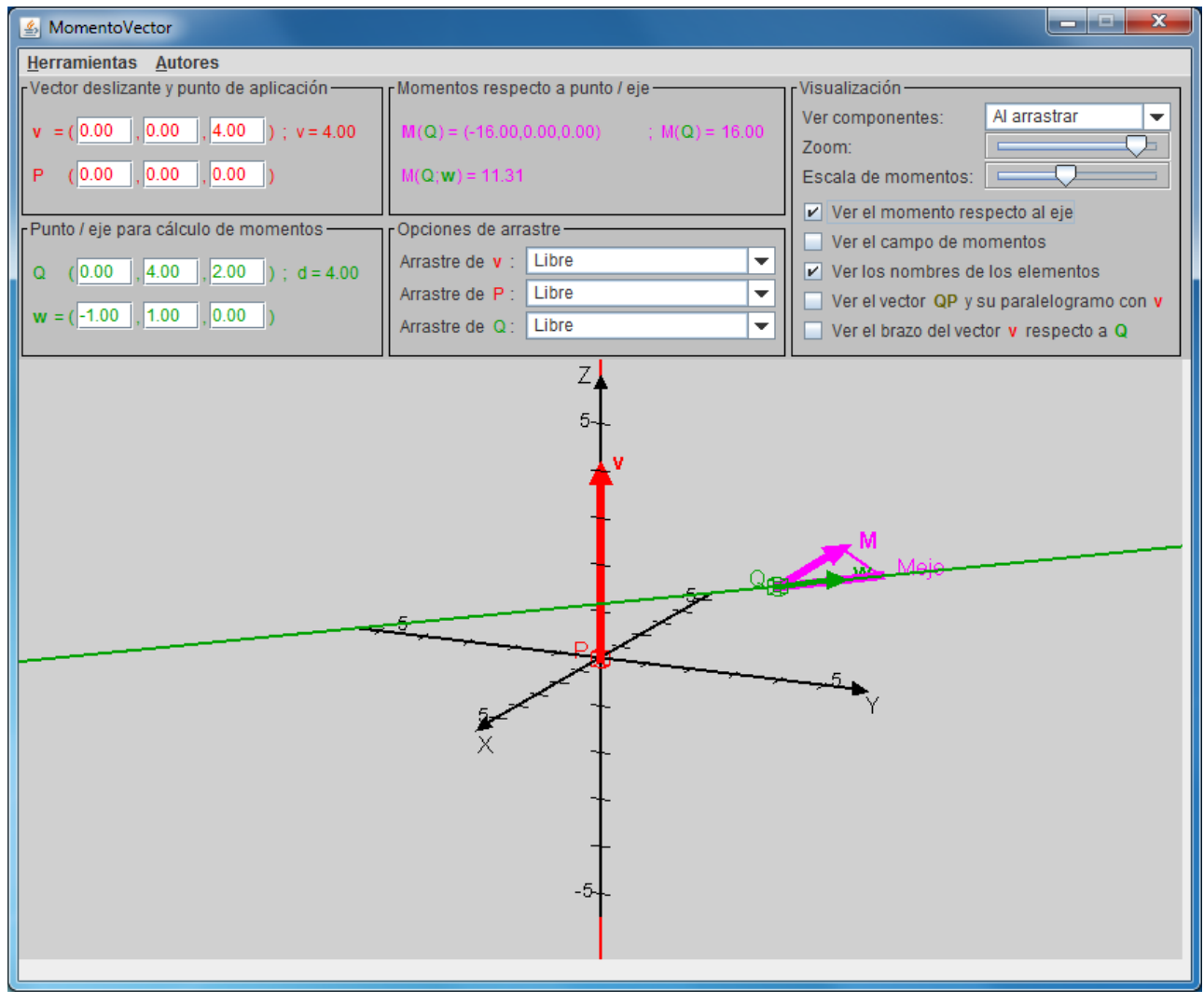

Fig. 3 Laboratorio virtual para la visualización de momentos de un vector deslizante

De forma alternativa, en lugar de introducir la información directamente con el teclado, el usuario puede modificar en el visor, arrastrando el ratón, tanto el vector como su punto de aplicación y el punto respecto al que se calcula el momento. De este modo, puede observar de forma interactiva cómo afectan esos elementos al momento resultante. Se puede elegir entre que esas modificaciones interactivas sean libres o estén sujetas a ciertos condicionantes de interés. Dado que el entorno mostrado en el visor es 3D, mientras que el ratón se mueve en 2D, no es posible modificar por arrastre las tres componentes de un vector, ni las tres coordenadas de un punto, de forma simultánea. Por ese motivo, solamente se modifican dos de ellas (cuáles en concreto depende del punto de vista utilizado). Sin embargo, es posible seleccionar una componente o coordenada cualquiera pulsando la tecla $\mathrm{X}, \mathrm{Y}$ o Z. Por ejemplo, si se arrastra el extremo de un vector mientras se mantiene pulsada la tecla $\mathrm{X}$, sólo se modifica esta componente. 
En el panel Momentos respecto a punto / eje se muestran los valores del vector momento respecto al punto y su módulo. Si está seleccionada la opción Ver el momento respecto al eje del panel Visualización se muestra también el momento respecto del eje.

En el panel Opciones de arrastre se puede controlar el comportamiento de la aplicación al seleccionar un punto o un vector, y arrastrarlo con el ratón. Al arrancar la aplicación aparece seleccionada la opción Libre en todas las listas desplegables, lo que permite mover libremente el vector $\vec{v}$, y/o los puntos $P$ y $Q$. Además de esta opción, según el caso, se dispone de las siguientes posibilidades:

- $\quad$ Arrastre de $\vec{v}$ :

- Módulo y sentido: permite cambiar el módulo y sentido del vector sin modificar su dirección (línea de aplicación del vector).

- Orientación: para cambiar la dirección del vector sin modificar su módulo.

- $\quad$ Arrastre de $P$ :

- Sobre línea de acción: desplaza el punto $P$, pero manteniéndolo siempre sobre la misma línea de acción del vector.

- $\quad$ Arrastre de $Q$ :

- Paralelo línea de acción: mueve el punto $Q$, manteniéndolo siempre en una línea paralela al vector $\boldsymbol{v}$.

- Radial línea de acción: el desplazamiento del punto $Q$ se realiza en una dirección perpendicular al vector $\vec{v}$.

- Circular línea de acción: desplaza el punto $Q$ siguiendo una circunferencia alrededor del vector $\vec{v}$. En este caso hay que tener en cuenta las restricciones del movimiento del ratón que es solamente en 2D, por lo que dependiendo de la perspectiva utilizada, no es posible describir la circunferencia completa alrededor del vector $\vec{v}$.

- Sobre el eje: esta opción solamente se puede utilizar cuando se visualiza el momento respecto al eje, seleccionando la opción correspondiente el panel de Visualización. En ese caso, la opción permite desplazar el punto $Q$ sobre el eje $(Q ; \vec{w})$.

Por último, mediante el panel Visualización se controlan varias opciones de la interfaz gráfica del applet. La opción Ver componentes hace que se muestren unos hilos (líneas verdes en el ejemplo de la Figura 4), que permiten visualizar más cómodamente la posición 3D Al arrastrar, Siempre o Nunca en función de la elección realizada. 


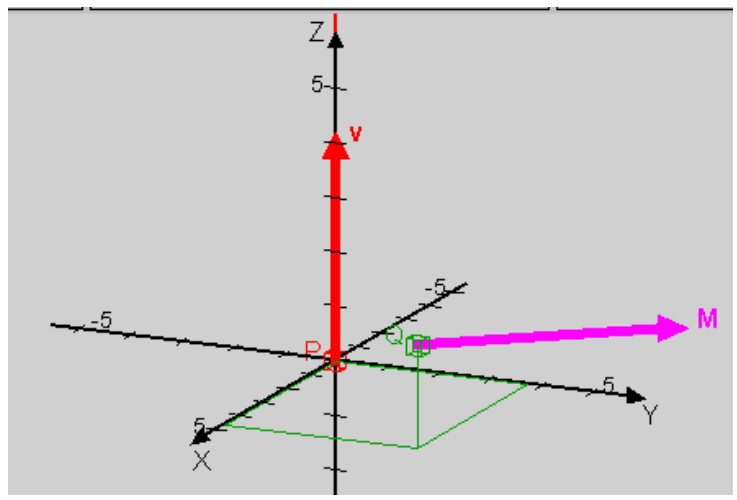

Fig. 4 Coordenadas del punto $Q$

La deslizadera Zoom permite ampliar o reducir el área visualizada en pantalla. La deslizadera Escala de momentos permite modificar la escala con que aparecen los momentos en el visor (téngase en cuenta que la magnitud del momento no es la misma que la de $\vec{v}$, por lo que no se corresponde con la graduación de los ejes del visor).

Por último, se proporciona una serie de opciones seleccionables mediante una casilla de verificación. Ver el momento respecto al eje (Figura 5a) permite ocultar y mostrar el momento respecto al eje. Ver el campo de momentos (Figura $5 \mathrm{~b}$ ) permite seleccionar entre visualizar o no el patrón de momentos alrededor del vector deslizante $\vec{v}$. Ver los nombres de los elementos permite elegir entre mostrar los nombres de los vectores y puntos junto a su representación gráfica, o bien ocultarlos para aclarar el visor. Ver el vector $Q P$ y su paralelogramo con $v$ (Figura 5 c) hace que se muestre en pantalla el paralelogramo definido por dichos vectores, lo que facilita ponerlo en relación con la definición de momento como un producto vectorial. Finalmente, Ver el brazo del vector $v$ respecto a $Q$ (Figura $5 \mathrm{~d}$ ) permite ver el brazo $d$ del vector deslizante respecto al punto, esto es, la distancia de $Q$ a la línea de acción de $\vec{v}$.

(a)

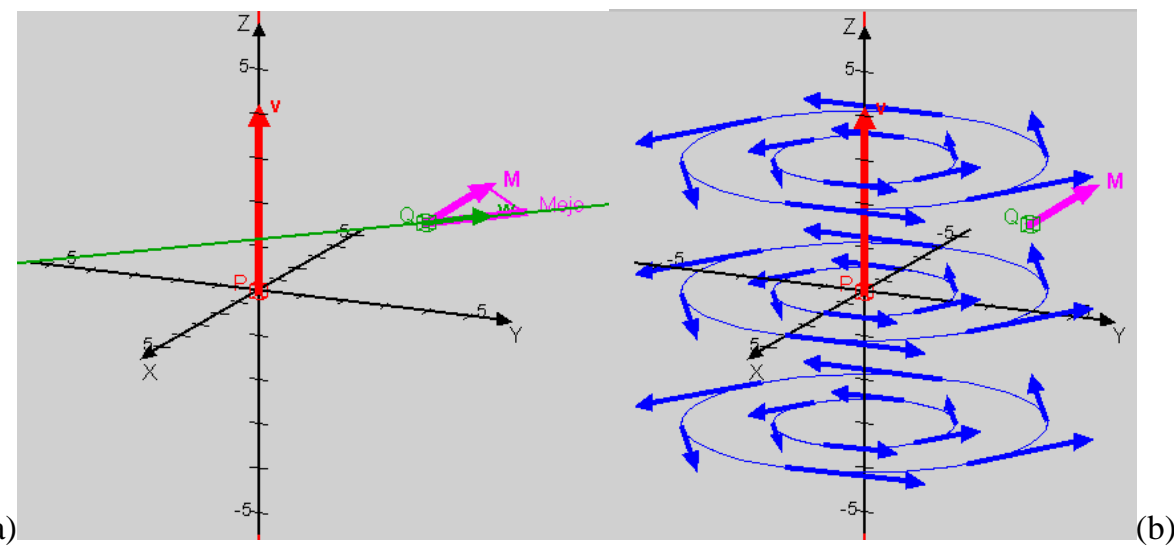

2018, Universitat Politècnica de València 


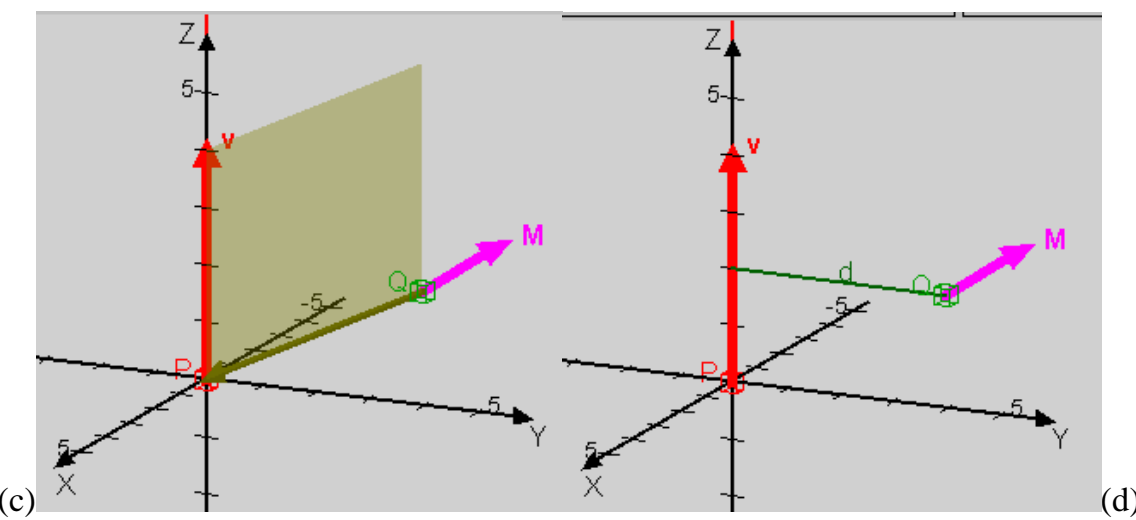

Fig. 5 Ejemplos del visor con diferentes opciones de visualización seleccionadas. (a) Ver el momento respecto al eje. (b) Ver el campo de momentos. (c) Ver el vector QP y su paralelogramo con v. (d) Ver el brazo del vector $v$

respecto a $Q$. En todos los casos está también seleccionada la opción de ver los nombres de los elementos

Por último, es interesante señalar que se utiliza un código de colores para identificar claramente cada uno de los elementos que se representan en el visor. El color es el mismo en el visor que en los diferentes paneles de la aplicación: rojo para el vector deslizante y su punto de aplicación, verde claro para el punto y eje para el cálculo de momentos, magenta para el momento, y azul para representar el campo de momentos.

\section{Resultados}

\subsection{Método de evaluación}

Con el objetivo de valorar la influencia del uso del laboratorio virtual "Visualizador de momentos de un vector deslizante" sobre el aprendizaje de los alumnos, durante el presente curso académico (2017/18) se han elegido dos grupos de control. Los dos grupos pertenecen al primer curso de dos títulos de grado de la Escuela Técnica Superior de Ingeniería del Diseño (ETSID) de la UPV y a dos asignaturas de física en las que figura en sus programas el tema de "Momentos de vectores deslizantes". Los grupos son:

- En el grupo de la asignatura "Complementos de Física" del grado en Ingeniería Mecánica se ha impartido el tema de Momentos utilizando el laboratorio virtual. Los alumnos de esta asignatura no tenían ningún conocimiento previo sobre el tema de Momentos. Por ello, una vez explicado el tema, se realizó un examen PoliformaT para valorar su aprendizaje.

- En la asignatura optativa "Física Básica” del grado en Ingeniería Eléctrica se ha impartido de forma clásica, sin utilizar el apoyo del laboratorio virtual. Los alumnos de esta asignatura optativa ya habían estado trabajando sobre este tema en la asignatura de "Física", por lo que se hizo un estudio comparativo entre los que habían cursado ambas asignaturas (grupo "Física Básica + Física”) y el resto de los estudiantes que solamente han cursado la asignatura de "Física” (grupo "Física”). 
José A. Gómez-Tejedor, Juan A. Monsoriu, Isabel Salinas, Juan A. Sans, Vanesa P. Cuenca-Gotor y Marcos H. Giménez

Para poder analizar el efecto del uso del laboratorio virtual sobre el rendimiento académico de los estudiantes se han realizado unas pruebas de respuesta numérica abierta. Asimismo, para conocer cuál ha sido el grado de satisfacción respecto a la utilización del laboratorio virtual se ha realizado una encuesta anónima a los alumnos de la asignatura "Complementos de Física". La encuesta plantea ocho cuestiones y las respuestas son valoradas con cinco niveles (TDA: totalmente en desacuerdo; DA: en desacuerdo; IND: indiferente; A: de acuerdo; TA: totalmente de acuerdo).

\subsection{Test de rendimiento académico}

En primer lugar, al comparar los resultados obtenidos en las pruebas realizadas, encontramos que el valor medio de las puntuaciones es muy dispar. La nota media en "Complementos de Física" (utilizando el laboratorio virtual) ha sido de 9,07 con una desviación estándar de 1,17 (figura 6a), mientras que en el caso de "Física Básica" (sin utilizar el laboratorio virtual) la nota media ha sido de 6,74 con una desviación estándar de 2,08 (figura 6b).

Analizando los resultados obtenidos por los alumnos que utilizaron el laboratorio virtual, podemos observar que el poder interactuar con los parámetros que afectan al momento de un vector deslizante mejora el nivel de comprensión del tema abordado. Así mismo, a partir de la experiencia de los profesores en el aula, podemos afirmar que el nivel de motivación es muy alto.

Por otra parte, los alumnos que solamente cursaron la asignatura "Física" obtuvieron una nota media de 6,38 con una desviación estándar de 2,21. Si comparamos estos resultados con los de los alumnos que han recibido una clase de refuerzo (grupo "Física Básica + Física"), podemos observar que estos últimos han mejorado la nota media, como se muestra en la figura $6 \mathrm{~b}$.

\section{Complementos de Física}
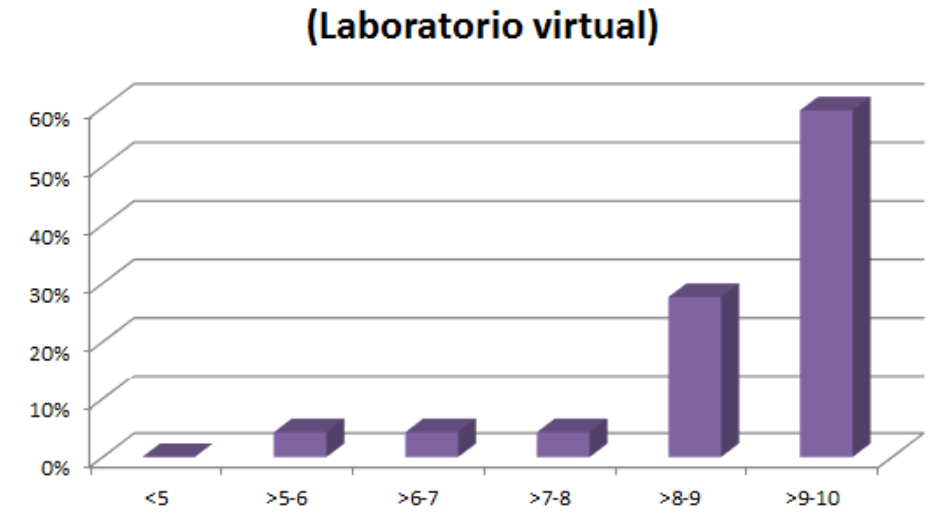

Fig. 6a Representación gráfica del porcentaje de alumnos que han obtenido una determinada calificación en la asignatura "Complementos de Física" donde se ha utilizado el laboratorio virtual. 


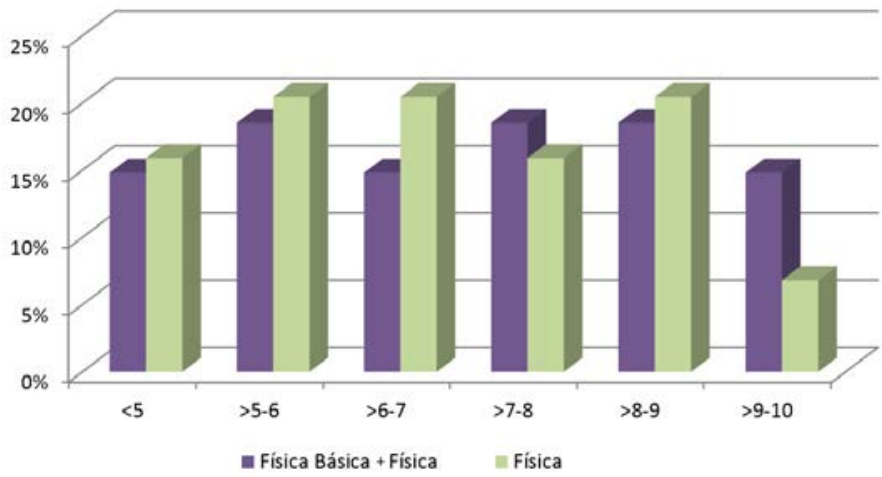

Fig. 6 b Representación gráfica del porcentaje de alumnos que han obtenido una determinada calificación en los exámenes de los grupos "Física Básica+Física" y "Física".

\subsection{Encuesta de opinión}

La encuesta se ha realizado en el grupo de estudiantes que ha utilizado el labora-torio virtual. En la Tabla 1 se muestran las preguntas y las respuestas obtenidas sobre una muestra de 34 alumnos.

Las respuestas de las cuestiones que están relacionadas con la manejabilidad del laboratorio virtual nos dicen que más del $76 \%$ de los estudiantes exploró las opciones que esta herramienta ofrece (Q6), y el 88,2\% encontró que el manejo del laboratorio virtual era intuitivo y sencillo (Q2).

La percepción del estudiante sobre la mejoría experimentada en la comprensión del tema de Momentos, después de haber utilizado el laboratorio virtual, es también muy positiva ya que el 82,4\% manifiesta haber mejorado (Q4) y más del 94\% que le ha sido útil (Q1).

Tabla 1. Preguntas y resultados de la encuesta de opinión

\begin{tabular}{|c|l|c|c|c|c|c|}
\hline \multicolumn{2}{|l|}{ PREGUNTA } & TDA & DA & IND & A & TA \\
\hline Q1 & $\begin{array}{l}\text { Me ha resultado útil el laboratorio virtual } \\
\text { "Visualizador de momentos de un vector deslizante". }\end{array}$ & 0 & 0 & 2 & 10 & 22 \\
\hline Q2 & $\begin{array}{l}\text { Me ha resultado fácil e intuitivo el manejo del } \\
\text { laboratorio virtual "Visualizador de momentos de un } \\
\text { vector deslizante". }\end{array}$ & 0 & 0 & 4 & 20 & 10 \\
\hline Q3 & $\begin{array}{l}\text { En general, mi nivel de comprensión de los conceptos } \\
\text { antes de utilizar el laboratorio de "Visualizador de } \\
\text { momentos de un vector deslizante" era bueno. }\end{array}$ & 0 & 4 & 8 & 18 & 4 \\
\hline Q4 & $\begin{array}{l}\text { Mi nivel de comprensión de los conceptos después de } \\
\text { utilizar el laboratorio virtual "Visualizador de } \\
\text { momentos de un vector deslizante" ha mejorado }\end{array}$ & 0 & 0 & 6 & 14 & 14 \\
\hline
\end{tabular}


José A. Gómez-Tejedor, Juan A. Monsoriu, Isabel Salinas, Juan A. Sans, Vanesa P. Cuenca-Gotor y Marcos H. Giménez

\begin{tabular}{|l|l|c|c|c|c|c|}
\hline & respecto a mi nivel previo. & & & & & \\
\hline Q5 & $\begin{array}{l}\text { Me resulta más motivador repasar el tema "Momento } \\
\text { de un vector deslizante" utilizando el laboratorio } \\
\text { virtual de "Visualizador de momentos de un vector } \\
\text { deslizante", que revisar comentarios aportados por el } \\
\text { profesor (apuntes, notas, diapositivas...) }\end{array}$ & 0 & 2 & 6 & 20 & 6 \\
\hline Q6 & $\begin{array}{l}\text { Cuando he utilizado el laboratorio virtual de } \\
\text { "Visualizador de momentos de un vector deslizante" } \\
\text { he explorado muchas de las opciones que ofrece. }\end{array}$ & 0 & 2 & 6 & 14 & 12 \\
\hline Q7 & $\begin{array}{l}\text { Mi valoración general del laboratorio virtual de } \\
\text { "Visualizador de momentos de un vector deslizante" } \\
\text { es buena. }\end{array}$ & 0 & 0 & 0 & 20 & 14 \\
\hline Q8 & $\begin{array}{l}\text { El laboratorio de "Visualizador de momentos de un } \\
\text { vector deslizante" ha contribuido a mejorar mi } \\
\text { habilidad para analizar y resolver problemas. }\end{array}$ & 0 & 2 & 8 & 14 & 10 \\
\hline
\end{tabular}

Dada la importancia de la motivación en el proceso de aprendizaje se analiza la pregunta Q5, que está vinculada con este factor. Esta cuestión trata de indagar sobre el efecto motivador del laboratorio virtual comparado con el material aportado por el profesor de una forma más tradicional, como apuntes, notas, diapositivas, etc. En la Figura 7 se muestra mediante un gráfico qué porcentaje de los estudiantes ha respondido en cada uno de los cinco niveles utilizados para valorar la pregunta. Observamos que un porcentaje muy elevado, el 77\%, ha encontrado más motivadora la utilización del laboratorio frente a un $23 \%$ que, o bien no lo ha considerado así en absoluto, 6\%, o no ha apreciado diferencia, $17 \%$.

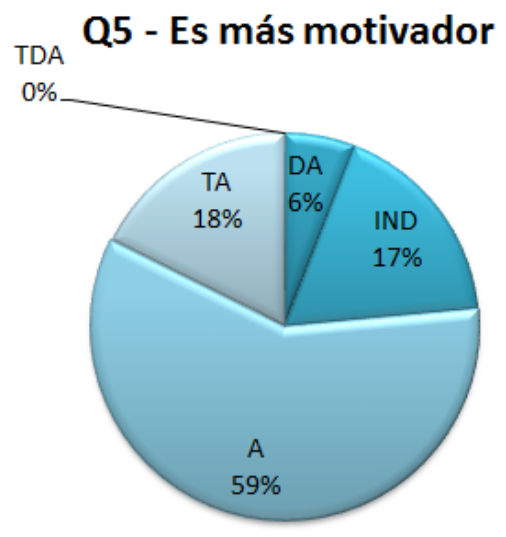

Fig. 7 Representación gráfica del porcentaje de alumnos que ha respondido en cada uno de los cinco niveles de la pregunta Q5. 
La pregunta Q7 da respuesta a la valoración general del laboratorio. Como se puede observar en el gráfico de la Figura 8, la valoración de los alumnos es muy positiva ya que el $100 \%$ está de acuerdo o totalmente de acuerdo con la afirmación de que es bueno.

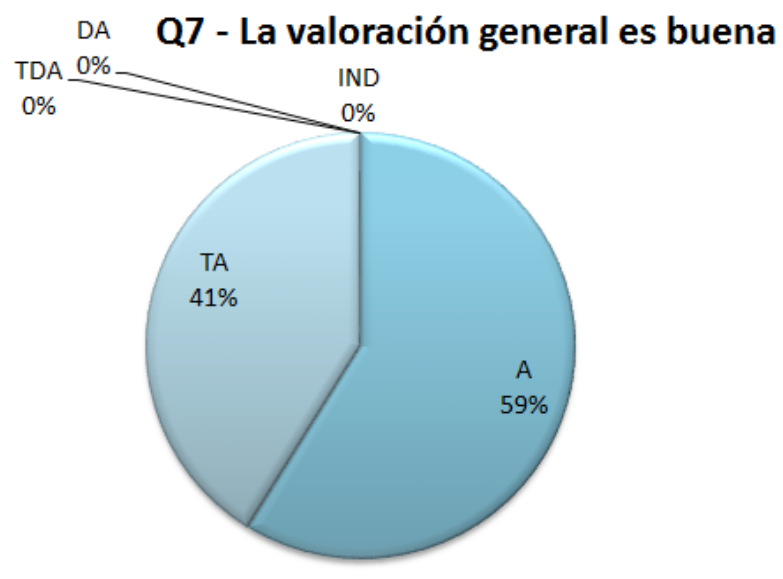

Fig. 8 Representación gráfica del porcentaje de alumnos que ha respondido en cada uno de los cinco niveles de la pregunta Q7.

\subsection{Competencias transversales}

Este laboratorio proporciona a los estudiantes los medios para desarrollar su propia comprensión sobre el tema de cálculo, visualización y aplicación práctica de los momentos de vectores deslizantes. El profesor actúa como guía, proporcionando a los estudiantes las herramientas y mostrándoles las diferentes formas en que pueden aplicarse al proceso de aprendizaje. De este modo, el laboratorio virtual que presentamos sirve de herramienta para la obtención de varias competencias transversales clave de las COMPETENCIAS TRANSVERSALES UPV, que ayudarán al alumno a tener una formación más completa para su futuro profesional. El estudiante debe:

- Demostrar la comprensión e integración de los conocimientos, tanto en la propia especialización como en otros contextos más amplios (CT1-Comprensión e Integración).

- Aplicar los conocimientos a la práctica, atendiendo a la información disponible y estableciendo el proceso a seguir para alcanzar los objetivos con eficacia y eficiencia (CT2Aplicación y Pensamiento Práctico).

- Realizar tareas que requieren procesos de razonamiento más o menos complejos y, en muchos casos, no simplemente una acción asociativa y de rutina. También debe identificar y definir los elementos significativos de un problema para su análisis y resolución efectivos (CT3-Análisis y Resolución de Problemas).

- Desarrollar un pensamiento crítico, interesado en las bases sobre las que se basan las ideas, acciones y juicios, tanto propios como ajenos. Esto implica cuestionar las suposicio-nes que subyacen a nuestras formas habituales de pensar y actuar (СT9Pensamiento Crítico). 
José A. Gómez-Tejedor, Juan A. Monsoriu, Isabel Salinas, Juan A. Sans, Vanesa P. Cuenca-Gotor y Marcos H. Giménez

- Utilizar el aprendizaje de manera estratégica, autónoma y flexible, para manipular el conocimiento, actualizarlo y seleccionar lo que es apropiado para un contexto específico en función del objetivo perseguido (CT11-Aprendizaje Permanente).

El estudiante debe prepararse para enfrentar situaciones complejas acomodando los recursos disponibles. El uso de estas herramientas (laboratorios virtuales) promueve la autonomía y la iniciativa. El estudiante aprende y aplica conocimientos y habilidades de manera autónoma, de esta forma mejora su capacidad de analizar y resolver problemas (Figura 9).

\section{Q8 - Mejora la capacidad de analizar y resolver problemas}

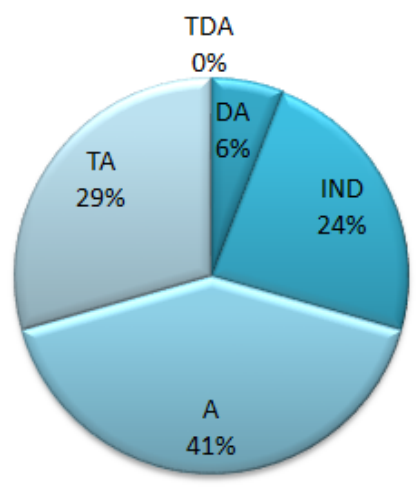

Fig. 9 Representación gráfica del porcentaje de alumnos que ha respondido en cada uno de los cinco niveles de la pregunta Q8

\section{Conclusiones}

El desarrollo de un laboratorio virtual sobre el tema de cálculo, visualización y aplicación práctica de los momentos de vectores deslizantes ha demostrado ser una herramienta muy útil para incrementar el aprendizaje de los alumnos y su motivación, en los grupos de estudio de este trabajo. Pensamos que esta metodología de visualización en una representación tridimensional de determinadas magnitudes puede ser aplicada a otros temas tanto de física como de otras asignaturas. Este tipo de metodología puede facilitar también el trabajo de algunas competencias transversales de forma más sencilla que mediante una metodología clásica.

\section{Agradecimientos}

JAS agradece al programa Ramón y Cajal la financiación y al Instituto de Diseño para la Fabricación y Producción Automatizada (IDF-UPV) por su apoyo. 


\section{Referencias}

DAINEKO, Y., DMITRIYEV, V. y IPALAKOVA, M. (2017). "Using virtual laboratories in teaching natural sciences: An example of physics courses in university" en Computer Applications in Engineering Education 25, 39-47.

DEPCIK, C. y ASSANIS, D.N. (2005). "Graphical user interfaces in an engineer in educational environment” en Computer Applications in Engineering Education, 13, 48-59.

DUFFY, T. y JONASSEN, D. (1992) Constructivism and the technology of instruction. Hillsdale, New Jersey: Lawrence Erlbaum Associates.

Easy Java Simulations. <http://fem.um.es/Ejs/> [Consulta: 13 de marzo de 2018].

GNU General Public License. <http://www.gnu.org/copyleft/gpl.html> [Consulta: 13 de marzo de 2018].

GÓMEZ TEJEDOR, J.A., MOLTÓ MARTÍNEZ, G. y BARROS VIDAURRE, C. (2008) “An Online Virtual Laboratory of Electricity” en International Journal of Distance Education Technologies, 6 (2), 21-34.

JIMOYAINNI, A. y KOMIS, V. (2001). “Computer simulations in physics teaching and learning” en Computers \& Education, 36, 183-204.

LYNCH T. y GHERGULESCU I., (2017) "NEWTON Virtual Labs: Introduction and Teacher Perspective” en 17th International Conference on Advanced Learning Technologies (ICALT), IEEE, 343-345.

SALINAS MARÍN, I., GIMÉNEZ VALENTÍN, M.H. y MONSORIU SERRA, J.A. Visualizador de momentos de un vector deslizante (2013). <http://hdl.handle.net/10251/30531> [Consulta: 13 de marzo de 2018].

UNIVERSITAT POLITÈCNICA DE VALÈNCIA. Competencias Transversales UPV (2012). $<$ http://www.upv.es/contenidos/COMPTRAN/> [Consulta: 23 de marzo de 2018]

VIDAURRE, A., RIERA, J., GIMÉNEZ, M.H. y MONSORIU, J.A. (2002). “Contribution of digital simulation in visualizing physics processes” en Comput. Appl. Eng. Educ. 10(1), 45-49. 


\title{
Aspectos metodológicos para la elaboración de videos docentes para su uso como objetos de aprendizaje modulares y reutilizables
}

\author{
Eva María Llera a , Ignacio Zabalza, Begoña Peña, Sergio Usón, Amaya Martínez, Luis \\ Miguel Romeo
}

Universidad de Zaragoza - Departamento de Ingeniería Mecánica, 50018 Zaragoza, España. ae-mail: ellera@unizar.es

\begin{abstract}
The objective of this work is to reflect on the main methodological aspects to take into account in the development of video teaching for use as modular and reusable learning objects. This reflection is one of the results of the work carried out by the authors in a teaching innovation project funded by the University of Zaragoza during the academic years 2015-16, 2016-17 and 2017-18. In this project, 25 educational videos under licenses have been created to improve the learning outcomes of five subjects in the field of thermodynamics and thermal engineering, currently taught at three different qualifications. Preparing educational videos requires different strategies compared with an in real time session and aspects such as the approach of the contents, the adaptation to the environment and technical quality influence the effectiveness as a learning tool by what must be taken into account in its development phase.
\end{abstract}

Keywords: instructional videos, active methodologies, engineering education

\section{Resumen:}

El objetivo de este trabajo es reflexionar sobre los principales aspectos metodológicos a tener en cuenta en el desarrollo de vídeos docentes para su uso como objetos de aprendizaje modulares y reutilizables.

Esta reflexión es uno de los resultados del trabajo desarrollado por los autores en un proyecto de innovación docente financiado por la Universidad de Zaragoza durante los cursos académicos 2015-16, 2016-17 y 2017-18. En este proyecto, se han creado 25 videos docentes bajo licencias para mejorar los resultados de aprendizaje de cinco asignaturas en el campo de la Termodinámica y la Ingeniería Térmica, que actualmente se imparten en tres titulaciones distintas.

Preparar vídeos docentes requiere estrategias diferentes a las de una clase en vivo y aspectos como el enfoque de los contenidos, la adecuación al medio y la calidad técnica influyen en la efectividad como herramienta de aprendizaje por lo que deben de ser tenidos en cuenta en su fase de desarrollo.

Palabras clave: vídeos docentes, metodologías activas, enseñanza de la ingeniería 


\section{Introducción}

Numerosos autores (Kearney et al, 2012; Stefanova, 2014) y otras experiencias documentadas (Zabalza et al., 2017) demuestran cómo el uso de videos docentes crea auténticas oportunidades de aprendizaje para los estudiantes y fomentan el rigor académico.

Willmot et al. (2011) manifiestan que incorporar videos otras actividades de aprendizaje centradas en el estudiante conlleva, entre otros, un aumento de la motivación de los estudiantes, una mejora en la experiencia de aprendizaje, calificaciones más altas, un mayor potencial de desarrollo para aprendizajes más profundos y el desarrollo de la autonomía del estudiante.

Además de dichos beneficios, disponer de videos docentes facilita la aplicación de otros métodos de enseñanza-aprendizaje como el modelo de aula invertida (Peña et al, 2017), en el que los estudiantes pueden asimilar los fundamentos de un tema a su ritmo permitiendo explorar el contenido con mayor profundidad durante la sesión de clase.

No obstante, la efectividad de estos videos en el proceso enseñanza-aprendizaje depende de numerosos aspectos, algunos relacionados con la predisposición del estudiante (Cole et al., 2017), otros con la habilidad del profesor (Sujo de Montes and Gonzales, 2000), y muchos inherentes a su elaboración entre los que destacan el enfoque de los contenidos, la adecuación al medio y la calidad técnica.

En esta contribución se presenta cómo se definieron estos últimos aspectos en la elaboración del conjunto de videos resultante de un proyecto de innovación docente de la Universidad de Zragoza.

El proyecto, financiado por la Universidad de Zaragoza durante los cursos académicos 2015-16, 2016-17 y 2017-18 tenía como principal objetivo aprovechar las oportunidades que ofrecen las nuevas tecnologías del aprendizaje y del conocimiento para mejorar el proceso de enseñanza-aprendizaje en asignaturas del ámbito de la termodinámica y la ingeniería térmica, que actualmente se imparten en la Escuela de Ingeniería y Arquitectura de la Universidad de Zaragoza.

A lo largo del proyecto de innovación, se han creado 25 videos docentes (Tabla 1) bajo licencias para mejorar los resultados de aprendizaje de 5 asignaturas en el campo de la Termodinámica y la Ingeniería Térmica, que actualmente se imparten en tres titulaciones distintas (Tabla 2).

Tabla 1. Temática (y número) de vídeos docentes utilizados en las asignaturas

\begin{tabular}{ll}
\hline \multicolumn{2}{c}{ Temas } \\
\hline Tutorial del programa “Engineering Equation Solver”-EES (3) & Ciclos de refrigeración (2) \\
\hline Propiedades de las sustancias puras (4) & Psicrometría (2) \\
\hline Modelo de gas ideal (2) & Método de diferencias finitas-MDF (2) \\
\hline
\end{tabular}

(cc) EY-NC-ND 2018, Universitat Politècnica de València

Congreso IN-RED (2018) 


\begin{tabular}{ll}
\hline Balance de energía en sistemas cerrados (1) & Intercambiadores de calor (2) \\
\hline Balance de masa y energía en volúmenes de control (2) & Convección forzada exterior (1) \\
\hline Ciclos de potencia con turbina de gas-Brayton (1) & Motores Térmicos (1) \\
\hline Ciclos de potencia con turbina de gas-Rankine (2) & \\
\hline
\end{tabular}

Tabla 2. Asignaturas seleccionadas para el uso de vídeos docentes

\begin{tabular}{|c|c|c|c|c|c|}
\hline Asignatura & Titulación & Curso & $\begin{array}{l}\text { Créditos } \\
\text { ECTS }\end{array}$ & $\begin{array}{l}\mathrm{N}^{0} \text { de } \\
\text { vídeos } \\
\text { usados }\end{array}$ & $\begin{array}{c}\mathrm{N}^{\mathrm{o}} \text { de } \\
\text { estudiantes }\end{array}$ \\
\hline $\begin{array}{l}\text { Termodinámica Técnica y } \\
\text { Fundamentos de Transmisión } \\
\text { de Calor }\end{array}$ & $\begin{array}{l}\text { Grado en Ingeniería } \\
\text { de Tecnologías } \\
\text { Industriales }\end{array}$ & $2^{\circ}$ & 6 & 19 & 70 \\
\hline $\begin{array}{l}\text { Termodinámica Técnica y } \\
\text { Fundamentos de Transmisión } \\
\text { de Calor }\end{array}$ & $\begin{array}{l}\text { Grado en Ingeniería } \\
\text { Mecánica }\end{array}$ & $2^{\circ}$ & 6 & 19 & 64 \\
\hline $\begin{array}{l}\text { Termodinámica Técnica y } \\
\text { Fundamentos de Transmisión } \\
\text { de Calor }\end{array}$ & $\begin{array}{l}\text { Grado en Ingeniería } \\
\text { Electrónica y } \\
\text { Automática }\end{array}$ & $2^{\circ}$ & 6 & 10 & 85 \\
\hline Ingeniería Térmica & $\begin{array}{l}\text { Grado en Ingeniería } \\
\text { de Tecnologías } \\
\text { Industriales }\end{array}$ & $2^{\circ}$ & 6 & 2 & 50 \\
\hline Máquinas y Motores Térmicos & $\begin{array}{l}\text { Grado en Ingeniería } \\
\text { Mecánica }\end{array}$ & $3^{\circ}$ & 6 & 2 & 70 \\
\hline
\end{tabular}

\section{Objetivos}

El objetivo de este trabajo es presentar los principales aspectos metodológicos a tener en cuenta en el desarrollo de vídeos docentes para su uso como objetos de aprendizaje modulares y reutilizables desde la propia experiencia de los autores.

Asimismo, a partir del análisis de los resultados obtenidos por una muestra de los estudiantes involucrados en el proyecto docente, se analiza si los aspectos inherentes a la elaboración de los videos contribuyen a su efectividad como herramientas de mejora del proceso de enseñanza-aprendizaje.

\section{Desarrollo de la innovación}

Los videos sobre los que se discute son el resultado de un proyecto de innovación docente de la Universidad de Zaragoza.

El objetivo de dicho proyecto, todavía en curso, es mejorar la eficiencia en el proceso de adquisición, por parte del alumnado, de las competencias específicas y los resultados de aprendizaje de cuatro asignaturas del ámbito de la Ingeniería Térmica, impartidas en la Escuela de Ingeniería y Arquitectura (EINA) a través del uso de videos docentes. 
Hasta el momento se han elaborado 25 videos que han sido utilizados en diversas actividades formativas de 5 asignaturas relacionadas con la termodinámica aplicada y para los que se ha medido a través de diversos indicadores, el grado de satisfacción de los estudiantes y la mejora del proceso de enseñanza-aprendizaje obtenida a través de los vídeos puestos a su disposición.

La elaboración de los videos corrió íntegramente de cuenta de los profesores que participan en el grupo. Los profesores pertenecen al Área de Máquinas y Motores Térmicos y son expertos en el programa de las asignaturas.

Uno de los principales retos del proyecto derivó del hecho de que los videos fueron concebidos como objetos de aprendizaje modulares y reutilizables (RLO, por sus siglas en inglés), es decir, un mismo video podría ser utilizado para cubrir los objetivos de aprendizaje de diferentes asignaturas y en distintas titulaciones.

Los RLO tienen entre sus principales características la brevedad, la flexibilidad para revisiones y/o actualizaciones, la compatibilidad con los formatos y dispositivos digitales más comunes y el hecho de que sean autocontenidos y tengan un carácter descontextualizado que facilite su reutilización.

El diseño y la elaboración de cada video fue responsabilidad de un único profesor, no obstante, al inicio y al final de cada una de las actividades del proyecto (ver Tabla 3) se llevaron a cabo reuniones entre todos los miembros del grupo en las que se tomaron decisiones colegiadas sobre ciertos aspectos que fueron considerados en todos los videos.

En concreto fue durante la fase de desarrollo (concretamente las actividades 1, 2 y 4) en la que se plantearon las discusiones relativas al enfoque de los contenidos, la adecuación al medio y la calidad técnica, entre otros, que dan lugar a este trabajo.

Tabla 3. Actividades incluidas en el proyecto docente

\begin{tabular}{ll}
\hline Actividad 1 & $\begin{array}{l}\text { Selección de la herramienta de captura de vídeo, diseño de la plantilla y formato de las } \\
\text { presentaciones incluidas en los vídeos }\end{array}$ \\
\hline Actividad 2 & Definición de los vídeos docentes a realizar y selección de la plataforma para su visionado \\
\hline Actividad 3 & $\begin{array}{l}\text { Preparación de cuestionarios para la evaluación de la mejora del proceso de enseñanza- } \\
\text { aprendizaje a través de los vídeos }\end{array}$ \\
\hline Actividad 4 & $\begin{array}{l}\text { Elaboración y utilización de los vídeos docentes como objetos de aprendizaje y lanzamiento de los } \\
\text { cuestionarios en Moodle2 }\end{array}$ \\
\hline Actividad 5 & $\begin{array}{l}\text { Compilación y análisis de los resultados. Planteamiento de acciones de mejora y análisis de } \\
\text { nuevas necesidades de innovación docente }\end{array}$ \\
\hline
\end{tabular}

\subsection{El enfoque de los contenidos}

La primera fase consistió en seleccionar los videos, las asignaturas en las que iban a ser utilizados y planificar su contenido.

El carácter RLO de los videos desarrollados exige planificar el contenido del video desde una perspectiva más amplia, que recoja los objetivos de aprendizaje comunes de las

(cc) BY-NC-ND 2018, Universitat Politècnica de València

Congreso IN-RED (2018) 
asignaturas en las que ser utilizados en un alto porcentaje y teniendo constancia de que el resto de los objetivos podían ser completados por otras actividades que reflejaran las especificidades de cada asignatura.

Tomando como base las guías docentes de todas las asignaturas, cada profesor responsable de una asignatura en las que se iba a utilizar un video en concreto elaboró un listado de los objetivos de aprendizaje esperados.

El profesor desarrollador del video planteo una propuesta de desarrollo del video y en una de las reuniones de coordinación se comprobó que se cubrieran todos los objetivos de aprendizaje comunes.

No se dio ningún caso en el que no fueran cubiertos; que todos los profesores pertenecieran a la misma área de conocimiento y tuvieran experiencia docente en todas las asignaturas para las que iban a ser utilizados facilitó la tarea.

En los casos en que la propuesta cubrió más objetivos que los comunes se discutió sobre la idoneidad de mantenerlos o no, optando en la mayoría de los videos por mantenerlos.

\subsection{La adecuación al medio}

Aunque existen diferencias entre la comunicación virtual y la presencial, de la misma forma que en el aula, aunque acrecentado cuando el canal de comunicación es la pantalla de su ordenador, uno de los mayores desafíos para la elaboración de videos docentes es atraer y mantener el interés de los estudiantes.

Hay ciertas técnicas que pueden utilizarse para lograr y mantener el interés de los estudiantes en la creación de videos educativos y de capacitación de alta calidad como, por ejemplo, insertar materiales complementarios a lo largo del visionado como preguntas, cuestiones o ejercicios cortos que pueden ayudar a los estudiantes a percibirlo como una experiencia de aprendizaje más auténtica. Por ello, se está trabajando para incorporar en cada video, cuestionarios que permitan al estudiante su auto-evaluación y sirvan para reforzar los objetivos de aprendizaje planteados.

La duración del video también juega en contra de mantener dicha atención. Los videos deben ser relativamente cortos. Se decidió que la duración media debería de ser de 10 minutos y en el caso de contenidos más largos se hicieron divisiones en partes.

Otra forma de conectarse con los estudiantes es que aparezca la imagen del profesor en el video. Es más fácil que los estudiantes establezcan una conexión cuando los alumnos ven al profesor presentando en persona el contenido. No obstante, dado que los videos eran para una disciplina técnica, se decidió favorecer la atención a otras animaciones y videos y prescindir de la imagen del profesor si bien estaba presente como narrador.

Finalmente, para romper la monotonía, se optó por que los videos fueran ligeramente diferentes entre sí: unos con diapositivas, otros con videoclips, otros con grabación de pantalla (screencasts), etc.

\subsection{La calidad técnica}

(c)) EY-NG-ND 2018, Universitat Politècnica de València

Congreso In-Red (2018) 
No puede perderse de vista que los estudiantes actuales poseen expectativas muy altas respecto a los productos audiovisuales por lo que se prestó atención especial a la calidad técnica de los videos.

A partir de la revisión realizada sobre ventajas y limitaciones de las distintas herramientas informáticas disponibles para la captura y edición de vídeos, los profesores participantes en este proyecto decidieron utilizar la herramienta Camtasia debido a que sus funcionalidades permiten crear vídeos de gran calidad técnica en formato mp4 de una manera sencilla, en contraste con otras herramientas gratuitas más limitadas desde el punto de vista técnico.

Dicho software tiene buena una buena capacidad tanto de edición de video como de audio.

Los videos requieren una preparación diferente a la de una clase en vivo. En primer lugar, hay que decidir si hablar desde un script o libremente. En el primer caso, debe de sonar como cuando se habla, por lo que hay que comprobarlo leyendo en voz alta mientras se desarrolla. Con cualquiera de las dos opciones, se debe de ensayar con anterioridad d la grabación para que las palabras sean correctas y suenen naturales. El tono debe de ser confiado y optimista, no agresivo, cansado, impaciente o aburrido. El momento de la grabación debe de elegirse con cuidado, evitando momentos en los que la voz aparezca cansada.

Muchos expertos sostienen que la calidad del audio importa mucho más que la calidad de video. Tras la fase de evaluación se detectaron problemas con el sonido en algún video por lo que va a volver a grabarse el audio con un micrófono de configuración direccional.

Para dar homogeneidad y consistencia a los vídeos docentes, se diseñó una plantilla común de PowerPoint con formatos establecidos para la portada, el índice de contenidos, los títulos y subtítulos de las distintas secciones, el tipo de letra y el fondo, teniendo en cuenta las recomendaciones generales recogidas en la bibliografía especializada.

- Utilizar dos o tres tipos de video como máximo (con una imagen fija contando dos

- Utilizar uno o como máximo dos tipos de transición dentro de cada video, preferentemente simples.

- Utilizar solo un color principal y uno o máximo dos fuentes por video (una principal y otra para acentuar conceptos).

- Elegir colores que sean fáciles para los ojos (p.ej. el azul) y fuentes que sean fácilmente legibles.

Por otra parte, dentro de esta actividad se incluyó una revisión de los tipos de licencias Creative Commons (CC) y las distintas posibilidades de reconocer la autoría de los vídeos docentes realizados, optándose finalmente por utilizar la licencia CC BY NC ND.

\section{Resultados}

El resultado de las decisiones tomadas por el equipo de profesores con respecto a los aspectos metodológicos presentados en la anterior sección, fueron validaron con las 
respuestas de los estudiantes recopiladas a través de los cuestionarios intermedios (Zabalza et al., 2017).

Dicho cuestionario consiste en 5 preguntas en una escala Likert de 1 a 5 , con las que los estudiantes establecieron la valoración de cada video utilizado atendiendo a cinco características:

1. Amenidad y capacidad de motivación

2. Adecuación de la duración del vídeo

3. Utilidad para resolver dudas y asimilar contenidos

4. Calidad técnica del vídeo

5. Valoración global del vídeo

La cuestión 3 está relacionado con el aspecto "Enfoque de los contenidos”, las cuestiones 1 y 2 con “Adecuación al medio” y la cuestión 4 está directamente relacionada con el aspecto del mismo nombre.

En la figura 1 se muestra la distribución de las respuestas dadas por el mismo grupo de estudiantes para el conjunto de los vídeos utilizados (19) en una de las asignaturas. Se observa que más del $40 \%$ de los estudiantes otorga una puntuación de 4 puntos o más (en una escala del 1 al 5) en los aspectos de amenidad, duración, utilidad para la resolución de dudas y calidad técnica de los videos docentes. Por otro lado, a pesar de haberse limitado, la duración del video es considerada como el aspecto peor valorado. Asimismo, el 50\% de los estudiantes asigna una puntuación igual o superior a los 4 puntos como calificación global de los videos pudiéndose concluir que la mayoría de los estudiantes han quedado muy satisfechos con los videos utilizados.

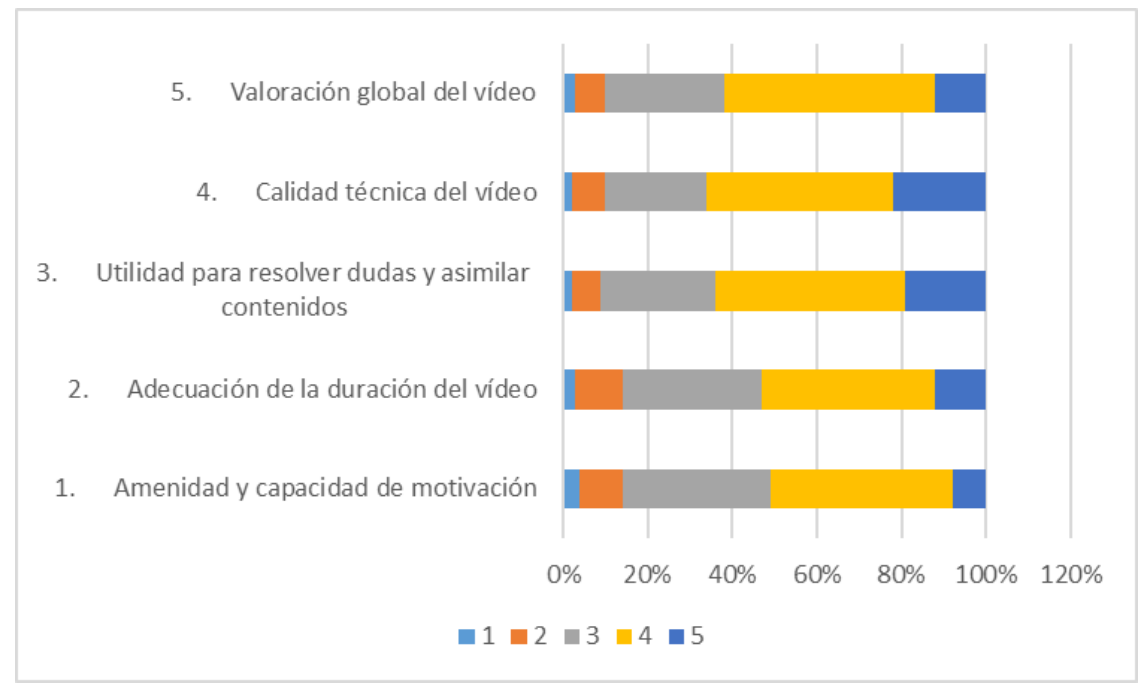

Fig. 1 Valoración de los aspectos metodológicos por parte de los estudiantes

En cuanto a la mejora de las calificaciones obtenida por el mismo alumnado en la prueba de evaluación de la asignatura, tal como muestra la Figura 2, se puede observar como en el curso 2015-16 aumentaron 10 puntos las calificaciones en la horquilla de 8 a 9, y en 9 
puntos las calificaciones en la zona de sobresaliente, reduciéndose las calificaciones más bajas. Esta mejora queda también manifiesta en un aumento de la nota promedio en 0.25 puntos.

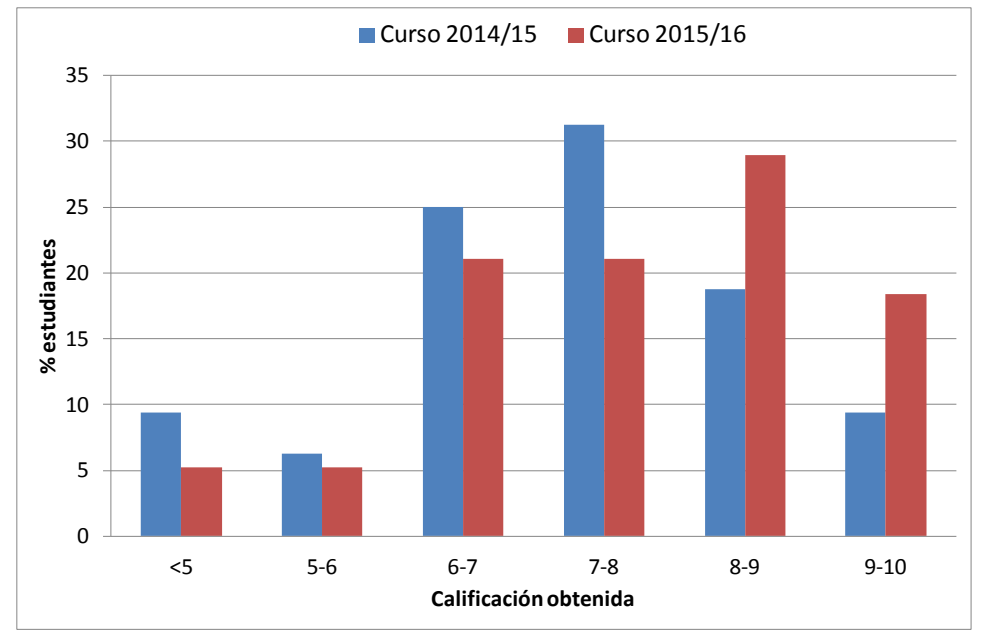

Fig. 2 Comparativa de las calificaciones obtenidas en las prácticas de la asignatura analizada en los cursos académicos 2014-15 y 2015-16

Finalmente, queda por comprobar en qué grado la efectividad de los videos en la mejora del proceso del aprendizaje se debe a los aspectos inherentes a su elaboración y no solo a la predisposición del estudiante o a la habilidad del profesor.

Dado que la predisposición del estudiante es un aspecto difícil de medir, sobre todo cuando se pretende comparar resultados de dos grupos de estudiantes, para responder a la cuestión se han analizado las calificaciones obtenidas a lo largo de todo el proceso de evaluación de un único grupo de estudiantes, en concreto el grupo de 70 estudiantes de la asignatura "Máquinas y motores térmicos”.

Dicha asignatura posee un sistema de evaluación continua que con el fin de cumplir con el Reglamento de Normas de Evaluación del Aprendizaje de la Universidad de Zaragoza coexiste con la evaluación global.

La Tabla 4 resume el conjunto de pruebas que constituyen la evaluación continua de la asignatura con una breve descripción de su realización y criterios, así como su peso sobre la calificación final del estudiante en la asignatura. Estas pruebas se encuentran alineadas con las tres actividades principales que se desarrollan en la asignatura (clases, prácticas y trabajo), las competencias genéricas que son evaluadas y los resultados de aprendizaje previstos.

Los dos videos utilizados en la asignatura según se recoge en la Tabla 2 se incluyeron dentro de 2 de las 5 actividades desarrolladas como "Prácticas de laboratorio". En concreto, los videos "Ciclos de potencia con turbina de gas-Brayton” y "Motores Térmicos” debieron de ser visionados por los alumnos antes de realizar la práctica.

(cc) EY-NC-ND 2018, Universitat Politècnica de València

Congreso IN-RED (2018) 
Tabla 4. Sistema de evaluación de la asignatura "Máquinas y Motores Térmicos"

\begin{tabular}{|l|l|c|}
\hline Instrumento & Realización/criterios & Peso \\
\hline \multirow{2}{*}{$\begin{array}{l}\text { Examen: prueba escrita } \\
\text { individual de teoría y problemas }\end{array}$} & $\begin{array}{l}\text { Cuestiones teóricas y/o teórico-prácticas: } \\
\text { Diez cuestiones teórico-prácticas } \\
\text { orientadas a conceptos, definiciones, etc. } \\
\text { Se evalúan conocimientos teóricos }\end{array}$ & $\begin{array}{l}19.5 \% \\
\text { (30\% de 65\%) }\end{array}$ \\
\cline { 2 - 3 } & $\begin{array}{l}\text { Problemas: 2 problemas de media o larga } \\
\text { extensión. Se evalúa la capacidad de } \\
\text { aplicar conocimientos a la práctica y } \\
\text { capacidad de análisis }\end{array}$ & $\begin{array}{c}45.5 \% \\
\text { (70\% de 65\%) }\end{array}$ \\
\hline $\begin{array}{l}\text { Prácticas de laboratorio: prueba } \\
\text { escrita }\end{array}$ & $\begin{array}{l}\text { Informe escrito según directrices del } \\
\text { guión. Se evalúa la aplicación de los } \\
\text { conocimientos teóricos }\end{array}$ & $15 \%$ \\
\hline Trabajo de asignatura & $\begin{array}{l}\text { Se propone un estudio del caso para } \\
\text { realizar en equipo. La documentación } \\
\text { puede estar en inglés. Se evalúa por } \\
\text { medio de un entregable, una tutoría de } \\
\text { control y la defensa oral del trabajo }\end{array}$ & $20 \%$ \\
\hline
\end{tabular}

Con el fin de identificar el efecto del uso de los videos, se separaron las calificaciones de las actividades en las que se habían utilizado los videos de las actividades en las que no. Se calcula el promedio de las calificaciones "no vinculadas" con los videos asumiendo que pueden ser un buen indicador de la predisposición del estudiante, de forma que la diferencia de las calificaciones de las dos prácticas con dicho valor promedio y dado que el profesor también es el mismo puede ser únicamente atribuible a los aspectos relacionados con la elaboración de los videos.

Las figuras 3 y 4 resumen los resultados obtenidos para las 40 observaciones válidas y permiten concluir sobre la influencia positiva del uso de videos. En la Figura 3 se muestra la estadística de las calificaciones no influidas directamente por los videos mientras que la Figura 4 muestra la misma estadística para las calificaciones de las dos prácticas.

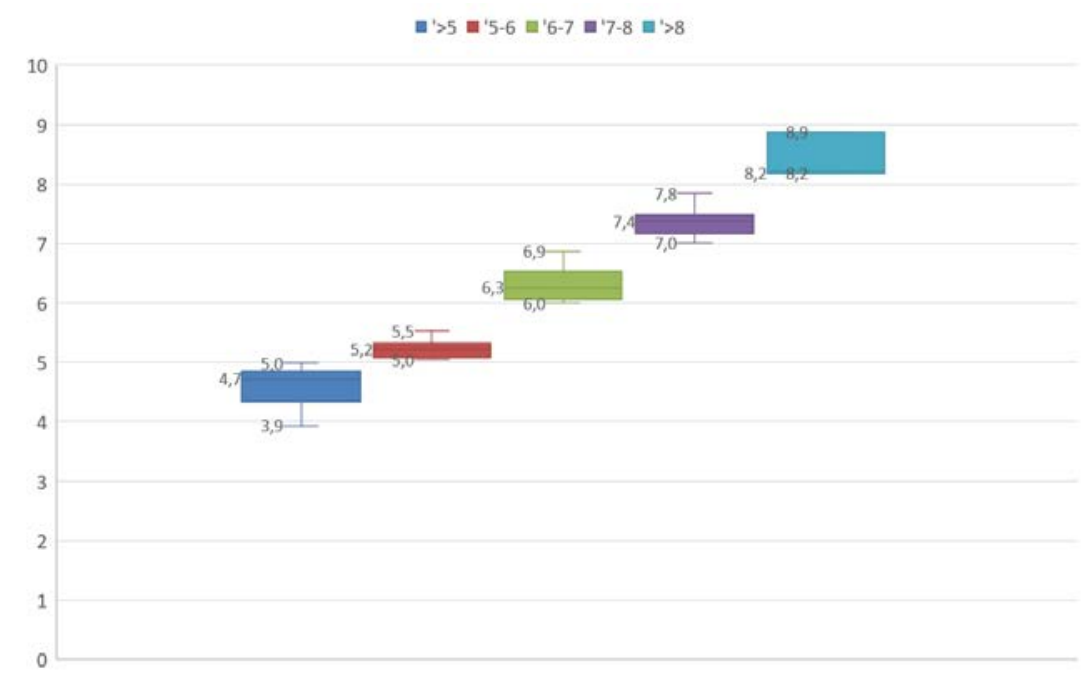

Fig. 3 Distribución de las calificaciones obtenidas en las actividades no vinculadas a los videos docentes 


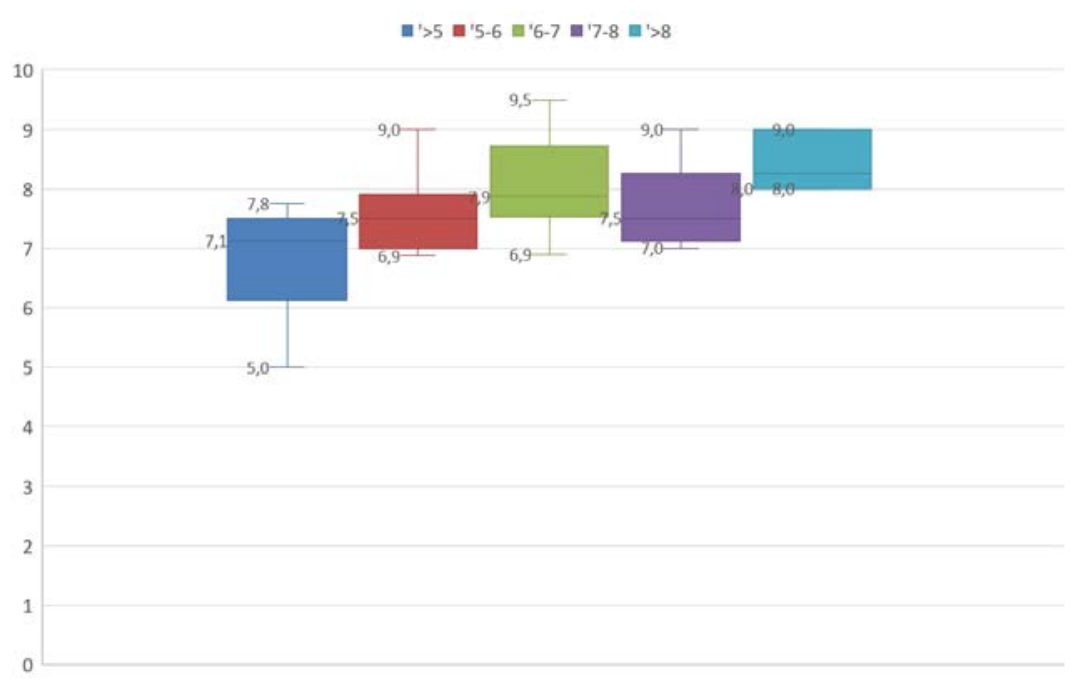

Fig. 4 Distribución de las calificaciones obtenidas en las actividades vinculadas a los videos docentes

Se observa que las notas de las actividades sujetas al proyecto de innovación (Figura 4) son en general superiores a las del resto de las actividades docentes (Figura 3). El incremento en la nota es apreciablemente mayor en el caso del $79 \%$ de los estudiantes que son los que obtienen notas por debajo del notable (las medias pasan de 4.7 a 7.1, de 5.2 a 7.5 y de 6.3 a 7.9) mientras que en los grupos con mejores notas no se observa una incidencia tan clara. Como consecuencia de ello, las calificaciones de las actividades apoyadas con los videos muestran una distribución más homogénea entre los estudiantes.

Todo lo anterior permite concluir que hay evidencias de que el uso de los videos docentes tal y como fueron diseñados en el proyecto que se describe han cumplido con las expectativas con las que fueron planteados. Asimismo, puede concluirse que son los estudiantes con niveles medios y bajos de predisposición al aprendizaje los que encuentran un mayor beneficio en este tipo de herramientas docentes lo que impulsa a los autores a continuar incorporando este tipo de materiales al resto de actividades docentes de las asignaturas.

\section{Conclusiones}

Crear videos docentes de alta calidad requiere mucho más trabajo que preparar una sesión presencial, ya que además de dominar la materia, supone un desafío creativo para el que el profesor se encuentra en ocasiones limitado. La creación de grupos de trabajo o el apoyo de unidades audiovisuales en los centros puede facilitar dicha tarea.

Invertir más tiempo en la fase de desarrollo no necesariamente hace que los videos sean mejores desde una perspectiva pedagógica, ya que deben de ser complementados con otras actividades y metodologías, pero probablemente facilitan los resultados.

Además, la buena aceptación que han tenido por parte de los estudiantes y la constancia expresa de que les ha ayudado en su proceso de aprendizaje, motivan a los profesores a

(cc) EY-NC-ND 2018, Universitat Politècnica de València

Congreso IN-RED (2018) 
continuar en la aplicación de metodologías docentes que hagan uso de los videos producidos, a mejorarlos paulatinamente desde la experiencia adquirida y a crear nuevos.

Asimismo, a partir del análisis de los resultados obtenidos por una muestra de los estudiantes involucrados en el proyecto docente, se demuestra cómo un adecuado enfoque de los contenidos, la adaptación al medio visual y la calidad técnica de los videos, contribuyen a su efectividad en el proceso de enseñanza-aprendizaje.

\section{Agradecimientos}

Este trabajo ha sido financiado por medio de los proyectos de innovación docente PIIDUZ_17_299 y PIIDUZ_17_165 (Programa de Proyectos de Innovación Docente para Grupos de Profesores del Vicerrectorado de Política Académica de la Universidad de Zaragoza).

\section{Referencias}

Kearney, M., Jones, G., \& Roberts, L. (2012). An emerging learning design for student-generated 'iVideos'. In C. Alexander, J. Dalziel, J. Krajka \& E. Dobozy (Eds.), Teaching English with Technology, Special Edition on LAMS and Learning Design volume 3, 12(2), 103-120, http://www.tewtjournal.org.

Tereza Angelova Stefanova, Using of Training Video Films in the Engineering Education, Procedia Social and Behavioral Sciences, Volume 116, 2014, Pages 1181-1186, ISSN 1877-0428, https://doi.org/10.1016/j.sbspro.2014.01.366.

ZABALZA, I., PEÑA, B., LLERA, E.M., USÓN, S., MARTÍNEZ, A. y ROMEO, L.M. (2017). "Evaluación de la mejora del proceso de enseñanza-aprendizaje mediante la integración de objetos de aprendizaje reutilizables en un curso abierto OCW” en Congreso In-Red 2017, 13 y 14 de julio de 2017. Valencia.

Willmot, P., Bramhall, M., \& Radley, K. (2011). Introducing audio-visual media for inspirational learning and positive engagement, SEFI. International Conference on Engineering Education, Lisbon, Portugal, September 2011, Lisbon, SEFI, 420-426.

Cole, A. W.; Allen, M.; Anderson, C.; Bunton, T.; Cherney, M. R.; Draeger, Jr., R.; Featherston, M.; Fisher, V. C.; Motel, L.; Nicolini, K. M. \& Peck, B. (2017). Student predisposition to instructor feedback and perceptions of teaching presence predict motivation toward online courses. Online Learning, 21(4), 245-262. doi: 10.24059/olj.v21i4.966

Sujo de Montes, L.E. \& Gonzales, C.L. (2000). More than Having a Connection: Qualitative Factors that Affect Learning in a Web-based University Course. In D. Willis, J. Price \& J. Willis (Eds.), Proceedings of SITE 2000--Society for Information Technology \& Teacher Education International Conference (pp. 177-182). Chesapeake, VA: Association for the Advancement of Computing in Education (AACE). Retrieved March 25, 2018 from https://www.learntechlib.org/p/15549/.

PEÑA, B., ZABALZA, I., USÓN, S., LLERA, E.M., MARTÍNEZ, A. y ROMEO, L.M. (2017). "Experiencia piloto de aula invertida para mejorar el proceso de enseñanza-aprendizaje en la asignatura de Termodinámica Técnica” en Congreso In-Red 2017, 13 y 14 de julio de 2017. Valencia. 


\title{
HERRAMIENTAS TIC Y SOFTWARE ESPECÍFICO. UN BUEN COMPLEMENTO EN EL AULA UNIVERSITARIA.
}

\author{
Artal-Sevil J.S. a , Peña Pellicer B. ${ }^{\text {b }}$, Luesma Bartolomé M.J. ${ }^{\text {c }}$ y Gargallo Castel A.F. ${ }^{\text {d }}$ \\ ${ }^{a}$ Dpto. Ingeniería Eléctrica. Escuela de Ingeniería y Arquitectura. Universidad de Zaragoza. \\ Campus Río Ebro. Zaragoza (Spain). email: jsartal@unizar.es. \\ ${ }^{\mathrm{b}}$ Dpto. Ingeniería Mecánica. Escuela de Ingeniería y Arquitectura. Universidad de Zaragoza. \\ Campus Río Ebro. Zaragoza (Spain). email: bpp@unizar.es. \\ ${ }^{\text {c }}$ Dpto. Anatomía e Histología Humanas. Facultad de Ciencias. Universidad de Zaragoza. \\ Campus San Francisco. Zaragoza (Spain). email: mjluesma@,unizar.es. \\ ${ }^{\mathrm{d}}$ Departamento de Dirección y Organización de Empresas. Facultad de Ciencias Sociales y Humanas \\ de Teruel. Universidad de Zaragoza. Teruel (Spain). email: gargallo@unizar.es.
}

\begin{abstract}
This document presents an educational methodology Simulation-based learning (SbL) centered on the student through the application of an activecollaborative strategy. The incorporation of technology in the classroom has allowed to change the way in which students interact with information and content. The strategy is based on the use of specific software supplemented with a series of free ICT tools. The results show how the methodology has two main advantages. On the one hand, it facilitates obtaining technical and personal skills. While on the other hand the students solve real problems. The objective has been to show an interdisciplinary experience within the Flipped Classroom pedagogical approach.
\end{abstract}

Keywords: Flipped Classroom, Blended-Learning, ICT Tools, Educational resources and Interactive tools, Specific software, smartphone, tablet, free software, learning by competences.

\section{Resumen}

En este documento se presenta una metodología educativa Simulation-based Learning (SbL) centrada en el estudiante mediante la aplicación de una estrategia activa-colaborativa. La introducción de la tecnología en las aulas ha permitido cambiar la forma en la que los estudiantes interactúan con la información y contenidos. La estrategia está basada en el uso de software especifico complementado con una serie de herramientas TIC gratuitas. Los resultados muestran cómo la metodología posee dos ventajas principales. Por un lado facilita la obtención de competencias técnicas y personales. Mientras que por otro lado los estudiantes resuelven problemas reales. El objetivo ha sido mostrar una experiencia interdisciplinar dentro del enfoque pedagógico Flipped Classroom.

Palabras clave: Flipped Classroom, Blended-Learning, Herramientas TIC, Recursos educativos y Herramientas interactivas, software especifico, smartphone, tablet, software gratuito, Aprendizaje por Competencias. 


\section{Introducción}

Hoy en día, nadie discute que la introducción de las TIC en la enseñanza universitaria ha proporcionado muchas ventajas y beneficios sobre la educación. La incorporación de la tecnología en las aulas ha permitido cambiar la forma en la que los estudiantes interactúan con la información y contenidos. En todas sus variantes, las tecnologías educativas están siendo un instrumento muy valioso para la enseñanza (Artal-Sevil et al., 2015). También es necesario especificar el gran número de aplicaciones que existen en el mercado destinadas a estos fines. Por lo que resulta conveniente desarrollar un análisis detallado para seleccionar aquellas que resultan más útiles, eficaces y que mejor se adaptan al entorno educativo.

Ahora bien, ¿es posible aplicar nuevos enfoques metodológicos apoyados en recursos tecnológicos que hoy en día existen?, ¿nos ayudan las herramientas TIC a hacer nuestras clases más interactivas, colaborativas y amenas? Apostar por la metodología Flipped Classroom, combinándola con otras técnicas basadas en el Blended-Learning, Puzzle-Based Learning, Game-Based Learning, Problem-Based Learning, Case-Method, Role-Playing,... y usar determinadas herramientas y aplicaciones TIC puede ayudar a contestar a esta serie de cuestiones (Artal-Sevil et al., 2017b), (Toppo, 2011).

La paulatina incorporación de herramientas TIC en el aula ha propiciado que los estudiantes puedan acceder fácilmente a todos los recursos educativos necesarios, ya sean archivos, vídeos, presentaciones o documentos de apoyo multimedia desde sus dispositivos móviles. Obteniéndose de este modo un adecuado aprovechamiento de los contenidos (Jonsson, 2015). Con ellas se ha pretendido lograr un aprendizaje más activo e interactivo. El uso de estas herramientas ha supuesto un impacto evidente en los estudiantes y en su proceso educativo en general. Este hecho las ha convertido en recursos con un gran potencial para la educación universitaria (Touron et al., 2014).

Ahora bien, la irrupción en estos últimos años de gran cantidad de aplicaciones TIC ha hecho a los docentes replantearse el uso de otras aplicaciones o software específicos que se venían utilizando en el aula o laboratorio hasta ese momento. Hay que recordar que en la mayoría de las ocasiones estas herramientas TIC son utilizadas por el profesor sólo como medio para crear un ambiente más dinámico, participativo e interactivo en el aula. Es innegable que son un buen aliado del profesor en la consecución de los objetivos de aprendizaje (Artal-Sevil et al., 2017). Aunque no hay que pasar por alto, ni tampoco olvidar, que sigue siendo el software específico de las asignaturas el encargado de crear y proporcionar gran parte de ese conocimiento reflexivo y profundo en los estudiantes. El objetivo del presente trabajo académico es mostrar una experiencia interdisciplinar de aplicación de las tecnologías TIC y recursos multimedia como complemento a programas de software específico dentro de un enfoque pedagógico Flipped Classroom.

\section{Objetivos}

En el presente documento se presenta una experiencia de innovación docente con carácter interdisciplinar. La experiencia está basada en la aplicación del enfoque pedagógico

(c)) BY-NC-ND 2018, Universitat Politècnica de València

Congreso IN-RED (2018) 
Flipped Classroom junto con la incorporación de diversas actividades activas-colaborativas desarrolladas dentro y fuera del aula durante el curso académico 2016/17. El ensayo educativo fue afrontado desde una perspectiva de investigación-acción en equipo docente. Las actividades pedagógicas del equipo docente universitario estuvieron orientadas a:

- Uso de nuevas aplicaciones, herramientas activas y mecanismos para la supervisión continua del estudiante. Facilitar la comprensión de conceptos y la adquisición de habilidades, destrezas y competencias asociadas a cada disciplina de conocimiento.

- Estructurar diferentes actividades académicas para desarrollarse dentro y fuera del aula (seminar y webinar). Motivar a los estudiantes durante el desarrollo de sus diferentes tareas académicas.

- Mejorar el acceso a recursos multimedia, archivos, materiales y documentación a lo largo del curso. Complementar el proceso de enseñanza-aprendizaje mediante el uso de sistemas online para promover un aprendizaje más cooperativo, reflexivo y significativo.

\section{Desarrollo de la innovación}

Se presenta una experiencia interdisciplinar de innovación educativa y renovación metodológica cuyo objetivo ha sido la incorporación del enfoque pedagógico Flipped Classroom en el aula. La implementación de nuevas herramientas TIC durante el proceso educativo ha permitido garantizar el éxito de la experiencia. En las asignaturas se maneja diferente software específico complementado con herramientas TIC gratuitas mediante el uso de smartphones, tablets y ordenadores portátiles, analizando su repercusión dentro y fuera del aula. Como conclusión del uso de los distintos recursos se puede afirmar que la actuación llevada a cabo ha resultado muy positiva para el alumnado, el profesorado y las asignaturas implicadas.

Los profesores implicados en la experiencia pertenecen a diferentes centros y áreas de conocimiento de la Universidad de Zaragoza: Área de Máquinas y Motores Térmicos, Área de Organización de Empresas, Área de Ingeniería Eléctrica o el Área de Anatomía y Embriología Humana lo que ha garantizado ese carácter interdisciplinar tan necesario en la implementación de experiencias de innovación educativa. A continuación se presentan las diferentes experiencias llevadas a cabo con software específico, complementado a su vez con múltiples recursos multimedia y herramientas TIC. En todos los supuestos el propósito ha sido alcanzar los objetivos iniciales en las asignaturas implicadas consiguiendo a su vez un aprendizaje más reflexivo, dinámico y significativo en el estudiante.

\subsection{Experiencia dentro del Área de Máquinas y Motores Térmicos.}

Los profesores del área de Máquinas y Motores Térmicos imparten asignaturas propias de la Ingeniería Térmica. En ellas se utilizan diversos programas específicos, además de las típicas hojas de cálculo, para el análisis, el dimensionamiento y la optimización de instalaciones energéticas. Por ser los más utilizados, aquí se presentan y comparan dos de ellos: Engineering Equation Solver (EES) y TermoGraf (Peña et al., 2017) 
El primero, EES (Fchart, 2018), se trata de un programa comercial para resolver sistemas de ecuaciones, con la ventaja de que incluye las funciones necesarias para calcular propiedades termodinámicas y para obtener otros parámetros importantes en el diseño de intercambiadores de calor, que de otra manera habría que obtener con tablas o modelos. En la figura 1 se muestra un ejemplo de programa junto con la solución obtenida. Este programa, de fácil manejo pero potente, resulta útil tanto a nivel educativo como a nivel profesional, aunque no es software libre y se debe pagar una licencia en función del uso.

Este programa se utiliza prácticamente en todas las asignaturas impartidas por el área tanto para las prácticas, como para trabajos tutorizados y actividades de evaluación. También es un programa muy utilizado en trabajos fin de estudios (TFG o TFM), ya que además de ser un software sencillo que resuelve ecuaciones, pueden hacerse simulaciones completas de instalaciones energéticas, a través de ventanas interactivas y diagramas de ciclos, figura 2.

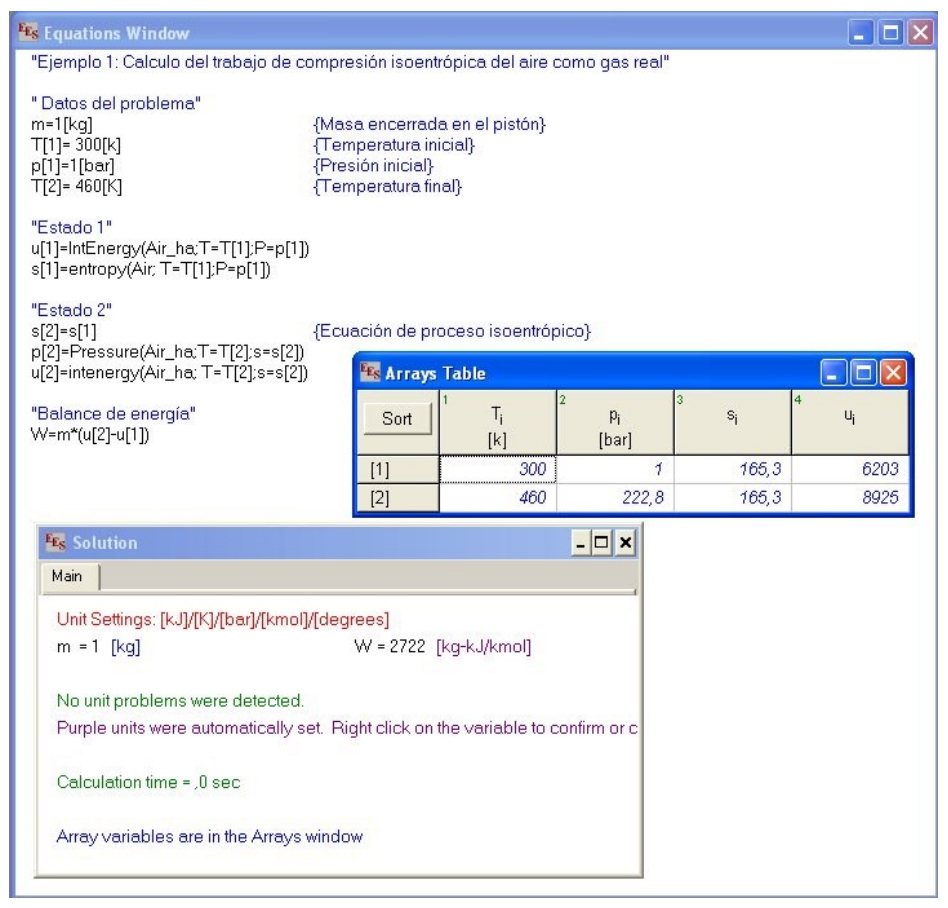

Fig. 1. Ejemplo de programa desarrollado en EES y la solución calculada.

El segundo programa, TermoGraf (TermoGraf, 2018), es un programa de software libre desarrollado en el área de Máquinas y Motores Térmicos de la Universidad de Zaragoza. Además, recientemente se ha desarrollado una aplicación para el móvil, Thermonator, que puede utilizarse como una calculadora para problemas de termodinámica. Su principal ventaja, además de que es completamente gratuito, es su enfoque eminentemente educativo: su uso es muy intuitivo y puede utilizarse en clase para generar fácilmente diagramas de propiedades en los que representar procesos y ciclos.

Este software tiene la ventaja de poder preparar lo que se denomina multiejercicios, que consisten en ejercicios con casos múltiples, es decir, con datos diferentes para cada estudiante. Cuando el estudiante accede con su número personal se le asigna un caso

(c)) EY-NC-ND 2018, Universitat Politècnica de València 
específico, cuya corrección es automática si se dispone de la licencia de profesor. Esto reduce la copia y el tiempo invertido en la corrección, aunque al no entregar la resolución completa no se puede identificar cuál ha sido el error cometido por el estudiante. Debido a los errores propagados no se puede evaluar si los cálculos posteriores son correctos o no; de esta forma el trabajo del estudiante puede estar minusvalorado. La desventaja principal es que su alcance está muy focalizado en termodinámica y no resulta tan útil en otras asignaturas en las que se involucra a otras disciplinas como transferencia de calor o termotecnia. Por esta razón, este software se utiliza esencialmente en la asignatura de Termodinámica Técnica, que es común a varios grados.

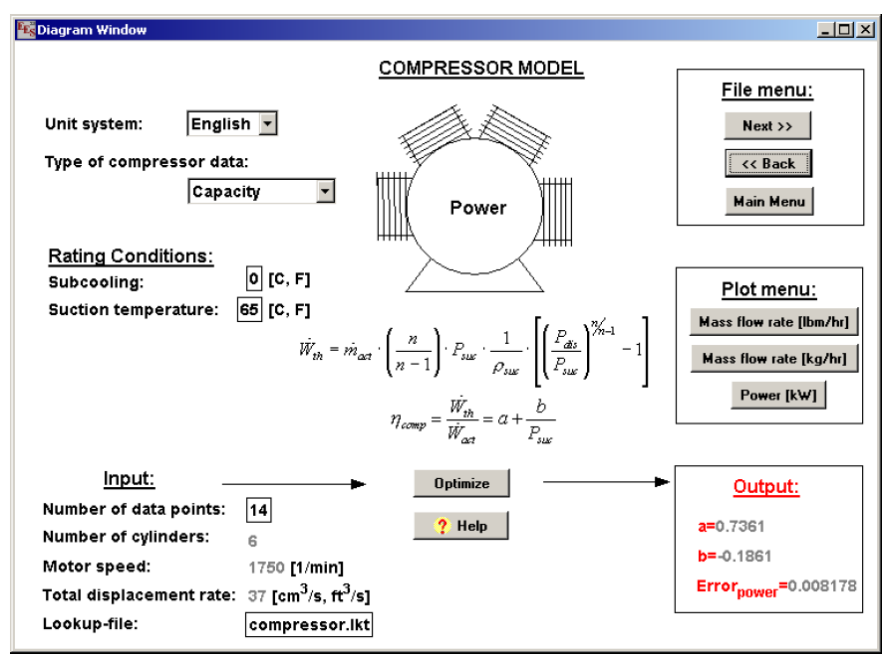

Fig. 2. Diagramas de ciclos y ventanas interactivas en EES (Manual de EES en (Fchart, 2018)).

En este trabajo se presentan las experiencias principalmente desarrolladas con el programa EES, por ser aplicable a problemas más generales. Concretamente, se muestra cómo ciertas herramientas TIC se combinan con el uso del programa para preparar las sesiones de prácticas y laboratorio. De esta manera se fomenta que el estudiante lleve la asignatura al día. En las sesiones de prácticas se resuelven con EES problemas de cierta complejidad, como calcular las prestaciones de un ciclo termodinámico completo y analizar el efecto de variar ciertos parámetros relevantes. Para la primera sesión, los estudiantes no conocen de antemano el manejo del programa, lo que ralentiza el desarrollo de la práctica y hace que, si no se toman medidas adicionales, los alumnos deban terminar los cálculos en casa, con el consiguiente riesgo de copia y de que queden dudas sin resolver. Por esta razón, se han utilizado algunas TIC que permitan al estudiante preparar la práctica, aprovechar mejor el tiempo en el aula y terminar el trabajo.

Por un lado, para la preparación de cada práctica y para aprender el manejo del programa EES, se han puesto a disposición de los estudiantes videos desarrollados por profesores del Área de Máquinas y Motores Térmicos dentro del proyecto PIIDUZ_15_079 (Zabalza, 2016-2017). De esta forma, el alumno puede visualizarlos tantas veces como necesite, puede practicar con el programa antes de la primera práctica y recopilar dudas concretas que puede resolver con el profesor al comienzo de la sesión. Para el presente curso además, 
se han implementado cuestionarios de autoevaluación para que el alumno pueda autoevaluarse de los contenidos de cada video.

Con respecto a las actividades de aprendizaje y evaluación, se han utilizado diversas metodologías y recursos. Tras finalizar cada tema, el alumno dispone de alrededor de una semana para resolver un cuestionario en Moodle sobre la parte teórica y un trabajo consistente en problemas de tipo examen que puede resolver con el programa EES. Durante el presente curso además, las soluciones de estos trabajos deben introducirse en Moodle para una corrección automática.

\subsection{Experiencia en el Área de Organización de Empresas.}

Dentro del ámbito de la docencia en administración y dirección de empresas son diversos los softwares utilizados. Por una parte, son destacables los simuladores de gestión empresarial integral, a modo de "juego de empresas", donde los alumnos interactúan en un contexto de competencia con otros participantes y toman decisiones encaminadas a aplicar los conocimientos adquiridos a lo largo de la titulación, para mejorar los resultados económicos de la empresa y en última instancia su supervivencia (Delgado et al., 2007). Por otra parte, existen softwares específicos útiles para facilitar la adquisición de diversas competencias en las distintas materias de los diferentes planes de estudios, ya se trate de programas para la gestión de inventarios, para el análisis estadístico, para la gestión contable o para la elaboración de modelos de negocio, entre otros. En este documento se presenta la experiencia correspondiente al uso de dos softwares específicos en "Dirección de Recursos Humanos", asignatura perteneciente al Grado en Administración y Dirección de Empresas, en la Facultad de Ciencias Sociales y Humanas.

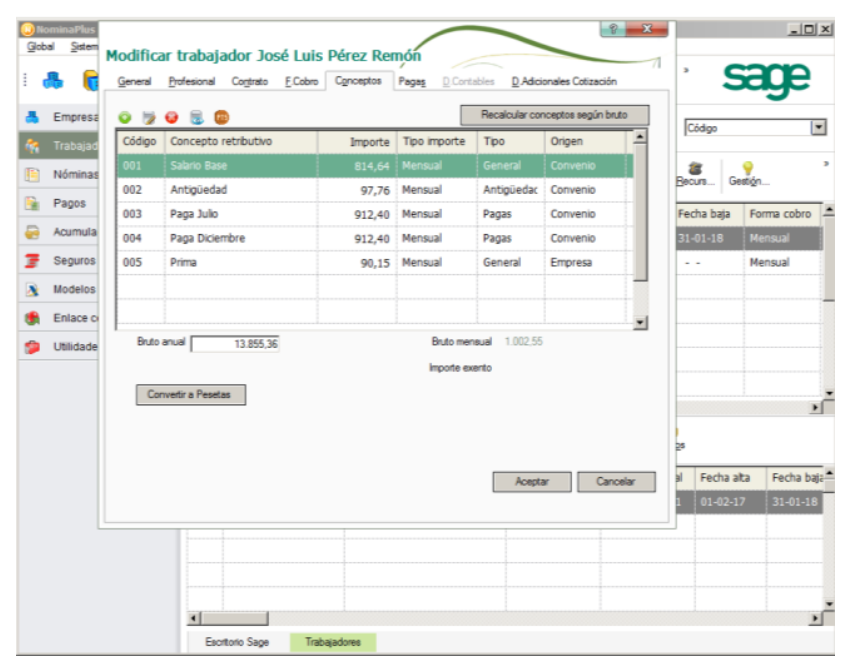

Fig. 3. Ejemplo del interface de usuario del software NominaPlus.

Dentro del ámbito de los recursos humanos existen gran variedad de programas dirigidos a mejorar la eficiencia empresarial. Estos programas suelen cubrir un amplio abanico de funciones como la gestión del personal, de los programas de formación, de los salarios, de

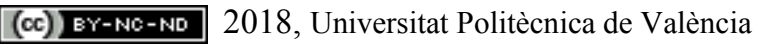

Congreso IN-RED (2018) 
los procesos de selección, etc. Existen tanto programas que integran las funcionalidades de recursos humanos a través de extensiones dentro de un software principal, incluido normalmente un sistema de planificación de recursos empresariales o ERP (Enterprise Resource Planning), como programas específicos de recursos humanos diseñados como soluciones independientes sin necesidad de integrarse en un programa mayor.

Por otra parte, puede distinguirse entre aquellos programas que requieren una licencia para su uso y aquellos programas gratuitos que permiten a las empresas de reducida dimensión acceder a utilidades diseñadas para la gestión de recursos humanos a un coste reducido o incluso nulo para un uso básico, pudiéndose completar con las versiones premium. De este modo también es relevante y destacable la aplicación de programas específicos de recursos humanos. Así pues se dan a conocer a los alumnos tanto programas gratuitos para la gestión de recursos humanos, como un programa con licencia para el cual la universidad dispone de permiso de uso. De esta manera el alumno conoce dos opciones diferentes y puede comprobar las utilidades ofrecidas por cada una de ellas. A continuación se pasa a describir brevemente cada uno de ellos:

Nominaplus. Se trata de un programa ampliamente utilizado por las empresas, ofrecido bajo licencia por el Grupo SAGE y para el cual la Facultad de Ciencias Sociales y Humanas de la Universidad de Zaragoza dispone de una licencia especial de uso educativo, figura 3. Su funcionalidad principal es la de un programa de nóminas que permite gestionar la relación con los empleados, las incidencias, el cálculo de los recibos de salarios, la liquidación de impuestos y seguros sociales, etc. Este programa presenta grandes similitudes con otros productos de la compañía como Contaplus o Facturaplus, con los que los alumnos pueden tener contacto en otras asignaturas o en posteriores cursos de especialización.

Factorial. Es un programa de creación reciente, que está destinado a automatizar las tareas del departamento de RRHH de las pequeñas y medianas empresas. En su versión gratuita, que es con la que se trabaja en clase, permite realizar distintas actividades relacionadas con la gestión documental, la obtención de informes, etc. y permite disponer de toda la información en la nube. Las funciones básicas son ampliadas en su versión premium.

Tal y como se recoge en la guía de la asignatura, la utilización del laboratorio y de herramientas TIC constituye una de las metodologías de enseñanza-aprendizaje aplicables a la asignatura Dirección de Recursos Humanos. Los objetivos que se persiguen con la utilización de los software anteriormente indicados son varios. Por una parte, se desea que el alumno sea conocedor de la existencia de estas herramientas, de las ventajas e inconvenientes que presenta cada una de ellas para la gestión de recursos humanos en las empresas y que se familiarice con su funcionamiento e interface. Por otra parte, estas actividades permiten consolidar los contenidos y competencias recogidos en la guía de la asignatura, complementando las actividades llevadas a cabo durante las clases de teoría y el resto de sesiones prácticas. Además, mediante el uso del software específico se fomentan las competencias relacionadas con la capacidad de análisis y el manejo de herramientas informáticas. 
El modo y momento de utilización varía dependiendo del software. En el caso del software Nominaplus, se realizan prácticas adicionales para completar un bloque concreto del temario, correspondiente a las retribuciones. En este caso únicamente se utiliza una parte de las utilidades que ofrece el programa, pues gran parte de ellas quedan fuera del alcance de la asignatura. En el caso del software Factorial, como se ha indicado, engloba un conjunto de funciones generales del departamento de RRHH, por lo que se utiliza en la gestión de los recursos humanos. En este caso las sesiones permiten al alumno iniciarse en el manejo de un programa generalista. Como se trata de un software gratuito, el alumno puede trabajar fuera del aula, de manera que las sesiones presenciales se complementan con el trabajo autónomo del alumno.

Ahora bien, ¿qué actividades desarrollan los estudiantes? La utilización de los software indicados se realiza fundamentalmente en las aulas de informática del centro. En el caso del software con licencia esta es la única opción posible. Sin embargo, en el caso del software libre, los alumnos pueden trabajar también fuera del aula, por lo que algunas de las actividades se planifican teniendo en cuenta estas circunstancias. En ambos casos los alumnos deben comenzar el proceso con la creación de una empresa en la aplicación, y la incorporación o alta de los distintos trabajadores y condiciones a aplicar, calendario laboral, etc. Posteriormente, los alumnos deben resolver los casos prácticos facilitados por el profesor. La corrección se lleva a cabo en el aula, de manera que el profesor puede indicar al alumno donde se han producido los fallos. Las prácticas se diseñan para favorecer el logro de los objetivos de aprendizaje y la adquisición de competencias.

Como ventaja principal destaca la oportunidad de vincular los conocimientos teóricos vistos en la asignatura y los ejercicios prácticos tradicionales o "en papel", especialmente los relativos al módulo correspondiente a las retribuciones, con la utilización de herramientas informáticas propias de los departamentos de recursos humanos. Esto influye positivamente en la motivación del alumnado, que percibe una mayor relación entre los conceptos vistos en la asignatura y la práctica empresarial real, lo que favorece la implicación del alumno. Sin embargo, la dificultad principal reside en la necesidad de encajar la utilización de dicho software con las disponibilidades de tiempo para el desarrollo de la asignatura.

\subsection{Experiencia en el Área de Ingeniería Eléctrica.}

En la última década, ha surgido un nuevo concepto dentro del escenario de la tecnología educativa: Simulation-based Learning (SbL). La mayoría de los educadores en ciencias e ingeniería creen que la experiencia en el laboratorio es un complemento necesario frente a otro tipo de actividades pasivas, como leer libros de texto y escuchar conferencias; esta serie de actividades constituye una gran parte del tiempo disponible (Rutten et al., 2012). Hoy en día, los métodos de aprendizaje en las universidades se encuentran en constante proceso de revisión. Aplicaciones enfocadas al SbL han permitido acelerar el proceso de aprendizaje (Artal-Sevil et al., 2015), facilitando el diseño e implementación de los recursos interactivos en el aula. Simulation-based Learning o Learning by-doing son técnicas muy efectivas para que los estudiantes adquieran conocimientos, si están bien motivados. Estos

(c)) BY-NC-ND 2018, Universitat Politècnica de València

Congreso IN-RED (2018) 
modelos de aprendizaje no son nuevos, y permiten integrar simultáneamente las ventajas del método e-learning (recursos multimedia, simulaciones interactivas, webinar, etc.) con aspectos relacionados con el método tradicional (interacción face-to-face).
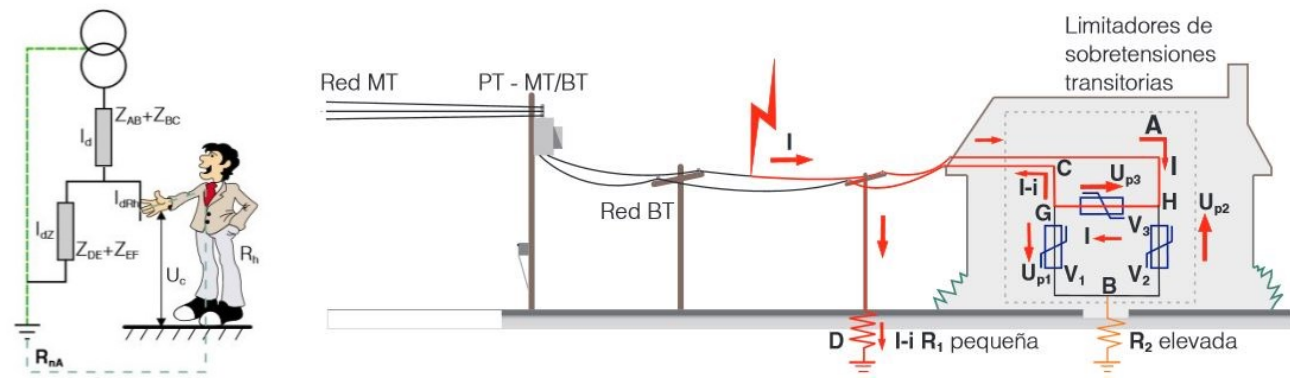

Fig. 4. Ejemplo de software de simulación e interface gráfico. Comprensión de los conceptos de corrientes de fuga en distribución y sistemas de protección diferencial.

La implementación de esta serie de técnicas educativas permite al instructor tener una visión más amplia de los conocimientos y destrezas adquiridas por los estudiantes durante el cuatrimestre académico. Debe notarse que el profesor tiene un feedback importante sobre la adquisición de conocimiento de los estudiantes. Por otra parte, este tipo de metodología docente permite desarrollar un método de evaluación más amplio, en comparación con otros métodos más tradicionales. Así pues es posible identificar no sólo el conocimiento del estudiante, ya que se cuestiona, analiza, sintetiza,... sino verificar también el proceso de asimilación de contenidos. Desde el punto de vista del profesor la técnica SbL es valorada positivamente, ya que ofrece una visión reflexiva e interactiva de la educación.

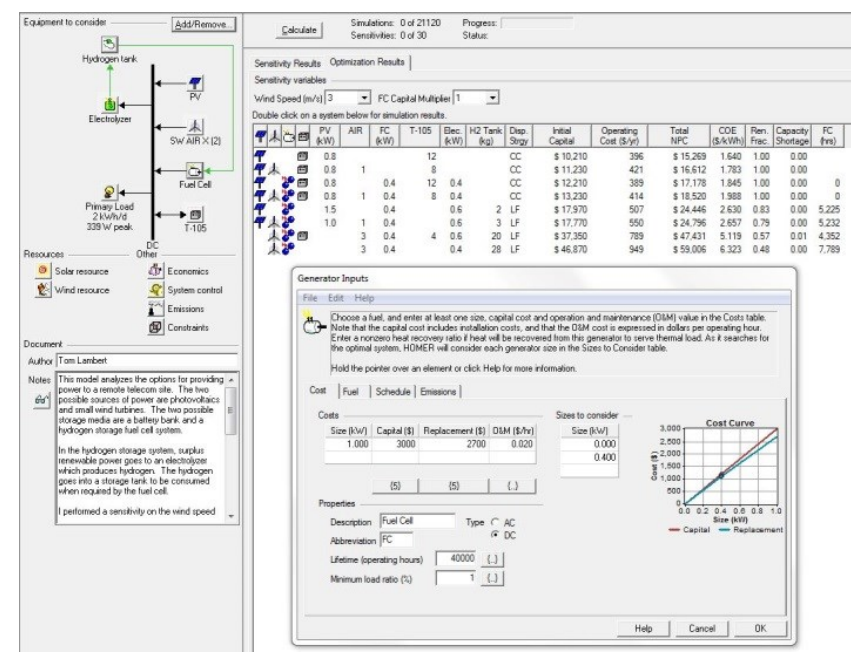

Fig. 5. Ejemplo del software de simulación utilizado en Ingeniería y su interface gráfico. Software educacional versión-demo del programa HOMER Renewable Energy.

La figura 5 muestra un ejemplo de software de simulación destinado al análisis y cálculo de sistemas híbridos de energía renovable. HOMER es un software para microrredes y diseño y optimización de sistemas de generación distribuida. La aplicación también puede 
incorporar las curvas de recursos renovables para realizar las estimaciones necesarias. Se puede descargar en la dirección web http://www.homerenergy.com/.

Este tipo de herramientas se han convertido en importantes recursos educativos. El cálculo, la estimación y el desarrollo de los diferentes modelos tecnológicos son actividades que los estudiantes pueden realizar fuera del aula, de modo que se optimiza el tiempo de clase (enfoque pedagógico Flipped Classroom). Así pues, el aula se transforma en un seminario para responder a diversas preguntas asociadas con el análisis del modelo (parámetros o coeficientes de simulación, configuraciones, tiempo de respuesta, etc.) y no asociadas al entorno del software de simulación usado.

Por lo tanto, si el objetivo es ayudar a los estudiantes a familiarizarse con el diseño y dimensionamiento de instalaciones e implementación de sistemas en el mundo real, el uso de estas tecnologías se hace inevitable. Asimismo ofrecen un terreno fértil para desarrollar nuevas técnicas innovadoras con objeto de involucrar e inspirar al estudiante. La satisfacción general de los estudiantes con respecto a los métodos de enseñanza adoptados y las técnicas aplicadas es muy buena. También debe tenerse en consideración que este procedimiento requiere mayor atención por parte del docente debido a la necesidad de verificar y revisar todos los modelos y simulaciones efectuados por cada estudiante.

Las fases iniciales han permitido que los alumnos puedan aplicar los conocimientos y contenidos adquiridos. Al mismo tiempo, han aprendido a superar las dificultades inherentes al proceso de creación, cálculo y diseño de los modelos planteados. En general, los modelos de simulación desarrollados por los estudiantes, que combinan aspectos técnicos y teóricos, tienen una calidad aceptable. Además, se ha demostrado que el uso de estas herramientas ha introducido un aprendizaje más significativo. El factor de curiosidad que representa el uso del software de simulación (no hay que olvidar que está vinculado con problemas reales de ingeniería) facilita una buena recepción por parte de los estudiantes.

En el caso analizado en este epígrafe, el curso se encuentra soportado por abundantes recursos multimedia junto con otras demostraciones y tutoriales en video. Las diferentes actividades académicas desarrolladas por los estudiantes son debidamente documentadas (aplicación de la técnica e-portfolio). Se han utilizado varias herramientas TIC como complemento al software específico, con el propósito de obtener un feedback inmediato. Por otra parte la plataforma educativa Moodle ha sido usada como repositorio de información y contenidos para los estudiantes.

\subsection{Experiencia dentro del Área de Anatomía y Embriología Humana.}

La enseñanza práctica de la asignatura "Anatomía e Histología ocular”, cursada en el primer año académico en el Grado de Óptica-Optometría, se basa en el aprendizaje cooperativo, para ello los alumnos se dividen en grupos pequeños liderados por uno de ellos al que se le denomina jefe de mesa o alumno monitor, sobre el que recae la responsabilidad de la práctica. Este rol va rotando en las diferentes prácticas realizadas durante el año académico. Para acompañar a los alumnos tanto en su aprendizaje autónomo como en la

(c)) BY-NC-ND 2018, Universitat Politècnica de València

Congreso IN-RED (2018) 
responsabilidad de dirigir a sus compañeros en la labor que le ha sido asignada, se ha elaborado un material docente-guía para las sesiones prácticas (Luesma et al., 2013).

El aprendizaje electrónico (u-learning), especialmente en el ámbito de la educación biomédica, permite el acceso a la información, al entreno con gran inmediatez y una actualización continuada (Grau-Perejoan, 2008), siendo un medio tan efectivo para la educación sanitaria como los sistemas tradicionales (Wutho et al., 2004). Si además, la enseñanza se realiza de manera compatible con el estilo de aprendizaje de los estudiantes, éstos aprenderán mejor, retendrán más ese conocimiento y tendrán una actitud más positiva frente al objeto de estudio.

Según el modelo de la Programación Neurolingüística de Bandler y Grinder (1988), también llamado visual-auditivo-kinestésico (VAK), tenemos tres grandes sistemas para representar mentalmente la información, relacionados directamente con los estilos de aprendizaje: el visual, el auditivo y el kinestésico. El docente debe de conocer el perfil de sus estudiantes y las singularidades de sus disciplinas, seleccionando la modalidad sensorial que mejor se adapte para el proceso enseñanza-aprendizaje y diseñando actividades adaptadas a cada estilo. Se cree que el $40 \%$ de los estudiantes presentan un aprendizaje fundamentalmente visual (Clark et al., 2006), aspecto que beneficia enormemente a la docencia de nuestra asignatura, altamente visual, al ser muy descriptiva y basada en la observación directa de la naturaleza de nuestro organismo.
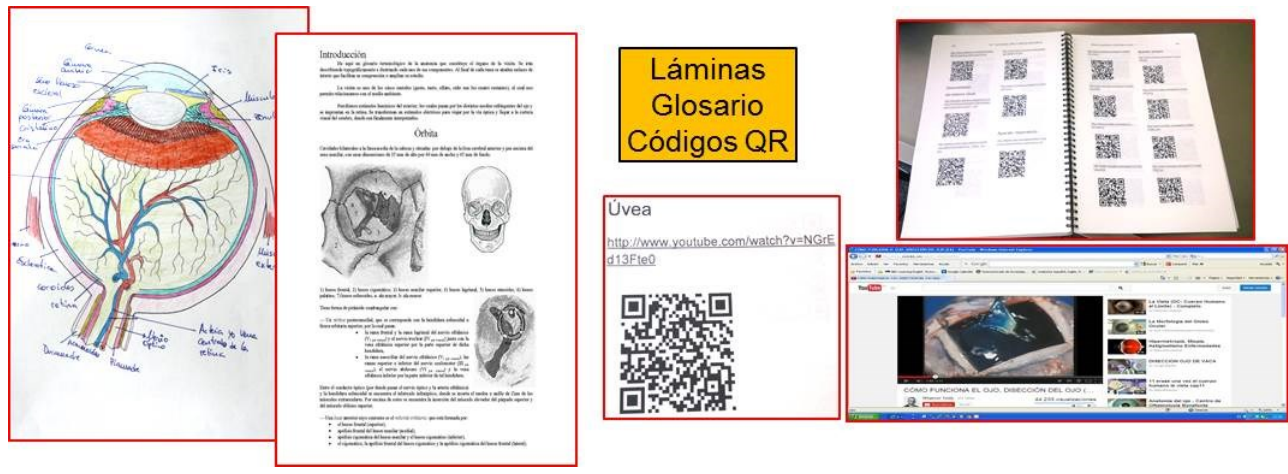

Fig. 6. Ejemplo de diferentes materiales utilizados por los estudiantes en el contexto señalado.

Por otra parte, uno de los problemas al que se suele enfrentar el alumno de nuevo ingreso en una Facultad en el ámbito de la Profesión Sanitaria, es abordar un vocabulario complejo, muy técnico y nuevo para él, de hecho, suele ser una de las mayores barreras para el aprendizaje de las ciencias, incluidas las biomédicas (Wellington y Osbourne, 2001). Tal es el caso de la Anatomía e Histología. El profesor dentro de su rol de mediador entre la disciplina y los estudiantes debe de facilitar el canal adecuado con el fin de incrementar el rendimiento de los estudiantes; desarrollar herramientas visuales, interactivas y rápidas le va a ayudar a conseguir ese objetivo.

Valorando todos estos aspectos, fue diseñada una guía-manual, reinventando metodologías clásicas combinadas con tecnologías más modernas. Esta guía es un material interactivo que sirve de hoja de ruta tanto al instructor como a los otros miembros del grupo en cada sesión práctica. Recoge una colección de láminas que el alumno debe ilustrar y completar, 
y un apéndice-glosario terminológico que facilitará la resolución de dudas que puedan ir surgiendo en el transcurso de la unidad práctica de manera autónoma y sólida. Igualmente se proponen enlaces con páginas web y una colección de códigos QR (quick response code) de interés para cada una de las materias abordadas. Toda esta información puede ser consultada por los alumnos durante la realización de la práctica a través de sus dispositivos móviles (smartphone, tablets, etc.) gracias a herramientas digitales gratuitas.

Los códigos de respuesta rápida o código $\mathrm{QR}$, se caracterizan por almacenar gran cantidad de información gracias a una matriz de puntos. Para poder descifrar la información es necesario disponer de un lector de códigos QR, cuya aplicación se encuentra disponible para teléfonos móviles y tablets mediante dispositivos de captura de imagen, y una conexión a Internet para las direcciones web (http://www.qrcode.com/en/history/). Este material permite que los alumnos en la propia sala de disección identifiquen estructuras, consulten un glosario terminológico especializado o enlacen con web de interés en tiempo real. Es evidente que múltiples de sus sentidos se encuentran trabajando simultáneamente de manera individual y grupal, lo que además confiere un carácter lúdico que también es clave en el aprendizaje, ya que sirve de estrategia afectiva puesto que desinhibe, relaja y motiva. La gamificación favorece la memorización cuando el juego consiste en repetir una estructura o sistemas mnemotécnicos.

Según nuestra experiencia y a la luz de los resultados, el aprendizaje electrónico ha revelado ser un medio muy efectivo para la educación biosanitaria. Hay que destacar su gran utilidad para adquirir habilidades en las que el componente visual es predominante, tal es el caso de imágenes histológicas de tejidos orgánicos, disecciones cadavéricas, etc. tan necesarios en esta disciplina y que el alumno puede consultar on-line a través de la Bitácora a tiempo real mientras se está desarrollando la sesión práctica.

\section{Diferentes Herramientas TIC utilizadas}

En la actualidad la introducción de las herramientas TIC en la enseñanza ha proporcionado muchos beneficios sobre la educación universitaria. De esta forma ha sido posible facilitar el aprendizaje de los estudiantes, incrementar su interés y mejorar su rendimiento. Estos recursos tecnológicos se han convertido en un aliado poderoso para el profesor, pues introducen mejoras en el proceso enseñanza-aprendizaje. En la experiencia desarrollada aquí, se han utilizado diferentes herramientas TIC interactivas y recursos multimedia que han mejorado las sesiones de enseñanza; destaca el uso del software gratuito y libre. Como ejemplo, el instructor prepara una sesión con preguntas (Q\&A) relacionadas con los conocimientos básicos impartidos en el aula y cada estudiante utiliza su propio smartphone para responder a cada pregunta; los resultados son inmediatos. Profesor y estudiante obtienen un feedback inmediato. Además esta estrategia permite mejorar las actividades de aprendizaje ayudando al estudiante a aprender de una manera más divertida y entretenida.

Socrative, Quizizz o Kahoot son aplicaciones de software gratuito que permiten desarrollar cuestionarios en línea con el fin de que los estudiantes respondan en tiempo real a través de cualquier dispositivo móvil, convertido en un mando (iClickers). Los resultados se obtienen

(cc) EY-NC-ND 2018, Universitat Politècnica de València

Congreso IN-RED (2018) 
de inmediato y se pueden mostrar a los alumnos en tiempo real; de este modo constituyen buenos materiales interactivos. Estas herramientas son muy sencillas e intuitivas y sólo requieren de unos pocos segundos para iniciar la sesión. Las respuestas del alumnado y su puntuación se presentan visualmente a través de un gráfico o diagrama. Los estudiantes reciben feedback personal en su dispositivo.

Google-Apps (G-Suite) ofrece un conjunto de herramientas de gran alcance que se pueden utilizar para desarrollar entornos de colaboración entre los estudiantes. La plataforma cuenta con un grupo diverso de aplicaciones que pueden ser destinadas a la educación, tales como: Google-Drive, Google-Classroom, Gmail, Calendar, Docs, Google-Search, Forms, Hangouts, Slides, etc. Estas aplicaciones permiten la comunicación, almacenar información en la nube, desarrollar actividades de planificación, búsqueda de información, etc.

Evernote y OneNote son aplicaciones gratuitas que permiten la creación del e-portafolio, se utilizan principalmente para organizar la información a través de una libreta virtual, notebook. Incorporan una amplia gama de funciones y herramientas diversas. Su uso es relativamente simple e intuitivo. Permite mantener actualizadas y organizadas las tareas y notas relativas a la asignatura. También es posible desarrollar una evaluación formativa. El interface es simple y agradable, ya que está basado en un editor de texto básico. Los cuadernos personales son siempre privados y totalmente controlados por el usuario. En cada nota es posible incluir nuestras ideas, listas de tareas y recordatorios incorporando texto, imágenes, audio, dibujos, notas manuscritas, ecuaciones matemáticas, etc.

Screencast-O-Matic, Windows Movie Maker, EDpuzzle o Movenote son una serie de aplicaciones destinadas a la elaboración de materiales audiovisuales. Estos programas permiten la grabación de video-lecciones, fraccionar un vídeo e introducir un conjunto de preguntas sobre los diferentes fragmentos. Los estudiantes visualizan el vídeo con mayor atención, ya que tienen que responder a una serie de preguntas más adelante. Estas herramientas son muy versátiles, su uso es relativamente sencillo y no requiere un nivel de conocimientos profundo.

\section{Resultados y Conclusiones}

El desarrollo de esta experiencia ha permitido analizar la utilidad de la estrategia Flipped Classroom complementada por otra serie de técnicas y recursos en el contexto universitario. La tecnología y las actividades de aprendizaje se convierten en fundamentales en este nuevo modelo al que podríamos englobar en un tipo de Blended Learning, facilitado a través de la combinación eficiente de recursos virtuales y físicos. Este modelo es un enfoque integral que combina la instrucción directa del alumnado con métodos constructivistas. De este modo se han podido analizar las bondades y beneficios que ofrece esta nueva estrategia en los diversos procesos de enseñanza-aprendizaje.

Las diferentes acciones llevadas a cabo han mejorado el paradigma enseñanza-aprendizaje, fomentando la utilización de recursos educativos destinados a la innovación dentro y fuera del aula. El uso del software específico complementado con diferentes herramientas TIC gratuitas (Kahoot, Socrative, Quizizz, EverNote, EDPuzzle, QR-Codes,...) ha permitido 
crear cuestionarios interactivos (Q\&A), e-portfolio, material audiovisual, etc. fomentando los procedimientos de autoevaluación y coevaluación de los estudiantes. La plataforma Moodle2.0 ha sido utilizada en la mayoría de los casos como repositorio de información, archivos, videos, contenidos multimedia, etc., también ha permitido la entrega de diferentes actividades académicas así como la evaluación de los estudiantes a través de cuestionarios. Se ha podido comprobar que los alumnos valoran muy positivamente el uso del software específico en las diferentes asignaturas.

Así pues, el uso adecuado de las TIC en las diferentes asignaturas ha producido un estímulo sobre el alumno, mejorando la percepción ante sus tareas académicas. Como punto esencial innovador, se puede destacar la introducción de estas herramientas tecnológicas tan actuales y habituales en nuestra sociedad en el proceso de enseñanza-aprendizaje con fines realmente educativos, y su repercusión en los distintos niveles de enseñanza. También se ha observado como la introducción de esta estrategia de aprendizaje ha incrementado el grado de motivación del estudiante. Al mismo tiempo los estudiantes prefieren procedimientos de enseñanza-aprendizaje más dinámicos, flexibles, participativos y con evaluación continua. Estas herramientas educativas interactivas han incrementado las destrezas, habilidades y competencias de los estudiantes. La experiencia llevada a cabo nos muestra resultados positivos desde una triple vertiente: tanto para los estudiantes, como para el profesorado y para las propias asignaturas implicadas.

La experiencia de innovación docente aquí presentada es económicamente sostenible, eficiente y transferible a otras disciplinas de conocimientos. Diferentes estudios indican que la integración del Flipped Classroom junto con técnicas de e-learning pueden mejorar los resultados de los estudiantes, al mismo tiempo que se obtiene un aprendizaje más profundo y significativo. Así la metodología implementada ayuda a mejorar el aprendizaje del alumno. Los estudiantes han conseguido el mismo nivel de conocimiento que en cursos académicos anteriores con metodologías de aprendizaje más tradicionales. El grado de satisfacción de los estudiantes durante la experiencia ha sido alto, tal y como han revelado las encuestas de evaluación de la actividad docente en las diferentes asignaturas.

\section{Agradecimientos}

Los autores agradecen el apoyo financiero de la Universidad de Zaragoza para el desarrollo del presente trabajo, a través del Programa de Innovación e Investigación Educativa para Grupos de Profesores del Vicerrectorado de Política Académica de la Universidad de Zaragoza (PIIDUZ 2017/18). El trabajo aquí mostrado se ha desarrollado dentro del marco de los proyectos con los siguientes identificadores: PIIDUZ_17_299 y PIIDUZ_17_059.

\section{Referencias}

ARTAL-SEVIL, J.S., ROMERO E., and ARTACHO J.M. (2017a). Quick surveys in classroom. Mobile phone, a Powerful Teaching tool. 11th International Technology, Education and Development Conference, INTED17. IATED Digital Library. Valencia, Spain. 06-08 March 2017; pp.: 9282-9291. DOI: $10.21125 /$ inted.2017.2194

(cc) EY-NC-ND 2018, Universitat Politècnica de València

Congreso IN-RED (2018) 
ARTAL-SEVIL, J.S., LUESMA, M.J., GUILLEN-MONZON, N., and ROMERO-PASCUAL, E. (2017b). Addressing flipped classroom from several teaching methodologies. An interdisciplinary experience. 9th International Conference on Education and New Learning Technologies, EDULEARN'17. IATED Digital Library. 3-5 July, 2017 Barcelona, Spain; pp: 5051-5061. DOI:10.21125/edulearn.2017.2132

ARTAL-SEVIL, J.S., BERNAL-AGUSTIN, J.L., and DOMINGUEZ J.A. (2015). m-Learning (mobile Learning) in Education. The impact of smartphone as interactive learning tool. 7th International Conference on Education and New Learning Technologies, EduLearn15. IATED Digital Library. Barcelona, Spain. 06-08 July 2015; pp.: 8212-8221.

BANDLER, R. y GRINDER, J. (1988). Use su cabeza para variar. Seminario sobre técnicas de Programación Neurolingüística (PNL). Cuatro vientos, Santiago de Chile.

CLARKE, I., FLATHERTY, T. and YANKEY, M. (2006). Teaching the visual learner: The use of Visual summaries in Marketing Education. Journal of Marketing Education 28(3), 218-226.

DELGADO, J. M., ESPITIA, M. A., \& ROSELL, J. (2007). Experiencias docentes a partir de la gestión virtual de empresas. En: Innovación docente, tecnologías de la información y la comunicación e investigación educativa en la Universidad de Zaragoza: caminando hacia Europa (p. 66). Universidad de Zaragoza.

FCHART (2018) Engineering Equation Solver. F-Chart Software, LLC. <http://www.fchart.com/ees/> [Consulta: 17 de marzo de 2018].

GÁMEZ-MONTALVO, M.J. y TORRES-MARTÍN, C. (2013). Las técnicas de grupo como estrategia metodológica en la adquisición de la competencia de trabajo en equipo de los alumnos universitarios. Journal for Educators, Teachers and Trainers 4, 14-25.

GRAU-PEREJOAN, Ov. (2008). Formación on-line. Educación Médica 11(3), 139-146.

JONSSON, H. (2015). Using flipped classroom, peer discussion, and just-in-time teaching to increase learning in a programming course. Frontiers in Education Conference (FIE 2015). IEEExplore Digital Library. Recuperado el 02/10/16 de http://ieeexplore.ieee.org/document/7344221/

LUESMA BARTOLOMÉ, M.J. y FRANCO BALLESTÍN, A. (2013). Bitácora Anatómica e Histológica Ocular. Prensas Universitarias de Zaragoza, España.

PEÑA, B. et al. (2017). Pilot experience for the application of the flipped classroom in subjects of the field of Thermal Engineering. En: INTED17 Proceedings of the 11th annual International Technology, Education and Development Conference, Valencia, IATED Academy, pp. 3601-3610. DOI: 10.21125/inted.2017.0887.

RUTTEN N., van JOOLINGEN W.R. and van der VEEN J.T. (2012). The learning effects of computer simulations in science education. Elsevier ScienceDirect. Computers \& Education. Volume 58, Issue 1; pp 136 to 153.

TERMOGRAF (2018) TermoGraf, simulador termodinámico. Universidad de Zaragoza. $<$ http://termograf.unizar.es/www/index.htm $>$ [Consulta: 17 de marzo de 2018].

TOPPO, G (2011). Flipped Classrooms take advantage of technology. USA Today, July 10. Recuperado el 04/10/16 de http://usatoday30.usatoday.com/news/education/story/2011-10-06/flipped-classroomsvirtual-teaching/50681482/1

TOURÓN, J., SANTIAGO, R., \& DÍEZ, A. (2014). The Flipped Classroom. Cómo convertir la escuela en un espacio de aprendizaje. Barcelona: Digital-text.

WELLINGTON, J. and OSBOURNE, J. (2001). Language and literacy in science education. Philadelphia, PA: Open University press.

WUTOH, R., BOREN, S.A. and BALAS, E.A. (2004). e-Learning: A Review of Internet-Based Continuing Medical Education. The Journal of Continung Education in the Health Professions 24(1), 20-30.

ZABALZA, I., PEÑA, B., LLERA, E.M. and USÓN, S. (2016) "Improving the teaching-learning process using educational videos as reusable learning objects in the field of thermal engineering", Proceedings of the 8th International Conference on Education and New Learning Technologies (EDULEARN 2016), Barcelona, IATED Academy, pp. 363-372. DOI: 10.21125/edulearn.2016.1068.

(c) ) EY-NC-ND 2018, Universitat Politècnica de València 


\section{Introducción de Matlab en la docencia de ingeniería nuclear. Caso práctico: estudio de la cinética puntual}

\section{N. Olmo-Juan ${ }^{\mathrm{a}}$, T. Barrachina ${ }^{\mathrm{b}}$, R. Miróc , J. Sancho $^{\mathrm{d}}$ y G. Verdú}

${ }^{a}$ Dpto. de Ingeniería Química y Nuclear. Universitat Politècnica de València. nioljua@iqn.upv.es, bDpto. de Ingeniería Química y Nuclear. Universitat Politècnica de València. tbarrachina@iqn.upv.es, 'Dpto. de Ingeniería Química y Nuclear. Universitat Politècnica de València. rmiro@iqn.upv.es, ${ }^{d}$ Dpto. de Ingeniería Química y Nuclear. Universitat Politècnica de València. jsancho@iqn.upv.es, eDpto. de Ingeniería Química y Nuclear. Universitat Politècnica de València. gverdu @iqn.upv.es.

\section{Abstract}

One of the great challenges to be tackled in the teaching and teaching of subjects related to the intensifications of the degrees and masters is the development of tools and procedures that allow the student to achieve a deep learning of the complex concepts studied in classroom theory classes. .

This effort is in most cases contemplated within the time allocated in the development of each subject to the practices, whether they are performed in a laboratory, a computer laboratory or, even, in classroom practices. These practices, properly focused, are a powerful tool, both for the teacher and the student, because they allow to overcome the limitations existing in the theoretical classes that continue to be mainly master classes.

In the present work, the teaching innovation introduced in the teaching of a practice is detailed, for which a methodology has been defined and which has been implemented using the Matlab computer tool, which allows to deepen the foundations of the equations for the calculation of the neutron population in a nuclear reactor and its variation over time in the simplification of point kinetics. These contents are common to different subjects of degree and master so this innovation has an extensive application.

Keywords: point kinetic, Matlab, teaching innovation

\section{Resumen}

Uno de los grandes retos a abordar en la docencia e impartición de asignaturas correspondientes a las intensificaciones de los grados y másteres es el desarrollo de herramientas y procedimientos que permitan al alumno alcanzar un aprendizaje profundo de los conceptos complejos estudiados en las clases de teoría de aula.

Dicho esfuerzo es en la mayoría de los casos contemplado dentro del tiempo destinado en el desarrollo de cada asignatura a las prácticas, ya sean desempeñadas en un laboratorio, una sala informática o, incluso, en las prácticas de aula. Estas prácticas, enfocadas adecuadamente, son una poderosa herramienta, tanto para el docente como el alumno, pues permiten superar las limitaciones existentes en las clases teóricas que siguen siendo mayoritariamente clases magistrales. 
En el presente trabajo se detalla la innovación docente introducida en la impartición de una práctica, para la que se ha definido una metodología y que ha sido implementada haciendo uso de la herramienta informática Matlab, que permite profundizar en los fundamentos de las ecuaciones para el cálculo de la población de neutrones en un reactor nuclear y su variación en el tiempo en la simplificación de la cinética puntual. Estos contenidos son comunes a diversas asignaturas de grado y máster por lo que esta innovación tiene una extensa aplicación.

Palabras clave: cinética puntual, MATLAB, innovación docente

\section{Introducción}

La impartición de docencia en las asignaturas consideradas de intensificación o especializantes, que se ofertan en las fases finales de los grados y másteres, presentan con frecuencia el reto añadido de iniciar al alumnado en un nuevo campo o disciplina, que habitualmente tan sólo le ha sido escuetamente descrito o introducido.

A este contexto también se le puede añadir la necesidad de transmitir al alumno la gran cantidad de conceptos que conforman el proceso de especialización, en un período de tiempo reducido. Esto se traduce en que se intente impartir al alumno una gran cantidad de conocimientos que, en ocasiones, resultan ser densos conceptos que requieren de un sosegado razonamiento y una detenido análisis para los que no se dispone del tiempo material necesario.

La responsabilidad de solventar estas limitaciones corresponde al docente que, haciendo uso de los distintos recursos y facilidades a su alcance, debe superar cualquier restricción que impida que el alumno adquiera los conocimientos que demanda para su futuro desempeño laboral.

Una de las intensificaciones que, por su evidente complejidad, se ajusta enormemente a la situación descrita es la intensificación de energía nuclear. En la misma, se procede a la inmersión del alumno en los conceptos y fenomenología relativos a la física del reactor (Murray, 2017), la termohidráulica, la seguridad nuclear, la protección radiológica e, incluso, la medicina nuclear. Nos encontramos, por tanto, ante una intensificación con un enorme contenido a impartir dentro de la limitación temporal que define su confinamiento al período reservado a la especialización.

Por este motivo, en el presente trabajo, con la finalidad de facilitar el proceso de aprendizaje de los fundamentos de la cinética puntual (Snoj, 2011) de los reactores nucleares, se describe la metodología seguida en la impartición de una práctica informática. En la misma se han incluido diversas mejoras que tienen como finalidad mejorar el soporte disponible para el docente e incrementar el protagonismo del alumno durante la actividad.

Para ello, se ha utilizado una herramienta informática que los alumnos ya han trabajado en cursos anteriores como es Matlab (Giménez et al., 2016). Además es un recurso que los alumnos tienen disponible a través de licencia universitaria.

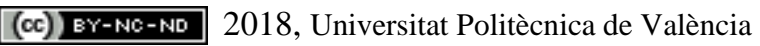

Congreso IN-RED (2018) 
Este artículo se organiza de la siguiente manera: en primer lugar se detallan los objetivos principales así como, el contexto y fundamentos teóricos que justifican el desarrollo de esta metodología. A continuación, se presenta con detalle el desarrollo de la innovación implementada. Finalmente, se presentan los resultados obtenidos y las principales conclusiones.

\section{Objetivos}

Los objetivos de este trabajo son dos:

- Testar el comportamiento descrito por las ecuaciones que rigen la cinética puntual.

- Valorar la influencia que poseen diversas fuentes de realimentación en la inserción de reactividad en la fenomenología de un reactor

\section{Justificación de la innovación}

Se detalla a continuación el contexto en el que se enmarca la innovación docente considerada y una breve descripción de las particularidades que presentan las ecuaciones de la cinética puntual.

\subsection{Contexto}

La metodología introducida pretende servir como ayuda al profesor que desea que el alumno profundice en su comprensión de la cinética puntual. Por este motivo, el aprendizaje del alumno como fin último del proceso, se ha concebido a éste como protagonista destacado de todo el proceso.

La innovación docente implementada ha sido diseñada con la intención de ser completamente válida para la impartición de una práctica informática, independientemente de que la asignatura en que sea programada esté contenida de un grado o máster.

Esta versatilidad nos resulta de gran interés puesto que nos permite disponer de una práctica "modular" perfectamente definida y debidamente validada para su incorporación en el programa de cualquier asignatura en que la cinética puntual sea tratada.

De esta forma, se prevé que pueda resultar de gran utilidad su incorporación a las asignaturas:

- Operación de reactores nucleares. $4^{\circ}$ curso del Grado en Ingeniería de la Energía.

- Tecnología Nuclear. $3^{\circ}$ curso del Grado en Ingeniería de la Energía.

- Dinámica Nuclear. $1^{\circ}$ curso del Máster Universitario en Seguridad Industrial y Medio Ambiente.

- Energía Nuclear y radiaciones. $2^{\circ}$ curso del Máster Universitario de Ingeniería Industrial.

Con la finalidad de verificar la idoneidad de las distintas actividades contempladas y la adopción, en caso de ser necesarias, de medidas correctoras; se ha incluido, inicialmente, la

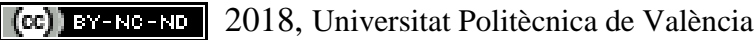


práctica en la programación de la asignatura de Operación de reactores nucleares del presente curso. Dado el buen desempeño obtenido se espera su implementación en el resto de las asignaturas en la próxima edición.

\subsection{La cinética puntual}

Las ecuaciones de la cinética puntual son una aproximación clásica de la ecuación de transporte neutrónico dependiente del tiempo y las ecuaciones de la densidad de precursores (Bell and Glasstone, 1970). Las hipótesis que se asumen y bajo las que podemos emplear dicha aproximación son la inexistencia o escasa relevancia de la influencia espacial dentro del reactor en los transitorios contemplados, así como en una reducida duración estimada de los mismos.

De esta forma, se llega a un sistema de ecuaciones simplificado en el que sólo se tiene en cuenta la evolución de la reactividad debida a la densidad neutrónica, pudiéndose considerar uno o dos grupos de energía, y el acoplamiento de la misma con la densidad de precursores de neutrones diferidos. La elección de sólo un grupo o de diversos grupos de precursores, con la influencia que dicho nivel de detalle posee en la inercia del sistema frente a los cambios, conduciría a la definición de un sistema que comprendería entre 2 ecuaciones acopladas, en su caso más simplificado, y 8 ecuaciones, en aquellos casos en que se necesite un mayor nivel de detalle.

Sin embargo, pese a la relativa complejidad que puede llegar a alcanzar el sistema de ecuaciones, las ecuaciones de la cinética puntual son mucho más simples que las correspondientes a la ecuación de difusión o del transporte, lo que permite que su resolución sea claramente más sencilla dado que existe una solución directa del sistema de ecuaciones. Por este motivo, su resolución se ve simplificada y permite su implementación en un entorno de desarrollo, como Matlab.

La implementación del sistema de ecuaciones en una herramienta de software matemático, no sólo aporta la obtención de la solución del modelo planteado sino que también proporciona un método de resolución rápido, lo que permite al alumno modificar los valores de los distintos parámetros de entrada. Con ello, se facilita la comprensión del alumno de la influencia e importancia de cada una de las variables.

Por último, se ha introducido en el programa un modelo termohidráulico simplificado que nos permitirá, si así lo deseamos, tener en cuenta la influencia de la realimentación termohidráulica ante un suceso de inserción de reactividad.

\section{Desarrollo de la innovación}

Con la finalidad de despertar el interés del alumno se ha contemplado el desarrollo como un acto dividido en tres partes. Se pretende con ello lograr una actitud por parte del alumnado lo más activa posible, evitando que el desempeño de la actividad quede confinada en exclusividad a la duración de la práctica.

(c) EY-NG-ND 2018, Universitat Politècnica de València

Congreso IN-RED (2018) 
Pese a que la innovación docente presentada comprende tres etapas diferenciadas, como son las tareas previas a la práctica, el desempeño de la misma y la actividad posterior a ella; cabe recordar que existe una etapa previa indispensable a todo el proceso que es, la enseñanza de los principios teóricos en el aula. Dicha introducción, en su desempeño óptimo, debe ser impartida preparando, además, al alumno para lo que verá en la práctica. Lográndose así la sinergia en la que las actividades teóricas y prácticas se tratan perfectamente alineadas.

Sin embargo, no es el objetivo de esta innovación docente determinar cómo debe ser la cinética puntual tratada en las prácticas de aula, por lo que respecto a esta fase previa tan sólo se comentarán las puntualizaciones ya realizadas.

Procedemos seguidamente a la descripción cronológica de las actividades contempladas en la innovación:

\subsection{Actividad previa a la práctica}

Antes de realizar la práctica se le envía al alumno un guión de la práctica, junto con el recordatorio de la misma. Aunque las fechas, horarios y aulas están disponibles desde el inicio del curso en el sitio web de la Escuela, se considera muy adecuado enviar un recordatorio unos días antes, a modo de recordatorio, pero también, como una forma de contextualizar al alumno en la práctica que en pocos días realizará.

Dicho documento previo tiene la finalidad, por tanto, de indicar al alumno que contenidos teóricos serán enlazados en la práctica y como se desempeñará la misma. Así, en un documento breve, de 6 páginas, para no saturar al alumno y que éste prescinda de su lectura; se realiza una breve introducción a los contenidos teóricos, se detallan todas las variables que se emplearán junto con su significado y se explica cómo están programadas las funciones. Al final del documento también se presentan las actividades que serán realizadas y su forma de resolución. El hecho de que el alumno pueda ver como ejecutar las tareas planteadas y su resolución, no nos supone ningún inconveniente. Al contrario, lo que queremos es que el alumno realice un pensamiento crítico del resultado y valore el peso de cada factor en la respuesta final.

\subsection{Desempeño de la práctica}

Por lo que respecta a las tareas realizadas durante la práctica, se presenta la descripción de la impartición de la misma, de su implementación en Matlab. Aunque la duración de la práctica podría adaptarse a los requisitos del profesor, número de alumnos, etc. la duración inicial considerada es de 2 horas.

\subsubsection{Impartición de la práctica}

$\mathrm{Al}$ inicio de la práctica se comprueba que los alumnos hayan leído el previo y entendido correctamente, solventándose las dudas que pudieran ser expuestas. A continuación, se 
proyecta una presentación que vuelve a enlazar con las ecuaciones expuestas en clase, así como la fenomenología asociada y que será vista en la práctica.

Cabe destacar que este inciso teórico, que viene a refrescar lo ya visto en clase y en la actividad previa, difiere en su alcance y presentación del documento previo ya comentado. Dicha divergencia tiene como finalidad que el alumno que ha realizado el previo, tal y como se le ha pedido, no considere que se le está repitiendo de nuevo el mismo contenido. Pero, por otra parte, se considera indispensable dicho inciso para asegurarnos de que todos los alumnos, incluso los que no hayan realizado la lectura previa, partan desde el punto deseado.

A lo largo de la presentación, se realizarán preguntas a los alumnos, buscando activar su participación activa en la práctica y evaluando, de paso, si están procesando y razonando los contenidos tal y como el docente desea.

Una vez finalizada la presentación, se procede a la descripción de la implementación de las ecuaciones realizada en Matlab, su explicación y su funcionamiento. En el siguiente apartado serán descritas en de talle.

Una vez que los alumnos han entendido el funcionamiento de la práctica, se les plantean 3 ejercicios, ya presentados en el previo, que deben realizar. La ejecución de los mismos es realizada por toda la clase a la vez ya que se concibe la ejecución en Matlab como un medio con el que visualizar el comportamiento de la cinética puntual, siendo la finalidad la correcta comprensión de éste y la influencia que en él tienen distintos fenómenos también vistos.

Los ejercicios consisten en modificaciones de los parámetros de entrada y el análisis de su influencia en la salida, así como en el uso de modelos que resuelven el sistema de ecuaciones considerando el reactor como un ciclo abierto o cerrado, teniendo en cuenta en éste caso la influencia de la fenomenología asociada a un suceso de inserción de reactividad.

La clase finalizará cuando se hayan realizado todas las actividades y el docente considere que los alumnos han superado debidamente los objetivos contemplados.

\subsubsection{Implementación en Matlab}

La implementación del sistema de ecuaciones en Matlab se ha realizado mediante la creación de diversas funciones que serán invocadas según el caso de problema que se desee resolver. No se ha considerado el uso de la herramienta Matlab GUIDE ya que se ha intentando realizar un programa lo más modular y comprensible posible, para el alumno como para docentes no familiarizados con el uso de dicha herramienta.

De esta forma, se han escrito 8 funciones diferentes en Matlab que permiten al alumno trabajar directamente con la fuente y además sectorizar debidamente la la tarea realizada en cada una de ellas.

La mitad de estas funciones tienen como finalidad devolver el valor del parámetro de interés (Reactividad, existencia de una fuente de neutrones, temperatura del combustible o temperatura del refrigerante) para cada paso de tiempo. Es decir, nos permitirían obtener el resultado para un caso en el que algunos de estos parámetros fluctuara en el tiempo.

(cc) EY-NC-ND 2018, Universitat Politècnica de València

Congreso IN-RED (2018) 
Por otra parte, el resto de funciones permiten la resolución del sistema de ecuaciones según se desee resolverlo considerando el modelo en bucle abierto o cerrado, con realimentación termohidráulica. Para cada caso, se contemplan dos funciones conteniendo una, la principal, el procesamiento de las variables de entrada, la llamada a las 4 funciones de parámetros relevantes, así como la metodología idónea para la resolución del sistema de ecuaciones correspondiente y la impresión de los resultados; mientras que la otra contiene el sistema de ecuaciones que será invocado para su resolución.

Son como puede imaginarse, una serie de funciones relativamente sencillas y simplificadas que permiten tratar de forma independiente cada parámetro y sistema de ecuaciones. El método de resolución empleado para cada uno de los modelos, abierto o cerrado, es el método Runge-Kutta de segundo orden (ode45) y el método de orden variable de Adams-BashforthMoulton (ode113), respectivamente.

La forma de ejecutar cada uno de los modelos parte de la definición en el escritorio principal de Matlab de las variables que serán transmitidas en la llamada a la función deseada. Una vez especificadas e invocada la función principal, correspondiente al modelo en bucle abierto o cerrado, el usuario obtendrá directamente las gráficas de la evolución de los parámetros de interés para cada modelo, concentración de neutrones y de precursores de neutrones diferidos para el sistema abierto; a los que se les añade la evolución de las temperaturas del combustible y el refrigerante para el sistema cerrado.

En caso de desear modificar alguno de los parámetros de entrada bastará con modificarlos en la llamada inicial a la función correspondiente si no son uno de los 4 parámetros de mayor relevancia, o bien en el interior de sus respectivas funciones.

Por lo que respecta a la elección de un modelo de sistema abierto o cerrado basta con invocar a la función principal correspondiente, habiendo definido adecuadamente las variables de entrada necesarias para cada caso.

\subsection{Actividad posterior}

Una vez finalizada la práctica no se considera indispensable la realización de un trabajos posterior. En la mayoría de las asignaturas el número de alumnos es reducido y el seguimiento de éstos es cercano.

Sin embargo, si que puede resultar interesante solicitar, en aquellos grupos en el que el número de alumnos sea considerable, la realización de una memoria en la que el alumno detalle como hacer uso de la implementación en Matlab y un análisis de los resultados vistos y otros sugeridos, incluyendo un análisis de sensibilidad de determinados parámetros que son de interés en el control del reactor.

De esta forma, nos aseguraríamos que el alumno ha entendido correctamente el funcionamiento y ejecución de la implementación en Matlab, así como que es capaz de evaluar la influencia e importancia que cada parámetro posee.

(cc) EY-NC-ND 2018, Universitat Politècnica de València 


\section{Resultados}

Como se ha comentado en el apartado en que se ha contextualizado la innovación docente, la impartición descrita ha sido abordada inicialmente en la programación de una única asignatura, Operación de reactores nucleares. La elección de esta asignatura se ha basado en el gran peso que en su contenido posee la cinética puntual, así como el número reducido de alumnos que nos permiten tener una realimentación crítica constante debida al trato cercano entre el alumno y el profesor.

Así, los resultados obtenidos acerca de la introducción de la innovación docente y su eficacia, han sido obtenidos directamente consultando a los alumnos y observando su evolución.

Uno de los aspectos que mejor han sido valorados ha sido la óptima ubicación de la práctica en la programación de la asignatura. La práctica ha sido realizada tras iniciar el estudio de la cinética puntual y antes de finalizar dicho bloque. Lo que ha permitido al alumno la introducción preliminar de los conceptos, su visualización durante la práctica $\mathrm{y}$, posteriormente, la recapitulación de éstos en clase.

Otros factores que han recibido buena acogida ha sido la elección de la herramienta Matlab como herramienta informática. Los alumnos ya conocen este programa de anteriores asignaturas que, además, puede ser descargado desde el repositorio de software que la Universidad pone a disposición de los alumnos.

Sin embargo, se ha constatado que no todos los alumnos realizaron la lectura previa a la práctica, por lo que deberá realizarse alguna corrección en la metodología para lograr una mayor implicación del alumno en todas las fases consideradas.

\section{Conclusiones}

Se ha llevado a cabo la implementación de una innovación docente para mejorar la impartición de la cinética puntual. Para ello se ha creado una metodología completa que define desde las actividades previas a la práctica, como su desempeño y su posible memoria posterior.

Además, la innovación ha sido basada en el uso de la herramienta de software matemático, Matlab. Esta elección nos permite no sólo la resolución del sistema de ecuaciones planteado sino también una vérsatil en la que poder realizar, con facilidad, modificaciones de los valores correspondientes a los distintos parámetros de entrada. Además, es una herramienta con la que el alumno se encuentra plenamente familiarizado.

Los resultados obtenidos han sido satisfactorios, considerándose su implementación de gran ayuda para el docente y suponiendo su correcta programación y ejecución, de gran ayuda para el aprendizaje del alumnado.

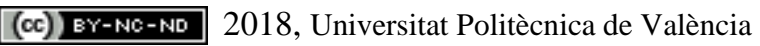

Congreso IN-RED (2018) 


\section{Trabajos futuros}

Pese al buen desempeño y satisfactorio resultado de la innovación docente, en el marco de un proceso de mejora contínua, diversos aspectos pueden ser señalados.

Con el objetivo de mejorar la participación del alumno en el desempeño de la práctica, se considera interesante lograr aumentar la motivación del alumno, que le lleve a disponer una actitud más proactiva hacia el aprendizaje a lo largo de todas las fases consideradas. Un buen ejemplo de ello sería que todos los alumnos realizasen la actividad previa contemplada.

Por lo que respecta a la implementación de la práctica en Matlab, se contempla la posibilidad de mejorar el proceso de ejecución de la misma, así como la presentación de los resultados. Se señala como una posible mejora la reescritura del programa haciendo uso de la herramienta Matlab GUIDE.

\section{Referencias}

BELL, G.I.., y GLASSTONE, S. (1970). Nuclear reactor theory. New York, U.S.: Van Nostrand Reinhold Inc.,U.S.

GIMÉNEZ, F., MONSORIU, F.A. y ABRAHAM, S. (2016). " Aprender métodos matemáticos programando con Matlab" en Congreso In-Red 2016. Valencia, pp. 276-284. Disponible en: http://ocs.editorial.upv.es/index.php/INRED/INRED2016/paper/viewFile/4430/2000 [Consulta: $25 \mathrm{de}$ marzo de 2018]

MURRAY, R.L., (2017). "Reactor Kinetics Pedagogical Insight" en Nuclear science and Engineering. $118: 4,268-271$.

SNOJ, L. et al, (2011). "Advanced methods in teaching reactor physics" en Nuclear science and Engineering. 241 (4), 1008-1012.

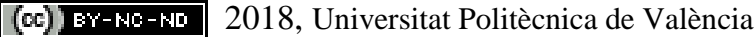




\title{
Creación de página Web para promover aprendizaje colaborativo en alumnos de máster
}

\author{
María González-Béjar ${ }^{\text {ab }}$, Daniel Cuaran-Acosta ${ }^{\mathrm{a}}$, Lorena Andrés-Olmos ${ }^{\mathrm{b}}$, Ignacio \\ Rosa-Pardo $^{\mathrm{b}}$, Raquel del Rincón ${ }^{\mathrm{bc}}$, Elena Zaballos-García ${ }^{\mathrm{a}}$, Julia Pérez-Prieto ${ }^{\mathrm{ab}}$ \\ ${ }^{a}$ Departamento de Química Orgánica, 'Instituto de Ciencia Molecular, Universitat de Valencia, \\ (maria.gonzalez@uv.es), ${ }^{\circ}$ Departamento de Química Inorgánica, Universitat de Valencia.
}

\begin{abstract}
A Web page has been designed by master students in order to engage them in collaborative and cooperative learning, thus improving their learning and comprehension of relevant concepts and topics. To that purpose, topics included in the subject Advanced Techniques in Chemistry which is part of the Master in Sustainable Chemistry of the University of Valencia have been included in the Webpage with the help of WIX software. This approach makes intensive use of the Web as a key technological resource for learning, where the information seen in the subject is summarized and given in an applicative and pertinent context that is easy to understand for all public interested in the topics discussed in there.

This tool allows the development of a key digital competence in the Spanish educational system, articulating the development of the Website with the management of multimedia content. It also allows a sense of initiative and entrepreneurship, since it is of total freedom on the part of the students working in group, the uploaded content, always following the knowledge developed and acquired in the subject.
\end{abstract}

Keywords: collaborative learning, web design, group learning, methodology.

\section{Resumen}

Se ha diseñado una página web para involucrar a los estudiantes de máster en el aprendizaje colaborativo y cooperativo, mejorando así su aprendizaje y comprensión de los temas y conceptos relevantes. Para ello, los temas incluidos en la asignatura Técnicas Avanzadas en Química que forma parte del Máster en Química Sostenible de la Universidad de Valencia se han incluido en la página web con la ayuda del software WIX. Este enfoque hace un uso intensivo de la web como recurso tecnológico clave de aprendizaje, donde se resume la información vista en la asignatura y se le da un contexto aplicativo y pertinente fácil de entender para todo el público interesado en los temas allí tratados.

Esta herramienta permite el desarrollo de una competencia digital clave en el sistema educativo español, articulando el desarrollo de la página web con el manejo de contenido multimedia. Además permite un sentido de iniciativa y emprendimiento, ya que hay libertad por parte de los estudiantes trabajando en grupo, para sellecionar el contenido de la página, siempre siguiendo el 
conocimiento desarrollado y adquirido en la asignatura y el asesoramiento de la profesora.

Palabras clave: aprendizaje colaborativo, diseño página web, aprendizaje en grupo, metodología.

\section{Introducción}

El aprendizaje cooperativo/ colaborativo es un método de enseñanza y aprendizaje en el cual los estudiantes se unen para explorar una pregunta importante o crear un proyecto significativo. (Barkley et al., 2007). Para alcanzar la calidad en la educación es indispensable que los alumnos cooperen para adquirir el aprendizaje necesario. (Torrego y Negro, 2012).

En este contexto, NANOINNOVA es un proyecto de innovación docente que surge de la renovación de metodologías docentes (plan B en la convocatoria de innovación de la Universidad de Valencia de 2017-2018) con el objetivo de desarrollar la capacidad de aprendizaje colaborativo entre los alumnos. (González-Béjar et al., 2017)

Es muy importante utilizar variedad de tecnologías de la comunicación tanto para proporcionar la flexibilidad necesaria para cubrir necesidades individuales y sociales como para lograr entornos de aprendizaje efectivos y una buena interacción entre estudiantes y profesores. (Cabero et al., 2003)

Por ello, esta actividad tiene como objetivo principal utilizar la tarea colaborativa como metodología de enseñanza y aprendizaje. En este contexto, se ha seleccionado como proyecto significativo la creación de una página Web para desarrollar competencias en el marco de un espacio colaborativo entre las alumnas y alumnos de la asignatura de Técnicas Avanzadas en Química del Máster Interuniversitario en Química Sostenible de la Universidad de Valencia, utilizando como material didáctico parte de los materiales docentes de la asignatura y artículos científicos relacionados con dicho contenido. Específicamente, la actividad está dirigida a los alumnos matriculados en la asignatura involucrada en dicho máster en la Universidad de Valencia y se hace referencia tanto a técnicas de separación y purificación como de determinación estructural y caracterización de compuestos orgánicos y nanomateriales.

Además, en la actualidad es cada vez más común utilizar los entornos virtuales de aprendizaje (EVA, por sus siglas en inglés) (Quesada, 2013; Tapscott, 1998), ya que están al alcance de la mayoría y es una forma muy rápida de recopilar gran cantidad de información. Con este tipo de tarea se estimula la creatividad del alumno, debido a que este deja de ser un mero espectador de la clase y pasa a tener un papel más colaborativo, aumentando así la necesidad de intercambiar ideas y negociar opiniones con sus compañeros y/o profesor, entre otros (UNESCO, 2004).

Teniendo en cuenta todo lo mencionado hasta ahora, se han planteado los objetivos descritos a continuación con la finalidad de diseñar una página web para involucrar a los estudiantes de máster en el aprendizaje colaborativo y cooperativo. Esta herramienta permite además el

(cc) EY-NC-ND 2018, Universitat Politècnica de València

Congreso IN-RED (2018) 
desarrollo de una competencia digital clave en el sistema educativo español y favorece la adquisición de competencias del alumnado mediante el trabajo en equipo.

\section{Objetivos}

- Adquirir y afianzar conceptos importantes y competencias en la asignatura.

- Relacionar conocimientos teóricos con aplicaciones reales.

- Simplificar la información a un lenguaje de fácil comprensión.

- Desarrollar competencias tecnológicas.

- Crear una página web con los contenidos más atractivos e innovadores de la asignatura para motivar al estudiantado y reforzar el aprendizaje de competencias.

- Desarrollar la capacidad de trabajo en equipo fomentando:

- La comunicación alumno-profesor y alumno-alumno.

- La responsabilidad del alumno.

- La toma de decisiones.

- La interdependencia positiva.

- La asunción de roles.

\section{Desarrollo de la innovación}

Como parte del desarrollo de la asignatura "Técnicas Avanzadas en Química (TAQ)" del Máster Interuniversitario en Química Sostenible de la Universidad de Valencia, se propuso el desarrollo de una página web donde se expusiera de manera sencilla y clara los contenidos adquiridos. La tarea fue asignada como una única tarea para el grupo de 5 estudiantes, impulsando con ello el trabajo conjunto y la innovación en la asignatura.

El profesor ha facilitado la creación de un clima de aprendizaje y colaboración al despertar el interés de los alumnos alineando los objetivos con los contenidos del temario (Erkens et al., 2006) y ha proporcionado los recursos necesarios para abordar el reto de la creación de contenidos en la página web. Asimismo, se han planificado sesiones de seguimiento para dialogar, razonar y asesorar al estudiantado en la elaboración de la página.

En primer lugar, el estudiantado ha asimilado el contenido de la asignatura mediante asistencia a clases teóricas y prácticas de laboratorio. Cabe destacar que tanto en las clases teóricas como prácticas se ha dado con antelación acceso a recursos docentes preparados por la profesora en el Aula Virtual. De esta forma se ha fomentado un aprendizaje previo basado en el interés de cada participante motivado por la futura creación de la página web.

En este punto, de forma grupal, cada participante ha dialogado y razonado la información que considera adecuada para incluir en la web basándose en los conocimientos previos adquiridos. Se fomenta la comunicación (saber escuchar, comunicar ideas), es decir, el diálogo. Es un método constructivo de aprendizaje dado que el alumnado está implicado. A diferencia de la clase magistral, los alumnos colaboran (Barkley et al. 2007), participan y no son meros receptores de conocimiento. Este proceso permite que el alumno tome conciencia de la interdependencia y repercusión del trabajo de cada componente del grupo. Por otra parte, se fomenta la toma de decisiones ya que los participantes deciden que incluyen y por qué y razonan con la profesora los motivos de la selección de contenidos (Bruffee, 1993). 
La página web fue creada mediante el uso de la plataforma de desarrollo Wix (www.wix.com). Pese a que los conceptos se encuentran al alcance de cualquier buscador, la página web diseñada presenta grandes diferencias: mediante el uso de contenido multimedia permite un aprendizaje más rápido y sencillo, y el uso de artículos científicos como herramienta complementaria a los conceptos permite encontrar una aplicación real de los mismos. El tenerlo todo recopilado en una sola página web hace la búsqueda más sencilla y llamativa para el alumnado y los posibles visitantes de la Wix.

Si bien la obtención de una herramienta útil de trabajo para los alumnos de esta asignatura (página web) es un logro a destacar en el presente proyecto, el mayor logro reside en las competencias que han ido desarrollando en los alumnos a lo largo del proceso en cuanto a la sus capacidades de aprendizaje y también en cuanto a la adquisición de conocimientos propios de la asignatura; altamente relacionado con el proceso de aprendizaje. Merece ser destacado, que el proceso seguido ha permitido, por ejemplo, estimular al alumno y desarrollar un mayor grado de responsabilidad con su trabajo, haciendo que tome conciencia del papel de interdependencia positiva que desarrolla en el equipo.

Tal y como indican Bazo y Luengo, no es suficiente para adquirir una competencia que un alumno sea capaz, cuando se le demanda, de realizar una operación para la que ha sido entrenado o de repetir el enunciado que ha memorizado. "Debe ser capaz, de entre los recursos que se poseen (o que es capaz de buscar), de escoger aquellos que mejor conviene a la situación, para lo cual tendrá que movilizar todos los saberes que posea, tanto explícitos como implícitos, y tendrá que hacerlo mediante los procesos cognitivos adecuados. Una competencia no es la simple adición de conocimientos, sino la capacidad de ponerlos en interacción en función del uso que se le pueda dar en el tratamiento de las situaciones". (Luengo y Bazo, 2009)

Evaluación: Los estudiantes ha de hacer una presentación final una vez concluida la creación de la página. A partir de esta presentación la profesora evalúa el trabajo realizado por los alumnos y la cooperación e implicación que han tenido todos ellos para realizar esta página Web de manera conjunta, eliminando con este método de trabajo el reparto de tareas y la falta de conexión de las partes del trabajo cuando se realiza de manera individual. Además de la evaluación de la profesora, cada alumno deberá evaluar tanto la implicación de cada uno de sus compañeros como la suya propia. De esta manera, al hacer una autocrítica, cada alumno puede reconocer y consensuar su grado de implicación en la asignatura.

\section{Resultados}

Para el desarrollo de la página ha sido necesario un trabajo en equipo, donde cada uno de los integrantes ha aportado sus conocimientos de tecnología y diseño para crear la plataforma base donde se comienza a incluir la información. La página web diseñada se encuentra disponible para libre acceso en el siguiente link: $\leq$ https://taquv17.wixsite.com/nanoparticles $>$, el cual a su vez se publicará en la página oficial 
del Máster en Química Sostenible de la Universidad de Valencia, con lo que se mejora el público objetivo de la web.

La web será una herramienta en constante desarrollo y actualización por parte de los estudiantes de TAQ, quienes dispondrán de acceso como administradores y podrán modificar, complementar y/o actualizar la web para evitar su obsolescencia.

En la Figura 1 se observa la portada de la web. Mediante la inclusión de algunos botones y un video descriptivo del tema general, se plantea de manera intuitiva el contenido que podrá allí encontrarse.

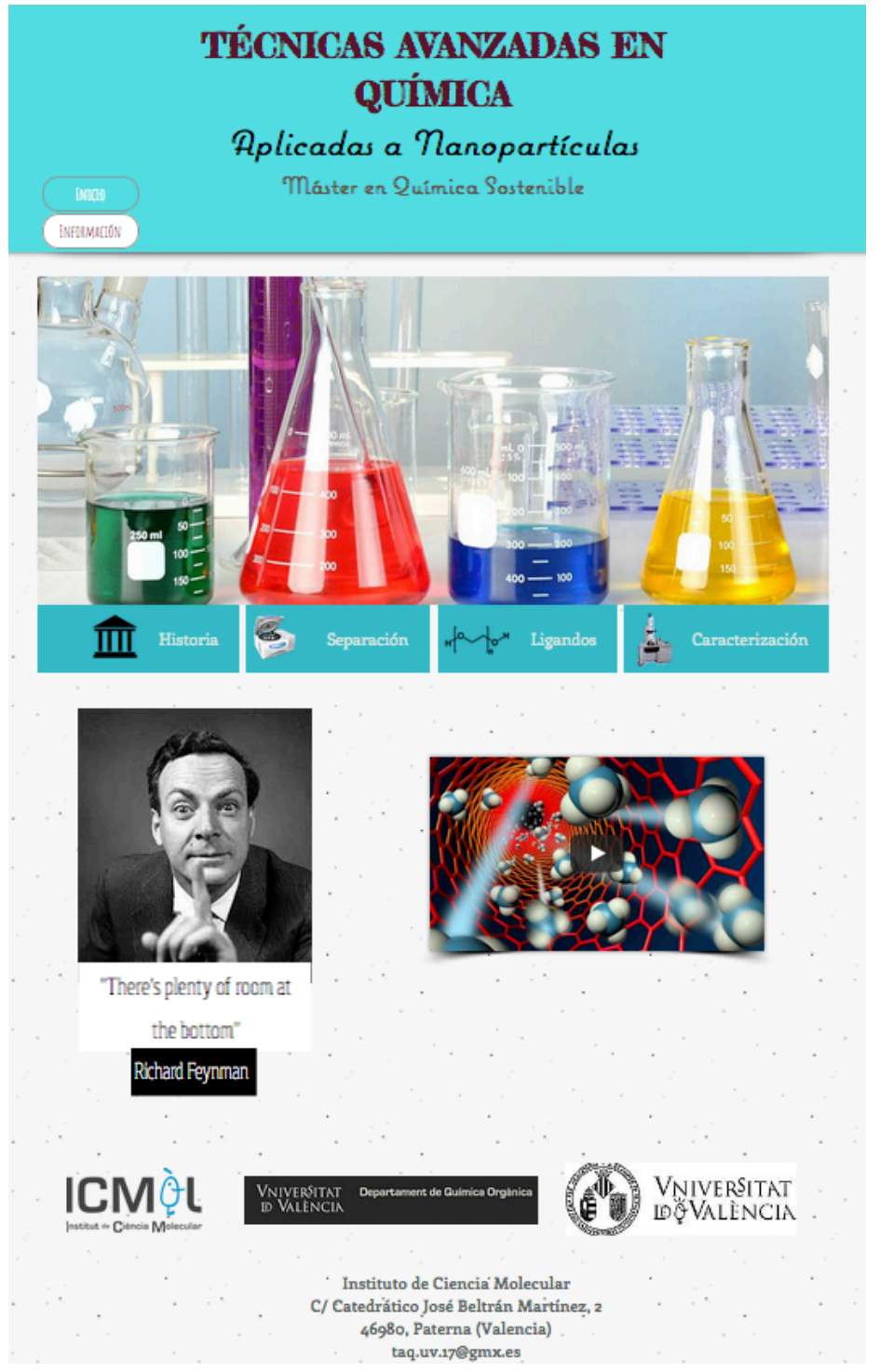

Fig. 1 Portada de la página Web diseñada. 
Para el contenido temático enlazado en cada apartado, se requirió de conocimiento teórico adquirido en la asignatura, así como elementos multimedia de YouTube u otras páginas web y la inclusión de elementos PDF de libre acceso.

Al final, como se observa en las Figuras 2 y 3, para cada temática se incluyen 3 factores clave: multimedia, conceptos e información adicional.

Multimedia: Videos, esquemas, tablas o imágenes.

Conceptos: Información teórica sencilla y corta para dar un panorama general del tema a tratar.

Información adicional: Información asociada mediante hipervínculos, que puede ser de interés para ampliar el conocimiento del tema, tales como handbooks, tesis doctorales, libros y artículos científicos de libre acceso, entre otros.

\section{ESPECTROSCOPIA FOTOELECTRÓNICA DE RAYOS X (XPS)}
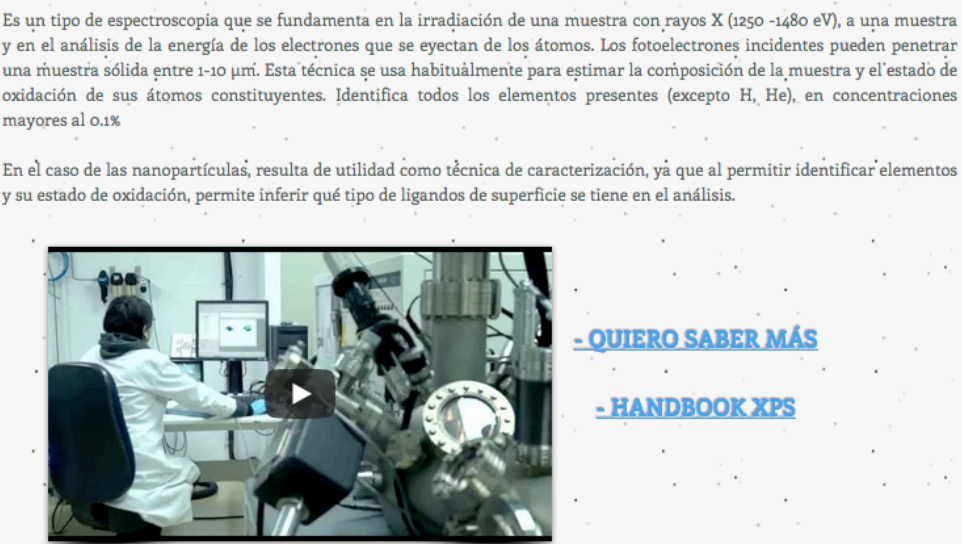

\section{MICROSCOPIA ELECTRÓNICA DE TRANSMISIÓN (TEM)}

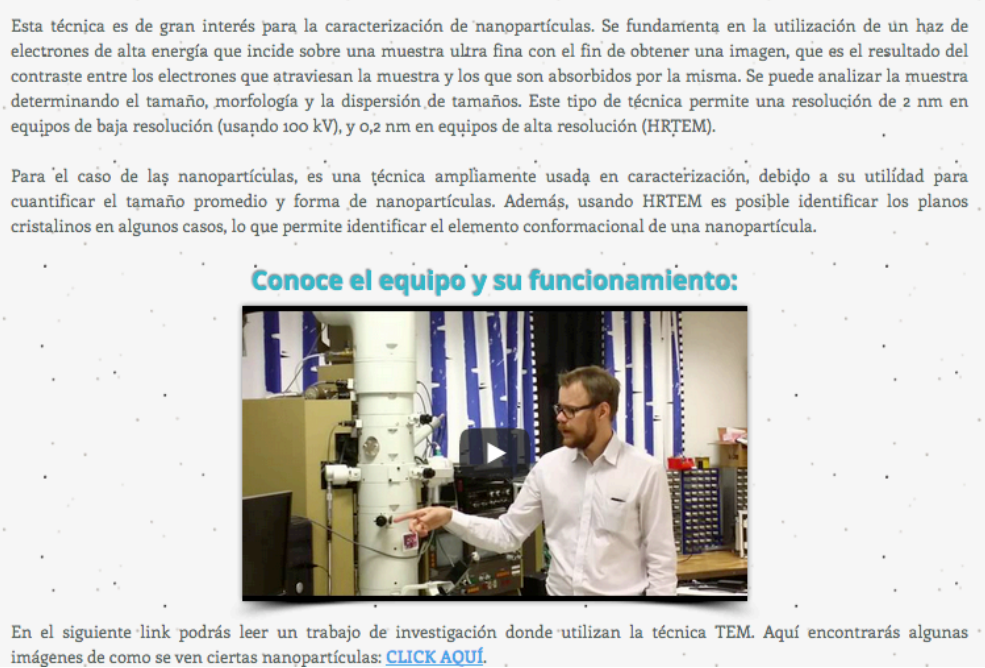

imágenes de como se ven ciertas nanopartículas: CLICK AOUf

Fig. 2. Ejemplos de un tema incluido en la web, donde se puede observar una breve explicación de las técnicas, así como un video ilustrativo del proceso. 


\section{TÉCNICAS AVANZADAS EN} QUÍMICA

\section{LIGANDOS DE NANOPARTÍCULAS METÁLICAS}

Las nanopartículas metálicas presentan una elevadísima área superficial, por lo que pueden ser fácilmente funcionalizadas y bioçonjugadas, modificando sụs propiedades superficialęs. Por ejemplo, una nanopartícula de oro (AuNP), de anm de diámetro de núcleo podría, en principio, ser conjugada a $\sim 100$ moléculas en los ligandos disponibles $(n=\sim 108)$. De hecho, recientemente Gibson y col. anclaron 70 moléculas del agente quimioterapéutico paclitaxel en una AuNP de anm de diámetro.

La funcionalización de las AuNPs se realiza generalmente mediante enlaces «tiol», si bien también muestran afinidad por los grupos amino, fosfito y bisulfito. Numerosas moléculas han sido ligadas a la superficie de las AuNPs con distintos propósitos, ampliando su rango de aplicación. Se pueden utilizar procedimientos de modificación post-sintética para funcionalizar la superficie de la partícula con porciones biocompatibles tales como oligo(etilenglicol) (OEG) y poli(etilenghicol) (PEG).

Ejemplos de estrategias de funcionalización de las AuNPs de aphicación en terapia del cáncer son la conjugación con PEGtiolado para conseguir una vectorización pasiva hacia células tumorales (aumenta el tiempo de vida media en el torrente sanguíneo y muestra una mejora de la permeabilidad y del efecto de retención en el tumor); y la utilización de anticuerpos específicos de biomarcadores moleculares sobrẹexpresados en là superfiçe de células cancerígenas,o la utilización de. péptidos con propiedades de reconocimiento específico de componentes intracelulares. Estos pueden ser conjugados directamente a las AuNPs o mediante puentes de PEG tiolado.

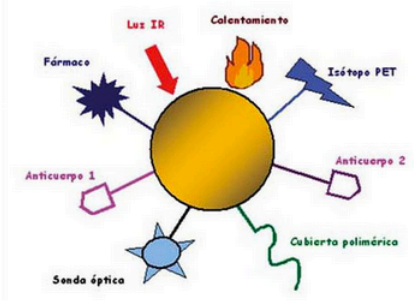

Imagen 1. NP esférica multifuncionalizada con posibles ligandos: fármacos, anticuerpos de vectorización, polímero, sondas de diagnóstico por imagen, etc.

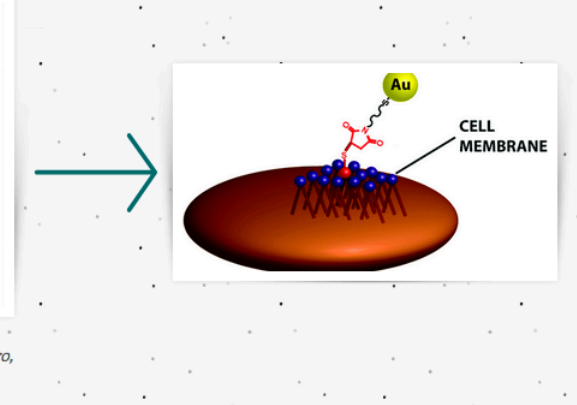

Para mayor comprensión, en el siguiente link podrás encontrar un trabajo doctoral realizado en la Universidad de la Rioja, donde sintetizan nañopartículas de oro y plata con diferentes ligandos orgánicos, dándole una aplicabilidad real a los conceptos aquí indicados: VER TESIS

Los ligandos se encuentran entre las nanopartículas y el medio en el que se encuentran. Por ello, forman parte de las. interacciones entre las nanopartículas y su entorno. Además muchas aplicaciones se basan o depende del intercambio de ligandos, El intecambio que puede llevarse a cabo mediante ditintas formas:

Fig. 3. Ejemplo de otro tema incluido en la web, donde se puede observar una breve explicación de la técnica, así como enlaces a materiales de interés en internet.

Los resultados del aprendizaje abordan todos los niveles cognitivos de la taxonomía de Bloom son: conocer, comprender, aplicar, analizar, evaluar y crear. (Peña, 2010).

\section{Conclusiones}

El alumnado de máster ha creado trabajando en grupo una página web estimulante y motivadora donde se puede encontrar de forma rápida, clara y sencilla los contenidos más relevantes de la asignatura de Técnicas Avanzadas en Química, en concreto la mayoría de 
técnicas e información necesaria para trabajar con nanomateriales, especialmente nanopartículas.

Al realizar este trabajo de forma conjunta utilizando la creación de la página web como catalizador para promover la enseñanza-aprendizaje, cada participante se ha involucrado, intercambiado ideas expresando opiniones y, en grupo han sido capaces de escoger entre los recursos que se poseen (o que se han buscado) movilizando así todos los saberes que posee, tanto explícitos como implícitos para conseguir una visión global de todo el contenido de la asignatura y es capaz de explicar y encontrar información relativa a las técnicas estudiadas.

Además, se han adquirido competencias digitales clave en el sistema educativo español, articulando el desarrollo de la página web con el manejo de contenido multimedia.

Cabe destacar que todos los estudiantes implicados destacan la mayor facilidad de asimilación de contenidos de la asignatura en forma global y el incremento del interés y la motivación en su proceso de aprendizaje.

\section{Referencias}

BARKLEY, E.F., CROSS, K. P., \& MAJOR, C. H. (2007). Técnicas de aprendizaje colaborativo: manual para el profesorado universitario. Madrid: Editorial Morata.

BRUFFEE, K. A. (1998). Collaborative Learning: Higher Education, Interdependence, and the Authority of Knowledge (2nd edition). Baltimore, Md: Johns Hopkins University Press.

CABERO, J., CASTAÑO, C., CEBREIRO, B., GISBERT, M., MARTINEZ, F., MORALES, J. A., SALINAS, J. (2003). Las nuevas tecnologias en la actividad universitaria. Píxel-Bit. Revista de medios y educación, 20, 81-100.

ERKENS, C., JAKICIC, C., JESSIE, L., KING, D., KRAMER, S. V., TWADELL, E. (2008). The Collaborative Teacher: Working Together as a Professional Learning Community. Bloomington, IN: Solution Tree.

GONZÁLEZ-BÉJAR, M., GALIAN, R. E., PÉREZ-PRIETO, J., ZABALLOS-GARCÍA, FRANCÉS SORIANO, L., GONZÁLEZ CARRERO, S., y ESTEBANEZ, N. (2017-2018). NANOINNOVA: Aprendizaje colaborativo en síntesis y caracterización de nanomateriales, Proyecto de Innovació educativa de la Universitat de València (UV-SFPIE_RMD17-588248), Vicerectorat de Polítiques de Formació i Qualitat Educativa Valencia (ESPAÑA)

LUENGO, F., \& BAZO, P. (2009). La práctica de la comunicación lingüistica Proyecto Atlántida.

PEÑA, J. (2010). El aprendizaje cooperativo y las competencias. Revista d'Innovació Docent Universitària, 2, 1-9. 10.1344/105.000001520

QUESADA, A. (2013). Aprendizaje colaborativo en entornos virtuales: los recursos de la Web 2.0. Revista de Lenguas Modernas, (18), 337.

TAPSCOTT, D. (1998). Growing Up Digital: The Rise of the Net Generation. McGraw Hill, Nueva York.

TORREGO, J. C., NEGRO, A. (2012). Aprendizaje cooperativo en las aulas: fundamentos y recursos para su implantación. Madrid: Alianza.

UNESCO. (2004). Las tecnologías de la información y la comunicación en la formación docente: Guía de Planificación. Traducción TRÍAS y ARDANS.

(cc) EY-NC-ND 2018, Universitat Politècnica de València

Congreso IN-RED (2018) 


\title{
Metodología para mejorar la percepción de utilidad de conceptos básicos estadísticos a través de Facebook
}

\begin{abstract}
Ángeles Calduch-Losa ${ }^{a}$, José Antonio Ontalba-Ruipérez ${ }^{\mathrm{b}}$, Enrique Orduna-Malea ${ }^{\mathrm{b}}$, Jorge Serrano-Cobos ${ }^{\mathbf{b}}$, Rosa María Alcover ${ }^{\mathrm{a}}$ y Elena Vázquez ${ }^{\mathrm{a}}$

${ }^{a}$ Departamento de Estadística e Investigación Operativa Aplicadas y Calidad, Universitat Politècnica de València (mcalduch@eio.upv.es, evazquez@eio.upv.es, ralcover@eio.upv.es) y ' Instituto de Diseño y Fabricación (IDF) (joonrui@upv.es, enorma@upv.es, jorserc2@har.upv.es)
\end{abstract}

\begin{abstract}
The main objective of this work is to describe a learning innovation experience aimed to improve the student's perception and understanding about statistical applications in the real world through the use of social networks. The experience was carried out with students of bachelor and master's degrees from the School of Computer Engineering (Universitat Politècnica de València) during the academic course 2015 - 2016. Lecturers involved created a closed Facebook group with the students. By means of the group, teachers shared scientific and informative articles related to the subjects taught, in order to be subsequently commented by the students. Posts (including research on statistical practical cases) were discussed, thereby fostering the participation in a simple, fluent and friendly way by the students.
\end{abstract}

Keywords: Education 2.0, Higher Education, Statistics, Social Networks

\begin{abstract}
Resumen
En este trabajo se presenta una experiencia de innovación docente basada en la utilización de redes sociales. El principal objetivo de la experiencia es que los alumnos mejoren la percepción y comprensión de las aplicaciones de la Estadística en el mundo real. La experiencia fue realizada en el curso 2015 2016 con alumnos de grado y de máster que cursaban sus estudios en la Escuela Técnica Superior de Informática de la Universitat Politècnica de València. Los profesores implicados crearon un grupo cerrado de Facebook a través del cuál compartían artículos científicos y divulgativos relacionados con las asignaturas impartidas, y que comentaban los estudiantes. Estos artículos se discutían fomentando la participación y la investigación de casos prácticos de una forma sencilla, fluida y familiar para el alumno.
\end{abstract}

Palabras clave: Educación 2.0, Educación Superior, Estadística, Redes Sociales 
Metodología para mejorar la percepción de utilidad de conceptos básicos estadísticos a través de Facebook

\section{Introducción}

\subsection{Contextualización de la experiencia}

Esta innovación se desarrolló dentro del marco del PIME B-13 de la convocatoria 20152016.

La experiencia se ha realizado en la Escuela Técnica Superior de Informática (ETSINF) durante el citado curso académico, con dos tipos de alumnos:

Alumnos de la asignatura troncal Estadística de 6 créditos que se imparte en el primer curso del Grado en Ingeniería Informática (GII), y que se cursa en el segundo cuatrimestre. En concreto, fueron los de los grupos 1A, 1B y $1 \mathrm{H}$, con 117 alumnos matriculados de los que participaron 103.

Alumnos de la asignatura de 4,5 créditos obligatoria Técnicas de investigación e innovación del Máster Universitario de Gestión de la Información (MUGI), también del segundo cuatrimestre, con 20 alumnos matriculados, de los que participaron la totalidad.

\subsection{Justificación y motivación}

Los alumnos no suelen apreciar la utilidad de una asignatura de primer curso para su vida laboral. Sin embargo, cuando llega el momento de integrarse en un puesto de trabajo o de adquirir cierta formación de posgrado aplicada, necesitan poner en práctica estos conocimientos, pues son la base para comprender las complejas tareas de un profesional, especialmente en el campo de la ingeniería. Las razones por las que esto sucede son principalmente las siguientes: a) olvido: desfase temporal entre la impartición de esos contenidos y la necesidad de su aplicación; y b) incomprensión: el carácter generalmente más complejo y abstracto de estos contenidos (enfocados al uso del pensamiento abstracto, fundamental en las competencias de un ingeniero) provoca cierta indiferencia entre los alumnos a la hora de aplicarlos en casos reales.

Además, los actuales planes de estudio han llevado a que asignaturas que antes eran anuales hayan pasado a ser cuatrimestrales (con una considerable reducción del temario impartido), por lo que resulta complicado impartir los conocimientos necesarios para la titulación y poder explicar adicionalmente aplicaciones al mundo laboral.

La idea de utilizar un grupo de Facebook viene de la experimentación ya realizada en la UPV con los grupos de redes sociales (Calduch-Losa et al, 2014; Poza-Luján et al, 2014) y su valoración positiva, tanto por el alumnado como por el profesorado implicado. La utilización de estos entornos favorece entre los alumnos su participación en las actividades al sentirse en una plataforma que les permite desarrollar sus habilidades sociales tanto con los profesores como con el resto de compañeros. Así mismo, la plataforma permite de una forma sencilla utilizar diversas tecnologías para crear y difundir contenidos en distintos formatos que permitan la interactividad de todos los participantes, así como la medición del grado de participación y satisfacción.

(cc) EY-NC-ND 2018, Universitat Politècnica de València

Congreso IN-RED (2018) 


\section{Objetivos}

El objetivo general de este proyecto es que los alumnos mejoren la comprensión de las aplicaciones que la asignatura Estadística tiene en el mundo real, concretamente en el mundo laboral, para que puedan apreciar y captar mejor los contenidos de la asignatura, lo que redundará en la adquisición de nuevas habilidades que podrían ayudarles a mejorar su nivel profesional y laboral.

Los objetivos específicos que planteamos conseguir en el proyecto son los siguientes:

1. Identificar la percepción que los alumnos tienen de los contenidos de la asignatura Estadística.

Nivel de logro: Al iniciar y al finalizar el cuatrimestre se realizará una encuesta a los alumnos, y una de las cuestiones será que valoren la percepción que tienen acerca de la asignatura. Se contrastarán las respuestas que hayan dado en las dos ocasiones.

2. Incorporar el uso de las redes sociales en las asignaturas implicadas para fomentar la participación de los alumnos en el desarrollo del proceso enseñanza-aprendizaje.

Nivel de logro: La participación activa del grupo en la red social creado para el objeto del proyecto.

3. Fomentar la participación del alumnado, proponiendo preguntas directas después de cada ejemplo expuesto.

Nivel de logro: Que cada alumno del grupo responda y/o participe en los ejemplos expuestos.

4. Obtener interacción del alumnado de distintos perfiles.

Nivel de logro: La interacción se producirá, ya que en el mismo espacio de trabajo tendremos alumnos de grado y de máster, con la visión propia de la asignatura que estén cursando.

5. Trasladar los ejemplos a otros ámbitos.

Nivel de logro: Que los alumnos, a partir de los casos de estudio vistos, sean capaces de extrapolarlos o proyectarlos a otros entornos laborables de su interés.

6. Analizar estadísticamente las métricas web de las interacciones llevadas a cabo por los alumnos en la plataforma de Facebook, así como implicar a los alumnos en esta actividad con el fin de que éstos adquieran estas habilidades de análisis web.

Nivel de logro: Por una parte, conseguir obtener datos válidos para evaluar la actividad llevada a cabo y, por otra parte, que los alumnos sean capaces de participar en esta fase de análisis estadístico de métricas web.

\section{Desarrollo de la innovación}

Se creó un grupo cerrado de Facebook, en el que participaron los seis profesores implicados en el PIME y unos 120 alumnos. Los alumnos no estaban obligados a participar en él, pero 
Metodología para mejorar la percepción de utilidad de conceptos básicos estadísticos a través de Facebook

en el caso de la asignatura Estadística, su participación podía conllevarles el 10\% de la nota de la calificación final, que se obtiene participando en la asignatura, y que cada profesor puede elegir la manera de valorarla.

Los alumnos fueron comentando los artículos colgados en el grupo por el profesorado. De este modo se generó un debate, ya que los alumnos podían comentar sobre los artículos publicados y sobre las opiniones del resto de sus compañeros.

El primer trabajo compartido fue una ponencia presentada por algunos de los profesores en un congreso, en la que se hacía un estudio descriptivo de unos datos, y se les hacía preguntas a los alumnos, como puede verse en la Figura 1. Las preguntas se formulaban de una manera dirigida, para que los alumnos supieran las acciones que tenían que realizar.

\section{A. Ángeles Calduch Losa ha subido un archivo.}

Hola, aquí tenéis un caso práctico de Estadística Descriptiva. Comentadlo

e indicad de qué otro modo lo hubiérais explicado, qué pasaría si se aplicara a empresas de otros sectores, si los resultados son como esperábais, o si pensábais que habría más presencia online o en las redes sociales...

Fig.1 Ejemplo de pregunta a los alumnos

Iniciado el cuatrimestre, encontramos noticias online actuales en ese momento con matices estadísticos, por lo que redirigimos la orientación y la cantidad de los temas a tratar en el grupo, y finalmente se presentaron 10 posts en los que se combinaban casos prácticos y artículos divulgativos junto con artículos científicos con aplicaciones tanto de temas vistos en clase como de temas que no se ven, para que los alumnos vieran la utilidad de ir un poco más allá en la materia.

En la Figura 2 se ve el caso de un artículo científico redactado por algunos de los profesores participantes en el PIME, y en la redacción de la pregunta se intentó que los alumnos tuvieran que pensar en tipos de variables. Respecto a los métodos tratados, se combinaron uno visto en clase con uno que no, para que los estudiantes pudieran ver las similitudes y las diferencias entre ambos. 
Aquí está un estudio realizado con datos reales de los alumnos de la Escuela de hace algunos años. Los árboles de decisión no se ven en el temario de la asignatura Estadística, pero son intuitivos y creo que no tendréis ningún problema en interpretarlos; y regresión es el último tema de la asignatura.

Notad que tenemos variables tanto cualitativas como cuantitativas.

¿Por qué decimos que las técnicas utilizadas son predictivas?... Ver más

\section{Análisis del rendimiento académico en los estudios de informática de la Universidad Politécnica de Valencia aplicando técnicas de minería de datos.pdf}

Formato de documento portátil

Descargar Vista previa Subir nueva versión

\section{Me gusta \\ Comentar}

5

Ver 24 comentarios más

Este estudios debería realizarse en cualquier organización educativa porque muchas veces se aplican medidas sin saber realmente los efectos que tendrán en los estudiantes de nuevo ingreso en su primer año de carrera y son muy importantes para un buen s... Ver más Me gusta - Responder - 1

Este estudio al usar regresión te hace ver como todas las variables recogidas que en un primer contacto parecen independientes entre si pero con este metodo se analiza como dependen entre ellas, aunque con el sentido común la formación de los padres y... Ver más

Me gusta - Responder

Fig.2 Ejemplo de un artículo científico

Como se ha comentado con anterioridad, se incorporaron a la experiencia artículos divulgativos, extraídos de medios de comunicación online. En la Figura 3 tenemos un ejemplo de uno de ellos. 
Metodología para mejorar la percepción de utilidad de conceptos básicos estadísticos a través de Facebook

En la asignatura de Estadística hemos visto regresión, aunque no regresión logística, que es de la que trata este artículo.

Me gustaría que os informarais de lo que es la regresión logística y hablarais un poco de ella, así como de para qué otros casos la veis útil ¿Se os ocurre otra manera en la que se podrían pronosticar los resultados con los métodos vistos en clase?... Ver más

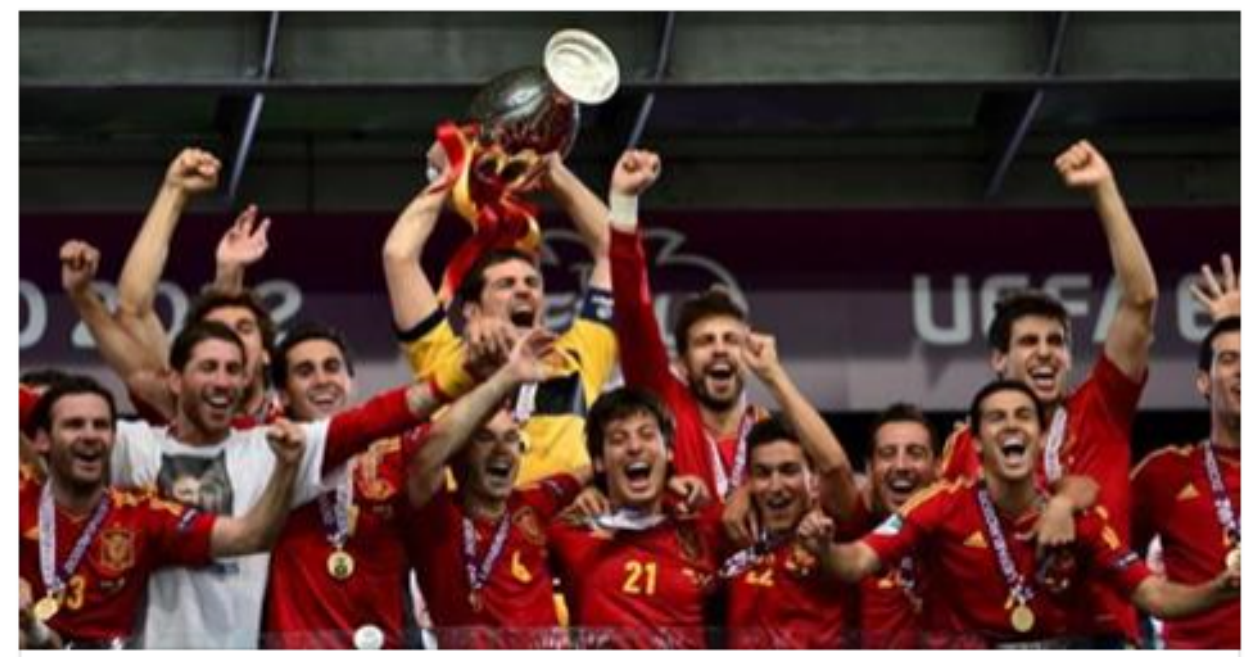

\section{Matemáticos predicen que el ganador de la Eurocopa será...}

Un grupo de matemáticos de la Universidad de Economía de Innsbruck ya sabe quién será el ganador de la Eurocopa 2016. Cuando todavía faltan 8 días para..

ELMUNDO.ES

It Me gusta $\quad \Rightarrow$ Comentar $\quad \Rightarrow$ Compartir

Ver 42 comentarios más

Fig.3 Ejemplo de un artículo divulgativo

Y en la Figura 4 puede apreciarse un caso práctico expuesto sobre métricas web, en concreto indicadores relativos al impacto de publicaciones científicas. 


\section{Enrique Orduña Malea}

En ocasiones, los Gobiernos, organizaciones o empresas se preguntan qué investigadores son aquellos que han logrado un mayor impacto. Quizás una posible forma de conocerlo es a través del impacto que han obtenido los trabajos de investigación que éstos han publicado durante su vida.

Pero... ¿qué ocurre cuando tengo muchos indicadores relativos al impacto?, ¿miden todos lo mismo?, ¿existen familias de indicadores que midan distintas dimensiones del impacto?

Quizás la realizaci... Ver más

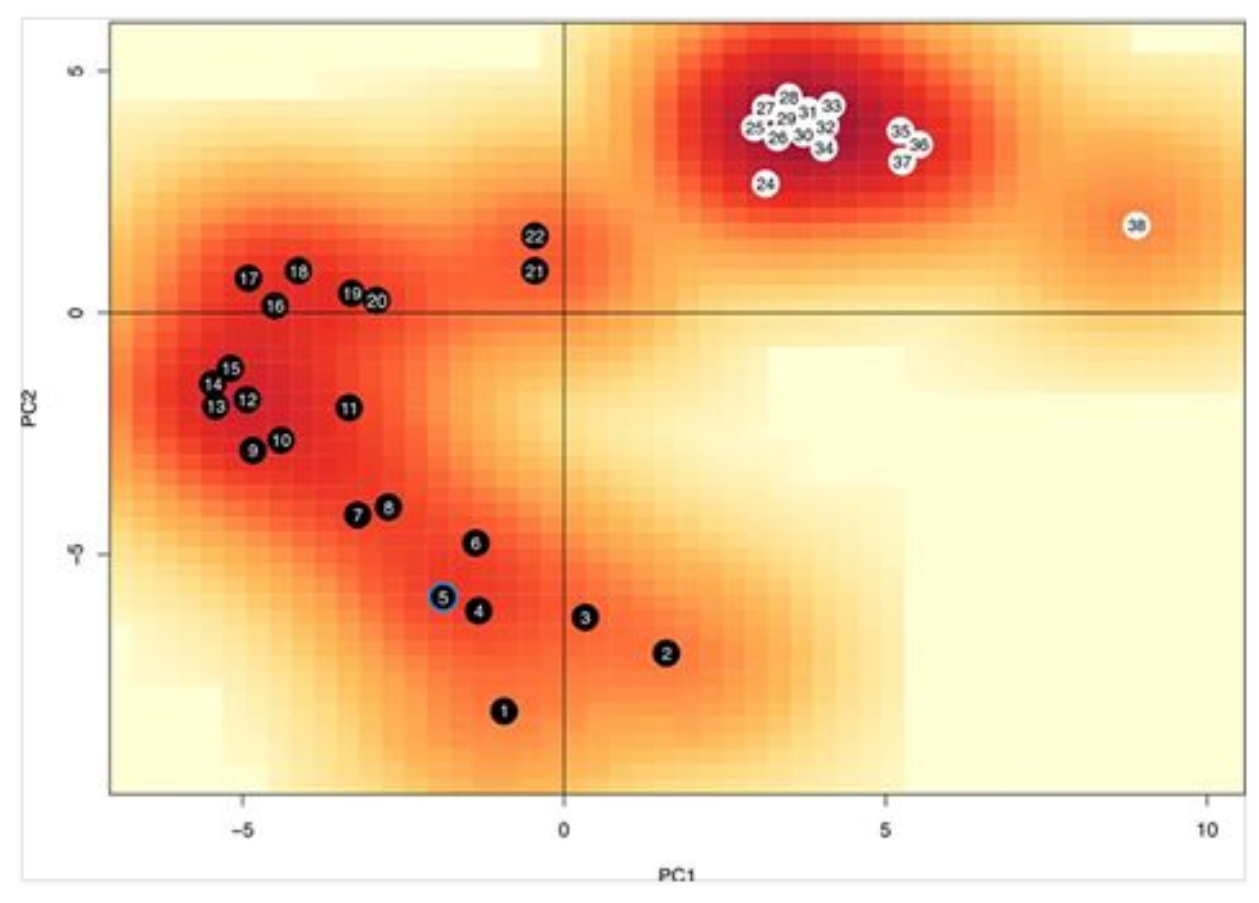

Me gusta

\section{Comentar}

Fig.4 Ejemplo de caso práctico sobre métricas web

\section{Resultados}

\section{1. ¿Se han conseguido los objetivos? ¿Qué resultados se han obtenido?}

Recordemos que el objetivo general de este proyecto es que los alumnos mejoren la comprensión de las aplicaciones que la asignatura Estadística tiene en el mundo real. Creemos que se ha cumplido con creces, por lo que nos han contestado en la encuesta final que se les ha pasado al acabar el cuatrimestre.

Veamos la consecución de los objetivos específicos: 
Metodología para mejorar la percepción de utilidad de conceptos básicos estadísticos a través de Facebook

1. Identificar la percepción que los alumnos tienen de los contenidos de la asignatura Estadística.

A los alumnos implicados se les han pasado dos encuestas: una al inicio del cuatrimestre, anónima mediante GoogleDocs, y otra al finalizar la asignatura, utilizando la plataforma Socrative. Por sus respuestas, la percepción de la asignatura ha mejorado.

2. Incorporar el uso de las redes sociales en las asignaturas implicadas para fomentar la participación de los alumnos en el desarrollo del proceso enseñanza-aprendizaje.

Han participado en el grupo de Facebook el $88 \%$ de los alumnos de grado y el $100 \%$ de los alumnos de máster.

3. Fomentar la participación del alumnado, proponiendo preguntas directas después de cada ejemplo expuesto.

Según los datos obtenidos por www.grytics.com, que es una herramienta que realiza estadísticas en los grupos de Facebook, el 89\% de las acciones realizadas en el grupo han sido comentarios, el 9\% corresponden a "me gusta", mientras que el 2\% restante son los posts que contenían los diversos artículos y trabajos presentados.

4. Obtener interacción del alumnado de distintos perfiles.

Aunque los alumnos de los dos niveles comentaron los artículos y trabajos presentados, las respuestas que se han dado entre ellos han sido entre compañeros de asignatura.

5. Trasladar los ejemplos a otros ámbitos.

En alguno de los ejemplos propuestos, ha habido alumnos que lo han replicado en otros campos, como puede verse en la Figura 5, ya que han realizado sorteos con compañeros de clase o con deportistas.

6. Analizar estadísticamente las métricas web de las interacciones llevadas a cabo por los alumnos en la plataforma de Facebook, así como implicar a los alumnos en esta actividad con el fin de que éstos adquieran estas habilidades de análisis web.

Se ha medido la participación del alumnado en el grupo, pero no se les ha hecho partícipes de ello.

(cc) EY-NC-ND 2018, Universitat Politècnica de València

Congreso IN-RED (2018) 
Como dice en el artículo, una solución sencilla seria asignar un número a cada alumno, con esto conseguiríamos que cada alumno que quiere entrar tenga la misma probabilidad de ello. Para demostrarlo he creado un pequeño programa en java que genera números aleatorios (entre 1 y el número de alumnos que quieren entrar) y va sumando el número de veces que sale. Yo he cogido como ejemplo la lista de la clase $1 \mathrm{H} 2$ y les he asignado un número (en total son 20 alumnos). He generado posteriormente 1000 números aleatorios y he conseguido los siguientes resultados:

Cada alumno tiene un numero asignado seguido del número de veces que ha salido y su porcentaje de aparición. (Ver imagen)

Como podemos observar el número que más ha salido ha sido el de Ismael (el 9). Si volviésemos a ejecutar el programa estos resultados cambiarían totalmente. Pero en definitiva todos tienen la misma probabilidad de entrar (1/20), ya que como se puede apreciar están muy ajustados los resultados. Además, podemos generar más números aleatorios para evitar posibles empates.

Comparto el código del programa:

https://gist.github.com/.../d23a7c2d1e0b262d0f14f89fcb14f023

\begin{tabular}{|c|c|c|c|}
\hline & Alfonso Safont, Adrian & 45 & $4,5 e s$ \\
\hline & Almela Seller, Carlos & 44 & 4,405 \\
\hline & Anchel Urda, David & 51 & $5,1 e x$ \\
\hline 4 & Ávila Fernández, Sergi & 58 & $5,8 e x$ \\
\hline 5 & Ben Kasem Agbalu, Isaac & 53 & $5,3 e x$ \\
\hline & Cerro Montoya, Pablo & 53 & $5,30 x$ \\
\hline & Correa Julve, Jorge & 41 & $4,1 e x$ \\
\hline & Costa Vidal, victor & 54 & $5,4 e x$ \\
\hline & Diaz Segrelíes, Ismael & 64 & 6,408 \\
\hline 10 & Dolz Martinez, Vicent & 53 & $5,3 e x$ \\
\hline 11 & Fernández De La Torre, Diego & 59 & 5, gex \\
\hline 12 & Gavila Martinez, Joan & 58 & $5,8 e x$ \\
\hline 13 & López Andrango, Kevin Danilo & 39 & $3,9 e x$ \\
\hline 14 & Martinez Ponce, Raúl & 46 & $4,6 e s$ \\
\hline 15 & Navarro Font, Cristina & 51 & $5,10 x$ \\
\hline 16 & Palomares Badenas, Raúl & 42 & 4,205 \\
\hline 17 & Pérez Martinez, Alejandro & 49 & $4,9 e x$ \\
\hline 18 & Rivas Ferri, Francisco José & 43 & $4,3 e s$ \\
\hline 19 & Sahuquillo Soriano, Adrian & 5) & 5,705 \\
\hline 20 & Sinves Tosca, Juan Jose & 40 & 4 , ees \\
\hline
\end{tabular}

Me gusta - Responder - 17

Realizando un Sorteo por Letra similar al realizado en el artículo de los jugadores del Valencia Basket, he obtenido los siguientes datos de estudio:

\begin{tabular}{|l|lllr}
\hline 1 & Apellido & Nombre & Probabilidad Porcentaje \\
2 & DIOT & Antoine & $216 / 729$ & 29 \\
\hline
\end{tabular}

Fig.5 Ejemplo de réplicas por parte de los alumnos

\subsection{Metodología y técnicas utilizadas para el tratamiento y análisis de los datos}

Antes de comenzar con la experiencia, se consultó a los alumnos sus opiniones iniciales acerca de la asignatura a través de una encuesta realizada en GoogleDocs. Estos datos fueron vistos mediante Excel y el paquete estadístico Statgraphics Centurion XVI, para saber cuál era el punto de partida.

A partir de ahí, los temas tratados en el grupo de Facebook se colgaron como posts mediante documentos pdf o enlaces a medios digitales. Los datos de participación en el grupo han sido tomados y medidos con la herramienta Grytics (www.grytics.com). Paralelamente, se confeccionó en Excel un listado con las participaciones de cada uno de 
los alumnos de la asignatura Estadística, para poder puntuarlas como nota de clase. Al finalizar la asignatura se han obtenido las opiniones del alumnado con la herramienta Socrative (www.socrative.com). Esta app proporciona los datos en Excel, y de nuevo han sido analizados con el paquete estadístico Statgraphics Centurion XVI.

\section{Conclusiones}

La experiencia ha aunado aplicaciones de nuestras asignaturas con las redes sociales (en este caso Facebook), y se ha podido comprobar un alto grado de aceptación por parte de los alumnos. A los estudiantes les ha gustado trabajar con ejemplos reales, lo que nos ha permitido mejorar su grado de percepción de utilidad de la materia.

Mediante la aplicación combinada de plataformas de redes sociales y de herramientas para obtener métricas de uso, resulta relativamente sencillo replicar experimentos similares, que podrían ser extrapolables a otras asignaturas que adolezcan de similares problemas (escasa percepción de utilidad por parte de los estudiantes de ingeniería y materias fundamentadas en conceptos abstractos).

Tras la experiencia, se ha seguido trabajando de forma satisfactoria con los grupos cerrados de Facebook en alguna de nuestras asignaturas.

\section{Referencias}

CALDUCH LOSA, Á., POZA-LUJÁN, J.L., TERUEL, D., ALBORS SOROLLA, A., CABRERA, M., REBOLLO, M. (2014). "Pautas de actuación para optimizer el uso de las redes socials en la docencia universitaria”. En Jornadas de Enseñanza Universitaria de la Informática (JENUI). Oviedo. Actas de las XX Jenui. 59 - 65

POZA-LUJÁN, J.L., CALDUCH-LOSA, Á., ALBORS, A., CABRERA, M., TERUEL, D., REBOLLO, M. y DÍEZ, R. (2014). "Propuesta de parámetros y caracterización de los grupos de las redes sociales orientados a la docencia universitaria: experiencia y resultados" en Revista de Educación a Distancia (RED). Año XIII. Número 44. (http://www.um.es/ead/red/44)

CAMACHO MARTÍ, M. (2010). "Las redes sociales para enseñar y aprender. Reflexiones pedagógicas básicas” en Castañeda Quintero, L. Aprendizaje con redes sociales. Tejidos educativos para los nuevos entornos. Sevilla: Eduforma. 91 - 104

SANMARTÍN, O.R. (2016). "Tres de cada 10 universitarios no ven útil su título para encontrar trabajo”. En El http://www.elmundo.es/sociedad/2016/07/22/57911b17e2704ec2158b464f.html [Consulta: 23 de julio de 2016]

TÚÑEZ LÓPEZ, M., SIXTO GARCÍA, J. (2012). "Las redes sociales como entorno docente: análisis del uso de Facebook en la docencia universitaria” en Pixel-Bit.Revista de Medios y Educación. Número 41. 77 - 92

(cc) EY-NC-ND 2018, Universitat Politècnica de València 


\title{
El Reel Videocurrículum como estrategia para el fomento del marketing profesional
}

\begin{abstract}
Ángela María Sánchez Sánchez-Manjavacasa, María Soledad Folgado Canellesb, Antonia Madueño Toribio ${ }^{c}$, Amparo Martín Moret ${ }^{d}$ y Luis Valero Taverner $^{\mathrm{e}}$

aprofesora ISEP CEU CV, angela_maria.sanchez@ciclosformativosceu.es, ${ }^{b}$ Profesora ISEP CEU CV, marisol.folgado@ciclosformativosceu.es, $\quad{ }^{c}$ Profesora ISEP CEU CV, antonia.madueno@ciclosformativosceu.es, $\quad{ }^{\mathrm{d} P r o f e s o r a} \quad$ ISEP CEU CV, amparo.martin3@ciclosformativosceu.es,_ ${ }^{e}$ Profesor ISEP CEU CV, luis.valero@ciclosformativosceu.es
\end{abstract}

\begin{abstract}
La realización del proyecto Reel-Videocurrículum combina en una misma pieza el recurso del Vídeo Book y el Videocurrículum, tanto en castellano como en inglés, con el fin de potenciar el marketing y la comunicación en el profesional del ámbito audiovisual. Asimismo, esta iniciativa se presenta como un método de enseñanzaaprendizaje novedoso para los alumnos en el área de la orientación laboral y el emprendimiento de proyectos, plasmando de manera visual y atractiva la compilación de trabajos, competencias y habilidades que los alumnos han ido adquiriendo a lo largo de su formación y bagaje profesional. Acorde con ello, se destaca la capacidad por parte de los alumnos de demostrar unos resultados altamente satisfactorios en el reconocimiento de las competencias específicas aprendidas. Este proyecto, asimismo, contribuye a fomentar las nuevas tecnologías y el trabajo con la plataforma virtual Blackboard, al permitir la divulgación de contenidos y facilitar que tanto docentes como alumnos puedan compartir el conocimiento. Finalmente, se destaca la importancia de trabajar de manera transversal con diferentes módulos del ciclo formativo, con el objetivo de proporcionar la lógica y fundamentación adecuada al proceso en su conjunto.
\end{abstract}

Keywords: reel-videocurrículum, método de enseñanza-aprendizaje, TIC, marketing profesional.

\begin{abstract}
The video $\mathrm{CV}$ reel production project combines in one piece the resource of the Video Book and that of the video CV, both in Spanish and English, in order to enhance marketing and communication for audio-visual professionals. In addition, this initiative is presented as an innovative teaching and learning method for students in the area of career guidance and projects entrepreneurship, capturing in a visual
\end{abstract}


El Reel-Videocurrículum como estrategia para el fomento del marketing profesional.

Ángela María Sánchez Sánchez-Manjavacas, María Soledad Folgado Canelles, Antonia Madueño

Toribio, Amparo Martín Moret y Luis Valero Taverner.

and attractive way the compilation of assignments, skills and abilities that students have acquired throughout their training and professional background. Accordingly, the ability of the students to show highly satisfactory results in the recognition of the specific competences learned is highlighted. Moreover, this project also helps to promote new technologies and work with the virtual platform Blackboard by allowing the diffusion of content and facilitating that both teachers and students share knowledge. Finally, the importance of working transversally with different subjects in this training short cycle is emphasised with the aim of providing the appropriate logic and foundation to the process as a whole.

Keywords: video CV reel, teaching and learning methods, ICT, professional marketing.

\section{Introducción}

La realización del proyecto Reel-Videocurrículum significa la unión en una misma pieza del recurso del Video Book y el Videocurrículum. El objetivo principal estriba en potenciar el marketing profesional del alumnado, promoviendo la adquisición y el desarrollo de métodos de enseñanza-aprendizaje novedosos en el ámbito de la Realización de Proyectos Audiovisuales y Espectáculos.

Cabe subrayar que las TIC han llevado al nacimiento de nuevos enfoques y ambientes de aprendizaje que a su vez ha creado la necesidad de diseñar nuevas estrategias de enseñanza utilizando dichos recursos, pero no obstante, estas nuevas tecnologías, además de producir cambios en el proceso de enseñanza deben producir cambios en los procesos de aprendizaje y se deben evaluar diversos aspectos al momento de estructurar la información a impartir (González y Pérez, 2016; Ovando, 2018).

Esta iniciativa permite trabajar de forma innovadora el área de la orientación laboral y el emprendimiento de proyectos, plasmando de manera visual y atractiva la compilación de trabajos, competencias y habilidades que los alumnos/as van adquiriendo a lo largo de su formación y bagaje. Los alumnos/as cuentan, además, con la motivación de trabajar contenidos, que habitualmente consideran alejados de su sector o sus intereses, mediante herramientas y procesos más atractivas por el interés que su propio sector audiovisual les genera. En este sentido, se ensalza el principio motivacional en la docencia que afirma que aquello que nos interesa lo aprendemos mejor (Gallardo y Camacho, 2008). Del mismo modo, facilitará que los estudiantes puedan promocionar sus puntos fuertes, aptitudes y aspiraciones en el ámbito profesional, impulsando con ello una mayor proyección de futuro (Álvarez Martínez, et al., 2016). Y es que, este recurso promueve que el alumno se dé a conocer a nivel laboral, tanto por cuenta ajena (para formar parte de un equipo de trabajo dentro de una empresa), como por cuenta propia (impulsando un negocio). Asimismo, no debemos olvidar incluir en este trabajo la importancia del inglés como forma de expansión de conocimientos e incremento del valor añadido en el alumnado.

(cc) EY-NC-ND 2018, Universitat Politècnica de València

Congreso IN-RED (2018) 
Otro punto importante a destacar es la transversalidad de los diferentes módulos del curso presentes en el proyecto, aprovechando con ello las ventajas que ofrece la integración de los contenidos de "Empresa e Iniciativa Emprendedora"; "Inglés Técnico", "Procesos de Realización en Cine y Vídeo", "Realización del Montaje y Postproducción en Audiovisuales” y "Medios Técnicos Audiovisuales”.

En esta misma línea, el proyecto también integra la transversalidad en competencias básicas tales como la resolución de problemas, aprender a aprender, competencia digital, comunicación lingüística, sentido de la iniciativa y espíritu emprendedor o conciencia y expresiones culturales, las cuales permiten enseñar conocimientos de los módulos aquí referenciados con el objetivo de que el alumno/a alcance una formación integral al finalizar su etapa académica y que, del mismo modo, sea capaz de aplicar los conocimientos adquiridos a su vida real. De esta manera, el alumno reconocerá y controlará sus propios procesos de aprendizaje, ajustándolos en tiempo y demanda de actividades, hasta un aprendizaje bilingüe, autónomo y transversal.

Con todo, el proyecto aspira a proyectar los objetivos laborales y empresariales del alumno/a de forma internacional, necesitando tener en cuenta a tal efecto la multiculturalidad de un mercado laboral y empresarial global.

\section{Objetivos}

Como objetivos generales de la innovación desarrollada destacamos los siguientes:

1.- Analizar y utilizar los recursos y oportunidades de aprendizaje relacionados con la evolución científica, tecnológica y organizativa del sector y las tecnologías de la información y la comunicación, para mantener el espíritu de actualización y adaptarse a nuevas situaciones laborales y personales.

2.- Desarrollar la creatividad y el espíritu de innovación para responder a los retos que se presentan en los procesos y en la organización del trabajo y de la vida personal.

3.- Desarrollar técnicas de liderazgo, motivación, supervisión y comunicación en contextos de trabajo en grupo, para facilitar la organización y coordinación de equipos de trabajo.

4.- Aplicar estrategias y técnicas de comunicación, adaptándose a los contenidos que se van a transmitir, a la finalidad y a las características de los receptores, para asegurar la eficacia en los procesos de comunicación.

5.- Utilizar procedimientos relacionados con la cultura emprendedora, empresarial y de iniciativa profesional, para realizar la gestión básica de una pequeña empresa o emprender un trabajo.

Asimismo, y de manera más específica, resaltamos los siguientes objetivos generales de índole técnico en el campo profesional del alumnado destinatario:

1.- Aplicar los códigos expresivos, narrativos y comunicativos audiovisuales básicos de la expresión audiovisual. 
2.- Decidir y gestionar las necesidades y funciones de los equipamientos técnicos y materiales para determinar sus características en la realización del proyecto.

3.- Aplicar las técnicas de programación de la actividad y recursos, tanto humanos como materiales, para planificar el proceso de trabajo de realización del proyecto audiovisual.

4.- Aplicar técnicas narrativas y expresivas de planificación de secuencias y puesta en escena para la elaboración de la documentación técnica de realización de la grabación del proyecto audiovisual.

5.- Analizar y aplicar las técnicas de montaje idóneas en la consecución de los objetivos comunicativos, para realizar el montaje/edición y postproducción del proyecto.

6.- Planificar y coordinar las operaciones de preparación de materiales y efectos, para la realización del proceso de montaje/edición y postproducción del proyecto.

\section{Desarrollo de la innovación}

El Reel-Videocurrículum como proyecto de innovación se desarrolló en el contexto de la formación profesional, más concretamente en el curso 2016-2017, del ciclo formativo de grado superior de Realización de Proyectos Audiovisuales y Espectáculos.

Dado la importancia que tiene la adquisición de una base previa de conocimientos de los destinatarios en el área de estudio, el proyecto se llevó a cabo con los dieciocho alumnos de segundo curso del ciclo.

\subsection{Módulos implicados en la innovación:}

A continuación, se detallan los módulos del ciclo formativo que tuvieron una implicación en la realización de este proyecto, por orden cronológico de impartición, durante los meses de enero y febrero de 2017.

\subsubsection{Empresa e Iniciativa Emprendedora:}

Número de sesiones que comprende: 3 sesiones (9h lectivas).

Espacios utilizados: Aula de Apoyo de Fotografía y Aula Mac (CEPAB.- Centro de Producción Multimedia).

Materiales: Recursos de vídeo (ejemplos de formatos reel), documentos explicativos/bibliografía (apuntes proporcionados por la profesora, CV de los alumnos). Empresa e Iniciativa Emprendedora, editorial Paraninfo (Asensio y Vázquez, 2016), y Empresa e Iniciativa Emprendedora, editorial MacGrawHill (Salinas Sánchez, et al., 2015).

\section{Objetivos específicos:}

- Presentar una alternativa a la carta de presentación y al currículum vítae tradicional.

(cc) EY-NC-ND 2018, Universitat Politècnica de València

Congreso IN-RED (2018) 
- Desarrollar materiales de presentación de la vida laboral como mecanismo de promoción y comunicación.

- Potenciar la imagen del autoempleo y emprendimiento.

\section{Contenidos:}

- Vocabulario: Recursos específicos sobre la búsqueda de empleo y el emprendimiento.

- Redacción: Contenidos sobre el Currículum Vítae.

\subsubsection{Inglés técnico:}

Número de sesiones que comprende: 2 sesiones (4h lectivas).

Espacios utilizados: Aula de Apoyo de Fotografía.

Materiales: Recursos de vídeo y documentos explicativos/bibliografía (apuntes proporcionados por la profesora, páginas web especializadas en CV en lengua inglesa y Video CV en inglés, fichas para autocompletar). BBC website, Commercially Speaking (Irvine y Cadman, 1999), Business Vocabulary (Mascull, 2010), Presentations in English (Williams, 2008).

\section{Objetivos específicos:}

- Producir mensajes orales en lengua inglesa, en situaciones habituales del ámbito social y profesional de la empresa reconociendo y aplicación las normas propias de la lengua inglesa.

- Utilizar recursos, estructuras lingüísticas, y léxico básico relacionados con el ámbito laboral: currículum vitae en distintos modelos.

\section{Contenidos:}

- Vocabulario: Recursos y estructuras lingüísticas del ámbito laboral (tecnicismos y estructuras lingüísticas inglesas prototípicas del sector laboral y del marketing).

- Gramática: Condicionalidad. Diferentes formas de expresar futuro (II).

- Redacción: CV.

- Expresión Oral: Búsqueda de empleo. Video CV. La entrevista de trabajo.

\subsubsection{Medios Técnicos Audiovisuales:}

El módulo de Medios Técnicos Audiovisuales forma parte del primer curso del ciclo formativo. No obstante, es importante el apoyo y asesoramiento en la elección del material técnico necesario para ejecutar el Proyecto.

Número de sesiones que comprende: 1 sesión (2h lectivas).

Espacios utilizados: Aula de Apoyo de Fotografía y diferentes instalaciones del Centro de Producción Audiovisual (platós). 
Materiales: Recursos de vídeo y documentos explicativos/bibliografía (apuntes proporcionados por la profesora y manual del módulo Medio Técnicos Audiovisuales). Iluminación para cine y video (Brown, 2012), Televisión, realización y lenguaje audiovisual (Castillo, 2016), Tecnología básica del sonido (I yII) (Cuenca y Gómez, 2006), Manual básico de tecnología audiovisual (Martínez y Vila, 2004), Las lentes y sus aplicaciones (Ray, 2001).

\section{Objetivos específicos:}

- Seleccionar objetivos y sistemas ópticos de cámara de vídeo en función de las características de cada proyecto de grabación concreto.

- Seleccionar las distintas configuraciones de iluminación, tipos de focos, selección de filtros y elementos lumínicos para la resolución de una variada tipología de procesos audiovisuales.

- Concretar las prestaciones técnicas de captación de sonido, justificando el uso de diversos micrófonos y accesorios necesarios según las características funcionales y operativas de cada proyecto.

- $\quad$ Elaborar el listado de localizaciones posibles y estudio de posibilidades técnicas dependiendo si son interiores (Centro de Producción Audiovisual, salas de control, platós, etc.) o exteriores.

- Elegir el formato de grabación, aspecto de imagen y resolución de imagen.

\section{Contenidos:}

- $\quad$ Tipos de cámaras, objetivos y soportes a elegir.

- $\quad$ Tipo de iluminación y filtros.

- $\quad$ Sonido, uso de micrófonos, capas de audio y video, y elección del formato.

- Localización para la grabación.

\subsubsection{Procesos de Realización en Cine y Vídeo:}

Número de sesiones que comprende: 4 sesiones (6h lectivas).

Espacios utilizados: Aula de Apoyo de Fotografía, aula de ordenadores Mac CEPAB, Instalaciones CEPAB (platós, estudios y salas de montaje y protools).

Materiales: Recursos de vídeo, apuntes proporcionados por la profesora, páginas web especializadas en CV y recursos técnicos para la grabación de los proyectos (cámaras, micrófonos, equipos de iluminación, trípodes, monitores, etc.). Manual del productor audiovisual (Martínez y Fernández, 2010), La producción cinematográfica (Mollá Furió, 2012), Cortos en cine y video (Irving y Rea, 2010).

\section{Objetivos específicos:}

- Planificar la realización de un vídeo-currículum que presente los trabajos realizados por los alumnos, así como sus aptitudes individuales. 
- Pensar y diseñar un estilo de realización propio e individual de acuerdo con el trabajo que se va a hacer sin perder los objetivos del mismo, así como, elegir el espacio o los espacios donde se va a llevar a cabo la grabación.

- Elegir y utilizar los recursos técnicos pertinentes para su grabación. Tipo de cámara, soportes de grabación, iluminación y microfonía.

- Realizar las labores de preparación del set, iluminación, toma de sonido, selección de encuadres, etc.

- Realizar la grabación audiovisual técnicamente correcta para su posterior edición en las clases correspondientes al módulo de Montaje y Postproducción.

\section{Contenidos:}

- Desarrollo de la idea del proyecto. Guión a dos columnas.

- Listado de recursos técnicos y humanos para la grabación.

- Gestión y reserva del espacio o espacios a usar en la grabación.

- Plan de rodaje.

- $\quad$ Orden de rodaje.

\subsubsection{Realización del Montaje y Postproducción en Audiovisuales:}

Número de sesiones que comprende: 2 sesiones (7h lectivas).

Espacios utilizados: Aula de Apoyo de Fotografía, aula de ordenadores Mac CEPAB, Instalaciones CEPAB (platós, estudios y salas de montaje y protools).

Materiales: Recursos de vídeo, apuntes proporcionados por la profesora, páginas web especializadas en CV y recursos técnicos para la grabación de los proyectos (cámaras, micrófonos, equipos de iluminación, trípodes, monitores, etc.). Postproducción en Alta Definición (Browne, 2008), Edición de vídeo con Avid (Moreno Lacalle, 2007), Avid: edición de video (Kauffmann, 2010), Manuales imprescindibles (Martínez y Panadero, 2013; Moreno Lacalle, 2013).

\section{Objetivos específicos:}

- Editar los reels de presentación bajo unas premisas orientadas a que cada uno de los alumnos siguiese los criterios de creatividad particulares.

- Repasar y poner en práctica todo lo aprendido durante el curso en el modulo.

\section{Contenidos:}

- Edición básica y avanzada.

- Etalonaje.

- Sonorización.

- Trabajo con máscaras y varias capas de vídeo.

- Efectos audiovisuales.

- Exportación y formatos. 
El Reel-Videocurrículum como estrategia para el fomento del marketing profesional.

Ángela María Sánchez Sánchez-Manjavacas, María Soledad Folgado Canelles, Antonia Madueño

Toribio, Amparo Martín Moret y Luis Valero Taverner.

\subsection{Detalle de acciones realizadas:}

A continuación, se detalla la estrutura básica de las sesiones realizadas en cada uno de los módulos, así como las acciones específicas llevadas a cabo en el desarrollo del proyecto Reel Videocurrículum.

\subsubsection{Empresa e Iniciativa Emprendedora:}

$1^{\text {a }}$ sesión. 26 de enero: Concreción de la idea del proyecto general. Relación del proyecto con el marketing y la búsqueda de empleo. Análisis del Currículum Vítae y los trabajos audiovisuales previos realizados por los alumnos.

$2^{a}$ sesión. 2 de febrero: Selección de contenidos para desarrollar el Reel-VideoCV. Concreción de imágenes, secuencias de proyectos y trabajos realizados con anterioridad (tanto en el ciclo formativo como a nivel particular/amateur). Concreción de las aptitudes a resaltar relacionadas con el trabajo en el ámbito de la realización audiovisual. Concreción de la información a destacar en la grabación de la entrevista (relacionada con la experiencia y formación alcanzada). Selección de la música para el Reel-VideoCV (incluyendo el nombre de las canciones y los autores en los títulos).

$3^{a}$ sesión. 9 de febrero: Desarrollo de la estructura cronológica del contenido del ReelVideoCV. Ordenación de la información en forma de secuencias y tiempo utilizado para cada recurso. Presentación y recogida del documento.

\subsubsection{Inglés Técnico:}

$1^{\text {a }}$ sesión. 7 de febrero: Presentación de vocabulario de los tecnicismos y estructuras lingüísticas inglesas prototípicas del sector laboral y del marketing. Actividades de expresión oral para practicar la teoría presentada.

$2^{a}$ sesión. 14 de febrero: Presentación de ejemplos de perfiles profesionales y proyectos empresariales en lengua inglesa en diversos formatos y plataformas. Elaboración por parte de los alumnos/as de una compilación de datos procedentes de sus perfiles profesionales y sus proyectos empresariales en lengua inglesa para adaptarlos al guión de sus respectivos Reel- Video CV.

\subsubsection{Medios Técnicos Audiovisuales:}

$1^{\text {a }}$ sesión. 7 de febrero: en la sesión de orientación destinada en este módulo se generó un feedback entre docente y alumnos para intercambiar opiniones sobre diferentes elementos técnicos, en función de la tormenta de ideas que cada alumno había desarrollado para su proyecto.

Resaltamos en mayor medida los siguientes aspectos: análisis de las necesidades y funciones de los equipamientos técnicos y materiales; toma de decisiones sobre el equipamiento de cámaras, iluminación y sonido de forma fundamentada y, consulta de

(cc) EY-NC-ND 2018, Universitat Politècnica de València

Congreso IN-RED (2018) 
bibliografía que pudiese servirles de guía. Este último hecho resultó especialmente positivo ya que contribuyó a que los alumnos recurriesen a los libros como fuente de formación y ayuda, y no como un mero material para examen.

\subsubsection{Procesos basicos de Realización en Cine y Vídeo:}

$\mathbf{1}^{\text {a }}$ sesión. 7 de febrero: Visionado y análisis de las diferentes opciones de vídeocurrículums que existen en el mercado. Feedback. Desarrollo de la idea.

$2^{\text {a }}$ sesión. 9 de febrero: Presentación idea individual y preproducción proyecto. Elaboración de guiones. Formación de grupos de grabación por localizaciones, de forma que los alumnos que coincidan en el mismo espacio de grabación, se ayudarán unos a otros en las labores de grabación e iluminación. Organización del orden de rodaje.

$3^{a}$ sesión. 14 de febrero: Grabación individual de los alumnos presentando sus trabajos y cualidades así como las imágenes de recurso de ellos trabajando en el control de realización, con las cámaras, en las salas de montaje, etc.

$4^{a}$ sesión. 16 febrero: Grabación individual de los alumnos presentando sus trabajos y cualidades así como las imágenes de recurso de ellos trabajando en el control de realización, con las cámaras, en las salas de montaje, etc. Ingesta de archivos en el servidor y creación de proyectos para las labores de montaje en las horas lectivas que corresponden a la asignatura de Montaje y Postproducción.

\subsubsection{Realización del Montaje y Postproducción en Audiovisuales:}

$\mathbf{1}^{\text {a }}$ sesión. 17 febrero: Edición de los propios reels de presentación bajo premisas claras orientadas a que cada uno de los alumnus llevase a cabo el trabajo acorde con sus propios criterios de creatividad.

$2^{a}$ sesión. 24 febrero: Continuación del desarrollo del proceso de edición con utilización del sistema AVID de edición y sistema AFTER EFFECTS, para terminar ofreciendo un acabado más profesional a sus trabajos.

\section{Resultados}

Desde el conjunto de módulos estudiados en el segundo curso del ciclo formativo de grado superior en Realización de Proyectos Audiovisuales y Espectáculos, determiner que se ha innovado bajo el punto de vista del trabajo transversal que los alumnos han llevado a cabo con el proyecto audiovisual. Su finalidad estriba, por tanto, en desarrollar un vídeo que será utilizado en el presente y/o futuro como herramienta propia del mismo alumno a la hora de encontrar trabajo y dar a conocer de manera innovadora sus capacidades y habilidades adquiridas en el ámbito. 
El Reel-Videocurrículum como estrategia para el fomento del marketing profesional.

Ángela María Sánchez Sánchez-Manjavacas, María Soledad Folgado Canelles, Antonia Madueño

Toribio, Amparo Martín Moret y Luis Valero Taverner.

Al hilo de esta idea, consideramos que el mejor o peor resultado del trabajo puede influir directamente en el uso que el alumno/a quiera hacer de esta herramienta, mucho más allá de la nota académica. En este sentido, desde la totalidad de módulos, los docentes han orientado técnicamente para enfocar este trabajo como una herramienta esencial con la que destacar frente a otros posibles candidatos a un puesto laboral, al presenter de manera más atractiva y visual su bagaje formative y profesional.

Asimismo, determinamos que el hecho de tratarse de un caso práctico real donde los propios estudiantes son los primeros beneficiarios de un buen resultado, supone una motivación añadida para el aprendizaje de los contenidos teórico-prácticos de los módulos. $\mathrm{Y}$ es que, se aprecia un notable aumento de la curiosidad por los contenidos trabajados, fomentando que en numerosas ocasiones los mismos/as alumnos/as sean quienes soliciten más recursos y materiales relacionados con aquellos integrados en el proyecto.

Se observa que, tras las dinámicas de las actividades aplicadas a la preparación, ensayo y realización del Reel-Videocurrículumv, los alumnus son capaces de recorder los procedimientos necesarios en cada uno de los módulos, interiorizando de manera más eficaz el contenido impartido con anterioridad en el aula, así como trabajar con el vocabulario técnico, las estructuras y expresiones técnicas del sector con mayo facilidad (tanto en lengua española como inglesa).

La interacción con otros módulos del mismo ciclo, a su vez, contribuye a que los alumnos no perciban estos como compartimentos estancos, sino que aprecien que lo aprendido en cada uno de ellos sirve para alcanzar un fin común, que es el de su formación profesional integral, en general, y la realización del proyecto, en particular.

A continuación, se destacan imágenes utilizadas en cada uno de los vídeos. En total, dieciocho proyectos de una duración de entre un minuto y dos minutos, cada uno de ellos.

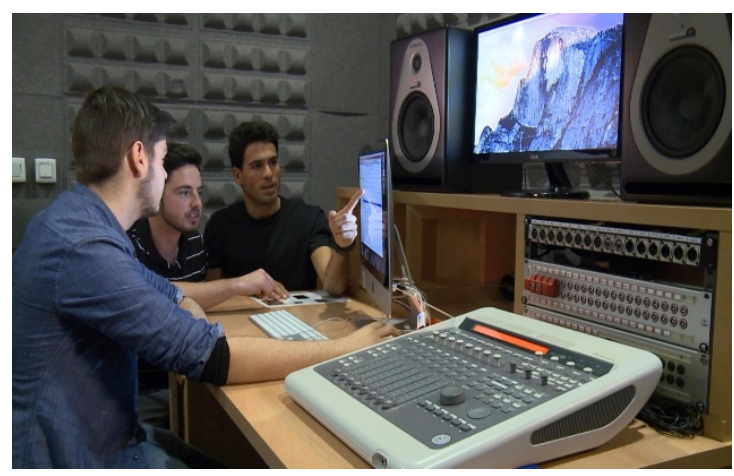

Fig. 1 Trabajo conjunto en control de realización 
El Reel-Videocurrículum como estrategia para el fomento del marketing profesional Ángela $M^{a}$ Sánchez Sánchez-Manjavacas, $M^{a}$ Soledad Folgado Canelles, Antonia Madueño Toribio, Amparo Martín Moret y Luis Valero Taverner

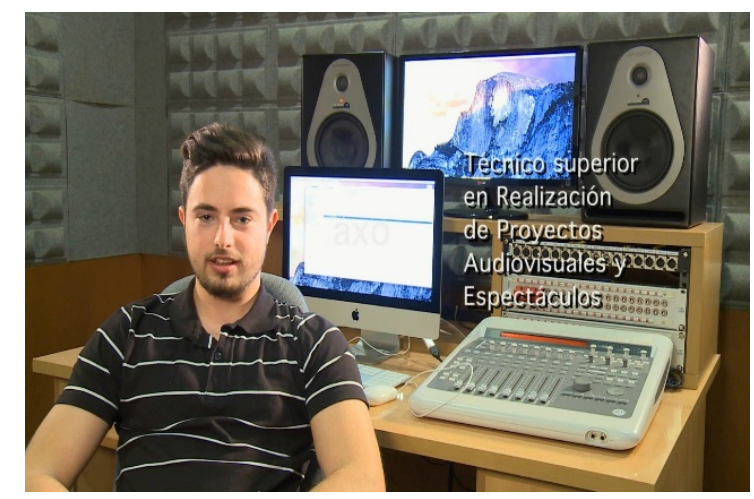

Fig. 2 Imagen con contenido específico a destacar I

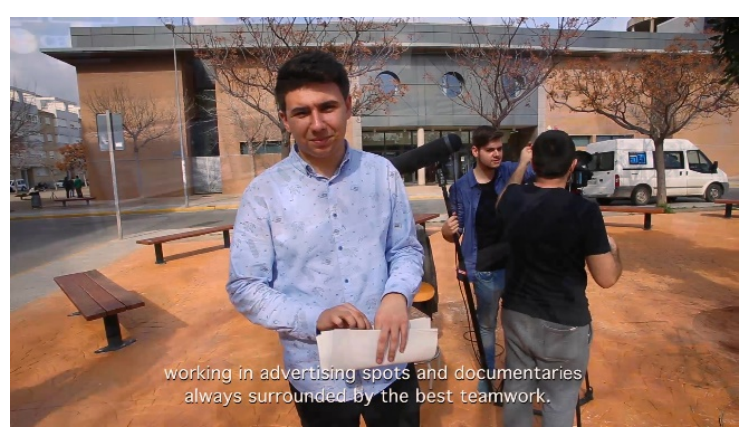

Fig. 3 Imagen con contenido específico en inglés a destacar

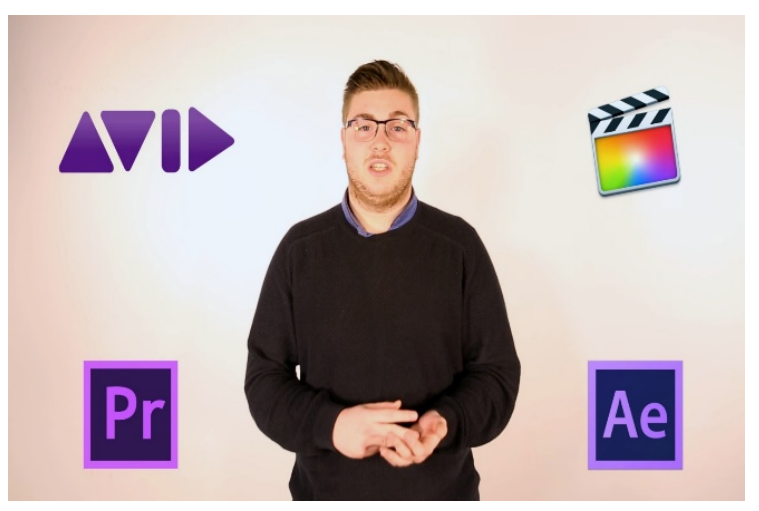

Fig. 4 Imagen con contenido específico a destacar II

(cc) EY-Nc-ND 2018, Universitat Politècnica de València

Congreso In-Red (2018) 
El Reel-Videocurrículum como estrategia para el fomento del marketing profesional.

Ángela María Sánchez Sánchez-Manjavacas, María Soledad Folgado Canelles, Antonia Madueño

Toribio, Amparo Martín Moret y Luis Valero Taverner.

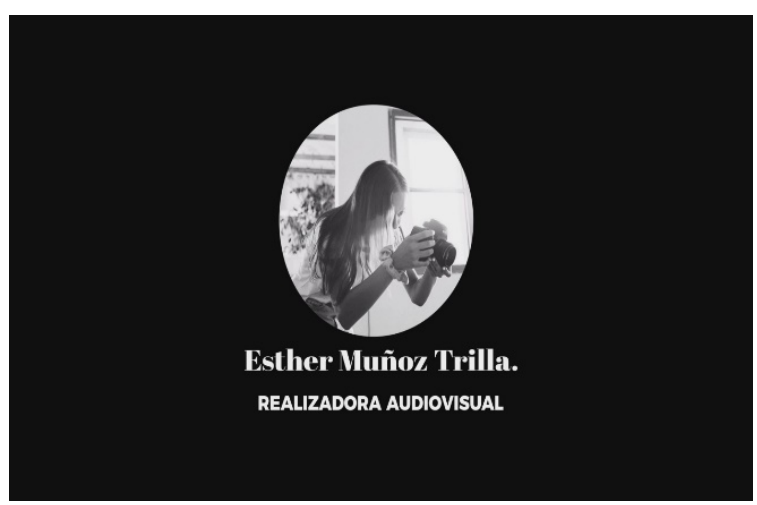

Fig. 5 Imagen con contenido específico a destacar III

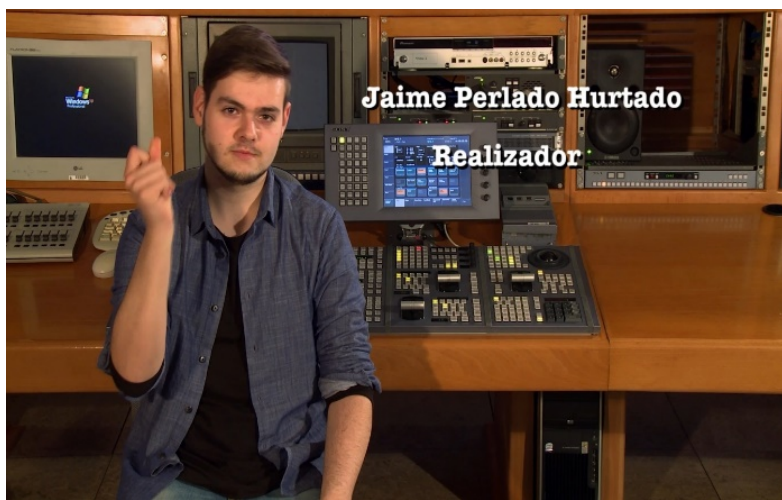

Fig. 6 Imagen con contenido específico a destacar IV

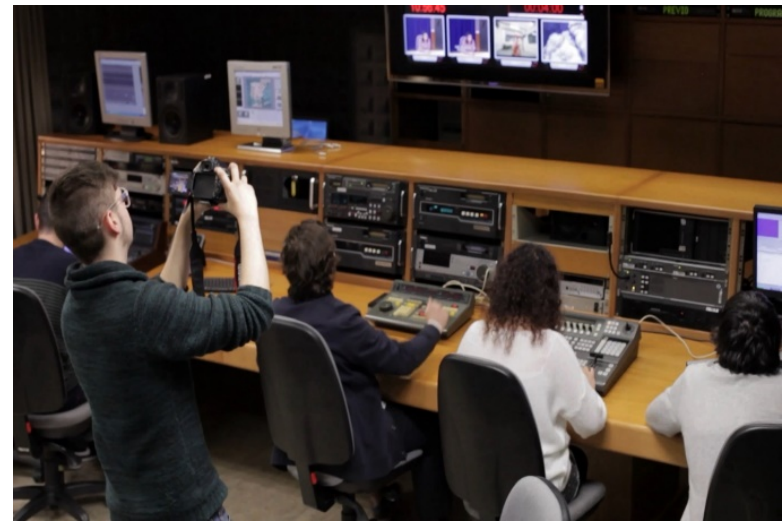

Fig. 7 Trabajo conjunto en control I

(cc) BY-NC-ND 2018, Universitat Politècnica de València

Congreso IN-RED (2018) 


\section{Conclusiones}

Es de suma importancia la elaboración de esta innovadora herramienta que permite al alumno distinguirse de los demás por sus habilidades sociales, creativas y profesionales. Sin duda, la realización del proyecto Reel-Videocurrículum sirve a los estudiantes de carta de presentación novedosa a la hora de su incorporación en el mercado laboral (Álvarez Martínez, et al., 2016).

De este modo, los alumnos/as han comprobado en primera persona que el trabajo desarrollado por medio del contenido de la actividad les ha proporcionado un resultado que podrán utilizar a corto plazo con el objetivo real de buscar empleo en el sector audiovisual no solo a nivel nacional, sino internacional. Este aspecto genera en ellos/as una certeza inmediata de utilidad del conocimiento adquirido.

Así pues, la realización de este proyecto implica resaltar las posibilidades de expansión de los protagonistas de dichos vídeos, al combinar los contenidos con el inglés como idioma fundamental en un contexto pragmático real (Gallardo y Camacho, 2008). De esta manera, incrementan su valor añadido y polivalencia ante un mercado laboral cada vez más competitivo (González y Pérez, 2016). Y es que, la enseñanza moderna de lenguas extranjeras y sus variedades específicas, como en este caso el inglés técnico para la comunicación audiovisual, exige la integración de sus elementos lingüísticos y sus habilidades comunicativas dentro del ámbito sociolaboral, siendo posible a través del proyecto de forma natural y fluida.

La posibilidad para los y las estudiantes de trabajar los contenidos de los diferentes módulos haciendo lo que realmente les motiva y les genera curiosidad, como es la preproducción, producción y postproducción de vídeos, ha garantizado que incrementaran su esfuerzo y dedicación para conseguir los objetivos de aprendizaje, sin apenas estímulo externo por parte de la docente. Constatamos, por tanto, una remarcable y positiva influencia de la motivación extrínseca.

Este proyecto, asimismo, contribuye a fomentar las nuevas tecnologías y el desarrollo de la plataforma virtual Blackboard (como herramienta de trabajo y comunicación entre docentes y alumnos utilizado por el ISEP CEU CV), al permitir la divulgación de contenidos y facilitar que todos los protagonistas del proyecto puedan compartir el conocimiento. Por otra parte, y de manera complementaria, el uso de la plataforma permite controlar el proceso, no sólo de manera presencial, sino también on-line, consiguiendo con ello mayor capacidad de reacción y respuesta en el proceso de enseñanza-aprendizaje.

No debemos olvidar la colaboración entre los diferentes módulos y contenidos que conforman el ciclo formativo, por lo que el complemento de la transversalidad ha estado muy presente en los profesionales docentes. Así pues, de manera cronológica, se han ido combinando y organizando los módulos a impartir en el segundo curso del ciclo, proporcionando una lógica y fundamentación a la totalidad del proceso.

Por todo ello, se destaca la capacidad por parte de los alumnos de demostrar, tras la finalización del proceso de aprendizaje, unos resultados altamente satisfactorios y cuantificables en las competencias específicas citadas a lo largo de este trabajo. Y es que, 
en un solo proyecto los alumnos han puesto en práctica todos y cada uno de los temas impartidos a lo largo del curso (especialmente en las materias de índole más técnico).

Sin embargo, esta labor también presenta ciertas limitaciones al respecto como es la no obligatoriedad de subir los contenidos a los diferentes portales de Internet, como pueden ser Youtube y Vimeo, ni a las distintas redes sociales, como Facebook e Instagram, entre otras. Este hecho dificulta ciertamente la medición del impacto de los trabajos en el ámbito sociolaboral.

Por ello, y como futuras líneas de investigación, debemos considerar la posibilidad de hacer un mayor seguimiento sobre el porcentaje de inserción laboral de los alumnos/as una vez finalizado el ciclo formativo, valorando en la medida de lo posible la repercusión que la herramienta del Reel-Videocurrículum ha tenido en los procesos de reclutamiento de las empresas. No obstante, para ello, se entiende fundamental que los y las estudiantes puedan suban dichos materiales a los diferentes portales y redes sociales, con el fin de generar mayor impacto en su labor.

\section{Referencias}

ÁLVAREZ MARTÍNEZ, J.C.; HERRÁEZ VIDAL, P. y PRIETO GARCÍA, M.A. (2016). Formación y Orientación Laboral. Madrid: MacMillan Education.

ASENSIO DEL ARCO, E. y VÁZQUEZ BLÖMER, B. (2016). Empresa e Iniciativa Emprendedora. $3^{a}$ edición actualizada 2016. Madrid: Paraninfo ciclos formativos.

Portal oficial de BBC. Get that Job.

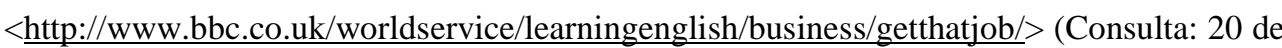
marzo de 2017)

BROWN, B. (2012). Iluminación para cine y video. Andoain: Ed. Focal Press.

BROWNE, S.E. (2008). Postproducción en Alta Definición. Andoain: Ed. Escuela de Cine y Vídeo.

CASTILLO, J.M. (2016). Televisión, realización y lenguaje audiovisual. Madrid: Ed. Instituto RTVE.

CUENCA, I. y GÓMEZ, E. (2006). Tecnología básica del sonido (I y II). Madrid: Editorial Paraninfo.

GALLARDO, P. y CAMACHO, K.J.M. (2008). La motivación y el aprendizaje en educación. Wanceulen Educación.

GONZÁLEZ ACEDO, J.C. y PÉREZ AROCA, R. (2016). Formación y Orientación Laboral. Madrid: Paraninfo Ciclos Formativos.

IRVINE, M. y CADMAN, M. (1999). Commercially Speaking. Oxford: Oxford University Press. 
K. IRVING, D. y W. REA, P. (2010). Cortos en cine y video. Producción y dirección. Barcelona: Ediciones Omega, S.A.

KAUFFMANN, S. (2010). Edición de video con avid media composer. Barcelona: Anaya multimedia.

MARTÍNEZ ABADÍA, J. y VILA FUMÁS, P. (2004). Manual básico de tecnología audiovisual y técnicas de creación, emisión y difusión de contenidos. Madrid: Editorial Paidós.

MARTÍNEZ, J. y FERNÁNDEZ, F. (2010). Manual del productor audiovisual. Barcelona: Editorial UOC.

MARTÍNEZ SOTILLOS, M. y PANADERO RIOL, J.C. (2013). Manual imprescindible After Effects CS6. Madrid: Anaya Multimedia.

MASCULL, B. (2010). Business Vocabulary in Use Intermediate with Answers. Cambridge: Cambridge University Press.

MOLLÁ FURIÓ, D. (2012). La producción cinematográfica. Las fases de la creación de un largometraje. Barcelona: Editorial UOC.

MORENO LACALLE, R. (2007). Avid: Edición de video. Barcelona: Anaya multimedia.

MORENO LACALLE, R. (2013). Manuales imprescindibles: Avid Media Composer. Barcelona: Anaya multimedia.

RAY, S. (2001). Las lentes y sus aplicaciones. Andoain: Ed. Escuela de cine y video.

SALINAS SÁNCHEZ, J.M., GÁNDARA MARTÍNEZ, J. y ALONSO SÁNCHEZ, A. (2015). Empresa e Iniciativa Emprendedora. Madrid: McGrawHill Education.

WILLIAMS, E.J. (2008). Presentations in English: find your voice as a presenter. Madrid: MacMillan. 


\title{
Organización didáctica de los materiales tecnológicos: el caso del blog educativo
}

\author{
Fernando Gómez-Gonzalvo, Silvia Cardiel, Julio Guerrero, Elena Pardos-Mainer y \\ Lucía Sagarra-Romero \\ ${ }^{a}$ Universidad San Jorge. Grado en Ciencias de la Actividad Física y el Deporte.
}

\begin{abstract}
In the present work an experience in the use of blogs in the physical activity and sports sciences degree in three subjects of the degree is shown. Two of them of the first course (danza y expresión corporal and sistemática del ejercicio) and one of third course (juegos y deportes alternativos). An inductive type analysis is carried out to extract the categories in which the students, through the comments of the blog, show their perceptions about the use of the blog in university educational contexts.
\end{abstract}

Keywords: blogs, collaborative knowledge, assessment, ICT

\begin{abstract}
Resumen
En el presente trabajo se muestra una experiencia en el uso de blogs en el grado de ciencias de la actividad física y el deporte en tres asignaturas de la titulación. Dos de ellas del primer curso (danza y expresión corporal y sistemática del ejercicio) y una de tercer curso (juegos y deportes alternativos). Se realiza un análisis de tipo inductivo para extraer las categorías en las que el alumnado, a través de los comentarios del blog, muestra sus percepciones sobre el uso del blog en contextos educativos universitarios.
\end{abstract}

Palabras clave: Blogs, aprendizaje cooperativo, evaluación, TIC

El presente trabajo procede del proyecto de innovación educativa El uso de blogs en educación superior. Aproximación al aprendizaje colaborativo, la evaluación formativa y el aprendizaje significativo, financiado por la Universidad Francisco de Vitoria, en la convocatoria 2018. 


\section{Introducción}

La tecnología se posiciona hoy en día como un elemento esencial en la sociedad ya que se ha convertido en un elemento con entidad propia que, además, se ha posicionado como herramienta de comunicación en las sociedades occidentales. Está presente en todos los ámbitos de la sociedad y es considerada uno de los principales ejes entrono a los que se está construyendo la realidad, los cuerpos y el poder (Harari, 2016).

Según algunos autores, el uso de las tecnologías de la información y la comunicación (TIC) en el ámbito educativo ha supuesto una mejora del proceso de enseñanza-aprendizaje por la innovación aportada por estas herramientas y, además, ha supuesto un cambio de paradigma educativo (Marqués y Álvarez, 2014). Esta posición ha sido duramente criticada debido a que la introducción de una herramienta, por sí sola, no es capaz de cambiar el contexto, sino que debe estar integrada en una planificación metodológica y didáctica (Gros y Suárez, 2016). Bates (2009) señala que la utilización de las tecnologías únicamente ha supuesto una traducción al formato digital de las actividades y contenidos que se encuentran en los libros de texto, y mantiene intacta la lógica de la educación: el alumnado debe repetir lo que se realiza en las actividades que se desarrollan en el aula.

La innovación no es un proceso universal, sino que depende de dos factores. El primero de ellos es el contexto donde se realiza y, el otro, es que el elemento que se introduce aporte algo no realizado hasta el momento. Es decir, el uso de una tecnología puede ser innovador únicamente si se introduce en un contexto donde no existía antes y es capaz de lograr un cambio en las dinámicas que se realizan. No obstante, y siguiendo a Sparkes (1992), existen diferentes niveles de cambio educativo. Según este autor, existen tres niveles de cambio, y cada uno de ellos, se caracteriza por lograr un cambio más profundo y complejo en la realidad. El primer nivel de cambio se realiza a la hora de introducir nuevos materiales curriculares; en el segundo nivel se produce un cambio en los estilos de enseñanza y en las dinámicas de clase y; el tercer nivel de cambio, se produce cuando se modifican los sistemas de valores, creencias e ideologías.

Se ha escrito mucho sobre los beneficios e inconvenientes del uso de blogs en todos los niveles educativos, de forma que se acepta como una herramienta válida para favorecer el aprendizaje. Entre los beneficios se ha encontrado que desarrollan las habilidades de lectoescritura, las habilidades sociales y de comunicación, el intercambio de ideas y la participación del alumnado que suele ser menos participativo (Santos y Fernández-Rio, 2012; Sim y Hew, 2010), e incluso, aumenta la toma de responsabilidades del alumnado cuando el blog depende de ellos (Wang y Hsua, 2008). Como inconvenientes se ha encontrado que supone una carga extra de trabajo para alumnado y profesorado, que existen limitaciones técnicas que pueden dificultar el acceso al blog y que se tiene la posibilidad de abandonar el blog si la experiencia resulta negativa (Domingo y Marqués, 2013; Wang, Lin y Liao, 2012).

Como señalan algunos autores, las características de los blogs permiten fomentar espacios de debate, de intercambio de ideas y de interacción entre el alumnado (Coutinho, 2007), pero en la mayoría de casos se utiliza como un complemento de la clase presencial (Aparicio, 2010). Sin embargo, las posibilidades de uso de los blogs van más allá del uso

(cc) BY-NC-ND 2018, Universitat Politècnica de València

Congreso IN-RED (2018) 
como complemento de clase. Antolín, Molina, Villamón, Devís-Devís y Pérez-Samaniego (2011) señalan cuatro usos del blog en función de la participación del alumnado y profesorado:

- Como transmisor de información: el blog se utiliza para colgar información sobre la asignatura por parte del profesorado.

- Abierto a la participación del alumnado a través de los comentarios: Su utilización se centra en que el alumnado debe realizar comentarios a los post propuestos por el profesorado.

- Abierto a la participación del alumnado a través de post: este uso se caracteriza porque además de poder realizar comentarios, el alumnado puede proponer la realización de post propios de forma que éstos colaboran como autores del blog.

- Alumnado como administradores del blog: este uso se caracteriza porque el alumnado administra su propio blog tomando decisiones sobre la configuración del blog, el contenido o la forma de los post.

Tal y como indican estos autores, los diferentes tipos de uso de blog se pueden ordenar en un continuo según la participación del alumnado, desde posturas pasivas hasta la muy activas. De esta forma, el uso del blog como transmisor de información se sitúa como la opción más pasiva del alumnado, en la que únicamente recibe información. El uso del blog en que el alumnado pueda realizar comentarios o entradas supone una opción moderadamente activa puesto que la implicación del alumnado es considerable, pero no afecta a la gestión y organización del blog. Por último, que el alumnado sea el administrador de su propio blog es la opción de uso más activa, no sólo porque debe decidir sobre el contenido o la gestión, sino que también debe responder a los comentarios del resto de compañeros creando situaciones de feedback autorregulado por el alumnado.

Hasta el momento, las propuestas realizadas en torno al uso de blogs en entornos universitarios, han estado integradas dentro de las planificaciones docentes de las asignaturas, pero existen pocas propuestas que hayan tratado de integrar de forma transversal el uso de blogs siguiendo una planificación que implique a varias asignaturas. La intención de la presente propuesta de innovación es que el proceso de uso del blog no quede como una anécdota en una asignatura, sino que esté integrado en el grado de forma que el alumnado vaya asumiendo mayor grado de responsabilidad en su uso.

\section{Objetivos}

Los objetivos que se plantearon para el alumnado a través de esta propuesta innovadora fueron:

\subsection{Objetivos generales:}

- Responder a los nuevos requerimientos educativos mediante el uso de las TIC y de un blog (objetivo 1).

- Integrar el blog educativo como una herramienta transversal de aprendizaje que permita mejorar la adquisición competencial de capacidad para aplicar las TIC en el ámbito de las ciencias de la actividad física y el deporte (objetivo 2). 


\subsection{Objetivos específicos:}

- Utilizar el blog con fines educativos, de difusión o informativos sobre la actividad profesional y/o académica del alumnado (objetivo 3).

- Generar recursos didácticos accesibles, prácticos y de gran utilidad relacionados con contextos específicos de las diferentes asignaturas (objetivo 4).

- Desarrollar las capacidades de búsqueda, selección, síntesis y expresión de la información (objetivo 5).

- Asentar conocimientos de enseñanza-aprendizaje de una forma interactiva y motivante para el alumnado (objetivo 6).

- Compartir ideas y debatir sobre temas relacionados con el campo de la actividad física y el deporte enfocado desde cada asignatura (objetivo 7).

- Favorecer la utilización de una herramienta de trabajo útil que permita la integración, participación activa y socialización del alumnado (objetivo 8).

- Explorar formas de evaluación que impliquen de forma activa al alumnado (objetivo 9).

\section{Desarrollo de la innovación}

Este proyecto se desarrolló en el grado en ciencias de la actividad física y el deporte (CCAFD) de la Universidad San Jorge, abarcando 3 asignaturas de $1^{\mathrm{er}}$ y $3^{\mathrm{er}}$ curso de la titulación.

Tal y como se ha señalado anteriormente, la introducción de los blogs como elementos de innovación ha de tener en cuenta el contexto en el cual se realiza. En este sentido, el grado de CCFAD no contaba con experiencias previas de utilización y puesta en práctica de esta herramienta innovadora en ninguna asignatura desde su implantación en el curso 2011/2012. Consecuentemente, esta es la primera vez que se lleva a cabo el presente proyecto en el contexto de este grado universitario.

El diseño y desarrollo del blog se ha implementado en tres asignaturas del grado en CCAFD: danza y expresión corporal, sistemática del ejercicio y juegos y deportes alternativos.

La asignatura de danza y expresión corporal $\left(1^{\mathrm{er}}\right.$ semestre) y sistemática del movimiento ( $2^{\circ}$ semestre) pertenecen al $1^{\mathrm{er}}$ curso mientras que juegos y deportes alternativos ( $2^{\circ}$ semestre) es una asignatura del $3^{\text {er }}$ curso del grado.

El proyecto tiene la intención de no sobrecargar el trabajo del profesorado y, además, conseguir que el trabajo del alumnado sea público y democrático a exponer qué se está realizando. La presentación a través del blog permite compartir el contenido con el resto de compañeros, y con la población en general, para que estos puedan dar feedback y mejorar el trabajo y añade un componente innovador que pretende aumentar la motivación del alumno ante la tarea. 
En la asignatura de Danza y Expresión corporal estaban matriculados 63 alumnos y alumnas. La participación en el blog se evaluaba con un $10 \%$ de la calificación final y se pedía al alumnado un mínimo de 10 comentarios para su evaluación. El profesorado era el administrador del blog y este se utilizó de forma abierta a la participación del alumnado, de forma que, además de los comentarios a los post que proponía el profesorado podían realizar post de elaboración propia. Los comentarios debían tener una extensión entre 500700 palabras. El alumnado realizó 5 post con temáticas diferentes como el análisis de obras que había visto, la explicación de diversas danzas del mundo, propuestas innovadoras en teatro o la exposición de los trabajos que habían realizado en clase.

El blog se compuso de un total de 16 post en los que se desarrollaban contenidos sobre expresión corporal a través de vídeos, artículos, reflexiones e imágenes. Los temas tratados fueron el gesto y el simbolismo, la construcción musical, el ritmo, la construcción coreográfica, definición de danza y expresión corporal, currículum oficial de educación física y talleres que se realizaron a lo largo del curso. Por último, se realizó un post de reflexión final donde el alumnado expresó su opinión y evaluó el desarrollo del blog. Este post fue utilizado en el análisis de datos.

En la asignatura de sistemática del ejercicio había un total de 65 alumnos y alumnas matriculadas. La participación en el blog se evaluaba con un porcentaje de calificación de $20 \%$. En esta asignatura la tarea que debía realizar el alumnado en el blog era la publicación del trabajo individual. Este consistía en la elaboración de un post relacionado con el tema a trabajar que se asignaba al alumnado. Eran ellos quienes se encargan de aportar contenido al blog de la asignatura. Por lo tanto, se utilizó el blog de forma abierta a la participación del alumnado de forma que ellos eran quienes debía desarrollar el contenido íntegro del blog mientras que la administración quedaba a cargo del profesorado.

Se elaboraron unas directrices que debían seguir para elaborar el post. La primera parte era una introducción, en la que debían investigar brevemente sobre el tema a desarrollar; el desarrollo del trabajo con las propuestas prácticas de distintos ejercicios orientados al tema trabajado y; finalmente, los alumnos debían incorporar las referencias bibliográficas que habían utilizado para desarrollar el post. Entre las directrices dadas al alumnado se les pedía que incluyeran, en la medida de lo posible, material multimedia de autoría propia. Los temas del trabajo del blog se asignaban de manera aleatoria entre el alumnado y se debía presentar el post terminado en la fecha indicada. De esta forma se intentó crear una dinámica en la que cada semana el blog tuviera varias entradas nuevas relacionadas con el trabajo que se realizaba en la clase teórica y respetando la planificación de contenidos, de forma que, se publicaban los trabajos individuales del alumnado en la misma semana en la que se trabajaban esos mismos contenidos en las clases teóricas.

En el caso particular de esta asignatura, el blog está en este momento en sus inicios por lo que todavía no es posible detallar resultados del mismo. No obstante, la impresión por el momento es positiva y se aprecia interés por parte del alumnado en cuanto al trabajo propuesto. Al finalizar el blog se recogerán datos de forma cualitativa para su análisis a través de un último post de autovaloración.

(cc) EY-Nc-No 2018, Universitat Politècnica de València 
Por último, en la asignatura de juegos y deportes alternativos el blog sirve como herramienta para poner en común las sesiones que realiza cada grupo de trabajo sobre un deporte alternativo. En esta asignatura había matriculados un total de 71 alumnos y alumnas. El blog se evaluaba con un $50 \%$ de la calificación del trabajo en grupo que, a su vez, era calificado con el $20 \%$ de la nota final de la asignatura. El profesorado compartía parte de la responsabilidad dejando al alumnado como administrador del blog.

\section{TCHOUKBALL}

\section{HISTORIA DEL TCHOUKBALL}

El Tchoukball fue diseñado por el Dr. Brandt de la Universidad de Génova, haciendo una adaptación del Balonmano con la intención de evitar al máximo las situaciones conflictivas con el jugador o jugadora adversaria. Y posteriormente fue introducido en España por Manuel Martínez Gámez, maestro y licenciado en educación física, especialista en Juegos y Deportes Alternativos y ex-presidente de la Asociación Española de Tchoukball (AETB).

El 28 de julio de 2011 queda registrada por el Ministerio la Asociación Española de Tchoukball. La primera vez que la selección participó en un campeonato internacional fue en Ferrara (Italia), equipo que preparó David García Castro

El 3 de agosto de 2011 se aprueba nuestro ingreso en la FITB (Federación Internacional de Tchoukball).

REGLAMENTO DEL TOUCHKBALL

\section{El Terreno de juego:}

- Dimensiones $40 \times 20$ metros.

- Zona prohibida: radio de 3 metros.

- Líneas (ancho $5 \mathrm{~cm}$ ):

- Líneas laterales.

- Líneas de atrás.

- Línea central.

- Obstáculos separados $1-2$ metros por fuera del campo.

- Marco: fijado al suelo durante el juego.

El balón:

- Categoria masculina: circunferencia de 58 y $60 \mathrm{~cm}$ y peso de 425 y $475 \mathrm{gr}$.

- Categoría femenina: circunferencia de 54 y $56 \mathrm{~cm}$ y peso de 325 y $400 \mathrm{gr}$

- Categoría mixta: usaremos el de la categoría femenina.

(cc) EY-NC-ND 2018, Universitat Politècnica de València 


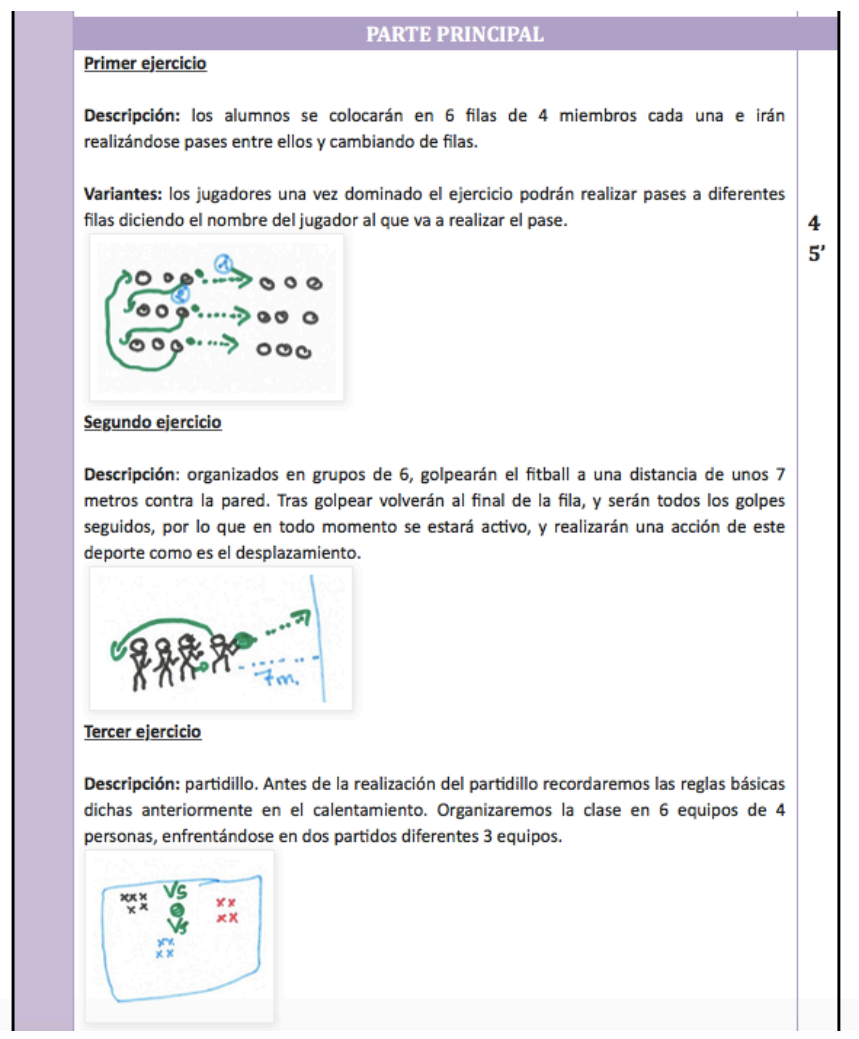

Imagen 1:Ejemplo de post de la asignatura de Juegos y deportes alternativos

El alumnado realizaba su post basándose en una serie de pautas facilitadas por el profesorado para escribirlo. Debía incluir un breve resumen del deporte alternativo sobre el que trabajaban; debían plasmar la sesión práctica que iban a realizar a través de enlaces a otras páginas web, imágenes, vídeos, infografías u otro tipo de recurso y; debían grabar y editar un vídeo de la sesión práctica (una vez realizada) aportando un comentario autocrítico sobre la sesión que habían realizado.

De la misma forma que la asignatura anterior, este blog se encuentra en fase de implementación al ser una asignatura del $2^{\circ}$ semestre de la titulación, por lo que no es posible extraer resultados concisos sobre él. No obstante, la acogida por parte del alumnado y el trabajo realizado hasta el momento parece satisfactorio. Al finalizar el blog se recogerán datos de forma cualitativa para su análisis a través de un último post de autovaloración.

En los tres blogs se realiza un último post enfocado a que el alumnado evalúe y reflexione críticamente sobre el trabajo desarrollado en él, es decir, que muestre cuál es su valoración del blog. Este post de reflexión final se utilizó para evaluar la experiencia por parte del profesorado y, concretamente, los comentarios que el alumnado realizó se utilizan para el análisis de datos (objetivo 9). 


\section{Análisis de los datos}

Dado las características de los datos recogidos, los comentarios que realizó el alumnado en blog para la pregunta de autoevaluación final, se utiliza una metodología cualitativa para su análisis. La investigación narrativa la define Bolívar (2002) como el análisis de los textos reconstruidos por las personas que plasman su experiencia, entendida y enmarcada en un contexto, que es capaz de otorgar significado a las vivencias personales a través de un proceso reflexivo. Bruner (1988) añade que la narrativa es una forma de construir la realidad desde la subjetividad ya que las palabras median, construyen y configuran la construcción social, que se torna realidad a través de la propia experiencia. El intercambio de subjetividades, en un proceso dialógico, se convierte en un modo de construir conocimiento.

Para analizar los discursos del alumnado optamos por un análisis categorial inductivo que permite emerger los significados y la realidad del uso del blog en nuestras asignaturas. Para comprender las vivencias en cuanto a los beneficios, limitaciones y mejoras que el alumnado considera que tiene este recurso didáctico, se analizaron los discursos agrupando las ideas que expresaban para, posteriormente, crear categorías de análisis.

Antes del análisis, se procedió a corregir las faltas de ortografía y se realizó una corrección gramatical para dar sentido a las ideas del alumnado de forma que se introdujeron puntos y comas para facilitar la compresión del texto.

\section{Resultados}

Los resultados que se presentan perteneces únicamente a una de las asignaturas (danza y expresión corporal) puesto que las otras dos, pertenecientes al segundo semestre, todavía están en activo.

En las asignaturas donde el blog está en proceso de elaboración, se pretenden recoger datos de forma cualitativa para su posterior análisis a través de post de autovaloración a la finalización de éstos. En el post de autovaloración de la asignatura de danza y expresión corporal se realizaron un total de 41 comentarios. Los nombres utilizados son pseudónimos.

En el contexto de la Universidad San Jorge y, concretamente en el grado en ciencias de la actividad física y el deporte, el uso de blogs es una herramienta innovadora puesto que el alumnado señala que no habían utilizado los blogs previamente ni en los ciclos anteriores (primaria, secundaria, bachillerato o ciclos de formación profesional) ni en ninguna otra asignatura del primer semestre de la titulación. En este sentido, la introducción de una herramienta educativa puede ser innovadora o no dependiendo del contexto por lo que la innovación tiene un componente experiencial clave. Incluso, dentro del mismo contexto puede ser innovadora para algunas personas pero no para otras.

"El blog de la asignatura de danza me ha parecido algo innovador, ya que solo lo hemos realizado en esta asignatura y, sinceramente, yo no me lo esperaba ya que, en todos los años que llevo estudiando, nunca había

(cc) EY-NC-ND 2018, Universitat Politècnica de València

Congreso IN-RED (2018) 
utilizado un blog para trabajar sobre documentos, vídeos, reflexiones que son de mucha información...” (Esteban).

\subsection{Desarrollo de habilidades}

El blog ha permitido desarrollar diversas habilidades instrumentales en el alumnado como son las habilidades de escritura, de búsqueda de información en la web y en otros soportes o la síntesis y resumen de ideas y textos de otros autores (objetivos 4 y 5). En este sentido, Agustín señala que:

"En mi caso, he aprendido a buscar información, en libros de la biblioteca de la universidad; y sobre todo en Internet, en las revistas digitales relacionadas con el deporte y la Educación Física, y libros que se podían leer a través de la vista previa"

Otra compañera expresa la misma idea señalando que (objetivo 6):

"El blog de la asignatura ha sido una herramienta de trabajo y aprendizaje muy positiva. No solo ha ayudado al alumnado a desarrollar competencias, como la autonomía o la expresión escrita, sino también al profesorado para que conozca el feedback que nosotros los alumnos, quienes al fin y al cabo realizamos los talleres y absorbemos la información que nos proporcionan, podemos plasmar a cerca de todos esos títulos propuestos en el blog” (Aitana).

Estudios previos indican que a través del blog el alumnado desarrolla habilidades de escritura y lectura, ya que enfrentarse a la redacción de un comentario o post para el blog requiere movilizar los aprendizajes y habilidades previas para conseguir la tarea. También, mejora la capacidad de buscar y reorganizar la información para darle sentido a las ideas y poder expresarlas a través de la producción escrita (Sim y Hew, 2010).

\subsection{Aprendizaje cooperativo}

Otro de los beneficios que se indica en el uso de blogs es que sirve como espacio para poder conocer las ideas de resto de compañeros (Coutinho, 2007). Esto favorece la creación de nuevas relaciones sociales con alumnado con el que habitualmente no se interactúa en las clases presenciales y, también, para el fortalecimiento de las relaciones sociales que ya existentes (Santos y Fernández-Rio, 2012). El progreso y la consecución del objetivo 8 quedó reflejado a través del registro personal del alumnado sobre la utilidad del blog para lograr un aprendizaje cooperativo.

"Otro aspecto a destacar sobre el blog ha sido la posibilidad de contrastar ciertas opiniones mediante los comentarios del resto de los compañeros de clase” (Juan) 
Algunos autores señalan que el intercambio de ideas es fundamental a la hora de establecer dinámicas de aprendizaje cooperativo (Huang et al.,2011). El alumnado valora positivamente poder conocer las ideas de los demás e incluso utilizarlas para poder construir a partir de ellas sus propias ideas, rebatirlas o construir de forma compartida el conocimiento sobre los temas de la asignatura (Coutinho, 2007). Esto se observa en palabras de Víctor:

"La reafirmación o discusión de lo que se presenta como comentario de cada participante, permite un debate que, por norma general, es enriquecedor para valorar aspectos positivos y negativos de los comentarios realizados”

No obstante, como el mismo Víctor señala: “[...] las opiniones y análisis han sido muy cerrados, con distintos puntos de vista, pero sin confrontación dialéctica entre ellos”. Sería necesario favorecer no sólo el poder acceder a las ideas de los demás, sino que se generara un debate que enriqueciera las posturas de todos los participantes. De este modo, además de generar dinámicas de aprendizaje cooperativo se favorece el sentido crítico puesto que los comentarios serán puestos a prueba por el colectivo de alumnos en un ciclo de feedback continuo.

\subsection{Evaluación del blog}

En relación a la evaluación del uso del blog y los aspectos de mejora (objetivo 9), el alumnado destaca entre los aspectos negativos que la posibilidad de hacer comentarios a los post debería poder realizarse durante los 15 días siguientes a su publicación. En cambio, se proponía que se pudieran realizar los comentarios en cualquier momento antes de la fecha de entrega del trabajo. En este sentido, un aspecto negativo que el alumnado encontraba era que los comentarios debían tener entre 500 y 700 palabras puesto que señalaban que en ocasiones era complicado llegar a ese número de palabras y, en otras, la extensión era insuficiente.

"Un aspecto negativo que he visto ha sido la duración de cada entrada, sólo duraban 2 semanas, para mi hubiera estado bien que se quedaran abiertas sin límite de duración” (Rafa).

"Por otro lado, había temas que se me hacían cortos, incluso llegando a 700 palabras, y otros que llegar a las 500 era un suplicio” (Carmen).

A pesar de esto, la introducción de nuevas herramientas y metodologías requieren de un tiempo de toma contacto y habituarse a las dinámicas para su aceptación. Dado que esta herramienta resulta novedosa para el alumnado es preciso fomentar su práctica y formarlos en ellas. La toma de decisiones en cuanto a las limitaciones que destaca el alumnado están basadas en experiencias previas realizadas en el uso de blogs y en las propias del 
profesorado participante, acumuladas a lo largo de la investigación previa y su uso en diferentes contextos educativos (véase Molina, Valencia-Peris y Gómez-Gonzalvo, 2016) y no a un criterio arbitrario por parte del profesorado.

\section{Conclusiones}

En este trabajo se constata que el uso del blog en las asignaturas ha alcanzado similares aprendizajes que en las experiencias previas tanto a nivel internacional como nacional. Se han encontrado que las percepciones e ideas del alumnado con respecto al uso del blog son similares a las encontrados por otros autores en cuanto al desarrollo de habilidades a través del blog, a las dinámicas de aprendizaje cooperativo que se desarrollan en él y que ha sido una propuesta de innovación en el contexto y para el alumnado al que estaba enfocado.

No obstante, como indican Molina, Valencia-Peris y Gómez-Gonzalvo (2016), los aspectos positivos de los blogs se dan en cualquier asignatura y contexto debido a las posibilidades de adaptación de esta herramienta. Estos autores identifican una serie de principios a la hora de utilizar el blog para garantizar cierta parte de éxito como son: informar al alumnado de qué se va hacer con el blog; cuál es el objetivo del blog en la asignatura y; otorgar al trabajo del blog un peso en la calificación acorde al trabajo que se va a realizar.

Como limitaciones cabe destacar que el proyecto se encuentra en fase de realización e implementación (queda por terminar el $2^{\circ}$ sementre del curso académico) y el objetivo de explorar una organización que permita progresar metodológicamente en su uso hacia la cesión de autonomía al alumnado todavía se encuentra en activo. Es por este motivo que los resultados aquí presentados son parciales y limitados por lo que deben ser tenidos en cuenta como provisionales.

\section{Referencias bibliográficas}

Antolín, L.; Molina, P.; Villamón, M.; Devís-Devís, J. y Pérez-Samaniego, V. (2011). “Uso de blogs en Ciencias de la Actividad Física y el Deporte”. @tic. revista d'innovació educativa, 7.

Bates, T. (2009). "Promesas y mitos del aprendizaje virtual en la educación postsecundaria”. En M. Castells (ed.). La sociedad red: una visión global (pp. 335-359). Madrid: Alianza Editorial.

Bolivar, A. (2002). “¿De nobis ipsis sile mus?”: Epistemología de la investigación biográfico-narrativa en educación. Revista Electrónica de Investigación Educativa, 4(1).

Bruner, J. (1988). Realidad mental, mundos posibles. Barcelona: Gedisa.

Coutinho, C. (2007). "Cooperative Learning in Higher Education using Weblogs: a study with undergraduate students of Education in Portugal". World multi-conference on systemics, cybernetic and informatics, 11 (1), 60-64. Disponible en 
http://repositorium.sdum.uminho.pt/bitstream/1822/6721/1/Webblogs.pdf?origin=publicati on_detail

Domingo, M. y Marqués, P. (2013). "Práctica docente en aulas 2.0 de centros de educación primaria y secundaria de España”. Píxel-Bit. Revista de Medios y Educación, 42, 115-128.

Gros, B y Suárez, C. (2016). Pedagogía Red. Una educación para tiempos de internet. Barcelona: Octaedro.

Harari, Y. (2017). Homo Deus. Madrid. Debate.

Huang, T. -C., Huang, Y. -M. y Yu, F. -Y. (2011). "Cooperative Weblog Learning in Higher Education: Its Facilitating Effects on Social Interaction, Time Lag, and Cognitive Load”. Educational Technology \& Society, 14 (1), 95-106.

Marqués, P. y Álvarez, I. (2014). "El Currículum bimodal como marco metodológico y para la evaluación: principios básicos y mejoras obtenidas en aprendizajes y rendimiento de los estudiantes”. Educar, 50(1), 149-166.

Molina, P.; Valencia-Peris, A. y Gómez-Gonzalvo, F. (2016). "Innovación en docencia universitaria: edublogs, evaluación formativa y aprendizaje colaborativo”. Profesorado. Revista de currículum y formación del profesorado, 20(2), 432-449.

Santos, L. y Fernández-Rio, J. (2012). "Uso pedagógico del blog: un proyecto de investigación-acción en la materia de educación física en educación secundaria”. Revista electrónica de tecnología educativa [EDUTEC], 42.

Sim, J.W.S. y Hew, K.F. (2010). "The use of weblogs in higher education settings: A review of empirical research”. Educational Research Review, 5, 151-163.

Sparkes, A. (1992). "Reflexiones sobre las posibilidades y los problemas del proceso de cambio en la Educación Física”. En Devís-Devís, J. y Peiró-Velert, C. (Ed.), Nuevas perspectivas curriculares en Educación Física: la salud y los juegos modificados (pp. 5166). Barcelona: Inde.

Wang, S.K. y Hsua, H.Y. (2008). "Reflections on using blogs to expand in-class discussion”. TechTrends, 52(3), 81-85.

Wang, Y.S., Lin, H.H. y Liao, Y.W. (2012). "Investigating de individual difference antecedents of perceived enjoyment in students' use blogging”. British journal of educational technology, 43(1), 139-152. 


\title{
Integración del "User Experience Questionnaire Short" en MOOCs UPV*
}

\author{
Rosario Sanchis-Font ${ }^{1}$, María José Castro-Bleda ${ }^{2}$, Carlos Turró-Ribalta ${ }^{3}$ \\ e Ignacio Despujol-Zabala ${ }^{3}$
}

${ }^{1}$ Escuela Doctorado, Universitat Politècnica de València, rosanfon@doctor.upv.es ${ }^{2}$ Dpto. Sistemas Informáticos y Computación, Universitat Politècnica de València, mcastro@dsic.upv.es

${ }^{2}$ Área de Sistemas de la Información y las Comunicaciones, Universitat Politècnica de València, turro@cc.upv.es, ndespujol@asic.upv.es

\begin{abstract}
The assessment of the learning experience of Massive Open Online Courses (MOOCs) at Universitat Politècnica de València (UPV) is currently performed through a questionnaire which only evaluates the pedagogical methodology and the functionality of the platforms edX and UPVx, without registering the pleasure of the learning experience. This paper shows the integration of User eXperience (UX) perspective in this questionnaire. User perception on usability and pleasure of using the e-learning platform will be measured in order to achieve a deeper knowledge of users preferences with the ultimate goal to upgrade the UPV MOOCs. To this end, the short version of the validated UX questionnaire of Thomaschewski (2017) "User Experience Questionnaire Short" (UEQ-S) has been adapted to Spanish for UPV MOOC users in order to retrieve answers about joy of use, attractiveness, efficiency and usability of UPV MOOC platforms. In conclusion, the integration of the adapted UEQ-S within the current UPV $M O O C$ questionnaire will provide us new data for further research on the interaction within the platform. The aim is to enhance and improve the future learning experience in UPV MOOCs in order to position them as the best global massive open online courses and UPV as the top world-wide reference in MOOCs.
\end{abstract}

Keywords: User experience, UX, MOOC, usability, pleasure of interaction, human computer interaction, interactive experience, e-learning perception, interface design evaluation, on-line platforms.

\footnotetext{
${ }^{*}$ Trabajo parcialmente financiado por la Escola Tècnica Superior d'Enginyeria Informàtica de la Universitat Politècnica de València.
} 


\begin{abstract}
Resumen
Actualmente la evaluación de la experiencia de los Massive Open Online Course (MOOCs) de la Universitat Politècnica de València (UPV) se realiza a través de una encuesta que valora únicamente la metodología pedagógica del curso y la funcionalidad de las plataformas edX y UPVx, sin registrar el placer de la experiencia de aprendizaje del usuario. Con esta propuesta se evaluará la formación on-line por primera vez en la UPV con items que valoren la experiencia de la interacción o User eXperience (UX). Esto significa conocer la percepción del usuario sobre la usabilidad y placer de uso de la plataforma con el fin de mejorar los UPV MOOCs. Para ello, se ha integrado en la encuesta sobre los MOOC UPV el modelo breve de cuestionario de Thomaschewski (2017) "User Experience Questionnaire Short" (UEQ-S). Esta encuesta se ha adaptado al español y al usuario de la encuesta MOOC UPV, con el objeto de obtener valores sobre el placer de uso, atractivo, eficiencia, estimulación y usabilidad de la plataforma de e-learning. Así, la integración del UEQ-S en el cuestionario MOOC UPV nos permitirá obtener nuevos datos para investigar sobre la interacción con la plataforma con el fin de potenciar y mejorar el futuro de la experiencia de aprendizaje en los MOOCs UPV y posicionar a la UPV como referente en formación on-line abierta masiva.
\end{abstract}

Keywords: experiencia usuario, MOOC, usabilidad, placer de interacción, plataformas on-line, percepción e-learning, UX, user experience, cuestionario aprendizaje interactivo, diseño de interfaces.

\title{
1 Introducción
}

La incipiente demanda de la formación on-line por un público masivo y global ha originado la producción de Massive Open Online Courses (MOOCs) en universidades de todo el mundo. De esta manera, desde 2012 los cursos abiertos a un público ilimitado a través de plataformas en internet como edX, Udacity, FutureLearn o Coursera están experimentando un crecimiento exponencial (Espada y col. 2014). En este ámbito de educación abierta masiva on-line, la Universitat Politècnica de València (UPV) actualmente ofrece los MOOCs a través de las plataformas edX y UPVx. Atendiendo a la clasificación MOOC (2014) (Espada y col. 2014), los MOOCs UPV son "xMOOCs", puesto que se generan en el contexto de la universidad y siguen una estructura y metodología similar a otros cursos universitarios, siendo además impartidos por miembros de la propia UPV. Actualmente la UPV se posiciona como la quinta universidad a nivel mundial en número de cursos realizados en edX (la plataforma de MOOC impulsada por Harvard y el MIT), con más de 60 cursos y más de 200.000 alumnos (Noticia UPV: Top 5 mundial en MOOC La Universitat Politècnica de València y la plataforma edX, impulsada por MIT y Harvard, renuevan su colaboración 2018). En 2018, la UPV se ha convertido en la primera universidad de habla hispana en superar el millón de inscripciones en edX (Noticia UPV: La UPV, primera universidad de habla hispana en superar el millón de inscripciones en edX, la plataforma de MOOC impulsada por Harvard y el MIT 2018).

Los MOOCs UPV son cursos on-line abiertos a toda la población mundial, y fundamentalmente de habla hispana, donde cientos de miles de estudiantes acceden a 
la plataforma de aprendizaje con diversidad de habilidades, de edad, de culturas, de procedencia y de lugares físicos de acceso, en diversos momentos y con diferencias en tiempo y en comportamiento de navegación (Sanchis-Font y col. 2017). Por ello, se requiere en estos entornos interactivos un diseño de interfaces de aprendizaje que incluyan las experiencias, motivaciones, sentimientos y necesidades de todos los usuarios con el fin de llevar a cabo el proceso de aprendizaje con éxito a través de los cursos on-line. Para ello, es prioritario conocer la experiencia de usuario o "User eXperience" (UX) de los usuarios de entornos interactivos. El concepto UX es multidimensional y centrado en las necesidades humanas y aspectos de belleza, diversión, placer y crecimiento personal que se experimentan en la interacción humana con la computadora (Zaharias y Mehlenbacher 2012).

El concepto UX es una ampliación del concepto de usabilidad, que se define como la cualidad de facilidad y satisfacción de uso en un contexto determinado (Bevan 2001). La disciplina UX y sus aplicaciones miden no sólo las cualidades de uso, sino que integran todas las cualidades experienciales (emociones, creencias, comportamientos,...) en sistemas interactivos entre ordenador-persona, además de las características de usabilidad. Desde la perspectiva de la interacción humana con la computadora, la normativa ISO 9241-210:2010 ( 2009) describe el UX como todas las emociones, creencias, preferencias, percepciones, respuestas físicas y psicológicas, comportamientos y logros que ocurren antes, durante y después del uso.

Con el fin de mejorar esta experiencia digital de aprendizaje masivo, los productores de MOOCs y universidades utilizan herramientas de evaluación de la experiencia de sus usuarios pero desde la perspectiva de la usabilidad (Espada y col. 2014). Sin embargo, es cada vez más necesario evaluar el aspecto de placer y diversión en el aprendizaje en línea en estas plataformas MOOC, a las cuales acceden usuarios diversos y desde diferentes dispositivos tecnológicos. En este proyecto de investigación se presenta la integración de un cuestionario UX, el "User Experience Questionnaire Short" (UEQS) (Schrepp, Hinderks y Thomaschewski 2017) en la actual encuesta que realiza la UPV en sus MOOCs con el fin último de potenciar el placer de la experiencia de interacción y aprendizaje en las plataformas edX y UPVx.

\section{Objetivos}

El objetivo general de este trabajo es la integración del cuestionario validado "User Experience Questionnaire Short" (UEQ-S) (Schrepp, Hinderks y Thomaschewski 2017) para obtener una rápida evaluación de la experiencia del usuario en la interacción con las plataformas MOOC UPV de los usuarios durante 6 meses aproximadamente (desde abril a septiembre 2018). Con la versión breve del cuestionario se pretende medir el impacto en el usuario del entorno MOOC UPV, valorando así la estética y funcionalidad de la plataforma desde las 6 escalas y comparando los valores con respecto a otros productos interactivos. En concreto, los objetivos específicos son:

1. Integrar en la plataforma en encuestas UPV "Limesurvey" ${ }^{1}$, el cuestionario UEQ-S en el actual modelo de cuestionario de evaluación del usuario MOOC UPV con el fin que nos permita recabar los datos sobre la percepción del usuario

\footnotetext{
${ }^{1}$ https://www.limesurvey.org/es/
} 


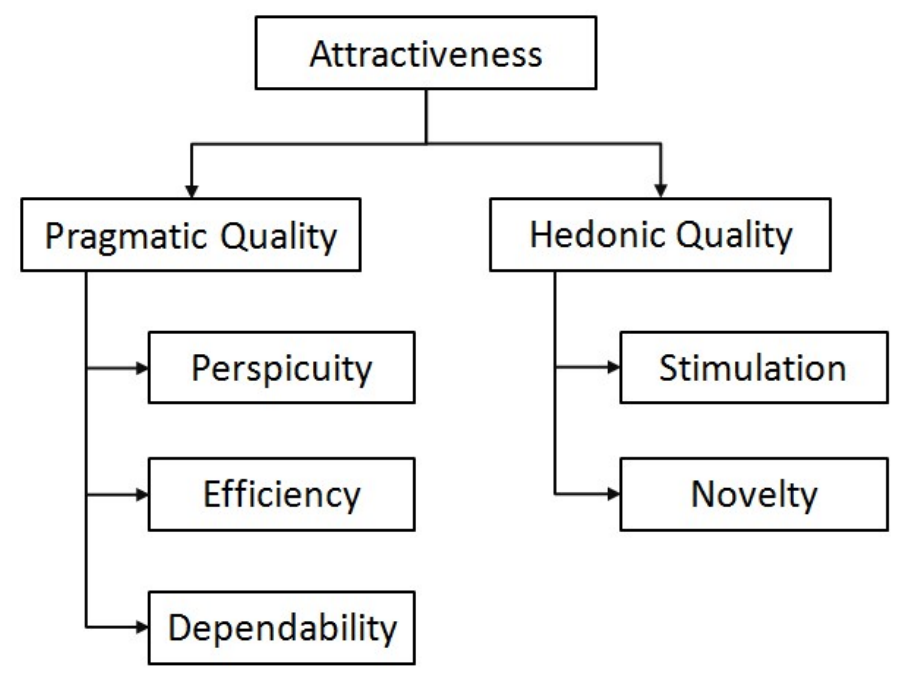

Fig. 1: Estructura de las 6 escalas valoradas en el UEQ-S: atracción, claridad, eficiencia, fiabilidad, motivación y novedad (Rauschenberger y col. 2013).

de las plataformas MOOC UPV de manera fácil y rápida desde las siguientes escalas con los valores del UEQ-S: atracción, claridad, eficiencia, fiabilidad, motivación y novedad.

2. Obtener el registro de datos del máximo de usuarios de todos los cursos MOOC UPV desde abril hasta septiembre 2018, con el fin de poder generar gráficas y comparativas por tipos de usuarios (ej. hombres, mujeres, etc), tipos de cursos, ediciones de un mismo curso y comparativas con respecto a otros productos interactivos del mercado con los valores del UEQ (informe benchmark) (Laugwitz, Held y Schrepp 2008).

3. Testar la plataforma MOOC UPV en base al diseño de la experiencia del usuario (UX) mediante el cuestionario validado científicamente UEQ-S.

\section{Desarrollo de la innovación}

\section{1 ¿Qué es UEQ-S?}

El cuestionario UEQ-S (Schrepp, Hinderks y Thomaschewski 2017) es la versión breve del cuestionario "User Experience Questionnaire" (UEQ) (Rauschenberger y col. 2013), que evalúa el impacto y percepción del usuario sobre las propiedades de un producto interactivo. Ambos cuestionarios evalúan las cualidades de "eXperiencia del Usuario", disciplina tambien conocida como "User eXperience" o UX, la cual valora no solo la usabilidad del producto interactivo, sino que además se centra en su atractivo y el placer de uso percibido por el usuario.

Con esta finalidad, el cuestionario UEQ-S mide dos grandes grupos de cualidades sobre la experiencia de uso del producto, plataforma o entorno interactivo (pragmático y hedónico) organizadas en 6 escalas: atracción, claridad, eficiencia, fiabilidad, motivación y novedad (véase Figura 1). 


\begin{tabular}{|c|c|c|c|c|}
\hline \multirow{4}{*}{ 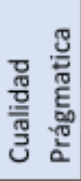 } & 1 & obstructive & 0000000 & supportive \\
\hline & 2 & complicated & 0000000 & easy \\
\hline & 3 & inefficient & 0000000 & efficient \\
\hline & 4 & confusing & 0000000 & clear \\
\hline \multirow{4}{*}{ 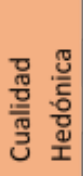 } & 5 & boring & 0000000 & exciting \\
\hline & 6 & not interesting & 0000000 & interesting \\
\hline & 7 & conventional & 0000000 & inventive \\
\hline & 8 & usual & 0000000 & leading edge \\
\hline
\end{tabular}

Fig. 2: Ítems y cualidades de la versión inglesa del cuestionario UEQ-S (Schrepp, Hinderks y Thomaschewski 2017) con los ítems destacados en dos colores según la cualidad que valoran (azul: cualidad pragmática; naranja: cualidad hedónica).

\begin{tabular}{|c|c|c|c|c|}
\hline \multirow{4}{*}{ 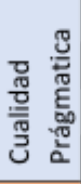 } & 1 & obstructivo & 0000000 & impulsor de apoyo \\
\hline & 2 & complicado & 0000000 & fácil \\
\hline & 3 & ineficiente & 0000000 & eficiente \\
\hline & 4 & confuso & 0000000 & claro \\
\hline \multirow{4}{*}{ 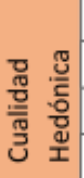 } & 5 & aburrido & 0000000 & emocionante \\
\hline & 6 & no interestante & 0000000 & interesante \\
\hline & 7 & convencional & 0000000 & original \\
\hline & 8 & convencional & 0000000 & novedoso \\
\hline
\end{tabular}

Fig. 3: Ítems y cualidades en español del cuestionario UEQ-S, extraídos de la versión española del UEQ (Rauschenberger y col. 2013), con los ítems destacados en dos colores según la cualidad que valoran (azul: cualidad pragmática; naranja: cualidad hedónica).

\section{2 ¿Qué ítems valora UEQ-S?}

Ya hemos comentado que el cuestionario UEQ-S es la versión reducida del cuestionario UEQ (Rauschenberger y col. 2013). El cuestionario original UEQ registra 26 ítems para evaluar esas mismas 6 escalas. En la versión reducida UEQ-S los ítems 1 a 4 evalúan la cualidad pragmática (usabilidad) y los ítems 5 a 8 miden la cualidad hedónica (placer de uso) como ilustra la Figura 2, versión inglesa, y la Figura 3, versión española. Cada uno de los ítems se valora con una puntuación de 1 a 7 según la escala likert (Likert 1932).

En 2017, R. Sanchis-Font realizó la adaptación de determinados ítems a un castellano más comprensible para el usuario hispanohablante y de entornos interactivos de educación superior on-line de universidades españolas. Esta adaptación se realiza para el cuestionario UEQ original de 26 ítems para la investigación en UX del entorno de los másteres oficiales on-line de la Universitat de València desarrollados desde Fundación IVI. Así, el UEQ se adapta en lenguaje con la previsión de poder aplicarlo en los productos interactivos on-line de otras universidades españolas. De estos ítems algunos pertenecen al cuestionario UEQ-S, tal y como se observa en la Figura 4. 


\begin{tabular}{|r|r|r|l|}
\cline { 2 - 4 } \multicolumn{1}{|c|}{} & Item opuesto (izquierda) & Valores de la escala likert & Item opuesto (derecha) \\
\hline $\mathbf{1}$ & entorpecedor & 1234567 & ofrece ayuda \\
\hline $\mathbf{2}$ & complicado & 1234567 & fácil \\
\hline $\mathbf{3}$ & ineficiente & 1234567 & eficiente \\
\hline $\mathbf{4}$ & claro & 1234567 & confuso \\
\hline $\mathbf{5}$ & aburrido & 1234567 & emocionante \\
\hline $\mathbf{6}$ & interesante & 1234567 & nada interesante \\
\hline $\mathbf{7}$ & innovador & 1234567 & convencional \\
\hline $\mathbf{8}$ & tradicional & 1234567 & novedoso \\
\hline
\end{tabular}

Fig. 4: Adaptación propia del cuestionario UEQ-S para usuarios hispanohablantes de universidades españolas. Los ítems de pares opuestos están ordenados de izquierda a derecha según la escala likert ascendente y con los valores asignados por los autores del UEQ-S.

Las herramientas de medición y valores que provee el cuestionario UEQ-S son las mismas que las del cuestionario largo UEQ (Laugwitz, Held y Schrepp 2008). En este sentido, los autores facilitan herramientas de análisis validadas para realizar una evaluación benchmark que integra los valores evaluados de 246 productos interactivos con un total de 9905 participantes (Rauschenberger y col. 2013).

\subsection{Actual cuestionario sobre la experiencia en los MOOCs UPV}

La educación abierta de la UPV en formato MOOC realiza una encuesta a sus alumnos/as al finalizar el curso para conocer un poco más sobre su experiencia en la realización del curso y poder mejorar la experiencia de próximas ediciones. El cuestionario que ofrece los MOOC UPV son 12 preguntas sobre el curso, 5 sobre la plataforma y una sobre los módulos.

En las Figuras 5 a 7 se muestran las pantallas de visualización desde el ordenador de un usuario realizando el cuestionario MOOC UPV a fecha de 23 enero 2018 (Encuesta MOOC UPV al curso edX Liderazgo para mandos intermedios 2018). Estas cuatro pantallas impresas pertenecen al cuestionario del curso MOOC UPV "Liderazgo para mandos intermedios" realizado a través de la plataforma edX.

\subsection{Integración del cuestionario UX en las plataformas MOOC UPV}

Para la integración del cuestionario UX en la sección "sobre la plataforma" del cuestionario MOOC UPV se han adoptado las siguientes propuestas:

1. Mantener las dos últimas preguntas ya existentes: sobre los navegadores y comentarios de mejora.

2. Integrar los 8 pares-ítem del UEQ-S en la sección de preguntas sobre la plataforma, la cual se encuentran en la pantalla 3 (Figura 7). 


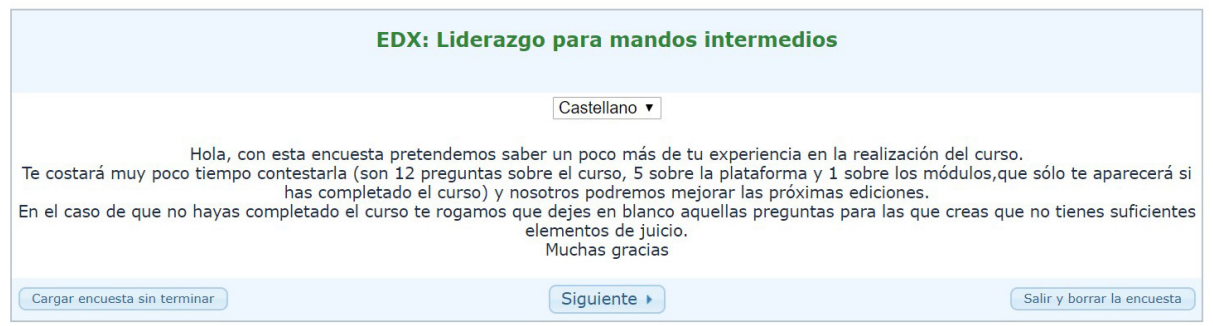

Fig. 5: Cuestionario MOOC UPV (Pantalla 1).

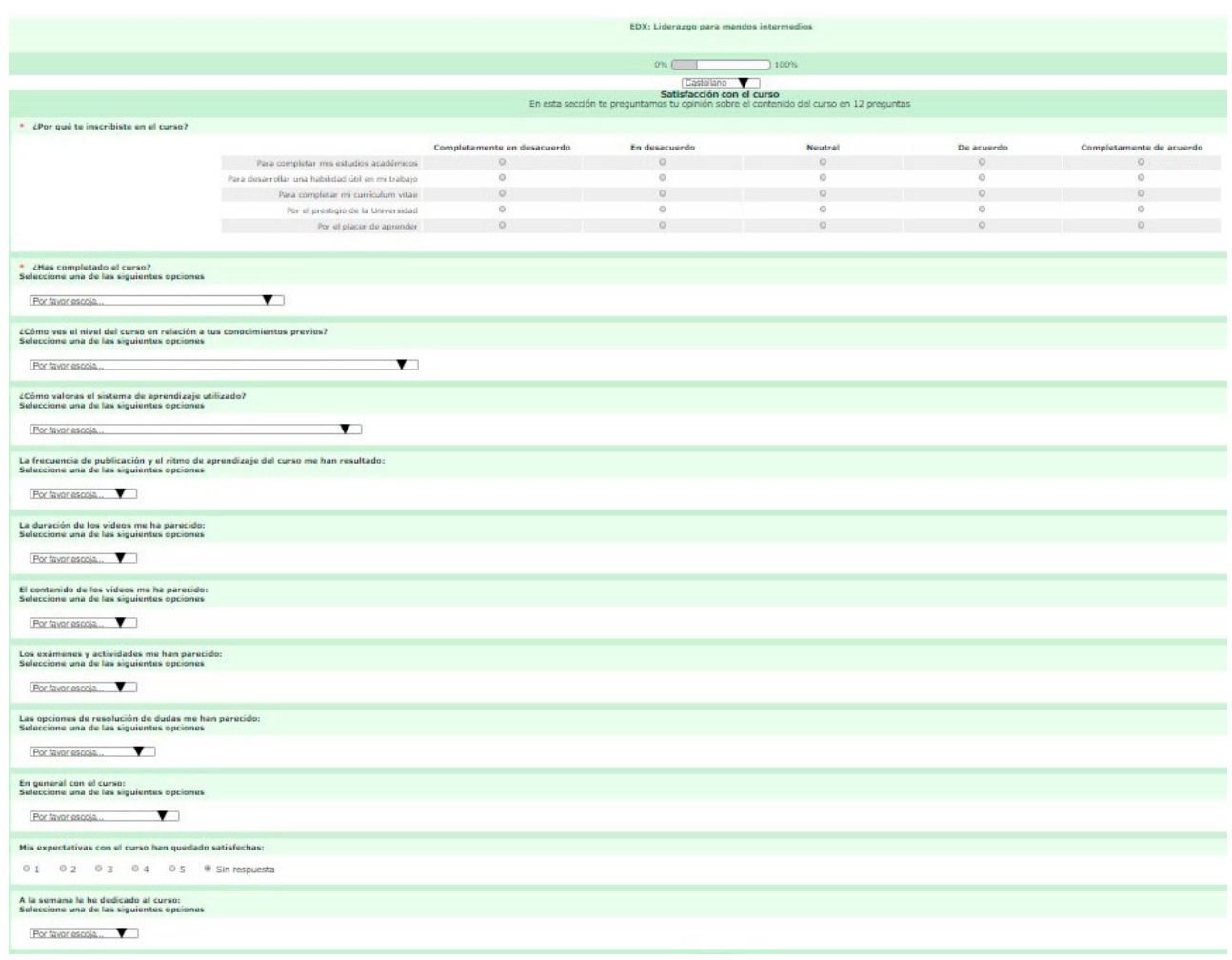

Fig. 6: Cuestionario MOOC UPV (Pantalla 2).

3. Después valorar con detenimiento aquellas preguntas que el actual cuestionario de MOOC UPV presenta y las cuales encontramos de manera similar desde el cuestionario UEQ-S, se propone eliminar las primeras 3 preguntas de la sección de la plataforma (pantalla 3, Figura 7). Las preguntas que podríamos evaluar desde el cuestionario UEQ-S son:

Creo que la velocidad de respuesta de la plataforma ha sido...

(Esta pregunta estaría incluida en el par "ineficiente-eficiente") 


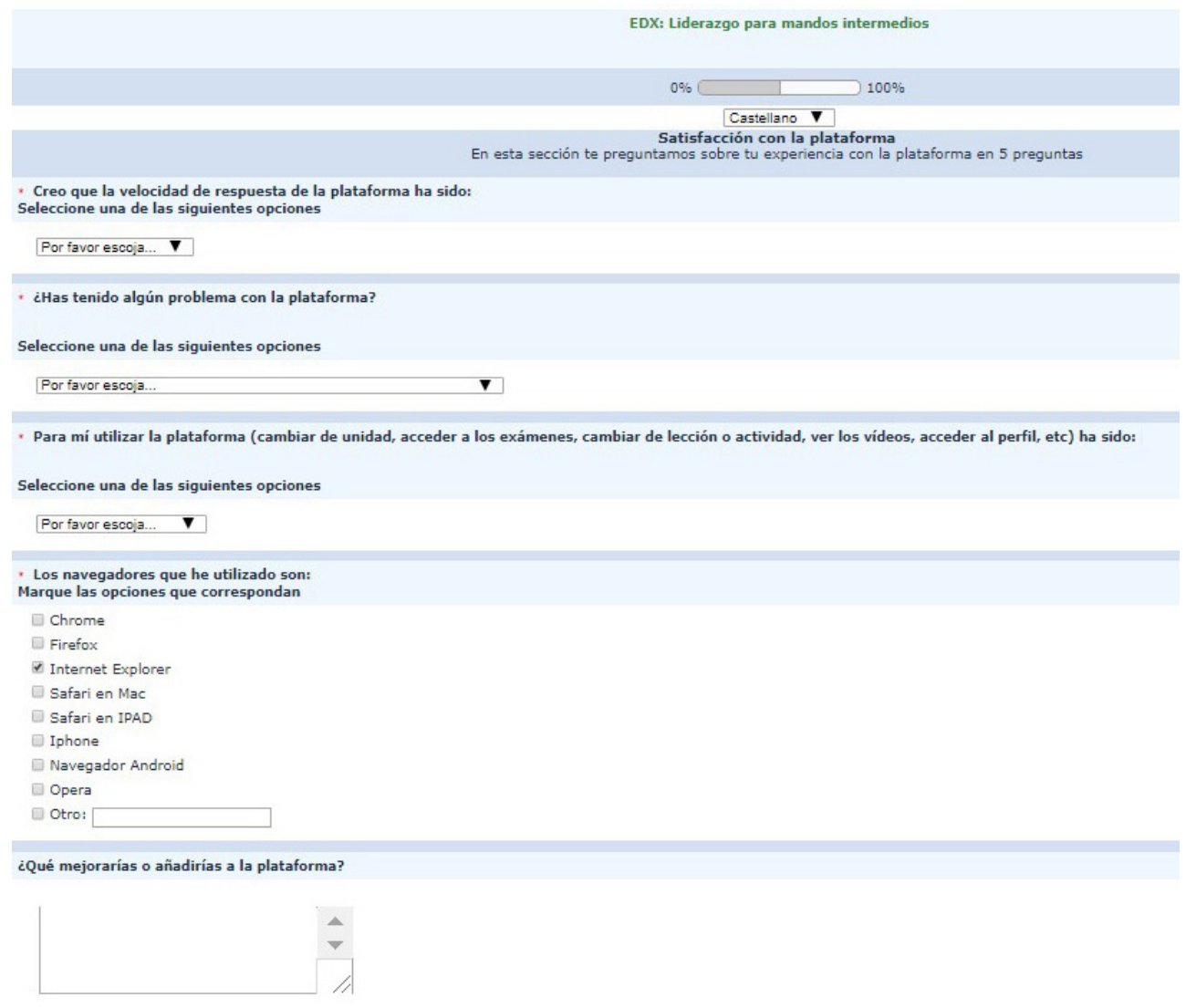

Fig. 7: Cuestionario MOOC UPV (Pantalla 3).

¿Has tenido algún problema con la plataforma?

(Esta pregunta estaría incluida en los pares de ítems en color azul -escalas pragmáticas-)

Para mí utilizar la plataforma (cambiar de unidad, acceder a los exámenes, cambiar de lección o actividad, ver los vídeos, acceder al perfil, etc) ha sido...

(Esta pregunta estaría incluida en los pares de ítems en color azul -escalas pragmáticas-)

4. En el caso de que "edX Analytics" nos impida conocer los dispositivos de acceso al curso MOOC UPV por el usuario, se incluirá la siguiente pregunta:

¿Con qué dispositivos accedes al curso? (puedes seleccionar más de 1): PC / Tablet / Móvil / Otros

5. El cuestionario UEQ-S se ha adaptado para el usuario MOOC UPV del siguiente modo (véase Figura 8). La Figura 9 muestra la interfaz gráfica del cuestionario: 


\begin{tabular}{|c|c|c|c|}
\hline \multicolumn{4}{|c|}{$\begin{array}{l}\text { Por favor, selecciona la opción más próxi } \\
\text { "La plataforma MOOC UPV es... }\end{array}$} \\
\hline 1 & entorpecedora & $\begin{array}{l}0000000 \\
1234567\end{array}$ & $\begin{array}{l}\text { de apoyo } \\
\text { Por ejemplo: la plataforma ofrece funciones y } \\
\text { contenidos que nos permiten tener el control de } \\
\text { navegación y de interacción, la plataforma permite la } \\
\text { opción de poder adaptarla a nuestras necesidades y } \\
\text { tipo de uso,... }\end{array}$ \\
\hline 2 & complicada & $\begin{array}{l}0000000 \\
1234567\end{array}$ & $\begin{array}{l}\text { fácil } \\
\text { Por ejemplo: Es fácil aprender el funcionamiento de } \\
\text { navegación de la plataforma, fácil conocer el acceso a } \\
\text { los contenidos y como interactuar en ella,... }\end{array}$ \\
\hline 3 & ineficiente & $\begin{array}{l}0000000 \\
1234567\end{array}$ & $\begin{array}{l}\text { eficiente } \\
\text { Por ejemplo: la velocidad de respuesta de la } \\
\text { plataforma ha sido rápida, las pantallas muestran la } \\
\text { información y los accesos de manera organizada, ... }\end{array}$ \\
\hline 4 & confusa & $\begin{array}{l}0000000 \\
7654321\end{array}$ & $\begin{array}{l}\text { clara } \\
\text { Por ejemplo: La navegación por la plataforma está } \\
\text { muy clara y es bastante transparente, es fácil } \\
\text { reconocer los accesos y complementos en las }\end{array}$ \\
\hline 5 & aburrida & $\begin{array}{l}0000000 \\
1234567\end{array}$ & $\begin{array}{l}\text { entretenida } \\
\text { Por ejemplo: ha sido entretenido y ha sido un disfrute } \\
\text { navegar e interactuar en la plataforma, etc. }\end{array}$ \\
\hline 6 & $\begin{array}{r}\text { nada } \\
\text { interesante }\end{array}$ & $\begin{array}{l}0000000 \\
1234567\end{array}$ & $\begin{array}{l}\text { interesante } \\
\text { Por ejemplo: las opciones de interacción y de } \\
\text { navegación han mantenido constantemente el interés } \\
\text { y las ganas de continuar, ... }\end{array}$ \\
\hline 7 & convencional & $\begin{array}{l}0000000 \\
7654321\end{array}$ & $\begin{array}{l}\text { innovadora } \\
\text { Por ejemplo: la plataforma presenta un aspecto y } \\
\text { ofrece una navegación diferente al resto de } \\
\text { plataformas e-learning, ... }\end{array}$ \\
\hline 8 & tradicional & $\begin{array}{l}0000000 \\
1234567\end{array}$ & $\begin{array}{l}\text { novedosa } \\
\text { Por ejemplo: la plataforma presenta un aspecto y } \\
\text { ofrece una navegación de última generación, ... }\end{array}$ \\
\hline
\end{tabular}

Fig. 8: Cuestionario UEQ-S adaptado para MOOC UPV.

a) Semánticamente para que todos los ítems sean adjetivos y de género femenino (acorde con el sustantivo calificado: "la plataforma es...').

b) Semánticamente los ítems se diferencien más entre sí, y se ajusten más al aspecto valorado por el usuario MOOC UPV de habla hispana (por ejemplo, el ítem "impulsor de apoyo" se modificó en la versión larga para actuales investigaciones de plataformas de estudios de posgrado a "ofrece ayuda", en la propuesta para MOOCs UPV se ha resumido en una frase adjetivo, "de apoyo"). 


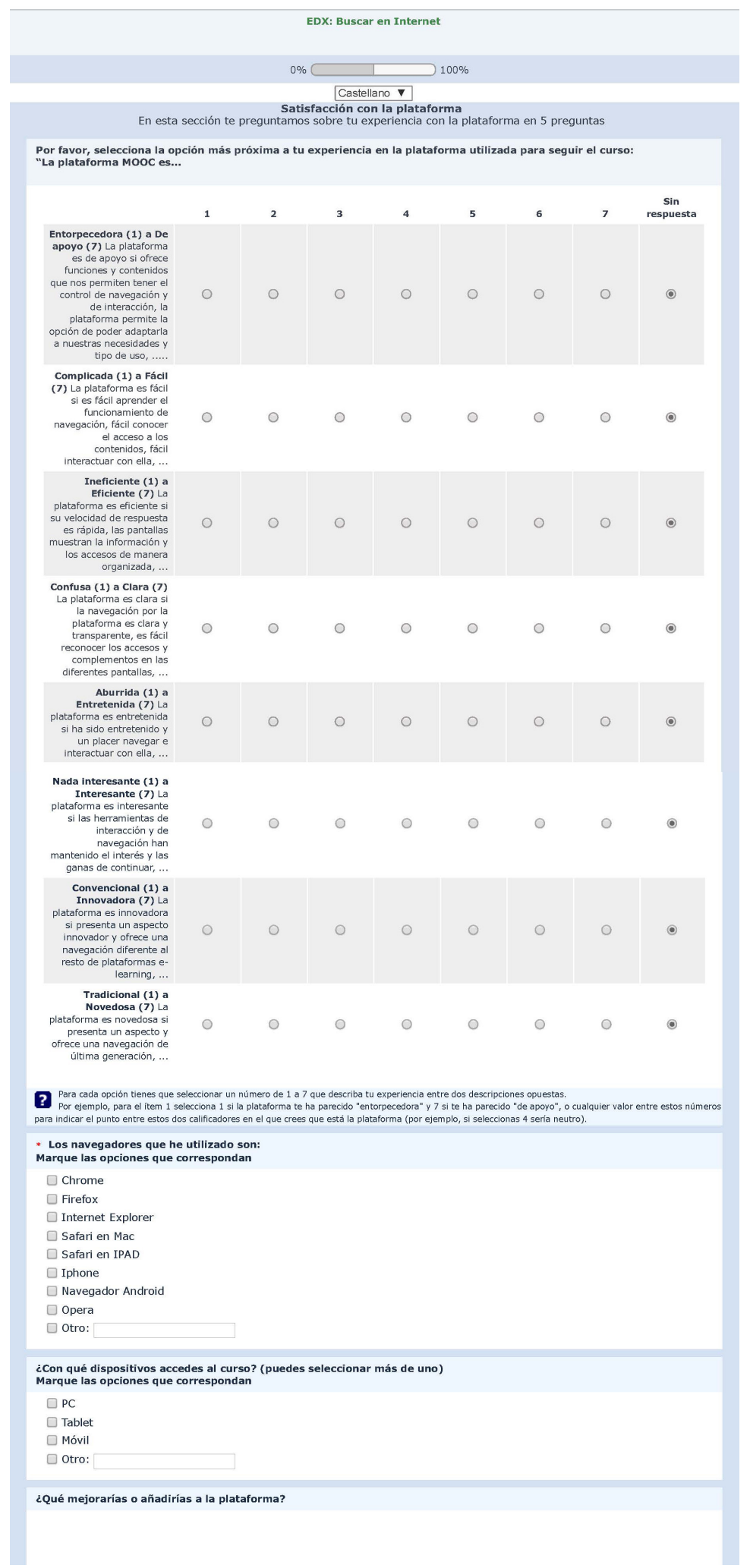

Fig. 9: Interfaz del cuestionario UEQ-S integrado en el cuestionario MOOC UPV extraído en Abril 2018 del curso en edX "Buscar en Internet".

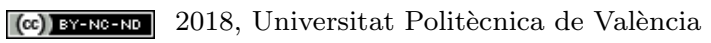
Congreso IN-RED (2018) 
c) Para cada ítem semánticamente positivo se incluyen ejemplos para facilitar al usuario su comprensión. Estos ejemplos son más genéricos por dos motivos, uno de ellos es para no influir demasiado en la decisión del usuario en el momento de la respuesta. Otra de las razones atiende a que cada usuario es diferente y su percepción también. El ejemplo genérico permitirá que, dentro esa diversidad de usuarios, que cada encuestado pueda ver recogida todas sus experiencias interactivas y asignarles un valor percibido. Por eso también los ejemplos se presentan con verbos impersonales.

No obstante, se propone dejar el cuestionario UX lo más genérico posible en esta primera fase de recogida de datos (de abril a septiembre 2018) ya que es susceptible de ajuste para una segunda recogida. Tras los resultados preliminares se prevé poder obtener información sobre aspectos valorados positivamente y negativamente de la plataforma MOOC UPV y poder centrar la investigación en aquellos aspectos de interés según tipo de usuario (por ejemplo: usuario hombre y usuario mujer), de manera que podamos detallar ejemplos e incluso incluir nuevas preguntas sobre su experiencia interactiva.

d) Además, estéticamente para no confundir al usuario en el método de presentación de las respuestas se presentarán todos los ítems semánticos con connotaciones positivas a la derecha y todos los negativos a la izquierda. Este cambio implica que algunos pares de ítems inviertan el orden de visualización asignado por los autores del UEQ-S.

\section{Conclusiones}

Por primera vez la UPV introduce un cuestionario validado científicamente en la evaluación de los MOOC por los estudiantes, y que además evalúa la experiencia de la interacción de los usuarios desde la perspectiva UX. La integración del cuestionario corto de experiencia del usuario UEQ-S en los MOOC UPV nos permitirá conocer tanto la usabilidad como el placer de uso que experimentan la multitud y diversidad de usuarios de cursos abiertos masivos on-line de la UPV. Los datos obtenidos en las encuestas nos facilitará información sobre aspectos de preferencia y comportamiento de la interacción de los usuarios con el fin último de potenciar experiencias placenteras de aprendizaje online. Los resultados analizados de este cuestionario integrado en los MOOC UPV nos ayudarán a establecer las pautas para desarrollar un diseño de interfaz de experiencias positivas de aprendizaje masivas, en abierto, online y adaptado a todos los usuarios. De esta manera se pretende que todo usuario global de MOOC escoja siempre a la UPV como su primera opción para su formación en abierto y en línea porque ofrece experiencias de aprendizaje online placenteras, atractivas y motivadoras.

\section{Referencias bibliográficas}

(2009). Ergonomics of human system interaction-Part 210: Human-centred design for interactive systems. International Standardization Organization (ISO). Switzerland.

Bevan, Nielg (2001). "International standards for HCI and usability". En: International Journal of Human-Computer Studies 55.4, págs. 533-552. DOI: $10.1006 /$ ijhc. 2001.0483.

2018, Universitat Politècnica de València Congreso IN-RED (2018) 
Encuesta MOOC UPV al curso edX Liderazgo para mandos intermedios (2018). Accedido Ene 23, 2018. https ://encuesta.upv . es/index . php/374466?token= 625590\&lang=es.

Espada, J. P. y col. (2014). "Method for analysing the user experience in MOOC platforms". En: 2014 International Symposium on Computers in Education (SIIE). IEEE, págs. 157-162. DOI: 10.1109/siie.2014.7017722.

Laugwitz, Bettina, Theo Held y Martin Schrepp (2008). "Construction and Evaluation of a User Experience Questionnaire". En: Lecture Notes in Computer Science. Springer Berlin Heidelberg, págs. 63-76. DOI: 10.1007/978-3-540-89350-9_6.

Likert, R. (1932). "A technique for the measurement of attitudes". En: Archives of Psychology 22.140.

Noticia UPV: La UPV, primera universidad de habla hispana en superar el millón de inscripciones en edX, la plataforma de MOOC impulsada por Harvard y el MIT (2018). Accedido May 24, 2018. https://www.upv.es/noticias-upv/noticia10053-cursos-masivos-es.html.

Noticia UPV: Top 5 mundial en MOOC La Universitat Politècnica de València y la plataforma edX, impulsada por MIT y Harvard, renuevan su colaboración (2018). Accedido Feb 2, 2018. https: //www . upv . es/noticias-upv/noticia-9788top-5-mundial-e-es.html.

Rauschenberger, Maria y col. (2013). "Efficient Measurement of the User Experience of Interactive Products. How to use the User Experience Questionnaire (UEQ). Example: Spanish Language Version". En: International Journal of Interactive Multimedia and Artificial Intelligence 2.1, págs. 39-45. DOI: 10.9781 / ijimai . 2013. 215.

Sanchis-Font, R. y col. (2017). "Improving the virtual learning experience: Usercentered design in e-learning". En: INTED2017 Proceedings. 11th International Technology, Education and Development Conference. Valencia, Spain: IATED, págs. 9902-9907. DOI: 10.21125/inted.2017.2356.

Schrepp, Martin, Andreas Hinderks y Jorg Thomaschewski (2017). "Design and Evaluation of a Short Version of the User Experience Questionnaire (UEQ-S)". En: International Journal of Interactive Multimedia and Artificial Intelligence 4.6, págs. 103-108. DOI: 10.9781/ijimai.2017.09.001.

Zaharias, Panagiotis y Brad Mehlenbacher (2012). "Editorial: Exploring User Experience (UX) in Virtual Learning Environments". En: Int. J. Hum.-Comput. Stud. 70.7, págs. 475-477. DOI: 10.1016/j.ijhcs. 2012.05 .001$. 


\section{2}

Metodologías activas de enseñanza/aprendizaje 


\title{
Desarrollo de una Actividad de Aprendizaje Experiencial para el aprendizaje de planes de control de la calidad.
}

\author{
Oscar Trull-Domínguez ${ }^{a}$, Ángel Peiró-Signes ${ }^{b}$, Marival Segarra-Oña ${ }^{c}$ \\ ${ }^{a}$ Departamento de Estadística e Investigación Operativa Aplicada y Calidad (Universitat Politècnica \\ de València, otrull@eio.upv.es), b Departamento de Organización de Empresas (Universitat \\ Politècnica de València, anpeisig@omp.upv.es) y ${ }^{\mathrm{c}}$ Departamento de Organización de Empresas \\ (Universitat Politècnica de València, maseo@omp.upv.es).
}

\begin{abstract}
This paper develops an Experiential Learning Activity (ELA) that focuses on the learning of concepts, procedures and documents necessary for the creation and effective use of control plans for quality assurance. The activity immerses the student in an environment of play and competition that allows the students to enjoy adequate motivation and concentration for the teachinglearning process. The activity has specially designed catapults, with which the students must perform three phases: assembly of them, learning to use and use in context, competing with their peers. The learning itinerary begins with experimentation, to move on to understanding and finally to creation and design.
\end{abstract}

Keywords: Experiential Learning Activities, control plan, quality, quality assurance.

\begin{abstract}
Resumen
Este artículo desarrolla una Actividad de Aprendizaje Experimental (ELA) que permite el aprendizaje de los conceptos, procedimientos y documentos necesarios para la creación y uso efectivo de planes de control de aseguramiento de la calidad. La actividad sumerge al alumno en un ambiente de juego y competición que permite al alumno disfrutar de la motivación y concentración adecuadas para el proceso de enseñanzaaprendizaje. La actividad dispone de unas catapultas especialmente diseñadas, con las que los alumnos deben realizar tres fases: ensamblaje de las mismas, aprendizaje de uso y utilización en contexto, compitiendo con sus compañeros. El itinerario del aprendizaje empieza con la experimentación, para pasar a la comprensión y finalmente a la creación y diseño.
\end{abstract}

Palabras clave: Aprendizaje experiencial, planes de control, calidad, aseguramiento de la calidad.

\section{Introducción}

La enseñanza tradicional basa su metodología de enseñanza-aprendizaje en la secuencia básica de profesor al alumno. El profesor, mediante clases magistrales, muestra una serie de conceptos y procedimientos que el alumno debe comprender para su ejercicio posterior 
Desarrollo de una Actividad de Aprendizaje Experiencial para el aprendizaje de planes de control de la calidad.

mediante una serie de prácticas. Esta metodología es válida en la mayoría de los entornos académicos. Sin embargo, la enseñanza de conceptos de calidad requiere de un particular interés por parte del profesor. Es importante resaltar que, si el concepto calidad resulta complicado de asimilar por gran parte del personal con experiencia laboral, este concepto resulta realmente complicado para aquellos alumnos sin esa experiencia. Lo mismo sucede con las herramientas de la calidad. Resulta prácticamente imposible dar a conocer conceptos y herramientas sofisticadas a algunos menos que no disponen de experiencia previa.

Según los estudios recientes sobre motivación del alumnado y su capacidad de adquisición de conceptos, se indica que el fundamento del proceso de enseñanza-aprendizaje debe recaer sobre el estudiante. Esto sugiere un cambio de perspectiva en la enseñanza. Los procesos habituales han sido orientados con el flujo de la formación desde el profesor hacia el alumno y una retroalimentación en las evaluaciones. Sin embargo, con este nuevo enfoque, el alumno es el que transmite la necesidad de aprendizaje y el formador evalúa constantemente las necesidades del alumno guiándole en una dirección efectiva hacia el aprendizaje. Pero llevar a cabo esta metodología no es inmediata. Es por ello, que las actividades de aprendizaje experiencial (ELA) se constituyen como una potente herramienta de aprendizaje (Peiró-Signes et al., 2017a and 2017b, Trull-Domínguez et al., 2017). Este tipo de técnicas tienen una serie de características inherentes al proceso:

- Aprendizaje deductivo de los conceptos. El alumno adquiere conceptos partiendo de la experiencia, viendo su utilidad y posteriormente comprendiendo los conceptos. A partir de ahí, al alumno será capaz de generar nuevas situaciones donde aplicar los conceptos.

- Aplicabilidad. Los conceptos se adquieren a través de la experiencia en diferentes aplicaciones. Ello provoca una abstracción de la aplicación y una generalización del problema. Internamente, el alumno está desarrollando el aprendizaje de forma consciente y estructurada.

- Escalabilidad. Los problemas prácticos pueden Disponerse de forma escalable. Así, el alumno refuerza contenidos ante la adquisición de nuevos conceptos.

- Motivación. El hecho de utilizar actividades lúdicas provoca una motivación en el alumnado que de otro modo difícilmente se podría conseguir.

Todas estas características tienen como resultado una ELA sofisticada. La planificación de estas actividades es meticulosa y debe ser en parte retroalimentada y revisada en cada nueva situación. Finalmente, la ejecución de la ELA debe estar limitada en el tiempo y bajo una estricta supervisión por parte del formador.

En este artículo se presenta una actividad experiencial dirigida a estudiantes de ingeniería en los cursos finales de su formación. En ella se tratan conceptos de calidad previamente adquiridos, y se desarrolla el concepto de plan de control de calidad o de aseguramiento de la calidad. Para que la actividad tenga un mayor éxito experiencial, se utilizará un juego de catapultas que los alumnos utilizarán para sus pruebas y finalmente habrá un desafío (elemento altamente motivador) con el que poner en práctica los conocimientos adquiridos. Esta actividad está organizada en dos sesiones de dos horas.

(cc) EY-NC-ND 2018, Universitat Politècnica de València

Congreso IN-RED (2018) 


\section{Objetivos}

El principal objetivo de la actividad experiencial de aprendizaje (ELA) desarrollada en este artículo consiste en aprender técnicas básicas del aseguramiento de la calidad. La ELA desarrolla el concepto de Planes de Control (CP) así como el Análisis Modal de Fallos y Efectos (FMEA), con el trabajo realizado por los alumnos cuando revisan los procesos de ensamblado de la catapulta, identificando los posibles errores, causas y efectos. Con ello, el alumno entiende los errores cometidos, y cómo un plan de control ayuda a evitarlos, sobretodo en un ambiente industrial plagado de procesos. Adicionalmente, se desarrollan actividades transversales, como es el trabajo cooperativo, en equipo, comunicación, etc.

(LaForge y Busing, 1998), indican los pasos a seguir para realizar una actividad experiencial, organizado en fases: una primera fase de planificación, una de desarrollo de la actividad y una última de toma de datos y retroalimentación para la mejora de la actividad.

En la fase de planificación, el formador debe emplear su experiencia para desarrollar una actividad que pueda resultar lo más veraz y cercana a la actividad industrial, teniendo en cuenta el nivel de conocimientos de los alumnos, y los objetivos a desarrollar (Harpeln and Hakel, 2013). Se trata, sin duda, de la fase más compleja. Hay que tener en cuenta, además, que, en esta actividad, el estudiante debe tener la capacidad de reflexionar sobre sus decisiones y de poder ejecutar él conocimiento adquirido. Es fundamental para una motivación positiva (Kold, 2014, Wheeler and McLeod, 2002).

En la fase de introducción, el instructor explica los elementos básicos de la experiencia, objetivos, organización y recursos utilizados, así como la reglas a observar durante el desarrollo de la actividad.

En la fase de desarrollo, del estudio ante debe estar relajado y motivado. Esta actitud permite de forma inconsciente una mejor atención al desarrollo de la actividad y consigue que el alumno esté inmerso en la actividad. Realizar actividades sin una motivación plena pude motivar una pérdida constante de atención, independientemente del nivel del alumnado. Sin embargo, en esta dase, el formador debe trabajar con la atención plena del alumnado. Debe estar atento para que el alumnado no divague en la actividad y pierda el fundamento. No hay que olvidar tampoco, que, en la ejecución de la actividad, aspectos transversales de la formación también se deben desarrollar, como el trabajo en equipo, proactividad, respeto a las decisiones ajenas, etc.

Finalmente, en la fase de recopilación, es necesario observar el nivel de adquisición de conceptos realizados por los alumnos, así como la percepción de los conceptos menos del resultado de la actividad.

\section{Desarrollo de la innovación.}

\subsection{Planificación}

La planificación se realiza teniendo en cuenta los aspectos fundamentales de distribución del tiempo, espacios y alumnos. Como las actitudes transversales son de especial 
Desarrollo de una Actividad de Aprendizaje Experiencial para el aprendizaje de planes de control de la calidad.

importancia, los alumnos se organizarán en grupos. La actividad grupal permite el desarrollo de las lluvias de ideas, trabajo en equipo y resolución de problemas.

Uno de los aspectos principales es la conexión del problema con el mundo real. Esta es la base que consolida el aprendizaje. La motivación forma parte del engranaje que debe hacer funcionar toda la actividad, que junto con una formación práctica deben conseguir que la actividad se desarrolle de forma funcional y eficiente.

Por lo tanto, se organiza la actividad del siguiente modo:

1. Una primera fase en la que disponen de material y procedimientos a seguir. Esta es una fase puramente procedimental. Conviven con el concepto de planes de control.

2. Una fase de deducción. Qué es lo que han hecho y la utilidad en la industria.

3. Aplicación y desarrollo los alumnos crean un nuevo plan de control aplicado a una nueva situación.

4. Recapitulación. El final de la práctica debe recoger todos los aspectos adquiridos y valorarlos. El formador aporta mejoras y se pone en común los diferentes planes realizados por los grupos para entablar una discusión y fortalecer los conocimientos adquiridos.

Un elemento diferenciador de esta actividad es el uso de catapultas y el realizar un reto entre los alumnos para vencer unos a otros. Está claro que la rivalidad no es un gran valor, pero sin duda es capaz de activar realmente la motivación del alumnado.

\subsection{Introducción.}

Para conseguir una completa motivación del alumnado, es importante comenzar la actividad con un elemento sorpresa que cree expectación. El instructor llevará el material en un maletín o lo tendrá preparado antes de la llegada de los estudiantes. Mostrará una catapulta completamente montada y discutirá con los alumnos cómo montarla de forma eficiente y sin cometer errores. Tras unos minutos de discusión, el formador dividirá a los estudiantes en grupos de tres, o en caso necesario, en grupos de cuatro. Se les dará el material necesario, y entonces se explica el objetivo inicial. Esta introducción durará alrededor de media hora. El material mínimo necesario constará de:

- Un juego completo de catapulta y herramientas.

- Un checklist con los materiales suministrados.

- Unas instrucciones de montaje.

- Un plan de control para el montaje.

(c) EY-NC-ND 2018, Universitat Politècnica de València

Congreso IN-RED (2018) 


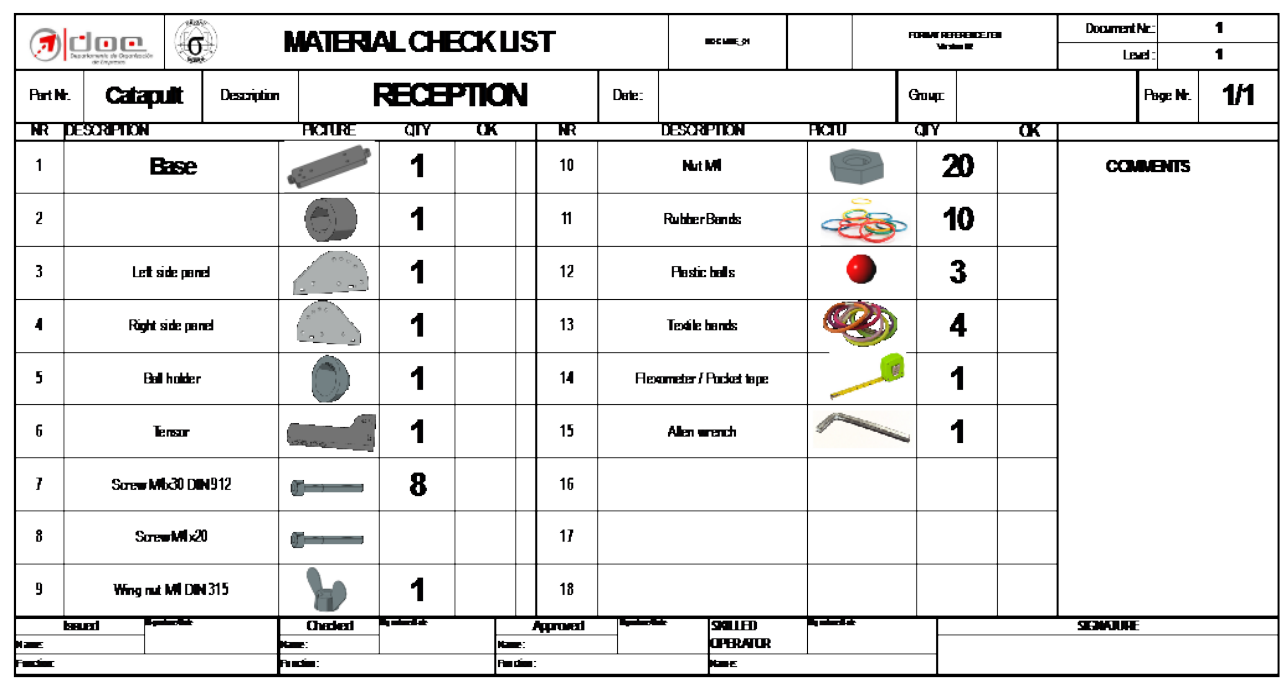

Fig 1. Lista de comprobación del material para la realización de la práctica.

\subsection{Actividad}

Para la correcta organización del equipo, uno de los componentes debe montar la catapulta, mientras que otro debe leer las instrucciones y otro seguir el plan de control. En caso de haber un alumno más, las tareas de controlar las instrucciones y la asesorar el montaje puede dividirse entre dos componentes.

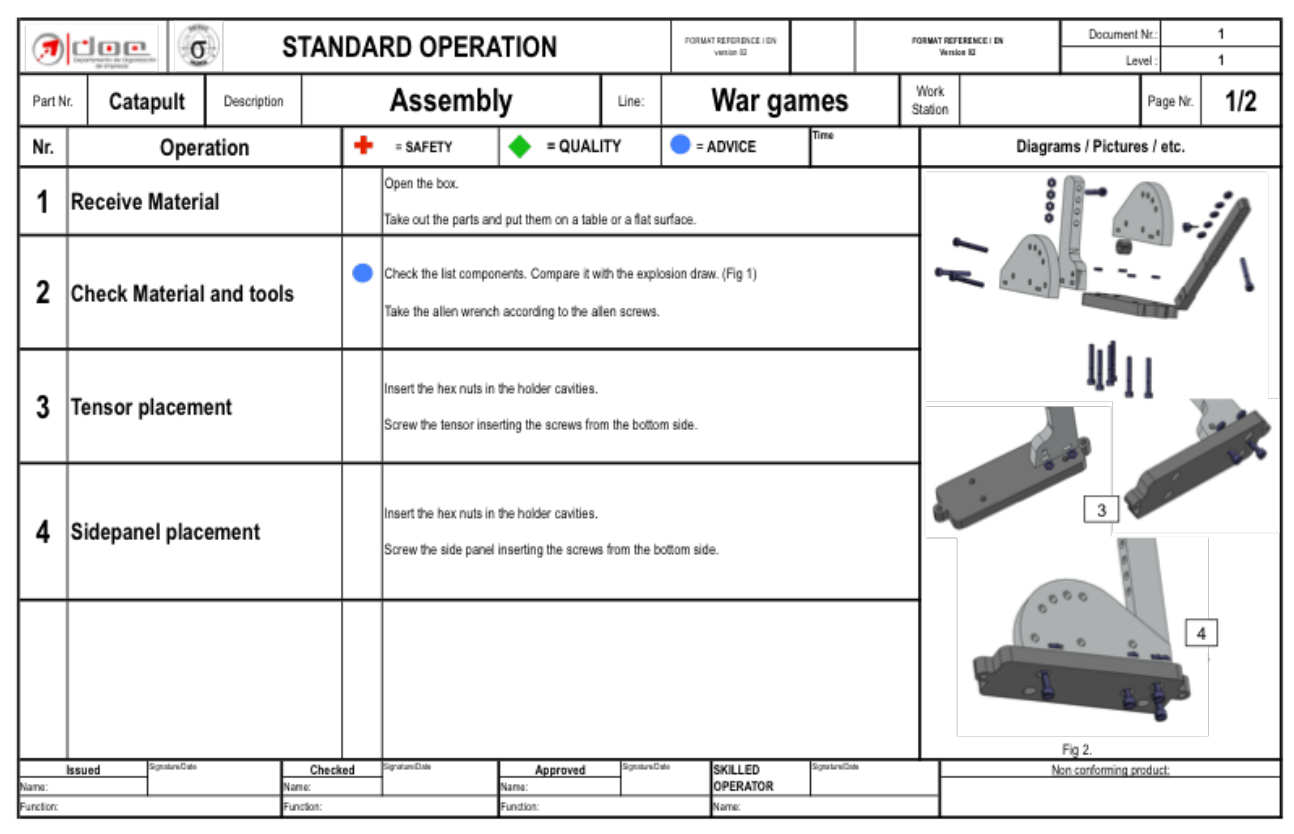

Fig 2. Operación estándar de montaje de la catapulta.

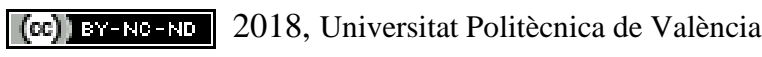
Congreso In-Red (2018) 
Desarrollo de una Actividad de Aprendizaje Experiencial para el aprendizaje de planes de control de la calidad.

Los grupos montan las catapultas. Deben controlar el tiempo de montaje y los fallos que realizan para posteriormente realizar el debate. Si es posible realizarlo, es conveniente introducir dificultades con piezas mal indicadas, que falten, o con alguna instrucción no muy clara. Así se puede poner en práctica el plan de control.

Una vez terminado, se debate sobre las actividades realizadas. Su conveniencia, ventajas y desventajas deben ser abordados en el debate. Por último, el formador debe exponer un problema real de la industria o servicios y discutir sobre esta herramienta.

Este debate debe ser aprovechado por el formador para explicar los diferentes aspectos del plan de control, así como la parte práctica para realizar un plan de control. Esta actividad debe durar entre cuarenta y cincuenta minutos.

A los alumnos se les informa de los nuevos objetivos: deben realizar un combate entre ellos para ganar destruyendo al ejército enemigo. El juego consiste en disponer cada grupo de cinco muñecos de pequeño tamaño que se disponen en formación triangular y aúna distancia determinada, de modo que alternen distancias cortas de casi 1,5 metros hasta más largas como 3 metros. Estas distancias han de ser medidas y anotadas. Los componentes del grupo realizan hasta un máximo de tres lanzamientos y anotan el número de muñecos abatidos en cada lanzamiento. Los muñecos abatidos no se levantan hasta el siguiente lanzador. El juego se organiza por turnos, y cada vez ha de lanzar un equipo, y dentro de cada equipo, un integrante. Los turnos dentro de cada equipo han de ser rodados, de modo que todos los integrantes lancen aproximadamente el mismo número de lanzamientos. Los lanzamientos se organizan por pares: dos grupos hasta que se haya completado una ronda con todos los lanzadores. Luego se intercambian grupos y así sucesivamente mientras el tiempo destinado a la actividad pueda realizarse.

Esta actividad durará 20 minutos, y en el proceso los alumnos deben anotar las incidencias que observan, así como las actuaciones positivas que llevan al abatimiento de muñecos contrarios. Es importante recalcar esta última indicación porque será la base para la siguiente parte de la actividad.

Terminado el tiempo, se proclama vencedor al que mayor número de muñecos haya derribado. Pero la actividad empieza a partir de ese momento. Los alumnos han estado practicando y aprendiendo el manejo de las catapultas, $\mathrm{y}$ ahora establecen el plan de control para el proceso de lanzamiento.

Con la ayuda del formador, se debe crear un plan de control para el lanzamiento de las bolas independientemente de la distancia a la que se encuentren. La secuencia se consigue del siguiente modo: primero, separar los diferentes procesos para el disparo; segundo, ver los posibles fallos y errores que se puedan prever. A partir de aquí, se proponen ya actividades: características a medir, tener en cuenta cómo se controla la característica que se está tratando, planes de acción, etc. Este plan quedará formalizado y se pondrá en común para todos los grupos. Esta fase puede durar unos 40 minutos.

(c) EY-NC-ND 2018, Universitat Politècnica de València

Congreso IN-RED (2018) 


\section{Actividad extendida}

En caso de disponer de suficiente tiempo con el alumnado, debería poderse poner en práctica el plan de control realizado. Esto consistiría en realizar de nuevo el combate anterior, pero aplicando los conocimientos adquiridos y poniendo énfasis en seguir el plan de control. Por supuesto, no hay demasiado aporte didáctico en esta fase, aunque si motivador, ya que poner en práctica el plan construido por el alumnado permite comprobar su utilidad. Esta actividad supondría entre 20 y 30 minutos.

\subsection{Debate y discusión}

Al final de la sesión se propone una discusión y un debate sobre la actividad. Es importante recabar información sobre los contenidos adquiridos, así como de la percepción del alumnado acerca del aprovechamiento de la actividad experiencial para su desarrollo formativo. La forma más práctica para realizar esta acción es entablar un debate abierto acerca de los conceptos, y posteriormente realizar un cuestionario para la evaluación de la adquisición, y otro para la percepción. Pocas preguntas y muy directas.

Las preguntas deben ser del tipo: ¿Qué logramos con un plan de control? ¿Podemos evitar los errores estableciendo un plan de control en toda la empresa? ¿Cuántos planes de control pueden ser necesarios en una empresa?

La duración de esta parte debe rellenar el tiempo necesario hasta los 120 minutos planteados.

Finalmente se propone una serie de actividades posteriores para el completo desarrollo de la actividad. Los alumnos de cada grupo deben escoger una actividad conocida y simple, y desarrollar un plan de control sencillo en el que se incluyan aspectos tales como la recepción de material, procesos operativos, entrega a cliente, y desarrollando todos los puntos del plan.

\section{Resultados}

Evaluamos los resultados de la primera ejecución de la actividad a través de una pequeña encuesta de las percepciones de los estudiantes completada después de la clase. Utilizamos un cuestionario con una escala Likert de 1 a 5 , donde 1 corresponde a totalmente en desacuerdo y 5 a totalmente de acuerdo.

A continuación, se muestran resultados obtenidos de la encuesta de percepción por parte del alumnado sobre la comprensión y adquisición de los nuevos conceptos. Las preguntas comparan la familiaridad del Alumno con los conceptos trabajados. En una primera instancia, los alumnos fueron preguntados en un test anterior a esta práctica por los conceptos, que denominamos preguntas del grupo 1 preactividad. Los datos se comparan con las mismas respuestas dadas por los alumnos tras la actividad.

Las figuras 1 a 4 representan los datos obtenidos para esta encuesta. En ellas se pueden apreciar cómo los resultados obtenidos tras la realización de la ELA. contribuyen a mejorar la percepción del alumno de su proceso de aprendizaje y formación. 
Desarrollo de una Actividad de Aprendizaje Experiencial para el aprendizaje de planes de control de la calidad.

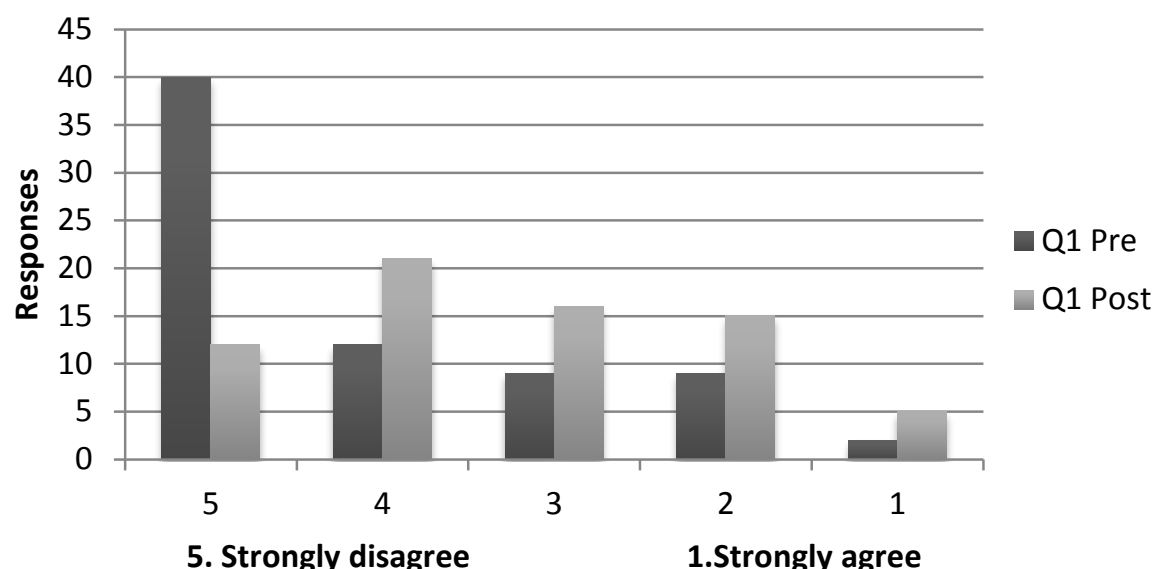

Fig 3. ¿Qué significa "Plan de Control"?. Explica su utilidad.

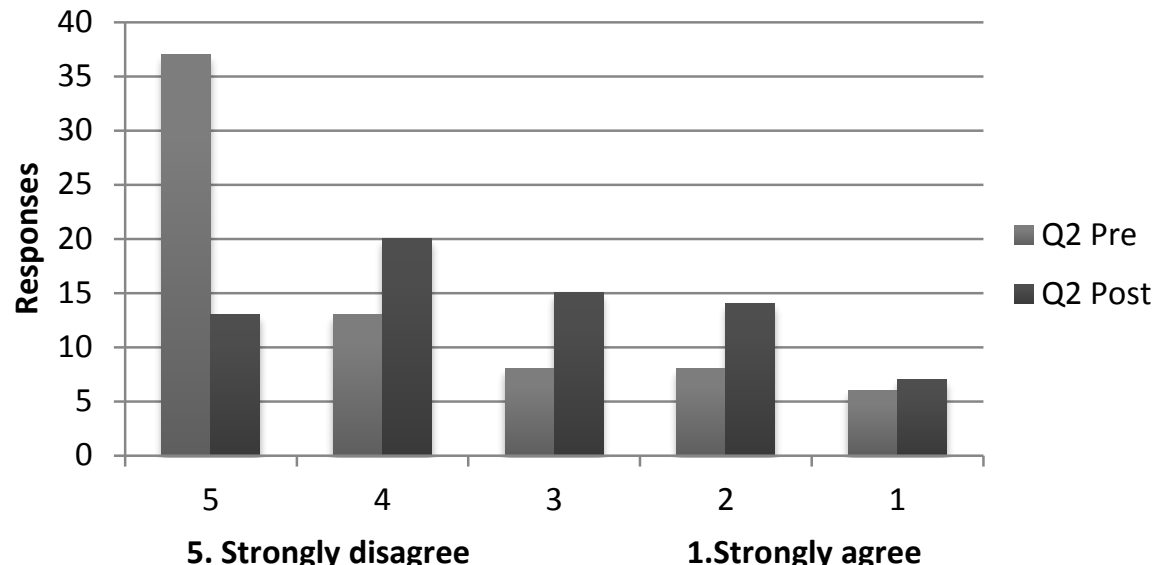

Fig. 4. Explica los requerimientos del plan de acción y cómo se asignan sus tareas.

(c) EY-NC-ND 2018, Universitat Politècnica de València

Congreso IN-RED (2018) 


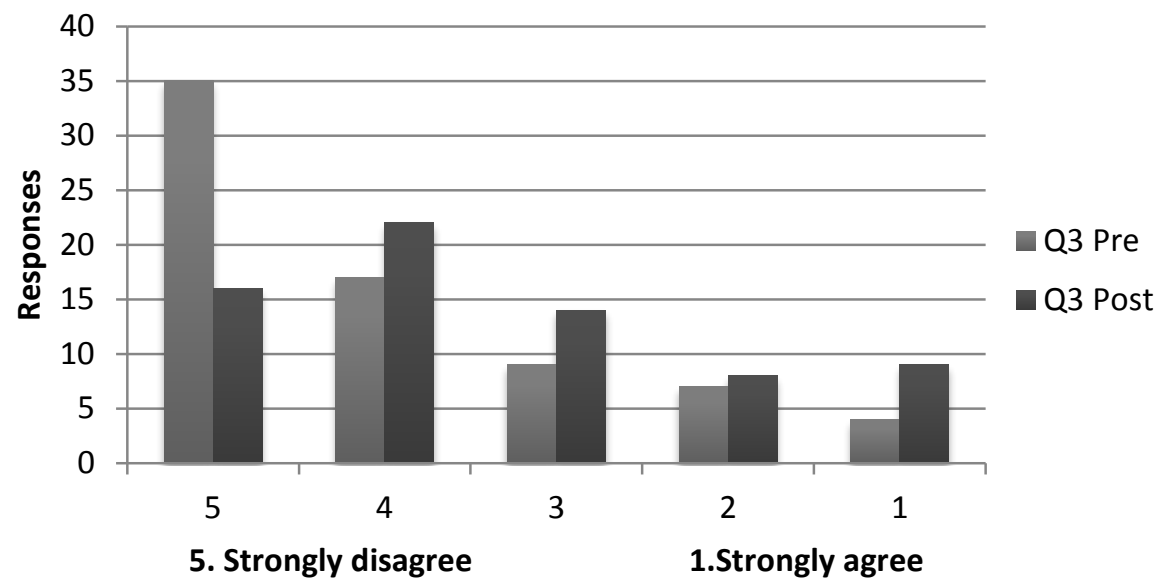

Fig. 5. Explica los elementos de especificación de un plan de control.

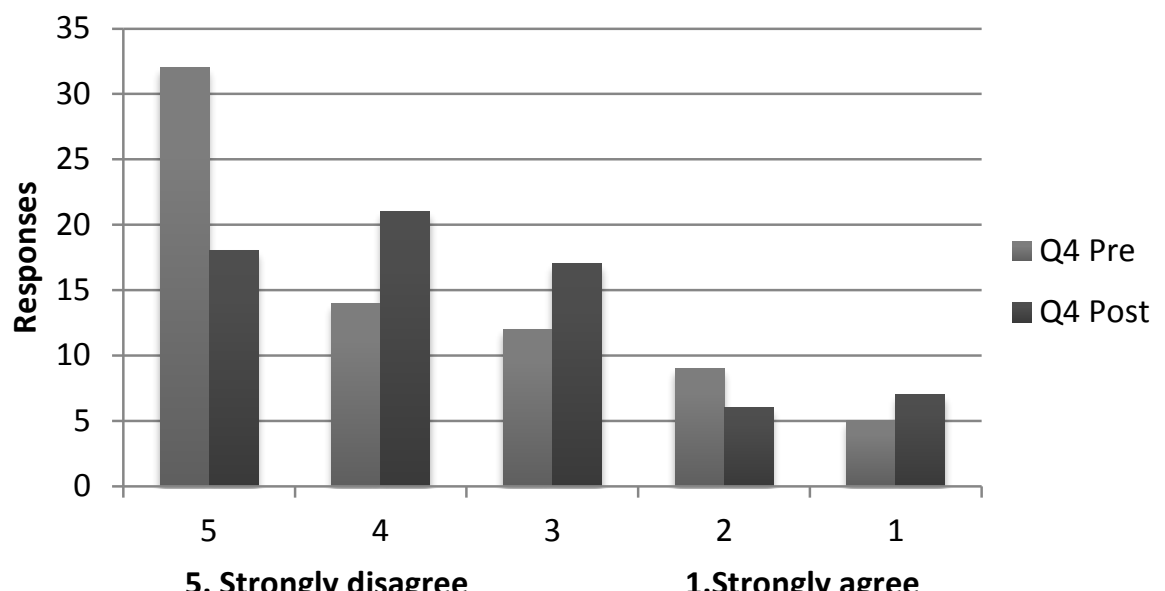

Fige 6. Describe los métodos necesarios en un plan de control.

\section{Conclusiones}

Este artículo describe una actividad experiencial basada en el uso de catapultas para introducir conceptos complejos de calidad de forma sencilla y motivadora, superando la metodología tradicional de enseñanza basada en explicaciones.

Se describe la problemática de la enseñanza de la calidad, y como las ELA pueden jugar un papel Importante en la innovación del Proceso de enseñanza -aprendizaje. Se describe la activad a realizar y cómo poder evaluarla. Por último, se analizan resultados fruto de la Actividad ya realizada y testeada con alumnos. El resultado obtenido muestra una mejora 
Desarrollo de una Actividad de Aprendizaje Experiencial para el aprendizaje de planes de control de la calidad.

sustancial en la capacidad del alumno de relacionar el trabajo realizado con la calidad y profundizar en los conceptos adquiridos.

\section{Agradecimientos}

Este trabajo forma parte del estudio desarrollado por el Grupo de Aprendizaje Experiencial (GAE) creado como EICE en la Universidad Politécnica de Valencia (UPV). Los autores desean agradecer a la UPV por el apoyo a través del PIME 2018-2019 "Adaptación y desarrollo de aprendizajes experienciales al contexto de las asignaturas ".

\section{Referencias}

PEIRO-SIGNES, A., TRULL-DOMINGUEZ, O., SEGARRA-ONA, M. V. AND DE-MIGUELMOLINA, B. (2017). Using simple experiential learning activities encourage learning of operations management concepts. Proceedings of EDULEARN17 Conference, pp. 8712-8718.

PEIRO-SIGNES, A., SEGARRA-ONA, M. V., TRULL-DOMINGUEZ, O. AND DE-MIGUELMOLINA, B. (2017). Bean bags: an experiential learning activity for quality control. Proceedings of EDULEARN17 Conference, pp. 8216-8221.

TRULL-DOMINGUEZ, O., PEIRO-SIGNES, A. AND SEGARRA-ONA, M. V. (2017). Learning statistical capacity concept through an experiential learning activity. Proceedings of EDULEARN17 Conference, pp. 8797-8801.

LAFORGE, R. AND BUSING, M. (1998). The use of industrial software to create experiential learning activities in operations management courses. Prod. Oper., vol. 7, no. 3, pp. 325-334.

HALPERN,D. AND HAKEL,M. (2003). Applying the science of learning to the university and beyond: Teaching for long-term retention and transfer. Mag. High. Learn.

KOLB,D. (2014). Experiential learning: Experience as the source of learning and development. Pearson Education, Inc.

WHEELER, J. AND MCLEOD, P. (2002). Expanding our teaching effectiveness: Understanding our responses to 'in-the-moment' classroom events. J. Manag. Educ.

(cc) EY-NC-ND 2018, Universitat Politècnica de València

Congreso IN-RED (2018) 


\title{
Los “One minute paper” como elemento de evaluación continua en la búsqueda de la mejora de la evaluación en una asignatura del Grado en Derecho.
}

\section{Ixusko Ordeñana Gezuraga}

Profesor Derecho Procesal Universidad del País Vasco, ixusko.ordenana@ehu.eus

\begin{abstract}
In the framework of new active teaching-learning methodologies, having recovered student's centrality in this process and adopting teacher's guidance task, evaluation formula becomes an essential element: it is essential to assess adequately that student acquires competences and knowledge linked to specific subject. Leaving aside old formulas that based student's evaluation exclusively on a final exam, an experience of teaching innovation developed in a subject of Law Degree, in the first semester of 2017/2018 academic year, is described: 5 one minute paper have been combined with one final test, using a formative and summative evaluation formula.
\end{abstract}

\section{Keywords:}

One minute paper, evaluation, improving, teaching-learning process

\section{Resumen}

En el marco de las nuevas metodologías activas de enseñanza-aprendizaje, habiendo recuperado el estudiante la centralidad que le corresponde en este proceso y adoptando el docente la labor de guía, deviene elemento esencial la fórmula de evaluación: es imprescindible tasar adecuadamente que el alumnado adquiere las competencias y conocimientos vinculados a la asignatura concreta. Prescindiendo de formulas antiguas que basaban la evaluación exclusivamente en un examen final, se presenta la experiencia de innovación docente desarrollada en el primer cuatrimestre del curso 2017/2018 en una asignatura del Grado en Derecho: se han combinado 5 “one minute paper” con una prueba final, utilizando una fórmula de evaluación formativa y sumativa.

\section{Palabras clave:}

“One minute paper”, evaluación, mejora, proceso enseñanza-aprendizaje. 


\section{Introducción}

Seis años después de que la Universidad del País Vasco-Euskal Herriko Unibertsitatea ${ }^{1}$ introdujera el nuevo plan de estudios en la formación jurídica, familiarizados con las nuevas metodologías de enseñanza-aprendizaje, actuando en nuestra labor docente, conforme al aprendizaje cooperativo, aprendizaje basado en problemas y al método del caso, seguimos buscando la forma más adecuada de evaluar al alumnado. En este sentido, nos encontramos con un límite principal de orden público: la UPV-EHU, en general, y su Facultad de Derecho, en particular, nos exigen que, como mínimo, el alumno pueda obtener 3 puntos sobre 10 a lo largo del curso, mediante pruebas, ejercicios o prácticas varias. En este contexto, los últimos cursos hemos seguido distintas fórmulas de evaluación, si bien a todas les hemos detectado defectos o taras. Estabamos intentando buscar la fórmula "cuasiperfecta", cuando en un curso de formación docente ofrecido por el Servicio de Asesoramiento Educativo de la UPV/EHU, nos hablaron del "One minute paper" como fórmula o prueba de evaluación continua. Convencidos de que nada perdíamos por probarlo -sumaría un intento más-, el primer cuatrimestre de este curso 2017/2018 lo hemos utilizado en tres grupos del Grado en Derecho como elemento de evaluación continua. En las siguientes líneas, queremos explicar la experiencia, calificándola, desde un principio, como éxito rotundo.

\section{Objetivos}

La experiencia que vamos a relatar en el IV Congreso Nacional de Innovacion Educativa y Docencia en red $^{2}$ persigue:

1. Partiendo de la importancia del método de evaluación del estudiantado en el marco de los sistemas activos de enseñanza-aprendizaje, fijar uno que case adecuadamente con las competencias a adquirir en la asignatura Derecho Procesal I, argumentando pedagógicamente la opción por el mismo.

2. Analizar el marco jurídico en el que nos podemos mover (la normativa de la UPV/EHU al respecto) y el margen de maniobra y mejora.

3. Exponer la implementación del método de evaluación empleado el primer cuatrimestre del curso 2017/2018, detectando sus bondades y debilidades. Se tendrá en cuenta, al efecto, especialmente la visión o perspectiva del alumnado, además de la del docente.

4. Obtener un feed-back por parte de los asistentes al IN-RED 2018, dirigido, en su caso, a mejorar el método de evaluación expuesto.

${ }^{1}$ En los sucesivo, UPV-EHU.

2En lo sucesivo, IN-RED 2018.

(c) EY-NC-ND 2018, Universitat Politècnica de València

Congreso IN-RED (2018) 


\section{Desarrollo de la innovación}

\subsection{Marco teórico de la experiencia de innovación: la evaluación universitaria y su importancia. Fundamentos pedagógicos y normativa vigente en la Universidad del País Vasco.}

\subsubsection{Líneas elementales de la evaluación universitaria hoy.}

En un contexto de educación superior, en el desarrollo de cualquier Grado universitario, deviene esencial tasar o valorar el aprendizaje del estudiantado ${ }^{3}$. No únicamente por resultar un elemento formal esencial, exigido institucionalmente para poder conceder un título oficial profesionalizante, sino -principalmente- por ser parte sustancial del proceso de enseñanza-aprendizaje. La evaluación es, en sí misma, un elemento de aprendizaje para el alumnado $^{4}$. No obstante, en la evaluación intervienen activamente los/as dos protagonistas: el/la docente y el/la alumno/a. Mediante la evaluación el profesor/a -encargado/a de plantear situaciones y ofrecer al alumnado los instrumentos para aprender-, persigue (1) hacerse con evidencias o pruebas procedentes de aquéllos/as, a los que (2) aplica unos criterios de corrección, que le permiten (3) comprobar el nivel de dominio de los objetivos planteados para la materia para, con ello, realizar un juicio de valor ${ }^{5}$. Los tres elementos integran lo que se denomina "sistema de evaluación".

Conforme a los nuevos tiempos y metodologías activas, concebido el aprendizaje "como proceso constructivo y no meramente receptivo" 6 , el sistema de evaluación no lo debe protagonizar el/la docente en su labor de calcular u obtener una nota final oficial que expresa un rendimiento académico. La evaluación debe centrarse especialmente en el estudiante, sirviendo para orientarle en su proceso de aprendizaje, motivarle y ayudarle a superar trabas. La evaluación ayuda especialmente al estudiante a conocer si su organización respecto a la materia (el tiempo y esfuerzo invertido y método utilizado) es adecuada y, por ende, y como consecuencia, a articular estrategias de futuro respecto al proceso de aprendizaje que protagoniza ${ }^{7}$. En este sentido, deviene esencial el feed-back o

\footnotetext{
${ }^{3}$ Describen la evaluación como parte esencial del proceso de enseñanza y aprendizaje, ÁLVAREZ VALDIVIA, I.M., ARTILES ARMADA, K. "La evaluación en la universidad: Estudio preliminar”, Aula Abierta (2001), núm. 78. Oviedo: Instituto de Ciencias de la Educación de la Universidad de Oviedo. En la misma línea, remarcando que es uno de los elementos que "mayor impacto" tiene en el estudiantado en su proceso de aprendizaje, GARGALLO CASTEL, A., "Aproximación al estudio de la evaluación en la universidad: un análisis exploratorio con alumnos semipresenciales”, Contextos educativos: Revista de educación (2009), núm. 12. La Rioja: Universidad de La Rioja.

4 En este último sentido, se habla de la "evaluación orientada al aprendizaje”. Explican su fundamento, incidiendo en sus tres elementos esenciales (participación activa de los estudiantes, retroalimentación y tareas auténticas), IBARRA SAIZ, M.S., RODRÍGUEZ GÓMEZ, G., GÓMEZ RUÍZ, M.A., "La evaluación entre iguales: beneficios y estrategias para su práctica en la universidad”, Revista de educación (2012), núm. 359. Madrid: Ministerio de Educación, Cultura y Deporte.

${ }^{5}$ Remarca que la evaluación siempre "aboca a un juicio sobre algo", PIDONE, C.L., "Evaluación de los aprendizajes en la Universidad”, Diálogos educativos (2005), núm. 9. Chile: Universidad Metropolitana de Ciencias de la Educación.

${ }^{6}$ Con SAENZ DEL BURGO MARTíNEZ, L., PURAS OCHOA, G., “Aplicación de metodologías activas para aprender a gestionar la oficina de farmacia: Una experiencia en el aula”, IJERI: International journal of Educational Research and Innovation (2018), núm. 9. Sevilla: Universidad Pablo de Olabide.

${ }^{7}$ En esta senda, apoyado en literatura del campo de la pedagogía, al tiempo que expone una experiencia de innovación docente en el ámbito jurídico, MORENO OLIVOS, T., “La evaluación del aprendizaje en la universidad: Tensiones, contradicciones y
} 
retroalimentación que aporta el/la docente al alumno/a ${ }^{8}$. Se aplaude, incluso, que el alumnado pueda elegir o configurar su propio sistema de evaluación ${ }^{9}$-algo por lo que hemos optado nosotros mediante el "contrato programa", como relataremos a posteriori-. Todo ello es parte fundamental de un aprendizaje significativo, en el que el alumno/a puede relacionar lo nuevo con lo que ya conoce ${ }^{10}$.

No se puede obviar, igualmente, que el método de evaluación es, al tiempo, un instrumento muy útil para el/la docente: le permite conocer las dificultades del estudiantado en la materia, y por tanto, donde hacer más hincapié en su impartición; es, al tiempo, un instrumento vital para la re-organización y planificación de la docencia (contenidos, formas en general,... $)^{11}$. Lo es porque muestra la congruencia entre los objetivos planteados en la guía docente para la asignatura y los resultados obtenidos.

El sistema de evaluación puede ser sumativo o formativo. El primero supone la emisión de un (único) juicio por parte del docente, al finalizar un período de enseñanza, para calificar en función del rendimiento apreciado. Es el mecanismo que denota que el/la estudiante posee las competencias que requieren el ejercicio profesional del Grado que estudia, en general, y que se vinculan con la disciplina o materia de la que es evaluado, en particular, y que se supone que antes de cursarla no tenía. El segundo, por su parte, supone la emisión, por parte del docente, de juicios a lo largo de un período de enseñanza, haciendo partícipe de ellos al alumnado, permitiendo esta práctica que ambos mejoren (optimicen, si se quiere, en términos empresariales) su rol en el proceso de enseñanza-aprendizaje ${ }^{12}$. Ambos sistemas no son, no obstante, incompatibles, entendiendo que es su conjunción lo que mejor casa con las nuevas metodologías activas y con la pedagogía constructivista.

Por último, convivene remarcar, como hemos apuntado, que en el contexto de las metodologías activas, evaluamos competencias que se muestran mediante tareas que recogen los resultados de aprendizaje correspondientes.

desafíos”, Revista mexicana de investigación educativa (2009), núm. 41. México: Consejo Mexicano de Investigación Educativa. También, JANÉ, M., “Evaluación del aprendizaje: ¿problema o herramienta?”, Revista de estudios sociales (2005), núm. 20. Colombia: Universidad de Los Andes-Facultad de Ciencias Sociales.

${ }^{8}$ Lo entienden "estrategia clave para mejorar la enseñanza y el aprendizaje”, CANO GARCÍA, E., CABRERA LANZO, N., “Evaluación formativa de competencias a través del blog en la Universidad”, Digital Education Review (2013), núm. 23. Barcelona: Universitat de Barcelona-Digital Education Observatory

9 En nuestro apoyo, PORTO CURRÁS, M., “Evaluación de estudiantes en la universidad de Santiago de Compostela: percepciones de los propios alumnos”, REDU: Revista de Docencia Universitaria (2009), núm. 3. Valencia: Red Estatal de Docencia Universitaria

${ }^{10}$ En este sentido, definen la evaluación como "evolución y cambio”, RAMOS HERNANDO, C., BERASALUCE DIÉZ, R., PEIRÓ I GREGORI, S. (2016), "La evaluación por competencias en la universidad”, AAVV, XIV Jornadas de redes de investigación en docencia universitaria, p. 2615: Alicante: Universidad de Alicante.

${ }^{11}$ Remarcan la importancia de la evaluación para el propio docente, atendiendo a su experiencia, QUIROGA, V., MENA GARCÍA, E., PORLAN JUY, J., MORALES MARTÍNEZ, E., MÁRQUEZ SÁNCHEZ, L., "La evaluación continua en el Grado de Trabajo Social de la Universidad de Barcelona”, Cuadernos de trabajo social (2014), núm. 2. Madrid: Universidad Complutense.

${ }^{12}$ Luego, el alumno puede mejorar el aprendizaje y el docente la enseñanza.

(c) B BY-NC-ND 2018, Universitat Politècnica de València

Congreso IN-RED (2018) 


\subsubsection{La normativa de evaluación vigente en la UPV/EHU}

Partiendo de la doble naturaleza de la evaluación (formal y pedagógica), el primer elemento nos dificulta modificaciones en el sistema de apreciación o control del aprendizaje que quebranten el marco mínimo garantizador que ordena la Universidad -en nuestro caso la UPV/EHU-. Concretamente, tenemos que estar al Acuerdo de 15 de diciembre de 2016, del Consejo de Gobierno de la UPV/EHU, por el que se aprueba la Normativa reguladora de la Evaluación del alumnado en las titulaciones oficiales de Grado $^{13}$. Resumimos sus líneas generales:

1.Se realiza una apuesta por los sistemas de evaluación continua, "facilitando y fomentando la implantación de sistemas de evaluación continua en los que el peso de pruebas finales se reduzca, e incluso desaparezca, a favor de la implantación de actividades de evaluación distribuidas a lo largo del periodo de docencia” (artículos ${ }^{14} 1$ y 8 )

2. Se reconoce el derecho del alumnado a ser evaluado con garantías de equidad y justicia, y de acuerdo con el nivel de enseñanza impartida (art. 2)

3. El objetivo de la evaluación es medir los resultados de aprendizaje "con los criterios e indicadores de evaluación específicos definidos en las guías docentes” (art. 4).

4. La evaluación debe ser formativa y ofrecer información y orientación adecuada al alumnado sobre el nivel de adquisición de competencias y las mejoras que se sugieren en su proceso de aprendizaje (art. 5)

5. Se preferencia la evaluación continua, quedando a salvo siempre el derecho del alumno "a ser evaluado mediante el sistema de evaluación final, independientemente de que haya participado o no en el sistema de evaluación continua" ${ }^{15}$ (art. 8.3)

6 En la evaluación continua, "las pruebas podrán realizarse exclusivamente a lo largo del periodo formativo o bien, realizarse a lo largo del periodo formativo, y complementarse con una prueba en la fecha oficial establecida para la convocatoria de exámenes correspondiente" (art. 8.2 a))

A priori, y conectando esta ordenación con la configuración de la evaluación en la universidad actual, vemos que la UPV/EHU acata los postulados y exigencias de los nuevos tiempos y nuevas metodologías de enseñanza-aprendizaje.

\subsection{Marco práctico de la experiencia de innovación o el cúmulo de problemas a tener en cuenta: los grupos a evaluar y el fracaso de métodos de evaluación anteriores.}

\footnotetext{
${ }^{13}$ Publicado en el Boletín Oficial del País Vasco del 13 de marzo de 2017.

${ }^{14}$ En lo sucesivo, art.

15 “Para ello, el alumnado deberá presentar por escrito al profesorado responsable de la asignatura la renuncia a la evaluación continua, para lo que dispondrán de un plazo de 9 semanas para las asignaturas cuatrimestrales y de 18 semanas para las anuales, a contar desde el comienzo del cuatrimestre o curso respectivamente, de acuerdo con el calendario académico del centro. La guía docente de la asignatura podrá establecer un plazo mayor” añade el precepto mentado.
} 


\subsubsection{El estudiantado a evaluar y sus circunstancias}

En el marco jurídico descrito, y para poder entender nuestra experiencia, deviene imprescindible examinar sus circunstancias. Conviene apuntar especialmente que el primer cuatrimestre del curso 2017/2018 hemos sido responsables de tres grupos de estudiantes ${ }^{16}$. Dos en el Grado en Derecho -uno de castellano y otro de euskera ${ }^{17}$ - y uno en el doble Grado Derecho y Administración de Empresas -también en euskera-. El grupo de castellano cuenta con 100 estudiantes y los de euskera con 40 más o menos cada uno. En suma sencilla, hemos enseñado a casi 200 alumnos y alumnas, de cuyas evaluaciones obviamente- también nos hemos encargado.

La asignatura que impartimos -y, por tanto, evaluamos- es Derecho Procesal I, dotada con una carga de 6 créditos. Se caracteriza por un temario muy extenso (15 lecciones) y esencial para la formación del futuro jurista, que se trabaja en el aula en 42 horas de clase magistral y 18 horas de prácticas. Conforme al cómputo del crédito europeo, estas actividades requieren, fuera del aula, 63 y 27 horas de trabajo del alumnado, respectivamente. Nuestra experiencia de más de 15 años en la impartición de la materia nos dicta que el estudiantado percibe la asignatura como de dificultad media-alta.

\subsubsection{Los sistemas de evaluación anteriores y sus circunstancias}

Con un contexto parecido al descrito, los últimos 6 cursos, el tiempo que lleva instaurado el Grado en Derecho en nuestra Facultad, y hasta dar con el método de evaluación implementado este curso 2017/2018, hemos utilizado previamente otros dos. Ambos tienen en común que valorábamos en 7 puntos la teoría de la materia y en 3 la práctica, cumpliendo la normativa de nuestra propia Facultad.

En uno primero, que implementamos durante tres cursos, el examen teórico era oral en la fecha oficial, y los puntos correspondientes a las prácticas se distribuían, para el alumnado de evaluación continua, en 3 prácticas que realizaban fuera del horario escolar y corregía el docente en su despacho individualmente y en el aula colectivamente. Estas prácticas eximían al estudiante, que optaba por la evaluación continua, de realizar un examen práctico (también valorado en 3 puntos) el día del examen oficial ${ }^{18}$. En juicio crítico de este sistema, y fijándonos únicamente en la evaluación continua -que, como hemos visto, es la que fomenta el marco normativo de la UPV/EHU-, el alumnado se quejaba de que las prácticas suponían mucha carga de trabajo y no tenía una repercusión similar en la nota final. Se alegaba mucho, asimismo, la dificultad de las prácticas, sugiriendo muchos estudiantes que sería mejor hacer mayor número de prácticas pero menos complejas. La prueba final -el examen oral, en el que el estudiantado debía responder a dos preguntas de otros tantos temas elegidos por sorteo-, que casaba muy bien con las competencias

\footnotetext{
${ }^{16}$ Describimos la situación de este último curso, sin perjuicio de que en los anteriores ha sido parecida, incluso, con mayor número de alumnado por grupo.

${ }^{17}$ Lenguaje cooficial de la Comunidad Autónoma vasca en la que se imparte docencia de Grado.

${ }^{18}$ Luego, a sensu contrario, el alumno/a que optaba por la evaluación final, tenía que realizar el día del examen oficial, una prueba oral teórica y otra práctica escrita.
}

(c)) EY-NC-ND 2018, Universitat Politècnica de València

Congreso IN-RED (2018) 
generales de la titulación y de nuestra asignatura (la comunicación es esencial, junto a la capacidad de síntesis y análisis crítico), tenía sus defensores y sus retractores en el estudiantado. Desde una perspectiva docente, las prácticas suponían una gran carga de trabajo, pues se corregían todas las prácticas individualmente y reportaba el correspondiente feed-back, colectivamente, en el aula e, individualmente, en el despacho. En relación a la prueba teórica oral nos preocupaba especialmente el grado de subjetividad en la evaluación, inevitable cuando se ha de hacer frente a 200 exámenes en pocos días consecutivos.

Valoradas las debilidades y fortalezas del sistema de evaluación descrito, escuchando especialmente las protestas y anhelos del alumnado, los siguientes dos cursos, modificamos el sistema de evaluación. Era nuestro segundo intento de mejora. El examen final dejó de ser oral y pasó a ser un test con 30 items, que se convertían en 7 puntos de la nota final. Con ello, entendíamos que ganábamos objetividad en la corrección, si bien perdíamos el trabajar con el estudiantado la competencia de comunicación oral, para ahondar en la de análisis crítico de la materia En cuanto a las prácticas, también valoradas en 3 puntos para la nota final para el alumando de evaluación continua, pasaron a ser 30 casos sencillos, que realizaban fuera del aula y se corregían colectivamente -todas- en el aula y 10 individualmente por el profesor. Los/as estudiantes que optaban por la evaluación final tenían que hacer una práctica valorada en 3 puntos el día del examen oficial. Entendemos que el gran acierto de este sistema fue el examen test. Nos garantizaba una corrección rápida, objetiva y un feed-back sencillo. Nos percatamos, al tiempo, que el índice de alumnos y alumnas que se presentaba al examen se incrementó de manera considerable. Tenemos que reconocer, asimismo, que el alumnado valora muy positivamente esta prueba. El tema de las prácticas nos siguió sin convencer: el estudiantado seguía reiterando la misma crítica (mucho trabajo para tan poco peso en la nota final) y nuestro trabajo aumentó considerablemente; si antes corregíamos 3 prácticas (aunque fueran complejas) a cada estudiante, ahora corregíamos 10. Nos pasamos semanas completas corrigiendo las prácticas.

\subsubsection{Conclusión: la necesidad de mejorar el sistema de evaluación.}

Entendiendo la evaluación como un elemento esencial de nuestra docencia ${ }^{19}$, y que no hay "una regla única para evaluar”20, aunque sí un marco normativo mínimo que hay que obedecer, buscando la mejora continua en el proceso de enseñanzaaprendizaje, para satisfacer, en primer lugar, al alumnado, y, en segundo, también al docente, el primer cuatrimestre del curso 2017/2018 hemos utilizado otra fórmula de evaluación. Relatamos, en lo sucesivo, la experiencia.

\footnotetext{
${ }^{19}$ Gráficamente, SANTOS GUERRA, M.A., “20 paradojas de la evaluación del alumnado en la universidad española”, Revista electrónica interuniversitaria de formación del profesorado (1999), núm. 1. Zaragoza: Asociación Universitaria de Formación del Profesorado-Universidad de Zaragoza, señala que se podría decir “dime cómo evaluas y te diré que tipo de profesional eres”.

${ }^{20}$ Literal, DÍAZ CANALS, J.F., MORATALLA ISASI, S., “Los exámenes en la Universidad”, Ensayos: Revista de la Facultad de Educación de Albacete (2009), núm. 24. Albacete: Universidad de Castilla-La Mancha: Escuela Universitaria de Magisterio de Albacete.
}

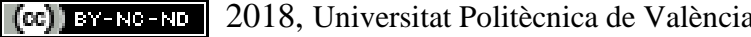




\subsection{El sistema de evaluación ideado y su implementación. El relato de una experiencia de innovación docente centrada en la evaluación continua.}

\subsubsection{Génesis del nuevo sistema de evaluación.}

Estábamos reflexionando sobre nuestro sistema de evaluación, sobre sus posibilidades de mejora, discutiendo propuestas con compañeros y compañeras de asignatura, cuando el Servicio de Asesoramiento Educativo de nuestra Universidad nos ofreció la posibilidad de asistir a un curso sobre evaluación en el marco de Formacion del Profesorado Universitario. En una formación excelente, se nos presentó un marco teórico y práctico que nos permitió conocer experiencias de otros centros y Grados. Nos tranquilizó sobremanera el constatar que el sistema de evaluación continua era un quebradero de cabeza para casi todos los docentes. ¿Cómo casar un trabajo equilibrado del alumnado con las exigencias de la materia? ¿Cómo ofecer un feed back adecuado al estudiantado? ¿Cómo evitar las horas interminables de corrección individual en el despacho? Eran cuestiones compartidas por profesores y profesoras asistentes.

De todas las fórmulas y posibilidades que se ofrecieron en el curso, entendimos que los “one minute paper" eran un instrumento que podía ayudarnos a mejorar el proceso de enseñanza-aprendizaje de nuestra materia, en general, y su sistema de evaluación, en particular.

\subsubsection{El "one minute paper" como recurso para mejorar la evaluación continua.}

Conforme a la literatura pedagógica ${ }^{21}$, el “one minute paper” (papel de un minuto, en español) es una técnica didáctica conforme a la cual, originalmente, al final de una clase magistral, el profesor/a pregunta a su aforo dos cuestiones: (1)¿Qué ha sido para tí lo más importante que has aprendido en esta clase? (2) ¿Qué es lo que te ha quedado más confuso? El alumnado debe responder brevemente, por escrito, en un minuto. Obtiene, así, el profesor un feed back claro y rápido, que le permite conocer la opinión del alumnado y preparar la próxima clase. Esta fórmula originaria, cuya utilización primaria se imputa a un profesor de Física de la Universidad californiana de Berkeley ${ }^{22}$, ha sido adaptada con éxito en muchas experiencias, manteniendo la esencia de fórmula consistente en "una tarea rápida por escrito" como base para un feed-back al tiempo que se ha convertido en

\footnotetext{
${ }^{21}$ La apunta, GIBBONS, R., “Adapting the One-Minute Paper for Active Learnig”, Academic Exchange Quarterly (2007), núm. 2. Chattanooga: Chattanooga State Technical Community College

${ }^{22}$ Por todos, ANGELO, T.A., CROSS, K.P. (1993), Classroom Assessment Techniques, 2 ed. San Francisco: Jossey Bass.
} 
un elemento de evaluación ${ }^{23}$. Las evidencias se pueden corregir fácil y rápidamente en el aula, guiados por el/la docente, trabajando sobre cada "paper" el propio alumno/a que lo ha confeccionado o un compañero/a suyo/a. También es posible que, primero, las corrija el docente fuera del aula y, luego, las lleve a ésta para comentarlas en grupo. Es indudable que, en cualquier caso, pueden funcionar como evidencia del domino de la materia por parte del estudiantado y que facilitan una retroalimentación rápida y sencilla.

\subsubsection{Sistema de evaluación propuesto: combinación de one minute paper y prueba objetiva final.}

Con la historia y antecedentes descritos, en las circunstancias apuntadas, respetando la normativa de evaluación vigente en la UPV/EHU, el primer cuatrimestre del curso 2017/2018 hemos implementado un sistema de evaluación diferente. Su primera característica es que se reconoce al alumnado el derecho de suscribir un contrato-programa para elegír la evaluación que quiere seguir en su proceso de aprendizaje: continua o final. La no suscripción del contrato se interpreta como opción por la final. Además, en su clausulado se recoge expresamente la posibilidad de abandonar el sistema de evaluación continua, debiendo notificarlo, como máximo, en la víspera del examen oficial ${ }^{24}$. Define el contrato-programa claramente ambos sistemas. "El sistema de evaluación continua: integrado por 5 pruebas parciales de estilo one minute paper (50\% calificación final) y un ejercicio téórico-práctico final de evaluación continua en forma de test, integrado por 30 items (50\% calificación final) ${ }^{25}$," "El segundo sistema: evaluación final: se integra de una única prueba test, que se realizará el día del examen oficial. Integrado por 40 items, de los que, al menos, 10 tendrán contenido meramente práctico, tiene un valor de 10/10 en la nota final". Centrándonos en el primero, se explica que "Siguiendo el método norteamericano conocido como one minute paper, durante el curso escolar, sin que sea necesaria la concreción de fecha con anterioridad, el alumnado deberá realizar 5 pruebas caracterizadas por su brevedad, que pueden consistir en: (1) respuesta a cuestión sobre lección trabajada por el alumnado fuera del aula, (2) respuesta a cuestión expuesta por el docente en el aula y (3) resolución de caso o cuestión práctica (expediente judicial, jurisprudencia, supuestos fácticos, escritos judiciales, tests,...) (...) Cada prueba/one minute paper tendrá un valor de 1/10 para la nota final; se corregirán en el aula y no es obligatoria la realización de todas ellas. El alumnado conocerá, con antelación y siempre antes del ejercicio final de evaluación continua, su resultado en las mismas".

\footnotetext{
${ }^{23}$ En este sentido, relatan como convirtieron las evidencias obtenidas mediante el "one minute paper” en elemento de evaluación continua, VIVEL BÚA, M., FERNÁNDEZ LÓPEZ, S., LADO-SESTAYO, R., “Innovación docente con One Minute Paper: ¿afecta al rendimiento académico?”, REDIE: Revista Electrónica de Investigación Educativa (2015), núm. 2. California: Universidad Autónoma de Baja California-Instituto de Investigación y Desarrollo Educativo.

${ }^{24}$ Se mejora, en este punto, la normative de la UPV/EHU a favor del alumnado.

${ }^{25}$ Nótese, pues, que la evaluacion continua suma la mitad de la nota final, lo que supone mejorar el porcentaje que exige la normativa de la Facultad (30\%), y cumple el deseo de la Universidad de preferenciar la evaluación continua.
} 


\section{Resultados}

Tras implementar el sistema de evaluación propuesto, fijándonos en la modalidad de evaluación continua basada en los ejercicios de one minute paper, podemos destacar los siguientes resultados:

1. Por primera vez, desde que se instauró el Grado en Derecho, y gracias a los que hemos llamado contrato-programa, el alumnado ha participado activamente en la elección de su sistema de evaluación, elemento eje del proceso enseñanzaaprendizaje, contribuyendo a que se sienta más protagonista de éste.

2. El $80 \%$ del alumnado ha optado por la evaluación continua ab initio, habiéndola abandonado únicamente el $2 \%$.

3. Los one minute paper han resultado un ejercicio excelente de evaluación continua. Desde la perspectiva docente, han resultado un instrumento ágil y sencillo para adquirir evidencias del nivel de conocimiento y dominio de la materia por parte del alumnado; han facilitado la retroalimentación y han reducido considerablemente la carga de tarea del docente. En opinión del estudiantado, es "la primeva vez que siguen una verdadera evaluación continua”, que les "ha exigido llevar la materia al día” y "les ha facilitado mucho su superación gracias a la retroalimentación del docente".

4. Los datos objetivos avalan la experiencia: los resultados finales han sido los mejores de los últimos años. No sólo ha sido superior el índice de superación de la materia (70\% del alumnado) sino, también, las calificaciones finales obtenidas (más de un $60 \%$ ha obtenido un notable).

\section{Conclusiones}

La experiencia de innovación docente implementada el primer cuatrimestre del curso 2017/2018, centrada en la mejora de la evaluación, en general, y de la evaluación continua, en particular, mediante los ejercicios denominados one minute paper, nos permite concluir:

1.Es posible y totalmente beneficioso para el proceso de enseñanza-aprendizaje implicar al alumnado en la forma de evaluación de éste. Funciona como elemento motivador e incentivador, no sólo del estudiante, sino también del docente.

2. Entendemos fundamental que el estudiantado aprehenda los beneficios y ventajas de la evaluación continua, sistema de evaluación que está fomentando la normativa universitaria y que casa perfectamente con las metodologías activas y el rol que éstas exigen al estudiante y al docente. Somos consciente, al tiempo, de la dificultad que supone para el docente implementar una verdadera y adecuada evaluación continua.

3. Después de muchos años de búsqueda e intentos más o menos acertados, el one minute paper ha resultado un instrumento muy pedagógico, eficiente y adecuado para desarrollar la evaluación continua. Especialmente destacables son el feed-back que facilita; la evidencia que constituye y las opciones de actuación posterior que permite.

(cc) EY-NC-ND 2018, Universitat Politècnica de València

Congreso IN-RED (2018) 
4. La experiencia de innovación relatada nos ha mostrado in situ, en el aula, con nuestro estudiantado, la trascendencia de la adecuada configuración e implementación del sistema de evaluación en el resultado final del proceso de enseñanza y aprendizaje.

\section{Referencias}

ÁLVAREZ VALDIVIA, I.M., ARTILES ARMADA, K. "La evaluación en la universidad: Estudio preliminar”, Aula Abierta (2001), núm. 78. Oviedo: Instituto de Ciencias de la Educación de la Universidad de Oviedo.

ANGELO, T.A., CROSS, K.P. (1993), Classroom Assessment Techniques, 2 ed. San Francisco: Jossey Bass.

CANO GARCÍA, E., CABRERA LANZO, N., "Evaluación formativa de competencias a través del blog en la Universidad”, Digital Education Review (2013), núm. 23. Barcelona: Universitat de Barcelona-Digital Education Observatory

DÍAZ CANALS, J.F., MORATALLA ISASI, S., "Los exámenes en la Universidad", Ensayos: Revista de la Facultad de Educación de Albacete (2009), núm. 24. Albacete: Universidad de Castilla-La Mancha: Escuela Universitaria de Magisterio de Albacete.

GARGALLO CASTEL, A., “Aproximación al estudio de la evaluación en la universidad: un análisis exploratorio con alumnos semipresenciales”, Contextos educativos: Revista de educación (2009), núm. 12. La Rioja: Universidad de La Rioja.

GIBBONS, R., “Adapting the One-Minute Paper for Active Learnig”, Academic Exchange Quarterly (2007), núm. 2. Chattanooga: Chattanooga State Technical Community College

IBARRA SAIZ, M.S., RODRÍGUEZ GÓMEZ, G., GÓMEZ RUÍZ, M.A., "La evaluación entre iguales: beneficios y estrategias para su práctica en la universidad”, Revista de educación (2012), núm. 359. Madrid: Ministerio de Educación, Cultura y Deporte.

JANÉ, M., “Evaluación del aprendizaje: ¿problema o herramienta?”, Revista de estudios sociales (2005), núm. 20. Colombia: Universidad de Los Andes-Facultad de Ciencias Sociales.

MORENO OLIVOS, T., "La evaluación del aprendizaje en la universidad: Tensiones, contradicciones y desafíos”, Revista mexicana de investigación educativa (2009), núm. 41. México: Consejo Mexicano de Investigación Educativa

PIDONE, C.L., "Evaluación de los aprendizajes en la Universidad”, Diálogos educativos (2005), núm. 9. Chile: Universidad Metropolitana de Ciencias de la Educación

PORTO CURRÁS, M., "Evaluación de estudiantes en la universidad de Santiago de Compostela: percepciones de los propios alumnos", REDU: Revista de Docencia Universitaria (2009), núm. 3. Valencia: Red Estatal de Docencia Universitaria

(c) ) EY-NC-ND 2018, Universitat Politècnica de València 
QUIROGA, V., MENA GARCÍA, E., PORLAN JUY, J., MORALES MARTÍNEZ, E., MÁRQUEZ SÁNCHEZ, L., "La evaluación continua en el Grado de Trabajo Social de la Universidad de Barcelona”, Cuadernos de trabajo social (2014), núm. 2. Madrid: Universidad Complutense

RAMOS HERNANDO, C., BERASALUCE DIÉZ, R., PEIRÓ I GREGORI, S. (2016), “La evaluación por competencias en la universidad”, AAVV, XIV Jornadas de redes de investigación en docencia universitaria. Alicante: Universidad de Alicante.

SAENZ DEL BURGO MARTÍNEZ, L., PURAS OCHOA, G., “Aplicación de metodologías activas para aprender a gestionar la oficina de farmacia: Una experiencia en el aula”, IJERI: International journal of Educational Research and Innovation (2018), núm. 9. Sevilla: Universidad Pablo de Olabide.

SANTOS GUERRA, M.A., “20 paradojas de la evaluación del alumnado en la universidad española”, Revista electrónica interuniversitaria de formación del profesorado (1999), núm. 1. Zaragoza: Asociación Universitaria de Formación del Profesorado-Universidad de Zaragoza.

VIVEL BÚA, M., FERNÁNDEZ LÓPEZ, S., LADO-SESTAYO, R., "Innovación docente con One Minute Paper: ¿afecta al rendimiento académico?”, REDIE: Revista Electrónica de Investigación Educativa (2015), núm. 2. California: Universidad Autónoma de Baja California-Instituto de Investigación y Desarrollo Educativo 


\title{
Herramienta de evaluación continua basada en problemas personalizados de corrección automática: análisis de su implantación en la asignatura "Mercados Energéticos"
}

\section{Manuel Alcázar-Ortega ${ }^{\mathrm{a}}$, Carlos Álvarez-Bel ${ }^{\mathrm{a}}$}

a Departamento de Ingeniería Eléctrica, Universidad Politécnica de Valencia. Camino de Vera, s/n, edificio 5E, 2º Planta.46022 Valencia (España). malcazar@iie.upv.es, calvarez@die.upv.es.

\begin{abstract}
The strategies for learning of technical teaching are based, to a large extent, on the realization of practical problems on the part of the students. However, the correct use of these strategies would entail a personalized correction and a follow-up that, when the volume of students is high, is practically unmanageable. In this context, this work presents a tool that facilitates the realization of personalized problems for each student, its semi-automatic correction and the feedback to the student in order to facilitate their learning and to carry out a continuous follow-up throughout the course. This tool has been successfully implemented into the course on "Energy Markets", corresponding to the Degree in Energy Engineering of the Polytechnic University of Valencia. Moreover, the impact on the obtained results obtained by students in the last years is analyzed in this work.
\end{abstract}

Keywords: tool, problems, self-evaluation, feedback, engineering, energy, markets

\begin{abstract}
Resumen
Las estrategias de aprendizaje de las enseñanzas técnicas están basadas, en gran medida, en la realización de problemas prácticos por parte de los alumnos. Sin embargo, la correcta utilización de estas estrategias conllevaría una corrección personalizada y un seguimiento que, cuando el volumen de alumnos es elevado, resulta prácticamente ingestionable. En este contexto, este trabajo presenta una herramienta que facilita la realización de problemas personalizados para cada estudiante, su corrección semiautomática y la realimentación al alumno de cara a facilitar su aprendizaje y realizar un seguimiento continuo a lo largo del curso. Esta herramienta se ha implantado con éxito en la asignatura "Mercados Energéticos", correspondiente al Grado en Ingeniería de la Energía de la Universidad Politécnica de Valencia, cuyo impacto en los resultados obtenidos por los estudiantes en los últimos años se analiza en este trabajo.
\end{abstract}

Palabras clave: herramienta, problemas, autoevaluación, realimentación, ingeniería, energía, mercados 
Herramienta de evaluación continua basada en problemas personalizados de corrección automática: análisis de su implantación en la asignatura "Mercados Energéticos"

\section{Introducción}

El desarrollo de herramientas tecnológicas (informáticas o de otro tipo) para facilitar el aprendizaje de los estudiantes de ingeniería se ha demostrado muy útil a la hora de hacerles más atractivo este campo (Plaza Merino et al, 2016), proporcionando a los alumnos una mejor comprensión de la materia y a los profesores un medio para impartir las clases de una forma más estimulante (Carreras y Snider, 1998).

Entre otras ventajas, las herramientas tecnológicas favorecen la realimentación a los alumnos sobre sus aciertos y errores, lo que conlleva un proceso de aprendizaje más consistente (Jattie y Timperley, 2007). Sin embargo, dado el elevado número de estudiantes o la excesiva dedicación necesaria para la corrección de ejercicios, no es viable realizarla en un tiempo adecuado, lo que constituye un problema importante (Wiggins, 2012). En este sentido, la herramienta aquí propuesta ataca directamente este problema, proporcionando una corrección suficientemente rápida y una comunicación con los alumnos casi automática, a través del correo electrónico.

Existen herramientas desarrolladas por docentes para favorecer la comprensión de algunos temas específicos dentro del campo de la ingeniería, tales como los sistemas eléctricos de potencia (Córdova-Acosta et al, 2018) o ingeniería de procesos (Wagner et al, 2016). La herramienta desarrollada en el trabajo que aquí se presenta se centra en aspectos relacionados con los mercados energéticos, cuya trascendencia es cada vez más importante en las enseñanzas técnicas universitarias.

La producción, suministro y compra-venta de energía ha tenido tradicionalmente una estructura muy simple, donde un mismo agente realizaba, de forma monopolista y verticalmente integrada, todas las actividades relacionadas. Sin embargo, debido a las múltiples ineficiencias en este modo de funcionar (que resultaba en precios excesivos para los consumidores de productos energéticos), la situación cambió drásticamente a final del siglo XX, dando como resultado un modelo de mercado liberalizado mediante la creación de diferentes estructuras complejas para desarrollar las actividades comerciales y técnicas relacionadas con la energía (Strbac y Kirschen, 2004). Estas estructuras incluyen mercados, operadores, complejas redes de suministro, etc., donde intervienen múltiples agentes realizando labores especializadas cada uno y que requieren en algunos casos una coordinación muy precisa.

La comprensión de todos estos aspectos no es sencilla, sobre todo para el alumno que se enfrenta por primera vez a esta problemática. Por lo tanto, el desarrollo de este tipo de herramientas, que de forma interactiva le permitirán adquirir soltura en la gestión de estos conceptos, resulta esencial para llevar a cabo un aprendizaje continuo y donde los conocimientos básicos utilizados en este campo creen un sustrato consistente que le servirá a lo largo de toda su vida académica y profesional.

El artículo se estructura de la siguiente forma: El capítulo 2 presenta los objetivos de la herramienta, los cuales se desarrollarán de forma detallada en el capítulo 3, donde se describen sus funcionalidades y principales características. El capítulo 4 muestra los resultados obtenidos a lo largo de los últimos años en la asignatura de Mercados

(cc) EY-NC-ND 2018, Universitat Politècnica de València

Congreso IN-RED (2018) 
Energéticos, donde la herramienta se ha implantado durante tres cursos, permitiendo evaluar el impacto que su utilización ha supuesto en los alumnos. Finalmente, las conclusiones del presente trabajo se incluyen en el capítulo 5.

\section{Objetivos}

Los objetivos en base a los cuales se ha diseñado y aplicado esta herramienta son los siguientes:

- En primer lugar, permitir que los alumnos pongan en práctica los conocimientos adquiridos en clase a lo largo del curso a través de problemas directamente relacionados con los contenidos de las diferentes unidades temáticas.

- Conseguir que los alumnos pongan en práctica dichos conocimientos de forma individualizada, ya que los problemas están particularizados para cada estudiante en función de su número de identificación personal (DNI o NIE)

- Favorecer el trabajo en grupo, dado que, aunque los datos de los ejercicios son diferentes para cada alumno, los problemas propuestos pueden ser abordados de forma conjunta por varios alumnos. De esta manera, grupos de estudiantes colaborarían para obtener el procedimiento de resolución, aunque cada uno de ellos tuviera que trabajar de forma individual con sus datos personales para obtener el resultado definitivo.

- Permitir al profesor realizar un seguimiento particularizado de cada alumno de una manera cómoda, rápida y efectiva, ya que los problemas se corrigen automáticamente a través de la herramienta.

- Finalmente, ayudar a que el alumno pueda auto-evaluar su proceso de aprendizaje de forma progresiva al recibir por correo electrónico la corrección de sus ejercicios, permitiéndole, de esta forma, aprender de sus errores y afianzar los conocimientos adquiridos.

\section{Desarrollo de la innovación}

La herramienta se ha programado utilizando el paquete Visual Basic proporcionado por Microsoft EXCEL. De esta forma, los problemas a resolver se facilitan a los alumnos en formato .xls, lo que hace posible que puedan ser utilizados en cualquier ordenador personal.

La herramienta consta de dos módulos:

- Una plantilla que se entrega a los alumnos con los enunciados de los problemas que tienen que resolver y los espacios necesarios para indicar las respuestas.

- Un corrector donde el profesor puede cargar la información proporcionada por los alumnos en cada una de las plantillas. Dicho corrector permite no sólo evaluar los resultados de cada ejercicio, sino que también es capaz de enviar de forma automática un correo electrónico a cada estudiante informándole de su 
Herramienta de evaluación continua basada en problemas personalizados de corrección automática: análisis de su implantación en la asignatura "Mercados Energéticos"

calificación, de las respuestas correctas o incorrectas y de la solución adecuada en el caso de las incorrectas.

\subsection{Plantilla para el alumno}

En la plantilla que se facilita al alumno están los enunciados de los problemas a resolver. Normalmente, cada plantilla contiene entre 2 y 3 ejercicios, cada uno de los cuales se estructura en diversos apartados.

La información que el alumno debe introducir, tal y como se muestra en la Figura 1, es la siguiente:

- Su nombre y apellidos

- $\quad$ Su número de identificación, sin letras (DNI, NIE, pasaporte). Esta información es importante porque en base a ella se calcularán los coeficientes con los que se obtienen los parámetros de los ejercicios a resolver.

- Su e-mail. Esta dirección de correo se utilizará para notificar al alumno su calificación y el resultado de la corrección de la plantilla.

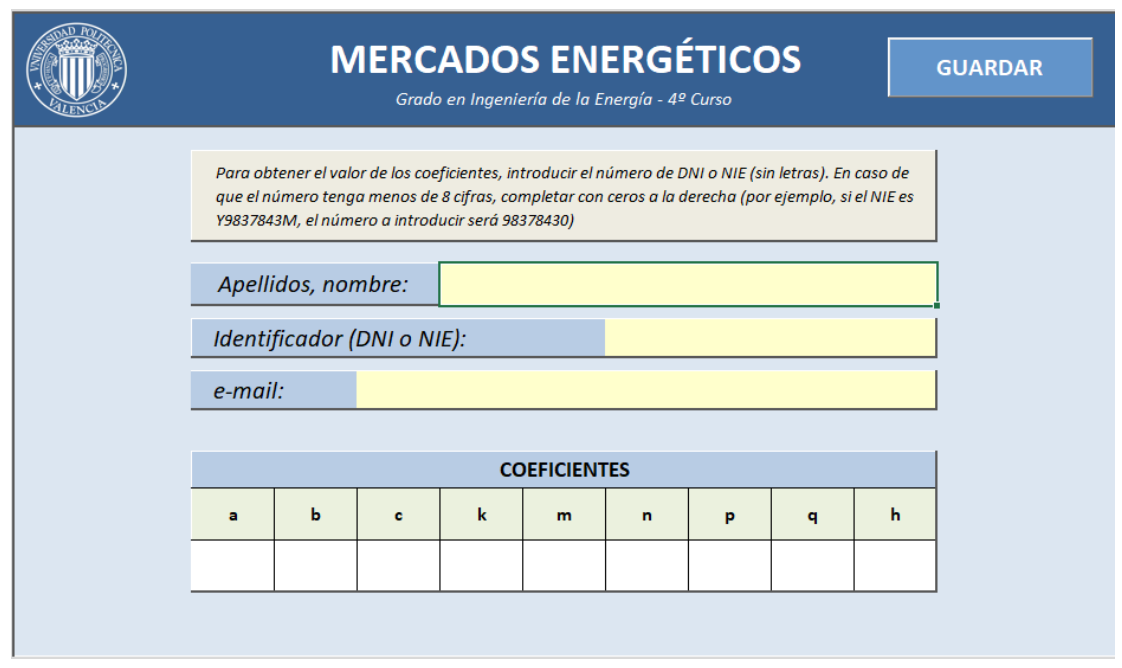

Figura 1. Plantilla para la introducción de datos del alumno

\subsubsection{Cálculo de los coeficientes}

Los coeficientes en base a los cuales se obtendrán los parámetros de los ejercicios están calculados a partir de los caracteres del número de identificación del alumno. Para realizar dicho cálculo, es necesario que el número de identificación del alumno tenga exactamente 8 cifras. En caso de que el número de identificación tuviera letras o un número de cifras diferente a 8, el alumno tendría que escribir únicamente las 8 primeras cifras, o completar a 
la derecha con cerros hasta alcanzar el número indicado. Al hacerlo, la plantilla calcularía los coeficientes, tal y como se muestra en la Figura 2.

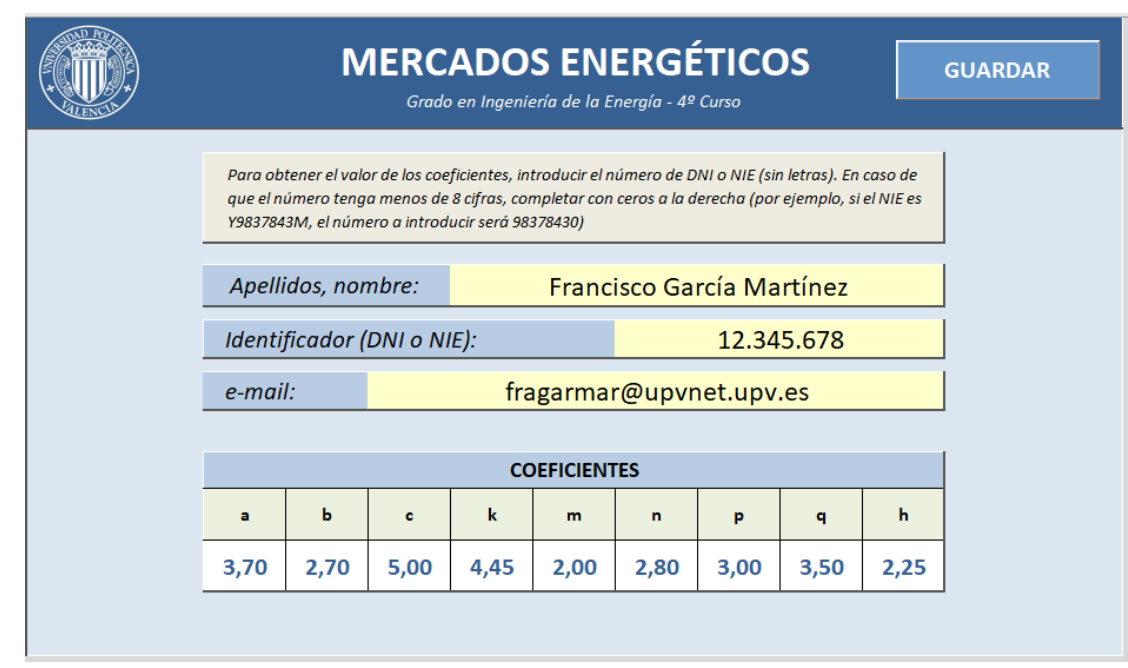

Figura 2. Obtención de los coeficientes de cálculo

En función de sus 8 caracteres, el número de identificación $I D$ del alumno que utiliza la herramienta sería el siguiente:

$$
I D=\sum_{i=1}^{8} N_{i} \cdot 10^{(8-i)}
$$

Donde $\mathrm{N}_{1}, \mathrm{~N}_{2}, \ldots \mathrm{N}_{8}$ son cada uno de los caracteres del número de identificación del alumno (unidades, decenas, centenas,...).

Utilizando estos caracteres, la herramienta calcula los 9 coeficientes para la parametrización de los problemas. Estos coeficientes se ajustan de manera semi-empírica, de forma que los parámetros de los enunciados tengan una variedad admisible y los resultados obtenidos sean razonables. Como ejemplo, se muestran las expresiones utilizadas para calcular los coeficientes $a$ y $b$, siendo análogo el cálculo del resto de coeficientes: 


$$
\begin{aligned}
& a=\left\{\begin{array}{l}
1, \text { si }\left(\frac{N_{4}}{1,5}+1\right) \leq 0 \\
\left(\frac{N_{4}}{1,5}+2\right), \text { si } 0<\left(\frac{N_{4}}{1,5}+1\right)<1 \\
\left(\frac{N_{4}}{1,5}+1\right), \text { si } 1 \leq\left(\frac{N_{4}}{1,5}+1\right)<4 \\
\left(\frac{N_{4}}{3}+\frac{1}{2}\right), \text { si }\left(\frac{N_{4}}{1,5}+1\right) \geq 4
\end{array}\right. \\
& b=\left\{\begin{array}{l}
1, \text { si }\left(N_{5}+N_{2}-\frac{N_{3}}{5}\right) \leq 0 \\
\left(N_{5}+N_{2}-\frac{N_{3}}{5}\right)+1, \text { si } 0<\left(N_{5}+N_{2}-\frac{N_{3}}{5}\right)<1 \\
\left(N_{5}+N_{2}-\frac{N_{3}}{5}\right), \text { si } 1 \leq\left(N_{5}+N_{2}-\frac{N_{3}}{5}\right) \leq 4 \\
\left(\frac{N_{5}+N_{2}}{2}-\frac{N_{3}}{10}\right), \text { si }\left(N_{5}+N_{2}-\frac{N_{3}}{5}\right)>4
\end{array}\right.
\end{aligned}
$$

\subsubsection{Diseño del enunciado e identificación de las variables}

La Figura 3 muestra el enunciado de uno de los problemas propuestos en la asignatura de Mercados Energéticos, correspondiente al tema "Introducción a los mercados energéticos: conceptos de microeconomía”. El diseño e implementación del enunciado de cada problema debe considerar los siguientes pasos:

- En primer lugar, se debe elegir un problema que pueda ser resuelto de forma automática, por lo que la respuesta a las preguntas realizadas debe ser cerrada y, preferiblemente, numérica. En caso de no ser numérica, las posibles respuestas deben estar previamente establecidas de cada a no ofrecer duda al alumno a la hora de responder.

- Es necesario identificar los parámetros que se van a personalizar para cada alumno en función de los coeficientes calculados en el apartado anterior. En el caso del ejemplo mostrado en la Figura 3, los parámetros seleccionados aparecen remarcados en color azul y están calculados a partir de los coeficientes obtenidos a partir del número de identificación del alumno. Por ejemplo, en la primera ecuación del problema, parametrizada de la siguiente manera:

$$
C(y)=A \cdot y^{2}+B \cdot y+C
$$


los factores A, B y C se calcularían de la siguiente forma:

$$
\begin{gathered}
A=10 \cdot k \\
B=100 \cdot m \\
C=10000 \cdot n
\end{gathered}
$$

donde k, m y n son los coeficiente mostrados en la Figura 2 que se calculan en función del número de identificación del alumno.

- Finalmente, hay que indicar el lugar en el que el alumno debe contestar la pregunta considerada en el enunciado. La respuesta a cada pregunta debe ser única y el lugar donde debe ser contestada debe estar claramente definido. Es esencial que estén indicadas las unidades en las que la pregunta debe ser contestada, ya que, de otra forma, la herramienta no interpretaría correctamente el resultado. En el ejemplo de la Figura 3 se indica con un cuadro de color amarillo el lugar donde cada respuesta debe ser consignada.

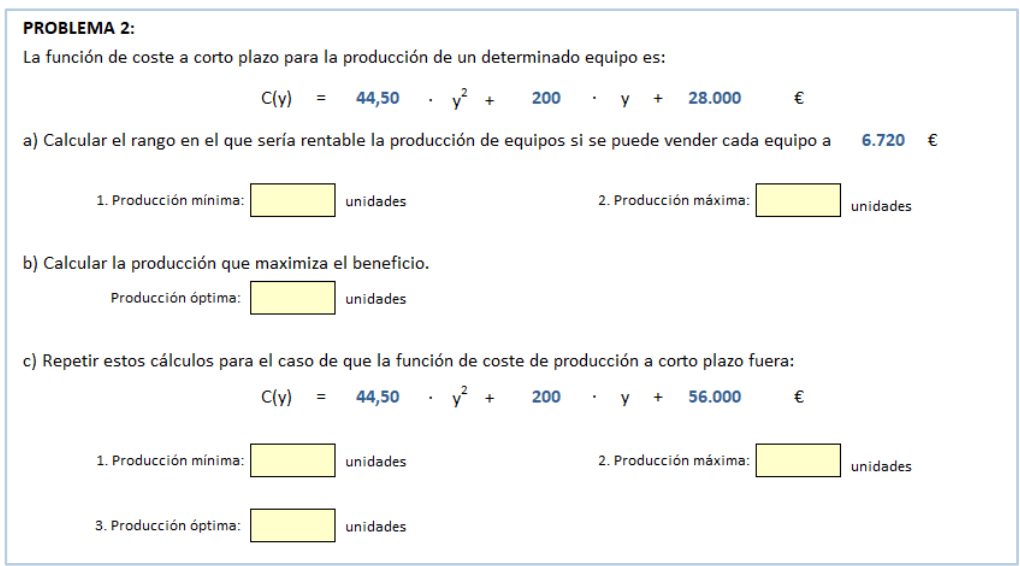

Figura 3. Diseño del enunciado e identificación de variables (azul)

Es posible que, en función de los parámetros de un alumno en concreto, alguno de los apartados no tenga solución. En ese caso, se debe indicar en las instrucciones que se facilitan cómo ha de proceder el alumno, ya que no es lo mismo no responder una pregunta, que el que la solución sea cero o no exista. En la herramienta, esta casuística se ha resuelto de la siguiente manera:

- Si la celda de una respuesta está vacía, se considera que el alumno no ha sido capaz de obtener la respuesta y no la ha contestado.

- Si la celda contiene un cero, significa que la respuesta a la pregunta es igual a cero.

- Si, debido a los parámetros particulares del alumno, la respuesta no tiene solución, se deberá indicar en la celda $N / E$ (no existe).

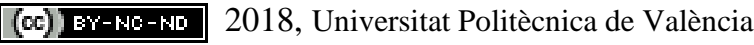

Congreso In-Red (2018) 
Herramienta de evaluación continua basada en problemas personalizados de corrección automática: análisis de su implantación en la asignatura "Mercados Energéticos"

\subsubsection{Diseño del enunciado e identificación de las variables}

Cuando la plantilla ha sido completada por el alumno, éste debe guardarla y puede enviarla para su corrección al profesor indicado, bien por correo electrónico o mediante otras plataformas habilitadas al efecto (por ejemplo, Poliformat en la UPV). Para ello puede hacer uso de un botón de "Guardar" habilitado para tal fin, tal y como se muestra en el ángulo superior derecho de la Figura 2.

\subsection{Corrector para el profesor}

El proceso de corrección de los ejercicios planteados en la plantilla descrita en el apartado anterior debe ser rápido y automático. Para ello, la herramienta dispone de un corrector que, de forma secuencial, realiza las siguientes tareas, tal y como se muestra en la Figura 4 :

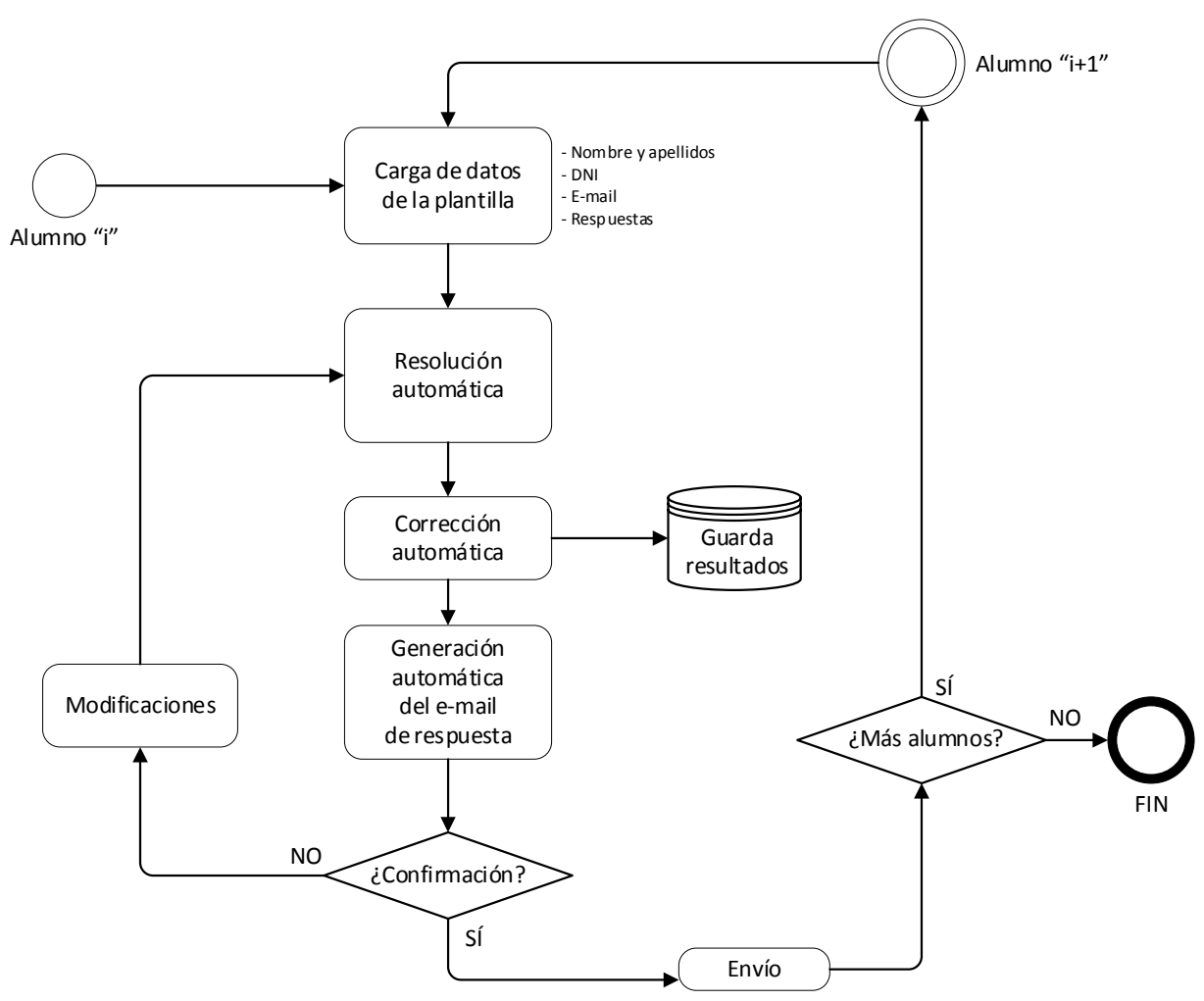

Figura 4. Secuencia de tareas de la herramienta de corrección

1. Carga de los datos de la plantilla. Esta acción se ejecuta pulsando un botón que permite seleccionar el fichero donde se encuentra la plantilla del alumno deseado. Los datos que se cargan corresponden a la identificación del alumno (nombre,

(cc) EY-NC-ND 2018, Universitat Politècnica de València

Congreso IN-RED (2018) 
apellidos, DNI y correo electrónico) y a las respuestas que haya proporcionado en la plantilla a evaluar.

2. Resolución automática. El corrector resuelve automáticamente los ejercicios planteados en función de los coeficientes del alumno, calculados a partir de su número de identificación personal.

3. Corrección automática. El corrector compara los datos cargados de la plantilla del alumno con los resultados correctos evaluados en el paso anterior y determina qué respuestas son correctas y qué respuestas son erróneas. De cara a evitar el efecto de los posibles redondeos a la hora de considerar un número determinado de cifras significativas, el corrector tiene un margen de tolerancia personalizable. Por defecto, se ha establecido el error máximo admisible en un $\pm 5 \%$. Una vez realizada la corrección, la herramienta guarda el resultado en la lista de calificaciones de la asignatura.

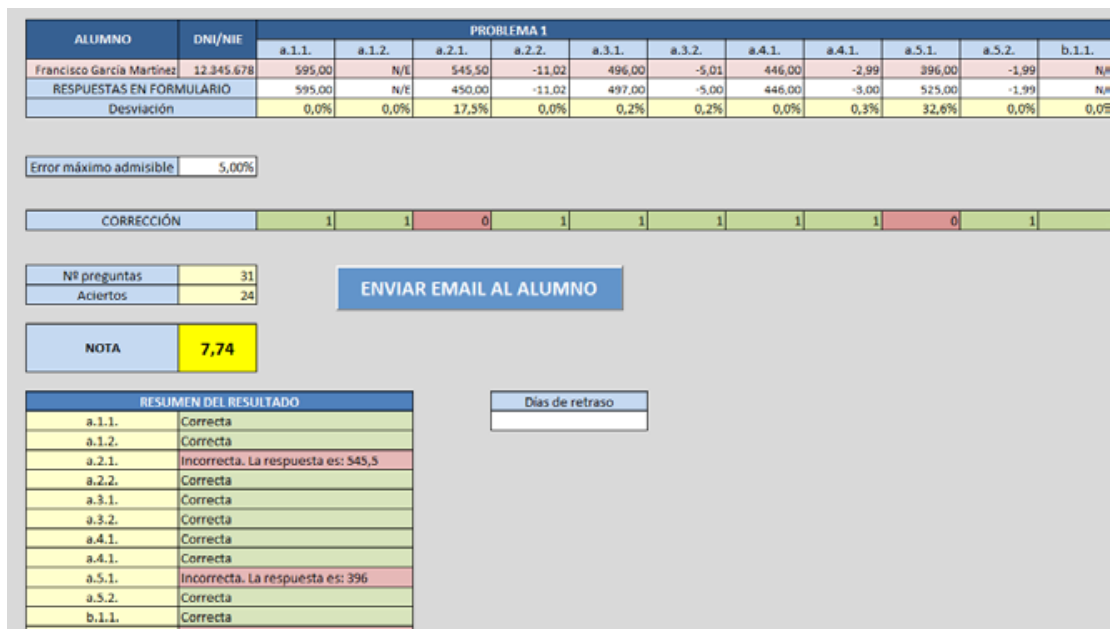

Figura 5. Fragmento de la pantalla de la herramienta de corrección

4. Generación automática del e-mail de respuesta. De cara a notificar al alumno sobre el resultado de su ejercicio, la herramienta dispone de un generador automático de correos electrónicos, el cual enviará un e-mail a cada alumno indicando:

- Su calificación en el ejercicio entregable, que se calculará en función del número de aciertos y de errores.

- Qué preguntas son correctas y cuáles incorrectas.

- $\quad$ En el caso de las preguntas incorrectas, cuál es la solución correcta.

Un ejemplo del tipo de e-mail enviado se muestra en la Figura 6.

5. Confirmación de envío. Una vez generado el correo automático, el profesor debe confirmar si desea enviarlo o si, por el contrario, es necesario realizar alguna 
Herramienta de evaluación continua basada en problemas personalizados de corrección automática: análisis de su implantación en la asignatura "Mercados Energéticos"

revisión o modificación sobre la corrección. Si el profesor confirma el envío, la corrección del alumno considerado habrá finalizado y la herramienta permitirá entonces cargar la plantilla del siguiente alumno, comenzando nuevamente el proceso.

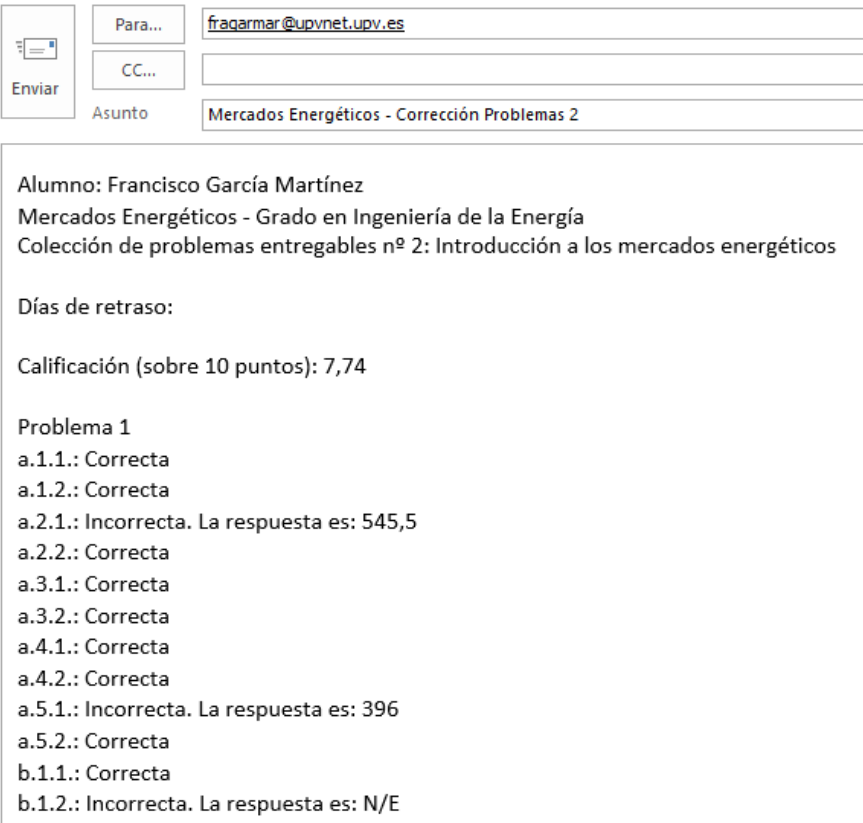

Figura 6. Ejemplo de correo electrónico sobre la corrección del ejercicio entregable

Por último, el corrector permite aplicar una penalización a los ejercicios que hayan sido entregados fuera de la fecha indicada. Por ejemplo, para el caso de aplicación considerado en este artículo, cuyos resultados se presentan la sección siguiente, se dio a los alumnos un plazo de 10 días para completar la resolución del ejercicio desde la publicación del enunciado, aplicándose una penalización de 0,1 puntos por día de retraso para las entregas fuera de plazo.

\section{Resultados: impacto en las calificaciones de los alumnos}

La herramienta descrita en la sección anterior se ha utilizado en varias asignaturas impartidas por los autores en la Universidad Politécnica de Valencia. En particular, se presenta en este apartado el análisis comparativo de los resultados obtenidos por los alumnos en la asignatura "Mercados Energéticos", correspondiente a la titulación de Grado en Ingeniería Energética que se imparte en la Escuela Técnica Superior de Ingenieros Industriales, antes y después de aplicarse dicha herramienta. De esta forma, puede medirse de una forma objetiva el impacto producido por su implantación mediante el análisis de las calificaciones históricas en dicha asignatura durante un período de 8 años. Los resultados se

(c) EY-NC-ND 2018, Universitat Politècnica de València

Congreso IN-RED (2018) 
han organizado en 20 clases, considerándose la puntuación obtenida por los alumnos de 0 a 10 con un intervalo de 0,5 puntos.
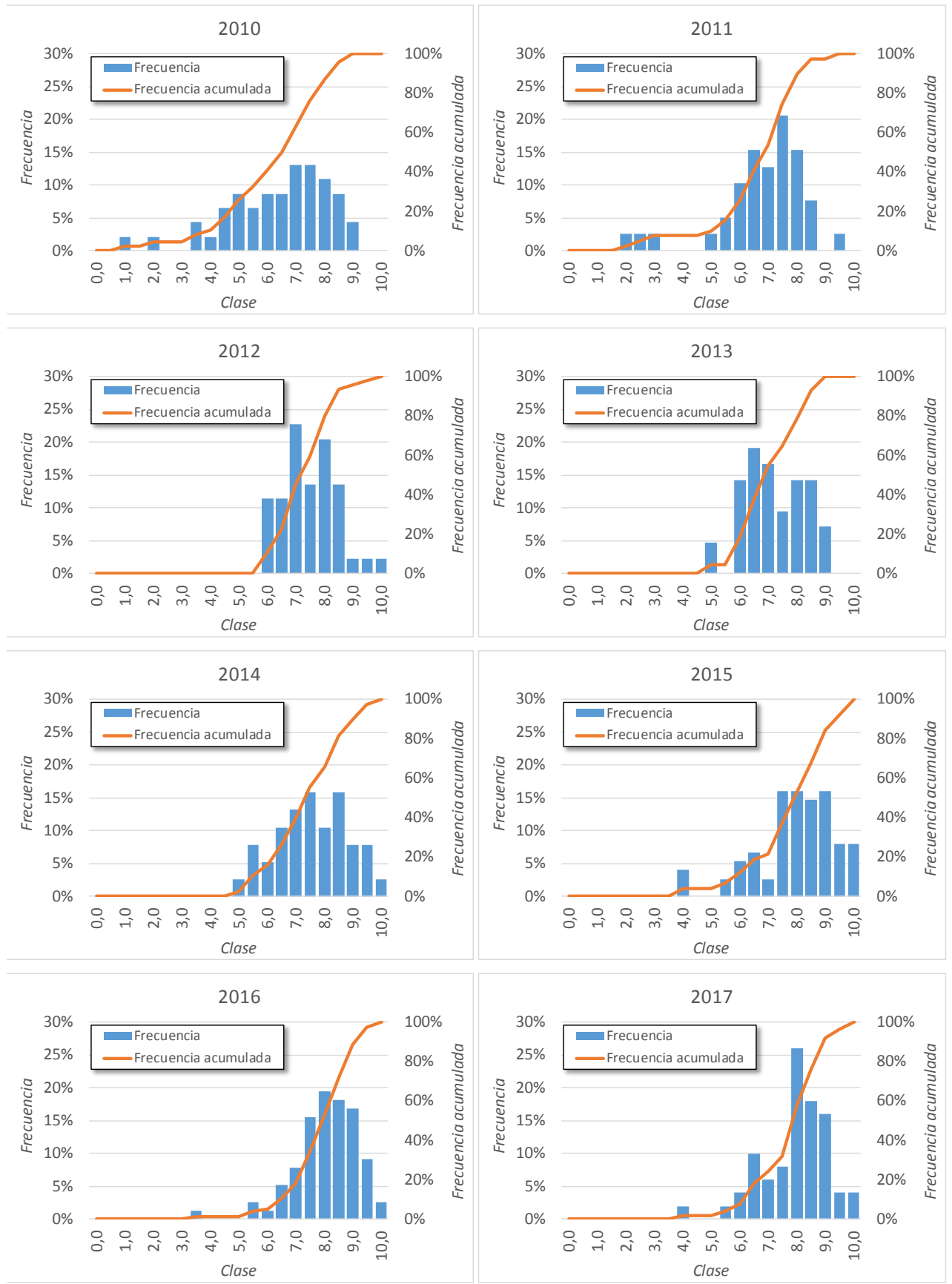

Figura 7. Histogramas de calificación de la asignatura "Mercados Energéticos" 
Herramienta de evaluación continua basada en problemas personalizados de corrección automática: análisis de su implantación en la asignatura "Mercados Energéticos”

Hasta el curso 2012-2013, dicha asignatura formaba parte del plan de estudios del Máster en Tecnología Energética para un Desarrollo Sostenible. Desde el curso 2013-2014, la asignatura de trasladó a la titulación del Grado. Sin embargo, como puede apreciarse en los histogramas de las calificaciones de los alumnos mostrados en la Figura 7, los cambios comienzan a apreciarse a partir del curso 2015-2016, que es el momento en que se implanta la herramienta.

En los años anteriores a 2015, el $40 \%$ de los alumnos obtuvo calificaciones de 7 puntos (sobre un máximo de 10 puntos) o menos. En cambio, la franja de alumnos con esta puntuación se redujo a la mitad a partir de 2015, cuando se implantó la herramienta, pasando al 21\%. Esto quiere decir que el $79 \%$ de los alumnos obtuvo más de 7 puntos como nota media, lo que supone un incremento de 20 puntos porcentuales con respecto a los resultados de años anteriores. Estos porcentajes se han mantenido durante los dos años siguientes en los que la herramienta ha continuado utilizándose, con un 82\% (2016) y un 76\% (2017) de alumnos que han superado los 7 puntos en su nota media.

Este resultado también se aprecia en la parte superior de la escala de evaluación, ya que si hasta el año 2014 el número de alumnos que alcanzó la calificación de sobresaliente (9 puntos) se situaba en un 7-8\%, a partir del año 2015 esta proporción ha llegado al 16\% (2015), 17\% (2016) y 16\% (2017), lo que supone un incremento del $100 \%$ con respecto a los resultados obtenidos antes de implantarse la herramienta.

Estos resultados se muestran gráficamente de una forma más evidente en la Figura 8, donde se representa el diagrama de porcentaje acumulado para todos los años evaluados.

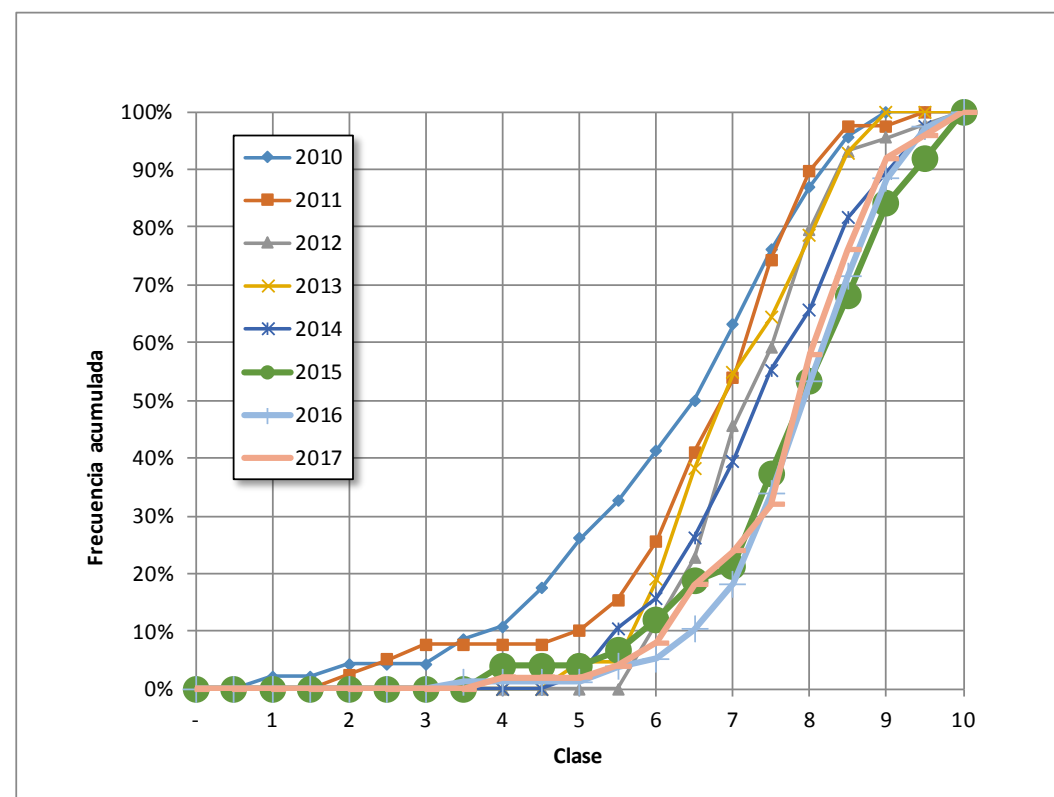

Figura 8. Frecuencia acumulada de calificaciones. 2010 - 2017

(cc) EY-NC-ND 2018, Universitat Politècnica de València 
Tal y como se aprecia en la figura, las series correspondientes a los tres últimos años aparecen claramente desplazadas hacia la derecha, lo que denota una mejora sustancial en las calificaciones obtenidas por los alumnos tras la utilización de la herramienta.

\section{Conclusiones}

Este artículo presenta una herramienta de evaluación continua, basada en la realización de ejercicios prácticos en el campo de la ingeniería, que permite realizar una corrección automática y una rápida realimentación a los alumnos que les permita mejorar en su proceso de aprendizaje. La herramienta se basa en una plantilla facilitada al estudiante y un corrector para el uso del profesor. Se presenta un caso práctico de aplicación donde la herramienta, programada en Microsoft EXCEL, se ha implantado con éxito en la asignatura "Mercados Energéticos" que se imparte en la Universidad Politécnica de Valencia. El impacto en las calificaciones de los estudiantes se observa desde el primer año de aplicación, mejorando tanto en la calificación media como la proporción de estudiantes con resultados más altos. De este modo, la proporción de estudiantes con al menos 7 puntos sobre 10 se ha incrementado en 20 puntos porcentuales, mientras que el número de alumnos con calificación de sobresaliente se ha duplicado, alcanzando el 16\% en el último curso. Estos resultados evidencian la conveniencia de desarrollar y utilizar herramientas como la que aquí se presenta para facilitar el seguimiento continuo del proceso de aprendizaje de los alumnos, mejorar sus resultados académicos y favorecer el desarrollo de competencias profesionales.

\section{Referencias}

CARRERAS, F. y SNIDER, A.D. (1998). "A Matlab educational software tool for teaching complex analysis in engineering" en IEEE Southeastcon '98: Engineering for a New Era (24-26 abril 1998). Orlando, FL, USA: IEEE, p. 204-207. DOI: 10.1109/SECON.1998.673329

CÓRDOVA-ACOSTA, A., CALDERÓN-GUIZAR, J.G., FRAGOSO-DÍAZ, O.G. (2018). "An educational tool for introducing power engineering students with modal extraction concepts". Computer Applications in Engineering Education, p. 1-13. DOI: 10.1002/cae.21899

HATTIE, J. y TIMPERLEY, H. (2007). "The power of feedback" en Review of Educational Research, vol. 77, issue 1, p. 81-112. DOI: 10.3102/003465430298487

PLAZA MERINO, P., SANCRISTÓBAL RUIZ, E., CARRO FERNÁNDEZ, G. y CASTRO GIL, M. (2016). "Robotic Educational Tool to engage students on Engineering" en IEEE Frontiers in Education Conference (12-15 octubre 2016). Erie, PA, USA: IEEE, 1-4. DOI: 10.1109/FIE.2016.7757417

STRBAC, G. y KIRSCHEN, D. (2004). Fundamentals of Power System Economics. John Wiley \& Sons, Ltd. ISBN: 978-0-470-02058-6 
Herramienta de evaluación continua basada en problemas personalizados de corrección automática: análisis de su implantación en la asignatura "Mercados Energéticos"

WAGNER, C., SCHÜLlER, A., FLEISCHACKER, C. y EPPLE, U. (2016). "An Educational Framework for Process Control Theory and Engineering Tools" en $11^{\text {th }}$ IFAC Symposium on Advances in Control Education (1-3 junio 2016). Bratislava, República Eslovaca. IFAC-PapersOnLine, vol. 49, issue 6, p. 46-51. DOI: 10.1016/j.ifacol.2016.07.151

WIGGINS, G. (2012). "Seven keys to effective feedback” en Feedback for Learning, vol. 70, issue 1 , p. 10-16. 


\title{
EI lenguaje visual y los mapas colaborativos para el desarrollo de ideas innovadoras
}

\author{
${ }^{a}$ Virginia Santamarina Campos, ${ }^{\mathrm{c}}$ María de Miguel Molina, ${ }^{\mathrm{d} B l a n c a}$ de Miguel Molinad, \\ ${ }^{\mathrm{b}}$ María Ángeles Carabal Montagud, ${ }^{\mathrm{e}}$ María del Val Segarra Oña y ${ }^{\mathrm{f}}$ Ángel Peiro Signes \\ a - bepartamento de Conservación y Restauración de Bienes Culturales; ${ }^{\mathrm{c}}$ - Departamento de \\ Organización de Empresas
}

\begin{abstract}
Cooperative learning, based on problem solving and the design of conceptual mobile maps, provides clarity and helps to make ideas more visible, tangible and sequential. Mobile cards allow to obtain system models more efficient by allowing more smoothly reiteration. On the other hand, teamwork with the use of mobile notes results in a richer systemic model, because it synthesizes different viewpoints, merging mental models and making it easier to understand and solve complex problems in a cooperative, creative and innovative way.
\end{abstract}

Keywords: cooperative learning, teaching innovation, teamwork, conceptual maps, mind maps, mental models, mobile cards, problem analysis, problem solving, project design

\begin{abstract}
Resumen
El aprendizaje cooperativo, basado en la resolución de problemas, mediante el diseño de mapas conceptuales móviles, proporciona claridad, ayudando a hacer las ideas visibles, tangibles y secuenciales. Las tarjetas móviles, permiten obtener modelos de sistemas más eficaces, al permitir la reiteración con mayor fluidez. Por otro lado el trabajo en grupo con el empleo de notas móviles da como resultado un modelo sistémico más rico, porque sintetiza diferentes puntos de vista, fusionando modelos mentales, y facilitando la tarea de entender y resolver problemas complejos de forma cooperativa, creativa e innovadora.
\end{abstract}

Palabras clave: aprendizaje cooperativo, innovación docente, trabajo en grupo, mapas conceptuales, mapas mentales, modelos mentales, tarjetas móviles, análisis de problemas, resolución de problemas, diseño de proyectos.

\section{Introducción}

El uso de notas móviles nos permite obtener modelos más eficientes y ricos para resolver problemas, ya que proporcionan una herramienta flexible para su análisis. Además, el diseño 
de mapas conceptuales móviles aporta claridad mostrando las ideas de una manera visual. Las secuencias del proceso pueden variarse, añadiendo ideas de una manera creativa, utilizando palabras clave o dibujos. Los objetivos y retos de cada sesión necesitan ser diseñados por anticipado para guiar a los alumnos durante el proceso de aprendizaje, independientemente de a qué área pertenezca la asignatura.

Por otro lado, se trabajan cuatro competencias transversales (UPV, 2017):

- Trabajo en equipo y liderazgo: "implica crear y desarrollar un clima de confianza mutua entre los componentes que permita trabajar de forma responsable y cooperativa...compartir conocimientos, compromiso y responsabilidad. Supone el reparto de tareas y roles y el respeto a las normas y reglas de juego establecidas por y para el grupo".

- Planificación y gestión del tiempo: "implica ser capaz de organizar y distribuir correctamente el tiempo del que disponemos y distribuirlo en función de las actividades necesarias para alcanzar nuestros objetivos a corto, medio y largo plazo".

- Innovación, creatividad y emprendimiento: "La innovación se entiende como la capacidad de dar respuesta satisfactoria a las necesidades personales, organizativas y sociales, modificando procesos y/o resultados para generar nuevo valor. A su vez, el desarrollo de esta competencia requiere, tanto el pensar de otro modo para aportar distintas perspectivas (creatividad), como el comprometer determinados recursos por iniciativa propia, con el fin de explorar una oportunidad, asumiendo el riesgo que esto comporta (emprendimiento)".

- Análisis y resolución de problemas: "Los problemas son situaciones nuevas que requieren que los individuos respondan con comportamientos nuevos. Resolver un problema implica realizar tareas que demandan procesos de razonamiento más o menos complejo y, en muchas ocasiones, no simplemente una acción asociativa y rutinaria".

El uso de mapas conceptuales, teniendo claros los objetivos y la manera de evaluarse, son una herramienta muy potente para afianzar los conceptos clave y conseguir un alineamiento constructivo (Biggs, 2004).

La metodologia se ha implementado en las siguientes asignaturas:

1. Product Development (31852). Obligatoria. Número de ECTS: 2,5. $\mathrm{N}^{\mathrm{a}}$ de estudiantes: 30. Facultad Administración y Dirección de Empresa, Master Universitario en Gestión de Empresas, Productos y Servicios.

2. Product Project (31855). Obligatoria. Número de ECTS: 20. N de estudiantes: 30. Facultad Administración y Dirección de Empresa, Master Universitario en Gestión de Empresas, Productos y Servicios.

3. Nuevas Tendencias en Estrategia de Servicio (31985). Optativa. Número de ECTS: 5. $\mathrm{N}^{\mathrm{a}}$ de estudiantes: 30. Facultad Administración y Dirección de Empres, Master Universitario en Gestión de Empresas, Productos y Servicios.

4. Metodologías de investigación (32257). Optativa. Número de ECTS: 3. $\mathrm{N}^{\mathrm{a}}$ de estudiantes: 30. Facultad Administración y Dirección de Empresa. Master Universitario en Gestión de Empresas, Productos y Servicios. 
5. Gestión del patrimonio inmaterial (33848). Optativa. Número de ECTS: 4,5. Na de estudiantes: 35. Departamento de Conservación y Restauración de Bienes Culturales, Máster Universitario en Conservación y Restauración de Bienes Culturales.

6. Desarrollo, gestión y dirección de proyectos de restauración. Optativa. Número de ECTS: 4,5. $\mathrm{N}^{\mathrm{a}}$ de estudiantes: 35. Departamento de Conservación y Restauración de Bienes Culturales, Máster Universitario en Conservación y Restauración de Bienes Culturales.

7. Historia de la Conservación y restauración de bienes culturales (33841). Optativa. Número de ECTS: 4. $\mathrm{N}^{\mathrm{a}}$ de estudiantes: 35. Departamento de Conservación y Restauración de Bienes Culturales, Máster Universitario en Conservación y Restauración de Bienes Culturales.

En el diseño de proyectos, la fase más importante es la de identificación, en la que se analizará la situación existente para crear una visión de la situación deseada y seleccionar las estrategias que se emplearán para lograrla. Hasta ahora una de las principales herramientas empleadas en el análisis de problemas para poder plantear una idea innovadora, ha sido el método dafo. Este método permite identificar los puntos fuertes y débiles de un área concreta y las amenazas y oportunidades del entorno, obteniendo una imagen global de la problemática del recurso patrimonial. A pesar de que esta técnica puede ayudar en la elaboración de estrategias o alternativas que mitiguen las debilidades a partir de las potencialidades y fortalezas existentes, no permite obtener una visión objetiva del problema focal, así como de sus causas y efectos. Actualmente la visualización de las relaciones causales de los problemas de una forma clara, supone una tarea fundamental. Por tanto la elaboración de un diagnostico que permita obtener un conocimiento profundo de la situación como base para la toma de decisiones, exige el empleo de una herramienta que permita entender porque se ha producido esa situación no desea y cuales con sus consecuencias, facilitando la priorización de los problemas y el llegar a un acuerdo colaborativo en el diagnóstico entre implicados.

En este caso los mapas conceptuales móviles cooperativos, han permitido visualizar las relaciones causales, priorizar los problemas y llegar a un acuerdo en el diagnóstico entre implicados, a través del trabajo colaborativo. La posibilidad de trabajar con mapas móviles, ha permitido la revisión colaborativa hasta verificar que el sistema es valido, haciendo los ajustes necesarios y llegando a consenso sobre su estructura.

\section{Objetivos}

El objetivo de la dinámica es analizar un problema complejo y buscar soluciones utilizando los mapas conceptuales móviles, de manera que a través de preguntas de enfoque el alumno vaya de lo general a lo específico, para buscar una solución en equipo.

De acuerdo con el "Modelo para la enseñanza del diseño creativo" de Glen et al. (2015: 190), podemos desarrollar distintas actividades:

1. Identificar problemas: a los equipos se les plantea un reto (o pregunta de enfoque) y deben identificar problemas y oportunidades.

2. Observación: pensando de la misma manera que el usuario. 
3. Visualización y reflexión: mostrando los resultados de la observación a toda la clase de manera visual para compartir, hacer preguntas y explicar.

4. Brainstorming de ideas, votando las mejores para reducir las soluciones.

5. Usar y probar prototipos, observando a los usuarios para captar nuevas ideas.

6. Test de viabilidad, explorando las opciones de modelos de negocio y las distintas posibilidades de generar valor.

En este caso, se han desarrollado actividades de los tipos 1, 3 y 4 . De todos modos, dependiendo de la asignatura o session se podrían añadir otras actividades. Por ejemplo, se podría hacer un juego de rol (role-playing) para aplicar las actividades 2 y/o 5. O hacer un estudio de caso utilizando la actividad 6.

\section{Descripción del desarrollo de la innovación}

Antes de comenzar la dinámica, son importantes dos tareas por parte del profesor:

- Redactar unas instrucciones previas para los estudiantes.

- Comprar el material necesario. Nosotros compramos tarjetas de la marca post-it que nos permiten manejar distintos tamaños, colores y formas.

Los grupos se forman con 3-5 alumnos. Se les plantea un reto y ellos deben identificar los distintos problemas, expresándolos con palabras clave o dibujos en notas móviles de un color determinado.

De acuerdo con el proceso de resolución de problemas, los grupos buscarán soluciones para cada problema por medio de la tormenta de ideas (brainstorming), de forma que al final se seleccionará una solución consensuada para cada problema. Dicha solución se expresará también con palabras clave o dibujos en una nota móvil de otro color, y que se conectará con el problema a resolver. Es decir, de cada problema una nota y de cada solución otra nota. En este momento, el professor revisará los modelos de cada grupo para detector información que falte por completer.

Al mostrar este modelo con las notas móviles pegadas en la pared, tendremos dos filas de ideas, problemas y soluciones. Entonces se plantea un nuevo reto, que es proponer medidas para prevenir que esos problemas aparezcan. Estas medidas, se escribirán o dibujarán en una nota móvil mayor y con un tercer color.

Asimismo, se podría plantear un tercer reto que sería establecer otras conexiones entre problemas y soluciones. Es decir, conectar soluciones que pueden ser communes para solucionar varios problemas.

Con el modelo final, el resto de grupos se desplazan por el aula para observar los modelos del resto de equipos y así pueden comparar dichos modelos con el suyo propio. Pero la mitad del grupo se queda en su modelo para explicar dudas a los "visitantes" o recoger las "recomendaciones" de sus compañeros. Acabada la ronda, cada grupo vuelve a reunirse para enriquecer su modelo con todas las ideas aportadas. 


\section{Resultados}

En ambas facultades, podemos comprobar que las ideas pueden representarse por texto (palabras clave) o con dibujos, dependiendo del reto propuesto y los objetivos.

Este tipo de ejercicios visuales, les ayuda a organizar ideas y a entender las relaciones o "conectores" entre los problemas y las soluciones. Además, las notas móviles permiten hacer cambios y resolver errores de una manera más sencilla, a la vez que los colores ayudan a diferenciar los conceptos.

La integración de distintos puntos de vista de modo colaborativo es muy importante en la resolución de problemas, por lo que el resultado final es más rico, pero, al mismo tiempo, es sencillo de comprender. Además, les ayuda a reflexionar sobre la necesidad de tener en cuenta el punto de vista de distintos actores.

A partir de la digitalización de las distintas fases de los trabajos de los alumnos, se ha realizado un análisis cuantitativo de los nodos, enlaces, uso de imágenes o uso de palabreabas claves, y los resultados obtenidos han sido:

$1^{\circ}$. E1 $90 \%$ de los diseños siempre presentan nodos y enlaces.

$2^{\circ}$. Los diseños que combinan enlaces y nodos, muestran un nivel de complejidad en función del número de nodos que suelen ir entre 6 y 8 . Los que utilizan menos nodos son más sencillos de entender, mientras que los que emplean más de 13 dan como resultado mapas complejos que dificultan su comprensión. Por lo que el número adecuado de nodos en un mapa, si se quiere mostrar algo de forma visual, debería estar entre 5 y 13 .

\section{Conclusiones}

Esta experiencia nos ha mostrado que el uso de notas móviles ayuda a impulsar el trabajo colaborativo en distintas asignaturas, se usen palabras clave o dibujos. Y, evidentemente, el trabajo colaborativo es fundamental a la hora de resolver problemas (Arquilla y Motta, 2011), ya que distintos actores pueden estar involucrados y las relaciones interpersonales son fundamentales (Muñoz González, 2014). El intercambio de ideas enriquece la visión de los problemas y la generación de posibles soluciones.

Es cierto que los cursos de postgrado suelen tener grupos pequeños, por lo que estas dinámicas son más sencillas de aplicar y además ayudan a impulsar el trabajo colaborativo, a la vez que ayudan a gestionar el tiempo puesto que cada fase tiene un tiempo máximo para que la dinámica pueda completarse en la sesión. Y estas son competencias transversales o "soft" que demandan los empleadores (Wu-Pong et al., 2013), más allá de conocimientos específicos. Incluso si los estudiantes no son expertos en la materia, y vienen de titulaciones distintas, este trabajo cooperativo les ayuda a trabajar en equipos interdisciplinares.

Se abren distintas preguntas a la hora de evaluar este trabajo, puesto que es difícil marcar elementos objetivos que ayuden al profesor, siendo más una evaluación por observación en el aula, combinada con el resultado final. Algunas sugerencias podrían ser: valorar la integración del equipo, valorar la cantidad y calidad de ideas expuestas (problemas 
detectados y/o soluciones propuestas), valorar el número de conexiones entre los problemas y soluciones, valorar la capacidad de síntesis (a través de palabras clave o dibujos), valorar la creatividad a la hora de exponer el mapa, valorar el ajuste al tiempo dado, etc. Como conclusiones finales podemos destacar tres puntos:

1. Los diferentes diseños, representan mapas conceptuales, que revelan puntos de vista diferentes. A pesar de no ser expertos en diseño de mapas conceptuales, logran de forma intuitiva dividir procesos complejos en tareas simples, organizándolo y sintetizarlo en un mapa.

2. La facilidad con la que se puede modificar un mapa, está vinculada con nuestro interés de mejorar el modelo. Así que un sistema con notas post-it no solo es más dinámico y flexible, sino que también genera más nodos que los dibujos realizados directamente sobre el papel.

3. Los mapas conceptuales colaborativos, logran integrar la diversidad de puntos de vista individuales de todos los alumnos. Estos nuevos sistemas contienen un elevado número de nodos, incluso nuevas ramificaciones y patrones, empleando diferentes colores de tarjetas, pero para los alumnos no resultan complejos porque participan en la construcción de estos modelos comunes.

\section{Referencias}

ARQUILLA, V. y MOTTA, R. (2011). "Student brain: tools and methods to support the students' creativity and to improve the learning and co-learning processes. The Polibrain case" En: INTED2011: 5th International Technology, Education and Development Conference, pp. 4651-4661.

BIGGS, J. (2004). Calidad del aprendizaje universitario. Madrid: Narcea.

BUZÁN, T. (1996). The Mind Map Book: How to Use Radiant Thinking to Maximize Your Brain's untapped potential. New York (USA): Plume.

FERRERO Y DE LOMA-OSORIO, G. Ed. (2009). Identificación y formulación de proyectos de cooperación para el desarrollo: gestión del ciclo del proyecto y enfoque del marco lógico. Valencia: Editorial UPV.

GLEN, R.; SUCIU, CH.; BAUGHN, C.CH. y ANSON, R. (2015). “Teaching design thinking in business schools" en The International Journal of Management Education, vol. 13, no. 2, pp. 182-192. <http://dx.doi.org/10.1016/j.ijme.2015.05.001> [consulta: 25 marzo de 2017].

J.M. Muñoz González, R. Serrano Rodríguez and V. Marín Díaz, El aprendizaje colaborativo y su desarrollo a través de mapas mentales. Una innovación educativa en la formación inicial docente, Educatio Siglo XXI, Vol. 32, 2015.

K.C. Laudon and J.P. Laudon (2016), Management information systems: managing the digital firm, Boston: Pearson, 14th ed. 
LAUDON, K.C. y LAUDON, J.P. (2016). Management information systems: managing the digital firm. Boston: Pearson.

MUÑOZ GONZÁLEZ, J.M.; SERRANO RODRÍGUEZ, R. y MARÍN DÍAZ, V. (2015). “El aprendizaje colaborativo y su desarrollo a través de mapas mentales. Una innovación educativa en la formación inicial docente" en Educatio Siglo XXI, Vol. 32.

R. Glen, Ch. Suciu, C.Ch. Baughn and R. Anson, "Teaching design thinking in business schools", The International Journal of Management Education, vol. 13, no. 2, pp. 182-192, 2015, doi: http://dx.doi.org/10.1016/j.ijme.2015.05.001.

S. Wu-Pong, et al., "The Future of the Pharmaceutical Sciences and Graduate Education: Recommendations from the AACP Graduate Education Special Interest Group", American Journal of Pharmaceutical Education, vol. 77, no. 4, 2013.

V. Arquilla and R. Motta, "Student brain: tools and methods to support the students' creativity and to improve the learning and co-learning processes - The Polibrain case", Inted2011: 5th International Technology, Education and Development Conference, pp. 46514661, 2011.

WUJEC, T (2013). Got a wicked problem? First, tell me how you make toast. TED Global 2013.

$<$ https://www.ted.com/talks/tom_wujec_got_a_wicked_problem_first_tell_me_how_you_ make_toast?language $=$ en $>$ [Consulta: 22 de marzo de 2016]. 


\title{
La doble evaluación: un medio para aprender de los errores y para mejorar el rendimiento en matemáticas
}

\author{
Francisco J. Boigues ${ }^{a}$, Vicente D. Estruch ${ }^{\mathrm{b}}$, Anna Vidal ${ }^{\mathrm{c}}$ y José I. Pastor ${ }^{\mathrm{d}}$ \\ Departament de Matemàtica Aplicada, Universitat Politècnica de València-Campus de Gandia \\ Grup d’Innovació Educativa i Recerca en Màteries Cientifiques \\ afraboipl@mat.upv.es, bvdestruc@mat.upv.es, cavidal@mat.upv.es,..jpastogi@mat.upv.es
}

\begin{abstract}
This paper presents an educational innovation in the field of mathematics consisting of implementing a "double assessment" system (DDE). Any assessment in teaching should not only measure the acquisition of knowledge in the broadest sense, but also should help overcome the obstacles and difficulties experienced during learning. In the double evaluation, students face a first test of control and, within a few days, they face another test with the same learning objectives. In the time interval between the two tests, in class, those contents are worked especially where greater learning deficiencies have been observed. The experience has been carried out during the first semester of the 2017/2018 academic year and 61 first-degree students from the Degree in Environmental Sciences of the Polytechnic University of Valencia participated. The results of the experience show significant improvements in the performance of the students and in addition there is a greater implication of the students in their own learning.
\end{abstract}

Keywords: Double-Assessment, feedback, mathematics, innovation.

\section{Resumen}

Este trabajo presenta una innovación educativa en el campo de las matemáticas consistente en implementar un sistema "De Doble Evaluación" (DDE). Cualquier evaluación en docencia no solo debe medir la adquisición de conocimientos en sentido amplio; sino que además debería ayudar a superar los obstáculos y dificultades experimentados durante el aprendizaje. En la doble evaluación, los estudiantes se enfrentan a un primer examen de control y, a los pocos días, se vuelven a enfrentar a otro examen con los mismos objetivos de aprendizaje. En el intervalo de tiempo entre las dos pruebas, en clase, se trabajan especialmente aquellos contenidos donde se han observado mayores deficiencias de aprendizaje. La experiencia se ha llevado a cabo a lo largo del primer cuatrimestre del curso 2017/2018 y participaron 61 estudiantes de primer curso del Grado de Ciencias Ambientales de la Universitat Politècnica de València. Los resultados de la experiencia demuestran mejoras significativas en el rendimiento de los estudiantes y además se constata una mayor implicación de los estudiante en su propio aprendizaje. 
La doble evaluación: un medio para aprender de los errores y para mejorar el rendimiento en matemáticas

Palabras clave: Doble-Evaluación, realimentación, matemáticas, innovación.

“Quien nunca ha cometido un error, nunca ha probado algo nuevo.”

A. Einstein

\section{Introducción}

El rendimiento académico de los estudiantes universitarios depende de muchos y diversos factores: los conocimientos previos, los hábitos de estudio, la motivación, las metodologías predominantes, el sistema de evaluación, etc. Consecuentemente, analizar dichos factores, en el sentido de valorar su influencia en el rendimiento final, ayudará a promover mejoras en los sistemas de enseñanza/aprendizaje universitarios, que conllevarán necesariamente progresos adecuados en el rendimiento (Myers y Myers, 2007; Mourshed, Chijioke y Barber,2010; Zabalza,2004).

De entre los factores mencionados, uno de los que condicionan de manera significativa la forma en que los estudiantes estudian determinada materia académica es el método de evaluación (Gargallo, 2015).

Existen diversas maneras de entender la evaluación, dependiendo de las necesidades, propósitos u objetivos de la institución educativa, como pueden ser, por ejemplo, el control y la medición, el enjuiciamiento de la validez del objetivo o la rendición de cuentas (Isabel y Vargas, 2004). Los modelos Tylerianos (Tyler, 1974), que siguen plenamente vigentes en la actualidad, ponen especial atención en los objetivos relacionados con el rendimiento de los estudiantes. Para estos modelos, la evaluación debe medir hasta qué punto han sido alcanzados los objetivos de aprendizaje. Para ello, deben establecerse mecanismos que permitan comparar los resultados de aprendizaje frente los objetivos, establecidos éstos de antemano y, asimismo, propuestos en los planes de estudios (Tyler, 1974, Hernández, 2010). Por lo tanto, uno de los objetivos de la evaluación será obtener una medida de los conocimientos adquiridos. En matemáticas, cuando nos referimos a los conocimientos adquiridos, éstos no se concretan únicamente en aspectos teóricos como las definiciones, las proposiciones o las propiedades. También son muy importantes los algoritmos de cálculo, así como la aplicación de los conocimientos a la resolución de problemas. Estos tres aspectos (teoría-práctica-aplicabilidad) constituyen la base de lo que se entiende actualmente como competencia matemática (BOE 1105/2014).

Myers y Myers (2007) encontraron que aquellos estudiantes que realizaron exámenes o controles a menudo obtuvieron mejores resultados académicos en matemñaticas que otros estudiantes que realizaron los mínimos controles posibles. Además, aquellos estudiantes que tuvieron más controles manifestaron una actitud más positiva frente a la clase de matemáticas. Pero existe un límite ya que evaluaciones muy frecuentes, por ejemplo exámenes semanales, no conduce a mejores resultados (Haberyan, 2003). Por lo tanto, hay que buscar un equilibrio a la hora de programar actos de evaluación, teniendo en cuenta

(cc) EY-NC-ND 2018, Universitat Politècnica de València

Congreso IN-RED (2018) 
también que los estudiantes necesitan cierto margen para manejar y gestionar su tiempo y sus estrategias de estudio.

Toda evaluación efectiva ha de tener en cuenta la dimensión formativa, es decir informar, tanto al profesor como al alumno, sobre los avances en el proceso de enseñanza/aprendizaje. Algún trabajo reciente (Fabregat y Pelayo, 2016) reivindica que la dimensión formativa de la evaluación debería tener mayor consideración en la práctica docente. En la faceta formativa, la retroalimentación ("feedback") debe ser una componente esencial (Sadler y Good,2006). El feedback ha de permitir que el estudiante sea consciente de lo que ha realizado bien y de lo que ha realizado mal, y además que pueda identificar las causas de sus errores, es decir identificar las estructuras cognitivas que son deficientes (Simon y Tzur, 2004). Como conclusión a lo expuesto, parece razonamble asumir que hay que poner en práctica modelos o métodos de evaluación que promuevan un aprendizaje más significativo, de forma que se obtengan, consecuentemente, mejores resultados académicos.

\section{Objetivos}

En este trabajo se describe la puesta en práctica de un modelo de evaluación que denominamos “De Doble Evaluación" (DDE), el cual tiene en cuenta la dimensión formativa de la evaluación. Además, se analizan los resultados de su puesta en práctica en la asignatura Matemáticas, del Grado de Ciencias Ambientales de la Universitat Politècnica de València (GCCAA-UPV). En concreto, se quiere verificar si se producen mejoras en el rendimiento académico de los alumnos y si, con el sistema de evaluación, también se influye positivamente en la actitud de los alumnos hacia las matemáticas y, consecuentemente, en el interés de los alumnos por aprenderlas.

\section{Descripción y desarrollo de la innovación}

\subsection{Descripción}

El modelo DDE es simple: tras haber trabajado una parte de la materia, se realiza un primer control de evaluación. El resultado de dicho control informa a alumno y profesor del nivel de adquisición de competencias alcanzado. El siguiente paso es desarrollar actividades formativas orientadas a subsanar las lagunas competenciales y errores detectados en el primer control, dando de esta forma feedback al alumno. Finalmente se realiza un segundo control de evaluación, cuyo resultado proporcionará una nueva valoración del nivel competencial del alumno en esa parte concreta de la materia (figura 1).

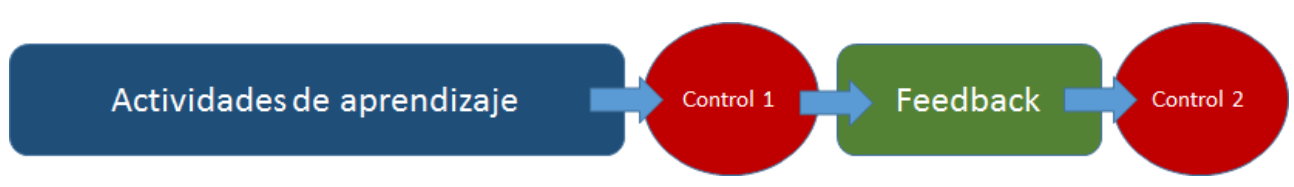

Fig.1 Esquema del modelo DDE 
El modelo DDE se fundamenta en el hecho de que es normal cometer errores durante y después del proceso de aprendizaje de algo nuevo (Huitrado y Climent, 2013; Rico, 1998; Socas, 2007). Más aún, cometer errores es una parte natural del proceso de aprendizaje y, en el caso de las matemáticas, los errores cometidos proporcionan al alumno información muy valiosa sobre el nivel competencial alcanzado, y lo que es más importante, nuevas oportunidades de aprendizaje con un conocimiento más claro de aquello que no se sabe o no se sabe hacer.

Los resultados del primer control también van a ser muy importantes para los profesores ya que informarán sobre aquello que no ha funcionado en el proceso de enseñanza/aprendizaje inicial. Los errores de los alumnos constituyen un indicador inestimable para verificar en qué aspectos el profesor debe profundizar o poner más énfasis, qué explicaciones vale la pena repetir o qué estrategias de enseñanza es conveniente revisar o cambiar. En definitiva, se trata de "aprovechar" los errores iniciales de los alumnos, identificándolos oportunamente a partir del primer control de evaluación, para convertirlos en nuevas oportunidades en favor del aprendizaje. Obviamente, sería deseable que las sesiones de feedback se desarrollen de forma que se proporcione a los alumnos solamente la mínima ayuda, aquella estrictamente necesaria para que sean ellos, por ellos mismos, los que subsanen los errores y resuelvan los problemas. Sin embargo esto último necesita de un tiempo del que, en general, no se dispone en la universidad, teniéndose que recurrir al desarrollo de actividades bastante dirigidas.

\subsection{Participantes}

En la experiencia participaron 61 estudiantes de primer curso del Grado en Ciencias Ambientales, del Campus de Gandia de la Universitat Politècnica de València, durante el primer cuatrimestre del curso 2017/2018. Todos ellos cursaban la asignatura Matemáticas $\mathrm{y}$, como viene siendo habitual, formaban un grupo muy heterogéneo si se tiene en cuenta lo estudiado en el curso anterior (diversos bachilleratos, ciclos formativos y repetidores). Por esta razón, al observar los conocimientos matemáticos previos en el grupo, nos encontramos con un número importante de alumnos que en $2^{\circ}$ de bachillerato no cursaron matemáticas, alumnos procedentes de un ciclo formativo profesional así como un número significativo de alumnos repetidores.

Si fijamos el objetivo en la manera en que los estudiantes hacen frente al estudio de las matemáticas, resultan más que evidentes ciertas actitudes poco convenientes: asistencia irregular a las clases, manifiesta incompetencia a la hora de elaborar sus propios apuntes y realización de las tareas de aprendizaje de forma irregular en el tiempo, como la preparación de los exámenes a última hora. Pero quizás lo más destacable sea una actitud previa hacia las matemáticas que, en general, cuando no es negativa es de indiferencia. En base a los elementos contextuales anteriores, es inmediato prever un índice alto de fracaso en las asignaturas de matemáticas. Por lo tanto se impone actuar para evitar en la medida de lo posible el fracaso, al tiempo que se pueda facilitar un aprendizaje significativo.

(cc) EY-NC-ND 2018, Universitat Politècnica de València

Congreso IN-RED (2018) 


\subsection{Temporalización de la innovación}

El primer cuatrimestre del curso académico tiene una duración media de 14 semanas y en cada semana la asignatura Matemáticas tiene asignadas dos clases de teoría/problemas de 90 minutos. El periodo de 14 semanas se estructuró en dos periodos de igual duración (7 semanas cada uno). Durante el primer periodo, a lo largo de cinco semanas, se impartieron una serie de contenidos (teoría y problemas). Dicho periodo finalizó con un control o acto de evaluación. A la vista de los resultados de éste, la sexta semana se inició repasando aquellos contenidos que fueron detectados como más problemáticos para los alumnos. Además, se suministraron varios modelos de exámen para que los alumnos los fuesen realizando. La última sesión del primer periodo se dedicó a la realización de otro control o acto de evaluación. En el $2^{\circ}$ periodo del curso se estableció una distribución de clases y controles análoga a la seguida primer periodo (ver tabla 1 ).

Tabla 1. Estructura temporal de los periodos de cada cuatrimestre del grupo de innovación

\begin{tabular}{|c|c|c|}
\hline & 1ạ clase semanal & $2^{2}$ clase semanal \\
\hline 1a y 8 a Semana & Teoria/Problemas & Teoría/Problemas \\
\hline 2a y 9a Semana & Teoria/Problemas & Teoría/Problemas \\
\hline 3a y 10 a Semana & Teoria/Problemas & Teoría/Problemas \\
\hline 4a y 11a Semana & Teoria/Problemas & Teoría/Problemas \\
\hline $5^{\mathrm{a}}$ y $12^{\mathrm{a}}$ Semana & Teoria/Problemas & Control 1 (C1) \\
\hline 6a y 13a Semana & Repaso/feedback & Repaso/feedback \\
\hline 7ạ y 14a Semana & Repaso/feedback & Control 2 (C2) \\
\hline
\end{tabular}

La revision del primer control y las sesiones de repaso proporcionan feedback al estudiante, de forma que éste puede revisar lo aprendido y no aprendido. En el segundo control el estudiante tiene la oportunidad de mejorar la valoración obtenida en el primer control, en base a un aprendizaje más efectivo de los contenidos. La nota final otorgada al alumno para cada una de las partes fue la máxima nota al considerar los dos controles (max(Nota C1, Nota C2)). 
La doble evaluación: un medio para aprender de los errores y para mejorar el rendimiento en matemáticas

\subsection{Contenidos}

Los contenidos desarrollados en el primer periodo (7 semanas) corresponden a tópicos propios del cálculo diferencial. El segundo periodo se dedicó al cálculo integral. En la tabla 2 se exponen con más detalle los contenidos desarrollados.

Tabla 2. Estructura temporal de los periodos del primercuatrimestre

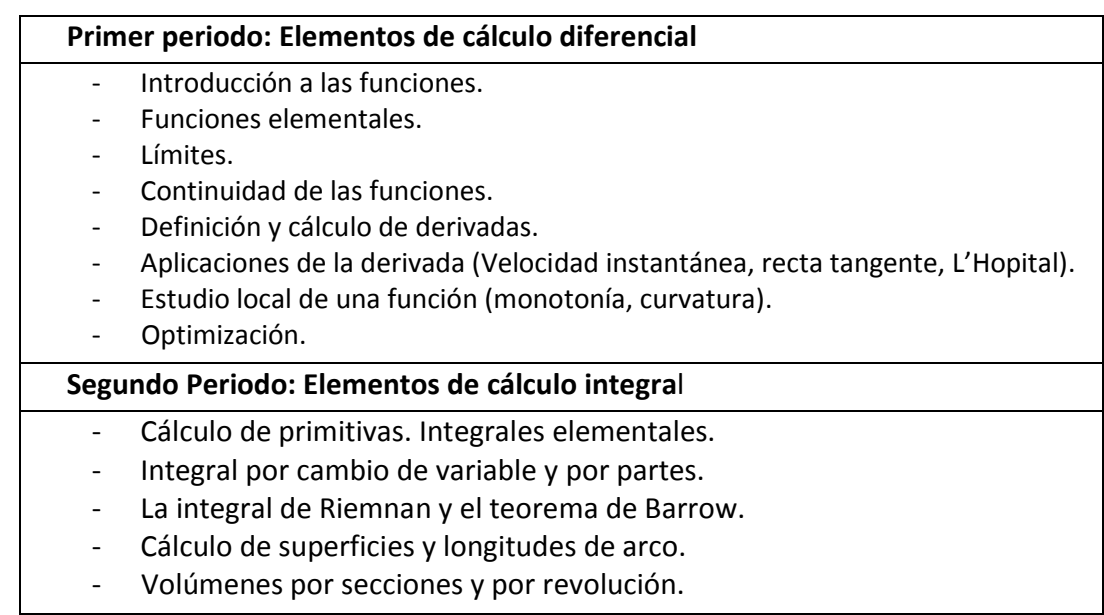

\section{Resultados y discusión}

El análisis de resultados del primer cuatrimestre del curso 2017/2018 se realiza a partir de las distribuciones de las notas correspondientes a los controles, los cuales se han valorado entre 1 y 10. Como elemento de control se tienen los resultados correspondientes al curso 2016/2017. En dicho curso, en el primer cuatrimestre, también se diferenciaron dos partes correspondientes a cálculo diferencial y cálculo integral y se siguió una metodología de evaluación, que denominaremos "tradicional”, consistente en un control para cada parte (cálculo diferencial y cálculo integral) durante el curso y la posibilidad de recuperar las partes no aprobadas (sólo una o las dos) en una única sesión de examen, al final del cuatrimestre, en la que se diferenciaban las dos partes a recuperar. Los controles consistieron, en todos los casos, en 5 preguntas de respuesta abierta con un nivel de dificultad similar.

En primer lugar se analizarán los resultados de la parte de cálculo diferencial, en concreto los correspondientes al primer control del curso 2017/2018 que se comparan con los del control de cálculo diferencial del curso 2016/2017. Seguiremos con el estudio de los resultados del segundo control de cálculo diferencial del curso 2017/2018 que se compararán con los resultados de la recuperación de cálculo diferencial, en el examen final, del curso 2016/2017. A continuación, se realiza un análisis análogo al descrito anteriormente, pero en este caso se estudian los resultados de la parte dedicada al cálculo integral. Finalmente, se compara la tasa de aprobados en todos los controles objeto de estudio.

(cc) EY-NC-ND 2018, Universitat Politècnica de València

Congreso IN-RED (2018) 


\subsection{Primera parte: Cálculo diferencial}

En la tabla 3 y la figura 2 se resume la distribución de los resultados (frecuencias absolutas, f.a. y frecuencias relativas, f.r.), por grupos de notas, y los valores promedio y de dispersión (desviación típica y coeficiente de variación, C.V.) del primer control del curso 2017/2018 (C1/CD-17) y del primer control parcial del curso 2016/2017 (C1/CD-16) que corresponden a cálculo diferencial. Los resultados evidencian las dificultades de los estudiantes de los dos cursos frente a su primer examen de matemáticas en la universidad. En ambos cursos sólo aprueban alrededor del 13\%, y además en un porcentaje bastante elevado la nota está por debajo del 2’5. Se observa también que, en ambos cursos, la nota media es muy baja, y la dispersión bastante alta, si se la compara con la media, sobre todo en el curso 2016/2017 (ver valores de C.V. en la tabla 3).

Tabla 3. Cálculo diferencial. Distribución de los resultados del primer control para los cursos 2016/2017 (C1/CD-16) y 2017/2018 (C1/CD-17)

\begin{tabular}{|c|c|c|c|c|}
\hline Intervalos & f.a. C1/CD-16 & f.a. C1/CD-17 & f.r. C1/CD-16 & f.r. C1/CD-17 \\
\hline$\left[0,2^{\prime} 5[\right.$ & 39 & 29 & $72,2 \%$ & $50,0 \%$ \\
\hline$\left[2^{\prime} 5,5[\right.$ & 8 & 22 & $14,8 \%$ & $37,9 \%$ \\
\hline$\left[5,7^{\prime} 5[\right.$ & 6 & 7 & $11,1 \%$ & $12,1 \%$ \\
\hline$\left[7^{\prime} 5,10\right]$ & 1 & 1 & $1,9 \%$ & $1,7 \%$ \\
\cline { 2 - 4 } Total & 54 & 59 & \multicolumn{3}{l}{} \\
\cline { 2 - 5 } & \multicolumn{5}{r|}{}
\end{tabular}

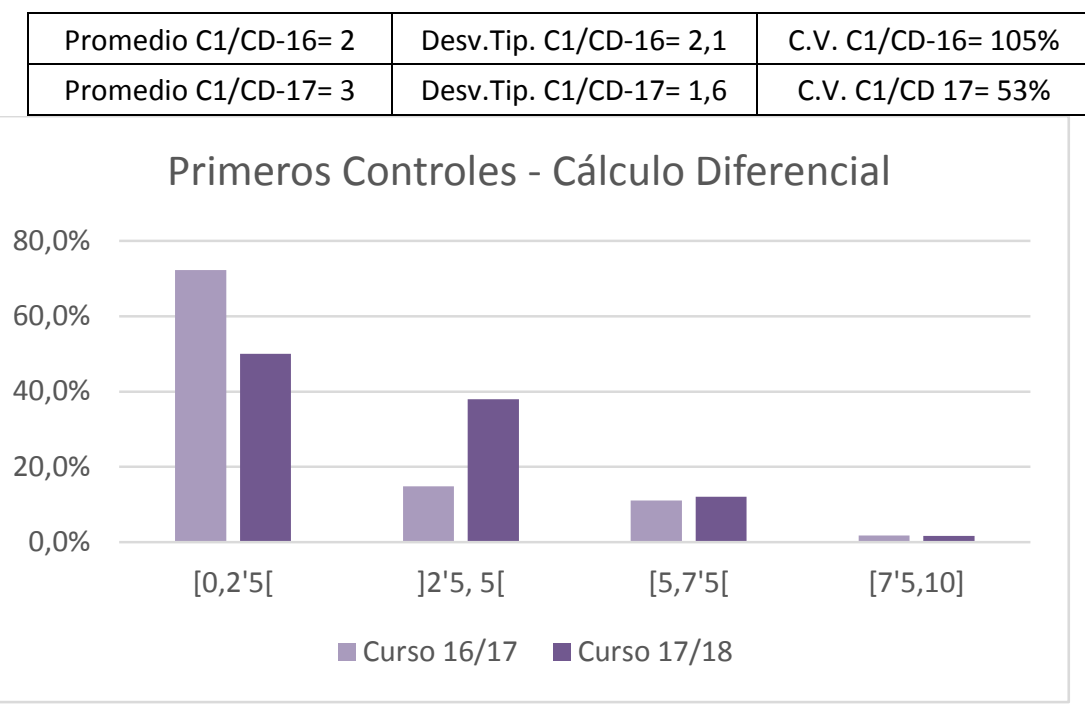

Fig. 2 Diagrama de barras de la distribución de notas del primer control del cálculo diferencial para los dos cursos

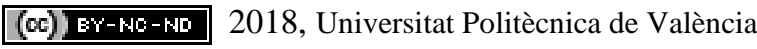




\subsection{Calculo diferencial. Control 2 (2017/2018) y examen final (2016/2017)}

Las distribuciones de los resultados para cálculo diferencial del control 2 del curso 2017/2018 (C2/CD-17) y del examen final de cálculo diferencial del curso 2016/2017 (EF/CD-16) (tabla 4 y gráfico 3) indican que los dos grupos obtienen un porcentaje de aprobados similar (30\% aprox.). Siguen siendo resultados pobres pero en el grupo DDE la nota media es más alta, el porcentaje de estudiantes que estan en el intervalo más bajo de nota es bastente menor y la dispersión respecto a la media también es mucho menor (ver valores de C.V. en la tabla 4).

Tabla 4. Cálculo diferencial. Distribución de los resultados del segundo control del curso 2017/2018 (C2/CD-17) y del examen final del curso 2016/2017 (EF/CD)

\begin{tabular}{|c|c|c|c|c|}
\hline Intervalos & f.a. EF/CD-16 & f.a. C2/CD-17 & f.r. EF/C-16 & f. r. C2/CD-17 \\
\hline$\left[0,2^{\prime} 5[\right.$ & 22 & 8 & $40,7 \%$ & $13,3 \%$ \\
\hline$\left[2^{\prime} 5,5[\right.$ & 15 & 33 & $27,8 \%$ & $55,0 \%$ \\
\hline$\left[5,7^{\prime} 5[\right.$ & 16 & 16 & $29,6 \%$ & $26,7 \%$ \\
\hline$\left[7^{\prime} 5,10\right]$ & 1 & 2 & $1,9 \%$ & $3,3 \%$ \\
\cline { 2 - 4 } Total & 54 & 59 & \multicolumn{3}{r}{} \\
\cline { 2 - 5 } & \multicolumn{4}{|r}{}
\end{tabular}

\begin{tabular}{|l|l|l|}
\hline Promedio EF/CD-16=3,4 & Desv. Tip. EF/CD-16=2,5 & C.V. EF/CD-16=73.5\% \\
\hline Promedio C2/CD-17=4,3 & Desv. Tip. C2/CD-17=1,6 & C.V. C2/CD-17=37.2\% \\
\hline
\end{tabular}

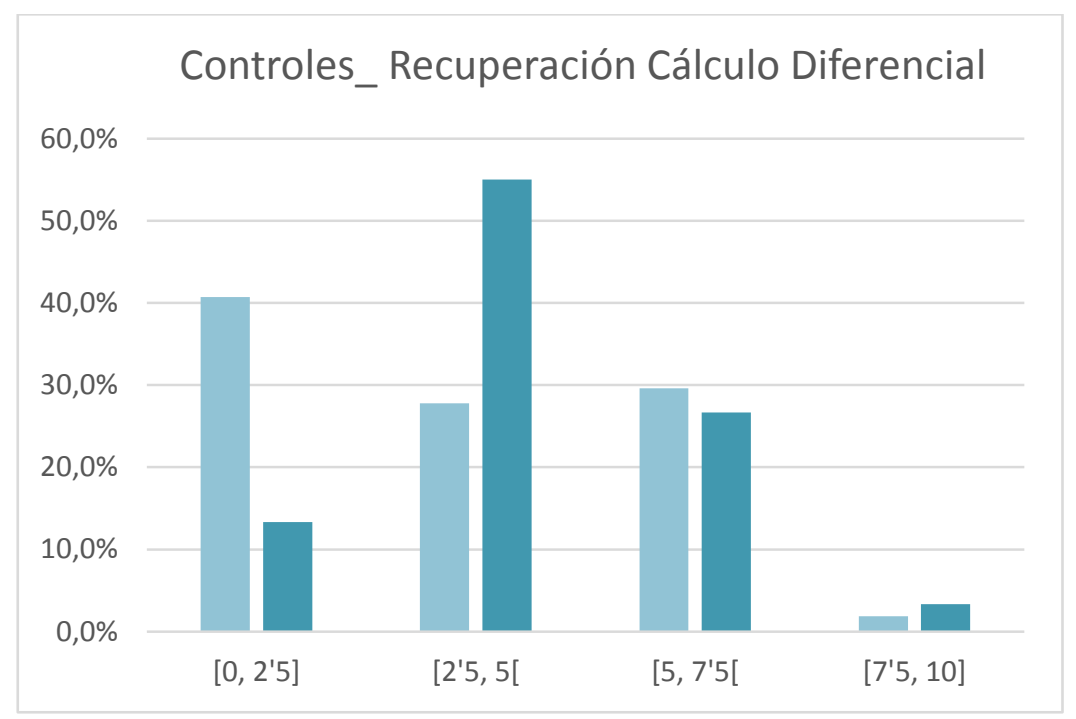

Fig. 3 Diagrama de barras de la distribución de las notas en $C 2 / C D$ (Curso 17/18) y EF/CD (Curso 16/17) 


\subsection{Segunda parte: Cálculo integral}

En la tabla 5 y el gráfico 4 se resumen los resultados, por grupos de notas, del primer control de cálculo integral del curso 2017/2018 (C1/CI-17) y del control parcial de la misma parte del curso 2016/2017 (C1/CI-16). El grupo que sigue una evaluación tradicional (curso 2016/2017), tiene unos resultados similares a los obtenidos en C1/CD-16. En cambio, en el grupo con evaluación DDE se incrementa la tasa de aprobados, estableciéndose una diferencia notable en el rendimiento al comparar los dos grupos. La diferencia entre la nota media de los dos grupos es de más de 2 puntos.

Tabla 5. Cálculo integral. Distribución de los resultados del primer control para los cursos 2016/2017 (C1/CI-16) y 2017/2018 (C1/CI-17)

\begin{tabular}{|c|c|c|c|c|}
\hline Intervalos & f.a. C1/Cl-16 & f.a. C1/Cl-17 & f.r. C1/Cl-16 & f.r.C1/Cl-17 \\
\hline$\left[0,2^{\prime} 5[\right.$ & 22 & 8 & $57,9 \%$ & $16,7 \%$ \\
\hline$\left[2^{\prime} 5,5[\right.$ & 9 & 17 & $23,7 \%$ & $35,4 \%$ \\
\hline$\left[5,7^{\prime} 5[\right.$ & 5 & 16 & $13,2 \%$ & $33,3 \%$ \\
\hline$\left[7^{\prime} 5,10\right]$ & 2 & 7 & $5,3 \%$ & $14,6 \%$ \\
\cline { 2 - 4 } Total & 38 & 48 & \multicolumn{1}{l}{} \\
\cline { 1 - 4 } & \multicolumn{4}{|r}{}
\end{tabular}

\begin{tabular}{|l|l|l|}
\hline Promedio $\mathrm{C} 1 / \mathrm{Cl}-16=2,6$ & Desv. Tip. $\mathrm{C} 1 / \mathrm{Cl}-16=2,5$ & C.V. $\mathrm{C} 1 / \mathrm{Cl}-16=96.15 \%$ \\
\hline Promedio $\mathrm{C} 1 / \mathrm{Cl}-17=4,9$ & Desv. Tip. $\mathrm{C} 1 / \mathrm{Cl}-17=2,4$ & C.V. $\mathrm{C} 1 / \mathrm{Cl}-17=48.98 \%$ \\
\hline
\end{tabular}

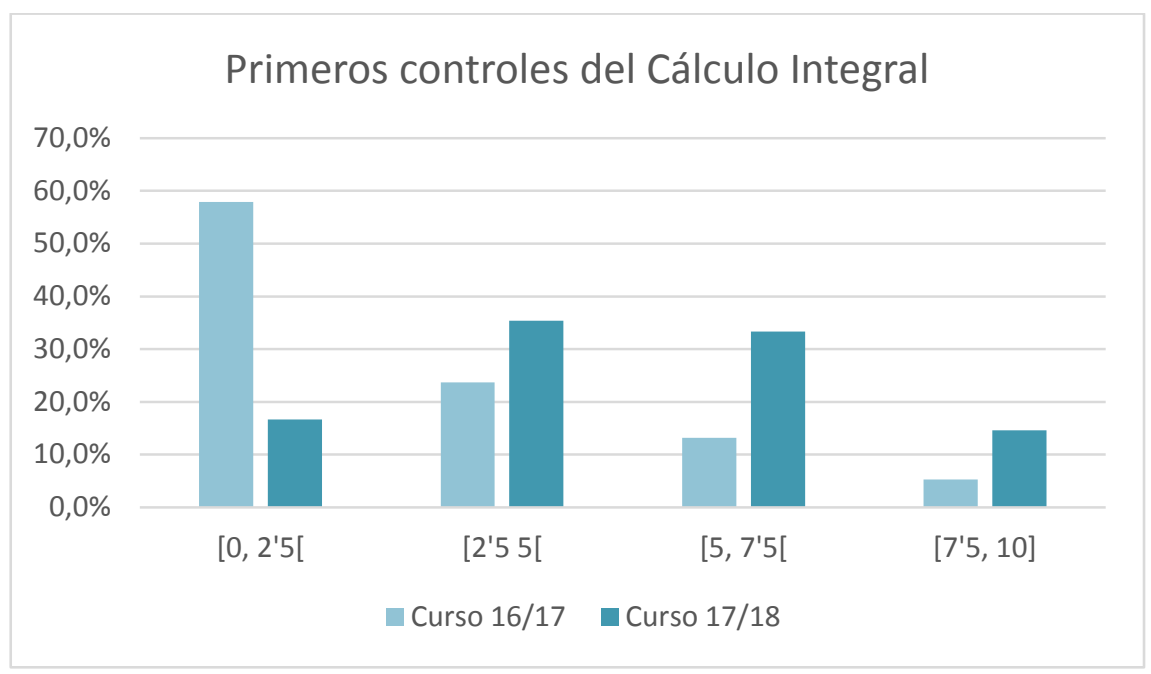

Fig. 4 Diagrama de barras de la distribución de notas del primer control de cálculo integral para los dos cursos 
4.4 Cálculo Integral. Control 2 (2017/2018) y examen final (2016/2017)

Según los resultados que se resumen en la tabla 6 y el gráfico 5, el grupo DDE presenta una tasa de aprobados más alta que el grupo con evaluación tradicional. La diferencia en el promedio de las notas supera los dos puntos. Además, sigue habiendo en el grupo DDE un transvase de estudiantes desde los intervalos de notas más bajas hacia intervalos de notas más altas.

Tabla 6. Cálculo integral. Resultados del segundo control del curso 2017/2018 (C2/CI-17) y del examen final del curso 2016/2017 (EF/CI-16)

\begin{tabular}{|c|c|c|c|c|}
\hline Intervalos & f.a. EF/Cl-16 & f.a. C2/Cl-17 & f.r. EF/Cl-16 & f.r. C2/Cl-17 \\
\hline$\left[0,2^{\prime} 5[\right.$ & 20 & 5 & $50,0 \%$ & $9,8 \%$ \\
\hline$\left[2^{\prime} 5,5[\right.$ & 9 & 19 & $22,5 \%$ & $37,3 \%$ \\
\hline$\left[5,7^{\prime} 5[\right.$ & 9 & 20 & $22,5 \%$ & $39,2 \%$ \\
\hline$[7,5,10]$ & 2 & 7 & $5,0 \%$ & $13,7 \%$ \\
\hline \multirow{2}{*}{ Total } & 40 & 51 & & \\
\cline { 2 - 5 } & & &
\end{tabular}

\begin{tabular}{|l|l|c|}
\hline Promedio $\mathrm{EF} / \mathrm{Cl}-16=3,00$ & Desv. Tip. $\mathrm{EF} / \mathrm{Cl}-16=2,5$ & C.V. $\mathrm{EF} / \mathrm{Cl}-16=83.33$ \\
\hline Promedio $\mathrm{C} 2 / \mathrm{Cl}-17=5,13$ & Desv. Tip. $\mathrm{C} 2 / \mathrm{Cl}-17=2,2$ & C.V. $\mathrm{C} 2 / \mathrm{Cl}-17=42.88 \%$ \\
\hline
\end{tabular}

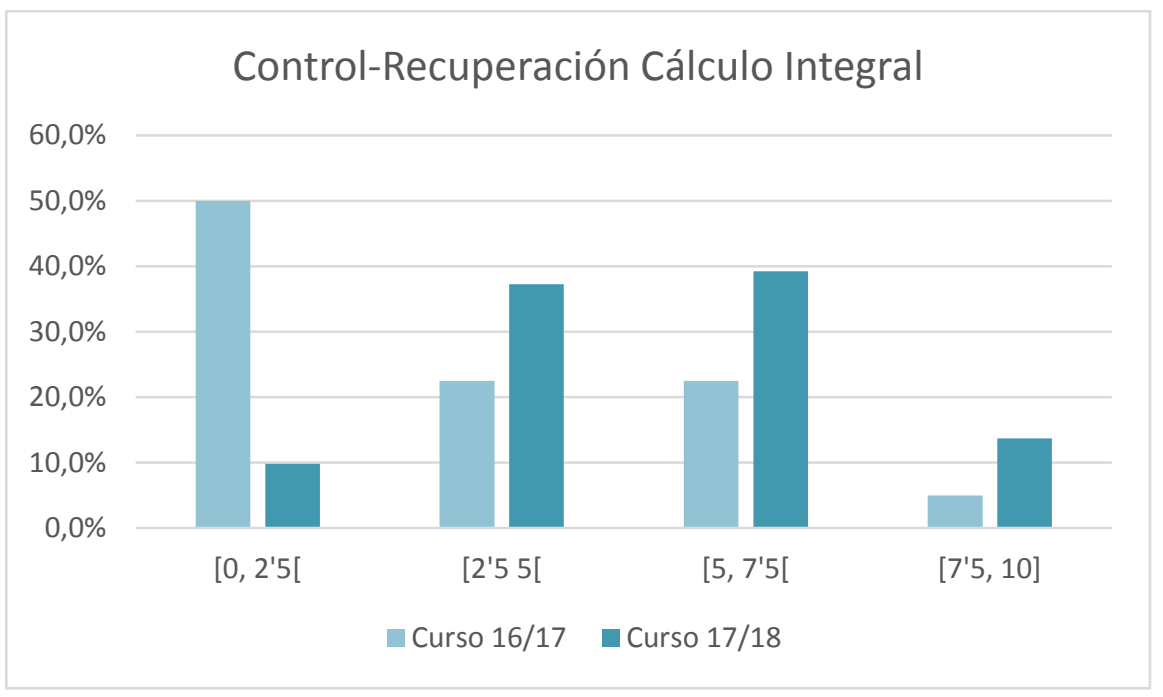

Fig. 5 Diagrama de barras correspondiente a la distribución de las notas en C2/CI (Curso 17/18) y EF/CI (Curso 16/17)

\subsection{Evolución de la tasa de aprobados}

Al observar la tasa de aprobados (aprobados/presentados) representada en la figura 6, en el curso 2016/2017 se observa una tendencia característica, que se repite curso tras curso, en la cual el cálculo integral presenta serias dificultades para los alumnos, lo cual se evidencia

(cc) EY-NC-ND 2018, Universitat Politècnica de València 
en la línea, con pendiente negativa, que corresponde al paso desde C2-EF/CD a C1/CI. En el caso de la poligonal correspondiente al DDE (curso 2017/2018) se mantiene una tendencia claramente creciente en todo el cuatrimestre, lo cual constituye una evidencia de la mejora del rendimiento, así como de la actitud del alumnado frente a la asignatura. Las diferencias con el grupo que seguía un sistema de evaluación tradicional son obvias.

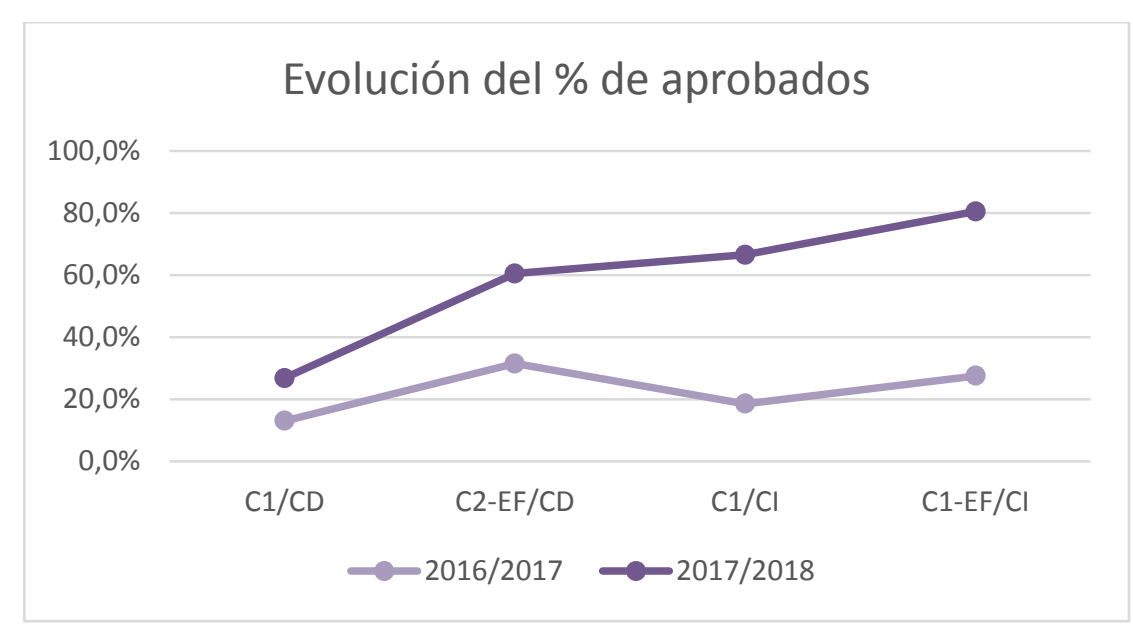

Fig. 6 Evolución de la tasa de aprobados a lo largo del cuatrimestre (cursos 2016/2017 y 2017/2018).

\section{Conclusiones}

Los resultados del análisis realizado ponen en evidencia las dificultades que los estudiantes tienen con las matemáticas al acceder a estudios universitarios. En el primer examen (C1/CD-16 y C1/CD-17), se observa claramente que hay un elevado número de estudiantes que no solo no aprueban, sino que obtienen notas muy bajas, tanto en el grupo con evaluación tradicional como el DDE. El paso de la educación secundaria a la universitaria sigue siendo complicado en matemáticas, especialmente para estudiantes de grados científicos.

Con el sistema de doble evaluación, o DDE, (Enseñanza+Evaluación 1+Refuerzo (feedback)+Evaluación 2) se consigue cierta mejora en el rendimiento, pasando de un $12 \%$ a un 53\% de aprobados, y además, el porcentaje de los que estaban en el nivel más bajo de notas pasa de un $50 \%$ a solo un $9{ }^{\prime} 5 \%$. Si se comparan estos resultados con los obtenidos en el grupo con sistema de evaluación trdicional, el progreso resulta evidente.

Teniendo en cuenta el contexto, las características de los grupos y los resultados, se considera que dicha mejora se debe principalmente al cambio en la metodología de evaluación empleada, que se caracteriza sobre todo por reforzar el aprendizaje de los contenidos a partir de los errores y deficiencias observadas en el primer control, y no esperar demasiado tiempo para que los alumnos puedan demostrarse a si mismos que las matemáticas son accesibles y, por lo tanto, que es posible mejorar los resultados. 
La doble evaluación: un medio para aprender de los errores y para mejorar el rendimiento en matemáticas

\section{Referencias}

FABREGAT, J. y PELAYO, I. (2016).”Plan inicial, progresos explícitos y evaluación de una trama de feedforwarding sobre campus virtual en una asignatura de matemáticas” en IN-RED 2016 Congreso de Innovación Educativa y Docencia en Red de la Universitat Politècnica de Valencia. Valencia. Disponible en http://ocs.editorial.upv.es/index.php/INRED/INRED2016/paper/view/4404 [Consulta: 1 de febrero de 2018].

GARGALLO, B. GARCÍA E., MORERA I. y BENAVENT A. (2015). "Métodos innovadores y enfoques de aprendizaje en estudiantes” en IN-RED 2015 Congreso de Innovación Educativa y Docencia en Red de la Universitat Politècnica de Valencia. Valencia. Disponible en http://dx.doi.org/10.4995/INRED2015.2015.1576 [Consulta: 30 de enero de 2018].

HABERYAN, K. A. (2003) "Do weekly quizzes improve student performance on general biology exams?” The American Biology Teachers, 65, p. 110-114..

HERNÁNDEZ SÁNCHEZ, A.A., (2010). "Necesidad de la evaluación en el proceso de aprendizaje” en monografías.com Disponible en http://www.monografias.com/trabajos80/ necesidad-evaluacion-proceso-aprendizaje/necesidad-evaluacion-proceso-aprendizaje.shtml [Consulta: 1 de febrero de 2018].

HUITRADO, J. L. y CLIMENT, N. (2013). Conocimiento profesional del profesor ante errores relativos al álgebra de los alumnos de secundaria. En A. Berciano, G. Gutiérrez, A. Estepa y N. Climent (Eds.), Investigación en Educación Matemática XVII (pp. 327-336). Bilbao: SEIEM.

ISABEL, A. y VARGAS, M. (2004). La Evaluación Educativa: Concepto, Períodos y Modelos. Actualidades Investigativas en Educación, 4(2), p. 1-28. http://doi.org/10.15517/aie.v4i2.9084

MOURSHED, M., CHIJIOKE, C. y BARBER M. (2010). How the world's most improved school systems keep getting better. London: McKinsey y Company. Disponible en http://hub.mspnet.org/index.cfm/22017 . [Consulta: 30 de enero de 2018]

MYERS, C. B. y MYERS, S. M. (2007). “Assenssing assessment: The effects of two exam formats on course achievement and evaluation” en Innovative Higher Education, 31, p. 227-236.

RICO, L. (1998). Errores y dificultades en el aprendizaje de las matemáticas. En J. Kilpatrick et al (Eds.), Educación Matemática: Errores y dificultades de los estudiantes, Resolución de problemas, Evaluación e Historia (pp. 69-108). Bogotá: Una Empresa Docente.

SADLER, P. M. y GOOD, E. (2006). "The impact of self-and peer-grading on student learning”. Educational assessment, vol. 11, 1, p. 1-31.

SIMON, M. A. y TZUR, R. (2004). Explicating the Role of mathematical Tasks in conceptual Learning: An Elaboration of the Hypothetical Learning Trajectory. Mathematical Thinking and Learning, 6(2), p.91-104.

SOCAS, M. (2007). Dificultades y Errores en el Aprendizaje de las Matemáticas. Análisis desde el Enfoque Lógico Semiótico. En M. Camacho, P. Flores y M.P. Bolea (Eds.), Investigación en Educación Matemática XI (pp. 19-52). Tenerife: SEIEM.

TYLER, R.W. (1974). Principios básicos del currículo. Buenos Aires, Troquel

ZABALZA, M.A. (2004).” Innovación en la enseñanza universitaria” en Contextos Educativos, 6-7, p. 113- 136

(cc) EY-NC-ND 2018, Universitat Politècnica de València

Congreso IN-RED (2018) 


\title{
Aplicación de la metodología ApS en alumnos del Grado de Logopedia: intervención con personas de la tercera edad.
}

Teresa Perez Gil ${ }^{\mathrm{a}}$, Claudia Lahiguera Lujan ${ }^{\mathrm{b}}, \mathbf{M}^{\mathrm{a}} \mathrm{Jose}$ Bautista Pérez${ }^{\mathrm{b}}$, Soraya Triguero Tarazona $^{\mathrm{b}}$, Sheila Baguena Mancebo ${ }^{\mathrm{b}}$, y Dolores Ortiz-Masià ${ }^{\mathrm{c}}$

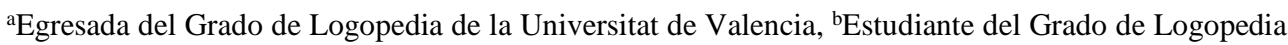
de la Universitat de Valencia y 'Profesora Ayudante Doctora, Departamento de Medicina. Facultad de Medicina y Odontología. Universitat de Valencia (m.dolores.ortiz@uv.es).

\begin{abstract}
Service-learning (SL) is a methodology that contributes to the formation of values and the citizenship of university students, who can acquire a relevant role in the construction of a more dignified, inclusive, cohesive and equitable citizenship. The objective of the project is to relate and integrate the curricular objectives of the subject "Clinical Neurology applied to Speech Therapy" and the objectives of the community's service. The proposed activity consisted of Speech Therapy second year students implementing the basic clinical propaedeutic (anamnesis, neurological and cognitive exploration) in elderly people, all framed in a service-learning activity. Some Speech therapy students and the professor responsible of the subject guided the interventions. The interventions were previously reviewed and practiced in the practical seminars. Once the intervention was done, the students made reports with their conclusions, which were evaluated by the teacher and the collaborating students.
\end{abstract}

Keywords: speech therapy, service-learning, senior citizens, clinical propaedeutic, evaluation.

\section{Resumen}

El aprendizaje-servicio (ApS) es una metodología que contribuye a la formación en valores y para la ciudadanía de los estudiantes universitarios, los cuales pueden adquirir un papel relevante en la construcción de una ciudadanía más digna, inclusiva, cohesionada y equitativa. El objetivo del proyecto es relacionar e integrar los objetivos curriculares de la asignatura "Neurología Clínica aplicada a la Logopedia" y los objetivos de servicio a la comunidad. La actividad propuesta consistió en que alumnos de $2^{\circ}$ de Logopedia implementen la propedéutica clínica básica (anamnesis, exploración neurológica y cognitiva) en personas de la tercera edad, todo ello encuadrado en una actividad de aprendizaje-servicio. Cada una de las intervenciones fueron guiadas por alumnos colaboradores de $3^{\circ}$ de Logopedia $y$ por el profesor responsable de la asignatura. Las intervenciones fueron previamente revisadas, y practicadas en los seminarios prácticos. Una vez realizada la intervención, los alumnos realizaron informes con sus conclusiones, que fueron evaluadas por el profesor y los alumnos colaboradores. 
Palabras clave: logopedia, aprendizaje-servicio, tercera edad, propedéutica clínica, evaluación.

\section{Introducción}

La formación ética y en valores, en los estudiantes universitarios, es necesaria para construir una ciudadanía interactiva e inclusiva. Por otro lado, el aprendizaje-servicio (ApS), conocido internacionalmente como Service learning (SL), es una metodología que contribuye a la formación en valores y para la ciudadanía de los estudiantes universitarios, los cuales pueden adquirir un papel relevante en la construcción de una ciudadanía más digna, inclusiva, cohesionada y equitativa (Martínez, 2010). Los proyectos de ApS permiten a los participantes aplicar los conocimientos adquiridos en las aulas al servicio de necesidades concretas de la comunidad (Puig, Batlle, Bosch y Palos, 2007).

Dentro de los programas de ApS se pueden distinguir cuatro tipos de servicios en los que concretan el aprendizaje: servicio directo, servicio indirecto, investigación y advocacy (Casado de la Gala, 2015).

La formación de Grado en Logopedia está regulada por la ORDEN CIN/726/2009, de 18 de marzo, donde se establecen los objetivos y competencias que los egresados deben tener para el correcto desarrollo de la profesión. Dentro de los objetivos que cita dicha ORDEN se encuentra el objetivo "Explorar, evaluar, diagnosticar y emitir pronóstico de evolución de los trastornos de la comunicación y el lenguaje desde una perspectiva multidisciplinar, fundada en la capacidad de interpretación de la historia clínica para lo que se aplicarán los principios basados en la mejor información posible y en condiciones de seguridad clínica". El citado objetivo se implementa de forma concreta durante el desarrollo de la asignatura “Neurología Clínica Aplicada a la Logopedia”. Para alcanzar el objetivo se deben adquirir competencias muy relacionadas con la evaluación y diagnóstica (propedéutica clínica básica) tales como:

- Conocer los fundamentos del proceso de evaluación y diagnóstico.

- Conocer y aplicar los modelos, técnicas e instrumentos de evaluación.

- Realizar la evaluación de las alteraciones del lenguaje en los trastornos específicos del desarrollo del lenguaje como las alteraciones del lenguaje en el envejecimiento y los trastornos degenerativos.

- Redactar un informe de evaluación logopédica.

- Realizar una evaluación tras la intervención.

La asignatura, dentro del plan de estudios, se encuentra en segundo. En ese mismo curso se inician las prácticas académicas externas que permiten aplicar y complementar los conocimientos adquiridos en la formación académica, favoreciendo la adquisición de competencias que preparan para el ejercicio de actividades profesionales (reguladas por el Real Decreto 592/2014, de 11 de julio).

En el Departamento de Medicina, de la Universidad de Valencia, en el curso 2017-2018 se ha implantado una metodología docente adicional a las prácticas externas. Con el fin de potenciar la adquisición de las competencias propias de la asignatura se pretende incorporar

(cc) EY-NC-ND 2018, Universitat Politècnica de València

Congreso IN-RED (2018) 
actuaciones de servicio voluntario a la comunidad, en el contexto universitario. En la planificación del proyecto de ApS se planteó la intervención de personas de la tercera edad ya que suele ser un colectivo susceptible a alteraciones del lenguaje por el envejecimiento y/o por los trastornos degenerativos.

El proyecto ApS diseñado se encuadra dentro de la categoría de servicio directo donde los objetivos curriculares y los objetivos de servicio se encuentran relacionados e integrados.

\section{Objetivos}

El objetivo general es ofrecer un servicio a la comunidad, y fomentar las enseñanzas que pueden obtener los alumnos de Logopedia a la vez que prestan el servicio. De forma concreta los objetivos que se desean alcanzar con la implantación del proyecto ApS entre los alumnos del Grado de Logopedia son:

- En relación a los estudiantes: formar logopedas competentes para trabajar en residencias de ancianos, desarrollando actitudes favorables a la diversidad, adquisición de destrezas y habilidades técnicas y comunicativas, así como tener una visión global de la práctica profesional del logopeda.

- $\quad$ En relación a las personas de la tercera edad: mejorar la calidad de vida de las personas de la tercera edad con necesidades de acompañamiento, de planificación socio-sanitaria relacionada con alteraciones del lenguaje y en la atención a la dependencia.

- En relación a estudiantes y personas de la tercera edad: potenciar el intercambio de conocimientos intergeneracional.

- En relación a los estudiantes colaboradores de tercer curso y recién egresados: se pretende que adquieran las mismas competencias que los estudiantes de $2^{\circ}$ curso, pero adicionando otras competencias como son el desarrollo del liderazgo, toma de decisiones, y la adquisición de competencias de enseñanza-aprendizaje.

- $\quad$ En relación al profesor de la UV: realizar un análisis de la implantación de un proyecto de ApS en alumnos de segundo de Logopedia y comparar los resultados con alumnado que no recibió esta metodología docente.

\section{Desarrollo de la innovación}

El presente proyecto se centra en una propuesta de intervención basada en la metodología educativa del Aprendizaje-Servicio para la asignatura Neurología Clínica aplicada a la Logopedia impartida en el $2^{\circ}$ curso del Grado de Logopedia. El proyecto se encuentra dentro del programa B, Renovación de metodologías docentes en el marco de las ayudas para el desarrollo de proyectos de innovación educativa y mejora de la calidad docente de la Universitat de Valencia. Dentro del programa B, el proyecto se encuentra en la categoría RMD-ESTIC, donde el equipo de trabajo está formado por un profesor docente investigador de la UV (PDI) y cuatro estudiantes del Grado de Logopedia y un estudiante de Logopedia recién egresado. El objetivo de este tipo de ayudas se centra en el trabajo cooperativo del proceso enseñanza-aprendizaje, con acciones de soporte y orientación del estudiante en su proceso de aprendizaje. 
En la ejecución del proyecto, se aspira a implantar la metodología de ApS como complemento de los créditos prácticos de la asignatura "Neurología Clínica aplicada a la Logopedia” mediante la aplicación práctica de los conocimientos adquiridos en las clases teóricas en personas de la tercera edad (con la colaboración de la Cruz Roja). El proyecto se implementó en sustitución a la sesión de 3 horas de prácticas que se desarrollan de forma ordinaria en las instalaciones de la Facultad de Psicología. Debido al gran volumen de alumnado (unos 40 alumnos por sesión práctica), el proyecto fue una opción voluntaria para los alumnos que deseaban participar. El proyecto se desarrolló para 15 estudiantes. Debido a que el número de solicitudes fue superior al número de plazas ofertadas (45 solicitudes), se procedió al sorteo de las solicitudes. Los alumnos que no deseaban participar o no salieron en el sorteo desarrollaron la práctica de forma habitual, aplicando la propedéutica clínica básica a sus compañeros de clase.

Como se ha mencionado en los objetivos, los estudiantes colaboradores, junto con el profesor responsable, ayudaron en la implementación de los objetivos del proyecto de ApS mediante la realización de videos demostrativos con ayuda de los Técnicos de Innovación Educativa del Servicio de Formación Permanente e Innovación Educativa (SFPIE), fichas de exploración , seminarios sobre propedéutica clínica básica, desplazamiento del alumnado a la sede de la Cruz Roja e implantación del proyecto en las personas de la tercera edad en la sede.

\section{Actividades vinculadas a los objetivos}

1. Los alumnos colaboradores realizaron, junto con el profesor responsable, simulacros didácticos de las intervenciones que debían realizar los estudiantes con las personas de la tercera edad. Los simulacros serán grabados y se utilizarán durante los seminarios prácticos. 2. Los alumnos (por parejas) prepararon y practicaron con sus compañeros -antes de la intervención- los diferentes apartados de la anamnesis y la exploración neurológica, prestando atención a las posibles dificultades y las características de las personas mayores. Durante el seminario práctico resolvieron todas sus dudas e inquietudes.

3. Los 15 alumnos se desplazaron, junto con los alumnos colaboradores y el profesor responsable, a la sede de la Cruz Roja el 22 de febrero donde pusieron en práctica la propedéutica clínica básica con las fichas diseñadas por el profesor y los alumnos colaboradores (ver Figura 1 y 2). El desplazamiento fue en transporte público.

4. Al finalizar la actividad los alumnos realizaron un informe de la actividad en todas sus fases, con el fin de planificar una posible intervención socio-sanitaria.

5. Los alumnos colaboradores participaron activamente en la evaluación del proyecto y de los estudiantes mediante la implementación de fichas de seguimiento y participando en las sesiones de reflexión con las personas mayores. Con el fin de evaluar la mejora docente con respecto a los compañeros que no participaron en el proyecto ApS, los alumnos colaboradores pasaron la misma ficha de seguimiento y participación a 15 alumnos que no asistieron a la sede de la Cruz Roja.

(cc) EY-NC-ND 2018, Universitat Politècnica de València

Congreso IN-RED (2018) 


\section{Análisis estadístico de los datos}

Los datos obtenidos de las diferentes fichas y encuestas se expresaron como media \pm SEM y se compararon mediante la prueba t de Student desapareada. Se consideró que un valor $\mathrm{p}$ $<0.05$ era estadísticamente significativo.

\section{MINI MNETAL STATE EXMINATION (MMSE)}

Folstein et al. (1975), Lobo et al. (1979)/

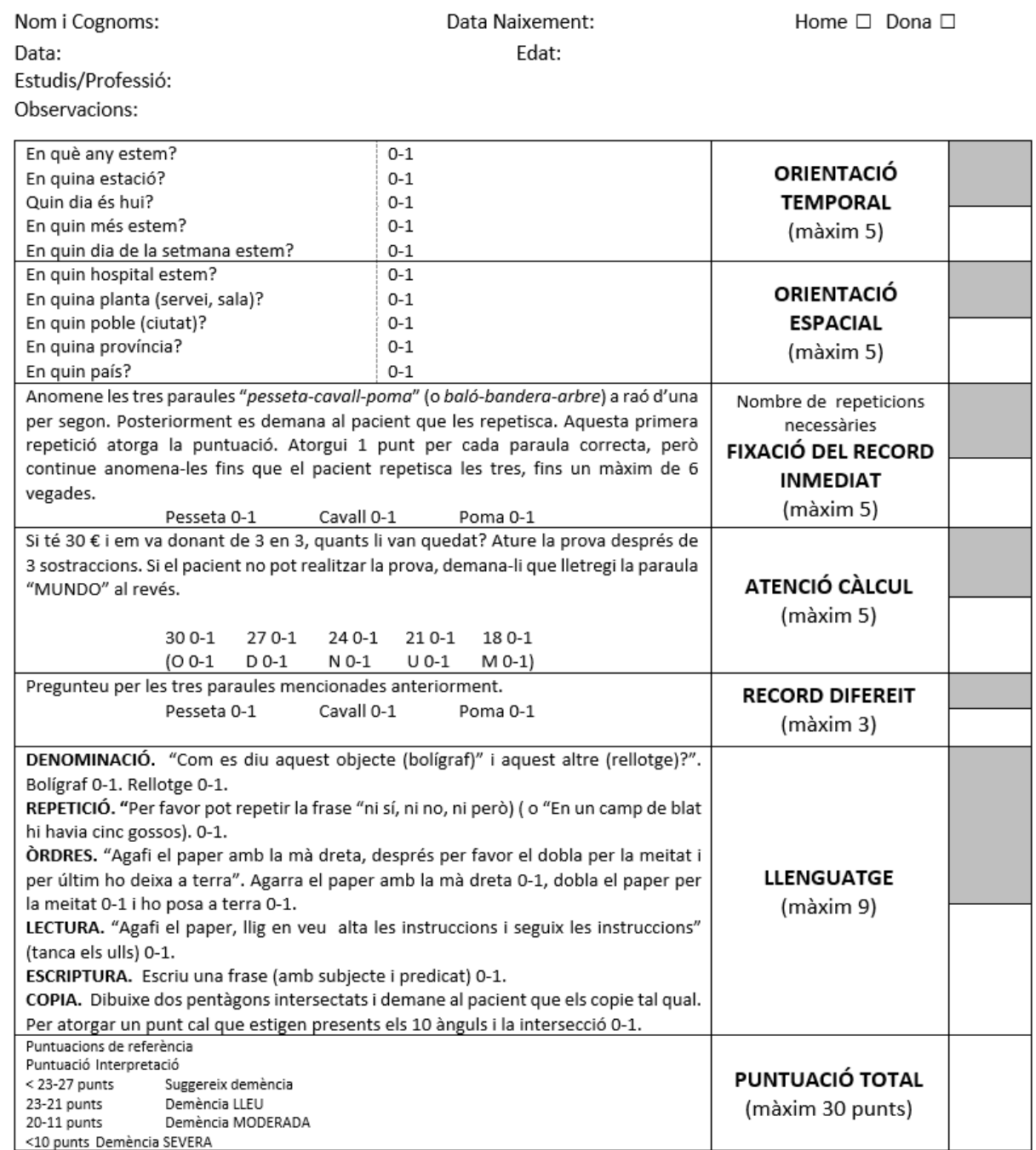

Fig 2. Ficha diseñada para el estudio del estado mental utilizada en la intervención. 
Aplicación de la metodología ApS en alumnos del Grado de Logopedia: intervención con personas de la tercera edad.

\section{EXPLORACIÓ DELS PARELLS CRANIALS DE LA PARLA}

\begin{tabular}{|c|c|c|}
\hline $\begin{array}{l}\text { Nom i Cognoms: } \\
\text { Data: } \\
\text { Estudis/Professió: } \\
\text { Observacions: }\end{array}$ & $\begin{array}{l}\text { Data Naixement: } \\
\text { Edat: }\end{array}$ & Home $\square$ Dona $\square$ \\
\hline \multirow{2}{*}{$\begin{array}{l}\text { PPCC V } \\
\text { TRIGÈMIN }\end{array}$} & $\begin{array}{l}\text { Amb un cotó avalua la sensació al toc suau del front, les galtes i la } \\
\text { mandibula. }\end{array}$ & $\begin{array}{l}\square \text { Nervi oftàlmic (front-ulls-nas) } \\
\square \text { Nervi Maxil-lar (galtes) } \\
\square \text { Nervi Mandibular (mandibula) }\end{array}$ \\
\hline & Demani al pacient que tanqui i obri la mandíbula. & $\begin{array}{l}\square \text { Debilitat } \\
\square \text { Desviació de la mandíbula } \\
\square \text { Atròfia }\end{array}$ \\
\hline \multirow{3}{*}{$\begin{array}{l}\text { PPCC VII } \\
\text { FACIAL }\end{array}$} & $\begin{array}{l}\text { Front. Observi la simetria facial en repòs. Demaneu al pacient que arrugui el } \\
\text { front i miri cap al sostre. }\end{array}$ & $\begin{array}{l}\square \text { Simetria Facial } \\
\square \text { Simetria de les arrugues } \\
\end{array}$ \\
\hline & Ulls. Demaneu al pacient que tanque els ulls amb tota la força com pugui. & $\square$ Simetria de tancament parpelles \\
\hline & $\begin{array}{l}\text { Boca. } \\
\text { Demaneu que somrigui, i que li mostre els dents. } \\
\text { Demaneu que faci un mohín. }\end{array}$ & $\begin{array}{l}\square \text { Simetria llavis } \\
\square \text { Simetria arrugues del coll }\end{array}$ \\
\hline $\begin{array}{c}\text { PPCC IX } \\
\text { GLOSSOFARINGI }\end{array}$ & $\begin{array}{l}\text { "Reflex faringi (no més s'aplica quan no hi ha una correcta elevació del } \\
\text { paladar) } \\
\text { Demaneu al pacient que obri la boca i, amb l'ajuda d'un depressor lingual, } \\
\text { estimuli cada costat de la paret posterior de la faringe. }\end{array}$ & $\begin{array}{l}\text { - Contracció faringe, desplaçament } \\
\text { posterior de la llengua i sensació } \\
\text { nàusea }\end{array}$ \\
\hline \multirow[b]{2}{*}{$\begin{array}{l}\text { PPCC } X \\
\text { VAGUE }\end{array}$} & $\begin{array}{l}\text { Elevació del paladar tou } \\
\text { Demani al pacient que obri la boca i digui "a", el que produirà l'elevació del } \\
\text { vel del paladar. } \\
\text { Observi l'úvula (si la llengua no l'hi permet, abaixa-la amb l'ajuda d'un } \\
\text { depressor) }\end{array}$ & $\begin{array}{l}\square \text { Úvula en posició medial (simetria). } \\
\square \text { Elevació del paladar* }\end{array}$ \\
\hline & $\begin{array}{l}\text { Avaluació funció laríngia } \\
\text { Demaneu a pacient que hi faci una fonació llarga de la vocal /a/ } \\
\text { Demaneu al pacient que incrementi/disminuia el de la vocal /a/ } \\
\text { Demaneu al pacient que hi faci un grunyit breu i agut. Demaneu que tussi. } \\
\text { Demaneu al pacient que conte fins } 300 .\end{array}$ & $\begin{array}{l}\square \text { Més de7-8 segons } \\
\square \text { Capacitat de modificar el to } \\
\square \text { Tancament glòtic: so és intens i } \\
\text { agut. } \\
\square \text { Esforç del mecanisme vocal }\end{array}$ \\
\hline \multirow{4}{*}{$\begin{array}{l}\text { PPCC XI } \\
\text { ESPINAL }\end{array}$} & Avalua la simetria dels músculs esternocleidomastoideos. & $\square$ Simetria \\
\hline & $\begin{array}{l}\text { Demaneu al pacient que giri el cap un costat i la mantingui en aquesta } \\
\text { posició. Mentrestant intenteu tornar el cap a la línia mitja. }\end{array}$ & $\square$ Debilitat lateral \\
\hline & Repetiu l'operació però el cap cap endavant. & $\square$ Debilitat anterior/posterior \\
\hline & Demaneu al pacient que alci les espatlles a contra resistència. & $\square$ Debilitat anterior/posterior \\
\hline \multirow{6}{*}{$\begin{array}{l}\text { PPCC XII } \\
\text { HIPOGLós }\end{array}$} & Avalua la llengua en repòs & $\begin{array}{l}\square \text { Atrofia } \\
\square \text { Fasciculacions }\end{array}$ \\
\hline & Demaneu al pacient que traga la llengua & 口 Punta llengua en línia mitja \\
\hline & Demaneu al pacient que mogui la llengua d’una comissura a l'altra. & $\square$ Velocitat adequada \\
\hline & $\begin{array}{l}\text { Demaneu al pacient que pressioni la llengua contra cadascuna de les galtes, } \\
\text { oposant-se l'explorador col-locant externament els seus dits. }\end{array}$ & $\square$ Debilitat cos de la llengua \\
\hline & Demaneu que pronuncii els fonemes linguals $/ \mathrm{r} / / \mathrm{l} / \mathrm{i} / \mathrm{t} /$. & $\begin{array}{l}\square \text { Debilitat en l'elevació de la punta } \\
\text { de la llengua }\end{array}$ \\
\hline & Demaneu que pronuncii els fonemes linguals / k/ i/g/. & $\begin{array}{l}\square \text { Debilitat en l'elevació part } \\
\text { posterior de la llengua }\end{array}$ \\
\hline
\end{tabular}

Fig 3. Ficha diseñada para el estudio de los pares craneales involucrados en el habla.

(cc) EY-NC-ND 2018, Universitat Politècnica de València 


\section{Resultados}

El objetivo general del presente proyecto es realizar un análisis de la implantación de un proyecto de ApS en alumnos de segundo de Logopedia en comparación con alumnado que no recibió esta metodología docente. Tras la implantación del proyecto, el análisis de los datos obtenidos a partir de las fichas mostró que, de forma global, los estudiantes que habían participado en el proyecto ApS obtuvieron calificaciones significativamente superiores en la evaluación de la propedéutica clínica respecto al alumnado que no participó (Figura 3). El análisis de los ítems por separado (Figura 4) mostró que las competencias que mejoraron significativamente en los alumnos que implementaron el ApS eran las relacionadas con el secreto profesional, el trato del paciente, la comunicación oral con el paciente, y la empatía. Sin embargo, no se observaron diferencias significativas en cuestiones teórico-prácticas, como es la realización de una correcta exploración neurológica, que fue similar en ambos grupos (Figura 4).

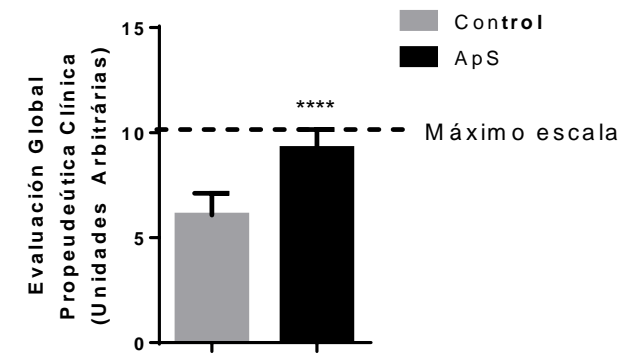

Fig 3. Comparación de las calificaciones obtenidas en alumnos que participaron o no en el proyecto ApS.

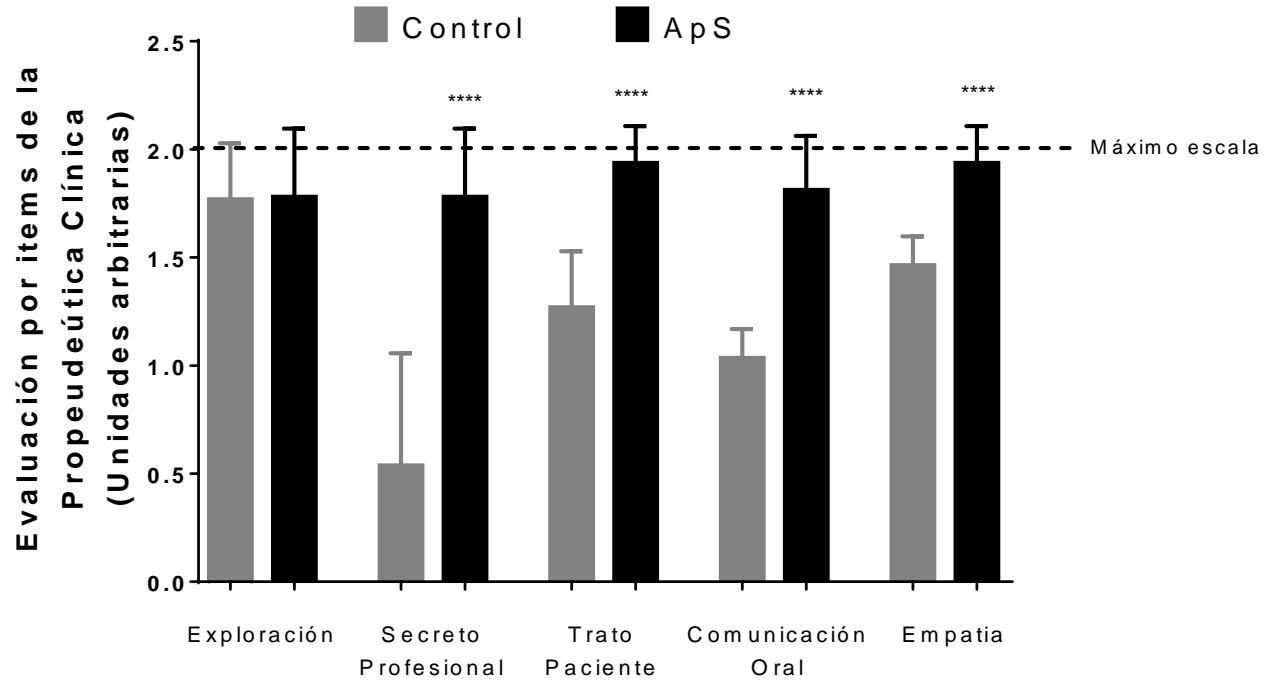

Fig 4. Comparación de las calificaciones obtenidas en los diferentes ítems en alumnos que participaron o no en el proyecto ApS. Los ítems utilizados fueron: exploración (explora de manera eficiente los pares craneales (PC) que participan en la inervación de la musculatura encargada del habla), secreto profesional (evita comentar información reservada que no sea estrictamente necesaria para el caso. Mantiene el máximo secreto profesional), trato paciente (trabaja de manera adecuada, cuidando de manera específica las formas y adaptándose al nivel y las características del paciente), comunicación oral (comunica de forma oral correctamente y fundamentada profesionalmente sus observaciones y conclusiones) y empatía (sabe escuchar sin interrumpir. Sabe interpretar el lenguaje no oral del paciente. Muestra autocontrol emocional en las interacciones. Observa y escucha activamente). 
Aplicación de la metodología ApS en alumnos del Grado de Logopedia: intervención con personas de la tercera edad.

En relación a la evaluación docente del proyecto, los alumnos colaboradores realizaron una encuesta acerca de su experiencia. Los resultados mostraron, como se puede ver en la Figura 5 , que los alumnos colaboradores no necesitaron cambiar las estrategias didácticas durante las diferentes intervenciones, y las actividades desarrolladas se diseñaron teniendo en cuenta las características y motivaciones de los alumnos de segundo.

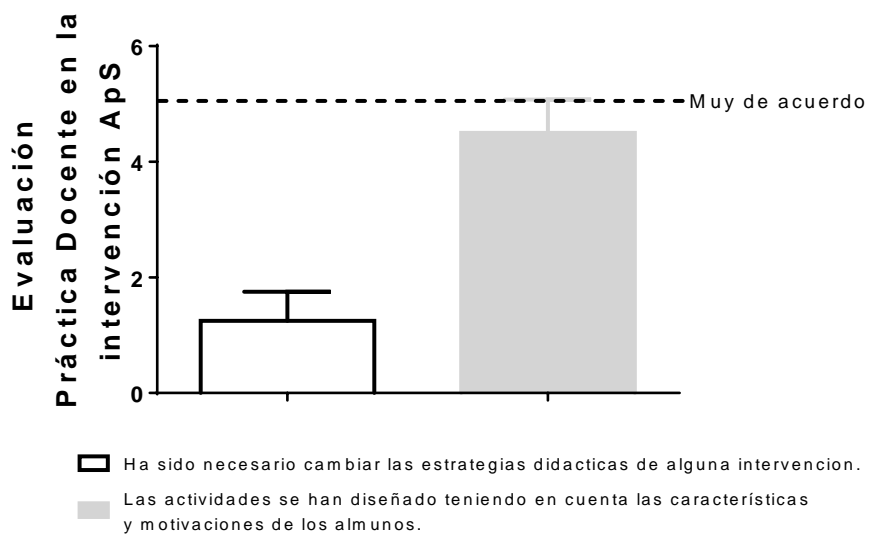

Fig 5. Evaluación de la práctica docente desarrollada durante la implantación del proyecto ApS. Encuestas realizadas por los alumnos colaboradores que participaron activamente en la implementación del proyecto.

Al finalizar la intervención, tanto los alumnos como las personas de la tercera edad realizaron encuestas de satisfacción (Figuras 6, 7 y 8). En cuanto a las personas mayores (Figura 6), las encuestas reflejaron que de forma general la experiencia había sido de su agrado, se sintieron cómodos con los alumnos y volverían a repetir.

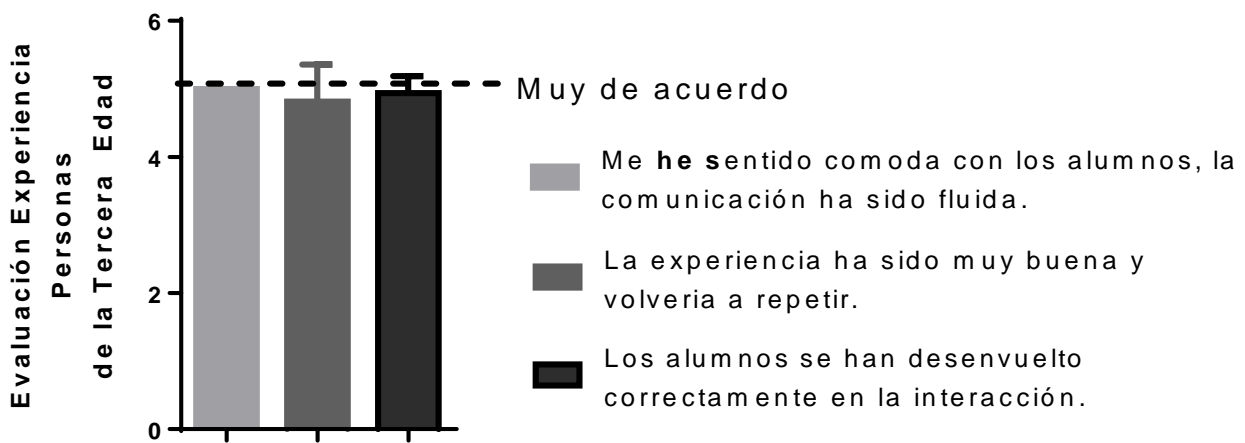

Fig 6. Resumen de los datos obtenidos en la encuesta de satisfacción realizada por las personas de la tercera edad subsidiarias del proyecto ApS.

En relación al alumnado que participó en la experiencia, la encuesta de satisfacción se dividió en dos categorías: evaluación de los elementos del curriculum y adecuación de las intervenciones planteadas durante la implantación del proyecto ApS. En relación a los

(cc) EY-NC-ND 2018, Universitat Politècnica de València

Congreso IN-RED (2018) 
elementos del curriculum desarrollados en el proyecto ApS, los estudiantes consideraron que en general habían mejorado sus competencias en la exploración neurológica (tanto en el MMSE (Minimental Test) como en la exploración de los PC involucrados en el habla), que el tiempo de desarrollo de las actividades había estado ajustado y que la estrategia didáctica basada en ApS les había fomentado el interés por aprender y hacer la propedéutica clínica de una forma correcta (Figura 7).

En relación a la adecuación de las intervenciones planteadas, se puede ver en la Figura 8 que los estudiantes consideraban que tenían las competencias necesarias para el desarrollo de las actividades, y que las intervenciones realizadas se ajustaban al curriculum de la asignatura. Además, valoraron de forma muy positiva la experiencia.

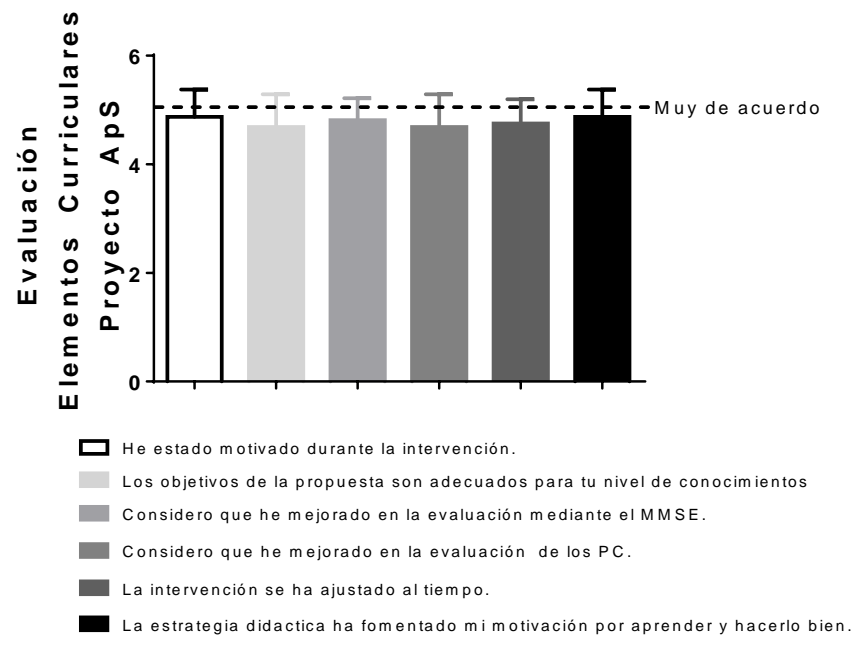

Fig 7. Resumen de los datos obtenidos en la encuesta que evaluaba los elementos del curriculum desarrollados en el proyecto ApS.

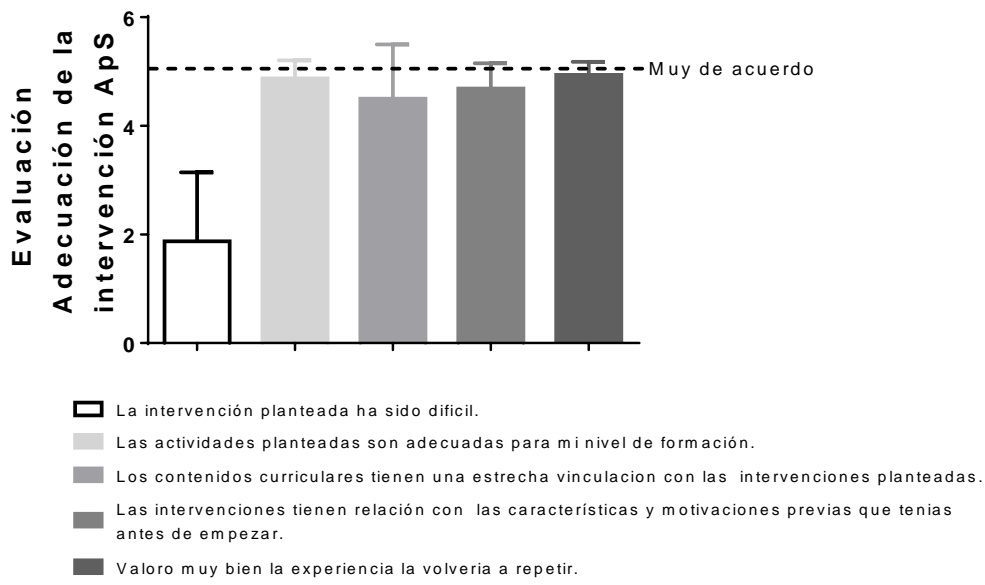

Fig 8. Resumen de los datos obtenidos en la encuesta que evaluaba la adecuación de la intervención de la intervención y de los contenidos curriculares del proyecto ApS. 


\section{Conclusiones}

La implantación del proyecto de ApS en los alumnos de segundo del Grado de Logopedia ha permitido abrir vías de encuentro entre la educación formal y la no formal en el Grado de Logopedia. Con el proyecto ApS se ha potenciado que el alumnado asuma las respuestas a las necesidades del entorno como responsabilidad compartida permitiendo que la UV se abra a la ciudad de Valencia. De forma específica, los alumnos de segundo de Logopedia que participaron en el proyecto ApS han reforzado sus competencias relacionadas con la evaluación y diagnósticos de las alteraciones del lenguaje en el envejecimiento y/o trastornos degenerativos. Además, la aplicación de la metodología de ApS en los alumnos potenció de manera significativa sus habilidades comunicativas, de secreto profesional y de empatía tan necesarias para el desarrollo de su profesión.

Cabe señalar que las personas de la tercera edad fueron evaluadas satisfactoriamente por parte de los estudiantes, se les realizó un diagnóstico de sus posibles alteraciones relacionadas con el habla y se les aconsejó con el fin de mejorar su calidad de vida. Todo ello trajo de la mano que tanto estudiantes como jubilados fueran participes de un intercambio de conocimientos intergeneracional, favoreciendo así competencias relacionadas con la comunicación oral y empatía en los estudiantes.

Por otro lado, los estudiantes colaboradores y gracias al proyecto ApS, se iniciaron en competencias relacionadas con el desarrollo de liderazgo, toma de decisiones y nuevas metodologías de enseñanza-aprendizaje.

\section{Referencias}

CASADO DE LA GALA, L. (2015). Aprendizaje servicio, proceso de mejora para la ciudadanía. Palencia: Facultad de Educación de Palencia, Universidad de Valladolid.

MARTÍNEZ, M. et al. (2010). Aprendizaje servicio y responsabilidad social de las Universidades. Barcelona: Ediciones Octaedro, S.L. y Universitat de Barcelona.

PUIG, JM., BATLLE, R., BOSCH, C., PALOS, J. (2007). Aprendizaje servicio: educar para la ciudadanía. Madrid: Ministerio de Educación y Ciencia. Centro de Investigación y Documentación Educativa. Ediciones Octaedro.

\section{Legislación y normas}

España. Orden CIN/726/2009, de 18 de marzo, por la que se establecen los requisitos para la verificación de los títulos universitarios oficiales que habiliten para el ejercicio de la profesión de Logopeda. BOE. 26 de marzo de 2009, núm. 73, p. 29159-29163.

España. Real Decreto 592/2014, de 11 de julio, por el que se regulan las prácticas académicas externas de los estudiantes universitarios. BOE. 30 de julio de 2014, núm. 184, p 8138.

Universitat de Valencia. Resolució de 3 d'abril de 2017, del Vicerectorat de Polítiques de Formació i Qualitat Educativa, per la qual es convoquen les ajudes per al desenvolupament dels projectes d'innovació educativa i millora de la qualitat docent per al curs 2017/2018.

(cc) EY-NC-ND 2018, Universitat Politècnica de València

Congreso IN-RED (2018) 


\title{
Aprendizaje cooperativo en las prácticas de laboratorio de la asignatura "Ciencia de Materiales"
}

\author{
L. Quiles-Carrillo ${ }^{\mathrm{a}}$, V. Fombuena ${ }^{\mathrm{a}}$, T. Boronat ${ }^{\mathrm{a}}$, R. Balart ${ }^{\mathrm{a}}$, N. Montanes ${ }^{\mathrm{a}}$
}

${ }^{a}$ Grupo de Innovación de Prácticas Académicas (GIPA), Universitat Politècnica de València, Plaza Ferrándiz y Carbonell s/n, Alcoy, Alicante (ESPAÑA).

\begin{abstract}
The authors have restructured the way of imparting the practices of the subject Materials Science of the degree of chemical engineering approaching a model based on cooperative learning. With this methodology, students are able to obtain and improve different skills and abilities while increasing their knowledge in a group and effective manner. During the process the students assume different roles and responsibilities, generating among them a direct feedback with the course of each practice and generating a positive work environment where each of them is a fundamental part of the final objective. In this way, they all generate a positive boost in the career of their selflearning, always supported by the teacher as the main guide. The satisfaction of the students in relation to the new method has been evaluated and not only good results have been obtained, but an improvement in the academic performance and in the motivation of the students.
\end{abstract}

Keywords: Cooperative learning, new methodologies, transversal competences, critical thinking

\footnotetext{
Resumen

Los autores han reestructurado la manera de impartir las prácticas de la asignatura Ciencia de Materiales del grado de ingeniería química acercándose a un modelo basado en el aprendizaje cooperativo. Con esta metodología los alumnos son capaces de obtener y mejorar diferentes competencias y habilidades mientras aumentan su conocimiento de una manera grupal y efectiva. Durante el proceso los alumnos asumen diferentes roles y responsabilidades, generando entre ellos una retroalimentación directa con el transcurso de cada práctica y generando un ambiente de trabajo positivo donde cada uno de ellos es parte fundamental del objetivo final. De esta manera entre todos generan un empuje positivo en la carrera de su autoaprendizaje siempre apoyados por el profesor como guía principal. Se ha evaluado la satisfacción del alumnado en relación al nuevo método y no solo se han obtenido buenos resultados, sino una mejora en el rendimiento académico y en la motivación del alumnado.
}

Palabras clave: Aprendizaje cooperativo, nuevas metodologías, competencias transversales, pensamiento crítico. 


\section{Introducción}

El ser humano tiene la capacidad de pensar de manera innata. Es una de las principales diferencias que nos separan del resto de las especies. Aunque tengamos la capacidad de pensar, esta habilidad es necesario desarrollarla a un nivel superior, para así seguir creciendo y adquiriendo nuevas habilidades.

Investigadores del Proyecto Zero de Harvard de entre los que se encuentra como director el conocido psicólogo Howard Gardner dicen que la mayoría de las personas no desarrollan su pensamiento. En general las personas se muestran pasivas e indiferentes y no cultivan actitudes de pensamiento profundo. Este factor puede ser un grave problema a la hora de tomar decisiones, pensar diferente por un tiempo y aprovechar todas las oportunidades que inciten a la reflexión.

Si nos centramos en las prácticas de laboratorio de las asignaturas estas brindan a los estudiantes la posibilidad de entender cómo se construye el conocimiento dentro de una comunidad científica, cómo trabajan los científicos, cómo llegan a acuerdos y cómo reconocen desacuerdos, qué valores mueven la ciencia, cómo se relaciona la ciencia con la sociedad, con la cultura, la industria, etc. (López Rua 2012)

Según González (Eduardo 1992) "Muchos alumnos realizan los experimentos o las sesiones de prácticas sin tener una idea clara de que están haciendo; no son capaces de identificar las cuestiones básicas, los conceptos y los fenómenos involucrados en el experimento, y además, no ven la experimentación como un proceso de construcción del conocimiento”.

Por diversas razones es necesario un cambio visible en la concepción de la clase. Como indica Montanes (Montanes 2017) "Se hace imprescindible la sustitución de los sistemas clásicos de docencia, por nuevas prácticas educativas en las que el alumnado no sea un mero receptor de las informaciones y datos expuestos por el profesorado, sino un agente activo que intervenga en su propio proceso de enseñanza-aprendizaje”.

La implantación de una docencia alejada de las clases magistrales permite mejorar de manera directa no solo la capacidad de pensar de los alumnos, sino sus aptitudes y el incremento en la retención de conceptos. En este ámbito se pretende utilizar el aprendizaje cooperativo como nuevo método de aprendizaje en las prácticas para favorecer al máximo el conocimiento del alumno.

El aprendizaje cooperativo es un enfoque de enseñanza en el cual se pretende utilizar al máximo actividades en las cuales es necesaria la ayuda entre estudiantes, ya sea en pares o grupos pequeños, dentro de un contexto enseñanza-aprendizaje. El aprendizaje cooperativo se basa en que cada estudiante intenta mejorar su aprendizaje y resultados, pero también el de sus compañeros (García 2001). Como bien afirmaron y defendieron sus autores más representativos, Freire y Habermas, la finalidad de este tipo de metodología es que cada estudiante intente mejorar su aprendizaje y resultados pero también el de obtener por su cuenta una serie de competencias que le permitan crecer profesional y personalmente. (Habermas 2008)

(cc) EY-NC-ND 2018, Universitat Politècnica de València

Congreso IN-RED (2018) 
La aplicación del aprendizaje cooperativo en el aula le permite al docente alcanzar varias metas importantes al mismo tiempo. En primer lugar, leayuda a elevar el rendimiento de todos sus alumnos, incluidos tanto los especialmente dotados, como los que tienen dificultades para aprender. En segundo lugar, le ayuda a establecer relaciones positivas entre los alumnos, sentando así las bases de una comunidad de aprendizaje en la que se valore la diversidad. En tercer lugar, les proporciona las experiencias que necesitan para lograr un saludable desarrollo social, psicológico y cognitivo. La posibilidad que brinda el aprendizaje cooperativo de abordar estos tres frentes al mismo tiempo lo hace superior a todos los demás métodos de enseñanza. (Johnson 1999)

En la actualidad es necesaria la sustitución de los clásicos sistemas de docencia con la finalidad de obtener unos estudiantes capaces de no solo, tener amplios conocimientos técnicos, sino buenas capacidades y aptitudes antes diferentes problemas, teniendo su propio pensamiento crítico y habilidades para trabajar en grupo. Todo esto es de vital importancia para formar buenos profesionales que sepan desenvolverse de manera adecuada en la empresa o puestos de elevada responsabilidad.

\section{Objetivos}

El objetivo principal de la inclusión del aprendizaje cooperativo en las prácticas de la asignatura "Ciencia de materiales" es darle un nuevo enfoque al proceso de enseñanza, ofreciendo un nuevo trasfondo mucho más profundo y permitiendo que los alumnos se dediquen a resolver de forma coordinada los diferentes problemas y actividades que se van planteando a lo largo de las prácticas de la asignatura. Además, tienen que ser capaces de adquirir ciertas responsabilidades, tanto grupales como individuales para funcionar como un engranaje hacia un bien común. Todo esto siempre supervisado por el profesor que será el guía en los diferentes niveles de aprendizaje con el objetivo de que los alumnos desarrollen su propio aprendizaje.

La finalidad de esta nueva visión, no solo se centra en la mejora en la adquisición de conocimientos, sino en la mejora de las aptitudes y competencias de cada alumno. Dentro de la Universitat Politècnica de València (UPV) existe un proyecto con el objetivo de orientar las prácticas docentes a una educación superior basada en las competencias, en el cual se han establecido 13 competencias tranversales.(UPV 2017) La aplicación de este nuevo enfoque nos permite trabajar dentro de las aulas diferentes competencias como son:

- Comprensión e Integración: Comprender quiere decir "percibir y tener una idea clara del que se llama, se hace o sucede, o descubrir el sentido profundo de algo". Para demostrar que algo se ha comprendido, la persona identifica y recupera la información, y lo explica con sus palabras, interpretando e integrando las ideas desde su perspectiva.

- Aplicación y Pensamiento Práctico: El estudiante, en la vida real, necesita estar preparado para hacer frente a situaciones en las que no basta aplicar recetas o 
fórmulas y en las que las decisiones o soluciones que se propongan deben estar argumentadas y acomodarse a los recursos disponibles. En este sentido, esta competencia desarrolla el modo de pensar dirigido a la acción, que permite adaptarse a nuevas situaciones, tomar decisiones y, consecuentemente, ACTUAR.

- Trabajo en equipo y liderazgo: El trabajo en equipo implica crear y desarrollar un clima de confianza mutua entre los componentes que permita trabajar de forma responsable y cooperativa. El término más apropiado para describir esta situación es COMPARTIR: compartir conocimientos, compromiso y responsabilidad. Supone el reparto de tareas y roles y el respeto a las normas y reglas de juego establecidas por y para el grupo.

- Comunicación efectiva: Comunicarse efectivamente significa tener desarrollada la capacidad de transmitir conocimientos y expresar ideas y argumentos de manera clara, rigurosa y convincente, tanto de forma oral como escrita, utilizando los recursos apropiados adecuadamente y adaptándose a las circunstancias y al tipo de público.

- Planificación y gestión del tiempo: Esta competencia implica ser capaz de organizar y distribuir correctamente el tiempo del que disponemos y distribuirlo en función de las actividades necesarias para alcanzar nuestros objetivos a corto, medio y largo plazo.

- Pensamiento crítico: El pensamiento crítico va más allá de las destrezas del análisis lógico, ya que, implica poner en cuestión los supuestos subyacentes en nuestras formas habituales de pensar y actuar y, en base a ese cuestionamiento crítico, estar preparado para pensar y hacer diferente.

Se trabajan gracias a los objetivos principales que persigue el aprendizaje cooperativo como son la interdependencia positiva, la exigibilidad individual, la interacción cara a cara, habilidades interpersonales y de trabajo en grupo y reflexión en grupo. De este modo se pretende lograr un proceso de enseñanza-aprendizaje capaz de englobar las virtudes de los distintos puntos de vista para obtener el objetivo principal de cualquier proceso de enseñanza: aprender de manera efectiva. Además, con la incorporación de esta nueva metodología, se pretende aprovechar la inercia del aprendizaje cooperativo implantado en la asignatura de "Ciencia de Materiales" para que sacar el mayor potencial posible en la continuación de esta asignatura en tercero del Grado de ingeniería química "Ampliación de Ciencia de Materiales”. Esto permitirá obtener una mayor cantidad de resultados sobre el aprendizaje cooperativo, ya que se podrá ver en primera mano los conocimientos o ideas principales que han sido asimilados por los alumnos.

\section{Desarrollo de la innovación}

La implantación del aprendizaje cooperativo se ha aplicado en las prácticas de la asignatura "Ciencia de Materiales" con una asignación de 0.75 créditos de un total de 4.5 en el segundo curso, primer cuatrimestre, del Grado de Ingeniería Química. La media de alumnos por curso es de 40 alumnos. Y las prácticas se llevan a cabo durante 5 semanas a 1,5 horas semanales.

(cc) EY-NC-ND 2018, Universitat Politècnica de València

Congreso IN-RED (2018) 
La idea principal ha sido cambiar por completo la dinámica actual de las prácticas de la asignatura alejándose de la explicación generalista del profesor y la repetición por parte del alumno de los pasos. La repetitividad aporta resultados a corto plazo, pero esto no aporta realmente un conocimiento profundo.

Se ha pretendido conseguir a partir del aprendizaje cooperativo una dinámica global que permita mejorar la concepción de los conceptos principales y permitan a los alumnos crecer notablemente en ciertas aptitudes como el trabajo en equipo, el liderazgo, la colaboración, la mejora de análisis de resultados, etc. Todo esto para que el alumno trabaje y mejore las competencias de manera directa tratando de cumplir los objetivos de la UPV y además le sirva de modelo real a la hora de trabajar en una empresa.

En la primera sesión de laboratorio de la asignatura, el profesor se encarga de explicar la dinámica de las prácticas a todos los integrantes de la clase, además de explicar el funcionamiento y la finalidad principal de cada una de las maquinas a utilizar. Esta primera práctica sirve para poner en contexto sobre, maquinarias, materiales y factores generales del desarrollo de la práctica, para que los alumnos tengan una base inicial a partir de la cual empezar a contruir conocimientos.

A continuación, los alumnos se organizan en grupos reducidos de 4 personas. A cada grupo se le asigna inicialmente por sorteo una de las máquinas del laboratorio, por lo que serán responsables de la máquina durante el desarrollo de las prácticas.

Dentro de los grupos de cuatro personas, se generan cuatro roles diferentes de los cuales cada uno se encargará de una función principal, pero todos tendrán un continuo feedback y autoaprendizaje para el correcto funcionamiento de la dinámica. Estos cuatro roles irán rotando con el cambio de las prácticas o actividades, para que los diferentes integrantes se muevan en los diversos puestos, y sobretodo que cada alumno al final de las prácticas habrá sido el responsable de alguna máquina. Al haber 5 sesiones de prácticas, las prácticas giran alrededor de 5 máquinas diferentes: Máquina de tracción, Maquina de Flexión, Máquina de dureza, Péndulo de charpy y Microscopios ópticos.

Los cuatro roles que se generan dentro de cada grupo son:

1. Encargado de la máquina. Se encarga de conocer el funcionamiento principal de la máquina, sus posibilidades y las limitaciones de esta. Tiene que ser capaz de explicar al resto de sus compañeros tanto el funcionamiento como los conocimientos adquiridos sobre la máquina, así como obtener las aptitudes necesarias para utilizarla en cualquier situación.

2. Encargado de materiales y parámetros generales. El alumno encargado de los materiales y parámetros tiene que saber las limitaciones existentes para cada ensayo con los distintos materiales y que parámetros son importantes a la hora de realizar el ensayo. Esto afecta directamente a los parámetros de la máquina por lo que la retroalimentación en cada práctica entre el encargado de los materiales y parámetros con el encargado de la máquina debe de ser directa. 
3. Analítico de los resultados. Este rol se centra principalmente en analizar y valorar los resultados obtenidos en cada ensayo con cada material. Debe conocer que se ha realizado, en qué condiciones y con qué materiales, para así poder valorar y analizar los resultados finales. Esto permite mantener una relación directa con los anteriores compañeros, ya que de esta manera puede conseguir un resultado global lo más adecuado posible.

4. Encargado de interrelaciones y gestión de tiempo. El cuarto integrante del grupo se encarga de que todo el proceso se lleve a cabo de manera correcta y en el tiempo establecido. Este integrante no solo tendrá en cuenta el trabajo de su grupo, sino que se encarga de las interrelaciones entre grupos. Esto es algo de vital importancia durante el desarrollo de las prácticas ya que cada práctica o ejercicio esta interrelacionado entre los diversos grupos con la finalidad de obtener un objetivo global, favoreciendo el trabajo en equipo y que todos los integrantes conozcan limitaciones y resultados reales.

Hay que tener en cuenta que, aunque existen roles establecidos, la libertad de decisión y el objetivo grupal permite que todos los integrantes conozcan en todo momento el trabajo del compañero, facilitando un autoaprendizaje y generando debates y toma de decisiones de grupos pequeños a grupos más grandes.

Cada semana van rotando tanto las máquinas como los roles dentro del grupo lo que favorece el aprendizaje cooperativo. Al rotar semanalmente los puestos, el responsable de cada máquina será el encargado de explicarle a sus nuevos compañeros el funcionamiento de esta. De este modo se trabaja por ejemplo, la competencia transversal: Comprensión e integración.. Además, al inicio de cada práctica se crean pequeñas reuniones para comparar entre grupos experiencias y problemas que pueden surgir durante el desarrollo de la práctica. A medida que van pasando las semanas y hay más grupos que han pasado por los mismos puestos y se van incrementando estas reuniones, notándose un aumento en los conocimientos generales.

Esto permite que los alumnos sean los encargados de explicar los conocimientos aprendidos, consiguiendo al finalizar las prácticas de laboratorio diferentes puntos de vista de cada máquina y rol establecido.

El objetivo principal ha sido desarrollar grupos interactivos, que sean capaces de trabajar tanto individualmente, como en grupos grandes y pequeños. Hay que resaltar que las prácticas tienen una finalidad y unos casos reales, en los cuales los alumnos pueden debatir con el objetivo de obtener los mejores resultados y soluciones para el problema planteado.

Un ejemplo dado sería: una empresa necesita caracterizar un nuevo material plástico que cumpla una serie de expectativas y una serie de restricciones. Los grupos deben determinar

(cc) BY-NC-ND 2018, Universitat Politècnica de València

Congreso IN-RED (2018) 
el polímero o material más adecuado. En cada caso, cada grupo trabaja inicialmente por separado para obtener los resultados pertinentes, pero siempre teniendo en cuenta los valores de su compañeros y los resultados finales. En resumen, se aprecia un gran trabajo en equipo, donde todos los integrantes cooperan en una dirección además de aprender de manera dinámica diferentes conceptos y aptitudes.

\section{Resultados}

Los resultados obtenidos de la aplicación de esta nueva metodología son muy positivos. Durante el desarrollo de las prácticas se ha observado un aumento notable en el interés y la motivación de los alumnos. Además de eso las encuestas realizadas y el análisis de los resultados académicos han aportado una mejora notable respecto a años anteriores.

Al final de la asignatura se realizó una pequeña encuesta general a los alumnos sobre la aplicación de esta nueva metodología. Los resultados aparecen en la Tabla 1. En la encuesta participaron un total de 38 alumnos de la asignatura Ciencia de Materiales:

- Pregunta 1: ¿Has mantenido el interés en la asignatura con esta dinámica de grupo más que en una práctica convencional?

- Pregunta 2: ¿Te gustaría tener más prácticas de laboratorio con este método?

- Pregunta 3: ¿Has aprendido más conocimientos de los que esperabas?

- Pregunta 4: ¿Te ves capaz de aplicar lo aprendido en clase en una empresa?

- Pregunta 5: ¿Te has sentido a gusto trabajando en grupo?

- Pregunta 6: Del 1 al 10 ¿Qué calificación le das a las prácticas de la asignatura?

Tabla 1. Datos de la encuesta.

\begin{tabular}{|l|l|l|}
\hline & SI & NO \\
\hline Pregunta 1 & $94 \%$ & $6 \%$ \\
\hline Pregunta 2 & $92 \%$ & $8 \%$ \\
\hline Pregunta 3 & $90 \%$ & $10 \%$ \\
\hline Pregunta 4 & $86 \%$ & $14 \%$ \\
\hline Pregunta 5 & $79 \%$ & $21 \%$ \\
\hline Pregunta 6 & \multicolumn{2}{|c|}{ Media total 8,7} \\
\hline
\end{tabular}

Como se ha comentado con anterioridad, los resultados obtenidos de la encuesta hacen ver un aumento en el interés y la adquisición de diversas aptitudes. Los alumnos han salido contentos al finalizar la asignatura. La valoración obtenida por la asignatura ha sido muy positiva, con una media de 8,7 . 
La mejora en la adquisición de conocimientos y aptitudes de los alumnos se podrá ver reflejada en la continuación de la asignatura en el siguiente año, donde será posible analizar en mayor profundidad la retención de conceptos y procedimientos explicados el año anterior de una manera mucho más fluida que antes de la introducción del aprendizaje cooperativo.

\section{Conclusiones}

Después de analizar los resultados obtenidos, y sobre todo la satisfacción de los alumnos, se puede apreciar como aplicación del aprendizaje cooperativo en las prácticas de la asignatura incrementa no solo el nivel de atención del alumno, sino la mejora en la adquisición de conceptos mejorando las aptitudes y el proceso de enseñanza-aprendizaje de estos.

El alejamiento de las clases magistrales y las prácticas donde la repetitividad era el elemento principal de aprendizaje se produce con la inclusión de estas nuevas metodologías. Las competencias transversales, consiguen de una manera muy sencilla trabajar en gran medida las competencias establecidas por la UPV y aumentar de manera notable el interés del alumno y la adquisición de conceptos. Hay que resaltar que el interés por el trabajo en equipo y la cooperación en los tiempos actuales se está teniendo muy en cuenta, no solo en ámbitos académicos, sino también en el ámbito profesional. La aplicación del aprendizaje cooperativo en este tipo de prácticas, parece ser un buen punto de partida para ir mejorando no solo los conocimientos adquiridos, sino también las aptitudes y las habilidades del estudiante.

(cc) EY-NC-ND 2018, Universitat Politècnica de València

Congreso IN-RED (2018) 


\section{Referencias}

Eduardo, M. G. (1992). "¿ Qué hay que renovar en los trabajos prácticos?" Enseñanza de las ciencias: revista de investigación y experiencias didácticas 10(2): 206-211.

García, R., J. A. Traver and I. Candela (2001). "Aprendizaje cooperativo." Fundamentos, características y técnicas. Madrid: CCS.

Habermas, J. (2008). El discurso filosófico de la modernidad, Katz Editores.

Johnson, D. W., R. T. Johnson and E. J. Holubec (1999). "El aprendizaje cooperativo en el aula."

López Rua, A. M. and Ó. E. Tamayo Alzate (2012). "Las prácticas de laboratorio en la enseñanza de las ciencias naturales." Revista Latinoamericana de Estudios Educativos (Colombia) 8(1)

Montanes, N., R. Balart, L. Sánchez-Nacher, L. Quiles-Carrillo and V. Fombuena (2017). "Buenos días: la clase de hoy es un juego ¿̇ y porqué no?".

UPV, U. P. d. V. (2017). "Competencias Transversales UPV." Retrieved Marzo 2017, from http://www.upv.es/contenidos/COMPTRAN/. 


\title{
Gamificación e Informática. Comparativa de una experiencia mixta en Grado y Máster.
}

\section{Juan Vicente Oltra Gutiérrez ${ }^{\mathrm{a}}$}

${ }^{a}$ Escuela Técnica Superior de Ingeniería Informática. Universitat Politècnica de València. jvoltra@omp.upv.es

\begin{abstract}
The same gamification experience is applied in two similar subjects in terms of their contents and both with a reduced number of students, where the fundamental difference between them lies in the characteristics of the student, because while one is developed in the Double Degree in Computer Science and Business Administration, the other one in Master.

Intuitively, better results were expected a priori with a student that is usually classified as "more mature". In this paper, we try to compare the results obtained .
\end{abstract}

Keywords: gamification, methodology, evaluation.

\begin{abstract}
Resumen
Se aplica la misma experiencia de gamificación en dos asignaturas de corte similar en lo que respecta a sus contenidos y ambas con un número de alumnos reducido, donde la diferencia fundamental entre las mismas radica en las características del alumno, pues mientras una se desarrolla en el Doble Grado de Informática y Administración de Empresas, la otra lo hace en Máster.

De forma intuitiva se esperaba a priori unos resultados mejores con un alumnado que suele ser catalogado como "más maduro" En el presente trabajo se trata de comparar los resultados obtenidos.
\end{abstract}

Palabras clave: gamificación, metodología, evaluación.

\section{Introducción}

La percepción de la madurez de los alumnos, de cómo éstos cambian su actitud ante los estudios conforme se van cargando de años y experiencia, ha sido estudiada desde múltiples prismas y en distintos escenarios (Boza, 2012); (Creed, 2012); (Donoso, 1998); (Kinash, 2017).

Aun sin necesidad de recurrir a análisis centrados en la percepción obtenida por los docentes, en cualquier conversación informal surge como idea el que los alumnos que cursan estudios de máster son más constantes y se preocupan más por su propio aprendizaje que sus compañeros de grado. A título personal esta idea preconcebida de diferencia de 
grados de maduración, sin poder constatar mediante herramientas científicas la misma, me ha servido para hacer diseños diferentes para asignaturas en distintos años. Con el presente trabajo se trata de cuantificar esa la constancia del alumnado, en dos asignaturas que de forma intencional han mantenido un cierto paralelismo (en la medida en que lo permite la diferencia entre las mismas), de forma en que se nos permita establecer comparaciones. Ambas asignaturas además tienen un perfil similar de contenidos (aunque una profundiza más que la otra en determinadas materias), transcurren en el mismo semestre del mismo curso, y sobre ambas se aplica una misma técnica específica, de forma que los resultados, presentando la lógica disparidad por sus diferentes orígenes, permitan elaborar una comparación del seguimiento que los alumnos han hecho de las mismas.

\section{Definición del escenario:}

Las asignaturas a comparar son:

- Marco Legal y Deontológico (Máster Universitario en Gestión de la Información), código 34015, en adelante MLD

- Deontología y Profesionalismo (Doble grado en Informática y Administración de Empresas), código 11550, en adelante DyP

Ambas comparten una serie de características comunes que las hacen idóneas para la comparación. Por una parte sus contenidos son de corte similar, aunque obviamente en niveles distintos de complejidad. Ambos temarios descansan en la deontología informática y en los aspectos legales básicos de los sistemas de información. También la extensión es similar, pues ambas tienen una carga teórica de tres créditos. Además, en ambos casos el número de alumnos matriculados es reducido. Al describir la experiencia delimitaremos el conjunto de semejanzas y disimilitudes de una forma más precisa.

Para poder establecer la comparación, usamos una técnica empleada desde hace varios cursos en ambas asignaturas, ya consolidada en procedimientos y de uso uniforme en ambos casos: usaremos la llamada "gamificación", descrita en versiones anteriores (Oltra 2016a); (Oltra, 2016b). De igual modo, de forma sucinta delimitaremos los cauces por los que transcurre.

\section{Objetivos}

Vamos a comparar una serie de resultados, algunos obtenidos de la observación directa, y otros de herramientas automatizadas, que nos van a permitir observar diferencias y analogías en el desarrollo de una actividad concreta, la "gamificación”.

Conviene fijar el punto de partida, definiendo que entendemos por "gamificación", un término que emplearemos con asiduidad y del que, por comodidad, a partir de este momento prescindiremos de las comillas.

El término gamificación (gamification) vino de la mano de Nick Pelling (Pelling, 2011)], un programador y desarrollador de videojuegos que trato de lograr que las interfaces no relacionadas con juegos se parecieran más a los juegos, para lograr unas transacciones divertidas y rápidas" conocidos mundialmente. El término aparece en 2002, pero comenzó a

(cc) EY-NC-ND 2018, UniversitatPolitècnica de València

Congreso IN-RED (2018) 
ganar vuelo cuando se popularizó por las empresas y eventos científicos, pudiendo definirse como "El uso de elementos de diseño de juegos en contextos no relacionados con juegos".(Deterding et al., 2011), o, (Werbach, 2014), "El proceso de hacer actividades más parecidas a juegos"

Siguiendo trabajos precedentes (Oltra 2016a y Fuchs, 2014), en este contexto empleamos la palabra y sus derivados por su extenso uso dentro de la comunidad docente, evitando otros con menos éxito en la misma, como ludificación o juguetización. Entenderemos como tal el uso de, elementos y dinámicas propias de los juegos en actividades no lúdicas con el fin fijado en el apoyo al aprendizaje, siendo un elemento a destacar en este tipo de actividades una serie de recompensas otorgadas una vez se alcanzan pequeños logros.

Cabe indicar desde este momento, para evitar la confusión con el aprendizaje basado en juegos (en inglés, game-based learning), fenómeno próximo en apariencia a este que nos ocupa de la gamificación, las diferencias principales con la experiencia que aquí se describe. El aprendizaje basado en juegos está clasificado como una rama de los juegos que se ocupa de asumir los objetivos de aprendizaje desde otros entornos. Y precisamente nosotros no cambiamos de entorno, puesto que lo único que adoptamos del mecanismo del juego es la competición, su dinámica. No creamos un juego propio ni tan siquiera adaptamso un juego pre-existente. No buscamos tan siquiera enseñarles a jugar. Se mantiene una serie de semejanzas, como sus metas principales centradas en la resolución de muchos de los problemas que se dan en el aula, tales como la falta de atención, desmotivación, etc., pero estas metas son suficientemente comunes con tantas estrategias alternativas como para desechar una equiparación por las mismas.

A pesar de que se emplea la gamificación desde hace cinco semestres, para esta ocasión se ha simplificado, en aras de facilitar la toma de datos. La descripción exhaustiva de la experiencia original puede verse en (Oltra, 2016b), pero para esta ocasión ha quedado reducida a tres vías:.

- Uso de Twitter. Desde la cuenta del profesor, se mantiene un contacto con los alumnos, voluntario por su parte. Entre los tuits emitidos se cuentan algunos acompañados de un hastag con las siglas de la asignatura (\#DyP; \#MLD) que contienen noticias o comentarios relativos a temas vistos o próximamente a ver en las sesiones de la asignatura. Los alumnos responden a los mismos y se "premia" el mejor comentario (texto aclaratorio, enlace o desmentido si la noticia resulta ser falsa).

- Uso de los foros de la asignatura. Usando las herramientas que nos ofrece la plataforma Poliformat de la Universitat Politécnica de Valencia, se generan debates online sobre casos vistos en la asignatura, con una duración de una semana. Las mejores participaciones son premiadas.

- Debates en aula. Algunas de las sesiones presenciales terminan con un debate de aula sobre un caso real que se analiza a la luz de los contenidos teóricos de la asignatura. Estos casos darán paso a tareas que deben realizar o test online que deben responder. Pero durante el desarrollo del debate estos se animan "gamificándolos" empleando a tal fin unos billetes falsos, como los que se 
emplean en juegos de mesa tales como el Monopoly, que, al final de la sesión, son recogidos para ser convertidos en calificaciones. Puede verse que es esta la única vía donde el alumno conoce inmediatamente su resultado de participar en la actividad.

Para animar la competición, se fija un tope, un máximo a alcanzar, y se premia a los primeros en llegar a él, tanto socialmente, reconociéndolo en clase, como con una mínima puntuación extra. Ese tope se ha fijado en un (1) punto.

Y una vez descrito el camino a seguir, nos queda describir a los participantes. Hay factores cualitativos y otros cuantitativos a tener en cuenta $\mathrm{y}$, aunque los primeros pequen de subjetividad no cabe orillarlos pues el hacerlo nos provocaría una visión parcial de la experiencia.

\subsection{Participantes:}

El perfil de los alumnos y sus variables que pueden ser cuantificados de forma numérica puede verse en la tabla 1 .

Hagamos notar una observación antes de ver la tabla: el número de participantes en MLD se cifra en 20, y no 21, que es el número de matrícula, pues el alumno que falta no solo no vino a una sesión de la asignatura, sino que era un completo desconocido para sus compañeros.

Para poder efectuar visualmente las comparaciones, al lado del número bruto de estudiantes indicado en cualquier característica, se indica el porcentaje que ese número resulta del total de alumnos en la asignatura. Esta representación se repite en las tablas siguientes.

Tabla 1. Características de los participantes.

\begin{tabular}{|c|c|c|c|c|}
\hline Asignatura / características de los alumnos & DyP & & MLD & \\
\hline Número de alumnos reales & 29 & & 20 & \\
\hline $\begin{array}{l}\text { Alumnos españoles o residentes permanentes en } \\
\text { España }\end{array}$ & 29 & $\begin{array}{l}100 \\
\%\end{array}$ & 10 & $50 \%$ \\
\hline $\begin{array}{l}\text { Alumnos de otras procedencias (Rusia, Colombia...) } \\
\text { que residen en el país para cursar sus estudios }\end{array}$ & 0 & $0 \%$ & 10 & $50 \%$ \\
\hline Alumnos que simultanean trabajo con estudios & 1 & $\begin{array}{l}3,5 \\
\%\end{array}$ & 6 & $30 \%$ \\
\hline Rango de edad (años) & $20-21$ & & $22-36$ & \\
\hline Alumnos con conocimientos previos de la materia & 0 & $0 \%$ & 5 & $25 \%$ \\
\hline $\begin{array}{l}\text { Alumnos emancipados (viven solos o con su familia, } \\
\text { asumiendo una parte significativa de los gastos de la } \\
\text { vivienda, sin financiación familiar) }\end{array}$ & 0 & $0 \%$ & 3 & $15 \%$ \\
\hline
\end{tabular}

Fuente: Elaboración propia 


\subsection{Asignaturas:}

En la tabla 2 vemos las diferencias más significativas entre las asignaturas. A continuación de la tabla revisamos esas diferencias para matizar en qué modo pueden afectar a la comparación.

Hagamos notar que en las 10 sesiones de MLD se incluyen tanto las sesiones de presentaciones de trabajos. Los trabajos, obligatorios en MLD, adquirían la característica de voluntarios en DyP, sirviendo para que aquellos alumnos en el límite de una calificación a otra superior, pudieran dar el salto. En este semestre se presentaron tan solo dos trabajos.

Tabla 2. Características de las asignaturas.

\begin{tabular}{|c|c|c|}
\hline Asignatura / características & $\overline{\text { DyP }}$ & MLD \\
\hline Créditos totales de teoría & 3 & 3 \\
\hline Créditos totales de práctica & 1,5 & 0 \\
\hline Inicio de clases & 5/sept & $10 /$ nov \\
\hline Fin de clases & 22/dic & 20/dic \\
\hline Duración de una clase de teoría (en horas) & 2 & 3 \\
\hline $\mathrm{N}^{0}$ de clases de teoría a la semana & 1 & 2 \\
\hline $\mathbf{N}^{0}$ de clases de teoría en el semestre & 13 & 10 \\
\hline No de tareas que se evalúan & 3 & 5 \\
\hline Peso de las tareas en la nota de la asignatura & $30 \%$ & $50 \%$ \\
\hline$N^{0}$ de casos de aula con test que se evalúan & 5 & 2 \\
\hline Peso de los casos evaluados en la nota de la asignatura & $35 \%$ & $20 \%$ \\
\hline $\mathbf{N}^{0}$ de casos de aula totales que se realizan & 7 & 5 \\
\hline Se presenta trabajo de asignatura & Voluntario & SI \\
\hline Peso del trabajo en la nota de la asignatura & $0 \%$ & $30 \%$ \\
\hline $\mathbf{N}^{0}$ de trabajos de prácticas que se evalúan & 4 & 0 \\
\hline Peso de los trabajos de prácticas en la nota de la asignatura & $35 \%$ & $0 \%$ \\
\hline Gamificación. Foros abiertos para debate & 7 & 2 \\
\hline Gamificación. Foros empleados realmente para debate & 1 & 2 \\
\hline Gamificación. Semanas de actividad en Twitter & 10 & 5 \\
\hline Gamificación. Debates de aula & 7 & 5 \\
\hline
\end{tabular}


Vemos que no se trata de dos desarrollos idénticos, pero observemos cuales son las diferencias para tratar de señalar aquellos puntos que puedan distorsionar la comparación.

- Tamaño en créditos de la asignatura: observamos que en la asignatura de grado existe una parte práctica de la que carece la asignatura de Máster. Dado que las actividades de gamificación se practican exclusivamente en la parte teórica, este elemento no nos afecta.

- Sesiones de teoría: la diferencia es evidente, tanto en número y tamaño (menos sesiones y de más duración para el máster) como en su ubicación en el calendario. Efectivamente MLD se imparte de forma condensada en la segunda mitad del primer semestre del curso. Esto provoca una disminución en determinadas actividades temporales (por ejemplo, hay menos semanas donde está abierta la gamificación con Twitter) pero, por otra parte, al "competir" con menos asignaturas (el resto de asignaturas del plan de estudios del máster registra las mismas características, repartiéndose el semestre en dos mitades, de forma que mientras en grado DyP comparte calendario con un número equivalente al $50 \%$ de las asignaturas, MLD lo hace con tan solo un $25 \%$ de las mismas). Este factor podría afectar negativamente a las cifras obtenidas en los resultados de MLD, por lo que volveremos al mismo cuando evaluemos los resultados.

- Distintos pesos en las evaluaciones: aunque podríamos establecer criterios de comparación reduciendo diferencias considerando elementos que tienen pesos parecidos en una y otra asignatura (p.e. trabajo de asignatura en MLD vs peso de las prácticas en DyP), dado que nos centramos en la gamificación, cifraremos nuestro interés en estos valores (participación en foros, Twitter y debates) y la frecuencia con la que pueden ser recogidos (número de foros y debates, número semanas en las que la gamificación está activa en Twitter), sin considerar elementos tales como cuales de los casos que van asociados al debate tienen una nota específica, pues esto no afecta al modo en que se trata la gamificación en ellos. Vemos que, de nuevo, el ajustado calendario de la asignatura de Máster, provoca que aparezcan menos oportunidades de gamificación. Sin embargo, comprobaremos que estas oportunidades han sido más aprovechadas. Valga como muestra el que siendo muchos más los foros abiertos en poliformat para ofrecer espacio a la gamificación en la asignatura de grado, el número de foros realmente empleados por los alumnos es más reducido que el número de foros que emplean los alumnos de máster.

\subsection{Comparación:}

Los elementos que nos permitirán establecer comparaciones vienen de dos vías: la primera, la observación del profesoren el desarrollo de las distintas actividades de gamificación. La segunda, las estadísticas que la herramienta poliformat nos facilita sobre el acceso a las distintas herramientas que presenta.

(cc) EY-NC-ND 2018, UniversitatPolitècnica de València

Congreso IN-RED (2018) 


\section{Desarrollo de la innovación}

La experiencia, desarrollada en el ámbito temporal y docente que queda delimitado en el anterior apartado, no pudo ser aplicada de forma idéntica en número de actos a evaluar por la diferencia tan abultada en el lapso de tiempo y sesiones. Eso provocó que el número de elementos en la asignatura de máster, MLD, fuera significativamente más reducida (véase tabla 2). De todas formas, aunque los datos en bruto nos mostrarán que esta reducción en el número de eventos gamificables no parece provocar una abultada diferencia en favor de la participación de los alumnos de grado, normalizaremos estos datos buscando que las proporciones sean equilibradas, aportando un dato calculado que de la participación media por evento.

Con respecto al perfil de los alumnos participantes, cabe añadir a los datos objetivos recogidos en las tablas que los alumnos de DyP, cursada dentro del doble grado de Administración de Empresas más Informática, tiene un perfil que se diferencia del resto de alumnos que cursan DyP, en el segundo semestre, matriculados en el grado de informática. La diferencia más cuantificable la tenemos en su nota de acceso a la universidad (3,3 puntos mayor para los primeros), además de que cursan la materia en el primer semestre de su tercer curso, en lugar de en el segundo semestre de segundo curso. Sus notas son ostensiblemente más altas que la media (se triplica el porcentaje de sobresalientes, se duplica el de notables y se reduce a cero el número de suspensos y no presentados). Así como en otros grupos existe un número no numeroso pero ni mucho menos despreciable de alumnos que no realizan alguna actividad (un caso de aula, una práctica), esta circunstancia no se da en el grupo de doble grado, donde todos los participantes mostraron una constancia y un seguimiento de las clases absolutas.

Los datos que se muestran provienen de la observación directa del profesor, de su cuaderno de campo y preguntas realizadas a los alumnos y de la recogida automática de datos al final de la experiencia, gracias a las herramientas automatizadas de la plataforma docente.

La recogida manual de datos se efectuaba nada más cerrada una actividad (al final de un debate en aula, cuando concluía una semana en twitter -se consideraban activos los lapsos de sábado a viernes- y cuando se finalizaba un foro de debate (estos a priori permanecían abiertos durante una semana, pero cuando había interesados en participar, el plazo se alargaba al doble).

\section{Resultados}

Vamos a mostrar desglosados los datos obtenidos en cada una de las tres subactividades de gamificación y, a continuación, el uso que unos y otros alumnos hacen de las distintas herramientas y posibilidades de la plataforma, haciendo especial hincapié en las relacionadas con la gamificación estudiada y en los contenidos de la asignatura (todo el material de teoría se encontraba disponible en "contenidos").

Tabla 3. Uso de los foros para la gamificación, por parte de los alumnos.

\begin{tabular}{llc}
\hline Foros & DyP & MLD \\
\hline
\end{tabular}




\begin{tabular}{lcccc}
\hline Abiertos & 7 & \multicolumn{2}{c}{2} \\
Empleados & 1 & & 2 & $30 \%$ \\
Participación & 2 & $7 \%$ & 6 & $30 \%$ \\
Participación media por foro & 2 & $7 \%$ & 6 & Fuente: Elaboración propia \\
\hline
\end{tabular}

La lectura de esta primera tabla, referida a los foros, nos hace ver que, mientras en DyP se abren muchos más foros (por disponer de más semanas activas de clase), solo uno de ellos (de los siete abiertos) es realmente usado por los alumnos, en concreto por dos de ellos. En MLD, con un número muy inferior de foros (2) el uso es muy superior, hablemos de números brutos o de porcentajes.

Tabla 4. Debates realizados en clase y su cuantificación en la gamificación.

\begin{tabular}{llccc}
\hline Debates & DyP & \multicolumn{3}{c}{ MLD } \\
\hline Realizados & 7 & & 5 & $55 \%$ \\
Participación & 13 & $45 \%$ & 11 & $45 \%$ \\
Participación media por debate & 8 & $28 \%$ & 9 & Fuente: Elaboración propia
\end{tabular}

Observamos que tanto en la participación total (alumnos que han participado en algún debate) como en la que promedia el número de participantes por debate, el alumno de máster resulta más activo que el de grado.

Tabla 5. Actividad de los alumnos en Twitter, dentro de las actividades de gamificación.

\begin{tabular}{llllc}
\hline Twitter & DyP & \multicolumn{3}{c}{ MLD } \\
\hline Semanas de actividad & 10 & & 5 & $50 \%$ \\
Participación & 9 & $31 \%$ & 10 & $40 \%$ \\
Participación media por semana & 6 & $21 \%$ & 8 & Fuente: Elaboración propia \\
\hline
\end{tabular}

De igual manera que en los casos anteriores, podemos observa que el alumno de máster se muestra más activo.

Cerremos este apartado con una tabla que nos muestra la información sobre la gamificación en general, tanto con respecto a su actividad como sobre las notas máximas y mínimas alcanzadas. 
Tabla 6. Participación de los alumnos en actividades de gamificación: actividad y notas alcanzadas.

\begin{tabular}{llllll}
\hline Participación total & \multicolumn{2}{c}{ DyP } & \multicolumn{3}{c}{ MLD } \\
\hline $\begin{array}{l}\text { Alumnos participantes en al menos una } \\
\text { actividad }\end{array}$ & 22 & $76 \%$ & 12 & $60 \%$ \\
\hline $\begin{array}{l}\text { Alumnos que participan de las tres vías } \\
\text { Alumnos que participan en todas las ocasiones }\end{array}$ & 4 & 10 & $34 \%$ & 8 & $40 \%$ \\
Nota máxima obtenida por gamificación & 1,3 & & 0,9 & $30 \%$ \\
\hline \begin{tabular}{l} 
Nota mínima obtenida por gamificación \\
\hline
\end{tabular} & 0 & & 0 & \\
\hline
\end{tabular}

En la tabla anterior aparece una aparente contradicción que trataremos de aclarar. Si bien hemos visto hasta ahora que los alumnos de máster se mostraban más activos, el hecho de que el número de semanas de actividad de la asignatura de grado duplicara a la de máster provocó que un buen número de alumnos, quizá por probar, realizaran alguna actividad, si bien en muchos casos sin persistir en la experiencia. Vemos que los alumnos que no solo participan de todas las posibilidades, sino que "no se pierden una" (participan en todos los debates, foros, tuits), es más elevado en los alumnos de máster.

Otra posible sorpresa es la nota más alta alcanzada, más alta en DyP que en MLD. Esto tiene una doble explicación: de nuevo, el tiempo, que provoca que los interesados tengan más oportunidades para sacar una mejor nota, y por otra que, en este colectivo de alumnos excelentes, hubo dos de ellos que se tomaron muy en serio la competición que propuse: el primero en alcanzar la nota umbral (un punto) sería premiado con "una medalla de oro": 0,3 puntos extras. Ese dulce ofrecido al principio provocó hasta el final una verdadera carrera, con adelantamientos semana si, semana también.

Vamos ahora a ver los datos que la plataforma de forma automática nos recoge.

Tabla 7. Información ofrecida por la plataforma docente.

\begin{tabular}{lllll}
\hline Evento & DYP & MLD & $\begin{array}{l}\text { DYP por } \\
\text { alumno }\end{array}$ & $\begin{array}{l}\text { MLD } \\
\text { por } \\
\text { alumno }\end{array}$ \\
\hline Leer mensaje de foro & 15 & 50 & 0,52 & 2,50 \\
\hline Responder foro de mensaje & 2 & 12 & 0,07 & 0,60 \\
\hline Nuevo tema de foro & 1 & 10 & 0,03 & 0,50 \\
\hline Editar tema de un foro & 3 & 2 & 0,10 & 0,10 \\
\hline Acceso a una sección de contenidos & 2372 & 1520 & 81,79 & 76,00 \\
\hline
\end{tabular}




\begin{tabular}{|c|c|c|c|c|}
\hline Evento & DYP & MLD & $\begin{array}{l}\text { DYP por } \\
\text { alumno }\end{array}$ & $\begin{array}{l}\text { MLD } \\
\text { por } \\
\text { alumno }\end{array}$ \\
\hline Nuevo mensaje & 40 & 51 & 1,38 & 2,55 \\
\hline Responder mensaje & 11 & 7 & 0,38 & 0,35 \\
\hline Leer correo interno & 93 & 134 & 3,21 & 6,70 \\
\hline Leer recurso & 3174 & 2276 & 109,45 & 113,80 \\
\hline Acceso a calendario & & 42 & 0,00 & 2,10 \\
\hline Acceso a calificaciones & 51 & 31 & 1,76 & 1,55 \\
\hline Acceso a anuncios & 26 & 17 & 0,90 & 0,85 \\
\hline
\end{tabular}

En la información se añade una simple división, para saber cuántos de esos eventos se han producido por alumno. Observamos que en la única actividad de gamificación que puede seguirse desde la plataforma, la que está basada en el uso de foros, los números siguen indicando una mayor participación del alumno de MLD.

Otros datos se muestran como simple escenario. Por ejemplo, los relativos a los mensajes, consulta de calificaciones o lectura de los anuncios en el tablón. Como dato curioso, en DyP ningún alumno consultó el calendario de la plataforma.

De esta tabla podemos ver que el uso de los recursos y contenidos tienen ligeras variaciones en uno u otro sentido. Hay que indicar que este elemento no sirve más que como orientación muy superficial, pues el numero de recursos (documentos) y contenidos es inferior en máster frente a grado por el menor número de temas de una asignatura frente a la otra (menos temas, más complejos, pero con menos elementos a descarga o consulta, a pesar de que cada uno de ellos pueda ser de más tamaño). Por eso, excusamos el indicar mediante tablas el acceso a los contenidos y recursos clasificado por meses.

Por último, veremos a modo de comparativa las notas finales

Tabla 8. Notas finales.

\begin{tabular}{|c|c|c|c|c|}
\hline & DyP & DyP (\%) & MLD & $\begin{array}{l}\text { MLD } \\
(\%)\end{array}$ \\
\hline MH & 1 & $3,44 \%$ & 1 & $5 \%$ \\
\hline SB & 9 & $31,03 \%$ & 4 & $20 \%$ \\
\hline NT & 17 & $58,62 \%$ & 11 & $55 \%$ \\
\hline AP & 2 & $6,89 \%$ & 4 & $20 \%$ \\
\hline SP & 0 & $0 \%$ & 0 & $0 \%$ \\
\hline
\end{tabular}




\begin{tabular}{lllll}
\hline No presentados & 0 & $0 \%$ & 0 & $0 \%$ \\
PRES & 29 & & 20 & \\
NO PRES & 0 & & 1 & \\
NOTA MEDIA & 8,27 & $(10-5)$ & 7,85 & $(10-5,4)$ \\
\hline
\end{tabular}

Las notas, más altas en grado que en máster pueden deslucir lo anteriormente expuesto. Pero solo en apariencia. Porque si consideramos el alto número de alumnos excelentes que conformaban la matrícula, y que con las actividades programadas, no de forma extra, como la gamificación, sino las que estrictamente se enumeran en la guía docente, estamos ante un resultado que el docente esperaba desde los primeros días de clase. Por dar un ejemplo concreto, en la prueba concreta del primer caso que se evalúa en aula, que es además la primera actividad de la cual los alumnos obtienen una nota, y que en el desarrollo habitual de la asignatura (alumnos de grado) el número de suspensos ronda un 40\%. Con estos alumnos de doble grado, nadie suspendió, siendo las notas máximas las que alcanzaron ese $40 \%$.

\section{Conclusiones}

Hemos realizado una comparación con dos grupos de alumnos, unos cursando Máster y otros un doble grado, para intentar comprobar si el foco de su atención se centraba más o menos en una actividad que, siendo voluntaria, les permite subir nota en la asignatura.

Todo participante sabía que podía subir y bajar de la experiencia a voluntad. El docente siempre iba a considerar la nota que hubiera obtenido, fuera cual fuera el rango de fechas y actividades con el que las obtuviera.

Siendo actividades donde muchas veces el participante no obtiene nada (por definición solo se premiaba las mejores participaciones, y a veces quedaba desierto) la voluntad del alumno influye mucho más en su seguimiento que en las actividades ordinarias, de carácter obligatorio, con que la asignatura cuenta.

De los datos obtenidos observamos que, pese a la gran calidad del alumno de doble grado que era evaluado, los alumnos de máster, cuya diferencia con los anteriores en sentido positivo cabe cifrar en una mayor experiencia vital y laboral por su mayor edad, son más participativos. ¿Significa esto que esa "verdad no contrastada", que compartimos muchos docentes en charlas de pasillo, asumiendo una mayor maduración en el alumno de máster frente al alumno de grado es una realidad?. Dada la ausencia de datos a gran escala que permitan hacer una comparación y, obviamente, así mismo de la ausencia de perfiles psicológicos a los que acudir, no se puede dar una respuesta a esta pregunta. Pero lo que si se constata es una mayor participación en actividades de carácter voluntario, y un mayor uso de los recursos que desde la plataforma se ofertaba, por parte de los alumnos de máster. Para ser honrado, debo indicar que a título personal, sin ser los datos concluyentes, se subraya esa percepción íntima. 
Cabe añadir como una conclusión accesoria, que de estos resultados el docente obtiene una determinación: eliminar el uso de los foros para la gamificación, quedando descartados para posteriores ediciones por su muy bajo uso.

Para posteriores ediciones, queda el propósito de extender esta iniciativa a otras asignaturas de otras titulaciones y poder realizar una comparativa más amplia, al tiempo que aparece la idea de localizar elementos que puedan medir científicamente ese grado de maduración, y que puedan ser obtenidos de forma no intrusiva del alumnado..

\section{Referencias}

Boza Carreño, A.; Tocano Cruz, M. De La O. (2012) "Motivos, actitudes y estrategias de aprendizaje: aprendizaje motivado por alumnos universitarios". Profesorado, 16(1): 125142 (2012). [http://hdl.handle.net/10481/22994] [Consulta: 10 de marzo 2018]

Creed, P.A.; Hughes, T. (2012)."Career development strategies as moderators between career compromise and career outcomes in emerging adults". En Journal of Career Development, 40(2), 146-163. doi: 10.1177/0894845312437207[Consulta: 10 de marzo 2018]

Deterding, S., Dixon, D., Khaled, R., \& Nacke, L. (2011). "From game design elements to gamefulness: Defining "gamification."' In Proceedings of the 15th International Academic MindTrek Conference: Envisioning Future Media Environments (pp. 9-15). New York: ACM.

Donoso, S. (1998)."La reforma educacional y el sistema de selección de alumnos a las universidades: impactos y cambios demandados" Estudiospedagógicos.n.24 pp. 7-30 Valdivia. http://dx.doi.org/10.4067/S0718-07051998000100001. [Consulta: 10 de marzo 2018]

Fuchs, M., Fizek, S., Ruffino P., Schrape, N. (2014) Rethinking Gamification. Lüneburg, Alemania: Meson press.

Kinash, S.; Crane, L.; Capper, J., Young, M.; Stark, A. (2017). "When do university students and graduates know what careers they want: A research-derived framework." Journal of Teaching and Learning for Graduate Employability, 8(1), 3-21.21 https://doi.org/10.21153/jtlge2017vol8no1art584 [Consulta: 10 de marzo 2018]

Oltra Gutiérrez, J.V.; Garrigós-Simón, F.J.; Narangajavana, Y. (2016). "Introducción de actividades de Gamificación en una asignatura humanista para informáticos”. En IN-RED 2016. Valencia: Universitat Politècnica de Valencia. DOI: http://dx.doi.org/10.4995/INRED2016.2016.4430. [Consulta: 10 de marzo 2018]

Oltra Gutiérrez, J.V.; Garrigós-Simón, F.J.; Narangajavana, Y.; Montesa Andrés, J.O. (2016). "Gamificación dentro y fuera del aula: una experiencia. Deontología y Profesionalismo para informáticos.”. En INNODOCT 2016. Valencia: Universitat Politècnica de Valencia PP. 559-566

Pelling, N. (2011). "The (short) prehistory of gamification. Funding Startups (\& other impossibilities)". Haettu ,7, 2013.

Werbach, K. (2014). "(Re) Defining Gamification: A Process Approach. In Persuasive Technology" (pp. 266-272). Springer International Publishing.

(cc) EY-NC-ND 2018, UniversitatPolitècnica de València

Congreso IN-RED (2018) 


\title{
Método del caso como medio de evaluación dentro del modelo FLIP-Teaching. Una experiencia con una asignatura de corte jurídico para ingenieros.
}

\author{
Juan Vicente Oltra Gutiérrez ${ }^{\text {a }}$ \\ ${ }^{a}$ Escuela Técnica Superior de Ingeniería Informática. Universitat Politècnica de València. \\ jvoltra@omp.upv.es
}

\begin{abstract}
The following work presents an experience centered on the use of the case method as one of the evaluative methods to be used in the development of flip teaching, on a group of the subject Deontología y Profesionalismo, taught at the Escuela Técnica Superior de Informática (ETSINF) of the Universitat Politècnica de València.

The phases of the case method are described and the results obtained during the same are reported.
\end{abstract}

Keywords: Case Method, Flip Teaching, methodology, evaluation.

\begin{abstract}
Resumen
En el siguiente trabajo se presenta una experiencia centrada en el uso del método del caso como uno de los métodos evaluativos a utilizar en el desarrollo de la enseñanza inversa, sobre un grupo de la asignatura Deontología y Profesionalismo, impartida en la Escuela Técnica Superior de Informática (ETSINF) de la Universitat Politècnica de València.

Se describen las fases del método del caso y se da cuenta de los resultados obtenidos durante la misma.
\end{abstract}

Palabras clave: método del caso; clase inversa; metodología, evaluación.

\section{Introducción}

En el siguiente trabajo se presenta una experiencia centrada en el uso del método del caso como uno de los métodos evaluativos a utilizar en el desarrollo de la enseñanza inversa. El propósito último es avanzar hacia la alineación del eje enseñanza-aprendizaje-evaluación, cubriendo una meta a corto plazo: mejorar y documentar las mejoras de la experiencia que, sobre grupos de la asignatura Deontología y Profesionalismo, se viene realizando desde hace ya cuatro cursos académicos (OLTRA, 2015).

Usaremos indistintamente los términos enseñanza inversa y flip teaching, por el extendido uso de ambos y, porque un reciente estudio bibliométrico (inédito, pendiente de publicación en el congreso INNODOCT 18) nos indica que ambas expresiones son empleadas de forma similar en la producción científica en español (40\%-60\% aproximadamente). 


\section{Definición de los términos de partida. Flip Teaching.}

El modelo Flip Teaching, según (SEIN-ECHALUCHE, 2017) comenzó con el intercambio del lugar donde habitualmente se realizan dos de las principales actividades educativas: "la lección y los deberes” cifrando su punto de partida como método en el año 2000. Este año como punto de partida toma como origen la iniciativa de un grupo de profesores de economía en la Universidad de Miami (Ohio) (VIDAL MELÓ, 2016), aunque de su forma conocida hoy no aparece registro hasta 2007, cuando Jonathan Bergmann y Aaron Sams, profesores de química en Woodland Park High School, Colorado, empezaron a grabar en soporte video los contenidos de sus asignaturas y a subirlos a la red y relacionarlos con una serie de trabajos a realizar en casa sobre los mismos liberando el tiempo de aula para resolver dudas y realizar actividades aumentando la interacción profesor-alumno. (VIDAL MELÓ, 2017).

Otros autores que analizan el fenómeno antes de ese año (ANDREU, 2004), sin embargo se remontan a 1870, entendiendo como un claro precedente la experiencia de Chistopher Laudell en los estudios de derecho de la Universidad de Harvard. La definición del método está sujeta a muchas variantes en los detalles, aunque en lo elemental podríamos decir, siguiendo a (SEIN-ECHALUCE LACLETA, 2015) que, frente al modelo de formación habitual basado en impartir lecciones magistrales en el aula, con un alumnado pasivo, que ocasionalmente puede ser empujado a realizar actividades fuera del horario presencial, lo que se trata es de invertir el proceso y que el muy escaso tiempo de aula se emplee para trabajar sobre contenidos teóricos, que el alumno ha debido adquirir antes de asistir. Así, para provocar que fuera de clase ocurra la transferencia de conocimientos, el alumno contará con una serie de recursos dejando el tiempo de aula para la asimilación de los mismos. (CANALES VARGAS, 2014)

\section{Definición de los términos de partida. Método del caso.}

Mientras el flip teaching es algo relativamente novedoso, el método del caso es un viejo conocido para los docentes. Con él, buscamos provocar el análisis y la resolución de una situación que carece de solución única, compleja y a menudo con variantes que presentan dilemas éticos, a través de la puesta en común con el discente quien, mediante la reflexión y el diálogo, toma decisiones a la luz de la teoría que el docente le presentó, y así trata de resolver los problemas planteados, de manera colaborativa.

Hay múltiples experiencias ((CASTELLÓ-SIRVENT, 2017), (CANALES VARGAS, 2014) entre otros) pero básicamente en todas el guión es el mismo: los alumnos confrontan informaciones reales, incluso en ocasiones en apariencia contradictorias, en las que se apoyarán para resolver el problema o problemas planteados, con un apoyo no solo basado en los materiales preparados para la actividad en particular, sino con el obligado contraste con el contenido teórico de la asignatura.

\section{Objetivos.}

Si tuviéramos que definir un único objetivo, sin duda señalaríamos el intentar la consecución de ese término que entre utópico y acariciado aparece recurrentemente en la 
mente de todo docente: la evaluación continua, equilibrando enseñanza, evaluación y aprendizaje.

Aplicando el método del caso tratamos de efectuar un alto nivel de transferencia de conocimientos. Para ello nos apoyamos en casos reales, que el alumno puede conocer a través del material que el profesor le suministra, pero también a través de sus propios rastreos en buscadores generalistas o especializados (Aranzadi, AENOR...)

Al tratarse de acontecimientos donde profesionales informáticos se han visto implicados, en algunos casos incluso con consecuencias penales, se focaliza la atención del alumno permitiendo una participación activa del mismo. Más allá de acercar la teoría a la realidad, el propósito es acercar la realidad a la teoría. Realidad que el alumno puede contrastar por sí mismo, y en algún caso incluso forma parte de su memoria reciente (pues se trata de emplear casos no solo relevantes sino, en la medida de lo posible muy mediáticos y próximos en el tiempo).

Consideramos, con (ANDREU, 2004), que el aprendizaje precisa de una participación activa del estudiante en lugar de esperar a que el profesor desarrolle de forma teórica el contenido. El objetivo último es fomentar la curiosidad y el desarrollo de destrezas que permiten el autoaprendizaje a lo largo de toda la vida.

Una relación más amplia, y por tanto ambiciosa, de los objetivos, incluiría

- El mejor aprovechamiento del tiempo de aula en busca de unas clases más productivas

- Apoyándonos en el interés que el alumno (estudiante de Grado en Informática) tiene por las tecnologías de la información y la comunicación, explotar de forma extensa las oportunidades que las herramientas que nos proporciona la universidad, nos ofrece.

- Propiciar búsquedas de información que tradicionalmente no pueden hacerse en el aula por falta de tiempo o de medios, de forma que desde su domicilio, en un lugar de trabajo compartido con otros compañeros, alcancen mayor profundidad de la que el docente podría exponer en una clase presencial. Esto, abunda en la idea de lograr mayor creatividad en profesores y alumnos.

- En suma, evadir las debilidades típicas del modelo puramente presencial, la monotonía y el uso de un tiempo que se nos escapa entre las manos, dando el volante al propio alumno, que pasa de ser pasajero a conductor en el itinerario de su aprendizaje.

\section{Desarrollo de la experiencia.}

La experiencia se desarrolla en el único grupo de la asignatura Deontología y Profesionalismo perteneciente al doble grado en Informática y Administración de Empresas, durante el primer semestre, código 11550, en adelante DyP. Esta asignatura tiene otros siete grupos en el segundo semestre, dentro del grado de Informática. El número y características principales de los alumnos pueden verse en la tabla 1. 
Con respecto al perfil de los alumnos participantes, hay que añadir a los datos objetivos recogidos en la tabla que tienen un perfil que se diferencia del resto de alumnos que cursan DyP, en el segundo semestre, matriculados en el grado de informática. La diferencia más cuantificable la tenemos en su nota de acceso a la universidad (3,3 puntos mayor para los primeros), además de que cursan la materia en el primer semestre de su tercer curso, en lugar de en el segundo semestre de segundo curso. Sus notas son ostensiblemente más altas que la media (se triplica el porcentaje de sobresalientes, se duplica el de notables y se reduce a cero el número de suspensos y no presentados).

Tabla 1. Características de los participantes.

\begin{tabular}{|lll|}
\hline Asignatura / características de los alumnos & DyP & \\
\hline Número de alumnos reales & 29 & \\
\hline Alumnos que simultanean trabajo con estudios & 1 & $3,5 \%$ \\
\hline Rango de edad (años) & $20-21$ & \\
\hline $\begin{array}{l}\text { Alumnos con conocimientos previos de la materia } \\
\text { Alumnos emancipados (viven solos o con su familia, asumiendo una } \\
\text { parte significativa de los gastos de la vivienda, sin financiación } \\
\text { familiar) }\end{array}$ & 0 & $0 \%$ \\
\hline
\end{tabular}

Fuente: Elaboración propia

La asignatura DyP trata de aproximar los contenidos relativos a la profesión informática (marcos profesionales empleados en la Unión Europea), legislación informática más relevante y el marco deontológico de la profesión informática a los alumnos, contando para ellos con 4,5 créditos ECTS. Los datos más relevantes para caracterizar a la asignatura y sus métodos de evaluación pueden verse en la tabla $n^{\circ} 2$.

Tabla 2. Características de las asignaturas.

\begin{tabular}{ll}
\hline Asignatura / características & DyP \\
\hline Créditos totales de teoría & 3 \\
\hline Créditos totales de práctica & 1,5 \\
\hline Inicio de clases & $5 / s e p t$ \\
\hline Fin de clases & $22 /$ dic \\
\hline Duración de una clase de teoría (en horas) & 2 \\
\hline $\mathbf{N}^{0}$ de clases de teoría a la semana & 1 \\
\hline $\mathbf{N}^{\mathbf{0}}$ de clases de teoría en el semestre & 13 \\
\hline
\end{tabular}




\begin{tabular}{|ll|}
\hline Asignatura / características & DyP \\
\hline $\mathbf{N}^{\circ}$ de tareas que se evalúan & 3 \\
\hline Peso de las tareas en la nota de la asignatura & $30 \%$ \\
\hline $\mathbf{N}^{0}$ de casos de aula con test que se evalúan & 5 \\
\hline Peso de los casos evaluados en la nota de la asignatura & $35 \%$ \\
\hline $\mathbf{N}^{0}$ de casos de aula totales que se realizan & 7 \\
\hline $\mathbf{N}^{0}$ de trabajos de prácticas que se evalúan & 4 \\
\hline Peso de los trabajos de prácticas en la nota de la asignatura & $35 \%$ \\
\hline
\end{tabular}

Anticipábamos que tratamos con la presente experiencia de eliminar la inactividad del alumnado en el aula, idea fundamental en el flip teaching, empleando para ello, entre otros elementos, el método del caso.

En el mismo, presentamos de una serie de elementos factibles y/o verídicos buscando provocar la reflexión del alumnado. Para ello, primero se presenta un problema que luego es analizado y, en algunas situaciones, resuelto.

Basados en hechos reales, preferentemente noticias de actualidad y de impacto relevante en la profesión, además de transmitir hechos o datos importantes nos permite potenciar el pensamiento crítico en el alumnado. Con (MENENDEZ, 2003) incidimos en lo prioritario de que el caso se apoye en la vida profesional actual intentando recrear los condicionantes reales en la práctica profesional

Las fases en que se descompone el desarrollo del mismo son:

1. Compartir (generalmente mediante "recursos" en la plataforma educativa) la narración del caso y elementos de apoyo. Se les indica que contenidos teóricos están relacionados y se les sugiere también búsquedas de material de apoyo. En este momento, se hacen públicos los objetivos de aprendizaje del caso y, con ellos en cuenta, se da a conocer el mecanismo de evaluación y que evidencias permitirán cuantificar ésta. A la selección del caso más adecuado hay que sumar la programación previa, esto es: estudiar en qué momento de la asignatura se realiza (no solo para que los contenidos teóricos hayan podido ser vistos, sino para evitar colapsos de agenda en los alumnos, intentando no coincidir con periodos intensos de entregas por parte de éstos).

2. Antes del trabajo en aula, se les indica a los alumnos la necesidad de una lectura y análisis individualizado de los documentos compartidos.

3. Debate y discusión en aula. El grupo se divide en subgrupos de trabajo (de un tamaño de 4 a 6 miembros). Dado que emplearemos en algunos casos test rápidos de respuesta para 
evaluar el caso, provocamos que se planteen preguntas, de forma que esta aportación de los alumnos y sus informes permitan construir el propio elemento de evaluación. Esto es: se les evaluará en buena medida con sus propias preguntas. Durante este debate se aplican técnicas de gamificación que permiten al profesor animar el mismo y motivar a los presentes. El debate se utiliza para introducir dilemas éticos. Durante el mismo el docente actúa no solo como conductor, sino que va interpretando los roles de facilitador de información, mediador en caso de conflictos, orientador si surgen dudas sobre el aparato teórico, etc., además de controlar la participación en forma y fondo de los alumnos en el mismo.

4. Evaluación. Una vez acabado el trabajo en aula, para determinados casos se abre un pequeño examen en la plataforma educativa. En el resto de ellos, la única evaluación es la procedente de la gamificación (sobre la gamificación cabe indicar en este momento que la descripción de este proceso y los datos asociados de forma completa se han presentado. en una comunicación a INRED 20178, estando la misma pendiente de aprobación)

Recordemos que no buscamos una solución concreta, pues muchas veces esta no es única y de las posibles, los matices éticos de cada una pueden hacerlas más o menos adaptables por los distintos grupos.

Un ejemplo de una instanciación concreta lo podemos ver en la figura siguiente.

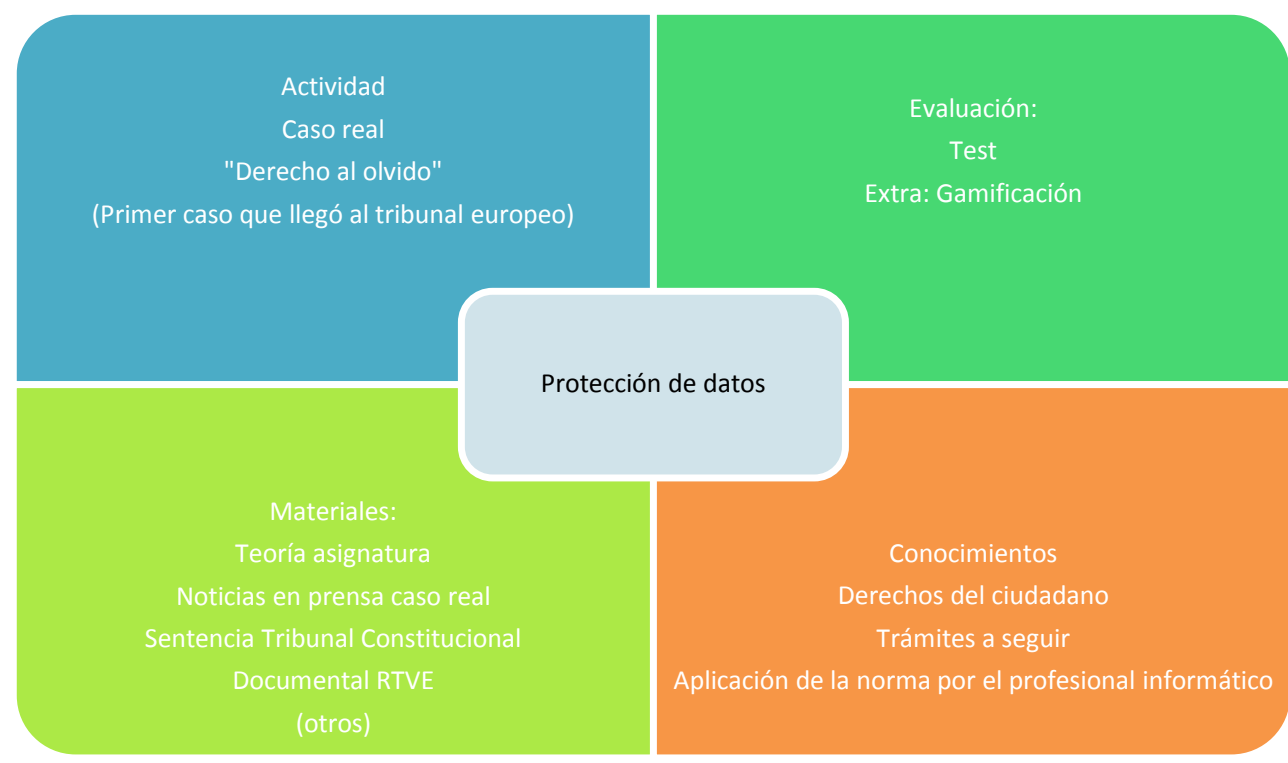

Fig. 1 Caso "Derecho al olvido", resumen gráfico. 


\subsection{Ficha del caso.}

Por cada uno de los casos, el profesor genera una ficha, tanto para apoyo propio como para posibilitar la reutilización del caso por otros docentes, basado en el trabajo de (REYNOLDS, 1992).

En ella, se identifica el caso por su título y temas de teoría relacionados, indicando los objetivos didácticos perseguidos y un cálculo del tiempo de trabajo que tanto dentro como fuera del aula va a conllevar a los alumnos.

Indicamos los aspectos esenciales, como la bibliografía recomendada y el trabajo recomendado con plazos dados a los alumnos, tanto dentro como fuera del aula.

A modo de guía para el docente se indican unas guías de actuación para el debate (elementos que aparecen con frecuencia, por ejemplo), así como distintas soluciones y sugerencias aportadas por los alumnos en situaciones precedentes, si las hay (recuérdese que se trata de emplear casos de rabiosa actualidad)

Puede verse en la fig.2 un ejemplo de la ficha de apoyo para el docente

Ficha del caso "Muerto pixelado"

Temas de teoría relacionados: Tema 5 DyP, "Protección de Datos"

Objetivos didácticos perseguidos: Diferenciación entre protección de datos y derecho al honor. Definición de responsabilidad profesional del encargado del tratamiento de datos.

Cálculo del tiempo de trabajo: 30 minutos en aula. 30 minutos en casa.

Bibliografía recomendada: apuntes de la asignatura. Reglamento Europeo de Protección de Datos.

Plazos: La tarea se entrega a la semana de su apertura.

Guía de actuación para el profesor: refrescar los conceptos de dato personaly derivados. Cambios legales en la protección de datos de fallecidos. Es importante observar que con el marco legal anterior la situación variaba diametralmente a este respecto.

Fig. 2 Ficha de un caso. Elaboración propia.

\section{Resultados.}

Al buscar elementos cuantificables nos encontramos con dos posibilidades: medir la actividad en sí (mediante el acceso a los recursos y la participación en aula) y los resultados de la evaluación de la misma: las notas.

En la tabla siguiente podemos ver la relación completa de casos. Vemos la participación premiada en el proceso de gamificación, la nota máxima que se podía obtener en el examen planteado y dos valores: el de los alumnos suspendidos y el de los alumnos con una nota que supera el $80 \%$ del valor que podría obtenerse. El acceso medio a los recursos por 
alumno ha sido de unas 109 interacciones, lo que se corresponde muy bien con el acceso a los recursos disponibles, de forma unitaria.

Tabla 3. Calificaciones obtenidas por los alumnos en el método del caso.

\begin{tabular}{rlrrrr}
\hline Caso (no) & $\begin{array}{l}\text { Peso } \\
\text { (puntos) }\end{array}$ & $\begin{array}{l}\text { Gamificación } \\
\text { (participación) }\end{array}$ & Nota media & Suspendidos & $\begin{array}{c}\text { Nota } \\
>80 \%\end{array}$ \\
\hline $\mathbf{1}$ & 0 & $24 \%$ & & & \\
$\mathbf{2}$ & 0,5 & $21 \%$ & 0,38 & $0 \%$ & $66 \%$ \\
$\mathbf{3}$ & 1 & $45 \%$ & 0,65 & $17 \%$ & $31 \%$ \\
$\mathbf{4}$ & 0 & $24 \%$ & & & \\
$\mathbf{5}$ & 0,5 & $24 \%$ & 0,33 & $21 \%$ & $41 \%$ \\
$\mathbf{6}$ & 1 & $45 \%$ & 0,68 & $3 \%$ & $41 \%$ \\
$\mathbf{7}$ & 0,5 & $24 \%$ & 0,22 & $41 \%$ & $17 \%$ \\
\hline
\end{tabular}

Esta tabla denota un gran seguimiento y un éxito en líneas generales en la evaluación, con algún "pinchazo" como el producido durante el último caso (realizado ya muy próximos los exámenes y con los alumnos pensando más en estos que en otras actividades). Podemos comprobar esto con la tabla siguiente, que nos muestra las finales de la asignatura (donde, recordemos, los casos implican un 35\% de la nota total)

Tabla 4. Notas finales.

\begin{tabular}{lcc}
\hline & DyP & DyP (\%) \\
\hline MH & 1 & $3,44 \%$ \\
NB & 9 & $31,03 \%$ \\
AP & 17 & $58,62 \%$ \\
SP & 2 & $6,89 \%$ \\
No presentados & 0 & $0 \%$ \\
PRES & 0 & $0 \%$ \\
NO PRES & 29 & \\
NOTA MEDIA & 0 & $(10-5)$ \\
\hline
\end{tabular}

\section{Conclusiones}

Aplicando esta técnica grupal fomentamos la participación del alumno, desarrolla el espíritu crítico y nos ayuda a prepararle para la toma de decisiones el contraste de 
opiniones con los demás componentes del grupo. Además nos permite tomar el pulso a la clase, y comprobar de primera mano que conceptos necesitan un refuerzo y cuales se encuentran asumidos. Por otra parte, al provocar la confrontación de puntos de vista opuestos abre unas posibilidades estupendas para la evaluación de competencias como la ética o el pensamiento crítico.

Al permitir contrastar la realidad con la teoría, facilitamos que el alumnado centre su atención, pues los contenidos de la asignatura dejan de ser algo difuso para convertirse en algo que está pasando, que es noticia de telediario.

Los resultados obtenidos en las calificaciones y los datos de participación nos muestran una mayor implicación y éxito en las pruebas que alumnos de grupos con metodologías docentes convencionales. Las notas globales de la asignatura, significativamente más altas, parecen apuntar (algo que habría que precisar en posteriores estudios considerando grupos con estructura análoga de alumnos por origen y temporización docente) a un efecto claramente positivo de las estrategias empleadas.

También para posteriores experiencias se plantea la preparación de un pequeño cuestionario de satisfacción.

Por último, el dato elevado de resultados obtenidos en la gamificación, recordemos que como actividad voluntaria, subraya siquiera sea desde criterios subjetivos la idea de que la actividad despierta el interés en el alumnado.

\section{Referencias}

AKEMI IKEDA, A.; MODESTO VELUDO-DE-OLIVEIRA, T. CORTEZ CAMPOMAR, M. (2005). “O caso como estratégia de ensino na áreade Administração”. En Revista de Administraçao -RAUSP, Universidade de São Paulo. São Paulo, Brasilvol. 41, núm. 2, abril-junio, 2006, pp. 147-157. http://www.redalyc.org/articulo.oa?id=223417482003 [Consulta: 18 de marzo de 2018]

ANDREU, Mª́ Á; GONZÁLEZ, J.A.; LABRADOR, Mª J.; QUINTANILLA, I.; RUIZ, T. (2004). “Método del caso. Ficha descriptiva y de necesidades" UPV. http://www.upv.es/nume/descargas/fichamdc.pdf [Consulta: 18 de marzo de 2018]

CANALES VARGAS, G. (2014). "Medio ambiente, ciencia y valores". En XI Jornadas Internacionales de Innovación Universitaria, Villaviciosa de Odón, 7-8 de Julio, 2014.<http://hdl.handle.net/11268/3767>[Consulta: 18 de marzo de 2018]

CASTELLÓ-SIRVENT, F.; CRISTINA SANTOS ROJO, C. (2017);” Aplicación del método del caso en el EEES: el ere de Coca-Cola” En Revista Jurídica de Investigación e Innovación Educativa. № 16, junio 2017. Universidad de Málaga. Málaga. 35-55 $<$ https://ideas.repec.org/a/erv/rejiee/y2017i1605.html>[Consulta: 18 de marzo de 2018]

MENENDEZ, J.M., GUIRAO, B., RIVAS, A. Y NIÑO, A. (2003). “La enseñanza de la Planificación del Transporte mediante el análisis de casos”. Actas del I Encuentro Internacional de Enseñanza de la Ingeniería Civil, 18-20 de septiembre, Ciudad Real. (CITADO)

OLTRA GUTIÉRREZ, J.V. (2015). "Diseño de una experiencia de Flip-Teaching para la asignatura Deontología y Profesionalismo a impartir en la Escuela Técnica Superior de Ingeniería Informática de la UPV" En INRED 2015. Valencia, UPV.

$<$ http://ocs.editorial.upv.es/index.php/INRED/INRED2015/paper/viewFile/1646/484>[Consulta: 18 de marzo de 2018] 
REYNOLDS, J.I. (1992). "El método del caso y la formación en gestión. Guía práctica". Valencia: Instituto de la Pequeña y Mediana Industria Valenciana.

SEIN-ECHALUCE LACLETA, M. L.; FIDALGO BLANCO, A.; GARCÍA PEÑALVO, F. (2015) “Metodología de enseñanza inversa apoyada en b-learning y gestión del conocimiento" En III Congreso Internacional sobre Aprendizaje, Innovación y Competitividad (CINAIC 2015). Zaragoza. Universidad de Zaragoza. 464-468

SEIN-ECHALUCE. M.L. FIDALGO-BLANCO, A. GARCÍA-PEÑALVO, F.J. (2017)“Trabajo en equipo y FlipTeaching para mejorar el aprendizaje activo del alumnado” En IV Congreso Internacional sobre Aprendizaje, Innovación y Competitividad (CINAIC 2017). Zaragoza. Universidad de Zaragoza. 610615.

VIDAL MELÓ, A.; ESTRUCH FUSTER, V.D.; BOIGUES PLANES, F. J. (2017). “Flipped Teaching aplicado al estudio de los métodos elementales de integración aproximada. Una experiencia educativa” En ROIG-VILA, R. (coord.). Redes colaborativas en torno a la docencia universitaria. Alicante: Universidad de Alicante, Instituto de Ciencias de la Educación (ICE), 2017. ISBN 978-84-617-8973-3, 571 p. $<$ http://hdl.handle.net/10045/70977>[Consulta: 18 de marzo de 2018]

VIDAL MELÓ, A.; ESTRUCH FUSTER, V.D.; BOIGUES PLANES, F.J. DEL REY TORMOS, R.; ALBA, J.; ROIG SALA, B.; TORREGROSA, C. (2016). "Flipped Teaching: una metodología en construcción..." En INRED 2016. Valencia, UPV.

$<$ https://www.researchgate.net/publication/305026754_Flipped_Teaching_una_metodologia_en_constr uccion>[Consulta: 18 de marzo de 2018]

(c) EY-Nc-ND 2018, Universitat Politècnica de València 


\title{
Metodologías de Aprendizaje Cooperativo y Proyectos online con un enfoque sistemático, en la asignatura "Profesionalización y Gestión” de $4^{\circ}$ curso del Grado de Creación y Diseño.
}

Da Ana María Sainz Gil

apProfesora Titular de la Facultad de BB.AA. de la UPV/EHU; (anamaria.sainz@ehu.eus)

\begin{abstract}
The Student Guide delivered to students of the subject "Professionalization and Management" of 4th year of the Degree of Creation and Design has been reformulated in the "Workshop DOITU 2017 within the Training Plan for teacher improvement organized by the UPV / EHU. It has managed to align the planning and development of the teaching-learning process of this subject with the criteria that define the teaching model-IKD (Ikaskuntza Kooperatibo eta Dinamikoa) of the UPV / EHU, through active teaching methodologies and educational multimedia materials, as well as with reality 2.0. for the creation of companies focused on the client / user. The subject is worked with the methodology of Cooperative Learning, with the Bill Aulet methodology (2015) focused on the client / user to create or boost companies in the field of design and online resources that prepare students for a current job market, within a digital society.
\end{abstract}

The result has been a Student's Guide that has obtained the highest score in the Dimension 1 rubric of DOCENTIAZ 2017. DOCENTIAZ is the program of evaluation of the teaching activity of the UPV / EHU teaching staff that complies with the requirements established by the DOCENTIA program of the ANECA Quality Agency.

\section{Keywords:}

Student's Guide, Docentiaz, Professionalization and Management, Degree of Creation and design, online companies, Cooperative Learning, Bill Aulet, community manager.

\section{Resumen}

La Guía del Alumnado que se entrega a los estudiantes de la asignatura "Profesionalización y Gestión" de $4^{\circ}$ curso del Grado de Creación y Diseño ha sido reformulada en el "Taller DOITU 2017 dentro del Plan de formación para la mejora docente organizado por la UPV/EHU. Se ha conseguido alinear la planificación y desarrollo del proceso de enseñanza-aprendizaje de ésta asignatura con los criterios que definen el modelo de enseñanza-IKD 
Metodologías de Aprendizaje Cooperativo y Proyectos online basados en el enfoque sistemático de Bill Aullet (2015) en la asignatura "Profesionalización y Gestión" de $4^{\circ}$ curso del Grado de Creación y Diseño.

(Ikaskuntza Kooperatibo eta Dinamikoa) de la UPV/EHU, a través de metodologías docentes activas y materiales multimedia educativos, así como con la realidad 2.0. para la creación de empresas centradas en el cliente/usuario. La materia se trabaja con la metodología de Aprendizaje Cooperativo, con la metodología de Bill Aulet (2015) centrada en el cliente/usuario para crear o dinamizar empresas en el ámbito del diseño y con recursos online que preparan al alumnado para un mercado laboral actual dentro de una sociedad digital.

El resultado ha sido una Guía del Alumnado que ha obtenido la máxima puntuación en la rúbrica de la Dimensión 1 de DOCENTIAZ 2017. DOCENTIAZ es el programa de evaluación de la actividad docente del profesorado de la UPV/EHU que cumple con los requisitos establecidos por el programa DOCENTIA de la Agencia de Calidad ANECA.

Palabras clave: Guía del Alumnado, Docentiaz, Profesionalización y Gestión, Grado de Creación y diseño, empresas online, Aprendizaje Cooperativo, Bill Aulet, community manager.

\section{Introducción}

\subsection{Competencias docentes básicas en la UPV/EHU: Modelo IKD-Aprendizaje Cooperativo y Dinámico}

La Guía del Alumnado que entrega el profesorado al comenzar la asignatura, contiene de forma explícita la planificación y el desarrollo del proceso enseñanza-aprendizaje, ésta planificación ha de servir de brújula en la ruta de la asignatura, e instrumento de mejora contínua en el proceso. La Guía del Alumnado ha de estar en línea con el título y con el modelo IKD-Aprendizaje Cooperativo y Dinámico, que es el modelo educativo de la UPV/EHU y que pretende formar a los estudiantes con nuevas maneras de enseñar y aprender, más ágiles y cooperativas, ver más en https://www.ehu.eus/es/web/sae-helaz/ikd.

Las acciones entre otras que apoyan la construcción de IKD-Aprendizaje Cooperativo y Dinámico, y que permiten al profesorado trazar un camino para su desarrollo profesional, son el programa de formación en metodologías activas de enseñanza Eragin (Aprendizaje Cooperativo, Aprendizaje basado en Problemas, Aprendizaje basado en Proyectos y Método de Caso), y las herramientas de evaluación docente formativa DOCENTIAZ, que veremos más adelante y que evalúan la docencia del profesorado con criterios alineados con IKD en tres Dimensiones, con sus Rúbricas formativas correspondientes.

La Guía del Alumnado de “Profesionalización y Gestión”, asignatura de $4^{\circ}$ curso del Grado de Creación y Diseño, quiere reformularse para dar respuesta adecuada a las Competencias docentes básicas del modelo IKD-Aprendizaje Cooperativo y Dinámico, como son, optimizar el proceso de aprendizaje mostrando un alto grado de coherencia interna en su desarrollo, y situar al alumnado como centro de éste proceso; también IKD quiere enfocar

(cc) EY-NC-ND 2018, Universitat Politècnica de València

Congreso IN-RED (2018) 
el aprendizaje en conexión con las necesidades sociales y laborales de la actualidad, para favorecer el progreso profesional y socio-personal.

\subsection{Competencias específicas de la asignatura en línea con IKD-Aprendizaje Cooperativo y Dinámico}

La asignatura de $4^{\circ}$ curso "Profesionalización y Gestión” prepara al alumnado para que sea un agente activo de su propio aprendizaje, y lo hace a través de la metodología activa del Aprendizaje Cooperativo porque es una metodología que subraya el aprendizaje autónomo, pone énfasis en las competencias sociales, y se adquieren habilidades para un trabajo futuro; con el Aprendizaje Cooperativo se alcanzan competencias sobre todo referidas a la organización y a la interacción de los protagonistas de los trabajos, en proyectos comunes (Prieto, 2005). El aprendizaje cooperativo confiere una práctica de mucha autonomía en el aprendizaje, pero hay que prepararla con todo detalle para que se logren los objetivos más valiosos (Pujolas, 2008). Evaluar el aprendizaje (cantidad y calidad) y la interacción grupal (resolución de conflictos), requiere de esfuerzo redoblado por la diversidad del feedback que hay que evaluar (evaluación y autoevaluación grupal) (Johnson y Johnson, 2014).

La metodología de Aprendizaje Cooperativo se trabaja en la asignatura con dos de sus técnicas, la del Group Investigation - Grupo de Investigación (Sharan y Sharan, 1976), y la del Jigsaw, Puzzle o Rompecabezas (Aronson y otros, 1975, y Slavin 1980), técnicas que se han estudiado para éste trabajo a través de Prieto (2005) y que sus creadores han desarrollado en publicaciones recientes (Sharan y Sharan, 2004; Aronson y Shelley, 2011; Slavin, 2002).

El alumnado ha de estar en un contraste continuo con la realidad social y profesional, por lo que en "Profesionalización y Gestión" se trabajará el proceso de planificación de una empresa de diseño, con un enfoque cómo el propuesto por Bill Aulet (2015) profesor del MIT (Instituto Tecnológico de Massachusetts en EE.UU.), porque es un enfoque sistemático que se centra en el emprendimiento y está basado en el cliente, lo que necesariamente coloca al alumnado en un contraste continuo con la realidad social y profesional, para diseñar empresas nuevas o dinamizar las ya existentes.

Las nuevas tecnologías están transformando a gran velocidad la realidad social y profesional, están presentes en el proceso de enseñanza-aprendizaje con materiales multimedia educativos: Cursos mooc (Miriadax, ...), plataformas de apoyo a la docencia reglada (eGela, ...), vídeos didácticos, grabaciones polimedia, asignaturas publicadas en OCW, etc., y también están presentes en el diseño de nuevos productos con el enfoque 2.0. de las empresas en una sociedad digital. La empresa web se combina con branding en canales como FaceBook, Instagram, Twitter, YouTube, etc., y se ve la necesidad de hacerse cargo del marketing de las redes sociales, contando con una gestión de contenido a través de un community manager (Mejía, 2013).

Es necesario identificar con el alumno la necesidad de prepararse para la inercia, aún vigente en las empresas, de trabajar sin un plan elaborado o política bien definida acerca del uso de estos recursos (Rojas y Redondo, 2013). Hay que trabajar con una mentalidad nueva (Stalman, 2014). 
Metodologías de Aprendizaje Cooperativo y Proyectos online basados en el enfoque sistemático de Bill Aullet (2015) en la asignatura "Profesionalización y Gestión" de $4^{\circ}$ curso del Grado de Creación y Diseño.

La mayoría de las convocatorias de emprendimiento actuales se hacen eco de la sociedad digital que tenemos delante, y apoyan diseños de empresas con recursos 2.0., y con estructuras de branding definidas por un community manager, desde nuestra asignatura las empresas que se diseñan, no pierden de vista todos estos elementos con el objeto de favorecer el progreso profesional de los alumnos.

\subsection{Plan de formación en IKD para el profesorado}

Para apoyar la construcción de IKD-Aprendizaje Cooperativo y Dinámico y sus Competencias docentes básicas, se cuenta en la UPV/EHU con la evaluación docente formativa del profesorado, que desarrolla el Servicio de Evaluación Docente (SED/IEZ), y dispone entre otras, de dos actividades principales, que son el Programa Docentiaz

(ver https://www.ehu.eus/documents/1882427/8924136/ManualV8_cast/aafaa3bc-962b7630-eb04-acf4303b3871) y la Encuesta de Opinión al Alumnado sobre la docencia de su profesorado, tanto de grado cómo de postgrado (ver https://www.ehu.eus/es/web/sediez/erabilitako-tresna-graduko-galdetegia).

Con estas actividades evaluadoras, se pretende asesorar al profesorado en los criterios de calidad que apoyan la construcción del modelo IKD.

El instrumento de evaluación docente formativa Docentiaz, evalúa diferentes Dimensiones para alcanzar las Competencias de calidad IKD, y cuenta con una Dimensión específica para la Planificación y Desarrollo del proceso de enseñanza-aprendizaje en la Guía del Alumnado, que es la Dimensión 1, con un peso del $50 \%$ en la evaluación docente formativa; por otra parte está La Dimensión 2, con un peso del 20\% en la evaluación Docentiaz, y que valora los resultados a través de las Tasas de éxito y la Encuesta de opinión del alumnado, y la Dimensión 3, con un peso del 30\% en la evaluación docente formativa, que valora el desarrollo profesional docente (Liderazgo docente, Innovación docente en educación Superior, etc.).

El objeto de la Dimensión 1, en la evaluación docente pedagógica Docentiaz es: "Valorar la calidad de la planificación docente y si el desarrollo del proceso de enseñanza-aprendizaje está en consonancia con las directrices establecidas en el título y con el modelo IKD” como reza en la Rúbrica Docentiaz 2017 (ver infra Tabla 4). Hay Indicadores dentro de la Rúbrica Docentiaz, como los siguientes referidos a la Encuesta de Opinión del Alumnado:

Indicadores 17-18 para la subdimensión 1.1.Planificación docente de la materia, e Indicadores 29-30-31-32 para la subdimensión 1.2. Desarrollo del proceso de EnseñanzaAprendizaje.

La mejora de todas las dimensiones de DOCENTIAZ tiene un Plan de formación organizado por el SED/IEZ que se puede ver en https://www.ehu.eus/es/web/sediez/irakaskuntza-hobetzeko-prestakuntza-plana.

Es dentro de éste Plan de formación donde está el Taller DOITU, de 50 horas de duración, que es el que hemos cursado y que está destinado a la mejora de la Planificación docente de la asignatura, Dimensión 1 de Docentiaz, es un Taller que se evalúa al final con la Rúbrica propia de Docentiaz para la Dimensión 1.

(cc) EY-NC-ND 2018, Universitat Politècnica de València

Congreso IN-RED (2018) 
En ésta “Rúbrica para evaluar la Guía del Alumnado en DOITU”, que podemos ver más adelante en (infra ídem), los Indicadores relacionados con la Encuesta de Opinión al Alumnado, no se tienen en cuenta para evaluar DOITU, ya que se revisan con posterioridad a la puesta en marcha de la Planificación Docente trabajada en éste Taller, y sirven de punto de partida para la siguiente mejora de la Guía del Alumnado a través del taller DOITU.

\section{Objetivos}

Partiendo de la Guía Docente de la asignatura “Profesionalización y Gestión”, de $4^{\circ}$ curso del Grado de Creación y Diseño, que se obtiene en:

https://www.ehu.eus/es/grado-creacion-y-diseno/creditos-yasignaturas?p_redirect $=$ consultaAsignatura \&p_cod_proceso $=$ egr \&p_anyo_acad $=20170 \&$ p_ciclo $=X \& p \_$curso $=4 \& p \_$cod_asignatura $=26943$

Se quiere reformular la Guía del Alumnado, para orientarla hacia los criterios que definen el modelo de enseñanza-aprendizaje IKD -Aprendizaje Cooperativo y Dinámico de la UPV/EHU (ver supra 1.1.), para ello nos servimos del Taller DOITU, incluido dentro del Plan de formación para la mejora docente, organizado por el SED/IEZ.

La Planificación docente reformulada en la Guía del Alumnado, es evaluada en DOITU desde la Rúbrica de la Dimensión 1 de Docentiaz (ver parte de ésta Rúbrica DOITU en infra Resultados (Tabla 4), y completa en Drive $<$ https://drive.google.com/drive/folders/1ZLk7PX1GUBHK8iyHtHk3WHp5_UV_B 8A?usp=sharing $>$ ).

Además de ofrecer los resultados de ésta evaluación de la Guía del Alumnado en DOITU, se pretenden mostrar los Resultados de Aprendizaje que vayan apareciendo en el grupo 02 del presente curso 2017-2018, consecuencia de la puesta en práctica de la planificación docente, y el desarrollo del proceso de enseñanza-aprendizaje trabajados en el Taller DOITU.

\subsection{Puntos de partida en DOITU}

En el “Taller DOITU 2017: ¿Qué puedo hacer en mi planificación docente?,” se trabaja con un punto de partida para reestructurar la planificación de la asignatura, y no es otro que el análisis de los resultados de aprendizaje, y de la opinión del alumnado sobre la docencia recibida en el curso anterior 2016-2017, que en nuestro caso coincide también con el inicio de impartición de ésta asignatura.

En Doitu 2017, los Indicadores relativos a la Encuesta de satisfacción del alumnado de Grado, para identificar la propuesta de mejora, son los que aparecen en la Tabla1:

Los 2 únicos items (1 y 2) de la Dimensión Planificación de la docencia, y el único ítem (25) de la Dimensión Satisfacción general. Los otros Indicadores tenidos en cuenta, son el resto de Dimensiones que componen la Encuesta de la evaluación del alumnado, y aquí, los ítems son elegidos en función del criterio de mejora que quiere realizar el profesor, en nuestro caso, se trata de mejorar el "Item más bajo en la dimensión”.

(cc) EY-NC-ND 2018, Universitat Politècnica de València

Congreso In-Red (2018) 
Metodologías de Aprendizaje Cooperativo y Proyectos online basados en el enfoque sistemático de Bill Aullet (2015) en la asignatura "Profesionalización y Gestión" de $4^{\circ}$ curso del Grado de Creación y Diseño.

Así pues, la puntuación obtenida en la Encuesta de opinión del alumnado en el curso 20162017, es el punto de partida para identificar las áreas de mejora en las que se va a trabajar.

Tabla 1.Indicadores a mejorar con el Taller DOITU

\begin{tabular}{|c|c|c|c|}
\hline Indicador & Valor & Criterio & $\begin{array}{l}\text { Aspecto a mejorar } \\
\text { (ítem general o } \\
\text { aspectos del mismo) }\end{array}$ \\
\hline $\begin{array}{l}\text { (item1) "La programación está } \\
\text { enfocada hacia el desarrollo de } \\
\text { competencias para nuestra profesión }\end{array}$ & 4,1 & \multirow{7}{*}{$\begin{array}{l}\text { Quiero mejorar } \\
\text { unos } \\
\text { indicadores. } \\
\text { Ítem más bajo } \\
\text { en la dimensión }\end{array}$} & $\begin{array}{l}\text { Dimensión } \\
\begin{array}{l}\text { Planificación de la } \\
\text { docencia }\end{array}\end{array}$ \\
\hline $\begin{array}{l}\text { (ítem 2) “El programa de la } \\
\text { asignatura contiene la información } \\
\text { necesaria para seguimiento de la } \\
\text { misma" }\end{array}$ & 3,7 & & $\begin{array}{l}\text { Dimensión } \\
\begin{array}{l}\text { Planificación de la } \\
\text { docencia }\end{array}\end{array}$ \\
\hline Dimensión “Metodología Docente” & 3,8 & & $\begin{array}{l}\text { (ítem 4) ”Los recursos } \\
\text { utilizados por el } \\
\text { profesor o profesora } \\
(\ldots) \text { ".. }\end{array}$ \\
\hline $\begin{array}{llll}\begin{array}{l}\text { Dimensión } \\
\text { docencia" }\end{array} & \text { "Desarrollo de } & \text { la } \\
\end{array}$ & 3,8 & & $\begin{array}{l}\text { (ítem9) "Establece } \\
\text { conexiones entre ésta } \\
\text { asignatura y otras } \\
\text { asignaturas afines" }\end{array}$ \\
\hline $\begin{array}{l}\text { Dimensión "Interacción con el } \\
\text { alumnado" }\end{array}$ & 3,8 & & $\begin{array}{lr}\text { (ítem 16)”Muestra } \\
\text { disponibilidad ante las } \\
\text { demandas } & \text { del } \\
\text { alumnado (en clase } \\
\text {...)" }\end{array}$ \\
\hline $\begin{array}{l}\text { Dimensión "Evaluación de } \\
\text { aprendizajes" }\end{array}$ & 3,5 & & $\begin{array}{l}\text { (ítem23) ”El sistema } \\
\text { de evaluación me } \\
\text { permite conocer si } \\
\text { voy alcanzando ..." }\end{array}$ \\
\hline $\begin{array}{l}\text { (ítem 25) "En general, pienso que es } \\
\text { un buen profesor o profesora" }\end{array}$ & 3,7 & & $\begin{array}{l}\text { Dimensión } \\
\text { Satisfacción general }\end{array}$ \\
\hline
\end{tabular}

El curso 2016-2017 que sirve de referencia en DOITU para elaborar la Guía del Alumnado, fue trabajado con grupos de alumnos y alumnas para diseñar distintas empresas con la metodología de Bill Aulet (2015), el resultado fue de 4 empresas web (ver en DRIVE https://drive.google.com/drive/folders/1ZL-

k7PX1GUBHK8iyHtHk3WHp5_UV_B8A?usp=sharing): Pintamonas (ilustradoras de cómic y manga). Tantum (anillos de porcelana). B-one (bolsas para universitarios/as de la facultad de ciencias) y PAP (promoción audio-visual proyectada)).

La evidencia de estas cuatro empresas web del curso 2016-2017 sirve también para comenzar a trabajar con la Guía del Alumnado en DOITU, y por supuesto el punto de partida de la Guía Docente, que es común para todos los grupos de la asignatura “Profesionalización y Gestión” de $4^{\circ}$ curso del Grado de Creación y Diseño. 


\section{Desarrollo de la innovación}

Se ha trabajado la GUIA DEL ESTUDIANTE /GUIA DEL ALUMNADO como se puede ver en DRIVE (https://drive.google.com/drive/folders/1ZLk7PX1GUBHK8iyHtHk3WHp5_UV_B8A?usp=sharing) reformulándola en base a los criterios explicitados en la Rúbrica de DOITU (ver infra Resultados: Tabla 4).

La Guía para el Alumnado elaborada tiene una doble aplicación, es el soporte principal de la presentación de la asignatura, y también es la hoja de ruta para la profesora y alumnado durante todo el curso. Es una guía donde se explicitan todo el abanico de competencias que se pretenden impulsar con la materia, y que se encuentran en el plan de estudios. Los Resultados de Aprendizaje concretos serán las evidencias del nivel adquirido en las competencias (ver infra Tabla 3).

Se han reorganizado los Contenidos de la asignatura por medio de un enfoque sistemático a través de los Pasos de Bill Aulet (2015, 2018), con propuestas de empresas en conexión directa con el cliente/usuario, con el objeto de dar una respuesta a las necesidades sociales más actuales, y prestando atención a los formatos más demandados, los on-line dentro de ésta sociedad digital. Los Pasos más importantes que se trabajan en la asignatura son los relativos a los apartados QUIÉN ES TU CLIENTE (Segmentación de mercado, Selecciona un mercado inicial, Traza el perfil del usuario final, Describe al personaje del mercado inicial) , ¿QUÉ PUEDES HACER POR TU CLIENTE? (Caso de uso de la vida útil del producto, Especificación de alto nivel del producto, Propuesta de valor cuantificada, Posición competitiva), ¿CÓMO ADQUIERE TU CLIENTE EL PRODUCTO? (UTD (Unidad Toma de Decisiones), ¿CÓMO OBTIENES DINERO CON TU PRODUCTO? (CAC (Coste de adquisición de un cliente)).

El modelo IKD encauza un modelo de enseñanza basado en la autonomía del alumnado en su aprendizaje y en el trabajo colaborativo, inmerso en contextos sociales y profesionales actuales; para conseguir éste objetivo, hemos trabajado la Guía desde la metodología de Aprendizaje Cooperatvo, con dos técnicas, la del Grupo de Investigación para diseñar la empresa que vertebra todo el curso, y la técnica del Puzzle o Rompecabezas en una tarea del curso, para comprobar cómo los diseños enfocados al cliente, tanto de empresa, concepto, objeto etc., tienen fundamentos similares. Las fases de las dos técnicas de AC son conocidas y aquí presentamos parte del Cronograma de la asignatura para apreciar cómo se empiezan a distribuir las fases del G.I.: Grupo de Investigación (ver todas las fases de las dos técnicas de AC y Cronograma completo en DRIVE, ídem)

Tabla 2. Cronograma de la asignatura en la Guía del Alumnado

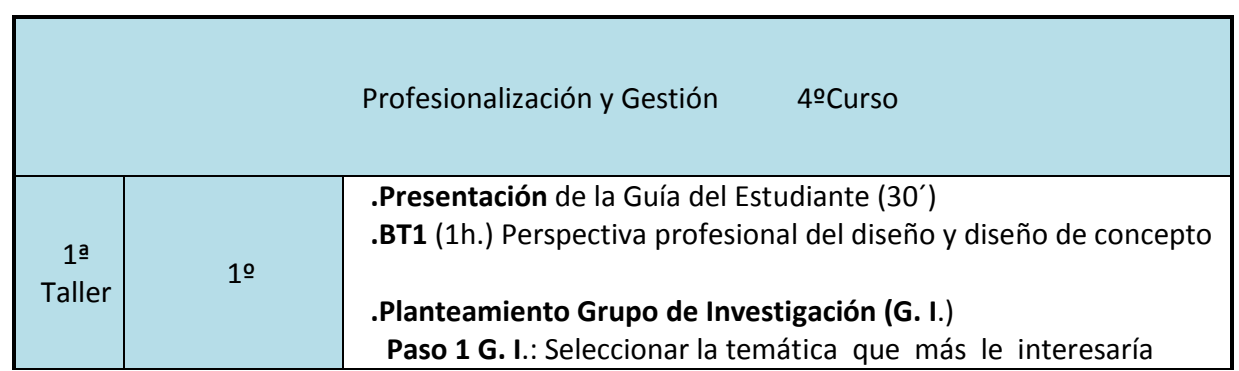

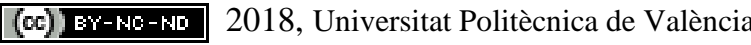

Congreso In-Red (2018) 
Metodologías de Aprendizaje Cooperativo y Proyectos online basados en el enfoque sistemático de Bill Aullet (2015) en la asignatura "Profesionalización y Gestión" de $4^{\circ}$ curso del Grado de Creación y Diseño.

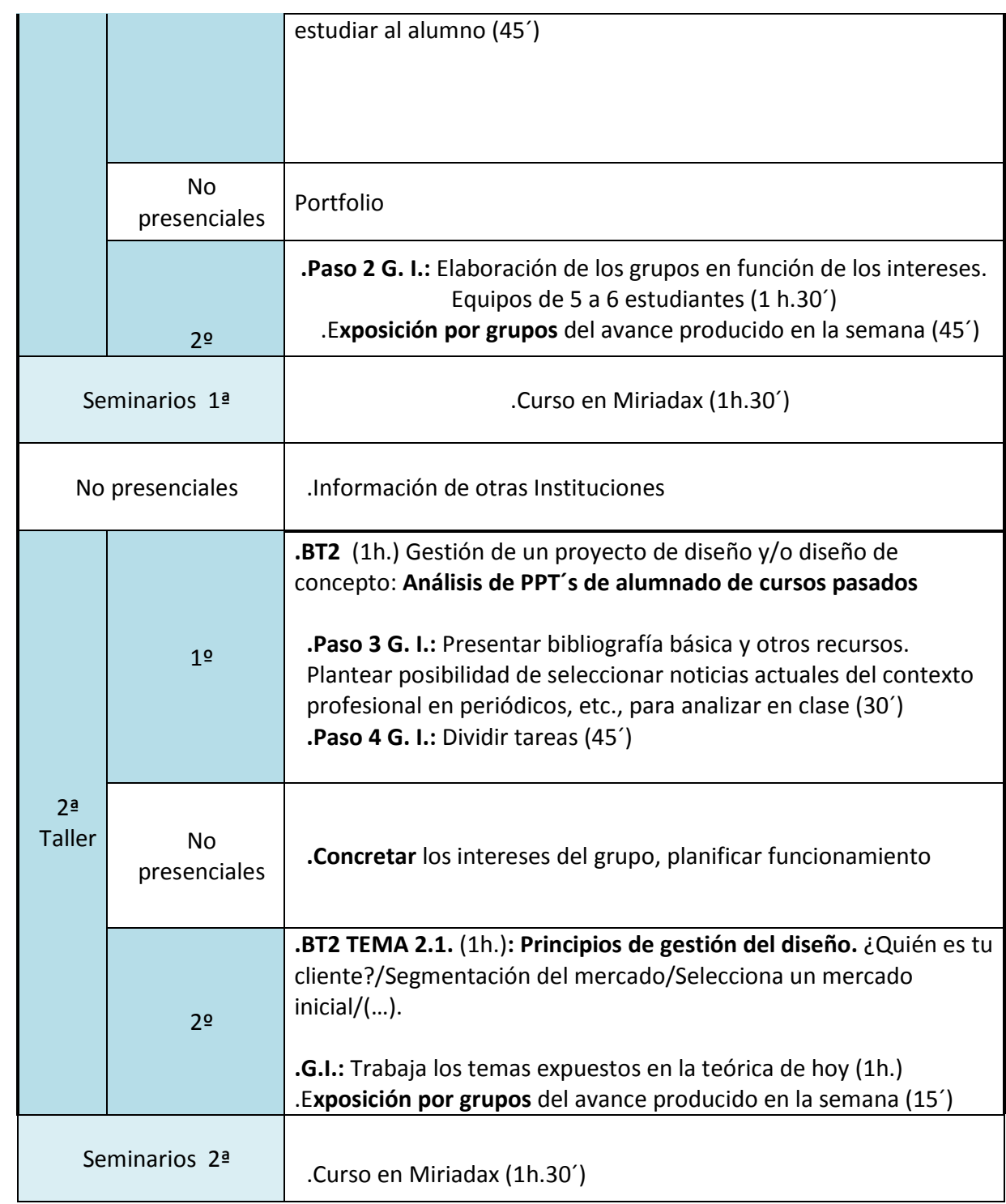

(Ver completo en DRIVE: Guía del Alumnado https://drive.google.com/drive/folders/1ZLk7PX1GUBHK8iyHtHk3WHp5_UV_B8A?usp=sharing)

La evaluación tiene un carácter formativo y continuo, cada una de éstas técnicas de A C se evalúan por separado, en cada una de ellas se evalúa el aprendizaje individual y grupal, la coevaluación y la autoevaluación. El completo sistema de evaluación de la asignatura se puede ver en (DRIVE, ibídem) y parte de la Rúbrica de aprendizaje grupal del G. I. la podemos ver en la Tabla 3, donde aparecen los Resultados de Aprendizaje de la asignatura (ver Rúbrica de aprendizaje grupal completa en DRIVE, ídem). 
Tabla 3. Rúbrica aprendizaje grupal del G.I. en la Guía del Alumnado

\begin{tabular}{|c|c|c|c|c|c|}
\hline \multirow[b]{3}{*}{ 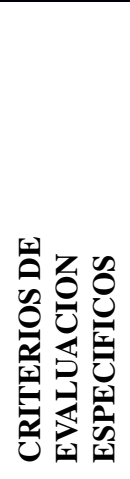 } & \multicolumn{5}{|c|}{ GRADACIÓN } \\
\hline & $\begin{array}{l}\text { Matrícula } \\
\text { de Honor } \\
\text { (10) }\end{array}$ & $\begin{array}{l}\text { Sobresaliente } \\
\text { (9) }\end{array}$ & $\begin{array}{l}\text { Notable } \\
\text { (8-7) }\end{array}$ & $\begin{array}{l}\text { Aprobado } \\
\text { (6-5) }\end{array}$ & $\begin{array}{l}\text { Suspenso } \\
\quad(0-4)\end{array}$ \\
\hline & $\begin{array}{l}\text { Completa } \\
\text { realización: } \\
\text { Participa muy } \\
\text { activamente } \\
\text { en... }\end{array}$ & $\begin{array}{c}\text { Realización } \\
\text { solvente con } \\
\text { incorrecciones } \\
\text { mínimas: } \\
\text { Participación } \\
\text { significativa } \\
\text { en... }\end{array}$ & $\begin{array}{c}\text { Realización } \\
\text { con } \\
\text { incorrecciones } \\
\text { importantes } \\
\text { pero no } \\
\text { esenciales: } \\
\text { Participación } \\
\text { notable en... }\end{array}$ & $\begin{array}{c}\text { Realización de } \\
\text { lo elemental: } \\
\text { Escasa } \\
\text { participación } \\
\text { en... }\end{array}$ & $\begin{array}{c}\text { No realiza lo } \\
\text { elemental y/o } \\
\text { lo realiza con } \\
\text { ausencias } \\
\text { importantes e } \\
\text { incoherencias: } \\
\text { Ninguna o } \\
\text { escasa } \\
\text { partición en... }\end{array}$ \\
\hline RA1 & \multicolumn{5}{|c|}{$\begin{array}{l}\text { Elaboración de las } 8 \text { fases de la realización del proyecto de empresa, elaboración de la } \\
\text { presentación visual (PPT, Impress etc), del dosier escrito y de la presentación oral }\end{array}$} \\
\hline RA2 & \multicolumn{5}{|c|}{ Elaboración de los 6 Pasos de Bill Aulet (2015) } \\
\hline RA3 & \multicolumn{5}{|c|}{$\begin{array}{l}\text { Relación entre las metodologías innovadoras (gestión y creación) centradas en el } \\
\text { cliente/usuario: La teoría Océano Azul (2015), Promotores Netos (2012), Tim Brown } \\
\text { (2009) y Alejandro Aravena (2014) con la metodología de Bill Aulet (2015) }\end{array}$} \\
\hline RA4 & \multicolumn{5}{|c|}{$\begin{array}{c}\text { Estudio de las aplicaciones directas del trabajo llevado a cabo en la asignatura con el } \\
\text { Contexto profesional cercano en el Campo del diseño UPV/EHU: con ZITEK (“Bizkaia } \\
\text { Creativa”/“Think Big”) y con EHU/DENDA y otras instituciones diversas elegidas por el } \\
\text { alumnado (Cuadro 2) }\end{array}$} \\
\hline \multirow[t]{2}{*}{ RA5 } & \multicolumn{5}{|c|}{$\begin{array}{c}\text { Correcta aplicación de su curso Miriadax al proyecto de empresa de la asignatura e } \\
\text { identifica más de * ideas del proyecto de empresa que se hayan generado a través de los } \\
\text { fundamentos de la creatividad de Edward De Bono (1991), Joaquín Lorente (2011), Luis } \\
\text { Bassat (2014) y otros }\end{array}$} \\
\hline & $* 4$ ideas & $* 4$ ideas & $* 3$ ideas & * $\quad * 2 \mathrm{ide}$ & \begin{tabular}{c|c}
$0-$ \\
is & ea \\
\end{tabular} \\
\hline RA6 & \multicolumn{5}{|c|}{$\begin{array}{c}\text { Correcta aplicación de las herramientas de Diseño Gráfico que han cursado durante el } \\
\text { Grado para la comunicación visual destinada a transmitir el mensaje del } \\
\text { proyecto de empresa }\end{array}$} \\
\hline RA7 & \multicolumn{5}{|c|}{$\begin{array}{c}\text { Correcta aplicación de un sistema de exposición oral en público para las presentaciones } \\
\text { semanales del avance en el proyecto de empresa y para la defensa y } \\
\text { presentación final del proyecto }\end{array}$} \\
\hline RA8 & \multicolumn{5}{|c|}{$\begin{array}{l}\text { Correcta comunicación audio-visual, visual, oral y escrita del proyecto de empresa de la } \\
\text { asignatura en la defensa y presentación final para optimizar su comunicación global } \\
\text { Defensa y presentación final oral: Interrelación de lo Visual y Escrito }\end{array}$} \\
\hline
\end{tabular}

(Ver completa en DRIVE, ídem Tabla 2)

\section{Resultados}

La Guía del Alumnado elaborada obtuvo la máxima puntuación (5) en todos los Indicadores de la Rúbrica DOITU (Dimensión 1 de DOCENTIAZ 2017), por lo que tanto la planificación como el desarrollo del proceso de enseñanza-aprendizaje de la materia, es adecuado. 
Metodologías de Aprendizaje Cooperativo y Proyectos online basados en el enfoque sistemático de Bill Aullet (2015) en la asignatura "Profesionalización y Gestión" de $4^{\circ}$ curso del Grado de Creación y Diseño.

Se pueden ver parte de éstos Indicadores en la Tabla 4 y en DRIVE $<$ https://drive.google.com/drive/folders/1ZLk7PX1GUBHK8iyHtHk3WHp5_UV_B8A?us $\mathrm{p}=$ sharing $>$ la evaluación completa de la Guía del Alumnado en DOITU.

La puntuación (5) de la Rúbrica indica que La Guía del Alumnado de la asignatura “Profesionalización y Gestión” está en línea con el modelo IKD, es decir, que se promueve una enseñanza centrada en el alumnado, con aprendizaje autónomo y trabajo colaborativo, dando respuesta a las necesidades sociales y laborales.

Tabla 4. Rúbrica para evaluar la Guía del Alumnado en DOITU

Dimensión 1.- Planificación y Desarrollo del proceso Enseñanza-Aprendizaje
Objeto de la Dimensión 1: Valorar la calidad de la planificación docente y si el desarrollo
del proceso de enseñanza-aprendizaje está en consonancia con las directrices establecidas en
el título y con el modelo IKD.
1. 1 Planificación docente de la materia:

Criterio: Guía para el Alumnado estructurada, completa y clara (Peso del criterio 10 sobre 25$)$

Indicador 1: Contiene los datos de identificación de la materia y del profesorado.

\begin{tabular}{|l|}
\hline Indicador 2: Contextualiza la asignatura en el marco de la titulación. \\
\hline $\begin{array}{l}\text { Indicador 3: Presenta las competencias específicas y transversales y/o resultados } \\
\text { de aprendizaje. }\end{array}$ \\
\hline Indicador 4: Incluye los contenidos teórico-prácticos de cada tema. \\
Indicador 5: Contiene aclaraciones sobre la metodología de enseñanza- \\
aprendizaje y especifica los tipos de actividades de aprendizaje integradas en las \\
distintas modalidades docentes. \\
Indicador 6: El sistema de evaluación incluye criterios, instrumentos y su valor \\
porcentual. \\
(...)
\end{tabular}

1.2. Desarrollo del proceso de Enseñanza-Aprendizaje:

Criterio: Método coherente y en línea con metodología activa y cooperativa (IKD) (Peso del criterio 10 sobre 25)

Indicador 19: Se desarrollan actividades de aprendizaje en equipos de trabajo colaborativo, caracterizados por la ayuda y el aprendizaje entre iguales, así como la implicación de los miembros del equipo.

Indicador 20: Los requerimientos de las actividades de aprendizaje llevan al alumnado a autorregular el propio proceso de aprendizaje, a la autonomía, a aprender $\mathbf{a}$ aprender.

(...)

Fuente: Rúbrica de DOCENTIAZ 2017

(Ver completa en DRIVE: Rúbrica DOITU, ídem sitio web Tabla 2 y Tabla 3)

Durante el presente curso 2017-2018, se están realizando cinco empresas (Tandem (artistas profesionales), Kunstkapital (B2B entre artista emergente y coleccionista de arte), Unoart (B2B entre galería y taller de artista), Bem (B2B en slow design), L'artkbook (catálogo artístico en moda), que pasamos a identificar en Fig.1, 2, 3, 4 y 5 a través de sus logotipos, imagotipos, isotipos y con una muestra de su trabajo, que a éstas alturas de curso está casi completo; vamos a extraer de cada una de estas empresas, uno de los 5 Pasos más 
importantes de Bill Aulet (2015, 2018), Pasos entorno a ¿QUÉ PUEDES HACER POR TU CLIENTE? y la UTD (ver todos los Pasos en supra Desarrollo de la Innovación):

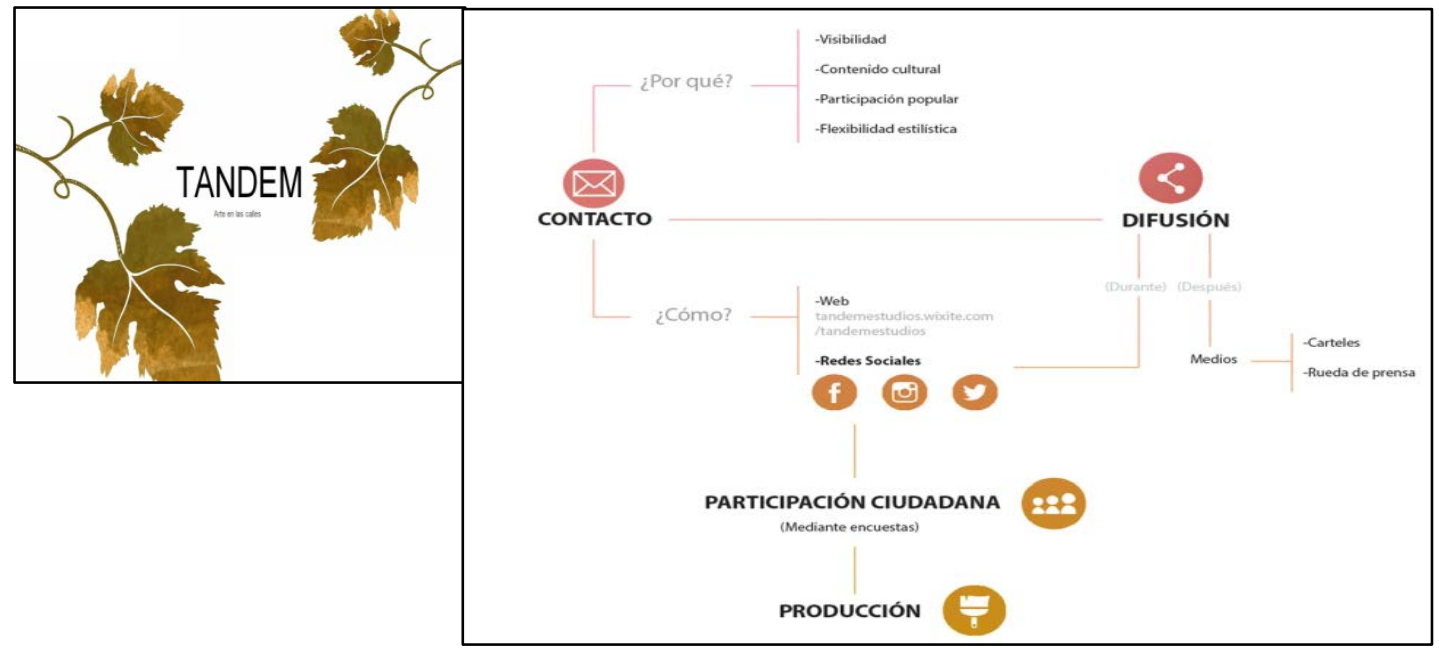

Fig 1. Logotipo y "El Caso de uso de la vida útil del producto" para averiguar la forma en la que cada cliente decide que tiene la necesidad de tener el producto y la forma en que lo usará.

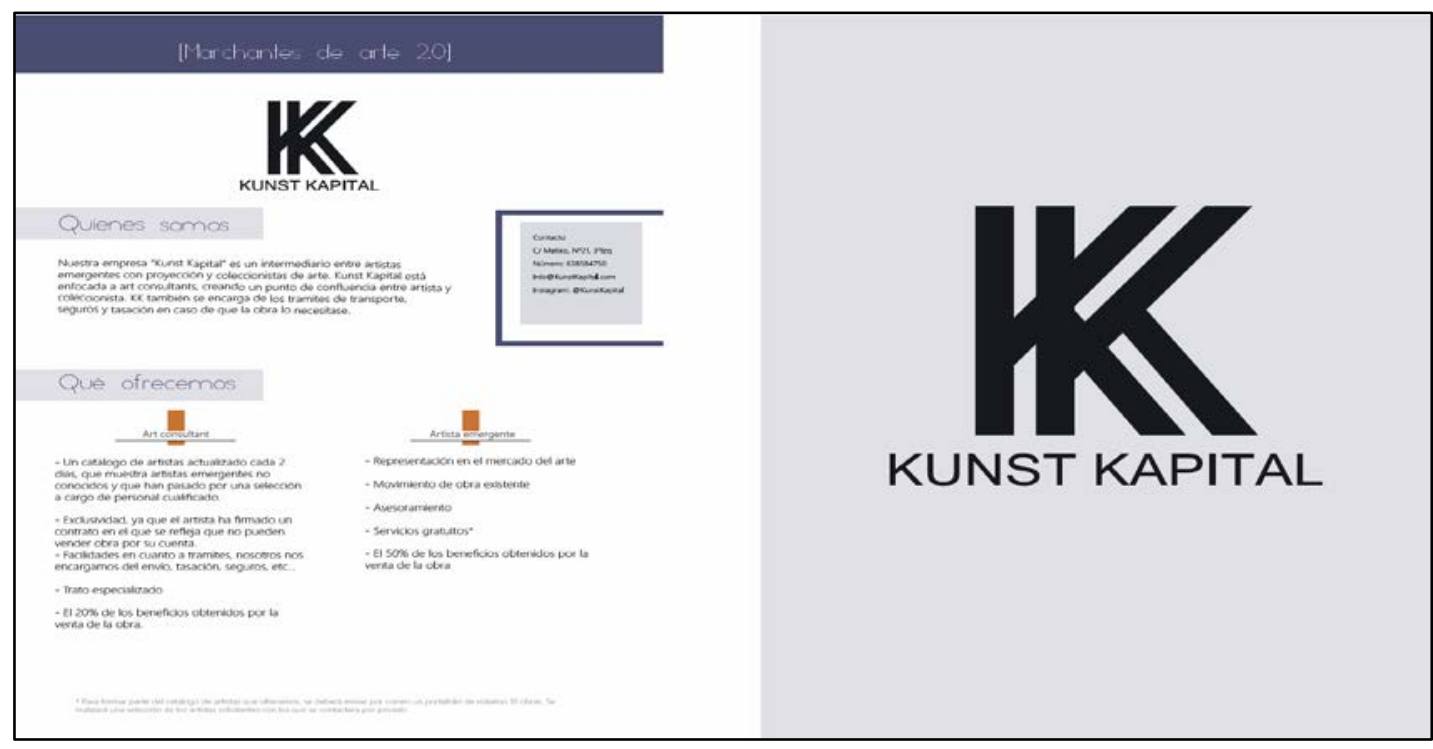

Fig 2. Imagotipo y "Especificación de alto nivel del producto" para ver el producto desde el punto de vista de la persona que lo consumirá. 
Metodologías de Aprendizaje Cooperativo y Proyectos online basados en el enfoque sistemático de Bill Aullet (2015) en la asignatura "Profesionalización y Gestión" de $4^{\circ}$ curso del Grado de Creación y Diseño.

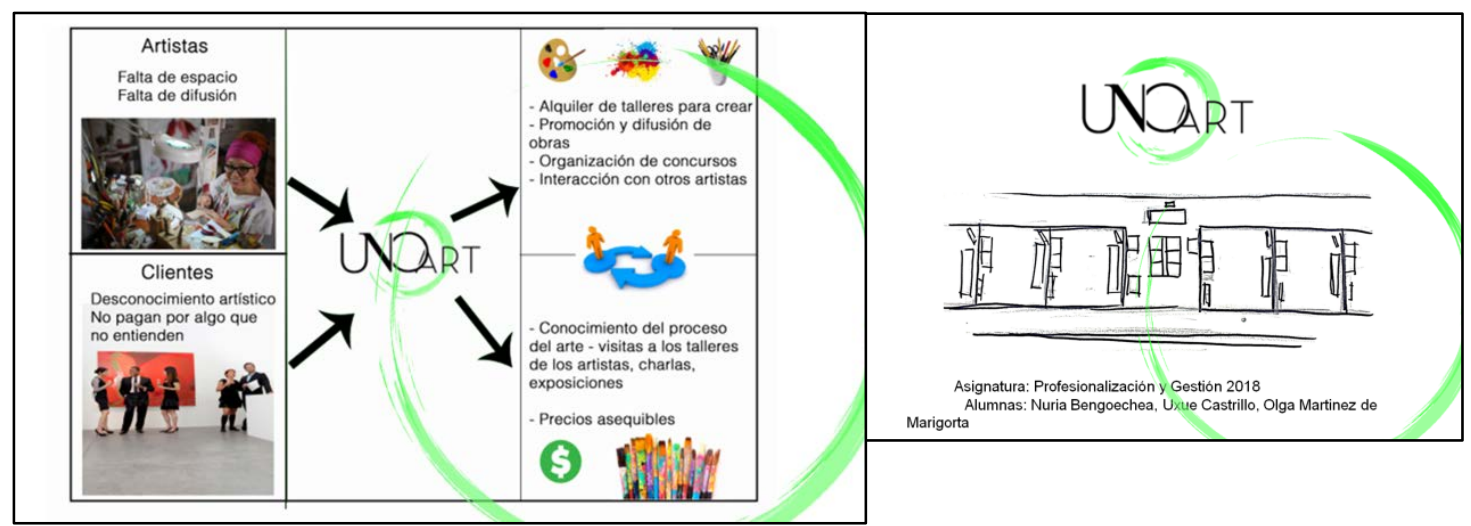

Fig 3. Isotipo y "La propuesta de valor cuantificada" para averiguar el estado actual del cliente frente al estado posible con el producto.
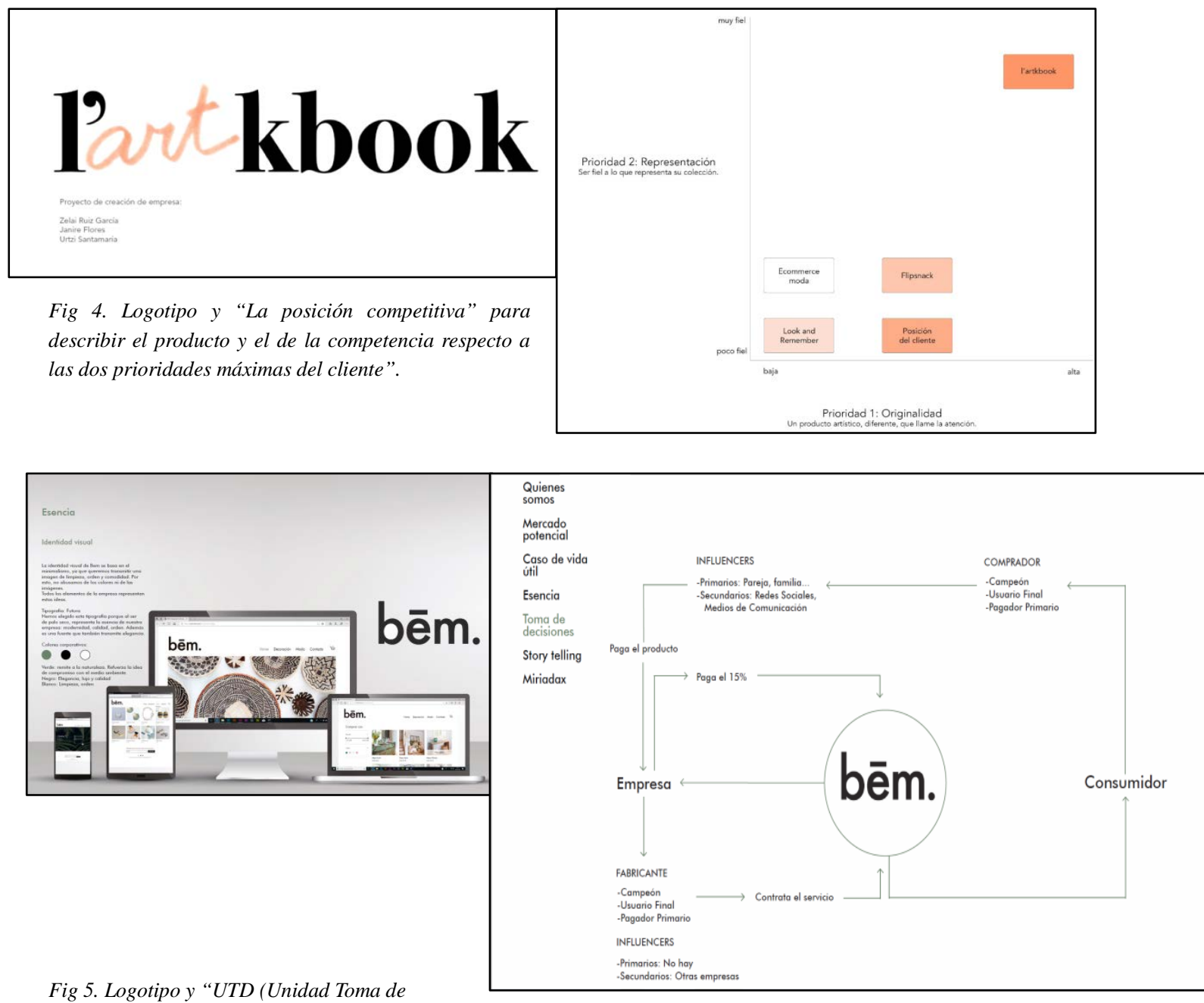

Decisiones)" para descubrir el circuito de personas con las que se debe negociar para poder llegar al cliente.

\section{Conclusiones}

(cc) EY-NC-ND 2018, Universitat Politècnica de València

Congreso IN-RED (2018) 
A través de la evaluación realizada con la "Rúbrica para evaluar la Guía del Alumnado en DOITU” (Tabla 4), se muestra que La Guía del Alumnado para el Grupo 02, de la asignatura "Profesionalización y Gestión" de $4^{\circ}$ curso del Grado de Creación y Diseño, es una guía bien estructurada y completa, con explicaciones adecuadas para poder aprender con garantías y expuesta de forma clara y comprensible.

Ésta Guía del Alumnado también se ha puesto en práctica y está siendo la hoja de ruta del presente curso 2017-2018. Podemos avanzar que actualmente se están realizando 5 empresas: Tandem, Kunstkapital, Unoart, Bem, L'artkbook (Fig.1, 2, 3, 4 y 5).

Nos encontramos aún sin finalizar la asignatura y no podemos ofrecer resultados definitivos de las empresas diseñadas, ni de la valoración del alumnado en los ítems relacionados con la Guía del Estudiante, dado que la Encuesta de opinión al alumnado sobre la docencia de su profesorado se realiza al finalizar la asignatura, ésta encuesta arrojaría más datos sobre la idoneidad de la Planificación docente y el desarrollo del Proceso de enseñanza-aprendizaje; sin embargo para saber si se iba por buen camino en la orientación propuesta, y dado que el curso ya está bastante avanzado, se ha hecho una consulta al alumnado con dos preguntas: ¿Te está gustado el enfoque de la asignatura?/ ¿La metodología centrada en el cliente utilizada para crear y/o dinamizar una empresa te parece extrapolable a cualquier ámbito de tu futura profesión?, el 100\% de los alumnos ha contestado afirmativamente a las dos preguntas, argumentando la idoneidad del aprendizaje en términos de practicidad para su perfil profesional.

También podemos decir que en éste curso 2017-18 se siguen utilizando cómo herramientas online de enseñanza-aprendizaje y búsqueda de información: Diapositivas en PPT, plataformas de apoyo a la docencia reglada (eGela), You-Tube, artículos online, páginas web, blogs y cursos mooc en Miriadax.

El alumnado recoge información sobre el cliente/usuario, a través de redes sociales desde el aula: Whatsapp, FaceBook, Twitter, etc., lo que ha posibilitado atender variedad de asuntos de forma simultánea, en tiempo real y sin límites espaciales. También se cuentan con recursos online para el diseño de las empresas que se están ideando actualmente, se dispone de Página Web, además de Instagram, FaceBook, Twitter, etc.

Los Resultados de Aprendizaje que se están logrando, permiten planificar una empresa de diseño con un enfoque sistemático, que es el propuesto por Bill Aulet $(2015,2018)$ profesor del MIT (Instituto Tecnológico de Massachusetts en EE.UU.); ésta metodología por Pasos es aplicable a empresas de reciente creación y a toda empresa que desee ser más ágil e innovadora.

Podemos avanzar que las 5 empresas: Tandem (artistas profesionales), Kunstkapital (B2B entre artista emergente y coleccionista de arte), Unoart (B2B entre galería y taller de artista), Bem (B2B en slow design), L'artkbook (catálogo artístico en moda), se están realizando como acabamos de indicar, con recursos combinados de web y redes sociales en la dimensión online, y son interesantes sobre todo, por haberse diseñado desde una necesidad real y contrastada con el cliente, tal y como propone Bill Aulet (2015) y su workbook (2018); también podemos adelantar que los Resultados de Aprendizaje de la 
Metodologías de Aprendizaje Cooperativo y Proyectos online basados en el enfoque sistemático de Bill Aullet (2015) en la asignatura "Profesionalización y Gestión" de $4^{\circ}$ curso del Grado de Creación y Diseño.

asignatura se cumplirán en su totalidad (Tabla 3) y que la evaluación que se va practicando hasta el momento, arroja resultados positivos tanto de grupo como individuales; también se puede avanzar que el ambiente de trabajo es dinámico y positivo, lo que se corresponde con un interés efectivo por el trabajo que realiza el alumnado.

Las técnicas de Aprendizaje Cooperativo Group Investigation (Sharan and Sharan, 1976) y Jigsaw, Puzzle o Rompecabezas (Aronson y otros, 1975, y Slavin 1980) que menciona Prieto (2005), están permitiendo que los alumnos alcancen entre otras, las habilidades sociales tan necesarias para la práctica profesional. La metodología de Aprendizaje Cooperativo es muy beneficiosa para la maduración del alumnado como futuro profesional, y los proyectos de empresa ideados tanto en dimensiones online, como offline para el producto diseñado, ponen en contacto al alumnado con la realidad digital, la innovación y el emprendimiento; en éste sentido también están respaldados por la Administración. Todas las empresas ideadas en el presente curso, gracias a la metodología utilizada, cumplen con los requisitos de la convocatoria actual de emprendimiento de la DFB-Programa Bizkaia Creativa. $\leq$ https://info.beaz.bizkaia.eus/ailec-event/dfb-programa-bizkaia-creativa-2018/>, lo que permitirá que puedan presentarse a ésta convocatoria antes de su finalización el 20 de abril en curso.

Podemos concluir que el disponer de DOITU para introducir en la asignatura mejoras, tanto en su planificación, como en su desarrollo, y responder más adecuadamente a las directrices establecidas en el título y al modelo IKD-Aprendizaje Cooperativo y Dinámico, agiliza e impulsa la calidad en las prácticas académicas.

Por otra parte, podemos decir que la evaluación docente formativa del profesorado, que desarrolla el Servicio de Evaluación Docente (SED/IEZ), y dos de sus actividades principales, como son el Programa Docentiaz en su conjunto y específicamente en su Dimensión 1 para la Planificación docente, así como la Encuesta de Opinión al Alumnado sobre la docencia de su profesorado, son actividades que aportan información fiel y cotejada y propician el progreso en la calidad de las prácticas académicas.

\section{Referencias}

ARONSON, E. y SHELLEY, P. (2011). Cooperation in the Classroom: The Jigsaw Method. London: Pinter \& Martin Ltd.

AULET, B. (2015). La disciplina de emprender. 24 pasos para lanzar una startup exitosa, (prol. Rafael del Pino). Madrid: Lid.

AULET, B. (2018). El workbook de la disciplina de emprender. Madrid: Lid.

DIPUTACIÓN FORAL DE BIZKAIA-Programa Bizkaia Creativa:

<https://info.beaz.bizkaia.eus/ai1ec-event/dfb-programa-bizkaia-creativa-2018/> [Consulta: 14 de marzo de 2018]

(cc) EY-NC-ND 2018, Universitat Politècnica de València

Congreso IN-RED (2018) 
JOHNSON, D. W. y JOHNSON, R. T. (2014). La evaluación en El aprendizaje cooperativo: Como mejorar la evaluación individual a través del grupo. Madrid: SM.

MEJÍA LLANO, J. C. (2013). La guía del community manager: estrategia, táctica y herramientas, Madrid: Anaya Multimedia.

PRIETO, L. (2005). El aprendizaje cooperativo. Madrid: PPC.

PUJOLAS MASET , P. (2008). 9 ideas clave: El aprendizaje cooperativo. Barcelona: GRAO.

ROJAS, P. y REDONDO, M. (2013). Cómo preparar un plan de social media marketing. Barcelona: Gestión 2000.

SERVICIO DE ALOJAMIENTO DE ARCHIVOS - DRIVE: (Guia del Alumnado resultado de la reformulación en Doitu/ Rúbrica del curso Doitu/ 4 empresas web curso 2016-2017) $<$ https://drive.google.com/drive/folders/1ZLk7PX1GUBHK8iyHtHk3WHp5_UV_B8A?usp=sharing> [Consulta: 6 de marzo de 2018]

SHARAN, Y. y SHARAN, S. (2004). El desarrollo del aprendizaje cooperativo a través de la investigación en grupo. Sevilla: MCEP.

SLAVIN, R. E. (2002). Aprendizaje Cooperativo: Teoría, Investigación y práctica. Buenos Aires: Aique.

STALMAN, A. (2014). Brandoffon. El branding del futuro. Barcelona: Gestión 2000.

UNIVERDIDAD DEL PAÍS VASCO/EUSKAL HERRIKO UNIVERSITATEA. WEBs de (Modelo IKD-Aprendizaje Cooperativo y Dinámico/ Programa Docentiaz/ Encuesta de Opinión al Alumnado/ Plan de formación organizado por el SED/IEZ/ Guía Docente de la asignatura “Profesionalización y Gestión” de $4^{\circ}$ curso) $<$ https://www.ehu.eus/es/> [Consulta: 6 de marzo de 2018] 


\title{
Heat Kit: Creación de un prototipo para ‘tocar’ el calor.
}

\section{César Martín Gómez ${ }^{a}$, Elia Ibáñez Puy y Amaia Zuazua Ros ${ }^{\mathrm{a}}$}

a Universidad de Navarra, Escuela de Arquitectura, Departamento de Construcción, Instalaciones y Estructuras. Campus Universitario, 31080, Pamplona, España. Tfn. 0034948425600. instetsaun@unav.es

\begin{abstract}
The understanding of heat transfer processes and its affection in buildings is one of the difficulties that the students of architecture have to face when receiving building services courses knowledge, specifically in those related to hygrothermal conditioning.

In a simplified form, it can be said that they must internalise the existence of a heat source, a machine that transfers the heat and an element that absorbs or dissipates the heat in the rooms.

The traditional solution of master classes, visits to real facilities... had a demonstrated effectiveness in the past, however, they fail transferring the implications of thermodynamics in their complexity.

The teaching innovation project entitled "Heatkit - Creation of a prototype to 'touch' the heat", which is the origin of these text, expects that the students of architecture can feel the heat transfer with the construction of a simple and easily replicable thermoelectric prototype.
\end{abstract}

Keywords: Training; arquitecture; engineering; heat transfer; prototype; methodology.

\section{Resumen}

Una de las dificultades de los alumnos de Arquitectura en las asignaturas de instalaciones y concretamente en las que reciben conocimientos de acondicionamiento higrotérmico, es comprender los procesos de transferencia de calor y sus afecciones en el edificio.

De forma simplificada, puede decirse que deben interiorizar que existe una fuente de energía, una máquina que transfiere el calor y un elemento que toma calor, o lo cede, en los locales.

Las soluciones tradicionales de clases magistrales, visitas a instalaciones reales...han demostrado su efectividad en el pasado, sin embargo, no consiguen trasladar en su complejidad las implicaciones de la termodinámica.

Lo que pretende el proyecto de innovación docente titulado "Heatkit Creación de un prototipo para 'tocar' el calor", origen de este texto, es que los alumnos de Arquitectura, puedan sentir la transferencia de calor con la creación de un prototipo termoeléctrico sencillo y fácilmente replicable. 
Palabras clave: Formación; arquitectura; ingeniería; transferencia de calor; prototipo; metodología.

\section{Introducción}

"El bienestar - entendido como respuesta a la temperatura, la humedad, la iluminación e incluso a factores acústicos- ha sido la fuerza motriz en la arquitectura del siglo veinte. Ya estén ocultas, expuestas o de manera integrada, las instalaciones se han convertido en las protagonistas en el ámbito de la construcción” (Granf \& Marino, 2016).

Esta evolución en el ámbito de la Arquitectura es un ejemplo más de que el mundo se encuentra en un cambio constante que también debe hacerse presente en la educación. Así, las escuelas de Arquitectura españolas buscan formar futuros profesionales realmente competentes, capaces de resolver estas nuevas necesidades de la sociedad. Para ello es necesaria una educación integral y significativa, que imparta los conocimientos necesarios buscando alcanzar los niveles superiores del aprendizaje (cfr Monedero Isorna, 2002).

Aumentar la calidad de la enseñanza para alcanzar esta educación integral es una de los principales objetivos de la comunidad educativa. Desde la escuela primaria (Can, 2016), pasando por los institutos (Vega-Moreno, Cufí Solé, José Rueda, \& Llinás, 2016) hasta las universidades (Ben Amara \& Ayari, 2016), la innovación en las aulas se hace cada vez más presente. Nuevas formas de enseñar están siendo desarrolladas (Amran \& Rahman, 2017; De Menezes Maciel, Do Rêgo, \& Carlos, 2017; Deniz \& Simsek, 2015) basadas en estudios que profundizan en la diversidad de los estudiantes (R. M. Felder \& Brent, 2005) y de los tipos de enseñanza y aprendizaje (R. Felder \& Silverman, 1988).

La Escuela de Arquitectura de la Universidad de Navarra, en los últimos años, ha realizado también este esfuerzo por mejorar la calidad de su enseñanza sobre instalaciones. Se han diseñado armarios técnicos dedicados a diferentes conceptos de instalaciones: iluminación de emergencia (Martín-Gómez, Bermejo-Busto, \& Mambrilla-Herrero, 2015), sistemas de climatización, electricidad e incendios (Martín-Gómez, Zapata, Zuazua, Villanueva, \& Olaizola, 2014). Estos armarios funcionan como laboratorios móviles donde el alumno puede observar los sistemas, tocarlos y ponerlos en funcionamiento, acercando los conocimientos teóricos a la realidad.

Un grupo de investigación de la Universidad de Navarra lleva trabajando desde hace años en termoelectricidad, como se detallará más adelante, una tecnología que permite 'visualizar' con gran facilidad los procesos de transferencia de calor. Resultado de estos trabajos son varios prototipos que permiten climatizar un volumen cerrado. Una simplificación de este volumen, para que la transferencia de calor sea fácilmente entendible, montable y transportable por los alumnos, es el objeto del proyecto de innovación docente que se presenta.

(cc) EY-NC-ND 2018, Universitat Politècnica de València

Congreso IN-RED (2018) 


\section{Objetivos}

Lo que pretende el proyecto de innovación docente origen de esta comunicación, es la creación de un prototipo para 'tocar' el calor. Gracias a este prototipo los alumnos de arquitectura, en la asignatura de 'Instalaciones 3', puedan sentir la transferencia de calor, observar la diferencia entre el agua y el aire como medios de disipación, conocer la tecnología Peltier y comprender parámetros eléctricos como la corriente y el voltaje.

Los dos prototipos termoeléctricos utilizados son sencillos y fácilmente replicables, lo que facilita el desarrollo de la sesiones y la interacción de los estudiantes con la termoelectricidad. Además, a través de esta pequeña experiencia se introduce en el aula el mundo de la investigación, despertando en los estudiantes la iniciativa y el espíritu emprendedor que caracteriza a los investigadores y descubriendo una faceta especialmente relevante en el mundo científico.

Se considera que es una técnica educativa innovadora en las escuelas de arquitectura permitiendo trabajar las instalaciones de una manera práctica y que busca fomentar el aprendizaje significativo desde un enfoque transversal que incluye contenidos de diversas materias: ingeniería térmica, transmisión de calor, instalaciones, electricidad, etc.

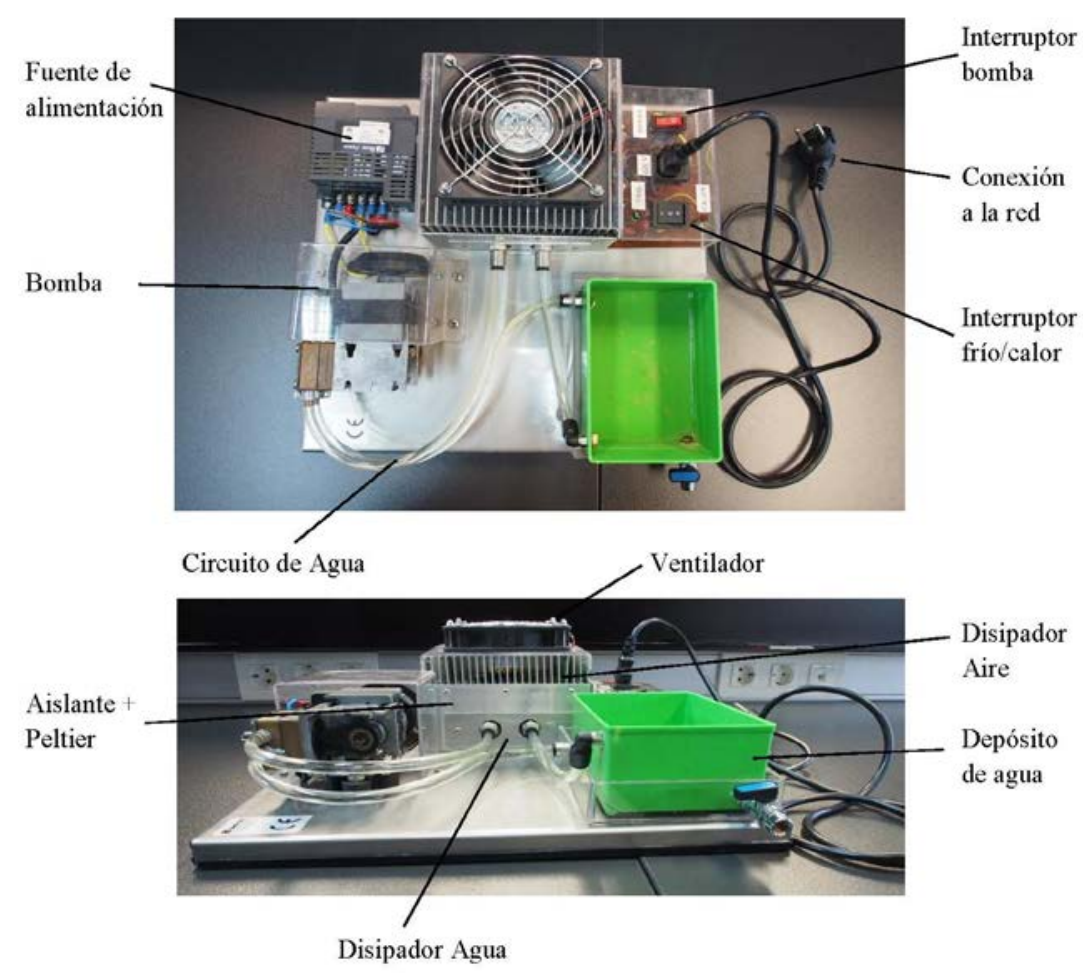

Fig 1. Prototipo de disipación por agua. 


\section{Desarrollo de la innovación}

La idea de esta iniciativa nace del trabajo de un equipo de investigación centrado en el acondicionamiento higrotérmico con termoelectricidad, utilizando células Peltier como medio para la transferencia de calor (Ibáñez-Puy et al, 2014; Ibañez-puy et al, 2017; María Ibañez-Puy et al, 2018; Ibañez-Puy et, 2015; Martín-Gómez et al., 2010). El estudio de esta tecnología, así como su evidente interés docente, han dado como resultado el desarrollo de una sesión práctica que acercan la investigación y la termoelectricidad a los futuros profesionales, al mismo tiempo que les permite interiorizar conceptos básicos para su formación.

La acción educativa consiste en desarrollar una sesión en grupos pequeños con prototipos termoeléctricos, donde se hagan visibles los conceptos de intercambio de calor e ingeniería térmica vistos durante la carrera (Fig. 1).

\subsection{Contenidos}

Como se ha indicado anteriormente las transversalidad es un elemento presente en esta iniciativa, pues aunque la práctica se realice en la asignatura de `Instalaciones 3Acondicionamiento Higrotérmico's se trabajan conceptos de diversos ámbitos.

\subsubsection{Transferencia de calor y acondicionamiento higrotérmico}

Se desarrollan varios conceptos de transferencia de calor:

- $\quad$ Medios de disipación. Se explican dos medios de disipación diferentes, el aire y el agua. Esta característica permite a los estudiantes entender la diferencia entre las dos posibilidades, observar el diferente comportamiento, saber qué implica cada tipología y reflexionar sobre cuál es la mejor solución (Fig. 2).

- $\quad$ Disipador. Se considera importante que los estudiantes toquen y observen in situ diferentes tipologías de disipadores, comprendiendo la justificación de las diferentes morfologías de las aletas, la distancia entre ellas, la rugosidad, etc.

- Termoelectricidad. Es un fenómeno basado en la transferencia de calor. Las células Peltier son capaces de generar una diferencia de temperaturas cuando se les aplica una corriente eléctrica. Es una tecnología en auge que se prevé tenga aplicación en la Arquitectura.

- Concepto de frio y calor. La mayoría de veces los conceptos abstractos de absorber y ceder calor no se comprenden en su totalidad. Con esta experiencia se pretenden materializar estos conceptos ayudando a su comprensión total a través de un aprendizaje significativo.

- $\quad$ Bomba de calor. La célula Peltier puede ser utilizada como bomba de calor. Esta experiencia permite facilitar el tanto el funcionamiento de la bomba como de la termoelectricidad.

(cc) EY-NC-ND 2018, Universitat Politècnica de València

Congreso IN-RED (2018) 


\subsubsection{Electricidad}

A priori, estos conceptos pueden resultar conceptos más propios del mundo de la ingeniería, sin embargo, su comprensión es realmente útil para el funcionamiento de las instalaciones.

- $\quad$ Parámetros eléctricos. El voltaje y la intensidad se conciben como parámetros fundamentales para comprender el funcionamiento de las células Peltier y de cualquier sistema de acondicionamiento higrotérmico.

- $\quad$ Fuente de alimentación. En la sesión los estudiantes pueden tocar y observar de cerca una fuente de alimentación, identificar sus partes y los requisitos para su correcta conexión y funcionamiento.

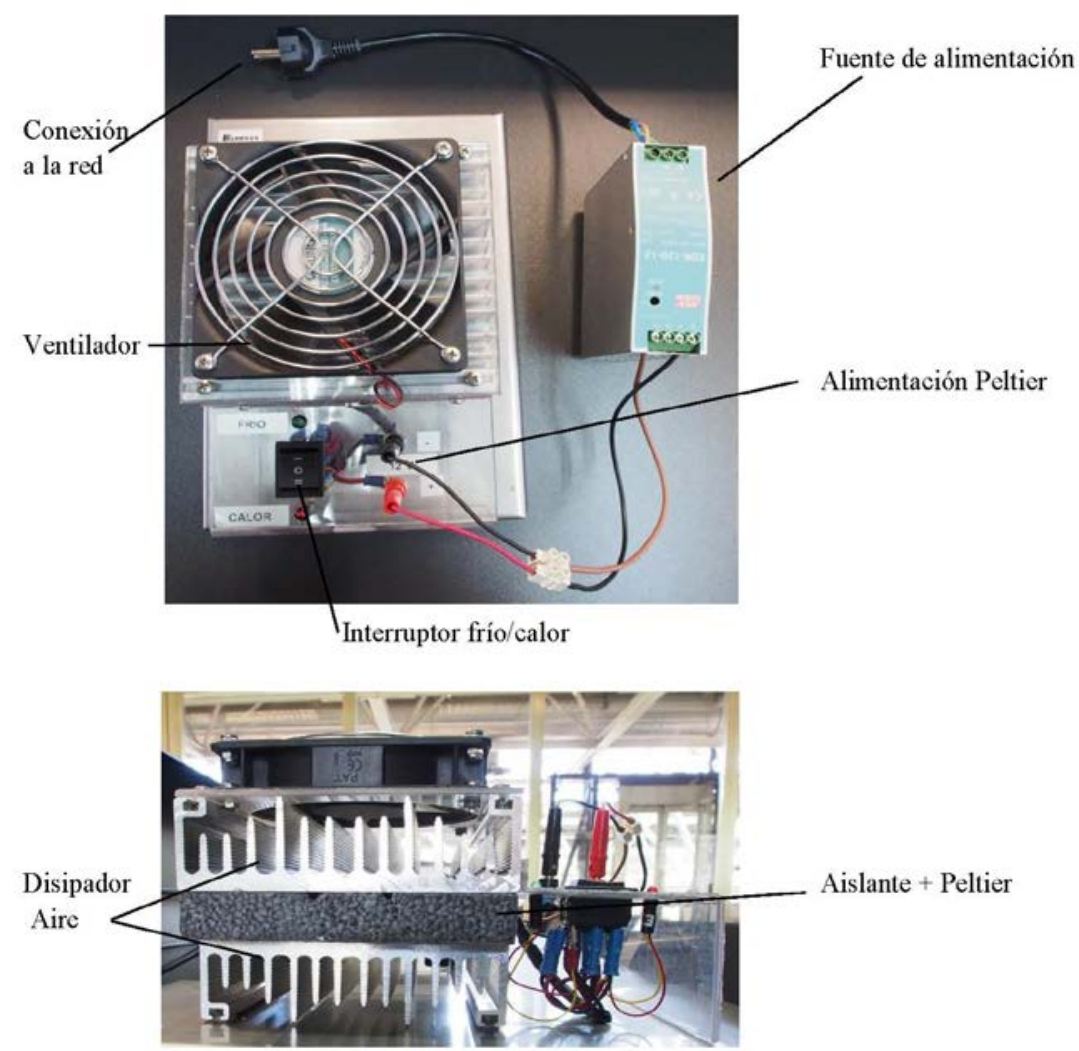

Fig .2 Prototipo de disipación por aire.

\subsection{Metodología}

Para el desarrollo de la sesión se recomienda dividir a los alumnos en grupos reducidos (máximo 10 personas) buscando mejorar la calidad del aprendizaje y el clima de trabajo, favoreciendo la interacción con los prototipos y la resolución de dudas de forma más personalizada. La razón por la que se recomiendan grupos pequeños es facilitar que todos los alumnos puedan participar de manera directa, fomentando el aprendizaje significativo y constructivo (Fig. 3).

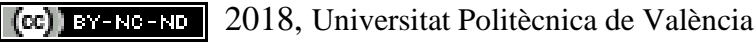


Es fundamental por tanto, desarrollar el papel activo de los alumnos y que sean conscientes de que su aprendizaje depende de su propia implicación en la sesión. El nivel de profundización de los conceptos depende de las preguntas y el interés de los alumnos. De esta forma, se pretende fomentar que los estudiantes sean protagonistas de la sesión.

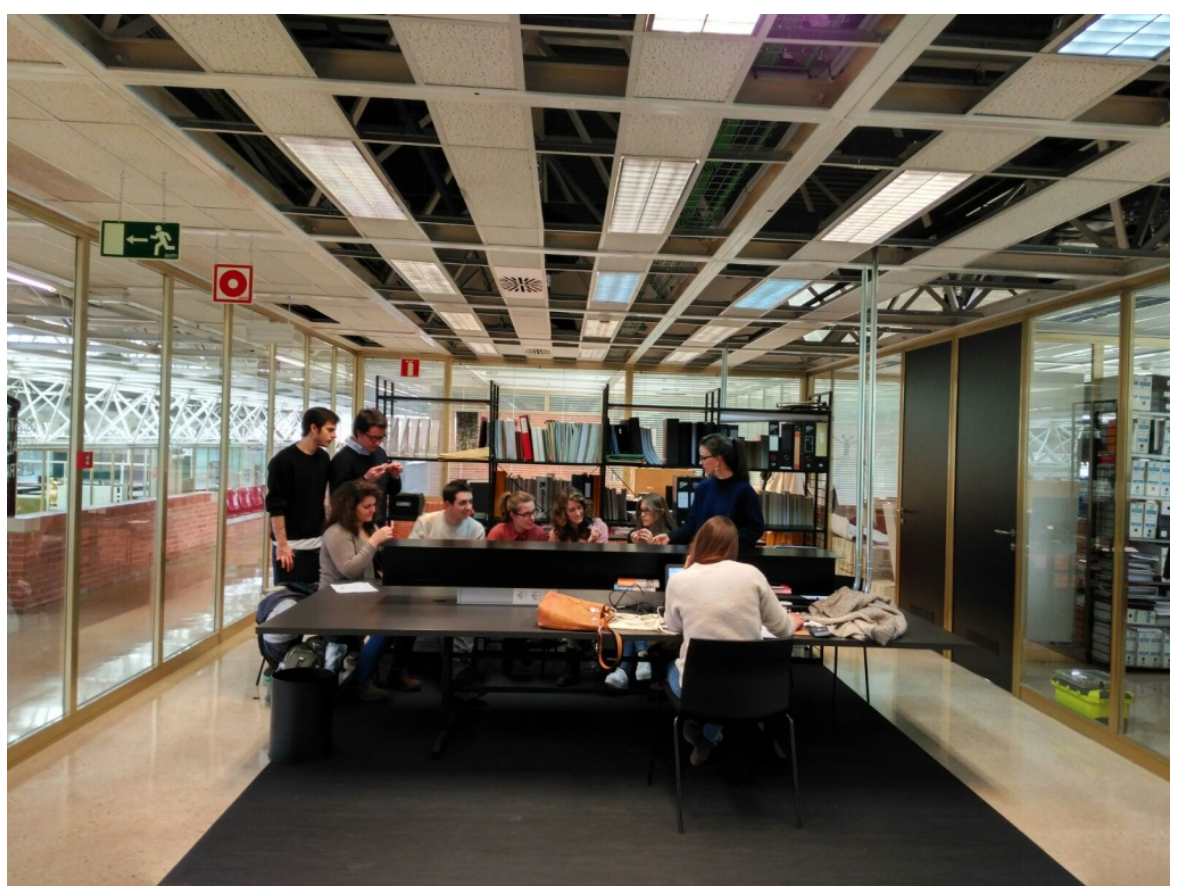

Fig 3. Imagen de una sesión con un grupo de alumnos.

Además, este aprendizaje autorregulado se hace presente durante el desarrollo de toda la práctica donde los alumnos tienen la posibilidad de enchufar, encender y apagar, tocar o cambiar la polaridad de los equipos.

La integración de contenidos de diferentes ámbitos en una única sesión es un ejemplo de la apuesta por la transversalidad docente. Se quiere fomentar que los alumnos no asimilen los conocimientos como estancos, sino que sean capaces de relacionar unos con otros y aplicar la totalidad de su conocimiento ante cualquier situación.

\subsection{Desarrollo de la práctica}

La práctica se realiza con dos prototipos termoeléctricos, uno de aire y uno de agua, que los alumnos deben identificar, poner en marcha y analizar. La sesión se divide en cinco partes:

a) Realización de la encuesta para analizar los conocimientos previos.

b) Parte teórica. Se explican los conceptos básicos que se deben conocer para realizar la práctica.

o Termoelectricidad: fenómeno basado en la transferencia de calor que obtiene una diferencia de temperaturas a partir de la electricidad o viceversa. 
o Célula Peltier: se toca una célula Peltier y el interior de la misma. Se explica su composición y su funcionamiento.

o Medios de disipación de calor: Se explican las diferencias entre el aire y el agua como medio de disipación y se hace reflexionar sobre sus ventajas e inconvenientes.

c) Explicación e identificación de los componentes del sistema.

o Se identifican los dos prototipos termoeléctricos. Se explica cómo están construidos y la localización de las células Peltier.

o Se identifican los disipadores diferenciando los dos medios.

o Se identifica la bomba y las fuentes de alimentación.

d) Parte práctica. Los alumnos ponen en funcionamiento los prototipos y analizan sus comportamientos comentando qué diferencias observan y razonándolas.

o Prototipo de disipación con agua: Se pone en marcha el primero porque su inercia es más lenta y el efecto tarda más en hacerse visible.

o Prototipo de disipación con aire.

o Análisis de los comportamientos, deben reflexionar sobre el comportamiento de los sistemas e identificar en qué posición se encuentra la célula Peltier.

e) Realización de la encuesta final.

Las preguntas o dudas que puedan tener los alumnos se resuelven durante el transcurso de toda la sesión. Se busca fomentar un ambiente de aprendizaje donde el estudiante tenga libertad de realizar las aportaciones que considere importantes durante la práctica.

\section{Resultados}

Para poder valor la eficacia de la sesión los estudiantes realizan una encuesta antes de la sesión y otra después donde se evalúan los conocimientos previos de los estudiantes y su valoración de la prueba. Existe también la posibilidad de añadir propuestas de mejora, de esta forma se han podido identificar aspectos de la práctica que necesitan ser mejorados basándose en la propia experiencia de los estudiantes. Han realizado la encuesta 37 alumnos de Quinto curso de Arquitectura.

La finalidad de las encuestas es alcanzar un primer análisis de la eficacia de la sesión y de poder comprobar su utilidad. Las encuestas presentan pocos ítems (4-5) que se centran en recoger la percepción del estudiante sobre su aprendizaje de los conceptos y valorar si la practica ha servido para mejorarlo (Fig. 4). La mayoría de las preguntas son Sí/No. Existe una sola pregunta de respuesta múltiple para valorar la utilidad de la sesión en su formación y una última pregunta de respuesta libre donde los estudiantes pueden proponer sus mejoras.

Se considera que gracias a estas encuestas se recoge la valoración de los alumnos de manera rápida y eficaz sin invertir mucho tiempo en la recogida de datos. De esta manera, se facilita el análisis de los datos y la incorporación de mejoras casi de manera inmediata.

(cc) EY-Nc-No 2018, Universitat Politècnica de València 
La encuestas se realizan en español y en inglés para los alumnos extranjeros de la escuela así como para que la experiencia sea replicable por otras universidades internacionales.
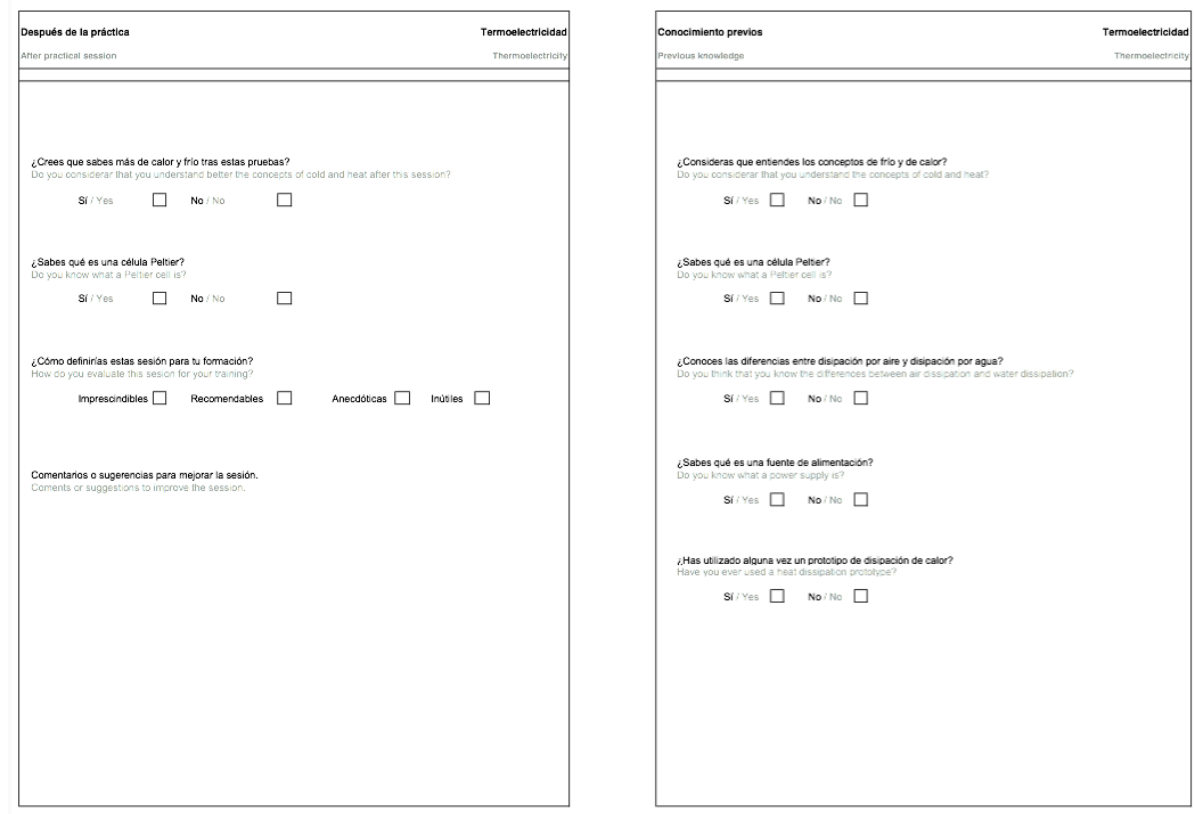

Fig 4. Encuesta de conocimientos previos y de satisfacción realizadas antes y después de la práctica.

Los resultados de la encuesta de conocimientos previos permite analizar qué grado de interiorización de los conceptos se han alcanzado en la asignaturas y además, identificar los puntos fuertes y las áreas de mejora donde se debe incidir en la práctica (Fig. 5).

Se observa que los conceptos de frío y calor y fuentes de alimentación están asentados en el conocimiento de los estudiantes (100\% y 92\%). Sin embargo, un prototipo de disipación y una célula Peltier obtienen los porcentajes más elevados de desconocimiento (84\% y 78\%). La pregunta relacionada con las diferencias entre medios de disipación presenta los resultados más equilibrados de todos los conceptos con un 65\% de alumnos que sí consideran que dominan el concepto.

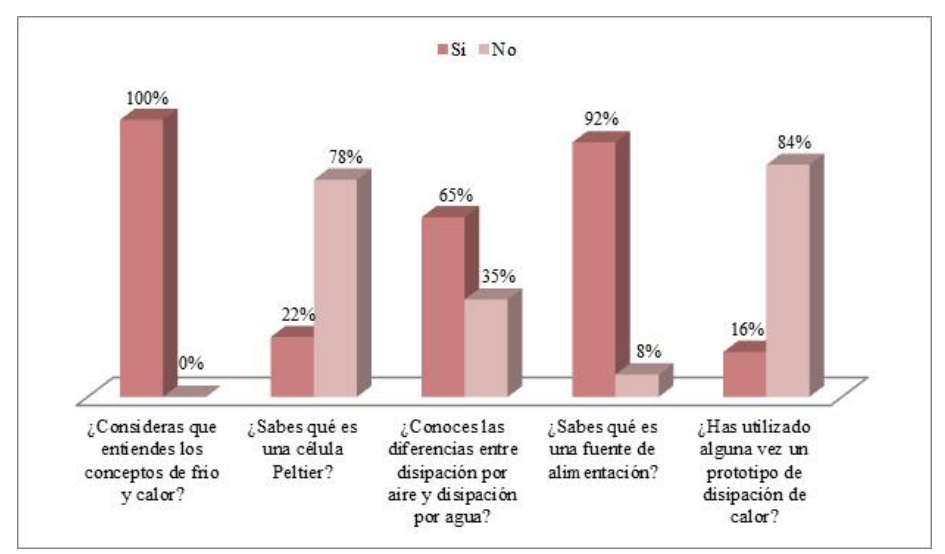

Fig 5. Datos obtenidos en la encuesta de conocimientos previos realizada antes de la sesión.

(c) ) EY-NC-ND 2018, Universitat Politècnica de València

Congreso IN-RED (2018) 
La encuesta realizada tras las pruebas se analiza en dos partes. El primer análisis se centra en la percepción que tiene los alumnos sobre su propio aprendizaje en la sesión. Se puede observar en el diagrama (Fig. 6). Un alto porcentaje de alumnos (96\%) que consideran que ha mejorado su aprendizaje de los conceptos de frío y calor, fundamentales en la asignatura de instalaciones, a pesar de que como se ha comentado anteriormente, todos los alumnos creían que dominaban este concepto antes de la práctica. Del mismo modo, se observa claramente que la sesión permite ampliar los conocimientos sobre células Peltier (96\%).

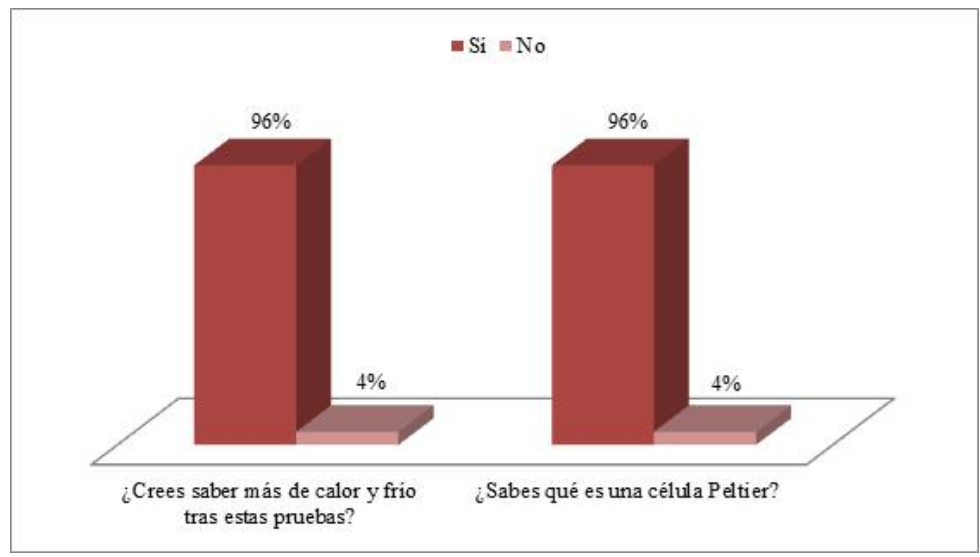

Fig 6. Datos obtenidos tras la realización de la sesión, se valora si los estudiantes han apreciado alguna mejora en el aprendizaje de los conceptos.

La segunda parte del análisis responde a las dos últimas preguntas de la encuesta (Fig. 7). que se centran en la opinión de los estudiantes sobre la sesión y su utilidad para su formación. Un 13\% la considera imprescindible, el mayor porcentaje de alumnos (82\%) considera que la práctica es recomendable y otro $4 \%$ la valora como anecdótica.

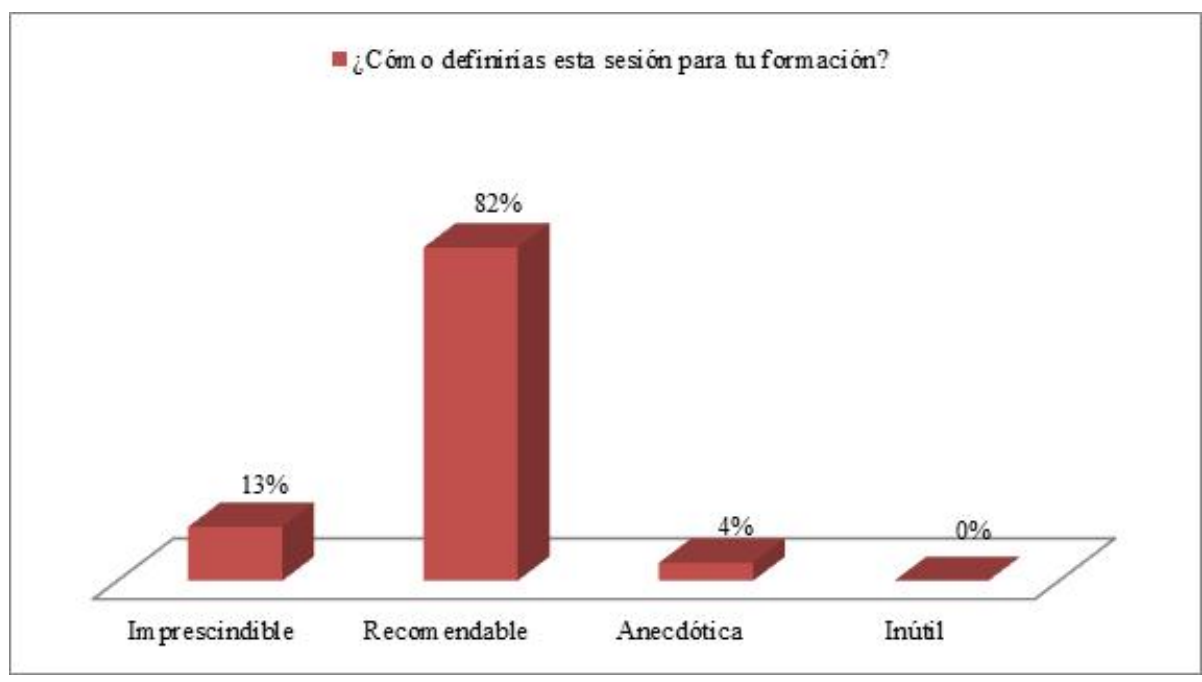

Fig 7. Valoración de los alumnos de la importancia de la sesión para su formación. 


\section{Conclusiones}

La primera conclusión que se confirma tras el análisis de las respuestas de los alumnos es la comprobación de que la formación en las aulas se centra generalmente en el aprendizaje de conocimientos teóricos y muchas veces abstractos. Esto conlleva un déficit a la hora de enseñar y trabajar los conocimientos más prácticos y sus aplicaciones. Se hace explícito en la encuesta de conocimientos previos y los conceptos mejor asimilados por lo estudiantes son los teóricos, como el frío y el calor, mientras que los relacionados con los prototipos de disipación presentan los niveles de entendimiento más bajos.

Se considera que para alcanzar un aprendizaje integral se debe dominar un concepto a todos los niveles, comprensión aplicación, relación, etc. Resulta llamativo que la mayoría de los alumnos consideren que conocen las diferencias entre los medios de disipación (65\%) pero no hayan visto nunca un prototipo de disipación (solo un 16\%). Estos resultados prueban la necesidad de profundizar en los conceptos desde todos los niveles de conocimiento para poder asegurar el proceso de aprendizaje completo.

Los datos analizados también demuestran que esta experiencia educativa fomenta el aprendizaje constructivo. A partir de las clases teóricas impartidas en el aula se completan y asimilan los conceptos en su totalidad con otro tipo de metodologías como las sesiones prácticas. El 100\% de los alumnos afirma conocer los conceptos de frío y calor antes de realizar la práctica, sin embargo, con la realización de la sesión un elevado porcentaje (96\%) considera que estos conocimientos se han afianzado y asimilado mejor. Estos datos confirman por tanto, la eficacia de la sesión para profundizar en los contenidos.

Por otra parte, se considera fundamental la realización de prácticas de este tipo que fomente en papel activo de los alumnos, donde ellos son los guías de su propio aprendizaje. Este tipo de herramientas educativas permiten desarrollar las competencia de aprender a aprender y de iniciativa y espíritu emprendedor, difíciles de integrar en clases teóricas y con mayor número de alumnos.

Los datos permiten también conocer de cerca la opinión de los alumnos sobre la sesión y sus propuestas de mejora. Un elevado porcentaje (82\%) considera que es una experiencia recomendable para su formación como arquitectos, un 13\% la considera imprescindible y tan solo un $4 \%$ la valora como anecdótica. Cabe destacar que ningún alumno ha considerado la sesión inútil, este dato confirma que la sesión realmente posee un valor educativo para los futuros arquitectos.

Por último, los alumnos han realizado diferentes propuestas de mejora en el último apartado de la encuesta, algunas de las más relevantes son: incluir el dibujo del esquema de los prototipos para facilitar su identificación, y poder profundizar en la tecnología manipulando más aplicaciones reales de las Peltier. Es también común la petición de más clases de este tipo y visitar otros prototipos a escala. Estas opiniones demuestran el interés y la motivación que genera la sesión en los alumnos y además, permite la mejora continua de la práctica ya que se pueden incluir las propuestas interesantes en la docencia de próximos cursos.

(cc) EY-NC-ND 2018, Universitat Politècnica de València

Congreso IN-RED (2018) 


\section{Agradecimientos}

Queremos agradecer el apoyo provisto por el proyecto BIA2013-46463- del Ministerio de Ciencia e Innovación del Gobierno de España y el proyecto 0011-1365-2016-000289 del Gobierno de Navarra.

También queremos agradecer a Jesús Maria Sánchez de Berotza por la ejecución de los equipos termoeléctricos.

\section{Referencias}

Amran, M. S., \& Rahman, S. (2017). The use of humour in mathematics teaching and its relationship with students' concentration and motivation. Advanced Science Letters, 23(2).

Ben Amara, F., \& Ayari, W. (2016). Team-based serious games and useful mathematics in engineering education. In International Symposium on Project Approaches in Engineering Education (Vol. 6).

Can, E. (2016). A different method proposal to improve of skills and success of the subtraction at primary schools in turkey. Turkish Online Journal of Educational Technology, 2016(NovemberSp).

De Menezes Maciel, A., Do Rêgo, R. G., \& Carlos, E. J. (2017). Pedagogic possibilities for using photographic images in didactic mathematics books | Possibilidades pedagógicas do uso da imagem fotográfica no livro didático de matemática. Bolema Mathematics Education Bulletin, 31(57).

Deniz, S., \& Simsek, I. (2015). The effect of 3D virtual learning environments on mathematic success: Second life sample. Turkish Online Journal of Educational Technology, 2015.

Felder, R. M., \& Brent, R. (2005). Understanding Student Differences. Journal for Engineering Education, 94(1), 57-72.

Felder, R., \& Silverman, L. (1988). Learning and teaching styles in engineering education. Engineering Education, 78(June), 674-681.

Granf, F., \& Marino, G. (2016). Building Environment and Interior Comfort in 20thCentury Architecture: Understanding Issues and Developing Conservation Strategies. Laboratory of Techniques and Preservation of Modern Architecture.

Ibañez-Puy, M., Bermejo-Busto, J., Martín-Gómez, C., Vidaurre-Arbizu, M., \& SacristánFernández, J. A. (2017). Thermoelectric cooling heating unit performance under real conditions. Applied Energy, 200, 303-314.

Ibañez-Puy, M., Martín-Gómez, C., Bermejo-Busto, J., Sacristán, J. A., \& Ibañez-Puy, E. (2018). Ventilated Active Thermoelectric Envelope (VATE): Analysis of its energy performance when integrated in a building. Energy and Buildings, 158, 1586-1592.

Ibáñez-Puy, M., Martín-Gómez, C., Vidaurre-Arbizu, M., \& Sacristán Fernandez, J. A. (2014). Theoretical Design of an Active Façade System with Peltier. Energy Procedia, 0, 0-4.

Ibañez-Puy, M., Sacristán Fernández, J. A., Martín-Gómez, C., \& Vidaurre-Arbizu, M. (2015). Development and Construction of a Thermoelectric Active Facade Module. Journal of Facade Design and Engineering, 3(1), 15-25. 
Martín-Gómez, C., Bermejo-Busto, J., \& Mambrilla-Herrero, N. (2015). Emergency lighting cabinet for fire safety learning. Case Studies in Fire Safety, 3, 17-24.

Martín-Gómez, C., Ramos, J. C., Rivas, A., Eguaras-Martínez, M., Mambrilla-Herrero, N., \& Torres, J. (2010). Prototype Thermoelectric Climate System For Its Use In Residential Buildings. In 29th International Conference on Thermoelectrics. Shangai, China. Retrieved from

Martín-Gómez, C., Zapata, O., Zuazua, A., Villanueva, S., \& Olaizola, P. (2014). Building services cabinets as teaching material in a degree in architecture. European Journal of Engineering Education, 39(2), 143-156.

Monedero Isorna, J. (2002). Enseñanza y práctica profesional de la arquitectura en Europa y EEUU-España. (Vol 2).

Vega-Moreno, D., Cufí Solé, X., José Rueda, M., \& Llinás, D. (2016). Integración de robótica educativa de bajo coste en el ámbito de la educación secundaria para fomentar el aprendizaje por proyectos Low cost educational robotics integration at high school scope to promote project- based learning. International Journal of Educational Research and Innovation, 6, 26-11. 


\title{
¿Puede el aprendizaje de la geotecnia ser divertido?
}

\section{Julio Garzón-Roca ${ }^{\mathrm{a}}$, F. Javier Torrijo ${ }^{\mathrm{b}}$, Guillermo $\operatorname{Cobos}^{\mathrm{c}}$ y Luis Fernández ${ }^{\mathrm{d}}$}

${ }^{a}$ Depto. de Ingeniería del Terreno, ETSICCP, Universitat Politècnica de València, jugarro@upv.es

bopto. de Ingeniería del Terreno, ETSICCP, Universitat Politècnica de València, fratorec@trr.upv.es

${ }^{\mathrm{c}}$ Depto. de Ingeniería del Terreno, ETSICCP, Universitat Politècnica de València, gcobos@trr.upv.es

${ }^{\mathrm{d}}$ Depto. de Ingeniería del Terreno, ETSICCP, Universitat Politècnica de València, luiferp2@trr.upv.es

\begin{abstract}
Geotechnical engineering is usually an awkward topic for many students of civil engineering degrees who are often more focused on getting the final number of a given problem than in the process conducted to arrive to the solution. This issue is especially significant when teaching advance topics of geotechnical engineering such as Tunneling or Ground Improvement. Those topics are normally taught in the last years of the degrees and in many cases students are used to the classical teaching in Higher Education. All of this normally results in a low motivation of students, mainly interested in obtaining the degree itself, more than in learning. This article shows an active learning methodology based on autolearning which leads to involving the engineering students in those advanced geotechnical engineering topics, even enjoying with them. The core activity of the learning methodology is the preparation of a part of the subject by the own students, who work in groups and have to give a real lecture to their colleagues.
\end{abstract}

Keywords: Teaching innovation, Higher Education, active methodology, formative assessment, flips teaching

\section{Resumen}

La Geotecnia es en ocasiones una materia difícil e incómoda para el estudiante de ingeniería civil, el cual normalmente suelen centrarse más en obtener el número final de un problema determinado que en el proceso llevado a cabo para llegar a la solución. Esto es especialmente significativo cuando se enseñan temas avanzados de la disciplina, tales como el diseño y construcción de túneles o la mejora de terrenos, temas que se estudian en los últimos años de los grados, con unos alumnos acostumbrados a la enseñanza clásica en la Educación Superior. Todo esto lleva a que la motivación sea baja, estando los alumnos más interesados en obtener el título en sí, que en aprender. Así, este artículo muestra una metodología de aprendizaje activa basada en el autoaprendizaje que persigue involucrar a los alumnos en temas avanzados de la Geotecnia, llegando incluso a disfrutar con ellos. El núcleo central de la metodología es la preparación, en grupos, de una parte de la asignatura por parte de los propios alumnos, quienes deben dar una clase real a sus compañeros.

Palabras clave: Innovación docente, Educación Superior, metodología activa, aprendizaje por proyectos, clase inversa 


\section{Introducción}

La Geotecnia es a menudo una materia difícil e incluso incómoda para el alumno de Ingeniería Civil, normalmente más acostumbrado a enfocarse en obtener el número final del problema que en el proceso, usando el pensamiento ingenieril, llevado a cabo para plantear éste y llegar a una solución (que puede no ser única). Esto se hace especialmente significativo en los últimos años de los grados, cuando se enseñan temas avanzados de la Ingeniería Geotécnica, tales como el diseño y construcción de túneles o la mejora de terrenos. Los alumnos, acostumbrados a la enseñanza clásica de la Educación Superior, una educación muy reglada y basada fundamentalmente la transmisión de grandes conocimientos teóricos y técnicos, se encuentran así escasamente motivados, muchos de ellos deciden no asistir a las clases, y en el fondo están interesados principalmente en obtener el título en sí mismo, más que en el aprendizaje.

Se hace por tanto necesario desarrollar metrologías activas de forma que se consiga involucrar a los alumnos en el aprendizaje, considerando el pragmatismo inherente y típico de la profesión de ingeniero civil, y por qué no, consiguiendo que los alumnos lleguen incluso a disfrutar aprendiendo.

La asignatura objeto de la innovación que se presenta en esta comunicación pertenece al ámbito temático de la Ingeniería Geotécnica, se enmarca en el último año de grado y se imparte desde el año 2013, coincidiendo con la implantación de los grados y el Plan Bolonia, en la titulación de Ingeniero Civil.

Se tienen así fundamentalmente dos aspectos a trabajar:

- Implementar una evaluación continua, en contraposición a la fórmula tradicional de uno o dos únicos exámenes, la cual esté basada en un enfoque pragmático de la asignatura.

- Proponer actividades de carácter activo, que permita el seguimiento de la asignatura por parte de todo el alumnado, logre su motivación y los involucre en el aprendizaje de la asignatura y en el suyo propio.

\section{Objetivos}

La innovación planteada en esta comunicación se inscribe en el contexto de los alumnos de $4^{\circ}$ de Grado en Ingeniería Civil, los cuales se encuentran a las puertas de ejercer su titulación, y pretende conseguir una mayor motivación de éstos hacia la asignatura y la temática de ésta (la Ingeniería Geotécnica) al tiempo que proporcionales un cierto control sobre su propio aprendizaje.

A los alumnos se les ofrece la oportunidad de superar la asignatura mediante una evaluación continua a lo largo del cuatrimestre. Para ello, y como núcleo central de la innovación, los alumnos tienen que desarrollar por grupos una parte del temario de la asignatura, debiendo realizar entregas parciales (con retroalimentación posterior) al profesor encargado de tutorar al grupo así como una presentación final al resto de sus

(cc) BY-NC-ND 2018, Universitat Politècnica de València

Congreso IN-RED (2018) 
compañeros mediante la impartición de una clase real. Los temas desarrollados por los alumnos son eminentemente prácticos, y se les anima a que la presentación de éstos a sus compañeros sea lo más activa e interactiva posible, llegando incluso a lo lúdico, de forma que sea posible aprender divirtiéndose.

Se proponen así los siguientes objetivos a alcanzar con la innovación:

- Involucrar al alumno en la asignatura y despertar su interés por ella.

- Hacer partícipe al alumno de su propio aprendizaje y evaluación.

- Desarrollar la capacidad de autocrítica del alumno respecto a su propio conocimiento

- Fomentar el trabajo en grupo.

Esta innovación sigue el trabajo desarrollado por los profesores de la asignatura tanto fuera de la actividad docente como en varias experiencias docentes previas (Murillo, 2003; Zabala y Arnau, 2007; Santos et al., 2012; Torrijo et al., 2012, 2017), fomenta la motivación y la responsabilidad del alumno por su propio aprendizaje (Tedesco, 2010; Monroy et al., 2012) y combina fundamentalmente cuatro tipos de metodologías de aprendizaje: lección magistral participativa, aprendizaje cooperativo, aprendizaje autónomo y clase inversa (flipped classroom).

\section{Desarrollo de la innovación}

\subsection{Planteamiento}

La asignatura se divide fundamentalmente en dos partes, una primera más reglada y conducida por el profesorado, en la que se combina la lección magistral participativa y el aprendizaje cooperativo y autónomo, y una segunda parte, basada casi exclusivamente en un aprendizaje mediante clase inversa, en la que el alumno es el único protagonista del aprendizaje y en donde son los propios alumnos los que imparten (de manera grupal) las clases a sus compañeros.

La Tabla 1 recoge el calendario de la asignatura, relativo a las clases de teoría de aula y prácticas de aula, seguido durante el último curso académico (2017-2018), el cual, con pequeñas variaciones, es similar al planteado desde el inicio de la asignatura, en el año 2013. Además de estas clases de aula, en la asignatura también se realizan prácticas de laboratorio y una práctica de campo, en las que los alumnos son acompañados en el aprendizaje por uno o varios profesores. Este calendario es conocido por los alumnos desde el inicio de curso, de forma que además de la distribución del temario, los alumnos tienen conocimiento de la metodología docente y del profesor responsable de cada sesión.

Puesto que en general la terminología de aprendizaje es desconocida por el alumnado, se aprovecha el primer día de clase para explicar brevemente en qué consiste cada una de las metodologías que se emplearán a lo largo del curso, de forma que los alumnos tomen conciencia de lo que se espera de ellos en cada sesión y qué pueden esperar ellos del profesor, para que, en definitiva, adquieran control sobre su propio aprendizaje.

(cc) EY-NG-ND 2018, Universitat Politècnica de València

Congreso In-Red (2018) 
Tabla 1. Calendario de la asigntura (curso 2017-2018)

\begin{tabular}{|c|c|c|}
\hline Fecha & Tema & Metodología docente \\
\hline 05/09/2017 & Presentación de la asignatura & Lección magistral participativa \\
\hline 06/09/2017 & Planificación de reconocimientos del terreno & Aprendizaje autónomo \\
\hline $12 / 09 / 2017$ & Técnicas genéricas de prospección & Ap. cooperativo y autónomo \\
\hline $13 / 09 / 2017$ & Interpretación de datos geotécnicos en suelos y rocas & Aprendizaje autónomo \\
\hline 19/09/2017 & Descripción de macizos rocosos & Lección magistral participativa \\
\hline 20/09/2017 & Instrumentación y auscultación geotécnica & Ap. cooperativo y autónomo \\
\hline 26/09/2017 & Resistencia de macizos rocosos I & Lección magistral participativa \\
\hline $27 / 09 / 2017$ & Resistencia de macizos rocosos II & Lección magistral participativa \\
\hline 03/10/2017 & Deformabilidad de macizos rocosos & Lección magistral participativa \\
\hline 04/10/2017 & Casos prácticos de macizos rocosos & Ap. cooperativo y autónomo \\
\hline $10 / 10 / 2017$ & $\begin{array}{l}\text { Conferencia: Movimientos y deslizamientos del } \\
\text { terreno }\end{array}$ & Lección magistral participativa \\
\hline $11 / 10 / 2017$ & $\begin{array}{l}\text { Seminario abierto Cineforum (visionado de película- } \\
\text { documental) }\end{array}$ & Aprendizaje autónomo \\
\hline $17 / 10 / 2017$ & Estabilidad de taludes en rocas I & Ap. cooperativo y autónomo \\
\hline $18 / 10 / 2017$ & Estabilidad de taludes en rocas II & Ap. cooperativo y autónomo \\
\hline $24 / 10 / 2017$ & Estabilidad de taludes en suelos & Ap. cooperativo y autónomo \\
\hline $25 / 10 / 2017$ & $\begin{array}{l}\text { Técnicas de contención y corrección de } \\
\text { deslizamientos }\end{array}$ & Ap. cooperativo y autónomo \\
\hline $31 / 10 / 2017$ & Diseño y proyecto de la obra subterránea & Clase inversa \\
\hline 07/11/2017 & Cálculo geotécnico-estructural del túnel & Clase inversa \\
\hline 08/11/2017 & $\begin{array}{l}\text { Métodos de construcción de túneles y su } \\
\text { instrumentación y auscultación }\end{array}$ & Clase inversa \\
\hline $1411 / 2017$ & Casos prácticos sobre túneles & Clase inversa \\
\hline $15 / 11 / 2017$ & Compactación dinámica & Clase inversa \\
\hline $21 / 11 / 2017$ & Vibroflotación y columnas de grava & Clase inversa \\
\hline 22/11/2017 & Precarga & Clase inversa \\
\hline 28/11/2017 & Inyecciones y Jet Grouting & Clase inversa \\
\hline 29/11/2017 & Casos prácticos sobre mejora del terreno I & Clase inversa \\
\hline 05/12/2017 & Casos prácticos sobre mejora del terreno II & Clase inversa \\
\hline $12 / 12 / 2017$ & Resumen y dudas de la asignatura I & Ap. cooperativo y autónomo \\
\hline $13 / 12 / 2017$ & Resumen y dudas de la asignatura II & Ap. cooperativo y autónomo \\
\hline
\end{tabular}

(cc) EY-NC-ND 2018, Universitat Politècnica de València 


\subsection{Visionado de la asignatura}

La primera parte de la asignatura es en cierto modo similar a las clásicas clases teóricas, de forma que es el profesor quien dirige las clases, estructura el contenido a tratar y fija en cierta medida el ritmo del aprendizaje. No obstante, se procura que el profesor no acapare todo el protagonismo. Así, en esta parte de la asignatura el profesor imparte unas pautas de puntos básicos de la materia que se va a trabajar y se proponen actividades a los alumnos. Se procura así que éstos tengan un papel lo más activo posible, desarrollando las clases de la forma más interactiva posible. Para ello, se emplean técnicas como el panel de expertos, el visionado de algunos fragmentos de videos documentales obtenidos directamente de internet (a través de la plataforma Youtube), el planteamiento de casos reales o la realización de sencillos tests empleando la aplicación informática kahoot. Con esto se pretende tanto motivar al alumno y captar su interés, como mostrarle diferentes alternativas a la típica lección magistral, metodología que es usualmente asociada por los alumnos con lo que es una clase.

La segunda parte de la asignatura se desarrolla con la metodología de clase inversa y su desarrollo se basa, como se ha indicado antes, en que son los propios alumnos los que imparten las clases. Mediante esta metodología de clase inversa se consigue dar el protagonismo al alumno así como la responsabilidad sobre su propio aprendizaje (Bergmann y Sams, 2012; Sams y Bergmann, 2013). El primer día de clase, tras informar a los alumnos sobre el funcionamiento del curso, la metodología a seguir y la evaluación, se les pide que formen de manera libre diez grupos de 3-5 personas (en función del número de alumnos), debiendo comunicar a los profesores en el plazo máximo de una semana qué personas forman cada uno de los grupos.

Aproximadamente dos semanas después de iniciado el curso, se cita a cada grupo para encomendarles la parte de la asignatura que deben preparar y sobre la que luego deben impartir una clase de 2 horas de duración. A cada grupo se le hace ver que van a ser ellos los responsables de una de las clases de la segunda parte de la asignatura, de forma que van a tomar el papel de profesor. Para preparar la clase, los alumnos cuentan con la ayuda de uno de los profesores de la asignatura, el cual tutora al grupo y controla el ritmo del trabajo a través de reuniones más o menos periódicas en las que se proporciona feedback a los alumnos, así como realizando sesiones de apoyo y acompañamiento. No obstante, el papel del profesor tutor es menor. Tras haber asignado a cada grupo el tema a impartir, para con ello centrarles en su desarrollo del aprendizaje, se indica a los alumnos que la preparación de la clase, tanto como quieren impartirla como los recursos a suministrar a sus alumnos (esto es, sus compañeros) es completamente responsabilidad suya. Esto crea en un primer momento desconcierto, miedo e incredulidad en los alumnos.

Superada esta primera etapa y una vez el grupo empieza a esbozar una primera idea de los contenidos de la clase, el tutor del grupo les recuerda la importancia que tienen los aspectos prácticos en la ingeniería civil y les anima a que la clase a impartir sea interactiva, dinámica y lúdica, de forma que se procure en lo posible que sus compañeros aprendan divirtiéndose. Esto en ocasiones lo resumimos con la siguiente frase: "Impartid la clase como si fuera la clase ideal que os hubiera gustado recibir en vuestra vida".

(cc) EY-NC-ND 2018, Universitat Politècnica de València 
Con ello se consigue que los alumnos preparen actividades realmente interesantes y divertidas. Así, en la Fig. 1 podemos ver a los alumnos del grupo responsable de impartir la clase realizando un kahoot a sus compañeros, en el que como premio se entregaba al ganador una tableta de chocolate.
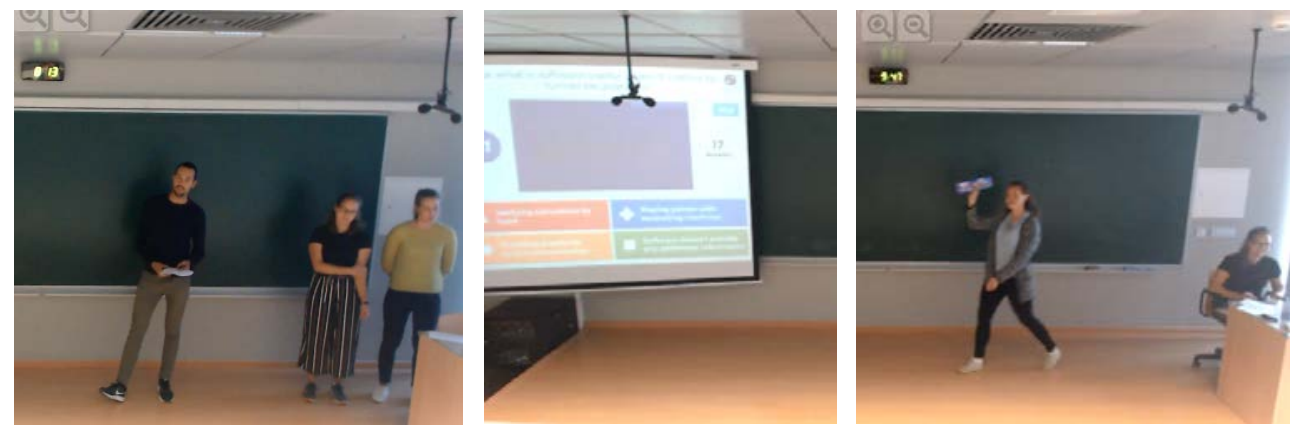

Fig. 1. Alumnos impartiendo el tema Cálculo geotécnico-estructural del túnel, correspondiente a la $18^{a}$ sesión de la asignatura

En la Fig. 2 podemos ver el aprendizaje de la compactación dinámica de suelos a través de una simulación real preparada por los alumnos del grupo responsable de impartir la clase con el fin de que sus compañeros entendiesen jugando los fundamentos de esta técnica y los efectos que lleva aparejada cuando es aplicada en un terreno.
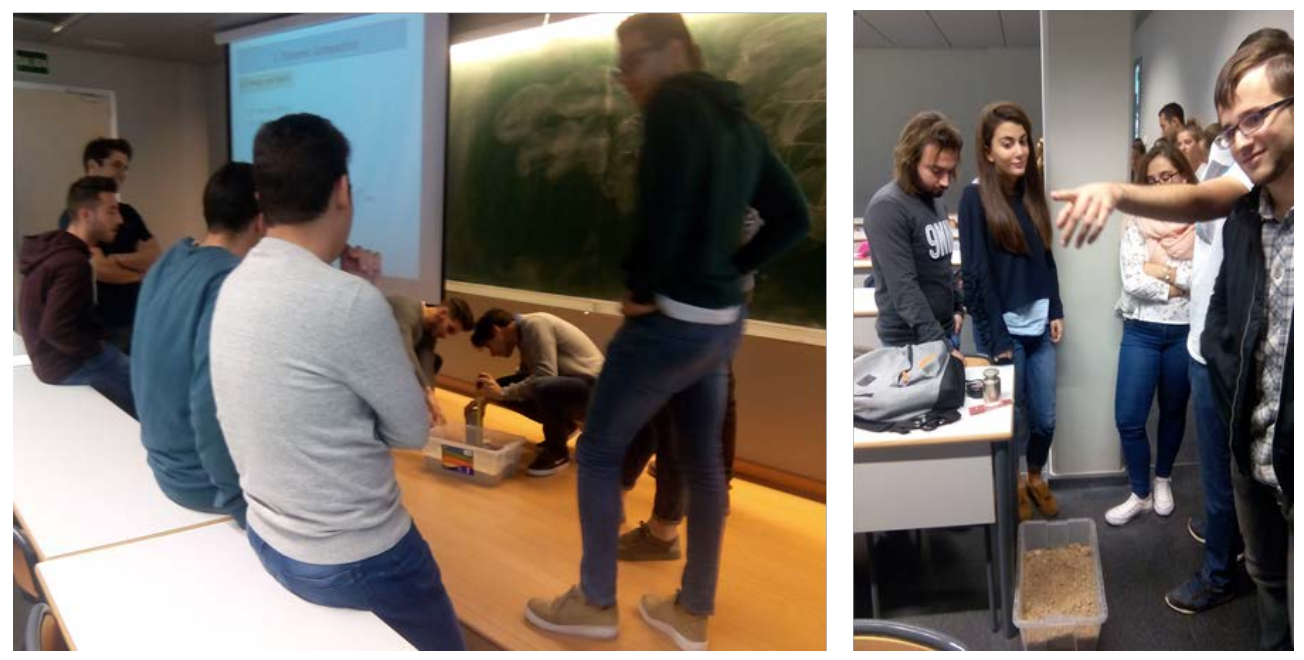

Fig. 2. Alumnos impartiendo el tema Compactación dinámica, correspondiente a la $21^{a}$ sesión de la asignatura

Este tipo de actividades, unido a la realidad de que son sus propios compañeros los que están impartiendo la clase (Fig. 3), lleva a que exista una participación notable por parte de los alumnos así como una implicación superior a la que se observaba antes de implantar esta metodología. Los alumnos terminan normalmente superando el miedo escénico a hablar en público y en algunas clases se producen debates sobre el tema impartido con una participación muy alta por parte de los alumnos.

Es interesante señalar que este cambio en el comportamiento de los alumnos se empieza a dar ya en la primera parte de la asignatura en la que las metodologías empleadas son la 
lección magistral participativa y el aprendizaje cooperativo y autónomo, ya que en ese momento ya llevan semanas trabajando para preparar lo que será su clase, lo que empieza a darles cierta seguridad en clase y los predispone a colaborar en la misma.
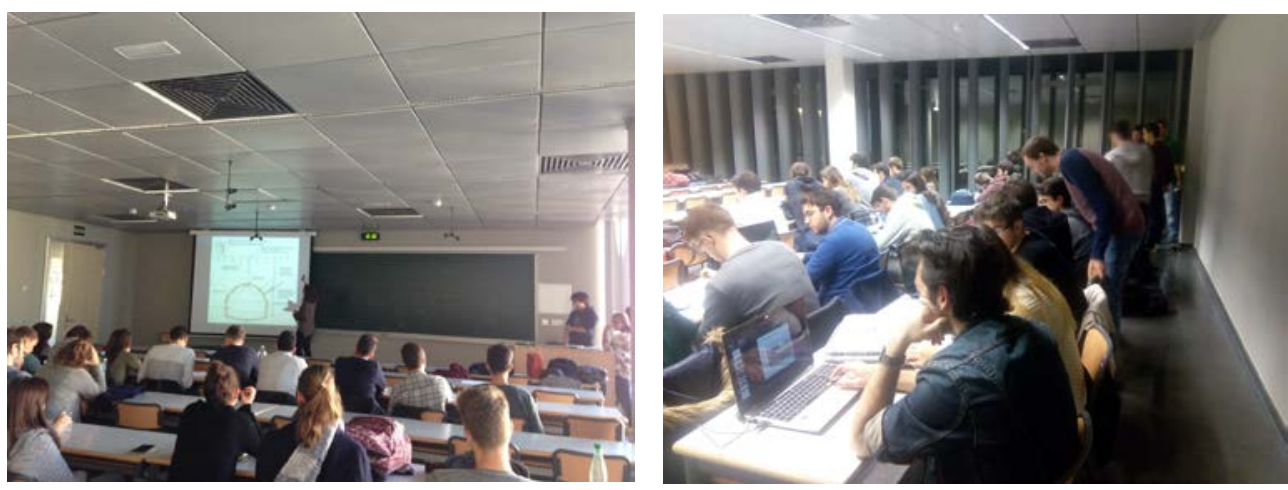

Fig. 3. Alumnos impartiendo los temas Métodos de construcción de túneles y su instrumentación y auscultación (izquierda) y Precarga (derecha) correspondiente a las $19^{a}$ y $23^{a}$ sesiones de la asignatura

\subsection{Recursos utilizados para el desarrollo de la asignatura}

Los recursos utilizados como material para el alumnado para lograr el éxito de la innovación pueden resumirse en:

- Información y datos necesarios para realizar su trabajo de forma autónoma y grupal: a los alumnos se les facilita al inicio del curso abundante material disponible en PoliformaT, en forma de material escrito y vídeos que sirven de punto de partida y acercamiento a la asignatura.

- Material teórico (apuntes y videos): se trata de un material que los alumnos pueden utilizar para retroalimentar su aprendizaje. Se encuentra disponible en PoliformaT, se comenta en clase y es la base para el desarrollo de las clases basadas en las metodologías aprendizaje autónomo y lección magistral participativa.

- Material teórico-práctico: este material puede ser utilizado por los alumnos para llevar a cabo de manera óptima el aprendizaje cooperativo y su trabajo grupal.

- Recursos bibliográficos: al principio del curso, así como durante la preparación de las clases por parte de los alumnos para ser impartidas durante la segunda parte de la asignatura, se facilita un amplio listado de referencias bibliográficas, tanto genéricas como específicas, que puedan consultar en los archivos de la Universidad.

\subsection{Evaluación}

Para los alumnos que siguen la metodología de la innovación planteada, la asignatura se evalúa en dos partes, correspondiendo a la división de la asignatura indicada anteriormente, a lo que se suma la evaluación de las prácticas laboratorio y de campo: 
- La primera parte de la asignatura, la cual se centra en aspectos más teóricos, se evalúa por medio de una prueba escrita de respuesta abierta, de carácter teóricopráctico, donde al alumno debe resolver cuestiones similares a las realizadas en clase. Esta prueba supone el 40\% de la calificación final.

- La segunda parte, correspondiente a las clases dadas por los alumnos, supone el $40 \%$ de la calificación final y se evalúa mediante coevaluación basada en tres ítems con el mismo peso (un tercio cada uno):

o Evaluación por pares, por parte de los compañeros presentes en la clase y ajenos al grupo que imparte la clase. La evaluación es anónima y se realiza una vez terminada la clase.

o Evaluación por pares, de cada uno de los alumnos del grupo que ha impartido la clase, de sus propios compañeros de grupo. La evaluación es anónima y se realiza una vez terminada la clase.

o Evaluación por parte del profesor que ha tutorizado al grupo tras comentar el trabajo desarrollado por los alumnos con el profesor o profesores presentes en la clase impartida por éstos (en el caso de que el profesor que tutoriza al grupo no esté presente).

- Las prácticas de laboratorio suponen un $10 \%$ de la calificación final y las evalúa el profesor responsable de las mismas en base a un trabajo escrito realizado individualmente por los alumnos.

- La práctica de campo suponen un $10 \%$ de la calificación final y la evalúa el profesor responsable de las misma en base a un trabajo escrito realizado individualmente por los alumnos.

Es interesante señalar que se da un peso importante a la evaluación por pares basada en la preparación de una parte del temario por parte de los alumnos y la impartición de una clase sobre dicho temario por ellos a sus compañeros, ya que se persigue fomentar la capacidad del alumno para seleccionar y presentar técnicamente la información que considere interesante para su público objetivo (en este caso, el resto de compañeros de clase), así como su capacidad para criticar técnicamente el trabajo de ingeniería realizado por sí mismo o por un tercero.

Asimismo, es importante destacar que al inicio del curso se plantea el sistema de evaluación de la asignatura, y a los alumnos se les da la oportunidad de ser evaluados tanto siguiendo la metodología anterior como a través de la fórmula tradicional consistente en dos exámenes. En este último caso, el primer examen es idéntico al examen de la primera parte de la innovación, mientras que el segundo examen es una prueba escrita de respuesta abierta, de carácter teórico-práctico, que versa sobre los temas tratados en la segunda parte de la asignatura.

\section{Resultados}

La Tabla 2 muestra los resultados de seguimiento de la asignatura por parte de los alumnos desde su implantación en el curso 2012-2013. Durante el primer año se seguía una 
metodología más tradicional, basada en casi exclusivamente el uso de la lección magistral y la evaluación del alumnado mediante dos exámenes. Ya en el curso 2013-2014 comenzó a implantarse la metodología expuesta en la presente comunicación, la cual ha sufrido poca variación, si bien sí se ha ido mejorando y puliendo poco a poco con el tiempo. Como puede observarse, el cambio de metodología supuso un claro y drástico descenso en el número de alumnos no presentados (quizás podría implicar más motivación), siendo menor a un $5 \%$.

Tabla 2. Resultados del seguimiento de la asignatura.

\begin{tabular}{lcccccc}
\hline & \multicolumn{6}{c}{ Curso } \\
\cline { 2 - 7 } & $\mathbf{2 0 1 3 - 2 0 1 4}$ & $\mathbf{2 0 1 3 - 2 0 1 4}$ & $\mathbf{2 0 1 4 - 2 0 1 5}$ & $\mathbf{2 0 1 5 - 2 0 1 6}$ & $\mathbf{2 0 1 6 - 2 0 1 7}$ & $\mathbf{2 0 1 7 - 2 0 1 8}$ \\
\hline No presentados & $32(27 \%)$ & $1(1 \%)$ & $5(3 \%)$ & $4(3 \%)$ & $4(5 \%)$ & $0(0 \%)$ \\
Presentados & $85(73 \%)$ & $84(99 \%)$ & $167(97 \%)$ & $131(97 \%)$ & $75(95 \%)$ & $86(100 \%)$ \\
\hline
\end{tabular}

En la Tabla 3 se recogen los resultados académicos de los alumnos presentados desde el curso 2012-2013 hasta el presente curso, 2017-2018. Se observa que la implementación de la innovación docente ha llevado aparejado un aumento general del porcentaje tanto de aprobados como de notas medias (Notables), si bien no se evidencia un aumento significativo en el número de Sobresaliente y Matrícula de Honor. Esto indica que la nueva metodología consigue mejorar el rendimiento académico de los alumnos medios, los cuales ven incrementadas sus calificaciones. Por su parte, los alumnos que ya eran excelentes siguen siéndolo.

Tabla 3. Resultados de las calificaciones de los alumnos presentados*

\begin{tabular}{lcccccc}
\hline & \multicolumn{7}{c}{ Curso } \\
\cline { 2 - 7 } & $\mathbf{2 0 1 2 - 2 0 1 3}$ & $\mathbf{2 0 1 3 - 2 0 1 4}$ & $\mathbf{2 0 1 4 - 2 0 1 5}$ & $\mathbf{2 0 1 5}-\mathbf{2 0 1 6}$ & $\mathbf{2 0 1 6 - 2 0 1 7}$ & $\mathbf{2 0 1 7 - 2 0 1 8}$ \\
\hline Suspensos & $12(14 \%)$ & $0(0 \%)$ & $0(0 \%)$ & $1(1 \%)$ & $0(0 \%)$ & $8(9 \%)$ \\
Aprobados & $65(77 \%)$ & $14(17 \%)$ & $46(27 \%)$ & $42(32 \%)$ & $33(44 \%)$ & $51(59 \%)$ \\
Notables & $7(8 \%)$ & $53(63 \%)$ & $119(68 \%)$ & $82(62 \%)$ & $39(52 \%)$ & $20(23 \%)$ \\
Sobresalientes & $1(1 \%)$ & $14(16 \%)$ & $2(1 \%)$ & $0(0 \%)$ & $1(1 \%)$ & $3(4 \%)$ \\
Mat. de Honor & $0(0 \%)$ & $3(4 \%)$ & $0(0 \%)$ & $6(5 \%)$ & $2(3 \%)$ & $4(5 \%)$ \\
Nota Media & 5,21 & 8,02 & 7,40 & 7,25 & 7,20 & 6,33 \\
Nota Máxima & 9,00 & 10,00 & 9,20 & 9,40 & 9,60 & 10,00 \\
Nota Mínima & 0,20 & 5,80 & 5,00 & 4,00 & 5,50 & 1,60 \\
Des. estándar & 5,87 & 0,96 & 1,22 & 1,25 & 0,80 & 1,65 \\
\hline \multirow{2}{*}{ Los por } & &
\end{tabular}

* Los porcentajes están respecto a los alumnos presentados

Es interesante señalar que del total de alumnos que han cursado la asignatura desde el curso 2013, momento en que se puso en marcha la innovación, de los 543 alumnos que decidieron seguir la asignatura de manera continua, casi la totalidad de estos han aprobado, tan sólo 9 han suspendido, varios de los cuales debido a un abandono de la asignatura. Asimismo, del 
análisis de las calificaciones se desprende que la media ha aumentado respecto al empleo de la metodología anterior entorno a punto y medio y la desviación estándar obtenida es reducida.

En lo que respecta a aspectos relacionados con el nivel de implicación, motivación y valoración de la asignatura por parte de los alumnos, la Tabla 4 recoge los resultados de una encuesta llevada a cabo por el ICE de la UPV en este último curso académico con el fin de evaluar la implantación de la metodología de la clase inversa. Debe señalarse que de los años anteriores no se tienen datos, por lo que no es posible realizar comparaciones. No obstante, desde un punto de vista cualitativo, se observó ya desde el curso 2013-2014 que la innovación planteada aumentaba significativamente el grado de implicación y la motivación de los alumnos.

Tabla 4. Resultados de la encuesta sobre la metodología aplicada, curso 2017-2018

\begin{tabular}{|c|c|c|c|c|c|}
\hline \multirow{2}{*}{ Pregunta } & \multicolumn{5}{|c|}{ Valoración* } \\
\hline & 1 & 2 & 3 & 4 & 5 \\
\hline \multicolumn{6}{|l|}{$\begin{array}{l}\text { Con la aplicación de la metodología realizada en esta } \\
\text { asignatura, muestra tu grado de acuerdo con las siguientes } \\
\text { afirmaciones }\end{array}$} \\
\hline He ido a clase con un trabajo previo realizado & $0 \%$ & $8 \%$ & $33 \%$ & $42 \%$ & $17 \%$ \\
\hline Ha contribuido a aumentar mi implicación en la asignatura & $8 \%$ & $8 \%$ & $17 \%$ & $42 \%$ & $25 \%$ \\
\hline Me ha resultado gratificante & $17 \%$ & $0 \%$ & $42 \%$ & $17 \%$ & $25 \%$ \\
\hline $\begin{array}{l}\text { Ha permitido que el profesor dispusiera de más tiempo en } \\
\text { clase para aclarar dudas }\end{array}$ & $8 \%$ & $33 \%$ & $25 \%$ & $17 \%$ & $17 \%$ \\
\hline Ha fomentado el trabajo en grupo & $0 \%$ & $17 \%$ & $8 \%$ & $42 \%$ & $33 \%$ \\
\hline Me ha ayudado a llegar mejor preparado a los exámenes & $25 \%$ & $8 \%$ & $17 \%$ & $50 \%$ & $0 \%$ \\
\hline \multicolumn{6}{|l|}{$\begin{array}{l}\text { Lo que más te ha gustado de la aplicación de la metodología } \\
\text { realizada en esta asignatura ha sido }\end{array}$} \\
\hline $\begin{array}{l}\text { Los materiales facilitados por el profesor (vídeos y } \\
\text { documentos utilizados) }\end{array}$ & $8 \%$ & $8 \%$ & $8 \%$ & $58 \%$ & $17 \%$ \\
\hline El trabajo realizado en clase (actividades de aula) & $0 \%$ & $17 \%$ & $33 \%$ & $33 \%$ & $17 \%$ \\
\hline El trabajo realizado en casa necesario para seguir las clases & $17 \%$ & $0 \%$ & $67 \%$ & $17 \%$ & $0 \%$ \\
\hline La relación con el profesor, más cercana y de trabajo conjunto & $0 \%$ & $8 \%$ & $8 \%$ & $33 \%$ & $50 \%$ \\
\hline La relación con mis compañeros & $8 \%$ & $0 \%$ & $17 \%$ & $50 \%$ & $25 \%$ \\
\hline El sistema de evaluación empleado & $8 \%$ & $17 \%$ & $0 \%$ & $42 \%$ & $33 \%$ \\
\hline \multicolumn{6}{|l|}{ Valoración general } \\
\hline Estoy muy satisfecho con esta experiencia & $8 \%$ & $17 \%$ & $25 \%$ & $42 \%$ & $8 \%$ \\
\hline Recomendaría esta experiencia a mis compañeros & $0 \%$ & $17 \%$ & $33 \%$ & $42 \%$ & $8 \%$ \\
\hline
\end{tabular}

(cc) EY-NC-ND 2018, Universitat Politècnica de València

Congreso IN-RED (2018) 
Del análisis de la Tabla 4 se deprende que la metodología activa planteada en la innovación logra los objetivos de fomentar el trabajo en grupo y de aumentar el nivel de implicación en la asignatura. Esto último parece que tiene un doble efecto colateral, pues motiva a que el alumno acuda a clase con el trabajo previo (ver un video, resolver un ejercicio práctico, leer algún fragmento de un tema, etc.) realizado y ayuda en cierta medida al alumno a llegar mejor preparado a los exámenes.

Por otra parte, lo que más valoran los alumnos, además del material facilitado por los profesores, es la posibilidad de aprender junto con sus compañeros tanto dentro como fuera del aula. Como era de esperar, la creación de un buen entorno social favorece el aprendizaje y esto queda reflejado en la experiencia de los alumnos con la asignatura. El sistema de evaluación empleado también es positivamente valorado por los alumnos, los cuales aprecian el ofrecimiento que les da la asignatura de ser aprobada mediante una evaluación continua y no a través de uno o dos exámenes independientes del curso en sí.

Finalmente, es importante señalar que a la gran mayoría de los alumnos les ha gustado la metodología docente seguida y recomendarían a sus compañeros seguirla en los cursos venideros.

\section{Conclusiones}

Tras cinco cursos aplicando la nueva metodología activa basada en el autoaprendizaje y el empleo de la clase inversa, es indudable que su implantación ha conseguido aumentar la motivación de los alumnos así como su predisposición para participar activamente en la asignatura.

La innovación ha permitido que los alumnos transformen, al menos en cierta medida, su típica visión de memorizar extrañas teorías y sistematizar la resolución de los problemas del examen, enfoque clásico de los alumnos de Ingeniería Civil ante una materia teóricopráctica como la Geotecnia, a un nuevo marco en el que son ellos los que aprenden de forma continua, día a día, acompañados de los profesores que les ayudan a afrontar los obstáculos. Los alumnos son los verdaderos protagonistas de las clases, llegando incluso a ser ellos quienes las imparten al resto de compañeros. Y todo ello bajo un enfoque lo más práctico e interactivo posible, e incluso lúdico en algunos casos, que busca claramente que el alumno aprenda haciendo así como que aprenda divirtiéndose.

Así, la metodología educativa implantada ha supuesto un avance en la evaluación formativa completa de los alumnos, ha mejorado su rendimiento académico, en especial el de los alumnos medios, y ha reducido ostensiblemente el absentismo académico así como el fracaso escolar en la Educación Superior, teniéndose unas cifras de alumnos presentados cercanas todos los años al 100\%, así como una tasa de alumnos suspensos muy reducida o incluso nula.

Finalmente, es interesante destacar que la innovación ha sido el fruto del trabajo cooperativo de todos los profesores de la asignatura, quienes han colaborado en mayor o en menor medida a que la innovación haya sido implantada exitosamente a lo largo de estos cinco cursos académicos. El trabajo en equipo y la reflexión compartida entre nosotros, tal 
y como indicaban Santos et al. (2012), ha permitido salvar las inseguridades generadas por hacer algo diferente e innovador.

\section{Referencias}

BERGMANN, J. y SAMS, A. (2012). "Flip your classroom : Talk to Every Class Every Day”. ISTE, Washington D.C.

KAHOOT. Kahoot! < https://kahoot.com /> [Consulta: 15 de marzo de 2017]

MONROY, R., TORRIJO, F.J. y HERNÁNDEZ-PINA, F. (2012). "Lecturers' perceptions of students' learning needs in geo-engineering in Spain” en McCabe, Pantazidou \& Phillips. Shaking the Foundations of Geo-engineering Education. London: Taylor \& Francis Group. 225-230.

MURILLO, F.J. (2003). "El movimiento teórico-práctico de Mejora de la Escuela. Algunas lecciones aprendidas para transformar los centro docentes” en Revista Electrónica Iberoamericana sobre Calidad, Eficacia y Cambio en Educación, vol. 1, issue 2, p. 1-22.

SAMS, A. y BERGMANN, J. (2013). Flip Your Students’ Learning” en Technology-Rich Learning, $70, n^{\circ} 6$.

SANTOS, M., CASTEJÓN, F.J. y MARTÍNEZ, L.F. (2012). "La innovación docente en evaluación formativa y metodología participativa. Un proyecto compartido a raíz de la implantación de los nuevos grados” en Psychology, Society \& Education, vol. 4, issue 1 p. 73-86.

TEDESCO, J.C. (2010). “La educación en el horizonte 2020”. Fundación Santillana, Madrid.

TORRIJO, F.J., CORTÉS, R. y VALIENTE, R. (2012). “Indagación y mejora docente en el campo de la Geología Aplicada”. Universidad Politécnica de Valencia. En Jornadas de Innovación Eductaiva 2012. Valencia. 376-378.

TORRIJO, F.J., GARZÓN-ROCA, J., COBOS, G. y ALIJA, S. (2017). “Implementación de la metodología de Clase Inversa en el campo de la Ingenieria del Terreno”. International Conference on Innovation, Documentation and Education, INNODOCT 2017, 25 - 27 de Octubre de 2017, Valencia.

ZABALA, A. y ARNAU, L. (2017). “11 ideas clave. Cómo aprender y enseñar competencias”. Colección Ideas Clave. Serie Didáctica / Diseño y desarrollo curricular. Editorial Graó de Irif, S.L., Barcelona. 


\title{
Análisis de estructuras algebraicas mediante la modelización de puzzles y rompecabezas*
}

\author{
María José Felipe $^{1}$ y Víctor Manuel Ortiz Sotomayor ${ }^{2}$ \\ ${ }^{1}$ Depto. Matemática Aplicada, ETS Ingeniería Industrial, Universitat Politècnica de \\ València \\ ${ }^{2}$ Instituto Universitario de Matemática Pura y Aplicada, Universitat Politècnica de \\ València
}

\begin{abstract}
The subject Algebraic Methods and their Applications of the Master in Mathematical Research is focused on showing the applicability that some abstract algebraic structures have in various scientific areas, in both pure mathematics and other more applied contexts of real life. One of the main troubles when learning these structures is their high degree of abstraction which difficults the understanding, specially for beginner students in this topic, as well as the lack of applicability they have been treated before, focusing only in the mathematical aspect.

The method of using games in teaching is an innovative and effective tool known as "game-based learning". This pedagogic tendency is used as a playful component in a concrete learning objective. In this direction, the present paper concerns about the mathematical modelling of different puzzles and brainteasers, as well as the analysis of their solubility, through algebraic techniques that have been used in the aforementioned subject. The goal is to address the study of both the structure of a group and also its most basic properties. To do this, we make use in the classroom of the computational algebraic system GAP (Groups, Algorithms and Programming), which eases the computations in discrete algebra and which helps in a better understunding of this abstract structure. The case of the Rubik's cube, one of the most celebrated and best-selling games in the world, and its variations are specially considered.
\end{abstract}

Keywords: Computational algebra, group theory, modelling, puzzles, GAP.

\footnotetext{
* El primer autor quiere agradecer la financiación del proyecto Proyecto Prometeo II/2015/011, Generalitat Valenciana. El segundo autor agradece la financiación recibida por la beca predoctoral ACIF/2016/170, Generalitat Valenciana. Este trabajo ha sido financiado por el Proyecto de Innovación Docente PDI-DMA-2018 "Modelizaciones algebraicas de algunos juegos matemáticos", Departamento de Matemática Aplicada (UPV). Nos gustaría agradecer especialmente a Ana Martínez Pastor sus siempre valiosos comentarios.
} 


\begin{abstract}
Resumen
La asignatura Métodos Algebraicos y sus Aplicaciones del Máster en Investigación Matemática está orientada a mostrar la aplicabilidad que ofrecen algunas estructuras algebraicas abstractas en diversas áreas científicas, tanto en la propia matemática pura como en otras áreas más aplicadas de nuestro entorno real. Uno de los principales problemas en el aprendizaje de dichas estructuras es su alto grado de abstracción que dificulta su entendimiento, principalmente para alumnos que se inician por primera vez en este campo, y la falta de aplicabilidad con las que han sido tratadas con anterioridad, centrándose en su aspecto puramente matemático.

El método de utilizar juegos en la enseñanza es una innovadora y eficaz herramienta conocida como "game-based learning". Esta tendencia pedagógica es utilizada como componente lúdica con un objetivo concreto de aprendizaje. En esta línea, la presente comunicación trata sobre la modelización matemática de diversos puzzles y rompecabezas, así como el estudio de su resolubilidad, mediante técnicas algebraicas que han sido utilizadas en la citada asignatura para abordar el estudio de la estructura de grupo y el análisis de sus propiedades más básicas. Para ello, hacemos uso en el aula del sistema algebraico computacional GAP (Groups, Algorithms and Programming), el cual facilita los cálculos en álgebra discreta y posibilita una mejor comprensión de esta estructura. El caso del cubo de Rubik, uno de los juegos más célebres y vendidos en el mundo, y sus variantes son considerados especialmente.
\end{abstract}

Keywords: Álgebra computacional, teoría de grupos, modelización, puzzles, GAP.

\title{
1 Introducción
}

La asignatura Métodos Algebraicos y sus Aplicaciones forma parte del plan de estudios del Máster en Investigación Matemática, máster interuniversitario de la Universitat de València y la Universitat Politècnica de València. Este máster está orientado a iniciar a los alumnos en las técnicas básicas de la investigación matemática actual, tanto en el ámbito de la matemática pura como aplicada, formándolos en la adquisición de herramientas matemáticas de alto nivel y técnicas matemáticas avanzadas cubriendo las expectativas de graduados en matemáticas, ingenieros y otras ciencias básicas. La asignatura mencionada tiene un doble objetivo: profundizar en el estudio de las principales estructuras algebraicas tratadas de forma abstracta (semigrupos, monoides, grupos, anillos y cuerpos, álgebras, espacios vectoriales y módulos, retículos, anillos de polinomios, geometría algebraica, etc.) y en el conocimiento de una visión más aplicada de dichas estructuras en ámbitos tan diversos como la criptografía, teoría de códigos, teoría de autómatas y lenguajes formales, estructuras moleculares, teoría de grafos, resolución de ecuaciones diferenciales, etc. (véase Lidl y Pilz 1998).

Sin embargo, un hándicap importante a tener en cuenta en la impartición de esta asignatura es la gran diversidad del alumnado que la cursa, pues podemos encontrarnos titulados en: física, ingeniería, informática, arquitectura, matemáticas, etc. El desajuste de conocimientos matemáticos adquiridos y la diversidad en la formación previa con la que acceden estos estudiantes influyen sustancialmente en la forma 
de presentar las unidades didácticas y la forma de trabajar en el aula. Así podemos encontrar alumnos con una formación matemática amplia pero una visión aplicada insuficiente y, al mismo tiempo, alumnos con una previa formación matemática más deficitaria pero, sin embargo, con unas capacidades prácticas mucho más trabajadas. Una de las principales preocupaciones docentes es pues mitigar este desajuste, adaptando la programación de la asignatura al alumnado matriculado de forma que suscite el mayor interés y atención en todos los estudiantes, aumentando de esta forma su motivación en el aula y manteniendo, al mismo tiempo, las expectativas particulares de cada estudiante. Por otro lado, otro de los principales retos es dar una visión más aplicada de los conocimientos abstractos matemáticos cuya falta puede observarse en los alumnos con una formación más teórica.

En la presente comunicación mostramos algunas técnicas desarrolladas en la citada asignatura con el fin de paliar los problemas expuestos anteriormente, utilizando la modelización matemática de algunos juegos y puzzles matemáticos que son familiares a los estudiantes y analizando su posible resolución. En esta misma línea, muchos profesionales han optado por utilizar de forma exitosa diversas técnicas, alternativas a la usual clase presencial, como son la gamificación, los serious games o el gamebased learning. Estas técnicas presentan ciertas diferencias entre sí, pero todas ellas nos permiten utilizar el juego como herramienta auxiliar del aprendizaje. Diversos estudios ponen de manifiesto que los formatos gamificados de formación mejoran la retención y la asimilación de contenidos teóricos que pueden resultar bastante tediosos. El enfoque motivador de los juegos educacionales convierte el proceso de enseñanza y aprendizaje en algo dinámico e interesante, y ayuda al estudiante-jugador a expandir su conocimiento, consolidar y reforzar los conceptos ya aprendidos e investigar nuevas ideas que en ellos puedan surgir.

El caso del cubo de Rubik, uno de los rompecabezas más célebres en el mundo, y sus diferentes variantes, así como otros puzzles que pueden jugarse libremente de forma online, han sido especialmente tratados por tener un alto contenido algebraico implícito y por proporcionar ejemplos sencillos de grupos de simetrías cuyas propiedades más básicas pueden ser analizadas de forma exhaustiva por los estudiantes. Hemos realizado una modelización de dichas simetrías utilizando la teoría de grupos, y abordamos su resolución en el aula mediante el sistema algebraico computacional GAP de libre acceso (véase la referencia The GAP Group s.f.). De esta forma, tenemos la ventaja de utilizar la tecnología disponible a nuestro alcance, fomentando los conocimientos informáticos y el manejo de dispositivos digitales, imprescindibles en la actualidad para el desarrollo personal y profesional de nuestros titulados. Concretamente en nuestro caso, estos conocimientos resultan necesarios para iniciarse en la computación matemática.

\section{Objetivos}

La teoría de grupos es conocida tradicionalmente como la teoría matemática de la simetría. Ello es debido a que la estructura de grupo aparece de manera natural al considerar el conjunto de todas las aplicaciones biyectivas que mantienen una estructura determinada. El uso de la teoría de grupos no queda confinado solo al ámbito de la matemática pura, sino que la idea de grupo como medida de simetría desempeña un importante papel en otras ramas del saber científico, como es el caso de la química, 
la física, las ciencias de la computación y teoría de la información, la arquitectura e incluso en ciencias humanas y sociales.

La definición de la estructura de grupo es abstracta y en muchas ocasiones no resulta fácil de comprender para el alumnado. Sin embargo, los diferentes movimientos de ciertos puzzles y rompecabezas llevan implícitos el concepto de permutación y aparece de forma natural el grupo de las permutaciones permitidas. La idea es analizar propiedades básicas y profundizar en la estructura de los diferentes grupos de permutaciones que aparecen en el estudio de dichos movimientos. Desde un punto de vista docente, este tipo de técnicas pueden ayudar a comprender algunos conceptos teóricos de la teoría de grupos (como grupo libre, grupos de permutaciones, grupo simétrico y alternado, homomorfismos de grupos, construcciones de grupos como producto directo, producto semidirecto y producto orlado, etc.) y ver como aparecen de forma natural ejemplos sencillos sin necesidad de usar construcciones teóricas tediosas y mucho más artificiales.

En la presente comunicación presentamos la modelización de algunos rompecabezas matemáticos sencillos usando conceptos básicos de la teoría de grupos y analizado su resolubilidad. Sin embargo, los métodos de resolución de los mismos conllevan unos cálculos que resultan inviables de realizar sobre el papel. El software utilizado ha sido GAP (Groups, Algorithms and Programming) el cual es un programa especializado en la computación en teoría de grupos y álgebra discreta. Este software fue desarrollado en el Lehrstuhl D für Mathematik (LDFM), en RWTH Aachen, Alemania, desde 1986 hasta 1997. Después el desarrollo de GAP y su mantenimiento fue coordinado por School of Mathematical and Computational Sciences en la Universidad de St. Andrews, Escocia. En el verano de 2005 la coordinación fue de nuevo transferida a una asociación de 4 'Centros GAP', localizados en la Universidad de St. Andrews, RWTH Aachen, el Technische Universität Braunschweig y la Universidad Estatal de Colorado. La elección de dicho programa se ha debido principalmente a que es de libre distribución, lo cual es fundamental para que los alumnos puedan consolidar posteriormente en sus hogares los conceptos aprendidos en el aula, y su actualización es constante como puede comprobarse en The GAP Group s.f.

En resumen, nuestro principal objetivo en el aula es doble: por un lado, modelizar algunos puzzles y rompecabezas utilizando conceptos básicos de teoría de grupos y, por otro lado, ilustrar algunos métodos de resolución de los mismos mediante el uso del software GAP. Algunas de estas modelizaciones pueden encontrarse en un artículo docente que está siendo sometido en la actualidad (Felipe y Ortiz Sotomayor 2018). Con ello se pretende que los alumnos trabajen con aplicaciones reales de la teoría de grupos, mediante la formulación de problemas cotidianos que les son familiares, poniendo en valor el uso de la abstracción teórica y la modelización matemática. 


\section{Desarrollo de la innovación}

La asignatura Métodos Algebraicos y sus Aplicaciones del Máster en Investigación Matemática se imparte en el segundo cuatrimestre y tiene asignados 3 créditos ECTS. Normalmente utilizamos un par de sesiones, de dos horas cada una de ellas, en las que introducimos los conceptos teóricos necesarios e ilustramos la modelización matemática de rompecabezas tales como el cubo de Rubik y algunas variantes. Comenzamos modelizando el famoso cubo inventado por el escultor y profesor de arquitectura húngaro Erno Rubik, en 1974, y definimos el grupo de permutaciones Rubik asociado a sus movimientos básicos. Utilizando permutaciones y homomorfismos de grupos analizamos su resolubilidad en el caso de que sea posible, como sucede con los posibles "huevos fritos" que podemos formar en el cubo (ver Figura 1).

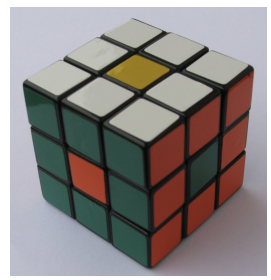

Fig. 1: Un cubo de "huevos fritos"

Posteriormente, entregamos diferentes cubos a los alumnos desordenados y se les insta a su formalización matemática (ver Figura 2). Los estudiantes trabajan in situ los conceptos impartidos en el aula en grupos de 2 o 3 personas, obteniendo su resolución mediante el programa GAP. Una vez resuelto este puzzle, se ensaya con otras modelizaciones análogas de rompecabezas que son variaciones del famoso cubo, como son el caso de los cubos 4x4, 5x5, el cubo Skewb y otras variantes geométricas como es el caso del Pyraminx que tiene una estructura piramidal (véase las Figuras 3, 4, 5 y 6 ).
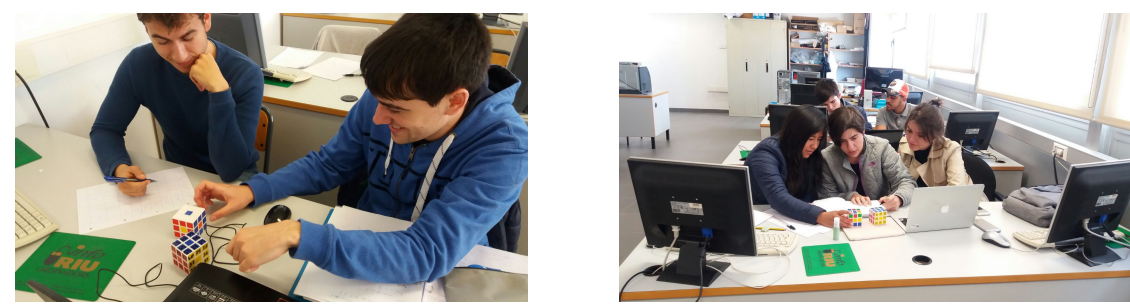

Fig. 2: Alumnos modelizando matemáticamente el cubo de Rubik

Consideramos también el caso de la resolubilidad de los famosos puzzles de deslizamientos (Figura 7) que nos permitirán motivar la introducción de la paricidad de las permutaciones y los grupos alternados. Posteriormente, se plantean algunos ejercicios con otros juegos que pueden modelizarse de una forma similar aplicando grupos de permutaciones como los anillos tricolores de Rubik (Figura 8) y el juego Top Spin, para que sean trabajados de forma autónoma en casa. Para ello, se les facilita a los alumnos la referencia Scherphuis s.f. donde se recopilan una gran cantidad de juegos de este tipo, que pueden jugarse libremente de forma online. La idea es que los estudiantes analicen e investiguen las nuevas estructuras que aparecen y se cuestionen 
sus diferentes variantes. Los ejercicios propuestos son expuestos en exposiciones orales frente al resto de sus compañeros para compartir los resultados obtenidos y para que sean debatidas las técnicas utilizadas.

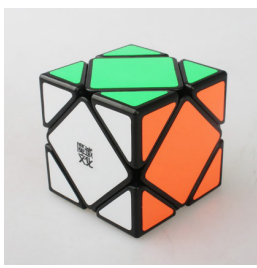

Fig. 3: Cubo Skewb

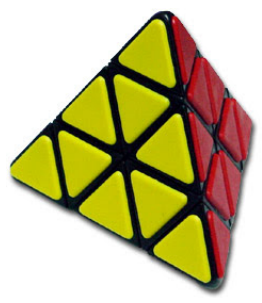

Fig. 5: Pyraminx

\begin{tabular}{||c|c||c||c||}
\hline 1 & 2 & 3 & 4 \\
\hline 5 & 6 & 7 & 8 \\
\hline 9 & 10 & 11 & 12 \\
\hline 13 & 15 & 14 & \\
\hline \hline
\end{tabular}

Fig. 7: Puzzle del deslizamiento $4 \times 4$

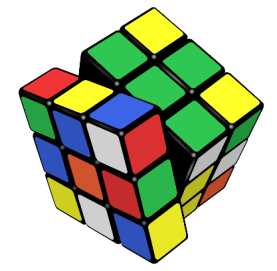

Fig. 4: Cubo de Rubik en movimiento

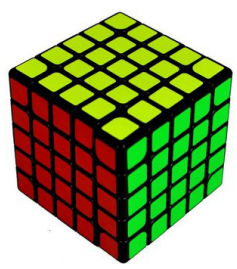

Fig. 6: Cubo de Rubik 5x5

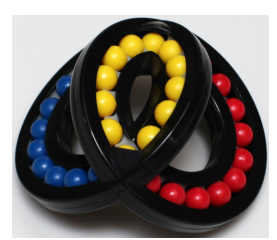

Fig. 8: Anillo tricolor de Rubik

Hemos de señalar que las experiencias que hemos tenido estos últimos años en clase son satisfactorias y que los alumnos muestran un buen ambiente de trabajo. Personalmente, debemos destacar un claro aumento de la motivación, la cual se desea continuar potenciando a lo largo de los próximos cursos académicos. Se ha pasado al final de curso una encuesta sobre la satisfacción de las actividades docentes que se han llevado a cabo, las cuales los alumnos han respondido de manera anónima, obteniendo datos objetivos de dichas actividades y pudiendo así planificar una lista de posibles mejoras, las cuales debatimos en la siguiente sección. Es importante decir también que las técnicas utilizadas en estas modelizaciones son una buena manera de que el alumnado desarrolle otras competencias transversales más específicas como son la resolución de problemas, aplicación y pensamiento práctico, trabajo en equipo y liderazgo y comunicación efectiva entre otras. Las actividades lúdicas programadas con las modelizaciones matemáticas de estos entretenimientos nos permitirán obtener nuevos parámetros para poder evaluar estas competencias, como por ejemplo la comunicación efectiva, de la que la citada asignatura es punto de control. Mencionar que ser punto de control de una competencia transversal implica plantear actividades para, en el desarrollo de los contenidos, trabajar la competencia transversal y evaluarla, recogiendo evidencias de los logros alcanzados. 


\section{Resultados}

Tal y como hemos comentado en la sección anterior, las experiencias previas de cursos anteriores en los que hemos ido introduciendo la innovación mencionada de forma inicial y las opiniones que nos han manifestado los alumnos implicados han sido muy satisfactorias. Sin embargo, en este curso académico hemos realizado unas encuestas, las cuales los alumnos han rellenado anónimamente, con el fin de valorar el impacto y obtener datos objetivos del proceso.

El número total de alumnos matriculados este año en la asignatura ha sido de 7 . Hemos realizado las siguientes 14 cuestiones, las cuales los alumnos han valorado eligiendo una de las opciones de respuesta: TED - Totalmente en desacuerdo, MBD - Más bien en desacuerdo, IND - Indeciso, MBA - Más bien de acuerdo, TDA - Totalmente de acuerdo. A continuación, resumimos en unos histogramas los resultados obtenidos:

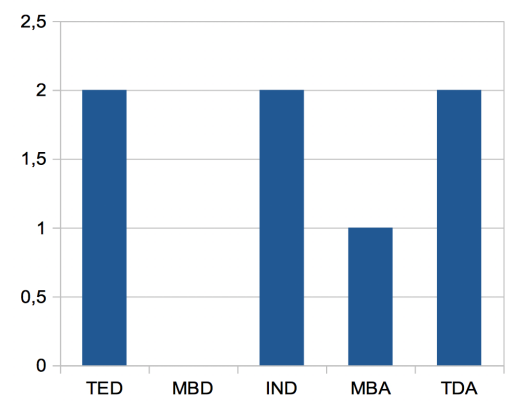

Fig. 9: ¿Crees que tu nivel de conocimiento teórico de las estructuras algebraicas era bueno antes del comienzo del curso?

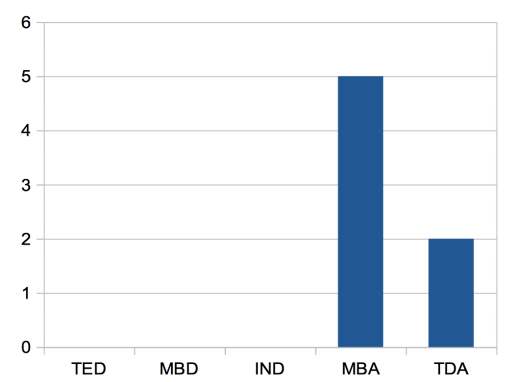

Fig. 11: ¿Consideras que los contenidos impartidos en la asignatura son importantes para complementar tu formación matemática?

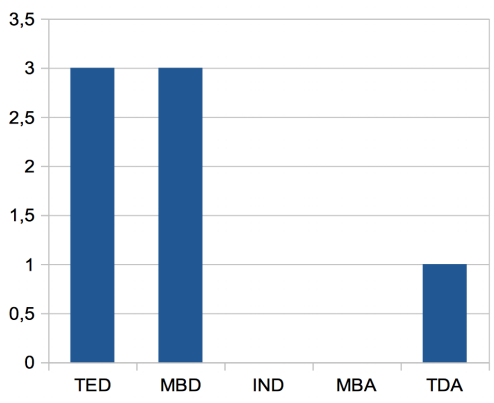

Fig. 10: ¿Crees que tu conocimiento sobre aplicaciones prácticas de las estructuras algebraicas era bueno antes del comienzo del curso?

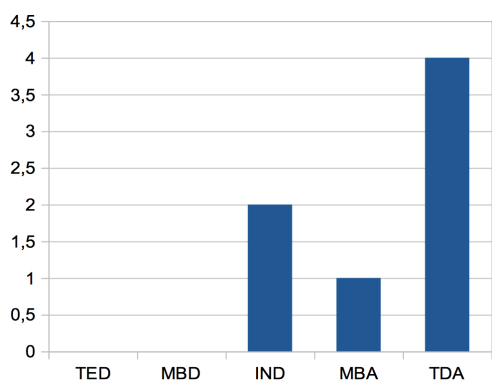

Fig. 12: ¿Consideras que la distribución de contenidos teórico-prácticos de la asignatura son adecuados?

A la vista de los resultados, podemos sacar varias conclusiones. Con la Figura 9 comprobamos cómo los conocimientos teóricos de las estructuras algebraicas que posee el alumnado al comienzo del curso es bastante diverso, tal y como comentamos en la introdución, debido principalmente a la diversidad de las titulaciones con las que acceden al máster. También vemos cómo en general escasea el conocimiento de aplicaciones prácticas de dichos conocimientos teóricos (Figura 10). Queda presente que los alumnos que cursan la asignatura finalizan bastante satisfechos con los contenidos 


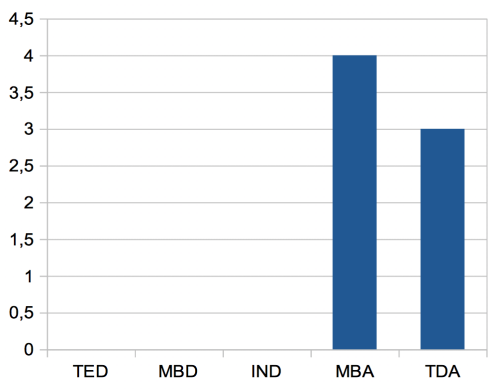

Fig. 13: ¿Crees que la asignatura te ha servido para aumentar dicho nivel del conocimiento teórico?

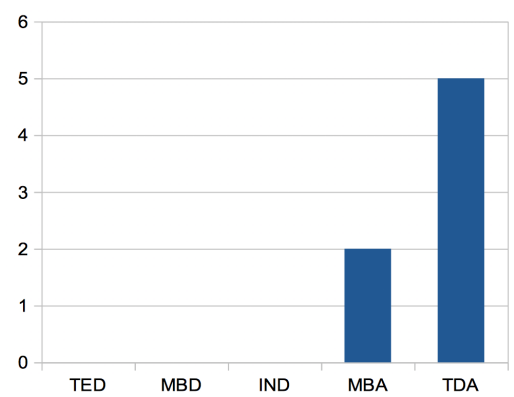

Fig. 14: ¿Crees que el curso te ha servido para aumentar dicho nivel de aplicaciones prácticas?

impartidos, tanto teóricos como prácticos, como se observa en los histogramas de las Figuras 11, 12, 13 y 14.

De hecho, cabe destacar la valoración en general positiva que realizan del software GAP y de las modelizaciones llevadas a cabo:

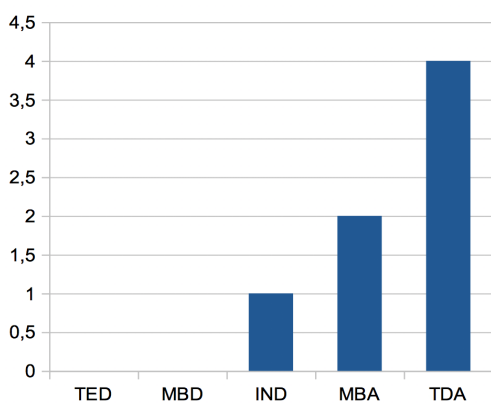

Fig. 15: ¿Consideras que el uso del software algebraico GAP te ha ayudado en la comprensión y manejo de las estructuras algebraicas?

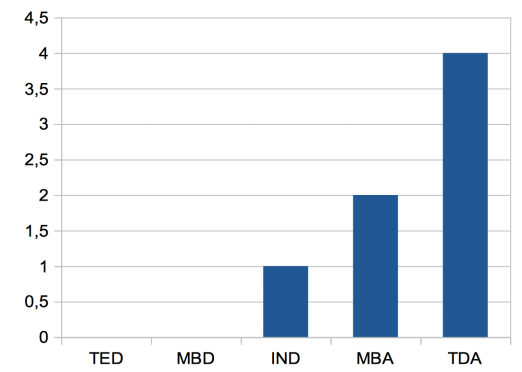

Fig. 17: ¿La práctica relativa a la modelización de puzzles (cubo Rubik) con GAP te resultó interesante?

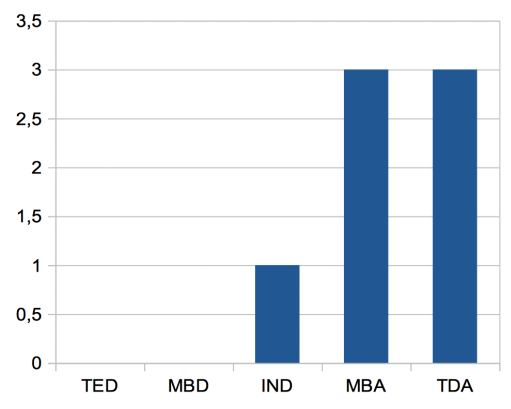

Fig. 16: En general, ¿te han resultado motivadoras las clases de GAP?

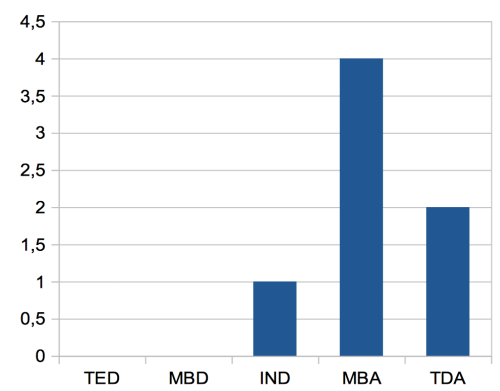

Fig. 18: ¿Crees que deberían plantearse más ejemplos de modelización que motiven los conceptos teóricos impartidos en la asignatura?

Las Figuras 15 y 16 muestran cómo el software GAP ayuda al alumnado a la comprensión de las estructuras algebraicas y aumenta la motivación de los mismos, los 


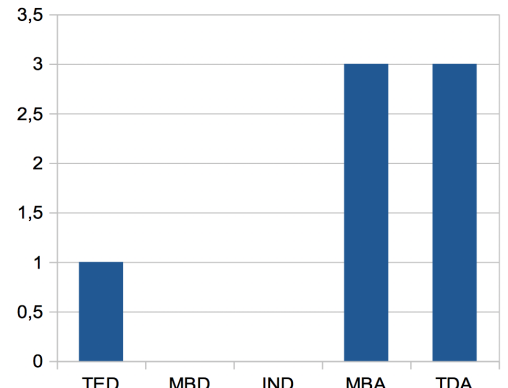

Fig. 19: ¿Crees conveniente conocer modelizaciones que hagan uso de programas algebraicos (como GAP, Singular, Magma, etc?) para abordar aplicaciones a problemas reales?

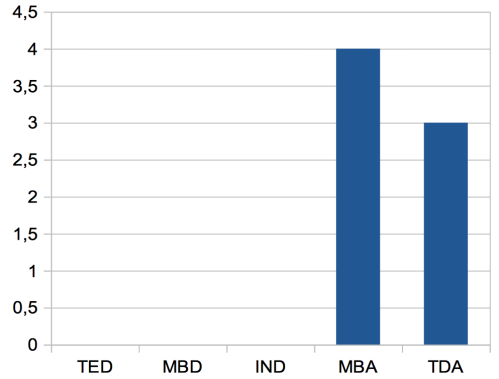

Fig. 20: En general, ¿consideras que los contenidos impartidos cubren las expectativas que inicialmente tenías de la asignatura?

cuales eran dos objetivos principales a conseguir. Con las Figuras 17, 18 y 19 vemos el agrado mayoritario de los alumnos con modelizaciones que motiven los conceptos teóricos explicados en clase y con el uso de programas algebraicos que ayuden en los cálculos. Con la última figura (20) queda de manifiesto la satisfacción general de los estudiantes con los contenidos impartidos a lo largo de la asignatura.

Finalmente, queremos señalar también unos últimos apartados de las encuestas dedicados a la libre opinión sobre la asignatura, de donde destacamos las siguientes manifestaciones de los alumnos:

"Aunque los contenidos hacia final de curso se han ido complicando, los conceptos han quedado claro gracias a los ejemplos."

"Creo que la asignatura se ha adaptado bastante bien a los diferentes niveles de los alumnos."

"Personalmente busco ejemplos aplicados, y al presentar al final de la materia una aplicación del interés del estudiante nos permite investigar y ampliar más nuestros conocimientos en el campo que queramos formarnos profesionalmente o académicamente."

\section{Conclusiones}

Podríamos pensar que los rompecabezas y puzzles pueden servir únicamente de entretenimiento y diversión. Sin embargo, dichos entretenimientos pueden entenderse como juegos realmente educativos, no solo porque desarrollan nuestro intelecto, nuestra visión espacial, capacidad lógica y de razonamiento, sino porque constituyen además una eficaz herramienta en el entendimiento de algunas estructuras algebraicas que, debido a su alto grado abstracción matemática, son de difícil comprensión. El estudio de los movimientos "legales" en cierto rompecabezas y las simetrías asociadas a estos movimientos permiten estimular el aprendizaje de las nociones más básicas de la teoría de grupos mediante permutaciones. En Joyner 2008 puede encontrarse una recopilación más amplia de otros juegos que pueden ser tratados de forma similar a 
los presentados en esta comunicación. Lo más relevante es que hemos apostado por un tratamiento más computacional de dichas modelizaciones, tanto respecto a su estudio como a la resolución de estos puzzles, mediante la utilización del sistema algebraico GAP. De esta forma se pretende utilizar la tecnología disponible a nuestro alcance, a la cual están acostumbrados nuestros estudiantes, para fomentar las habilidades informáticas imprescindibles en la actualidad para el desarrollo de la matemática computacional, necesaria tanto a nivel docente como investigador.

De forma general, con las actividades y técnicas presentadas en la presente comunicación en la modelización de juegos se pretende principalmente ayudar al aprendizaje de las estructuras algebraicas de una forma lúdica, conseguir que los alumnos se "enganchen" por la materia independientemente de su abstracción matemática. También desarrollar habilidades y destrezas asociadas a ciertas competencias transversales tales como la resolución de problemas, pensamiento crítico y comunicación efectiva, así como incentivar su interés por la materia y disfrutar de los contenidos aprendidos mejorando al mismo tiempo el compromiso de los estudiantes en su propio aprendizaje.

A la vista de todos los datos, en resumen podemos calificar la innovación docente realizada como muy satisfactoria. Para finalizar, destacar que en la actualidad continuamos trabajando con otras modelizaciones matemáticas que involucran estructuras algebraicas alternativas, como son los anillos de polinomios haciendo énfasis en las bases de Gröbner, las cuales poseen multitud de aplicaciones como es el caso de las coloraciones de grafos, teoría de códigos, resolución de curvas algebraicas, ecuaciones diferenciales y, en relación con los entretenimientos matemáticos, la resolución de sudokus. Para estas nuevas modelizaciones estamos utilizando los programas GAP y Singular, que es un sistema de álgebra computacional de manipulación polinomial con especial énfasis en álgebra conmutativa, geometría algebráica y teoría de la singularidad y el cual es también de libre distribución.

\section{Referencias bibliográficas}

Felipe, M.J. y V.M. Ortiz Sotomayor (2018). "Jugando con la Teoría de Grupos: rompecabezas, puzzles y otros entretenimientos matemáticos". En: sometido.

Joyner, D. (2008). Adventures in group theory: Rubik's cube, Merlin's machine, and other mathematical toys. Baltimore: The Johns Hopkins University Press.

Lidl, R. y G. Pilz (1998). Applied Abstract Algebra. New York: Springer-Verlag.

Scherphuis, J. Jaap's puzzles page. URL: https://www.jaapsch.net/puzzles.

The GAP Group. GAP - Groups, Algorithms, and Programming. Ver. 4.8.10. URL: http://www.gap-system.org. 


\title{
¿Por qué es importante aplicar Docencia Inversa? ¿cómo hacerlo?
}

\author{
N. Montanes ${ }^{\mathrm{a}}$, L. Sánchez-Nacher ${ }^{\mathrm{a}}$, O. Fenollar ${ }^{\mathrm{a}}$,
} D. Garcia-Sanoguera ${ }^{\mathrm{a}}$ y L. Quiles-Carrillo ${ }^{\mathrm{a}}$

${ }^{a}$ Grupo de Innovación de Prácticas Académicas (GIPA), Universitat Politècnica de València, Plaza Ferrándiz y Carbonell s/n, Alcoy, Alicante (ESPAÑA).

\begin{abstract}
The Flipped Learning methodology is so called because it is based on reversing the traditional scheme of the learning process. It offers a host of potential benefits, such as having more time to attend individually each student during their own class time, the opportunity to develop an active and collaborative learning, or the possibility that the student is who sets his own pace in the learning process, among many others. But it is also true that, like any other change, the application of this new methodology will imply the realization of an initial effort based on the replanning of the classes and the topics, as well as the preparation or reconversion of the teaching materials. The objective of this paper is to present methods, tools and technological resources used successfully in the application of the Flipped Learning methodology, in a subject of the Industrial Design Engineering and Product Development Degree, taught at the Universitat Politècnica de València (UPV). At the same time it also shows how it is possible to combine the application of the Flipped Learning methodology with the development and work of certain transversal competences of the UPV.
\end{abstract}

Keywords: Flipped Learning, methodology, active learning, collaborative learning, transversal competences.

\section{Resumen}

La aplicación de la metodología de Docencia Inversa, llamada así porque se basa en invertir el esquema tradicional del proceso de aprendizaje, ofrece un sinfín de beneficios potenciales, como por ejemplo disponer de más tiempo para atender individualmente a cada alumno durante el propio espacio de clase, la oportunidad de desarrollar un aprendizaje activo y colaborativo, o la posibilidad de que sea el alumno el que marque su propio ritmo en el proceso de aprendizaje, entre otros muchos. Pero también es cierto que, como cualquier cambio, la aplicación de esta nueva metodología va a llevar implícito la realización de un esfuerzo inicial en base a la replanificación de las clases y los temarios, así como en la preparación o reconversión de determinados materiales docentes. El objetivo del presente trabajo es presentar métodos, herramientas y recursos tecnológicos utilizados con éxito en la aplicación de la metodología de Docencia Inversa, en una asignatura 
del Grado en Ingeniería en Diseño Industrial y Desarrollo de Productos, impartida en la Universitat Politècnica de València (UPV). Al mismo tiempo también se expone cómo es posible combinar la aplicación de la metodología de Docencia Inversa con el desarrollo y trabajo de determinadas competencias transversales de la UPV.

Palabras clave: Docencia Inversa, metodología, aprendizaje activo, aprendizaje colaborativo, competencias transversales.

\section{Introducción}

En la actualidad una nueva forma metodológica de transmitir conocimientos, de desarrollar la tarea docente, de redirigir el aprendizaje, etc., está en pleno auge. Esta nueva metodología es la denominada Docencia Inversa, o en inglés Flipped Learning, y es llamada así porque se basa en invertir el esquema tradicional del proceso de aprendizaje (Roach, 2014).

Las largas clases magistrales con las que los profesores llenaban el tiempo del que disponían con sus alumnos en las aulas es liberado. Para ello, los profesores deben preparar materiales docentes adecuados para que los alumnos trabajen los contenidos de las antiguas clases magistrales en casa. Y una vez en el aula el tiempo es empleado para realizar toda una serie de actividades que refuercen los conocimientos trabajados en casa (Roach, 2014).

Según el equipo del Proyecto The Flipped Classroom, la metodología Flipped "trata de un enfoque integral que combina la instrucción directa con métodos constructivistas y el incremento de compromiso e implicación de los estudiantes con el contenido del curso y la mejora de su comprensión conceptual. Se trata de un enfoque integral que, cuando se aplica con éxito, apoya todas las fases de un ciclo de aprendizaje (Taxonomía de Bloom)” (Network, 2018).

Así pues, al quedar libre el tiempo de clase, los alumnos pueden participar en su propio aprendizaje de manera activa a través de actividades aplicadas, discusiones, debates, preguntas, etc. De esta manera se fomenta la exploración, la articulación y la aplicación de ideas en un ambiente de aprendizaje dinámico e interactivo (Network, 2018).

La metodología de Docencia Inversa ofrece muchos beneficios potenciales, como por ejemplo disponer de más tiempo para atender individualmente a cada alumno durante el propio espacio de clase, la oportunidad de desarrollar un aprendizaje activo y colaborativo, o la posibilidad de que sea el alumno el que marque su propio ritmo en el proceso de aprendizaje. Con esta metodología se puede conseguir un mejor uso del tiempo de clase para que los estudiantes participen en actividades que impliquen el desarrollo de estrategias de aprendizaje de nivel superior. Por otro lado, se promueve la participación de los estudiantes haciéndolos más visibles y se producen mejores interacciones entre los docentes y los alumnos, con un mayor feedback hacia los profesores (Bergmann and Sams, 2012; Bishop and Verleger, 2013; Roach, 2014; Network, 2018).

(cc) EY-NC-ND 2018, Universitat Politècnica de València

Congreso IN-RED (2018) 
Pero también es cierto que, como cualquier cambio, la metodología de Docencia Inversa va a llevar implícito la realización de un esfuerzo inicial en base a la replanificación de las clases y los temarios, así como en la preparación o reconversión de determinados materiales docentes, pero todos estos trabajos son asequibles y muchos los beneficios que se pueden lograr desde un punto de vista docente. Además en ningún momento se exige que una asignatura pase a ser trabajada mediante Docencia Inversa al $100 \%$ de un día para otro. Es más bien como un camino a recorrer, durante un determinado tiempo, pero con una meta clara.

Por último, cabe comentar que muchas de las herramientas y actividades empleadas en la metodología de Docencia Inversa permiten a su vez el desarrollo de las denominadas competencias transversales. En el marco del Espacio Europeo de Educación Superior (EEES) se ha producido un cambio de paradigma en el que la educación se está orientado a una formación basada en competencias. En el presente trabajo se expone también cómo es posible combinar la aplicación de la metodología de Docencia Inversa con el desarrollo y trabajo de determinadas competencias transversales de la Universitat Politècnica de València (UPV).

\section{Objetivos}

El objetivo del presente trabajo es presentar métodos, herramientas y recursos tecnológicos utilizados con éxito en la aplicación de la metodología de Docencia Inversa, en una asignatura del Grado en Ingeniería en Diseño Industrial y Desarrollo de Productos, impartida en la Universitat Politècnica de València (UPV). Se trata de la asignatura de Envase y Embalaje, del tercer curso, segundo cuatrimestre, que tiene una asignación de 4,5 créditos y 68 alumnos de media por curso.

La aplicación de dicha metodología va a requerir trabajar en dos frentes distintos: por un lado, se deberán establecer las actuaciones y materiales para el contexto casa y, por otro lado, se deberán plantear las actividades y materiales para el contexto aula.

En el contexto casa deben preparase una serie de materiales docentes que comprendan todos aquellos contenidos que en el método tradicional el profesor expone durante el tiempo de clase, mediante un discurso oral, apoyándose en presentaciones de transparencias, o en la pizarra. Para ello el docente puede elaborar videos explicativos de los contenidos, screencast, apuntes o recomendar lecturas interesantes, entre otras cosas.

Y de este modo, al quedar libre el tiempo de clase, en el contexto aula se pueden realizar por ejemplo actividades aplicadas, resolución de ejercicios, debates, exposiciones, juegos de preguntas y respuestas que refuercen los contenidos vistos en casa, etc. Lo importante es que los alumnos participen e interactúen y que el ambiente sea dinámico. En ese tiempo en el aula, el profesor puede atender de una manera más personal a cada uno de los alumnos y tener un feedback de cómo van avanzado en el aprendizaje de los contenidos de la asignatura, ya que no tiene que estar preocupándose de exponer contenidos teóricos. 
Además de todo esto, como se ha manifestado con anterioridad, en el presente trabajo también se va a exponer cómo es posible combinar la aplicación de la metodología de Docencia Inversa con el desarrollo y trabajo de determinadas competencias transversales de la UPV.

\section{Desarrollo de la innovación}

\subsection{Contexto casa}

El primer paso es analizar los contenidos que se desarrollan en la asignatura en cuestión, tras lo cual es posible decidir que partes, tanto de la teoría, como de la práctica, pueden trabajar los alumnos en casa con ayuda de determinados materiales docentes. Cabe comentar que la Universitat Politècnica de València cuenta con una serie de herramientas en línea para el aprendizaje. De todas esas herramientas se han escogido los objetos polimedia, los screencast y los artículos docentes como base para el desarrollo de los materiales a emplear en casa, para la aplicación de la Docencia Inversa, en la asignatura mencionada.

Los objetos polimedia son una grabación de un fragmento de 5 a 10 minutos de duración. En ellos se muestra, de forma sincronizada, la imagen y voz del profesor y una pantalla en la que se aparecen los contenidos de una presentación, una pizarra electrónica, un programa informático o una combinación de estos elementos. Este polimedia va dirigido a facilitar el aprendizaje del alumno de un concepto y/o procedimiento concreto, es decir, tiene una finalidad didáctica (Universitat Politècnica de València, 2018) (Fig. 1).
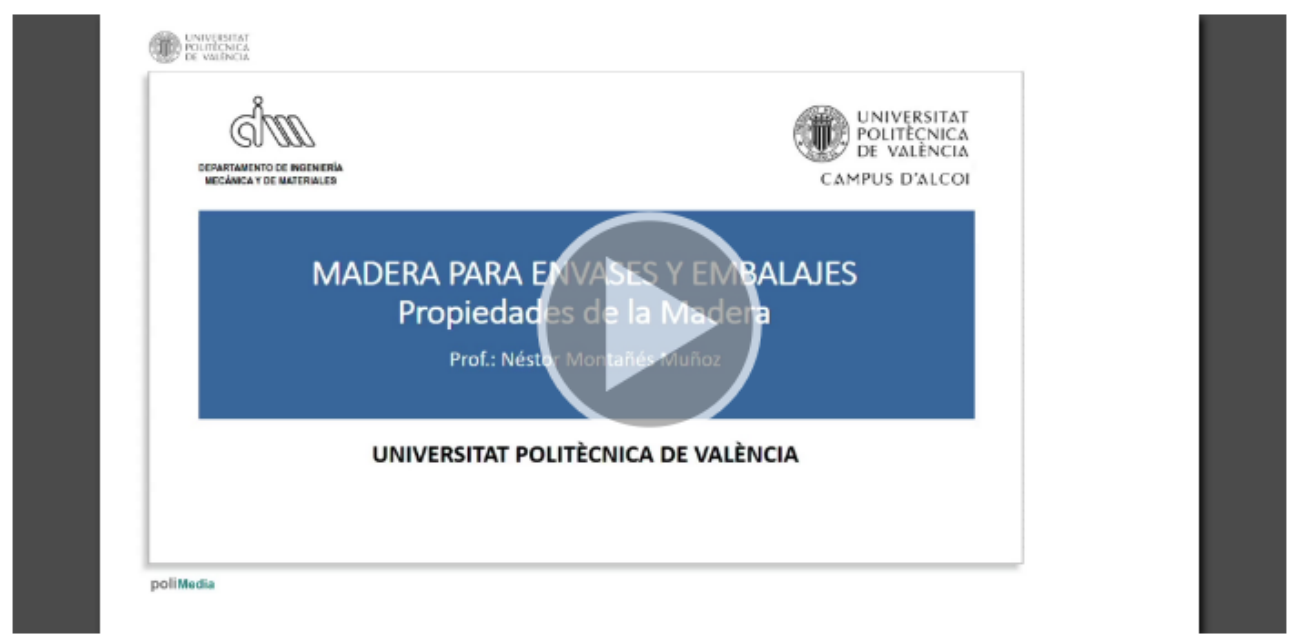

Fig. 1 Ejemplo de objeto polimedia

Por su parte los screencast son fragmentos de video educativo de una duración aproximada de entre 5 y 10 minutos. En ellos se muestran los contenidos generados mediante la captura de la pantalla del ordenador, acompañados de la voz en off del profesor o de un locutor. El screencast va dirigido a facilitar el aprendizaje del alumno de un concepto y/o procedimiento concreto, es decir, tiene una finalidad didáctica (Universitat Politècnica de 
València, 2018). Los screencast son ideales para enseñar el manejo de programas informáticos (Fig. 2).
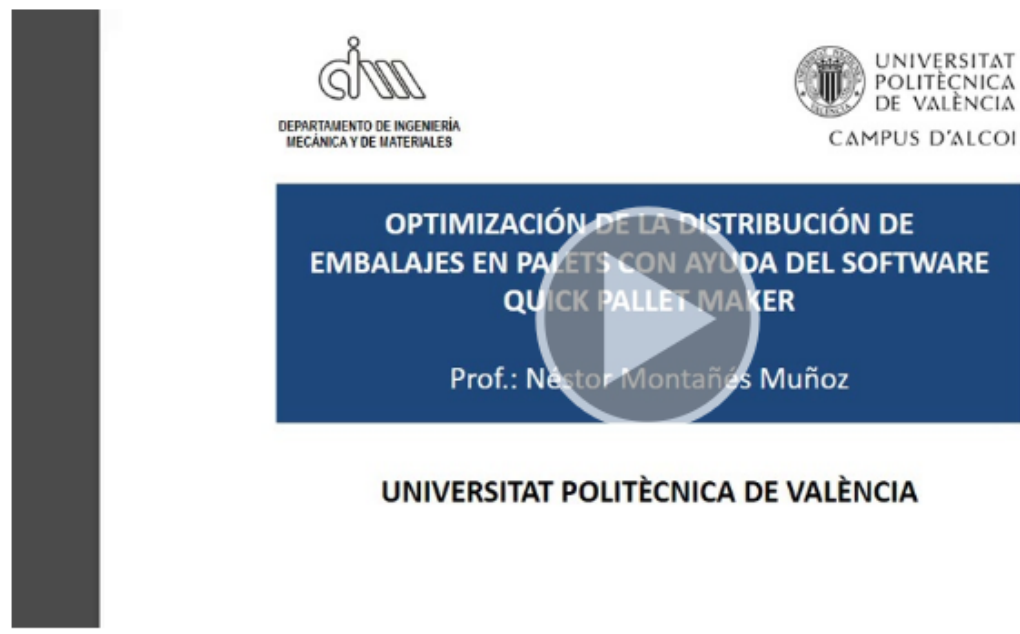

\section{UNIVERSITAT POLITÈCNICA DE VALÈNCIA}

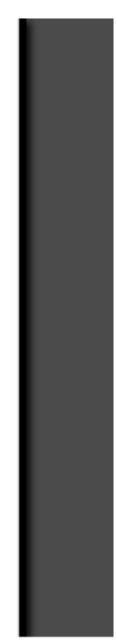

Fig. 2 Ejemplo de screencast

Por último, los artículos docentes son objetos de aprendizaje en formato texto digital, con una extensión entre 5 y 10 páginas, cuyo objetivo es facilitar el aprendizaje del alumno de un concepto y/o procedimiento concreto. Es decir, tiene una finalidad didáctica, por lo que debe ser motivador y enfocado al aprendizaje. No se tratan de artículos científicos, sino que su condición de objeto hace que sea algo totalmente aplicado y dirigido a guiar al alumno en su aprendizaje (Universitat Politècnica de València, 2018) (Fig. 3).

Así pues, se trata de ir preparando unidad a unidad, tema a tema, concepto a concepto, distintos materiales docentes con ayuda de estas herramientas en línea, siendo que en todo momento estos materiales docentes pueden ser complementados con, por ejemplo, apuntes elaborados por los profesores responsables de la asignatura, o con lecturas recomendadas de libros y artículos de revista. Pero tal y como se ha comentado anteriormente, este trabajo no tiene porque realizarse de golpe. El cambio de un método docente tradicional a la Docencia Inversa puede ser paulatino e ir realizándose a lo largo de los años. 


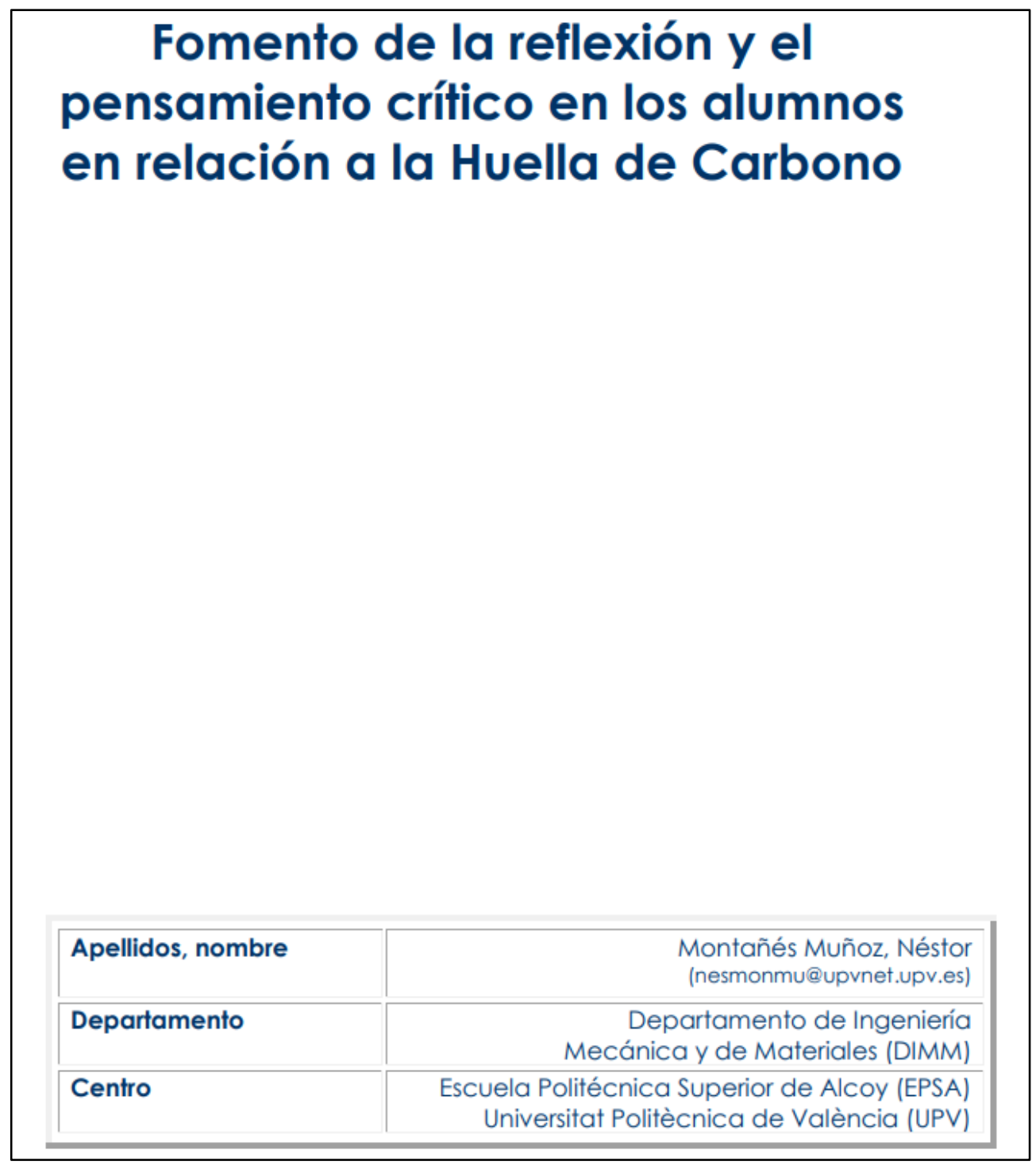

Fig. 3 Ejemplo de artículo docente

\subsection{Contexto clase.}

Una vez que los estudiantes han abordado los contenidos más teóricos de una sesión de clase, en casa, en el tiempo de clase es momento de realizar toda una serie de actividades que refuercen los conceptos adquiridos en casa. Por ejemplo, se pueden llevar a cabo actividades aplicadas, resolución de ejercicios, debates, exposiciones, juegos de preguntas/respuestas o desarrollo de pequeños proyectos, por citar algunas de las posibilidades.

A continuación se exponen ejemplos de algunas de estas actividades desarrolladas en el tiempo de clase de la asignatura Envase y Embalaje: 
- Actividades aplicadas: diseñar un envase de cartón o de hojalata para un frasco de perfume.

- Ejercicios / problemas: calcular cuantas unidades de un determinado envase caben en un palet normalizado y comparar los resultados obtenidos con los que muestra un programa informático que realiza este tipo de cálculos, cuyo manejo se ha aprendido en casa con ayuda de un screencast.

- Debates moderados: $\underline{\text { debatir }}$ de manera argumentada sobre los envases de plástico y el medio ambiente.

- Exposiciones: explicar ante el resto de los compañeros una parte de un tema. En el seno del Proyecto de competencias transversales de la UPV se encuentra la competencia “Comprensión e Integración”. Comprender quiere decir percibir y tener una idea clara de lo que se dice, se hace o sucede o descubrir el sentido profundo de algo. Para demostrar que algo se ha comprendido, la persona identifica y recupera la información y la explica con sus propias palabras, interpretando e integrando las ideas desde su propia perspectiva (Universitat Politècnica de València, 2018). Así pues, esta sería una actividad con la que además se desarrolla y trabaja una de las competencias transversales de la UPV.

- Proyectos: diseñar un envase de cartón para un frasco de perfume. Calcular el empaque óptimo en palets. Valorar el impacto medioambiental global del envase más el embalaje.

En los párrafos anteriores se han remarcado en negrita una serie de verbos, los cuales están en relación con la Taxonomía de Bloom. El objetivo es pues tratar de desarrollar actividades que promuevan el aprendizaje en los niveles superiores de dicha taxonomía. Lo importante es que los alumnos participen e interactúen, que el ambiente sea dinámico, que se refuercen los conocimientos trabajados en casa y que el docente se preocupe de tener un feedback continuo de la situación de cada alumno.

Por otro lado, también se pueden desarrollar actividades más lúdicas, como juegos grupales de preguntas y respuestas, en relación a un tema visto en casa. Así pues, son numerosos los métodos y herramientas con los que se puede desarrollar la Docencia Inversa en el aula.

\subsection{Ejemplo de aplicación en una unidad específica de la asignatura: Materiales de Madera para Envases y Embalajes.}

Como se ha comentado con anterioridad, el primer paso es analizar los contenidos que se desean desarrollar, así como los objetivos que se pretende que los alumnos alcancen. Tras ello se debe planificar y programar cada una de las sesiones, distribuir en el tiempo los materiales docentes y establecer cuáles serán las actividades a desarrollar en clase de manera que no sean repetitivas. Esta planificación inicial será necesario ir reprogramándola según avance el curso, con el feedback de se obtenga de los alumnos en el tiempo de clase. Un ejemplo de programación para una de estas sesiones puede ser el siguiente:

Polimedias: 
- Madera para Envases y Embalajes. Principios Generales. (Montañés, 2017) https://media.upv.es/player/?id=c8eb1be0-3595-11e7-8aa7-5b2740a8fd5f

- Madera para Envases y Embalajes. Propiedades de la Madera. (Montañés, 2017) https://media.upv.es/player/?id=dedb6950-3595-11e7-8aa7-5b2740a8fd5f

- Madera para Envases y Embalajes. Transformación de la Madera. (Montañés, 2018) https://media.upv.es/player/?id=6d1c4150-4a1f-11e8-af70-03116a2e3d4b

- Madera para Envases y Embalajes. Usos Específicos. (Montañés, 2018) https://media.upv.es/player/?id=76cbf600-4a1f-11e8-af70-03116a2e3d4b

- Madera para Envases y Embalajes. Palets. (Montañés, 2018) https://media.upv.es/player/?id=7f827da0-4a1f-11e8-af70-03116a2e3d4b

\section{Artículos:}

- ¿ ¿Cómo usando más madera se conservan los montes? (Plaza, 2016) http://www.maderea.es/usar-madera-y-conservar-los-montes/

- Toyota crea un coche de madera. (Maderea, 2016) http://www.maderea.es/toyota-crea-un-coche-de-madera/

- La madera transparente, ¿¿El fin del vidrio? (Maderea, 2016) http://www.maderea.es/madera-transparente/

- $\quad$ El fin del roble en España. (Parra, 2016) http://www.maderea.es/el-fin-del-roble-en-espana/

- Más madera contra el cambio climático. (Público, 2010) http://www.publico.es/ciencias/mas-madera-cambio-climatico.html

\section{Actividades en el aula:}

\section{Exposiciones:}

Se trata de que por grupos los alumnos expongan los contenidos de cada uno de los polimedias mencionados, asumiendo el rol de profesor. Se da un tiempo corto en clase para que preparen las exposiciones.

\section{Debates:}

La clase se divide en dos grandes grupos. Un grupo estará a favor de potenciar el uso de la madera en el sector del envase y el embalaje. El otro en contra. Apoyados en la información de los artículos entregados que previamente habrán leído en casa, así como en una pequeña búsqueda de información en clase, durante un tiempo cada grupo preparará sus argumentaciones. Tras ello cada grupo expondrá sus argumentos, tras lo cual comenzará un debate abierto moderado por el profesor. A los alumnos cuyas argumentaciones sean más sólidas y se apoyen en fuentes fiables, se les otorgará una puntuación extra a sumar en su nota final.

\subsection{Competencias transversales.}

Con las actividades comentadas en el apartado anterior del contexto clase se pueden trabajar de paso algunas de las 13 competencias transversales de la UPV. Por ejemplo, con

(c) ) EY-NC-ND 2018, Universitat Politècnica de València

Congreso IN-RED (2018) 
las exposiciones y los debates se puede desarrollar la competencia de "Comprensión e integración” como se ha visto. La resolución de actividades aplicadas y de ejercicios ayudarán a desarrollar la competencia "Análisis y resolución de problemas". El abordaje de pequeños proyectos colaborará en el desarrollo de la competencia "Diseño y proyecto”. Los juegos de preguntas y respuestas en grupos fomentarán la competencia de "Trabajo en equipo y liderazgo”. Los debates pueden ayudar a desarrollar un "Pensamiento crítico”.

De este modo, con una buena planificación de las actividades del tiempo de clase, sería posible trabajar prácticamente las 13 competencias transversales de la UPV.

\section{Resultados}

En el caso de la asignatura de Envase y Embalaje en la que se centra este artículo, la metodología de Docencia Inversa comenzó a aplicarse de manera paulatina a partir del curso 2015/2016. En el curso anterior, el 2014/2015, el método docente se basaba en las tradicionales clases magistrales.

Así pues, realmente solo se dispone de datos de dos cursos, ya que el curso actual, 2017/2018 todavía no ha acabado. Se ha analizado para estos dos cursos mencionados el rendimiento académico y la satisfacción de los alumnos registrada en las encuestas de evaluación de la docencia.

En los gráficos siguientes (Fig. 4 y Fig. 5), se puede observar como parece producirse un aumento en el rendimiento académico año tras año, reduciéndose el porcentaje de "No aptos" a apenas un $2 \%$ en el último curso, y como la satisfacción general de los alumnos, recogida en las encuestas de evaluación de la docencia, se ha incrementado en más de 1 punto respecto a cuándo el método docente que se empleaba eran las clases magistrales.

En cualquier caso, como se ha comentado, es pronto como para establecer conclusiones sólidas, ya que por ejemplo en relación a la mejora en el rendimiento académico, siendo tan grande el número de alumnos matriculados en la asignatura, las diferencias entre cursos pueden estar originadas por tan sólo uno o dos alumnos. 


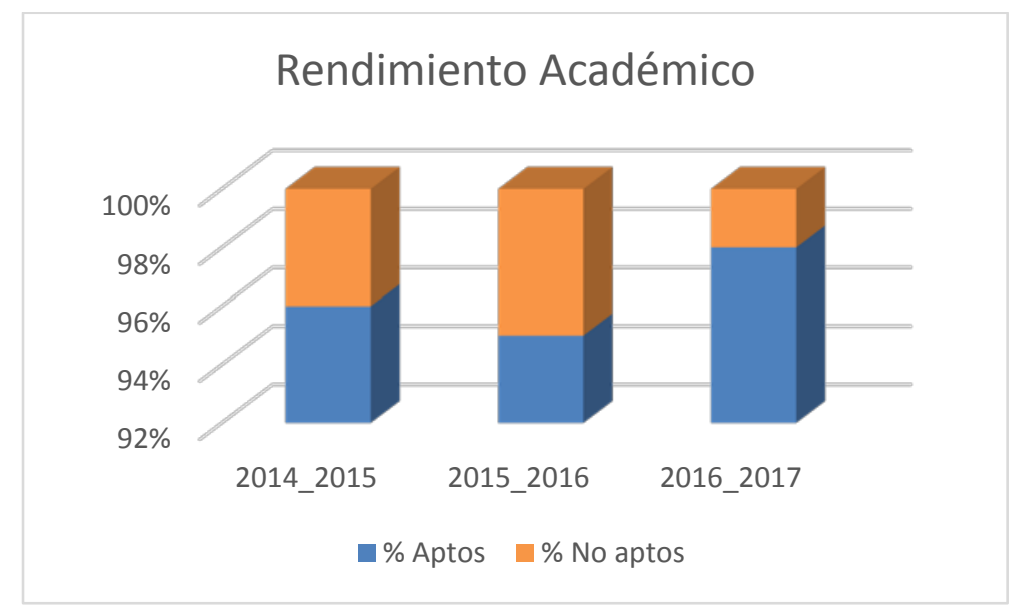

Fig. 4 Rendimiento académico de los alumnos de la asignatura de Envase y Embalaje de los últimos cursos

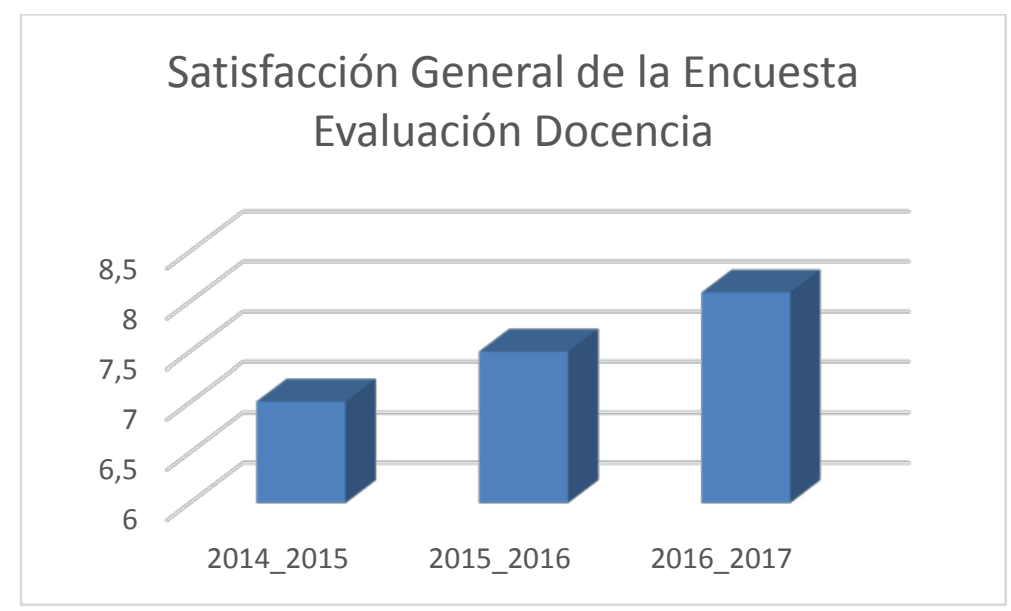

Fig. 5 Resultados de las encuestas de evaluación de la docencia para la asignatura de Envase y Embalaje de los últimos cursos

\section{Conclusiones}

Como se ha visto, la metodología de Docencia Inversa ofrece muchos beneficios potenciales en el proceso de aprendizaje de los alumnos. Si bien su aplicación requiere de un pequeño esfuerzo inicial por parte de los profesores, un replanteamiento de la asignatura y la elaboración de determinados materiales docentes, dichos beneficios mencionados a nivel pedagógico hacen que compense el esfuerzo a realizar por parte del profesorado.

En el presente trabajo se han expuesto a modo de ejemplo muchas herramientas y actividades con las que se puede realizar este cambio metodológico, tanto para el contexto casa (o fuera del aula), como para el contexto clase.

Por último, en relación a los resultados obtenidos de la aplicación del método de Docencia Inversa en la asignatura de "Envase y Embalaje", parece que se ha producido un aumento

(cc) BY-NC-ND 2018, Universitat Politècnica de València 
del rendimiento académico y se ha mejorado la satisfacción tanto de los alumnos, como de los profesores implicados, lo cual es muy positivo, aunque al disponer aún de pocos datos, no es posible establecer conclusiones muy firmes.

\section{Agradecimientos}

Este trabajo es fruto del esfuerzo que está realizando el Grupo de Innovación de Prácticas Académicas (GIPA) de la UPV en pro de la mejora docente. Los autores quieren mostrar su agradecimiento a la UPV y al Instituto de Ciencias de la Educación (ICE) de la UPV por su ayuda y colaboración en la formación del Equipo de Innovación y Calidad Educativa (EICE) denominado GIPA.

\section{Referencias}

Bergmann, J. and A. Sams (2012). Flip your classroom: Reach every student in every class every day, International Society for Technology in Education.

Bishop, J. L. and M. A. Verleger (2013). The flipped classroom: A survey of the research. ASEE National Conference Proceedings, Atlanta, GA.

Maderea, B. (2016). "La madera transparente, ¿El fin del vidrio?" Retrieved Junio 2018, from http://www.maderea.es/madera-transparente/.

Maderea, B. (2016). "Toyota crea un coche de madera." Retrieved Junio 2018, from http://www.maderea.es/toyota-crea-un-coche-de-madera/.

Montañés, N. (2017). "Madera para Envases y Embalajes. Principios Generales." Retrieved Junio 2018, from https://media.upv.es/player/? id=c8eb1be0-3595-11e7- 8aa7-5b2740a8fd5f.

Montañés, N. (2017). "Madera para Envases y Embalajes. Propiedades de la Madera." Retrieved Junio 2018, from https://media.upv.es/player/?id=dedb6950-3595-11e78aa7-5b2740a8fd5f.

Montañés, N. (2018). "Madera para Envases y Embalajes. Palets." Retrieved Junio 2018, from https://media.upv.es/player/?id=7f827da0-4a1f-11e8-af70-03116a2e3d4b.

Montañés, N. (2018). "Madera para Envases y Embalajes. Transformación de la Madera." Retrieved Junio 2018, from https://media.upv.es/player/? id=6d1c4150-4a1f-11e8-af70-03116a2e3d4b.

Montañés, N. (2018). "Madera para Envases y Embalajes. Usos Específicos." Retrieved Junio 2018, from https://media.upv.es/player/?id=76cbf600-4a1f-11e8-af7003116a2e3d4b.

Network, F. L. (2018). "What is the Flipped Classroom." Retrieved Marzo 2018, from https:/www.theflippedclassroom.es/what-is-innovacion-educativa/.

Parra, I. T. (2016). "El fin del roble en España." Retrieved Junio 2018, from http://www.maderea.es/el-fin-del-roble-en-espana/.

Plaza, B. S. (2016). "¿Cómo usando más madera se conservan los montes?" Retrieved Junio 2018, from http://www.maderea.es/usar-madera-y-conservar-los-montes/.

Público. (2010). "Más madera contra el cambio climático." Retrieved Junio 2018, from http://www.publico.es/ciencias/mas-madera-cambio-climatico.html. 
Roach, T. (2014). "Student perceptions toward flipped learning: New methods to increase interaction and active learning in economics." International Review of Economics Education 17: 74-84.

Universitat Politècnica de València, U. (2018). "Competencias Transversales UPV." Retrieved Marzo 2018, from http://www.upv.es/contenidos/COMPTRAN/.

Universitat Politècnica de València, U. (2018). "Docencia en Red: GUÍA PARA LA CREACIÓN DE ARTÍCULOS DOCENTES." Retrieved Marzo 2018, from http://www.upv.es/contenidos/DOCENRED/infoweb/docenred/info/PlantillaArticu losDocentes.dot.

Universitat Politècnica de València, U. (2018). "Docencia en Red: GUÍA PARA LA CREACIÓN DE GRABACIONES POLIMEDIA." Retrieved Marzo 2018, from http://www.upv.es/contenidos/DOCENRED/infoweb/docenred/info/guiaPolimedia scast.pdf.

Universitat Politècnica de València, U. (2018). "Docencia en Red: GUÍA PARA LA CREACIÓN DE GRABACIONES SCREENCAST." Retrieved Marzo 2018, from

http://www.upv.es/contenidos/DOCENRED/infoweb/docenred/info/U0759502.pdf 


\title{
Trabajo por proyectos en diseño de maquinaria
}

Rafael R. Sola-Guirado ${ }^{\mathrm{a}}$; Gregorio Blanco-Roldan ${ }^{\mathrm{a}}$; Jesús Gil-Ribes ${ }^{\mathrm{a}}$; Juan AgüeraVega $^{a}$

a E.T.S.I.A.M. Universidad de Córdoba. Ed. Leonardo Da Vinci, Ctra. N IV, km. 396. 14014. Córdoba.

\begin{abstract}
A project-based exercise has been introduced in the subject "Design of agricultural machinery". The students have to go through all phases of product development methodologies: information search, work planning, design, calculation, manufacturing, etc. to solve the problem. At the end, they must obtain a mock-up that emulates the work of an agricultural machine with loader functions. The students chose a methodology of group work by sequential engineering, instead of the one recommended by concurrent engineering, and at the end of the exercise they explained the problems encountered having learned of the pros and cons of both. The exercise covers a practical and enjoyable part of the curricular competences and allows the knowledge of specific engineering software. The practice indicators show the improvement of the teaching quality with greater participation of the students and with better academic results. However, teachers are required an extra dedication, as well as more resources, so in the future the practice should be coordinated with other similar subjects or with continuing education courses.
\end{abstract}

Keywords: mock-up; project; design; learning; machinery

\section{Resumen}

Se propone la introducción de un ejercicio basado en proyectos en la asignatura de "Diseño de maquinaria agraria". Para resolver el problema los alumnos han de pasar por todas las fases de las metodologías de desarrollo de productos: búsqueda de información, planificación del trabajo, diseño, cálculo, fabricación, etc. Al final, deberán obtener una maqueta que modele el trabajo de una máquina agrícola con funciones de cargadora. Los alumnos eligieron una metodología de trabajo en grupo por ingeniería secuencial, en lugar de la aconsejada por ingeniería concurrente, y al final del ejercicio expusieron los problemas encontrados habiendo aprendido de los pros y contras de ambas. El ejercicio cubre de forma práctica y amena gran parte de las competencias curriculares y permite el conocimiento de software específico ingenieril. Los indicadores finales de la práctica muestran la mejora de la calidad docente con mayor participación del alumnado y con mejores resultados académicos. Sin embargo, se requiere del profesorado una dedicación y tiempo extra en la asignatura, así como mayores recursos, por lo que en el futuro se debería intentar la coordinación de la práctica con otras materias similares o con cursos de formación permanente.

Palabras clave: maqueta, proyectos, diseño, aprendizaje, maquinaria 


\section{Introducción}

En el estudio de ingeniería, el método tradicional de resolución de problemas permite poner en práctica los contenidos estudiados en clase. Sin embargo, el "trabajo por proyectos" abre un mayor número de posibilidades, permitiendo a los alumnos afrontar las adversidades que se le plantean, generar hipótesis y tomar decisiones (Mills y Treagust, 2003). Además, acerca al alumno a una realidad más profesional, compleja y global (Hmelo-Silver, 2004).

Un correcto diseño de una práctica basada en proyectos debe aunar diferentes elementos (Han y Bhattacharya, 2001), para abarcar e integrar gran parte de los contenidos cursados, y difícilmente puede obviar la puesta en práctica de otras habilidades adquiridas en otras asignaturas a lo largo de la titulación. Para que el alumnado pueda adquirir las competencias exigidas en el marco laboral, es necesario planificar las actividades con una perspectiva unificada e interdisciplinar (Parra et al., 2011).

En métodos basados en "trabajo por proyectos", el profesor debe dar el control a los propios estudiantes para cambiar su rol tradicional y convertirlos en sujetos activos de construcción y gestión de su conocimiento (Fosnot, 1996). Todo ello, ha de apoyarse en una cooperación entre los estudiantes en la que formen equipos activos de trabajo (García, 2015). Es el grupo el que decide cómo realizar la tarea, qué procedimientos adoptar, cómo dividir el trabajo, y las tareas a realizar. Así, se pretende mantener a los estudiantes comprometidos y motivados en su propio proceso de aprendizaje, lo que posibilita el alcance de sus logros.

Otro aspecto relevante en el curso de materiales ingenieriles, es la necesidad de la utilización de herramientas informáticas que faciliten la resolución de determinadas tareas. Por ello, es esencial que el alumnado conozca y maneje software específico que le permitan adquirir ciertas habilidades para el posterior desempeño profesional (Moursund, 1999).

La asignatura de "Diseño de maquinaria agraria. Automática agraria” ( $4^{\circ}$ curso, Obligatoria, Itinerario de Ingeniería Rural, Grado de Ingeniería Agroalimentaria y del Medio Rural) ha sufrido una reducción del tiempo disponible para la impartición de materia enmarcada en el campo de "Desarrollo de productos". Sin embargo, la evolución de la titulación y el itinerario exige conocer ciertos contenidos como elementos mecánicos, oleohidráulicos, electrónicos y de control. Por tanto, dada la necesidad y la limitación temporal, la mejor forma de hacerlo, es mediante la combinación teórico-práctica, mediante el trabajo en base a proyectos.

\section{Objetivos}

En este trabajo se plantea una práctica docente basada en la resolución de un problema que desemboca en la construcción de un prototipo de máquina agrícola. Para afrontar el trabajo, los alumnos tuvieron que desempeñar una serie de actividades que se encuentran entre las comunes en fases de diseño y desarrollo de productos (DDP), cuyo fundamento teórico se cursó en la asignatura. Se utilizó un enfoque constructivista en el tratamiento interdisciplinar de las actividades planteadas. Para ello, se dotó al alumnado de material de apoyo, como herramientas metrológicas y de taller, y de software específico.

(cc) EY-NC-ND 2018, Universitat Politècnica de València

Congreso In-Red (2018) 
El objetivo general persiguió que el alumnado aplicara los conocimientos adquiridos en la asignatura "Diseño de maquinaria agraria. Automática agraria”, mediante la resolución del problema práctico, planteado como un Proyecto, y en un proceso de colaboración con varios compañeros. Además, se pretendió mejorar la calidad de la asignatura en su ámbito docente. A continuación, se analizan las bases de la práctica planteada.

\section{Desarrollo de la innovación}

PROYECTO: Planificación, diseño, fabricación y automatización de un prototipo que simule una máquina con funciones de manipulación (Figura 1) (cargador frontal, manipuladora telescópica, etc.). Estas máquinas son muy empleadas en el sector agrícola, disponiendo de una conjunción de sistemas mecánicos, oleohidráulicos y eléctricos, lo que justifica su elección para el objetivo del trabajo.

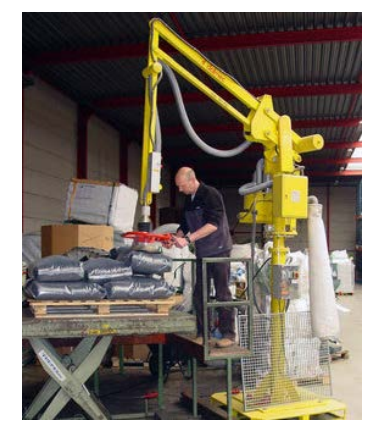

Fig. 1. Máquina cargadora de productos agrícolas.

PROBLEMA: El prototipo (maqueta) no podrá superar las dimensiones de 40x40x40 cm ni el peso de $2 \mathrm{~kg}$ y deberá trasladar un objeto de peso y dimensiones determinadas (paquete de pañuelos) desde un punto inicial hasta otro situado a $10 \mathrm{~cm}$ a su derecha y $10 \mathrm{~cm}$ de altura.

COOPERACIÓN: Los alumnos deberán formar un grupo y repartir las tareas necesarias para la resolución del problema pudiendo elegir cualquiera de las metodologías de Diseño explicadas en clase: Ingeniería Secuencial (un sector del grupo ejecuta las tareas que le corresponde, transfiere los resultados al siguiente y queda a la espera de una segunda interacción) o Ingeniería Concurrente (todos los sectores del grupo desarrollan las tareas coordinadamente y paralelamente de manera que todas las actividades ocurran al mismo tiempo y con decisiones consensuadas).

ENTREGABLES: Se deberá entregar unos informes que indiquen los resultados obtenidos en todas las fases que implica un DDP: estudio de la técnica, planificación del trabajo, diseño conceptual y de detalle, cálculo, documentación de taller, fabricación, ensamblaje y puesta en marcha. Al final de la práctica, los alumnos se expondrá una presentación con los resultados obtenidos en las diferentes fases y se evaluará por los profesores.

ANÁLISIS DE LA PRÁCTICA: Los alumnos expondrán una matriz DAFO para obtener las principales debilidades, amenazas, fortalezas y oportunidades que haya ofrecido esta práctica. Los profesores que imparten la asignatura realizarán una evaluación de los principales indicadores del éxito sobre la mejora de la calidad en la docencia, indicando un

(cc) EY-Nc-ND 2018, Universitat Politècnica de València

Congreso IN-RED (2018) 
valor numérico: mucho (4), bastante (3), poco (2) o nada (1), para evaluar la incidencia del proyecto en el programa docente.

\section{Resultados obtenidos y discusión}

Los alumnos eligieron trabajar según la metodología de Ingeniería Secuencial, esto es, se reparten las tareas entre ellos, según las fases a entregar, y realizan varias iteraciones, pero sin interactuar entre ambos. La elección de este modelo vino motivada por sus preferencias de trabajar de manera individual y gestionando sus propios tiempos. Los resultados de las diferentes fases se muestran en la Tabla 1.

Tabla 1. Cuadro resumen de las actividades realizadas en la práctica, los resultados obtenidos, las decisiones tomadas y las principales herramientas usadas.

\begin{tabular}{|c|c|c|c|c|}
\hline & Actividades & Resultados & Decisión & Herramientas \\
\hline 1 & $\begin{array}{l}\text {-Búsqueda de } \\
\text { información de } \\
\text { máquinas similares } \\
\text {-Lluvia de ideas }\end{array}$ & $\begin{array}{l}\text {-Listado de máquinas } \\
\text { similares y webs de } \\
\text { consulta } \\
\text {-Listado de ideas } \\
\text { sobre mecanismos, } \\
\text { materiales }\end{array}$ & $\begin{array}{l}\text {-Mecanismo pantógrafo para } \\
\text { mantener la horizontalidad de } \\
\text { una pinza de apertura en } \\
\text { movimientos de elevación. } \\
\text {-Actuadores hidráulicos con } \\
\text { cilindros (jeringuillas) para } \\
\text { los diferentes movimientos. } \\
\text {-Material: madera (ligero y de } \\
\text { fácil manipulación). }\end{array}$ & $\begin{array}{l}\text {-Base de datos: } \\
\text { Google y } \\
\text { propias de la } \\
\text { biblioteca UCO. }\end{array}$ \\
\hline 2 & $\begin{array}{l}\text {-Planificación del } \\
\text { trabajo y } \\
\text { estimación de } \\
\text { costes para } \\
\text { abastecimiento de } \\
\text { recursos. }\end{array}$ & $\begin{array}{l}\text {-Cronograma } \\
\text { (diagrama de Gantt) } \\
\text { de actividades. } \\
\text {-Presupuesto de } \\
\text { medios y materiales } \\
\text { necesarios }\end{array}$ & $\begin{array}{l}\text {-Cada equipo realiza una } \\
\text { actividad ( } 1 \text { semana) y pasa } \\
\text { los resultados al siguiente con } \\
\text { interacción mínima. } \\
\text {-50 € de materiales (madera, } \\
\text { pegamentos y tornillería). }\end{array}$ & $\begin{array}{l}\text {-Project } \\
\text { (Microsoft): } \\
\text { Cronogramas. } \\
\text {-Excel } \\
\text { (Microsoft): } \\
\text { Presupuesto. }\end{array}$ \\
\hline 3 & $\begin{array}{l}\text {-Bocetos del } \\
\text { mecanismo. } \\
\text {-Diseño de detalle } \\
\text { con un modelo } \\
\text { CAD }\end{array}$ & & $\begin{array}{l}\text {-Utilizar el diseño CAD } \\
\text { planteado para la fabricación } \\
\text { de la maqueta. } \\
\text { Modificaciones en una } \\
\text { segunda iteración para } \\
\text { incorporar los actuadores }\end{array}$ & $\begin{array}{l}\text {-SolidWorks } \\
2010 \text { (Dassault } \\
\text { Systemes): } \\
\text { Diseño } \\
\text { paramétrico y } \\
\text { ensamblaje. }\end{array}$ \\
\hline 4 & $\begin{array}{l}\text {-Cálculo de } \\
\text { tensiones. } \\
\text {-Cálculo } \\
\text { cinemático de } \\
\text { recorridos. } \\
\text {-Cálculo de } \\
\text { sistema hidráulico. }\end{array}$ & & $\begin{array}{l}\text {-Redefinir ligeramente el } \\
\text { diseño planteado. } \\
\text {-Integración de jeringuillas en } \\
\text { los alojamientos del diseño. }\end{array}$ & $\begin{array}{l}\text {-SolidWorks } \\
\text { 2010: Cálculo } \\
\text { estático. } \\
\text {-Winmecc } \\
\text { (UMA): } \\
\text { Cinemática de } \\
\text { mecanismos. } \\
\text {-Modelos } \\
\text { cinemáticos. }\end{array}$ \\
\hline
\end{tabular}




\begin{tabular}{l|l|l|l|l|}
\hline 5 & $\begin{array}{l}\text {-Generación de } \\
\text { documentación } \\
\text { para la fabricación } \\
\text { de la maqueta. }\end{array}$ & $\begin{array}{l}\text {-Planos técnicos de los } \\
\text { componentes a montar } \\
\text {-Órdenes de trabajo y } \\
\text { planificación de procesos a } \\
\text { realizar. } \\
\text {-Corte de piezas. Algunas de } \\
\text { ellas fueron obtenidas } \\
\text { mediante una fresadora 2D. }\end{array}$ & $\begin{array}{l}\text {-SolidWorks } \\
\text { 2010: Planos } \\
\text {-Vetric Aspire): } \\
\text { CNC para corte. } \\
\text {-Máquinas } \\
\text { CNC. } \\
\text {-Herramientas } \\
\text { de bricolaje. }\end{array}$ \\
\hline 6 & $\begin{array}{l}\text {-Automatización } \\
\text { de movimientos } \\
\text { con elementos de } \\
\text { control. }\end{array}$ & $\begin{array}{l}\text {-Propuesta práctica en } \\
\text { la que los } \\
\text { movimientos (base de } \\
\text { giro) se realizarían } \\
\text { con servomotores } \\
\text { controlados por una } \\
\text { placa de Arduino. }\end{array}$ & $\begin{array}{l}\text {-Debido a la falta de } \\
\text { entendimiento y mala gestión } \\
\text { nel tiempo no se implantó }\end{array}$ & $\begin{array}{l}\text {-Arduino 1.8.5 } \\
\text { (IDE). }\end{array}$ \\
\hline 7 & $\begin{array}{l}\text {-Ensamblaje y } \\
\text { puesta a punto de } \\
\text { componentes }\end{array}$ & &
\end{tabular}

La matriz DAFO de los alumnos sobre el ejercicio planteado se muestra en la Tabla 2.

Tabla 2. Matriz DAFO sobre el ejercicio planteado

\begin{tabular}{lll}
\hline \multirow{3}{*}{ Debilidades } & o & Acabado de las piezas. \\
& o & Fases de trabajo secuenciales. \\
& o & Carencia de conocimientos base (física, matemáticas, etc.). \\
& o & Cambio de mentalidad en la enseñanza-evaluación. \\
\hline \multirow{4}{*}{ Amenazas } & o & Subestimar el proyecto. \\
& o & Tiempo limitado en clase. \\
& 0 & Necesidad de conocimiento de software. \\
& 0 & Falta de comunicación entre equpos. \\
\hline \multirow{4}{*}{ Fortalezas } & 0 & Acceso a todo tipo de información. \\
& 0 & Asesoramiento del profesorado. \\
& 0 & Disponibilidad de máquinas, herramientas y software \\
& 0 & Gran flexibilidad para la creativdad de la solución. \\
\hline \multirow{3}{*}{ Oportunidades } & 0 & Comprender de manera práctica los mecanismos. \\
& 0 & Poner en marcha un proyecto real. \\
& 0 & Comprender pros y cons de ingeniería concurrente vs secuencial. \\
& 0 & Aprender sofware específico que no se cursa en la titulación. \\
\hline
\end{tabular}

(cc) EY-NC-ND 2018, Universitat Politècnica de València

Congreso IN-RED (2018) 
Los resultados de mejora en los indicadores de mejora docente, con la introducción de este proyecto, según el profesorado, indican que el uso de las tutorías, la asistencia a clase y el interés por la comprensión de los contenidos ha aumentado, pero poco. Además, se ha mejorado la comunicación entre los alumnos, aunque finalmente eligieran el modo trabajo de menor cooperación. Todo ello, se ha plasmado en una mejora del rendimiento de los alumnos en sus notas finales.

La comunicación entre el alumno y el profesor ha aumentado poco, pero ha mejorado bastante el clima de trabajo y la participación en clase del alumnado. Ha mejorado bastante la coordinación de actividades entre el profesorado a la hora de la planificación de la asignatura, por la necesidad de adaptarla levemente y dotarla con un enfoque más práctico. Ello ha permitido que el grado de cumplimiento de los objetivos de la asignatura sea bastante mejor al de otros años. La realización del proyecto ha permitido trabajar las siguientes competencias de la titulación: CB2 (resolución de problemas con creatividad, iniciativa, metodología y razonamiento crítico); CB4 (búsqueda y utilización de la normativa y reglamentación relativa a su ámbito de actuación); CU2 (conocer y perfeccionar el nivel de usuario en el ámbito de las TIC); CEC7 (capacidad para conocer, comprender y utilizar los principios de ingeniería del medio rural: estructuras, construcción, hidráulica, máquinas, proyectos técnicos); CEC9 (toma de decisiones mediante el uso de los recursos disponibles para el trabajo en grupos multidisciplinares); CEMC4 (conocer, comprender y utilizar los principios de mecanización agraria).

\section{Conclusiones}

El ejercicio propuesto como un proyecto ha cubierto de manera práctica las competencias a adquirir en la asignatura, permitiendo descubrir otros recursos como software específico ingenieril. La elección de la metodología de trabajo secuencial ha permitido que los alumnos comprendan las desventajas y utilidades de esta frente a una concurrente, pero la elección de esta última lo posibilitaría del mismo modo. Sin embargo, ello ha conllevado a que la resolución técnica de la práctica no haya sido excelente y a que algunas fases, como la automatización, no se haya realizado por falta de coordinación

A nivel docente se ha mejorado la participación e interacción de los alumnos con el profesorado, así como la coordinación horizontal de la asignatura. Las limitaciones de tiempo y recursos pueden ser un escollo para llevar a cabo el proyecto con un grado de éxito mayor, aunque los alumnos admiten que es una oportunidad para utilizar nuevos medios que no podrían aprender con la enseñanza tradicional. La integración vertical de esta práctica con asignaturas afines permitiría aumentar el tiempo para desarrollar contenidos complementarios como software, aunque si no es así, los alumnos podrían disfrutar de cursos de formación permanente que complementen sus competencias.

\section{Agradecimientos}

Los autores del trabajo agradecen a la Universidad de Córdoba la financiación recibida en proyectos de innovación docente. 


\section{Referencias}

GARCÍA, A. E. (2015). "El aprendizaje por proyectos y el trabajo colaborativo, como herramientas de aprendizaje, en la construcción del proceso educativo, de la Unidad de aprendizaje” en RIDE Revista Iberoamericana para la Investigación y el Desarrollo Educativo, 3(5), 123-138.

FOSNOT, C. T. \& Perry, R. S. (1996). “Constructivism: A Psychological theory of Learning”, en Constructivism: Theory, Perspective and Practice, Teacher College, 2, 8-33

MOURSUND, D. G. (1999). "Project-based learning using information technology” en International society for technology in education.

MILLS, J. E., y TREAGUST, D. F. (2003). “Engineering education-Is problem-based or projectbased learning the answer" en Australasian journal of engineering education, 3(2), 2-16.

HAN, S., y BHATTACHARYA, K. (2001). “Constructionism, learning by design, and project based learning” en Emerging perspectives on learning, teaching, and technology. E-book (http://www.coe.uga.edu/epltt/LearningbyDesign.htm . [Consulta: 15 de Marzo de 2018]

HMELO-SILVER, C. E. (2004). “Problem-based learning: What and how do students learn?” en Educational psychology review, 16(3), 235-266

PARRA-COSTA, C. J., et al. (2011). "Estrategias de coordinación horizontal y vertical en los planes de estudios adaptados al EEES” en Congreso Internacional de Innovación Docente, Cartagena, 2011. Cartagena: Universidad Politécnica de Cartagena, 2011. p.1815-1824

(cc) EY-NC-ND 2018, Universitat Politècnica de València 


\title{
Mejora de la planificación temporal y adaptación de la metodología docente de la asignatura de IDEs del grado de Ingeniería Geomática mediante estadísticos de encuestas anónimas de horas dedicadas
}

\section{Martinez-Llario Jose ${ }^{\mathrm{a}}$, Coll Eloina}

${ }^{a}$ Departamento de Ingeniería Cartográfica, Geodesia y Fotogrametría, Universitat Politècnica de València, jomarlla@cgf.upv.es, ecoll@cgf.upv.es

\begin{abstract}
In this paper, a teaching methodology adapted to support a very flexible way of delivery times of the practical contents of a subject.

The aim is to give the student the possibility of using many more hours than the average in a given module in order to avoid sending incomplete tasks or abandoning the subject.

To do this, a series of surveys are used and with its statisticians the schedule of the subject is designed for the next course.

In addition, the methodology is adapted with reverse teaching and principally all the contents are adapted to give the possibility to the student to finish any task outside teaching hours.
\end{abstract}

Keywords: flip teaching, geomatics, polls

\footnotetext{
Resumen

En este artículo presentamos una metodología docente adaptada para soportar tiempos de entrega de los contenidos prácticas de una asignatura de forma muy flexible.

Se busca dar la posibilidad al alumno de utilizar muchas más horas que la media en un determinado módulo para así evitar el envío de tareas incompletas o abandono de la asignatura.

Para ello, se utilizan una serie de encuestas y con sus estadísticos se diseña el cronograma de la asignatura para el curso siguiente.

Además, se adapta la metodología con docencia inversa y principalmente se adaptan todos los contenidos para dar la posibilidad al alumno de finalizar cualquier tarea fuera de horario docente.
}

Palabras clave: gestión del tiempo, docencia inversa, encuesta, planificación temporal, geomática 
Mejora de la planificación temporal y adaptación de la metodología docente de la asignatura de IDEs del grado de Ingeniería Geomática mediante estadísticos de encuestas anónimas de horas dedicadas

\section{Introducción}

La metodología docente mostrada en este artículo se aplica desde hace cinco años en la asignatura de Infraestructuras de Datos Espaciales (IDEs) en el grado de Ingeniería Geomática de la ETSIGCT de la UPV. Es una asignatura de 6 créditos, dividida en 50\% prácticas de laboratorio y $50 \%$ de teoría.

El tiempo necesario para el desarrollo de los contenidos prácticos de esta asignatura requieren de unas habilidades que dependen mucho de las destrezas informáticas de cada alumno, y también de los problemas técnicos que se pueden encontrar en su realización y que pueden ser diferentes para cada alumno, ya que cada uno trabaja con diferentes datos.

El primer año de la asignatura el profesorado se encontró con los problemas mencionados en el párrafo anterior, y es que el tiempo necesario para la realización de los módulos de prácticas era muy variado en función de cada alumno, debido a dos causas:

- La heterogeneidad en las destrezas de cada alumno en cuanto a la aplicación de determinados conocimientos relaciones con las ciencias de la computación.

- Los problemas encontrados en cada módulo de prácticas pueden ser muy diferentes para cada alumno.

Nos encontramos que un mismo módulo de prácticas, un alumno lo realizaba en 4 horas mientras que otro podía necesitar 12 horas para su finalización.

Además, especialmente para los alumnos que empleaban en un módulo muchas horas, no podían finalizarlo en el laboratorio y debían de acabarlo fuera de horas lectivas.

\section{Objetivos}

Los objetivos consisten en diseñar una metodología docente que sea flexible en cuanto al tiempo necesario para cada alumno en la realización de prácticas pero siguiendo una estructura común basada en datos empíricos de años anteriores.

Se busca dar la posibilidad al alumno de utilizar muchas más horas que la media en un determinado módulo para así evitar el envío de tareas incompletas o abandono de la asignatura.

Para ello debemos de:

- Averiguar el tiempo medio de forma empírica en la realización de las prácticas de cada módulo.

- Crear un sistema flexible en cuanto a las fechas de entrega de los trabajos basado en los estadísticos obtenidos anteriormente.

- Adaptar el material de la asignatura para soportar la posibilidad de finalizar las prácticas fuera del horario docente.

- Adaptar la metodología docente con el uso de herramientas de formación a distancia para dar soporte fuera de horario docente.

(c) EY-NC-ND 2018, Universitat Politècnica de València

Congreso IN-RED (2018) 


\section{Desarrollo}

\subsection{Cálculo del tiempo empleado en cada módulo}

Para el cálculo del tiempo se empleó la herramienta de Sondeos de PoliformaT (realización de encuestas anónimas), cada alumno al finalizar la entrega de las prácticas de un módulo (la asignatura consta de 11 módulos) realiza una encuesta anónima (figura 1).

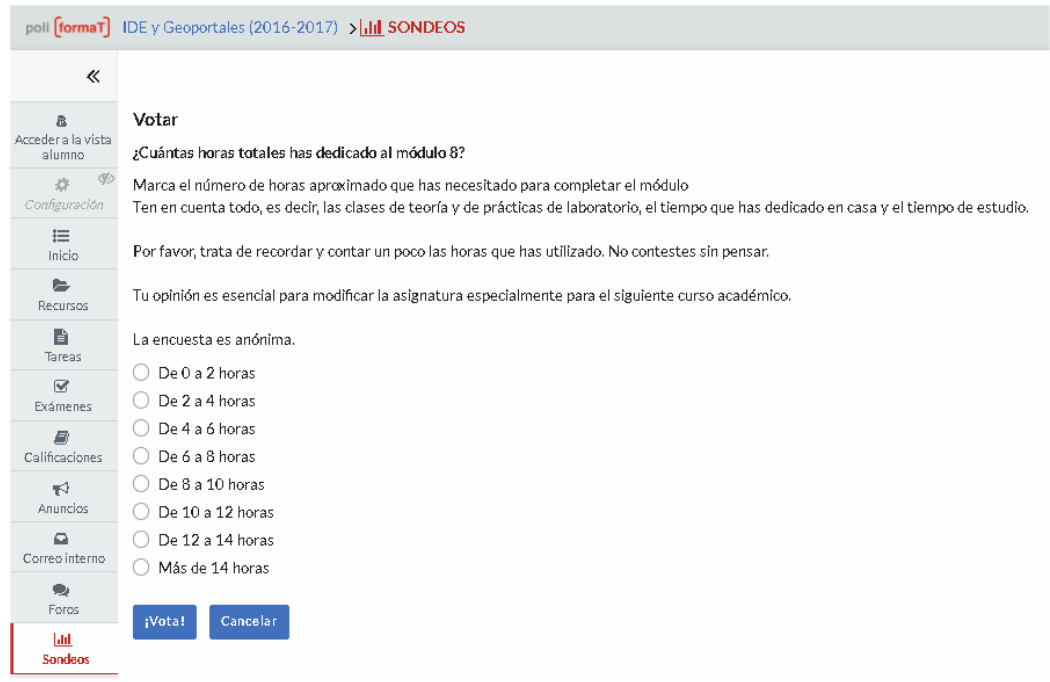

Fig. 1 Encuesta (sondeo en PoliformaT) anónima de un módulo

Los rangos de horas en la encuesta son amplios (2 horas) para facilitar la respuesta. Al finalizar el curso académico se estudian las encuestas y se obtienen los estadísticos para cada uno de los módulos.

En la figura 2 se puede ver como la moda de tiempo empleado en la finalización del módulo 2 corresponde sobre 9 horas (31\% de los alumnos), aunque un 15\% de los alumnos han necesitado más de 14 horas para su finalización lo cual indica la disparidad de las horas empleadas por los alumnos debido a las causas comentadas en el apartado anterior.

Se reduce en gran medida la posibilidad de que un alumno envíe el módulo sin completar, ya que se ha observado que cuando un alumno se encuentra con problemas en un módulo y requiere más horas de las normales para su realización prefiere dedicarle más horas aunque sea fuera de las horas lectivas y finalizar completamente el módulo. 
Mejora de la planificación temporal y adaptación de la metodología docente de la asignatura de IDEs del grado de Ingeniería Geomática mediante estadísticos de encuestas anónimas de horas dedicadas

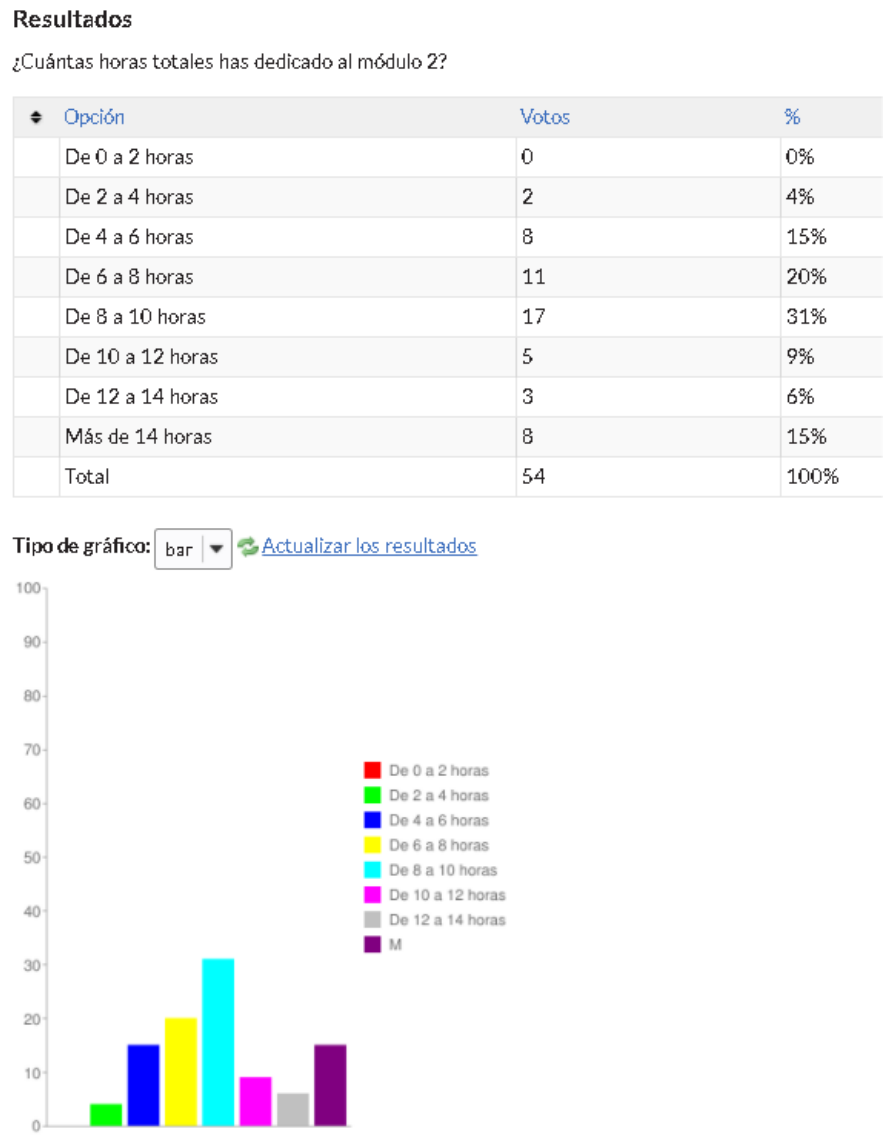

Fig. 2 Resultado al finalizar el curso de las encuestas de un módulo

\subsection{Sistema flexible de entrega}

Basado en los datos obtenidos de las encuestas se elabora un cronograma de rangos flexibles (entendiendo por rango flexible que el tiempo desde la apertura y a la entrega máxima permitida es fácilmente el doble o el triple del tiempo medio empleado por todos los alumnos del curso anterior) para la realización de cada módulo. La figura 3, muestra el cronograma que se ha realizado para el curso 2017-2018. La figura 2, mostraba el tempo medio empleado por un módulo.

Se puede ver como por ejemplo para el módulo 6, se da un total de 6 semanas para su realización. El alumno que emplee un número de horas medio (según los datos de las encuestas del año anterior) se moverá en la franja verde-amarilla.

Un alumno puede entregar el módulo 6 desde la primera semana de octubre hasta la tercera semana de noviembre como máximo.

Para los últimos módulos se alarga la fecha de entrega máxima hasta una semana antes de la entrega de las actas.

(cc) EY-NC-ND 2018, Universitat Politècnica de València 
Las fechas de entrega y duración de los módulos quedan plasmados en PoliformaT mediante las tareas cuyas fechas de apertura y entrega siguen de forma rigurosa el cronograma.
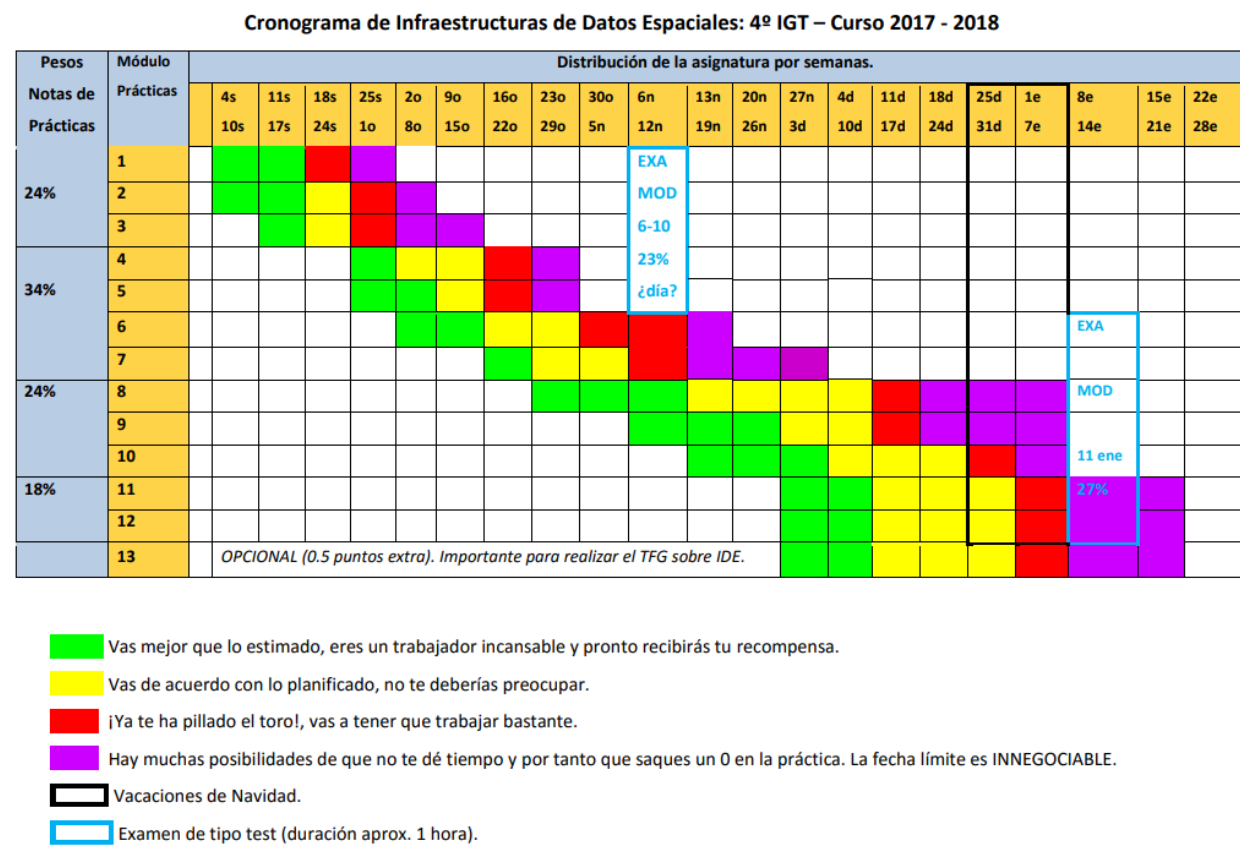

Fig. 3 Cronograma realizado a partir de las encuestas del curso del año anterior

\subsection{Adaptación del material docente}

Como se ha comentado anteriormente se debe dar la posibilidad al alumno de que finalice o realice cualquier tarea fuera del horario docente, así pues ha sido necesario rediseñar todo el material docente de las prácticas de la asignatura para que de forma autónoma un alumno puede trabajar fuera del laboratorio y completar parte de las prácticas. Se ha realizado una redacción y guiado minucioso de todas las prácticas.

Hay que comentar que cada alumno trabaja con datos y cartografía diferente y se evita de esta forma en gran medida que se copien las prácticas al tener la posibilidad de trabajar sin la supervisión del profesor.

Queremos mencionar que según los cálculos de las encuestas, aproximadamente los alumnos necesitan un 20-60\% de dedicación horaria fuera de laboratorio para finalizar todos los módulos.

\subsection{Herramientas de formación a distancia}

Se han incluido foros en PoliformaT para facilitar la respuesta del profesor o de otros compañeros cuando un alumno está realizando una práctica fuera de horario docente.

(c) EY-NC-ND 2018, Universitat Politècnica de València 
Mejora de la planificación temporal y adaptación de la metodología docente de la asignatura de IDEs del grado de Ingeniería Geomática mediante estadísticos de encuestas anónimas de horas dedicadas

También, se han incluido un gran número de vídeos screen cast y se ha creado una máquina virtual para que el alumno trabaje en el laboratorio con todo el software y una vez acabe la práctica se pueda llevar todo el trabajo realizado para su continuación si es necesario fuera del laboratorio.

\section{Resultados y conclusiones}

Se ha creado un sistema de encuestas, adaptado el material docente para que el alumno pueda finalizar las prácticas fuera de horario docente si es necesario y utiliza algunas herramientas de formación a distancia como la utilización de foros, vídeos screen cast, etc.

Hemos adaptado los tiempos de entrega de las tareas como aparece en la figura 4 permitiendo una flexibilidad que contemple la disparidad en horas que necesita cada alumno. Además en dicha figura se puede ver como prácticamente todos alumnos han entregado todas las prácticas.

\begin{tabular}{|c|c|c|c|c|}
\hline Título de la Tarea & Estado & Abierto & Entrega & Entregados \\
\hline Prácticas módulo 01 & Cerrado & $04-$ sep-2017 0:00 & 01-oct-2017 23:55 & $\underline{33 / 32}$ \\
\hline \& Prácticas módulo 02 & Cerrado & 04-sер-2017 0:00 & 08 -oct-2017 23:55 & $\underline{31 / 28}$ \\
\hline Prácticas módulo 03 & Cerrado & $11-$ sер-2017 0:00 & 15 -oct-2017 23:55 & $\underline{32 / 30}$ \\
\hline S Prácticas módulo 04 & Cerrado & 25 -sер-2017 0:00 & 29-oct-2017 23:55 & $\underline{34 / 30}$ \\
\hline SPrácticas módulo 05 & Cerrado & $25-$-ер-2017 0:00 & 29 -oct-2017 23:55 & $\underline{29 / 27}$ \\
\hline Prácticas módulo 06 & Cerrado & 02-act-20170:00 & 26-nov-2017 23:55 & $\underline{33 / 31}$ \\
\hline Prácticas módulo 07 & Cerrado & 16-oct-2017 0:00 & 10-dic-2017 23:55 & $\underline{29 / 27}$ \\
\hline S Prácticas módulo 08 & Cerrado & 23-act-2017 0:00 & 07-ene-2018 23:55 & $\underline{34 / 33}$ \\
\hline Prácticas módulo 09 & Cerrado & 06-nov-2017 0:00 & 07-ene-2018 23:55 & $\underline{33 / 33}$ \\
\hline Prácticas módulo 10 & Cerrado & $13-$ nov-2017 0:00 & 07-ene-2018 23:55 & $\underline{34 / 29}$ \\
\hline Prácticas módulo 11 & Cerrado & $27-n \circ v-20170: 00$ & 21-ene-2018 23:55 & $\underline{30 / 30}$ \\
\hline Prácticas módulo 12 & Cerrado & 27-nov-2017 0:00 & 21-ene-2018 23:55 & $\underline{26 / 22}$ \\
\hline
\end{tabular}

Fig. 4 Prácticas entregadas. Fechas adaptadas al cronograma de las encuestas

La metodología docente requiere un esfuerzo extra del profesor, debido a que es necesario la elaboración de un material que permita el alumno finalizar las tareas fuera de laboratorio si es necesario. Además, lo normal es que en el laboratorio los alumnos estén realizando prácticas de hasta 4 módulos diferentes y el profesor debe estar centrado para resolver todas las dudas de forma ágil.

Se ha observado que esta metodología evita abandonos en la asignatura y aumenta la tasa de rendimiento. Como conclusión podemos decir que un alumno prefiere si se le da la suficiente flexibilidad y lo necesita de forma puntual (al encontrarse con dificultades extra), dedicar muchas más horas que la media para finalizar un módulo que dejarlo sin entregar o realizarlo de forma no correcta.

También se ha comentado con los propios alumnos que el sistema les produce meno ansiedad y estrés que las entrega de prácticas fija o la obligación de finalización de una práctica en horario lectivo.

(cc) EY-NC-ND 2018, Universitat Politècnica de València

Congreso IN-RED (2018) 
Por último, decir que las encuestas docentes de la asignatura y también las encuestas de docencia inversa, corroboran que la metodología docente es del agrado de los alumnos.

\section{Referencias}

Barrera, A.G. (2013). El aula inversa: cambiando la respuesta a las necesidades de los estudiantes. Avances en Supervisión Educativa.

López Rodríguez, D., et al. (2016). Elaboración de material para la realización de experiencias de clase inversa (flipped classroom). ISBN 978-84-617-5129-7, págs. 16651679.

Polanco, A. (2005). “La motivación en los estudiantes universitarios”. Revista Electrónica "Actualidades Investigativas en Educación. Vol. 5, núm. 2, pp. 1-13

Salinas, J. (2004). Innovación docente y uso de las TIC en la enseñanza universitaria. Revista de Universidad y Sociedad del Conocimiento (RUSC). [artículo en línea]. UOC. Vol. $1, \mathrm{n}^{\mathrm{o}} 1$. 


\title{
Red de Tecnoparques del Servicio Nacional de Aprendizaje - SENA - Colombia. Una mirada desde la línea de ingeniería y diseño nodo Bogotá
}

\author{
Adela Marcela Triana Arevalo ${ }^{a}$, John Eduard Gómez Bohórquez ${ }^{\text {b }}$ y Juan Sebastian \\ Avila Foreroc \\ a Diseñadora Industrial, Gestora Tecnoparque SENA Nodo Bogotá, adelmar87@misena.edu.co, \\ bIngeniero Aeronáutico, Gestor Tecnoparque SENA Nodo Bogotá, jeduard.gomez@misena.edu.co, \\ ${ }^{\mathrm{c}} \mathrm{PhD}(\mathrm{c})$, Profesor de Diseño Industrial Universidad El Bosque de Bogotá, \\ avilajuan@unbosque.edu.co.
}

\begin{abstract}
The National Service of Learning (SENA) is a Colombian public institution that offers technical training programs for human resources for the labor market. Performs business, community and technological development activities.

The SENA Technoparks are a technological innovation program aimed at all Colombians, which acts as an accelerator for the development of $R \& D \& I$ projects materialized in functional prototypes in four technological lines that promote technology-based entrepreneurship: Electronics and Telecommunications, Virtual Technologies, Biotechnology, Nanotechnology and Engineering and Design.

Specifically, for the Engineering and Design line, we present their services and results in the following areas: Analysis and simulation, industrial design, product and process engineering, design and materials for manufacturing and assembly, digital product manufacturing, reverse engineering. Illustrating the developments through projects, which have the potential to become companies with technological impact or in outstanding opportunities for employment and sales of products or services.
\end{abstract}

Keywords: Innovation, $R \quad \& \quad D$, FabLab, Technical education, Entrepreneurship.

\section{Resumen}

El Servicio Nacional de Aprendizaje SENA (Sena.edu.co, 2018) es una institución pública colombiana que ofrece programas de formación complementaria y titulada. Enfatiza su misión en la capacitación técnica del recurso humano; formando personas para vincularlas al mercado laboral y realiza actividades de desarrollo empresarial, comunitario y tecnológico. 
Los Tecnoparques SENA, (Tecnoparque.sena.edu.co, 2018) son un programa de innovación tecnológica dirigida a todos los Colombianos, que actúa como acelerador para el desarrollo de proyectos de $I+D+i$ materializados en prototipos funcionales en cuatro líneas tecnológicas que promueva el emprendimiento de base tecnológica: Electrónica y Telecomunicaciones, Tecnologías Virtuales, Biotecnología, Nanotecnología e Ingeniería y Diseño.

Específicamente, para la línea de Ingeniería y Diseño queremos dar a conocer sus servicios y resultados en las siguientes áreas: planeación, análisis y simulación, diseño industrial, ingeniería de productos y procesos, diseño y materiales para la manufactura y ensamble, fabricación digital de productos, ingeniería inversa. Ilustrando los desarrollos a través de algunos proyectos, que tienen potencial de convertirse en empresas de impacto tecnológico o en oportunidades destacadas de vinculación laboral, o venta de productos o servicios.

Palabras clave: Innovación, I + D, FabLab, Educación técnica, Emprendimiento.

\section{Introducción}

El SENA fue fundado en 1957, cuenta con varias sedes en Bogotá y en los 32 departamentos de Colombia, el enfoque principal del SENA durante sus primeros años fue brindar instrucción técnica a los trabajadores y empleados de la industria, el comercio y el sector agropecuario. Sin embargo, en la actualidad atiende la demanda de sectores como el financiero, tecnológico y de la salud. Lo anterior lo ha llevado a convertirse en una de las mejores alternativas de instrucción para colombianos de escasos recursos, así como trabajadores y empresarios. La oferta regular para formación profesional: técnicos, tecnólogos y trabajadores especializados incluye más de 522 programas. A lo largo de sus más de 50 años el SENA se ha destacado por ser uno de los más importantes centros de educación técnica de América Latina. (Lineabase.sena.edu.co, 2018)

El programa Red TecnoParque Colombia, es una iniciativa de innovación tecnológico del SENA adscrito a la Dirección de Formación Profesional - Grupo gestión estratégica de la investigación, desarrollo tecnológico e innovación SENNOVA, (Sena.edu.co, 2018), para el desarrollo integral del talento humano, que, con ambientes de aprendizaje especializados para la apropiación de innovación y tecnología, complementa la formación ofrecida por el SENA e integra actores adicionales de los sectores público, privado y educativo.

El SENA, desde el programa Red Tecnoparque Colombia cuenta con cuatro líneas de investigación y apoyo a los empresarios. La línea de ingeniería y diseño, el cual tiene como función: prestar sus servicios en las siguientes áreas: Análisis y simulación, diseño industrial, ingeniería de productos y procesos, diseño y materiales para la manufactura y ensamble, fabricación digital de productos e ingeniería inversa. De esta manera se ha promovido y potencializando la creación de negocios a partir del uso de las herramientas del diseño industrial y la ingeniería; a través de la asesoría, acompañamiento a iniciativas orientadas hacia la optimización, desarrollo de planes de acción para la diversificación y 
diferenciación de la oferta del sector productivo nacional, impulsando la innovación y el emprendimiento de los aprendices.

\section{Objetivos:}

Socializar las actividades y gestión llevada a cabo durante el funcionamiento y operación de la línea ingeniería y diseño de TecnoParque nodo Bogotá, evidenciando los aciertos y dificultades de los proyectos asesorados en el periodo 2015-2017.

\subsection{Objetivos específicos:}

1. Dar a conocer la experiencia en el desarrollo de proyectos innovadores de base tecnológica desde el nodo Tecnoparque de Bogotá, que han contribuido al crecimiento económico y la competitividad de pequeñas empresas en Colombia.

2. Ilustrar algunos factores de articulación entre gobierno, empresa y academia para el desarrollo de acciones conjuntas enfocadas hacia la innovación.

3. Evidenciar los escenarios donde los aprendices y futuros emprendedores colombianos, desarrollan proyectos de base tecnológica con alto potencial innovador, pudiendo materializar prototipos funcionales y productos tecnológicos con el apoyo de una entidad pública.

\section{Innovación educativa a partir de proyectos de base tecnológica:}

La estrategia de la línea de ingeniería y diseño está establecida en diferentes ejes, el primero de ellos es la diferenciación en la aplicación de conceptos de diseño en el desarrollo y consecución de los proyectos de base tecnológica, el segundo la integración de planes de acción dependiendo del tipo del proyecto vinculado al nodo, siendo la personalización en el servicio a cada uno de los aprendices uno de los factores fuertes del programa. El tercero la planificación como proceso de definición sistémica en los lineamientos para la toma de decisiones, la asignación y distribución de los recursos y la consecución de los objetivos principales del proyecto vinculado al nodo.

Para las instituciones de formación de profesionales del país en áreas de diseño, salud, ingeniería diseño automotriz entre otras, esta iniciativa permite a los emprendedores, pymes y público en general contar con la infraestructura de la línea para ayudar a apalancar el desarrollo del país a través de la especialización en línea de desarrollo tecnológico (LDT) con prototipos y productos mínimos viables (MVP, del inglés Minimum Viable Product). (Producto viable mínimo, 2017).

Con estos prototipos funcionales los aprendices representan sus ideas de diseño antes de obtener un producto final. En algunas industrias o empresas la palabra prototipo se utiliza para versiones de productos próximos a lanzar a un mercado como el producto final. (Avila Forero, J. S. 2016). Con esta estratègia se ha ido articulando y haciendo transferencia de conocimiento y de tecnología para las redes de trabajo de acuerdo con las habilidades y especialización de cada nodo según las habilidades de cada uno de los estudiantes que se inscriben al programa. 
Dentro de los servicios que tiene la línea de ingeniería y diseño está el atender a la población objetivo, como aprendices, técnicos y tecnólogos que se encuentran en los centros de formación del SENA en cualquier programa de formación, al igual que instructores SENA, grupos de investigación, empresas, entidades de educación y público en general. La asesoría de cada proyecto es un acompañamiento técnico y personalizado para el desarrollo del proyecto. El acompañamiento se hace por parte de un equipo interdisciplinario de profesionales con experiencia y formación académica para el análisis, planeación, diseño, ingeniería, desarrollo, pruebas y simulación de proyectos y prototipos tanto virtuales como materiales.

\subsection{Trabajo en nodos como estrategia para optimizar recursos:}

La operación del programa de la Red de Tecnoparques de Colombia se desarrolla a través de nodos, entendidos como unidades adscritas a un Centro de Formación o Dirección Regional de la jurisdicción en que se encuentre ubicado en el país. El recurso humano de la planta de personal y los contratistas que requieran los nodos para su funcionamiento, están a cargo del Centro de Formación o Regional al cual esté adscrito. Desde 2015 se cuenta a nivel nacional con quince (15) nodos: dos en Antioquia (Rionegro y Medellín), uno en Tolima (La Granja), uno en Caldas (Manizales), dos en Santander (Bucaramanga y Socorro), uno en Cundinamarca (Cazucá), uno en Valle (Cali), uno en Cesar (Valledupar), tres en Huila (Pitalito, Neiva y La Angostura), uno en Risaralda (Pereira), uno en Norte de Santander (Ocaña) y uno en Bogotá. Estos nodos cuentan con infraestructuras similares donde se comparten desarrollos administrativos, conocimientos técnicos, métodos de trabajo y filosofías misionales para apoyar a los estudiantes, aprendices y emprendedores de Colombia en todas las regiones del país. (Tecnoparque.sena.edu.co, 2018)

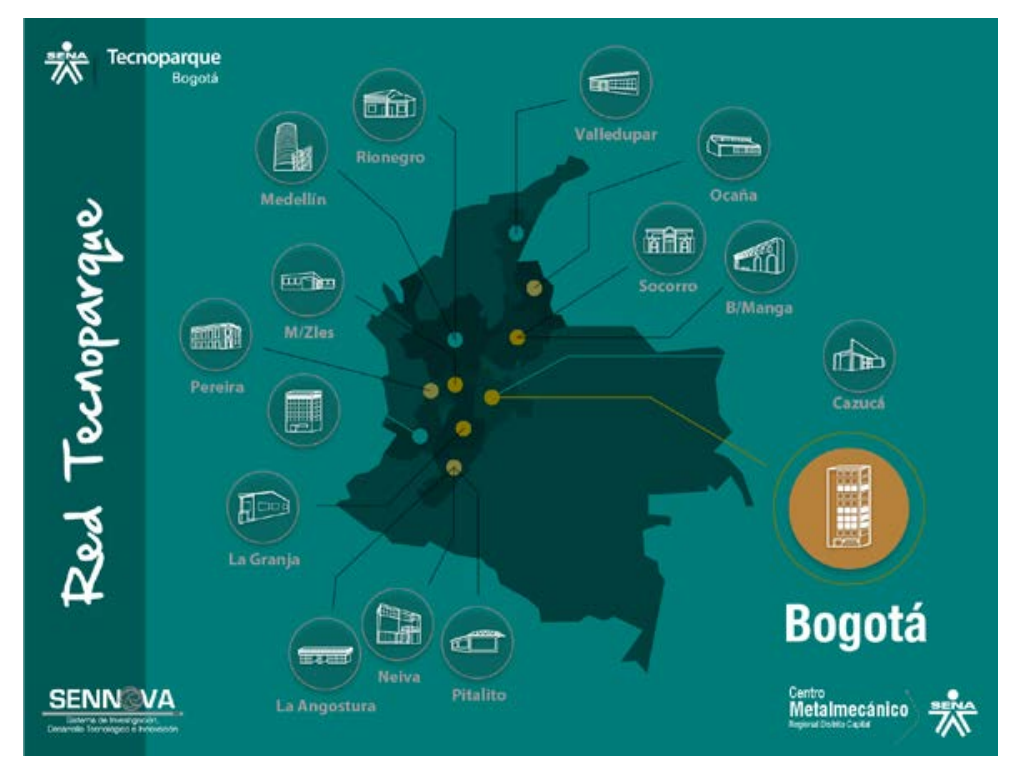

Fig. 1. Ubicación de Nodos Tecnoparque en la Geografía Colombiana. Autor Corporativo. 2016 
A través del programa de la red Tecnoparque SENA, se busca conectar el sector productivo con el talento formado en el SENA a través de procesos de innovación abierta, para desarrollar de forma colaborativa proyectos de I+D+i, compartiendo los recursos, el talento humano, información estratégica y diferentes conocimientos entre los quince nodos. De esta forma se apropia el conocimiento interno y externo existente, generando ventajas competitivas en el mercado para los actores que se forman en estos centros, co-ejecutando Proyectos de Base Tecnológica (PBT) y acciones internodos que apuntan al fortalecimiento de trabajo en red.

\subsection{Eventos de Divulgación Tecnológica (EDT):}

Como parte de las estrategias desarrolladas en la Red Tecnoparque, se ha propuesto una forma de compartir avances tecnológicos, formas de hacer y transferir conocimientos denominados EDT. Un EDT es una socialización grupal sobre temas puntuales de actualidad tecnológica dictados por especialistas, generalmente de forma presencial a modo de conferencia o taller, estos eventos ayudan a aprendices e instructores a conocer y apropiarse de nuevas competencias técnicas. Los EDT se dividen en dos categorías fundamentalmente:

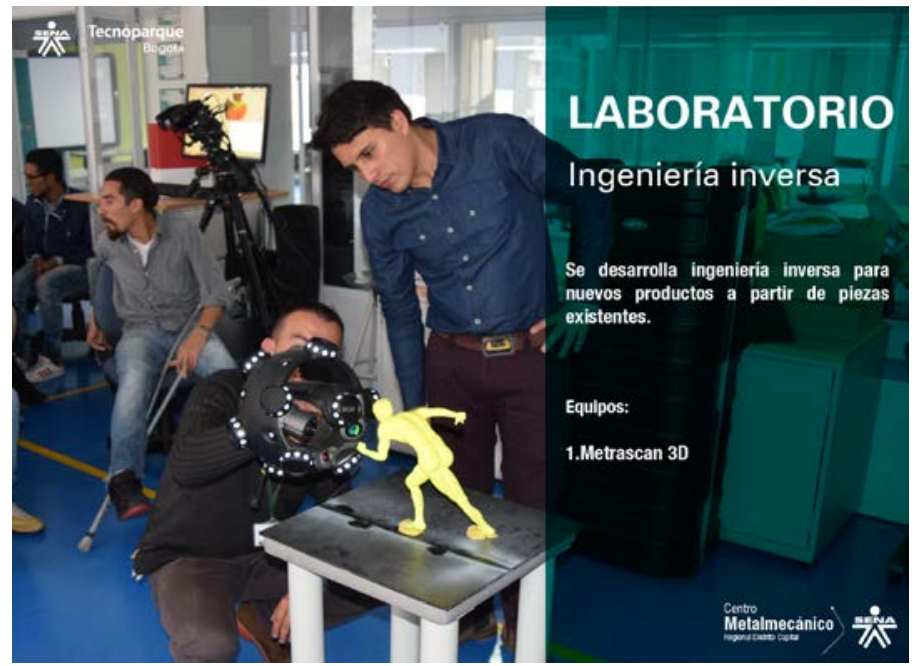

Fig. 2. EDT Procesos de Ingeniería Inversa y Escaneo 3D. Tecnoparque Nodo Bogotá. 2016

\subsubsection{Eventos de conocimiento y tecnología:}

Cuyo objetivo es poner al alcance de los usuarios de la Red Tecnoparque como empresas, academia y comunidad SENA, nuevas tecnologías, técnicas de actualidad, lecciones aprendidas, experiencias en convocatorias de Innovación, entre otros. La información de los expositores en estos eventos alimenta una base de datos de la Red de aliados y expertos que permite direccionar futuros proyectos con los recursos idóneos, permitiendo optimizar recursos y agilizar procesos. 


\subsubsection{Talleres de innovación:}

Son sesiones dinámicas que ponen en práctica los principios de la metodología de Design Thinking (Brown, T. 2016), para la generación colaborativa de ideas innovadoras y pasos adicionales para la solución a las problemáticas o necesidades de las empresas participantes en convocatorias de innovación abierta de la Red Tecnoparque.

\section{Metodología “NoteBooks” de desarrollo de los Nodos Tecnoparque:}

La metodología de desarrollo de proyectos de la Red Tecnoparque, consiste en once (11) actividades a ser realizadas en equipo, mediante un proceso interactivo con la plataforma de gestión de información GDrive de Google, bajo unos formatos estandarizados, que permiten regular la información de forma eficaz desde cualquier computador conectado a internet y en tiempo real (Canchica de Medina, Marbelys Elizabeth. 2016). Si los resultados obtenidos tras el desarrollo de una actividad o módulo no son satisfactorios, el equipo debe regresar a la actividad anterior con el fin de identificar posibles oportunidades de mejora y realizar los ajustes necesarios, todo en tiempo real.

Las actividades para realizar un proyecto en la Red son las siguientes:

Inspiración:

1. Observación.

2. Vigilancia tecnológica.

3. Prospectiva.

Ideación:

4. Concepto.

5. Sostenibilidad.

6. Modelo de Negocio.

7. Validación.

Prototipado:

8. Preparación.

9. Creación.

10. Verificación y testeo.

11. Retroalimentación. 


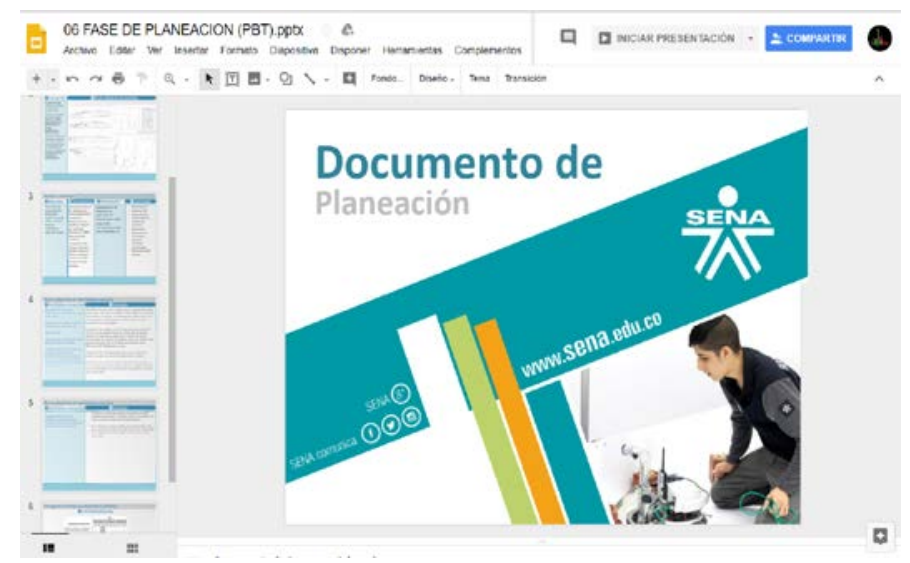

Fig. 3. Captura de pantalla, documento de trabajo en la plataforma de GDrive de Google. Autor Corporativo. 2016

Para facilitar la apropiación de la metodología, existe una guía de trabajo, que aborda desde cada una de las fases, etapas y actividades que la componen y que son necesarias para la ejecución de un proyecto desarrollado en un nodo Tecnoparque. De igual manera cada uno de los lectores podrá apoyarse en un Book de GDrive, con la información, descripción y documentación necesaria para desarrollar cada una de las fases, etapas y actividades de la metodología.

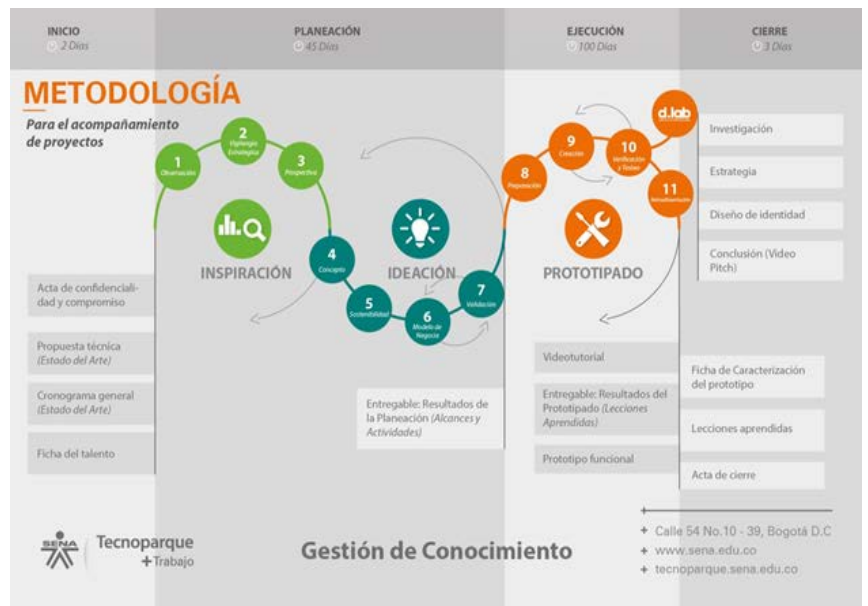

Fig. 4. Metodología para el acompañamiento de proyectos. Tecnoparque. Autor Corporativo. 2016

\section{Resultados destacados:}

\subsection{Simulador de entrenamiento por laparoscopia:}

El desarrollo y masificación de las tecnologías de diseño y fabricación digital en las últimas dos décadas, ha permitido que un número creciente de emprendedores comiencen a 
formular proyectos de base tecnológica en diferentes ámbitos y sectores económicos. La impresión aditiva se ha convertido en un factor de alto impacto y en la tecnología más representativa de ésta nueva forma de materializar ideas. En el campo de las áreas de la salud, específicamente en el diseño y la fabricación de simuladores se ha encontrado un nicho de desarrollo importante de aplicación. Como resultado a estas dinámicas, se desarrolló un prototipo de simulador de entrenamiento para operaciones laparoscópicas en asocio con investigadores universitarios en cabeza del profesor de diseño industrial Juan Sebastián Ávila de la Universidad El Bosque de Bogotá, una universidad privada enfocada en áreas de la salud y gestores de proyecto del Tecnoparque del SENA, bajo la convocatoria de apoyo a proyectos de SENNOVA 2016. Este proyectos es un claro ejemplo de las dinámicas y resultados del trabajo coordinado y en red entre diferentes instituciones, donde cada uno de los integrantes tiene un rol determinado, que fue esencial para el desarrollo exitoso del proyecto, por una parte, desde el Tecnoparque se ofrece todo el soporte y respaldo técnico y tecnológico para materializar ideas, y por otra parte la Universidad El Bosque aporta el conocimiento científico y los escenarios de experimentación y comprobación real del proyecto, siendo un proyecto significativo al unir dos grandes áreas del conocimiento como lo es la medicina y la ingeniería - diseño, vinculando no solamente a profesionales, sino que también a estudiantes en formación. Por otra, parte, éste proyecto también es un buen ejemplo del trabajo coordinado entre una entidad de carácter público y una entidad de carácter privado, que fueron capaces de sacar adelante un proyecto conjunto, superando las diferencias de gestión y manejo administrativo.

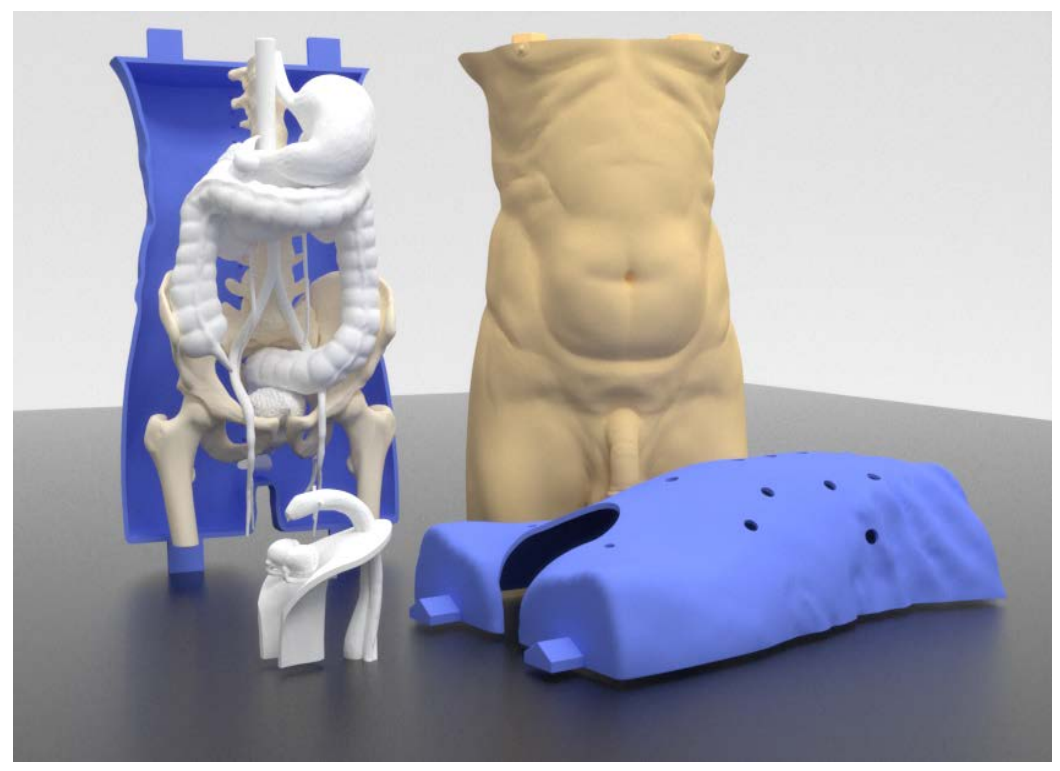

Fig.5. Modelado 3D, Proyecto Simulador de entrenamiento para cirugías por laparoscopia. 2016

\subsection{Pintack:}


Este proyecto fue realizado por el aprendiz SENA Iván Hernández en 2016, quien desarrolló una herramienta de mano resistente cuya principal función es la de sostener puntillas y grapas al momento de ser clavadas manteniendo los pulgares y otros apéndices de forma segura. PinTack tiene un cómodo agarre de goma fijado en torno a una superficie sólida duradera que alberga un sistema mecánico en el extremo, capaz de sostener cualquier elemento de fijación, especialmente puntillas de 1/2" hasta 1/1/2" mediante un paquete magnético y tiene una capacidad de agarre de hasta 5 milímetros de diámetro, posee un sistema de imanes de alta potencia que permiten adherirse a la herramienta de trabajo, facilitando así su almacenaje.

Este proyecto se asesoró desde la línea de ingeniería y diseño por el Ing. John Eduard Gómez basado en la metodología para el desarrollo de proyectos, haciendo énfasis en el ciclo de vida del producto, apoyado en la lógica de diseño de producto, factores ergonómicos, secuencias de uso, materiales, mecanismos y prototipado final del producto. Este proyecto fue desarrollado en coordinación con diferentes nodos del Tecnoparque, que aportaron desde diferentes perspectivas, como el mercadeo, la ingeniería, el diseño, comunicación, entre otros. Cabe resaltar que este dispositivo se encuentra de proceso de otorgación de patente en modelo de utilidad por la Superintendencia de Industria y Comercio de Colombia, demostrando que sí es posible realizar proyectos completos, desde su fase de formulación hasta una patente y posterior comercialización en el mercado.

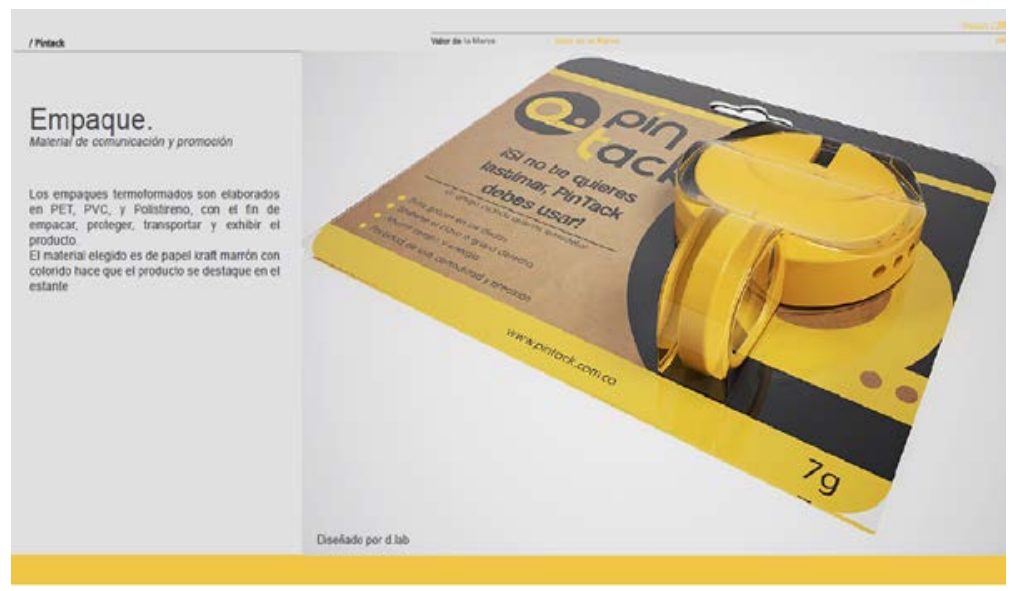

Fig. 6. Desarrollo 3D prototipo pintack-Tecnoparque. Autor Corporativo. 2016

\subsection{Patín para rehabilitación de extremidades superiores e inferiores:}

Este proyecto fue realizado por el talento Luís Alfonso Díaz, quien desarrolló varios prototipos del patín para terapias de rehabilitación, dirigido a personas con fracturas o lesiones en las extremidades superiores e inferiores. Dentro del nodo Bogotá, en la línea de Ingeniería y diseño se realizó el proceso de acompañamiento para el desarrollo de la idea, en un trabajo conjunto con aprendices SENA del curso de tecnología en diseño y desarrollo de producto industriales (Tecnología en Gestión de la Producción Industrial. 2018). que aportaron al desarrollo del diseño CAD del prototipo, en una primera fase de diseño mecánico se contó con la participación de Leonardo Zuluaga, ingeniero mecánico y dinamizador del tecnoparque, asesorando los sistemas de amortiguación, sistema de frenado 
y sistema de movimiento esto con el fin de generar un control, dominio y uso del prototipo con el usuario, para una segunda fase de desarrollo se profundizó en el factor ergonómico y estético para reflejar una mejor comunicación en la interacción del usuario con el objeto, utilizando sistemas de fabricación digital y de impresión 3D al tiempo se hizo una articulación con la Escuela Colombiana de Rehabilitación para la validación de los prototipos con expertos en ergonomía. Este proyecto es valioso en el sentido que muestra el trabajo coordinado de diferentes profesionales y entidades tanto públicas como privadas para alcanzar un bien común, articulado por conceptos de diseño, ingeniería y proyectos de base tecnológica.
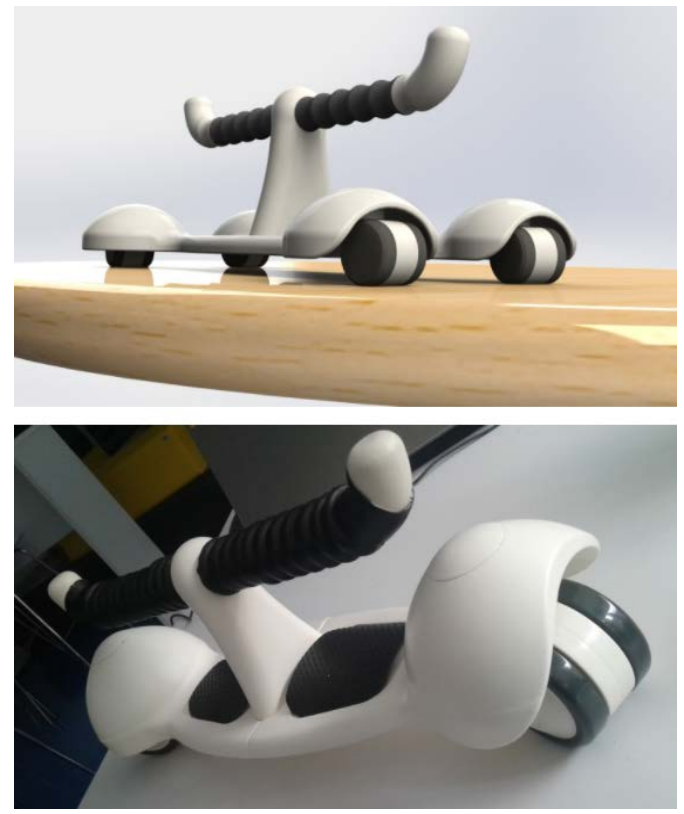

Fig. 7. Diseño modelado 3D y prototipo, proyecto patín para rehabilitación de extremidades superiores $e$ inferiores . Tecnoparque Nodo Bogotá. 2017.

\section{Conclusiones:}

La línea de diseño e ingeniería del Tecnoparque nodo de Bogotá, cuenta con una infraestructura de laboratorios y oficinas de 350 mts2 ubicados en Chapinero, una zona privilegiada por ser una de las zonas de mayor afluencia de jóvenes en el centro de la capital de Colombia. El espacio está dividido en Zona de laboratorio, Taller de construcción de prototipos, Laboratorio fabricación digital, Ambiente de asesoría y trabajo co-working. En el laboratorio de fabricación digital se cuenta con 3 impresoras 3D de tecnología FDM, un escáner 3D, una máquina universal de ensayos, una cortadora láser y una termoformadora, asimismo en el área de asesoría contamos con ordenadores de gran capacidad de procesamiento, que cuentan con programas especializados en el área de ingeniería y diseño, dispuestos para el uso de toda la comunidad de forma gratuita.

En los últimos 3 años de trabajo, la línea de ingeniería y diseño del nodo de Bogotá ha formado y acompañado el proceso de aprendizaje de cerca de 186 aprendices que 
generalmente tienen un perfil profesional como tecnólogos en diseño de productos industriales ó técnicos en mecánica industrial. Adicionalmente se prestaron servicios de asesoría a 70 empresas de todos los sectores productivos y se realizó el acompañamiento aproximadamente a 230 emprendedores, que buscaron la Red para materializar sus ideas de forma profesional. Durante estos casi tres años de ejecución del proyecto de la Red de Tecnoparque solamente el nodo Bogotá, se han asesorado 430 proyectos en total, se ha acompañado el proceso de solicitud de 15 patentes, se ha logrado realizar 45 articulaciones de proyectos conjuntos con universidades y grupos de investigación formales, inscritos al sistema nacional de ciencia y tecnología de Colombia - Colciencias y 74 empresas de diferentes sectores económicos.

Se estima que en toda la Red TecnoParque de Colombia, durante el año 2017 se asesoraron 1066 proyectos que culminaron en prototipos funcionales, 458 en prototipos puestos en el mercado, se articularon 171 grupos de investigación, se asesoraron 407 empresas y se realizaron 412 eventos de divulgación EDT. (SENNOVA SGPSV24 2018).

Este tipo de iniciativas ha propuesto una continuidad para estudiantes de formación técnica y tecnológica, que buscan continuar su formación de la mano de instructores, dinamizadores y profesionales especializados a partir de proyectos de base tecnológica y relacionamiento con industrias reales e instituciones universitarias.

Entre los factores de mejora que hemos encontrado para fortalecer y mejorar el proyecto de Red de Tecnoparques están:

-La divulgación de los servicios, resultados e infraestructura, que se tiene a disposición de toda la comunidad y sea más reconocida tanto a nivel local como nacional.

-Continuar con la mejora de la infraestructura y distribución de nodos por todo el territorio nacional, ya que la tecnología avanza con gran velocidad y es necesario estar a la vanguardia para prestar los servicios con herramientas de alta calidad y ser competitivos en términos de innovación.

-Promover estrategias y políticas de integración más fuertes con entidades públicas y privadas, para que más aprendices, emprendedores y empresas conozcan los servicios que ofrece Tecnoparque y puedan acceder a estos beneficios.

\section{Referencias bibliográficas:}

\section{Revista:}

Canchica de Medina, Marbelys Elizabeth. (2016). Modelo gavilán para el desarrollo de competencias en el manejo de información a través de google drive. una experiencia innovadora. Academia y Virtualidad, 9(2), 10-26. 10.18359/ravi.1822 


\section{Capítulo de un libro:}

Avila Forero, J. S. (2016). Design of training materials for teaching anatomy. En E. U. València (Ed.), IFDP'16 - Systems \& Design:Beyond Processes and Thinking (págs. 10151030). Valencia: Universitat Politècnica de València.

\section{Página web:}

Brown, T. (15 de 5 de 2016). http://dschool-old.stanford.edu. Obtenido de Design Thinking: http://dschool-old.stanford.edu/use-our-methods/

Historia, Visión, Misión, Valores y Símbolos. (2018). Lineabase.sena.edu.co. Retrieved 14 March 2018, from https://lineabase.sena.edu.co/acerca-del-sena/quienessomos/Paginas/Historia-Vision-Mision-Valores-y-Simbolos.aspx

SENA. (2018). Sena.edu.co. Retrieved 14 March 2018, from http://www.sena.edu.co/esco/formacion/Paginas/tecnologia-innovacion.aspx

SENNOVA SGPSV24. (2018). Sennova.senaedu.edu.co. Retrieved 13 January 2018, from http://sennova.senaedu.edu.co/

Somos. (2018). Sena.edu.co. Retrieved 14 March 2018, from http://www.sena.edu.co/es$\mathrm{co} /$ sena/Paginas/quienesSomos.aspx

Producto viable mínimo. (2017, 30 de octubre). Wikipedia, La enciclopedia libre. Fecha de consulta: 20:49, marzo 14, 2018 desde https://es.wikipedia.org/w/index.php?title=Producto_viable_m\%C3\%ADnimo\&oldid=1030 11339.

TecnoParque Colombia. (2018). Tecnoparque.sena.edu.co. Retrieved 14 March 2018, from http://tecnoparque.sena.edu.co/Paginas/default.aspx

Tecnología en Gestión de la Producción Industrial. (2018). Cdtisena.com. Retrieved 17

February 2018, from http://www.cdtisena.com/gestion-produccion-industrial.html 


\title{
Evolución positiva en la satisfacción del alumnado en la Asignatura “Genómica” del Grado de Biotecnología tras la implementación de metodologías de aprendizaje activo.
}

\section{Santiago Vilanova y José Gadea}

Departamento de Biotecnología, Universitat Politècnica de Valéncia, Camino de Vera s/n 46022, Valéncia.jgadeav@ibmcp.upv.es sanvina@upvnet.upv.es

\begin{abstract}
The speed at which strategies and technologies are developed in Biotechnology makes mandatory a learning method focused on autonomous learning and practical cases. The objective of this study is to evaluate the evolution of the student's level of satisfaction regarding the learning strategies applied in the subject "Genomics" of the UPV Biotechnology Degree among two consecutive academic years. Several changes were introduced these years in project-based learning and flip-teaching.A substantial improvement in the level of satisfaction in these two strategies indicates the key aspects that have to be considered when applying flip-and project-based learning in Biotechnology.
\end{abstract}

Keywords: autonomous learning, flip-teaching, active learning, project, biotechnology

\footnotetext{
Resumen

La velocidad a la que las tecnologías y estrategias están cambiando in Biotecnología hace necesario un aprendizaje más enfocado a casos prácticos y aprendizaje autónomo. El objetivo de esta comunicación es evaluar la evolución en el grado de satisfacción de los estudiantes en referencia a los métodos docentes aplicados en la asignatura Genómica del Grado de Biotecnología de la UPV en dos años consecutivos. Varias modificaciones han sido introducidas en este curso académico. La sustancial mejora en el nivel de satisfacción obtenido indica sobre qué aspectos es necesario incidir para aplicar con éxito metologías como la clase inversa o el aprendizaje basado en proyectos.
}

Palabras clave: apendizaje autónomo, clase inversa, aprendizaje activo, proyectos, biotecnología 


\section{Introducción}

La Biotecnología es una disciplina donde debe implementarse el aprendizaje autónomo. La velocidad a la que tecnologías y estrategias experimentales cambian obliga a un aprendizaje muy diferente a la mera transmisión de conocimientos, que pueden quedarse obsoletos en un período de tiempo muy reducido. Este aprendizaje debe incluir la búsqueda activa de las posibilidades existentes para solucionar un determinado problema y la toma de decisiones para seleccionar una determinada estrategia de trabajo, sin tener la certeza de que sea la única manera de abordar dicho problema. También implica enfrentarse a situaciones de incertidumbre, a respuestas argumentadas, pero sin solución única, un escenario al que los estudiantes no están acostumbrados. Además, los proyectos biotecnológicos reales son multidisciplinares, por lo que el conocmiento en todos los ámbitos de un proyecto no exuste, y un aprendizaje cooperativo es imprescindible. Esta última situación mitiga la excesiva competitividad existente entre los alumnos de Biotecnología, lo que podría ser beneficioso para ellos a largo plazo.

Por otra parte, el aprendizaje autónomo implica la intervención del estudiante en el establecimiento de sus objetivos, procedimientos, recursos, evaluación y momentos de aprendizaje (Crispin et al, 2011). Estas estrategias confían en un aprendizaje activo, eliminando el sistema pasivo basado en clases magistrales, pone énfasis en un aprendizaje más profundo y un mejor entendimiento del tema tratado, aumenta la responsabilidad por parte del estudiante e incrementa su sentido de autonomía, y al mismo tiempo, proporciona un ambiente donde la relación profesor-alumno puede ser replanteada.

Entre las estrategias utilizadas para ejercitar el aprendizaje autónomo, en la asignatura Genómica del grado de Biotecnología utilizamos desde hace años una combinación de diseño de proyectos en equipos de estudiantes, y de clase estructurada en casos reales. El aprendizaje basado en proyectos es una metodología que permite a los alumnos adquirir los conocimientos y competencias clave en el siglo XXI mediante la elaboración de proyectos que dan respuesta a problemas de la vida real. El trabajo en equipos, por otra parte, refuerza otras competencias transversales, ya que actualmente las organizaciones requieren de personas que sepan administrarse dentro de los equipos de trabajo (Northwest Regional Educational Laboratory, 2006).

El año 2016-2017 introdujimos aprendizaje basado en clase inversa en nuestra asignatura, y presentamos los resultados de satisfacción del alumnado en las diferentes estrategias utilizadas en la asignatura (estructura general, tareas de clase inversa, proyectos). El resultado más destacable fue la elevada satisfacción por el proyecto de trabajo en grupo, así como la baja aceptación de la clase inversa. Esta año, presentamos los resultados comparados de dos cursos académicos consecutivos, y discutimos las mejoras obtenidas en relación a los ejercicios que se han implementado, lo que puede dar ideas sobre la implementación exitosa de la clase inversa.

\section{Objetivos}

Desde el curso académico 2012-2013, llevamos proponiendo diseños de proyectos en Genómica como ejercicio de aprendizaje autónomo a los estudiantes de Biotecnología de

(c)) BY-NC-ND 2018, Universitat Politècnica de València

Congreso IN-RED (2018) 
tercer curso de la Universidad Politécnica de Valencia. Los proyectos consisten en emular los diferentes pasos que un profesional en biotecnología deberá realizar al enfrentarse a un proyecto de estas características, búsqueda bibliográfica, selección de tecnologías, toma de decisiones, diseño experimental, localización de reactivos y equipamiento, presupuesto económico y cronograma de realización, basándose en cada punto en estudios similares que ya estén publicados en contextos diferentes. Con esto, los alumnos se enfrentan a la realidad de un proyecto de investigación (o un proyecto empresarial), que requiere no sólo un conocimiento teórico de un ámbito concreto de la Biotecnología, sino tener en cuenta muchos otros factores que condicionan el éxito real del proyecto.

Por otra parte, en el curso 2016-2017 iniciamos una estrategia docente de clase inversa, con tareas planteadas a los estudiantes, cuyo objetivo fue intentar que se consolidara la información teórica que los estudiantes reciben con clases magistrales distribuidas selectivamente a lo largo de la asignatura. Los estudiantes realizaban sobre todo tareas en Google Drive, alternando lectura de artículos científicos seleccionados, con visionado de videos o búsqueda de información en la web. Los resultados obtenidos en las encuestas de clase inversa nos forzaron a reestructurar las tareas, reduciendo el tiempo necesario en casa para realizarlas, ampliando plazos de entrega, y no abusando de la lectura completa de artículos científicos. Por tod ello, la presente comunicación pretende:

- Realizar una encuesta al alumnado para conocer el grado de satisfacción de la asignatura

- Evaluar la evolución en la estructura de la asignatura utilizando los datos de las encuestas de dos años consecutivos, teniendo en cuenta las mejoras explicadas en el documento.

\section{Desarrollo de la innovación}

\subsection{Encuestas de evaluación}

Mediante el uso de encuestas enfocadas a evaluar la experiencia de los estudiantes en esta iniciativa, se contactó a los estudiantes de Biotecnología del curso 2017-2018, y se elaboraron resultados que permiten la interpretación detallada. Las encuestas pretenden desvelar su grado de satisfacción con este tipo de docencia, la repercusión de este tipo de aprendizaje en el conocimiento de la asignatura, la originalidad y valor añadido de los mismos, relación profesor-alumno, etc. Las encuestas se realizaron online utilizando la herramienta de formularios de Goole Drive (https://www.google.com/intl/es_ALL/drive/).

La encuesta consta de 21 items con la siguiente escala de evaluación de Likert (Briones, 1995) : Muy en desacuerdo(1), En desacuerdo(2), Indiferente(3), De acuerdo(4) o Muy de acuerdo(5). Los items se subdividen en cuatro secciones: a) estructura general de la asignatura, b) la experiencia en la realización de casos prácticos, c) la experiencia en la realización de tarea de clase inversa, y d) la experiencia en la realización de trabajos/proyectos de investigación

El cuestionario fue el siguiente: 


\section{(EA) Estructura general de la asignatura}

EA1.Me ha resultado más EFECTIVA que la clase tradicional (profesor explicando y alumnos atendiendo) para entender los contenidos y su aplicación.

EA2. Me ha resultado más ENTRETENIDA que la clase tradicional (profesor explicando y alumnos atendiendo) para entender los contenidos y su aplicación.

EA3. Me ha ayudado a COMPRENDER contenidos en lugar de MEMORIZARLOS

EA4.Me ha ayudado a SABER APLICAR contenidos en lugar de MEMORIZARLOS

EA5. Hace que el profesor esté más implicado en la docencia, y por tanto interacciono más con él.

EA6. En un plan de estudios ideal sin tanta sobrecarga, recomendaría este tipo de docencia a otras asignaturas.

EA7. Respecto a las otras asignaturas con las que se ha compartido en el año ¿Has dedicado más o menos tiempo de estudio a GENOMICA?

\section{(CP) Casos Prácticos}

CP1. Me han ayudado a CONSOLIDAR los contenidos teóricos

CP2. Me han ayudado a ver cómo se APLICA la teoría en la realidad

CP3. Me han quitado el miedo a enfrentarme a artículos científicos

CP4. Me han confundido más que ayudado

\section{(T) Tareas}

T1. Me han servido de BASE para la materia que se iba a explicar en clase, si son anteriores, o de CONSOLIDACIÓN, si son posteriores

T2. Me han quitado mucho tiempo de estudio

T3. Siendo sincero/a...¿¿ué porcentaje de las tareas has contestado como si fuera a ser puntuada como una pregunta de examen?

\section{(P) Proyectos}

P1. Me han ayudado de discriminar entre información más relevante y menos relevante para mis objetivos

P2. Me han ayudado a darme cuenta de que puedo seguir adelante sin entender todos los detalles de un proyecto

P3. Me han ayudado a unir información proveniente de diferentes fuentes para resolver problemas específicos

P4. Me han ayudado a mejorar mis habilidades en estructurar la información escrita y oral

P5. Me han ayudado a mejorar mis habilidades en trabajar con otros en grupo

P6. Me han ayudado a mejorar mis habilidades en organizar y planificar mi tiempo

P7. Me ha motivado especialmente ver que soy capaz de crear un proyecto que nadie ha planteado hasta entonces.

\subsection{Análisis de datos}

(cc) EY-NC-ND 2018, Universitat Politècnica de València

Congreso IN-RED (2018) 
Los datos obtenidos a partir de las encuestas se analizaron mediante la aplicación hojas de calculo de Google Drive.

\section{Resultados}

Disponemos actualmente de más de 70 encuestas realizadas durante el curso anterior (Vilanova y Gadea, 2017), y de 34 encuestas delaño 2017-2018, con el objetivo de evaluar si la experiencia ha mejorado en dos años consecutivos. Para el año 2016-2017, representa el 70\% de los estudiantes matriculados este año, y para el año 2017-2018, el 40\%, por lo que consideramos la encuesta significativa. Para el año 2017-2018, un 38\% de los encuestados están matriculados en el grupo de Alto Rendimiento Académico del Grado en Biotecnología, y el resto en el grupo que se imparte en castellano.

A continuación pasamos a detallar los resultados más relevantes obtenidos en este proyecto:

\subsection{Estructura de la asignatura.}

Los estudiantes fueron preguntados si la estructura de la asignatura, de modo general (incluyendo tareas de clase inversa, clases magistrales alternas, y realización de trabajos de investigación, así como su división temática en casos, les ayudaba a comprender y/o a saber aplicar los contenidos en lugar de a memorizarlos, así como si este tipo de docencia les parecía más efectiva respecto a la docencia clásica de clase magistral, y si les parecía más entretenida. Finalmente, se les preguntaron aspectos generales como si recomendarían este tipo de docencia en un plan de estudios ideal sin tanta carga académica, y si habían dedicado más o menos tiempo de estudio a esta asignatura como consecuencia del tipo de docencia.

En el año académico 2016-2017, se observó que una no despreciable proporción del alumnado (42\%) se mostraba indiferente ante la efectividad de la asignatura, a pesar de que consideraban la estructura más entretenida (EA2 Fig1). Ese mismo año, se observó una tendencia positiva en cuanto a si el método docente les ha ayudado a comprender y saber aplicar mejor los conceptos de la asignatura (EA3 Fig 1. y EA4 Fig 1.). Un 52\% consideró positiva la experiencia, frente a un $30 \%$ que no ve diferencia entre este método y el aprendizaje clásico. Sin embargo, llamaba la atención el porcentaje de estudiantes que aún se decantan por un aprendizaje más clásico, ya que el 20\% consideraron esta estructura más inefectiva, y un 40\% no ven ninguna ventaja respecto al aprendizaje tradicional (EA1 Fig 1.). Recalcábamos que muchos de ellos podrían preferir un sistema de memorización pasiva, al que ya están habituados desde pequeños, y que les genera unos mejores rendimientos en cuanto a notas, frente a un nuevo sistema que les obliga a implicarse activamente en el aprendizaje.

Este año, las mejoras introducidas en la asignatura, sobre todo en la reestructuración de las tareas de clase inversa, así como en la mayor tutorización del trabajo de grupo, han provocado cambios positivos en las encuestas de satisfacción, como se observa en la Figura 1. Por una parte, destaca el alto porcentaje de alumnos que esta vez ha considerado la metodología más efectiva (70\%), sin detrimento de lo entretenida (67\%). Asimismo, el porcentaje de alumnos que consideran que la estructura les ha ayudado a comprender 
mejor, a saber aplicar, o a interaccionar con el profesor, ha aumentado sustancialmente (EA3, EA4 y EA5, respectivamente, con 63\%, 67\% y 67\% de estudiantes con valoración positiva o muy positiva, frente a $52 \%, 45 \%$ y $44 \%$ en el año anterior). Es de destacar que seguimos este año sin aumentar la carga que los estudiantes tienen que dedicar a esta asignatura, con un 67\% dedicándole el mismo tiempo o incluso menos que a otras asignaturas del año).
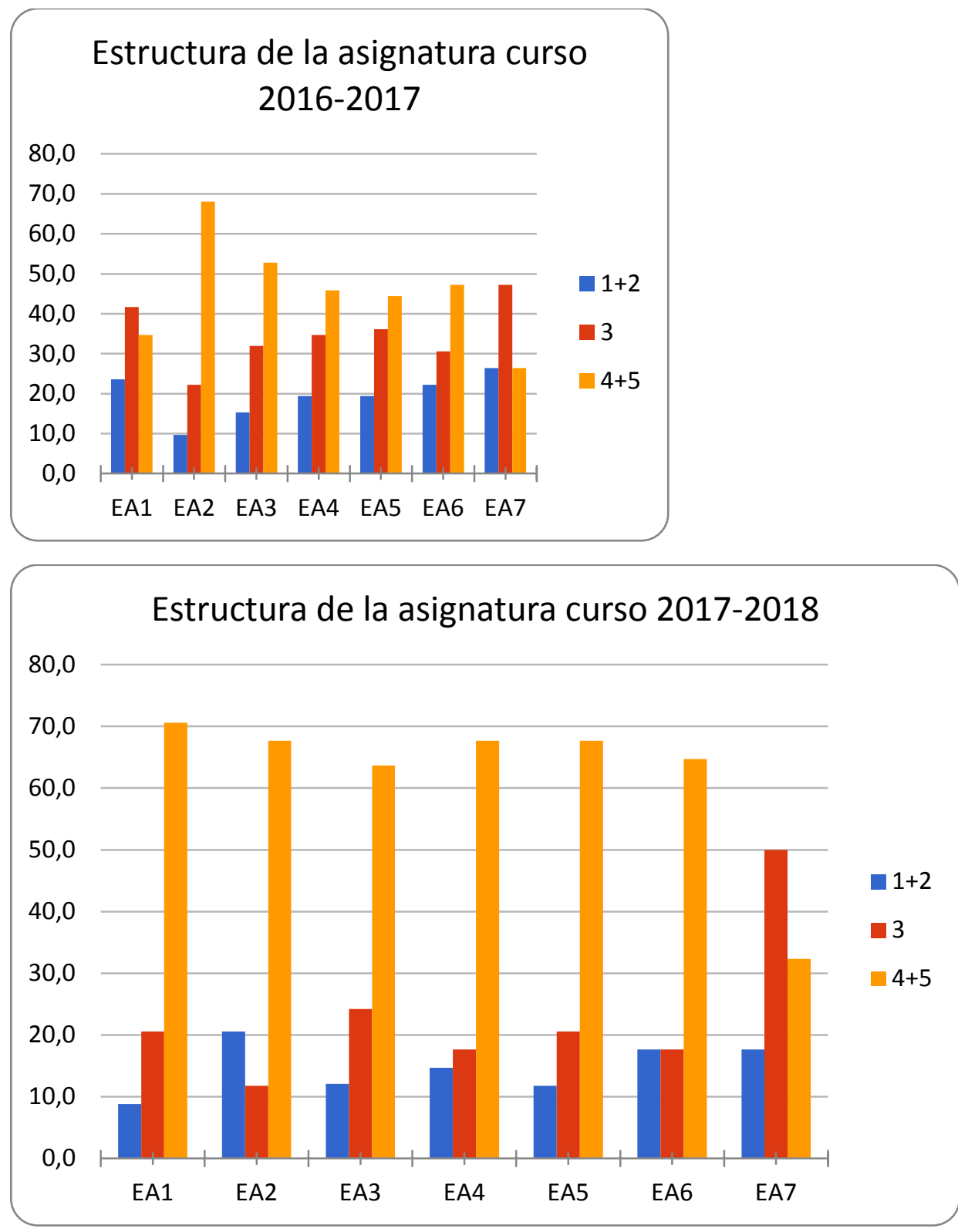

Fig. 1. Diagrama de barras que indica las puntuaciones de los items para la sección Estructura general de la asignatura en los años 2016-2017 y 2017-2018. Se han sumado las puntuaciones 1 y 2 que muestran disconformidad (Muy en desacuerdo y En desacuerdo) así como las puntuaciones 4 y 5 que muestran conformidad (De acuerdo y Muy de acuerdo). Los ítems EA1 a EA7 están detallados en el apartado 4.1

(cc) EY-NC-ND 2018, Universitat Politècnica de València 


\subsection{La estructura en casos prácticos}

Los estudiantes fueron preguntados, de nuevo, si una estructura en casos prácticos ayuda a comprender y saber aplicar los contenidos. Como dato muy positivo, (y similar a lo obtenido el año anterior para un 77\% de los estudiantes), un $85 \%$ de los encuestados este año piensa que este división las ayuda mucho a saber aplicar los contenidos (CP2 Fig. 2), ya que así pueden individualizar los conceptos y aplicarlos en casos tipo. Preguntados si con la lectura de artículos científicos (muchos casos plantean este tipo de ejercicios) habían conseguido perderle el miedo a lecturas de artículos, conseguimos nuestro objetivo de mejorar respecto al año anterior , con un 70\% con valoración positiva o muy positiva (CP3 Fig 2.). El año anterior, concluíamos que la lectura en un idioma extranjero (el $100 \%$ de los artículos propuestos están en inglés) podía ser una causa de este último porcentaje. Esta año, los artículos científicos seleccionados se entregan con texto resaltado en únicamente los párrafos y conceptos más relevantes para poder afrontar el caso práctico estudiado. De este modo, los estudiantes realizan una lectura “dirigida” y "simplificada” del artículo, lo que puede favorecer su comprensión. 


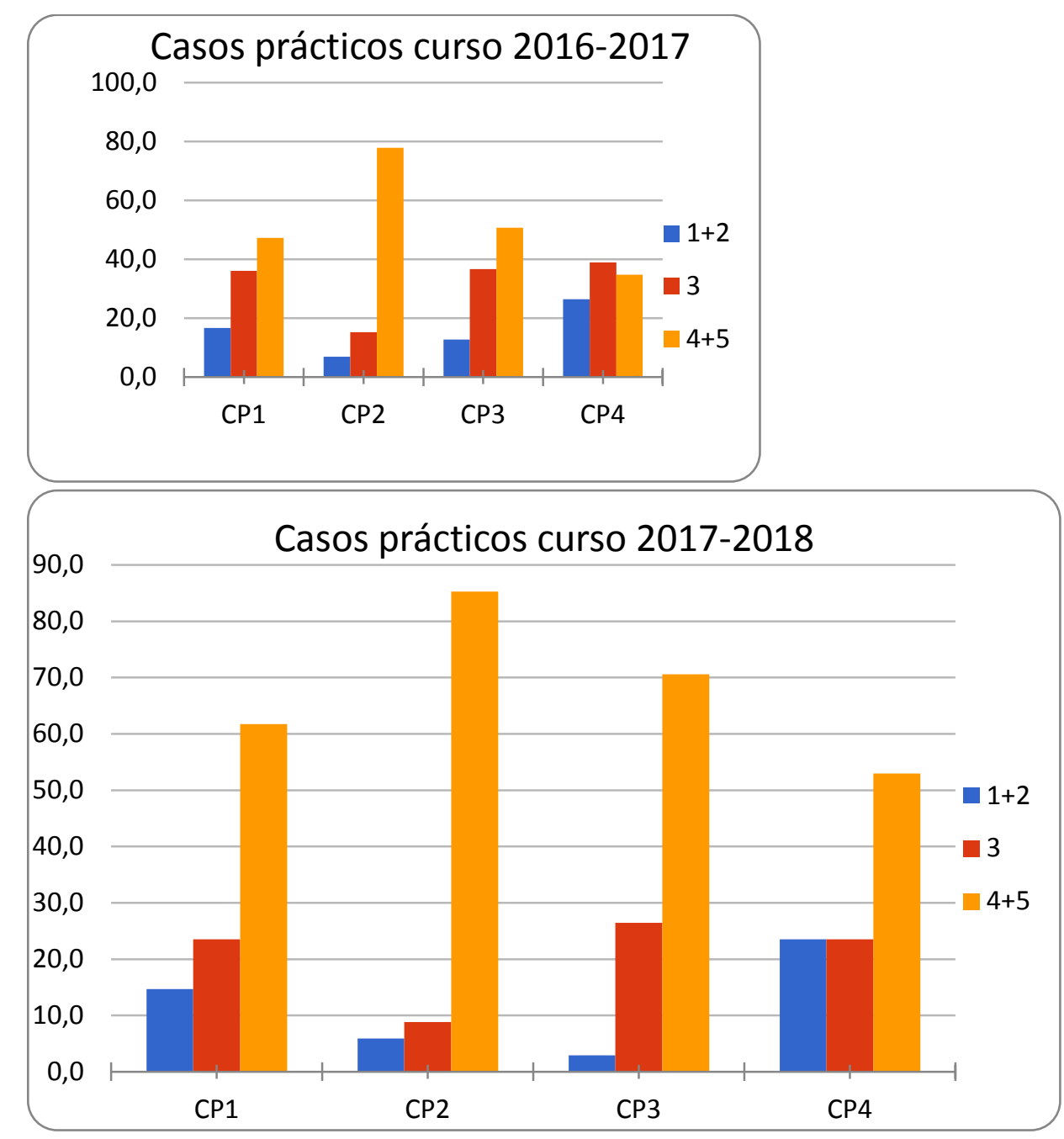

Fig. 2. Diagrama de barras que indica las puntuaciones de los items para la sección casos prácticos en los años 2016-2017 y 2017-2018. Se han sumado las puntuaciones 1 y 2 que muestran disconformidad (Muy en desacuerdo y En desacuerdo) así como las puntuaciones 4 y 5 que muestran conformidad (De acuerdo y Muy de acuerdo). Los ítems CP1 a CP4 están detallados en el apartado 4.2

\subsection{Las tareas en casa (La clase inversa).}

El año anterior, el punto más conflictivo de la encuesta lo encontramos en la implantación del sistema de clase inversa. Preguntados si este tipo de clases con tareas en casa, anteriores o posteriores a los conceptos temáticos, que sirvan de base, o ayuden a consolidar los contenidos, había sido útil, las respuestas siguieron una distribución normal centrada en el punto central (ni sí ni no), con un 30\%, un 27\% en contra y el resto más indiferentes(T1 Fig 3.). El año académico 2016-2017 fue es el primer año de la implantación en nuestra asignatura de la clase inversa, y quizá este resultado reflejaba las enormes posibilidades de mejora que teníamos todavía. Al mismo tiempo, un $48 \%$ de los estudiantes indicaron que la realización de estas tareas le había quitado mucho tiempo de estudio (T2 Fig 3.), lo que quizá se refleja en la calidad de las respuestas, ya que hasta un 35\% confiesa que no han

(cc) EY-NC-ND 2018, Universitat Politècnica de València 
respondido a las tareas como si fueran preguntas de examen, probablemente por la falta de tiempo en su realización(T3 Fig 3.). Este año, hemos ajustado las tareas en tiempo y cantidad (tiempo máximo de trabajo en casa 15-20 minutos, y sólo un par de tareas por caso) para evitar la saturación y conseguir una mayor implicación del alumno en las mismas. Según las encuestas de este año, estas modificaciones han resultado positivas, ya que observamos que frente a un $28 \%$ que no consideraba esta metodología nada útil (respuestas negativas o muy negativas) hemos reducido esta porcentaje hasta el 12\%, y esta reducción ha supuesto un aumento del número de valoraciones positivas (del 30\% el año pasado al $48 \%$ este año). La reducción del tiempo de las tareas se ve reflejada en la pregunta T2, donde un 56\% de los estudiantes no consideró que dichas tareas le quitaban tiempo de estudio, frente a sólo el 22\% el año anterior. La reducción del número de tareas y su simplificación ha hecho que los estudiantes respondan ahora con más seguridad, como refleja la pregunta T3.

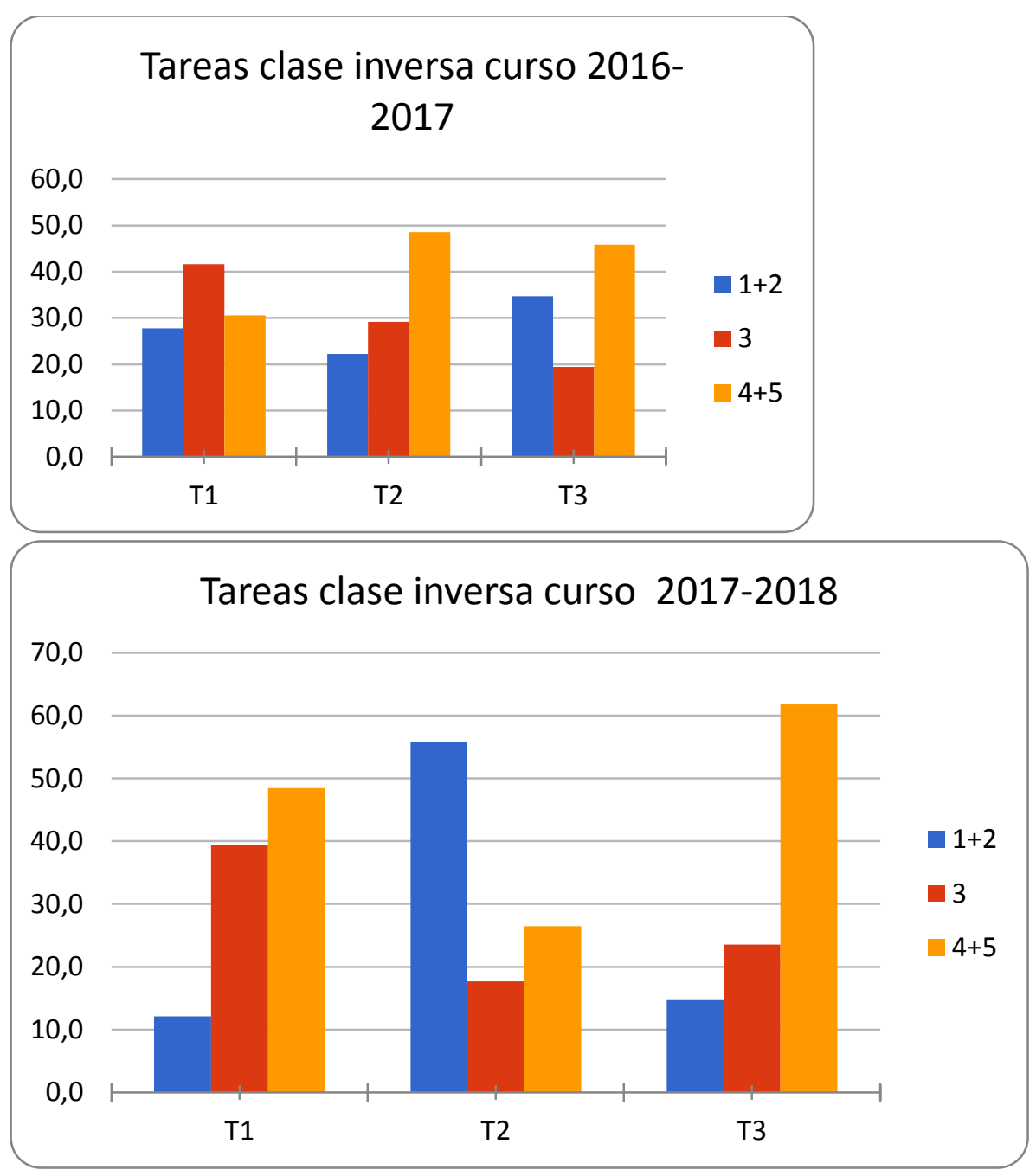

Fig. 3. Diagrama de barras que indica las puntuaciones de los items para la sección Tareas en casa. Se han sumado las puntuaciones 1 y 2 que muestran disconformidad (Muy en desacuerdo y En desacuerdo) así como las 
puntuaciones 4 y 5 que muestran conformidad (De acuerdo y Muy de acuerdo). Los ítems T1 a T3 están detallados en el apartado 3.1

\subsection{Los trabajos/proyectos de investigación}

Este punto sigue siendo el aspecto más positivo de la asignatura. Implantados desde el año 2012-2013, estos trabajos han supuesto desde hace años un modo de involucrar a los estudiantes en proyectos casi reales, y el feedback recibido durante estos años ha sido muy positivo. Este tipo de trabajos evalúa la Competencia Transversal "Diseño de Proyectos". Los estudiantes fueron preguntados por aspectos como los siguientes: si les ha ayudado a discriminar información relevante e irrelevante para un determinado objetivo (P1 Fig 4.), si les ha ayudado a entender que pueden seguir adelante sin entender todo un proceso (P2 Fig 4.), si les ha ayudado a buscar e integrar diferentes fuentes para crear algo nuevo (P3 Fig 4.), si les ha ayudado a trabajar en grupo y a planificar su tiempo (P4,P5 y P6 Fig 4.), y si les ha motivado crear algo nuevo desde cero (P7 Fig 4.).

Este año, hemos introducido una mayor tutorización en la realización de los mismos, lo que hasta la fecha se ha traducido en un mayor rendimiento académico, aunque la asignatura es anual y los resultados definitivos no se tendrán hasta el mes de junio.

La tendencia general hasta la fecha es muy positiva en todas las respuestas, y nos anima a seguir con esta iniciativa original que, que sepamos, no realiza ninguna otra asignatura de nuestro actual plan de estudios. Este año, los porcentajes de valoración positiva aumentan, con un 79\% que reconoce que la realización de estos trabajos le ha motivado, frente a sólo un $8 \%$ que lo ve negativamente, (P7 Fig 4.). Algunos porcentajes particularmente interesantes con tendencias al alza respecto al año anterior: Más de un $80 \%$ considera que les ha ayudado a discriminar información no relavante y a salir adelante sin entender la totalidad de un problema (P1 y P2 Fig 4.), o un 76\% que indica que le ha ayudado a encontrar fuentes diversas y crear algo nuevo (P3 Fig 4.), de nuevo porcentajes mejorados respecto al año anterior en aspectos importantes en la multidisciplinaridad de proyectos como los que se manejan en esta asignatura.

Finalmente, preguntados qué sentían mientras realizaban este proyecto, más de un 60\% contestó esta opción: "Nunca he olvidado que era una obligación, pero encantado/a de que me obliguen a cosas así!”., aumentando la cantidad de alumnos que disfrutan con esta actividad (frente a un 50\% del año anterior).

(cc) EY-NC-ND 2018, Universitat Politècnica de València

Congreso IN-RED (2018) 


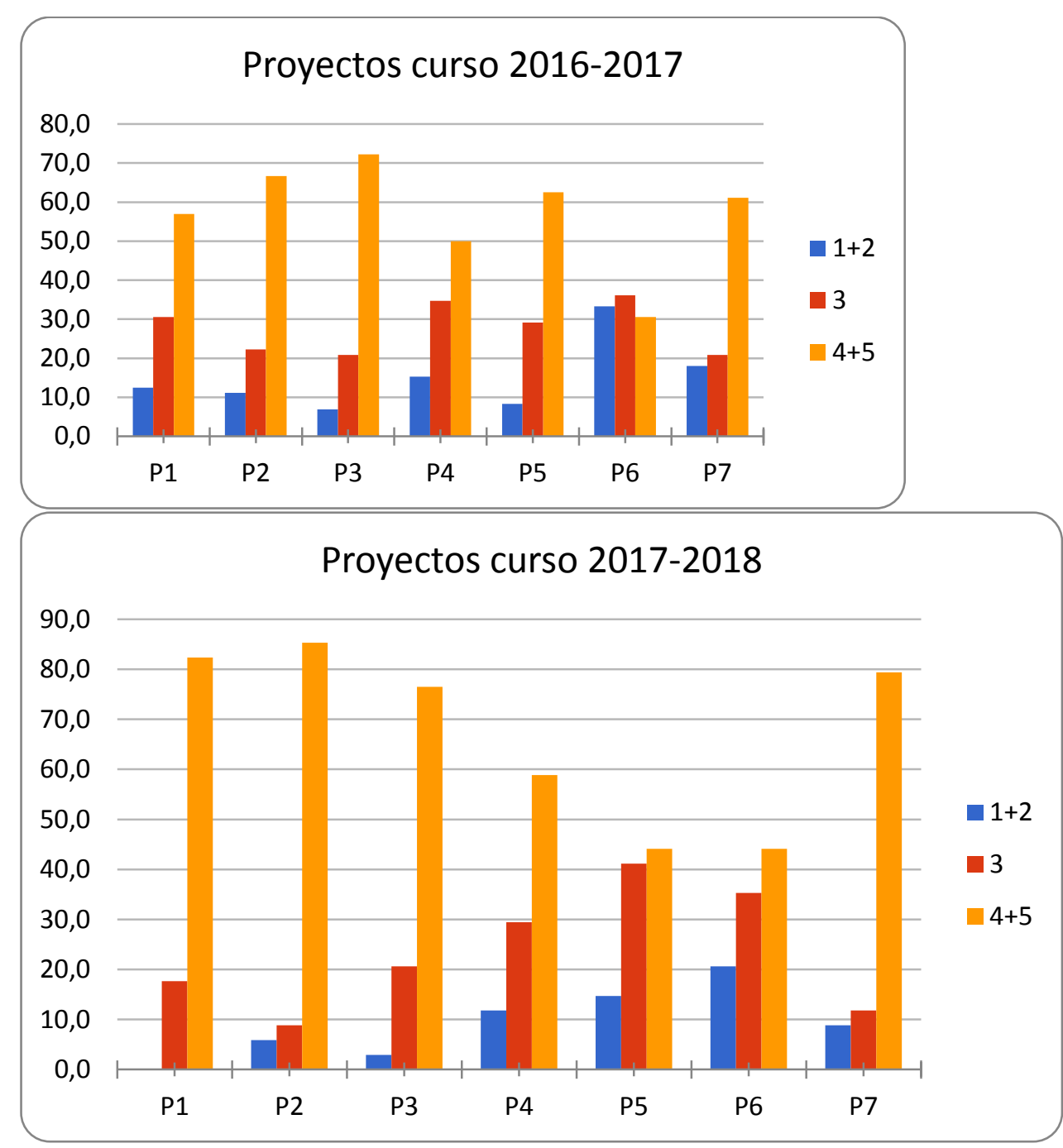

Fig. 4. Diagrama de barras que indica las puntuaciones de los items para la sección Proyecto de investigación para los cursos 2016-2017 y 2017-2018. Se han sumado las puntuaciones 1 y 2 que muestran disconformidad (Muy en desacuerdo y En desacuerdo) así como las puntuaciones 4 y 5 que muestran conformidad (De acuerdo y Muy de acuerdo). Los ítems P1 a P7 están detallados en el apartado 3.1

\section{Conclusiones}

Los resultados obtenidos este año académico, mejorados respecto a los buenos resultados del año anterior, nos siguen animando a continuar con el sistema docente que hemos implantado en esta asignatura de tercer curso del grado de Biotecnología. La reducción del tiempo de dedicación de los alumnos en casa para la realización de las tareas de clase inversa creemos que ha sido la clave de la mayor aceptación de las mismas, así como a reducción del número de tareas. Esto ha llevado a una mayor satisfacción general de la asignatura y a que sea considerada una asignatura "atractiva". Desde luego, quedan muchos aspectos susceptibles de mejora, pero demuestran que las metodologías de aprendizaje 
autónomo son una muy buena herramienta para el aprendizaje en Biotecnología. Los aspectos de la asignatura que ya parecen más enraizados y que según la encuesta siguen siendo una excelente iniciativa son los proyectos de investigación aplicada, implantados ya desde hace 6 años. Este año, la mayor tutorización de los estudiantes en la realización de los mismos ha contribuido a la mejora de unos ya elevados porcentajes de satisfacción respecto al año anterior.

En resumen, la implantación de estrategias de aprendizaje autónomo que ponga énfasis en un aprendizaje más aplicado, que aumente la responsabilidad por parte del estudiante e incremente su sentido de autonomía, es visto con buenos ojos por una alta proporción del alumnado en esta encuesta bianual, y debería ser implantado de un modo organizado en los planes docentes, sustituyendo o alternando con estrategias docentes más tradicionales.

\section{Referencias}

BRIONES, G. (1995). Métodos y Técnicas de Investigación para las Ciencias Sociales,2a reimp., Ed. Trillas, México.

CRISPIN BERNARDO, MARÍA LUISA, AND MA. DEL CARMEN DORIA SERRANO (2011). Aprendizaje autónomo orientaciones para la docencia. México: Universidad Iberoamericana. http://www.uia.mx/web/files/publicaciones/aprendizaje-autonomo.pdf.

NORTHWEST REGIONAL EDUCATIONAL LABORATORY (2016). Aprendizaje por proyectos. http://www.eduteka.org/AprendizajePorProyectos.php; ABP en Eduteka. [Consultado el 25 de Marzo de 2017].

GADEA, J y VILANOVA S. (2017) Evaluación de Diferentes Metodologías de Aprendizaje Activo desde el Punto de Vista del Estudiante en la Asignatura Genómica del Grado de Biotecnología. INRED-2017

(cc) EY-NC-ND 2018, Universitat Politècnica de València 


\title{
Teatralización en grupos tutorizados de Biología en Medicina: una estrategia diferente para el aprendizaje colaborativo.
}

\section{Teresa San-Miguel Díez ${ }^{a}$, Javier Megías Vericat ${ }^{b}$ y Eva Serna García}

${ }^{a}$ Departamento de Patología, Universitat de València. Teresa.miguel@uv.es bepartamento de Patología, Universitat de València. Javier.megias@uv.es y ${ }^{\mathrm{c}}$ Departamento de Fisiología, Universitat de València. Eva.serna@uv.es.

\begin{abstract}
Dramatization as a teaching methodology remains relatively unknown in higher education. It can be especially useful to work cross-disciplinary skills because of the cooperative nature that is intrinsic to the theater itself. The subjects and disciplines that can benefit from it must be adequately valued by teachers. Here we present an activity in small groups, focused on rare diseases with a known genetic cause, in which the theater is used as a motivating axis to gather information and organize it by creating a storyline.
\end{abstract}

Keywords: theater, TIE (theater in education), intrinsec motivation, rare diseases.

\begin{abstract}
Resumen
La teatralización como metodología de enseñanza es una gran desconocida en la educación superior. Su utilización para trabajar competencias transversales puede resultar especialmente útil por el carácter cooperativo intrínseco al propio teatro y las temáticas y disciplinas que pueden beneficiarse de ella deben ser adecuadamente valoradas por los docentes. Presentamos una actividad en grupos tutorizados, centrada en enfermedades raras con causa genética conocida, en la que el teatro sirve como eje motivador para recabar la información y organizarla creando un hilo argumental.
\end{abstract}

Palabras clave: teatro, MABAE (metodología de aprendizaje basado en artes escénicas), motivación intrínseca, enfermedades raras

\section{Introducción}

Durante la última década, los intentos de innovación en educación han sido una apuesta continua desde todas las administraciones. Con una aplicación más sencilla y temprana en las aulas de niveles preuniversitarios, es relativamente reciente el interés en la Universidad por aprender a enseñar (Durán, 2014), incentivar la actividad docente y formar mejor al profesorado dentro del Espacio Europeo de Educación Superior (EEES). En este sentido, la Universitat de València convoca proyectos de Innovación Educativa de manera periódica, y se están aumentando los recursos con, por ejemplo, programas de formación del profesorado como son el Pla de Formació d'Impuls al Lideratge Docent (PILD) o la Formación Integral para el Profesorado Universitario (FIPU). 
Así, se han puesto en marcha diferentes fórmulas para favorecer el desarrollo de procesos educativos innovadores (Peña, 2014), y escuchamos de manera cotidiana, nombrar metodologías como el "aprendizaje cooperativo o colaborativo", "aprendizaje basado en proyectos”, “aprendizaje basado en problemas”, "puzles de Aaronson”, "blended-learning” o "gamificación". Por otra parte, se nos explica la necesidad de orientar nuestros mecanismos de evaluación a la adquisición de competencias y no meramente a los contenidos; en este ámbito también aparecen nomenclaturas propias para los nuevos sistemas de evaluación que se nos sugieren, como evaluación por pares, evaluación entre iguales, evaluación combinada, sumativa, o evaluación mediante rúbricas entre muchas otras.

Ante tal variedad terminológica y diversidad de enfoque, el problema es que la mayoría continua enseñando y aprendiendo con idénticas estrategias que hace décadas (Acaso, 2013). Al profesor se le exige la actualización en el formato pedagógico mientras que el alumno permanece expectante (Álvarez-Domínguez, 2016) y la implementación del cambio es compleja. No es descabellado tratar de buscar herramientas pedagógicas integrativas que nos permitan, por una parte innovar en la metodología y por supuesto, lograr nuestro objetivo didáctico a la par que los estudiantes adquieren un papel más protagonista en las competencias que pretendemos que alcancen. En este sentido, las artes escénicas como metodología de enseñanza-aprendizaje en la universidad, resultan un campo inexplorado y con un gran potencial en cualquier disciplina. Evidentemente, hay grados en los que será más utilizable en primeros cursos y otros en los que se puede aplicar de manera puntual, en cualquier momento del proceso formativo de los estudiantes.

Ante la necesidad de bautizar todo método de enseñanza-aprendizaje que se introduce en el aula, estaríamos hablando de la ·Metodología de Aprendizaje Basado en las Artes Escénicas (MABAE), o más simplificado en inglés Theater in education (TIE). La teatralización puede lograr un aprendizaje holístico, más transversal y que conecta contenidos y emociones. Los estudiantes pueden integrar el aprendizaje basado en problemas o en proyectos y el apredizaje cooperativo, siendo ellos auténticamente los protagonistas de sus aprendizajes. La técnica se conoce como "Role-playing” y es sin duda, novedosa como concepto pedagógico dentro del aula universitaria (Navarro, 2010). Además, se trata de una técnica que potencia la motivación intrínseca del alumnado: el hecho de tener que teatralizar crea en el alumno-actor la necesidad de conocer su papel y por tanto, de comprender mejor los aspectos que va a representar.

En el caso concreto de este trabajo, se escogió el método para lograr el trabajo colaborativo que se espera cuando los alumnos realizan trabajos en grupo. Tradicionalmente consistía una exposición oral, por lo que los alumnos, que ya trabajan con herramientas on-line como Google Drive para, de acuerdo al sistema blended-learning, poder trabajar tanto presencialmente como de manera virtual, tendían a repartirse las tareas de manera completamente fragmentada, cayendo en lo que se conoce como balcanismo del conocimiento, y memorizando lo que los otros compañeros han aportado a cada una de sus separadas partes del trabajo. Al introducir la teatralización, los papeles de los personajes que participan interactúan entre ellos y tienen, en muchos casos, conocimientos solapantes,

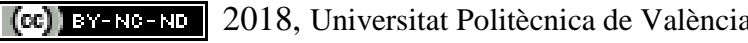


de manera que durante la búsqueda de información, que sí, sigue siendo fragmentada, deben compartir sus hallazgos, ponerlos en común y consensuar el mensaje final para evitar contradicciones y lograr una línea argumental coherente. El teatro actúa como vehículo para que el alumno tome conciencia de su propio aprendizaje y lo encarne. El hecho de teatralizar la temática, nos permite incluir (Torre, 2005):

- Concienciación de la temática

- Sentimiento y experimentación de la información como un contenido que afecta al propio individuo

- Reflexión sobre el tema en términos de acción

- Ejecución de la práctica a la propuesta escénica

- Integración y trascendencia de lo expuesto

Aprender de manera diferente es un reto en Educación Superior y, por ello, el papel del profesor como facilitador y guía es imprescindible para estructurar adecuadamente los planteamientos metodológicos que se quieren introducir. En base a esto, desarrollamos la actividad que a continuación se describe.

\section{Objetivos}

El objetivo principal es que los alumnos conozcan el concepto general de "enfermedades raras” y comprendan en profundidad una de ellas, de origen genético conocido, con sus repercusiones clínicas (la enfermedad a nivel genético, organular, celular y tisular), familiares (tratamiento, estudio genético y recomendaciones) y sociales (investigación, asociaciones, perspectivas).

La temática del trabajo pretende que los alumnos realicen un trabajo de investigación en grupo para trabajar en las competencias específicas del grado y en las de la asignatura de Biología: conocer la estructura y función celular y la implicación de las biomoléculas, conocer los mecanismos de de la información, expresión, regulación génica así como los patrones de herencia, comprender las consecuencias de una alteración genética puntual y su relación con fenotipos complejos, saber utilizar las tecnologías de la información y comunicación en actividades clínicas, terapéuticas, preventivas y de investigación.

Además, se pretenden desarrollar las competencias transversales propias de un profesional de la Medicina, y para ello se diseña la actividad como un proyecto teatralizado. Las competencias transversales a trabajar son:

CT1: Organizar y planificar adecuadamente la carga de trabajo

CT2: Capacidad para trabajar en equipo y para relacionarse con otras personas del mismo o distinto ámbito profesional

CT3: Capacidad crítica y autocrítica

CT4: Capacidad para comunicarse con colectivos profesionales de otras áreas

(c)) EY-NC-ND 2018, Universitat Politècnica de València

Congreso In-Red (2018) 
CT5: Reconocimiento de la diversidad y multiculturalidad

CT6: Considerar la ética como valor primordial en la práctica profesional

\section{Desarrollo de la innovación}

\subsection{Destinatarios y planificación}

La actividad se desarrolló dentro del programa de grupos tutelados de primer curso del grado de Medicina. Los destinatarios fueron los alumnos matriculados en el grupo de prácticas L5 de la asignatura Biología (34446) de la Facultat de Medicina i Odontologia de la Universitat de València en el primer cuatrimestre del curso 2017-2018, lo que supone un total de 38 alumnos. Se realizó una sesión de presentación de la actividad el 23/10/17 en la que se explicó a los participantes la finalidad del trabajo y se proporcionaron las pautas para su ejecución así como los plazos y mecanismos de evaluación.

En primer lugar, el docente estructuró los grupos de trabajo y los comunicó en dicha sesión: se formaron un total de 5 grupos de 7-8 participantes cada uno. A continuación se explicó la temática: realizar un trabajo de investigación en grupo sobre un enfermedad de origen genético con afectación organular concreta. Los temas ofertados, a elegir por los grupos de trabajo fueron: Síndrome de la triple A y síndrome de Rett (afectación del núcleo celular), Síndrome de Hurler-Scheie, síndrome de Gaucher y síndrome de Hunter (afectación del lisosoma), Síndrome de Zellweger (afectación del peroxisoma), Distrofia muscular de Duchenne (afectación de la membrana plasmática), Neuropatía óptica de Lebber (afectación de la mitocondria). El contenido que debían abordar fue descrito en la misma sesión y compartido con los alumnos para que lo tuvieran por escrito. Debía comprender

- Aspectos genéticos: causa responsable de la alteración fenotípica

- Biología celular: descripción del orgánulo o esctructura celular implicada y alteraciones que sufre

- Fisiopatología de la enfermedad: cuadro clínico

- Otros: diagnóstico, pronóstico, terapia, investigaciones actuales y perspectivas futuras

- Conclusiones y bibliografía.

Se explicaron los documentos y actividades que debían ejecutarse para la evaluación de la actividad:

- Documento resumen: máximo 6 hojas

- $\quad$ Póster en formato congreso: explicación de formato.

- Presentación en formato ppt o similar: guía de la representación y decorados.

Además se especificó la fecha final para la presentación del documento resumen y la representación teatralizada, con una extensión máxima de 15 minutos y un turno de preguntas por parte del profesorado presente y los compañeros a todos los miembros del grupo sobre cualquiera de los aspectos tratados.

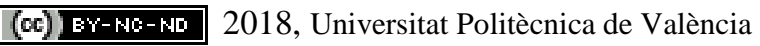

Congreso IN-RED (2018) 


\subsection{Estructura de la acción}

Se presentó el reparto de tareas para la teatralización, de manera que cada uno de los miembros del grupo debía adoptar uno de los roles planteados, con flexibilidad para su creatividad y adecuado a la patología (Fig. 1). De manera general en todos los grupos debía haber:

- Paciente: descripción de los síntomas como afectado, con terminología corriente.

- Médico: aporta la nomenclatura clínica de los síntomas y la sospecha diagnóstica como consecuencia

- Bioquímico-Genetista: realiza las pruebas diagnósticas solicitadas por el médico y aporta los resultados bioquímicos y genéticos correspondientes (gen, tipo de alteración, loci implicados cuando se identifique...)

- Profesor de Biología: caracteriza el orgánulo afectado en condiciones normales y los defectos consecuencia de la alteración y los relaciona con la fisiopatología

- Farmacéutico: describe el tratamiento sintomático, paliativo, dietético o experimental

- $\quad$ Padre/madre/hermano: averigua la epidemiología de la enfermedad, se implica en el tipo de herencia de cara a obtener un consejo genético, busca asociaciones de apoyo en España y perspectivas futuras para su familiar y para futuros afectados.

- Expertos polivalentes: para no obligar a la presentación teatralizada a los alumnos más tímidos, se ofrece la posibilidade destinar a 1-2 miembros a centrarse en la organización de los contenidos, desarrollo del guión y formatos escritos a presentar.

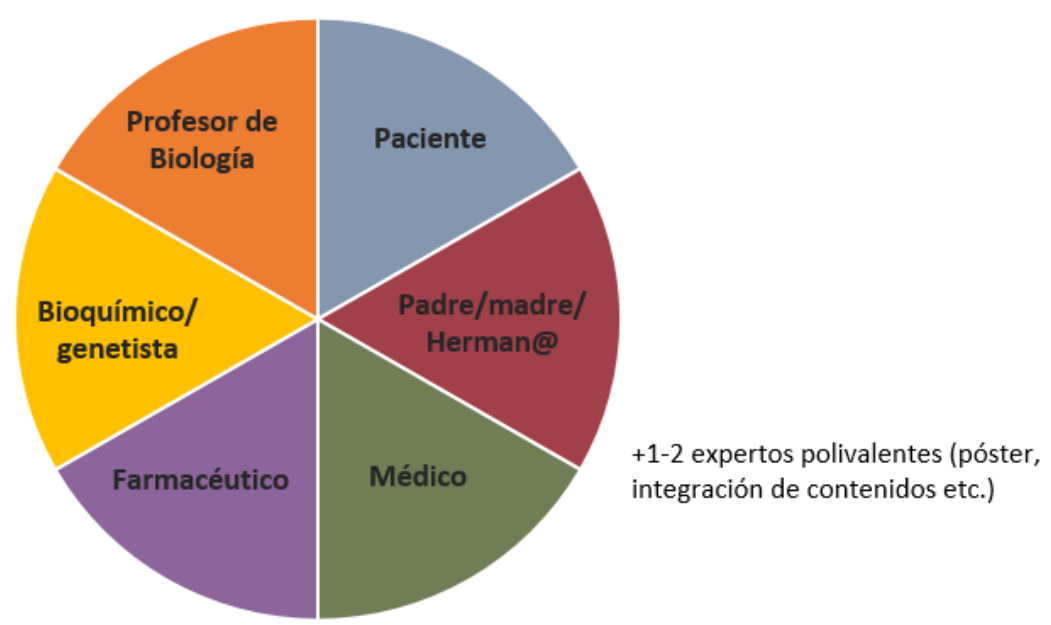

Fig. 1 Distribución de roles para la teatralización 
Teatralización en grupos tutorizados de Biología en Medicina:una estrategia diferente para el aprendizaje colaborativo

Se estableció un calendario de tutorías para la supervisión de los avances en las tareas de investigación, de asistencia obligatoria y los avances mínimos establecidos para cada sesión.

\subsection{Evaluación de la actividad}

Para la evaluación se utilizó una escala de calificación (tabla 1), que integra las cualidades de la ejecución y la escala para indicar el nivel de logro. Se evaluaron 12 criterios en una escala del 1 (mínimo) al 4 (máximo) para finalmente normalizar la nota sobre 1 punto que representa de la nota final de la asignatura. En ella se valoró conjuntamente todos los materiales proporcionados, la representación y la respuesta a las cuestiones planteadas tras la presentación.

Tabla 1. Escala de calificación

\begin{tabular}{|c|c|c|c|c|c|}
\hline & CRITERIOS EVALUADOS & 1 & 2 & 3 & 4 \\
\hline 1 & El trabajo escrito es formalmente correcto & & & & \\
\hline 2 & El trabajo escrito desarrolla todos los aspectos solicitados & & & & \\
\hline 3 & El póster está bien estructurado y transmite los aspectos clave del tema & & & & \\
\hline 4 & Los alumnos distribuyen equitativamente la carga de trabajo & & & & \\
\hline 5 & Los alumnos asisten a las reuniones con los objetivos de cada sesión alcanzados & & & & \\
\hline 6 & La terminología utilizada es apropiada y se interpreta su significado correctamente & & & & \\
\hline 7 & Se aprecia una profunda comprensión sobre el orgánulo afectado y la causa genética & & & & \\
\hline 8 & $\begin{array}{l}\text { Los alumnos demuestran comprender la diversidad funcional de los afectados y las } \\
\text { consecuencias para los familiares }\end{array}$ & & & & \\
\hline 9 & Cada rol se relaciona de manera apropiada con los otros roles representados & & & & \\
\hline 10 & $\begin{array}{l}\text { Los alumnos expresan correctamente las consecuencias éticas de los hallazgos genéticos } \\
\text { en su estudio }\end{array}$ & & & & \\
\hline 11 & $\begin{array}{l}\text { Se profundiza en las necesidades de afectados y familias y se conocen las asociaciones } \\
\text { existentes }\end{array}$ & & & & \\
\hline 12 & $\begin{array}{l}\text { El trabajo demuestra el análisis crítico de la problemática planteada y se responde } \\
\text { apropiadamente a las preguntas planteadas }\end{array}$ & & & & \\
\hline
\end{tabular}

Además, se distribuyó un cuestionario mediante "Formularios Google” vía enlace en el Aula Virtual que incluía preguntas sobre el esfuerzo requerido para la ejecución del proyecto, sobre el desarrollo del proyecto y sobre su valoración del trabajo en equipo. Las preguntas sobre estos aspectos se plantearon como elementos Likert. Se establecieron 5 niveles de respuesta, pero los enunciados en ellos eran diferentes por lo que no se aplicó la suma propia de las escalas Likert. Por último se solicitó que aportaran palabras que piensan ahora al pensar en enfermedades raras y sugerencias. 


\section{Resultados}

\subsection{Representación de los proyectos.}

Los alumnos participantes desarrollaron 5 representaciones teatrales ante uno o dos profesores de la asignatura, según horarios y uno o dos de los grupos restantes. Todos ellos firmaron, de manera voluntaria, su consentimiento para la realización de fotografías para la difusión de la actividad realizada (Fig. 2). En su tarea de investigación, dos de los grupos solicitaron realizar el trabajo sobre temas no incluidos en el listado, que tras valorarse por el docente, fueron aceptados: la ataxia de Friedrich (grupos 2) y el síndrome MELAS (grupo 5), además del síndrome de la triple A (grupo 1), el síndrome de Hunter (grupo 3) y la Neuropatía óptica de Lebber (grupo 4).

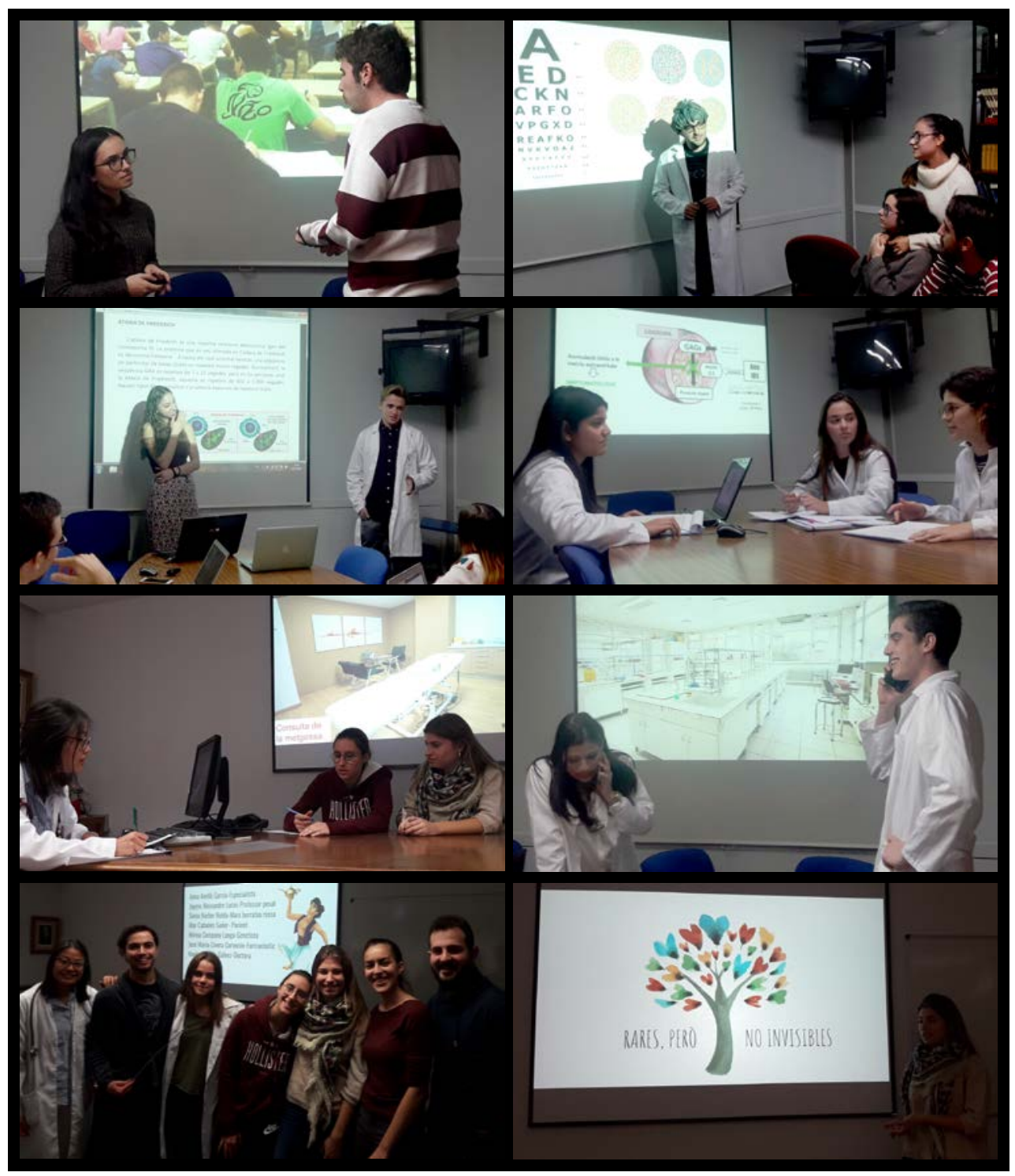

Fig. 2. Fotografías realizadas durante las representaciones teatralizadas 
El primer resultado destacable fue que, a pesar de tener la posibilidad de que algún miembro de cada equipo no tuviera que actuar, el 100\% de los alumnos decidieron adoptar un rol de actor además de trabajar en la integración de contenidos y en la preparación de los documentos físicos a presentar. Todos los grupos se adaptaron al tiempo y formato previstos.

\subsection{Consecución de los objetivos.}

Los objetivos propuestos se alcanzaron muy satisfactoriamente y los alumnos, de acuerdo a la escala de calificación, obtuvieron puntuaciones entre el 0,86 puntos y 1 punto. Las historias concebidas para transmitir los contenidos trabajados lograron incorporar en todos los casos apropiadamente:

- La fisiopatología de la enfermedad: con la interpretación de los síntomas clínicos en términos comprensibles y médicos simultáneamente, representando físicamente aquellos en que era posible y describiendo aquellos no interpretables.

- La genética de la enfermedad, con especial atención al tipo de herencia y el consiguiente estudio genético y consejo para los posibles familiares afectados

- La biología organular: la manera de incorporar los contenidos teóricos de biología celular fue sorprendente. El grupo 1 reflejó un flash-back en que los familiares protagonistas habían estudiado medicina y recordaban sus clases. El grupo 2 reflejó un matrimonio en que la médico que está trabajando con la familia afectada está casada con un profesor de biología que le recuerda los contenidos. El grupo 3 realizó un sketch en el que nos representaron a los profesores de la asginatura explicando juntos el orgánulo en cuestión. El grupo 4 unió la lección de biología al papel de genetista, aportando una explicación completa para ayudar al papel del médico. En el grupo 5, el familiar del afectado acudió a la facultad para recibir del profesor la información necesaria.

- Situación actual y perspectivas futuras: todos los estudiantes encontraron una o varias asociaciones de afectados en la Comunidad Valenciana o a nivel nacional. Varios grupos contactaron con ellas para mejorar su comprensión sobre las dificultades reales que afrontan los afectados. Los participantes encontraron tratamientos farmacológicos novedosos y/o ejemplos de nueva terapias génicas. Con estos resultados cabe decir que para el profesorado ha sido una experiencia muy grata y que las presentaciones, además de amenas, fueron muy completas y detalladas.

\subsection{Evaluación de los participantes}

De las 38 encuestas anónimas distribuidas se recibieron 21 respuestas voluntarias y anónimas. De ellas, se extrajo que, a pesar de tener que elaborar un trabajo escrito, una presentación guía, un póster de presentación en congreso y realizar una representación

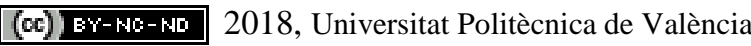

Congreso IN-RED (2018) 
teatralizada, la percepción del esfuerzo necesario para ejecutar todas las tareas en 3 semanas, fue "medio" para más de la mitad de los alumnos con un 52,4\%. Fue "bastante" para el 33,3\% y solo "mucho" para un 14,3\% de los alumnos (Fig. 3). El sistema de teatralización logra, en opinión de los estudiantes, el trabajo en equipo, en un 87,5\% de los casos. Sólo un alumno piensa que el trabajo no se ha distribuido de manera equitativa dentro de su grupo (Fig. 4).

Sobre el desarrollo del proyecto, el diseño ha sido bien valorado por los estudiantes con excepción de un alumno, y los temas tratados y el soporte recibido por el tutor también han sido muy bien valorados con el $100 \%$ de las opiniones entre de acuerdo y muy de acuerdo. El 90\% valoran positivamente la actividad desarrollada y solo un alumno no es partidario de extender este tipo de actividades a otros programas de tutelados; si bien el $14 \%$ se manifestaron “neutros”, más del 80\% está a favor de extenderlo.

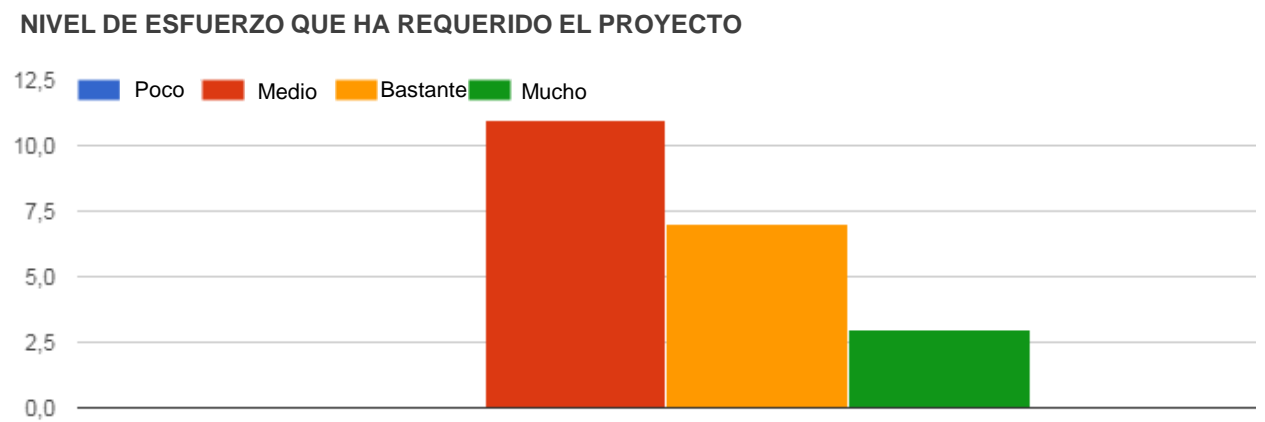

(en comparación con la tutela de otras asignaturas)

Fig. 3. Valoración del nivel de esfuerzo que ha requerido el proyecto

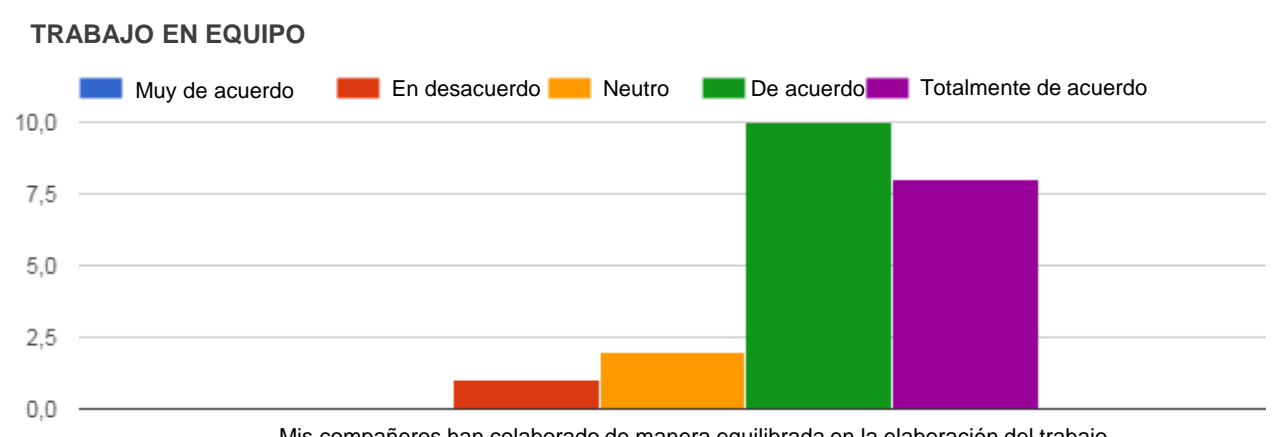

Mis compañeros han colaborado de manera equilibrada en la elaboración del trabajo

Fig. 4 Valoración del trabajo en equipo 
Teatralización en grupos tutorizados de Biología en Medicina:una estrategia diferente para el aprendizaje colaborativo

El resultado menos positivo es sobre la temporalización, ya que sólo el 76,2\% valoran positivamente su adecuación, con un $14,3 \%$ de opiniones neutras y un 9,5\% en desacuerdo con que haya sido adecuado a las necesidades (Fig. 5).

Por último, en relación a las palabras que piensan ahora al oir hablar de enfermedades raras, podemos resumir que: "investigación” o "desarrollo de investigación” e "investigación en genética” fueron nombradas 10 veces. Referencias a las dificultades, el desconocimiento, la falta de información y de inversión, y a la ausencia de cura se nombraron 12 veces. Llama la atención la cantidad de referencias a emociones: entre ellas, sorprende la relación a la frustración con expresiones como "marginales", "dolor” (x3), "pena” (x2), "incertidumbre”, "impotencia", e incluso "rabia”. Con un carácter más positivo, son numerosas las que hacen referencia a la "ayuda” (x4), "asociaciones”, "tolerancia”, "respeto” (x2) y "fortaleza” (x3). Finalmente, las expresiones sobre investigación pero con un carácter positivo motivador, se encontraron en 12 comentarios, del tipo "necesario" (x3), "importante” (x2), "curioso" (x2), “interesante” (x2), "colaborativo”, y “futuro” (x2).

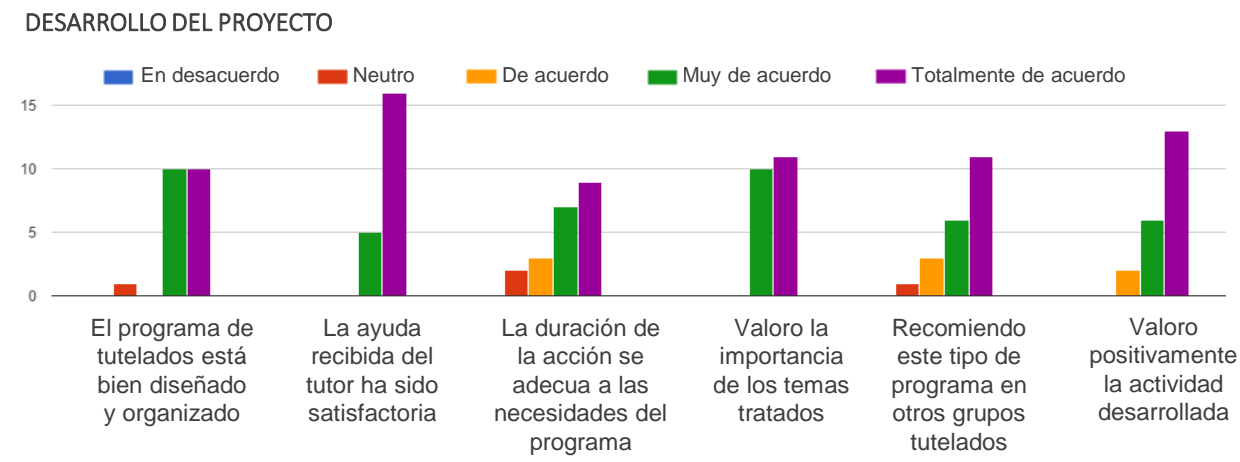

Fig. 5 Evaluación del desarrollo del proyecto.

\section{Conclusiones}

La teatralización como actividad ha tenido una acogida excelente entre los alumnos. Es muy importante que, indirectamente, ha logrado mejorar el reparto de tareas en el trabajo, por lo que valoramos muy positivamente su uso para lograr la cooperación en la creación de conocimiento para nuestros estudiantes. El reparto de roles, en que cada uno de los actores es experto en el desarrollo de su parte del trabajo, ayuda al estudiante a no sentir la carga de tener que crear un trabajo completo pues comienza con la especialización en su area concreta; sin embargo, el punto de teatralizar ayuda sin sensación de sobreesfuerzo a la integración de todos los contenidos. Los roles adjudicados tenían todos asociados tareas de investigación solapantes: no se pueden aprender los síntomas clínicos sin su explicación cotidiana, no se puede comprender el fenotipo de la enfermedad sin comprender su causa genética. Esto, a su vez, convierte la propia creación de la obra en una especie de puzle de

(cc) EY-NC-ND 2018, Universitat Politècnica de València

Congreso IN-RED (2018) 
Aaronson en que cada experto aporta y recibe, creando un flujo de conocimiento extraordinario. Por estas razones, el profesorado valora de manera conjunta la teatralización como una estrategia pedagógica muy apropiada. Es evidente que cuantas más estrategias tengamos a nuestra disposición para lograr un objetivo didáctico concreto, más probable es lograr el éxito (Pérez-Aldeguer, 2017).

Como estrategia para el próximo curso, dado que los discentes refieren falta de tiempo para abarcar todos los aspectos del proyecto, y que las valoraciones en cuanto al esfuerzo dedicado fueron muy positivas, observamos el deseo de hacer un trabajo más profundo y detallado. Así, nos planteamos modificar los requisitos de documentación a entregar para que resulte menos laborioso. De esta manera, los alumnos dispondrían de más tiempo para ahondar en los conocimientos que necesitan interiorizar.

Por otra parte, y en relación a la evaluación de competencias, en este curso hemos utilizado el sistema de "Escala de Calificación" para caracterizar los criterios de evaluación a introducir y decidir los grados de consecución. Sobre esta escala, ya trabajada, resultará más sencillo construir un rúbrica, en la que se describirán los objetivos a alcanzar en cada grado y se modificará el peso relativo de los criterios, que en este caso, fue homogéneos para todos los parámetros incluidos. La finalidad de construir una rúbrica meditada y ensayada a partir de una escala previa, es familiarizarse con el sistema de calificación; esto se ha logrado, y sobre ello, podemos construir una herramienta de evaluación que pueda ser distribuida a los alumnos antes de comenzar el proyecto, de manera que tengan claro qué y cómo se va a evaluar desde el principio de la actividad.

Es importante señalar que el hecho de tener que realizar una representación teatral, obliga al alumno a lograr un dominio de los contenidos muy importante y crea en él la necesidad de comprender los aspectos que va a tratar, para alcanzar la seguridad necesaria para teatralizar; dado que están en primer curso del grado, requiere de amplias explicaciones en las sesiones de tutoría para proporcionar una primera aproximación simplificada, a conceptos que tratarán en cursos más avanzados. Esto nos obliga a reflexionar: la innovación y traslación de la responsabilidad de aprender a los alumnos, obliga también al docente a estar a la altura de sus necesidades.

Podemos concluir que la actividad ha sido fructífera y que se ha trabajado de una manera mejorada en las competencias transversales. Sin duda el trabajo colaborativo adquiere una dimensión especial con este tipo de actividad, el aprendizaje se logra tanto en tutorías como con el trabajo en casa, virtual y cooperativo, e incluso se puede considerar gamificado, ya que aunque no incluye el concepto típico de clasificación por puntos, ludifica los procesos de enseñanza-aprendizaje convirtiéndolo en un proceso creativo muy formativo a la vez que gratificante. Aunando estrategias logramos aumentar la motivación intrínseca de nuestros estudiantes, generando en ellos la necesidad propia de crear conocimiento desde una perspectiva que deja huella: estamos seguros de que no olvidaran las emociones asociadas al acto teatral y por tanto, a las enfermedades raras que han presentado en este curso. 
Teatralización en grupos tutorizados de Biología en Medicina:una estrategia diferente para el aprendizaje colaborativo

\section{Referencias}

ÁLVAREZ-DOMÍNGUEZ, P. y MARTÍN-LÓPEZ, A. (2016). “El teatro como herramienta didáctica en la enseñanza de la Historia de la Educación Contemporánea” en. Revista Digital de Investigación en Docencia Universitaria 10 (1), 41-51.

ACASO, M. (2013). Reduvolution: hacer la revolución en la educación. Barcelona: Paidós

TORRE, S. y MORAES, M.C. (2005). Sentipensar: fundamentos y estrategias para reencantar la educación. Archidona: Aljibe.

DURÁN, D. (2014). Aprenseñar. Evidencia e implicaciones educativas de aprender enseñando. Madrid: Narcea

GONZÁLEZ PARERA, M. (2012). “El teatro como estrategia didáctica” en: Simposio Internacional de Didáctica de Español para Extranjeros. Argel (Argelia). Disponible en: https://cvc.cervantes.es/ensenanza/biblioteca_ele/publicaciones_centros/PDF/argel_2012/04_gonzalez .pdf [Consulta: 21 de marzo de 2018].

NAVARRO, M.R. (2010). "La Dramatización y la Promoción de Valores Democráticos en la Enseñanza Superior” en XXIX Seminario Interuniversitario de Teoría de la Educación, Madrid (España). Disponible en: <http://redsite.es/docu/29site/4navarro.pdf > [Consulta: 21 de marzo de 2018].

PÉREZ-ALDEGUER, S. (2017). “Las artes escénicas como metodología educativa en la educación superior” en Foro de Educación 15(22), 1-7. Disponible en: <http://dx.doi.org/10.14516/fde.587> [Consulta: 21 de marzo de 2018].

PEÑA, B. (2014). Fórmulas para la innovación en la docencia universitaria. Madrid: Visión Libros.

(cc) EY-NC-ND 2018, Universitat Politècnica de València

Congreso IN-RED (2018) 


\title{
Innovación docente: los alumnos diseñan un manual cooperativo mediante el flipclass
}

\author{
Victoria Esgueva López ${ }^{\mathrm{a}}, \mathbf{M}^{\mathrm{a}}$ Angeles Carabal Montagud \\ ${ }^{a}$ Departamento de Dibujo, Universitat Politècnica de València, maeslo2@dib.upv.es. ${ }^{\text {b Departamento }}$ \\ de Conservación y Restautración de Bienes Culturales. Universitat Politècnica de València,
}

\begin{abstract}
This teaching innovation allows students to generate a theoretical-practical document, which includes all the graphic techniques used in the field of drawing, putting into practice the flipclass method. A system that reverses the traditional teaching process, so it starts working at home and ends with an autonomous and group work in the classroom.

Innovation takes advantage of the synergy that fosters collaborative work. Because the efforts of each group are combined, providing a fragment of knowledge, achieving maximum results to be shared by all students. On the other hand, it facilitates teachers to evaluate transversal competences such as team work and leadership, or effective communication.
\end{abstract}

Keywords: flipclass, cooperative work, transversal skills, drawing techniques, theoretical-practical analysis.

\begin{abstract}
Resumen
Esta innovación docente permite al alumnado generar un documento teóricopráctico, que recoge todas las técnicas gráficas usadas en el ámbito del dibujo, poniendo en práctica el método de flipclass. Un sistema que invierte el proceso de enseñanza tradicional, por lo que empieza trabajando en casa y acaba con un trabajo autónomo y grupal en el aula.

La innovación aprovecha la sinergia que propicia el trabajo colaborativo. Porque se combinan los esfuerzos de cada grupo, que aporta un fragmento de conocimiento, consiguiendo maximizar los resultados al ser compartidos por todos los alumnos. Por otra parte facilita al profesorado la evaluación de competencias transversales como el trabajo en equipo y liderazgo, o la comunicación efectiva.
\end{abstract}

Palabras clave: flipclass, trabajo cooperativo, competencias transversales, técnicas de dibujo, análisis teorico-práctico. 


\section{Introducción}

La asignatura de Procesos, técnicas y materiales del Dibujo es una asignatura fundamentalmente práctica, basada en el trabajo de taller. En este tipo de disciplinas la parte teórica, si se imparte de manera pasiva a modo de clase tradicional, resulta tediosa para el alumno y por otra parte, dificulta su evaluación al no haber en la guía docente actos de evaluación específicos de pruebas de respuestas abiertas.

Por eso se ha diseñado un método activo que obligue al alumnado a trabajar implicándose en su propio aprendizaje, que requiera su participación más dinámica y constante. Para ello nos centramos en dos conceptos que ayudan a poner en práctica este fin, es la clase inversa y el trabajo colaborativo.

La clase inversa o flipped classroom, es un método que exige al alumno mayor constancia y le obliga implicarse y ser autónomo en su aprendizaje.

"De esta forma, se hace un uso más efectivo del tiempo en el aula, dedicándolo a actividades de aprendizaje centradas en los estudiantes. En realidad, los estudiantes no necesitan tanto al profesor en el aula, durante la exposición teórica, sino más bien en la resolución de problemas.“ (BOIGUESA, F.J., ESTRUCHB, V. y VIDAL, A. 2017).

Por lo tanto, es un sistema que obliga al alumno a interaccionar entre sus iguales y con el profesor. Además exige un seguimiento más sistemático por parte del profesor, que se traduce en la creación de unas pautas de trabajo continuadas para el alumnado.

De la misma manera, la competencia transversal trabajo en equipo y liderazgo, es fundamental para el desarrollo profesional del alumno.

"En la vida profesional la competencia de trabajo en equipo es requerida en dos de cada tres demandas de puestos de trabajo con cierto nivel de responsabilidad. Se pide capacidad para integrarse en un equipo de trabajo, dotes para crear y dirigir equipos, etc. De hecho, los procesos de selección dedican parte de la entrevista a profundizar en este tema, cuando no incluyen en los mismos procesos entrevistas de grupo o actividades llamadas dinámicas de grupo, si bien tan sólo tratan de observar el desempeño de los asistentes cuando se hallan en un contexto grupal”. (VILLA, A. y POBLETE, M. 2007)

En el diseño de la presente innovación se ha tenido en cuenta que sea un tarea atractiva, para ello se solicita la participación grupal. Y la finalidad es generar un manual teóricopráctico de las técnicas del dibujo, que pasará a ser propiedad colectiva. Se plantea que cada grupo hace una parte y luego todos los grupos comparten esa información, teniendo un documento específico primordial para cursos posteriores.

Además se han unido estos planteamientos, para facilitar que los alumnos establezcan vínculos entre ellos y pautas de trabajo autónomo. Que afiancen los conceptos clave y obtengan un aprendizaje más profundo. Y a su vez, este diseño es una herramienta que posibilita al profesorado la evaluación de la parte teórico-práctica en los contenidos genéricos de la asignatura, así como las competencias transversales.

(cc) EY-NC-ND 2018, Universitat Politècnica de València

Congreso IN-RED (2018) 


\section{Objetivos}

Los objetivos que afronta este ejercicio de innovación se estructuran desde dos puntos de vista: por una parte los que hacen referencia al alumnado y por otra los que atañen al profesor.

Los objetivos que atienden a la enseñanza del alumnado, (aprendizaje):

1. Motivar e implicar al alumnado.

2. Conseguir un trabajo en equipo.

3. Conocer el sistema de enseñanza basado en la clase inversa.

4. Saber hacer una exposición formal y publica de su trabajo.

5. Realizar un manual de técnicas gráficas que recoja la parte teórica y práctica en el uso de procedimientos del dibujo. y que quede para ellos como material técnico para su uso posterior.

Y los objetivos que hacen referencia al profesor, (didácticos):

1. Conseguir crear una acción que ayude a evaluar la parte teórica de la asignatura, sin necesidad de una prueba escrita.

2. Facilitar la evaluación de la competencia transversal CT-06 Trabajo en equipo y liderazgo en el primer nivel de dominio. Al ser una asignatura de segundo curso y punto de control de esta competencia.

3. Abordar de manera incipiente otras competencias transversales como CT-03 Análisis y resolución de problemas. CT-08 Comunicación efectiva. Planificación y CT- 012 Gestión del tiempo, porque de manera tangencial se tienen en cuenta.

4. Verificar el aprendizaje individual y colectivo.

\section{Desarrollo}

A modo de preámbulo cabe aclarar que la innovación se ha aplicado en los cursos 2015-2016 y 2016-2017 en la asignatura de Procesos, Técnicas y Materiales del Dibujo, de segundo curso del Grado de Conservación y Restauración de Bienes Culturales. Asignatura troncal de 15 créditos. Se pone en práctica en dos grupos, cada uno de 32 alumnos aproximadamente. En ambos se crean 8 grupos de entre cuatro y cinco personas, y en cada uno de ellos los alumnos se reparten las funciones.

El número de horas dedicadas a la actividad es de 7 presenciales y 8 no presenciales. Esto supone una dedicación de 1,5 créditos dentro de la asignatura.

Ante todo, es fundamental exponer al alumnado el procedimiento del trabajo mediante un enunciado detallado que indique las fases y temporalización. Porque es complejo y precisa entender la secuencialidad, al tener una parte teórica y otra práctica.

La innovación en primer lugar, ayuda a entender la vertiente teórica de las técnicas y procedimientos del dibujo que abordábamos sobretodo de forma práctica en clase. En segundo lugar quisimos que este proyecto sirviera para incorporar la competencia

(cc) EY-Nc-ND 2018, Universitat Politècnica de València

Congreso In-Red (2018) 
transversal CT-O6, Trabajo en equipo, que se debía evaluar como punto de control en la asignatura. Y por último requeríamos la utilización de un método que ayudara a dinamizar las clases teóricas. Por lo que decidimos diseñar un proyecto que mezclara estos aspectos, bajo el método de clase inversa.

\section{Parte Teórica:}

En el desarrollo del trabajo comenzamos abordando los aspectos teóricos. A partir de los videos de Facebook de la asignatura de dibujo, y de otros materiales que se facilitan, como videos, artículos, visitas físicas y virtuales a colecciones y museos, y bibliografía, los alumnos arrancan el trabajo en casa supervisando el material dado.

Se continúa con sesiones de trabajo teórico-práctico en el aula, generando foros y debates por grupos, con el fin de cumplimentar una plantilla teórica dada. Cabe decir que alguna información sí se encuentra en el material facilitado, pero otra parte exige que el grupo extraiga conclusiones propias, este proceso se realiza en presencia de la profesora que orienta los foros de debate.

Esto tiene también una ventaja para el alumnado, que se pueda evaluar una parte teórica sin la necesidad de someterse a pruebas escritas. No tendrá una prueba de respuesta abierta, aunque sí se evaluará a partir de las fichas que han de rellenar. La parte teórica complementa el trabajo de taller.

\section{Parte Práctica:}

La segunda parte, en la que entra el apartado practico, se fundamenta en las conclusiones teóricas extraídas previamente, y de nuevo, mediante la supervisión previa de material digital y elección de obras artísticas relevantes trabajan fuera del aula.

Se exige que busquen obras realizadas con esa técnica, que identifiquen el procedimiento y modo de utilización. Luego en una sesión de clase, ya en el taller, realizan un catálogo o muestrario con esas tipologías, incluyendo una ficha técnica con el procedimiento.

\section{Parte final:}

Exposición pública del proyecto. Cada grupo y alumno tiene un tiempo estipulado para desarrollar una parte del guion que han decidido y todos presentan sus trabajos con una comunicación oral utilizando programas como Power point o Prezi, a partir de un índice dado. Al acabar cada exposición pública, se genera un debate y el resto de grupos hace una valoración entre iguales. (Tabla 1).

(c) EY-NC-ND 2018, Universitat Politècnica de València 
La propuesta resultante exige que con unos ítems comunes se genere un documento o manual en el que se contemplen todas las técnicas gráficas, realizadas mediante el trabajo colaborativo. Lo que supone el reparto de tareas y roles, por tanto implica que los alumnos acepten y cumplan de las reglas del juego.

Por otra parte el profesorado evalúa dos aspectos, primero los contenidos genéricos de la asignatura con otros procesos más dinámicos, que evitan la prueba escrita, y en segundo lugar las competencias transversales por medio de rubricas institucionales, en el primer nivel de dominio, al ser una asignatura de segundo curso. (UPV, 2007).

Tabla 1. Guion desarrollado por los alumnos

\begin{tabular}{|c|}
\hline Guion que el alumno desarrolla \\
\hline $\begin{array}{l}\text { 1. VÍDEOS, MUSEOS, COLECCIONES, DOCUMENTALES, } \\
\text { BIBLIOGRAFÍA. }\end{array}$ \\
\hline $\begin{array}{l}\text { 2. PLANTILLA TÉCNICAS GRÁFICAS } \\
\text { 2.1. Técnicas húmedas, secas y mixtas }\end{array}$ \\
\hline 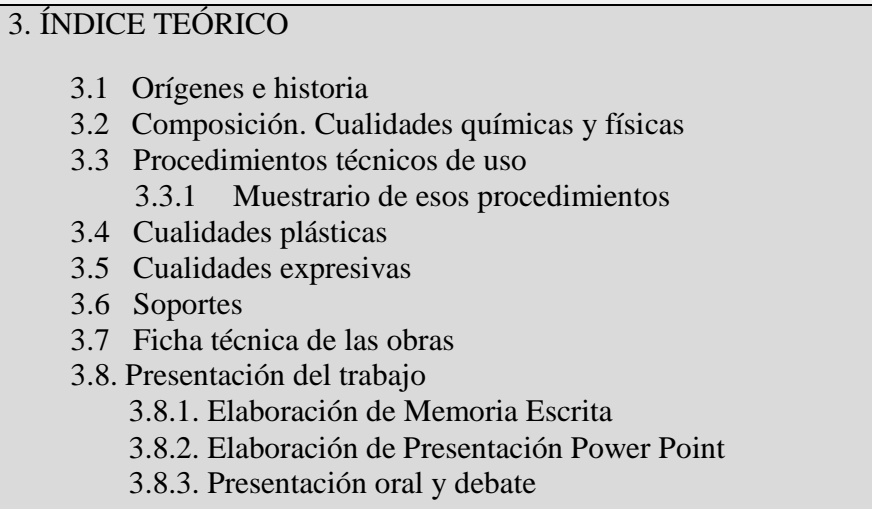 \\
\hline 3.8.4. Evaluación entre iguales \\
\hline
\end{tabular}

\section{Resultados}

Se recogen los resultados, algunos salen de evidencias objetivas como participación en el aula, notas y encuestas, mientras que otros son más interpretativos, como por ejemplo hemos notado un aumento de motivación a nivel individual. Aunque ese rasgo no se ha verificado de forma objetiva, sí lo hemos podemos observar.

La evidencias que se ven de manera clara , es la participación en el aula, todos excepto un mínimo porcentaje, alrededor de 3 \% han participado, han integrado los grupos de trabajo y han expuesto en público (Fig. 1)

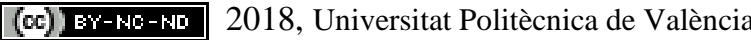




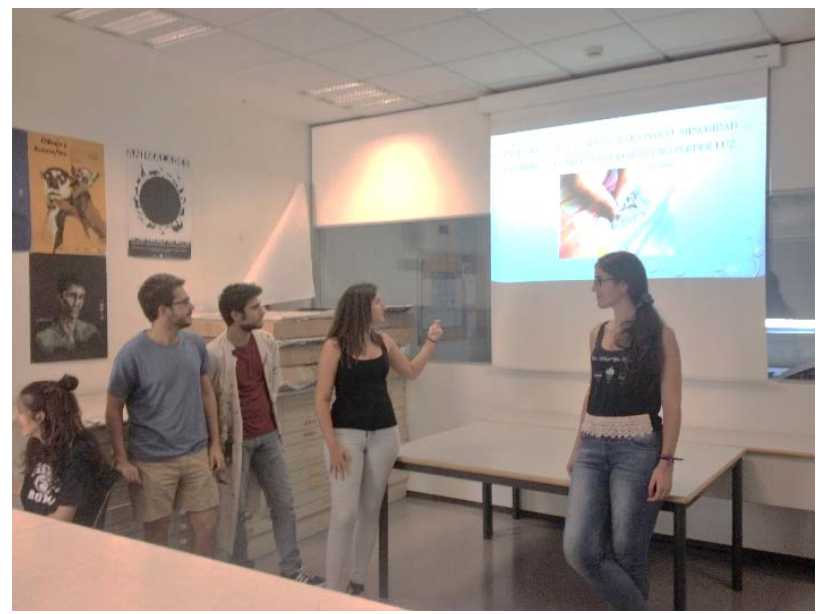

Fig. 1. Estudiantes de la asignatura Procesos, técnicas y materiales del Dibujo exponiendo.

Además se pasó una encuesta al final del curso 2015/2016, haciendoles preguntas específicas sobre la actividad.

1. ¿ ¿Te ha parecido dinámica esta actividad?

2. ¿Te ha resultado monótona?

3. ¿Crees que has aprendido más con este método grupal?

4. ¿ ¿Te ha hecho ser más exigente con los resultados?

5. ¿Prefieres la evaluación práctica por equipo?

6. ¿Prefieres la evaluacion mediante examen?

7. ¿Lo recomendarías?

8. ¿Harías algún cambio?

Los resultados de estas encuestas se recogen en la siguiente tabla. (Tabla 2)

Tabla 2. Resultados encuesta

\begin{tabular}{|c|c|}
\hline Ítems & Porcentaje \\
\hline $\begin{array}{l}\text { Dinamismo en la clase, No } \\
\text { monotonía. }\end{array}$ & $70 \%$ \\
\hline Crees que aprendes más & $20 \%$ \\
\hline Mejora nivel de autoexigencia & $66 \%$ \\
\hline $\begin{array}{l}\text { Qué mantendría, qué } \\
\text { cambiaría. }\end{array}$ & 75\% quitaría la exposion oral \\
\hline Mejor que prueba de examen & $68 \%$ \\
\hline Lo recomendarías. & $40 \%$ \\
\hline
\end{tabular}

(cc) EY-NC-ND 2018, Universitat Politècnica de València

Congreso IN-RED (2018) 
La tabla demuestra que están incomodos con la puesta en común oral, pero consideran buena opción utilizar el método de plantilla para evaluar el contenido teórico, como alternativa a la prueba escrita.

También han reconocido que el trabajo en equipo ayuda a la consecución de objetivos comunes y a la resolución de problemas porque amplía la creatividad. Además a nivel grupal, ha habido una necesidad de gestionar el tiempo y organizar encuentros del grupo fuera del aula. (Fig. 2)

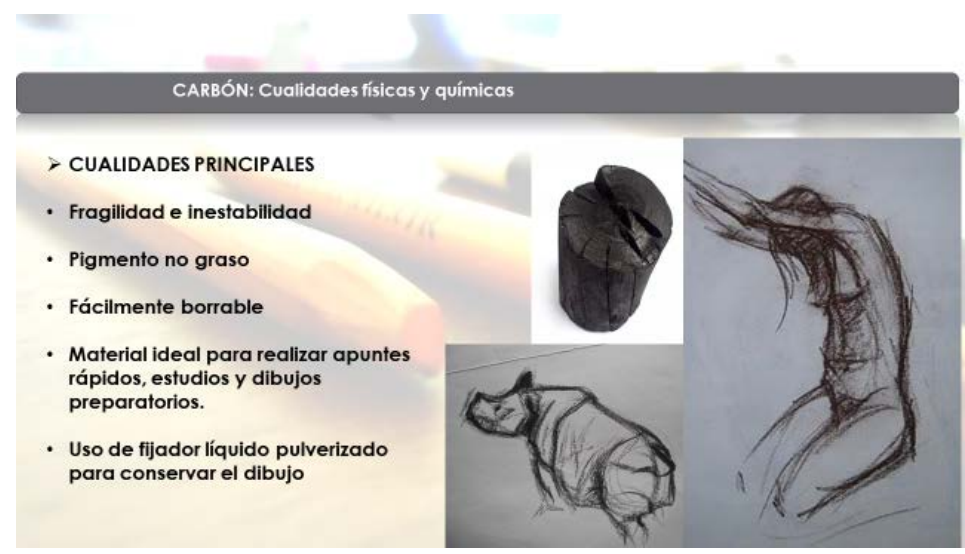

Fig. 2 .Parte del estudio de técnicas .

Por otra parte, una prueba clara son las calificaciones que recoge la tabla 3, que muestra los resultados de esta parte de contenido impartida mediante el proyecto de innovación Flipclass, o anteriormente con el sistema tradicional. Se verifica con una subida consustancial.

Tabla 3. Resultados academicos

\begin{tabular}{llc}
\hline Años & Tipos de docencia & $\begin{array}{c}\text { Calificación media de } \\
\text { los dos grupos }\end{array}$ \\
\hline $2014 / 2015$ & Docencia tradicional & 6.0 \\
$2015 / 2016$, & Docencia Inversa & 6.8 \\
$2016 / 2017$ & Docencia Inversa & 6.5 \\
\hline
\end{tabular}

Destacamos para finalizar que, inicialmente se muestran reticentes al hacer una evaluación entre iguales, aunque posteriormente aumenta el debate en el aula. Además con esta práctica les ayuda a adquirir criterios definidos para valorar un proyecto teórico-práctico, tan necesarios en las titulaciones artísticas.

\section{Conclusiones}

(c) EY-NC-ND 2018, Universitat Politècnica de València

Congreso In-Red (2018) 
Esta práctica nos ha demostrado que el trabajo colaborativo y la clase inversa es un proceso que ayuda a los alumnos a implicarse en la asignatura, siendo lo más significativo que prácticamente desaparece el índice de abandono en esa actividad. ya que todos lo hacen por deferencia a sus compañeros.

También se evidencia una mejora en la actitud frente a un tema teórico, porque dinamiza más la clase y lo convierten en un foro participativo con el fin de resolver problemas. No están preocupados por estudiar sistemáticamente para la prueba escrita, porque se evalúa de otra manera. Al estar enfocada la actividad en grupos de trabajo de iguales se crea un clima en el aula más relajado, y se consigue un tipo de docencia más personalizada.

Cabe destacar, que mejora algo el rendimiento académico, se ve en el gráfico de notas. Consideramos que han conseguido un aprendizaje autónomo, con mayor implicación, y sin duda más en profundidad que se mantiene a largo plazo. Esta conclusión se puede justificar porque el tiempo empleado cuando se plantea la docencia inversa es mayor, y la actividad se estructura en plazos cortos para conseguir objetivos concretos. Ante esta exigencia, los alumnos responden con un obligado y continuado aprendizaje. Que el profesor chequea cada vez que se alcanzan los objetivos.

Por otro lado utiliza la sinergia que propicia el trabajo colaborativo, es decir que todos recogen más resultados que los que han realizado ellos mismos. Por lo tanto ellos comprueban que se optimiza su esfuerzo, ya que cada grupo hace un fragmento, y luego comparten la totalidad de las técnicas. Por tanto se quedan para ellos un documento que les será útil en otras asignaturas posteriores.

En contrapartida, se tiene que tener en cuenta que al principio los alumnos están reticentes por considerarlo una labor muy compleja. Sobretodo el último paso de la exposición pública, ya que encuentran mucha dificultad por su inexperiencia.

Además se puede cuestionar si esta iniciativa sería viable ante un grupo con un número muy elevado de alumnos. Podemos decir que en cierta medida la innovación ha funcionado, porque el número de alumnos de cada grupo, no superior a 35 , ha posibilitado que se realizara un seguimiento y una evaluación real.

\section{Referencias}

BOIGUESA, F.J., ESTRUCHB, V. y VIDAL, A. (2017).”Luces y sombras del Flipped Teaching con estudiantes de primero de turismo", en InRed 2017 III Congreso Nacional de Innovación Educativa y Docencia en Red. Valencia: Universitat Politècnica de València. 350-360 Disponible en http://ocs.editorial.upv.es/index.php/INRED/INRED2017/paper/viewFile/6788/2634 [Consulta: 3 de marzo de 2018]

DÍAZ PADILLA R. (2007) “El dibujo del natural : en la época de la postacademia”. Madrid: Akal

HAYES, C. (1992) “Guía completa de pintura y dibujo : Técnicas y materiales”. Barcelona: Tursen, S.A. Hermann Blume.

(c) ) EY-NC-ND 2018, Universitat Politècnica de València

Congreso IN-RED (2018) 
LAGE, M.J., PLATT, G.J. y TREGLIA, M. (2000). "Inverting the classroom: A gateway to creating an inclusive learning environment” en The Journal of Economic Education, vol. 31, p. 30-43.

MAYER, Ralf. (1988) “Materiales y técnicas del arte”. Barcelona: Blume.

OLTRA GUTIÉRREZ, J. V. "Evaluación en FLIP-Teaching: una alternativa a los exámenes parciales. Evaluación continua mediante tareas y casos”. en InRed 2017 III Congreso Nacional de Innovación Educativa y Docencia en Red. Valencia: Universitat Politècnica de València. 350-360 Disponible en file:///C:/Users/Rafa/Downloads/6889-18015-1-PB\%20(1).pdf [Consulta: 3 de marzo de 2018].

RIZZO, S. [et al.]. (2015). "Flipped classroom, LCA y materiales de construcción: una experiencia didáctica para una actividad de aprendizaje cooperativa y activa”. Jornades sobre Innovació Docent en Arquitectura (JIDA). "III Workshop on Educational Innovation in Architecture (JIDA'15), Barcelona School of Architecture, 25th to 29th May 2015". Barcelona: Grup per a la Innovació i la LogísticaDocent en l'Arquitectura, 2015.<http://hdl.handle.net/2117/81700> [Consulta: 8 de marzo de 2018].

UNIVERSITAT POLITÈCNICA DE VALÈNCIA (2007) “Competencias transversales". http://www.upv.es/entidades/ICE/info/U0724624.pdf [Consulta: 20 marzo 2018].

UNIVERSITAT POLITÈCNICA DE VALÈNCIA (2010). "Trabajo en equipo y liderazgo". http://www.upv.es/contenidos/COMPTRAN/info/954879normalc.html) [Consulta: 22 marzo 2018].

VILLA, A. y POBLETE, M. (2007) “Aprendizaje basado en competencias: una propuesta para la evaluación de las competencias genéricas”. Bilbao: Ediciones Mensajero. pp. 241-248. http://biblio.upmx.mx/textos/14633.pdf [Consulta: 10 marzo 2018]. 


\title{
La experiencia de Aprendizaje en Acción en el barrio de Benicalap: una innovación docente impulsada en el Máster en Cooperación al Desarrollo de la Universitat Politècnica de València
}

\author{
Victoria Pellicer-Sifres ${ }^{\mathrm{a}}$, Alejandra Boni ${ }^{\mathrm{b}}$, Monique Leivas Vargas ${ }^{\mathrm{c}}$, Vania Wassel \\ Antich $^{\text {d }}$ \\ ${ }^{\mathrm{a}}$ INGENIO (CSIC-UPV), Universitat Politècnica de València. vicpelsi@ingenio.upv.es, ${ }^{\mathrm{b}}$ INGENIO \\ (CSIC-UPV), Universitat Politècnica de València. aboni@dpi.upv.es, ${ }^{\mathrm{c}}$ INGENIO (CSIC-UPV), \\ Universitat Politècnica de València. moleivas@ingenio.upv.es, ${ }^{\mathrm{d}}$ Investigadora \\ independiente.vania zz@hotmail.com
}

\begin{abstract}
This article aims to analyze an innovative teaching and learning experience carried out by the "Development Cooperation Master's Degree" taught at the Politechnical University of València (UPV), Spain. During two weeks, the students of the Master carried out an Action Learning process in the neighborhood of Benicalap (Valencia), with the aim to explore how the housing conditions in the neighborhood influence on the youth's learning and aspirations. The process was developed with the participation of three local organization. As outputs of this research, some proposals for improving the neighbourhood were presented to several actors from Benicalap. University exercised then a part of its social responsibility, moving lessons from the classroom to the street. In turn, UPV students acquired social and technical skills for their personal and professional development.
\end{abstract}

Keywords: Action Learning, Innovative pdagogy, Development, Cooperation, Youth'saspirations

\section{Resumen}

Desde el Máster Universitario de Cooperación al Desarrollo de la UPV se impulsó en el barrio de Benicalap una acción de innovación educativa para conectar la universidad con su entorno social. La metodología utilizada fue la del "Aprendizaje en acción”, el cual se define como un proceso de aprendizaje que es aplicable a situaciones donde los y las participantes se enfrentan a problemas complejos y aprenden explorando nuevas oportunidades, en lugar de aplicar las rutinas de sistemas pre-establecidos. Durante 12 días, el alumnado del máster trabajó conjuntamente con tres asociaciones del barrio (el IES Benicalap, con Casa Caridad y con la asociación Ultramarins 154), con el fin de explorar cómo influyen las condiciones de habitabilidad de los y las jóvenes de Benicalap en su aprendizaje. A partir de esta investigación, se lanzaron propuestas de mejora del barrio y se compartieron públicamente con los actores y vecinos/as del barrio. De esta manera la Universidad ejerció en parte su responsabilidad social, trasladando el aula al barrio. A su vez, el alumnado de la UPV adquirió competencias sociales y técnicas que les servirán para su desarrollo personal y profesional. Es esta comunicación, contamos la experiencia, los aprendizajes obtenidos y algunas reflexiones entorno a la metodología de aprendizaje. 
Palabras clave: Aprendizaje en acción, innovación educativa, desarrollo, cooperación, aspiraciones de la juventud

(Nota: el texto de la presente comunicación está basado en la publicación de las mismas autoras: Boni et al, 2017).

\section{Introducción}

La experiencia de Aprendizaje en Acción en el barrio de Benicalap fue una iniciativa educativa impulsada por el Máster en Cooperación al Desarrollo de la UPV, en colaboración con la asociación Ultramarins 154, la ONG Casa Caridad y el Instituto de Educación Secundaria (IES) Benicalap.

Durante los días comprendidos entre el 29 de mayo y el 9 de junio de 2017 los y las estudiantes del Máster en Cooperación de la Universitat de València (UPV) realizaron un proceso de Aprendizaje en Acción en el barrio de Benicalap (Valencia), con el objetivo de explorar cómo influyen las condiciones de habitabilidad del barrio en las aspiraciones de aprendizaje de los y las jóvenes de Benicalap.

\subsection{El Máster en Cooperación al Desarrollo de la UPV y el Aprendizaje en Acción}

El Máster en Cooperación al Desarrollo de la UPV tiene como objetivo formar a profesionales del desarrollo comprometidos, sensibles a los diferentes contextos, con visión crítica y cuya práctica sea a su vez consciente y reflexiva. Por ello, durante la planificación de su itinerario educativo se plantea la integración de metodologías docentes que consigan desarrollar e implementar dichas capacidades.

Con este fin, en el marco de la asignatura de "Procesos de Desarrollo" se consideró apropiado incorporar la metodología de "Aprendizaje en Acción" (en adelante AA). Se considera que este proceso, al ser desarrollado en un contexto con problemáticas reales y a la vez cercanas, contribuye más al desarrollo de dicha práctica crítica y reflexiva que las clases teóricas dentro de las aulas.

En concreto, el AA se define como un proceso de aprendizaje que es aplicable a situaciones donde los y las participantes se enfrentan a problemas complejos y aprenden explorando nuevas oportunidades, en lugar de aplicar las rutinas de sistemas pre-establecidos (Pedler y Burgoyne, 2000). Este tipo de aprendizaje tiene también una dimensión ética (De Carli y Kinnear, 2015), por la cual las experiencias de las participantes forman parte de una amplio tipo de actividades que pueden contribuir positivamente a las iniciativas de las organizaciones locales que acompañan el AA. La contribución puede ser en forma de generar productos (como informes de investigación) o de iniciar procesos (por ej. de diálogo y movilización) que tienen una relevancia para las necesidades y aspiraciones de las organizaciones participantes.

\subsection{Las organizaciones participantes en el proceso de $\mathrm{AA}$ en el barrio de Benicalap}

De lo anterior se desprende que la implicación en el proceso por parte de las organizaciones con las que se desarrolla el AA es un requisito indispensable para poder identificar, 
comprender y analizar las problemáticas así como para poder elaborar propuestas de acción realistas y alineadas con las necesidades de las organizaciones. En nuestra experiencia participaron tres organizaciones del barrio de Benicalap: Ultramarins 154, Casa Caridad y el IES Benicalap.

Ultramarins 154 (UTM154) es una asociación que promueve actividades culturales, lúdicas y gastronómicas en el barrio de Benicalap. Colaboró durante el proceso de AA poniendo a disposición toda su infraestructura para la realización de las diferentes actividades. Durante los 12 días del proceso, fue el lugar de referencia para los encuentros formales e informales, los momentos de trabajo en grupos, las sesiones de formación y los espacios de reflexión en plenario.

Casa Caridad (Asociación Valenciana de Caridad) es una institución sin ánimode lucro, privada, independiente, sin ninguna identidad política o religiosa, cuyo fin es promover la reinserción y prevenir la exclusión social en personas vulnerables. Los y las estudiantes del máster trabajaron concretamente con la Escuela Infantil del centro, que cuenta con 90 niños y niñas en riesgo de exclusión social de entre 1 a 3 años. El objetivo de la escuela, más allá de ofrecer un lugar de convivencia y aprendizaje infantil, es también permitir conciliar la vida laboral y familiar a los padres y madres y facilitarles la búsqueda de empleo.

El IES Benicalap es un centro en el que se imparten diferentes niveles educativos: ESO; bachillerato en las modalidades de Ciencias, Tecnología y Humanidades; ciclos formativos de grado medio (electromecánica y carrocería), de grado superior (automoción, artista fallero y construcción de escenografías) y dos programas de cualificación profesional inicial (carrocería e informática). Los y las estudiantes del máster trabajaron concretamente con dos clases de bachillerato (Humanístico y Mixto) y con una clase de $4^{\circ}$ de la ESO (de Programa de Refuerzo).

Imagen 1: Plano del Barrio Benicalap y ubicación de las organizaciones participantes

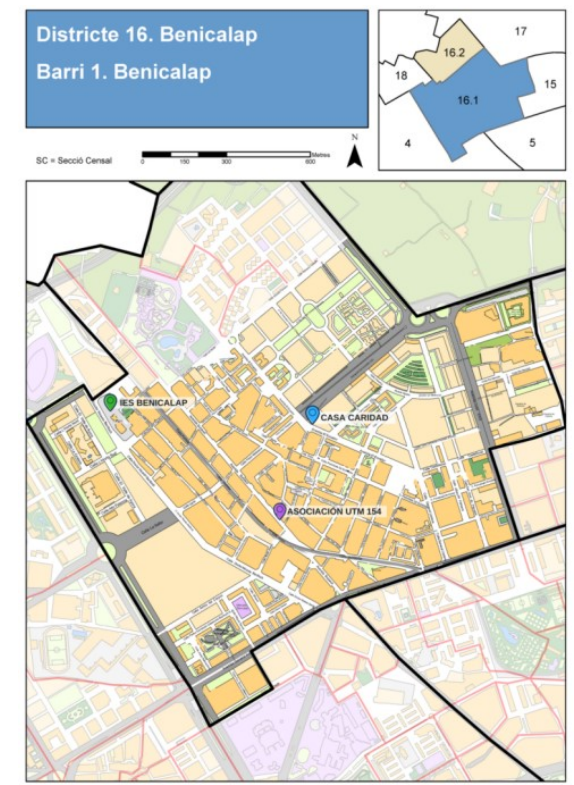

Fuente: Oficina de estadística del Ayuntamiento de Valencia (2016)

En la imagen 1 se muestra la ubicación de las 3 organizaciones en el barrio de Benicalap. Este barrio fue un municipio con autonomía propia hasta finales del siglo XIX, cuando fue 
anexionado a la ciudad de Valencia. Su población censada en 2016 era de 39.635 habitantes (Oficina de Estadística de Valencia, 2016). En los años 50 el barrio estaba habitado por un reducido número de personas, autóctonas, que vivían de trabajar la huerta. Durante los años 60, el barrio de Benicalap crece exponencialmente debido a que recibe inmigración de otros pueblos y ciudades que buscan trabajo en Valencia. Se construyen viviendas de manera no planificada y el barrio se convierte en un barrio dormitorio de la ciudad de Valencia. A partir de los años 70 empiezan las movilizaciones de las vecinas y vecinos del barrio que se agrupan en la Asociación de Benicalap exigiendo demandas básicas como la instalación de alumbrado público, espacios verdes o dotaciones educativas.

En la actualidad, la gran mayoría de la población trabaja en sectores que necesitan poca cualificación. Existe un elevado índice de familias en situación de exclusión social: según el estudio del Ayuntamiento de Valencia sobre áreas vulnerables (2016), el 27,7\% de la población de Benicalap se encuentra en situación de vulnerabilidad. El tejido asociativo es débil y está desvinculado de la juventud del barrio. El patrimonio histórico y cultural de barrio está descuidado por parte de la administración pública y existen muchos solares abandonados.

\section{Objetivos: El proceso de Aprendizaje en Acción en el barrio de Benicalap}

La temática de investigación del proceso de AA fue pensada y dialogada previamente con las organizaciones participantes, con la finalidad de escoger un tema que fuese relevante y de interés para las organizaciones a la vez que viable y realista con las limitaciones del proceso de AA (escaso tiempo y recursos, principalmente).

Se optó por plantear como temática general compartida explorar "cómo las condiciones de habitabilidad de Benicalap influyen en el bienestar de los y las jóvenes del barrio". Entre los estudiantes del máster se formaron cuatro grupos con objetivos de estudio distintos. De esta manera, en función de la naturaleza de cada grupo se concretó y matizó esta pregunta general inicial. (Ver tabla 1).

Tabla 1: Características generales de los grupos

\begin{tabular}{|c|c|c|c|c|}
\hline $\begin{array}{l}\text { Nombre } \\
\text { del grupo }\end{array}$ & $\begin{array}{c}\mathrm{N}^{\mathrm{o}} \\
\text { estudiantes } \\
\text { del máster }\end{array}$ & $\begin{array}{l}\text { Grupo objeto } \\
\text { de estudio }\end{array}$ & ¿Pregunta de investigación? & $\begin{array}{c}\text { ¿Utiliza } \\
\text { herramientas } \\
\text { visuales? }\end{array}$ \\
\hline $\begin{array}{l}\text { Grupo } \\
\text { Proceso } \\
\text { Máster }\end{array}$ & 4 & $\begin{array}{l}\text { El alumnado } \\
\text { del máster ( } 21 \\
\text { estudiantes) }\end{array}$ & $\begin{array}{l}\text { ¿Qué elementos del AA } \\
\text { facilitan u obstaculizan las } \\
\text { aspiraciones de aprendizaje } \\
\text { de los y las estudiantes del } \\
\text { máster? }\end{array}$ & Sí \\
\hline $\begin{array}{l}\text { Grupo } \\
\text { Espacio } \\
\text { Público }\end{array}$ & 4 & $\begin{array}{l}\text { Jóvenes de } \\
\text { Benicalap } \\
\text { (muestra no } \\
\text { predefinida) }\end{array}$ & $\begin{array}{l}\text { ¿De qué manera el espacio } \\
\text { público del barrio de } \\
\text { Benicalap afecta al bienestar } \\
\text { de las/los jóvenes del barrio? }\end{array}$ & Sí \\
\hline $\begin{array}{l}\text { Grupo } \\
\text { Casa } \\
\text { Caridad }\end{array}$ & 7 & $\begin{array}{l}\text { Escuela } \\
\text { Infantil de } \\
\text { Casa Caridad }\end{array}$ & $\begin{array}{l}\text { ¿Cómo las condiciones de } \\
\text { habitabilidad en las que se } \\
\text { encuentran las familias } \\
\text { influyen y afectan al } \\
\text { bienestar y el aprendizaje de }\end{array}$ & No \\
\hline
\end{tabular}




\begin{tabular}{|c|c|c|c|c|}
\hline & & & $\begin{array}{l}\text { los niños y niñas que acuden } \\
\text { a la Escuela Infantil? }\end{array}$ & \\
\hline $\begin{array}{l}\text { Grupo } \\
\text { IES }\end{array}$ & 6 & $\begin{array}{l}3 \text { clases del } \\
\text { IES Benicalap }\end{array}$ & $\begin{array}{l}\text { ¿Cómo influyen las } \\
\text { condiciones de habitabilidad } \\
\text { en las aspiraciones de } \\
\text { aprendizaje de los y las } \\
\text { estudiantes del instituto de } \\
\text { Benicalap? }\end{array}$ & No \\
\hline
\end{tabular}

El primero de los grupos -Grupo Proceso Máster- albergó dos objetivos de naturaleza distinta a los demás: en primer lugar documentar el proceso de AA de los y las estudiantes del máster, y en segundo lugar reflexionar críticamente sobre dicho proceso, analizando qué elementos potenciaron o limitaron el aprendizaje de los y las estudiantes. Fruto del trabajo de este grupo se editó un vídeo resumen del proceso, accesible en http://bit.ly/AA_videoprocesos

El segundo de los grupos -Grupo Espacio Público- exploró cómo las condiciones de habitabilidad del barrio influían en el bienestar de los y las jóvenes. Este grupo se diferenciaba del resto por no contar con un colectivo concreto con quien desarrollar conjuntamente el proceso de AA, de manera que el grupo no disponía a priori de una muestra de estudio acotada. También en este caso, fruto del trabajo del grupo se editó un vídeo resumen con los principales hallazgos, accesible en http://bit.ly/AA_videoespaciopublico

El tercer grupo -Grupo Casa Caridad- trabajó conjuntamente con los padres y madres cuyos hijos/as asisten a la Escuela Infantil. En este caso, cuando se exploraron las condiciones de habitabilidad no únicamente se preguntó por el espacio público del barrio, sino que también se incluyeron cuestiones relativas a la propia Escuela Infantil y a los hogares de las familias. En relación al bienestar, se indagó en referencia al bienestar de los y las niñas que acudían a la escuela.

Finalmente, el cuarto grupo -Grupo Instituto- trabajó conjuntamente con estudiantes de dos clases de $1^{\circ}$ de Bachiller y una clase de $4^{\circ}$ d'E.S.O., así como con profesorado implicado e interesado en el proceso de AA. En este caso, también las condiciones de habitalidad fueron entendidas más allá del espacio público del barrio (se incluyó también condiciones relativas a la infraestructura del propio instituto y a los hogares de los y las alumnas). En cuanto al bienestar, este se concretó acotándose finalmente en torno a la cuestión de los aprendizajes de los estudiantes (aprendizajes obtenidos, potenciados, limitados, aspiraciones, etc.).

Cada grupo contó con el acompañamiento de una facilitadora por parte del equipo de profesorado del máster (que corresponden a las cuatro autoras de esta comunicación).

\section{Desarrollo de la innovación}

El proceso de AA fue planificado en base a cinco fases principales que tuvieron lugar durante los doce días que duró la investigación: 1) Preparación; 2) Diagnóstico; 3 ) Análisis; 4) Propuestas acción y 5) Devolución / difusión de los resultados. En la Figura 1 se representan de manera gráfica. 
Figura 1: Fases del proceso de Aprendizaje en Acción

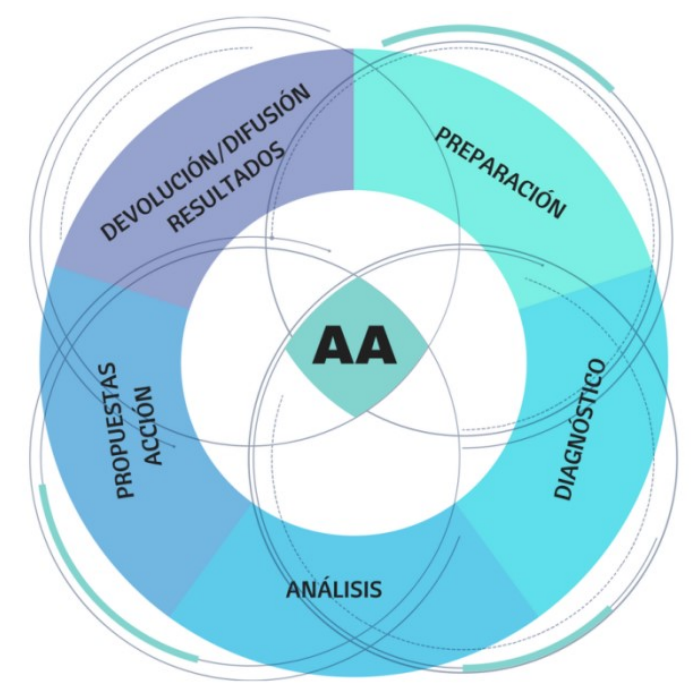

Fuente: Elaboración propia

En cada fase, distintas técnicas de investigación fueron empleadas:

\section{Fase 1: Preparación}

En esta fase (días 1-2), el grupo se familiarizó con el barrio y con los actores con los que cada grupo iba a trabajar. Se realizó un primer recorrido por el barrio para conocer sus lugares de referencia (técnica transecto) y se conocieron a los representantes de las distintas organizaciones. Se presentaron los elementos teóricos que orientarían la investigación y se planificó la agenda de trabajo.

\section{Fase 2: Diagnóstico}

En esta fase (días 2-7) el grupo recabó la información para responder a las preguntas de investigación. Las técnicas empleadas para ellofueron:
* Cuestionarios
* Talleresparticipativos
* Narrativaspersonales
* Entrevistassemi-estructuradas
* Observaciónparticipante

La realidad de cada grupo (su pregunta de investigación, su grupo objeto de estudio, etc) así como la realidad de las organizaciones participantes (su disponibilidad, su capacidad de implicación, etc) supuso que no todos los grupos pudiesen poner en práctica todas las técnicas de investigación. Para mayor detalle sobre las técnicas utilizadas en cada grupo, ver tabla 2.

Tabla 2: Técnicas utilizadas durante la fase de diagnóstico

\begin{tabular}{|c|c|c|c|c|}
\hline Técnica & G1-Proceso & $\begin{array}{l}\text { G2-Espacio } \\
\text { Público }\end{array}$ & $\begin{array}{c}\text { G3-Casas } \\
\text { Caridad }\end{array}$ & G4-Instituto \\
\hline
\end{tabular}

(cc) EY-NC-ND 2018, Universitat Politècnica de València 


\begin{tabular}{|c|c|c|c|c|}
\hline Transecto & $\begin{array}{l}1 \text { transecto en } \\
\text { colectivo, al } \\
\text { inicio del } \\
\text { proceso }\end{array}$ & $\begin{array}{c}\text { Varios } \\
\text { transectos a lo } \\
\text { largo de la } \\
\text { primera semana }\end{array}$ & $\begin{array}{l}1 \text { transecto en } \\
\text { colectivo, al } \\
\text { inicio del } \\
\text { proceso }\end{array}$ & $\begin{array}{l}1 \text { transecto en } \\
\text { colectivo, al } \\
\text { inicio del } \\
\text { proceso }\end{array}$ \\
\hline Cuestionario & $\begin{array}{l}\text { Al inicio y al } \\
\text { final del } \\
\text { proceso }\end{array}$ & $\begin{array}{c}\text { No se realizaron } \\
\text { cuestionario }\end{array}$ & $\begin{array}{c}21 \\
\text { cuestionarios a } \\
\text { los padres y } \\
\text { madres de la } \\
\text { Escuela Infantil }\end{array}$ & $\begin{array}{l}70 \text { cuestionarios } \\
\text { a los y las } \\
\text { estudiantes del } \\
\text { instituto }\end{array}$ \\
\hline $\begin{array}{c}\text { Talleres } \\
\text { Participativos }\end{array}$ & $\begin{array}{l}\text { No se } \\
\text { realizaron } \\
\text { talleres }\end{array}$ & $\begin{array}{c}\text { No se realizaron } \\
\text { talleres }\end{array}$ & $\begin{array}{c}1 \text { taller con } 25 \\
\text { padres y } \\
\text { madres de la } \\
\text { Escuela Infantil }\end{array}$ & $\begin{array}{c}9 \text { sesiones: } 3 \\
\text { talleres en } 3 \\
\text { aulas de } 10-20 \\
\text { estudiantes/aula }\end{array}$ \\
\hline Narrativas & $\begin{array}{l}\text { No se } \\
\text { realizaron } \\
\text { narrativas }\end{array}$ & $\begin{array}{c}\text { No se realizaron } \\
\text { narrativas }\end{array}$ & $\begin{array}{l}\text { No se } \\
\text { realizaron } \\
\text { narrativas }\end{array}$ & $\begin{array}{l}\text { Con } 8 \\
\text { estudiantes del } \\
\text { instituto }\end{array}$ \\
\hline Entrevistas & $\begin{array}{c}\text { Diarias: a los } \\
21 \text { estudiantes } \\
\text { y a las } 4 \\
\text { facilitadoras }\end{array}$ & $\begin{array}{c}\text { A } 12 \text { jóvenes, } 4 \\
\text { adultos y } 2 \\
\text { representantes } \\
\text { de asociaciones } \\
\text { del barrio. Se } \\
\text { utilizaron } \\
\text { fotografías } \\
\text { como recursos }\end{array}$ & $\begin{array}{c}\text { A } 3 \\
\text { trabajadoras } \\
\text { Casa Caridad y } \\
6 \text { familias }\end{array}$ & $\begin{array}{c}\text { A } 4 \\
\text { profesores/as } \\
\text { del instituto }\end{array}$ \\
\hline $\begin{array}{l}\text { Observación } \\
\text { participante }\end{array}$ & $\begin{array}{l}\text { Durante todo el } \\
\text { proceso }\end{array}$ & $\begin{array}{l}\text { Durante todo el } \\
\text { proceso }\end{array}$ & $\begin{array}{l}\text { Durante todo el } \\
\text { proceso }\end{array}$ & $\begin{array}{c}\text { Durante todo el } \\
\text { proceso }\end{array}$ \\
\hline
\end{tabular}

\section{Fase 3: Análisis}

En esta fase (días 6-8) se analizó la información recogida y se obtuvieron los resultados de la investigación. Para ello, se generaron categorías de análisis tomando como referencia los elementos teóricos pertinentes. A lo largo de esta fase se planificaron espacios para compartir con el resto de grupos los hallazgos preliminares y los finales.

\section{Fase 4: Propuestas para la Acción}

Esta fase (días 8-11) se trabajó de manera coordinada con la fase anterior. Los hallazgos preliminares permitieron obtener unas primeras ideas de propuestas para la acción. En el caso de los grupos de Casa Caridad e Instituto, estas propuestas fueron discutidas y complementadas con las organizaciones.

\section{Fase 5: Devolución y difusión de los resultados}

En esta fase (días 11-12) se prepararon los materiales de difusión de los resultados del proyecto: 2 posters explicativos del proceso y 3 posters que sintetizaron los resultados de 
los grupos Espacio Público; Casa Caridad e Instituto, respectivamente. El grupo Espacio Público, además, preparó un vídeo resumen de su experiencia.

El último día del proceso de AA se realizó una presentación pública de los resultados. En la plaza del barrio se expusieron los 5 posters, se presentó el vídeo del grupo Espacio Público y se generó un espacio de diálogo entre los participantes del proceso y los y las vecinas del barrio. Este fue un momento clave para compartir aprendizajes e impresiones, así como para reflexionar sobre cómo el proceso de AA podía estar contribuyendo a mejorar el bienestar de los y las jóvenes de Benicalap

Imagen 2: Estudiantes presentando los pósters durante la presentación pública

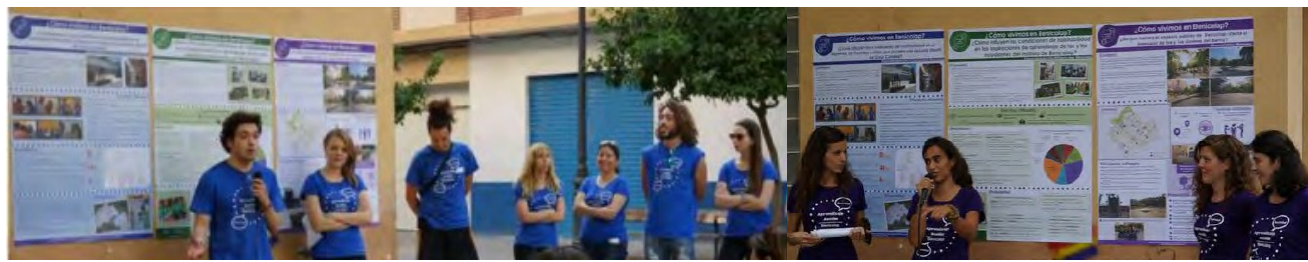

Fuente: Fotografia realizada por Carola Calabuig Tormo

Imagen 3: Estudiantes y vecindario visionando el vídeo durante la presentación pública

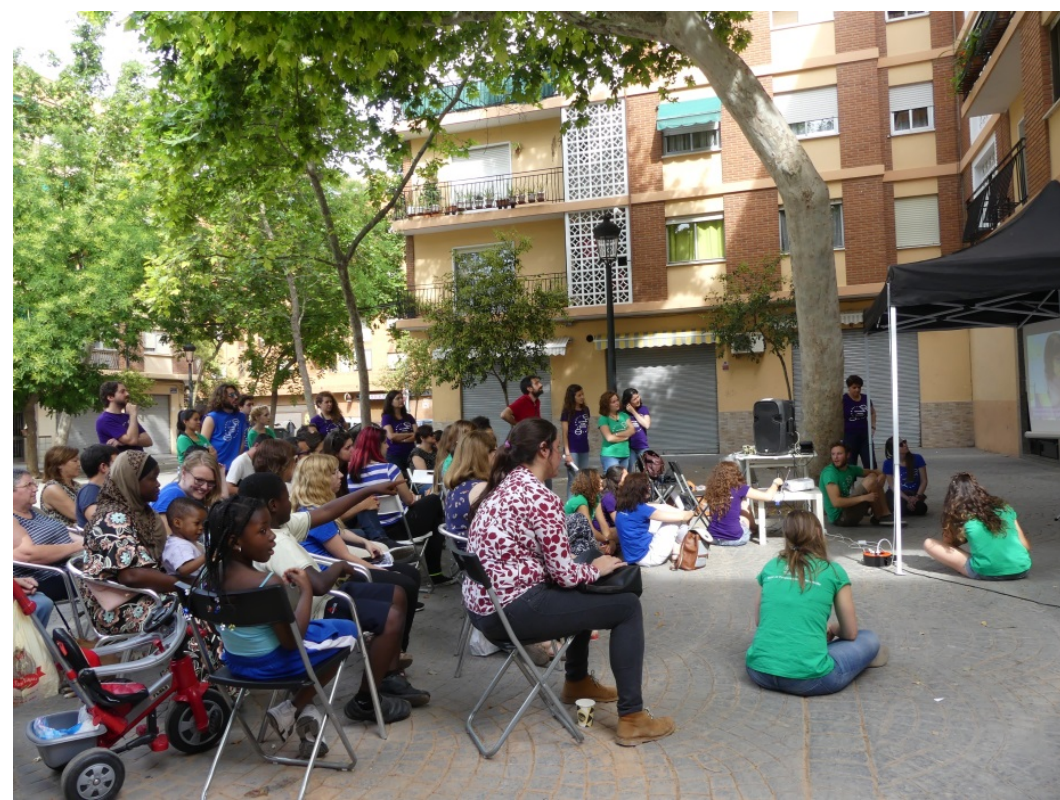

Fuente: Fotografia realizada por Carola Calabuig Tormo

El Grupo 1 - Procesos siguió trabajando durante este día de presentación pública de resultados. En los momentos de reflexión colectiva, recogió evidencias para dar respuesta a su pregunta de investigación y grabó material para ser incluido en el vídeo final del proceso. Este vídeo se presentó a todo el grupo del máster en la sede de Ultramarins, 15 días después de finalizar el AA. Para el grupo de los estudiantes del máster y las facilitadoras del proceso, significó un momento relevante para poder realizar un buen cierre. Habiendo podido tomar perspectiva, asentados algunos aprendizajes, reposadas las emociones y habiendo descansado, los estudiantes recibieron el vídeo producido por las compañeras del Grupo Procesos con gran agradecimiento y con amplio orgullo por los resultados conseguidos.

(cc) EY-NC-ND 2018, Universitat Politècnica de València 


\section{Resultados}

En este apartado planteamos unos resultados generales síntesis de los resultados individuales de cada uno de los cuatro grupos de trabajo.

\subsection{Sobre el espacio público}

Los diferentes grupos con los que se ha trabajado coinciden en afirmar que las dotaciones públicas de las que dispone el vecindario de Benicalap son insuficientes.

Los y las jóvenes demandan más lugares donde poder disfrutar de su ocio de una manera tranquila sin que se les rechace. Aquellos señalan una fuerte presencia policial en las zonas frecuentadas por la juventud, lo que contribuye a incrementar una sensación de malestar entre los y las jóvenes cuando ocupan los espacios públicos. Además, particularmente para las mujeres, la presencia policial no disminuye la sensación de inseguridad.

A las familias usuarias de la Casa de la Caridad también les gustaría que existieran espacios públicos limpios y adaptados para sus hijos e hijas pequeñas. Estos espacios deberían además estar mejor conectados a través del transporte público que también aparece como un limitante para las familias con pocos recursos económicos.

Los y las estudiantes del Instituto también demandan lugares donde reunirse para su ocio pero también para el estudio, y sugieren que el Instituto podría proporcionar algunos de estos espacios si se abriera más al barrio.

En definitiva, parece muy necesaria una mayor inversión pública en dotaciones para el barrio para el ocio y la participación juvenil. Las inversiones hechas en los últimos años (que básicamente se ubican en el nuevo Benicalap) no son accesibles para las personas con menos recursos económicos $\mathrm{y}$ han aumentado la sensación de un barrio dividido $\mathrm{y}$ fragmentado.

\subsection{Condiciones de habitabilidad}

La investigación ha arrojado dos resultados en esta línea; por un lado el estado de las aulas del Instituto no reúne las condiciones para que el aprendizaje se desarrolle adecuadamente. Los y las estudiantes manifiestan que la climatización de las aulas es bastante mejorable, tanto en invierno como en verano.

Con respecto a las familias usuarias de la Casa de la Caridad sí que se percibe que las condiciones de sus viviendas no son las más adecuadas para el bienestar de sus hijos e hijas. Tampoco lo es la limitada oferta de transporte público para poder desplazarse desde sus hogares hasta la Escuela Infantil lo que, en ocasiones, limita el acceso a ese recurso por parte de algunas familias.

En relación con la infraestructura de la Casa de la Caridad, las familias tienen una opinión muy positiva de los espacios que esta institución pone a disposición de sus hijos e hijas, excepto por lo que se refiere a espacios al aire libre de los que no dispone la institución. Esto se ve agravado por la falta de espacios públicos adecuados para los niños y niñas, como ya se ha señalado anteriormente. 
Nuevamente parece necesaria una mayor inversión pública para poder mejorar las condiciones del Instituto, la red de transporte del barrio y la mejora de las condiciones de habitabilidad.

\subsection{Aspiraciones de aprendizaje}

Los y las jóvenes de Benicalap que han participado en la investigación podrían ser considerados como una muestra relativamente representativa de una juventud que vive, crece y camina en un modelo social, marcado por la crisis económica, social y política, y construido en torno a valores capitalistas como el individualismo, el consumo, el dinero como indicador de éxito personal, etc.

Así pues, no es de extrañar que los resultados de los cuestionarios indicasen que la gran mayoría de las personas entrevistadas del Instituto consideraban el aprendizaje como una herramienta meramente instrumental para conseguir un trabajo o tener estabilidad económica; la mayoría de familias entrevistadas de Casa Caridad señalaban la opción "disponer de dinero" como aquello que más puede contribuir a la felicidad de sus hijos/as; y algunos jóvenes del barrio que aceptaron ser entrevistados por el grupo de espacio público explicaron que para ellos el bienestar era "tenerlo todo" o "tener estabilidad económica". No cabe duda de que una situación de precariedad económica tiene consecuencias directas en el bienestar de los y las jóvenes. No obstante, con ello la investigación refleja las consecuencias de un sistema en el que valores como la justicia, el bien común, la participación, la colectividad, las relaciones sociales o la sostenibilidad, por ejemplo, no son las guías de referencia.

Sin embargo, cuando a los y las jóvenes (del Instituto) se les da voz, sí que demandan poner en práctica los canales de participación de los que disponen o reclaman nuevos. Los espacios educativos formales se perfilan como lugares privilegiados en un contexto como el de Benicalap donde fomentar valores distintos a los mayoritarios en la sociedad donde viven los y las jóvenes.

Asimismo, aunque no abordado directamente en la investigación, los espacios asociativos (por ej. grupos de música, danza, cultura, voluntariado, etc.) pueden también ser espacios informales de aprendizaje donde poner en valor la participación, la colectividad, las relaciones sociales, etc. Como se ha señalado anteriormente, Benicalap no cuenta con una oferta de espacios a disposición de los y las jóvenes donde poder reunirse colectivamente y poder tener alternativas. Por ello, un barrio con una oferta de espacios a disposición de las organizaciones y con medidas activas de fomento del asociacionismo tiene mayor potencial para contribuir a la construcción de una juventud más activa $y$ comprometida con valores como la participación colectiva y que le da importancia a las relaciones sociales.

Como consecuencia de lo expuesto anteriormente, las propuestas de los estudiantes del máster de cooperación apuntaban a iniciativas para promover espacios de encuentro y participación entre los jóvenes de Benicalap, bien a través de la reutilización de espacios públicos existentes o con la construcción de espacios nuevos.

\subsection{Redes entre actores}

Tras el proceso de AA realizado y tras el espacio de debate público en la plaza del pueblo el día de la presentación pública, se visibiliza la importancia de conectar organizaciones del Benicalap, públicas y privadas, como son Ultramarins 154, el IES Benicalap, la Casa 
Caridad o la Asociación de Vecinos. El establecimiento de redes entre estas organizaciones sería muy relevante para dos objetivos principalmente:

- Para demandar colectivamente más inversión pública en infraestructura destinada al ocio y a la participación juvenil, la mejora de las condiciones del Instituto así como las condiciones de los parques y jardines del barrio.

- Para generar alianzas sólidas y promover acciones en el barrio que muestren a una juventud implicada y constructiva, al tiempo que reconozcan y potencien, de manera inclusiva y respetuosa, la amplia riqueza cultural del barrio.

El barrio de Benicalap tiene un gran potencial derivado de la gente que lo habita; también tiene un patrimonio muy rico, aunque por las limitaciones temporales de esta investigación no ha podido ser explorado adecuadamente. El esfuerzo conjunto de organizaciones con más trayectoria en el barrio, como la asociación de vecinos, conjuntamente con organizaciones de más reciente creación, como Ultramarins 154, e instituciones como el IES Benicalap o la Casa de la Caridad que están brindando un servicio esencial para el barrio, es necesario para la mejora de las políticas públicas hacia Benicalap y para incrementar las opciones para participar colectivamente y ofrecer otros modelos de convivencia y relaciones sociales. Esto es especialmente relevante para el público juvenil que ha sido el foco principal de nuestra investigación.

\section{Conclusiones}

Finalmente, en este apartado incluimos nuestras conclusiones acerca de la metodología de AA. Como docentes del máster en Cooperación al Desarrollo, sí consideramos positivo y satisfactorio haber incluido esta innovación educativa en el programa docente del máster. Desde nuestro punto de vista, gracias a esta metodología se ha conseguido que el aprendizaje de los y las estudiantes del másterhaya podido ser más profundo y más interiorizado por el hecho de haberse obtenido a través de la propia práctica. Enumeramos a continuación cuatro aspectos clave para los que consideramos que la metodología del AA es una herramienta pedagógica realmente apropiada:

\subsection{EI AA como proceso de aprendizaje relevante para los y las profesionales del desarrollo}

El proceso de AA realizado ha sido valorado muy positivamente entre los y las estudiantes del máster de cooperación. Se realizó un proceso de sistematización y algunas evaluaciones intermedias, y a través de ambas técnicas se comprobó que los y las estudiantes del Máster de Cooperación habían desarrollado habilidades relacionadas con el trabajo en equipo y la facilitación, con la realización de análisis sociales colaborativos o con la traducción y presentación de evidencias de la investigación a audiencias no académicas, entre otras.

El total de los y las estudiantes consideró que el AA había sido una metodología apropiada para poner en prácticas las cuestiones teóricas aprendidas durante el curso, como por ejemplo el uso de las técnicas de investigación, el análisis de datos, la complejidad de los procesos de participación, etc.

\subsection{El AA, un proceso generador de capacidades para el aprendizaje colectivo}


Los cuatro grupos experimentaron, a lo largo de los doce días intensos de trabajo, momentos de tensión, de conflicto, de desencuentros, de necesidad de toma de decisiones rápidas y de frustración. La complejidad de los procesos de desarrollo; el trabajo en tiempo real con organizaciones con agendas, ritmos e intereses distintos; la inseguridad por falta de experiencia; y, en definitiva, la imprevisibilidad de los procesos vivos son factores que forman parte natural del propio proceso de AA. No pueden tenerse en cuenta pero sí puede aprenderse a manejarlos en el momento en el que aparezcan.

A este aspecto hacían referencia los y las estudiantes del máster cuando afirmaban haber puesto en práctica capacidades personales y sociales como la escucha activa, el respeto, la resolución de conflictos y el reconocimiento a las diferencias de opiniones, entre otras. En resumen, podríamos concluir que el proceso de AA ha contribuido a construir y reforzar capacidades con las que superar, de manera colectiva, las barreras encontradas a lo largo del proceso.

\subsection{El AA, un proceso para aprender sobre facilitación}

Un segundo aspecto relevante al que el proceso de AA contribuyó directamente fue a la puesta en práctica del rol de facilitador/a de procesos de desarrollo. A pesar de haber reflexionado durante las clases teóricas acerca de cuán importante son cuestiones como promover una participación real; vigilar y minimizar las dinámicas de poder; cuidar los espacios, los tonos, las palabras; etc., los estudiantes confesaban que fue a través de los talleres y entrevistas realizadas cuando realmente tomaron conciencia de la complejidad y la importancia de todas estas cuestiones.

La gran mayoría de estudiantes marcó el aprendizaje entorno a la figura del dinamizador/a de procesos como uno de los principales retos del proceso, y reconocieron la necesidad de seguir profundizando en este aprendizaje a través de la práctica.

\subsection{El AA, un proceso que reconoce la importancia de los espacios (formales e informales) para compartir y dialogar}

La agenda de los doce días que duró del proceso de AA estaba relativamente organizada, de manera que cada grupo pudiese adaptarla a sus necesidades. Las fases, tal y como se ha explicado en el punto 1.3.2, estaban organizadas según: preparación; diagnóstico; análisis; propuestas acción y devolución de los resultados. No obstante, existieron durante estas fases multitud de espacios de encuentros, de diálogo y de compartir que marcaron la identidad del proceso.

Algunos de estos espacios estaban previamente agendados, como los plenarios para compartir con el resto de grupos la evolución de cada investigación, o la presentación pública en la plaza del pueblo. Otros espacios de intercambio emergieron o sucedieron de manera informal, como los momentos de las comidas, los descansos o los encuentros por el barrio con otros actores. Para los y las estudiantes, tanto unos como otros resultaron fundamentales para compartir emociones, conectar con la realidad de los otros grupos y sentir el proceso de AA como un proceso realmente colectivo. El aprendizaje a este respecto fue el de reconocer la importancia de cuidar, mantener y contribuir a que emerjan estos espacios. 
Como conclusión general, podríamos afirmar que ciertas cuestiones de las aprendidas, útiles y necesarias en la formación de un o una profesional del desarrollo, únicamente pueden llegar a aprenderse a través de una práctica como esta.

\section{Referencias}

- BONI, A., PELLICER-SIFRES, V; LEIVAS M. y WASSEL V. (2017). “¿Cómo vivimos en Benicalap? Una experiencia de Aprendizaje en Acción". En Cuadernos Docentes en Procesos de Desarrollo, vol2.

- DE CARLI, B. y KINNEAR, M. (2015).“Learning amidst urban practices: reflections on Architecture Sans Frontières" en Charrette, vol 2, issue 1, p. 46-56.

- OFICINA D'ESTADÍSTICA DE L'AJUNTAMENT DE VALÈNCIA (2016): Àrees vulnerables a la ciutat de València. Valencia. $<$ http://www.valencia.es/ayuntamiento/webs/estadistica/CatPub/files/Arees\%20Vulnera bles.pdf $>$ [Consulta: 01 de junio de2017]

- PEDLER, M. y BURGOYNE, J.G. (2000). Handbook of Action Research: Participative Inquiry and Practice. London: Sage. 


\title{
El estudio de un caso empresarial de decisiones de inversión con técnicas de gamificación en la motivación del alumnado
}

\author{
Paola Plaza Casado ${ }^{1}$, Carmen de la Orden de la $\mathrm{Cruz}^{2}$, Sandra Escamilla Solano ${ }^{3}$
}

\begin{abstract}
The disconnection between university and business is one of the permanent debates in the educational and business spheres. This fact causes that the students feel demotivation when not appreciating the application of the learned ones during their formation in the real work. The objective of this work was to evaluate the motivation of the student through a gamification activity with incentives based on a real case about making investment decisions in the company. The activity was carried out with students of the Degree in Accounting and Finance and their double degrees for the 2017/18 academic year. The results of the research confirm that the realization of an activity based on a real case with gamification techniques and with the establishment of incentives in the final grade has positive effects on student motivation.
\end{abstract}

\section{Keywords: \\ gamification, study of real cases, incentives, motivation, Socrative}

\begin{abstract}
Resumen
La desconexión entre universidad y empresa es uno de los debates permanentes en los ámbitos educativo y empresarial. Este hecho provoca que los alumnos sientan desmotivación al no apreciar la aplicación de los aprendido durante su formación en el mundo laboral. El objetivo de este trabajo fue evaluar la motivación del alumno a través de una actividad de gamificación con incentivos basada en un caso real sobre la toma decisiones de inversión en la empresa. La actividad fue realizada con alumnos del Grado de Contabilidad y Finanzas y sus dobles grados del curso 2017/18. Los resultados de la investigación confirman que la realización de una actividad basada en un caso real con técnicas de gamificación y con establecimiento de incentivos en la calificación final tiene efectos positivos en la motivación del alumnado.
\end{abstract}

Palabras clave: gamificación, estudio de casos reales, incentivos, motivación, Socrative.

\footnotetext{
${ }^{1}$ Universidad Rey Juan Carlos, paola.plaza@urjc.es

${ }^{2}$ Universidad Rey Juan Carlos, carmen.delaorden@urjc.es

${ }^{3}$ Universidad Rey Juan Carlos sandra.escamilla@urjc.es
} 


\section{Introducción}

Vivimos en un mundo cambiante, que se mueve muy rápido y la educación y transferencia del conocimiento no se pueden quedar atrás, de ahí que surja la necesidad de una mejora y actualización continua. Las universidades tienen la responsabilidad social de asegurar la transmisión del conocimiento contextualizado y actualizado (García -Ramírez, 2011; Bozu y Canto, 2009). Además, el ámbito universitario es un lugar que no puede mantenerse al margen de la realidad social y económica y debe enseñar a los alumnos a desarrollar capacidades que les permitan enfrentarse al mundo laboral.

La adaptación de las universidades españolas a Espacio Europeo de Educación Superior (EEES) ha supuesto el reto para los docentes de mejorar la docencia impartida y adaptarla a los nuevos tiempos y a una realidad cambiante. Uno de los objetivos principales del EEES es un cambio metodológico de la enseñanza convirtiendo el aprendizaje en el eje de la educación, dónde el alumno tiene un papel más activo (Blanco, 2010). Si bien, hay que tener en cuenta que, para realizar esos cambios, se parte con dos problemas importantes como son: la falta de motivación del alumnado (García y Álvarez, 2007) y también la del profesorado (Chain Navarro, Martínez Solís y Sánchez Baena, 2008). Centrándonos en la motivación del alumno como uno de los grandes factores asociados al rendimiento académico (Vargas, 2007), se entiende por motivación "el conjunto de razones por las que las personas se comportan de las formas en que lo hacen” (Ajello, 2003). Así, en el ámbito educativo, la motivación debe ser considerada como" la disposición positiva para aprender y continuar haciéndolo de manera autónoma" (Pereira, 2009), con dinámicas que logran captar el interés y la participación de los estudiantes, motivándoles hasta conseguir un pensamiento creativo e innovador, facilitando así el conocimiento de competencias transversales y profesionales (González, 2014).

Los proyectos de innovación docente aseguran una enseñanza renovada e interdisciplinar, que junto con que las Tecnologías de la Información y la Comunicación (en adelante, TIC) y las redes sociales posibilitan la divulgación del conocimiento (Molina, 2012; Salinas, 2004). Las TIC, los entornos virtuales de aprendizaje personal y el uso de herramientas didácticas ayudan con el diseño de actividades, lo que mejora la innovación docente y los factores que motivan, e interesan y refuerzan el aprendizaje del alumnado (Díaz-Marín, Vázquez Martínez y McMullin, 2014; Espuny, González, Leixa y Gisbert, 2011).

Muchos trabajos académicos establecen relación entre las metodologías activas, la motivación y las nuevas tecnologías. Estos estudios hablan de un impacto positivo de una enseñanza activa que se ve reflejada en la motivación y, a la larga, tiene como resultado un aprendizaje duradero. Las posiciones de los distintos autores respecto a la motivación y el aprendizaje son las se resumen en la tabla 1.

Tabla 1: Motivación y aprendizaje

\begin{tabular}{|l|l|}
\hline Relación entre la motivación y el aprendizaje & \multicolumn{1}{|c|}{ Autores } \\
\hline $\begin{array}{l}\text { Los estudiantes tienen una mayor motivación } \\
\text { cuando aprenden con un método activo }\end{array}$ & $\begin{array}{l}\text { Ochsendorf, Boehncke, Sommerlad y Kaufmann } \\
(2006)\end{array}$ \\
\hline Aprendizaje basado en problemas & Nalesnik, Heaton, Olsen, Haffner y Zahn (2004) \\
\hline
\end{tabular}

(cc) EY-NC-ND 2018, Universitat Politècnica de València

Congreso IN-RED (2018) 


\begin{tabular}{|l|l|}
\hline $\begin{array}{l}\text { Mejora de la satisfacción del alumno cuando hay } \\
\text { motivación }\end{array}$ & Cheng, Rhee, Baik y Os (2009) \\
\hline $\begin{array}{l}\text { La motivación intrínseca es un factor predictivo } \\
\text { del éxito académico }\end{array}$ & Deci y Ryan (1985) \\
\hline
\end{tabular}

Fuente: Elaboración propia

Motivación y gamificación están íntimamente ligadas. Werbach y Hunter (2010) definen esta técnica como la utilización de elementos de juego y sus técnicas de diseño en otros ámbitos que no son de juego. En este sentido, cabe precisar que la gamificación es distinta de los que se conoce como serious game o game-based learning, el cual se basa en la utilización de juegos como tal para el aprendizaje (Contreras, 2016).

Los diversos estudios realizados demuestran que la gamificación aumenta la motivación a aprender (Bergin y Reilly, 2005; Kapp, 2012, entre otros) y mejora la experiencia del aprendizaje (Meister, 2013). Además, aumenta el rendimiento académico (Perrota, Featherstone, Aston y Houghton., 2013) y desarrolla capacidades de pensamiento estratégico, de decisión en grupo y de negociación (Kirriemuir y McFarlane, 2007). La utilización de esta técnica para incrementar el interés de los estudiantes ha sido explorada en Educación en diversos ámbitos como en programación informática (Becker, 2001), sistemas operativos (Hill et al., 2003), idiomas (Martínez y Terrón, 2016), publicidad y relaciones públicas (Estanyol, Montaña y Lalueza, 2013) y en otros ámbitos (véase la revisión de la literatura realizada por Fui-Hoon, Zeng, Rajasekhar y Padmanabhuni (2014).

En Finanzas, el área de conocimiento en el que se centra este trabajo, los estudios realizados se abordan en el ámbito de los mercados financieros al basarse en juegos de gestión de carteras (Dressler, Rachfall, Kapanen y Foerster-Trallo, 2016, Gómez-Martínez, Prado-Roman y Escamilla-Solano, 2016) de finanzas corporativas. Cabe precisar que los estudios realizados son profesionales y fuera del sector educativo (Petridis, Hadjicosta, Dunwell, Lameras, Baines, Shi, Ridgway, Baldin y Lightfoot, 20016). De este modo, este trabajo prentede cubrir el otro área de las Finanzas, las corporativas, en el cual aún no ha sido constratada la gamificación en cursos de grado de la universidad. Para ello, se realizó una actividad de gamificación con incentivos basada en un caso real sobre la toma de una decisión de un proyecto de inversión en una empresa con el objetivo de evaluar la motivación del alumnado en el aprendizaje de la asignatura mediante estas herramientas. La metodología se ha basado en un cuestionario y en la realización de un modelo de regresión.

Tras esta breve introducción, a continuación se detallan los objetivos del estudio, cómo fue el desarrollo de la innovación, los resultados de la misma, finalizando con unas conclusiones.

\section{Objetivos}

El objetivo principal de este trabajo implica una doble contribución en el análisis de la motivación del alumnado. Por una parte, con la utilización de una actividad de un caso real de una empresa con técnicas de gamificación y, por otra, con el establecimiento de un incentivo en la calificación de la nota final por su realización. 
Para ello, la evaluación se realiza en dos partes. En la primera, se analiza la motivación de los alumnos por la realización de la actividad como un juego a través de un cuestionario donde los objetivos intermedios a evaluar fueron: la percepción sobre adquisición de conocimientos, la mejora de conocimientos, el estudio de caso ligado a la motivación y la motivación en su conjunto (véase tabla 2). Y, en la segunda parte, se intenta cuantificar específicamente mediante una regresión simple el grado de sensibilidad entre la motivación y el incentivo dado en la actividad. El modelo de regresión planteado fue el recogido en la ecuación 1.

$$
y=\alpha+\beta x+\varepsilon \quad(\text { ecuación } 1)
$$

Siendo:

y: el grado de motivación del juego

x: cómo se valora el incentivo dado en la nota de la actividad

\section{Desarrollo de la innovación}

La experiencia de la investigación se llevó a cabo en el ámbito educativo universitario, en concreto, en el grado de Contabilidad y Finanzas y sus dobles grados con Derecho y con Relaciones Laborales, en la asignatura de Decisiones de Inversión y Financiación.

La investigación consistió en hacer un juego en clase en grupos proporcionando a los alumnos un caso empresarial real donde tenían que realizar la estimación de flujos de caja y, posteriormente, tomar la decisión de llevarlo o no cabo utilizando el método de decisión más adecuado entre los que habían sido estudiados durante el curso. La actividad se realizó en clase en el horario habitual con técnicas de gamificación, pero con medios tradicionales (entrega de caso en papel, bolígrafo, calculadora y entrega de documento con la solución y decisión). La duración fue de dos horas. Adicionalmente, para aquellos alumnos que lo realizaran, se estableció un incentivo en la calificación de la evaluación de la asignatura consistente en obtener un máximo de 0,25 puntos que se sumarían a la nota final de la misma. El registro de incentivo conseguido era variable en función de la superación de distintos apartados planteados en el ejercicio práctico.

Con el fin de llevar a cabo la investigación, se realizó una encuesta donde las características técnicas se recogen en la tabla 2.

Tabla 2: ficha técnica de la investigación

\begin{tabular}{l|l}
\hline Universo de la población & $\begin{array}{l}\text { Alumnos del } 2^{\circ} \text { curso, Grado de Contabilidad y } \\
\text { Finanzas y sus dobles grados con Derecho y } \\
\text { con Relaciones Laborales }\end{array}$ \\
\hline Tamaño muestral & 187 \\
\hline Encuestas contestadas y validas & 148 \\
\hline Ámbito geográfico & Comunidad de Madrid \\
\hline Recogida de información & Socrative \\
\hline Tipo de estudio & Encuesta \\
\hline Periodo de obtención de datos & Diciembre 2017 \\
\hline
\end{tabular}

(cc) EY-NC-ND 2018, Universitat Politècnica de València

Congreso IN-RED (2018) 
La encuesta estaba compuesta por 15 preguntas. Las 4 primeras hacían referencia a la información sobre aspectos socioeconónmicos como: género, situación laboral, tipo de grado que cursan y campus donde recibían la docencia. En relación al segundo bloque de preguntas, según se observa en la tabla 3 , se establecieron cuáles fueron objeto de estudio y qué objetivos se perseguían. Las preguntas del cuestionario se midieron con una escala de Likert de 0 a 10.

Tabla 3: Cuestiones clave en el análisis del impacto en la motivación del alumno

\begin{tabular}{|c|c|}
\hline Cuestiones objeto de estudio & Objetivos perseguidos \\
\hline $\begin{array}{l}\text { Antes del juego, ¿en qué grado tenías los } \\
\text { conceptos claros? }\end{array}$ & \multirow[t]{2}{*}{ Percepción sobre adquisición de conocimientos } \\
\hline $\begin{array}{l}\text { Después del juego, ¿en qué grado tenías los } \\
\text { conceptos claros? }\end{array}$ & \\
\hline $\begin{array}{l}\text { ¿En qué grado la actividad te ha resultado útil } \\
\text { para poner en práctica tus conocimientos? }\end{array}$ & Mejora de conocimientos \\
\hline $\begin{array}{l}\text { ¿Qué grado de realidad has apreciado en este } \\
\text { juego? }\end{array}$ & \multirow[t]{2}{*}{ Estudio de caso } \\
\hline $\begin{array}{l}\text { ¿En qué medida te ha resultado útil para } \\
\text { mejorar tus conocimientos? }\end{array}$ & \\
\hline ¿En qué grado te ha motivado el juego? & \multirow{3}{*}{ Motivación } \\
\hline $\begin{array}{l}\text { ¿Cómo valoras el incentivo en la nota para } \\
\text { realizar esta actividad ? }\end{array}$ & \\
\hline $\begin{array}{l}\text { ¿En qué medida te parece interesante implantar } \\
\text { nuevas técnicas de aprendizaje? }\end{array}$ & \\
\hline
\end{tabular}

Fuente: elaboración propia

El proceso de recogida de datos se realizó al finalizar la actividad en el propio aula. Los alumnos debían coger su móvil y, a través de la aplicación Socrative ${ }^{4}$, contestar a la encuesta facilitada por la profesora. Al acceder debían identificarse con el número de alumno y el de grupo de trabajo al que pertenecían para preservar la identidad. Según los alumnos iban contestando, se iba haciendo el registro en la aplicación en tiempo real. Posteriormente, la base de datos fue guardada en una hoja de cálculo para su procesamiento.

\section{Resultados}

Los resultados de este primer estudio en cuanto a las primeras preguntas de la encuesta relativas a los datos socioeconómicos de los alumnos se recogen a continuación.

Comenzando por el género, los datos muestran que del total de alumnos encuestados, el femenino predomina sobre el masculino, siendo respectivamente un 55,41\% y 44,59\%.

\footnotetext{
${ }^{4}$ Socrative es una aplicación que permite interactuar con los alumnos en clase en tiempo real (véase https://www.socrative.com/). El Instituto Nacional de Teconologías Educativas y de Formación de Profesorado (INTEF), perteneciente al Ministerio de Educación, Cultura y Deporte de España, recomienda su utilización

(véase http://recursostic.educacion.es/blogs/malted/index.php/2012/09/24/socrative-el-sistema-de-respuesta-inteligente)
} 


\section{Gráfico 1: Género del alumnos}

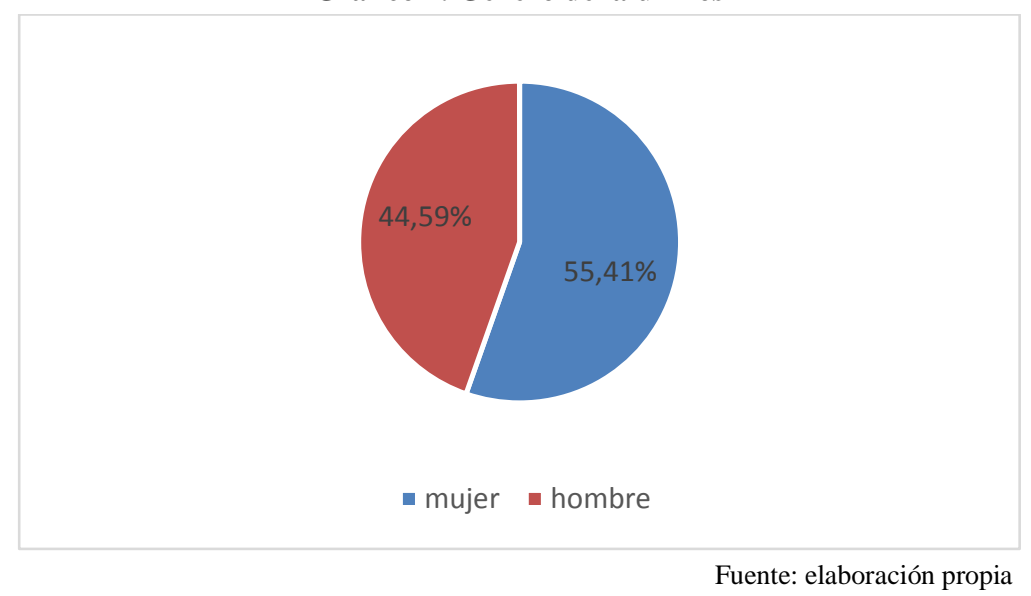

En el estudio hay otra variable significativa necesaria a tener en cuenta para entender el comportamiento de los alumnos a la hora de afrontar el estudio de una asignatura que es la situación laboral. La investigación muestra que más del 55\% no trabaja.

Gráfico 2: Situación laboral del alumnado

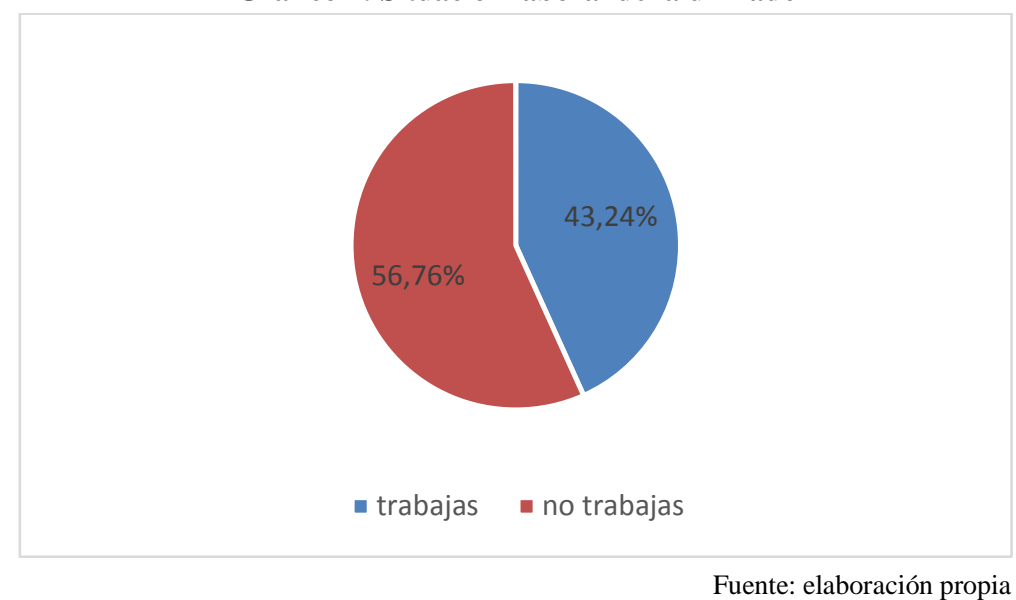

Los gráficos 3 y 4 ponen de manifiesto el contexto actual del alumnado en función del género y la situación laboral en la que se encuentran. La investigación muestra que existe un gran predominio de un perfil, tanto de hombre como de mujer, que se encuentra únicamente cursando estudios universitarios, siendo un 59,09\% para el hombre y un $54,88 \%$ para la mujer.

(cc) EY-NC-ND 2018, Universitat Politècnica de València 


\section{Gráfico 3: Datos según género y situación laboral}

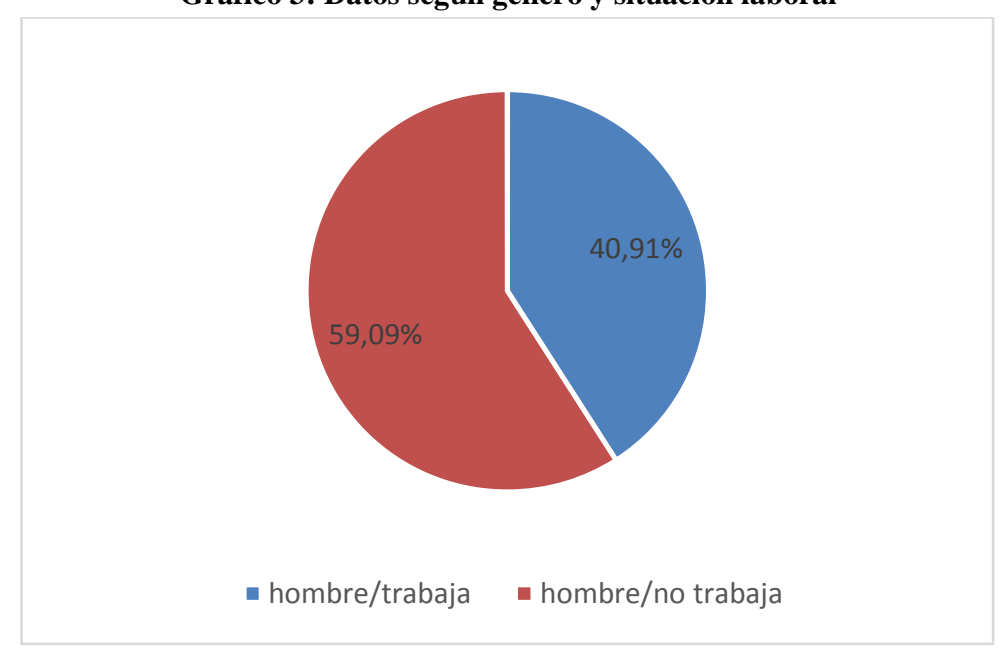

Fuente: elaboración propia

\section{Gráfico 4: Datos según género y situación laboral}

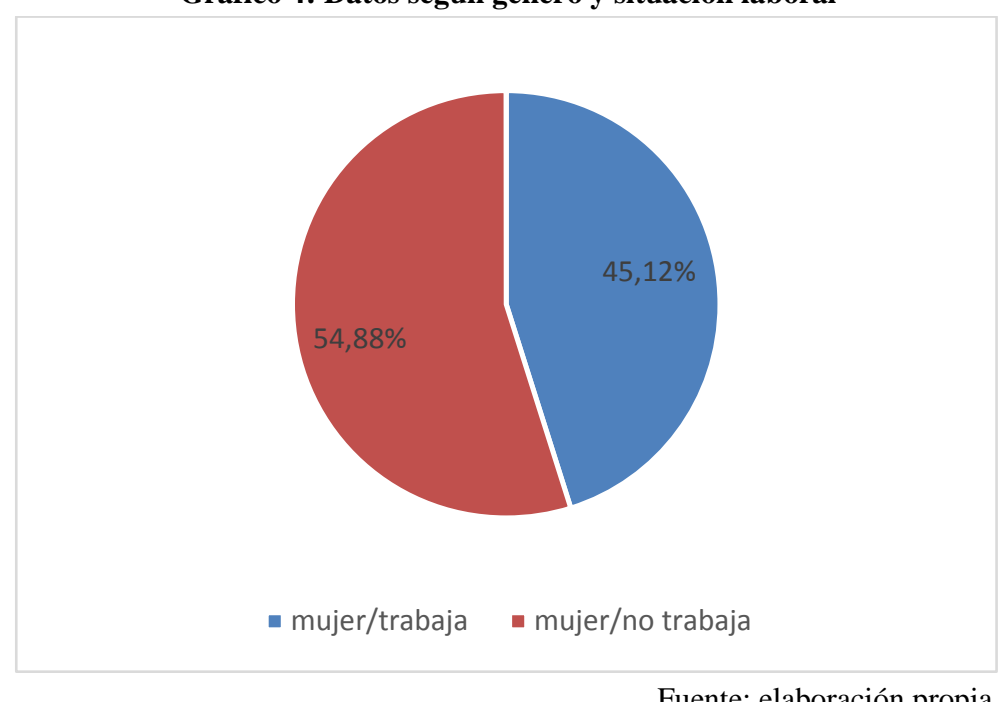

Fuente: elaboración propia

Asimismo, si tratamos de comparar ambos gráficos, se puede observar que es mayor el número de mujeres que estudian y trabajan $(45,12 \%)$ a la vez con respecto a los hombres $(40,91 \%)$.

Otro aspecto que se tuvo en cuenta fue el tipo de grado ya que dentro de las titulaciones que imparte la Universidad Rey Juan Carlos, existe la posibilidad de tener en un mismo aula 
El estudio de un caso empresarial de decisiones de inversión con técnicas de gamificación en la motivación del alumnado

alumnos que provienen de distintas titulaciones. En esta investigación se pone de manifiesto que el $83,11 \%$ de los alumnos estudian grado y el 16,89\% cursan un doble grado (véase gráfico 5).

\section{Gráfico 5: Tipo de grado que los alumnos cursan}

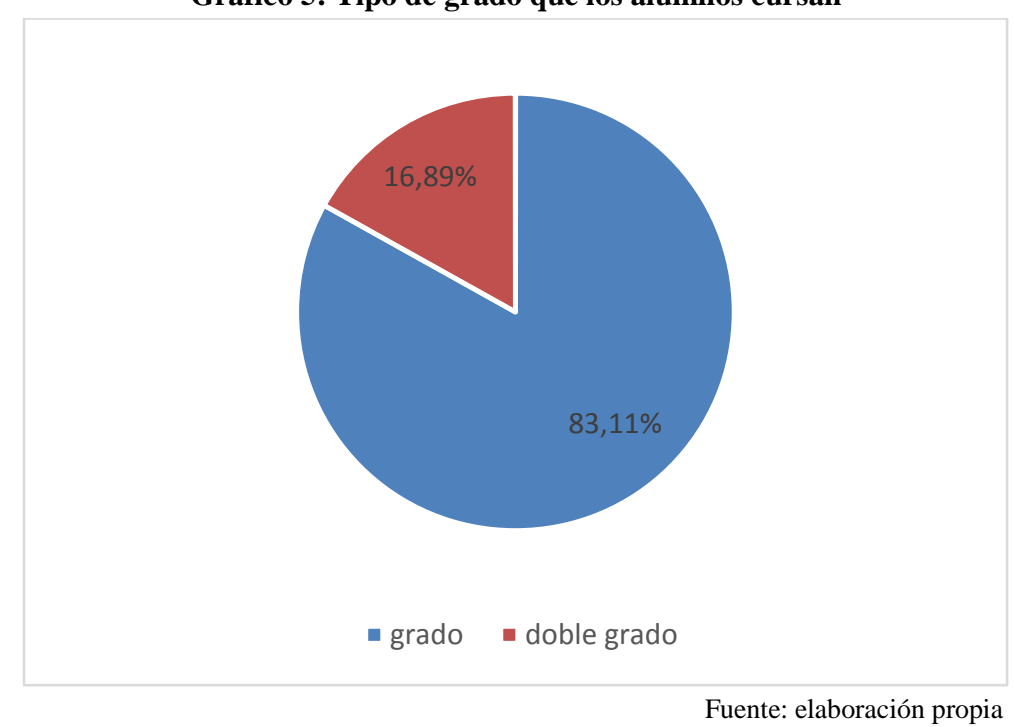

Una vez analizados los datos resultantes de la parte socioeconómica, se procede a presentar los datos correspondientes a la experiencia realizada en el aula con los alumnos.

Gráfico 6: Antes del juego, ¿en qué grado tenías los conceptos claros? (0:nada claros - 10: muy claros)

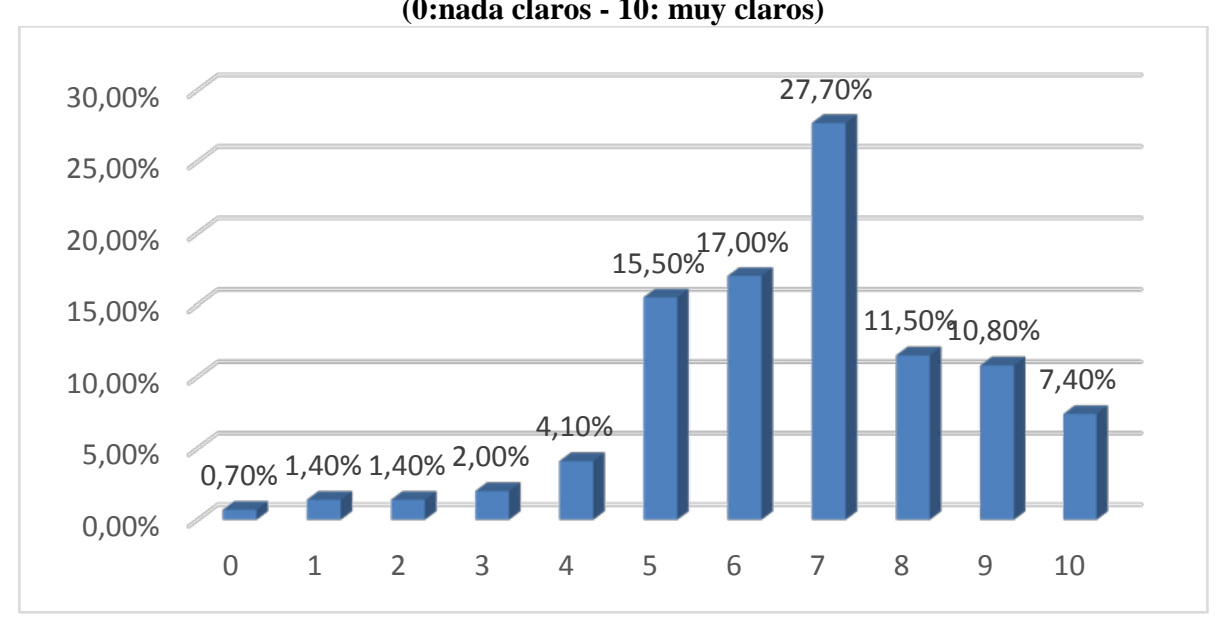

Fuente: elaboración propia

La investigación muestra que más del 74,40\% tenía un alto grado de conocimientos de la asignatura, considerando como tal las respuestas a partir de la valoración de 6 .

(cc) EY-NC-ND 2018, Universitat Politècnica de València 
Gráfico 7: Después del juego, ¿en qué grado tenías los conceptos claros? (0:nada claros - 10:muy claros)

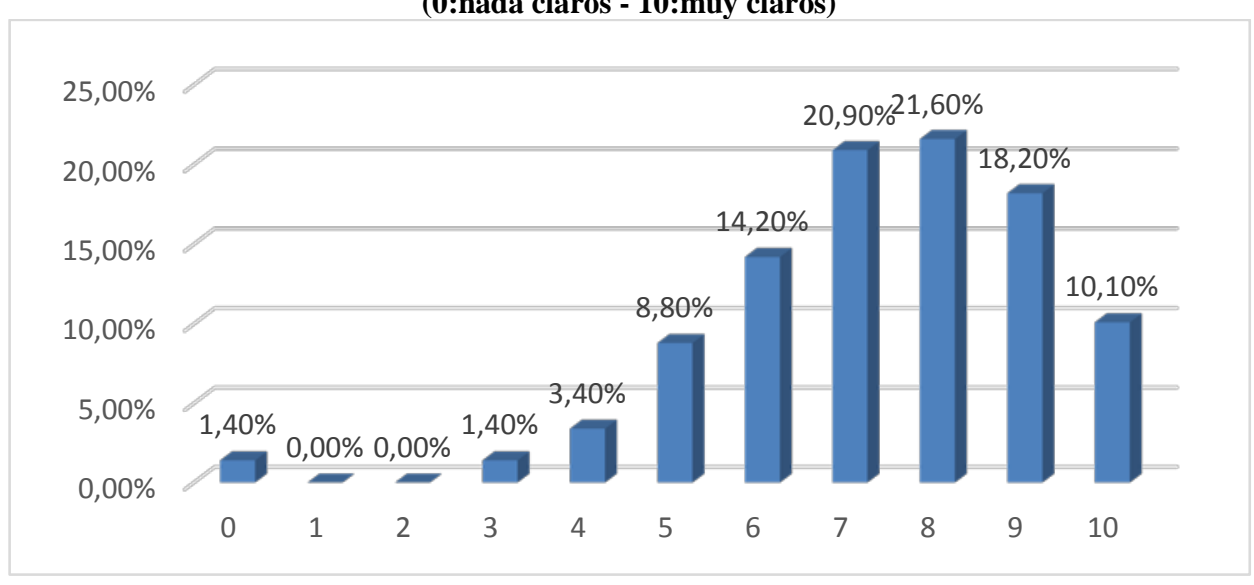

Fuente: elaboración propia

Una vez realizada la experiencia en el aula, se observa que el 85,00\% de los alumnos han aumentado el grado de clarificación de los contenidos, aumentando en este caso las puntuaciones de 8,9 y 10 con respecto al gráfico 7 .

Gráfico 8: ¿En qué grado la actividad te ha resultado útil para poner en práctica tus conocimientos? ( 0 :nada útil - 10:muy útil)

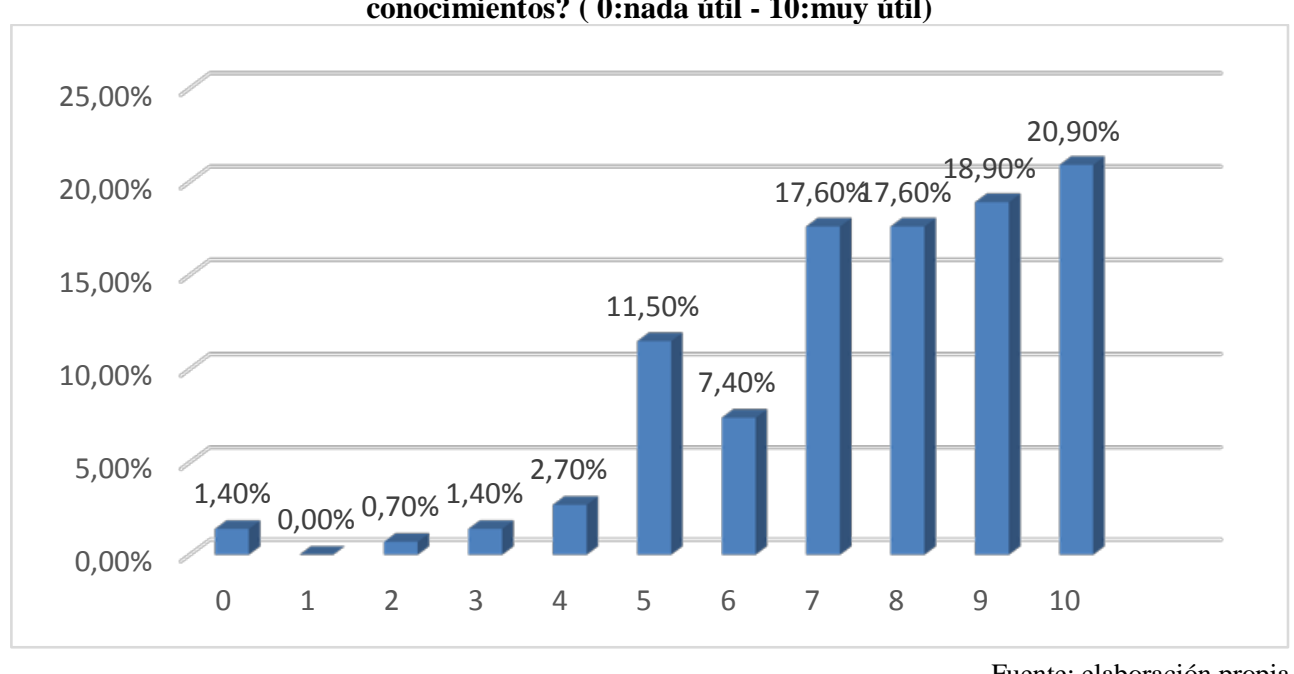

A la pregunta de ¿En qué grado la actividad te ha resultado útil para poner en práctica tus conocimientos? Más del $80 \%$ muestran que la actividad les ha resultado útil, aspecto bastante relevante para la investigación dado que se valora la realización de estudio de casos reales en el ámbito de las aulas. Ello les permite acercarse a la realidad empresarial en la toma de decisiones. 
Gráfico 9: ¿Qué grado de realidad has apreciado en este juego? (0:nada real - 10: muy real)

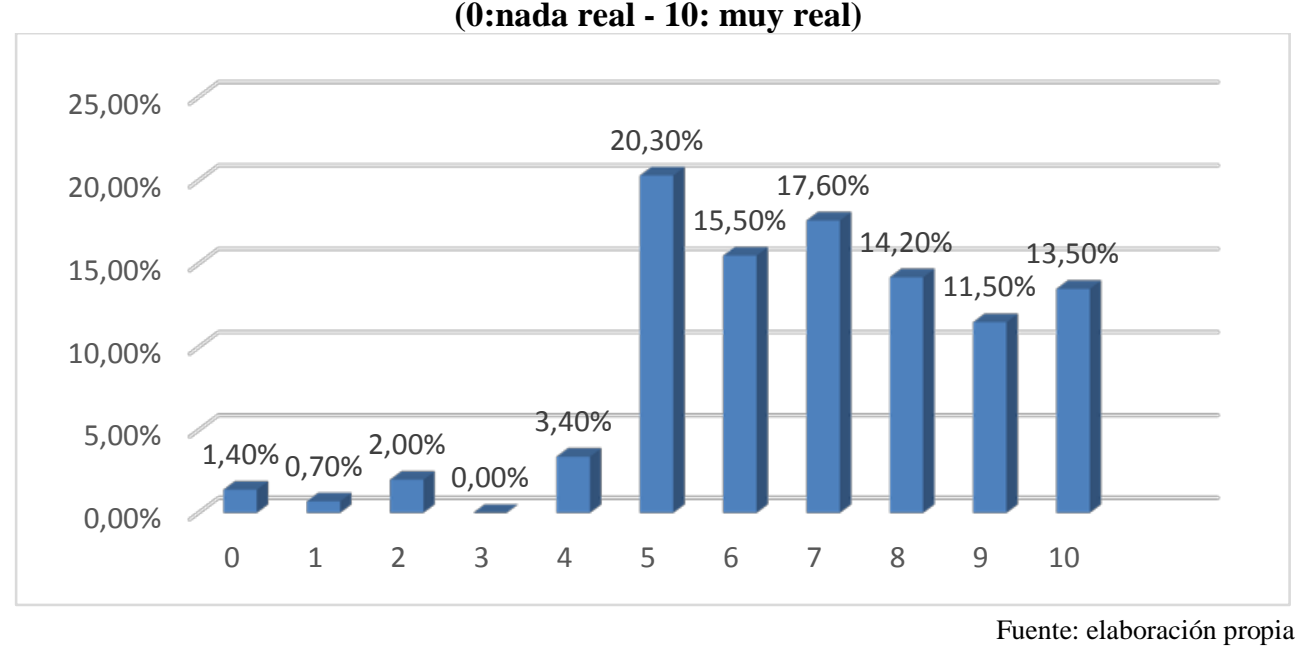

Esta pregunta presenta un poco de controversia. La actividad presentada es un caso empresarial real que se llevó a cabo en el aula, pero los resultados de la la investigación apuntan una escasa apreciación de la realidad por parte de los alumnos. El 72,30\% presentan valores dentro de la escala de Likert entre 6 y 10, pero el dato más alto de la encuesta es un 20,30\%. Este resultado apunta que el valor medio de apreciación de la realidad del caso es un 5 .

Gráfico 10: ¿En qué medida te ha resultado útil para mejorar tus conocimientos? (0:nada útil - 10:muy útil)

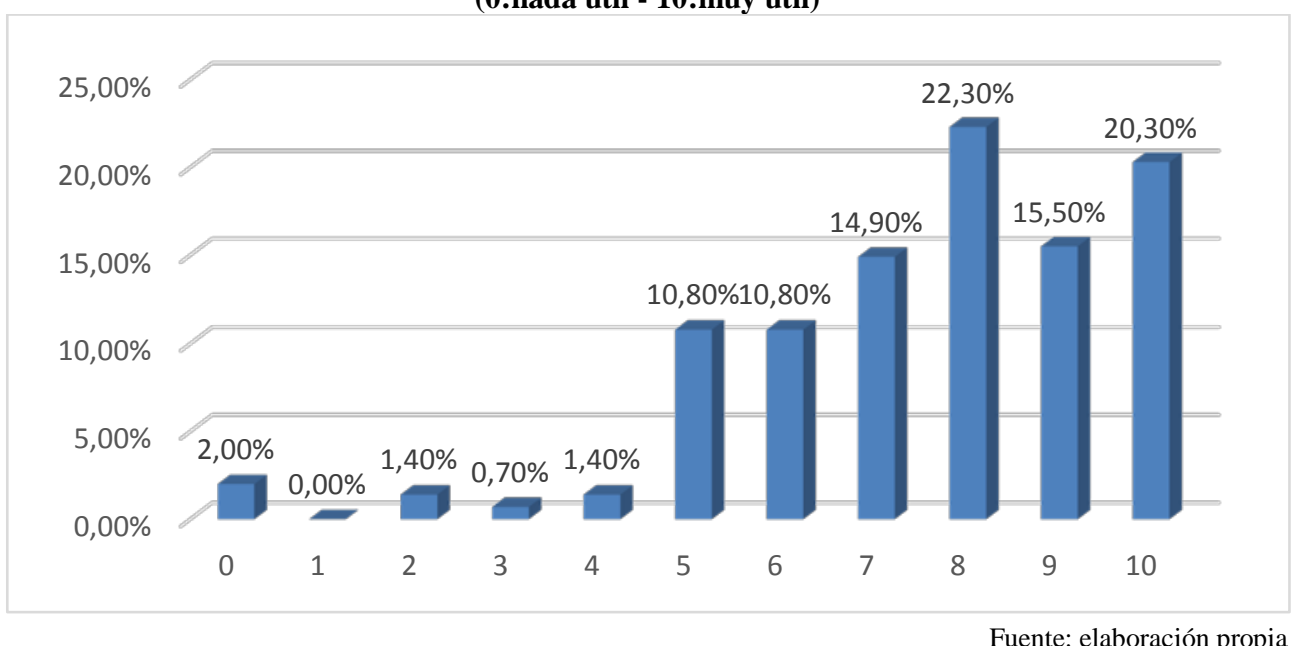

Esta pregunta arroja datos interesantes puesto que más de un $83 \%$ manifiesta que la actividad le ha servido para mejorar los conocimientos, obteniendo un 58,10\% en los 
valores 8, 9, 10. Estos datos muestran que la realización de esta actividad va más allá de los meros ejercicios de decisiones de inversión realizados en clase, lo que corrobora que ayudan al alumno comprender mejor la asignatura.

\section{Gráfico 11:¿En qué grado te ha motivado el juego?}

(0: mínimo - 10: máximo)

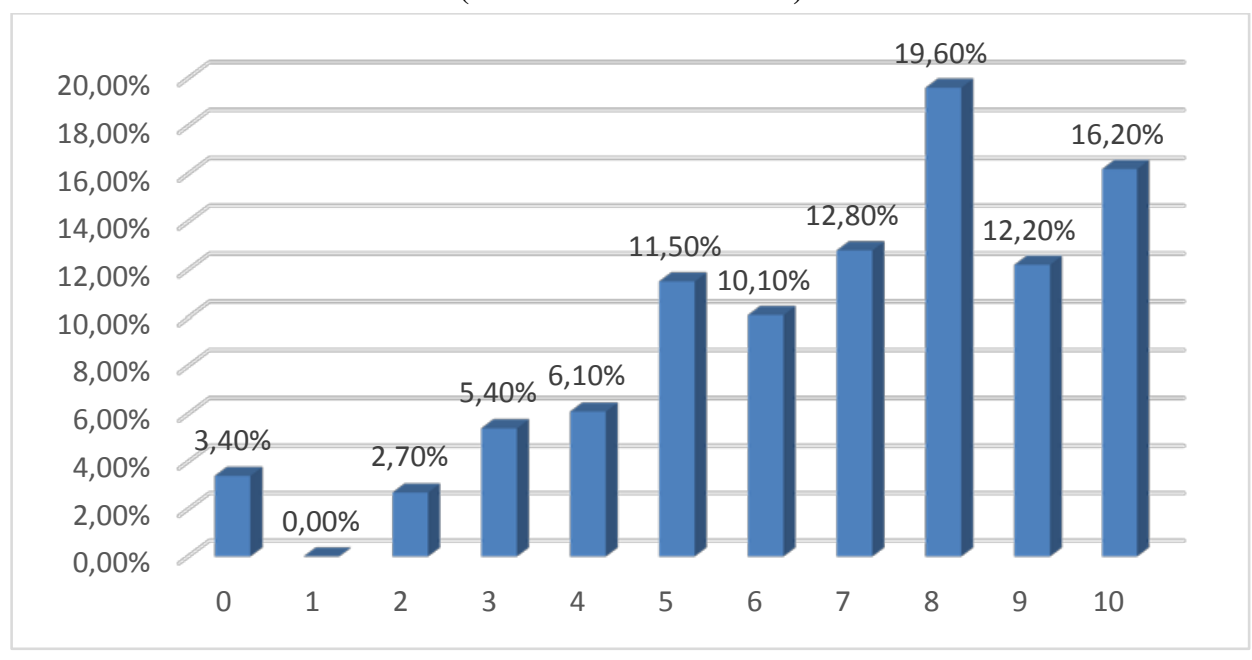

Fuente: elaboración propia

Otro aspecto a reslatar es el resultado que muestra el gráfico 11 ya que revela que el $70,90 \%$ considera que el juego ha aumentado su motivación. Además, dicho valor se concentra un $48 \%$ en los valores 8,9 y 10 .

Gráfico 12: ¿Cómo valoras el incentivo en la nota para realizar esta actividad ? (0:nada incentivador - 10:muy incentivador)

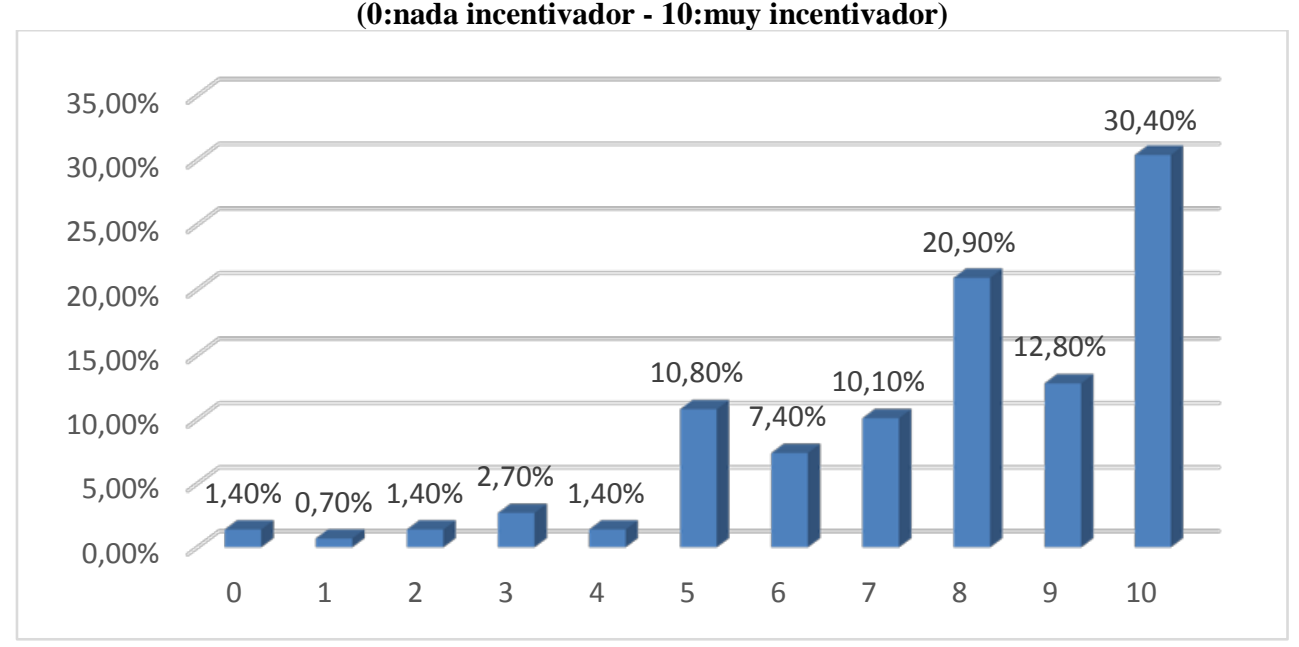

Fuente: elaboración propia

La pregunta valorada en el gráfico 12 muestra cómo el tipo de incentivo en la nota de la actividad es considerada positiva por parte de los alumnos puesto que el $64,10 \%$ otorga 
valores altos a la pregunta, donde la mitad de las respuestas han contestado el máximo de 10.

Además, dentro de la investigación se consideró relevante analizar en concreto si el grado de motivación del alumno dependía del incentivo ofrecido con la actividad. Si lo analizamos en términos generales, se obtienen los siguientes datos recogidos en la tabla 4 .

Tabla 4: Correlación de Pearson para relacionar la motivación y el incentivo

\begin{tabular}{c|c|c}
\hline & $\begin{array}{c}\dot{E} \text { En qué grado te ha motivado } \\
\text { el juego? }\end{array}$ & $\begin{array}{c}\dot{\mathrm{C}} \text { Cómo valoras el incentivo en } \\
\text { la nota para realizar esta } \\
\text { actividad? }\end{array}$ \\
\hline $\begin{array}{c}\text { ¿En qué grado te ha motivado } \\
\text { el juego? }\end{array}$ & 1,000 &, 320 \\
$\begin{array}{c}\text { ¿Cómo valoras el incentivo en } \\
\text { la nota para realizar esta } \\
\text { actividad? }\end{array}$ &, 320 & 1,000 \\
\hline
\end{tabular}

La tabla 4 muestra el resultado del análisis de correlación de Pearson entre la motivación y el incentivo de la actividad, confirmando así la existencia de una correlación positiva entre ambas.

\begin{tabular}{|c|c|c|c|c|}
\hline Modelo & $\mathrm{R}$ & R cuadrado & $\begin{array}{c}\text { R cuadrado } \\
\text { ajustado }\end{array}$ & $\begin{array}{c}\text { Error estándar de la } \\
\text { estimación }\end{array}$ \\
\hline 1 &, $320^{\mathrm{a}}$ & ,102 & ,096 & 2,416 \\
\hline
\end{tabular}

Tal y como puede verse en la tabla 5, se puede comprobar que la motivación queda explicada en un $10,2 \%$ por el incentivo en la nota.

Tabla 6: Resumen coeficientes modelo de regresión

\begin{tabular}{|c|c|c|c|c|c|c|}
\hline & \multirow[b]{2}{*}{ Modelo } & \multicolumn{2}{|c|}{$\begin{array}{l}\text { Coeficientes no } \\
\text { estandarizados }\end{array}$} & \multirow{2}{*}{$\begin{array}{c}\text { Coeficientes } \\
\text { estandarizados } \\
\text { Beta }\end{array}$} & \multirow[b]{2}{*}{$\mathrm{T}$} & \multirow[b]{2}{*}{ Sig. } \\
\hline & & B & $\begin{array}{c}\text { Error } \\
\text { estándar }\end{array}$ & & & \\
\hline 1 & $\begin{array}{c}\text { (Constante) } \\
\text { ¿Cómo } \\
\text { valoras el } \\
\text { incentivo en } \\
\text { la nota para } \\
\text { realizar esta } \\
\text { actividad? }\end{array}$ & 4,080 & ,701 & ,320 & 5,819 & ,000 \\
\hline
\end{tabular}

a. Variable dependiente: ¿En qué grado te ha motivado el juego?

De esta forma, una vez realizada la regresión de nuestro análisis, se obtienen los valores de los coeficientes (tabla 6) quedando la ecuación 2 y manifestando que las variables son significativas.

$$
\text { motivación }=4,08+0.355 * \text { incentivo }+\varepsilon \quad(\text { ecuación } 2)
$$


Por último, en cuanto a la pregunta relativa al grado de interés en la implantación de nuevas técnicas de aprendizaje, los alumnos muestran una rotunda aceptación.

Gráfico13: Grado de interes en implantar nuevas técnicas de aprendizaje (0:ninguno - 10:máximo)

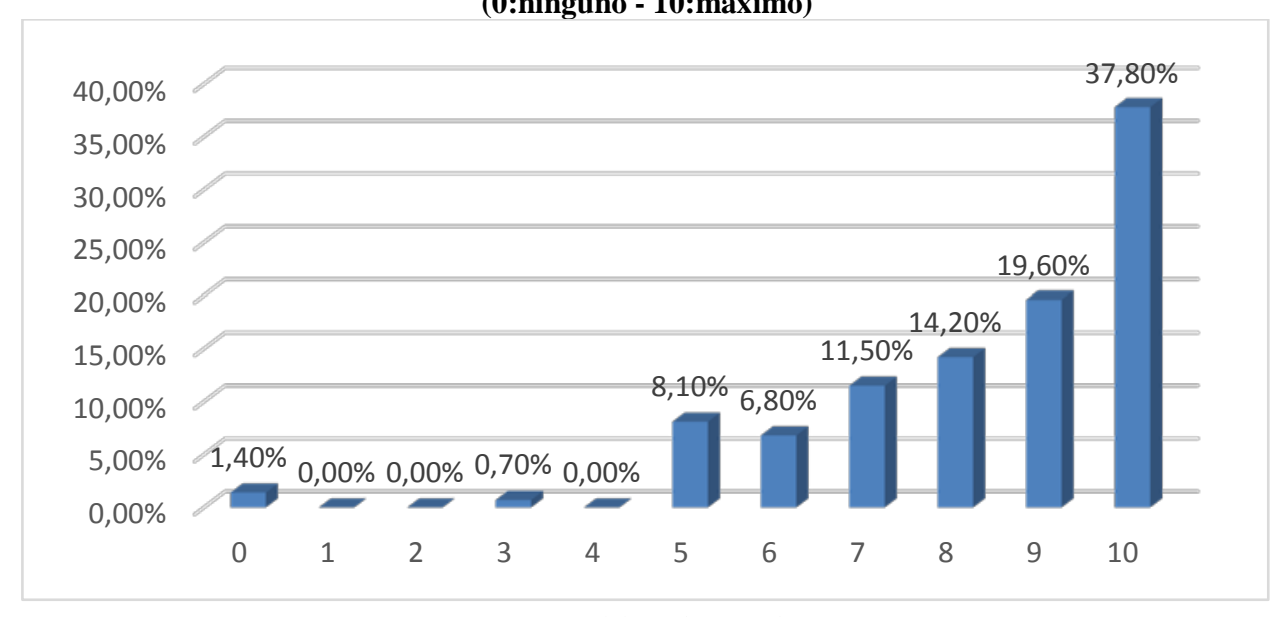

Fuente: elaboración propia

\section{Conclusiones}

Mejorar la motivación de los alumnos sigue siendo una asignatura pendiente en todos los niveles educativos. En el caso de la universidad, la necesidad es aún mayor pues es el paso previo al mundo laboral. Este es uno de las líneas de trabajo que se está desarrollando en la innovación docente. En este trabajo se pretende se hacer una propuesta para abordar la motivación del alumno con nuevas herramientas como: la gamificación, la utilización de un caso real y el establecimiento de incentivos cuantitativos en la calificación de la asignatura.

Los resultados de este trabajo confirman que una actividad innovadora mejora la motivación en un colectivo de alumnos casi paritario en sexo (ligeramente predominan las mujeres) y situación laboral (en este caso, hay ligeramente más hombres trabajando).

Según los objetivos perseguidos en la investigación, se concluye que los alumnos confirmaron una mejora en el aprendizaje tras la realización de la actividad. Les permitió aclarar conceptos y mejora del conocimiento cuantificado en una mejora de diez puntos, significativo dado que la valoración previa a la actividad era ya elevada (en torno al 75\% los alumnos mostraban ya un alto grado de aprendizaje de la asignatura). También el alto grado de utilidad que señalaron los alumnos (más del 80\%) respalda la realización de este tipo de actividades dentro del aula, si bien mostraron una baja apreciación de la realidad. Este resultado quizás plantea la necesidad de realizar la actividad fuera del entorno habitual y con otros medios menos tradicionales a pesar de haber aplicado técnicas de gamificación. Todo ello ha revertido en un resultado positivo pues más del 70\% revelaron que la actividad 
había aumentado su motivación, donde el $16 \%$ respondieron el máximo de aumento de motivación. Cabe señalar que este resultado se ha producido a pesar de que la introducción del incentivo en la nota no ha supuesto una influencia importante, tal y como arroja el análisis de regresión. En este apecto, quizás el incentivo adoleció de ser escaso. Finalmente, los alumnos avalan este tipo de iniciativas al manfiestar rotundamente su interés en las mismas.

Dados estos resultados y las clásicas limitaciones que presentan los primeros estudios de una actividad docente que se pone en marcha por primera vez (tamaño de la muestra, preparativos del caso, materiales utilizados, etc.), se hace necesario mejorar las condiciones para llevar a cabo la actividad y evaluar de nuevo para confirmar la consistencia de esta propuesta de innovación docente.

\section{Referencias}

AJELLO, A. M. (2003). La motivación para aprender. En C. Pontecorvo (Coord.), Manual de psicología de la educación (pp. 251-271). España: Popular

BECKER, K. (2001). Teaching with games: the minesweeper and asteroids experience. Journal of Computing Sciences in Colleges, 17(2), 23-33.

BERGIN, S. \& REILLY, R. (2005) The influence of motivation and comfort-level on learning to program. In Proceedings of the 17th Workshop on Psychology of Programming - PPIG’05, 293-304.

BLANCO, A. (Coord.) (2010): Desarrollo y evaluación de competencias en educación superior. Narcea, Madrid

BOZU, Z. y CANTO, P. (2009). El profesorado universitario en la sociedad del conocimiento: competencias profesionales docentes. Revista de Formación e Innovación Educativa Universitaria, 2(2), 87-97.

CAMACHO, M. (2012). El uso de mandos interactivos: una innovación docente para aumentar la motivación y mejorar el aprendizaje del alumnado universitarios. TESI 13(1), pp 412-436. Universidad de Salamanca

CHAÍN-NAVARRO, C.; MARTÍNEZ-SOLÍS, L. y SÁNCHEZ-BAENA, J.J. (2008). Motivar desde la innovación en la enseñanza universitaria: el blog Qalidad. Revista de Educación a Distancia, 21. Extraído el 1 de marzo, 2010, de http://www.um.es/ead/red/21/chain.pdf.

CHENG, E.K.; RHEE, J.A.; BAIK, Y.H. y OS, A. (2009). The effect of team based learning in medical ethics education. Medical Teacher, 31(11), 1013-1017.

CONTRERAS, R. S. (2016).Juegos digitales y gamificación aplicados en el ámbito de la educación. RIED: Revista Iberoamericana de Educación a Distancia, 19(2), 27-33.

DECI, E.L. y RYAN, R.M. (1985). Intrinsic motivation and self-determination in human behavior. New York: Plenum Press.

DIAZ-MARIN, V., VAZQUEZ-MARTINEZ, A., \& MCMULLIN, K. (2014). First steps towards a university social network on personal learning environments. The International Review of Research in Open and Distance Learning, 15(3), 93-119.

DRESSLER, S.; RACHFALL, T.; KAPANEN, A.; FOERSTER-TRALLO, D. (2016): "Improved learning performance due to the implementation of a stock market game - a case study about the possibility of enhancing student skills with game based learning”. Chova LG; MARTINEZ AL y TORRES IC (Coord.). En ICERI2016: 9TH International Conference of Education, Research and Innovation. pp: 2974-2980. Disponible en: https://library.iated.org/view/DRESSLER2016IMP2 ELLIOTT, J. (1993). El cambio educativo desde la investigación-acción. Ediciones Morata 
ESPUNY, C., GONZALEZ, J., LLEIXA, M. Y GISBERT, M. (2011). Actitudes y expectativas del uso educativo de las redes sociales en los alumnos universitarios. Revista de Universidad y Sociedad del Conocimiento (8)1, 171-185.

ESTANYOL, E., MONTAÑA, M., \& LALUEZA, F. (2013). Comunicar jugando. Gamificación en publicidad y relaciones públicas. Breaking the Media Value Chain, 171-172.

FUI-HOON NAH, F., ZENG, Q., RAJASEKHAR, V.,PADMANABHUNI, A., Y ESCHENBRENNER, B. (2014). Gamification of Education: A review of Literature. HCI in Business, 8527, 401-409.

GARCÍA RODRÍGUEZ, N. y ÁLVAREZ ÁLVAREZ, M.B. (2007). La motivación del alumnado a través de la satisfacción con la asignatura. Efecto sobre el rendimiento. Estudios sobre Educación, 13, 89-112.

GARCIA-RAMIREZ, JM. (2011). Una reconsideración de la excelencia visible en la educación superior: la escucha empática. Andaluciaeduca, 66, 84.

GARCIA-RAMIREZ, JM. (2015).La motivación de logro mejora el rendimiento académico. ReiDoCrea, 5 1-8.

GÓMEZ-MARTÍNEZ, R.; PRADO-ROMÁN, C. y ESCAMILLA-SOLANO, S. (2016): Game Driven Education in Finance Through On-line Trading Tools. Education Tools for Entrepreneurship, 113-124. Springer.

GONZÁLEZ, C. (2014). Estrategias para trabajar la creatividad en la Educación Superior: pensamiento de diseño, aprendizaje basado en juegos y en proyectos. RED, Revista de Educación a Distancia, 40

HILL, J., RAY, C., BLAIR, J y CARVER, C. (2003) Puzzles and games: Addressing different learning styles in teaching operating systems concepts, in Proc. 34th ACMSpecial Interest Group on Computer Science Education (SIGCSE) Technical Symp.Computer Science Education, 182-186.

KAPP, K. M. (2012). The gamification of learning and instruction, Game-based methods and strategies for training and education. San Francisco: Pfeiffer.

KIRRIEMUIR, J. y MCFARLANE, A. (2007). Literature Review in Games and Learning. A NESTA Futurelab Research report - report 8. 2004. Disponible en: https://telearn.archivesouvertes.fr/file/index/docid/190453/filename/kirriemuir-j-2004-r8.pdf

MARKETS y MARKETS (2016): Gamification Market worth 11.10 Billion USD by 2020. Disponible en: https://www.marketsandmarkets.com/PressReleases/gamification.asp

MARTÍNEZ, N. M. M., OLIVENCIA, J. J. L., y TERRÓN, A. M. (2016). Mobile learning, Gamificación y Realidad Aumentada para la enseñanza-aprendizaje de idiomas. IJERI: International Journal of Educational Research and Innovation, (6), 16-34.

MEISTER, J.C. (2013). How Deloitte made learning a game, Harvard Business Review. Disponible en: https://hbr.org/2013/01/how-deloitte-made-learning-a-g/

MOLINA, AM. (2012). Las TIC en la educación superior como vía de formación y desarrollo competencial en la sociedad del conocimiento. ReiDoCrea, 1, 106-114.

NALESNIK, S.W.; HEATON, J.O.; OLSEN, C.H.; HAFFNER, W.H.J. y ZAHN, C.M. (2004). Incorporating problem based learning into obstetrics/gynecology clerkship: Impact on student satisfaction and grades. American Journal of Obstretics and Gynecology, 190(5), 1375-1381.

OCHSENDORF, F.R.; BOEHNCKE, W.H.; SOMMERLAD, M. AND KAUFMANN, R. (2006). Interactive large group teaching in a dermatology course, Medical Teacher, 28(8), 697701.

PEREIRA, M. L. N. (2009). Motivación: perspectivas teóricas y algunas consideraciones de su importancia en el ámbito educativo. Revista Educación, 33(2), 153-170.

PERrotTA, C., FEATHerstone, G., ASTON, H., y HOUGHTON, E. (2013). Gamebased Learning: Latest Evidence and Future Directions. National Foundation Educational Research. Research Programme: Innovation in Education. Disponible en: https://www.nfer.ac.uk/publications/GAME01 
PETRIDIS, P.; HADJICOSTA, K.; DUNWELL, I.; LAMERAS, P.;BAINES, T.;SHI, V.G.; RIDGWAY, K.; BALDIN, J. \& LIGHTFOOT, H. (2006): Gamification: Using Gaming Mechanics to promote a business. Disponible https://www.researchgate.net/profile/Panagiotis_Petridis/publication/263236374_Gamification_using _gaming_mechanics_to_promote_a_business/links/53e4b36c0cf2fb748710dbe4.pdf

PRADO, A.; GÓMEZ,R.y CRUZ, A. (2017). Gestión del producto en el ámbito empresarial como herramienta de formación educativa. XXXI Congreso Anual AEDEM. Esic

SALINAS, J. (2004). Innovación docente y uso de las TIC en la enseñanza universitaria. Revista Universidad y Sociedad del Conocimiento, 1(1), 1-16.

TECHNAVIO (2016): Global Education Gamification Market 2016-2020. Disponible en: https://www.technavio.com/report/global-education-technology-global-education-gamificationmarket-2016-2020?utm_source=T3\&utm_medium=BW\&utm_content=Media

WERBACH, K., \& HUNTER, D. (2010). For the win, How game thinking can revolutionize your business. Philadelphie: Wharton Digital Press.

(cc) EY-NC-ND 2018, Universitat Politècnica de València 


\section{Análisis de la metodología Flipped learning en el entorno de la práctica de la Fisiología Médica. ESTHER ESCUDERO ${ }^{\text {a }}$, ISABEL SANCHEZ-VERA ${ }^{\mathrm{b}}$, URSULA MUÑOZ ${ }^{\mathrm{c}}$, RIMA BARHOUM $^{d}$, ASIER JAYO ${ }^{e}$

\author{
a estheresc@ceu.es; bisanver@ceu.es; $\quad$ cursula.munozmoron@ceu.es; $\quad$ drbarho@ceu.es;
} \\ easier.jayoandres@ceu.es}

Todos los autores tienen como procedencia: Sección de Fisiología. Dpto. Ciencias Médicas Básicas. Facultad de Medicina. Universidad CEU San Pablo, Madrid.

Abstract

The Physiology professors from the Medicine School of Universidad CEU San Pablo, are involved since five years ago in updating the teaching methodology. To this end, in the present year we have presented to the students a novel learning tool: flipped learning in the practice class. The professors have provided to the students written and audiovisual material (video tutorial) to explain the contents of practice of respiratory system with the aim that they perform a comprehension work before arrived at the laboratory. To made the tutorial video teachers have been using the Powtoon platform and then they have developed two differents surveys with Kahoot (to quantify the knowledge acquired and the degree of satisfaction). The activity has been positive received for the students and the professors value positively the implantation of this teaching methodology. The target of this aproache is to expand students' skills so that they can deepen the acquisition of knowledge and promote their own learning.

Keywords: Flipped learning, Kahoot, Powtoon, Práctice, Physiology.

\section{Resumen}

En la asignatura de Fisiología I del Grado de Medicina los profesores aplican actividades de innovación docente desde hace cinco años en la impartición de las clases teóricas. Este curso hemos aplicado en una clase de prácticas la metodología flipped learning. Para ello hemos proporcionado material escrito y audiovisual (video tutorial) para que el alumno realizara un trabajo de comprensión previo a la llegada al laboratorio. Para la realización del video los profesores han utilizado la plataforma Powtoon y para cuantificar los conocimientos adquiridos y el grado de satisfacción con la metodología se ha utilizado la plataforma Kahoot. La acogida por parte de los alumnos ha sido positiva, sobre todo del material audio visual. El desarrollo de la práctica se ha realizado en menor tiempo y las puntuaciones obtenidas por los alumnos que han realizado la práctica con esta metodología son similares a los de los alumnos de metodología tradicional. Los profesores valoramos positivamente la implantación de esta metodología docente evidenciando que habrá que realizar algunas acciones de mejora.

Palabras clave: Flipped learning, Kahoot, Powtoon, Practicas, Fisiología 


\section{Introducción}

Con el método didáctico de flipped learning se pretende enfocar al alumno hacia una manera distinta de aprender. La idea es cambiar el método tradicional expositivo y deductivo por un aprendizaje en el que el centro de atención se focaliza más en el alumno (Prieto Martin, 2017). Con esta metodología se prioriza cambiar sus hábitos de estudio, mejorar su aprendizaje y aumentar la adquisición de competencias del alumno por el método inductivo, utilizando el razonamiento crítico para desarrollar un aprendizaje autónomo (Gargallo 2015).

El flipped learning engloba distintas metodologías basadas todas ellas en que el alumno, previo a la clase, debe comprender y familiarizarse con la información que el profesor pone a su disposición mediante documentos, presentaciones, vídeos o cualquier otro medio didáctico. Con el flipped learning el aprendizaje del alumno directamente se vincula con un mayor sentimiento de compromiso por su parte, ya que se le demanda investigar, cuestionar, hacer aportaciones propias, ser autónomo, y además tener una visión crítica sobre la adquisición de su conocimiento. Con esta metodología el alumno pasa a estar en primera línea respecto a su proceso de aprendizaje y puede regular la evolución de su conocimiento (Machemer 2007), de tal manera que se consigue cambiar el paradigma del profesor como único instructor y conseguir que en el aula se genere un ambiente de aprendizaje activo (Zabalza, 2012) donde el profesor se trasforma en un facilitador de aprendizaje (Monereo y Pozo, 2003).

Durante los últimos cinco años, los profesores de la asignatura de Fisiología I de la Facultad de Medicina han utilizado la metodología de "aprendizaje/facilitación del aprendizaje” orientado a potenciar las competencias de los alumnos sobre: la obtención autónoma de información, el manejo de motores de búsquedas informáticos y repositorios bibliográficos, el manejo de distintas modalidades de divulgación de sus conocimientos (videos o presentaciones con diapositivas), le realización de autoevaluaciones en la plataforma BlackBoard y el uso de un foro informático para la puesta en común de información aportada por los alumnos. En todas las actividades se les pidió que cumplimenten un cuestionario para que balaran la utilizad docente de cada una de las actividades propuestas. Del análisis de estas propuestas anteriores hemos evidenciado que: primero, los alumnos abordan esta asignatura de manera muy positiva en comparación con otras del curso y, segundo, que mayoritariamente hay una gran aceptación por su parte sobre el uso de nuevas metodologías de aprendizaje para aumentar su rendimiento académico (Escudero et al 2017; Sanchez-Vera et al 2017).

Estos antecedentes nos han animado a implementar metodologías de innovación no solo en las clases de teoría sino en planificar una flipped classroom en las prácticas de la asignatura. El "aula inversa" es un modelo pedagógico que pretende trasferir el trabajo que se realiza fuera para posteriormente dentro del aula focalizarlo en un proceso de aprendizaje en el que la adquisición de competencias se realiza con una mayor interacción entre los miembros del grupo (Santiago R, 2017)

(cc) EY-NC-ND 2018, Universitat Politècnica de València

Congreso IN-RED (2018) 
La intención de nuestra actividad de innovación ha estado dirigida a potenciar, además de las competencias citadas anteriormente, el trabajo colaborativo entre diferentes actores para favorecer las relaciones interpersonales (Muñoz González, 2014), que es un rasgo trasversal demandado en la actualidad en el ámbito profesional además de los conocimientos. Por otro lado, con esta actividad pretendemos evitar la pasividad del alumnado dotándoles de más protagonismo, fomentando el estudio, el análisis y la comprensión previa a la realización de la actividad.

En los últimos años, con las prestaciones ofrecidas por las nuevas tecnologías, están apareciendo los videos tutoriales, que son sistema instructivos de autoaprendizaje que muestran al alumno el desarrollo de algún procedimiento o los pasos para realizar una determinada actividad (He, 2012 y Jordan, 2016). Un video tutorial se caracteriza por su facilidad a la hora de explicar conceptos o procesos complejos de manera visual y clara (Arasasingham, 2011 y Bloom, 1984).

Siguiendo esta nueva tendencia, durante este curso académico nos hemos propuesto abordar una clase práctica utilizando flipping learning con el apoyo de un video tutorial, con el objetivo de proponer al alumno que haga un trabajo previo reflexivo y de autoaprendizaje. Para ello, los profesores de la asignatura hemos elaborado un video animado utilizando la plataforma Powtoon. La idea ha consistido en que los alumnos contaran con material de texto (guión de teoría de la práctica) y un video tutorial explicativo sobre la metodología de manejo de los aparatos para recoger un registro respiratorio, con la finalidad de que en el laboratorio pudieran adquirir destrezas de autonomía que no se fomentan en la clase práctica tradicional.

\section{Objetivos}

Con la puesta en marcha de esta experiencia hemos buscado favorecer la autonomía de aprendizaje del alumno, darle preferencia al estudio previo de los conceptos que se van a utilizar posteriormente en el laboratorio, que el alumno detecte los conceptos en los que se encuentra más débil, y sin embargo pueda ejercer de instructor de los conceptos en los que está fortalecido. Se pretende focalizar la labor del profesor como instructor que resuelve únicamente las dudas específicas que se presenten en cada grupo de trabajo en caso de que ninguno de los componentes puedan hacerlo. Por último, se ha intentado que los alumnos afronten la realización de la actividad con un mayor grado de implicación personal, con la finalidad de aprender de forma más inductiva.

\section{Desarrollo de la innovación}

Presentamos el análisis y las conclusiones sobre la realización de la práctica del Sistema Respiratorio en la asignatura Fisiología I durante el curso académico 2017-2018. La asignatura se imparte en el primer semestre del $2^{\circ}$ curso del Grado en Medicina. Es de carácter obligatorio y consta de 7,5 créditos ECTS, de los cuales 1.5 ECTS son de materia práctica.

La actividad de innovación se ha realizado sobre la práctica de Sistema Respiratorio que dura dos días consecutivos. La totalidad de los alumnos de la asignatura se dividió en dos 
mitades, de tal manera que una de ellas realizó la práctica de la forma tradicional con una explicación previa del profesor (78 alumnos), y la otra mitad de alumnos la realizaron con flipped learning (78 alumnos). En ambos casos los alumnos se distribuyeron en grupos de prácticas de aproximadamente 10 alumnos.

\section{Recursos utilizados y metodología de trabajo.}

Para la realización de la práctica de Sistema Respiratorio todos los alumnos tuvieron a su disposición en el campus virtual un guión de teoría que debían leer y comprender antes de empezar la práctica y un cuadernillo de resultados para cumplimentarlo durante el desarrollo de la misma. Los alumnos contaban en el laboratorio de Fisiología con todo el material y aparataje necesario para realizar la toma del registro respiratorio.

\section{-Realización de la actividad tradicional.}

Los alumnos que realizaron la práctica de forma tradicional (78) además de consultar, leer y comprender el guión teórico contaron con una explicación completa por parte del profesor antes del inicio de la práctica.

\section{- Realización de la actividad flipped learning.}

Los alumnos que realizaron la práctica con innovación docente (78) contaron con el mismo material y además en su campus virtual tuvieron un video explicativo en el que en una parte se les exponía la metodología a seguir para hacer el registro respiratorio y en otra parte se explicaba los cálculos para poder interpretarlo. Estos alumnos debían traer leída y comprendida la guía teórica y además visionado el video explicativo. Al ser una práctica que se desarrolló en dos días consecutivos el primer día antes de empezar se hizo un Kahoot de comprensión de conceptos. Así los profesores valoramos cuántos de ellos habían visionado los videos, cuantos habían leído el guion de teoría y cuanto era el grado de conocimiento de los alumnos sobre la utilización de los aparatos y su grado de comprensión de la metodología para efectuar correctamente el registro respiratorio. Posteriormente se les dejó realizar la práctica organizándose dentro del grupo por parejas, de tal manera que un alumno ejercía de médico y el otro de paciente. Una vez obtenido el registro, este se analizaba por parejas, pero tenían permitido hacer una puesta en común de todos los registros del grupo y poder resolver dudas entre todos los miembros del grupo de prácticas. El profesor atendió a demanda las dudas que iban surgiendo, supervisando la realización de cada uno de los pasos de la práctica. Al finalizar la actividad, el segundo día de práctica, se les hizo otro Kahoot para valorar su grado de satisfacción con la nueva metodología.

\section{-Realización de un examen de prácticas}

Finalmente, todos los alumnos de la asignatura, tanto los que la hicieron por el método tradicional como los que la hicieron con la metodología flipped learning, realizaron un examen con preguntas de tipo test y resolución de problemas para cuantificar lo aprendido en la práctica. 


\section{Resultados.}

El número de alumnos que han participado en la realización de la práctica de Sistema Respiratorio con metodología flipped learning son 78, el resto de los alumnos de la asignatura de Fisiología hicieron la práctica usando la forma habitual y también fueron 78 alumnos.

\section{Resultados sobre el uso de Kahoot.}

La totalidad de los 78 alumnos participantes de flipped learning contestaron en el primer Kahoot a las preguntas de comprensión de cómo había que realizar la práctica, sin embargo sólo 64 alumnos participaron en el segundo Kahoot sobre la valoración de la actividad de innovación. Lo que supone una participación en el primero de un $100 \%$ frente a un $80 \%$ de participación en el segundo. Estos datos representan una pérdida de participación del 20\%, que en la mayoría de los casos se justificó o por problemas de conexión a internet dentro del laboratorio de prácticas o por olvidos del dispositivo móvil.

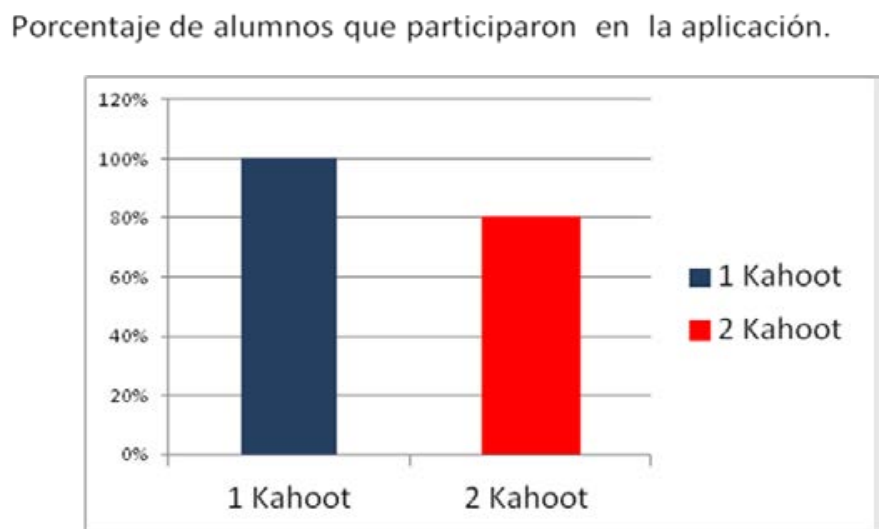

Figura 1. Porcentaje de alumnos que participaron en los Kahoot de la actividad. 


\section{Resultados sobre el visionado de los videos.}

Se analiza el número de alumnos que participaron en la actividad flipped learning y que visionaron el video. El video estuvo a disposición de los alumnos en el campus virtual desde 10 días antes de hacer la práctica y permaneció disponible hasta la finalización del cuatrimestre. Los resultados indican que el $79 \%$ de los alumnos acudieron a la práctica habiéndolo visto con anterioridad, frente a $21 \%$ que no.

\section{Porcentaje de alumnos que han visto los videos}

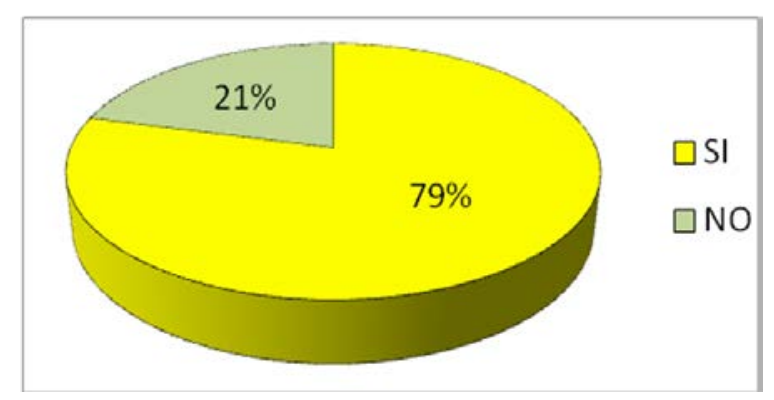

Figura 2. Porcentaje de participación en ver los videos. El número de alumnos implicados en la realización de la actividad fue de 64.

\section{Resultados sobre la consulta previa del guion teórico antes de la actividad.}

Se analiza el número de alumnos que consultaron de forma comprensiva el guión de teoría. Al igual que el material visual, el guión de teoría estuvo a disposición de los alumnos en el campus virtual desde 10 días antes de hacer la práctica y permanecieron disponibles hasta la finalización del cuatrimestre. En la figura 2 observamos que el 60,3\% de alumnos consultó el guión teórico frente a un 39.7\% que no lo hizo.

\section{Porcentaje de alumnos que han consultado el guion teórico}

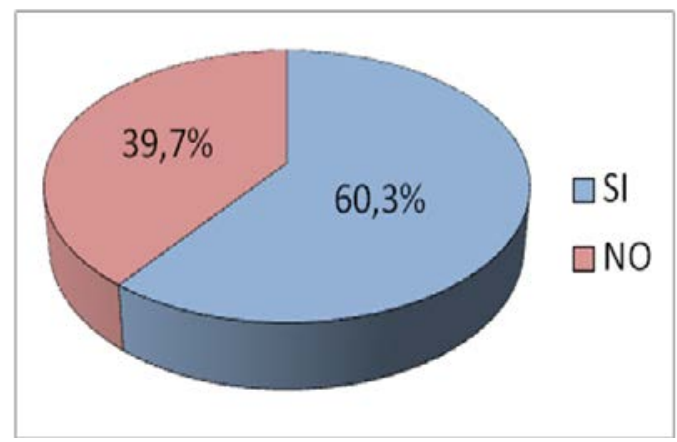

Figura 2. Porcentaje de participación de los alumnos en consultar el guión teórico antes de hacer la práctica. El número de alumnos implicados en la realización de la actividad fue de 64.

(cc) EY-NC-ND 2018, Universitat Politècnica de València 
3. Resultados sobre el número de alumnos que vieron los videos y también consultaron el guion de teoría.

Se analizó el número de alumnos que realizaron el abordaje de preparación de la actividad al completo, visualizando el video y estudiando el guión de prácticas. Los resultados de la figura 3 evidencian que un poco más de la mitad de los alumnos realizaron ambas actividades formativas antes de acudir a la práctica (52\% si vs48\% no)

\section{Porcentaje de alumnos que han consultado el guion teórico $y$ han visto el video}

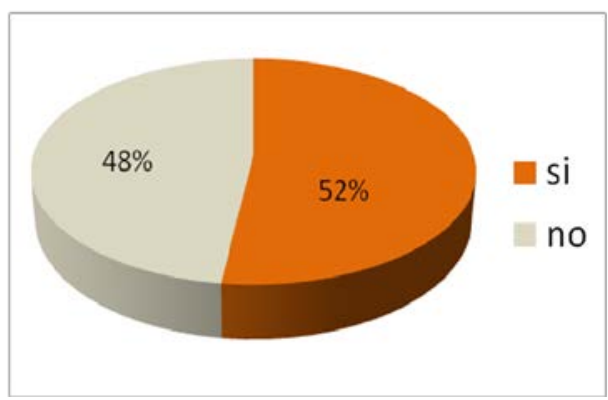

Figura 3. Porcentaje de participación de los alumnos que han consultado el guión teórico y la visualización de los videos antes de hacer la práctica.

4. Resultados que indican la percepción de los alumnos sobre el grado de comprensión que habían hecho de los conceptos explicados a través del video.

Se preguntó a los alumnos si tras ver el video habían comprendido correctamente la metodología para hacer ellos la práctica de forma autónoma. El 96.2\% de los alumnos consideraban que tras ver el video se encontraban preparados para afrontarla (fig. 4a).

Porcentaje de alumnos que han entendido

los conceptos de la práctica utilizando el video explicativo

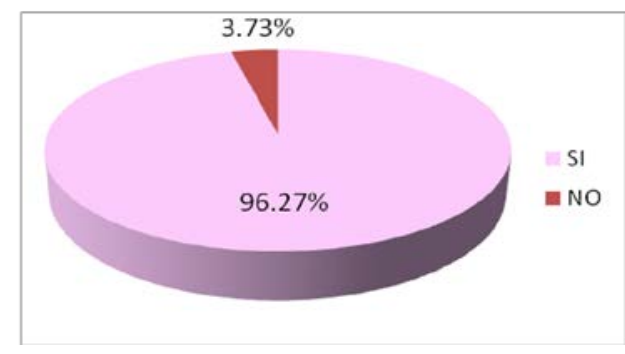

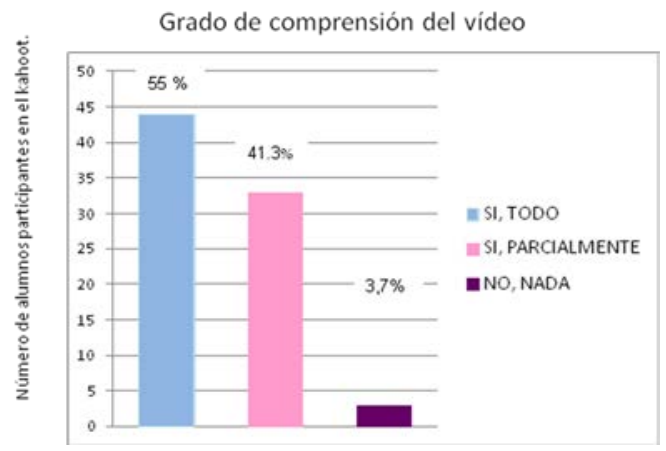

Figura $4 a$ y 4 b. Se representa el grado de comprensión de cómo realizar la práctica después de haber visto el vídeo

Sin embargo analizando los datos el 55 \% consideraba que sí les había quedado todo claro mientras que un 41,3\% tras ver el video tenía algunas dudas. Casi un $4 \%$ de los alumnos consideró que no había entendido nada de la práctica viendo el video (fig. 4b). 
5. Resultados que indican el grado de comprensión de los conceptos necesarios para afrontar la práctica de forma autónoma.

Antes de comenzar la práctica y con el fin de comprobar quienes habían comprendido suficientemente el método para realizar la práctica de forma autónoma, se les plantearon 10 preguntas a través de un Kahoot. Contestaron todos los alumnos excepto 2 de los que participaban en el flipped learning. En la gráfica (fig. 5) se representa el número de respuestas correctas respecto al número de alumnos que las acertaron. Como se observa los alumnos que vieron el video contestaron entre 6 y 10 preguntas de forma correcta, mientras que los alumnos que no lo habían visto contestaron de 1 a 6 preguntas correctamente.

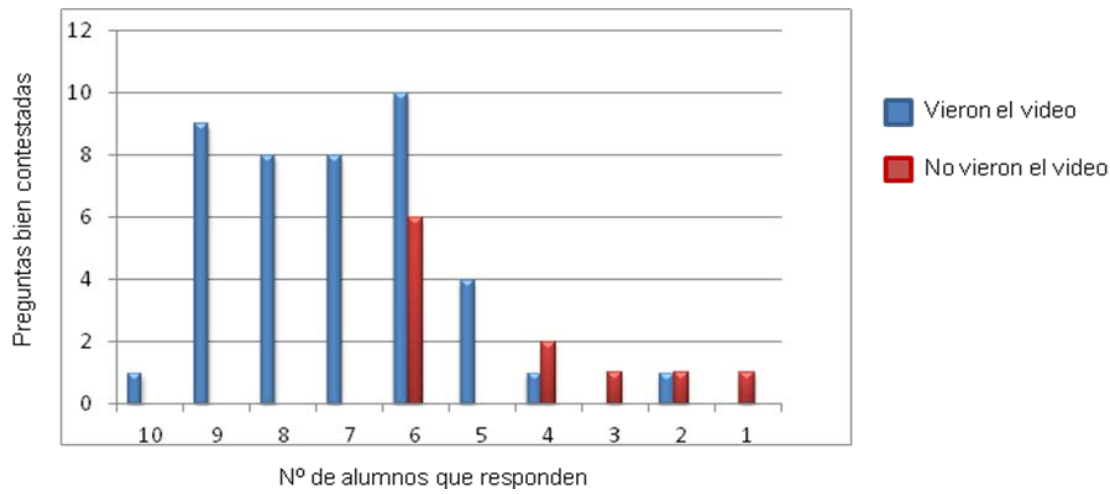

Figura 5. Se representa el número de respuestas correctas en el Kahoot de comprensión de la práctica.

6. Resultados sobre la aceptación de la implantación del video como método explicativo. Cuando se concluyó la práctica se realizó otro Kahoot para valorar la opinión de los alumnos sobre la implantación del sistema de clase inversa. A la respuesta de si les había gustado ver el video antes de hacer la práctica, la respuesta fue mayoritariamente positiva, con un grado de aceptación por parte de los alumnos de un $82,8 \%$ frente a un $17,2 \%$ que no le gustó (fig. 6).
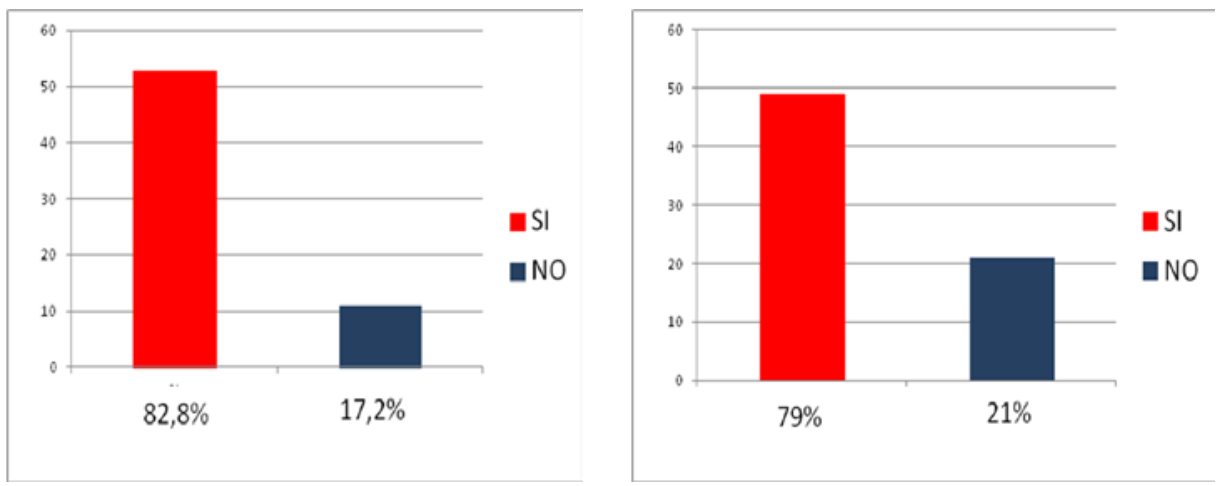

Figura 6. Se representa el porcentaje de alumnos que aceptaron positivamente el video

Figura 7. Se representa el porcentaje de alumnos que preferirían que la práctica fuese tradicional.

(c) EY-NC-ND 2018, Universitat Politècnica de València

Congreso IN-RED (2018) 
Sin embrago, y sorprendentemente, cuando les preguntamos ¿Prefieres la clase tradicional donde el profesor te explica al llegar qué tienes que hacer? Encontramos que el 79 \% contestó que sí (fig. 7)

\section{Resultados sobre la nota obtenida en el examen de prácticas}

Una vez que la totalidad de los alumnos de la asignatura de Fisiología I realizó la práctica se les hizo el mismo examen.

En la gráfica de la figura 8 se representa la nota media obtenida por los alumnos divididos en dos grupos: los que hicieron la práctica con el sistema tradicional (es decir el profesor explicó los contenidos y resolvió dudas generales), y los quela realizaron con la metodología flipped learning (en las que el alumno debía sentirse más autónomo para afrontar el manejo de laboratorio después del estudio previo).

Los resultados indican que la nota media obtenida por los alumnos fue similar en ambos grupos. El grupo de flipped learning, obtuvo una nota media de 7.38 mientras que el grupo tradicional obtuvo una nota de 7,41 (fig. 8).

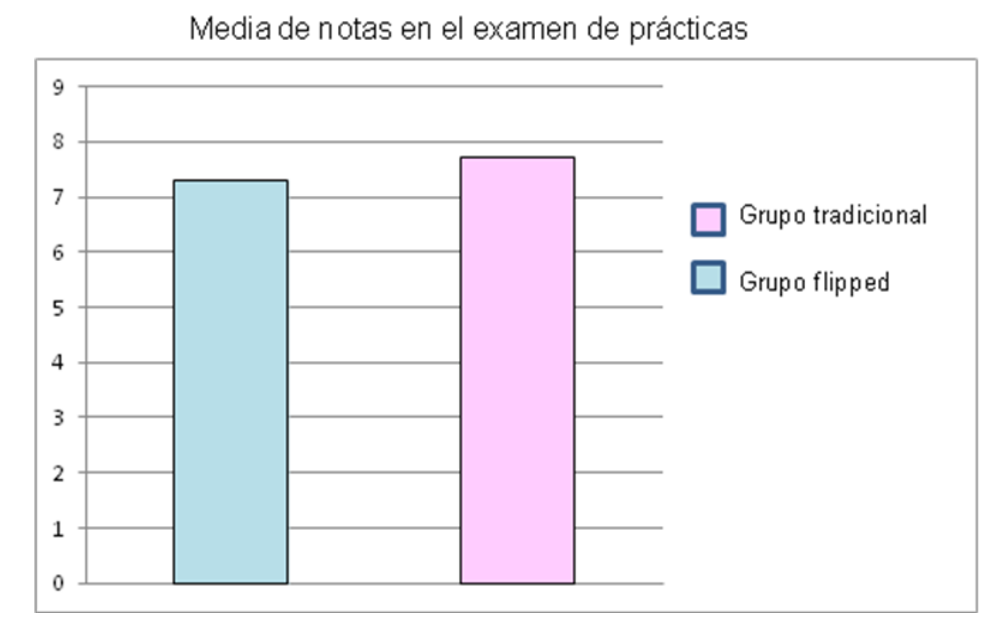

Figura 8. Se representa la puntuación del examen de prácticas

\section{Conclusiones.}

En general, los alumnos de segundo de Medicina abordan la asignatura de Fisiología con mucha positividad. El manejo de innovación docente en la clase de teoría de esta asignatura y la alta implicación del profesorado por mantener una constante renovación docente ha conseguido, a lo largo de los últimos años, generar un ambiente de éxito en la superación de la convocatoria ordinaria. Los profesores valoramos de manera muy positiva la buena acogida que tienen las propuestas de innovación por parte de nuestro alumnado, lo que nos ha impulsado este curso a aplicar técnica de flipped learning en la docencia práctica de la asignatura. 
Nos planteamos como objetivo que el alumno realizara un trabajo inicial fuera del aula para posteriormente transferirlo al laboratorio, permitiendo la realización de la práctica de manera más autónoma. Para ello contaban con material impreso y un video tutorial explicativo y durante el desarrollo de la práctica los alumnos también utilizaron la plataforma Kahoot.

Los resultados evidencian una muy buena acogida del uso de la plataforma Kahoot para cuantificar sus conocimientos, como muestran los resultados de la figura 1. Lo mismo que ha sucedido con la acogida del video tutorial, que ha tenido un seguimiento del $79 \%$ de los alumnos. (fig. 2). Sin embargo el uso de material didáctico en texto tiene una repercusión menor, como se pone de manifiesto en los resultados de la figura 3, donde hubo casi un $40 \%$ de alumnos que optó por no utilizar este material.

Respecto al grado de comprensión, tanto de los conceptos teóricos necesarios para abordar la práctica así como de las maniobras ventilatorias y manejo del aparataje para realizar correctamente el registro respiratorio, fue mejor en aquellos alumnos que habían visto el video tutorial. Los alumnos también tenían una percepción personal de contar con más autonomía para realizar la práctica ya que un 55\% de ellos consideraba que había comprendido toda la práctica tras ver el video y un 41.3 \% consideraba que aunque con algunas dudas también habían comprendido la mayoría del proceso (fig. 4a y 4b).

Los resultados sobre el número de aciertos que tuvieron los alumnos contestando a las preguntas de comprensión de la práctica, evidencian que aquellos alumnos que vieron el video tuvieron un rango de aciertos entre 6 a 10 preguntas correctas en comparación con aquellos que no lo hicieron y cuyo rango de aciertos fue menor de 6 respuestas. (fig. 5.).

Respecto a la valoración sobre la ventaja de ver el video tutorial antes de acudir a la práctica el 82,8\% de los alumnos lo consideraba positivo frente al 17,2 \%, (fig. 6) .

Sin embargo, sorprendentemente, a la pregunta de si preferían que la práctica hubiera sido impartida de manera habitual, con los primeros 60 minutos dedicados a la explicación del profesor, un 79\% de alumnos dijo que sí, frente a un 21 \% que consideró que no (fig. 7)

Por último, las puntuaciones obtenidas por los alumnos que realizaron flipped learning fueron iguales que las de aquellos alumnos que no, con una nota media en ambos casos próxima a 7,5 sobre 10 (fig. 8).

Los profesores implicados en la innovación hemos valorado positivamente la ganancia de tiempo al aplicar flipped learning que permite abordar la parte práctica propiamente dicha mucho antes que con el método tradicional. Sin embargo los alumnos no perciben esta ganancia de tiempo como una ventaja para poder profundizar más en los conceptos, sino que lo entienden como salir antes de clase. También valoramos positivamente las interacciones habilitadas entre los alumnos, que les abren la posibilidad de ejercer de instructores unos con otros fomentando el trabajo colaborativo. Sin embargo consideramos que el tiempo que hay que dedicar a la preparación del material por parte del profesor y el tiempo de dedicación al estudio por parte del alumno se puede interpretar como una contingencia.

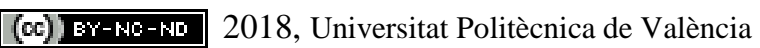

Congreso IN-RED (2018) 
Finalmente, a grandes rasgos la actividad ha sido muy positiva tanto desde el punto de vista de los alumnos como de los profesores, pero necesita algunas acciones de mejora. Entre ellas consideramos que la encuesta Kahoot sobre su grado de satisfacción con la implantación de los videos hay que desgranarla en más puntos, para tener una perspectiva mas exhaustiva sobre qué partes del video consideran positivos y negativos y aunque la cobertura de internet ha sido muy satisfactoria en el laboratorio seria mejorable, para evitar el no perder la cobertura ni en un solo dispositivo.

\section{Referencias}

Arasasingham, R.D., Martorell, I. y McIntire, T. (2011). En J. College. Sci. Teach., vol. 40, p. $70-79$.

Bloom, B.S. (1984). En Educ. Res., vol. 13, p. 4-16.

Escudero E, Sánchez-Vera I, Barhoum R, Puche J E, Muñoz U, (2017). Análisis del uso de autoevaluaciones en una plataforma digital en el entorno de la Fisiología Médica. Doi: http://dx.doi.org/10.4995/INRED2017.2017.6809

Gargallo, B, García- Félix, I, Morera, C. y Benavent, A. (2015). Métodos innovadores y enfoques de aprendizaje en estudiantes universitarios

Doi: http://dx.doi.org/10.4995/INRED2015.2015.1576

He, Y., Swenson, S. y Lents N. (2012). "On line video tutorials increase learning of difficult concepts in an undergraduate Analytical Chemistry course” en J. Chem. Educ., vol. 89, p. 1128-1132.

Jordan, J.T., Box, M.C., Eguren, K.E., Parker, Th.A., Saraldi-Gallardo, V.M., Wolfe, M.I. y Gallardo-Williams, M.T. (2016). "Effectiveness of student-generated video as a teaching tool for an instrumental technique in the Organic Chemistry laboratory” en J. Chem. Educ., vol. 93, p. 141-145.

Machemer, P. L y Crawford, P. (2007). "Student perceptions of active learning in a large cross disciplinary classroom”, en Active Learning in Higher Education, 8 (1), 9-30.

Monereo C. y Pozo J. I. (2003). La universidad ante la nueva cultura educativa. Enseñar y aprender para la autonomía. Madrid: Síntesis

Prieto Martín, Alfredo (2017): “Flipped learning. Aplicar el modelo de aprendizaje Inverso”. Madrid: Narcea.

Muñoz González JM y Serrano Rodríguez R.

El uso de mapas mentales en la formación inicial docente. Revista Latinoamericana de Tecnología Educativa, Vol. 13 (2) (2014) 7788 
Sánchez-Vera I, Escudero E, Muñoz U, Borrego, M J, Barhoum R, (2017). Experiencia en la elaboración de videos didácticos por alumnos de Fisiología como parte de su proceso de aprendizaje. Doi: http://dx.doi.org/10.4995/INRED2017.2017.6819

Santiago Raul. "Flipped Classroom: 4 principios para tener en cuenta y 4 errores a evitar”. Ponencia/INRED2017.2017

Zabalza, M.A. (2012). “Metodología docente”, en REDU (Revista de Docencia Universitaria, 9 (3), 75-98 


\title{
Herramientas para la mejora de la práctica docente de la Informática. Experiencia piloto en el Grado en Gestión y Administración Pública.
}

\section{Francisco Mata ${ }^{a}$, Luis Gonzaga Pérez ${ }^{b}$ y Carlos Porcel ${ }^{c}$}

a Departamento de Informática, Universidad de Jaén, email: fmata@ujaen.es, bepartamento de Informática, Universidad de Jaén, email: lgonzaga@ujaen.es 'Departamento de Informática, Universidad de Jaén, email: cporcel@ujaen.es.

\begin{abstract}
In this paper we introduce the teaching innovation initiative based on the use of concept maps and cooperative learning for teaching computer science in non-technical degrees, in particular in Management and Public Administration Degree. The combination of both methodologies gather peculiarities we believe useful for students of this degree or similar degrees, improving skills (teamwork, responsibility and leadership) and academic results. It is a pilot experience that is under development currently. According first results, we believe it will be a successful case. Although we have focused on a specific discipline and degree, this experience may be extended or adapted to other disciplines with complex contents or unsatisfactory academic results.
\end{abstract}

Keywords: concept maps, cooperative learning, computer science.

\begin{abstract}
Resumen
En este trabajo presentamos la iniciativa de innovación docente basada en el uso de mapas conceptuales y aprendizaje cooperativo para la enseñanza de la informática en titulaciones no técnicas, en particular en el Grado en Gestión y Administración Pública. Ambas metodologías reúnen peculiaridades que creemos que pueden se útiles para los estudiantes de esta titulación y titulaciones similares, mejorando sus competencias (trabajo en equipo, responsabilidad y liderazgo) y resultados académicos. Se trata de una experiencia piloto que actualmente está en fase de desarrollo y que a tenor de los primeros resultados creemos que va a ser un éxito. Si bien nos hemos centrado en una disciplina y titulación en concreto, consideramos que la experiencia puede ser exportada y/o adaptada a otras disciplinas con un contenido complejo o con resultados académicos poco satisfactorios.
\end{abstract}

Palabras clave: mapas conceptuales, aprendizaje cooperativo, informática. 


\section{Introducción}

En la literatura podemos encontrar numerosas definiciones sobre el concepto de Innovación Docente, siendo todas ellas coincidentes básicamente en la idea de aplicar nuevas herramientas y metodologías docentes con el propósito de mejorar la calidad de la docencia impartida.

En línea con las ideas recogidas en el preámbulo y objetivos del Plan de Innovación Docente de la Universidad de Jaén (I2D-UJA, 2016) en lo que concierne a "una mejora de la calidad docente, la adquisición de competencias y los resultados académicos del alumnado de la Universidad de Jaén", en este trabajo presentamos dos iniciativas de innovación docente, mapas conceptuales y el aprendizaje cooperativo, que proponemos incorporar a nuestra práctica docente de la informática en el grado en Gestión y Administración Pública con el propósito de mejorar las competencias de nuestros estudiantes y en consecuencia sus resultados académicos.

Enseñar informática en titulaciones no técnicas requiere adaptar los contenidos y las estrategias de aprendizaje al perfil de los alumnos que en muchos casos ven la informática con recelo al considerarla fuera de su ámbito de estudio actual e incluso futuro. Si embargo, creo que estaremos todos de acuerdo, la informática, no desde el punto de vista del desarrollo de aplicaciones sino desde el punto de vista del uso de un ordenador de forma eficiente, es una destreza que ningún alumno, independientemente de titulación debería descuidar. En titulaciones técnicas esta disciplina se ha implantado sin demasiados problemas y ha sido rápidamente asumida como parte esencial de su curriculum por el alumnado. Sin embargo, en otras titulaciones, como es el caso de que aquí tratamos, su impartición resulta compleja y de ahí que los resultados académicos no sean los esperados. En nuestro caso concreto venimos impartiendo la docencia utilizando una metodología de enseñanza clásica basada en clases magistrales en gran grupo y clases prácticas en aulas de informática. Los alumnos ponen en práctica una estrategia clásica de aprendizaje memorístico que no obtiene los resultados esperados porque son incapaces de establecer relaciones entre los conceptos si previamente no han sido aprendidos, es decir, aprenden de memoria conceptos y definiciones pero sin tener claro su significado ni relaciones entre los mismos. Este tipo de aprendizaje que, para materias como legislación o similares puede ser válido, en nuestro caso consideramos que no lo es.

Partiendo de esta reflexión y haciendo nuestra la frase del creador del proyecto de Wikipedia Jimmy Wales “aprender a aprender" (Wales, 2018), nos hemos planteado cambiar el modelo de aprendizaje actual hacia un modelo en el que los alumnos, partiendo de unos conocimientos básicos, sean capaces de generar nuevo conocimiento, tanto de forma individualizada como trabajando en grupo. Para conseguirlo estamos desarrollando una experiencia piloto basada en el uso de mapas conceptuales y aprendizaje cooperativo. Ambos conceptos se introducen en la siguiente sección, dedicando el resto del trabajo a la presentación de los objetivos del proyecto, la metodología para ponerlo en marcha y los resultados esperados.

(cc) BY-NC-ND 2018, Universitat Politécnica de Valencia

Congreso IN-RED (2018) 


\subsection{Mapas conceptuales}

Los mapas conceptuales fueron propuestos por Novak (Novak, 1990) a raíz de un proyecto de investigación sobre el aprendizaje de la ciencias en niños. Tomando como referencia las propuestas del psicólogo estadounidense David Ausubel (Ausubel, 1968), Novak planteó representar el conocimiento de los niños de una forma gráfica, dando lugar a lo que hoy en día se conoce por mapas conceptuales (Novak \& Musonda, 1991).

Los mapas conceptuales son una herramienta de aprendizaje basada en la representación gráfica de conceptos y relaciones entre ellos, que apoyándose en una estructura jerárquica o de tipo grafo, permite una estructuración y organización del conocimiento. Partiendo de conceptos generales en los niveles superiores de la estructura, se puede ir descendiendo en la búsqueda de conceptos más específicos los cuales están enlazados por palabras o verbos significativos que representan relaciones entre los elementos enlazados. Se sustentan en dos elementos principales, i) conceptos, representados normalmente por cajas, y ii) relaciones, representadas por líneas que unen conceptos y están etiquetadas con proposiciones que describen el tipo de relación entre conceptos. En la Figura 1 se muestra un ejemplo de mapa conceptual sobre las estaciones del año y su relaciones con conceptos como la cantidad de luz solar y la altura del sol.

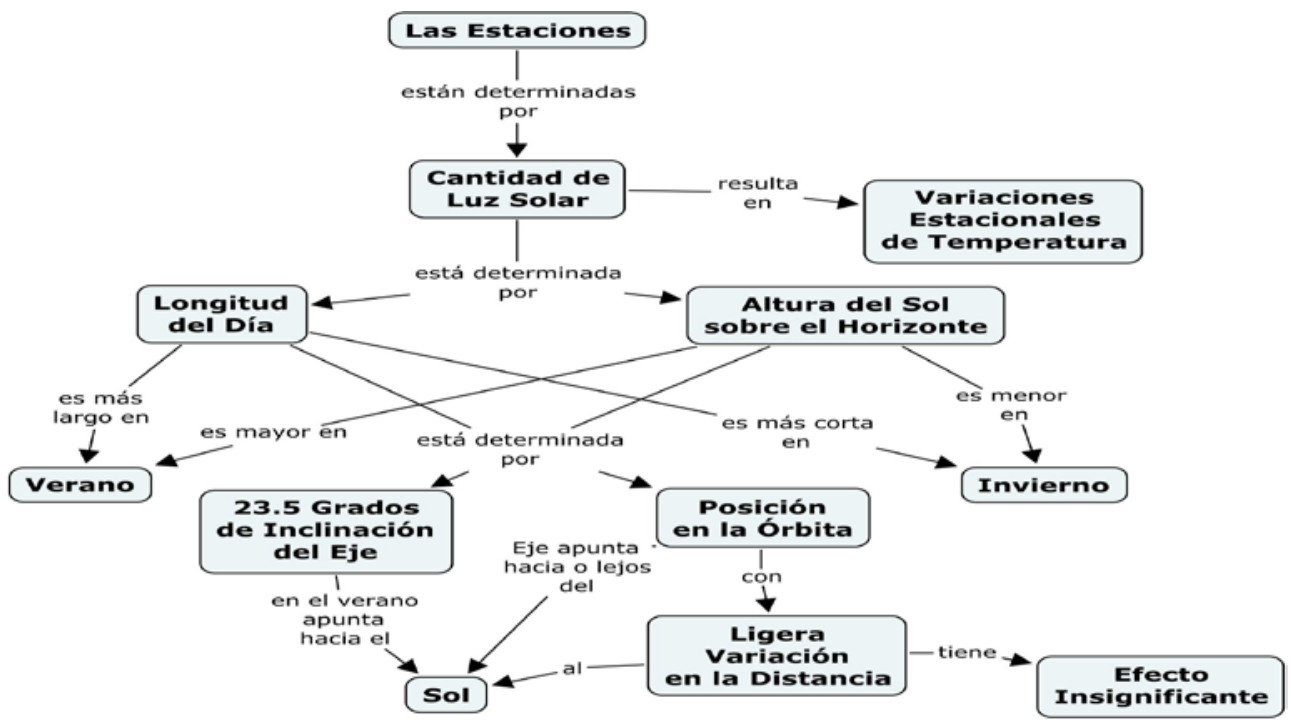

Fig. 1 Ejemplo de mapa conceptual ${ }^{1}$

\footnotetext{
${ }^{1}$ Fuente, https://cmap.ihmc.us/docs/images/Theory/spanish/Fig5CmapEstaciones-gr.jpg
} 
De forma general, el recorrido de un mapa conceptual comienza por el nodo superior de la jerarquía, descendiendo a continuación por cada una de las ramas. Cada rama representa una especificación del nodo superior, existiendo la posibilidad de establecer relaciones entre conceptos de ramas diferentes (enlaces cruzados), favoreciendo de esta forma la creatividad y la creación de nuevo conocimiento. Dependiendo del tema, los últimos nodos de la estructura jerárquica pueden ser en algunos casos ejemplos concretos sobre el concepto predecesor que ayudan a aclararlo.

Los mapas conceptuales son considerados como un ejemplo de aprendizaje significativo (Ausubel, 1963) basado en la idea del aprendizaje por descubriendo frente al aprendizaje por memorización (Tamayo, 2006). El aprendizaje significativo, a diferencia del memorístico basado en la idea de memorizar datos y conceptos, se basa en la idea de descubrir nuevos conceptos y relaciones, i.e. inferir nuevo conocimiento, a partir de la organización y estructuración del conocimiento previo y la incorporación de nuevos conceptos. Se puede decir que es la búsqueda de nuevos contenidos a partir del establecimiento de relaciones con el conocimiento del que ya se dispone.

Una de las ventajas principales del aprendizaje significativo y su implementación con mapas conceptuales es la representación estructurada de conocimiento de un individuo que, debidamente motivado, es capaz de construir nuevo conocimiento. Por lo tanto, la combinación de ambas estrategias pueden incrementar significativamente la creatividad de los individuos, en nuestro caso de los estudiantes.

Groso modo, el aprendizaje a través de mapas conceptuales se puede enfocar al menos desde dos puntos de vista.

a) Aprendizaje que se consigue cuando es el alumno el encargado de crear el mapa conceptual. Los expertos coinciden en que posiblemente esta es la mayor ventaja de los mapas conceptuales, pues obliga a que el sujeto tome una actitud activa en la búsqueda información, identificando nuevos conceptos y relaciones, y genere el mapa conceptual. Esto implica que se ejercite la parte creativa del estudiante y que un mismo problema sea enfocado de forma diferente por cada individuo. Pero por el contrario, requiere que el alumno tengan unos conocimientos mínimos que les permitan generar un estructura básica de conocimiento y a partir de esta, inferir el nuevo conocimiento.

b) Aprendizaje a partir de "mapas esqueleto" construidos por expertos (O'Donnell, et al., 2002). Este tipo de enfoque está pensado para aquellos casos en los que se aborden temas nuevos y/o complejos y alumno carezca de conocimientos y experiencia suficiente. La idea es partir de un mapa conceptual básico desarrollado por un experto y a partir de este, el estudiante ha de seguir construyéndolo incorporando nuevos conceptos y relaciones.

En la experiencia piloto que aquí estamos presentado estamos aplicando este segundo enfoque debido a que nuestros alumnos no tienen conocimientos ni experiencia para generar un mapa conceptual desde cero.

(cc) EY-NC-ND 2018, Universitat Politécnica de Valencia

Congreso IN-RED (2018) 


\subsection{Aprendizaje cooperativo}

$\mathrm{Al}$ igual que ocurre con el aprendizaje significativo, el aprendizaje cooperativo tiene su origen en la teoría constructivista propuesta por Piaget en la que el alumno juega un papel principal y activo en el proceso de aprendizaje (Piaget, 1973). El aprendizaje cooperativo, también conocido como colaborativo, se puede definir como una técnica de aprendizaje en la que los alumnos trabajan por grupos para alcanzar unos objetivos comunes, siendo responsables de su consecución todos los miembros del grupo (Servicio de Innovación Educativa, 2008). Johnson lo define cooperativo como aquel aprendizaje que persigue que los alumnos trabajen juntos para lograr objetivos que sean beneficiosos para todos los miembros del grupo (Johnson \& Johnson, 1991).

En la docencia en general y en la universitaria en particular es frecuente poner en práctica lo que los expertos denominan aprendizaje individualista, en el que el alumno se centra únicamente en la realización de su tarea y en conseguir, a nivel individual, sus objetivos previstos. Por tanto, el hecho de que un estudiante consiga de forma individual sus objetivos no influye en que sus compañeros también los alcancen. El aprendizaje individualista puede fácilmente derivar hacia otro tipo de aprendizaje denominado competitivo donde, además de trabajar de forma individualizada, se introduce el concepto de competitividad. Este concepto se traduce en el hecho de que alcanzar unos objetivos, en muchas ocasiones, implica la no consecución de esos objetivos por el resto de estudiantes (Garcia, et al., 2001). Según Prieto (Prieto, 2007), cada uno de los tipos de aprendizaje tiene sus pros y sus contras. Lo ideal sería aplicar un tipo de aprendizaje u otro en función del objetivo que se persiga y del contexto en el que se produzca el aprendizaje. Así, hay situaciones en las que se requiere que el estudiante trabaje de forma individual y otras en las que se requiere trabajar en grupo.

Centrándonos en el aprendizaje cooperativo, Johnson señala cinco características principales (Johnson, et al., 1999):

a) Interdependencia positiva. El éxito del grupo depende del éxito de cada uno de los miembros del grupo. Esta interdependencia implica la necesidad de apoyo entre todos los miembros del grupo.

b) Interacción "bis a bis”. Implica que los alumnos deben compartir conocimientos, recursos e interactuar entre sí para alcanzar el objetivo común.

c) Responsabilidad individual. Cada alumno debe ser responsable de llevar a cabo correctamente su tarea asignada y asumir tanto el éxito como el fracaso en el objetivo común del grupo.

d) Habilidades sociales. Permite poner en práctica las habilidades sociales de cada uno de los miembros del grupo desde el punto de vista de liderazgo y resolución de conflictos.

e) Autoevaluación. Es importante que el grupo realice una fase de autocrítica donde entre a valorar el funcionamiento del grupo y el grado de consecución de sus objetivos tanto a nivel individual como colectivo. Esta es la forma de aprender de los errores y plantearse nuevas estrategias para trabajos futuros.

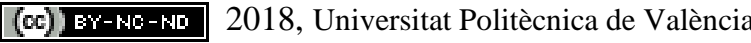

Congreso In-Red (2018) 
Herramientas para la mejora de la práctica docente de la Informática. Experiencia piloto en el Grado en Gestión y Administración Pública

\section{Contexto de la propuesta de innovación.}

Antes de enumerar los objetivos principales de esta experiencia piloto es necesario definir el contexto académico en el que se está llevando a cabo la misma. Este trabajo describe las líneas de actuación del proyecto de innovación docente titulado "Herramientas para la mejora de la práctica docente en la asignatura Introducción a la Informática de Gestión, grado en Gestión y Administración Pública”, encuadrado dentro del Plan de Innovación Docente de la Universidad de Jaén.

Hemos de tener en cuenta que transmitir conocimientos y competencias de la informática para alumnos cuyo perfil e interés en esta materia es escaso resulta muchas veces complicado a la par que desalentador tanto para el profesorado como para el propio estudiante. Aunque estamos notando cambios en los últimos años, todavía para muchos de los alumnos de titulaciones no técnicas, la informática les genera cierta desazón e incluso rechazo.

La experiencia piloto se está llevando a cabo sobre la asignatura Informática Aplicada a la Gestión, del Grado en Gestión y Administración Pública. Esta asignatura se imparte en el primer curso, primer cuatrimestre, con una carga teórica de 3 créditos y una carga práctica de otros 3. El número de alumnos por curso se mueve entre 20 y 50 alumnos lo que, según nuestra opinión, permite poner en práctica esta prueba piloto. El contenido está planteado como una primera toma de contacto con la disciplina de la informática desde el punto de vista de usuario de ordenadores y aplicaciones informáticas. Contempla conceptos generales de la Informática (software, hardware, Internet, Software Libre,...), destacando su parte práctica donde el alumno debe manejar de forma correcta y eficiente un equipo informático y un conjunto de aplicaciones (paquete de ofimática Open Office, navegadores web, etc). Estos contenidos se amplían en una segunda asignatura, Informática aplicada a la Administración Pública, que se imparte en el segundo cuatrimestre del mismo curso.

Los alumnos disponen de apuntes elaborados por el profesorado en formato libro. Desde el punto de vista metodológico, seguimos una metodología tradicional basada en clases magistrales en gran grupo apoyadas en recursos multimedia (presentaciones Power Point, videos,...) y evaluación con examen tanto teórico como práctico. Desde el punto de vista de los resultados medidos en número de aprobados y suspensos, aproximadamente el $30 \%$ no supera la asignatura, teniendo unos resultado peores que el resto de asignaturas del mismo curso, circunstancia que nos preocupa y que ha llevado entre otras cosas a poner en marcha esta iniciativa de innovación docente.

\section{Objetivos}

Una vez introducidos los aspectos más relevantes de las herramientas de innovación que vamos a poner en práctica y el contexto donde se está llevando a cabo la experiencia piloto, describiremos los problemas que hemos observado en la impartición de esta materia y plantearemos los objetivos a cubrir en el proyecto de innovación docente.

Problemas:

(cc) EY-NC-ND 2018, Universitat Politécnica de Valencia

Congreso IN-RED (2018) 
a) Aunque existe un material en formato libro elaborado por el profesorado y en continua actualización, el contenido teórico es exigente y requiere un trabajo diario del alumnado que hemos comprobado que no se realiza. Este material se elaboró para evitar que el alumno tuviese que tomar apuntes de unos contenidos completamente desconocidos y que en muchas ocasiones implicaba exámenes pobres y con muchas inexactitudes. Este material, que en principio puede verse como algo positivo puesto que recoge los contenidos teóricos de forma precisa, produce que un número importante de alumnos dejen de asistir a clase y confíen el aprobado al estudio memorístico del material suministrado.

b) Por diferentes motivos (selectividad en septiembre, cambios de universidad, etc), parte del alumnado se incorpora tarde a clase, cuando varios de los temas teóricos y prácticas ya se hayan impartido; consecuencia, les resulta complicado reengancharse a la asignatura y seguir el ritmo de las clases prácticas.

c) A esta titulación acceden alumnos con perfiles muy diferentes y con interés muy diferenciados. Alumnos que tienen más o menos claro el perfil de la titulación, alumnos de cierta edad que provienen de escalas básicas de la administración y que buscan con esta titulación una posible promoción interna y alumnos que no han sido admitidos en otras titulaciones y que finalmente se decantan por esta. Esta amalgama de estudiantes implica desequilibrios desde el punto de vista de la motivación y el interés en la materia así como en el dominio y destrezas en el uso de equipos informáticos.

Teniendo presente estos problemas, nuestra propuesta de mejora de la enseñanza de la informática en esta titulación persigue dos objetivos principales:

a) Para facilitar la asimilación de contenidos, la motivación y la creatividad de nuestros estudiantes, proponemos usar como herramienta de aprendizaje los mapas conceptuales. En concreto, el profesorado facilitará al alumnado un conjunto de mapas conceptuales esqueleto o básicos que los estudiantes deben usar como punto de partida para ampliar y mejorar su contenido. De esta forma el estudiante se convertirá en un agente activo en el proceso de aprendizaje y asimilará los conceptos a partir de la generación de nuevos contenidos y conocimiento.

b) Para evitar que, tanto el alumnado que se incorpora tarde o como el que tiene problemas en el uso de ordenadores y/o aplicaciones informáticas se pueda quedar descolgado en la parte práctica de la asignatura, pondremos en marcha un modelo de aprendizaje cooperativo conforme al paradigma introducido anteriormente. Tal y como se indica en el siguiente apartado, se han creado pequeños grupos de estudiantes con el objetivo común de colaborar y apoyarse entre sí en las clases prácticas con ordenadores.

Con la puesta en práctica de ambas estrategias de aprendizaje esperamos potenciar competencias tan importantes como el trabajo en equipo, creatividad y liderazgo. Como consecuencia, esperamos mejorar los resultados académicos de nuestros estudiantes.

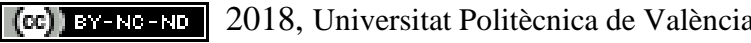


Herramientas para la mejora de la práctica docente de la Informática. Experiencia piloto en el Grado en Gestión y Administración Pública

\section{Desarrollo}

Fijados los objetivos, en este apartado comentaremos las estrategias y tareas que vamos a utilizar para alcanzar los objetivos propuestos.

\subsection{Mapas conceptuales.}

Nuestro propósito es realizar mapas conceptuales del temario teórico de la asignatura. Antes de incorporar el ordenador como una herramienta de trabajo, los mapas se solían dibujar a mano alzada o bien se utilizaban otro tipo de recursos como post-its, que se desplegaban sobre algún tipo de soporte que permitiese su desplazamiento, por ejemplo una pizarra. Actualmente existen herramientas informáticas, más o menos especializadas, para crear mapas conceptuales que se almacenan en formatos digitales que permiten su reproducción en equipos informáticos (ordenadores, tablets, smartphones,...) y su distribución a través de la red. Tras una revisión de varias aplicaciones software (Xmind, Inspiration, SmartDraw), nos hemos decantado por usar la aplicación CmapTools desarrollada por Florida Institute for Human \& Machine Cognition, IHMC (Cañas, et al., 2004). Esta herramienta puede crear mapas conceptuales tanto en modo local como en la nube, permitiendo la interacción entre individuos en diferentes ubicaciones físicas. Además permite, no solo representar conceptos y relaciones, sino incorporar otros elementos multimedia (imagen, sonido, video) y distribuirlos y compartillos por Internet. Otra de las ventajas de esta herramienta es la posibilidad de buscar información o recursos en internet relacionados y filtrados por los conceptos recogidos en mapa conceptual. Esto permite encontrar nueva información que se puede ir incorporando al mapa conceptual de forma relativamente sencilla. Por último añadir que este software se distribuye bajo licencia Free software y es sencillo de utilizar.

Desde el punto de vista de aprendizaje, lo ideal sería que el alumnado elaborase sus propios mapas conceptuales a partir de los apuntes que tienen a su disposición, pero esto requeriría un grado de conocimiento previo sobre la materia que no tienen. Parte del el equipo docente ya tiene cierta experiencia en la elaboración de mapas conceptuales y los ha incorporado a su docencia como material de apoyo complementario. Ahora pretendemos que los mapas conceptuales adquieran un papel principal en nuestra praxis docente y releguen a los apuntes a un papel secundario como material de apoyo para la creación de los mapas, desplazando en gran medida el aprendizaje memorístico por el significativo.

(cc) EY-NC-ND 2018, Universitat Politécnica de Valencia

Congreso IN-RED (2018) 


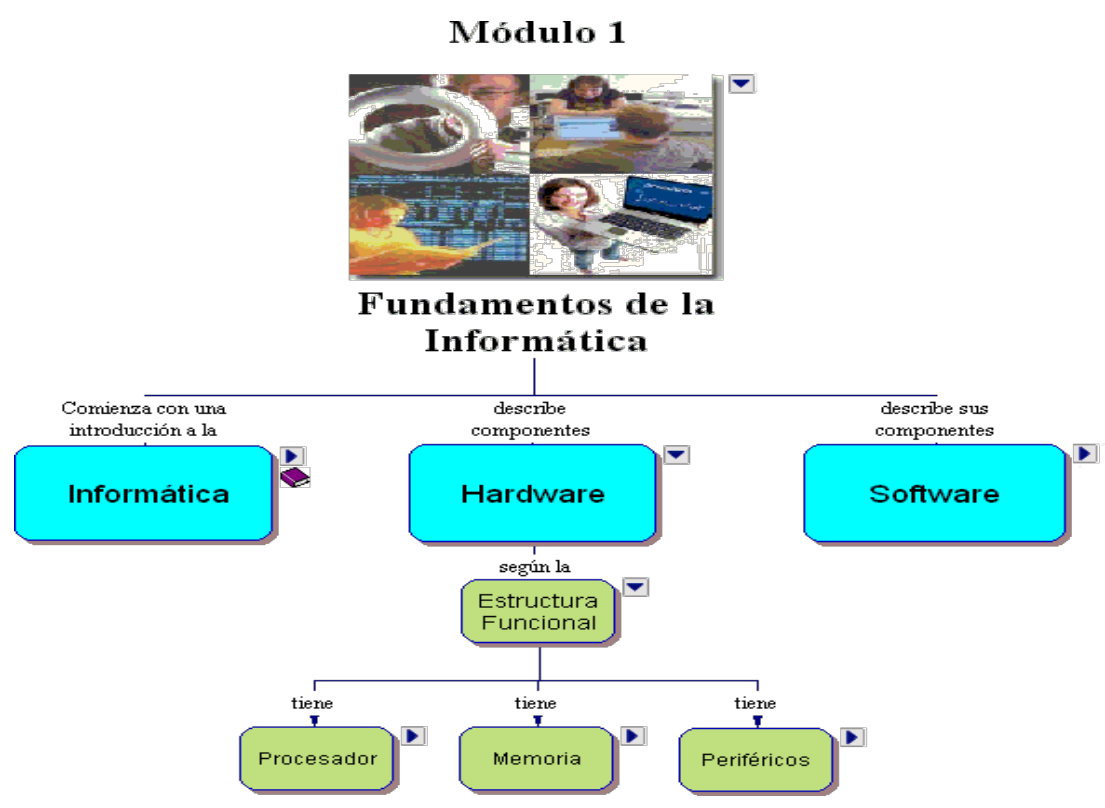

Fig. 2 Ejemplo de mapa conceptual

Para acometer esta tarea, el equipo docente está diseñando mapas conceptuales básicos, tipo esqueleto, con los principales conceptos y relaciones que deben contener en función del tema tratado (ver Figura 2). Estos mapas esqueleto deben servir de guía y ayuda a los estudiantes para que los completen y extiendan sirviéndose de los apuntes de la asignatura y de la utilidad de búsqueda de información disponible en la herramienta CmapTools. El trabajo de alumno se hará de forma individualizada. Las clases magistrales se usarán para explicar los mapas esqueleto y orientar a los alumnos en la elaboración mapas. Respecto a la evaluación, se tomará nota de la calidad de los mapas y del trabajo realizado en clase y se sumará a la nota obtenida en el examen final de la teoría.

\subsection{Aprendizaje cooperativo}

Respecto a la implementación del aprendizaje cooperativo, este va a ser puesto en marcha en la componente práctica de la asignatura. Como hemos indicado anteriormente, la mitad de los créditos de esta asignatura son créditos prácticos que se evalúan a partir de medir destreza en el uso de un equipo informático y serie de una serie aplicaciones informáticas, principalmente de ofimática. Estas destrezas se adquieren y entrenan en sesiones prácticas que se realizan en aulas de informática. Dependiendo de diversos factores (conocimientos previos, uso diario de la aplicaciones) nos encontramos con alumnos que suelen seguir las clases prácticas sin mayor problema y otros que les supone un verdadero hándicap. Este segundo grupo suele abandonar y/o suspender el examen práctico que se realiza a final del cuatrimestre.

A partir de las experiencias disponibles en la literatura, hemos diseñado un modelo de aprendizaje en el que los alumnos trabajan en pequeños grupos (3 o 4 estudiantes) con el objetivo común de mejorar las calificaciones individuales en el examen práctico. Los estudiantes se sientan juntos en el aula de informática y se apoyan los unos en los otros para realizar correctamente cada una de las prácticas. Consideraremos que el objetivo se ha 
alcanzado si todos los miembros del grupo alcanzan en la evaluación de las competencias prácticas una nota igual o superior a 6.5 puntos. Para dinamizar y tirar del grupo, se ha definido la figura de un líder que se encarga de emprender las iniciativas que considere oportunas para alcanzar el objetivo previsto. Si el objetivo se consigue, el líder será recompensado con un aumento de su calificación final en la asignatura. Si no es así, se le calificará con la nota obtenida de forma individual. La figura del líder va en la línea de cubrir la competencia de "liderazgo" recogida en el listado de competencias generales de la memoria del grado de la titulación y potenciar la capacidad de alumno para asumir responsabilidades y tomar decisiones.

La combinación de ambas herramientas ha de traducirse en una mejora de los resultados académicos así como de la puntuación obtenida en las encuestas de satisfacción del alumnado que anualmente se pasan sobre esta asignatura. Para la comparación usaremos los resultados disponibles de años anteriores.

\section{Resultados}

Como indicamos en la introducción, el proyecto de innovación docente ha empezado a ponerse en práctica este curso académico 2017-18. En lo que se refiere a los mapas conceptuales, actualmente estamos desarrollando los mapas esqueleto de cada uno de los temas, teniendo previsto entregárselos a los alumnos el siguiente curso 2018-19. Por lo tanto carecemos de datos para poder medir el impacto de los resultados de esta iniciativa.

Por el contrario, si que estamos muy satisfechos con las sensaciones y resultados de la puesta en marcha del aprendizaje cooperativo en las sesiones prácticas en aulas con ordenadores. Todos los años detectamos sombre un $15 \%$ de alumnos que abandonaban la asistencia a prácticas motivadas principalmente porque no son capaces de seguir el ritmo de las clases, bien porque se han incorporado tarde, bien por sus propias limitaciones en el trabajo con ordenadores. Sin embargo, este año no hemos detectado ningún abandono de la asignatura por estos motivos. De hecho hemos comprobado como alumnos, que de haberse mantenido el sistema anterior casi con total seguridad hubiesen abandonado la asignatura, este año no lo han hecho. Además, el clima de trabajo en la sesiones prácticas han cambiado sensiblemente a mejor. Los alumnos se muestran más activos y los que asumieron el papel de líderes han ejercido como tales. Se ha preocupado de que los miembros de sus equipos más rezagados aprendiesen a realizar las prácticas correctamente, juntándose en algunas ocasiones fuera del horario lectivo para realizar los guiones de prácticas. Como cabría esperar con estos cambios, los resultados académicos en la prueba práctica de la convocatoria de febrero han mejorado respecto a años anteriores (ver Figura 3). Así, podemos ver como han descendido el número de suspensos y no presentados y ha aumentado porcentualmente el número de sobresalientes y matrículas de honor.

(cc) EY-NC-ND 2018, Universitat Politécnica de Valencia

Congreso IN-RED (2018) 


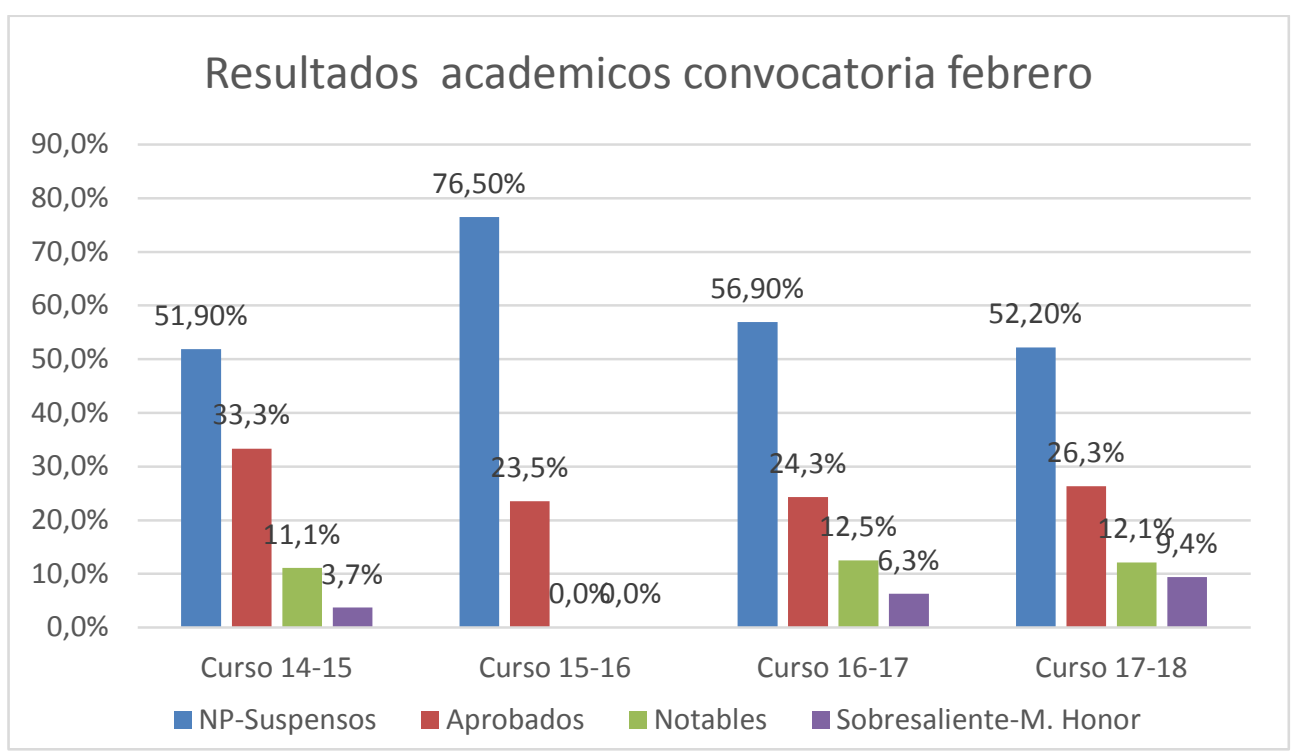

Fig. 3 Resultados académicos convocatoria de febrero

\section{Conclusiones}

En este trabajo hemos presentado las dos iniciativas de innovación docente que actualmente estamos desarrollado para mejorar las competencias y resultados académicos de una de las dos asignaturas de informática que se imparten en el grado en Gestión y Administración Pública. Esta asignatura viene obteniendo resultados insatisfactorios para el equipo docente que la imparte debido a dos motivos principales, i) la incorporación tardía al curso de una parte importante de estudiantes y ii) la dificultad en sí de los contenidos y la falta de destrezas en el manejo aplicaciones informáticas.

Para intentar paliar estos problemas, hemos propuesto incorporar como innovación docente el uso de mapas conceptuales para abordar los contenidos teóricos y el aprendizaje cooperativo para resolver el problema de la mejora de las destrezas prácticas. Vistas las peculiaridades de ambas metodologías, el equipo docente considera que su combinación puede ser una buena solución para intentar resolver los problemas detectados en esta asignatura y alcanzar los objetivos propuestos, además de cubrir varias de las competencias que suelen venir recogidas en las memorias de grado en cuanto a fomentar el trabajo en equipo, responsabilidad y liderazgo.

Desde el punto de vista de la transversalidad, entendemos que esta experiencia puede ser aplicada y/o extendida a otras asignaturas que se imparte en titulaciones con un perfil similar al grado en Gestión y Administración Pública (Derecho, Trabajo Social, Relaciones Laborales, ...), o en asignaturas con un contenido teórico complejo o en las que los resultados académicos de la parte práctica no sean los esperados y/o deseados.

\section{Agradecimientos.}

Este trabajo se enmarca dentro del Proyecto de Innovación Docente UJA PI2D-2017, correspondiente a la convocatoria de proyectos de innovación docente recogidos en el Plan 
Herramientas para la mejora de la práctica docente de la Informática. Experiencia piloto en el Grado en Gestión y Administración Pública

de Innovación e Incentivación de la Buenas Prácticas Docentes de la Universidad de Jaén 2016-2019.

\section{Referencias}

AUSUBEL, D. P. (1963). The psychology of meaningful verbal learning. New York: Grune and Stratton.

AUSUBEL, D. P. (1968). Educational psychology: A cognitive view. New York: Holt, Rinehart and Winston.

CAÑAS, A. J. et al. (2004). CmapTools: A knowledge modeling and sharing environment. Pamplona, Universidad Pública de Navarra, pp. 125-133.

GARCIA, R., TRAVER, J. y CANDELA, I. (2001). Aprendizaje cooperativo. Fundamentos, características y técnicas. Madrid: CCS.

I2D-UJA, (2016). "Plan de Innovación e Incentivación de las buenas prácticas docentes en la Universidad de Jaén (Plan I2D-UJA 2016)". [Online] Available at: https://www10.ujaen.es/conocenos/organos-gobierno/vicestudios/planinnovacion

JOHNSON, D. y JOHNSON, R. (1991). Learning Together and Alone. Cooperative, Competitive and Individualistic learning. 3rd ed. Needham Heights, Allyn and Bacon.

JOHNSON, D., JOHNSON, R. y HOLUBEC, E. (1999). El aprendizaje cooperativo en el aula. Buenos Aires: Paidós.

Novak, J. D. (1990). "Concept maps and vee diagrams: Two metacognitive tools for science and mathematics education". Instructional Science, Issue 19, pp. 29-52.

NOVAK, J. D. y MUSONDA, D., 1991. "A twelve-year longitudinal study of science concept learning". American Educational Research Journal, 28(1), pp. 117-153.

O'DONNELl, A., DANSEREAU, D. \& HALL, R. H. (2002). "Knowledge maps as scaffolds for cognitive processing". Educational Psychology Review, Issue 14, pp. 71-86.

PIAGET, J. (1973). La representación del Mundo en el Niño.. Madrid: Morata.

PRIETO, L. (2007). El aprendizaje cooperativo. Madrid: PPC.

Servicio de Innovación Educativa, 2008. Aprendizaje Cooperativo, s.l.: Universidad Politécnica de Madrid.

TAMAYO, M. F. A. (2006). "El mapa conceptual como una herramienta para aprender y enseñar". Plasticidad y Restauración Neurológica, 5(1), pp. 62-72.

WALES, J., (2018). "Apreder cómo aprendee es más importante que nunca". El pais. [Online]

Available at: http://aprendemosjuntos.elpais.com/especial/el-aprendizaje-informal-jimmywales/

(cc) EY-NC-ND 2018, Universitat Politécnica de Valencia

Congreso IN-RED (2018) 


\title{
Coordinación vertical/horizontal en Ingeniería Química a través de proyectos transversales desglosados en ABP.
}

S.C. Cardona Navarrete, María-Fernanda López-Pérez, J. Lora García, Vicent Fombuena Borrás

Departamento de Ingeniería Química y Nuclear. Universitat Politècnica de València (UPV). Plaça Ferràndiz i Carbonell, s/n 03801 Alcoy, Alicante (Spain). scardona@iqn.upv.es, malope1@iqn.upv.es, jlora@iqn.upv.es, vifombor@upvnet.upv.es

\begin{abstract}
Vertical/horizontal coordination between different subjects of Chemical Engineering Degree is important in order that students can reach the skills that they will need in a future, in their profession. This means coordinating contents, methodologies and timing of concepts. Therefore, teachers of Campus d'Alcoi have developed a project named "Adsorption column design for the elimination of dyes in wastewater from the textile industry". The students solve a part of the project using BPL methodology in every subject and complete the project sequentially throughout the degree. This work shows the steps to start this project and an example of the problems proposed in the subject Chemical Engineering Laboratory II.
\end{abstract}

Keywords: Vertical/horizontal coordination, BPL, Projects

\begin{abstract}
Resumen
El nivel de coordinación vertical/horizontal entre las diferentes asignaturas impartidas en los grados es esencial para que el alumno pueda adquirir todas las competencias necesarias para ejercer su profesión. Ello conlleva coordinar contenidos, metodologías y temporalización. En esta línea, los profesores del Campus d'Alcoi han desarrollado un proyecto "Diseño de una columna de adsorción para la eliminación de colorantes en aguas residuales de la industria textil" para que los alumnos lo tengan que resolver parcialmente en cada asignatura mediante la metodología docente de ABP y completarlo de forma secuencial a lo largo de la titulación. En este trabajo se muestra cómo han sido los pasos para poner en marcha el proyecto y un ejemplo de los problemas planteados en la asignatura Experimentación en Ingeniería Química II.
\end{abstract}

Palabras clave: Coordinación vertical/horizontal, ABP, Proyectos

\section{Introducción}

Los cambios sociales y los nuevos perfiles profesionales que el mercado laboral demanda, han provocado la necesidad de que la Universidad española esté cambiando los modelos y metodologías pedagógicas para adaptarse a los nuevos procesos de enseñanza-aprendizaje, centrada en este último. Parte fundamental de esta metodología es fomentar la figura del 
docente como gestor del aprendizaje, es decir, el profesor será la guía para que los alumnos aprendan y hagan un uso adecuado de los recursos disponibles e instrumentos que necesiten (Cardenas-Rodríguez, 2015). Además, actualmente el enfoque por competencias en la educación implica cambios sustanciales en las instituciones educativas a todos los niveles. Como consecuencia, los nuevos títulos de grado y posgrado de la UPV incorporan de manera explícita la exigencia de que los estudiantes sean formados en competencias y que sea evaluado su nivel de logro. Por ello, cualquier tipo de iniciativa debe tener en cuenta este hecho, e ir encaminado a que el alumno adquiera las competencias transversales en cada asignatura.

Unas de las tecnologías activas de aprendizaje, basadas principalmente en el aprendizaje colaborativo, son las metodologías ampliamente descritas en la bibliografía como son el Aprendizaje basado en problemas (ABP), Aprendizaje basado en proyectos (ABP) y el Aprendizaje basado en casos (ABC) (García-Sevilla, 2008, Charoula, 2002).

Este tipo de metodología participativa, en resumen, tiene las siguientes características:

- Enfoque centrado en el desarrollo de habilidades y conocimiento en los que se plantean situaciones reales a resolver.

- Método interactivo basado en la construcción del conocimiento, aprendizaje participativo. Al ser un aprendizaje colaborativo, se basa en la organización de pequeños grupos para la resolución del problema.

- Es una metodología centrada en la interacción alumno-profesor-contenido. Debe haber seminarios, tutorías, etc.

- El rol del profesor es proporcionar condiciones adecuadas como instructor en la comunicación para el aprendizaje.

- El rol del alumno debe ser participativo, que propone soluciones de forma autónoma.

La principal característica de este método de abordar el aprendizaje activo consiste en que se plantea un reto al alumnado, que sirve para generar la demanda por parte del mismo de una serie de conocimientos y competencias, directamente relacionados con el área técnica objeto del aprendizaje, en este caso la Ingeniería Química (Hirshfield, 2018). La situación a resolver, normalmente un problema técnico, se formula teniendo en cuenta que debe ser posible dividirlo en varios subproblemas perfectamente secuenciados y articulados entre sí, de modo que a través de la resolución de los mismos, el alumno alcanza los resultados de aprendizaje planteados (López-Guede, 2015).

Todo lo expuesto anteriormente, además de la necesidad de proporcionar una utilidad inmediata de los contenidos impartidos en las asignaturas a nuestros estudiantes, debido a que la motivación de la Generación Z se basa en ello (Cruz, 2016), dio como resultado proponer un proyecto basado en $\mathrm{ABP}$. El planteamiento de este proyecto se tradujo en un Proyecto de Innovación y Mejora Educativa (PIME) titulado "Coordinación en el Grado en Ingeniería Química del Campus d’Alcoi: Aprendizaje Basado en Problemas como Metodología de Conexión entre Asignaturas” (López-Pérez, 2017).

(cc) EY-NC-ND 2018, Universitat Politècnica de València 
Como el título del proyecto indica, el objetivo del mismo consiste en utilizar el ABP como metodología docente para mejorar el aprendizaje de nuestros estudiantes, combinar la adquisición de conocimientos con la adquisición de competencias y que, si los problemas tienen enunciados sugerentes para nuestros alumnos y ven una utilidad práctica a los mismos con temas que pueden buscar y relacionar con problemas reales, la herramienta puede ser el nexo de unión entre asignaturas, para facilitar la coordinación de las mismas.

Los problemas planteados en el PIME son proyectos normalmente de diseño, cuyas partes puedan ser resueltas en varias asignaturas, obligando a los docentes implicados en ellas a coordinarse tanto a nivel conceptual como secuencial, para que el problema tenga un desarrollo temporal adecuado. Estas actividades llevan consigo una coordinación tanto horizontal como vertical y, como consecuencia, que todos los profesores se impliquen y conozcan de forma global el Grado donde imparten docencia, en este caso el Grado de Ingeniería Química, Campus d’Alcoi (Cardona, 2018).

El motivo por el que pensamos que un proyecto basado en ABP planteado en las diferentes asignaturas del Grado puede dar como resultado una verdadera coordinación se debe a experiencias previas como la experiencia en el PIME "Utilización de MATLAB como estrategia didáctica y de coordinación horizontal y vertical entre asignaturas del Grado de Ingeniería Química”, en el cual se llegó a la conclusión que, para que se produzca una verdadera coordinación de contenidos entre las asignaturas, debe haber un nexo de unión entre ellas (López-Pérez, 2015, López-Pérez, 2016).

En este trabajo se va a presentar cuales son los pasos que se han pensado para poner en marcha un proyecto multidisciplinar que los alumnos desarrollen durante todo el Grado y que permita una mejor coordinación del mismo. Para ello, la primera actividad, será realizar encuestas para conocer el punto de partida en cuanto a coordinación, posteriormente, se diseñará el problema con sus actividades secuenciadas, incluyendo el máximo de asignaturas. Finalmente, se mostrarán los primeros resultados obtenidos y un ejemplo de ficha con la que el alumnos trabajará en una asignatura.

\section{Objetivos}

El objetivo general es desarrollar una serie de problemas/proyectos complejos que los alumnos tengan que resolver parcialmente en cada asignatura y completar de forma secuencial a lo largo de la titulación. En este trabajo se muestra cómo se ha planteado el proyecto "Diseño de una columna de adsorción para la eliminación de colorantes en aguas residuales de la industria textil" en cuanto a temporización de contenidos en cada una de las asignaturas. Posteriormente, se mostrará una ficha completa de una asignatura, Experimentación en Ingeniería Química II.

Los objetivos específicos que deben alcanzarse para poder desarrollar el proyecto son:

- Revisar y contrastar la secuenciación de contenidos en el conjunto de materias y de asignaturas, evitando solapes y lagunas. 
- Diseñar problemas abiertos (enunciados, estructura, secuencia de resolución, evaluación), para ser utilizados en las diferentes asignaturas, agrupándolas según los resultados anteriores.

- Aplicar la Metodología docente ABP en las asignaturas

- Evaluar la coordinación alcanzada después de la aplicación de la metodología.

\section{Desarrollo de la innovación}

\subsection{Realización de encuestas y análisis de resultados}

El primer paso es analizar los contenidos de cada una de las asignaturas para determinar la temporalización de las actividades que vamos a desarrollar en cada uno de los problemas que se van a plantear. Es por ello que es necesario realizar una serie de encuestas a los profesores del Grado de Ingeniería Química para que puedan indicarnos qué contenidos son los que necesitan o imparten. La encuesta se pasó en formato electrónico y contenía un desglose, por materia, de cada uno de los descriptores que aparecen en el documento Verifica. La encuesta se contestó por cada asignatura impartida en el grado en Ingeniería Química, indicando si un determinado descriptor es impartido o simplemente se necesita, siendo una información primordial en la coordinación vertical de las asignaturas (Figura 1). Con dicho análisis seremos capaces de organizar grupos de asignaturas relacionadas por contenidos y cronológicamente, para cada uno de los problemas a plantear.

\section{Materia Matemáticas}

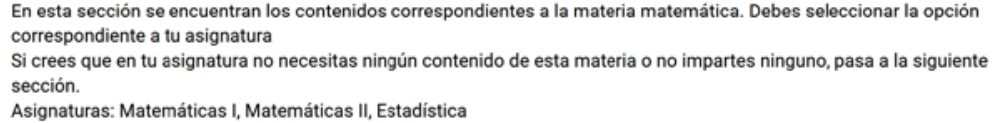

Fig. 1 Encuesta asignaturas Grado en Ingeniería Química

\subsection{Diseño del proyecto transversal basado en la metodología ABP}

En la fase correspondiente al diseño de proyectos transversales basados en la metodología de aprendizaje basado en problemas, indicar que en un principio se definieron 12 posibles proyectos transversales (Tabla 1). Estos están relacionados con sectores pertenecientes al ámbito de actuación de la Ingeniería Química como son Refino de Petróleo/Petroquímica, Energía, Salud/Cuidado Personal, Medio Ambiente y Alimentación y con el entorno socio- 
económico del Campus de Alcoi de la UPV: Tratamiento de Aguas, Fabricación de Cerveza e Industria Cosmética.

Tabla 1. Proyectos transversales posibles

\begin{tabular}{|c|c|}
\hline Sector & Título del proyecto transversal \\
\hline Refino de & 1.- Diseño de un reactor de polimerización para la obtención de polietileno \\
\hline $\begin{array}{l}\text { Petróleo } \\
\text { /Petroquímica }\end{array}$ & $\begin{array}{l}\text { 2.- Diseño de una torre de destilación para la separación de diferentes tipos } \\
\text { de combustibles en una refinería }\end{array}$ \\
\hline \multirow{2}{*}{ Energía } & $\begin{array}{l}\text { 3.- Diseño de un proceso de obtención de biodiesel a partir de aceites } \\
\text { vegetales de fritura usados }\end{array}$ \\
\hline & $\begin{array}{l}\text { 4.- Diseño de una pila de combustible de hidrógeno para el automóvil del } \\
\text { futuro }\end{array}$ \\
\hline $\begin{array}{l}\text { Salud } \\
\text { /Cuidado Personal }\end{array}$ & $\begin{array}{l}\text { 5.- Diseño de un proceso de obtención de liofilizados de colágeno para la } \\
\text { industria cosmética }\end{array}$ \\
\hline \multirow{4}{*}{ Medio Ambiente } & 6.- Diseño de una planta de tratamiento biológico de aguas \\
\hline & $\begin{array}{l}\text { 7.- Diseño de una columna de adsorción para la eliminación de colorantes } \\
\text { en aguas residuales de la industria textil }\end{array}$ \\
\hline & $\begin{array}{l}\text { 8.- Diseño de un proceso de ósmosis inversa para la desalación de agua de } \\
\text { mar }\end{array}$ \\
\hline & $\begin{array}{l}\text { 9.- Diseño de una torre de absorción para la eliminación de ácido } \\
\text { sulfhídrico en una refinería }\end{array}$ \\
\hline \multirow{3}{*}{ Alimentación } & 10.- Diseño de un túnel de congelado de guisantes \\
\hline & 11.- Diseño de un reactor de fermentación de cerveza \\
\hline & 12.- Diseño de un sistema de obtención de café descafeinado \\
\hline
\end{tabular}

El objetivo a la hora de plantear estos proyectos transversales ha sido que los alumnos, desde primer curso, se familiaricen con las actividades intrínsecas de la Ingeniería Química, entre las que destaca el diseño de procesos, con los diversos sectores donde la Ingeniería Química tiene mucho que aportar, así como con la industria cercana al ámbito de influencia del Campus de Alcoi. A continuación se mostrarán algunos detalles del proyecto transversal "Diseño de una columna de adsorción para la eliminación de colorantes en aguas residuales de la industria textil”. En la Tabla 2 se presenta un cronograma que muestra las asignaturas implicadas, las actividades planteadas, las fases en las que se ha dividido el proyecto transversal y su temporalización durante cuatro cursos.

Destacar que en la propuesta presentada en esta comunicación intervienen 21 de 39 asignaturas troncales, 9 departamentos, que el proyecto se desglosa en la presentación del mismo a los alumnos y 24 actividades, que cada actividad se acomete mediante resolución de problemas y que los grupos estarán formados entre 3 y 5 alumnos, trabajando de forma cooperativa.

\subsubsection{Presentación del proyecto}

En esta presentación se les planteará a los alumnos que acaban de entrar en el Grado en Ingeniería Química cuál es el reto a resolver, en qué consiste el proyecto que se les plantea 
y cuál es su contexto. También se definirá con qué tecnología se va a resolver el proyecto planteado, qué actividades se harán a lo largo del mismo y qué asignaturas/departamentos están involucrados. Adicionalmente se indicará cómo se evaluarán las actividades y cuáles son las metas a alcanzar al cabo de su viaje académico de cuatro cursos.

Esta presentación la harán los profesores que imparten los últimos cursos a los alumnos de primer curso en un seminario fuera de las horas de clase, con la finalidad de reforzar el mensaje a los alumnos que la resolución del proyecto pasa por la adquisición de competencias ya en los primeros cursos.

En este seminario con los alumnos de primer curso se les proporcionará el enunciado completo del proyecto a resolver en formato electrónico. Evidentemente en esta presentación no se puede entrar en detalles que los alumnos aún no están preparados para comprender, pero debe ser motivadora y esclarecedora de qué hace un ingeniero químico, reforzando la decisión de aquellos alumnos que hayan escogido la Ingeniería Química por vocación. Para ello se hará uso de los medios audiovisuales necesarios (vídeos, Powerpoint, etc).

Es muy importante durante esta sesión motivar a los alumnos de primer curso y ayudarles a comprender el papel que tiene cada asignatura, independientemente que sea de los primeros cursos, en la consecución del objetivo final que es diseñar un determinado proceso.

\subsubsection{Actividades}

La descripción de las actividades a realizar en cada asignatura la realizará cada profesor dentro de su asignatura en horario de clase, entrando en los detalles que sean necesarios. En el punto 4.2 se mostrará una ficha que elaborará el profesor de cada asignatura, en la que se indican los problemas concretos a resolver para desarrollar cada una de las actividades. Los alumnos irán trabajando estos problemas a lo largo del curso y su evaluación quedará integrada en la evaluación de la asignatura.

Actividad 1.

En la asignatura de Química (Quím) se trabajará la preparación de disoluciones a diferentes concentraciones con colorantes, así como la búsqueda y análisis de las fichas de seguridad de los mismos.

\section{Actividad 2.}

En Física (Fís) los alumnos ensayarán las disoluciones agua+colorante con diferentes concentraciones para determinar propiedades físicas como la densidad, viscosidad, tensión superficial, etc.

\section{Actividad 3.}

En Expresión Gráfica (EG) los alumnos realizarán los planos correspondientes a una columna de adsorción industrial. Dado que los alumnos aún no saben qué dimensiones va a tener la columna que diseñarán hacia el final del Grado, el profesor se las proporcionará.

(cc) EY-NC-ND 2018, Universitat Politècnica de València

Congreso IN-RED (2018) 


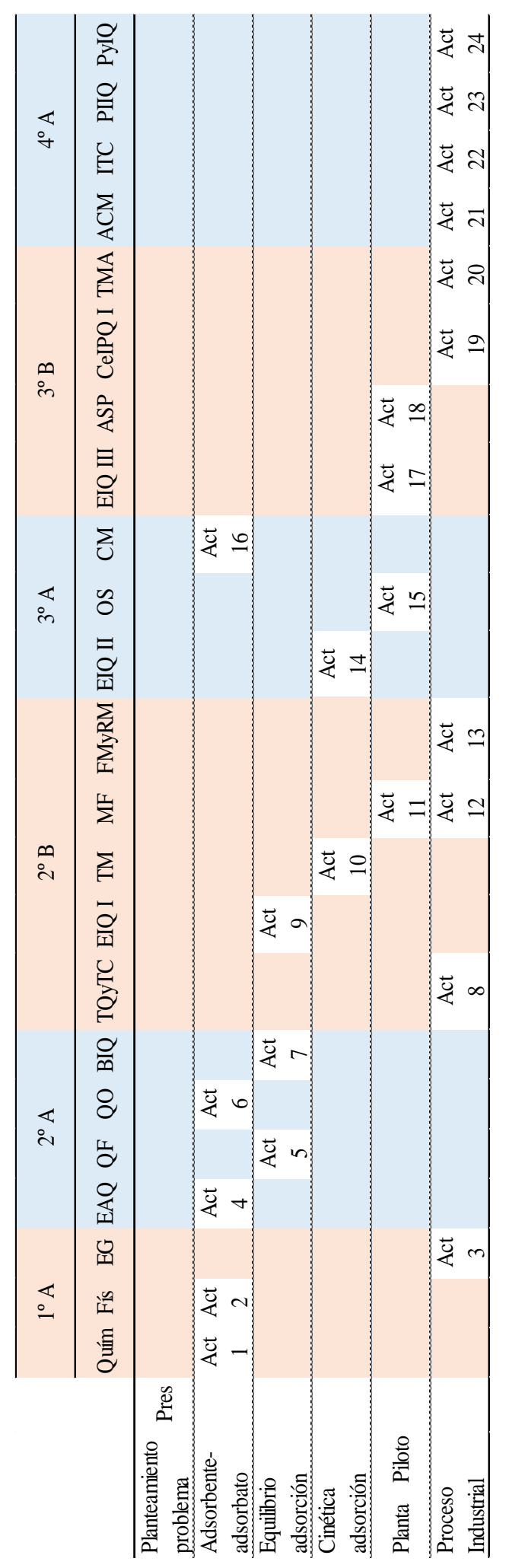

Tabla 2. Cronograma

(cc) BY-No-ND 2018, Universitat Politècnica de València 
Actividad 4.

La definición y el uso de las técnicas analíticas para determinar la concentración del colorante tiene lugar en Experimentación en Análisis Químico (EAQ). Los alumnos obtendrán por espectrofotometría la longitud de onda del máximo de absorción, realizarán rectas de calibrado, etc.

Actividad 5.

En Química-Física (QF) se trabajarán las principales isotermas del equilibrio de adsorción: Langmuir, Freundlich y Sips.

Actividad 6.

El estudio de las propiedades químicas de los colorantes, los diferentes tipos, rutas de síntesis, etc. tendrá lugar en Química Orgánica (QO).

\section{Actividad 7.}

En Bases de la Ingeniería Química (BIQ) los alumnos aplicarán los balances de materia en régimen no estacionario a un proceso de adsorción en un tanque agitado discontinuo.

\section{Actividad 8}

El estudio de la transmisión de calor en el interior de la columna de adsorción con el fin de averiguar si se puede considerar isoterma o no, tendrá lugar en Termodinámica Química y Transmisión de Calor (TQyTC). De nuevo será el profesor el que proporcionará a los alumnos las dimensiones de la columna y las propiedades de su interior.

Actividad 9.

En Experimentación en Ingeniería Química I (EIQ I) los alumnos obtendrán de forma experimental los datos del equilibrio de adsorción y determinarán los parámetros de ajuste de las diferentes isotermas estudiadas en la act. 5, decidiendo cual será la más adecuada para el caso concreto. Para ello emplearán las técnicas analíticas y rectas de calibrado resultantes de la act. 4 .

Actividad 10.

El modelado de la cinética del proceso de adsorción, considerando tanto el fenómeno de transferencia de materia interna como externa, tendrá lugar en Transferencia de Materia (TM). Este modelado debe incluir las isotermas de adsorción estudiadas en la act. 5 y el balance de materia planteado en la act. 7 .

Actividad 11.

En Mecánica de Fluidos (MF) los alumnos harán una determinación experimental de las pérdidas de carga de una columna de relleno en planta piloto y obtendrán los parámetros característicos de la ecuación de Ergun.

(c)) EY-NC-ND 2018, Universitat Politècnica de València

Congreso In-Red (2018) 
Actividad 12.

También en MF los alumnos diseñarán la instalación hidráulica necesaria en una planta industrial en la que haya una columna de adsorción: diámetros internos de tuberías, accidentes hidráulicos, bomba de impulsión, etc. Para ello partirán del dato de caudal de líquido a tratar proporcionado en la presentación del proyecto, así como de las propiedades obtenidas en las act. 2 y 11, y de un esquema de la instalación proporcionada por el profesor de la asignatura.

Actividad 13.

En Fundamentos de Máquinas y Resistencia de Materiales (FMyRM) se realizará el diseño mecánico de una columna industrial, determinando su espesor y los soportes necesarios. También se determinará el espesor de las tuberías de la instalación hidráulica diseñada en la act. 12. El profesor fijará el tipo de material de la columna y de las tuberías.

Actividad 14.

El estudio experimental de la cinética de adsorción y la estimación de los coeficientes de transferencia de materia interna y externa tendrá lugar en EIQ II. Para ello se partirá del modelo matemático obtenido en la act. 10 y de los parámetros de las isotermas de adsorción determinados en la act. 9, así como de la información analítica de la act. 4.

\section{Actividad 15.}

En Operaciones de Separación (OS) se hará uso de los principales modelos prácticos y simplificados correspondientes al diseño y análisis de columnas de adsorción.

\section{Actividad 16.}

La determinación de las propiedades más importantes de las partículas de carbón activado que se utilizará como adsorbente se realizará en Ciencia de Materiales (CM). Parámetros como la distribución de tamaños de partícula, la porosidad, etc., se obtendrán en esta actividad.

Actividad 17.

En EIQ III se realizará el estudio experimental de la columna de adsorción de una planta piloto y se compararán los resultados experimentales con las predicciones generadas por los modelos prácticos de columnas de adsorción trabajados en la act. 15.

Actividad 18.

En Análisis y Simulación de Procesos (ASP) se obtendrá el modelo fundamental y se simulará el comportamiento de la columna de adsorción de la planta piloto. Se comparará esta simulación con la proporcionada por los modelos prácticos y los datos experimentales de la act. 17, decidiendo finalmente el modelo más adecuado para diseñar y simular columnas de adsorción. 


\section{Actividad 19.}

La definición de toda la instrumentación necesaria en un proceso industrial de adsorción: sensores, controladores y elementos finales de control, tendrá lugar en la asignatura Control e Instrumentación de Procesos Químicos I (CeIPQ I).

\section{Actividad 20.}

En Tecnología del Medio Ambiente (TMA) se analizará la gestión del residuo industrial que supone el adsorbente agotado de las columnas industriales de adsorción, después de su uso. También se analizará la legislación ambiental para fijar la concentración máxima a la que puede salir el colorante de la instalación que se va a diseñar.

Actividad 21.

La selección de los diferentes tipos de materiales necesarios en todos los equipos de la instalación industrial como depósitos, tuberías, la columna de adsorción, etc. tendrá lugar en Ampliación de Ciencia de Materiales (ACM).

Actividad 22.

En Instalaciones Térmicas y Climatización (ITC) se realizará el diseño de un intercambiador de calor aprovechando el caudal de fluido problema que se va a tratar mediante adsorción.

Actividad 23.

En Procesos Industriales de Ingeniería Química (PIIQ) se diseñará la columna de adsorción industrial haciendo uso del mejor modelo matemático deducido en la act. 18, de las características de las aguas problema definidas en la presentación del proyecto y de la concentración deseada a la salida fijada en la act. 20.

\section{Actividad 24.}

Finalmente, en Proyectos de Ingeniería Química (PyIQ), se realizará el diseño completo de la planta industrial de adsorción. Para ello se recalcularán todos los diseños parciales del proceso llevados a cabo en cada una de las actividades anteriores, haciendo uso de todos los resultados generados a lo largo del título. Para concluir se llevará a cabo una estimación/evaluación económica del proceso.

Dado que las asignaturas troncales terminan en el primer semestre del cuarto curso, durante el segundo semestre cada grupo preparará un póster que recoja todo el diseño de la planta industrial realizado a lo largo de toda su titulación, los cuales serán expuestos en el centro de estudios.

\subsubsection{Ficha de actividades}

Es necesario que cada profesor realice una ficha de actividades para definir los problemas que los alumnos tienen que hacer en su asignatura. Dicha ficha debe contener información respecto a la actividad de la que se trate, en qué asignatura se llevará a cabo, en qué curso y semestre está la asignatura, así como el grupo destinatario de la ficha. Puede darse el caso 
que la ficha sea la misma para todos los grupos de alumnos o que el profesor particularice dicha ficha para cada grupo.

Es importante que se haga una estimación del tiempo previsto de dedicación a la actividad, tanto de carácter presencial como no presencial. Aunque cada actividad puede necesitar un tiempo de dedicación diferente, los profesores comprometidos en este proyecto transversal deben dedicar un mínimo de horas presenciales consensuado por los profesores de todas las asignaturas.

Se indicarán qué actividades anteriores van a tener que consultar los alumnos para extraer los datos que sean necesarios para utilizar en la actividad descrita en la ficha. Así como las actividades posteriores que van a necesitar de los resultados que se generen en esta actividad. Es necesario relacionar muy bien una actividad con las anteriores y posteriores para mostrar a los alumnos las dependencias entre las diversas asignaturas del grado.

Dado que la metodología que se utiliza como nexo de unión para la coordinación vertical/horizontal de las asignaturas es el aprendizaje basado en problemas, es de vital importancia plantear correctamente los problemas concretos que se deben resolver para afrontar la actividad planteada.

Por otra parte, se debe especificar el número de entregables, su planificación temporal y los resultados concretos que se deben mostrar en cada uno de los entregables. Los entregables periódicos permiten al profesor hacer un seguimiento del trabajo de los grupos a lo largo del desarrollo de la actividad.

También es necesario indicar qué competencias del grado, tanto específicas como transversales, son las que se van a trabajar en la actividad.

Finalmente, debe especificarse cómo va a evaluarse la actividad y cómo se enmarca dicha evaluación en la de la asignatura. Se definirá una forma de evaluación común a todas las actividades, de manera que se tengan en cuenta los entregables y una prueba de conocimientos mínimos de carácter individual (exigibilidad individual), aunque puede cambiar el peso que cada asignatura proporciona a la actividad en su evaluación.

\section{Resultados}

Actualmente, se han llevado a cabo dos de los objetivos planteados en el proyecto, el análisis de las encuestas y el diseño de un Proyecto completo para desarrollar con metodología ABP.

\subsection{Análisis de los datos obtenidos en las encuestas}

Una vez recogidas las encuestas de todas las asignaturas de la titulación, seleccionamos las correspondientes a las asignaturas que participaban en el proyecto propuesto.

Los resultados de las encuestas nos ofrecen dos análisis, el primero, las carencias que pueden sufrir las asignaturas, ya que algunas impartían contenidos que deberían haberse

(cc) EY-NC-ND 2018, Universitat Politècnica de València

Congreso IN-RED (2018) 
impartido en asignaturas de semestres anteriores y que no están en sus descriptores. Siendo el segundo análisis que se puede extraer de los datos, la temporalización de las actividades a realizar en el proyecto.

Por ejemplo, en la materia Física, los descriptores de la materia en el documento Verifica son: magnitudes, unidades, análisis dimensional, cálculo vectorial, geometría de masas, cinemática, introducción a la mecánica de fluidos, electromagnetismo, corriente continua, corriente alterna y termodinámica química. Si observamos la figura 2, vemos que la asignatura Física responde a los contenidos como IMPARTO, ya que pertenecen a la materia indicada, pero también observamos que hay asignaturas de cursos superiores que responden con el mismo ítem. Los descriptores magnitudes, unidades, análisis dimensional se imparten, además de en la asignatura Física, en asignaturas como Bases de la Ingeniería Química, Transferencia de Materia, Mecánica de Fluidos, Fundamentos de Máquinas y Resistencia de los Materiales y Ampliación de Ciencias de los Materiales. Esta coincidencia de contenidos nos lleva a preguntarnos si es necesario que se repita tanto durante la titulación, o es un punto de atención para que los profesores responsables de estas asignaturas puedan analizar esta coincidencia y las causas de la misma y si la coordinación es adecuada. Sin embargo, hay coincidencias en las respuestas que son coherentes, como es el caso de termodinámica química, que aparece tanto en Física como en Termodinámica Química y Transmisión de Calor o en Experimentación en Ingeniería Química I. En estos casos, sería conveniente que los profesores responsables de estas asignaturas se reunieran para coordinar correctamente los contenidos para evitar repeticiones. Otro análisis interesante es el observar si hay contenidos en alguna asignatura que más adelante se utilizan muy poco o nada, y analizar cuánto tiempo se dedica en la asignatura a impartir este concepto (Figura 3).

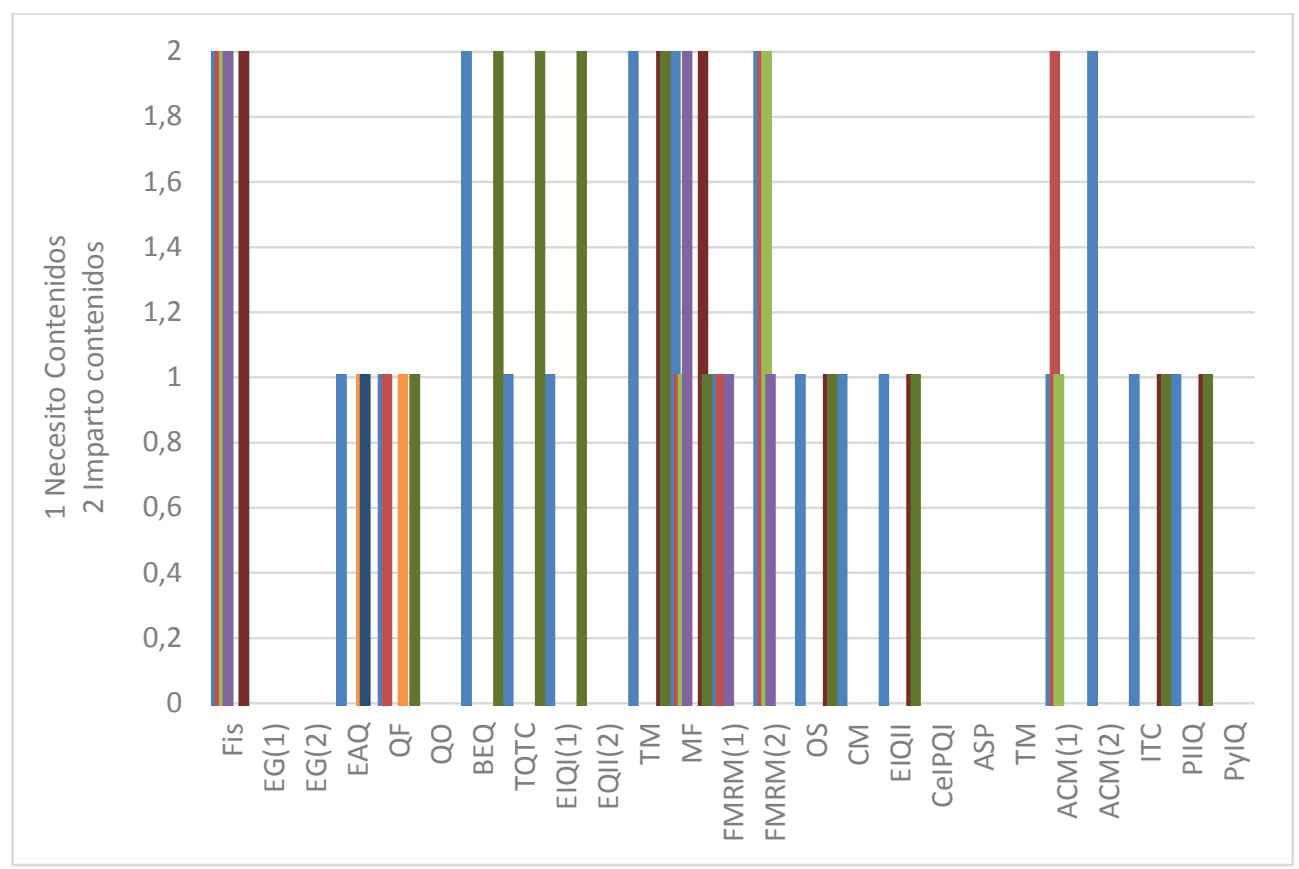

Fig. 2 Respuestas en la materia Física.

Magnitudes, unidades, análisis dimensional,

Cálculo vectorial, 
Geometría de masas, Cinemática, — Electromagnetismo, — Corriente continua, $\square$ Corriente alterna,

$\square$ Mecánica de Fluidos, $\square$ Termodinámica Química.

Como ejemplo hemos escogido el descriptor mecánica de fluidos computacional; este aparece en el documento Verifica, y por lo tanto, debe impartirse, aunque solo es utilizado en la misma asignatura donde se imparte, lo que nos lleva a reflexionar sobre ciertas cuestiones como son ¿Cuánto tiempo dedica a este concepto? Si este concepto se encuentra en el descriptor del verifica puede ser útil para el Ingeniero Química, entonces ¿Por qué no se utiliza en otra asignatura? Como se ha indicado antes, no se trata de imponer a ningún profesor el cambio de sus unidades docentes, pero si el que podamos optimizar el tiempo que se le da a los conceptos que los alumnos deben adquirir en las asignaturas. Con todo ello, también se favorece que los profesores conozcan lo que imparten sus compañeros y por lo tanto, mejorar la coordinación de las asignaturas.

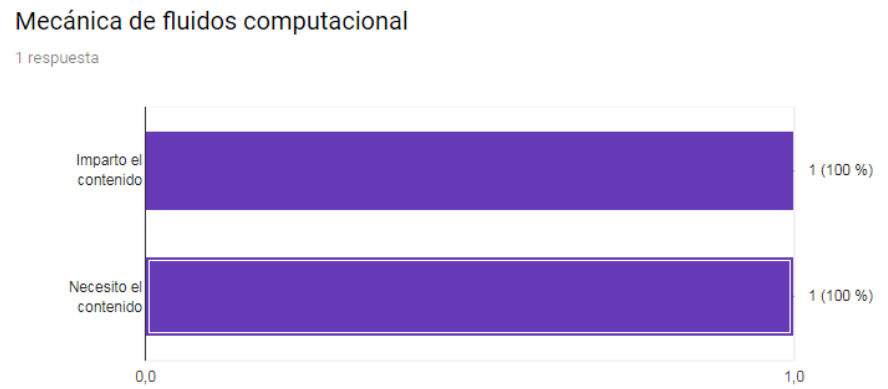

Fig.3 Respuestas del contenido de Fluidos Computacional en la materia Mecánica de Fluidos

\subsection{Ficha propuesta para la actividad 14}

Tal y como se ha comentado anteriormente, es importante realizar una ficha de cada una de las actividades para que los estudiantes tengan toda la información del ABP a desarrollar en una asignatura y que corresponde a una actividad. En este caso se presenta, a modo de ejemplo, la ficha propuesta para la actividad 14, que se realiza en la asignatura EIQ II (Tabla 3).

En la asignatura EIQ II, se deberán desarrollar tres ABP experimentales, con sus respectivos informes obteniendo resultados que se utilizarán en actividades posteriores como son las actividades 15,17,18 y 23.

En esta ficha se planifican las tareas de evaluación y el alumno también puede consultar qué competencias adquiere con la resolución de los problemas.

\section{Conclusiones}

El desarrollar el PIME con una metodología de Aprendizaje Basado en Problemas de carácter transversal ha permitido, en primer lugar, empezar a analizar cómo es la coodinación del Grado en Ingeniería Química. Esto ha sido posible gracias a la información recogida en las encuestas realizadas a los profesores que imparten docencia en el Grado,

(cc) EY-NC-ND 2018, Universitat Politècnica de València

Congreso IN-RED (2018) 
siendo satisfactoria ya que, en general, muestran una buena secuenciación de los contenidos en las asignaturas del grado.

Tabla 3. Ficha de la actividad 14

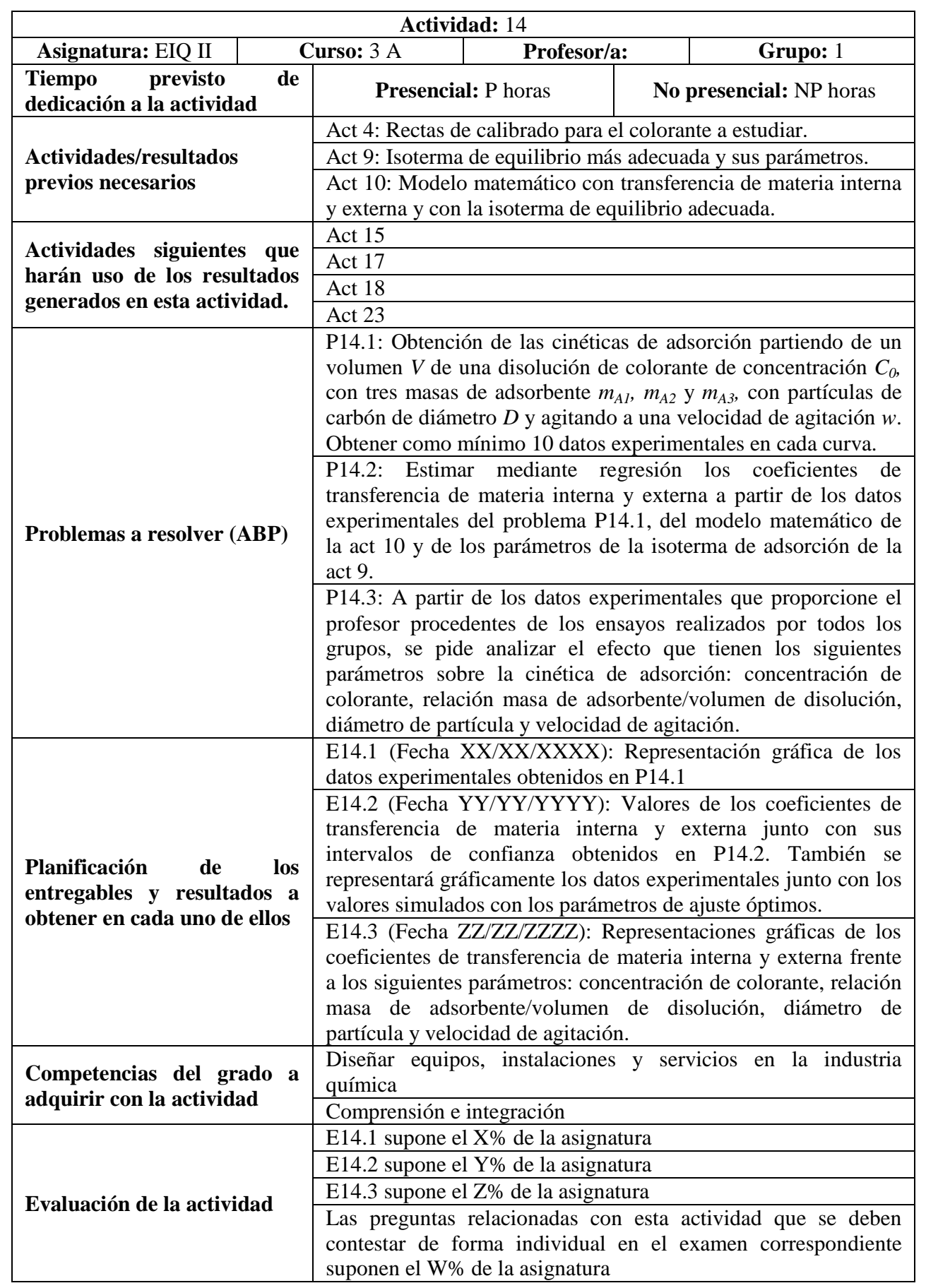


El plantear un proyecto como es el diseño de una columna de adsorción va a ayudar a una mejor coordinación del Grado de Ingeniería Química, Campus d’Alcoi, lo que conllevará que el alumno sea capaz de enlazar de forma más eficaz los contenidos más relevantes de la titulación. De esta forma se mejorará la adquisición, por parte del alumno, de las competencias, habilidades y conocimientos a través de la resolución de los numerosos problemas en los que se divide el proyecto transversal planteado. Además, el alumno comprenderá el papel que tiene cada una de las asignaturas estudiadas en el grado para cubrir sus necesidades como profesional de la Ingeniería Química.

\section{Agradecimientos}

Agradecimiento al PIME de la UPV (2017) Referencia A19: “Coordinación en el Grado en Ingeniería Química del Campus d’Alcoi: Aprendizaje Basado en Problemas como Metodología de Conexión entre asignaturas”

\section{Referencias}

Cárdenas-Rodríguez, R., Terrón-Caro, T., Monreal-Gimeno, C. (2015). "Interdisciplinariedad o multidisciplinariedad en el ámbito universitario. desafíos para la coordinación docente” en Bordon. Revista de pedagogía. vol 67, issue 3, p. 167-183.

Cardona, S.C., López-Pérez, María-Fernanda, Lora J., “Aprendizaje basado en problemas en Ingeniería Química como metodología de coordinación vertical/horizontal entre asignaturas” comunicación en IV Congreso De Innovación Docente En Ingeniería Química (CIDIQ) libro de resúmenes, Santander. 2018. ISBN: 978-84-697-8931-5. DL SA 10-2018. P. 40

Charoula, A. (2002) “Teachers' Practical Theories for the Design and Implementation of ProblemBased Learning” en Science Education International vol. 13, issue 3, p. 9-15.

Cruz, F.J., Fernández Díaz, M.J. (2016). “Los docentes de la Generación Z y sus competencias digitales” en Comunicar. Revista Científica de Educomunicación, Vol. 25, issue 46

García-Sevilla J. (2008). “La metodología del Aprendizaje Basado en Problemas” en Universidad de Murcia, Servicio de Publicaciones.

Hirshfield, L., Koretsky, M.D. (2018) "Gender and Participation in an Engineering Problem-Based Learning Environment” Interdisciplinary Journal of Problem-based Learning, Vol.12, issue 1. < $>$ [Consulta : 22 de marzo de 2018]

López-Guede, J.M. (2015). “Experiencia docente mediante la Metodología de Aprendizaje Basado en Problemas” en Ikastorratza.e-Revista de Didáctica, Vol.14, pp.72-85

López-Pérez, María-Fernanda, Cardona, S.C., Lora, J., Abad, A., Torregrosa, J.I. (2015). "Resultados del Proyecto de Innovación y Mejora Educativa. Utilización de MATLAB como estrategia didáctica y de coordinación horizontal y vertical entre asignaturas del Grado de Ingeniería Química” Comunicación en Congreso IN-Red. 2015. http://inred.blogs.upv.es/

López-Pérez, María-Fernanda, Cardona, S.C., Lora, J., Abad A. (2016). “Analysis and Problem Solving Competency Development in Chemical Engineering Degree using MATLAB” Multidisciplinary Journal for Education, Social and Technological Sciences EISSN: 2341-2593 http://dx.doi.org/10.4995/muse.2016.4623.

(cc) EY-NC-ND 2018, Universitat Politècnica de València

Congreso IN-RED (2018) 
López-Pérez, M.F., Cardona Navarrete, S.C., Lora García, J. (2017) “Coordinación en el Grado en Ingeniería Química del Campus d’Alcoi: Aprendizaje Basado en Problemas como Metodología de Conexión entre Asignaturas” en XXV CUIEET. Badajoz. 373-380. V03_049_039. 


\title{
Propuesta de una metodología de evaluación del aprendizaje basada en las TIC
}

\section{M.D.ReyesTolosa ${ }^{\mathrm{a}}$, O. Sahuquillo ${ }^{\mathrm{a}}$}

${ }^{a}$ Departamento de Ingeniería Mecánica y de Materiales, Universitat Politècnica de València, Camino de Vera s/n, 46022, Valencia. mareto@upvnet.upv.es

\begin{abstract}
Is vital for teachers to assess accurately the continuous learning of students, obtaining of this assessment is not just a rating of each one of the students, if not also monitor the student's learning, and can reinforce those topics that are necessary.

To this end, a series of questions, each of the topics of theoretical, using an online tool, have been implemented specifically SOCRATIVE, which is a tool that incorporates the use of technology and is made available from the learning. Methodology highlights because it is an active and motivational methodology with the advantage of offering the results instantly and above all enable new possibilities in the learning process.

In addition, at end of course, it is planned a survey of evaluation of the methodology in order to optimize its use in subsequent courses.
\end{abstract}

Keywords: evaluation of learning, online, methodology tool active

\begin{abstract}
Resumen
Es de vital importancia para los docentes poder evaluar de forma precisa el aprendizaje continuo de los alumnos, obteniendo de esta evaluación no solo una calificación de cada uno de los alumnos, sino también un seguimiento del aprendizaje del alumno, pudiendo reforzar aquellos temas que sean necesarios.
\end{abstract}

Para ello, se han implementado una serie de preguntas, correspondientes a cada uno de los temas teóricos, empleando una herramienta online, concretamente SOCRATIVE, siendo esta una herramienta en la que se incorpora el uso de la tecnología y se pone a disposición del aprendizaje. La metodología destaca por tratarse de una metodología activa y motivadora con la ventaja de ofrecer los resultados instantáneamente y sobretodo permitir nuevas posibilidades en el proceso de aprendizaje.

Además, a final de curso, se ha previsto una encuesta de evaluación de la metodología con el fin de optimizar en cursos posteriores su uso.

Palabras clave: evaluación del aprendizaje, herramienta online, metodología activa. 


\section{Introducción}

Como es sabido, el nuevo marco docente dibujado por la convergencia hacia el Espacio Europeo de Educación Superior (EEES) supone una reformulación de las metodologías docentes, que han de estar basada en el aprendizaje del alumno y no solo en la enseñanza. Es por ello que en la docencia superior universitaria se desarrollan en los últimos años nuevas formas de llegar al alumno, empleando para ello aquellas herramientas con las que están familiarizados y que despiertan su interés.

De hecho, los docentes universitarios nos encontramos ante un alumnado diferente, debido precisamente a su generación, la llamada generación Z, aquellos nacidos a partir de 2001 hasta la actualidad, los cuales se caracterizan por las siguientes características mostradas en la tabla 1.

Tabla 1. Generación Z

\begin{tabular}{|c|c|c|c|c|}
\hline Generación & $\begin{array}{l}\text { Periodo de } \\
\text { nacimiento }\end{array}$ & Contexto nacional & $\begin{array}{c}\text { Herramientas } \\
\text { educativas }\end{array}$ & $\begin{array}{c}\text { Modelo pedagógico- } \\
\text { educativo }\end{array}$ \\
\hline $\begin{array}{c}\text { Nativos } \\
\text { digitales o } \\
\text { generación Z }\end{array}$ & $\begin{array}{c}\text { 2001- } \\
\text { Actualidad }\end{array}$ & $\begin{array}{l}\text { Avances importantes en } \\
\text { tecnología } \\
\text { computacional (tablets, } \\
\text { impresión 3D, etc.) } \\
\text { telefonía móvil, redes } \\
\text { sociales, economía del } \\
\text { conocimiento, } \\
\text { innovación de productos } \\
\text { y servicios globalizados }\end{array}$ & $\begin{array}{c}\text { Herramientas } \\
\text { tecnológicas } \\
\text { educativas desde nivel } \\
\text { escolar como las } \\
\text { pizarras electrónicas, } \\
\text { proyecciones en el } \\
\text { aula, etc. }\end{array}$ & $\begin{array}{c}\text { Competencias bajo el } \\
\text { enfoque socio- } \\
\text { formativo, el profesor es } \\
\text { un facilitador y el } \\
\text { alumno una persona de } \\
\text { aprendizaje significativo } \\
\text { autónomo y responsable } \\
\text { que se enfrenta a } \\
\text { problemas críticos }\end{array}$ \\
\hline
\end{tabular}

En este contexto, la responsabilidad del docente ya no sólo es tener el conocimiento de la asignatura y transmitirlo, si no ahora está la responsabilidad de aprender a utilizar las herramientas tecnológicas actuales (TIC), enseñar los estudiantes a encontrar la información correcta en sitios web fiables, analizar y sintetizar esta información y convertirla en competencias para su desarrollo (Echevarría, 2017).

Del mismo modo que las herramientas de docencia cambian de acuerdo a la generación a la que el docente se expone, han de cambiar también los métodos de evaluación. La evaluación en el ámbito académico, comparte la función formativa y certificadora (Villardón 2006). La dimensión formativa de la evaluación ha de complementarse con la función meramente certificadora (López, 2009). La evaluación así entendida ha de centrarse más en el alumno y su aprendizaje (Goñi 2005) que en la enseñanza del profesor y, si el alumno ha de ser el protagonista de su propio aprendizaje, es lógico que este participe en su proceso de evaluación (Arribas, 2012), donde los métodos basados en la coevaluación cada vez más van teniendo más relevancia.

(cc) EY-NC-ND 2018, Universitat Politècnica de València 
Así pues, parece evidente el enorme potencial que puede tener el uso de herramientas TIC en el aprendizaje de los alumnos de generación $\mathrm{Z}$, de forma que se implanta a su vez, una metodología activa por medio de la autoevaluación, con un elevado factor motivador para los alumnos debido al uso de las mismas.

\section{Objetivos}

El principal objetivo se basa en evaluar parte del aprendizaje del alumno durante el curso mediante el uso de nuevas tecnologías (TIC) con herramientas online con un doble enfoque: como herramienta de evaluación desde el punto de vista del docente y como autoevaluación continua para el alumno.

Se plantea el desarrollo de un sistema de evaluación atractivo para el alumno, conciso y con retroalimentación inmediata, de forma que tanto el docente como el alumno puedan evaluar la formación continua, el aprendizaje y el seguimiento de la materia. Constituye así una prueba experimental cuyo objetivo radica en la evaluación alternativa a los portafolios escritos manualmente empleados en la evaluación actual.

\section{Desarrollo de la innovación}

El desarrollo de la innovación surge ante la necesidad del docente de poder evaluar de forma continua al alumno fundamentalmente en grupo medianos o grandes, ofreciéndole al mismo mediante esta evaluación una autoevaluación a lo largo del curso, despertando así en el alumno la auto superación y a la vez, preparándole para la evaluación final de la asignatura.

Se decidió realizar una evaluación de manera continua a lo largo del cuatrimestre, de forma que tras la exposición de uno o varios temas teóricos y su posterior estudio práctico en el aula por parte del profesor, el alumno debería contestar una serie de preguntas de una dificultad media-alta. De manera que el alumno, se enfrenta a preguntas "tipo examen" y puede autoevaluar su nivel de aprendizaje y la eficacia de su estudio. A su vez, el docente dispone de una valoración del esfuerzo continuo de cada uno de los alumnos, sabiendo donde reforzar sus explicaciones, disponer registro de su evolución y disponer de datos fiables y objetivos para su evaluación global.

El método propuesto desarrollado para la evaluación continua tiene las siguientes características principales, de forma que resulte lo más atractivo:

- Uso de nuevas tecnologías TIC

- Atractiva para el alumno, técnica de gamificación (aprender jugando)

- Facilidad de uso en el aula y accesible a un gran número de alumnos

- Retroalimentación inmediata

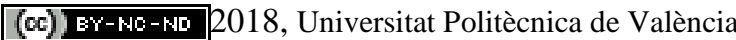

Congreso In-Red (2018) 
Se decidió, por tanto, el uso de una APP comercial (tecnología TIC) que el alumno pudiera instalar de forma gratuita en su Smartphone o en pc propio o del aula, así como accediendo directamente a la web con la intención de ser atractiva para el alumno, y de fácil uso en el aula. Concretamente se eligió la aplicación SOCRATIVE entre otras, por su facilidad de uso y la capacidad para captar la atención del alumnado gracias al amplio abanico de posibilidades interactivas que ofrece.

Se trata de una herramienta gratuita online que actúa como un sistema de respuesta inteligente con el que el docente puede lanzar varios tipos de preguntas, quizzes, juegos, a los que los alumnos pueden responder en tiempo real desde sus dispositivos. Una vez acabada la serie de preguntas el profesor puede ver los informes de resultados como una hoja de cálculo y puede emplearlo para realizar la evaluación.

La metodología de evaluación que se ha implementado en SOCRATIVE, consiste en la formulación de preguntas con 4 respuestas posibles a modo de quizz.

En tiempo real, el profesor puede ver los alumnos que se han unido al ejercicio, los cuales deben identificarse con su nombre completo, para poder exportar posteriormente los resultados identificando al alumno. Cada uno de estos alumnos, contestará a las preguntas, bien con su Smartphone o pc, en la Fig. 1 se muestra un ejemplo de la visualización en el dispositivo. El orden de las preguntas y respuestas posibles en cada una de ellas es aleatorio para cada alumno, de manera que se reduce el riesgo de copiado.

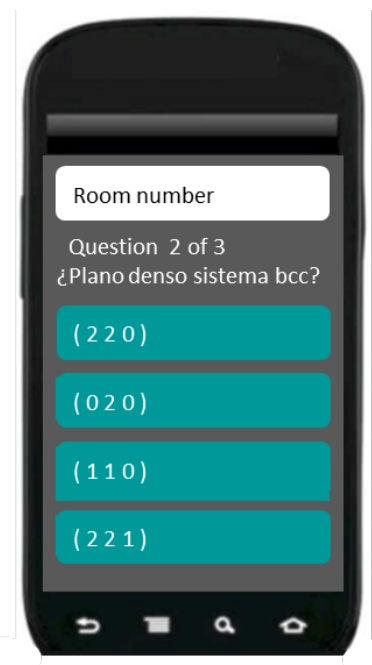

Fig. 1 Ilustración de visualización de la pregunta en un smartphone

A medida, que los alumnos van respondiendo a las preguntas se puede realizar un seguimiento de aquellos que han contestado y de los que todavía faltan por hacerlo. Durante la realización del ejercicio sólo se visualiza el progreso de las cuestiones planteadas sin mostrar las respuestas individuales de cada alumno, como muestra la Fig.2.

(cc) BY-NC-ND 2018, Universitat Politècnica de València

Congreso IN-RED (2018) 


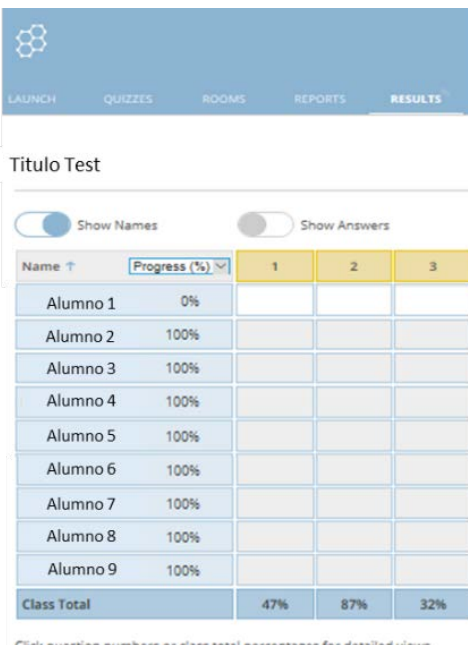

Fig. 2 Visualización del progreso del ejercicio

Finalmente, el número de respuestas correctas que conteste el alumno respecto al total planteadas se tendrá en cuenta en la calificación correspondiente al portafolio del alumno, constituyendo estos un punto sobre diez en la calificación global de la asignatura en la que se ha implementado como experiencia piloto, siendo esta la que se expresa en base 10:

NOT $A=0.7 \cdot$ Examen teoría y problemas $+0.2 \cdot$ Laboratorio $+0.1 \cdot$ Portafolio

De ese mismo modo, la metodología también supone incentivar la motivación y la competitividad, con una técnica basada en la gamificaicón, donde los alumnos se espera que se esfuercen en el aprendizaje continuo de la asignatura para intentar conseguir el mayor número de respuestas correctas fomentando el espíritu de superación, pudiendo además comparar con las obtenidas por sus compañeros.

Con la intención de poder evaluar la metodología empleada se propone una encuesta final a los alumnos (Barrado, 1999), de forma que se tenga una evaluación del método. La encuesta desarrollada se presenta en la Tabla 2. 
Tabla 2.-Encuesta de satisfacción con la evaluación continua y TIC empleada

\begin{tabular}{|l|c|}
\hline \multicolumn{1}{|c|}{ PREGUNTA } & RESPUESTA \\
\hline El método de evaluación continua está claro desde el inicio de curso & SI \\
\hline El método de evaluación continua es justo & SI \\
\hline La metodología TIC empleada me resulta fácil y práctica & SI NO \\
\hline $\begin{array}{l}\text { Las preguntas realizadas en Socrative me han servido para detectar los } \\
\text { aspectos que debo reforzar }\end{array}$ & SI NO \\
\hline $\begin{array}{l}\text { La evaluación continua realizada con esta metodología me ha ayudado en } \\
\text { el aprendizaje continuo de la asignatura }\end{array}$ & SI \\
\hline $\begin{array}{l}\text { ¿Consideras la metodología empleada motivadora en el aprendizaje de la } \\
\text { asignatura? }\end{array}$ & SI \\
\hline $\begin{array}{l}\text { A pesar de sus limitaciones, consideras que la metodología utilizada } \\
\text { debería de seguir utilizándose incluso en otras asignaturas }\end{array}$ & SI \\
\hline
\end{tabular}

\section{Resultados}

La prueba piloto del nuevo método de evaluación continua se está desarrollando en la actualidad en el Grado de Ingeniería Aeroespacial, en la asignatura de Ciencia de Materiales del primer curso de la E.T.S. Ingeniería del Diseño de la Universitat Politècnica de València, concretamente en uno de los grupos de teoría que cuenta aproximadamente con 80 alumnos matriculados en el presente curso. Dicha asignatura se imparte en el segundo cuatrimestre y por lo tanto actualmente se encuentra en desarrollo y tan solo se tienen resultados tras mes y medio de evaluación.

Los resultados que se muestras a continuación se corresponden con la primera sesión de preguntas formuladas a través de SOCRATIVE.

Una vez, se ha realizado el quizz en el aula, el profesor puede generar una hoja de cálculo con los resultados obtenidos, de forma que resulta muy fácil y práctico extraer conclusiones. La siguiente imagen (Fig.3) muestra un ejemplo de cómo se muestran esos resultados. 


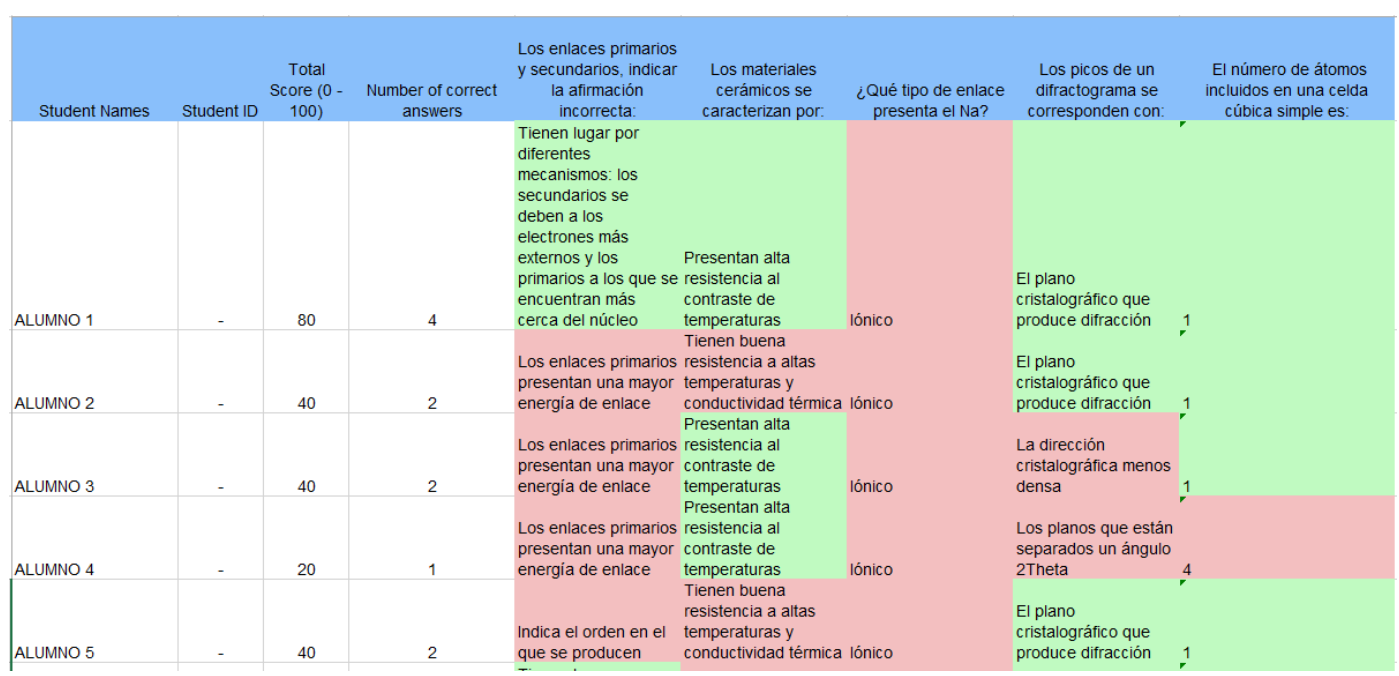

Fig.3 Visualización de resultados en excel

Como puede verse en la Fig.3. el programa SOCRATIVE nos genera una hoja de cálculo de resultados en el que se puede ver para cada alumno:

- Puntuación obtenida

- Numero de respuestas correctas

- Respuesta marcada por el alumno: correcta (verde) o incorrecta (rojo).

Resulta por tanto, muy práctico el feedback prácticamente instantáneo que el profesor recibe y con el que puede detectar que parte del temario es aquella en la que más dificultades están encontrando los alumnos, y poder así reforzarla. Al igual, que de forma directa se obtiene una calificación del alumno para el ejercicio desarrollado. Así mismo el alumno puede antes de la evaluación a través de parciales detectar sus deficiencias y poner medios para superarlas.

Además se pretende realizar un análisis para cada uno de los ejercicios, de forma que el docente pueda autoevaluar y discriminar la efectividad de las preguntas formuladas. Es decir, se puede determinar que preguntas de las formuladas en los ejercicios discriminan el nivel de esfuerzo o aprendizaje de los alumnos, diferenciándose preguntas:

- Muy buenas: aquellas que solo contestan bien los alumnos que contestan bien a más del $80 \%$ de las preguntas propuestas.

- Buenas: aquellas que solo contestan correctamente los alumnos que contestan bien entre el 60 y $80 \%$ de las preguntas formuladas.

- Regulares: preguntas que contestan bien los alumnos que saben la respuesta correcta de al menos el 50\% de las preguntas

- Malas: aquellas que contestan bien todos o prácticamente todos los alumnos. 
Hasta el momento, tan solo se tienen datos de un primer ejercicio, y de él se pueden extraer los siguientes resultados que se exponen:

- En un primer ejercicio de 5 preguntas con 4 respuestas posibles por cuestión, el porcentaje de alumnos que ha contestado bien a 3 o más preguntas (calificación de aprobado o superior) constituye un 59\%. Por tanto, puede decirse que aproximadamente el 60\% de los alumnos mantiene un estudio activo y continuo de la asignatura, y que además la metodología docente y de estudio por parte del alumno resulta efectiva. Tal y como puede verse en la figura 4.

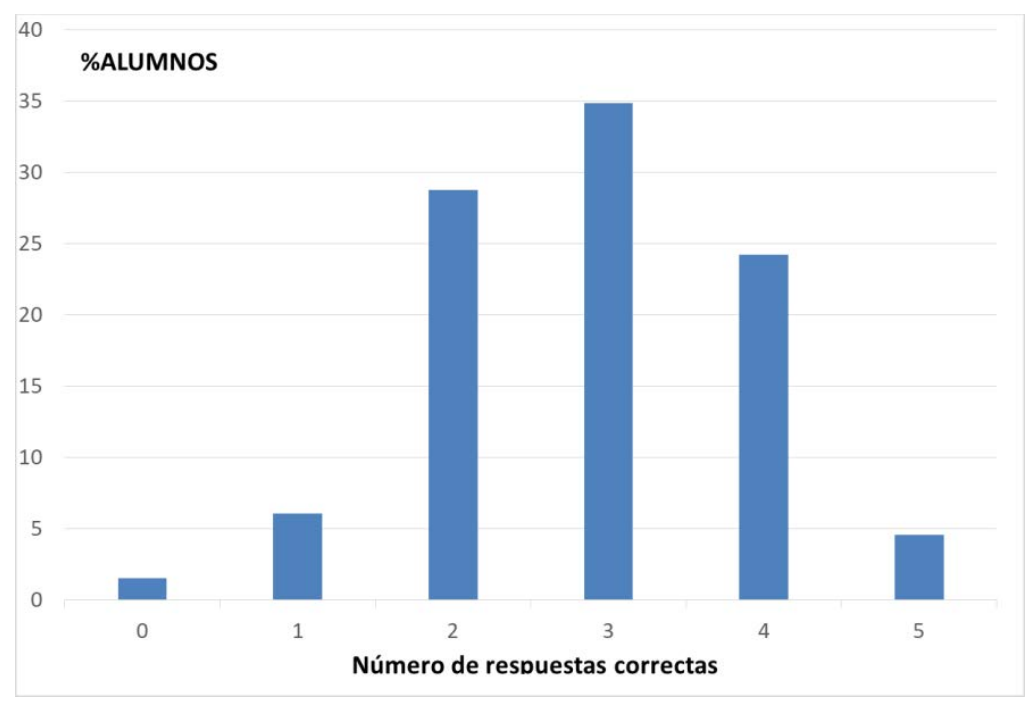

Fig.4 Distribución de preguntas correctamente contestadas.

- Contabilizando el número de alumnos que ha contestado bien cada una de las peguntas, se puede determinar la eficiencia de dicha pregunta, en el caso de aplicación, se ha obtenido:

Tabla 2.-Calidad de las preguntas formuladas en función del porcentaje de acierto

\begin{tabular}{|l|l|l|l|l|l|}
\hline & PREG.1 & PREG.2 & PREG.3 & PREG 4. & PREG 5. \\
\hline \% ACIERTOS & $25.75 \%$ & $33.33 \%$ & $59 \%$ & $59 \%$ & $96.97 \%$ \\
\hline
\end{tabular}

Se extrae, por tanto que si bien la pregunta 1 y 2 son altamente discriminatorias entre aquellos alumnos que han estudiado de los que no, y que por tanto pueden clasificarse como muy buena y buena respectivamente, no ocurre lo mismo con las preguntas 3, 4 y 5, siendo esta última de categoría mala pues el 95\% de los alumnos la contesta acertadamente sin discriminar entre aquellos que han estudiado y de los que no.

(cc) BY-NC-ND 2018, Universitat Politècnica de València 
Ahondando más en el análisis de los resultados para ver la efectividad del método, se han realizado los cálculos de los "índices de dificultad y discriminación de las preguntas”(Morales, 2009), de forma que los docentes tengamos la información necesaria para evaluar nuestras propias preguntas.

Dichos índices, se calculan con el 25\% de los alumnos que han obtenido las notas más altas y el $25 \%$ de los alumnos que han obtenido una puntuación total más baja. El número de sujetos en ambos grupos es el mismo y sólo se analiza el 50\% de alumnos (se prescinde del $50 \%$ central).

Se definen:

- Índice de dificultad: Indica la proporción de aciertos en la muestra de alumnos que estamos utilizando. Un índice mayor indica que la pregunta es más fácil.

$$
D_{f}=\frac{A S+A I}{N+N}
$$

Siendo:

- AS: Número de acertantes en el grupo superior con la puntuación total más alta.

- $\quad$ AI: Número de acertantes en el grupo inferior con la puntuación total más baja.

- N: Número de sujetos analizados en uno de los dos grupos (ambos grupos tienen idéntico número de sujetos)

En nuestro caso para cada una de las preguntas realizadas:

Tabla 3.-Indice de dificultad para cada una de las preguntas formuladas

\begin{tabular}{|c|c|c|c|c|}
\hline & AS & AI & N & Df \\
\hline P1 & 16 & 0 & 16 & $\mathbf{0 , 5}$ \\
\hline P2 & 16 & 0 & 16 & $\mathbf{0 , 5}$ \\
\hline P3 & 16 & 0 & 16 & $\mathbf{0 , 5}$ \\
\hline P4 & 16 & 0 & 16 & $\mathbf{0 , 5}$ \\
\hline P5 & 16 & 14 & 16 & $\mathbf{0 , 9 4}$ \\
\hline
\end{tabular}

Se corrobora mediante el análisis de este índice que la pregunta 5 es claramente fácil y no discriminatoria, ya que ha tenido un $949 \%$ de aciertos.

- Índice de discriminación: Consiste en la diferencia entre dos proporciones, proporción de aciertos en el grupo superior (AS/N) menos la proporción de aciertos en el grupo inferior $(\mathrm{AI} / \mathrm{N})$. Expresa, por tanto hasta qué punto una pregunta es capaz de discriminar.

En nuestro caso:

(cc) EY-NC-ND 2018, Universitat Politècnica de València 


$$
D_{c}=\frac{A S-A I}{N}
$$

Tabla 4.-Indice de discriminación para cada una de las preguntas formuladas

\begin{tabular}{|c|c|c|c|c|}
\hline & AS & AI & N & Dc \\
\hline P1 & 16 & 0 & 16 & $\mathbf{1}$ \\
\hline P2 & 16 & 0 & 16 & $\mathbf{1}$ \\
\hline P3 & 16 & 0 & 16 & $\mathbf{1}$ \\
\hline P4 & 16 & 0 & 16 & $\mathbf{1}$ \\
\hline P5 & 16 & 14 & 16 & $\mathbf{0 , 1 2 5}$ \\
\hline
\end{tabular}

Analizando los resultados del índice obtenido, se puede determinar que las 4 primeras preguntas, son discriminatorias ya que únicamente las aciertan los del grupo superior, mientras que no hay ninguna respuesta correcta en el grupo inferior. Haciendo así que el índice alcance su valor máximo.

Al contrario ocurre con la pregunta número 5, con un índice de 0.125 , lo que significa, que tanto alumnos del grupo inferior y superior contestan acertadamente a la pregunta, y por lo tanto no discrimina, lo que significa que es una pregunta muy fácil y conviene que sea revisada.

\section{Conclusiones}

En primera instancia y a falta de la encuesta de satisfacción, en la primera sesión con los alumnos la han acogido con satisfacción basándonos en la percepción del docente. Además, los alumnos agradecen el poder practicar este tipo de pruebas objetivas antes de la evaluación escrita, ya que por lo general tienden a no sentirse muy seguros antes los exámenes tipo test, y de esta forma pueden practicar y conocer la forma de preguntar del docente, ganando así seguridad.

El uso de las TIC predispone a los alumnos con una actitud receptiva hacia el aprendizaje, por el uso del smartphone o el pc, así como introducir la componente juego y competición a la hora de intentar conseguir el mejor resultado posible y que además formará parte de su evaluación final.

La metodología y la herramienta son de fácil uso tanto para el profesor como para el alumno, como también lo es la interpretación de los resultados derivados de este acto de evaluación.

En cuanto al feedback de la metodología empleada al alumno le reporta información por medio de su autoevaluación durante todo el periodo lectivo y el profesor recibe la

(cc) EY-NC-ND 2018, Universitat Politècnica de València 
retroalimentación de aquellos puntos en los que los alumnos están encontrando más dificultades y por tanto puede reforzarlos.

A priori y con sólo los primeros resultados obtenidos, parece ser una posible alternativa los portafolios escritos manualmente dado que es posible emplearla en grupos de gran tamaño además de resultar atractiva al alumnado y reportarle información sobre su progreso y servir de retroalimentación y como herramienta de evaluación al profesor.

Mediante el uso de este tipo de evaluación, y realizando el análisis del mismo,tanto el alumno como el docente adquieren un aprendizaje continuo.

$>$ El alumno es capaz de evaluar sus conocimientos adquiridos y reforzar aquellos puntos más débiles, además de enfrentarse a una evaluación de tipo objetiva que a priori, tanto les cuesta.

$>$ El docente, es capaz de ver que partes del temario han quedado más claras y cuales menos, pudiendo reforzar en clase estos puntos. Además mediante el análisis de las preguntas formuladas es capaz no solo de identificar el nivel medio del aula, sino también de formular preguntas que garanticen la discriminación de conocimientos entre alumos manteniendo el nivel de dificultad adecuado en cada una de las preguntas que se formulen.

\section{Referencias}

Arribas, J.M. (2012). "El rendimiento académico en función del sistema de evaluación empleado" Revista Electrónica de Investigación y Evaluación educativa.

https://www.uv.es/RELIEVE/v18n1/RELIEVEv18n1_3.htm [Consulta: 22 de marzo de 2018]

Barrado, C., Usemos las encuestas a los alumnospara mejorar nuestra docencia. ReportUPC-DAC1999-70, Departamentd'Arquitectura de Computadors, UniversidadPolitécnica de Cataluña, 1999.

<ftp://ftp.ac.upc.es/pub/reports/DAC/1999/UPC-DAC-1999-70.ps.Z> [Consulta: 22 de marzo de 2018]

Echevarría Echevarría, S.T (2017). "Una formación docente acorde a los cambios generacionales, tecnológicos e innovadores en los programas de postgrado nacionales” en Temas de Ciencia y Tecnología., vol 21, número 63, p 33-38.

Goñi, J.M. (2005). El espacio europeo de educación superior, un reto para la universidad. Barcelona: Ed. Octaedro.

López, V. (2009). “La evaluación formativa y compartida en docencia universitaria: propuestas, técnicas, instrumentos y experiencias”. Madrid: Narcea.

Villardón, L. (2006). "Evaluación del aprendizaje para promover el desarrollo de competencias". Educatio. Siglo XXI, volumen 24, p. 15-35.

Morales, P. (2009). “Análisis de ítems en las pruebas objetivas”. Universidad Pontífica de Comillas, Facultad de Ciencias Humanas y Sociales.

(cc) EY-Nc-ND 2018, Universitat Politècnica de València

Congreso In-Red (2018) 


\title{
Prevención Primaria como aprendizaje experiencial real.
}

\author{
Carla de Paredes $^{\mathrm{a}}$, Lucia Aparicio ${ }^{\mathrm{b}}$, Elisa Gimenez ${ }^{\mathrm{c}}$ y Cristina Escamilla ${ }^{\mathrm{d}}$
}

anuniversidad Europea de Valencia carla.deparedes@universidadeuropea.es, ${ }^{b}$ Universidad Europea de Valencia, lucia.aparicio@universidadeuropea.es y ${ }^{\mathrm{c}}$ Universidad Europea de Valencia elisa.gimenez@universidadeuropea.es, ${ }^{\mathrm{d}}$ Universidad Europea de Valencia, mariacristina.escamilla@universidadeuropea.es

\section{Abstract}

This paper presents an opportunity for university students for "experiential learning", with the aim of developing a project aimed at vulnerable children with the aim of a primary prevention tool in school. A transversal theme was selected in subjects of the Double Degree of Criminology and Psychology, the "Child Grooming", focused on a real situation, beyond the "simulation". It is intended that children learn strategies to identify and avoid certain dangers in the network.

The methodology consisted in the development by consecutive phases: 1st Unification Criteria with the institution where the activity was carried out; 2nd Development and elaboration of the tool; 3rd. Simulation; 4th Real situation. The results of the activity were very satisfactory, from learning to usefulness.

The conclusions, the implementation of this methodology was very satisfactory for several reasons: to carry out the practice of what was learned and work in relation to the degree; for practicing the future profession in one of its areas such as "prevention"; for the feeling of being using friends who contribute to the community, and as a motivation to continue studying, learning and growing in the professional field.

Keywords: prevention, learnig by doing, real experiential learning, social sciences

\section{Resumen}

En este trabajo se presenta una actividad a los estudiantes universitarios mediante el "aprendizaje experiencial”, con el que desarrollar un proyecto dirigido a menores vulnerables con el fin de establecer una herramienta de prevención primaria en la escuela. Se seleccionó un tema transversal en asignaturas del Doble Grado de Criminología y Psicología, el "Child Grooming”, enfocado hacia una situación real, más allá de la "simulación". Se pretende que los menores aprendan estrategias de identificación y evitación de ciertos peligros en la red.

La metodología consistió en desarrollo por fases consecutivas: $1^{a}$ Unificación criterios con la institución donde se llevó a cabo la actividad; $2^{a}$ Desarrollo y elaboración de la herramienta; $3^{a}$. Simulación; $4^{a}$ Situación real. Los resultados de la actividad fueron muy satisfactorios, desde el aprendizaje, hasta la utilidad.

Las conclusiones, la puesta en marcha de esta metodología fue muy satisfactoria por varias razones: por llevar a cabo la práctica de lo aprendido y elaborado en relación con la titulación; por practicar la futura profesión en uno de sus ámbitos como es la 
"prevención"; por la sensación de sentirse útiles aportando su contribución a la comunidad, y como motivación para seguir estudiando, aprendiendo y creciendo en el campo profesional.

Palabras clave: child grooming, prevención, learnig by doing, aprendizaje experencial, ciencias sociales

\section{Introducción}

Hoy en día estamos asistiendo a nuevas formas de enfocar la educación de nuestros estudiantes, gracias en parte a la implantación del Espacio Europeo de Educación Superior (EEES) que promueve la mejora del sistema educativo universitario, al mismo tiempo que fomenta una mayor implicación del estudiante en su propio proceso de aprendizaje. En este sentido, los sistemas educativos van evolucionando, fomentando continuas transformaciones y las nuevas metodologías de aprendizaje se adaptan para poder dar respuesta a las nuevas necesidades y demandas (Benito y Cruz, 2005).

La docencia tradicional, basada en clases magistrales presenciales, ha ido perdiendo cada vez más influencia por lo que se apuesta por procesos de aprendizaje basados en otro tipo de metodologías docentes, dirigidas a valorar un conjunto de oportunidades y condiciones que ofrecer a los estudiantes y así promover su aprendizaje (De Miguel, 2005; Labrador y Andreu, 2008). Esta nueva conceptualización implica necesariamente un cambio en el rol del profesor y del alumno, fomentando la participación activa del alumno y restando protagonismo a la labor del docente (Miguel-Dávila, López-Berzosa y Martín-Sánchez, 2012).

Dentro de estas innovaciones docentes, el aprender a hacer se acomoda dentro de este cambio de perspectiva que transita la concepción de la docencia basada en la enseñanza a otra centrada en el aprendizaje (Zabalza, 2011). Esto permite que la formación del alumno no se base únicamente en la adquisición de conocimientos, que pueden ser de carácter teórico o práctico, sino también promueven el desarrollo de competencias y habilidades que les proporcionan las herramientas necesarias para poder prosperar en una sociedad cada vez más compleja (Aparicio y De Paredes, 2016).

Para implantarlo plenamente y con éxito es necesaria la utilización de herramientas que promuevan el aprendizaje constructivo y creativo de los alumnos. De este modo, los alumnos podrán desempeñar un papel más activo, en lugar de ser meros receptores de conocimientos, convirtiéndose así en los auténticos protagonistas de su proceso formativo.

Un gran aporte al proceso de enseñanza-aprendizaje es el "aprendizaje experiencial” que se presenta como una metodología educativa con un especial potencial para responder a los nuevos retos a los que se enfrenta la educación superior universitaria en estos momentos, en especial en relación con las nuevas demandas competenciales y conceptuales y la obtención de una formación lo más realista posible a los nuevos modelos del mundo laboral (Ariza, 2010; March, 2006).

(c) ) EY-NC-ND 2018, Universitat Politècnica de València

Congreso IN-RED (2018) 
En este sentido, el aprendizaje experiencial, basado en el pionero modelo de Dewey (1938) y retomado posteriormente por diferentes autores (Chisholm, Harris, Northwood y Johrendt, 2009; Itin, 1999) enfatiza elementos distintivos como la experimentación fuera del aula que permite una verdadera interacción con el medio y una aplicabilidad del conocimiento al contexto de aprendizaje o la reflexión personal que otorga el significado después de vivenciar la experiencia (Smith, 2001).

Así pues, este tipo de aprendizaje proporciona un efecto sinérgico, basado en el potencial que tiene la interacción con la propia realidad que favorece un desempeño superior en el propio sujeto al tener que lidiar con problemas que dependen de su propio esfuerzo cognitivo (Raelin, 2000).

La experiencia propuesta en este trabajo, además de su carácter multidisciplinar (psicología, criminología y derecho), se enmarca dentro del conjunto de técnicas de aprendizaje activas, progresivas y consecutivas, desarrollándose el aprendizaje cooperativo, la simulación y el aprendizaje experiencial aplicados a una situación real.

Para llevar a cabo dicho proyecto se seleccionó un tema de actualidad, de gran importancia y donde las políticas criminales sufren continuas modificaciones, dado su carácter cambiante y dinámico, el "Child Grooming”. Este fenómeno aparece hoy en día como parte de nuestra realidad debido a que pertenecemos a un mundo globalizado donde internet y las redes sociales crecen y cambian de manera exponencial y se extienden a un ritmo increíblemente rápido $(\mathrm{Li}, 2006)$.

Cuando es un adulto quien aprovecha los recursos de las nuevas tecnologías para engatusar a menores, y provocar encuentros sexuales fuera del ciberespacio, este comportamiento es considerado como "Child Grooming” (Berson, 2003; Brown, 2001; Gillespie, 2002; Monge Fernández, 2010). Este proceso de embaucamiento o seducción por parte de un adulto se realiza mediante las TRIC (Tecnologías de la Información, Relación y Comunicación), es decir, mediante el uso de las redes sociales, como puede ser Facebook, Instagram, etc que tan habituales son entre los nativos digitales (Prensky, 2001)

Es por tanto una necesidad fomentar el adecuado conocimiento y las estrategias de afrontamiento necesarias entre nuestros jóvenes que les posibiliten hacer frente debidamente a este tipo de situaciones en las que se pueden ver implicados. Y para lograr este propósito es necesario desarrollar programas de intervención adecuados e implantar las acciones necesarias que sean capaces de minimizar, si no eliminar totalmente, estas amenazas en los centros escolares.

Siguiendo estos dos propósitos se planteó una actividad basada en el aprendizaje experiencial que fuera capaz de fomentar este tipo de metodologías de innovación educativa entre nuestros estudiantes universitarios, dándoles la oportunidad de vivenciar lo aprendido y de hacerlos responsables y protagonistas de su propio aprendizaje a la vez que conseguíamos concienciar, sensibilizar y formar a jóvenes ante el fenómeno del Grooming.

Este proyecto llamado INTUYE EL “CHILD GROOMING” se enmarcó dentro de la asignatura Víctímología, de $3^{\circ}$ curso del Doble Grado en Psicología y Criminología, vinculada con Psicología Criminal y Derecho Penal II. Participaron 12 alumnos, divididos 
en 4 grupos de 3 estudiantes cada uno, quienes llevaron a cabo el diseño, la planificación, la elaboración y el desarrollo de una estrategia de prevención primaria en una escuela valenciana con niños de $5^{\circ}$ y $6^{\circ}$ de primaria, dos grupos por curso.

Este trabajo se evaluó en su totalidad, formando parte de los trabajos prácticos de la asignatura: trabajo de investigación, realización de un programa de prevención y exposición oral.

\section{Objetivos}

Los objetivos de este proyecto son:

- Relacionar los contenidos teórico y prácticos de varias asignaturas para el desarrollo posterior de una actividad.

- Planificar, diseñar y elaborar una intervención de prevención primaria en la escuela que permita experimentar lo aprendido en el aula.

- Practicar las habilidades de comunicación e interacción con un determinado público externo.

- Desarrollar la intervención en una situación real que ofrezca el contexto necesario para reflexionar y enfrentarse a una futura situación profesional.

- Reflexionar sobre la utilidad del trabajo realizado.

- Sensibilizar a los menores de los peligros del mal uso de las nuevas tecnologías.

\section{Desarrollo de la innovación}

Dentro de la asignatura "Victimología", es donde se desarrolla la actividad descrita en el presente trabajo. Una vez impartidos los conocimentos sobre la prevención de la victimización en personas vulnerables, en especial los relacionados con menores víctimas del acoso o abuso sexual vía internet, se trabajan los tipos de estrategias o medidas de prevención primaria posibles a desarrollar en el ámbito de la escuela. Todo ello unido a contenidos recibidos en otras asignaturas, como la Psicología Criminal, donde se estudia el perfil del agresor y su funcionamiento para cometer el delito; y Derecho Penal II, donde se trabaja las tipologías delictivas relacionadas con las agresiones y abusos sexuales en los menores.

En un primer momento se trabajó en el aula mediante actividades de aprendizaje cooperativo, donde los grupos de estudiantes se encontraban estrechamente vinculados para elaborar el proyecto propuesto en el ámbito de la prevención primaria en la escuela. Este entrenamiento permite desarrollar competencias académicas y profesionales, además de habilidades interpersonales (Fernández, 2006).

En un segundo momento, el aula se transformó en un escenario práctico, donde los alumnos pasaron a ser protagonistas de su propio aprendizaje. Aquí es donde se desarrolla el aprendizaje práctico mediante la "simulación”. Esta técnica, ofrece al alumnado "un marco

(cc) EY-NC-ND 2018, Universitat Politècnica de València

Congreso IN-RED (2018) 
donde aprender de manera interactiva por medio de una experiencia viva, afrontar situaciones que quizá no están preparados para superar en una situación real, expresar sus sentimientos respecto al aprendizaje y experimentar con nuevas ideas y procedimientos" (Fernández, 2006, p.50). El profesorado ofreció pautas desde la primera fase de la simulación hasta la última, dada la importancia de que el progreso de las tareas se desarrollara eficazmente, puesto que el éxito de la posterior práctica en la situación real, depende, en gran parte, del trabajo realizado en este tipo de aprendizajes (Crookall y Oxford, 1990).

Para finalizar, se desarrolló el propio aprendizaje experiencial “real”, es decir, se trasladó el aula a una situación no simulada. De esta manera se involucra al individuo en una interacción directa con aquello que se está estudiando, y a un lugar donde puede practicarlo con agentes reales. Ya se deja en el aula la contemplación o descripción intelectual.

Una vez acabado el proyecto, este finaliza en el aula, con una sesión para asegurar el aprendizaje, de manera que el alumno se sienta íntimamente ligado a un proceso de reflexión personal, construyendo significados a partir de la experiencia vivida (Smith, 2001, citado en Ariza, 2010). Además, como culminación del trabajo, los participantes entregaron un informe escrito con la investigación y descripción del trabajo realizado, por lo que se evaluó en su totalidad, formando parte de los trabajos prácticos de la asignatura: trabajo de investigación (20\%), realización de un programa de prevención (30\%)y exposición oral (10\%), lo que hacía un total del 50\% de la asignatura.

A continuación, se explicitan las fases del proyecto:

\subsection{Fases de la intervención:}

El programa para realizar la intervención INTUYE EL “CHILD GROOMING”, se dividió en 4 fases y 7 sesiones, dos en cada fase, excepctuando la $1^{\text {a }}$ que solo tenía una sesión.

Fase 1: En primer lugar, se estableció una reunión con la dirección del centro escolar para analizar la necesidad de la intervención y establecer los contenidos relacionados con el fenómeno del Child Grooming. A este acto acudieron tres representantes del alumnado, para que su aprendizaje comenzara desde la negociación y posibilidades de realizar la intervención.

Fase $2^{\circ}$ Aprendizaje cooperativo en aula, se marcaron los objetivos a conseguir, se ofrecieron directrices básicas para la elaboración del proyecto, se organizaron los grupos y distribuyeron las responsabilidades y tareas que cada alumno tenía que desarrollar en lo referido a elaboración de contenidos y material con el que se iba a desarrollar la intervención, adaptándola al alumnado al que iba dirirgida, según edad y conocimientos previos, etc. 
$\underline{\text { Fase } 3^{\mathbf{0}}}$. Simulación. Antes de iniciar la simulación propiamente dicha, se comprobó que todos los participantes tuvieran claro en qué iba a consistir y con qué instrumentos contaban para desarrollar la situación planteada, de forma que pudieran debatir sobre ella y adoptar las soluciones que cada participante del grupo estimara oportunas. A continuación, comenzó la simulación y otro grupo de estudiantes se convirtieron en observadores. También se entrenaron y pusieron en práctica las estrategias más adecuadas de comunicación. Al finalizar la segunda simulación, se abrió un debate para tratar cuestiones que se podían mejorar, modificar, ampliar, etc., siempre con el docente como guía. De esta manera, se permitió a los aprendices proporcionar su propio feedback, comentando lo sucedido y planteando sus dudas, inseguridades, etc.

Fase $4^{\mathbf{0}}$. Aprendizaje experiencial real. Desarrollo de la intervención durante dos sesiones de 45 minutos llevada a cabo por tres estudiantes en cada uno de los grupos, conducida en todo momento por el docente de la asignatura. En la Figura 1, se puede observar a un grupo de universitarios en uno de los momentos de dicha intervención.

Sesión final. Esta sesión se desarrolló en el aula como reflexión del trabajo realizado, dudas y otras cuestiones para su mejora y entrega de un informe escrito con la descripción de la herramienta de prevención para su posterior evaluación como parte práctica de la asignatura.

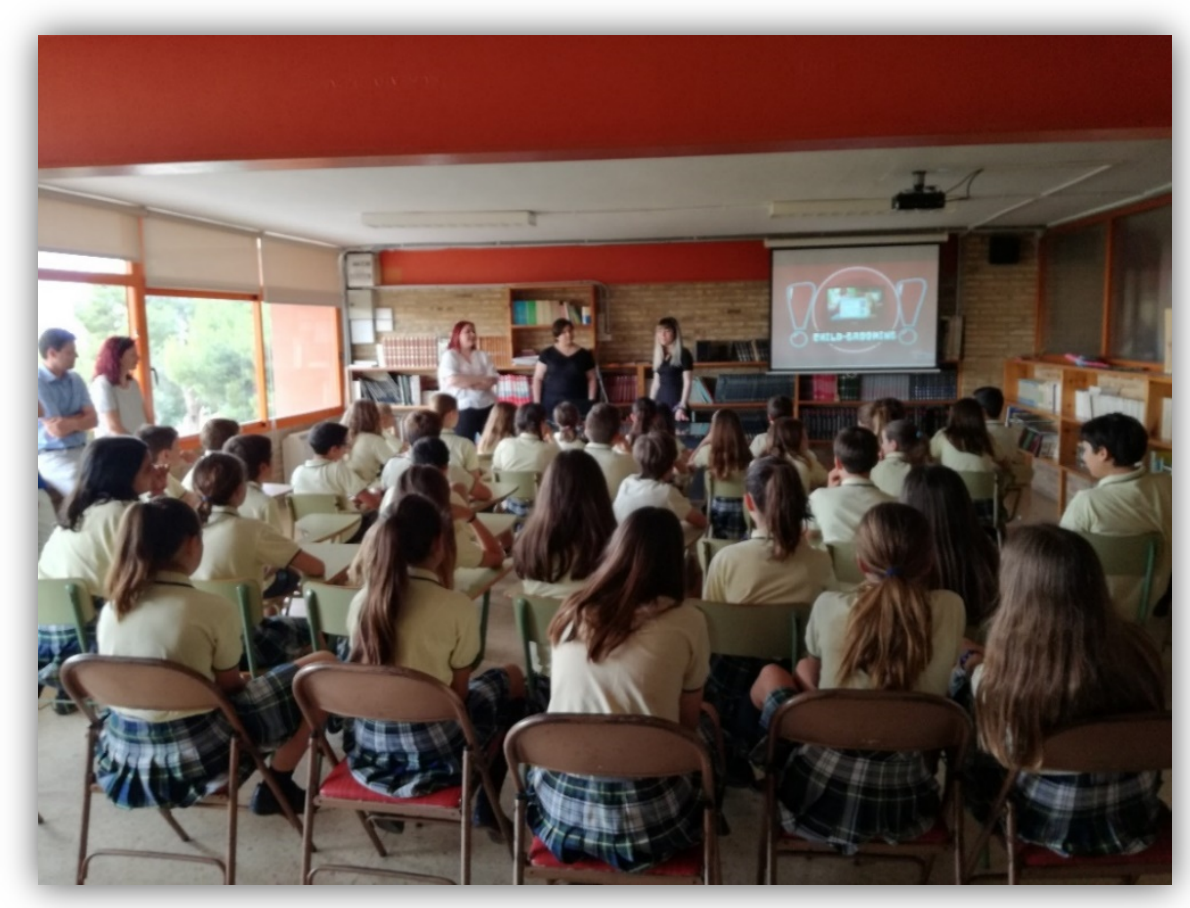

Figura 1. Situación real de la intervención “Child Grooming” en el Colegio Alfinach. 


\subsection{Cronograma de la metodología}

En la Figura 2 se puede observar, de forma más visual, la distribución de las sesiones del INTUYE EL “CHILD GROOMING”, desarrolladas en semanas consecutivas.
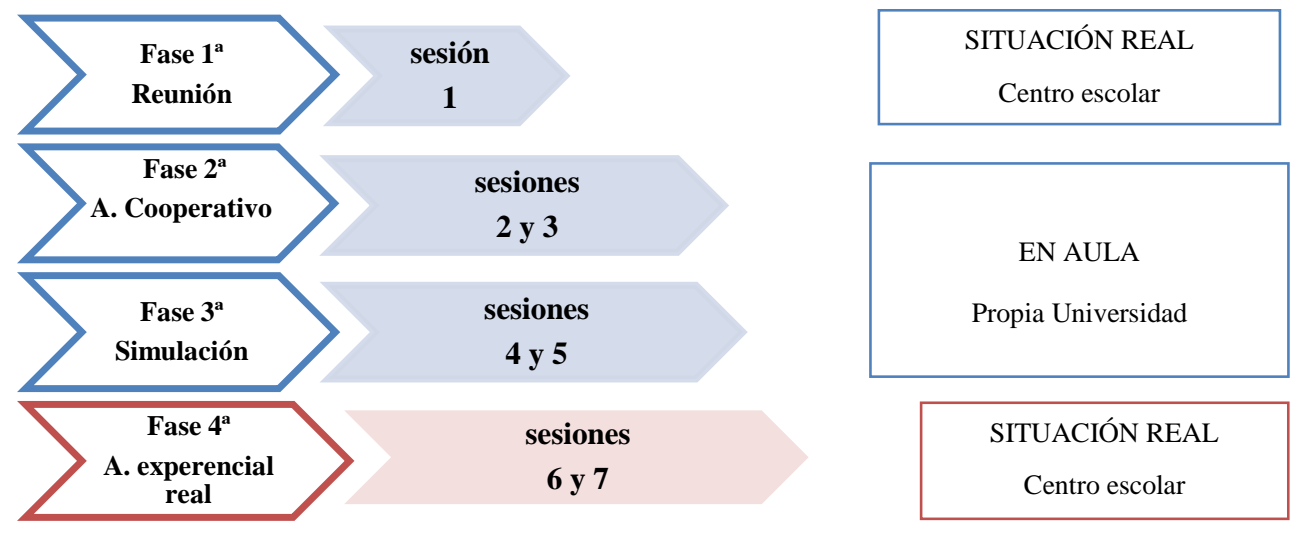

Figura 2. Cronograma de las sesiones que componen la intervención.

\subsection{Material utilizado}

A continuación se presentan algunas de las diapositivas del material empleado, por uno de los grupos de universitarios, para el desarrollo de INTUYE EL "CHILD GROOMING" (Figura 3):

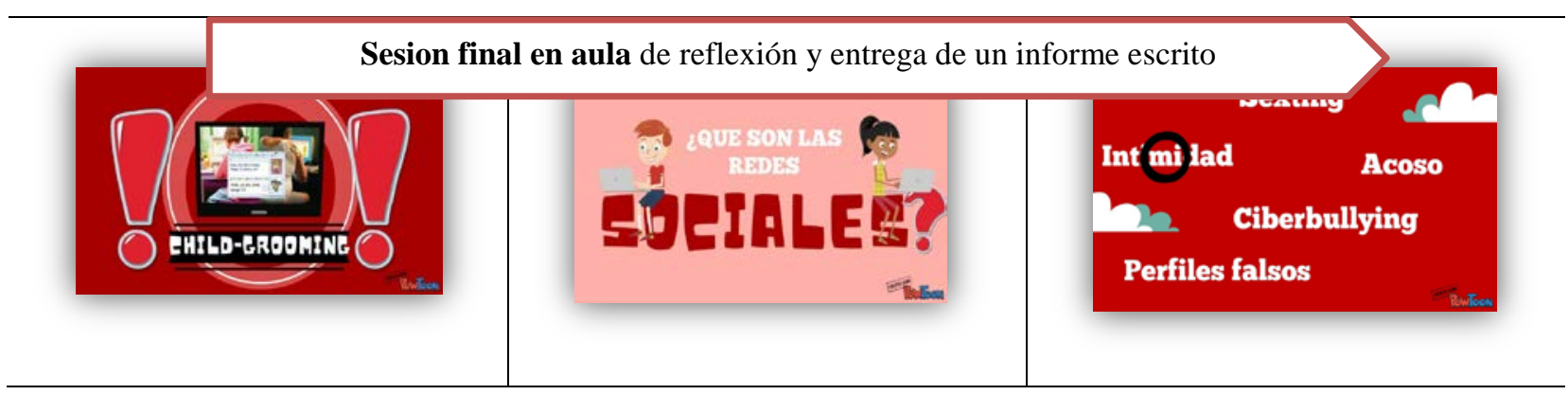

(c)) EY-NG-ND 2018, Universitat Politècnica de València

Congreso In-Red (2018) 


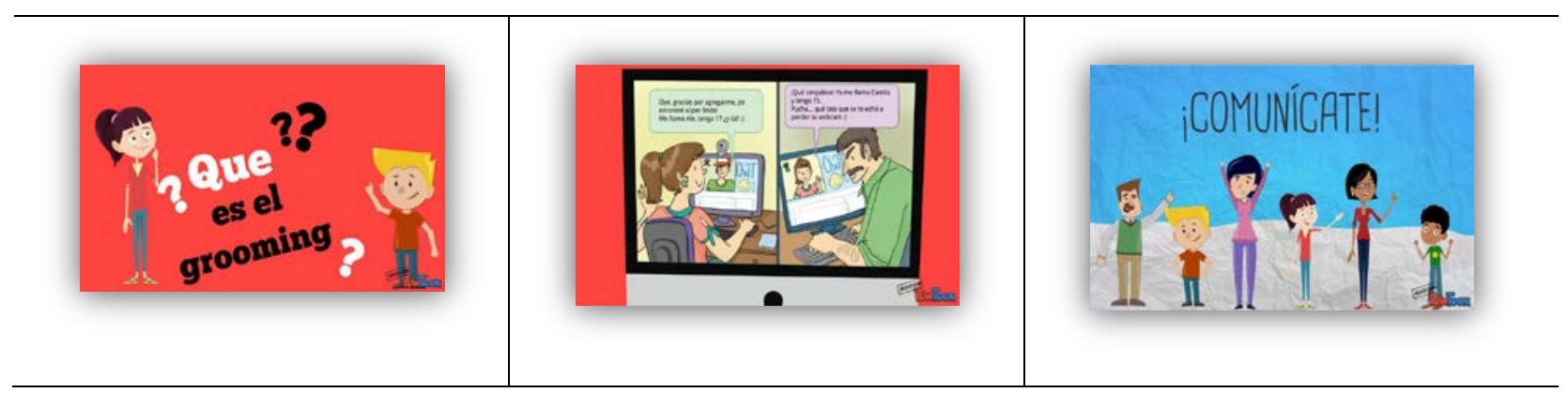

Figura 3. Ejemplo de 6 diaptositivas de la intervención INTUYE EL “CHILD GROOMING”

\section{Resultados}

Los resultados de evaluación de la intervención por parte de los 12 estudiantes universitarios fueron muy satisfactorios, según manifestaron en el cuestionario compuesto por 10 ítems, con tipo de respuesta cuantitativa, con valoraciones entre 0 a 10 puntos. Dicho cuestionario mide variables relacionadas con el aprendizaje de las asignaturas, en conocimiento teóricos y prácticos, así como para la futura profesión del estudiante; el aprendizaje en habilidades comunicativas; la percepción de utilidad de la intervención para la comunidad; la motivación que ha provocado en el estudiante desarrollar el proyecto; la recomendación de la actividad; así como la satisfacción personal. En la Figura 4, se muestran los resultados obtenidos sobre las medias de las puntuaciones ofrecidas por los

\section{Resultados evaluación actividad experiencial}

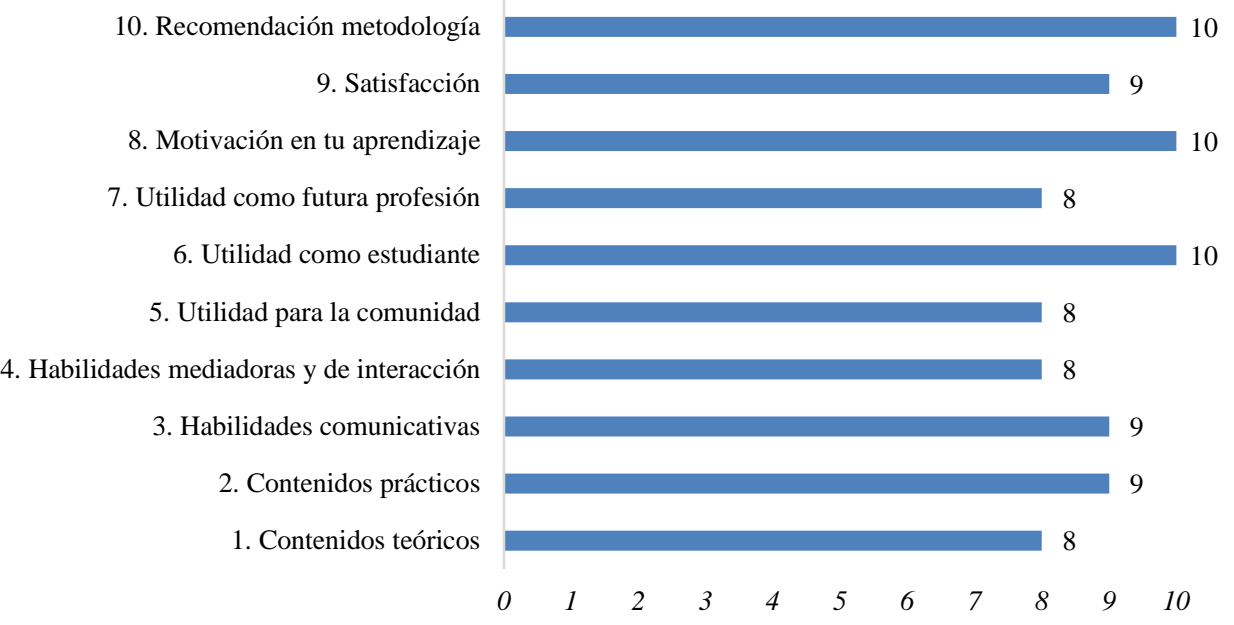

estudiantes.

Figura 4. Resultados de la evaluación presentado los ítems resumidos con las puntuaciones medias de las valoraciones aportadas por los estudiantes. Elaboración propia.

(cc) EY-NC-ND 2018, Universitat Politècnica de València

Congreso IN-RED (2018) 


\section{Conclusiones:}

Este proyecto fue muy motivador para los estudiantes ya que por unanimidad manifestaron que su aprendizaje había sido diferente, más creativo, innovador y vivencial. La propia elaboración de un proyecto vivo en el que ellos podrían actuar y no quedara en una carpeta, ha significado conseguir muchas de las competencias exigidas en el grado, como su autonomía, su capacidad de análisis, de planificación, además del trabajo en equipo. Otras capacidades que se plamaron al finalizar la actividad y como resumen de seguimiento, fue la capacidad de análisis y crítica, reflexión personal, capacidad de extrapolar los conocimientos a la práctica y la capacidad de influencia en la comunidad.

Esta influencia fue comprobada en el momento en que los menores intercambiaban sus pensamientos con los estudiantes universitarios partícipes, consiguiendo sensibilizarles sobre los peligros del mal uso de las nuevas tecnologías. Además, a este hecho, se suma la posterior comunicación con el centro, donde se pudo comprobar la satisfacción de los menores sobre la charla recibida.

Cabe señalar que las notas de los trabajos prácticos de la asignatura fueron mejores y más completas en comparación con años anteriores.

Es fundamental poder fomentar este tipo de prácticas entre los alumnos de grado que les capaciten para poder vivenciar y experimentar situaciones reales que aumenten su seguridad y motivación y favorezcan su interés hacia uno de los campos profesionales en los que la Criminología y la Psicología actúan.

\section{Referencias}

Aparicio, L. y De Paredes, C. (2016). El role-playing o experiencias de simulación como instrumento educativo en los estudios universitarios de Ciencias Sociales. Tamara Ramiro-Sánchez, $\mathrm{M}^{\mathrm{a}}$ Teresa Ramiro-Sánchez, y M Ma Paz Bermúdez (Comp.). XIII Foro Internacional sobre la Evaluación de la Calidad de la Investigación y de la Educación Superior (FECIES). Granada. España.

Ariza, M. R. (2010). El aprendizaje experiencial y las nuevas demandas formativas. Revista de antropología experimental, (10), 89-102.

Benito, Á. y Cruz A. (2005). Nuevas claves para la docencia universitaria: en el espacio europeo de educación superior. Madrid: Narcea Ediciones.

Berson, I. R. (2003). Grooming cybervictims: The psychosocial effects of online exploitation for youth. Journal of School Violence, 2(1), 5-18.

Brown, D. (2001). Developing strategies for collecting and presenting grooming evidence in a high tech world. National Center for Prosecution of Child Abuse. Update, 14(11). 
Chisholm, C.U., Harris, M.S.G., Northwood, D.O. y Johrendt, J.L. (2009). “The Characterisation of Work-Based Learning by Consideration of the Theories of Experiential Learning” en European Journal of Education, III, 44: 319-337.

Crookall, D. y Oxford, R. (1990). Simulation, Gaming and Language Learning. New York: Newbury House Publishers.

De Miguel, M. (2005). Modalidades de Enseñanza centradas en el desarrollo de Competencias: Orientaciones para promover el cambio metodológico en el Espacio Europeo de Educación Superior. Proyecto EA2005-0118. Universidad de Oviedo.

Fernández, A. (2006). Metodologías activas para la formación de competencias. Educatio siglo XXI, 24: 35-5

Gillespie, A. (2002). Child protection on the internet challenges for criminal law. Child and Family Law Quarterly, 14(4), 411-425.

Itin, C.M. (1999). "Reasserting the philosophy of experiential education as a vehicle for change in the 21st Century”. Journal of Experiential Education, 85-97.

Labrador-Piquer, M. J. y Andreu-Andrés, M. A. (2008). Metodologías activas. Valencia: Editorial UPV.

Li, Q. (2006). Cyberbullying in schools a research of gender differences. School Psychology International, 27(2), 157-170.

March, A. F. (2006). Metodologías activas para la formación de competencias. Educatio siglo $X X I, 24,35-56$.

Miguel-Dávila, J., López-Berzosa, D. y Martín-Sánchez, M. (2012). ¿Una participación activa del alumno pronostica una buena nota en el examen? Working Papers on Operations Management, 3(2), 71-83.

Monge, A. (2010). De los abusos y agresiones sexuales a menores de trece años tras la reforma penal de 2010. Revista De Derecho, 15, 85-106.

Prensky, M. (2001). Digital Game-Based Learning. New York: McGraw-Hill.

Raelin, J.A. (2000). Work-based Learning: The New Frontier of Management Development. Nueva Jersey: Prentice Hall Inc.

Smith, M.K. (2001, 2010)). David A Kolb on Experiential Learning, The Encyclopedia of Informal Education. [http://www.infed.org/b-explrn.htm. Recuperado: 02-122017.

Zabalza, M.A. (2011), Metodología docente, REDU: Revista de Docencia Universitaria, Vol. 9, Nº 3, 2011 (Ejemplar dedicado a: El espacio europeo de educación superior. ¿Hacia dónde va la Universidad Europea?) p.81. 


\title{
Aprendizaje combinado en el aula: clase magistral y peer instruction modificada
}

\section{Isabel Sánchez-Vera ${ }^{\mathrm{a}}$, Rima Barhoum ${ }^{\mathrm{b}}$, Esther Escudero $^{\mathrm{c}}$, Úrsula Muñoz ${ }^{\mathrm{d}}$}

isanver@ceu.es, brbarho@ceu.es, cestheresc@ceu.es, dursula.muñozmoron@ceu.es, Todos los autores tienen la misma procedencia: Sección de Fisiología. Dpto. Ciencias Médicas Básicas. Facultad de Medicina. Universidad San Pablo CEU, Madrid.

\begin{abstract}
This work has been described and analyzed the incorporation of a new methodology that has been combined in the same day, about 30-35 minutes of masterful talk together with the application for 15-20 minutes of the methodology peer instruction or teaching by fellow, included within the learning flipped, modified and adapted by us. The teaching experience has been very successful for teachers and pupils. 94\% of surveyed students shown in favor of this methodology and the many advantages offering them this method include its perception that are acquiring knowledge and improving their learning, is dynamic, easy, entertaining, value positive resolution of doubts, as well as encouraging attendance in class and work with colleagues. In spite of this, a large number of students referred to as main disadvantage that reduce the exposure time to the professor. The conclusions of this work lead us to think that the shift towards a new teaching methodology has to be carried out gradually, since the students, accustomed to a kind of teaching are more traditional, which are more wary to the change through new methodologies.
\end{abstract}

Keywords: new methodology, peer instruction, learning, talk, flippped

\section{Resumen}

En este trabajo se ha descrito y analizado la incorporación de una nueva metodología en la que se ha combinado en el mismo día, unos 30-35 minutos de la charla magistral junto con la aplicación durante 15-20 minutos de la metodología peer instruction o enseñanza por compañeros, englobada dentro del flipped learning y modificada y adaptada por nosotros. La experiencia docente ha sido muy satisfactoria para profesores y alumnos. Un 94\% de los alumnos encuestados se muestra a favor de esta metodología y entre las numerosas ventajas que les ofrece este método destaca su percepción de que están adquiriendo conocimientos y mejorando su aprendizaje, es dinámico, fácil, entretenido, valoran positivamente la resolución de dudas, además de fomentar la atención en clase y el trabajo con compañeros. A pesar de ello, un elevado número de alumnos refieren como principal desventaja que se reduzca el tiempo de exposición al profesor. Las conclusiones de este trabajo nos llevan a pensar que el cambio hacia una nueva metodología docente tiene que realizarse de forma progresiva, puesto que son los propios 
alumnos, acostumbrados a un tipo de enseñanza más tradicional, los que se muestran más recelosos al cambio mediante nuevas metodologías.

Palabras clave: nueva metodología docente, enseñanza por compañeros, peer instruction, flippped learning, charla magistral

\section{Introducción}

Las alternativas al modelo de enseñanza tradicional están cada vez más en auge. Sin embargo, para los profesores y alumnos acostumbrados a la metodología tradicional, ni de la clase magistral se puede prescindir tan fácilmente, ni las nuevas metodologías docentes como el flipped learning se pueden implantar de forma tan sencilla.

Es evidente que el modelo tradicional de enseñanza, basado únicamente en la transmisión de información por parte del profesor, presenta más desventajas que fortalezas. Durante la clase de teoría los alumnos escuchan las charlas magistrales de sus profesores, intentando asimilar la información que el profesor le transmite mediante explicaciones en la pizarra, presentaciones en power point, o incluso, en los últimos tiempos y gracias a las nuevas tecnologías, reproducción de vídeos. Así, la enseñanza tradicional lo que fomenta en el aula es una actitud pasiva en la mayor parte de los alumnos, cuyo papel principal es como mucho preguntar las dudas que le surjan durante las explicaciones del profesor (Lujan, 2006). Sin embargo, no cabe duda que para conseguir una buena formación de los alumnos es necesario que éstos adquieran unos conocimientos sólidos y por ello no debemos olvidar que los profesores, que son expertos en sus materias, pueden y deben contribuir a ello con sus explicaciones

Por otro lado, los téminos flipped classroom y flipped learning se oyen cada vez más en el ámbito universitario, desde que dicha metodología se inició en la Woodland Park High School en Colorado (Estados Unidos) en el año 2007, por los profesores de química Jonathan Bergmann y Aaron Sams, si bien ya existían algunos métodos de enseñanza precedentes, como el aprendizaje activo o los métodos inductivos, funcionales o de indagación (Bergamnn y Sams, 2105). Esta nueva metodología docente presenta numerosas ventajas pedagógicas respecto al modelo de enseñanza tradicional. Entre ellas, el modelo inverso mejora los resultados del aprendizaje de los alumnos y la adquisición de competencias, así como fomenta un ambiente colaborativo entre profesores y alumnos (O'Flaherty y Phillips, 2015). Sin embargo, para que el profesor pueda implementar con éxito esta nueva metodología requerirá una elevada carga de trabajo, especialmente en los primeros años, en los que tiene que generar material para el estudio previo de

(cc) EY-NC-ND 2018, Universitat Politècnica de València

Congreso IN-RED (2018) 
los alumnos y necesitará también desarrollar una serie de habilidades tanto pedagógicas como tecnológicas, lo que no hace fácil su puesta en marcha (Prieto, 2017).

Pero además, a las ventajas e inconvenientes pedagógicos de ambas metodologías docentes tenemos que tener en cuenta también otros aspectos que nos pueden hacer a los profesores decantarnos por uno u otro método.

En primer lugar la organización académica sigue estructurada como antiguamente. Los alumnos durante su horario tienen el tiempo distribuido en tres o cuatro horas diarias de clases teóricas con un pequeño descanso de diez minutos entre ellas. A pesar de estos descansos, nuestra capacidad de atención es limitada (Guillén, 2012). Así, numerosos artículos han propagado la idea de que no somos capaces de prestar una atención sostenida durante más de 10-15 minutos (Bradbury, 2016), y que la atención comienza a decrecer a los 20 minutos de la exposición (TokuhamaEspinosa, 2011), pero en realidad parece ser que todos ellos se basan en un único manuscrito publicado hace años por Hartley (Hartley, 1978). En cualquier caso, de lo que no hay duda es de que la enseñanza tradicional mediante charlas magistrales tiene que "evolucionar" hacia otras metodologías que no se basen en la atención sostenida en el tiempo (Imbernon, 2009) y algunos expertos en educación sugieren que hay que acabar con el formato de clases de 50 minutos (Mora, 2017).

El aula donde se imparten las clases teóricas sigue siendo, en muchos casos, un espacio diseñado para la enseñanza tradicional. El profesor explica desde la tarima que hay al lado de la pizarra y aunque se mueva por los pasillos de la clase, los bancos están anclados al suelo, sin posibilidad de moverlos, lo que dificulta la implantación de metodologías que conlleven en el aula trabajos en grupo, por ejemplo. La discusión de casos por grupos de trabajo, la colaboración entre alumnos y el estudio por equipos se hace difícil en un aula diseñada para otro tipo de metodología docente, aunque no por ello los profesores debemos quedarnos en el intento de innovar con otros métodos de enseñanza. De hecho, la metodología peer instruction o enseñanza por compañeros, ideada y diseñada por Eric Mazur, profesor de física en Harvard en 1997, solventa el inconveniente de impartir clase en un aula tradicional (Mazur, 1997). En esta metodología, los alumnos resuelven por parejas preguntas de opción múltiple diseñadas para poner a prueba su compresión conceptual. Esta técnica es metodológicamente sencilla de implementar, ya que los alumnos pueden trabajar comodamente en clase por parejas sin necesidad de moverse, levantarse o cambiar de sitio el mobiliario del aula. 
Los alumnos también son a veces un factor limitante en la implantación de las nuevas metodologías. En ocasiones los alumnos se sienten desbordados de clases teóricas y prácticas, seminarios, trabajos fuera del aula, exámenes, y se muestran reacios a los cambios, prefiriendo la clase tradicional, donde cogen apuntes para estudiar posteriormente fuera del aula lo explicado en clase. Esto dificulta en la metodología flipped learning que algunos alumnos se impliquen con la consecunción de este método y de entrada, la actitud por su parte es reticente a trabajar de forma autónoma previo a la clase. La labor de marketing y de motivación del alumno por parte del profesor se hace absolutamente imprescindible para instaurar con éxito el aula invertida, y aún así con determinados alumnos es difícil de conseguir (Prieto, 2017).

Por último, la implantación de nuevas metodologías docentes como el flipped learning, suponen para el profesor generar un elevado volumen de material docente con el que llevar a cabo dicha metodología, especialmente el primer año de su consecución (Prieto, 2017). La generación de este material didáctico puede ser postergado debido al elevado número de horas de clase, dirección de trabajos, tesis, investigación, seminarios, conferencias y demás actividades que se incluyen en el día a día del profesor universitario.

Así, a día de hoy es difícil decantarse por una metodología docente que prevalezca por encima de las demás como mejor alternativa para conseguir un aprendizaje óptimo de los alumnos dentro del aula, puesto que cada método presenta sus pros y sus contras, y que además se adapte a las necesidades del profesor y al contexto particular de la propia universidad donde se quiere llevar a cabo.

\section{Objetivos}

El objetivo principal de este trabajo es describir y analizar la combinación simultánea en el aula de la enseñanza tradicional (mediante la clase magistral) con la enseñanza por compañeros o peer instruction, como método docente que fomente la atención y participación de los alumos y mejore su aprendizaje.

\section{Desarrollo de la innovación}

La metodología de trabajo que se ha llevado a cabo se describe a continuación y en ella se ha combinado la clase tradicional con la metodología peer instruction o enseñanza por compañeros, con algunas modificaciones respecto a la metodología original diseñada por Eric Mazur. 
La experiencia docente se ha llevado a cabo en la asignatura Fisiología II, que se imparte en el segundo semestre del $2^{\circ}$ curso del Grado en Medicina (www.uspceu.com). Dicha asignatura es de carácter obligatorio y consta de 7,5 créditos ECTS. La metodología combinada se ha llevado a cabo de forma simultánea en cuatro grupos, lo que supone un total de 167 alumnos matriculados.

\section{Pautas para la metodología combinada: clase magistral y peer instruction}

En la presentación de la asignatura el profesor explica la metodología que se va a llevar a cabo, con el fin de que los alumnos conozcan la nueva dinámica con la que se va a trabajar.

El profesor tiene que proporcionar a los alumnos, al inicio de la asignatura, todas las diapositivas y/o información con la que se va a explicar la materia. Los alumnos, por su parte, deberán acudir a clase con el material aportado por el profesor. Lo habitual es que los alumnos vayan con las diapositivas impresas en papel, aunque cada vez es más frecuente que acudan con la información en sus ordenadores portátiles o tablets. Darles toda la información al inicio de la asignatura presenta varias ventajas y así se les hace ver a los alumnos el día de la presentación:

- Por un lado, los alumnos pueden mirarse la información el día antes de la clase, lo que facilita la explicación y presenta beneficios. Este trabajo autónomo del alumno fuera del aula y previo a la clase, es en sí mismo la esencia del flipped learning, pero por los motivos expuestos en la introducción, para la metodología que proponemos no se hace necesario. Así, los alumnos más reacios a trabajar de forma autónoma previo a la clase no se sienten molestos con esta dinámica, pero poco a poco se irá consiguiendo que aumenten su motivación y su implicación en la asignatura.

- Estar en clase con la información que ha proporcionado el profesor es imprescindible para, como exponemos en el siguiente apartado, trabajar por parejas en el aula y obtener el máximo rendimiento.

El primer día de clase los alumnos tendrán que buscar un compañero con el que vayan a trabajar en el aula de forma conjunta a lo largo de la asignatura. Por tanto, el profesor dispondrá de un listado con las parejas de alumnos que se han formado, para así poder evaluar el trabajo que hacen en el aula. El formar parejas de alumnos desde el inicio y siempre las mismas, hace que los alumnos se motiven entre ellos para ir a clase, puesto que si uno de ellos falla, su compañero 
se quedará colgado y no tendrá con quién discutir y razonar con los ejercicios y preguntas que se planteen en la clase.

\section{Desarrollo de la clase combinada:}

Cada día de clase el profesor va a estructurar el desarrollo de la clase de la siguiente manera:

- Comenzará explicando los contenidos mediante la enseñanza tradicional, es decir, mediante charla magistral, con explicaciones en la pizarra, con diapositivas en power point o lo que considere oportuno. En definitiva, durante aproximadamente los 20 primeros minutos de la clase, el profesor sentará las bases del conocimiento sobre el que a continuación los alumnos van a trabajar.

- A continuación, el profesor repartirá en clase el material para trabajar por parejas. Así, se les dejará un tiempo durante el cual los alumnos discutirán y resolverán juntos los ejercicios o preguntas propuestas. Durante este tiempo el profesor irá por todas las parejas resolviendo las dudas y supervisando el trabajo de los alumnos, para orientarles y guiarles en su aprendizaje autónomo.

- El tiempo de trabajo por parejas dependerá del ejercicio que se les proponga, pero lo ideal sería hacer una tanda de ejercicios o preguntas que les llevara aproximadamente unos 10 minutos de discusión. Menos tiempo puede no ser suficiente para resolver las preguntas o casos propuestos, y más tiempo puede suponer que los más rápidos o que mejor trabajen acaben hablando de otros temas no relacionados con la asignatura, provocando que el ambiente de trabajo se altere, sobre todo si el grupo es muy numeroso, o incluso moleste a las aulas contiguas donde también se está impartiendo clase.

- Por último, el profesor explicará otros 10-15 minutos y se les dejará los 5-10 minutos finales de la clase para nuevamente, por parejas, los alumnos discutan y razonen los conocimientos adquiridos.

- Todos los trabajos efectuados se recogerán por el profesor al finalizar la clase y se irán guardando como parte de la evaluación de cada alumno. Como feedback por parte del profesor, los trabajos se corregirán, se evaluarán y se devolverán a los alumnos como material docente para su estudio y comprensión, de forma que individualmente o nuevamente por parejas, los alumnos puedan volver a repasar fuera del aula los razonamientos que han llevado a cabo en la clase. 
- Por último, la evaluación de los trabajos realizados por los alumnos en el aula puede ser empleada como método de motivación para la asistencia a clase y la implicación activa en la asignatura. Si el profesor los corrige y los puntúa, puede ir actualizando un listado con el ranking de aciertos por parejas.

\section{Ejemplos de ejercicios propuestos:}

- Preguntas tipo test de elección múltiple: para que los alumnos puedan discutir y razonar de forma que asienten los conocimientos previos que acaba de explicar el profesor en el aula estas preguntas no sólo deben ir encaminadas a recordar lo que se ha escuchado, sino que tienen que estar diseñadas para examinar la comprensión de los conceptos explicados. Como ejemplo de estas preguntas conceptuales, en nuestras clases aprovechamos las preguntas del examen MIR para que nuestros alumnos sean capaces de trasladar los conocimientos básicos que acaban de aprender, con la resolución de casos clínicos.

- Casos prácticos: se les plantean situaciones o casos, reales o imaginarios, para razonar. En concreto, en nuestra asignatura les entregamos casos clínicos que, junto a las preguntas de elección múltiple anteriormente descritas, los alumnos puedan entender la aplicación práctica de lo que están estudiando y sean capaces de ver la trascendencia de los conceptos esenciales.

- Imágenes para identificar y completar: en estas imágenes se han eliminado las leyendas y toda la información relativa a ella. Por ejemplo, en nuestro caso se les proporciona una imagen de los riñones, uréteres y vejiga renal y tienen que identificar las distintas partes morfológicas y de inervación nerviosa, para a partir de ahí deducir el proceso de la micción. Así, los alumnos deben completarlas con todo tipo de detalles, lo que les ayuda a fijarse en detalles que muchas veces son importantes pero que fuera del aula les pasa desapercibidos.

- Búsquedas en internet: la mayor parte de los alumnos están en clase con sus ordenadores portátiles o incluso con el móvil, desde donde tienen acceso a internet. Esto facilita las búsquedas en la web como parte de su proceso de aprendizaje. En ocasiones les proponemos que busquen algún concepto en concreto para entender otro, o para afianzar conceptos, para ver la aplicación práctica o simplemente para poder contestar una pregunta de elección múltiple 
donde alguna de las respuestas propuestas no se ha explicado en clase y por tanto desconocen.

- Realización de esquemas o dibujos explicativos: algunas veces se les propone que ellos mismos hagan un esquema de lo que se les acaba de explicar o incluso hagan un dibujo. En nuestra asignatura el estudio por imágenes es muy efectivo, por lo que con esta actividad lo que se pretende es que afiancen los conceptos al ser ellos mismos los que tienen que crear la imagen. Por ejemplo, un ejercicio propuesto es que vayan dibujando en cada una de las células que hay en la nefrona, los distintos transportadores que intervienen, para posteriomente discutir acerca del mecanismo de acción de los diuréticos.

\section{Análisis de la experiencia docente}

Para conocer el grado de satisfacción con la metodología propuesta se elaboró una encuesta en la que los alumnos valoraron el desarrollo de la misma mediante preguntas abiertas. Dado el carácter exploratorio del estudio se les hicieron cuatro preguntas:

1. ¿Qué opinión le merece el método docente empleado?

2. ¿Qué ventajes cree que ofrece este método para su formación y aprendizaje?

3. ¿Qué desventajas cree que supone la aplicación de esta metodología?

4. ¿Cómo solventaría estas desventajas?

5. ¿Qué añadiría/quitaría/modificaría del método?

\section{Resultados}

\section{Valoración de los alumnos del método combinado en el aula}

La valoración del método propuesto la realizaron un total de 132 alumnos de los 167 matriculados (79\%) luego los resultados son altamente significativos y muestran la percepción de la mayor parte de los alumnos. Dado que la encuesta se decidió hacerla abierta para poder analizar mejor sus impresiones, en esta memoria hemos agrupado las mismas respuestas repetidas o parecidas para analizar los resultados y mostrar el \% de alumnos con una opinión similar.

Respecto a la primera pregunta en la que se les pidió que valoraran de forma global la metodología docente (Figura 1), si agrupamos todas las respuestas positivas que muestran una opinión favorable a este método, un 94\% de los alumnos se muestra a 
favor de este tipo de aprendizaje. Las respuestas más repetidas son: es un buen método, interactivo, divertido, ameno, dinámico, entretenido, facilita mucho el aprendizaje, eficaz para asimilación de conceptos. Sólo a un 1\% no les aporta nada pero tampoco les parece mal y ningún alumno se ha mostrado en contra de esta metodología.

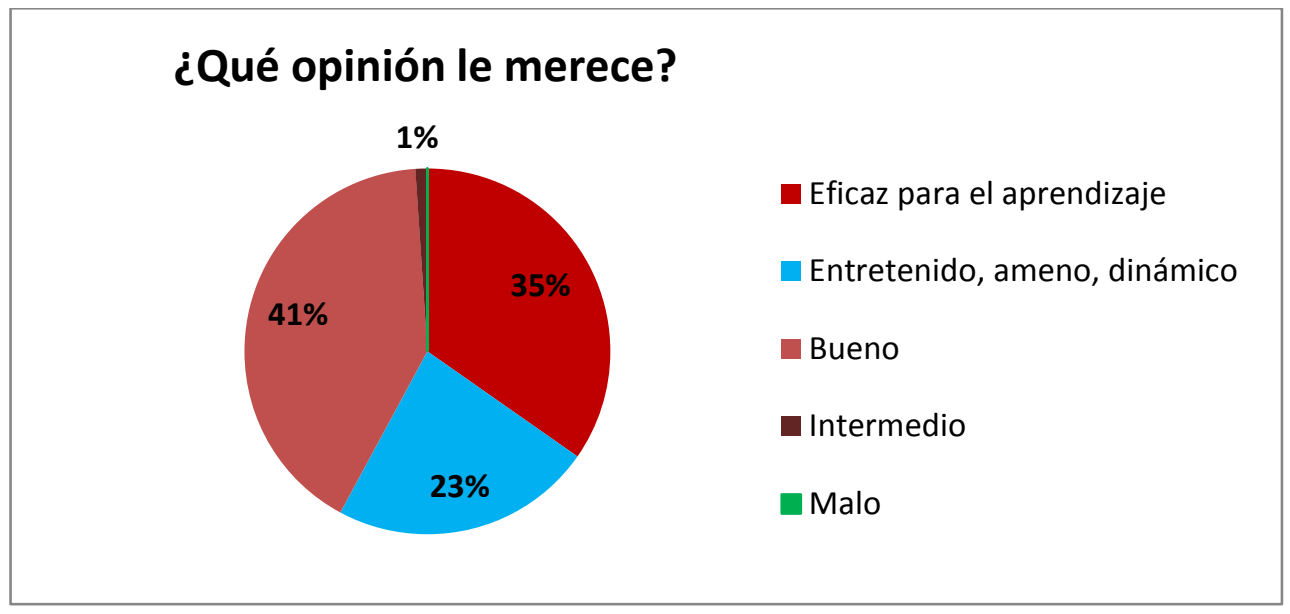

Figura 1. Opinión global de los alumnos sobre la metodología empleada

Cuando se les pregunta acerca de las ventajas que ofrece esta metodología (Figura 2), las respuestas siguen la misma línea que en la pregunta anterior: la mayor parte de los alumnos cree que esta metodología les ayuda en la adquisición de conocimientos (28\%), es dinámico, fácil de seguir (23\%), les ayuda a familiarizarse con las preguntas de opción múltiple (22\%), les ayuda a discernir los contenidos más importantes (9\%), están más atentos en clase (5\%), se fomenta el trabajo con los compañeros (5\%) y valoran las resolución instantánea de las dudas por parte del profesor (8\%).

\section{Ventajas del método aplicado}

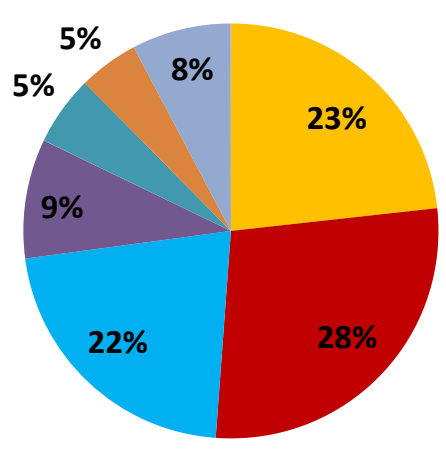

Es dinamico y fácil de seguir

- Adquirir conocimientos

Aprender a resolver preguntas de opción múltiple - Seleccionar lo importante

- Trabajo en grupo

- Prestar más atención en clase

Resolución de dudas

Figura 2. Percepción de los alumnos sobre las ventajas de la metodología empleada 
Las desventajas y debilidades que los alumnos observan de esta metodología se observan en la Figura 3. Un 25\% de los alumnos encuestados responden que esta forma de impartir la clase no presenta ninguna desventaja, luego consideran positivo la introducción de ejercicios y están a favor de cambiar la dinámica de la enseñanza de forma tradicional. Sin embargo, el mayor porcentaje de alumnos, un $48 \%$ opina que con esta metodología se reduce el tiempo de explicación del profesor. Es interesante esta apreciación de los alumnos pues refleja que casi la mitad de ellos ven de forma desfavorable que disminuya el tiempo de explicación del profesor, es decir, la charla magistral. Se trata por tanto de alumnos reacios a los cambios, que siguen prefiriendo la clase tradicional a la que están acostumbrados. Algunos alumnos valoran como negativo por su dificultad, los ejercicios con imágenes (un 3\%) y aplicar esta metodología en todos los temas, especialmente en aquellos que son más complejos (un 8\%). Por último, el aprendizaje por parejas algunos lo consideran una debilidad, un $5 \%$ al no poder ser evaluados de forma individual, y un $11 \%$ porque piensan que un alumno más vago les perjudica y retrasa en su aprendizaje y otros porque tampoco les gusta si su compañero es más rápido y razona mejor que ellos.

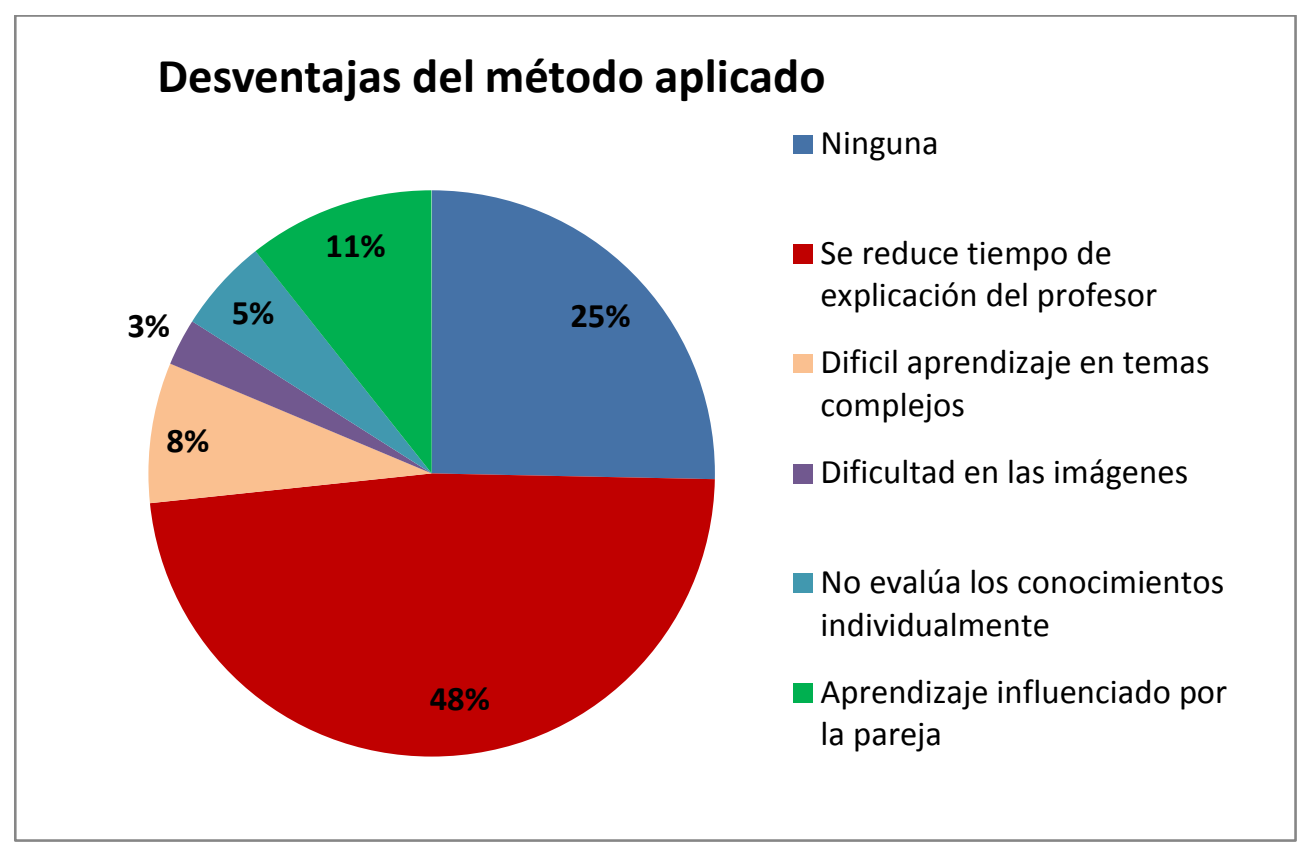

Figura 3. Percepción de los alumnos sobre las desventajas de la metodología empleada

Las propuestas sobre cómo solucionarían ellos las debilidades de este método se muestran en la Figura 4. La mayor parte de los alumnos (un 36\%) no considera que sea necesario mejorar ningún aspecto, la mayoría porque no le ven ninguna debilidad, y otros porque no han respondido a esta pregunta, presumiblemente por 
no saber cómo solventar las desventajas. Como sugerencias se encuentran: sólo aplicarlo cuando el tema que se explica es sencillo (19\%), trabajar de forma individual (11\%), darles más tiempo para trabajar en el aula (6\%), proporcionarles los ejercicios con antelación (15\%) y realizar las actividades una vez que ellos hayan estudiado los temas (13\%).

\section{Cómo solventar las desventajas planteadas}

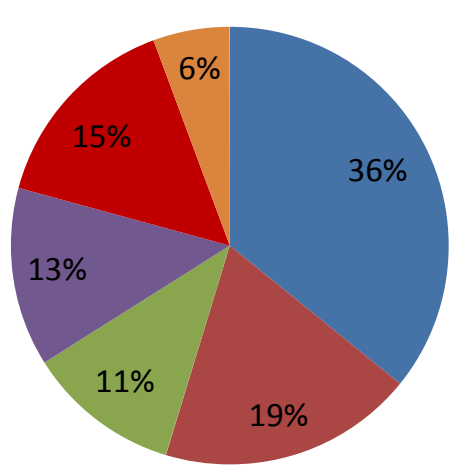

No necesario solventar desventajas

- Sólo aplicarlo en temas sencillos

- Proporcionar ejercicios individuales

Formación previa a la realización de la actividad

- Proporcionarles el material con antelación

Más tiempo para ejercicios

Figura 4. Sugerencias de los alumnos sobre las desventajas de la metodología empleada

Por último, en la Figura 5 se muestran las sugerencias de los alumnos a la pregunta ¿qué añadiría/quitaría/modificaría del método?. Al igual que en la pregunta anterior, un 37\% de los alumnos se muestra muy conforme con la dinámica y no cambiarían ni quitarían nada. El resto de los alumnos proponen incluir el empleo de aplicaciones informáticas, tipo kahoot o socrative (22\%), añadir más ejercicios con imágenes (3\%) y más tiempo para hacerlos (9\%), trabajo individual (13\%) y un $16 \%$ opina que le gustaría hacer en clase simulacros del examen final de la asignatura. 


\section{Aportaciones/modificaciones}

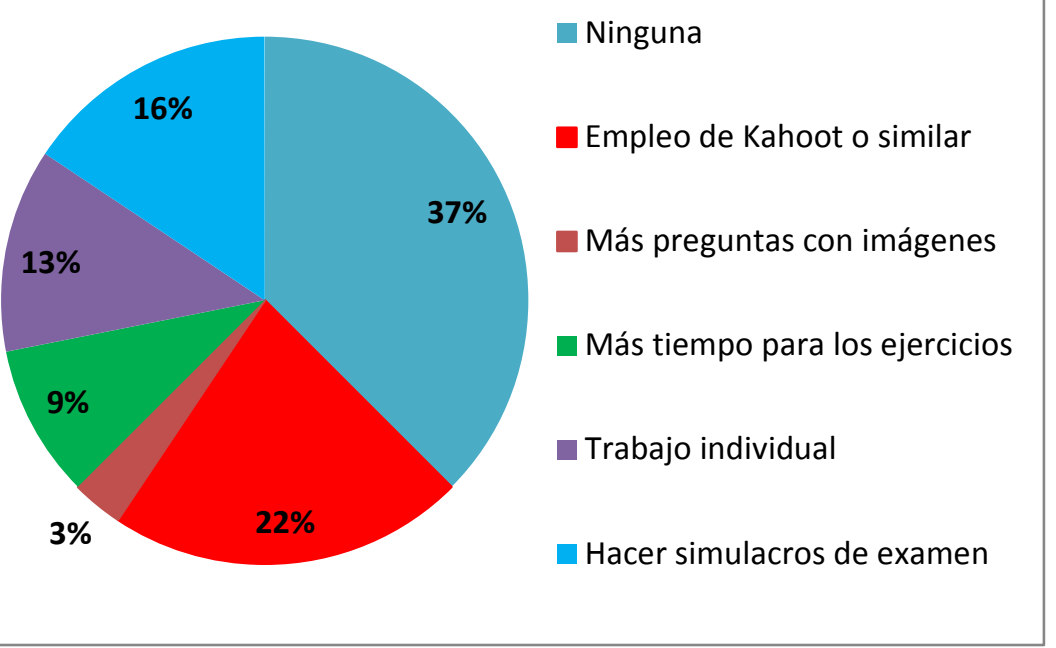

Figura 5. Propuestas de los alumnos sobre la metodología empleada

\section{Valoración de los profesores del método combinado en el aula}

La valoración global de la experiencia docente por parte de los profesores es totalmente satisfactoria. La inclusión de casos prácticos, ejercicios y demás trabajos durante el tiempo de exposición del profesor ha aumentado no sólo la asistencia a clase sino también la participación activa de los alumnos. Limitar el tiempo seguido de exposición del profesor durante las explicaciones ha contribuido a que hayan permanecido más callados y a una mayor atención e implicación de los alumnos, evitando que se despisten.

Por otro lado, durante el trabajo por parejas los alumnos han seguido concentrados en la asignatura y han aprovechado el tiempo. Esos 10-15 minutos de razonar y discutir juntos las actividades que se les ha proporcionado les han motivado y les ha entretenido, aumentando su interés por la asignatura. La participación ha sido total, y se han podido resolver dudas individuales a los alumnos en al aula.

En general la dinámica de la clase ha sido activa, entretenida y ha fomentado el aprendizaje de los alumnos. 


\section{Conclusiones}

En este trabajo se ha descrito y analizado la incorporación de una nueva metodología en la que se ha combinado en el mismo día, unos 30-35 minutos de la charla magistral junto con la aplicación durante 15-20 minutos de la metodología peer instruction o enseñanza por compañeros, englobada dentro del flipped learning y modificada y adaptada por nosotros. La experiencia docente ha sido muy satisfactoria para profesores y alumnos. Un 94\% de los alumnos encuestados se muestra a favor de esta metodología y entre las numerosas ventajas que les ofrece este método destaca su percepción de que están adquiriendo conocimientos y mejorando su aprendizaje, es dinámico, fácil, entretenido, valoran positivamente la resolución de dudas, además de fomentar la atención en clase y el trabajo con compañeros.

A pesar de ello, un elevado número de alumnos refieren como principal desventaja que se reduce el tiempo de exposición del profesor y preferirían aplicarlo sólo en los temas más sencillos y que no entrañan dificultad. Estas respuestas indican que aún estando conforme con la metodología empleada en la clase, a una parte mayoritaria de los alumnos les cuesta adaptarse al cambio, no por el método en sí mismo, sino por la inseguridad que les genera introducir dinámicas nuevas de cara a examinarse de la asignatura.

Las conclusiones de este trabajo nos llevan a pensar que el cambio hacia una nueva metodología docente tiene que realizarse de forma progresiva, puesto que son los propios alumnos, acostumbrados a un tipo de enseñanza más tradicional, los que se muestran más recelosos al cambio mediante nuevas metodologías.

\section{Referencias}

BERGMANN, J., SAMS A. (2015). Dale la vuelta a tu clase: Lleva tu clase a cada estudiante, en cualquier momento y cualquier lugar. Biblioteca Innovación educativa. Editorial SM.

BRADBURY, N. A. (2016). Attention span during lectures: 8 seconds, 10 minutes, or more? Advances in Physiology Education, 40(4), 509-513.

GUILLÉN, J. C. (2012). La atención: un recurso limitado. En escuela con cerebro $<$ https://escuelaconcerebro.wordpress.com/2012/03/04/la-atencion-un-recursolimitado/>

IMBERNON, F. (2009). Cuadernos de docencia universitaria. Editorial Octaedro.

LUJAN H. L., (2006). Too much teaching, not enough learning: what is the solution? Adv Physiol Educ 30: 17-22.

(c) EY-NC-ND 2018, Universitat Politècnica de València

Congreso In-Red (2018) 
MAZUR, E. (1997). Peer instruction: A User`s Manual Prentice Hall Series in Educational Innovation Englewood. Clifts, NJ: Prentice Hall.

MORA, F. (2013) Hay que acabar con el formato de clases de 50 minutos.

<lhttps://elpais.com/economia/2017/02/17/actualidad/1487331225_284546.html>

O'FLAHERTY, J., PHILLIPS, C. (2015). The use of flipped classrooms in higher education: A scoping review en Internet and Higher Education 25 85-95.

PRIETO, A. (2017). Flipped learning. Aplicar el modelo de apredizaje inverso. Editorial Narcea.

TOKUHAMA-ESPINOSA, T (2011). Mind, brain, and education science. A comprehensive guide to the new brain-based teaching. W. W. Norton \& Company. 


\title{
Trabajo por proyectos en el urbanismo industrial
}

\section{Aguilar ${ }^{a}$, J. Deltoro ${ }^{a}$, V. Albero ${ }^{b}$ y.M. Montalváa}

a Departamento de Ingeniería de la Construcción y Proyectos de ingeniería civil, Universidad Politécnica de Valencia, (magal001@urb.upv.es, judelso@cts.upv.es,jmonsu@cst.upv.es).

bDepartamento de Mecánica de los medios continuos y teoría de estructuras, Universidad Politécnica de Valencia (valbero@mes.upv.es).

\begin{abstract}
This paper exposes the methodology used in the Urbanism part of the subject "Construction, architecture and industrial urbanism" through the realization of the Urban Planning Project of an economic activity sector in groups of three students combining "project based learning" and "cooperative work".

All the contents taught in the subject are applied in the project in a completely practical way on a real case of an existing industrial urban area and its extension. In addition, working in teams supposes a great resemblance with professional practice,

The work contributes to the acquisition of specific competences of the degree and cross-sectional competences of the Polytechnic University of Valencia. The survey conducted on the opinion of the students about it gives us a positive vision of the obtained results.
\end{abstract}

Keywords: project based learning, cooperative working, urbanism, industrial engineering

\section{Resumen}

Este artículo expone la metodología utilizada en la parte de Urbanismo de la asignatura "Construcción, arquitectura y urbanismo industrial"mediante la realización de un Proyecto de ordenación urbanística de un sector de actividad económica en grupos de tres alumnos que aúna el "trabajo por proyectos" y "trabajo cooperativo".

Se puede destacar que el proyecto consiste en la aplicación de los contenidos impartidos en la asignatura de una manera totalmente práctica sobre un caso real de un polígono industrial y su ampliación. Además, el hecho de realizarlo en equipo también supone una semejanza mayor con la práctica profesional.

El trabajo contribuye a la adquisición de competencias tanto específicas de la titulación como transversales de la Universidad Politécnica de Valencia y la realización de una encuesta sobre la opinión de los alumnos nos aporta una visión positiva de los resultados obtenidos.

Palabras clave: trabajo por proyectos, trabajo cooperativo, urbanismo, ingeniería industrial 


\section{Introducción}

Actualmente, como resultado de la puesta en marcha del Espacio Europeo de Educación Superior (EEES) (Bolonia, 1999), es necesario que los nuevos modelos y técnicas educativas centradas en el alumno se vean incrementadas. Los estudiantes no solo deben adquirir habilidades especificas relacionados con su campo de estudio, sino que además deben también desarrollar otras competencias transversales, altamente demandadas y apreciadas por empresas y empleadores. De hecho, en el Comunicado de Bucharest (2012) quedó explicitada la necesidad de combinar competencias transversales y específicas en el ámbito universitario con el objetivo de contribuir a las demandas actuales del mercado y la sociedad.

El interés en dar a los estudios de ingeniería un enfoque práctico (Luce y Henry, 2002) ha supuesto que, desde el punto de vista universitario, cada día sea más necesario diseñar metodologías que permitan a los alumnos simular ejercicios de la vida profesional. En este sentido la aplicación de innovadoras técnicas de aprendizaje como el aprendizaje basado en proyectos, Project Based Learning PBL (Gwem, 2003), ha permitido la adaptación de la educación superior a este nuevo escenario. El aprendizaje basado en proyectos es una metodología centrada en el estudiante que, en grupos pequeños, se enfrenta al planteamiento y desarrollo de proyectos que pretenden dar solución a una necesidad real. Esta metodología se basa en presentar un contexto lo más realista posible que permita al estudiante simular un escenario de la vida profesional. Concretamente, esta tipología metodológica fue aplicada con éxito en el ámbito de la medicina en los años setenta con el objetivo de conseguir una mayor motivación de los estudiantes (Woods et al., 2000) y se ha aplicado posteriormente a otros ámbitos de ingeniería como la ingeniería civil (Mahendran, 1995), la simulación de elementos finitos (Ural, 2013) o la ingeniería estructural (Tejero et al. 2015). Así, se ha convertido en una metodología docente muy popular durante las últimas décadas que resulta realmente útil para incrementar la motivación de los alumnos.

Hoy en día, la metodología basada en proyectos se ha convertido en una metodología de aprendizaje fundamental en los nuevos modelos de educación superior. De hecho, se han realizado diversos estudios que han revelado sus múltiples beneficios en comparación con las metodologías docentes más tradicionales (Maldonado, 2008). Gracias a esta metodología es posible trabajar en el desarrollo de multitud de habilidades y capacidades transversales como el tratamiento de información de múltiples fuentes, el trabajo en grupo, el pensamiento crítico, la planificación y organización de actividades o la toma de decisiones (de Miguel, 2006). Durante todo el proceso de desarrollo de la actividad los estudiantes tienen que trabajar en grupo, planificar y distribuir tareas, analizar diversas situaciones y definir todas las variables involucradas en el diseño final. Para alcanzar de forma satisfactoria el objetivo marcado, los estudiantes deben adoptar una actitud proactiva e interaccionar con sus compañeros para contrastar ideas y opiniones, llegando finalmente a la toma de decisiones.

Este trabajo presenta una aplicación real del método de aprendizaje basado en proyectos diseñada para los estudiantes de la asignatura Construcción, Arquitectura y Urbanismo Industrial del Máster Universitario en Ingeniería Industrial de la Universidad Politécnica de

(cc) EY-NC-ND 2018, Universitat Politècnica de València

Congreso IN-RED (2018) 
Valencia. En este sentido la actividad desarrollada, utilizando esta metodología, permite una aproximación real de los alumnos al ámbito de los proyectos de urbanismo industrial obteniendo unos excelentes resultados y una buena acogida entre el alumnado.

\section{Contexto}

El proyecto descrito en esta comunicación se desarrolla dentro del Máster Universitario en Ingeniería Industrial en la E.T.S.I. INDUSTRIALES. La asignatura, obligatoria y troncal, en la que se desarrolla es la de Construcción, Arquitectura y Urbanismo Industrial (CAUI, Código: 33806) de 5,25 créditos (Teoría: 2,80. Prácticas: 2,45) constituye la base formativa para alcanzar los objetivos que, en el ámbito de la construcción, la arquitectura y el urbanismo, permiten proyectar, calcular y diseñar polígonos industriales.

El temario de la asignatura permite dividir la misma en dos áreas temáticas diferenciadas, Contrucción y Arquitectura industrial y Urbanismo.

Tabla 1. Unidades didácticas

\begin{tabular}{lll}
\hline $\begin{array}{l}\text { Contrucción } \\
\text { Arquitectura } \\
\text { industrial }\end{array}$ & - & $\begin{array}{l}\text { La arquitectura de la planta industrial: La distribución en planta, } \\
\text { Iluminación natural, Protección contra incendios }\end{array}$ \\
\hline Urbanismo & - & Elementos constructivos: Forjados, Soleras, Cerramientos \\
& - & $\begin{array}{l}\text { Introducción al Urbanismo: El suelo de actividades económicas, } \\
\text { Evolución de los asentamientos industriales, Caracterización del } \\
\text { espacio industrial en la Comunitat Valenciana }\end{array}$ \\
& - & $\begin{array}{l}\text { Legislación y planeamiento en la Comunitat Valenciana } \\
\text { Los modelos - La estructura viaria }\end{array}$ \\
& - & Parcelación - Tipologías de edificación \\
&
\end{tabular}

Ambas partes se desarrollan en paralelo con sesiones tanto teóricas como prácticas. La experiencia que se presenta en esta comunicación se incluye dentro la parte de Urbanismo.

Combinando los contenidos teóricos y prácticos, y con un enfoque docente eminentemente aplicado, se desarrollan un conjunto de temas que permitirán al alumno, de manera autónoma, mediante la realización de cálculos y análisis sobre casos reales, teniendo en cuenta la legislación, las normas y los reglamentos de obligado cumplimiento, abordar el proyecto de análisis y de ordenación urbanística de una instalación industrial.

Esta es una asignatura que integra una buena parte de las capacidades anteriormente adquiridas por el alumno, y que posibilita desarrollar su razonamiento crítico, creatividad e iniciativa, alcanzando a comprender la responsabilidad que tendrá, como profesional, sobre los recursos humanos y materiales puestos a su disposición, individualmente o formando parte de un equipo multidisciplinar, para el completo desarrollo del proyecto de construcción, edificación, infraestructuras y urbanismo, en el ámbito de la ingeniería industrial.

La actividad realizada consiste en el análisis de una zona industrial para su reforma y/o ampliación y el desarrollo de un proyecto de ordenación urbanística de una zona de actividades económicas. 
Las metodologías utilizadas para el desarrollo de la actividad descrita son diversas:

- Aprendizaje basado en problemas. Posee un enfoque educativo orientado al aprendizaje y a la instrucción en el que los alumnos abordan problemas reales en pequeños grupos y bajo la supervisión de un tutor. La agrupación propuesta es de tres alumnos.

- Aprendizaje basado en proyectos: Se plantea en situaciones en las que el alumno debe explorar y trabajar un problema práctico aplicando conocimientos interdisciplinares. En este proyecto se deben aplicar conocimientos previos que los alumnos poseen, así como los nuevos conceptos aprendidos previamente o en paralelo dentro de la asignatura CAUI.

- Trabajo colaborativo o grupal: Se realizan sesiones supervisadas donde los estudiantes trabajan en tareas grupales y reciben asistencia y guía cuando es necesaria.

- Aprendizaje significativo aplicado a un contexto real. La elección de un polígono existente ayuda a comprender los conceptos relacionándolos entre sí y obtener una visión completa.

Las competencias (básicas, generales y específicas) que se trabajan en la parte de Urbanismo de la asignatura e incluidas dentro de la Verificación por el Consejo de Universidades del Máster Universitario en Ingeniería Industria, son las siguientes: CB10(G), CB7(G), CB8(G), ,CB9(G), GE2(G), ,GE8(G), CB6(G), IPC1(E), ,IPC2(E).

Las competencias transversales de la UPV trabajadas en la parte de urbanismo son la siguientes:

Tabla 2. Competencias transversales

\begin{tabular}{|c|c|c|c|}
\hline $\begin{array}{c}\text { Competencias } \\
\text { transversales de la } \\
\text { UPV }\end{array}$ & Actividades & Descripción & $\begin{array}{l}\text { Criterios de } \\
\text { evaluación }\end{array}$ \\
\hline (05) Diseño y proyecto & $\begin{array}{l}\text { Aprendizaje } \\
\text { orientado a } \\
\text { proyectos }\end{array}$ & $\begin{array}{l}\text { Análisis de una zona industrial } \\
\text { para su reforma y/o ampliación } \\
\text { y desarrollo del proyecto de } \\
\text { ordenación urbanística de una } \\
\text { zona de actividades } \\
\text { económicas. }\end{array}$ & $\begin{array}{c}\text { Conjunto de rúbricas } \\
\text { para la evaluación de } \\
\text { las diferentes etapas } \\
\text { del proyecto. }\end{array}$ \\
\hline $\begin{array}{l}\text { (07) Responsabilidad } \\
\text { ética, medioambiental y } \\
\text { profesional }\end{array}$ & $\begin{array}{l}\text { Estudio de } \\
\text { casos. }\end{array}$ & $\begin{array}{l}\text { Análisis de una zona industrial } \\
\text { para su reforma y/o ampliación. }\end{array}$ & $\begin{array}{l}\text { Redacción de } \\
\text { informes. }\end{array}$ \\
\hline $\begin{array}{l}\text { (12) Planificación y } \\
\text { gestión del tiempo }\end{array}$ & Proyectos. & $\begin{array}{l}\text { Adecuada organización y } \\
\text { secuenciación temporal para el } \\
\text { desarrollo del proyecto de } \\
\text { ordenación urbanística de una } \\
\text { zona de actividades } \\
\text { económicas. }\end{array}$ & $\begin{array}{l}\text { Conjunto de rúbricas } \\
\text { para la evaluación de } \\
\text { las diferentes etapas } \\
\text { del proyecto. }\end{array}$ \\
\hline
\end{tabular}

(c) B EY-NC-ND 2018, Universitat Politècnica de València

Congreso IN-RED (2018) 
A parte de los objetivos explícitamente formulados a través de las competencias básicas, específicas y transversales que se han enunciado previamente, la realización del proyecto tambiñen persigue la consecución de otros objetivos no explícitos como el fomentar el trabajo cooperativo, el desarrollo de la comunicación escrita en la redacción de informes y el fomento de un juicio y pensamiento crítico.

\section{Descripción del proyecto}

\subsection{Punto de inicio}

El trabajo de Urbanismo del curso, realizado en equipos de 3 alumnos que se constituyen de forma voluntaria, consiste en el análisis de la situación actual de ordenación urbanística de un sector de actividad económica y en la propuesta de ampliación y de ordenación urbanística, de un sector de actividad económica situado en el mismo municipio, con una extensión delimitada en la información gráfica facilitada. La elección de la localización del mismo es distinta cada curso académico. Para alcanzar el objetivo descrito, se desarrollan las siguientes actividades:

- Estudio de la evolución histórica del urbanismo desde el punto de vista de la configuración de las áreas de actividad económica. CONOCIMIENTO

- Análisis de la realidad del suelo de actividades económicas en el ámbito de la Comunitat Valenciana, como referente inmediato que sirve de modelo al análisis general. CRÍTICA.

- Estudio de las herramientas de planeamiento y de proyecto necesarias para el correcto desarrollo de nuevos sectores de actividad económica, junto con los requerimientos técnicos asociados, para la realización del proyecto básico de implantación. EXPERIENCIA DE PROYECTO

Las sesiones teóricas y prácticas de la asignatura permiten abordar progresivamente el proyecto de ordenación de un área de actividad económica, de acuerdo con el enunciado que se facilita. Mediante la realización de este análisis y propuesta urbanística, se pretende obtener un aprendizaje eficaz, a través de la puesta en práctica de los conocimientos y normativas aprendidas en la parte teórica de la asignatura mediante la reflexión y la experimentación.

\subsection{Análisis}

La primera parte del trabajo consiste en la realización de un análisis de un polígono industrial. Para su realización los profesores y alumnos visitan conjuntamente la zona a estudiar. El departamento organiza una salida desde la Universidad al polígono para permitir a todos los alumnos poder recoger y constatar in situ los datos que posteriormente reflejarán en sus presentaciones. 

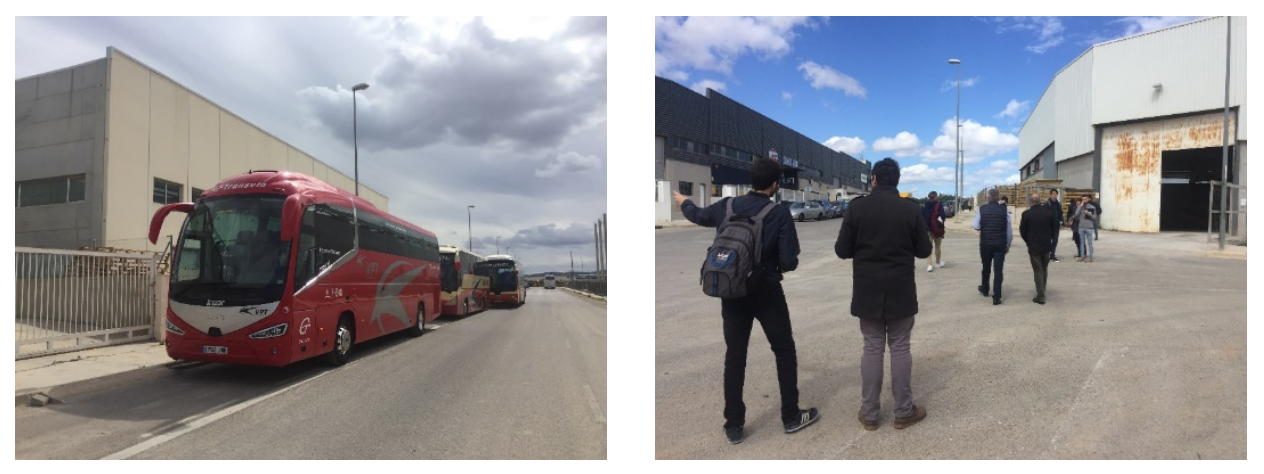

Fig. 1 Visita inicial al área de estudio.

El análisis realizado por los alumnos debe contener la información extraida en unos planos especificados previamente, como la elaboración de un DAFO (debilidades, amenazas, fortalezas y oportunidades, del área objeto de estudio), un reportaje fotográfico y un plano de estructura viaria, usos, parcelación y edificación. Los planos, en formato DIN A3 que los alumnos deben presentar obligatoriamiente son los siguientes:

- A1. Emplazamiento, inserción territorial Y DAFO. E: 1/15.000.

- A2. Composición fotográfica del sector.

- A3. Estructura viaria, usos, parcelación y edificación. E: 1/3.000.

\subsection{Propuesta}

La segunda parte del trabajo consiste en proyectar la ampliación del sector de actividad económica que se ha analizado en la primera parte del curso. Los grupos se mantienen de tres componentes para esta parte del trabajo.

Los alumnos se tienen que adaptar a la superficie prevista para la ampliación establecida por los profesores, de esta forma tratamos de que el ejercicio se asemeje a la realidad. Cuando se va a realizar un proyecto urbano, el promotor, sea público o privado, dispone de un terreno concreto fruto de las expropiaciones o recalificaciones pertinentes.

La propuesta también debe responder a algunos condicionantes que le den verosimilitud: debe adecuarse a la normativa urbanística vigente y se tratará de obtener un rendimiento del suelo razonable. Además, la ordenación debe diseñarse de modo que se produzca una adecuada conexión con el polígono existente y su entorno tanto funcional como formal. Se conectará con las principales infraestructuras viarias y las parcelas y naves proyectadas deben tener unas dimensiones semejantes. La estructura viaria deberá tener una adecuada jerarquización pero no debe comprender más de tres tipos de secciones de calle que deberán diseñar, al margen de posibles vías interiores de servicio. No hay condiciones singulares en relación con la parcelación, ocupación parcelaria, edificabilidad, etc.; se trata de realizar una propuesta libre en el tamaño, número y forma de las parcelas, respetando las reglas formales básicas de composición. Se diseñará la distribución de zonas verdes y aparcamientos y en cuanto a los usos, además del uso industrial, pueden decidir incluir algún equipamiento público o actividades del sector terciario. 
Sin embargo, en cuanto al modo de presentación del proyecto no se permiten tantos grados de libertad. Al igual que en el análisis se establece el número de planos y el contenido que debe haber en cada uno y se aportan las plantillas en formato de autocad.dwg para que trabajen sobre ellas. En la mayoría de los planos se establece la escala a la que se deberá trabajar. Pensamos que los alumnos no están familiarizados con la presentación de proyectos y que darles directrices claras sobre cómo organizar la información les facilita la tarea y pueden centrarse en el proyecto en sí de ampliación de polígono industrial.

Los diferentes planos incluyen tablas en las que los alumnos deberán especificar las superficies globales de cada uso del suelo y porcentajes respecto del total de la zona de ampliación del área industrial. También se cuantificará para cada uso las superficies y porcentajes parciales para completar la definición de los usos del suelo (industrial, terciario y dotacional) el viario y su jerarquización y la caracterización de las zonas verdes. Las tablas permiten comprobar el cumplimiento de los estándares del proyecto

Todos los planos se presentan en tamaño A3. Se establece la presentación obligatoria de los 4 primeros planos, su realización permite alcanzar un 10 de puntuación y se sugiere la realización de dos planos más de carácter voluntario con los que se puede complementar la nota de los anteriores. Los planos obligatorios que se deberán realizar son:

- P1. Propuesta de ordenación general: E: 1/3.000.

- P2. Estructura viaria, usos y espacios verdes: E: 1/3.000.

- P3. Parcelas y ordenanza dibujada: Escala libre.

- P4. Plantas y secciones viarias: E: 1/100, E: 1/200.

Los dos planos optativos son:

- $\quad$ P5. Guías de diseño: E: 1/10, 1/50, 1/100

- $\quad$ P6. Perspectiva general de la propuesta.

\subsection{Rol del profesor / alumno}

Se pretende que el alumno sea capaz de desarrollar autónomamente esta actividad, por lo que el rol del profesor es principalmente de guía, de orientador y supervisor del aprendizaje. Realiza también de transmisor de la información previa necesaria para el desarrollo de la actividad, al inicio de la misma ofreciendo las herramientas y conocimientos necesarios para que la puedan desarrollar posteriormente.

El alumno en este caso debe asumir la responsabilidad de su propio aprendizaje, debe actuar con iniciativa y colaborar y trabajar en equipo con sus compañeros para lograr alcanzar el objetivo y alcanzar las competencias y resultados de aprendizaje esperados.

\subsection{Evaluación}

La asignatura se organiza en dos bloques temáticos: Construcción y arquitectura industrial y Urbanismo. La calificación final de la asignatura se obtiene haciendo media de ambas partes. 
La parte de la asignatura de Urbanismo comprende, a su vez, dos partes. Por un lado se imparten una serie de contenidos teóricos que, además de aplicarse durante la realización del proyecto de urbanismo, se evaluarán mediante un examen escrito individual. La prueba consta de un test de preguntas con respuesta múltiple y de un ejercicio de resolución gráfica y cuenta un $40 \%$ de la nota de Urbanismo. El 60\% de la nota de Urbanismo corresponde al trabajo en equipo. De esta forma se pretende ajustar la calificación para valorar el grado de adquisición de conocimientos real de cada miembro del equipo. De este $60 \%$, la parte de la fase de análisis tiene un peso del $20 \%$ de la nota del trabajo y la fase de propuesta un $80 \%$.

Para la evaluación tanto del análisis como de los proyectos se utilizan rúbricas de corrección que los alumnos pueden consultar durante la realización del trabajo, ya que disponen de ellas desde el principio. La utilización de las rúbricas permite una autoevaluación o evaluación previa que los alumnos pueden realizar a través de unos criterios establecidos y negociados previamente en base a una propuesta realizada por el profesorado al estudiante. Este tipo de evaluación permite incorporar también técnicas de coevaluación que permitan la evaluación significativa del trabajo.

En las rúbricas para la corrección del proyecto se valoran tres aspectos de cada plano y se especifica un porcentaje de peso en la nota de cada uno de ellos. Cada aspecto se puntua eligiendo entre 4 niveles de puntuación: deficiente (0), insuficiente (4), aprobado (7), excelente (10). Se valora con un $10 \%$ de la nota del trabajo a la coherencia de la propuesta, todos los planos de un mismo equipo deberán unificar criterios, gamas de colores, tipos del letra, tamaño de letra.. etc.

\section{Resultados y análisis final}

\subsection{Resultado de los trabajos}

Para los alumnos del Máster en Ingeniería industrial el trabajo propuesto en urbanismo es totalmente nuevo. Los alumnos están habituados a trabajar en proyectos más concretos y técnicos y abordar temas de ciudad es un reto para ellos, tanto por la escala utilizada como por la cantidad de factores que deben tener en cuenta.

Si analizamos las propuestas presentadas por los alumnos se puede constatar que las propuestas alcanzan un nivel de calidad muy satisfactorio. Partiendo de unos mismos criterios y la uniformidad en la forma de presentación se obtienen propuestas muy diferentes entre sí pero válidas y realistas a la hora de afrontar la ampliación del polígono industrial. Para entender mejor los ejemplos aportados correspondientes al curso 2016-17 se muestra un plano de situación del ejercicio planteado ese curso, en Almussafes.

(cc) EY-NC-ND 2018, Universitat Politècnica de València

Congreso IN-RED (2018) 


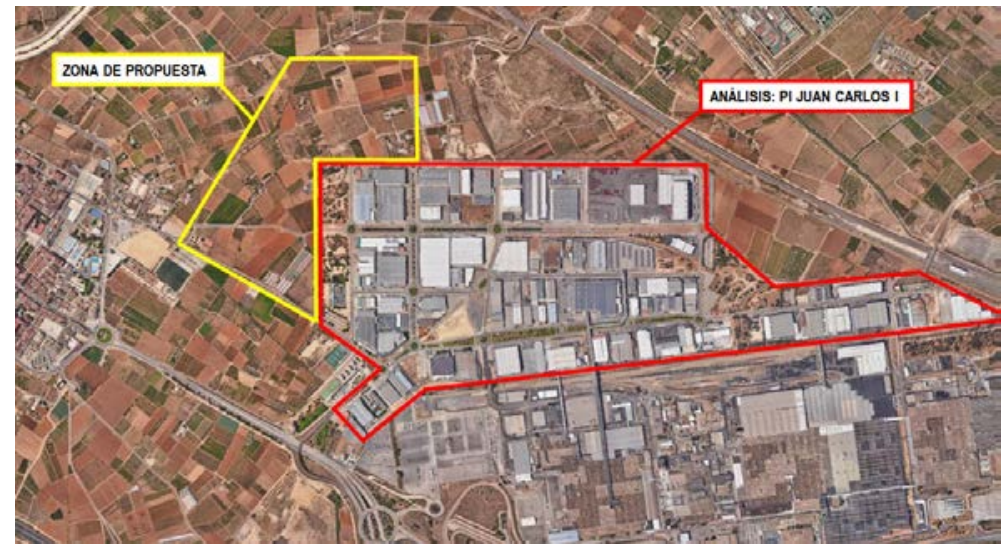

Fig. 2 Plano de situación del proyecto.

Como se puede apreciar a continuación todas las propuestas establecen una clara conexión y continuidad con el polígono existente pero hay diferentes soluciones en cuanto a la situación del viario principal. Mientras algunas de las propuestas lo situaban en la calle más cercana al polígono preexistente otras los llevaban al interior de la zona de ampliación.
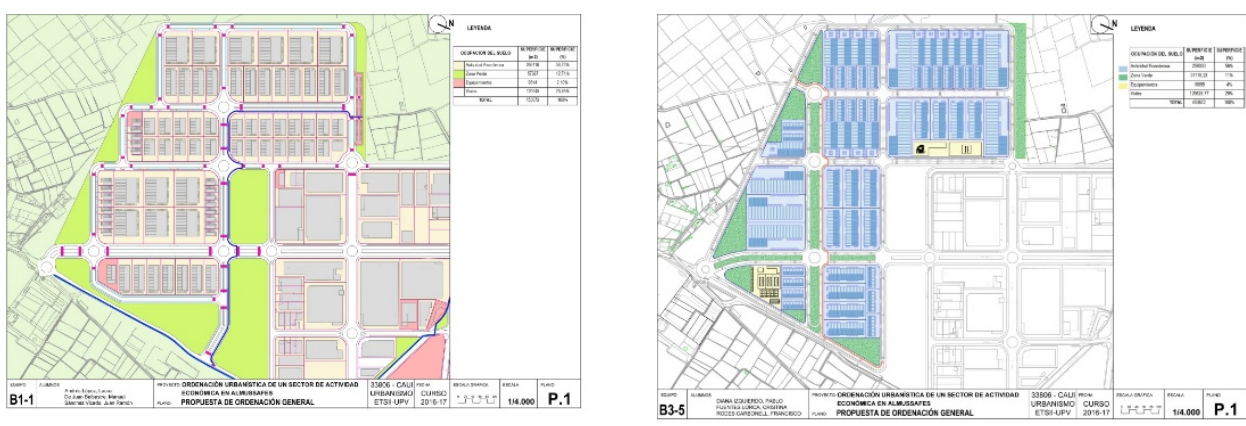

Fig. 3 Ejemplo 1. Plano de ordenación de trabajos de alumnos.

En general, la mayoría de las propuestas continuaban la trama ortogonal del polígono preexistente y utilizaban zonas verdes con formas sensiblemente triangulares para absorber las irregularidades de la parcela. Sin embargo alguno de los equipos optó por girar la trama viaria para ajustarse a la forma de la zona de actuación y resolver las irregularidades en la parte interior de la propuesta, adaptando la forma de las parcelas o introduciendo zonas verdes en estas zonas.
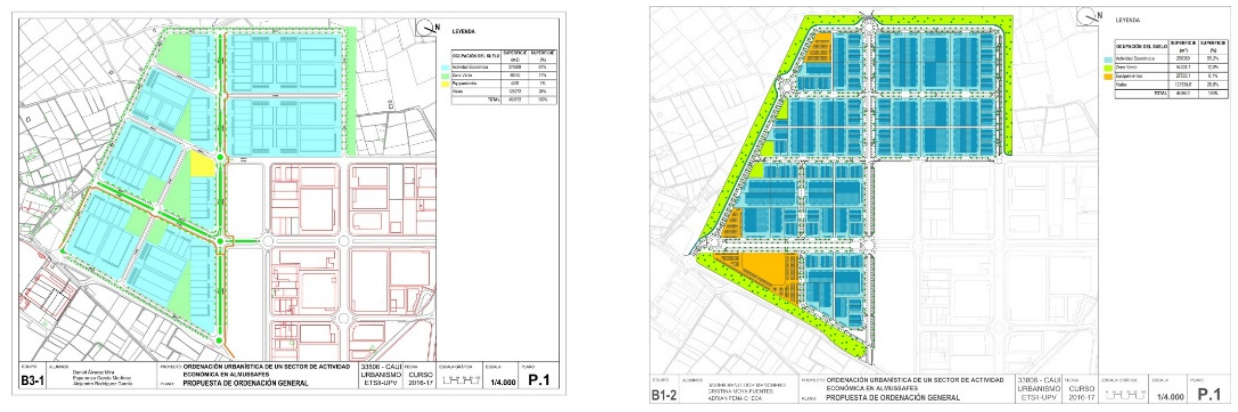

Fig. 4 Ejemplo 2. Plano de ordenación de trabajos de alumnos.

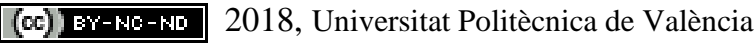

Congreso In-Red (2018) 
En la mayoría de los casos las zonas verdes, caracterizadas como jardín o áreas de juego se han utilizado para completar geometrías irregulares y dejar para las parcelas las formas más ortogonales. Además, la mayoría ha optado por resolver el viario principal mediante boulevar ajardinado. Sin embargo también ha habido equipos que han utilizado las áreas verdes para realizar un anillo perimetral verde y mejorar así su integración con el territorio aportando un colchón verde de transición.

En cuanto a los usos del suelo complementarios al uso industrial las propuestas han sido muy variadas, pero predominan las propuestas de implantación de equipamientos deportivos, guarderías, gasolineras y terciario, principalmente servicios de restauración.

Las propuestas, como ya se ha explicado, incorporaban la definición de las parcelas insutriales y sus ordenanzas especificando todas sus características y representándolo gráficamente.
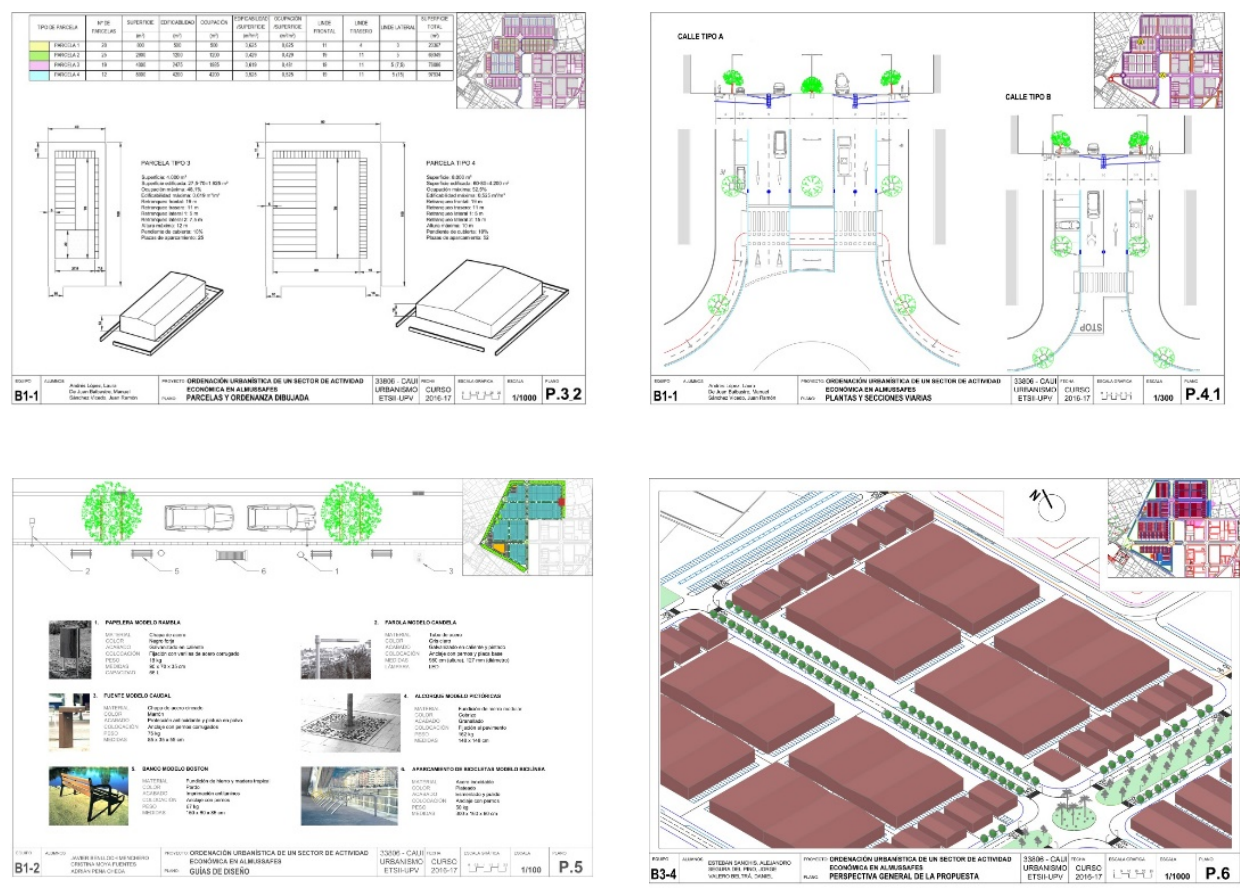

Fig. 5 Ejemplo 3. Planos de parcelación, secciones viarias, guías de diseño y perspectiva de trabajos de los alumnos.

Uno de los aspectos más importantes del trabajo era que se familiarizaran con el diseño de la calle y sus diferentes elementos por lo que se ha insistido en la correcta definición de las secciones viarias de la propuesta.

La mayoría de los equipos optaron por completar el trabajo realizando los dos plamos optativos que se proponía por lo que podemos pensar que los alumnos estaban motivados con el trabajo y se implicaron con el mismo para llegar a un alto grado de definición del proyecto. 


\subsection{Resultado encuestas alumnos}

Finalmente se ha realizado una encuesta de evaluación a los alumnos, con el objetivo de obtener un feedback significativo sobre sus percepciones en la realización del trabajo de la asignatura. Esta encuesta permitirá al profesorado evaluar en nivel de satisfacción de los alumnos con la metodología planteada, así como detectar algunos aspectos a mejorar en los próximos cursos.

La encuesta realizada fue la siguiente:

Q1. ¿Crees que el trabajo ha sido útil para asimilar los conocimientos teóricos en la asignatura?

Q2. El trabajo de la asignatura ¿Te resultó motivador?

Q3. Con las herramientas adquiridas durante la realización del trabajo ¿Crees que serías capaz de realizar un proyecto similar durante tu trayectoria profesional?

Q4. Percepción sobre el grado de adquisición de diversas competencias transversales: Trabajo en equipo y liderazgo, Planificación y gestión del tiempo, etc.

Q5. Nivel de satisfacción general.

La encuesta se realizó de forma voluntaria y totalmente anónima. Para realizarla se empleo la herramienta web GoogleForm que permite una realización asíncrona de la misma y sin necesidad de ninguna infraestructura especial. Las respuestas se recogieron en una escala 15, siendo 5 una valoración totalmente positiva, 3 un nivel medio y 1 una valoración totalmente negativa. Cabe destacar que se recogieron un total de 68 respuestas. En la figura que se muestra más adelante se indican los resultados de algunas de las cuestiones realizadas.

En general puede concluirse que más del $80 \%$ de los alumnos tienen una percepción positiva general sobre la realización del trabajo (niveles 3-4-5) y más del 60\% la perciben de forma muy positiva (niveles 4-5).

Q1

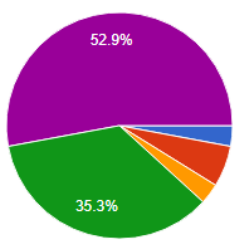

Q3

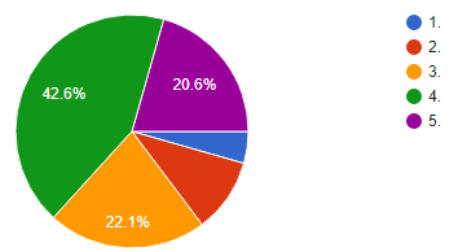




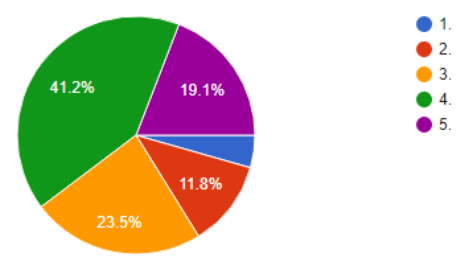

Fig. 6 Resultado de algunas de las cuestiones planteadas a los alumnos.

\section{Conclusiones}

Como ya se ha explicado, el desarrollo de la parte de urbanismo de la asignatura consiste en dos partes relacionadas pero claramente diferenciadas: la parte de teoría que se evalúa mediante una prueba escrita individual y el trabajo en equipo que tiene un mayor peso en la evaluación. Este artículo trata de valorar el resultado de la metodología utilizada en la realización del Proyecto de ordenación urbanística de un sector de actividad económica en equipos de tres alumnos.

Se puede destacar que el trabajo consiste en la aplicación de los contenidos impartidos en la asignatura de una manera totalmente práctica sobre un caso real de un polígono industrial y su ampliación. Además, el hecho de realizarlo por grupos también supone una semejanza mayor con la práctica profesional ya que, en muchos casos, estos proyectos se realizan en equipos multidisplicinares.

Aunque el mencionado trabajo se realiza en la asignatura desde hace varios rompe con la metodología tradicional de enseñanza de clase magistral y incide en un punto de vista aplicado mucho más práctico mediante el "trabajo por proyectos”.

Nuestra experiencia nos hace pensar que el proyecto que realizan los alumnos es capaz de motivarlos y contribuye a que fijen el aprendizaje de los contenidos aprendidos. Los alumnos se implican con el trabajo y se imponen un alto nivel de autoexigencia obteniendo trabajos de considerable calidad. En este sentido la realización del proyecto contribuye a la adquisición de las competencias específicas objetivo de la asignatura.

Además, la metodología utilizada en el trabajo de "trabajo cooperativo" refuerza varias competencias transversales de la Universidad Politécnica de Valencia.

Como ya se ha comentado, las encuestas realizadas nos confirman esa percepción y el grado de satisfacción de los alumnos, tanto en cuanto a la motivación en la realización del trabajo, como en cuanto a lo aprendido, es bastante positivo.

\section{Referencias}

BOLONIA COMUNICADO (1999). EHEA Bolonia Ministerial Conference. [Online] Available:

<http://media.ehea.info/file/Ministerial_conferences/02/8/1999_Bologna_Declaration_Engl ish_553028.pdf> [Consulta: Marzo 2018]

(cc) EY-NC-ND 2018, Universitat Politècnica de València

Congreso IN-RED (2018) 
BUCHAREST COMUNICADO (2012). EHEA Bolonia Ministerial Conference. [Online] Available:

$<$ http://media.ehea.info/file/2012_Bucharest/67/3/Bucharest_Communique_2012_610673.p df> [Consulta: Marzo 2018]

DE MIGUEL, M. (2006). Metodologías de enseñanza y aprendizaje para el desarrollo de competencias. Orientaciones para el profesorado universitario ante el Espacio Europeo de Educación Superior. Alianza Ed.

GWEN, S. (2003). Project-based learning: a primer. Technology and Learning, 23(6), 2030 .

LUCE, L. and HERNY, W.P. (2002). Public awareness of civil engineering and the infrastructure. Journal of Professional Issues in Engineering Education and Practice, 128(4), 165-166.

MAHENDRAN, M. (1995). Project-based civil engineering courses. Journal of Engineering Education, 84(1), 75-79.

MALDONADO, M. (2008). Aprendizaje basado en proyectos colaborativos. Una experiencia en Educación Superior. Revista de Educación, Laurus, 14(28), 158-180.

TEJERO, J., RAMÍREZ, E., MATA, F. y HARAFI, J. (2015). La experiencia del aprendizaje basado en problemas y trabajos proyectuales en las asignaturas de Ingeniería de Estructuras en la Escuela de Ingeniería de Almadén. Innovación educativa en las enseñanzas técnicas. 2, 615-627.

URAL, A. (2013). A hands-on finite element modeling experience in a multidisciplinary project-based freshman course. Computer Applications in Engineering Education, 21(2), 294-299.

Verificación por el Consejo de Universidades del Máster Universitario en Ingeniería Industrial. [Online] Available:

http://www.upv.es/entidades/AEOT/menu_urlc.html?/entidades/AEOT/infoweb/aeot/info/U 0653022.pdf [Consulta: Marzo 2018]

WOODS, D.R., FELDER, R.M., RUGARCIA, A. and STICE, J.E. (2000). The future of engineering education. Developing critical skills. Chemical Engineering Education, 34(2), 108-117. 


\title{
El Aprendizaje Colaborativo. Aplicación a la asignatura de Administración de Empresas
}

\section{$\mathbf{M}^{\mathrm{a}}$ Carmen Ruiz Jiménez ${ }^{\mathrm{a}}$}

a Departamento de Organización de Empresas, Marketing y Sociología, Facultad de Ciencias Sociales y Jurídicas, Universidad de Jaén (e-mail: cruiz@ujaen.es).

\begin{abstract}
The colaborative learning stands as the one wich allows the student play a more active role on its own learing process. Regarding the different techniques addressed in this field, the Aronson puzzle technique and problem based learning are the most relevant. This is the reason why we have decided to include these methodologies on the first course of the Labour Relations and Humarn Resources degree at the University of Jaén. The main objective of this paper is focused on comparatively analyzing both the academic results (in terms of basic acquired competences and on both group and individual transversal competences), as well as the degree of motivation, satisfaction and participation of students in that subject.
\end{abstract}

Keywords: colaborative learning, Aronson puzzle, Problem-based learning, methodologies.

\section{Resumen}

El aprendizaje colaborativo aparece entre las metodologías mejor valoradas como aquel que permite al alumno tener un papel más activo en su propio proceso de aprendizaje. Entre las distintas técnicas abordadas en este ámbito, la dinámica puzzle y el aprendizaje basado en problemas, son algunas de las más destacadas. Es por esto que decidimos aplicar de manera experiencial estas técnicas en la asignatura de Organización y Administración de Empresas de primer curso del grado en Relaciones Laborales y Recursos Humanos de la Universidad de Jaén. El objetivo principal de este trabajo se centra en analizar comparativamente tanto los resultados académicos (en términos de competencias básicas adquiridas y competencias transversales de carácter individual y grupal), como el grado de motivación, satisfacción y participación de los alumnos en dicha materia.

Palabras clave: aprendizaje colaborativo, puzzle de Aronson, $A B P$, metodologías docentes. 


\section{Introducción}

La educación superior es un componente esencial del desarrollo socioeconómico y cultural de las sociedades modernas. Al mismo tiempo, hoy en día existe una demanda cada vez mayor de desarrollo personal, de aptitudes y competencias, que exige que la educación superior responda con nuevas formas. Antes se formaban a las personas para trabajos más mecánicos; el alumno no tenía acceso a la información; el profesor era quien "sabía” y daba información al alumno, que "no sabía”; el proceso se centraba en "enseñar", en trasmitir información que el alumno recogía, procesaba, memorizaba y expulsaba en el examen y con esto era suficiente. Antes, el proceso se centraba en las competencias curriculares. Ahora para ser un buen profesional no basta con ser un buen estudiante. Un título académico, sin una cabeza bien amueblada, no sirve de nada. Las empresas necesitan personas capaces de tener ideas, abiertas al cambio, capaces de poner al día sus propios aprendizajes, de aprender, preocupadas por la investigación y la puesta al día profesional además de por la transformación sociocultural de nuestro entorno. El alumno, hoy en día, debe ser capaz de resolver los conflictos que va a encontrar fuera del aula. Por esto ahora los alumnos tienen otras necesidades. Y la sociedad, en general, demanda algo diferente.

La respuesta por parte de todo el sistema (instituciones, profesorado y alumnos) ha de venir por un cambio en la metodología y en los roles. Por un método más centrado en el aprendizaje y no la transmisión de información, más centrado en el estudiante, que incluya vías de aprendizaje flexibles y que reconozca las competencias obtenidas fuera de los planes de estudio oficiales. Con este cambio metodológico el centro del proceso debe ser el alumno y su aprendizaje, por lo que el profesor tiene que regular su actuación al servicio del aprendizaje efectivo del alumno (Calderón y González, 2009). Los roles deben modificarse y el profesor debe dejar de ser el centro de atención y convertirse en guía, moderador, y en alguien que trate de promover el aprendizaje. De igual manera, el rol del alumno también debe redefinirse, pasando de ser un sujeto pasivo a uno activo que construye el conocimiento que quiere aprender.

La mayor parte de los aprendizajes que se dan hoy en día en el aula universitaria son un aprendizaje adhesivo. Los conceptos se pegan a la superficie de la mente del alumno sin ser suficientemente interiorizados. Por tanto, el aprendizaje adhesivo es un aprendizaje condenado a lo efímero y superficial. El verdadero aprendizaje es aquel que nace de la vivencia y no de lo teórico. Si se aprende desde la experiencia, el aprendizaje que se genera es definitivo.

La única forma de seguir avanzando, hasta que definitivamente lleguemos a una verdadera implantación y un auténtico cambio, es seguir introduciendo de forma progresiva y en la medida de lo posible, actividades que permitan un mayor acercamiento a esta nueva concepción de la enseñanza.

En este contexto encontramos que la gran mayoría de los proyectos que utilizan métodos innovadores para la enseñanza y el aprendizaje incorporan el trabajo colaborativo. Algunos ejemplos de aplicaciones de esta técnica metodológica en la universidad española puede encontrarse en Saz (2001), Pérez-Poch (2004) y Fuster (2008).

(cc) BY-NC-ND 2018, Universitat Politècnica de València

Congreso IN-RED (2018) 
El trabajo colaborativo del profesorado es una buena estrategia para reflexionar sobre estos cambios e ir adaptándose a los mismos y una herramienta de docencia magnífica que han ido ganando relevancia durante los últimos años. En el caso de estudiantes, por ejemplo, el trabajo colaborativo es una de las estrategias metodológicas y evaluativas que cada vez más está utilizando el profesorado universitario (Ibarra y Rodríguez, 2007; Álvarez y Gómez, 2011). Se ha convertido en una competencia necesaria para una buena formación y en un elemento esencial en la mejora de la calidad educativa. Diferentes estudios también señalan los beneficios del trabajo colaborativo de los estudiantes como una estrategia más del proceso de convergencia europea (Coll et al., 2006; Ibarra y Rodríguez, 2007). En este sentido, cuando se da más responsabilidad al alumno en su proceso de enseñanza y evaluación, los resultados que se obtienen son, por lo general, mejores y más satisfactorios (Inda Caro et al., 2008). Cuanto más partícipe hagamos al alumno, más aprendizaje tendrá.

A partir de estos estudios y teniendo en cuenta que la clave no está en centrarnos en lo que el profesor enseña sino en lo que el alumno aprende, nuestro objetivo con este trabajo es analizar comparativamente los resultados obtenidos tanto a nivel académico como a nivel de motivación, satisfacción y participación del alumno, al trabajar con esta metodología de aprendizaje colaborativo en la materia de Administración de Empresas. Además de las razones indicadas más arriba sobre las fortalezas del aprendizaje colaborativo, el verdadero punto de inflexión que nos orientó a tomar este camino, ha sido la actitud manifiesta por parte del alumnado durante los últimos cursos, donde encontramos desmotivación y escasa atención e interés por la enseñanza.

\section{Técnicas de aprendizaje colaborativo: El puzzle de Aronson y el Aprendizaje Basado en Problemas}

El aprendizaje colaborativo es una estrategia basada en el trabajo en grupo, con objeto de lograr unos objetivos de aprendizaje comunes, donde cada miembro del grupo es responsable tanto de su aprendizaje como del logro de sus compañeros. Se trata, como señala Barkley (2007), de aprender mediante el trabajo en grupo, en vez de hacerlo trabajando solo. David y Roger Jonhson (2001), lo han definido como aquella situación de aprendizaje en la que los objetivos de los participantes se hallan estrechamente vinculados, de manera que cada uno de ellos sólo puede alcanzar sus objetivos si y sólo si los demás consiguen alcanzar los suyos. Para garantizar el progreso de todos es necesario que el profesor asigne a cada miembro un trabajo individual previo al trabajo en grupo. Este trabajo individual será el punto de partida y permitirá que todos los miembros participen activamente en la tarea colectiva que abordarán una vez finalizado su trabajo individual.

Son muchas y variadas las ventajas que presenta la técnica docente del aprendizaje colaborativo, frente a la clásica "lección magistral". Así, diversos autores señalan que esta metodología permite un papel activo por parte del alumno, incrementa el nivel de aprendizaje mediante el desarrollo de relaciones interpersonales, reduce la tasa de abandono debido a la mayor implicación y motivación, promueve el aprendizaje autónomo, facilita la comunicación oral y permite acomodar los diferentes estilos de aprendizaje de los 
estudiantes de hoy día. Permite una madurez intelectual y social a través del logro de competencias básicas como capacidad de razonamiento y de crítica, capacidad de resolución de conflictos, capacidad de cooperación, capacidad de liderazgo, formación en valores, mayor responsabilidad, respeto a la diversidad, tolerancia...

Habida cuenta de las fortalezas señaladas anteriormente, nos disponemos a investigar la manera de llevar al aula esta metodología. De entre las diversas formas en las que se puede abordar la aplicación de técnicas de aprendizaje colaborativo (véase Barkley et al., 2007), debíamos escoger la que mejor se adaptara al temario de nuestra asignatura y a sus objetivos, razón por la cual decidimos utilizar una combinación de la técnica del Puzzle de Aronson para mejorar la asimilación de conceptos básicos dentro del contenido teórico de la asignatura, y el Aprendizaje Basado en Problemas (ABP) y el estudio de casos para la parte práctica.

\section{Contextualización y desarrollo}

El contexto de aplicación de esta experiencia es la asignatura "Organización y Administración de Empresas", troncal, de siete créditos y medio (6 teóricos y 1,5 prácticos), correspondiente al primer curso (primer cuatrimestre) del Grado en Relaciones Laborales y Recursos Humanos de la Facultad de Ciencias Sociales y Jurídicas de la Universidad de Jaén. El grupo grande está formado por 61 alumnos que se distribuyen en dos grupos reducidos de prácticas. La docencia semanal comprende tres sesiones teóricas, y una sesión práctica, de 50 minutos cada una de ellas.

Para la puesta en práctica de esta dinámica nos hemos basado en los trabajos de Aronson (1978) y su aplicación en Martínez y Gómez (2010), en Fernández, A (2005) y Rebolloso, Ramírez, Gil y Gil (2008). Siguiendo tales recomendaciones, el proceso ha sido el siguiente:

\subsection{Primera etapa: Planificación, diseño y estructuración de las actividades de aprendizaje}

El diseño de situaciones de aprendizaje requiere inicialmente dedicar un tiempo a fijar el proceso y la dinámica de clase. Así como a replantear los contenidos, objetivos y competencias, el papel y responsabilidad del profesor y de los estudiantes, el método de evaluación y del entorno de aprendizaje.

\subsubsection{Proceso y dinámica de clase}

Decidimos dedicar la primera sesión de clase teórica a explicar a los alumnos qué es el aprendizaje colaborativo, qué objetivos persigue, por qué vamos a trabajar con esta metodología, cuáles son las técnicas que vamos a utilizar (el puzzle de Aronson, el Aprendizaje Basado en Problemas (ABP) y el estudio de casos) y cómo será el sistema de evaluación.

(cc) EY-NC-ND 2018, Universitat Politècnica de València

Congreso IN-RED (2018) 
Comenzamos trabajando con un cronograma que se ha ido modificando a medida que se ha conseguido feedback y se han ajustado los procesos de trabajo. Teniendo en cuenta el calendario académico nuestra estrategia ha sido comenzar, durante las primeras semanas lectivas, con la tradicional lección magistral, combinando con debates, grupos de discusión y participación activa de los alumnos. La razón ha sido simplemente dejar un tiempo para que el grupo comience a funcionar y se establezcan las primeras reglas y relaciones entre los alumnos y tener el grupo completo una vez pasadas todas las adjudicaciones de plazas. Esto es fundamental para poder formar y hacer que funcionen los grupos de trabajo. Pasado este tiempo, comenzamos con el trabajo colaborativo siguiendo las técnicas comentadas.

Aplicamos la técnica del puzzle de Aronson de la siguiente manera:

a) Formación de los grupos. El aprendizaje colaborativo parte de tres tipos de grupos (Johnson y Johnson, 2001): informales, formales y de base. Los grupos informales se constituyen durante un corto período de tiempo (una sesión de clase) para discutir cuestiones sobre casos concretos, asociados a las explicaciones de una materia en cuestión. Los grupos formales se forman para resolver tareas cuya duración puede abarcar desde una a varias sesiones. Por último, los grupos de base son a largo plazo (por ejemplo, todo el curso o varios cursos) y controlan el eficaz avance y progresión de cada uno de sus componentes en ámbitos que pueden incluso ir más allá de lo meramente académico.

Hemos trabajado con grupos formales e informales y el número de alumnos por grupo ha sido de cinco. La formación de los mismos se ha dejado a voluntad de los alumnos. A estos grupos les hemos llamado "grupo nodriza" (Martínez y Gómez, 2010). En cada grupo nodriza se han asignado una serie de roles (portavoz y controlador de tiempos) que han ido rotando, de forma que cada miembro del grupo ha tenido que desempeñar una labor diferente en cada caso.

b) Reparto de la materia. De los ocho temas que comprende el temario, los dos primeros se han trabajado con la metodología tradicional. El resto de los temas, se han repartido en cinco bloques cada uno, de forma que cada alumno del grupo nodriza elige y se hace experto estudiando y trabajando uno de esos cinco bloques.

c) Trabajo individual. Cada miembro del grupo trabaja su parte de forma autónoma, fuera de clase, y prepara un documento con las principales nociones que tendrá que compartir con sus compañeros de grupo.

d) Grupo de expertos. Cada miembro del grupo nodriza se reúne con el resto de alumnos que han elegido el mismo bloque. Estos alumnos conforman un nuevo grupo que se denomina "grupo de expertos". En la siguiente sesión de clase se reúnen y exponen sus ideas, sus dudas, debaten, comparten y preparan un documento con el contenido acordado en común de su bloque. Uno de los miembros es el que se encarga de elaborar el documento que recoja el contenido del bloque. Este rol irá rotando entre todos los miembros del grupo. Durante esta sesión el profesor supervisa las explicaciones y resuelve las dudas que hayan surgido durante la preparación de la materia.

e) Preparación individual. Una vez acordado el contenido de cada bloque, cada alumno experto prepara, fuera de clase, la exposición de su bloque. 
f) Reunión de los grupos nodriza. El grupo nodriza se reúne de nuevo en clase y, por turnos, cada miembro expone su parte a lo demás. Mientras se realiza esta reunión el profesor puede ir observando la actuación de cada alumno en el grupo. Resulta interesante constatar la seguridad con la que el estudiante expone a sus compañeros el tema, como si en realidad se tratara de un "experto" en la materia, así como también puede intermediar en el debate con la finalidad de que el trabajo propuesto no adquiera resultados insospechados.

En la siguiente sesión cada grupo nodriza entregará al profesor un informe que contenga las nociones básicas del tema y la principales reflexiones del grupo en relación a cómo han sido el trabajo realizado, qué objetivos se han logrado, qué aspectos han resultado más interesantes, cuáles menos...

g) Sesión de feedback. La siguiente sesión está destinada a que todos los grupos interaccionen entre sí, se haga un feedback de los contenidos del tema y se resuelvan las principales dudas.

h) Evaluación. El cambio en la metodología docente debe ir acompañado de un cambio en la evaluación que no puede consistir únicamente en la superación de un examen final de contenidos, sino que se debe valorar el proceso de aprendizaje seguido por el alumno durante todo el cuatrimestre. Así, evaluamos de forma continua, tanto la responsabilidad individual, respetando el progreso realizado por cada uno, como la interdependencia con el grupo. Además de evaluar contenidos (informes que presentan los grupos) también se evalúan los procesos (cómo ha trabajado el grupo). El sistema de evaluación seguido combina la autoevaluación y la co-evaluación entre grupos.

- En cada sesión de reunión de expertos y nodriza se evalúan competencias a nivel individual y grupal. Los alumnos son los protagonistas de la clase y el profesor toma nota de sus intervenciones, comentarios, aportaciones, preguntas o respuestas del alumno, como garantía del proceso de aprendizaje. Buscamos indicadores propios de cada competencia y pautas para su valoración. De esta manera nos centramos en la actitud, participación, colaboración, implicación, desempeño, cumplimiento de tareas y horarios. En cada grupo de expertos hay un alumno controlador de tiempos cuya labor consiste en asignar eficientemente el tiempo de la sesión para que todos los miembros del grupo puedan exponer su bloque adecuadamente. $\mathrm{Y}$ a nivel grupal valoramos el funcionamiento del grupo, participación de sus miembros, elaboración de material y cumplimiento de entregas. - La sesión siguiente al feedback está destinada a la evaluación individual y de grupos. En primer lugar repartimos a cada grupo una tarjeta en la que deben plantear dos cuestiones relativas a la materia que han estudiado. En esta ocasión lo que evaluamos es la originalidad y dificultad de las cuestiones que los grupos plantean. Posteriormente y por sorteo, cada grupo elige una tarjeta, elige un número (1 o 2) y debe responder a la pregunta que le ha tocado. Se les deja unos minutos al grupo para que acuerden en común la respuesta. Tras la evaluación de todos los grupos, se hace una prueba individual con una batería de preguntas tipo test.

La dinámica del puzzle de Aronson se ha trabajado durante las tres sesiones teóricas semanales asignadas a la materia y se ha combinado con una sesión práctica semanal en la que aplicamos la metodología ABP y el estudio de casos.

(cc) EY-NC-ND 2018, Universitat Politècnica de València

Congreso IN-RED (2018) 
La clase práctica mantiene los mismos grupos de trabajo. Previamente hemos diseñado 5 problemas básicos relacionados con los objetivos de la asignatura y con los objetivos de aprendizaje de los temas en cuestión. Hemos delimitado los tiempos de tal forma que a cada problema hemos dedicado entre una y dos sesiones prácticas. La dinámica ha sido la siguiente: el grupo debe identificar los puntos clave del problema planteado, planificar su propio aprendizaje (formulando hipótesis de trabajo, reconociendo qué información necesita, organizando tanto el trabajo individual como el del grupo) y finalmente ofrecer una solución del problema y debate sobre resultados.

En las sesiones prácticas se han combinado tanto el ABP como los casos de estudio. Los alumnos disponen desde el comienzo de la docencia de todo el material al respecto. Esto incluye un caso de estudio para cada tema de la asignatura. Los casos se han preparado sobre empresas reales y en función de los objetivos de aprendizaje de la materia. Previamente a la sesión presencial práctica, los alumnos deben leer el caso de manera individual y una vez en clase, resolver, acordar/debatir y exponer sus conclusiones.

La labor del profesor durante estas sesiones prácticas ha sido orientar la dinámica de clase y vigilar que la resolución de los problemas planteados y los casos de empresas haya estado enfocada hacia el logro de los objetivos de aprendizaje.

Como hemos señalado anteriormente, además de concretar el proceso y la dinámica de clase, también debemos replantear contenidos, objetivos y competencias, el papel profesoralumno, el método de evaluación y el entorno de aprendizaje.

\subsubsection{Contenidos de aprendizaje}

La asignatura de Organización y Administración de Empresas se estructura en ocho temas que abarcan desde la conceptualización de la empresa, tipologías, desarrollo y crecimiento, estrategias, cultura y funciones directivas (planificación, diseño organizativo, dirección del comportamiento y control). En cada tema trabajamos un problema empresarial y un caso práctico.

\subsubsection{Objetivos y competencias}

Además de los objetivos y competencias tradicionales establecidas para esta materia, ahora los alumnos van a necesitar tres competencias nuevas: competencias intelectuales (capacidad adecuarse al contexto distinto, saber dar respuesta a situaciones distintas, innovar, criticar, emprender....) competencias relacionales (saber relacionarse, controlar el lenguaje verbal y no verbal) y competencias emocionales (emoción en el aula).

\subsubsection{El rol de profesor y del estudiante}

Cambiamos los roles. Ahora el estudiante debe aprender "haciendo" y aprender en grupo, de los demás y con los demás, de manera que adquiera destrezas que favorezcan su 
autonomía en el aprendizaje. Ahora el alumno va a estar en el centro del proceso y va a ser responsable de su propio aprendizaje. El profesor estará acompañando, ayudándole a pensar, a comprender su realidad, a contactar con sus valores, retos y conflictos. Pasamos del profesor instructor a facilitador del aprendizaje. Ahora no somos meros transmisores de conceptos, no seremos la persona que da "siempre" respuestas, sino que asumimos la responsabilidad de diseñar experiencias intelectuales para nuestros alumnos, de definir condiciones de trabajo nuevas y de hacer que los grupos funcionen.

\subsubsection{Evaluación}

La nota final de la asignatura se obtiene de la suma del examen teórico individual y las técnicas de trabajo colaborativo desglosadas en cinco bloques (aptitud/asistencia, proceso, evaluación grupal, evaluación individual, sesiones prácticas), al 50\% cada parte.

\subsubsection{Entorno de aprendizaje}

A la hora de llevar a cabo una sesión en el aula, según López y Valls (2017), habría que tener en cuenta algunos aspectos.

-Asignar una tarea. La tarea principal es aprender pero además de ésta, en la plataforma de docencia virtual le facilitamos y actualizamos a los alumnos un planning de cada sesión en la cual fijamos de forma precisa cuál es la tarea que cada grupo y cada alumno debe realizar en cada momento.

- La gestión de los tiempos. Durante las dos primeras semanas hemos trabajado en fase experimental, una vez transcurrido este tiempo se han estabilizado los procesos y cada grupo se ha ajustado al tiempo establecido para cada tarea en cada sesión. Como ya hemos recogido anteriormente, en cada grupo se ha nombrado a un miembro como controlador de tiempos. Este rol también ha sido valorado entre las competencias.

- La demarcación del espacio. Cada tarea requiere un espacio específico. En nuestro caso y debido tanto al elevado número de alumnos como a la disposición del aula, en las sesiones de trabajo de los grupos de expertos y nodriza hemos tenido que ocupar dos aulas. De esa manera el trabajo de los grupos no se ha visto condicionado por el "ruido".

- La distribución de roles. Hemos establecido dos tipos de roles en cada grupo: portavoz y controlador de tiempos. Al establecer roles distintos que a su vez van a ir rotando, hacemos que el alumno se entrene en el ejercicio de experimentar diferentes roles y sean capaces de tener distintas perspectivas.

\subsection{Segunda etapa: Implementación del aprendizaje colaborativo}

Al comienzo del cuatrimestre, en la sesión que dedicamos a explicar esta nueva metodología, su implementación y el sistema de evaluación, hemos planteado a los alumnos la posibilidad de trabajar de forma totalmente voluntaria con esta metodología (que requiere

(cc) BY-NC-ND 2018, Universitat Politècnica de València

Congreso IN-RED (2018) 
por su parte trabajo, constancia y un fuerte compromiso con el grupo) o bien realizar un trabajo individualizado de estudio y tutorías, evaluado siguiendo el sistema tradicional con un examen final teórico-práctico. En la siguiente sesión de clase, deciden seguir esta nueva metodología un total de 58 alumnos. De los tres restantes, uno de ellos manifiesta la dificultad de compaginarlo con su horario laboral, otro decide abandonar sus estudios universitarios y el tercero prefiere trabajar de forma autónoma y examinarse al final del cuatrimestre.

La implementación de este aprendizaje supone centrarnos en algunos aspectos importantes: orientar al alumno, formar grupos y facilitar la colaboración de los estudiantes.

El aprendizaje colaborativo supone un cambio de roles tanto del profesor como de los alumnos. Es conveniente que este aspecto quede claro desde el principio. Los alumnos deben asumir nuevos roles y deben desarrollar nuevas competencias diferentes a las acostumbradas en el sistema tradicional.

Aunque, como ya hemos indicado, la formación de los grupos se ha dejado a la voluntad de los alumnos, el profesor debe observar el funcionamiento de cada uno, comprobar que los alumnos trabajan juntos y que el trabajo se realiza bien y ayudar a resolver los problemas que puedan surgir. En este sistema el profesor adopta el papel de mediador y tutor en el proceso de enseñanza-aprendizaje, siendo el alumno el verdadero protagonista y responsable de su propio proceso de aprendizaje, ocupándose de la autorregulación y autogestión del mismo.

\section{Resultados}

En este apartado nos detenemos en mostrar los resultados conseguidos tras el trabajo colaborativo mediante la técnica del puzzle de Aronson, el ABP y el estudio de casos.

Los resultados académicos obtenidos (80,62\% de aprobados) han sido mejores que los de cursos anteriores que se han situado alrededor del 65\%. La asistencia a las sesiones de trabajo ha sido elevada. Y la satisfacción de los estudiantes se ha visto reflejada en una encuesta de final de cuatrimestre, cuyo objetivo era valorar su opinión en relación a la metodología empleada. Nos detenemos en algunos aspectos que merecen ser comentados. Un 87,24 \% reconocen haber logrado un aprendizaje eficaz e interesante. Manifiestan que aunque han tenido que dedicar más tiempo a trabajar la asignatura, han llevado al día el temario y creen que así es más fácil preparar el examen final. Un 100\% han respondido en relación a contenidos que han aprendido sobre la materia, reconociendo que han aprendido bastantes conceptos en relación a la empresa. El grado de satisfacción con la metodología utilizada también ha tenido un índice de respuestas interesante: 32\% muy satisfecho, $61.70 \%$ satisfecho, un $6.38 \%$ poco satisfecho, $0 \%$ nada satisfecho. También les hemos preguntado en relación a lo que han trabajado mejor o lo que han trabajado peor y lo más frustrante del proceso o del contenido. Un 17\% no ha encontrado nada frustrante y han disfrutado con esta metodología. En relación a los comentarios expuestos por los alumnos, encontramos como temas interesantes a tener en cuenta de cara a mejorar estas dinámicas: la coordinación entre los grupos de trabajo, la distinta participación de sus miembros, el 
cumplimiento de las entregas de los informes, la inseguridad a la hora de exponer al resto de compañeros y las evaluaciones individuales. También le preguntamos por competencias y habilidades que creen que han adquirido. En relación a este tema, ellos manifiestan que han aprendido a perder la vergüenza, a resolver dudas entre compañeros, a comunicarse de una manera distinta con los demás, a trabajar en equipo, coordinarse y resolver problemas en grupo, a repartir y asignar trabajo en grupo y a organizar su tiempo de estudio. En relación a si les ha parecido interesante esta metodología, el 100\% han respondido afirmativamente. Y finalmente en las sugerencias de mejora, un 37,32\% han apuntado hacia el control más efectivo del proceso de trabajo en los grupos y tener algún mecanismo, al margen de las evaluaciones individuales, que penalice a aquel alumno que no cubre las expectativas de trabajo del grupo.

Estas respuestas nos llevan a la conclusión de que los resultados, en términos generales, han sido mejores que en cursos anteriores. Al margen de estos resultados puestos de manifiesto por los alumnos, hacemos a continuación nuestra valoración particular de la experiencia.

Durante todo el tiempo de aplicación de estas técnicas hemos podido apreciar un buen clima de trabajo así como un nivel de asistencia y participación elevado, debido a que los alumnos han encontrado esta metodología más interesante y motivadora que la tradicional lección magistral. La actitud y disposición de los alumnos a experimentar con técnicas distintas a las tradicionales ha sido excepcional. Esta mayor motivación puede ser debido a que las técnicas aplicadas han logrado que los alumnos se involucren más en su aprendizaje, ya que sienten que tienen la posibilidad de interactuar entre ellos y con la realidad y no ser simples sujetos pasivos observadores.

Igualmente percibimos, no solo la mejora, sino el desarrollo y la adquisición de ciertas habilidades que de otro modo no habrían logrado y que son esenciales para su desarrollo profesional. Han mejorado su capacidad de comunicación y liderazgo, han perdido el miedo a dar su opinión, a ser críticos, a razonar y defender sus ideas y a facilitar la participación de todos. Han practicado la discusión y la justificación de sus argumentos. Han repartido y aprendido a tener una mayor responsabilidad pues el avance del grupo depende de la contribución de cada uno de sus miembros. Han aprendido más y mejor. Han compartido sus experiencias y sobre todo han sido conscientes de que pueden aprender no sólo del profesor, sino por sí mismos, con y de los demás. El método de aprendizaje basado en problemas les ha permitido además la aplicación real de los conocimientos teóricos, lo cual lleva a los alumnos hacia un pensamiento crítico y creativo.

A pesar de que la valoración del proceso de aprendizaje del alumno ha sido muy positiva porque los alumnos han podido demostrar la adquisición no solo de conocimientos, sino también de competencias, lo cierto es que hemos detectado una serie de problemas en su aplicación que habría que intentar corregir.

Dos son las dificultades más importantes que encontramos a la hora de planificar y organizar este tipo de actividades. En primer lugar, el problema de la falta de objetividad en parte de la evaluación. Cuando adoptamos un enfoque de aprendizaje colaborativo, nos enfrentamos a una tarea muy difícil. No se trata de pedir a los alumnos que hagan un

(cc) BY-NC-ND 2018, Universitat Politècnica de València

Congreso IN-RED (2018) 
trabajo en grupo. Las técnicas cooperativas de enseñanza y aprendizaje requieren un trabajo muy exhaustivo de planificación de la materia, de desarrollo y de control y seguimiento. Al trabajar con evaluación continua, el estudiante va demostrado progresivamente los conocimientos y competencias adquiridas con cada tarea realizada. La evaluación del alumno ha de tener por objetivo comprobar que éste ha alcanzado dichas competencias, si bien en ocasiones es difícil para el profesor valorar con objetividad tanto el progreso realizado como el trabajo de cada alumno fuera del aula. Aunque hemos definido una serie de rúbricas al respecto, es difícil establecer un sistema de evaluación de contenidos actitudinales y procedimentales, lo que supone una limitación tanto en el proceso como en la evaluación.

En segundo lugar encontramos la desigual participación de los alumnos en el trabajo del grupo. Aunque se ha intentado que el trabajo autónomo del alumno fuera el mínimo posible, circunstancias como las dificultades para organizarse fuera del aula, las diferencias entre compañeros y la falta de cooperación de algunos miembros han generado conflictos. Estos conflictos se han tratado siempre como algo innato a la dinámica de grupos y a situaciones que el alumno tendrá que afrontar en su desarrollo profesional tarde o temprano.

Otras debilidades que también hemos percibido ha sido la mayor carga de trabajo que supone poner en marcha este tipo de metodologías, tanto para los alumnos como para el profesor. Al no estar habituado a trabajar de esta manera, la tendencia es que el alumno se resista a que el profesor abandone su papel de transmisor del conocimiento y sea reacio a tener que esforzarse y desempeñar un papel más activo tanto en clase como fuera de ella. Y sin embargo, aunque estos alumnos han tenido que trabajar de forma continuada a lo largo del cuatrimestre, manifiestan, como hemos señalado más arriba, el haber recibido un mayor y mejor aprendizaje que en otras materias. Por parte del profesorado, resulta especialmente compleja la planificación de esta metodología puesto que partimos de contenidos y planes incluidos en programas basados en una metodología tradicional y con gran parte de la docencia centrada en la clase magistral. Esta circunstancia afecta tanto al desarrollo de contenidos teóricos y prácticos, como a los tiempos para su desarrollo.

También queremos señalar como deficiencia el elevado tamaño de los grupos. Aunque esta variable se ha intentado corregir en los últimos años, seguimos con grupos de alumnos excesivamente grandes para estás dinámicas de aprendizaje. Esto dificulta enormemente el desempeño del aprendizaje cooperativo pues entorpece el desempeño en sí de las sesiones de trabajo y eleva el "ruido" en el aula. Cuando los grupos son numerosos, hay más probabilidad de que surjan comportamientos discordantes, siendo ésta la oportunidad de algunos pequeños grupos para contagiar al resto. Sin embargo, cuando los grupos son reducidos, generalmente surgen más comportamiento “ejemplares” que son imitados por el resto y así el resultado del grupo, en general, es mejor.

La conclusión de este apartado nos lleva a reconocer el logro de los principales hitos del aprendizaje colaborativo: interdependencia positiva, interacción cara a cara, responsabilidad personal, desarrollo de habilidades sociales y reflexión sobre el trabajo en grupo. $\mathrm{Y}$ a valorar que los aspectos positivos que hemos expuestos se ven compensados tras 
comprobar los buenos resultados logrados tanto desde el plano profesional como desde el ámbito emocional.

\section{Conclusiones}

El aprendizaje tradicional es un aprendizaje individual, autónomo y altamente teórico, donde la clase magistral es el principal vehículo transmisor de conocimiento entre profesor y alumno. Con esta experiencia hemos querido indagar y explorar otras alternativas. Hemos optado por aplicar una metodología activa en la que se fomente el aprendizaje colaborativo en contraposición con el carácter pasivo del alumno, dándole protagonismo y haciéndole partícipe y responsable de su propio aprendizaje.

La principal conclusión que se extrae es la buena acogida y favorable valoración otorgada a esta metodología. Este trabajo confirma que esta metodología motiva al alumno a llevar un seguimiento continuado de la asignatura, a asistir con regularidad a clase y a presentarse al examen final. El interés mostrado por la asignatura se refleja en la calificación final de los estudiantes, que ha mejorado sustancialmente. Además, los propios estudiantes valoran positivamente estas técnicas porque, a pesar de que reconocen que implican una mayor dedicación, consideran que les obliga a estudiar día a día la materia y, por consiguiente, logran una mejor comprensión de la misma y unos mejores resultados tanto académicos como personales.

Creemos, a modo de conclusión, que podemos seguir las indicaciones de muchos autores e intentar aplicar un amplio surtido de técnicas de aprendizaje colaborativo, pero el verdadero cambio es el que viene desde dentro y acompañado de un cambio en la concepción de todos los agentes implicados en la educación universitaria. La única forma de seguir mejorando, hasta que definitivamente lleguemos a un verdadero cambio en nuestra forma de enseñar, es seguir introduciendo de forma progresiva y en la medida de lo posible, actividades que permitan un mayor acercamiento a estas metodologías de aprendizaje. Por esta razón, nuestra intención es continuar complementando nuestro trabajo con la metodología colaborativa como herramienta eficaz de autoaprendizaje.

\section{Referencias}

ÁLVAREZ TERUEL, J.D. y GÓMEZ LUCAS, MªC. (2011). “El Espacio Europeo de Educación Superior, las competencias, el trabajo colaborativo, la calidad...Algunas pinceladas” en Gómez, M.C y Álvarez, J.D. El trabajo colaborativo como indicador de calidad del Espacio Europeo de Educación Superior.Alicante: Universidad de Alicante y Editorial Marfil. vol I, 17-34.

ARONSON, W. (1978). The jigsaw classroom. Beverly Hills, CA: Sage publications.

BARKLEY, E., CROSS, K. y MAJOR, C.H. (2007). Técnicas de aprendizaje colaborativo. Madrid: Ministerio de Educación y Ciencia y Ed. Morata.

CALDERÓN PATIER, C. y GONZÁLEZ LORENTE, A. (2009). "El papel del profesor universitario español en el EEES. Retos pendientes” en II International Conference: X Seminario Iberoamericano Motiva La Universidad y el Emprendimiento, Valencia, 27-30 octubre.

(cc) EY-NC-ND 2018, Universitat Politècnica de València

Congreso IN-RED (2018) 
COLL, C., MAURI, T. y ONRUBIA, J. (2006). “Análisis y resolución de casos y problemas mediante el aprendizaje colaborativo” en Revista de Universidad y Sociedad del Conocimiento, 3(2), 29-41.

DE MIGUEL DÍAZ, M. (2006). “Metodologías para optimizar el aprendizaje” en Revista Interuniversitaria de Formación del Profesorado, 20(3), 71-91.

FERNÁNDEZ MARCH, A. (2005). Nuevas metodologías docentes. Instituto de Ciencias de la Educación. Universidad Politécnica de Valencia. $<$ http://roble.pntic.mec.es/jprp0006/tesis/metodologia/nuevas_metodologias_docentes_de\%20fernand ez_march.pdf $>$ [Consulta: 15 de enero de 2018]

FUSTER GARCÍA, B. (2008). "Nuevas metodologías docentes en el ámbito del EEES: Una aplicación de los Grupos de Aprendizaje Cooperativo en la asignatura Economía Española de $2^{\circ}$ de Economía de la Universidad de Alicante” en VI Jornadas de Redes de Investigación en docencia Universitaria, Universidad de Alicante, Alicante, 9-10 junio.

IBARRA SÁIZ, M.S. y RODRÍGUEZ GÓMEZ, G. (2007). "El trabajo colaborativo en las aulas universitarias: reflexiones desde la autoevaluación” en Revista de Educación, 344, 355-375.

INDA CARO, M., ÁlVAREZ GONZÁlEZ, S. y ÁlVAREZ RUBIO, R. (2008). “Métodos de evaluación en la enseñanza superior” en Revista de Investigación Educativa, 26(2), 539-552.

JOHNSON, D., y JOHNSON, R. (2001). "Learning together and alone: An overview” en Cooperative Learning. Asia Pacific Journal of Education, 22 (1). 95-105.

JOHNSON, D. y JOHNSON, R. (2009). Introduction to Cooperative Learning. An Overview of Cooperative Learning. $\quad$ http://www.co-operation.org/home/introduction-to-cooperativelearning/>[Consulta: 3 de noviembre de 2017]

LÓPEZ PÉREZ, C. y VALLS BALLESTEROS, C. (2017). Coaching educativo. Las emociones, al servicio del aprendizaje. Ed. SM.

MARTÍNEZ LIROLA, M., CATALÁ COBOS, P. y DÍAZ SORIA, M. Aprender colaborando: Estrategias de aprendizaje colaborativo integradas en el aula universitaria. Departamento de Filología Inglesa, Universidad de Alicante. $<$ https://web.ua.es/es/ice/jornadas-redes/documentos/2013comunicaciones-orales/328708.pdf > [Consulta: 12 de diciembre de 2017]

TARÍ GUILLÓ, J.J., SABATER SEMPERE, V., VALDÉS CONCA, J., RIENDA GARCÍA, L., MANRESA MARHUENDA, E., GONZÁLEZ RAMÍREZ, M.R., FERNÁNDEZ SÁNCHEZ, J.A., DE JUANA ESPINOSA, S. y ANDREU GUERRERO, R. (2011). "El trabajo colaborativo del profesorado en asignaturas de organización de empresas: reflexiones sobre el EEES” en Gómez, M.C y Álvarez, J.D. El trabajo colaborativo como indicador de calidad del Espacio Europeo de Educación Superior. Alicante: Universidad de Alicante y Editorial Marfil. Vol II, 863-875.

MARTÍNEZ RAMÓN, J. y GÓMEZ BARBA, F. (2010). "La técnica puzzle de Aronson: descripción y desarrollo” en Arnaiz, P., Hurtado, Ma.D. y Soto, F.J. coords. 25 Años de Integración Escolar en España: Tecnología e Inclusión en el ámbito educativo, laboral y comunitario. Murcia: Consejería de Educación, Formación y Empleo.

PÉREZ-POCH, A. (2004). “Aprendizaje cooperativo: implantación de esta técnica en dos asignaturas reformadas y evaluación de resultados”en Actas de las X Jornadas de Enseñanza Universitaria de la Informática. Alicante, 14-16 junio.

REBOLLOSO FUENTES , M.M., RAMÍREZ ÁLVAREZ, M., GIL MONTOYA, C. y GIL MONTOYA, M.D. (2008). "Experiencias de aprendizaje cooperativo en 
ingeniería”.http://www.uem.es/myfiles/pageposts/jiu/ jiu2008/archivos/otras/mariadelmarrebollosoycol(almeria).pdf [Consulta: 12 de diciembre de 2017]

SAZ GIL, M.I. (2001). "Fundamentación y desarrollo de un modelo formativo de aprendizaje autónomo” en I Jornadas de innovación docente, tecnologías de la información y comunicación e investigación educativa en la Universidad de Zaragoza.

SEMPERE ORTELLS, J.M., GARCÍA IRLES, M., MARCO DE LA CALLE, F.M. y DE LA SEN FERNÁNDEZ, M.I. (2011). “Aprendizaje colaborativo: Un reto para el profesor en el nuevo contexto educativo” en Gómez, M.C y Álvarez, J.D. El trabajo colaborativo como indicador de calidad del Espacio Europeo de Educación Superior.Alicante: Universidad de Alicante y Editorial Marfil. Vol I, (89-104).

ÚBEDA GARCÍA, M., GARCÍA LILLO, F., MARCO LAJARA, B., SABATER SEMPERE, V., GARCÓ GASCÓ, J.L., LLOPIS TAVERNER, J. y MOLINA MANCHÓN, H. (2011). "Cooperar para aprender. El aprendizaje colaborativo y su aplicación a la asignatura de Diseño de la Organización” en Gómez, M.C y Álvarez, J.D. El trabajo colaborativo como indicador de calidad del Espacio Europeo de Educación Superior.Alicante: Universidad de Alicante y Editorial Marfil. Vol II, (757-773) 


\title{
La elección de la metodología de aprendizaje como fuente de innovación en los estudios de administración de empresas de la Universidad de Andorra
}

\author{
Rosa Maria Mariño-Mesías a, Josep Fortó-Areny ${ }^{\text {b }}$, Betlem Sabrià-Bernadóc \\ a'Universitat d’Andorra rmarino@uda.ad, bUniversitat d’Andorra jforto@uda.ad, 'Universitat \\ d’Andorrabsabria@uda.ad.
}

\begin{abstract}
At the time of designing a new curriculum of business administration studies of the University of Andorra (UdA), adapted to the European Higher Education Area (EHEA) and taking into account the high percentage of students who combine their studies with professional activities, several teaching innovations were introduced in order to improve the accessibility in these studies.

This paper presents the implemented learning methodology that allows students to choose their own mode of study (face-to-face, online or blended) according to their preferences. Students, not only has a total flexibility to choose the type of learning modality, but they also have the possibility of changing it throughout their training. A literature review aimed to elaborate a questionnaire that has allowed to know the opinion of the teaching staff about this new methodology.

The main conclusion of the study shows that aspects related to flexibility, access to information and support for learning are the best valued. In this line, the UdA also improves the accessibility and participatory equity promoted by the EHEA.
\end{abstract}

Keywords: Innovation, methodology, personalization, flexibility, teaching staff, virtual learning environment, bachelor of business administration, University of Andorra.

\begin{abstract}
Resumen
En el momento de diseñar un nuevo plan de estudios de administración de empresas de la Universitat d'Andorra (UdA), adaptado al Espacio Europeo de Educación Superior (EEES) y teniendo en cuenta el elevado porcentaje de estudiantes de la UdA que compaginan sus estudios con actividades profesionales, se introdujeron innovaciones docentes para mejorar la accesibilidad en estos estudios.

En este trabajo se presenta la metodología de aprendizaje implantada que permite a los estudiantes elegir su propia modalidad de estudio (presencial, virtual o semipresencial) en función de sus preferencias. Los estudiantes, no solo tienen una flexibilidad total para elegir el tipo de modalidad de aprendizaje, sino que también tienen la posibilidad de cambiarla a lo largo de su formación.

A partir de la revisión de la literatura se ha elaborado un cuestionario que ha permitido conocer la opinión del profesorado sobre esta nueva metodología.

La conclusión principal del estudio muestra que los aspectos relacionados con la flexibilidad, el acceso a la información y el soporte al aprendizaje son los mejor valorados. En esta línea, la UdA también mejora la accesibilidad y la equidad participativa promovida por el EEES.
\end{abstract}

Palabras clave: Innovación, metodología, personalización, flexibilidad, profesorado, entorno virtual de aprendizaje, bachelor en administración de empresas, Universidad de Andorra. 
La elección de la metodología de aprendizaje como fuente de innovación en los estudios de administración de empresas de la Universidad de Andorra

\section{Introducción}

El Principado de Andorra es un microestado europeo situado en la zona pirenaica con una extensión aproximada de $468 \mathrm{~km}^{2}$ y una población de 74.794 habitantes (Govern d'Andorra, Departament d'Estadística, 2018).

Existe un buen vínculo entre el Principado de Andorra y sus estados vecinos, España y Francia, que hacen que la influencia de estos países sea grande en muchos ámbitos y, en concreto, en el de la formación. En el país conviven tres sistemas que configuran su red educativa pública -el andorrano, el español y el francés-. Cada uno de estos sistemas sigue los planes de estudios y los programas que emanan de los Ministerios de Educación de los países respectivos.

La sociedad andorrana está experimentando grandes transformaciones que afectan a la manera de vivir de todos los ciudadanos, y en especial, la de los jóvenes. En el Principado de Andorra, el nivel formativo de los jóvenes en relación al de las generaciones anteriores se ha incrementado. El mercado laboral andorrano se caracteriza por tener una gran rotación y segmentación, en el que los jóvenes se encuentran en situaciones de mayor precariedad laboral (CRES, 2007).

A pesar de los esfuerzos llevados a cabo en el Principado de Andorra durante las últimas décadas en el ámbito de la formación y la educación, entre los que destaca la creación de la Universidad de Andorra, el nivel formativo de la población se ve condicionado de manera muy notable por la importancia de los flujos migratorios. Estas migraciones, básicamente representan una mano de obra no cualificada y, en consecuencia, unos déficits formativos elevados en el lugar de trabajo (Forma, 2007).

En el año 1988 se inició la educación superior en el Principado de Andorra. La Universidad de Andorra (UdA) es la única universidad pública del país. Durante el curso académico 2016-2017, se matricularon 1.243 estudiantes y dispone de un personal fijo formado por 34 personas, 22 de las cuales forman parte del personal docente e investigador. El resto de profesorado -eventual, colaborador y visitante- supone un total de 288 personas que provienen de otras universidades y organizaciones profesionales, tanto nacionales como extranjeras.

La estructura de la UdA es pequeña y flexible. Estos factores influyen positivamente en la adaptación a los cambios constantes que requiere la sociedad del conocimiento, pero también conllevan una serie de dificultades añadidas, ya que hay que coordinar colectivos e instituciones colaboradoras muy diversas.

A lo largo de los años, la UdA ha ido transformando sus prácticas educativas y el curso 2010-2011, cuando adaptó sus titulaciones al Espacio Europeo de Educación Superior (EEES), decidió ofrecer algunas de sus titulaciones siguiendo los tres modelos de docencia: presencial, semipresencial y virtual.

\section{Objetivos}

Tal como pone de manifiesto la revisión de la literatura, la demanda de educación virtual en la educación superior está aumentando. También aumenta la competencia entre universidades y, en consecuencia, invierten recursos significativos para mejorar la calidad de sus ofertas (Martínez-Caro, Cegarra-Navarro y Cepeda-Carrión, 2015). En este sentido, se considera que la apuesta por el uso de la tecnología puede mejorar la calidad de la educación (Mayisela, 2014; Nicolaou, Nicolaidou y Constantinou, 2005). 
Los estándares y directrices para el aseguramiento de la calidad en el EEES (ESG, 2015) destacan la importancia del aprendizaje, enseñanza y evaluación centrados en el estudiante, ya que de esta forma se motiva y promueve su participación en el proceso de aprendizaje. Tal como se especifica en la directriz que corresponde a este estándar, es necesario que las universidades presten atención al diseño y a la modalidad de enseñanza de los programas de estudio, así como a la evaluación de los resultados. En esta misma línea, a la hora de asignar, planificar y ofrecer los recursos de aprendizaje y de soporte a los estudiantes, se tienen en cuenta las necesidades de una población estudiantil diversa y las modalidades flexibles de aprendizaje y de enseñanza.

Según el trabajo desarrollado por Martínez-Caro et al. (2015), la mayoría de los investigadores coinciden en que los principales factores que afectan la satisfacción del estudiante son la interacción entre el profesorado y el estudiante, la interacción entre estudiantes, los contenidos del aprendizaje y, la flexibilidad y apoyo del sistema. Con la introducción de las nuevas tecnologías de la información y la comunicación (TIC), el número de herramientas para promover la interacción entre los participantes de una formación en línea ha aumentado enormemente.

Algunos autores (Castaño, Jenaro, Flores, 2017; López-Pérez, Pérez-López, RodríguezAriza, 2011), sostienen que las TIC proporcionan a los estudiantes y al profesorado un entorno de aprendizaje innovador para estimular y mejorar el proceso de enseñanza y aprendizaje y, en este contexto, se están desarrollando nuevos conceptos educativos, como el aprendizaje combinado o semipresencial. Esta innovación también ha supuesto un cambio de paradigma en cuanto a recursos e infraestructuras, tanto en el modelo de gestión, como en el de organización académica.

Asimismo, según Alebaikan y Troudi (2010) el aprendizaje combinado ha demostrado un considerable efecto positivo en el proceso de aprendizaje y proporciona flexibilidad y accesibilidad al aprendizaje tradicional, ya que integra el aprendizaje cara a cara con el aprendizaje a distancia. Según estos mismos autores, algunas universidades promueven el aprendizaje combinado como una estrategia, ofreciendo flexibilidad en el momento y el lugar de aprendizaje, y los estudiantes prefieren el aprendizaje combinado sobre el aprendizaje en línea.

A partir de la implementación de la innovación docente en el bachelor en administración de empresas (BAE) de la UdA, que combina los tres modelos de docencia: presencial, semipresencial y virtual, permitiendo una flexibilidad total al estudiante a la hora de escoger su modalidad de aprendizaje, el primero de los objetivos de este trabajo es presentar el perfil de los estudiantes de nuevo acceso a la UdA que han seguido estas metodologías.

Cabe destacar que en otro de los ESG desarrollados en el EEES para el aseguramiento de la calidad, se señala la importancia del papel del profesorado para crear una experiencia de calidad en los estudiantes y para facilitar la adquisición de conocimientos, competencias y habilidades. Tal como también se describe en la directriz correspondiente del estándar, las instituciones de educación superior son las principales responsables de la calidad de sus trabajadores y de proporcionarles un entorno que les permita llevar a cabo sus tareas con eficacia. Una de las características que debe presentar este entorno es fomentar la innovación en los métodos de enseñanza y el uso de las nuevas tecnologías.

Aunque el aprendizaje combinado requiere un alto nivel de disciplina por parte de los estudiantes, en la literatura existe consenso en que uno de los elementos fundamentales para el éxito de estas metodologías es el profesorado (Alebaikan y Troudi, 2010; Castaño et al., 2017; García-Varcálcel, Hernández-Martín y Recamán-Payo, 2012; Mayisela, 2014). En particular, su nivel de habilidad técnica y su desarrollo profesional en este tipo de docencia 
en línea (Alebaikan y Troudi, 2010; Tyilo, 2017). Asimismo, otro de los elementos que se consideran necesarios es contar con unas infraestructuras adecuadas para desarrollar este tipo de enseñanza (Nicolaou et al., 2005).

Siguiendo el hilo de la importancia del papel que desempeña el personal docente en el éxito de estas metodologías, el segundo de los objetivos de este trabajo es presentar el perfil del profesorado del BAE y conocer su opinión o valoración sobre esta metodología docente en línea, tal como también han hecho otros trabajos (Ferro, Martínez y Otero, 2009; Mayisela, 2014). Los trabajos de Lai, Lam y Lim (2016) y de Nicolaou et al. (2005), además de la opinión del profesorado, también analizan la opinión de los estudiantes. Otros autores, como por ejemplo, Martínez-Caro et al. (2015), McGorry (2003) y Wang (2003), en cambio, se han centrado únicamente en el punto de vista de los estudiantes, para proponer modelos de evaluación de la calidad en las formaciones virtuales o para evaluar su satisfacción en este tipo de formaciones.

Tal como se ha especificado a lo largo de este apartado del trabajo, los dos objetivos de esta investigación son los siguientes:

Por un lado, se pretende mostrar el perfil de los estudiantes del BAE que han seguido los tres modelos de docencia: presencial, semipresencial y virtual. Y por otro, presentar las características del profesorado de la titulación y, además, conocer su opinión sobre el uso del campus virtual como soporte a la flexibilidad en la elección de la metodología.

\section{Desarrollo de la innovación}

La UdA dispone de un entorno virtual de aprendizaje (EVA) propio desde el curso 20042005. Este entorno estaba integrado con tecnología Lotus Notes y tenía los dos objetivos siguientes a corto plazo:

- Ofrecer un valor añadido a los programas de formación presenciales existentes, basados en grupos reducidos de estudiants y en una atención personalizada.

- Permitir el desarrollo de nuevos programas de formación de contenidos específicos andorranos, siguiendo una metodología virtual.

En el 2009, la UdA cambió su gestor de cursos virtuales hacia la plataforma Moodle, que se fundamenta en una óptica de construcción del conocimiento basado en el diálogo entre los participantes. Después de un semestre de pruebas, en el curso 2010-2011 se instauró en todos los estudios de la UdA.

Para Zúñiga y Arnáez (2010) los entornos virtuales son comunidades virtuales de aprendizaje que, por medio de las TIC, brindan a los docentes y estudiantes espacios de aprendizaje activo donde la reflexión, la discusión y el intercambio de información producen experiencias significativas y construcción de conocimientos dentro de un contexto social virtual, siendo la capacidad de autoformación, una actividad imprescindible. Además, tal como sostiene Martínez-Caro (2011), estos entornos se centran en el estudiante y facilitan la flexibilidad del aprendizaje interactivo (en cualquier momento y lugar).

El modelo pedagógico subyacente en el nuevo campus virtual de la UdA está basado en el sociconstructivismo de Vigotsky (1984). En este modelo, el estudiante se considera constructor activo de su propio aprendizaje, a través de las interacciones con los demás. Pasa de ser un receptor pasivo de contenidos estáticos y memorísticos a ser el principal protagonista y a resolver problemas utilizando los conocimientos adquiridos. 
En función del grado de presencialidad o virtualidad entre el profesorado y el alumnado, se diferencian los tres tipos de modelos de docencia siguientes (Area y Adell, 2009; Area, San Nicolás y Fariña, 2010):

- La docencia presencial, en la que el aula virtual es un recurso complementario. En este caso, lo relevante sigue siendo el proceso de enseñanza presencial del aula y el profesor sigue haciendo lo de siempre, con la ayuda de las TIC.

- La docencia semipresencial, docencia mixta o blended learning, en la que se yuxtaponen los procesos de enseñanza-aprendizaje presenciales con otros que se desarrollan a distancia, mediante el uso de dispositivos electrónicos. Para Torrisi-Steele y Drew (2013), el blended learning se refiere al uso de la tecnología con la enseñanza presencial. En este caso, el aula virtual es un recurso de apoyo a la enseñanza presencial y constituye un espacio en el que el profesor genera y desarrolla acciones diversas para que sus alumnos aprendan. Asimismo, debe elaborar materiales y actividades para que el estudiante las desarrolle autónomamente fuera del contexto de la clase tradicional.

- La docencia virtual o e-learning, en la que el aula virtual es el único espacio educativo. En este caso, el material o recursos didácticos multimedia cobran una especial relevancia. La interacción comunicativa dentro del aula virtual se convierte en un factor clave y sustantivo para el éxito de la metodología.

La enseñanza y el aprendizaje usando las TIC ha supuesto un cambio de mentalidad para el docente y para el estudiante. Según Alabart, Escofet y Vilá (2008) este cambio de mentalidad es complejo pero es valorado como una transición obligatoria y, al mismo tiempo, irreversible en el contexto universitario. La dificultad más notoria que tienen las TIC para convertirse en herramientas que puedan generar conocimiento reside en encontrar, concebir, desarrollar e implementar usos que lleguen a ser pedagógicamente significativos y que favorezcan la apropiación socioeducativa de los recursos aportados a los estudiantes (Levis, 2011).

El EEES es un marco educativo ambicioso y complejo que la mayoría de países europeos, incluyendo el Principado de Andorra, han integrado con el objetivo de favorecer la convergencia europea, en materia de educación. Este nuevo escenario supone una renovación de los métodos docentes, con la aplicación de un nuevo modelo de enseñanza y de aprendizaje. Se trata de conseguir unos objetivos de formación que contemplen tanto la adquisición de conocimientos, como la adquisición de las competencias académicas y profesionales. En este sistema se reducen las horas de docencia directa o clases magistrales y se da más importancia a todo el proceso de aprendizaje del estudiante, ya que tiene un rol más activo y participativo durante todo su proceso de formación. En este escenario, las TIC son imprescindibles para gestionar y cuantificar de una manera eficiente el trabajo autónomo de los estudiantes y el EVA permite hacer un seguimiento del aprendizaje no presencial de los estudiantes.

Con la Ley 12/2008, del 12 de junio, de ordenación de la educación superior (Butlletí Oficial del Principat d'Andorra -BOPA-, 2008), el Principado de Andorra adecua su ordenamiento jurídico en materia de educación superior, de acuerdo con los principios del EEES. Para dar respuesta a la necesidad de formar profesionales con unos conocimientos básicos en el campo de la administración de empresas, se creó el título estatal del Bàtxelor en Administració d'Empreses, el cual proporciona una formación teórica y práctica, multidisciplinar y generalista, en consonancia con las características del mercado laboral andorrano (BOPA, 2010). La obtención de este título garantiza los conocimientos y las competencias necesarias para desarrollar las tareas principales vinculadas a la gestión 
La elección de la metodología de aprendizaje como fuente de innovación en los estudios de administración de empresas de la Universidad de Andorra

empresarial, principalmente en los ámbitos contable y financiero, comercial, tributario e internacional.

Esta formación de 180 créditos europeos (BOPA, 2011) se caracteriza por tener una metodología de aprendizaje flexible, que permite al estudiante disponer de un amplio abanico de posibilidades a la hora de decidir la carga lectiva que quiere asumir cada semestre. La totalidad de créditos europeos del plan de estudios se desglosa en 150 créditos obligatorios, 18 créditos optativos y 12 créditos de libre elección, los cuales se distribuyen en seis semestres, con una carga de 30 créditos cada uno.

El plan de estudios se apoya en bloques formativos relativos a la formación específica, que facilita una formación técnica, una formación en TIC, una formación instrumental y una formación en idiomas.

Para responder al primero de los objetivos de este trabajo, por un lado, se han extraído los principales datos sobre las características de los estudiantes, a partir de la encuesta que responden los nuevos estudiantes de la UdA sobre cuestiones generales de su entorno, al inicio de cada curso universitario, desde el curso 2012-2013. Los estudiantes que responden el cuestionario sobre su entorno son los que siguen la modalidad presencial o semipresencial, puesto que este cuestionario se distribuye y se responde, físicamente en la universidad. A la hora de formalizar la matrícula, una de las cuestiones que se les pregunta a los estudiantes del BAE, es que indiquen la modalidad de estudios que van a seguir (en función de sus preferencias), aunque esta modalidad puede variar a lo largo del curso académico en cualquiera de las asignaturas de la titulación, puesto que el sistema de evaluación es el mismo para cualquiera de las tres modalidades.

Con el propósito de responder al segundo de los objetivos de este estudio, se ha elaborado un cuestionario dirigido a la totalidad del profesorado del BAE. Concretamente, a partir de la revisión de la literatura se ha adaptado el cuestionario utilizado en la investigación de Ferro et al. (2009) sobre las ventajas de las TIC, desde el punto de vista de los docentes universitarios españoles. Este cuestionario ha permitido recoger la opinión del profesorado del BAE y extraer las principales conclusiones relativas a los aspectos más destacados de la metodología de docencia virtual utilizada.

El profesorado del BAE está formado por un total de 22 personas a las que se les envió un cuestionario (ver tabla 1), en el que se les pedía que valorasen en una escala de respuesta Likert de 5 opciones (en la que 1 significaba que ese ítem no tenía ninguna importancia y 5 significaba que su importancia era máxima), los siguientes ítems sobre la importancia del uso del campus virtual del BAE como herramienta de flexibilización de las metodologías de aprendizaje. La recogida de datos se realizó durante el mes de junio de 2017 y la tasa de respuesta fue del $100 \%$.

Tabla 1. Cuestionario destinado al profesorado del BAE

\begin{tabular}{|l|}
\hline \multicolumn{1}{|c|}{ Preguntas } \\
\hline P1: Mejora la comunicación entre los estudiantes \\
\hline P2: Permite una enseñanza más personalizada \\
\hline P3: Mejora la eficacia educativa \\
\hline P4: Facilita que los procesos formativos sean más abiertos y flexibles \\
\hline P5: Aumenta el interés y la motivación de los estudiantes \\
\hline P6: Mejora la comunicación profesor-estudiante \\
\hline P7: Da acceso rápido a la información \\
\hline
\end{tabular}




\begin{tabular}{|l|}
\hline \multicolumn{1}{|c|}{ Preguntas } \\
\hline P8: Permite que el profesorado tenga más tiempo para otras tareas \\
\hline P9: Facilita la interacción con la información \\
\hline $\begin{array}{l}\text { P10: Facilita la realización de actividades complementarias de apoyo } \\
\text { al aprendizaje }\end{array}$ \\
\hline P11: Rompe las barreras espacio-tiempo \\
\hline P12: Facilita el seguimiento de las asignaturas \\
\hline
\end{tabular}

Fuente: Ferro et al. (2009)

Con el objetivo de analizar los datos, se han utilizado técnicas de estadística descriptiva y técnicas de estadística inferencial, a partir del software estadístico R.

Dado que las variables no siguen una distribución Normal, se ha utilizado la prueba no paramétrica U de Mann-Whitney-Wilcoxon.

\section{Resultados}

En primer lugar, se presentan los resultados en relación al primero de los objetivos de este trabajo, es decir, en relación al perfil de los estudiantes del BAE.

Estos primeros resultados sobre el perfil de los estudiantes se han obtenido a partir del proceso de matrícula de la totalidad de los estudiantes matriculados en el BAE, desde el curso 2012-2013.

La media de edad de la primera matrícula realizada a los estudios de BAE es de 28,2 años, con una desviación típica de 7,9. Las edades oscilan entre los 18 y los 54 años y el $60 \%$ de los estudiantes tiene una edad superior a los 21 años.

Teniendo en cuenta que el BAE tiene una duración de tres años, hemos distribuido la edad en dos categorías: edad inferior o igual a 21 años y edad superior a 21 años, y hemos relacionado esta variable con la modalidad de matrícula.

El 66\% de los estudiantes presenciales tiene una edad inferior o igual a los 21 años, mientras que el 89\% de los estudiantes virtuales tiene una edad superior a los 21 años. Por último, el $64 \%$ de los estudiantes que siguen la modalidad semipresencial son mayores de 21 años.

A diferencia de los resultados obtenidos en el estudio Via Universitària (Sintes, 2016), realizado por la Xarxa Vives d'Universitats, que engloba 19 universidades de España, Francia y el Principado de Andorra en el que el 85,8\% de los estudiantes son presenciales, en el BAE, solo un $45,8 \%$ de los estudiantes optan por la modalidad presencial y asisten a clase regularmente. El $41,2 \%$ que siguen la modalidad virtual asisten a clase de forma muy esporádica y un $13 \%$ siguen la modalidad semipresencial.

Tal como se muestra en la tabla 2, la prueba de independencia Chi-cuadrado nos confirma que la edad es un factor determinante en la elección de la modalidad de matrícula a un nivel de significación del 99,99\% (p_value <0,000).

Tabla 2. Prueba Chi-cuadrado Edad-Modalidad de matrícula

\begin{tabular}{|l|c|c|c|}
\hline & Valor & gl & $\begin{array}{c}\text { Sig. asintótica } \\
\text { (bilateral) }\end{array}$ \\
\hline Chi-cuadrado de Pearson & $167,082(\mathrm{a})$ & 66 & $\mathbf{0 0 0}$ \\
\hline
\end{tabular}

(cc) B EY-NC-ND 2018, Universitat Politècnica de València

Congreso In-Red (2018) 
La elección de la metodología de aprendizaje como fuente de innovación en los estudios de administración de empresas de la Universidad de Andorra

\begin{tabular}{|l|c|c|c|}
\hline Razón de verosimilitudes & 197,637 & 66 &, $\mathbf{0 0 0}$ \\
\hline N de casos válidos & 322 & & \\
\hline
\end{tabular}

Siguiendo con el perfil de los estudiantes, a continuación se muestran los resultados que se han obtenido a partir de los datos de la encuesta sobre el entorno de los estudiantes. Tal como ya se ha especificado anteriormente, este cuestionario está dirigido a los estudiantes que siguen la modalidad presencial o semipresencial.

En la figura 1 se presenta la distribución de los estudiantes en función de la vía de acceso. Se constata que la mayoría de los estudiantes (presenciales o semipresenciales), el 48,65\%, proviene de un bachillerato general, pero también muchos de ellos (el 22,52\%) proceden de programas de formación profesional superior: Diploma profesional avanzado (DPA) -en el Principado de Andorra- o Ciclo Formativo de Grado Superior (CFGS). La vía de acceso del $21,62 \%$ de los estudiantes es a partir de un bachillerato profesional y el resto de los estudiantes, provienen de otras vías.

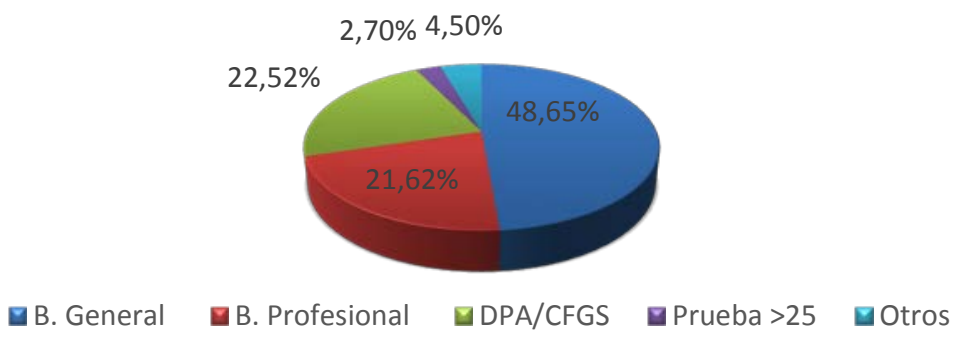

Fig. 1 Distribución de los estudiantes en función de la vía de acceso

Como ya hemos apuntado anteriormente, una característica importante de los estudiantes presenciales o semipresenciales del BAE es que muchos de ellos trabajan a jornada completa, media jornada o bien por horas. Tal como se muestra en la figura 2, tan solo un $45,95 \%$ de los estudiantes tienen dedicación exclusiva a los estudios. Se observa que más del 20\% trabaja más de 20 horas por semana, un 21,62\%, entre 10 y 20 horas, y un 11,71\% dedica menos de 10 horas al ámbito profesional.

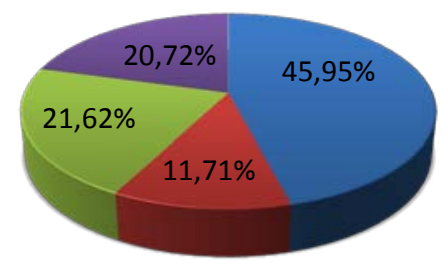

घ0h $\mathbf{a}$ Menos de $10 \mathrm{~h}$ Entre 10 y $20 \mathrm{~h}$ Más de $20 \mathrm{~h}$

Fig. 2 Distribución de los estudiantes en función de las horas de trabajo semanal remunerado

(cc) EY-NC-ND 2018, Universitat Politècnica de València

Congreso IN-RED (2018) 
A continuación, y en relación al segundo de los objetivos de este trabajo, se describe el perfil del profesorado del BAE y se muestran los resultados obtenidos a partir del cuestionario distribuido entre el profesorado.

El profesorado de la UdA está formado por personal fijo y mayoritariamente, por personal colaborador. Este último proviene, tanto de empresas del país, como de universidades de fuera. La combinación de docentes fijos y colaboradores externos es una característica diferencial de la UdA, que garantiza, tanto la solidez de la institución, como el dinamismo en la transmisión de conocimientos y el alcance internacional de su oferta formativa.

En la titulación concreta del BAE, aproximadamente el $60 \%$ del profesorado es fijo y el $40 \%$ restante, colaborador. Clasificando el profesorado por género, se observa que se está cerca de la paridad, ya que un $55 \%$ son hombres y un $45 \%$ mujeres.

La edad media del profesorado es de 43,5 años, la mediana de la serie de edades es de 45,5 años y la desviación típica es de 12,6 años. Esto indica que existe una importante dispersión de edades en el conjunto del profesorado. En la figura 3 se muestra el reparto del profesorado en función de la edad.

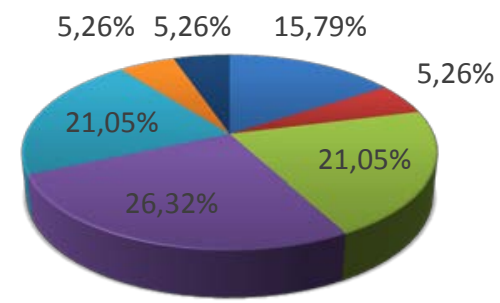

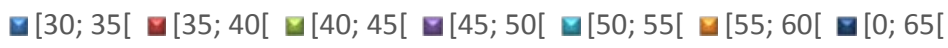

Fig. 3 Distribución del profesorado según su edad

A continuación (ver figura 4), se muestra la tipología del profesorado en función de los años de experiencia docente. Aproximadamente un $70 \%$ del profesorado tiene más de 10 años de experiencia. La experiencia media es de 17,3 años, la desviación típica es de 11,4 años y la mediana de la serie es de 22 años.
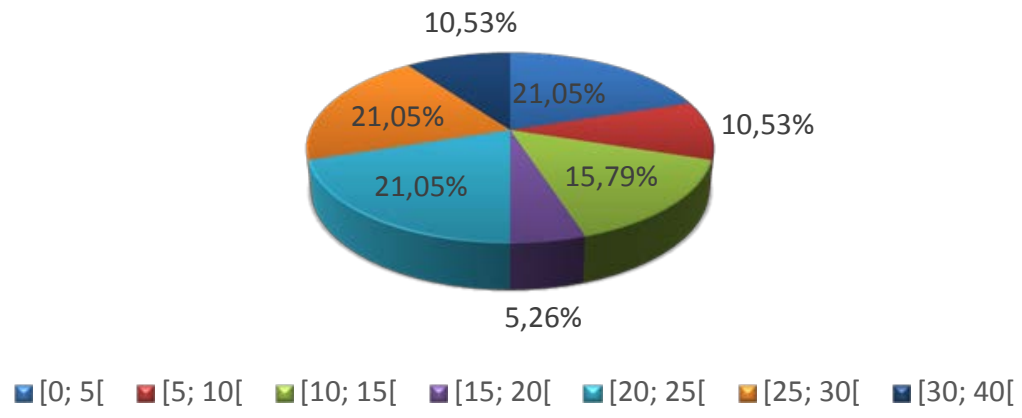

Fig. 4 Distribución del profesorado en función de los años de experiencia docente

En cuanto al análisis de los ítems que respondió el profesorado (ver figura 5), el mejor valorado fue el ítem que considera que el uso del campus virtual da acceso rápido a la información, con un valor medio de 4,59, seguido del ítem rompe las barreras espacio- 
La elección de la metodología de aprendizaje como fuente de innovación en los estudios de administración de empresas de la Universidad de Andorra

tiempo, con una puntuación igual a 4,45. Estos dos ítems también han sido los que han obtenido una desviación típica inferior $(0,67)$.

Contrariamente, el ítem con el valor más bajo fue el que considera que el uso del campus virtual permite que el profesorado tenga más tiempo para otras tareas, con un valor de 2,27, seguido del ítem aumenta el interés y la motivación de los estudiantes, con un valor medio de 2,64. Los valores de la desviación típica para estos dos ítems fueron de 1,16 y de 1 , respectivamente.

La mayor dispersión de opiniones en los encuestados se ha dado en el ítem mejora la comunicación entre los estudiantes, con un valor de desviación típica igual a 1,41.

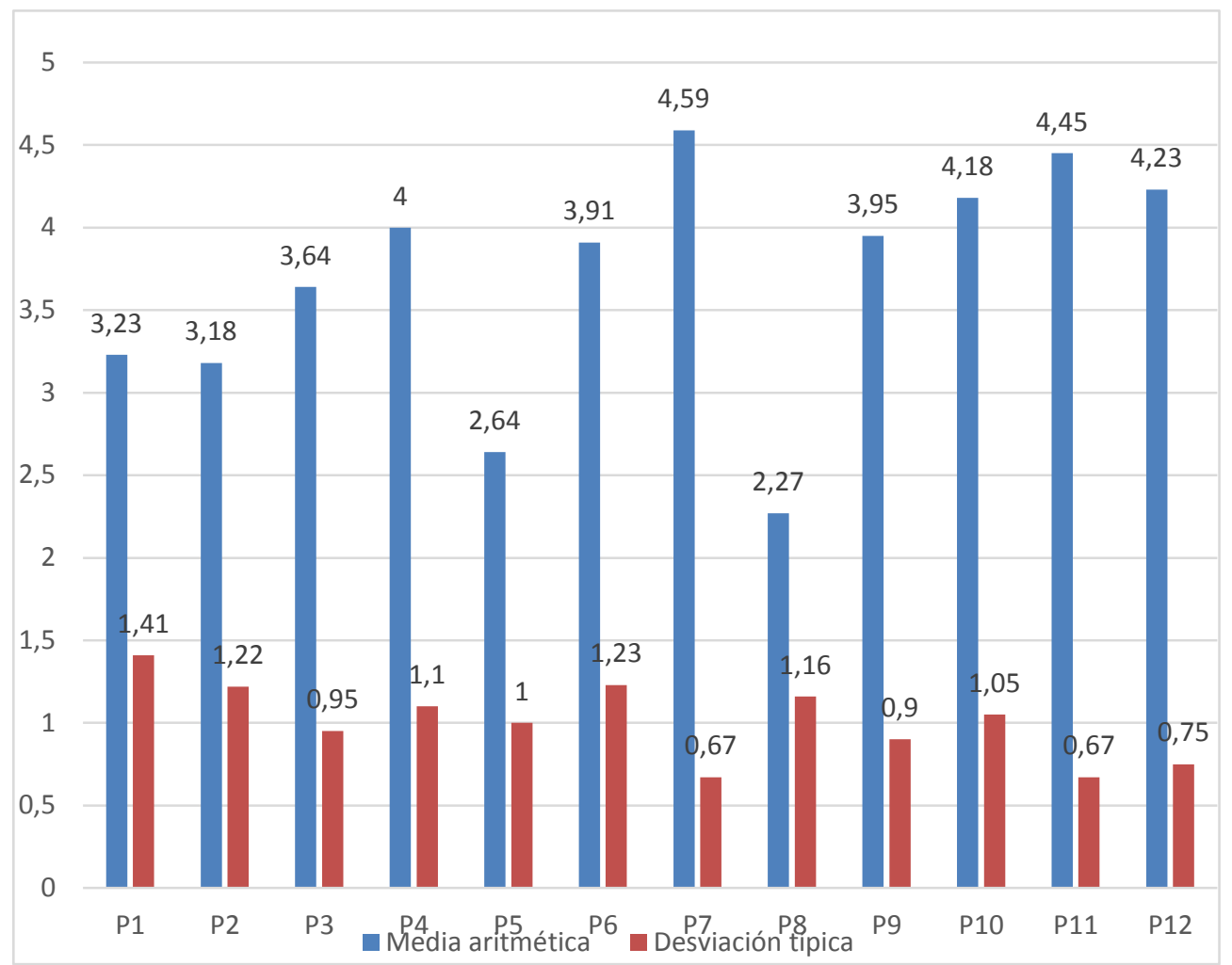

Fig. 5 Medias aritméticas y desviaciones típicas de las preguntas

Si comparamos las puntuaciones en función del sexo del encuestado (ver figura 6) se observa que la tendencia en las puntuaciones es la misma para las personas de ambos sexos, aunque en todas ellas la puntuación del sexo femenino es superior a la del masculino. 


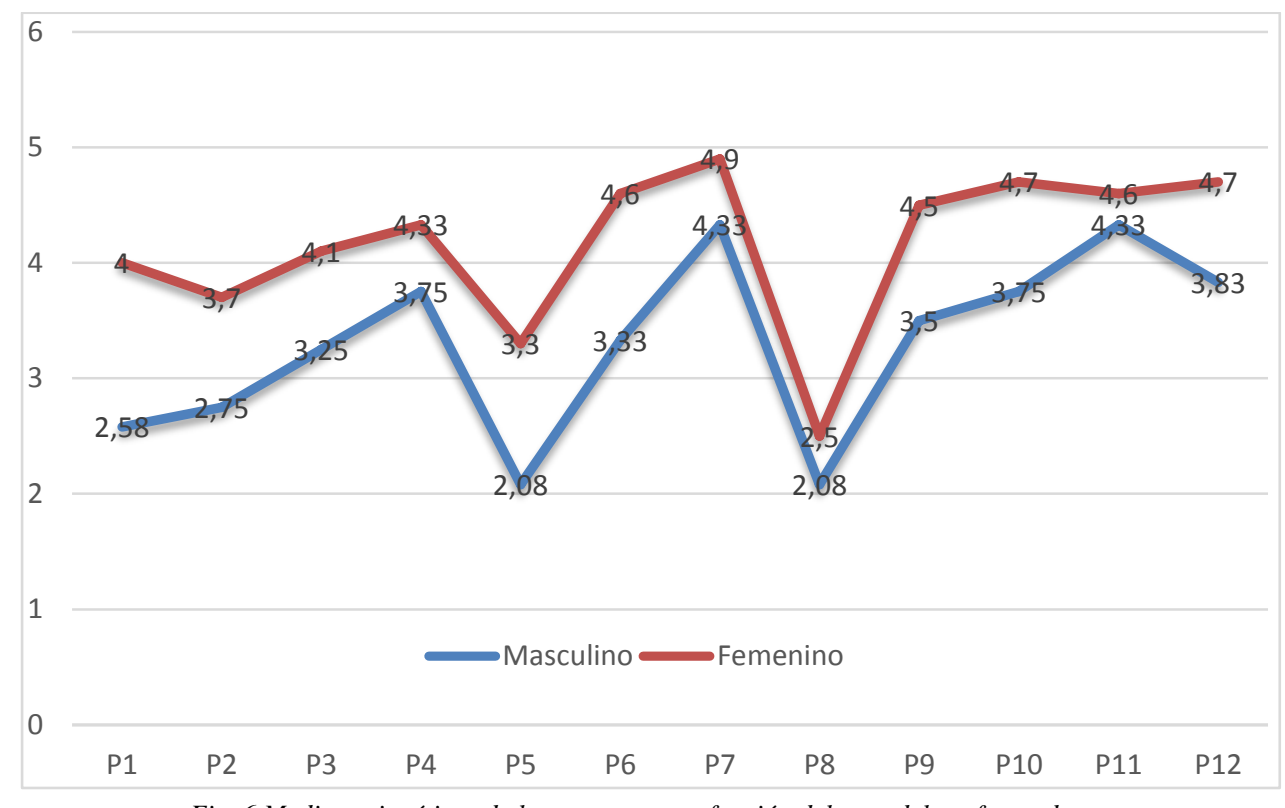

Fig. 6 Medias aritméticas de las preguntas en función del sexo del profesorado

A la vista de los resultados mostrados en el gráfico anterior, para poder indicar una dependencia del sexo con la puntuación, primero se comprobó empíricamente. Se contrastó la normalidad de los datos obtenidos en las 12 preguntas relativas al campus virtual, mediante el test de Saphiro-Wilk, puesto que la muestra tiene menos de 50 registros y este estadístico es el más adecuado. De las 12 variables, únicamente la variable P2 sigue una distribución normal. Por este motivo se consideró la conveniencia de aplicar pruebas no paramétricas en el estudio. En concreto, se estudió la dependencia de las puntuaciones de las 12 respuestas en función del sexo de la persona encuestada, mediante la prueba $U$ de Mann-Whitney-Wilcoxon. La hipótesis nula en este caso, es considerar que para cada una de las 12 preguntas su distribución es la misma independientemente del sexo del encuestado.

La tabla 3 muestra los resultados obtenidos en el p-value para cada una de las 12 preguntas especificadas en la tabla 1.

Tabla 3. Resultados prueba U de Mann-Whitney-Wilcoxon

\begin{tabular}{|l|c|c|c|c|c|c|}
\hline variable & $\mathrm{P} 1$ & $\mathrm{P} 2$ & $\mathrm{P} 3$ & $\mathrm{P} 4$ & $\mathrm{P} 5$ & $\mathrm{P} 6$ \\
\hline$p$-value & $3,503 * 10^{-4}$ & $1,758 * 10^{-4}$ & $4,640^{*} 10^{-5}$ & $6,817 * 10^{-5}$ & $1,340^{*} 10^{-4}$ & $5,161 * 10^{-5}$ \\
\hline variable & $\mathrm{P} 7$ & $\mathrm{P} 8$ & $\mathrm{P} 9$ & $\mathrm{P} 10$ & $\mathrm{P} 11$ & $\mathrm{P} 12$ \\
\hline$p$-value & $2,625 * 10^{-5}$ & $6,562 * 10^{-3}$ & $2,974 * 10^{-5}$ & $2,239 * 10^{-5}$ & $2,676^{*} 10^{-5}$ & $1,784 * 10^{-5}$ \\
\hline
\end{tabular}

Tal como puede observarse, todos los valores del p-value son inferiores a 0,05 , lo cual significa que se rechaza la hipótesis nula de igual distribución en los dos sexos para todas las variables y se comprueba empíricamente esta dependencia, que se aprecia visualmente en la figura 6.

\section{Conclusiones}

Con el objetivo de lograr una mejora de la calidad en la enseñanza y en el aprendizaje, el trabajo desarrollado por Nicolaou et al. (2005) propone diversos escenarios para 
implementar en la universidad. Estos escenarios van desde el apoyo complementario de los procedimientos de enseñanza tradicionales con recursos de e-learning -a través de una plataforma adecuada y mediante medidas de apoyo necesarias para los docentes interesados-, hasta el desarrollo de una estrategia de aprendizaje a distancia, ya sea a partir del desarrollo de nuevos programas de estudio o de módulos mejorados por la tecnología dentro de los programas existentes.

En línea con lo expuesto en el párrafo anterior, desde la UdA se introdujo una nueva metodología de enseñanza y de aprendizaje en el BAE.

Tanto el aprendizaje en línea como el combinado, están destinados a la individualización de la educación (Vanslambrouck, Zhu, Lombaerts, Philipsen y Tondeur, 2018). La atención personalizada podría ser considerada la principal característica de la UdA. Esto resulta relativamente fácil de conseguir, debido a la reducida dimensión de la UdA, que permite tener una relación estrecha con los estudiantes, si bien es cierto que este hecho todavía se ha evidenciado más desde que se incorporó la flexibilidad a partir de las tres modalidades de aprendizaje implementadas en estos estudios.

Tal como se ha expuesto en este trabajo, la media de edad de la primera matrícula realizada a los estudios de BAE es superior a los 28 años y se ha obtenido evidencia empírica de que la modalidad de aprendizaje escogida por los estudiantes está relacionada con la edad.

Este trabajo de investigación también pone de manifiesto que el profesorado considera que el uso del campus virtual del BAE, como herramienta de flexibilización de las metodologías de aprendizaje, rompe las barreras espacio-tiempo, tal como también argumentan Ferro et al. (2009) y Vanslambrouck et al. (2018). Además, según estos últimos autores, se debe buscar el equilibrio entre la enseñanza presencial y la virtual, y el profesorado debe orientar correctamente a los estudiantes y permitirles la flexibilidad necesaria para desarrollar su trabajo.

También se destaca la elevada valoración del acceso rápido a la información y la facilidad para realitzar actividades complementarias de apoyo al aprendizaje, igual que en el estudio de Ferro et al. (2009). Y en línea con estos autores, en este estudio también se pone de manifiesto que la utilización del campus virtual, a pesar de facilitar la realización de actividades complementarias de apoyo al aprendizaje, no permite que el profesorado tenga más tiempo para realitzar otras tareas.

Contrariamente a lo que argumenta la literatura y un ejemplo de ello es el estudio de Ferro et al. (2009), según este trabajo, el profesorado no piensa que el uso del campus virtual aumente el interés y la motivación de los estudiantes.

Los resultados alcanzados en este trabajo presentan algunas limitaciones como consecuencia del reducido tamaño de la UdA y del análisis de tan solo una parte de su profesorado, como es el del BAE. La opinión de un pequeño grupo de docentes universitarios no puede extrapolarse a la totalidad del sistema universitario, ni tan solo a la totalidad de las formaciones que ofrece la UdA con características similares.

En este sentido, como posibles futuras líneas de investigación, por un lado, se podría replicar la investigación en otras universidades de los países vecinos, con el objetivo de identificar si existe una homogeneidad en las opiniones del profesorado, en cuanto a las modalidades de aprendizaje descritas en este estudio. Por otro lado, se podría replicar este trabajo teniendo en cuenta la opinión de los estudiantes, tal como se ha hecho en otros estudios y determinar si los estudiantes tienen la misma opinión que el profesorado, en cuanto a los principales aspectos de estas modalidades de aprendizaje. 


\section{Referencias}

ALABART VILÀ, A., ESCOFET ROIG, A. y VILÀ BOSQUED, G. (2008). Enseñar y aprender con TIC en la Universidad. Barcelona: Colección Cuadernos de Docencia Universitaria ICE-Octaedro.

ALEBAIKAN, R. y TROUDI, S. (2010). "Blended learning in Saudi universities: challenges and perspectives". Research in Learning Technology, vol. 18, issue 1, p. 49-59.

AREA, M. y ADELL, J. (2009). "ELearning: Enseñar y Aprender en Espacios Virtuales” en De Pablos Pons J. (Coord.), La tecnología educativa en el siglo XXI. Málaga: Editorial Aljibe.

AREA, M., SAN NICOLÁS, M. y FARIÑA, B. (2010). "Buenas prácticas de aulas virtuales en la docencia universitaria semipresencial. Teoría de la Educación”. Educación y Cultura en la Sociedad de la Información, vol. 11, issue 3, p. 7-31.

BOPA (2008). Llei 12/2008, del 12 de juny, d'ordenació de l'ensenyament superior. Butlletí Oficial del Principat d'Andorra, núm. 54, any 20, del 16 de juliol. Principat d'Andorra.

BOPA (2010). Decret d'establiment del títol estatal de bàtxelor en administració d'empreses. Butlletí Oficial del Principat d'Andorra, núm. 9, any 22, del 17 de febrer. Principat d'Andorra.

BOPA (2011). Decret d'aprovació del pla d'estudis del bàtxelor en administració d'empreses de la Universitat d'Andorra. Butlletí Oficial del Principat d'Andorra, núm. 25, any 23, del 20 d'abril. Principat d'Andorra.

CASTAÑO, R., JENARO, C. y FLORES, N. (2017). "Percepciones de estudiantes del Grado de Maestro sobre el proceso y resultados de la enseñanza semipresencial: Blended Learning”. Revista de Educación a Distancia, núm. 52, artic. 2.

$<$ http://www.um.es/ead/red/52/castano_et_al.pdf> [Consulta: 18 de enero de 2018].

CRES (2007). Enquesta als joves d'Andorra. Sant Julià de Lòria: Pagés editors.

FERRO, C., MARTÍNEZ, A.I. y OTERO, M.C. (2009). "Ventajas del uso de las TICs en el proceso de enseñanza-aprendizaje desde la óptica de los docentes universitarios españoles". EDUTEC. Revista Electrónica de Tecnología Educativa, número 29. $<$ http://www.edutec.es/revista/index.php/edutec-e/article/view/451/185> [Consulta: 27 de enero de 2016].

FORMA (2007). La formació continuada a Andorra. Model organitzatiu i necessitats formatives. Andorra la Vella: Ecograf.

GARCÍA-VALCÁRCEL， A., HERNÁNDEZ, A. y RECAMAN, A. (2012). "La metodología del aprendizaje colaborativo a través de las TIC: una aproximación a las opiniones de profesores y alumnos”. Revista Complutense de Educación, vol. 23, issue 1, p. 161-188.

GOVERN D'ANDORRA. Departament d'estadística.

$<$ http://www.estadistica.ad/serveiestudis/web/index.asp?lang=4> [Consulta: 24 de marzo de 2018].

LAI, M., LAM, K.M. y LIM, C.P. (2016). "Design principles for the blend in blended learning: a collective case study”. Teaching in Higher Education, vol. 21, issue 6, p. 716729. 
LEVIS, D. (2011). "Redes Educativas 2.1. Medios sociales, entornos colaborativos y procesos de enseñanza y aprendizaje”. Revista de Universidad y Sociedad del Conocimiento, vol. 8, issue 1, p. 7-24. <https://rusc.uoc.edu/rusc/es/index.php/rusc/article/download/v8n1levis/965-1493-1-PB.pdf> [Consulta: 22 de noviembre de 2017].

LÓPEZ-PÉREZ, M.V., PÉREZ-LÓPEZ, M.C. y RODRÍGUEZ-ARIZA, L. (2011). "Blended learning in higher education: Students' perceptions and their relation to outcomes”. Computers \& Education, vol. 56, issue 3, p. 818-826.

MARTÍNEZ-CARO, E. (2011). "Factors affecting effectiveness in e-learning: An analysis in production management courses”. Computer Applications in Engineering Education, vol 19, issue 3, p. 572-581.

MARTÍNEZ-CARO, E., CEGARRA-NAVARRO, J.G. y CEPEDA-CARRIÓN, G. (2015). "An application of the performance evaluation model for e-learning quality in higher education”. Total Quality Management, vol. 26, issue 5-6, p. 632-647.

MAYISELA, T. (2014). “Assessing How E-learning Implementation has Enhanced the Lecturers' Teaching Practices at a South African University”. International Journal of Educational Sciences, vol 6, issue 1, p. 117-124.

MCGORRY, S.Y. (2003). "Measuring quality in online programs”. The Internet and Higher Education, vol. 6, issue 2, p. 159 - 177.

NICOLAOU, C.T., NICOLAIDOU, I.A. y CONSTANTINOU, C.P. (2005). "The eLearning movement as a process of quality improvement in higher education”. Educational Research and Evaluation: An International Journal on Theory and Practice, vol 11, issue 6, p. 605-622.

SINTES, E. (2016). Via Universitària: accés, condicions d'aprenentatge, expectatives i retorns dels estudis universitaris. Barcelona: Fundació Jaume Bofill.

STANDARDS AND GUIDELINES FOR QUALITY ASSURANCE IN THE EUROPEAN HIGHER EDUCATION AREA -ESG- (2015). Brussels, Belgium.

TORRISI-STEELE, G. y DREW, S. (2013). "The literature landscape of blended learning in higher education: the need for better understanding of academic blended practice". International Journal for Academic Development, vol. 18, issue 4, p. 371-383.

TYILO, N. (2017). "E-Learning as Instructional Innovation in Higher Education Institutions (HEI's): Lessons Learnt from the Literature”. Journal of Communication, vol 8, issue 1 , p. 87-93.

VANSLAMBROUCK, S., ZHU, C., LOMBAERTS, K., PHILIPSEN, B. y TONDEUR, J. (2018). "Students' motivation and subjective task value of participating in online and blended learning environments”. The Internet and Higher Education, vol. 36, p. 33-40.

VIGOTSKY, S. (1984). Cientocincuenta Años Después. Infancia y Aprendizaje, (27-28), Madrid: Akal.

WANG, Y.S. (2003). “Assessment of learner satisfaction with asynchronous electronic learning systems”. Information \& Management, vol. 41, issue 1, p. 75-86.

ZUÑIGA, V. y ARNÁEZ SERRANO, E. (2010). “Comunidades virtuales de aprendizaje, espacios dinámicos para enfrentar el Siglo XXI”. Tecnología en Marcha, vol 23, issue 1, p. 19-28. 


\title{
Metodologías ágiles en el grado de Tecnologías interactivas de la Escuela Politècnica Superior de Gandia
}

\author{
José Luis Giménez ${ }^{a}$, Daniel Palacio ${ }^{b}$, Francisco de Zuluetac, Rebeca Diez ${ }^{\mathrm{d}}$, Rafael \\ Seiz ${ }^{\text {, }}$, Jesus Garcia Laborda ${ }^{g}$ \\ jogilo@upvnet.upv.es, bdapasa@har.upv.es, 다razudo@har.upv.es ${ }^{\mathrm{d}}$ rdiez@har.upv.es, \\ emarch@dib.upv.es, rsseiz@upvnet.upv.es \\ Universitat Politècnica de València \\ g.jesus.garcialaborda@uah.es \\ Universidad de Alcalá
}

\begin{abstract}
In view of the continuous advance of newer technologies, higher education in engineering should transmit not only the methodological and developmental aspects of a conventional project, but the need for adaptation and continuous learning in the labour market. As a result, the new degree on Interactive Technologies B.E. at the Higher Polytechnic School of Gandia (EPSG) has been designed taking as reference the work oriented towards project-based learning (PBL), CDIO Initiative (Conceive Design Implement Operate), and a learning-teaching methodology based on Scrum. It is with these implementations that we hope to approach the working procedures that highperformance companies carry out: the so-called agile methodologies. As per the case, we can observe how the aforementioned methodologies have been integrated to higher education and, in particular, to the workshop "Project: Web Design and Development", which belongs to the second semester of the first bachellor's year. In this article we describe how the learning-teaching methodology (Scrum) has been introduced to the academic planning, the subject structure and methodology, as well as to the student competences, their avaluation and rubrics.
\end{abstract}

Keywords: agile methodologies, interactive technologies, problem-based learning, CDIO Initiative, Scrum

\footnotetext{
Resumen

Ante el avance de las nuevas tecnologías, la enseñanza universitaria en el ámbito de las ingenierías debe transmitir al alumno, además de los aspectos metodológicos y de desarrollo de un proyecto convencional, la necesidad de adaptación y aprendizaje continuado en el mundo laboral. En consecuencia, el nuevo grado de Tecnologías interactivas de la Escuela Politècnica Superior de Gandia (EPSG) se ha diseñado tomando como referencia el trabajo orientado a proyectos (PBL), la filosofía CDIO (concebir, diseñar, implementar y operar) y una metodología de aprendizaje-enseñanza basada en Scrum. Con estas implementaciones se pretende una aproximación a los procedimientos de trabajo que se realizan en empresas tecnológicas de alto
} 
Metodologías ágiles en el grado de Tecnologías interactivas de la Escuela Politècnica Superior de Gandia

rendimiento: las denominadas metodologías ágiles. En el caso que nos ocupa, podemos observar cómo dichas metodologías se han incorporado a la enseñanza universitaria $y$, en concreto, a la asignatura-taller "Proyecto: diseño y programación web", perteneciente al segundo semestre de primer año del grado. En el presente artículo se describen las adaptaciones del Plan de Ordenación Docente, de la estructura y metodología de la asignatura, así como de las competencias del alumno, de su evaluación y rúbricas, a la nueva metodología activa (Scrum) de enseñanza-aprendizaje.

Palabras clave: Metodologías ágiles, tecnologías interactivas, PBL, CDIO, SCRUM.

\section{Introducción}

En los últimos años prestigiosas universidades de todo el mundo (MIT, Aalborg, etc.) han implementado títulos utilizando metodologías como el aprendizaje basado en proyectos (PBL) dónde la formación en competencias transversales se integra de una forma racional con la formación en competencias específicas a través del desarrollo de proyectos de aplicación práctica en el mundo real, (Markham et. Al. 2003), (Baviera et Al, 2009).

Tomando esto como modelo se ha implementado en el Grado en Tecnologías Interactivas de la Escuela Politècnica Superior de Gandia de la UPV. Con ello se pretende dotar a sus estudiantes de las competencias específicas aplicando la filosofía CDIO: concibiendo, diseñando, implementando y operando productos y servicios tecnológicos a través de proyectos semestrales tematizados en las tecnologías que han emergido en los últimos tiempos y en otras nuevas que irán apareciendo, (CDIO, 2018). Con la implementación de la metodología de trabajo orientada a proyectos (PBL) (Magal-Royo et $\mathrm{Al}, 2006$ ), se pretende la formación integral de los estudiantes en las competencias transversales citadas y demandadas por las empresas y la evaluación de las mismas de forma objetiva a lo largo de los cuatro cursos del grado de Tecnologías Interactivas, (Philips, 1994), (Fernández et Al. 2003).

Para el correcto aprendizaje de métodos de trabajo, que se integren en el mundo empresarial, se ha optado por aplicar las metodologías ágiles. En concreto la metodología SCRUM, basada en el manifiesto Agile, (The Agile Manifiesto, 2018), (SCRUM, 2018). Este es un proceso en el que se aplica una metodología donde se trabaja colaborativamente, en equipo, para obtener un producto mínimo viable en cortos periodos de tiempo. Estas prácticas se basan en procesos iterativos, flexibles y altamente dinámicos que permiten obtener resultados ajustados a las necesidades del cliente. Procesos que se dan en equipos de trabajo altamente productivos de la empresa privada, (Tore y Torgeir,2008), (Salas et Al. 2009).

(c) EY-NC-ND 2018, Universitat Politècnica de València

Congreso IN-RED (2018) 


\section{Objetivos.}

Este documento pretende mostrar como se pueden implementar las metodologías ágiles empleadas en el mundo profesional en la enseñanza universitaria. En concreto en la asignatura de proyecto diseño y programación web del grado de tecnologías interactivas, que se imparte en la Escuela Politécnica Superior de Gandia. Este grado es de reciente creación, actualmente se imparte primer curso. Es el primero en España en realizar una formación por proyectos.

\section{Desarrollo de la innovación.}

En esta asignatura los alumnos desarrollan un proyecto que consiste en crear un site, según la metodología CDIO. Esta metodología se basa en una premisa comúnmente aceptada de que los graduados de ingeniería deberían ser capaces de: Concebir - Diseñar - Implementar - Operar sistemas complejos de ingeniería con valor agregado en un ambiente moderno y basado en el trabajo en equipos para crear sistemas y productos, (Rico y Sayani,2009).

La iniciativa CDIO ofrece entonces un modelo educativo que enfatiza los fundamentos de la ingeniería, en el contexto de la Concepción - Diseño - Implementación - Operación de procesos. Esta iniciativa es rica en proyectos estudiantiles con una gran carga practica. Implementa experiencias de aprendizaje activo grupal tanto en clases como en talleres de aprendizaje y laboratorios, además de valoración y procesos de evaluación, esto favorece un alto grado de motivación en el alumnado, (Ampuero et Al, 2011).

Los objetivos de la iniciativa CDIO son:

Educar a los estudiantes para el dominio profundo y aplicado de los fundamentos técnicos.

- Educar a los ingenieros para liderar en la creación y operación de nuevos productos y sistemas.

- Educar futuros investigadores para comprender la importancia y valor estratégico de su trabajo.

La iniciativa CDIO fue diseñada específicamente como un modelo que puede ser adaptado y adoptado por cualquier escuela universitaria de ingeniería (Manamendra, et Al., 2013). Dado que CDIO es un modelo de arquitectura abierta, está disponible para ser adaptado a las necesidades específicas de todos los programas de ingeniería universitarios. Las universidades participantes en esta iniciativa, desarrollan regularmente material y metodologías para compartir con otros, (Sherwood, 2004).

El grado de Tecnologías Interactivas esta basado desde sus inicios en esta filosofía CDIO.

En el primer semestre se imparten asignaturas básicas donde se le da al alumno un conocimiento teórico con asignaturas como: Álgebra matricial y geometría, Electrónica básica, Fundamentos físicos y Programación donde el alumno comprende y utiliza los principios de diseño arquitectónico y algorítmico para desarrollar aplicaciones, mediante el uso de un lenguaje de programación. Otra asignatura es Desarrollo de un proyecto electrónico utilizando metodología CDIO esta asignatura tiene una carga de 6 créditos 
Metodologías ágiles en el grado de Tecnologías interactivas de la Escuela Politècnica Superior de Gandia

ECTS. En este proyecto los alumnos han desarrollado unos sensores que permiten monitorizar una serie de parámetros en un campo. A partir de este proyecto nuestra asignatura de segundo semestre desarrolla un site donde muestra todos los datos que recogen los sensores en tiempo real. Permitiendo monitorizar el campo vía web.

La asignatura que nos ocupa (13949) “Proyecto diseño y programación web” es de carácter obligatorio. Pertenece al Módulo 4 Proyectos de las tecnologías interactivas, materia 13Proyecto Diseño y Programación Web. Se imparte en el primer curso segundo semestre. Tiene asignados 12 créditos, 6 de teoría y 6 de prácticas. Junto a ella también se imparten otras asignaturas como Diseño de interfaces y experiencias de usuario con 6 créditos, Programación 2 (6 créditos), Redes y servicios telemáticos. Estas asignaturas apoyan al proyecto de diseño y programación web.

Nuestra asignatura se desarrolla según los patrones de CDIO. Esto comprende analizar, planificar, organizar, desarrollar y diseñar el site, observando la usabilidad y la experiencia de usuario. A la hora de realizar el proyecto deben tener en cuenta el diseño de la aplicación front-end (hace referencia a la visualización del usuario por un lado), y del back-end (administrador del sitio con sus respectivos sistemas por el otro).

Al final se procederá a publicar el sitio y promocionarlo en la red. Con esto se observará el proceso completo de creación de un sitio web. Y podrá integrarse en un equipo de trabajo profesional.

\section{Metodología y métodos}

La educación en ingeniería y las demandas del mundo real sobre los ingenieros se han separado en los últimos años. Al darse cuenta de que esta creciente brecha debe ser zanjada, las principales escuelas de ingeniería de Estados Unidos, Europa, Canadá, Reino Unido, África, Asia y Nueva Zelanda formaron la Iniciativa CDIO: Una colaboración a nivel mundial para concebir y desarrollar una nueva visión de la enseñanza de la ingeniería, (Rousseau, 2012), (Rousseau y McCarthy, 2007).

Como indicamos anteriormente la iniciativa CDIO ofrece entonces un modelo educativo que enfatiza los fundamentos de la ingeniería, en el contexto de la Concepción - Diseño Implementación - Operación de procesos.

El proceso de aprendizaje-enseñanza estaría basado en la metodología SCRUM. Este es un proceso en el que se aplican de manera regular un conjunto de buenas prácticas para trabajar colaborativamente, en equipo, y obtener el mejor resultado posible de un proyecto. Estas prácticas se apoyan unas a otras y su selección tiene origen en un estudio de la manera de trabajar de equipos altamente productivos.

En SCRUM se realizan entregas parciales y regulares del producto final, priorizadas por el beneficio que aportan al receptor del proyecto. Por ello, Scrum está especialmente indicado para proyectos en entornos complejos, donde se necesita obtener resultados de forma rápida, donde los requisitos son cambiantes o poco definidos, donde la innovación, la competitividad, la flexibilidad y la productividad son fundamentales, (Hammersley, 2004).

(cc) EY-NC-ND 2018, Universitat Politècnica de València

Congreso IN-RED (2018) 


\section{Estructuración}

Los contenidos se dividen en seis apartados (ver tabla 1), fundamentales para la realización de un proyecto web. El primero de todos se centra en explicar los fundamentos del proyecto, su diseño, desarrollo y su gestión, para dejar definidos los roles y sus características. El segundo bloque introduce a los alumnos en el desarrollo front-end y back-end, estableciendo las pautas para un buen desarrollo. En el tercer bloque entramos de lleno en el desarrollo front-end a partir del lenguaje HTML, css y JavaScript. En el cuarto bloque pasamos a las tecnologías Back-end, lenguajes de servidor y bases de datos. Para en un quinto bloque publicar en la red nuestro proyecto. Pero no debemos olvidar el marketing, la promoción de nuestro site para que llegue al mercado en las mejores condiciones, que es lo que se trabajará en el sexto y último bloque.

Tabla 1. Estructuración de las unidades docentes de la asignatura.

1. Fundamentos diseño, desarrollo y gestión de un proyecto web

Diseño de un Product Backlog. Personas. Historias de usuario. Mapa de historias

Diseño incremental. Refactorización

Roles y tareas en un proyecto web

2. Introducción a Fundamentos del front-end y back-end (cliente servidor)

Arquitectura cliente-servidor

Direcciones y puertos IP. DNS

Fundamentos del protocolo HTTP

Instalación y gestión básica de un servidor web

Páginas estáticas y páginas dinámicas

3. Tecnologías implicadas en el desarrollo front-end

HTML estructura semántica

CSS: el diseño del front-end

JavaScript: el comportamiento del front-end

4. Tecnologías implicadas en el desarrollo back-end

Lenguajes de servidor y bases de datos

Envío de información al servidor. Métodos GET y POST

5. Tecnologías implicadas en la publicación

Gestión de usuario

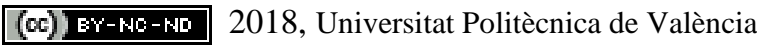

Congreso In-Red (2018) 
Metodologías ágiles en el grado de Tecnologías interactivas de la Escuela Politècnica Superior de Gandia

\section{Marketing, análisis y promoción web}

$$
\text { Promoción y reputación online }
$$

$$
\text { Plan de marketing online }
$$

Técnicas para fidelizar y uso de las redes sociales

Fuente: EICE, ABP-Diseño y Comunicación, 2018

A continuación, se detalla la distribución de las horas respecto a las unidades didácticas (Ver tabla 2).

\begin{tabular}{|c|c|c|c|c|c|c|}
\hline $\begin{array}{l}\text { Unidad } \\
\text { Didáctica }\end{array}$ & $\begin{array}{c}\text { Teoría de } \\
\text { Aula }\end{array}$ & $\begin{array}{l}\text { Práctica de } \\
\text { Laboratorio }\end{array}$ & $\begin{array}{c}\text { Actividades } \\
\text { de } \\
\text { Evaluación }\end{array}$ & $\begin{array}{l}\text { Trabajo } \\
\text { Presencial }\end{array}$ & $\begin{array}{l}\text { Trabajo No } \\
\text { Presencial }\end{array}$ & $\begin{array}{l}\text { Total } \\
\text { horas }\end{array}$ \\
\hline 1 & 15 & 12 & 6 & 33 & 30 & 63 \\
\hline 2 & 10 & 12 & 2 & 24 & 25 & 49 \\
\hline 3 & 20 & 16 & 2 & 38 & 60 & 98 \\
\hline 4 & 5 & 10 & 3 & 18 & 40 & 58 \\
\hline 5 & 5 & 5 & 1 & 11 & 25 & 36 \\
\hline 6 & 5 & 5 & 1 & 11 & 25 & 36 \\
\hline Total horas & 60 & 60 & 15 & 135 & 205 & 173 \\
\hline
\end{tabular}

Tabla 2. Distribución de las horas según las unidades docentes.

Fuente: EICE, ABP-Diseño y Comunicación, 2018

La asignatura está compuesta de distintos talleres que imparten distintos departamentos, acordes con la temática específica. (Ver tabla 3)

Tabla 3. Distribución de los créditos según los departamentos que intervienen

\begin{tabular}{|c|c|c|c|}
\hline MODULOS & TEORÍA & PRACTICA & TOTAL \\
\hline Seguimiento Proyecto (DIG) & 1,5 & 0,5 & 2 \\
\hline Análisis y diseño (DIG) & 2 & 1 & 3 \\
\hline Front-end (DCADHA) & 0,5 & 2,5 & 3 \\
\hline Back-end (DSIC) & 1,5 & 1 & 2,5 \\
\hline Promoción y seguimiento (DCADHA) & 0,5 & 1 & 1,5 \\
\hline Total proyecto & 6 & 6 & 12 \\
\hline
\end{tabular}

Fuente: EICE, ABP-Diseño y Comunicación, 2018 


\section{Evaluación}

Los estudiantes desarrollan un producto nuevo y único mediante la realización del proyecto. Este recogerá lo aprendido durante el semestre. Será la última prueba evaluativa y se entregará en la última semana del curso, (Guo et Al., 2016).

Para la realización del proyecto se crearán grupos de alumnos, que trabajarán en la realización del mismo a lo largo del semestre. El método de realización seguirá la metodología scrum. Esta metodología se basará en el CDIO (Concebir, Diseñar, Implementar y Operar).

Durante el primer mes se realizará el trabajo académico este tendrá un valor del 10\% de la nota global. A partir de ese mes se establecerán sprints de dos semanas, realizándose un total de 6 sprints. Siendo el último la presentación en exposición pública del proyecto. Los cinco primeros sprints (Examen oral), tendrán un valor cada uno del 8\% siendo el total de $40 \%$. Otro $10 \%$ será aportado por el método de observación durante el trabajo en los diferentes talleres.

El último sprint tendrá un valor del 40\%, donde se valorará la resolución del proyecto, la memoria aportada y su exposición. Dividiéndose la nota final obtenida entre todos ellos según el trabajo realizado. La evaluación final será la nota ponderada de todos los actos evaluativos. Ver tabla 4.

El proyecto será evaluado por un comité de profesores que ha ido impartiendo los contenidos necesarios para realizar el producto. Esta evaluación se realizará en una presentación pública conjunta, ante los demás miembros de la clase. La exposición se realizará durante la primera semana de la convocatoria oficial de exámenes, al final del cuatrimestre. La segunda semana se destinará a recuperaciones en el caso que el comité considere que es necesario recuperar alguna parte del proyecto del último sprint.

Los alumnos a los que se les conceda la dispensa de asistencia a actividades presenciales deberán integrarse en un equipo de trabajo desde el comienzo del cuatrimestre, utilizando para ello herramientas de trabajo colaborativo y asistiendo a las reuniones de manera virtual (por Skype, Polireunión etc.).

La asistencia a la presentación final del proyecto es obligatoria para todos los alumnos incluidos aquellos que tienen dispensa. Los alumnos con dispensa es recomendable su asistencia a las reuniones de final de Sprint (aproximadamente cada dos semanas). El método de evaluación será el mismo que para el resto de alumnos.

Tabla 4. en esta tabla queda reflejada el tipo de evaluación y el número de actos

\begin{tabular}{|c|l|c|c|}
\hline \multicolumn{1}{|c|}{ TIPO } & \multicolumn{1}{|c|}{ DESCRIPCIÓN } & ACTOS & PESO \\
\hline $\begin{array}{c}\text { (01) Presentación } \\
\text { oral }\end{array}$ & Sprints que se realizan cada dos semanas & 5 & $40 \%$ \\
\hline (11) Observación & $\begin{array}{l}\text { Estrategia basada en la recogida sistemática de datos en } \\
\text { el propio contexto de aprendizaje: ejecución de tareas, } \\
\text { prácticas }\end{array}$ & 1 & $10 \%$ \\
\hline (09) Proyecto & $\begin{array}{l}\text { Supone el análisis y la resolución de una situación } \\
\text { planteada que presenta problemas de solución múltiple, a }\end{array}$ & 1 & $40 \%$ \\
\hline
\end{tabular}


Metodologías ágiles en el grado de Tecnologías interactivas de la Escuela Politècnica Superior de Gandia

\begin{tabular}{|c|l|c|c|}
\hline & $\begin{array}{l}\text { través de la reflexión y el diálogo para un aprendizaje } \\
\text { grupal, integrado y significativo. Se presentará el proyecto } \\
\text { en el último Sprint }\end{array}$ & & \\
\hline $\begin{array}{c}\text { (05) Trabajo } \\
\text { académico }\end{array}$ & $\begin{array}{l}\text { Desarrollo de un trabajo escrito que puede ir desde } \\
\text { trabajos breves y sencillos hasta trabajos amplios y } \\
\text { complejos e incluso proyectos y memorias }\end{array}$ & 1 & $10 \%$ \\
\hline
\end{tabular}

Fuente: EICE, ABP-Diseño y Comunicación, 2018

\subsubsection{Rúbrica para la evaluación del proyecto final}

Para la correcta evaluación del proyecto final se facilita a los alumnos una rúbrica con los conocimientos que debe haber adquirido el alumno, ver tabla 5.

Tabla 5. Rubrica para la evaluación de proyecto

\begin{tabular}{|c|c|c|c|c|c|}
\hline $\begin{array}{l}\text { DEFINIR SUS } \\
\text { OBJETIVOS }\end{array}$ & $\begin{array}{l}\text { Los define y los } \\
\text { identifica } \\
\text { correctamente }\end{array}$ & $\begin{array}{c}\text { Los define, pero no } \\
\text { los identifica } \\
\text { correctamente }\end{array}$ & $\begin{array}{l}\text { Los define pero no } \\
\text { sabe identificarlos }\end{array}$ & $\begin{array}{l}\text { No los define } \\
\text { correctamente }\end{array}$ & $\begin{array}{l}\text { No se han } \\
\text { definido los } \\
\text { objetivos }\end{array}$ \\
\hline $\begin{array}{l}\text { MANEJO DE } \\
\text { INFORMACIÓN }\end{array}$ & $\begin{array}{l}\text { Clasificar y utilizar } \\
\text { la información } \\
\text { correctamente }\end{array}$ & $\begin{array}{c}\text { Clasificar la } \\
\text { información pero la } \\
\text { utiliza } \\
\text { incorrectamente }\end{array}$ & $\begin{array}{c}\text { Clasificar la } \\
\text { información pero no } \\
\text { la utiliza }\end{array}$ & $\begin{array}{c}\text { Clasificar la } \\
\text { información } \\
\text { incorrectamente }\end{array}$ & $\begin{array}{c}\text { No sabe } \\
\text { clasificar la } \\
\text { información }\end{array}$ \\
\hline $\begin{array}{l}\text { INNOVAR Y } \\
\text { CUMPLIR } \\
\text { OBJETIVOS }\end{array}$ & $\begin{array}{l}\text { Responder a los } \\
\text { objetivos e } \\
\text { innovar }\end{array}$ & $\begin{array}{c}\text { Responder a los } \\
\text { objetivos añadiendo } \\
\text { mejoras }\end{array}$ & $\begin{array}{c}\text { Responder a los } \\
\text { objetivos }\end{array}$ & $\begin{array}{l}\text { Dar respuesta a los } \\
\text { objetivos de forma } \\
\text { incorrecta }\end{array}$ & $\begin{array}{l}\text { No dar } \\
\text { respuesta a los } \\
\text { objetivos }\end{array}$ \\
\hline
\end{tabular}

Fuente: EICE, ABP-Diseño y Comunicación, 2018

\subsection{Competencias}

En esta signatura se trabajan específicamente competencias transversales al ser una asignatura que engloba varias asignaturas de distintos departamentos (ver tabla 6).

(cc) EY-NC-ND 2018, Universitat Politècnica de València

Congreso IN-RED (2018) 
Tabla 6. Competencias transversales que se trabajan en la asignatura

\begin{tabular}{|c|c|c|}
\hline MATERIA & COMPETENCIAS TRANSVERSALES & $\begin{array}{l}\text { PUNTO DE } \\
\text { CONTROL }\end{array}$ \\
\hline $\begin{array}{l}\text { Proyecto Diseño y } \\
\text { Programación Web }\end{array}$ & $\begin{array}{l}\text { (08) Comunicación efectiva } \\
\text { - Actividades desarrolladas relacionadas con la } \\
\text { adquisición de la competencia: presentación del } \\
\text { proyecto }\end{array}$ & $\mathrm{Si}$ \\
\hline $\begin{array}{l}\text { Proyecto Diseño y } \\
\text { Programación Web }\end{array}$ & $\begin{array}{l}\text { (12) Planificación y gestión del tiempo } \\
\text { - } \quad \text { Actividades desarrolladas relacionadas con la } \\
\text { adquisición de la competencia: Sprints } \\
\text { - Descripción detallada de las actividades: Periodos de } \\
\text { dos semanas donde el alumno tiene que desarrollar } \\
\text { la solución de los problemas planteados en el sprint } \\
\text { planing para alcanzar el producto mínimo viable } \\
\text { - Criterios de evaluación: Al finalizar el sprint se debe } \\
\text { valorar el resultado obtenido en ese periodo de } \\
\text { tiempo y si ha alcanzado el objetivo planteado en el } \\
\text { sprint planning, cada sprint tiene un valor de un } 8 \%\end{array}$ & $\mathrm{Si}$ \\
\hline
\end{tabular}

Fuente: EICE, ABP-Diseño y Comunicación, 2018

\section{Resultados}

Actualmente los alumnos están trabajando en grupos y desarrollando una dinámica de trabajo muy positiva, como parte de la aplicación de las metodologías ágiles trabajan con tableros de TRELLO (Fig. 1) donde aprenden a organizarse, distribuirse las tareas y administrarse el tiempo, según se establece en el Sprint Planing, lo cual forma parte de la metodología de trabajo de SCRUM, (Nejmeh y Weaver, 2014).

Como podemos ver en la Fig. 1, los alumnos realizan tableros que reflejan el flujo de trabajo, permite comprobar el estado del proyecto y la dinámica de grupo donde la consecución del sprint es lo más importante. Los alumnos saben que cada dos semanas tienen que entregar un producto mínimo viable. Lo que les obliga a mantener reuniones prácticamente diarias para poder trabajar de forma coordinada. Esto les da un alto grado de trabajo en equipo. 
Figura 1: Tablero de Trello de un equipo de trabajo

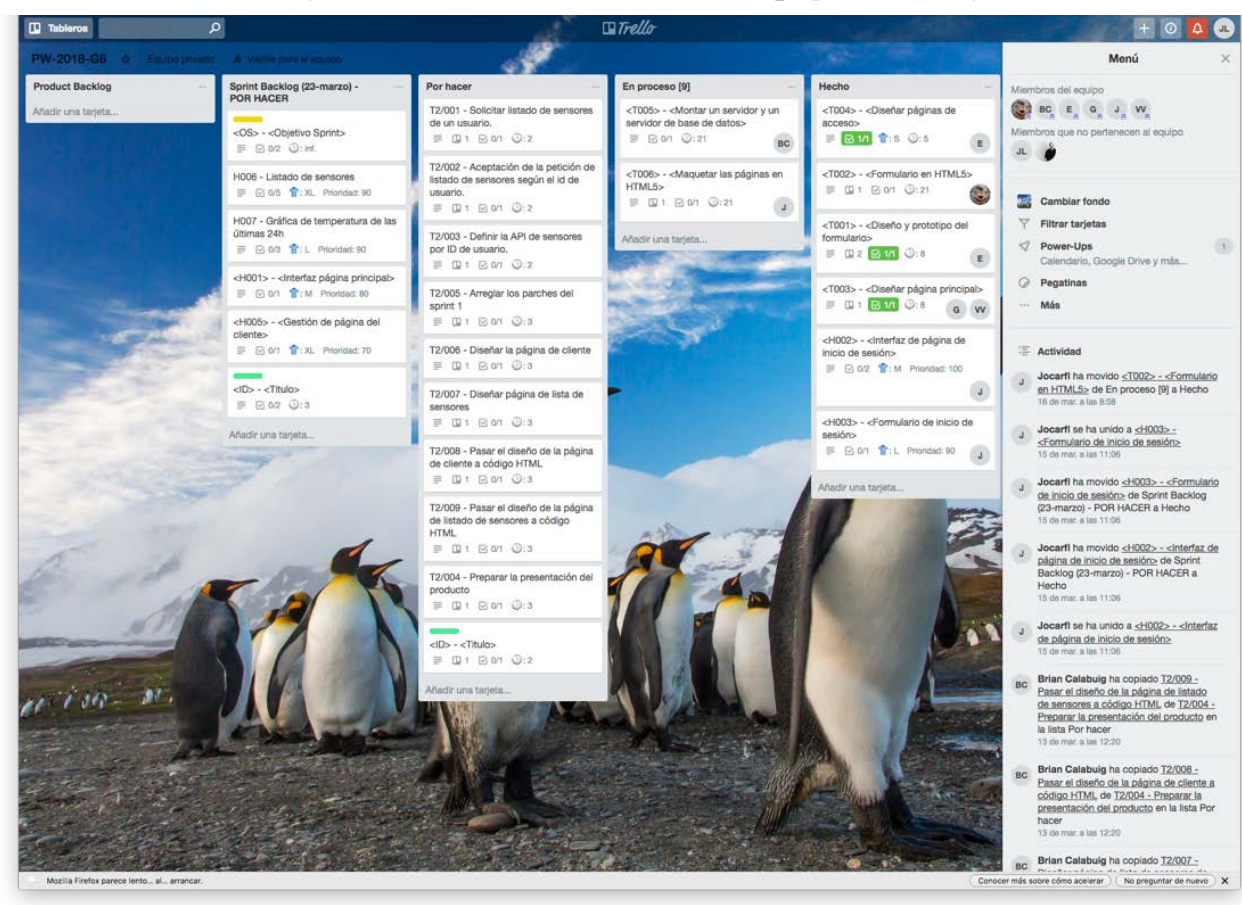

Fuente: EICE, ABP-Diseño y Comunicación, 2018

\section{Conclusiones}

Esta es la primera promoción del grado de Tecnologías interactivas y los resultados que se obtienen son provisionales. Se observa que esta forma de trabajo conlleva que los alumnos organizados en grupos adquieran un alto grado de responsabilidad sobre la ejecución de las tareas, organización y compromiso. Ya que la entrega de un producto mínimo viable cada dos semanas hace que entren en una dinámica de producción continua.

Al ser un proyecto práctico, cuyo resultado es un producto comercializable los alumnos ven como crece. Un producto que han concebido y diseñado ellos mismos, por lo tanto es un equipo motivado. Al mismo tiempo se establecen distintos roles en el equipo ya que debe de ser un equipo multidisciplinar y a lo largo de cada entrega los roles se intercambian entre los miembros del equipo. Por lo tanto están obligados a trabajar en equipo. Ser capaces de asumir el trabajo que ha realizado otro compañero.

Como indicamos anteriormente estas observaciones se realizan mientras los alumnos están trabajando en estos momentos en el proyecto. Deberemos esperar a tener los resultados a finales del semestre para tener datos de la evaluación con personas ajenas al proyecto. Como se indico en la evaluación. Pero los resultados observados invitan a indicar que hay un cambio notable en la actitud de los alumnos a la hora de enfrentarse con el proyecto. 


\section{Agradecimientos}

El desarrollo del presente articulo ha sido realizado gracias al trabajo de los profesores del equipo de innovación y calidad educativa EICE ABP-Diseño y Comunicación de las escuelas, Escuela Técnica Superior de Ingeniería de Diseño, ETSID y la Escuela Politécnica Superior de Gandia, EPSG. También queremos dar las gracias al profesor Jesús Garcia Laborda por sus aportaciones teóricas sobre innovación educativa planteadas.

\section{Referencias}

- AMPUERO CANELlAS, O. CISCAR CUÑA, J. ; DIEZ SOMAVILLA, R.; ENRIQUEZ CARRASCO, E. V.; GONZALEZ DEL RIO COGORNO, J.; .JORDA ALBIÑANA B, MARCH LEUBA, E. (2011) “Aprendizaje basado en proyectos orientado a la comunicación de productos y servicios de diseño”. En IV Jornada de Innovación Docente (JIDINF'11). Valencia, España.

- BAVIERA PUIG A.; CAPO VICEDO J.; GARCÍA FELIX E.V.; GASCH MOLINA E. ; GIMÉNEZ LÓPEZ J.L.; SARASA C.P. (2009). “¿Cómo motivar en el uso de metodologías activas? Algunas experiencias docentes”. En XVII Congreso Universitario de Innovación Educativa en las Enseñanzas Técnicas (CUIEET). (1-9). Valencia, España: ETSI Diseño. Universidad de Valencia

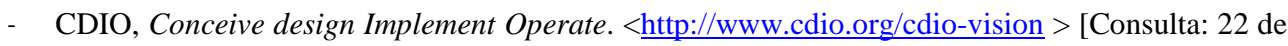
Marzo de 2018]

- FERNANDEZ, E. WILliAMSON, DAVID. M. (2003). "Using Project-based learning to teach object oriented application development “. En CITC4”03. (2003, issue 4, pp. 37-40).

- GUO, R., FARNSWORTH, T. J., \& HERMANSON, P. M. (2016). "Assessment of Evidencebased Management Training Program: Application of a Logic Model.” En International Journal of Management and Business, vol.7, issue1), pp. 57-74).

- HAMMERSLEY, M. (2004), "Some questions about evidence-based practice in education". En G. Thomas \& R. Pring (Eds.). Evidence-based practice in education Maidenhead: Open University Press.

- MANAMENDRA, M.A.S.C., MANATHUNGA K.N., PERERA K.H.D., KODAGODA N.(2013). "Improvements for agile manifesto and make agile applicable for undergraduate research projects”. En 8th International Conference in Computer Science \& Education (ICCSE) 2013 26-28 April 201, Colombo, Sri Lanka. pp. 539-544.

- MAGAL-ROYO T., TORTAJADA-MONTAÑANA I., JORDA-ALMIÑANA B., DEL RIOCOGORNO J. (2006). "El aprendizaje basado en proyectos dentro de la licenciatura de Comunicación Audiovisual”. X Congreso Internacional de Ingenieria de Proyectos . AEIPRO, Valencia 13-15 Septiembre, 2006

- $\quad$ MARKHAM, T., LARMER, J., \& RAVITZ, J. (2003). "Project-Based Learning Handbook: A Guide to Standards Focused Project-Based Learning for Middle and High School Teachers". Novato, CA: Buck Institute for Education.

- NEJMEH B. Y WEAVER S. D. (2014). "Leveraging scrum principles in collaborative interdisciplinary service-learning project courses”. Frontiers in Education Conference (FIE) (2014 IEEE, pp. 1-6).

- PHILIPS R. (1994) "Producing Interactive Multimedia Computer-based learning projects". Computer Graphics (Vol.28, issue1, pp.22-24).

- RICO D. F. Y SAYANI, H. H. (2009) "Use of Agile Methods" En Software Engineering Education. Agile Conference, Chicago pp. 174-179. DOI : 10.1109/AGILE.2009.13

- ROUSSEAU D.M. Y MCCARTHY S. (2007). "Educating Managers From an Evidence-Based Perspective.” Academy of Management Learning \& Education, (Vol. 6, issue 1, pp.84-101)

- ROUSSEAU, D. M. (Ed.). (2012). “The Oxford handbook of evidence-based management”. New York, NY: Oxford University Press 
Metodologías ágiles en el grado de Tecnologías interactivas de la Escuela Politècnica Superior de Gandia

- SALAS, E., WILDMAN, J. L., PICCOLO, R. F. (2009). "Using simulation-based training to enhance management education”. En Academy of Management Learning \& Education, (8, 559573)

- SCRUM. Scrum Organization. < $\quad$ https://www.scrum.org/resources/what-is-scrum $>$ [Consulta: 22 de Marzo de 2018]

- SHERWOOD, A. L. (2004). "Problem-based learning in management education: A framework for designing context”. En Journal of Management Education, (28, 536-557)

- THE AGILE MANIFIESTO, (2018). Agile software development. $<$ http://agilemanifesto.org/iso/es/manifesto.html > [Consulta: 22 de Marzo de 2018]

- TORE D. Y TORGEIR D.(2008). "Empirical studies of agile software development: A systematic review”. En Information and Software Technology. Elsevier. (2008,Vol.50, pp. 833-859). DOI:10.1016/j.infsof.2008.01.006

(cc) EY-NC-ND 2018, Universitat Politècnica de València 


\title{
Trabajo cooperativo en grupos de tutorías de Aditivos Alimentarios
}

\section{Francesc A. Esteve-Turrillas}

Departamento de Química Analítica, Universitat de València, Edificio Jeroni Muñoz, c/ Dr. Moliner 50, 46100 Burjassot, España (francesc.a.esteve@uv.es)

\begin{abstract}
In the present communication an strategy based on the Puzzle of Aronson has been applied to promote the cooperation in working groups in the tutorials of Food Additives course of the Degree in Science and Food Technology in the University of Valencia. This tool allows the training of transversal skills in the classroom such as: social and communication skills, decision making, and conflict resolution. A rubric has been applied to evaluate the cooperative work process and the obtained results have been discussed. Finally, we include data on the student satisfaction with the proposed activity through the completion of a survey.
\end{abstract}

Keywords: Cooperative learning, Aronson Puzzle, Group work, Food additives, Evaluation

\begin{abstract}
Resumen
En la presente comunicación se presentan los resultados obtenidos en el empleo de técnicas basadas en el Puzle de Aronson para fomentar el trabajo cooperativo en la asignatura Aditivos Alimentarios del Grado de Ciencia y Tecnología de Alimentos de la Universitat de València. Con esta herramienta se consigue trabajar competencias transversales en el aula relacionadas con el desarrollo de habilidades sociales, comunicativas, toma de decisiones y resolución de conflictos. Se ha aplicado una rúbrica para evaluar el proceso de trabajo cooperativo y se han discutido los resultados obtenidos. Finalmente, se incluyen datos del nivel de satisfacción de los alumnos con la actividad propuesta a través de la realización de una encuesta.
\end{abstract}

Palabras clave: Aprendizaje cooperativo, Puzle de Aronson, Trabajo en grupo, Aditivos Alimentarios, Evaluación

\section{Introducción}

El aprendizaje cooperativo se centra en la teoría constructivista que otorga un papel fundamental al alumno, el cual es el actor principal de su propio proceso de aprendizaje (Kagan, 1994). Una situación cooperativa consiste en que un grupo trabaje para alcanzar objetivos comunes que sean beneficiosos tanto para ellos mismos como para los demás miembros del grupo. De la misma forma la responsabilidad para la consecución del objetivo propuesto es compartida por todos los miembros del grupo. Resulta importante 
destacar la diferencia con el aprendizaje competitivo en que cada alumno trabaja en contra de los demás para alcanzar objetivos escolares individuales, o con el aprendizaje individualista, en el que los alumnos trabajan por su cuenta para conseguir objetivos escolares desvinculados a los demás compañeros (Johnson, 1994). Existen cinco elementos clave que se deben cumplir para asegurar que la cooperación se realice adecuadamente (Johnson, 1991).

- El primero de ellos consiste en la interdependencia positiva, que consiste en que grupo debe de hacer frente a un problema o resolver una situación que requiere la participación de todos los miembros del grupo. Del mismo modo, el beneficio obtenido no será individual, sino que beneficiará a todos los integrantes del grupo. Esta interdependencia entre los miembros del grupo fomenta el compromiso con el éxito de otras personas.

- El segundo elemento a cumplir consiste en la responsabilidad tanto individual como grupal. El grupo asume la responsabilidad de alcanzar sus objetivos, y cada miembro del grupo será el responsable de cumplir su tarea concreta de una forma autónoma, adquiriendo las competencias necesarias para realizarla. Asimismo, el individuo es responsable de comunicar al grupo los resultados obtenidos de una forma eficiente.

- El tercer elemento consiste en la interacción estimuladora. El grupo realiza juntos una tarea, en la que cada miembro debe promover el éxito de sus compañeros, compartiendo recursos, ayudándose, animándose, y felicitándose unos a otros por su empeño en aprender. Al participar activamente en el aprendizaje de los demás, los miembros del grupo adquieren un compromiso personal entre ellos, constituyendo un sistema de apoyo y de respaldo personal.

- El cuarto elemento consiste en guiar a los alumnos en la aplicación de prácticas interpersonales y grupales necesarias para funcionar como parte de un grupo de trabajo cohesionado, como ejercer la dirección, toma de decisiones, crear un clima de confianza y motivación, y sobre todo manejar los conflictos. Ya que las técnicas cooperativas promueven la práctica de procedimientos y técnicas para manejar de una manera constructiva los conflictos que se generen.

- Finalmente, el quinto elemento esencial en el trabajo cooperativo consiste en la evaluación grupal, donde los miembros del grupo analizan la consecución de las metas propuestas. En esta parte el grupo debe decidir qué acciones de sus miembros son positivas o negativas, y tomar decisiones para continuar o modificar estas conductas. En este sentido, el hecho de analizar los resultados obtenidos por el grupo durante la actividad y la propuesta de cambios en el plan inicial permite aumentar su eficacia.

El papel del profesor durante la realización de la actividad es fundamental ya que durante este proceso el profesor debe supervisar el correcto desarrollo de la actividad para guiar a los alumnos en la consecución del trabajo propuesto de forma cooperativa siguiendo las cinco pautas mencionadas anteriormente.

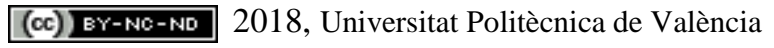

Congreso IN-RED (2018) 
La técnica del puzle de Aronson permite de una manera simple, dinámica y funcional promover el trabajo cooperativo en grupos de trabajo. En dicha estrategia de aprendizaje los estudiantes trabajan en grupos constituidos por un número de integrantes no superior a cuatro personas, en el que se realiza un reparto cooperativo de tareas (Martínez, 2010). Cada alumno se especializa en un tema y lo debe transmitir al resto de compañeros para ayudar a resolver un problema común propuesto. La propia estructura de la estrategia de puzle de Aronson promueve la generación de conflictos, cuya superación consolida, fortalece, prepara y anima al grupo para la resolución de futuros conflictos. Las habilidades que se trabajan y promueven en el desarrollo de actividades centradas en estrategias del tipo puzle de Aronson se basan en: 1) mejorar el aprendizaje cooperativo; 2) desarrollar habilidades sociales, asertivas y de comunicación; 3) desarrollar la solidaridad y el compromiso cívico entre el alumnado; 4) fomentar la autonomía en el aprendizaje; 5) aumentar el rendimiento académico; y 6) desarrollar competencias académicas y profesionales (Traver, 2004).

\section{Objetivos}

En la edición anterior de IN-RED 2017 se presentó la propuesta de implementación de una estrategia tipo Puzle de Aronson en las tutorías asistenciales de la asignatura Aditivos Alimentarios del Grado de Ciencia y Tecnología de los Alimentos de la Universitat de València (Esteve-Turrillas, 2017). A través de esta dinámica de trabajo de grupos se trabajan competencias relacionadas con el aprendizaje cooperativo, se desarrollan habilidades sociales y de comunicación, y se fomenta la autonomía en el aprendizaje. En esta segunda comunicación se aportan los resultados obtenidos en el curso 2017-2018. En primer lugar se evaluó la adecuación de la actividad propuesta para desarrollar el trabajo cooperativo de grupos a través del empleo de una rúbrica. Los resultados obtenidos a partir de dicha rúbrica se discuten en la presente comunicación, así como la valoración del estudiante sobre la dinámica realizada a través de una encuesta de opinión. Finalmente, se han comparado las calificaciones obtenidas en el presente curso, con aquellas obtenidas en el curso 2016-2017.

\section{Desarrollo de la innovación}

\subsection{Contexto de aprendizaje}

La técnica de trabajo cooperativo se ha aplicado por segundo año consecutivo en la asignatura Aditivos Alimentarios correspondiente al Grado de Ciencia y Tecnología de los Alimentos que se imparte en la Facultad de Farmacia de la Universitat de València. La asignatura incluye 25 horas de teoría, 15 horas de prácticas de laboratorio, 2 horas de seminarios coordinado y 2 horas de tutorías presenciales. La asignatura es optativa del grado y se imparte en cuarto curso, con una frecuencia de 2 horas semanales. El número de alumnos en el curso 2016-2017 fue de 33. La asignatura se imparte en un aula con asientos y mesas fijos con una capacidad de 120 personas. El perfil de los estudiante en el curso 
2017-2018 es el siguiente: 69.7 \% mujeres y 30.3 \% hombres, edad promedio de 24.4 años, un $93.9 \%$ no realiza ningún tipo trabajo remunerado. El $57.6 \%$ proceden de P.A.U., el $24.2 \%$ de un ciclo formativo superior, el $12.1 \%$ de programas internacionales de intercambio (Erasmus), el 3.0 \% de pruebas de acceso para mayores de 25 años, y el $3.0 \%$ traslado de otro grado.

\subsection{Contenidos de la asignatura}

Como indica la guía docente, los contenidos que se imparten en la asignatura Aditivos Alimentarios se dividen en 13 temas, correspondientes a las distintas categorías de aditivos alimentarios que se emplean y están permitidos en la Unión Europea. Asimismo se incluye un primer tema de introducción, uno de evaluación toxicológica y finalmente uno de legislación actual relacionada con el área de conocimiento. A continuación se indica el título de los temas impartidos, así como el número de horas asignado a cada tema.

Tema 1. Introducción (1 h)

Tema 2. Aditivos antioxidantes (3 h)

Tema 3. Aditivos antimicrobianos (3h)

Tema 4. Agentes depresores de la actividad de agua (1h)

Tema 5. Antiendurecedores (2 h)

Tema 6. Aromatizantes y potenciadores del sabor (2 h)

Tema 7. Edulcorantes (2 h)

Tema 8. Colorantes (2 h)

Tema 9. Espesantes y gelificantes (2 h)

Tema 10. Emulgentes (1 h)

Tema 11. Auxiliares tecnológicos de fabricación (2 h)

Tema 12. Evaluación toxicológica (2 h)

Tema 13. Legislación relativa a aditivos (2 h)

\subsection{Temporalización de la actividad}

La presente actividad se ha realizado en dos sesiones de tutorías presenciales en el aula (1 hora cada sesión) que se realizó a mitad del primer semestre. Ambas tutorías se realizaron en un plazo de dos semanas. Durante el tiempo transcurrido entre tutorías, el alumno complementó la información, buscando contenidos adicionales fuera del aula (biblioteca, Internet, visitas a supermercados) para preparar la actividad a realizar en la segunda tutoría.

\subsection{Descripción de la tarea}

En las tutorías de esta asignatura se desarrolló una actividad basada en el puzle de Aronson para fomentar el trabajo cooperativo de grupos. Los alumnos se dividieron en dos grupos de 16 personas aproximadamente para realizar las tutorías, ya que el número de alumnos fue relativamente reducido. La actividad propuesta consistió en la resolución por

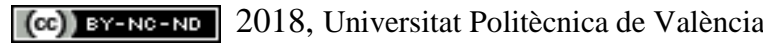

Congreso IN-RED (2018) 
grupos de trabajo de diferentes problemas prácticos relacionados con el uso de Aditivos Alimentarios en la formulación de alimentos de diferente tipo.

En una primera etapa, se crearon cuatro grupos de trabajo, con cuatro alumnos cada uno seleccionados de forma aleatoria. Se debe evitar la formación de grupos preconcebidos, para evitar el agrupamiento de alumnos acostumbrados a trabajar entre ellos que inconsciente presentarían roles pre-asignados, para de esta forma fomentar la interacción entre los alumnos miembros. A cada uno de estos grupos iniciales se les asigna la tarea de resolver un problema de tipo práctico, proponer de forma consensuada y razonada la adición de aditivos si fuera necesario y el por qué en un determinado alimento. En una segunda etapa cada uno de los miembros del grupo inicial se dividió en 4 grupos de expertos para que se formaran en una materia específica (ver esquema en Figura 1). Los cuatro expertos, procedentes de cada uno de los diferentes grupos iniciales, se forman durante este tiempo en un grupo concreto de aditivos alimentarios frecuentemente empleados en alimentos, como antioxidantes, conservantes, edulcorantes, y colorantes. Cada grupo de expertos se sitúa en los extremos del aula para no interferir entre ellos y el profesor va coordinando las actividades dentro de cada grupo de expertos, para orientar al grupo y dirigir su aprendizaje en aquellos temas clave. Durante esta etapa, la formación consiste en la consulta y discusión de los apuntes de clase, clasificando los aditivos por naturaleza, riesgo, frecuencia de uso, características físico-químicas y coste.

\section{Grupos de expertos}

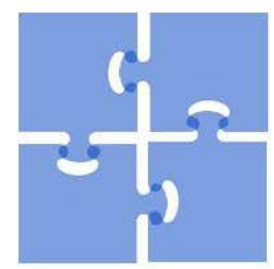

Antioxidantes

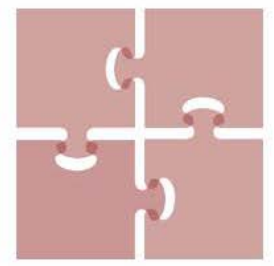

Conservantes

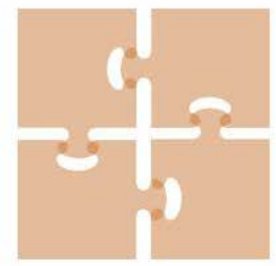

Edulcorantes

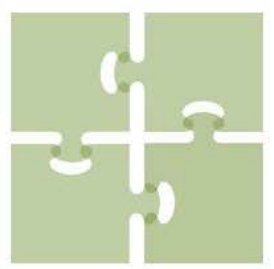

Colorantes

\section{Grupos de trabajo}
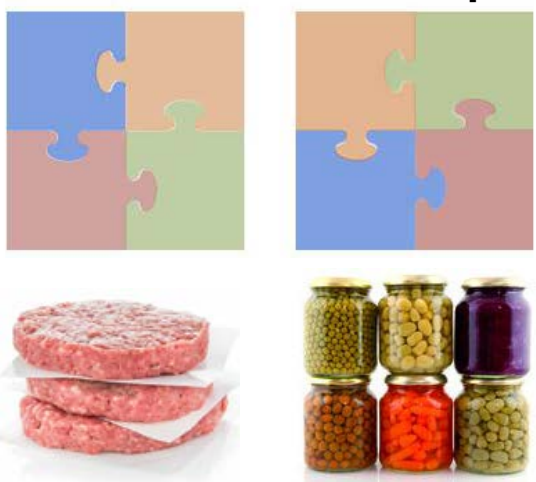

Vegetales
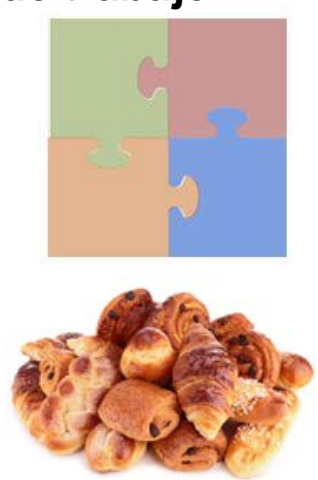

Bolleria
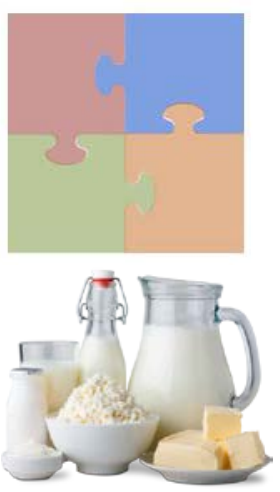

Lácteos

Fig. 1 Esquema de los grupos de expertos y de trabajo seleccionados en la actividad propuesta. 
Tras la primera sesión de tutoría, los expertos en aditivos buscan información adicional fuera del aula para complementar los conocimientos necesarios para poder ser empleados en la segunda tutoría. Esta búsqueda de información se realiza tanto por bibliografía reglada (libros, revistas, periódicos), como no reglada (consulta en Internet, foros, redes sociales, etc.). Además se hace especial hincapié en la evaluación de los ingredientes y aditivos que contienen los alimentos que los alumnos tengan en sus casas, y se propone la realización de trabajos de investigación con visitas a supermercados y tiendas locales para relacionar los diferentes aditivos estudiados en clase con ciertos grupos de alimentos. Durante las dos semanas que transcurren entre tutorías se hizo un seguimiento de la actividad para fomentar y promover esta búsqueda activa de etiquetas de alimentos. Este seguimiento se realizó durante el transcurso de clases de teoría.

La tercera fase se realizó el segundo día de tutoría. En ella, los expertos que se han formado en cada tipo de aditivos alimentarios se reagrupa en los cuatro grupos de trabajo iniciales para abordar la resolución del problema formulado el primer día de tutoría. La primera actividad a realizar consiste en la identificación y discusión de cada uno de los grupos de aditivos que contienen alimentos elaborados del siguiente tipo: productos cárnicos, vegetales envasados, panadería y bollería, y lácteos (ver Figura 1). Para la realización de esta actividad los alumnos deben de llevar a clase etiquetas de alimentos (o fotografías) recopiladas en los días previos a la realización de la segunda tutoría. En esta etapa, los alumnos proceden a realizar una evaluación del tipo de aditivos que llevan los alimentos, el por qué, posibles riesgos toxicológicos, consecuencias de su retirada de la formulación, propuesta de posibles sustitutos, y búsqueda de efectos sinérgicos. La Figura 2 muestra un ejemplo de las etiquetas originales que aportaron los estudiantes. Finalmente, cada grupo propone el tipo de aditivos a emplear en el alimento problema propuesto, su justificación, y si existe algún tipo de alternativa al empleo de los aditivos alimentarios propuestos.

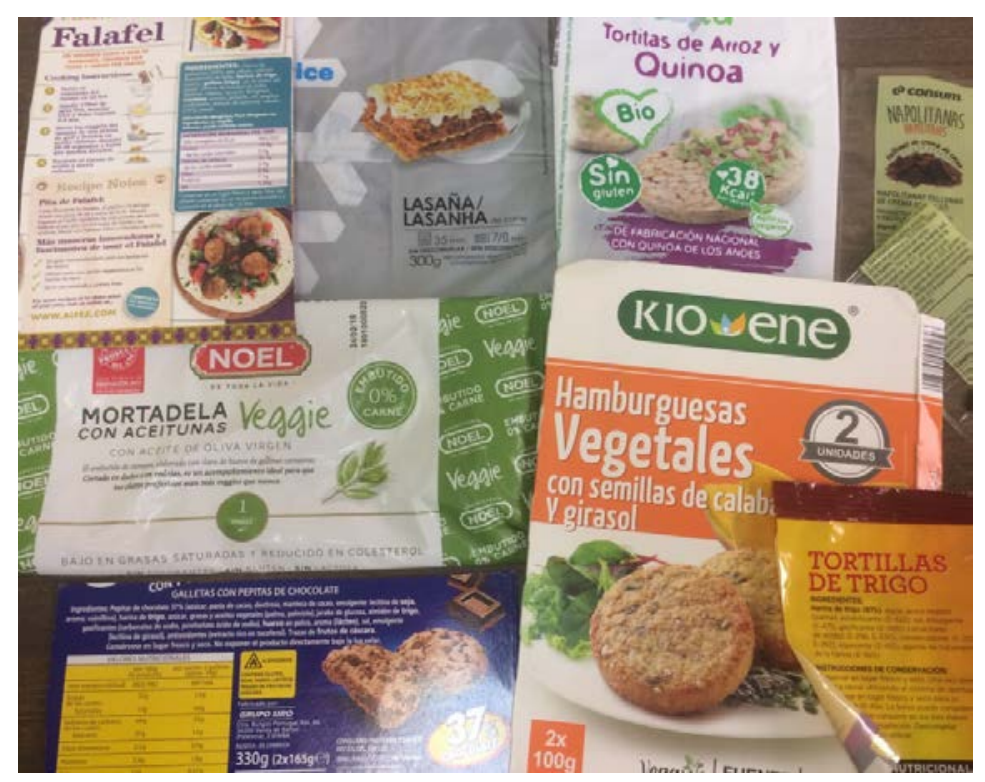

Fig. 2. Ejemplo etiquetas de alimentos recopiladas por los alumnos.

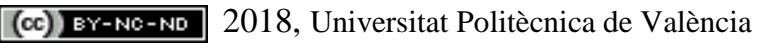

Congreso IN-RED (2018) 


\section{Resultados}

\subsection{Resultados de aprendizaje}

Con la tarea propuesta se pretende incitar al alumnado al empleo de herramientas cooperativas para facilitar la resolución de problemas. Concretamente se pretende desarrollar las siguientes competencias y habilidades sociales que figuran en la guía docente de la asignatura, como 1) capacidad de aplicar los conocimientos a la práctica; 2) razonamiento crítico que les permita emitir juicios argumentados y defenderlos con rigor y tolerancia; y 3) capacidad de trabajar en grupo, responsabilidad compartida, gestión de conflictos, y propuesta de soluciones objetivas. Adicionalmente, con el desarrollo de la actividad el alumno afianza los conceptos teóricos impartidos en clase, los complementa con información adicional y los pone en práctica. Debido a la temporalidad de la actividad, que se realiza a mitad de curso, el problema propuesto se centrará en aquellas familias de aditivos alimentarios más frecuentemente empleadas, que además se imparten en los primeros temas de la asignatura, como antioxidantes, antimicrobianos, edulcorantes y colorantes. En la primera sesión el estudiante repasa los conceptos teóricos y los amplía mediante la consulta de los apuntes de clase, consulta de libros especializados, o información adicional en Internet. En este sentido, resulta relevante el empleo de redes sociales y páginas de Internet para la búsqueda de contenidos adicionales, ya que esta información no reglada permite a los grupos de expertos discutir la veracidad o falsedad parcial de la información que está disponible en la red, lo que contribuye a fomentar su capacidad crítica.

En la segunda sesión de la actividad, lo grupos iniciales se reagrupan con cuatro expertos, ya formados, en cada uno de los aditivos alimentarios a evaluar. Cada grupo de trabajo comenzó a evaluar, discutir y justificar los aditivos presentes en las distintas etiquetas de alimentos suministradas por el profesor y también por los mismos alumnos. Durante esta etapa, los alumnos ven cuales son los aditivos que se emplean más frecuentemente y deben intentar relacionar ciertos aditivos específicos para grupo de alimentos concretos.

Finalmente, se les propone formular los aditivos que debe llevar un alimento concreto para que el grupo decida de una manera consensuada, razonada y justificada los productos químicos que se les debe añadir para ampliar su vida útil. En esta etapa del proceso cada miembro experto del grupo debe justificar y defender la presencia de su tipo de aditivo en la formulación final del alimento, lo que contribuye a la aparición de conflictos, que se deben resolver de forma consensuada para conseguir el mejor producto final. La resolución de conflictos y toma de decisiones comunes son competencias que resultarán de gran utilidad para el desarrollo de la carrera profesional de los alumnos.

\subsection{Evaluación de la actividad}

El aprendizaje por trabajo cooperativo se incorporó a la asignatura de Aditivos Alimentarios en el curso 2016-2017. En este primer año se hizo una evaluación del proceso de aprendizaje meramente cualitativa, y no se disponía de indicadores cuantitativos para asegurar que el alumno conseguía trabajar de forma cooperativa. Para la evaluación de 
dicha actividad se ha empleado una evaluación de tipo mixta con una parte formativa que valoró solo el proceso de aprendizaje (trabajo cooperativo) y otra sumativa para valorar la viabilidad y adecuación del resultado al problema propuesto. La contribución de cada una de estas partes será del $50 \%$. La evaluación de la parte formativa se realizó a través de la autoevaluación del alumno mediante el empleo de una rúbrica para conocer lo útil que ha sido esta herramienta para fomentar el trabajo cooperativo. La Tabla 1 muestra la rúbrica empleada con 7 criterios a evaluar en cuatro niveles. Los criterios fueron 1) Participación grupal, 2) Roles dentro del grupo, 3) Responsabilidad compartida, 4) Delegación de responsabilidad, 5) Calidad de interacción, 6) Calidad de las fuentes, y 7) ¿̇Se han cumplido los objetivos del equipo?. Mientras que el cumplimiento de cada criterio se evaluó como excepcional, admirable, aceptable o mejorable, puntuables con 10, 6, 4 y 0 puntos respectivamente. Se consideró que se ha trabajado de forma cooperativa cuando la nota final (la suma de todos los puntos obtenidos en cada criterio dividido por el número de criterios) era superior a 5 puntos. La evaluación de la parte formativa la realizó el profesor tras comprobar el resultado al problema propuesto y su correcta justificación.

El grado de cooperación conseguido en el trabajo en equipo propuesto se muestra en la Figura 3, con los resultados obtenidos a través de la autoevaluación por medio de la rúbrica anteriormente mencionada. En general la mayoría de criterios mostraron una respuesta favorable respecto al trabajo cooperativo, sobre todo el criterio 1 referente a la participación grupal con un 80.6 \% de puntuaciones excepcionales. Sin embargo, cabe destacar la menor puntuación del criterio 4 (delegación de responsabilidad) en el que un $51.6 \%$ valuaron como excepcional, mientras que un $41.9 \%$ como admirable. Esto se puede deber a que cada estudiante se hace responsable de la información que se le ha asignado buscar, pero en muchos casos no se identifica adecuadamente qué información es necesaria y relevante para el grupo y cual no. Por lo que se debe trabajar y hacer más hincapié en que la responsabilidad es compartida por todos los miembros del grupo y no existe ningún tipo de jerarquía con miembros con más responsabilidad o funciones que otros. Otro aspecto a tener en cuenta está relacionado con el criterio 6 (calidad de las fuentes), en el que a pesar que mayoritariamente se ha evaluado como excepcional (67.7\%) existe un porcentaje relativamente elevado de resultados aceptables (12.9\%), e incluso mejorable (3.2 \%). Este resultado es relevante, ya que a pesar de no ser mayoritario, existe un número determinado de alumnos que solo utilizó los apuntes de clases para realizar la tarea propuesta o incluso en algún caso no se utilizó ninguna fuente, mostrando una falta de interés en realizar esta actividad. Los aspectos que han tenido una menor puntuación se intentarán mejorar en el próximo curso, principalmente aquellos relacionados con la responsabilidad compartida del grupo y la falta de interés. De todos modos, se considera que los alumnos realizaron mayoritariamente la tarea propuesta mediante trabajo en grupo cooperativo de una manera muy satisfactoria. Además, el empleo de la rúbrica propuesta nos permite identificar aquellos puntos del proceso donde tenemos que hacer un esfuerzo extra tanto en el momento inicial en el que se plantea la tarea como en la supervisión del profesor durante su ejercicio. 
Tabla 1. Rúbrica propuesta para evaluar la capacidad de cooperación del grupo para solucionar un problema propuesto.

\begin{tabular}{|c|c|c|c|c|c|}
\hline & $\begin{array}{c}\text { Excepcional } \\
\text { (10 puntos) }\end{array}$ & $\begin{array}{c}\text { Admirable } \\
\text { (6 puntos) }\end{array}$ & $\begin{array}{l}\text { Aceptable } \\
\text { (4 puntos) }\end{array}$ & $\begin{array}{c}\text { Mejorable } \\
\text { (0 puntos) }\end{array}$ & Total \\
\hline $\begin{array}{l}\text { Participación } \\
\text { grupal }\end{array}$ & $\begin{array}{l}\text { Todos los } \\
\text { estudiantes } \\
\text { participan } \\
\text { activamente en } \\
\text { la actividad. }\end{array}$ & $\begin{array}{l}\text { La mayoría de los } \\
\text { estudiantes } \\
\text { participan } \\
\text { activamente. }\end{array}$ & $\begin{array}{l}\text { Al menos la mitad } \\
\text { de los estudiantes } \\
\text { presentan ideas } \\
\text { propias. }\end{array}$ & $\begin{array}{l}\text { No existe } \\
\text { participación } \\
\text { activa. }\end{array}$ & \\
\hline $\begin{array}{l}\text { Roles dentro del } \\
\text { grupo }\end{array}$ & $\begin{array}{l}\text { Cada estudiante } \\
\text { tiene un rol } \\
\text { asignado bien } \\
\text { definido. }\end{array}$ & $\begin{array}{l}\text { Cada estudiante } \\
\text { tiene un rol } \\
\text { asignado, pero no } \\
\text { está claramente } \\
\text { definido o no es } \\
\text { consistente. }\end{array}$ & $\begin{array}{l}\text { Hay roles } \\
\text { asignados a los } \\
\text { estudiantes, pero } \\
\text { no se adhieren } \\
\text { consistentemente a } \\
\text { ellos. }\end{array}$ & $\begin{array}{l}\text { No hay ningún } \\
\text { esfuerzo de } \\
\text { asignar roles a } \\
\text { los miembros. }\end{array}$ & \\
\hline $\begin{array}{l}\text { Responsabilidad } \\
\text { compartida }\end{array}$ & $\begin{array}{l}\text { Todos comparten } \\
\text { por igual la } \\
\text { responsabilidad } \\
\text { sobre la tarea }\end{array}$ & $\begin{array}{l}\text { La mayor parte de } \\
\text { los miembros del } \\
\text { grupo comparten } \\
\text { la responsabilidad } \\
\text { en la tarea }\end{array}$ & $\begin{array}{l}\text { La responsabilidad } \\
\text { es compartida por } \\
\text { la mitad de los } \\
\text { integrantes del } \\
\text { grupo }\end{array}$ & $\begin{array}{l}\text { La } \\
\text { responsabilidad } \\
\text { recae en una sola } \\
\text { persona }\end{array}$ & \\
\hline $\begin{array}{l}\text { Delegación de } \\
\text { responsabilidad }\end{array}$ & $\begin{array}{l}\text { Cada estudiante } \\
\text { en el grupo puede } \\
\text { explicar qué } \\
\text { información es } \\
\text { necesaria para el } \\
\text { grupo y qué } \\
\text { información es } \\
\text { responsable de } \\
\text { localizar. }\end{array}$ & $\begin{array}{l}\text { Cada estudiante } \\
\text { en el grupo puede } \\
\text { explicar qué } \\
\text { información es } \\
\text { responsable de } \\
\text { localizar. }\end{array}$ & $\begin{array}{l}\text { Cada estudiante en } \\
\text { el grupo puede, } \\
\text { con la ayuda de } \\
\text { sus compañeros, } \\
\text { explicar qué } \\
\text { información es } \\
\text { responsable de } \\
\text { localizar. }\end{array}$ & $\begin{array}{l}\text { Uno o más } \\
\text { estudiantes en el } \\
\text { grupo no pueden } \\
\text { explicar qué } \\
\text { información } \\
\text { ellos son } \\
\text { responsables de } \\
\text { localizar. }\end{array}$ & \\
\hline $\begin{array}{l}\text { Calidad de } \\
\text { interacción }\end{array}$ & $\begin{array}{l}\text { Todos los } \\
\text { alumnos se } \\
\text { expresan } \\
\text { adecuadamente, } \\
\text { saben escuchar y } \\
\text { se respetan los } \\
\text { puntos de vista y } \\
\text { opiniones de los } \\
\text { demás. }\end{array}$ & $\begin{array}{l}\text { La mayor parte de } \\
\text { los alumnos se } \\
\text { expresa } \\
\text { adecuadamente, } \\
\text { sabe escuchar y } \\
\text { respeta los puntos } \\
\text { de vista y } \\
\text { opiniones de los } \\
\text { demás. }\end{array}$ & $\begin{array}{l}\text { Una minoría de los } \\
\text { alumnos se } \\
\text { expresa } \\
\text { adecuadamente, } \\
\text { sabe escuchar y } \\
\text { respeta los puntos } \\
\text { de vista y } \\
\text { opiniones de los } \\
\text { demás. }\end{array}$ & $\begin{array}{l}\text { Existe muy poca } \\
\text { interacción, } \\
\text { conversación } \\
\text { muy breve, } \\
\text { distracciones o } \\
\text { desinterés. }\end{array}$ & \\
\hline $\begin{array}{l}\text { Calidad de las } \\
\text { fuentes }\end{array}$ & $\begin{array}{l}\text { Se han utilizado } \\
\text { los apuntes de la } \\
\text { signatura y se han } \\
\text { ampliado en } \\
\text { búsquedas por } \\
\text { Internet y } \\
\text { legislación } \\
\text { oficial. }\end{array}$ & $\begin{array}{l}\text { Se han utilizado } \\
\text { los apuntes de la } \\
\text { signatura y se han } \\
\text { ampliado en } \\
\text { búsquedas por } \\
\text { Internet. }\end{array}$ & $\begin{array}{l}\text { Se han utilizado } \\
\text { los apuntes de la } \\
\text { asignatura } \\
\text { exclusivamente. }\end{array}$ & $\begin{array}{l}\text { No se ha } \\
\text { utilizado ningún } \\
\text { tipo de fuente. }\end{array}$ & \\
\hline $\begin{array}{l}\text { ¿Se han } \\
\text { cumplido los } \\
\text { objetivos del } \\
\text { equipo? }\end{array}$ & $\begin{array}{l}\text { Si, con gran } \\
\text { probabilidad de } \\
\text { implantación. }\end{array}$ & $\begin{array}{l}\text { Sí, con poca } \\
\text { probabilidad de } \\
\text { implantación. }\end{array}$ & Parcialmente. & No. & \\
\hline & & & & \multicolumn{2}{|l|}{$\begin{array}{l}\text { Nota final = } \\
\text { (puntos } / 7 \text { ) }\end{array}$} \\
\hline
\end{tabular}

Para finalizar, el rendimiento académico conseguido fue de $3.3 \%$ matrícula de honor, $6.7 \%$ sobresaliente, $56.7 \%$ notable, $30.0 \%$ aprobado, $3.3 \%$ suspenso, y $9.1 \%$ no presentado. El número de aprobados en la asignatura es inferior al curso 2016-2017, pero se debe tener en cuenta que aún falta realizar la segunda convocatoria de dicha asignatura, por lo que es probable que a final de curso el porcentaje de aprobados sea superior. 


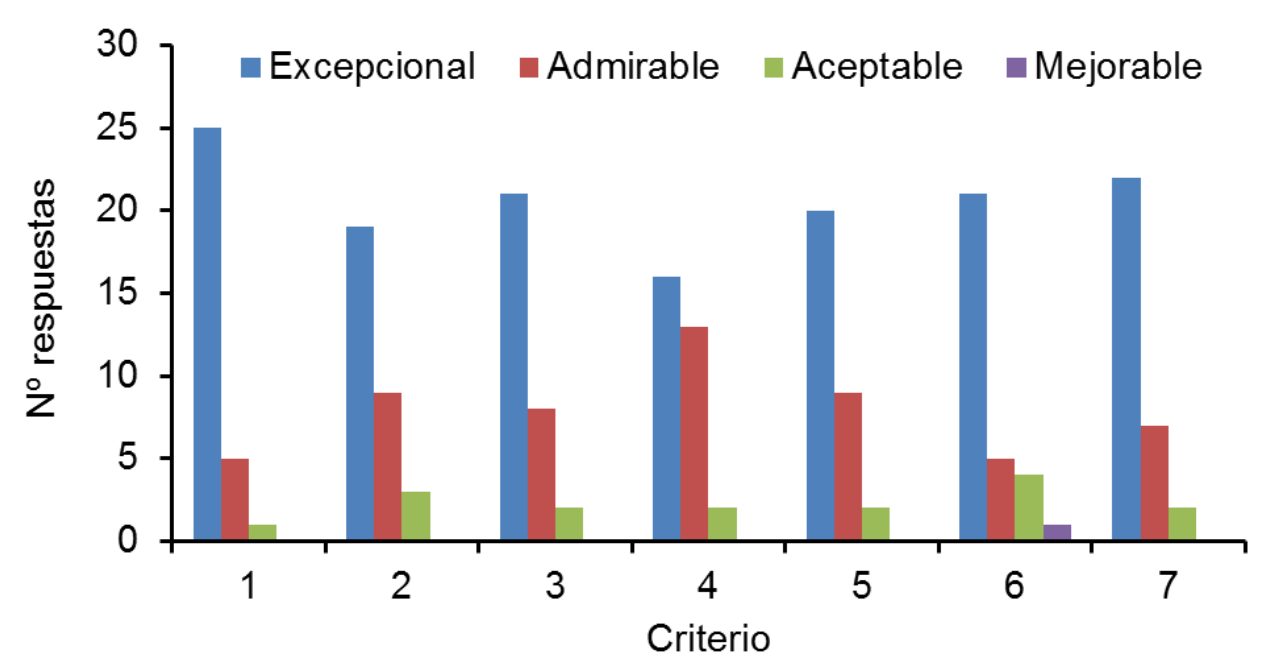

Fig. 3. Resultados obtenidos para cada criterio de la rúbrica.

Adicionalmente, al finalizar la tarea propuesta los alumnos rellenaron un cuestionario para conocer su grado de satisfacción y opinión acerca del trabajo cooperativo en grupo. A los alumnos se le hicieron cuatro preguntas cortas: 1) ¿Has realizado con anterioridad alguna actividad para fomentar el trabajo cooperativo?, 2) ¿Crees que se ha incrementado tu capacidad para trabajar de forma cooperativa?, 3) ¿Qué opinas del trabajo cooperativo?, y 4) Indica tu grado de satisfacción con la actividad propuesta. La Figura 4 muestra las respuestas a las cuatro preguntas efectuadas. Como se observa en la figura el 45 \% de los alumnos habían realizado con anterioridad actividades que implicaban trabajo cooperativo y un 19\% nunca. Sin embargo, lo más relevante es el 36\% de alumnos que dudan o no están seguros de haber realizado dichas tareas. Algo similar ocurre con la percepción para trabajar de forma cooperativa, en el que $68 \%$ duda sobre si se ha incrementado o no su capacidad de trabajo, mientras que un $32 \%$ afirma rotundamente que sí lo ha hecho. Eso refleja claramente la confusión entre trabajo en grupo y trabajo en grupo cooperativo cuya barrera no está claramente delimitada para el alumno y su percepción es ambigua. Por lo que para el próximo año, se hará más hincapié en la explicación del trabajo cooperativo y las diferencias fundamentales con trabajo individual y competitivo. Respecto a la utilidad del trabajo cooperativo un $77 \%$ lo considera muy útil y un $23 \%$ cree que puede tener alguna utilidad, siendo el grado de satisfacción para un $42 \%$ es adecuado y para un 52 $\%$ medio-alto.

Debido a la respuesta favorable y el interés mostrado por los alumnos se continuará realizando la presente actividad el curso que viene, incorporando ligeros cambios para asegurar la correcta aplicación del trabajo en grupo y mejorar la motivación entre aquellos estudiantes de baja participación. Además, el desarrollo de este tipo de actividades nos permite trabajar competencias transversales que son difíciles de incorporar y no se aplican habitualmente en el aula.

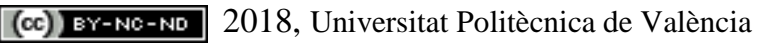

Congreso IN-RED (2018) 

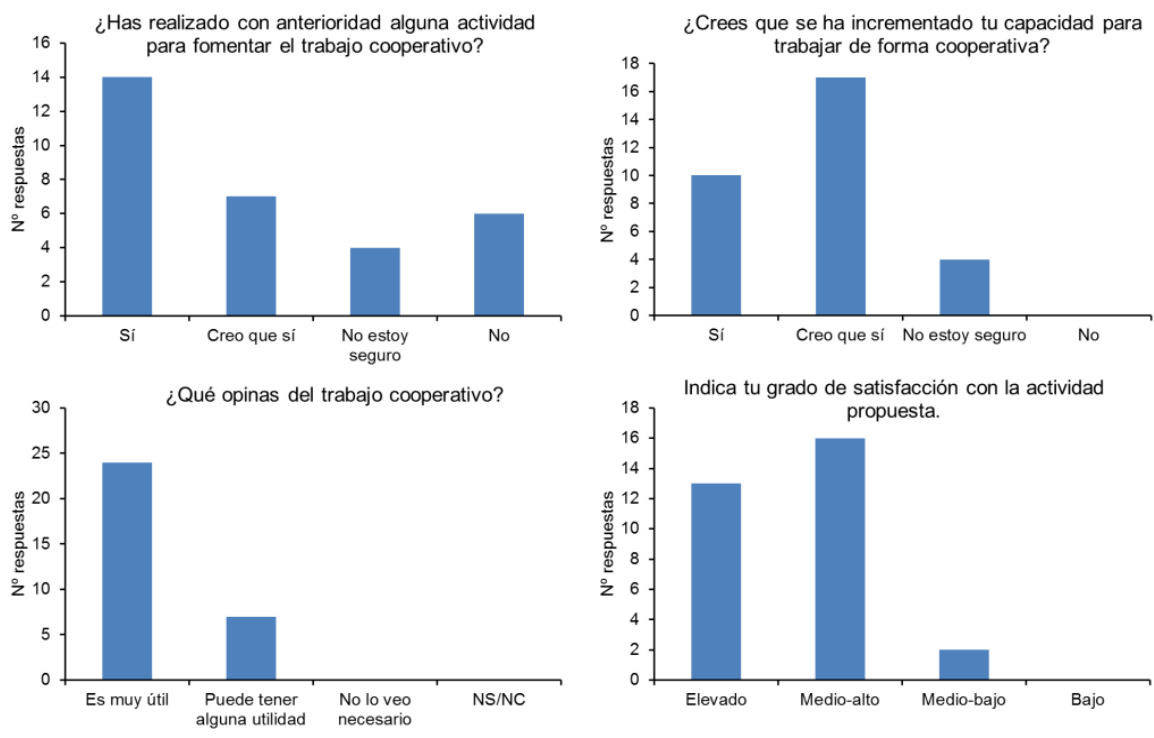

Fig. 4. Cuestionario de opinión de la actividad propuesta.

\section{Conclusiones}

El empleo de una dinámica de trabajo cooperativo en grupo, basada en el puzle de Aronson, se ha incorporado por segundo año consecutivo a las tutorías de la asignatura de Aditivos Alimentarios del Grado de Ciencia y Tecnología de los Alimentos de la Universitat de València. A través del empleo de esta metodología se trabajan en el aula competencias relacionadas con el trabajo cooperativo, se desarrollan habilidades sociales y de comunicación, y se fomenta la resolución de conflictos del grupo. En este segundo año, se ha empleado una rúbrica para evaluar el proceso de trabajo cooperativo que ha resultado de mucha utilidad para asegurar la consecución del objetivo propuesto. Adicionalmente, los resultados obtenidos a través de dicha rúbrica nos han permitido en algunos casos detectar fallos de ejecución, que se intentarán mejorar en la aplicación de esta dinámica el curso que viene. En este sentido, se debe fomentar que el alumno perciba que la responsabilidad en la resolución del problema propuesto debe recaer en todos sus miembros. Adicionalmente, se realizó una encuesta para evaluar el grado de utilidad y satisfacción para el alumno en la consecución de dicha tarea. El grado de satisfacción fue muy elevado entre el alumnado, así como la visión positiva de las técnicas de trabajo cooperativo. Sin embargo, se ha identificado que el alumno no percibió con claridad las diferencias entre trabajo en grupo y trabajo cooperativo en grupo, ya que la encuesta ha reflejado dudas a la hora de identificar si la actividad propuesta ha mejorado su capacidad de trabajar cooperativamente. Finalmente, desde el punto de vista del profesor, el balance final ha sido muy positivo ya que se ha fomentado el desarrollo de habilidades sociales y el trabajo en grupos cooperativos para la resolución de problemas, todo ello en un marco estrechamente ligado a los conocimientos teóricos-técnicos que se imparten en la asignatura de aditivos alimentarios. 


\section{Referencias}

JOHNSON, D. y JOHNSON, R. (1991). Learning together and alone. Cooperative, competitive and individualistic learning. Needham Heights, Allyn and Bacon.

JOHNSON, D.W., JOHNSON, R.T., y HOLUBEC, E.J. (1994). Cooperative Learning in the Classroom. Association For Supervision and Curriculum Development, Virginia, USA.

KAGAN, S. (1994). Cooperative Learning. San Clemente, CA, USA.

MARTÍNEZ, J. y GÓMEZ, F. (2010). La técnica puzzle de Aronson: descripción y desarrollo, en Arnaiz, P., Hurtado, M.D., y Soto, F.J. 25 Años de Integración Escolar en España: Tecnología e Inclusión en el ámbito educativo, laboral y comunitario. Murcia: Consejería de Educación, Formación y Empleo.

TRAVER, J. A. y GARCÍA, R. (2004). "La enseñanza-aprendizaje de la actitud de solidaridad en el aula: una propuesta de trabajo centrada en la aplicación de la técnica puzzle de Aronson” en Revista Española de Pedagogía, 229, 419.

ESTEVE-TURRILLAS, F.A. y ARMENTA, S. (2017). "Empleo de la estrategia puzle de Aronson para fomentar la cooperación en grupos” en Congreso In-Red 2017, Valencia. Disponible

http://dx.doi.org/10.4995/INRED2017.2017.6867> 


\title{
Generación colaborativa de conocimiento. Una experiencia de aprendizaje basada en equipos o Team Based Learning (TBL) en la práctica odontológica.
}

\author{
Úrsula Muñoz $^{\mathrm{a}}$, Esther Escudero ${ }^{\mathrm{b}}$, Rima Barhoum ${ }^{\mathrm{c}}$, Maria de la Cruz Sádaba ${ }^{\mathrm{d}}$, Isabel \\ Sánchez-Vera ${ }^{\mathrm{e}}$.
}

aursula.munozmoron@ceu.es, ${ }^{\text {bestheresc@ceu.es, }}$,rbarho@ceu.es,

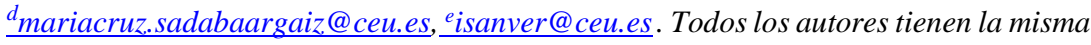
procedencia: Sección de Fisiología. Dpto. Ciencias Médicas Básicas. Facultad de Medicina. Universidad San Pablo CEU, Madrid.

\begin{abstract}
Lectureres teaching Physiology in the degree of Dentistry at the San Pablo CEU University have been involved in the past years in updating the teaching methodology in the field. The aim has been to favour the acquisition of several competencies by the students such us work autonomy along the progress of the subject, ability to look for and to find information from different sources, acquisition and use of several communication techniques and the implementation of collaborative work. The ultimate goal of these competencies is to broaden their abilities and deepen in knowledge acquisition so they become able to communicate and expand this knowledge in an academic environment. In this work we analyse one of these methodologies, an experience based in Team Based Learnign (TBL) in which additonallyy we have iused gamification learning techniques. The implementation of the new method has been carried out by using digital tools to facilitate information acquisition. The results obtained indicate that this new methodology increases the acquisition of knowledge, minimizes the time of work outside the classroom and improves their communication skills.
\end{abstract}

Keywords: team work, puzzle technique, expert groups ,test, polls, participation 
Generación colaborativa de conocimiento. Una experiencia de aprendizaje basada en equipos o Team Based Learning (TBL) en la práctica odontológica.

\begin{abstract}
Resumen
En la asignatura de Fisiología del Grado de Odontología los profesores están comprometidos de forma activa en actualizar la metodología docente a utilizar. En los últimos años, se ha fomentado que el alumno adquiriera distintas competencias como son: el aumento de su autonomía para gestionar su progreso en la asignatura, la búsqueda de información en fuentes diversas, el manejo de distintas modalidades de comunicación y el trabajo colaborativo. El objetivo de estas competencias está dirigido a que amplíen sus destrezas para profundizar en la adquisición de los conocimientos y que sean capaces de divulgarlos en el entorno académico. Con esta intención, en la asignatura de Fisiología, se han ofrecido a los alumnos distintas metodologías de aprendizaje. En la presente memoria se aborda el análisis de una de estas metodologías, la experiencia en el aprendizaje basada en equipos o Team Based Learning (TBL), dónde además se han ulizado técnicas de gammificación. La implementación de este método se ha llevado a cabo a través de herramientas digitales para facilitar la recogida sistémica de información. Los resultados obtenidos indican que esta nueva metodología aumenta la adquisición de conocimientos, minimiza el tiempo de trabajo fuera del aula y mejora sus capacidades comunicativas.
\end{abstract}

Palabras clave: Trabajo colaborativo y cooperativo, técnica puzzle, grupo de expertos, autoevaluación, encuestas, participación

\title{
Introducción
}

Para la adquisición de conocimiento por parte del alumnado es imprescindible el compromiso de realizar un trabajo autónomo de integración, comprensión, relación y almacenamiento de conceptos relacionados con el saber (Jensen et al., 2003). Además, es parte vertebral del aprendizaje que los conocimientos que se transmiten en clase sean asimilados, entendidos y relacionados de forma integral por los alumnos (Arceo et al., 2002). Por otro lado, es importante conseguir un abanico amplio de destrezas cognitivas y para ello es importante proporcionar métodos de aprendizaje activos de diferentes características (Zabalza, 2012), de tal manera que el proceso de aprendizaje no esté basado únicamente en el profesor como instructor, sino que en el aula se genere un binomio de "aprendizaje/facilitación del aprendizaje" (Barr and Tagg, 1995; García Valcárcel, 1993; Monereo y Pozo, 2003). Este último modelo está enfocado a favorecer la adquisición del saber a través de un aprendizaje autónomo de tal manera que el conocimiento se elabore de forma colaborativa entre iguales y que el profesor actúe como un mediador (Gargallo et al., 2015). Así el alumno pasa a estar directamente implicado en su proceso de aprendizaje investigando, cuestionando, haciendo aportaciones propias y siendo capaz de autoevaluarse y regular la evolución de su conocimiento (Machemer y Crawford, 2007).

En los últimos años, los profesores de la asignatura de Fisiología han pretendido implementar el método "aprendizaje/facilitación del aprendizaje" pretendiendo obtener distintas competencias por parte del alumnado como son: la búsqueda de información en diversas fuentes fiables, el manejo de distintas modalidades de comunicación, y el aumento de la autonomía para gestionar su progreso en la asignatura y el trabajo colaborativo. El objetivo

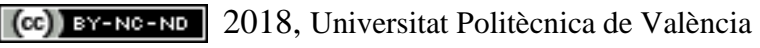

Congreso IN-RED (2018) 
ha estado dirigido a ampliar las destrezas de los alumnos para que profundicen en el conocimiento y a formarles como divulgadores de su pensamiento en el entorno académico. Con esta intención, se ha planteado que el alumno realice distintas actividades, que han sido:

- realización de autoevaluaciones en la plataforma BlackBoard,

- uso de un foro informático para la puesta en común de información aportada por los alumnos,

- cumplimentación de un cuestionario para valorar la utilizad docente de cada una de las actividades propuestas.

- manejo de motores de búsquedas informáticos y repositorios bibliográficos

- trabajos en equipo

- exposición de trabajos orales

Muchas de estas actividades ya se han puesto en marcha en nuestro Departamento con una gran aceptación por parte del alumnado y un aumento de su rendimiento académico. Un ejemplo de estas metodologías fue la realización de autoevaluaciones en la plataforma BlackBoard y el uso de un foro informático para la puesta en común de la información aportada por los alumnos (Escudero et al 2017; Sanchez-Vera et al 2017). Otras actividades, como la elaboración de seminarios por parte de los alumnos, están siendo modificadas con el objetivo de aumentar la adquisición de conocimientos, minimizar el tiempo de trabajo fuera del aula y mejorar sus capacidades comunicativas. Para poder llevar a cabo este objetivo hemos desarrollado una nueva metodología de aprendizaje siguiendo la experiencia en el aprendizaje basado en equipos o Team Based Learning (TBL) (Larry Michaelsen et al. 2004, Michaelsen y Sweet 2009, Estelles-Miguela et al 2017) que hemos modificado utilizando nuevas técnicas de aprendizaje basado en cooperación (Ricard, 2010).

Este tipo de metodologías nos ha permitido mejorar el aprendizaje colaborativo mediante la creación de equipos de alto rendimiento que cooperan entre ellos a la vez que compiten para demostrar el resultado de aprendizaje deseado. La implementación de este método para fomentar el estudio previo y el trabajo en equipo se lleva a cabo mediante los smartphones de los alumnos mediante programas como Socrative, Kahoot, o Quizizz. Este tipo de plataformas se utilizan en clase, permiten al alumno conocer las respuestas de forma inmediata y al profesor la recogida de resultados de forma automática. Además, consideramos muy interesante utilizar este tipo de metodologías de aprendizaje cooperativo, ya que, generan estructuras de interacción y de ayuda mutua en la que todos salen ganando. A veces para el alumno es más fácil cuando tienen dificultades acudir a un igual, el aprendizaje cooperativo ayuda a crear estas vías cercanas y alternativas al profesor. El aprendizaje mejora cuando enseñas y aprendes de otros.

\section{Objetivos}

El objetivo principal de este trabajo es proponer una nueva metodología de aprendizaje basada en equipos o Team Based Learning (TBL) junto con el uso de técnicas de aprendizaje cooperativo. 
para aumentar el porcentaje de aciertos en preguntas aplicadas sobre fisiología del sistema nervioso en las pruebas de evaluación continua realizadas a los alumnos de primer curso del Grado en Odontología.

Con la puesta en marcha de esta experiencia se buscaba dos objetivos concretos:

1. Aumentar la participación activa del alumno en la generación de nuevo conocimiento a partir de conocimientos aprendidos en el aula y fuera de ella.

2. Familiarizarse con preguntas aplicadas basadas en el conocimiento previo.

\section{Desarrollo de la innovación}

En esta memoria se presenta el análisis y las reflexiones obtenidas sobre la aplicación de una metodología basada en el Aprendizaje Basado en Equipos o Team Based Learning (TBL) en la preparación de un seminario sobre una aplicación clínica de una parte de los conocimientos desarrollados en la asignatura de Fisiología. Esta asignatura se imparte en el segundo semestre del $1^{\circ}$ curso del Grado en Odontología, es de carácter obligatorio y consta de 6 créditos ECTS. El estudio se ha realizado con los 84 alumnos matriculados en los dos grupos del curso académico 2017-18.

\section{Fase previa a la organización del seminario}

El tema propuesto para el seminario es el dolor orofacial. Este tema es uno de lo más importantes para los estudiantes de Odontología, ya que tienen que integrar los conocimientos aprendidos previamente acerca de la fisiología del sistema nervioso con una aplicación clínica como es el dolor orofacial y sus tratamientos. Por ello, en esta fase previa el profesor les explica en el aula todos los conceptos fundamentales para poder desarrollar posteriormente esta actividad. Una vez explicado el tema, para saber si los alumos han comprendido la materia impartida se evalúa el grado de adquisión de conocimiento básico antes de la experiencia TBL utilizando la aplicación Socrative donde se les pregunta cuestiones importantes relacionadas con la fisiología del sistema nervioso. Posteriormente se pasa al desarrollo de la actividad propuesta con la novedad de que en la preparación del seminario no se forman equipos independientes si no cooperativos.

La elaboración del seminario tiene un peso del 5\% de la nota final de la asignatura y se ha divido a su vez en tres fases que se describirán con detalle en los siguientes apartados:

\section{$1^{a}$ Fase (Organización de equipos inteligentes, reparto de tareas y búsqueda de información)}

Durante esta fase el profesor divide la clase en dos grupos, de modo que en cada una se van a preparar dos seminarios sobre dolor orofacial. A su vez, cada grupo (formado más o menos por la mitad de la clase) se divide en 4 equipos compuesto cada uno de ellos por 4 ó 5 alumnos, de modo que cada equipo se va a encargar de buscar la información referente a un apartado en los que se ha dividido el trabajo (en cada equipo se elige 1 coordinador, 1 portavoz y $2 / 3$ vocales).

El tema propuesto se divide en cuatro apartados: 1. Definición y tipos de dolor orofacial (según el estímulo, según la transmisión...), 2. Receptores y neuroquímica de la nocicepción

(cc) BY-NC-ND 2018, Universitat Politècnica de València

Congreso IN-RED (2018) 
orofacial (tipo, localización, estructura...), 3. Vías de transmisión y centro nervioso, 4. Tipos de tratamientos; el profesor asigna a cada equipo la elaboración de uno de ellos. Los apartados se han creado en función de conceptos estudiados previamente en clase sobre fisiología del sistema nervioso, concretamente sobre la fisiología del dolor.

En esta fase, el objetivo es que los alumnos de cada equipo sean capaces de buscar información y aplicar conocimientos previos sobre la somatocepción del dolor en general al caso específico de dolor orofacial y en concreto al apartado específico que les haya tocado. Por ejemplo, uno de los apartados es que definan dolor orofacial y enumeren que tipos de dolor hay según su origen. Para el desarrollo de este apartado cuentan de base con la definición de dolor y tipos que hay siendo lo que tienen que definir el caso específico de dolor orofacial. Para llevar a cabo este objetivo cada equipo de trabajo cuenta con un plazo de una semana fuera del aula. Se les da libertad para que usen los recursos que ellos crean conveniente como apuntes de clase, biblioteca, internet ....... y sentido común.

Durante el desarrollo del trabajo, cada equipo debe preparar un portfolio que contenga:

a) el plan de trabajo del equipo detallado

b) un documento que explique cuales han sido sus fuentes de información

c) un trabajo escrito con la información del apartado que le ha tocado desarrollar.

La entrega portfolio al profesor deberá realizarse por el coordinador de cada equipo.

\section{$2^{a}$ Fase (Elaboración del seminario en equipos cooperativos)}

Esta fase se desarrolla dentro del aula y los 8 equipos formados en cada clase ya tienen que tener preparada la información que les ha tocado. Dado que el trabajo está organizado en 4 apartados, en esta etapa los dos equipos encargados de buscar la misma información se deben juntar con el fin de poner en común la infomación recabada por separado. Así, la dinámica de esta fase consiste en crear grupos de expertos formados por los portavoces de ambos equipos. Estos alumnos se intercambian la información recogida y vuelven a sus grupos nodrizas para explicar a sus compañeros las nuevas aportaciones. Para finalizar, cuentan con 15 minutos para elaborar 2 diapositivas del apartado que les ha tocado.

\section{$3^{a}$ Fase (Presentación del seminario y evaluación del conocimiento adquirido)}

Una vez finalizada la fase de elaboración del seminario, cada grupo debe preparar una presentación con cada uno de los apartados que van a formar el seminario del dolor orofacial. De esta manera, utilizando la técnica de aprendizaje puzzle contaremos en cada clase con dos seminarios.

La presentación oral de cada seminario se realiza por uno de los vocales de cada equipo que haya participado en la elaboración del trabajo y tendrá lugar en el aula de cada clase de teoría con los medios disponibles, con una duración máxima de 10 minutos para cada grupo. Tras la presentación se abre un turno de preguntas y comentarios por parte del resto de equipos hacia el grupo que ha realizado la presentación (unos $5 \mathrm{~min}$ ). 
Una vez concluidas las presentaciones de los seminarios cada equipo valora qué seminario ha sido mejor ejecutado y por tanto le ha aportado más información. El resultado de dicha valoración por parte del alumnado se tiene en cuenta en la evaluación final de cada equipo.

Por último, para evaluar el grado de adquisición de nuevos conocimientos de manera individual generados tras las distintas competencias empleadas en la elaboración del seminario, se realiza una prueba de autoevaluación utilizando la aplicación Socrative donde se les pregunta cuestiones importantes relacionadas con los apartados que los estudiantes previamente han trabajado de manera colaborativa. El tiempo de la prueba no será de más de 30 min y el número de preguntas será de 2 a 3 por apartado.

\section{Resultados}

\section{Resultados de aprendizaje. Conocimiento básico antes de la experiencia TBL junto con el uso de técnicas de aprendizaje cooperativo.}

Antes de la elaboración del seminario por los equipos cooperativos se realizó una prueba de autoevaluación en la que participaron 60 de los 82 alumnos matriculados en el curso 2017/2018. Lo que corresponde aproximadamente con un 73,2\% de alumnos matriculados. La prueba consistía en 20 preguntas tipo test sobre fisiología general del sistema nervioso (temario que se impartió en clase previamente). Para la realización de esta prueba se utilizó la aplicación Socrative que nos facilitó un registro del porcentaje de preguntas acertadas por los alumnos de cada grupo de teoría. En la figura 1 se puede observar que la mayoría de los alumnos tienen entre un $80 \%$ y $85 \%$ de preguntas acertadas en ambos grupos, este resultado nos animó a poner en marcha la actividad propuesta.

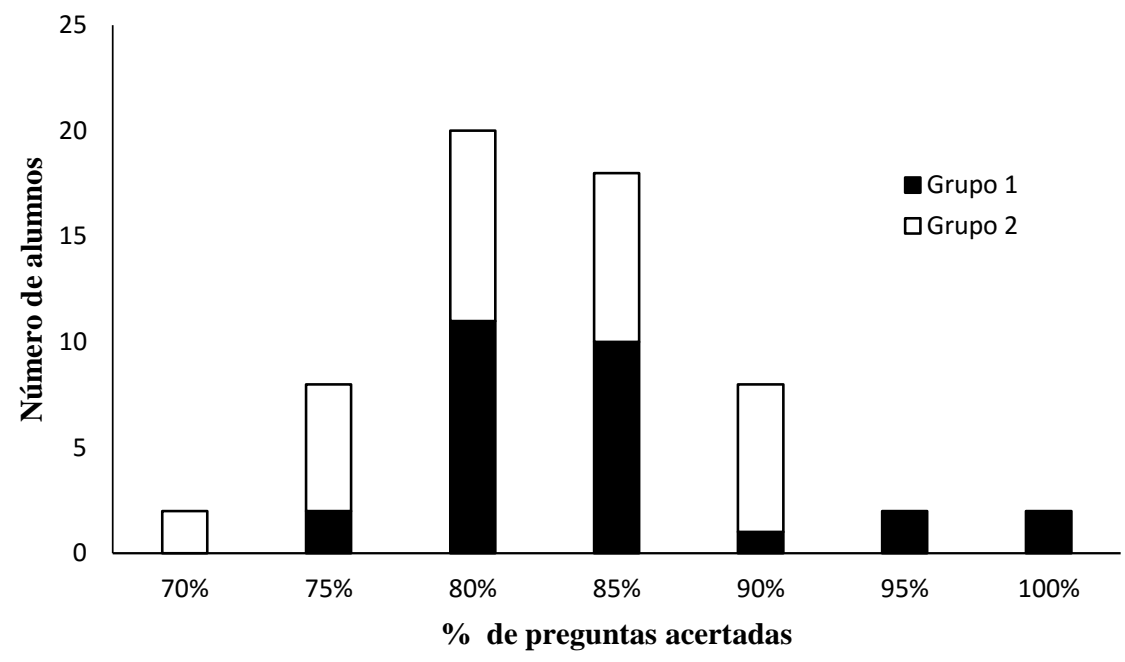

Figura 1. Porcentaje de preguntas acertadas sobre fisiología general por número de alumnos de cada grupo de teoría. Las columnas negras representan a los alumnos del grupo 1 y las blancas a los del grupo 2 . 
2. Resultados de aprendizaje. Conocimiento aplicado después de la experiencia TBL junto con el uso de técnicas de aprendizaje cooperativo.

De los 82 alumnos matriculados en los dos grupos del curso participaron en la actividad propuesta 62 alumnos (un 79,2\%). De esos 62 completaron las tres fases de la actividad 52 alumnos $(84 \%)$. Para ver si era eficaz este nuevo método de aprendizaje se realizaron dos evaluaciones diferentes: una durante el procedimiento, después del seminario realizado en la fase 3 del desarrollo de la actividad y una evaluación final en la prueba de evaluación continua donde a parte de las preguntas sobre fisiología general del sistema nervioso se incluyó también preguntas aplicadas relacionada con la actividad propuesta.

Los resultados de estas evaluaciones se muestran en los siguientes subapartados:

\subsection{Resultados de aprendizaje. Conocimiento aplicado durante la actividad.}

Para evaluar el conocimiento adquirido tras la presentación del seminario se realizó una primera prueba de evaluación donde se plantearon dos preguntas cortas, dos preguntas de verdadero/falso y dos preguntas de elección múltiple. Para el registro de las repuestas por parte de los alumnos se utilizó la aplicación Socrative. Los resultados se muestran en la figura 2, donde se puede observar que la mayor parte de los alumnos de ambos grupos contestaron bien el $100 \%$ de las preguntas planteadas.

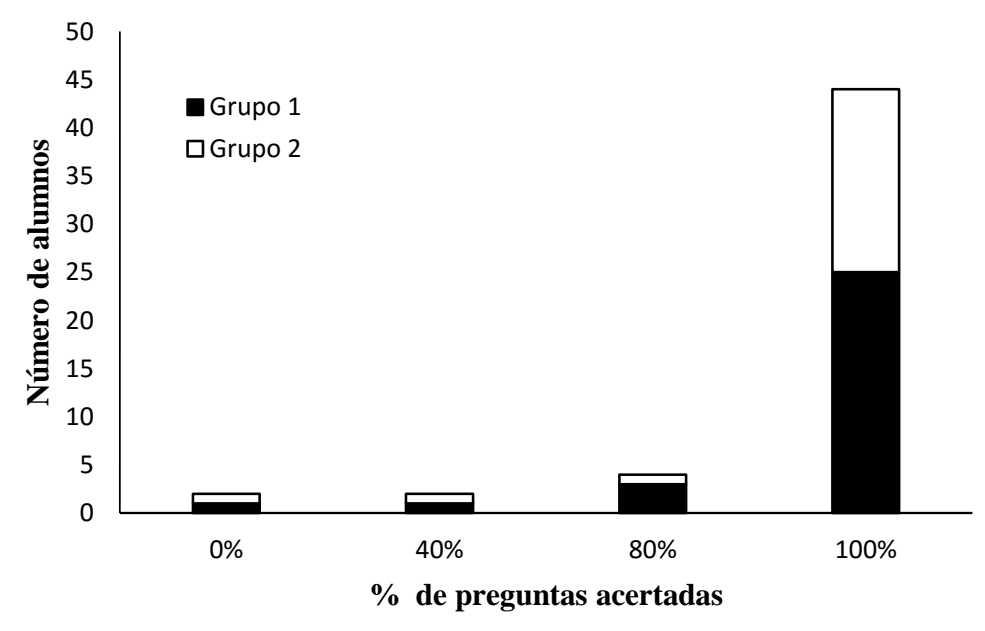

Figura 2. Porcentaje de preguntas acertadas sobre el dolor orofacial por número de alumnos de cada grupo de teoría. Las columnas negras representan a los alumnos del grupo 1 y las blancas a los del grupo 2. 
Generación colaborativa de conocimiento. Una experiencia de aprendizaje basada en equipos o Team Based Learning (TBL) en la práctica odontológica.

\subsection{Resultados de aprendizaje. Conocimiento aplicado en la prueba de evaluación continua}

Para la evaluación formativa, que se realiza después del aprendizaje se utilizó la prueba de evaluación continua dónde además de las preguntas sobre el temario de la asignatura se incluyó una pregunta sobre la actividad desarrollada (fue una pregunta tipo test con cuatro posibles respuestas). Dado que cada curso consta de dos grupo de teoría lo primero que quisimos ver es si ambos grupos se comportaban de manera homogénea, para ello analizamos el resultado del aprendizaje por separado como describimos a continuación:

A la prueba de evaluación continua se presentaron 36 alumnos de los 40 matriculados en grupo 1 y 33 alumnos de los 42 matriculados en el grupo 2. En total el $84 \%$ de los alumnos matriculados en curso actual. Los resultados en el grupo 1 fueron los siguientes: un 83,3\% de los alumnos contestaron bien, un 13,9\% contestaron mal y un 2,8 \% dejaron la pregunta sin contestar. En el caso del grupo 2 un 78,8 \% de los alumnos contestaron bien, un 12,1\% mal y un 9,10\% dejaron la pregunta sin contestar. Cuando se compararon los resultados de ambos grupos no existían diferencias significativas entre ellos como era de esperar ya que en ambos grupos se utilizó la misma metodología de aprendizaje. Estos resultados se muestran la figura 3.

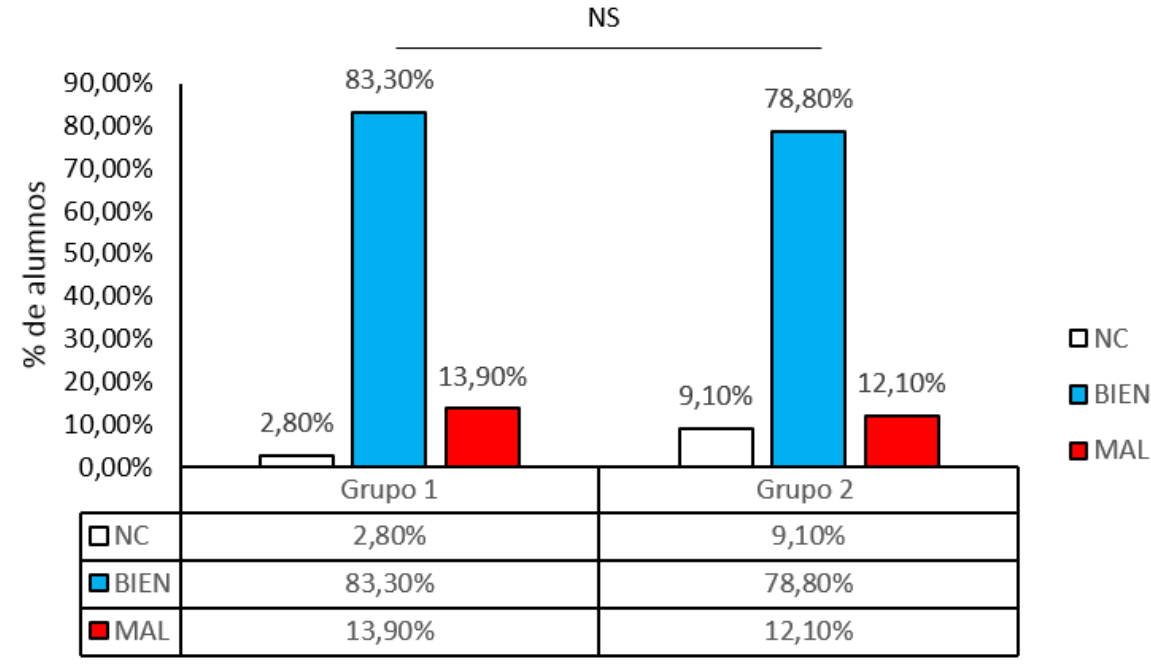

Figura 3. Porcentaje alumnos que no contestan (NC), que contestan bien (BIEN) y que contestan mal (MAL) a la pregunta sobre el dolor orofacial en la prueba de evaluación en el grupo 1 y el grupo 2 del curso 2017/2018. Las barras representan el porcentaje de alumnos que NC, que contestan bien o que contestan mal a la pregunta del dolor orofacial en relación al número total de individuos analizados en cada grupo. NS $=$ no se encontraron diferencias significativas cuando se realizó la prueba $\chi^{2}$ de Pearson.

Una vez demostrada la homogenidad entre los grupos se agruparon ambos en uno solo llamado curso (2017/18).

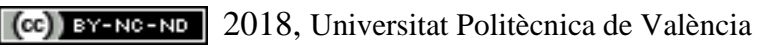

Congreso IN-RED (2018) 


\section{Comparación de los resultados de aprendizaje de conocimiento aplicado utilizado la metodología nueva y la tradicional.}

Por último, para probar que la nueva metodología de aprendizaje propuesta en esta memoria es realmente útil comparamos los resultados de aprendizaje de conocimiento aplicado obtenidos en la prueba de evaluación continua del curso actual (2017/2018) con los resultados obtenidos en la prueba de evaluación continua de los alumnos del curso anterior (2016/2017).

La diferencia entre ambos cursos fue que en el curso 2016/2017 la elaboración del seminario de dolor orofacial se hizo de forma tradicional, es decir, sin aplicar las nuevas técnicas de aprendizaje cooperativo (equipos inteligentes, grupo de expertos...) mientras que en el curso actual 2017/2018 se utilizó la metodología descrita en esta memoria.

$\mathrm{Al}$ analizar los resultados de la prueba de evaluación continua de ambos cursos donde se les realizo una pregunta parecida sobre el dolor orofacial pudimos observar que en el curso anterior un $20 \%$ de los alumnos contestaron bien, un $54 \%$ contestaron mal y un $26 \%$ dejaron la pregunta sin contestar. En el caso del curso actual un $81,2 \%$ de los alumnos contestaron bien, un $13 \%$ mal y un 5,8 \% dejaron la pregunta sin contestar (figura 4). La prueba $\chi^{2}$ de Pearson demostró que hay diferencias significativas entre el curso 2016/2017 y el curso 2017/2018 ( $<<0,0001$ ). Este resultado prueba que la metodología actual es más eficaz que la tradicional aumentando el aprendizaje de conocimiento aplicado por parte del alumnado.

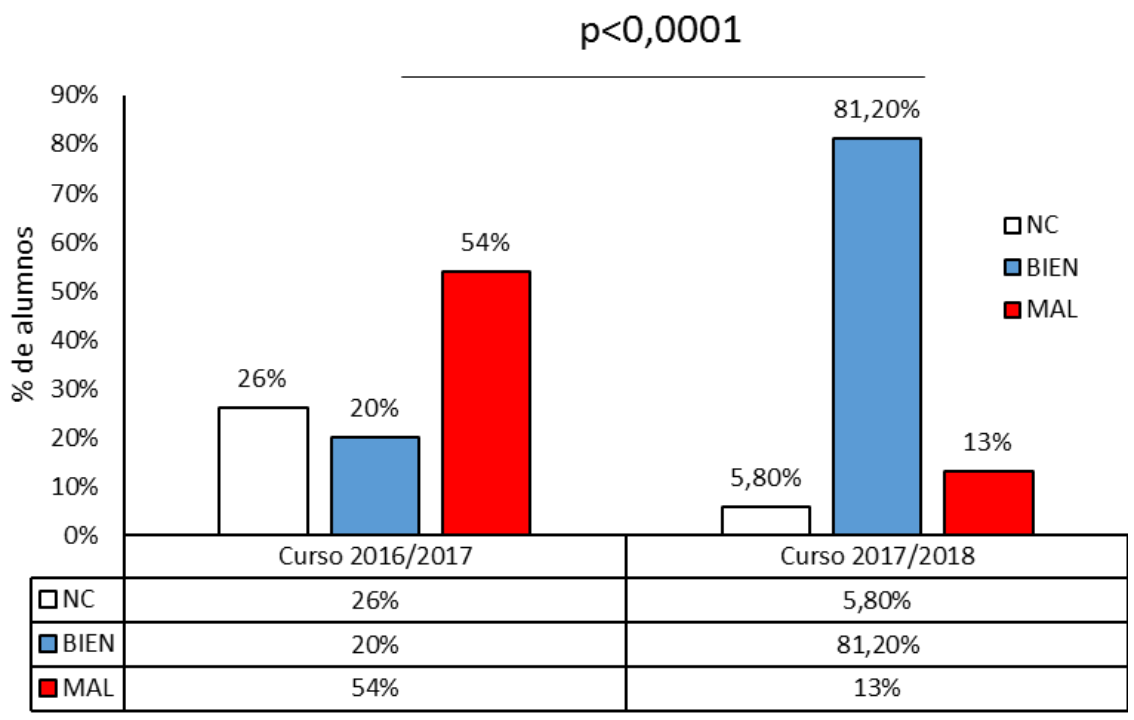

Figura 4. Porcentaje alumnos que no contestan (NC), que contestan bien (BIEN) y que contestan mal (MAL) a la pregunta sobre el dolor orofacial en la prueba de evaluación del curso 2016/2017 y del curso 2017/2018. Las barras representan el porcentaje de alumnos que NC, que contestan bien o que contestan mal a la pregunta del dolor orofacial en relación al número total de individuos analizados en cada curso académico.

\section{Grado de satisfacción de los alumnos con la nueva metodología.}


Generación colaborativa de conocimiento. Una experiencia de aprendizaje basada en equipos o Team Based Learning (TBL) en la práctica odontológica.

Para valorar la acogida de los alumnos a la nueva metodología de aprendizaje se les paso una encuesta con cuatro preguntas para ver la opinión de los alumnos sobre tiempo empleado, trabajo en equipo, el aprendizaje de nuevos conocimientos y si les había gustado más o menos que otras metodologías. En la encuesta participaron el $79 \%$ de los alumnos que completaron las tres fases de la actividad. Los resultados de las preguntas de la encuesta se muestran a continuación.

En la Figura 5 se recoge los resultados de la primera pregunta de la encuesta en la que se evaluó el esfuerzo percibido por los alumnos respecto al desarrollo de esta actividad. Con este fin se les preguntó si fué mucho el tiempo que invirtieron fuera del aula para su desarrollo. La mayor parte de los alumnos, el $66 \%$, contestaron que no les llevo mucho tiempo, un $27 \%$ contestaron que el tiempo de desarrollo fue intermedio y solo un pequeño porcentaje de alumnos consideraron que les supuso mucho tiempo.

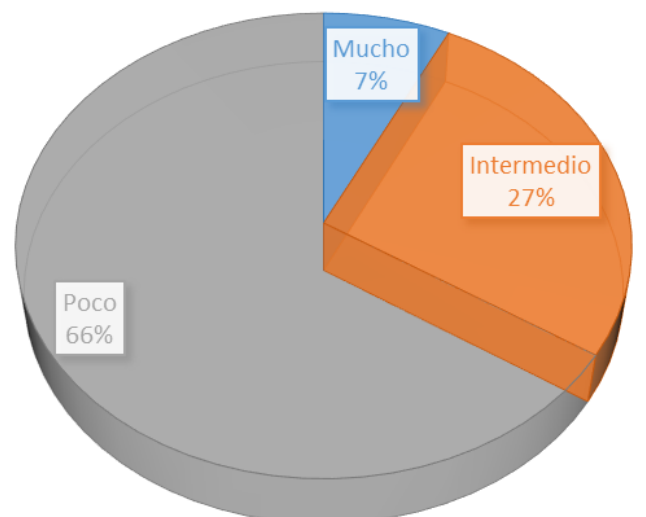

Figura 5. Tiempo requerido por el alumno para realizar la actividad.

Para saber si el trabajo en grupo fue una experiencia positiva para el alumno se les pregunto si les había gustado trabajar en equipo. La mayoría de los alumnos contestaron de manera afirmativa; incluso un porcentaje notable destaco que les había gustado mucho. Solo un porcentaje bajo contestó que preferían trabajar de manera individual, como podemos observar en la figura 6.

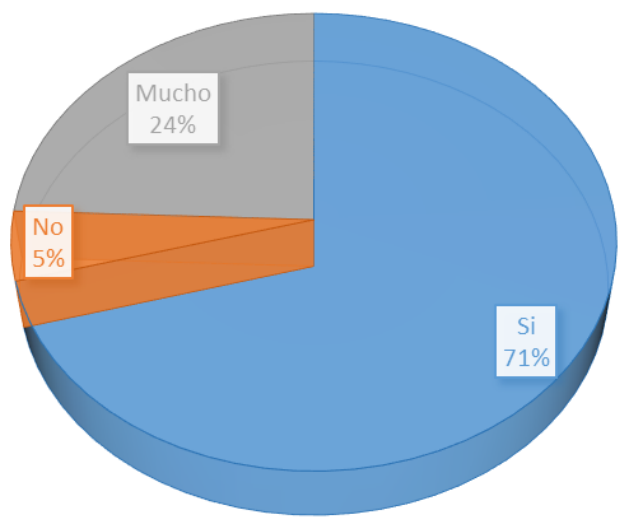

Figura 6. Grado de satisfacción del alumno por el trabajo en equipo.

(cc) EY-NC-ND 2018, Universitat Politècnica de València

Congreso IN-RED (2018) 
Respecto a la pregunta en la que se les consulta si consideraban positiva esta actividad en cuanto a su aprendizaje, como se puede ver en la Figura 8, la mayor parte de los alumnos contestaron de manera afirmativa.

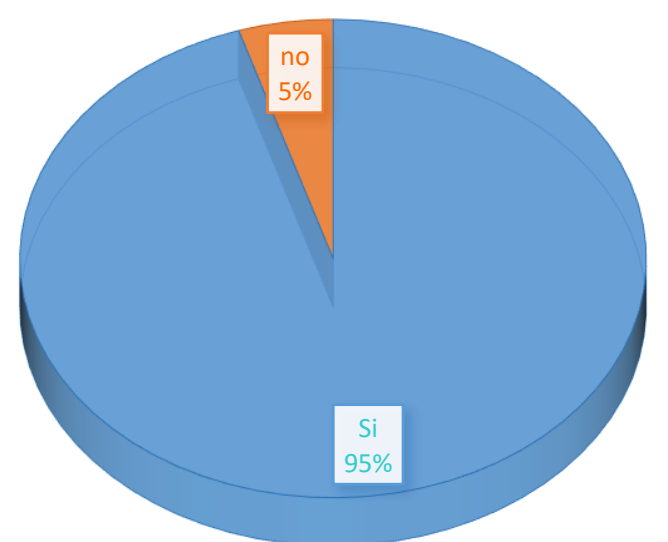

Figura 8. Aprendizaje de nuevo conocimiento.

Para finalizar, quisimos conocer la preferencia de los alumnos sobre el uso de la nueva metodología de aprendizaje versus a la antigua. La mayor parte de los alumnos prefieren la nueva metodología y sólo una pequeña parte de los alumnos consideraron que les gustaba más la antigua o las dos por igual (figura 9). Entre los comentarios de los alumnos queremos destacar la opinión de que el trabajo en equipos cooperativos es un buen método para aprender ya que fomenta el compañerismo, reduce el tiempo de trabajo y les ayuda a resolver dudas.

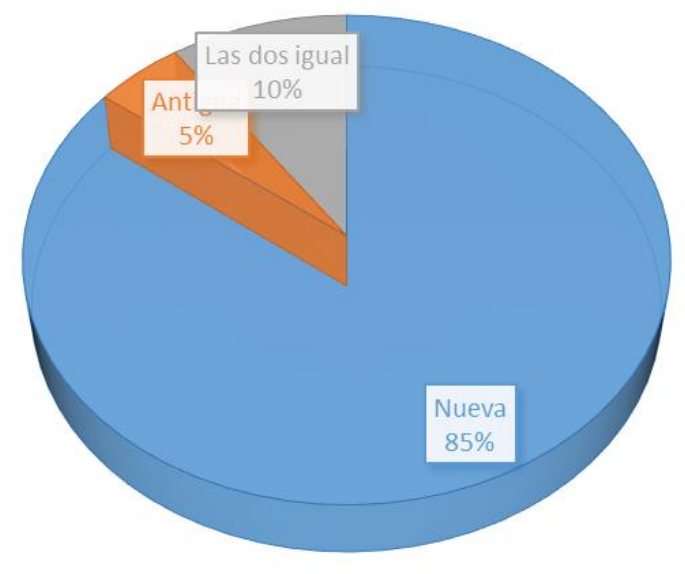

Figura 9. preferencia de los alumnos sobre el uso de la nueva metodología de aprendizaje versus a la antigua 


\section{Conclusión}

Hemos diseñado y realizado una nueva actividad formativa para que los alumnos participen más a la hora de generar nuevos conocimientos a partir de los conocimientos previos y pierdan el miedo a resolver preguntas aplicadas. El análisis de los resultados obtenidos indica que esta nueva metodología incrementa de manera significativa el porcentaje de acierto en preguntas aplicadas en pruebas de evaluación continua con respecto a otros cursos donde no se había puesto en marcha esta actividad, poniendo de manifiesto la eficacia del método. Además, podemos concluir que la nueva metodología de aprendizaje minimiza el tiempo de trabajo fuera del aula, aumenta la participación activa del alumno en la adquisición de nuevos conocimientos, fomenta el compañerismo y los alumnos la eligen frente a otras metodologías. La eficacia del método en el aprendizaje junto a la aceptación del mismo por el alumnado nos anima a seguir trabajado en esta dirección en los futuros cursos académicos.

\section{Referencias}

ARCEO FDB, ROJAS GH, GONZÁLEZ ELG (2002). Estrategias docentes para un aprendizaje significativo: una interpretación constructivista. Libro electrónico: mapas.eafit.edu.co.

BARR, R.B Y TAGG, J. (1995). "From teaching to learning. A new paradigm for undergraduate education", en Change, 27 (6), pp. 13-25. Revista electrónica de Tecnología Educativa, $n^{\circ} 29$

ESCUDERO E, SÁNCHEZ-VERA I, BARHOUM R, PUCHE J E, MUÑOZ U (2017). Análisis del uso de autoevaluaciones en una plataforma digital en el entorno de la Fisiología Médica. Doi: http://dx.doi.org/10.4995/INRED2017.2017.6809

GARCÍA VALCÁRCEL, A. (1993). “Análisis de los modelos de enseñanza empleados en el ámbito universitario”, en Revista Española de Pedagogía, 194, 27-53

GARGALLO, B, GARCÍA- FÉLIX , I, MORERA, C. Y BENAVENT, A. (2015). Métodos innovadores y enfoques de aprendizaje en estudiantes universitarios. Doi:http://dx.doi.org/10.4995/INRED2015.2015.1576

JENSEN E, VILLALBA A (2003) Cerebro y aprendizaje: competencias e implicaciones educativas. Sumario Editorial

LARRY MICHAELSEN, ARLETA BAUMAN AND L. DEE FINK (2004). Team-Based Learning: A Transformative Use of Small Groups in College Teaching. Stylus Publishing (VA)

MACHEMER, P. L. . Y CRAWFORD, P. (2007). "Student perceptions of active learning in a large crossdisciplinary classroom", en Active Learning in Higher Education, 8 (1), 930.

MICHAELSEN, L.K.; SWEET, M. (2009) "The essential elements of team-based learning", Team-Based Learning: Small Group Learning's Next Big Step. New Directions in Teaching and Learning, p. 7-27. 
MOLERO LÓPEZ-BARJAS D., RUIZ CARRASCOSA J (2005). La evaluación de la docencia universitaria. Dimensiones y variables más relevantes. Revista de Investigación Educativa 23 (1)

MONEREO C. Y POZO J. I. (2003). La universidad ante la nueva cultura educativa. Enseñar y aprender para la autonomía. Madrid: Síntesis

RICARD, MATTHIEU (2010). "Educación: Promueve la cooperación, no la competitividad". http://www.matthieuricard.org/es/blog/posts/educacion-promueve-lacooperacion-no-la-competitividad [Consulta: 14 de marzo de 2017].

SÁNCHEZ-VERA I, ESCUDERO E, MUÑOZ U, BORREGO, M J, BARHOUM R (2017). Experiencia en la elaboración de videos didácticos por alumnos de Fisiología como parte de su proceso de aprendizaje. Doi: http://dx.doi.org/10.4995/INRED2017.2017.6819

SOFÍA ESTELLES-MIGUELA, JOSÉ MIGUEL ALBARRACÍN GUILLEMB, MARTA ELENA PALMER GATO Y MARTA PERIS-ORTIZ (2017) "Desarrollo de la Competencia de Trabajo en Equipo en la Asignatura de Dirección de Producción y Operaciones". Doi: http://dx.doi.org/10.4995/INRED2017.2017.6892

ZABALZA BERAZA, M.A. (2012). El estudio de las "buenas prácticas" docentes en la enseñanza universitaria. Revista de Docencia Universitaria. REDU, 10 (1), 17-42. Extraído el 2 de abril, 2012 de http://redaberta.usc.es/redu/index.php/REDU/article/view/363. 


\title{
Gamificación en la evaluación dinámica de contenidos de la materia básica del Grado en Criminología
}

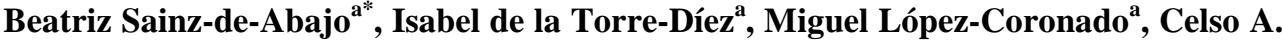 \\ Couto $^{\mathrm{a}}$ y Carlos de Castro Lozano ${ }^{\mathrm{b}}$
}

${ }^{a}$ Departamento de Teoría de la Señal, Comunicaciones e Ingeniería Telemática. Universidad de Valladolid. Paseo de Belén, 15, 47011 - Valladolid. E-mail: beasai@tel.uva.es ${ }^{*}$, isator@tel.uva.es, miglop@tel.uva.es, celso.couto@uva.es

${ }^{\mathrm{b}}$ Departamento de Informática y Análisis Numérico. Universidad de Córdoba. Carretera MadridCádiz Km.396-A, 14071-Córdoba. E-mail: ma1caloc@uco.es

\begin{abstract}
This study aims to motivate the students, transforming the learning process through gamification as a pedagogical tool, seeking to arouse students' interest in the subject, and encouraging them through a system of rewards that add up to the grade end of the course. In order to evaluate the level of previous knowledge that the student has, on the subject, we can apply this technique at the beginning of the lesson, adjusting the contents anticipated in the development of the session at this level, focusing on aspects where there are more problems of understanding. Applying the gamification in the final minutes of the lesson will allow us to evaluate the comprehension of the contents of the subject and to improve the level of attention of the student, who knows that what was presented in the session will be immediately tested at the end of the presentation.
\end{abstract}

Keywords: gamification, KAHOOT!, competition, training, self-examination, motivation, smartphones, reward.

\section{Resumen}

El objetivo de este trabajo es motivar a los alumnos, convirtiendo en lúdico el proceso de aprendizaje a través de la gamificación como herramienta pedagógica, buscando interesar a los alumnos por la materia, e incentivándoles a través de un sistema de recompensas que se sumen en la nota final del curso. Para evaluar el nivel de conocimientos previo que el alumno tiene sobre la materia, podemos aplicar esta técnica al inicio de la clase, ajustando los contenidos previstos en el desarrollo de la sesión a ese nivel, enfocándonos en los aspectos donde muestran más problemas de comprensión. Aplicar la gamificación en los minutos finales de la clase, nos permite evaluar el alcance de comprensión de los contenidos del tema y mejorar el nivel de atención del alumno, que sabe que lo expuesto en la sesión será inmediatamente testeado al finalizar la exposición.

Palabras clave: gamificación, KAHOOT!, competición, entrenamiento, autoevaluación, motivación, smartphones, recompensa. 


\section{Introducción}

La dificultad con la que los profesores nos encontramos en el aula es que la transmisión del conocimiento llegue al alumno de forma efectiva y que la interioricen a través de aprendizajes más activos. Desde el Espacio Europeo de Educación Superior (EEES) se nos insta en el uso de técnicas pedagógicas para lograr ese fin (Tejedor y García-Valcárcel, 2007). Y enfocados en ese esfuerzo las universidades nos animan a adaptar la metodología para atender a la diversidad del alumnado, entendiendo sus circunstancias y ajustando el programa para favorecer el éxito en los resultados.

En una sociedad cada vez más tecnológica, donde nuestros estudiantes manejan con gran soltura los dispositivos, parece lógico pensar en el uso de las tecnologías como método de instrucción y entrenamiento para maximizar el aprendizaje del discente. Hemos pasado de pedir a nuestros alumnos que apaguen sus dispositivos durante la clase, para evitar distracciones, a fomentar su uso. En este sentido, la importancia de este diseño pedagógico en la educación actual ha derivado en el desarrollo de toda una rama del conocimiento, englobada en el llamado m-learning, fundamentado básicamente en el uso de dispositivos móviles (smartphones, tabletas u ordenadores portátiles) en la docencia (San Miguel et al., 2017; Rodríguez-Fernández, 2017). Por ello empresas e instituciones desarrollan aplicaciones para apoyar la tecnología Bring Your Own Device (BYOD), donde los estudiantes traen un dispositivo móvil de propiedad personal para usar en cualquier lugar y momento con el propósito de aprender (Song, 2014).

La gamificación es una herramienta que aplica técnicas de juego en entornos que no son juegos o, como citan más ampliamente en internet numerosas fuentes, entre ellas el blog Proyecta (2018), “es el empleo de dinámicas y mecánicas de juego en entornos y aplicaciones no lúdicas con el fin de potenciar la motivación, la concentración, el esfuerzo, la fidelización y otros valores positivos comunes a todos los juegos”.

En pro de incentivar al alumno han aparecido numerosas aplicaciones gestoras gratuitas de participación como tendencia educativa motivadora, para la realización de test en línea que mejoran notablemente la atención de los estudiantes, siendo las más conocidas KAHOOT! (https://kahoot.com/), SOCRATIVE (https://www.socrative.com/), QUIZIZZ (https://quizizz.com/) o GOOGLEFORMS (https://www.google.com/forms/about/). En estos últimos años son muchos los trabajos que avalan de forma positiva la influencia motivadora de los juegos en el aula (Barnes, 2017; Chaiyo \& Nokham, 2017; San Miguel et al., 2017; Garcia-Garcia et al., 2017; Peña et al., 2017; Roger et al., 2017; Llerena y Rodriguez, 2017; Wang y Lieberoth, 2016). Si además a los alumnos se les premia con la posibilidad de mejorar la calificación final, si obtienen la mejor puntuación en la competición en relación al resto de compañeros, esta mecánica de juego puede ser motivadora y convertir en entretenido el proceso de aprendizaje (Iwamoto et al., 2017).

A la estrategia que se planteó en cursos pasados: visitas programadas y prácticas de laboratorio, que fueron muy valoradas por la mayoría de los alumnos, y que les permite asimilar mejor los contenidos teóricos y conceptos vistos en el aula, se suma en este curso

(cc) BY-NC-ND 2018, Universitat Politècnica de València

Congreso IN-RED (2018) 
una "nueva" tendencia educativa: la gamificación. Es necesario habilitar mecanismos para que, a pesar del absentismo que a priori se espera en el aula los días planificados como clase magistral, se alcancen los objetivos previstos adaptando la metodología.

La idea es que los alumnos que hagan el esfuerzo de acudir al aula, tengan como incentivo el reconocimiento de su asistencia, su puntualidad, su atención en clase y su colaboración en las tareas propuestas.

\section{Objetivos}

El objetivo principal de nuestra experiencia es conocer el progreso de los estudiantes en la materia, aumentar su compromiso y despertar su curiosidad.

Podemos evaluar su nivel de conocimientos previo, antes del inicio del tema, mediante un cuestionario rápido. Esto nos permitirá ajustar los contenidos de la sesión para profundizar en los puntos donde los alumnos parecen tener más dificultades.

Finalizado el tema se aplica nuevamente la gamificación, para testar el alcance de la comprensión. El discente sabe que los fallos no restan en la evaluación, por lo que se anima a participar. Igualmente sabe que puede obtener una recompensa en forma de puntos que sumen en la nota final del curso, con lo que este acicate mejora el nivel de atención, dado que lo expuesto en la sesión será evaluado al finalizar el tema. La ludificación se convierte de esta forma en una técnica entretenida que nos permite mejorar el rendimiento académico del alumno.

\section{Desarrollo de la innovación}

\subsection{Contexto}

El grupo que participó en esta metodología está integrado por un total de 17 estudiantes de la asignatura de carácter básico "Recursos Documentales e Informáticos", del Curso de Adaptación del Grado en Criminología. Se ha desarrollado en el primer cuatrimestre del curso académico 2017-18 en la Universidad de Valladolid.

Los alumnos pertenecen a las fuerzas y cuerpos de seguridad del estado (policía nacional, guardia civil y policía municipal). La media de edad ronda los cuarenta, algunos incluso los cincuenta años, y su interés es la obtención del Grado para poder ascender laboralmente (ver Fig. 1). Son inmigrantes digitales y el uso de nuevas herramientas tecnológicas y plataformas les supone un esfuerzo considerablemente mayor que a los alumnos de 18 años. Sin embargo, no tuvieron ninguna dificultad con KAHOOT!. 


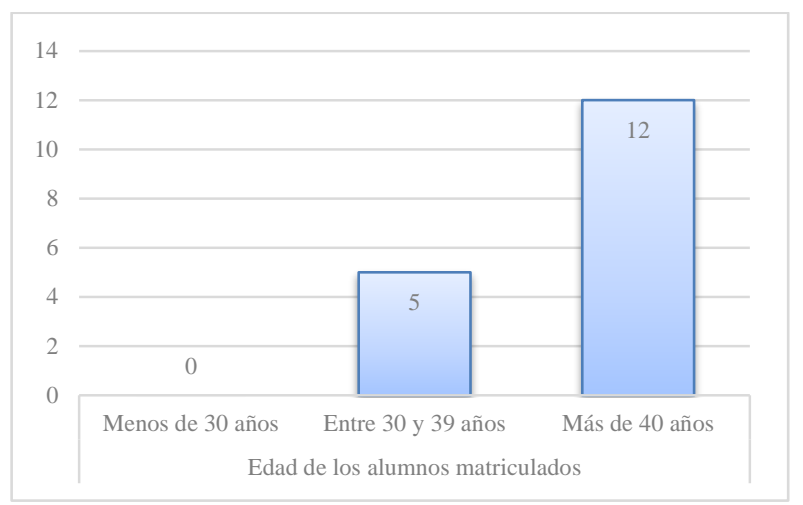

Fig.1 Edad de los alumnos que participaron en la experiencia

Se ha observado en los pasados cursos, que la gran mayoría únicamente asiste los días donde se programa una actividad que suma en la nota final de la evaluación o aquellas de asistencia obligada. En caso contrario el absentismo es generalizado. $\mathrm{Y}$ ante tanta desmotivación, ¿cómo les incentivamos?, ¿cómo podemos ayudar a gente madura que no estudia desde hace años? La solución está en ofrecer un aliciente: ¡JUGUEMOS! Y es que los seres humanos se sienten irremediablemente atraídos por los juegos.

\subsection{Procedimiento}

La aplicación de la metodología contó con una serie de fases (Fig. 2):

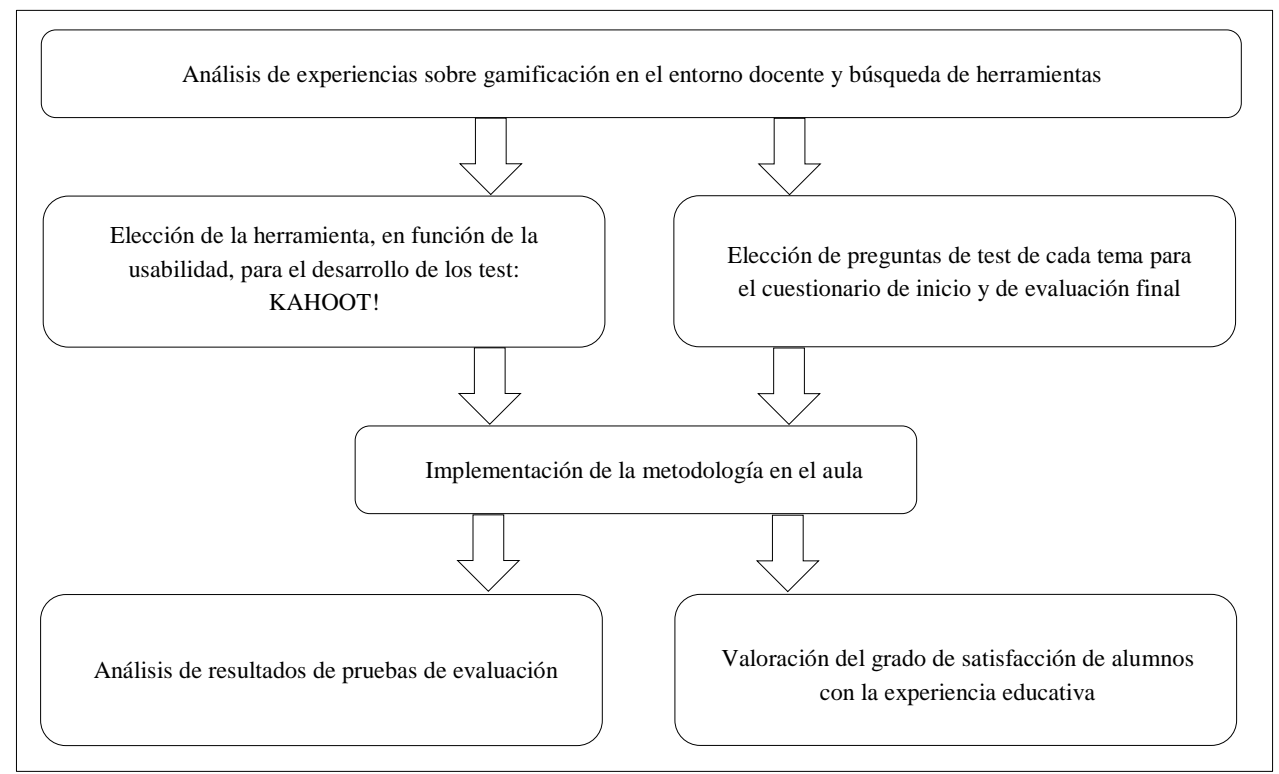

Fig. 2 Diagrama de flujo de la metodología implementada.

(cc) EY-NC-ND 2018, Universitat Politècnica de València

Congreso IN-RED (2018) 
Antes del inicio del curso se optó por gamificar con KAHOOT! para la elaboración de los test en línea, por su estética y sencillez de uso, ya que permite participar sin necesidad de conocer previamente el manejo al ser muy intuitiva. KAHOOT! es una aplicación pedagógica en continuo desarrollo que va incorporando más funcionalidades. Junto con SOCRATIVE se han convertido en una de las herramientas de gestión más populares (Fuertes et al., 2016).

Se plantearon diferentes test evaluativos para medir los conocimientos de los alumnos en relación con la materia vista. Para ello se seleccionaron un conjunto de preguntas de cada tema con diferente grado de dificultad. Los de inicio de tema contaban con 5 o 10 cuestiones, mientras que los de evaluación final incluían entre 20 y 25 cuestiones. A través de las respuestas de los alumnos y el grado de acierto se pudo valorar si los contenidos eran entendibles. Algunas de las preguntas planteadas en el test de inicio fueron incluidas en el test final. El alumno se muestra satisfecho cuando sabe dar respuesta a una pregunta que no pudo contestar al inicio del tema. Igualmente, el test final sirve como sesión de repaso de los contenidos fijando los conceptos más importantes.

A través del Campus Virtual se informó, mediante recordatorios en el calendario, de los días previstos en que se iba a realizar la gamificación. Sorprendentemente la asistencia resultó del $100 \%$ de los matriculados a pesar de que la asistencia no era obligatoria y no había control por firmas. La justificación ante esta masiva asistencia no es otra que la recompensa, que puede suponer una mejora sustancial en la nota final de la evaluación.

Durante la actividad cada alumno contaba con su smartphone y competían de forma individual, dado que el número de alumnos matriculados no ha sido elevado en este curso académico. Para evitar que los alumnos con falta de conectividad o sin dispositivo estuvieran en desventaja, las sesiones se programaban en la sala de ordenadores, de forma que todos tenían acceso fijo o inalámbrico.

\subsection{Análisis de resultados y grado de satisfacción de los discentes}

A fin de valorar la experiencia educativa por parte de los alumnos se desarrolló una encuesta, voluntaria y anónima, cuyos ítems se evaluaban en una escala de 5 niveles de percepción (siendo 1-Muy malo y 5-Muy bueno). También se plantearon una serie de preguntas abiertas (ver Fig. 3). La encuesta fue completada por el 100\% de los alumnos, tras el último test de evaluación a través de KAHOOT!, dado que todos asistieron al aula.

Hemos constatado que la gamificación, que busca motivar convirtiendo el proceso de aprendizaje en algo lúdico, mejora los resultados de los alumnos. Las calificaciones en las pruebas de evaluación ordinaria mostraron una mejora significativa en los resultados respecto a convocatorias anteriores. Todos los alumnos superaron la evaluación. La continuación del uso de la metodología mostrará si en un futuro se sigue esta tendencia. 


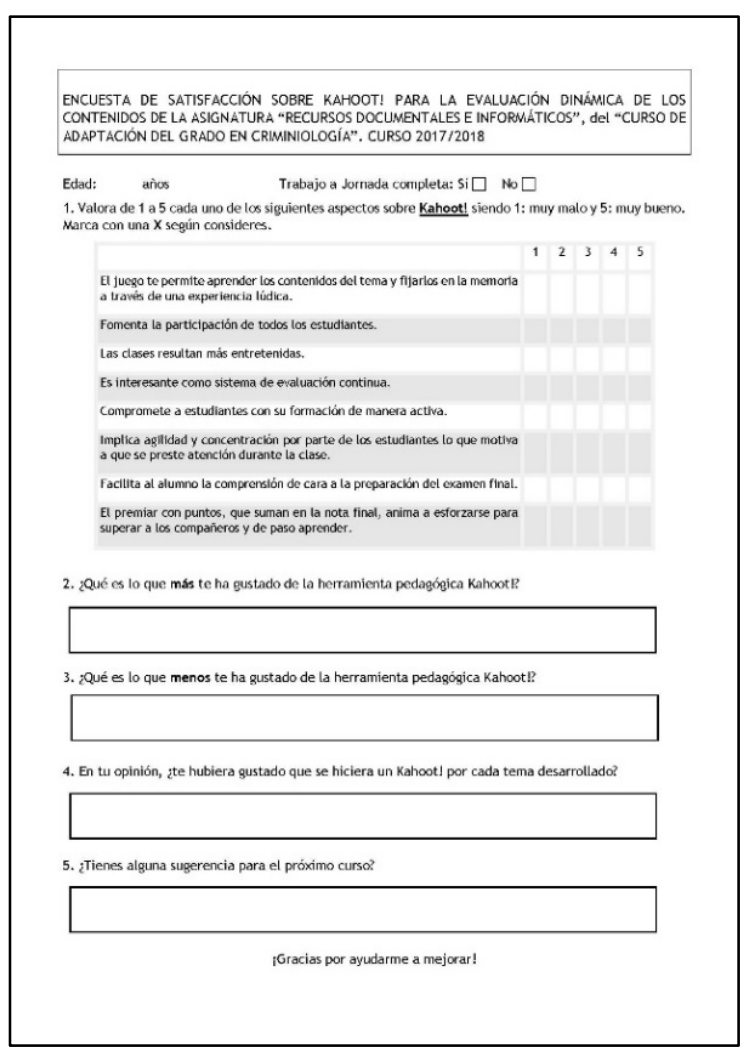

Fig. 3 Encuesta de satisfacción de la metodología de gamificación con KAHOOT!

\section{Resultados}

Los datos extraídos de las encuestas muestran la satisfacción por parte del alumno con esta actividad, que rompe con la linealidad de las clases magistrales.

Se les solicitó que valoraran las siguientes cuestiones:

1. El juego te permite aprender los contenidos del tema y fijarlos en la memoria a través de una experiencia lúdica.

2. Fomenta la participación de todos los estudiantes.

3. Las clases resultan más entretenidas.

4. Es interesante como sistema de evaluación continua.

5. Compromete a estudiantes con su formación de manera activa.

6. Implica agilidad y concentración por parte de los estudiantes lo que motiva a que se preste atención durante la clase.

7. Facilita al alumno la comprensión de cara a la preparación del examen final.

8. El premiar con puntos, que suman en la nota final, anima a esforzarse para superar a los compañeros y de paso aprender.

(c) EY-NC-ND 2018, Universitat Politècnica de València

Congreso IN-RED (2018) 
En la figura 4 se muestran los resultados. Los colores asignados a los niveles de percepción de la escala son: 1-Muy malo (azul claro), 2-Malo (morado), 3-Normal (verde), 4-Bueno (burdeos) y 5-Muy bueno (azul).

\begin{tabular}{|l|l|l|l|}
\hline CUESTIÓN 1 & CUESTIÓN 2 & CUESTIÓN 3 & CUESTIÓN 4 \\
\hline CUESTIÓN 5 & CUESTIÓN 6 & CUESTIÓN 7 & CUESTIÓN 8 \\
\hline
\end{tabular}

Fig. 4 Encuesta de satisfacción de la metodología de gamificación con KAHOOT!

La mayor parte de los alumnos puntuaron todas las preguntas con valores 4 y 5 . Solamente un alumno respondió con una valoración de 2 a la pregunta 7. Otro alumno respondió con 1 a la pregunta 8. Por tanto, ¡la metodología queda avalada!

La aplicación de esta metodología ha permitido:

- Valorar el nivel previo de conocimientos sobre la materia que tiene el alumno para ajustar el temario, la profundidad y rapidez de impartición de los contenidos, incidiendo en los puntos débiles de la materia.

- Evitar el absentismo gracias al hecho de otorgar reconocimiento, que se suma a la nota final de aquellos alumnos que han obtenido mejor calificación en los test. Los alumnos valoraron que era positivo poder sumar puntos de cara a la evaluación final.

- Aumentar la participación del alumno durante las clases, así como su atención, tan necesaria en la retención de los conceptos. La herramienta de evaluación muestra la respuesta correcta tras cada pregunta. Es eficaz que la transición entre preguntas las marque el docente, al poder plantear dudas en las pausas para clarificar conceptos y entender el porqué no se ha respondido correctamente a la cuestión (bien porque no entienden la pregunta o porque no saben la respuesta). Resulta interesante y didáctico exponer la pregunta de forma diferente para que entiendan conceptos que a priori pueden resultar abstractos. Es útil entablar un diálogo para aclarar los conceptos más importantes. Cuando los resultados sean negativos hay que explicar el motivo, de forma que resulte más sencillo asimilar conceptos de cara a la evaluación final. 
- Demostrar una mejora de los resultados académicos de los alumnos, tras el análisis de los datos obtenidos durante el curso y compararlos con los de años anteriores, cuando no se aplicaba la gamificación.

\section{Conclusiones}

Buscando la mejora de los resultados y la motivación de los alumnos, en este trabajo se plantea el uso de la ludificación, como didáctica encaminada a promover una enseñanza en la cual queda patente la comprensión y asimilación de los contenidos. La experiencia nos ha demostrado que la técnica de gamificación mejora los resultados de la evaluación final en comparación con los de cursos anteriores. Se trata de una dinámica integradora donde se compite de forma amable respondiendo a las preguntas que se plantean sobre la materia. Y es que en la gamificación las recompensas son elementos cruciales para el éxito, y más si suma en la nota final de la asignatura. También la sana competencia entre los estudiantes puede resultar un acicate para dedicar tiempo al estudio.

Gracias a los resultados de un sencillo test al inicio del tema, podemos conocer el nivel previo de conocimientos sobre la materia que tiene el alumno para ajustar el temario, la profundidad y rapidez de impartición de los contenidos e incidir en los puntos débiles.

El uso de incentivos, por obtener la mejor puntuación en relación al resto de compañeros en las pruebas de KAHOOT!, que se suman a la nota de la asignatura, claramente motiva y reduce el absentismo. La sola asistencia a la sesión es indicativa del interés de los alumnos.

La ingente cantidad de artículos y trabajos presentados en congresos demuestra el éxito de esta estrategia "amable", y puede animar a otros docentes con alumnos desmotivados. La realimentación proporcionada por alumnos permitirá los ajustes pertinentes, y el análisis de los datos extraídos, a través de las encuestas, mejorará la experiencia beneficiando al propio equipo implicado y, por supuesto, a los estudiantes.

Dada la eficacia de la metodología, en cursos posteriores se mantendrá en la asignatura de "Recursos Documentales e Informáticos" e implementará en otras asignaturas de grado, máster y doctorado.

\section{Agradecimientos}

Este trabajo no hubiera sido posible sin el apoyo proporcionado por el Vicerrectorado de Docencia de la Universidad de Valladolid (Proyecto de Innovación Docente No 134).

\section{Referencias}

BARNES, R. (2017). "Kahoot! in the Classroom: Student Engagement Technique” en Nurse Educator, vol. 42, issue 6, p. 280-280.

CHAIYO, Y.; NOKHAM, R. (2017). "The Effect of Kahoot, Quizizz and Google forms on the Student's Perception in the Classrooms Response System”. En: 2017 International Conference on

(cc) EY-NC-ND 2018, Universitat Politècnica de València

Congreso IN-RED (2018) 
Digital Arts, Media and Technology (ICDAMT) - Digital Economy for Sustainable Growth. pp. 178182. Chiang Mai.

FUERTES, A.; GARCÍA, M.; CASTAÑO, M. A.; LÓPEZ, E.; ZACARES, M.; COBOS, M.; FERRIS, R.; GRIMALDO, F. (2016). "Uso de herramientas de respuesta de audiencia en la docencia presencial universitaria. Un primer contacto”. En Actas de las XXII Jenui. pp. 262-268. Almería. Disponible en https://www.uv.es/grimo/publications/jenui2016.pdf [Consulta: 10 de marzo de 2018]

GARCIA-GARCIA, D.; CARBONELL-VERDU, A.; MONTAÑES, N.; QUILES, L.; FOMBUENA, V. (2017). "Incorporación de la aplicación Kahoot! para la evaluación de las prácticas de la asignatura de "Ciencia de Materiales”. Fernández Prada, M. Á. y Botti Navarro, V. J. (coord.) En: IN-RED 2017. Congreso nacional de innovación educativa y de docencia en red. pp. 1209-1217. Valencia: Editorial Universitat Politècnica de València. Disponible en http://hdl.handle.net/10251/86908 [Consulta: 15 de marzo de 2018]

GOOGLEFORMS <https://www.google.com/forms/about/> [Consulta: 3 de marzo de 2018]

IWAMOTO, D. H.; HARGIS, J.; TAITANO, E. J.; VUONG, K. (2017) “Analyzing the efficacy of the testing effect using Kahoot (TM) on student performance” en Turkish Online Journal of Distance Education, vol. 18, issue 2, p. 80-93.

KAHOOT!. <https://kahoot.com/> [Consulta: 26 de febrero de 2018]

LLERENA, E. G.; RODRIGUEZ, C. P. (2017) "Kahoot! A Digital Tool for Learning Vocabulary in a language classroom” en Revista Publicando, vol. 4, isuue 12, p. 441-449.

PEÑA, B.; ZABALZA, I.; USÓN, S.; LLERA, E. M.; MARTÍNEZ, A.; ROMEO L. M. (2017). "Experiencia piloto de aula invertida para mejorar el proceso de enseñanza-aprendizaje en la asignatura de TermodinámicaTécnica”. Fernández Prada, M. Á. y Botti Navarro, V. J. (coord.) En: IN-RED 2017. Congreso nacional de innovación educativa y de docencia en red. pp.583-596. Valencia: Editorial Universitat Politècnica de València. Disponible en http://hdl.handle.net/10251/86908 [Consulta: 14 de marzo de 2018]

PROYECTA (2018). “Gamificación: jugar para aprender”, http://www.plataformaproyecta.org/es/recursos-educativos/gamificacion-jugar-para-aprender [Consulta: 1 de marzo de 2018]

QUIZIZZ < https://quizizz.com/> [Consulta: 3 de marzo de 2018]

RODRIGUEZ-FERNANDEZ, L. (2017). "Smartphones and learning: use of Kahoot in the university classroom” en Revista Mediterranea Comunicacion-Journal of Communication, vol. 8, isuue 1, p. 181-189.

ROGER, S.; COBOS, M.; AREVALILLO-HERRÁEZ, M.; GARCÍA-PINEDA, M. (2017). "Combinación de cuestionarios simples y gamificados utilizando gestores de participación en el aula: experiencia y percepciónn del alumnado”. Fernández Prada, M. Á. y Botti Navarro, V. J. (coord.) En: IN-RED 2017. Congreso nacional de innovación educativa y de docencia en red. pp.1128-1139. Valencia: Editorial Universitat Politècnica de València. Disponible en http://hdl.handle.net/10251/86908 [Consulta: 16 de marzo de 2018]

SAN-MIGUEL, T.; MEGIAS, J.; SERNA, E. (2017). “Gamificación en la universidad II: aprendemos a divertirnos enseñando. Se divierten aprendiendo”. Fernández Prada, M. Á. y Botti Navarro, V. J. (coord.) En: IN-RED 2017. Congreso nacional de innovación educativa y de docencia en red. pp. 484-492. Valencia: Editorial Universitat Politècnica de València. Disponible en http://hdl.handle.net/10251/86908 [Consulta: 18 de marzo de 2018]

SOCRATIVE < https://www.socrative.com/> [Consulta: 3 de marzo de 2018]

(cc) EY-NC-ND 2018, Universitat Politècnica de València

Congreso In-Red (2018) 
SONG, Y. (2014). ““'Bring Your Own Device (BYOD)” for seamless science inquiry in a primary school” en Computers \& Education, vol. 74, p. 50-60.

TEJEDOR, F.J.; GARCÍA-VALCÁRCEL, A. (2007). "Causas del bajo rendimiento del estudiante universitario (en opinión de los profesores y alumnos). Propuestas de mejora en el marco del EEES” en Revista de Educación, vol. 342, p. 443-473.

WANG, A. I.; LIEBEROTH, A. (2016). "The Effect of Points and Audio on Concentration, Engagement, Enjoyment, Learning, Motivation, and Classroom Dynamics Using Kahoot!” En: Proceedings of the 10th European Conference on Games-Based Learning. pp. 738-746. Paisley.

(cc) EY-NC-ND 2018, Universitat Politècnica de València 


\title{
Estrategias de aprendizaje en estudiantes universitarios de nuevo ingreso y su relación con la vía de acceso a la universidad
}

\section{Francisco Javier Tortajada Blanca ${ }^{a}$, Pablo Chust Hernández}

${ }^{a}$ Servicio de Orientación Universidad Católica de Valencia, Escuela de Doctorado Universidad de Valencia, fj.tortajada@ucv.es, bServicio de Orientación Universidad Católica de Valencia, Escuela de Doctorado Universidad Católica de Valencia, pablo.chust@ucv.es

\begin{abstract}
Objectives: To analyze the learning strategies most used by new university students at the Catholic University of Valencia, along with the strategies that are least used, and the differences in the use of learning strategies according to the university access route (Training Cycles and A levels), and by the type of High School. Methods: a cross-sectional descriptive study was conducted on 1465 new students in 28 degrees at the Catholic University of Valencia, who answered the Questionnaire for the Evaluation of Learning Strategies in University Students (CEVEAPEU). Results: Strategies that are least used by students are "Extrinsic motivation", "External attributions", "Anxiety", "Knowledge of objectives and evaluation criteria", "Planning", "Knowledge of sources and search for information", "Storage. Simple repetition." Students from high school show better management of strategies related to theoretical study, while those from the Formative Cycles present higher ratings in motivational strategies. Students from the Bachelor of Science and Technology present a better strategic profile compared to those from the Bachelor of Social Sciences and Humanities. Discussion and conclusions: Results are analyzed and implications for practice are suggested.
\end{abstract}

Keywords: learning strategies, self-regulated learning, academic achievement, college students, secondary school, vocational training.

\footnotetext{
Resumen

Objetivos: Analizar las estrategias de aprendizaje que mejor utilizan los estudiantes universitarios de nuevo ingreso en grados de la Universidad Católica de Valencia, así como las estrategias que peor utilizan, y las diferencias en el uso de estrategias de aprendizaje en función de la vía de acceso a la universidad (Ciclos Formativos y Bachillerato), y del tipo de Bachillerato. Método: estudio descriptivo de corte transversal, llevado a cabo sobre 1465 estudiantes de nuevo ingreso en 28 titulaciones de la Universidad Católica de Valencia, que respondieron al Cuestionario de Evaluación de Estrategias de Aprendizaje en Estudiantes Universitarios (CEVEAPEU). Resultados: Las estrategias que peor utilizan los alumnos son "Motivación extrínseca”, “Atribuciones externas”, "Ansiedad”,
} 
“Conocimiento de objetivos y criterios de evaluación”, "Planificación”, "Conocimiento de fuentes y búsqueda de información”, "Almacenamiento. Simple repetición”. Los estudiantes provenientes de Bachillerato manejan mejor las estrategias relacionadas con el estudio teórico, mientras que los provenientes de Ciclos Formativos presentan puntuaciones más altas en las estrategias motivacionales. Los estudiantes provenientes de Bachillerato de Ciencias y Tecnología presentan un mejor perfil estratégico que los provenientes de Bachillerato de Ciencias Sociales y Humanidades. Discusión y conclusiones: se analizan los resultados y se sugieren implicaciones para la práctica.

Pablabras clave: Estrategias de aprendizaje, aprendizaje autorregulado, rendimiento académico, estudiantes universitarios, Bachillerato, Ciclos Formativos

\section{Introducción}

La entrada a la universidad constituye un cambio radical en la vida del estudiante, que supone modificaciones significativas en el contexto educativo y en el afrontamiento de nuevas situaciones (Pulido et al., 2011). A pesar de que todo el alumnado tiene experiencia previa en otros niveles de estudio (Bachillerato, Formación Profesional, etc.), los universitarios de nuevo ingreso tienen que hacer frente a una serie de demandas nuevas y diferentes a las que hasta ahora se han enfrentado: diferentes formas de evaluación, metodologías docentes, etc.

Para poder hacer frente a estas exigencias y poder superar con éxito el primer curso de universidad, los estudiantes deben adquirir una serie de recursos y estrategias que les permitan alcanzar sus objetivos académicos.

Los factores que inciden en el rendimiento académico de los estudiantes universitarios son múltiples y complejos y constituyen una maraña en la que se hace muy difícil ponderar la influencia concreta de cada uno (Gargallo et al., 2007-A-). En las últimas dos décadas se han estudiado las relaciones entre algunas de estas variables con el rendimiento académico. Así, se ha evidenciado que los estudiantes universitarios que llevan a cabo un mayor y mejor uso de las estrategias de aprendizaje presentan también un mayor rendimiento académico (Juárez et al., 2016; Bahamón et al., 2013; Gargallo et al., 2012; Yip, 2012; Gargallo et al., 2009; Soares et al., 2009; Gargallo et al., 2007-B; Diset y Marthinsen, 2003). Por tanto, las estrategias de aprendizaje están, pues, directamente relacionadas con la calidad del aprendizaje del estudiante, ya que permiten identificar y diagnosticar las causas del bajo o alto rendimiento académico (Beltrán, 2003). Por ello, las estrategias de aprendizaje son uno de los instrumentos más importantes dentro de la enseñanza de los estudiantes (Gargallo et al., 2012).

Las estrategias de aprendizaje pueden definirse como un "conjunto organizado, consciente e intencional de lo que hace el aprendiz para lograr con eficacia un objetivo de aprendizaje

(cc) BY-NC-ND 2018, Universitat Politècnica de València

Congreso IN-RED (2018) 
en un contexto social dado" (Gargallo et al., 2009). Actuar estratégicamente implica el deseo de querer aprender eficazmente y el diseño y ejecución de planes de acción que se ajusten a las metas previstas y a las condiciones del contexto. Para ello, se deben seleccionar y poner en marcha procedimientos, habilidades y técnicas eficaces para aprender (García y Pintrich, 1993). La función principal de las estrategias de aprendizaje es la de facilitar la asimilación de la información que llega del exterior al sistema cognitivo del alumno (Monereo, 1990).

Otros autores también hacen referencia a las estrategias de aprendizaje como actividades propositivas que influyen en el proceso de la recopilación de información (Camarero y cols, 2000), a partir de las cuales el alumno puede decidir recuperar los conocimientos que necesita para poder afrontar una determinada tarea o lograr un objetivo (Nuñez et al., 1998).

Existen diversas clasificaciones de estrategias de aprendizaje. Román y Gallego (2001) categorizan cuatro tipos de estrategias: de adquisición, de codificación, de recuperación de apoyo. Zimmerman (2002), establece 3 categorías principales: estrategias de apoyo, cognitivas y metacognitivas.

No obstante, una de las clasificaciones más recientes y, a nuestro juicio, más completas es la establecida por Gargallo et al. (2009), quienes establecen 25 estrategias diferentes de estudio, relativas a componentes motivacionales, afectivos, metacognitivos, de control del contexto, de interacción social, de manejo de recursos, de búsqueda y selección de la información, y de procesamiento y uso de dicha información.

\section{Objetivos}

1. Analizar las estrategias de aprendizaje que mejor utilizan los estudiantes universitarios de nuevo ingreso en grados de la Universidad Católica de Valencia, así como las estrategias que peor utilizan.

2. Analizar las diferencias en el uso de estrategias de aprendizaje en los estudiantes universitarios de nuevo ingreso en grados de la Universidad Católica de Valencia, en función de la vía de acceso a la universidad (Bachillerato o Ciclos Formativos).

3. Analizar las diferencias en el uso de estrategias de aprendizaje en los estudiantes universitarios de nuevo ingreso en grados de la Universidad Católica de Valencia, en función del tipo de Bachillerato cursado por el alumno (Bachillerato de Ciencias y Tecnología o Bachillerato de Ciencias Sociales y Humanidades).

\section{Desarrollo de la innovación}

\subsection{Diseño del estudio}

Para el presente estudio se utilizó un diseño descriptivo transversal. 


\subsection{Población y muestra}

La población de estudio estuvo compuesta por todos los estudiantes de nuevo ingreso en todos los Grados de la Universidad Católica de Valencia, en el curso 2017-2018. No se excluyó ningún alumno. Para participar tenían que cumplir los siguientes criterios: haber acudido a clase el día del pase de encuestas, comprender adecuadamente el idioma español escrito y mostrar su conformidad con participar en el estudio firmando un consentimiento informado.

\subsection{Instrumentos utilizados}

Cuestionario de Evaluación de Estrategias de Aprendizaje en Estudiantes Universitarios (CEVEAPEU), confeccionado por Gargallo et al. (2009). Se trata de un instrumento de 88 ítems que evalúa 25 estrategias de aprendizaje, divididas en 6 subescalas. Estas 6 subescalas están integradas, a su vez, en dos escalas. Utiliza una escala tipo Likert con 5 opciones de respuesta. En cada estrategia se puede obtener una puntuación entre 1 y 5 puntos. Cuanto más baja es la puntuación peor uso de dicha estrategia realiza el estudiante. Cuanto más alta es la puntuación mejor uso de dicha estrategia realiza el estudiante.

En la tabla 1 se puede observar la estructura del CEVEAPEU, con sus datos de fiabilidad.

\begin{tabular}{|c|c|c|}
\hline Escala & Subescala & Estrategia \\
\hline \multirow{15}{*}{$\begin{array}{l}\text { Escala I } \\
\text { Estrategias afectivas, } \\
\text { de apoyo y control (o } \\
\text { automanejo) } \\
(\alpha=.819)\end{array}$} & \multirow{7}{*}{$\begin{array}{l}\text { Subescala } 1 \\
\text { Estrategias } \\
\text { motivacionales } \\
(\alpha=.692)\end{array}$} & 1. Motivación intrínseca $(\alpha=.500)$ \\
\hline & & 2. Motivación extrínseca $(\alpha=.540)$ \\
\hline & & 3. Valor de la tarea $(\alpha=.692)$ \\
\hline & & 4. Atribuciones internas $(\alpha=.537)$ \\
\hline & & 5. Atribuciones externas $(\alpha=.539)$ \\
\hline & & 6. Autoeficacia y expectativas $(\alpha=.743)$ \\
\hline & & $\begin{array}{l}\text { 7. Concepción de la inteligencia como } \\
\text { modificable }(\alpha=.595)\end{array}$ \\
\hline & \multirow{2}{*}{$\begin{array}{l}\text { Subescala } 2 \\
\text { Componentes afectivos } \\
(\alpha=.707)\end{array}$} & 8. Estado físico y anímico $(\alpha=.735)$ \\
\hline & & 9. Ansiedad $(\alpha=.714)$ \\
\hline & \multirow{4}{*}{$\begin{array}{l}\text { Subescala } 3 \\
\text { Estrategias } \\
\text { metacognitivas } \\
(\alpha=.738)\end{array}$} & $\begin{array}{l}\text { 10. Conocimiento de objetivos y criterios } \\
\text { de evaluación }(\alpha=.606)\end{array}$ \\
\hline & & 11. Planificación $(\alpha=.738)$ \\
\hline & & 12. Autoevaluación $(\alpha=.521)$ \\
\hline & & 13. Control, autorregulación $(\alpha=.660)$ \\
\hline & \multirow[b]{2}{*}{$\begin{array}{l}\text { Subescala } 4 \\
\text { Estrategias de control del } \\
\text { contexto, } \\
\text { social interacción } \\
\text { recursos } \\
(\alpha=.703)\end{array}$} & 14. Control del contexto $(\alpha=.751)$ \\
\hline & & $\begin{array}{l}\text { 15. Habilidades de interacción social y } \\
\text { aprendizaje con compañeros }(\alpha=.712)\end{array}$ \\
\hline \multirow{7}{*}{$\begin{array}{l}\text { Escala II } \\
\text { Estrategias relacionadas } \\
\text { con el procesamiento } \\
\text { de la información } \\
(\alpha=.864)\end{array}$} & \multirow{2}{*}{$\begin{array}{l}\text { Subescala } 5 \\
\text { Estrategias de búsqueda y } \\
\text { selección e información } \\
(\alpha=.705)\end{array}$} & $\begin{array}{l}\text { 16. Conocimiento de fuentes y búsqueda } \\
\text { de información }(\alpha=.685)\end{array}$ \\
\hline & & 17. Selección de información $(\alpha=.630)$ \\
\hline & \multirow{5}{*}{$\begin{array}{l}\text { Subescala } 6 \\
\text { Estrategias de } \\
\text { procesamiento y uso de la } \\
\text { información } \\
(\alpha=.821)\end{array}$} & 18. Adquisición de información $(\alpha=.677)$ \\
\hline & & 19. Elaboración $(\alpha=.739)$ \\
\hline & & 20. Organización $(\alpha=.810)$ \\
\hline & & $\begin{array}{l}\text { 21. Personalización, creatividad y } \\
\text { pensamiento crítico }(\alpha=.771)\end{array}$ \\
\hline & & 22. Almacenamiento. Memorización. \\
\hline
\end{tabular}

(c)) EY-NC-ND 2018, Universitat Politècnica de València 


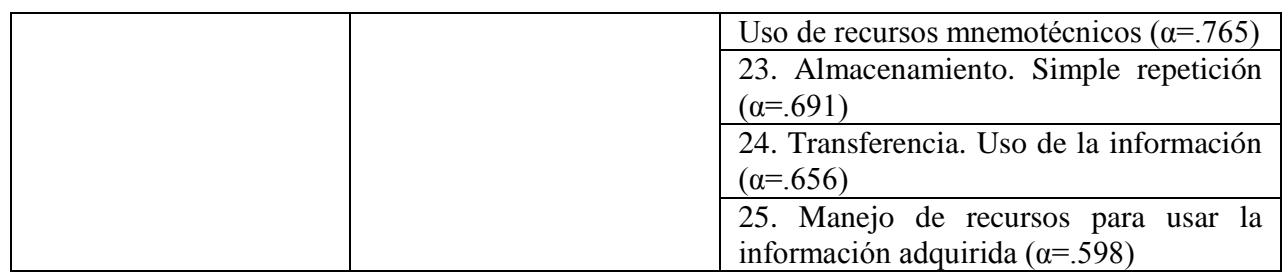

Tabla 1. Estructura del Cuestionario de Evaluación de Estrategias de Aprendizaje en Estudiantes Universitarios (extraído de Gargallo et al., 2009)

Se analizaron variables sociodemográficas, (sexo y edad) y variables de acceso a la universidad (modo de acceso) con ítems de creación propia.

\subsection{Recogida de datos}

La recogida de datos se realizó en Septiembre de 2017, el $1^{\text { }}$ día de clases. Las encuestas fueron administradas por el equipo de orientación psicológica y pedagógica de la universidad.

\subsection{Aspectos éticos}

El estudio fue aprobado por el Comité de Ética de la Investigación de la Sociedad Valenciana de Bioética. Se aseguró la confidencialidad de datos a todos los participantes.

\subsection{Análisis estadístico}

El análisis estadístico se realizó con el paquete estadístico IBM SPSS v23.0.

Para describir las variables se utilizó la estadística descriptiva. Se utilizaron medidas de tendencia central (media) y de dispersión (desviaciones estándar) de las variables analizadas.

Para evaluar la normalidad de las variables se utilizó la prueba Z de Kolmogovov-Smirnov.

La comparación de medias de dos grupos se realizó mediante la prueba $\mathrm{T}$ Student, considerando que existen diferencias estadísticamente significativas con valores de $\mathrm{p}<0,05$.

\section{Resultados}

La muestra quedó conformada por 1465 estudiantes (935 mujeres -63,82\%-; 530 hombres 36,18\%-) de 28 titulaciones y dobles titulaciones: Magisterio de Educación Primaria, Magisterio de Educación Infantil, Psicología, Educación Social, Logopedia, Terapia Ocupacional, Podología, Ciencias de la Actividad Física y Deportiva, Fisioterapia, Nutrición, Enfermería, Medicina, Odontología, Administración y dirección de empresas, Gestión Económico-Financiera, Derecho, Criminología, Multimedia y Artes Digitales, Biotecnología, Veterinaria, Ciencias del Mar, Magisterio de Educación Infantil + Educación Primaria, Magisterio de Educación Primaria + Ciencias de la Actividad Física y 
Deportiva, Educación Social + Magisterio de Educación Primaria, Educación Social + Trabajo Social, Terapia Ocupacional + Fisioterapia, Derecho + Criminología y Podología + Enfermería.

La edad media fue de 19,37 años, siendo la mínima edad 17 años la mayor 45. En cuanto a la vía de acceso a la universidad, 607 estudiantes (41,4\%) son provenientes de Bachillerato de Ciencias y Tecnología, 483 (33\%) de Bachillerato de Ciencias Sociales y Humanidades, y 287 (19,6\%) de Ciclo formativo superior. El resto (6\%) entraron a la universidad por otras vías de acceso (Bachillerato de Artes, otra titulación universitaria, prueba de acceso para mayores de 25 y 40 años).

Los resultados de las pruebas de normalidad para las variables fueron valores mayores de 0,05 .

En la tabla 2 se pueden observar las 7 estrategias de aprendizaje en las que la muestra total de estudiantes extrae una mayor puntuación.

\begin{tabular}{ll}
\hline \multicolumn{1}{c}{ Estrategia } & $\begin{array}{c}\text { Media (Desviación } \\
\text { estándar) }\end{array}$ \\
\hline Estrategia 3. Valor de la tarea & $4,41\left({ }^{ \pm} 0,43\right)$ \\
Estrategia 4. Atribuciones internas & $4,16\left({ }^{ \pm} 0,52\right)$ \\
Estrategia 18. Adquisición de información & $4,14\left({ }^{ \pm} 0,51\right)$ \\
Estrategia 1. Motivación intrínseca & $4,09\left({ }^{ \pm} 0,53\right)$ \\
Estrategia 7. Concepción de la inteligencia como modificable & $4\left({ }^{ \pm} 0,8\right)$ \\
Estrategia 13. Control, autorregulación & $3,96\left({ }^{ \pm} 0,46\right)$ \\
Estrategia 6. Autoeficacia y expectativas & $3,95\left({ }^{ \pm} 0,54\right)$ \\
\hline Tabla 2. Estrategias de aprendizaje en las que los estudiantes extraen mayor puntuación
\end{tabular}

En la tabla 3 se muestran las 7 estrategias de aprendizaje en las que la muestra total de estudiantes extrae una puntuación menor.

\begin{tabular}{lc}
\hline \multicolumn{1}{c}{ Estrategia } & $\begin{array}{c}\text { Media (Desviación } \\
\text { estándar) }\end{array}$ \\
\hline Estrategia 9. Ansiedad & $2,71\left(^{ \pm} 0,89\right)$ \\
Estrategia 16. Conocimiento de fuentes y búsqueda de información & $3,13\left({ }^{ \pm} 0,65\right)$ \\
Estrategia 23. Almacenamiento. Simple repetición & $3,14\left({ }^{ \pm} 0,98\right)$ \\
Estrategia 2. Motivación extrínseca & $3,25\left({ }^{ \pm} 0,99\right)$ \\
Estrategia 10. Conocimiento de objetivos y criterios de evaluación & $3,32\left({ }^{ \pm} 0,88\right)$ \\
Estrategia 5. Atribuciones externas & $3,32\left({ }^{ \pm} 0,89\right)$ \\
Estrategia 11. Planificación & $3,36\left({ }^{ \pm} 0,72\right)$ \\
\hline
\end{tabular}

Tabla 3. Estrategias de aprendizaje en las que los estudiantes extraen menor puntuación

En la tabla 4 se muestran las estrategias que presentan puntuaciones con diferencias significativas entre los estudiantes provenientes de Bachillerato y los provenientes de Ciclos Formativos.

En el resto de estrategias no se hallaron diferencias significativas en función de la vía de acceso.

\begin{tabular}{cccc}
\hline & Bachillerato & Ciclos & \\
Estrategia & $(\mathrm{n}=1090)$ & $\begin{array}{c}\text { Formativos } \\
\text { Media }\end{array}$ & P valor \\
& (Desviación & Media & \\
\hline
\end{tabular}




\begin{tabular}{|c|c|c|c|}
\hline & Estándar) & $\begin{array}{l}\text { (Desviación } \\
\text { Estándar) }\end{array}$ & \\
\hline Estrategia 1. Motivación intrínseca & $4,07\left({ }^{ \pm} 0,53\right)$ & $4,17\left({ }^{ \pm} 0,53\right)$ & 0,006 \\
\hline Estrategia 5. Atribuciones externas & $3,28\left({ }^{ \pm} 0,91\right)$ & $3,45\left({ }^{ \pm} 0,84\right)$ & 0,004 \\
\hline $\begin{array}{l}\text { Estrategia 7. Concepción de la inteligencia como } \\
\text { modificable }\end{array}$ & $3,97\left({ }^{ \pm} 0,80\right)$ & $4,11\left({ }^{ \pm} 0,80\right)$ & 0,01 \\
\hline Estrategia 13. Control, autorregulación & $3,97\left({ }^{ \pm} 0,45\right)$ & $3,9\left({ }^{ \pm} 0,52\right)$ & 0,03 \\
\hline Estrategia 14. Control del contexto & $3,88\left({ }^{ \pm} 0,61\right)$ & $3,73\left({ }^{ \pm} 0,68\right)$ & $<0,001$ \\
\hline Estrategia 17. Selección de la información & $3,42\left({ }^{ \pm} 0,57\right)$ & $3,26\left({ }^{ \pm} 0,60\right)$ & $<0,001$ \\
\hline Estrategia 20. Organización & $3,90\left({ }^{ \pm} 0,80\right)$ & $3,80\left({ }^{ \pm} 0,73\right)$ & 0,048 \\
\hline $\begin{array}{l}\text { Estrategia 22. Almacenamiento. Memorización. } \\
\text { Uso de recursos mnemotécnicos }\end{array}$ & $3,67\left({ }^{ \pm} 0,90\right)$ & $3,49\left({ }^{ \pm} 0,89\right)$ & 0,002 \\
\hline $\begin{array}{l}\text { Estrategia 24. Transferencia. Uso de la } \\
\text { información }\end{array}$ & $3,84\left({ }^{ \pm} 0,53\right)$ & $3,94\left({ }^{ \pm} 0,48\right)$ & 0,006 \\
\hline
\end{tabular}

En la tabla 5 se muestran las estrategias que presentan puntuaciones con diferencias significativas entre los estudiantes provenientes de Bachillerato de Ciencias y Tecnología y los provenientes de Bachillerato de Ciencias Sociales y Humanidades.

En el resto de estrategias no se hallaron diferencias significativas en función de la vía de acceso.

\begin{tabular}{|c|c|c|c|}
\hline Estrategia & $\begin{array}{l}\text { Bachillerato } \\
\text { Ciencias y } \\
\text { Tecnología } \\
\text { (n=607) } \\
\text { Media } \\
\text { (Desviación } \\
\text { Estándar) }\end{array}$ & $\begin{array}{c}\text { Bachillerato } \\
\text { Ciencias } \\
\text { Sociales y } \\
\text { Humanidades } \\
\text { (n=483) } \\
\text { Media } \\
\text { (Desviación } \\
\text { Estándar) }\end{array}$ & $\mathrm{P}$ valor \\
\hline Estrategia 1. Motivación intrínseca & $4,1\left({ }^{ \pm} 0,5\right)$ & $4,03\left({ }^{ \pm} 0,56\right)$ & 0,017 \\
\hline Estrategia 2. Motivación extrínseca & $3,36\left({ }^{ \pm} 0,95\right)$ & $3,05\left({ }^{ \pm} 1,02\right)$ & $<0,001$ \\
\hline Estrategia 5. Atribuciones externas & $3,34\left({ }^{ \pm} 0,84\right)$ & $3,20\left({ }^{ \pm} 0,98\right)$ & 0,013 \\
\hline $\begin{array}{l}\text { Estrategia 7. Concepción de la inteligencia como } \\
\text { modificable }\end{array}$ & $4,07\left({ }^{ \pm} 0,77\right)$ & $3,86\left({ }^{ \pm} 0,84\right)$ & $<0,001$ \\
\hline Estrategia 11. Planificación & $3,47\left({ }^{ \pm} 0,73\right)$ & $3,25\left({ }^{ \pm} 0,69\right)$ & $<0,001$ \\
\hline Estrategia 18. Adquisición de información & $4,19\left({ }^{ \pm} 0,5\right)$ & $4,11\left({ }^{ \pm} 0,52\right)$ & 0,014 \\
\hline Estrategia 19. Elaboración & $3,49\left({ }^{ \pm} 0,84\right)$ & $3,38\left({ }^{ \pm} 0,72\right)$ & 0,018 \\
\hline $\begin{array}{l}\text { Estrategia 22. Almacenamiento. Memorización. } \\
\text { Uso de recursos mnemotécnicos }\end{array}$ & $3,75\left({ }^{ \pm} 0,86\right)$ & $3,58\left({ }^{ \pm} 0,94\right)$ & 0,002 \\
\hline $\begin{array}{l}\text { Estrategia 23. Almacenamiento. Simple } \\
\text { repetición }\end{array}$ & $3,26\left({ }^{ \pm} 0,96\right)$ & $2,97\left({ }^{ \pm} 1,02\right)$ & $<0,001$ \\
\hline
\end{tabular}

\section{Discusión y conclusiones}

El primer objetivo de este estudio fue analizar las estrategias de aprendizaje que mejor utilizan los estudiantes universitarios de nuevo ingreso en grados de la Universidad Católica de Valencia, así como las estrategias que peor utilizan. Los resultados muestran que los estudiantes presentan serias dificultades en cuanto al control de la ansiedad en exámenes, exposiciones orales e intervenciones en público (estrategia 9). Manifiestan 
también un nivel de motivación extrínseca frente a los estudios que les llevaría a estudiar para no defraudar a su familia, necesitando que otras personas le ayuden a estudiar (estrategia 2). Del mismo modo, estos alumnos presentan puntuaciones bajas en las atribuciones externas lo que significa que los alumnos consideran, en cierta medida, que el aprobar o no las asignaturas depende en gran parte de la suerte y de los profesores (estrategia 5).

Por otro lado, los resultados evidencian también que muchos alumnos que acceden por primera vez a la universidad tienen carencias en cuanto a su planificación, lo que implica que no organizan su tiempo con un horario de trabajo personal, y que no llevarían al día el estudio de las diferentes asignaturas, estudiando solo antes de los exámenes (estrategia 11). Del mismo modo, muchos de ellos tendrían problemas con respecto al conocimiento de fuentes y búsqueda de información, no siendo capaces de integrar la información de diferentes fuentes, amplíar el material de clase con otros libros, revistas, etc. y tratar de entender los contenidos estableciendo relaciones entre lo que le explican en clase y lo que ellos leen (estrategia 16). Por todo ello, no es de extrañar que muchos alumnos realicen un estudio puramente memorístico, en el que se limitan a repetir los contenidos una y otra vez, estudiando contenidos de memoria aunque no los entiendan (estrategia 23).

Por último, los estudiantes manifiestan también un nivel limitado en el conocimiento de los objetivos y criterios de evaluación de las diferentes asignaturas y materias (estrategia 10).

Gargallo et al. (2012), en un estudio realizado sobre estudiantes de nuevo ingreso de 11 titulaciones de la Universidad Politécnica de Valencia (UPV), evidenciaron las puntuaciones más bajas, que implican un peor uso por parte de los estudiantes, en las mismas estrategias que muestran los resultados de este estudio (2, 5, 9. 11, 16, 23), a excepción de la estrategia 10 (Conocimiento de los objetivos y criterios de evaluación). Estos hallazgos sugieren que los estudiantes de nuevo ingreso en universidades de la Comunidad Valenciana podrían acceder a sus estudios superiores con las mismas carencias en lo que a estrategias de aprendizaje se refiere. No obstante, harían falta más estudios para poder generalizar los resultados a todos los estudiantes de nuevo ingreso de dicha comunidad autónoma.

El segundo objetivo consistió en analizar las diferencias en el uso de estrategias de aprendizaje en los estudiantes universitarios de nuevo ingreso en grados de la Universidad Católica de Valencia, en función de la vía de acceso a la universidad (Bachillerato o Ciclos Formativos).

Los resultados muestran que las puntuaciones más altas en los estudiantes provenientes de Bachillerato se dan en estrategias más relacionadas con lo que podría suponer un estudio más teórico que práctico:

- Estrategia 13: control y autorregulación. Se refiere capacidad de cambiar de estrategias cuando las que se utilizan no funcionan, a la capacidad de adaptar el modo de trabajo a las exigencias de los diferentes profesores y materias, al intento de aprender nuevas técnicas y habilidades para estudiar mejor y rendir más...

(cc) EY-NC-ND 2018, Universitat Politècnica de València

Congreso IN-RED (2018) 
- Estrategia 14: control del contexto. Se refiere a la adecuación e idoneidad del lugar y del ambiente de estudio

- Estrategia 17: selección de la información. Se refiere a la capacidad de seleccionar la información necesaria para estudiar con garantías las asignaturas, sabiendo separar la información fundamental de la que no lo es y a la habilidad para discriminar la fiabilidad de los materiales que se encuentran en internet.

- Estrategia 20: organización. Se refiere a la habilidad para organizar la información en esquemas, resúmenes, tablas, gráficos, mapas conceptuales, y otras técnicas similares

- Estrategia 22: almacenamiento de la información; uso de recursos mnemotécnicos. Se refiere a la capacidad para poner en marcha técnicas y estrategias de memorización, como la categorización, recursos mnemotécnicos o memorización a través de palabras clave.

Este hallazgo podría tener su explicación en el hecho de que los alumnos que acceden a la universidad desde Bachillerato hayan estado sometidos a estudios más teóricos que los que se imparten en Ciclos Formativos, que suelen ser estudios de carácer más práctico y profesionalizante, por lo que los estudiantes de Bachillerato habrían desarrollado mejores estrategias para hacer frente a dichos contenidos teóricos.

Por el contrario, los estudiantes provenientes de Ciclos Formativos manifiestan mejor motivación intrínseca (es decir, mayor satisfacción por entender a fondo los contenidos) que los provenientes de Bachillerato. Este hallazgo podría deberse a que los Ciclos Formativos que cursan los estudiantes suelen tener gran relación y ser de la misma área que los posteriores estudios universitarios que realizan. Normalmente estos estudiantes, al iniciar sus estudios universitarios, ya tienen experiencia profesional o pre-profesional en las areas profesionales relativas a dichas titulaciones superiores (Sanidad, Educación Infantil, Odontología, Actividad física y deportiva, etc.), por lo que podrían comenzar sus estudios superiores con mayor ánimo de aprendizaje que sus homólogos provenientes de Bachillerato, cuyos estudios previos no están directamente relacionados con profesiones concretas. Por otra parte, muchos de los estudiantes que previamente han cursado Ciclos Formativos trabajan en dichas áreas, por lo que, si deciden iniciar sus estudios universitarios es porque realmente lo desean, lo cual podría aumentar su motivación ante los estudios. Estos mismos hechos podrían explicar también las mayores puntuaciones de estos alumnos en la estrategia 24 "Transferencia. Uso de la información”. Los alumnos con puntuaciones altas en dicho índice, utilizan lo aprendido en una asignatura para otras asignaturas y para situaciones de la vida cotidiana, aplicando sus conocimientos a situaciones y tareas nuevas.

No obstante, serían necesarios más estudios para analizar la veracidad y consistencia de estas posibles explicaciones a los hallazgos descritos en los párrafos anteriores.

El tercer objetivo fue analizar las diferencias en el uso de estrategias de aprendizaje en los estudiantes universitarios de nuevo ingreso en grados de la Universidad Católica de Valencia en función del tipo de Bachillerato cursado por el alumno. Los resultados muestran que los estudiantes provenientes de Bachillerato de Ciencias y tecnología 
presentan mejor uso en 9 de las 25 estrategias que los estudiantes provenientes de Bachillerato de Ciencias sociales y Humanidades. Concretamente, los primeros presentan un mejor uso de las estrategias de tipo motivacional, y en las relativas al procesamiento y uso de la información, así como en la planificación temporal del estudio. En las 16 estrategias restantes no se observan diferencias significativas en función de la modalidad de Bachillerato.

Futuros estudios podrían tratar de esclarecer las causas de que los estudiantes provenientes de Bachillerato de Ciencias y Tecnología presenten un mejor perfil estratégico que los de Ciencias sociales y Humanidades.

\subsection{Implicaciones para la práctica}

Aunque la dinámica de primer curso y el mismo trabajo que conlleva ya proporciona al alumnado la adquisición o mejora de algunas de las estrategias de aprendizaje, para la consecución de otras se necesitará un refuerzo/apoyo por parte del equipo docente o de otros profesionales. Por ello, se hace necesaria la formación en estrategias de aprendizaje que ayuden a los alumnos a aprender a aprender (Gargallo et al., 2014; Bahamón et al., 2013; Gargallo et al., 2012). Dicha formación se puede realizar con programas específicos de refuerzo o enseñanza de las estrategias de aprendizaje (Tuckman y Kennedy, 2011; Hernández et al., 2006). Como agente educativo, la universidad puede promover la actuación de servicios de apoyo y orientación psicopedagógica al estudiante. Otra forma de ayudar a los estudiantes a adquirir y potenciar las estrategias de aprendizaje es integrar dichos contenidos en la metodología docente en el aula (McCune y Entwistle, 2011; Gargallo et al., 2010; Biggs y Tang, 2007), utilizando métodos alternativos a la exposición magistral, como el estudio de casos, la pregunta socrática y el diálogo en clase, el trabajo cooperativo, el uso de webquests, etc.

A la luz de los resultados de este estudio, las intervenciones dirigidas a mejorar el uso de estrategias de aprendizaje en los estudiantes de nuevo ingreso en la universidad deberían centrarse especialmente en aspectos de tipo afectivo y motivacional, como la ansiedad ante los exámenes y las exposiciones orales, el establecimiento de una adecuada motivación y de unas atribuciones internas al rendimiento académico. Las estrategias metacognitivas, tales como la clarificación de los objetivos y criterios de evaluación de las diferentes asignaturas, o la planificación del estudio también deberían ser abordadas. Por último, se debería atender también a estrategias relacionadas con el uso de la información, tales como el conocimiento de fuentes y búsqueda de información y el estudio por medio de estrategias diferentes a la simple repetición. Los resultados sugieren la conveniencia de proporcionar ayuda y/o orientación académica a los estudiantes provenientes de Ciclos Formativos con respecto a las estrategias relacionadas con el estudio teórico, así como a los estudiantes de Bachillerato en cuanto a las estrategias motivacionales. Dentro de este último grupo de estudiantes, los resultados evidencian que se debe prestar especial atención a los estudiantes provenientes de Bachillerato de Ciencias sociales y Humanidades.

(cc) EY-NC-ND 2018, Universitat Politècnica de València

Congreso IN-RED (2018) 


\section{Referencias}

BAHAMÓN, M., Vianchá, M., ALARCÓN, L. y BOHÓRQUEZ, C. (2013). "Estilos y estrategias de aprendizaje relacionados con el logro académico en estudiantes universitarios” en Pensamiento Psicológico, 11(1), 115-129.

BELTRÁN, J. (2003). “Estrategias de aprendizaje” en Revista de Educación, 332, 55-73

BIGGS, J.B. Y TANG, C. (2007). Teaching for Quality Learning at University (3rd Edition). Buckingham, UK: SRHE \& Open University Press.

CAmarero, F., Martín, F. y Herrero, J. (2000). "Estilos y estrategias de aprendizaje en estudiantes universitarios” en Psicothema, 12(4), 615-622

DISETH, Á. y MARTINSEN, Ø. (2003). “Approaches to learning, cognitive style, and motives and predictors of academic achievement” en Educational Psychology, 23, 195-207.

GARCÍA, T. Y PINTRICH, P.R. (1993). "Selfschemas, motivational strategies and selfregulated learning" en Annual Meeting of the American Educational Research Association. Atlanta (EEUU). Disponible en https://files.eric.ed.gov/fulltext/ED359234.pdf

Gargallo, B., Pérez, C., Serra, B., SÁnchez, F. y Ros, C. (2007-A). “Actitudes ante el aprendizaje y rendimiento académico en estudiantes universitarios” en Revista Iberoamericana de Educación, 42, 1-25.

Gargallo, B., SuÁrez, J. y Ferreras, A. (2007-B). "Estrategias de aprendizaje y rendimiento académico en estudiantes universitarios" en Revista de Investigación Educativa, 25(2), 421-441

Gargallo, B., SuÁrez-Rodríguez, J.M. y Pérez-PÉrez, C. (2009). "El cuestionario CEVEAPEU. Un instrumento para la evaluación de las estrategias de aprendizaje de los estudiantes universitarios” en Relieve, 15(2), 1-31.

Gargallo, B., Garfella, P.R., Pérez, C. y Fernández, A. (2010). "Modelos de enseñanza y aprendizaje" en XXIX Seminario Interuniversitario de Teoría de la Educación. Formación y participación de los estudiantes en la universidad. Madrid, Universidad Complutense. Disponible en http://www.ucm.es/info/site/docu/29site/ponencia3.pdf

Gargallo, B., Almerich, G., SuÁrez-Rodríguez, J. M. y García-Félix, E. (2012). "Estrategias de aprendizaje en estudiantes universitarios excelentes y medios. Su evolución a lo largo del primer año de carrera” en Relieve, 18(2), 1-22

Gargallo, B., Almerich, G., Giménez, J.A., Campos, C. y SARriá, B. (2014). "La evaluación de enfoques y estrategias de aprendizaje en estudiantes universitarios” en XII Jornadas de Redes de Investigación en Docencia Universitaria. El reconocimiento docente: innovar e investigar con criterios de calidad, Alicante, Universidad de Alicante. Disponible en https://rua.ua.es/dspace/bitstream/10045/42169/1/2014_XII_Jornadas_Redes_158.pdf

Hernández-Pina, F., Rosário, P., Cuesta, J.D., Martínez, P. y Ruiz, E. (2006). "Promoción del aprendizaje estratégico y competencias de aprendizaje en estudiantes de primero de universidad” en Revista de Investigación Educativa, 24(2), 615-632

(cc) EY-NC-ND 2018, Universitat Politècnica de València 
JuÁrez, C. S., RodríGueZ, G., EsCoto, M. C. y LunA, E. (2016). “Relación de los estilos y estrategias de aprendizaje con el rendimiento académico en estudiantes universitarios” en Revista de Estilos de Aprendizaje, 9(17), 268-288

MCCune, V. Y ENTwISTLE, N. (2011). "Cultivating the disposition to understand in 21st century university education” en Learning and Individual Differences, 21, 303-310.

MonereO, C. (1990). "Las estrategias de aprendizaje en la educación formal: enseñar a pensar y sobre el pensar” en Infancia y Aprendizaje, 50, 3-25

NúÑEz, J. C., GonzÁlez-PiendA. J. A., García, M., GonzÁlez-PumariegA, S., Roces, C., Álvarez, L., y GonZÁlez, M. C. (1998). "Estrategias de aprendizaje, autoconcepto y rendimiento académico” en Psicothema, 10(1), 97-109

Pulido, M.A., Serrano, M.L., Valdés, E., Chávez, M.T., Hidalgo, P. y Vera, F. (2011). “Estrés académico en estudiantes universitarios” en Psicología y Salud, 21, 31-37.

ROMÁN, J.M. y GALLEGO, S. (2001). Escala de Estrategias de Aprendizaje ACRA. Madrid: TEA Ediciones.

SoAres, A.P., Guisande, M.A., AlmeidA, L.S. Y PÁrAmo, M. (2009). “Academic achievement in first-year Portuguese college students: The role of academic preparation and learning strategies” en International Journal of Psychology, 44(3), 204-212.

TucKman, B.W. Y Kennedy, G.J. (2011). “Teaching Learning Strategies to Increase Success of First-Term College Students” en Journal of Experimental Education, 79, 478504.

YIP, M.C.W. (2012). "Learning strategies and self-efficacy as predictors of academic performance: a preliminary study” en Quality in Higher Education, 18(1), 23-34.

ZIMMERMAN, B.J. (2002). “Becoming a self-regulated learner: An overview” en Theory into practice, $41(2), 64-70$ 


\title{
Nuevo método de evaluación de contenidos prácticos en la docencia universitaria
}

Eva Miedes ${ }^{a}$ y Lucía Jordáb

a,b Universidad Politécnica de Madrid. E.T.S.I. Agronómica, Alimentaria y de Biosistemas. Dpto. Biotecnología-Biología Vegetal. Avenida Complutense, 3, 28040. Madrid. SPAIN. eva.miedes@upm.es, lucia.jorda@upm.es

\begin{abstract}
The practical contents in the University subjects are essential for an effective learning of taught theoretical concepts. The evaluation of the learning results of these practices involves, in some subjects, difficulties such as plagiarism and undue dedication of the teacher. This work presents a teaching innovation experience that automates evaluation, avoids plagiarism, promotes continuous practical learning, improves the students' scores and their assessment of the subject.
\end{abstract}

Keywords: automation, schematization, self-evaluation, plagiarism and teaching efficiency

\footnotetext{
Resumen

Los contenidos prácticos en las asignaturas universitarias son fundamentales para un aprendizaje efectivo de los conceptos teóricos impartidos. La evaluación de los resultados de aprendizaje de estas prácticas entraña, en algunas asignaturas, dificultades como plagios y una indebida dedicación por parte del profesor. En este trabajo se presenta una experiencia de innovación educativa que automatiza la evaluación, evita el plagio, promueve el aprendizaje práctico continuo, mejora las calificaciones de los estudiantes y su valoración de la asignatura.
}

Palabras clave: automatización, esquematización, autoevaluación, plagios y eficiencia docente. 


\section{Introducción}

Contexto de aplicación del nuevo método de evaluación de contenidos prácticos en la docencia universitaria.

La implementación del nuevo método de evaluación de los contenidos prácticos se llevó acabo en la Universidad Politécnica de Madrid, entre la Escuela Técnica Superior de Ingeniería de Telecomunicación (http://www.etsit.upm.es/) (teoría) y la Escuela Técnica Superior de Ingeniería Agronómica, Alimentaria y de Biosistemas (http://www.etsiaab.upm.es/) (prácticas).

El proyecto de innovación docente se desarrolló específicamente en la parte práctica de la asignatura de Bioquímica Estructural, que se imparte en el segundo semestre del primer curso del Grado de Ingeniería Biomédica (http://www.etsit.upm.es/estudios/grado-en-ingenieriabiomedica.html), durante los cursos 2014-2015 y 2015-2016. Los alumnos que cursan este Grado cuentan con unas de las notas de acceso más altas de la Universidad Politécnica de Madrid. Se trata de una asignatura obligatoria de 6 ECTS, de los que 1 ECTS pertenecen a la parte práctica. Esta parte consta de dos sesiones teóricas de técnicas instrumentales de bioquímica (4h), dos sesiones teóricas y de problemas de explicación de los fundamentos de las prácticas (3h) y cinco prácticas desarrolladas en tres sesiones en el laboratorio, de cuatro horas cada una (12h). En el curso 2014-2015 y anteriores, la evaluación de esta parte práctica se realizó mediante la media de dos actividades evaluables. La primera consistió en la entrega de un cuaderno de resultados individual por cada una de las cinco prácticas (71 alumnos x 5 prácticas $=355$ cuadernos de prácticas), que se entregaba en papel y en el departamento una semana después de realizar cada práctica. Y la segunda, fue un examen tipo test verdadero/falso (V/F) de 40 preguntas que se realizaba junto con el examen teórico final de la asignatura.

\section{Identificación de puntos de mejora}

Al finalizar el curso 2014-2015, se identificaron, tras la auto-evaluación de la parte práctica de la asignatura, varios aspectos mejorables de la misma. El primero fue la necesidad de reducir el excesivo tiempo de corrección de los cuadernos de resultados. Eran unos 500 cuadernos y el tiempo disponible para la corrección era reducido, ya que los cuadernos eran devueltos a los alumnos con las correcciones oportunas antes del examen final. Esto reducía la posibilidad de implementar nuevas metodologías y mejorar la docencia ya que el tiempo estaba comprometido por las correcciones (Sabagh y Saroyan, 2014). El segundo punto de mejora que se identificó fue el desaprovechamiento de los alumnos de las 12 horas presenciales de prácticas en el laboratorio. Se observó que, aunque el estudiante había recibido una clase de explicación de fundamentos y protocolos con anterioridad, no tenían preparados los contenidos de las mismas y perdían el tiempo intentando comprenderlos en el laboratorio. El tercer punto de mejora se centró en reducir el elevado número de plagios y copias parciales de los cuadernos de resultados (Cronan et al., 2018). Los plagios se identificaron por repetición de errores poco habituales y peculiares que demostraban la copia. En este punto no se usó ninguna de las herramientas de detección de plagios que ofrece la

(cc) EY-NC-ND 2018, Universitat Politècnica de València

Congreso IN-RED (2018) 
UPM como Turnitin (http://turnitin.com/es/) al tratarse de 355 documentos manuscritos. El cuarto aspecto de mejora se centró en aumentar las calificaciones respecto al curso anterior. Los alumnos habían reducido sus notas respecto al curso 2013-2014 debido a la reducción de las notas correspondientes a las prácticas. Y el último aspecto a mejorar, fue la valoración de la asignatura. En la encuesta final de la asignatura, los estudiantes habían evaluado peor que al año anterior la asignatura debido a que consideraban elevada la dedicación a la parte práctica de la misma. Si bien, al inicio de curso, se les había explicado la justa dedicación que debían hacer a la parte práctica (horas) siguiendo los criterios que indica el EEES (www.eees.es).

\section{Objetivos}

Los objetivos del nuevo método de evaluación de contenidos prácticos en la docencia universitaria presentado aquí son: 1) Reducir el tiempo de corrección de los cuadernos de resultados y exámenes; 2) aumentar la preparación del estudiante previa a las sesiones presenciales de prácticas; 3 ) evitar copias en una de las pruebas de evaluación (cuadernos de resultados); 4) mejorar el aprendizaje práctico continuo y las calificaciones y 5) mejorar la valoración de la asignatura por parte de los alumnos.

\section{Desarrollo de la innovación}

Al terminar el curso 2014-2015 se realizó la autoevaluación de la asignatura y se identificaron varios puntos de mejora. Para solucionar estos aspectos mejorables descritos anteriormente, se diseñaron una serie de actuaciones. En la elección y diseño de las actuaciones se priorizó el aprendizaje práctico continuo y la evaluación continua del estudiante, debido a la demostrada eficiencia de los mismos (Seitz, 2018).

Las distintas actuaciones que se detallan a continuación conforman un proyecto de innovación educativa donde se presenta una nueva metodología de evaluación de los contenidos prácticos en la docencia universitaria. La primera de las actuaciones se centró en mejorar la preparación previa (contenidos y fundamentos) del estudiante a las sesiones prácticas. Para ello, los alumnos debían entregar, al comenzar cada sesión práctica, un esquema del protocolo/guion de la(s) práctica(s) a realizar ese día y completar un test de 5 preguntas relativo a la sesión. Dicho test se corregía durante la sesión y se devolvía al estudiante antes de finalizar la sesión para que fuera corregido entre todos. Además, los estudiantes debían completar el cuaderno de resultados en la misma sesión práctica pero no lo entregaban, algo que antes hacían una semana después. Los resultados recogidos en este cuaderno eran importantes ya que posteriormente constituían parte de la materia de la que eran evaluados. La segunda de las actuaciones se centró en reducir el tiempo de corrección por parte de los profesores de los aproximadamente 355 cuadernos de prácticas. Para ello, se optó por una evaluación continua on-line, más automatizada y completa empleando la plataforma de teleenseñanza Moodle-UPM de la asignatura (https://moodle.upm.es/titulaciones/oficiales/). Se diseñó un cuestionario de evaluación por 
cada una de las tres sesiones prácticas que los alumnos completaban tres días después de realizar la sesión práctica. Cada uno de los cuestionarios contaba con 10 preguntas de V/F, 5 preguntas de respuesta múltiple sobre errores prácticos, 2 preguntas tipo gráfica/figura/tabla sobre los resultados obtenidos y recogidos en el cuaderno de prácticas y 3 preguntas sobre datos numéricos procesados (con unidades) obtenidos por cada grupo en las prácticas. Para incluir esos valores numéricos, los estudiantes habían tenido que completar correctamente el cuaderno de resultados en las prácticas o trabajarlo en casa. El cuestionario tenía una duración determinada de entre 8-12 minutos y estaba abierto en una franja horaria acordada previamente con la clase. Al terminar el cuestionario, el estudiante obtenía una evaluación automática de las preguntas contestadas correcta e incorrectamente, así como una retroalimentación explicativa de todas las preguntas. Los resultados numéricos de cada uno de los cuestionarios se obtenían directamente en un archivo de datos y además se añadían a las calificaciones individuales en la plataforma que aloja los espacios virtuales de las asignaturas (Moodle UPM). En resumen, se sustituyó la entrega del cuaderno de resultado de las prácticas por una evaluación continua automatizada on-line del mismo y se eliminó el examen final de prácticas.

Una vez descritas las actuaciones, se diseñaron e implementaron en la plataforma educativa. Seguidamente, se incorporaron como nueva metodología de evaluación en la guía docente del curso siguiente. En la primera clase de presentación de la asignatura, se les explicó a los alumnos el nuevo método de evaluación. Por último, tras aplicar los cambios durante el semestre, se evaluaron los resultados del método de evaluación aplicado en ambos cursos. Para ello se usaron las calificaciones de la parte práctica de la asignatura y varias cuestiones de las encuestas anónimas que los alumnos completan sobre la asignatura y el profesorado.

\section{Resultados}

Los resultados de la aplicación del nuevo método de evaluación de contenidos prácticos en la docencia universitaria se obtuvieron mediante dos indicadores objetivos como son: 1) el análisis comparativo de las calificaciones de los estudiantes de los cursos 2014-2015 (en adelante 2015) y 2015-2016 (en adelante 2016) y 2) el análisis comparativo de los resultados de la encuesta de la asignatura por parte de los alumnos de ambos años.

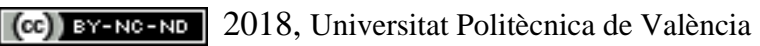

Congreso IN-RED (2018) 


\section{Calificaciones de los estudiantes}

A continuación, se presenta el análisis comparativo de los resultados (calificaciones) obtenidos por los alumnos en la parte práctica de la asignatura (Figura 1).

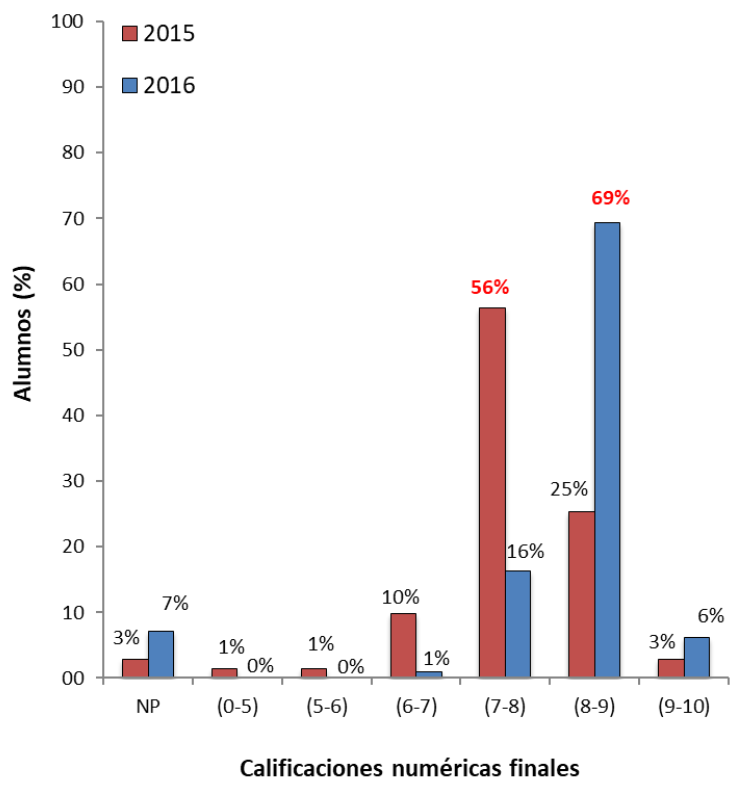

Fig. 1 Comparación de las calificaciones obtenidas por los alumnos de la parte práctica de la asignatura Bioquímica Estructural en los años $2015(n=71)$ y 2016 (n=98). NP: No Presentado.

Como muestra la Figura 1, las calificaciones de los alumnos han mejorado significativamente en el curso 2016 respecto al curso 2015. Los alumnos con notas entre 5 y 8 se han reducido en el curso 2016, mientras que se han incrementado los que alcanzaron una nota entre 8 y 9 . Por lo tanto, la media se ha incrementado un punto y el porcentaje de alumnos con dicha nota ha crecido un 13\%. Los alumnos con calificaciones excelentes (9 y 10) aumentaron un $3 \%$. Los estudiantes no presentados se incrementaron un $4 \%$ en el curso 2016. Esto fue debido al aumento de alumnos Erasmus o bien a otros que pidieron el traslado de Grado. Cabe destacar que las calificaciones no mostraron diferencias significativas entre los cuatro grupos de prácticas (Figura 2). 

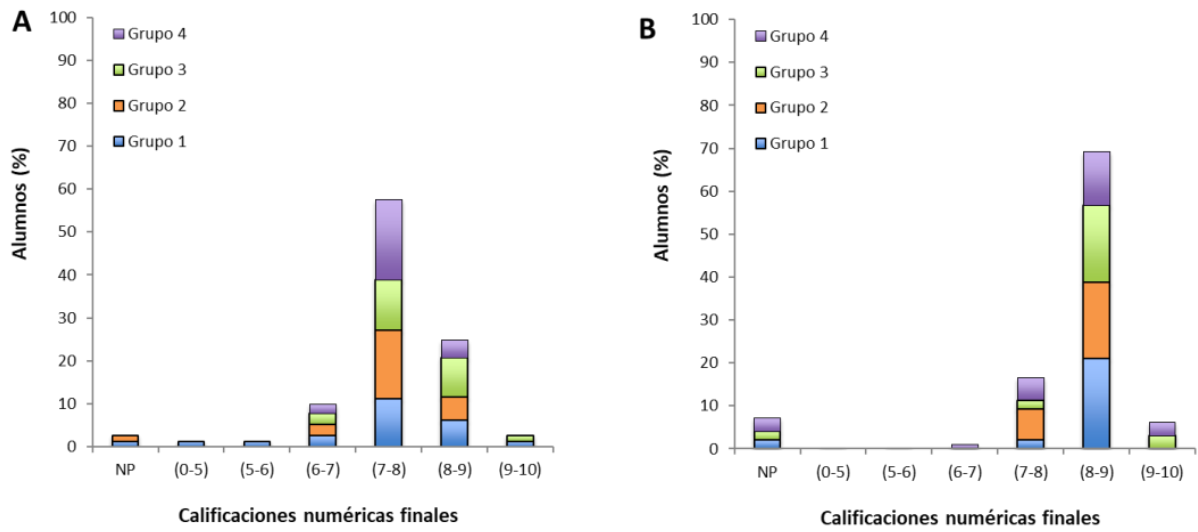

Fig. 2 Comparación de las calificaciones obtenidas por los alumnos de la parte práctica de la asignatura Bioquímica Estructural en los años (A) 2015 (n= 71) y (B) 2016 (n=98) distribuida por grupos.

\section{Evaluación de la parte práctica de la asignatura por parte de los estudiantes}

El análisis comparativo de los resultados de la encuesta de los alumnos de la parte práctica de la asignatura Bioquímica Estructural y de la profesora de prácticas (que fue la misma ambos cursos evaluados), se muestran en la Figura 3. 


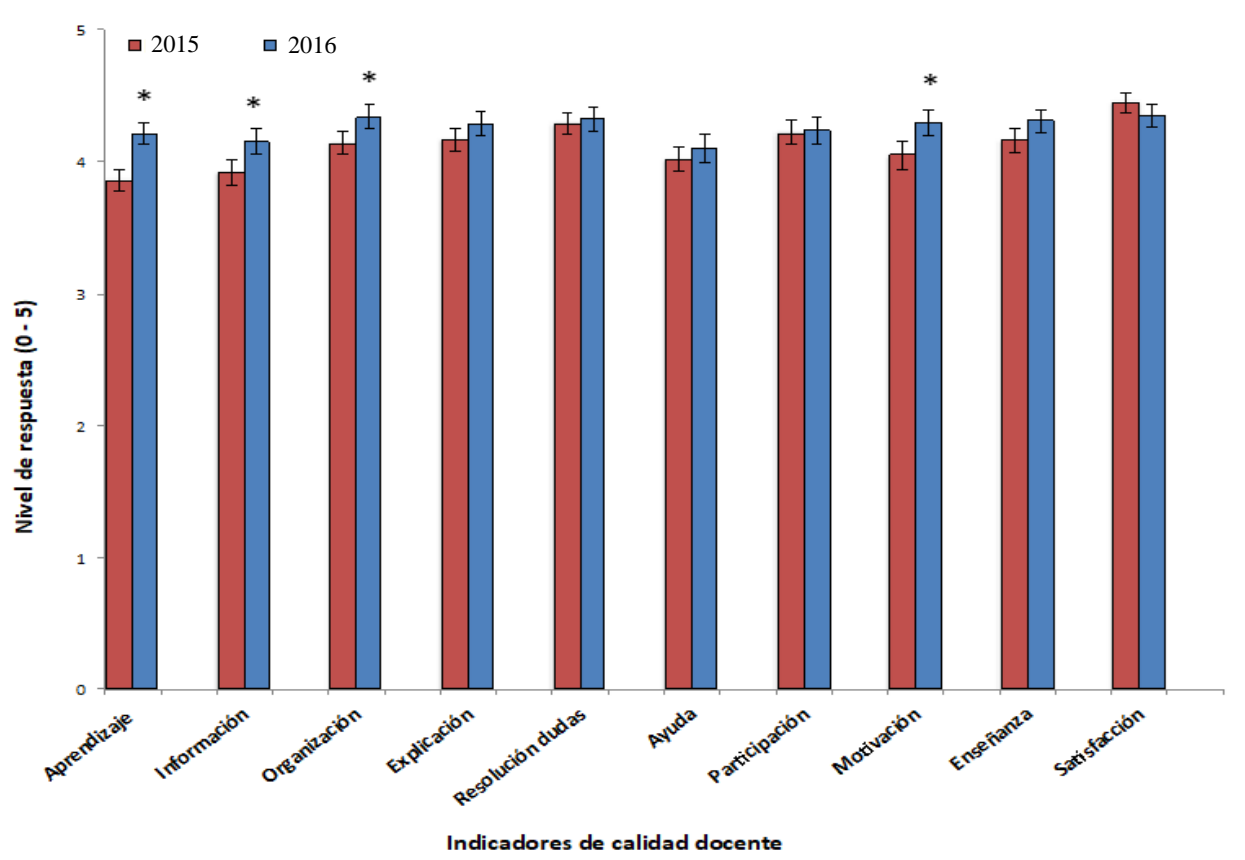

Fig. 3 Comparación de los resultados de la encuesta de los alumnos de la parte práctica de la asignatura Bioquímica Estructural en los años $2015(n=63)$ y $2016(n=74)$. El asterisco (*) muestra diferencias significativas ( $t$-test, $p$-valor $\leq 0.05$ ) entre ambos cursos.

Los resultados de la encuesta de valoración de la asignatura y la profesora han mejorado en el curso 2016 en 9 de los 10 parámetros de calidad que se representan (Figura 3). Se registraron valores significativamente mayores en el año 2016 respecto al 2015 en relación al aprendizaje de los alumnos, información de la asignatura, organización de la asignatura y motivación de los alumnos. Además, la asignatura y la profesora de prácticas mostró unas calificaciones por encima de la media registrada del resto de profesores del Grado de Ingeniería Biomédica (datos no mostrados).

\section{Conclusiones}

Se ha diseñado, aplicado y analizado un nuevo método de evaluación de los contenidos prácticos en la docencia universitaria. Con la puesta en marcha de este proyecto de innovación educativa se han mejorado los puntos críticos identificados. De este modo, se redujo el tiempo de corrección de las pruebas de evaluación y se evitaron los plagios/copias en las mismas. Se aumentó la preparación previa de los estudiantes en contenidos/fundamentos prácticos, lo que mejoró el aprendizaje práctico continuo y elevó las calificaciones. Por último, los estudiantes valoraron y apreciaron muy positivamente el nuevo método de evaluación y, en consecuencia, la valoración general de la asignatura. Con todo ello, las profesoras de la asignatura concluyen que los cambios introducidos mejoran y corrigen significativamente los aspectos problemáticos identificados previamente. 


\section{Referencias}

CRONAN, TP; MULLINS, JK y DOUGLAS, DE. (2018). "Further Understanding Factors that Explain Freshman Business Students' Academic Integrity Intention and Behavior: Plagiarism and Sharing Homework" en Journal of Business Ethics, vol. 147, issue 1, pp. 197-220.

ESCUELA TECNICA SUPERIOR DE INGENIERIA AGRONOMICA, ALIMENTARIA Y DE BIOSISTEMAS. Página general. <http://www.etsiaab.upm.es/> [Consulta: 3 de mayo de 2018] [institucional]

ESCUELA TÉCNICA SUPERIOR DE INGENIEROS DE TELECOMUNICACIONES. Grado en Ingeniería biomédica. <http://www.etsit.upm.es/estudios/grado-en-ingenieria-biomedica.html> [Consulta: 3 de mayo de 2018] [institucional]

ESCUELA TÉCNICA SUPERIOR DE INGENIEROS DE TELECOMUNICACIONES. Página general. <http://www.etsit.upm.es/> [Consulta: 3 de mayo de 2018] [institucional]

ESPACIO EUROPEO DE EDUCACION SUPERIOR. Página general. <http://www.eees.es/> [Consulta: 3 de mayo de 2018] [institucional]

SABAGH, Z y SAROYAN, A. (2014). "Professors' perceived barriers and incentives for teaching improvement" en International Education Research, vol. 2, issue 3, p. 18-30.

SEITZ, AR. (2018). "A New Framework of Design and Continuous Evaluation to Improve Brain Training" en Journal of Cognitive Enhancement, vol. 2, issue 1, pp. 78-87.

TURNITIN. Servicios para la mitigación de riesgo del plagio académico y profesional. <http://turnitin.com/es/> [Consulta: 3 de mayo de 2018]

UNIVERSIDAD POLITÉCNICA DE MADRID. Moodle, herramienta de gestión del aprendizaje para estudios oficiales. <https://moodle.upm.es/titulaciones/oficiales/> [Consulta: 3 de mayo de 2018] [institucional]

(cc) EY-NC-ND 2018, Universitat Politècnica de València

Congreso IN-RED (2018) 


\title{
Nuevos horizontes para la enseñanza de la fotografía. Retos de la aplicación de proyectos colaborativos y redes multidisciplinares en la enseñanza superior artística.
}

\author{
Ana Martí Testón \\ Universitat Politécnica de Valencia, anmartes@upv.es
}

\begin{abstract}
Photography is an essential artistic and creative discipline that has not acquired the academic acknowledgment it deserves in the university context. In this sense, and struggling to change this perception, and improve its status, from the master's in photography at the Polytechnic University of Valencia, we have worked on different collaborative projects in which the students have been the main axis of the application of new methodologies in which we have created international networks while promoting creativity.
\end{abstract}

Keywords: Photography, art, collaborative, projects, exchanges, International, development, interdisciplinary, higher education.

\footnotetext{
Resumen

La fotografía es una disciplina artística y creativa fundamental que no ha adquirido el reconocimiento académico que merece en el contexto universitario. En este sentido, y luchando por cambiar esta percepción, y mejorar su estatus, desde el Máster en Fotografía de la Universidad Politécnica de Valencia, hemos trabajado en diferentes proyectos colaborativos en los que las alumnas y alumnos han sido el eje principal de la aplicación de nuevas metodologías en las que hemos creado redes internacionales a la vez que fomenamos la creatividad.
}

Palabras clave: Fotografía, arte colaborativo, proyectos, intercambios, Internacional, desarrollo, interdisciplinar, enseñanza superior.

\section{Introducción}

La fotografía es una disciplina que se encuentra a medio camino entre las bellas artes y los medios de comunicación (Chevrier, 2007). Desde su invención en 1839, ha sido utilizada como un medio idóneo para documentar, comprender o interpretar el mundo. Asimismo, ha supuesto una importante aportación a la evolución de las artes y la representación visual, en parte gracias a su capacidad para documentar la realidad, pero también por su habilidad 
para reproducirse, al permitir la amplia circulación y distribución de imágenes. Precisamente en la actualidad, esta capacidad de reproducir la imagen se ha incrementado hasta límites incluso descomunales, debido mayoritariamente a la llegada del Internet y las redes sociales (Fontcuberta, 2016).

De hecho, la fotografía es la disciplina creativa que más gente práctica, y así lo muestran las estadísticas, que ponen de manifiesto como la fotografía, seguida del vídeo o la pintura, es la practica artística más utilizada en el contexto español, como se puede observar en el gráfico de la ilustración 1, extraído de las encuetas realizadas por el Ministerio de Educación respecto a los principales indicadores de prácticas artísticas en 2014-2015 (Subdirección General de Estadística y Estudios, 2015).

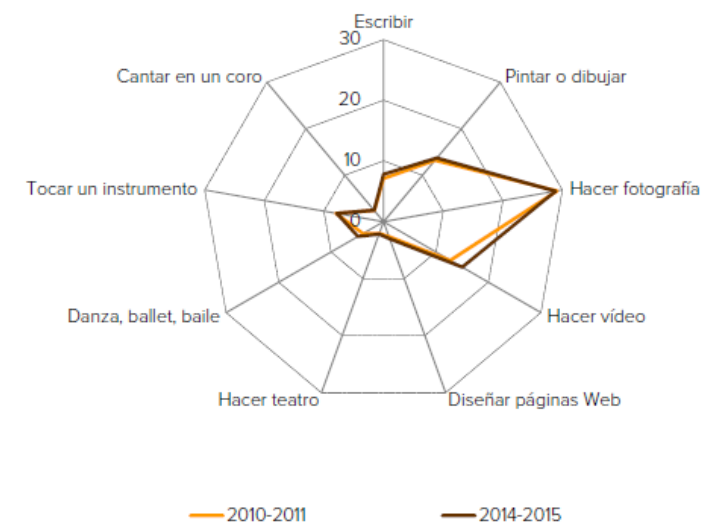

Ilustración 1. Evolución de los principales indicadores de prácticas artísticas. Fuente: Ministerio de Educación, Cultura y Deporte.

Este interés por la fotografía también se hace evidente en la gran cantidad de festivales y concursos que se realizan anualmente en todo el panorama nacional e internacional (Vega, 2017). En los que muchos fotógrafos, aficionados y profesionales, acuden para reunirse con otros colegas y conocer a las figuras importantes del sector. Pero lo cierto es que los usuarios de estos festivales y concursos son en su mayoría personas con un perfil autodidacta (Bourdieu, 2003), puesto que todavía hoy existen pocos lugares oficiales en los que estudiar esta materia. Y pese a que en los últimos años han aparecido distintas escuelas y academias en las que poder estudiar la fotografía (Condés, 2018) en su mayoría se trata de estudios no reglamentados que además presentan un profesorado poco cualificado.

Todavía a principios del siglo XXI, resulta complicada la aceptación de la fotografía en las instituciones educativas superiores, y por ello, desde el Máster en fotografía de la Universidad Politécnica de València llevamos más de 12 años trabajando por cambiar este panorama. Apostando por la enseñanza de la fotografía de calidad, y buscando siempre el máximo reconocimiento en el mundo profesional y artístico.

(cc) EY-NC-ND 2018, Universitat Politècnica de València

Congreso IN-RED (2018) 
El máster nació con el propósito de cubrir algunos de los vacíos que existen todavía hoy en la formación superior de esta disciplina. La mayoría de las universidades públicas a nivel estatal no ofrecen la posibilidad de especializarse en esta materia. Si bien es cierto que se puede estudiar en grados medios y superiores de enseñanzas artísticas, no existe ningún grado específico en ninguna universidad pública en el que estudiar fotografía, y apenas existe reconocimiento dentro de otros grados superiores afines como pueden ser Bellas Artes o Comunicación Audiovisual, carreras en las que apenas se ofrece una asignatura optativa en la que estudiarla (Hernández, 2013). Por ello, la mayoría de los alumnos que vienen a nuestro máster proceden de distintas carreras con perfiles muy variados, lo que supone un importante reto pedagógico a la hora de trabajar con las capacidades técnicas y creativas de las alumnas y alumnos.

Si bien es cierto que la técnica es una parte imprescindible en la enseñanza de la fotografía, debemos señalar que ésta por sí sola no es capaz de transmitir significado a las obras. Por lo tanto, en la docencia de este tipo de disciplina, se deben desarrollar al mismo tiempo las destrezas técnicas y las capacidades creativas (Bridges, 2013). Pues no se trata sólo de hacer una buena fotografía, sino de analizar y explicar por qué queremos hacerla.

Desde nuestro grupo de trabajo creemos importante desarrollar metodologías que fomenten la creatividad, y no se queden ancladas en la obsesión por perfeccionar la técnica. Pero la posibilidad de desarrollar competencias creativas en los alumnos de postgrado que provienen, como ya hemos indicado, de diferentes perfiles, resulta realmente complicado, y supone un reto para los docentes de esta materia. De hecho, fomentar la creatividad y las ideas originales resulta bastante más complejo que el reto de enseñar la técnica fotográfica, pues normalmente ésta requiere un mayor nivel intelectual (Sontag, 2010). Asimismo, la parte técnica es más fácilmente evaluable y objetivable que la parte creativa. Con demasiada frecuencia, y especialmente los estudiantes más jóvenes, interpretan erróneamente el éxito creativo de las obras basándose en la técnica, mientras que el problema creativo reside fuera de ésta, y se debe trabajar y mejorar independientemente de las herramientas que se utilicen (Bridges, 2013), como ocurre en el desarrollo de otras enseñanzas artísticas.

\section{Objetivos}

Uno de los principales objetivos al que nos enfrentamos es experimentar nuevos modos de enseñanza-aprendizaje de la fotografía en el marco superior basados en la experimentación práctica en las que poder explotar las capacidades creativas de los alumnos en cuanto al desarrollo de ideas innovadoras.

Con la intención de fomentar la creatividad en los alumnos y alumnas que provienen de distintos ámbitos, con distintas capacidades, hemos organizado diferentes actividades colaborativas en las que han podido desarrollar sus intereses y descubrir nuevas posibilidades expresivas en el ámbito del arte y el comisariado de exposiciones.

Otro objetivo importante de este tipo de actividades es ampliar los horizontes culturales de los alumnos, e intercambiar experiencias con otros masters de distintos países con los que 
hemos colaborado con el fin de mejorar la calidad de la enseñanza superior en fotografía. Especialmente en lo que se refiere a la capacidad de comprender nuevas posibilidades para aprender esta materia y relacionarla con otras disciplinas artísticas.

Asimismo, queremos ir un paso más allá en la enseñanza de la fotografía como una disciplina artística y alejarnos de la obsesión por la mejora de la técnica, para centrarnos en la posibilidad de crear proyectos comunes y colaborativos que se aproximen a la realidad a la que se enfrentan los artistas contemporáneos.

Uno de los objetivos de la colaboración con otros másteres es la difusión del trabajo de los alumnos y ex alumnos de las universidades que forman la red. Asimismo, hemos apostado por avanzar en la innovación pedagógica en fotografía, propiciando el intercambio de alumnos y profesores, y la producción de proyectos colaborativos.

El objetivo de estas experiencias es buscar nuevas maneras de ampliar los limites convencionales expositivos de la fotografía y mejorar la comunicación de estas pensando en el nuevo público contemporáneo y heterogéneo. Otro objetivo es llevar a los alumnos fuera del ámbito académico para que se relacionen con otros entornos con los que deberán trabajar una vez terminen sus estudios.

\section{Desarrollo de la innovación}

Con la idea de mejorar la creatividad de los alumnos y las alumnas y dar prioridad a sus intereses, nos hemos basado en distintas metodologías contemporáneas que hemos puesto en práctica en el desarrollo de varias experiencias innovadoras. Una de ellas es la metodologia del Design Thinking, o pensamiento del diseño, una metodologia que proviene del mundo de los creativos y diseñadores, y cuenta con una parte de aplicación práctica importante para el desarrollo y materialización de las ideas creativas y originales, que consideramos es ideal en el desarrollo de las capacidades artísticas. Para ello, se propuso realizar proyectos colaborativos entre distintos grupos de alumnos en los que utilizaríamos esta metodología para aprender de los errores y reconstruir las ideas en función de éstos. Los alumnos son los encargados de desarrollar su propia experiencia y deben aprender mediante la práctica colaborativa de organizar una exposición, o un evento, que se debía desarrollar de una manera poco habitual en un espacio no convencional.

La idea que propusimos era escoger un tema genérico que se trabajó por los distintos grupos. El curso pasado el tema escogido fué el "cambio". Las alumnas y los alumnos del máster debían desarrollar distintos proyectos expositivos en los que trabajaron con la fotografía, el video y las artes visuales, en entornos poco habituales, en base a la idea del cambio. En función de la aproximación al tema que habían escogido, debían realizar una primera fase de sensibilización para empezar a diseñar y presentar sus propuestas expositivas. Una vez analizados los distintos puntos de vista de los grupos, y las ideas propuestas por cada uno, se pasó a la definición concreta de la solución escogida y su desarrollo, para posteriormente materializarlo y evaluarlo según los resultados, y finalmente realizar los cambios pertinentes y determinar la presentación final. Un ejemplo realizado por un grupo de alumnos del curso pasado fue la realización una instalación artística y un

(cc) BY-NC-ND 2018, Universitat Politècnica de València

Congreso IN-RED (2018) 
concierto, que tuvo lugar en un solar del barrio del Cabañal de Valencia, hablando de las personas que habían habitado este espacio antes de ser derruido, y utilizaron la fotografía y la imagen como un nexo para explicar su evolución y desolación. Otro grupo decidió realizar la publicación de un fanzine para el que contaron con la colaboración de distintos

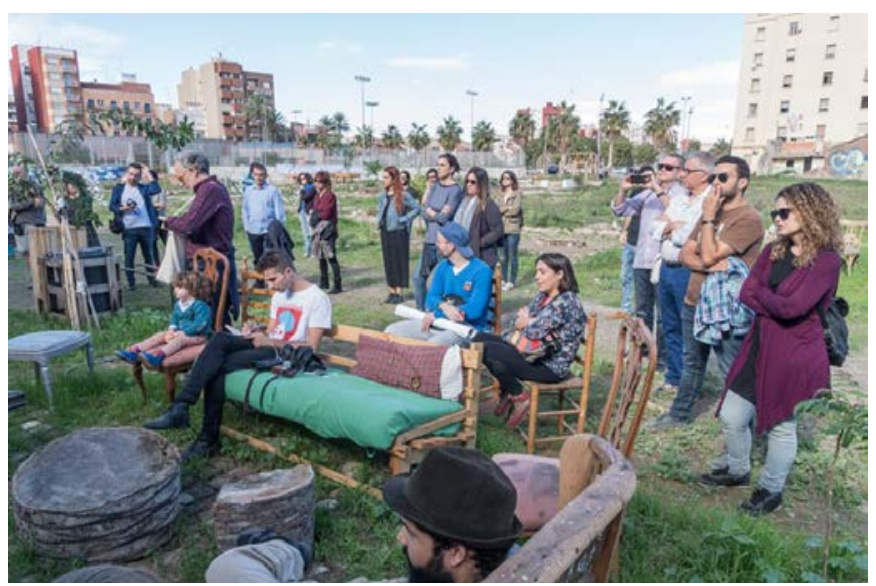

Ilustración 2. Ejemplo de intervención en un solar del Cabañal de Valencia.

fotógrafos y escritores o críticos que trataron el tema del cambio.

Utilizando esta misma metodología, propusimos a los alumnos que se encargaran de comisariar una galería en el centro de la ciudad de Valencia, en la Fundación La Posta, en la que debían ponerse de acuerdo para ver qué tipo de contenidos querían exponer y como podían dinamizar el local para fomentar el interés de distintos perfiles de visitantes. La mayoría de los alumnos apenas contaban con experiencia en este campo, y tuvieron que aprender a marchas forzadas mediante la práctica y experimentando distintos errores de los que posteriormente aprendieron. El grupo de alumnas y alumnos que se encargaron del espacio realizaron un borrador de propuestas que posteriormente evaluamos los docentes del máster para terminar de perfilar la propuesta expositiva, y en base a ello, comenzar a materializar las ideas. Cada alumno debía encargarse de una tarea, entre las que se encontraba el diseño de los carteles y la publicidad, la comunicación de los eventos y las exposiciones, la financiación, las actividades relacionadas, los contactos, etc.

Otro proyecto diferente que hemos realizado en los últimos años con la idea de ampliar las miras de los alumnos y mejorar su capacidad crítica, es la colaboración con otros alumnos de otros másteres internacionales. En esta experiencia pusimos en práctica la metodología ya bien conocida de las clases invertidas "flipped Classroom", en las que se fomenta que en el aula se realicen las cuestiones prácticas y se deja para casa, o para que cada alumno desarrolle a su ritmo, la parte de investigación teórica. En este tipo de metodología, contraria a las clases magistrales tradicionales, el alumno adquiere un rol más activo, pues ellos mismos eligen el momento y modo en que realizan el aprendizaje, motivando una vez más el pensamiento crítico al enfrentarse a distintos problemas complejos para los que ya cuentan con la ayuda del profesor o docente dentro del aula. Para ello, se han aprovechado además las oportunidades que nos brindan los medios digitales y de comunicación, que se 
han utilizado para que las alumnas y alumnos se comunicaran con otros estudiantes de otros másteres internacionales.

El principal objetivo de este proyecto era crear una red de universidades que nos ayudase a mejorar la calidad de la enseñanza y mismo tiempo que nos posibilitara la capacidad de ampliar los horizontes pedagógicos con nuevas experiencias que nos van enriqueciendo. Por ello, decidimos huir de la enseñanza al estilo "tradicional” de seminarios y clases teóricas, para apostar por una enseñanza activa en la que buscamos desarrollar nuevas experiencias enriquecidas gracias a la colaboración, investigación y desarrollo de los proyectos conjuntos de los alumnos (Ivern Magaña, 2009).

Gracias a la experiencia que habíamos acumulado en los últimos años, al colaborar con distintas universidades en proyectos europeos de investigación, en el año 2016 decidimos empezar a desarrollar una red europea de estudios superiores en fotografía: ENMAP: European Network of Máster Studies in Photography ${ }^{1}$. Una red formada por nueve universidades europeas con estudios de postgrado en fotografía entre las que se encuentran la universidad de Aalto en Finlandia, la Ecole de Recherche Graphique de Bruselas, Falmouth University, Leiden University, London College of Communication, Plymouth University o la Universidad de Westminsiter.

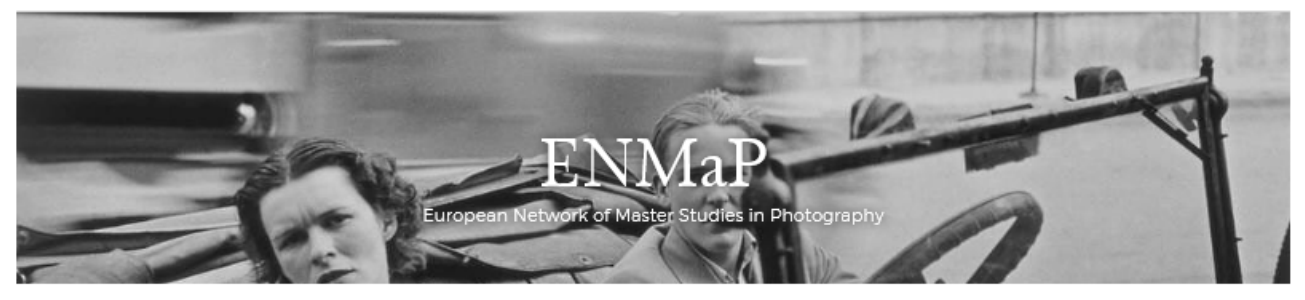

Ilustración 3. Cabecera de la web de la asociación ENMAP

Todas las universidades del consorcio cuentan con importantes programas docentes y un reconocido prestigio internacional en el ámbito de las enseñanzas artísticas y especialmente en el campo de la fotografía. En una primera reunión los socios presentamos los distintos programas educativos y lo primero que nos llamó la atención eran las grandes diferencias que existen en los programas de cada universidad.

Existen muchas diferencias en el estatus de la fotografía como disciplina artística en el ámbito universitario, entre los distintos países europeos, y esto se evidencia en los planes de estudios con distintas formas de enseñar y de enfocar el proceso de enseñanza aprendizaje. A partir de la posibilidad de compartir estas experiencias pudimos aprender de las prácticas de las otras universidades. Por ejemplo, el programa del Máster en fotografía de la UPV está organizado con bastantes horas de carga docente de profesores invitados que vienen al máster a hacer máster class, clases magistrales. El programa se divide en dos grandes bloques, por un lado, la teoría y por otro lado la práctica; El máster de Leiden es un máster

${ }^{1} \underline{\text { http://gr3.be/enmap/ }}$

(cc) EY-NC-ND 2018, Universitat Politècnica de València

Congreso IN-RED (2018) 
teórico más enfocado hacia la hacia el comisariado de exposiciones y la crítica; La situación de las universidades inglesas es totalmente diferente, puesto que los socios ingleses cuentan con alumnos que normalmente han estudiado un grado fotografía, cosa que en España no es posible de momento (ni en otros países europeos). Los programas de las universidades inglesas que participan en el consorcio son bastante parecidos entre ellos; normalmente mezclan la teoría con la práctica y tienen muy pocas horas de carga docente, dejando mucha libertad a los alumnos y el desarrollo de sus propios proyectos artísticos. En el caso del máster de la Escuela de Arte de Bruselas, se trata unos estudios mucho más integrados en las bellas artes, y no son tan cerrados a la fotografía, con procesos creativos multidisciplinares como pueden ser la performance o el vídeo. Rápidamente nos dimos cuenta de que la mayoría de los programas se podían complementar unos a otros, y podríamos compartir experiencias, así como profesores y alumnos, y empezamos a trabajar en las distintas líneas de analizar de qué manera podríamos sacar provecho.

Se propuso la realización de una exposición conjunta en la que se mostrasen los trabajos de los alumnos de los distintos másteres, pero quisimos que esta exposición fuera diseñada y organizada por los propios alumnos y las alumnas del máster de Valencia, para que fueran ellos, mediante el proceso del aprendizaje por proyectos colaborativos, quienes nos fueran pidiendo a los profesores los recursos que necesitan para desarrollar sus ideas.

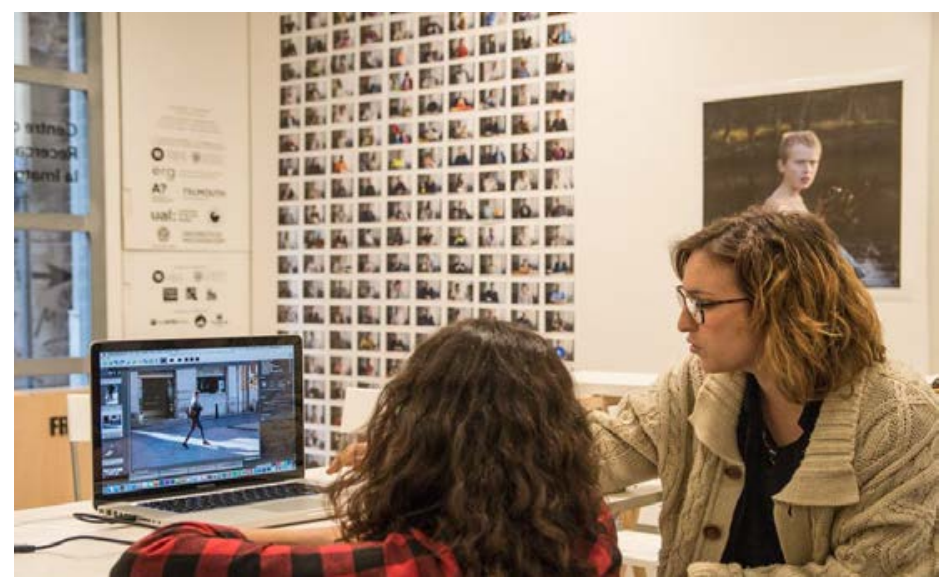

Ilustración 4. Unas alumnas debaten sobre cómo realizar un proyecto colaborativo.

Con el objetivo de escoger un tema que englobase los trabajos expuestos de los alumnos y alumnas de los distintos másteres, los alumnos de la UPV se tuvieron que poner en contacto con los compañeros de otros países y preguntarles por los detalles de los proyectos que habían desarrollado. Como un medio espontáneo para establecer estas comunicaciones se popularizó el uso de las redes sociales, y especialmente Facebook, para comunicarse entre ellos. Como resultado de estas comunicaciones, se crearon debates y foros en los que intercambiaron opiniones y materiales hasta escoger el tema que los podía englobar: "NeXoS". 


\section{Resultados}

Después de la realización de los distintos proyectos efectuamos sesiones de evaluación con los alumnos implicados con la intención de analizar los puntos positivos y las limitaciones con las que se habían encontrado.

Una de las primeras conclusiones que empezamos a recoger de estas experiencias es que cuanto más radical era la propuesta que les planteábamos, más efectivo era el proceso de aprendizaje. El hecho de proponer la realización de una exposición con un formato innovador fomentó la creación de ideas originales que surgieron a partir de las experiencias de cada uno de los alumnos, ya que aportaron los recursos de los que disponían. De este modo, aprendieron bastante más de lo que podían haber aprendido con una clase magistral de comisariado de exposiciones. Asimismo, hemos podido comprobar cómo estas experiencias colectivas han supuesto una lanzadera para futuros proyectos profesionales de los alumnos, que al terminar el máster han optado por desarrollar proyectos innovadores en el campo profesional de la fotografía, por ejemplo, con la promoción de publicaciones o el

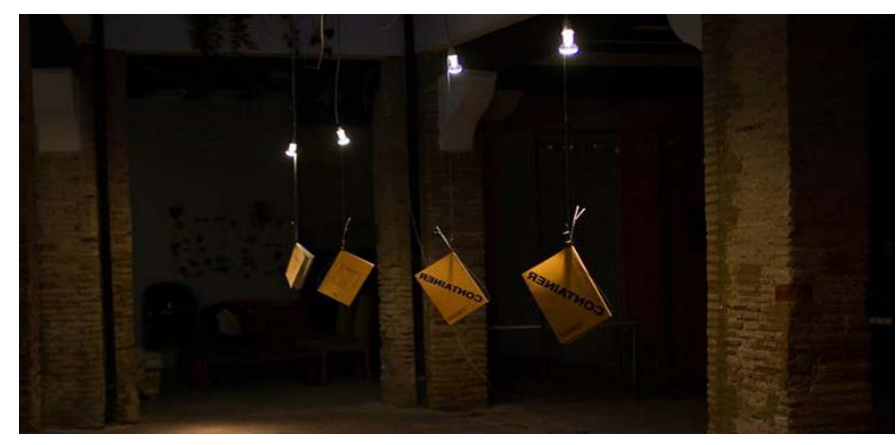

Ilustración 5. Muestra de una de las exposiciones de los alumnos en la que mostraban una publicación conjunta

comisariado de exposiciones.

En los últimos dos años hemos realizado diversas acciones que han resultado de gran ayuda para la formación artística de los alumnos del máster. Por un lado, como consecuencia de la creación de la red de másteres internacionales, realizamos intercambios de profesorado e invitamos a profesores de otros másteres a impartir seminarios en el nuestro y viceversa. De este modo, completábamos los programas curriculares con otras asignaturas que podían complementar a las ya impartidas y aprovechamos para mantener el contacto con los diferentes profesores y alumnos de otras universidades. De hecho, esta oportunidad ha posibilitado la creación de otras experiencias diferentes, como puede ser invitar a algunos alumnos a participar en exposiciones conjuntas realizadas en otros países, o la posibilidad de hacer encuentros en verano en festivales de fotografía.

Por otro lado, realizamos distintas clases online en las que utilizamos los recursos de streaming de que dispone la Universitat Politécnica de Valencia para compartir las experiencias con los otros másteres. Además, de la ya comentada exposición en las que se

(cc) EY-NC-ND 2018, Universitat Politècnica de València

Congreso IN-RED (2018) 
seleccionaron los trabajos de los alumnos que terminaron ese año los estudios. De hecho, fueron los propios alumnos quienes seleccionaron los artistas que podrían exponer siguiendo una idea o un tema expositivo que había sido escogido por ellos. Se determinó que, en el futuro, cada año, una universidad diferente se encargaría de organizar la exposición en su país con la posibilidad de que itinere a otros países de los otros másteres. Como resultado de esta primera experiencia realizada por los alumnos de Valencia, se decidió que los alumnos de la universidad de Leiden se encargan de escribir los textos a modo de crítica artística sobre los trabajos expuestos, puesto que provienen de un máster fundamentalmente teórico. El resultado fue realmente interesante, e incluso se logró que la exposición formase parte del festival FotOn sobre fotografía y fotoeriodismo que se desarrolla en la ciudad de Valencia.

Esta primera experiencia piloto fue muy positiva, y los alumnos han declarado sentirse muy satisfechos con ella. De hecho, al comparar la experiencia y los resultados obtenidos con alumnos de ediciones anteriores, nos hemos percatado de que el nivel de los proyectos personales y artísticos de los alumnos también había mejorado, probablemente enriquecidos por todas estas actividades paralelas realizadas en los distintos proyectos.

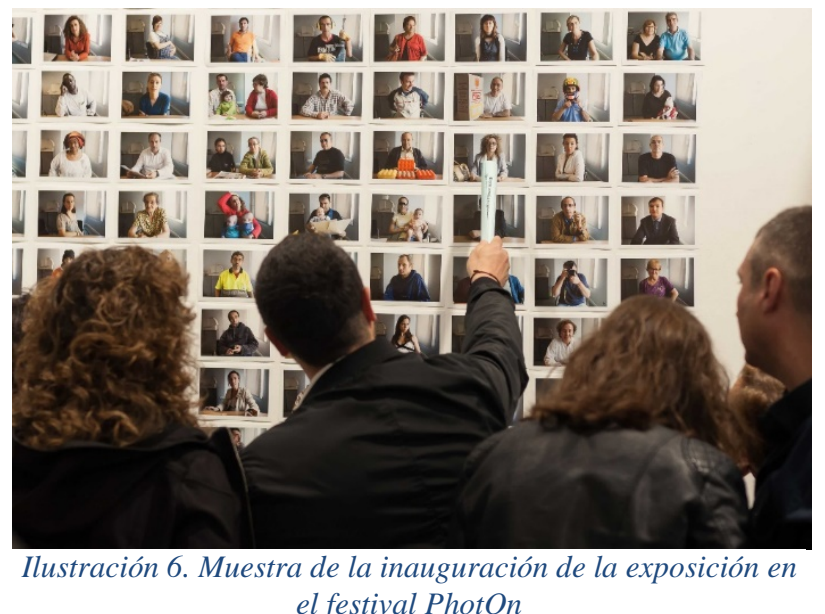

\section{Conclusiones}

Después de más de un siglo desde que naciera la fotografía, hemos podido comprobar como esta disciplina se ha popularizado en la sociedad. Pero lamentablemente en lo que se refiere a innovaciones pedagógicas en el campo de la educación artística, apenas ha evolucionado. El modo que prevalece por excelencia es el de clases magistrales y exposiciones de trabajos de los alumnos en espacios convencionales como museos o galerías (Jackson, 2007).

Pero el uso de tecnologías educativas emergentes ha supuesto un reto que muchos docentes están aprovechando. En concreto, nosotros, las hemos aprovechado para el desarrollo de proyectos colaborativos como los que hemos comentado en este artículo, y gracias a ellas, hemos podido poner en práctica la metodologia del aula invertida ya comentada. Las tecnologías digitales nos han permitido ayudar a los alumnos a acceder a los contenidos 
cuando ellos lo deseaban, fuera y dentro del aula, permitiendo el acceso continuo tanto dese ordenadores como dispositivos móviles. De este modo, los estudiantes se han convertido en los responsables de gestionar su aprendizaje, y así lo ha demostrado su evaluación positiva de la experiencia. Asimismo, han declarado que las temáticas de los proyectos se han ajustado mejor a las expectativas personales de aprendizaje de cada uno de ellos.

Por otro lado, estas tecnologías han servido de puente entre los alumnos y profesores de nuestro máster con otros alumnos y profesores de otros másteres internacionales. Gracias a internet y la posibilidad de comunicarnos y conocernos mediante las redes sociales, el correo electrónico y las plataformas como Polimedia, hemos reducido las distancias y hemos colaborado con otros profesionales y estudiantes que se encuentran lejos, propiciando el interés e incluso la posibilidad de conocerse en persona.

Con la intención de realizar una evaluación más objetiva de las capacidades artísticas de los alumnos y las alumnas, determinamos que cada grupo se debía de encargar de evaluar las propuestas de los otros compañeros. $\mathrm{Y}$ a pesar de que esta idea en un primer momento resultó chocante para algunos de ellos, posteriormente reconocieron que el hecho de evaluar el trabajo de otros les había servido para realizar una reflexión autocrítica con su propio trabajo. Posteriormente, los profesores y profesoras del máster realizamos también nuestra valoración de las actividades y su evaluación de acuerdo con unos valores ya indicados con anterioridad.

Por otro lado, queremos comentar como nos sorprendió que no todos los alumnos se mostraran igual de contentos con la idea de trabajar en grupos, y en algunos grupos, de hecho, surgieron roces y problemas que afectaron al normal desarrollo de las actividades. Como docentes, estamos sorprendidos con la poca capacidad de los alumnos de trabajar en equipo, y la necesidad de muchos de ellos de mostrar su liderazgo o los problemas surgidos por el exceso de ego, - que es bastante normal en los alumnos de bellas artes, especialmente en los primeros cursos, pero no es tan común a nivel de máster-. De hecho, nos sorprende que, en lugar de encontrarnos limitaciones a la hora de aplicar metodologías innovadoras en espacios expositivos no convencionales, los problemas surgieran de algo tan básico como es el trabajo en grupo. Efectivamente, creemos que esto mismo supondrá una barrera para estos alumnos que se tendrán que enfrentar al terreno profesional, dónde su trabajo será continuamente cuestionado, y cuando en muchas ocasiones se tendrán que desenvolver al trabajar en equipo.

No obstante, en todo momento hemos intentado fomentar las capacidades creativas de los alumnos que acuden a estudiar un máster en fotografía para completar su formación. Muchos de ellos llegan con grandes esperanzas y expectativas que no siempre se cumplen, pero desde nuestra postura, como docentes, debemos intentar facilitarlo en la medida que sea posible. De hecho, los primeros beneficiados de todos los proyectos que realizamos son los alumnos, y no los profesores, pues para los profesores suele suponer un sobreesfuerzo, que no siempre es recompensado. Pero, aunque estamos más cansados, estamos encantados de poder tener la oportunidad de hacerlo, pues, aunque realizamos estas actividades paralelamente al currículum oficial, esperamos que en ediciones posteriores este tipo de

(cc) EY-NC-ND 2018, Universitat Politècnica de València

Congreso IN-RED (2018) 
proyectos puedan tener un mayor protagonismo en las guías docentes, y que los alumnos y las alumnas puedan valorar y aprovechar el aprendizaje adquirido.

Estamos convencidos de que cuanto más radicalizamos las metodologías de aprendizaje experimental mediante el desarrollo de proyectos colaborativos, como los que hemos expuesto, basados en el uso del pensamiento del diseño, el pensamiento crítico y la propuesta del aula invertida, podemos mejorar cualitativamente las capacidades creativas de las alumnas y los alumnos.

\section{Referencias}

Bourdieu, P. (2003). Un arte medio. Barcelona: Gustavo Gili.

Bridges, M. (2013). Creativity Education. En G. Rand, \& R. D. Zakia, Teaching Photography. London: Elseiver. Obtenido de Teaching Photography : https://www.safaribooksonline.com/library/view/teachingphotography/9780240807676/013_9781136105890_chapter5.html

Chevrier, J.-F. (2007). La fotografía entre las bellas artes y los medios de comunicación. Barcelona: Gustavo Gili.

Condés, O. (4 de mayo de 2018). ¿Cuál es el mejor método para estudiar fotografía? Obtenido de Xataka Foto: https://www.xatakafoto.com/trucos-y-consejos/cual-esel-mejor-metodo-para-estudiar-fotografia

Fontcuberta, J. (2016). La furia de las imágenes. Notas sobre la postfotografía. Barcelona: Galaxia Gutenberg.

Hernández, A. L. (16 de diciembre de 2013). ¿Dónde estudiar fotografía? Recuperado el 18 de marzo de 2018, de Foto Blogger.

Ivern Magaña, J. (Junio de 2009). Por una nueva metodología en los estudios superiores de las artes. Recuperado el 20 de marzo de 2018, de http://www.raco.cat/index.php/Observar/article/viewFile/179280/231740

Jackson, F. (2007). Teaching Photography as Art: A Short Critical History. Smithsonian American Art Journal, 21(3), 19-24.

Sontag, S. (2010). Sobre la fotografía. Barcelona: Debolsillo.

Subdirección General de Estadística y Estudios. (2015). Encuesta de hábitos y prácticas culturales en España 2014-2015. Madrid: Ministerio de Educación, Cultura y Deporte.

Vega, C. (2017). Fotografía en España (1839-2015). Ediciones Cátedra. 


\title{
El enfoque superficial y profundo en la realización de proyectos de diseño: una aproximación desde la perspectiva docente
}

\author{
Olga Ampuero-Canellas ${ }^{\mathrm{a}}$, Jimena Gonzalez-Del-Rio ${ }^{\mathrm{b}}$, Begoña Jorda-Albiñanac ${ }^{c}$, Teresa \\ Magal-Royo $^{\mathrm{d}}$, Javier Ciscar ${ }^{\mathrm{e}}$ y Maria-Elisa March-Leuba ${ }^{\mathrm{f}}$ \\ ${ }^{a}$ Universitat Politècnica de València, olga@mag.upv.es, ${ }^{b}$ Universitat Politècnica de València, \\ jimena@mag.upv.es, ${ }^{\mathrm{c}}$ Universitat Politècnica de València, bego@mag.upv.es, ${ }^{\mathrm{d}}$ Universitat \\ Politècnica de València, tmagal@degi.upv.es, ${ }^{\mathrm{e}}$ Universitat Politècnica de València, \\ jaciscu@degi.upv.es y ${ }^{\mathrm{f}}$ Universitat Politècnica de València, emarch@dib.upv.es.
}

\begin{abstract}
There is no single way to learn or study, but different learning styles that describe the different ways in which students face the resolution of academic tasks. This project aims to describe the attitudes, strategies and behaviors used by students in the development of a project within the field of design. To this end, a systematic observation and collection of information by a group of teachers is carried out in several subjects in which the methodology of project-based learning is applied. The collected data are subsequently analyzed and cataloged according to the widely accepted differentiation in the pedagogical field between superficial learning and deep learning approaches. The results allow us to differentiate between two forms of work in the development of a design project that would differentiate those students who seek to solve the project by applying little original guidelines and without going too deeply (superficial approach) and those who seek a high level of understanding of the problem to solve and a very original solution (deep approach).
\end{abstract}

Keywords: learning styles, deep approach learning, superficial approach learning, project-based learning, higher education, design education.

\footnotetext{
Resumen

No existe una única manera de aprender o estudiar, sino diversos estilos de aprendizaje que describen las distintas formas en las que los alumnos se enfrentan a la resolución de las tareas académicas. Este proyecto pretende describir las actitudes, estrategias y conductas utilizadas por los alumnos en el desarrollo de un proyecto dentro del ámbito del diseño. Para ello se lleva a cabo una observación y recogida sistemática de información por parte de un grupo de docentes durante la impartición de varias asignaturas en las que se aplica la metodología del aprendizaje basado en proyectos. Los datos recogidos son posteriormente analizados y catalogados en función de la diferenciación ampliamente aceptada en el ámbito pedagógico entre enfoque de aprendizaje superficial y profundo. Los resultados nos permiten diferenciar entre dos formas de trabajo en el desarrollo de un proyecto de
} 
El enfoque superficial y profundo en la realización de proyectos de diseño: una aproximación desde la perspectiva docente

diseño que diferenciaría a aquellos alumnos que buscan resolver el proyecto aplicando pautas poco originales y sin profundizar demasiado (enfoque superficial) y aquellos que buscan un alto nivel de comprensión del problema a resolver y una solución muy original (enfoque profundo).

Palabras clave: estilos de aprendizaje, enfoque profundo, enfoque superficial, aprendizaje basado en proyectos, educación superior, educación en diseño.

\section{Introducción}

Parece ser un tema pedagógico ampliamente aceptado que los alumnos aprenden y estudian de distinta manera (Hawk y Shah, 2007). Esta forma de aprender varía en función de la concepción de la tarea que tienen que realizar y del aprendizaje, de sus experiencias previas y de la situación o contexto (Duff, 2004).

El concepto de "estilos de aprendizaje" explica las estrategias que eligen los estudiantes al resolver una tarea académica (Soler, 2013). Conociendo el estilo de aprendizaje de sus alumnos, el docente puede adaptar los métodos y actividades aplicados en el aula para conseguir mejores resultados de aprendizaje (Hawk y Shah, 2007); y ahí radica la importancia de su estudio y se justifica el amplio número de investigaciones que se han desarrollado en torno a este tema.

Figura 1. Principales modelos de estilos de aprendizaje

\begin{tabular}{llll}
\hline \multicolumn{1}{c}{ Modelo } & \multicolumn{1}{c}{ Variables } & \multicolumn{1}{c}{ Tipologías } & Instrumento \\
\hline $\begin{array}{l}\text { Dunn and Dunn } \\
\text { (1975) }\end{array}$ & $\begin{array}{l}\text { Estímulos ambientales, } \\
\text { emocionales, } \\
\text { sociológicos, físicos y } \\
\text { cognitivos }\end{array}$ & & PEPS \\
& Percepción (abstracción, & Concreto-secuencial & GSD \\
\hline Gregorc and & concreción) & Abstracto-secuencial & \\
Ward (1977) & Orden (secuencial, al & Concreto-al azar & \\
& azar) & Abstracto-al azar & \\
\hline Kolb (1984) & Experiencia concreta & Convergente & LSI \\
& Observación reflexiva & Divergente & \\
& Conceptualización & Asimilador & \\
& abstracta & Acomodador & ILS \\
& Experiencia activa & Activo/Reflexivo & Activos/Reflexivos \\
\hline Felder y & Sensorial/Intuitivo & Sensitivos/Intuitivos & \\
Silverman (1988) & Visual/Verbal & Visuales/Verbales & \\
& Secuencial/Global & Secuenciales/Globales & \\
\hline VARK (Fleming, & Visual & Visual & VARK \\
2001) & Auditivo & Auditivo & \\
& Lectura/escritura & Lectura/escritura & \\
& Kinésico & Kinésico & \\
\hline
\end{tabular}

(cc) EY-NC-ND 2018, Universitat Politècnica de València

Congreso IN-RED (2018) 
En la Figura 1 podemos ver los principales modelos que tratan de describir y explicar cómo sucede el proceso de aprendizaje. Para cada uno de ellos se indica el autor y la fecha de la primera propuesta del modelo, las variables que configuran el estilo de aprendizaje y la tipología de estilos a que da lugar la aplicación del modelo. Por último, en la última columna se indica el instrumento de medida diseñado por cada autor para medir el estilo de aprendizaje según el modelo y las variables propuestas. Para cada tipo de alumno resultante, habría un conjunto de metodologías más apropiadas que otras y que conllevarían un aprendizaje más efectivo (Hawk y Shah, 2007).

Aunque cada modelo defina el proceso de aprendizaje de distinta manera y cada uno presente sus propias variables, parecen coincidir al menos en dos aspectos: el interés por desarrollar instrumentos de medición de las estrategias y estilos de aprendizaje, y el intento de comprobar si existe relación entre estilo de aprendizaje y rendimiento académico (Cano García y Justicia Justicia, 1993).

Sumado a esto, Marton y Saljo (1976) diferencian dos tipos de enfoques de aprendizaje: profundo y superficial. Cada uno de estos enfoques se asocia a una motivación y estrategias diferentes como se detalla en la Figura 2; pudiendo resumirse en que el enfoque profundo es aquel que busca la comprensión de la materia y el aprendizaje superficial aquel que se limita a reproducir lo aprendido.

Posteriormente, Biggs (1988) y Entwistle (1988) argumentan que existe un tercer enfoque denominado estratégico. Desde esta perspectiva, el alumno trata de alcanzar el mayor rendimiento posible al realizar su trabajo, planificando cuidadosamente las tareas, el material necesario, el esfuerzo a realizar y el tiempo disponible.

El hecho de que un alumno actúe de un modo u otro depende no solo de sus características individuales sino también del contexto de enseñanza (Biggs et al., 2001) y de la motivación intrínseca o grado de interés por el contenido y su importancia (Entwistle, 1988), entre otros factores. Profesor y alumno son entonces responsables del resultado del proceso de enseñanza-aprendizaje: el profesor por habilitar las circunstancias para que este se produzca y el alumno por abordarlas.

Figura 2. Características del enfoque profundo y superficial

\begin{tabular}{lll}
\hline \multicolumn{1}{c}{ Fuente } & \multicolumn{1}{c}{ Superficial } & Profundo \\
\hline $\begin{array}{l}\text { García Cano y Justicia } \\
\text { Justicia (1993) }\end{array}$ & Tiende al detalle, a la descripción & $\begin{array}{l}\text { Tiende al significado, a la } \\
\text { conclusión }\end{array}$ \\
\hline Lizzio et al. (2002) & $\begin{array}{l}\text { Estrategias reproductivas con escaso } \\
\text { interés por integrar la información }\end{array}$ & Aplica y compara ideas \\
\hline Duff (2004) & $\begin{array}{l}\text { Trata las partes de la materia como } \\
\text { entidades separadas e integra los } \\
\text { temas en un todo coherente. }\end{array}$ & $\begin{array}{l}\text { Relaciona la materia con otras } \\
\text { experiencias e ideas, manteniendo } \\
\text { una visión crítica }\end{array}$ \\
\hline Gargallo et al. (2006) & $\begin{array}{l}\text { Aprendizaje por operación (estrategia } \\
\text { serialista, imprevisión) } \\
\text { Miedo al fracaso }\end{array}$ & $\begin{array}{l}\text { Aprendizaje por comprensión } \\
\text { (estrategia holista, injustificación) }\end{array}$ \\
\hline Soler (2013) & Motivación extrínseca & Motivación intrínseca \\
\hline
\end{tabular}


Las investigaciones llevadas a cabo sobre estilos y estrategias de aprendizaje muestran una relación entre un buen aprendizaje y el enfoque de aprendizaje que denominamos profundo, así como con otras variables como la capacidad de autorregulación del propio aprendizaje, las motivaciones de tipo intrínseco, un buen autoconcepto y confianza en sí mismo y el uso de estrategias cognitivas y metacognitivas a la hora de planificar y revisar su proceso de estudio (Martín et al., 2008). Todo ello lleva a lograr un aprendizaje significativo y, por tanto, más eficiente.

\section{Objetivos}

La experiencia docente aquí descrita se propone describir, desde la perspectiva docente, las actitudes, estrategias y comportamientos que los alumnos del ámbito de diseño suelen utilizar al abordar la resolución de un proyecto en cualquiera de sus asignaturas de tipo proyectual donde preferentemente se opta por una metodología de aprendizaje basado en proyectos. Posteriormente, y con el fin de ahondar y reflexionar sobre los datos encontrados, se pretende ordenar las conductas encontradas asimilándolas a los enfoques de aprendizaje superficial y profundo definidos por Marton y Saljo (1976). Dejamos para un desarrollo posterior, establecer los comportamientos que entrarían dentro del enfoque estratégico propuesto por Biggs (1988) y Entwistle (1988).

Todo ello debería conducirnos al final a una mejor identificación del proceso de trabajo de nuestros alumnos y, por tanto, a contar con un punto de partida para diseñar metodologías y actividades que potencien en los alumnos un enfoque de aprendizaje profundo que revierta en un aprendizaje más efectivo.

\section{Desarrollo de la innovación}

El proyecto se desarrolla en dos fases. La primera de ella consiste en la recogida de datos a partir de la observación participante del trabajo llevado a cabo por los alumnos por parte de los docentes implicados en la investigación. La recogida de datos se llevó a cabo durante el curso 2016-2017 y el primer semestre del curso 2017-2018, en asignaturas de tercer y cuarto curso del Grado en Ingeniería en Diseño Industrial y Desarrollo de Productos (Escuela Técnica Superior de Ingeniería del Diseño de la Universitat Politècnica de València). Todas estas asignaturas utilizan de forma preferente la metodología del aprendizaje basado en proyectos y a lo largo de ellas los alumnos han de desarrollar uno o más proyectos sobre diseño de producto o diseño gráfico.

Para sistematizar la recogida de información, se creó una rejilla para introducir los datos dividida en cuatro apartados que reflejaban las principales fases del desarrollo de un proyecto en el ámbito del diseño: definición, conceptualización, desarrollo y prototipado. Tras cada sesión presencial, los profesores anotaban en esa rejilla, a modo de diario de

(cc) EY-NC-ND 2018, Universitat Politècnica de València

Congreso IN-RED (2018) 
observación, los comportamientos observados en sus alumnos a la hora de resolver las diferentes fases del proyecto.

Tras la recogida de información, se realizó una reunión de todos los profesores implicados en la que se procedió a eliminar las conductas repetidas y a clasificar las restantes en los dos tipos de enfoques: superficial y profundo; definidos al comienzo. A su vez, se vio necesario añadir otra categoría más que recogiese conductas relativas a la organización del trabajo (tutorías, correcciones, entregas...) y que se habían observado a lo largo de todo el desarrollo del proyecto y no solo en una etapa concreta.

Como resultado, se describieron dos formas de trabajar a la hora de enfrentarse a un proyecto de diseño: la de aquellos alumnos que buscan resolver el proyecto aplicando pautas poco originales y sin profundizar demasiado (enfoque superficial) y la de aquellos que buscan un alto nivel de comprensión tanto del problema como de la solución aportada (enfoque profundo).

\section{Resultados}

A continuación se describen las actitudes, estrategias y conductas observadas en los alumnos al realizar un proyecto sobre diseño de producto o gráfico. Se divide la descripción en las distintas fases del proyecto (definición, conceptualización, desarrollo y prototipado), comentando en primer lugar el perfil considerado propio de un enfoque de aprendizaje superficial y después el perfil del enfoque profundo. Por último, se añade un apartado final que recoge aspectos sobre la organización del trabajo.

\subsection{Etapa 1: Definición del proyecto}

En la Figura 3 se recogen de modo abreviado las conductas relacionadas con la etapa de definición del proyecto para cada uno de los dos enfoques estudiados: superficial y profundo.

Figura 3. Enfoque superficial y profundo en la etapa de definición del proyecto

\begin{tabular}{|c|c|c|}
\hline Tarea & Superficial & Profundo \\
\hline $\begin{array}{l}\text { Presentación del } \\
\text { proyecto por el } \\
\text { profesor }\end{array}$ & $\begin{array}{l}\text { Registra la información de } \\
\text { manera automática y acrítica. }\end{array}$ & $\begin{array}{l}\text { Plantea dudas y solicita más } \\
\text { información. } \\
\text { Propone pequeñas alternativas. }\end{array}$ \\
\hline $\begin{array}{l}\text { Redacción del } \\
\text { briefing }\end{array}$ & $\begin{array}{l}\text { Olvida aspectos clave. } \\
\text { No resume el problema en dos o } \\
\text { tres palabras clave. }\end{array}$ & $\begin{array}{l}\text { Detalla todos los aspectos. } \\
\text { Resume en una sola frase el } \\
\text { problema principal. }\end{array}$ \\
\hline $\begin{array}{l}\text { Búsqueda de } \\
\text { información }\end{array}$ & $\begin{array}{l}\text { No lo considera necesario. } \\
\text { Consulta fuentes de escasa } \\
\text { validez académica. } \\
\text { Copia sin citar la fuente } \\
\text { consultada. }\end{array}$ & $\begin{array}{l}\text { Busca información en webs } \\
\text { especializadas, libros y revistas. } \\
\text { Contrasta la información encontrada } \\
\text { y la expone con sus propias palabras } \\
\text { citando la fuente. }\end{array}$ \\
\hline $\begin{array}{l}\text { Búsqueda de } \\
\text { referentes }\end{array}$ & $\begin{array}{l}\text { Busca pocos referentes. } \\
\text { Consulta una sola fuente. } \\
\text { Dentro del ámbito del proyecto. }\end{array}$ & $\begin{array}{l}\text { Busca muchos referentes. } \\
\text { Consulta varias fuentes. } \\
\text { Se basa sobre todo en diseñadores de }\end{array}$ \\
\hline
\end{tabular}

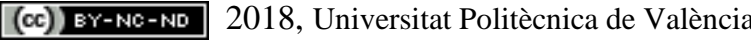

Congreso In-Red (2018) 


\begin{tabular}{ll} 
No cuestiona su relevancia. & reconocido prestigio. \\
Analiza los proyectos de manera & Busca referentes en otros campos. \\
superficial y poco crítica. & Analiza con detalle estos referentes. \\
\hline
\end{tabular}

\subsubsection{Enfoque superficial}

En el momento de la explicación del proyecto a realizar, se limita a registrar de manera automática y sin ninguna crítica, la información dada por el profesor.

El alumno redacta el briefing de manera superficial, pudiendo dejar algunos aspectos clave sin definir. El proceso de redacción es escasamente analítico y al final no es capaz de resumir el problema a resolver utilizando dos o tres palabras clave.

No ve la necesidad de buscar más información más allá de sus conocimientos para completar el briefing. En caso de que lo exija el enunciado del proyecto, se limita a consultar un número reducido de fuentes, principalmente digitales, de escasa validez académica. Después, copia (a veces, literalmente) lo que allí encuentra, olvidándose de citar la fuente consultada. Si el profesor ha indicado algunas fuentes a consultar, se limita a consultarlas, sin añadir ninguna más.

No ve la necesidad de analizar proyectos anteriores en los que basar su propuesta. Solo cuando lo exige el enunciado del proyecto, busca ejemplos de una única fuente tipo Wikipedia, Pinterest o Instagram; sin juzgar el criterio de elección seguido al seleccionar los proyectos allí mostrados. El análisis que realiza de los referentes es superficial y poco crítico, limitándose a buscarlos en el campo en el que se inscribe el proyecto.

\subsubsection{Enfoque profundo}

En el momento de la explicación del proyecto, plantea dudas y solicita más información al profesor hasta obtener una imagen clara del objetivo del proyecto. Se asegura de haber entendido bien el proyecto antes de comenzar a trabajar en él. Puede proponer pequeñas alternativas al proyecto presentado por el profesor.

Redacta a conciencia el briefing del proyecto, detallando todos los aspectos implicados sin olvidar ninguno. Mientras redacta el documento, analiza la información y extrae los elementos clave, siendo capaz al terminar de resumir en una sola frase el problema principal que debe resolver el proyecto.

Aunque no se exija en el enunciado del proyecto, busca información para completar el briefing recurriendo a un número amplio de webs especializadas de validez académica contrastada así como libros y revistas existentes en la biblioteca. Es capaz de resumir su necesidad de información en unas pocas palabras clave, con lo que la búsqueda es más rápida y eficaz. Contrasta la información encontrada, la evalúa y expone de manera ordenada y con sus propias palabras, indicando claramente de qué fuente ha extraído la información. Guarda las referencias de los documentos consultados por si tuviera que volver a consultarlos.

(cc) EY-NC-ND 2018, Universitat Politècnica de València

Congreso IN-RED (2018) 
Aunque no se exija en el enunciado del proyecto, busca referentes sobre proyectos de características similares resueltos por diseñadores de reconocido prestigio. Consulta libros de la biblioteca o páginas web especializadas. Aunque utilice también redes sociales populares (Pinterest o Instagram), busca siempre la fuente original para contrastar su validez. Si dispone de tiempo, busca también referentes en otros campos no directamente relacionados con el ámbito del proyecto. Analiza con detalle estos referentes, anotando las conclusiones extraídas, para poder consultarlas en las siguientes fases del proyecto. Guarda las referencias de los documentos consultados por si tuviera que volver a consultarlos.

\subsection{Etapa 2: Conceptualización}

La Figura 4 recoge de modo abreviado las conductas relacionadas con la conceptualización del proyecto para cada uno de los dos enfoques estudiados: superficial y profundo.

Figura 4. Enfoque superficial y profundo en la etapa de conceptualización

\begin{tabular}{|c|c|c|}
\hline Tarea & Superficial & Profundo \\
\hline $\begin{array}{l}\text { Generación de } \\
\text { ideas }\end{array}$ & $\begin{array}{l}\text { Intuitivo y desestructurado. } \\
\text { Pocas ideas y poco originales. } \\
\text { Se queda con la primera idea } \\
\text { "factible” que encuentra. } \\
\text { Define las ideas con poco detalle. } \\
\text { Poco o nada relacionadas con el } \\
\text { briefing. }\end{array}$ & $\begin{array}{l}\text { Organizado y estructurado. } \\
\text { Gran cantidad de ideas. } \\
\text { Ideas alejadas de lo habitual. } \\
\text { Define cada idea con detalle y } \\
\text { precisión. } \\
\text { Válidas para solucionar el problema. }\end{array}$ \\
\hline $\begin{array}{l}\text { Realización de } \\
\text { bocetos }\end{array}$ & $\begin{array}{l}\text { No siempre realiza bocetos a } \\
\text { mano. } \\
\text { Pocos bocetos. } \\
\text { Bocetos mal definidos y poco } \\
\text { detallados. } \\
\text { Poca relación entre boceto e idea. }\end{array}$ & $\begin{array}{l}\text { Siempre realiza bocetos a mano. } \\
\text { Gran cantidad de bocetos. } \\
\text { Bocetos detallados y bien } \\
\text { ejecutados. } \\
\text { Estrecha relación entre idea y } \\
\text { boceto. }\end{array}$ \\
\hline $\begin{array}{l}\text { Evaluación de } \\
\text { ideas }\end{array}$ & $\begin{array}{l}\text { Según sus preferencias } \\
\text { personales. } \\
\text { Deja en manos del profesor la } \\
\text { elección de la idea a desarrollar. } \\
\text { Puede que ninguna idea se ajuste } \\
\text { totalmente al briefing. }\end{array}$ & $\begin{array}{l}\text { Según el briefing y el futuro usuario. } \\
\text { Elige de manera autónoma la idea a } \\
\text { desarrollar. } \\
\text { Varias ideas sea ajustan totalmente } \\
\text { al briefing. }\end{array}$ \\
\hline
\end{tabular}

\subsubsection{Enfoque superficial}

El proceso de creación de este estudiante es fuertemente intuitivo y desestructurado. No le preocupa demasiado obtener ideas poco originales, que repiten esquemas establecidos y no aportan nada nuevo. Prefiere apostar por lo seguro que arriesgarse a fracasar.

Piensa en pocas ideas ya que luego solo va a poder desarrollar una. Pensar en más ideas le parece una pérdida de tiempo. Por ello, se queda con la primera idea "factible" que encuentra y no indaga un poco más por si pudiera encontrar otra mejor. Enumera los conceptos encontrados sin preocuparse por desarrollarlos ni elaborarlos totalmente y presenta conceptos muy similares entre sí. Las ideas se relacionan poco o nada con las exigencias planteadas en el briefing.

(c) EY-NC-ND 2018, Universitat Politècnica de València 
No considera necesario realizar bocetos a mano antes de empezar a trabajar la idea en el ordenador. Si el profesor no lo exige, evitará hacerlos y se limitará a expresar verbalmente los conceptos que va a trabajar y qué planteamiento va a seguir antes de pasar a trabajar directamente con el ordenador. Solo cuando el profesor lo exija, realizará bocetos pero estos serán limitados en número y estarán construidos a partir de líneas y trazos inseguros y mal definidos. Además, el boceto presentará el concepto de manera muy general, sin especificar detalles. Este tipo de estudiante encuentra difícil materializar visualmente en un boceto el concepto elegido, por lo que a veces no existe relación entre el boceto que desarrolla y el concepto elegido.

Evalúa las ideas en primer lugar basándose en sus preferencias personales y en segundo lugar, según los requisitos marcados en el briefing. Su opinión cuenta más que la opinión del futuro usuario del producto. Suele resultarle difícil seleccionar el mejor concepto o boceto a desarrollar y en muchas ocasiones deja en manos del profesor el tomar esta decisión. En ocasiones, no es capaz de elegir un solo concepto y renunciar a los demás, por lo que a veces termina eligiendo más de un concepto aunque se trate de ideas inconexas y difíciles de ensamblar. Como presenta pocas ideas, puede encontrarse con que ninguna de ellas se ajuste a todos los requisitos marcados en el briefing y verse obligado a elegir "la menos peor de todas".

\subsubsection{Enfoque profundo}

El proceso de creación es organizado y estructurado, utilizando técnicas de generación de ideas como el brainstorming. Anota todas las ideas que van surgiendo, posponiendo el proceso de evaluación. Trata de producir la mayor cantidad posible de ideas, aunque en el proyecto solo se le exija desarrollar una. Define cada concepto de manera detallada y precisa. Busca conseguir ideas brillantes, atractivas y originales, alejadas de las soluciones habituales. No le importa producir ideas arriesgadas y poco vistas. Presenta varios conceptos y bien diferenciados entre sí. Las ideas encontradas son válidas para solucionar el problema planteado en el briefing.

Considera un paso fundamental realizar bocetos a mano antes de comenzar a trabajar en el ordenador y, por ello, aunque en el enunciado del proyecto no se indique, los realizará. Los bocetos destacan por el gran nivel de detalle con el que se explica cada idea o concepto, así como por los trazos bien definidos y su cuidadosa ejecución. Realiza gran cantidad de bocetos para luego poder seleccionar aquellos que mejor presentan sus ideas. Existe una estrecha relación entre el concepto y su materialización visual en forma de boceto.

Evalúa las ideas y los bocetos a la luz de las exigencias marcadas en el briefing, dejando sus preferencias al margen. Se pone en la piel del futuro usuario para seleccionar cuál de todos los conceptos le resultará más atractivo. Testea su propuesta recabando la opinión de personas que podrían ser futuros usuarios del producto. Es capaz de elegir de manera autónoma y con gran confianza la idea y boceto que quiere llevar a cabo. Como presenta muchas ideas, la mayoría de las veces se encuentra con más de una opción válida para desarrollar el proyecto con grandes garantías de éxito.

(cc) EY-NC-ND 2018, Universitat Politècnica de València

Congreso IN-RED (2018) 


\subsection{Etapa 3: Desarrollo del proyecto}

La Figura 5 recoge de modo abreviado las conductas relacionadas con el desarrollo del proyecto para cada uno de los dos enfoques estudiados.

Figura 5. Enfoque superficial y profundo en la etapa de desarrollo del proyecto

\begin{tabular}{|c|c|c|}
\hline Tarea & Superficial & Profundo \\
\hline Diseño & $\begin{array}{l}\text { Utiliza imágenes sacadas de } \\
\text { internet sin juzgar su calidad. } \\
\text { Propone solo una o dos opciones. } \\
\text { No hace pruebas previas de } \\
\text { prototipo. }\end{array}$ & $\begin{array}{l}\text { Genera sus propios recursos gráficos } \\
\text { o usa recursos ajenos de calidad. } \\
\text { Propone múltiples opciones. } \\
\text { Experimenta con los recursos de } \\
\text { manera original. } \\
\text { Realiza pruebas de prototipo previas. }\end{array}$ \\
\hline Consulta teoría & No consulta la teoría. & $\begin{array}{l}\text { Consulta la teoría para resolver } \\
\text { problemas y evaluar su trabajo. }\end{array}$ \\
\hline Uso de referentes & Copia soluciones de otros. & $\begin{array}{l}\text { Presenta soluciones propias y } \\
\text { diferentes de los referentes. }\end{array}$ \\
\hline $\begin{array}{l}\text { Uso de la } \\
\text { herramienta } \\
\text { informática }\end{array}$ & $\begin{array}{l}\text { Poco profesional y descuidado. } \\
\text { Olvida las directrices dadas en } \\
\text { clase. } \\
\text { No revisa el archivo final. }\end{array}$ & $\begin{array}{l}\text { Profesional. } \\
\text { Sigue las indicaciones dadas en } \\
\text { clase. } \\
\text { Revisa el archivo final. }\end{array}$ \\
\hline
\end{tabular}

\subsubsection{Enfoque superficial}

Busca sin mucho criterio fotos e ilustraciones en internet para incorporarlas a su proyecto. Utiliza lo primero que encuentra aunque no tenga coherencia con el concepto o boceto planteado. Se queda con la primera tipografía que por defecto le facilita el programa. Tampoco prueba distintas combinaciones de color ni composiciones alternativas. Elige opciones sin pensar si tiene o no la habilidad y recursos suficientes para llevarlas a cabo correctamente. Busca encontrar una solución aceptable en el menor tiempo posible. Repite de manera mecánica soluciones vistas en clase o que ha utilizado en proyectos anteriores, sin probar alternativas más arriesgadas. Copia soluciones dadas por otros sin aportar grandes cambios. No cree necesario imprimir ni hacer pruebas previas para comprobar cómo quedará el prototipo. Lo que ve en el ordenador es suficiente para juzgar la idoneidad de su trabajo. No encuentra necesario consultar la teoría de la asignatura porque no ve relación entre ella y el proyecto que debe desarrollar.

Utiliza el programa informático de manera poco profesional y descuidada; olvidando o no siguiendo las directrices dadas en clase. Soluciona los problemas de la manera más rápida posible aunque sea poco profesional. Al preparar el documento final antes del prototipo, no revisa que contenga toda la información necesaria ni elimina elementos sobrantes. Lo prepara sin chequear las especificaciones dadas por el profesor. 
El enfoque superficial y profundo en la realización de proyectos de diseño: una aproximación desde la perspectiva docente

\subsubsection{Enfoque profundo}

Toma como referencia otros proyectos pero es capaz de presentar una solución propia y perfectamente diferenciable. Si va a trabajar con fotografía genera sus propios recursos o busca imágenes de buena calidad libres de derechos. Trabaja con ilustraciones propias y coherentes con el mensaje. Pasa un boceto al ordenador de manera ordenada y sistemática; y partir de ahí, propone múltiples composiciones y opciones de diseño, explorando muchas alternativas en cada decisión. Experimenta con el grosor de la tipografía y sus formas como elemento de comunicación; con las imágenes, los lenguajes plásticos y la composición. Conoce sus habilidades y saca partido de ellas en la realización del proyecto. Busca encontrar la solución más adecuada aunque tenga que invertir más tiempo que sus compañeros. No se queda satisfecho hasta que el resultado final tiene una alta calidad. Realiza pruebas impresas para perfilar su diseño y comprobar la validez de distintas opciones.

Consulta la teoría de la asignatura para resolver los problemas que se le plantean así como para evaluar su proceso de trabajo y asegurarse de que responde a los principios establecidos en la disciplina.

Utiliza el programa informático de manera profesional, siguiendo las indicaciones dadas en clase y preguntando al profesor las dudas que puedan surgirle. Prepara el archivo digital con el diseño definitivo revisando que las especificaciones están bien aplicadas y eliminando elementos innecesarios.

\subsection{Etapa 4: Prototipado}

La Figura 6 recoge de modo abreviado las conductas relacionadas con la etapa del prototipado para cada uno de los dos enfoques estudiados.

Figura 6. Enfoque superficial y profundo en la etapa de prototipado

\begin{tabular}{lll}
\hline \multicolumn{1}{c}{ Tarea } & \multicolumn{1}{c}{ Superficial } & \multicolumn{1}{c}{ Profundo } \\
\hline $\begin{array}{l}\text { Elección del } \\
\text { material }\end{array}$ & $\begin{array}{l}\text { Según razones ajenas al briefing. } \\
\text { No prueba su validez. }\end{array}$ & $\begin{array}{l}\text { Se basa en las indicaciones del } \\
\text { briefing. } \\
\text { Comprueba su validez. }\end{array}$ \\
\hline Prueba previa & No realiza un prototipo previo. & Realiza un primer prototipo. \\
\hline Montaje & $\begin{array}{l}\text { Monta el prototipo con dejadez y } \\
\text { descuido. }\end{array}$ & $\begin{array}{l}\text { Es meticuloso, preciso y limpio. } \\
\text { Cuida hasta el mínimo detalle. }\end{array}$ \\
& $\begin{array}{l}\text { Da poca importancia a los } \\
\text { detalles. }\end{array}$ & \\
\hline Proveedores & $\begin{array}{l}\text { Elige el más asequible. } \\
\text { No valora la calidad del } \\
\text { resultado. } \\
\text { No repite el prototipo aunque la } \\
\text { calidad sea deficiente. }\end{array}$ & $\begin{array}{l}\text { Compara varios proveedores. } \\
\text { Valora la calidad del resultado. } \\
\text { Se plantea repetir el prototipo si no } \\
\text { tiene suficiente calidad. }\end{array}$ \\
& & \\
\hline
\end{tabular}

(cc) EY-NC-ND 2018, Universitat Politècnica de València

Congreso IN-RED (2018) 


\subsubsection{Enfoque superficial}

Elige el soporte o material del prototipo basándose en razones ajenas a lo especificado en el briefing. Además, no considera necesario probar antes si es válido para el prototipo que quiere realizar. No considera necesario hacer un prototipo previo para prevenir errores antes de realizar el definitivo. Monta el prototipo con dejadez y descuido, quizá acuciado por no llegar a la fecha de entrega. Da poca importancia a los detalles. Si necesita encargar la realización del prototipo, elige aquel proveedor que le resulte más asequible (por precio o por cercanía), sin valorar la calidad del resultado. Si el prototipo obtenido es de baja calidad, no lo repite.

\subsubsection{Enfoque profundo}

Elige el soporte definitivo en función de las indicaciones marcadas en el briefing. Realiza un primer prototipo para comprobar dimensiones y acabados, llegando incluso en ocasiones a realizar más de uno hasta llegar a una solución de calidad profesional. Es meticuloso, preciso y limpio al montar el prototipo. Cuida hasta el mínimo detalle como si de un proyecto real se tratara. Si para realizar el prototipo necesita encargar el trabajo a una empresa, busca un resultado de calidad comparando varios proveedores. En caso de no obtener la calidad buscada, repite el prototipo.

\subsection{Organización}

La Figura 7 recoge de modo abreviado las conductas relacionadas con la organización del alumno a lo largo del proyecto para cada uno de los dos enfoques estudiados.

Figura 7. Enfoque superficial y profundo en la organización

\begin{tabular}{|c|c|c|}
\hline Tarea & Superficial & Profundo \\
\hline Tutorización & $\begin{array}{l}\text { Implementa las correcciones sin } \\
\text { añadir nada nuevo. } \\
\text { Puede no aplicar las correcciones. } \\
\text { No la considera necesaria. }\end{array}$ & $\begin{array}{l}\text { Realiza todas las correcciones y } \\
\text { luego continúa su trabajo. } \\
\text { Valora las correcciones. } \\
\text { Procura corregir más de una vez. }\end{array}$ \\
\hline $\begin{array}{l}\text { Defensa del } \\
\text { trabajo }\end{array}$ & $\begin{array}{l}\text { Describe sin explicar el proceso. } \\
\text { Justifica su proyecto basándose } \\
\text { en gustos personales. }\end{array}$ & $\begin{array}{l}\text { Explica con detalle el proceso. } \\
\text { Justifica su proyecto basándose en el } \\
\text { briefing y conceptos teóricos. }\end{array}$ \\
\hline Entrega final & $\begin{array}{l}\text { No revisa las indicaciones. } \\
\text { Lo entregado no se corresponde } \\
\text { totalmente con lo que se pide. } \\
\text { Pide aplazar la entrega. }\end{array}$ & $\begin{array}{l}\text { Revisa las indicaciones. } \\
\text { La entrega se ajusta a lo que se pide. } \\
\text { Cumple con el plazo de entrega. }\end{array}$ \\
\hline $\begin{array}{l}\text { Trabajo no } \\
\text { presencial }\end{array}$ & $\begin{array}{l}\text { Trabaja sobre todo en el aula. } \\
\text { Fuera del aula dedica poco } \\
\text { tiempo al proyecto. }\end{array}$ & $\begin{array}{l}\text { Acude a clase con dudas concretas. } \\
\text { Trabaja dentro y fuera del aula. }\end{array}$ \\
\hline $\begin{array}{l}\text { Seguimiento de } \\
\text { etapas }\end{array}$ & $\begin{array}{l}\text { Deja el trabajo para el final. } \\
\text { Incumple algunas entregas } \\
\text { intermedias. }\end{array}$ & $\begin{array}{l}\text { Trabaja de manera secuencial. } \\
\text { Cumple con todas las entregas } \\
\text { intermedias. }\end{array}$ \\
\hline Motivación & $\begin{array}{l}\text { Intenta aprobar haciendo el } \\
\text { menor trabajo posible. } \\
\text { Dedica poco tiempo. }\end{array}$ & $\begin{array}{l}\text { Busca obtener un trabajo de calidad } \\
\text { que añadir a su portafolio. } \\
\text { Alto grado de implicación. }\end{array}$ \\
\hline
\end{tabular}




\subsubsection{Enfoque superficial}

Tras la corrección del profesor, implementa las pautas dadas por él de manera literal y no añade nada nuevo. En ocasiones, bien por olvido o por dejadez, no aplica las correcciones dadas por el profesor. Entiende las indicaciones del profesor como una meta a la que llegar y no como una dirección por la que avanzar y seguir mejorando el proyecto. Revisa únicamente el proyecto en el aula, sin pedir una tutoría o enviar un e-mail de consulta ante los problemas que puedan surgirle. La corrección con el profesor es un mero trámite y no la ve totalmente necesaria.

$\mathrm{Al}$ explicar y defender su trabajo, se limita a describirlo sin referirse al proceso seguido en su realización y las decisiones tomadas en el proceso. Justifica su proyecto basándose en gustos personales o de personas ajenas al público objetivo, mencionando solo de manera tangencial lo establecido en el encargo o en el briefing.

Entre una sesión y otra, no suele presentar cambios importantes en su proyecto pues trabaja sobre todo en el aula y dedica poco tiempo fuera de ella a trabajar en el proyecto.

No presta demasiada atención a las indicaciones dadas por el profesor respecto a qué debe entregarse. En lugar de revisar de nuevo el enunciado del proyecto, se guía por lo que recuerda o le dicen otros. Esto conduce a que, en ocasiones, lo que entrega no se corresponda totalmente con lo que pedía el profesor: o faltan documentos o estos no tienen el formato ni las características exigidas. En ocasiones en la memoria o en el prototipo no están indicados los nombres de los autores. Suele dejar la carga de trabajo al final, cuando la fecha de entrega se aproxima. Suele pedir un día o dos más para entregar el proyecto.

Intenta aprobar el proyecto haciendo el menor trabajo posible y dedicándole el menor tiempo posible.

\subsubsection{Enfoque profundo}

Acude a clase con preguntas concretas sobre los problemas que ha encontrado en el trabajo desarrollado desde la última sesión y el profesor puede percibir fácilmente la evolución habida en el trabajo desde la última corrección.

Realiza las correcciones indicadas por el profesor sin olvidar ninguna y, a partir de ahí, sigue mejorando su trabajo. Entiende las correcciones que le hacen como una dirección que seguir y no como una meta a la que ha llegado y ya no puede avanzar. Pregunta al profesor o solicita una tutoría para resolver los problemas que se le plantean a lo largo del proyecto. Valora las correcciones dadas por el profesor y procura corregir más de una vez tanto en clase como a través de tutorías.

Cuando presenta su trabajo, explica con detalle el proceso seguido en su realización y los problemas encontrados. Sabe identificar cuál son los puntos fuertes y débiles de su propuesta. Justifica su proyecto basándose en las especificaciones del encargo y el briefing; así como en los conceptos teóricos de la disciplina.

(cc) EY-NC-ND 2018, Universitat Politècnica de València

Congreso IN-RED (2018) 
Antes de la entrega, revisa en el enunciado del proyecto las indicaciones dadas por el profesor sobre cómo se ha de realizar esta. De esta manera, lo entregado por este alumno se ajusta a la perfección a lo solicitado por el profesor. Tanto en la memoria como en el prototipo aparecen claramente identificados los autores del proyecto. El prototipo se entrega en un envase o caja protectora. Cumple con el plazo de entrega.

Trabaja de manera gradual, planificando bien el tiempo disponible y llegando a la entrega final sin agobios. Además de aprobar el proyecto, busca contar con un trabajo de calidad que añadir a su portafolio. La realización del proyecto influye en su satisfacción personal. Se implica mucho y no le importa dedicar más horas que el resto de sus compañeros.

\section{Conclusiones}

El proyecto de innovación docente aquí planteado se proponía como objetivo describir, desde la perspectiva docente, las actividades que llevan a cabo los alumnos del ámbito de diseño al abordar la resolución de un proyecto en cualquier asignatura de tipo proyectual en la que se utiliza el aprendizaje basado en proyectos como metodología docente. El desarrollo del proyecto nos ha llevado a identificar y caracterizar una serie de actitudes y comportamientos que luego han podido ser clasificados y etiquetados como propios de un enfoque de aprendizaje profundo o un enfoque de aprendizaje superficial.

En primer lugar, podemos apreciar que la observación de los diferentes alumnos que han pasado por las diversas asignaturas ha dejado claro que, al igual que ocurre con la forma de aprender y estudiar, el abordaje del proyecto es diferente para cada alumno, aunque partan de las mismas instrucciones dadas por el profesor. Sus características personales, su entorno, su experiencia anterior en trabajos similares y otros aspectos que deberían medirse de manera rigurosa y que en el desarrollo de este proyecto no se han determinado, provocan que cada etapa del proyecto sea llevada a cabo de manera particular y personal, de forma diferenciada al resto de alumnos.

En segundo lugar, consideramos que el proyecto aquí comenzado no debería quedarse en esta primera etapa descriptiva sino que debería ser impulsado para trasladar los datos encontrados a la práctica y mejora docente. Quizá el modo más rápido sería trasladar los ítems encontrados a una rúbrica que, presentada el primer día de clase, diera a los alumnos unas pautas sobre qué tipo de conductas han de seguir para obtener un aprendizaje de calidad y duradero. Esta rúbrica también podría utilizarse como instrumento de autoevaluación a lo largo de la realización del proyecto y al finalizar este, dando al alumno indicaciones de qué tipo de enfoque ha utilizado (superficial o profundo) y, por tanto, cómo ha sido su proceso de aprendizaje.

En tercer lugar, esta descripción del proceso de trabajo característico de un enfoque profundo y de un enfoque superficial en la realización de un proyecto, constituye un instrumento útil para la elección y diseño de las metodologías docentes a utilizar en estas asignaturas. Si optamos por motivarlos hacia un enfoque de aprendizaje profundo, esta descripción nos permite conocer qué comportamientos debemos promover en ellos y, por tanto, valorar qué metodologías y actividades van a contribuir mejor a ello.

(c) ) EY-NC-ND 2018, Universitat Politècnica de València 
El enfoque superficial y profundo en la realización de proyectos de diseño: una aproximación desde la perspectiva docente

Por último, resultaría interesante reforzar la validez de estos resultados ampliando el estudio a otras asignaturas y titulaciones en las que también se trabaje con el aprendizaje basado en proyectos en el ámbito del diseño, así como realizar una consulta a los estudiantes matriculados en estas asignaturas para que ellos mismos describieran qué procesos siguen en la realización de un proyecto.

\section{Agradecimientos}

El desarrollo de este proyecto se ha llevado a cabo dentro del equipo de innovación y calidad educativa EICE ABP-Diseño y Comunicación en el que participan docentes de la Escuelas Técnica Superior de Ingeniería del Diseño (ETSID) y de la Escuela Politécnica Superior de Gandía (EPSG), ambas pertenecientes a la Universitat Politècnica de València.

\section{Referencias}

BIGGS, J.B. (1988). “Assessing study approaches to learning” en Australian Psychologist, 23, p. 197206.

BIGGS, J. B.; KEMBER, D. y LEUNG, D. Y. P. (2001). "The revised two factor study process questionnaire: R-SPQ-2F” en British Journal of Educational Psychology, 71, p. 133-149.

DUFF, A. (2004). "The Revised Approaches to Studying Inventory (RASI) and its use in management education” en Active Learning in Higher Education, 5, 1, p. 56-72.

ENTWISTLE, N. (1988). La comprensión del aprendizaje en el aula. Barcelona: Centro de Publicaciones del Ministerio de Educación y Ciencia.

ENTWISTLE, N.; MCCUNE, V. y TAIT, H. (1997). The approaches and study skills inventory for students (ASSIST). Edinburgh: Centre for Research on Learning and Instruction, University of Edinburgh.

CANO GARCIA, F. y JUSTICIA JUSTICIA, F. (1993). "Factores académicos, estrategias y estilos de aprendizaje” en Revista de psicología general y aplicada: Revista de la Federación Española de Asociaciones de Psicología, 46, 1, p. 89-99.

GARGALLO LOPEZ, B.; GARFELLA ESTEBAN, P. R. y PEREZ PEREZ, C. (2006). "Enfoques de aprendizaje y rendimiento académico en estudiantes universitarios” en Bordón: Revista de Orientación Pedagógica, 58, 3, p. 327-343.

HAWK, T. F. y SHAH, A. J. (2007). "Using learning style instruments to enhance student learning" en Decision Sciences Journal of Innovative Education, 5, 1, p. 1-19.

LIZZIO, A.; WILSON, K. y SIMONS, R. (2002). “University students' perceptions of the learning environment and academic outcomes: implications for theory and practice” en Studies in Higher Education, 27, 1, p. 27-52.

MARTIN, E.; GARCIA, L. A.; TORBAY, Á. y RODRIGUEZ, T. (2008). "Estrategias de aprendizaje y rendimiento académico en estudiantes universitarios” en International Journal of Psychology and Psychological Therapy, 8, 3, p. 401-412.

MARTON, F. y SALJO, R. (1976). "On Qualitative Differences in Learning I -Outcomes and Processes” en British Journal of Educational Psychology, 46, p. 4-11.

(c) EY-NC-ND 2018, Universitat Politècnica de València

Congreso IN-RED (2018) 
SOLER, M. G. (2013). "Validación de los instrumentos "Cuestionario de Enfoques de aprendizaje y Cuestionario de Enfoques de Enseñanza” traducidos y adaptados para caracterizar los enfoques en estudiantes y profesores de Ciencias en el contexto colombiano". En: Memorias del IX Congreso Internacional sobre Investigación en Didáctica de las Ciencias. Girona. p. 3399-3405. 


\title{
El aprendizaje de la terminología mediante deeper learning
}

\section{Anna I. Montesinos López}

Universitat Politècnica de València, amontelo@idm.upv.es

\begin{abstract}
In this work we proposed a methodology by competences for the learning of the engineering terminology. Given the characteristics of such learning, an effective way is learning by developing the competences in the students. A methodology that brings together the competences for success is deeper learning, which gives students a high degree of motivation as well as the achievement of the main professional competences through the learning of terminology.
\end{abstract}

Keywords: engineering terminology, deeper learning, acquisition of terminology, educational competences.

\footnotetext{
Resumen

En este trabajo se propone una metodología por competencias para el aprendizaje de la terminología de las ingenierías. Dadas las características de dicho aprendizaje, una manera eficaz es el aprendizaje por el desarrollo de las competencias en el alumnado. Una metodología que reúne las competencias para el éxito es el deeper learning o aprendizaje profundo, el cual otorga al alumnado un alto grado de motivación así como el logro de las principales competencias profesionales mediante el aprendizaje de la terminología.
}

Palabras clave: terminología de las ingenierías, aprendizaje profundo o deeper learning, adquisición de la terminología, aprendizaje por competencias.

\section{Introducción}

Es evidente que la terminología específica de una materia se adquiere por medio del estudio de la propia materia específica. Es bien sabido por todos que el alumnado de una materia especializada específica no sólo aprende los contenidos y los conocimientos de dicha materia, sino que también adquiere la forma en la que estos se articulan, se expresan y se transmiten. No obstante, a menudo se debe aprender la terminología de una materia en otras lenguas diferentes a la que se adquirió, puesto que generalmente hay más de una lengua de uso especializada y el alumnado o el profesional debe ser competente en más de una lengua 
de especialidad, bien para la divulgación y la docencia, o bien para la gestión profesional, pongamos por caso. En nuestro trabajo, el alumnado de las asignaturas de Valencià Tècnic de la Universitat Politècnica de València, estudia la lengua y el discurso especializado dentro del contexto de las ingenierías. Una parte importante de esta formación es el aprendizaje de la terminología con la que se construyen los discursos y la comunicación de las ingenierías.

Tradicionalmente, el aprendizaje de la terminología ha estado ligado al estudio de listas de términos equivalentes en diversas lenguas. Con el tiempo y los resultados obtenidos, es ciento que se trata de una forma poco eficaz de aprendizaje de la terminología, puesto que sirve para superar un examen, pero no para su uso posterior en contextos diferentes de la vida profesional.

Las últimas tendencias de la neuroeducación apuntan que el cerebro necesita emocionarse para aprender y por lo tanto el modelo pedagógico basado en un alumnado como receptor pasivo no funciona. Por lo tanto, ya no sirve que el profesor ofrezca los contenidos y que el alumnado los reciba pasivamente.

Por todo esto, la didáctica de la terminología debe ser lo más integrada posible en el contexto de la especialidad y tener un aprendizaje significativo para el alumnado, es decir, los términos tienen que aprenderse dentro de los textos y los contextos específicos de las ingenierías para que el alumnado sienta su utilidad y su necesidad de uso. Para ello, como vemos en el presente trabajo, el alumnado consigue aprender la materia, que es la terminología propia de su ingeniería, mediante la práctica de la metodología del trabajo terminológico de forma colaborativa y la reflexión sobre su propio itinerario de aprendizaje.

\section{Objetivos}

El principal objetivo del aprendizaje de la terminología es el uso correcto y adecuado de la terminología de las ingenierías por parte del alumnado de las asignaturas de Valencià Tècnic de la Universitat Politècnica de València. Más concretamente, en este estudio nos referiremos a la asignatura de Valencià Tècnic aplicat a la informàtica i a les telecomunicacions de l'Escola Tècnica Superior d'Enginyeria Informàtica de dicha universidad. Así pues, para el logro del objetivo principal, el alumnado debe adquirir determinadas competencias, conocimientos y habilidades con el fin de la consecución del éxito formativo y de su futuro profesional.

Entre los objetivos de la innovación educativa destacamos la aplicación de un aprendizaje adecuado a los nuevos aprendizajes y al propio carácter de la institución, así como promover actitudes positivas hacia el uso de la terminología en el marco de la especialidad y sus implicaciones en la competencia comunicativa; también, el de crear un espacio para aplicar una experiencia novedosa que contribuya a un mejor uso terminológico.

Según la fundación Hewlett (Tourón, 2016a), el método deeper learning es un enfoque educativo que tiene como objetivo potenciar seis competencias, que son las siguientes:

- dominar la materia

(cc) EY-NC-ND 2018, Universitat Politècnica de València

Congreso IN-RED (2018) 
- $\quad$ pensar críticamente y resolver problemas complejos

- trabajar colaborativamente

- comunicar efectivamente

- $\quad$ aprender a aprender o aprendizaje autodirigido

- desarrollar una mentalidad académica incremental y positiva

Esta última competencia, la Fundació Jaume Bofill (2017) la define como un alumnado confiado en sus propias capacidades y que ve la relevancia del trabajo que desarrolla, ya que se vinculan los aprendizajes a los retos y a los problemas reales.

Por lo que se refiere a los contenidos para el aprendizaje de la terminología (Cabré, 1992; Franquesa, 2008; TERMCAT, 2010), los objetivos específicos de la materia terminológica que debe lograr el alumnado son los ítems siguientes:

- Conocer los mecanismos de creación de los términos asociados a las ingenierías.

- Conocer las fuentes terminológicas de autoridad en línea y los recursos terminológicos electrónicos.

- $\quad$ Proponer adaptaciones de los términos no integrados todavía en las fuentes terminológicas de autoridad o neologismos.

- Resolver problemas terminológicos que se plantean con los neologismos.

- Conocer la metodología del trabajo terminológico con el fin de elaborar un vocabulario básico multilingüe de especialidad.

- Saber desarrollar un recurso terminológico adecuado a un contexto determinado y a un perfil de necesidades.

- Buscar en fuentes textuales válidas para la extracción de términos.

- Trabajar de manera colaborativa en mapas conceptuales y campos semánticos.

Una vez planteados los objetivos específicos del aprendizaje de la terminología en las asignaturas de lenguaje de especialidad, pasamos a exponer la metodología a utilizar para la consecución de los objetivos marcados.

\section{Metodología y desarrollo}

Como ya hemos citado anteriormente, el método propuesto es el llamado deeper learning o aprendizaje profundo. Este es una herramienta de transformación educativa que tiene como fin acelerar el aprendizaje profundo, por lo que se refiere a las competencias, los conocimientos y las habilidades que el alumnado debe desarrollar en su formación para lograr el éxito.

Tourón (2016a) plantea que estas competencias implican tres dominios interrelacionados: cognitivo, interpersonal e intrapersonal. En el dominio cognitivo, el alumnado debe lograr una sólida base académica en la materia. A medida que el alumnado domina el contenido, será más capaz de trasferir el conocimiento a otras situaciones o tareas y deben analizar y sintetizar la información, reconocer patrones y relaciones con el fin de identificar y resolver problemas y evaluar la eficacia de las soluciones propuestas.

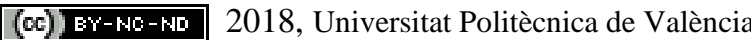


En el dominio interpersonal, el alumnado trabaja colaborativamente en las tareas y genera trabajo compartido, así como resuelve los problemas en grupo. También aprende a comunicar eficazmente los conceptos de forma lógica y significativa.

En el dominio intrapersonal, el alumnado aprende cómo supervisar y dirigir su propio aprendizaje, reconocer lo que saben y lo que no, identificar obstáculos para su aprendizaje y plantear estrategias de resolución. En el desarrollo de una mentalidad de crecimiento académica, el alumnado es capaz de verse con éxito y comportamientos académicos positivos y productivos.

En esta metodología por competencias, el profesorado se convierte en un verdadero guía del aprendizaje, el cual hace ver al alumnado que este es el responsable de su propio proceso de aprendizaje. De esta manera, Martínez, McGrath \& Foster (2016), también Tourón (2016b), proponen que para preparar el alumnado de cara a los nuevos retos, el profesorado debe:

- Empoderar al alumnado como aprendices.

- Contextualizar el conocimiento haciéndolo coherente.

- Conectar el aprendizaje con experiencias del mundo real.

- Extender el aprendizaje más allá del centro educativo.

- Inspirar a los estudiantes personalizando sus experiencias de aprendizaje.

- Incorporar la tecnología decididamente para enriquecer, más que automatizar, el aprendizaje.

Así, la consecución de los objetivos se realiza gracias a las prácticas educativas por consecución de las competencias. De esta manera, el dominio de la materia terminológica se produce gracias a la práctica de las actividades y proyectos relacionados con cada una de las competencias.

El alumnado realiza lecturas programadas de los mecanismos de formación terminológica antes de las sesiones presenciales con el fin que puedan resolver determinadas actividades propuestas por el profesorado para el dominio de dichos mecanismos. Para ello, se utilizan diversas posibilidades de la aplicación Poliformat.

En una fase posterior, cuando ya son conocedores de los mecanismos de formación terminológica, y con el fin de trabajar el pensamiento crítico y la resolución de problemas complejos, el alumnado lleva a cabo otras actividades prácticas donde sistematizan las características de la terminología de un campo específico y deben buscar soluciones a los problemas que plantean los términos que todavía no se han adaptado o neologismos, bien porque todavía se está valorando o bien porque son bastante recientes. Una de las opciones que tienen para el proyecto es realizar las consultas electrónicas al organismo que es autoridad en la materia terminológica (el TERMCAT), así como participar en las sugerencias de las propuestas neológicas de dicho organismo. Asimismo, tienen que realizar un control de calidad en las definiciones según los parámetros establecidos.

En cuanto al trabajo colaborativo, el alumnado debe conocer la terminología de su propio campo profesional y de la metodología del trabajo terminológico. Para ello, en grupos, tienen que elaborar un mapa conceptual y los campos semánticos mediante la extracción de

(cc) EY-NC-ND 2018, Universitat Politècnica de València

Congreso IN-RED (2018) 
términos de textos electrónicos de la especialidad. Deben debatir qué términos formaran parte del vocabulario terminológico que están elaborando y sus equivalencias en otras lenguas para establecer sus propuestas neológicas.

La comunicación efectiva es sumamente importante tanto en la forma oral como en la escrita. Los grupos exponen a sus compañeros y compañeras el trabajo realizado teniendo en cuenta los parámetros asignados, tanto formales como metodológicos de la materia. Se deja un espacio temporal para el debate en el aula en cuanto a los posibles problemas terminológicos encontrados y sus soluciones.

Además, tienen que comunicar por escrito de forma efectiva mediante la presentación de una memoria individual que recoge los procedimientos de formación terminológica empleados en el vocabulario terminológico realizado en grupo, así como el planteamiento de las dificultades encontradas y sus soluciones. Así mismo, deben incluir en la memoria algunos ítems que se refieren a su estilo de aprendizaje y la satisfacción con el método de aprendizaje empleado en la asignatura.

El desarrollo de una mentalidad académica positiva se produce en todo el proceso de aprendizaje, pero especialmente en la consideración y la aplicación de las soluciones que el alumnado plantea, así como mediante el autoconocimiento del propio aprendizaje terminológico, puesto que incorpora un grado de confianza en su propia capacidad y competencia.

Las fases en las que se desarrolla el aprendizaje de la terminología mediante esta metodología son las siguientes:

En la primera fase, se establecen los objetivos, método y actividades con el alumnado.

En la segunda fase, se procede a las lecturas y debates en clase sobre los mecanismos de formación terminológica.

En la tercera fase, se le propone, al alumnado, actividades en grupo que implican la aplicación de la resolución de problemas terminológicos, una vez conocen las tendencias terminológicas y los organismos de consulta.

En la cuarta fase, los grupos de alumnos deben elegir una área terminològica de su campo de conocimiento y elaborar autónomamente un vocabulario terminológico.

En la quinta fase, los grupos presentan su trabajo delante de la clase i explican su proceso de elaboración y los resultados más importantes.

En la última fase, el alumnado entrega a la profesora una memoria individual del trabajo realizado (donde se valoran todas las fases, así como su efectividad y satisfacción con estas).

Finalmente, la evaluación, la cual forma parte del continuo proceso de enseñanzaaprendizaje, recoge la valoración cuantitativa de las tareas y actividades siguientes:

- Actividades de aproximación y asentamiento de la metodología terminológica.

- Actividades de búsqueda y propuesta terminológica.

(cc) EY-NC-ND 2018, Universitat Politècnica de València

Congreso In-Red (2018) 
- Presentación oral en grupo a elegir entre un cartel de divulgación terminológica y un vocabulario terminológico.

- Presentación escrita en grupo del proceso de elaboración del recurso terminológico.

- Dosier de la evolución llevada a cabo y de las dificultades encontradas, así como la temporalización del trabajo. Incluye un resumen de cómo se ha aplicado la metodología del trabajo terminológico.

\section{Resultados}

En cuanto a los resultados obtenidos con el ejercicio de la metodología del aprendizaje profundo, expondremos los que hacen referencia a la asignatura Valencià tècnic aplicat a la informàtica i a les telecomunicacions de l'Escola Tècnica Superior d'Enginyeria Informàtica con un total de 32 alumnos y alumnas.

El estudio se ha realizado desde dos perspectivas: una cuantitativa y otra cualitativa. Por lo que se refiere a la primera, se ha pasado unas cuestiones escritas al alumnado que debía incorporar a la memoria escrita que se le solicitaba en la última fase del aprendizaje, y que consta de tres preguntas:

- Has aprendido mejor la terminología con esta metodología?

- Has aprendido más que la terminología propiamente dicha?

- Estás satisfecho/a con esta metodología?

En cuanto a la primera pregunta, un $87,5 \%$ ha contestado que sí; en cuanto a la segunda, un $93,7 \%$ ha contestado que sí; y, en cuanto a la tercera, un $84,3 \%$ ha respondido que sí en general.

Desde la perspectiva cualitativa, al final del cuadrimestre, se ha mantenido una conversación individual de diez minutos con 10 alumnos voluntarios que han expuesto sus ideas alrededor de la metodología utilizada y su aprendizaje terminológico (según las tres preguntas del dosier) y que pueden explicar los resultados obtenidos de forma cuantitativa.

En este sentido, la primera cosa que han remarcado era que aunque aprendían más y mejor les suponía un mayor esfuerzo que estudiar una lista de palabras de cara a un examen. A pesar de ello, el desarrollo de las seis competencias no es posible mediante el estudio del listado. No obstante, han reconocido una mayor motivación y implicación tanto en la materia como en la asignatura mediante este método, así como un aumento en su autonomía, ya que conocen los mecanismos de búsqueda y solución de problemas, además de convertirse ellos en los protagonistas. Finalmente, un aspecto que han considerado muy positivo era la reflexión sobre el propio proceso de aprendizaje y un aumento en la toma de conciencia sobre el mejor método de aprendizaje para sí mismo.

(c) EY-NC-ND 2018, Universitat Politècnica de València

Congreso IN-RED (2018) 


\section{Conclusiones}

El aprendizaje de la terminología de las ingenierías mediante los métodos tradicionales no han generado buenos resultados a lo largo de su enseñanza, por ello la búsqueda de métodos innovadores que incorporen las competencias necesarias para la formación con éxito del alumnado siempre son necesarias. Este aprendizaje llevado a cabo mediante un conjunto de competencias no sólo ha beneficiado el interés por el aprendizaje de la terminología y del método del trabajo terminológico, sino que además ha motivado en gran manera al alumnado a su realización, así como a su autoconciencia sobre su proceso de aprendizaje, lo que le ha llevado a un mayor desarrollo del aprender a aprender, del trabajo colaborativo y de la comprensión de la materia, según los datos aportados por el alumnado en el dosier final de la asignatura. Finalmente, podemos concluir que con el método deeper learning, nuestros alumnos se han beneficiado enormemente de una actitud positiva en el aprendizaje de la materia terminológica, gracias a un aumento de la motivación y la implicación del alumnado en su aprendizaje y en la asignatura.

\section{Referencias}

CABRÉ, M.T. (1992). La terminologia. La teoria, els mètodes, les aplicacions. Barcelona : Empúries. FRANQUESA, E. (2008). La terminologia. Un mirall del món. Barcelona : Editorial UOC.

FUNDACIÓ JAUME BOFILL (2017). eer learning. Descobreix les 6 competències clau de l'aprenentatge profund.

$<$ http://www.educaciodema.es/tendencies/deeper-learning/> [Consulta: 15 de marzo de 2018].

MARTÍNEZ, M.R., MCGRATH, D.R. y FOSTER, E. (2016). How Deeper Learning Can Create a New Vision for Teaching. Arlington: The National Commission on Teaching \& America's Future.

TERMCAT (2010). El diccionari terminològic. Barcelona -Vic: TERMCAT-Eumo editorial. TOURÓN, J. (2016a). El rol del profesor en un aprendizaje más profundo (Deep learning). $<$ http://www.javiertouron.es/el-rol-del-profesor--en-un-aprendizaje/> [Consulta: 15 de marzo de 2018].

TOURÓN, J. (2016b). Hacia un aprendizaje más profundo : Deeper learning in Action!.

$<$ http://www.javiertouron.es/hacia-un-aprendizaje-mas-profundo/> [Consulta: 15 de marzo de 2018] 


\title{
Experiencia de evaluación por pares usando retornables en el Grado de Ingeniería Informática (UPV)
}

\author{
María Teresa Gassó Matoses ${ }^{\mathrm{a}}$, Antonio Martí-Campoy ${ }^{\mathrm{b}}$, Vicente Atienza Vanacloig \\ Salvador Petit Martí y Franciso Rodríguez-Ballester ${ }^{\mathrm{b}}$ \\ ${ }^{a}$ Departamento Matematica Aplicada, Universitat Politecnica Valencia, Camino de Vera s/n, 460021 \\ Valencia. mgasso@mat.upv.es, ${ }^{\mathrm{b}}$ Departamento Disca, Universitat Politécnica Valencia, Camino de \\ Veras/n 46021 Valencia. \{amarti, spetit,vatienza, prodrig\}@disca.upv.es.
}

\begin{abstract}
This work present the results of a peer assessment experiment performed with a learning tool named "returnable" in the subjects "Algebra" and "Computer Fundamentals" from the Computer Engineering degree that is conducted at Universitat Politècnica de València (UPV). A returnable is a set of exercises that are similar to those that can be found in a conventional exam and that are carried out after the corresponding topic has been taught. The main benefit of the tool comes from its usage in a peer assessment context since the feedback to the students is delivered earlier. Moreover, it allows the development of the high-level skills that are necessary to analyze and evaluate other student returnables.
\end{abstract}

The main goal of the experiment is to validate the marks that the students obtain from their peers. The validation will increase the usefulness of the returnable tool as a feedback mechanism and for the overall course evaluation.

Keywords: continuous assessment, peer assessment, computer engineering degree.

\footnotetext{
Resumen

En este trabajo, se presenta una experiencia de evaluación por pares utilizada con la herramienta "retornables" en las asignaturas de Álgebra y de Fundamentos de Computadores en el Grado de Ingeniería Informática. Los "retornables" son una colección de ejercicios representativos tipo examen, realizado al finalizar cada tema. Su principal interés radica en la evaluación por pares que los alumnos deben llevar a cabo. De esta forma además de tener un feedback temprano que les sirve de entrenamiento para los siguientes actos de evaluación, desarrollan habilidades de alto nivel como son analizar y evaluar el trabajo de un compañero.

El objetivo de este trabajo es determinar en qué medida es válida o no la calificación que dan los alumnos a sus compañeros. Esta validación es especialmente relevante para el alumno receptor de la calificación, y
} 
también para el profesor que quiera utilizar dicha calificación en su evaluación.

El trabajo concluye analizando los motivos que justifican estos resultados y dando pautas sobre el uso correcto que cabe dar a esta herramienta atendiendo a las pequeñas limitaciones detectadas. Este trabajo ha sido financiado por el programa Proyectos de Innovación y Mejora Educativa (PIME B05 16_17) y la ETSINF de la UPV.

Palabras clave: evaluación continua, evaluación por pares, grado en informática.

\section{Introducción y objetivos}

El nuevo modelo de Bolonia ha traído consigo la transformación de los estudios universitarios no sólo en una reestructuración de las materias, asignaturas y cursos, sino también en la forma y el momento en que los alumnos deben ser evaluados. De este modo la evaluación de una asignatura pasa de uno o unos pocos exámenes presenciales a múltiples actos de evaluación, presenciales o no, a lo largo del semestre y utilizando diferentes herramientas

Para realizar esta evaluación continua, los autores desarrollaron una herramienta docente (no informática) llamada "retornables", basada principalmente en la evaluación por pares.

La evaluación por pares forma parte fundamental de la herramienta "retornables" y ha sido utilizada por los autores desde 2010 como complemento en la evaluación en las asignaturas de Álgebra y Fundamentos de Computadores que se imparten en el grado en Ingeniería Informática de la Universitat Politècnica de València

Hay gran cantidad de trabajos relacionados con la evaluación por pares. Por ejemplo, en (Krathwohl 1964) y (Davies 1998) se postula que la evaluación y la crítica son habilidades de alto nivel en la taxonomía de Bloom y por tanto los estudiantes que participan en el proceso de revisión por pares consiguen no solo mejorar el aprendizaje de los objetivos básicos de la asignatura sino que también logran objetivos de más alto nivel. Otros muchos trabajos publicados concluyen que la evaluación por pares presenta beneficios, aunque no está exenta de inconvenientes. Uno de los problemas más importantes es la desviación en la calificación que se da a un compañero respecto a la merecida, tanto a favor como en contra. Esta desviación puede ser intencionada, por ejemplo por motivos de amiguismo o de fuerte competencia, o por desconocimiento de la materia que se está evaluando (Ibarra 2012), (Marqués 2013).

El principal objetivo del trabajo que aquí se presenta es saber hasta que punto es válida la nota asignada por los propios compañeros. Es decir, saber si un alumno puede confiar en la realimentación que recibe por parte de sus compañeros, y si el profesor puede emplearla como parte de la evaluación de la asignatura. Para alcanzar este objetivo se ha analizado la

(cc) EY-NC-ND 2018, Universitat Politècnica de València

Congreso IN-RED (2018) 
variación de la nota entre la corrección realizada por los alumnos y la corrección realizada por los profesores en los cursos 14/15, 15/16 y 16/17.

\section{Antecedentes}

De forma muy breve y para poner en contexto al lector, se describe qué es y cómo se usan los retornables.

Un retornable es una colección de ejercicios de un tema de la asignatura que los alumnos deben resolver de forma no presencial. Una vez resuelto, lo intercambian con sus compañeros para corregirlos y evaluarlos. Los alumnos disponen de criterios de corrección pero no de las soluciones. Dado que para cada tema hay dos modelos de retornable, se intenta que el alumno corrija el modelo que no ha resuelto. Finalmente el profesor registra las notas y devuelve el retornable al alumno que lo resolvió.

Una descripción detallada de qué son los retornables, cómo se usan, sus objetivos primarios y secundarios, las experiencias realizadas y el grado de satisfacción de los alumnos con esta herramienta se puede encontrar en (Martí-Campoy 2013, 2014).

\section{Análisis de la evaluación por pares}

Durante los tres cursos comprendidos entre el año 2014 y 2016 cursos los profesores han revisado y reevaluado la corrección que de los alumnos. Del total de 1102 retornables entregados, 991 fueron recorregidos por el profesor. Esto representa un $89,2 \%$ de los retornables entregados por los alumnos. Así pues en los análisis siguientes se consideran únicamente estos 991 retornables que han sido corregidos tanto por un alumno como por un profesor.

El rango de notas de cada retornable es diferente, ya que cada pregunta se puntúa entre $0 \%$ y $100 \%$ y la nota final del retornable es la suma de los porcentajes obtenidos en cada pregunta. Así, la nota máxima de un retornable variará en función del número de preguntas que contenga.

La variable que se estudía en los siguientes análisis es la diferencia entre la nota del profesor y la nota del alumno (Nota profesor - Nota alumno). Para poder comparar todos los datos recopilados, y al mismo tiempo obtener valores númericos fáciles de interpretar, esta diferencia se ha normalizado al rango $[-10,+10]$. La Tabla 1 muestra los descriptores estadísticos básicos para Nota profesor - Nota alumno, estando las notas en el rango de $0 \mathrm{a}$ 10 cómo se ha dicho anteriormente.

La Fig. 1 muestra gráficamente el porcentaje de casos en que la nota del profesor coincide, es menor, o es mayor que la nota asignada inicialmente por el alumno. En esta gráfica se puede observar que en un 35\% de los casos la corrección realizada por los alumnos es correcta y coincide con la que haría el profesor. Para aquellos casos donde el profesor y el alumno no coinciden, es mucho más frecuente que el alumno conceda una nota más elevada que la del profesor. 
Tabla 1. Descriptores estadísticos básicos para Nota profesor - Nota alumno

\begin{tabular}{lr}
\hline Descriptor & Valor \\
\hline Recuento & 991 \\
Promedio & $-0,74$ \\
Desviación Estándar & 1,59 \\
Mínimo & $-6,4$ \\
Máximo & 6,0 \\
Rango & 12,4 \\
Recuento valores $=0$ & $346(34,9 \%)$ \\
Recuento valores $<0$ & $484(48,8 \%)$ \\
Recuento valores $>0$ & $161(16,2 \%)$ \\
\hline
\end{tabular}

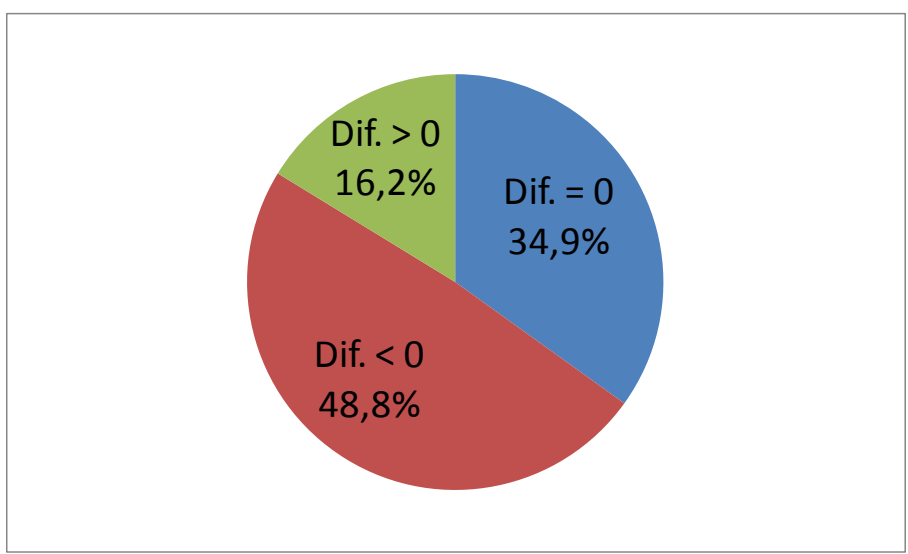

Fig 1: Grado de coincidencia entre la nota dada por el alumno corrector y la del profesor. Valores negativos indican que el alumno a dado una nota mayor que la del profesor.

Para ver con más detalle las discrepancias en la evaluación entre el profesor y los alumnos, se presenta en la Fig. 2 el histograma para Nota profesor - Nota alumno. En esta figura puede verse que la discrepancia entre la nota del profesor y la nota del alumno, tanto al alza como a la baja, se encuentra en el rango ]-1, +1 [ para el $60 \%$ de los casos. También se aprecia una tendencia hacia los valores negativos, tanto en número de casos como en magnitud. Es decir, respecto de la nota del profesor, los alumnos dan notas más altas y en más casos que en el sentido contrario.

(cc) EY-NC-ND 2018, Universitat Politècnica de València 


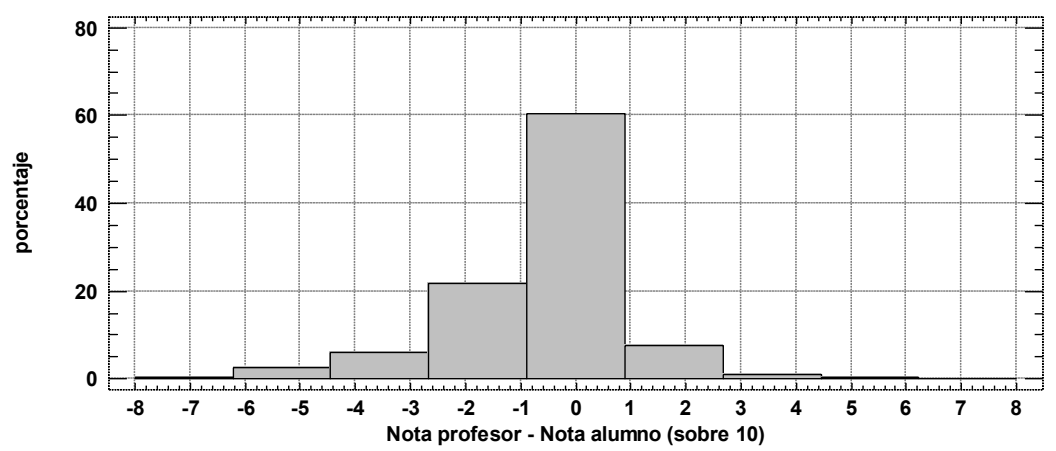

Fig 2. Histograma de frecuencia para la diferencia entre la nota del profesor y la nota del alumno, sobre 10.

La Tabla 2 muestra los principales descriptores estadísticos para la misma variable (Nota profesor - Nota alumno) separados por asignaturas. La diferencia en el recuento se debe al número de profesores, y por tanto de grupos de alumnos, que participan en la experiencia, siendo dos profesores en FCO y una profesora en Álgebra. Exceptuando esta diferencia, los valores de los descriptores son muy similares.

Tabla 2. Descriptores estadísticos básicos para Nota profesor - Nota alumno separados por asignatura

\begin{tabular}{lrr}
\hline Descriptor & Valor Álgebra & Valor Fundamentos \\
\hline Recuento & 319 & 672 \\
Promedio & $-0,7$ & $-0,5$ \\
Desviación Estándar & 1,7 & 1,4 \\
Mínimo & $-6,0$ & $-6,4$ \\
Máximo & 6,0 & 4,0 \\
Rango & 12,0 & 10,4 \\
Recuento valores $=0$ & $114(35,7 \%)$ & $232(34,5 \%)$ \\
Recuento valores $<0$ & $155(48,6 \%)$ & $329(49,0 \%)$ \\
Recuento valores $>0$ & $50(15,7 \%)$ & $111(16,5 \%)$ \\
\hline
\end{tabular}

En Fig. 3 y Fig. 4 se muestran los histogramas de frecuencia para Nota profesor - Nota alumno para la asignatura Álgebra y Fundamentos de Computadores, respectivamente. En este caso se aprecia una diferencia significativa en la distribución de la diferencia de nota. Se produce un trasvase de un $10 \%$ de los casos desde el intervalo ]-1, +1 [ hacia valores más negativos. Es decir, los alumnos de Álgebra son un poco más generosos en sus calificaciones que los de Fundamentos. Esta diferencia puede deberse a las características de las asignaturas, a los alumnos que han participado en la experiencia ya que no son los mismos en las dos asignaturas, o a la diferencia en el número de casos estudiados para cada asignatura. 


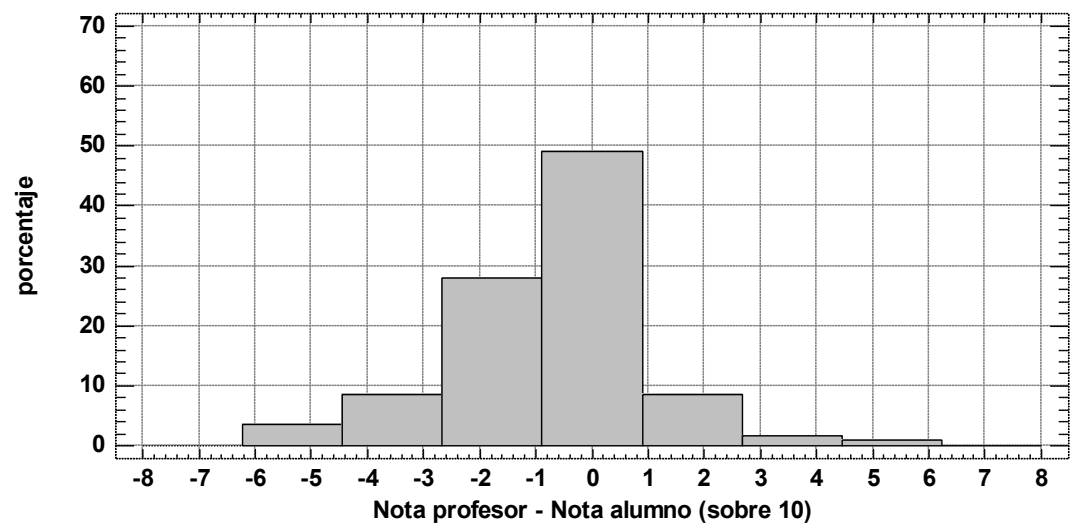

Fig 3. Histograma de frecuencia para la diferencia entre la nota del profesor y la nota del alumno, sobre 10 en la asignatura Álgebra.

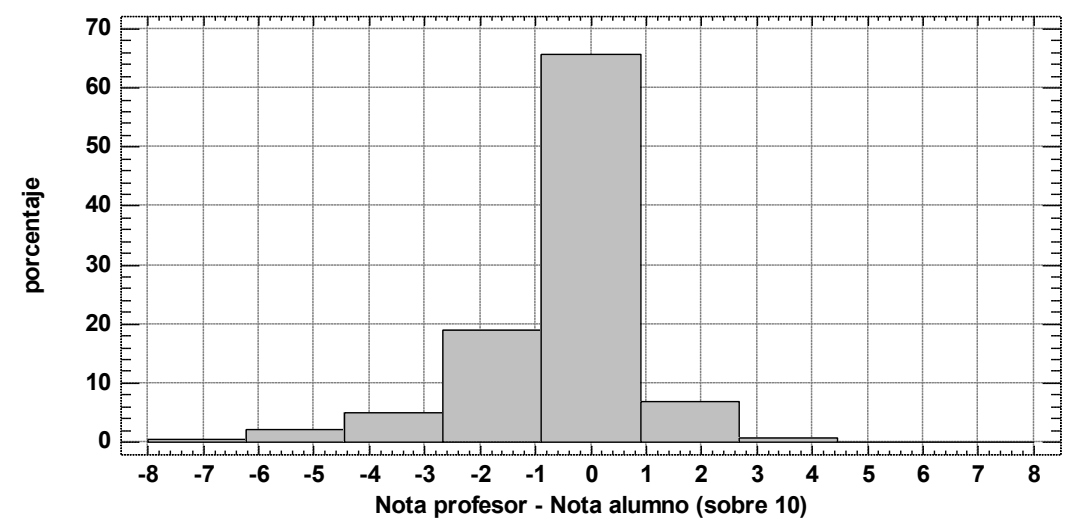

Fig 4. Histograma de frecuencia para la diferencia entre la nota del profesor y la nota del alumno, sobre 10 en la asignatura Fundamentos de Computadores.

\section{Discusión}

En primer lugar, es evidente que un $100 \%$ de concordancia entre la nota de los alumnos y de los profesores sería una anomalía, por lo que cabía esperar las desviaciones de menor magnitud que finalmente se han recogido.

En segundo lugar, en cuanto a las discrepancias de mayor magnitud, las observaciones de los profesores y comentarios de los alumnos han permitido identificar las siguientes situaciones:

Si la nota del alumno es mayor que la del profesor es debido a:

1. Alumnos que no dominan en absoluto la materia del retornable, y corrigen ejercicios mal resueltos como buenos.

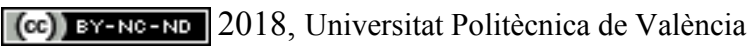


2. Alumnos que dedican poco o incluso nada de tiempo a corregir el retornable y no realizan una correcta verificación de los ejercicios contenidos en él, dándolos todos por buenos.

3. Alumnos que aplican mal los criterios de corrección. Muchos de estos alumnos consideran que el criterio de corrección penaliza excesivamente el error, y deciden aplicar una penalización menor.

Si la nota del alumno es menor que la del profesor es debido a:

1. Alumnos que no han comprendido correctamente alguna parte de la materia relacionada con el retornable y dan por erróneas soluciones correctas. En la mayoría de los casos estos alumnos presentan a su compañero su propia solución, por lo que suele producirse un debate entre ellos o con el profesor.

2. Alumnos que aplican incorrectamente los criterios de corrección penalizando excesivamente respuestas erróneas. Este caso es poco frecuente.

\section{Conclusiones}

En este trabajo se presenta un estudio sobre la fiabilidad de la nota asignada por los alumnos. Esta fiabilidad se define como la concordancia con la nota que asignaría un profesor.

Los datos muestran que para alrededor del $60 \%$ de los casos, la discrepancia entre la nota recibida y la nota merecida es de \pm 1 punto, aunque es cierto que esta desviación es más frecuente en favor del alumno, es decir, el alumno recibe una nota mayor que la merecida. Para aproximadamente un $20 \%$, la nota recibida es entre 1 y 3 puntos más alta que la merecida.

De los resultados obtenidos, y considerando que la nota de los retornables supone un $10 \%$ de la calificación final en la asignatura, los autores consideran que la nota de los alumnos puede ser utilizada directamente en la calificación final. La existencia de otros actos de evaluación, presenciales e individuales, ayudará a corregir las desviaciones introducidas por la evaluación por pares.

Para la tranquilidad de los alumnos y de los propios profesores, es importante realizar un muestreo y revisar algunas correcciones, especialmente de aquellos retornables que obtienen la máxima nota, o en el caso de alumnos con nota muy dispar respecto a la de sus anteriores retornables.

Cómo trabajo futuro se pretender identificar los factores que producen errores significativos en la corrección de los alumnos, permitiendo al profesor estar atento y centrar sus esfuerzos de revisión en los casos importantes. 


\section{Referencias}

DAVIES, R., and BERROW, T. (1998), “An evaluation of the use of computer sopported peer review for developing higer-level skills". Computers \& Education. Volume 30, Issues 1-2, January 1998, Pages 111-115

IBARRA, M.S., RODRIGUEZ, G., y GOMEZ, M. A. (2012) "La evaluacion entre iguales;beneficios y estrategias para su práctica en la universidad". Revista de la Educación. 359, septiembre-diciembre 2012, pp206-231.

Krathwohl, R.R. , Bloom, B.S., and MasiA, B. (1994). Taxonomy of Educational Objectives: The Classification of Educational Goals. Handbook 2: Affective Domain. London, UK. Longman July.

MARQUES, M., BADIA, J. M., MARTINEZ-MARTIN, E.(2013) "Una experiencia de evaluación formadora por compañeros" . ReVisión, Vol 6, No 2, 2013. http://hdl.handle.net/10234/84749 Accedido 1 de marzo de 2018

MARTÍ-CAMPOY, A., ALONSO, M., PETIT MARTÍ, S., ATIENZA VANACLOIG, V., MARTÍNEZ, J. C., GONZÁLEZ, A. (2012) "Los retornables como herramienta motivadora en Fundamentos de computadores". En XXI Congreso Universitario de Innovación Educativa en las Enseñanzas Técnicas (CUIEET). Valencia, 2013. Pp 1009-1020.

MARTÍ-CAMPOY, A., PETIT MARTÍ, S., GASSÓ MATOSES, M. T., ATIENZA VANACLOIG, V., RODRÍGUEZ-BALLESTER, F. (2014) "Using peer-assessed returnables in multiple stages to improve learning in computer organization courses". En XI Congreso Bienal de Tecnología, Aprendizaje y Enseñanza de la Electrónica (TAEE). Bilbao, Julio 2014. Pp: 193-198. 


\title{
Sistema de evaluación para la formación a distancia de profesionales
}

\section{del Teso, $\mathbf{R}^{\mathrm{a} 1}$, Estruch, E. ${ }^{\mathrm{a} 2}$, Gómez, E. ${ }^{\mathrm{a} \text {, }}$ Soriano, J. ${ }^{\mathrm{a} 4}$}

${ }^{a}$ ITA, Departamento de Ingeniería Hidráulica y Medio Ambiente. Escuela Técnica Superior de Ingenieros industriales. Universitat Politècnica de València. ${ }^{a 1}$ rodete@ita.upv.es, a2maesjua1@ita.upv.es, ${ }^{\text {a3}}$ elgosel@ita.upv.es, ${ }^{24}$ jasool@ita.upv.es

\begin{abstract}
The online training of students in the field of hydraulic engineering entails the need to undertake periodic self-evaluations to ensure their understanding of the topics developed. The lack of some preliminary key concepts may lead to a deficient understanding in future more complicated developments. Therefore, a solid foundation is crucial to ensure that students understand the most complex concepts of each topic.

To achieve this goal, a self-assessment system has been designed for all elearning courses taught by the ITA, in both posgraduated and specific programs. This system ensures that students reach the specific objectives of each course. This evaluation system has been used since 2010, in the 20 courses taught by the ITA concernint efficient urban water management. More than 1,500 students have been assessed with this system, with a success rate higher than $90 \%$.
\end{abstract}

Keywords: assessment, urban water systems, hydraulics, online learning, online courses, checkpoint, test

\section{Resumen}

La formación a distancia en el campo de la ingeniería conlleva la necesidad de definir un sistema de autoevlación, que permita al alumno asegurarse que va alcanzando los objetivos y la comprensión de los temas desarrollados. No dominar los conceptos clave puede conllevar al no entendimiento de desarrollos posteriores más complejos. Es necesario establecer una base sólida que permita al alumno profundizar poco a poco en aspectos más específicos y elevados.

Para conseguir este objetivo se ha desarrollado para todos los cursos online impartidos por el ITA, tanto de formación superior como de formación específica, un sistema de autoevaluación que permita asegurar que el alumno aquiere los conocimientos específicos de cada asignatura. Este sistema de evaluación se lleva utilizando desde 2010, en los 20 cursos que se imparten desde relacionados con la gestión eficiente del agua urbana, formando a más de 1.500 alumnos con un porcentaje de aprobados superior al $90 \%$.
} 
Palabras clave: evaluación, agua urbana, hidráulica, formación a distancia, cursos online, checkpoint, test.

\section{Introducción}

La metodología usada en formación a distancia es fundamental para asegurar que los alumnos que la superan con éxito han adquirido los conocimientos mínimos requeridos para aprobar (Sun et al., 2006). Más aún cuando esta formación a distancia va enfocada a conseguir un título de posgrado, tal y como ocurre en la formación a distancia impartida por el ITA.

El sistema de evaluación implementado por el ITA para la formación a distancia tiene el objetivo de garantizar que los conocimientos se van adquiriendo y consolidando por parte de los estudiantes a través de una serie de puntos de control, o “checkpoints” que permitirán verificar el grado de compresión del alumno sobre el contenido desarrollado hasta el momento. Al final de cada unidad, además, deberá responder un test en el que se preguntan los conceptos teóricos principales estudiados en la unidad, ya que tener claros estos conceptos le permitirá en un futuro resolver casos prácticos de aplicación. Para reafirmar la comprensión de estos conceptos, una vez finalizados todos los contenidos, el alumno se enfrentará a un test final que reúne preguntas sobre todos los conceptos teóricos y prácticos que se han visto en el curso. Tanto los puntos de control, como los test de las unidades y el test final, forman parte de la evaluación del curso. Además, en los cursos más prácticos, donde el alumno debe resolver problemas, o donde debe trabajar con programas informáticos, se plantea la resolución de una serie de ejercicios prácticos que deberá enviar para que los profesores del curso los evalúen y proporcionen una retroalimentación acera de la idoneidad de la solución propuesta por el alumno.

En este trabajo se presenta el sistema de evaluación utilizado en los módulos de título propio y formación específica impartidos por el ITA. La superación de estos módulos, conlleva la obtención de títulos propios de posgrado como son el Máster en Gestión Eficiente del Agua Urbana, el Diploma de Especialización en Análisis y Diseño de Redes de Agua, el Experto Universitario en EPANET y el Experto Universitario en Transitorios Hidráulicos con Allievi. Títulos de posgrado muy específicos que pueden ofrecer una vía de acceso a puestos laborales especializados, y que por lo tanto, deben asegurar unos conocimientos mínimos para desarrollar labores tan específicas.

Con los cursos de formación a distancia desarrollados por el ITA, de los que el sistema de evaluación que se presenta es una parte fundamental, se ha formado a más de 1.500 alumnos. En los últimos dos años se ha observado una creciente demanda debido a la implantación de los títulos propios denominados anteriormente. La gran mayoría de los alumnos provienen principalmente de Latinoamérica así como de empresas tanto públicas como privadas. Esto hace que la labor de conseguir que el alumno adquiera los conocimientos mínimos exigidos para superar la formación sea imprescindible (Bhuasiri et al., 2011). 


\section{Objetivos}

La evaluación en formaciones a distancia donde existe un elevado número de alumnos suele ser una tarea compleja, ya que el seguimiento de los alumnos por parte de los tutores de la formación se complica conforme el número de alumnos matriculados crece. Por esta razón, es necesario preparar un sistema de evaluación automatizado que permita al alumno conocer su grado de aprendizaje respecto a lo estudiado en el curso. Este aprendizaje no debe evaluarse únicamente al final de la formación, si no durante toda ella, lo que garantiza que el alumno sea consciente de donde está errando, o qué conceptos le resultan más complejos. Esto le permitirá volver a estudiar aquello que no tiene claro o ponerse en contacto con los tutores para pedir apoyo en las tareas que no haya superado.

De esta manera, se trata de conseguir que el alumno adquiera con seguridad los conocimientos básicos desde el comienzo de la formación, para ir profundizando en temas más complejos conforme avanza su estudio.

El objetivo del sistema de evaluación utilizado en la formación a distancia del ITA es conseguir que los alumnos adquieran los conocimientos mínimos requeridos en el curso. Esto se consigue con una evaluación que considera cuatro tipos de tareas distintos: puntos de control o "checkpoints", test de evaluación en cada una de las unidades, test final una vez finalizados los desarrollos del curso y ejercicios prácticos que el alumno debe enviar. Cada una de estas evaluaciones están pensadas de manera diferente para conseguir que una vez el alumno finalice el curso tenga las competencias pertinentes (Frydenberg, 2002). Una vez finalizado el curso, el alumno dispondrá de la capacidad de incorporarse al mercado laboral con unos conocimientos muy específicos sobre hidráulica, modelación de redes o gestión eficiente del agua.

\section{Desarrollo de la innovación}

En la Plataforma de formación Cursosagua, se ha desarrollado cuatro sistemas de evaluación complementarios que permitirán al alumno autoevaluarse a lo largo del estudio del curso. Estos sistemas de evaluación se desarrollan en profundidad a continuación, teniendo pesos diferentes en la nota final del curso en función de las características del mismo.

\subsection{Puntos de control}

Los puntos de control son los más utilizados a lo largo del curso, normalmente aparecerán en dos o más ocasiones en cada unidad, en función de la complejidad y carácter práctico de la formación. En los cursos donde existe mayor información teórica, los puntos de control son menos frecuentes que en aquellos cursos prácticos donde el alumno debe realizar cálculos y resolver problemas planteados paso a paso.

El objetivo de estos puntos de control, es permitir al alumno autoevaluarse a medida que avanza en el estudio del curso, de manera que tras estudiar algún apartado importante el alumno se encontrará ante una evaluación que no podrá saltarse hasta haberla finalizado por completo. Los puntos de control tienen un doble objetivo, por un lado reforzar los conocimientos de los alumnos y que éstos reciban feedback de su trabajo, por otro lado 
mantener activo al alumno durante su estudio (González de la Fuente y Carabantes Alarcón, 2018).

Esta evaluación consistirá en una serie de preguntas teóricas sobre el contenido desarrollado, o prácticas sobre los casos prácticos vistos en la unidad.

En el caso de preguntas teóricas, el alumno seleccionará aquella respuesta que considere correcta de entre una serie de opciones, es decir, se enfrenta a preguntas de selección múltiple con una única respuesta válida. La evaluación de contenidos teóricos se lleva a cabo mediante preguntas multirespuesta debido a las ventajas que ofrece este método de evaluación. Las preguntas multirespuesta son un recurso muy valioso debido a la objetividad de su calificación y la versatilidad que ofrecen para ser aplicables a cualquier cuestión objeto de evaluación (Mendes et al., 2011; Ventouras et al., 2010). Además, este tipo de evaluación permite fácilmente manejar grupos de alumnos numerosos con independencia del lugar en el que se encuentren y el momento en el que realicen el test, cualidades imprescindibles en el aprendizaje a distancia (Singh y (Ruth) de Villiers 2017).

Las opciones de respuesta que los alumnos encontrarán en los puntos de control podrán ser o bien texto o bien imágenes. En el primer caso, la pregunta siempre va acompañada de una imagen que apoya a la pregunta, tal y como se muestra en la Fig. 1.

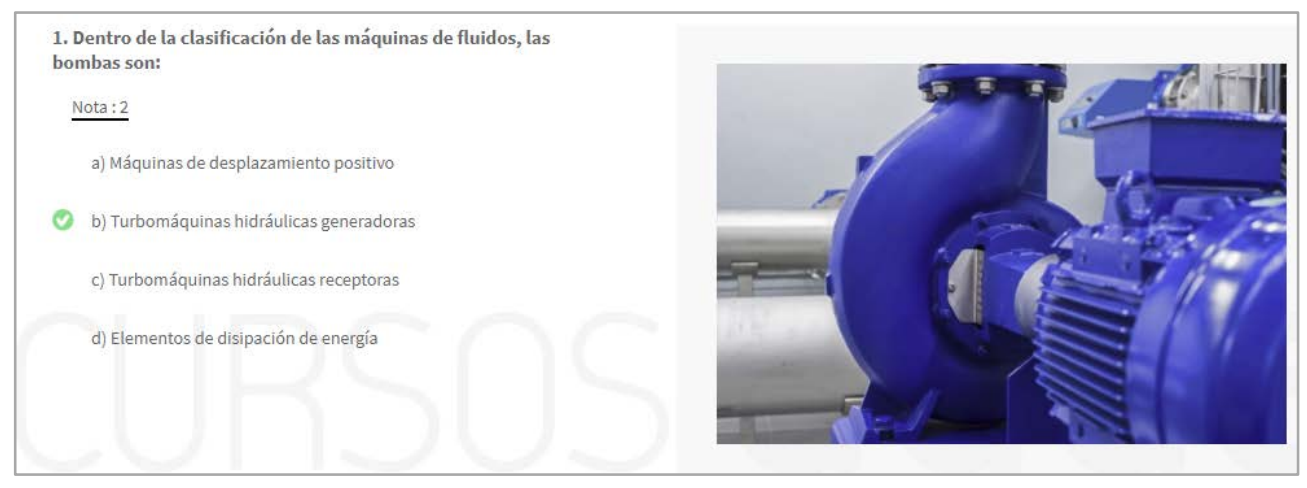

Fig. 1 Pregunta de un punto de chequeo del tipo opción múltiple con texto

En el caso de ser opciones con imágenes, al clicar sobre cada una de las imágenes ésta se amplía de manera que el alumno pueda distinguir sin problemas el contenido de la misma. Este tipo de pregunta suele usarse para reconocer y diferenciar elementos físicos explicados en el curso, como puede ser diferentes tipos de bombas o válvulas. Otro uso frecuente de las preguntas con imágenes es la representación de gráficas. Al alumno se le presentan una serie de gráficos y debe seleccionar aquel que se corresponda con la pregunta planteada, este tipo de preguntas tienen un enfoque más práctico, y suele utilizarse en cursos donde se trabaja con programas informáticos. La Fig. 2 muestra un ejemplo de una pregunta de opción múltiple con imagen. 


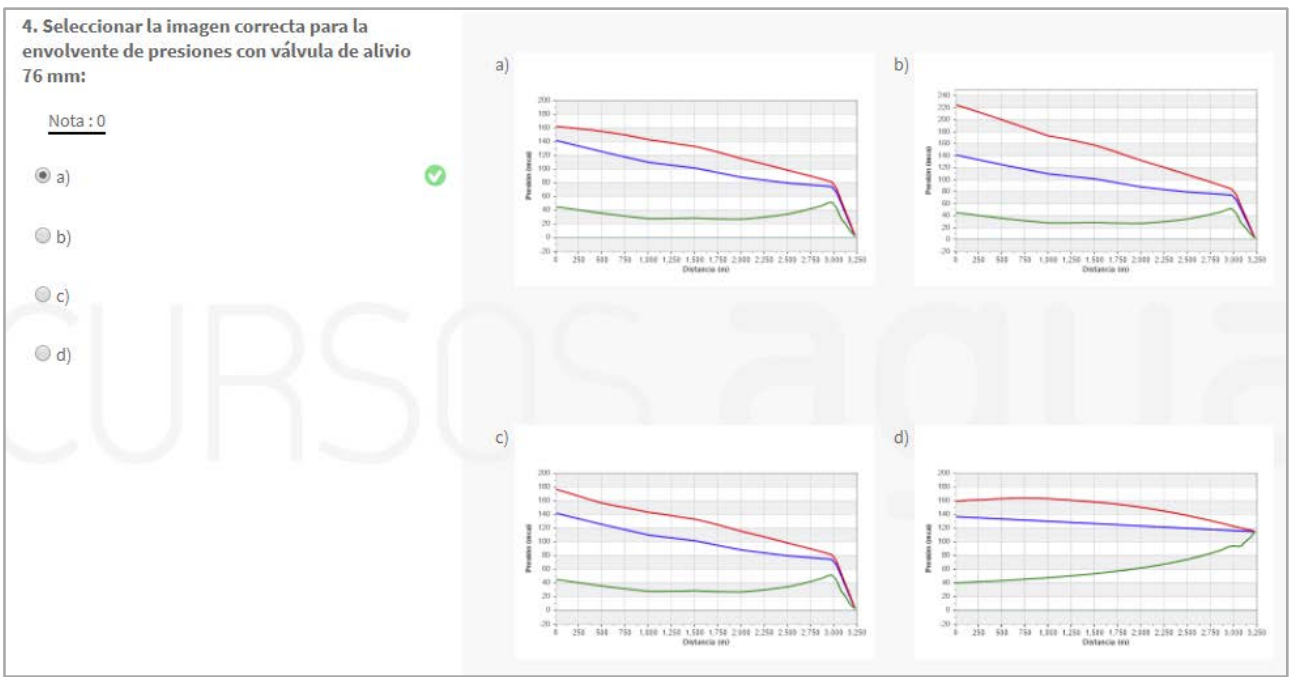

Fig. 2 Pregunta de un punto de chequeo del tipo opción múltiple con imagen

En este tipo de preguntas, el alumno no puede pasar a la siguiente cuestión hasta que no haya seleccionado la respuesta correcta. De manera que cada vez que se contesta de forma errónea, la puntuación de la pregunta baja en función del número de respuestas, hasta ser de cero en el caso de fallar todas las opciones y quedarse únicamente con la válida.

El segundo tipo de pregunta se trata de preguntas numéricas y está enfocada al desarrollo de casos prácticos. Al alumno se le solicita un valor numérico concreto, la pregunta no se dará por correcta hasta que el alumno no introduzca el valor solicitado. Para tener en cuenta los redondeos y posibles pequeños errores en el cálculo, se admite un rango de tolerancia de manera que la pregunta se da por correcta dentro de un rango permitido. Este rango dependerá del orden de magnitud del valor solicitado. En el caso de fallar la respuesta en su primer intento, al alumno se le ofrece una pista sobre la resolución de la cuestión. Esta pista permite orientar al alumno sobre los pasos a seguir y proporciona ayuda acerca de los errores que puede estar cometiendo. De este modo, se proporciona al alumno retroalimentación inmediata que le ayude a encontrar la respuesta correcta (Bailey y Card, 2009). En el siguiente intento, si el valor vuelve a ser erróneo le aparece de nuevo la pista, si vuelve a errar en su tercer intento se le indica el valor correcto de la respuesta para que no se quede bloqueado en la pregunta y pueda continuar con el curso, pero en este caso, su valoración en la pregunta será de cero. Al igual que en el caso de preguntas de selección múltiple, la puntuación de la pregunta disminuye en función del número de intentos fallidos.

En cualquier momento el alumno puede salir del punto de control para buscar la solución de la pregunta, esto obliga al alumno a repasar lo ya estudiado si no sabe la respuesta, asegurando que repasa los contenidos importantes. En caso contrario, la nota de la evaluación será baja y no se superará el curso.

El número de preguntas variará en cada punto de control, dependiendo de la necesidad, pero tratando de no realizar puntos de control muy largos que puedan resultar tediosos al 
alumno. El objetivo es conseguir que el alumno se autoevalúe pero sin llegar a resultarle pesado.

La nota de los puntos de control representa el 30\% de la evaluación final en aquellos cursos donde no existen envíos de ejercicios. Mientras que, en el caso de los cursos con resolución de casos prácticos a evaluar, el peso de los puntos de control es del $10 \%$, ya que se le da un mayor peso a la resolución de ejercicios prácticos, 40\%.

\subsection{Test de unidades}

Al finalizar cada una de las unidades que componen la formación, una vez resueltos los puntos de control y los contenidos teóricos, la plataforma habilita automáticamente un test con diferentes preguntas multirespuesta sobre conceptos teóricos de la unidad. Estas preguntas son del tipo selección múltiple con texto, donde el alumno deberá seleccionar una única respuesta correcta. En este caso, a diferencia de los puntos de control, la pregunta no va acompañada de una imagen que pueda dar indicios de la respuesta y además no se le muestra al alumno si la pregunta contestada ha sido resuelta correctamente, las respuestas correctas y la nota del test se le ofrece una vez finalizado y enviado el mismo. El número de preguntas varía entre unidades en función de la importancia de los conceptos vistos, estableciendo un mínimo de 5 preguntas y un máximo de 10. Cada pregunta errada no descuenta, únicamente se puntúa con cero. Una vez finalizado el test, el alumno puede consultar la nota y los fallos y aciertos realizados tal y como se muestra en la Fig. 3.

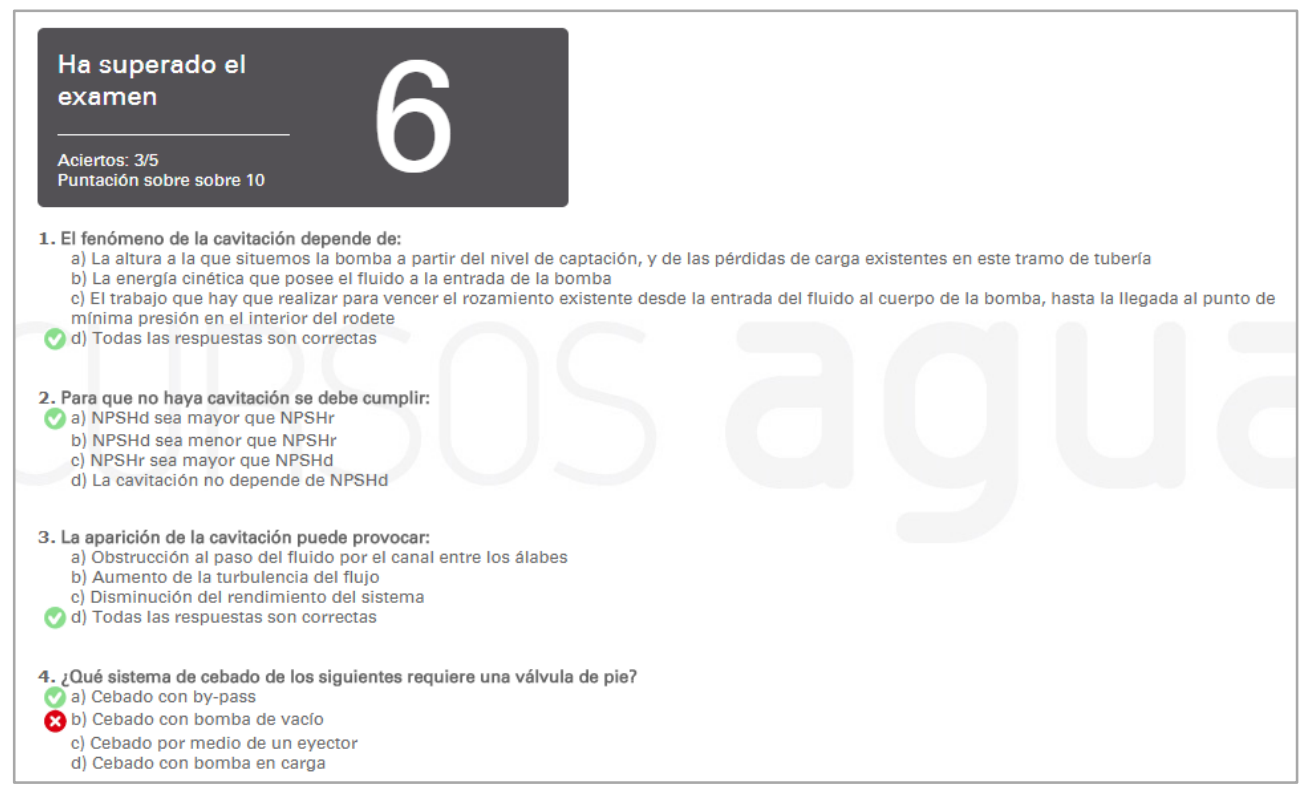

Fig. 3 Consulta de un test de unidad una vez finalizado

El alumno no está obligado a responder el test de la unidad una vez la haya finalizado, puede continuar con el desarrollo del curso y realizarlo posteriormente. De esta manera el alumno es el que decide cuando está preparado para presentarse a estos test, ya que en ocasiones el estudio del resto de unidades facilita la asimilación y comprensión de algunos conceptos.

(cc) EY-NC-ND 2018, Universitat Politècnica de València

Congreso IN-RED (2018) 
El peso del test de las unidades varía en función de si el curso requiere el envío de ejercicios o no. En el caso de no existir envío de ejercicios, los test de las unidades representan el 30\% de la evaluación final. Mientras que en los cursos con envíos de caso prácticos representan el $10 \%$ de la nota total, ya que se le da un mayor peso a este tipo de evaluación.

\subsection{Test final del curso}

Una vez desarrollados los contenidos del curso, con sus correspondientes puntos de control, así como los test de cada una de las unidades, se habilita automáticamente en la plataforma el test final del curso. Éste es similar a los test de las unidades, con preguntas multirespuesta de tipo teórico en las que el alumno debe elegir la respuesta correcta entre varias opciones, la diferencia radica en que en esta ocasión el test engloba todo el contenido desarrollado.

El número de preguntas del test final varía entre 10 y 20 preguntas. Al igual que en los test de las unidades, cada pregunta errada no descuenta, únicamente se puntúa con cero. En este caso, tanto en los cursos con envío de ejercicios como en los que no se requiere el envío de casos resueltos, el test final representa el $40 \%$ de la nota del curso. Las preguntas que aparecerán en este test final son preguntas esenciales para la superación del curso. Por esta razón, el test final tiene un peso importante dentro de la nota final. No superarlo dificulta notablemente aprobar el curso.

Al igual que en los test de las unidades, una vez culminado el test final, el alumno puede consultar la nota y los fallos y aciertos realizados, el aspecto es similar al del test que aparece en la Fig. 3.

\subsection{Entrega de ejercicios}

A lo largo de las unidades el alumno puede encontrarse con ejercicios o casos prácticos guiados. Normalmente este tipo de actividades se centran en la última unidad del curso, una vez desarrollados todos los conceptos teóricos, y realizados los casos prácticos guiados que van surgiendo en las diferentes unidades. No obstante, existen cursos muy prácticos relacionados con programas informáticos sobre hidráulica en los que el alumno deberá resolver ejercicios a lo largo de todo el curso, sea cual sea la unidad. No todos los cursos tienen ejercicios, siendo característicos de los cursos más prácticos.

$\mathrm{Al}$ alumno se le plantea el enunciado y las actividades prácticas a resolver en el ejercicio. Estos ejercicios deben ser resueltos y enviados a los tutores del curso junto con un informe que describa el proceso seguido para su resolución, y cualquier comentario al respecto que desee realizar el estudiante. En cualquier momento se puede solicitar una aclaración o ayuda al tutor del curso, tanto mientras desarrolla los contenidos como mientras resuelve el ejercicio, pero debe existir un envío final de cada ejercicio junto con el informe correspondiente que será el que sea evaluado, corregido y comentado con el alumno (Seoane y García, 2018, Bailey y Card, 2009).

Si el ejercicio no ha sido resuelto correctamente, se solicitará al alumno que vuelva a enviarlo dándole una serie de instrucciones para poder resolverlo de manera adecuada. El 
ejercicio no se puntuará hasta que el alumno lo haya enviado correctamente, el mero envío del ejercicio no da derecho a su evaluación. De esta manera, el alumno trabaja con el caso práctico planteado una y otra vez hasta dar con la solución, siempre bajo la supervisión y seguimiento del tutor. La valoración de los ejercicios depende del tutor, basándose en criterios objetivos y en la cantidad de cuestiones y envíos que haya realizado el alumno hasta la correcta solución.

Los ejercicios representan el $40 \%$ de la nota final del curso, siendo un peso muy importante en aquellos cursos prácticos donde se busca que el alumno trabaje de manera individual con la resolución de los ejercicios propuestos.

El alumno podrá responder el test final del curso antes del envío de los ejercicios solicitados, no obstante, el curso no se dará por terminado hasta la entrega de los ejercicios. Por lo tanto, aunque el alumno esté aprobado con una nota superior a 5 sin enviar los ejercicios, no se dará por superado el mismo hasta la correcta resolución de los ejercicios.

\section{Apartado de evaluaciones}

En todo momento el alumno tiene acceso al progreso de sus notas desde la propia plataforma donde se desarrolla el curso. Este apartado de notas y evaluaciones ha sido creado y desarrollado específicamente para implantar la metodología de evaluación descrita en este trabajo, de manera que el alumno se encuentra con una interfaz accesible y amigable que le permite consultar el porcentaje de evaluaciones realizadas, el peso de cada una de ellas respecto a la nota final y la nota obtenida en cada evaluación ya realizada.

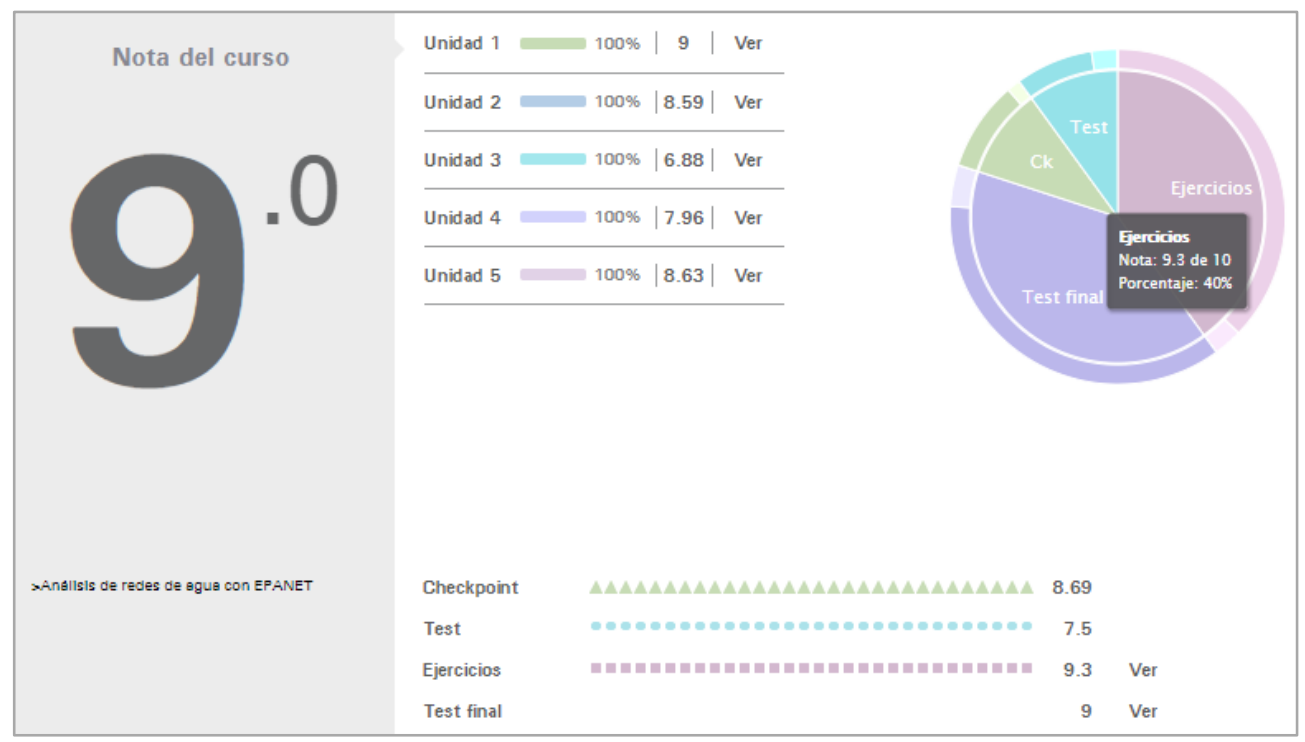

Fig. 4 Pantalla de notas y evaluaciones del curso en la Plataforma Cursosagua

Al comienzo del curso se parte de una nota de cero y se van sumando puntos progresivamente conforme se realizan las diferentes evaluaciones antes explicadas. Tal y como muestra la Fig. 4, en la parte izquierda de la pantalla evaluaciones, en números

(cc) EY-NC-ND 2018, Universitat Politècnica de València

Congreso IN-RED (2018) 
grandes, aparece la nota que tiene el alumno en cada momento. Una vez finalizado el curso y todas sus evaluaciones, esta nota representará la nota final de la formación sobre 10.

Desde este apartado de evaluaciones se accede a los test de cada unidad y al test final del curso, habilitándose progresivamente según se van finalizando las unidades. De esta manera el alumno no puede realizar el test de una unidad que previamente no haya finalizado.

Además de la nota global del curso, en esta ventana el alumno encuentra la nota desglosada por unidades, como se puede visualizar en la Fig. 5, donde se puede consultar la nota obtenida en el test y en los puntos de control que tiene la unidad, permitiendo el acceso a su consulta desde el mismo apartado, para repasar en qué cuestiones ha fallado y acertado.

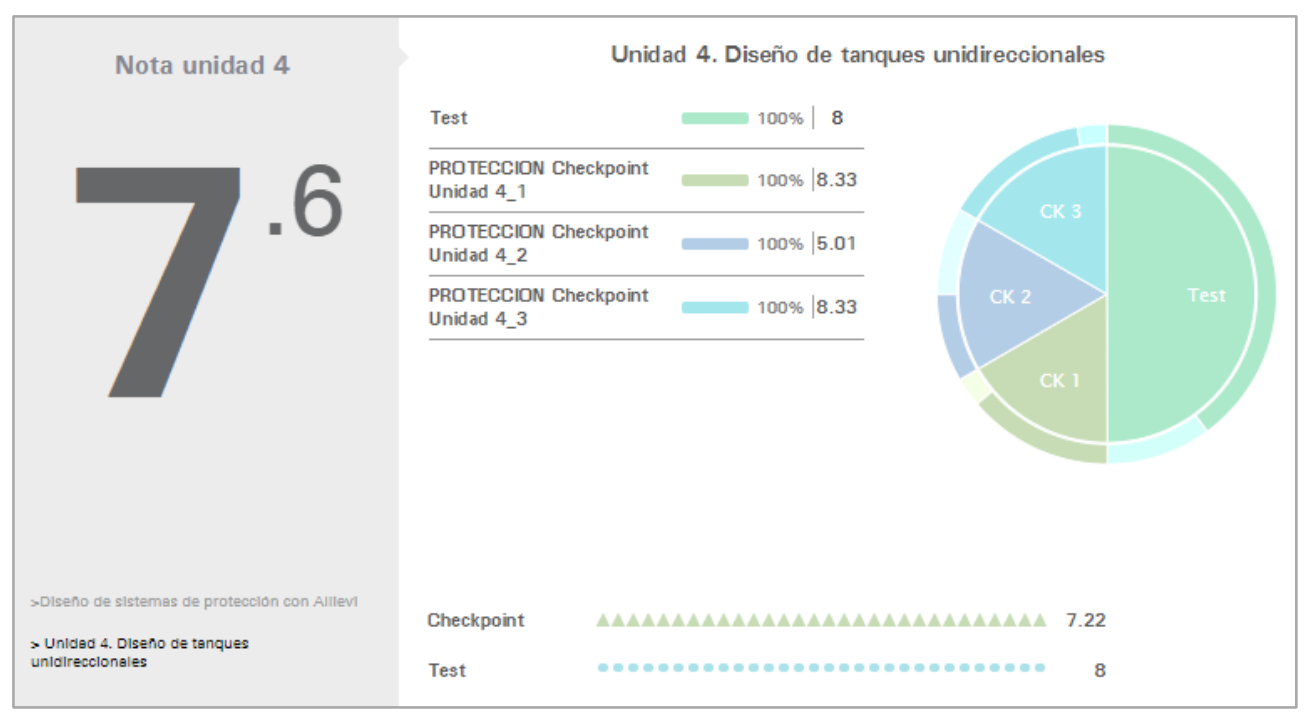

Fig. 5 Pantalla de notas y evaluaciones de una unidad en la Plataforma Cursosagua

Un gráfico circular a la derecha superior de la pantalla permite tener una primera visualización de las notas obtenidas en cada evaluación y el peso que representa cada una respecto a la nota final. Al pasar el cursor por cada una de las partes aparecerá un cuadro de texto indicando la nota y el porcentaje que representa sobre el total.

Finalmente, en la parte inferior de la pantalla, se visualiza un resumen de las notas obtenidas en cada una de las partes, pudiendo acceder desde aquí a la nota obtenida en cada uno de los ejercicios y al test final del curso.

\section{Resultados}

Los resultados de la metodología utilizada para evaluar los conocimientos adquiridos por los alumnos que realizan los cursos de formación a distancia impartidos por el ITA y que conducen a la obtención de títulos propios, son magníficos, con una tasa de aprobados superior al $90 \%$.

Los resultados de las encuestas realizadas desde el Centro de Formación Permanente (CFP) de la UPV sobre estos cursos, son muy positivos tal y como se observa en la Fig. 6, 
especialmente en lo referente a la evaluación de los contenidos: preguntas F, H e I, detalladas a continuación:

F. El módulo/asignatura ha incluido la realización de ejercicios, casos prácticos o simulaciones que han reforzado la adquisición de conocimientos

H. Las actividades y tareas (la carga de trabajo del módulo/asignatura en general) a lo largo del curso han estado adecuadamente distribuidas

I. Considero que el sistema de evaluación empleado ha sido el adecuado

\section{COMPARATIVA DE LAS PREGUNTAS}

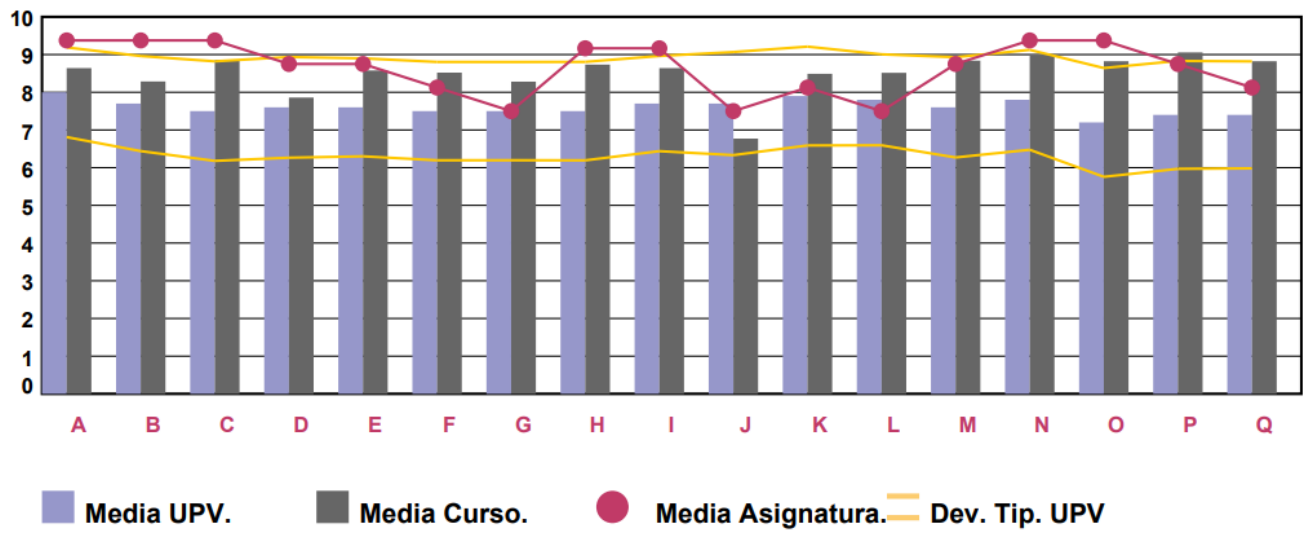

Fig. 6 Resultado de las encuestas de la asignatura Análisis de redes de abastecimiento de agua

Asimismo, en las encuestas de satisfacción realizadas por los alumnos a través del CFP, se refleja la satisfacción del alumnado con la metodología utilizada y la organización general del curso, con unos resultados por encima de la media de los cursos impartidos por la UPV, donde la satisfacción media de los alumnos a lo largo de las diferentes ediciones celebradas es superior a 9 sobre 10 tal y como se puede observar en la Fig.7. 
COMPARATIVA DE LAS PREGUNTAS

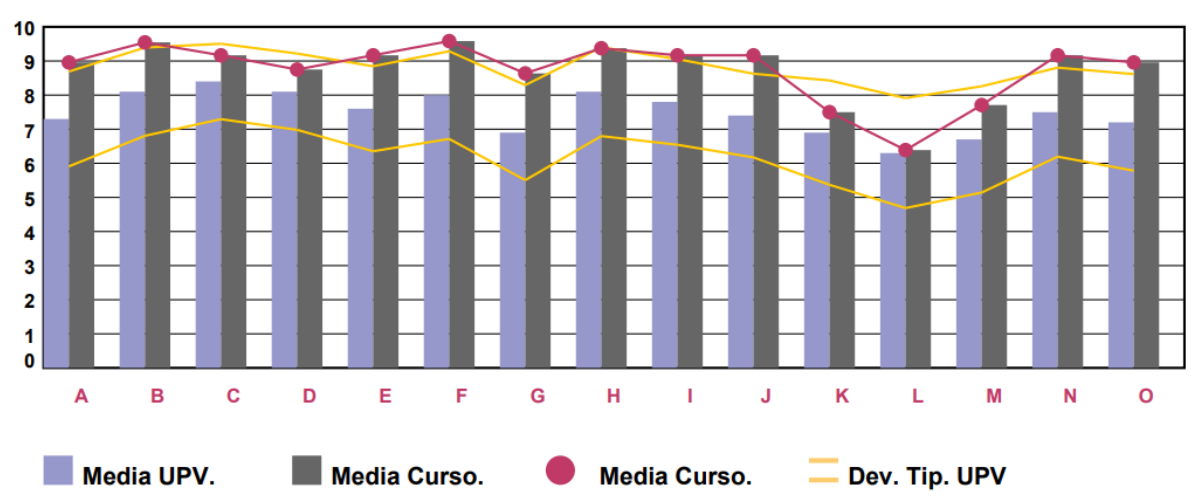

Enunciados de las preguntas:

\begin{tabular}{lr}
\hline A. La organización general del curso es buena. & 9 \\
\hline B. Puedo contactar con la dirección/coordinación del curso siempre que lo solicito. & $\mathbf{9 , 5}$ \\
\hline C. El trato recibido por parte del equipo de dirección/coordinación del curso es correcto & $\mathbf{9 , 2}$ \\
\hline D. En términos generales, la relación profesor-alumno es buena. & $\mathbf{8 , 8}$ \\
\hline E. El material de promoción consultado tenía la información suficiente. & $\mathbf{9 , 2}$ \\
\hline F. El horario actual del curso se adapta a mi disponibilidad. & $\mathbf{9 , 6}$ \\
\hline G. Hay suficiente coordinación entre las diferentes asignaturas. & $\mathbf{8 , 6}$ \\
\hline H. Considero que la realización del curso puede ser útil en mi campo profesional. & $\mathbf{9 , 4}$ \\
\hline I. En términos generales, la documentación entregada en el curso es útil para mi. & 9,2 \\
\hline J. Los métodos de enseñanza utilizados me parecen adecuados el tipo de curso. & $\mathbf{9 , 2}$ \\
\hline K. Las actividades complementarias (visitas a empresas, etc.), en caso de haberse & $\mathbf{7 , 5}$ \\
\hline organizado, me parecen interesantes. & $\mathbf{6 , 4}$ \\
\hline L. La realización del curso me ayuda a crear relaciones profesionales útiles. & $\mathbf{7 , 7}$ \\
\hline M. La relación entre la calidad del curso y su precio de inscripción me parece adecuada. & $\mathbf{9 , 2}$ \\
\hline N. Opino que la calidad del curso es buena. & $\mathbf{9}$ \\
\hline O. Mis expectativas ante el curso quedan satisfechas. &
\end{tabular}

Fig. 7 Resultado de las encuestas del título propio de posgrado:Máster en gestión eficiente del agua urbana

El sistema de evaluación junto con los excelentes resultados obtenidos por los alumnos ha suscitado un creciente interés por las empresas para formar a sus empleados, ya que permite una flexibilidad y seguimiento de los contenidos compatible con las tareas laborales. La Fig. 8 muestra el aumento de alumnos matriculados pertenecientes a empresas. No hay que olvidar que el acceso a la plataforma es de 24 h los 365 días al año, permitiendo a todos los alumnos acceder cuando mejor les convenga, sin restricciones horarias. 


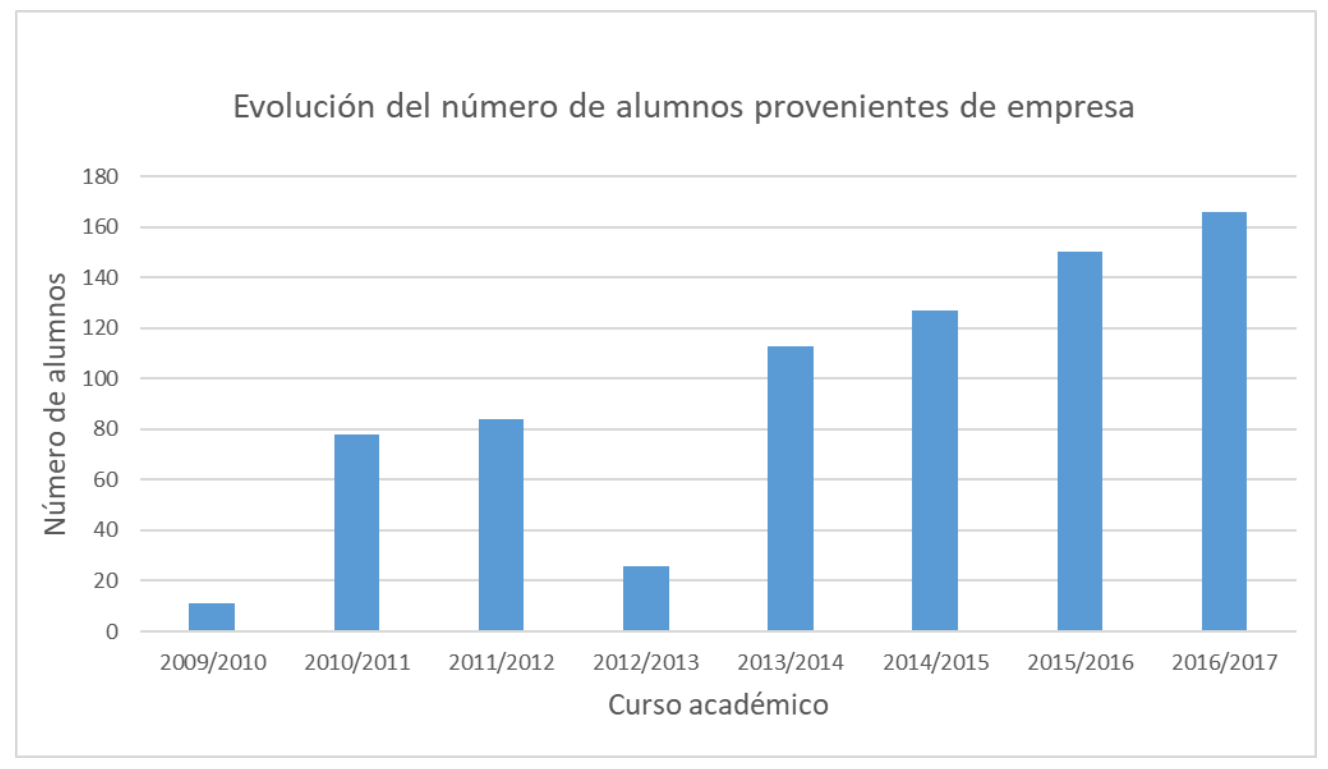

Fig. 8 Evolución del número de alumnos provenientes de empresas

La calidad en la formación a distancia del ITA se refleja no sólo en la excelente puntuación obtenida en las encuestas, sino también a través del creciente número de alumnos matriculados y del número de módulos realizados, ya que muchos de éstos optan por ampliar su formación con el ITA. La Fig.9 muestra el aumento de módulos cursados. Se puede observar como en el último año académico se ha casi duplicado este valor. Esto es debido a la gran aceptación que han tenido los cuatro títulos de posgrado que se imparten desde el curso académico 2016/2017.

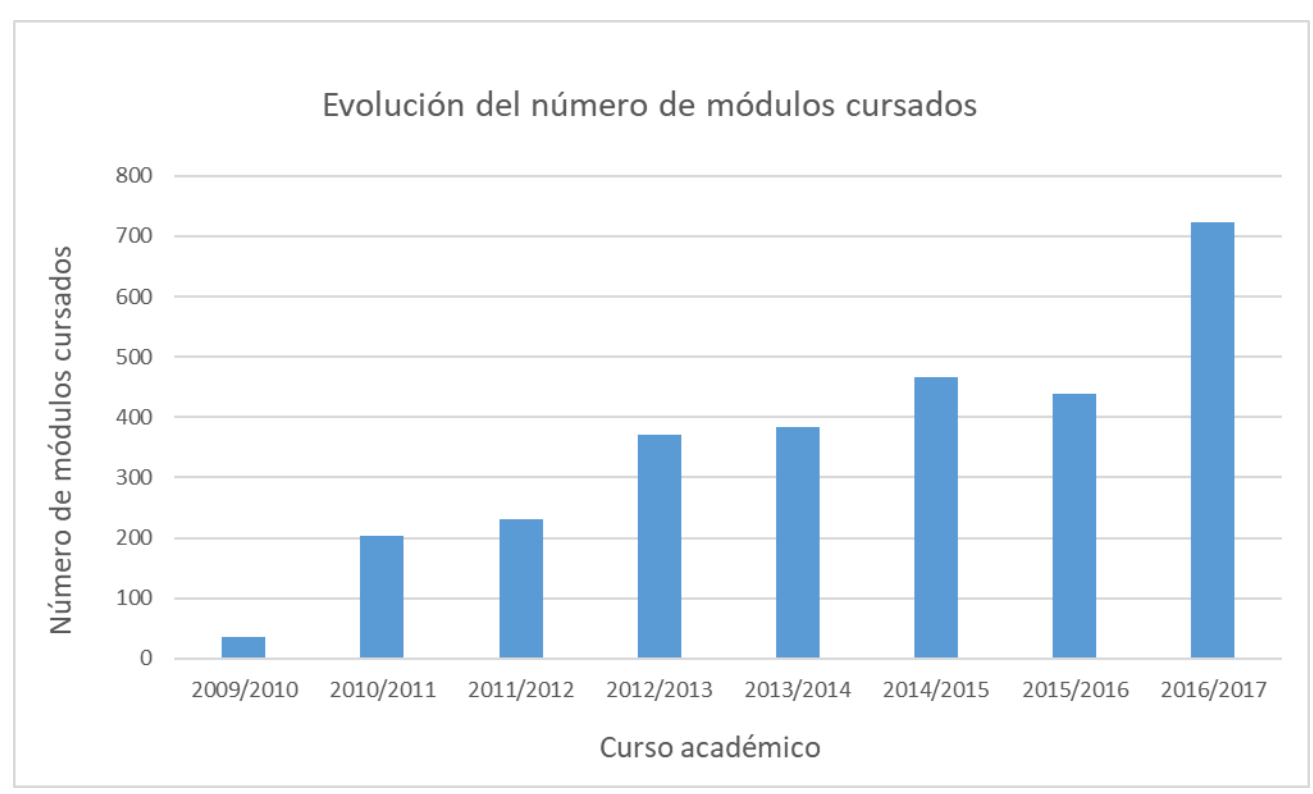

Fig. 9 Evolución del número de módulos cursados

(c)) EY-NC-ND 2018, Universitat Politècnica de València

Congreso IN-RED (2018) 


\section{Conclusiones}

El sistema de evaluación presentado está diseñado para asegurar que los alumnos consiguen superar el curso cumpliendo con los requisitos mínimos exigidos, siempre más difíciles de evaluar en formación a distancia.

Esta tarea de asegurar que el alumno dispone de los conocimientos estudiados una vez finaliza la formación, es vital en formaciones técnicas, más aún en el campo de la hidráulica, la modelación de redes y la gestión eficiente de agua, pues suponen conocimientos muy concretos de aplicabilidad directa a casos reales, que usualmente suelen servir de acceso a puestos de trabajo de carácter técnico y especializado.

Este objetivo se cumple con este sistema de evaluación, ratificado por el creciente número de empresas interesadas en formar a sus empleados aplicando este sistema, y por las encuestas de satisfacción realizadas por los alumnos una vez finalizado el curso.

\section{Referencias}

BAILEY, C. J., CARD, K. A. (2009). "Effective pedagogical practices for online teaching: Perception of experienced instructors”. The Internet and Higher Education, 12(3-4), 152-155.

BHUASIRI W., XAYMOUNGKHOUN O., ZO H., JAE JEUNG RHO J., CIGANEK A. (2011). "Critical success factors for e-learning in developing countries: A comparative analysis between ICT experts and faculty” Computers \& Education 58(2):843-855 (February 2012) DOI10.1016/j.compedu.2011.10.010

FRYDENBERG, J. (2002). “Quality standards in eLearning: A matrix of analysis”. The International Review of Research in Open and Distributed Learning, 3(2).

GRUPO DE INVESTIGACIÓN EN INTERACCIÓN Y ELEARNING (GRIAL). UNIVERSIDAD DE SALAMANCA. "Manual de Tutoría Online”.

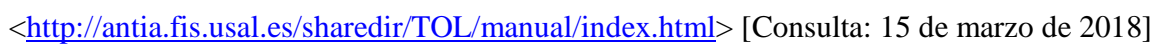
[Antonio M. Seoane Pardo y Francisco J. García Peñalvo]

MENDES, A.C., CURTO, S., COHEUR, L. (2011). "Bootstrapping multiple-choice tests with thementor”. Computational Linguistics and Intelligent Text Processing, 451-462. Heidelberg: Springer.

SINGH, U.G., (RUTH) DE VILLIERS, M.R., (2017). “An evaluation framework and instrument for Evaluating e-Assessment Tools”. International Review of Research in Open and Distance Learning, 18(6), pp.164-185.

SUN P., RAY J. TSAI R., FINGER G., CHEN Y., DOWMING Y. (2006). "What drives a successful e-Learning? An empirical investigation of the critical factors influencing learner satisfaction" en Computers \& Education 50(4):1183-1202. DOI10.1016/j.compedu.2006.11.007

VENTOURAS, E., TRIANTIS, D., TSIAKAS, P., STERGIOPOULOS, C. (2010). "Comparison of examination methods based on multiple choice questions and constructed-response questions using personal computers”. Computers \& Education, 54(2), 455-461. 
VICERRECTORADO DE CALIDAD. UNIVERSIDAD DE EXTREMADURA. "Consejos para la creación y gestión de MOOC - Miriada X".

$<$ https://www.unex.es/organizacion/gobierno/vicerrectorados/vicecal/archivos/ficheros/moocs /Consejos_rapidos_para_formato_MOOC.pdf/view> [Consulta: 20 de mayo de 2018] [Ángel González de la Fuente y David Carabantes Alarcón]

(cc) EY-NC-ND 2018, Universitat Politècnica de València 


\title{
Traducción, adaptación y validación de un instrumento de autoevaluación para alumnado universitario: hacia el éxito en el aprendizaje
}

\section{Elena Escolano-Pérez ${ }^{\mathrm{a}}$, Rita Pilar Romero Galisteo ${ }^{\mathrm{b}}$ y Pablo Gálvez Ruiz}

${ }^{a}$ Universidad de Zaragoza. Facultad de Educación. Departamento de Psicología y Sociología, eescola@unizar.es, bUniversidad de Málaga. Facultad de Ciencias de la Salud. Departamento de Fisioterapia, rpromero@uma.es, 'Universidad Internacional de La Rioja. Facultad de Educación. Departamento de Educación en Internet, pablo.galvez@unir.net.

\begin{abstract}
Many university students have difficulties in their autonomous learning due to deficits in their executive functions, which leads to a negative impact on their training and academic performance. Thus, early detection of students with such difficulties will allow the design of actions for improvement, contributing ultimately to a greater academic and work success. However, in the Spanish university context, there is a lack of reliable and valid instruments to carry out an evaluation of the executive functions, so the objective of this study is to translate, adapt and validate to the university population of new entry in the University of Zaragoza, an instrument for the assessment of the executive functions (Amsterdam Executive Function Inventory). The results showed adequate psychometric properties, with a good internal consistency and a goodness of fit adjustment in the indices considered of the confirmatory factor analysis. Thus, the instrument used is a reliable and valid to identify students with difficulties in executive functions and therefore, students are likely to have problems in their autonomous learning, which will allow not only the identification of the same, but the ultimate aim of being able to intervene for their improvement and optimization.
\end{abstract}

Keywords: Autonomous Learning, Executive Functions, European Higher Education Area, beginner university students.

\section{Resumen}

Muchos estudiantes universitarios presentan dificultades en su aprendizaje autónomo debidas a su vez a déficits en sus funciones ejecutivas, lo que conlleva repercusiones negativas en su formación y rendimiento académico. Así, detectar tempranamente estudiantes con dichas dificultades permitirá diseñar acciones para su mejora, contribuyendo en última instancia a un mayor éxito académico y laboral. Sin embargo, en el contexto universitario español se carece de instrumentos fiables y válidos que permitan llevar a cabo una evaluación de las funciones ejecutivas, por lo que el objetivo de este estudio es traducir, adaptar y validar para la población universitaria de 
nuevo ingreso en la Universidad de Zaragoza un instrumento de evaluación de las funciones ejecutivas (Amsterdam Executive Function Inventory). Los resultados mostraron adecuadas propiedades psicométricas, con una buena consistencia interna y un buen ajuste en los índices considerados del análisis factorial confirmatorio. Así, la herramienta empleada supone un instrumento fiable y válido a la hora de identificar alumnado con dificultades en las funciones ejecutivas y por tanto, alumnado con probabilidad de presentar problemas en su aprendizaje autónomo, lo que permitirá no sólo la identificación de los mismos, sino la finalidad última de poder intervenir para su mejora y optimización.

Palabras clave: Aprendizaje autónomo, funciones ejecutivas, Espacio Europeo de Educación Superior, alumnado universitario de nuevo ingreso.

\section{Introducción}

El aprendizaje autónomo constituye un concepto clave en la Educación Superior, entendiéndose como tal aquel aprendizaje en el que el estudiante se responsabiliza de la organización de su trabajo y de la adquisición de las diferentes competencias según su propio ritmo. Implica, por tanto, que quien aprende debe asumir la responsabilidad y el control de las decisiones sobre la planificación, realización y evaluación de sus actividades (Francis y Flanigan, 2012). Es preciso remarcar que la autonomía en el aprendizaje se concede con respecto a las condiciones pero no sobre su resultado o producto. El estudiante debe dar respuesta a las demandas específicas de conocimiento formuladas por el docente, pero escogerá por sí mismo aquellas condiciones contextuales de tiempo, lugar, herramientas, etc. que estime necesarios para elaborar aquella respuesta (Rué, 2009). El docente se convierte en guía, compañero y apoyo en ese proceso de aprendizaje del alumno. Su tarea esencial consiste en diseñar tareas, situaciones y contextos de aprendizaje lo más cercanas posible al contexto real que supongan un desafío a los estudiantes, orientando y ayudando a estos en la construcción de unas estructuras mentales que les permitan gestionar la información disponible de manera óptima, integrando y relacionando las demandas externas, el contexto y las características personales en una estructura de significado que dé respuesta al problema concreto al que se enfrenta en cada caso. Estos problemas, así como la información disponible para su solución, van a ser continuamente cambiantes, pues así lo es el contexto en el que vivimos. Nuestra sociedad se caracteriza por su cambio constante (Pozo y Monereo, 2009), lo cual imposibilita que el estudiante, durante su etapa universitaria o incluso durante toda su educación reglada, pueda adquirir todos los conocimientos que necesitará en su futura labor profesional. Ni siquiera resulta posible predecir cuáles serán estos conocimientos específicos. Por tanto, la formación universitaria no puede dotar a sus estudiantes de todos los conocimientos y saberes imprescindibles en su futuro profesional. Sin embargo, lo que puede y debe hacer es formar a los futuros profesionales para que sean aprendices más flexibles, eficaces y autónomos, dotándoles para ello de capacidades de aprendizaje y no sólo de conocimientos o saberes específicos, muchos de ellos, probablemente, obsoletos en un futuro no demasiado lejano (Pozo y

(cc) EY-NC-ND 2018, UniversitatPolitècnica de València

Congreso IN-RED (2018) 
Monereo, 2009). El alumno, más que centrarse con exclusividad en la adquisición y dominio de conocimientos y saberes, debe hacerlo en el desarrollo de habilidades y procesos cognitivos que le ayuden a resolver de manera creativa y eficaz los problemas y exigencias que se le presenten en esta sociedad del cambio en la que vivimos. Es en este sentido que distintos autores defienden que el aprendizaje autónomo de los alumnos se encuentra estrechamente unido a sus funciones ejecutivas (Zelazo, Blair y Willoughby, 2016), entendidas estas como procesos cognitivos de alto nivel que permiten la coordinación de sus pensamientos, emociones y actos durante la resolución activa de un problema, especialmente en aquellos problemas que resultan complejos y requieren un enfoque novedoso (Carlson, Zelazo y Faja, 2013; Diamond, 2013; Miyake y Friedman, 2012).

Así, las "funciones ejecutivas" nos permiten organizar y planificar una tarea, seleccionar apropiadamente los objetivos, iniciar un plan y mantenerlo en la mente mientras lo ejecutamos, controlarnos para no responder automáticamente, inhibir o resistir las distracciones, detectar los errores, cambiar de estrategias de modo flexible, considerar las consecuencias de las acciones, autorregular y controlar el curso de nuestra acción para asegurarnos de que la meta propuesta está en vías de conseguirse, reflexionar sobre las experiencias pasadas y planificar las futuras. En definitiva, todos estos procesos cognitivos hacen referencia a la habilidad que tiene el individuo de adaptarse de manera óptima a los continuos cambios del contexto para lograr superar situaciones específicas, lo que le permitirá desenvolverse con éxito en su vida diaria (Diamond, 2013; Diamond y Lee, 2016). En este sentido, y dado que la función de la Universidad es formar ciudadanos competentes que sean capaces de dar respuesta a las demandas continuamente cambiantes del contexto, desarrollar las funciones ejecutivas del alumnado se convierte en una prioridad del sistema educativo universitario. Así, un buen funcionamiento ejecutivo se asocia con un buen aprendizje autónomo, lo que a su vez contribuye de manera importante a un buen rendimiento académico y éxito laboral en la adultez, así como a un nivel socioeconómico mayor (Miyake y Friedman, 2012; Müller y Kerns, 2015).

Esta relevancia de las funciones ejecutivas queda asimismo patente en la abundante proliferación de trabajos que en los últimos años se han publicado sobre las mismas. Sin embargo, las funciones ejecutivas constituyen un área de estudio donde los aspectos conceptuales se encuentran en mejor estado de conocimiento que los aspectos referidos a su desarrollo y medición (Willoughby, Holochwost, Blanton y Blair, 2014). Así, son muy escasos los instrumentos de evaluación de las funciones ejecutivas en contextos educativos; y los existentes consisten por lo general en cuestionarios contestados por terceros informantes (frecuentemente, profesorado), por lo que su fiabilidad puede quedar en entredicho, especialmente debido a la influencia de la deseabilidad social, posibles fallos de recuerdo y memoria de los informantes e incluso falta de familiaridad y sensibilidad para percibir y detectar determinadas conductas del sujeto evaluado. Además, dichos instrumentos generalmente están compuestos por numersos items y son comercializados implicando un alto coste económico, por lo que resultan muy costosos tanto en términos temproales como económicos (más aún teniendo en cuenta la situación de crisis en la que se encuentra la universidad española actualmente).

(cc) EY-NC-ND 2018, UniversitatPolitècnica de València 
De cara a superar estas limitaciones, y en especial aquella que hace referncia a la posible fiabilidad limitada de la información recogida a través de terceros, la literatura aboga por la construcción y uso de herramientas de autoevaluación donde sea el mismo individuo quien informa de su propio funcionamiento ejecutivo en su contexto educativo, pudiendo ser ayudado para ello por el profesorado en caso de que sea necesario (Willoughby et al., 2014). Es en esta línea en la que se sitúa el presente proyecto, al tener como objetivo la traducción, adaptación y validación a población universitaria de nuevo ingreso en la Universidad de Zaragoza del "Amsterdam Executive Funtioning Inventory" (AEFI) de Baars, Bijvank, Tonnaer y Jolles (2015), destinado a la evaluación de las funciones ejecutivas, a contestar por el propio alumnado. Dicho instrumento está compuesto por 10 ítems convirtiéndolo así en una herramienta muy optimizada, además de tener acceso gratuito.

Disponer de una versión validada en castellano de esta herramienta para la evaluación de las funciones ejecutivas de nuestros estudiantes al comienzo de sus estudios, permitirá conocer las habilidades que se encuentran implicadas en su aprendizaje autónomo, lo que a su vez posibilitará detectar alumnado con probabilidades de presentar dificultades en sus estudios universitarios y bajo rendimiento académico, cuestiones que pueden llevar incluso al abandono. Sin embargo, la detección temprana de estos estudiantes a través de la herramienta a validar permitirá diseñar e implementar acciones de intervención destinadas a la mejora de sus habilidades implicadas en su aprendizaje autónomo y en última isntancia, a la mejora de su aprendizaje y rendimiento. Estas acciones podrán formar parte del Plan de Orientación Universitaria que está desarrollando la Universidad de Zaragoza, ya que mejorar el rendimiento académico de los estudiantes constituye un aspecto clave en las metas de las políticas públicas a nivel nacional e internacional y por tanto, también de nuestra universidad. En este sentido, consideramos que este proyecto puede contribuir a ello, más aún teniendo en cuenta que se dirige a estudiantes de nuevo ingreso y es entonces, durante el primer año universitario, cuando se produce el mayor desajuste alumno-contexto de aprendizaje y consecuentemente, la mayor tasa de abandono universitario (Esteban, Bernardo y Rodríguez-Muñiz, 2016). La tasa de abandono constituye un indicador de la calidad de las instituciones universitarias, conllevando además numerosos costos personales, económicos y sociales (Colás, 2015). Queda patente, por tanto, el interés de este proyecto, que supera los beneficios a corto plazo para los estudiantes y su formación, alcanzando beneficios institucionales y sociales.

\section{Objetivo}

El objetivo de este trabajo es traducir, adaptar y validar para la población universitaria de nuevo ingreso en la Universidad de Zaragoza el instrumento de evaluación de las funciones ejecutivas Amsterdam Executive Function Inventory (AEFI; Baars et al., 2015) que permita identificar alumnado con dificultades en las mismas y por tanto, alumnado con probabilidad de presentar problemas en su aprendizaje autónomo. Se trata de un instrumento compuesto por tres dimensiones y 10 ítems: atención (ítems 3, 6 y 9), autocontrol (ítems 1, 5, 8 y 10) y planificación (ítems 2, 4 y 7). Las respuestas a los ítems del AEFI se recogen en una escala

(cc) BY-NC-ND 2018, UniversitatPolitècnica de València

Congreso IN-RED (2018) 
tipo Likert de 3 puntos con las siguientes opciones de elección: 1 = "no verdadero", 2 = "parcialmente verdadero", y 3 = "verdadero".

\section{Desarrollo de la innovación}

Para llevar a cabo esta experiencia se ha seguido el procedimiento que se indica a continuación, en el cual puede distinguirse dos grandes fases destinadas a la: 1) traducción y adaptación del instrumento y 2) validación del instrumento.

1.- Traducción y adaptación del instrumento original.

Para llevar a cabo la traducción del cuestionario AEFI se siguió el método de traducción directa/inversa recomendado en la literatura científica especializada (Forsyth y Lessler, 1991; Hambleton, 2005; Hambleton y Patsula, 1999). Para ello, dos traductores independientes tradujeron individualmente la versión original del AEFI al castellano, originándose así las denominadas versión 1 y versión 2 del intrumento en castellano. Cada una de estas dos versiones en castellano fueron evaluadas a través del juicio de tres expertos (profesorado universitario con una experiencia media de 24,6 años en Psicología de la Educación, aprendizaje y funciones ejecutivas; oscilando su experiencia entre 14 y 35 años), resultando la versión 3 en castellano del AEFI que fue utilizada para determinar la validez de contenido. Para ello, participó un nuevo grupo formado por siete expertos, todos profesores universitarios con una experiencia media en el ámbito de la Educación Superior de 20,5 años (oscilando su experiencia entre 8,5 años y 30 años). Cada uno de estos siete expertos valoró ésta versión 3 del instrumento cumplimentando una plantilla relativa a la claridad de cada ítem entendiédose que un ítem presenta claridad cuando este se comprende fácilmente, es decir, su sintáctica y semántica son adecuadas. Así, se utilizó la siguiente escala según la propuesta de Escobar y Cuervo (2008): 1 No cumple con el criterio: el ítem no es claro; 2 Bajo nivel: el ítem requiere bastantes modificaciones o una modificación muy grande en el uso de las palabras de acuerdo con su significado o por la ordenación de las mismas; 3 Moderado nivel: se requiere una modificación muy específica de algunos de los términos del ítem; y 4 Alto nivel: el ítem es claro, tiene semántica y sintaxis adecuada. Todos los items resultaron ser claros, obteniéndose una puntuación media de 3,56 y desviación típica 0,33.

A partir de esta versión 3 del instrumento en castellano, otros dos profesores universitarios y bilingües llevaron a cabo una retrotraducción de manera independiente. Es decir, cada uno de ellos realizó una retrotraducción de la versión 3 en castellano al inglés, originándose así las versiones 1 y 2 del instrumento en inglés. Posteriormente, estas mismas personas pusieron en común sus versiones y discutieron sobre las mismas hasta llegar a una versión consensuada: versión 3 del instrumento en inglés.

Posteriormente, una persona bilingüe y experta en Psicología de la Educación, comparó la versión original del instrumento AEFI con la versión 3 del instrumento en inglés, considerándolas equivalentes. Por tanto, se obtuvo así la versión 4 del instrumento en castellano a administrar al alumnado para proceder posteriormente a su validación.

(cc) EY-NC-ND 2018, UniversitatPolitècnica de València 
Los ítems empleados para la recogida de datos tras el proceso de traducción y adaptación fueron los siguientes:

1. A menudo reacciono demasiado rápido. Hago o digo algo antes de que sea mi turno.

2. Me organizo bien. Por ejemplo, planifico adecuadamente lo que realizaré a lo largo del día.

3. No soy capaz de concentrarme en el mismo tema durante un largo periodo de tiempo.

4. Trabajo de manera muy ordenada.

5. Comparado con otros, hablo mucho.

6. Me distraigo fácilmente.

7. Soy caótico o desorganizado.

8. Antes de actuar no pienso en las consecuencias de mis actos.

9. Mi pensamiento se dispersa fácilmente.

10. Soy un bocazas, hablo más de la cuenta y de forma indiscreta.

2.- Validación del cuestionario.

La versión 4 del instrumento en castellano fue adminsitrada a una muestra de 148 estudiantes de nuevo ingreso en la Universidad de Zaragoza, pertenecientes al Grado en Magistero en Educación Infantil. Todos eran de género femenino salvo uno y respondieron de forma voluntaria y anónima al cuestionario, que fue administrado en los últimos 10 minutos de una clase habitual en el mes de diciembre de 2017. Los estudiantes pertenecían a los dos grupos del Grado existentes en el centro.

Se efectuaron análisis descriptivos de los ítems. Se calculó la pertinencia del análisis factorial exploratorio (AFE) y se finalizó con un análisis factorial confirmatorio (AFC) de la escala mediante el software AMOS 20.0. La bondad de ajuste del modelo de medida propuesto se evaluó mediante diferentes pruebas, utilizando para la estimación de parámetros la técnica de máxima verosimilitud. Por un lado, los índices de ajuste global o absoluto fueron el valor de chi-cuadrado $\left(\chi^{2}\right)$, la ratio $\chi^{2} / g l$, y los índices RMSR (Root Mean Square Residual) y RMSEA (Root Mean Square Error or Approximation), mientras que los índices de ajuste incremental o de comparación empleados fueron TLI (Tucker-Lewis Index), IFI (Incremental Fit Index) y CFI (Comparative Fit Index). Para la ratio $\chi^{2} / \mathrm{gl}$, un valor inferior a 3 supone un indicativo de un buen ajuste (Kline, 2005). Los valores de los índices TLI, IFI y CFI deben ser superiores a .90 para considerar aceptable el ajuste del modelo (Hair, Black, Babin, Anderson y Tatham, 2006). El índice RMSEA es considerado el mejor indicador del ajuste global (Marsh, Balla y Hau, 1996) y al igual que el índice RMSR, valores entre .05 y .08 son considerados como aceptables, mientras que valores inferiores a .05 se consideran óptimos (Batista y Coenders, 2012).

(cc) EY-NC-ND 2018, UniversitatPolitècnica de València

Congreso IN-RED (2018) 


\section{Resultados}

Los estadísticos descriptivos de los ítems mostraron valores de asimetría y curtosis entre 3 y 10 respectivamente, cumpliendo así el rango de normalidad (Marôco, 2010). Los valores medios más elevados se corresponden con dos ítems pertenecientes a la dimensión Planificación (ítem 2: 2,43; ítem 4: 2,49). El resto de ítems obtuvieron una valoración por encima del punto medio de la escala. La pertinencia del AFE mostró un índice de adecuación muestral $\mathrm{KMO}=.72 \mathrm{y}$ significatividad en el test de Esfericidad de Bartlett $\left[\chi^{2}(45)=289.34 ; p<.01\right]$. Utilizando una rotación oblícua Oblimin, se obtuvo una solución de tres factores que explicaban el $57,7 \%$ de la varianza. El análisis de fiabilidad mostró un valor $\alpha$ de .71 para la escala global.

El AFC realizado para el modelo de medida indicó un ajuste a los datos satisfactorio, situándose los diferentes índices considerados en el análisis dentro del rango aceptable $\chi^{2}(32)=47.01(\mathrm{p}<.001) ; \chi^{2} / \mathrm{gl}=1.46 ; \mathrm{RMSR}=.026$; RMSEA=.058; TLI=.917; IFI=.944; CFI=.941]. La ratio $\chi^{2} / \mathrm{gl}$ asumió un valor inferior a 3, los valores para TLI, IFI y CFI se situarion por encima del criterio .90 recomendado, el índice RMSR obtuvo un ajuste óptimo mientras que el ajuste del índice RMSEA fue aceptable.

\section{Conclusiones}

Disponer de este instrumento de evaluación válido en nuestro contexto permitirá detectar a todos aquellos alumnos universitarios de nuevo ingreso que presentan dificultades en su aprendizaje autónomo. Además, las características particulares del instrumento (breve y gratuito) permitirán llevar a cabo esta detección de manera rápida y viable económicamente. Estas cuestiones son importantes, preocupándonos como docentes de modo especialmente lo referido al tiempo. Son muchos los estudiantes que comienzan la universidad con dificultades en su aprendizaje autónomo, con las consecuencias negativas que ello implica para su formación, rendimiento y éxito académico. Por ello, cuanto antes se lleve a cabo la detección de estos estudiantes, antes podrá intervenirse y mayores y más perdurables serán sus beneficios. Estas intervenciones podrán realizarse dentro del Plan de Orientación de la Universidad de Zaragoza (Allueva, Zulaica y Abadía, 2016), pues si bien dispone de una estructura y contenidos generales para todos los estudiantes, es altamente flexible para que cada centro lo personalice atendiendo a las necesidades y demandas de sus estudiantes.

Por otro lado, el hecho de disponer de esta herramienta válida en nuestro contexto abre interesantes y necesarias líneas de trabajo a desarrollar en futuros proyectos con la finalidad, por ejemplo, de conocer si determinadas variables del alumnado (género, edad, tipo de centro al que acudieron en niveles educativos previos, rendimiento académico previo y Grado que estudian) se asocian con una mayor probabilidad de dificultades en las funciones ejecutivas y en el aprendizaje autónomo, pudiendo establecerse un perfil de alumnado con mayor riesgo de déficits en su aprendizaje. Ello permitiría trabajar con este alumnado con potecial riesgo de presentar dificultades en su aprendizaje incluso antes de comenzar sus estudios universitarios, por ejemplo, en los denominados "Cursos Cero" que 
imparte la Universidad de Zaragoza (actividades que se realizan en el mes de septiembre y que se dirigen al alumnado de nuevo ingreso con el fin de facilitar a los estudiantes algunas herramientas para poder desarrollar con éxito sus estudios en los siguientes años).

Asimismo, el cuestionario obtenido podría validarse para estudiantes de otros cursos de la Universidad de Zaragoza, lo que permitirá hacer un seguimiento de la mejora de las funciones ejecutivas y aprendizaje autónomo de los estudiantes. También esta validación realizada con estudiantes de la Universidad de Zaragoza puede constituir el primer paso para una futura validación a nivel nacional con participación de otras Universidades.

\section{Referencias}

ALlUEVA, P., ZULAICA, F., ABADÍA, A. R. (2016). "Plan de Orientación Universitaria de la Universidad de Zaragoza. Integración de los estudiantes en la Universidad: Binomio Tutor-Mentor” en Castejón, J.L. Psicología y Educación: Presente y Futuro. Madrid: Asociación Científica de Psicología y Educación; pp. 2273-2281.

BAARS, M. A. E., BIJVANK, M. N., TONNAER, G. H., JOLLES, J. (2015). “Self-report measures of executive functioning are a determinant of academic performance in first-year students at a university of applied sciences” en Frontiers in Psychology, Vol. 6, núm. 1131. $<$ https://www.frontiersin.org/articles/10.3389/fpsyg.2015.01131/full>. [Consulta: 10 de mayo de 2017]

BATISTA, J. M., COENDERS, G. (2012). Modelos de ecuaciones estructurales ( $2^{a}$ Ed.). Madrid : La Muralla.

CARLSON, S. M., ZELAZO, P. D., FAJA, S. (2013). “Executive function” en Zelazo, P.D. The Oxford handbook of developmental psychology, Vol. 1: Body and mind. New York: Oxford University Press. (pp. 706-743).

COLÁS, P. (2015). “El abandono universitario” en Revista Fuentes, Vol. 16, pp. 9-14.

DIAMOND, A. (2013). “Executive Functions” en Annual Review of Psychology, Vol. 64, pp. 135168. <10.1146/annurev-psych-113011-143750>. [Consulta: 15 de enero de 2018]

DIAMOND, A., LEE, D. S. (2016). “Conclusions about interventions, programs, and approaches for improving executive functions that appear justified and those that, despite much hype, do not” en Developmental Cognitive Neuroscience, Vol. 18, pp. 34-48.

ESCOBAR, J., CUERVO, A. (2008). "Validez de contenido y juicio de expertos: una aproximación a su utilización” en Avances en Medición, Vol. 6, núm. 1, pp. 27-36. <http://www.humanas.unal.edu.co/psicometria/files/7113/8574/5708/Articulo3_Juicio_de_expertos_2 7-36.pdf> [Consulta: 12 de enero de 2018]

ESTEBAN, M., BERNARDO, A. B., RODRÍGUEZ-MUÑIZ, L. J. (2016). "Permanencia en la universidad: la importancia de un buen comienzo”en Aula Abierta, Vol. 44, pp. 1-6.

FORSYTH, B. H., LESSLER, J. T. (1991). “Cognitive laboratory methods: a taxonomy” en Bierner, P. et al. Measurement errors in surveys. NewYork: Wiley; pp. 393-418.

FRANCIS, A., FLANIGAN, A. (2012). "Self-Directed Learning and Higher Education Practices: Implications for Student Performance and Engagement” en International Journal of the Scholarship of Teaching and Learning, Vol. 7, núm. 3, pp. 1-18.

(cc) EY-NC-ND 2018, UniversitatPolitècnica de València

Congreso IN-RED (2018) 
HAIR, J. F., BLACK, W. C., BABIN, B., ANDERSON, R. E., TATHAM, R. L. (2006). Multivariate Data Analysis (6 ${ }^{a}$ Ed.). Upper Saddle River, NJ: Prentice-Hall.

HAMBLETON, R. K. (2005). "Issues, designs, and technical guidelines for adapting tests into multiple languages and cultures” en Hambleton, R.K., Merenda, P., Spielberger, C. Adapting educational and psychological tests for cross-cultural assessment. Mahwah, NJ: Lawrence Erlbaum; pp. 3-38.

HAMBLETON, R. K., PATSULA, L. (1999). “Increasing the Validity of Adapted Tests: Myths to be Avoided and Guidelines for Improving Test Adaptation Practices” en Journal of Applied Testing Technology, $\quad$ Vol. $\quad 1, \quad$ núm. $\quad 1, \quad$ pp. 1-13. $<$ http://www.jattjournal.com/index.php/atp/article/view/48345/39215>. [Consulta: 20 de mayo de 2017]

KLINE, R. B. (2005). Principles and practice of structural equation modeling ( ${ }^{a}$ Ed.). New York: The Guilford Press.

MARÔCO, J. (2010). Análise de Equações Estructurais. Fundamentos teóricos, Software \& Aplicações. Pero Pinheiro: Rolo y Filhos II, SA.

MARSH, H., BALLA, J. R., HAU, K. T. (1996). "An evaluation of incremental fit indices: A clarification of mathematical and empirical processes” en Marcoulides, G.A., Schumacker, R.E. Advanced structural equation modeling techniques. Hilsdale, NJ: Erlbaum; pp. 115-353.

MIYAKE, A., FRIEDMAN, N. P. (2012). "The nature and organization of individual differences in executive functions: four general conclusions” en Current Directions in Psychological Science, Vol. 21, pp. 8-14. <10.1177/0963721411429458>. [Consulta: 15 de enero de 2018]

MÜLLER, U., KERNS, K. A. (2015). “The development of executive function” en Liben, L.S., Müller, U., Lerner, R.M. Handbook of Child Psychology and Developmental Science: Cognitive Processes. Hoboken, NJ: John Wiley and Sons; pp. 571-623.

POZO, J. I., MONEREO, J. I. (2009). “Introducción: La nueva cultura del aprendizaje universitario o por qué cambiar nuestras formas de enseñar y aprender” en Pozo, J.I., Pérez Echeverría, M.P. Psicología del aprendizaje universitario: La formación en competencias. Madrid: Morata; pp. 9-28.

RUÉ, J. (2009). El aprendizaje autónomo en educación superior. Madrid: Narcea.

WILLOUGHBY, M. T., HOLOCHWOST, S. J., BLANTON, Z. E., BLAIR, C. B. (2014). "Executive Functions: Formative versus Reflective measurement” en Measurement: Interdisciplinary Research and Perspectives, Vol. 12, núm. 3, pp. 69-95. <10.1080/15366367.2014.929.453>. [Consulta: 10 de diciembre de 2017]

ZELAZO, P. D., BLAIR, C. B., WILLOUGHBY, M. T. (2016). Executive Function: Implications for Education (NCER 2017-2000). Washington, DC: National Center for Education Research, Institute of Education Sciences, U.S. Department of Education. <http://ies.ed.gov/> [Consulta: 15 de enero de 2018] 


\title{
Incorporación de Internet de las Cosas (IoT) en la docencia universitaria en dos etapas: hardware y software*
}

\author{
Santiago Felici Castell ${ }^{1}$, Jaume Segura Garcia ${ }^{1}$, Juan J. Pérez Solano ${ }^{1}$,
} Miguel García Pineda ${ }^{1}$ y Antonio Soriano Asensi ${ }^{1}$

${ }^{1}$ Dpt Informàtica - Universitat de València

\begin{abstract}
IoT is a concept referred to a network of common objects interconnected through the Internet. This is one of the main areas with growing interest and also necessary for the Telecommunication and Telematics Engineering students. The main constraints which face the students with IoT are the integration of the hardware as well as the need for management systems to handle the amount of data they generate by specific software. This work shows some experiences done by a group of students in the Telematics Engineering Degree and the Master of Telecommunications.
\end{abstract}

Keywords: IoT, experiences, FIWARE, Raspberry Pi, ThingSpeak.

\section{Resumen}

IoT es un concepto que hace referencia a una red de objetos cotidianos interconectados a través de Internet. Ésta es una de las áreas de creciente interés y necesario conocimiento para los estudiantes de Ingeniería de Telecomunicaciones/Telemática. Los principales obstáculos a los que se enfrentan los estudiantes con IoT son por un lado la integración del hardware, así como la necesidad de disponer de sistemas de gestión para manejar el volumen de datos que generan. Este trabajo muestra unas experiencias realizadas con un grupo de estudiantes en el grado de ingeniería telemática y en el máster de telecomunicación.

Keywords: IoT, experiencias, FIWARE, Raspberry Pi, ThingSpeak.

\footnotetext{
${ }^{*}$ Proyecto financiado por la Universitat de València UV-SFPIE RMD17-587626
} 


\section{Introducción}

En la nueva sociedad digital, los ecosistemas de plataformas orientadas a la Internet de las Cosas (IoT) serán la base de las creaciones con valor añadido, y un motor para el desarrollo de aplicaciones innovadoras IoT para el usuario final. Es por ello que en los próximos años será necesaria la actualización de los planes de estudio de las titulaciones en el ámbito de las TIC, con el fin de incorporar todas las tecnologías relacionadas con la IoT. El término IoT suele hacer referencia a una red de objetos cotidianos interconectados a través de Internet. Es una de las áreas de creciente interés por parte de la industria y la investigación, abarcando también otras áreas como la gestión de recursos, vigilancia y seguridad. Las tecnologías basadas en IoT se están convirtiendo en un elemento casi indispensable en las ciudades inteligentes, que estamos incorporando en nuestro modus vivendi.

La percepción sensorial del entorno urbano por parte de los seres humanos ha sido ampliamente estudiada desde el final de la Segunda Guerra Mundial en Europa (Meer y col. 2011). En las últimas decadas, la percepción de la contaminación ambiental ha aumentado considerablemente y ha llegado a ser un problema muy serio en entornos urbanos. La contaminación acústica(WHO 2011), del aire (Anderson, Thundiyil y Stolbach 2012) o lumínica son fuentes importantes de molestia a los ciudadanos en las ciudades y tiene un impacto negativo sobre su salud, afectando a los colectivos más vulnerables, como niños y ancianos, o personas alérgicas. Además, la OMS ha estimado que el $23 \%$ de todas las muertes mundiales están relacionadas con el medio ambiente, 1,4 millones en Europa (Anderson, Thundiyil y Stolbach 2012).

Las plataformas del IoT se están convirtiendo en una poderosa herramienta de monitorización y de recogida de información para la toma de decisiones. Estas plataformas de IoT permiten a las instituciones y a los investigadores supervisar y controlar los puntos finales (ya que son los nodos de la WSN), crear aplicaciones para satisfacer las necesidades de la administración y la industria digitales, y serán una herramienta esencial en el desarrollo y la evolución de la sociedad/mercado digital. Los principales obstáculos a los que se enfrentan las IoT para que puedan ser implementadas a gran escala son por un lado la integración del hardware así como la necesidad de disponer de sistemas de gestión con características adecuadas que den solución a uno de los principales retos que presenta la gestión del gran volumen de información que se genera en IoT.

Una plataforma IoT debería facilitar la comunicación, el flujo de datos y la gestión de dispositivos, permitiendo la funcionalidad de aplicaciones especificas en el marco del IoT. Estas aplicaciones permiten la conexión entre máquinas, dispositivos, aplicaciones y personas a centros de datos y control. La integración de diferentes sensores o actuadores y protocolos de comunicación es otra característica intrínseca del concepto IoT. Las plataformas IoT están basadas en hardware embebido y software específico. Por lo que las aplicaciones desarrolladas en éste ámbito requieren del desarrollo de arquitecturas ad-hoc, y de nuevas tecnologías que faciliten la comunicación, el control y la gestión de los dispositivos. Con especial énfasis en la seguridad de los puntos finales y la interconexión entre diferentes plataformas del entorno de la IoT.

En este trabajo se presenta una prueba piloto orientada a los estudiantes de las asignaturas de Redes Avanzadas I del Grado de Ingeniera Telemática (GIT) de la ETSE y Redes de Comunicaciones Móviles en el marco del Máster de Ingeniería en Telecomunicaciones (MITUV). El objetivo de esta experiencia es en primer lugar que 
el estudiante se familiarice con los dispositivos hardware IoT, por ejemplo los nodos Raspberry Pi o computador de placa simple (single board computer o SBC) de bajo coste. En segundo lugar, también se pretende formar a los futuros ingenieros en el uso de aplicaciones dedicadas a la recogida y gestión de información (como FIWARE, ThingSpeak, Kaa, etc.)(Wang y col. 2015).

\section{Trabajos relacionados}

En este punto vamos a introducir diversos trabajos previos donde se ha utilizado la tecnología relacionada con arquitecturas IoT en entornos docentes para acercar al alumnado los últimos avances en las arquitecturas de red.

El artículo (Donelkys Santana Medina 2016) tiene como finalidad identificar los antecedentes, la realidad actual y las proyecciones de las arquitecturas IoT en la dinámica de la actividad educativa en espacios universitarios. Según sus autores los resultados alcanzados hasta estos momentos evidencian la factibilidad que tienen las universidades en impulsar la preparación de las condiciones para la introducción y utilización de la Internet de las Cosas en el proceso de enseñanza-aprendizaje. La introducción de IoT constituye un reto a la ingeniería relacionada con la internet, la informática, la computación y la comunicación, las cuales han de innovar creadoramente, con vistas a personalizar este proceso en las prácticas del proceso docente educativo de las universidades.

Un ejemplo materializado de la introducción de la tecnología IoT en las aulas universitarias se puede ver en (Martínez 2015). En este artículo se muestra la aproximación que en la asignatura Dispositivos y Redes Inalámbricas (DRI), del Grado de Ing. Informática impartida en la ESII de Albacete, se hace al desarrollo de competencias en el mundo de IoT, mediante el estudio del estándar de comunicación BLE. En este caso el bloque temático dedicado a IoT en la asignatura se limitó a cuatro semanas y las actividades a realizar fueron: a) Estudio del protocolo BLE, b) Descubrimiento de dispositivos y servicios y c) Consumo de servicios de la IoT. Todas están actividades fueron desarrolladas con dispositivos IoT. El artículo concluye que el incluir la tecnología IoT en el temario de una titulación de Grado en Ingeniería TIC es una decisión que no debe verse condicionada por la falta de recursos hardware y/o software disponible, que como se ve en este trabajo son más que suficientes para el diseño de una asignatura. Y, tampoco el grado de madurez de la tecnología IoT, ni la dificultad de sus contenidos son excusa para no incluir la IoT el plan de estudios de una Ingeniería TIC.

Finalmente, en (Catalán Cantero y Blesa Gascón 2016) se propone una modelo de programación basado en Arduino para Raspberry Pi, con el objeto de facilitar la programación de sistemas empotrados enmarcados en los paradigmas CPS e IoT. Este tipo de sistemas requieren multitarea y comunicación mediante TCP/IP. Dicho modelo, junto con su framework, ha empezado a utilizarse en una asignatura orientada a proyectos impartida a alumnos con carencias en la programación de aplicaciones con dichos requisitos. Los primeros resultados indican que los alumnos ven simplificado el desarrollo de sus proyectos, por lo que estos pueden tener un nivel mayor de complejidad con soluciones divergentes, facilitando así el empleo de la mencionada metodología docente. 
Como se puede observar se están empezando a desarrollar estrategias para introducir nuevas arquitecturas de red en la enseñanza universitaria. Esto es debido a la evolución que están sufriendo las redes, además como docentes universitarios debemos de enseñar todo aquello que se está implementado hoy en día en la empresa y dar algunas pinceladas de aquello que está por venir.

\section{Metodología}

El desarrollo metodológico que ha motivado el proyecto que nos ocupa está basado en la apreciación y necesidad de renovar materiales para el desarrollo teórico-práctico de los laboratorios de las asignaturas de Redes Avanzadas I del Grado de Ingeniería Telemática (GIT) de la ETSE y Redes de Comunicaciones Móviles en el marco del Máster de Ingeniería en Telecomunicaciones (MITUV) en base a los planteamientos que demanda la sociedad de la información y la industria para los próximos años.

Este desarrollo metodológico se basa en la introducción de una serie de experiencias/prácticas en el contexto de las asignaturas mencionadas. Estas prácticas tendrán en cuenta los conocimientos de las tecnologías con las que se implementan las aplicaciones orientadas a IoT (i.e. tecnologías de comunicación, protocolos de routing y comunicación de mensajes/información, arquitectura del sistema IoT, etc.).

Para ello, y como elementos básicos, usaremos sensores (por ejemplo, DHT11 para recoger temperatura y humedad, FSR para recoger información de presión táctil, etc.), Raspberry Pi como IoT edge y Gateway del sistema IoT, ThingSpeak como Back-end IoT a nivel de grado y FIWARE a nivel de máster.

Los estudiantes participantes de GIT, dentro de la asignatura Redes Avanzadas I (1er cuatrimestre) y los estudiantes de MITUV dentro de la asignatura Redes de Comunicaciones Móviles (2do cuatrimestre), deben de realizar un proyecto (o práctica) que involucre el diseño e implementación de una red basada en IoT.

Los estudiantes de grado realizarán una práctica enfocada al hardware de las IoT y los estudiantes de máster otra práctica enfocada al software y la integración de las IoT. Además cada grupo elaborará un enunciado en los idiomas anteriores. Estas prácticas se explicarán a los estudiantes de estas asignaturas por los propios alumnos participantes en sesiones especiales organizadas, tanto a nivel informativo como para poder realizarlas en sus respectivos cursos. La figura 1 muestra los respectivos esquemas de desarrollo para GIT y MITUV.

Al finalizar los alumnos rellenarán unos cuestionarios donde valorarán la nueva tecnología docente e introducirán sugerencias y/o posibles mejoras. 

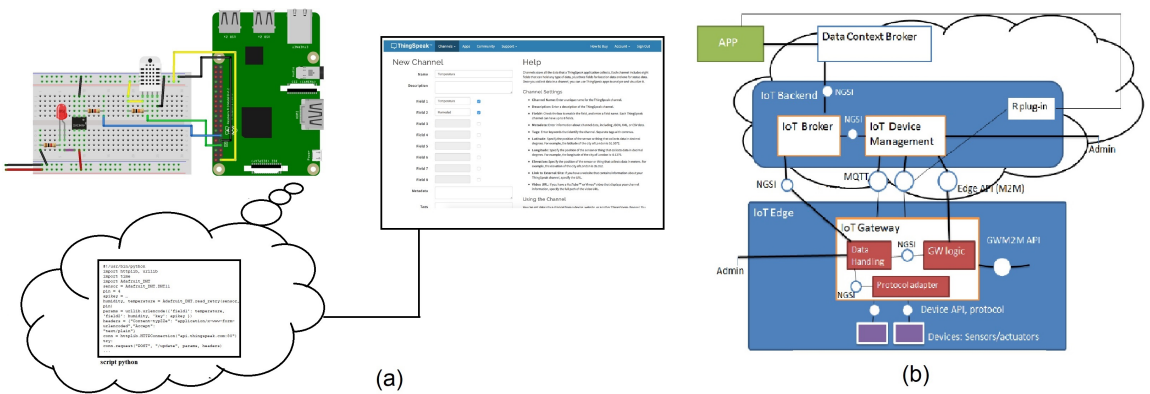

(b)

Fig. 1: (a) Esquema de desarrollo en GIT; (b) Esquema de desarrollo en MITUV

\section{Desarrollos del proyecto}

La consecución de los objetivos del proyecto, a partir de la metodología establecida ha permitido el desarrollo de las siguientes experiencias/prácticas por parte de los estudiantes participantes en el programa piloto.

\subsection{Experiencia en GIT: Raspberry Pi, Sensor DHT y ThingSpeak}

El objetivo de esta experiencia realizada en el laboratorio de Redes Avanzadas I es servir como introducción a IoT mediante el uso de materiales económicos y comunes con una Raspberry Pi (RPi) (Raspberry Pi 2017) como elemento central, debido a su bajo coste, versatilidad y facilidad de uso. Los componentes usados se encuentran disponibles en cualquier tienda de electrónica. Como material adicional se preparó un video en el cual se indican los pasos necesarios para la preparación de la RPi, los programas y librerías necesarias.

La experiencia continúa montando el circuito sensor que se muestra en la figura 2 que está compuesto por la RPi como elemento principal que se encargará de gestionar todo el sistema, un sensor de temperatura y humedad DHT11, el optoacoplador "4N35" como actuador, que separa el circuito principal, del secundario que es un LED aislado del circuito anterior.

La RPi incorpora una serie de scripts en Python para control de envío de la información. También permiten leer el sensor y actuar sobre el optoacoplador. Finalmente, incorpora un pequeño programa servidor en PHP.

\subsection{Experiencia en MITUV: Raspberry Pi y FIWARE}

A nivel de Máster, se realiza otra experiencia relacionada con sistemas IoT basada en FIWARE (FIWARE 2018). La plataforma FIWARE fue creada por Telefónica como un framework modular de herramientas Open-Source. El proyecto fue financiado principalmente por la Unión Europea a través del programa FP7 en 2011.

Proporciona un conjunto de APIs/Aplicaciones bastante simples pero potentes, que facilitan el desarrollo de aplicaciones inteligentes en múltiples sectores. Las especificaciones de estas APIs son públicas y sin derechos de autor. Además, existe publicada 


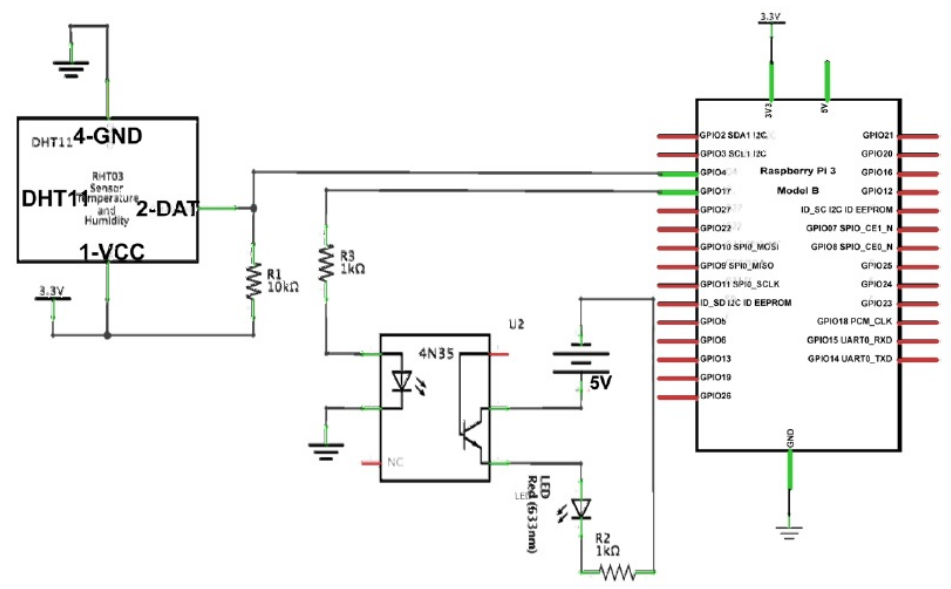

Fig. 2: Circuito esquemático

una documentación libre de cada implementación de todos los componentes de FIWARE, de tal forma que se puedan desarrollar soluciones de forma rápida y a bajo coste.

Estas aplicaciones son llamadas Generic Enablers (GE) que suelen ser usados de forma general y común en cualquier proyecto que se base en FIWARE. Por otra parte, la plataforma agrupa estos GEs dependiendo del contexto de utilización de estos, creando así 6 bloques: Context Management, Internet of Things (IoT) SErvices Enablers, Applications/Services Ecosystem and Delivery Framework, Advanced Web-bases User Interface, Security, Cloud Hosting, Interface to Networks and Devices (I2ND).

Implementar una solución con FIWARE básicamente consiste en utilizar los distintos GEs que proporciona FIWARE. Esto no implica que sea necesario implementar todos los GEs existentes,

Por otra parte, para la instalación de cualquier GE existen 4 formas distintas:

1. Compilación desde su código de github

2. Mediante repositorios de paquetes en distribuciones de Linux (apt-get, yum, ...)

3. Utilizando contenedores de Docker ${ }^{1}$

4. Utilizando Instancias en su Laboratorio (FIWARE)

En este caso se ha descartado el uso de la compilación del código fuente debido a las complicaciones de dependencias y su lentitud, errores de compilación y complejidad. También se ha descartado la instalación mediante repositorios de paquetes, ya que no

\footnotetext{
${ }^{1}$ Docker es un proyecto de código abierto que automatiza el despliegue de aplicaciones dentro de contenedores de software, proporcionando una capa adicional de abstracción y automatización de virtualización a nivel de sistema operativo en Linux.
} 
todas los GEs están en uno, ni todos los GEs están disponibles para todos los SO. Un ejemplo es Orion y Wirecloud; mientras Orion está disponible en repositorios para Centos/Fedora, Wirecloud sólo está disponible para Ubuntu/Debian. Esto hace que sea necesario tener varias máquinas virtuales con distintos $\mathrm{SO}$ y distintas versiones de estos para poder instalar toda la solución de FIWARE.

Una opción interesante es utilizar el laboratorio online que proporciona la plataforma de FIWARE para el desarrollo de soluciones, pero presenta varios incovenientes: No se tiene control de la plataforma (puede ser válido para el desarrollo, pero no para implementaciones) y el acceso no es libre (debe ser aprobado).

Con todo esto se ha decidió utilizar Docker, ya que permite crear contenedores que virtualizan un entorno completo de Linux. Es decir, en una máquina con Centos 5, es posible simular un Ubuntu 16.04 para así implementar todas las herramientas y características que posee, como puede ser el uso de su repositorio de paquetes.

Como se ha comentado anteriormente FIWARE es modular, por lo que en la elaboración de esta experiencia sólo se han utilizado los GEs necesarios para los servicios de recogida de información sobre IoT que se desea implementar:

- Orion (Context Broker): El centro de FIWARE. Es el encargado de manejar el estado actual de los objetos. Además permite la creación de suscripciones/notificaciones.

- Cygnus (Context Manager): Es un conector que se encarga de guardar los estados (información de contexto) de Orion de forma persistente.

- IDAS (IoT Agent): Se encarga de comunicar los dispositivos IoT con Orion.

- Keryrock (Identity Manager): Componente central de seguridad para FIWARE. Proporciona una interfaz web para la creación de aplicaciones, usuarios y roles.

- AuthZForce (Authorization): Implementa decisiones de autorización basadas en políticas y peticiones de del PEP (Policy Enforcement Point).

- PEP Proxy: Proxy que permite implementar seguridad a los accesos a GEs.

- Wirecloud (Application Mashup): Implementa un dashboard que permite la utilización de widgets para crear una aplicación propia.

La figura 3 presenta la arquitectura completa de la plataforma FIWARE para la recogida de información basada en IoT.

Además de estos GE, también se ha utilizado otras aplicaciones necesarias para el funcionamiento de estos:

- Mongo DB: Base de datos no SQL, encargada de guardar toda la información recibida por Cygnus (versión recomendada de mongodb es 3.2).

- Postgress: Base de datos SQL, encargada de almacenar los datos del GE Wirecloud.

- NGINX: Utilizado como proxy para el acceso a los GEs Wirecloud y Keyrock, proporciona una capa de seguridad. 


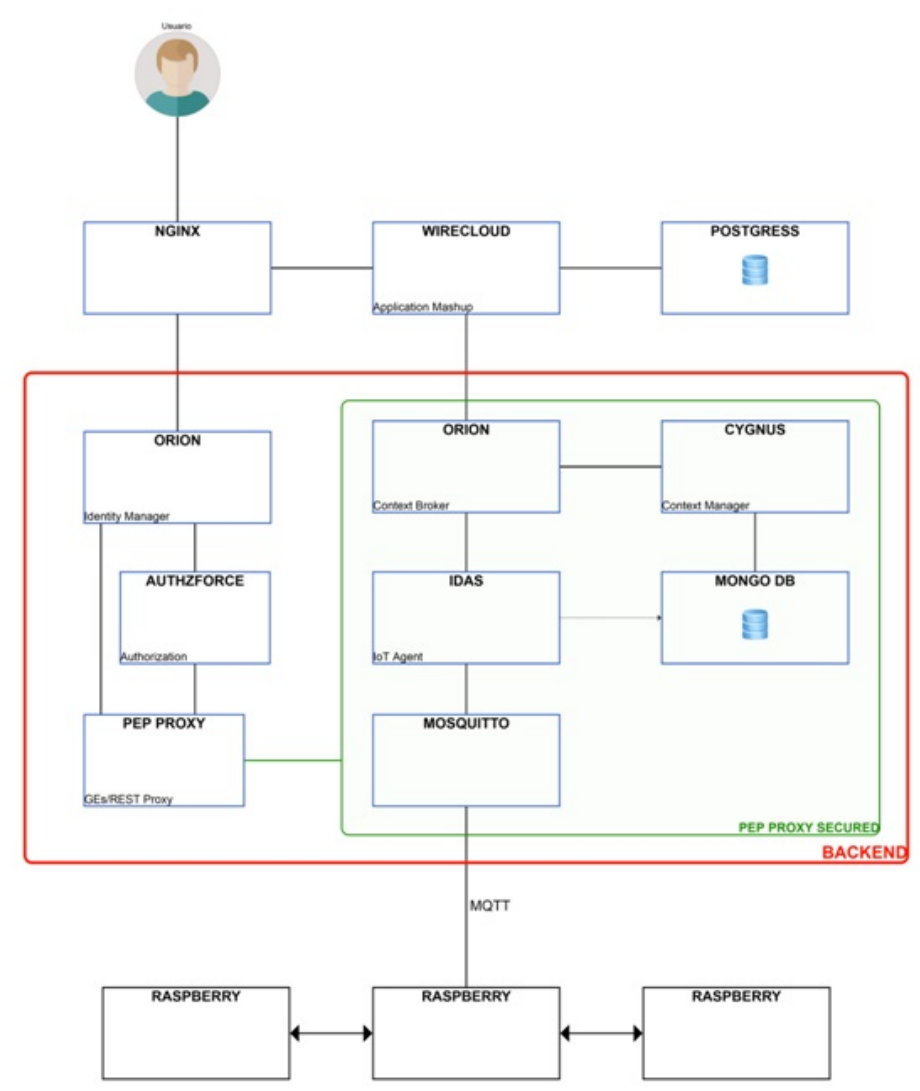

Fig. 3: Esquema de módulos para la implementación de una plataforma IoT para recoger información de una red de Rpi sensoras

- Mosquitto: Aplicación que implementa el protocolo MQTT para la intercomunicación entre el GE IDAS y las Rpi.

Finalmente, en esta experiencia los estudiantes después de su instalación, deben configurar los diferentes módulos con sus correspondientes contenedores y lanzar los servicios necesarios para el correcto funcionamiento de la aplicación diseñada.

\subsection{Resultados de la encuesta a los estudiantes}

Con el objetivo de analizar la percepción que los estudiantes han tenido sobre las experiencias planteadas en las asignaturas de comunicaciones en redes en el GIT y MITUV, se les ha planteado una pequeña encuesta diseñada 'ad-hoc' para recoger las valoraciones que pretendemos analizar en el proyecto.

Dentro de este pequeño estudio, se les preguntó a los estudiantes 3 preguntas a las que contestaron después de la sesión de práctica sobre IoT. La tabla 1 muestra los resultados 
- Q1: Antes de esta sesión, ¿habías experimentado con tecnologías IoT?

- Q2: ¿En qué grado valoras (de 1 -muy poco- a 5 -mucho-) la introducción de experimentalidad en las asignaturas de comunicaciones?

- Q3: ¿En qué grado consideras positiva (de 1 -muy poco- a 5 -mucho-) la experiencia realizada respecto a su implicación industrial y social?

En la figura 4 se puede ver un momento de la realización de la práctica guiada por los estudiantes que han redactado y llevado a cabo el desarrollo de la práctica, haciendo una actividad dinámica y trabajo colaborativo en grupo.

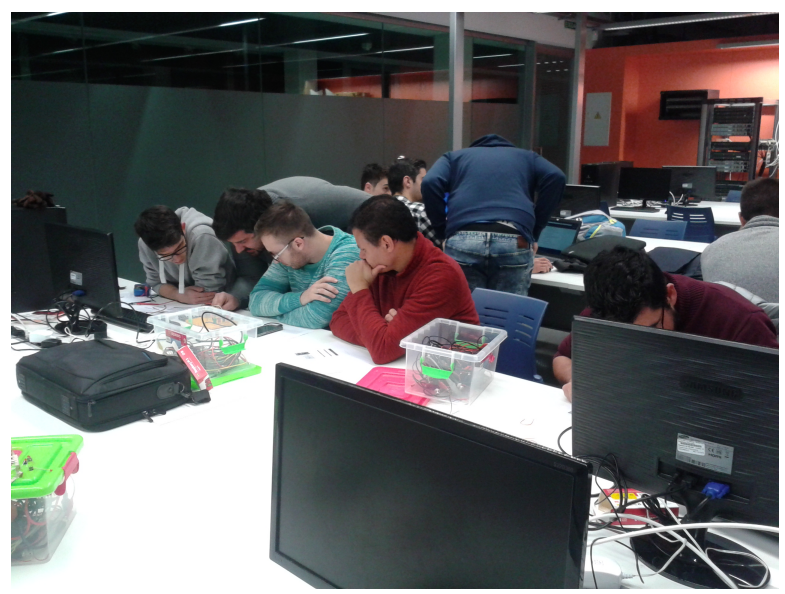

Fig. 4: Fotografía de la experiencia en la asignatura de GIT

Tabla 1: Respuestas de los estudiantes

\begin{tabular}{|l|l|l|}
\hline & Porcentaje positivo ( \%) & Promedio de valoración \\
\hline Q1 & $58 \%$ & - \\
\hline Q2 & - & 4.5 \\
\hline Q3 & - & 4.8 \\
\hline
\end{tabular}

\section{Conclusiones}

En este artículo se presenta el trabajo realizado en colaboración con algunos estudiantes en relación a la introducción de conceptos y experiencias relacionados con IoT en el ámbito de las asignaturas de Redes Avanzadas I de GIT y Redes de Comunicaciones Móviles de MITUV.

Las experiencias diseñadas y desarrolladas combinan todas las fases de un sistema IoT. A nivel de grado se trabaja más la parte hardware y se utiliza una plataforma propietaria como ThingSpeak y por tanto se da más importancia a la fase sensora, de comunicación y enrutamiento de la información. Por otro lado, a nivel de máster se trabaja más la parte de recolección y tratamiento de esa información por parte del back-end. 
En la encuesta a los estudiantes, se evidencia que la apreciación global ha sido muy positiva en lo que respecta a la introducción de conceptos innovadores que la industria y la sociedad reclaman con un alto grado de experimentalidad en estas asignaturas.

\section{Agradecimientos}

Los autores quieren agradecer al Servei de Formació Permanent i Innovació Educativa - Centre de Formació i Qualitat "Manuel Sanchis Guarner" de la Universitat de València por la ayuda concedida para el soporte parcial de este proyecto de innovación docente (ref: UV-SFPIE RMD17-587626).

\section{Referencias bibliográficas}

Anderson, Jonathan O., Josef G. Thundiyil y Andrew Stolbach (2012). "Clearing the Air: A Review of the Effects of Particulate Matter Air Pollution on Human Health". En: Journal of Medical Toxicology 8.2, págs. 166-175. ISSN: 1937-6995. DOI: $10.1007 / \mathrm{s} 13181-011-0203-1$.

Catalán Cantero, Carlos y Alfonso Blesa Gascón (2016). "Enseñanza de sistemas empotrados: de Arduino a Raspberry Pi". En: Actas de las XXII JENUI. Universidad de Almería, págs. 351-354.

Donelkys Santana Medina, Mariano Isla Guerra y Manuel Ramírez Pírez y (2016). "El internet de las cosas en contextos universitarios: realidad y retos". En: Congreso Universidad. ISSN: 2306-918X.

FIWARE, Foundation (2018). FIWARE Developer website. [Online]. https://www . fiware.org/developers/.

Martínez, Francisco Manuel Delicado (2015). "Una incursión docente en el mundo de la "Internet of Things"". En: Experiencias Docentes en Redes de Computadores 1.1.

Meer, E. van der y col. (2011). Human Perception of Urban Environment and Consequences for its Design. Springer, págs. 305-331.

Raspberry Pi, Foundation (2017). «Raspberry Pi 3 Model B,»1 Febrero 2016. [Online]. https://www .raspberrypi .org/products/raspberry-pi-3-model-b/.

Wang, Feng y col. (2015). "Software Toolkits: Practical Aspects of the Internet of Things-A Survey". En: International Journal of Distributed Sensor Networks 11.9, pág. 534378. DOI: 10.1155/2015/534378.

WHO (2011). Burden of Disease From Environmental Noise-Quantification of Healthy Life Years Lost in Europe. [Online]. http : / / www . who . int/ quantifying _ ehimpacts/publications/e94888.pdf?ua=1 (accessed on 18 February 2018). 


\title{
Aplicación del modelo de clase inversa en el campo de la Ingeniería Térmica: análisis y comparación de varios contextos ${ }^{1}$
}

\author{
Begoña Peña ${ }^{a}$, I. Zabalza ${ }^{b}$, E. Llera ${ }^{c}$, S. Usón ${ }^{d}$, L.M. Romeo
}

Universidad de Zaragoza - Departamento de Ingeniería Mecánica (España)

abpp@unizar.es, bizabal@unizar.es, ellera@unizar.es, ${ }^{\mathrm{d}}$ suson@unizar.es, ${ }^{\mathrm{e}}$ luismi@unizar.es.

\begin{abstract}
The flipped classroom model (FCM) presents many advantages with respect to the traditional model, as the students play a leading role in attendance sessions increasing their motivation and satisfaction, active methodologies and Information and Communication Technologies (ICT) are naturally integrated into the learning process, and certain transverse competencies can be developed and evaluated in the classroom.

Motivated by these advantages, the authors have carried out various experiences in FCM during the last two academic courses in the context of Thermal Engineering at the University of Zaragoza (Spain). Under the framework of two projects financed by the Program for Promoting Teaching Innovation (PIIDUZ_16_032 and PIIDUZ_17_299), different methodologies and resources have been implemented for in-class and home activities.

The observations and results of these experiences in different subjects and academic levels are here analyzed and compared with respect to various criteria. In all cases, the reception from the students was very positive, but the influence on the learning process depends in large extent on the use that students make of the materials provided by the teacher. Some aspects to this respect are discussed in the paper.
\end{abstract}

Keywords: Moodle, Educational Videos, Flipped Classroom, University Innovation, Engineering Education.

\section{Resumen}

El modelo de clase inversa (FCM) presenta muchas ventajas con respecto al modelo tradicional, ya que los estudiantes desempeñan un papel principal en las sesiones presenciales aumentando esto su motivación y satisfacción, las metodologías activas y las Tecnologías de la Información y la Comunicación (TIC) se integran naturalmente en el proceso de aprendizaje, y ciertas competencias transversales pueden ser desarrolladas y evaluadas en el aula.

Motivados por estas ventajas, los autores han llevado a cabo varias experiencias en FCM durante los dos últimos cursos académicos en el contexto de la Ingeniería Térmica en la Universidad de Zaragoza (España).

\footnotetext{
${ }^{1}$ Este trabajo se ha desarrollado dentro de los proyectos de innovación docente PIIDUZ_17_299 y PRAUZ_17_002 (Programa de Proyectos de Innovación Docente para Grupos de Profesores del Vicerrectorado de Política Académica de la Universidad de Zaragoza).
} 
Uso de recursos y rendimiento en las actividades evaluación: análisis y comparación de resultados en el Grado en Ingeniería de Tecnologías Industriales

En el marco de dos proyectos financiados por el Programa de Incentivación de la Innovación Docente (PIIDUZ_16_032 y PIIDUZ_17_299), se implementaron diferentes metodologías y recursos para las actividades a realizar dentro y fuera del aula.

Las observaciones y los resultados de estas experiencias en diferentes materias y niveles académicos se analizan aquí y se comparan con respecto a varios criterios. En todos los casos, la recepción de los estudiantes fue muy positiva, pero la influencia en el proceso de aprendizaje depende en gran medida del uso que los estudiantes hacen de los materiales proporcionados por el profesor. Algunas cuestiones a este respecto se discuten en el presente documento.

Palabras clave: Moodle, Vídeos Didácticos, Clase Inversa, Innovación Universitaria, Educación en Ingeniería.

\section{Introducción}

El Espacio Europeo de Educación Superior (EEES) y los nuevos retos planteados por la sociedad actual están impulsando una profunda revisión de los modelos de enseñanzaaprendizaje y supondrán en el futuro un cambio sustancial en los roles que juegan profesor y alumno. En este sentido, el modelo pedagógico conocido como clase inversa (flipped classroom model, FCM) presenta muchas ventajas (Bergmann 2012) frente al modelo tradicional de clase centrada en la transferencia de información del profesor al alumno (Figura 1).

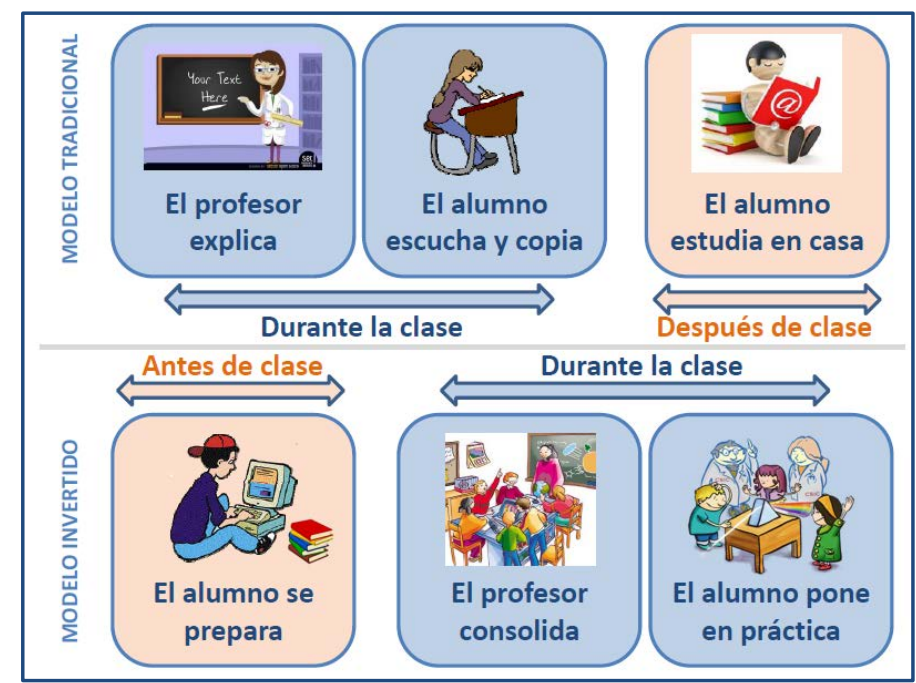

Fig.1 Comparación de la distribución de actividades en el modelo tradición y el modelo de clase inversa (elaboración propia, (Varios, 2018))

(cc) EY-NC-ND 2018, Universitat Politècnica de València

Congreso IN-RED (2018) 
Por un lado, el modelo FCM permite implantar en el aula metodologías activas, como el aprendizaje basado en problemas, la simulación, los debates o la metodología del puzzle, que han demostrado ser muy eficaces para conseguir un aprendizaje profundo.

Estas metodologías estimulan los niveles superiores de razonamiento de la taxonomía de Bloom (Anderson, 2001) que tan necesarios son para los titulados universitarios, pero requieren un tiempo en el aula que con el modelo tradicional no está disponible. Bajo el modelo de clase inversa, la transferencia de información que ocuparía prácticamente todo el tiempo en la clase magistral se traslada mediante diversos recursos a un momento previo en el que el alumno prepara la clase. De esta forma, aunque el profesor explique ciertos conceptos y resuelva dudas durante la clase, quedará tiempo suficiente para que los alumnos practiquen lo que han aprendido con metodologías, actividades y recursos que serán seleccionados por el profesor en función de cada materia y del nivel académico.

En este entorno, las TIC se integran de manera natural en el proceso de aprendizaje, contribuyendo a una mayor participación del alumnado, a través de herramientas como Kahoot! o Socrative. En la clase tradicional, los alumnos suelen mostrarse poco participativos, especialmente si el grupo es numeroso, incluso cuando el profesor dinamiza la clase con preguntas o ejercicios. Si la clase no se centra en las explicaciones del profesor, el alumno se siente más relajado para plantear sus dudas, responder a preguntas o discutir sobre la materia estudiada.

Además, el modelo FCM favorece el desarrollo y facilita la evaluación de competencias trasversales, como el trabajo en grupo, la autonomía o aprender a aprender, que tan buscadas son por los empleadores entre los titulados universitarios. Todo esto hace que el alumno cobre protagonismo en las clases presenciales, aumentando su grado de motivación y de satisfacción y permitiendo una mejor gestión de la diversidad por parte del profesor (Figura 2).

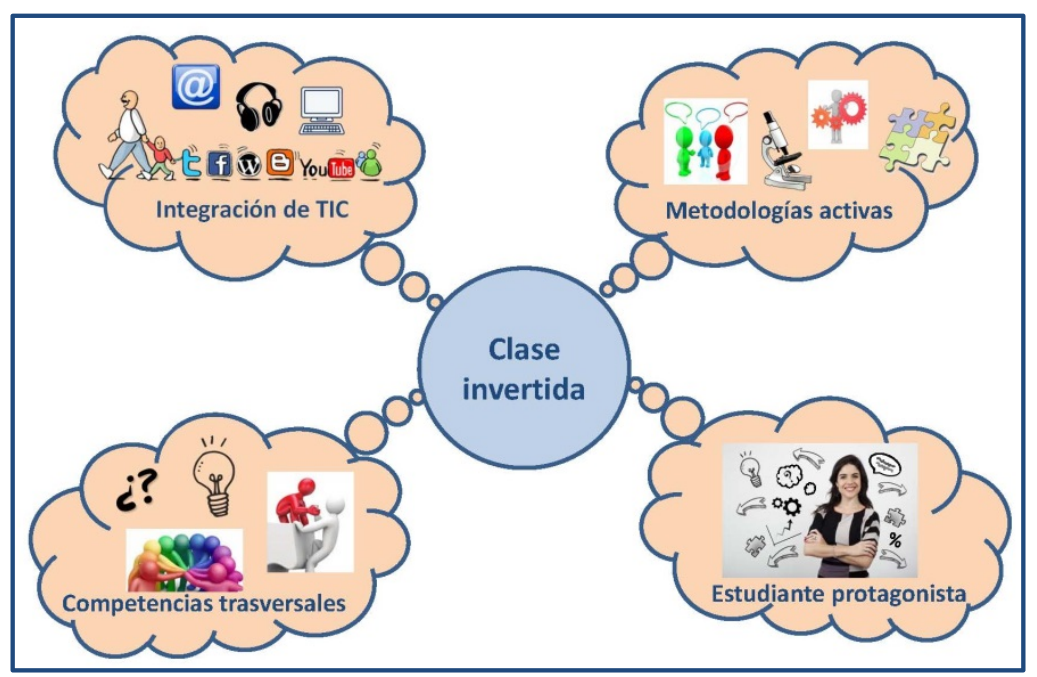

Fig.2 Ventajas del modedo de clase inversa (elaboración propia, (Varios, 2018)). 
De acuerdo con esto, el rol del profesor cambia, pero sigue siendo esencial en el aprendizaje del estudiante para seleccionar los recursos y metodologías de trabajo, para planificar, guiar y servir de apoyo en las actividades de aprendizaje y para evaluar tanto los resultados alcanzados por el estudiante, como el éxito del proceso en sí (Tourón, 2015).

Este modelo se ha ido adoptando primero en las escuelas de Primaria y Secundaria, para más recientemente llegar a la Universidad. El modelo de clase inversa se está implantando en los mejores centros de enseñanza del mundo, como el Shireland Collegiate Academy (Inglaterra), la Universidad de Harvard o el Instituto Tecnológico de Massachusetts (MIT). En España, la Universidad Politécnica de Valencia es pionera en dos líneas de trabajo: implantar el modelo de clase inversa en cursos completos de varias titulaciones y en desarrollar un procedimiento a nivel institucional para la evaluación de las competencias trasversales y su inclusión en el expediente académico de cada estudiante (UPV, 2017). El trabajo que aquí se presenta pretende sumarse a estas iniciativas con el objetivo fundamental de aprovechar al máximo el tiempo que alumno pasa en clase y en última instancia mejorar los resultados de aprendizaje y la adquisición de competencias.

La idea nace de la experiencia docente de los autores en varias titulaciones impartidas en la Escuela de Ingeniería y Arquitectura (EINA) de la Universidad de Zaragoza y de la demanda continua por parte de los alumnos de hacer las clases más participativas y sobre todo más prácticas. Adicionalmente, el tiempo dedicado a ciertas materias del área de Máquinas y Motores Térmicos se ha visto reducido en los nuevos planes de estudio, sin que hayan cambiado las competencias que deben adquirir los alumnos. Ante este reto, es preciso aprovechar al máximo el tiempo en el aula y se ha apostado por el modelo de clase inversa en el marco de dos proyectos financiados por el Programa de Incentivación de la Innovación Docente (PIIDUZ_16_032 y PIIDUZ_17_299).

En este trabajo se recogen las metodologías, las observaciones y los resultados de varias experiencias en diferentes materias y niveles académicos y se comparan con respecto a varios criterios. Finalmente, se extraen los aspectos positivos y aquellos en los que se puede mejorar o en los que se deben implementar acciones correctivas para superar los problemas detectados hasta ahora.

\section{Objetivos}

El objetivo de este trabajo es comparar las experiencias que han desarrollado los autores sobre FCM en los dos últimos cursos en diferentes asignaturas y titulaciones, con el fin de difundir las prácticas que han resultado positivas para que se puedan repetir en otros ámbitos. También se recogen los problemas encontrados en algunos casos para su implantación y sugerencias para mejorar su eficacia, de manera que nuestra experiencia sirva a otros profesores para el diseño de sus propias materias.

Los objetivos específicos de este trabajo son:

- Recopilar los datos de las diversas experiencias: observaciones, encuestas.

- Comparar experiencias enfocadas al mismo tipo de clase: magistral o prácticas.

(cc) EY-NC-ND 2018, Universitat Politècnica de València

Congreso IN-RED (2018) 
- Comparar la información en base a dos criterios: nivel de estudios (grado/máster) y perfil profesional de la titulación (mecánico, químico, industrial).

- Recopilar las buenas prácticas, los problemas encontrados y estrategias propuestas para mejorar en el futuro.

\section{Desarrollo de la innovación}

El presente estudio se ha llevado a cabo con alumnos de diferentes titulaciones impartidas en la EINA (Universidad de Zaragoza). Las asignaturas se han elegido en base a la experiencia previa de los profesores, tanto en aula invertida como en la impartición de las propias asignaturas. Con respecto a la materia concreta en la que se aplicará el modelo de aula inversa, se ha tenido en cuenta que tenga un carácter esencialmente aplicado, que no entrañe conceptos complejos que dificulten el aprendizaje autónomo y la disponibilidad de materiales ya desarrollados propios y ajenos. En la Tabla 1 se resume la información básica de las experiencias en FCM analizadas en este documento.

Tabla 1. Datos generales de las experiencias en FCM.

\begin{tabular}{|c|c|c|c|c|}
\hline Asignatura & Matriculados & Horas & $\begin{array}{l}\text { Titulación } \\
\text { / Semestre }\end{array}$ & Curso \\
\hline Termodinámica Técnica y Fund. & 70 & 6 & CITI S & 2016-2017 \\
\hline Transmisión de Calor & 52 & 6 & Gl11 S3 & 2017-2018 \\
\hline Ingeniería Térmica & 51 & 5 & GITI S4 & 2016-2017 \\
\hline Termotecnia & 32 & 3 & GIQ S6 & 2016-2017 \\
\hline Máquinas y Motores Térmicos & 106 & 3 & GIM S6 & 2016-2017 \\
\hline $\begin{array}{l}\text { Eficiencia Energética en la } \\
\text { Edificación }\end{array}$ & 8 & 2 & MUERyEE & 2016-2017 \\
\hline
\end{tabular}

Todas las asignaturas son de 6 ECTS y obligatorias de grado, excepto la asignatura de Eficiencia Energética en la Edificación que es optativa de 5 ECTS en el Máster Universitario de Energías Renovables y Eficiencia Energética (MUERyEE). La nomenclatura utilizada en la tabla para los diferentes grados es la siguiente: GITI - Grado en Ingeniería de Tecnologías Industriales, GIQ - Grado en Ingeniería Química, GIM Grado en Ingeniería Mecánica. En los siguientes epígrafes se describe brevemente la metodología de trabajo seguida en cada asignatura.

\subsection{Termodinámica Técnica y Fundamentos de Transmisión de Calor}

Esta asignatura es la base de todas las asignaturas posteriores de la rama energética y, por lo tanto, esencial para la titulación. La metodología seguida se ha adaptado a cada lección particular. El modelo FCM se ha aplicado principalmente en la lección completa que corresponde a los procedimientos para el cálculo de propiedades de sustancias puras y en ciertas sesiones de los temas de ciclos termodinámicos, por ser temas esenciales para la 
asignatura y además disponer de videos explicativos suficientes que se proporcionan para cada sesión junto con otros materiales a través de Moodle (Peña, 2017-2018). Las sesiones presenciales se dedican a resolver dudas y problemas en pequeños grupos.

En las prácticas también se ha seguido este modelo con el fin de solventar el desfase que hay con respecto a las clases de teoría: a través de Moodle se proporcionan con antelación una serie de materiales (guion, apuntes, videos) para que el estudiante prepare la práctica y resuelve un cuestionario que entrega antes de la práctica. En la sesión, el profesor realiza un breve resumen, resuelve las dudas y deja el resto del tiempo para que los estudiantes por parejas reuelvan un problema más complejo, cuyos resultados entregan al final de la sesión.

Para completar la experiencia en FCM se realizan encuestas antes y después para valorar el nivel de satisfacción de los estudiantes.

\subsection{Ingeniería Térmica}

Esta asignatura se imparte también en el segundo curso pero en el semestre siguiente a la asignatura explicada en el punto anterior. Los contenidos son esencialmente complementarios, aunque ciertas definiciones y conceptos son los explicados en la asignatura de Termodinámica Técnica. El grupo es el mismo y, por lo tanto, salvo repetidores los alumnos son los mismos. Dadas las fechas de la presente publicación, sólo se dispone de la información correspondiente al curso 2016-2017.

Para la implementación de FCM se eligió el tema de Intercambiadores de Calor, por ser un tema eminentemente de práctico. Con antelación, se desarrollaron los videos necesarios y se distribuyeron a través de Moodle, junto con bibliografía para preparar cada una de las sesiones. Una vez en el aula, se realiza un repaso general del contenido de los videos y se remarcan las ideas más importantes. Tras resolver las dudas, los estudiantes resuelven diversas cuestiones y problemas.

\subsection{Termotecnia}

La asignatura de Termotecnia (semestre S6) es continuación natural de la asignatura de Termodinámica Técnica y Fundamentos de Transmisión de Calor (semestre S4), en la que se explican los mecanismos básicos y se realiza una introducción a la conducción del calor. Para la experiencia en FCM, se ha seleccionado el tema de Conducción en Problemas Unidimensionales, que es un tema ya estudiado en una asignatura previa al que se le puede dedicar poco tiempo, pero que, en general, los alumnos no recuerdan.

Con antelación suficiente, se informa a los estudiantes de cómo y cuándo se realizará la actividad y se cuelgan en Moodle los recursos necesarios para que el estudiante repase la materia correspondiente (apuntes y ejemplos resueltos). El día de la sesión presencial, se realiza un breve repaso, se resuelven dudas y a continuación se plantean dos problemas para consolidar el aprendizaje. Al final de la sesión se ponen en común las soluciones.

(cc) EY-NC-ND 2018, Universitat Politècnica de València

Congreso IN-RED (2018) 


\subsection{Máquinas y Motores Térmicos}

Esta asignatura de tercer curso (semestre S6) cierra las materias obligatorias de la rama de energía en el Grado de Ingeniería Mecánica, tras dos asignaturas básicas en las que se estudia Termodinámica Técnica (S2) y Transferencia de Calor (S5). El modelo FCM se ha aplicado a una práctica de simulación sobre Ciclos de Turbina de Vapor, con el programa Engineering Equation Solver (EES).

Parte de sus contenidos deberían ser conocidos por el alumno, pero se sabe de cursos anteriores que no los tienen bien asimilados o los han olvidado debido el tiempo transcurrido desde su impartición (S2). Por ello, con varias semanas de antelación, se pone a disposición del estudiante el material necesario: guion, video específico de ciclos de turbina de vapor y un archivo EES con el modelo semiresuelto. Durante la primera hora de la sesión se repasan los aspectos clave, se plantean preguntas para comprobar que se han cubierto los objetivos tras ver el video y se resuelven las dudas que hayan surgido. En las siguientes dos horas el estudiante completa el modelo con ayuda del profesor y entrega el informe de resultados al finalizar la práctica.

\subsection{Eficiencia Energética en la Edificación}

Esta asignatura constituye la única experiencia realizada en estudios de Máster y en una asignatura optativa. A la diferencia existente en el nivel académico y en la motivación con respecto las experiencias anteriores, hay que añadir que el número de alumnos matriculados es mucho menor. Todo esto plantea una situación a priori muy diferente.

El tema seleccionado ha sido la Arquitectura bioclimática y estrategias pasivas de ahorro energético en edificios. Para la preparación de la materia se les proporciona documentación en formato texto vía Moodle y bibliografía específica. En clase se plantea un cuestionario con más de 20 preguntas para evaluar el aprendizaje sobre el tema y para abrir una discusión entre los alumnos sobre temas concretos, que resuelva dudas que a priori no se habían planteado. En principio, cada pregunta se asigna a un estudiante concreto, para después dar el turno a los demás con la moderación del profesor.

$\mathrm{Al}$ final de la clase, se realizan dos encuestas para conocer su opinión sobre las clases universitarias y sobre su satisfacción con respecto al modelo FCM.

\section{Resultados}

Con el fin de documentar las observaciones de los profesores de una forma sistemática, se han desarrollado dos formularios: uno en el que registrar la información específica de cada sesión (Figura 3) y otro en el que se resumen las observaciones generales de la experiencia y la metodología seguida en la misma (Figura 4). Se trata de primeras versiones que se irán completando en función de las deficiencias observadas o de que se planteen nuevos estudios comparativos. 


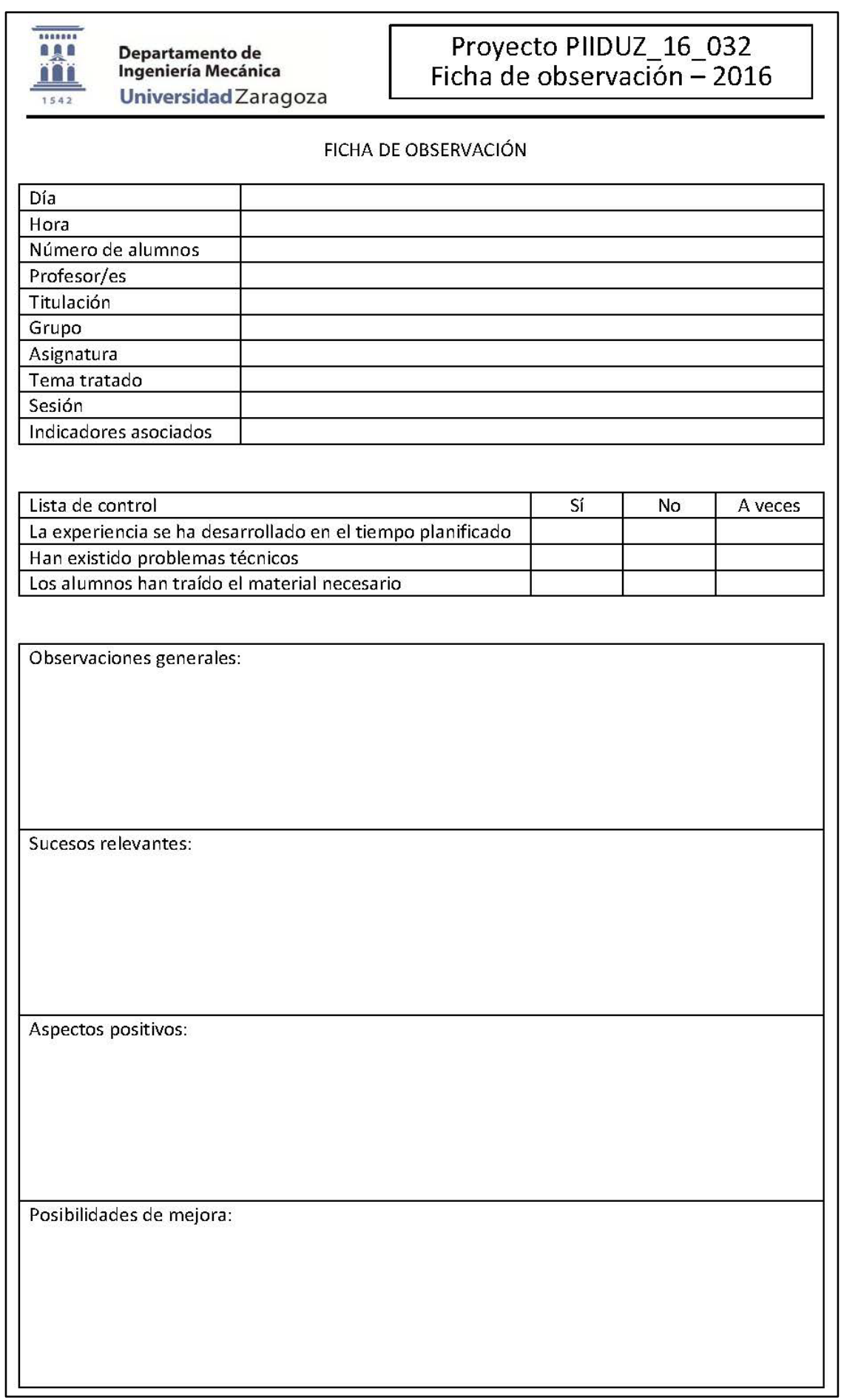

Fig.3 Ficha de observación a completar por el profesor en cada sesión de FCM.

(cc) EY-NC-ND 2018, Universitat Politècnica de València

Congreso IN-RED (2018) 


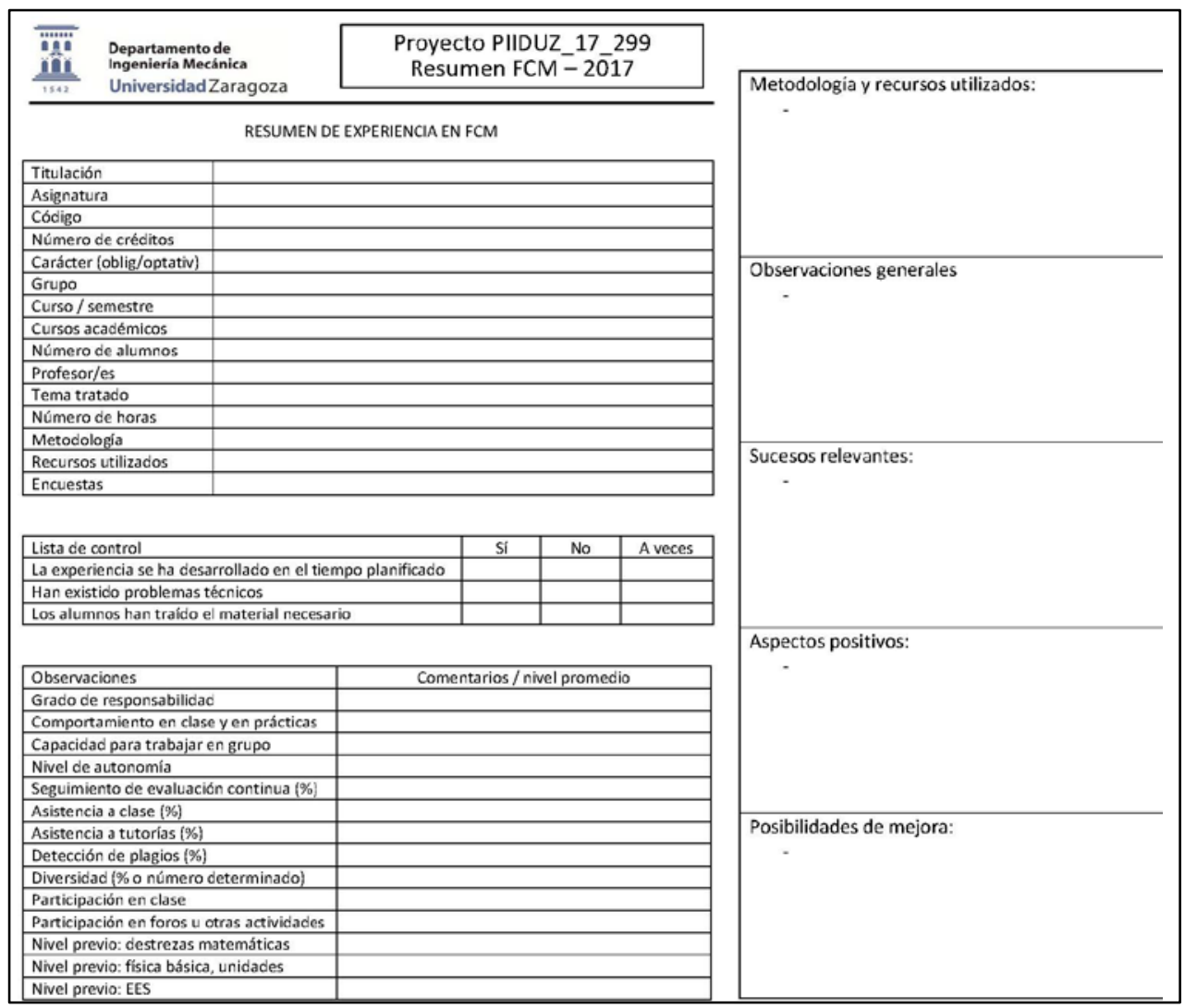

Fig.4 Plantilla a completar por cada experiencia en FCM a modo de resumen.

Asimismo se han desarrollado dos encuestas para los estudiantes: una sobre su experiencia personal sobre los modelos y metodologías utilizados en las clases universitarias y otra especifica de la experiencia en FCM, con el fin de evaluar su grado de satisfacción (Peña, 2017). Además, la evaluación de cada video docente se ha realizado a través de una encuesta breve de Moodle con sólo cinco preguntas (escala de Likert) para promover la participación (Zabalza, 2017-2018). La comparativa que se presenta en los siguientes apartados se ha realizado en base a la información recogida en esos formularios y encuestas.

\subsection{Experiencias orientadas a las sesiones de prácticas}

Uno de los problemas abordados mediante el modelo de clase inversa ha sido la desincronización temporal entre las clases magistrales y las prácticas de laboratorio, que en muchas ocasiones no se puede evitar por la rigidez del calendario oficial. Como se ha explicado en los epígrafes 2.1 y 2.4, se ha aplicado una metodología similar en las asignaturas de Termodinámica Técnica (TT) y de Máquinas y Motores Térmicos (MMT): proporcionar materiales (textos, videos) con antelación para preparar la práctica, reducir el tiempo dedicado a la explicación y dejar más tiempo para que el alumno resuelva el caso planteado. En TT se ha aplicado este modelo durante los tres últimos cursos académicos, mientras que en MMT sólo se dispone de los datos del curso 2016-2017.

(c) ) EY-NC-ND 2018, Universitat Politècnica de València 
Para los cursos 2015-2016 y 2016-2017, en ambas asignaturas se comprueba en Moodle que sólo alrededor del $50 \%$ de los alumnos había visto el video con antelación y de hecho en GIM se detectó que algunos estudiantes estaban viendo el video durante la sesión. Además, pocos alumnos responden correctamente a las preguntas de control que el profesor hace mientras repasa los conceptos más importantes, lo que demuestra que los alumnos dedican poco (o nada) de tiempo a preparar la práctica.

En MMT se ha propuesto preparar un cuestionario evaluable previo para incertivar el trabajo previo. Sin embargo, esta medida no ha resultado efectiva en la asignatura de TT, en la cual, habiéndose detectado este problema en cursos anteriores, se vienen utilizando cuestionarios desde el inicio del grado en 2011. Hasta el presente curso se entregaban en papel y no tenían un peso definido en la nota final. Ahora se han implementado en Moodle y cuentan 1 punto de la nota de prácticas. La proporción de alumnos que ha visto el video ha subido hasta el $60 \%$ y la nota de esos cuestionarios ha mejorado desde una media de 7 hasta una media de 9 puntos. Sin embargo, no se ha observado una mejora significativa en la preparación de los estudiantes para resolver el problema de simulación. Por tanto, el aumento podría deberse a una mayor facilidad para ‘copiar’ y no a un mayor interés.

Por esta razón, se está planteando la posibilidad de que resuelvan un cuestionario de autoevaluación sobre el video asociado a cada práctica, bien integrado en el propio video, bien en Moodle, y que el cuestionario de evaluación se realice durante los primeros 10 minutos de la sesión y sea obligatorio alcanzar una nota mínima para poder realizar la práctica. En caso de no superarse, el estudiante debería volver otro día para una sesión específica de recuperación.

En ambas asignaturas se ha observado que los alumnos, en general, tienen poca iniciativa, baja capacidad de reflexión y poca autonomía para abordar problemas nuevos. Esto creemos que se debe a que el modelo tradicional de enseñanza-aprendizaje no favorece estas competencias. Por esta razón, se está tratando de implementar FCM en estas mismas asignaturas también en las clases magistrales. Sin embargo, el problema trasciende a toda la titulación y deberían adoptarse medidas globales para atajarlo.

\subsection{Experiencias orientadas a las sesiones magistrales}

Aquí se van a comparar las observaciones en dos asignaturas para el mismo curso y grupo del grado GITI (Termodinámica Técnica e Ingeniería Térmica) y la asignatura de Termotecnia en GIQ. En los tres casos se ha seguido un procedimiento similar: proporcionar videos y textos para preparar la materia, resolver dudas al comienzo de la clase y dejar que los alumnos resuelvan varios ejercicios en grupo y con ayuda del profesor.

En todos los casos, la mayor cercanía del profesor favorece la interacción y que los alumnos planteen abiertamente sus dudas. Tanto es así que hay muchos momentos en que varios alumnos tienen que esperar su turno. Se planteó ya el curso pasado la conveniencia de que haya apoyo de un segundo profesor en el aula y esto se ha aplicado durante el presente curso en TT, siendo una solución que ha tenido buena acogida entre los estudiantes.

(cc) EY-NC-ND 2018, Universitat Politècnica de València 
En todos los casos, se considera que los objetivos mínimos de aprendizaje se han cumplido, pero también es cierto que a la mayoría de los estudiantes no les da tiempo de completar las tareas encomendadas para cada clase, especialmente en las primeras sesiones en que están menos habituados. Por esta razón, es muy importante que el profesor planifique cuidadosamente las tareas que el alumno debe abordar y las priorice guiando a los alumnos hacia los apartados más importantes, dejando para casa lo que es de repaso o repetitivo.

\subsection{Diferencias entre grados de distinto perfil profesional}

El comportamiento ha sido diferente entre grados. En GITI, un buen número de alumnos no ha traído el material necesario el primer día y tardan bastante en ponerse a trabajar en la primera sesión. Esta actitud cambia en las siguientes sesiones que son mucho más provechosas, con buen ambiente de trabajo y con un porcentaje de alumnos pasivos que va decreciendo progresivamente. En Ingeniería Térmica, incluso se observó un aumento de la asistencia desde un $60 \%$ hasta casi un $90 \%$. Como se ha explicado antes, por tratarse del mismo grupo de alumnos que para Termodinámica Técnica, la mayoría conocían el procedimiento de la clase inversa y han podido estar más motivados para asistir.

Se han observado diferencias reseñables en la actitud de los estudiantes con respecto a Termotencia de GIM. En este grupo, parecen tener un mayor grado de responsabilidad y compromiso. La gran mayoría viene a las sesiones de FCM con los materiales necesarios y se ponen a trabajar de manera inmediata. Lo más llamativo es que, en general, prefieren trabajar de forma individual y contrastar con el profesor o con sus compañeros los resultados finales. Hay que destacar que en el grado GIQ existe una proporción del 45\% de estudiantes de género femenino frente al $20 \%$ de GITI. Consideramos que sería interesante analizar la influencia de este hecho en los hábitos y actitudes de los alumnos desde un punto de vista global a nivel universitario.

\subsection{Comparativa entre diferentes niveles educativos}

Como se recoge en la Tabla 1, sólo se ha realizado una experiencia de FCM en máster y, además, ésta corresponde al único caso en que la asignatura es optativa y el grupo es mucho menos numeroso que para las asignaturas de grado. En general, se observa un mayor grado de responsabilidad y de motivación y una mejor preparación académica para abordar la asignatura. Esto se debe, obviamente, a un mayor grado de madurez y al hecho de ser una asignatura no obligatoria, cuya matrícula indica interés en la materia.

La metodología seguida para la preparación de las clases es similar a la usada en las asignaturas de grado: dejar documentación y bibliografía específica en la plataforma Moodle. Por el contrario, se realiza una actividad diferente en la clase presencial: un cuestionario de más de 20 preguntas clave obliga a que los alumnos razonen y expliquen la respuesta a los compañeros. Además, el carácter abierto de la respuesta de algunas de las preguntas da pie a que se realice un pequeño debate sobre las mejores soluciones en cada caso.

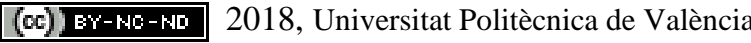

Congreso In-Red (2018) 
A pesar de todas estas diferencias, la actitud de los alumnos no difiere demasiado de la observada en los grados. La mayoría de los estudiantes responden a las preguntas más en base al sentido común y a conocimientos de asignaturas básicas, que razonando con argumentos específicos de la materia que deberían haber preparado con los recursos proporcionados para la sesión. De nuevo, se observa que, aunque la participación en el debate es alta y tratan de responder correctamente y de comprender las explicaciones a cada pregunta, los estudiantes dedican poco esfuerzo a preparar las clases como ocurre también en los grados.

Con respecto a su opinión sobre este tipo de modelo pedagógico y a las clases universitarias en general, se obtienen curiosamente resultados muy parecidos a los obtenidos en el grado GITI (Peña, 2017). La mayor demanda es la misma: que las clases sean más prácticas y que el profesor resuelva más problemas. En ambos estudios consideran que el modelo tradicional se sigue en más de un $80 \%$ de las clases. El nivel de asistencia también ronda el $80 \%$ entre los encuestados, aunque hay que decir que solo alrededor del $75 \%$ de los matriculados en ambos casos estaba en el aula para hacer la encuesta. La mayor diferencia está en que más del $80 \%$ los alumnos encuestados del máster consideran que el grado de aprovechamiento en las clases tradicionales es alto o muy alto, frente al 27\% de GITI.

Con respecto a la experiencia en FCM las opiniones están repartidas en torno al 50\% entre el modelo tradicional y el aula invertida, tanto en grado como en máster. En cuanto a los materiales, un 50\% de los estudiantes de GITI consideraron los videos de gran utilidad frente al 20\% de los alumnos del máster. En cualquier caso, una buena proporción (35\% en GITI y $80 \%$ en MUERyEE) reconoce que, aunque los considera interesantes, no les ha dedicado mucho tiempo. En este sentido, parece necesario insistir en que es imprescindible estudiar esos materiales para aprovechar las horas presenciales y concentrarlos al máximo para que su extensión no desmotive al alumnado. Además, hay que tener en cuenta factores externos a la asignatura, tales como actividades de otras asignaturas y vacaciones o festividades, que lejos de motivar al estudio reducen la dedicación a este tipo de tareas.

En cuanto al grado de satisfacción con respecto al modelo FCM, fue alto o muy alto para el $30 \%$ de GITI y para el 65\% de MUERyEE. Sin embargo, el grado de aprovechamiento en opinión de los estudiantes fue alto o muy alto para un 50\% en GITI, mientras que sólo lo fue para el 20\% de los estudiantes de MUERyEE. Esto puede deberse a que los alumnos no dedicaron el tiempo suficiente a los materiales colgados en Moodle, como así lo reconoce el $65 \%$ de los alumnos. En cualquier caso, será necesario investigar con mayor detalle el por qué de estos resultados en la asignatura de Eficiencia Energética para mejorar en los próximos cursos. 


\section{Conclusiones}

En este trabajo se han analizado y comparado cinco experiencias sobre clase inversa en diferentes asignaturas, titulaciones y niveles académicos. En todos los casos, el profesor considera que es un método eficaz, que habrá que seguir mejorando, y que en general ha tenido buena acogida por parte de los estudiantes. Las encuestas y las fichas de observación han demostrado ser herramientas necesarias para la evaluación del modelo pedagógico y para mejorar curso a curso.

Las principales conclusiones que se extraen de este estudio son las siguientes:

- Los materiales para preparar las clases deben ser muy específicos del tema a tratar, con una extensión lo más reducida posible para esto no desmotive al alumno. En este sentido, causa mejor imagen que estén desarrollados por el profesor y que no sean textos genéricos de la asignatura.

- También es motivador que entre los recursos proporcionados para preparar la práctica exista algún tipo de tarea en la que apliquen lo aprendido. Esto servirá de herramienta de control para que el profesor compruebe que han estudiado y para que el alumno se autoevalúe y vuelva sobre aquellos conceptos que no tiene claro.

- Aunque no debería ser tarea del profesor, parece ser muy importante recordar con cierta insistencia la necesidad de revisar los materiales antes de la sesión, ya que tanto en grado como en máster los alumnos han reconocido que no han dedicado suficiente tiempo.

- En grupos numerosos se ha constatado la necesidad de contar con dos profesores para atender las dudas de los alumnos, ya que la cercanía del profesor y la actividad práctica crean un ambiente abierto en el que los alumnos se hacen más preguntas y quieren resolver sus dudas.

- En su aplicación a las prácticas de laboratorio, convendrá que los alumnos resuelvan un cuestionario de autoevaluación sobre los recursos asociados a cada práctica y que se realice un cuestionario de evaluación durante los primeros minutos de la sesión en el que sea obligatorio alcanzar una nota mínima para poder realizar la práctica. En caso de no superarse, el estudiante debería volver otro día para realizar la práctica en una sesión específica de recuperación. Tenemos conocimiento de que este procedimiento se aplica con éxito en titulaciones del área científica y médica y pensamos que también resultará eficaz para aumentar el compromiso en nuestras asignaturas. 
Uso de recursos y rendimiento en las actividades evaluación: análisis y comparación de resultados en el Grado en Ingeniería de Tecnologías Industriales

\section{Referencias}

ANDERSON, L.W. et al. (2001). “A Taxonomy for Learning, Teaching, and Assessing: A revision of Bloom's Taxonomy of Educational Objectives”. New York: Pearson, Allyn \& Bacon.

BERGMANN, J. y SAMS, A. (2012) "Flip your classroom: Reach every student in every class every day”, Washington, DC: Internal Society for Technology in Education, 2012.

PEÑA, B. et al. (2017) "Experiencia piloto de aula invertida para mejorar el proceso de enseñanzaaprendizaje en la asignatura de Termodinámica Técnica”. En: Actas del congreso INRED 2017, Valencia, Editorial Universitat Politècnica de València. Doi: 10.4995/INRED2017.2017.6868. Disponible en: < http://ocs.editorial.upv.es/index.php/INRED/INRED2016/paper/view/4430>.

PEÑA, B. (2018) “Defining quantitative and automated rubrics from assessment activities scores” En: INTED18 Proceedings of the $12^{\text {th }}$ annual International Technology, Education and Development Conference, Valencia, IATED Academy, pp. Doi:

TOURÓN, J. y SANTIAGO, R. (2015). “El modelo Flipped Learning y el desarrollo del talento en la escuela”. Revista de Educación, n ${ }^{\circ}$ 368, p. 196-231.

UPV (2017). Flip Teaching. Universidad Politécnica de Valencia. https://www.upv.es/entidades/ETSINF/info/967104normalc.html [Consulta: 19 de enero 2017].

VARIOS (2018). Imágenes de diferentes fuentes: http://www.csicenlaescuela.csic.es/; http://clipground.com/image-post/59640-networking-clipart-11.jpg.html; https:/www.vexels.com; commons.wikimedia.org/wiki/File:Jigsaw.svg; www.flickr.com/photos/96737006@N04/9071059572, http://www.premioscortesdecadiz.es/jovenemprendedor/roberta-medina/. [Consulta 16 de mayo de 2018].

ZABALZA, I., PEÑA, B., LLERA, E.M. y USÓN, S. (2016) "Improving the teaching-learning process using educational videos as reusable learning objects in the field of thermal engineering", Proceedings of the $8^{\text {th }}$ International Conference on Education and New Learning Technologies (EDULEARN 2016), Barcelona, IATED Academy, pp. 363-372. Doi: 10.21125/edulearn.2016.1068.

ZABALZA, I., et al. (2017) "Development of educational videos as reusable learning objects for their integration into an Open Courseware on fundamentals of thermodynamics and thermal engineering", En: INTED17 Proceedings of the $11^{\text {th }}$ annual International Technology, Education and Development Conference, Valencia, IATED Academy, pp. 4453-4461. Doi: 10.21125/inted.2017.1055.

(c) EY-NC-ND 2018, Universitat Politècnica de València 


\title{
Focos de investigación sobre aprendizaje universitario en el área de dirección de operaciones
}

\author{
Juan A. Marin-Garcia ${ }^{a}$ \\ ${ }^{a}$ ROGLE Research Group (DOE Universitat Politècnica de València, jamarin@omp.upv.es)
}

\begin{abstract}
What are the topics that higher education professors of the area of operations management in Spain are researching about learning of their students in recent years? Are the approaches that support these investigations adequate?

We aim to collect and summarize the main works on learning research, carried out by members of ACEDEDOT and published in the last year (2017), identifying themes and focus on the type of student learning. With this we intend to create a map of the current situation and propose possible suggestions to build an evidence-based operations management teaching.
\end{abstract}

Keywords: scholarship; student learning; student engagement

\begin{abstract}
Resumen
En esa investigación analizamos cuales son los focos de investigación sobre aprendizaje de los profesores universitarios de dirección de operaciones españoles y reflexionamos sobre si las preguntas de investigación abordadas son las más adecuadas.

Nos centraremos en las investigaciones llevadas a cabo por las personas vinculadas a la asociación científica ACEDEDOT y publicadas en el año 2017. Identificaremos los temas y enfoques de aprendizaje abordados. Con ello pretendemos dibujar un mapa del estado actual de la investigación en el área y plantear sugerencias para hacer avanzar hacia una docencia universitaria de dirección de operaciones basada en evidencias.
\end{abstract}

Palabras clave: docencia basada en evidencias; aprendizaje de los estudiantes; implicación de los estudiantes en el aprendizaje.

\section{Introducción}

La docencia basada en la evidencia de qué es lo que mejor favorece el aprendizaje de nuestros alumnos (Burke-Smalley, 2014; Cascio, 2007; Morrell \& Learmonth, 2015) es una corriente de trabajo e investigación que poco a poco va ganando terreno y se relaciona con la base del movimiento creado bajo la etiqueta de scholarship (Boyer, 1990; Delbecq, 2007; Fernandez March, 2008; Pearce, 2007).

Todo esto se ha visto condicionado por la evolución del significado e implicaciones de los niveles de concepción docente (Biggs \& Tang, 2011 (1st edition 1999); Ramsden, 1992) y los enfoques de aprendizaje de los estudiantes (superficial, estratégico y profundo) (Marton et al., 2005; Paricio Royo, 2013; Paricio Royo \& Allueva Pinilla, 2011). Todos estos 
desarrollos clásicos en la pedagogía han estado marcando la metodología y enfoque de la investigación sobre aprendizaje de finales del siglo pasado y principio de este.

Sin embargo, ¿estamos aprovechando los docentes de Dirección de Operaciones estos desarrollos? ¿Qué estamos investigando en el último año los profesores universitarios del área en España? ¿̇Son adecuados los planteamientos que sustentan nuestras investigaciones?

Nuestra investigación pretende recoger y resumir los principales trabajos sobre investigación de aprendizaje, realizados por miembros de ACEDEDOT en el año 2017, identificando temáticas, métodos, niveles de concepción docente y enfoque sobre tipo de aprendizaje de los alumnos. Con ellos pretendemos crear un mapa de la situación actual y plantear posibles sugerencias para ir construyendo una docencia de dirección de operaciones basada en evidencias.

\section{Objetivos}

Identificar los focos de investigación sobre aprendizaje de los trabajos publicados, en revistas científicas revisadas por pares, por profesores de Dirección de Operaciones que imparten asignaturas universitarias en España (en grado o máster).

\section{Desarrollo de la innovación}

En este trabajo vamos a trabajar con dos dimensiones que nos permitirán identificar los focos de investigación (Figura 1). Por un lado, nos centraremos en el punto de vista del investigador/profesor y analizaremos el nivel de conceptualización docente que sustenta sus preguntas de investigación (Biggs \& Tang, 2011 (1st edition 1999); Ramsden, 1992). Como nivel 1 caracterizaremos las preguntas de investigación que intentan identificar el mejor método/recurso para lograr el aprendizaje de los alumnos. El nivel 2 agrupa las preguntas relacionadas con cómo enfocan el aprendizaje los alumnos. El nivel 3 centra sus preguntas en identificar, en contextos específicos, en qué consiste un buen aprendizaje y qué están aprendiendo los alumnos.

Por otro lado, una de las variables que mejor explica la variabilidad de los resultados o las conductas de los estudiantes son los enfoques de aprendizaje que presenta el alumno (Marton et al., 2005). Por ello, analizaremos cuales son los que están presentes, explícita o implícitamente en las investigaciones publicadas. Los enfoques de aprendizaje que eligen los estudiantes pueden clasificarse en tres (Coffey \& Gibbs, 2002; Gibbs \& Coffey, 2000; Marton et al., 2005; Paricio Royo, 2013; Paricio Royo \& Allueva Pinilla, 2011; Ramsden, 1992): superficial (almacenar información inconexa de manera rutinaria), estratégico (hacer las tareas o mostrar los comportamientos que son calificados favorablemente por el profesor, para obtener la máxima nota posible, con el mínimo esfuerzo necesario para ello) y profundo (implicarse apasionadamente en el aprendizaje dando sentido a los conceptos de la materia y vinculándolos al desarrollo personal). Las categorías de los enfoques de aprendizaje tienen una relación directa con las categorías en las que se pueden agrupar las concepciones del aprendizaje, las concepciones de la enseñanza o los resultados de aprendizaje. Por ejemplo, el enfoque estratégico suele exigir al alumno, en casi todas las

(cc) EY-NC-ND 2018, Universitat Politècnica de València

Congreso IN-RED (2018) 
asignaturas universitarias, que demuestre unas capacidades o que pueda aplicar un conocimiento en un contexto conocido (preguntas tipo de examen o ejercicios parecidos a los realizados en clase o ajustarse a lo que se muestra en las rúbricas de corrección), pero normalmente no van más allá de presentar una respuestas coherentes con escasas argumentaciones pues no han invertido tiempo en intentar comprender profundamente.

En principio, las investigaciones bajo cualquiera de los niveles de conceptualización pueden estar relacionadas con cualquiera de los enfoques de aprendizaje. Así, por ejemplo, una investigación de nivel 3 puede plantearse identificar cuáles son los resultados de aprendizaje de los estudiantes y si estos reproducen información (superficial) o son capaces de comprender (profundo). Del mismo modo una investigación de nivel 1 puede plantearse cuál es el mejor método para logra aprendizaje profundo en los alumnos.

En la investigación educativa se ha avanzado mucho en lo general y poco en lo específico. Es decir, hay mucho camino andado en los niveles 1 y 2 de conceptualización docente, pero es preciso seguir investigando en preguntas relacionadas con el nivel 3. Debemos intentar conocer los factores externos e internos que condicionan el aprendizaje de una materia en un contexto determinado. Para ello, es imprescindible el trabajo de los profesores investigando desde sus didácticas específicas (Fernandez March, 2008; Fernández March, 2010).

\begin{tabular}{|c|c|c|c|c|}
\hline $\begin{array}{l}\text { Nivel de } \\
\text { conceptualización } \\
\text { docente }\end{array}$ & $\begin{array}{l}\text { Enfoques de } \\
\text { aprendizaje }\end{array}$ & $\begin{array}{l}\text { Concepción } \\
\text { del } \\
\text { aprendizaje }\end{array}$ & $\begin{array}{l}\text { Concepción } \\
\text { de la } \\
\text { enseñanza }\end{array}$ & $\begin{array}{ll}\text { Resultados de } & \text { de } \\
\text { aprendizaje } & \end{array}$ \\
\hline $\begin{array}{l}\text { Nivel } 1 \\
\text { ¿Cómo enseño? } \\
\text { Centrado en la } \\
\text { docencia. ¿cuál es } \\
\text { el mejor método } \\
\text { para...? }\end{array}$ & Superficial & $\begin{array}{l}\text { Almacenar } \\
\text { información o } \\
\text { aumentar el } \\
\text { conocimiento } \\
\text { de forma } \\
\text { rutinaria }\end{array}$ & $\begin{array}{l}\text { Impartir } \\
\text { información / } \\
\text { Transmitir } \\
\text { conocimiento }\end{array}$ & $\begin{array}{l}\text { Listas } \\
\text { incoherentes de } \\
\text { información. } \\
\text { Descripciones } \\
\text { breves } \\
\text { reproducidas }\end{array}$ \\
\hline $\begin{array}{l}\text { Nivel } 2 \\
\text { ¿Cómo aprenden? } \\
\text { Centrado en el } \\
\text { estudiante ¿qué } \\
\text { hacen los } \\
\text { estudiantes o de } \\
\text { qué depende que } \\
\text { elijan un enfoque } \\
\text { de aprendizaje u } \\
\text { otro? }\end{array}$ & Estratégico & $\begin{array}{l}\text { Aplicar } \\
\text { conocimiento } \\
\text { y capacidades }\end{array}$ & $\begin{array}{l}\text { Dirigir el } \\
\text { aprendizaje } \\
\text { activo }\end{array}$ & $\begin{array}{ll}\text { Esbozo } & \text { de } \\
\text { respuestas } & \\
\text { coherentes } & \text { sin } \\
\text { argumentar } & \end{array}$ \\
\hline $\begin{array}{l}\text { Nivel } 3 \\
\text { ¿Qué aprenden? } \\
\text { Centrado en el } \\
\text { estudiante. ¿qué } \\
\text { significa } \\
\text { aprender/compren } \\
\text { der en el contexto } \\
\text { de mi asignatura y } \\
\text { cómo puedo } \\
\text { medirlo? }\end{array}$ & Profundo & $\begin{array}{l}\text { Dar sentido a } \\
\text { las ideas y } \\
\text { desarrollarse } \\
\text { personalment } \\
\text { e }\end{array}$ & $\begin{array}{lr}\text { Facilitar la } \\
\text { comprensión } \\
\text { profunda y } \\
\text { potenciar el } \\
\text { cambio } \\
\text { conceptual }\end{array}$ & $\begin{array}{l}\text { Explicaciones } \\
\text { completas } \\
\text { argumentadas. } \\
\text { Concepciones } \\
\text { individuales } \\
\text { sobre el tema. } \\
\text { Pensar como } \\
\text { piensan los } \\
\text { profesionales }\end{array}$ \\
\hline
\end{tabular}


Hemos seleccionado para el análisis sólo las publicaciones en revistas científicas arbitradas por pares. Los trabajos en congresos suelen adolecer de diseños metodológicos incompletos y mostrar planteamientos preliminares que, en caso de resultar interesantes, pueden ser enriquecidos con las opiniones recibidas en el congreso para convertirlos en envíos a revistas. Consideramos que los trabajos que han finalizado su recorrido académico en la fase de congreso y no se han llevado a revistas, son trabajos incompletos o intranscendentes o con escaso potencial y, por lo tanto, sus autores deciden no dedicar el esfuerzo necesario para elevarlos a una conversación académica de alto nivel (como la que puede propiciarse en el proceso de revisión y posterior divulgación en revistas científicas).

La disciplina académica de dirección de operaciones se enmarca (en España) en el campo científico de las Ciencias Empresariales. Las asignaturas de esta disciplina suelen estar presentes sólo en los grados o máster de Administración de empresas y en alguna de las ingenierías de la rama industrial (especialmente en el Grado en Ingeniero de Organización o el master ingeniero industrial). Quizás por ello, los profesores universitarios de una asignatura de dirección de operaciones suelen tener una formación básica de Administración de Empresas o de Ingeniería. En España hay dos asociaciones científicas en las que se suelen dar cita los profesores universitarios de Dirección de Operaciones. Por un lado, podemos señalar a ACEDEDOT, que es la sección de operaciones y tecnología de la asociación científica de economía y dirección de empresas (ACEDE). Por otro, la asociación para el desarrollo de la ingeniería de organización (ADINGOR). Aunque algunos profesores están presentes en ambas asociaciones, en general podemos considerar que, en ACEDEDOT, predominan los profesores con perfil más de administración de empresas y más vinculados a ciencias sociales (aunque también haya ingenieros o personas del área de investigación operativa); mientras que en ADINGOR hay más presencia de ingenieros.

Para este trabajo, seleccionaremos los artículos, relacionados con aprendizaje universitario, publicados en 2017 por profesores adscritos a ACEDEDOT (pudiendo extender en investigación futura a otros años recientes y a profesores adscritos a ADINGOR).

Hemos contactado por mail o personalmente con los profesores de la sección solicitándoles que nos envíen los trabajos publicados sobre investigación en aprendizaje. Los trabajos recibidos se han revisado para comprobar que cumplían los criterios para ser seleccionados en esta revisión (ver Tabla 1)

Tabla 1.- Criterios de inclusión y exclusión

\begin{tabular}{|l|l|}
\hline $\begin{array}{l}\text { Criterios } \\
\text { de } \\
\text { inclusión }\end{array}$ & $\begin{array}{l}\text { - Publicados en revistas científicas } \\
\text { - Durante el año } 2017 \\
\text { Investigación cuya contribución principal es sobre aprendizaje de estudiantes } \\
\text { universitarios }\end{array}$ \\
$\begin{array}{l}\text { Al menos uno de los autores pertenece a ACEDEDOT y sus líneas de } \\
\text { investigación y/o docencia son de dirección de operaciones }\end{array}$ \\
\hline $\begin{array}{l}\text { Criterios } \\
\text { de }\end{array}$ & $\begin{array}{l}\text { Contribuciones a congresos, tesis, entradas de blog u otro material no } \\
\text { publicado }\end{array}$ \\
\hline
\end{tabular}

(cc) EY-NC-ND 2018, Universitat Politècnica de València

Congreso IN-RED (2018) 


\begin{tabular}{|l|l|}
\hline exclusión & $\begin{array}{l}\text { Investigación sobre aspectos de dirección de operaciones cuya contribución } \\
\text { no es aprendizaje }\end{array}$ \\
& $\begin{array}{l}\text { La contribución no es aplicable a estudiantes universitarios (solo se centran en } \\
\text { profesionales) }\end{array}$
\end{tabular}

Cada uno de los trabajos seleccionados se ha codificado extrayendo la siguiente información:

- Área académica de cada uno de los autores: marcando como “dirección de operaciones” u “otros” en función de las principales publicaciones del autor, indexadas en Scopus o Web Of Science o Google Scholar, en los últimos 3 años ( 2014-2017)

- Preguntas de investigación que abordan en el artículo: las preguntas o contribución establecida explícitamente en el trabajo

- Para cada contribución o pregunta de investigación

o Nivel de conceptualización docente: nivel1, nivel2, nivel3, no definido

o Enfoques de aprendizaje: superficial, estratégico, profundo, no definido

- Información de contexto:

o Nivel académico donde se enmarca la contribución: $1^{\circ} / 2^{\circ}$ de grado, $3^{\circ} / 4^{\circ}$ de grado, máster, no definido

o Asignatura objeto de estudio: en el caso de ser una investigación centrada en una asignatura concreta

o Tamaño medio de grupo (alumnos matriculados por grupo): pequeño (menos de 20 alumnos); mediano (mas de 20 y menos de 60); grande (más de 60 alumnos); no definido

o Nombre de la titulación en la que se enmarca la/las asignaturas

o Universidad

El proceso de codificación y análisis ha sido realizado con la ayuda del programa Atlas.ti (Friese, 2012; Marin-Garcia, 2007)

\section{Resultados}

En los 22 trabajos analizados nos encontramos abundante desinformación para contextualizar las experiencias. Algunos trabajos (entre 4 y 6 según la variable a considerar) tienen un enfoque genérico y no se circunscriben a un contexto concreto (universidad, grado, asignatura, año de estudios o tamaño del grupo), pues su contribución, en principio, se plantea como generalizable a cualquiera de esos contextos. Sin embargo, el resto de los trabajos hacen referencia a una experiencia concreta. Siete de ellos hacen explícito que se contextualiza en el grado de dirección de empresas, otros dos se refieren a ingeniería electrónica, uno a ingeniería aeroespacial y los otros tres con información sobre el grado son posgrados (un master en economía, otro en dirección de empresas y un especialista universitario en producción ajustada). Respecto a las asignaturas, 7 son de dirección de operaciones, 1 de cadena de suministro, otra de producción ajustada, otra de mejora de procesos, dos sobre trabajos final de grado o máster y las otras dos son de 
organización de empresas. Dada los criterios de selección no es de extrañar que abunden las titulaciones relacionadas con administración de empresas y que la mayoría, de las que aportan información, se centren en asignatura vinculadas a dirección de operaciones. No hay demasiada información sobre el tamaño de grupo, pero cuando la aportan, la investigación sobre aprendizaje se suele realizar en asignaturas con grupos pequeños.

Las preguntas de investigación abordadas por los trabajos analizados se centran, principalmente, en enfoques de conceptualización de nivel 1 (Figura 2). 26 de las 31 preguntas identificadas se centran en lo que hace el profesor, y buscan justificar la "mejor forma de lograr algo”, bien sea la mejor metodología para lograr un resultado de aprendizaje de los alumnos o el mejor método para evaluar lo que los alumnos han adquirido ( $\mathrm{N}$ es mayor que 22 pues algunos trabajos tienen varias preguntas/contribuciones, cada una de ellas en el mismo o diferente nivel de conceptualización o enfoque de aprendizaje). Sólo en 5 casos hemos detectado indicios de que la contribución se centra en el estudiante, bien en cómo aprenden o en qué sería adecuado que aprendieran en la asignatura.

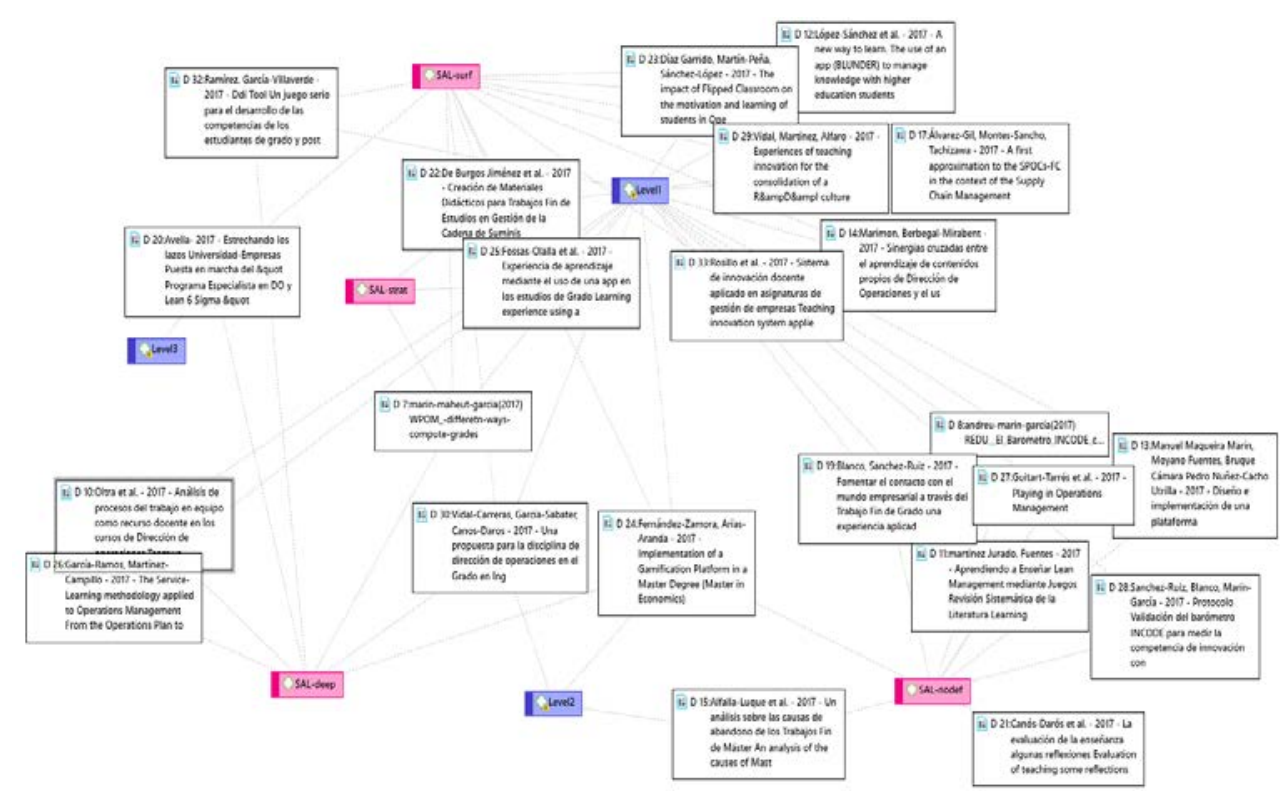

Figura 2.- Niveles de conceptualización y enfoques de aprendizaje

En la Tabla 2 podemos observar como la mayoría de los trabajos tienen un nivel 1 de conceptualización docente $\mathrm{y}$, al mismo tiempo analizan un enfoque de aprendizaje superficial. No obstante, 4 de los trabajos con nivel 1, buscan reflexionar sobre aprendizajes profundos de los alumnos y otros tres sobre aspectos que se podrían asociar a aprendizaje estratégico. Aparte de eso, 9 preguntas de investigación no hemos podido asociarlas a ningún enfoque de aprendizaje concreto, debido a falta de información.

(cc) EY-NC-ND 2018, Universitat Politècnica de València

Congreso IN-RED (2018) 
Tabla 2.-Trabajos y numero de preguntas/contribuciones por nivel de conceptualización y enfoques de aprendizaje

\begin{tabular}{|l|l|l|l|l|l|l|l|}
\hline ID & Level1 & Level2 & Level3 & $\begin{array}{l}\text { SAL- } \\
\text { surf }\end{array}$ & $\begin{array}{l}\text { SAL- } \\
\text { strat }\end{array}$ & SAL-deep & SAL-nodef \\
\hline (Alfalla-Luque et al., 2017) & & 1 & & & & & 1 \\
\hline (Alhely et al., 2017) & & & & & & & 1 \\
\hline (Álvarez-Gil et al., 2017) & 2 & & & 2 & & & \\
\hline (Andreu-Andrés et al., 2017) & 1 & & & & & & 1 \\
\hline (Avella Camarero, 2017) & & & 1 & 1 & & 2 & \\
\hline (Blanco \& Sanchez-Ruiz, 2017) & 1 & & & & & & 1 \\
\hline (Canós-Darós et al., 2017) & & & & & & & 1 \\
\hline (De Burgos Jiménez et al., 2017) & 1 & & & 1 & 1 & & \\
\hline (Díaz Garrido et al., 2017) & 1 & & & 1 & & & \\
\hline (Fernández-Zamora \& Arias-Aranda, 2017) & 3 & 2 & & 2 & & 3 & 1 \\
\hline (Fossas-Olalla et al., 2017) & 1 & & & 1 & 2 & & \\
\hline (García-Ramos \& Martínez-Campillo, 2017) & 1 & & & & & 1 & \\
\hline (Guitart-Tarrés et al., 2017) & 1 & & & & & & 1 \\
\hline (López-Sánchez et al., 2017) & 1 & & & 2 & & & \\
\hline (Maqueira Marín et al., 2017) & 1 & & & & & & 1 \\
\hline (Marimon \& Berbegal-Mirabent, 2017) & 1 & & & 1 & & & \\
\hline (Marin-Garcia et al., 2017) & 2 & & & 2 & 2 & 2 & \\
\hline (Martínez Jurado \& Moyano Fuentes, 2017) & 1 & & & & & & 1 \\
\hline (Oltra Mestre et al., 2017) & 1 & & & & & 1 & \\
\hline (Ramírez \& García-Villaverde, 2017) & 1 & & & 1 & & 1 & \\
\hline (Rosillo et al., 2017) & 2 & & & 1 & & & \\
\hline (Sanchez-Ruiz et al., 2017) & 1 & & & & & & 1 \\
\hline (Vidal et al., 2017) & 2 & & & 1 & & & \\
\hline (Vidal-Carreras et al., 2017) & 1 & 1 & & 2 & & 1 & \\
\hline Totales & 26 & 4 & 1 & 18 & 5 & 11 & 10 \\
\hline
\end{tabular}

A modo de ejemplo, presentamos en la Tabla 3 cómo se podría transformar una pregunta de investigación de nivel 1 en una batería de preguntas que situarían el foco de la investigación en una conceptualización docente de nivel 2 o nivel 3.

Tabla 3.- Ejemplo de propuesta de reformulación de preguntas de investigación para pasar de nivel 1 a nivel 2 y nivel 3 de conceptualización

En lugar de... (nivel 1) ¿la gamificación es una buena herramienta docente?, o ¿̇la gamificación sirve para que los alumnos aprendan más?

\section{... Formularlo de este modo (nivel 2 y nivel 3)}

¿Qué ocurre con los estudiantes de la asignatura xxxx del curso 2017/2018 cuando se enfrentan a la actividad YYYY (o conjunto de actividades) gamificadas? ¿Se estresan más o se motivan más? ¿sólo se genera motivación extrínseca o esa motivación les hace invertir más horas y, además, aumentar la motivación intrínseca? ¿Se orientan sólo a los resultados que resalta el panel de gamificación, o desarrollan un aprendizaje profundo y de alta intensidad respecto a los objetivos del curso y amplían, además, sus objetivos personales? ¿Qué tipo de objetivos/resultados de aprendizaje ayuda a construir esta experiencia de gamificación? 


\section{Conclusiones}

Tras los análisis realizados, parece que la mayoría de la investigación se queda en un nivel de conceptualización muy básico, que reproduce el tipo de investigaciones habituales antes de 1980. Este tipo de preguntas se consideran desfasadas pues aspiran a encontrar una "silver bullet" que funcione de manera exitosa en cualquier contexto y para cualquier estudiante. Es decir, que si los profesores elegimos el método o actividad correcta, nuestros estudiantes lograrán los resultados de aprendizaje esperados. Como si el problema consistiera en identificar el botón o palanca que activa en todos nuestros estudiantes el proceso de aprendizaje que los lleva a alinearse con los objetivos que proponemos, y a dedicar el esfuerzo necesario para alcanzarlos. No obstante, los resultados de los últimos 30-40 años de investigación sobre aprendizaje parece apuntar a que los mecanismos que orientan los procesos de aprendizaje de las personas matriculadas en nuestras asignaturas son demasiados complejos y son el resultado de la interacción de demasiadas variables como para poder ajustarse a modelos tan sencillos como los que sustentan las investigaciones de nivel 1. Por ello, la investigación que puede ser útil en estos momentos es aquella que se sitúa en el nivel 2, o mejor, en el nivel 3.

Como limitaciones de este trabajo, sólo hemos analizado las publicaciones del último año (2017) y de un subconjunto de los profesores universitarios españoles del área. Sería conveniente en una investigación futura, ampliar a las publicaciones de los últimos años (desde 2015) e incluir a una muestra más amplia de profesores (incorporando a los que pertenecen a la otra gran asociación científica del área, ADINGOR). Por otra parte, la identificación de artículos se ha realizado en base a las contestaciones de los autores potenciales. Este procedimiento puede haber dejado falsos negativos por no respuesta o despiste de los autores. En investigación futura se podría buscar las publicaciones de cada una de las personas adscritas a ADINGOR y ACEDEDOT en Web Of Science y Scopus y filtrar con los criterios de la Tabla 1. También se podría completar con una actualización de la revisión de Medina-López et al (Medina-López et al., 2011/d) restringiendo a los últimos años y autores españoles.

Entendemos que las reflexiones derivadas de los resultados no se pueden generalizarse al conjunto de investigación sobre aprendizaje realizado por profesores universitarios españoles sin realizar estudios similares en otras áreas de conocimiento.

\section{Referencias}

ALFALLA-LUQUE, R., GARRIDO-VEGA, P., DEL MAR GONZÁLEZ-ZAMORA, M., MEDINALÓPEZ, C., \& SACRISTÁN-DÍAZ, M. (2017). Un análisis sobre las causas de abandono de los trabajos fin de máster an analysis of the causes of master's thesis dropouts. Working Papers on Operations Management, 8, 32-49. doi:10.4995/wpom.v8i0.7114

ALHELY, B., CHÁVEZ, C., \& MIGUEL-DÁVILA, J.-Á. (2017). Experiencia docente de aplicación de kaizen en una empresa teaching experience of application of kaizen in a company. Working Papers on Operations Management, 8, 58-61. doi:10.4995/wpom.v8i0.7138

ÁLVAREZ-GIL, M. J., MONTES-SANCHO, M. J., \& TACHIZAWA, E. M. (2017). A first approximation to the spocs-fc in the context of the supply chain management. WPOM-Working Papers on Operations Management, 8(151-163). doi:10.4995/wpom.v8i0.7198

(cc) EY-NC-ND 2018, Universitat Politècnica de València

Congreso IN-RED (2018) 
ANDREU-ANDRÉS, M. A., MARÍN-GARCÍA, J. A., \& GARCÍA-CARBONELL, A. (2017). El barómetro incode como herramienta de autoevaluación de las competencias de innovación the barometer incode as a self-assessment tool of innovation competencies. REDU Revista de Educación Universitaria, 15(152), 275-294.

AVELLA CAMARERO, L. (2017). Estrechando los lazos universidad-empresas: Puesta en marcha del programa especialista en do y lean 6 sigma en respuesta a la demanda formativa de la industria. Working Papers on Operations Management, 8, 54-57. doi:10.4995/wpom.v8i0.7135

BIGGS, J., \& TANG, C. (2011 (1st edition 1999)). Teaching for quality learning at university. New York: McGraw-Hill Education, SRHE and Open University Press.

BLANCO, B., \& SANCHEZ-RUIZ, L. (2017). Fomentar el contacto con el mundo empresarial a través del trabajo fin de grado: Una experiencia aplicada a la temática de subcontratación encouraging contact with the business world through the final year project: An experience applied to the outsourcing field. Working Papers on Operations Management, 8, 62-66. doi:10.4995/wpom.v8i0.7159

BOYER, E. L. (1990). Scholarship reconsidered. Priorities of the professoriate. Princeton, NJ: Carnegie Foundation for the Advancement of Teaching.

BURKE-SMALLEY, L. A. (2014). Evidence-based management education. Journal of Management Education, 38(5), 764-767. doi:10.1177/1052562914529418

CANÓS-DARÓS, L., MORERA, C. P., SANTANDREU MASCARELL, C., PILAR, Y., \& VIDALCARRERAS, I. (2017). La evaluación de la enseñanza: Algunas reflexiones evaluation of teaching: Some reflections. Working Papers on Operations Management, 8, 67-71. doi:10.4995/wpom.v8i0.7163

CASCIO, W. F. (2007). Evidence-based management and the marketplace for ideas. Academy of management Journal, 50(5), 1009-1012. doi:10.5465/amj.2007.27151942

COFFEY, M., \& GIBBS, G. (2002). Measuring teachers' repertoire of teaching methods. Assessment and Evaluation in Higher Education, 27(4), 383-390. doi:10.1080/0260293022000001382

DE BURGOS JIMÉNEZ, J., FELIPE, J., GUERRERO, J., \& TARIFA FERNÁNDEZ, J. (2017). Creación de materiales didácticos para trabajos fin de estudios en gestión de la cadena de suministro creation of didactic materials for dissertation in supply chain management. Working Papers on Operations Management, 8, 19-26. doi:10.4995/wpom.v8i0.7107

DELBECQ, A. L. (2007). Scholarship and teaching that matters: Juxtaposing inner freedom with street-smart credibility. Journal of Management Education, 31, 376-391.

DÍAZ GARRIDO, E., MARTÍN-PEÑA, M. L., \& SÁNCHEZ-LÓPEZ, J. M. (2017). The impact of flipped classroom on the motivation and learning of students in operations management. WPOMWorking Papers on Operations Management, 8, 15-18. doi:10.4995/wpom.v8i0.7091

ENTWISTLE, N. (2000). Promoting deep learning through teaching and assessment. In L. Suskie (Ed.), Assessment to promote deep learning: Insight from aahe's 2000 and 1999 assessment conferences. (pp. 78). Washington: American Association for Higher Education

FERNÁNDEZ-ZAMORA, J. C., \& ARIAS-ARANDA, D. (2017). Implementation of a gamification platform in a master degree (master in economics). WPOM-Working Papers on Operations Management, 8, 181-190. doi:10.4995/wpom.v8i0.7431

FERNANDEZ MARCH, A. (2008). Training teachers in higher education. Teoria De La Educacion, 20, 275-312.

(c) 2018, Universitat Politècnica de València 
FERNÁNDEZ MARCH, A. (2010). La evaluación orientada al aprendizaje en un modelo de formación por competencias en la educación universitaria. Revista de Docencia Universitaria, 8(1), 11-34.

FOSSAS-OLALLA, M., MINGUELA-RATA, B., FERNÁNDEZ-MENÉNDEZ, J., \& GIMÉNEZFERNÁNDEZ, E. (2017). Experiencia de aprendizaje mediante el uso de una app en los estudios de grado learning experience using an app in bachelor degree. Working Papers on Operations Management, 8, 92-100. doi:10.4995/wpom.v8i0.7175

FRIESE, S. (2012). Qualitative data analysis with atlas.Ti. London: SAGE Publications Ltd.

GARCÍA-RAMOS, C., \& MARTÍNEZ-CAMPILLO, A. (2017). The service-learning methodology applied to operations management: From the operations plan to business start up. WPOM-Working Papers on Operations Management, 8(171-176). doi:10.4995/wpom.v8i0.7200

GIBBS, G., \& COFFEY, M. (2000). Training to teach in higher education: A research agenda. Teacher Development, 4(1), 31-44. doi:10.1080/13664530000200103

GUITART-TARRÉS, L., NÚÑEZ-CARBALLOSA, A., JARÍA CHACÓN, N., ACHCAOUCAOU, F., CRUZ-CÁZARES, C., MIRAVITLlES, P., \& HUERTAS GARCÍA, R. (2017). Playing in operations management. WPOM-Working Papers on Operations Management, 8, 81-85. doi:10.4995/wpom.v8i0.7171

LÓPEZ-SÁNCHEZ, J. I., FOSSAS-OLALLA, M., RODRÍGUEZ-DUARTE, A., \& SANDULLI, F. (2017). A new way to learn. The use of an app (blunder) to manage knowledge with higher education students. WPOM-Working Papers on Operations Management, 8(0), 86-91. doi:10.4995/wpom.v8i0.7174

MAQUEIRA MARÍN, J. M., MOYANO FUENTES, J., \& BRUQUE CÁMARA PEDRO NUÑEZCACHO UTRILLA, S. (2017). Diseño e implementación de una plataforma erp como entorno de aprendizaje en dirección de operaciones design and implementation of an erp platform as practice environment for learning in operations management. Working Papers on Operations Management, 8, 27-31. doi:10.4995/wpom.v8i0.7112

MARIMON, F., \& BERBEGAL-MIRABENT, J. (2017). Sinergias cruzadas entre el aprendizaje de contenidos propios de dirección de operaciones y el uso de herramientas de análisis genéricas cross learning synergies between operation management content and the use of generic analytic tools. Working Papers on Operations Management, 8, 13-14. doi:10.4995/wpom.v8i0.7015

MARIN-GARCIA, J. A. (2007). Taller sobre grounded theory y análisis cualitativo de datos con atlas.Ti

MARIN-GARCIA, J. A., MAHEUT, J., \& GARCIA-SABATER, J. J. (2017). Comparison of different ways of compute the grades of continuous assessment in the final grade. WPOM-Working Papers on Operations Management, 8(SpIss), in press.

MARTÍNEZ JURADO, P. J., \& MOYANO FUENTES, J. (2017). Aprendiendo a enseñar lean management mediante juegos: Revisión sistemática de la literatura learning to teach lean management through games: Systematic literature review. Working Papers on Operations Management, 8, 164170. doi:10.4995/wpom.v8i0.7199

MARTON, F., HOUNSELL, D., \& ENTWISTLE, N. (2005). The experience of learning. Implications for teaching and studying in higher education. 3rd (internet) edition. Edinburgh: University of Edinburgh, Centre for Teaching, Learning and Assessment.

MEDINA-LÓPEZ, C., ALFALLA-LUQUE, R., \& MARIN-GARCIA, J. A. (2011). Research in operations management teaching: Trends and challenges. Intangible Capital, 7(2), 507-548.

(cc) EY-NC-ND 2018, Universitat Politècnica de València

Congreso IN-RED (2018) 
MORRELL, K., \& LEARMONTH, M. (2015). Against evidence-based management, for management learning. Academy of Management Learning \& Education, 14(4), 520-533. doi:10.5465/amle.2014.0346

OLTRA MESTRE, M. J., GARCIA PALAO, C., \& FLOR, M. (2017). Análisis de procesos del trabajo en equipo como recurso docente en los cursos de dirección de operaciones teamwork process analysis as a teaching resource in operations management courses. Working Papers on Operations Management, 8, 76-80. doi:10.4995/wpom.v8i0.7170

PARICIO ROYO, J. (2013). ¿repensar la formación del profesorado?¿porqué habríamos de hacer tal cosa? REDU: Revista de Docencia Universitaria, 11(3).

PARICIO ROYO, J. (2017). Los focos de la investigación en educación superior, Valencia (Spain).

PARICIO ROYO, J., \& ALLUEVA PINILLA, A. I. (2011). Prácticas y modelos innovadores para la mejora y calidad de la docencia: Prensas Universitarias de Zaragoza.

PEARCE, J. L. (2007). We are who we teach - how teaching experienced managers fractures our scholarship. Journal of Management Inquiry, 16(2), 104-110. doi:10.1177/1056492607302412

RAMÍREZ, F. J., \& GARCÍA-VILLAVERDE, P. M. (2017). Ddi tool: Un juego serio para el desarrollo de las competencias de los estudiantes de grado y postgrado en el entorno de la dirección de operaciones ddi tool: A serious game for the development of competences of graduate and postgraduate students in the operations management environment. Working Papers on Operations Management, 8, 50-53. doi:10.4995/wpom.v8i0.7127

RAMSDEN, P. (1992). Learning to teach in higher education: Routledge.

ROSILLO, R., ÁNGEL, J., DÁVILA, M., ROBLES, C. F., \& REDONDO, M. M. (2017). Sistema de innovación docente aplicado en asignaturas de gestión de empresas teaching innovation system applied in business management subjects. Working Papers on Operations Management, 8, 143-150. doi:10.4995/wpom.v8i0.7195

SANCHEZ-RUIZ, L., BLANCO, B., \& MARÍN-GARCÍA, J. A. (2017). Protocolo: Validación del barómetro incode para medir la competencia de innovación con la teoría de medición de rasch protocol: Validation of the incode barometer to measure the innovation competence through the rasch measurement theory. Working Papers on Operations Management, 8, 120-124. doi:10.4995/wpom.v8i0.7190

VIDAL-CARRERAS, P. I., GARCIA-SABATER, J. J., \& CANOS-DAROS, L. (2017). Una propuesta para la disciplina de dirección de operaciones en el grado en ingeniería electrónica industrial y automática a proposal for a course of operations management in the degree in industrial electronic and automatic engineering. Working Papers on Operations Management, 8, 177-180. doi:10.4995/wpom.v8i0.7205

VIDAL, J. V., MARTINEZ, P. C., \& ALFARO, J. A. (2017). Experiences of teaching innovation for the consolidation of a r\&d\&i culture. WPOM-Working Papers on Operations Management, 8, 125139. doi:10.4995/wpom.v8i0.7191 


\title{
Balance de resultados en la aplicación de metodologías activas de aprendizaje en la asignatura de Máquinas Hidráulicas (Grado de Ingeniería en Tecnologías Industriales)
}

\author{
Rosa M. Llácer-Iglesias, Estíbaliz Fernández de Velasco Sanz y F. Javier Martínez- \\ Solano \\ Departamento de Ingeniería Hidráulica y Medio Ambiente, Universitat Politècnica de València. \\ rollaig@hma.upv.es; esferde@dihma.upv.es; jmsolano@upv.es.
}

\begin{abstract}
After three years since the flipped teaching methodology started to be applied, the results might be considered as quite good. The progressive modification of resources and methods in order to reinforce aspects that are considered key, such as the students' awareness of the change in methodology and the obtaining of specific feedback on reverse teaching, have contributed significantly to the improvement of results in its application. In the same way, the introduction to additional resources, such as gamification, have also had a positive impact.The marks obtained by the students together with the successive modifications and continuous improvements introduced since then allow to draw conclusions in a more general way. These conclusions are likely to be extended to other subjects in a wide range of fields.
\end{abstract}

Keywords: laboratory class; flipped teaching; gamification; self-learning

\begin{abstract}
Resumen
Transcurridos tres años desde la aplicación por primera vez de metodologías activas de aprendizaje en las prácticas de la asignatura Máquinas Hidráulicas, el balance global se considera muy positivo. La modificación progresiva de materiales y métodos con el fin de reforzar aspectos que se consideran clave, tales como la toma de conciencia por parte del alumnado del cambio de metodología y la obtención de retroalimentación específica sobre la docencia inversa han contribuido notablemente a la mejora de resultados en su aplicación. La introducción además de recursos adicionales, como la gamificación también han tenido una repercusión positiva. Los resultados obtenidos y las sucesivas modificaciones y mejoras introducidas desde entonces, permiten extraer conclusiones de una forma más general y por tanto, probablemente extensibles a otras asignaturas, en muy diferentes áreas de conocimiento.
\end{abstract}

Palabras clave: prácticas de laboratorio; docencia inversa; gamificación; aprendizaje autónomo 


\section{Introducción}

Durante el curso 2015-2016, los autores de este trabajo empezaron a implantar la metodología de Docencia Inversa en la asignatura de Máquinas Hidráulicas, obligatoria del Grado en Ingeniería de Tecnologías Industriales, correspondiente al primer semestre del último curso ( $\left.4^{\circ} \mathrm{A}\right)$ (Llácer-Iglesias \& Martínez-Solano, 2016). Esta asignatura tiene un elevado número de alumnos matriculados (280 en el curso 2017-2018, con una media cercana a los 290 en el balance de los últimos 5 años) repartidos en cinco grupos de teoría. Estos grupos de teoría se dividen a su vez en tres grupos de prácticas dando como resultado 15 grupos de prácticas con un número medio de alumnos de 19 alumnos por grupo, aunque por los distintos horarios ofrecidos, la distribución entre ellos no es demasiado homogénea, dando lugar tanto a grupos reducidos de 8-10 alumnos, como a grupos numerosos con hasta 25 asistentes. La asignatura consta de 4,5 créditos ECTS (2 ECTS de lección magistral, 1,6 de prácticas en el aula, 0,3 de prácticas en laboratorio y 0,6 de prácticas informáticas).

La asignatura se engloba dentro de un Grado diseñado en el marco del Espacio Europeo de Educación Superior (EEES), también conocido como Plan Bolonia. Desde el principio, el interés de la Escuela Técnica Superior de Ingenieros Industriales ha buscado la inclusión de técnica innovadoras de enseñanza aprendizaje. Esta misma inquietud fue asimilada por el equipo docente, compuesto en la actualidad por 8 profesores. Y así, durante el curso 20152016 se comenzó a introducir la metodología de la docencia inversa en la asignatura (Llácer-Iglesias \& Martínez-Solano, 2016).

En su planteamiento, el primer desafío con el que se encontró el equipo docente fue el elevado número de alumnos matriculados y de grupos, que claramente dificultaban las labores de coordinación y seguimiento. Ante esta perspectiva, la inversión de recursos para abordar la implantación de esta metodología en la totalidad de la asignatura se presentaba como un proyecto excesivamente ambicioso e incluso arriesgado. Sin embargo, el interés por introducir este tipo de innovaciones hizo que finalmente se plantease llevarlo a cabo, a modo de experiencia piloto, en una pequeña parte de la asignatura. Por ser especialmente significativa se eligió para ello las prácticas de laboratorio. Puesto que además en el curso anterior se había reducido el número de créditos presenciales para esta práctica, se consideró que la utilización de la docencia inversa para su preparación previa podría permitir un mayor aprovechamiento del tiempo en el laboratorio.

Hasta el curso anterior al de inicio de la experiencia, estas prácticas constaban de 2 sesiones de 2,5 horas de duración cada una, en las que se llevaban a cabo un total de 2 ó 3 ensayos. En función del número de alumnos asistentes, como se ha comentado muy variable, y de su predisposición, el ritmo de las mismas podía ser muy diferente. Con este planteamiento, en años anteriores se venían observando además en muchos casos esperas y tiempos muertos, que generalmente no eran aprovechados por los alumnos. A ello se añadía que aunque habitualmente el material de prácticas se encontraba disponible con anterioridad a su realización, su preparación no era una práctica habitual entre los estudiantes, a pesar de la importancia que conlleva. Por tanto al inicio de las sesiones resultaba necesario consumir una cantidad importante de tiempo para exponer todos los contenidos y los procedimientos de operación en cada ensayo, y aún así, se seguían produciendo tiempos inactivos o no

(cc) EY-NC-ND 2018, Universitat Politècnica de València

Congreso IN-RED (2018) 
válidos durante su realización, por no haber comprendido el alumno en esa explicación la operativa a seguir.

Por ello, se decidió que una buena forma de aprovechar mejor el tiempo de permanencia en el laboratorio pasaba por asegurarse de que los alumnos entraban con los fundamentos básicos ya asimilados. Ahí surge la posibilidad de utilizar los conceptos típicos de la docencia inversa. Sams \& Bergmann (2013) propusieron en el año 2007 un sistema mediante el cual los alumnos que tenían y que por cualquier razón no podían asistir a una clase tuvieran la posibilidad de recuperarla mediante el visionado de grabaciones de la misma. A la vista de los resultados, extendieron la experiencia al resto de los alumnos, permitiendo que las partes más básicas del temario fuese preparada por estos también en ese caso e incidiendo posteriormente en clase en aspectos más complejos o aplicados.

Por todo ello, se consideró que las prácticas de laboratorio podrían ser la parte de la asignatura que podía encontrar mayores beneficios en la aplicación piloto de esta nueva metodología docente, ya que, además de fomentar activamente el autoaprendizaje, se intentaba también que el tiempo que el alumno permanecía en el laboratorio fuera aprovechado al máximo. De este modo, el desarrollo de los ensayos hace ahora 3 años se concentró en una única sesión de 3 horas y el primer año se elaboró nuevo material que facilitase la preparación previa, el apoyo durante su realización y análisis de resultados posterior.

Así, en el curso 2015-2016 se puso en práctica una experiencia piloto de aplicación de técnicas típicas de la docencia inversa a las prácticas de laboratorio de la asignatura de Máquinas Hidráulicas de $4^{\circ}$ curso del Grado de Ingenerio en Tecnolocías Industriales (GITI).

La práctica de laboratorio consiste en la realización de ensayos en 3 montajes de circuitos hidráulicos sencillos para caracterización de las bombas que los componen y aplicación de algunos conceptos básicos de su funcionamiento y operación. Estos ensayos son llevados a cabo en equipo, formando como máximo 3 (uno para cada montaje) entre todos los asistentes a la sesión. El número de miembros en cada equipo puede variar entre 4 y 9 en función del total de alumnos en el grupo. Los alumnos van realizando de forma rotativa los ensayos, de modo que cada equipo empieza en un montaje distinto, y al finalizar la sesión todos ellos han llevado a cabo los 3 ensayos.

En todos los casos, el objetivo principal es familiarizar al alumno con los métodos de ensayo de bombas para la obtención de sus curvas características H-Q, P-Q y १-Q, así como con la instrumentación a emplear. Existen también objetivos adicionales relacionados con otros conceptos importantes expuestos en el temario. En concreto actualmente los tres bancos de trabajo consisten en:

- Banco 1: Ensayo de bomba centrífuga en aspiración. Caracterización de la bomba.

- Banco 2: Ensayo de bomba sumergida con variador de frecuencia. Caracterización de la bomba a diferentes frecuencias y aplicación de la teoría de semejanza. 
- Banco 3: Ensayo de dos bombas centrífugas en carga, con opción de funcionamiento simultáneo en asociación en serie o en paralelo. Caracterización de una bomba individual y caracterización de ambas asociaciones.

La aplicación de la docencia inversa ese primer año en las clases de prácticas de laboratorio de la asignatura funcionó bastante bien, consiguiéndose mejoras en las calificaciones no solo en la parte práctica sino también y de manera más significativa en los conceptos propios de las lecciones magistrales. Sin embargo, se observaron tres áreas de mejora que se han intentado aplicar desde el curso 2016-2017 (Llácer-Iglesias \& Martínez-Solano, 2016):

- Concienciación. Se detectó una falta de familiaridad de los alumnos con la nueva metodología. Se hacía por tanto necesario realizar un esfuerzo didáctico de la importancia del trabajo previo para garantizar el éxito de la misma.

- Retroalimentación. Más allá de las calificaciones, resultaba importante conocer la percepción que los alumnos tenían de la nueva metodología.

- Evaluación. Se planteó como forma de comprobar el trabajo previo la posibilidad de contrastar hasta qué punto se habían adquirido ciertos conceptos básicos.

Por último, también se detectó falta de familiaridad de los alumnos con determinados protocolos más propios del ámbito de la prevención de riesgos laborales que de la propia hidráulica. Esta percepción, sin embargo, no es nueva. González Rogado et al. (2014) también han detectado lagunas en este sentido. En la Universidad Politécnica de Valencia (UPV) existe un Servicio Integrado de Prevención y Salud Laboral que se encarga entre otras funciones de elaborar guías prácticas dirigidas tanto a alumnos como a personal de la Universidad. Estas guías son específicas de cada tipo de laboratorio o taller, distinguiendo entre riesgos químicos, eléctricos y mecánicos. Sin embargo, no hay un control real del seguimiento de estas guías por parte del alumnado. De hecho, en muchos casos el alumnado desconoce su existencia. Por ello, se decidió que, puesto que no forma parte del temario de la asignatura pero sí constituyen una parte fundamental de los conocimientos que deben adquirirse antes de empezar a trabajar en el laboratorio, era una buena oportunidad de aplicar la docencia inversa.

Además, si bien no está incluida entre las 13 competencias transversales que la UPV evalúa, la competencia de prevención de riesgos en los laboratorios constituye una competencia que debería ser evaluada en algún punto de la titulación. En esta línea se desarrolla también el trabajo desarrollado por González Rogado et al. (2014) en la Universidad de Salamanca. En dicho trabajo, estos autores realizan una evaluación de la competencia antes de entrar en el laboratorio.

\section{Objetivos}

El objetivo principal de la presente contribución es el de presentar, tras tres años de experiencia, el balance de resultados y conclusiones en la aplicación de la docencia inversa a las prácticas de laboratorio de la asignatura Máquinas Hidráulicas del $4^{\circ}$ curso del Grado en Ingeniería de Tecnologías Industriales, de modo que pueda animar a docentes de muy

(cc) EY-NC-ND 2018, Universitat Politècnica de València

Congreso IN-RED (2018) 
diversas áreas a introducir de forma gradual y sencilla aspectos basados en esta metodología, sin necesidad de recurrir a herramientas complejas o a tener que reestructurar por completo sus asignaturas. Esta posibilidad puede ser una opción especialmente interesante en el caso de asignaturas con un elevado número de alumnos y numerosos grupos como en el caso que nos ocupa.

Para conseguir dicho objetivo se han planteado los siguientes objetivos específicos:

- Evaluar la adecuación de las materiales y métodos utilizados.

- Analizar el impacto sobre los resultados de las distintas modificaciones y mejoras introducidas de forma sucesiva a lo largo de estos tres años, tanto mediante análisis de resultados académicos como con la información aportada por los alumnos a través de encuestas.

- Analizar los beneficios observados y las principales limitaciones encontradas, tanto de forma general, como específica a la aplicación de esta metodología a prácticas de laboratorio.

\section{Desarrollo de la innovación}

\subsection{Materiales desarrollados}

\subsubsection{Documentación escrita: instrucciones y procedimientos}

Si bien los métodos audiovisuales son los más frecuentemente utilizados cuando nos encontramos con experiencias relacionadas con la docencia inversa, ya el primer año se apostó por la utilización de materiales más sencillos, basados en documentos, procedimientos e instrucciones de operación escritas por varios motivos.

En primer lugar, por el firme convencimiento de los autores de que al menos parte de la formación del alumno, debería continuar basándose en la lectura, como forma más activa de autoaprendizaje. El riesgo de basarse únicamente en materiales audiovisuales y presentaciones, que en cierto modo pudiesen alejar al alumno de ingeniería del hábito fundamental de lectura durante su formación académica, era uno de los principales temores al inicio de la experiencia. Entre el profesorado de la asignatura se encuentran profesionales del mundo de la industria que recalcaban la importancia de incluir actividades que continuaran fomentando la comprensión lectora como una actividad más del proceso de formación y adquisición de competencias por parte de los estudiantes. Igualmente importante se consideró en el ámbito académico, habiendo observado a lo largo de los años casos frecuentes de fallos importantes en actos de evaluación, por el mero hecho de no haber realizado una correcta lectura de las cuestiones planteadas. Teniendo en cuenta que en la actualidad en todos los ámbitos existe una mayor tendencia a la utilización de métodos audiovisuales, se consideró conveniente adoptar documentación escrita para esta asignatura, de modo que se ampliara el espectro de herramientas y métodos a utilizar en el autoaprendizaje continuo que el desarrollo de su carrera profesional va a requerir una vez se incorporen al mundo profesional.

En segundo lugar, porque la experiencia desde el primer año ha mostrado que para el caso concreto de prácticas de laboratorio, y en particular para las de esta asignatura, que cuenta 
con un elevado número de alumnos, este planteamiento podría optimizar los resultados, en cuanto a aprovechamiento y rendimiento académico obtenido de las horas presenciales en el laboratorio por parte del alumno. Visto que los alumnos deben llevar a cabo los ensayos por sí mismos, las numerosas variables a tener en cuenta y que la sesión de prácticas tiene un tiempo limitado, se observó que resultaba inevitable tener que realizar al inicio por parte de los profesores una breve introducción y una revisión rápida de los procedimientos a llevar a cabo en los distintos bancos de ensayo, con el fin de transmitirles una cierta seguridad en lo que van a trabajar. En caso de basar la preparación previa en la visualización de grabaciones multimedia realizando esas mismas explicaciones, básicamente consistiría en una repetición, lo que se consideró que no resultaría tan enriquecedor. Al mismo tiempo, dicha introducción podría transmitirles mayor confianza y contribuir a la interacción alumnos/profesor a lo largo de toda la sesión.

De este modo, finalmente se decidió que todo el material de las prácticas fuera documentación escrita, elaborada de tal forma que sirviese de apoyo al alumno, tanto para su preparación (antes de la sesión), como de guía durante la realización de los ensayos y en el análisis de resultados y conclusiones posterior a la práctica.

El material que sirve de soporte a las prácticas debe permitir al alumno familiarizarse con el mismo antes de haber entrado en el laboratorio. Por ello, debe cumplir una serie de requisitos:

- Debe estar muy estructurado, manteniendo la secuencia lógica de contenidos. Debe ser claro y conciso, pero completo a la vez. Es decir, no debe contener excesiva información, que no sea necesaria para la práctica, pero sí toda la suficiente para su correcto desarrollo.

- Debe ser fiel al objeto, equipamiento y procedimiento a seguir. Dicho de otra forma, debe describir exactamente los equipos e instrumentación que se van a utilizar y los ensayos a realizar. Es fundamental que el material fuese totalmente adaptado a lo que los alumnos encontrarán en el laboratorio y a las actividades que realizarán durante la práctica. Esto implica una continua actualización del material para responder a las necesarias variaciones en los montajes de prácticas de laboratorio.

Puesto que a lo largo de estos tres años se han producido modificaciones importantes en los ensayos a realizar (cambios de equipos y metodología de obtención de datos), lógicamente este material se ha ido actualizando año tras año, manteniendo la misma esencia, pero con los cambios necesarios para reflejar exactamente lo que el alumno iba a encontrarse en el laboratorio y debía hacer durante la práctica.

Inicialmente el primer año la documentación se estructuró en 3 partes. La Parte I, Normas de seguridad y prevención de riesgos en el ambiente de trabajo, formaba parte del protocolo de acceso al laboratorio. Si bien no queda reflejado en ningún sitio, desde la asignatura se propuso desde el principio la necesidad de formar a los alumnos en la prevención de riesgos laborales. Por ello, para acceder al laboratorio era necesario en primer lugar entregar cumplimentado previamente un test, Anexo a dicha parte, en el que se les planteaban

(cc) EY-NC-ND 2018, Universitat Politècnica de València

Congreso IN-RED (2018) 
cuestiones básicas relacionadas con la naturaleza y origen de los riesgos en el mismo. La Parte II describía los protocolos y procedimientos necesarios para la realización de los ensayos, y también llevaba un Anexo con cuestiones a entregar cumplimentado al inicio de la sesión. Por último, la Parte III incluía las tablas con los datos que deben ser recogidos en el laboratorio, así como los cálculos y resultados que debían entregarse al finalizar la sesión para completar la evaluación. Todo el material estaba disponible en la plataforma PoliformaT con anterioridad suficiente a la sesión.

No obstante, con esta distribución y con la reestructuración de la práctica de laboratorio en una única sesión, se observaron resultados muy dispares entre los 15 grupos, dependiendo no sólo del grado de preparación de los miembros de cada equipo de trabajo, sino también en parte del número de asistentes totales a la sesión. En grupos en los que el número de alumnos total superaba la veintena, las posibles incidencias o lentos desarrollos de un equipo tenía una influencia importante en los otros dos. Además de esta circunstancia, se consideró también que el aprovechamiento, tanto de las horas de laboratorio, como del aprendizaje de la práctica en su conjunto, podría optimizarse y repartirse de forma más homogénea entre todos los alumnos, incluyendo un análisis de resultados más detallado posterior a la práctica. De este modo una de las modificaciones del segundo año incluyó un cambio en la distribución de la documentación y en base a ello, de la evaluación.

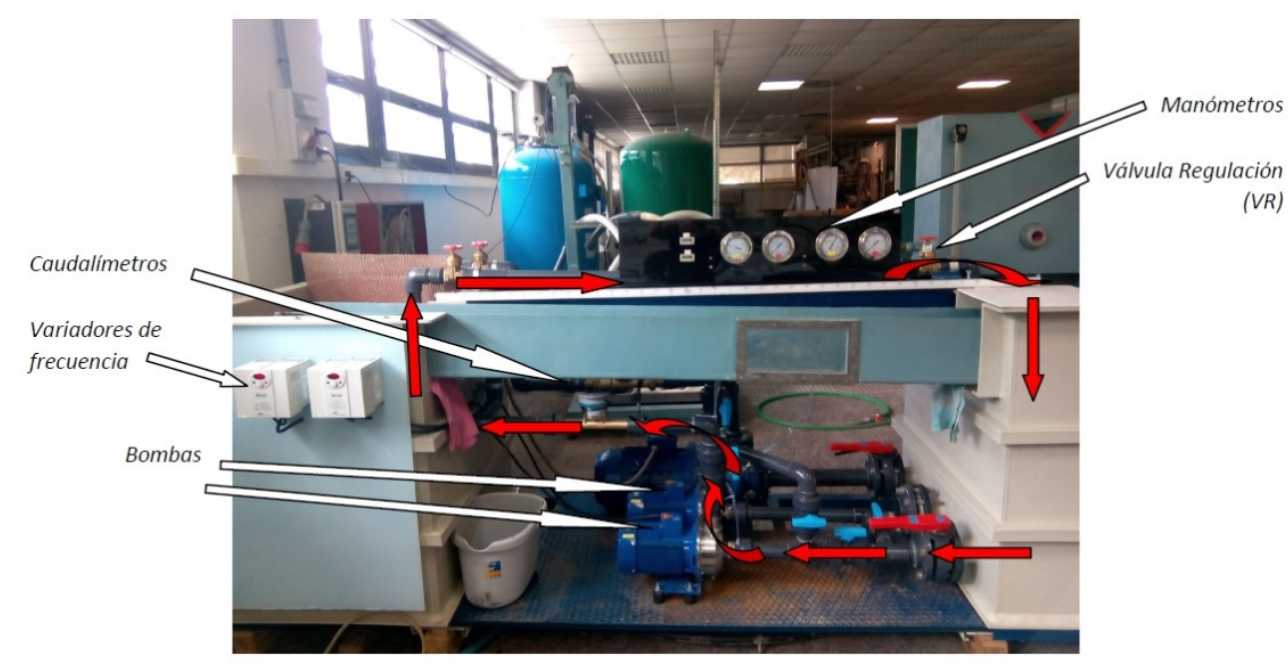

Figura 1. Ejemplo de fotografía incluida en el documento Parte II, en la descripción del banco de trabajo (Ensayo $n^{\circ}$ 3: Asociación en serie-paralelo).

Así, la documentación actualmente se estructura del siguiente modo:

- Parte I: Riesgos y normas de seguridad en el laboratorio.

- Parte II: Documento explicativo de los ensayos, incluyendo para cada uno de ellos una introducción teórica, descripción del circuito hidráulico y equipos (ver Figura 1) y procedimiento operativo para llevar a cabo el ensayo.

- Parte III: Hojas de toma de datos experimentales y cálculos preliminares. 
- Parte IV: Cálculos y análisis de resultados.

Y las entregas para evaluación se han distribuido del siguiente modo:

- Al inicio de la práctica (como trabajo previo): Se ha mantenido la entrega de forma individual y cumplimentada a mano de los Anexos correspondientes a las partes I y II.

- Al finalizar la sesión (a modo de control como trabajo durante la misma): Por cada equipo de trabajo, la parte III, ahora únicamente con datos experimentales y un par de cálculos sencillos.

- A las 5-6 semanas de finalizar las prácticas (como trabajo posterior): También por cada equipo de trabajo, entrega de archivo con cálculos y análisis más detallado de resultados.

\subsubsection{Encuestas}

Otra de las modificaciones introducidas el segundo año, tiene que ver con el aumento de la retroalimentación por parte del alumnado, sobre aspectos específicos de la metodología de docencia inversa, como una de las áreas de mejora identificadas inicialmente (LlácerIglesias \& Martínez-Solano, 2016).

Para ello, durante el curso 2016-2017 se elaboró una encuesta interna, basada en la estructura de las utilizadas de forma general en la UPV para la evaluación del profesorado y con los mismos baremos de puntuación, pero añadiendo un par de preguntas específicas sobre la docencia inversa (ver figura a continuación).

Docencia:

Programación: Antes de la práctica se proporciona información clara sobre la misma (objetivos, programa, metodología y criterios de evaluación).

Contenido: Las actividades realizadas en la práctica son de gran ayuda para el aprendizaje de la asignatura.

Profesorado: La profesora contribuye a crear un buen clima de trabajo y anima a los alumnos a participar en las clases.

Profesorado: Teniendo en cuenta las limitaciones, pienso que la profesora que imparte esta práctica debe considerarse una buena profesora.

\section{Metodología Docente (Docencia Inversa):}

Material: El material docente habilitado en PoliformaT para la práctica es coherente con los contenidos del programa, representa una importante ayuda para su aprendizaje y para alcanzar los objetivos.

Metodología: Teniendo en cuenta que la docencia inversa implica un trabajo previo a la práctica con ayuda del material disponible, y viendo lo que he aprendido, considero que es una metodología útil para el aprendizaje y adecuada para estas prácticas de laboratorio.
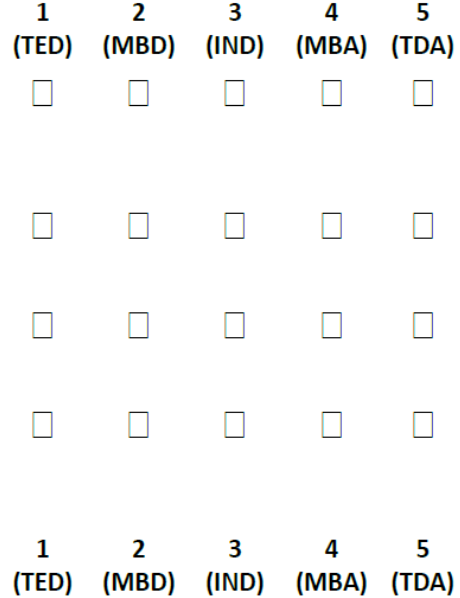

Figura 2. Preguntas sobre docencia inversa en encuesta interna realizada el curso 2016-2017.

(c)) EY-NC-ND 2018, Universitat Politècnica de València

Congreso IN-RED (2018) 
Para intentar ampliar dicha información, con detalles más específicos sobre la docencia inversa, en el tercer año (curso 2017-2018) se optó por no realizar encuesta interna, sino llevar a cabo la encuesta prevista por el Proyecto Docencia Inversa.

\subsection{Métodos utilizados}

\subsubsection{Labor de concienciación}

Una importante lección aprendida el primer año de la experiencia, fue la identificación de la necesidad de concienciar a los alumnos desde el inicio de la asignatura del propio concepto de docencia inversa, ya que se observó que muchos de ellos ni siquiera eran conscientes de que se va a utilizar dicha metodología en la asignatura en la que se habían matriculado (Llácer-Iglesias \& Martínez-Solano, 2016). Para abordar esta cuestión, en el segundo curso que se empleó docencia inversa, se reforzó la información a los alumnos mediante las siguientes acciones:

- A modo de introducción, el primer día de la asignatura, el profesor de teoría correspondiente, recalcó desde el inicio, de que en las prácticas de laboratorio se emplearía esta metodología.

- Transcurridas unas semanas, pero con 10-15 días de antelación a la realización de las prácticas, durante una de las clases teóricas, los profesores de laboratorio realizaron una presentación específica de las prácticas, explicando con detalle objeto, contenido, materiales, metodología y métodos de evaluación, y haciendo especial hincapié en la importancia de preparar con antelación la sesión conforme a las pautas expuestas. Con el fin de aumentar la motivación a la preparación de la sesión, se planteó la posibilidad de que se realizasen preguntas, aleatorias dado el elevado número de alumnos, sobre el procedimiento que tendrían que seguir, que formarían parte de la evaluación.

Aunque las presentaciones realizadas el segundo año con anterioridad a la práctica ayudaron claramente a facilitar que los alumnos entendieran el cambio de concepto, a nivel práctico todavía se observó grado de implicación y preparación muy mejorable.

No obstante, cabe añadir que las limitaciones que se siguen encontrando a este respecto son en su mayor parte intrínsecas a la asignatura, por el hecho de tratarse de una sesión única y tener un número muy elevado de alumnos (con grupos de prácticas heterogéneos, y frecuentemente numerosos a su vez), o a la naturaleza de las propias prácticas, en las que uno de los objetivos es el trabajo en equipo. Dado lo numeroso de los grupos, inevitablemente todo esto conlleva un reparto de tareas frecuentemente poco equitativo entre los distintos miembros de un grupo, de modo que se detectó que seguía habiendo un elevado número de alumnos que claramente confían en que no va a ser necesario ningún esfuerzo a nivel individual.

\subsubsection{Introducción de la evaluación competitiva: gamificación}

Con el fin de aumentar la preparación efectiva de la práctica, y viendo que la posibilidad de que se realizaran preguntas aleatorias sobre los contenidos, no había producido tampoco el efecto deseado, el tercer año se ha intentado fomentar la implicación de los alumnos 
mediante la introducción de un incentivo positivo. Para ello se ha recurrido al uso de la Gamificación Educativa como herramienta motivacional.

La gamificación es un recurso que cobra cada vez mayor importancia en las dinámicas motivacionales de las aulas (Marín Díaz, 2015). Según esta autora, la gamificación se puede definir como el empleo del juego como herramienta que facilita la cohesión del grupo y la motivación de los alumnos. Los resultados obtenidos con la gamificación son: la motivación, integración del grupo e impacto psicológico individual. Algunas experiencias previas han demostrado el potencial de esta herramienta para mejorar la adquisición de conocimientos. Rodríguez, Loro, \& Villén (2015) definen los cinco elementos que debe incluir una docencia basada en el juego:

a) Asignar un valor cuantitativo (la calificación)

b) Plantear un objetivo (la tarea)

c) Establecer formatos de clasificación (el nivel)

d) Ofrecer compensaciones (la recompensa)

e) Diseñar elementos de clasificación grupal (la integración)

Independientemente del perfil del alumno (los autores anteriores describen cuatro perfiles: competidor, conseguidor, socializador y explorador), la gamificación aprovecha la competitividad de los alumnos para conseguir una mayor motivación. Una de las aplicaciones de la gamificación como técnica educativa es la evaluación competitiva. Así, Iglesias-Rey \& Martínez-Solano (2017) emplean la evaluación competitiva como herramienta de evaluación de la docencia basada en proyectos obteniendo buenos resultados tanto a nivel de evaluación como de implicación del alumnado.

Siguiendo el ejemplo de los trabajos anteriores, en la documentación descrita en el apartado 3.1.1, se introdujo a propósito un error de concepto. El error aparecía en la parte III, donde se exponen los conceptos teóricos y procedimientos operativos, en concreto en el desarrollo y obtención de la expresión a utilizar para calcular, a partir de los datos experimentales obtenidos en el laboratorio, uno de los parámetros clave en uno de los tres ensayos (la $\mathrm{H}$ de la bomba), aplicando conceptos básicos de la mecánica de fluidos (ecuación de Bernouilli).

El día de la presentación de las prácticas, se les habló de la existencia de este error, y se planteó el incentivo. La evaluación se realizaría siguiendo dos criterios independientes. Por un lado se realizaría una evaluación clásica en función de los resultados presentados.Por otro lado, para cada grupo de teoría (5 en total como se ha mencionado en la introducción) el primer alumno de cada grupo que enviase un correo electrónico, identificando el error y justificando cuál sería la respuesta correcta, automáticamente obtendría una mejora en la nota de las prácticas de laboratorio. Una vez comentado en todos los grupos, se puso a su disposición en PoliformaT dicha documentación.

Para evitar que este incentivo no provocara una falta de atención en la práctica del alumno que lo consiguiera, y seguir manteniendo el interés del grupo en todo momento, se informó que no se confirmaría el resultado hasta una vez finalizadas todas las sesiones de prácticas.

(cc) EY-NC-ND 2018, Universitat Politècnica de València

Congreso IN-RED (2018) 


\section{Resultados}

El análisis de los resultados de la aplicación de la metodología basada en docencia inversa se realizará desde dos enfoques. Por un lado, se estudiará el impacto general sobre la asignatura en su conjunto a través del análisis de las encuestas que año tras año pasa el Instituto de Ciencias de la Educación (ICE) de la UPV a todos los alumnos matriculados. Por otra parte, como forma de incluir cierta retroalimentación a la aplicación de la metodología, durante el curso 2016-2017 se elaboraron las encuestas internas anteriormente mencionadas. En este curso 2017-2018 sin embargo, la iniciativa Proyecto Docencia Inversa de la UPV ha elaborado sus propias encuestas.

De las encuestas elaboradas por el ICE, cabe destacar el impacto positivo inicial en la aplicación de la metodología, tal y como se puede observar en la Figura 3.

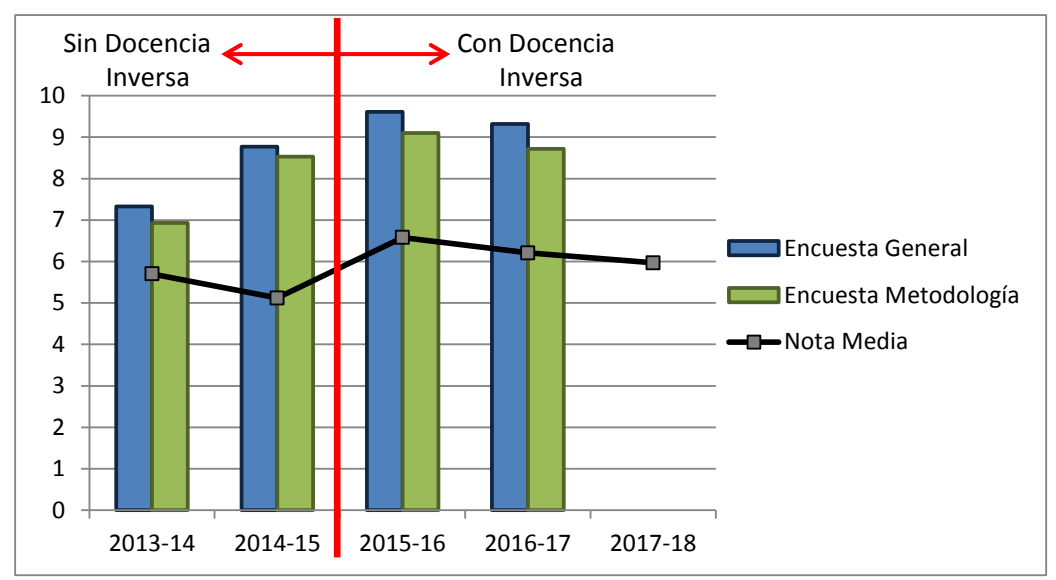

Figura 3. Evolución de la percepción por parte del alumno de la asignatura en general (barra azul), la metodología docente (barra verde) y de la calificación final de la asignatura. (Nota: las encuestas correspondientes al curso 2017-2018 no están disponibles en el momento de la elaboración de este trabajo)

Este análisis tiene la ventaja que afecta a la totalidad de los alumnos. Las encuestas tienen una larga tradición en la Universidad y llevan pasándose desde hace mucho tiempo. Por ello, el nivel de respuesta de los alumnos es elevado.

Las encuestas preparadas exprofeso tienen la ventaja de que están más dirigidas a evaluar la percepción de la metodología de docencia inversa. Sin embargo, al haber sido pasadas en el presente curso a través de la plataforma PoliformaT la respuesta recibida no ha sido tan amplia (se han recibido 14 encuestas de un total de 280 alumnos matriculados). Se constata en cualquier caso que de entre aquellos que sí han respondido a la encuesta, la percepción es positiva.

En este punto es necesario mencionar que el planteamiento de las encuestas específicas de docencia inversa en los dos cursos en los que se ha pasado es distinto. En el curso 20162017 la encuesta fue elaborada por los propios profesores y se intentó que fuese en la misma línea que las encuestas tradicionales, pero aplicada exclusivamente a las sesiones en las que la docencia inversa había sido aplicada. Así, las preguntas planteadas en la Figura 2 
se han sintetizado en las mismas categorías que las representadas en la Figura 3: Docencia General y Metodología. La Figura 4 recoge los resultados de esta encuesta interna.
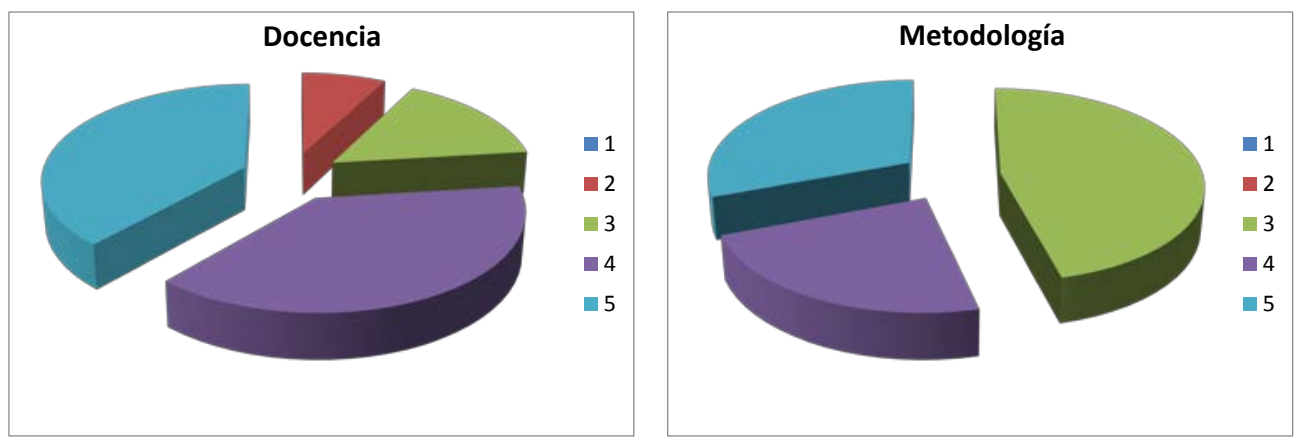

Figura 4. Resultados de la encuesta interna pasada sobre la percepción de la docencia inversa durante el curso 2016-2017. Izquierda: valoración de la docencia en general; Derecha: valoración de la metodología de Docencia Inversa. (1: Totalmente en Desacuerdo - 5: Totalmente de Acuerdo).

Por su parte, los resultados obtenidos por las encuestas específicas pasadas por el Proyecto Docencia Inversa son bastante similares. En este caso, las encuestas se han agrupado en tres grandes dimensiones:

a) Grado de satisfacción con la experiencia basada en la Docencia Inversa.

b) Recomendación de la metodología para otros compañeros que no la han seguido.

c) Propuesta de extensión de la metodología a otras asignaturas o campos dentro de la propia titulación.

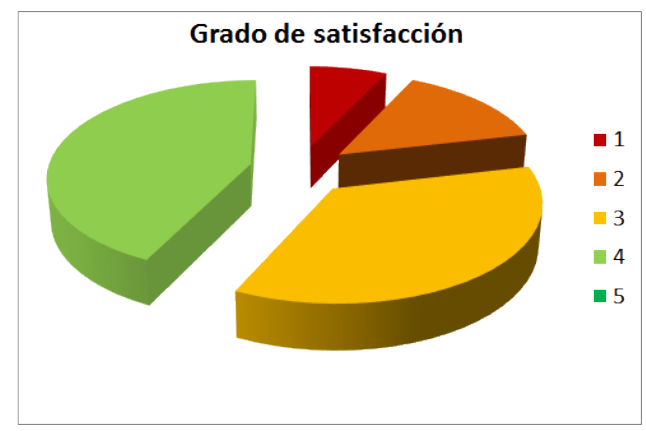

Figura 5. Encuesta del Proyecto Docencia Inversa. Grado de satisfacción.

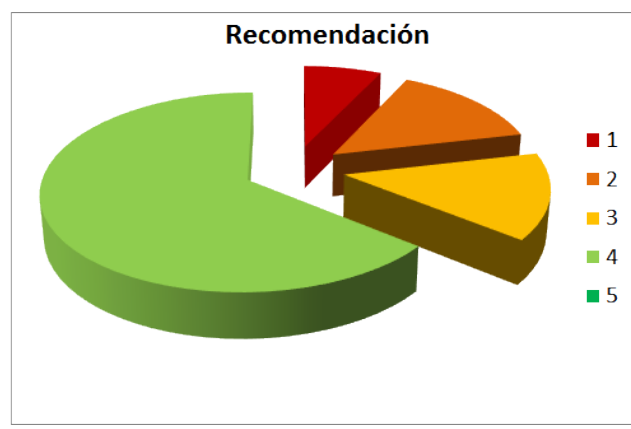

Figura 6. Encuesta del Proyecto Docencia Inversa. Recomendación a los compañeros.

(cc) EY-NC-ND 2018, Universitat Politècnica de València

Congreso IN-RED (2018) 


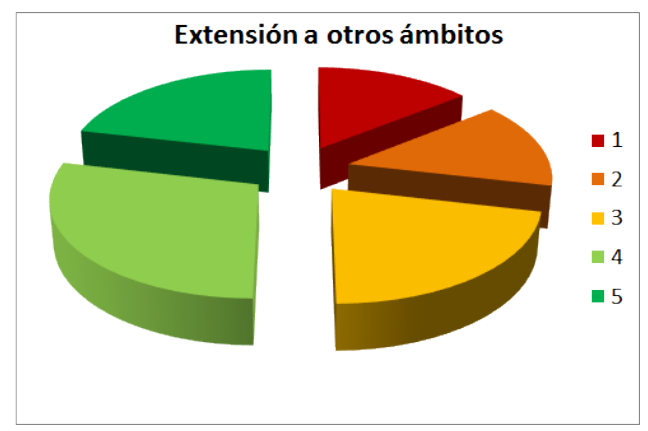

Figura 7. Encuesta del Proyecto Docencia Inversa. Extensión a otros ámbitos.

Los resultados de las encuestas clasificados en sus correspondientes dimensiones se muestran en las Figuras 5 a 7. La escala de respuestas varía desde 1 (Totalmente en Desacuerdo) hasta 5 (Totalmente de Acuerdo). Estos resultados se pueden clasificar como de aceptables, con una media global de la metodología de 3,26 sobre 5. Sin embargo, hay algunos aspectos que mejorar. En todas las dimensiones hay más opiniones favorables (4-5) que desfavorables (1-2). Esto es especialmente destacado en la recomendación a otros compañeros (2 de cada tres alumnos lo recomendaría). Sin embargo, una de las encuestas recogidas se ha mostrado muy crítica con la metodología, estando totalmente en desacuerdo con la misma. Además, se ha obtenido un nivel de respuestas bajo (un 5\%, 14 de 280). Esto hace que sea necesario plantearse los métodos de obtención de la retroalimentación.

\section{Conclusiones}

Se ha observado una evolución favorable a lo largo de estos tres años, en la implantación de la metodología e impacto en los resultados, considerando la experiencia como muy positiva en términos generales. Tras el balance a fecha actual se pueden apreciar de forma más clara las ventajas de la aplicación de esta metodología, en particular a prácticas de laboratorio, y con ello animar a docentes de asignaturas de esta magnitud (en cuanto a número de alumnos), en las que probablemente se observe una mayor complejidad o reticencia al cambio de metodología, a introducir este tipo de innovaciones de forma progresiva en sus materias. A la vista de los resultados de las encuestas (Figura 7), la mitad de los alumnos están de acuerdo o totalmente de acuerdo con esta afirmación.

Entre las ventajas se ha observado un progresivo aumento de la preparación de los alumnos a lo largo de los tres años que ha abarcado esta experiencia, que ha resultado evidente con el consecuente aumento en la participación y respuestas a las cuestiones que se plantean durante la breve introducción y revisión de los procedimientos realizada al inicio de la sesión. Además, la implantación de la metodología de Docencia Inversa muestra un efecto positivo tanto en la percepción de la asignatura por parte de los alumnos como en las calificaciones obtenidas (Figura 3).

Entre los cursos 2016-2017 y 2017-2018 (segundo y tercer año de implantación) se ha observado también una mayor calidad en la entrega de la parte IV (manipulación y análisis de resultados), especialmente en cuanto a conclusiones. Esto evidencia un gran aprovechamiento de la práctica, especialmente durante su desarrollo. 
Por otra parte, la aplicación de técnicas innovadoras en la actividad docente, y especialmente en el caso de la Docencia Inversa, requiere un trabajo continuo por parte del docente. Es por tanto importante tener presente que para poder aplicar la metodología tal y como aquí se ha descrito, es necesario realizar una revisión y actualización continua de la documentación cada curso para asegurarse que se mantiene totalmente la fidelidad a lo que el alumno va a encontrarse en el laboratorio y al procedimiento de ensayo que debe seguir.

La retroalimentación por parte del alumno continúa considerándose una herramienta fundamental para la mejora continua de resultados. En este sentido, claramente la posibilidad de realizar encuestas presenciales con un número no demasiado elevado de preguntas se considera puede aportar mucha mayor información. En cuanto a otro aspecto clave como es la toma de conciencia del alumno del cambio de metodología, resultaría bastante conveniente intentar aumentar las labores de concienciación por parte de la Universidad o de las Entidades Responsables de los Títulos (ERT) a nivel institucional. Esto podría realizarse de forma más evidente incluyendo la información sobre el tipo de metodología empleada incluso en el propio proceso de matrícula de las asignaturas.

De forma general, se considera que las principales limitaciones van más ligadas a la magnitud de la asignatura, y a la naturaleza de las clases (prácticas en grupo), que a la metodología en sí. Dado lo positivo de la experiencia, se plantea ampliar la metodología a otras partes de la asignatura en cursos posteriores.

\section{Agradecimientos}

La experiencia aquí descrita se ha llevado a cabo como parte de los trabajos desarrollados en el EICE DESMAHIA "Desarrollo de metodologías activas y estrategias de evaluación aplicadas al campo de la Ingeniería Hidráulica". Los autores agradecen a la UPV, y en particular al ICE, el apoyo prestado para llevar a cabo esta iniciativa.

\section{Referencias}

González Rogado, A. B., Vivar Quintana, A. M., Rodríguez Conde, M. J., Revilla Martín, I., Martínez Abad, F., Olmos Miguelañez, S., \& Barrientos Diego, P. (2014). Adquisición de la competencia de prevención de riesgos en el laboratorio mediante tecnología móvil. Congrés Internacional de Docència Universitària I Innovació (CIDUI), (1), 1-18.

Iglesias-Rey, P. L., \& Martínez-Solano, F. J. (2017). Combinación de una metodología basada en proyectos y de una evaluación competitiva en la asignatura Análisis y modelación de redes de distribución de agua. In Libro de Actas IN-RED 2017 - III Congreso Nacional de Innovación Educativa y de Docencia en Red. Valencia: Universitat Politècnica València. https://doi.org/10.4995/INRED2017.2017.6828

Llácer-Iglesias, R., \& Martínez-Solano, F. J. (2016). Experiencia en la aplicación de la docencia inversa para el aprendizaje de la asignatura de Máquinas Hidráulicas (Grado de Ingeniería en Tecnologías Industriales). In Libro de Actas IN-RED 2016 - II Congreso Nacional de Innovación Educativa y de Docencia en Red. Valencia: Universitat Politècnica València. https://doi.org/10.4995/INRED2016.2016.4288

Marín Díaz, V. (2015). La Gamificación educativa. Una alternativa para la enseñanza creativa. Digital Education Review, (27).

(cc) EY-NC-ND 2018, Universitat Politècnica de València

Congreso IN-RED (2018) 
Rodríguez, F., Loro, F., \& Villén, S. (2015). Experiencia de gamificación en alumnos de magisterio para la evaluación de la asignatura Sociología de la educación mediante el uso de la plataforma Kahoot. In INNODOCT 2015 (pp. 223-231). Valencia (España): Universitat Politècnica de València.

Sams, A., \& Bergmann, J. (2013). Flip Your Students’ Learning. Educational Leadership, 70(6), 1620.

(cc) EY-Nc-ND 2018, Universitat Politècnica de València 


\title{
La habilidad negociadora en el Aprendizaje-Servicio con enfoque de la Educación para el Desarrollo: ¿una herramienta pedagógica?
}

Ana Cano-Ramírez ${ }^{\text {a }}$ Francisco Cabrera-Suárez

âUniverdidad de Las Palmas de Gran Canaria, ana.cano@ulpgc.es y ${ }^{\text {b} U n i v e r d i d a d ~ d e ~ L a s ~ P a l m a s ~ d e ~}$ Gran Canaria, fcabrera@dma.ulpgc.es

\begin{abstract}
This paper aims to investigate negotiation as an educational tool within the service-learning experiences implemented as part of the undergraduate degree in social work at the University of Las Palmas de Gran Canaria during the 2012-13-14 and 2016-17-18 academic years. These experiences focus on Education for Development and Global Citizenship (EDGC).

To this end, feedback was obtained from students representing each of the four year groups, once they had completed the task set. Here they provided their views regarding their acquisition of negotiation skills as a result of the experience.

The current study seeks to organize this experience in such a way that it allows for the combined service-learning and EDGC methodology to be explored and to demonstrate the possibilities which this offers for the human development of the students as they experience situations which favour their empowerment, by enhancing their negotiation skills and illustrating their ability to take on responsibilities. This is particularly relevant among social work students, as their professional activity aims to encourage people to undergo processes of this kind in order to overcome the difficulties which have led to their being assisted by the Public Social Services System.
\end{abstract}

Keywords: Service-learning, Education for Development, negotiation skills, critical education theory

\footnotetext{
Resumen

El trabajo que se presenta tiene como objetivo aproximarnos a la negociación como herramienta pedagógica en las experiencias de Aprendizaje-Servicio con enfoque de la Educación para el Desarrollo para la Ciudadanía Global, puestas en práctica durante los cursos 2012-13-14 y 2016-17-18, en Grado de Trabajo Social (Universidad de Las Palmas de Gran Canaria).

Como resultado, una vez finalizada la tarea asumida por los propios estudiantes de los cuatro cursos, hemos podido obtener la valoración que
} 
ellos perciben sobre la adquisición de aprendizaje de la habilidad negociadora a través de la experiencia llevada a cabo.

Se trata aquí de sistematizar la experiencia de manera que ello permita explorar y mostrar el potencial que la metodología ApS, en combinación con la EDCG, aporta en el desarrollo humano de los estudiantes al vivenciar situaciones que contribuyen a su empoderamiento, a través de potenciar las habilidades negociadoras y de verse con capacidad para asumir compromisos, lo que adquiere una relevancia sustancial en los estudiantes de Trabajo Social en tanto que la finalidad de su ejercicio profesional está dirigida a favorecer que las personas afronten procesos de esta índole para superar las dificultades por las que están siendo atendidas en el Sistema Público de Servicios Sociales.

Palabras clave: Aprendizaje-Servicio, Educación para el Desarrollo, habilidad negociadora, teoría crítica educación 


\section{Introducción}

Se presenta en este apartado introductorio elementos que se estiman esenciales para justificar y fundamentar el por qué de la iniciativa pedagógica que se viene impulsando. Por ello, en e aportaremos un marco teórico-conceptual del que se nutre la experiencia, así como de la presentación grosso modo sobre los fundamentos que construye el currículum institucional-profesional y el currículum institucional-académico.

En los apartados siguientes presentamos los objetivos perseguidos, la experiencia de innovación educativa que impulsamos, y de la que hemos ido recopilando una serie de resultados a tenor de los objetivos y procedimiento aplicado. De todo ello, alcanzamos unas conclusiones finales que reportamos, para finalizar con las fuentes bibliográficas con las que hemos tratado de ahondar en el conocimiento del contexto y de la acción docente.

Antes de continuar, estimamos pertinente advertir al lector que, el trabajo que aquí nos ocupa es, amén de la estructura convencional que se evoca en este tipo de documento, fruto de una construcción combinada de la teoría y la praxis. En este sentido, recomendamos considerar que los contenidos referidos al currículum institucional-profesional y currículum institucional-académico son fruto y, por tanto, también se constituyen como resultados, de la observación a la que la práctica docente nos ha sumergido, permitiéndonos analizar y reflexionar sobre el sentido y la coherencia de la misma respecto a aquellos. Procede decir que, de alguna forma, lo que aquí estamos tratando es de sistematizar una experiencia de Aprendizaje-Servicio haciendo un "servicio docente" mediante el que, a su vez, estamos aprendiendo como profesores.

\section{Fundamentación de la habilidad negociadora en la experiencia docente}

En esta sección vamos a realizar un recorrido por la literatura que nos aporta elementos que justifican la necesidad de trabajar con nuestros estudiantes la habilidad negociadora. Para ello acudimos, en primer lugar, al marco conceptual del enfoque metodológico de la Educación para el Desarrollo para la Ciudadanía Global (en adelante EDCG) y del instrumento práctico que lo hace posible, el Aprendizaje-Servicio (en adelante ApS).

En segundo lugar, nos adentramos en el currículum institucional-profesional, para desvelar qué se nos dice desde el currículum profesional al respecto. En tercer y último lugar, dedicamos un espacio para justificar la experiencia docente desde el enfoque de la narrativa académica.

\subsection{Fundamentación teórica}

A continuación se aportan elementos de fundamentación conceptual con el propósito de delimitar el trabajo pedagógico objeto de atención del presente documento. En esta ocasión adoptamos la definición de ApS como "una forma de educación basada en la experiencia, en la que el aprendizaje se produce a través de un ciclo de acción y reflexión gracias al cual los estudiantes trabajan con otros compañeros en un proceso de aplicación de lo que han aprendido a los problemas de la comunidad y, al mismo tiempo, reflexionan sobre la experiencia de perseguir objetivos reales para la comunidad e incrementar su propia

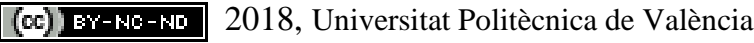

Congreso In-Red (2018) 
comprensión y destrezas, es decir, desarrollan de manera conexa las múltiples dimensiones humanas y cultivan la responsabilidad cívica y social” (Eyler \& Gilers, 1999, citado en Francisco y Moliner, 2013:71). A este ejercicio profesional reflexionado, añadimos la perspectiva de Aramburuzabala (2013:6) cuando señala un ApS guiado por la justicia social, con especial referencia a los colectivos en situación de vulnerabilidad social, todos ellos aspectos trascendentales de los trabajadores sociales.

Esta definición sostiene exquisitos hilos de conexión con lo que viene a definirse como EDCG, al entenderse ésta como "un proceso educativo, continuo, democrático, emancipador, basado en valores humanísticos, para que la persona tome conciencia crítica frente a las complejas relaciones sociales, económicas y políticas, y se posicione con sensibilidad contra las injusticias sociales y actúe para transformarlas, a la vez que construir un mundo más justo para ser feliz” (Cano, 2014:421).

Consideradas las definiciones ApS y de la EDCG, se desprende que sostienen una íntima relación en tanto que una se constituye en oportunidad pedagógica de la otra. Dicho esto, este trabajo pretende evidenciar en qué medida, el ApS contribuye a aprendizajes desde el enfoque de la EDCG, en concreto identificando la adquisición de la capacidad de negociar y llegar a compromisos, como habilidad que se puede abordar en el marco del currículum oculto, es decir, aprendizajes que adquieren los estudiantes sin que éstos sean objeto intencionado ni consciente del currículum institucional ni del currículum ofrecido (Zabalza, 2003: 32-33; Alvárez Méndez, 2009: 208; Acaso, 2012: 45).

Siguiendo con la EDCG, cabe decir que se nutre de las teorías constructivistas de la psicología y de la las teorías contemporáneas de la pedagogía. Entre ellas, se desprende con especial protagonismo las siguientes: Pedagogía de la Liberación de Paulo Freire, la Construcción Histórico-socio-cultural del Conocimiento de Vigotsky, la Teoría del Aprendizaje Significativo de Ausubel y la Teoría de los Intereses del Conocimiento de Habermas (Díaz, 2010), teorías, todas ellas, inspiradoras de la iniciativa pedagógica que nos ocupa.

Sin pretención de entrar a explicar las teóricas citadas, sí resulta de interés hacer presente, por el objeto que nos ocupa, el planteamiento que Habermas sostiene cuando apunta a que la educación persigue alguno de los tres intereses que él identifica como: interés práctico, interés técnico e interés emancipatorio. Para él, la ciencia se ordena según estos tres tipos de intereses, y el saber se adquiere de las siguientes formas que se corresponde con cada uno de los intereses señalados: empírico-analítico, histórica-hermenéutico y crítico (Grundy, 1998). Atendiendo a ello, y considerando las palabras de Boni (2005), cuando señala que la finalidad de la EDCG es "contribuir a desarrollar unos conocimientos, habilidades, valores y actitudes coherentes con el objetivo político que propone: la consecución del desarrollo humano sostenible para todo el planeta”, a partir de una educación crítica y emancipadora, resulta que la Teoría de Habermas que refiere al interés emancipador es la que mantiene coherencia con la EDCG, en el que nos posicionamos como docentes.

A este respecto, y siguiendo con la propuesta de Habermas, Grundy (1998) desarrolla de manera muy interesante la perspectiva del currículum, que debe contemplar una finalidad emancipadora, para que los estudiantes adquieran autonomía y pensamiento crítico. Entre

(c) EY-NC-ND 2018, Universitat Politècnica de València 
estas sugestivas ideas aparece el concepto de "currículum negociado" como modelo pedagógico que evidencia el compromiso activo de los profesores con sus alumnos. Este currículum negociado resulta de un acto de negociación entre ambas partes, no de forma espontánea ni improvisada, sino como resultado de un ejercicio de reflexión sistemático. En este sentido, las experiencias docentes que abordamos persigue alcanzar ese currículum negociado que plantea Grundy.

Añade el autor que el aprendizaje se basa en un proceso de investigación-acción, de manera que a la vez que hace, indaga e investiga sobre ello, reflexiona, analiza y actúa, mejorando la praxis, para volver a ella. Esta es la práctica pedagógica que puede garantizar el proceso emancipador, a partir de desarrollar esa actitud crítica. Este interés emancipador requiere que la acción vaya acompañada necesariamente de la reflexión (Grundy, 1998). Este proceso de investigación-acción nos está permitiendo desvelar el alcance de los objetivos de empoderamiento de los estudiantes, a través de la revisión continuada de la praxis guiada por la teoría, retroalimentándonos continuamente.

Apunta también la teoría de los intereses de la educación, en concreto siguiendo con la emancipadora, que cuando se evalúa a un estudiante, se ha de hacer desde un posicionamiento crítico, no solo sobre los resultados obtenidos del aprendizaje, sino sobre cómo se han producido aquellos. Para la realización de esta evaluación, solo tiene poder reconocido los que han experimentado el proceso, por lo que queda excluida la intervención de cualquier agente externo que tenga interés por evaluar (Grundy, 1998).

De todo ello se puede extraer la idea de que la acción evaluadora del profesor sea cuestionada, en tanto que este no conoce con exactitud qué ha experimentado y qué cambios se han producido en sus estudiantes. Si lo que se quiere es estimular un aprendizaje orientado al desarrollo de habilidades o competencias superiores (pensamiento crítico y creativo, capacidad de resolución de problemas, capacidad de análisis y síntesis, etc.), es necesario practicar una evaluación que vaya en consonancia con ello (Álvarez Méndez, 2009). Este aprendizaje sitúa al estudiante como el principal agente para identificar y reconocer sus propios aprendizajes, quedando vinculado al modelo de autoevaluación, como la fórmula más coherente con este modelo de aprendizaje. Este criterio ha sido perfilado en la segunda etapa de la experiencia pedagógica que presentamos, estableciendo los propios estudiantes cúales eran los criterios de evaluciación del trabajo grupal realizado, así como el modelo de evaluación a aplicar.

Así mismo, compartimos con De Paz (2009) que es necesario considerar el compromiso que los estudiantes adoptan con las formas de trabajar. Este compromiso está íntimamente relacionado con su participación en tomar decisiones sobre lo que ha de hacer, decisiones que resultan de los procesos de negociación, especialmente cuando la decisión a adoptar incluye planos de carácter grupal/colectivo, como es el caso que intentamos proyectar.

A ello se suma que en la propuesta de trabajo pedagógico coincidimos con Bain (2005: 45) cuando esboza que la práctica docente desde la EDCG necesita "ajustar los objetivos y el nivel conceptual a la situación de los estudiantes”. Esta indicación exige identificar qué conocimientos de partida tienen los estudiantes para definir los resultados que se espera deben alcanzar los mismos. Ello requiere que las dificultades del tema deben presentarse según el nivel de comprensión del grupo objetivo, pero debe tener una dificultad algo 
mayor de lo que ya sabe, a fin de que se vaya incrementando sus conocimientos. No obstante, se debe cuidar que no sea de tal complejidad que le impida asimilarla. Se tiene que considerar que el estudiante no llega aséptico al aula, sino que viene con una cubierta de su contexto social y cultural que ha de considerarse tanto desde las ventajas como desde las desventajas que conlleve (Gimeno, 2005). Por todo ello, la apertura de espacios y tiempos de debate compartidos en el aula, ha favorecido que tanto los estudiantes como la docente tomemos pulso a cómo nos vemos a nosotros mismos ante la innovación docente que afrontamos, en tanto que exigirá sacar a la luz, además de nociones teóricas, habilidades y actitudes que en el modelo docente tradicional se encuentran cercenados.

Para finalizar esta sección, como apuntan Juanjo Celorio (1995, citado en Argibay y Celorio, 2005) y Luque (2011), los contenidos deben sostener una lógica en función a problemas relevantes, que conecten con los intereses de los estudiantes. La propuesta que formulamos expone al estudiante a la búsqueda de organizaciones que gestionan servicios sociales, atendiendo a sus inquietudes, intereses o preocupaciones. Con ello, nos sumamos a la estrategia que De Paz (2009) propone respecto a establecer iniciativas que integran a los recursos de la comunidad y del entorno para educar en problemáticas de relevancia académica personal y de relevancia social, vinculándose con el aprendizaje de la teoría de Vigotsky, que se sostiene en la construcción histórica-social y cultural. En este sentido, los intercambios constantes con otras personas portadoras de creencias, de diferentes formas de vida cotidiana, así como de la propia formación permanente como facilitadores de los profesores, enriquecen y contribuyen a la construcción de nuevos significados del mundo (Hegoa/Incyte, 2003: 59). "Todo ello sostiene coherencia con que la pedagogía debe corresponder a las raíces culturales y al contexto comunitario y político”, esto es a las condiciones y características del grupo (Hegoa/Incyte, 2003), a la vez que con el aprendizaje significativo, de la Teoría de Ausubel.

\subsection{Fundamentación con base al currículum institucional-profesional}

A partir de 2014, y como resultado de un largo periodo de revisión, el Comité Ejecutivo de la Federación internacional de Trabajadores Sociales y la Junta de la Asociación Internacional de Escuelas de Trabajo Social, alcanzan una definición global consensuada de Trabajo Social: "el Trabajo Social es una profesión basada en la práctica y una disciplina académica que promueve el cambio y el desarrollo social, la cohesión social, y el fortalecimiento y la liberación de las personas. Los principios de la justicia social, los derechos humanos, la responsabilidad colectiva y el respeto a la diversidad son fundamentales para el Trabajo Social. Respaldada por las teorías del Trabajo Social, las ciencias sociales, las humanidades y los conocimientos indígenas, el Trabajo Social involucra a las personas y las estructuras para hacer frente a desafíos de la vida y aumentar el bienestar."

Dicho esto, resulta evidente la complejidad del ejercicio profesional de los trabajadores sociales, por lo que su transcurso por la universidad ha de contribuir de manera clara e intencionada a la capacitación de habilidades y actitudes que le permita poner en práctica las nociones conceptuales que configuran la profesión. Ello exige una profunda reflexión sobre el modelo educativo dominante definido en los planes de estudio y las prácticas

(cc) EY-NC-ND 2018, Universitat Politècnica de València

Congreso IN-RED (2018) 
metodológicas docentes que se están llevando a cabo en las aulas, y buscar respuesta a si se está haciendo una formación que atiende a las exigencias de la sociedad, entendida como el sector de población privadas de derechos sociales y que se encuentra demandando respuestas a su situación de vulnerabilidad y/o exclusión social, de una parte, pero también del conjunto de la ciudadanía privadas de procesos de desarrollo comunitario y participación social que les permita alcanzar un nivel de bienestar social que dignifique sus vidas.

\subsection{Fundamentación según currículum institucional-académico}

Ahora vamos a centrar la atención sobre el por qué la negociación se constituye en un necesario foco de atención como habilidad objeto de aprendizaje, la cual se proyecta desde la práctica pedagógica en la titulación de Grado de Trabajo Social.

\subsubsection{Libro Blanco de Grado de Trabajo Social}

Con relación a la capacidad negociadora de la que han de dotarse los trabajadores sociales, el Libro Blanco de Grado de Trabajo Social nos indica que “(...) la competencia laboral implica movilizar una serie de atributos para trabajar exitosamente en diferentes contextos y bajo diferentes situaciones emergentes. Los conocimientos se combinan con las habilidades y la percepción ética de los resultados del trabajo en el intorno y el entorno, con la capacidad de comunicarse y entender los puntos de vista de los compañeros de profesión y usuarios/clientes, la habilidad para negociar e intercambiar informaciones, etc.” (Agencia Nacional de Evaluación de la Calidad y Acreditación, 2004:110).

Continúa el Libro Blanco señalando cinco ámbitos competenciales profesionales, identificando los siguientes criterios de realización que requieren de la habilidad negociadora de los profesionales:

- Mediar y negociar cuando las personas tienen puntos de vista diferentes.

- Negociar cuándo los planes deben ser ampliados o reducidos y dónde se necesita y está disponible el apoyo adicional necesario.

- Trabajar con el sistema cliente identificando, negociando y seleccionando la mejor forma de representación.

- Realizar el seguimiento del nivel de riesgo y renegociando la acción planificada cuando se producen cambios.

- Negociar y establecer las propias responsabilidades profesionales dentro de la relación.

- Negociar y establecer las propias expectativas con respecto a la relación, y las que otros tienen del trabajador social dentro de la relación.

1.3.2. Memoria de verificación del Título de Grado de Trabajo Social de la ULPGC 20102011

La Universidad de Las Palmas de Gran Canaria (ULPGC), con la llegada del EEES, y con todo el engranaje de ordenamiento de sus títulos de grado (Ley Orgánica 4/2007, de 12 de 
abril, por la que se modifica la Ley Orgánica 6/2001, de 21 de diciembre, de Universidades, y Real Decreto 1393/2007, de 29 de octubre, por el que se establece la ordenación de las enseñanzas universitarias oficiales), define en la memoria de verificación del Título de Grado de Trabajo Social de la ULPGC 2010-2011, lo siguiente con relación a la habilidad negociadora que ha de ser abordada durante el proceso formativo de los futuros trabajadores sociales.

De un lado, entre los resultados de aprendizajes que ha de alcanzar los estudiantes en la materia relativa a Métodos, Modelos y Técnicas del Trabajo Social, se tiene el hecho de que: sea capaz de consultar y cooperar con otros, incluidos los usuarios de servicios, negociando los límites institucionales y profesionales y reconociendo las diferencias de identidad o lenguaje; sea capaz de diseñar, implementar y evaluar planes de intervención con las personas atendidas y otros profesionales negociando el uso de servicios y revisar la eficacia de dichos planes; y sea capaz de aplicar las estrategias de resolución de conflictos por medio de la negociación y la mediación

De otro lado, como resultados de aprendizaje en la materia relativa a Habilidades Sociales y de Comunicación del Trabajo Social, el estudiante ha de ser capaz de establecer relaciones profesionales al objeto de identificar la forma más adecuada de intervención y de aclarar y negociar la finalidad de tales contactos y los limites de su implicación.

Y, finalmente, con relación al Trabajo Fin de Grado, se persigue que se alcance como resultado de aprendizaje que sea capaz de diseñar, implementar y evaluar proyectos de intervención social y planear de forma negociada una secuencia de acciones y seguir y evaluar su desarrollo.

\section{Objetivos}

La finalidad del trabajo es demostrar si la puesta en práctica de metodologías docentes basadas en el ApS, permiten el aprendizaje de las habilidades que define a la EDCG.

En este trabajo hemos focalizado la atención en el objetivo de analizar si la aplicación del ApS favorece, al margen de las competencias explícitas y específicas de la asignatura que se han indicado en las guías docentes, la adquisición de la "capacidad de negociar y de llegar a acuerdos”, habilidad definida por la EDCG (Boni, et. al., 2013).

La hipótesis de trabajo es que el ApS es una metodología docente que contribuye a la adquisición de los aprendizajes esta habilidad.

El proceso del trabajo de indagación ha consistido en la elaboración de un cuestionario, recogida de datos, transcripción de la información al programa excel, presentación de resultados, análisis de los datos obtenidos y elaboración de conclusiones.

El instrumento de recogida de datos es la encuesta, con tipo de pregunta cerrada (¿cuál de los siguientes contenidos se adquiere con la experiencia Aps?), con opción de respuesta dicotónica ("sís" o "no").

La recogida de datos se efectúa el último día de clase, a la totalidad de estudiantes que asisten al aula. En el momento de cumplimentar la encuesta, los estudiantes desconocen la

(c) BY-NC-ND 2018, Universitat Politècnica de València

Congreso IN-RED (2018) 
existencia de los atributos, pues no se configuran de manera intencionada en la guía docente, ni se ha explicitado verbalmente durante el semestre, lo que significa que responden ipso facto su valoración sobre el aprendizaje/adquisición que han obtenido sobre aquellos.

\section{Desarrollo de la innovación}

La innovación docente que hemos llevado a cabo se circunscribe a la puesta en práctica de la herramienta del ApS, con enfoque de EDCG. Hemos tenido dos modelos de experiencias: uno durante los cursos 2012-13 y 2013-14 (con estudiantes de primer curso, asignatura Organización de los Servicios Sociales, y de segundo curso con la asignatura Programas y Prestaciones de los Servicios Sociales), y un segundo modelo durante los cursos 2016-17 y 2017-18 (con estudiantes de segundo curso con la asignatura Programas y Prestaciones de los Servicios Sociales).

Como rasgos comunes a ambos episodios se destaca:

- El carácter voluntario de los estudiantes para optar a llevar a cabo la experiencia, en ningún momento impuesta por la docente. Este formato favorece de manera esencial contar con el compromiso de los estudiantes con la acción pedagógica perseguida.

- Se viven situaciones de debate y reflexión compartidas en el aula, a la vez que a nivel intragrupal, e individual. Se trata de espacios de negociación y toma de decisiones al interno del aula.

- En todos los casos, los estudiantes, bien a nivel individual (primera experiencia), o grupal (segunda) asumen dirigirse directamente a organizaciones gestoras de servicios sociales con las que deberán negociar y acordar la posibilidad de llevar a cabo la actividad de ApS y/o el trabajo grupal. No se produce en ningún momento la intermediación por parte de la docente entre estudiantes y organizaciones. Se trata de negociación y toma de decisiones al externo del aula.

Estos tres elementos sitúan al estudiantado en conexión con lo académico y con la realidad del contexto, desempeñando un papel de relaciones complejas que repercuten en sus aprendizajes.

Los asuntos sometidos a negociación y a toma de decisiones que conlleva a compromisos suponen dos fases claves: la primera fase versa sobre ¿asumir (o no) un modelo de aprendizaje dirigido/ cerrado/ no negociado/ impuesto por la docente? ¿asumir (o no) el reto de intentar aprender de otra manera más activa, participativa y en contacto con el entorno y la realidad?. En todas las experiencias este periodo de debate, análisis y reflexión se torna como mecanismo pedagógico de aprendizaje, exigiendo la puesta en práctica de habilidades $\mathrm{y}$ actitudes individuales en el aula.

Respecto a esta primera fase, en la primera etapa (2012-14), la propuesta acordada se caracterizó por una toma de decisión individual por la que el estudiante acogido a esta modalidad debía contactar, explicar, negociar y tomar decisiones sobre el compromiso que asumía directamente con una organización (escogida por el mismo) gestora de programas o prestación de servicios sociales. En esta ocasión se trata de sustituir el examen como 
estrategia de evaluación por la experiencia de ApS que conlleva la contribución del estudiantes de 15 h (primer año) y 20 h, (en el seguno) de presencia y participación en las actividades que la organización y estudiante acordaron, atendiendo a las necesidades de la misma y en consonancia con contenidos de la asignatura, de manera que cada estudiante ha de definir, desde el inicio, de manera consciente e intencionada, qué objetivos de aprendizaje y qué objetivos de servicio se propone (con relación a esta experiencia puede ampliarse información en: Cano, Díaz y Guedes, 2013; Cano y Cabrera, 2015).

En la segunda etapa (2016-18), la decisión inicial adoptada por los grupos de trabajo de la asignatura, afectaría al grupo clase en su conjunto, de manera que la decisión última supondría que todos trabajaríamos el mismo proyecto. En esta ocasión, la propuesta se circunscribe al trabajo grupal obligatorio establecido en la guía docente. Tras el acuerdo adoptado, toda la clase trabajó en torno a la organización y celebración de lo que fueron los II y III Encuentros de Sensibilización sobre las Realidades Sociales. Durante el proceso, estudiantes y docente abordamos conjuntamente la idealización, coordinación, organización, y celebración de sendos encuentros. Cada una de estas estrategias de trabajo conllevó reflexión, negociación y toma de decisiones, que suponen compromisos de realización de tareas y acciones dirigidas al objetivo de celebración del encuentro, aprendizaje por proyecto que, pedagógicamente, se torna como mecanismo de "disculpa" sobre el que gira todo el proceso. Adoptamos decisiones sobre: qué hacer, cómo hacerlo, cuándo, con qué, con quiénes y dónde hacerlo (el primer año se hizo en las instalaciones de la Facultad de Ciencias Jurídicas y la Facultad de Economía, Empresa y Turismo; el segundo año se celebró en la Escuela de Ingenierías Industriales y Civiles y en la Escuela de Ingeniería, Telecomunicaciones y Electrónica). En un momento avanzado del proceso de trabajo, se planea la idealización de criterios de evaluación y modelo de evaluación (autoevaluación y coevaluación) (con relación a esta experiencia puede ampliarse información en: Cano: 2015; Cano y Cabrera: 2016, 2017a, 2017b y 2017c).

\section{Resultados}

Atendiendo a la finalidad definida anteriormente, presentamos a continuación los resultados obtenidos. Estos refieren a la valoración que los estudiantes perciben respecto a si la experiencia pedagógica que han desarrollado, les ha permitido (o no) mejorar su "capacidad de negociar y llegar a compromisos”.

En esta ocasión nos interesa obtener una visión global y comparada entre las dos experiencias (2012-14 y 2016-18) por lo que centraremos la atención en el análisis de los datos obtenidos de ambas.

Se tiene que, de un total de 246 encuestas (100\%), 197 estudiantes (80,1\%) responden positivamente respecto a haber desarrollado más esta habilidad a través de la experiencia de ApS que se ha llevado a cabo en su asignatura.

De ese total, podemos distinguir que durante la experiencia de los cursos 2012-13-14 casi las tres cuartas partes de las respuestas obtenidas responden afirmativamente $(72,1 \%)$, mientras que este dato queda superado por la experiencia de los cursos 2016-17-18, con un $88,9 \%$. 
Tabla 2. Resultados del análisis factorial

\begin{tabular}{cccc}
\hline $\begin{array}{c}\text { Experiencias } \\
\text { cursos }\end{array}$ & Total encuestas & $\begin{array}{c}\text { Total respuestas positivas: } \\
\text { adquisición de la capacidad de } \\
\text { negociar y de llegar a compromisos }\end{array}$ & Porcentaje \\
\hline $2012-13-14$ & 129 & 93 & 72,1 \\
$2016-17-18$ & 117 & 104 & 88,9 \\
Totales & 246 & 197 & 80,1 \\
\hline
\end{tabular}

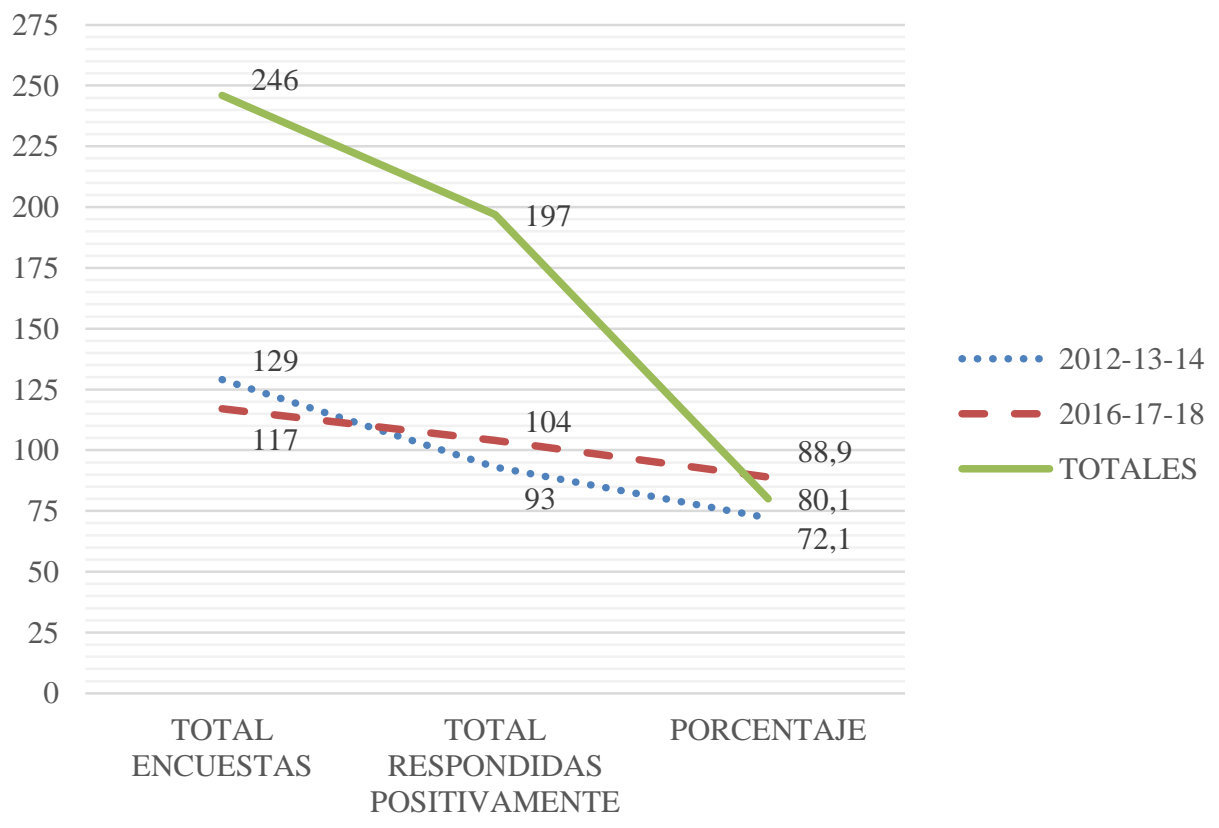

Gráfica 1 Resultados de la encuesta

\section{Conclusiones}

En primer lugar, y atendiendo a la narrativa observada en el apartado de fundamentación de la propuesta docente que presentamos, podemos concluir que la "capacidad de negociar y llegar a compromisos" se configura como una de las destrezas contempladas en el currículum profesional y el currículum académico, sosteniendo una coherencia y sintonía entre sí, a la par que dotando de sentido a la práctica docente que estamos aplicando.

Centrándonos ahora en las experiencias, dadas las diferencias de procedimiento entre los dos formatos realizados (2012-14 y 2016-18), y atendiendo a las respuestas obtenidas, se concluye que el modelo seguido en los dos últimos años, acentúa su contribución a la 
adquisición de esta habilidad. Este positivo progreso y sistematización de la praxis, contribuye a la maduración y consolidación del enfoque pedagógico de la EDCG y enfoque metodológico con el ApS.

Además, se confirma que, por un lado, sin estar explícita esta competencia en las guías docentes de la asignaturas (y sin posibilidad de ello en tanto que no están reconocidas dentro de las materias del Plan de Estudios del Titulo, esto es el currículum institucional) y, por otro lado, cumpliendo con los objetivos y aprendizajes previstos en la guía docente de la asignatura (currículum ofrecido), el enfoque metodológico aplicado permite adquirir otros aprendizajes, configurándose como currículum oculto y que, en este caso, complementa al currículum real, como aprendizajes que efectivamente adquieren los estudiantes.

Por tanto, podemos afirmar que la hipótesis de indagación se confirma, en tanto que el ApS, con enfoque de EDCG favorece la adquisición de la capacidad negociadora y de llegar a compromisos.

Poniendo la mirada hacia el futuro, y atendiendo a todo lo anterior, visto los datos arrojados, se propone que durante la revisión del plan de estudios del Grado de Trabajo Social se estime la conveniencia de incorporar la adquisición de la competencia en las asignaturas de la materia de servicios sociales, permitiendo visibilizarlo en el currículum ofrecido, esto es, en la guía docente.

Y, para finalizar, esta introspección que venimos haciendo, nos insta a profundizar respecto la identificación, aanálisis y reflexión sobre los hitos que caracterizan el procedimiento pedagógico que están contribuyendo al desarrollo de la habilidad, de manera que nos permita introducirlas mejoras en futuros cursos.

\section{Referencias}

ACASO, M. (2012). Pedagogías invisibles. El espacio del aula como discurso. Madrid: Catarata.

AGENCIA NACIONAL DE EVALUACIÓN DE LA CALIDAD Y ACREDITACIÓN (2004). Libro Blanco Título de Grado de Trabajo Social.

$<$ http://www.aneca.es/var/media/150376/libroblanco_trbjsocial_def.pdf> [Consulta: 10 de abril de 2017].

ÁLVAREZ MÉNDEZ, J.M. (2009). “Evaluar el aprendizaje en una enseñanza centrada en las competencias”. Gimeno Sacristán, J. (Comp) en: Educar por competencias ¿qué hay denuevo?. Madrid: Ediciones Morata. Pp 206-234.

ARAMBURUZABALA, P. (2013). “Aprendizaje-Servicio: Una herramienta para educar desde y para la justicia social” en Revista internacional de educación para la justicia social, vol. 2, Núm. 2, p. 5-11. <http://www.rinace.net/riejs/numeros/vol2-num2/editorial.pdf> [Consulta: 7 de abril de 2017].

ARGIBAY, M. Y CELORIO, G. (2005). Educación para el Desarrollo. Vitoria: Servicio Central de Publicaciones del Gobierno Vasco-HEGOA.

BAIN (2005). Lo que hacen los mejores profesores de universidad. Valencia: Servicio de Publicaciones de la Universidad de Valencia.

(cc) EY-NC-ND 2018, Universitat Politècnica de València

Congreso IN-RED (2018) 
BONI, A. (2005). Tesis La Educación para el Desarrollo en la enseñanza universitaria como una estrategia de la cooperación orientada al desarrollo humano. Universidad de Valencia. <http://ccd.webs.upv.es/files/Fondo_documental/Tesis/Alejandra\%20Boni Aristizábal.pdf>

BONI, A., LÓPEZ, E. Y R. BARAHONA (2013). “Approaching quality of global education practices through action research. A non-governmental development organization-university collaborative experience”en International Journal of Development Education and Global Learning 5(2), pp. $31-46$.

CANO-RAMÍREZ, A., DÍAZ GONZÁLEZ, N. Y VIERA GUEDES, D. (2013). “AprendizajeServicio: una práctica docente que acerca a los estudiantes de Grado de Trabajo Social a la realidad social y profesional”. Universidad de Málaga. XII Congreso Estatal de Trabajo Social: la intervención social en tiempos de malestares. Madrid: Consejo General de Trabajo Social.

CANO-RAMÍREZ, A. (2014). Exploración de las prácticas docentes con enfoque de Educación para el Desarrollo para la Ciudadanía Global. Aproximación diagnóstica en los títulos de grado de las universidades españolas tras la implementación del EEES. Tesis Doctoral. Las Palmas de Gran Canaria: Universidad de Las Palmas de Gran Canaria. <http://hdl.handle.net/10553/12352> [Consulta: 21 de marzo de 2017]

CANO-RAMÍREZ, A. (2015). Aprendizaje-Servicio y Educación para el Desarrollo: aproximación a los aprendizajes a partir de la experiencia docente. Foro de Investigación en Educación para el Desarrollo y Ciudadanía Global. Universidade de Coruña.

CANO-RAMÍREZ, A. Y CABRERA SUÁREZ, F. (2016). “Estudio sobre la adquisición de habilidades desde la perspectiva de la Educación para el Desarrollo a partir de la experiencia de Aprendizaje-Servcio en Grado de Trabajo Social de la ULPGC” en González Barea, E.M. y Moreno Yus, MA. (Eds). Aprendizaje-Servicio, desarrollo y comunidades profesionales de aprendizaje en Educación Superior. Murcia: Universidad de Murcia. Vol. II, pp 274-279.

CANO-RAMÍREZ, A. Y CABRERA-SUÁREZ, F. (2017a). ApS y procesos de empoderamiento de los estudiantes a través de la organización de un evento: II Encuentro de Semnsibilización sobre Realidades Sociales en la ULPGC. VIII Congreso Nacional y III Internacional de AprendizajeServicio Universitario ApS-U8. Sevilla: Universidad Pablo Olavide. Pendiente de publicación.

CANO-RAMÍREZ, A. Y CABRERA SUÁREZ, F. (2017b). "Estudio sobre la adquisición de habilidades de la Educación para el Desarallo como resultado de la experiencia docente de aprendizaje-servicio”. Universidad Jaume I. VI Jornada Nacional sobre Estudios Universitarios. Castellón.

CANO-RAMÍREZ, A. Y CABRERA-SUÁREZ, F. (2017c). “Motivaciones de los estudiantes pada acogerse a una metodología docente basada en el Aprendizaje-Servicio” en J. Carrillo-Rosúa, J.L. Arco-Tirado \& F.D. Fernández-Martín (eds.). Investigando la mejora de la enseñanza universitaria a través del aprendizaje-servicio (pp. 61-67). Granada: Editorial Universidad de Granada. <http://hdl.handle.net/10481/46881> [Consulta: 27 de enero de 2018]

DE PAZ ABRIL, D. (2009). "La escuela como espacio de diálogo. Un camino de esperanza”, en Consorcio Conectando Mundos, Educar para una ciudadanía global. Construir un mundo justo desde la escuela. España: Intermón Oxfam. Pp.95-99.

DÍAZ PINTO, C.F. (2010). Viejas y Nuevas Ideas en Educación. Una historia de la pedagogía. Madrid: Editorial Popular.

FEDERACIÓN INTERNACIONAL DE TRABAJADORES SOCIALES (2014). "La agenda global para el trabajo social $y$ el reporte del progreso de desarrollo social”. <http://cdn.ifsw.org/assets/ifsw_105524-8.pdf> [Consulta: 24 de febrero de 2017] 
FRANCISCO, A. Y MOLINER, L. (2010). "El Aprendizaje Servicio en la Universidad: una estrategia en la formación de ciudadanía crítica” en Revista Interuniversitaria de Formación del Profesorado, 13(4). <http://www.aufop.com> [Consulta: 2 de octubre de 2016]

GIMENO SACRISTÁN, J. (2005). La educación que aún es posible. Madrid: Ediciones Morata.

GRUNDY, S. (1998). Producto o praxis del currículum. $3^{\mathrm{a}}$ edición. Madrid: Ediciones Morata.

LEY ORGÁNICA 4/2007, de 12 de abril, por la que se modifica la Ley Orgánica 6/2001, de 21 de diciembre, de Universidades (BOE núm. 89, del 13 de abril de 2007). <http://www.boe.es/boe/dias/2007/04/13/pdfs/A16241-16260.pdf>

POLYGONE (2003). Mosaico educativo para salir del laberinto. Red Internacional de educación para el desarrollo y educación popular. Vitoria-Gasteiz: HEGOA/Incyte.

REAL DECRETO 1393/2007, de 29 de octubre, por el que se establece la ordenación de las enseñanzas universitarias oficiales (BOE núm. 260, del 30 de octubre de 2007). $<$ https://www.boe.es/buscar/act.php?id=BOE-A-2007-18770> [Consulta: 13 de enero de 2017]

Universidad de Las Palmas de Gran Canaria. Proyecto de Título de Grado de Trabajo Social de la Universidad de Las Palmas de Gran Canaria 20110-11. <www.ulpgc.es> [Consulta: 13 de enero de 2017]

ZABALZA, M.A. (2003). Competencias docentes del profesorado universitario. Calidad y desarrollo profesional. Madrid: Narcea.

(cc) EY-NC-ND 2018, Universitat Politècnica de València 


\title{
Cómo conseguir una transición coherente entre bachillerato y universidad. Tecnología e ingenierías
}

\section{Enric Torres Barchino ${ }^{a}$, Manuel Contero González ${ }^{\mathrm{b}}$ y Manuel Martínez Torán ${ }^{\mathrm{c}}$}

a I3B, Universitat Politècnica de València, entorbar@ega.upv.es, ${ }^{b} \mathrm{I} 3 \mathrm{~B}$, Universitat Politècnica de València, mcontero@upv.es y 'Departamento de Dibujo, Universitat Politècnica de València, mmtoran@upv.es

\begin{abstract}
LOMCE (2013) and Decrees of "urgent measures to turn on the calendar implementation" (BOE 298, RD 5/2016 of 9th December), and "characteristics, design and content of the High School evaluation in order to access to the University "(BOE 309, Order ECD 1941/2016 of 23rd December), eliminate the possibility to be examined of specific subjects in the University Access Tests (PAU, now called EvAU). Industrial Technology subject suffers this problem and it isn't anymore a Modality Core with a weight of 0.2. Its curriculum is oriented to the transition of students towards engineering and architecture studies. According to data from the CRUE 2015 (page 15), "the loss of registration in engineering education is worrisome because of the need of technological employment that requires an economy based on innovation". Men continue being the majority of registrations in engineering (76.4\%) opposite to women (23.6\%). In addition, the employment rate (2014) in Engineering and Architecture is $80.8 \%$. The paper proposes the interdisciplinary content between STEM subjects, which through the methodology of projects or problems (PBL), improves the capacity of know-how, creativity and innovation.
\end{abstract}

Keywords: LOMCE, High School, PAU, curriculum, Industrial Technology, PBL, STEM, professional skills, transition to engineering and architecture.

\section{Resumen}

La LOMCE (2013) y los Decretos de "medidas urgentes para la aplicación del calendario de implantación” (BOE 298, RD 5/2016 de 9 dic.), y “características, diseño y contenido de la evaluación de Bachillerato para el acceso a la Universidad" (BOE 309, Orden ECD 1941/2016 de 23 dic.), eliminan la posibilidad de que el alumnado pueda examinarse de las materias específicas en las Pruebas de Acceso a la Universidad (PAU, ahora denominada EvAU). La materia de Tecnología Industrial sufre este problema, que era Troncal de Modalidad con ponderación de 0,2. Su currículo está orientado para la transición del alumnado hacia los estudios de Ingeniería y Arquitectura. Según datos de la CRUE 2015 (pág.15), "la pérdida de matrícula observada en la enseñanza de Ingeniería, resulta preocupante dada la necesidad de empleo tecnológico que requiere una economía basada en la innovación”. Los hombres continúan siendo 
mayoritarios en la matrícula de las ingenierías $(76,4 \%)$ frente al de mujeres (23,6\%). Además, la tasa de empleo (2014) en Ingeniería y Arquitectura es del 80,8\%. La ponencia plantea la interdisciplinariedad de contenidos entre las materias STEM, que a través de la metodología de proyectos o problemas (PBL), mejora la capacidad del saber hacer, la creatividad y la innovación.

Palabras clave: LOMCE, Bachillerato, PAU, currículo, Tecnología Industrial, PBL, STEM, habilidades profesionales, transición a ingenierías y arquitectura.

\section{Introducción}

La Ley Orgánica para la Mejora de la Calidad Educativa (LOMCE, 2013) ${ }^{[1]}$ establece en la Educación Secundaria Obligatoria (ESO) dos itinerarios en $4^{\circ}$ curso: la vía académica (la que da acceso a Bachillerato), y la vía profesional (la que da acceso a la Formación Profesional). En la actualidad, aunque la normativa vigente indica que se tiene que ofrecer la materia de Tecnología en los dos itinerarios formativos, existen muchas dificultades para que los centros educativos ofrezcan Tecnología en la vía académica, ya que se asocia esta materia con el grupo de asignaturas de la vía profesional, y no con el itinerario que da acceso a Bachillerato.

Es más, con la LOMCE se pierden conocimientos y habilidades tecnológicas desde $3^{\circ}$ curso ESO, mientras que se incrementan en la FP-Básica (a partir de 15 años, alumnos con dificultades de aprendizaje). Con la FP-Básica se da continuidad de formación para el acceso a la FP-Grado Medio (16-18 años).

Por otra parte, en el tramo de educación secundaria postobligatoria de Bachillerato, y con la entrada en vigor de los decretos sobre "medidas urgentes para la aplicación del calendario de implantación" (BOE 298, RD 5/2016 de 9 dic.) ${ }^{[2]}$, y el de "características, diseño y contenido de la evaluación de Bachillerato para el acceso a la Universidad" (BOE 309, Orden ECD 1941/2016 de 23 dic. $)^{[3]}$, se establece que los alumnos sólo se examinarán de las asignaturas Troncales, dejando sin validez a las asignaturas Específicas, como por ejemplo, Tecnología Industrial, Tecnología de la Información y la Comunicación (TIC), Informática, etc.

\footnotetext{
[1] Organigrama Sistema educativo en España, 2013. MECD.

Disponible: $\langle\underline{\text { https:} / / \text { www.mecd.gob.es/educacion/mc/lomce/lomce/itinerarios.html }>}$ [Consulta: 28 de mayo de 2018]

${ }^{[2]}$ Real Decreto 5/2016 de 9 dic. Medidas urgentes para la aplicación del calendario de implantación LOMCE. Disponible: 〈https://www.boe.es/boe/dias/2016/12/10/pdfs/BOE-A-2016-11733.pdf > [Consulta: 28 de mayo de 2018]

[3] Orden ECD 1941/2016 de 23 dic. Características, diseño y contenido de la evaluación de Bachillerato para el acceso a la Universidad.

Disponible: 〈https://www.boe.es/boe/dias/2016/12/23/pdfs/BOE-A-2016-12219.pdf >

[Consulta: 23 de mayo de 2018]
}

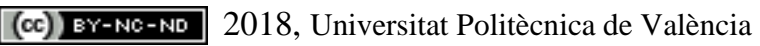

Congreso IN-RED (2018) 
La decisión de no incluir las materias Específicas en las Pruebas de Acceso a la Universidad (PAU, ahora EvAU), supone de facto la posterior desaparición o destinterés por las mismas, ya que el alumnado que aunque tenga interés por cursarlas, no verá recompensada su decisión por la ausencia de ponderación en las PAU. Esta es una de las consecuencias de la aplicación de dichos decretos; el drástico descenso de alumnado con conocimientos y habilidades tecnológicas para su continuidad en las distintas ramas de Ingeniería y Arquitectura.

A estos problemas, se añaden otros de carácter conceptual, y es confundir o asociar por ejemplo, tecnología con las tecnologías digitales, con la informática, o con robótica y programación. En el actual currículo de la modalidad de Ciencias del Bachillerato, existen las asignaturas de Tecnología Industrial, TIC, Dibujo Técnico e Informática que son enlace con sus homónimas en los estudios de las ingenierías y arquitectura, y que al ser materias optativas, difícilmente son cursadas en su globalidad por los alumnos.

Veamos sus diferencias y sus coincidencias. Enseñar y aprender las $\mathrm{TIC}^{[4]}$, es sobre todo adquirir habilidades para el uso de ordenadores, aplicaciones para los teléfonos inteligentes, tabletas, pizarras digitales, o comunicar informaciones online. Mientras que enseñar y aprender Informática ${ }^{[5]}$, es sobre todo aprender un lenguaje de programación, desarrollar algoritmos o conjunto de reglas ordenadas y bien definidas que permita realizar una actividad mediante pasos sucesivos para obtener una solución.

Mientras que enseñar y aprender Tecnología ${ }^{[6]}$, es sobre todo saber idear objetos y máquinas, manipular artefactos y herramientas, diseñar soluciones innovadoras, construir elementos de máquinas y sistemas capaces de resolver un problema técnico. De la misma manera, enseñar y aprender Dibujo Técnico ${ }^{[7]}$, es sobre todo saber imaginar y dibujar objetos y sistemas técnicos, interpretar normas y símbolos, o representar un conjunto de piezas de un proyecto constructivo en papel o informatizado.

En definitiva, estamos hablando de un mismo lenguaje, que desde diferentes puntos de vista se hacen tareas que enriquecen el proyecto o problema tecnológico a resolver, y donde se incorporan conceptos y procedimientos como: analizar, interpretar, diseñar, dibujar, programar, construir, optimizar, automatizar, etc.

Hoy en día, tratar de coordinar los currículos de las materias afines como Dibujo Técnico, Informática, Tecnología y TIC del Bachillerato de Ciencias, y establecer criterios, como por ejemplo, compartir conocimientos y recursos, ser eficientes y no duplicar contenidos, o

\footnotetext{
${ }^{[4]}$ Wikipedia. Disponible:

<https://es.wikipedia.org/wiki/Tecnolog\%C3\%ADas_de_la_informaci\%C3\%B3n_y_la_comunicaci\% C3\%B3n > [Consulta: 28 de mayo de 2018]
}

${ }^{[5]}$ Wikipedia. Disponible: <https://es.wikipedia.org/wiki/Inform\%C3\%A1tica > [Consulta: 28 de mayo de 2018]

${ }^{[6]}$ Wikipedia. Disponible: 〈https://es. wikipedia.org/wiki/Tecnolog\%C3\%ADa > [Consulta: 28 de mayo de 2018]

[7] Wikipedia. Disponible:〈https://es.wikipedia.org/wiki/Dibujo_t\%C3\%A9cnico > [Consulta: $28 \mathrm{de}$ mayo de 2018] 
experimentar y realizar proyectos que cohesionen los diferentes ámbitos de conocimiento, no debería ser tan complicado.

La realidad, es que cada una de estas asignaturas, están adscritas a Departamentos diferentes, lo que dificulta enormemente su integración en proyectos educativos como STEM (Science, Technology, Engineering and Mathematics).

El currículo actual ofrece a los alumnos montañas de conocimientos teóricos, sin una conexión interdisciplinaria que facilite e interrelacione los aprendizajes adquiridos para aplicarlos en la resolución de problemas tecnológicos reales. La LOMCE y su desarrollo normativo permite que los alumnos con aptitudes y actitudes de continuar estudios en las distintas ramas de Ingeniería, Arquitectura o Formación Profesional de Grado Superior, puedan no matricularse de las materias Específicas (optativas), a excepción del Dibujo Técnico (Troncal obligatoria) ya que sólo esta asignatura está ponderada en las PAU. Esta situación está generando contradicciones innecesarias en los itinerarios formativos del alumnado. Así por ejemplo, se da la circunstancia de que un alumno pueda matricularse de Ingeniería Informática, sin haber cursado la asignatura de Informática en la etapa anterior de Bachillerato. De igual manera, sin cursar Tecnología Industrial se puede acceder a Ingeniería Industrial, Aeroespacial, etc.

Ante esta situación, nos planteamos: ¿es posible integrar teoría y práctica a través de la metodología de proyectos o problemas (PBL Project or Problem Based Learning)?, el conocimiento interdisciplinar que se plantea desde los aprendizajes STEM (Science, Technology, Engineering and Mathematics), ¿es viable en el contexto de Bachillerato?

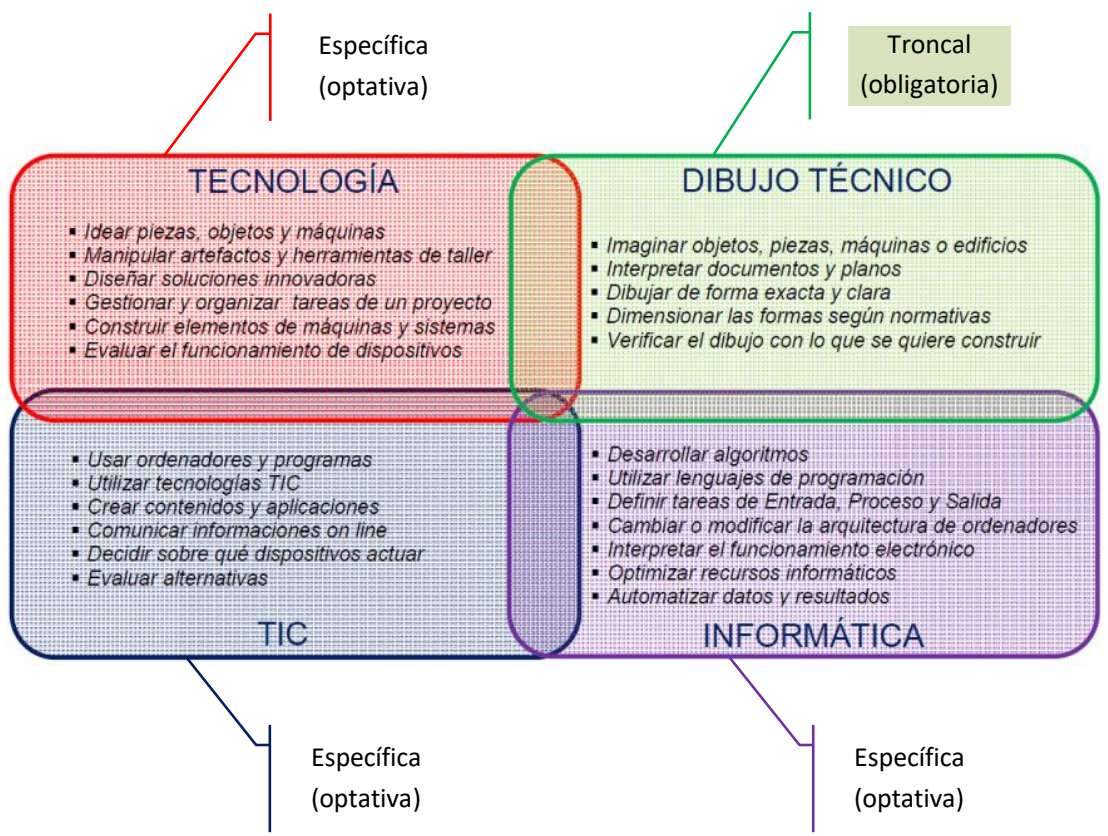

Fig. 1 Asignaturas ofertadas del ámbito tecnológico en el Bachillerato de Ciencias (Fuente: Elaboración propia)

(c)) BY-NC-ND 2018, Universitat Politècnica de València

Congreso IN-RED (2018) 
Desde hace tiempo, existe la percepción social (pros y contras) de lo que representa la ciencia y la tecnología ${ }^{[8]}$. Se suele afirmar que los conceptos y procedimientos que se enseñan en Tecnología (ESO y Bachillerato) son propios de los estudios de Formación Profesional, ya que sus contenidos curriculares (se dice) son muy específicos o son más bien para el entretenimiento $^{[9]}$. Otra de las afirmaciones que se suele decir, es que en Tecnología no existen conceptos como tal, ya que esta materia sirve para adquirir destrezas técnicas, procedimientos y habilidades manuales propios de taller. Estas afirmaciones representan falta de rigor y un volver al pasado, pues seleccionar a los alumnos tal y como lo hace la LOMCE, por conceptos (Bachillerato) o por procedimientos (FP), ni integra a las alumnas y alumnos con interés y capacidades por la CyT, pero tampoco se mejora el rendimiento académico, la tasa de abandono de tareas, ni la gestión del talento.

En la Fig.2 se muestra la estructura horaria de la asignatura Tecnología (ESO y BC), indicando si es Troncal (obligatoria) o Específica (optativa), y los bloques de contenidos del currículo.

\begin{tabular}{|c|c|c|c|}
\hline ESO & Trocal / Específica & Horas / semana & Bloques de contenido \\
\hline 10 curso & T. Obligatoria & $2 \mathrm{~h}$ & \multirow{4}{*}{$\begin{array}{l}\text { B.1. Proceso de resolución de problemas tecnológicos } \\
\text { B.2. Materiales de uso técnico } \\
\text { B.3. Estructuras y mecanismos } \\
\text { B.4. Tecnologías de la información y la comunicación } \\
\text { B.5. Elementos transversales a la asignatura }\end{array}$} \\
\hline $2 \cong$ curso & T. Obligatoria & $2 \mathrm{~h}$ & \\
\hline & & & \\
\hline 3o curso & E. Optativa & $2 \mathrm{~h}$ & \\
\hline 4ำ curso (vía académica) & E. Optativa & $3 \mathrm{~h}$ & \multirow{2}{*}{$\begin{array}{l}\text { B.1. Tecnología y sociedad } \\
\text { B.2. Instalaciones en viviendas } \\
\text { B.3. Electrónica } \\
\text { B.4. Control y robótica } \\
\text { B.5. Neumática e hidráulica }\end{array}$} \\
\hline 4ㅇ curso (vía aplicadas) & T. Obligatoria & $3 \mathrm{~h}$ & \\
\hline
\end{tabular}

\begin{tabular}{|c|c|c|c|}
\hline BACHILLERATO (*) & Trocal / Específica & Horas / semana & Bloques de contenido \\
\hline 10 curso & E. Optativa & $3 \mathrm{~h}$ & $\begin{array}{l}\text { B.1. Productos tecnológicos } \\
\text { B.2. Introducción a la ciencia de los materiales } \\
\text { B.3. Máquinas y sistemas } \\
\text { B.4. Procedimientos de fabricación } \\
\text { B.5. Recursos energéticos } \\
\text { B.6. Elementos transversales a la asignatura }\end{array}$ \\
\hline $2^{\circ}$ curso & E. Optativa & $4 \mathrm{~h}$ & $\begin{array}{l}\text { B.1. Materiales } \\
\text { B.2. Principios de máquinas } \\
\text { B.3. Sistemas automáticos } \\
\text { B.4. Circuitos y sistemas lógicos } \\
\text { B.5. Control y programación de sistemas automáticos } \\
\text { B.6. Elementos transversales a la asignatura }\end{array}$ \\
\hline
\end{tabular}

Fig.2 Cuadro horario y bloques de contenido ESO y Bachillerato de Ciencias (Fuente: Elaboración propia)

[8] FECYT. Percepción social de la Ciencia y la Tecnología en España, 2016. Disponible: <https://www.fecyt.es/es/publicacion/percepcion-social-de-la-ciencia-y-la-tecnologia-en-espana2016> [Consulta: 28 de mayo de 2018]

[9] Cuaderno de campo. M. Fernández Enguita. ¿Tecnología para crecer o para entretenernos? La brecha de uso de las nuevas tecnologías en la escuela española. Disponible: <http://blog.enguita.info/2018/03/tecnologia-para-crecer-o-para.html > Consulta: [28 mayo de 2018] 


\subsection{Situación de la oferta de Tecnología Ind. en la Comunitat Valenciana}

Respecto de la Comunitat Valenciana, la oferta de Tecnología Industrial en Bachillerato de Ciencias (BC) está estancada desde hace años. De los 325 institutos públicos con BC, solo en $35(11 \%)$ de los centros públicos se está impartiendo Tecnología Ind.-II, pese a que la red de centros con BC es de 455 (325 públicos, 130 concertados y privados). En el año 2014 el número de institutos que ofrecían Tecnología Ind.I ( $1^{\circ}$ curso) fue de 58 (18\%), mientras que los institutos que ofrecían Tecnología Ind.-II ( $2^{\circ}$ curso), era tan solo de 35 (11\%). En el año 2018 estas cifras no han variado significativamente.

Tabla 1. Situación en la C.Valenciana

\begin{tabular}{|r||c|c|c||c|}
\hline \multicolumn{1}{|c|}{2014} & $\begin{array}{c}\text { IES públicos } \\
\text { con BC }\end{array}$ & $\begin{array}{c}\text { IES públicos } \\
\text { con Tec. Ind.-I }\end{array}$ & $\begin{array}{c}\text { IES públicos } \\
\text { con Tec. Ind.-II }\end{array}$ & $\begin{array}{c}\text { Total alumnos } \\
\text { acceso PAU }\end{array}$ \\
\hline \hline València & 156 & $28(18 \%)$ & $17(11 \%)$ & 447 \\
\hline Alacant & 129 & $23(17 \%)$ & $14(10 \%)$ & 213 \\
\hline Castelló & 40 & $7(17 \%)$ & $4(10 \%)$ & 135 \\
\hline C.Valenciana & $\mathbf{3 2 5}$ & $\mathbf{5 8 ( 1 8 \% )}$ & $\mathbf{3 5}(\mathbf{1 1 \%})$ & $\mathbf{7 9 5}$ \\
\hline
\end{tabular}

\section{Objetivos}

La ponencia se centra en el análisis del contexto educativo y trata de actualizar el modelo de enseñanza y aprendizaje por proyectos (PBL) en el que se incluya tecnologías acordes con la sociedad del conocimiento y la innovación. La formación en red, la escuela 2.0, los métodos de aprendizaje y la integración de saberes del ámbito STEM, o STEAM ${ }^{[10]}$, han empezado a despegar y tienen por delante grandes expectativas que ofrecer. En términos de la investigación (tesis doctorando ID 11125, UPV) los objetivos que nos compete son:

- Documentar las experiencias más relevantes respecto del aprendizaje basado en proyectos o problemas (PBL) y la interdisciplinariedad de áreas STEM.

- Demostrar la viabilidad de todas las fases de la metodología PBL, es decir: planteamiento del problema, desarrollo de conceptos, diseño virtual de objetos, experimentación y construcción de proyectos, y exposición de conclusiones.

- Realizar un análisis cualitativo y cuantitativo a través de encuestas de opinión, cuestionarios y entrevistas con expertos y no expertos en educación.

- Definir las condiciones óptimas para lograr la interdisciplinariedad STEM en secundaria postobligatoria de Bachillerato.

${ }^{[10]}$ El término STEAM (Science, Technology, Engineering, Art and Math) fue concebido por John Maeda (EE.UU, Seattle, 1966) siendo presidente de la Rhode Island School of Design (EE.UU, Rhode Island). Disponible: <https://www.risd.edu/> Consulta: [28 mayo de 2018]

(cc) EY-NC-ND 2018, Universitat Politècnica de València

Congreso IN-RED (2018) 


\section{Desarrollo de la innovación}

La economía y la sociedad cambian cuando los factores de producción se combinan de una manera novedosa (Schumpeter, 1961). Schumpeter introdujo el concepto de innovación y desarrolló las siguientes ideas: la búsqueda a través de la investigación de nuevos conocimientos o soluciones suponen curiosidad y renovación, y las invenciones e innovaciones son la clave del crecimiento económico y social.

En este sentido, aquí se identifican de manera resumida los factores que promueven o dificultan para que se produzca innovación en el contexto escolar [11] [12] [13].

Factores que promueven la innovación educativa:

- Equipos docentes sólidos y comunidad educativa receptiva

- Redes de intercambio y cooperación (uso de TIC)

- Contexto social, compromiso y creatividad

- Institucionalización de la innovación

- Reflexión y evaluación

- Políticas de la Administración educativa y formación docente

Factores que dificultan la innovación educativa:

- Estructura escolar rígida y casi invarable desde el s.XIX

- Resistencia y rutinas del profesorado

- Individualismo y corporativismo

- Pesimismo y malestar docente

- Efectos perversos de las reformas y currículum fragmentado

- Divorcio entre teoría y práctica

Para promover innovación en el aula, hace falta conocer y aplicar cuantas más y diversas metodologías mejor. A veces, la innovación se produce por el solo hecho de estructurar las ideas, trabajar en equipo, tener en cuenta el contexto social, para que más tarde se concreten en acciones.

[11] Innovación educativa. Serie "Herramientas de apoyo para el trabajo docente". Texto 1 (UNESCO oficina de Perú, marzo 2016). Disponible: $<$ http://docentesinnovadores.perueduca.pe/wpcontent/uploads/2017/05/UNESCO INNOVACI\%C3\%93N.pdf > Consulta: [28 de mayo de 2018]

${ }^{[12]}$ Estudio sobre innovación educativa en España, No17. (MECD, 2011). Disponible: <https://sede.educacion.gob.es/publiventa/estudio-sobre-la-innovacion-educativa-enespana/educacion-espana/14970> Consulta: [28 de mayo de 2018]

[13] Innovación educativa en España: un estudio descriptivo a partir de los datos contenidos en REDINED. Disponible: 〈http://redined.mecd.gob.es/xmlui/handle/11162/86731> Consulta [28 de mayo de 2018]

(cc) EY-NC-ND 2018, Universitat Politècnica de València 
Respecto de la innovación entendida como planificación de la tesis doctoral, queda reflejada en el siguiente mapa mental, en donde se destaca:

1. Tiempo de dedicación a la investigación

2. Actividades formativas específicas

3. Trabajo de campo y contraste con la realidad

4. Seguimiento de los cambios producidos en educación

5. Tendencias en innovación PBL e integración de áreas STEM

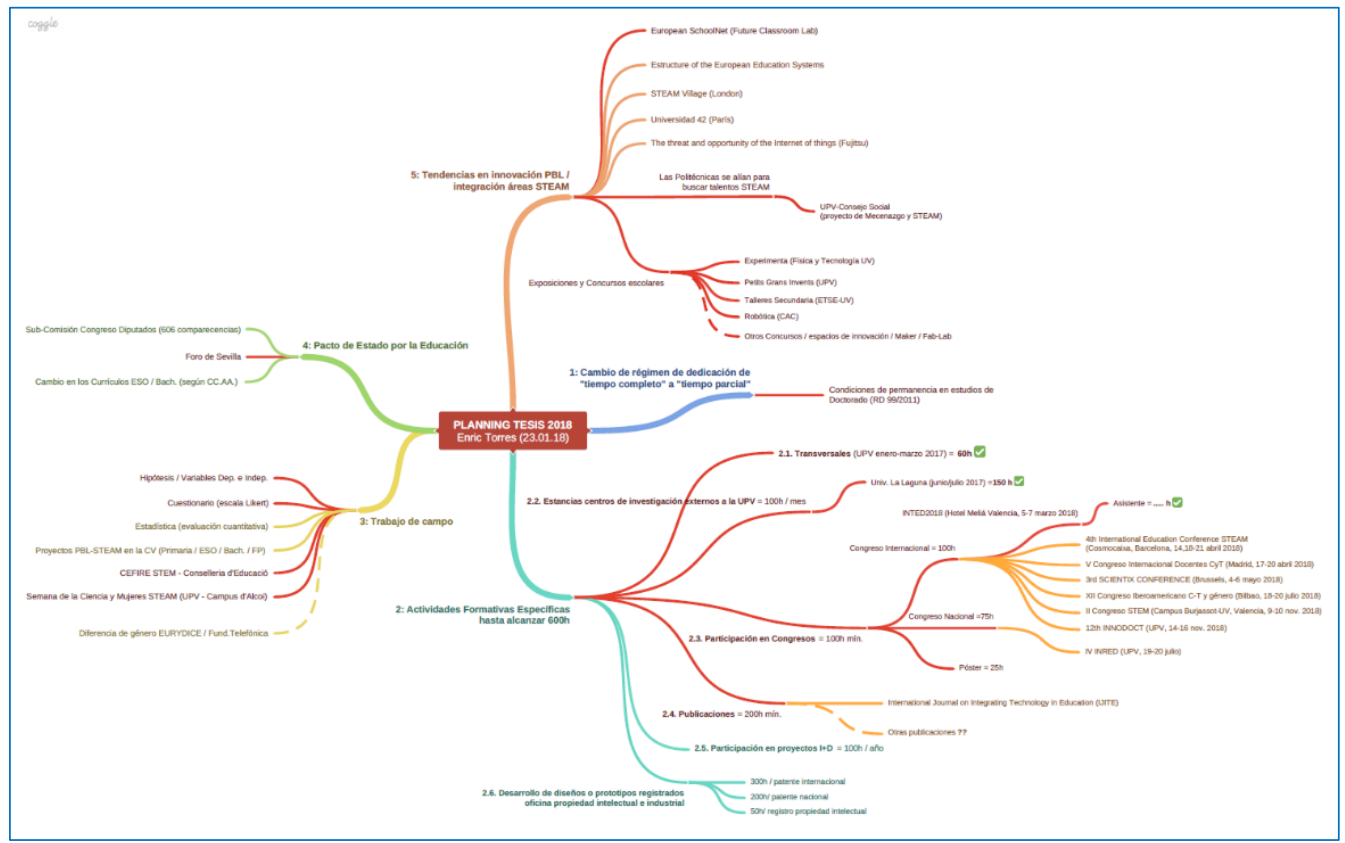

Fig.3 Mapa mental de los aspectos más relevantes de la investigación (Fuente: Elaboración propia)

\subsection{El aprendizaje basado en proyectos o problemas (PBL)}

Diversos autores como J.Dewey (1967), J.Piaget (1955), D.Ausubel (1983), L.Vygotski (1979), H.S.Barrows \& R.M.Tamblyn (1980), R.Tippelt \& H.Lindemann (2001) entre otros, definieron el concepto de "enseñanza por proyectos o problemas (PBL)", mientras que el concepto de "enseñanza problémica" fue definido por M.I.Majmutov (aprox.1970) más centrado en la resolución de problemas. Por su relevancia, destacamos los primeros trabajos de J.Dewey (El método del problema, 1908) y sobre todo de su discípulo W.H.Kilpatrick (El método de proyectos, 1918) $)^{[14]}$.

[14] Método de proyectos. Disponible: 〈https://es.wikipedia.org/wiki/M\%C3\%A9todo_de_proyectos〉 Consulta: [28 de mayo de 2018]

(cc) EY-NC-ND 2018, Universitat Politècnica de València 
El objetivo del aprendizaje basado en proyectos (PBL) es hacer transitar al estudiante por caminos similares a los que recorre el científico para llegar a unas conclusiones. En este sentido, el alumno no solo se apropia del conocimiento, sino de la lógica y del método científico a la hora de resolver un problema determinado. Existe una diferencia de matices entre lo que significa el aprendizaje basado en proyectos y el aprendizaje basado en problemas:

\begin{tabular}{|c|c|}
\hline Aprendizaje basado en proyectos & Aprendizaje basado en problemas \\
\hline $\begin{array}{l}\text { - } \quad \text { Énfasis en el producto } \\
\text { - } \quad \text { Problema complejo } \\
\text { - Se busca la utilización de los } \\
\text { conocimientos }\end{array}$ & $\begin{array}{l}\text { - } \quad \text { Énfasis en el proceso } \\
\text { - } \quad \text { Problema no excesivamente complejo } \\
\text { conocimientos }\end{array}$ \\
\hline
\end{tabular}

El método de aprendizaje PBL consiste en que los estudiantes no reciban el material de estudio en forma preparada, sino que sean capaces de saber elegir de manera activa, y que desarrollen sólidos conocimientos que les permita utilizarlos en la práctica. El método PBL no excluye sino que refuerza los principios de la didáctica tradicional, facilita la interdisciplinaridad y la integración de conocimientos, atravesando las barreras propias del conocimiento fragmentado de las disciplinas y materias.

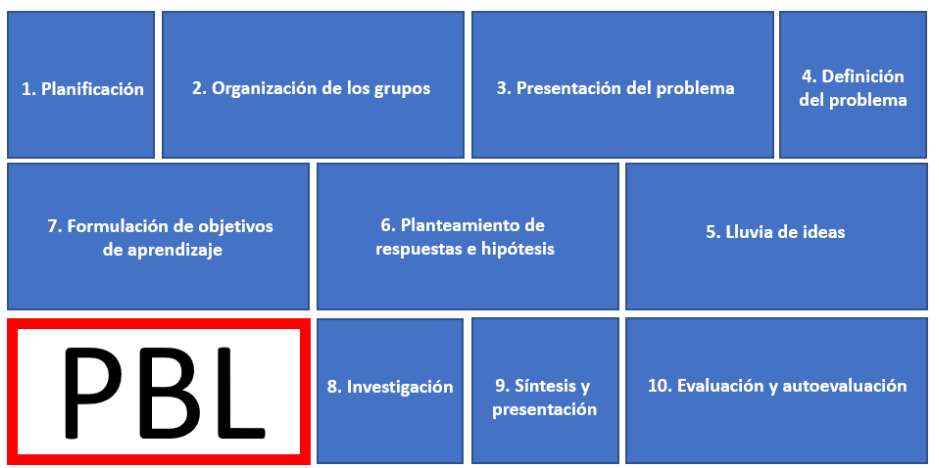

Fig.4 Esquema del aprendizaje basado en proyectos o problemas (Fuente: Elaboración propia)

El aprendizaje basado en proyectos, parte de situaciones reales, y puede desarrollarse de manera aislada en el contexto de cada asignatura, o coordinando diferentes áreas o asignaturas. Básicamente, en el PBL se distinguen tres fases:

- La adquisición de los conocimientos técnicos y científicos necesarios para la comprensión y el ejercicio de la actividad tecnológica.

- El análisis y manipulación de los objetos tecnológicos.

- La emulación de procesos de resolución de problemas existentes. 
La metodología PBL desarrollará los distintos conceptos y procedimientos, tomando como punto de partida los conocimientos previos que tiene el alumno, o bien que provienen de otras disciplinas, y que se irán verificando con alguna de las actividades que al mismo tiempo se introducirán. Es decir, se pasa de la abstracción a la concreción.

Llevar a la práctica la metodología PBL, es tratar de:

- Definir el problema susceptible de ser resuelto (objetivos y competencias).

- Debatir ideas en grupo y decidir las mejores opciones (preguntas guía).

- Buscar, analizar datos y seleccionar la información pertinente.

- Elaborar la secuencia del proyecto (asigna recursos y tiempos).

- Diseñar objetos, experimentos o prototipos como posible solución.

- Comprobar y ensayar soluciones, según las especificaciones iniciales.

- Establecer conclusiones (autoevaluación del proyecto).

- Elaborar la documentación necesaria para comunicar los resultados.

\subsection{Metodologías activas de enseñanza-aprendizaje ${ }^{[15]}$}

Aunque aquí no se desarrollan las denominadas metodologías activas de enseñanzaaprendizaje, todas ellas suelen centrarse en los intereses de los alumnos, como en el trabajo en grupo, la experiencia previa, el escenario de actuación y en los problemas del mundo real. Entre las metodologías activas más utilizadas se encuentran las siguientes:

- Aprendizaje cooperativo

- Aprendizaje basado en proyectos o problemas (PBL)

- El contrato aprendizaje

- Estudio de casos

- Visual Thinking

- Aprendizaje personal de trabajo en red (PLN)

- Entorno de aprendizaje personal (PLE)

- Mapa de empatía

- Esquemas y mapas mentales

- Heurísta UVE de Gowin

[15] Metodologías activas. Disponible: <http://blogbibliotecas.mecd.gob.es/2015/10/27/nuevosmodelos-de-ensenanza-libros-recientes-en-la-biblioteca/> Consulta: [28 de mayo de 2018]

(c) EY-NC-ND 2018, Universitat Politècnica de València

Congreso IN-RED (2018) 


\subsection{Planificación de proyectos en Bachillerato}

Una buena organización escolar se basa fundamentalmente en un plan anual de actividades, donde participen las asignaturas y el profesorado. De la misma manera, la organización del Departamento de Tecnología, tendrá en cuenta el contexto para decidir qué proyectos se incluirán y en qué momento del curso.

A modo de ejemplo, se incluye un resumen de los proyectos realizados en el IES 25 d'Abril (Alfafar, València) entre los años 2007 a 2012.

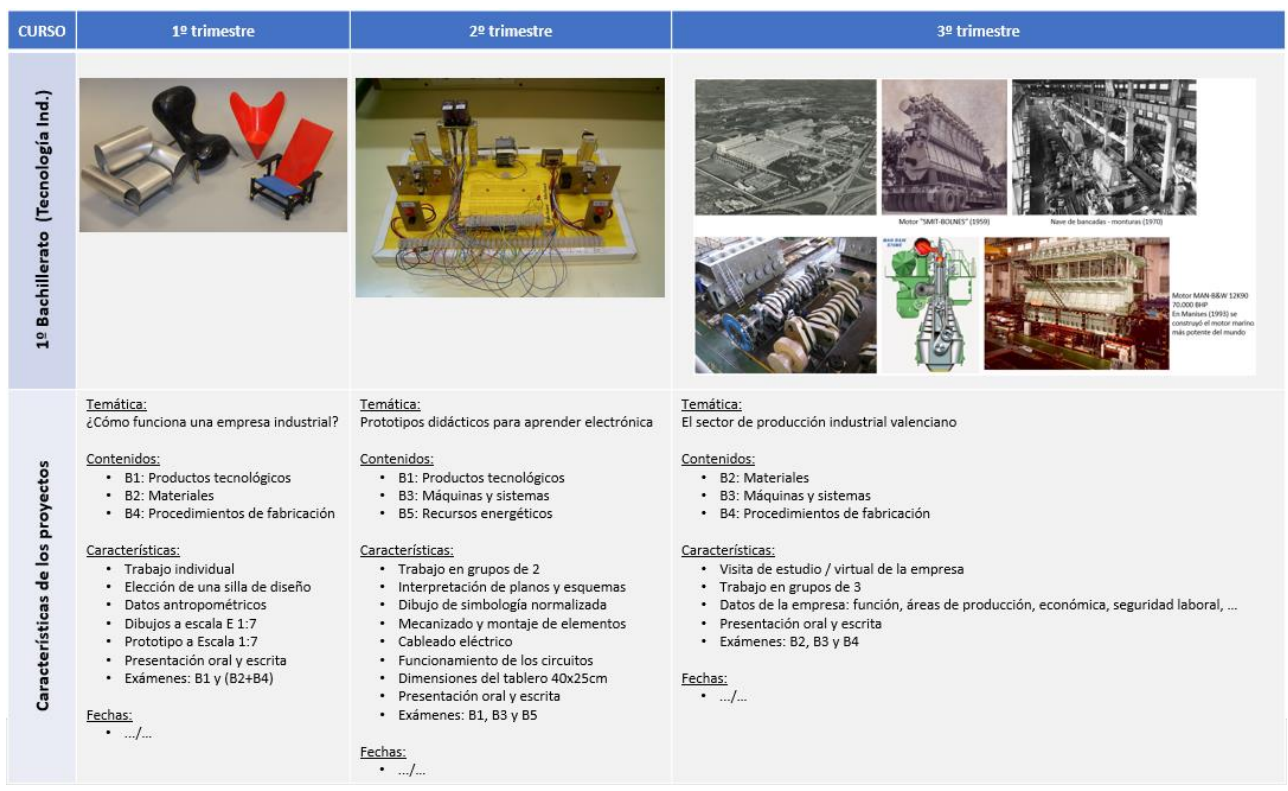

Fig.5 Planificación de proyectos de Tecnología Ind.-I (Fuente: Elaboración propia) 


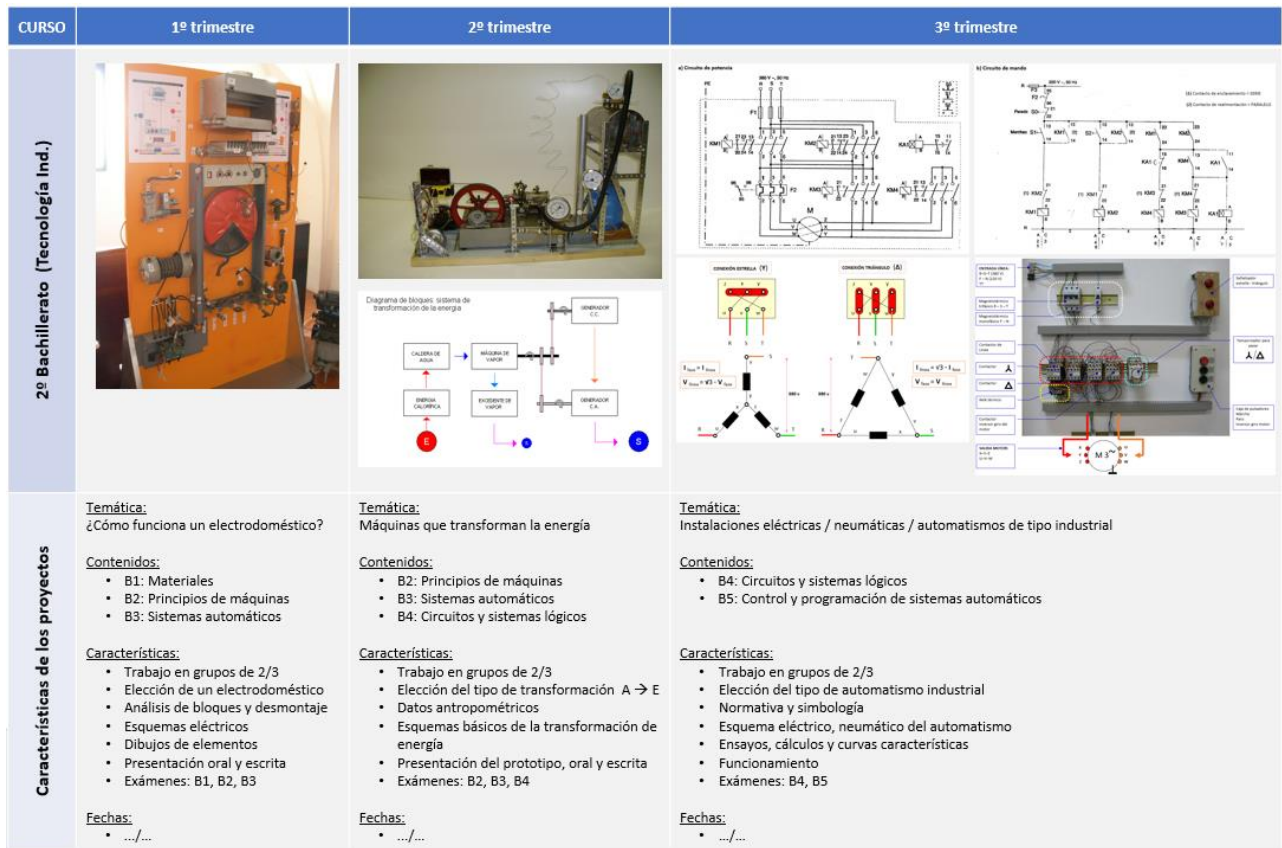

Fig.6 Planificación de proyectos de Tecnología Ind.-II (Fuente: Elaboración propia)

\subsection{Ejemplos de exámenes de acceso a la universidad (PAU 2016)}

Los cuadros adjuntos incluyen las características de los exámenes de Tecnología Industrial. Aquí se analizan las pruebas de la C.Valenciana, C.Madrid, País Vasco, y Catalunya.

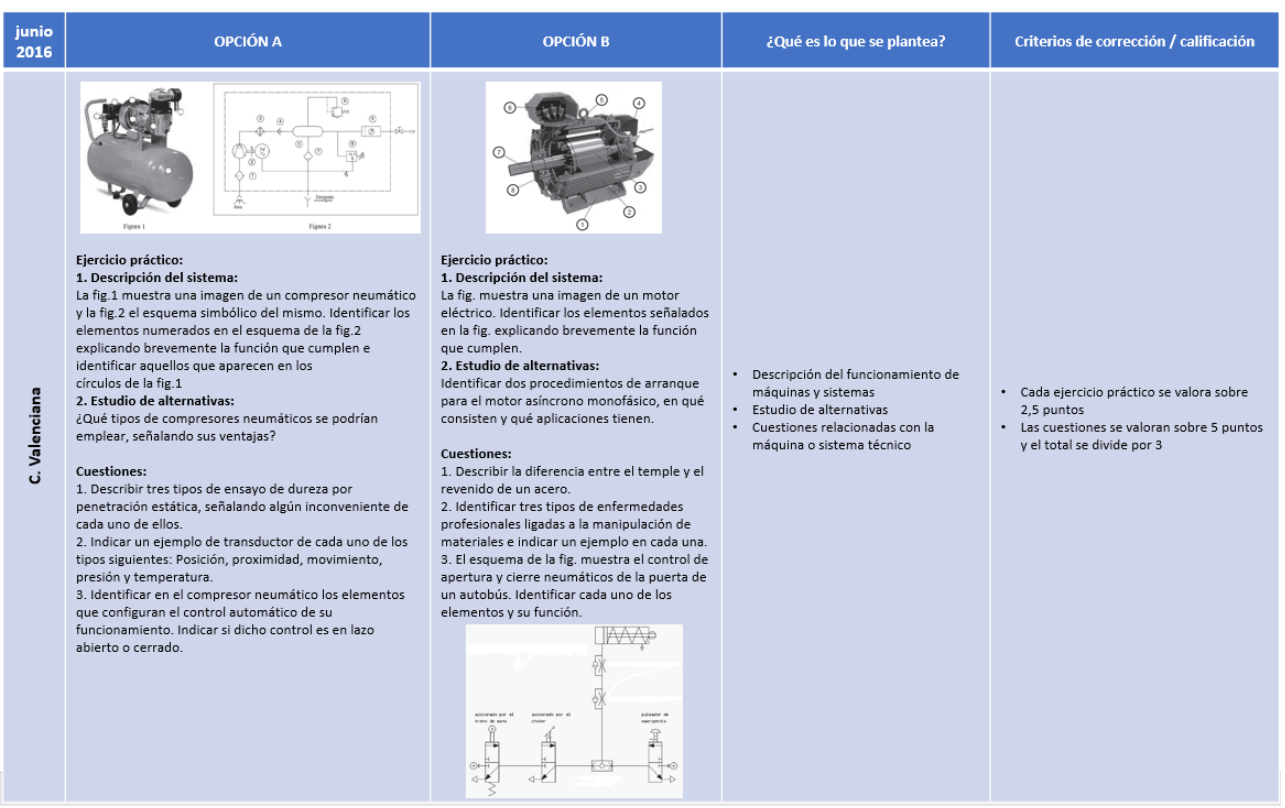

Fig.7 Modelo de examen de Tecnología Industrial (C.Valenciana)

(cc) EY-NC-ND 2018, Universitat Politècnica de València

Congreso IN-RED (2018) 


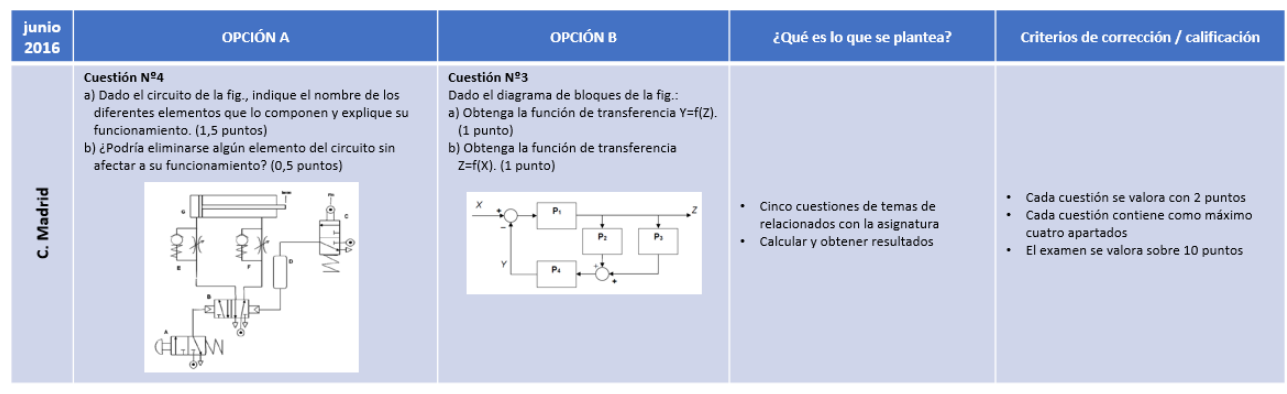

Fig.8 Modelo de examen de Tecnología Industrial (C.Madrid)

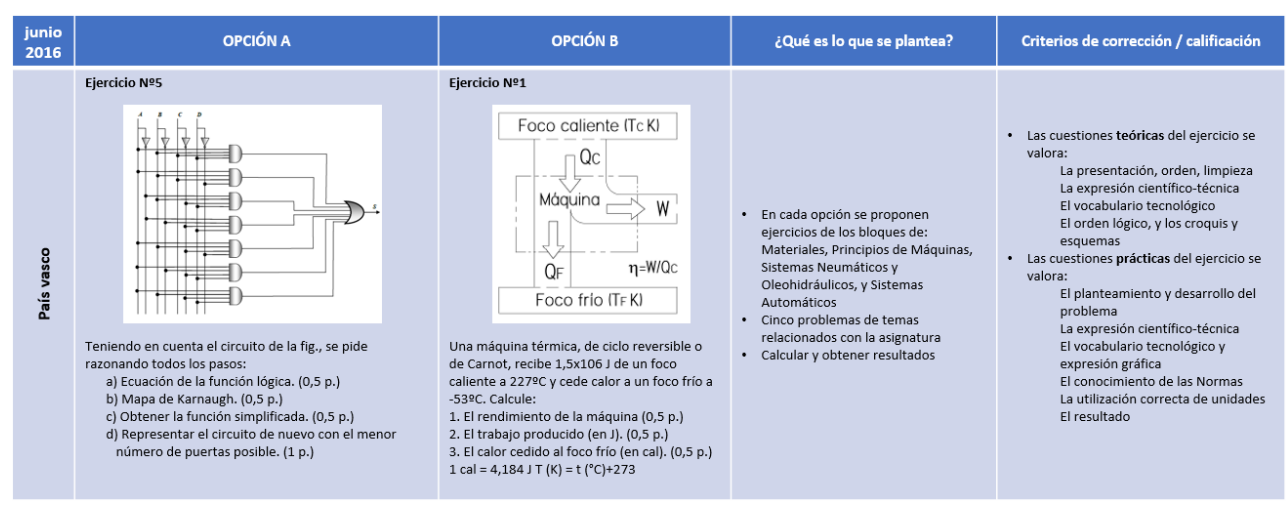

Fig.9 Modelo de examen de Tecnología Industrial (País Vasco)

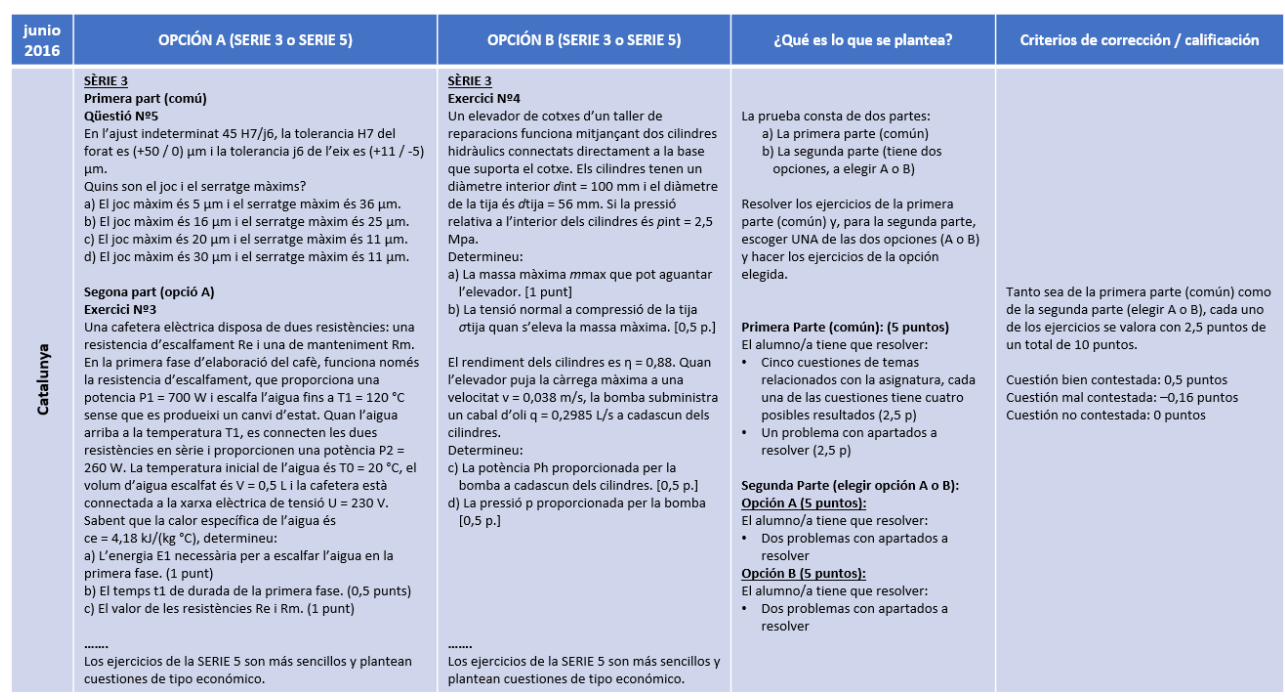

Fig.10 Modelo de examen de Tecnología Industrial (Catalunya)

(c)) EY-NC-ND 2018, Universitat Politècnica de València Congreso In-Red (2018) 


\section{Resultados}

Respecto de las metodologías aplicadas para la realización de proyectos tecnológicos en el tramo post-obligatorio de Bachillerato, no existen informes que contrasten y cuantifiquen los resultados obtenidos por el alumnado de la Comunidad Valenciana, ni tampoco se conoce sus consecuencias en la transición y adaptación de los alumnos en el entorno de los estudios de Ingeniería y Arquitectura.

Ahora bien, lo que sí que existe es una percepción positiva del profesorado que incluye diversidad de metodologías y buenas prácticas educativas, por lo que se puede decir que exista un elevado grado de satisfacción en cuanto a la actitud, competencias (conocimientos y habilidades) que los alumnos adquieren a lo largo de un curso escolar.

Es de destacar la implicación por la innovación educativa que están teniendo tanto el Ministerio de Educación, Cultura y Deporte (MECD), como la Fundación Española para la Ciencia y la Tecnología (FECYT), así como diversas instituciones privadas para fomentar en la sociedad la Ciencia y la Tecnología (CyT). En el caso de la Conselleria d'Educació, Investigació, Cultura i Esport de la Generalitat Valenciana, es a través de la red de Centros de Formación, Innovación y Recursos Educativos ${ }^{[16]}$ (CEFIRE, asesorías CTEM), se está realizando un importante esfuerzo por los programas de CyT.

El programa piloto "Aprofundeix-CV: anàlisi de resultats $i$ propostes de millora pel curs escolar 2016-2017" [17] avala la tendencia y los resultados de incluir programas escolares y formación del profesorado STEM.

\subsection{Evolución del número de alumnos en las pruebas PAU}

El Sistema Universitario Público Valenciano (SPV) ${ }^{[18]}$ incluye a las universidades UJI, UV, UPV, UMH, UA, y publica anualmente los resultados de las convocatorias de las PAU. El gráfico adjunto (Fig.10) hace referencia a las convocatorias de los años 2010 a 2016. En dicho gráfico, se recogen los alumnos aptos en el ámbito de las materias STEM-STEAM. En el caso de la C.Valenciana, es a partir de la convocatoria de junio de 2017, cuando dejan de evaluarse por primera vez en 25 años, las materias específicas de Bachillerato, entre las que se encuentra Tecnología Industrial.

\footnotetext{
${ }^{[16]}$ Mestre a casa. Disponible <http://mestreacasa.gva.es/web/cefireambitctm/home $>$ Consulta: [28 de mayo de 2018]

${ }^{[17]}$ Programa piloto Aprofundeix-CV. Disponible <http://www.ceice.gva.es/documents/162880217/163288902/INFORME+COMPLET+AVALUACI \%C3\%93\%20APROFUNDEIX.pdf/f3e6f6ea-7b27-410c-95f9-4e3904354a6a> Consulta: [28 de mayo de 2018]

${ }^{[18]}$ Sistema Universitario Público Valenciano. Disponible <http://www.siuvp.es/es/> Consulta: [28 de mayo de 2018]
}

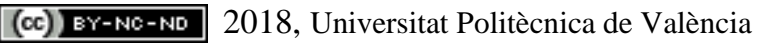

Congreso IN-RED (2018) 


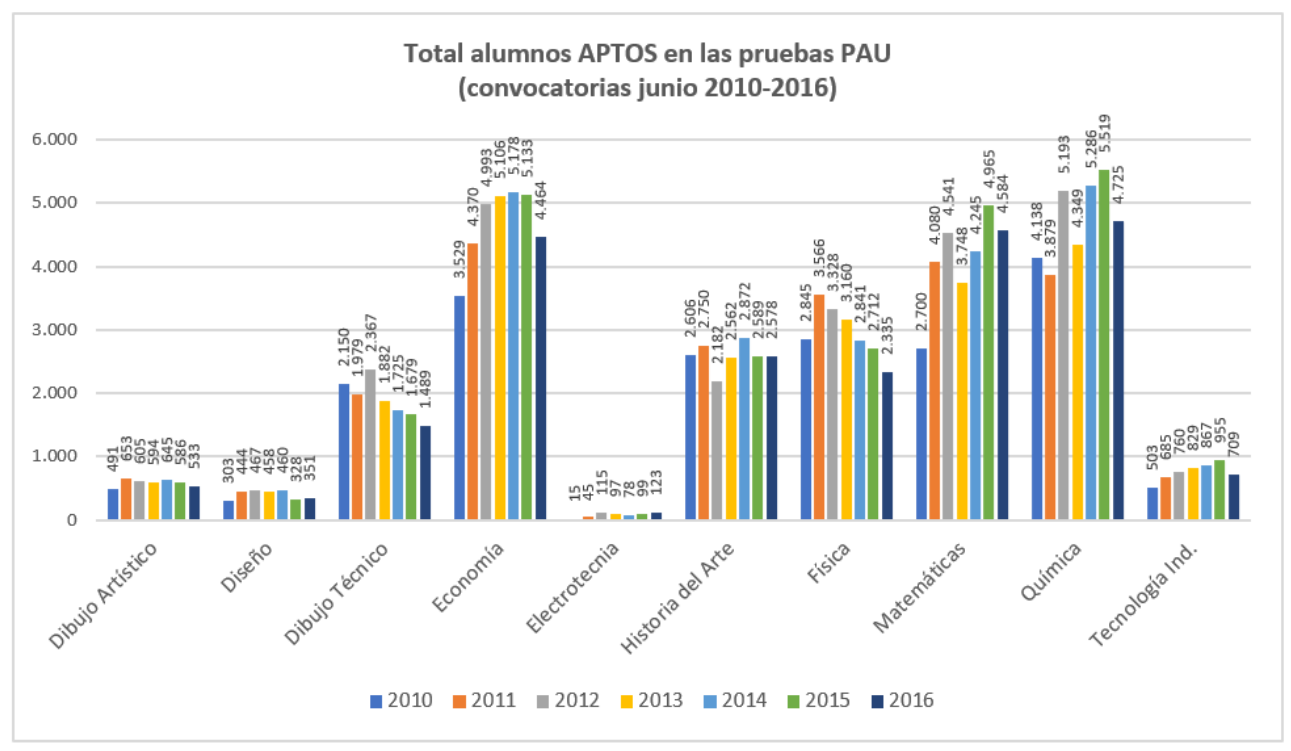

Fig.11 Resultados de las PAU entre los años 2010-2016 (Fuente: Datos del SPV y elaboración propia)

En la Fig.10 se observan tres grandes grupos de asignaturas, aquellas que presentan un elevado número de alumnos (entre 3.000 y 5.500), y cuya tendencia varía según qué convocatoria, liderando Economía, Matemáticas y Química. El segundo bloque de asignaturas (entre 1.000 y 3.000) está formado por Dibujo Técnico, Historia del Arte, y Física. Por último, el grupo de asignaturas (entre 10 y 1.000) formado por Dibujo Artístico, Diseño, Electrotecnia y Tecnología Industrial, cuya tendencia ha sido más estable. Con la nueva selectividad (PAU 2017), al no ponderar las asignaturas Específicas de Electrotecnia y Tecnología Industrial, obviamente estas tenderán a desaparecer del Bachillerato.

\subsection{Pérdida de vocaciones en áreas de Ciencias y Tecnología, y demanda laboral}

Una de las consecuencias anteriores, es la pérdida progresiva de estudiantes que eligen asignaturas del ámbito de Ciencias y Tecnología. En la última década, la demanda de los estudios de Ingeniería ha caído un $23,3 \%$. En contraposición, la demanda laboral de las empresas del sector tecnológico, es del $50 \%$ de las ofertas de empleo que se generan en nuestro país. En Europa crece esta demanda al ritmo de un $14 \%$ anual, pero sólo un $7 \%$ de los estudiantes está cursando estas titulaciones. Según Randstad Professionals [19], las competencias más valoradas y los sectores que impulsarán la creación de empleo en los próximos años, serán las áreas asociadas a las Ingenierías, Ciencias de la Salud, Física y Matemáticas, junto con la automatización de los procesos industriales, como electrónica, robótica, mecatrónica, informática, telecomunicaciones, y el sector Big Data.

${ }^{\left[{ }^{19]}\right.}$ Randstad. Disponible < $<$ https://www.randstad.es/nosotros/sala-prensa/ingenieros-perfiles-it-ventasy-retail-seran-los-perfiles-mas-buscados-en-2018/> Consulta: [28 de mayo de 2018] 
Mientras tanto, en el $48^{\circ}$ Foro Económico Mundial ${ }^{[20]}$ (Davos-Klosters, Switzerland, 23-26 enero 2018) se decide sobre el impacto de la Cuarta Revolución Industrial (industria 4.0), que acabará con más de 5 millones de puestos de trabajo en los 15 países más industrializados del mundo. Estos cambios generaran nuevos empleos y nuevas habilidades según sectores.

\section{Conclusiones}

a) La educación tecnológica es un conjunto de saberes que integran competencias y habilidades necesarias para desarrollar el saber hacer, el ingenio, la creatividad y la innovación. Desarrollando estos saberes a lo largo de las diferentes etapas educativas, los alumnos comprenden en su conjunto los procesos industriales, que va desde la elaboración de ideas, hasta la realización de objetos, prototipos, máquinas y sistemas técnicos. En definitiva, la materia de Tecnología de la ESO y Bachillerato promueve según su currículo el análisis, el diseño y la construcción de objetos y sistemas en forma de prototipos o maquetas.

b) La metodología de proyectos (PBL) es ampliamente utilizada en Secundaria, además, la materia de Tecnología contribuye a desarrollar competencias, entendidas como la capacidad de responder a demandas complejas y llevar a cabo tareas diversas de forma adecuada. Las competencias suponen una combinación de habilidades prácticas, conocimientos, motivación y otros componentes sociales y de comportamiento que se movilizan conjuntamente para lograr una acción eficaz. Las competencias están desarrolladas en el sistema educativo (Orden ECD/65/2015, BOE $n^{\circ} 25,29$ enero 2015), y describen las relaciones entre las competencias, los contenidos y los criterios de evaluación de la educación Primaria, Secundaria y Bachillerato.

c) La materia de Tecnología facilita el trabajo colaborativo e interdisciplinar entre diversas materias del currículo, como por ejemplo las afines de Dibujo Técnico, TIC e Informática, aproximándonos al desarrollo de proyectos interdiciplinares STEM.

d) Los decretos mencionados en la introducción (BOE 298, RD 5/2016 de 9 dic., y BOE 309, Orden ECD 1941/2016 de 23 dic.), están dificultando el desarrollo de proyectos tecnológicos y por tanto la posibilidad de que el alumnado opte por este tipo de enseñanzas en Bachillerato, de tal manera que peligra su formación y continuidad en Ingenierías.

e) Una excelente muestra de cómo integrar saberes del ámbito tecnológico y de cómo analizar objetos y sistemas complejos, lo encontramos en el diseño de las pruebas

[20] Foro Económico Mundial. Disponible < $\underline{\text { https://www.weforum.org/agenda/2018/01/gender- }}$ inequality-and-the-fourth-industrial-revolution/> Consulta: [28 de mayo de 2018]

(cc) EY-NC-ND 2018, Universitat Politècnica de València

Congreso IN-RED (2018) 
de selectividad (PAU) de la asignatura Tecnología Industrial. Sin embargo, después de 25 años de realización de pruebas selectivas para la universidad, esta asignatura al igual que las consideradas "específicas" han dejado de ser evaluables para acceder por ejemplo a Ingenierías. Esta circunstancia, está generado un gran desconcierto entre el profesorado de Tecnología de Bachillerato y una evidente pérdida de alumnado que cursa esta asignatura, al no ser considerada evaluable en las PAU.

f) Aunque el diseño curricular de la asignatura de Tecnología Industrial de Bachillerato, proviene de la LOGSE (1990), en la actualidad sigue teniendo un enfoque esencialmente para la "producción industrial", puesto que las diferentes reformas educativas no han actualizado sus contenidos curriculares, ni tampoco se han adaptado al contexto social-laboral, ni tampoco para la transición hacia los estudios de ingeniería. Objetivamente, no se conoce la incidencia que existe entre aquellos alumnos de Bachillerato que cursan asignaturas del ámbito tecnológico (Tecnología, Dibujo Técnico, TIC e Informática) de Bachillerato y aquellos que no las cursan, y de qué manera mejoran sus expectativas y continuidad en Ingeniería y Arquitectura.

g) En la actualidad, los programas educativos STEM son la base de la innovación en los países más avanzados de nuestro entorno. El movimiento educativo STEM, busca integrar diversas áreas de conocimiento cuantitativo y experimental en el currículo, comprender el impacto de estas disciplinas, y preparar a los estudiantes para la complejidad tecnológica de la sociedad del conocimiento y de la innovación.

\section{Referencias}

\section{Libros}

BAIGORRI, J. (1997). Enseñar y aprender Tecnología. Barcelona: ICE-Horsori.

CANONGE, F. y DUCEL, R. (1992). La educación técnica. Barcelona: Paidós Educador.

ELLIOTT, J. (1990). La investigación-acción en educación. Madrid: Morata.

FERNÁNDEZ ENGUITA, M. (2018). Más escuela y menos aula. Madrid: Morata.

HARGREAVES, A. (2003). Enseñar en la Sociedad del conocimiento. Barcelona: Octaedro.

MARINA, J.A. (2010). La educación del talento. Barcelona: Ariel.

MORIN, E. (1999). Los siete saberes necesarios para la educación del futuro. París: Unesco.

SALINAS, J., PÉREZ, A. y BENITO, B. de. (2008). Metodologías centradas en el alumno para el aprendizaje en red. Madrid: Síntesis.

(c) ) EY-NC-ND 2018, Universitat Politècnica de València 
SOLER, A.J. (2004). El mètode de projectes com un entorn favorable d'aprenentatge en el context de la teoría a l'activitat. Barcelona: UB. Depart. didàctica de les ciencies experimentals i la matemàtica.

ROBINSON, K. (2015). Escuelas creativas. Barcelona: Grijalbo.

VÁZQUEZ, Á. y MANASSERO, Ma A. (2007). Los intereses curriculares en ciencia y tecnología de los estudiantes de secundaria. Palma de Mallorca: Universitat de les Illes Balears.

\section{Artículo de revistas}

GIL, D. y VILCHES, A. (2007). La necesaria renovación de la formación del profesorado para una educación científica de calidad. València: Revista TED-2007, Universitat de València.

\section{Referencias electrónicas}

EL MUNDO. (2016). Así se enseña en el aula del futuro. Madrid: El Mundo.

<http://www.elmundo.es/sociedad/2016/09/08/57d061c646163fd86d8b45cc.html>

[Consulta: 25 de marzo de 2018]

GOSÁLVEZ, P. (2015). Los jesuitas revolucionan el aula. Lleida: El País.

<http://politica.elpais.com/politica/2015/03/27/actualidad/1427473093_128987.html>

[Consulta: 25 de marzo de 2018]

ROSELL, L. (2004). Más de 250 expertos debaten sobre educación, formación y tecnología. Barcelona: El País.

<http://www.elpais.com/articulo/cataluna/250/expertos/debaten/educacion/formacion/tecnologia/elpe piespcat/20040617elpcat 25/Tes >

[Consulta: 21 de marzo de 2018]

ROSENBERG, N. (2005). España va a sufrir mucho si no empieza a innovar. Madrid: El País. 〈http://www.elpais.com/articulo/sociedad/Espana/va/sufrir/mucho/empieza/innovar/elpepisoc/200505 08elpepisoc_3/Tes $>$

[Consulta: 23 de marzo de 2018]

UNESCO. (2001). La enseñanza de las ciencias, la tecnología y las matemáticas en pro del desarrollo humano. Goa: Unesco-Castme.

$\langle$ http://es.scribd.com/doc/142725393/Informe-Unesco>

[Consulta: 25 de marzo de 2018]

\section{Páginas web}

CONSELLERIA D'EDUCACIÓ, INVESTIGACIÓ, CULTURA I ESPORT. Servei d'Ordenació acadèmica. Normativa Curriculum ESO.

<http://www.ceice.gva.es/ca/web/ordenacion-academica/secundaria/normativa/eso> [Consulta: 23 de marzo de 2018]

CONSELLERIA D'EDUCACIÓ, INVESTIGACIÓ, CULTURA I ESPORT. Servei d'Ordenació acadèmica. Currículo LOMCE ESO y Bachillerato por materias.

<http://www.ceice.gva.es/web/ordenacion-academica/curriculo-eso-bachillerato-por-materias//documentos/eaWDKFxNg2Dz/folder/162655315?p_auth=9E9Pz3hu >

[Consulta: 23 de marzo de 2018]

CONSELLERIA D'EDUCACIÓ, INVESTIGACIÓ, CULTURA I ESPORT. Servei d'Ordenació acadèmica. Currículo LOMCE ESO. Tecnología.

<http://www.ceice.gva.es/documents/162640733/162655315/Tecnología+\%28PDF\%29/f241d69a0b70-4149-993c-bea1938e1948>

[Consulta: 23 de marzo de 2018]

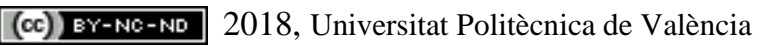

Congreso IN-RED (2018) 
CONSELLERIA D'EDUCACIÓ, INVESTIGACIÓ, CULTURA I ESPORT. Servei d'Ordenació acadèmica. Currículo LOMCE Bachillerato. Tecnología Industrial.

<http://www.ceice.gva.es/documents/162640733/162655315/Tecnología+Ind.+\%28PDF\%29/3db760

2a-2770-43ca-aa80-01c9064a51d5>

[Consulta: 23 de marzo de 2018]

CONSELLERIA D'EDUCACIÓ, INVESTIGACIÓ, CULTURA I ESPORT. Mestre a casa. I Congrés CTEM CV. Maig 2016.

〈http://mestreacasa.gva.es/web/congresctem/inici>

[Consulta: 24 de marzo de 2018]

CONSELLERIA D’EDUCACIÓ, INVESTIGACIÓ, CULTURA I ESPORT. Mapa de les infraestructures escolars 2015-16.

<http://www.ceice.gva.es/documents/161634256/162538872/XifresMapaInfraestructuresEscolars.pdf/ b00fa4ed-a9f0-4076-bbbb-2911698b97cb>

[Consulta: 25 de marzo de 2018]

CONSELLERIA D’EDUCACIÓ, INVESTIGACIÓ, CULTURA I ESPORT. Proves d'accés a la universitat. Estadístiques 2009-2017.

<http://www.ceice.gva.es/ca/web/universidad/estadisticas $>$ [Consulta: 25 de marzo de 2018]

INTED. Paper search tool.

〈https://iated.org/concrete3/session_overview.php?event_id=30>

[Consulta: 25 de marzo de 2018]

MINISTERIO DE EDUCACIÓN, CULTURA Y DEPORTE. Enseñanzas no universitarias. Estadísticas de la educación.

〈http://www.mecd.gob.es/servicios-al-ciudadano-mecd/estadisticas/educacion/no-universitaria.html> [Consulta: 25 de marzo de 2018]

PLATAFORMA ESTATAL DEL PROFESORADO DE TECNOLOGÍA. ¿Qué es la Tecnología?. 〈http://peapt.blogspot.com.es/p/que-es-la-tecnologia.html>

[Consulta: 25 de marzo de 2018]

PÚBLICO. La OCDE señala a España por la falta de evaluación a sus docentes. <http://www.publico.es/sociedad/ocde-senala-espana-falta-evaluacion.html >

[Consulta: 25 de marzo de 2018]

SCIENTIX. The community for science education in Europe.

$<$ http://www.scientix.eu/>

[Consulta: 25 de marzo de 2018]

\section{Legislación y normas}

España. Ley Orgánica de Mejora de la Calidad Educativa. Ley Orgánica 8/2013, 9 de diciembre de 2013, núm. 295, p. 97858-97921

España. Competencias clave en el Sistema Educativo Español. Orden ECD/65/2015, 21 de enero, BOE $\mathrm{n}^{\mathrm{o}} 25$ de 29 de enero de 2015 , p. 6986-7003

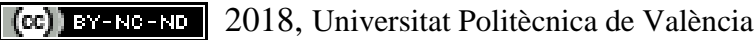




\title{
Architecture in practice: Elaboration and constructive projects definition
}

Vicente López Mateu ${ }^{a}$, Javier Benlloch Marco ${ }^{b}$

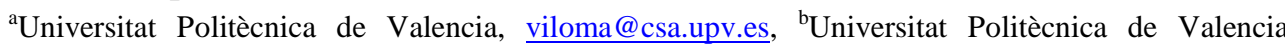
jabenllo@csa.upv.es.

\begin{abstract}
The resolution of practical exercises that approach studies to real-life issues, known as Problem-Based Learning (PBL), is currently a well-known methodology, that has been applied in engineering education, Nevertheless, it has different possibilities and particularities in Architecture.

This paper introduces to the experience developed recently in the subject Constructive Project of the Master degree in Architecture. In this subject, the students must develop a complete architectural project, approaching as much as possible to an "Execution Project".

This process presents the difficulty of collecting and reviewing the knowledge students should get along their degree training. There are different matters and skills involved, from the creative and technical aspects to the transversal ones, such as teamwork or the organization and management of time.

The common thread is complete a technical project, with a degree of complexity that allows its development. Some aspects are adapted, but the students must elaborate accurate proposals and justify the solutions combining technical point of view and different regulations compliance.

The develop of this methodology has been a very important challenge, both for teachers and students. The results have been very positive, despite there are different aspects that should be improve little by little, but the main benefit is clear, drive them better to their professional future.
\end{abstract}

Keywords: PBL Project based learning in Architecture, building technology learning-teaching, Master degree teaching in architecture 


\title{
EL PROYECTO DE ARQUITECTURA: LA PRÁCTICA EN SU ELABORACIÓN Y DEFINICION CONSTRUCTIVA
}

\author{
Vicente López Mateu ${ }^{a}$, Javier Benlloch Marco ${ }^{b}$ \\ ${ }^{a}$ Universitat Politècnica de Valencia, viloma@csa.upv.es, ${ }^{b}$ Universitat Politècnica de Valencia \\ jabenllo@csa.upv.es.
}

\begin{abstract}
Resumen
La resolución de ejercicios o prácticos que se aproxime a casos reales conocido por Aprendizaje Basado en Problemas o bien su para realizar un Proyecto más general es algo bastante conocido y aplicado actualmente en la formación de las ingenierías, pero tiene particularidades en arquitectura.

Este artículo presenta la experiencia desarrollada recientemente en la asignatura Proyecto Constructivo del Master Habilitante de la ETSAV. En ella los estudiantes deben desarrollar un Proyecto Arquitectónico completo, aproximándose lo máximo posible a un "Proyecto de Ejecución".
\end{abstract}

Este proceso plantea la dificultad de recopilar y repasar los distintos conociminentos que los estudiantes han ido adquiriendo en su formación en el grado, desde los aspectos creativos y técnicos a otros transversales como la organización y gestión del tiempo o el trabajo en equipo.

El hilo conductor es un proyecto técnico, con un grado de complejidad que permitiera su desarrollo posterior. Los estudiantes deben elaborar sus distintas propuestas y justificar las soluciones desde el punto de vista técnico, así como el cumplimento de la diversa normativa.

El desarrollo de esta metodología ha sido un desafío importante, tanto para profesores como para estudiantes. Los resultados son positivos, a pesar de que hay diferentes aspectos que deben mejorarse poco a poco, pero el principal beneficio está claro, llevar mejor a los estudiantes su futuro profesional.

Palabras clave: Aprendizaje basado en problemas (ABP) en Arquitectura, Aprendizaje y enseñanza en construcción arquitectónica, formación en Máster de Arquitectura. 


\section{Introducción general y aprendizaje basado en problemas en arquitectura}

La metodología de aprendizaje que desarrolla proyectos a partir de solución de problemas conocida por Aprendizaje Basado en Problemas (ABP) o Problem Based Learning (PBL), actualmente está bastante extendida en las carreras técnicas y de ingeniería. Sin embargo, su aplicación se inició en los estudios de medicina (Barrows y Tamblyn 1980) y se extendió progresivamente a otras materias, como la programación informática.

En todos los casos, aplicar esta metodología requiere su adaptación, que en arquitectura es un poco más compleja, pues necesita interacción entre distintas materias y partes del currículum (Maitland, 1997). En este sentido, se puede reconocer que presenta ciertas peculiaridades que son diferentes de otros estudios técnicos o ingenierías, principalmente porque necesita una visión holística, más global y de conjunto (Grabe, 2010).

Aunque la documentación en este campo no es muy amplia, se dispone de experiencias en distintas universidades y escuelas de arquitectura que se pueden comparar (Bridges, 2006). Entre ellos cabe citar la TU Delft en Holanda, la universidad de Newcastle, así como la N.S.W. de Australia. En estas escuelas los resultados fueron muy variables según la implicación del profesorado y el apoyo institucional, aspectos clave para su desarrollo.

También se conocen algunas experiencias en la aplicación de esta metodología para mejorar el aprendizaje de aspectos o soluciones constructivas concretas (LaBoube et al., 2014). En ellas se propone mayoritariamente la elaboración de "modelos" o maquetas, en las que se prioriza la utilización de materiales específicos, reales o próximos a ellos, para reconocer mejor los aspectos constructivos fundamentales de estas soluciones.

Finalmente, cabe destacar que en esta metodología los estudiantes están en constante actividad y el rol del docente se transforma en un "facilitador" del aprendizaje (Stolovich y Keeps, 2002). Es necesario que tenga buen conocimiento de la materia y práctica en el desarrollo de proyectos, pero también una experiencia pedagógica que le permita afrontar los retos y dificultades de la tutorización (VVAA, Moya y Palomares, 2008).

\section{Justificación y condiciones de implantación}

En cualquier caso, todas estas experiencias nos llevan a que resulta necesario mejorar las habilidades prácticas de los estudiantes de arquitectura y llevar su formación hacia la mejora de las competencias profesionales. Parece que el momento formativo más adecuado para ello sería en la formación impartida en el Máster, en particular en el "máster habilitante" de arquitectura, que lleve a la aplicación práctica de los conocimientos adquiridos en el Grado.

Hay que tener en cuenta, que cuando los estudiantes concluyen los estudios de Arquitectura tendrán, "al menos sobre el papel”, la capacidad de proyectar, dirigir y en su caso gestionar íntegramente una obra de construcción con la complejidad que tiene. Esto requiere un periodo de entrenamiento y preparación, que los vaya acercando progresivamente a la realidad, a las dificultades propias y a la complejidad que esto supone. 
La experiencia docente que se ha utilizado para mejorar este acercamiento a la realidad se ha utilizado en la asignatura denominada "Proyecto Constructivo", de nueva implantación en el Máster Habilitante de Arquitectura Superior en la ETS de Arquitectura de Valencia.

Se viene impartiendo desde 2015-2016, tiene 4,5 créditos y se desarrolla en el primer cuatrimestre de cada curso lectivo. El planteamiento general consiste en desarrollar un "Proyecto de Ejecución”, a partir de un "Proyecto Básico" o "Anteproyecto" que se les proporciona. A partir de aquí, los estudiantes deben resolver todos los aspectos técnicos y constructivos, siguiendo las instrucciones iniciales y las aclaraciones posteriores en su caso, así como el seguimiento y la tutorización del profesorado de la asignatura.

Las principales novedades de este planteamiento son tres:

- Recopilar y aplicar los conocimientos que los estudiantes deben tener al final de los estudios y de la titulación de arquitectura, especialmente los aspectos técnicos.

- Aproximarse lo máximo posible a un "proyecto real” en el campo profesional, con todos sus requisitos organizativos y formales.

- Aplicar distintas competencias transversales en el desarrollo del proyecto, como la gestión de tiempo, evaluación de costes reales, trabajo en equipo, etc.

A continuación, se expone brevemente los aspectos más relevantes de esta modalidad de aprendizaje basado en problemas, aunque se trata más bien de un proyecto integrado "medio o largo recorrido" de distintos pasos o elementos que deben resolverse de manera escalonada pero conjunta, para integrarse en un proyecto unitario y completo.

\section{Planteamiento del Proyecto}

Seguidamente se describen las principales características y fases del planteamiento del Proyecto, a través de las diferentes actividades a realizar. Este planteamiento se ha ido revisando y mejorando en los distintos cursos y puede seguirse como esquema general. No obstante, cada curso ha ido adquiriendo distintos matices con la idea de revisión y mejora continua de la docencia, similar a la del desarrollo de proyectos a largo plazo.

\subsection{Organización y planificación}

Según el vigente Plan de Estudios la asignatura se desarrolla en un cuatrimestre y se divide en varias fases o etapas. Entre ellas destacan: clases presenciales, desarrollo de ejemplos prácticos, tutorías por grupo y exposiciones parciales o final del trabajo con las conclusiones. En la Guía Docente se explican estos apartados, y la documentación se facilita vía Web.

Durante el desarrollo del proyecto se resuelven por el profesorado las dudas que se van presentando, tanto formales como de aspectos técnicos concretos del trabajo con recursos adicionales. La búsqueda de información y la necesidad de plantear estas aclaraciones también es un aspecto de aprendizaje, ya que en el desarrollo de un proyecto profesional real se van definiendo poco a poco distintos aspectos que influyen unos sobre otros.

(cc) EY-NC-ND 2018, Universitat Politècnica de València

Congreso IN-RED (2018) 
Las tareas docentes se dividen entre los distintos profesores, generalmente dos o tres por grupo, los cuales pueden impartir un aspecto o apartado específico del proyecto en el cual son especialistas, como las instalaciones, las mediciones y presupuestos o bien seguridad y salud. También puede impartirlo un mismo profesor en los grupos más reducidos de docencia en inglés.

Los equipos de trabajo se forman libremente por los estudiantes, así indican mayoritariamente que lo prefieren, produciéndose los ajustes necesarios por los profesores. Se fomentan algunas dinámicas para que los grupos se conozcan un poco mejor, aunque mayoritariamente ya suelen conocerse entre ellos por asignaturas previas.

Estos equipos deben elaborar al inicio del curso una planificación completa del proyecto y de sus contenidos. Para elaborarla toman como referencia el índice del CTE (Código Técnico de la Edificación, Anexo I), y se apoyan en algunas Webs profesionales a las que se les da acceso temporal, como la del CTAV o la guía Index ARQ del CSCAE.

La mayor dificultad inicial para los estudiantes supone la planificación de las tareas, dado que no tienen una experiencia previa en el desarrollo completo de un proyecto. Se les solicita la elaboración de un planteamiento básico de estructura EDP (Estructura Desagregada de Proyecto) y diagrama PERT asignando tiempos y tareas en un desarrollo temporal acotado.

En cualquier caso, significa ya una primera aproximación a los proyectos reales en arquitectura en cuanto a su planificación, contenido y requisitos formales-administrativos.

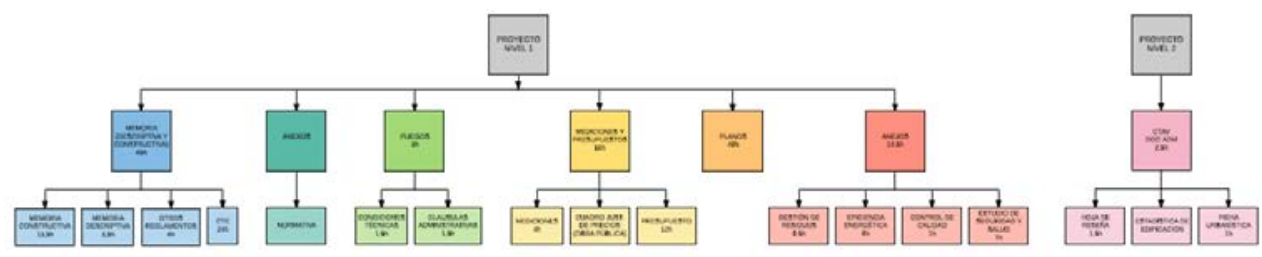

Fig. 1 A. Barranco, J. Torres, F. Carbonell, EDP Estructura del Desarrollo del Proyecto 


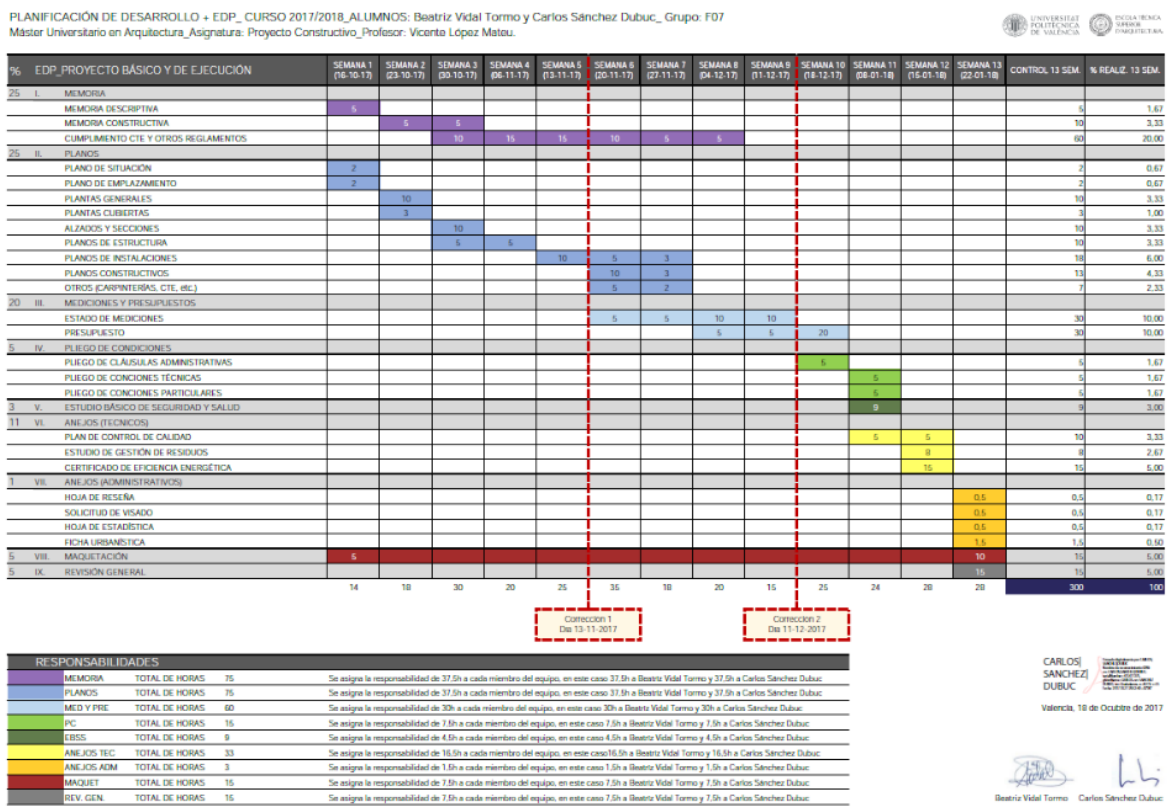

Fig. 2 Planificación aportada por el grupo F07 curso 2017-18, C. Sánchez Dubuc y B. Vidal Tormo

\subsection{Modelo}

$\mathrm{Al}$ inicio del curso se plantea un modelo a los estudiantes que tiene las características de lo que podríamos llamar un "proyecto simplificado" en el cual están definidas la estructura y la envolvente (fachadas y/o cubiertas) de forma general. Estos elementos deben ser precisados por los estudiantes con el detalle suficiente para que pudieran ser construidos. Se deben llegar a justificar todas las soluciones y los materiales con los cálculos necesarios.

Se trata de dejar en segundo plano los aspectos de "diseño inicial” aunque en el modelo se proponen unas condiciones de entorno cambiantes como la localización o la orientación, en una parte de un barrio o bien en un emplazamiento que seleccionan los propios estudiantes en la ciudad. Esto permite un primer nivel de diversidad y adaptación de las soluciones propuestas en el proyecto, así como la aplicación de las distintas normativas urbanísticas.

Finalmente, en este modelo básico, cada equipo de trabajo introduce las variaciones o modificaciones que considera necesarias como la distribución concreta, localización y trazado de las instalaciones, o detalles puntuales de su mejora para cumplir los requisitos de accesibilidad. También se requiere al final del proyecto la organización básica de la obra en aquellos aspectos como la Seguridad y Salud o las previsiones de ejecución de obra.

Es fundamental tomar en consideración estos tres aspectos, dado que se trata de un proyecto único que desarrollan los distintos equipos de trabajo, pero con ciertas variaciones y peculiaridades. Es necesaria una contextualización de cada proyecto y su adaptación a las circunstancias particulares del entorno por cuestiones que se consideran básicas actualmente como el coste económico, el ahorro de energía, su mantenimiento y conservación, etc.

(cc) BY-NC-ND 2018, Universitat Politècnica de València 

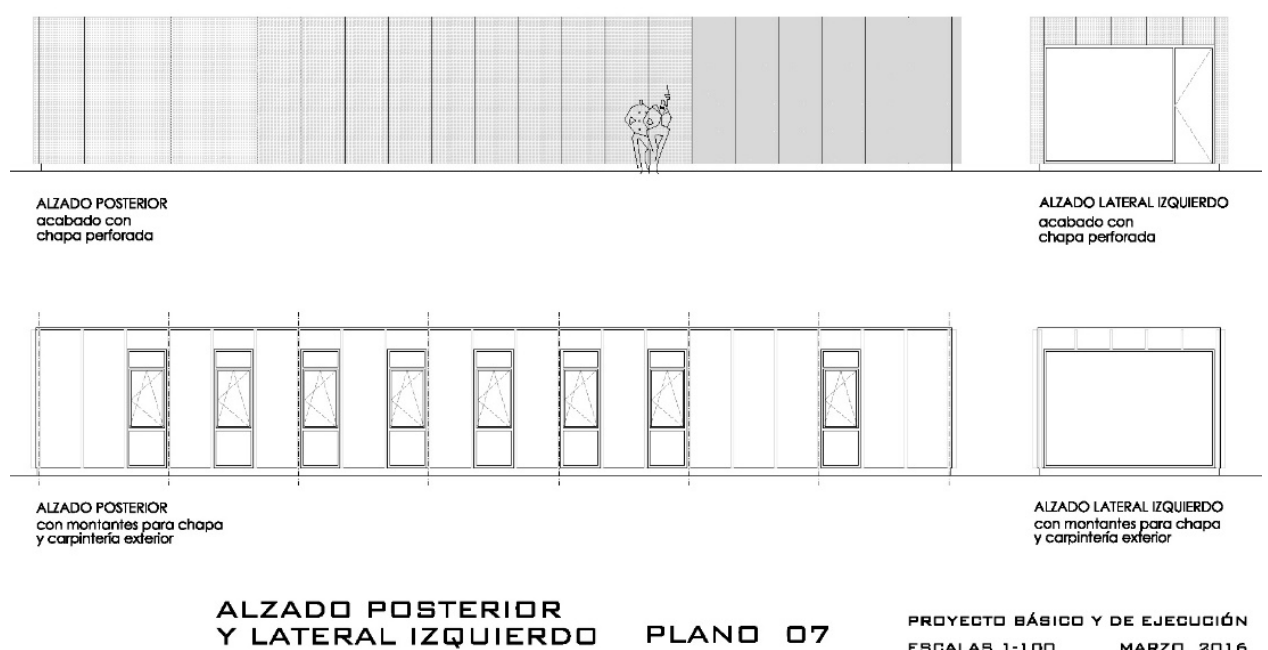

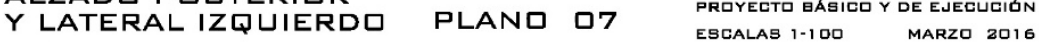

Fig. 3 Ejemplo de la documentación gráfica básica proporcionada a los estudiantes. J. Benlloch Marco (2016)

\section{Actividades desarrolladas}

A continuación, se describen brevemente las distintas actividades desarrolladas

- Clases presenciales, que suelen consistir en un repaso de los aspectos fundamentales a tratar o desarrollar en el Proyecto. La duración de estas clases se va reduciendo poco a poco, pasando al desarrollo de los aspectos prácticos.

- Examen inicial tipo test, para verificar la asimilación de los contenidos teóricos en lo referente a la organización general de un proyecto. Los estudiantes también formulan preguntas entre ellos en una sesión preparatoria o adicional de motivación.

- Entregas o revisiones parciales para aportar una parte de documentación. Se revisa y se dan indicaciones para mejorar o ampliar la documentación, así como para corregir aquellos aspectos incorrectos.

- Clases prácticas, en las que se completan o mejoran aspectos de la formación de los estudiantes. Se utilizan distintas herramientas informáticas, referidas a cálculos de ahorro energético (CE3x, HULC) así como a los presupuestos, la Seguridad y Salud.

- Los estudiantes aprenden a utilizar otros aspectos como el certificado o la firma digital que resulta necesaria para la entrega final del proyecto. Este aspecto es necesario en la tramitación ante los Colegios Profesionales o la Administración, por lo que resulta imprescindible que manejen este tipo de requisitos formales.

- Las tutorías periódicas, es uno de los aspectos fundamentales. Los estudiantes consultan dudas generales o puntuales en el desarrollo del proyecto, y es el ámbito 
propicio para conocer el funcionamiento de los equipos. Se plantean dos o tres, y otras adicionales bajo demanda, habitualmente próximas a las entregas intermedias.

- Exposición parciales y final. Durante el desarrollo del trabajo y a su conclusión se hacen una serie de exposiciones y se van obteniendo conclusiones. El proyecto califica en cada apartado y a través de la entrega y presentación final por equipos.

Como puede apreciarse es un conjunto de actividades diversas, generalmente de corta duración. Se trata de conseguir el objetivo en un plazo relativamente corto, un cuatrimestre, por lo que el ritmo y la intensidad de trabajo se mantienen bastante altos en este plazo.

\section{Medios y recursos digitales utilizados}

Para el intercambio de información se utiliza la Plataforma "PoliformaT" de la UPV, aunque también otros servicios como Google Drive o Dropbox, pues los archivos de CAD y los gráficos tienen un gran volumen. Estos recursos son imprescindibles para optimizar el trabajo en equipo y los estudiantes manifiestan mayoritariamente que los prefieren frente a otros medios, aunque también se utiliza la plataforma "Intercambio de ficheros UPV”.

Otros programas utilizados para la redacción de textos se utilizan del software que la Universidad proporciona con licencias para los estudiantes como Office, aunque sería deseable su ampliación a programas específicos de presupuestos y cálculos específicos en el ámbito de la arquitectura, como igualmente los estudiantes han manifestado en la encuesta realizada recientemente.

\section{Ejemplos de trabajos realizados}

Los proyectos resultantes están próximos a un Proyecto de Ejecución real, a falta de algunos aspectos concretos, aunque incluso calculan sus posibles honorarios profesionales lo cual les resulta sorprendente al ser la primera vez. Los estudiantes consiguen, como ellos reconocen, practicar elaborando un Proyecto de ejecución completo. La planificación y organización son fundamentales, no el resultado o la solución, lo fundamental es el proceso en sí mismo. 


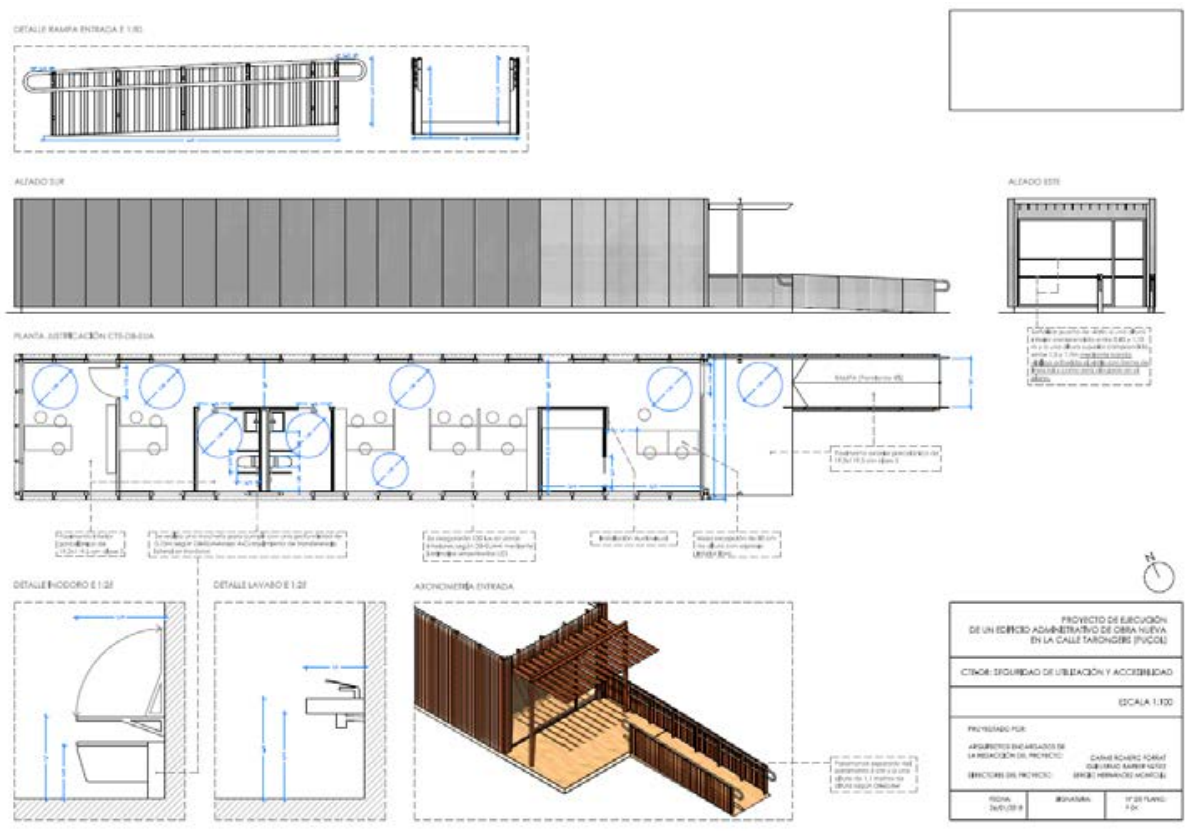

Fig. 3 Plano sobre aspectos de accesibilidad, Grupo A03 2017-18, C. Romero, G. Barber, S. Hernández

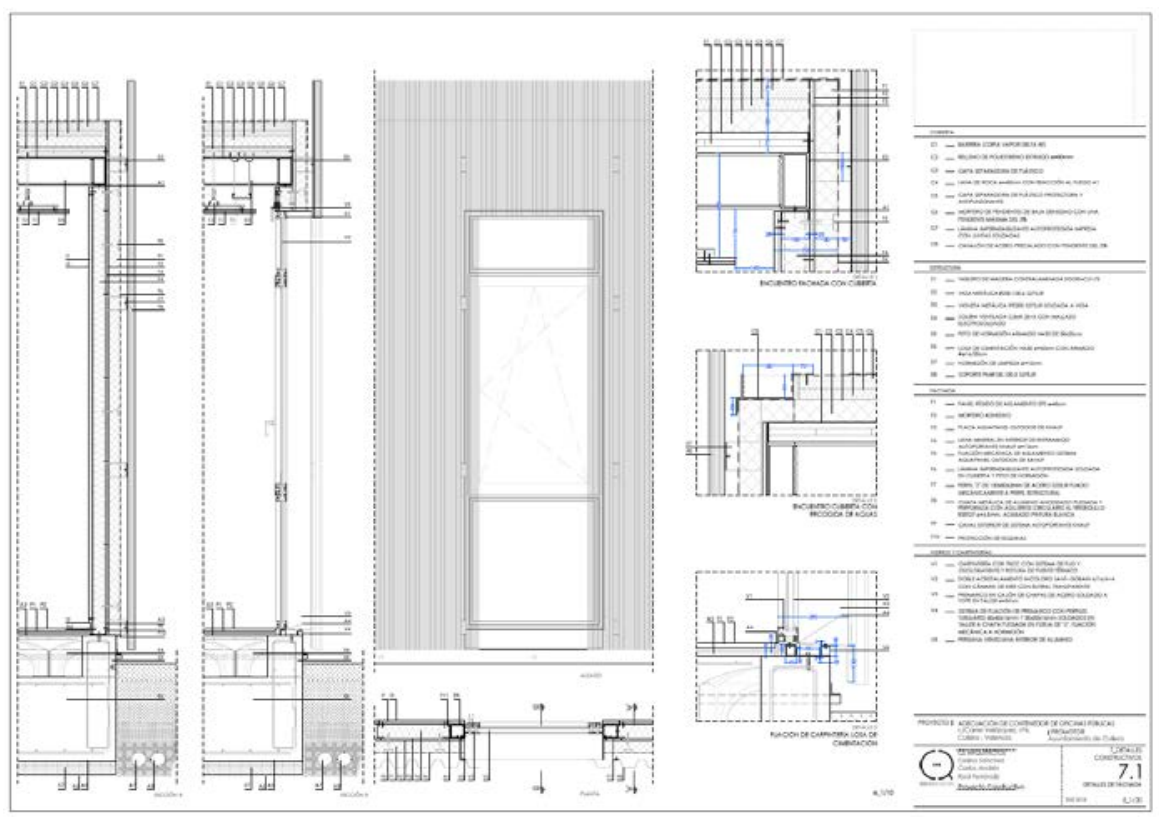

Fig. 4 Detalles constructivos del cerramiento, Grupo A06 2017-18, C. Sánchez, C. Andrés, R. Ferrandiz.

\section{Evaluación y criterios de calidad aplicados}

La evaluación del trabajo se hace de manera continua y progresiva, de manera que se van danto indicaciones a los estudiantes en las distintas entregas parciales. Se valora fundamentalmente la unidad de todo el trabajo y la visión de conjunto. Se puede establecer una división de tareas, pero debe estar coordinada, evitando "adiciones inconexas". 
Una parte clave del desarrollo del proyecto es el Presupuesto y las especificaciones técnicas de los detalles constructivos, ya que a través de ellos se reconoce en detalle sus aspectos más importantes, así como la coherencia del Proyecto. Esto último es un aspecto fundamental para comprobar que realmente se ha realizado un trabajo coordinado y en equipo.

Además de esto se presta especial atención a otros aspectos formales que también necesitarán como la documentación administrativa para su tramitación en el Colegio de Arquitectos, fichas urbanística y estadística, etc. Todo ello está orientado a que conozcan la realidad profesional de un proyecto con todos sus requisitos técnicos y formales.

\section{Resultados y valoraciones}

Las valoraciones generales de la asignatura en los tres años de desarrollo han sido bastante positivas, en torno a 8,1 puntos respecto a 10. En el último curso 2017-18, la apreciación global de las encuestas que lleva a cabo la UPV ha descendido ligeramente 6,1 puntos respecto a 10, lo cual ha coincidido también con el cambio de tipo de proyecto.

En cursos anteriores se realizaban proyecto de viviendas, más habitual y sencillo para los estudiantes, frente a un edificio de tipo terciario (oficinas), que presenta mayores dificultades. Sin embargo, este tipo de cambios son necesarios para que no se reproduzcan y repitan los ejercicios de años anteriores, aunque supone una cierta complejidad en el aprendizaje.

En la encuesta realizada recientemente a los estudiantes que combina una parte de respuestas abiertas con otra de selección múltiple de opciones, la valoración media de la asignatura está en 7,8 puntos sobre 10. Lo que valoran como más positivo y aspecto fundamental es el desarrollo del Proyecto, la aplicación concreta de la normativa, y la "aplicación que tiene para el futuro"

Hay que reseñar también entre los aspectos a mejorar otros relativos a la organización y coordinación propia de una asignatura de nueva implantación como esta. Principalmente, establecer unas revisiones más periódicas y pautadas, organizar mejor la documentación disponible en la web (PoliformaT) y la coordinación con otras asignaturas impartidas en el Máster o incluso de trabajos o cursos anteriores como base o punto de partida del proyecto.

Asimismo, resulta sorprendente que propongan mayoritariamente que los profesores establezcan o discriminen mejor la valoración del trabajo individual respecto al trabajo desarrollado en equipo, lo cual supone un reto respecto a la forma de evaluar el aprendizaje. Esto abre una vía de reflexión sobre la competencia transversal del trabajo en equipo colaborativo, aunque esta competencia no se ha establecido como prioritaria recientemente para esta asignatura en el próximo curso.

\section{Conclusiones}

El desarrollo de esta asignatura todavía es corto, pero la metodología desarrollada de realizar un trabajo que se aproxima a un Proyecto profesional ha tenido buena acogida entre

(cc) EY-NC-ND 2018, Universitat Politècnica de València

Congreso IN-RED (2018) 
los estudiantes. Valoran muy positivamente la oportunidad que se ofrece de aproximarse a una situación real para mejorar sus capacidades y competencias, lo cual lleva a tener más posibilidades de empleabilidad y trabajo.

En este tipo de trabajos es bastante habitual que se produzca una división y una cierta disgregación-agrupación de los contenidos. Si no se gestiona adecuadamente, esto lleva a que aparezcan discrepancias entre unas partes y otras, que pueden ser desde un nivel formal a un nivel más importante de contenidos, lo que podría ser catastrófico en un proyecto real.

Los profesores consideramos que es un buen camino, en el conviene ir mejorando algunos aspectos. Llevar a la práctica y a su aplicación concreta los conocimientos técnicos durante la formación de Grado en arquitectura es algo clave, que debe tener su conclusión en la formación de Máster para resultar realmente "habilitante” en la profesión de arquitecto.

\section{Referencias y notas}

Bridges, A.; A Critical Review of Problem Based Learnin in Architectural education, Communicating Space(s) 24th eCAADe Conference Proceedings Volos (Greece) 6-9 September 2006, pp. 182-189.

Barrows, H.S. \& Tamblyn R.M., Problem-Based Learning: An Approach to Medical Education. Springer Publishing Company, New York1980.

Elbert, S., Dietsch, P., Winter, S.; Interdisciplinary design projects and practical project work in the education of civil engineers. WCTE World Conference on Timber Engineering. Viena, Agosto, 2016.

LaBoube, R.A.;Yildirim, S.G.; Baur, S. W.,Problem-Based Learning with Framing Construction in Architectural Engineering. Journal of Engineering and Architecture. Diciembre 2014, vol.2, no .2, pp. 63-74.

Maitland, B., Problem-based Learning for Archi-tecture and Construction Management, in Boud, D. and Feletti, G., The Challenge of Problem-Based Learning, Kogan Page Ltd, London, UK. 1997

Stolovich, H.D., Keeps, E., No se lo cuente, jenséñeselo!, Ediciones Gestión 2000, Barcelona 2007, traduccíon del original Telling Ain't training, American Society for Traning and Developing, 2002.

VVAA, Escribano, A.; Del Valle, A. (coord), El aprendizaje Basado en Problemas. Una propuesta metodológica en Educación Superior. Narcea, Madrid 2008.

VVAA, Guerra, A., Ulseth, R., Kolmos, A. (Eds), PBL in Engeniering Education, Sense Publishers, Rotherdam, 2017.

«PoliformaT» es la plataforma de teleformación de la Universidad Politécnica de Valencia adaptada y mantenida por el ASIC en base al desarrollo realizado por Sakai.

CTE (Código Técnico de la Edificación), Ministerio de Fomento Real Decreto 314/2006.

COACV-CTAV son el Colegio Autonómico y Territorial de arquitectos de Valencia su web es accesible para los estudiantes temporalmente con permisos especiales en http://www.coacv.org

Index-ARQ. Manual de Calidad del Proyecto Arquitectónico elaborado por el CSCAE disponible para los arquitectos en https://www.cscae.com/index.php/es/conoce-cscae/area-tecnica

CE3x y HULC, son herramientas para el cálculo de la eficiencia energética de una construcción, disponible en la página web https://www.codigotecnico.org/index.php/menu-ahorro-energia.html 


\title{
Implementación de la metodología ABP (Aprendizaje Basado en Problemas) en estudiantes de último año de la carrera de Nutrición
}

\begin{abstract}
Alejandro Martínez-Rodríguez ${ }^{\text {a }}$ Stephanie Torrijo-Boix ${ }^{b}$
${ }^{a}$ Departamento de Química Analítica, Nutrición y Bromatología. Facultad de Ciencias. Universidad de Alicante. amartinezrodriguez@ua.es y ${ }^{b}$ Departamento de Química Analítica, Nutrición y Bromatología. Facultad de Ciencias. Universidad de Alicante. stephanie.torrijo@ua.es
\end{abstract}

\section{Resumen}

La innovación docente en el aula cursa con involucrar al alumnado en el proceso enseñanza-aprendizaje. Los objetivos fueron favorecer el desarrollo de las competencias y objetivos educativos de la parte práctica de la asignatura de Nutrición Deportiva, así como comparar los resultados obtenidos con el alumnado del curso inmediatamente anterior, en relación con la participación en jornadas científicas y las calificaciones académicas. En este trabajo, se ha desarrollado la implementación de la metodología ABP (Aprendizaje Basado en Problemas) en el alumnado de cuarto curso del Grado en Nutrición Humana y Dietética. La evaluación de los cambios producidos en la implementación se realizaron mediante entrevistas al alumnado, registro de actividades y calificaciones académicas. Los resultados manifestaron que el alumnado que realizó la parte práctica de la asignatura mediante la metodología ABP presentaron una mayor participación en jornadas científicas, y obtuvieron mejores calificaciones en significativamente. Asimismo, también mostraron cambios favorables en el desarrollo de las competencias y objetivos educativos en materia de nutrición deportiva. A modo de conclusión, el alumado implementado con la metodología ABP, tuvieron consonancia en el conocimiento y aplicación de estrategias de resolución de problemas que puede ser empleada en el contexto profesional del dietista-nutricionista.

Palabras clave: competencias, innovación, formación, enseñanza. 


\section{Introducción}

Enmarcadas en el Espacio Europeo de Educación Supuerior (EEES), las instituciones, inmersas en un periodo de cambios en la oferta educativa (Michavila, 2009), apuestan por un proceso de formación de adquisición de las competencias necesarias por parte del alumnado (Mauri, 2008). Es por ello, que desde las universidades se promueven múltiples propuestas e iniciativas innovadoras que tratan de integrar nuevas herramientas y estrategias con el propósito de mejorar el proceso de enseñanza-aprendizaje (Salinas, 2004). Habitualmente, los cambios que se producen en la enseñanza a partir de los proyectos de innovación, se centran predominantemente en la utilización de nuevos materiales didácticos (García, 2010), sin embargo, para mejorar el aprendizaje del alumnado también se han de tener en cuenta tanto las tareas que se asignan, la agrupación del alumnado y la relación de este con el profesorado.

Según autores de referencia (Beraza, 2013), ponen de manifiesto que la innovación en docencia se basa en la aplicación de tres condiciones importantes, como son la apertura (cierta flexibilidad que permite un "compromiso activo"), la actualización (aplicación de los nuevos conocimientos y recursos en los sistemas de enseñanza) y la mejora. Aparte de esto, se ha de tener en cuenta en la innovación educativa tanto la documentación como la evaluación. En este sentido, la evaluación va a ser un factor determinante en la aplicación de cualquier acción de innovación docente. De hecho, no se puede entender como efectiva ninguna innovación docente que carezca de un adecuado proceso de evaluación(López Pastor, 2008). Ya que a partir de la evaluación, permite la realización de reajustes del proceso enfocados a mejorar.

En alusión a las nuevas metodologías, se pueden encontrar nuevos paradigmas del aprendizaje (Michavila, 2009), que fundamentan los cambios en las tecnologías educativas, que no solamente están centradas en aplicaciones informáticas o comunicativas. Aunque hay que destacar la facilidad en la consulta de documentación que aporta la utilización de dispositivos digitales, y que cada vez tienen mayor presencia, tanto dentro como fuera del aula, frente a los convencionales (Singer, 2017). Esto no compite con que el nuevo modelo educativo se centra especialmente al estudiante (Michavila, 2009), y trata de buscar un refuerzo en la formación práctica, que sirva de sustento en la adherencia y consecución de los objetivos educativos (Peiteado, 2013) y competencias del alumnado (Cabra, 2008).

En la búsqueda del desarrollo de las competencias, se ha demostrado que la interacción con otros es uno de los factores que potencia el mismo (Cabra, 2008; Jofré, 2013). En relación con ello, el Método de Aprendizaje Basado en Problemas (ABP) se puede aplicar en el aula como nueva estrategia metodológica (Jofré, 2013). La ABP se basa en la identificación de un problema, que deberá ser analizado y sintetizado, para después de formular una 
hipótesis, permita poder elegir la estrategia que aporte una mejor solución al problema. Asimismo, también permite incorporar el aprendizaje colaborativo (Cuéllar, 2010), ya que la responsabilidad de la resolución del problema pasa por la cooperación entre los miembros del grupo, con los aspectos positivos que esto también conlleva dentro del proceso enseñanza-aprendizaje (interdependencia positiva, interacciones cara a cara, desarrollo de habilidades sociales y auto-reflexión en grupo). Mediante la ABP el alumnado ha demostrado mejora de diferentes habilidades como pueden ser la capacidad de análisis o síntesis. Y que además promueve el cambio de rol entre el profesor y el alumno, que entra a formar parte del proceso enseñanza-aprendizaje como protagonista (Gálvez, 2007).

Dentro de los desafíos que se plantean durante el proceso de enseñanza-aprendizaje, son diversas las variables que pueden influir en el mismo, como son el entorno (centro de estudios, materiales) o el tiempo (cuando el alumnado desarrolla las actividades) (Salinas, 2004). A partir de ahora, la formación de los docentes y la asunción de los nuevos modelos educativos, se convierte en otro de los factores importantes del proceso de enseñanzaaprendizaje (Esteban, 2005). En el que tienen que estar cada vez más formados, actualizados en las últimas evidencias empíricas (Novak, 2017), y tener la capacidad de influir y mediar con el alumnado (Warren, 2017). De este modo, se produce una adaptación del docente como "única fuente de formación o información" hacia a ser un orientador para desempeño de tareas y utilización de herramientas o recursos de forma atractiva (Warren, 2017); y que sea el propio alumnado quiénes puedan conformar su propio conocimiento (Gálvez, 2007).

En definitiva, las propuestas de innovación de la docencia universitaria llevan asociadas a una mejorar de la calidad de la docencia, y que puede ser justificada mediante los resultados de aprendizaje del alumnado. Además, como sugieren expertos en el área, el estudio y análisis del proceso innovador, es motivo de investigación continuada (Mauri, 2008). Por todo ello, la hipótesis del presente trabajo de innovación docente se basa en que la aplicación del ABP en el alumnado de último curso del Grado en Nutrición Humana y Dietética, puede contribuir favorablemente al proceso de enseñanza-aprendizaje, aumentar el compromiso del alumnado con la materia y mejorar las calificaciones académicas.

\section{Objetivos}

El objetivo general de la implementación es desarrollar la parte prática de la asignatura de Nutrición Deportiva de $4^{\circ}$ del Grado en Nutrición Humana y Dietética en base al método de Aprendizaje Basado en Problemas. Así como favorecer el desarrollo de habilidades y destrezas sociales, actitudinales y cognitivas para la búsqueda, análisis, integración y transferencia de conocimientos.

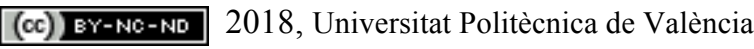


Los objetivos específicos son: a) Incorporar la metodología de Aprendizaje Basado en Problemas como estrategia transversal en las prácticas de Nutrición Deportiva; b) Desarrollar estrategias y métodos que permitan ser aplicados y transferidos en el futuro a situaciones semejantes para la resolución de problemas; c) Favorecer el aprendizaje autodirigido y el desarrollo de habilidades de comunicación en los estudiantes; d) Desarrollar la capacidad de trabajar en equipo y en redes a través de la posesión de actitudes y disposiciones que incluyen la flexibilidad y adaptabilidad; e) Estimular el pensamiento crítico en los estudiantes; d) Comparar los resultados de la participación en jornadas científicas y calificaciones académicas con el alumnado del curso anterior.

\section{Desarrollo de la innovación}

\subsection{Participantes}

En este estudio participaron estudiantes de cuarto curso del Grado en Nutrición Humana y Dietética, de la Universidad de Alicante, matriculados en la asignatura de Nutrición en la Actividad física y el Deporte. Esta asignatura es cuatrimestral y de carácter optativo, con una carga lectiva de 6 créditos ECTS, de los cuáles 1,2 son créditos ECTS prácticos. El número de estudiantes del curso 2016-2017 fue de 30, mientras que en 2017-2018 fueron 35 los estudiantes matriculados.

\subsection{Desarrollo de la innovación}

La implementación de la metodología ABP del proyecto, se basa en una metodología cualitativa de resolución de problemas. En esta, se emplea un problema definido como base para la orientación del alumnado durante el proceso de aprendizaje (Gálvez, 2007). Esta metodología de elaboración, análisis y respuesta o solución al problema, tiene como punto inicial un problema parecido al que el alumnado tendrá que dar respuesta en un futuro como profesional. En este sentido, se han de emplear los conocimientos previos adquiridos durante todo el proceso de formación previo $\left(1^{\circ}-3^{\circ}\right.$ curso). Para ello, tendrán que integrar los conocimientos de diferentes áreas y asignaturas, que darán como resultado una comprensión global y además serán capaces de detectar sus necesidades para dar solución al problema. Asimismo, tendrán a sus disposición todos los medios que consideren oportunos para ello, con la intención de garantizar la ayuda educativa ajustada al desarrollo de la autonomía y de la autorregulación del aprendizaje del alumno.

El problema inicial que se planteó fue la valoración de los hábitos alimentarios y el rendimiento deportivo en un grupo de deportistas, así como realizar una propuesta dietético-nutricional específica para los requerimientos de cada deporte en cada caso. Para el desarrollo del mismo, el alumnado trabajó en pequeños grupos y de forma colaborativa. Fueron los propios alumnos quiénes, en base a qué deporte realizaba el grupo de deportistas

(cc) EY-NC-ND 2018, Universitat Politècnica de València

Congreso IN-RED (2018) 
estudiado, eligieron aquellas pruebas de rendimiento deportivo que más información iban a dar sobre el deporte en cuestión.

Este problema, se enmarca dentro de la evaluación de la parte práctica de la asignatura, cuya evaluación se realizará de forma global, aunque se tendrá en cuenta todo el proceso llevado a cabo, coincidiendo con los diferentes aspectos que se evaluaron el curso anterior, están reflejados en la guía docente de la asignatura, y que son los siguientes: Resolución de casos de prácticas de problemas. Memorias, informes observación sistemática y cuaderno de notas de seminarios. Valoración nutricional de deportistas Trabajo bibliográfico realizado en pequeño grupo y exposición oral. Con ello, se pretendió completar los objetivos específos de la asignatura, que son: "Conocer las necesidades nutritivas y energéticas en diferentes situaciones de actividad física. Adquirir los conocimientos necesarios para realizar un balance energético equilibrado, para mantener y mejorar la salud a través de la práctica deportiva. Conocer y aplicar ténicas de evaluación nutricional, para la valoración de diferentes situaciones en la práctica deportiva."

\subsection{Evaluación}

En el proceso de recogida de datos se emplearon entrevistas iniciales, finales e informes de auto-seguimiento, siguiendo las indicaciones para estas según artículos de referencia para la evaluación de la innovación docente (Mauri, 2008).

Además de los datos recogidos en las entrevistas (antes y después de la implementación o no de la metodología ABP), se emplearon los datos de evaluación propios de la parte práctica de la asignatura, así como los datos de participación como asistentes o asistentes y ponentes en jornadas o congresos científicos.

\subsection{Análisis Estadístico}

Para la realización del análisis estadístico se empleó el software estadístico SPSS en su versión 24.0 para Mac (IBM Statistics, New York). Se llevaron a cabo estadísticos descriptivos (porcentajes o media \pm desviación estánar), prueba Kolmogorov-Sminornov, y comparación de medias mediante la prueba $\mathrm{T}$ para muestras independientes. Se fijó un nivel de significación de $\mathrm{p}<0,05$. Asimismo, se calculó el tamaño del efecto (TE) siguiendo las directrices de Cohen (1988). El TE se consideró despreciable $(<0,2)$, pequeño $(0,2-0,5)$, moderado $(0,5-0,8)$ y grande $(>0,8)$.

(cc) EY-NC-ND 2018, Universitat Politècnica de València 


\section{Resultados}

Los resultados del desarrollo de la innovación pusieron de manifiesto, en términos generales, una mayor participación del alumnado en relación a las tareas ofertadas. Así como un grado elevado de implicación con el trabajo de la asignatura, en el que se pone de manifiesto un interés explítico de la transferencia del trabajo en el contexto educativo hacia el ámbito profesional o de investigación, como son los congresos científicos. En la figura 1 se presentan los estadísticos descriptivos del alumnado durante los cursos 2016-2017 y 2017-2018. En esta se muestran los datos de la asistencia, por un lado, y presentación por parte del alumnado de comunicaciones científicas a congresos, por otro.

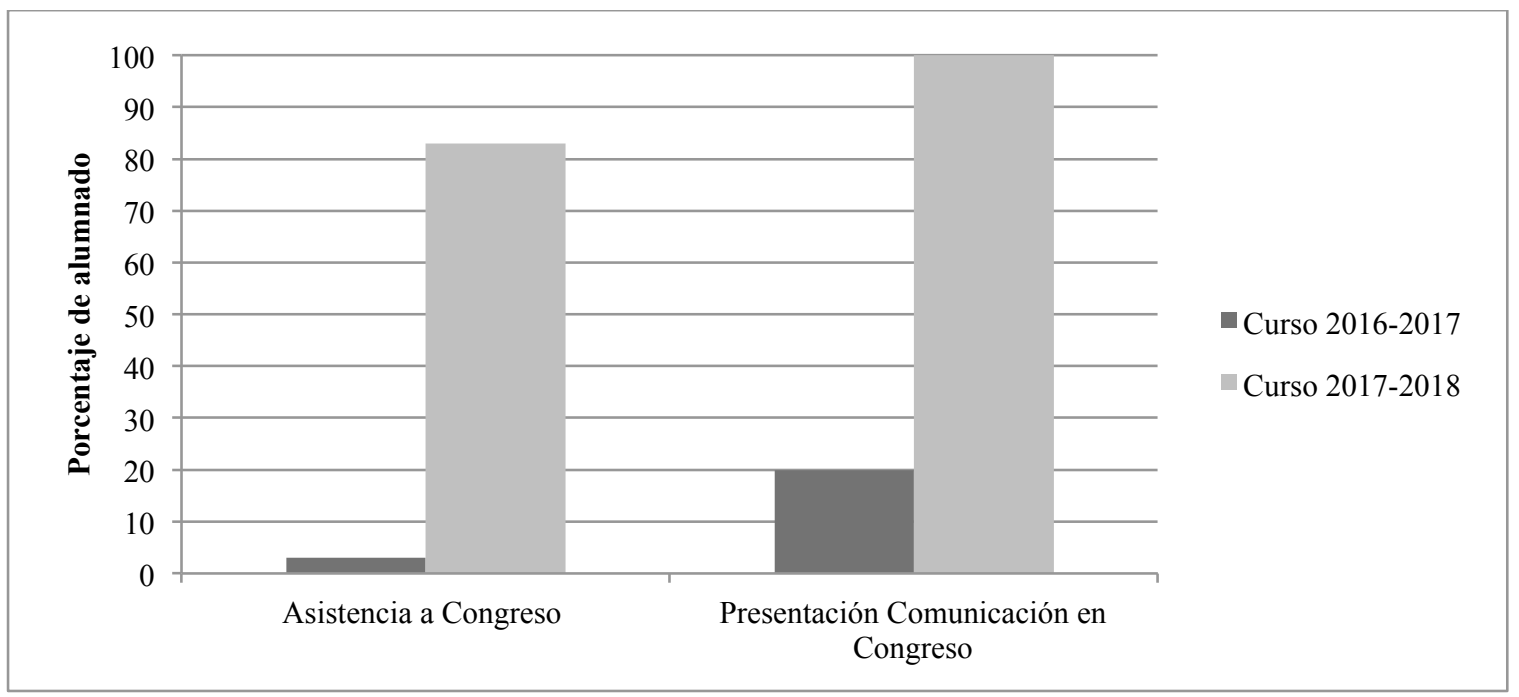

Fig. 1. Estadísticos descriptivos de asistencia a congresos y presentación de comunicaciones a congreso.

Asimismo, en la tabla 1 aparecen los resultados promedios de las calificaciones obtenidas por el alumnado en los cursos 2016-2017 y 2017-2018. Se pudo observar el alumnado del curso académico 2017-2018 obtuvieron calificaciones significativamente superiores, en comparación con el alumnado del curso previo, en la evaluación práctica de la asignatura, que también expresa un tamaño del efecto moderado-grande. 
Tabla 1. Resultados de la comparación de medias por curso académico de la evaluación práctica

\begin{tabular}{ccccc}
\hline Curso Académico & Estudiantes (n) & Evaluación Práctica & Significación & Tamaño Efecto (Cohen) \\
\hline $2016-2017$ & 30 & $7,0 \pm 0,7$ & $\mathrm{p}=0,040$ & 0,772 \\
$2017-2018$ & 35 & $7,5 \pm 0,6$ & \\
\hline
\end{tabular}

Además de la obtención de los estadísticos descriptivos y la realización de la comparación de ambos cursos, cabe destacar la importancia de los resultados obtenidos a través de las entrevistas iniciales y finales, después de la implementación ABP en ambos cursos.

En la entrevista inicial se abordaron cuestiones relacionadas con las características generales y específicas de la propuesta. Así como la distribución de las tareas por parte de los participantes, asumiendo ellos mismos sus responsabilidades. De forma inherente a la implementación educativa, se realizó la formación de los grupos, el diseño de la intervención a realizar, la valoración de la selección de los materiales (material antropométrico, balones medicinales, pulsómetros, etc.) a emplear, las actividades de evaluación que tendrán lugar, así como las expectativas de los resultados.

En el informe de seguimiento los grupos puso de manifiesto un adecuado desarrollo de las habilidades y destrezas sociales, actitudinales y cognitivas para la búsqueda, análisis, integración y transferencia de conocimientos. Además, los grupos aportaron las variaciones que habían realizado en relación con la propuesta inicial, así como la modificación parcial de algunos de los objetivos específicos propuestos en el caso del alumnado del curso 2017 2018. Mientras que el alumnado del curso anterior, no realizaron reajustes notables, ya que cada una de las sesiones se realizaron de forma guiada. Además, el alumnado del curso 2017-2018 aplicaron diversas variaciones, debido a la adaptación a las dificultades y obstáculos en las condiciones que se llevó a cabo la innovación. Asimismo, estos reflejaron un mayor interés en relación con la contribución al propio aprendizaje.

A través de la entrevista final, se identificó que en ambos casos ambos grupos del alumnado cumplieron los objetivos propuestos en la asignatura, así como se adquirieron las competencias planteadas en la guía docente de la asignatura. Cabe incidir en que la implicación, dedicación y el trabajo de calidad realizado, puso de manifiesto un interés elevado en la divulgación del trabajo científico por parte del alumnado en congresos específicos del área temática. Sin embargo, el alumnado del curso 2016-2017 mostraron un grado de satisfacción menor con el proceso de enseñanza-aprendizaje en comparación con los alumnos del curso 2017-2018. La valoración tanto de los elementos de la innovación como: las características organizativas, la cooperación, los aspectos metodológicos y

(cc) EY-NC-ND 2018, Universitat Politècnica de València 
didácticos y la evaluación, fueron mejores en el alumnado con el que se llevó a cabo la implementación de la metodología ABP.

Por ello, al mismo tiempo, el profesor refirió también implicaciones mayores en su preparación profesional. Debido a que durante el proceso debía hacer frente a nuevas actuaciones debido a la libertad de elección de intervenciones del alumnado, ya que durante el proceso también actuó como guía de apoyo en las situaciones más complejas o de difícil solución. resultado, el profesor acusará implicaciones en su preparación profesional, pues se le va a requerir, en suproceso de formación -inicial o de reciclaje-, ser usuarioaventajado de recursos de información. Junto a ello,necesitará servicios de apoyo de guías y ayudasprofesionales que le permitan participar enteramente enel ejercicio de su actividad.

\section{Conclusiones}

A modo de conclusión, cabe incidir en que la implementación metodológica del ABP has favorecido al desarrollo de las destrezas sociales, actitudinales y cognitivas para la búsqueda, análisis, integración y transferencia de conocimientos del alumando del Grado en Nutrición Humana y dietética. Con ello, el alumnado han desarrollado favorablemente estrategias y métodos que permitan ser aplicados y transferidos en el futuro a situaciones semejantes para la resolución de problemas. También, han demostrado la capacidad de auto-aprendizaje, trabajo en equipo y estimulación positiva del pensamiento crítco. Por último, destacar que los resultados obtenidos por el alumnado implementado con la metodología $\mathrm{ABP}$ mostraron mejores resultados en comparación con el alumnado no implementado con esta metodología.

\section{Referencias}

BERAZA, M. A. Z. (2013). "Innovación en la enseñanza universitaria". Contextos Educativos. Revista de Educación, (6), 113-136.

CUÉLLAR, A. I., Y ALONSO, M. I. (2010). "How evaluate the collaborative learning? A proposal valuing the process, content and the product of group interactivity". Revista General de Información y Documentación, 20, 221.

CABRA TORRES, F. (2008). "La evaluación y el enfoque de competencias: tensiones, limitaciones y oportunidades para la innovación docente en la universidad". Revista escuela de administración de negocios, (63).

COHEN J. (1988). Statistical Power Analysis for the Behavioral Sciences. 2nd ed. Hillsdale, NJ: Lawrence Erlbaum Associates.

ESTEBAN, C. M. R., \& Sánchez, C. M. (2005). "Innovación docente en la Universidad en el marco del EEES”. Educatio Siglo XXI, 23, 171-189.

(cc) EY-NC-ND 2018, Universitat Politècnica de València

Congreso IN-RED (2018) 
GARCÍA, C. M., RUÍZ, C. M., Y NOCHE, B. G. (2010). "Innovación educativa en España desde el punto de vista de sus protagonistas". Profesorado. Revista de Curriculum y Formación de Profesorado, 14(1), 111-134.

GÁlVEZ, I. E., REDRUELLO, R. A., MARTÍN, R. C., DE LA HERRÁN GASCÓN, A., DE MIGUEL BADESA, S., GARCÍA, M. G., ... E IZQUIERDO, R. M. R. (2007). "El aprendizaje basado en problemas como innovación docente en la universidad: posibilidades y limitaciones". Educación y futuro: Revista de investigación aplicada y experiencias educativas, (16), 85-100.

JOFRÉ, C., \& CONTRERAS, F. (2013). "Implementación de la metodología ABP (Aprendizaje Basado en Problemas) en estudiantes de primer año de la carrera de Educación Diferencial”. Estudios pedagógicos (Valdivia), 39(1), 99-113.

LÓPEZ PASTOR, V. M. (2008). "Desarrollando sistemas de evaluación formativa y compartida en la docencia universitaria. Análisis de resultados de su puesta en práctica en la formación inicial del profesorado". European Journal of Teacher Education, 31(3), 293311.

MAURI, T., COLL, C., Y ONRUBIA, J. (2008). "La evaluación de la calidad de los procesos de innovación docente universitaria. Una perspectiva constructivista". Revista de docencia universitaria, 1(1).

MICHAVILA, F. (2009). "La innovación educativa. Oportunidades y barreras". Arbor, 185(Extra), 3-8.

NOVAK, A. M., \& TREAGUST, D. F. (2017). “Adjusting claims as new evidence emerges: Do students incorporate new evidence into their scientific explanations?". Journal of Research in Science Teaching.

PEITEADO, M. G. (2013). "Los estilos de enseñanza y aprendizaje como soporte de la actividad docente". Journal of Learning Styles, 6(11).

SALINAS, J. (2004). "Innovación docente y uso de las TIC en la enseñanza universitaria". RUSC. Universities and Knowledge Society Journal, 1(1).

SINGER, L. M. Y ALEXANDER, P. A. (2017). "Reading on paper and digitally: What the past decades of empirical research reveal". Review of Educational Research, 87(6), 1007 1041 .

TIRADOS, R. M. G., Y MAURA, V. G. (2007). "Diagnóstico de necesidades y estrategias de formación docente en las universidades". Revista Iberoamericana de Educación,43(6), 6.

WARREN, C. A. (2017). "Empathy, Teacher Dispositions, and Preparation for Culturally Responsive Pedagogy”. Journal of Teacher Education, 0022487117712487. 


\title{
Aplicación de la metodología ApS en estudiantes de Finanzas. Valoración desde la perspectiva del estudiante y de la entidad receptora de la ApS
}

\author{
Begoña Cabanés-Cacho ${ }^{a}$, Nieves García-Casarejos ${ }^{b}$ e Israel Romera \\ ${ }^{a}$ Facultad de Economía y Empresa, Universidad de Zaragoza, bcabanes@unizar.es ${ }^{\text {b} F a c u l t a d ~ d e ~}$ \\ Economía y Empresa, Universidad de Zaragoza, ngarcia@unizar.es y ${ }^{\mathrm{C}}$ Facultad de Economía y \\ Empresa, Universidad de Zaragoza, iromera@unizar.es
}

\begin{abstract}
This project uses the Learning-service methodology, which combines the acquisition of skills with the service for social organizations, and applies it to the students of a subject in the Degree "Finance and Accounting". From its application is expected to achieve benefits for both parties, students and entities receiving the service.

Specifically, the aim of the Learning-service is to provide greater attention to the personal abilities and communication and professional skills that need to be achieved by the student of this Degree; and, on the other hand, to know the perception of the participating entities that receive the service in order to detect their satisfaction with the activity that is being carried out.

The spirit that guides the realization of this activity is no other than to train future professionals in the field of finance in values such as ethics, sustainability, transparency, equity and solidarity, that are such necessary nowadays.
\end{abstract}

Keywords: finance, values, Learning-service, social organizations, competencies, integral training, receiving entity, valuation.

\footnotetext{
Resumen

Este trabajo utiliza la metodología ApS, que combina la adquisición de competencias con el servicio a las organizaciones sociales, y lo aplica a los alumnos de una asignatura del Grado en Finanzas y Contabilidad. De su aplicación se espera conseguir beneficios para ambas partes, alumnos y entidades receptoras del servicio. En concreto, se trata de prestar mediante la metodología ApS una mayor atención a las competencias y habilidades personales, comunicativas y profesionales a alcanzar por parte del estudiante del Grado en Finanzas; y, por otro, conocer la percepción de las entidades participantes receptoras del servicio para detectar su satisfacción con la actividad realizada.

El espíritu que guía la realización de esta actividad no es otro que formar a los futuros profesionales del ámbito de las finanzas en valores como la ética, sostenibilidad, transparencia, equidad y solidaridad, tan necesarios en la actual sociedad.
} 
Aplicación de la metodología ApS en estudiantes de Finanzas. Valoración desde la perspectiva del estudiante y de la entidad receptora de la ApS

Palabras clave: finanzas, valores, ApS, organizaciones sociales, competencias, formación integral, entidad receptora, valoración.

\section{Introducción}

El proyecto nace con la finalidad de transferir a organizaciones y entidades, las competencias y habilidades alcanzadas por los estudiantes del grado en Finanzas y Contabilidad de la Universidad de Zaragoza, obligándoles a salir de las aulas, de su zona de confort y acercarse a colectivos con los que, habitualmente, no mantienen ningún tipo de relación, para poner en valor lo aprendido en el aula.

Para ello, además de centramos en conocer qué competencias alcanzan a través de la actividad de Aprendizaje-Servicio (en adelante ApS), así como la satisfacción del estudiante con la actividad, nos planteamos valorar cómo perciben este tipo de actuaciones las entidades receptoras de la ApS.

La actividad de ApS supone para los alumnos una experiencia transformadora, ya que parten de una situacion de conocimiento teorico pero de desconocimiento, en muchas ocasiones, de la realidad. Cuando realizan el servicio se producen en el estudiante nuevos pensamientos y sentimientos que le ayudan a reflexionar sobre su responsabilidad en el mundo, que sólo se podrá producir si el alumno tiene sensibilidad hacia las necesidades sociales que le rodean (Wong, 2007; Perez Gómez, 2010; Chiva-Bartoll, Pallarés-Piquer y Gil-Gómez, 2018).

En este contexto, la Universidad mediante estas ApS actúa de nexo de unión entre la enseñanza universitaria, que pretende una formación integral del alumno, y su entorno, la sociedad entendida en sentido amplio, que no está únicamente formada por entidades mercantiles sino también por entidades pertenecientes al tercer sector, ENL, ONGs, empresas de economía social, etc. Asimismo, esperamos que mediante la prestación de este servicio, las entidades, organizaciones o asociaciones potencien sus vínculos con la Universidad (Saz y Ramo, 2015).

El interés de este trabajo, aplicado a los estudiantes de la titulación de Finanzas y Contabilidad de la Facultad de Economia y Empresa, se justifica ya que: por un lado, permite incorporar prácticas que fomentan el desarrollo de valores sociales en los alumnos de una titulación con un alto contenido y visión economicista; por otro, consigue transmitir a la sociedad (a través de sus asociaciones, organizaciones no gubernamentales, instituciones educativas) parte de las competencias de responsabilidad social adquiridas en el aula, consiguiendo de este modo un efecto divulgativo, en consonancia con la Estrategia Europea 2020 que anima a difundir la RSE como herramienta para contribuir a la mejora de la competitividad de la economía de forma sostenible y con cohesión social.

Respecto al desarrollo de valores sociales, las ApS contribuyen a la formacion integral de los estudiantes, ya que el compromiso social que supone la actividad, genera un efecto sobre las personas hacia una actitud más social y responsable (Saz y Ramo, 2015).

La adquisición de competencias, es decir, las habilidades, actitudes, valores y conocimientos, tienen lugar como parte de un proceso de interconexióncon las formas de

(cc)) BY-NG-ND 2018, UniversitatPolitècnica de València

Congreso IN-RED (2018) 
ser, pensar, sentir y ver que caracterizan al grupo y al entorno en el que se desenvuelve nuestra vida (Lave y Wenger, 1991), y que se corresponde con los cuatro ejes del aprendizaje que recoge UNESCO: aprender a conocer, aprender a hacer, aprender a ser y aprender a convivir (Delors, 1996). Pero todo aprendizaje, en particular aquel que es relevante y duradero (Peréz Gómez, 2010), es fruto de la participación del individuo en prácticas sociales, por ser miembro de una comunidad social (Peréz Gómez y Soto, 2009) Este conocimiento lo construyen los estudiantes interpretando, analizando y evaluando, y no simplemente recitando información (Daniels y Bizar, 2005).

Además, para que el aprendizaje se produzca es necesario un alto grado de implicacion e interes por parte de los alumnos. Estos deben poder aplicar y consolidar las competencias adquiridas en el aula a una situación real (Gil-Gómez et al., 2016; Rodríguez, 2014).

Así, de los 39 matriculados en la asignatura optativa de "Gobierno corporativo y Responsabilidad Social”, 32 estudiantes aceptaron realizar esta actividad voluntaria, lo que supone un $82 \%$ del total.

\section{Objetivos}

Son dos los colectivos a los que se pretende impactar con este trabajo. Por un lado, a los estudiantes de la asignatura en la que se realiza la ApS y, por otro, a las entidades receptoras de la $\mathrm{ApS}$.

En el colectivo de estudiantes se pretende mejorar las siguientes competencias transversales:

1. Habilidades profesionales (resolución de problemas, organización, análisis y procesamiento de información, tecnológicas...).

2. Habilidades comunicativas (escucha activa, asertividad, comunicación verbal, comunicación no verbal, ...).

3. Habilidades personales (autoestima, seguridad, inteligencia emocional, proactividad, ...).

En el colectivo de las entidades receptoras de la ApS, se pretende:

1. Que conozcan mejor las competencias de los graduados en Finanzas de la Universidad de Zaragoza, y puedan valorar el impacto en la organización tras el servicio.

2. Conocer cual es su percepción del servicio, es decir, lo que les ha aportado participar en el proyecto.

3. Identificar su grado de satisfacción y necesidades futuras. 
Aplicación de la metodología ApS en estudiantes de Finanzas. Valoración desde la perspectiva del estudiante y de la entidad receptora de la ApS

\section{Desarrollo de la innovación}

El proyecto se lleva a cabo en la asignatura "Gobierno Corporativo y RSE” de cuarto del grado en Finanzas y Contabilidad en la Facultad Economía y Empresa durante el curso 2016-17, y el resumen de su ficha técnica se recoge en la Tabla 1. El proyecto tiene carácter voluntario para los estudiantes que optan por la modalidad de evaluación continua puesto que se recoge en la guía docente con un peso del 15\% de la nota final.

Tabla 1. Ficha técnica y contextualizacion de las Aps realizadas

\begin{tabular}{|c|c|}
\hline \multicolumn{2}{|c|}{$\begin{array}{c}\text { Contextualización de la ApS } \\
\text { Ficha Técnica }\end{array}$} \\
\hline Estudiantes matriculados en la asignatura & 39 \\
\hline Alumnos evaluación continua & 32 \\
\hline Alumnos que realizan ApS & 32 \\
\hline Número de ApS realizadas & 6 \\
\hline Media de estudiantes por grupo & 4 \\
\hline Método de selección de la ApS & Por el estudiante \\
\hline Grado de implicación del estudiante & Alto (en media) \\
\hline Edad de los estudiantes & $>20$ años \\
\hline Participación por género & $56 \%$ hombres; $44 \%$ mujeres \\
\hline
\end{tabular}

Fuente: Elaboración propia

La Metodología ApS permite al estudiante profundizar en su aprendizaje realizando un servicio a la comunidad. Además, desde un punto de vista docente permite llevar a cabo una práctica innovadora que los alumnos realizarán fuera del aula y pondrán en práctica las competencias adquiridas en la asignatura en una actividad de utilidad para una organización en particular, un colectivo o la sociedad en general, y que se espera que tenga un impacto formativo y transformador en los participantes, en la institución educativa y en la comunidad (Mayor, 2012)

Para ello, deberán planificar la actividad, desarrollarla fuera de las aulas y evaluar los resultados obtenidos de la misma, exponiéndolos ante del resto de compañeros. Previo a la planificación, se consensuará con el profesor la actividad a realizar. Los estudiantes organizan un calendario, del cual hará un seguimiento el profesor en base a tutorías grupales, así como un informe y exposición al final del semestre para transmitir el conocimiento y experiencia adquirida al resto de sus compañeros que servirá para poder evaluar el trabajo realizado.

A continuación, se describen los proyectos de aprendizaje-servicio realizados:

- Colaborar con la Oficina Verde la Universidad de Zaragoza. A petición de la Oficina Verde se realizaría una encuesta e informes para mejorar la prestación de servicios en el Campus Río Ebro en dos aspectos: temperatura de confort en los edificios y movilidad sostenible. Esta actividad se espera que tenga una repercusión positiva y mejore la conciencia medioambiental en el Campus Río Ebro.

(cc)) EY-Nc-ND 2018, UniversitatPolitècnica de València 
- Fundacion Federico Ozanam. . La actividad consistirá en que nuestros alumnos impartirán una charla sobre reciclado y uso responsable de los materiales para sensibilizar a a los alumnos de sus centros de formación ocupacional.

- Juego de rol, “Ethica”. Se trata de un juego diseñado para explorar el impacto social y ambiental de las actividades bancarias, las inversiones y los negocios, y aprender a tomar decisiones más responsables y éticas en cuanto a la gestión del dinero. Los alumnos explicarán el juego a alumnos de bachillerato del Instituto Grande Covián y llevaran a cabo alguna partida, ayudándoles a desarrollar un espíritu crítico cuando tomen decisiones de inversión.

- Videos explicativos sobre conceptos básicos de finanzas. Estos videos pretenden difundir al gran público cuestiones básicas a las que todo ciudadano se tiene que enfrentar en su relación con entidades financieras.

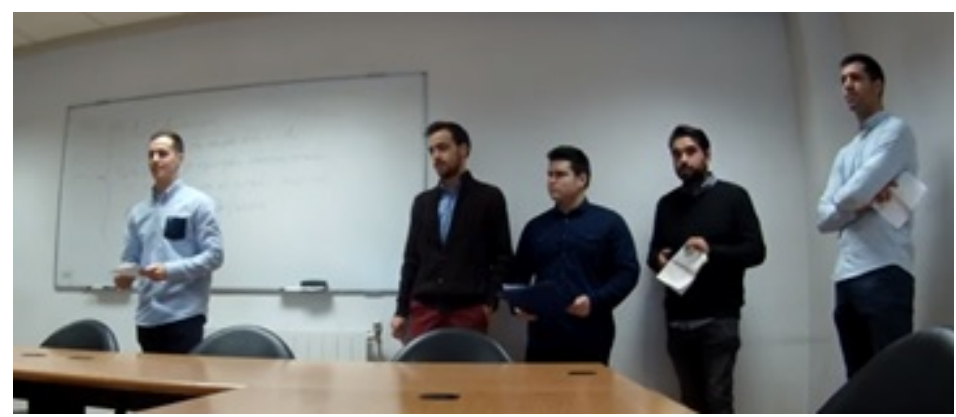

Fig. 1 Estudiantes de la asignatura realizando su ApS

Se supervisa y se lleva a cabo un seguimiento a través de tutorías, email, llamadas, etc. Al final del semestre cada grupo tendrá que explicar cuál ha sido su proyecto y que han aprendido al resto de sus compañeros. Para el seguimiento se utilizan, semanalmente, 10 minutos de clase, para hablar con los miembros de cada grupo y establecer las citas para tutorias, entrega de actividades parciales, etc. Cada grupo esta formado por, entre 3 y 6 personas.

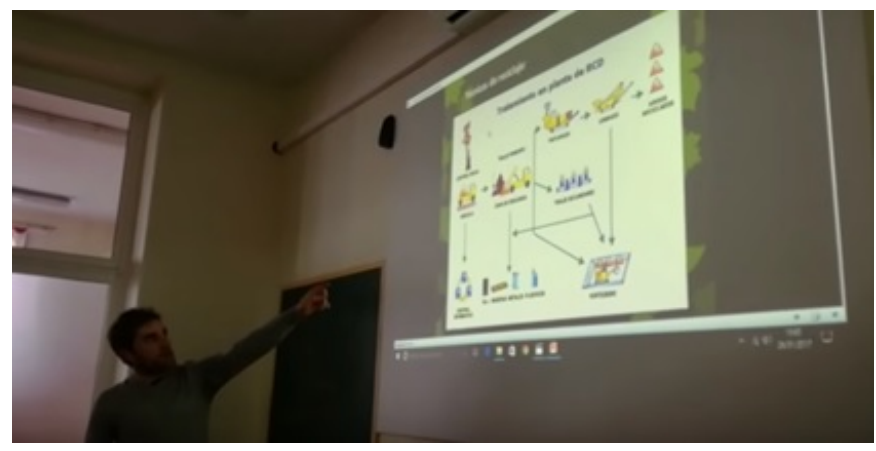

Fig. 2 Estudiante del Grado en Finanzas y Contabilidad concienciando medioambientalmente 
Los alumnos son los que seleccionan la ApS a realizar de acuerdo a sus intereses. Las ApS a su vez se seleccionan teniendo en cuenta la relacion existente entre los aprendizajes que se desean conseguir para los estudiantes con la realización del servicio y la motivación de mejorar algún aspecto concreto por parte de la entidad receptora solicitante del servicio. Esto hace que no todos los estudiantes desarrollen con la misma intensidad cada una de las competencias. Para trasladar lo aprendido al resto de compañeros, dado que las distintas ApS presentan situaciones no homogéneas, es por lo que los estudiantes exponen al resto de sus compañeros en clase lo que han hecho durante su ApS.

\section{Resultados}

Para cuantificar el impacto del aprendizaje alcanzado a través de la ApS en los estudiantes se ha elaborado un cuestionario para detectar la mejora percibida en la adquisición de competencias transversales, así como su grado de satisfacción con la actividad, en línea con estudios precedentes como el de Folgueiras et al. (2013), Ayuste et al. (2017).

Se han incorporado al mismo las siguientes cuestiones que se busca evaluar:

- Identificar el proyecto en el que ha participado el alumno.

- Tiempo total de dedicación, evaluado en horas y con carácter individual.

- Herramientas utilizadas por el grupo para la coordinación de la ApS.

- La significatividad del servicio para el estudiante.

- Grado de conexión de la ApS con el curriculum del estudiante.

- Reflexión del estudiante sobre lo alcanzado a través de la actividad, a través de distintas perspectivas.

- Grado de protagonismo del estudiante en su propia formación, en competencias, generales y específicas, y en valores.

- Adecuación del tiempo dedicado a la actividad para los objetivos alcanzados.

- Consecución de habilidades personales e interpersonales.

- Posibles áreas de mejora en la actividad.

Mediante estos ítems se pretende conocer la utilidad de la actividad realizada por el estudiante.

Las distintas habilidades profesionales, comunicativas y personales que el proyecto se plantea mejorar se trabajan integradas en la propia ApS, tal y como recoge en la Tabla 2. 
Tabla 2. Habilidades a trabajar en las ApS y forma en la que se trabajan

\begin{tabular}{ll}
\hline \multicolumn{1}{c}{ Habilidades } & \multicolumn{1}{c}{ Forma en la que se trabaja } \\
\hline $\begin{array}{l}\text { Habilidades profesionales (resolución de } \\
\text { problemas, organización, análisis y } \\
\text { procesamiento de información, } \\
\text { tecnológicas...). }\end{array}$ & $\begin{array}{l}\text { Planificando y desarrollando la propia actividad de } \\
\text { ApS }\end{array}$ \\
$\begin{array}{l}\text { Habilidades comunicativas (escucha activa, } \\
\text { asertividad, comunicación verbal, } \\
\text { comunicación no verbal, ...). }\end{array}$ & $\begin{array}{l}\text { Comunicándose con las entidades, con las personas } \\
\text { que reciben el servicio y en sus exposiciones }\end{array}$ \\
$\begin{array}{ll}\text { Habilidades personales (autoestima, seguridad, } \\
\text { inteligencia emocional, proactividad, ....). }\end{array}$ & $\begin{array}{l}\text { En si mismo se trabajan. El alumno se centra en } \\
\text { realizar la actividad, pero conforme consigue los } \\
\text { objetivos va adquiriendo seguridad en si mismo y } \\
\text { habilidades personales (disciplina, conciencia de sus } \\
\text { capacidades,...). }\end{array}$ \\
\hline
\end{tabular}

\section{Fuente: Elaboración propia}

En cuanto a la evaluación de dichas habilidades (en una escala de 0 a 7 , donde cero es totalmente en desacuerdo y 7 totalmente de acuerdo), cuya mejora se produce en un periodo corto de tiempo, concretamente en un semestre, el estudiante deberá ser el que realice su autoevaluacion para poder conocer el impacto de la ApS de cada uno de los grupos de habilidades.

Tabla 3. Valoracion de los alumnos de las ApS

\begin{tabular}{|c|c|c|c|c|}
\hline & $\begin{array}{c}\text { Oficina Verde } \\
\text { Unizar }\end{array}$ & $\begin{array}{c}\text { Fundación } \\
\text { Federico } \\
\text { Ozanam }\end{array}$ & $\begin{array}{l}\text { IES Francisco } \\
\text { Grande Covián }\end{array}$ & $\begin{array}{l}\text { YouTube } \\
\text { UNIZApS }\end{array}$ \\
\hline $\begin{array}{l}\text { Mejorar en mis habilidades } \\
\text { profesionales (resolución de } \\
\text { problemas, organización, análisis y } \\
\text { procesamiento de información, ...) }\end{array}$ & 4,14 & 4,67 & 4,25 & 4,00 \\
\hline $\begin{array}{l}\text { Mejorar en mis habilidades } \\
\text { comunicativas (escucha activa, } \\
\text { asertividad, comunicación verbal, } \\
\text { comunicación no verbal, ....) }\end{array}$ & 3,57 & 6,33 & 5,00 & 2,33 \\
\hline $\begin{array}{l}\text { Mejorar en mis habilidades } \\
\text { personales (autoestima, seguridad, } \\
\text { inteligencia emocional, proactividad, } \\
\text {...) }\end{array}$ & 2,86 & 5,50 & 4,25 & 3,00 \\
\hline
\end{tabular}

Fuente: Elaboración propia 
Aquellas ApS cuya prestación del servicio incluía una exposición pública del mismo, resaltaron que la habilidad que más habian mejorado era la comunicativa. Sin embargo, el resto de grupos habían mejorado sus habilidades profesionales (resolucion de problemas, organizacion, analisis y procesamimento de informacion, ...).

Para medir el impacto en las entidades receptoras, del mismo modo, al finalizar la actividad se realiza un cuestionario con el fin de conocer:

- $\quad$ Nombre de la organización, entidad o empresa.

- Persona que responde al cuestionario.

- Cargo.

- Servicio que ha recibido.

- Grado de satisfacción global con el servicio recibido.

- Implicación de los alumnos.

- Impacto que ha tenido el servicio en la organización.

- Adecuación de tiempo destinado a esta actividad y logro de los objetivos pretendidos.

- Habilidades personales, comunicativas, profesionales y valores que le permite al alumno alcanzar la actividad.

- Satisfacción con la organización de la actividad.

- Problemas detectados.

- Interés por volver a colaborar en un futuro

- Posibles temas para futuras colaboraciones

La opinión de la entidad receptora es valiosa no solo por la información que proporciona para la mejora de la actividad y para el engarce de la Universidad con el ámbito de la economía social, sino también porque una parte de la evaluación de la actividad es fruto del resultado de la valoración que del estudiante hace la entidad receptora de la ApS.

El impacto del proyecto ha sido positivo tanto en los estudiantes como para las entidades receptoras. En los alumnos se espera un incremento en la motivación de cara al estudio de la asignatura y a su vinculación con la sociedad que les rodea; y para las entidades receptoras ayudarles a poner en marcha una parte de sus proyectos, como en este caso será la concienciación medioambiental, formación financiera básica, formación integral, etc. 
Tabla 4. Valoracion de las entidades receptoras de las Aps

\begin{tabular}{lcccc}
\hline & $\begin{array}{c}\text { Oficina Verde } \\
\text { Unizar }\end{array}$ & $\begin{array}{c}\text { Fundación } \\
\text { Federico } \\
\text { Ozanam }\end{array}$ & $\begin{array}{c}\text { IES Francisco } \\
\text { Grande } \\
\text { Covián }\end{array}$ & $\begin{array}{c}\text { YouTube } \\
\text { UNIZApS }\end{array}$ \\
\hline $\begin{array}{l}\text { Grado de satisfaccion global } \\
\text { con el servicio recibido }\end{array}$ & 7,00 & 6,00 & 5,75 & 5,00 \\
$\begin{array}{l}\text { Implicacion de los alumnos } \\
\begin{array}{l}\text { Impacto que ha tenido el } \\
\text { servicio en la organización }\end{array}\end{array}$ & 7,50 & 6,00 & 6,00 & 5,75 \\
\hline
\end{tabular}

Fuente: Elaboración propia

La calificacion que los estudiantes obtienen en la ApS viene condicionada por varios aspectos: su exposicion en clase, si se han cumplido los objetivos marcados para la actividad y la opinion de la entidad receptora. Entendemos que si la entidad receptora no esta satisfecha con el servicio prestado la nota se ve condicionada por esta circunstancia. Esta actividad supone un $15 \%$ de la nota global de la asignatura.

Según se muestra en la Tabla 4, fue la Oficina Verde la que mejor ha valorado, en media, el servicio recibido, mientras que la peor ha valorado la actuación de los estudiantes fueron los videos de Youtube, principalmente por la baja implicación de los alumnos y porque el producto final obtenido era claramente mejorable. En una situación intermedia se encuentran el IES Grande Covián y la Fundación Federico Ozanam, en los que los valores más bajos otorgados se presentan en el impacto que ha tenido el sercicio en la propia organización.

\section{Conclusiones}

La metodología ApS promueve el aprendizaje a través de la práctica, trabajo colaborativo, grupos de discusión, etc.

En este proyecto los profesores son los que han diseñado la práctica de ApS, pero son los alumnos son los que definen y planifican su realización. Por ello, el resultado, en buena medida, depende de la motivación de los alumnos y del grado de implicación de las organizaciones participantes.

Por ello, trabajar con esta metodología supone situar al alumno en el centro, puesto que es quien elige en qué actividad participar, y los profesores pasan a ser meros facilitadores de contextos y materiales para que realmente se produzca el aprendizaje (Francisco y Moliner, 2010), y el eje en el que se sustenta la planificación de las ApS es el trabajo autónomo (Martínez-Fernandez y Rabanaque, 2008; Romero y Pérez, 2009).

La realización de este trabajo permite conocer: 1) el grado de satisfacción tanto del estudiante como de la entidad receptora de la ApS; 2) las habilidades, competencias 
Aplicación de la metodología ApS en estudiantes de Finanzas. Valoración desde la perspectiva del estudiante y de la entidad receptora de la ApS

genéricas y específicas alcanzadas por el alumno desde las dos ópticas, su propia percepción así como desde la perspectiva de la entidad receptora.

Este tipo de metodologías innovadoras no están circunscritas a unas pocas asignaturas o a un área de conocimiento determinado, sino que puede hacerse extensiva a todas las titulaciones. De este modo, se consigue que las entidades receptoras conozcan lo que los alumnos formados en la Universidad de Zaragoza les pueden aportar. Simplemente hay que encontrar la experiencia adecuada para que se desarrollen las competencias transversales y los resultados de aprendizaje vinculados a dicha asignatura. Esta sería una nueva modalidad de prácticas que se une a las tradicionales prácticas en empresas privadas, y que responden a la exigencia y demanda de un mayor compromiso social y ético.

\section{Referencias}

AYUSTE GONZALEZ, A., GROS SALVAT, B., PAYÁ SANCHEZ, M., y RUBIO SERRANO, L. (2017) "Valoración de proyectos ApS desde sus protagonistas: Un medio para la formación inicial de maestros/as" en Carrillo-Rosúa, F.J. et al. Researching The University Teaching Through ServiceLearning. Granada: Editorial Universidad de Granada, p. 35-45

CHIVA-BARTOLL, Ó., PALLARÉS-PIQUER, M., y GIL-GÓMEZ, J. (2018). “Aprendizaje-servicio y mejora de la Personalidad Eficaz en futuros docentes de Educación Física” en Revista Complutense de Educación, vol. 29 (1), p. 181-197

DANIELS, H. y BIZAR, M. (2005). Teaching the best practice way: Methods that matter. Portland, ME: Stenhouse Publishers

DELORS, J, et al. (1996). Informe a la Unesco de la comisión internacional sobre la educación para el siglo XXI: La educación encierra un tesoro. Madrid: Santillana, Ediciones UNESCO

FOLGUEIRAS BERTOMEU, P., LUNA GONZALEZ, E., y PUIG, G.(2013). “Aprendizaje y servicio: estudio del grado de satisfacción de estudiantes universitarios” en Revista de Educación, vol. 362, p. 159-185

FRANCISCO AMAT, A., y MOLINER MIRAVET, L. (2010). "El Aprendizaje Servicio en la Universidad: una estrategia en la formación de ciudadanía crítica” en Revista electrónica interuniversitaria de formación del profesorado, vol. 13 (4), p. 69-77

GIL-GÓMEZ, J., MOLINER-GARCÍA, O., CHIVA-BARTOLL, O. y GARCÍA LÓPEZ, R. (2016). "Una experiencia de aprendizaje-servicio en futuros docentes: desarrollo de la competencia social y ciudadana” en Revista Complutense de Educación, vol. 27 (1), p. 53-73

LAVE, J. y WENGER, E. (1991). Situated Learning: Legitimate Peripheral Participation. Cambridge, UK: Cambridge University Press.

MARTÍNEZ-FERNÁNDEZ, J. R. y RABANAQUE, S. (2008). “Autorregulación y trabajo autónomo del estudiante en una actividad de aprendizaje basada en las TIC” en Anuario de Psicología, vol. 39 (3), p. 311-331.

MAYOR PAREDES, D. M. (2012). “Aprender realizando una actividad social. Guía básica para el diseño de proyectos de Aprendizaje-Servicio" en RES: Revista de Educación Social, vol. 16, p. 1-14

PÉREZ GÓMEZ, A.I. (2010). "La naturaleza del conocimiento práctico y sus implicaciones en la formación de docentes” en Infancia y aprendizaje, vol. 33(2), p. 171-177

(cc) EY-NC-ND 2018, UniversitatPolitècnica de València

Congreso IN-RED (2018) 
PÉREZ GÓMEZ, A.I. y SOTO GÓMEZ, E. (2009). “Competencias y contextos escolares. Implicaciones mutuas” en Organización y Gestión Educativa: Revista del Fórum Europeo de Administradores de la Educación, vol. 17 (2), p. 17-22

RODRÍGUEZ GALLEGO, M. R. (2014). “El Aprendizaje-Servicio como estrategia metodológica en la universidad” en Revista Complutense de Educación, vol. 25 (1), p. 95-113

ROMERO ARIZA, M. y PÉREZ FERRA, M. (2009). “Cómo motivar a aprender en la universidad: una estrategia fundamental contra el fracaso académico en los nuevos modelos educativos” en Revista Iberoamericana de Educación, vol. 51, p. 87-105

SAZ GIL, I.; RAMO GARZARÁN, R.M. (2015) “Aproximación a los impactos y beneficios del aprendizaje servicio en la Universidad de Zaragoza” en. RIDAS, Revista Iberoamericana de Aprendizaje y Servicio, vol. 1, p. 9-27

WONG, D. (2007). "Beyond control and rationality: Dewey, aesthetics, motivation, and educative experiences” en Teachers College Record, vol. 109 (1), p. 192-220 


\title{
Aprendizaje usando modelos BIM para motivar un conocimiento sostenible de los edificios e instalaciones de la Universidad de Oviedo.
}

\author{
Agustín Menéndez Díaz a, Celestino Ordoñez Galán 'b, Silverio García Cortes b, \\ Alfonso Lozano Luengas a , María Concepción Crespo Turrado c . \\ a Departamento de Construcción e Ingeniería de Fabricación, Universidad de Oviedo, \\ amenendez@uniovi.es, b Departamento de Explotación y Prospección de Minas, Universidad de \\ Oviedo $\mathrm{y}^{\mathrm{c}}$ Ingeniero de Mantenimiento de la Universidad de Oviedo. Vicerrectorado de Recursos \\ Materiales y Tecnológicos.
}

\begin{abstract}
The main goal that arises in this teaching innovation project, is to identify works and infrastructure of buildings and allow extract of the same parties that become problems of engineering for students. This search focuses on the works of reform, expansion, new installation or improvement of buildings of the University of Oviedo.

In many cases students only to see the classroom and the laboratory where he taught class, but have not stopped to think about the constructive elements, the functionality of the building they occupy, or its interaction with the environment. The buildings are our environment closer and it depends on our comfort, and therefore they are an ideal excuse to pose real problems, which help students to study and better understand the concepts of engineering.
\end{abstract}

The ultimate goal is to involve students and the University community in the knowledge of the buildings, their interaction with the environment, the sustainable maintenance of its facilities.

Keywords: CAD, BIM, Building Sustainability.

\begin{abstract}
Resumen
El objetivo principal que se plantea en este trabajo de innovación docente, es identificar obras e infraestructuras de edificios que se estén realizando, y que permitan extraer de las mismas partes que se conviertan en problemas dosificados para los alumnos de ingeniería. Para ello se plantea poner el foco de esta búsqueda en las obras de reforma, ampliación, nueva instalación o de mejora de los edificios de la propia Universidad de Oviedo.

En muchos casos los alumnos solo ven el aula o el laboratorio donde imparten clase, pero no se han parado a pensar los elementos constructivos, la funcionalidad del edificio que ocupan, o su interacción con el entorno. Los edificios son nuestro medio ambiente más próximo y de ello depende nuestra comodidad y nuestro confort, y por lo tanto son una excusa ideal para plantear problemas reales, que ayuden a los alumnos a estudiar y
\end{abstract}


comprender mejor, los conceptos propios de cada rama tecnológica de la ingeniería.

El fin último es involucrar a los alumnos y a la comunidad universitaria en el conocimiento de los edificios, su interacción con el medio ambiente, el mantenimiento sostenible de sus instalaciones

Palabras clave: CAD, BIM, Sostenibilidad de Edificios.

\section{Introducción}

El planteamiento en este trabajo es presentar un proyecto innovación docente cuyo fin es identificar problemas reales en los edificios e infraestructuras universitarias, que puedan ser presentados a los alumnos como problemas aplicados de su futuro trabajo profesional. Realizando visitas a las obras que se están ejecutando para mejorar esos edificios, se ha buscado que los alumnos conozcan los edificios de su Universidad, analicen la necesidad de las obras ejecutadas, y desde un espíritu crítico sean capaces de identificar soluciones sostenibles a los problemas planteados. El elemento conductor que se plantea en este proyecto de innovación docente, son las obras de reforma, ampliación, y mejora de instalaciones en los edificios de la propia Universidad de Oviedo.

Cuando en las instalaciones de la Universidad se hacen obras estos espacios se clausuran y muchas veces no puede accederse a ellos (“Cerrado por Obras”). El planteamiento de este trabajo, es abrir esos espacios de los edificios para que los alumnos conozcan las obras (“Abierto por Obras”) y presentarles directamente los problemas específicos de ingeniería que se están resolviendo en ese momento.

Habitualmente los alumnos solo ven el aula o el laboratorio donde imparten clase, pero no se han parado a pensar en los elementos constructivos y la funcionalidad del edificio que ocupan, en su interacción con el entorno y en el coste tanto medio ambiental como económico derivado de su explotación, así como en la propia relación alumno-edificio, grado de confort, comodidad etc. Estas obras pueden ser una excusa ideal para plantear problemas reales, que ayuden a los alumnos a comprender mejor los conceptos propios de cada rama tecnológica que estén estudiando.

Trabajos similares han sido desarrollado en proyectos educativos como los descritos en [Liu and Hatipkarasulu, 2014], [McGough et al., 2013] y [Pikas et al., 2017]. En la mayor parte de los casos, la metodología educativa se articula sobre los sistemas de modelado de edificios BIM (Building Information Modeling) [Han and Golparvar-Fard, 2017], integrando elementos más específicos como los de sostenibilidad a partir de los problemas energéticos [Choi, 2016].

Por otro lado, este proyecto de innovación se ha realizado teniendo en cuenta alumnos de tres asignaturas que son: Expresión Gráfica (31 alumnos) del Grado de Ingeniería Química, Fotogrametría II (10 alumnos) del Grado en Ingeniería en Geomática y Topografía, y Construcción (27 alumnos) del Grado en Ingeniería Forestal. Han participado en el mismo, profesores de tres áreas de conocimiento (Expresión Gráfica, Explotación de Minas,

(cc) EY-NC-ND 2018, Universitat Politècnica de València

Congreso IN-RED (2018) 
Construcción), así como la ingeniera de mantenimiento del Vicerrectorado de Recursos Materiales y Tecnológicos de la Universidad de Oviedo.

\section{Objetivos y herramientas previas basadas en BIM.}

El objetivo principal que se plantea en este proyecto de innovación, es identificar problemas reales de las infraestructuras universitarias, analizar ejemplos específicos y buscar soluciones desde una perspectiva de desarrollo sostenible, que puedan ser estudiados por los alumnos insitu, involucrándolos desde sus áreas de conocimiento.

Para desarrollar este objetivo general se han cubierto una serie de objetivos específicos:

- Identificar proyectos singulares de obras en la universidad, y plantearlos como ejercicios de curso para los alumnos.

- Desarrollar modelos virtuales que simulen el estado presente o futuro que va a tener un edifico, antes y después de una obra nueva o una obra de mantenimiento. Se utilizarán técnicas de modelado virtual, como el uso de sistemas de registro digitales usando scanner 3D y fotogrametría, así como programas de diseño CAD (Computer Aided Design) y técnicas BIM (Building Information Modeling).

- Involucrar a los alumnos y a la comunidad universitaria en el conocimiento de los edificios, su interacción con el medio ambiente, el mantenimiento de sus instalaciones y el uso del mismo desde una visión sostenible.

- Plantear proyectos fin de carrera que den soluciones similares o alternativas a obras proyectadas o en ejecución dentro de la universidad.

Para realizar dichos objetivos, fue fundamental usar y desarrollar una serie de herramientas que nos permitieron traducir los problemas técnicos de los edificios en un BIM. El resultado de dichas herramientas fueron una serie de maquetas virtuales que pudieron ser manipuladas y consultadas por los alumnos, para comprender toda la complejidad de los elementos estructurales y de las instalaciones de cada edificio.

Para cada edificio se partió de los planos en papel y de los datos espaciales suministrados por un escaner 3d (RIEGL LMS-Z390i). Se procedió a la digitalización de los edificios y de sus instalaciones obteniendo una nube de puntos 3D lo más fidedigna posible (ver Fig 1). Para ello se usó el programa RISCAN PRO que trabaja sobre datos del escáner georefenciando y filtrando los mismos. A continuación se clasificaron usando el programa AutoDesk RECAP.

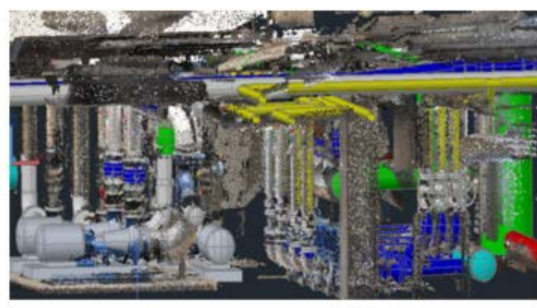

Láser escáner terrestre RIEGL LMS-Z390i

- Precisión $6 \mathrm{~mm}$

- Área de toma: $80^{\circ}$ vertical y $360^{\circ}$ horizontal

Nube de puntos

RISCANPRO

RECAP

(c) $)$ EY-NC-ND 2018, Universitat Politècnica de València

Congreso In-Red (2018) 
Fig. 1 Herramientas usadas para generar, filtrar y clasificar las nubes de puntos escaneadas.

Posteriormente se identificaron las redes de tuberías con AutoDesk PLANT y paralelamente con el programa REVIT, se hizo lo mismo con los elementos estructurales (paredes, forjados, cubiertas, paramentos, etc). Finalmente con las herramientas de NAVISWORK 3D (ver Fig 2) se montaron las maquetas virtuales de los edificios, sobre las que se sustenta todo el proyecto de innovación que se describe a continuación.

\section{AUTOCAD PLANT}
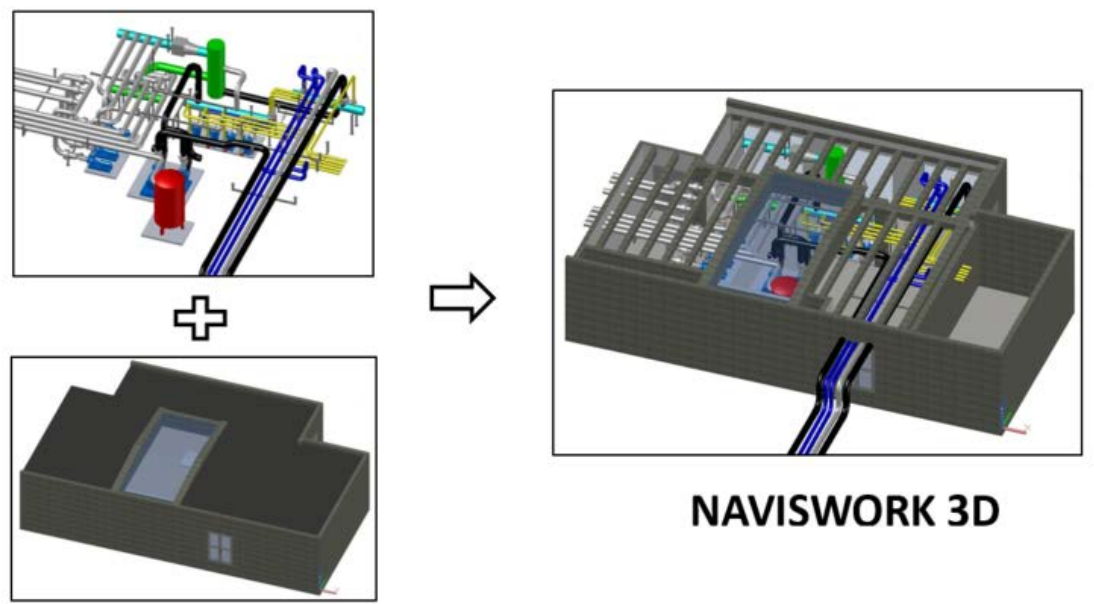

NAVISWORK 3D

\section{REVIT}

Fig. 2 Herramientas usadas para generar los modelos BIM de las instalaciones y edificios.

\section{Metodología desarrollada.}

En el desarrollo del proyecto se han identificado cuatro proyectos singulares de obras en la universidad que son:

- Sistema de ventilación de formaldehido en la Facultad de Medicina.

- Sistema de calefacción de la Facultad de Química.

- Sistema de calefacción con la sala de calderas y de bombeo de la EPM (Escuela Politécnica de Mieres).

- La auditoría de la eficiencia energética en edificios y el desarrollo de una Red Calor en el Campus de Llamaquique (Se tomó como referencia para los PFG y PFM).

La idea fue presentar ordenadamente cada uno de estos proyectos a los alumnos, aprovechando las obras que se estaban realizando en ese momento. Sin embargo, el primer día de clase de Expresión Gráfica de Ingeniería Química, se produjo una avería en la calefacción de la Facultad de Químicas que afectó la actividad docente del centro y que tardó en ser resulta dos días por el Servicio de Mantenimiento de la Universidad de Oviedo. La noticia apareció en prensa (ver Fig 3-a) y fue el pretexto ideal para explicar este problema en clase. 
El paradigma de “abierto por obras”, se transformó en “abierto por avería”. Se les explicó a los alumnos lo que había pasado, porque había sido necesario trasladar parte de las clases a otro lugar, porque habían sido afectadas unas partes del edificio y otras no. Todo esto se documentó mediante planos y fotografía para explicar la avería.

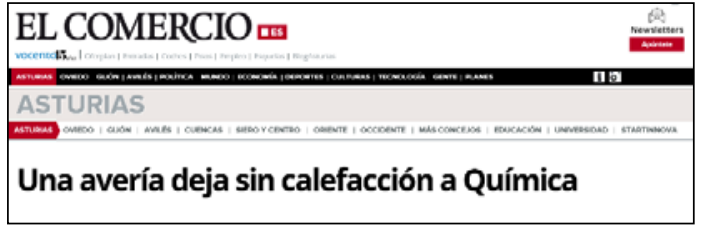

a)

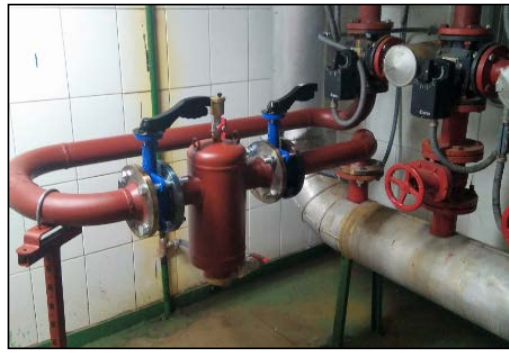

b)

Fig. 3 Noticia que apareció el primer día de clase en la Fac. de Químicas y reparación realizada.

Posteriormente se hizo una visita a las instalaciones de la sala de caldera de la Facultad de Químicas, explicando el funcionamiento de la sala y la reparación realizada (Fig 3-b). Esta consistió básicamente en el montaje de una nueva bomba de recirculación y de un nuevo filtro de agua. En las clases teóricas se explicó el plano de sección de la bomba, y se hizo especial referencia a la necesidad de instalar los filtros adecuadas en la red de tuberías.

Con este caso, queremos indicar la filosofía básica de este proyecto de innovación docente, que es aprovechar cualquier obra o reparación que se produzca en los edificios de la universidad, para que los alumnos puedan aprender de ellas. En ese mismo curso, se hizo un trabajo de tuberías, más detallado que ampliaba el conocimiento que los alumnos deben de tener sobre una sala de calderas, explicando el resto de elementos básicos (tipos de calderas, compensadores hidráulicos, colectores, válvulas de recirculación, válvulas de mezclado, vaso de expansión, etc).

El resto de visitas se ajustó a una planificación similar. Todas las actividades se iniciaban con una charla expositiva de unos 45 min y a continuación una visita a los edificios y a sus instalaciones de otros 30 min. En las siguientes Figs $(4,5,6,7)$ se indican varias salidas, así como las maquetas virtuales y planos utilizados para documentar cada instalación.

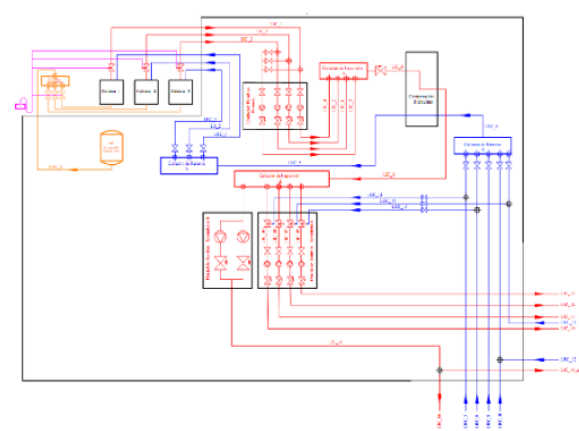

a)

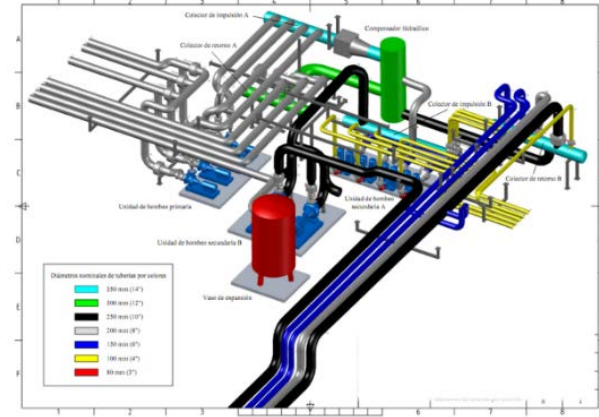

b)

Fig 4. Esquema y maqueta virtual usando BIM de una sala de calderas y de bombeo de la EPM. 


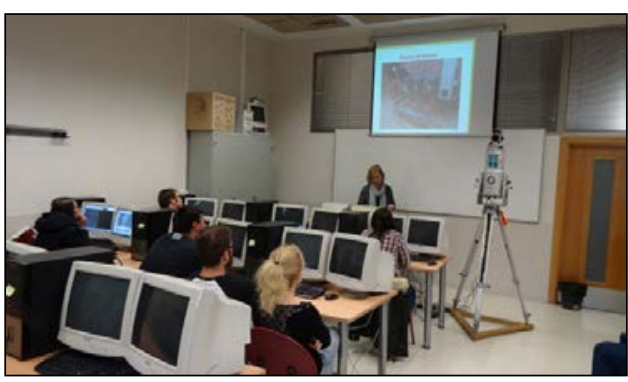

a)

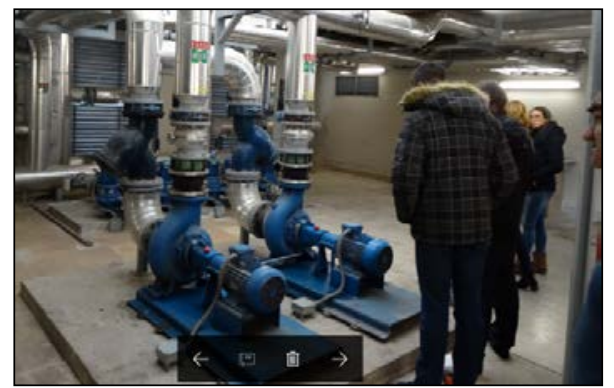

b)

Fig 5. Charla a Ing. Geomática con el escaner a) y visita posterior a las instalaciones b).

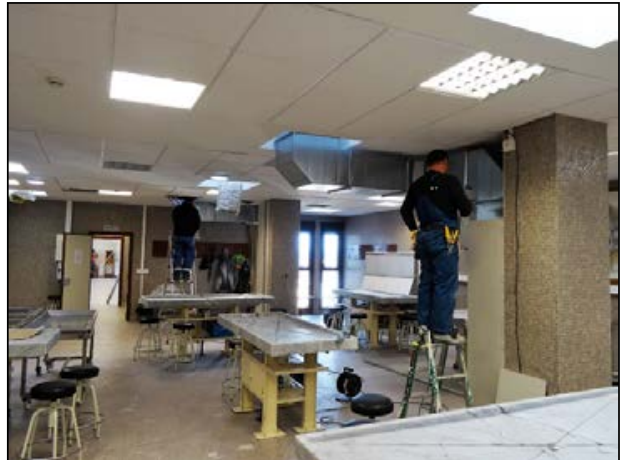

a)

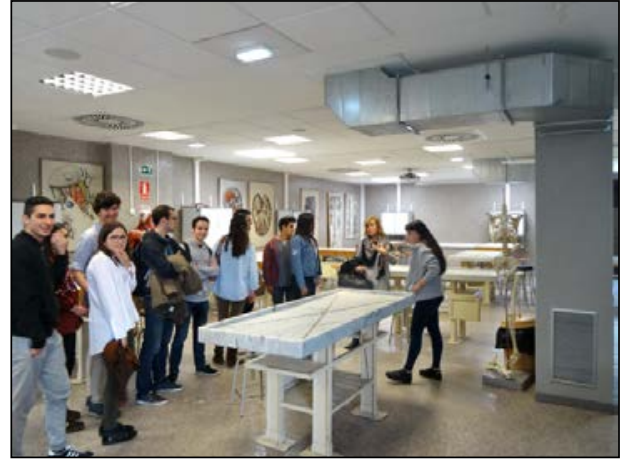

b)

Fig 6. Visita a la sala de disecciones de la Fac. de Medicina de los alumnos de Ing. Química.

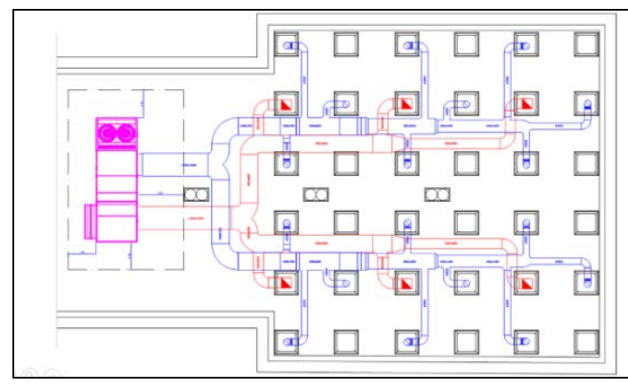

a)

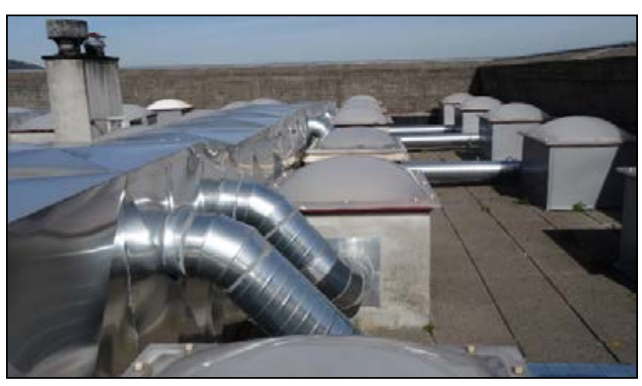

b)

Fig 7. Disposición del sistema de ventilación de formaldehido en la azotea de la Fac. de Medicina.

Todo este trabajo se organizó en seis fases:

- Fase 1: Identificación de los problemas en cada edificio.

- Fase 2: Realización de modelos virtuales usando técnicas CAD y BIM.

- Fase 3: Elaboración de presentaciones usando diferentes soportes (videos, reportajes fotográficos, presentaciones) para explicar cada obra.

(cc) EY-NC-ND 2018, Universitat Politècnica de València

Congreso IN-RED (2018) 
- Fase 4: Realización de charlas (45 minutos) y las visitas a las obras directamente a continuación (30 minutos).

- Fase 5: Discusión en clase con los profesores de otras titulaciones de las instalaciones visitadas.

- Fase 6: Realización de trabajos de curso relacionados con estas visitas.

La Fase 1 y Fase 2 se realizaron antes de iniciar el segundo cuatrimestre. Se tomó como referencia los edificios en los que cada alumno recibe sus clases. El objetivo es que el alumno de cada edificio, conociese aspectos de los mismo que desconocía. La Fase 3 se realizó durante el mes de enero, una vez que ya había finalizado la obra de la sala de disecciones de la Facultad de Medicina. Para esas fechas también se compiló toda la información disponible en formato digital de las salas de calderas y de bombeo que se visitaron. La Fase 4 se concretó en tres charlas y dos visitas en Ingeniería Química, mientras que en las asignaturas de la EPM se hicieron dos charlas y se realizaron dos visitas a la sala de calderas y a la sala de bombeo del sistema ACS (Agua Caliente Sanitaria) del edificio. La Fase 5 se realizó solamente en Ingeniería Química en la que todos los alumnos debían presentar una colección de 10 planos en DWG (AutoCAD) presentando varias instalaciones, entre ellas, el prediseño de la sala de disecciones de la Facultad de Medicina.

En la Fase 1 participamos todos los profesores del proyecto de innovación docente, aportando cada uno nuestro punto de vista, y desarrollando los problemas fundamentales en las obras a realizar en los edificios. Así los profesores de topografía se centraron más en el escaneo mediante de los espacios donde realizar las obras, el profesor de Expresión Gráfica en la recopilación de todos los planos e información gráfica necesaria para explicar la obra, y el profesor de Construcción en desglosar cada parte de la obra a ejecutar, analizando los elementos estructuras prexistentes y como estos iban a ser modificados.

La elaboración de todo el material gráfico y de maquetas virtuales corrió a cargo fundamentalmente de Agustin Menendez y Silverio García (Fases 2 y 3). Y en las charlas más específicas de cada asignatura, participó el profesor cada asignatura (Agustin Menéndez, Silverio Castro y Alfonso Lozano) así como la responsable de mantenimiento de la Universidad, Concha Crespo (Fase 4). Por ultimo Celestino Ordoñez participó en la Fase 5 y fue el encargado de realizar las encuestas y la revisión de los trabajos presentados.

Para completar las temáticas propuestas en el proyecto, durante su desarrollo se ha iniciado la realización de dos proyectos fin de grado y de un proyecto fin de master. Dichos proyectos fueron dirigidos por Alfonso Lozano y Agustin Menendez, y también colaboró con el profesor Francisco Javier Iglesias que estaba desarrollando un proyecto sobre eficiencia energética en la Escuela de Minas de Oviedo.

El desarrollo de las charlas y la realización de las modelizaciones y maquetas virtuales, se realizó en tres asignaturas que son: Expresión Gráfica (31 alumnos) del Grado de Ingeniería Química, Fotogrametría II (10 alumnos) del Grado en Ingeniería en Geomática y Topografía, y Construcción (27 alumnos) del Grado en Ingeniería Forestal. Han participado en el mismo, profesores de tres áreas de conocimiento (Expresión Gráfica, Explotación de 
Minas, Construcción), así como la ingeniera de mantenimiento del Vicerrectorado de Recursos Materiales y Tecnológicos de la Universidad de Oviedo.

Respecto a los recursos empleados, se ha utilizado el material didáctico de cada una de las asignaturas, ya disponible en el campus virtual como hasta ahora, pero complementada con planos y modelos virtuales que permitan a los alumnos comprender cada obra o actuación.

Para ello, se facilitaron planos de obras que pudieron ser consultados por los alumnos sobre los elementos estructurales diseñados, así como los proyectos de ejecución e inventarios fotográficos de los que disponía. Esta parte fue coordinada en este proyecto docente por la ingeniera de instalaciones de la Universidad de Oviedo (Concha Crespo Turrado). Toda esta documentación se ha obtenido de obras similares a las ejecutadas, así como de información facilitada por el Vicerrectorado de Recursos Materiales y Tecnológicos.

La elaboración de las maquetas virtuales se ha realizado usando los programas de software con los que se imparten la clase de CAD y BIM en los distintos centros, utilizando los equipos del Aula de Fotogrametría de Mieres, así como los medios informáticos de la sala de RPAS (Remotely Piloted Aircraft Systems) de la EPM.

\section{Resultados alcanzados y evaluación.}

Son resultados directos que avalan el desarrollo del proyecto, los siguientes:

- La presentación a los alumnos de obras y trabajos reales que se desarrollan en los edificios de la universidad.

- La elaboración de planos usado técnicas gráficas y geomáticas para hacer modelos virtuales de las obras realizadas.

- La elaboración de inventarios fotográficos de las obras que permiten estudiar las mismas y ver su evolución en el tiempo.

- El desarrollo de dos PFG y un PFM ligados a los edificios de la propia Universidad de Oviedo.

Para estimar dichos resultados se realizó la estimación de 4 indicadores que fueron:

1. Número de aprobados en cada asignatura.

2. Porcentaje de alumnos que participen en las actividades, realizando además una encuesta de autoevaluación.

3. Número de trabajos o modelos virtuales elaborados por los estudiantes, relacionados con edificios de la Universidad.

4. Número de TFG y TFM iniciados en la temática de Sostenibilidad de Edificios.

(cc) EY-NC-ND 2018, Universitat Politècnica de València

Congreso IN-RED (2018) 
Los resultados de dichos indicadores fueron los siguientes (ver Tabla 1):

Tabla 1. Criterio de Evaluación: valoración obtenida

\begin{tabular}{|c|l|l|l|}
\hline $\mathbf{N}^{\mathbf{0}}$ & \multicolumn{1}{|c|}{ Indicador } & \multicolumn{1}{|c|}{ Justificación } & \multicolumn{1}{|c|}{ Resultados Obtenidos } \\
\hline 1 & Número de aprobados en cada asignatura & $\begin{array}{l}\text { Notas una vez realizados todos los } \\
\text { exámenes ordinarios y extraordinarios }\end{array}$ & $\begin{array}{l}\text { Aprobados }=70,59 \% \\
70 \%-100 \%-\text { Bueno }\end{array}$ \\
\hline 2 & $\begin{array}{l}\text { Porcentaje de alumnos que participen en las } \\
\text { actividades, realizando además una } \\
\text { encuesta de autoevaluación. }\end{array}$ & $\begin{array}{l}\text { Se controlará la asistencia de los } \\
\text { alumnos a las obras a obras y labores } \\
\text { de mantenimiento en los edificios, } \\
\text { evaluando con una encuesta su } \\
\text { participación. }\end{array}$ & $\begin{array}{l}\text { Alumnos participantes }=51 \\
\text { Valor obtenido }=75 \% \\
70 \%-100 \%-\text { Bueno }\end{array}$ \\
\hline 3 & $\begin{array}{l}\text { Número de trabajos o modelos virtuales } \\
\text { elaborados por los estudiantes, relacionados } \\
\text { con edificios de la Universidad }\end{array}$ & $\begin{array}{l}\text { Se evaluará el ratio: trabajos } \\
\text { presentados/número de alumnos } \\
\text { totales }\end{array}$ & $\begin{array}{l}\text { Trabajos presentados }=26 \\
\text { Ratio }=26 / 68=0.38 \\
0.3<\text { Ratio }<0.8 \text { Aceptable }\end{array}$ \\
\hline 4 & $\begin{array}{l}\text { Número de TFG y TFM iniciados en la } \\
\text { temática de Sostenibilidad de Edificios. }\end{array}$ & $\begin{array}{l}\text { Se aporta carta de aceptación de } \\
\text { proyectos PFC y TFM en realización. }\end{array}$ & 3 proyectos - Aceptable \\
\hline
\end{tabular}

El criterio indicador $\mathrm{N}^{\circ} 1$ viene justificado en la Tabla 2 donde se indica el número de aprobados en cada asignatura en función del número de alumnos matriculados.

Tabla 2. Criterio de Evaluación: número de aprobados.

\begin{tabular}{|l|l|c|c|c|}
\hline \multicolumn{1}{|c|}{ Asignatura } & \multicolumn{1}{|c|}{ Titulación } & $\begin{array}{c}\text { Número } \\
\text { total } \\
\text { de alumnos }\end{array}$ & $\begin{array}{c}\text { Número } \\
\text { de } \\
\text { aprobados }\end{array}$ & $\begin{array}{c}\text { \% } \\
\text { Aprobados }\end{array}$ \\
\hline Expresión Gráfica & Grado en Ingeniería Química & $\mathbf{3 1}$ & $\mathbf{2 3}$ & $74,19 \%$ \\
\hline Fotogrametría II & Grado en Ingeniería en Geomática y Topografía & $\mathbf{1 0}$ & $\mathbf{9}$ & $90,00 \%$ \\
\hline Construcción & Grado en Ingeniería Forestal & $\mathbf{2 7}$ & $\mathbf{1 6}$ & $59,26 \%$ \\
\hline Total & Todas & $\mathbf{6 8}$ & $\mathbf{4 8}$ & $\mathbf{7 0 , 5 9 \%}$ \\
\hline
\end{tabular}

Respecto al criterio indicador $\mathrm{N}^{\circ} 2$ indicar que el número de alumnos que participo fue de 30 en Expresión Gráfica, unos 4 en Fotogrametría II (había 4 alumnos polacos de Erasmus que al no impartirse las clases en inglés no asistieron a las actividades de forma regular), y de los alumnos de Construcción participaron unos 17 alumnos. El número de alumnos que participó asiduamente fue de 51 personas (el $75 \%$ de los matriculados).

Como complemento a estos valores obtenidos resumimos también los resultados de la encuesta realizada por los alumnos. La encuesta se articuló en 8 preguntas que se recogen en la Tabla 3. Cada pregunta se ha contestado indicando 5 niveles de satisfacción: 1mínimo, 2, 3, 4, 5-máximo. La encuesta fue anónima y voluntaria, recibiendo se un total de 18 respuestas. La participación en la encuesta fue del 35 \% de los alumnos asistentes, debido en parte a que la encuesta se realizó a finales del segundo cuatrimestre, cuando los alumnos ya están inmersos en el periodo de exámenes. Se aprecia que hubo una mayor participación en aquellos centros en los que se hicieron más actividades, como es el caso de Ingeniería Química. En todo caso, esta encuesta arroja una valoración muy positiva en casi todas las preguntas realizadas. 
A modo de resumen, si consideramos la Pregunta 7 "Indícanos tu grado de interés en asistir a actividades similares en próximos cursos”, las contestaciones fueron las siguientes:

- 1 nivel de satisfacción mínimo (0 \%).

- 2 nivel de satisfacción bajo (0 \%).

- 3 nivel de satisfacción medio (11\%).

- 4 nivel de satisfacción alto (39\%).

- 5 nivel de satisfacción máximo. (50 \%).

Por otro lado, el 89 \% de los encuestados repetiría en años sucesivos claramente una actividad similar a la implementada en este proyecto de innovación docente.

Tabla 3. Criterio de Evaluación: número de aprobados

\begin{tabular}{|c|c|}
\hline $\begin{array}{c}\text { ID } \\
\text { PREGUNTA }\end{array}$ & TEXTO DE LA PREGUNTA \\
\hline $\mathbf{0 .}$ & $\begin{array}{l}\text { Indica la titulación en la que estas matriculado. } \\
\text { 1. Grado en Ingeniería Química } \\
\text { 2. Grado en Ingeniería Forestal } \\
\text { 3. Grado en Ingeniería en Geomática y Topografía }\end{array}$ \\
\hline 1. & $\begin{array}{l}\text { Consideras que las charlas dadas sobre los edificios de la Universidad han sido positivas. } \\
\text { Valora de } 1 \text { a } 5 \text { según tu grado de satisfacción ( } 1 \text { - mínimo, } 5 \text { - máximo) }\end{array}$ \\
\hline 2. & $\begin{array}{l}\text { Consideras que las visitas a instalaciones de edificios realizadas han sido didácticas. } \\
\text { Valora de } 1 \text { a } 5 \text { según tu grado de satisfacción ( } 1 \text { - mínimo, } 5 \text { - máximo) }\end{array}$ \\
\hline 3. & $\begin{array}{l}\text { Consideras adecuada la participación en las charlas de técnicos de otras especialidades. } \\
\text { Valora de } 1 \text { a } 5 \text { según tu grado de satisfacción ( } 1 \text { - mínimo, } 5 \text { - máximo) }\end{array}$ \\
\hline 4. & $\begin{array}{l}\text { Consideras que las actividades desarrolladas son más prácticas que teóricas. } \\
\text { Valora de } 1 \text { a } 5 \text { según tu grado de satisfacción ( } 1 \text { - mínimo, } 5 \text { - máximo) }\end{array}$ \\
\hline 5. & $\begin{array}{l}\text { Las actividades desarrolladas te han permitido conocer mejor los edificios de la Universidad. } \\
\text { Valora de } 1 \text { a } 5 \text { según tu grado de satisfacción ( } 1 \text { - mínimo, } 5 \text { - máximo) }\end{array}$ \\
\hline 6. & $\begin{array}{l}\text { De las actividades desarrolladas has podido encontrar temas en los que podrías desarrollar tu proyecto } \\
\text { fin de carrera al final de tus estudios. } \\
\text { Valora de } 1 \text { a } 5 \text { según tu grado de satisfacción ( } 1 \text { - mínimo, } 5 \text { - máximo) }\end{array}$ \\
\hline 7. & $\begin{array}{l}\text { Indícanos tu grado de interés en asistir a actividades similares en próximos cursos. } \\
\text { Valora de } 1 \text { a } 5 \text { según tu grado de satisfacción ( } 1 \text { - mínimo, } 5 \text { - máximo) }\end{array}$ \\
\hline 8. & $\begin{array}{l}\text { Indique otros aspectos técnicos que te gustaría conocer de los edificios de la Universidad. } \\
\text { Valora de } 1 \text { a } 5 \text { según tu grado de satisfacción ( } 1 \text { - mínimo, } 5 \text { - máximo) }\end{array}$ \\
\hline
\end{tabular}

Por último, los tres proyectos desarrollados para justificar el criterio indicador $\mathrm{N}^{\circ} 4$ son:

- Título del Proyecto Fin de Grado: "Estudio de la eficiencia energética de un edificio de la Universidad de Oviedo situado en el Campus de Llamaquique”. Titulación Ingeniería Mecánica. Director del Proyecto: Alfonso Lozano Martínez Luengas.

- Título del Proyecto Fin de Master: "Estudio viabilidad técnica y económica de una instalación solar térmica para satisfacer parte de la demanda de calefacción en la Escuela de Ingeniería de Minas, Energía y Materiales de Oviedo”. Titulación Master en Ingeniería de Minas. Director del Proyecto: Francisco Javier Iglesias Rodríguez.

- Título del Proyecto Fin de Grado: "Desarrollo de una red de calor en el campus de Llamaquique”. Titulación Doble Grado de Ingeniería Civil e Ingeniería de los Recursos Mineros y Energéticos. Director del Proyecto: Agustin Menendez Díaz.

(cc) EY-NC-ND 2018, Universitat Politècnica de València

Congreso IN-RED (2018) 
Consideramos que se han cumplido con holgura los objetivos planteados, ya que en primer y segundo curso de las carreras en las que hemos desarrollado el proyecto de innovación docente, los alumnos aun ven lejano orientar su proyecto fin de grado

\section{Conclusiones y valoración de global del proyecto.}

El trabajo desarrollado nos permite contar con un fondo de proyectos ligados a edificios de nuestra universidad, perfectamente documentamos y que pueden usarse como ejemplos de aplicación en cursos posteriores.

Entre los puntos fuertes podemos indicar:

- Se ha fortalecido la formación multidisciplinar por el intercambio de profesores de varias titulaciones y departamentos, lo que permite a los alumnos ver los problemas en su conjunto, pero también con nuevas vertientes y ramificaciones técnicas.

- Los resultados de la evaluación y la encuesta de alumnos nos ha permite valorar dicha actividad de forma positiva, animándonos a trasladar para cursos posteriores estas actividades de innovación docente de una forma más regular, e insertarlas dentro de las actividades normales de un cuatrimestre.

- Por otra parte, creemos que este proyecto nos ha permitido mejorar la percepción que los alumnos tienen de los edificios de nuestra Universidad. Son capaces de identificar más elementos funcionales de los edificios, y son más conscientes de los problemas que pueden producirse si no se mantienen adecuadamente.

Entre los puntos débiles debemos indicar:

- Las limitaciones en tiempo no nos han permitieron debatir los proyectos de las obras de cada edificio, congregando en una misma sesión a alumnos de distintas asignaturas y titulaciones. Hubiese sido preciso planificar el traslado de alumnos de un edifico a otro, y coordinar horarios intentando afectar lo menos posible a otras asignaturas, de ahí que no se planteó su realización conjunta.

- Las obras visitadas corresponden obras realizadas la Universidad de Oviedo, pero hubiese sido interesante ver otros proyectos similares en edificios del entorno.

- Es difícil coordinar las visitas a obras e instalaciones en funcionamiento, especialmente cuando dichas obras se están realizando, o cuando las instalaciones están en pleno fase de trabajo. Hay que garantizar la seguridad de los alumnos e interferir lo menos posible en las obras en realización. Esto hace que algunas de las visitas que podrían ser muy interesantes, no se haya podido realizar.

Finalmente queremos indicar que proyectos de innovación como el aquí desarrollado pueden aportar a la propia Universidad y a sus alumnos un valor añadido importante, e implicarlos de forma más firme en aspectos tan importantes como son las medidas de ahorro energético y sostenibilidad los edificios. 


\section{Referencias}

CHOI, J.; SHIN, J.; KIM, M.; KIM, I. (2016). "Development of openBIM-based energy analysis software to improve the interoperability of energy performance assessment”, Automation In Construction, 72:52-64, DOI: 10.1016/j.autcon.2016.07.004.

HAN, KK.; GOLPARVAR-FARD, M. (2017). "Potential of big visual data and building information modeling for construction performance analytics: An exploratory study”, Automation In Construction, 73: 184-198, DOI: 10.1016/j.autcon.2016.11.004.

LIU, R.; HATIPKARASULU Y. (2014). "Introducing Building Information Modeling Course into a Newly DevelopedConstruction Program with Various Student Backgrounds”, in 121st Asee Annual Conference \& Exposition, Indianapolis, Paper ID \#9291: 1-9.

MCGOUGH, D.; AHMED A.; AND AUSTIN S. (2013). "Integration of BIM in higher education: case study of the adoption of bim into Coventry university’s department of civil engineering, architecture and building”, in Sustainable Building Conference, Coventry University, UK., 394-403.

PIKAS, E.; SACKS R.; AND HAZZAN O. (2017). "Building information modeling education for construction engineering and management”. II: Procedures and implementation case study. Journal Of Construction Engineering And Management, 139:1-11.

(cc) EY-NC-ND 2018, Universitat Politècnica de València 


\title{
“Cuanto más practiques, mejor lo harás”: evaluación multi-informante en el contexto de un curso e-learning
}

Alexandra Morales \& Mireia Orgilés

Universidad Miguel Hernández de Elche, España

\begin{abstract}
The objective of this work was to describe the process of multi-informant evaluation of an activity fot the resolution of clinical cases in an e-learning course with Edx platform. Possible differences in anxiety, self-efficacy and task performance were analyzed among the three informants: the students, their classmates and the professor. The students elaborated educational videos in which they solved a clinical case following the instructions of the professor. The evaluations were conducted independently with Google Forms. The results showed differences in the variables evaluated among the evaluations of the three informants. The peer and professor evaluations were more similar to each other, and differed from the students' self-assessments. Although the scores were acceptable, the students tended to self-evaluate more anxious and more negatively in their performance compared to the evaluations of the peers and the professor. Older students self-evaluated more negatively in terms of performance and self-efficacy than their younger peers. The multi-informant evaluation is applicable to other educational contexts to provide a more enriching vision of the learning process. We reflect on this pilot evaluation experience and propose some ideas for the future.
\end{abstract}

Keywords: evaluation, multi-informant, EdX, competencies, clinical cases.

\section{Resumen}

El objetivo de este trabajo fue describir el proceso de evaluación multiinformante de una actividad docente de resolución de casos clínicos en un curso e-learning con la plataforma Edx. Se analizan posibles diferencias en ansiedad, autoeficacia y desempeño de la tarea entre los tres informantes: los propios alumnos, sus compañeros y el profesor. Los alumnos elaboraron vídeos docentes en los que resolvían un caso clínico siguiendo las instrucciones del profesor. Las evaluaciones se realizaron independientemente con Google Forms. Los resultados arrojaron diferencias entre las evaluaciones de los tres informantes en las variables evaluadas. Las evaluaciones de los compañeros y de los profesores fueron más similares entre sí, y se diferenciaron de las autoevaluaciones de los alumnos. Aunque las calificaciones fueron notables, los alumnos tendieron a autoevaluarse más ansiosos y más negativamente en su ejecución respecto a las valoraciones de los compañeros y el profesor. Los alumnos de mayor edad se autoevaluaron más negativamente en términos de desempeño y autoeficacia que los compañeros de menor edad. La evaluación multi-informante es 
aplicable a otros contextos educativos para aportar un visión más enriquecedora del proceso de aprendizaje. Se reflexiona sobre esta experiencia piloto de evaluación y se proponen algunas ideas para el futuro.

Palabras clave: evaluación, multi-informante, EdX, competencias, casos clínicos.

\section{Introducción}

Plataformas docentes como Edx ofrecen un entorno de aprendizaje dinámico y atractivo para el alumno, alternativo o complementario a las clases presenciales. Son múltiples las variantes que ofrecen los entornos virtuales de aprendizaje. En este sentido, los recursos y objetivos del curso/asignatura son determinantes para seleccionar el formato y la metodología de aplicación y evaluación. Habitualmente estos cursos constan de videconferencias, clases prácticas, debates y foros de intercambio de opiniones. Además, ponen a disposición del equipo docente diversos sistemas de evaluación para verificar los objetivos de aprendizaje alcanzados durante el curso.

En los últimos años las universidades y otros centros docentes se han esforzado por incorporar los entornos virtuales a su oferta docente, con el fin de facilitar la formación de un público cada vez más diverso e internacional. Entre las modalidades disponibles están los cursos e-learning, que se caracterizan por presentar contenidos de formación cerrados, requieren de matricula previa para acceder y acreditan los aprendizajes a través de la evaluación de los alumnos (UAB, 2017). Actualmente se ofrece un importante número de cursos y másteres oficiales en formato e-learning, con la ventaja principal de facilitar el aprendizaje a quienes no pueden asistir presencialmente por diversas razones (Hernández y Carril, 2012). Sin embargo, una de las principales limitaciones de los entornos virtuales de aprendizaje es la dificultad para evaluar los contenidos prácticos a distancia, de forma controlada y bajo la supervisión del profesor.

La metodología de evaluación en el proceso de aprendizaje puede determinar los resultados académicos (p.ej., examen tipo test, una prueba situacional o un examen oral). Por parte del alumno, dos de los factores que pueden influir en su desempeño y en la transferencia de los contenidos teóricos a la práctica son: el nivel de ansiedad experimentado durante la actividad y su percepción de eficacia para poner en práctica las habilidades necesarias y para alcanzar los objetivos docentes establecidos (Álvarez y Muñoz, 2018; Contreras et al., 2005).

La ansiedad ha sido definida como una respuesta adaptativa al medio que nos permite anticipar situaciones díficiles y movilizar los recursos necesarios para afrontarlas (Orgilés, 2014; Spielberger, 1979). Hay evidencia de que un nivel moderado de ansiedad favorece el rendimiento del estudiante (Sue, 1996). No obstante, cuando la ansiedad es alta o desproporcionada a la situación, se reduce la probabilidad de lograr un adecuado afrontamiento. Esto puede deberse a la interferencia para controlar los pensamientos automáticos irracionales (p.ej. "no voy a poder” o "no valgo”) y otros síntomas vegetativos asociados a la respuesta ansiosa (p.ej. temblor, sudores o tartamudeo) (ver Spielberger, 1979). Diversos estudios han demostrado que cuando el nivel de ansiedad es elevado, el

(cc) EY-NC-ND 2018, Universitat Politècnica de València

Congreso IN-RED (2018) 
rendimiento académico disminuye, especialmente en situaciones valoradas por el estudiante como difíciles o potencialmente ansiosas (Eysenck, 2013; Sommers-Flanagan y SommersFlanagan, 2012; Sue, 1996).

Otra variable altamente asociada al rendimiento académico, y que predice el éxito posterior es la autoeficacia (Bandura, 1997), que se define como la capacidad percibida para hacer frente a situaciones o tareas concretas. Los alumnos que presentan una baja autoeficacia son más propensos a obtener peores resultados (Bandura, 1992). A su vez, la percepción de incapacidad para alcanzar las metas académicas incrementa la probabilidad de experimentar ansiedad. Por ello autoeficacia y ansiedad están estrechamente relacionadas, y ambas influyen en el rendimiento académico.

Desde el ámbito educativo, diversos estudios han explorado el papel de la ansiedad y la autoeficacia para una mejor comprensión de los mecanismos que facilitan o dificultan la ejecución del alumno (Álvarez y Muñoz, 2018; Contreras et al., 2005; Sue, 1996). A menudo la ansiedad y la autoeficacia suelen estudiarse desde el punto de vista del alumno con el fin de mejorar las prácticas pedagógicas y de aprendizaje. Sin embargo, a pesar de tratarse de variables subjetivas en su evaluación y con un gran peso en el rendimiento académico, no han sido exploradas desde una perspectiva multi-informante en una actividad propuesta desde un curso e-learning. Además de la auto-valoración del propio alumno, sería interesante obtener la valoración de los compañeros del curso y del profesor sobre el desempeño de éste, su nivel de ansiedad y autoeficacia para aplicar habilidades y obtener éxito en la tarea. La aplicación de una estrategia multi-informante es altamente recomendable para realizar una evaluación más exhaustiva y completa (Gómez, 2004). Además, permite comparar las evaluaciones de los informantes y reflexionar sobre posibles diferencias observadas entre lo que uno percibe de sí mismo y lo que los demás observan en su desempeño.

\section{Objetivos}

El objetivo principal de este estudio fue describir el proceso de evaluación desde una perspectiva multi-informante de la ansiedad, autoeficacia y desempeño global de alumnos de postgrado para realizar una actividad práctica (propuesta a través de la plataforma Edx). Los objetivos específicos fueron: (a) analizar posibles diferencias en las evaluaciones de ansiedad, autoeficacia y desempeño global de la tarea entre los tres informantes (el propio alumno, sus compañeros y el profesor), y (b) analizar la relación entre la edad del alumno y su ansiedad, autoeficacia y desempeño para realizar la tarea (y analizar posibles diferencias entre los informantes).

A partir de estudios previos que indican una baja consistencia entre las evaluaciones realizadas por diferentes informantes (Gómez, 2004) y lo expuesto anteriormente se hipotetizó que: a) Habrá diferencias en la valoración de ansiedad, autoeficacia y desempeño global entre los tres evaluadores. Sería esperable que, en la autoevaluación, los alumnos indicarán un mayor nivel de ansiedad, menor autoeficacia y desempeño respecto a las valoraciones de los compañeros y los profesores; y b) A mayor edad (entendida aquí como mayor experiencia, aunque no necesarimente) menor ansiedad, mayor autoeficacia y mejor desempeño en la tarea. 


\section{Desarrollo de la innovación}

\subsection{Procedimiento}

En el curso académico vigente arrancó por primera vez la modalidad online del Máster en Terapia Psicológica con Niños y Adolescentes (http://mtpna.edu.umh.es/). Puesto que esta modalidad debe ser equivalente a la presencial, avalada por la Agencia Nacional de Evaluación de la Calidad y Acreditación (ANECA), el equipo docente se ha esforzado por adaptar los contenidos y metodologías docentes aplicados habitualmente en las clases presenciales al entorno virtual.

Una de las principales dificultades encontradas fue la adaptación de los sistemas de evaluación de las actividades prácticas dirigidas al entrenamiento en habilidades y competencias del terapeuta infantil. En este contexto surge una propuesta de innovación docente que consiste en plantear un sistema de evaluación multi-informante en red para proporcionar feedback sobre las habilidades terapéuticas de los alumnos del curso online. En este proceso se implicó a cada alumno en su evaluación (autoevaluación), a los compañeros matriculados y a los profesores de la asignatura con el fin de evaluar la actividad y favorecer el aprendizaje colaborativo.

Con el propósito de mejorar las competencias y habilidades terapéuticas de los alumnos, se planteó una actividad de entrenamiento que culminaba con la elaboración de un vídeo docente. Cada alumno debía grabarse en una situación simulada (previamente descrita y trabajada con el profesor) en la que actuaba como terapeuta junto a un voluntario (que hacía de paciente). Se mostraba cómo el terapeuta interaccionaba con el paciente para resolver una casuística en particular. En el plazo establecido, cada alumno enviaba el vídeo al equipo docente siguiendo las instrucciones. Además, el alumno evaluaba online su ejecución a partir del visionado de su vídeo. Todas las grabaciones fueron guardadas en una carpeta de Drive compartida, a la que los alumnos podían acceder para visualizar su vídeo y el del resto de compañeros. Los vídeos presentaban situaciones comunes que pueden darse en el contexto de una consulta psicológica y que los profesores valoraron su manejo como interesante para su formación. Posteriormente, cada alumno evaluaba a través de un formulario online a dos compañeros (uno que tenía la misma situación terapéutica y otro con una situación diferente). Esto les permitía, además de tener resueltos diferentes casos clínicos, aprender nuevas formas de afrontar una misma situación. Paralelamente, el profesor evaluaba los vídeos para puntuar la actividad. Todas las evaluaciones se realizaron online a través de Google Forms. En la Figura 1 se muestra gráficamente el proceso:

(cc) EY-NC-ND 2018, Universitat Politècnica de València

Congreso IN-RED (2018) 
1

- Actividad de entrenamiento en habilidades terapéuticas para resolver casos clínicos

- Alumnos envían su vídeo docente y el formulario de autoevaluación online

3 - Asignación de los compañeros que debe evaluar cada alumno por parte del profesor

4 - Evaluación de las competencias de los alumnos por parte de sus compañeros

5 • Evaluación de las competencias de los alumnos por parte del profesor

6

- Envío de las evaluaciones de los compañeros y del profesor a cada alumno

7

- Evaluación final de la actividad docente

Fig 1. Proceso de evaluación de las competencias

\subsection{Participantes}

Todos los alumnos de la modalidad online $(N=30)$ fueron invitados a participar en esta actividad de innovación docente. Salvo dos hombres, el resto eran mujeres. La edad del grupo osciló entre los 22 y 46 años $(M=29.79 ; D T=7.17)$. Hubo dos alumnas internacionales (Argentina y Ecuador) y los demás residían en España distribuidos en diferentes áreas geográficas.

\subsection{Medidas de evaluación}

Se realizaron tres evaluaciones online simultáneas de cada vídeo docente: autoevaluación (cada alumno sobre su ejecución), la evaluación de los compañeros y la evaluación del profesor. Todos respondieron a las mismas preguntas pero en formularios independientes y haciendo referencia siempre al alumno de cada vídeo. El evaluador valoraba lo siguiente:

- Ansiedad percibida en el terapeuta. La respuesta comprendía un rango de 0 (nada ansioso/a) a 10 (muy ansioso/a).

- Capacidad del terapeuta para aplicar las habilidades entrenadas (autoeficacia). La respuesta comprendía un rango de 0 (muy mala) a 10 (muy buena).

- Capacidad del terapeuta para resolver con éxito el caso clínico (autoeficacia). La respuesta comprendía un rango de 0 (muy mala) a 10 (muy buena).

- Valoración global de la actuación del terapeuta (desempeño). La respuesta comprendía un rango de 0 (muy mala) a 10 (muy buena).

- Edad del alumno autoinformada en años. 


\subsection{Análisis de datos}

Se realizaron análisis sencillos para obtener la media en las evaluaciones de los propios alumnos, de los compañeros y del profesor en las variables: ansiedad percibida, autoeficacia (para aplicar las habilidades y para resolver con éxito el caso clínico) y la evaluación gobal. Los análisis de correlación bivariada de Spearman (rho) permitieron evaluar si existía relación entre la edad de los alumnos, y el desempeño del alumno en la actividad desde el punto de vista del alumno, de los compañeros y del profesor. Todos los análisis se realizaron con el paquete estadístico SPSS v25.

\section{Resultados}

En la Tabla 1 se muestran las medias y desviaciones típicas para cada variable evaluada en el estudio desde una perspectiva multi-informante: alumno, compañeros y profesor. En lo que respecta al nivel de ansiedad del terapeuta, se observa una diferencia estadísticamente significativa entre los tres informantes. Los alumnos se percibieron más nerviosos en la grabación (autoevaluación) respecto a la evaluación de los compañeros y del profesor. En la valoración de la autoeficacia observamos que los alumnos tendieron a puntuarse ligeramente por debajo de la puntuación emitida por el profesor y sus compañeros. Esto sugiere que el profesor y los compañeros perciben a los alumnos más capaces de aplicar las habilidades terapéuticas y resolver con éxito el caso clínico que los propios alumnos (evaluándose a ellos mismos). Resultados similares fueron encontrados en la variable de valoración global de la actuación del terapeuta. El profesor puntuó más positivamente la actuación del terapeuta que los alumnos su propia ejecución.

Tabla 1. Evaluación multifuente del entrenamiento en resolución de casos clínicos

\begin{tabular}{|c|c|c|c|c|}
\hline Evaluador & $\begin{array}{c}\text { Ansiedad } \\
\text { percibida } \\
M(D T)\end{array}$ & $\begin{array}{c}\text { Autoeficaci } \\
\text { a percibida } \\
\text { para } \\
\text { aplicar las } \\
\text { habilidades } \\
M(D T)\end{array}$ & $\begin{array}{c}\text { Autoeficaci } \\
\text { a percibida } \\
\text { para } \\
\text { resolver } \\
\text { con éxito el } \\
\text { caso } \\
M(D T)\end{array}$ & $\begin{array}{c}\text { Valoración } \\
\text { global } \\
M(D T)\end{array}$ \\
\hline Alumno (autoevaluación) & $5.26(2.45)$ & $7.41(1.42)$ & $7.74(.90)$ & $7.37(1.41)$ \\
\hline Compañeros de clase & $2.92(2.11)$ & $7.92(1.09)$ & $8.07(1.03)$ & $8.04(.99)$ \\
\hline Profesores de la asignatura & $2.29(1.36)$ & $8.11(1.19)$ & $8(1.26)$ & $8.17(1.13)$ \\
\hline
\end{tabular}

En la Tabla 2 se observan los coeficientes de correlación de Spearman entre la edad de los alumnos, y la ansiedad percibida, la autoeficacia y la valoración general. Solo hubo correlaciones indirectas y estadísticamente significativas entre la edad de los alumnos y la autoeficacia percibida para resolver con éxito la evaluación y la valoración global en el caso de la autoevaluación de los alumnos. Esto indica que cuando los alumnos evaluaron su propia ejecución como terapeutas tendieron a evaluarse más negativamente y a percibirse menos capaces de resolver con éxito el caso clínico a medida que tienen más edad. En otras

(cc) EY-NC-ND 2018, Universitat Politècnica de València

Congreso IN-RED (2018) 
palabras, los alumnos de mayor edad tendieron a autoevaluarse más negativamente que los compañeros de menor edad. Sin embargo, es destacable que no existe asociación entre la edad y las variables analizadas en las evaluaciones de los compañeros y el profesor. Por tanto, la edad no estuvo relacionada con la evaluación emitida sobre la ansiedad, la autoeficacia y el desempeño por parte de los compañeros y el profesor.

Tabla 2. Relación entre el desempeño del alumno y la edad del alumno para cada informante: alumnos, compañeros y el profesor

\begin{tabular}{lcccc}
\hline Evaluador & Ansiedad & $\begin{array}{c}\text { Autoeficacia } \\
\text { percibida } \\
\text { para aplicar } \\
\text { las }\end{array}$ & $\begin{array}{c}\text { Autoeficacia } \\
\text { percibida } \\
\text { para } \\
\text { resolver con } \\
\text { habilidades }\end{array}$ & $\begin{array}{c}\text { Valoración } \\
\text { global }\end{array}$ \\
\hline Alumno (autoevaluación & & \\
Compañeros de clase & .28 & -.08 & $-.43^{*}$ & $-.41^{*}$ \\
Profesores de la asignatura & .17 & -.09 & .01 & -.25 \\
\hline$p<.05$. & -.06 & .03 & -.03 & -.09 \\
\hline
\end{tabular}

El presente trabajo describe el proceso de evaluación multi-informante aplicado al entrenamiento de las competencias de los terapeutas infantiles en un curso e-learning. Los resultados de esta experiencia piloto confirman la hipótesis inicial, que indica que la evaluación de la ansiedad, la autoeficacia y el desempeño difiere en función del informante: los propios alumnos (autoevaluación), la valoración de los compañeros y la del profesor. Los datos sugieren que los alumnos tienden a evaluar sus habilidades y competencias con prudencia y honestidad, si tomamos en cuenta que los otros informantes presentaron independientemente calificaciones similares. Por lo tanto, podrían considerarse las respuestas de autoevaluación bastante objetivas.

Conviene destacar que los alumnos se perciben significativamente más ansiosos en la grabación respecto a la evaluación de los compañeros y el profesor, que los perciben significativamente menos ansiosos. Una explicación a este resultado podría ser que los alumnos estén evaluando el nivel de ansiedad que recuerdan haber experimentado en la situación de grabación, y no realmente la ansiedad que perciben en ellos mismos en el vídeo. Los signos de ansiedad visibles (p.ej. sudoración excesiva, tartamudeo o automanipulaciones) pueden estar menos presentes en personas que tienen un adecuado manejo de la ansiedad, como podría ser el caso de alumnos de psicología, que a menudo se exponen a hablar en público. Por otro lado, la presencia de signos de ansiedad no visibles (p.ej. palpitaciones o pensamientos negativos intrusivos) pudo explicar las diferencias observadas entre los informantes. La ansiedad se considera una respuesta adaptativa para afrontar las demandas del ambiente; no obstante, cuando el nivel de ansiedad no se corresponde con la amenaza real, ésta tiene efectos negativos en la capacidad del individuo 
para resolver situaciones (ver Sommers-Flanagan y Sommers-Flanagan, 2012). En este sentido, las autovaloraciones de los alumnos sobre su capacidad para aplicar las habilidades entrenadas y para resolver el caso clínico son positivas, si bien, algo inferiores (si tomamos la media) con respecto a la valoración de los compañeros y los profesores. En consecuencia, percibirse ansioso para resolver el caso clínico pudo afectar a la percepción de la capacidad para resolverlo correctamente (autoeficacia) en los alumnos. En lo que respecta a la valoración global, las evaluaciones de todos los informantes fueron similares y positivas (calificación media de notable), aunque la del profesor fue ligeramente más positiva que la de los alumnos (autoevaluación) y los compañeros.

En este estudio se muestra que la edad del alumno influye en su propia percepción de autoeficacia para resolver con éxito la situación y su desempeño global como terapeuta infantil. Concretamente los alumnos de mayor edad tendieron a evaluarse más negativamente y a percibirse menos capaces de resolver con éxito el caso clínico. Este resultado no confirma nuestra hipótesis inicial. Sin embargo, esta asociación entre edad y competencia del terapeuta no se refleja en las evaluaciones de los compañeros y la del profesor. Estas diferencias en la autoevaluación de los alumnos pueden deberse a que los más mayores son más exigentes con la evaluación de su competencia como terapeutas. No obstante, también sería esperable un mejor manejo de la situación si se sobreentiende una relación entre la experiencia práctica y la edad (aunque no siempre es así). Mayor evidencia empírica es necesaria para extraer resultados concluyentes.

\section{Conclusiones}

A partir de esta propuesta de innovación docente se pueden extraer al menos tres conclusiones de los resultados: 1) La evaluación de una actividad difiere según el evaluador (el propio alumno, los compañeros o el profesor), 2) Ante una misma situación, los propios alumnos tienden a percibirse más ansiosos, menos autoeficaces y con un peor desempeño respecto a las evaluaciones de los compañeros y del profesor, y 3) Los alumnos con mayor edad se percibieron menos autoeficaces para resolver la situación con éxito y valoraron más negativamente su desempeño global que los más jóvenes. Sin embargo, las evaluaciones de los compañeros y del profesor no estuvieron relacionadas con la edad del alumno.

En base a lo mencionado anteriormente, el proceso de evaluación multi-informante se considera interesante para el aprendizaje por varias razones. Nos permite obtener información de utilidad sobre las percepciones y creencias de los alumnos asociadas a su proceso de aprendizaje y autoeficacia. Paralelamente se establece una vía de aprendizaje colaborativo, en la que los alumnos proporcionan feedback unos a otros, y aprenden de la experiencia del otro y observando cómo lo hacen otros. Como ya indicaba Bandura (1986), el modelado (imitación o aprendizaje observacional) es una de las principales formas de aprendizaje. Teniendo en cuenta que los cursos e-learning presentan riesgo de convertirse en procesos de aprendizaje solitarios (en comparación con las clases presenciales), tener la oportunidad de aprender de otros e interaccionar es fundamental. En esta línea, los vídeos docentes grabados por nuestros alumnos están en proceso de edición para ser parte del material docente el próximo año. 
Esta experiencia docente puede extrapolarse a cualquier nivel educativo, desde primaria a postgrado, adaptando el proceso de evaluación a las características del alumnado y de la actividad propuesta. Puede ser especialmente recomendable para la evaluación de habilidades prácticas de atención al paciente (p.ej. Grado de Medicina, Grado de Enfermería y Grado en Terapia Ocupacional) y para el entrenamiento de habilidades de comunicación en general. Desde una perspectiva psicológica, la metodología de esta actividad es positiva para que los alumnos relativicen el nivel de ansiedad percibida y su autoeficacia para realizar con éxito una tarea en el contexto académico. A menudo, los propios alumnos son más críticos con su propia ejecución que otros observadores externos. Por otro lado, recibir feedback positivo y críticas constructivas por parte de los compañeros, además del profesor, contribuye al aprendizaje colaborativo, así como a fortalecer la autoestima y la autoeficacia de los propios alumnos.

En futuros proyectos está previsto favorecer la interacción de los alumnos de este curso elearning en sesiones presenciales con los alumnos de la modalidad presencial y a través de nuevas aplicaciones móviles como MyLearningMentor (Alario-Hoyos, Estévez-Ayres, Pérez-Sanagustín, Leony y Kloos, 2015) y MyMOOCSpace (Ramírez-Donoso et al., 2015; Ramírez-Donoso et al., 2017). Nuevas formas de evaluación de los aprendizajes prácticos a través de los entornos virtuales deben explorarse para su incorporación próximamente.

\section{Agradecimientos}

El Programa de Innovación Educativa Universitaria (PIEU-UMH 2017-18) de la Universidad Miguel Hernández, España (Ref. PIEU2017/24), ha apoyado económicamente este trabajo.

\section{Referencias}

ALARIO-HOYOS, C., ESTÉVEZ-AYRES, I., PÉREZ-SANAGUSTÍN, M., LEONY, D. y KLOOS, C. D. (2015). "MyLearningMentor: A Mobile App to Support Learners Participating in MOOCs”. Journal of Universal Computer Science, vol. 21, issue 5, p. 735753.

ÁLVAREZ, I. M. y MUÑOZ, A. L. (2018). Estudio neuropsicológico de la funcionalidad visual, las estrategias de aprendizaje y la ansiedad en el rendimiento académico. Aula abierta, vol. 47, issue 2, p. 245-254.

BANDURA, A. (1982). Self-efficacy mechanism in human agency. American Psychologist, vol. 37, issue 2, p. 122-147.

BANDURA, A. (1996). Teoría del aprendizaje social. Madrid: Espasa-Calpe, S.A

BANDURA, A. (1997). Self-efficacy: The exercise of control. New York: N.H. Freeman.

CONTRERAS, F., ESPINOSA, J. C., ESGUERRA, G., HAIKAL, A., POLANÍA, A. y RODRÍGUEZ, A. (2005). Autoeficacia, ansiedad y rendimiento académico en adolescentes. Diversitas: Perspectivas en Psicología, vol.1, issue 2, p. 183-194.

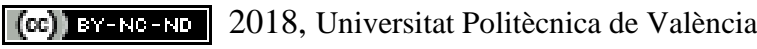


"Cuanto más practiques, mejor lo harás":

evaluación multi-informante en el contexto de un curso e-learning

EYSENCK, M. W. (2013). Anxiety: The cognitive perspective. Hove, UK: Psychology Press.

GÓMEZ, I. (2004). Evaluación Infantil Cognitivo-Comportamental. Evaluación Multimetodal y Multinforme. Revista Neuropsicología, Neuropsiquiatría y Neurociencias, vol. 6, issue 1, p. 21-25.

HERNÁNDEZ, N. y CARRIL, P. C. (2012). Trabajo colaborativo en entornos e-learning y desarrollo de competencias transversales de trabajo en equipo: Análisis del caso del Máster en gestión de Proyectos en Cooperación Internacional, CSEU La Salle. $<$ http://openaccess.uoc.edu/webapps/o2/handle/10609/26321> [Consulta: 27 de marzo de 2018]

ORGILÉS, M. (2014). Tratando... fobia a la oscuridad en la infancia y adolescencia. Madrid: Ediciones Pirámide.

RAMÍREZ-DONOSO, L., PÉREZ-SANAGUSTÍN, M., NEYEM, A. y ROJAS-RIETHMULLER, J. S. (2015, octubre). "Promoviendo la colaboración efectiva en MOOCs a través de aplicaciones móviles” en Congreso IEEE Chilecon 2015, Santiago de Chile, Chile). Disponible en $<$ https://www.researchgate.net/publication/280778018_Promoviendo_la_Colaboracion_Efe ctiva_en_MOOCs_a_traves_de_Aplicaciones_Moviles> [Consulta: 27 de marzo de 2018]

RAMÍREZ-DONOSO, L., ROJAS-RIETHMULLER, J. S., PÉREZ-SANAGUSTÍN, M., NEYEM, A. y ALARIO-HOYOS, C. (2017). "MyMOOCSpace: A cloud-based mobile system to support effective collaboration in higher education online courses”. Computer Applications in Engineering Education, vol. 25, issue 6, p. 910-926.

SOMMERS-FLANAGAN, J. y SOMMERS-FLANAGAN, R. (2012). Counseling and psychotherapy theories in context and practice: Skills, strategies, and techniques ( ${ }^{\text {nd }}$ ed.). New Jersey: John Wiley \& Sons

SPIELBERGER, C. (1979). Tensión y ansiedad. México: Harla, S.A.

SUE, D. (1996). Comportamiento anormal. Mexico: Mc Graw-Hill.

UAB (Universidad Autónoma de Barcelona) (2017). MOOC. Diferencias con los cursos online. $<\underline{\text { http://www.uab.cat/web/estudiar/mooc/diferencias-con-un-curso-online- }}$ $\underline{1345668281279 . h t m l}>$ [Consulta: 25 de marzo de 2018]

(cc) EY-NC-ND 2018, Universitat Politècnica de València

Congreso IN-RED (2018) 


\title{
Reducción del tamaño de la clase de Inglés empleando Blended Learning como estrategia de aprendizaje
}

\section{Clayton Carrasco Grijalva}

Profesor de Inglés e investigador de la Universidad de Guayaquil, clayton.carrascog@ug.edu.ec, clay_u2@hotmail.com

\begin{abstract}
The present work aims to detail the occurrences and results obtained from a research project achieved with first semester students in the subject of English I that is part of the curriculum of the career of Chemistry and Pharmacy in an Ecuadorian University. The main objective targeted the class size reduction, which stands for the reduction of student-teacher ratio that also implied the reduction of the class time length without affecting the learning quality. To achieve this objective the course of study was adapted to the Blended Learning mode and supported by the application NOMON PILLBOOK and NOMON CISE as an educational technology tools that were developed by the researcher.
\end{abstract}

Keywords: class size, blended learning, educational technology tool, learning quality, innovation, ubiquitous learning

\begin{abstract}
Resumen
El presente trabajo detalla incidencias y resultados obtenidos de un proyecto de investigación realizado con estudiantes del primer semestre en la asignatura de inglés I que forma parte de la malla curricular de la carrera de Química y Farmacia en una universidad ecuatoriana. El objetivo central de la intervención fue reducir el tamaño de la clase; es decir reducir el ratio de alumnos por profesor, lo que implicó reducir también la duración presencial de dichas clases sin afectar la calidad del aprendizaje. Para lograr este objetivo se empleó la modalidad Blended Learning y como herramientas tecnológicas educativas de apoyo la aplicaciones NOMON PILLBOOK y NOMON CISE de desarrollo propio.
\end{abstract}

Palabras clave: tamaño de la clase, aprendizaje fusionado, herramienta tecnológica educativa, calidad del aprendizaje, innovación, aprendizaje ubicuo

\section{Introducción}

Para distintos expertos la reducción del tamaño de la clase es un factor de incidencia clave que sumado a otros factores metodológicos permite la mejora en la adquisición del aprendizaje generando un ambiente de aprendizaje más activo. Hughes (2005) manifiesta que la reducción del tamaño de clase permite a los profesores emplear mejor pedagogía así 
como la adopción de cambios de contexto que incluyen diversidad, inclusión y evaluación. Como plantea el autor, la conducta del estudiante mejora en clases pequeñas y el aprendizaje se convierte en una tarea de mayor responsabilidad y compromiso para éste. De acuerdo a diversos autores, la efectividad de este proceso responde a diferentes situaciones. Mayer \& Peterson (1999) destacan como una de estas situaciones al tipo de organización que tenga la institución educativa. Sin embargo, Calero \& Escardibul (2007) mencionan que cuando se comparan diferentes estudios en torno a la reducción del tamaño de clase, las conclusiones no son coincidentes. Biddle \& Berliner (2008) corroboran este criterio señalando que existen grupos en favor y otros en contra de que clases más pequeñas conduzcan a los estudiantes a mayor rendimiento estudiantil.

En cuanto a la reducción del tamaño de la clase, hay dos aspectos importantes que deben considerarse según Chingos (2013): uno es el ratio o relación de alumnos por profesor y otro el tamaño promedio de las clases. El autor menciona que proyectos como el Tennessee STAR (Mosteller, 1995) estiman una reducción ideal de entre 20 a 15 alumnos por profesor, de clases que fluctuaban en inicio entre 35 a 30 alumnos por profesor.

El informe "Education at a Glance" (OECD, 2011) cita como aspectos de incidencia que las clases pequeñas o reducidas permiten a profesores enfocarse más en las necesidades particulares de cada estudiante, situación que permite suponer que éstas tienen mayor costo que las tradicionales, por ende requieren de profesorado mejor entrenado, mejor calidad de material didáctico, mayores recursos tecnológicos para el aula, etc.

Por otro lado, hablar de aprendizaje ubicuo no solo se refiere al acceso que se tiene a la información desde cualquier lugar, sino como lo describe Burbules (2012), se trata de tener el control de dónde, cuándo, cómo y por qué cada individuo está aprendiendo. El Aprendizaje Fusionado conocido también como Blended Learning cumple con esta lógica de darle dicho "control" al estudiante. Vera (2008) lo define como un modelo híbrido por medio del cual tutores hacen uso de sus metodologías presenciales en el aula y paralelamente potencian el desarrollo de sus temáticas empleando una plataforma virtual, la que a la vez está dotada de un sinnúmero de recursos entre los que pueden encontrarse los juegos serios y otros asociados a la gamificación. Singh (2003) sugiere que las organizaciones deben emplear Aprendizaje Fusionado en función de proveer el contenido correcto a la gente correcta en el tiempo correcto.

En lo que respecta al aprendizaje de inglés en las universidades, Hans \& Hans (2015) indican que los programas por lo general son del tipo EFL (inglés como lengua extranjera) o ESP (inglés para fines específicos). Muchos de los currículos para la enseñanza de inglés en las Universidades latinoamericanas incluidas las ecuatorianas, de acuerdo a Cronquist y Fiszbein (2017) emplean el Marco Común Europeo de Referencia para las Lenguas (Instituto Cervantes, 2012) como estándar del aprendizaje. Al ser el aprendizaje de inglés de corte técnico con fines de profesionalización más que de corte social, como lo señalan Garrido y Pernas (2005) surgen conflictos cuando los estudiantes carecen de los conocimientos base necesarios para seguir un programa de este tipo. Mora (2015) agrega como factor negativo y recurrente la falta del empleo de las TIC.

(cc) EY-NC-ND 2018, Universitat Politècnica de València 


\section{Objetivo}

El objetivo de esta innovación fue reducir el tamaño de una clase presencial en la asignatura de Inglés I, considerando como factores para dicha reducción: el ratio de alumnos por profesor y la duración del tiempo presencial de la clase; y que esta combinación de factores no afecte la calidad del aprendizaje. El estudio planteó tres hipótesis para su validación.

En cuanto al método de comprobación, el estudio se enfocó en comparar el desempeño académico en la asignatura de Inglés I durante el primer ciclo semestral del año lectivo 2017-2018 de un grupo de estudiantes en modalidad presencial (grupo de control sin intervención) y un grupo de estudiantes en modalidad Blended Learning (grupo experimental con intervención) de 40 estudiantes cada uno.

Se plantearon las hipótesis:

a) Puede reducirse el tamaño de la clase de Inglés empleando la modalidad Blended Learning sin afectar la calidad del aprendizaje.

b) La modalidad Blended Learning puede reforzar de mejor forma el aprendizaje del idioma Inglés en comparación al aprendizaje presencial.

c) El uso de una herramienta tecnológica de apoyo permite reducir el tiempo presencial de una clase de Inglés sin afectar la calidad del aprendizaje.

\section{Desarrollo}

El enfoque metodológico empleado fue de tipo cuantitativo, dado a que este tipo de metodología permite entender a modo de tendencia comparativa las connotaciones más relevantes, así como los resultados y cambios se logran a partir de la innovación.

Los participantes del estudio correspondieron a estudiantes del primer semestre cuyas edades fluctuaron entre los 18 y 22 años. El tamaño de la muestra fue de 80 estudiantes. Se tuvo de contexto a la Facultad de Ciencias Químicas de la Universidad Estatal de Guayaquil.

Como fundamento pedagógico de la innovación fue adoptado el modelo Flipped Classroom o clase inversa que permitió establecer el criterio de emplear el tiempo presencial para la práctica y evaluación de contenidos dejando las actividades tipo lección tutorial para el tiempo virtual del que los estudiantes pudieran disponer en función de sus capacidades y necesidades.

Para la reducción del tamaño de la clase se adoptó la siguiente estrategia: el grupo experimental antes de la innovación solía ser 1 grupo de 40 estudiantes con una frecuencia de 4 horas por semana en modalidad presencial empleando material didáctico tradicional. Aplicando la innovación de la clase de tamaño reducido, esto cambió para tener 4 grupos en lugar de solo 1 empleando la modalidad Blended Learning, con una frecuencia de 1 hora de clase presencial por semana para cada grupo pero haciendo uso de una herramienta tecnológica de apoyo para el aprendizaje autónomo y considerando un mínimo de 3 horas 
Reducción del tamaño de la clase de inglés empleando Blended Learning como estrategia de aprendizaje

por semana. El grupo de control se mantuvo en el formato de clase presencial, lo que quiere decir 1 grupo de 40 estudiantes con una frecuencia de 4 horas de clase presencial por semana.

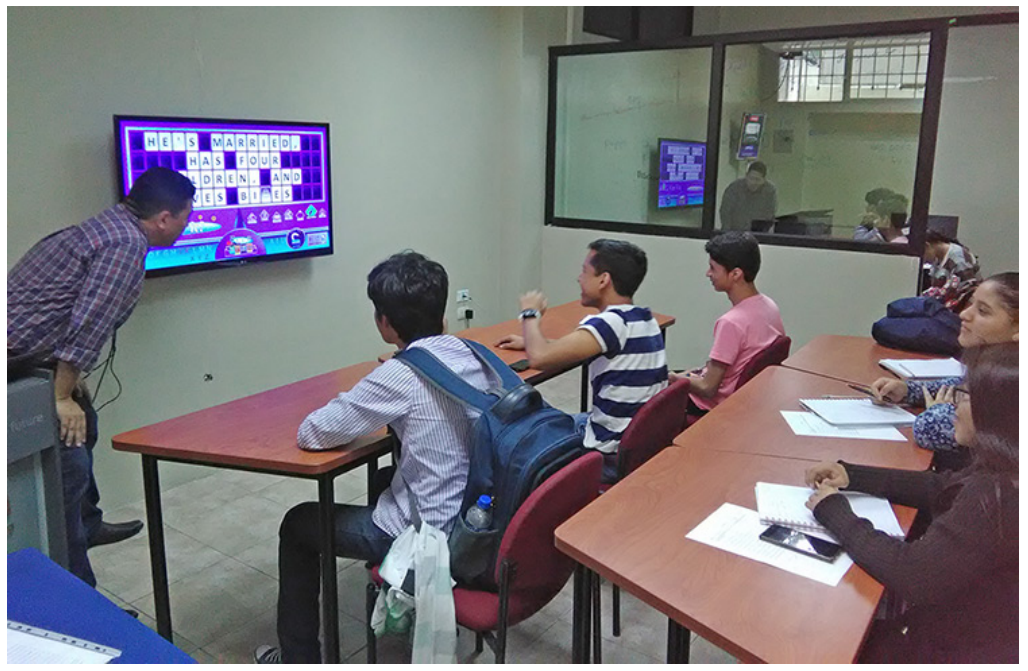

Fig. 1 Clase reducida, grupo experimental

Tanto el grupo experimental como el grupo de control recibieron los mismos contenidos en sus sesiones de clase de acuerdo al silabo de la asignatura. Cada grupo tuvo un profesor diferente, ambos profesores de la misma universidad y calificados para la enseñanza del idioma inglés.

En el caso del grupo de control que empleó modalidad de clase presencial, hizo uso de material didáctico tradicional como libros de texto, material de audio, etc., en concordancia con los contenidos y objetivos curriculares del silabo de la asignatura. El profesor de este grupo empleó un salón de clase con capacidad para 40 estudiantes acondicionado con un pizarrón y sistema de proyección para diapositivas.

En el caso del grupo experimental que empleó modalidad de clase Blended Learning, no hizo uso de material didáctico tradicional como lo hizo el grupo de control, en su lugar empleó la herramienta tecnológica de apoyo denominada NOMON PILLBOOK. Esta herramienta es una aplicación web que hace las veces de un libro digital que incluye en lecciones semanales las siguientes secciones: a) vocabulario incluida la práctica con ejercicio de contextualización, b) lección tutorial en video que incluye práctica con ejercicios de uso de lenguaje, c) dialogo para práctica oral y de comprensión auditiva, d) videos sobre el uso de verbos regulares y regulares; y e) panel de ejercicios orales para la pronunciación. Todos los contenidos de este recurso fueron personalizados en concordancia con los contenidos y objetivos curriculares del silabo de la asignatura. Les fue informado a los estudiantes de este grupo que debían realizar las actividades y seguir los contenidos fuera del tiempo de clase donde ellos mejor lo estimen (en sus casas o en la misma universidad, pero a través de sus computadoras personales) y en el tiempo que ellos establezcan, reflexionando en que el fundamento base del método era cumplir con los 
objetivos de aprendizaje de cada lección que en todos los casos se tradujo en el desarrollo de una determinada competencia o habilidad.

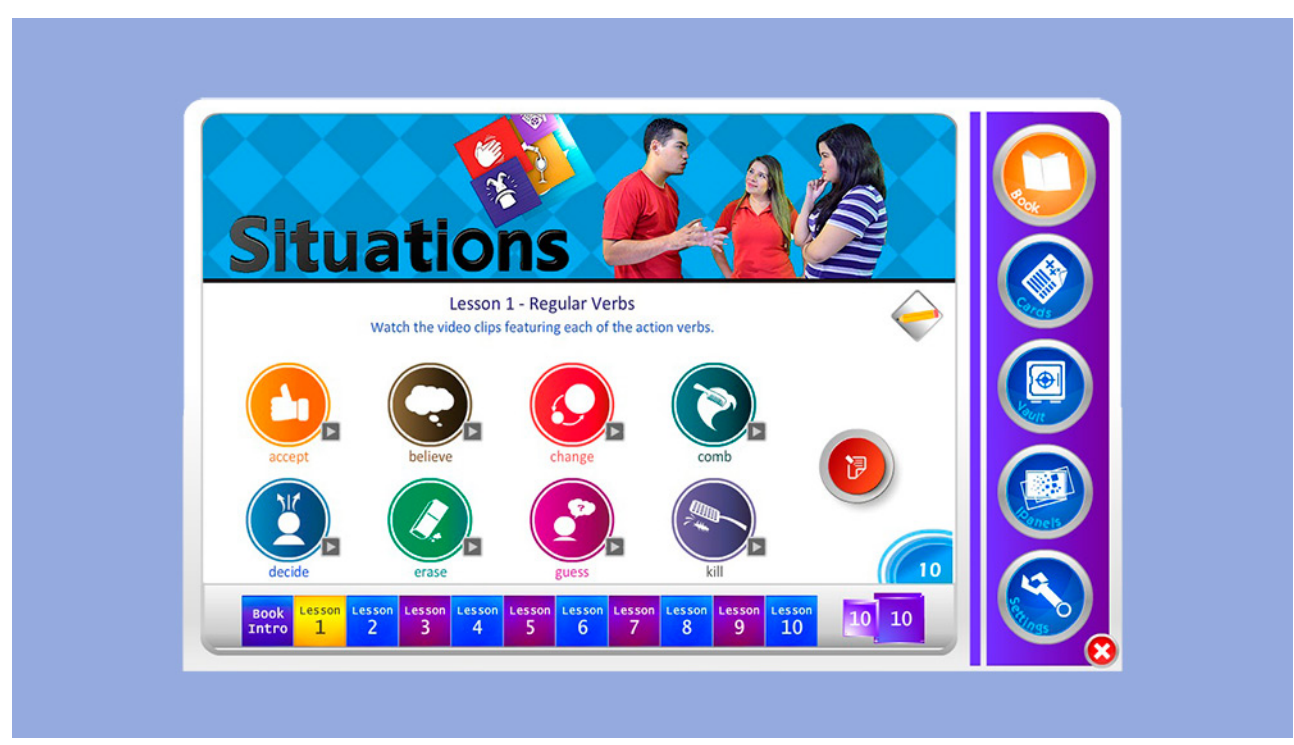

Fig. 2 Aplicación NOMON PILLBOOK

Para la parte presencial de una hora de clase de los 4 grupos de 10 estudiantes de las clases reducidas en la modalidad Blended Learning se destinó este tiempo a la evaluación y practica de los contenidos que los estudiantes previamente habían estudiado por medio de la aplicación NOMON PILLBOOK. El profesor para este acometido contó con la aplicación NOMON CISE que es complemento de la aplicación NOMON PILLBOOK. NOMON CISE muestra los contenidos de NOMON PILLBOOK pero en formato de juegos serios y actividades de ejercitación, además incluye diferentes funciones como asignar turnos, mostrar gráficos, evaluar ejercicios, etc. NOMON CISE a través de una pantalla de proyección de 48' muestra sus contenidos como si fuese un pizarrón inteligente en el que pueden hacerse anotaciones. El profesor de este grupo contó con un salón de clase especial adaptado para 10 estudiantes y acondicionado de acuerdo a los requerimientos de esta metodología. 


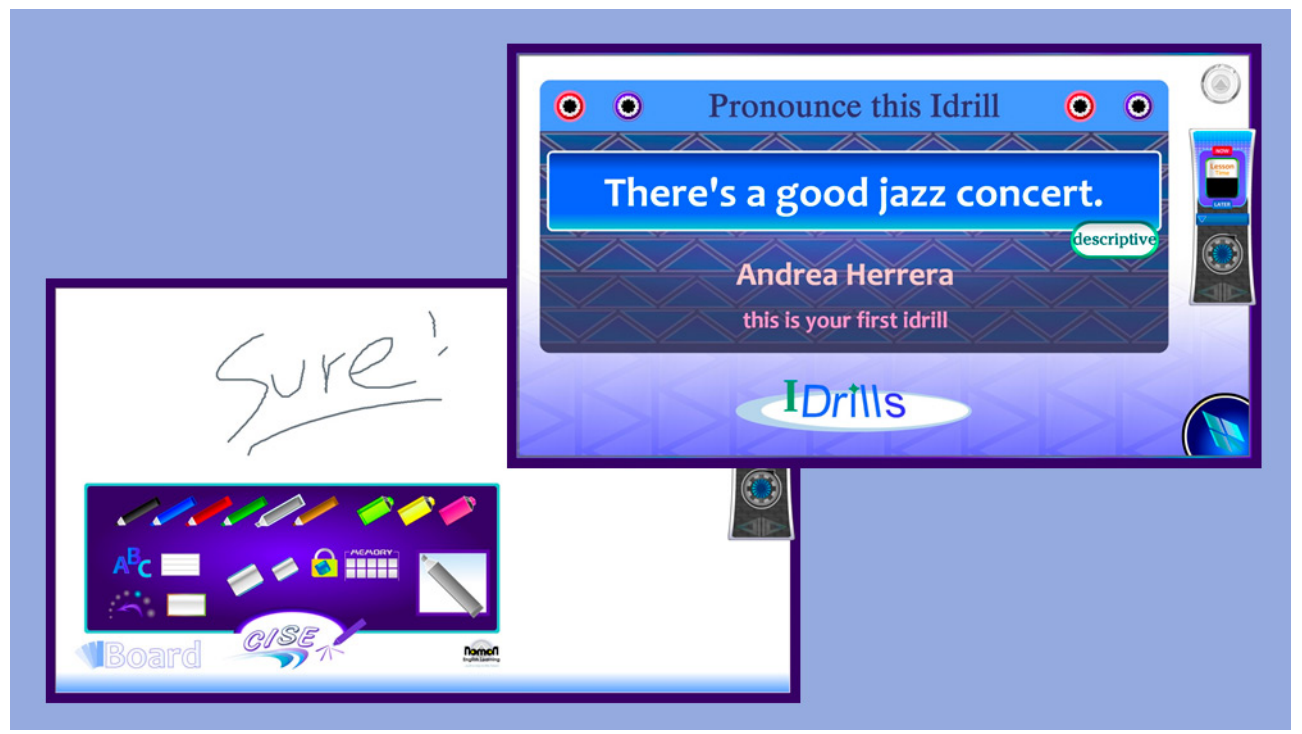

Fig. 3 Aplicación NOMON CISE

El rediseño de la unidad que propuso esta innovación se basó en el modelo instruccional de las 5E (Enganchar, Explorar, Explicar, Elaborar, Evaluar), que según explica Bybee (2002) permite resolver problemas al estudiante enfocándose en su propio aprendizaje. De acuerdo al autor, este modelo en referencia al diseño instruccional tiene como pasos: 1) enganchar la lección; 2) explorar la lección; 3) explicar la lección; 4) elaborar la lección y, 5) evaluar la lección.

Como instrumentos de evaluación de los conocimientos se emplearon pruebas estandarizadas de pretest y post test adaptadas del examen KET de la Universidad de Cambridge que en tres secciones miden el conocimiento de las habilidades lingüísticas de Reading y Writing, Listening y Speaking. La sección Reading y Writing del examen KET estandarizado está compuesta por 9 partes de las cuales se tomaron para la prueba adaptada las partes 1, 2, 3, y 4. La sección Listening está compuesta por 5 partes de las cuales se tomaron para la prueba adaptada las partes 1, 2 y 3. La sección Speaking está compuesta por 2 partes de las cuales se tomó solo la parte 1 para la prueba adaptada.

La prueba de pretest y post test tuvo una ponderación de 10 puntos. Se estableció una escala de valoración por rangos de acuerdo a puntos obtenidos: excelente $=10-9.6$, muy bueno $=$ 9.5-8.5, bueno $=8.4-7.5$, regular $=7.4-6.5$, deficiente $=6.4-0$. Se diseñó una rúbrica para la parametrización de esta escala con criterios de logros. Se evaluaron 3 aspectos del aprendizaje en las pruebas así como en las actividades de clase: estructura gramatical, correcto uso del lenguaje y vocabulario.

\section{Resultados}

El siguiente cuadro muestra los resultados del pretest tanto del grupo de control como del grupo experimental por número de estudiantes de acuerdo a la escala de valoración por 
rangos en cada uno de los tres aspectos evaluados: estructura gramatical, correcto uso del lenguaje y vocabulario.

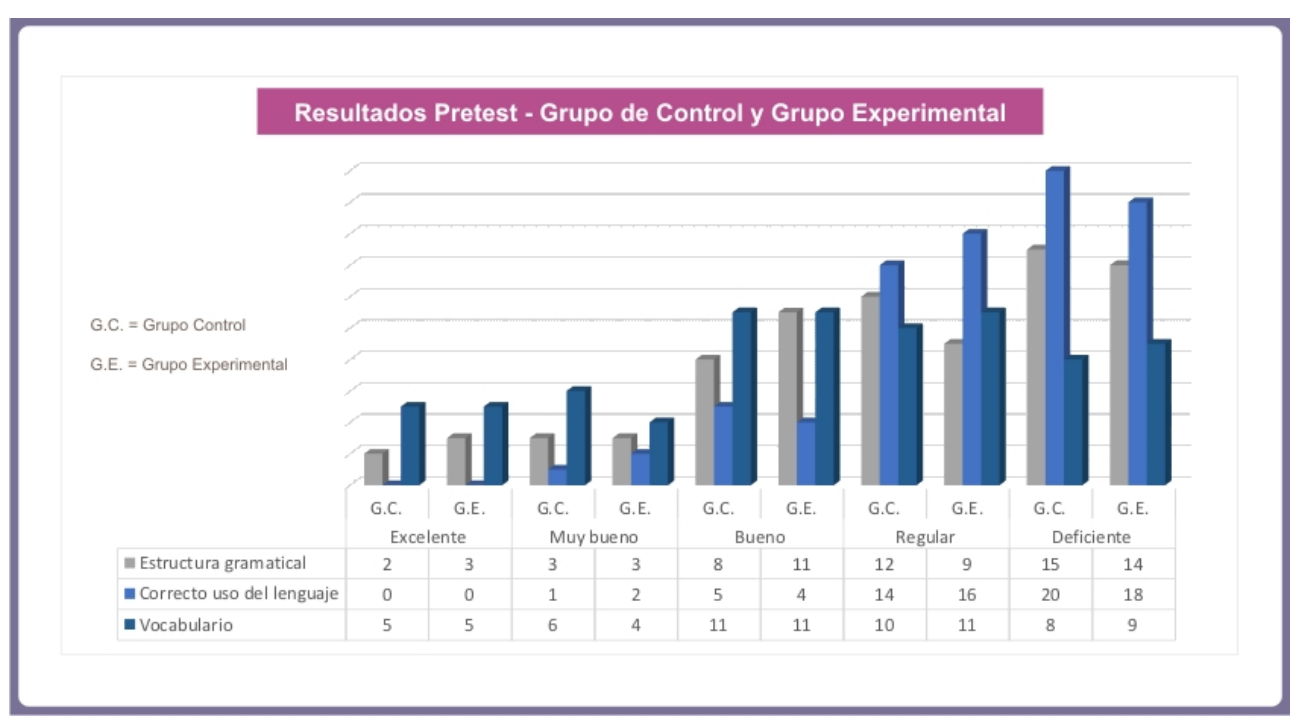

Fig. 4 Resultados del Pretest

Los resultados del pretest en lo que concierne a estructura gramatical arrojaron que en cuanto al grupo de control, $5 \%$ de los estudiantes se ubicaron en el rango de excelente, $27.5 \%$ en el rango de entre muy bueno y bueno; y $67.5 \%$ en el rango de entre regular y deficiente. En cuento al grupo experimental, $7.5 \%$ de los estudiantes se ubicaron en el rango de excelente, $35 \%$ en el rango de entre muy bueno y bueno; y 57.5\% en el rango de entre regular y deficiente.

Los resultados del pretest en lo que concierne a correcto uso del lenguaje para el grupo de control determinó que $15 \%$ de los estudiantes se ubicaron en el rango de entre muy bueno y bueno, y $85 \%$ en el rango de entre regular y deficiente. En cuento al grupo experimental, $15 \%$ de los estudiantes se ubicaron entre muy bueno y bueno; y $85 \%$ entre regular y deficiente. No hubo estudiantes en el rango de excelente para este aspecto.

Por último, los resultados del pretest para el aspecto de vocabulario determinó para el grupo de control que $12.5 \%$ de los estudiantes se ubicaron en el rango de excelente, $42.5 \%$ entre muy bueno y bueno; y $45 \%$ en el rango de entre regular y deficiente. Por su lado, el grupo experimental tuvo resultados en este aspecto de $12.5 \%$ de los estudiantes en el rango de excelente, $37.5 \%$ entre muy bueno y bueno; y $50 \%$ en el rango de entre regular y deficiente.

El pretest indicó que al iniciar el curso los alumnos de ambos grupos considerando los rangos regular y deficiente mostraron deficiencias en los conocimientos en lo que respecta a estructura gramatical en más de un $60 \%$, correcto uso del lenguaje en un $85 \%$; y vocabulario en cerca de un $48 \%$.

El siguiente cuadro muestra los resultados del post test tanto del grupo de control como del grupo experimental en los tres aspectos evaluados: estructura gramatical, correcto uso del lenguaje y vocabulario. 


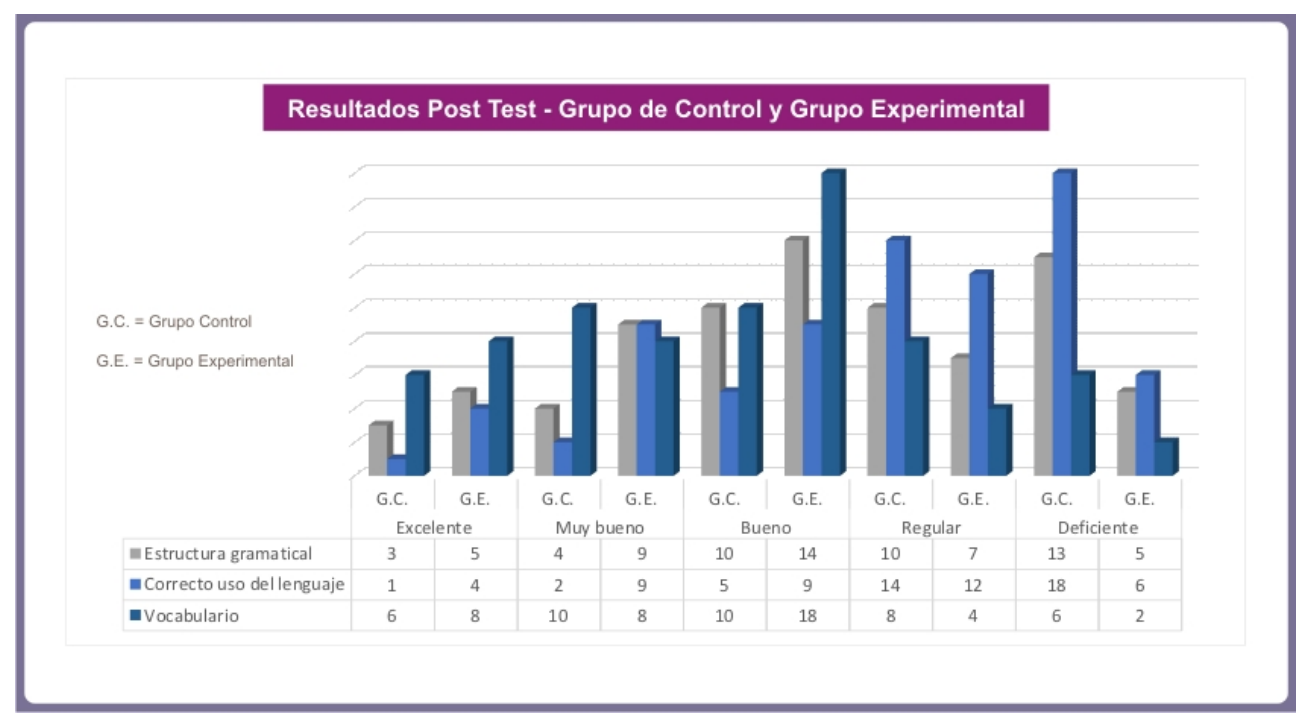

Fig. 5 Resultados del Post Test

Los resultados del post test evidenciaron aumentos y reducciones porcentuales con respecto a los resultados del pretest. El grupo de control en el aspecto de estructura gramatical registró cambios de +2.5 excelente, +2.5 muy bueno, +5 bueno, -5 regular, -5 deficiente. El grupo experimental logró cambios de +5 excelente, +15 muy bueno, +10 bueno, -5 regular, -25 deficiente.

El grupo de control en el aspecto de correcto uso del lenguaje registró cambios de +2.5 excelente, +2.5 muy bueno, 0 bueno, 0 regular, -5 deficiente. El grupo experimental logró cambios de +10 excelente, +17.5 muy bueno, +20 bueno, -10 regular, -37.5 deficiente.

El grupo de control en el aspecto de vocabulario registró cambios de +2.5 excelente, +10 muy bueno, -2.5 bueno, -5 regular, -5 deficiente. El grupo experimental logró cambios de +7.5 excelente, +10 muy bueno, +22.5 bueno, -17.5 regular, -22.5 deficiente.

El post test indicó diferencias considerables en el mejoramiento de todos los aspectos que lograron los participantes del grupo experimental en relación a los resultados del pretest. Persistieron deficiencias en el grupo de control. El siguiente cuadro muestra porcentualmente los resultados tanto del pretest como del post test. 


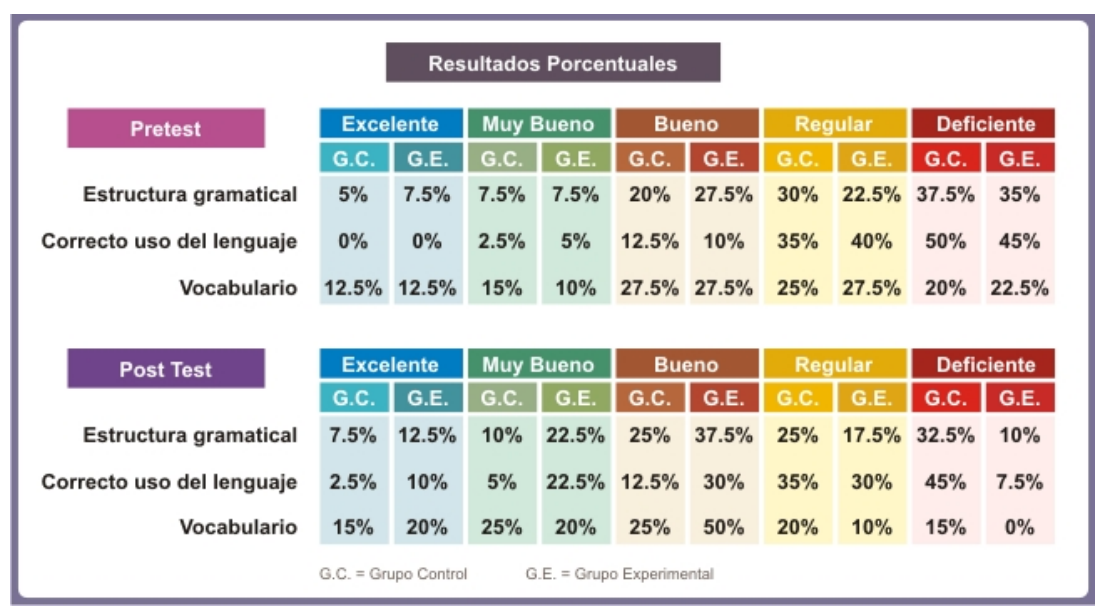

Fig. 6 Resultados porcentuales Pretest y Post Test

\section{Conclusiones}

Reducir el tamaño de la clase de la asignatura de Inglés I fue satisfactoriamente posible, en concordancia al objetivo establecido. Este estudio comprobó positivamente las tres hipótesis planteadas.

Se comprobó como muy beneficiosa la reducción del tamaño de la clase de Inglés empleando la modalidad Blended Learning, que para los participantes del grupo experimental significó una novedad en la que según ellos a través de una encuesta de opinión realizada, indicaron que estudiar en base a su tiempo y a su comodidad aportó a tener mejor desempeño. El hecho de contar con videos tutoriales, ejercicios orales y escritos a su completa disposición en un formato más dinámico tanto en forma virtual como presencial les permitió estar en ventaja con el grupo de control. Los resultados demuestran que fue superior el desempeño del grupo experimental en relación al grupo de control teniendo como indicadores destacados de dicho desempeño: mejora progresiva en la producción oral y la pronunciación, así como la comprensión auditiva comprobando que la modalidad Blended Learning puede reforzar de mejor forma el aprendizaje del idioma Inglés en comparación al aprendizaje presencial que para este estudio demostró como incidencia el inferior desempeño que lograron los estudiantes del grupo de control que según lo expresado por su profesor no promovió el trabajo autónomo ni el trabajo en equipo como se hubiera querido.

Otras de las validaciones importantes del estudio fue determinar que para poder reducir el tamaño de una clase empleando la modalidad Blended Learning es indispensable el uso de recursos tecnológicos educativos de apoyo como fue el caso de las aplicaciones NOMON PILLBOOK y NOMON CISE, ya que entre sus bondades de uso aplicado está el dar un marco de ordenamiento a la secuencia metodológica de la clase, así también como un recurso optimizador del esfuerzo del profesor y los estudiantes que permitió que dicho esfuerzo cognitivo hecho estuviese centrado en el aprendizaje, de allí la posibilidad de reducir el tiempo de la clase sin afectar la calidad del aprendizaje. 
Reducción del tamaño de la clase de inglés empleando Blended Learning como estrategia de aprendizaje

De parte de los profesores que participaron en el estudio se trató siempre en la medida posible de evitar el cometimiento de sesgos en la aplicación de ambos métodos. Al final del experimento, por parte de ambos profesores se concluyó que las clases reducidas pueden mejorar aspectos como la motivación, la objetividad y el trabajo colaborativo. Así mismo, esta discusión determinó también como aspectos negativos o amenazantes que deben considerarse para las clases reducidas empleando Blended Learning a aspectos como que el tiempo presencial destinado podría resultar muy limitado para ciertos estudiantes que requieren mayor apoyo tutorial; y que el profesor hace mayores gastos de esfuerzo en comparación a las clases tradicionales no reducidas.

Otro de los aspectos de consideración que surgieron de este estudio: es la posición de la institución educativa, ya que realizar una innovación de este tipo involucra asumir nuevos roles metodológicos que intervengan paradigmas vigentes del aprendizaje tradicional. Esto también se refiere a la inversión de recursos y esfuerzos que de no realizarse adecuadamente habrían afectado la calidad del experimento.

Se recomienda repetir el experimento con nuevas poblaciones estudiantiles ya sea con la misma asignatura o su asignatura post-requisito para la comparación y validación de resultados.

\section{Bibliografía}

Biddle, B., \& Berliner, D. (2008). Small Classes and its effects.

Burbules, N. (2012). El aprendizaje ubicuo y el futuro de la enseñanza.

Encounters/Encuentros/Rencontres on Education Vol. 13, 3-14.

Bybee, R. (2002). Learning Science and the Science of Learning. NSTA Press.

Calero, J., \& Escardibul, J. (2007). Evaluación de servicios educativos: El rendimiento en los centros públicos y privados medido en Pisa-2003. Barcelona: Treball 2007.

Chingos, M. (2013). Tamaño de la clase y resultados de los estudiantes: investigación e implicaciones politicas. Ponencia en el Instituto Nacional de Evaluación Educativo.

Council for Cultural Cooperation Education Committee. (2002). Common European Framework for

Languages: Learning, Teaching, Assessment. Strasbourg: Language Policy Division.

Cronquist, K., \& Fiszbein, A. (2017). El aprendizaje del inglés en América Latina. El Diálogo

Liderago para las Américas.

Garrido, C., \& Pernas, M. (2005). El aprendizaje del idioma inglés en las carreras de Ciencias Médicas. Instituto Superior de Ciencias Médicas de La Habana.

Hans, A., \& Hans, E. (2015). A Comparative Study of English for Specific Purposes (ESP) and English as a Second Language (ESL) Programs. International Journal on Studies in English Language and Literature (IJSELL), 26-31.

Hughes, L. (2005). Current issues in cchool leadership. Mahwah, New Jersey: Lawrence Erlbaum Associates, Publishers.

Instituto Cervantes. (2012). MArco Común Europeo de Referencia para las Lenguas: Aprendizaje, Enseñanza, Evaluación. Madrid: Artes Gráficas Fernandez.

(cc) EY-NC-ND 2018, Universitat Politècnica de València

Congreso IN-RED (2018) 
Mayer, S., \& Peterson, P. (1999). Earning and Learning, How schools matter. Washington D.C.: Brookings Institution Press.

Mora, J. (2015). Hacia un curriculum alternativo para la enseñanza del inglés a nivel universitario. Bogota: Universidad Militar Nueva Granada.

Mosteller, F. (1995). The Tennessee Study of Class Size in the Early School Grades. The Future of Children Critical Issues for Children and Youths Vol. 5 • No. 2, 113-127.

OECD. (2011). Education at a Glance 2011: OECD Indicators. OECD Publishing. Obtenido de http://dx.doi.org/10.1787/eag-2011-en

Singh, H. (2003). Building Effective Blended Learning Programs . Issue of Educational Technology, Volume 43, Number 6, 51-54.

SISTEMA DE ENSEÑANZA NOMON ENGLISH LEARNING, Carrasco C. (2014) IEPI.

Vera, F. (2008). La modalidad Blended Learning en Educación Superior. Rancagua, Chile. 


\section{3 \\ Desarrollo de competencias en el alumno}




\title{
Una experiencia de coordinación dirigida a trabajar las competencias necesarias para superar con éxito el Trabajo de Fin de Grado en Derecho
}

\section{Ixusko Ordeñana Gezuraga}

Profesor Derecho Procesal Universidad del País Vasco, ixusko.ordenana@ehu.eus

\begin{abstract}
An experience of teaching innovation that 16 professors of Law Faculty of the University of the Basque Country are implementing is taken to IV National Congress on Educational Innovation and Network Teaching. Concerned about troubles that students perceive to overcome their Final Degree Project, which is linked to the basic competences of the jurist, a coordinated action has been proposed to work on them, inspired by active and autonomous learning. The origins and basis of this experience are explained.
\end{abstract}

\section{Keywords:}

teaching innovation project, Final Degree Project, competences, active and autonomous learning

\section{Resumen}

Se presenta al IV Congreso Nacional de Innovación Educativa y Docencia en Red la experiencia de innovación docente que están implementando 16 profesores y profesoras de la Facultad de Derecho de la Universidad del País Vasco. Preocupados por los problemas que advierten en el estudiantado para superar el Trabajo Fin de Grado, que se vincula con las competencias básicas del jurista, se han planteado una acción coordinada para trabajarlas, bebiendo, al efecto, del aprendizaje activo y autónomo. Se explican los orígenes y fundamento del mismo.

\section{Palabras clave:}

Proyecto de innovación docente, Trabajo Fin de Grado, competencias, aprendizaje activo y autónomo 


\section{Introducción}

Más de un lustro después del pleno desarrollo del Grado en Derecho, en el marco del Espacio Europeo de Educación Superior, en la Facultad de Derecho de la Universidad del País Vasco-Euskal Herriko Unibertsitatea ${ }^{1}$, el profesorado hemos tenido ocasión de constatar las ventajas y debilidades del nuevo Plan de estudios. En nuestro empeño de implementar con éxito nuevas formas y métodos de enseñanza-aprendizaje, adecuados a las exigencias actuales, en el contexto del aprendizaje cooperativo y dinámico ${ }^{2}, 16$ profesores de la Facultad, encargados de todas las materias que integran el plan de estudios, hemos puesto en marcha un proyecto de innovación educativa centrado en, lo que a nuestro juicio, es una debilidad de nuestro Grado, en general, y del método de enseñanza-aprendizaje que estamos implementando, en particular: el estudiantado llega al último curso del Grado sin dominar las competencias necesarias para realizar y defender el Trabajo Fin de Grado ${ }^{3}$. Queremos aprovechar el IV Congreso Nacional de Innovación Educativa y Docencia en $\operatorname{Red}^{4}$ para relatar nuestro proyecto y experiencia, desde la premisa de que, seguramente, nuestro "problema" y las posibles soluciones que planteamos para el mismo, se repiten en otros Grados y otras Facultades. Al mismo tiempo, nos mueve el interés de socializar nuestro proyecto de intervención en el aula, conscientes de que la opinión que sobre el mismo nos pueden aportar otros docentes pueden ayudar a enriquecerlo y optimizar su resultado.

Una última nota introductoria: el proyecto lleva a penas un curso en marcha, por lo que vamos a compartir su planteamiento y lo implementado hasta la fecha, sin perjuicio de que nos comprometemos a acudir al IN-RED 2019 para relatar su culminación.

\section{Objetivos}

Ante el "problema" planteado -que nosotros y nosotras siempre hemos leido como reto-, el grupo de profesores mentado, integrado por personas con más y menos experiencia en innovación, bajo la coordinación del profesor Ordeñana, nos hemos unido en el proyecto que les vamos a relatar para aunar esfuerzos con los siguientes objetivos principales:

1. Constatar objetivamente la cuestión, ahondando en sus causas.

2. Diseñar un programa o plan de actuación que abarque todas las asignaturas del Grado en Derecho, basado en el aprendizaje activo y autónomo.

3. Implementar el plan de actuación o intervención en el aula, dirigido a obtener las competencias necesarias para superar con éxito el TFG.

\footnotetext{
${ }^{1}$ En lo sucesivo, UPV-EHU.

2 En el marco del modelo pedagógico instaurado por la UPV/EHU, "Irakaskuntza Kooperatiboa eta Dinamikoa” (IKD) (en castellano, "Enseñanza Cooperativa y Dinámica”)

${ }^{3}$ En lo sucesivo, TFG.

${ }^{4}$ En lo sucesivo, IN-RED 2018
}

(cc) EY-Nc-No 2018, Universitat Politècnica de València

Congreso IN-RED (2018) 
4. Que nuestro alumnado no conciba el TFG como algo ajeno al resto de materias que integran el Grado en Derecho. Lejos de ello, aspiramos a que lo sienta no sólo como parte, sino como culmen del proceso de enseñanza-aprendizaje vinculado al Grado en Derecho, tarea que le permite "demostrar haber adquirido los contenidos formativos, capacidades, competencias y habilidades para los que le capacita la correspondiente titulación” (art. 1.3. Reglamento para la elaboración y defensa de los TFG de la Facultad de Derecho de la UPV/EHU) ${ }^{5}$. Por ello, pretendemos que, lejos de verlo como obstáculo (último) para obtener la Graduación, lo perciban como ejercicio de afianzamiento del conocimiento y competencias adquiridas.

5. Objetivamente, nos daríamos por satisfechos si la mayoría de nuestro alumnado (un 70\%) defendiera el TFG en la primera convocatoria del año de matriculación y obtuviera como media un 7,5. Ambos indicadores de aprendizaje reflejarían una mejora considerable de la realidad actual.

Todo ello guiado con la noble intención de mejorar el aprendizaje del estudiantado de Derecho en la adquisición de competencias básicas de la titulación. Efectivamente, el TFG, integrado en el cuarto módulo del Grado en Derecho de la Facultad de Derecho de la UPV/EHU -Especialización, Investigación y Práctica del Derecho-, persigue asentar competencias genéricas y transversales de la titulación ${ }^{6}$, entre las que cabe destacar: 1) la capacidad de análisis crítico, interrelación e integración de conocimientos jurídicos; 2) la comunicación oral y escrita; 3) la capacidad de síntesis y exposición, con utilización de técnicas de argumentación y razonamiento crítico y 4) la gestión del propio proceso de aprendizaje hacia una formación integral y respetuosa con los valores democráticos.

Las primeras tres competencias apuntadas se trabajan, igualmente, en distintas asignaturas de los tres módulos restantes del Grado. La última, por su parte, casa a la perfección con la metodología de enseñanza-aprendizaje que quiere impulsar y emplear el proyecto educativo que se propone: el aprendizaje activo y autónomo del alumnado.

\section{Desarrollo de la innovación}

\subsection{Sobre su origen}

El germen primario del proyecto de innovación educativa que estamos describiendo son muchas conversaciones -formales e informales- entre los profesores y profesoras integrantes del grupo los últimos años y las consiguientes reflexiones individuales y grupales, previas y posteriores. Todos los miembros del equipo hemos realizado labores de dirección y evaluación de TFGs. Nuestra experiencia de más de 5 años en la materia, nos lleva a entender que "la memoria, estudio, informe o dictamen original vinculado a alguna/s de las materias desarrolladas en el Grado" (art. 1 REDTFG) que debe realizar el estudiante para culminar el Grado en Derecho se ha convertido para muchos estudiantes

\footnotetext{
${ }^{5}$ En lo sucesivo, REDTFG

${ }^{6}$ En estos conceptos ahondaremos en breve.
} 
en un trámite muy duro de superar. A pesar de que los 16 docentes integrantes del equipo que propone el proyecto mantenemos que en la enseñanza-aprendizaje de las asignaturas que impartimos trabajamos más o menos directamente las competencias que se vinculan al TFG ((1)capacidad de análisis crítico, interrelación e integración de conocimientos jurídicos; (2) comunicación oral y escrita; (3) capacidad de síntesis y exposición, con utilización de técnicas de argumentación y razonamiento crítico y (4) gestión del propio proceso de aprendizaje hacia una formación integral y respetuosa con los valores democráticos), cuando nos encontramos mano a mano con el alumno o alumna al que tenemos que dirigir el TFG, advertimos que tienen muchas y verdaderas dificultades para realizarlo. Son numerosos los problemas que percibimos: les cuesta elegir y determinar el tema concreto del TFG -algo difícil de entender cuando ya han cursado todas las materias de la carrera-; no son, en general, diestros en la búsqueda de información, mostrando verdaderos apuros para articular y manejar la bibliografía (casi su único recurso es google); les cuesta sintetizar y construir un argumento sistemático, coherente y crítico, y presentarlo, tanto por escrito, como oralmente; y en todo este proceso buscan en nosotros y nosotras un padre o madre que apruebe cada una de sus decisiones y opiniones (¿dónde está la gestión del propio proceso de aprendizaje que se les supone para estas alturas del Grado?). Sin duda alguna, todas ellas son competencias que, al final del TFG, deben obtener pero que parece que previamente no han adquirido.

\subsection{Constatación del "problema”, mejor llamado "reto"}

Explicado el origen de nuestro proyecto, la primera actuación desarrollada en su implementación ha sido la constatación del "problema". Al efecto, hemos utilizado dos elementos: la estadística y la consulta directa al estudiantado. La primera viene a avalar la preocupación del equipo docente involucrado en el proyecto. Los datos oficiales obtenidos muestran que la mayoría del estudiantado del cuarto curso del Grado en Derecho presenta el TFG en la segunda convocatoria de su año de matriculación. Además, la nota media del ejercicio los dos últimos cursos es un 6,5. Ambos elementos requieren un juicio subjetivo: se nos antoja difícil de entender que la mayoría del alumnado presente su TFG en segunda convocatoria, cuando tienen un cuatrimestre completo vacío, sin asignaturas ${ }^{7}$, para confeccionarlo. No consideramos que sea un problema tanto de tiempo, como de inseguridad. Por otra parte, la nota obtenida en el ejercicio no nos parece excesivametne buena, sino más bien escasa, si advertimos especialmente que las competencias vinculadas con el TFG son esenciales del Grado en Derecho.

Cuestionado el estudiantado, informalmente en el transcurso de los cursos, y más formalmente, con ocasión de la preparación del proyecto de innovación educativa que estamos describiendo -preguntamos a más de 40 estudiantes que el curso pasado (2016/2017) se matricularon para hacer el TFG con nosotros y nosotras- es tajante: no se sienten preparados para afrontar el TFG. No asocian tareas y actividades realizadas

${ }^{7}$ El segundo del cuarto curso.

(c) EY-Nc-ND 2018, Universitat Politècnica de València 
previamente en otras asignaturas con el último ejercicio o requisito para obtener la Graduación. Se sienten inexpertos y muy perdidos.

Por tanto, y resumiendo, entendemos que el proyecto de innovación docente que estamos implementando viene a responder a una necesidad práctica: la superación de los obstáculos que encuentra el alumnado en la realización y superación del TFG, en cuanto forma de garantizar que adquiere sobradamente las competencias básicas que se requieren al jurista. Entendemos, al respecto, el TFG como elemento excelente para ahondar en "la gestión personal del propio aprendizaje” que se le vincula como competencia básica. Para ello, es necesario previamente trabajar consciente y sistemáticamente el aprendizaje activo y autónomo del alumnado.

\subsection{Un plan para fomentar el aprendizaje activo y autónomo del alumnado dirigido a adquirir las competencias necesarias para superar con éxito el TFG.}

\subsubsection{Elementos esenciales del plan.}

Luego, al hilo de lo descrito, el eje pedagógico de la intervención que les estamos relatando es el aprendizaje activo y autónomo del alumnado. Se trata, concretamente, de fomentarlo por los docentes que integran el proyecto, en los cursos previos del Grado de Derecho y antes de la realización del TFG, para que puedan demostrarlo en la confección de éste, salvándolo con éxito. Concebimos la realización y superación del TFG como la mejor evidencia de que el estudiantado ha adquirido las competencias correspondientes mediante el aprendizaje activo y autónomo.

En las próximas líneas vamos a ahondar en el marco teórico y práctico de los elementos esenciales de nuestro plan de actuación: las competencias a adquirir y el aprendizaje activo y autónomo como instrumento, al efecto. Relataremos, por último, la serie de actividades previstas en el marco de nuestro plan de actuación.

\subsubsection{Sobre las competencias a adquirir.}

Alejándonos de discusiones vanas ${ }^{8}$, sin negar su origen del mundo laboral ${ }^{9}$ y que se han convertido en la piedra angular para la confección de los planes de estudios ${ }^{10}$, entendemos por competencia "la capacidad de hacer frente con garantías de éxito a una situación problemática en un determinado contexto"11, integrándose por una operación (acción

\footnotetext{
8 Da fé de ello, GUZMÁN MARÍN, F., “El concepto de competencias”, Revista Iberoamericana de Educación (2012), núm. 4. Iberoamérica: Organización de Estados Iberoamericanos para la Educación, la Ciencia y la Cultura.

9 Incide en ello, LUIS MANRÍQUEZ P. “¿Evaluación en competencias?”, Estudios pedagógicos (2012), núm. 1, Chile: Facultad de Filosofía y Humanidades Universidad Austral de Chile, argumentando que es una característica de la época en la que nos toca vivir. En el mismo sentido, ESTEBAN ALBERT, M., SÁEZ CARRERAS, J., "Las profesiones, las competencias y el mercado”, REDU: Revista de Docencia Universitaria (2008), núm. 2, Valencia: Universidad Politécnica.

${ }^{10}$ Así la califican, con total acierto, DEL CARMEN LEVÍ ORTA, G., RAMOS MÉNDEZ, E., “Componentes de las competencias en los nuevos grados de algunas universidades españolas”, Revista de educación (2013), núm. 362. Madrid: Ministerio de Educacion, Cultura y Deporte.

${ }^{11}$ Definición otorgada por GOÑI ZABALA, J.M. (2005), El Espacio Europeo de Educación Superior, un reto para la Universidad. Barcelona: Octaedro, p. 105 y ss. En sentido similar, ZABALZA, M.A. (2009), Competencias docentes del profesorado universitario. Calidad y desarrollo profesional, 4. ed. Madrid: Narcea.
}

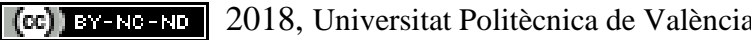


mental) sobre un objeto (que es lo que habitualmente llamamos conocimiento) para el logro de un fin determinado (contexto de aplicación).

Las competencias, incidiendo en su tipología, pueden ser generales o de titulación y específicas.

Denominamos competencia general o de titulación a aquélla que debe adquirir el estudiante al finalizar el Grado. Estas competencias se escalonan por cursos o módulos, integrando su conjunto las características descritas en el perfil del graduado. En el marco de las competencias generales debemos destacar una categoría especial: las competencias transversales. Llamamos así a aquéllas que deben ser trabajadas en todos los niveles inferiores a aquél en que está ubicada ${ }^{12}$.

Por su parte, denominamos competencia específica a aquélla correspondiente a cada módulo y/o asignatura.

Pasando del plano meramente teórico al práctico, ¿Cuáles son las competencias generales a adquirir por los alumnos en el Grado en Derecho de la UPV-EHU? Son 5:

1) Poseer y comprender las bases terminológicas y de conocimiento fundamental del Derecho Público y del Privado con plena capacidad de sistematización, análisis crítico, interrelación, integración y síntesis, con espíritu de liderazgo y emprendizaje.

2) Aplicar adecuadamente los conocimientos y técnicas adquiridos a lo largo de sus estudios de grado en orden a la correcta resolución de los problemas jurídicos, adoptando decisiones de manera creativa y afrontando situaciones diversas, con respeto a la diversidad y la tolerancia, apoyado en una suficiente capacidad de organización, trabajo en pequeños grupos y planificación.

3) Adaptarse permanentemente a los cambios normativos y a las situaciones novedosas con el imprescindible compromiso ético y la sensibilidad social, económica y medioambiental, en general, primando los aspectos de calidad e innovación, de modo específico, en el ámbito de las TIC.

4) Gestionar satisfactoriamente las relaciones interpersonales y sociales, a partir del oportuno dominio de los procesos de comunicación oral y escrita que faculte al alumnado para transmitir información, tanto a un público especializado, como al no especializado, utilizando técnicas de argumentación y razonamiento crítico.

5) Gestionar el proceso de aprendizaje de modo continuado y autónomo, de modo que se obtenga una formación integral coherente con los derechos fundamentales de igualdad, no discriminación y fomento de la cultura de la paz, y así poder afrontar con éxito estudios posteriores de especialización o reciclaje.

Estas competencias las ha de adquirir el egresado en Derecho poco a poco, escalonadamente, mientras estudia las diferentes asignaturas que integran los cuatro módulos en los que se estructura la carrera ${ }^{13}$. Y, en su contexto, tenemos que entender las competencias específicas -ya expuestas- que se vinculan al TFG. Con todo, entendemos que la obtención por el alumnado de estas competencias exige al profesorado "poner en práctica

\footnotetext{
${ }^{12}$ Muestra otras definiciones GARCÍA MARTÍNEZ, J. (2007), “Las competencias y la nueva organización de la enseñanza”, en AAVV (Coor. LEÓN BENÍTEZ, M.R.), La Licenciatura de Derecho en el contexto de la convergencia europea. Valencia: Tirant lo Blanch, pp. 168-173.

${ }^{13}$ Los cuatro módulos son: (1) las bases del derecho, (2) el derecho público general y especial, (3) el derecho privado, y (4) especialización, investigación y práctica del derecho
}

(cc) EY-NC-ND 2018, Universitat Politècnica de València 
nuevas pedagogías coherentes con el sentido y significado de dichas competencias” ${ }^{14}$. De ahí el proyecto que les relatamos.

\subsubsection{La forma de adquirir las competencias vinculadas con el TFG: el aprendizaje activo} y autónomo.

Entendemos que la forma o recurso pedagógico idóneo para que el estudiantado adquiera las competencias apuntadas es el aprendizaje activo y autónomo ${ }^{15}$. Planteamos beber de esta fuente conscientemente para mejorar el proceso enseñanza-aprendizaje.

En el marco del aprendizaje activo ${ }^{16}$, entendemos imprescindible utilizar estrategias en nuestra docencia que involucren dinamicamente al estudiantado, para que obtengan una comprensión más profunda de los contenidos, que les permita desarrollar un pensamiento crítico y habilidades para solventar problemas (análisis, síntesis, argumentación y defensa), al tiempo que les motivemos, y animemos a la interacción y trabajo con sus semejantes ${ }^{17}$. Entendemos necesario, al efecto, resignificar los roles de los propios estudiantes y el nuestro, otorgando al alumando el protagonismo máximo que se merece en el proceso ${ }^{18}$. Tenemos que configurar, asimismo, un nuevo concepto del lugar de trabajo: aula o espacio ajeno a ella ${ }^{19}$.

En el proceso descrito, totalmente vinculado, deviene igual de importante lo que se viene llamando aprendizaje autónomo, autoaprendizaje o estudio autodirigido. Es necesario trabajar con los y las estudiantes la capacidad de detectar déficits en el propio conocimiento y superarlas mediante la reflexión crítica y la elección de la mejor actuación al respecto. Y es que el aprendizaje autónomo "implica por parte del que aprende asumir la responsabilidad y el control interno del proceso personal de aprendizaje” ${ }^{20}$.

\footnotetext{
${ }^{14}$ Literal, GOYES MORENO, I. (2013)“Competencias pedagógicas para la formación jurídica por competencias”, Academia: revista sobre enseñanza del derecho de Buenos Aires, núm. 21. Buenos Aires: Facultad de Derecho de la Universidad de Buenos Aires.

${ }^{15}$ Es más, justifica que esta forma de aprendizaje se corresponde con la dimensión actitudinal de las competencias, RIBAS FERRER, V. (2011) “El aprendizaje por competencias y su coordinación en los estudios de Derecho”, Anuario de la Facultad de Derecho (Universidad de Alcalá), núm. 4. Madrid: Universidad de Alcalá.

${ }^{16}$ Exponen sus fundamentos en aplicación a una experiencia real, VIDAL SALAZAR, M.D., FERRÓN VÍLCHEZ, V., LEYVA DE LA HIZ, D.I. (2014), “Promoviendo el aprendizaje activo del alumnado universitario mediante el trabajo autónomo”, AAVV, Prácticas de innovación docente en ciencias sociales y jurídicas. Granada: Comares, pp. 41-47.

${ }^{17}$ Remarca la importancia de que el alumno vaya tomando decisiones, PÉREZ DE ALBÉNIZ ITURRIAGA, A. (2015), et al, “Metacognición en un proceso de aprendizaje autónomo y cooperativo en el aula universitaria”, Contextos educativos: Revista de educación, núm. 18. La Rioja: Universidad de La Rioja. Nos movemos, por otra parte, en los postulados de lo que los norteamericanos denominan cooperative learning (aprendizaje cooperativo). Sobre sus características, ORDEÑANA GEZURAGA, I. (2010), "Mediation: an adequate tool to solve consumer dispute", AAVV (Ed. IATED), EDULEARN 2010 Proceedings. Barcelona: IATED.

${ }^{18}$ En este sentido, TEJADA FERNÁNDEZ, J. (2002), "El docente universitario ante los nuevos escenarios: implicaciones para la innovación docente”, Acción Pedagógica, núm. 2. Venezuela: Universidad de los Andes.

${ }^{19}$ No en vano, con la configuración actual y vigente, cada crédito de las asignaturas supone 10 horas de docencia en el aula y 15 de trabajo externo.

${ }^{20}$ Literal, con mucho soporte bibliográfico, ESCRIBANO GONZÁLEZ, A. (1995), “Aprendizaje cooperativo y autónomo en la enseñanza universitaria”, Enseñanza \& Teaching: Revista interuniversitaria de didáctica, núm. 13. Salamanca: Universidad de Salamanca.
}

(c)) EY-NC-ND 2018, Universitat Politècnica de València 


\subsubsection{Líneas básicas del plan.}

Con las premisas expuestas, los 16 miembros del equipo del proyecto de innovación docente hemos planificado una serie de actividades divididas por cursos y asignaturas, basadas en la metodología del aprendizaje activo y autónomo para trabajar (y adquirir, obviamente) las competencias vinculadas al TFG, que -repetimos- son, al tiempo, esenciales en el Grado en Derecho.

Estamos ante un plan o sistema de actuación que abarca todos los módulos, cursos y materias del Grado en Derecho; así tiene que ser pues pretendemos entrenar conscientemente a nuestros alumnos y alumnas para realizar y superar sin problema alguno el TFG, por ser ello la mejor evidencia de que, además de gestionar su propio aprendizaje, detentan las competencias más importantes del jurista.

En este marco el equipo docente vamos a convertirnos en meros facilitadores o instructores, ayudando a los y las estudiantes a buscar los instrumentos necesarios para superar las dificultades que se les planteen. Deben ser ellos los protagonistas de su aprendizaje, adquiriendo un rol o intervención primordial en el establecimiento de los objetivos, recursos, procedimientos, y evaluación del mismo. Deben partir de sus conocimientos actuales, para con nuestra ayuda, construir los futuros. Sólo así estarán preparados para ser los verdaderos protagonistas de su TFG.

Esta planificación se ha realizado teniendo en cuenta los siguientes criterios:

a)Realidades de las asignaturas concretas (curso, metodología, temario, nivel de dificultad,...)

b)Necesidades y capacidades del estudiantado.

c)Características de los grupos de alumnado.

d)Tiempo dedicable al proyecto de innovación educativa.

En aplicación de los mismos, se ha programado una actividad por cada asignatura de los tres módulos precedentes dirigida directamente a preparar la confección del TFG, trabajando conscientemente las competencias que requiere éste. Todas las actividades están coordinadas y directamente relacionadas. Cabe apuntar, además, que conforme a nuestra planificación todo el alumnado del Grado en Derecho -sin perjuicio del curso en el que se encuentre, y por tanto, más o menos cerca del TFG- va a estar trabajando consciente y coordinadamente las competencias básicas del Grado, que coinciden básicamente con las vinculadas al TFG.

En el primer curso, en las tres asignaturas involucradas en el proyecto (Historia del Derecho, Derecho Romano y Teoría del Derecho), se van realizar tareas de síntesis y esquematización de sentencias y textos jurídicos básicos, presentes y pasados, en grupo e individualmente. Así mientras en Historia del Derecho se les va a pedir que hagan un resumen del contenido del Fuero Viejo de Vizcaya, en Derecho Romano van a esquematizar las Leyes Licinias.Por su parte, en Teoría del Derecho van a leer y resumir una sentencia del Tribunal Constitucional. En las tres asignaturas se va a hacer especial hincapié en que la capacidad de comprensión y síntensis es esencial en el Grado en Derecho. Únicamente la actividad de Teoría del Derecho será individual; las otras dos serán grupales.

Con mayor exigencia y dedicación, el segundo curso, en Introducción al Derecho Procesal, Derecho Administrativo, Derecho Internacional Público y Derecho Constitucional, en el marco del proyecto de innovación docente que estamos describiendo, 
el alumnado va a redactar, en grupo, textos jurídicos relativos a cuestiones controvertidas actuales (independencia judicial, déficit y servicios públicos, guerras olvidadas, modificación constitucional...) para, posteriormente, defenderlos en un debate público. Concretamente, en Introducción al Derecho Procesal se va a trabajar sobre una noticia periodística en relación a la objetividad judicial; en Derecho Administrativo un bando municipal se va a convertir en la excusa para que el estudiantado presente alegaciones en contra del mismo; en Derecho Internacional Público van analizar la situación del Yemen, para remitir a la ONU misivas solicitando que se ponga atención a la guerra olvidada que vive este país. Por último, en Derecho Constitucional, se va a proponer, por escrito, una reforma constitucional, dividiendo, al efecto, al alumnado en grupos correspondientes al arco de partidos políticos existentes en España. En todas las actividades, además de articular un texto grupal con un índice, cuerpo central y conclusiones, el estudiantado tendrá que defender su contenido en un debate público colectivo, actuando como moderador/a el docente correspondiente.

Superado el ecuador del Grado en Derecho, el tercer curso, al tiempo que los estudiantes trabajan las asignaturas más jurídicas (Derecho Procesal Civil, Derecho Procesal Penal, Derecho Penal, Derecho Laboral y Derecho Internacional Privado) aprovecharemos las clases prácticas de las mismas para que configuren escritos de posiciones diversas y textos judiciales, en grupo e individualmente. A todos ellos, les seguirán defensas públicas, individuales y grupales, y los consiguientes debates. Concretamente, en Derecho Procesal Civil, redactarán grupalmente un escrito de demanda y en Derecho Procesal Penal, individualmente, un escrito de acusación. En Derecho Penal realizarán escritos de calificación individualmente y en Derecho Laboral redactarán un convenio colectivo en grupo. Por último, en Derecho Internacional Privado, individualmente, cada alumno se pondrá en el lugar de un letrado/a que solicita alimentos en el supuesto de un divorcio internacional. Todos los profesores y profesoras implicados en este proyecto de innovación educativa encargados de estas asignaturas harán expresamente hincapié al alumando en la necesidad de trabajar la capacidad de análisis crítico, interrelación e integración de conocimientos jurídicos; la comunicación oral y escrita; y la capacidad de síntesis y exposición, con utilización de técnicas de argumentación y razonamiento crítico. Se les exigirá, al tiempo ,que sean capaces de gestionar el propio proceso de aprendizaje, tomando las decisiones pertinentes de forma madura, coherente y crítica.

Ya, el último curso, el primer cuatrimestre, y antes de realizar el TFG, en el segundo, en el transcurso de las últimas asignaturas del Plan de estudios (Derecho Financiero, Derecho Civil IV y Derecho Mercantil) se realizarán breves trabajos de investigación y defensa pública sobre cuestiones no estudiadas en el aula, pero directamente relacionadas con ellas, sobre temas planteados por el propio alumnado. Se trata de emular la actividad que va a exigir el TFG a continuación, sirviendo de entrenamiento -mejor calentamiento- previo. En los tres casos se va a seguir la misma dinámica exigida para los TFGs, si bien adaptada a su condición de ejercicio preparatorio (la extensión va a ser dos tercios menos que la exigida al TFG; las tutorías de preparación van a ser colectivas y las defensas en el aula y con posibilidad de intervención del resto de alumnado).

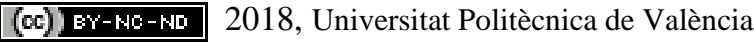




\section{Resultados}

Con el proyecto de intervención en el aula que les estamos describiendo vivo y sin culminar, con las actividades desarrolladas hasta el momento, podemos destacar los siguientes resultados:

1. Constatación clara del problema, que hemos convertido en reto: la preocupación y sospecha inicial del equipo docente involucrado (las taras del alumnado para encarar el TFG) ha venido avalada por las primeras fases del proyecto, en general, y en especial, por la constatación, de manera objetiva, de las debilidades que muestra el estudiantado cuando se enfrenta al TFG.

2. Pleno acierto en la puesta en marcha del proyecto de innovación docente: el reto que nos planteamos exige una actividad conjunta y coordinada del claustro del Grado en Derecho de la Facultad de Derecho de la UPV/EHU. Se han dado los primeros pasos, al respecto, y en lo consiguiente, se realizarán los posteriores encaminados a obtener los resultados de aprendizaje mentados.

3. Planificación completa, sistemática y coordinada de una serie de actividades a desarrollar en el marco de todos los módulos que integran el Grado en Derecho, a lo largo de sus cuatro cursos: el proyecto que les hemos descrito tiene el valor fundamental de suponer la primera ocasión en que todas las asignaturas que integran el plan de estudios del Grado en Derecho se coordinan dirigidas a obtener un resultado común. Ha sido esencial, en este sentido, la labor -y la paciencia- de los 16 profesores y profesoras involucrados en el proyecto. Tras muchas discusiones y debates, hemos conseguido configurar un proyecto común que comparte objetivos (adquirir las competencias mentadas) y metodología (aprendizaje activo y autónomo)

\section{Conclusiones}

En el momento en el que nos encontramos en la implementación del proyecto de innovación docente que les hemos descrito, en este prestigioso foro del IN-RED 2018, y desde la perspectiva de la coordinación del mismo, queremos presentar las siguientes conclusiones:

1. El equipo docente involucrado en el proyecto entiende esenciales para el jurista las competencias que se vinculan al TFG: 1)capacidad de análisis crítico, interrelación e integración de conocimientos jurídicos; 2)capacidad de comunicación oral y escrita; 3) capacidad de síntesis y exposición, con utilización de técnicas de argumentación y razonamiento crítico y 4) gestión del propio proceso de aprendizaje hacia una formación integral y respetuosa con los valores democráticos. Son las competencias aceptadas por el ANECA al verificar el plan de estudios del Grado en Derecho de la UPV/EHU y que, al tiempo, entendemos imprescindibles en la formación del futuro jurista.

2. El equipo docente involucrado y el alumnado consultado avienen que, en la actualidad, en los años que lleva en vigor el nuevo plan de estudios del Grado en Derecho, de la mano del Espacio Educativo Europeo Superior, no se está garantizando la adquisición plena, por parte del estudiantado, de las competencias mentadas.

3. Por ende, resulta esencial la intervención en el aula, al efecto. El proyecto de innovación educativa que se ha descrito está llamado a garantizar que el futuro jurista adquiere competencias que le son esenciales y que se vinculan especialmente con el TFG.

(cc) EY-NC-ND 2018, Universitat Politècnica de València

Congreso IN-RED (2018) 
4. La intervención mentada no puede ser aislado o individual, más debe ser colectiva, sistemática y coordinada.

5. El aprendizaje activo y autónomo consciente y planificado puede ser la metodología adecuada para que el estudiantado adquiera las competencias mentadas.

\section{Referencias}

DEL CARMEN LEVí ORTA, G., RAMOS MÉNDEZ, E., "Componentes de las competencias en los nuevos grados de algunas universidades españolas", Revista de educación (2013), núm. 362. Madrid: Ministerio de Educacion, Cultura y Deporte.

ESCRIBANO GONZÁLEZ, A. (1995), “Aprendizaje cooperativo y autónomo en la enseñanza universitaria”, Enseñanza \& Teaching: Revista interuniversitaria de didáctica, núm. 13. Salamanca: Universidad de Salamanca.

ESTEBAN ALBERT, M., SÁEZ CARRERAS, J., "Las profesiones, las competencias y el mercado", REDU: Revista de Docencia Universitaria (2008), núm. 2. Valencia: Universidad Politécnica.

GARCÍA MARTÍNEZ, J. (2007), "Las competencias y la nueva organización de la enseñanza”, en AAVV (Coor. LEÓN BENÍTEZ, M.R.), La Licenciatura de Derecho en el contexto de la convergencia europea. Valencia: Tirant lo Blanch, pp. 168-173.

GOÑI ZABALA, J.M. (2005), El Espacio Europeo de Educación Superior, un reto para la Universidad. Barcelona: Octaedro, p. 105 y ss.

GOYES MORENO, I. (2013), “Competencias pedagógicas para la formación jurídica por competencias”, Academia: revista sobre enseñanza del derecho de Buenos Aires, núm. 21. Buenos Aires: Facultad de Derecho de la Universidad de Buenos Aires.

GUZMÁN MARÍN, F., "El concepto de competencias", Revista Iberoamericana de Educación (2012), núm. 4. Iberoamérica: Organización de Estados Iberoamericanos para la Educación, la Ciencia y la Cultura.

LUIS MANRÍQUEZ P. “¿Evaluación en competencias?”, Estudios pedagógicos (2012), núm. 1, Chile: Facultad de Filosofía y Humanidades Universidad Austral de Chile.

ORDEÑANA GEZURAGA, I. (2010), "Mediation: an adequate tool to solve consumer dispute”, AAVV (Ed. IATED), EDULEARN 2010 Proceedings. Barcelona: IATED

PÉREZ DE ALBÉNIZ ITURRIAGA, A. (2015), et al, “Metacognición en un proceso de aprendizaje autónomo y cooperativo en el aula universitaria", Contextos educativos: Revista de educación, núm. 18. La Rioja: Universidad de La Rioja.

RIBAS FERRER, V. (2011) "El aprendizaje por competencias y su coordinación en los estudios de Derecho”, Anuario de la Facultad de Derecho (Universidad de Alcalá), núm. 4. Madrid: Universidad de Alcalá.

TEJADA FERNÁNDEZ, J. (2002), "El docente universitario ante los nuevos escenarios: implicaciones para la innovación docente”, Acción Pedagógica, núm. 2. Venezuela: Universidad de los Andes. 
Una experiencia de coordinación dirigida a trabajar las competencias necesarias para superar con éxito el Trabajo de Fin de Grado en Derecho

VIDAL SALAZAR, M.D., FERRÓN VÍLCHEZ, V., LEYVA DE LA HIZ, D.I. (2014), "Promoviendo el aprendizaje activo del alumnado universitario mediante el trabajo autónomo”, AAVV, Prácticas de innovación docente en ciencias sociales y jurídicas. Granada: Comares, pp. 41-47.

ZABALZA, M.A. (2009), Competencias docentes del profesorado universitario. Calidad y desarrollo profesional, 4. ed. Madrid: Narcea.

(c) EY-NC-ND 2018, Universitat Politècnica de València 


\title{
Integrando la competencia transversal responsabilidad ética, medioambiental y profesional en una asignatura de Máster
}

\author{
María de Miguel Molina ${ }^{a}$, Blanca de Miguel Molina ${ }^{b}$, Ángel Peiró Signes ${ }^{c}$ y Marival \\ Segarra Oña ${ }^{d}$ \\ ${ }^{a}$ Departamento de Organización de Empresas, Universitat Politècnica de València, \\ mademi@omp.upv.es, 'bepartamento de Organización de Empresas, Universitat Politècnica de \\ València, bdemigu@omp.upv.es, ' ${ }^{\circ}$ Departamento de Organización de Empresas, Universitat \\ Politècnica de València, anpeisig@omp.upv.es, ${ }^{\mathrm{d}}$ Departamento de Organización de Empresas, \\ Universitat Politècnica de València, maseo@omp.upv.es
}

\begin{abstract}
Usually, it is difficult to include in Master level some activities to promote the general competence "professional and social responsibility", because at the academic environment we frequently prepare activities to apply technical knowledge rather than "common sense". However, experiential learning, involving the student in a "real case study", can help them to interiorize that ethical knowledge in a practical way. Moreover, using learning tools such as LEGO Serious Play ${ }^{\circledR}$ enhances participation and decision-making in groups. Our goal is that the master students will be able to make a decision that affects people's lives in the most human way, without losing the opportunity that some technical advances can represent to improve the welfare of everybody.
\end{abstract}

Keywords: ethical responsibility, environmental responsibility, professional responsibility, experiential learning, sustainable development goals

\section{Resumen}

El integrar en las asignaturas de máster actividades que promuevan la competencia transversal "responsabilidad profesional y social" no es una tarea sencilla. En el ámbito académico, no siempre se dan situaciones en las que el alumno deba aplicar su "sentido común" sino más bien conocimientos técnicos. Sin embargo, el aprendizaje experiencial en el que el alumno se vea envuelto en un caso "real", puede servir para que interiorice estos conocimientos de una manera práctica. Además, el uso de metodologías como LEGO Serious Play ${ }^{\circledR}$ fomenta la participación y la toma de decisiones en grupo. Nuestro objetivo es que los alumnos de máster sean capaces de tomar una decisión que afecta a las personas de la manera más humana posible, 
sin perder de vista la oportunidad que determinados avances tecnológicos pueden prestar para mejorar la calidad de vida de todas las personas.

Palabras clave: responsabilidad ética, responsabilidad medioambiental, responsabilidad profesional, aprendizaje experiencial, objetivos de desarrollo sostenible.

\section{Introducción.}

Las competencias genéricas o transversales, representan una combinación dinámica de conocimiento, comprensión, habilidades y aptitudes (European Union, 2017). Dentro de ellas, la competencia "responsabilidad ética, medioambiental y profesional", se refiere al conjunto de conocimientos, habilidades, destrezas y actitudes (Universitat Politècnica de València, 2017):

- Útiles para interactuar con el entorno, en orden a evitar o disminuir los efectos negativos producidos por las prácticas inadecuadas que ocasiona la actividad humana y para promover los beneficios que pueda generar la actividad profesional en el ámbito medioambiental, teniendo en cuenta sus implicaciones económicas y sociales.

- Que orientan la acción humana en un sentido racional, por lo que se relaciona con las acciones y su valor moral.

- Que posibilitan una valoración positiva o negativa por el impacto ecológico de una decisión o no decisión (generalmente, al daño causado a otras especies, a la naturaleza o a las futuras generaciones), sea individual o en grupo.

- Que nos ayudan a interiorizar en nuestra conciencia una responsabilidad con dos objetivos primordiales: evitar toda falta voluntaria y disminuir, en lo posible, el número de faltas involuntarias por debilidad humana, flaqueza propia o negligencia ajena.

En este caso particular, para los alumnos del Máster Universitario en Gestión de Empresas, Productos y Servicios de la Facultad de ADE, hemos seguido un esquema circular, en el que la ética es un concepto que se aplica tanto de manera individual como colectiva, lo que hace que el beneficio sea mutuo. Si el individuo en su vida normal, como persona y ciudadano, actúa de manera ética, lo hará también a nivel profesional. Despúes, llevará esa práctica a la empresa y la empresa beneficiará a la sociedad. De este modo, esa cultura social se irá transmitiendo a los individuos que, en ese contexto, sabrán qué actuaciones son éticas y cuáles no. Así, el ciclo se retroalimenta (Figura 1).

(cc) EY-NC-ND 2018, Universitat Politècnica de València

Congreso IN-RED (2018) 


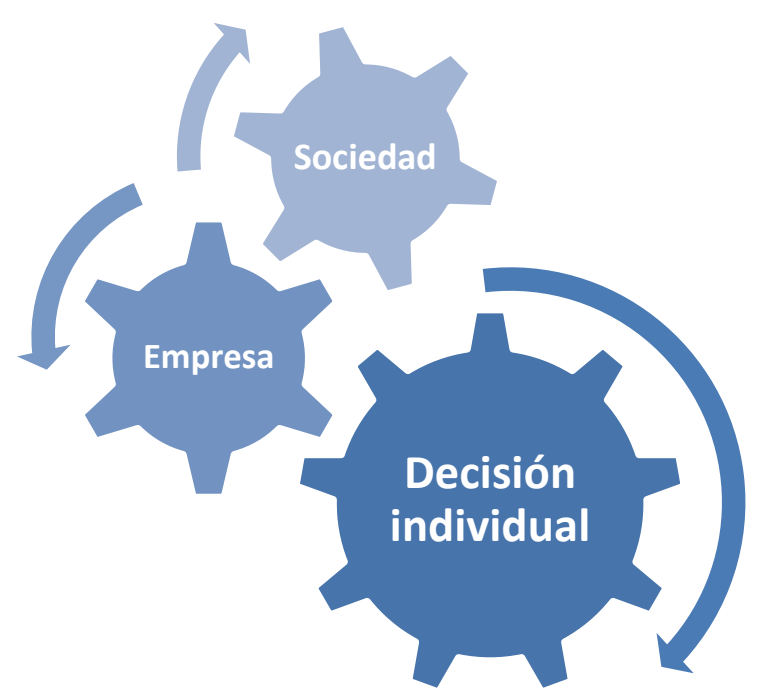

Fig. 1. Esquema circular de la actuación ética.

Fuente: elaboración propia.

\section{Objetivos y metodología.}

Los objetivos que se quisieron cumplir son los propios del tema que se trataba, y que fueron cuatro:

- $\quad$ 01: Analizar el papel social que representa la empresa en su entorno, como motor de un desarrollo local sostenible, desde el punto de vista económico.

- O O2: Conocer qué es la ética empresarial y la necesidad de una cultura empresarial basada en ella.

- O3: Impulsar la responsabilidad individual de los directivos y potenciar un modelo de liderazgo enfocado hacia las personas, a través de la colaboración interna y externa. En este caso, tomando decisiones que afectaban a las personas, su privacidad, y el medio ambiente.

- O4: Relacionar esas decisiones con las oportunidades que brindan las tecnologías de la información para cumplir con los Sustainable Development Goals (SDGs), objetivos de desarrollo sostenible. Estos objetivos son promovidos por las Naciones Unidas, tal como muestra la International Telecommunication Union (ITU, 2017).

Para cumplir cada uno de estos objetivos, a través de la metodología LSP se fueron proponiendo varios "retos":

O1: representar una empresa que actúe de manera ética.

(cc) B EY-NC-ND 2018, Universitat Politècnica de València 
O2: a partir de los conocimientos teóricos que se explican en el aula, representar la empresa tomando el punto de vista del "bien común".

O3: tener en cuenta los grupos de interés que pueden estar afectados por la actividad empresarial que se quiere desarrollar.

O4: detectar qué SDGs se cubren con la propuesta final.

Para alcanzar los objetivos que nos proponemos, hemos creído que la mejor manera es aplicar el Aprendizaje experiencial (Kolb, 2014). Para ello, de acuerdo con De Miguel et al. (2015), la herramienta LEGO Serious Play (LSP) logra que los alumnos, a través del proceso de la herramienta, participen al 100 \%. Además, fomenta la creatividad del grupo y consigue una mayor eficiencia en los objetivos de aprendizaje y en la gestión de la comunicación grupal. Además, otros autores como Mabogunje et al. (2008) o Swann (2011), también han utilizado LSP para la toma de decisiones de una manera más participativa.

La metodología LSP parte de la creación de grupos de trabajo de no más de 6 personas. A partir de estos grupos, los retos se resuelven primero de una manera individual, y después de forma colectiva, teniendo que llegar a un acuerdo sobre el modelo final propuesto.

\section{Desarrollo de la innovación.}

En primer lugar, se les dio a los alumnos una breve introducción sobre los conceptos que se iban a tratar, diferenciando la responsabilidad colectiva (responsabilidad social corporativa o corporate social responsibility-CSR) de la responsabilidad individual (profesional).

Siguiendo la clasificación de Garriga y Melé (2004), se exponen las teorías sobre CSR en cuatro grupos:

A) Teorías instrumentales: las que se centran en conseguir objetivos económicos a través de actividades sociales. En estas teorías podríamos encontrar, por ejemplo, negocios recientes que se han basado en dar servicios o beneficiar a personas de bajo nivel económico ("The Fortune at the Bottom of the Pyramid”-BoP).

B) Teorías políticas: las que buscan un uso responsable del poder empresarial en el plano político-social. Estas teorías podrían incluir tanto las posiciones extremas de los movimientos anti-globalización, como aquellas promovidas desde organismos internacionales para concienciar a las empresas y lograr un compromiso social.

C) Las teorías integradoras: lo que pretenden es que se cubran las demandas sociales que en cada momento/país/comunidad se demanden. Su visión se centra en lo local o aquello que le afecte, teniendo en mente obtener la mejor ventaja competitiva.

D) Las teorías éticas: se centran en que solo la búsqueda del bien común es la manera de alcanzar una buena sociedad. Y para lograr el bien común hay que pensar en todos los grupos de interés (stakeholders) que se puedan ver afectados por la actividad empresarial. En su revisión del estado del arte sobre la “teoría de los stakeholders”, Freeman et al (2010)

(cc) EY-NC-ND 2018, Universitat Politècnica de València

Congreso IN-RED (2018) 
conciben ésta como una teoría aplicada a la práctica de la empresa y a la toma de decisiones de sus directivos, donde cada situación debe analizarse. Aboga por poner a la ética en el centro de la empresa y a la empresa en el centro de la ética, siendo una teoría pragmática donde no se contemplan ética y empresa como elementos aislados sino interdependientes. Dentro de estas teorías éticas, también se encontraría la de Desarrollo Sostenible propuesta por Bruntland (1987), para quien es necesario no olvidar el desarrollo de las generaciones futuras.

En el caso de los negocios internacionales, no todos los países tienen el mismo concepto de cómo hacer negocios. Entonces, ¿cómo se puede enfrentar una empresa o directivo ante un dilema ético en otro país? De acuerdo con el relativismo, nos adaptaríamos a la cultura del país en cuestión (si el país es corrupto, solo cabe ceder a la corrupción). Por otro lado, según el imperialismo sólo la forma de pensar propia (normalmente occidental) es válida y no hay que tener en cuenta la cultura de dicho país. Sin embargo, si pensamos en el respeto a los derechos humanos, una cultura intermedia nos llevaría a intentar entender la cultura de ese país pero sin dejarnos llevar a posturas que dañen más que mejoren la situación y/o que ataquen los bienes éticos universales.

De este modo, con el uso de la herramienta LSP, se les propone trabajar en grupo para resolver este reto:

En la actualidad, el "Internet de las cosas" (The Internet of Things-IoT) permite que determinados aparatos, en base a una extensa red de datos personales, presten servicios sin ayuda humana. El desarrollo de este modelo de negocio también ha llegado a los países en vías de desarrollo (BoP), lo que puede plantear oportunidades y amenazas para sus ciudadanos.

En base a algunos ejemplos subidos al espacio PoliformaT de la asignatura, se les plantea a los alumnos que, pensando en esas oportunidades y amenazas, pero sin repetir los ejemplos proporcionados, desarrollen un servicio de IoT, destinado a una comunidad que entre en el concepto de BoP, teniendo en cuenta varios aspectos:

- Que sea un servicio que pueda contribuir al desarrollo de la localidad.

- Que no suponga una invasión de la privacidad de los usuarios.

- Que sea medioambientalmente sostenible.

- Que pueda relacionarse con uno o varios de los SDGs.

En este caso, los grupos que se formaron fueron cuatro, y estuvieron compuestos por 4-6 alumnos, siendo un total de 20 alumnos. Al inicio de la actividad los alumnos están un poco desorientados porque, además de la dificultad del reto, el expresarlo con las piezas LEGO no es fácil para ellos (Imagen 1). Sin embargo, ese ejercicio intelectual les permite pensar bien todos los factores a tener en cuenta. 


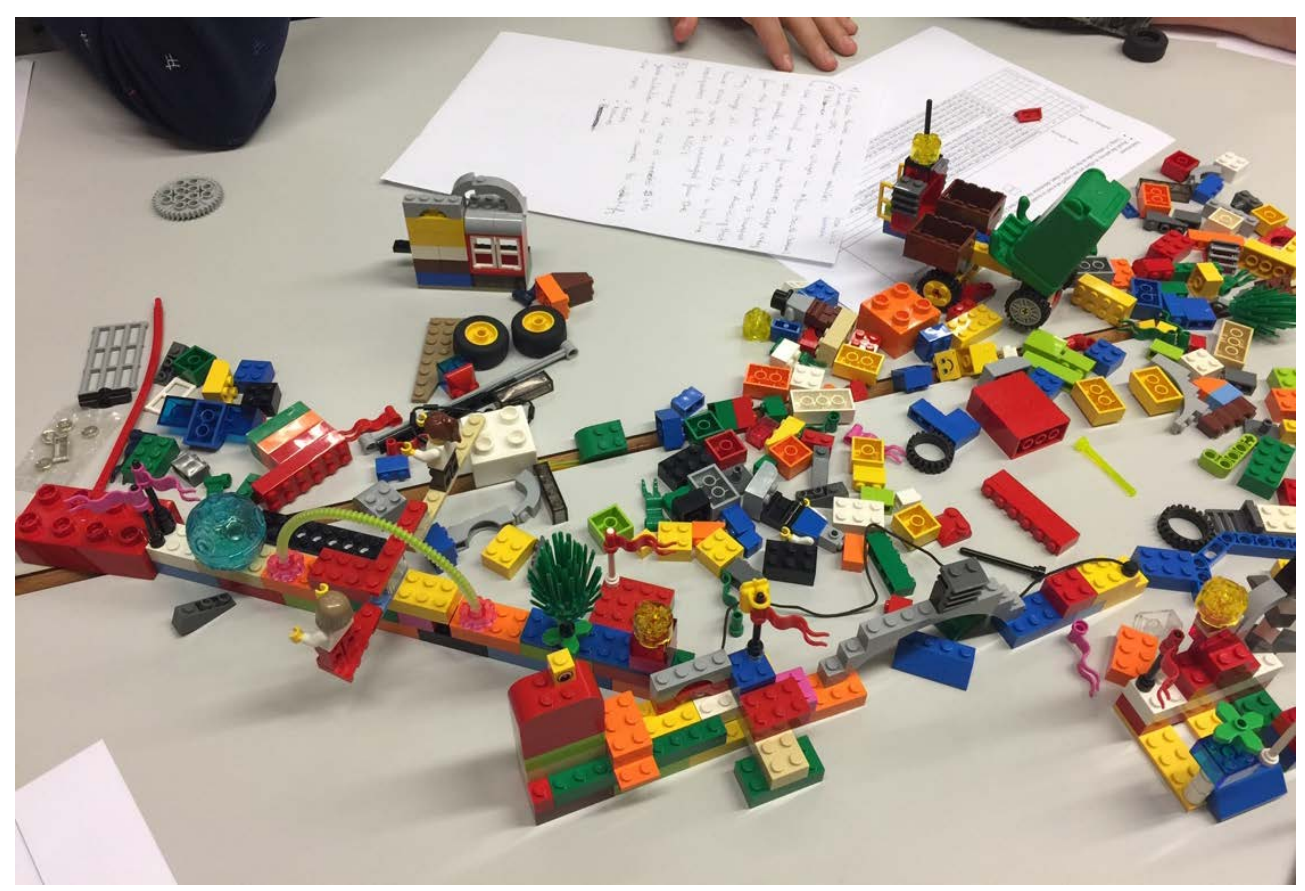

Imagen 1. Inicio de la actividad en grupo con las piezas LEGO.

Fuente: elaboración propia, curso 2017-2018.

Conforme va pasando la actividad, y con la ayuda del profesor (facilitador), el modelo va tomando forma y van integrando tanto los aspectos sociales como medioambientales, de manera que el resultado final es más rico de lo que podría pensarse en un inicio (Imagen 2).

\section{Resultados.}

El reto se desarrolla en 6 apartados:

1) Cuál es el producto o servicio que se va a ofrecer. Con qué tipo de recursos y/o energía va a funcionar. Tiene que enfocarse en un país o localidad con problemas de desarrollo. Debe ser un servicio basado en el IoT.

2) A qué personas irá destinado. Se debe de pensar en el concepto de BoP.

3) Qué tipo de datos personales son necesarios y cómo se va a manejar la información de los usuarios. Se debe de tener en cuenta el derecho a la privacidad, independientemente del país en el que nos encontremos.

4) Qué problemas éticos se pueden plantear.

5) De qué manera podrán resolverse.

6) Qué SDGs podrán cubrirse con este servicio. 


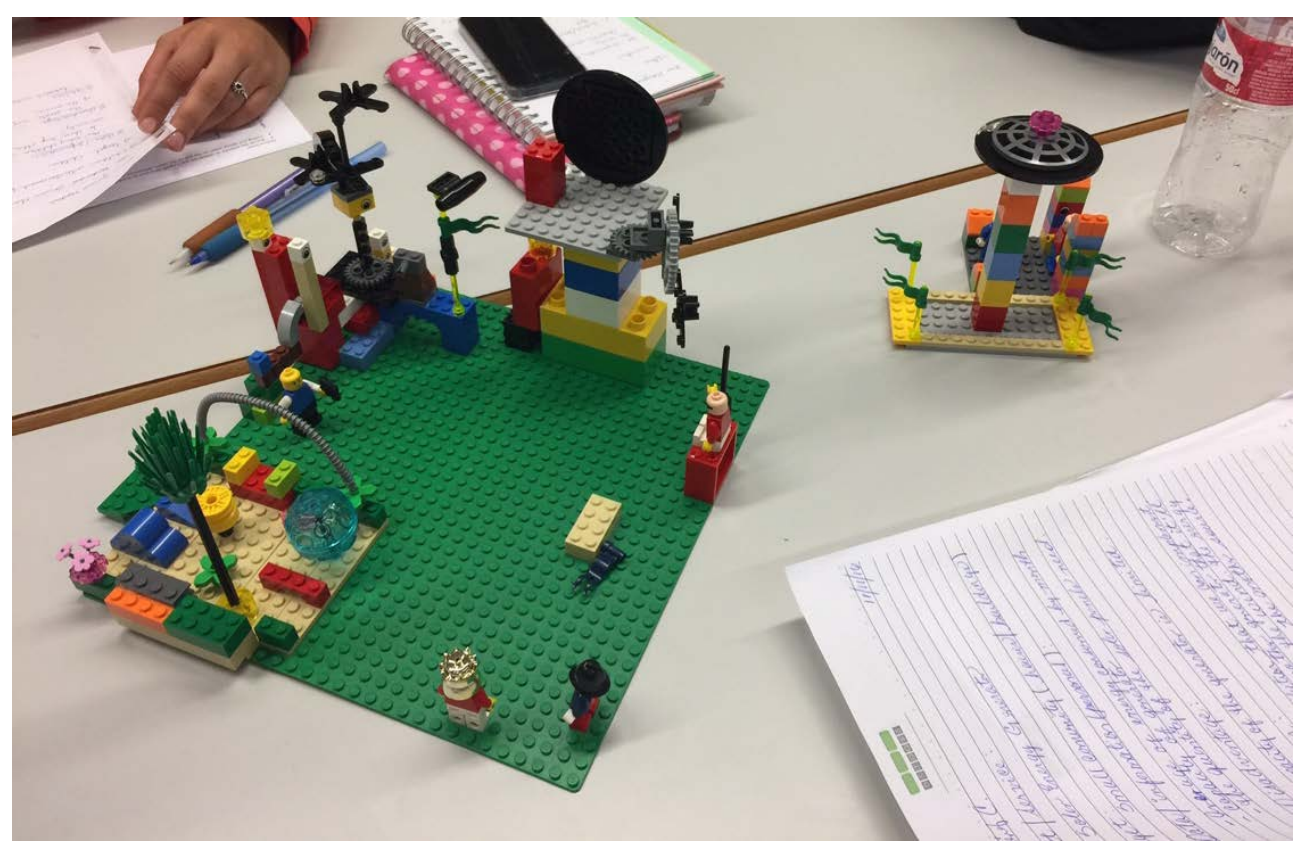

Imagen 2. Modelo propuesto por un equipo de alumnos.

Fuente: elaboración propia, curso 2017-2018.

Siguiendo el método LSP (De Miguel et al., 205), cada alumno piensa en un modelo pero después, en grupos de entre 4-6 alumnos, deben proponer un modelo común. Estos modelos se van presentando después entre los distintos grupos para lograr el feedback necesario para revisar el modelo.

Al final de esta actividad, se les pide un informe en el que expliquen los pasos que han seguido y que reflexionen sobre su decisión final (que puede ser justificada de manera distinta por cada grupo). De esta manera, podemos evaluar la competencia transversal "responsabilidad ética, medioambiental y profesional".

Como ejemplo, uno de los equipos propuso un servicio de reciclado en el que los ciudadanos pueden llevar materiales para ser reutilizados para la construcción. Estos materiales se emplearían para construir viviendas destinadas a familias pobres con menores a su cargo. Se podría hacer una aplicación (app) sencilla para saber qué materiales son necesarios, dónde dejarlos, cuándo van a estar las viviendas disponibles, cómo se va desarrollando la lista de espera, etc. De esta manera, las propias familias que reciclan se pueden ver beneficiadas. En este caso, se van a recopilar datos personales de los ciudadanos (nivel económico, menores a su cargo, domicilio, ubicación, etc), por lo que la protección de su privacidad es esencial. Esta propuesta se relacionaría, además, con los siguientes SGDs: No poverty-Industry Innovation and Infrastructure-Economic Growth-Climate. 


\section{Conclusiones.}

Si bien evaluar esta competencia siempre va a tener limitaciones, el ofrecer una práctica real en la que la toma de decisiones se base en la experiencia, tanto individual como grupal, puede ayudarnos a observar cómo los alumnos han interiorizado los conceptos explicados al inicio de la actividad.

De este modo, podemos decir que los objetivos planteados se han cubierto. En concreto:

- $\quad$ O1: se ha visto cómo la empresa puede ser motor de desarrollo incluso en entornos desfavorecidos.

- $\quad$ O2: se ha interiorizado cómo la ética empresarial es posible si la Alta Dirección lo promueve.

- O3: para el éxito de cualquier empresa, la colaboración interna y externa es primordial, y hay que tener en cuenta que las decisiones de la empresa afectan a las personas y el medio ambiente y, en este caso, además, a la privacidad de los usuarios.

- O4: relacionar esas decisiones con los Sustainable Development Goals (SDGs), nos ayuda a pensar de una manera global mientras se actúa en lo local.

Los modelos elaborados suelen ser muy ricos, en el sentido que la suma de la experiencia del grupo hace que se tengan en cuenta más factores y se presenten soluciones más creativas.

El resultado son modelos reales, que perfectamente podrían desarrollarse en países o localidad en desarrollo, de manera medioambientalmente sostenible y teniendo en cuenta la privacidad de sus usuarios. La evaluación se realiza teniendo en cuenta de qué manera han interiorizado todos los pasos y han aplicado los conceptos explicados al inicio de la sesión.

\section{Agradecimientos.}

Los autores desean agradecer a la UPV su apoyo a través del PIME 2018 “Adaptación y desarrollo de aprendizajes experienciales al contexto de las asignaturas”, dirigido por el profesor Ángel Peiró.

\section{Referencias}

DE-MIGUEL-MOLINA, M.; ALBORS-GARRIGÓS, J. CERVELLÓ-ROYO, R.; DE-MIGUELMOLINA, B.; SEGARRA-ONA, M.V. y PEIRÓ-SIGNES, A. (2015). Competencias transversales y Lego Serious Play: la necesidad de un enfoque adecuado. In-Red 2015 - Congreso de Innovación Educativa y Docencia en Red. Universitat Politècnica de València. $<$ http://dx.doi.org/10.4995/INRED2015.2015> [Consulta: 29 de marzo de 2017]

EUROPEAN UNION. Tuning Educational Structures in Europe (competences). $<$ http://www.unideusto.org/tuningeu/competences.html> [Consulta: 23 de marzo de 2017]

FREEMAN, R.E., HARRISON, J.S., WICKS, A.C., PARMAR, B.L. y DE COLLE, S. (2010). Stakeholder theory: The state of the art. Cambridge University Press.

(cc) EY-NC-ND 2018, Universitat Politècnica de València

Congreso IN-RED (2018) 
GARRIGA, E. Y MELÉ, D. (2004). Corporate Social Responsibility Theories: Mapping the Territory, Journal of Business Ethics, 53, pp. 51-71.

ITU. ICTs for a Sustainable World \#ICT4SDG. <http://www.itu.int/en/sustainableworld/Pages/default.aspx> [Consulta: 20 de noviembre de 2017]

KOLB, D.A. (2014). Experiential learning: Experience as the source of learning and development. FT press.

MABOGUNJE, A., HANSEN, P.K., ERIS, O. y LEIFER, L. (2008). Product Design and Intentional Emergence facilitated by Serious Play. DS 50: Proceedings of NordDesign 2008 Conference.

SWANN, D. (2011). NHS at Home: Using Lego Serious Play to Capture Service Narratives and Envision Future Healthcare Products. INCLUDE 2011 Proceedings.

UNIVERSITAT POLITÈCNICA DE VALÈNCIA. Competencias Transversales, competencia responsabilidad ética, medioambiental y profesional. $<$ http://www.upv.es/contenidos/COMPTRAN/info/954882normalc.html> [Consulta: 29 de marzo de 2017] 


\title{
La resolución de problemas con distintos actores: una actividad basada en la economía colaborativa
}

\section{María de-Miguel-Molina ${ }^{a}$ y Daniel Catalá-Pérez}

${ }^{a}$ Departamento de Organización de Empresas, Universitat Politècnica de València, mademi@omp.upv.es, 'bepartamento de Organización de Empresas, Universitat Politècnica de València, dacape@omp.upv.es

\begin{abstract}
The collaborative economy presents new business models through digital platforms that sometimes fight with services that have traditionally been provided with strong regulation. This may be the case of the taxi sector, which requires to be reformulated in order to be competitive. In this activity, we analyze the need to raise these issues through a governance model where all stakeholders can express their opinions, trying to achieve solutions as consensual as possible. This requires an analysis of the regulations involved and the opinions of the users, without losing sight of the economic groups in conflict. In order to achieve this consensus, the public administration will play a crucial role in the future.
\end{abstract}

Keywords: collaborative economy, stakeholders, transport, regulation, public administration, public-private partnerships.

\begin{abstract}
Resumen
La economía colaborativa presenta nuevos modelos de negocio a través de plataformas digitales que, en ocasiones, chocan con servicios que tradicionalmente se han prestado con una fuerte regulación. Este puede ser el caso del sector del taxi, que precisa de una reformulación para poder ser competitivo. En esta actividad, se analiza la necesidad de plantear estos temas a través de un modelo de gobernanza donde todos los grupos de interés puedan expresar su opinión y se intenten conseguir soluciones lo más consensuadas posible. Ello requiere un análisis de la normativa implicada y de la opinión de los usuarios, sin perder de vista los grupos económicos en conflicto. Para lograr este consenso, el papel que juegue la administración pública en el futuro será fundamental.
\end{abstract}

Palabras clave: economía colaborativa, grupos de interés, transporte, regulación, modelos de colaboración público-privada. 


\section{Introducción}

De acuerdo con la Comisión Europea (2016: 3), la economía colaborativa se basa en,

"modelos de negocio en los que se facilitan actividades mediante plataformas colaborativas que crean un mercado abierto para el uso temporal de mercancías o servicios ofrecidos a menudo por particulares. La economía colaborativa implica a tres categorías de agentes i) prestadores de servicios que comparten activos, recursos, tiempo y/o competencias pueden ser particulares que ofrecen servicios de manera ocasional («pares») o prestadores de servicios que actúen a título profesional («prestadores de servicios profesionales»); ii) usuarios de dichos servicios; y iii) intermediarios que -a través de una plataforma en línea - conectan a los prestadores con los usuarios y facilitan las transacciones entre ellos («plataformas colaborativas»). Por lo general, las transacciones de la economía colaborativa no implican un cambio de propiedad y pueden realizarse con o sin ánimo de lucro".

A pesar de esta extensa explicación, el concepto no cuenta con la unanimidad académica y determinados servicios se consideran o no "economía colaborativa" en función del autor y de las distintas interpretaciones que han realizado los tribunales.

Para Doménech (2015: 66),

"La causa principal del surgimiento de la economía colaborativa es.. el espectacular progreso experimentado por las tecnologías de la información, que ha posibilitado abaratar exponencialmente las actividades de obtención, almacenamiento, procesamiento y comunicación de información que los interesados han de llevar a cabo para colaborar en la producción y consumo de bienes y servicios, intercambiándolos o compartiéndolos”.

Dentro de la economía colaborativa, el sector del transporte, y concretamente el transporte público, se ha visto salpicado por distintas interpretaciones, normativas, e incluso conflictos debido al impacto de la economía digital. Y, específicamente, el transporte público de taxis en España ha sido objeto de fuertes disputas.

Servicios de transporte de pasajeros, como Uber o Cabify, han tenido un impacto distinto en función del Estado Europeo en el que nos encontremos y, dentro de España, en cada comunidad autónoma. Incluso, más allá de estos conflictos, nos podemos preguntar si este caso entraría o no dentro de la economía colaborativa.

Más aún, el Tribunal de Justicia de la Unión Europea, en sentencia de 20 de diciembre de 2017, en el asunto de la Asociación Profesional Élite Taxi contra Uber Systems Spain, S.L. (TSJUE, 2017), falló en contra de Uber, indicando que no era un servicio de intermediación ni una libre prestación de servicios y cualquiera no puede darse de alta.

Por ello, siendo tantos los grupos de interés implicados en ello, es un caso de análisis muy interesante para nuestros alumnos del Grado en Gestión y Administración Pública. Sin embargo, y según el punto de vista que tomemos, puede ser también de interés para otros Grados como Administración y Dirección de Empresas o Ingeniería Informática.

La economía colaborativa, fundamentalmente, reformula modelos de negocio que tradicionalmente hemos conocido de una manera, pero que el futuro les lleva a tener que

(cc) EY-NC-ND 2018, Universitat Politècnica de València

Congreso IN-RED (2018) 
reinventarse y replantearse cómo afrontar estos cambios. Blablacar, por ejemlo, es otro modelo sustitutivo completamente distinto, pero con el mismo objetivo. Y siendo un transporte público, el papel que juegue la administración pública también es fundamental.

\section{Objetivos}

La práctica, titulada "La guerra de los taxis", se planteó dentro del aula para trabajar en grupo, y se encuadró dentro del tema "La colaboración público-privada”, de la asignatura Dirección Estratégica de Organizaciones Públicas (Catalá Pérez, 2017), que se imparte en el $3^{\circ}$ curso del Grado en Gestión y Administración Pública.

El objetivo de la dinámica fue analizar un problema complejo y buscar soluciones de colaboración público-privada utilizando los mapas conceptuales móviles (De Miguel et al, 2017a), de manera que planteasen una solución en equipo. De este modo, se relacionaba este tema con otros dados en la asignatura como el trabajo en equipo o la gobernanza (De Miguel et al, 2017b), puesto que el conseguir el mayor consenso posible entre los grupos de interés cada vez resulta más necesario para dar legitimidad a las decisiones públicas.

Las tareas a desarrollar fueron cuatro:

1. Identificar problemas (el reto): ¿es posible un sistema de colaboración público-privada para el servicio de taxis? Ventajas e inconvenientes (¿para quién? Identificar los distintos actores).

2. Brainstorming de ideas: ¿qué soluciones de colaboración público-privada serían posibles? Votar las mejores para reducir las soluciones a máximo 3.

3. Captar nuevas ideas: los grupos van rotando para explicar sus soluciones y que los demás les den feedback.

4. Selección y revisión de una única solución de colaboración público-privada.

\section{Desarrollo de la innovación}

Para identificar los problemas, se les proporcionó a los alumnos diversas noticias extraídas de la prensa para analizar la situación:

- Conflictos con las licencias VTC (para arrendamiento de vehículos de turismo con conductor) para chóferes privados, pues su número ha ido variando con el tiempo lo que ha provocado paralizaciones de solicitudes y sentencias que, en ocasiones, han obligado a otorgarlas durante unos años (Fernández, 2017).

- Empresas que han planteado alternativas al taxi, como Uber o Cabify (Otero, 2017).

- Diferentes interpretaciones sobre lo que se considera "liberalizar el mercado" (Domínguez del Valle, 2017 y Herce, 2017).

- Nuevas demandas por parte de los usuarios (Esteve, 2016).

(cc)) EY-NG-ND 2018, Universitat Politècnica de València

Congreso In-Red (2018) 
- Regulación del taxi en España basada en un modelo de licencias muy caras frente a las VTC, traspaso o acumulación de licencias, grupos de taxistas divididos aunque han conseguido crear una app conjunta (MyTaxi, 2016).

Después de este análisis por equipos de 3-5 alumnos, los profesores repartieron unas tarjetas post-it de distintos tamaños, colores y formas para desarrollar cada punto de la práctica. En este caso, necesitaron 4 tipos diferentes.

1. Tras haber identificado los distintos problemas, los podían expresar con palabras clave o dibujos en notas móviles de un color determinado (en este caso naranja, Imagen 1). Era importante ponerse en la "piel" de los distintos actores para tomar perspectiva. En este sentido, también se analizaron las ventajas de cada servicio (en este caso rosa, Imagen 1).

2. De acuerdo con el proceso de resolución de problemas, los grupos buscaron soluciones de colaboración público-privada para cada problema por medio de la tormenta de ideas (brainstorming), de forma que se seleccioban como máximo 3 soluciones consensuadas. Dichas soluciones se expresaban también con palabras clave o dibujos en una nota móvil de otro color (en este caso azul, Imagen 1), y se conectaron con los problemas a resolver. En este momento, el profesor revisó los modelos de cada grupo para detectar información que faltase por completar. Al mostrar este modelo con las notas móviles pegadas en la pared, teníamos tres filas de ideas: problemas, ventajas y soluciones.

3. Con estas posibilidades, el resto de grupos se desplazaron por el aula para observar los modelos del resto de equipos y así poder obtener feedback de los compañeros. La mitad del grupo se quedaba en su sitio para explicar dudas a los "visitantes" o recoger las "recomendaciones" de sus compañeros. Acabada la ronda, cada grupo volvía a reunirse para enriquecer un modelo específico de colaboración público-privada con todas las ideas aportadas (Tabla 1). Se eligía y revisaba el que pensaban que podía cubrir mejor las "necesidades” de los "actores” que habían dado su feeback. Esta última solución se mostró en una cuarta fila con otro tipo de nota móvil (en este caso, más grande y de color verde, Imagen 1).

Tabla 1. Tipos de colaboración público-privada contractual

\begin{tabular}{|l|l|l|}
\hline TIPO & $\begin{array}{l}\text { TAREAS } \\
\text { OPERACIONES }\end{array}$ & DESCRIPCIÓN \\
\hline O\&M & Operate-Mantain & $\begin{array}{l}\text { El sector público contrata con un agente privado la gestión } \\
\text { y mantenimiento de un servicio específico. El sector } \\
\text { público retiene propiedad y gestión general de la instalación } \\
\text { o sistema público. }\end{array}$ \\
\hline DB & $\begin{array}{l}\text { Lesign-Build } \\
\text { La más básica de las fórmulas de CPP y la que menos } \\
\text { obligaciones y riesgos transfiere al sector privado. El agente } \\
\text { privado diseña y construye el proyecto. El organismo } \\
\text { público es responsable de la financiación, pero ahorra } \\
\text { costos y tiempo de realizarlo en contratos separados y } \\
\text { puede formalizar una operación de O\&M con el agente }\end{array}$ \\
\hline
\end{tabular}

(cc) EY-NC-ND 2018, Universitat Politècnica de València 


\begin{tabular}{|c|c|c|}
\hline & & privado u realizar estas tareas de forma interna. \\
\hline DBO & $\begin{array}{l}\text { Design-Build- } \\
\text { Operate }\end{array}$ & $\begin{array}{l}\text { Similar a la anterior excepto por que el agente privado } \\
\text { también gestiona el proyecto. La gestión de proyectos a } \\
\text { gran escala habitualmente requiere de una amplia } \\
\text { experiencia técnica y de importantes inversiones en } \\
\text { personal. Esta fórmula permite al sector público transferir } \\
\text { esta responsabilidad al agente privado, mientras mantiene } \\
\text { las de financiación de la construcción y del mantenimiento. }\end{array}$ \\
\hline DBM & $\begin{array}{l}\text { Design-Build- } \\
\text { Mantain }\end{array}$ & $\begin{array}{l}\text { Similar a la estructura DB, excepto en que el sector privado } \\
\text { también mantiene el proyecto. El sector público paga una } \\
\text { cantidad acordada por estos servicios y si se requieren más } \\
\text { fondos, suele ser responsabilidad del sector privado } \\
\text { asumirlos. Ser capaz de trasladar la responsabilidad de las } \\
\text { reparaciones al agente privado puede resultar en ahorros } \\
\text { significativos para el sector público. }\end{array}$ \\
\hline DBOM & $\begin{array}{l}\text { Design-Build- } \\
\text { Operate-Maintain }\end{array}$ & $\begin{array}{l}\text { El agente privado es responsable del diseño, construcción y } \\
\text { de la O\&M del proyecto. El sector público mantiene la } \\
\text { propiedad y es responsable de la financiación de la } \\
\text { construcción y obtiene la ventaja de transferir al agente } \\
\text { privado la responsabilidad sobre la gestión y el } \\
\text { mantenimiento. }\end{array}$ \\
\hline DBF & $\begin{array}{l}\text { Design-Build- } \\
\text { Finance }\end{array}$ & $\begin{array}{l}\text { Con este se adjudica un contrato por el diseño, la } \\
\text { construcción y la financiación total o parcial de una } \\
\text { instalación. La responsabilidad del mantenimiento a largo } \\
\text { plazo y la explotación de la instalación permanecen en el } \\
\text { sector público. Este enfoque permite al sector público } \\
\text { aplazar la financiación durante la fase de construcción del } \\
\text { proyecto. }\end{array}$ \\
\hline DBFO & $\begin{array}{l}\text { Design-Build- } \\
\text { Finance-Operate }\end{array}$ & $\begin{array}{l}\text { Esta estructura es similar a la estructura de DBO, excepto } \\
\text { que el agente privado también es responsable de la } \\
\text { financiación del proyecto. El agente privado puede cobrar } \\
\text { del organismo público o de los usuarios finales del } \\
\text { proyecto. }\end{array}$ \\
\hline DBFOM & $\begin{array}{l}\text { Design-Build- } \\
\text { Finance-Operate- } \\
\text { Maintain }\end{array}$ & $\begin{array}{l}\text { Bajo esta estructura, el agente privado es responsable del } \\
\text { diseño, construcción, financiación, gestión y mantenimiento } \\
\text { del proyecto durante un período especificado. En esta } \\
\text { estructura, el proyecto es propiedad del sector público. El } \\
\text { agente privado puede cobrar del organismo público o de los } \\
\text { usuarios finales del proyecto. }\end{array}$ \\
\hline DBFOMT & $\begin{array}{l}\text { Design-Build- } \\
\text { Finance-Operate- } \\
\text { Maintain- Transfer }\end{array}$ & $\begin{array}{l}\text { Esta estructura es similar al modelo DBFOM, excepto que } \\
\text { el sector privado posee el activo durante el plazo del } \\
\text { contrato de PPP después de lo cual la propiedad, operación } \\
\text { y mantenimiento son transferidos a la agencia pública. }\end{array}$ \\
\hline BOT & Build-Operate- & Un consorcio privado recibe licencia de la Administración \\
\hline
\end{tabular}




\begin{tabular}{|c|c|c|}
\hline & Transfer & $\begin{array}{l}\text { para financiar y construir un equipamiento, otorgándole al } \\
\text { mismo tiempo la concesión para explotarlo comercialmente } \\
\text { durante un determinado período. Finalizado el plazo de } \\
\text { concesión, la instalación pasará a depender de la } \\
\text { Administración Pública, quien deberá decidir si se encarga } \\
\text { directamente de su explotación o la cede a un operador } \\
\text { privado. El plazo de concesión se intenta establecer a priori } \\
\text { de forma que la entidad privada haya obtenido una } \\
\text { rentabilidad adecuada sobre la inversión inicial realizada. }\end{array}$ \\
\hline BTO & $\begin{array}{l}\text { Build-Transfer- } \\
\text { Operate }\end{array}$ & $\begin{array}{l}\text { Se trata de un sistema similar al anterior, pero en esta } \\
\text { ocasión las instalaciones para la prestación del servicio } \\
\text { pasan a ser propiedad de la Administración contratante, } \\
\text { inmediatamente, tras finalizar su construcción por el } \\
\text { operador privado. Éste tendrá el derecho a explotarlas } \\
\text { durante un cierto período, en virtud de un acuerdo de } \\
\text { arrendamiento a largo plazo que deberá concederle la } \\
\text { Administración Pública, al final del cual la Administración } \\
\text { debe decidir entre explotar el proyecto directamente o } \\
\text { volver a arrendarlo a un operador privado, que ahora no } \\
\text { tiene que ser la entidad que inicialmente lo desarrolló. }\end{array}$ \\
\hline BROT & $\begin{array}{l}\text { Build-Rent-Operate- } \\
\text { Transfer }\end{array}$ & $\begin{array}{l}\text { Se trata de una variante de los proyectos BOT ó BTO, en la } \\
\text { que el operador privado explota las instalaciones pero } \\
\text { arrienda los bienes físicos por la duración del acuerdo. }\end{array}$ \\
\hline BLOT & $\begin{array}{l}\text { Build-Lease- } \\
\text { Operate-Transfer }\end{array}$ & $\begin{array}{l}\text { Variedad del anterior método en la que en el arrendamiento } \\
\text { se contempla la posibilidad de que el arrendatario ejercite } \\
\text { una opción de compra. }\end{array}$ \\
\hline BOOT & $\begin{array}{l}\text { Build-Own-Operate- } \\
\text { Transfer }\end{array}$ & $\begin{array}{l}\text { En este caso, el operador privado se compromete a } \\
\text { financiar, construir, explotar y mantener una infraestructura, } \\
\text { a cambio del derecho a cobrar por ello a los usuarios. En } \\
\text { virtud de este acuerdo la entidad privada es propietaria de } \\
\text { las instalaciones y los bienes hasta el final de la concesión. } \\
\text { En cualquier caso, puede estar sujeta a restricciones legales } \\
\text { sobre su gestión o las tarifas a cobrar. }\end{array}$ \\
\hline BOO & Build-Own-Operate & $\begin{array}{l}\text { Variación de la fórmula BOOT; el operador privado es } \\
\text { propietario perpetuo del equipamiento y no tiene obligación } \\
\text { de traspasarlo a la Administración pero tiene la opción de } \\
\text { comprarlo. }\end{array}$ \\
\hline BBO & Buy-Build-Operate & $\begin{array}{l}\text { Un operador privado adquiere un activo a la Administración } \\
\text { Pública. Aquél se ocupa de la renovación o ampliación } \\
\text { necesarias del equipamiento para la prestación de un } \\
\text { servicio público, según la demanda, sin que se establezca un } \\
\text { momento de finalización. La entidad pública puede utilizar } \\
\text { el acuerdo de licencia para la prestación del servicio para } \\
\text { establecer las condiciones de acceso al servicio, seguridad, } \\
\text { tarifas e incluso qué instalaciones auxiliares se deben }\end{array}$ \\
\hline
\end{tabular}

(cc) EY-NC-ND 2018, Universitat Politècnica de València

Congreso IN-RED (2018) 


\begin{tabular}{|l|l|l|}
\hline LDO & $\begin{array}{l}\text { Lease-Develop- } \\
\text { Operate }\end{array}$ & $\begin{array}{l}\text { Equivalente al anterior pero en lugar de adquirir los activos, } \\
\text { el operador privado los arrienda a la Administración. La } \\
\text { inversión inicial es menor y el interés por la participación } \\
\text { del sector privado reside en las mejoras en eficiencia en la } \\
\text { prestación del servicio por su capacidad de gestión. }\end{array}$ \\
\hline WAA & $\begin{array}{l}\text { Wraparound } \\
\text { Addition }\end{array}$ & $\begin{array}{l}\text { Un operador privado financia y construye la ampliación de } \\
\text { una infraestructura pública ya existente. Posteriormente } \\
\text { gestiona y explota comercialmente ambas partes, bien por } \\
\text { un período establecido, o bien hasta que haya recuperado la } \\
\text { inversión inicial y una rentabilidad sobre la misma. }\end{array}$ \\
\hline
\end{tabular}

Fuente: Catalá Pérez, D. (2017)

Al finalizar la práctica, cada grupo pegó sus notas en orden en un folio (o los necesarios) y lo entregó al profesor con el nombre de los integrantes del equipo (Imagen 1).

\section{Resultados}

La propuesta: ¿es posible un sistema de colaboración público-privada contractual para el servicio de taxis?, fue resuelta por todos los grupos de manera positiva, buscando una solución al problema.

En primer lugar, identificaron el mapa de actores (Figura 1).

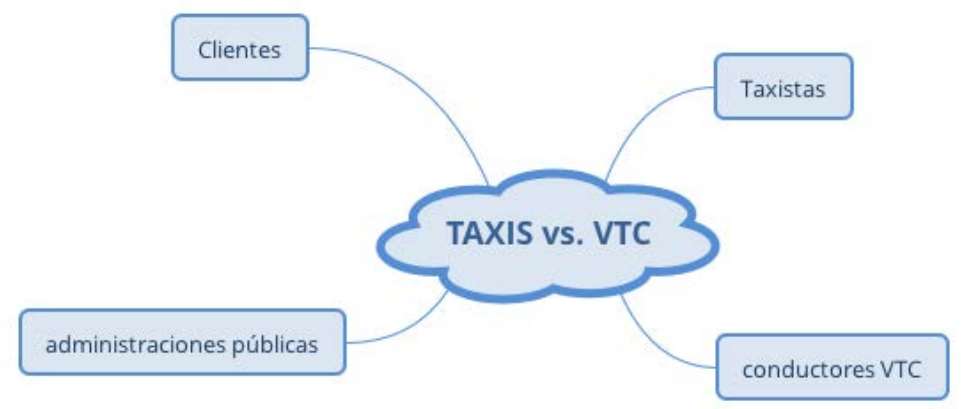

Fig. 1 Mapa de actores de la "guerra de los taxis".

Fuente: elaboración propia.

Desde el punto de vista de los usuarios-clientes, entre los aspectos positivos del uso de plataformas con conductores VTC (tipo Uber), se destacaron una aplicación sencilla de manejar, coches amplios y limpios y un precio total menor (aunque el mínimo suele ser mayor). En cuanto a los aspectos negativos, los principales son el tiempo de espera que suele ser mayor (y no se puede acudir a una parada) y una menor oferta (puesto que hay menos licencias VTC que de taxis).

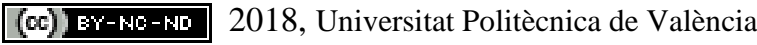

Congreso In-Red (2018) 
Desde el punto de vista de los taxistas, la queja principal es que las licencias VTC son más baratas que las licencias de taxis y en algunas ciudades no se cumplen ratios VTC/taxis, lo que satura la oferta de servicio. Sin embargo, los conductores VTC quieres hacerse un espacio que no acaban de encontrar en un sector que se supone liberalizado pero que todavía se rige por muchas normas que deberían revisarse.

Por último, el papel que juegan las administraciones públicas no es sencillo, puesto que hay muchos intereses en conflico, por un lado el de grandes empresas como Uber o Cabify, y por otro el del sector del taxi que es un fuerte lobby en España. En la actualidad no parece que vaya a haber muchos cambios normativos, pero la economía digital es un fenómeno imparable por lo que no es una situación que pueda sostenerse mucho tiempo.

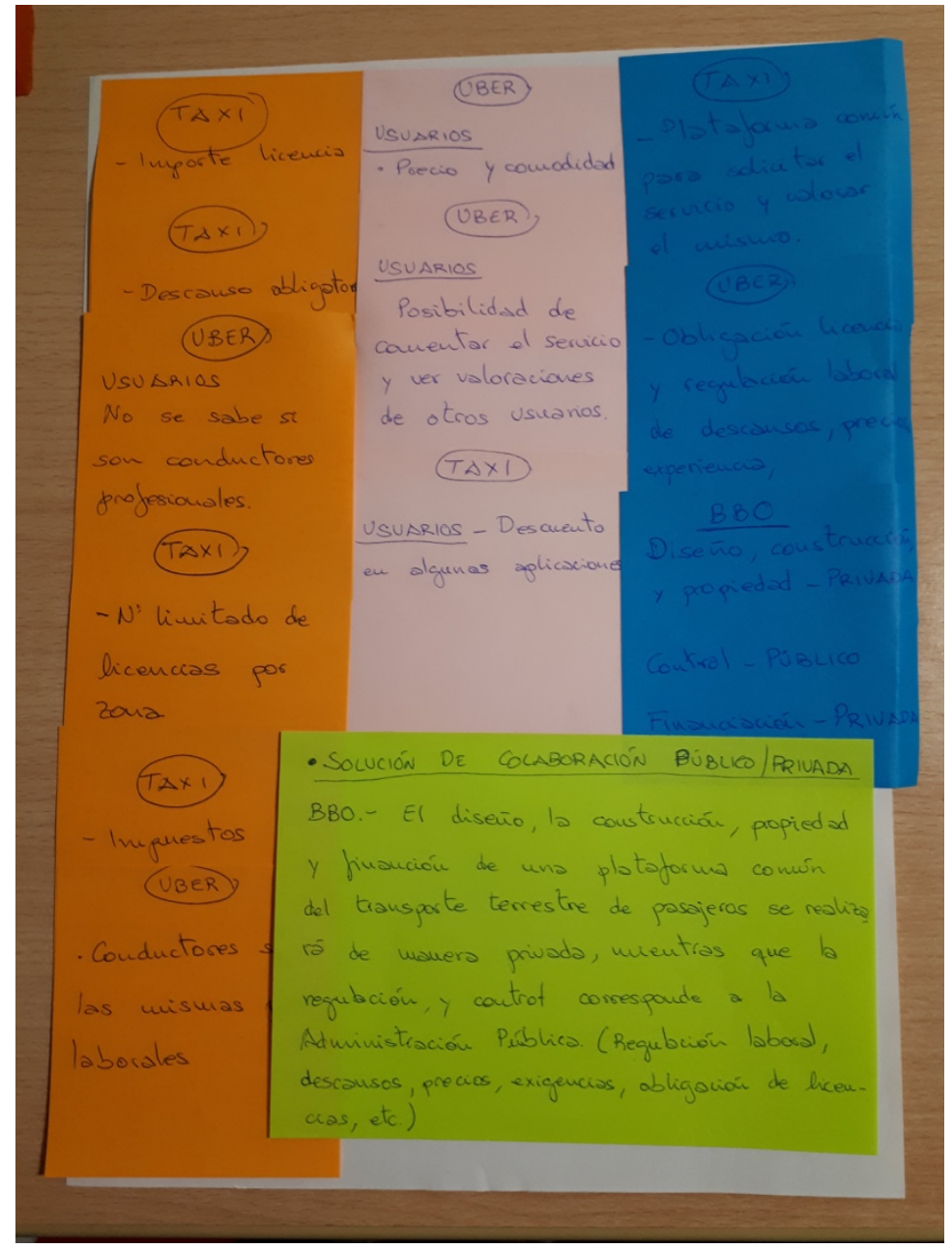

Imagen. 1 Resolución de la práctica por uno de los grupos, curso 2017-2018.

Fuente: elaboración propia 
En cuanto a las posible soluciones de CPP, de los 4 grupos, 3 se decantaron por la misma fórmula: BBO (Buy-Build-Operate), si bien el peso que le dio cada grupo al sector público o privado varió. En uno de los grupos, se le dio todo el "peso" del contrato a la administración pública, mientras que en los otros dos grupos el sector privado asume más riesgos, haciéndose cargo de la construcción y gestión de una plataforma digital y dejando únicamente a la administración pública la función de control y regulación. Solo el cuarto grupo escogió otra fórmula, la WAA (Wraparound Addition), transfiriendo mayores riesgos al sector privado pero dejando en manos de la administración el control y la regulación.

\section{Conclusiones}

Nos encontramos con un problema complejo que necesita una análisis sistémico para encontrar soluciones, con la participación de todos los grupos de interés en conflicto.

Se ha podido observar que, por un lado, hay poco control en el traspaso o adquisición de licencias en ambos casos, pero, por otro lado, se quiere mantener un modelo de negocio que no es sostenible en el escenario actual.

La práctica ha permitido a los alumnos del Grado en Gestión y Administración Pública aplicar unos conocimientos complejos, como son los de la colaboración público-privada, a una problema actual y que les es cercano, por lo que pueden interiorizar mejor esos conocimientos. Evidentemente, una práctica de 2 horas no puede llegar a unas conclusiones profundas del problema, pero se introduce el tema y se enseña una metodología que les puede servir en su futuro profesional a la hora de tomar decisiones en grupo.

Para ello se ha utilizado como técnica, desde un enfoque de stakeholders o grupos de interés, la toma de decisiones en equipo mediante el uso de notas móviles.

\section{Agradecimientos}

Este trabajo parte del proyecto de investigación Prometeo en el que participa la profesora María De Miguel, “La regulación de la transformación digital y la economía colaborativa”, y que es dirigido por el profesor Lorenzo Cotino Hueso (PROMETEO/2017/064, Generalitat Valenciana).

Así mismo, ha formado parte del Proyecto de Innovación y Mejora Educativa (PIME), "La resolución de problemas a través del diseño creativo y la visualización colaborativa” de la UPV, coordinado por la profesora V. Santamarina.

\section{Referencias}

CATALÁ-PÉREZ, D. (2017). “La colaboración público-privada” en De-Miguel-Molina, M.; Bañón Gomis, A.J.; Catalá-Pérez, D. Management para las Administraciones públicas. Valencia: Editorial Universitat Politècnica de València, pp. 131-158. 
Comisión Europea. Comunicación de la Comisión al Parlamento Europeo, al Consejo, al Comité Económico y Social Europeo y al Comité de las Regiones. Una Agenda Europea para la economía colaborativa. Comisión Europea, 2 de junio de 2016, COM(2016) 356 final, 1-18.

DE-MIGUEL-MOLINA, M.; DE MIGUEL MOLINA, B.; SANTAMARINA CAMPOS, V.; CARABAL-MONTAGUD, A. (2017a). "Problem-solving in group using mobile notes" en 11th International Technology, Education and Development Conference (INTED 2017, Valencia). Valencia: IATED Digital Library. 3825-3830.

DE-MIGUEL-MOLINA, M.; BAÑÓN GOMIS, A.J.; CATALÁ-PÉREZ, D. (2017b). Management para las Administraciones públicas. Valencia : Editorial Universitat Politècnica de València.

DOMENECH PASCUAL, G. (2015). "La Regulación de la Economía Colaborativa. El caso «Uber contra el taxi»” en Revista CEFlegal, n. 175-176, pp. 61-104.

DOMÍNGUEZ DEL VALLE, E. (2017) "En contra: Mejor un taxi público que uno privatizado" en El País, 11 de mayo, $<$ https://elpais.com/elpais/2017/05/10/opinion/1494436161_707931.html> [Consulta: 4 de febrero de 2018]

ESTEVE, J. (2016) "Uber, Cabify o Car2Go: probamos las alternativas al taxi. ¿Cuál es mejor?” en El Confidencial, 5 de abril, <http://www.elconfidencial.com/tecnologia/201604-05/uber-taxi-cabify-car2go-alternativas-transporte-madrid_1178533/> [Consulta: 4 de febrero de 2018]

FERNÁNDEZ, D. (2017) "El TS inflama la guerra del taxi en Madrid con 3.000 nuevos permisos de Uber y Cabify" en El Confidencial, 15 de febrero, $<$ http://www.elconfidencial.com/espana/madrid/2017-02-15/supremo-taxi-madridlicencias-vtc_1331985/> [Consulta: 4 de febrero de 2018]

HERCE, J.A (2017) “ A favor: la movilidad en las ciudades inteligentes” en El País, 12 de mayo, <https://elpais.com/elpais/2017/05/09/opinion/1494349480_105972.html?rel=mas> [Consulta: 4 de febrero de 2018]

MYTAXI. Acerca mytaxi. <https://es.mytaxi.com/taxistas.html > [Consulta: 4 de febrero de 2018]

OTERO, C. (2017) "Por qué Cabify, Uber y similares enfadan tanto a los taxistas" en AS (Betech), 30 de mayo, $<$ https://as.com/betech/2017/05/30/portada/1496154650_719396.html> [Consulta: 4 de febrero de 2018]

TSJUE. Sentencia del Tribunal de Justicia (Gran Sala) Procedimiento prejudicial Artículo 56 TFUE - Artículo 58 TFUE, apartado 1 - Servicios en el ámbito de los transportes - Directiva 2006/123/CE - Servicios en el mercado interior - Directiva 2000/31/CE - Directiva 98/34/CE - Servicios de la sociedad de la información Servicio de intermediación que permite, mediante una aplicación para teléfonos inteligentes, conectar a cambio de una remuneración a conductores no profesionales que utilizan su propio vehículo con personas que desean realizar desplazamientos urbanos Exigencia de una autorización». InfoCuria, 20 de diciembre de 2017, Asunto C-434/15, 112. 


\title{
Utilización de Microsoft EXCEL en la enseñanza de sistemas eléctricos de potencia: desarrollo de un método matricial para la resolución del problema de despacho económico
}

\section{Manuel Alcázar-Ortega ${ }^{a}$, Carlos Álvarez-Bel ${ }^{a}$}

aDepartamento de Ingeniería Eléctrica, Universidad Politécnica de Valencia. Camino de Vera, s/n, edificio 5E, $2^{\circ}$ Planta. 46022 Valencia (España).

\begin{abstract}
The realization of lab practices in electrical power system requires the use of simulation programs, given the impossibility of performing field practices in many cases since experimenting with real electrical systems is unfeasible in many cases. However, the use of this kind of programs requires the purchase of expensive licenses and the specific learning of the use of each of them by students. This article makes evident the suitability of programs like Microsoft EXCEL, easily accessible and familiar to students, for the development of practices related to electrical power systems. In particular, a method for the systematic resolution of the economic dispatch problem is illustrated by means of a matrix method that can be easily implemented in a spreadsheet.
\end{abstract}

Keywords: economic dispatch, matrix method, electric power systems

\begin{abstract}
Resumen
La realización de prácticas de sistemas eléctricos de potencia requiere de la utilización de programas de simulación, dada la imposibilidad de realizar en muchos casos prácticas de campo por la inviabilidad de experimentar con sistemas eléctricos reales. Sin embargo, la utilización de dichos programas requiere la compra de costosas licencias y el aprendizaje específico de la utilización de cada uno de ellos por parte del alumno. Este artículo evidencia la idoneidad de programas como Microsoft EXCEL, fácilmente accesibles y con los que los alumnos están familiarizados, para la realización de prácticas relacionadas con los sistemas eléctricos de potencia. En particular, se ilustra un método para la resolución sistemática del problema de despacho económico utilizando un método matricial de resolución de ecuaciones lineales que puede ser fácilmente implementado en una hoja de cálculo.
\end{abstract}

Palabras clave: despacho económico, método matricial, sistemas eléctricos de potencia 


\section{Introducción}

Las prácticas de laboratorio son una de las mejores estrategias de aprendizaje en ingeniería (Montes Granada, 2004), utilizadas para afianzar los conocimientos adquiridos en clase y materializar, desde un punto de vista práctico, su aplicación a la vida profesional, consiguiendo que los estudiantes "aprendan haciendo" (Patiño, 2001). Sin embargo, en el caso de algunas áreas como los sistemas eléctricos de potencia, resulta inviable la realización de prácticas de campo dada la complejidad de dichos sistemas y la imposibilidad de someterlos a solicitaciones reales. Es por esto que, habitualmente, las prácticas de laboratorio en esta área están basadas en la realización de simulaciones mediante las que puede analizarse el comportamiento de sistemas, más o menos complejos, en los que se operan las redes y todos sus elementos tanto en régimen permanente como en régimen transitorio.

Existen diversos programas comerciales de simulación en base a los cuales se estructuran las prácticas que, en esta materia, se realizan en diversas universidades alrededor del mundo. Se pueden encontrar algunos ejemplos de manuales docentes de prácticas de sistemas eléctricos de potencia basados en programas de simulación genéricos como MATLAB (Balaji, 2010) o más específicos como PowerWorld (Glover et al., 2008), ETAP (Sridevi, 2015) o PSCADEMTDC (Mohan, 2010). Sin embargo, en este artículo se aborda la posibilidad de utilizar el paquete de Microsoft Office y, en particular, el programa Microsoft EXCEL, para la resolución de este tipo de problemas. De forma más detallada, la utilización de Microsoft EXCEL presenta las siguientes ventajas:

- Es una herramienta con la que los estudiantes están familiarizados, ya que se utiliza con frecuencia en múltiples ámbitos académicos y no académicos. Sin embargo, es cierto que la mayor parte de los usuarios no suele emplear toda la potencialidad que ofrece la herramienta para este tipo de análisis (números complejos, cálculo matricial), lo cual se favorece mediante la aplicación aquí propuesta.

- Es fácilmente accesible al estar instalada de serie en prácticamente la totalidad de los ordenadores personales. En cualquier caso, las universidades y otras instituciones académicas facilitan licencias en sus propios campus o para la utilización de los ordenadores personales de los alumnos ${ }^{1}$.

- A diferencia de los programas comerciales de simulación, donde el alumno se limita a introducir unos parámetros y a interpretar los resultados obtenidos, la utilización de Microsoft EXCEL requiere que sea el propio alumno quien cree el programa de cálculo mediante la introducción de las ecuaciones desarrolladas a partir de los conocimientos teóricos adquiridos en clase que, de esta forma, se aplican directamente.

- En el caso de procedimientos iterativos, como los requeridos para la resolución del problema de flujo de carga, estimación del estado o el despacho económico con pérdidas en la red, Microsoft EXCEL muestra el resultado tabulado de cada una de las iteraciones realizadas en una hoja de cálculo, lo que facilita la detección de

\footnotetext{
${ }^{1}$ Por ejemplo, la Universidad Politécnica de Valencia proporciona acceso a la licencia educativa de Microsoft Office 365 que tiene contratada para sus estudiantes y personal.
}

(cc) EY-NC-ND 2018, Universitat Politècnica de València

Congreso IN-RED (2018) 
errores por parte del propio alumno. De esta forma, el estudiante aprende de sus propios errores, lo que afianza el proceso de aprendizaje (Sasso, 2015).

Los autores han venido proponiendo diversas aplicaciones prácticas en el campo de los sistemas eléctricos de potencia (Álvarez Bel y Alcázar Ortega, 2012) de cara a su resolución con Microsoft EXCEL. En particular, este artículo presenta un método de cálculo para abordar el problema del despacho económico en sistemas eléctricos mediante cálculo matricial que puede ser realizado fácilmente con la ayuda de una hoja de cálculo. La resolución sistemática de este tipo de problemas resulta básica de cara a afrontar casos más complejos (por ejemplo, para la programación de unidades de generación en sistemas multiárea) donde es necesario solucionar diferentes despachos económicos de forma iterativa hasta alcanzar la solución al problema planteado (Wook y Wollenberg, 1984).

El artículo se estructura de la siguiente forma: El capítulo 2 presenta los objetivos de la aplicación descrita en este documento, los cuales se desarrollarán de forma detallada en el capítulo 3, incluyendo su fundamento teórico y su implementación mediante el método matricial. El capítulo 4 muestra los resultados obtenidos en un caso práctico donde el método matricial se ha implementado mediante Microsoft EXCEL. Finalmente, las conclusiones del presente trabajo se incluyen en el capítulo 5 .

\section{Objetivos}

Los objetivos del trabajo que aquí se presenta son los siguientes:

- En primer lugar, presentar las ventajas que ofrece Microsoft EXCEL para el análisis de problemas prácticos relacionados con el estudio de los sistemas eléctricos de potencia

- Describir un método desarrollado por los autores para resolver, de forma sistemática, problemas prácticos de despacho económico en sistemas eléctricos de potencia, así como su implementación en una hoja de cálculo

- Mostrar a los docentes de este campo las potencialidades que la utilización de Microsoft EXCEL presenta para la realización de prácticas de sistemas eléctricos de potencia frente a otros programas de simulación utilizados habitualmente.

- Finalmente, ilustrar a los alumnos sobre cómo resolver problemas prácticos en el área de los sistemas eléctricos con una hoja de cálculo.

\section{Desarrollo de la innovación}

\subsection{Fundamento teórico}

El despacho económico es una estrategia utilizada en el análisis y operación de los sistemas eléctricos de potencia para determinar la cantidad de potencia activa que debe ser entregada por cada una de las unidades de generación conectadas al sistema para satisfacer la demanda de los consumidores al menor coste posible. Es, por tanto, una herramienta económica que se basa en optimizar los costes de producción de cada uno de los generadores conectados al 
Utilización de Microsoft EXCEL en la enseñanza de sistemas eléctricos de potencia: desarrollo de un método matricial para la resolución del problema de despacho económico

sistema, siendo necesario un modelo económico de cada unidad de producción que represente tanto sus costes fijos como variables (coste del combustible, costes de operación, costes de mantenimiento, etcétera).

El coste individual de producción de una unidad de generación $i$ suele representarse mediante una ecuación polinómica de segundo o tercer grado (Glover et al., 2008) de acuerdo con la siguiente expresión:

$$
C_{i}=a_{i}+b_{i} \cdot P_{G_{i}}+c_{i} \cdot P_{G_{i}}^{2}+d_{i} \cdot P_{G_{i}}^{3} € / h
$$

donde:

- $\quad P_{G i}$ es la potencia activa horaria entregada al sistema por la unidad ${ }_{\mathrm{i}}$ expresada en MW

- $a_{i}$ representa el coste horario fijo de producción de la unidad $i$, en $€ / \mathrm{h}$

- $b_{i}, c_{i} \mathrm{y} d_{i}$ representa el coste variable de producción, en función de la potencia producida, de la unidad $i$, en $€ / \mathrm{MWh}$

El despacho económico es un problema de optimización, donde se determina el valor de las potencias generadas por cada unidad de generación conectada al sistema al menor coste posible. No obstante, el valor de dichas potencias no puede ser arbitrario y está sujeto a las siguientes restricciones de igualdad y desigualdad:

- Restricción de igualdad: la potencia total entregada por los $N$ generadores del sistema debe ser igual a la potencia total demandada por los consumidores más las pérdidas producidas en las redes de transporte y distribución:

$$
\sum_{i=1}^{N} P_{G_{i}}=P_{D}+P_{\text {pérdidas }} \quad M W
$$

- Restricciones de desigualdad: Dado que los generadores no pueden trabajar fuera de sus márgenes de operación, la potencia generada por cada uno de ellos estará acotada por sus valores máximo y mínimo de producción:

$$
P_{G_{i}}^{\min } \leq P_{G_{i}} \leq P_{G_{i}}^{\operatorname{máx}} \quad M W
$$

Para el caso del método propuesto en este trabajo, se considerará que no existen pérdidas de potencia en los diferentes elementos del sistema, lo cual, aunque inadmisible desde el punto de vista real (las pérdidas pueden alcanzar el 15\% de la potencia total generada), resulta de

(c) EY-NC-ND 2018, Universitat Politècnica de València

Congreso IN-RED (2018) 
especial utilidad para comprender el problema. Si se desprecian las pérdidas, la restricción de igualdad queda de la siguiente manera:

$$
\sum_{i=1}^{N} P_{G_{i}}=P_{D} \quad M W
$$

El procedimiento para llevar a cabo la optimización es el siguiente (Elgerd, 1982):

- Paso 1: Se calcula el valor de potencia producido por cada generador para minimizar el coste total de producción, teniendo en cuenta la restricción de igualdad. Para ello, se construye una función objetivo $F$ que incluye el coste total de producción y la restricción de igualdad multiplicada por el operador de Lagrange $\lambda$ :

$$
F\left(P_{G_{1}}, P_{G_{2}}, \ldots P_{G_{N}}, \lambda\right)=\sum_{i=1}^{N} C_{i}+\lambda\left(P_{D}-\sum_{i=1}^{N} P_{G_{i}}\right) \quad M W
$$

- Paso 2: Se calculan las derivadas parciales de la función objetivo y se igualan a cero para obtener un sistema de ecuaciones que permita determinar la potencia entregada por cada unidad de generación con un coste total mínimo:

$$
\left\{\begin{array}{l}
\frac{\partial F}{\partial P_{G_{1}}}=\frac{\partial C_{1}}{\partial P_{G_{1}}}-\lambda=0 \\
\frac{\partial F}{\partial P_{G_{2}}}=\frac{\partial C_{2}}{\partial P_{G_{2}}}-\lambda=0 \\
\vdots \\
\sum_{i=1}^{N} P_{G_{i}}=P_{D}
\end{array}\right.
$$

- $\quad$ Paso 3: Del cálculo anterior resulta un sistema de $(\mathrm{N}+1)$ ecuaciones con $(\mathrm{N}+1)$ incógnitas, el cual se puede resolver a través de diversos métodos de cálculo. El resultado son las $N$ potencias entregadas por cada uno de los $N$ generadores, así como el valor de $\lambda$. El parámetro $\lambda$ representa el coste incremental de operación del área y constituye el coste de producir una unidad adicional de potencia.

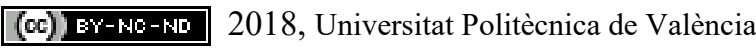


- Paso 4: Obtenidos los valores de potencia entregada por cada generador, deben verificarse las restricciones de desigualdad, de forma que los generadores cuya potencia quede fuera de sus límites técnicos será fijado a su máximo (o mínimo) técnico y se recalculará la optimización con las unidades restantes.

\subsection{Desarrollo del método matricial}

El sistema de ecuaciones mostrado en (6) puede resolverse utilizando diversos métodos. El método matricial aquí desarrollado tiene las siguientes ventajas:

- Se construye fácilmente a partir de los coeficientes de las curvas de coste de los generadores participantes en el despacho, por lo que no es necesario desarrollar el sistema de ecuaciones en cada caso.

- Se resuelve fácilmente en dos pasos, siendo su única complejidad la inversión de una matriz y su producto por un vector columna.

- Es fácilmente programable, lo que facilita su utilización en sistemas con un gran número de generadores. En particular, en la sección siguiente se explicará cómo dicho método puede aplicarse para la resolución del despacho económico mediante Microsoft EXCEL.

Si se sustituyen las curvas de coste de los generadores en (6), construidas tal y como se indica en (1), el sistema de ecuaciones resultante puede escribirse de la siguiente manera:

$$
\left\{\begin{array}{l}
b_{1}+2 \cdot c_{1} \cdot P_{G_{1}}-\lambda=0 \\
b_{2}+2 \cdot c_{2} \cdot P_{G_{2}}-\lambda=0 \\
\vdots \\
b_{N}+2 \cdot c_{N} \cdot P_{G_{N}}-\lambda=0 \\
P_{G_{1}}+P_{G_{1}}+\ldots+P_{G_{N}}=P_{D}
\end{array}\right.
$$

Reordenando (7) para dejar en el primer miembro de cada ecuación los términos variables y en el segundo miembro los términos independientes, el sistema quedaría como sigue.

$$
\left\{\begin{array}{l}
2 \cdot c_{1} \cdot P_{G_{1}}-\lambda=-b_{1} \\
2 \cdot c_{2} \cdot P_{G_{2}}-\lambda=-b_{2} \\
\vdots \\
2 \cdot c_{N} \cdot P_{G_{N}}-\lambda=-b_{N} \\
P_{G_{1}}+P_{G_{1}}+\ldots+P_{G_{N}}=P_{D}
\end{array}\right.
$$

(cc) EY-NC-ND 2018, Universitat Politècnica de València

Congreso IN-RED (2018) 
En forma matricial, dicho sistema se podría escribir de la siguiente forma:

$$
\left[\begin{array}{ccccc}
2 \cdot c_{1} & 0 & 0 & 0 & -1 \\
0 & 2 \cdot c_{2} & 0 & 0 & -1 \\
\vdots & \vdots & \ddots & \vdots & \vdots \\
0 & 0 & 0 & 2 \cdot c_{N} & -1 \\
1 & 1 & 1 & \cdots & 0
\end{array}\right] \times\left[\begin{array}{c}
P_{G_{1}} \\
P_{G_{2}} \\
\vdots \\
P_{G_{N}} \\
\lambda
\end{array}\right]=\left[\begin{array}{c}
-b_{1} \\
-b_{2} \\
\vdots \\
-b_{N} \\
P_{D}
\end{array}\right]
$$

obteniéndose un sistema de la forma: $[\mathrm{A}] \mathrm{x}[\mathrm{P}]=[\mathrm{B}]$. El despacho económico consistirá, por tanto, en obtener los valores del vector columna $[\mathrm{P}]$ a partir de los valores de la matriz $[\mathrm{A}] \mathrm{y}$ del vector columna [B].

Analizando en detalle las características de las matrices [A] y [B], se puede concluir lo siguiente:

- La matriz [A] es una matriz cuadrada de dimensiones $(\mathrm{N}+1) \mathrm{x}(\mathrm{N}+1)$, siendo $N$ el número de generadores participantes en el despacho. Esta matriz puede descomponerse en cuatro submatrices de acuerdo con la siguiente estructura:

$$
[A]=\left[\begin{array}{l|l}
A_{1} & A_{2} \\
\hline A_{3} & A_{4}
\end{array}\right]
$$

La submatriz $\mathrm{A}_{1}$ es una matriz diagonal de dimensiones NxN. Si se asocia cada fila $i$ y columna $i$ con el generador $i$, el elemento de la diagonal principal $\mathrm{A}_{1-\mathrm{i}, \mathrm{i}}$ será igual al coeficiente que multiplica a $P_{G i}{ }^{2}$ en la curva de costes del generador $i$ multiplicado por dos.

La submatriz $\mathrm{A}_{2}$ es un vector columna de dimensión $\mathrm{Nx} 1$ en el que todos los elementos son igual a -1 .

La submatriz $A_{3}$ es un vector fila de dimensión $1 \times N$ en el que todos sus elementos son igual a 1 .

Finalmente, la submatriz $\mathrm{A}_{4}$ tiene dimensión $1 \mathrm{x} 1 \mathrm{y}$ es igual a cero.

- $\quad$ El vector columna [B] tiene dimensiones $(\mathrm{N}+1) x 1$ y sus $N$ primeros elementos para cada fila $i$ son iguales al coeficiente que multiplica a $P_{G i}$ en la curva de costes del generador $i$. El último elemento de la columna es igual a la demanda total del sistema, la cual debe ser satisfecha por todos los generadores participantes en el despacho.

El vector columna $[\mathrm{P}]$ contiene todas las incógnitas que deben ser calculadas en el despacho económico, a saber: la potencia entregada por cada uno de los generadores y el valor del coste incremental de operación del área $\lambda$.

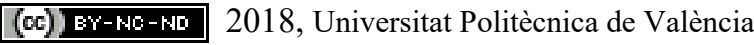


Construidas las matrices $[\mathrm{A}] \mathrm{y}[\mathrm{B}]$ a partir de las curvas de costes de todos los generadores y el valor de la potencia total demandada en el sistema, $P_{D}$, el vector de incógnitas puede calcularse a partir de la siguiente expresión:

$$
[P]=\left[\begin{array}{c}
P_{G_{1}} \\
P_{G_{2}} \\
\vdots \\
P_{G_{N}} \\
\lambda
\end{array}\right]=[A]^{-1} \times[B]
$$

Una vez calculadas todas las incógnitas, es necesario verificar las restricciones de desigualdad. Se pueden dar los siguientes casos:

- Existen generadores en los que $P_{G_{i}}>P_{G_{i}}^{m a x}$. Si algún generador supera en la solución del despacho su potencia máxima, se fijará a su producción a dicho valor máximo y será retirado del despacho. Ello se traduce en la eliminación de la fila y columna correspondientes a dicho generador en las matrices $[\mathrm{A}]$, $[\mathrm{B}]$ y $[\mathrm{P}]$ y en la modificación de la potencia total demandada a cubrir por los generadores en despacho, a la que habrá que sustraer la que se ha asignado al generador retirado.

- Existen generadores en los que $P_{G_{i}}<P_{G_{i}}^{\min }$. Estos generadores serán mantenidos al realizar una nueva evaluación del despacho económico después de retirar aquellos que hubieran superado su potencia máxima ya que, en un nuevo redespacho, podría serles asignada parte de la potencia excedente de los generadores retirados $\mathrm{y}$, con ello, pasarían a operar por encima de su valor mínimo.

- Los generadores que satisfagan las restricciones de desigualdad serán aquellos que, cubriendo la demanda total asignada al menor coste posible, son físicamente capaces de poder hacerlo.

\section{Resultados: resolución mediante la utilización de Microsoft EXCEL}

En este apartado se presenta la aplicación del método propuesto anteriormente a un caso práctico, que se resolverá mediante la utilización de Microsoft EXCEL. Considérense cuatro sistemas eléctricos interconectados, tal y como se muestra en la Figura 1, cada uno de los cuales dispone de recursos propios de generación que deben satisfacer una demanda conjunta de $1.500 \mathrm{MW}$.

Cada una de las cuatro áreas tiene unos costes de generación que se pueden estimar a partir de las siguientes curvas:

$$
\begin{aligned}
& C_{1}=280+13,2 \cdot P_{G_{1}}+0,08 \cdot P_{G_{1}}{ }^{2} \quad \epsilon / h \\
& C_{2}=315+10,5 \cdot P_{G_{2}}+0,06 \cdot P_{G_{2}}{ }^{2} \quad \epsilon / h
\end{aligned}
$$




$$
\begin{aligned}
& C_{3}=187+11,7 \cdot P_{G_{3}}+0,09 \cdot P_{G_{3}}{ }^{2} \quad \epsilon / h \\
& C_{4}=255+9,2 \cdot P_{G_{4}}+0,10 \cdot P_{G_{4}}{ }^{2} \quad \epsilon / h
\end{aligned}
$$

Las potencias máximas y mínimas que pueden ser producidas por cada generador son las siguientes:

$$
\begin{aligned}
& 50 \leq P_{G_{1}} \leq 550 \quad M W \\
& 75 \leq P_{G_{2}} \leq 750 \quad M W \\
& 20 \leq P_{G_{3}} \leq 400 \quad M W \\
& 10 \leq P_{G_{4}} \leq 250 \quad M W
\end{aligned}
$$

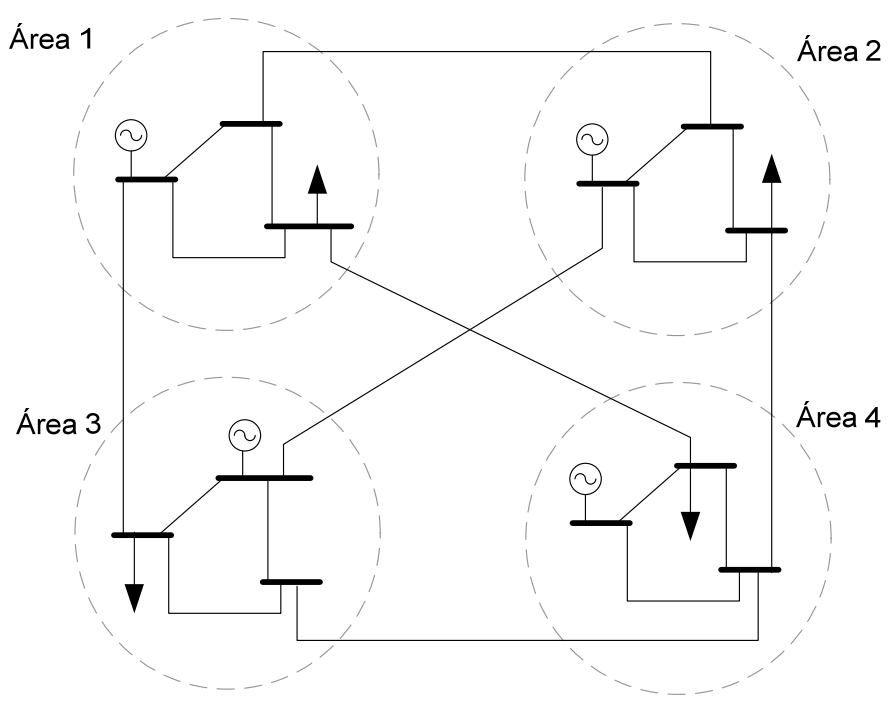

Figura 1. Caso de aplicación con cuatro áreas eléctricas interconectadas

De acuerdo con la metodología planteada en la sección anterior, los coeficientes que se debería utilizar para la construcción de las matrices $[\mathrm{A}]$ y $[\mathrm{B}]$ procedentes de las expresiones anteriores serían los siguientes: 


$$
[A]=\left[\begin{array}{ccccc}
2 \cdot c_{1} & 0 & 0 & 0 & -1 \\
0 & 2 \cdot c_{2} & 0 & 0 & -1 \\
0 & 0 & 2 \cdot c_{3} & 0 & -1 \\
0 & 0 & 0 & 2 \cdot c_{4} & -1 \\
1 & 1 & 1 & 1 & 0
\end{array}\right]=\left[\begin{array}{ccccc}
0,16 & 0 & 0 & 0 & -1 \\
0 & 0,12 & 0 & 0 & -1 \\
0 & 0 & 0,18 & 0 & -1 \\
0 & 0 & 0 & 0,20 & -1 \\
1 & 1 & 1 & 1 & 0
\end{array}\right]
$$

$$
[B]=\left[\begin{array}{c}
-b_{1} \\
-b_{2} \\
-b_{3} \\
-b_{4} \\
P_{D}
\end{array}\right]=\left[\begin{array}{c}
13,2 \\
-10,5 \\
-11,7 \\
-9,2 \\
1500
\end{array}\right]
$$

La solución del despacho económico se obtendría calculando el vector columna [P] a partir de la expresión (11). Para hacerlo con Microsoft EXCEL habrá que seguir los siguientes pasos:

i) Escribir en un bloque de celdas $5 \times 5$ los coeficientes de la matriz [A], y en otro bloque de celdas $5 \times 1$ los coeficientes de la matriz [B], de acuerdo con las expresiones (20) y (21)

ii) Calcular la matriz $[\mathrm{A}]^{-1}$. Para ello:

a. Seleccionar en la hoja de cálculo una región $5 \times 5$ donde la matriz inversa debe estar escrita.

b. Escribir en la celda superior izquierda de dicha región la expresión:

$$
=\operatorname{MINVERSA}((1,1):(5,5))
$$

Siendo $(1,1)$ la celda superior izquierda de la región donde aparecerá la matriz inversa, y $(5,5)$ la celda inferior derecha. En la Figura 2, donde se muestra la resolución completa del ejemplo con Microsoft EXCEL, la referencia $(1,1)$ correspondería con la celda $\mathrm{C} 3$, mientras que $(5,5)$ sería la celda G7.

c. Pulsar la tecla ENTER. Al hacerlo, aparecerá en la celda $(1,1)$ el elemento $(1,1)$ de la matriz inversa.

d. Con el ratón (o con las teclas de desplazamiento), seleccionar toda la región de la hoja de cálculo donde debe aparecer la matriz inversa. Debe ser un bloque $5 \times 5$.

e. Pulsar la tecla F2 para que la expresión (22) adquiera carácter editable y, a continuación, pulsar simultáneamente las tecla Ctrl, Alt y ENTER. Al 
hacerlo, aparecerá la matriz inversa $[\mathrm{A}]^{-1}$ completa, tal y como se muestra en la Figura 2.

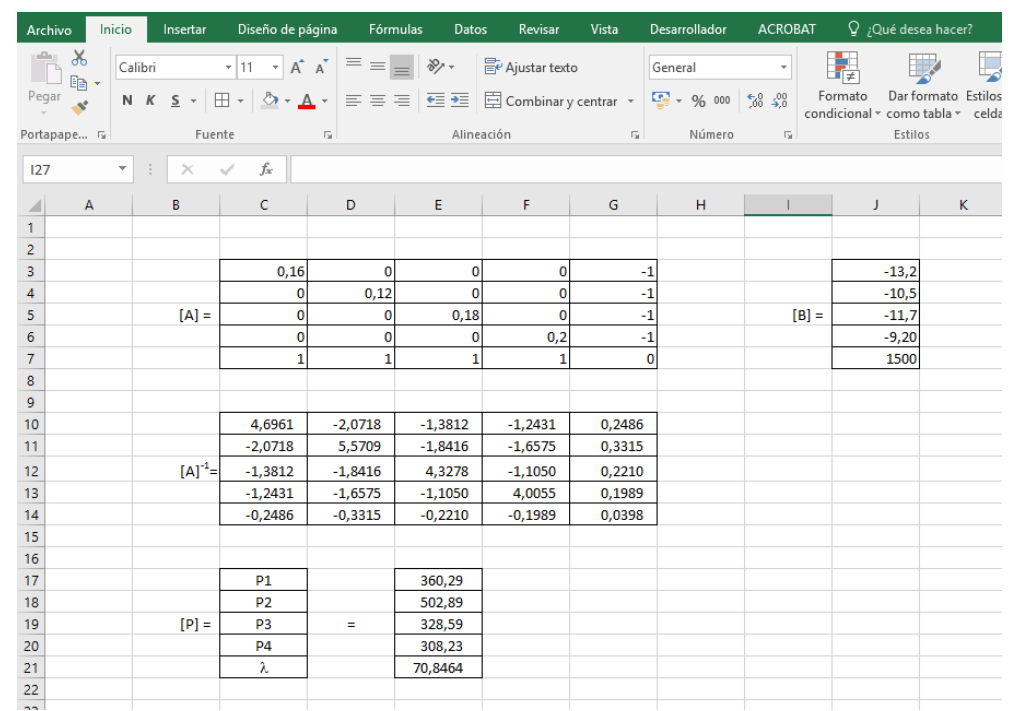

Figura 2. Resolución del sistema matricial mediante Microsoft EXCEL

iii) Calcular $[\mathrm{P}]$ como producto de la matriz $[\mathrm{A}]^{-1}$ y la matriz [B]. Para ello se seguirá un procedimiento similar al del cálculo de la matriz inversa:

a. Seleccionar en la hoja de cálculo la región $5 \times 1$ donde aparecerán los coeficientes del vector columna [P].

b. Escribir en la celda superior izquierda de dicha región la expresión:

$=M M U L T\left(\right.$ rango de celdas de $[A]^{-1}$; rango de celdas de $\left.[B]\right)$

En el ejemplo mostrado en la Figura 2, dicha expresión sería la siguiente:

$$
=M M U L T(C 10: G 14 ; J 3: J 7)
$$

c. Pulsar la tecla ENTER. Al hacerlo, aparecerá en la celda superior del vector $[\mathrm{P}]$ el elemento $(1,1)$ de dicho vector.

d. Con el ratón (o con las teclas de desplazamiento), seleccionar toda la región de la hoja de cálculo donde debe aparecer el vector [P]. Debe ser un bloque $5 \times 1$.

e. Pulsar la tecla F2 para que la expresión (23) adquiera carácter editable y, a continuación, pulsar simultáneamente las tecla Ctrl, Alt y ENTER. Al hacerlo, aparecerá el vector columna $[\mathrm{P}]$.

De acuerdo con la resolución al ejercicio planteado, los valores de la potencia entregada por cada área serían de 360,29 MW para el área 1, 502,89 MW para el área 2, 328,59 MW para el área 3 y 308,23 MW para el área 4. De acuerdo con las expresiones (15), (16), (17) y (18),

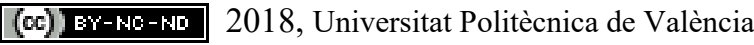


Utilización de Microsoft EXCEL en la enseñanza de sistemas eléctricos de potencia: desarrollo de un método matricial para la resolución del problema de despacho económico

los generadores de las tres primeras áreas tienen una producción adecuada, ya que se encuentran entre sus respectivos límites superior e inferior. En cambio, el área 4 tiene una potencia máxima de $300 \mathrm{MW}$ mientras que el despacho le ha asignado una cantidad superior. Para solucionar esta restricción, tal y como se indicó en la metodología, hay que fijar la potencia del área 4 en su límite superior de $300 \mathrm{MW}$ y recalcular el despacho entre los generadores de las áreas restantes. Al utilizar el método matricial, este cálculo es inmediato, ya que sólo hay que eliminar la fila y la columna correspondiente al generador 4 de las matrices $[\mathrm{A}]$ y $[\mathrm{B}]$ y volver a calcular el resultado del vector columna $[\mathrm{P}]$, donde también se ha eliminado la fila correspondiente al área sustraída del despacho.

El resultado se muestra en la Figura 3, donde el sistema obtenido se ha reducido en una dimensión ( $4 \mathrm{x} 4$ para la matriz [A]' y 4x1 para los vectores columna [B]' y [P]'). La fila y columna eliminadas aparecen sombreadas en color gris. Asimismo, se observa cómo la última fila del vector columna [B]' muestra la demanda total del sistema menos la que ya se ha fijado a la generación del área $4(1500-300 \mathrm{MW})$.

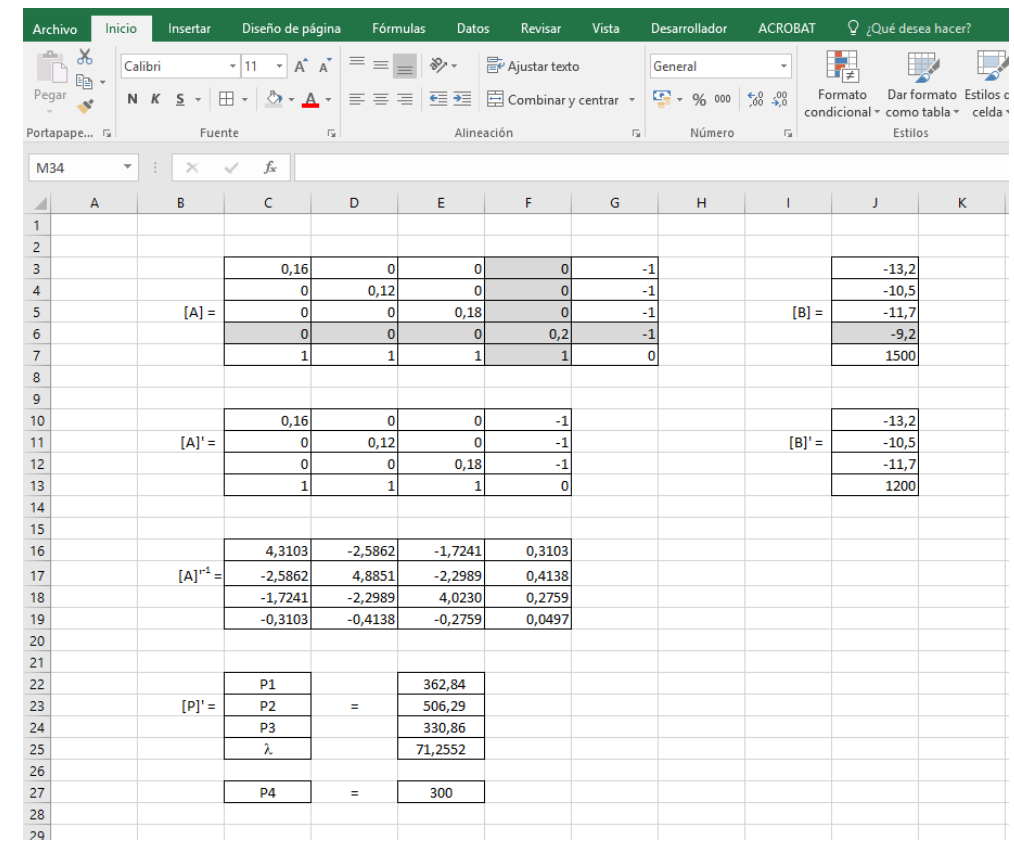

Figura 3. Resolución del sistema matricial mediante Microsoft EXCEL. Eliminación de la restricción del área 4

En este caso, todas las potencias del despacho están acotadas por los límite superior e inferior de cada área, por lo que ésta sería la solución definitiva del despacho.

(c)) EY-NC-ND 2018, Universitat Politècnica de València

Congreso IN-RED (2018) 


\section{Conclusiones}

Este artículo presenta un método matricial para la resolución del problema de despacho económico sin pérdidas en sistemas eléctricos de potencia, mediante el que es posible obtener soluciones rápidas con la sola utilización de los coeficientes de la función de costes de los generadores participantes en el despacho.

Una de las principales ventajas de este método es la posibilidad de agregar o eliminar cualquier generador o área productora, simplemente añadiendo o eliminando una fila y columna en las matrices [A] y [B], así como la facilidad de repetir este cálculo tantas veces como sea necesario de cara a verificar el cumplimiento de las restricciones de los generadores participantes.

Asimismo, se ilustra la aplicación de dicho método para la resolución sistemática del problema de despacho económico en Microsoft EXCEL, que puede ser fácilmente implementado en una hoja de cálculo.

Este software presenta múltiples ventajas, tales como su accesibilidad y popularidad entre los estudiantes, su facilitad de utilización o su idoneidad para la resolución de procedimientos iterativos. Además, desde el punto de vista educacional, Microsoft EXCEL resulta idóneo para trabajar desde la base la resolución de los problemas prácticos relacionados con las clases teóricas. Ello es debido a que, a diferencia de los programas comerciales donde el estudiante introduce unos parámetros y obtiene directamente unos resultados, aquí se requiere que sea el pripio alumno quien cree el programa de cálculo mediante la introducción de las ecuaciones básicas que rigen el problema analizado. Ello hace de Microsoft EXCEL una herramienta de excepcional utilidad que, aunque es poco utilizada en el área de los sistemas eléctricos de potencia, resulta muy versátil en la realización de ejercicios prácticos aplicados a este campo.

\section{Referencias}

ÁlVAREZ BEL, C. y ALCÁZAR ORTEGA, M. (2012). Prácticas de Sistemas Eléctricos de Potencia. Universitat Politècnica de València. Ref. 0461P03

BALAJI, V. (2010). Power system simulation laboratory. Dhanalakshmi College of Engineering. DOI: 10.13140/RG.2.1.4794.6485

ELGERD, O. (1982). Electric energy systems theory: an introduction. McGraw-Hill, New York, USA, ISBN 0070192308

GLOVER, J., SARMA, M.S., OVERBYE, T. (2008). Power systems. Analysis and design. Thompson Corporation, Toronto, Canada. ISBN 9780534548841

MOHAN, N. (2010). Power Systems Laboratory. University of Minnesota, Minneapolis, MN, USA. 
Utilización de Microsoft EXCEL en la enseñanza de sistemas eléctricos de potencia: desarrollo de un método matricial para la resolución del problema de despacho económico

MONTES GRANADA, W.F. (2004). "Prácticas de laboratorio en ingeniería: una estrategia efectiva de aprendizaje" en Notas Universitarias, vol. 4, núm. 11. Ibagué, Colombia. CEDIP, ISSN: 1794-1997.

PATIÑO, G. (2001). "El taller, un continuum entre enseñanza y aprendizaje. La Práctica de la Enseñanza” en Notas Universitarias. Ibagué, Colombia. CEDIP, ISSN: 1794-1997

SASSO, P. (2015). "El error como herramienta del aprendizaje" en Reflexión Académica en Diseño y Comunicación, vol. 25, p. 25-27. Buenos Aires, Argentina, ISSN 1668-1673.

SRIDEVI, J. (2015). Power systems Lab. Gokaraju Rangaraju Institute of Engineering and Technology.

WOOK, A.J., WOLLENBERG, B.F. (1984). Power generation, operation and control. John Willey and Sons, New York, USA. ISBN 0471586994 


\title{
Adquisición de competencias básicas en la formación de futuros docentes
}

Salvador Oriola ${ }^{a}$, Alba Montoya ${ }^{b}$ y Adrien Faure ${ }^{c}$

Universidad de Barcelona (모lvaoriola@ub.edu, b albamontoya@ub.edu, cadrienfaure@ub.edu)

\begin{abstract}
The main goal pursued by primary schools today is to provide students with the necessary elements that allow them to acquire basic competences so they can deal with everyday problems effectively and satisfactorily. Teachers, faced with this new reality, will have to readapt their role in the classroom and place students as the protagonists of their own learning, so that they can learn more and better. Education faculties conscious of the methodological revolution that all this implies are beginning to modify their study plans, imparting the didactic through procedural and transversal learning. The aim is to equip future teachers with tools to be able to compete proficiently in a changing society. The objective of this paper is to expose some of the methodologies (cooperative work, work by projects, gamification ...) and resources (emotional education, TAC ...) that are being implemented in the Faculty of Education at the University of Barcelona. The evaluations and the positive results of both, professors and students involved, confirm the good acceptance of competency-based learning in that faculty.
\end{abstract}

Keywords: competences, faculty of education, University of Barcelona, teacher's degree, methodologies, resources

\footnotetext{
Resumen

El objetivo principal que persiguen las escuelas de primaria en la actualidad es proporcionar a los alumnos los elementos necesarios que les permitan adquirir unas competencias básicas para que puedan hacer frente a los problemas cotidianos de forma eficaz y satisfactoria. Los maestros ante esta nueva realidad tendrán que readaptar su rol dentro del aula y situar a los alumnos como los protagonistas de su propio aprendizaje, para que aprendan más y mejor. Las facultades de educación conscientes de la revolución metodológica que todo ello implica están empezando a modificar sus planes de estudio, impartiendo las didácticas a través de aprendizajes procedimentales y transversales. La finalidad es dotar a los futuros docentes de herramientas para poder ejercer su profesión de forma competente en una sociedad cambiante y en constante evolución. El objetivo de este trabajo es exponer algunas de las metodologías (trabajo cooperativo, trabajo por proyectos, gamificación...) y recursos (educación emocional, TAC...) que se están implantando en la Facultad de Educación de la Universidad de Barcelona. Las valoraciones y los resultados positivos tanto de los profesores como de los alumnos implicados confirman la buena aceptación de los aprendizajes competenciales en dicha facultad.
}

(c) EY-NC-ND 2018, Universitat Politècnica de València 
Palabras clave: competencias, facultad de educación, Universidad de Barcelona, grado de maestro, metodologías, recursos

\section{Introducción}

La formación integral de los alumnos a través del desarrollo y el logro de competencias básicas es el principal objetivo que se persigue en las escuelas de primaria. Hoy en día estamos inmersos en una importante revolución metodológica donde las clases magistrales han sido reemplazadas por ambientes, proyectos, trabajos en equipo, liderazgo, etc. Por ello las facultades de educación, encargadas de formar a los futuros docentes, han empezado a modificar sus planes docentes, dejando a un lado las metodologías basadas principalmente en la acumulación de conceptos. En el grado de maestro de Educación Primaria de la UB, concretamente en el Departamento de Didácticas Aplicadas, se está apostando por clases de carácter competencial donde los alumnos hacen un aprendizaje multidimensional, es decir, en las clases se trabaja la didáctica de una forma procedimental y transversal. Todas las áreas, además de contenidos propios, también incorporan conocimientos sobre ámbitos que no suelen tener un espacio específico dentro las facultades como por ejemplo la educación emocional, las tecnologías para el aprendizaje y la comunicación (TAC), el trabajo cooperativo, la gamificación, la creatividad, etc.

\section{Objetivos}

El presente trabajo tiene como objetivo difundir la renovación docente que vive actualmente la facultad de educación de la Universidad de Barcelona a través de la muestra de algunos recursos y metodologías que se están implementando en las clases de las didácticas aplicadas.

\section{Desarrollo de la innovación}

La génesis del cambio de perspectiva metodológico y la incorporación de nuevos recursos en las aula de la universidad se produjo con la aprobación de la LOE y la inclusión de las TAC en las aulas. A partir de ese momento los alumnos universitarios empezaron a manifestar un descontento significativo en relación a su formación. El contenido y las metodologías de las didácticas impartidas en la universidad se alejaban de la realidad de las aulas de primaria que percibían cuando realizaban las prácticas. Todo ello propició constantes quejas y desmotivación, lo cual se reflejaba en un clima de aprendizaje negativo y bajas cualificaciones académicas.

Ante esta situación y aprovechando la incorporación al departamento de un elevado número de profesores asociados, vinculados directamente con las aulas de educación primaria y secundaria, se empezaron a modificar los planes de estudio incorporando toda una serie de metodologías y recursos que pudieran dar una respuesta eficaz a las demandas de la educación actual. Estos planes, dejaron de ser documentos reproductivos, para convertirse 
en documentos productivos y contextualizados, es decir, instrumentos vivos y flexibles que cada año se revisan y se modifican a partir de las valoraciones que realizan alumnos y profesores, de la normativa y la legislación educativa estatal, de los nuevos avances científicos (neurociencias, educación emocional...), de las indicaciones de la Unión Europea dentro del marco para la cooperación en materia de educación, etc.

Este cambio de perspectiva, hacia un modelo de aprendizaje competencial y funcional ha repercutido principalmente en la modificación de las metodologías utilizadas. Con el concepto metodología se hace referencia a cómo se llevarán a cabo las clases e integra todas las decisiones, materiales, organización espacial y temporal... orientadas a organizar el proceso de enseñanza-aprendizaje que se desarrollará en las aulas (Ballester y Sánchez, 2010). A continuación pasamos a explicitar las innovaciones metodológicas más significativas que se están llevando a cabo en el contexto de la facultad de educación de la UB.

\section{Diseño y aplicación de rúbricas online}

La evaluación en el aprendizaje competencial juega un papel fundamental, pues tiene que ir más allá de las tradicionales notas y convertirse en un instrumento que ayude a los alumnos a identificar sus propias dificultades. Para ello los alumnos han de conocer y pactar junto con los profesores aquellos criterios y procedimientos sobre los que se les evaluará. Por lo tanto, todos participan en la evaluación a través del diseño de rúbricas y de acuerdo con Alsina (2013):

- Permiten al estudiante autoregular y liderar su propio estudio, autoevaluándose y favoreciendo la asunción de responsabilidad sobre los aprendizajes.

- Reducen la subjetividad de la evaluación facilitando que, diferente profesorado que imparte una misma asignatura se coordine y comparta los criterios de evaluación.

- Facilitan un feedback casi inmediato, dado que permite acortar sustancialmente el tiempo de regreso al ofrecer unos resultados cuantitativos y cualitativos basados en estándares conocidos previamente al desarrollo de la tarea.

Para el diseño de las rúbricas se utiliza la plantilla corubrics disponible en los complementos de las hojas de cálculo de Google.

\section{Gamificación}

La gamificación o ludificación consiste en adoptar la mecánica de los juegos en ámbitos en principio ajenos a ellos con el fin de motivar a los participantes (Teixes, 2014). En nuestro caso adoptamos aquellas características que más nos interesan de este tipo de metodologías y concretamente la aplicamos en las aulas a partir de:

- La participación en premios y concursos. Informamos a los alumnos de las bases de premios o concursos que tienen relación con los contenidos de la asignatura para poder así motivarlos y que participen voluntariamente en ellos con el objetivo de poder ganar.

- El uso en clase de aplicaciones como Kahoot, Socrative, Brainscape, Cerebriti, etc., para trabajar de forma lúdica contenidos de clase. 
- Invención de juegos para el aula. Se propone a los alumnos que inventen un juego y lo pongan en práctica con los compañeros de clase para comprobar si cumple con las expectativas que se tienen.

\section{Tecnologías para el aprendizaje y la comunicación}

El uso y la evolución constante de las tecnologías en la sociedad actual es la razón por la que la adquisición y el desarrollo de la competencia digital se haya convertido indispensable en la formación integral de todos los alumnos. Los futuros docentes tendrán que conocer y utilizar un amplio abanico de nuevas tecnologías que favorezca el conocimiento y el buen uso de éstas entre sus alumnos. Por ello en las clases de didáctica además de utilizar las TAC como recurso para enriquecer las experiencias de aprendizaje también se hará hincapié en las infinitas posibilidades que ofrecen éstas en la creación de nuevos recursos, la interacción o el trabajo cooperativo, entre otras. El docente tendrá que actualizarse de forma continua para poder dotar a los alumnos de herramientas funcionales que les permitan ser prudentes y responsables ante el uso masivo de dichas tecnologías. En las aulas universitarias con el uso y el aprendizaje de las TAC nos referimos a:

- Edición de audio, imagen y video a través de softwares y aplicaciones como Audacity, Reaper, iMovie, Pinacle, Quick...

- Flipped Classroom. Esta metodología conocida como clase invertida se lleva a cabo a través de las explicaciones de algunos contenidos mediante un vídeo que los alumnos visionarán en sus casas. Las clases presenciales se aprovecharán para solucionar dudas y debatir sobre los contenidos visionados (Prats, Simón y Ojando, 2017). Todo ello favorece un mejor aprovechamiento de las clases presenciales, las cuales se dedican principalmente a aprendizajes procedimentales, dejando en un segundo plano las explicaciones teóricas.

- El aprendizaje y uso de la Realidad aumentada y los códigos QR para crear cuadernos virtuales, tareas con complementos digitales...

- Fomentar la creación a través del conocimiento de editores de partituras, secuenciadores, tablas de mezclas virtuales...

- La presentación de mSchools Toolbox como plataforma online de aplicaciones y contenido educativo validado y comprobado dirigido a escuelas, docentes, padres y alumnos. Los contenidos, seleccionados por docentes y expertos de la educación, garantizan que todas las experiencias y los recursos expuestos sean significativos en cuanto a su funcionalidad dentro de las aulas. Además, sirve como espacio para compartir y evaluar contenidos educativos realizados por alumnos y docentes.

\section{Educación emocional}

La educación emocional como recurso de primer orden para la formación integral de las personas ha ido ganando terreno dentro de las aulas en las últimas décadas, gracias a los beneficios intrapersonales e interpersonales que aporta a los alumnos, como el aumento de motivación, la mejora de resultados académicos, clima social positivo... (Bisquerra, 2009). Pese al auge actual de este concepto, los docentes han sabido siempre que en una clase es imposible separar la parte emocional de la parte académica (Cohen, 1999), es decir, que 
hace falta conocer a los alumnos, escucharlos, saber cómo piensan y qué sienten para sacar un mayor rendimiento por lo que a la parte académica respecta. En la facultad de educación se priorizan asignaturas académicas dejando un espacio residual a temas de carácter socioemocional como tutorías, orientación académica, resolución de conflictos..., por ello los profesores han de ser capaces de trabajar estos temas de forma interdisciplinar. Desde las didácticas se intenta diseñar actividades que además de tratar contenidos propios de cada área también estén relacionadas o sirvan como recursos para conocer los pilares básicos de la educación emocional como son: conciencia emocional, control emocional, autoeficacia emocional, competencias sociales y competencias para la vida y el bienestar (GROP, 2018).

\section{Resultados}

La implementación de los citados recursos metodológicos en las aulas de la facultad de educación ha repercutido de forma positiva, tal y como confirman los siguientes resultados:

- Mejora significativa del clima social de las aulas. Elevada asistencia (85\% aprox.) a las clases y participación activa de los alumnos a través de preguntas, aportaciones en los foros...

- Mejora de la motivación y las calificaciones. Las encuestas de evaluación que realizan los alumnos sobre las asignaturas que incorporan las citadas metodologías es de 8.83 y la nota media de las calificaciones académicas de los grupos se sitúa en torno 8.15.

- Los alumnos cuando realizan las prácticas manifiestan tener un amplio abanico de recursos metodológicos que les ayudan a hacer frente a las múltiples realidades educativas presentes en las escuelas del siglo XXI.

\section{A modo de conclusión}

En la actualidad vivimos inmersos en una sociedad en la que las nuevas tecnologías y los cambios sociales no ceden, es lo que se conoce como realidad VUCA (en inglés Volatility, Uncertainty, Complexity, Ambiguity). En este contexto, cualquier docente es consciente de la necesidad de estar al día, reciclándose constantemente, por lo que respecta al uso de las nuevas metodologías y las TAC (Tecnologías para el Aprendizaje y el Conocimiento), para poder así emplear en sus clases recursos didácticos efectivos, que se adapten a las múltiples realidades sociales presentes en cualquier aula. Ante este nuevo escenario educativo las facultades de educación tienen la responsabilidad de actualizarse para formar a futuros docentes competentes que puedan hacer frente a los retos que propone una sociedad cambiante y en constante evolución.

\section{Referencias}

ALSINA, J. (2013). (Coord.). Rúbriques per a l'avaluació de competencies. Barcelona: Octaedro, S. L.

BISQUERRA, R. (2009). Psicopedagogía de las emociones. Madrid: Editorial Síntesis.

COHEN, J. (Ed.). (1999). Educating Minds and Hearts. Alexandria, Virginia: ASCD. 
GROP (2018). Grup de Recerca i Orientació Psicopedagògica. <http://www.ub.edu/grop/es/> [Consulta: 20 de febrero de 2018]

PRATS, M. A., SIMÓN, J. y OJANDO, E. S. (2017). (Coords.). Diseño y aplicación de la flipped classroom. Barcelona: Graó.

TEIXES, F. (2014). Gamificación: fundamentos y aplicaciones. Barcelona: Editorial UOC. 


\title{
TRANSFERENCIA DEL CONOCIMIENTO DE ENFERMERIA A LOS TUTORES INSTITUCIONALES EN EL CONTEXTO DE LA PRÁCTICA CLÍNICA
}

Martinez-Momblan, Ma Antonia, Colina-Torralva Javier, Basco-PradoLuis, Delgado-Hito, P, De la Cueva-Ariza Laura, Romero-García, M. Departamento de enfermería Fundamental y Medicoquirúrgica de la Universidad de Barcelona

\begin{abstract}
In the field of clinical practice, different agents intervene: the institutional tutor, academic tutor and coordinators of clinical practice subjects. It was proposed to train institutional tutors from specific and adequate training to ensure their training in the context of clinical practice subjects. OBJECTIVE. To evaluate the level of satisfaction of the institutional tutors with the training received in the context of the clinical practice of the Degree in Nursing Design. Descriptive and transversal. Population and sample. 162 institutional tutors during the academic year 2016-2017 who teach in the subjects of Clinical Stages I and I. Sampling for convenience. Instruments and procedure. To assess the level of satisfaction, an Ad-hoc Questionnaire with 5 dimensions was elaborated: Teaching, Methodology, Organization and facilities, Thematic contents and Satisfaction. The questionnaire had 14 items. The Microsoft Excel 2010 Program will be used as support. RESULTS. The final sample consisted of $90 \%(n=146)$ of the institutional tutors, with 93\% $(n=136)$ women. The overall level of satisfaction was 50.4, with minimum values of 38 and maximums of 56. CONCLUSIONS: The levels of overall satisfaction of the training received by the Institutional Tutors vary between satisfactory and very satisfactory.
\end{abstract}

Keywords: learning, nursing, students, practicum evaluation, satisfaction.

\section{Resumen}

En el ámbito de la práctica clínica intervienen diferentes agentes: el tutor institucional, tutor académico y coordinadores de asignaturas de práctica clínica. Se planteó formar a los tutores institucionales a partir de formación específica y adecuada para poder garantizar su formación en el contexto de las asignaturas de práctica clínica. OBJETIVO. Evaluar el nivel de satisfacción de los tutores institucionales con la formación recibida en el contexto de la práctica clínica del Grado de Enfermería Diseño. Descriptivo y 
TRANSFERENCIA DEL CONOCIMIENTO DE ENFERMERIA A LOS TUTORES INSTITUCIONALES EN EL CONTEXTO DE LA PRÁCTICA CLÍNICA

transversal. Población y muestra. 162 tutores institucionales durante el curso académico 2016-2017 que imparten docencia en las asignaturas de Estancias Clínicas I y I. Muestreo por conveniencia. Instrumentos y procedimiento. Para evaluar el nivel de satisfacción se elaboró un Cuestionario ad-hoc con 5 dimensiones: Docencia profesorado, Metodología, Organización e instalaciones, Contenidos temáticos y Satisfacción. El cuestionario contó con 14 ítems. Se utilizará como soporte el Programa Microsoft Excel 2010. RESULTADOS. La muestra final estuvo formada por el 90\% $(n=146)$ de los tutores institucionales siendo un 93\% $(n=136)$ mujeres. El nivel de satisfacción global fue de 50,4, con valores mínimos de 38 y máximos de 56. CONCLUSIONES: Los niveles de satisfacción global de la formación recibida por los Tutores Institucionales oscilan entre satisfactorios y muy satisfactorios.

Palabras clave: Aprendizaje enfermeria, estudiantes, evaluación, prácticas y satisfacción.

\section{Introducción}

En el ámbito de la práctica clínica intervienen diferentes agentes: el tutor institucional, tutor académico y coordinadores de asignaturas de práctica clínica. El Sistema Nacional de Innovación (SIN), establece que tan importante es generar el conocimiento, como difundirlo adecuadamente entre todos los agentes que lo conforman, siendo los tutores/as institucionales el nexo de unión entre el ámbito asistencial y el académico.

Los tutores institucionales se definen como aquellos enfermeros que participan en la formación de los estudiantes en las asignaturas de prácticas clínicas, a través de la evidencia y la reflexión de todas aquellas situaciones clínicas dando ayuda y soporte a la construcción 
Martinez-Momblan, Ma Antonia, Colina-Torralva Javier, Melero García Angeles, Fernández Cervilla Ana Belen, Delgado-Hito, P, De la Cueva-Ariza Laura, Romero-García, M.

del conocimiento. El tutor/a institucional se convierte en un elemento clave para apoyar la transferencia de conocimientos competenciales en la práctica clínica y promover una cultura de aprendizaje dentro de la organización $(1,2)$. Para asegurar la calidad e idoneidad del proceso formativo en las asignaturas de prácticas clínicas, es necesario que los tutores/as institucionales conozcan el marco general, normativa de la formación práctica, y actividades formativas y evaluativas necesarias para favorecer la calidad docente y mejorar el proceso enseñanza-aprendizaje del estudiante (3).

De acuerdo al Código Ético de las enfermeras y enfermeros de Cataluña, la formación de los estudiantes del Grado de Enfermería forma parte del compromiso profesional; así en su artículo 72 establece que "la enfermera colabora en la formación de los estudiantes de enfermería, creando un entorno propicio para el aprendizaje y transmitiendo los valores, conocimientos y habilidades propios de la profesión” (4).

La formación de las asignaturas de práctica clínica queda vinculada a la universidad ya que es quién define y articula el plan docente, selecciona los diferentes centros con convenio con la universidad donde los estudiantes realizaran sus periodos de prácticas clínicas y quién supervisa el desarrollo del proceso enseñanza aprendizaje del estudiante. Los centros que acogen a los estudiantes en prácticas juegan un papel principal en la formación de los estudiantes en prácticas, su seguimiento, realización de actividades formativas y la 
TRANSFERENCIA DEL CONOCIMIENTO DE ENFERMERIA A LOS TUTORES INSTITUCIONALES EN EL CONTEXTO DE LA PRÁCTICA CLÍNICA

evaluación de los resultados de aprendizaje en base a la adquisición de las competencias $(5,6)$.

Por todo lo dicho con anterioridad, se planteó formar a los tutores institucionales a partir de formación específica y adecuada para poder garantizar una formación de calidad en el contexto de las asignaturas de práctica clínica $(7,8)$ en las asignaturas de Estadas Clínicas I y II del Grado de Enfermería de la Facultad de Medicina y Ciencias de la Salud de la Universidad de Barcelona. Algunas evidencias consultadas, constatan la necesidad de mejorar su labor formativa a través de la formación especializada $(9,10)$.

\section{Objetivo}

Evaluar el nivel de satisfacción de los tutores institucionales con la formación recibida en el contexto de la práctica clínica del Grado de Enfermería de la Universidad de Barcelona.

\section{Desarrollo de la innovación}

En el contexto de la práctica clínica de los estudios de Ciencias de la Salud, intervienen diferentes agentes que deben adquirir conocimiento y habilidades que repercutiran directamente en la calidad de lo que hace y como lo hace. Es por ello, que la transferencia de conocimiento en el tutor institucional la hemos implementado a lo largo del año académico y en todos los centros que intervienen en la formación en prácticas clínicas de 
Martinez-Momblan, Ma Antonia, Colina-Torralva Javier, Melero García Angeles, Fernández Cervilla Ana Belen, Delgado-Hito, P, De la Cueva-Ariza Laura, Romero-García, M.

los estudiantes de la Escuela Universitaria de Enfermeria y dentro del Departamento de enfermería Fundamental y Medicoquirúrgica.

\section{Metodología}

Método. Metodología cuantitativa de tipo descriptivo y transversal.

Ámbito de estudio. La Escuela de Enfermería de la Facultad de Medicina y Ciencias de la Salud de la Universidad de Barcelona.

Población y muestra. 162 tutores institucionales de los siguientes centros sanitarios:

Consorci Sanitari Parc Taulí, Sant Joan Despí Moisés Broggi, Hospital de Viladecans, Fundació Esperit Sant, Sagrat Cor, Fundació Plató durante el curso académico 2016-2017 que imparten docencia en las asignaturas de Estancias Clínicas I y II del Grado de Enfermería. Muestreo por conveniencia.

Instrumentos y procedimiento. Para evaluar el nivel de satisfacción se elaboró un Cuestionario ad-hoc con 5 dimensiones y 14 ítems: Docencia profesorado; ¿Se han explicado con claridad?,¿Se han alentado la participación?. ¿Han facilitado el intercambio de experiencias? Y ¿Dominaba el tema a desarrollar. Metodología; ¿ha adquirod nuevos conocimientos?, ¿Se han cubierto los objetivos? Y ¿Ha sido adecuada la metodología alos objetivos planteados?.Organización e instalaciones; ¿La organización ha sido correcta?,¿La sala y/o instalaciones han sido adecuados? Y ¿El número de alumnos del grupo ha sido 
TRANSFERENCIA DEL CONOCIMIENTO DE ENFERMERIA A LOS TUTORES INSTITUCIONALES EN EL CONTEXTO DE LA PRÁCTICA CLÍNICA

adecuado?. Contenidos y temá; ¿En qué medida le han resultado útiles? ¿En qué medida se han cumplimentado las expectativas?. Satisfacción Global; ¿ ¿Grado de satisfacción con la teória impartida?, ¿Grado de satisfacción con la práctica impartida?. El cuestionario contó con 14 ítems y una pregunta abierta sobre posibles sugerencias en el contexto de la sesión recibida. Cada uno de los ítems se midió de acuerdo a una escala tipo Likert con 4 opciones de respuesta:1) Nada Satisfecho, 2) Poco Satisfecho, 3) Satisfecho, 4) Muy satisfecho, siendo la puntuación mínima de 14 y máxima de 56 (Tabla 1). También se recogieron variables sociodemográficas. La cumplimentación se realizó al finalizar las sesiones formativas a los tutores académicos de forma voluntaria y anónima. Dichas sesiones mostraron a los tutores académicos el marco normativo, las funciones del tutor/a académico, el marco competencial, los instrumentos de aprendizaje y la evaluación de los mismos, siempre desde la reflexión y evidencia en la práctica.

Tabla 1. Cuestionario ad-hoc satisfacción formación tutores institucionales

\begin{tabular}{|c|c|c|}
\hline $\begin{array}{c}\text { Dimensiones } \\
\text { de la escala }\end{array}$ & Nombre & Items del cuestinario \\
\hline 1 & Profesorado & 3 \\
\hline 2 & Metodología & 3 \\
\hline 3 & Organización/ & 2 \\
\hline 4 & Instalaciones & 2 \\
\hline 5 & Contenidos y temas & \\
\hline & Grado Satisfacción & \\
\hline
\end{tabular}

(cc) BY-NC-ND 2018, Universitat Politècnica de València Congreso IN-RED (2018) 
Martinez-Momblan, Ma Antonia, Colina-Torralva Javier, Melero García Angeles, Fernández Cervilla Ana Belen, Delgado-Hito, P, De la Cueva-Ariza Laura, Romero-García, M.

Aspectos éticos. Se solicitó el consentimiento informado a cada uno de los tutores participantes en las sesiones. Cuenta con la aprobación del Comité Bioético de la Universidad de Barcelona (IRB00003099).

Análisis de los datos. Análisis descriptivo mediante frecuencias y porcentajes e inferencial a partir del coeficiente de correlación de Spearman. Se utilizará como soporte el Programa Microsoft Excel 2010.

\section{Resultados}

La muestra final estuvo formada por el $90 \%(n=146)$ de los tutores institucionales siendo un 93\% (n=136) mujeres. El nivel de satisfacción global fue de 50,4, con valores mínimos de 38 y máximos de 56. En relación a las dimensiones analizadas se obtuvieron las siguientes medias de satisfacción: Docencia del profesorado de 3,9; Metodología 3,5; Organización e instalaciones 3,5; Contenidos Temáticos 3,6 y Satisfacción general 3,6. Las sugerencias muestran que el $37 \%(n=54)$ de los tutores institucionales necesita mayor información sobre el manejo de las rúbricas de evaluación (diario reflexivo, proceso enfermero, seminario de farmacología y seminario de nutrición) en el contexto de la práctica clínica y un 22\% $(n=32)$ refieren necesitar mayor formación a nivel general

\section{(Figura 2).}

(cc) EY-NC-ND 2018, Universitat Politècnica de València 


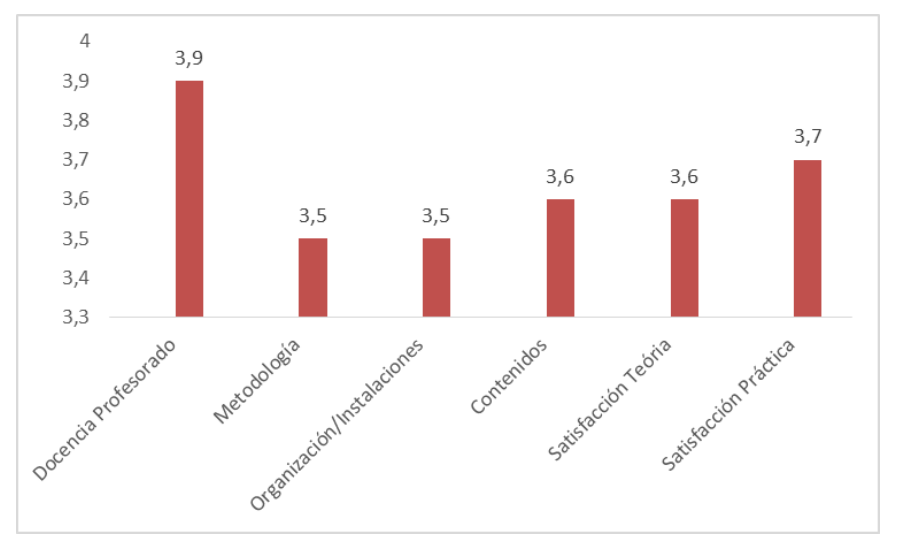

Figura 2. Satisfacción formación tutores institucionales

\section{Conclusiones}

Los niveles de satisfacción global de la formación recibida por los Tutores Institucionales oscilan entre satisfactorios y muy satisfactorios. Las sugerencias descritas nos orientan a acortar las distancias entre la tutora institucional y los responsables de asignaturas, estableciendo documentos marcos de práctica clínica que sirvan de guía y soporte en el proceso de seguimiento y evaluación de todos los agentes implicados en la formación de los estudiantes en el contexto de la práctica clínica.

\section{Bibliografía}

1.-Juvé Udina E, Farrero Muñoz S, Matad Calvo C, Monterde Prat D, Fierro Barrabás G, Marsal Serra R, Reyes Martin C, García Vidal B, Pons Prats A, Arnau Vives M, Martinez Luque $\mathrm{R}$, et al. ¿Cómo definen los profesionales de enfermería hospitalarios sus competencias asistenciales? Nursing 2007; 25 (7): 50-61. 
Martinez-Momblan, Ma Antonia, Colina-Torralva Javier, Melero García Angeles, Fernández Cervilla Ana Belen, Delgado-Hito, P, De la Cueva-Ariza Laura, Romero-García, M.

2.-Fahy A. Evaluating clinical competence assessment. Nurs Stand. 2011; 1723;25(50):42-48.

3.-Tanji S, Lopes CM, Vieira AP, Rodrigues W, De Paula C. Confrontación de criterios de evaluación del aprendizaje ante las apreciaciones de los estudiantes de enfermería. Enfermería Global. 2010; 9(1): 122-127.

4.-Judith Needham, Anne McMurray, Ramon Z. Shaban . Best practice in clinical facilitation of undergraduate nursing students. Nurse Education in Practice. 2016; 20: $131-138$.

5.-Kneafsey R. Developing skills in safe patient handling: mentors' views about their role in supporting student nurses. Nurse Educ Pract. 2007; 7(6):365-72.

6.-Ginsburg LR, Tregunno D, Norton PG. Self-reported patient safety competence among new graduates in medicine, nursing and pharmacy. BMJ Qual Saf. 2013; 22 (2): 147-54.

7.-Martínez Figueira, $M^{a}$ E. Ser tutor ¿cuestión de personalidad o de profesionalidad? Revista Española de Orientación y Psicopedagogía. 2010; 21 (3): 1-6.

8.-Molina, E. et al. La mejora del prácticum, esfuerzo de colaboración. Profesorado, Revista de Currículum y Formación de Profesorado. 2004; 8(2). 
TRANSFERENCIA DEL CONOCIMIENTO DE ENFERMERIA A LOS TUTORES INSTITUCIONALES EN EL CONTEXTO DE LA PRÁCTICA CLÍNICA

9.-Campbell,C.M., Smith,M., Dugan,J.P., and Komives, S.R. Mentors and college student

leadership outcomes: The importance of position and process. The Review of Higher

Education, 2012; 35(2): 595-625.

10.-Gershenfeld, S. A review of undergraduate mentoring programs. Review of

Educational Research, 2014; 84: 365-91.

(cc) EY-Nc-No 2018, Universitat Politècnica de València

Congreso IN-RED (2018) 


\title{
Correspondencia jerárquica entre las competencias y los resultados de aprendizaje. El caso de "Procedimientos de Construcción”
}

\section{Víctor Yepes}

ICITECH. Equipo de Innovación y Calidad Educativa EXCELCON. Departamento de Ingeniería de la Construcción y Proyectos de Ingeniería Civil. Universitat Politècnica de València, vyepesp@cst.upv.es

\begin{abstract}
This paper aims to establish a hierarchical corresponding structure between the competencies and the learning outcomes of a subject. To this end, after checking the different interpretations that exist between the two concepts, one chooses to consider that the learning outcomes are concretions of the competences for a certain level and that they are the result of the teachinglearning process. In addition, the necessary alignment between the programs of a subject, the acquisition of competencies and learning outcomes and the evaluation of the student, recommends to prioritize the learning results in two levels. As a result of the foregoing, this paper shows the applicability of this hierarchical correspondence to two subjects of the degree of Civil Engineering of the Universitat Politècnica de València: "Construction Procedures I and II".
\end{abstract}

Keywords: competences, learning outcomes, hierarchical correspondence, construction procedures, civil engineering

\footnotetext{
Resumen

El objetivo del artículo es establecer una estructuración de correspondencias jerárquicas entre las competencias y los resultados de aprendizaje de una asignatura. Para ello, tras comprobar las distintas interpretaciones que existen entre ambos conceptos, se opta por considerar que los resultados del aprendizaje son concreciones de las competencias para un determinado nivel y que son el resultado del proceso de enseñanza-aprendizaje. Además, el necesario alineamiento entre los programas de una asignatura, la adquisición de competencias y resultados de aprendizaje y la evaluación del estudiante, aconseja jerarquizar los resultados de aprendizaje en dos niveles. Como resultado de lo anterior, se muestra la aplicabilidad de esta correspondencia jerárquica a dos asignaturas del Grado de Ingeniería Civil de la Universitat Politècnica de València: "Procedimientos de Construcción I y II".
}

Palabras clave: competencias, resultados de aprendizaje, correspondencia jerárquica, procedimientos de construcción, ingeniería civil. 


\section{Introducción}

La Declaración de Bolonia, al tomar como foco el aprendizaje del estudiante, desencadenó un cambio profundo en el sistema universitario. Se trata de proporcionar competencias para que el futuro profesional tenga no solo la capacidad de innovar sino también la de adaptarse a los cambios utilizando y actualizando las competencias requeridas en su vida laboral (Yepes et al., 2012; Torres-Machí et al., 2013). Para asegurar la adquisición de estas competencias, los estudiantes deben alcanzar determinados resultados de aprendizaje. Dichos resultados deben alinearse con los contenidos programáticos, con los sistemas de evaluación y con las mismas competencias. Sin embargo, existe cierta confusión conceptual y organizativa que esta comunicación trata de resolver jerarquizando dichos conceptos y aplicándolo al caso concreto de un par de asignaturas, "Procedimientos de Construcción I y II” del Grado de Ingeniería Civil de la Universitat Politècnica de València (UPV).

Para Lasnier (2000) competencia es “un saber hacer complejo resultado de la integración, movilización y adecuación de capacidades y habilidades (de orden cognitivo, afectivo, psicomotor o social) y de conocimientos, utilizados eficazmente en situaciones que tengan un carácter común”. Según Vila y Poblete (2011) “una competencia supone la integración de una serie de elementos (conocimientos, técnicas, actitudes, procedimientos, valores) que una persona pone en juego en una situación problemática concreta demostrando que es capaz de resolverla". La Universitat Politècnica de València (UPV, 2006) destaca cuatro elementos en la definición de competencia: (a) saber hacer complejo: integración de elementos que permiten realizar tareas complejas; (b) integración: los componentes de las competencias tienen que estar relacionados de una manera sistémica, no lineal ni simplemente yuxtapuestos (puestos uno al lado del otro); (c) adecuación: la competencia activa las capacidades y habilidades pertinentes a la situación y tarea específica; y (d) carácter común de las situaciones: una competencia no es generalizable a todas y cualquiera de las posibles situaciones profesionales.

Los componentes de estas competencias expresan lo que el profesional ejecuta, con qué medios y para qué realiza ese saber hacer. Así, a partir de ellos se seleccionan los contenidos formativos, lo que implica diseñar acciones curriculares que promuevan el conocimiento conceptual, el desarrollo de actitudes y la adquisición de habilidades; acercar al estudiante a los contextos que constituirán su ámbito profesional y social, así como utilizar una metodología que facilite el aprendizaje de prácticas en las que, el estudiante, tenga que movilizar sus recursos. Sobre los componentes que conforman la competencia de un título resulta de interés el trabajo de Pellicer et al. (2013) y Yepes et al. (2016) sobre la adquisición de competencias en un máster en gestión de la construcción.

Así, el perfil académico-profesional de cada titulación debe concretar las competencias transversales y específicas. En ese sentido, el R.D. 1393/1997, de 29 de octubre, por el que se establece la ordenación de las enseñanzas universitarias oficiales, señala en su exposición de motivos que "los planes de estudios conducentes a la obtención de un título deberán tener en el centro de sus objetivos la adquisición de competencias por parte de los

(cc) EY-NC-ND 2018, Universitat Politècnica de València

Congreso IN-RED (2018) 
estudiantes, ampliando, sin excluir, el tradicional enfoque basado en contenidos y horas lectivas". En su Anexo I se indica que, para su correspondiente verificación, las universidades deben presentar "las competencias generales y específicas que los estudiantes deben adquirir durante sus estudios, y que sean exigibles para otorgar el título".

Además, en el Documento Marco sobre la integración del Sistema Educativo Español en el EEES, del Ministerio de Educación, Cultura y Deporte (2003), expone que en un Grado: "Los objetivos formativos de las enseñanzas oficiales de nivel de grado tendrán, con carácter general, una orientación profesional, es decir, deberán proporcionar una formación universitaria en la que se integren armónicamente las competencias genéricas básicas, las competencias transversales relacionadas con la formación integral de las personas y las competencias más específicas que posibiliten una orientación profesional que permita a los titulados una integración en el mercado de trabajo”; y en un Máster: "Los objetivos formativos serán más específicos que los de Grado y deberán estar orientados hacia una mayor profundización intelectual, posibilitando un desarrollo académico disciplinar e interdisciplinar, de especialización científica, de orientación a la investigación o de formación profesional avanzada”.

Con todo, los conceptos de competencia o resultado de aprendizaje no pocas veces se confunden (Yepes, 2017), tal y como se argumentará posteriormente. Para ello la comunicación se centra en su aplicación en las asignaturas "Procedimientos de Construcción I y II", del Grado de Ingeniería Civil impartido en la Escuela Técnica Superior de Ingenieros de Caminos, Canales y Puertos de Valencia (ETSICCP). La comunicación aclara la organización y jerarquía de estas competencias y resultados de aprendizaje en dichas asignaturas.

\section{Objetivos}

Esta comunicación tiene como objetivos los que se relacionan a continuación:

1. Justificar la necesidad de establecer una correspondencia jerarquíca entre las competencias de un título universitario y los resultados de aprendizaje de primer y segundo nivel necesarios para alcanzarlos

2. Mostrar un caso concreto de correspondencia jerárquica aplicado a las asignaturas "Procedimientos de Construcción I y II" del Grado de Ingeniería Civil de la UPV.

\section{Desarrollo de la innovación}

Este apartado plantea como novedad una correspondencia jerárquica entre las competencias y los resultados de aprendizaje, aclarando las diferencias entre estos conceptos. Las competencias específicas son las propias de un título y se orientan a la consecución de un perfil concreto del egresado, que incluyen las competencias básicas o generales y las competencias específicas propiamente. En el caso de los títulos que habilitan para el ejercicio de una actividad profesional regulada, las órdenes ministeriales correspondientes 
hacen referencia a las competencias que se deben requerir. Eso ocurre con el diseño del título de Grado en Ingeniería Civil en la UPV, basadas en lo recogido en el "Anexo I" de la Orden CIN/307/2009 incluye las competencias de carácter general y las competencias de las especializaciones que habilitan para la profesión de Ingeniero Técnico de Obras Públicas, complementándose con otras competencias adicionales dando lugar al listado completo recogido en la actual Memoria de Verificación del título, fechada el 30 de julio de 2015.

Por otra parte, un resultado de aprendizaje sería "una declaración de lo que el estudiante se espera que conozca, comprenda y sea capaz de hacer al finalizar un periodo de aprendizaje". Este concepto se considera como uno de los pilares del proceso de Bolonia (R.D. 1027/2011; ANECA, 2014). Sin embargo, esta noción, muy relacionada con el estudiante, se confunde en ocasiones con los objetivos de una asignatura, relacionados con el punto de vista del profesor. Un ejemplo de objetivo sería el siguiente: "presentar a los estudiantes los procedimientos de construcción básicos de túneles”. Como se puede comprobar, no es algo que se pueda evaluar. En cambio "elegir los procedimientos y la maquinaria más adecuada para la excavación de túneles” sí que se encuentra relacionado con lo que puede lograr el estudiante, siendo evaluable. También se podrían diferenciar los resultados de aprendizaje de un módulo, de una materia o de una asignatura. Además, cada resultado de aprendizaje de una asignatura se puede alcanzar con resultados de aprendizaje de segundo nivel correspondiente a las clases teóricas o las prácticas de aula, según se muestra en la Figura 1. Como se puede ver, los resultados del aprendizaje están directamente vinculados con una estrategia concreta de enseñanza y con unos métodos específicos de evaluación (Pellicer et al., 2016). Este alineamiento entre resultados, actividades de enseñanza y estrategias de evaluación dota de transparencia el proceso global de enseñanza- aprendizaje y permite garantizar la coherencia interna de los módulos y las asignaturas.

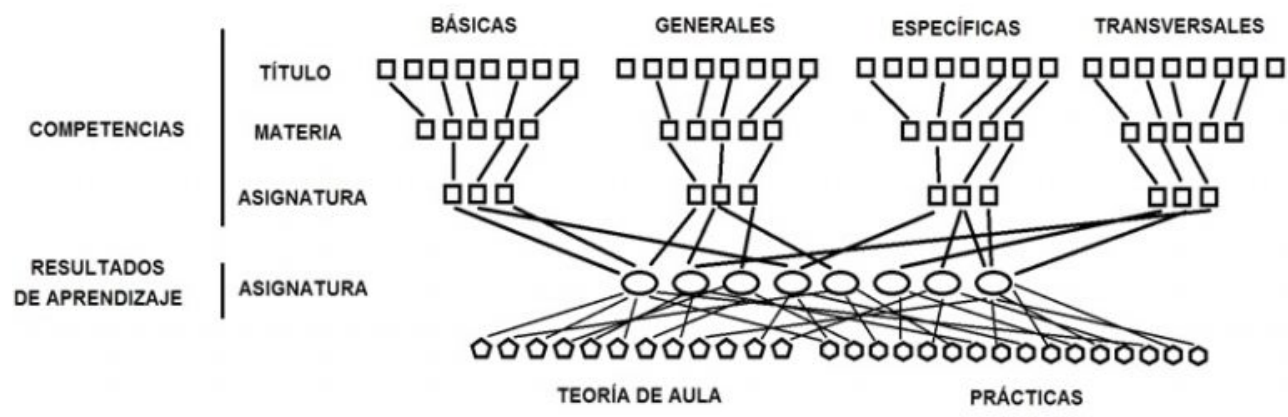

Fig. 1 Estructura de competencias y resultados de aprendizaje

Por otra parte, el contexto difumina en ocasiones la frontera entre resultado de aprendizaje y competencia. De hecho, hay países donde ambos conceptos son sinónimos. Así, el Marco Europeo de Cualificaciones para el aprendizaje permanente (EQF) considera que las competencias son parte de los resultados del aprendizaje. En cambio, el proyecto Tuning (Estructuras educativas en Europa) considera que las competencias se dividen en específicas y genéricas e incluyen “conocimientos y comprensión”, "saber cómo actuar” y

(cc) EY-NC-ND 2018, Universitat Politècnica de València

Congreso IN-RED (2018) 
"saber cómo ser", mientras que los resultados del aprendizaje, por su parte, expresan el nivel de competencia adquiridos. Sin embargo, en el Marco de Cualificaciones del EEES los resultados del aprendizaje son el producto del proceso de enseñanza, mientras que el término competencias se utiliza en un sentido amplio permitiendo la graduación de habilidades o destrezas, y se considera que está incluido en el concepto de resultados del aprendizaje.

En España, el uso del término "competencias" está más extendido que el de "resultados del aprendizaje”. Así, el R.D. 1393/2007 señala que "los planes de estudios conducentes a la obtención de un título deberán tener en el centro de sus objetivos la adquisición de competencias por parte de los estudiantes, ampliando, sin excluir, el tradicional enfoque basado en contenidos y horas lectivas". Los resultados del aprendizaje se mencionan en la exposición de motivos ("Se proponen los créditos europeos, ECTS, como unidad de medida que refleja los resultados del aprendizaje y volumen de trabajo realizado por el estudiante para alcanzar los objetivos establecidos en el plan de estudios") y en el punto 8 del Anexo I (la universidad debe presentar el "procedimiento general de la Universidad para valorar el progreso y los resultados del aprendizaje de los estudiantes"). Las órdenes ministeriales relacionadas con los títulos que habilitan para una profesión regulada se refieren a competencias, y no a resultados de aprendizaje. Éste último término sí que se utiliza en el R.D. 1027/2011 por el que se establece el Marco Español de Cualificaciones para la Educación Superior (MECES).

Ante esta confusión, se propone seguir el criterio de ANECA (2014), en donde se considera que los resultados del aprendizaje son concreciones de las competencias para un determinado nivel y que son el resultado del proceso de enseñanza-aprendizaje. Por tanto, se considera que los resultados del aprendizaje describen lo que los estudiantes deben ser capaces de hacer al término del proceso formativo o de la asignatura. Para que ello sea posible deben definirse con claridad; deben ser observables y evaluables; deben ser factibles y alcanzables por los estudiantes; deben diseñarse para asegurar su idoneidad y relevancia con respecto a la asignatura o enseñanza; deben guardar relación directa con los resultados del aprendizaje del programa; y deben corresponder al nivel definido en el MECES.

Los resultados del aprendizaje se definen con frases con un verbo de acción, un contenido u objeto sobre el que el estudiante tiene que actuar y un contexto o condiciones en las que se producirá la acción. Suele utilizarse la jerarquía de Bloom para su redacción. Remitimos al lector a la "Guía de apoyo para la redacción, puesta en práctica y evaluación de los resultados del aprendizaje” (ANECA, 2014).

Otro aspecto trascendental es la relación entre los resultados de aprendizaje y su evaluación (Yepes, 2017). En este sentido, los métodos y las actividades formativas y los sistemas de evaluación deben coordinarse para alcanzar los resultados del aprendizaje. Así, la ANECA considera importante esta alineación, como así queda reflejado en el "Criterio 6. Resultados de aprendizaje", en donde la directriz 6.1 a valorar para su cumplimiento indica "Las actividades formativas, sus metodologías docentes y los sistemas de evaluación empleados son adecuados y se ajustan razonablemente al objetivo de la adquisición de los resultados 
de aprendizaje previstos.” Por último, señalar que los resultados de aprendizaje son dinámicos, siendo aconsejable su revisión periódica y sistemática así como su interrelación con las metodologías docentes y las prácticas de evaluación.

\section{Resultados}

Lo anteriormente expuesto permite un proceso de reflexión que concluye en la formulación de los resultados de aprendizaje de primer y segundo nivel y su relación jerárquica con las competencias de distinto tipo establecidas en una asignatura, materia o título. A continuación se recoge como resultado de esta formulación su aplicación a las asignaturas de "Procedimientos de Construcción I y II" del Grado de Ingeniería Civil de la UPV. Los programas de estas asignaturas, que constituyen la base de esta formulación, se desarrollaron basándose en los contenidos determinados en la Memoria de Verificación del título oficial de "Graduado o Graduada en Ingeniería Civil por la Universitat Politècnica de València" (2502507) que fue aprobado por el Consejo de Universidades el 5 de noviembre de 2010, y cuya renovación de la acreditación del título oficial se resolvió favorablemente el 22 de julio de 2016. Se trata de asignaturas de la materia "Bases de la ingeniería de la construcción” perteneciente a la titulación del GIC, y por tanto es obligatoria para todos los estudiantes de esta titulación y se imparten en el segundo curso.

\subsection{Competencias de la materia "Bases de la Ingeniería de la Construcción"}

Las asignaturas "Procedimientos de Construcción I y II" pertenecen a la materia de carácter obligatorio "Bases de la Ingeniería de la Construcción". Cada una de ellas tiene una asignación de 4,5 créditos ECTS, repartidos en 2,5 créditos de teoría y 2,0 de prácticas. Además, también pertenecen a esta materia las siguientes asignaturas: "Electrotecnia", con 4,5 ECTS; "Materiales de construcción y sus aplicaciones a la ingeniería civil", con 6,0 ECTS; y "Química para la ingeniería civil", con 6,0 ECTS. Las competencias asignadas a esta materia, de acuerdo con la Memoria de Verificación, son:

\section{Competencias básicas y generales:}

A01 - Analizar críticamente los procesos propios de la Ingeniería Civil.

A02. - Aprender de manera autónoma nuevos conocimientos y técnicas adecuados para la Ingeniería Civil.

A03 - Comprender y asumir la responsabilidad ética y profesional de la actividad del Ingeniero Civil.

A04 - Comprender y utilizar el lenguaje propio de la ingeniería así como la terminología propia de la Ingeniería Civil.

A07 - Conocer y comprender las ciencias y las tecnologías correspondientes para la planificación, proyecto, construcción y explotación de las obras propias del Sector de la Ingeniería Civil. 
A08 - Dirigir y coordinar grupos de trabajo en el ámbito de la Ingeniería Civil, proponiendo métodos de trabajo estándar y herramientas a utilizar.

A10 - Tener la capacidad para organizar y gestionar técnica, económica y administrativamente los distintos medios de producción propios de la Ingeniería Civil.

A11 - Capacitar científica y técnicamente para el ejercicio de la profesión de Ingeniero Técnico de Obras Públicas con conocimiento de las funciones de asesoría, análisis, diseño, cálculo, proyecto, construcción, mantenimiento conservación y explotación.

A12 - Comprender los múltiples condicionamientos de carácter técnico y legal que se plantean en la construcción de una obra pública, y capacitación para emplear métodos contrastados y tecnologías acreditadas, con la finalidad de conseguir la mayor eficacia de la construcción dentro del respeto por el medio ambiente y la protección de la seguridad y salud de los trabajadores y usuarios de la obra pública.

\section{Competencias específicas:}

C02 - Comprender las propiedades químicas, físicas, mecánicas y tecnológicas de los materiales más utilizados en construcción.

C03 - Aplicar los conocimientos de materiales de construcción en sistemas estructurales, a partir del conocimiento de la relación entre la estructura de los materiales y las propiedades mecánicas que de ella se derivan.

C09 - Analizar la problemática de la seguridad y salud en las obras de construcción.

C10 - Comprender el sistema eléctrico de potencia: generación de energía, red de transporte, reparto y distribución, así como sobre tipos de líneas y conductores. Comprender la normativa sobre baja y alta tensión.

C12 - Comprender los procedimientos constructivos, la maquinaría de construcción y las técnicas de organización, medición y valoración de obras.

Estas competencias se desarrollan en las distintas asignaturas de la materia, según se muestra en la Tabla 1, según consta en la Memoria de Verificación del título y en las Guías Docentes de las asignaturas.

Tabla 1. Asignación de competencias en la materia "Bases de la ingeniería de la construcción” del Grado de Ingeniería Civil

\begin{tabular}{|c|c|c|c|c|c|c|c|c|c|c|c|c|c|c|}
\hline & \multicolumn{14}{|c|}{ Competencias } \\
\hline & \multicolumn{9}{|c|}{ Básicas y generales } & \multicolumn{5}{|c|}{ Específicas } \\
\hline Asignatura & A01 & A02 & A03 & A04 & A07 & A08 & A10 & A11 & A12 & $\mathrm{C02}$ & $\mathrm{C03}$ & C09 & C10 & C12 \\
\hline Electrotecnia & & & & $\bullet$ & & & & & & & & & $\bullet$ & \\
\hline $\begin{array}{l}\text { Materiales de } \\
\text { construcción y sus } \\
\text { aplicaciones a la I.C. }\end{array}$ & $\bullet$ & $\bullet$ & $\bullet$ & $\bullet$ & & & & $\bullet$ & $\bullet$ & $\bullet$ & $\bullet$ & & & \\
\hline $\begin{array}{l}\text { Procedimientos de } \\
\text { Construcción I }\end{array}$ & • & & & $\bullet$ & & & $\bullet$ & & $\bullet$ & & & $\bullet$ & & $\bullet$ \\
\hline
\end{tabular}




\begin{tabular}{|l|c|c|c|c|c|c|c|c|c|c|c|c|c|c|}
\hline $\begin{array}{l}\text { Procedimientos de } \\
\text { Construcción II }\end{array}$ & $\bullet$ & $\bullet$ & & $\bullet$ & $\bullet$ & $\bullet$ & $\bullet$ & $\bullet$ & & & & $\bullet$ & & $\bullet$ \\
\hline $\begin{array}{l}\text { Química para la } \\
\text { ingeniería civil }\end{array}$ & $\bullet$ & $\bullet$ & $\bullet$ & $\bullet$ & & & & & & $\bullet$ & $\bullet$ & & & \\
\hline
\end{tabular}

\subsection{Las competencias transversales en las asignaturas "Procedimientos de Construcción I y II"}

La ETSICCP ha escogido la asignatura “Procedimientos de Construcción II" como punto de control de la competencia CT09. Pero, además, se trabajan las competencias CT01 y CT06. Estas tres competencias también se trabajan en "Procedimientos de Construcción I". De acuerdo con esta asignación, la asignatura trabaja las competencias según lo acordado por la UPV (http://www.upv.es/contenidos/COMPTRAN/):

\section{CT01.- Comprensión e integración}

"Comprender quiere decir "percibir y tener una idea clara de lo que se dice, se hace o sucede o descubrir el sentido profundo de algo". Para demostrar que algo se ha comprendido, la persona identifica y recupera la información y la explica con sus propias palabras, interpretando e integrando las ideas desde su propia perspectiva”.

\section{CT06.- Trabajo en equipo y liderazgo}

"El trabajo en equipo implica crear y desarrollar un clima de confianza mutua entre los componentes que permita trabajar de forma responsable y cooperativa. El término más apropiado para describir esta situación es COMPARTIR: compartir conocimientos, compromiso y responsabilidad. Supone el reparto de tareas y roles y el respeto a las normas y reglas de juego establecidas por y para el grupo".

\section{CT09.- Pensamiento crítico}

“El pensamiento crítico va más allá de las destrezas del análisis lógico, ya que, implica poner en cuestión los supuestos subyacentes en nuestras formas habituales de pensar y actuar $y$, en base a ese cuestionamiento crítico, estar preparado para pensar y hace diferente. El pensamiento crítico es el pensamiento de los interrogantes: ¿por qué las cosas son así?, ¿por qué las cosas no pueden ser de otro modo?, ¿por qué tú crees que son así?, etc. En consecuencia, diremos que una persona lo ha desarrollado en la medida en que se interroga sobre las cosas y se interesa por los fundamentos en los que se asientan las ideas, las acciones, las valoraciones y juicios tanto propios como ajenos."

Puesto que la asignatura "Procedimientos de Construcción II" se imparte en $2^{\circ}$ del GIC, se ha de evaluar el Nivel 1 de dominio de la competencia transversal.

En el caso de la CT01, el estudiante ha de "describir, relacionar e interpretar situaciones y planteamientos sencillos”. Los indicadores son:

- Identificar correctamente las ideas o conceptos de un texto, problema, ejercicio...

- Explicar correctamente, con sus propias palabras, las ideas planteadas en un texto, problema, ejercicio...

(cc) EY-NC-ND 2018, Universitat Politècnica de València 
- Interpretar, expresando de modo personal, las ideas o conceptos planteados en un texto, problema, ejercicio...

- Integrar distintas ideas o conceptos de la asignatura en sus análisis.

En el caso de la CT06, el estudiante ha de "participar y colaborar activamente en las tareas del equipo, orientándose hacia el trabajo en común". Los indicadores son:

- Aceptar y cumplir los objetivos del equipo.

- Acudir y participar activamente en las reuniones del equipo.

- Realizar las tareas asignadas dentro del equipo en el plazo fijado.

En el caso de la CT09, el estudiante ha de "mostrar una actitud crítica ante la realidad, siendo capaz de analizar y cuestionar información, resultados, conclusiones y otros puntos de vista”. Los indicadores son:

- Mostrar una actitud crítica ante la realidad: se pregunta el porqué de las cosas.

- Profundizar en un tema con lógica e imparcialidad, contrastando información en fuentes fiables.

- Diferenciar hechos de opiniones, interpretaciones o valoraciones.

- Prever las consecuencias (implicaciones prácticas) de las decisiones.

En la metodología docente se proponen las actividades desarrolladas relacionadas con la adquisición de cada competencia y los criterios de evaluación. El candidato, junto con otros profesores de la asignatura, analizaron en distintos trabajos la valoración del pensamiento crítico como competencia transversal basada en la percepción de los estudiantes respecto a su importancia, tanto en los grados de Ingenieros de Obras Públicas como los de Ingeniería Civil (Halpern, 1989; Martí y Yepes, 2015; Yepes y Martí, 2015; Yepes et al., 2016; Yepes et al., 2017). Los resultados muestran como casi tres cuartas partes de los estudiantes han alcanzado suficientemente la competencia. Sin embargo, los resultados muestran cierta desconexión entre los resultados relativos a las competencias específicas y los resultados relativos a la competencia transversal. Estas evidencias manifiestan que la adquisición de la competencia transversal del pensamiento crítico se ve favorecida por los trabajos de discusión en grupo. No obstante, la adquisición de competencias específicas por parte de los estudiantes requiere no sólo de trabajos en grupo, sino también de trabajos individuales.

\subsection{Propuesta de resultados de aprendizaje de la asignatura "Procedimientos de Construcción I"}

Los resultados de aprendizaje propuestos para "Procedimientos de Construcción I" considera las competencias y los contenidos de la asignatura, influyendo los criterios de evaluación seguidos para su consecución. En la Tabla 2 se recogen las relaciones entre los resultados de aprendizaje y las competencias asociadas. A modo de resumen, al terminar con éxito esta asignatura los estudiantes serán capaces de "comprender los diferentes 
procedimientos constructivos y aplicar la maquinaria y los medios auxiliares necesarios para realizar dichos trabajos, especialmente en lo relativo a los sondeos y mejora de terrenos, las excavaciones y voladuras y a la ejecución de firmes, así como entender el funcionamiento de las instalaciones de fabricación de áridos y de aglomerado asfáltico".

Tabla 2. Resultados de aprendizaje de la asignatura "Procedimientos de Construcción I"

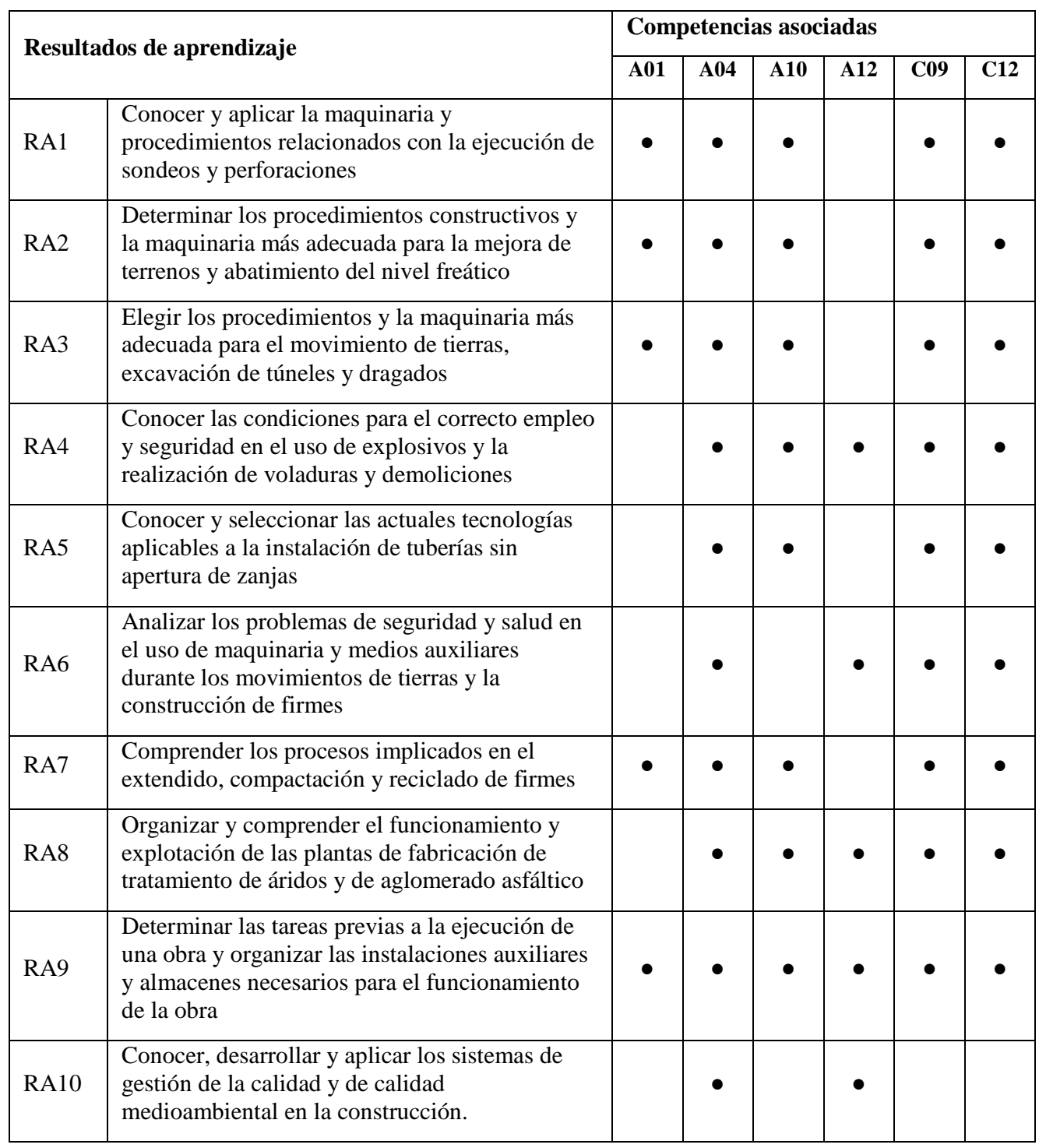

\subsection{Propuesta de resultados de aprendizaje de la asignatura "Procedimientos de Construcción II"}

Los resultados de aprendizaje propuestos para "Procedimientos de Construcción II", análogamente al caso anterior, se han formulado considerando las competencias y los contenidos de la asignatura, influyendo asimismo los criterios de evaluación. La Tabla 3 recoge las relaciones entre los resultados de aprendizaje y las competencias asociadas. De

(cc) EY-NC-ND 2018, Universitat Politècnica de València 
este modo, al terminar esta asignatura los estudiantes serán capaces de "comprender los diferentes procedimientos constructivos y aplicar la maquinaria y los medios auxiliares necesarios para realizar dichos trabajos, especialmente en lo relativo a la ejecución de cimentaciones y estructuras, así como entender el funcionamiento de las instalaciones de fabricación de hormigón y de prefabricados, evaluar los costes y la producción de los equipos y organizar y planificar las obras".

Tabla 3. Resultados de aprendizaje de la asignatura "Procedimientos de Construcción II"

\begin{tabular}{|c|c|c|c|c|c|c|c|c|c|c|}
\hline \multirow{2}{*}{\multicolumn{2}{|c|}{ Resultados de aprendizaje }} & \multicolumn{9}{|c|}{ Competencias asociadas } \\
\hline & & \multirow{2}{*}{$\begin{array}{l}\mathrm{A} \\
01\end{array}$} & \multirow{2}{*}{$\begin{array}{l}\mathbf{A} \\
\mathbf{0 2} \\
\bullet\end{array}$} & \multirow{2}{*}{$\begin{array}{l}\text { A } \\
04 \\
\\
\end{array}$} & \multirow{2}{*}{$\begin{array}{l}\text { A } \\
\mathbf{0 7}\end{array}$} & \multirow{2}{*}{$\begin{array}{l}\text { A } \\
08\end{array}$} & \multirow{2}{*}{$\begin{array}{l}\text { A } \\
10 \\
\\
\end{array}$} & \multirow{2}{*}{$\begin{array}{l}\text { A } \\
11 \\
\\
\end{array}$} & \multirow{2}{*}{$\begin{array}{l}\mathrm{C} \\
09\end{array}$} & \multirow{2}{*}{$\begin{array}{l}\mathrm{C} \\
12 \\
\end{array}$} \\
\hline RA1 & $\begin{array}{l}\text { Evaluar los rendimientos, la } \\
\text { productividad y los costes de los } \\
\text { equipos empleados en obra }\end{array}$ & & & & & & & & & \\
\hline RA2 & $\begin{array}{l}\text { Conocer el mantenimiento y la } \\
\text { explotación de la maquinaria en } \\
\text { función de sus características y del } \\
\text { uso al que vayan a estar sometidos }\end{array}$ & & & $\bullet$ & $\bullet$ & & $\bullet$ & $\bullet$ & & $\bullet$ \\
\hline RA3 & $\begin{array}{l}\text { Identificar los tipos y } \\
\text { características de la maquinaria y } \\
\text { de los medios auxiliares, su } \\
\text { funcionamiento y aplicabilidad en } \\
\text { las obras }\end{array}$ & & & $\bullet$ & & & $\bullet$ & $\bullet$ & & $\bullet$ \\
\hline RA4 & $\begin{array}{l}\text { Comprender y aplicar los } \\
\text { conceptos relacionados con la } \\
\text { teoría y práctica de los cables y la } \\
\text { maquinaria de elevación }\end{array}$ & & & $\bullet$ & & & • & • & & $\bullet$ \\
\hline RA5 & $\begin{array}{l}\text { Organizar y comprender el } \\
\text { funcionamiento y explotación de } \\
\text { las plantas de fabricación de } \\
\text { hormigón y de prefabricados }\end{array}$ & $\bullet$ & & $\bullet$ & • & • & • & $\bullet$ & & $\bullet$ \\
\hline RA6 & $\begin{array}{l}\text { Comprender los procesos } \\
\text { implicados en la fabricación, } \\
\text { transporte y puesta en obra del } \\
\text { hormigón }\end{array}$ & $\bullet$ & • & $\bullet$ & $\bullet$ & • & & $\bullet$ & & $\bullet$ \\
\hline RA7 & $\begin{array}{l}\text { Elegir los procedimientos } \\
\text { constructivos y la maquinaria más } \\
\text { adecuada para la construcción de } \\
\text { cimentaciones y estructuras }\end{array}$ & $\bullet$ & $\bullet$ & • & $\bullet$ & $\bullet$ & $\bullet$ & $\bullet$ & $\bullet$ & $\bullet$ \\
\hline RA8 & $\begin{array}{l}\text { Analizar los problemas de } \\
\text { seguridad y salud en el uso de } \\
\text { maquinaria y medios auxiliares al } \\
\text { ejecutar estructuras de hormigón }\end{array}$ & & $\bullet$ & $\bullet$ & & & & $\bullet$ & $\bullet$ & $\bullet$ \\
\hline RA9 & $\begin{array}{l}\text { Seleccionar, organizar y controlar } \\
\text { los recursos humanos y materiales } \\
\text { necesarios en la ejecución de una } \\
\text { unidad de obra }\end{array}$ & & $\bullet$ & • & • & $\bullet$ & $\bullet$ & $\bullet$ & $\bullet$ & $\bullet$ \\
\hline RA10 & $\begin{array}{l}\text { Aplicar las técnicas de } \\
\text { planificación y programación }\end{array}$ & $\bullet$ & $\bullet$ & $\bullet$ & $\bullet$ & & $\bullet$ & $\bullet$ & & $\bullet$ \\
\hline
\end{tabular}




\begin{tabular}{|l|l|l|l|l|l|l|l|l|l|l|}
\hline $\begin{array}{l}\text { temporal de una obra a partir de } \\
\text { una documentación básica }\end{array}$ & & & & & & & & & \\
\hline
\end{tabular}

\subsection{Ejemplo de integración jerárquica de resultados de aprendizaje y competencias}

A continuación se presenta como ejemplo de integración jerárquica de resultados de aprendizaje de segundo nivel (procedentes de las teoría de aula y de las prácticas de aula) en un resultado de aprendizaje de primer nivel y cómo éste se relaciona con algunas de las competencias del grado. Se ha elegido para ello el resultado de aprendizaje RA4 de la asignatura "Procedimientos de Construcción I", que a su vez se corresponde con la material “Bases de la Ingeniería de la Construcción” del Grado de Ingeniería Civil. Este resultado de aprendizaje se puede formular de la siguiente forma: “conocer las condiciones para el uso correcto del empleo y seguridad en el uso de explosivos y la realización de voladuras y demoliciones". La adquisición de este resultado de aprendizaje depende directamente de los temas teóricos T9 “Explosivos y accesorios de voladuras” y T10 "Voladuras de rocas, voladuras especiales y demoliciones”, además de la práctica de aula PA13 “Diseño de una voladura en banco en una cantera". Los resultados de aprendizaje de segundo nivel se detallan en la Tabla 4. La relación entre los resultados de primer y segundo nivel, y las competencias, se representan en la Figura 2. El conjunto completo de correspondencias jerárquicas para las dos asignaturas se puede consultar en el trabajo de Yepes (2017).

Tabla 4. Resultados de aprendizaje de segundo nivel correspondientes con el resultado RA4 de la asignatura "Procedimientos de Construcción II"

\begin{tabular}{|c|c|}
\hline \multicolumn{2}{|c|}{ Resultados de aprendizaje RA4 } \\
\hline Tema T09 & $\begin{array}{l}\text { Identificar y conocer los materiales explosivos y los accesorios utilizados en los } \\
\text { procesos de voladura. } \\
\text { Advertir la peligrosidad y medidas de precaución a tener en cuenta en cada tipo de } \\
\text { explosivo. } \\
\text { Conocer la aplicabilidad de los detonadores y su cálculo. }\end{array}$ \\
\hline Tema T10 & $\begin{array}{l}\text { Identificar el equipo especializado que se utiliza en los procesos de voladura. } \\
\text { Conocer las precauciones a tener en cuenta en durante todo el proceso de una voladura, } \\
\text { antes y después de la pega. } \\
\text { Diseñar voladuras para la explotación de canteras, apertura de tajos y canales y } \\
\text { perforación de túneles. } \\
\text { Conocer las técnicas de voladuras especiales, tanto bajo el agua como en atmósferas } \\
\text { peligrosas. } \\
\text { Comprender de la reglamentación existente en materia de explosivos, así como su uso y } \\
\text { manejo. }\end{array}$ \\
\hline $\begin{array}{l}\text { Práctica de } \\
\text { Aula } \\
\text { PA13 }\end{array}$ & $\begin{array}{l}\text { Seleccionar el tipo de explosivo y los accesorios necesarios en cada barreno } \\
\text { Diseñar la voladura en banco atendiendo a sus parámetros principales } \\
\text { Entender la importancia del diámetro del barreno en el diseño de la voladura } \\
\text { Calcular la perforación específica y la carga específica }\end{array}$ \\
\hline
\end{tabular}

(cc) EY-NC-ND 2018, Universitat Politècnica de València

Congreso IN-RED (2018) 
En la Tabla 2 se puede comprobar que el resultado de aprendizaje RA4 se encuentra relacionado con las competencias A04, A10, C09 y C12. Toda esta información se resume en la Figura 2, donde se grafían las relaciones entre los resultados de aprendizaje de primer nivel (RA4), de segundo nivel y las competencias correspondientes (Yepes, 2018).

El último paso sería establecer un sistema de evaluación que permitiese garantizar la adquisición del resultado de aprendizaje de primer nivel. Si observamos en la Tabla 4, la pormenorización en resultados de aprendizaje de segundo nivel permite, casi de forma directa, formular pruebas de evaluación.

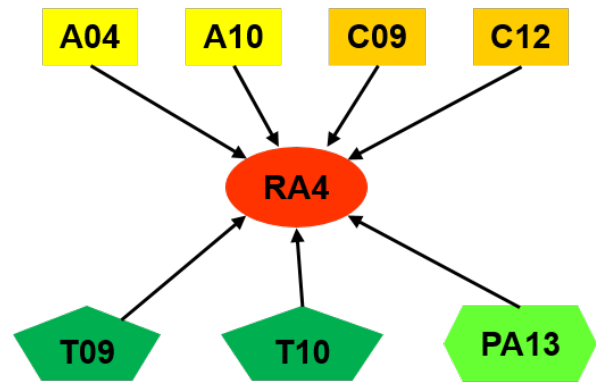

Fig. 2 Correspondencias jerárquicas entre un resultado de aprendizaje de primer nivel, las competencias y los resultados de aprendizaje de segundo nivel

\section{Conclusiones}

La comunicación se ha centrado, por una parte, en aclarar los conceptos de competencia y resultado de aprendizaje relacionados con una asignatura, muchas veces confusos en función del contexto. Para ello se ha optado por considerar que los resultados del aprendizaje son concreciones de las competencias para un determinado nivel y que son el resultado del proceso de enseñanza-aprendizaje. Por otra parte, se ha comprobado cómo las competencias se pueden clasificar y jerarquizar atendiendo al contexto del título, materia o asignatura. Lo mismo ocurriría con los resultados de aprendizaje que, en el caso de una asignatura, a su vez se pueden desglosar en resultados de segundo nivel en función de las clases teóricas o prácticas. Este desglose resulta necesario para poder diseñar sistemas de evaluación coherentes con la garantía en la adquisición de los resultados de aprendizaje, y por ende, de las competencias. Para que todo ello sea posible, es necesario establecer matrices de correspondencias jerárquicas entre las competencias y los resultados de aprendizaje. Como resultado de lo anterior, se ha presentado la aplicación práctica de esta propuesta en dos asignaturas, "Procedimientos de Construcción I y II" del Grado de Ingeniería Civil de la UPV. 


\section{Agradecimientos}

El autor agradece el apoyo recibido por la Universitat Politècnica de València (Equipo de Innovación y Calidad Educativa EXCELCON):

\section{Referencias}

ANECA (2014). Guía de apoyo para la redacción, puesta en práctica y evaluación de los resultados de aprendizaje. Madrid. Disponible en <http://www.aneca.es/Documentos-y-publicaciones/Otrasguias-y-documentos-de-evaluacion/Guia-de-apoyo-para-la-redaccion-puesta-en-practica-yevaluacion-de-los-RESULTADOS-DEL-APRENDIZAJE> [Consulta: 5 de marzo de 2018]

España. Orden CIN/307/2009, de 9 de febrero, por la que se establecen los requisitos para la verificación de los títulos universitarios oficiales que habiliten para el ejercicio de la profesión de Ingeniero Técnico de Obras Públicas. BOE, 18 de febrero de 2009, núm. 42, p. 17166-17170.

España. Real Decreto 1027/2011, de 15 de julio, por el que se establece el Marco Español de Cualificaciones para la Educación Superior. BOE, 3 de agosto de 2011, núm. 185, p. 87912-87918.

España. Real Decreto 1393/1997, de 29 de octubre, por el que se establece la ordenación de las enseñanzas universitarias oficiales. BOE, 30 de octubre de 2007, núm. 260, p. 44037-44048.

HALPERN, D.F. (1989). Thought and Knowledge: An Introduction to Critical Thinking. Hillsdale, New Jork: Erlbaum.

LASNIER, F. (2000). Réussir la formation par compétences. Montréal: Guérin.

MARTÍ, J.V. y YEPES, V. (2015). "Pensamiento crítico como competencia transversal en el grado de Ingeniería de Obras Públicas: valoración previa” en Congreso In-Red 2015. Valencia, pp. 1-12. Disponible en: <http://dx.doi.org/10.4995/INRED2015.2015.1560> [Consulta: 7 de marzo de 2018]

MINISTERIO DE EDUCACIÓN, CULTURA Y DEPORTE (2003). La integración del sistema universitario español en el Espacio Europeo de Enseñanza Superior. Documento-Marco. Disponible en <http://www.eees.es/pdf/Documento-Marco_10_Febrero.pdf> [Consulta: 6 de marzo de 2018]

PELLICER, E., SIERRA, L.A. y YEPES, V. (2016). “Appraisal of infrastructure sustainability by graduate students using an active-learning method" en Journal of Cleaner Production, vol. 113, p. 884-896.

PELLICER, E., YEPES, V. y ORTEGA, A.J. (2013). “Method for planning a graduate program in construction management” en Journal of Professional Issues in Engineering Education and Practice ASCE, vol. 139, issue 1, p. 33-41.

TORRES-MACHÍ, C., CARRIÓN, A., YEPES, V. y PELLICER, E. (2013). "Employability of graduate students in construction management” en Journal of Professional Issues in Engineering Education and Practice ASCE, vol. 139, issue 2, p. 163-170.

UNIVERSITAT POLITÈCNICA DE VALÈNCIA (2006). Guía docente de la UPV: criterios para su elaboración. Plan de acciones para la convergencia europea (PACE). Valencia: Instituto de Ciencias de la Educación. Disponible en: http://www.aqu.cat/doc/doc_52850666_1.pdf [Consulta: 6 de marzo de 2018]

UNIVERSITAT POLITÈCNICA DE VALÈNCIA. Competencias transversales. Disponible en: $<$ http://www.upv.es/contenidos/COMPTRAN/> [Consulta: 6 de marzo de 2018]

(cc) EY-NC-ND 2018, Universitat Politècnica de València

Congreso IN-RED (2018) 
VILA, A. y POBLETE, M. (2011). "Evaluación de competencias genéricas: principios, oportunidades y limitaciones” en Bordón, vol. 63, issue 1, p. 147-170.

YEPES, V. (2017). Proyecto docente. Concurso de acceso al cuerpo de catedráticos de universidad. Valencia: Universitat Politècnica de València.

YEPES, V. (2018) "Los resultados de aprendizaje de la asignatura «Procedimientos de Construcción»” en El Blog de Víctor Yepes, 16 de enero $<$ http://victoryepes.blogs.upv.es/2018/01/16/los-resultados-de-aprendizaje-de-la-asignaturaprocedimientos-de-construccion/> [Consulta: 5 de marzo 2018]

YEPES, V., PELLICER, E. y ORTEGA, J.A. (2012). "Designing a benchmark indicator for managerial competences in construction at the graduate level” en Journal of Professional Issues in Engineering Education and Practice ASCE, vol. 138, issue 2, p. 48-54.

YEPES, V. y MARTÍ, J.V. (2015). “Competencia transversal ‘pensamiento crítico’ en el grado de ingeniería civil: valoración previa” en XIII Jornadas de Redes de Investigación en Docencia Universitaria. Alicante, pp. 2944-2952. Disponible en <http://rua.ua.es/dspace/handle/10045/49970> [Consulta: 7 de marzo de 2018]

YEPES, V., SEGADO, S., PELLICER, E. y TORRES-MACHÍ, C. (2016). "Acquisition of competences in a Master Degree in Construction Management" en 10th International Technology, Education and Development Conference (INTED 2016). Valencia, pp. 718-727. Disponible en <https://library.iated.org/view/YEPES2016ACQ> [Consulta: 6 de marzo de 2018]

YEPES, V., MARTÍ, J.V. y MOLINA-MORENO, F. (2017). “Transverse competence 'critical thinking' in civil engineering graduate studies: preliminary assessment” en 11th annual International Technology, Education and Development Conference (INTED 2017). Valencia, pp. 2639-2649. Disponible en <https://library.iated.org/view/YEPES2017TRA> [Consulta: 7 de marzo de 2018] 


\title{
PROPUESTA DE INNOVACIÓN DOCENTE PARA LA ASIGNATURA: DE LA PLENITUD MEDIEVAL AL RENACIMIENTO
}

Silvia María Pérez González (spergon@upo.es)

Juan Carlos Arboleda Goldaracena (jcarbgol@upo.es)

Universidad Pablo de Olavide

Resumen: En el presente trabajo planteamos un conjunto de propuestas de innovación docente para el aprendizaje de una de las asignaturas asignadas al Área de Historia Medieval de la Universidad Pablo de Olavide, "De la Plenitud medieval al Renacimiento". Se formulan distintos modelos de trabajo para cada uno de los temas que conforman el temario, que incluye el trabajo en equipo y los foros de discusión para el comentario de textos históricos, películas, novelas, visitas. Todo ello basado en el empleo de la plataforma virtual. Finalmente, cada elemento susceptible de evaluación cuenta con la rúbrica correspondiente a fin de facilitar al alumno los criterios evaluables y los requisitos que han de cumplir. En definitiva, se trata a la vez de reflexionar sobre cómo los docentes estamos plasmando en la práctica distintas iniciativas de innovación, con especial atención a nuestro aprendizaje y visiones del alumnado. Al mismo tiempo queremos que el trabajo sea un reflejo de las diferentes maneras de abordar la innovación en el aula.

\begin{abstract}
The aim of this work is a set of teaching innovation proposals for the learning of one of the subjects assigned to the Area of Medieval History of the Pablo de Olavide University, "From the medieval Plenitude to the Renaissance". Different work models are formulated for each of the topics that make up the agenda, which includes teamwork and discussion forums for the commentary of historical texts, films, novels, and visits. All this based on the use of the virtual platform. Finally, each element subject to evaluation has the corresponding rubric in order to provide the student with the evaluable criteria and the requirements that must be met. In short, it is at the same time to reflect on how each of us is putting into practice our process of teacher training and innovation, with special attention to our learning and visions of the students. At the same time we want the work to be a reflection of the different ways of approaching innovation in the classroom.
\end{abstract}

Palabras clave: Edad Media. Nuevas tecnologías docentes. Aplicaciones en el aula. Materiales educativos. Modelos de trabajo. Docente. Estudiante universitario. Planificación de la educación. Innovación educativa. Tecnologías de la información.

Keywords: Middle Ages. New teaching technologies. Applications in the classroom. Educational materials. Work models. Teacher. College student. Education planning. Educational innovation. Information technology. 


\section{Introducción: Contextualización de la asignatura}

La asignatura "De la Plenitud Medieval al Renacimiento" es una asignatura obligatoria que se imparte en el primer cuatrimestre del grado de Humanidades y doble grado de Humanidades y Traducción e Interpretación. Tiene asignado un total de 7.5 créditos y se encuentra englobada en el módulo de Fundamentos Históricos. Desde el decanato de Humanidades se nos indica el porcentaje que hemos de dedicar a cada tipo de enseñanza: 50\% enseñanzas básicas, 40\% enseñanzas prácticas y de desarrollo y 10\% actividades dirigidas.

Varios son los condicionantes que hemos de tener en cuenta a la hora de diseñar la planificación (Gil Flores, 2004, Bernal, 2006) de la asignatura en parámetros de innovación docente. En primer lugar es necesario considerar que esta asignatura es continuación en el segundo curso del grado de Humanidades y el doble grado de Humanidades y Traducción e Interpretación de la impartida en el primer curso que lleva por título "La conformación de las civilizaciones cristiana e islámica medievales”. Por tanto, el alumno habrá de recibir, a través de las distintas vías que se implementarán, la formación necesaria para afrontar sin problemas la continuación de la asignatura recibida en el curso anterior (Morales, 2005).

Por otro lado, dado que en el nuevo contexto surgido al amparo del Espacio Europeo de Educación Superior el alumno (Del Val, 2013) se convierte en protagonista decisivo de su proceso de aprendizaje, será necesario considerar y reflexionar sobre el grupo de estudiantes al que la asignatura se va a impartir. La Facultad de Humanidades ofrece 30 plazas para los alumnos de Humanidades y otras 30 para los que van a cursar el doble grado. Ello suma un total de 60 alumnos. En principio el número puede limitar la aplicación de determinadas innovaciones docentes. Pero hemos de subrayar que la parte práctica de la asignatura se desglosa en dos grupos de tal manera que, aunque con motivo de las enseñanzas básicas (Danvila, 2013) contemos con 60 alumnos en el aula, en lo que se refiere a enseñanzas prácticas y de desarrollo, actividades dirigidas, tutorías, visitas académicas, correcciones, solo hemos de responsabilizarnos de la mitad, 30, un número muy adecuado para introducir las más variadas innovaciones docentes.

Pero en relación con los alumnos no solo hemos de tener en cuenta el número, sino también otros factores como la edad del colectivo estudiantil para el que vamos a diseñar la asignatura. La media de edad de los estudiantes es de unos 19-20 años, que ya en el primer curso han empezado a experimentar los nuevos caminos de la docencia. No obstante en los últimos años estamos asistiendo a una interesante llegada a las aulas de alumnos mayores de 25 años. Hablamos de interesante llegada porque muchas veces ayudan al profesor en las carencias de maduración que presentan los alumnos recién ingresados tras las pruebas de acceso a la 
Universidad. Por supuesto que estos alumnos “mayores", muchos de ellos ya diplomados o licenciados que están trabajando y que acuden a la Facultad de Humanidades con el fin de ampliar sus estudios y su preparación, tienen unos intereses y motivaciones distintas a las de sus compañeros. Pero en general se adaptan bien a los ritmos y pautas que el Espacio Europeo de Educación Superior (Metcalfe, 2006) les exige.

Antes de pasar a los siguientes apartados queremos indicar que muchos de esos ritmos y pautas forman parte de la guía docente que los alumnos tienen a su disposición a comienzos de la asignatura.

\section{Objetivos}

El objetivo teórico de esta asignatura es el estudio del pasado humano en sus diversos aspectos durante la Plena y Baja Edad Media, circunscrita al ámbito europeo-mediterráneo, con especial énfasis en la Europa cristiana como cuna de un determinado concepto de Europa vigente hasta nuestros días y principal conformador de la realidad continental hasta, al menos, el siglo XIX. El estudio de esta época permite al alumno conocer los grandes procesos históricos que construyeron los cimientos del período medieval durante el cual coexistieron tres grandes civilizaciones en el ámbito mediterráneo: el imperio de Oriente o Bizancio, el Islam y la Cristiandad latina. Al mismo tiempo se le introduce en un método que potencia la síntesis explicativa, basado en la capacidad de seleccionar, jerarquizar y articular los acontecimientos de la Historia Medieval en los procesos históricos de los que forman parte. Finalmente, no debemos olvidar que la Edad Media constituye una etapa fundamental de nuestro pasado histórico, que tan profundas huellas tiene en el presente.

A este objetivo (que sobre todo hace referencia a competencias cognitivas) queremos añadir otros que la asignatura nos permite diseñar al hilo de sus contenidos teóricos. Nuestra finalidad no es formar alumnos expertos en Historia Medieval, que lo sepan todo sobre este periodo y sus protagonistas y procesos. Nuestro deseo es que a través de esta asignatura adquieran las herramientas para encontrar toda la información que nosotros no les vamos a proporcionar, que aprendan a analizarla desde la crítica y el método histórico, que sean capaces de separar los contenidos válidos de los infructuosos y, también muy importante, que se desarrolle en ellos el sentido crítico a la hora de analizar el presente como momento histórico susceptible de ser transformado. En definitiva, y esperamos no caer en la utopía (Nevot, 2008), hacerles ver a través del pasado medieval que no todo lo que se les ofrece es válido y verdadero, sino que detrás de ello se pueden ocultar otras realidades e intenciones.

(c) B EY-NC-ND 2018, Universitat Politècnica de València Congreso In-Red (2018) 
Para ello analizaremos textos históricos que desde distintas perspectivas aborden un mismo acontecimiento, les enseñaremos los instrumentos del método histórico, organizaremos visitas a distintos monumentos para ver in situ su función política, social, económica y, si es el caso, religiosa, en la sociedad que los generó, escogiéndose los materiales de trabajo de acuerdo con los objetivos planteados.

\section{Desarrollo de la innovación}

\subsection{Competencias}

Este apartado constituye una de las grandes innovaciones en términos docentes que ha experimentado nuestra docencia. La actual enseñanza universitaria se concibe en términos competenciales, siendo necesario tanto por parte del profesor (Knight, 2005) como del alumno conocer las competencias que se van a trabajar y la metodología que se les va a aplicar (Miguel Díaz, 2006).

Para la selección de las competencias que se van a trabajar en la asignatura "De la Plenitud Medieval al Renacimiento" hemos tenido muy en cuenta los perfiles profesionales recogidos en la Memoria de verificación del título de graduado en Humanidades por la Universidad Pablo de Olavide. Finalmente nos hemos decidido a trabajar aquellas competencias que sean comunes a todos ellos, para que a la hora de enfrentarse a su futuro profesional los alumnos cuenten con instrumentos que aplicar a todas las salidas profesionales. También hemos tenido en cuenta el periodo temporal de que disponemos para el trabajo competencial, lo que nos ha llevado a seleccionar las tres siguientes:

\section{a) Instrumental:}

Comunicarse con corrección en lengua española, oralmente y por escrito, con un alto nivel en el uso de los diferentes recursos expresivos y con dominio del registro académico y científico.

b) Actitudinal:

Saber trabajar en un equipo en un equipo de forma cooperativa y responsable, respetando los principios de igualdad y diversidad como es propio de una cultura democrática, y buscando el entendimiento para la consecución de objetivos.

c) Sistémica:

Desarrollar la capacidad de aprendizaje autónomo.

\subsection{Contenidos de la asignatura (Temario)}

Lección 1: Aspectos generales del desarrollo económico y social del Occidente europeo durante la Plena Edad Media

(c)) EY-NC-ND 2018, Universitat Politècnica de València

Congreso In-Red (2018) 
I. Vínculos sociales plenomedievales

1. Introducción.

I. Vínculos horizontales. El sistema feudal. 3. Vínculos verticales. El señorío plenomedieval. IIDemografía. III- Economía rural. IV-Renacimiento urbano. IV- Economía urbana: Artesanía y comercio

Lección 2: El pontificado y la Reforma de la Iglesia

1. Clero Regular. 1.a) El monacato. 1.b) Las Órdenes Mendicantes.2-.Clero secular

Lección 3: Del renacimiento del siglo XII al apogeo de la cultura medieval

1. El paso de la escuela catedralicia a la universidad. 2. El nacimiento de las Universidades en el siglo XIII. 2.a) La gran triada universitaria europea del siglo XIII. 3. Organización universitaria. 4. La enseñanza. 4.a) Los estudios. 4.b) Los exámenes, 4.c) Calendario lectivo. 4.d) Los libros. 4.e) El método escolástico

Lección 4: Las estructuras políticas en la plenitud medieval

I. Las Cruzadas. 1. Los escenarios de las Cruzadas. 2. Causas de las Cruzadas. 2.a) Causas materiales. 2.b) Causas mentales. 3. La primera Cruzada (1097-1099). 4. La segunda Cruzada (1147-1149). 5. La tercera Cruzada (1189-1190). 6. La cuarta Cruzada (1202-1204). 7. La Cruzada infantil (1212). 8. La quinta Cruzada (1228-1229). 9. La sexta Cruzada (1248-1254). 10. La séptima Cruzada (1270). 11. Consecuencias de las Cruzadas. II. Las monarquías feudales

Lección 5: La Baja Edad Media ¿Tiempo de crisis?. La Iglesia. Las dificultades del pontificado y la religión como subversión

1. Introducción. 2. Periodización de la crisis. 3. Factores de la crisis. 3.a) El hambre. 3.b) La guerra. 3.c) La peste. 4. Consecuencias en el ámbito rural: Tensiones y luchas sociales. 4. a) en Flandes. 4. b) en Francia. 4.c) en Inglaterra. 5. La crisis en las ciudades: Las revueltas sociales en el medio urbano. 5.a) En Italia. 5.b) en Francia. 6. La Iglesia bajomedieval. 6.a) El pontificado de Aviñón (1309-1377). 6.b) El cisma de Occidente. 6.c) Situación de la Iglesia a fines del siglo XV. 7. Las transformaciones de la vida espiritual: los nuevos caminos de la piedad y las herejías. 7.a) Devotio moderna. 7.b) la piedad popular. 7.c) Las herejías.

En la siguiente matriz de especificaciones se indica la relevancia que cada tema tiene dentro de la asignatura:

\begin{tabular}{|c|c|c|c|c|c|}
\hline \multirow[b]{2}{*}{$\begin{array}{c}\text { Unidad de } \\
\text { competencia/Temas }\end{array}$} & \multirow[b]{2}{*}{$\begin{array}{c}\text { Pesos } \\
\text { pondera- } \\
\text { tivos }\end{array}$} & \multirow[b]{2}{*}{$\begin{array}{c}\mathrm{N}^{0} \\
\text { ítems }\end{array}$} & \multicolumn{3}{|c|}{$\begin{array}{c}\text { Prueba de conocimientos }\left(\mathrm{N}^{\mathrm{o}} \text { ítems y por niveles }\right. \\
\text { taxonómicos) }\end{array}$} \\
\hline & & & $\begin{array}{l}\text { Conoci- } \\
\text { mientos } \\
\text { ( } \mathrm{N}^{0} \text { ítems) }\end{array}$ & $\begin{array}{l}\text { Comprensión } \\
\text { (No ítems) }\end{array}$ & $\begin{array}{l}\text { Aplicación } \\
\text { ( }{ }^{0} \text { ítems) }\end{array}$ \\
\hline $\begin{array}{l}\text { 1. Aspectos generales } \\
\text { socio-económicos }\end{array}$ & 10 & 3 & 2 & 1 & \\
\hline
\end{tabular}

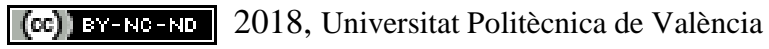

Congreso In-Red (2018) 


\begin{tabular}{|l|c|c|c|c|c|}
\hline $\begin{array}{l}\text { 2. El Pontificado y la } \\
\text { refoema de la Iglesia }\end{array}$ & 20 & 7 & 2 & 5 & \\
\hline $\begin{array}{l}\text { 3. Del apogeo al } \\
\text { renacimiento cultural }\end{array}$ & 25 & 15 & 4 & 8 & 4 \\
\hline $\begin{array}{l}\text { 4. Las estructuras políticas } \\
\text { plenomedievales }\end{array}$ & 25 & 15 & 4 & 7 & 6 \\
\hline 5. La Baja Edad Media & 20 & 10 & & 4 & 13 \\
\hline TOTAL & 100 & 50 & 12 & 25 & 4 \\
\hline
\end{tabular}

\subsection{Metodología y recursos}

Cada tema tendrá su propia metodología dentro del proceso de aprendizaje, que pasamos a especificar.

Tema 1: dentro de las clases correspondientes a las Enseñanzas prácticas y de desarrollo se analizarán los vínculos horizontales, concretamente el sistema feudal. En el apartado de los vínculos verticales estudiaremos el señorío plenomedieval, dividido en territorial y jurisdiccional. Los siguientes bloques se corresponden con II. Demografía, III. Economía rural, IV.Renacimiento urbano, V. Economía urbana: Artesanía y VI. Economía urbana: Comercio. Lo hacemos a través distintas fuentes históricas: documentos contemporáneos al proceso, visto por autores que estaban a favor de un hecho y en contra, y documentos de épocas posteriores donde los elementos medievales sirven como fundamento a creaciones políticas muy posteriores. Estos textos se comentan en las clases (Rivero, 2003) y también son objeto de debates en el foro del aula virtual (Hanna, 2002), herramienta a través de la cual les son proporcionados los textos. Para todo ello los alumnos se organizan en equipos (Elboj, 2002) que han de defender distintas posturas que ellos mismos eligen. A título individual cada estudiante debe elegir una película (v.g. El mercader de Venecia) sobre el periodo estudiado que habrá de comentar brevemente en las clases dedicadas a las actividades dirigidas.

Dado que se trata del primer tema de la asignatura consideramos de gran importancia introducir una sesión de tutoría (Álvarez, 2008), que es la primera de las programadas, con el objetivo de cumplir el nuevo papel que se le asigna al profesor dentro del marco de enseñanza y de los criterios establecidos en la Convención de Bolonia y en la legislación española adaptada al Espacio Europeo de Educación Superior. El docente debe adoptar la posición de tutor, que acompañará, seguirá y apoyará al estudiante en su proceso de crecimiento personal y aprendizaje profesional (Medina, 2003). En esta primera tutoría se trata de orientar al alumno en cuantas cuestiones considere que pueden ser importantes, en los problemas de comprensión y análisis que los textos puedan generarle, dejando siempre que el estudiante plantee soluciones y herramientas que puedan serle útiles en la resolución de los obstáculos que se le hayan podido 
plantear. Con ello queremos potenciar en el alumno la capacidad de desarrollar un aprendizaje continuo a lo largo de la vida (McIntosh, 2005), de tener un papel mucho más activo en la construcción de su propio aprendizaje. Atrás deben quedar esas tutorías destinadas tan solo a resolver dudas antes del examen; se trata de asistir al estudiante en la ejecución de su proyecto tanto personal como profesional.

De esta tutoría así como de las siguientes llevamos a cabo un registro en el que recogemos toda la información (observaciones, reflexiones, datos concretos, etc.) que consideremos necesarios para atender y tutorizar a los alumnos en los procesos de enseñanzaaprendizaje. Se trata de cuestiones como: preguntas planteadas por los alumnos o dudas que les surjan y respuestas a las mismas aportadas por ellos o por el profesor; cuestiones problemáticas en temas complejos; dificultades de los materiales que se han propuesto para ser trabajados; implicación e interés del alumno en las investigaciones que se le propone; dificultades surgidas en la tutoría; tiempo de desarrollo de la tutoría; idoneidad de la tutoría celebrada.

Tema 2: los contenidos teóricos se acompañan de la lectura de algunos capítulos seleccionados de la Vida de San Francisco y sobre la novela Imperator (Velasco, 2014). Ambas monografías son objeto de análisis por parte de los alumnos quienes por equipos, cuyos miembros deberán ser diferentes a los de los grupos constituidos para el tema anterior a fin de conseguir que todos trabajen con todos, deben exponer qué parte de ambos discursos pueden tener su aplicación a la contemporaneidad y en qué medida unos mismos procesos históricos pueden desarrollarse en momentos diferentes de la Historia, aun cuando los protagonistas, artífices y circunstancias sean otros. A nivel autónomo (Alonso, 2007) cada estudiante deberá buscar en los medios de comunicación esa huella del pasado de la Iglesia medieval. Preparamos también un blog con fotos de los conventos y monasterios de los pueblos originarios de los alumnos, donde además de la foto deberán incluir un comentario de su experiencia del contacto con un pasado que no deja de ser presente.

Una vez impartidos estos dos primeros temas el alumno ya estará en condiciones de asistir a una tutoría en la que se trabajará la competencia instrumental relativa a la comunicación correcta en lengua española, oralmente y por escrito, con un alto nivel en el uso de los diferentes recursos expresivos y con dominio del registro académico y científico. Esta tiene lugar durante el segundo mes de impartición de la asignatura y durante la misma se pregunta al estudiante sobre cuestiones relativas a estos dos primeros temas y se le pide que realice por escrito una síntesis muy breve de su opinión acerca del desarrollo de los mismos. Para la evaluación (Rodríguez de Miñón, 2003) de la competencia indicada introducimos la siguiente rúbrica (Fernández, 2016): 
Tabla 1: Rúbrica de evaluación de la competencia: comunicación escrita en lengua propia ${ }^{1}$

\begin{tabular}{|c|c|c|c|c|}
\hline & CORRECTA & BUENA & EXCELENTE & PUNTOS \\
\hline \multicolumn{5}{|l|}{ Lengua escrita } \\
\hline Expresión escrita & \begin{tabular}{|l|l|} 
Siguen un orden y \\
construyen las frases \\
correctamente
\end{tabular} & $\mid \begin{array}{llr}\text { Siguen un } & \text { orden y construyen las } \\
\text { frases } & \text { correctamente. } & \mathrm{El} \\
\text { vocabulario es adecuado } & \end{array}$ & \begin{tabular}{|l|} 
Siguen un orden y construyen las frases \\
correctamente. El vocabulario es rico y la \\
lectura muy agradable
\end{tabular} & \\
\hline \multirow{2}{*}{$\begin{array}{l}\text { Ortografía } \\
\text { gramática }\end{array}$} & \begin{tabular}{|l|} 
Hay algunos errores de \\
sintaxis, ortografía o léxico
\end{tabular} & Hay algunos errores de sintaxis. & $\begin{array}{l}\text { No hay prácticamente ningún error de } \\
\text { ningún tipo. }\end{array}$ & \\
\hline & $1-2-3$ & $4-5-6$ & $7-8-9$ & \\
\hline \multirow[t]{2}{*}{$\begin{array}{l}\text { Organización del } \\
\text { trabajo }\end{array}$} & 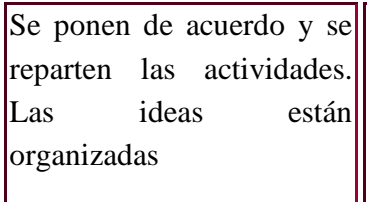 & $\begin{array}{l}\text { Se ponen de acuerdo y se reparten } \\
\text { las actividades. Las ideas están } \\
\text { organizadas y complementadas con } \\
\text { ejemplos }\end{array}$ & \begin{tabular}{|l|} 
Se ponen de acuerdo y se reparten las \\
actividades. Las ideas están perfectamente \\
organizadas, complementadas con detalles \\
y explicaciones aclaratorias
\end{tabular} & \\
\hline & $1-2-3$ & $4-5-6$ & $7-8-9$ & \\
\hline El resumen & Incluyen un resumen & \begin{tabular}{|l} 
Incluyen un resumen que cierra \\
correctamente el tema
\end{tabular} & $\begin{array}{l}\text { Incluyen un resumen que retoma las ideas } \\
\text { principales y cierra el tema de forma } \\
\text { especialmente atractiva. }\end{array}$ & \\
\hline TOTALES & & & & \\
\hline
\end{tabular}

Tema 3: se proyecta la película El nombre de la rosa, para que los alumnos identifiquen los elementos de la Iglesia medieval que incluye el film, siendo voluntario consultar la novela (Lobatón, 2013) homónima. Tras la explicación del tema se realiza una visita a Jerez de la Frontera para que los alumnos comprueben in situ el paso de la civilización islámica a la civilización cristiana. Los distintos hitos arquitectónicos son explicados por nuevos equipos de alumnos que eligen de forma autónoma el elemento que van a exponer. En una nueva sesión de tutoría han de tratar con el profesor los problemas que les han surgido en la preparación de la exposición, los motivos de la elección del tema, los recursos manejados, etc. Esta tutoría es un buen momento para evaluar la competencia actitudinal relativa al trabajo en grupo mediante la siguiente rúbrica:

\footnotetext{
${ }^{1}$ Tomada de: http://www.juntadeandalucia.es/averroes/cepmotril/webquest/trabajos/4esta/evaluacion.doc
} 
Tabla 2. Rúbrica de evaluación de la competencia: saber trabajar en equipo ${ }^{2}$

\begin{tabular}{|c|c|c|c|c|c|}
\hline Descriptores & 1 & 2 & 3 & 4 & 5 \\
\hline \multirow[t]{2}{*}{$\begin{array}{l}\text { Indicador 1: } \\
\text { Realiza las tareas } \\
\text { que le son } \\
\text { asignadas por el } \\
\text { grupo dentro de } \\
\text { los plazos } \\
\text { requeridos }\end{array}$} & $\begin{array}{l}\text { No cumple las tareas } \\
\text { asignadas }\end{array}$ & $\begin{array}{l}\text { Cumple } \\
\text { parcialmente las } \\
\text { tareas asignadas } \\
\text { y/o no cumple } \\
\text { con los plazos } \\
\text { requeridos }\end{array}$ & $\begin{array}{l}\text { Cumple las } \\
\text { tareas } \\
\text { asignadas en los } \\
\text { plazos requeridos }\end{array}$ & $\begin{array}{l}\text { Cumple las tareas } \\
\text { asignadas en los } \\
\text { plazos requeridos } \\
\text { y la calidad de la } \\
\text { tarea supone un } \\
\text { notable aporte al } \\
\text { equipo }\end{array}$ & $\begin{array}{l}\text { Cumple las tareas } \\
\text { asignadas en los } \\
\text { plazos requeridos y la } \\
\text { calidad de la tarea } \\
\text { supone un notable } \\
\text { aporte al } \\
\text { equipo. }\end{array}$ \\
\hline & 1 & 2 & 3 & 4 & 5 \\
\hline \multirow[t]{2}{*}{$\begin{array}{l}\text { Indicador 2: } \\
\text { Participa de } \\
\text { forma activa en } \\
\text { los espacios de } \\
\text { encuentro del } \\
\text { equipo, } \\
\text { compartiendo la } \\
\text { información, los } \\
\text { conocimientos y } \\
\text { las experiencias }\end{array}$} & $\begin{array}{l}\text { Se ausenta con } \\
\text { frecuencia y su } \\
\text { presencia } \\
\text { irrelevante }\end{array}$ & $\begin{array}{l}\text { Interviene poco } \\
\text { en el debate, } \\
\text { principalmente a } \\
\text { requerimiento de } \\
\text { los } \\
\text { demás }\end{array}$ & $\begin{array}{l}\text { Se muestra } \\
\text { activo } \\
\text { participativo en } \\
\text { los encuentros de } \\
\text { grupo }\end{array}$ & $\begin{array}{l}\text { Se muestra activo } \\
\text { y participativo en } \\
\text { los encuentros de } \\
\text { grupo. Con sus } \\
\text { intervenciones la } \\
\text { fomenta } \\
\text { participación y } \\
\text { mejora la calidad } \\
\text { de los resultados } \\
\text { del equipo }\end{array}$ & 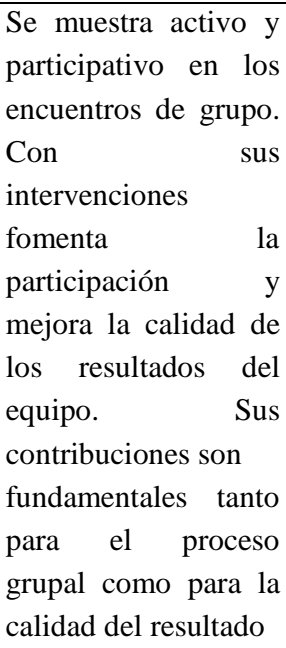 \\
\hline & 1 & 2 & 3 & 4 & 5 \\
\hline \multirow[t]{2}{*}{$\begin{array}{l}\text { Indicador 3: } \\
\text { Colabora en la } \\
\text { definición, } \\
\text { organización y } \\
\text { distribución } \\
\text { de las tareas de } \\
\text { grupo }\end{array}$} & $\begin{array}{l}\text { Manifiesta } \\
\text { resistencias } \\
\text { ante la organización } \\
\text { del } \\
\text { trabajo en el equipo }\end{array}$ & $\begin{array}{lr}\text { Se limita } & \text { a } \\
\text { aceptar } & \text { la } \\
\text { organización } & \text { del } \\
\text { trabajo propuesta } \\
\text { por } & \text { otros } \\
\text { miembros } & \text { del } \\
\text { equipo } & \end{array}$ & $\begin{array}{l}\text { Participa en la } \\
\text { planificación, } \\
\text { organización } \\
\text { y distribución del } \\
\text { trabajo en } \\
\text { equipo }\end{array}$ & $\begin{array}{l}\text { Participa en la } \\
\text { planificación, } \\
\text { organización } \\
\text { y distribución del } \\
\text { trabajo en } \\
\text { equipo. } \\
\text { organizado } \\
\text { distribuye } \\
\text { las tareas con } \\
\text { eficacia }\end{array}$ & $\begin{array}{l}\text { Participa en la } \\
\text { planificación, } \\
\text { organización } \\
\text { y distribución del } \\
\text { trabajo en equipo. Es } \\
\text { organizado } \\
\text { distribuye } \\
\text { las tareas con } \\
\text { eficacia. Fomenta } \\
\text { una organización del } \\
\text { trabajo aprovechando } \\
\text { los recursos de los } \\
\text { miembros del equipo }\end{array}$ \\
\hline & 1 & 2 & 3 & 4 & 5 \\
\hline $\begin{array}{l}\text { Indicador 4: } \\
\text { Toma en cuenta } \\
\text { los puntos de } \\
\text { vista de los } \\
\text { demás y } \\
\text { retroalimenta de }\end{array}$ & $\begin{array}{l}\text { No escucha las } \\
\text { intervenciones de sus } \\
\text { compañeros y las } \\
\text { descalifica } \\
\text { sistemáticamente. } \\
\text { Quiere imponer sus }\end{array}$ & $\begin{array}{l}\text { Escucha poco, no } \\
\text { pregunta, no se } \\
\text { preocupa por la } \\
\text { opinión de los } \\
\text { otros. Sus } \\
\text { intervenciones }\end{array}$ & $\begin{array}{l}\text { Acepta las } \\
\text { opiniones de los } \\
\text { otros y sabe dar } \\
\text { su punto de vista } \\
\text { en forma } \\
\text { constructiva }\end{array}$ & $\begin{array}{l}\text { Acepta las } \\
\text { opiniones de los } \\
\text { otros y sabe dar } \\
\text { su punto de vista } \\
\text { en forma } \\
\text { constructiva. }\end{array}$ & $\begin{array}{l}\text { Acepta las opiniones } \\
\text { de los otros y sabe } \\
\text { dar su punto de vista } \\
\text { en forma } \\
\text { constructiva. } \\
\text { Fomenta el diálogo }\end{array}$ \\
\hline
\end{tabular}

2 http://www.lapetus.uchile.cl/lapetus/recursos/documentos/Ejemplo_Rubrica_trabajo_en_equipo_UFGBE.pdf

(cc) EY-NC-ND 2018, Universitat Politècnica de València

Congreso In-Red (2018) 


\begin{tabular}{|c|c|c|c|c|}
\hline $\begin{array}{l}\text { forma } \\
\text { constructiva }\end{array}$ & opiniones & $\begin{array}{l}\text { son } \\
\text { redundantes y } \\
\text { poco sugerentes }\end{array}$ & $\begin{array}{ll}\text { Fomenta } & \text { e } \\
\text { diálogo } & \\
\text { constructivo } \\
\text { inspira } \\
\text { participación de } \\
\text { calidad de los } \\
\text { otros miembros } \\
\text { del grupo }\end{array}$ & $\begin{array}{l}\text { constructivo e inspira } \\
\text { la participación de } \\
\text { calidad de los otros. } \\
\text { Integra las opiniones } \\
\text { de los otros en una } \\
\text { perspectiva } \\
\text { superior, } \\
\text { manteniendo un } \\
\text { clima de } \\
\text { colaboración y apoyo } \\
\text { a miembros del } \\
\text { grupo. }\end{array}$ \\
\hline
\end{tabular}

Tema 4: las clases teóricas se completan con un documental sobre el proceso político, económico, social y cultural que supusieron las Cruzadas. En colaboración con profesores del grado en Traducción e Interpretación, se ha puesto en práctica en algunos cursos una iniciativa consistente en que los alumnos explican a sus compañeros de la otra titulación los orígenes de la actual Francia, que precisamente se encuentran en el reinado de los Capetos que, junto al de los Angevinos, forma parte de nuestro temario, mientras que los alumnos de Traducción ilustran a los de Humanidades sobre la actual Francia. Fruto del intercambio de conocimientos (Gibbons, 1995) cada alumno, a nivel individual, realiza un pequeño trabajo sobre la huella del pasado capeto y angevino en la Francia de la contemporaneidad. Nuestras ambiciones van un poco más lejos y en un futuro pretendemos llevar a los dos grupos de alumnos a la Aquitania francesa, la antigua Aquisgrán, que fue la capital del Imperio de Carlomagno. El objetivo es contemplar in situ las huellas del pasado plenomedieval francés y su evolución posterior. Otro recurso es la proyección de películas como El Reino de los Cielos, Robin Hood o Templario para analizar las Cruzadas. La parte de Historia política del tema se trabaja a través de películas como La princesa prometida, la serie Los pilares de la tierra, o El león en invierno, aunque siempre aceptando propuestas de los propios alumnos. La metodología de trabajo de las películas es la ya comentada para otros materiales: identificación de los elementos propios del tema expuesto y explicación de los mismos.

Tema 5: la Baja Edad Media se explica a partir de distintos textos y manifestaciones varias, que son comentados en clases con un carácter eminentemente práctico. Los ejemplos ofrecidos por los profesores deben ser enriquecidos con otros por los alumnos. Se visualiza la película Paseo por el amor y la muerte. Los conocimientos adquiridos con motivo de esta lección son plasmados en un trabajo sobre "El uso actual de la Edad Media”. 


\subsection{Temporalización}

La asignatura se desarrolla a lo largo de 16 semanas, recibiendo el alumno cada semana dos horas de clases teóricas y una de clases prácticas. A estas horas se han de añadir las que el estudiante debe dedicar de forma autónoma o en equipo a las distintas actividades fuera del horario lectivo, así como las planificadas para las actividades dirigidas. El cronograma para un posible curso en el que se incorporarn todas las iniciativas propuestas es el siguiente:

Tabla 3. Cronograma

\begin{tabular}{|c|c|c|c|}
\hline SEMANA & $\begin{array}{c}\text { TEMA } \\
\text { TEÓRICO }\end{array}$ & PRÁCTICAS & TUTORÍA \\
\hline 1 & 1 & Comentario de textos & \\
\hline 2 & 1 & Comentario de textos y películas & \\
\hline 3 & 2 & Comentario de textos & $\mathrm{X}$ \\
\hline 4 & 2 & Comentario de textos & \\
\hline 5 & 2 & Comentario de textos & $\mathrm{X}$ \\
\hline 6 & 3 & Comentario de textos & \\
\hline 7 & 3 & Organización de la visita & $\mathrm{X}$ \\
\hline 8 & 3 & Organización de la visita & \\
\hline 9 & 3 & Visita & \\
\hline 10 & 4 & Documental & \\
\hline 11 & 4 & $\begin{array}{l}\text { Intercambio de conocimientos con los } \\
\text { alumnos de Traducción }\end{array}$ & \\
\hline 12 & 4 & $\begin{array}{l}\text { Intercambio de conocimientos con los } \\
\text { alumnos de Traducción }\end{array}$ & \\
\hline 13 & 4 & ¿Visita a Aquisgrán? & \\
\hline 14 & 5 & $\begin{array}{lccc}\text { Comentario de } & \text { textos } & \text { y } \\
\text { manifestaciones varias } & & \end{array}$ & \\
\hline 15 & 5 & $\begin{array}{lcc}\text { Comentario de } & \text { textos } \quad y \\
\text { manifestaciones varias } & & \end{array}$ & \\
\hline 16 & 5 & $\begin{array}{lccc}\text { Comentario de } & \text { textos } & \text { y } \\
\text { manifestaciones varias } & & \end{array}$ & \\
\hline
\end{tabular}

\section{Resultados: la evaluación}

La evaluación de los alumnos se realiza a través de distintas herramientas. Una de ellas es la realización de un portafolios. En el mismo se recogen los distintos trabajos que el estudiante ha llevado a cabo a lo largo del curso. Aunque la entrega definitiva del mismo tiene lugar al final de la asignatura, en dos momentos del desarrollo del curso el estudiante debe entregar el portafolios para que el contenido del mismo le sea corregido y devuelto, a fin de que introduzca las modificaciones oportunas. Igualmente en las tutorías podrán plantear las dudas 
surgidas en el proceso de confección de los trabajos, así como solicitar cuantas orientaciones consideren oportunas. El portafolios ha de incluir como entradas obligatorias los comentarios de textos, novelas, documentales y películas (Rondina, 2012), el material trabajado con respecto a las visitas, un trabajo final sobre el uso de la Edad Media en nuestros días, y una reflexión crítica de lo que ha sido su proceso de aprendizaje de la asignatura. Además de estas entradas obligatorias los alumnos podrán acordar con el profesorado otras entradas voluntarias dentro del portafolios, que tendrán una valoración positiva en la evaluación del mismo.

Para que el alumno tenga claros los criterios a partir de los cuales se van a evaluar sus trabajos, especialmente el trabajo final, se le proporciona la siguiente hoja de evaluación:

Tabla 4. Hoja de evaluación

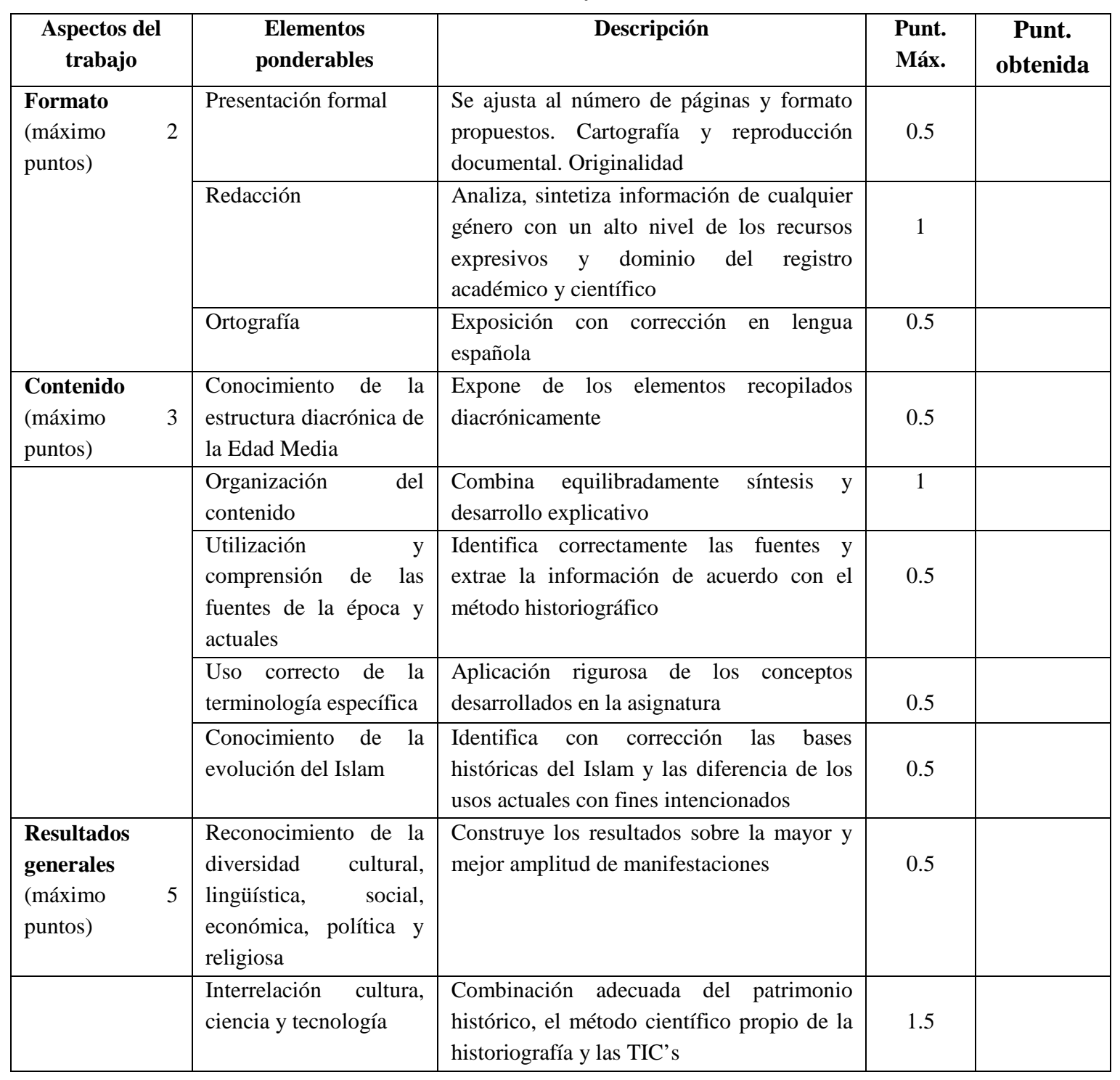




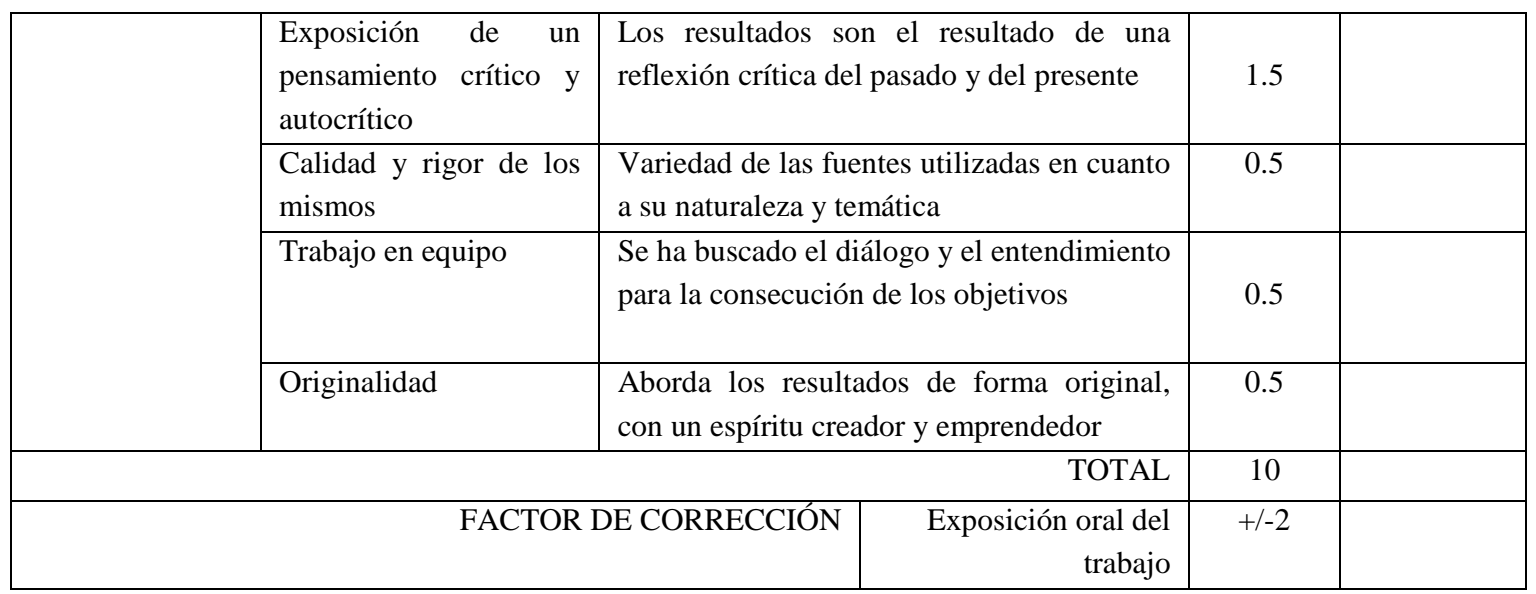

La evaluación de los contenidos teóricos de la asignatura se lleva a cabo a través de pruebas orales. A fin de facilitar la asimilación de los contenidos los estudiantes realizan las pruebas de dos en dos temas, habiendo de superar un total de dos pruebas orales (el tema 5 se evalúa a través del trabajo final). El objetivo de examinarlos oralmente no es otro que el fomentar el desarrollo de la competencia relativa a la correcta expresión oral en lengua española.

Dentro de este apartado relativo a la evaluación, las tutorías también tienen un papel importante, especialmente en lo que se refiere a la evaluación de las competencias que se van a trabajar a lo largo del curso. En el apartado sobre metodología ya hemos indicado cómo son evaluadas dichas competencias.

Finalmente, los alumnos han de participar activamente en las clases y en los debates surgidos dentro del aula y en los foros del aula virtual.

La ponderación de cada elemento a evaluar es la siguiente: portafolios: 40\%; pruebas orales: $40 \%$; tutorías: $10 \%$; foros y debates: $10 \%$.

\section{Conclusiones}

La renovación de los planes de estudio universitarios en España a raíz de la puesta en marcha de las directrices marcadas por el Espacio Europeo de Educación Superior, hace ya algunos años, supuso la necesidad de implementar proyectos de innovación docente para asignaturas nuevas que, aun siendo herederas de otras asignaturas similares en los viejos planes de estudio, necesitaban de una adaptación a la nueva realidad. Es lo que hemos presentado en este trabajo, abordando las distintas iniciativas puestas en marcha en la Universidad Pablo de Olavide para la enseñanza de la Historia Medieval.

(cc) EY-NC-ND 2018, Universitat Politècnica de València 
Desde el principio éramos conscientes del esfuerzo que habríamos de realizar para que los alumnos, acostumbrados a ser evaluados casi exclusivamente a partir de sus conocimientos teóricos, cumplieran con el proyecto aquí diseñado. Pero considerábamos que haciéndoles ver la utilidad de las herramientas y para qué servía el trabajo que iban a realizar a lo largo de la asignatura, el grado de implicación en el plan propuesto sería bastante alto, como así ha sido.

Un aspecto en el que teníamos desde el principio depositadas muchas ilusiones y confianza $^{3}$ es en el trabajo competencial. Dejando a un lado los idealismos, la inmensa mayoría de las personas que se matriculan en un título universitario lo hace con vistas a su futuro profesional. Hasta hace poco la Universidad se había limitado a ofrecerles contenidos teóricos, sin preocuparse de que los futuros profesionales llegaran a ser competentes para el mercado laboral en sus distintas actividades. En nuestro caso, nuestro objetivo no ha sido nunca conseguir egresados que sepan mucha Historia Medieval, sino que esos egresados a través de la materia que les hemos impartido y las herramientas adquiridas sean personas competentes de tal manera que el abanico de posibilidades laborales resulte lo más amplio posible.

Por último queremos resaltar que, de acuerdo con nuestra experiencia personal, el cambio siempre es absolutamente posible. La adopción de nuevos métodos de enseñanza para impartir las asignaturas, la participación más activa de los estudiantes en su proceso de aprendizaje, la mejora en los resultados académicos, el lograr egresados formados a nivel teórico y competentes, es ya una realidad. La innovación es y debe ser siempre un aspecto fundamental en nuestro proceso de formación como docentes (Romero, 2009). Un proceso donde la última etapa no existe, puesto que la innovación docente nunca debe estar concluida y cerrada.

\section{Referencias}

ALONSO CANO, C. et al. (2007). "Relatos de Innovación docente" en Revista Lationoamericana de Tecnología educativa, vol. 6, n 2, pp. 153-167.

ÁLVAREZ GONZÁLEZ, M. (2008). "La tutoría académica en el espacio europeo de la Educación Superior” en Revista interuniversitaria de formación del profesorado, $\mathrm{n}^{\circ}$ 61, pp. 7188.

BERNAL AGUDO, J.L. (2006). Pautas para el diseño de una asignatura desde la perspectiva de los ECTS. Universidad de Zaragoza. 2006.

DANVILA DEL VALLE, I. (2013). "El papel de la clase teórica en el Espacio Europeo de Educación Superior” en Estudios sobre el mensaje periodístico, $n^{\circ} 19$ (2), pp. 701-709.

\footnotetext{
3 Recuérdese la importancia de la confianza del profesor en la realización de la tarea docente es fundamental para generar actitudes positivas hacia el cambio tal como indica MARCHESI (1999)
}

(c)) EY-NC-ND 2018, Universitat Politècnica de València 
DEL VAL MERINO, C. (2013). "La integración del alumno al mundo laboral. El paradigma de la Inteligencia Emocional en el marco del Espacio Europeo de Educación Superior (EEES)” en Estudios sobre el mensaje periodístico, $\mathrm{n}^{\circ} 19$ (1), pp. 129-138.

ELBOJ, C, PUIGDELLIVOL, I, SOLER, M, VALLS, R. (2002). Comunidades de aprendizaje: transformar la educación. Barcelona: Graó.

FERNÁNDEZ ARAQUE, a. m. (2016). "La rúbrica como como instrumento de evaluación y de aprendizaje" en Formar mediante la evaluación en la Universidad: propuestas prácticas útiles para docentes. Valladolid: Universidad de Valladolid, pp. 53-64.

GIBBONS (1995). The New Production of Knowledge. London: Sage Publications.

GIL FLORES, J et al (2004). La enseñanza universitaria, planificación y desarrollo de la docencia. Madrid EOS.

HANNA, D. (2002). La enseñanza universitaria en la era digital. Barcelona: Octaedro.

KNIGHT, P. (2005). El profesorado de educación superior: formación para la excelencia. Madrid: Nancea.

LOBATÓN, g. E. (2013). La novella histórica como recurso didáctico en la enseñanza de la Historia. Tesis doctoral defendida en la Universidad Complutense de Madrid.

MARTÍN CEA, J. C., VILLANUEVA ZUBIZARRETA, O., BONACHÍA HERNANDO, J. A., DEL VAL VALDIVIESO, M. I. (2008). "Propuestas de innovación docente para el estudio de la Historia medieval “ en Innovación docente: docencia y TICs. Valladolid: Universidad de Valladolid, pp. 255-265.

MCINTOSH, C. Lifelong learning and Distance Higher Education Overview. Paris: Unesco.

MEDINA, J. L. (2002). "La deconstrucción o desaprendizaje: aproximación conceptual y notas para un método reflexivo de generación de nuevos saberes profesionales” en Revista electrónica Educare, $\mathrm{n}^{\circ} 21$ (1).

Disponible en: http://www.enfermeria21.com/revistas/educare/articulo/1021/

METCALFE, A. (2006). Knowledge management and higher education a critical analysis. London: Information Science Pub.

MIGUEL DÍAZ, M. (2006). Modalidades de enseñanza centradas en el desarrollo de las competencias. Orientaciones para promover el cambio metodológico en el marco del EEES. Oviedo: Universidad de Oviedo.

MORALES, P. (2005). Implicaciones para el profesor de una enseñanza centrada en el alumno. Madrid: Universidad Pontifica de Comillas (ICADE).

NEVOT LUNA, A. (2008). “Espacio Europeo de Educación Superior. ¿Una utopía?” en Dibujo técnico y matemáticas: una consideración interdisciplinar. Madrid: Ministerio de Educación y Ciencia, pp. 189-230.

RIVERO GRACIA, M. P. (2003). “Apuntes sobre el comentario de textos históricos” en Clío: History and History teaching, $\mathrm{n}^{\circ} 29 . \quad$ Disponible en: http://clio.rediris.es/materiales_universidad/comentario\%20texto.htm

RODRÍGUEZ DE MIÑÓN, P; BARBERO, M.I., NAVAS, M.J., SUÁREZ, J.C., HOLGADO, F.P., VILLARINO, A y RECIO, P. (2003) Recomendaciones para la elaboración de pruebas objetivas de evaluación y la interpretación de sus puntuaciones. Madrid. Facultad de Psicología de la Uned.

ROMERO MARTÍN, M. y RUESCAS NICOLAU, A. "El reto docente del Espacio Europeo de Educación Superior, ¿estamos preparados?” en Metas de enfermería, vol.12, nº9, 2009, pp. 6066.

RONDINA, G. y ANGELUCCI, M.S. (2012). “El uso del cine en la enseñanza universitaria” en Ars Boni et Aequi, vol. 8, n 1, pp. 171-201.

VELASCO MARTÍNEZ, L. (2014). "El uso de la literatura y sus adaptaciones en la enseñanza de la Historia” en Iber: Didáctica de las Ciencias Sociales, Geografía e Historia, nº 77, pp. 7380.

(cc) EY-NG-ND 2018, Universitat Politècnica de València 
Referencias electrónicas sobre webs con recursos para la enseñanza de la Historia Medieval: http://www.medievalismo.org http://labyrinth.georgetown.es http://www.tntech.edu/history/tech.html http://www.le.ac.uk/urbanhist/index.html http://www.storiadellacitta.it http://www.smr.herefordshire.gov.uk/education/medtowns_contents.html http://www.trytel.com tristan/towns/towns.html http://www.saint-denis.culture.fr/fr/index.html http://philae.sas.upenn.edu./French/caroly.html http://www.rhi.wur.nl/UK/links/rural/ http://www.arqueologiamedieval,com http://www.fordham.edu/halsall/women/womensbook.html http://www.ecohistory.net http://www.memebrs.aol.com/TeacherNet/Medieval.html http://www.library.yale.edu/rsc/history/medbib.html http://www.history-journals.de http://www.amea.unican.es http://www.journals.cambridge.org/action/display/Journal?jid=UHY http://www.edmrevistas.com/revistas/medieval http://www.jmems.dukejournals.org 


\title{
Adquisición de competencias profesionales en el Trabajo Fin de Máster: Colaborar para aportar soluciones reales
}

\author{
Irene Comeig Ramírez ${ }^{a}$ Alfredo Juan Grau Graub Lucía Pinar García ${ }^{c}$ Federico \\ Ramírez López y Amalia Rodrigo González ${ }^{\mathrm{e}}$ \\ a,b,d,e Departamento de Finanzas Empresariales, Facultat d’Economia (Universitat de València), Avda. \\ de los Naranjos, s/n, 46071 Valencia (Irene.Comeig@uv.es, Alfredo.Grau@uv.es, \\ Federico.Ramirez@uv.es y Amalia.Rodrigo@uv.es), 'Departamento de Economía Aplicada, Facultat \\ d’Economia (Universitat de València), Avda. de los Naranjos, s/n, 46071 Valencia \\ (Lucia.Pinar@uv.es)
}

\begin{abstract}
In order to motivate the student through a professional experience, and to improve the teaching-learning process by letting the student gain experience, we implement a collaborative learning-through-service methodology. This method increases the student involvement level and the deep understanding of the tools. As a matter of example, we present the implementation of this method in the Final Master Thesis (FMTh) of the Master on Corporate Finance at the University of Valencia (UV). In these FMTh, students have to valuate an actual innovation developed by UV researchers (on chemistry, in this case) with the goal of helping themto transfer (sell) this innovation to the industry. This collaborative learning-through-service methodology helps student put into practice the technics learned in the Master and give them a strong sense of the financial professional practice.
\end{abstract}

Keywords: Final Master Thesis, professional skills, collaborative work methodology, financial valuation.

\footnotetext{
Resumen

Con el objetivo de motivar al estudiante a través de una toma de contacto con la realidad profesional y mejorar el proceso de aprendizaje fomentando la interiorización de la técnicas de trabajo mediante un modelo colaborativo de tutorización, se plantea la inmersión del estudiante en un caso real al que debe aportar una solución. Aportamos como ejemplo la aplicación de esta técnica a la realización del Trabajo Fin de Master (TFM) del Master en Finanzas Corporativas de la Universidad de Valencia (UV). En estos TFMs, los estudiantes deben valorar un proyecto de inversión con consecuencias para la Transferencia de Resultados de Investigación de la UV: Se pretende responder a ¿Qué precio máximodebería estar dispuesta a pagar una empresa por los derechos de explotación de la investigación analizada? Para la realización de estos TFMs, se implementa la pedagogía Aprendizaje Servicio mediante la metodología de Trabajo Cooperativo que permite desarrollar una enseñanza centrada en la participación del alumnado favoreciendo el desarrollo de unos conocimientos más sólidos y duraderos.
} 
La innovación presentada permite al alumnado poner en práctica los conocimientos adquiridos en sus estudios de máster y les aproxima a la realidad empresarial..

Palabras clave:se trabajo fin de master, competencias profesionale, metodología de trabajo cooperativo, valoración financiera.

AGRADECIMIENTOS: Los autores agradecen el apoyo financiero del Vicerrectorado de Políticas de Formación y Calidad Educativa de la Universidad de Valencia, UV-SFPIE_RMD17-589360.

\section{Introducción}

$\mathrm{Al}$ final de cualquier master oficial los alumnos deben realizar su correspondiente Trabajo de Fin de Master (TFM), una práctica que cada vez es más común también en los títulos propios. La finalidad de este TFM es completar la asimilación de los conocimientos que se han adquirido durante el postgrado, desarrollando un ensayo teórico-práctico sobre algún aspecto relacionado con el master.

El RD 193/2007, de 29 de octubre, regula las enseñanzas universitarias oficiales y establece la obligatoriedad de completar el trámite del TFMpara conseguir el título de master oficial. Por otra parte, el RD 1027/2011, de 15 de julio, se centra en las competencias que deben adquirir los titulados en un master. Entre las competencias relacionadas con el TFM se incluyen, por ejemplo, el saber aplicar los conocimientos en entornos nuevos, evaluar y seleccionar la teoría científica adecuada y metodología precisas para formular juicios o saber transmitir claramente los resultados procedentes de la investigación científica.

Nuestra aportación a la innovación educativa radica en proporcionar al estudiante una opción colaborativa de inmersiónen la realidad profesional durante la realización del TFM. Con ello se mejora la motivación,y el proceso de aprendizaje-servicio fomenta la interiorizaciónde las técnicas profesionales que se adquieren mediante un modelo colaborativo de tutorización. En el ejemplo de aplicación que presentamos en la ejecución del TFM del Master en Finanzas Corporativas de la UV, el/la estudiante se pone en contacto con un grupo de investigación de la Universidad de Valencia (gracias a la publicidad hecha a través de los trípticos y de la página web desarrollada para dar publicidad de este proyecto de enseñanza-aprendizaje: RESEARCH+ CASHLab, y a contactos anteriores) y debe realizar como Trabajo de Fin de Máster (TFM) el análisis de la viabilidad financiera de la transferencia/venta a la industria de algún resultado de investigación de ese grupo. Concretamente, la pregunta que se pretende responder es: ¿Cuál es el precio máximo que una empresa debería estar dispuesta a pagar por laadquisición de los derechos de explotación de un producto de la investigación concreto generado por la Universidad de Valencia (patente, licencia, proceso, etc.)?

Este tipo de TFM ofrece un servicio de ayuda a la transferencia de resultados de investigación de las universidades, lo que motiva especialmente a los estudiantes y les traslada también la responsabilidad que sienten las/os encargados de las finanzas

(cc) BY-Nc-ND 2018, UniversitatPolitècnica de València

Congreso IN-RED (2018) 
empresariales. La valoración financiera del proyecto traduce a dinero y a rentabilidad la información sobre los productos derivados de la investigación, reduciendo así la asimetría de la información entre investigadores y empresarios compradores potenciales de dichos productos, lo que facilita la posterior transferencia de los resultados de la investigación al tejido empresarial.

\section{Objetivos}

El objetivo general que se plantea es que los estudiantes quefinalicen sus estudios de master sean capaces de desenvolverse en el cargo profesionalpara el que les prepara el máster. Para ello, se aplica una metodología de Trabajo Cooperativo para la adquisición de competencias profesionales.

Layer (2004) destaca que en estos úúltimos aaños las universidades manifiestan un destacado interés en la relación existente entre la Educación Superior y la inserción de sus titulados en el mundo laboral. Semeijnet al. (2005) advierte que todo esto le confiere al sistema universitario la gran responsabilidad a la hora de formar adecuadamente a su alumnado, para que en un futuro puedan desenvolverse de forma eficiente en sus puestos de trabajo.

Las competencias educativas, por un lado, robustecen las posibilidades de lograr un trabajo que no tiene por quéestar estrechamente asociado al área formativa, por otro lado, refuerzan las posibilidades de que puedan desarrollar de forma óptima las exigencias del puesto a ocupar (Heijkeet al., 2003).

Las competencias que se definen tienen que ser evaluables y por ello, la forma en la que éstas se formulen debe permitir la identificación de resultados de aprendizaje que puedan ser observables y mensurables (Riesco, 2008).

La Tabla 1 presentacomo ejemplo las competencias básicas y que se pretende desarrollar en los alumnos a través de la experiencia que implementamos.

La experiencia de innovación educativa que presentamos, utiliza la metodología de Trabajo Cooperativoy, concretamente, se desarrolla la pedagogía del Aprendizaje Servicio (APS) en los alumnos del master. Puig et al. (2009) definen de diferentes formas el APS incidiendo en dos componentes básicos: a) la eficacia del aprendizaje y la aplicación curricular de procedimientos y actitudes, b) el servicio volcado a la comunidad en este caso con la transferencia de resultados de investigación. Siguiendo a Puig et al (2006), el APS quiere dar respuestas a necesidades reales de la sociedad impulsando la participación y cooperación de los estudiantes con otras instituciones y entidades. Se impulsa, por tanto, con el APS la educación en valores a través de su práctica, permitiendo que los estudiantes puedan usar los conocimientos adquiridos en el master como una herramienta que les permita aportar soluciones reales al tejido socio-empresarial. 
Tabla 1. Competencias profesionales

\begin{tabular}{|c|c|}
\hline Código & Descripción \\
\hline CB2 & $\begin{array}{l}\text { Que los estudiantes sepan aplicar sus conocimientos a su trabajo o vocación de una } \\
\text { forma profesional y posean las competencias que suelen demostrarse por medio de la } \\
\text { elaboración y defensa de argumentos y la resolución de problemas dentro de su área } \\
\text { de estudio }\end{array}$ \\
\hline CG6 & Habilidad para analizar y buscar información proveniente de fuentes diversas \\
\hline CG12 & Capacidad para trabajar en equipo \\
\hline CG17 & Capacidad de aprendizaje autónomo \\
\hline CE2 & $\begin{array}{l}\text { Ser capaz de elaborar e interpretar la información contable, tanto la financiera, } \\
\text { destinada a los usuarios externos, como la interna, destinada al control de gestión y la } \\
\text { toma de decisiones }\end{array}$ \\
\hline CE4 & $\begin{array}{l}\text { Ser capaz de resolver problemas de valoración financiera, tanto en decisiones de } \\
\text { financiación, como de inversión empresarial, en el entorno nacional e internacional }\end{array}$ \\
\hline CE8 & $\begin{array}{l}\text { Conocer y analizar los mercados financieros, así como las operaciones financieras } \\
\text { anejas al ámbito empresarial }\end{array}$ \\
\hline CE49 & $\begin{array}{l}\text { Conocer los fundamentos básicos que rigen las operaciones y los mercados } \\
\text { financieros }\end{array}$ \\
\hline CE52 & $\begin{array}{l}\text { Capacidad para medir y valorar el riesgo de los activos financieros y sus aplicaciones } \\
\text { en las inversiones productivas }\end{array}$ \\
\hline CE56 & $\begin{array}{l}\text { Conocer los diferentes instrumentos de financiación y ser capaz de determinar la } \\
\text { política de endeudamiento de la empresa }\end{array}$ \\
\hline
\end{tabular}

Fuente: www.uv.es/economia (Grado en Administración y Dirección de Empresas)

Concretamente, con nuestra aportación a la innovación educativa de inmersión en la realidad profesional durante la realización del TFMse pretende reducir la brecha entre formación académica y el trabajo a desempeñar en la empresa donde se desarrollen laboralmente. Esta aportación:

1) Proporciona una primera toma de contacto al estudiante demaster con el díaa adía real de un profesional.

2) Mejora el proceso de enseñanza-aprendizaje fomentando la interiorización de la técnicas de trabajo del estudiante mediante la inmersión del estudiante en un caso real con un cliente real y consecuencias (para la Transferencia de Resultados de Investigación a la industria).

3) Fomenta la participación del estudiante realizando un aprendizaje-servicio, mediante una técnica de trabajo en colaboración con el grupo de investigación y con la/el profesor/a tutor/a. 
4) Pone en contacto el estudio universitario con el mercado laboral, puesto que el estudiante podrá participar en las entrevistas con las empresas interesadas en comprar la investigación, en nuestra aplicación concreta.

5) Impacta positivamente no solo en la formación del estudiante sino en la transferencia de resultados de investigaciónn de la Universidad de Valencia al tejido industrial.

6) Dado que los trabajos de Fin de Master están demostrando ser hasta ahora el talón de Aquiles de los masters profesionales, esta innovación educativa representa una posible solución para cambiar la tendencia.

\section{Desarrollo de la innovación}

\subsection{Metodología de Trabajo Cooperativocon Aprendizaje Servicio}

Para desarrollar la innovación planteada se ha seleccionado la metodología de Trabajo Cooperativo. La principal ventaja de este método es que permite desarrollar una enseñanza centrada en la participación del alumnado donde la responsabilidad del aprendizaje depende estrechamente de su nivel de implicación y compromiso. Ello conduce a adquirir unos conocimientos con mayor profundidad, interiorizarlos y, en consecuencia, favorecen su durabilidad a lo largo el tiempo y su aplicabilidad a distintos campos y situaciones.

Esta metodología se caracteriza por fomentar la adquisición de conocimientos, habilidades o actitudes como resultado del trabajo en grupo o, en otras palabras, un aprendizaje individual como resultado de un proceso grupal (Ariza, 2000).

Además, la participación e implicación personal del estudiante en el desarrollo del proceso para aportar una solución a un problema real interioriza el aprendizaje y fija los conocimientos con carácter duradero (Ramírez y Grau, 2016; Comeig y JaramilloGutiérrez,2011)

En la experiencia que implementamos de Aprendizaje Servicio (APS), la relación de cooperación no se limita a un contacto bidireccional entre docente y estudiante, sino que el alumno cuenta con, además del apoyo académico y científico del profesor, los conocimientos del grupo para el que realiza el trabajo (“cliente”). De esta forma, el resultado final se beneficia de las sinergias que implica trabajar con académicos(docente) y prácticos ('cliente').

El docente asume la figura de mediador entre los distintos integrantes del grupo, así como de garante de una actividad que se realice de forma satisfactoria para todas las partes implicadas. Se le confiere también la responsabilidad de promover la capacidad de reflexión en sentido constructivo ycrítico.

En nuestro ejemplo, el/la estudiante se pone en contacto con un grupo de investigación de la Universidad de Valencia (gracias a la publicidad hecha a través de los trípticos y de la página web desarrollada para dar publicidad de este proyecto de enseñanza- aprendizaje, RESEARCH+CASHLab, principalmente) y debe realizar como TFM el análisis de la 
viabilidad financiera de la transferencia/venta a la industria de algún resultado de investigación de ese grupo.

Este tipo de TFM motiva sustancialmente a los estudiantes y también les traslada la responsabilidad que sienten las/os encargados de las finanzas empresariales. La valoración financiera del proyecto reduce la asimetría de la información entre investigadores y empresarios compradores potenciales de dichos productos, lo que facilita la posterior transferencia de los resultados de la investigación al tejido empresarial.

Para analizar este proyecto de inversión se utilizan los indicadores financieros de valoración tradicionales: Cálculo de los flujos netos de caja del proyecto, VAN, TIR, análisis de sensibilidad y punto muerto, etc

\subsection{Ejemplo de aplicación de la opción colaborativa de inmersión en la realidad profesional durante la realización del TFM}

La innovación mediante elAprendizaje Servicio de los alumnos del Master de Finanzas Corporativas se integra con la metodología de Trabajo Cooperativopor la colaboración entre distintosgrupos de investigación y docencia. En nuestro ejemplo el grupo MINTOTA del Departamento de Química Analítica (Facultad de Química-UV) tiene una investigación que le interesaría llevar al mercado empresarial, el grupo RESEARCH+CASHLab del Departamento de Finanzas Empresariales (Facultad de Economía-UV) tiene los conocimientos para dar una valoración económico-financiera a ese resultado de investigación, y el/la estudiante del Máster en Finanzas Corporativas tiene el deseo de fijar los conocimientos en Finanzas Empresariales al realizar su TFM.

Como ejemplo de nuestra metodología de innovación educativa, presentamos un TFM dedicado a la valoración de un producto de la investigación del grupo MINTOTA del Departamento de Química Analítica (Facultad de Química-UV), que consiste en un sensor colorimétrico in situ que detecta la cantidad de aminas presentes en el aire.Estos sensores pueden ser de gran utilidad en la industria de la alimentación, ya que, al indicar el nivel de contaminantes (aminas) del alimento que incorpora este dispositivo, en función del color que muestra, permite identificar su grado de salubridad previo a ser consumido.

El RESEARCH+CASHLab, formado por investigadores del Departamento de Finanzas Empresariales (UV), representa el punto de encuentro entre investigadores, inversores y tejido empresarial. Por ello, está especialmente bien posicionado para ofrecer apoyo académico y científico a aquellos alumnos del Master en Finanzas Corporativas que soliciten desarrollar su trabajo fin de master bajo esta metodología de aprendizaje servicio. Se dedican a valorar innovación científica (ej. nuevos hallazgos relevantes, patentes, licencias) para que puedan llegar al mundo de la empresa y a la sociedad.

Las fases en que se desarrolla la valoración de los dispositivos pasivos son:

\section{FASE I. REUNIÓN CON EL GRUPO DE INVESTIGACIÓN}

En primer lugar, se reúnen el alumno del master de Finanzas Corporativas y su profesortutor con los miembros del grupo de investigación, en este caso MINTOTA. De esta primera reunión se extrae información relevante sobre las características del dispositivo 
pasivo atmosférico y sus ventajas diferenciadores frente a sus principales competidores. Se le proporciona todo tipo de datos inherentes al dispositivo y que serán necesarios para hacer la posterior valoración financiera.

\section{Fase II. Diseño de las hipótesis de Trabajo y los Estados Financieros Previsionales}

Con toda la información recabada, el alumno junto con el profesor-tutor y el apoyo adicional de RESEARCH+CASHLab diseñan las hipótesis de trabajo que servirán para estimar todas las magnitudes que concurren en el cálculo de la rentabilidad en la explotación de estos sensores pasivos.

Las hipótesis que se plantean son:

- Hipótesis sobre la estimación de los costes directos laborales: personal a jornada parcial, número de sensores a fabricar por hora, etc.

- Hipótesis sobre la estimación del crecimiento de las ventas.

- Hipótesis sobre la estimación de los costes fijos. publicidad, amortización derivado de la obtención de la licencia, etc.

- Hipótesis sobre la estimación de la Cuenta de Pérdidas y Ganancias.

\section{FASE III. CÁlCUlo de los FluJos Netos de CAJA}

Una vez establecidas las hipótesis de partida, el alumno estima los Flujos Netos de Caja (FNC) derivados de la realización del proyecto y necesarios para analizar los distintos instrumentos financieros conducentes a decidir si el proyecto será rentable.

\section{FASE IV. ESTUDIO Y ANÁLISIS DE LOS INSTRUMENTOS FINANCIEROS}

Seguidamente, el alumno hace uso de los distintos métodos de valoración a efectos de analizar la viabilidad financiera del proyecto planteado. Estos son:

- Valor Actual Neto (VAN). Medida de la rentabilidad absoluta neta. Este indicador va a servir para identificar si el valor del proyecto es superior a su coste, tomando en consideración la tasa del coste de oportunidad del capital invertido.

- Tasa Interna de Rentabilidad (TIR). Medida de la rentabilidad en términos relativos brutos y permite, al igual que el VAN, decidir si acometer o no el proyecto.

- Umbral de Rentabilidad Financiero o Punto Muerto (PM). Nos indica cuantos sensores hay que producir para igualar el valor con el coste y, conocer así, cuántas unidades se han que vender para empezar a obtener un VAN positivo.

- Análisis de Sensibilidad (AS). Con el fin de analizar posibles riesgos derivados de desviaciones en la estimación de las hipótesis iniciales en cuanto a ventas o costes adicionales, se plantea un análisis de sensibilidad. Esto permite identificar aquellos escenarios en los que el proyecto podría fracasar y, así, llevar un mayor control de estas contingencias.

- Método de Montecarlo (MM). Este método introduce aleatoriedad en una serie de variables definidas por el usuario para estudiar el comportamiento del modelo 
planteado. En este caso, se han establecido unos valores mínimos y máximos que ciertas variables podrían tomar y se han generado 1.000 valores diferentes del VAN según los diferentes valores de las variables aleatorias consideradas.

\section{FASE V. EMISIÓN DEL INFORME EJECUTIVO FINAL}

Finalmente, el alumno emite dos informes ejecutivos. El primero con todo el desarrollo al completo y el segundo más abreviado. Estos documentos se le entregan al grupo de investigación, en este ejemplo, MINTOTA, para corroborar la viabilidad financiera de la explotación de los dispositivos pasivos y, así, plantearse la explotación de su licencia.

Por otro lado, el alumno redacta su trabajo fin de master que recogerá todos los desarrollos mencionados anteriormente y que se ajustan a la guía académica del mismo.

\section{Resultados}

Como consecuencia de la aplicación de metodología colaborativa para aportar soluciones reales (aprendizaje servicio) en la realización del TFM, se adquieren competencias profesionales duraderas. El/la estudiante interioriza las cuestiones tratadas (en nuestro ejemplo: la valoración financiera tratada durante el Máster). Además, seadquieren competencias prácticas no solo sobre valoración financiera, sino también sobre trabajo en equipo, trasmisión de ideas, recopilación de información, gestión del tiempo y de la responsabilidad, etc. En definitiva, el/la estudiante adquiere experiencia profesional (en nuestro ejemplo sobre las finanzas empresariales), y de la gestión del trabajo en equipo, pero siempre bajo la tutela y con la colaboración del profesor/a.

En nuestro ejemplo, los resultados obtenidos con esta experiencia de innovación son de dos tipos: el académico y el de transferencia de investigación. En primer lugar, desde el punto de vista académico: (i) gracias a la elaboración del trabajo fin de master con la valoración de la explotación de la licencia del dispositivo pasivo para la detección in situ de aminas en gases, el alumno además de poder aplicar los conocimientos teóricos adquiridos, entra en contacto con empresas reales valorando proyectos de inversión en un contexto real; y (ii) en muchas ocasiones estos estudiantes que han desarrollado estas tareas de valoración, han acabado trabajando en las empresas donde han desempeñado esta actividad profesional.

Por otra parte, en el ámbito de la transferencia de resultados de investigación, (i) al grupo MINTOTA se le facilita una serie de informes ejecutivos de viabilidad económicofinanciera que le permitirán comercializar su licencia; y (ii) el grupo RESEARCH+CASHLab, está contribuyendo a la transferencia de los resultados de investigación a la empresa dado que facilita informes que permiten a los investigadores vender los resultados de su producción científica.

\section{Conclusiones}

La aplicación de metodología colaborativa para aportar una solución a un problema real (aprendizaje servicio) en la realización del TFM, ha permitido adquirir competencias 
profesionales duraderas. El/la estudiante interioriza los conocimientosimplicados en la solución. Además, seadquierenotras competencias prácticas como: trabajo en equipo, comunicación, recopilación de información significativa, y gestión del tiempo y de la responsabilidad. En definitiva, el/la estudiante adquiere experiencia profesional pero bajo la tutela y con la colaboración del profesor/a.

Llevar a cabo esta experiencia de innovación ha permitido la toma de contacto con el mundo real empresarial por parte del alumnado, y le ha permitido desarrollar gran parte de las competencias profesionales que precisan para desempeñar adecuadamente un puesto de trabajo en el área financiera.

Una de las principales ventajas de la colaboración interdepartamental (en nuestro ejemplo: MINTOTA, RESEARCH+CASHLab y Máster en Finanzas Corporativas), es que permite desarrollar con una mayor calidad los trabajos fin de máster en Finanzas Corporativas con una mayor motivación e interiorización por parte de los estudiantes, en un contexto real empresarial. Se ha comprobado que se han producido efectos sinérgicos que han favorecido a los resultados obtenidos tanto en el ámbitodocente-académico como en el científico.

Trabajar en esta línea de canalización del aprendizaje a ofrecer un servicio mediante la colaboración, da resultados muy positivos. En nuestro ejemplo, gracias al apoyo académico y científico prestado por RESEARCH+CASHLab. De esta forma se logra aproximar los intereses de los distintos grupos involucrados: alumnos, docencia, investigadores y empresas.

\section{Referencias}

ARIZA, A. (2000) "Las Nuevas Tecnologías de la Información y la Comunicación y una Propuesta para el Trabajo Colaborativo" en V Congreso Iberoamericano de Informática Educativa. http://www.edudistan.com/Adolfo\%20Ariza.htm (consultado el 10 de noviembre de 2017)

COMEIG, I.. y JARAMILLO-GUTIÉRREZ, A. (2011) "Experimentosinteractivospara la enseñanza de economía y finanzas: unaaplicación a la docencia de estadística” en Experiencias de innovacióndocente en estadistica, Universidad de Valencia, Valencia. p. 191-199.

España. Real Decreto 1393/2007, de 29 de octubre, por el que se establece la ordenación de las enseñanzas universitarias oficiales (publicado en BOE núm. 260, de 30 de octubre de 2007). Disponible en: https://www.boe.es/diario boe/txt.php?id=BOE-A-2007-20202 (consultado el 20 de diciembre de 2017).

España. Real Decreto 1027/2011, de 15 de julio, por el que se establece el Marco Español de Cualificaciones para la Educación Superior (publicado en BOE núm. 185, de 3 de agosto de 2011). Disponible en: https://www.boe.es/buscar/doc.php?id=BOE-A-2011-13317 (consulta el 20 de diciembre de 2017). 
HEIJKE, H., MENG, C. y RIS, C. (2003). "Fitting to the Job: The Role of Generic and Vocational Competencies in Adjustment and Performance" en Labour Economics, vol. 10, p. $215-229$

LAYER, G. (2004). Widening Participation and Employability. York: Learning and Teaching Support Network.

MUÑOZ, F., ARVAYO, K., VILlEGAs, C., GONZÁLEZ, F. y SOSA, O. (2014). “El método colaborativo como una alternativa en el trabajo experimental de Química Orgánica” en Educación Química, vol. 25, issue 4, p.464-469.

PUIG, J.M. y PALOS,J. (2006). "Rasgos pedagógicos del aprendizaje-servicio” en Cuadernos de Pedagogía, vol. 357, p.60-63.

PUIG, J.M., GIJON, M., MARTÍN, X. y RUBIO. L. (2009). Aprendizaje Servicio. Educación y compromiso cívico. Barcelona: Graó.

RAMÍREZ, F. y GRAU, A. J. (2016). “La Innovación Educativa y la Economía Experimental: Un experimento sobre el contagio del pánico bancario” en Innovación Universitaria: Digitalización 2.0 y Excelencia en Contenidos. Mc Grau Hill/ Interamericana. Madrid. p. 665-676.

RIESCO, M. (2008). "El enfoque por competencias en el EEES y sus implicaciones en la enseñanza y el aprendizaje” en Tendencias pedagógicas, vol. 13, p. 79-106.

SÁEZ, J. y RUÍZ, J.M. (2012). "Metodología didáctica y tecnología educativa en el desarrollo de las competencias cognitivas: aplicación en contextos universitarios” en Revista de Currículum y Formación del Profesorado, vol. 16, issue 3, p. 373-391.

SEMEIJN, J.H., VELDEN, R.K.., HEIJKE, J.A.., VLEUTEN, C.P. y BOSHUIZEN, H.C. (2005). Competence Indicators in Academic Education and Early Labour Market Success of Graduates in Health Sciences. Maastricht: Research Centre for Education and the Labour Market. 


\title{
El trabajo de final de grado en los estudios de Periodismo y Comunicación Corporativa: el caso de Serielizados
}

\author{
Joan Sabaté ${ }^{\mathrm{a}}$, Josep Lluís Micób y Míriam Díez \\ ${ }^{a}$ Facultad de Comunicación y Relaciones Internacionales Blanquerna, Universidad Ramon Llull, \\ JoanSS@blanquerna.url.edu, bFacultad de Comunicación y Relaciones Internacionales Blanquerna, \\ Universidad Ramon Llull, JosepLluisMS@blanquerna.utrl.edu ${ }^{c}$ Facultad de Comunicación y \\ Relaciones Internacionales Blanquerna, Universidad Ramon Llull, MiriamDB@blanquerna.url.edu
}

\begin{abstract}
The final degree project has been one of the main innovations in the pedagogical design of the new subjects of the Bologna Plan. Spanish universities have developed the subject as a theoretical or practical work, with the possibility of being done individually or in groups. In the studies of the Degree in Journalism and Corporate Communication of the School of Communication and International Relations Blanquerna, Ramon Llull University, these works are aimed at the realization of an entrepreneurial project of journalism or corporate communication. The final degree projects aim to work on new skills related to self-employment, which can be used as a further gateway in the employment of students. In addition, in the realization of the projects all the learning and competences developed during the degree are concentrated. In some cases, projects can be subsequently promoted through a knowledge transfer platform, the Media Innovation Lab, which helps students to launch their projects onto the market. One of the success stories of this methodology is the digital magazine Serielizados, a journalistic project about television series, which occupies a central position within the target audience of this audiovisual genre.
\end{abstract}

Keywords: journalism, enterprise, employability, entrepreneurship, corporate communication, final degree project, transfer, pedagogical innovation, methodological renewal, university

\section{Resumen}

El trabajo de final de grado ha sido una de las principales novedades en el diseño pedagógico de las nuevas asignaturas del Plan Bolonia. Las universidades españolas han desarrollado la asignatura como un trabajo teórico o práctico, con la posibilidad de realizarse individualmente o en grupo. En los estudios del Grado de Periodismo y Comunicación Corporativa de la Facultad de Comunicación y Relaciones Internacionales Blanquerna, Universidad Ramon Llull, estos trabajos se orientan a la realización de un proyecto periodístico o de comunicación corporativa emprendedor. Los trabajos de final de grado pretenden trabajar nuevas 
El trabajo de final de grado en los estudios de Periodismo y Comunicación Corporativa: el caso de Serielizados

habilidades competenciales vinculadas a la autoocupación, que puedan ser utilizadas como una puerta más en la inserción laboral de los estudiante. Además, en la realización de los proyectos se concentran todos los aprendizajes y competencias desarrolladas durante el grado. En algunos casos, los proyectos pueden ser posteriormente impulsados mediante una plataforma de transferencia del conocimiento, el Media Innovation Lab, que ayuda a los estudiantes en el lanzamiento de su proyecto al mercado. Uno de los casos de éxito de esta metodología es la revista digital Serielizados, un proyecto periodístico sobre series de televisión, que ocupa una posición de referencia dentro del público objetivo de este género audiovisual.

Palabras clave: periodismo, empresa, ocupabilidad, emprendimiento, comunicación corporativa, trabajo de final de grado, transferencia, innovación pedagógica, renovación metodológica, universidad 


\section{Introducción}

La Facultad de Comunicación y Relaciones Internacionales Blanquerna (FCRIB) fue la primera facultad española de su especialidad en adaptar sus tres grados de comunicación al Plan Bolonia. La dirección académica de la institución vio muy rápidamente las oportunidades de innovación pedagógica que potencialmente presentaba el cambio en el plan de estudios. Efectivamente, algunas de las novedades coincidían con el modelo pedagógico inicial del centro (grupos reducidos, trabajo por competencias, evaluación continuada...) y la transición de los planes de estudio se produjo de forma fluida.

El Trabajo de Final de Grado (TFG) se adoptó en todas las facultades de comunicación como una gran oportunidad para el cambio metodológico. No obstante, como ya ha sido recogido en otros artículos, "la aplicación práctica de la definición general ha sido variada en los centros en relación al número de créditos, el tipo de trabajo (teórico o práctico) o su forma de realización (individual o en grupo)” (SABATÉ i SALAZAR, 2017).

En el caso de la FCRIB, la aplicación del TFG se ha orientado a la realización de un trabajo práctico de carácter emprendedor en grupo. Este trabajo cuenta con la guía de un tutor o director de proyecto que se encarga de proporcionar apoyo a los estudiantes y de evaluarlo, conjuntamente con un tribunal.

Uno de los objetivos finales de estos trabajos es llegar a convertirse en un proyecto que funcione en el mercado, en la línea de lo apuntado por diversas investigaciones centradas en el sector español (MICÓ, MASIP Y BALLANO, 2012: 281-294; ARAUJO Y MICÓ, 2017: 167-181). En el caso de los trabajos del grado de Periodismo y Comunicación Corporativa, un proyecto sobresale en la consecución de este objetivo: Serializados ${ }^{1}$, una revista online dedicada a las series de televisión. El proyecto estaba formado inicialmente por cuatro estudiantes de la facultad, pero posteriormente se redefinió con la incorporación al equipo que finalmente desarrolló el proyecto de un estudiante de otra universidad.

En el presente artículo se expondrá la metodología utilizada en la FCRIB a partir del análisis de este caso de éxito.

\section{Objetivos}

Los objetivos y competencias trabajadas en el TFG están asociadas al Módulo VI del plan de estudios, vinculado a las materias de Empresa y Comunicación. Los objetivos son los siguientes:

1. Conciencia de los métodos y problemas de las diferentes ramas de la investigación en comunicación.

2. Capacidad de definir temas de investigación que puedan contribuir al conocimiento.

\footnotetext{
${ }^{1}$ https://serielizados.com
} 
El trabajo de final de grado en los estudios de Periodismo y Comunicación Corporativa: el caso de Serielizados

3. Capacidad de identificar y utilizar fuentes de cualquier tipo que sean significativas para el estudio de la comunicación.

4. Capacidad para la ideación, planificación y ejecución de proyectos comunicativos.

5. Habilidad de exponer de forma adecuada los resultados de la investigación de manera oral, escrita, audiovisual o digital conforme a los cánones de las disciplinas de comunicación.

6. Capacidad de trabajar en equipo.

\section{Desarrollo de la innovación}

\subsection{Metodología pedagógica}

El TFG es una asignatura anual que se divide en dos semestres, TFG I y TFG II, con una carga lectiva de 4 ECTS, respectivamente. A lo largo del año, los estudiantes deberán presentar los siguientes documentos: una idea de proyecto, una investigación de mercado que justifique la idea (anteproyecto) y un plan de negocio o de proyecto (proyecto final). Opcionalmente, pueden también realizar una maqueta, un número cero o un ejemplo de producción de su proyecto que les pueda ayudar en su presentación final.

Los estudiantes se agrupan en equipos de tres o cuatro personas. Por norma general, los equipos son del mismo grado, aunque en algunas ocasiones se ha permitido la formación de grupos con algún integrante de los otros dos grados de comunicación de la facultad (Comunicación Audiovisual y Publicidad, Relaciones Públicas y Marketing). Los estudiantes han recibido la información sobre el TFG durante el último semestre de tercer curso con el objetivo de facilitar el proceso de creación de los grupos y la generación de ideas.

\subsubsection{El TFG I: de la idea al anteproyecto}

Los contenidos del TFG I están asociados al conocimiento necesario para plantear un investigación de mercado, buscando los datos oportunos sobre el entorno, el público objetivo y la competencia. Esta investigación debe finalizar con un posicionamiento de una marca periodística o de comunicación corporativa. Esta asignatura recibe el apoyo de otras dos materias que los estudiantes realizan simultáneamente: Estructura de la Comunicación e Investigación y Metodología.

El programa de la asignatura de divide en cuatro puntos estructurales:

1. Prospectiva del mercado del periodismo y la comunicación corporativa.

2. Propuesta conceptual.

3. Análisis de oportunidades.

(cc) EY-NC-ND 2018, Universitat Politécnica de Valencia

Congreso IN-RED (2018) 
4. Formulación del anteproyecto.

Inicialmente, dos semanas después de iniciarse la asignatura, los grupos deben presentar sus ideas en un documento de dos páginas que incluya los siguientes elementos:

1. Definición del proyecto.

2. Público objetivo.

3. Necesidades a satisfacer.

4. Ventajas sobre la competencia.

5. Aproximación al modelo de negocio.

Estas ideas reciben una primera evaluación por parte de los tutores, que tiene como único objetivo seleccionar los proyectos en base a su oportunidad y posible viabilidad en el mercado. También se tiene en cuenta el grado de originalidad e innovación que aportan al sector del periodismo y de la comunicación corporativa. Esta es una primera barrera que deben superar los equipos. Hasta la fecha, todos los equipos han podido avanzar a la siguiente fase, aunque algunos estudiantes han tenido dificultades para definir correctamente su proyecto y se han visto obligados a corregir sus documentos o, incluso, a plantear una idea totalmente diferente. En cualquier caso, la voluntad de esta primera fase es que los grupos puedan seguir comprobando mediante su investigación si el planteamiento de sus proyectos es adecuado.

A continuación, los grupos empiezan el desarrollo de la investigación de mercado o anteproyecto, que finaliza con la entrega de un trabajo (máximo de 20 páginas de extensión) que consta de los elementos siguientes:

1. Resumen ejecutivo.

2. Análisis del entorno.

3. Análisis público objetivo.

4. Análisis competencia.

5. Análisis interno.

6. DAFO.

7. Posicionamiento.

8. Fuentes de información.

Los anteproyectos presentados en el primer semestre son evaluados por un tribunal técnico formado por tres profesores del grado. Normalmente, son los profesores que forman el equipo de tutores de los TFGs. A partir de la evaluación de los tribunales técnicos (40\% de la nota final) y previa aprobación de los proyectos por dichos tribunales, el tutor de proyecto evaluará individualmente a los estudiantes (60\% de la nota), pondrá la nota final y firmará las actas que conformarán las principales evidencias de la evaluación del TFG I. Las notas de las dos evaluaciones sólo pueden sumar a partir cuatro. Los grupos que no 
El trabajo de final de grado en los estudios de Periodismo y Comunicación Corporativa: el caso de Serielizados

superen la evaluación del tribunal pueden realizar correcciones en sus anteproyectos que presentarán a su tutor.

Es importante destacar que, a pesar de tratarse de un trabajo en grupo, la nota final de los estudiantes tiene un componente individual que permite ajustar la evaluación en función de su aportación personal. Efectivamente, este proceso permite corregir las posibles disfunciones provocadas por alguna actitud individual negativa, que a veces puede penalizar al conjunto del equipo.

En el caso de suspender esta parte del trabajo, los estudiantes deben volver a matricularse de TFG I el primer semestre del curso siguiente. Si sólo suspende un integrante del grupo o la mitad del mismo, el tutor valora si el resto del equipo sigue adelante con la misma idea o plantea un nuevo proyecto.

\subsubsection{El TFG II: del anteproyecto al plan de negocio}

En el TFG II se aborda el desarrollo del posicionamiento en un plan de negocio o proyecto. Como en el caso del TFG I, también cuenta con una asignatura de apoyo: Empresa Periodística. El programa de la asignatura se estructura en los siguientes temas:

1. Planificación del proyecto.

2. Desarrollo.

3. Producción.

4. Estrategia de difusión y promoción.

Los estudiantes de cuarto curso deben diseñar el plan empresarial que se concretará en un documento (sin límite de extensión), que incorporará los siguientes elementos:

1. Resumen ejecutivo.

2. Investigación de mercado.

3. Posicionamiento.

4. Plan de marketing.

5. Plan de operaciones.

6. Recursos humanos.

7. Estructura jurídica.

8. Plan económico y financiero.

9. Fuentes de información.

El tutor del primer semestre será el encargado de hacer el seguimiento de su desarrollo en el segundo semestre. La evaluación del proyecto final dependerá, nuevamente, de la aprobación de la presentación ante un nuevo tribunal ( $40 \%$ de la nota final) y la evaluación del propio tutor $(60 \%)$. Sin embargo, en este caso el tribunal tiene un carácter más

(cc) EY-NC-ND 2018, Universitat Politécnica de Valencia

Congreso IN-RED (2018) 
profesional, al estar formado por dos profesionales externos al grado y por un profesor de la facultad. La selección del tribunal profesional la realiza el equipo de dirección del grado, atendiendo a la experiencia profesional y al tipo de proyecto presentado. Así, los perfiles profesionales de los miembros del tribunal incluyen tanto a personas vinculadas a la gestión de empresas periodísticas o de comunicación corporativa como a la producción de contenidos. El denominador común es su vinculación a un proyecto empresarial que esté funcionando en el mercado.

Igual como en el TFG I, los estudiantes deben obtener una nota mínima de cuatro en las dos partes de la evaluación para que estas calificaciones sumen. En el caso de suspender, los estudiantes deben repetir el TFG II el siguiente curso ${ }^{2}$.

\subsubsection{El Media Innovation Lab: del proyecto al mercado}

Una vez superada la evaluación del TFG II finaliza el recorrido académico de los proyectos. Sin embargo, aquellos grupos que quieran lanzar su propuesta al mercado, tienen la posibilidad de utilizar los servicios que la facultad ofrece a través del Media Innovation Lab (MILAB).

El MILAB es "la plataforma digital que la Facultad ofrece a estudiantes y Alumni para desarrollar sus ideas o proyectos y ayudar a colocarlos en el mercado. Entendido como una lanzadera de proyectos, el Milab fomenta la creatividad y el emprendimiento de los alumnos convirtiéndose en un magnífico escaparate de sus trabajos y proyectos personales o académicos, a la vez que actúa como vínculo entre el sector de la comunicación y relaciones internacionales y el talento que surge de nuestra Facultad" ${ }^{3}$.

Entre los servicios que los estudiantes pueden encontrar en el MILAB destacan el acompañamiento y asesoramiento, así como la visualización de las ideas a los agentes empresariales del sector. Por otro lado, los estudiantes también pueden solicitar ayudas y becas gestionadas por el equipo del MILAB y también obtener ayuda para la presentación de sus proyectos en los concursos o festivales que sean más indicados para su promoción.

El MILAB depende orgánicamente del Vicedecanato de Empresa e Innovación, que se encarga de la coordinación de la plataforma con los equipos de dirección de los grados y las áreas de Alumni, carreras profesionales, prácticas y relación con las empresas.

En las siguientes páginas analizaremos cómo se concreta todo este proceso en el caso de Serielizados.

\subsection{Serielizados, un proyecto de éxito en la crítica de series de televisión}

\footnotetext{
${ }^{2}$ En algunos casos se permite avanzar la convocatoria de la recuperación al primer semestre del curso siguiente.

${ }^{3}$ Media Innovation Lab. <http://www.milabblanquerna.cat/?page_id=3140\&lang=es> [Consulta: 11 de marzo de 2018]
}

(c)) EY-NC-ND 2018, Universitat Politécnica de Valencia

Congreso In-Red (2018) 
El trabajo de final de grado en los estudios de Periodismo y Comunicación Corporativa: el caso de Serielizados

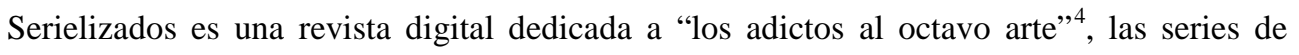
televisión. El proyecto nace el 21 de octubre de 2013, fundado por Betu Martínez y Víctor Sala. En la actualidad, cuenta con más de 70 colaboradores y un equipo fijo de cinco personas.

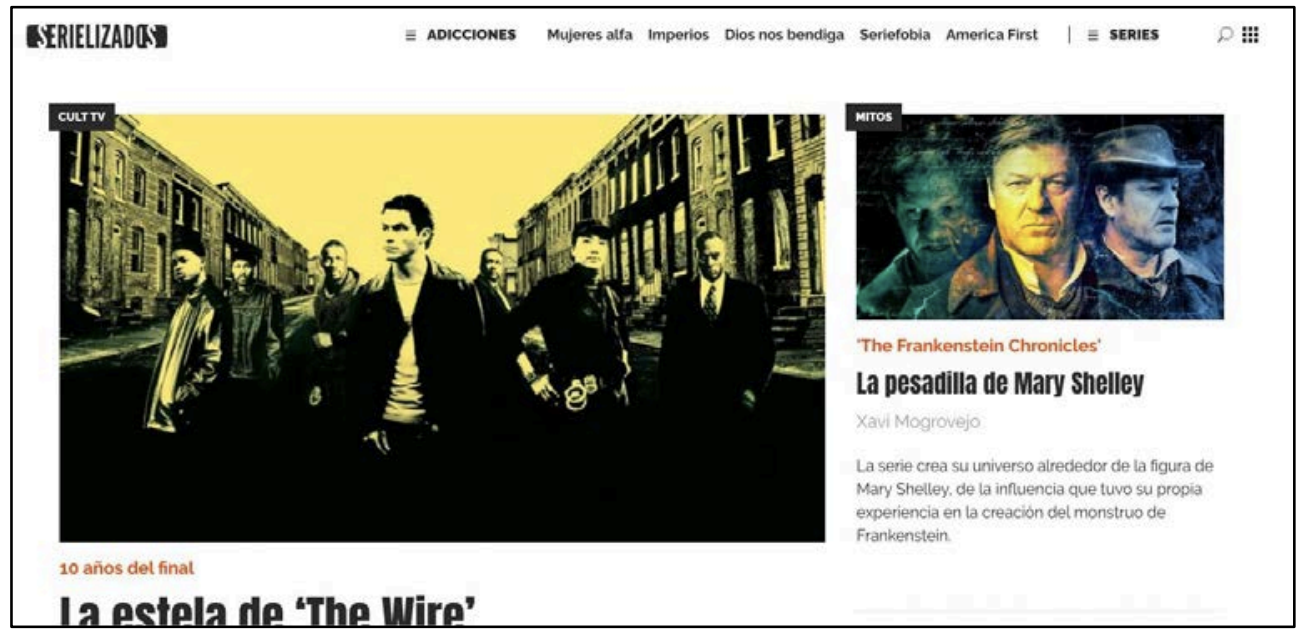

Fig. 1 Página principal de Serielizados

El proyecto ha obtenido unos buenos resultados de audiencia para una revista digital de sus características (ver la tabla 1), gracias en parte sus acuerdos de colaboración con otros medios, como por ejemplo la revista de ocio y cultura Time Out.

Tabla 1. Datos de audiencia de Serielizados

\begin{tabular}{|ll|}
\hline Principales indicadores de Serielizados \\
\hline Datos mensuales: & 60.000 usuarios únicos. \\
& 18.000 páginas vistas. \\
\hline Público objetivo & \\
\hline Sexo & $53,4 \%$ hombres. \\
& $46,6 \%$ mujeres. \\
\hline Edad & $18 \%$ de 18 a 24 años. \\
& $40 \%$ de 25 a 35 años. \\
& $25 \%$ de 36 a 44 años. \\
& $17 \%$ de 45 a 65 años. \\
\hline Procedencia geográfica (Facebook) & $57,2 \%$ España. \\
\hline
\end{tabular}

\footnotetext{
${ }^{4}$ Serielizados. <https://serielizados.com> [Consulta: 11 de marzo de 2018]
} 
39,4\% Sudamérica (Argentina, Chile,

Colombia, México, Venezuela, Ecuador, Perú)

Procedencia geográfica (Twitter) 90\% España

8\% Sudamérica

Fuente: Serielizados (2018)

Serielizados organiza además el festival de series Serielizados Fest (Ver tabla 2. 1ª edición realizada el 28 de febrero de 2014; la $5^{\text {a }}$ edición se celebrará del 27 al 30 de septiembre de 2018) y el Showcase de Pilotos de Ficción en colaboración con el Festival Zoom de Igualada, el Festival más antiguo de televisión en España ( $1^{\text {a }}$ edición celebrada el 25 de noviembre de 2014; la $5^{\text {a }}$ edición tendrá lugar este año conjuntamente con el Serielizados Fest y en colaboración con el Festival Zoom y el Festival de Series de Málaga, Screen TV).

Tabla 2. Datos de Serielizados Fest

Principales indicadores de Serielizados Fest

\begin{tabular}{|ll|}
\hline Espectadores & 3.500 espectadores \\
\hline Impactos en prensa & 398 \\
\hline Valoración económica de los impactos & 1,8 millones de euros \\
\hline
\end{tabular}

Serielizados nace como un TFG del grado de Periodismo el curso 2012-2013, con un equipo integrado por Betu Martínez, Marina Formoso, Maria Pujol y Raquel Rabadan. El proyecto se define inicialmente como "un proyecto sobre series de televisión norteamericanas, europeas, españolas y catalanas. Consiste en la creación de una publicación disponible vía web o en forma de aplicación para tabletas digitales y smartphones. Se trata de un proyecto rigurosamente periodístico con información de calidad. Estará dirigido a todos aquellos serieadictos de habla española que buscan encontrar algo más en las series que siguen” (FORMOSO, MARTÍNEZ, PUJOL Y RABADAN, 2012).

Los estudiantes plantearon el proyecto siguiendo un modelo de negocio dirigido a un público que "no tiene por costumbre pagar por los contenidos. Por este motivo, además de dirigirse a un público que potencialmente puede pagar por el servicio, se ofrece un modelo freemium” (FORMOSO, MARTÍNEZ, PUJOL Y RABADAN, 2012). Este público objetivo se caracterizaba por ser seguidores de series de televisión, 22 y 45 años y que utilizan internet y los nuevos dispositivos digitales como nueva forma de acceder a la información. En la cuantificación de este público objetivo, los estudiantes planteaban poder conseguir en tres años entre 80.000 y 200.000 lectores.

El proyecto superó de forma excelente las tres fases de evaluación de la idea al plan de negocio. Posteriormente, un único miembro del equipo de trabajo se aproximó al MILAB, Albert Martínez, para lanzar su idea al mercado y estableció contacto con un estudiante de la Universidad Pompeu Fabra, Víctor Sala, que aportó su experiencia en el ámbito de los 
estudios de comunicación audiovisual ${ }^{5}$. Desde el MILAB también se facilitó el contacto con diferentes profesores de la facultad para diferentes asesoramientos y se ayudó a conseguir la cesión de espacios de la facultad para la realización de los primeros actos públicos del proyecto.

\section{Resultados}

Los excelentes resultados conseguidos con el proyecto Serielizados son la muestra perfecta del éxito del diseño pedagógico del Trabajo de Final de Grado en la FCRIB. Este caso ejemplifica la capacidad y oportunidad del plan de estudios para integrar los conocimientos recibidos por los estudiantes a lo largo de su vida académica en el grado y en el postgrado, así como también la posibilidad de transferencia del conocimiento con el desarrollo de una empresa periodística viable.

Sin embargo, también hay que observar la dificultad para conseguir que muchos proyectos pasen a la fase de transferencia del conocimiento. Las dificultades reales del mercado, todavía azotado por la crisis publicitaria y de modelo de negocio, son una barrera muy importante para el salto final de los proyectos del ámbito estrictamente académico al profesional. Además, muchos de los grupos de estudiantes siguen caminos profesionales 0 académicos diferentes al finalizar el grado, que impiden la realización del mismo.

Por otro lado, la experiencia de este modelo ha permitido constatar que los estudiantes perciben el TFG como una asignatura demasiado alejada de la práctica periodística clásica. Una de las críticas principales de los estudiantes es que el TFG tiene un componente excesivamente empresarial. En este sentido, en la FCRIB se está ultimando un cambio substancial en el TFG: durante el primer semestre de cuarto, los estudiantes deberán presentar la totalidad del plan de proyecto. En el segundo semestre, los estudiantes producirán una parte o la totalidad del mismo, con el objetivo de vincular un trabajo de diseño empresarial con la aplicación periodística práctica del mismo. Además, las asignaturas de preparación del TFG se empezarán a impartir en el último semestre de tercero, permitiendo una mayor integración curricular del proyecto con las otras asignaturas del plan de estudios.

\section{Conclusiones}

El Trabajo de Final de Grado es una de las mayores oportunidades de innovación pedagógica recogidas en el Plan Bolonia. Las posibilidades del mismo hacen viables estrategias pedagógicas que abarquen todas las etapas de la formación universitaria, así como también de investigación y transferencia del conocimiento.

\footnotetext{
${ }^{5}$ Víctor Sala realizó posteriormente un máster en la FCRIB, cerrando el círculo curricular del proyecto desde el grado al postgrado.
}

(cc) EY-NC-ND 2018, Universitat Politécnica de Valencia

Congreso IN-RED (2018) 
Además, en un momento de crisis de la ocupabilidad en el sector de la información y la comunicación, los Trabajos de Final de Grado son una puerta de acceso más a la vida laboral de los estudiantes.

\section{Referencias}

ARAUJO, Àlex; MICÓ, Josep Lluís (2017): “La universidad asincrónica: Uso de las TIC en estudiantes de Periodismo". adComunica, 14, 163-181.

CIVIL I SERRA, Marta (2017): "Els estudis universitaris i la recerca en comunicació", en CIVIL I SERRA, Marta; CORBELLA CORDOMÍ, Joan M.; FERRÉ PAVIA, Carme; SABATÉ I SALAZAR, Joan, eds.: Informe de la comunicació a Catalunya 2015-2016. Barcelona: Institut de la Comunicació de la Universitat Autònoma de Barcelona: Generalitat de Catalunya. Direcció General de Difusió, pàgs. 256-277. Col-lecció Lexikon Informes, 5. ISSN 2014-2773. Disponible en: http://incom.uab.cat/informe/2015-16/ capitol15.pdf

FAPE (2016): Informe anual de la profesión periodística.

FORMOSO, M. ; MARTÍNEZ, A. ; PUJOL, M. ; RABADAN, R. (2012). Serielizados. Trabajo Final de Grado. Barcelona: Facultat de Comunicació i Relacions Internacionals Blanquerna, Univeristat Ramon Llull.

GÓMEZ MOMPART, Josep Lluís; HERRERO SUBÍAS, Mónica (2016): Jornadas sobre Formación y Empleo en Comunicación. Madrid: Asociación de Universidades con Titulaciones de Información y Comunicación.

MICÓ, Josep Lluís; MASIP, Pere; BALLANO, Sonia (2012). “Criterios de contratación y perfiles profesionales emergentes en los medios”. Ámbitos, 21, ps. 281-294.

Media Innovation Lab. <http://www.milabblanquerna.cat/?page_id=3140\&lang=es> [Consulta: 11 de marzo de 2018]

SABATÉ I SALAZAR, Joan (2017): "Estudio comparativo de los Trabajos de Final de Grado en diez facultades de comunicación españolas", en. Jornadas sobre Formación y Empleo en Comunicación (2017). Madrid: Asociación de Universidades con Titulaciones de Información y Comunicación (pendiente de publicación).

SÁNCHEZ-GARCIA, Pilar. (2017): Periodistas (in)formados. Un siglo de enseñanza periodística en España: Historia y tendencias. Madrid: Editorial Universitas S. L.

Serielizados. <https://serielizados.com> [Consulta: 11 de marzo de 2018] 


\title{
Autopercepción de los estudiantes acerca de la adquisición de las CTs y su contribución a la mejora de las actividades de aprendizaje
}

\section{Juan Antonio Llorens-Molina}

${ }^{a}$ E.T.S de Ingeniería Agronómica y del Medio Natural. Grupo IEMA, ICE Universitat Politècnica de València. E-mail : juallom2@qim.upv.es

\begin{abstract}
The self-perception of students about the acquisition of transversal competences can provide valuable guidelines for the design and assessment of learning activities, if considered these as the central axis of teaching planning. This paper presents the results of a survey carried out over two consecutive years, in which it has been tried to assess the degree to which students consider that some transversal competences are being developed from a certain activity. This has consisted in the elaboration through teamwork of screencasts based on a study of the composition and properties of foods of vegetable origin from the chemical point of view. The results have shown that this self-perception provides useful criteria to improve and adapt learning activities to the acquisition of some transversal competencies. Likewise, there are activities whose potential in this concern exceeds the limits of the control points, which would allows a more profound and effective assessment of the transversal competencies.
\end{abstract}

Keywords: Transversal competencies, assessment, self-perception, metacognition, screencasts, chemistry, food technology.

\footnotetext{
Resumen

La autopercepción de los estudiantes acerca de la adquisición de las competencias transversales puede proporcionar orientaciones valiosas para el diseño y evaluación de las actividades de aprendizaje, considerando éstas como el eje central de la planificación docente. En este trabajo se presentan los resultados de una encuesta realizada a lo largo de dos cursos consecutivos, en las que se ha evaluado el grado en que los estudiantes consideran que determinadas competencias transversales están siendo desarrolladas a partir de una determinada actividad. Ésta ha consistido en la elaboración mediante trabajo en equipo de screencasts basados en el estudio desde el punto de vista químico, de la composición y propiedades de alimentos de origen vegetal. Los resultados han evidenciado que dicha autopercepción proporciona criterios útiles para mejorar y adecuar las actividades de aprendizaje a la adquisición de determinadas competencias. Asimismo, es notorio también el hecho de que determinadas actividades poseen una potencialidad en este sentido que excede los límites de los puntos
} 
de control, lo que permitiría una evaluación más profunda y efectiva de las CTs.

http://inred.blogs.upv.es/

Palabras clave: Competencias trasnversales, evaluación, autopercepción, metacognición, screencasts, química, tecnología de alimentos.

\section{Introducción}

A lo largo de los últimos años se han prodigado numerosas y útiles propuestas en el marco del proyecto de Competencias Transversales de la Universidad Politécnica de Valéncia, (Poyecto Competencias Transversales UPV, 2015) tal como queda bien patente en las recientes ediciones de INRED. En este contexto de concreción y puesta en práctica de iniciativas para el desarrollo y evaluación de dichas competencias, el presente trabajo pretende incidir, desde esta óptica, en la evaluación de las actividades de aprendizaje.

Esta contribución parte de la consideración de las actividades, en cuanto a su naturaleza, diseño, secuenciación y evaluación como el eje de la planificación docente (Penzo, 2010). Desde este punto de vista es importante destacar el carácter dinámico y adaptativo que como consecuencia de la irrupción de las nuevas tecnologías ha adquirido su diseño. En efecto, la concepción estática, de las actividades de aprendizaje, característica del libro de texto y de los proyectos educativos tradicionales, puede actualmente considerarse superada. Los recursos tecnológicos de que ahora disponemos nos permiten adaptar cualquier actividad a los contextos tan diversos y cambiantes con que nos enfrentamos. Por otra parte, su desarrollo puede apoyarse en información ad hoc, tanto textual como audiovisual mediante instrumentos relativamente sencillos y asequibles. Si a ello añadimos la facilidad con que las nuevas tecnologías permiten crear ambientes de aprendizaje interactivos y colaborativos, puede afirmarse que el concepto de actividad de aprendizaje ha experimentado un cambio radical en los últimos años (Maceiras et al., 2010). Una importante consecuencia es el papel que adquiere la evaluación de las propias actividades en la planificación de la docencia, en sus diferentes niveles de concreción. Esta faceta no sería más que uno de los múltiples aspectos de la evaluación concebida, no como un proceso paralelo o complementario de la actividad docente, sino intrínsecamente ligado a la misma en sus múltiples aspectos (Boud y Douchy, 2010). Así, podemos formularnos, entre otras, las siguientes preguntas acerca del diseño de las actividades de aprendizaje:

- Forman parte de una secuencia estructurada? ¿Cuál es su papel en dicha secuencia? ¿Se tiene presente que dicha secuencia se enmarca, junto con otras, en el desarrollo de un curriculum aplicado en un contexto institucional concreto?

- ¿QQué procesos cognitivos entran en juego? ¿De qué recursos dispone el estudiante para abordarla?

- Tiene en cuenta la múltiple cantidad de aprendizajes generados por la vida cotidiana y el medio cultural del estudiante, al margen de las instituciones educativas? 
- ¿¿En qué grado producen el aprendizaje previsto? ¿Qué competencias entran en juego, tanto específicas como transversales? ¿Percibe conscientemente el estudiante que dichas competencias están siendo desarrolladas?

\section{Objetivos}

Si nos centramos en la última de las cuestiones planteadas, ha de considerarse el papel de la metacognición en el aprendizaje (Veenman et al., 2006). Este es un aspecto esencial del mismo. En efecto, la autopercepción por el estudiante de sus logros es un requisito para que un aprendizaje pueda considerarse como tal. Este proceso ha sido ampliamente estudiado en relación a la adquisición de las competencias transversales (Gomez-Puertas et al., 2014; Sanz et al., 2015). El objetivo de este trabajo se sitúa dentro de esta perspectiva y es evaluar el grado en que los estudiantes perciben que determinadas CTs están siendo puestas en juego en una determinada actividad. La actividad seleccionada ha sido la elaboración de un screencast por los estudiantes en torno a la naturaleza química y propiedades de determinados alimentos. Las CTs que a priori se han considerado involucradas en esta actividad han sido: Conocimiento y comprensión, trabajo en equipo y liderazgo, responsabilidad ética, medioambiental y profesional, comunicación efectiva, pensamiento crítico, planificación y gestión del tiempo, conocimiento de problemas contemporáneos e instrumental específica, siendo las dos últimas, puntos de control de la asignatura.

\section{Desarrollo de la innovación}

\section{1 ¿Por qué un screencast?}

Recordemos que el screencast consiste en la producción de un video a partir de la captura de pantalla de una secuencia de imágenes, acompañadas frecuentemente de la correspondiente grabación en audio, que puede ser creada, por ejemplo, a partir de una presentación de diapositivas.

¿Por qué se ha elegido el screencast? Por varias razones: en primer lugar, porque integra procesos comunicativos diversos: imágenes y textos orales y escritos; en segundo lugar, tal como se describirá más adelante, por su gran versatilidad en cuanto a su función en el proceso de aprendizaje; por último, porque puede crearse fácilmente mediante herramientas de acceso gratuito que proporcionan productos audiovisuales de razonable calidad sin necesidad de una gran experiencia previa en su uso.

El screencast es un recurso ampliamente utilizado tanto en la enseñanza online como material de apoyo a la clase presencial y sobre el que existe una amplia literatura relacionada con su diseño y modo de aplicación (Aguirre et al., 2012; Mohorovičić, 2012; Smith, 2014). La gran mayoría de investigaciones relacionadas con su utilización docente se refieren a material producido por el profesorado con diferentes finalidades. Sin embargo, otra importante contribución del screencast a la mejora de los procesos de aprendizaje es su elaboración por los estudiantes, con diversos objetivos. Diferentes autores coinciden en considerar esta herramienta como un formato idóneo para la realización de actividades que impliquen procesos de indagación y de relación entre conceptos. De este modo, constituyen 
también un buen punto de partida para la evaluación formativa. A partir de la información obtenida a través de los screencasts producidos por los estudiantes, puede proporcionarse una retroalimentación adecuada que favorezca la actividad metacognitiva del estudiante y la superación de errores conceptuales (Haxton y McGarvey, 2011; Croft et al., 2013; Soto y Ambrose, 2016)

Otra opción, a la que correspondería la actividad estudiada en este trabajo, es la elaboración y sistematización de información por los estudiantes de modo que pueda ser compartida por el resto de alumnos del grupo. En el ámbito agroalimentario puede citarse el estudio realizado por Pérez (2018).

\subsection{Contexto y metodología}

\subsubsection{Alumnado participante}

Este estudio ha sido realizado en la asignatura Fundamentos Químicos para Ciencia y Tecnología de Alimentos, dentro de la unidad didáctica dedicada a la introducción de la química orgánica, en el grado de Ciencia y Tecnología de los Alimentos, en la Universitat Politècnica de València. Se ha desarrollado a lo largo de los dos últimos cursos participando en la actividad un total de 154 estudiantes, siendo 135 el número de encuestas procesadas (55 y 80 en cada uno de los cursos, respectivamente).

\subsubsection{Descripción de la actividad}

Su realización se plantea de modo voluntario, aunque en la práctica es llevada a cabo por la mayoría de los estudiantes que participan de modo regular en la asignatura (81.5 \% y 96.7 \%, sobre el número de estudiantes calificados en la unidad didáctica, en los cursos 2016-17 y 2017-18, respectivamente). Dicha actividad ha consistido en la elaboración de un screencast de una duración entre 5 y 10 minutos, cuyos objetivos fueron:

- Describir detalladamente la composición química de un alimento de origen vegetal

- Representar la estructura molecular de cinco de los principales componentes, mediante la fórmula de esqueleto y un modelo tridimensional, utilizando aplicaciones informáticas específicas (ChemDraw ${ }^{\circledR}$ o $\quad$ ChemSketch ${ }^{\circledR}$, por ejemplo)

- Especificar en dichas moléculas qué grupos funcionales estudiados en el curso aparecen.

- Relacionar algunas de las propiedades nutritivas o medicinales de dicho alimento con la presencia de determinados compuestos químicos. En algunos casos podrá ser conveniente proporcionar alguna información sobre su procesado o modo de consumo.

En cuanto al modo de llevar a cabo la actividad, se realizó en equipos de tres personas. En cada uno de ellos, uno de los miembros asume el rol de interlocutor con el profesor de cara a enviar y recibir información a través de la plataforma "PoliformaT" de la UPV. Cada grupo elabora una presentación en Power-point ${ }^{\circledR}$ (entre 6 y 8 diapositivas, incluyendo la inicial) según los objetivos anteriormente descritos sobre un alimento asignado por el profesor. A partir de dicha presentación se realiza un vídeo que incorpora grabación de voz 
mediante un programa de descarga gratuita. En la primera diapositiva debe aparecer el alimento estudiado con una imagen, el nombre de la asignatura indicando que se trata de la Unidad Didáctica 1, y nombre y apellidos de los tres integrantes del grupo, presentándose también cada uno a través de la grabación en audio. La última diapositiva debe incluir la bibliografía consultada, sin olvidar citar la procedencia de las ilustraciones que no sean originales. Por último los vídeos son alojados en la plataforma https://media.upv.es/ a la que todos los alumnos pueden acceder para evaluar los vídeos.

La coevaluación se realizó online por el profesor y por tres compañeros de otros grupos, según una distribución realizada aleatoriamente por el profesor y comunicada a través de la plataforma PoliformaT. Se llevó a cabo a través de una rúbrica que responde a los objetivos de la actividad anteriormente señalados, cuyo diseño y aplicación son descritos más detalladamente por Llorens-Molina y Llorens. (2018).

\subsubsection{Encuesta planteada}

La encuesta planteada se aplicó en forma de escala Likert de acuerdo con las siguientes categorías: 1. Completamente de acuerdo; 2. De acuerdo; 3. Indiferentes; 4. En desacuerdo, 5. Completamente en desacuerdo. Fue remitida y contestada online a través de "espacio compartido" de PoliformaT y se introdujo mediante una breve explicación acerca de sus objetivos. Cada competencia transversal considerada se explicó brevemente en el propio texto de la encuesta, tal como se indica en el apéndice, al final del trabajo.

\section{Resultados}

Los siguientes diagramas (Fig. 1-9) muestran los resultados de la encuesta en los cursos 2016/17 y 2017/18. Las instrucciones y el formato fueron los mismos en ambos. Tan solo cabe indicar, como elementos diferenciales, la aportación en el segundo curso de vídeos tutoriales ("screencasts") para facilitar el uso de la aplicación ChemSketch y la divulgación, a modo de referencia, de dos de los vídeos realizados el curso anterior donde el tratamiento de las dos competencias transversales que son punto de control fue mejor aplicado.

La gráfica de la figura 1 muestra los datos globales correspondientes a los dos cursos. A pesar del resultado generalmente satisfactorio registrado para todas las competencias transversales evaluadas, si se considera la suma de "indiferente", "en desacuerdo" y "totalmente en desacuerdo", hay tres que muestran un resultado relativamente desfavorable: "Responsabilidad ética, medioambiental y profesional" (43.0\%), "Conocimiento de problemas contemporáneos", que es punto de control en la asignatura (33.3 \%) y "Pensamiento crítico" (24.5\%). El desarrollo del resto de competencias es percibido de un modo ampliamente favorable, si se considera la suma de "Muy de acuerdo" y "De acuerdo". Destacan principalmente: "Comprensión e integración” (94.1 \%), "Trabajo en equipo y liderazgo" (93.3 \%) y "Comunicación efectiva” (90.4\%). Ninguna de las tres es punto de control; no obstante "Instrumental específica", que sí lo es, registra también una elevada consideración (86.7 \%), del mismo modo que "Planificación y gestión del tiempo" (86.0 \%). 
Autopercepción de los estudiantes acerca de la adquisición de las CTs y su contribución a la mejora de las actividades de aprendizaje

Si se analizan las diferencias entre los dos cursos (Figuras 2-9), son generalmente pequeñas aunque ligeramente crecientes, sobre todo si los resultados se interpretan considerando dos bloques: "Muy de acuerdo" y "De acuerdo", y el resto. Así, por ejemplo, para “Comprensión e integración” tendríamos un 92,7 \% y 95.0 \%, para 2016/17 y 2017/18, respectivamente, "Trabajo en equipo y liderazgo", $90.9 \%$ y $95.1 \%$; "Responsabilidad ética, medioambiental profesional”, 52.7 \% y 60.0 \%; “Comunicación efectiva” 89.1 \% y 91.3\%; "Pensamiento crítico” 74.5 y 76.3 \%, "Planificación y gestión del tiempo”, 90.9 y 82.5 \% (única competencia en cuyo desarrollo se observa una disminución de la percepción positiva). Son precisamente las dos competencias que son punto de control las que registran un mayor aumento de su valoración positiva, que en el caso de "Conocimiento de problemas contemporáneos" es notable (58.5 - $72.5 \%$ ). "Instrumental específica” aumenta desde un 81.8 a un $90.0 \%$. Dado que los únicos cambios en el diseño y planteamiento de la actividad afectan, como ya se indicó anteriormente, a estas dos competencias, podría atribuirse a ellos la evolución observada, siempre teniendo en cuenta, por supuesto, el alcance y validez de datos cualitativos como los obtenidos en esta encuesta.

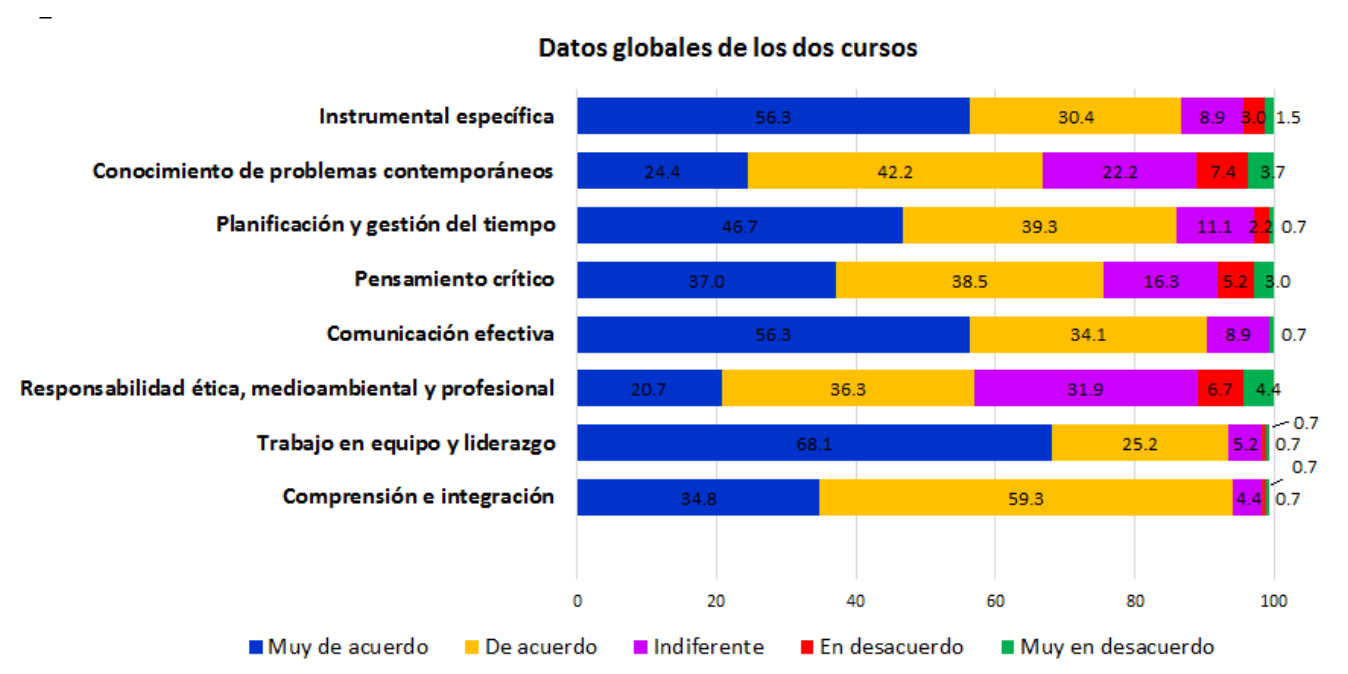

Fig. 1. Datos globales de los dos cursos para cada competencia transversal

\section{Comprensión e integración}

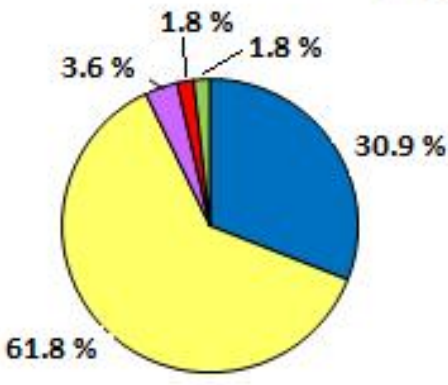

2016/17
Muy de acuerdo

$\square$ De acuerdo

$\square$ Indiferente

aEn desacuerdo

$\square$ Muy en desacuerdo

(cc) EY-NC-ND

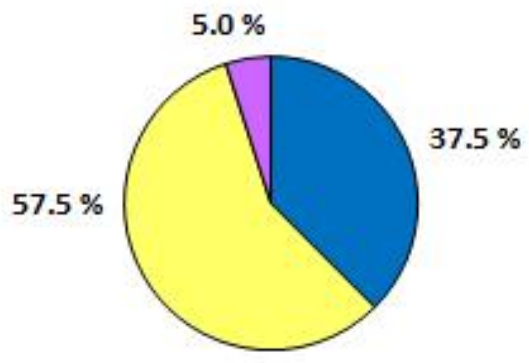

2017/18 
Fig. 2. Resultados de la encuesta relativos a la competencia transversal "Comprensión e integración"

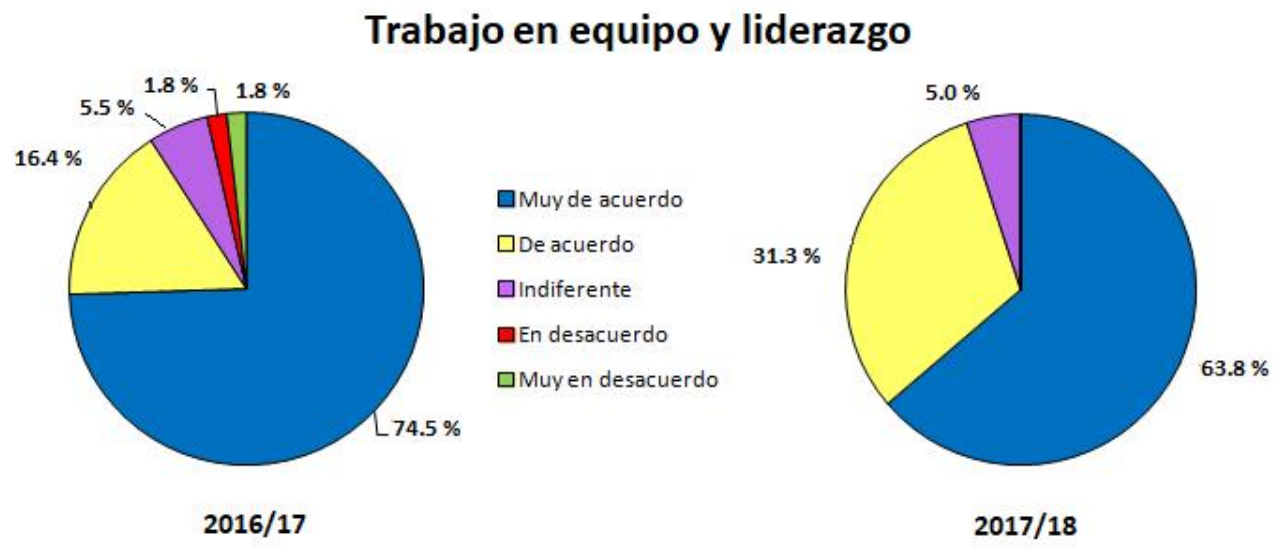

Fig. 3. Resultados de la encuesta relativos a la competencia transversal "Trabajo en equipo y liderazgo".

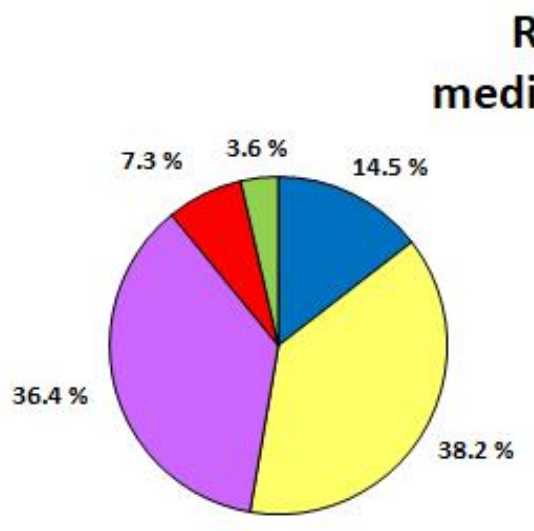

2016/17

\section{Responsabilidad ética,} medioambientaly profesional

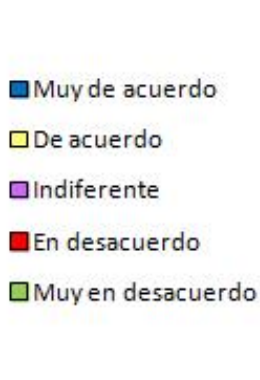

$\square$ Muy de acuerdo

$\square$ De acuerdo

口indiferente

En desacuerdo

$\square$ Muyen desacuerdo

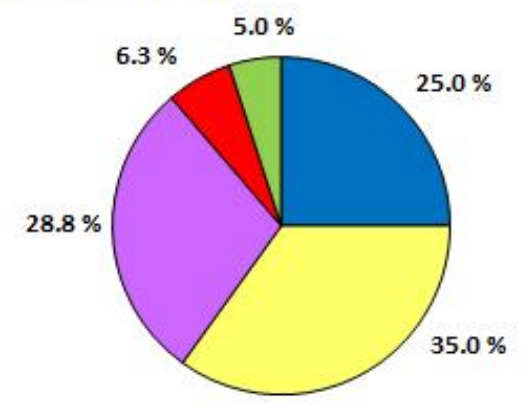

$2017 / 18$

Fig. 4. Resultados de la encuesta relativos a la competencia transversal "Responsabilidad ética, medioambiental y profesional"

2018, Universitat Politècnica de València

Congreso In-Red (2018) 


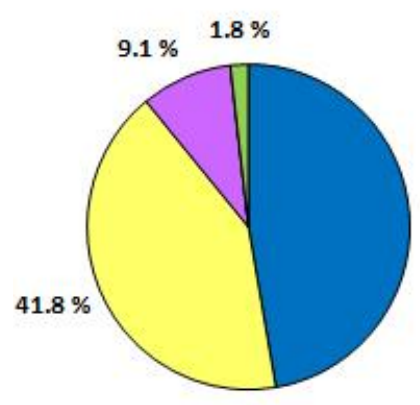

2016/17

\section{Comunicación efectiva}
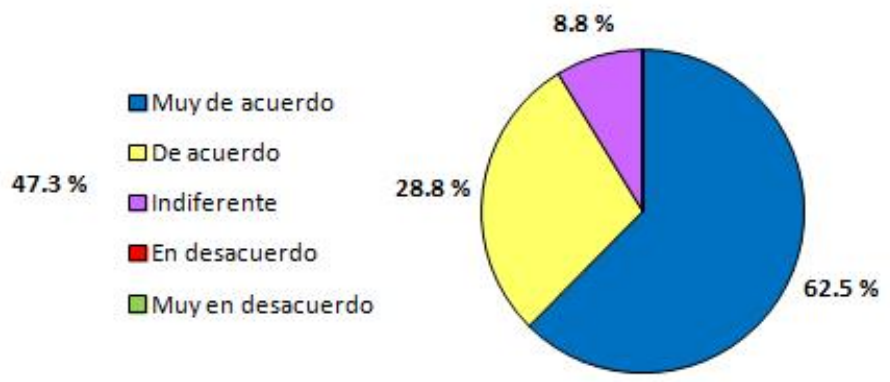

$2017 / 18$

Fig. 5. Resultados de la encuesta relativos a la competencia transversal "Comunicación efectiva"

\section{Pensamiento crítico}

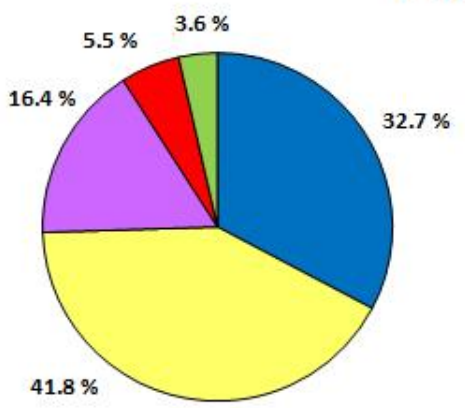

$2016 / 17$

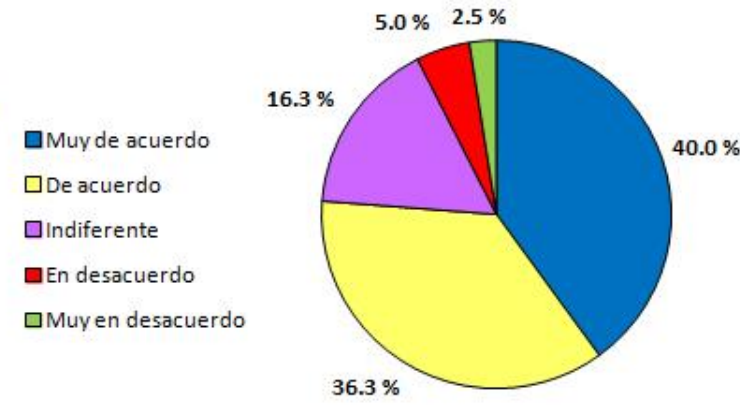

$2017 / 18$

Fig. 6. Resultados de la encuesta relativos a la competencia transversal "Pensamiento crítico"

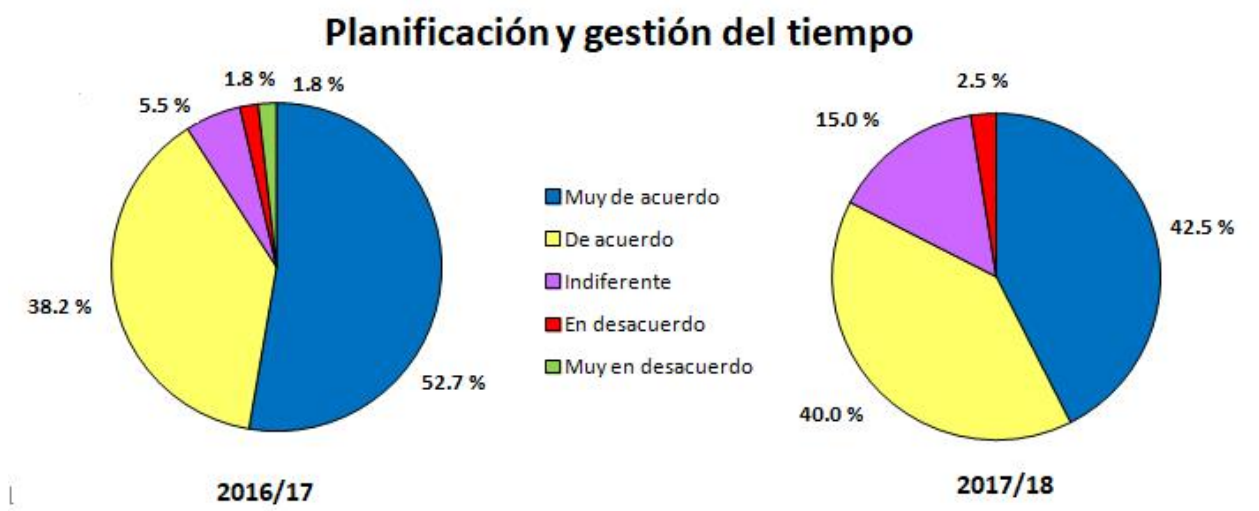

Fig. 7. Resultados de la encuesta relativos a la competencia transversal "Planificación y gestión del tiempo". 


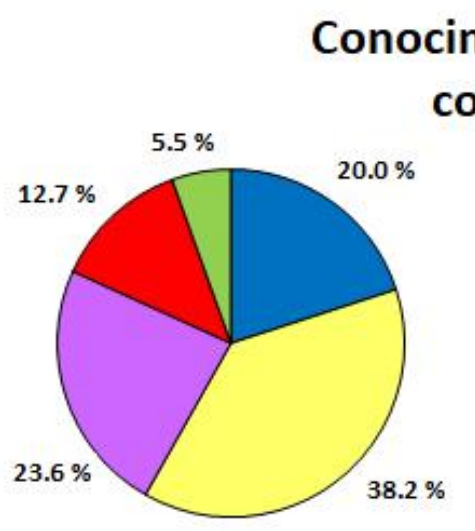

$2016 / 17$

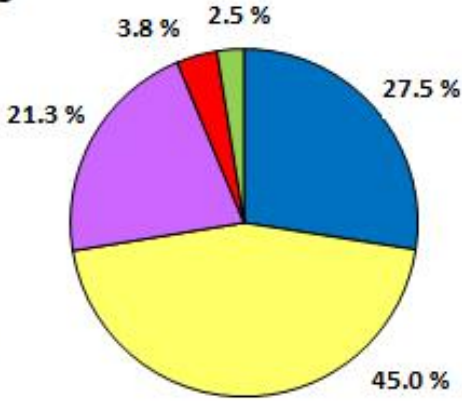

$2017 / 18$

$45.0 \%$

Fig. 8. Resultados de la encuesta relativos a la competencia transversal "Conocimeinto de problemas contemporáneos"

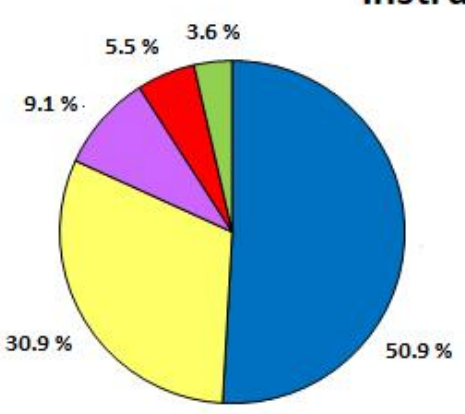

2016/17
๑Muyde acuerdo

口De acuerdo

口Indiferente

En desacuerdo

$\square$ Muy en desacuerdo

Fig. 9. Resultados de la encuesta relativos a la competencia transversal "Instrumental específica"

\section{Conclusiones}

Desde una planificación educativa centrada en el diseño y evaluación de las actividades de aprendizaje, cabría cuestionar el concepto de "punto de control" en la evaluación de las competencias transversales. Por una parte, es evidente que su asignación a cada asignatura permite asegurar su desarrollo y evaluación a lo largo del grado y en el conjunto de las distintas materias impartidas; no obstante, la evidencia de que determinadas actividades también contribuyen, tal vez en mayor grado, a la adquisición de otras que no son punto de control, llevaría a considerar la conveniencia de ser también evaluadas. La propuesta concreta sería que, una vez establecidas las competencias que son punto de control, se pudiera incluir la evaluación de otras cuyo desarrollo, a través de las actividades de la asignatura, resulte evidente y sea percibido por los estudiantes.

2018, Universitat Politècnica de València

Congreso In-Red (2018) 
Evaluar la percepción de los estudiantes muestra puede ser, por tanto, una práctica útil en la medida en que constituye un criterio para considerar qué competencias transversales cabe evaluar en una asignatura y proporciona un feed-back apropiado para mejorar el diseño de las actividades. Al margen de las dudas que pueda generar el hecho de una amplia aceptación de la actividad descrita en este trabajo (que puede deberse a una satisfacción general con la asignatura o el profesorado), aparecen diferencias lo suficientemente notorias como para replantear aspectos de su diseño y gestión. Es evidente, por ejemplo, que la actividad planteada adolece de escaso estímulo hacia un enfoque basado en la consideración de valores éticos, desde un punto un punto de vista crítico. Una contextualización más explícita de los objetivos de la actividad en problemas de interés tales como el de las distintas opciones surgidas en la sociedad frente a la alimentación, también podrían mejorar el tratamiento de la competencia «conocimiento de problemas contemporáneos », que es punto de control.

\section{Referencias}

AGUIRRE, S., BARRA, E., QUEMADA, J., MENDIOLA, M. A., PASTOR, J. Y., MARTINEZ, M. E. y PORTAENCASA, R. (2012). “Comunica-Media. Uso de la grabación de clases, el screencast y la videoconferencia en el aula“, Revista del Congrés Internacional de Docència Universitària i Innovació (CIDUI), 1(1), http://www.cidui.org/revistacidui/index.php/cidui/article/viewFile/396/390, (Consulta: 12 de marzo de 2018)

BOUD, D., y DOCHY, F. (2010). “Assessment 2020. Seven propositions for assessment reform in higher education“.

https://lirias.kuleuven.be/bitstream/123456789/263461/2/Assessment-2020_propositions_final.pdf (Consulta: 12 de marzo de 2018)

CARR, A. y LY, P. (2009). "More than words": screencasting as a reference tool“, Reference Services Review, vol. 37, issue 4, p. 408-420.

CROFT, T., DUAH, F., y LOCH, B. (2013). “I'm worried about the correctness': undergraduate students as producers of screencasts of mathematical explanations for their peers-lecturer and student perceptions“, International Journal of Mathematical Education in Science and Technology, vol. 44, issue 7, p. 1045-1055.

GOMEZ-PUERTAS, L., ROCA-CUBERES, C. y GUERRERO-SOLE, F. (2014). “¿Cómo perciben los estudiantes la adquisición de competencias? Análisis comparado: Teorías de la Comunicación en la Universidad Pompeu Fabra“, Historia y Comunicación Social, vol. 19, special issue february, p. 313-326.

HAXTON, K. J. y MCGARVEY, D. J. (2011). "Screencasting as a means of providing timely, general feedback on assessment", New Directions in the Teaching of Physical Sciences, vol.7, p. 1821.

LLORENS-MOLINA J. A. y LLORENS DE JAIME, J. (2018), "Screencasts in the Classroom. Design and Assessment“. INTED, 2018

LLORENS-MOLINA, J. A. (2018), "Introductory Organic Chemistry For Food Science And Technology“, INTED 2018.

MACEIRAS, R., CANCELA, Á. Y GOYANES, V. (2010). “Aplicación de nuevas tecnologías en la docencia universitaria », Formación universitaria, vol. 3, issue 1, p. 21-26.

MOHOROVICIC, S. (2012), «Creation and use of screencasts in higher education». In MIPRO, 2012 Proceedings of the 35th International Convention, p. 1293-1298.

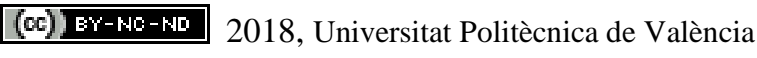

Congreso IN-RED (2018) 
PENZO, W., FERNANDEZ, V., GARCIA, I., GROS, B., PAGES, T., ROCA, M., Y VENDRELL, P. (2010). «Guía para la elaboración de las actividades de aprendizaje» Cuadernos de docencia universitaria, vol. 15, p. 1-67.

Pérez, S., Funciones de los Objetos de Aprendizaje en la Enseñanza de la Química de los Alimentos. FUNCIONES DE LOS OBJETOS DE APRENDIZAJE EN LA ENSEÑANZA DE LA QUÍMICA DE LOS ALIMENTOS. http://conhisremi.iuttol.edu.ve/articles.php?code=PUBL000018

PROYECTO INSTITUCIONAL DE COMPETENCIAS TRANSVERSALES (2015), Universitat Politècnica de València, https://www.upv.es/entidades/ICE/info/U0724624.pdf (Consulta: 12 de marzo de 2018)

SMITH, P. (2014). "Screencasting as a means of Enhancing the Student Learning Experience ».Learning and Teaching in Action, http://www.celt.mmu.ac.uk/ltia/Vol10Iss1/7 smith.pdf (Consulta: 12 de marzo de 2018).

SOTO, M. y AMBROSE, R. (2016). «Screencasts: Formative assessment for mathematical thinking », Technology, Knowledge and Learning, vol. 21, issue 2, p. 277-283.

VEENMAN, M. V., VAN HOUT-WOLTERS, B. H., y AFFLERBACH, P. (2006). « Metacognition and learning: Conceptual and methodological considerations » Metacognition and learning, vol.1, issue 1, p. 3-14. 


\section{Apéndice}

\section{ENCUESTA SOBRE COMPETENCIAS TRANSVERSALES (Presentación y texto explicativo de cada una)}

Como sabes, a partir de este curso se evalúan las competencias transversales. La actividad que has realizado sobre la composición química de los alimentos tiene como objetivo contribuir a su desarrollo y se ha introducido a nivel experimental. Por eso ha sido voluntaria y solamente contribuye a la calificación aumentándola.

Nos parece importante conocer vuestra opinión acerca de cómo esta actividad puede contribuir al logro de algunas de estas competencias. Para ello hemos preparado la siguiente encuesta. En ella verás una serie de competencias con una breve descripción de las mismas y una escala de valoración. Se trata simplemente de marcar con una cruz el recuadro correspondiente.

\section{COMPRENSIÓN E INTEGRACIÓN}

Comprender quiere decir "percibir y tener una idea clara de lo que se dice, se hace o sucede o descubrir el sentido profundo de algo". Para demostrar que algo se ha comprendido, la persona identifica y recupera la información y la explica con sus propias palabras, interpretando e integrando las ideas desde su propia perspectiva.

\section{TRABAJO EN EQUIPO Y LIDERAZGO}

El trabajo en equipo implica crear y desarrollar un clima de confianza mutua entre los componentes que permita trabajar de forma responsable y cooperativa. El término más apropiado para describir esta situación es COMPARTIR: compartir conocimientos, compromiso y responsabilidad.

\section{RESPONSABILIDAD ÉTICA, MEDIOAMBIENTAL Y PROFESIONAL}

Esta competencia se refiere al conjunto de conocimientos, habilidades, destrezas y actitudes, útiles para interactuar con el entorno, de forma ética, responsable y sostenible.

\section{COMUNICACIÓN EFECTIVA}

Comunicarse efectivamente significa tener desarrollada la capacidad de transmitir conocimientos, ideas y argumentos de manera clara y rigurosa, tanto de forma oral como escrita, con los recursos apropiados y adaptándose a las circunstancias y al tipo de público.

\section{PENSAMIENTO CRÍTICO}

El pensamiento crítico implica poner en cuestión nuestra forma habitual de pensar y actuar. Es el pensamiento de los interrogantes: ¿por qué las cosas son así?, ¿por qué las cosas no pueden ser de otro modo?, ¿por qué tú crees que son así?, etc.

\section{PLANIFICACIÓN Y GESTIÓN DEL TIEMPO}

Esta competencia implica ser capaz de organizar y distribuir correctamente el tiempo del que disponemos para alcanzar nuestros objetivos a corto, medio y largo plazo.

\section{CONOCIMIENTO DE PROBLEMAS CONTEMPORÁNEOS}

Esta competencia implica comprender las cuestiones y valores políticos, sociales, legales y medioambientales contemporáneos. Se trata de que desarrollen la capacidad de "estar al día" de los eventos actuales en su campo de conocimiento y en la sociedad en general. 


\section{INSTRUMENTAL ESPECÍFICA}

Esta competencia se refiere al uso de las herramientas y tecnologías necesarias para el ejercicio profesional asociado a cada titulación. El estudiante será capaz de identificar las herramientas más adecuadas en cada caso, conociendo sus utilidades y siendo capaz de integrarlas y combinarlas para poder resolver un problema, realizar un proyecto o un experimento.

(cc) EY-NC-ND 2018, Universitat Politècnica de València 


\title{
La evaluación de la competencia "Comunicación efectiva” a través de rúbricas para estrategias activas: el debate y la presentación de trabajos académicos.
}

\author{
P. Amparo López-Jiménez ${ }^{a}$ Modesto Pérez-Sánchez ${ }^{a}$, \\ a Departamento de Ingeniería Hidráulica y Medio Ambiente. Universitat Politècnica de València. \\ palopez@upv.es; mopesan1@upv.es.
}

\begin{abstract}
The efective communication transmits a clear and accurate message, that allows receptor to assimilate the information When a student is training, he/she has to transmite his/her ideas, projects or methods to rest of public. The transversal competence "Effective communication" is crucial in all phases, althought this competence is most important in last degrees or master courses, when the students are doing their final thesis of Bachelor or Master. The current research describes a learning strategy that was developed in one master subject, called "Polution dispersion in water and atmosphere". This subject is dicted in the second course of the Industrial Engineering Master Degree in ETSII (UPV). The research shows the results in two different periodes, when the acquisition results were excellent.
\end{abstract}

Keywords: effective comunication; contaminant dispersion; public exposition; rubbric

\section{Resumen}

La comunicación efectiva es aquella que transmite un mensaje claro y preciso y que permite al receptor asimilar dicho mensaje. Dentro de la formación de un estudiante, cualquiera que sea su formación, es necesario que sus ideas, proyectos o metodologías sepa transmitirlas al público potencial que se vea expuesto. Aunque es crucial en todas las fases, la competencia transversal "Comunicación efectiva" cobra una importancia esencial en los últimos cursos de grado o máster para la preparación en la defensa de los trabajos final de grado o máster. La presente comunicación expone la estrategia de aprendizaje llevada a cabo en la asignatura "Dispersión de Contaminantes en Agua y Atmósfera" en segundo curso del Máster en Ingeniería Industrial de la ETSII (UPV) y los resultados obtenidos en los dos cursos en los que se ha llevado a cabo, con un éxito tanto en el grado de adquisición de los resultados de aprendizaje como satisfacción del alumnado.

Palabras clave: Comunicación efectiva; Dispersión de contaminantes; exposición pública; rúbrica 


\section{Introducción}

La competencia Comunicación Efectiva, tal como se define en el proyecto de competencias transversales de la UPV (UPV, 2018) "Es la capacidad para transmitir conocimientos y expresar ideas y argumentos de manera clara, rigurosa y convincente, tanto de forma oral como escrita, utilizando los recursos gráficos y los medios necesarios adecuadamente, y adaptándose a las características de la situación y de la audiencia."

Una comunicación efectiva, por tanto, pasa por transmitir conceptos claros de una forma concisa y específica, de manera que los interlocutores capten la mayor parte del mensaje. En este sentido, la consideración de la comunicación efectiva como una competencia transversal en fases finales de la educación superior de los alumnos es una herramienta potente. Esta desarrolla en los alumnos una habilidad importante para su actividad profesional, ya cercana para ellos en los últimos cursos de máster.

Así pues, la comunicación efectiva es una vía para que los alumnos practiquen su capacidad de ser eficaces en el proceso de transmisión de información, muy específica cuando ya estos estudiantes se encuentran en sus últimas etapas. ¿Y qué conocimientos pueden comunicarse? ¿Pueden comunicarse también argumentos e ideas estructuradas para conseguir una opinión del resto de compañeros? Estas preguntas son las que se hacen los docentes que deciden proponer estrategias activas, en las que el alumno se involucre en la preparación de los contenidos a comunicar con el resto de sus compañeros. Más allá de las preguntas de cuáles son las posibles estrategias activas en las que los alumnos puedan involucrarse para la preparación de los contenidos, se encuentra la pregunta de cómo evaluar finalmente la competencia relacionada con la efectividad de la comunicación, mientras los alumnos desarrollan estas estrategias. Los autores de la presente contribución proponemos la utilización de rúbricas para tener en cuenta los diferentes aspectos que en ciertas actividades pueden involucrar una correcta comunicación efectiva, mezclada con la utilización de diferentes metodologías activas que en este caso han sido el debate y el desarrollo de trabajos finales en el desarrollo de la asignatura "Dispersión de Contaminantes en Agua y Atmósfera” en segundo curso del Máster en Ingeniería Industrial, desarrollado en la Escuela Técnica Superior de Ingenieros Industrial de la Universitat Politècnica de València. El propio análisis de cómo puede el problema evaluarse a través de ítems concretos, es en sí, una actividad novedosa para el profesorado. A juicio de los autores, la estrategia pone en valor la capacidad de las rúbricas para evaluar todo tipo de competencias.

\section{Objetivos}

El objetivo de la presente contribución es mostrar las rúbricas desarrolladas para la evaluación de la competencia transversal "Comunicación efectiva” implementadas en la asignatura "Dispersión de Contaminantes en Agua y Atmósfera" en segundo curso del Máster en Ingeniería Industrial de la ETSII (UPV) y los resultados obtenidos en los dos cursos en los que se ha llevado a cabo. La mejora en las capacidades de comunicación efectiva a través de estrategias diversas prepara a los alumnos hacia la presentación de su

(cc) BY-NC-ND 2018, Universitat Politècnica de València

Congreso IN-RED (2018) 
trabajo final de grado o máster mejorando su comunicación oral o escrita, en fases ya cercanas a esta fase de finalización de sus titulaciones.

El desarrollo de estas rúbricas se encuentra dentro del Proyecto de Innovación y Mejora Docente "Desarrollo de Metodologías de Evaluación y Diseño de Rúbricas de la CT-05 Diseño y Proyecto" aplicado al campo de la Ingeniería Hidráulica (Fase II), el cual se encuentra integrado el EICE Desarrollo de Metodologías Activas de evaluación aplicadas al campo de la Ingeniería Hidráulica (DESMAHIA).

\section{Desarrollo de la innovación docente}

El debate y la preparación de trabajos especializados como estrategia activa para el aprendizaje de las asignaturas de últimos cursos de máster.

\section{El debate}

El debate es una estrategia que permite a los alumnos manifestar y presentar sus conocimientos profundos de un tema, a la vez que estimula su espíritu crítico. Permite que los alumnos practiquen la argumentación, fundamentada en una documentación previa por su parte en fuentes fidedignas. Esto debe ser fundamentado en una investigación de los alumnos para fundamentar la tesis que tienen que defender en el mismo. De otro lado, los alumnos tienen que mejorar su capacidad de expresión oral, de improvisación y de ingenio al adaptarse rápidamente a las intervenciones de otros (López-Jiménez y Pérez-Sánchez, 2017a).

El debate permite a los alumnos conseguir el conocimiento profundo de los temas a los que se enfrentan, a la vez que desarrollar sus habilidades expositivas y de representación y análisis de problemas. Algunos de los objetivos docentes conseguidos con el debate son los siguientes (Rodriguez, 2010):

- Utilizar el leguaje específico de forma correcta, argumentando sus ideas con un vocabulario adecuado a los conceptos presentados. Asimismo, esto se consigue de forma mucho más eficiente cuando la temática que se desarrolla se presenta en una lengua que no es la materna para los alumnos.

- Presentar los conceptos con una calidad argumental, que permita convencer a sus compañeros del rol que han adoptado para defender sus posturas y describir sus argumentos. Particularmente ligado a aspectos ambientales de contaminación de agua o aire, siempre controvertidos.

- Defender el contenido de los argumentos presentados a través de fuentes bibliográficas con verosimilitud de forma que se validen, dichos argumentos, a través de la confianza científica de fuentes fidedignas y reconocidas por todos los participantes.

- Demostrar el dominio del tema abordado, con lo que se desarrolla por parte de los ponentes de cada uno de los roles un conocimiento específico del tema presentado. Este conocimiento fundado con una toma de contacto en muchas fuentes, todas 
ellas documentadas, propone un aprendizaje motivador y que, en la experiencia de los autores, permanece fuertemente presente en la memoria de los alumnos.

- Ser capaces de cambiar la opinión de un "oponente" o un auditorio sobre un tema en que se ha propuesto un desarrollo argumentativo.

\section{El desarrollo de trabajos académicos como parte de la profundización en nuevos contenidos.}

El trabajo académico en el contexto de las asignaturas a concurso, se desarrolla como una exposición por parte del alumno de un tema trabajado por el mismo, con mayor profundidad que se presenta en clase de manera argumentativa. Este tema se defiende a través de una presentación argumentativa frente al resto de la clase. Constituye una forma muy interesante de evaluación, puesto que permite al alumno, desarrollar varias destrezas. De un lado, hace que el alumno desarrolle un aprendizaje autónomo basado en la documentación de fuentes fidedignas que debe consultar; de otro, debe desarrollar su capacidad de organizar argumentos, comunicarse, esquematizar y organizar su tiempo.

Además, esta estrategia es muy útil en las asignaturas de nivel de máster, y la asignatura de dispersión de contaminantes en agua y atmósfera no es ajena. La experiencia con alumnos de último trimestre demuestra, a juicio de los autores, que su experiencia argumentativa y de comunicación todavía no se encuentra madura. En este sentido, la dedicación puesta a desarrollar y presentar estos trabajos meticulosamente, es muy útil y bien valorada por los alumnos. La evaluación de estos trabajos, incluida la competencia referida a la comunicación, se realiza a través de rúbricas, conocidas por los alumnos, para que la evaluación sea más efectiva y con unos criterios totalmente objetivos.

\section{La propuesta de rúbricas para la evaluación de las competencias transversales.}

Las rúbricas son guías de puntuación usadas en la evaluación del rendimiento de los estudiantes que describen las características específicas de un producto, proyecto o tarea en varios niveles de funcionamiento, con el fin de clarificar lo que se espera del trabajo del alumno, de valorar su ejecución y de facilitar la proporción de retroalimentación, (Fernández March, 2010).

Las rúbricas como guías de evaluación son particularmente útiles tanto para el profesor, al que permiten observar bajo criterios objetivos, la marcha de los alumnos y adaptarlas de una forma versátil a cada aspecto a evaluar; como para los alumnos, ya que permiten de antemano saber cuál es el nivel que se espera de cada tarea para conseguir una evaluación determinada.

En este sentido, las rúbricas se han desarrollado teniendo en cuenta que los alumnos son de tercer nivel, ya en una etapa final de máster y que las diferentes actividades van encaminadas no sólo a la comunicación efectiva, sino a la adquisición de conocimientos y argumentación especializada en el contexto de los contenidos de la asignatura.

(cc) EY-NC-ND 2018, Universitat Politècnica de València

Congreso IN-RED (2018) 


\section{Resultados}

La propuesta de las rúbricas aquí desarrolladas ha sido implementada durante dos cursos con anterioridad. Asimismo, debe contextualizarse en ambas actividades cual ha sido el carácter de los contenidos a evaluar, junto con la competencia referida a la comunicación efectiva.

Cabe indicar que esta competencia, no solo se evalúa en el desarrollo de esta asignatura, sino que también se trabaja. Cuando comienza cada clase, los alumnos de forma voluntaria se han preparado una presentación breve de un tema relacionado con los contenidos de dicho tema y se aplican las técnicas de comunicación audiovisual que, a juicio de la profesora y el resto de alumnos, son más efectivas para transmitir el mensaje. En experiencia de los autores, esta actividad voluntaria, guiada en las primeras iteraciones y más independiente en las últimas, se convierte en una rutina participativa que tiene muy buena acogida entre los alumnos. Al ser grupos poco numerosos ( 6 alumnos en el curso 2015-2016 y 10 alumnos en 2016-2107), cada alumno ha tenido ocasión de realizar varias presentaciones breves en castellano o inglés antes de que se lleve a cabo el debate o la presentación del trabajo académico de la asignatura.

\section{Rubrica para evaluación de la comunicación efectiva implementada en la actividad "Debate".}

Es importante describir cómo se presenta la actividad en el seno de la asignatura en que se desarrolla. Los alumnos son de último curso y segundo cuatrimestre de Master Ingeniero Industrial en la especialidad medioambiental. Se desarrolla un debate alrededor de la pregunta “¿Es el cambio climático una consecuencia directa de la actividad antropogénica?.

Los alumnos deben posicionarse en dos grupos, uno de ellos argumentar a favor y otros en contra. Se realiza una preparación de la argumentación por parte de ambos grupos y, tras un tiempo de preparación con ayuda de la bibliografía y cualesquiera consulta que desee hacerse, tiene lugar el debate. Los grupos son de entre cuatro y seis alumnos. Cada uno de ellos hace una presentación breve de su postura durante cinco minutos. Para ello se han preparado en equipo, de forma que la argumentación se complementa entre todos los integrantes del mismo grupo.

Terminada esta fase por parte de ambas facciones, se produce un turno de preguntas para defender las dudas que hayan quedado sobre los argumentos. Terminado el turno de preguntas, se produce una votación secreta para determinar cuál de los ponentes (de ambos grupos) ha sido más convincente, mejor argumentador y comunicador.

Por parte de los profesores, se ha desarrollado una rúbrica para evaluar la competencia trasversal de comunicación efectiva, descrita en la Tabla 1. En este caso solamente se han considerado los aspectos relacionados con la comunicación oral.

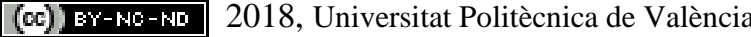


A modo de anécdota, cabe destacar que, en los dos cursos previos, los alumnos han presentado sus opciones y en ambas ocasiones ha resultado más valorada en su capacidad de comunicación y defensa argumental, aquella que defendía que el cambio climático no es consecuencia de la acción antropogénica.

Tabla 1. Rúbrica para la evaluación de la competencia Comunicación efectiva en la asignatura "Dispersión de contaminantes en agua y atmósfera" a través de la actividad: Debate

\begin{tabular}{|c|c|c|c|c|}
\hline \multirow[b]{2}{*}{ INDICADOR } & \multicolumn{4}{|c|}{ DESCRIPTOR } \\
\hline & $\begin{array}{c}\text { D. No } \\
\text { alcanzado }\end{array}$ & C. En desarrollo & B. Adecuado & A. Excelente \\
\hline $\begin{array}{c}\text { 1. Capacidad } \\
\text { de } \\
\text { comunicación } \\
\text { audiovisual }\end{array}$ & $\begin{array}{l}\text { No se ha } \\
\text { preparado una } \\
\text { argumentación } \\
\text { en el rol que ha } \\
\text { adoptado. } \\
\text { No presenta } \\
\text { fundamentos. }\end{array}$ & $\begin{array}{l}\text { No conoce bien el } \\
\text { tema en el rol que } \\
\text { ha adoptado y } \\
\text { cuando lo } \\
\text { presenta no es } \\
\text { convincente. } \\
\text { Presenta pocos } \\
\text { argumentos. }\end{array}$ & $\begin{array}{l}\text { Conoce el tema en } \\
\text { el rol que ha } \\
\text { adoptado, y cuando } \\
\text { lo presenta es } \\
\text { convincente } \\
\text { Presenta } \\
\text { argumentos a favor } \\
\text { de su posura, sin } \\
\text { fundamentar }\end{array}$ & $\begin{array}{l}\text { Demuestra un completo } \\
\text { dominio del tema en el rol } \\
\text { que ha adoptado. No } \\
\text { presenta fisuras en la } \\
\text { argumentación } \\
\text { Presenta muchos } \\
\text { argumentos a favor de su } \\
\text { postura, bien } \\
\text { fundamentados }\end{array}$ \\
\hline $\begin{array}{c}\text { 2. } \\
\text { Habilidades } \\
\text { lingüisticas }\end{array}$ & $\begin{array}{l}\text { No se entiende } \\
\text { bien su } \\
\text { pronunciación, } \\
\text { con tono y } \\
\text { volumen no } \\
\text { adecuados a la } \\
\text { defensa de una } \\
\text { argumentación } \\
\text { en debate }\end{array}$ & $\begin{array}{l}\text { Tiene modos } \\
\text { monótonos de } \\
\text { hablar, con mala } \\
\text { pronunciación, } \\
\text { sin controlar el } \\
\text { énfasis en la } \\
\text { argumentación, } \\
\text { con coletillas }\end{array}$ & $\begin{array}{c}\text { Habla } \\
\text { acpetablemente. } \\
\text { Usa un tono claro y } \\
\text { buena } \\
\text { pronunciación, sin } \\
\text { controlar el énfasis } \\
\text { en la argumentación }\end{array}$ & $\begin{array}{l}\text { Habla perfectamente. En } \\
\text { un tono claro y buena } \\
\text { pronunciación, } \\
\text { enfatizando su } \\
\text { argumentación. }\end{array}$ \\
\hline $\begin{array}{c}\text { 3. Lenguaje } \\
\text { corporal }\end{array}$ & $\begin{array}{l}\text { No tiene buena } \\
\text { postura. No } \\
\text { establece } \\
\text { contacto visual } \\
\text { con el auditorio. } \\
\text { No gestualiza. }\end{array}$ & $\begin{array}{l}\text { Tiene una postura } \\
\text { inexpresiva. No } \\
\text { muestra } \\
\text { entusiasmo por el } \\
\text { rol que defiende. } \\
\text { No tiene } \\
\text { argumentación } \\
\text { gestual. }\end{array}$ & $\begin{array}{c}\text { Tiene buena postura } \\
\text { y establece contacto } \\
\text { visual con el } \\
\text { auditorio la mayoria } \\
\text { del tiempo. } \\
\text { Tiene } \\
\text { argumentación } \\
\text { gestual, con poco } \\
\text { énfasis en las ideas } \\
\text { fuerza. }\end{array}$ & $\begin{array}{c}\text { Tiene buena postura. Se } \\
\text { encuentra relajado y } \\
\text { seguro en el rol que ha } \\
\text { adoptado } \\
\text { Establece contacto visual } \\
\text { con todo el auditorio, } \\
\text { particularmente con su } \\
\text { interlocutor en cada } \\
\text { argumento, apoyando las } \\
\text { ideas fuerza con gestos. }\end{array}$ \\
\hline $\begin{array}{l}\text { 4. Control del } \\
\text { tiempo }\end{array}$ & $\begin{array}{l}\text { No muestra } \\
\text { interés en la } \\
\text { coordinación del } \\
\text { tiempo como } \\
\text { parte de la }\end{array}$ & $\begin{array}{c}\text { Expone las ideas } \\
\text { desordenadas en } \\
\text { tiempos } \\
\text { demasiado cortos } \\
\text { o largos. }\end{array}$ & $\begin{array}{c}\text { Expone las ideas } \\
\text { desordenadas, en } \\
\text { tiempos adecuados. }\end{array}$ & $\begin{array}{c}\text { Expone las ideas } \\
\text { perfectamente ordenadas } \\
\text { en los tiempos previstos } \\
\text { para cada turno de } \\
\text { argumentación y diálogo. }\end{array}$ \\
\hline
\end{tabular}

(c) EY-NC-ND 2018, Universitat Politècnica de València 


\begin{tabular}{|c|c|l|l|}
\hline & presentación de & & \\
ideas ni de & & & \\
preguntas en & & & \\
fase de diálogo & & & \\
argumentativo & & & \\
\hline
\end{tabular}

Rubrica para evaluación de la comunicación efectiva implementada en la actividad “Trabajo académico".

Los trabajos académicos desarrollados por los alumnos en cada curso son propuestos por el profesorado, ya que los contenidos son complementarios a los presentados por los descriptores generales de la asignatura.

Para ilustrar este epígrafe como muestra, algunos de los trabajos académicos presentados por los alumnos en los cursos anteriores han versado sobre las siguientes temáticas:

- Modelos comerciales de dispersión de contaminantes en la atmósfera.

- Modelos comerciales de dispersión de contaminantes en aguas superficiales.

- Modelos comerciales de dispersión de contaminantes en aguas subterráneas.

- Accidentes graves de contaminación de aguas subterráneas: el accidente de Aznalcóllar.

- Accidentes graves de contaminación de aguas marinas: El accidente del Prestige.

- Normativa de análisis de dispersión de contaminantes en atmósfera.

- Normativa relacionada con la calidad de aguas superficiales.

- Emisarios submarinos en España. Principales diseños y casos reales.

- El diseño de la chimenea industrial. Casos reales que presentan las mayores chimeneas del mundo.

- La desalación como sistema de producción de agua potable y su impacto ambiental en relación con la dispersión de salmuera

Los trabajos se presentan durante 15 minutos, y a continuación se da un turno de preguntas. La Tabla 2 describe la rúbrica que los autores de la presente contribución han desarrollado para la evaluación la capacidad efectiva de comunicación, en su parte oral, para la presentación de estos trabajos académicos. Cabe destacar que, secuencialmente, el debate se realiza al final del primer parcial, mientras que la presentación de los trabajos académicos ocurre a 1 final del segundo parcial, de manera que los alumnos han tenido ya más ocasión de trabajar la competencia.

En cuanto a la valoración de la competencia transversal a lo largo de los dos años en que los alumnos han desarrollado los debates y trabajos académicos, los resultados han sido excelentes. Cabe destacar que estos alumnos han trabajado intensamente esta competencia transversal en fases anteriores e incluso con presentaciones breves en la presente asignatura.

(c)) EY-NC-ND 2018, Universitat Politècnica de València 
Esto ha hecho que los resultados hayan sido muy buenos en los dos años en que se han implementado las presentes rúbricas.

Tabla 2. Rúbrica para la evaluación de la competencia Comunicación efectiva en la asignatura "Dispersión de contaminantes en agua y atmósfera” a través de la actividad: Trabajos académicos.

\begin{tabular}{|c|c|c|c|c|}
\hline \multirow[b]{2}{*}{ INDICADOR } & \multicolumn{4}{|c|}{ DESCRIPTOR } \\
\hline & D. No alcanzado & $\begin{array}{c}\text { C. En } \\
\text { desarrollo }\end{array}$ & B. Adecuado & A. Excelente \\
\hline $\begin{array}{l}\text { 1. Capacidad } \\
\text { de } \\
\text { comunicación } \\
\text { audiovisual }\end{array}$ & $\begin{array}{l}\text { No se ha preparado } \\
\text { una presentación } \\
\text { clara. No hay indice, } \\
\text { ni transparencias } \\
\text { coherentes, los } \\
\text { tamaños de letra } \\
\text { impiden entender el } \\
\text { contenido. }\end{array}$ & $\begin{array}{l}\text { No conoce bien } \\
\text { el tema y la } \\
\text { presentación es } \\
\text { mediocre } \\
\text { Se sigue con } \\
\text { dificultad, a } \\
\text { pesar de tener } \\
\text { transparencias. }\end{array}$ & $\begin{array}{l}\text { Conoce el tema que ha } \\
\text { peparado. La } \\
\text { presentación se sigue } \\
\text { facilmente y tiene un } \\
\text { aspecto gráfico y } \\
\text { cientifico adecuado. }\end{array}$ & $\begin{array}{c}\text { Demuestra un completo } \\
\text { dominio del tema que } \\
\text { presenta. La } \\
\text { argumentación es } \\
\text { perfecta en el campo } \\
\text { audiovisual con figuras } \\
\text { y tamaños de letras } \\
\text { legibles y bien } \\
\text { graficadas. }\end{array}$ \\
\hline $\begin{array}{l}2 . \\
\text { Habilidades } \\
\text { lingüisticas }\end{array}$ & $\begin{array}{l}\text { No se entiende bien } \\
\text { su pronunciación, con } \\
\text { tono y volumen no } \\
\text { adecuados a la } \\
\text { defensa de una } \\
\text { argumentación en un } \\
\text { trabajo específico. }\end{array}$ & $\begin{array}{l}\text { Tiene modos } \\
\text { monótonos de } \\
\text { hablar, con mala } \\
\text { pronunciación, } \\
\text { sin controlar el } \\
\text { énfasis en la } \\
\text { presentación de } \\
\text { ideas, con } \\
\text { coletillas }\end{array}$ & $\begin{array}{l}\text { Habla aceptablemente. } \\
\text { Usa un tono claro y } \\
\text { buena pronunciación, } \\
\text { sin controlar el énfasis } \\
\text { en la descripción de } \\
\text { ideas }\end{array}$ & $\begin{array}{l}\text { Habla perfectamente. } \\
\text { En un tono claro y } \\
\text { buena pronunciación, } \\
\text { enfatizando su } \\
\text { argumentación. Motiva } \\
\text { al auditorio sobre el } \\
\text { tema que presenta a } \\
\text { traves de la modulacion } \\
\text { de su lenguaje oral. }\end{array}$ \\
\hline $\begin{array}{l}\text { 3. Lenguaje } \\
\text { corporal }\end{array}$ & $\begin{array}{l}\text { No tiene buena } \\
\text { postura. No establece } \\
\text { contacto visual con el } \\
\text { auditorio. No } \\
\text { gestualiza. }\end{array}$ & $\begin{array}{l}\text { No tiene buena } \\
\text { postura. No } \\
\text { muestra } \\
\text { entusiasmo por } \\
\text { el tema que está } \\
\text { presentando. }\end{array}$ & $\begin{array}{c}\text { Tiene buena postura y } \\
\text { establece contacto } \\
\text { visual con el auditorio } \\
\text { la mayoria del tiempo } \\
\text { Tiene argumentación } \\
\text { gestual, pero no apoya a } \\
\text { las ideas fuerza. }\end{array}$ & $\begin{array}{l}\text { Tiene buena postura. Se } \\
\text { encuentra relajado y } \\
\text { seguro en el conteido y } \\
\text { lenguaje de su } \\
\text { presentación. } \\
\text { Establece contacto } \\
\text { visual con todo el } \\
\text { audotorio, } \\
\text { particularmente con su } \\
\text { interlocutor en cada } \\
\text { argumento, apoyando } \\
\text { las ideas fuerza con } \\
\text { gestos y modos de } \\
\text { comunicarse. }\end{array}$ \\
\hline $\begin{array}{l}\text { 4. Control del } \\
\text { tiempo }\end{array}$ & $\begin{array}{l}\text { No muestra interés en } \\
\text { la coordinación del } \\
\text { tiempo como parte de } \\
\text { la presentación de } \\
\text { ideas }\end{array}$ & $\begin{array}{c}\text { Expone las } \\
\text { ideas en tiempos } \\
\text { demasiado } \\
\text { cortos o largos }\end{array}$ & $\begin{array}{c}\text { Expone las ideas } \\
\text { desordenadas, pero en } \\
\text { tiempos adecuados. }\end{array}$ & $\begin{array}{l}\text { Expone las ideas } \\
\text { perfectamente } \\
\text { ordenadas en los } \\
\text { tiempos previstos para } \\
\text { cada punto de su } \\
\text { presentación } \\
\text { audiovisual, incluidos } \\
\text { antecedentes y } \\
\text { conclusiones. }\end{array}$ \\
\hline
\end{tabular}

(cc) EY-NC-ND 2018, Universitat Politècnica de València 
Las Figuras 1 y 2 muestran los resultados obtenidos por los 16 alumnos de los cursos anteriores en cuanto a la aplicación de las rúbricas para su evaluación en ambas actividades.

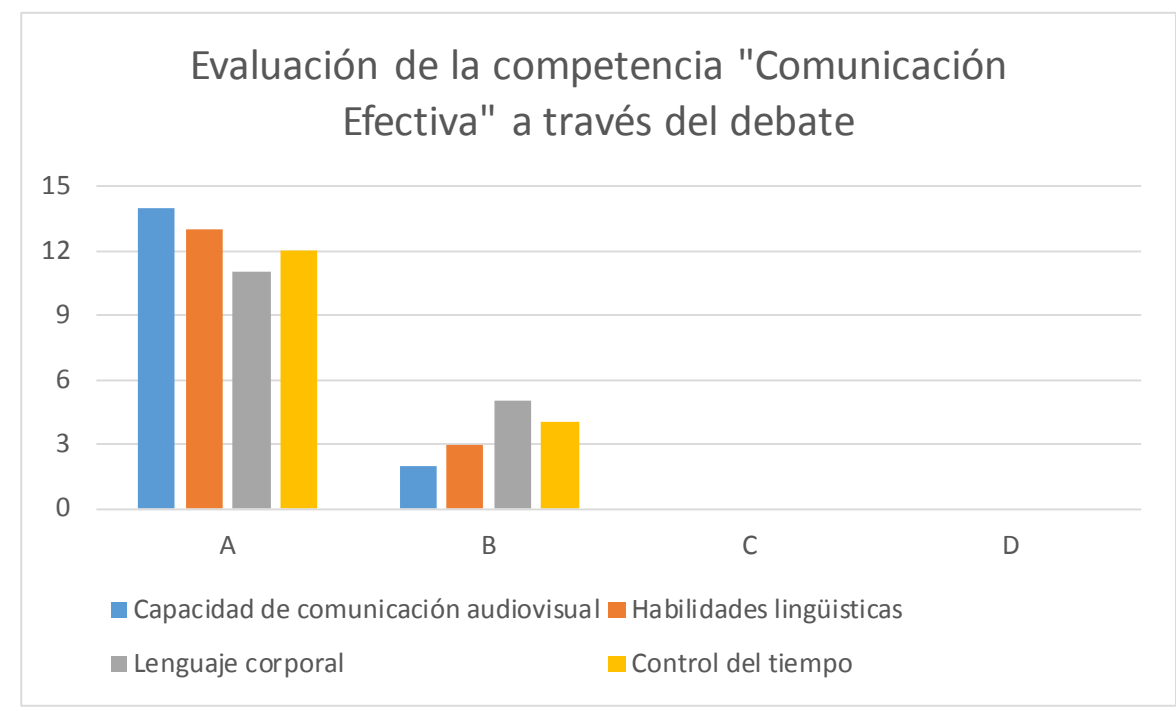

Figura 1. Resultados de la aplicación de la rúbrica de la Tabla 1 en los dos cursos anteriores sobre la actividad Debate.

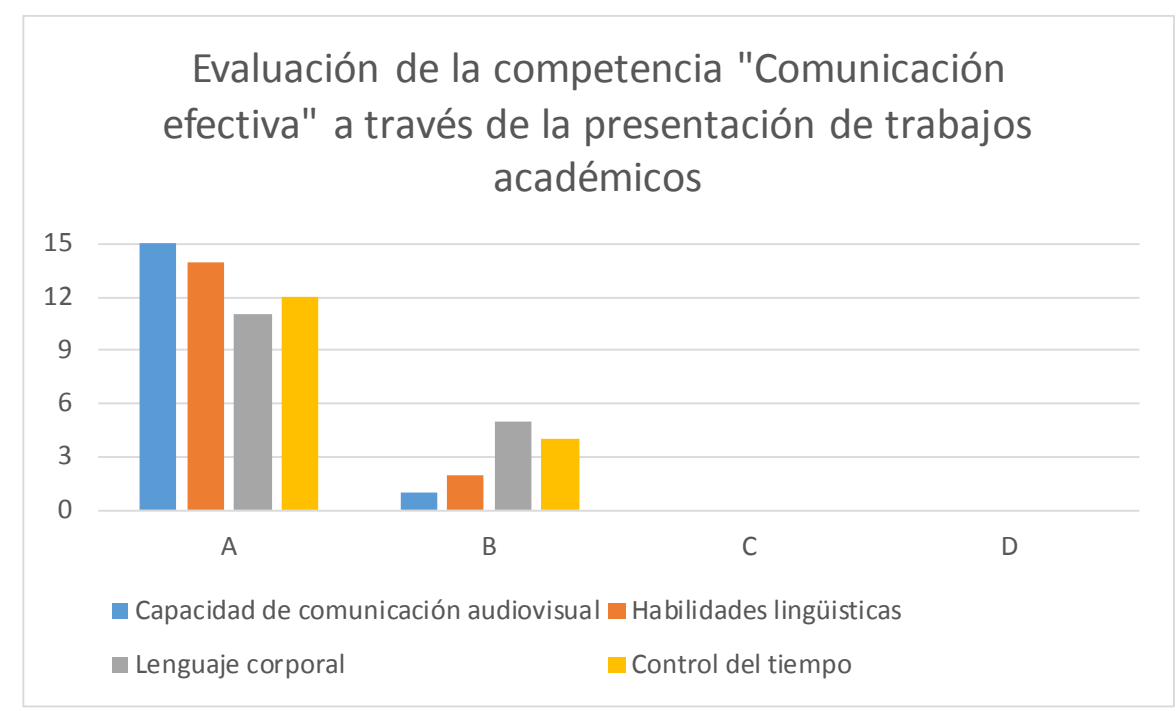

Figura 2. Resultados de la aplicación de la rúbrica de la Tabla 1 en los dos cursos anteriores sobre la actividad Presentación del trabajo académico.

(c) ) EY-NC-ND 2018, Universitat Politècnica de València 


\section{Conclusiones}

La aplicación de las rúbricas es una herramienta potente para contextualizar la aplicación de las competencias transversales en las carreras técnicas.

En la presente contribución se ha descrito cómo pueden desarrollarse estrategias activas para que los alumnos se impliquen en actividades que involucren la comunicación efectiva, y como la puesta en marcha del proyecto institucional de la UPV de Competencias transversales, puede llevarse a la práctica en aspectos de evaluación a través de las rúbricas. Las rúbricas presentadas para la evaluación de la competencia a nivel de alumnos de últimos cursos de máster ha sido aplicada con resultados muy satisfactorios y ha permitido tener constancia de cómo los alumnos han sido capaces de llevarla a la práctica en una fase final ya de su educación superior.

\section{Agradecimientos}

La experiencia aquí descrita se ha llevado a cabo como parte de los trabajos desarrollados en el EICE DESMAHIA "Desarrollo de metodologías activas y estrategias de evaluación aplicadas al campo de la Ingeniería Hidráulica". Los autores agradecen a la UPV, y en particular al ICE, el apoyo prestado para llevar a cabo esta iniciativa.

\section{Referencias}

Fernandez March, A. (2010) La evaluación orientada al aprendizaje en un modelo de formación por competencias en la educación universitaria. REDU VOL 8(1).

Pérez-SÁnchez, Modesto; López Jiménez, Petra Amparo (2017a).El debate como instrumento complementario de aprendizaje en la competencia de responsabilidad ética, medioambiental y profesional. En Congreso Nacional de Innovación Educativa y Docencia en Red (IN-RED 2017). (683 - 695). Valencia, Spain: Editorial UPV.

Rodriguez, M. L. (2010). El debate como herramienta pedagógica. Plataforma de Metodología de la Investigación Científica y para la Guía de Tesis de Grado. Consultado en Internet en agosto de 2017 en: https://metodologiasdelainvestigacion.wordpress.com/2010/11/24/el-debate-comoherramienta-pedagogica/

UPV (2018). La comunicación efectiva como competencia transversal. Consutado en marzo de 2018 en: http://excelcon.blogs.upv.es/2015/02/24/la-comunicacion-efectiva-comocompetencia-transversal/

(cc) EY-NC-ND 2018, Universitat Politècnica de València 


\title{
El acercamiento a las fuentes de la Historia como método de desarrollo de las competencias necesarias para la escritura académica
}

\section{Francisco J. Molina de la Torre ${ }^{a}$ y Sofía Pizarro Riñón}

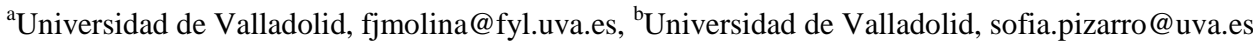

\begin{abstract}
The task of the historian is to create a narrative out of a number of very different historical sources. Writing, therefore, is an essential tool for all students and, actually, more than a tool: writing is learning. However, many of today's university students must be taught how to write at the academic level. The present paper explores an experience held at the University of Valladolid, in which students were given the opportunity to have direct contact with historical sources and to write a tutorized online essay about such sources.
\end{abstract}

\section{Keywords:}

History, historical sources, writing, collaborative learning, online tutorization.

\begin{abstract}
Resumen
La tarea del historiador es elaborar un relato a partir de una serie de fuentes escritas muy diversas, por lo que escribir se convierte en una herramienta imprescindible para todos los estudiantes. De hecho, es más que una herramienta, pues al escribir se aprende. Sin embargo, hoy en día es preciso enseñar a muchos de nuestros estudiantes universitarios a escribir un texto académico. Este trabajo analiza una experiencia desarrollada en la Universidad de Valladolid en la que los estudiantes tuvieron la oportunidad de entrar en contacto directo con las fuentes escritas y elaborar un trabajo tutorizado online acerca de dichas fuentes.
\end{abstract}

Palabras clave: Historia, fuentes históricas, escribir, aprendizaje colaborativo, tutorización online.

\section{Introducción}

La correcta expresión, tanto oral como escrita, constituye una de las más importantes competencias en la mayor parte de los perfiles profesionales, tanto en el campo de las humanidades y las ciencias sociales como en el de las ciencias de la salud y otras ciencias. Sin duda, en el caso de la titulación del Grado en Historia se erige como un pilar fundamental, de tal modo que, por ejemplo, la Universidad de Valladolid lo contempla tanto entre los objetivos generales del grado como entre las competencias generales, específicas y trasversales. Para lograrlo, en la exposición de los objetivos y competencias, 
se recoge que "la realización de trabajos escritos a lo largo de las diferentes asignaturas y, en especial, del Trabajo de Fin de Grado, pretenden desarrollar esta competencia” (UVA, Objetivos y competencias).

Además, desde la segunda mitad del siglo XX, a partir de los estudios de Brenner, Luria y, en particular, Vygotsky, se ha puesto de manifiesto que la escritura es un elemento clave en el proceso mismo de aprendizaje: no solo aprendemos a escribir, sino que escribiendo aprendemos. De este modo, la escritura se convierte no solo en una meta a alcanzar, sino también en un instrumento fundamental en todo proceso de enseñanza-aprendizaje.

Sin embargo, son frecuentes las quejas entre los docentes universitarios a causa del escaso dominio del registro escrito por parte de los alumnos, algo que, de todos modos, no ha sido objeto de estudio detenido en el ámbito español, a diferencia de lo que sucede en otros países hispanoparlantes (Gallego Ortega y Mendías Cuadros, 2012: 48). En cualquier caso, el panorama que se describe sobre la escritura entre los universitarios colombianos (Andrade Calderón, 2009: 326-327), caracterizado por la desmotivación, las faltas de ortografía, la mala estructuración del texto, el desconocimiento del tema sobre el que se escribe, entre otras cosas, no dista demasiado de lo que encontramos en nuestras aulas. Así pues, la realidad a la que nos enfrentamos se caracteriza, por un lado, por un alumnado que en buena medida ignora aspectos básicos de la escritura y, por otro lado, docentes que, siguiendo lo postulado en los programas, exigen la redacción de distintos tipos de trabajos escritos -incluido el Trabajo de Fin de Grado- pero que, considerando que todo alumno universitario ya debería dominar el registro escrito, se limita a evaluar sin más dichos trabajos.

Por otra parte, en el campo de la Historia, no podemos olvidar la trascendencia que las fuentes escritas tienen para la misma. Aunque no puede escribirse historia sin recurrir a los testimonios llegados a nosotros de los distintos periodos históricos, hay ocasiones en que el aprendizaje de la historia se convierte en la memorización de unos apuntes o unos manuales elaborados por el profesor o por un grupo de expertos en la materia, de tal manera que el alumno no tiene acceso directo a la documentación original que ha servido a los historiadores para construir su relato histórico.

Un elemento adicional que ha de tenerse en cuenta es la compleja implantación de las TICs en la enseñanza y aprendizaje de la historia. Si bien es cierto que en la actualidad hay numerosas posibilidades, también lo es que el número de docentes interesados por ellas es bastante reducido. Muestra clara del desinterés de los historiadores por la innovación docente es el número de comunicaciones recogidas en las actas de las ediciones anteriores de este Congreso vinculadas a dicho campo de estudio (no hemos sido capaces de identificar ningún trabajo propiamente histórico, aun cuando algunos versan sobre historia del arte, historia de la música, etc.).

Teniendo en cuenta todo lo anterior, un grupo de docentes de Historia de la Universidad de Valladolid, junto con algunos docentes de enseñanzas medias, planteamos un Proyecto de Innovación Docente con el título de "Las fuentes de la historia. Un binomio en la construcción de aprendizajes”. Con él pretendíamos subsanar algunas de las deficiencias

(cc) BY-NC-ND 2018, Universitat Politècnica de València

Congreso IN-RED (2018) 
observadas en la formación de los alumnos de Historia, al mismo tiempo que mejorar sus capacidades como docentes y avanzar en la reflexión sobre la auténtica mejora de la universidad. Dentro del abanico de actividades diseñadas y desarrolladas en el seno del proyecto, los llamados seminarios "Mil Historias" tenían por objeto acercar a los estudiantes a las fuentes primarias, al mismo tiempo que acompañarlos personalmente en el proceso de redacción de un trabajo escrito empleando algunos recursos de la nube.

El presente trabajo, por consiguiente, recoge la experiencia de los seminarios "Mil Historias”, desde su concepción hasta su evaluación por parte de los participantes y de los miembros del proyecto de innovación docente. No obstante, la mejor valoración tendrá lugar cuando, al año próximo, los estudiantes se enfrenten a la tarea de redactar su Trabajo de Fin de Grado y tengan la experiencia previa de haber redactado un trabajo tutorizado, con recursos 2.0 y en cuya elaboración han encontrado la colaboración, no solo de los docentes implicados, sino de otros alumnos participantes en el proyecto.

\section{Objetivos}

1. Acercar las fuentes escritas de la historia a los alumnos tanto a través de los recursos digitales como facilitando el acceso a los archivos de la ciudad de Valladolid.

2. Proporcionar a los alumnos herramientas para el análisis de las fuentes históricas y la elaboración de un discurso histórico a partir de las mismas.

3. Mostrar, por medio de ejemplos, cómo se elabora la historia a partir de diversas fuentes.

4. Ofrecer la posibilidad de realizar un trabajo tutorizado en el que se puedan poner en práctica las competencias a desarrollar.

5.Promover el uso de herramientas 2.0 para facilitar un aprendizaje colaborativo entre profesores y alumnos que enriquezca el resultado de los trabajos realizados.

\section{Desarrollo}

\subsection{Planificación}

La idea de crear un proyecto de innovación en el Grado en Historia de la Universidad de Valladolid surgió a raíz de la Convocatoria de Proyectos de Innovación Docente 2017-2018 publicada el 3 de julio, para "fomentar y apoyar el diseño y desarrollo de proyectos de innovación educativa que tienen como objetivo final mejorar la capacitación y cualificación de nuestros estudiantes” (UVA, Convocatoria).

Ante este reto, algunos docentes preocupados por la escasa capacidad de redacción que demuestran los alumnos en las pruebas de evaluación de las distintas asignaturas, así como por la falta de herramientas de que disponen a la hora de enfrentarse a la elaboración del TFG, crearon un equipo de profesores de diferentes áreas para trabajar cooperativamente en el desarrollo de la innovación. 
En el curso de una reunión preparatoria en la que se analizaron los problemas existentes que se planteaban resolver, las posibilidades que proporcionaba la estructura del grado y los recursos humanos con los que se contaban, surgió el proyecto ya mencionado de los seminarios "Mil Historias".

Se trataba de una actividad de carácter extracurricular y de naturaleza voluntaria dirigido fundamentalmente a los alumnos de $2 .^{\circ}$ y $3 .^{\circ}$ de grado. El público se eligió al considerar que los estudiantes, en estos cursos, ya cuentan con algunos rudimentos propios de la Historia, y disponen además de cierto bagaje y herramientas, como la paleografía, que les permiten acceder a las fuentes escritas de distintas épocas con cierta comprensión del contexto histórico en el que se enmarcan. Por otro lado, son cursos previos a la elaboración del TFG, en los que que se pueden ir asimilando los conocimientos que ayudarán al alumno a la realización de este trabajo.

A través de esta actividad se pretendía, en la línea del modelo educativo planteado por el EEES para el Grado en Historia (ANECA, 2004), el desarrollo de competencias por medio de una construcción activa y personal del aprendizaje, entendidas las competencias como la "combinación de conocimientos, capacidades, habilidades, actitudes y valores que se requieren para la comprensión y transformación de una realidad compleja” (Mateo, 2006; citado por Climent, 2010: 92). Entre otros aspectos, interesaba fomentar una mayor capacidad crítica, una autonomía en el aprendizaje y una curiosidad por conocer, junto con la ya mencionada capacidad de comunicación oral y escrita, lo que se ha tratado de llevar a cabo por medio del acercamiento a las fuentes escritas primarias.

El desarrollo de los seminarios se planteó con dos fases, una primera en la que se mostraría a los alumnos las posibilidades de estudio que presenta una sola fuente, y una segunda en la que los alumnos se convertirían en los protagonistas elaborando su propio trabajo a partir de un documento histórico.

\subsection{La primera fase de los seminarios "Mil Historias"}

La primera fase consistió en la elaboración de unos seminarios denominados "Mil Historias”. El título hacía referencia a los diferentes relatos que se pueden extraer a través de una fuente histórica y tenían como objetivo mostrar a los alumnos cómo debe ser la actitud del historiador ante los testimonios gráficos para hacer "hablar" a las fuentes.

El formato elegido para estas exposiciones fue el de seminario, es decir, una reunión especializada en la que se desarrolla un estudio profundo sobre una materia concreta, en la que además del docente, los alumnos también participan por medio de un aprendizaje activo interactuando con el guía (Monografías, 2018). Este formato ha sido empleado con éxito en otras experiencias de innovación docente (Mariles, 2012; Saiz y Susinos, 2017). De esta forma, los alumnos pudieron exponer sus dudas acerca del tema tratado, intercambiar impresiones y aportar nuevas ideas.

Los seminarios se desarrollaron en tres sesiones. La primera de ellas, titulada "La inscripción bajo la escalera del edificio histórico de la Universidad de Valladolid”, versó

(cc) BY-NC-ND 2018, Universitat Politècnica de València

Congreso IN-RED (2018) 
sobre una fuente epigráfica de época contemporánea. En este seminario se reflexionó sobre el carácter comunicativo de las inscripciones, el mensaje que pretenden comunicar, las personas y oficios implicados en su realización, descubriendo las múltiples investigaciones que se pueden realizar a partir de ellas.

En el segundo seminario se mostraron las posibilidades de investigación que ofrece un documento, en concreto, el sermón pronunciado en 1511 por Antonio de Montesinos, fraile dominico, en la isla de La Española sobre la defensa de la libertad e integridad de las poblaciones indígenas americanas. A través de él se presentaron las posibilidades de estudio para la conquista de América, en sus múltiples facetas, organización administrativa, encomienda, población indiana y las consecuencias que tuvo como punto de partida en el movimiento de defensa de los indios.

Por último, tuvo lugar un seminario en el que se estudió un libro y las diferentes vertientes de interpretación del mismo a partir del códice, o códices, de Las Partidas de Alfonso X el Sabio. En él se hizo hincapié en la necesidad de la interdisciplinariedad a la hora de elaborar un estudio como forma de enriquecer los resultados obtenidos y se puso en valor una fuente jurídica para el estudio de diversas facetas de la historia, además del derecho, como la sociedad y la economía.

La participación en los seminarios contó con la presencia entre 8 y 12 alumnos de $2 .^{\circ}$ y $3 .^{\circ}$ curso del Grado en Historia. Aunque pueda parecer una asistencia reducida, hay que tener en cuenta que el número de los alumnos matriculados por curso suele oscilar entre 50-60 estudiantes, por lo que la asistencia sería de algo más de un $10 \%$. De todas formas, esta baja implicación en el proyecto es una muestra más de la desmotivación que existe entre los universitarios.

\subsection{Los seminarios "guía"}

Una vez celebrados los tres seminarios "Mil Historias", comenzaba la segunda fase, la cual daba sentido al proyecto, pues era esta en la que los estudiantes se implicaban de forma directa. Para orientar a los participantes, organizamos dos seminarios "guía", uno al comienzo de esta fase y otro transcurrido un mes.

El primero de dichos seminarios tenía por objeto conocer el número real de participantes en esta fase del proyecto, elegir el tema sobre el que cada alumno deseaba trabajar y dar unas orientaciones generales sobre la redacción de los trabajos (vinculándolo con la redacción futura del TFG) y el uso de Google Drive.

Al final, fueron tan solo cinco los alumnos que decidieron voluntariamente participar en la segunda fase de los seminarios. Ello, pese a que parezca un número en exceso reducido, nos ofrecía la oportunidad de trabajar de una manera mucho más personalizada con los participantes. Así pues, ello nos permitía incidir en aquellos aspectos que han dado en llamarse "aprendizajes colaterales" (González Geraldo, 2014: 62-66), es decir, aquellos aspectos de la educación que no están planificados pero que son bien percibidos por los alumnos, pues "es posible que los alumnos aprendan más de sus profesores que de las 
propias materias” (González Geraldo et al., 2012: 198). En este sentido, además de la relación con los estudiantes en el marco de los seminarios (y, por consiguiente, fuera del ámbito académico estricto, permitiendo así una mayor cercanía y espontaneidad), el hecho de que algunos optaran por trabajar sobre fuentes de los archivos de la ciudad nos dio ocasión de acompañarles a los archivos, guiarles en la solicitud de la documentación, hablar con ellos sobre sus expectativas y dificultades, conocer su opinión sobre el Grado, etc.

En el segundo de los seminarios "guía” buscábamos poner en común y resolver de forma colaborativa algunas de las dificultades que los participantes en los seminarios se hubiesen encontrado.

Dichas dificultades iban a ser fundamentalmente de tres tipos: unas estaban relacionadas con el entorno tecnológico, pues, a pesar de que Google Drive no parece suponer ningún reto, su uso en nuestros ámbitos educativos es bastante reducido; otras complicaciones derivaban de la propia naturaleza de la fuente elegida para hacer el trabajo -bien por su extensión o bien por la dificultad de desentrañar el contenido de la misma (recordemos que la escritura castellana de los siglos XVI y XVII es, en muchos casos, difícil de comprender)-; y, finalmente, otra serie de dificultades estaban vinculadas al proceso mismo de redacción, desde la organización de las ideas, pasando por problemas de sintaxis y signos de puntuación, hasta la forma de citar.

Además de comentar las dificultades y de proponer algunas pautas generales para continuar con los trabajos, se incidió en la importancia de la colaboración de todos en la redacción de los textos. Para ello se comentó el artículo de Castelló, González e Iñesta (2010), que tenían disponible en un repositorio del Google Site en el que trabajábamos. En ese sentido, se advirtió que los comentarios ofrecidos a los demás debían ser constructivos, siendo admisibles correcciones de estilo y de ortografía, pero insistiendo en la importancia sobre todo de abrir nuevas perspectivas desde la experiencia personal.

Por último, en dicho seminario planteamos la posibilidad de que al final los trabajos se expusieran ante los demás participantes del proyecto. Era un tema que, dado que el proyecto estaba principalmente orientado hacia la expresión escrita, habíamos dejado en suspenso para conocer la opinión de los estudiantes. En definitiva, a la luz del debate que se suscitó, optamos por celebrar uno o dos seminarios de exposición, de modo que la experiencia no solo sirviese para trabajar en la comunicación escrita, sino en la oral, pues también esta es un elemento fundamental en la formación de futuros historiadores y docentes de historia.

\subsection{El trabajo online tutorizado}

Tras el primer seminario "guía” se dio paso a la elaboración de los trabajos de los estudiantes. En el Google Site se tenía acceso tanto al documento en el que elaborar personalmente el trabajo como a los documentos de los otros participantes, donde se podía intervenir libremente.

(cc) BY-NC-ND 2018, Universitat Politècnica de València

Congreso IN-RED (2018) 
A pesar de las dificultades iniciales (fundamentalmente derivadas de las diferencias entre el programa Word, con el que los participantes estaban más familiarizados, y el editor de texto de Google), en un plazo relativamente breve -dos o tres semanas- los participantes habían comenzado a redactar sus textos.

Dado que el número de participantes, como hemos indicado, no era muy elevado, la labor de tutorización la realizamos los dos autores del presente trabajo, recurriendo en algunos momentos a otros miembros del Proyecto de Innovación Docente. Dicha tutorización consistió sobre todo en hacer comentarios en el documento de Google relativos a muy diversos aspectos, tanto a nivel ortográfico y sintáctico como de estructuración del relato histórico. Procuramos respetar el estilo propio de cada estudiante, si bien hicimos sugerencias o comentarios que creíamos que les serviría primero para mejorar el texto que estaban preparando, pero también para futuras redacciones (en particular para el TFG).

Dado que observamos que la participación de los alumnos en los trabajos de los demás era bastante escasa, creímos conveniente, según hemos indicado en el apartado interior, que en el segundo seminario "guía" se tratase de esta cuestión. Nos pareció que el mencionado trabajo de Castelló, González e Iñesta, pese a que remite a los trabajos conducentes al doctorado, les resultaría esclarecedor, pues, como las autoras manifiestan de forma rotunda, "la revisión colaborativa mejora los textos finales" (2010: 534). A partir de ese seminario "guía" aumentó el número de intervenciones de los estudiantes en los textos de sus compañeros, produciéndose en algunos casos un intercambio de ideas realmente enriquecedor.

Al cabo de dos meses dimos por cerrado la redacción de los textos, que probablemente sirvan como base para futuros proyectos con nuevos estudiantes que quieran participar en los seminarios.

\subsection{Los seminarios de exposición}

Como hemos indicado más arriba, en el proyecto original de los seminarios "Mil Historias" no contemplábamos de forma definitiva la exposición de los trabajos realizados. El hecho de que el número de participantes fuera reducido, así como el interés que manifestaron cuando les propusimos la posibilidad, nos llevó a organizar los "seminarios de exposición", en los que brindamos a los participantes la oportunidad de exponer sus trabajos ante sus compañeros (la exposición estaba abierta a otros estudiantes que no habían participado en los seminarios).

A fin de disponer de tiempo para la exposición y la revisión de la misma, optamos por celebrar dos sesiones. En la primera expusieron su trabajo dos estudiantes y en la segunda otros dos (un participante no pudo exponerlo por diversas razones). En cada seminario, el procedimiento que se siguió fue el siguiente. Comenzábamos con la exposición por parte del estudiante, para la cual tenía un tiempo asignado de quince minutos. La mayoría se sirvió de un apoyo visual para la misma (fundamentalmente PowerPoint, aunque en un caso se empleó Prezi). La exposición era grabada por un miembro del Proyecto. Al acabar la exposición, se abría un tiempo de reflexiones generales en el que los presentes podían hacer 
sus comentarios acerca de la exposición -en este caso, advertimos que no nos interesaba tanto el contenido de la exposición cuanto la forma de la misma-.

Después de las dos exposiciones de los alumnos y de los comentarios generales, una vez que habían salido quienes no formaban parte de los seminarios, ofrecíamos la posibilidad de hacer un análisis más detenido de la exposición revisando el vídeo, a fin de identificar tanto las fortalezas como las debilidades de la misma y poder mejorar en el futuro. Con quienes accedieron a revisarlo, descubrimos algunas de las deficiencias más habituales que se observan en este tipo de presentaciones: velocidad excesiva en la dicción provocada por el nerviosismo, abuso de algunas muletillas, tono monótono, uso de demasiado texto en la presentación PowerPoint, etc.

\section{Resultados}

Los resultados que exponemos a continuación derivan fundamentalmente de las impresiones y datos que los miembros del proyecto hemos ido recabando mediante el diálogo con los participantes y el debate entre nosotros. Asimismo, en algunos casos (para los resultados 4 y 5) hemos aprovechado las encuestas que vía Google Forms han ido realizando los participantes en los seminarios para conocer el parecer de los participantes de una forma más formal.

\subsection{Los estudiantes entran en contacto directo con las fuentes de la historia.}

Uno de los grandes objetivos que nos planteábamos era facilitar a los participantes en el proyecto el contacto directo con las fuentes. Ello se ha logrado no solo mediante la participación en los seminarios de la primera fase (cuando se presentaba una fuente y las "mil historias" que pueden escribirse a partir de la misma), sino ante todo con los trabajos tutorizados. En este caso, los propios estudiantes han elegido la fuente sobre la que deseaban trabajar, de forma que el elenco de fuentes ha sido muy variado, tanto en su tipología como en su cronología, e incluso se ha trabajado sobre fuentes inéditas conservadas en el Seminario Diocesano, que podrían ser material para un futuro TFG.

\subsection{Los estudiantes escriben y, consiguientemente, aprenden.}

El mero hecho de ponerse a escribir constituye un elemento fundamental en el proceso de aprendizaje de los estudiantes. Además, advierten cómo los contenidos se fijan mucho más al dedicar tiempo a poner por escrito las ideas, pues exige un ejercicio de reflexión, de organización y de expresión que sin duda favorece la asimilación del tema sobre el que están trabajando.

\subsection{Los estudiantes advierten cómo la tutorización de los trabajos permite una mejora sustancial de los mismos.}

La tutorización de los trabajos ha posibilitado, en primer lugar, la identificación de las principales deficiencias de los alumnos a la hora de enfrentarse a la redacción de un texto. Ello ha contribuido no solo a que los alumnos adviertan en qué aspectos han de mejorar en su trabajo, sino también a que nosotros, como docentes, especialmente como tutores de 
TFGs, descubramos cuáles son los errores más frecuentes y podamos orientar mejor a los estudiantes. En segundo lugar, la tutorización mediante Google Drive ha permitido que los participantes se habituasen a trabajar en un entorno virtual, algo que, como señalamos anteriormente, no es excesivamente habitual en el mundo de la historia.

\subsection{Los estudiantes aprenden que el trabajo en colaboración con sus compañeros es un instrumento muy positivo para enriquecer los textos que escriben.}

El uso de Google Drive facilitó el intercambio de comentarios y sugerencias entre los participantes, si bien fue necesario insistir en ello para que los alumnos realmente interviniesen en el trabajo de los demás. En cualquier caso, además, como aparece en algunas de las evaluaciones de los alumnos, estos tienen interés en "preguntar dudas o vuestra opinión en caso de necesidad", y las respuestas brindadas no solo por los docentes, sino también por sus compañeros son generalmente bien valoradas.

\subsection{Los estudiantes muestran interés cuando se les ofrecen actividades orientadas a completar y mejorar su formación.}

Ciertamente se trata de algo que no puede aplicarse a la mayor parte del alumnado, pero sí a un porcentaje limitado (10-15\%), que participa en actividades académicas extraordinarias aun cuando no les reporten ningún tipo de beneficio en forma de créditos. Además, la participación no se limita a acudir a una charla y escuchar, sino que se muestran activos (evaluando las actividades, ofreciendo sugerencias para futuros proyectos y sobre todo redactando un trabajo tutorizado). Por ejemplo, en el caso de los seminarios de la primera fase, entre las sugerencias se planteaba "la posibilidad de enviar textos antes del seminario para prepararlos en casa y así poder comentarlos con el conferenciante”.

\section{Conclusiones}

La participación en el proyecto, al ser totalmente voluntaria, no ha sido muy elevada, como ya hemos mencionado, sin embargo podemos decir que para los alumnos que se han involucrado hasta el final ha sido una experiencia muy satisfactoria, cumpliéndose los objetivos propuestos inicialmente.

El trabajo con las fuentes escritas, sin las que no podríamos elaborar la historia, han mostrado a los participantes el verdadero significado del Grado que estudian, que no consiste únicamente en memorizar una lista interminable de hechos o personajes, sino en desarrollar la capacidad de comprender el pasado, profundizando en los hechos acaecidos, para entender el presente y mirar hacia el futuro. De esta forma han experimentado el papel que tiene el historiador a la hora de extraer la información que nos proporcionan las fuentes y generar nuevos relatos, estimulando en ellos la inquietud y curiosidad necesarias para el desarrollo de la ciencia.

El estudio de la documentación les ha llevado a adquirir algunas competencias transversales y específicas del grado de Historia, como la capacidad de análisis y la capacidad de relacionar lo estudiado en las distintas asignaturas con la investigación realizada. 
Los resultados del proceso de enseñanza-aprendizaje se han visto incrementados gracias al trabajo colaborativo, ya que en en el transcurso de la elaboración de los trabajos han podido participar aportando sugerencias, indicaciones, diversos puntos de vista, tanto los profesores vinculados al proyecto como los demás alumnos, que han enriquecido el resultado final. Esta colaboración del grupo, aunque el peso fundamental de la redacción era personal, ha sido factible gracias a las posibilidades que nos brindan las TIC, las cuales permiten hacer contribuciones sin necesidad de encontrarse reunidos, haciendo de esta forma más dinámicas las intervenciones. De todas formas, tampoco podemos olvidar los seminarios como otra herramienta, más tradicional, que ha permitido fomentar la colaboración.

Por lo tanto, podemos concluir que el trabajo colaborativo ha optimizado los resultados obtenidos favoreciendo el aprendizaje significativo y que las herramientas 2.0 han permitido, a su vez, llevar a cabo un trabajo más colaborativo y dinámico.

El proyecto ha concluido, por consiguiente, con el deseo de perdurar en años consecutivos ampliando su radio de acción a un número más amplio de estudiantes y con la esperanza de que las competencias adquiridas por los alumnos participantes tengan sus frutos en la elaboración de los futuros TFG, elevando el nivel de resultados de los mismos.

\section{Referencias}

ANDRAde CALderón, M. C. (2009). "La escritura y los universitarios” en Universitas humanistica, n. ${ }^{\circ}$ 68, julio-diciembre, pp. 297-340.

ANECA (2004). Libro Blanco: Título de Grado en Historia. $<$ http://www.aneca.es/var/media/150448/libroblanco_jun05_historia.pdf $>$ [Consulta: 18 de marzo de 2018].

CAstelló, M., GonzÁlez, D., IÑEsta, A. (2010). “La regulación de la escritura académica en el doctorado: el impacto de la revisión colaborativa en los textos” en Revista española de pedagogía, año LXVIII, n. ${ }^{\circ}$ 247, septiembre-diciembre, pp. 521-537.

Climent Bonilla, J. B. (2010). "Reflexiones sobre la Educación Basada en Competencias" en Revista Complutense de Educación, vol. 21, n. ${ }^{\circ}$ 1, pp. 91-106.

Gallego Ortega, J. L., y Mendías Cuadros, A. M. (2012). “¿Qué saben los estudiantes universitarios sobre la planificación de tareas de escritura? Un estudio de caso” en Revista de Investigación en Educación, $\quad$ n. ${ }^{\circ} \quad 10 \quad$ (2), $\quad$ pp. $47-61$. $<$ https://dialnet.unirioja.es/descarga/articulo/4732994.pdf> [Consulta: 15 de marzo de 2018].

GONZÁlez GERAldo, J. L. (2014). Hacia una universidad más humana. ¿Es superior la educación superior. Madrid: Biblioteca Nueva.

GonZÁLEZ GERALDO, J. L. et al. (2012). “Aprendizajes colaterales: límites y retos del aprendizaje por competencias” en ENSAYOS. Revista de la Facultad de Educación de Albacete, n. ${ }^{\circ}$ 29, 189-202. $<$ https://www.revista.uclm.es/index.php/ensayos/article/view/247> [Consulta: 20 de marzo de 2018].

MARILES Mora, S. (2012). "El seminario como fuente de aprendizaje cooperativo en el desarrollo de las ciencias biológicas” en Horizontes pedagógicos, vol. 14, n. ํ 1, pp. 141-155.

(cc) EY-NC-ND 2018, Universitat Politècnica de València

Congreso IN-RED (2018) 
MonografíAs, El Seminario. $\quad<$ http://www.monografias.com/trabajos93/seminariodiapositivas/seminario-diapositivas.shtml> [Consulta: 18 de marzo de 2018].

Saiz Linares, Á. y Susinos RadA, T. (2017). "Los seminarios colaborativos en un practicum reflexivo de maestros. Análisis de una experiencia en la Universidad de Cantabria (España)” en Perspectiva Educacional. Formación de Profesores, vol. 56 (3), pp. 3-24. $<$ file:///C:/Users/Sof\%C3\%ADa/Downloads/DialnetLosSeminariosColaborativosEnUnPracticumReflexivoDe-6153547.pdf> [Consulta: 18 de marzo de 2018].

UnIVERSIDAD DE VALlADOlid. Objetivos y competencias del Grado en Historia. $<$ http://www.uva.es/export/sites/uva/2.docencia/2.01.grados/2.01.02.ofertaformativagrados/_documen tos/historia_competencias.pdf $>$ [Consulta: 15 de marzo de 2018].

Universidad DE VAlLADOLID. Convocatoria de Proyectos de Innovación Docente. $<$ http://www.uva.es/export/sites/uva/7.comunidaduniversitaria/7.01.pdi/7.01.04.innovacioneducativa/ _documentos/Sellado_ConvocatoriaPID17-18.pdf> [Consulta: 16 de marzo de 2018]. 


\title{
Nuevas metodologías docentes para un nuevo mundo laboral
}

Peñaranda, David S. ${ }^{a^{*}}$, Naturil-Alfonso, Carmen ${ }^{a}$, Marco-Jiménez, Francisco ${ }^{a}$, y Vicente, José S. ${ }^{\text {a }}$

${ }^{a}$ Laboratorio de Biotecnología de la Reproducción, Departamento de Ciencia Animal, Universitat Politècnica de València. *Autor de correspondencia: dasncpea@upvnet.upv.es.

\begin{abstract}
The competences and skills to acquire by the student have evolved, so the educational methodology must also evolve. Society demands professionals with competences and skills in information and communication technologies (ICT), further a critical and deductive thinking.

The goal of this current paper is the description of a teaching project that proposes the implementation of flipped classroom in combination with ICT and learning stimulating methodologies, such as gamification. The teaching project will be applied in the subject: Animal and Human Physiology (Degree in Biotechnology, Universitat Piltècnica de València), which includes both "Alto Rendimiento Académico" (English group) and Spanish group.

Five activities have been designed to achieve the transversal competences selected for this subject. The teacher, based on the indicators of achievement and competence evidences, will be able to evaluate the effectiveness of the project, comparing the degree of achievement of the skills prior or postproject implementation. Furthermore, the final mark will also be compared with previous years, in order to test whether the innovative educational strategy has had a relevant impact on the final grade of the subject.
\end{abstract}

Keywords: flipped classrrom, ICT, gamification, teaching project

\footnotetext{
Resumen

Las competencias y habilidades a adquirir por parte del estudiante han evolucionado, por lo que la metodología educativa también debe evolucionar. La sociedad demanda profesionales con competencias y habilidades en tecnologías de la información y la comunicación (TIC) y que demuestren un pensamiento crítico y deductivo.

El objetivo del presente trabajo es la descripción de un proyecto docente que propone la implantación de la clase inversa en combinación con TIC y metodologías estimuladoras del aprendizaje, como la gamificación. El proyecto docente se aplicará en la asignatura de Fisiología Animal y Humana (Grado en Biotecnología; Universitat Piltècnica de València), tanto en el grupo Alto Rendimiento Académico (lengua vehicular inglés) como en un segundo grupo donde la lengua vehicular es el castellano.
} 
Han sido propuestas 5 actividades diseñadas para alcanzar las competencias transversales propuestas en la asignatura. El docente, basado en los indicadores de consecución y las evidencias de competencia, evaluará la efectividad del proyecto, comparando el grado de adquisición de las competencias previo o post-implantación del proyecto. Además, también se comparará la calificación final respecto a años anteriores, testando así si la innovadora estrategia educativa ha tenido un impacto en la nota final de la asignatura.

Palabras clave: clase invertida, TIC, gamificación, proyecto docente .

\section{Introducción}

El estilo de enseñanza tradicional persiste tanto en las escuelas primarias como secundarias, incluso a nivel de educación superior. De hecho, los estudiantes se sienten cómodos con este método, y la mayoría de ellos lo consideran una buena estrategia educativa (Thomasian, 2012). Con el objetivo de ofrecer un modelo de enseñanaza diferente, recientemente, se ha desarrollado un nueva metodología educativa: la clase inversa. Con esta metodología, los estudiantes pueden adquirir los resultados de aprendizaje fuera del aula, generalmente utilizando tecnologías de información y comunicación (TIC) como herramientas educativas en línea, screencast o videos grabados, mientras tanto, el tiempo de clase está reservado para la práctica, trabajo correctivo específico o actividades diseñadas para promover habilidades cognitivas de orden superior (Khan, 2012). Sin embargo, no todos los aspectos de la clase inversa son nuevos. En el marco de la educación tradicional, el docente también espera que los alumnos acudan al aula con cierta preparación previa, como haber leído o hecho material asignado (Davies et al., 2013). El elemento diferenciador reside en el gran avance de las herramientas TIC accesibles, tanto para estudiantes como para docentes (Davies y West, 2014), que permite que el aula invertida se haga realidad.

La forma de desarrollar la clase inversa puede variar, pero todos los modelos son básicamente los mismos (Talbert, 2012). El aprendizaje no se limita al aula, por lo que los estudiantes deben asumir la responsabilidad de su propio aprendizaje, ser más flexibles y adaptarse a esta metodología individualizada. Por otro lado, esta metodología educativa puede combinarse con otras tendencias de enseñanza innovadoras: como la adquisición de las competencias transversales. La sociedad contemporánea exige nuevas competencias tanto para docentes como para estudiantes, y estas competencias suelen estar relacionadas con actividades de aprendizaje electrónico, y por tanto con el uso de herramientas TIC. Aunque el uso de las TIC hace factible la implementación de la clase inversa, los investigadores han observado que la mayoría de los educadores aún adoptan pasivamente la tecnología como medio de aprendizaje (Wang et al., 2014). Estos resultados decepcionantes, han forzado a los educadores a reformar la enseñanza con el fin de mejorar los entornos de aprendizaje creativo. De esta forma, los alumnos son capaces de adquirir las competencias transversales a través de la resolución de problemas realistas y desarrollar habilidades cognitivas de orden superior (Lajoie y Azevedo, 2000). Para lograr este objetivo, la combinación de herraminetas TIC y la clase inversa pueden llegar a ser una

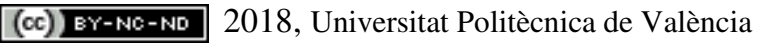

Congreso IN-RED (2018) 
metodología muy eficaz. El problema reside en que se requiere una alta formación, tanto por parte del docente como del estudiante, para el correcto uso de las TIC. Es por ello, que incluso en niveles de educación superior (universidad), la presencia de herramientas digitales y el desarrollo de competencias digitales es limitada. Hasta ahora, en la gran mayoría de los casos, las herramientas TIC se han utilizado de manera superficial, como en la planificación de lecciones, comunicación personal o procesamiento de textos (Drent y Meelissen, 2008), y la competencia digital de los alumnos se limita a habilidades básicas, incluidas herramientas de oficina y redes sociales (Valtonen et al., 2013).

Además de desarrollar las competencias transversales o adquirir la materia de la asignatura, la clase inversa tiene el objetivo de motivar a los estudiantes para el aprendizaje, y con este fin la clase inversa también puede ser combinada con estrategías educativas destinadas a este fin. Un ejemplo, sería la gamificación (Deterding et al., 2011; Huotari y Hamari, 2012). La gamificación ha sido implantada con resultados positivos en varios programas curriculares (Brewer et al., 2013; Fitz-Walter et al., 2011). Sin embargo, su implantación en la educación superior también ha sido limitada (Iosup y Epema, 2014), ya que si su evaluación no está bien equilibrada, puede inducir una disminución del interés en lugar de promover una motivación extra.

En conclusión, la clase inversa es una metodología educativa innovadora, lo suficientemente flexible como para incorporar otras estrategias de enseñanza como la gamificación o las TIC, facilitando el éxito en el logro de las competencias clave y transversales por parte del alumnado.

\section{Objetivo}

Aunque el objetivo del presente estudio es la descripción de un proyecto de enseñanza innovador a nivel de educación superior, el proyecto docente en si, presenta el siguiente objetivo:

- Trabajar y desarrollar tanto las competencias como las habilidades propopuestas para la asignatura "Fisiología Animal y Humana"

Para alcanzar el objetivo planteado, se implementarán nuevas metodologías docentes como la clase inversa y el uso de herramientas TIC.

\section{Desarrollo de la innovación}

\subsection{Descripción del ambiente de aprendizaje}

El proyecto docente se aplicará en la Universitat Politècnica de València (UPV), en el Grado en Biotecnología (http://www.upv.es/titulaciones/GB/index-en.html). El grado de Biotecnología de la UPV se encuentra en la primera posición del ranking de universidades españolas (http://www.elmundo.es/especiales/ranking-universidades/index.html), y la nota $\begin{array}{lllllll}\text { requerida de admisión es de } & 12.47 & \text { sobre } & 14\end{array}$ (https://www.upv.es/pls/oalu/sic_futuroalumno.notascorte?p_idioma=c). El grado se compone de 4 años académicos, incluyendo el trabajo final de grado (240 créditos del Sistema Europeo de Transferencia y Acumulación, ECTS). Además incluye el programa: Grupos de Alto Rendimiento Académico, grupos ARA 
(https://www.upv.es/contenidos/ARA/indexc.html). Este programa fue diseñado por el Generalitat Valenciana (http://www.ceice.gva.es/web/universidad/grupos-de-altorendimiento;\%20Generalitat\%20Valenciana) para reforzar el potencial de los estudiantes destacados con el fin de ayudarlos a lograr el mayor rendimiento académico.

El proyecto docente esta diseñado para implantarse en la asignatura anual: Fisiología Animal y Humana (código: 11109), correspondiente al segundo año académico, con 6 créditos ECTS de teoría y 3 de prácticas. La asignatura esta considerada como de formación básica, e incluye dos grupos: uno impartido en castellano y otro en inglés (ARA o grupo de alto rendimiento académico). Antes de asistir a este curso, los estudiantes deberían haber cursado las siguientes materias: Biología Celular, Química Biomolecular, Fundamentos de Química y Fundamentos de Física para Biotecnología. Por último, en el grupo ARA, para garantizar el logro de los resultados del aprendizaje, los estudiantes deben certificar que tienen un mínimo de nivel de inglés B2, según el Common European Framework of Reference for Languages (CEFR).

\subsection{Competencias y competencias transversales a adquirir}

El proyecto docente ha sido diseñado para lograr un conjunto de competencias:

- Capacidad de buscar y usar información

- Competencia para el aprendizaje continuo

- Capacidad para resolver problemas complejos

- Capacidad de evaluación crítica

- Trabajar en grupos multidisciplinarios

Con el objetivo de desarrollar estas competencias, se han definido los siguientes resultados de aprendizaje (Tabla 1). Por otro lado, todas las actividades han sido diseñadas para llevarse a cabo en grupos, desarrollando la competencia "Trabajo en grupos multidisciplinares".

Tabla 1. Competencias y resultados de aprendizaje

\begin{tabular}{|c|c|c|}
\hline & Competencias & Resultados de aprendizaje \\
\hline 1 & $\begin{array}{l}\text { Capacidad de buscar y usar } \\
\text { información }\end{array}$ & $\begin{array}{l}\text { Aplicar la regulación del Real Decreto para un caso práctico } \\
\text { de experimentación animal }\end{array}$ \\
\hline 2 & $\begin{array}{l}\text { Competencia para el } \\
\text { aprendizaje continuo }\end{array}$ & Ser capaz de realizar un diseño experimental \\
\hline 3 & $\begin{array}{l}\text { Competencia para el } \\
\text { aprendizaje continuo }\end{array}$ & Ser capaz de resumir y presentar un artículo de investigación \\
\hline 4 & Capacidad de evaluación crítica & Ser capaz de contrastar información usando herramientas TIC \\
\hline 5 & $\begin{array}{l}\text { Capacidad para resolver } \\
\text { problemas complejos }\end{array}$ & $\begin{array}{l}\text { Ser capaz de resolver problemas complejos mediante la } \\
\text { aplicación de los conocimientos adquiridos }\end{array}$ \\
\hline
\end{tabular}

(cc) EY-NC-ND 2018, Universitat Politècnica de València

Congreso IN-RED (2018) 


\subsection{Participantes y cronograma}

Antes de desarrollar el proyecto actual, la guía de enseñanza de Fisiología Animal y Humana incluía cinco seminarios, que consistían en dos presentaciones en el aula (trabajando en parejas) basadas en un tema específico o artículos científicos, además de 3 charlas en relación con la las últimas tecnologías de vanguardia relacionadas con la matería impartida.

Como se mencionó anteriormente, la asignatura incluye un grupo que usa el castellano como primer idioma y otro grupo que usa el inglés como idioma extranjero/segundo idioma. El grupo de inglés pertenece al programa ARA, que tiene un máximo de 25 estudiantes por aula. Por otro lado, el grupo de castellano está compuesto por alrededor de 100 estudiantes, divididos a su vez en cuatro grupos tanto para los seminarios como para las sesiones prácticas.

Las actividades docentes serán llevadas a cabo por un catedrático, un profesor titular y 2 profesores asociados, todos ellos pertenecientes al grupo de Laboratorio de Biotecnología Reproductiva, del Instituto de Ciencia y Tecnología Animal (ICTA) de la UPV. El proyecto ha sido diseñado para ser aplicado en 5 lecciones de 1 hora, correspondientes a los 5 seminarios descritos en la guía docente de la asignatura (https://gdocu.upv.es/alfresco/service/api/internal/shared/node/content/12lW_qRYQxadU_0 1JwgT3Q?a=true.pdf). Las actividades de enseñanza se llevarán desde de enero hasta mayo, y tendrán una periocidad mensual para cada uno de los grupos.

El material se entregará a través de la plataforma educativa en línea Poliforma $T$, que se basa en el sistema Sakai (http://asic.blogs.upv.es/tag/sakai/), siendo una herramienta TCI disponible tanto para estudiantes como para profesores. Esta plataforma educativa incluye una gran variedad de opciones, como una descripción de la guía de enseñanza, calendario, libro de calificaciones, anuncios y diferentes herramientas para comunicarse con los estudiantes: correo o chat (foros). Además, incluye una carpeta con recursos y una sección para realizar pruebas / cuestionarios y asignaciones. Finalmente, esta plataforma permitirá la entrega del material, como artículos científicos, guía de las diferentes actividades, material extra-material, screencasts o ejercicios. Por otro lado, los estudiantes también podrán subir sus posters, presentaciones o cualquier otra tarea solicitada. Se creará un foro para mejorar la comunicación, no solo con el responsable de la actividade sino también entre los compañeros de clase.

\section{4. • Desarrollo de la innovación}

Las actividades de enseñanza han sido diseñadas para alcanzar las competencias descritas con anterioridad. Todos ellos han sido organizados para ser realizados en grupos, con 5 miembros como máximo.

\subsubsection{Tarea 1: Experimentación animal en investigación}

Los animales son ampliamente utilizados en el campo de la biotecnología tanto para la investigación básica, desarrollo de fármacos, pruebas de toxicidad, fábricas 
biotecnológicas, etc. Sin embargo, todos estos procedimientos pueden causar dolor o sufrimiento en los animales, por lo que hay regulaciones estrictas para todos los estudios que incluyan experimentación animal. Como consecuencia, actualmente, no es posible solicitar un proyecto de investigación sin previa autorización por parte de un comité de ética independiente. Con el objetivo de introducir a los estudiantes en la regulación que concierne a la experimentación animal, se ha diseñado la siguiente actividad. Utilizando la plataforma Poliforma $T$, los alumnos tendrán acceso a las pautas y el material necesario para la realización de la actividad. Fuera del aula, los alumnos deberán rellenar un formulario tipo de experimentación animal basado en un caso real, el cual es proporcionado a los alumnos. En el formulario, los estudiantes deben describir el protocolo aplicado en el proyecto y confirmar si siguieron las normas de cuidado de la salud de los animales. Una vez en el aula, el profesor responsable de la actividad comentará los errores más comunes y las posibles dudas, y será posible abrir una discusión sobre la necesidad de regular la experimentación con animales.

Conocimiento a aprender: La regulación europea sobre experimentación animal

Habilidades a trabajar: Autonomía e iniciativa personal.

\subsubsection{Tarea 2: Realiza tu propio diseño experimental}

El diseño de experimentos que incluyen seres vivos es una responsabilidad y necesita conocimiento previo. Por tanto, una vez aprendido las reglas para realizar un diseño acorde al bienestar animal, los alumnos aprenderán a diseñar un experimento acorde criterios científicos. Para ello, los estudiantes diseñarán un experimento que incluirá un modelo animal siguiendo las pautas indicadas en la actividad. Para la realización de la actividad, tomarán como referencia artículos científicos que son accesibles tanto en papel como digitalmente en los servicios bibliográficos de la UPV. La actividad será entregada a través de la plataforma Poliforma $T$ y será se presentarda en el aula. Los profesores señalarán los posibles errores o dudas después de cada presentación.

Conocimiento a aprender: Aprender los principios básicos del diseño de un experimento que incluye seres vivos.

Habilidades a trabajar: Comunicación oral y creatividad.

\subsubsection{Tarea 3: Muestrame lo que sabes}

La capacidad de obtener la información más relevante y mostrarla de una manera atractiva es una tarea complicada. Con el objetivo de continuar con el aprendizaje progresivo, en la actividad actual los estudiantes deberán presentar los resultados del artículo científico utilizado en la actividad anterior, en un formato atractivo para llamar la atención a los demás científicos o al público en general. Para ello, los alumnos deberán elaborar un póster científico siguiendo los criterios descritos en la actividad fuera del aula, y una vez en el aula, realizarán una breve descripción de la investigación descrita en el póster. El responsable de la actividad señalará los posibles errores y mejoras.

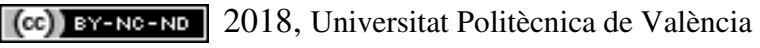

Congreso IN-RED (2018) 
Conocimiento a aprender: Aprender a obtener la información más relevante de un artículo científico.

Habilidades a trabajar: Síntesis, comunicación oral y creatividad.

\subsubsection{Tarea 4: No te creas todo lo lees}

Centrándonos en el mismo artículo científico de las dos actividades anteriores, en esta ocasión los alumnos deberán comprobar la veracidad de la discusión realizada, comprobando que las citas utilizadas son correctas e indicando que información relevante podría haberse incluido. Para ello, los alumnos subirán una presentación con el trabajo a la plataforma Poliforma T, y una vez en el aula realizarán una breve exposición.

Conocimiento a aprender: Aprender a contrastar información.

Habilidades a trabajar: Pensamiento crítico y habilidad para buscar información.

\subsubsection{Tarea 5: Encuentra quien es el culpable}

Una de las tareas más difíciles es aplicar la teoría para resolver un problema real. En la actividad actual, el profesor desarrollará un módulo de aprendizaje en la sección Lección de la plataforma Poliforma T. Este módulo de aprendizaje incluirá un screencast, más información adicional, en relación con los efectos de drogas o medicamentos. Luego, los estudiantes tendrán una actividad final con la descripción de una enfermedad. La tarea consistirá en descubrir cuáles son las causas de las enfermedades y qué órganos están involucrados.

Conocimiento a aprender: Aprender como las drogas/medicinas pueden afectar nuestro sistema nervioso.

Habilidades a trabajar: Pensamiento lógico y deductivo.

\subsection{Evaluación}

Las cinco actividades tendrán un peso del $15 \%$. Después de cada actividad y antes de la siguiente, el maestro entregará las calificaciones individuales para ser consultadas por cada alumno.

Con el objetivo de motivar a los estudiantes, el proyecto docente incluye una nueva metodología educativa: la gamificación. Imitando el ranking utilizado en las máquinas de videojuegos, los estudiantes se clasificarán según la marca que hayan obtenido después de cada actividad. Estableceremos tres categorías: el 33\% con las mejores calificaciones se colocará en la primera categoría, el siguiente $33 \%$ de las mejores calificaciones en la segunda categoría y el resto en la tercera categoría. Los estudiantes ubicados en la primera categoría obtendrán una puntuación extra de 0.5 puntos en la nota final de la asignatura, los estudiantes colocados en la segunda categoría de 0.25 puntos y los clasificados en la última no recibirán niguna puntuación extra.

La puntuación de cada actividad se realizará en base a los indicadores de consecución, los cuales se describen a continuación:

\subsubsection{Tarea 1: Experimentación animal en investigación}

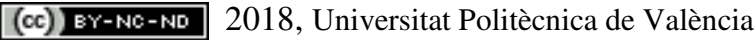

Congreso In-Red (2018) 
Descripción de los indicadores de consecución:

- Es capaz de identificar los puntos más relevantes del Real Decreto sobre experimentación animal.

- Sabe cómo aplicar la normativa descrita para la experimentación animal.

- Ha demostrado autonomía para desarrollar la actividad

La evidencia de la competencia será el formulario lleno entregado por el estudiante en la plataforma Poliforma T. Los alumnos deberán haber rellenado correctamente al menos un $40 \%$ del formulario para obtener una puntuación de aprobado ( 5 puntos) y más . completa $85 \%$ para obtener la máxima nota.

\subsubsection{Tarea 2: Realiza tu propio diseño experimental}

Descripción de los indicadores de consecución:

- Saber diseñar un experimento que se pueda llevar cabo según los criterios de bienestar y científicos especificados

- Conocer el procedimiento para diseño de un experimento que incluyacseres vivos.

- Mostrar creatividad

- Desarrollar habilidades orales

La evidencia de competencia será el documento del diseño experimental entregado por el alumno en la plataforma Poliforma T.

\subsubsection{Tarea 3: Muestrame lo que sabes}

Descripción de los indicadores de consecución:

- Habilidad de síntesis

- Mejorar la lectura comprensiva de artículos científicos escritos en una lengua extranjera (inglés)

- Mostrar creatividad

- Desarrollar habilidades orales

La evidencia de competencia será la presentación de los resultados en un formato de póster entregado por el alumno en la plataforma Poliforma T.

\subsubsection{Tarea 4: No te creas todo lo lees}

Descripción de los indicadores de consecución:

- Habilidad para buscar información

- Pensamiento crítico

- Capacidad de aplicar los conocimiento teóricos a casos prácticos

La evidencia de competencia será el documento, incluida la discusión de los resultados presentados en la tarea 3, y entregado por el alumno en la plataforma Poliforma T.

\subsubsection{Tarea 5: Encuentra quien es el culpable}

Descripción de los indicadores de consecución:

(c) EY-NC-ND 2018, Universitat Politècnica de València 
- Habilidad para resolver problemas complejos

- Capacidad de aplicar los conocimiento teóricos a casos prácticos

- Desarrollo del pensamiento lógico

- Mejora de la habilidaes deductivas

La evidencia de competencia será el documento que incluya la resolución del problema planteado, justificando la respuesta.

La evaluación de las diferentes competencias en cada actividad se llevará a cabo utilizando una nueva herramienta llamada iRubric, disponible en la plataforma Poliforma $\mathrm{T}$ (ejemplo: Tabla 2). Gracias a esta herramienta, iRubric, será posible evaluar las competencias desarrolladas en cada tarea usando una rúbrica específica, prediseñada para clasificar los resultados de aprendizaje en cada actividad.

Table 2. Ejemplo de iRubric para la evaluación de los estudiantes

\begin{tabular}{|c|c|c|c|c|c|c|c|}
\hline Categoría & 1 & 2 & 3 & 4 & Nota & Factor & $\begin{array}{c}\text { Nota } \\
\text { Defintiva }\end{array}$ \\
\hline Síntesis & $\begin{array}{c}\text { No cumple } \\
\text { con el } \\
\text { tiempo, } \\
\text { demasiados } \\
\text { datos } \\
\text { inútiles }\end{array}$ & $\begin{array}{l}\text { Cumple con } \\
\text { el tiempo, } \\
\text { pero } \\
\text { demasiada } \\
\text { información }\end{array}$ & $\begin{array}{c}\text { Cumple con el } \\
\text { tiempo y } \\
\text { muestra } \\
\text { (parcialmente) } \\
\text { los conceptos } \\
\text { más relevantes }\end{array}$ & $\begin{array}{l}\text { Cumple con el } \\
\text { calendario y } \\
\text { muestra (por } \\
\text { completo) los } \\
\text { conceptos más } \\
\text { relevantes }\end{array}$ & & $\mathrm{X} 2$ & \\
\hline Presentación & $\begin{array}{l}\text { Mal } \\
\text { estructurado } \\
\text { y difícil de } \\
\text { entender }\end{array}$ & $\begin{array}{c}\text { Bien } \\
\text { estructurado, } \\
\text { pero es } \\
\text { difícil de } \\
\text { seguir }\end{array}$ & $\begin{array}{c}\text { Bien } \\
\text { estructurado y } \\
\text { argumentado }\end{array}$ & $\begin{array}{c}\text { Bien } \\
\text { estructurado y } \\
\text { argumentado, } \\
\text { incluidos los } \\
\text { elementos que } \\
\text { lo hacen más } \\
\text { claro }\end{array}$ & & & \\
\hline Contentido & $\begin{array}{c}\text { No se ajusta } \\
\text { a lo } \\
\text { solicitado }\end{array}$ & $\begin{array}{c}\text { Se ajusta } \\
\text { parcialmente }\end{array}$ & $\begin{array}{l}\text { Coincide } \\
\text { correctamente } \\
\text { con lo que se } \\
\text { demandaba }\end{array}$ & $\begin{array}{c}\text { Coincide } \\
\text { perfectamente, } \\
\text { y además } \\
\text { incluye más } \\
\text { elementos que } \\
\text { dan un valor } \\
\text { extra }\end{array}$ & & $\mathbf{X 3}$ & \\
\hline $\begin{array}{c}\text { Expresión } \\
\text { oral }\end{array}$ & $\begin{array}{l}\text { No es capaz } \\
\text { de hablar en } \\
\text { público }\end{array}$ & $\begin{array}{l}\text { Muchos } \\
\text { errores }\end{array}$ & $\begin{array}{c}\text { Bien } \\
\text { presentado, } \\
\text { pero con } \\
\text { algunos } \\
\text { errores }\end{array}$ & $\begin{array}{c}\text { Bien } \\
\text { presentado, sin } \\
\text { errores }\end{array}$ & & & \\
\hline
\end{tabular}

\subsection{Conclusiones}

El objetivo de este proyecto docente es ayudar a los estudiantes a adquirir tanto las competencias como las habilidades propopuestas para la asignatura "Fisiología Animal y Humana" a través de la implementación de la clase inversa y el uso de herramientas TIC. El 
entorno donde se aplicará esta nueva metodología educativa serán en dos grupos docentes:: alumnos que usan el inglés o el español como lengua vehicular.

Para evaluar la efectividad del proyecto de enseñanza, compararemos la evaluación de competencias antes y después de la implantación del programa de enseñanza. Además, también se comparará la calificación final respecto a años anteriores, con el objetivo de observar si la nueva estrategia educativa ha tenido un impacto en los resultados de toda la asignatura, y no solo en parte relacionada con los seminarios.Finalmente, grado de satisfacción se evaluará a través de un cuestionario anónimo, en el que se les preguntará a los estudiantes qué actividades han sido más atractivas y qué aspectos cambiarán en el futuro.

Los resultados obtenidos serán presentados para ser difundidos en varias conferencias educativas, tales como:

- INRED 2018, IV Congreso Nacional de Innovación Educativa y Docencia en Red.

- $\quad 4^{\mathrm{a}}$ Conferencia Internacional sobre Avances en Educación Superior (HEAd'18).

\subsection{Referencias}

BREWER, R., ANTHONY, L., BROWN, Q., IRWIN, G., NIAS, J., y TATE, B. (2013). "Using Gamification to Motivate Children to Complete Empirical Studies in Lab Environments". In Proceedings of the 12th International Conference on Interaction Design and Children (pp. 388-391). New York, NY, USA: ACM. https://doi.org/10.1145/2485760.2485816

DAVIES, R. S., DEAN, D. L., y BALL, N. (2013). "Flipping the classroom and instructional technology integration in a college-level information systems spreadsheet course". Educational Technology Research and Development, Vol. 61(4), pp. 563-580. https://doi.org/10.1007/s11423-013-9305-6

SPECTOR, J. M., MERRILL, M. D., ELEN, J., y BISHOP, M. J., E.D. y DAVIES, R. S., y WEST, R. E. (2014). Technology Integration in Schools. In Handbook of Research on Educational Communications and Technology (pp. 841-853). New York, NY: Springer New York. https://doi.org/10.1007/978-1-4614-3185-5_68

DETERDING, S., DIXON, D., KHALED, R., y NACKE, L. (2011). "From game design elements to gamefulness: Defining gamification". Proceedings of the 15th International Academic MindTrek Conference on Envisioning Future Media Environments - MindTrek '11, 9-11. https://doi.org/10.1145/2181037.2181040

DRENT, M., y MEELISSEN, M. (2008). "Which factors obstruct or stimulate teacher educators to use ICT innovatively?" Computers y Education, Vol. 51(1), pp. 187199. https://doi.org/https://doi.org/10.1016/j.compedu.2007.05.001

FITZ-WALTER, Z., TJONDRONEGORO, D., y WYETH, P. (2011). "Orientation Passport: using gamification to engage university students". Proceedings of the 23rd Australian Computer-Human Interaction Conference on - OzCHI '11, 122-125. https://doi.org/10.1145/2071536.2071554

HUOTARI, K., y HAMARI, J. (2012). "Defining gamification". Proceeding of the 16th International Academic MindTrek Conference on - MindTrek '12, 17. https://doi.org/10.1145/2393132.2393137

IOSUP, A., y EPEMA, D. (2014). "An experience report on using gamification in technical higher education". Proceedings of the 45th ACM Technical Symposium on Computer

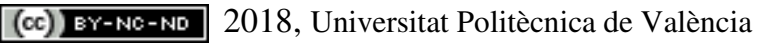

Congreso IN-RED (2018) 
Science Education - SIGCSE '14, (2008), 27-32. https://doi.org/10.1145/2538862.2538899

KHAN, S. (2012). The one world schoolhouse: Education reimagined. London: Hodder and Stoughton.

LAJOIE, S. P., y AZEVEDO, R. (2000). Cognitive tools for medical informatics. Computers as Cognitive Tools II: No More Walls: Theory Change, Paradigm Shifts and Their Influence on the Use of Computers for Instructional Purposes, 247-271.

THOMASIAN, J. (2012). Building a science, technology, engineering and math education agenda: an update of state actions. National Governors Association Center for Best Practices.

VALTONEN, T., HACKLIN, S., KONTKANEN, S., HARTIKAINEN-AHIA, A., KÄRKKÄINEN, S., y KUKKONEN, J. (2013). "Pre-service teachers' experiences of using social software applications for collaborative inquiry". Computers y Education, Vol. 69, pp. 85-95. https://doi.org/https://doi.org/10.1016/j.compedu.2013.07.001

WANG, S. K., HSU, H. Y., REEVES, T. C., y COSTER, D. C. (2014). "Professional development to enhance teachers' practices in using information and communication technologies (ICTs) as cognitive tools: Lessons learned from a design-based research study". Computers and Education, Vol. 79, pp. 101-115. https://doi.org/10.1016/j.compedu.2014.07.006

\subsection{Agradecimientos}

Este proyecto ha sido financiado por el Vicerrectorado de Estudios, Calidad y Acreditación de la Universidad Politécnica de Valencia (UPV) en el marco del Programa Proyectos de Innovación y Mejora Educativa (PIME/2017/B/010) y la Escuela de Ingeniería Agrícola y Medio Ambiente ( ETSIAMN) de la Universitat Politècnica de València (UPV). 


\title{
Evaluación de las competencias de trabajo en equipo y liderazgo y la comunicación efectiva en la asignatura de Distribución de la información espacial del MUIGG.
}

\author{
Eloina Coll Aliaga a , José Carlos Martínez LLario ${ }^{a}$ \\ a Departamento de Ingeniería Cartográfica, Geodesia y Fotogrametría (ecoll@cgf.upv.es), \\ (jomarlla@cgf.upv.es)
}

\begin{abstract}
This paper presents a real case used in the subject of master's degree for the evaluation of the transversal competences of leadership and team work and effective communication. The students develop these cross-disciplinary competences as well as the specific competences of the subject by acquiring a better understanding of the real work environment.
\end{abstract}

Keywords: leadership, teamwork, effective communication. Inspire

\begin{abstract}
Resumen
Este trabajo presenta un caso real utilizado en la asignatura de máster para la evaluación de las competencias transversales de liderazgo y trabajo en equipo y comunicación efectiva. Los estudiantes desarrollan dichas competencias transversales a la vez que las competencias específicas de la materia adquiriendo una mejor comprensión del entorno de trabajo real.
\end{abstract}

Palabras clave: liderazgo, trabajo en equipo, comunicación efectiva. Inspire

\section{Introducción}

La asignatura de Distribución de la Información Espacial es una asignatura troncal del Máster Universitario en Ingeniería en Geomática y Geoinformación de la Universitat Politècnica de València que cuenta con 6 créditos ECTS, (3 teóricos y 3 prácticos). Esta asignatura se centra en que los estudiantes sean expertos en las especificaciones de datos de la Directiva Europea Inspire. Se trabaja con el Marco Normativo de la información espacial. Se estudia el modelo genérico conceptual de Inspire y las especificaciones de datos. Se realiza la gestión de los modelos de datos utilizando bases de datos espaciales, operaciones de análisis espacial según especificación OGC (Open Geospatial Consortium) y se implementan modelos de datos cartográficos Inspire con postgreSQL y postGIS. Estos conocimientos técnicos son altamente demandados en los puestos de trabajos en los que se requieren técnicos especialistas en Geoinformación. 
En la actualidad, las empresas buscan estudiantes que además de ser buenos técnicamente, presenten otras habilidades, es decir, los estudiantes necesitan además de las competencias específicas, adquirir competencias transversales (CT) y para ello se debe utilizar un enfoque del aprendizaje basado en competencias y hacer entender al estudiante que es fundamental que se incorporen técnicas y métodos nuevos para que puedan aplicar los conocimientos a situaciones nuevas y puedan integrar las actitudes y valores para afrontar nuevos retos (Villa, 2011).

El aprendizaje basado en competencias ha supuesto una sustancial transformación de la docencia universitaria, tanto en lo referente a las metodologías empleadas como en la implantación de sistemas de evaluación y control de su calidad (Hermosilla, 2013). Para conseguir este aprendizaje la Universitat Politècnica de València (UPV) desarrolla, desde el curso 2013-14, un proyecto institucional que define 13 CT (ICE-UPV 2018) y tiene como objetivo principal que los egresados de cualquier título oficial impartido en esta universidad acrediten dichas CT. En dicho Proyecto se establecen actividades formativas y pautas para su evaluación a base de rúbricas y es la Entidad Responsable del Título (ERT) la que se encarga de repartir dichas competencias entre las asignaturas para que se trabajen a la vez que se imparte la docencia.

\subsection{Objetivos}

En el curso 2014-2015 se imparte por primera vez esta asignatura y se combina la docencia de clase magistral con algunas clases en las que se desarrollan trabajos colaborativos entre los alumnos y el profesor para estudiar una posible implementación de una especificación técnica. Se plantea que algunos alumnos expliquen los resultados obtenidos al resto de la clase y se observa que es una experiencia por la que deberían pasar todos los alumnos y que conociendo unas normas preestablecidas para realizar una presentación oral, sería fácil realizar una evaluación entre ellos. Al siguiente curso (2015-2016) desde la ERT se plantea que las asignaturas sean puntos de control de dos de las trece competencias transversales y se asignan a esta asignatura las competencias de liderazgo y trabajo en grupo y comunicación efectiva.

Es durante este curso acádemico, cuando se decide que todos los alumnos deben preparar en grupo una especificación técnica durante las clases presenciales y realizar una exposición publica donde todos ellos puedan ser evaluados por sus compañeros de la competencia oral de la comunicación efectiva, para ello se utilizan rúbricas de coevaluación y autoevaluación (De Miguel, 2006) conocidas desde el primer día de clase. Además se utilizan las rúbricas que han sido desarrolladas por los grupos de trabajo del ICE (https://www.upv.es/entidades/ICE/info/U0724624.pdf).

El objetivo perseguido es que el alumno adquiera las competencias transversales que son punto de control a la vez que las especificas. Para la comunicación efectiva, hay que tener en cuenta la parte oral y la parte escrita y para el trabajo en grupo y liderazgo hay que organizar actividades en las que los alumnos trabajen en grupo y que además demuestren el papel de lideres. Las competencias deben ser evaluadas durante el trascurso de la asignatura.

La presente comunicación pretende resumir esta experiencia docente, detallando las conclusiones a las que tanto profesores como estudiantes hemos llegado.

(cc) EY-NC-ND 2018, Universitat Politècnica de València

Congreso IN-RED (2018) 


\subsection{Procedimiento utilizado}

Durante el transcurso de la asignatura se van a realizar 6 trabajos en grupo (2 en la parte de teoría y 4 en la parte práctica), estos van a servir para valorar la competencia de liderazgo y trabajo en grupo. Se pretende que los estudiantes trabajen en diferentes grupos con criterios diferentes durante la asignatura y que sean capaces de obtener evidencias de dicha competencia. Para ello, deberán entregar actas de las sesiones de trabajo donde se explique el orden del día, los componentes de dicha reunión de trabajo y las conclusiones obtenidas durante la sesión.

Se realizan tres tareas durante las clases prácticas que se encuentran en el PoliformaT y que se realizan en grupo de 2 personas. Una de las tareas se realiza dentro de un módulo de aprendizaje (Fig, 1) donde existen objetos de aprendizaje que ayudan a los estudiantes a realizar más fácilmente las prácticas. Las prácticas son evaluadas por observación y por corrección de la memoria entregada en la tarea. Esta memoria servirá para evaluar la comunicación escrita.

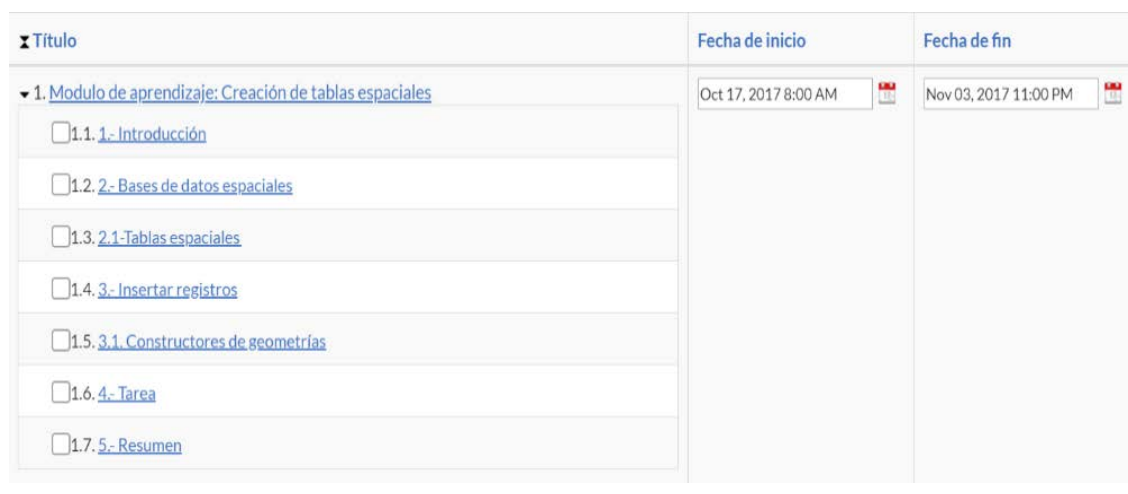

Fig. 1 Modulo de aprendizaje

Existen dos exposiciones públicas para adquirir la competencia de comunicación oral y al realizarse en grupo también sirve para evaluar el trabajo en grupo.

La primera se realiza en grupos de 4 personas elegidos por el profesor. En el PoliformaT existen presentaciones técnicas de formatos exigidos por el OGC para trabajar con información espacial y cada grupo elige una presentación. Durante una sesión de dos horas trabajan en el aula y al finalizar deben entregar un acta de la reunión realizada con las conclusiones sacadas del tema. Existe un día marcado en la temporización (fig. 2) donde expondrán el tema y serán evaluados con la rúbrica que se presenta en la tabla1 por parte de sus compañeros.

Dentro de la Directiva Inspire existen muchas especificaciones de datos. En una sesión de teoría se explica el modelo genérico de Inspire y se organizan los estudiantes en grupos de 5 personas para explicar una de las siguientes especificaciones de datos: Hidrografía, Redes 
Evaluación de las competencias de trabajo en equipo y liderazgo y la comunicación efectiva en la asignatura de Distribución de la información espacial del MUIGG.

de transporte, Unidades administrativas, Ocupación del suelo, Direcciones y nombres geográficos.

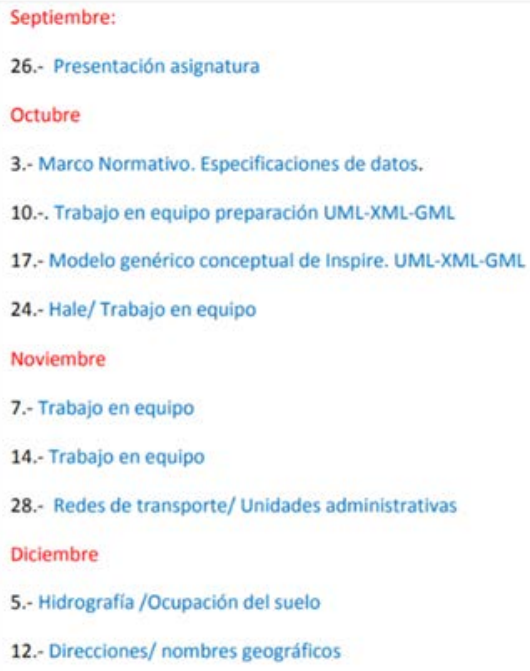

Fig. 2 Temporización de la asignatura

Los integrantes de estos equipos se eligen entre los estudiantes, así como la especificación que van a desarrollar. Durante tres sesiones de 2 horas se trabaja en clase para preparar la especificación y fuera del horario de la asignatura deben de realizar al menos dos reuniones más. En total deben entregar actas como mínimo de 5 reuniones, donde especificarán quien ha asumido el papel de líder y qué tareas han sido asignadas a cada uno de los miembros del grupo durante la sesión.

Las defensas de estas especificaciones están en la temporización de la asignatura y una de las condiciones que se pide es que se utilicen técnicas diferentes en cada presentación. Es decir, la dificultad de la especificación va de menor a mayor, ya que los conceptos generales se van a ir repitiendo, pero se exige que los recursos utilizados para el tema específico sea diferente (hacer un ejercicio práctico, un test, un kahoot, trabajar en equipo con diferentes cartografías, etc.). La complejidad técnica será menor, pero la confección de la presentación mayor.

Tabla 1. Rubrica utilizada para la coevaluación

\section{4}

3

\section{2}




\begin{tabular}{|c|c|c|c|c|}
\hline Pronunciación & $\begin{array}{l}\text { Habla despacio y } \\
\text { claro y vocaliza } \\
\text { bien }\end{array}$ & 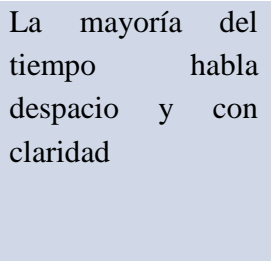 & $\begin{array}{l}\text { Unas veces } \\
\text { habla despacio } \\
\text { y con claridad } \\
\text { y otras es } \\
\text { difícil de } \\
\text { entender }\end{array}$ & $\begin{array}{l}\text { Habla rápido } \\
\text { o presenta } \\
\text { espacios sin } \\
\text { hablar. Con } \\
\text { muletillas }\end{array}$ \\
\hline Volumen & $\begin{array}{l}\text { Adecuado y lo } \\
\text { suficientemente } \\
\text { alto cuando } \\
\text { enfatiza } \\
\text { importante }\end{array}$ & $\begin{array}{l}\text { Levanta demasiado } \\
\text { la voz todo el } \\
\text { tiempo. }\end{array}$ & $\begin{array}{l}\text { Habla } \\
\text { demasiado bajo } \\
\text { al exponer y de } \\
\text { forma } \\
\text { monótona. }\end{array}$ & $\begin{array}{l}\text { El volumen } \\
\text { es muy débil, } \\
\text { casi no se le } \\
\text { oye }\end{array}$ \\
\hline $\begin{array}{l}\text { Postura del } \\
\text { cuerpo/contacto visual }\end{array}$ & $\begin{array}{lr}\text { La postura y los } \\
\text { gestos son muy } \\
\text { adecuados. } \\
\text { a todos los } \\
\text { compañeros con } \\
\text { naturalidad }\end{array}$ & $\begin{array}{lr}\text { La postura y los } \\
\text { gestos } & \text { son } \\
\text { adecuados pero } \\
\text { está apoyado en } \\
\text { algún lugar. Suele } \\
\text { mirar sólo a alguna } \\
\text { parte de la } \\
\text { audiencia. }\end{array}$ & $\begin{array}{l}\text { En ocasiones le } \\
\text { da la espalda a } \\
\text { sus } \\
\text { compañeros. } \\
\text { Algunas veces } \\
\text { mantiene la } \\
\text { postura } \\
\text { adecuada. }\end{array}$ & $\begin{array}{l}\text { No mantiene } \\
\text { la postura } \\
\text { apropiada de } \\
\text { una } \\
\text { exposición } \\
\text { oral y la } \\
\text { mayoría de } \\
\text { las veces no } \\
\text { mira a sus } \\
\text { compañeros. }\end{array}$ \\
\hline Contenido & $\begin{array}{l}\text { Demuestra un } \\
\text { completo } \\
\text { entendimiento } \\
\text { del tema. }\end{array}$ & $\begin{array}{l}\text { Demuestra un buen } \\
\text { entendimiento del } \\
\text { tema. }\end{array}$ & $\begin{array}{l}\text { Demuestra } \\
\text { entendimiento } \\
\text { de partes del } \\
\text { tema. }\end{array}$ & $\begin{array}{l}\text { No parece } \\
\text { entender } \\
\text { muy bien el } \\
\text { tema. }\end{array}$ \\
\hline Vocabulario & $\begin{array}{l}\text { Usa vocabulario } \\
\text { técnico que } \\
\text { enriquece a la } \\
\text { audiencia. }\end{array}$ & $\begin{array}{ll}\text { Usa vocabulario } \\
\text { técnico e incluye } \\
\text { algunas palabras } \\
\text { nuevas para la } \\
\text { mayor parte de la } \\
\text { audiencia }\end{array}$ & $\begin{array}{l}\text { Usa } \\
\text { vocabulario } \\
\text { apropiado y } \\
\text { conocido por la } \\
\text { audiencia. }\end{array}$ & $\begin{array}{l}\text { No usa } \\
\text { vocabulario } \\
\text { técnico y } \\
\text { repite } \\
\text { muchas } \\
\text { veces las } \\
\text { mismas } \\
\text { palabras }\end{array}$ \\
\hline $\begin{array}{l}\text { Comprensión/secuencia } \\
\text { ción }\end{array}$ & $\begin{array}{lr}\begin{array}{l}\text { Presenta } \\
\text { conexión }\end{array} \text { una } \\
\text { slguida, el } \\
\text { lógico en } \\
\text { exposición } \\
\text { contesta } \\
\text { preguntas } \\
\text { planteadas. }\end{array}$ & $\begin{array}{l}\text { Puede contestar } \\
\text { algunas preguntas y } \\
\text { la conexión entre } \\
\text { las diapositivas es } \\
\text { bastante buena, }\end{array}$ & $\begin{array}{l}\text { Realiza muy } \\
\text { poco la } \\
\text { conexión entre } \\
\text { las diapositivas } \\
\text { y contesta muy } \\
\text { poco a las } \\
\text { preguntas }\end{array}$ & 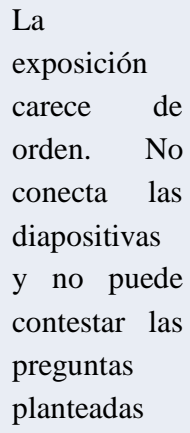 \\
\hline
\end{tabular}


Evaluación de las competencias de trabajo en equipo y liderazgo y la comunicación efectiva en la asignatura de Distribución de la información espacial del MUIGG.

Los grupos son evaluados utilizando la tabla 2. Cada alumno rellena su nombre y evalúa a los 4 compañeros que aparecen en la tabla.

Tabla 2. Tabla que rellenan los estudiantes en la coevaluación.

\begin{tabular}{|l|l|l|l|l|}
\hline Alumno: & Nombre1 & Nombre2 & Nombre3 & Nombre4 \\
\hline Pronunciación & & & \\
\hline Volumen & & & \\
\hline Postura del cuerpo/contacto & & \\
visual
\end{tabular}

El tercer trabajo en grupo es totalmente práctico y se realiza en grupo de 2 personas. Se trata de realizar la implementación de una especificación de datos utilizando bases de datos espaciales. Se realiza durante 5 sesiones de 2 horas, se entrega el código implementado y la defensa es individual.

\subsection{Resultados}

En la figura 3 se muestran los ítems de evaluación donde se evalúan a la vez las competencias específicas y las transversales: 3 trabajos prácticos en grupo 30\%. Presentación por grupos de la especificación técnica y entrega de las actas de las reuniones realizadas 30\%. Coevaluación alumno profesor 10\% e Implementación del modelo de datos $30 \%$. Entrega de la memoria y defensa sobre el ordenador del laboratorio donde se tenga instalado el modelo.

\begin{tabular}{|c|c|c|c|c|c|c|c|c|}
\hline Titulo* & & Media" & Fecha de entrega & Publicada para estudiantes & Incluido en la nota final & Ordenar & ndo $=$ & Editor de notas'". \\
\hline Ejercicios SOL & Editar & $9 / 10$ & 03-nov-2017 & s & Si & 1 & $\bar{\nabla}$ & desde Tareas \\
\hline creación de tablas & $\underline{\text { Editar }}$ & $9 / 10$ & 10-nov-2017 & s & Si & $2=$ & $=\mp$ & desde Tareas \\
\hline Creation of spatial tables & $\underline{\text { Editar }}$ & $9 / 10$ & 10-nov-2017 & $\mathrm{s}$ & Si & 3 & $=$ & desde Tareas \\
\hline Relaciones yoperadores espaciales & $\underline{\text { Editar }}$ & $9 / 10$ & 11-ene-2018 & s & Si & 4 & $=\mp$ & desde Tareas \\
\hline relations and spatial operators & $\underline{\text { Editar }}$ & 9/10 & 11 -ene-2018 & s & Si & 5 & $=\mp$ & desde Tareas \\
\hline coevaluación & $\underline{\text { Editar }}$ & $7 / 10$ & & s & Si & 6 & $=$ & \\
\hline Implementación modelo & $\underline{\text { Editar }}$ & $21 / 30$ & - & s & Sí & $7=$ & $=$ & \\
\hline presentacion & Editar & $22 / 30$ & - & $\mathrm{s}$ & $\mathrm{Si}$ & 8 & 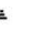 & \\
\hline
\end{tabular}

Fig. 3 Resumen de ítems de calificación (PoliformaT)

(cc) EY-NC-ND 2018, Universitat Politècnica de València

Congreso IN-RED (2018) 
Existe una coevaluación por parte de los estudiantes y del profesor (Fig. 4)

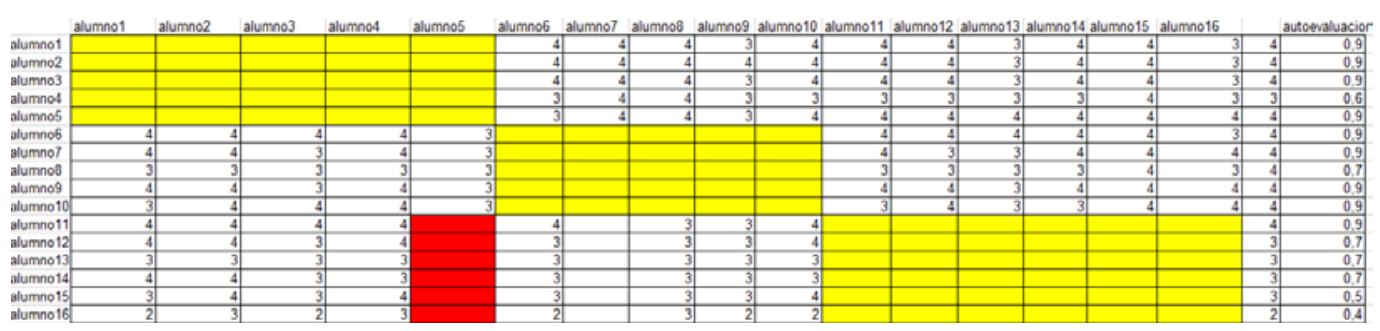

Fig. 4 Coevaluación de alumnos curso 2017-18

Al finalizar la asignatura se realiza una autoevaluación genérica (Fig. 5) donde el alumno evalúa su aportación en clase, su implicación en el trabajo en grupo y en las actividades individuales. Comenta su satisfacción personal y la valoración global de la asignatura.

Al finalizar el curso: Autoevaluación genérica

\begin{tabular}{|l|l|}
\hline & Puntos (1-10) \\
\hline 1. Participación y aportaciones en clase & \\
\hline $\begin{array}{l}\text { 2. Implicación en el trabajo en grupo (organización, } \\
\text { planificación, cumplimiento, participación, } \\
\text { aportaciones...) }\end{array}$ & \\
\hline 3. Capacidad de trabajo cooperativo & \\
\hline $\begin{array}{l}\text { 4. Implicación en las actividades individuales(organización, planificación, } \\
\text { cumplimiento...) }\end{array}$ & \\
\hline 5. Dedicación de tiempo a las diferentes actividades & \\
\hline 6. Apropiación de los contenidos trabajados & \\
\hline 7. Relaciones entre los miembros del grupo de trabajo & \\
\hline 8. Seguimiento de las tutorías & \\
\hline 9. Satisfacción personal & \\
\hline 10. Valoración GLOBAL & \\
\hline
\end{tabular}

Fig. 5 Autoevaluación genérica

\section{Conclusiones}

La principal conclusión que se obtiene, es que los estudiantes desde el inicio de la asignatura aceptan la evaluación conjunta de las competencias específicas y transversales.

$\mathrm{Al}$ tener que realizar varias exposiciones y tener que evaluar al resto de compañeros, hace que las clases sean más productivas.

En la asignatura se realiza un viaje de prácticas al Instituto Geográfico Nacional, que es el encargado de llevar a cabo la transformación de los datos espaciales a las especificaciones técnicas de Inspire y resulta altamente satisfactorio comprobar que los estudiantes se encuentran a la altura del lenguaje técnico utilizado por los responsables de estos trabajos. Recibimos felicitaciones del nivel que tienen y esto es debido a que trabajan durante 5 
sesiones profundamente con una especificación y luego la exponen al resto de sus compañeros. Además evalúan las exposiciones de los otros grupos de trabajo y finalmente realizan la implementación del modelo de datos de una especificación no vista en clase en una base de datos espacial.

Para facilitar el trabajo de los estudiantes se han desarrollado objetos de aprendizaje y módulo de aprendizaje que han sido utilizados para desarrollar la parte práctica.

El rendimiento académico de la asignatura es muy bueno, el 90\% de los estudiantes adquieren un nivel alto de las competencias que son punto de control y están muy contentos con el tipo de docencia recibida.

\section{Referencias.}

ICE-UPV (2018). Portal de competencias transversales de la Universitat Politècnica de València. http://www.upv.es/contenidos/COMPTRAN/ [Online; acceso 23-Marzo-2018].

https://www.upv.es/entidades/ICE/info/U0724624.pdf

HERMOSILLA Z., CLEMENTE M., TRINIDAD A., ANDRÉS J. (2013) “Competencia en comunicación oral: un reto para el ingeniero" En Garrigos et al. "New changes in technology and innovation.” INNODOCT 2013. Universidad Politècnica de Valencia.

DE MIGUEL, M. (2006) “Metodologías de enseñanza para el desarrollo de competencias. Orientaciones para el profesorado universitario ante el Espacio Europeo de Educación Superior.” en Educatio siglo XXI, Vol 24, pp 207-210.

VILLA SÁNCHEZ A., POBLETE RUIZ M. (2011) "Evaluación de competencias genéricas: principios, oportunidades y limitaciones” Bordón, Vol 63 Nº, pp147-170. 


\title{
Aplicación de metodologías de aprendizaje activo para promover la adquisición de competencias en la asignatura Minimización y Valorización de Residuos
}

\section{Luisa María Gómez Sainero a , Elena Díaz Nieto ${ }^{b}$, Asunción Quintanilla Gómez}

Sección de Ingeniería Química, Facultad de Ciencias, Universidad Autónoma de Madrid, Cantoblanco, 28049 Madrid, Spain luisa.gomez@uam.es, $\underline{\text { belena.diaz@uam.es, }}$ a asuncion.quintanilla@uam.es

\begin{abstract}
The subject of Waste Minimization and Valorization of the Master in Chemical Engineering from the Rey Juan Carlos University and Autonomous University of Madrid (elective with reduced number of students), was designed and taught using a methodology based on active learning that has been evaluated after four years of experience. In order to achieve the acquisition of all the competences associated with the subject, and therefore better learning outcomes, a great diversity of training activities were selected, aimed at enhancing each of the basic, general, transversal and specific competences assigned. These include cooperative, collaborative, problem-based learning methodologies, case studies, flipping and networked teaching. The activities that give more prominence to the student, Case Studies and Presentation, allow to evaluate more competences, they lead to very good learning results, with high grades in the frequent evaluation (8-9,3) and favor the acquisition and integration of the knowledge thus obtaining good final grades. In addition, the methodology applied encouraged the students' commitment and motivation, with the assessment of the subjects being high and superior to the average of the master's degree and the other elective subjects.
\end{abstract}

Keywords: Active learning, problems solving, case studies, flipped learning, network teaching.

\footnotetext{
Resumen

La asignatura de Minimización y Valorización de Residuos del Máster en Ingeniería Química por la Universidad Rey Juan Carlos y Universidad Autonoma de Madrid (optativa con número de alumnos reducido), se diseñó e impartió aplicando una metodología basada en el aprendizaje activo y participativo que ha sido evaluada tras cuatro años de experiencia. Con el objeto de conseguir la adquisición de todas las competencias asociadas a la asignatura, y por ende unos mejores resultados de aprendizaje, se seleccionaron una gran diversidad de actividades formativas enfocadas a potenciar cada una de las competencias básicas, generales, transversales y específicas asignadas. Éstas incluyen metodologías de aprendizaje colaborativo, cooperativo, basado en problemas, en casos de estudio, aula
} 
inversa y docencia en red. Las actividades que dan más protagonismo al estudiante, Casos de Estudio y Presentación, permiten evaluar más competencias, conducen a muy buenos resultados de aprendizaje, con altas calificaciones en la evaluación frecuente (8-9,3) y favorecen la adquisición e integración de los conocimientos lo que se traduce en buenas calificaciones finales. Además la metodología aplicada fomentó el compromiso y motivación de los estudiantes siendo la valoración de la asignatura por parte de los mismos alta y superior a la media del máster y de las otras asignaturas optativas.

Palabras clave: Aprendizaje activo, resolución de problemas, estudio de casos, aula inversa, docencia en red.

\section{Introducción}

Una de las principales funciones de la Universidad es la formación de profesionales que sean eficaces en el ejercicio de su profesión, contribuyendo al desarrollo científico, económico y social del país. Cumplir con este objetivo no es tarea fácil debido, principalmente, a la dificultad que arroja el crecimiento exponencial del saber en cualquiera de sus ramas, la falta de motivación de los estudiantes como consecuencia del marco social actual, y el carácter dinámico de nuestra sociedad, cuyo continuo cambio impide predecir cual será la formación que se exigirá a los profesionales en los próximos años. Estos factores han contribuido al cambio de orientación de las enseñanazas universitarias, que se han adaptado a las directrices del Espacio Europeo de Educación Superior (Sanabria-Codesal, 2014). Como consecuencia, los actuales planes de estudio y programaciones docentes se diseñan tomando como eje de referencia el propio aprendizaje de los alumnos. De esta manera la formación deja de entenderse como una simple transmisión de conocimientos, y se orienta hacia la adquisición de competencias que pretenden despertar en los alumnos actitudes receptivas y creativas que permitan desarrollar su capacidad de análisis y síntesis, imaginación, su iniciativa propia o capacidad para comunicarse y trabajar en equipo, aspectos altamente valorables en el perfil profesional de un Ingeniero Químico. El sector de la Industria Química, está influenciado tanto por el componente tecnológico como por el científico y sometido a un elevado ritmo de innovación. Existen más de 10 millones de sustancias químicas catalogadas e infinidad de procesos químicos (Heaton, 1996). Las empresas del sector reclaman profesionales cualificados capaces de adaptarse a las necesidades del momento, de conseguir información por sus propios medios, de comprenderla y criticarla, de crear e innovar.

La adquisición de estas competencias no es tarea sencilla y numerosos estudios en educación señalan la necesidad de emplear para ello metodologías activas que fomenten la participación del alumno en el proceso formativo (Olmedo, 2013). En general, el empleo de estas metodologías, entre las que se encuentran el aprendizaje colaborativo, cooperativo, basado en problemas, en casos de estudio o el aula inversa, conlleva una mejora significativa de los resultados de aprendizaje (Prince, 2004; Kember, 2005). El reto para los docentes radica en ampliar el repertorio metodológico intentando conocer bien $\mathrm{y}$ en profundidad las

(cc) EY-NC-ND 2018, Universitat Politècnica de València

Congreso IN-RED (2018) 
posibilidades de las diferentes estrategias e ir experimentado su aplicación en la práctica educativa (Fernández March, 2006).

El Máster en Ingeniería Química organizado conjuntamente por la Universidad Autónoma de Madrid y la Universidad Rey Juan Carlos, verificado en 2012 y modificado en 2017 por ANECA, ofrece al estudiante una formación avanzada para el ejercicio de la profesión de Ingeniero Químico. La estructura del plan de estudios se recoge en la Fig. 1 y toda la información relacionada con el título puede consultarse en el link del Máster Universitario en Ingeniería Química (Máster Universitario en Ingeniería Química). Se trata de un máster oficial con atribuciones profesionales, cuyas competencias se encuentran definidas en el Real Decreto 1393/2007 (básicas), 861/2010 (generales), 1027/2011 (transversales) y en la Resolución 12977 de 8 de junio de 2009, de la Secretaría General de Universidades (específicas).

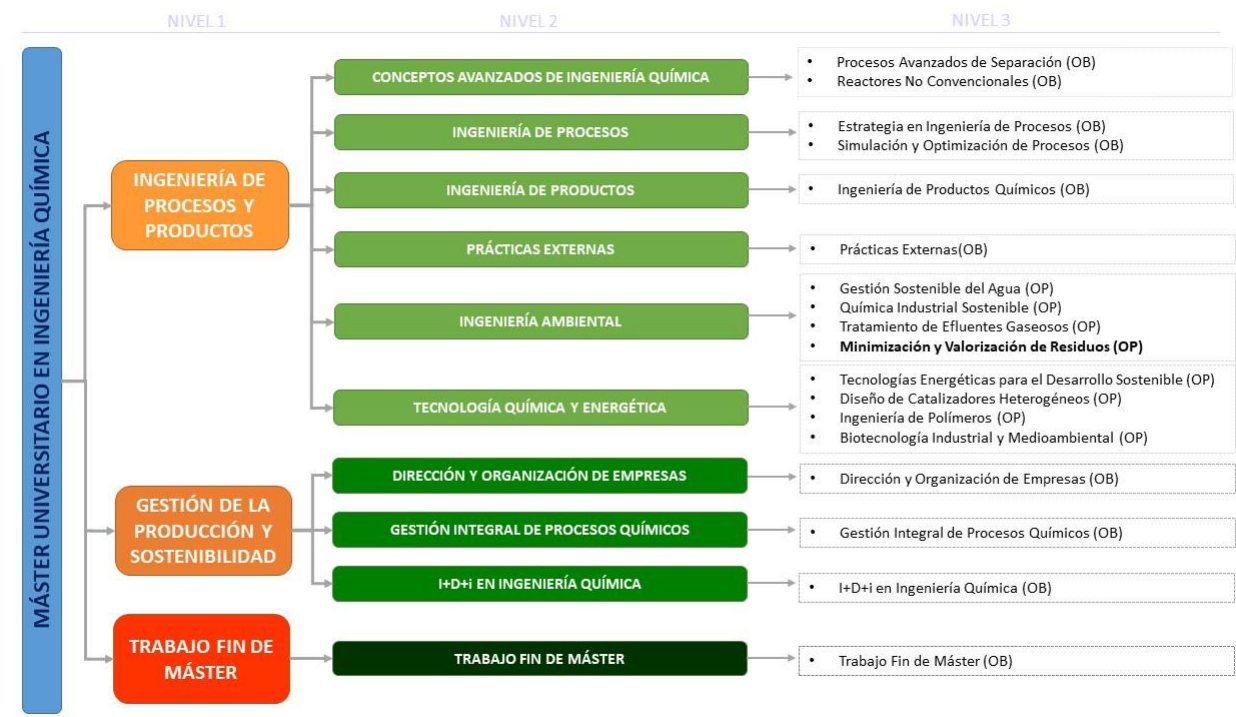

Fig. 1 Estructura del Máster en Ingeniería Química: NIVEL 1: módulos; NIVEL 2: materias; NIVEL 3: asignaturas. Se distinguen asignturas de carácter obligatorio $(O B)$ y optativo $(O P)$.

La asignatura de Minimización y Valorizacion de Residuos (MVR) es de carácter cuatrimestral, optativa, dotada con tres ECTS e impartida durante las primeras ocho semanas de curso. El número máximo de estudiantes está comprendido entre 25 y 30 . Los objetivos, competencias, contenidos, metodología y sistema de evaluación se recogen en la Guía Docente (Guía Docente de Minimización y Valorización de Residuos). El carácter optativo de la asignatura, el reducido número de estudiantes, su formación y su grado de madurez tras haber finalizado los estudios de grado, y el número de competencias adscritas a la asignatura (21) motivó al equipo docente a establecer diferentes metodologías activas para el desarrollo de la enseñanza, al cumplir la asignatura con los requisitos que garantizan el éxito de esta metodología (Fernández, 2016). 


\section{Objetivos}

El objetivo principal de este trabajo es la introducción de metodologías de aprendizaje activo y participativo que fomenten la adquisición de las competencias de la asignatura optativa Minimización y Valorización de Residuos del Máster en Ingeniería Química por la URJC y la UAM, centradas en la aplicación de los conocimientos adquiridos para al desarrollo de estrategias de gestión de residuos y de diseño de procesos de valorización de los mismos. Para ello, se han propuesto una serie de actividades docentes, coherentes con las competencias a adquirir, enmarcadas en metodologías de aprendizaje colaborativo, cooperativo, basado en problemas, en casos de estudio, aula inversa y docencia en red. La evaluación de la adquisición de las competencias como resultado de la implementación de esta metodología se realiza en base a las calificaciones obtenidas por los estudiantes (examen, evaluación frecuente y calificación global) en los primeros cuatro cursos de impartición en el máster.

Este trabajo nace de la convicción de que la enseñanza en el ámbito de la Minimización y Valorización de residuos debe tener lugar en situaciones lo más cercanas posibles al contexto profesional, con un nivel de dificultad y complejidad similares a los que los futuros egresados se encontrarán en la práctica profesional y, especialmente, bajo una actitud positiva de un aprendizaje activo útil para enfrentarse a problemas reales, aspecto que se evalúa de acuerdo al grado de satisfacción de los estudiantes con la asignatura.

\section{Desarrollo de la innovación}

\subsection{Presentación}

Tanto desde un punto de vista socioeconómico como técnico, el sector del tratamiento (y en particular de valorización) de residuos está en continuo crecimiento y constituye una fuente importante de empleo verde. Todo ello debe responder a las demandas de la sociedad, que percibe la generación de residuos como una de las mayores preocupaciones ambientales y como una responsabilidad individual y colectiva. El incremento en la generación de residuos a escala global es continuo y la prevención y correcta gestión son esenciales para evitar sus impactos negativos sobre el medio ambiente y la salud humana. Si hasta hace pocos años la valorización de residuos tenía como objetivo principal el cumplimiento de la normativa vigente, actualmente se está convirtiendo en una estrategia de negocio, lo que tiene una gran influencia al plantear el estudio técnico-económico de un proyecto de gestión de residuos. La relevancia del sector y sus expectativas de crecimiento hace necesario que se formen profesionales con capacidad para adaptarse a los retos que el desarrollo y la implantación de esta tecnología plantea y con capacidad para el auto aprendizaje a lo largo de la vida.

Bajo esa premisa, teniendo en cuenta que se trata de una asignatura optativa con una matrícula que oscila en torno a los 25 estudiantes y que se imparte en el último estadio de su formación, se diseñó e implementó un plan metodológico basado en el Aprendizaje Activo, que ha sido evaluado tras 4 años de implantación. Se realizó un riguroso análisis para seleccionar una

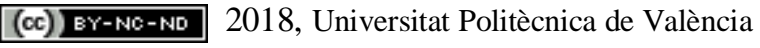

Congreso IN-RED (2018) 
amplia diversidad de actividades atendiendo a las competencias que deben adquirir los estudiantes al cursar esta signatura.

\subsection{Actividades formativas y adquisición de competencias}

Las competencias que los estudiantes deben adquirir tras cursar la asignatura se presentan en el Anexo I, e incluyen competencias básicas, generales, transversales y específicas. Para conseguir la adquisición de dichas competencias se han llevado a cabo las actividades formativas que se describen a continuación. En la Fig. 2 se presentan las actividades desarrolladas para cubrir cada una de las competencias de la asignatura.

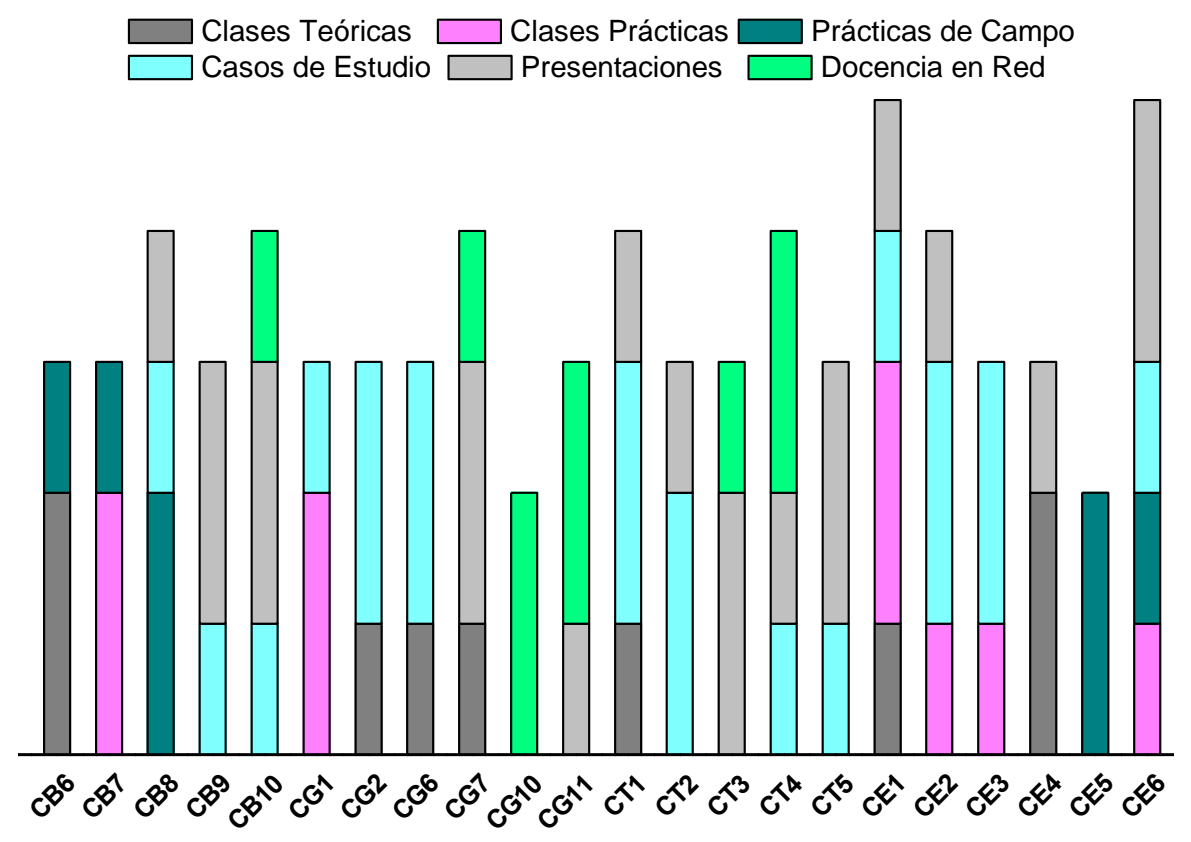

Fig. 2. Actividades formativas desarrolladas para fomentar la adquisión de las diferentes competencias.

\subsubsection{Actividades presenciales}

\section{Clases Teóricas en Aula}

Consisten en la exposición por parte del profesor de los contenidos fundamentales de la mayor parte de los temas. Se han diseñado para presentar los aspectos básicos de la gestión de residuos y su marco legislativo así como los conceptos científico-técnicos básicos de diferentes operaciones de valorización y los aspectos más relevantes de la tecnología implantada. En cada tema se establece una relación estudiante - profesor a través de la dinámica "preguntas y respuestas" para estimular el razonamiento crítico y la comprensión de las materias. 
Las clases teóricas en aula proporcionan conocimientos a los estudiantes que favorecen el desarrollo y aplicación de ideas, la solución de problemas y facilita el autoaprendizaje posterior ya que orienta sobre los contenidos a desarrollar.

\section{Clases prácticas en Aula}

Consisten en la preparación, resolución y/o discusión de problemas o casos de estudios: se proporcionan a los estudiantes problemas para resolver y se plantean temas de debate a partir de noticias actuales en temática de residuos. Se realizan tanto de forma individual como en grupo.

La resolución de problemas se ha considerado fundamental en la enseñanza de ciencias experimentales, de modo que no se podría entender su estudio sin demostrar que la teoría funciona. La didáctica de las ciencias experimentales conlleva implícitamente la habilidad de resolución de problemas (Pérez Bernabeú, 2016). La actividad profesional del Ingeniero Químico se centra principalmente en la práctica, por lo que la resolución de problemas resulta clave para hacer de puente entre el mundo académico y empresarial.

A través de esta actividad los estudiantes tienen que aplicar los conocimientos adquiridos y demuestran su capacidad para resolver problemas y establecer soluciones viables. Se trabajan competencias básicas, generales y específicas como la CB7, CG1 y CE1.

\section{Prácticas de Campo}

Se realizan dos actividades diferentes:

i) Visita a una instalación representativa del sector.

ii) Seminario impartido por un profesional en gestión de residuos.

Estas actividades tienen una gran importancia ya que en la mayoría de los casos suponen un primer contacto con el mundo empresarial de la gestión de residuos. Ofrecen la posibilidad de intercambiar conocimientos y experiencias con profesionales expertos en el área y conocer de forma directa procesos reales y los retos asociados al sector. Ambas actividades pretender proporcionar a los estudiantes una visión integral de la gestión de residuos dentro de un ámbito profesional concreto. Potencian competencias básicas y específicas como la CB8 y CE5.

\subsubsection{Actividades dirigidas}

\section{Casos de estudio}

Se plantean dos tareas dentro del epígrafe casos de estudios:

i) Planteamiento de una estrategia de gestión de residuos urbanos.

ii) Análisis de literatura científica relacionada con nuevas tecnologías para la valorización de residuos.

Con ellas se pretende, por una parte, potenciar la aplicación e integración de conocimientos que permitan diseñar una estrategia de gestión de residuos, y por otra, fomentar al estudiante el aprendizaje autónomo a partir de artículos científicos que les permitan el desarrollo continuo de su profesión.

(cc) EY-NC-ND 2018, Universitat Politècnica de València

Congreso IN-RED (2018) 
En el primer caso los estudiantes, mediante trabajo en grupo, tienen que plantear una estrategia para el tratamiento de un residuo y realizar un diseño básico de las operaciones de valorización seleccionadas. Es un caso totalmente abierto, que favorece la toma de decisiones, con sus consecuencias posteriores, ya que tienen la posibilidad de seleccionar la estrategia de tratamiento del residuo entre todas las alternativas disponibles. Lleva implícita la necesidad de discusión de las alternativas entre los integrantes del grupo y la de llegar a un consenso. Por otra parte, en función de la estrategia seleccionada tienen que plantear sus propios casos prácticos que posteriormente tendrán que resolver. Esto les ayuda a trabajar la primera y decisiva fase en la resolución de problemas que consiste en entender y explorar el problema (Polya, 2014). El cambio de rol, en el que el alumno pasa de resolver problemas a plantear los problemas que posteriormente ha de resolver, favorece el desarrollo de las habilidades del estudiante para enfrentarse a la resolución de problemas complejos.

La segunda actividad ofrece al estudiante la posibilidad de explorar tecnologías emergentes y abrir el horizonte de las posibilidades que ofrece el mundo de la valorización de residuos y su potencial para el beneficio de la sociedad y del medio ambiente y para sus posibilidades profesionales.

Esta actividad, junto con la de aula inversa tienen una gran relevancia ya que concentran la mayor parte de las competencias transversales y una buena parte de las competencias específicas de la asignatura. Se trabajan con intensidad las competencias CT1, CT2, CE2 y CE3.

\section{Presentaciones (Aula inversa)}

Mediante esta actividad los estudiantes elaboran y exponen un tema perteneciente al bloque "Valorización de residuos municipales, agrícolas e industriales". Esta actividad se realiza en grupo (3-4 estudiantes). Los temas a desarrollar son ofertados por el equipo docente y cambian cada curso académico. Los docentes proponen el esquema metodológico a seguir para el desarrollo de cada tema. Los estudiantes realizan la búsqueda de los contenidos, los seleccionan y organizan. Después realizan un documento de presentación y lo exponen en clase, con participación de todos los integrantes del grupo. De este modo, se utilizan metodologías de aprendizaje cooperativo y de cambio de roles ya que en este caso son los estudiantes los que preparan y exponen los temas. Se potencian, entre otras, competencias transversales como el trabajo en equipo, comunicación oral, aprendizaje autónomo y otras habilidades interpersonales (argumentación, consenso, negociación, etc..). Éstas son competencias en las que los recién titulados de grado presentan carencias, necesarias para el desempeño profesional en la sociedad actual, y que se adquieren con la práctica (Domingo, 2008; Chica, 2011), por lo que resulta más eficiente practicarlas en un máster que prepara especialistas con una formación avanzada y orientada a la especialización profesional (Ureña, 2012, Trigueros, 2016). Fomenta además la integración de conocimientos, emisión de juicios y toma de decisiones. Fomenta la adquisición de un importante número de competencias (Fig. 2), y de forma intensiva las CB9, CB10, CT3, CT5 y CE6.

\section{Docencia en red}

Se proporciona abundante material didáctico: legislación, planes estratégicos, información sobre instalaciones de gestión de residuos, artículos científicos, vídeos. El material de apoyo colgado en la plataforma Moodle pretende fomentar en los estudiantes el aprendizaje 
autónomo y la adaptación a los cambios y progresos a los que deberán enfrentarse como titulados Máster en Ingeniería Química.

\subsection{Evaluación del grado de adquisición de competencias}

El grado de adquisición de las competencias desarrolladas por el estudiante se determina mediante una evaluación frecuente (50-60\% de la nota final) y un examen (40-50\% de la nota final). La evaluación frecuente incluye: participación activa en las clases teóricas y prácticas, seminarios y prácticas de campo (10\% de la calificación final), entrega de casos prácticos (10-20\%) y presentaciones (20-30\%). De esta forma se asegura la evaluación de los resultados de aprendizaje en base a todas las competencias trabajadas.

La actitud de los estudiantes hacia la aplicación de metodologías de aprendizaje activo, aspecto clave para enfrentarse a la resolución de problemas reales, se evalúa de acuerdo al grado de satisfacción de los estudiantes con la asignatura. Éste queda recogido en el Informe Anual de Garantía de Calidad que la titulación elabora cada curso académico. En este Informe se resumen los resultados de las encuestas de satisfacción de los estudiantes con cada asignatura del Máster.

\section{Resultados}

Las actividades formativas planificadas en la asignatura MVR: Clases Teóricas, Clases Prácticas, Prácticas de Campo, Casos de Estudio, Presentaciones y Docencia en Red, integran todas las competencias que el estudiante debe adquirir durante el curso (Fig. 2). Como se observa en esta Fig. 2, las competencias CE1 y CE6 son las que más se fomentan por ser consideradas las más importantes para el desempeño profesional ya que atienden a la participación activa en la resolución de problemas de carácter técnico. Por el contrario, las competencias CG10 y CE5 son las que menos se desarrollan debido a que requiere que el estudiante se encuentre integrado en un contexto profesional real.

La Fig. 3 muestra que las actividades formativas Casos de Estudio y Presentaciones, son las que permiten el desarrollo (parcial) de un mayor número de competencias. Por esta razón, estas dos actividades formativas tienen un peso importante en la calificación final de la asignatura (hasta el 30\%). Sin embargo, hay que tener en cuenta, que aunque se trata de actividades colaborativas que les hace aprender mejor los contenidos gracias a las ayudas de sus iguales (Gómez Mújica, 2003), los estudiantes de un mismo grupo tienden a adquirir roles, siendo unos más activos que otros (Torrelles, 2011). Por este motivo, se contempla la evaluación individual en forma de examen escrito que supone el 40-50\% de la calificación final de la asignatura. El objetivo de esta prueba, que comprende una parte teórica y otra práctica, es conocer en qué grado los estudiantes han interiorizado los contenidos de la asignatura.

(cc) EY-NC-ND 2018, Universitat Politècnica de València

Congreso IN-RED (2018) 


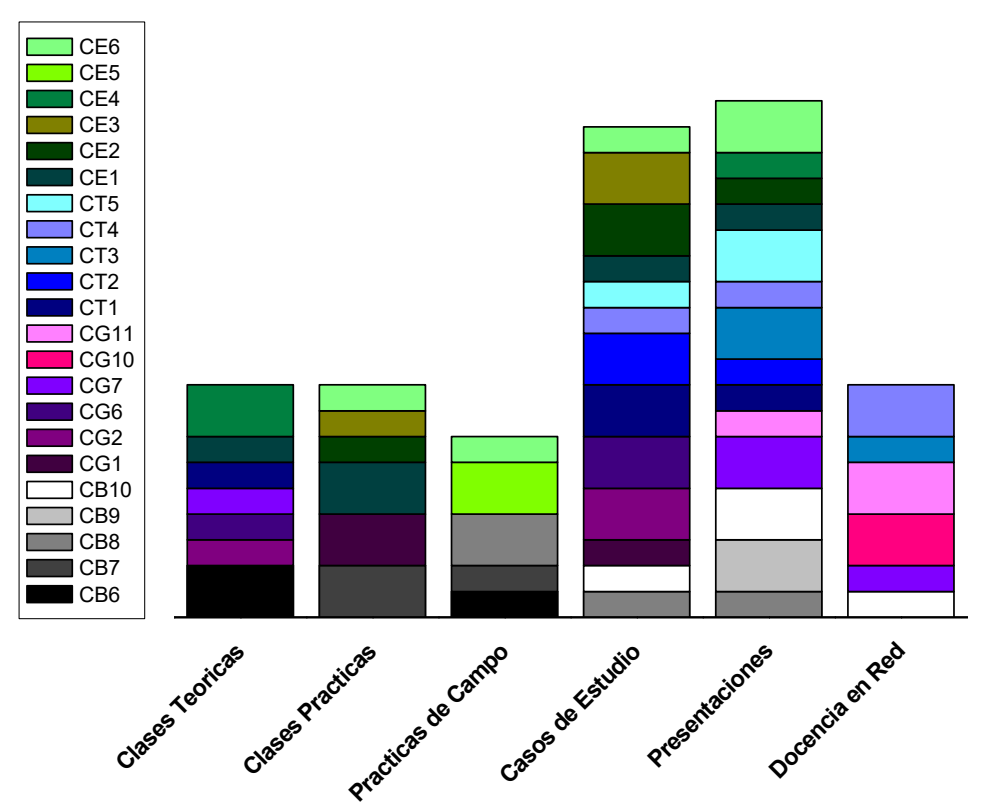

Fig. 3. Distribución ponderada de las competencias en las distintas actividades formativas aplicadas

Con el fin de valorar el grado de aprendizaje adquirido por los estudiantes en las competencias evaluadas en la asignatura MVR mediante la metodología basada en el aprendizaje activo y participativo se han analizado las calificaciones del examen, la evaluación frecuente y calificaciones globales obtenidas en los cuatro años académicos de impartición de la asignatura. En la Fig. 4 se aprecia que las calificaciones obtenidas en la evaluación frecuente son altas, comprendidas entre el notable y sobresaliente (8-9,3), es decir, que los estudiantes alcanzan un mayor grado de aprendizaje en las competencias adquiridas mediante estas actividades (Fig. 2 y 3). Se ha observado positivamente, que los estudiantes llegan a involucrarse y comprometerse más en la asignatura al responsabilizarse de su propio aprendizaje, siendo capaces de resolver los casos prácticos de manera adecuada, algunos incluso con simulaciones muy creativas y realizando, en general, unas presentaciones orales estructuradas y bien explicadas.

Por otro lado, la evaluación mediante examen escrito que incluye análisis, reflexión y justificación no supone una mejora en las calificaciones de la asignatura (Fig. 4). Ésta se realiza en un contexto más alejado de la práctica profesional ya que se trata de una prueba individual, sin intercambio de ideas y coordinación de esfuerzos, y sin apoyo de bases bibliográficas. Sin embargo, la nota media del examen es bastante alta lo que demuestra que la aplicación de estas metodologías favorece el aprendizaje global de la asignatura. Además, existe una tendencia de mejora de la calificación del examen con la evolución de la asignatura en el transcurso de los cursos, probablemente debido a la mayor experiencia y asentamiento de la metodología activa. 


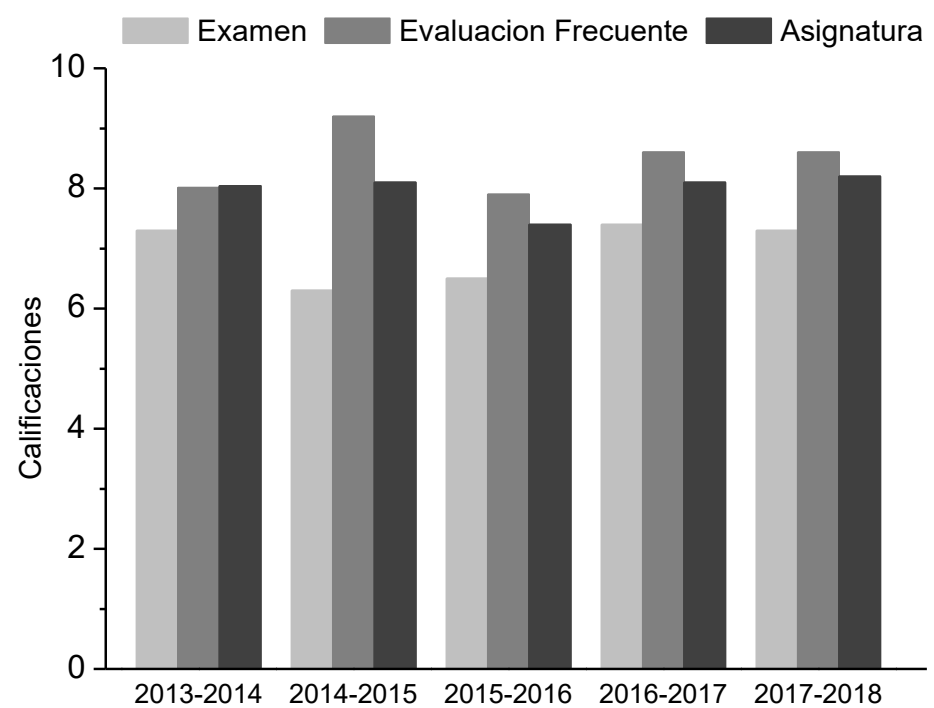

Fig. 4. Calificaciones promedio del examen escrito, de las actividades formativas (evaluación frencuente) y de la asignatura obtenidas en los diferentes cursos académicos

Otro aspecto interesante es el grado de satisfacción de los estudiantes con la asignatura. En la Fig. 5 se aprecia que es una asignatura con una elevada valoración, comprendida entre 4,3 y 4,6 sobre 5. Ésta es superior al grado de satisfacción promedio de todas las asignaturas optativas del máster y del máster en sí. Este grado de aceptación se puede comprobar también por el número de matriculados en la asignatura, siempre correspondiente a la capacidad máxima de matrícula (25-30 estudiantes, dependiendo del número de estudiantes matriculados en el máster cada curso académico).

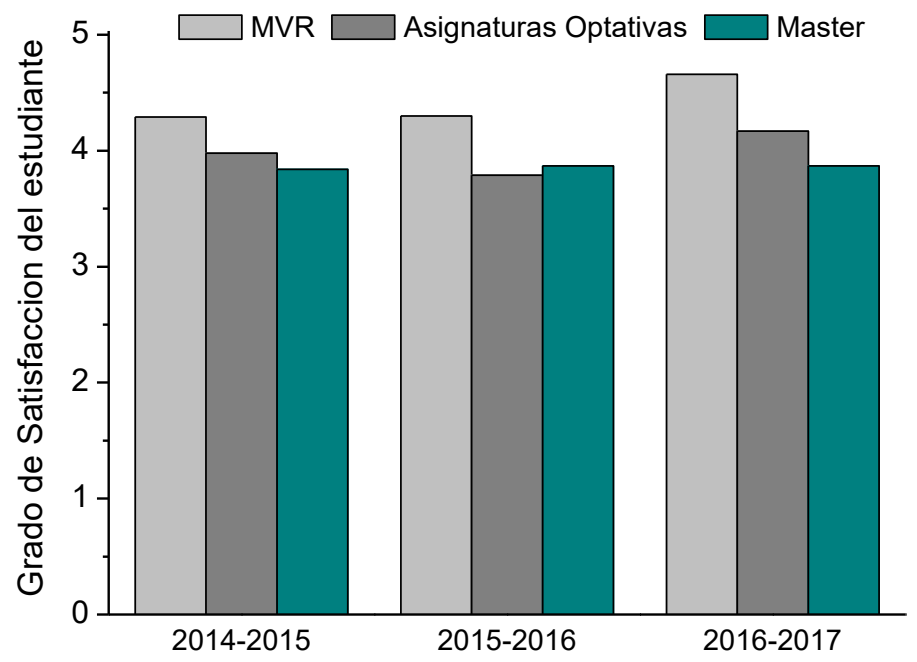

Fig. 5. Grado de satisfacción de los estudiantes en el Máster en Ingeniería Química por la URJC y UAM de la asignatura MVR y valoracion promedio de las asignaturas optativas y del máster. 


\section{Conclusiones}

Los resultados obtenidos en la aplicación de diversas metodologías de aprendizaje activo enfocadas a promover la adquisición de las competencias atribuidas a la asignatura de Minimización y Valorización de Residuos fueron satisfactorios. Los alumnos demostraron haber adquirido un aprendizaje extenso en la materia, destacando la calificación obtenida en las actividades de evaluación frecuente (8-9,3), en la que tiene mayor peso las actividades en las que el estudiante tiene un papel protagonista en su aprendizaje y que desarrollan además un mayor número de competencias. Estas metodologías favorecen la adquisición e integración de los conocimientos, lo que se refleja en los buenos resultados de la calificación global. Por otra parte, la metodología aplicada fomentó el compromiso y motivación de los estudiantes siendo la valoración de la asignatura por parte de los mismos elevada y superior a la media del máster y de las otras asignaturas optativas.

\section{Referencias}

CHICA, E. (2011) “Una propuesta de evaluación para el trabajo en grupo mediante rúbrica." Escuela Abierta, 2011, 14, 67-81

DOMINGO, J (2008) “El aprendizaje cooperativo" Cuadernos de Trabajo Social, Vol. 21 (2008): 231246

España. Real Decreto 1393/2007, de 29 de octubre, por el que se establece la ordenación de las enseñanzas universitarias oficiales. BOE, 30 de octubre de 2007, núm. 260, p. 1-28.

España. Resolución de 8 de junio de 2009, de la Secretaría General de Universidades, por la que se da publicidad al Acuerdo del Consejo de Universidades, por el que se establecen recomendaciones para la propuesta por las universidades de memorias de solicitud de títulos oficiales en los ámbitos de la Ingeniería Informática, Ingeniería Técnica Informática e Ingeniería Química. BOE, 4 de agosto de 2009, núm. 187, p. 66699-66710.

España. Real Decreto 861/2010, de 2 de julio, por el que se modifica el Real Decreto $1393 / 2007$, de 29 de octubre, por el que se establece la ordenación de las enseñanzas universitarias oficiales. BOE, 3 de julio de 2010, núm. 161, p. 58454-58468.

España. Real Decreto 1027/2011, de 15 de julio, por el que se establece el Marco Español de Cualificaciones para la Educación Superior. BOE, 3 de agosto de 2011, núm. 185, p. 8791287918.

FERNÁNDEZ, M.S., GARCÍA-FAYOS, B. y ARNAL ARNAL J.M. (2016) “Análisis de la mejora del aprendizaje tras la incorporación de metodologías activas en una asignatura optativa del Grado de Ingeniería Química" En : Congreso Nacional de Innovación Educativa y de Docencia en Red (julio, 2016, Valencia). Valencia : Editorial Universitat Politécnica de València.

FERNÁNDEZ MARCH, A. (2006) "Metodologías activas para la formación de competencias" En Educatio siglo XXI, 24, 35-56.

Guía Docente de Minimización y Valorización de Residuos. <http://www.uam.es/ss/Satellite/Ciencias les/1242655139058/listadoGuiasDocentes/Estudios de Posgrado.htm> [Consulta: 23 de marzo de 2018].

GOMEZ MUJICA, A. y ACOSTA RODRIGUEZ, H. (2003). « Acerca del trabajo en grupos o equipos ». ACIMED, http://eprints.rclis.org/5035/1/acerca.pdf .

HEATON, A. (1996) “An introduction to Industrial Chemistry” Chapman \& Hall. London.

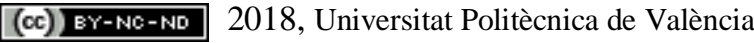

Congreso In-Red (2018) 
Aplicación de metodologías de aprendizaje activo para promover la adquisición de competencias en la asignatura Minimización y Valorización de Residuos

KEMBER, D., LEUNG, D.Y.P. (2005) "The influence of active learning experiences on the development of graduate capabilities" En : Studies in Higher Education, 30, 2, 155-170.

Máster Universitario en Ingeniería Química.

http://www.uam.es/ss/Satellite/es/1242684629435/1242669469071/masteroficial/masterOficia/Master Universitario en Ingenieria Quimica.htm> [Consulta: 23 de marzo de 2018].

OLMEDO, E. M. (2013). "Enfoques de aprendizaje de los estudiantes y metodología docente: Evolución hacia el nuevo sistema de formación e interacción propuesta en el EEES." Revista de Investigación Educativa, 31, 2, 411-429.

PÉREZ-BERNABEU, E., SELLÉS, M.A., GISBERT, V., SÁNCHEZ-CABALLERO, S. (2016) “Un enfoque diferente para la resolución de problemas." En : Congreso Nacional de Innovación Educativa y de Docencia en Red (julio, 2016, Valencia). Valencia : Editorial Universitat Politécnica de València POLYA, G. (2014). How to Solve It: A New Aspect of Mathematical Method. Princeton University Press.

PRINCE, M. (2004) "Does active learning work ? A review of the research." En : Journal of Engineering Education, 93, 3, 223-231.

SANABRIA-CODESAL, E., BOSCH, I., VICENT, M.C., LLORET, J., ALVAREZ, S., ROMERO, L (2014) "Análisis de las Dimensiones Competenciales Incluidas en Diferentes Asignaturas en Ingenierías" En: Jornadas de Innovación Educativa y de Docencia en Red (julio, 2014, Valencia). Valencia : Universidad Politécnica de Valencia.

TORRELLES C., COIDURAS J., ISUS S., CARRERA F. X. PARIS G., CELA J. M. (2011) "Competencia de Trabajo en equipo: definición y categorización. Profesorado". Revista de Currículum y Formación de Profesorado [online].

TRIGUEROS, S., PEREZ, D., SOLANA, P. y GARCIA, E. (2016) "Experiencia docente universitaria mediante el uso de metodologías activas para el aprendizaje como la evaluación formativa compartida y el trabajo de competencias transversales." En : Congreso Nacional de Innovación Educativa y de Docencia en Red (julio, 2016, Valencia). Valencia : Editorial Universitat Politécnica de València

UREÑA, N y RUIZ, E. (2012). "Experiencia de evaluación formativa y compartida en el Máster Universitario en Formación del Profesorado de Educación Secundaria" Psychology, Society \& Education, 4, 1, 29-44.

\section{Anexo I. Competencias asignadas a la asignatura}

Competencias Básicas (según Real Decreto 1393/2007, de 29 de octubre)

CB6 - Poseer y comprender conocimientos que aporten una base u oportunidad de ser originales en el desarrollo y/o aplicación de ideas, a menudo en un contexto de investigación.

CB7 - Que los estudiantes sepan aplicar los conocimientos adquiridos y su capacidad de resolución de problemas en entornos nuevos o poco conocidos dentro de contextos más amplios (o multidisciplinares) relacionados con su área de estudio.

CB8 - Que los estudiantes sean capaces de integrar conocimientos y enfrentarse a la complejidad de formular juicios a partir de una información que, siendo incompleta o limitada, incluya reflexiones sobre las responsabilidades sociales y éticas vinculadas a la aplicación de sus conocimientos y juicios.

CB9 - Que los estudiantes sepan comunicar sus conclusiones -y los conocimientos y razones últimas que las sustentan- a públicos especializados y no especializados de un modo claro y sin ambigüedades.

CB10 - Que los estudiantes posean las habilidades de aprendizaje que les permitan continuar estudiando de un modo que habrá de ser en gran medida autodirigido o autónomo.

Competencias generales (según Real Decreto 861/2010, de 2 de julio)

CG1 - Capacidad para aplicar el método científico y los principios de la ingeniería y economía, para formular y resolver problemas complejos en procesos, equipos, instalaciones y servicios, en los que la materia experimente cambios en su composición, estado o contenido energético, característicos de la industria química y de otros sectores

(cc) EY-NC-ND 2018, Universitat Politècnica de València

Congreso IN-RED (2018) 
relacionados entre los que se encuentran el farmacéutico, biotecnológico, materiales, energético, alimentario o medioambiental.

CG2 - Concebir, proyectar, calcular, y diseñar procesos, equipos, instalaciones industriales y servicios, en el ámbito de la ingeniería química y sectores industriales relacionados, en términos de calidad, seguridad, economía, uso racional y eficiente de los recursos naturales y conservación del medio ambiente.

CG6 - Tener capacidad de análisis y síntesis para el progreso continuo de productos, procesos, sistemas y servicios utilizando criterios de seguridad, viabilidad económica, calidad y gestión medioambiental.

CG7 - Integrar conocimientos y enfrentarse a la complejidad de emitir juicios y toma de decisiones, a partir de información incompleta o limitada, que incluyan reflexiones sobre las responsabilidades sociales y éticas del ejercicio profesional.

CG10 - Adaptarse a los cambios, siendo capaz de aplicar tecnologías nuevas y avanzadas y otros progresos relevantes, con iniciativa y espíritu emprendedor.

CG11 - Poseer las habilidades del aprendizaje autónomo para mantener y mejorar las competencias propias de la ingeniería química que permitan el desarrollo continuo de la profesión.

Competencias transversales (según Real Decreto 1027/2011, de 15 de julio)

CT1 - Adquirir conocimientos avanzados y demostrar, en un contexto de investigación científica y tecnológica o altamente especializado, una comprensión detallada y fundamentada de los aspectos teóricos y prácticos y de la metodología de trabajo en el campo de la Ingeniería Química.

CT2 - Saber aplicar e integrar los conocimientos, la comprensión de estos, su fundamentación científica y sus capacidades de resolución de problemas en entornos nuevos y definidos de forma imprecisa, incluyendo contextos de carácter multidisciplinar tanto investigadores como profesionales altamente especializados.

CT3 - Saber evaluar y seleccionar la teoría científica adecuada y la metodología precisa de sus campos de estudio para formular juicios a partir de información incompleta o limitada incluyendo, cuando sea preciso y pertinente, una reflexión sobre la responsabilidad social o ética ligada a la solución que se proponga en cada caso.

CT4 - Ser capaces de predecir y controlar la evolución de situaciones complejas mediante el desarrollo de nuevas e innovadoras metodologías de trabajo adaptadas al ámbito científico/investigador, tecnológico o profesional concreto, en general multidisciplinar, en el que se desarrolla la actividad de un titulado con el Máster Universitario en Ingeniería Química.

CT5 - Ser capaces de asumir la responsabilidad de su propio desarrollo profesional y de su especialización en el campo de la Ingeniería Química.

Competencias específicas (según Resolución 12977 de 8 de junio de 2009, de la Secretaría General de Universidades)

CE1 - Aplicar conocimientos de matemáticas, física, química, biología y otras ciencias naturales, obtenidos mediante estudio, experiencia, y práctica, con razonamiento crítico para establecer soluciones viables económicamente a problemas técnicos.

CE2 - Diseñar productos, procesos, sistemas y servicios de la industria química, así como la optimización de otros ya desarrollados, tomando como base tecnológica las diversas áreas de la ingeniería química, comprensivas de procesos y fenómenos de transporte, operaciones de separación e ingeniería de las reacciones químicas, nucleares, electroquímicas y bioquímicas.

CE3 - Conceptualizar modelos de ingeniería, aplicar métodos innovadores en la resolución de problemas y aplicaciones informáticas adecuadas, para el diseño, simulación, optimización y control de procesos y sistemas.

CE4 - Tener habilidad para solucionar problemas que son poco familiares, incompletamente definidos, y tienen especificaciones en competencia, considerando los posibles métodos de solución, incluidos los más innovadores, seleccionando el más apropiado, y poder corregir la puesta en práctica, evaluando las diferentes soluciones de diseño. CE5 - Dirigir y supervisar todo tipo de instalaciones, procesos, sistemas y servicios de las diferentes áreas industriales relacionadas con la ingeniería química.

CE6 - Diseñar, construir e implementar métodos, procesos e instalaciones para la gestión integral de suministros y residuos, sólidos, líquidos y gaseosos, en las industrias, con capacidad de evaluación de sus impactos y de sus riesgos. 


\title{
Metodologías activas: simulación de un proceso de centrifugado en Diseño de Experimentos en Ingeniería
}

\author{
V. Chirivella, R.M. Alcover, B. Richart
}

Departamento de Estadística e Investigación Operativa Aplicadas y Calidad

Universitat Politècnica de València

\{vchirive, ralcover, brichart\}@eio.upv.es

\begin{abstract}
In this paper we present a proposal of an active methodology for learning the subject Design of Experiments (DOE) on the university master's degree in Data Analysis Engineering, Process Improvement and Decision Making offered by the Polytechnic University of Valencia (UPV). The proposal, among other issues, includes the formation of work teams, the planning and realization of real experiments, its analysis and the presentation of its results. The objective of this methodology, besides stimulating the participation and motivation of the student, is to bring the classroom work closer to the real practice of the DOE in an industrial context, covering the greatest possible number of competences, increasing and improving the learning of the students.
\end{abstract}

Keywords: Design of Experiments; Laboratory; Educational innovation; Active methodologies; Classroom dynamization; Soft skills

\begin{abstract}
Resumen
En este trabajo se presenta una propuesta de metodología activa de aprendizaje de las asignaturas de Diseño de Experimentos (DOE) del máster universitario de Ingeniería de Análisis de Datos, Mejora de Procesos y Toma de Decisiones ofertado por la Universitat Politècnica de València (UPV). La propuesta, entre otras cuestiones, incluye la formación de equipos de trabajo, la planificación y realización por parte de los alumnos de experimentos reales, el análisis y la presentación de resultados. El objetivo de la metodología, además de estimular la participación y motivación del alumno, es aproximar el trabajo de aula a la práctica real del DOE en un contexto industrial, cubriendo el mayor número posible de competencias, incrementando y mejorando el aprendizaje de los estudiantes.
\end{abstract}

Palabras clave: Diseño de Experimentos; Laboratorio; Innovación educativa; Metodologías activas; Dinamización de aula; Competencias

\section{Introducción}

Numerosos son los trabajos que han resaltado el papel que las técnicas de Diseño de Experimentos (DOE) pueden desempeñar en la obtención de elevadas cotas de calidad y productividad, tanto en los productos como en los procesos productivos. Como se afirma en Romero y Zúnica (2004), una de las aportaciones esenciales de los planteamientos sobre Calidad Total ha sido la de enfatizar la importancia de las actividades que se desarrollan en 
las fases de diseño de productos y procesos. El objetivo básico de estas actividades es precisamente identificar y cuantificar los efectos que los parámetros de los productos y los procesos tienen sobre las características de calidad y productividad relevantes. Todo ello con el fin de obtener las condiciones operativas óptimas, identificar las causas de los problemas y seleccionar la mejor alternativa para resolverlos. Por estos motivos la materia de DOE tiene una especial relevancia en el ámbito de la Ingeniería y en la investigación, en general. La sociedad demanda cada día con mayor fuerza profesionales en el análisis y tratamiento de datos con el fin de conseguir una mayor información que guíe sus procesos de toma de decisiones.

Anticipándose a esta situación la UPV puso en marcha durante el curso 2009/2010 el máster universitario en Ingeniería de Análisis de datos, Mejora de procesos y Toma de decisiones, máster en el que se incluyen dos asignaturas de la materia DOE. Con esta materia, en el máster, se parte de conocimientos básicos y elementales, llegando a abordarse aspectos de elevado nivel complejidad. La materia de DOE se ubica en el módulo de Mejora de Procesos de dicho máster, y está organizada en dos asignaturas, DOE I y DOE Avanzado, de 3 créditos ECTS cada una de ellas.

Desde la puesta en marcha de la materia en el master hasta la actualidad (curso 2017/2018) los contenidos teóricos han variado mínimamente. El cambio más importante se ha llevado a cabo en los objetivos perseguidos en la materia, en la metodología docente utilizada y en el sistema de evaluación adoptado (Fernández, 2006). Todo ello ha repercutido en mejores resultados del alumnado, en un mayor rendimiento de la materia y en una mayor satisfacción tanto del alumnado como del profesorado implicado (González, 2013).

Durante las seis ediciones del máster la materia de DOE se ha ido reconduciendo con el fin de conseguir un mejor cumplimiento de las competencias requeridas tanto por el propio máster como por la UPV. Para ello, en primer lugar se ha reducido el tiempo dedicado a la exposición teórica del profesor, estrategia necesaria pero que difícilmente por sí sola fomenta el aprendizaje autónomo del alumnado, GIMA (2008). Además, siguiendo a diferentes autores (Peiró-Signes y Segarra-Oña, 2015), se han introducido nuevas actividades de dinamización del aula que garantizan el trabajo de las competencias específicas y transversales (Proyecto institucional de las competencias transversales UPV). Por su especial relevancia, el cambio más profundo en la materia, tanto en organización, metodología y evaluación, está relacionado con la adquisición de las competencias por los estudiantes.

Por otra parte, la introducción en el aula de nuevas actividades que motiven y promuevan la participación activa del alumnado es, hoy en día, un reto continuo para el profesorado. Además estas actividades suelen variar su nivel de complejidad según el tipo de alumnado al que vayan dirigidas. En la experiencia que presentamos en este trabajo, al tratarse de una materia de máster, la preparación de la actividad ha requerido un considerable número de horas de trabajo por parte del profesorado y del técnico de laboratorio implicado (Villa y Poblete, 2007). 
Tras analizar los resultados obtenidos por los alumnos matriculados en la materia desde el curso 2009/2010, se constata que, tras la modificación de la metodología docente y la realización de la nueva actividad en las asignaturas, los resultados son significativamente mejores, además de trabajar nuevas competencias que previamente se habían pasado por alto. Se consigue un incremento y mejora del aprendizaje. Así los alumnos pueden llegar a ser mejores profesionales en su campo.

\section{Objetivos}

Teniendo en cuenta que el temario de las asignaturas que engloban la materia de DOE no se ha reducido, ni se ha aumentado su número de créditos, los cambios introducidos en la materia de DOE se han planteado con los siguientes objetivos:

- Seleccionar el material adecuado para llevar a cabo en el aula un experimento in situ simulando un proceso genérico en el ámbito de la ingeniería.

- Elaborar una guía detallada para el alumno que le permita, en un tiempo razonable, simular el proceso estudiado utilizando únicamente el material disponible.

- Motivar e involucrar de lleno al alumno en un proceso real de su área de interés, pasando por todas las etapas de su ciclo de vida, hasta la presentación y discusión de resultados.

- Trabajar en un equipo multidisciplinar.

- Dinamizar el aula en sesiones de cinco horas y media creando un buen ambiente de trabajo.

- Mejorar el aprendizaje y rendimiento de los estudiantes.

\section{Desarrollo de la innovación}

Con los objetivos planteados en el apartado anterior y desde las asignaturas implicadas, hemos propuesto actividades centradas en el diseño y realización de experimentos que se puedan implementar fácilmente en el aula informática, tanto en tiempo como en recursos necesarios. A su vez, y al tratarse de una materia impartida en máster, estos experimentos deben ser lo suficientemente elaborados para cubrir el desarrollo y posterior evaluación de un gran número de competencias transversales en los alumnos. Entre todos ellos, hemos hecho una selección, teniendo en cuenta los criterios anteriores:

- El análisis de las principales estrategias posibles para el llenado de bolsas con básculas multicabezal, un proceso importante en la determinación del peso de los paquetes de panes tostados, galletitas, pasta,... regulado por el REAL DECRETO 1801/2008.

- El diseño y optimización del tiempo de vuelo de una semilla de arce, un diseño alternativo y barato de drones pasivos encargados de filmación de imágenes, cartografía, emergencias, logística, seguridad,...

- El diseño y optimización de una catapulta Trebuchet, el tipo de la catapulta medieval que ofrece mayor precisión y exactitud en su funcionamiento.

- El análisis del subproceso de centrifugado para la separación de un sólido en suspensión líquida mediante un centrifugador, indispensable en la fabricación de medicamentos. 
De los cuatro experimentos propuestos, escogemos el experimento de la centrifugadora por ser una experiencia muy visual, didáctica y con múltiples soluciones. Esto permite a los estudiantes, además de las competencias generales y específicas de la asignatura, trabajar la competencia transversal de innovación, creatividad y emprendimiento, proporcionando diseños y ensamblados novedosos de un proceso.

\section{El experimento de la centrifugadora}

Pretendemos analizar el subproceso de separación de un sólido en suspensión líquida mediante un centrifugador, una parte esencial en el proceso de producción de un medicamento. Dicho subproceso debe tener una cierta duración para que se produzca la separación efectiva del sólido, pero no debe prolongarse en el tiempo para no afectar a otras características de la mezcla, por lo que el tiempo de centrifugado es una variable de interés en la producción del medicamento. El análisis del subproceso se realizará por medio de un simulador, que los alumnos deben construir, en el que el tiempo de centrifugado vendrá dado por el tiempo de giro de una bola dentro de un embudo, al que llegará a cierta velocidad al descender por una rampa hasta el mismo.

Uno de los objetivos de este trabajo es conocer la relación que existe entre una variable respuesta, el tiempo de giro en el embudo, y los factores de diseño considerados para la misma, con el fin de poder fijar sus valores y alcanzar un cierto objetivo, un valor determinado del tiempo de giro (centrifugado).

Los principales factores de diseño para este experimento son la distancia recorrida por la bola en la rampa (100 cm máximo), el material con el que está hecha la misma (plástico, madera o acero) y su ángulo de inclinación (que depende del montaje). Por otro lado tenemos el tamaño de bola (2, 4, 6, 8, 10 y $12 \mathrm{~mm}$ ), el tipo de embudo (paredes rectas o paredes curvas), y finalmente se propone el estudio de un factor adicional, el sentido de giro de la bola en el embudo, que tiene un efecto teórico (aceleración de Coriolis) que no puede apreciarse a la escala del experimento. Los alumnos, trabajando en equipo, realizarán un montaje colocando una rampa en dos soportes de forma que tenga una inclinación ajustable, con uno de los extremos que desembocará en un embudo situado en un tercer soporte. Si se deja caer una bola por la rampa, ésta adquirirá velocidad debido a la inclinación y el recorrido en la misma, y al salir de ella embocará un embudo, en el que dará vueltas hasta que su energía no sea suficiente, descienda y termine por salir del mismo. El tiempo que tarda en salir del embudo se contaría desde el momento de entrada de la bola en el mismo, o desde que la bola se libera en la rampa, y sería la variable de interés en el experimento. Todos estos factores proporcionan al alumno una multitud de posibilidades de diseño del simulador.

El trabajo a realizar por el alumno se divide en cinco partes. La primera parte sería una toma de contacto con el material para construir el simulador y un primer enfrentamiento a las cuestiones logísticas de su implementación. En la segunda y tercera se realiza el análisis del problema, obteniendo en primer lugar un cierto conocimiento básico sobre el mismo, que llevará en la siguiente parte al planteamiento y ejecución del trabajo con el análisis completo del problema. En la cuarta parte los alumnos escribirán una memoria que

(cc) EY-NC-ND 2018, Universitat Politècnica de València

Congreso IN-RED (2018) 
documentaría toda la actividad realizada, y en la quinta prepararán dos presentaciones, una dirigida a sus compañeros de clase, y otra que se expondría a sus jefes en la "empresa". Con cierto detalle:

1. Lo primero que deben hacer los alumnos es observar el material disponible para la simulación, rampas, bolas, soportes, garras, cronómetros, cintas métricas, y unas piezas de madera en forma de "L" que tratan de encajar en el diseño. Escogen aquello que creen conveniente y se lo llevan a su puesto de trabajo para proponer un montaje a partir del material y de la idea de que "una bola debe recorrer una rampa y terminar dando vueltas en un embudo". Como se les pide encontrar seis factores que posiblemente afecten al tiempo de centrifugado en dicho montaje, así como el rango de los niveles o las variantes que le corresponderían a cada factor, emplean algo de tiempo en mover o cambiar ciertas partes de su diseño para tratar de encontrarlos. Analizan los problemas que hay en su montaje, sobre todo en lo que respecta a volver a poner las partes en la misma posición cuando realizan los ajustes en los diferentes niveles o variantes, y prueban los valores extremos de los niveles para ver si surgen problemas. Los miembros del grupo se organizan de una forma elemental para poder lidiar con todos los problemas que aparecen.

2. Transcurrido un tiempo conveniente, se les desvela el montaje de la Figura 1, y la función de la "L" de madera, que ha sido utilizada de forma muy imaginativa. Los equipos comparan los montajes para ver las ventajas e inconvenientes de su propio diseño, y proponen finalmente un montaje definitivo, así como los factores a analizar. En este momento deberían plantear lo que se conoce como un diseño de cribado, que permite determinar con un número mínimo de pruebas cuáles de los seis factores propuestos son los más relevantes para explicar tanto el promedio como la varianza del tiempo de centrifugado, y las interacciones que existen entre ellos. El comienzo en la realización de las pruebas no suele suponer cambios en el montaje, pero sí en la forma de proceder con ellas, y con los roles y tareas de cada miembro del equipo. Finalmente se realiza el análisis de los datos y se obtienen las conclusiones.

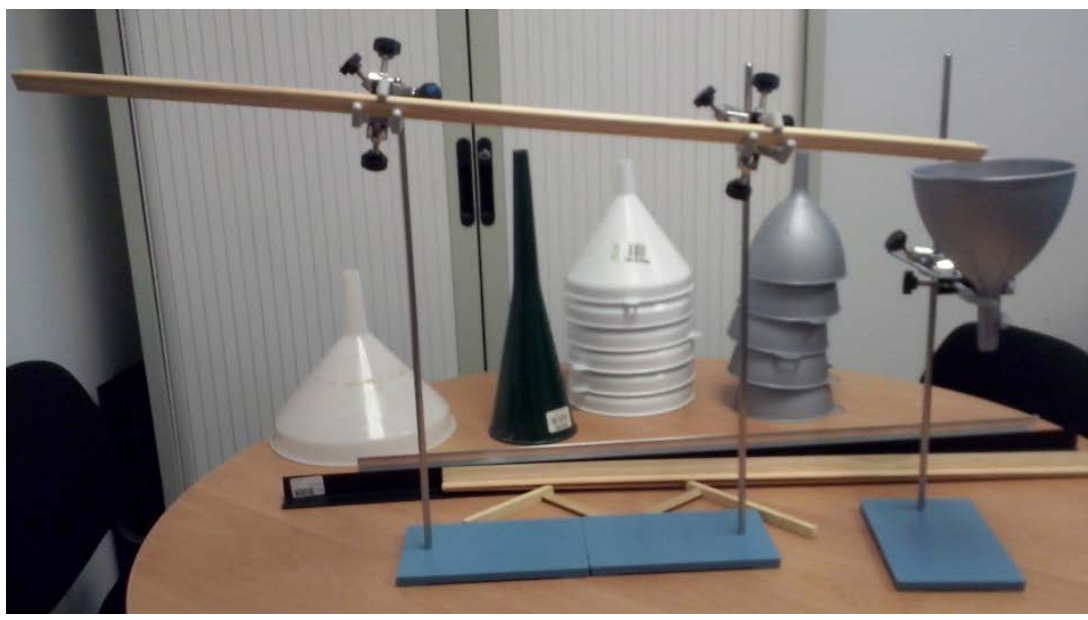

Fig. 1 Simulador de centrifugadora 
3. Con los resultados preliminares los alumnos son capaces de escoger la centrifugadora (embudo) que tiene el rango más amplio del tiempo de giro y centran en el mismo el siguiente análisis. Ahora deben proponer un nuevo diseño del experimento que permita ensayar los factores más relevantes encontrados, a los niveles y variantes que resulten adecuados, con el menor número de pruebas posible y con objeto de realizar el estudio definitivo del problema de la centrifugadora. Los alumnos planifican y realizan los correspondientes experimentos, y analizan la naturaleza de la relación de los factores seleccionados con el promedio del tiempo de centrifugado. Con estos mismo datos repiten los análisis, pero ahora con la varianza del tiempo de giro. Una vez explicado el proceso, los alumnos pueden ajustar el simulador a voluntad, por lo que determinan los valores de los factores para no sobrepasar los 25,0 segundos de giro con una probabilidad de un 99,99\%. Para comprobar que todo está bien, realizan un experimento confirmatorio final en las condiciones propuestas por ellos como óptimas.

4. El análisis está hecho, pero ahora deben documentar en una memoria final escrita todo el proceso de toma de decisión, los experimentos, los hallazgos realizados y las conclusiones obtenidas. El enfoque de este documento es el formal de un trabajo académico o de investigación.

5. Adicionalmente preparan dos exposiciones orales, una de 18 minutos en la que explican el documento final a sus compañeros, haciendo hincapié en los diseños escogidos y en las soluciones a los problemas encontrados durante la experimentación, y una segunda presentación de 8 minutos donde se supone que explicarían a los responsables de la empresa farmacéutica las conclusiones y las acciones propuestas sobre el proceso de fabricación. La presentación que realizará cada equipo será escogida al azar entre las dos existentes, y la exposición terminará con un turno de preguntas con el fin de aclarar las cuestiones necesarias.

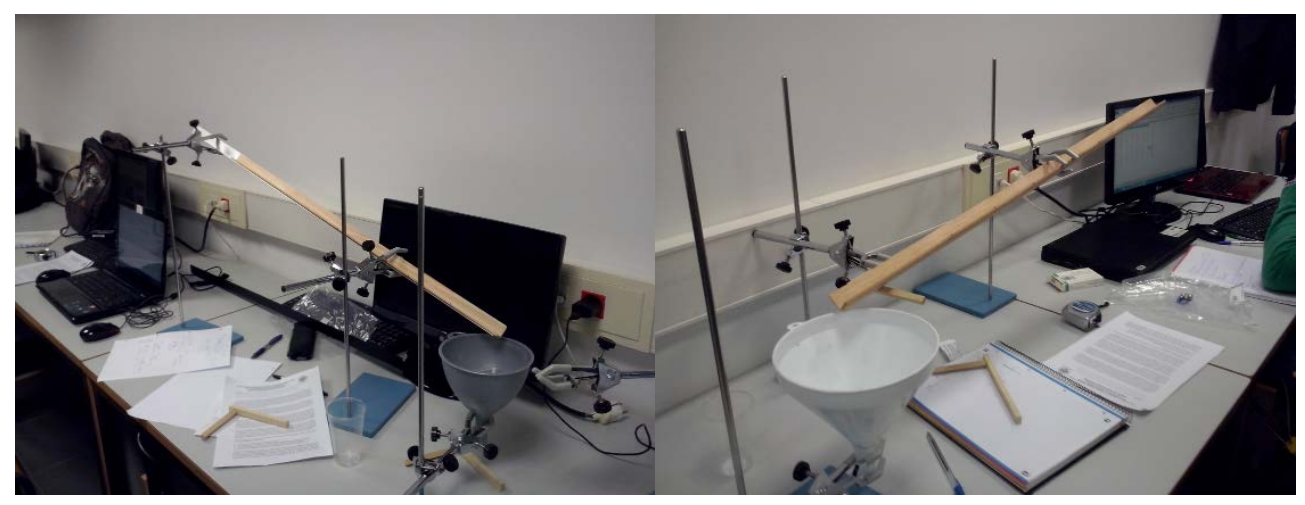

Fig. 2 Montajes realizados por los alumnos en una de las ediciones del máster.

Con este trabajo se ejercitan las competencias que los alumnos deben adquirir en el curso (http://www.upv.es/contenidos/COMPTRAN/). La primera competencia de todas sería la CT13 Instrumental específica, en este caso el uso de las herramientas estadísticas e informáticas necesarias para el ejercicio profesional. Para resolver el problema del centrifugador, los alumnos han seleccionado las herramientas estadísticas más adecuadas: diseño de experimentos, análisis de la varianza, regresión y optimización, integrándolas 
adecuadamente para conseguir el objetivo propuesto. Además han utilizado las herramientas informáticas que implementan las técnicas estadísticas mencionadas, y los programas ofimáticos para la elaboración del documento final y de las presentaciones. Por todo ello, con el trabajo de la simulación de la centrifugadora se ha llegado al nivel 3 de dicha competencia transversal. Esta competencia se evalúa mediante la nota obtenida en la memoria del trabajo, reconvirtiéndola en uno de los cuatro niveles posibles.

La competencia transversal CT01 Comprensión e integración también debe ser evaluada en la asignatura. Esta competencia se ejercita y evidencia en diversas fases del trabajo de los estudiantes. Así, el diseño del montaje realizado por los alumnos es una evidencia de la comprensión del objetivo y del funcionamiento del simulador; los diseños de experimentos por ellos escogidos son evidencia de haber entendido en cada caso la necesidad de establecer relación entre el tiempo de giro y los factores propuestos, de acuerdo a sus niveles y variantes. Las evidencias de la comprensión e integración aparecen tanto en la redacción de la memoria del trabajo como en sus posteriores exposiciones, donde se establecen relaciones de causa-efecto, se expresan sus ideas y se generan las conclusiones, tal como indica el nivel 3 de dicha competencia. Esta competencia se evalúa mediante la rúbrica que tiene establecida para ello la UPV.

Tabla 1. Rúbrica para la evaluación de la CT01 propuesta por la UPV

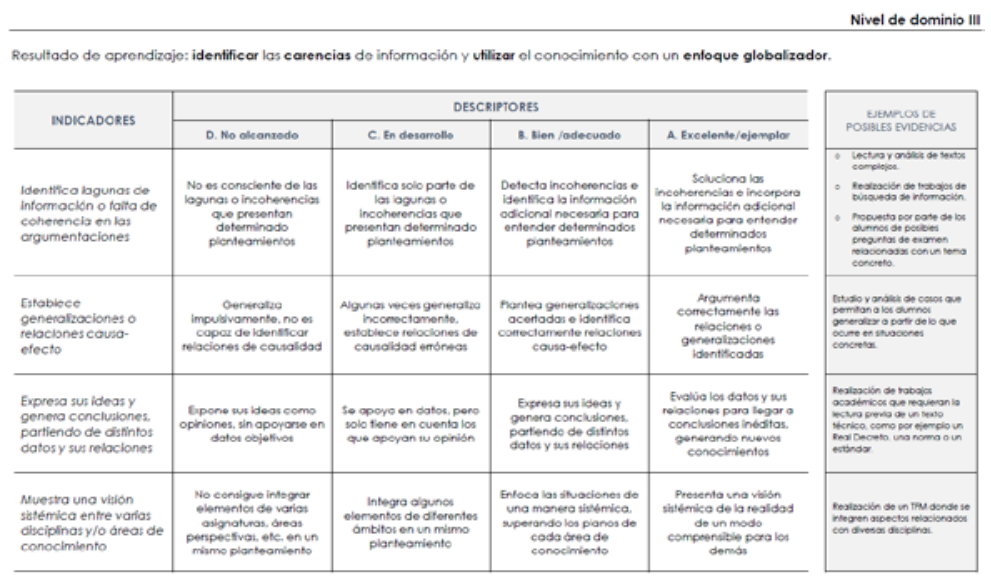

Además de la competencia transversal propia de la asignatura y la compresión e integración, se han trabajado otras competencias, con la posibilidad de evaluarlas, si la ERT lo desea. Sin pretender exhaustividad, se detallan ciertas competencias desarrolladas en la construcción y presentación del simulador.

\section{CT02 Aplicación y pensamiento práctico}

La competencia de tomar decisiones y actuar en consecuencia se ejercita en el trabajo propuesto, al tener que establecer los alumnos un plan coherente de acciones para conseguir el objetivo perseguido. Por ejemplo, el equipo debe planificar la construcción física del simulador, partiendo de cero, con el material que hay disponible, con unas pocas instrucciones y una escasa experiencia previa en la resolución de problemas similares, hasta 
convertirlo en realidad con sus propias manos. Además, y una vez realizado el montaje físico de los diferentes elementos del proceso simulado, el equipo de trabajo debe planificar una serie de experiencias que lleven al límite el simulador con el fin de encontrar errores de diseño o en el procedimiento de ejecución de las pruebas. De acuerdo a las definiciones de la competencia, son necesarias las de nivel 3 para realizar el montaje de la centrifugadora y validar su funcionamiento antes de comenzar los experimentos.

\section{CT03 Análisis y resolución de problemas}

El análisis y resolución de problemas es también una parte importante del diseño y de la construcción del simulador. Una vez aportadas las soluciones, al contrastar éstas con las necesidades reales aparecen situaciones no advertidas que los alumnos deben analizar y resolver, implementando cambios en el montaje y estableciendo nuevos procedimientos de trabajo. Ejemplos de ello son velocidades excesivas de la bola, los rebotes, los bloqueos por la posición de la garra, los desajustes del embudo, las bolas que caen de la mesa,... Los alumnos deben estudiar las causas de los problemas y generar e implementar unas soluciones factibles e inmediatas. De acuerdo a las definiciones de la competencia, son necesarias las de nivel 3 para realizar el análisis de la centrifugadora.

\section{CT08 Comunicación efectiva}

La competencia de la comunicación efectiva se trabaja tanto en su vertiente escrita como oral. El nivel exigido a los alumnos en la memoria y en la exposición corresponderá al identificado como nivel 3 de la competencia, puesto que realizarán una memoria de un trabajo original y completo, utilizando las convenciones y el lenguaje propio de la estadística, y las normas de redacción de documentos científicos. Además realizarán una presentación de duración media, con turno de preguntas en el que los alumnos defenderán con argumentos el trabajo realizado, generando en ocasiones un debate con los otros equipos. Finalmente, los alumnos harán uso de las herramientas visuales necesarias para presentar los resultados, como el PowerPoint.

\section{CT09 Pensamiento crítico}

La competencia de pensamiento crítico también se ejercita en la actividad de innovación propuesta. En primer lugar cuando los alumnos comparan el montaje que han realizado con el montaje facilitado en el enunciado. Los alumnos comparan su propuesta con el montaje facilitado por el profesor, y como resultado de la comparación, los equipos modificarán el suyo para tener en cuenta alguna característica relevante que pudiera influir en la construcción del simulador y que previamente se hubiera pasado por alto. También se trabaja esta competencia cuando los alumnos valoran los potenciales factores de diseño relevantes en el proceso estudiado en una sesión de brainstorming. En dicha sesión deben formular y argumentar juicios y valoraciones sobre cada uno de los factores propuestos. Por todo ello consideramos que la competencia se desarrolla al nivel 3 de dominio.

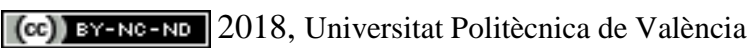

Congreso IN-RED (2018) 


\section{CT06 Trabajo en equipo y liderazgo}

La envergadura del trabajo hace que sea necesaria la participación de entre tres y cinco personas en el equipo, lo que implica colaboración y organización entre ellas. En un primer momento se procura que sean los propios alumnos los que muestren de forma natural su rol en el equipo, al forzar el inicio del trabajo sin apenas instrucciones y con cierto material de utilidad poco clara. Los alumnos ya han establecido previamente relaciones entre ellos durante las jornadas previas a esta, y en otras asignaturas del máster, y se espera que adquieran un cierto compromiso por ellos mismos en la organización de las actividades. Transcurrido un tiempo prudencial, los alumnos reciben un documento donde se enumeran los roles necesarios para construir y operar el simulador, y se solicita abiertamente que cada miembro del equipo debe escoger y ejercer el suyo: líder, secretario, facilitador, gestor del tiempo,.... El nivel de dominio mostrado depende del equipo concreto, y la tarea de los profesores ha sido la de observar la dinámica de trabajo en equipo para tomar nota de su funcionamiento y reconducir situaciones anómalas, que con frecuencia se han presentado.

\section{CT12 Planificación y gestión del tiempo}

Competencia indispensable para organizar y distribuir correctamente el tiempo de todas las actividades necesarias para alcanzar los objetivos propuestos. Las tres primeras actividades $\mathrm{y}$ un avance de los resultados deben realizarse en las cinco horas y media de clase previstas. En particular, la componente temporal es importante en la elección de los dos diseños de experimentos solicitados. El diseño escogido determina el número de pruebas a realizar, y la elección de un diseño u otro implica mucho más (o mucho menos) tiempo invertido en la ejecución del mismo. Además el problema se ha planteado de forma que los alumnos deban medir la envergadura temporal de la experimentación a realizar, y que esta sea una cuestión de peso en la elección de los diseños escogidos. Así mismo, la redacción de la memoria debe cumplirse en plazos, y la exposición de resultados completos se ajustará a los tiempos especificados. En este caso, las competencias exigidas para la parte final de la actividad propuesta corresponden al nivel 2, debido a que el trabajo se desarrolla en una única tarde, y la planificación de las tareas se realiza a muy corto plazo.

\section{Resultados}

Los resultados obtenidos en la materia con la introducción de la actividad de innovación y el cambio en la forma de evaluación son muy satisfactorios, de acuerdo a las impresiones manifestadas por los alumnos tanto al terminar la sesión de trabajo en el laboratorio como en la posterior presentación de los resultados. En todo momento la actitud mostrada por los estudiantes ha sido totalmente participativa y muy positiva, generando un buen ambiente de trabajo. El haber resuelto el problema, cuestión que queda patente para los alumnos en el experimento final, les produce una sensación de punto final con la evidencia de que todos los objetivos se han cumplido correctamente.

Desde el punto de vista de la evaluación de la asignatura, el análisis del montaje necesita de la mayor parte de los conocimientos estadísticos e informáticos que los alumnos han adquirido durante el curso. Además ha sido necesario que los alumnos conecten y estructuren mentalmente dichos conocimientos para llegar a la solución final. Y por si fuera 
poco, ha habido un proceso adicional de racionalización al escribir la memoria final, mostrando el dominio de un lenguaje específico que pueden adaptar al nivel de la audiencia. En definitiva, se trata de una completísima forma de evaluar los conocimientos de la asignatura.

Pero dado que la satisfacción no puede ser introducida en el acta, y una calificación numérica sí, será necesario comparar los resultados obtenidos en las seis ediciones en que la materia completa de DOE ha sido ofertada a los estudiantes del máster.

Teniendo en cuenta la introducción en la asignatura de la nueva metodología la calificación final de un alumno en la asignatura se obtiene a partir de la expresión:

$$
\text { NotaFinal }=0,6 * \text { NotaPracticas }+0,4 * \text { NotaActividad }
$$

Donde

- NotaPracticas corresponde a la nota media de todos los ejercicios realizados en las sesiones de prácticas en el aula informática. Se llevan a cabo cinco sesiones de aula informática, con una duración de dos horas y media cada una, y en las que los alumnos realizan once ejercicios prácticos. En estos ejercicios se les facilita un enunciado referente a una cierta problemática, con datos procedentes de las colaboraciones de los profesores de la asignatura en diferentes empresas, modificados por razones de confidencialidad. Los alumnos deben escoger la técnica estadística de análisis adecuada para el tratamiento de los datos utilizando software estadístico y elaborando un informe con las conclusiones del análisis y las recomendaciones de mejora.

- NotaActividad es la nota obtenida en la realización del trabajo relativo al experimento de la centrifugadora. Esta nota se obtiene a partir de la memoria entregada, de su presentación, y de la observación del proceso de trabajo del equipo.

La Tabla 2 muestra el detalle del número de alumnos que ha obtenido las diferentes calificaciones en la materia (Excelente, Notable, Aprobado, No Presentado) en cada uno de los seis cursos, y la Figura 3 muestra estos mismos resultados representados gráficamente. Es necesario señalar que los alumnos que figuran como no presentados lo son por haber conseguido un contrato laboral y no haber podido continuar los estudios por incompatibilidad de los horarios o trabajar finalmente fuera de España.

Tabla 2. Resultados de la evaluación en los seis años de impartición

\begin{tabular}{|ccccccc|}
\hline AÑO & Exc & Not & Apr & NP & Tot & Evaluación \\
\hline $\mathbf{2 0 0 9 - 2 0 1 0}$ & 0 & 2 & 5 & 1 & 8 & Trabajo \\
$\mathbf{2 0 1 1 - 2 0 1 2}$ & 0 & 5 & 17 & 1 & 23 & Trabajo \\
$\mathbf{2 0 1 3 - 2 0 1 4}$ & 0 & 4 & 0 & 0 & 4 & Trabajo \\
$\mathbf{2 0 1 5}-2016$ & 8 & 4 & 0 & 0 & 12 & Experimento \\
$\mathbf{2 0 1 6 - 2 0 1 7}$ & 4 & 10 & 0 & 0 & 14 & Experimento \\
$\mathbf{2 0 1 7}-2018$ & 5 & 2 & 0 & 1 & 8 & Experimento \\
\hline
\end{tabular}

(cc) EY-NC-ND 2018, Universitat Politècnica de València

Congreso IN-RED (2018) 


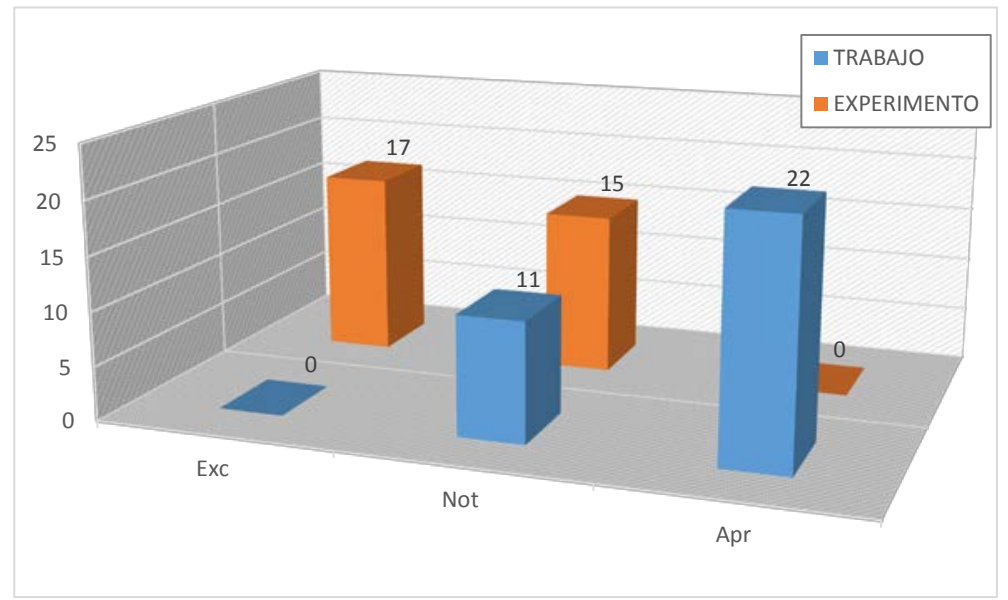

Fig. 3 Rendimiento de los alumnos en la materia de DOE en los seis años analizados, antes y después de la introducción de la innovación escogida

En los primeros años del máster la evaluación de la materia DOE se llevaba a cabo mediante la realización de un trabajo en el que los alumnos analizaban dos problemas reales, obtenidos a través de artículos de investigación publicados en revistas de ingeniería (referenciado como Trabajo en la Tabla 2). Los problemas se referían a la propuesta teórica de un diseño de experimentos y al análisis de los resultados del trabajo realizado por otros. Las notas obtenidas eran bastante discretas, con un porcentaje de aprobados de un $67 \%$ y un porcentaje de notables de un 33\%, como se puede observar en el diagrama de sectores en la izquierda de la Figura 4. Durante el curso 2015-2016 se introdujo el cambio en la metodología docente, incluyendo la experimentación real en el proceso de aprendizaje y cubriendo el vacío existente entre el propio diseño del experimento y el análisis de los datos resultantes (referenciado como Experimento en la Tabla 2). Esto ha propiciado replantearnos la asignatura atendiendo a las competencias a alcanzar por los alumnos. Como puede observarse en el diagrama de sectores de la derecha en la Figura 4, los resultados son muy satisfactorios, por ejemplo el rango de las calificaciones obtenidas ha pasado del aprobado-notable al notable-excelente, con un porcentaje de excelente de un $53 \%$, y de notable de un $47 \%$. Además, si se tiene en cuenta que ahora los estudiantes son evaluados de un número considerablemente mayor de competencias, la mejora es todavía mucho mayor. 

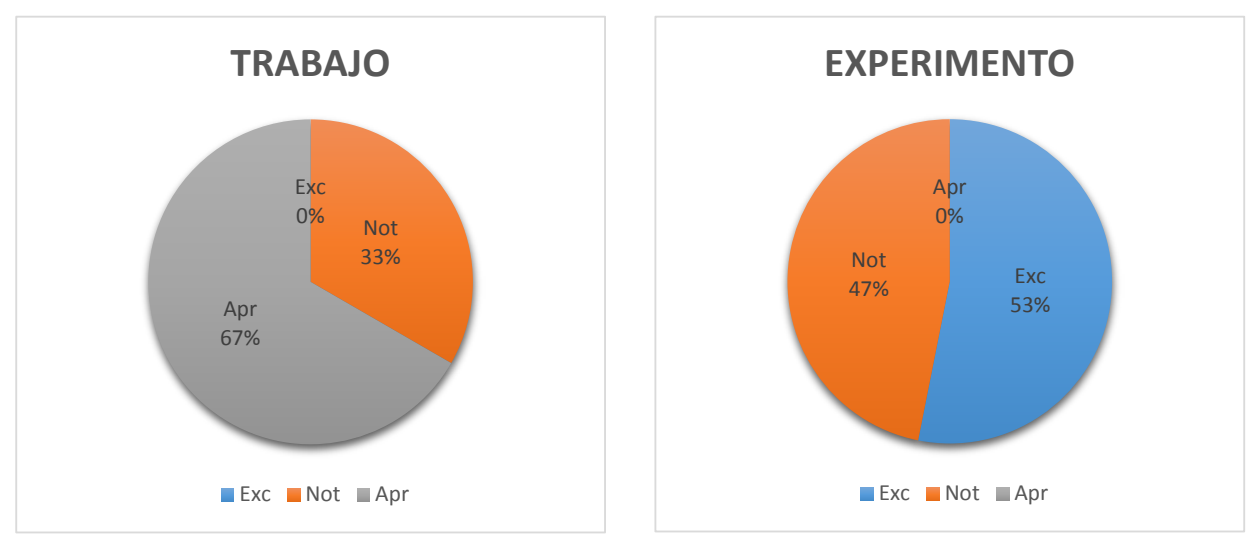

Fig. 4 Diagramas de sectores con las calificaciones de los alumnos, según han sido evaluados: mediante un trabajo final o mediante la actividad de innovación escogida

\section{Conclusiones}

En 2009 cuando se puso en marcha el máster de Ingeniería de Análisis de Datos, Mejora de Procesos y Toma de Decisiones, el profesorado de la UPV no estaba familiarizado con el concepto de aprendizaje basado en competencias. La materia de DOE se planteó con actividades que involucraran la participación activa del alumno y que reflejaran de forma “adecuada” su aplicación en la industria.

La introducción de las competencias de forma explícita y detallada en la guía de la asignatura, y en especial las competencias transversales ha permitido que el profesorado implicado en la docencia de esta materia realizara un cambio en la forma de proceder en las sesiones prácticas y en la evaluación de las asignaturas. La realización de experimentos reales en el laboratorio por parte de los alumnos surgió de manera natural para desarrollar y evaluar las competencias.

Se ha propuesto la realización de experimentos in situ que simulan procesos complejos en el ámbito de la ingeniería, lo que permite a nuestros alumnos reconocer la importancia que tiene el diseño de experimentos en la industria. Esta metodología activa refuerza los objetivos propuestos en las asignaturas: la selección del diseño de experimentos, la realización del análisis, la interpretación de los resultados y la determinación de las condiciones operativas óptimas asociadas al producto o proceso analizado. Además de estimular y motivar el trabajo y la participación activa del alumno, permite desarrollar las competencias de trabajo en equipo, planificación, análisis y resolución de problemas, así como la redacción y presentación pública de informes de carácter técnico-científico. Consideramos que el experimento propuesto proporciona una visión global de los contenidos ofrecidos en la materia, además de hacer explícitas y evaluables las competencias que se han comprometido con la ERT, incrementando y mejorando el aprendizaje. Sin lugar a dudas, pensamos que los alumnos formados con esta metodología serán mejores profesionales, ayudando así a cubrir las expectativas de formación que la sociedad demanda a la universidad. 


\section{Referencias}

FERNÁNDEZ MARCH, A. (2006). Metodologías activas para la formación de competencias. Educatio S.XXI núm. 24, pág. 35-56. En http://revistas.um.es/educatio/article/view/152/135.

GIMA (2008). Metodologías activas. Valencia : Universitat Politècnica de València, Editorial UPV.

GONZÁLEZ, N. (2013). "Metodologías activas en la docencia universitaria: importancia, conocimiento y uso en opinión del profesorado”. REVALUE Revista de evaluación educativa, (vol. 2, núm. 2, pág. 88-107). http://revalue.mx/revista/index.php/revalue/issue/current [Consulta: 18 de marzo de 2018].

PEIRO-SIGNES, A. y SEGARRA-OÑA, M. (2015). "Experiential learning as a dynamizer of class activity”. En Proceedings of International Conference of Education, Research and Innovation, pág. 1010-1013. Noviembre 2015, Sevilla.

ROMERO, R. y ZÚNICA, L.R. (2004). Métodos estadísticos en Ingeniería, Editorial Universitat Politèncica de València.

UPV, Universidad Politécnica de Valencia. Proyecto institucional de las competencias transversales. http://www.upv.es/contenidos/COMPTRAN/) [Consulta: 14 de marzo de 2018].

VILLA, A., POBLETE, M. (2007). Aprendizaje basado en competencias. Una propuesta para la evaluación de las competencias genéricas. Ediciones Mensajero. Bilbao. 


\title{
La actitud hacia el trabajo en equipo en estudiantes universitarios
}

\author{
María Yolanda González Alonso ${ }^{\mathrm{a}}$, Mónica Cano Rosás ${ }^{\mathrm{b}}$, Estíbaliz Jiménez Arberás ${ }^{\mathrm{c}}$ y \\ Thais Pousada García ${ }^{\text {. }}$ \\ ${ }^{\mathrm{a}}$ Universidad de Burgos, ${ }^{\mathrm{b}}$ Universidad de Salamanca, ${ }^{\mathrm{c}}$ Universidad de Oviedo, ${ }^{\mathrm{d}}$ Universidad de la \\ Coruña.
}

\begin{abstract}
Teamwork is considered a valuable competence in university teaching to acquire interpersonal and cognitive skills. The main objective is to analyze the perspectives and experiences that each student has had in relation to the groups to guide the active methodology that will be applied in the teachinglearning process of the subject. It is a quantitative, descriptive, interpretative investigation. The students of the first grade level $(n=69)$ answer a questionnaire about group attitudes at the beginning of the subject. The results confirm the importance of teamwork for students, the perception of their attitude towards teamwork is good, although only $55.1 \%$ is more inclined towards positive attitudes towards teams. The data provided help in the design of an innovation experience by applying an active methodology in which knowledge about positive attitudes to work in a team and apply them in different tasks must be included. The acquisition of these competences must be continuous and progressive on the part of the student and requires specific feedback on the correct behaviors to work effectively as a team and an evaluation that accompanies the learning process.
\end{abstract}

Keywords: Interaction, Cooperative learning, Evaluation, Interdependence, Responsibility, Feedback.

\section{Resumen}

El trabajo en equipo se considera una competencia valiosa en la enseñanza universitaria para adquirir destrezas interpersonales y cognitivas. El objetivo es analizar las perspectivas y experiencias que cada estudiante ha tenido en relación con los grupos para orientar la metodología activa que se aplicará en el proceso enseñanza aprendizaje de la asignatura. Se trata de una investigación cuantitativa, descriptiva interpretativa. El alumnado de primer curso de grado $(n=69)$ contesta al principio de la asignatura a un cuestionario sobre actitudes grupales. Los resultados confirman la importancia que tiene el trabajo en equipo para los estudiantes, la percepción sobre su actitud hacia el trabajo en equipo es buena, aunque solo el 55,1\% se inclina más a actitudes positivas ante los equipos. Los datos aportados ayudan en el diseño de una experiencia de innovación aplicando una metodología activa en la que se deben incluir conocimiento sobre cuáles son las actitudes positivas para trabajar en equipo y aplicarlas en las diferentes tareas. La adquisición de estas competencias debe ser continua y progresiva por parte del estudiante y requiere retroalimentación específica 
sobre las correctas conductas para trabajar eficazmente en equipo y una evaluación que acompañe el proceso de aprendizaje.

Palabras clave: Interacción, Aprendizaje cooperativo, Evaluación, Interdependencia, Responsabilidad, Retroalimentación.

\section{Introducción}

La sociedad exige la formación de universitarios en conocimientos actualizados, en habilidades y en competencias específicas sobre su carrera y también se necesita aprender a crecer y progresar en competencias personales y profesionales cambiantes y cada vez más complejas. La transmisión de actitudes, como la capacidad de trabajo en equipo es una de las labores más difíciles (Richardson, Dawson, Sadlo, Jenkins y Mcinnes, 2007).

En las últimas décadas se ha desarrollado una corriente importante en torno al trabajo en equipo y a los beneficios que pueden esperarse en cuanto a la efectividad y mejora de la calidad en todos los ámbitos del trabajo donde se necesita la participación de diversas disciplinas y profesionales, como es el caso de materias de ciencias de la salud (Durante y Noya, 2003).

La relevancia del trabajo en equipo se ha tratado por diferentes autores como herramienta para el desarrollo exitoso de la actividad docente que pretende la adquisición de conocimientos y el desarrollo de habilidades del alumnado (Pegalajar y Colmenero, 2013). Actualmente es frecuente programar diversas actividades donde el estudiante trabaja en grupo, participa en seminarios, elabora proyectos y diseña talleres (González-Alonso y Escolar-Llamazares, 2017).

El grupo ejerce una influencia muy poderosa sobre el individuo, puede modelar y modificar muchos comportamientos, aptitudes y actitudes individuales. En la Universidad se ha justificado su utilidad y validez académica considerándose una competencia muy demandada en el ámbito profesional y laboral, objeto de estudio en innovación docente (Fidalgo, 2016).

\subsection{Aprendizaje basado en competencias}

El concepto competencia ocupa un amplio espacio de reflexión dentro del modelo educativo universitario que puede definirse como el conjunto de conocimientos, actitudes y destrezas necesarias para desempeñar una función (Le Boterf, 2001).

El trabajo en equipo se define como una competencia básica a desarrollar por el estudiante en cualquier titulación, teniendo ésta un carácter transversal a lo largo de su itinerario (Zubimendi, Ruiz, Carrascal, y De la Presa, 2010) y siendo valiosa para la formación integral de los estudiantes.

Entre las estrategias de enseñanza-aprendizaje que el docente debe potenciar en el estudiante se encuentra la competencia del trabajo en equipo. Se trata de que el alumnado sea capaz de colaborar y participar como miembro de un grupo, asumiendo la responsabilidad y el compromiso propios hacia las tareas y funciones que se tienen

(cc) EY-NC-ND 2018, Universitat Politècnica de València

Congreso IN-RED (2018) 
asignadas para la consecución de unos objetivos comunes, siguiendo los procedimientos acordados y atendiendo a los recursos disponibles (Jacques y Jacques, 2007).

El trabajo en equipo también forma parte del perfil competencial del profesorado universitario junto con la competencia interpersonal, la metodológica, la comunicativa, la de planificación, la gestión de la docencia y la competencia de innovación (Zamorano y Parejo, 2016).

$\mathrm{Al}$ revisar la literatura aparecen numerosas investigaciones que argumentan que el trabajo en equipo contribuye a éxitos académicos de los estudiantes y al desarrollo de otras habilidades, estableciendo conexión entre aprendizajes teóricos y prácticos (Fernández, 2006; Nam y Zellner, 2011; Pujolás, 2008). Aunque no todas las experiencias han tenido éxito, Ariza y Oliva (2004) señalan algunos inconvenientes como la pérdida de iniciativa y compromiso, la conformidad, el retraso en el proceso del trabajo, el desentendimiento y los conflictos.

El aprendizaje en el aula debe ir dirigido a desarrollar prácticas didácticas innovadoras, que favorezcan la reflexión, la participación y la colaboración en la construcción de conocimientos. El trabajo en equipo supone un desafío para el profesorado que tiene que desarrollar nuevos enfoques metodológicos, más inductivos, críticos y colaborativos (Cano, 2005). En las metodologías que aplican trabajo en equipo los resultados son positivos, se mejora el clima de trabajo, las actitudes del estudiante y su grado de motivación, así como su rendimiento (Korkmaz, 2012).

El reto es determinar que metodología activa debe utilizar el docente para potenciar las habilidades de trabajo en equipo que son necesarias y así desarrollar esta competencia.

\subsection{El trabajo en equipo}

Diferentes autores han investigado la eficacia del trabajo en equipo en el aula demostrando que esta metodología enseña estrategias y habilidades de cooperación, facilita la comprensión de los aprendizajes, aumenta su rendimiento educativo y fomenta actitudes de respeto, tolerancia e interacción entre los estudiantes (Villa y Poblete, 2007). Aunque esta forma de enseñanza requiere un gran esfuerzo dinamizador e innovador por parte del profesorado.

A través de estos métodos se trata de lograr según Johnson y Johnson (2000) cinco elementos esenciales: uno, interdependencia positiva, cuando el estudiante piensa que está ligado con sus compañeros de manera que no tendrá éxito si los demás miembros del equipo tampoco lo tienen; dos, responsabilidad individual, si cada miembro rinde cuentas no solo de su parte del trabajo, también del trabajo del resto; tres, interacción cara a cara, los estudiantes se ayudan, se asisten, se animan y se apoyan en su esfuerzo por aprender de manera que se reúnan para ello; cuatro, habilidades sociales, tales como liderazgo, capacidades de decisión, de generar confianza y comunicación y de gestión de conflictos; y cinco, procesamiento grupal autónomo, que supone que el propio equipo analiza en qué medida se están logrando los objetivos y la relación de trabajo efectiva entre los participantes. 
Esta competencia se consigue a través de un proceso que conlleva la adquisición de diferentes habilidades, difíciles de alcanzar. El primer paso es determinar si el alumnado conocen los aspectos que caracterizan un trabajo en equipo eficiente y el segundo si el propio estudiante considera que su actitud hacia el trabajo en equipo es buena.

Con esta información el docente podrá elegir las actividades y metodología adecuada, se trata de adaptarlas a los objetivos de enseñanza aprendizaje, a la madurez y entrenamiento de los participantes, al tamaño del grupo, al ambiente físico, a las características de los miembros y a la capacidad del docente (López et al., 2014).

La hipótesis es que los estudiantes de primer curso valoran su actitud general hacia el trabajo en equipo de manera más positiva que la puntuación obtenida en las diferentes habilidades.

\section{Objetivos}

El objetivo de esta investigación es analizar las perspectivas y experiencias que cada estudiante ha tenido en relación con los grupos para orientar la metodología activa que se aplicará en el proceso enseñanza aprendizaje de la asignatura.

Para lo cual se plantea valorar al principio de curso la actitud hacia el trabajo en equipo del alumnado de primero de grado y analizar las diferencias entre la percepción subjetiva de cada estudiante sobre su actitud hacia el trabajo en equipo y el resultado obtenido en el cuestionario. A partir de este análisis se pretende orientar los contenidos y metodología de la asignatura para que al finalizar el curso el alumnado trabaje en equipo de manera eficaz.

Las preguntas claves fueron: ¿qué actitud para trabajar en equipo consideran que tienen los alumnos de primero en la universidad?, ¿coincide la actitud que cada estudiante cree que tiene, con su conocimiento sobre las habilidades que debe tener para trabajar en equipo de manera eficaz?, y ¿cómo influye esto en la planificación de la metodología enseñanzaaprendizaje del docente?

\section{Desarrollo de la innovación}

La experiencia se ha llevado a cabo en una asignatura de Grado de Terapia Ocupacional que se imparte en la Universidad de Burgos, durante el curso 2016-2017.

El grado de terapia ocupacional tiene unas competencias básicas, generales, transversales y específicas que ha de cumplir el alumnado cuando acaba su etapa de formación. Dentro de las competencias generales que se aprenden en esta asignatura está desarrollar la práctica profesional con respecto a otros profesionales, adquiriendo habilidades de trabajo en equipo.

\subsection{Participantes}

En esta investigación se ha utilizado una muestra de conveniencia no probabilística, formada por 69 estudiantes de primer curso del grado de Terapia Ocupacional. El alumnado matriculado en carreras de Ciencias de la Salud, en concreto en Terapia Ocupacional está formado principalmente por mujeres, en este curso el $85,5 \%$ son mujeres y la edad media es de 19 años. Se aplicó en una materia obligatoria, semestral, eminentemente experimental

(cc) EY-NC-ND 2018, Universitat Politècnica de València

Congreso IN-RED (2018) 
donde el tamaño real del grupo secundario está formado por un número reducido de estudiantes (15) y la asignatura cuenta con 6 créditos (ECTS).

\subsection{Instrumento}

Los datos que se incluyen en este estudio se han obtenido de un cuestionario sobre la Actitud ante los grupos, elaborado por Trechera, 2003 (Anexo I).

El cuestionario plantea treinta preguntas sobre situaciones grupales para conocer las distintas perspectivas y experiencias que cada estudiante ha tenido en relación a los equipos de trabajo. Para responder al cuestionario se rellena la puntuación de una escala Likert de 5 opciones donde 1 es totalmente en desacuerdo y 5 es totalmente de acuerdo. Al sumar las elecciones realizadas se obtiene una puntuación numérica que indica hacia dónde se inclina el alumnado en cuanto a dos posturas extremas: postura positiva hacia el trabajo en equipo y la contraria, negativa, que considera el equipo como una pérdida de tiempo. Aunque lo importante no es tanto la puntuación numérica, sino hacia dónde va la tendencia individual y los componentes del equipo, ya que indicará qué actitud subyace respecto al trabajo en equipo.

Al final del cuestionario se realiza una pregunta sobre la valoración subjetiva de cada estudiante, sobre su actitud para trabajar en equipo del 1 al 5 , siendo 1 muy mala y 5 muy buena.

\subsection{Procedimiento}

El primer día de clase de la asignatura Recursos y herramientas de la Terapia Ocupacional, todos los estudiantes asistentes rellenan un cuestionario sobre su actitud ante los grupos. Se les informa sobre los objetivos y se les dan las instrucciones previas para la adecuada cumplimentación, aplicando los criterios éticos y garantizando la confidencialidad de los datos.

\subsection{Tratamiento de datos}

Una vez recogidos los datos, con el programa estadístico SPSS (versión 24) se llevaron a cabo los análisis descriptivos. Se analizan los datos obtenidos tanto con el cuestionario como la valoración subjetiva y se comparan ambas en cada estudiante. Esta información ayuda a identificar en que habilidades se debe insistir más y tenerlo en cuenta en el diseño metodológico de la asignatura.

\section{Resultados}

Han participado en el estudio 69 estudiantes de los 73 matriculados en la asignatura.

Teniendo en cuenta los objetivos de la investigación se realizó en primer lugar un análisis descriptivo de los datos obtenidos en el cuestionario y así se puede observar la media y la desviación típica de los ítems con los que los estudiantes están más en desacuerdo y más de acuerdo. Se comprueba que de las treinta preguntas del cuestionario, en la tabla 1 aparecen las cuatro más elegidas que muestran su actitud más positiva y destaca el ítem si hay buen clima grupal y las personas están a gusto en el equipo, se implicarán y funcionarán mejor. Y de las cuatro que se alejan más de la actitud positiva que señalan más estudiantes (tabla 
2), destaca si los miembros de un equipo están unidos son capaces de conseguir cualquier tipo de objetivo.

Tabla 1. Ítems con actitud más positiva ante el equipo

ITEM

MEDIA

D. TÍPICA

$\begin{array}{lcc}\begin{array}{l}\text { 29. Si hay buen clima grupal y las personas están a gusto en el } \\ \text { equipo, se implicarán y funcionarán mejor }\end{array} & 1,40 & 0,92 \\ \begin{array}{l}\text { 8. Es importante que los miembros de una organización tengan que } \\ \text { conocer los objetivos, medios y actuaciones de la misma }\end{array} & 1,44 & 0,58 \\ \begin{array}{l}\text { 22. Comunicar y saber escuchar es fundamental para un buen } \\ \text { funcionamiento del equipo }\end{array} & 1,46 & 0,99 \\ \begin{array}{l}\text { 25. Es más efectivo que en el equipo las decisiones se tomen por } \\ \text { consenso }\end{array} & 1,91 & 1,08 \\ \end{array}$

Tabla 2. Ítems con actitud más negativa ante el equipo

ITEM

MEDIA

D. TÍPICA

6. Si los miembros de un equipo están unidos son capaces de 4,56 conseguir cualquier tipo de objetivo.

13. Es importante para ser operativos que las normas en un equipo ya estén dadas y sean claras para que no se pierda tiempo en organizarse o tener que elaborarlas

11. Para que el líder de un equipo sea imparcial, es mejor que no se implique afectivamente con los miembros

1. El ser humano tiende al conformismo y a dejarse influir por los demás

Las puntuaciones totales obtenidas por los estudiantes en el cuestionario se encuentran entre 58 y 102, teniendo en cuenta que la puntuación total de la actitud más positiva ante los grupos es 30 y la más negativa es 150. Si se divide la puntuación en 5 grupos: 5 (puntuación entre 30-54), 4 (puntuación entre 55-79), 3 (puntuación entre 80-104), 2 (puntuación entre 105-129) y 1 (puntuación entre 130-150) se puede ver que todos los estudiantes se encuentran entre el grupo 3 y 4 ).

En cuanto a los resultados que se obtienen tras el análisis de las valoraciones respecto a la percepción subjetiva que el estudiante tiene sobre su propia actitud para trabar en equipo, las puntuaciones se encuentran en un rango, entre 2-5 con una media de 4.

Al comparar ambas puntuaciones se comprueba que mientras el rango en el cuestionario está entre 3-4 siendo la puntuación media 3,5. La percepción del alumnado tiene un rango

(cc) EY-NC-ND 2018, Universitat Politècnica de València

Congreso IN-RED (2018) 
más amplio de 2 a 5, y medio punto de diferencia con la media de la percepción subjetiva. En menos de la mitad de los estudiantes coincide la puntuación subjetiva y la puntuación del cuestionario (36,3 \%), más de la mitad se valoran con un punto por encima $(50,7 \%)$ y muy pocos (8,7\%) se valoran por debajo. El 4,3\% se valoran dos puntos o más de diferencia tanto por arriba como por debajo. El mayor porcentaje en ambas puntuaciones está en 4 . La mayoría de los estudiantes dicen estar más cerca de la actitud positiva hacia los equipos $(65,9 \%)$ y en la puntuación en el cuestionario también, aunque más baja (55,1\%) (Tabla 3).

Tabla 3. Porcentajes de puntuación positiva en el cuestionario y percepción subjetiva de la actitud hacia el trabajo en equipo

\section{PUNTUACIÓN PERCEPCIÓN}

RANGO EN EL CUESTIONARIO

DEL ESTUDIANTE

\begin{tabular}{ccccc}
\hline & $\mathbf{\%}$ & $\mathbf{\%}$ & $\mathbf{\%}$ & $\mathbf{N}$ \\
5 & 0 & 0 & 17,4 & 12 \\
4 & $\mathbf{5 5 , 1}$ & 38 & $\mathbf{6 5 , 9}$ & 45 \\
3 & 44,9 & 31 & 15,9 & 11 \\
2 & 0 & 0 & 1,5 & 1 \\
1 & 0 & 0 & 0 & 0 \\
\hline TOTAL & 100 & 100 & 100 & 69 \\
\hline
\end{tabular}

Se puede apreciar que las posturas más negativas podrían impedir un trabajo en equipo eficaz, sin embargo son muchos los estudiantes que consideran que su actitud hacia el trabajo en equipo es muy positiva. Por lo que parece difícil que se preocupen de cambiar algunas de sus actuaciones para trabajar mejor en equipo, puesto que creen hacerlo bien. El ítem que mayor desviación típica presenta, es la pregunta relacionada con el líder para que el líder de un equipo sea imparcial, es mejor que no se implique afectivamente con los miembros.

Estos análisis proporcionan información valiosa a tener en cuenta por el docente en el diseño de metodologías y así potenciar estas habilidades acerca de esta competencia de trabajo en equipo.

\section{Conclusiones}

En definitiva, a pesar de las valoraciones altas en cuanto a la actitud positiva hacia el trabajo en equipo, el profesorado debe considerar algunos aspectos básicos que no tienen adquiridos los estudiantes, por lo que se hace necesario poner en marcha estrategias que faciliten el desarrollo de las habilidades de trabajo en equipo en el aula. El primer paso fue dar a conocer al estudiante que no cuenta con actitudes tan positivas como se cree y que sepa cuáles son sus errores. Para posteriormente conocer y practicar a través de metodologías activas las habilidades que se requieren en un trabajo en equipo para que sea 
eficaz y recibir retroalimentación continua sobre aquellas que se van adquiriendo, bien sea información de los compañeros y/o del docente.

En este caso se deseñaron metodologías activas como el puzle, el seminario, el aprendizaje basado en problemas, juegos de roles, talleres y estudio de casos. El propósito fue mejorar habilidades en estos estudiantes como el diseño de objetivos comunes, la aplicación del consenso de manera eficaz, la gestión de las emociones, el manejo del liderazgo y la reflexión y el análisis de contenidos. Es decir practicar al menos las cuatro habilidades con las que se encontraban más de acuerdo en el cuestionario que, reflejaban actitudes negativas hacia el trabajo en equipo.

Los futuros terapeutas ocupacionales, tendrán que desempeñar su empleo en diferentes grupos y con personas heterogéneas, lo cual convierte el trabajo en equipo en una competencia muy necesaria. Aunque durante su formación los estudiantes realizan diferentes trabajos en grupos, estas actividades por si solas no garantizan que a lo largo de todos los cursos se adquieran las capacidades requeridas si no reciben formación específica y retroalimentación continua. Hay que aprovechar que el alumnado tiene una actitud positiva aunque un primer paso es hacerles comprender que les faltan habilidades o que necesitan mejorarlas.

Una de las limitaciones de este estudio se debe al propio diseño descriptivo transversal que no permite generalizar los datos. Para futuras investigaciones se propone conocer la percepción del alumnado de otros cursos y de otras Universidades y valorar al estudiante al principio y al final de la impartición de la asignatura para comprobar si se adquiere una actitud más positiva hacia el trabajo en equipo tras aplicar las metodologías activas más apropiadas. No hay que olvidar, que el docente debe proporcionar una retroalimentación continua mientras el estudiante utiliza cada una de las técnicas. Así se va consiguiendo el cambio en aquellas actitudes que están frenando la adquisición de habilidades para un trabajo en equipo eficaz.

\section{Referencias}

ARIZA, A. Y OLIVA, S. (2004). "Las nuevas tecnologías de la información y la comunicación y una propuesta de trabajo colaborativo”. Comunidad Virtual de Tecnología y Liderazgo.

CANO, E. (2005). Cómo mejorar las competencias docentes. Guía para la autoevaluación y el desarrollo de competencias del profesorado. Barcelona. Graó.

DURANTE, P. Y NOYA, B. (2003). “Trabajo en equipo. Contribución del terapeuta ocupacional”. En Polonio, B., Durante, P. y Noya, B. Conceptos fundamentales de terapia ocupacional. Madrid: Panamericana.

FERNÁNDEZ, M. (2006). "Metodologías activas para la formación de competencias”. Education silo XXI, 24, 35-56.

FIDALGO, Á. (2016). “La innovación docente y los estudiantes”. La cuestión universitaria, (7), 8491.

(cc) BY-NC-ND 2018, Universitat Politècnica de València

Congreso IN-RED (2018) 
GONZÁLEZ-ALONSO, MY. Y ESCOLAR-LLAMAZARES, MC. (2017). "Valoración de las estrategias de participación del alumnado en el aula universitaria". Actas de las IX Jornadas de Redes de Investigación en Innovación Docente de la UNED. Madrid, junio 2017.

JACQUES, J. Y JACQUES, P. (2007). Cómo trabajar en equipo: Guía práctica. Madrid: Narcea Ediciones

JOHNSON, D. W Y JOHNSON, R. T. (2000). Cooperative learning. Buenos Aires. Paidos.

KORKMAZ, Ö. (2012). “A validity and reliability study of Online Cooperative Learning Attitude Scale (OCLAS)”. Computers \& Education, 59, 1162-1169.

LE BOTERF, G. (2001). Ingeniería de las competencias. Barcelona. Gedes

LÓPEZ, B. G., BERTOMEU, I. M., CHORNET, S. I., OLMEDO, M. J. C., OLTRA, S. N., Y FÉLIX, E. G. (2014). “Metodología centrada en el aprendizaje. Su impacto en las estrategias de aprendizaje y en el rendimiento académico de los estudiantes universitarios”. Revista española de pedagogía, 415-435.

NAM, CW. Y ZELLNER, RD. (2011). "The relative effects of positive interdependence and group processing on student achievement and attitude in online cooperative learning”. Computers \& Education, 56, 680-688.

PEGALAJAR, MC. Y COLMENERO, MJ. (2013). "Percepciones hacia el aprendizaje cooperativo en estudiantes del Grado de Maestro”. Revista Docencia Universitaria. REDU. Vol. 11 (3).

PUJOLÁS, P. (2008). El aprendizaje cooperativo: 9 ideas clave. Barcelona: Graó.

RICHARDSON, J. T., DAWSON, L., SADLO, G., JENKINS, V., Y MCINNES, J. (2007). "Perceived academic quality and approaches to studying in the health professions". Medical Teacher, 29 (5), e108-e116.

TRECHERA, J. L. (2003). Trabajar en Equipo: Talento y talante. Técnicas de dinámica de grupos. Bilbao: Desclée de Brouwer, S. A.

VILLA, A. Y POBLETE, M. (2007). Aprendizaje Basado en Competencias. Una propuesta para la evaluación de Competencias genéricas. Bilbao: Mensajero.

ZABALZA, M. Á. (2016). “Ser profesor universitario hoy”. La cuestión universitaria, (5), 68-80.

ZAMORANO, S., Y PAREJO, J. L. (2016). "La renovación de las metodologías educativas como garantía de calidad institucional”. La Cuestión Universitaria, (2), 45-64.

ZUBIMENDI, JL., RUIZ, MP, CARRASCAL, E. Y DE LA PRESA, H. (2010). El aprendizaje cooperativo en el aula universitaria. Manual de ayuda al profesorado. Universidad del País Vasco. 
Nombre y apellidos:

Fecha de nacimiento:

Fecha de hoy:

\section{TRABAJO EN EQUIPO}

Conteste a cada una de las proposiciones que aparecen a continuación según su grado de acuerdo o desacuerdo.

\begin{tabular}{|c|c|c|c|c|}
\hline $\begin{array}{c}\text { Totalmente en } \\
\text { desacuerdo }\end{array}$ & $\begin{array}{c}\text { En } \\
\text { desacuerdo }\end{array}$ & $\begin{array}{c}\text { Tengo } \\
\text { dudas }\end{array}$ & $\begin{array}{c}\text { De } \\
\text { acuerdo }\end{array}$ & $\begin{array}{c}\text { Totalmente de } \\
\text { acuerdo }\end{array}$ \\
\hline 1 & 2 & 3 & 4 & 5 \\
\hline
\end{tabular}

\begin{tabular}{|c|l|c|c|c|c|c|}
\hline 1 & $\begin{array}{l}\text { El ser humano tiende al conformismo y a dejarse } \\
\text { influir por los demás }\end{array}$ & 1 & 2 & 3 & 4 & 5 \\
\hline 2 & Es más rentable trabajar solola que en un equipo & 1 & 2 & 3 & 4 & 5 \\
\hline 3 & $\begin{array}{l}\text { Para ser operativos en la toma de decisiones, hay } \\
\text { que imponer decisiones por mayoria }\end{array}$ & 1 & 2 & 3 & 4 & 5 \\
\hline 4 & $\begin{array}{l}\text { El ideal de una organización es que todo el mundo } \\
\text { piense sienta y actúe de la misma manera }\end{array}$ & 1 & 2 & 3 & 4 & 5 \\
\hline 5 & $\begin{array}{l}\text { Si hay conficto en el equipo, lo más efectivo es } \\
\text { expulsar a los miembros discordantes }\end{array}$ & 1 & 2 & 3 & 4 & 5 \\
\hline 6 & $\begin{array}{l}\text { Si los miembros de un equipo están unidos son } \\
\text { capaces de conseguir cualquier tipo de objetivo }\end{array}$ & 1 & 2 & 3 & 4 & 5 \\
\hline 7 & $\begin{array}{l}\text { En general, en los equipos, los miembros se } \\
\text { esfuerzan menos que individualmente }\end{array}$ & 1 & 2 & 3 & 4 & 5 \\
\hline 8 & $\begin{array}{l}\text { No es importante que los miembros de una } \\
\text { organización tengan que conocer los objetivos, } \\
\text { medios y actuaciones de la misma }\end{array}$ & 1 & 2 & 3 & 4 & 5 \\
\hline 9 & $\begin{array}{l}\text { En los equipos es más fácil presionar a los } \\
\text { miembros para que unos pocos se salgan con la } \\
\text { suya }\end{array}$ & 1 & 2 & 3 & 4 & 5 \\
\hline 10 & $\begin{array}{l}\text { Para mantener la identidad de un equipo, es } \\
\text { preferible que se aisle de las influencias extemas }\end{array}$ & 1 & 2 & 3 & 4 & 5 \\
\hline 11 & $\begin{array}{l}\text { Para que el lider de un equipo sea imparcial, es } \\
\text { mejor que no se implique afectivamente con los } \\
\text { miembros }\end{array}$ & 1 & 2 & 3 & 4 & 5 \\
\hline 12 & $\begin{array}{l}\text { Es preferible que los miembros sean homogéneos } \\
\text { en conocimiento, formación, experiencia, actitudes, } \\
\text { etc. }\end{array}$ & 1 & 2 & 3 & 4 & 5 \\
\hline 13 & $\begin{array}{l}\text { Es importante para ser operativos que las normas } \\
\text { en un equipo ya estén dadas y sean claras para que } \\
\text { no se pierda tiempo en organizarse o tener que } \\
\text { elaborarlas }\end{array}$ & 1 & 2 & 3 & 4 & 5 \\
\hline
\end{tabular}

1

(cc) EY-NC-ND 2018, Universitat Politècnica de València Congreso IN-RED (2018) 


\begin{tabular}{|c|c|c|c|c|c|c|}
\hline 14 & $\begin{array}{l}\text { En un equipo siempre los intereses individuales } \\
\text { tiene que estar supeditados a los del equipo }\end{array}$ & 1 & 2 & 3 & 4 & 5 \\
\hline 15 & $\begin{array}{l}\text { Muchas personas no descubren sus capacidades } \\
\text { hasta que no forman parte de un equipo }\end{array}$ & 1 & 2 & 3 & 4 & 5 \\
\hline 16 & $\begin{array}{l}\text { Para tomar decisiones rápidas y evitar conflictos, es } \\
\text { preferible un liderazgo autoritario }\end{array}$ & 1 & 2 & 3 & 4 & 5 \\
\hline 17 & $\begin{array}{l}\text { Lo fundamental para un equipo es ser efectivo y } \\
\text { cumplir los objetivos que se ha planteado }\end{array}$ & 1 & 2 & 3 & 4 & 5 \\
\hline 18 & El trabajo en equipo es más lento y menos efectivo & 1 & 2 & 3 & 4 & 5 \\
\hline 19 & $\begin{array}{l}\text { Los equipos deben formarse y evolucionar } \\
\text { espontáneamente }\end{array}$ & 1 & 2 & 3 & 4 & 5 \\
\hline 20 & $\begin{array}{l}\text { Es imposible comunicar y poder llegar a acuerdos } \\
\text { con personas que piensan de forma distinta }\end{array}$ & 1 & 2 & 3 & 4 & 5 \\
\hline 21 & $\begin{array}{l}\text { Los equipos "Uniformizan" a sus integrantes;" "Dime } \\
\text { con quién andas y te diré quién eres" }\end{array}$ & 1 & 2 & 3 & 4 & 5 \\
\hline 22 & $\begin{array}{l}\text { Comunicar y saber escuchar es fundamental para } \\
\text { un buen funcionamiento del equipo }\end{array}$ & 1 & 2 & 3 & 4 & 5 \\
\hline 23 & $\begin{array}{l}\text { La capacidad para trabajar en equipo es innata al } \\
\text { sujeto }\end{array}$ & 1 & 2 & 3 & 4 & 5 \\
\hline 24 & $\begin{array}{l}\text { El equipo puede hacer que los integrantes se } \\
\text { esfuercen menos individualmente o se dejen llevar }\end{array}$ & 1 & 2 & 3 & 4 & 5 \\
\hline 25 & $\begin{array}{l}\text { Es más efectivo que en el equipo las decisiones se } \\
\text { tomen por consenso }\end{array}$ & 1 & 2 & 3 & 4 & 5 \\
\hline 28 & $\begin{array}{l}\text { Tener información es tener poder, de ahí que para } \\
\text { dirigir bien un equipo no haya que comunicar las } \\
\text { cosas }\end{array}$ & 1 & 2 & 3 & 4 & 5 \\
\hline 27 & $\begin{array}{l}\text { Es más efectivo trabajar como diez que hacer } \\
\text { trabajar a diez }\end{array}$ & 1 & 2 & 3 & 4 & 5 \\
\hline 28 & $\begin{array}{l}\text { "Más vale lo malo conocido que lo bueno por } \\
\text { conocer", es preferible mantener las actividades que } \\
\text { ya se dominan que abrirse a nuevos experimentos }\end{array}$ & 1 & 2 & 3 & 4 & 5 \\
\hline 29 & $\begin{array}{l}\text { Si hay buen clima grupal y las personas están a } \\
\text { gusto en el equipo se implicarán y funcionará mejor }\end{array}$ & 1 & 2 & 3 & 4 & 5 \\
\hline 30 & $\begin{array}{l}\text { Para no perder tiempo en el trabajo en equipo, es } \\
\text { más efectivo un liderazgo directivo }\end{array}$ & 1 & 2 & 3 & 4 & 5 \\
\hline
\end{tabular}

¿Cuál consideras que es tu actitud para trabajar en equipo del 1 al 5 , siendo 1 una actitud mury mala y 5 muy buena? 


\title{
La incorporación de un concurso de micrometrajes como innovación educativa en la asignatura de derecho de la información de $2^{\circ}$ de comunicación audiovisual de la Universitat Politècnica de València
}

\section{Gloria Doménech Martínez}

Profesora de la Universitat Politècnica de València (glodomar@urb.upv.es)

\begin{abstract}
The Universitat Poltècnica de Valencia (UPV) in the academic year 2013-2014 initiated a project that, in an experimental way, aims to accredit the transversal competences (CT) of its graduates. Among these competences is the CT 10 referred to the Knowledge of Contemporary Problems. For a graduate of the Audiovisual Communication Degree, the audiovisual product is his way of expressing his thoughts and ideas about the political, social and legal issues and values of the moment in which he lives. In the digital age we can not ignore the importance of the audiovisual product as a learning tool. We intend to introduce teaching innovation in the hand of activities that interest the student of the degree of Audiovisual Communication, and a good example of this, can be the micromanagement, an audiovisual tool suitable for this purpose. It is a teaching innovation of individual type that consists in the elaboration of a micrometraje, an audiovisual product. However, this will be a secondary element of our teaching innovation, the main objective is the reworking of the foundations of a contest (micromanagement) for which it is necessary to master the subject of intellectual property, compare and analyze the contents thereof with different assumptions, and ends with the development of a model contract of transfer of the intellectual property right contained in said micrometraje in favor of the sponsor of the contest.
\end{abstract}

Keywords: Transversal competition 10, educational short film, competition, transfer of rights, intellectual property

\section{Resumen}

La Universitat Poltècnica de València (UPV) en el curso académico 2013-2014 inició un proyecto que, de manera experimental, pretende acreditar las competencias transversales (CT) de sus egresados. Entre dichas competencias se encuentra la CT 10 referida al Conocimiento de los Problemas Contemporáneos. Para un egresado del Grado de Comunicación Audiovisual, el producto audiovisual es su modo de expresar sus pensamientos e ideas sobre las cuestiones y valores políticos, sociales y legales del momento en él vive. En la era digital no podemos ignorar la importancia del producto 
audiovisual, como herramienta de aprendizaje. Pretendemos introducir la innovación docente de la mano de actividades que interesan al alumno del grado de Comunicación Audiovisual, y un buen ejemplo de ello, puede ser el micrometraje, una herramienta audiovisual idónea para tal fin.

Se trata de una innovación docente de tipo individual que consiste en la elaboración de un micrometraje, un producto audiovisual. Sin embargo, este será un elemento secundario de nuestra innovación docente, el objetivo principal es la elaboración de las bases de un concurso (de micrometrajes) para la que es necesario dominar la materia de la propiedad intelectual, comparar y analizar los contenidos del mismo con distintos supuestos, y finaliza con la elaboración de un modelo de contrato de cesión del derecho de propiedad intelectual contenido en dicho micrometraje a favor del patrocinador del concurso.

Palabras clave: competencia transveral 10, micrometraje educativo, concurso, cesión derechos, propiedad intelectual

\section{1.- Introducción}

La Universitat Polítècnica de València (UPV) en el curso académico 2013-2014 inició un proyecto que, de manera experimental, pretende acreditar las competencias transversales $(\mathrm{CT})^{1}$ de sus egresados ${ }^{2}$. Todo ello en línea con la Declaración de Bolonia de 19 de julio de $1999^{3}$ y la regulación de las enseñanzas universitarias oficiales en España ${ }^{4}$. Entre dichas competencias se encuentra la CT 10 referida al Conocimiento de los Problemas Contemporáneos ${ }^{5}$. Con esta Competencia se alude a la necesidad de que los alumnos sean capaces de comprender las cuestiones y valores políticos, sociales y legales contemporáneos. Se pretende que en el entorno en el que se encuentran estén al día de los acontecimientos de la sociedad, en general, y de su campo del conocimiento, en particular. Para poder trabajar esta competencia de forma óptima se deben crear entornos, tanto en el aula, como fuera de ella, que permitan al alumno dialogar en profundidad en este tipo de cuestiones. Desde esta perspectiva y atendiendo a la materia de nuestro interés, el ámbito del derecho, en el grado de Comunicación Audivisual, no podemos ignorar, en la era

\footnotetext{
${ }^{1}$ http://www.upv.es/contenidos/COMPTRAN/info/955709normalc.html

2 Cáceres González P.A, Martínez García. A, Noguera Murray, P.,, Pérez Marín, E, y Sanabria-Codesal, E. Elaboración de materiales de apoyo para incorporar la competencia "Planificación y Gestión del Tiempo" en las asignaturas de la Universitat Politècnica de València. http://ocs.editorial.upv.es/index.php/INRED/INRED2016/paper/view/4346 (consulta marzo 2018).

${ }^{3}$ http://www.eees.es/es/documentacion (consulta marzo 2018)

${ }^{4}$ Real Decreto 861/2010, de 2 de julio, por el que se modifica el Real Decreto 1393/2007,por el que se establece la ordenación de las enseñanzas universitarias oficiales. B.O.E. núm. 161, pag. 58454-58468https://www.boe.es/boe/dias/2010/07/03/pdfs/BOE-A-2010-10542.pdf,

${ }^{5}$ https://www.upv.es/entidades/ICE/info/U0724624.pdf (consulta marzo 2018),
} 
digital, la importancia del producto audiovisual, en cualquiera de su mafiestaciones, ni menospreciar su papel como herramienta de aprendizaje.

Tampoco, como docentes nos pasa inadvertido el auge de la imagen como medio de comunicación con unas características especiales, como son la combinación de la imagen en movimiento con el sonido ${ }^{6}$. En nuestro objeto de análisis, cobra especial interés la diferencia entre lo que debemos entender por video didáctico y dimension conceptual, esto es, la diferencia conceptual que algunos autores hacen con respecto, por un lado, al concepto de "vídeo didáctico" y, por otro lado, a la utilización del vídeo didáctico; atendiendo a la definición de Cabero señala que "por vídeo didáctico vamos a entender aquel que ha sido diseñado y producido para transmitir unos contenidos, habilidades o actividades y que, en función de sus sistemas simbólicos, forma de estructurarlos y utilización, propicie el aprendizaje en los alumnos; por el contrario, con su utilización didáctica nos referimos a una visión más amplia de las diversas formas de utilización que puede desempeñarse en la enseñanza". Por analogía, diremos que en nuestro caso haremos "utilización didáctica de los micrometrajes", entendemos, que estos productos audiovisuales, son educativos, siguiendo a Juan Luis Bravo Ramos ${ }^{7}$, dado que dicho producto audiovisual es aceptado por los alumnos como educativo y como docente lo utilizó en un contexto en el que produce aprendizaje. Por ello, en nuestro caso, el producto audiovisual, el micrometraje, cumplirá con dicha función.

La asignatura que se va a ver implicada es Derecho de la Información, entre cuyo contenido, esta la regulación de la propiedad intelectual, caracterizada por sus especialidades con respecto al resto de regulaciones de los países pertenecientes a la U.E, y una gran diferencia con respecto a las de otros países como EEUU. El conocimiento y dominio de esta ordenación jurídica es imprescindible para un egresado en Comunicación Audiovisual (CAU) de la UPV, en cuya actividad profesional ejercida en la era digital está presidida por la globalización. El producto profesional del futuro egresado en CAU es objeto de protección a través de la propiedad intelectual, consecuentemente, el dominio de la regulación que le otorga el ordenamiento jurídico deviene en todo punto imprescindible. Pero el contenido de dicha materia es farragoso y de difícil comprensión motivo por el cual su estudio produce rechazo en los estudiantes. Esta asignatura se imparte en segundo curso del Grado de Comunicación Audiovisual, por lo general el número de alumnos es de 97 a 100 alumnos por curso. Los alumnos de CAU son alumnos muy motivados, con una nota de corte muy elevada y algunos ellos ya se han graduado en otra titulación. Por lo general, muchos de los conocimientos que forman parte del contenido de las asignaturas ya los han adquiridos con anterioridad a cursarla en su curriculum. Esta situación no se da en la asignatura de Derecho de la Información, primer y único contacto con la regulación jurídica

${ }^{6}$ Adiel Morales Ramos,L y Guzmán Florest. EL VÍDEO COMO RECURSO DIDÁCTICO PARA REFORZAR EL CONOCIMIENTO, enhttp://www.udgvirtual.udg.mx/encuentro/encuentro/anteriores/xxii/168-427-1-RV.htm (Consulta marzo 2018).

7 Juan Luis BRAVO RAMOS, ICE de la Universidad Politécnica de Madrid. ¿Qué es el vídeo educativo? http://www.ice.upm.es/wps/jlbr/Documentacion/QueEsVid.pdf (consulta marzo 2018 
que tienen a lo largo de su formación. El contenido de la asignatura referido al ordenamiento jurídico choca con su perfin creativo y con el resto de los contenidos del Grado de CAU, motivo por el cual encuentral dificultad para aprender el contenido de la asignatura.

Desafecto que hace necesario y urgente la búsqueda de una fórmula que mejore el aprendizaje de la materia. Situación que plantea la utilización de la herramienta de la innovación docente. Ésta debe ser entendida, como señala el Profesor Eduardo Gimenez, no necesariamente como un acto de creación, dicha innovación puede consistir en una adaptación, o, incluso, puede no ser algo nuevo. Pero, seguirá diciendo el autor, lo que la caracteriza es que debe suponer un cambio planificado y no accidental respecto a la situación previa. Atendiendo a los tipos que establece el Profesor citado, nuestra innovación es de tipo individual por estar relacionada con la asignatura y alude a las necesidades de los estudiantes y a las preocupaciones profesionales de los mismos.

\section{2.-Objetivos}

Nuestro objetivo es coherente con la finalidad del proyecto, el aprendizaje significativo de las normas que componen la materia de la propiedad intelectual. Atendiendo a las experiencias previas del alumno, rescataremos las bases de concursos donde ellos hayan participar con anterioridad, para analizar su contenido, proceder a la selección y elaboración de su clausurado y la producción de un contrato de cesión de derecho de propiedad, especial para aquel corto que resulte ganador, cuyos contenidos se ajustaran a los conocimientos que aprenderán en la asignatura. En la consecución de nuestros objetivos nos apoyaremos en la teoría del andamiaje desarrollada por David Wood y Jerone Bruner.

Todo ello permitirá:

1.- Estudiar, analizar, comparar, seleccionar y elaborar un nuevo clausurado de las bases del concurso de micrometrajes.

2.- Elaboración de un documento especial de cesión de derechos del micrometraje ganador y asumir su contenido comprometiéndose a su cumplimiento.

3.- Estudiar, analizar y elegir el problema de actualidad mas acorde con el intereses de los alumnos y la asignatura.

En resumen, la elaboración de un nuevo clausurado que para el alumno se percibirá como propio, por haber participado en su elaboración. Ádemás, se confeccionara un documento de cesión de los derechos de autor especifico para el cortometraje ganador que permitirá concienciarse de la transferencia de derechos que se ocasiona en dicho acto, como si se tratara de una venta. Se trata de unos objetivos claros, medibles, precisos y evaluables. Los materiales elaborados son independientes y, aparentemente, sin ninguna vinculación con la elección del tema o lema del concurso pero esto no significa que su elección sea baladí, es el nexo, el engranaje que motivara a los alumnos a participar y que los productos elaborados sean de su interés y motivación, por eso su consideración en último lugar no 
significa su poco relevancia, pues, a nuestro entender es el primer tema a tratar y determinar cuando se expone a los alumnos esta actividad. Esta temática debe ser de actualidad y vinculada al conocimiento de los problemas contemporáneos y vinculados con el contenido de la asignatura. Se elige la temática de la violencia de genero, problemática actual y de gran sensibilización en la sociedad. De la elección del tema dependerá el "enganche" posterior de los alumnos a la innovación.

\section{3.-Desarrollo de la innovación}

La elaboración del micrometraje no es nuestro objetivo principal, es el instrumento que nos permitirá despertar en el alumo el interés por la elaboración de las bases y el documento de cesión de derechos. Se trata de utilizar un instrumento que ellos conocen bien, para trabajar un campo que hasta el momento no han experimentado, como es, el ordenamiento jurídico y su vinculación al mundo de la comunicación. Los alumnos tendrán plena libertad en la elaboración de los micrometrajes, sólo deberán sujetarse al "tema" elegido, de acuerdo a las normas que ellos mismos han elaborado. Se comprometen, en caso de ser el ganador, a firmar el documento de cesión de derechos, que han redactado ellos. Por tanto, nos encontramos ante un supuesto de autoregulación, en el que el cumplimiento de las normas, no se concibe como algo impuesto sino como propia voluntad, y por tanto, más fácil de cumplir.

Las tareas propuestas están gamificadas. La elaboración de las claúsulas del concurso de micrometrajes es acorde con los objetivos marcados, pues conlleva la comparación de otras bases con los conceptos aprendidos y el análisis del origen de la modificación que en su caso se realice. También lo es, la participación en dicho concurso a través de una o varias obras, dado que dicha participación implica asumir, como propias, las cláusulas en cuyo contenido se ha participado, analizándolo y redactandolo.

En las distintas etapas se concretan las tareas a realizar, bien entendido que al tratarse de alumnos muy creativos y de gran inquietud, la elaboración de material de este tipo (cortometrajes) es habitual en ellos. Además, la propia Institución cuenta con material técnico apto para la elaboración de la producción de micrometrajes y en aquel supuesto en el que los alumnos requieran su uso para participar, se solicita su préstamo previa autorización de la profesora.

El proceso, o iter, vendrá determinado por las siguientes etapas:

En primer lugar, a través de la fórmula de lección magistral, se d an unas directrices de la peculiaridad de nuestra regulación con respecto los países de nuestro entorno .

En segundo lugar, se propone a los alumnos la elaboración de las bases concretas del concurso de micrometraje. Para ello se comparan las bases de elaboración propia y las diferencias existentes con el clausurado de otros modelos que previamente se ha solicitado a los alumnos que aporten a la sesión y se elige el tema sobre el que va a tratar.

En tercer lugar, los alumnos que lo desean, atendiendo al tema y al contenido de las bases, participan de forma individual o colectiva, sin limitación del número de integrantes del 
grupo. Una vez concluido el plazo de presentación de los micrometrajes, se le facilita una copia de cada uno de ellos a los miembros del jurado, que en el plazo establecido comunicarán el fallo a la profesora. Posteriormente se hará público el título y autor del micrometraje ganador. Por último, se hará entrega del premio al ganador y se cederán los derechos de dicho trabajo según se contienen en las bases elaboradas.

A través del cuadro de temporalización que acompañamos, se ofrece una visión de las acciones a realizar de una forma lógica, realista y cronólogica

\begin{tabular}{|c|c|c|c|c|c|c|c|c|c|c|c|c|}
\hline \multirow[t]{2}{*}{ Actividad } & \multirow{2}{*}{$\begin{array}{l}\text { Respon- } \\
\text { sable }\end{array}$} & \multicolumn{11}{|c|}{ Tiempo (sesiones) } \\
\hline & & 1 & & & & 5 & 6 & 7 & 8 & 9 & 10 & 11 \\
\hline $\begin{array}{l}\text { 1. Explicación por el } \\
\text { profesor } \\
\\
\qquad \begin{array}{ll}\text { (Lecc. } \\
\text { Magistral) }\end{array}\end{array}$ & Profesor & & & & & & & & & & & \\
\hline 2. Elaboración de las bases & $\begin{array}{l}\text { Profesor } \\
\text { alumnos }\end{array}$ & & & & & & & & & & & \\
\hline $\begin{array}{l}\text { 3. Realización y } \\
\text { posproducción del proyecto }\end{array}$ & Alumnos & & & & & & & & & & & \\
\hline 4 Presentación del trabajo & Alumnos & & & & & & & & & & & \\
\hline 5 Decision del jurado & $\begin{array}{l}\text { Profes. } \\
\text { colaborad }\end{array}$ & & & & & & & & & & & \\
\hline 6 Proclamación del vencedor & Profesor & & & & & & & & & & & \\
\hline 7 Entrega del premio & $\begin{array}{l}\text { Profesor y } \\
\text { colaborador }\end{array}$ & & & & & & & & & & & \\
\hline
\end{tabular}

\section{4.-Resultados}

Es evidente que la identificación de la fuente de información se encuentra en el profesor, a través de la clase magistral y las evidencias cuantitativas se dan por la participación y la realización del cortometraje. Evidencias cuantitivas que consisten en la creación de las bases con contenido jurídico, concretas a aplicar en el concurso y la puesta en práctica de dichas normas. Asi como la elaboración de un contrato de cesión de los derechos de autor, especifico, para el corto ganador del concurso que será suscrito por el representante del grupo autor del cortometraje ganador.

Es el Jurado quíen determina el ganador, de tal forma que se intenta aproximar la actividad lo máximo posible a la realidad profesional. Hasta el momento, en las dos ediciones realizadas, han formado parte tres profesores del grado con concocimientos específicos en el producto audiovisual. La actividad principal es la creación de las claúsulas de las bases del concurso. Dicha elaboración se realiza a través del análisis, estudio y criba de las diferentes bases que los participantes hayan podido encontrar a través de un proceso de búsqueda, en el que se propone que sean los propios alumnos quienes elijan aquellos que bajo su punto de vista, consideran los mas ajustados o mejor elaborados. De esta manera, se consigue que sean capaces de encontrar modelos para distinguir aquellos que tienen un contenido ajustado en la protección de sus derechos como autores del producto audivisual. 
Con dicha información de manera grupal se elaborara el clausurado de las bases que regiran el concurso.

Con este proceso, se busca que sean los alumnos los que sean capaces de analizar unas bases y determinar el alcanze y contenido de las mismas con respecto a sus derechos, con respecto al producto audivisual.

Se continua con la elaboración de un documento de cesión especifica del derecho de autor del micrometraje ganador.

Esta propuesta de innovación cuenta ya con dos ediciones, que se han desarrollado en dos cursos académicos correlativos. En la primera de ellas, la participación a dicho concuso se abrió a todos los alumnos de la U.P.V. Al determinar la participación del concurso a todos los estudiantes de la U.P.V, el contenido de las bases por imperativo institucional, debía ser elaborado por los servicios jurídicos de la UPV, motivo por el cual se pervirtio el fin de esta actividad innovadora. Es por ello, que se tuvo modificar la propuesta, en esa misma convocatoria, y centrar la experiencia al ámbito de la clase de Derecho de la Información. En esta oportunidad se presentarón 13 trabajos que aglutinaron 48 alumnos; puesto que el número de integrantes en cada grupo lo decide cada uno de ellos.

En la segunda edición, para evitar el obstáculo surgido, desde el inicio de la convocatoria se limitó la participación a los alumnos matriculados en la asignatura de Derecho de la Información en el curso académico en el que se iba a realizar el concurso, de esta forma se supero la limitación de la edición anterior y se acotaba el rango de participación a los alumnos de la clase de Derecho de la Información, de $2^{\circ}$ de Grado de Comunicación Audiovisial, de Gandia. No obstante, se permite la participación de otros alumnos siempre que el responsable del corto que se presente sea un alumno de dicha asignatura. En esta edición, el número de trabajos presentados fueron 7, que aglutinaban en total a 62 alumnos.

Junto con la entrega del premio, se suscribe el documento de cesión de derechos especial del corto ganadador, que como ya se ha inidicado antes, se elabora junto con las claúsulas del concurso.

Los cortos son cedidos para su exhibición en las sedes de las instituciones colaboradoras; Colegio de Abogados y Asociaciones en defensa de las Mujeres Maltratadas.
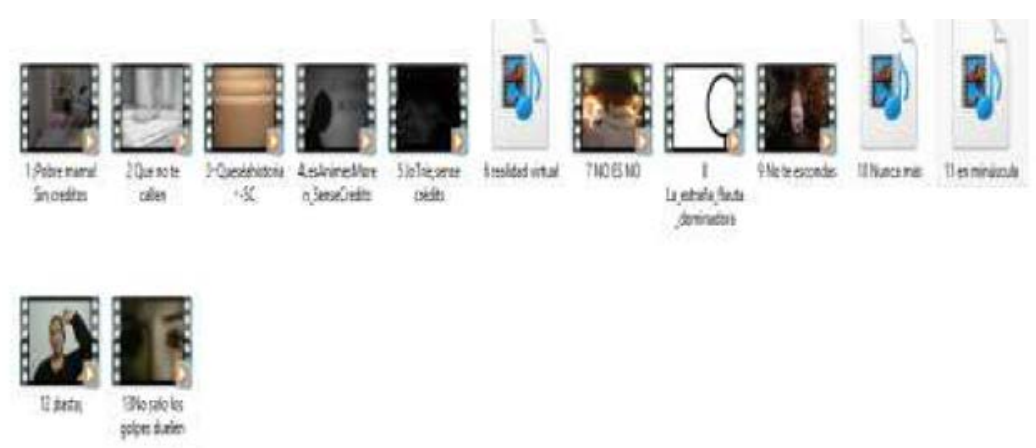

(cc) EY-NG-ND 2018, Universitat Politècnica de València

Congreso In-Red (2018) 
En la encuesta que se paso a los alumnos, tras la realización del concurso, estos manifestaron que consideraban que el mismo había facilitado la comprensión de la materia, y que debería fomentarse en los próximos años actividades similares. Asimismo, consideran que la participación debe ceñirse tal vez, a los alumnos del grado de Comunicación Audiovisual.

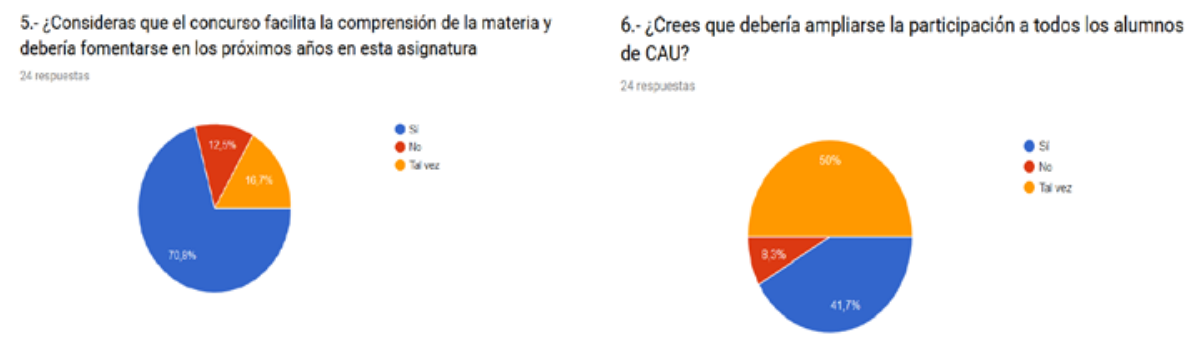

\section{5.- Conclusiones}

1.- La Universitat Politècnica de Valencia (UPV) en el curso académico 2013-2014 inició un proyecto que, de manera experimental, pretende acreditar las competencias transversales (CT) de sus egresados. Entre dichas competencias se encuentra la CT 10 referida al Conocimiento de los Problemas Contemporáneos. Con esta Competencia se alude a la necesidad de que los alumnos sean capaces de comprender las cuestiones y valores políticos, sociales y legales contemporáneos.

2.- Para un egresado del Grado de Comunicación Audiovisual, el producto audiovisual es su modo de expresar sus pensamientos e ideas sobre las cuestiones y valores políticos, sociales y legales del momento en el que vive.

3.- En la era digital no podemos ignorar la importancia del producto audiovisual, en cualquiera de su mafiestaciones, como tampoco su papel como herramienta de aprendizaje.

4.- Será de la mano de las actividades que interesan al alumno del Grado de Comunicación Audiovisual y que desarrollen las destrezas de los mismos, las que permitan introducir la innovación docente y el micrometraje, como producto audiovisual, es una buena herramienta para tal fin.

5.- Se trata de una innovación docente de tipo individual, relacionada con la asignatura y vinculada a las necesidades de los estudiantes y a las preocupaciones futuras de los egresados.

6.- A través de esta innovación se estudian y analizan cada una de las bases de los concursos en los que han participado los alumnos, detectando aquellas cláusulas que van en detrimento de su propiedad como autores de ese producto audiovisual y a partir de ellas, se 
elaboran unas nuevas bases que protegen y amparan su derecho de propiedad del producto audiovisual.

7.- La Innovación finaliza con un producto audiovisual, el micrometraje. Vehiculo que permite a través de la elaboración de un documento de cesión , la venta del derecho de propiedad del producto y la comprensión del contenido y sus efectos.

8.- La firma del documento de cesión de la propiedad intelectual permite el aprendizaje del sentido e importancia del ordenamiento jurídico, su territorialidad y la diferencia existente entre la normativa de los distintos países .

\section{6.- Referencias}

\section{BIBLIOGRAFICA}

-ADIEL MORALES RAMOS,L Y GUZMÁN FLOREST. El Vídeo Como Recurso Didáctico Para Reforzar El Conocimiento, enhttp://www.udgvirtual.udg.mx/encuentro/encuentro/anteriores/xxii/168-427-1-RV.htm (Consulta marzo 2018).

- BRAVO RAMOS, J.L. ICE de la Universidad Politécnica de Madrid. ¿Qué es el vídeo educativo? http://www.ice.upm.es/wps/jlbr/Documentacion/QueEsVid.pdf (consulta marzo 2018)

-CÁCERES GONZÁLEZ P.A, MARTÍNEZ GARCÍA. A, NOGUERA MURRAY, P.,, PÉREZ MARÍN, E, Y SANABRIA-CODESAL, E. Elaboración de materiales de apoyo para incorporar la competencia "Planificación y Gestión del Tiempo" en las asignaturas de la Universitat Politècnica de València. http://ocs.editorial.upv.es/index.php/INRED/INRED2016/paper/view/4346 ） (consulta marzo 2018).

URL

-http://www.upv.es/contenidos/COMPTRAN/info/955709normalc.html (consulta marzo 2018),

- https://www.upv.es/entidades/ICE/info/U0724624.pdf (consulta marzo 2018)

- http://www.eees.es/es/documentacion (consulta marzo 2018)

- https://www.boe.es/boe/dias/2010/07/03/pdfs/BOE-A-2010-10542.pdf 


\title{
Trabajar en grupo y aprender haciendo: desarrollo de competencias clave para los estudiantes del siglo XXI.
}

\section{María Jano Salagre ${ }^{\mathrm{a}}$ S Salvador Ortiz Serrano}

${ }^{a}$ Profesora del Departamento de Economía Aplicada de la Universidad Autónoma de Madrid, dolores.jano@uam.es y ${ }^{b}$ Profesor del Departamento de Economía Aplicada de la Universidad Autónoma de Madrid, salvador.ortiz@uam.es

\begin{abstract}
In recent times, a new competence that combines two verbs: learn and teach, is gaining relevance and is undoubtedly essential in a world of information overflow, uncertainty and drastic changes. Our students have to prepare to adapt quickly to changes and need to develop an active attitude. They have to learn to work as a team, collaborating to detect problems and teach others how to solve them, share knowledge and communicate in an effective way. These are the skills that we intend to expound on in the presented experience.

The objective of the communication is to describe the experience and assess the effect that the group may have on the individual's results. The results show that, discounting the effect that previous skills and knowledge may have, group work contributes to improving the individual grades of the student, whether she/he is assessed as a whole, or assessed individually.
\end{abstract}

\section{Keywords:}

Active learning, Cooperative Learning, Higher Education, Statistics, Learning Outcom

\section{Resumen}

En los últimos tiempos gana relevancia una nueva competencia que conjuga dos verbos: aprender y enseñar, y que sin duda es imprescindible en un mundo de sobreabundancia de información, incertidumbre y cambios drásticos. Nuestros alumnos han de prepararse para adaptarse rápidamente a los cambios, y necesitan desarrollar una actitud activa. Tienen que aprender a trabajar en equipo, colaborando para detectar problemas y enseñar a otros cómo resolverlos, compartiendo conocimientos y comunicando de una manera eficaz. Estas son las habilidades que se pretenden desarrollar en la experiencia que se presenta.

El objetivo de la comunicación es describir la experiencia y valorar el efecto que puede tener el grupo en los resultados del individuo. Los resultados muestran que, descontando el efecto que pudieran tener las habilidades $y$ conocimientos previos, el trabajo en grupo contribuye a mejorar las calificaciones individuales del estudiante, tanto si es valorado en su conjunto, como si se evalua individualmente. 
Palabras clave: Aprendizaje Activo, Aprendizaje cooperativo, Educación Superior, Estadística, Resultados de Aprendizaje

\section{Introducción}

Según afirmaciones basadas en la "pirámide del aprendizaje” enseñar es la mejor manera de aprender, habitualmente se dice que los aprendices retienen el 90\% de lo que aprenden cuando se lo enseñan a otros o lo utilizan de inmediato. No obstante son porcentajes discutidos por algunos autores (Lalley; J.P. y Miller; R.H. 2007) y habría que tener en cuenta el contexto en que se realiza la experiencia, la manera de llevarla a cabo, la implicación de los propios estudiantes y cómo se mide el aprendizaje.

El reto como profesores en esta nueva era es conseguir que el alumno asuma un papel activo, se haga cargo de su propio aprendizaje, lo comparta con otros y esté dispuesto a seguir como aprendiz a lo largo de su vida, desarrollando su "learnability" o habilidad de aprender rápida y eficazmente. Duran (2014) habla de "aprenseñar” y aprender en 3D; a lo largo, ancho y en lo profundo de nuestras vidas, que va más allá del aprendizaje permanente ó Lifelong Learning. Se trata no sólo de promover un enfoque activo, sino que además, hay que ayudarles a desarrollar otras competencias clave en su empleabilidad, en un mundo en el que la información que tendrán que manejar es amplia, heterogénea, compleja, altamente especializada y donde el trabajo conjunto con profesionales de diferentes áreas será cada vez más común. Por tanto hay que darles oportunidades para trabajar en grupo, resolver problemas y transmitir la información a otros de manera eficaz.

Con el aprendizaje activo se trataría de acabar con la enquistada y tradicional pasividad del alumno, generando contextos que promuevan situaciones para lograr un aprendizaje profundo, en los que los protagonistas sean los estudiantes que se relacionan entre ellos y con el profesor. Con el trabajo cooperativo, se trataría de fomentar aprendizajes a través del trabajo guiado y tutelado de grupos heterogéneos de estudiantes, a los que se proponen tareas que supongan un reto abordable para ellos, y en el que pongan en práctica los conocimientos teóricos adquiridos en situaciones concretas. Con ello los alumnos van logrando mayores grados de autonomía, responsabilidad y compromiso. En todo este proceso, el apoyo y la guía del profesor es imprescindible, de manera que una adecuada retroalimentación del proceso les permitirá aprender también de los errores cometidos. Hulsizer and Woolf (2008) comparten las mejores prácticas en la docencia en estadística que promueven situaciones de aprendizaje activo, cooperativo y basado en problemas. Además, existen innumerables experiencias en otros campos como Marketing Chad (2012), Chapman, Meuter, Toy, y Wright (2010); Administración de Empresas Kidder y Bowes-Sperry (2012) o en Economía Hettler (2015).

En cursos pasados se pusieron en marcha iniciativas para fomentar el aprendizaje activo, tareas para que los alumnos aprendan haciendo, resolviendo ejercicios propuestos por el profesor, preparando y exponiendo un tema completo y participando en una amplia batería de actividades que involucran al estudiante y le ayudan a aprender de manera continua y no sólo unas semanas antes del examen final (Jano y Ortiz 2017a y 2017b). Sin embargo hasta

(cc) EY-NC-ND 2018, Universitat Politècnica de València

Congreso IN-RED (2018) 
ahora no se habían explorado las posibilidades que ofrece el trabajo en grupo. Además de las propuestas en las que los alumnos asumen el rol del profesor, inventando problemas y explicando en clase cómo resolverlos al resto de compañeros, se han ido incorporado tímidamente actividades para fomentar el aprendizaje cooperativo y colaborativo en la docencia en la asignatura de Estadística Teórica.

La estructura de la comunicación se organiza en cuatro partes. Una primera parte donde se detallarán los objetivos de la presente comunicación, a continuación se explicará cómo se ha desarrollado la innovación, para continuar con un análisis de los resultados obtenidos y por último, se hará una reflexión sobre las lecciones aprendidas.

\section{Objetivos}

Es conocido que los estudiantes utilizan dinámicas para trabajar en grupo que no resultan adecuadas para el aprendizaje, como repartartirse las tareas, ir de polizón en el grupo, o no no asumir el compromiso individual necesario para lograr que el grupo logre los mejores resultados. Uno de los objetivos de nuestra propuesta es experimentar procedimientos que eviten esas situaciones y que fomenten que aquellos alumnos con más habilidades puedan facilitar el camino a los que se encuentran con más dificultades.

Un segundo objetivo, relacionado con el anterior, pretende comprobar si, como sería deseable, las calificaciones individuales se ven afectadas positivamene por la valoración que se hace del trabajo del grupo en su conjunto, y por el trabajo que el alumno hace con el apoyo del grupo, pero del que responde individualmente.

Además, hay otro componente importante en la valoración de los resultados individuales del estudiante que habría que considerar. No todos los alumnos parten del mismo punto de salida en la carrera, algunos tienen un bagaje y unas habilidades que les favorecen, una mejor predisposición en asignaturas cuantitativas o tienen hábitos de trabajo y productividad distintos. Por tanto, se contrastará si los resultados previos en una asignatura que se imparte en el curso anterior por el Departamento, la Estadística Descriptiva, es un factor significativo a la hora de predecir los resultados individuales del estudiante.

\section{Desarrollo de la innovación}

\subsection{Contexto en que se lleva a cabo}

Se trata de la docencia de la asignatura Estadística Teórica en dos grupos en el grado en ADE (Administración y Dirección de Empresas), de 6 créditos, en la que se explican cuestiones de probabilidad e inferencia, y que se imparte por los mismos profesores en el primer cuatrimestre del curso. En total se refiere a 110 alumnos, de los que sólo 11 están en segunda o posteriores convocatorias. En el análisis de los resultados se descartarán a estos últimos estudiantes, puesto que la mayoría optó porque su evaluación continua fuera a través de dos controles a lo largo del curso, y por otro lado ya han cursado la asignatura y parten de una situación diferente al resto. 
La nota final se obtiene en un $60 \%$ mediante un examen final, y un $40 \%$ por la evaluación continua a lo largo del curso. Ese $40 \%$ se reparte de la siguiente manera: $20 \%$ en dos controles escritos, $10 \%$ un trabajo en grupo en Excel (5\% la presentación de un informe conjunto del grupo y $5 \%$ una prueba en las aulas de informática) y un $10 \%$ de valoración del trabajo autónomo mediante la realización de una colección de ejercicios y la propuesta, resolución y exposición en clase de un problema original que se formula en grupo (5\% exámenes breves sobre los ejercicios propuestos y $5 \%$ la defensa individual de un ejericicio original). Además a lo largo del curso se propusieron abundantes tareas y actividades a realizar, algunas en clase y otras a través de la plataforma, que bonificaban la nota de evaluación continua en un máximo de 1,5 puntos.

\subsection{Propuesta de trabajo en grupo}

Se formaron diez grupos de cinco alumnos, heterogéneos en base a sus calificaciones en estadística despcriptiva. Se ordenaron las notas y se iban asignando a los grupos, garantizando que en todos ellos hubiera estudiantes con notas altas, intermedias y bajas.

Cada grupo debía trabajar sobre una base de datos distinta a partir de los microdatos que publica el INE (Instituto Nacional de Estadística). Se trataba de trabajar en la elaboración de un informe sobre un caso real que aborda de manera aplicada todos los aspectos teóricos explicados en la asignatura. En concreto, se analizaban las diferencias en los gastos por día de los turistas de distintas comunidades autónomas, según motivo de viaje. El informe debía dar respuesta a una serie de preguntas relativas a obtención de las muestras, estimación puntual y por intervalos, así como contrastes de diferencia de medias, unilaterales y bilaterales. Como apoyo para la realización de la práctica se dieron varias clases en el aula de informática, se prepararon varios vídeos que se pusieron a disposición de los estudiantes en el canal de youtube que aparece citado en la bibliografía, y se llevaron a cabo diversas tutorías para el seguimiento de los trabajos.

Pero además, el grupo debe inventar un ejercicio práctico referido a una parte del temario de la asignatura asignado al azar. El grupo trabaja junto para logar un enunciado original y proponer su resolución. La intención es crear un documento con los problemas propuestos y resueltos y ponerlo a disposición del resto de alumnos en un repositorio en Moodle.

Aunque el peso sobre la nota final de la valoración del grupo en su conjunto es muy bajo, sólo un 5\%, todas estas actividades están diseñadas para mejorar el aprendizaje y por tanto para conseguir buenos resultados en el examen final, que si tiene un peso importante en la nota final (60\%). Y no hay que olvidar que hay un porcentaje de la evaluación (un 5\%) que obtiene el alumno individualmente, pero al amparo del grupo. Sabían que podían repartirse el trabajo como consideraran conveniente, pero que todos debían saber defenderlo integramente, porque tendrían que demostrarlo individualmente en diversas pruebas.

\subsection{Propuestas de trabajo en grupo con valoración individual}

La valoración individual del trabajo en grupo tiene tres componentes:

(cc) BY-NC-ND 2018, Universitat Politècnica de València

Congreso IN-RED (2018) 
- La resolución de unos 16 problemas que iban haciendo por su cuenta a medida que se avanzaba en los contenidos teóricos del curso, y que eran valorados mediante una breve prueba en clase sobre algunos apartados de los problemas propuestos. Podían colaborar entre ellos antes de la prueba para solucionar los ejercicios, pero finalmene eran evaluados por escrito de manera individual. Más tarde se publicaban las soluciones para que ellos mismos comprobaran y detectaran los errores cometidos.

- La elaboración por grupos de un problema original, que tendrían que resolver y enviar al profesor para que diera su visto bueno, y que posteriormente explicaban a la clase. El profesor elige al azar qué parte tendrá que explicar cada uno.

- En la tercera, cada alumno tendría que resolver en las aulas de informática algún apartado del trabajo en grupo presentado y comentar brevemente los resultados obtenidos.

\section{Resultados obtenidos}

\subsection{Definición de las variables}

Aunque las calificaciones no siempre son un fiel reflejo de lo que sabe el estudiante, y de lo significativos que son esos aprendizajes, se utilizarán como indicadores para poder valorar cuantitativamente los resultados de la experiencia. Las variables utilizadas se resumen en la Tabla 1. Se valoran tres aspectos, el resultado individual, medido a través de la calificación en el examen final que incluye preguntas sobre todo lo trabajado en el curso. El resultado del trabajo en grupo, recogida a través de la calificación conjunta obtenida en el informe. El resultado del aprovechamiento del individuo dentro del grupo, recogido a través exposición que hace el alumno en clase de algún apartado del ejercicio original propuesto por el grupo. También se tendrá en cuenta, como referencia previa la calificación en Estadística Descriptiva.

Tabla 1. Variables analizadas.

\begin{tabular}{|l|}
\hline \multicolumn{1}{|c|}{ Etiquetas y codificación de variables } \\
\hline Nota del Examen Final: INDIVIDUAL \\
\hline Nota del Individuo en la Exposición del problema original: EN EL GRUPO \\
\hline Nota del Informe Elaborado por el Grupo: GRUPO \\
\hline Calidad de la participación del grupo: \\
- Mala GRM: Nota de Grupo menor a cinco (Grupo de referencia) \\
- Regular GRR: Nota de Grupo mayor o igual a cinco y menor de nueve \\
- Buena GRB: Nota de Grupo mayor o igual a nueve \\
\hline Calidad de la exposición individual del problema original: \\
- Mala ENGRM Nota de Grupo por debajo de la Mediana (Grupo de referencia) \\
- Buena ENGRB Nota de Grupo por encima de la Mediana \\
\hline Nota en la asignatura del curso pasado Estadística Descriptiva: DESCRIPTIVA \\
- Nivel Previo Bajo: Nota en Descriptiva por debajo de la Mediana \\
- Nivel Previo Alto: Nota en Descriptiva por encima de la Mediana \\
\hline
\end{tabular}

Fuente: Elaboración propia 
Además, en algunas ocasiones, y para facilitar la interpretación, se recodifican las variables referidas a las notas en tramos o escalas de calificacion. Se definirán tres categorías según la calidad en el trabajo en grupo; mala (menos de cinco puntos), regular (entre cinco y nueve puntos) y buena (nueve o más puntos). En el caso de las calificaciones en función de la calidad del trabajo individual realizado al amparo del grupo y de la nota previa de Estadística, sólo se definirán dos grupos (según estén por debajo o por encima de la mediana).

\subsection{Análisis de los resultados obtenidos}

Respecto a la valoración de la propuesta de innovación, se pueden destacar dos cuestiones. En primer lugar, el poco tiempo que disponen profesores y alumnos para una asignatura compleja y que se construye sobre los conocimientos que van adquiriendo y que requiere un proceso de consolidación de lo que se va construyendo. Se trata de 6 créditos en el primer cuatrimestre, lo que supone 3 horas de clase semanales para abordar probabilidad e inferencia estadística. Las últimas semanas del curso, cuando han de finalizar el trabajo y conseguir una visión global de la utilidad de la asignatura, los alumnos tienen mucha presión por entregar tareas y hacer exámenes en todas las asignaturas, se ven sobrepasados y muchos abandonan la asignatura para la convocatoria extraordinaria.

En segundo lugar, las calificaciones individuales son muy importantes para ellos, porque está en juego poder acceder al Programa de Cooperación Educativa, que consideran atractivo de cara a su futuro laboral. No quieren perder tiempo, ni que las notas en grupo puedan perjudicar sus expectativas.

La presión del tiempo es quizá uno de los factores más difíciles de superar en el proceso. Los alumnos aprenden, pero se quejan en las encuestas de valoración de este curso, de la excesiva carga de trabajo y sobre todo del elevado número de pruebas a lo largo del curso.

Quizá una alternativa podría ser utilizar la tecnología para no perder tiempo en clases y poder valorar de manera adecuada y con garantías la participación del alumno en el grupo. Por ejemplo, mediante la exposición individual del trabajo y de los problemas en vídeos, que se compartirán con todos los estudiantes y podrán ser vistos y valorados por todos ellos. Aunque también hay resistencias de algunos alumnos a exponerse públicamente de esa manera, ya que les causa mucha tensión, y a ser evaluados por sus compañeros, ya que puede generar conflictos entre ellos.

No obstante, valoran muy positivamente la cantidad de recursos y materiales de que disponen, y el trabajo en Excel, de cara a su futuro profesional.

Otra dificultad en el proceso es la gestión de los conflictos y dificultades que surgen en el trabajo con grupos. Un aspecto clave es que los profesores aprendan técnicas y procedimientos para mejorar las dinámicas y evaluación del trabajo en grupo, y que los alumnos también aprendan a gestionar conflictos, habilidad que les resultará clave e imprescindible su futuro profesional. Todo esto una vez más requiere tiempo y disposición de unos y otros, que a veces es difícil de encontrar.

(cc) EY-NC-ND 2018, Universitat Politècnica de València

Congreso IN-RED (2018) 
Respecto a la relación entre los resultados individuales en función del grupo y del desempeño del estudiantes al amparo del grupo y de sus conocimientos previos, en la Figura 1 se puede comprobar que el bagaje y habilidades previas que el estudiante trae, tiene un efecto en las calificaciones en los tres indicadores propuestos, que se refieren a: su trabajo individual (nota del examen final), su trabajo dentro del grupo (nota de la exposición del problema original) y el trabajo del grupo (nota del informe de grupo presentado). En todos ellos se observan mejores notas en este curso para los alumnos que están por encima de la mediana en Estadística Descriptiva. En media algo más de dos puntos en el Examen Final, un punto en la nota del Grupo y más de medio punto de la exposición individual del Trabajo en el Grupo. Por tanto, tendrá sentido descontar este efecto al estudiar los resultados de los alumnos en este curso.

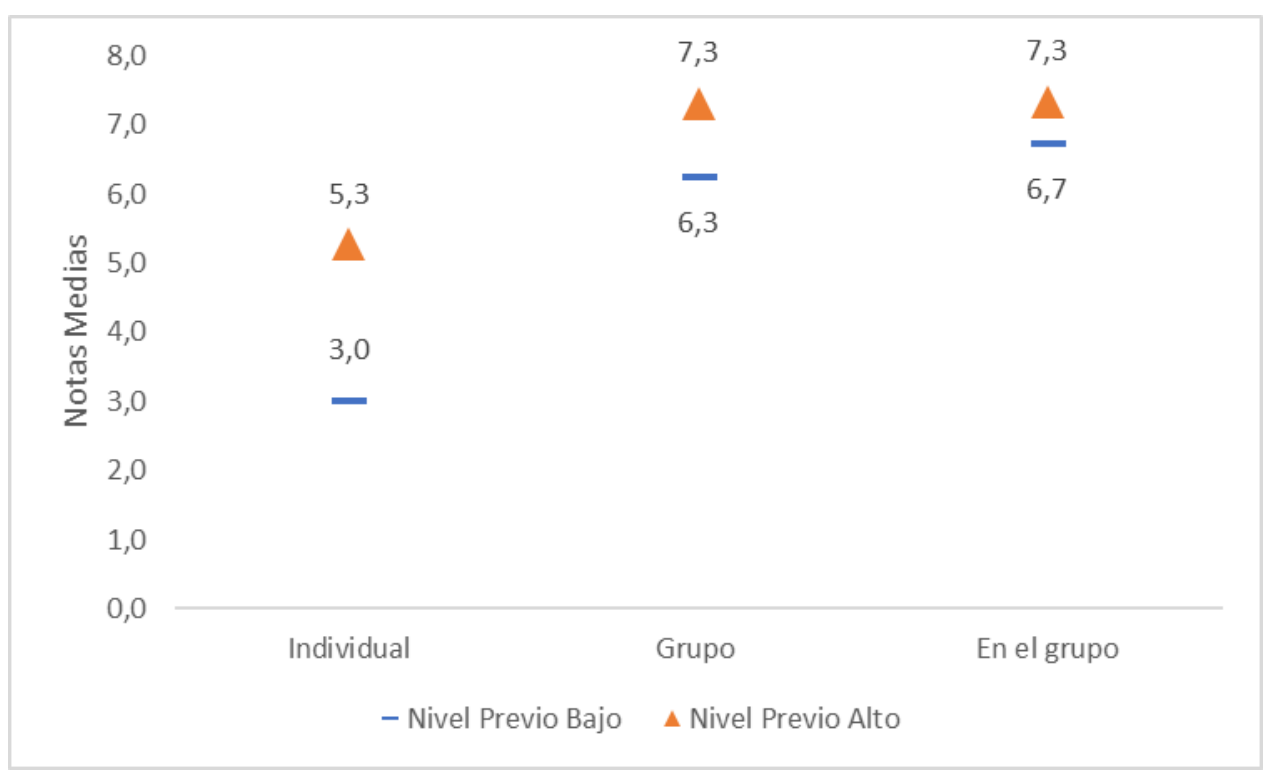

Fig. 1. Diferencias en notas medias del estudiante en este curso según sus conocimientos previos

Pero aunque los grupos son heterogéneos en función de las notas, y en todos ellos hay estudiantes de todos los niveles, hay variabilidad en las calificaciones de los informes. Si se analizan diferencias en los resultados según la calidad del trabajo del grupo dividido en tres categorías, Mala, Regular o Buena, se observa que hay un efecto en las notas. Esto es lo que se presenta en la Figura 2, donde se aprecia, en general, que hay una relación positiva entre la nota del trabajo en grupo y las notas individuales obtenidas por el alumno. Además, en todos los grupos se observan unas notas más altas cuando se cuenta con el apoyo del grupo repecto a las notas individuales en el examen final, si bien las diferencias se van haciendo más pequeñas. Es decir, a nivel descriptivo se observa que, en general, cuanto mejor es el grupo, mejor son los resultados individuales de sus miembros. 


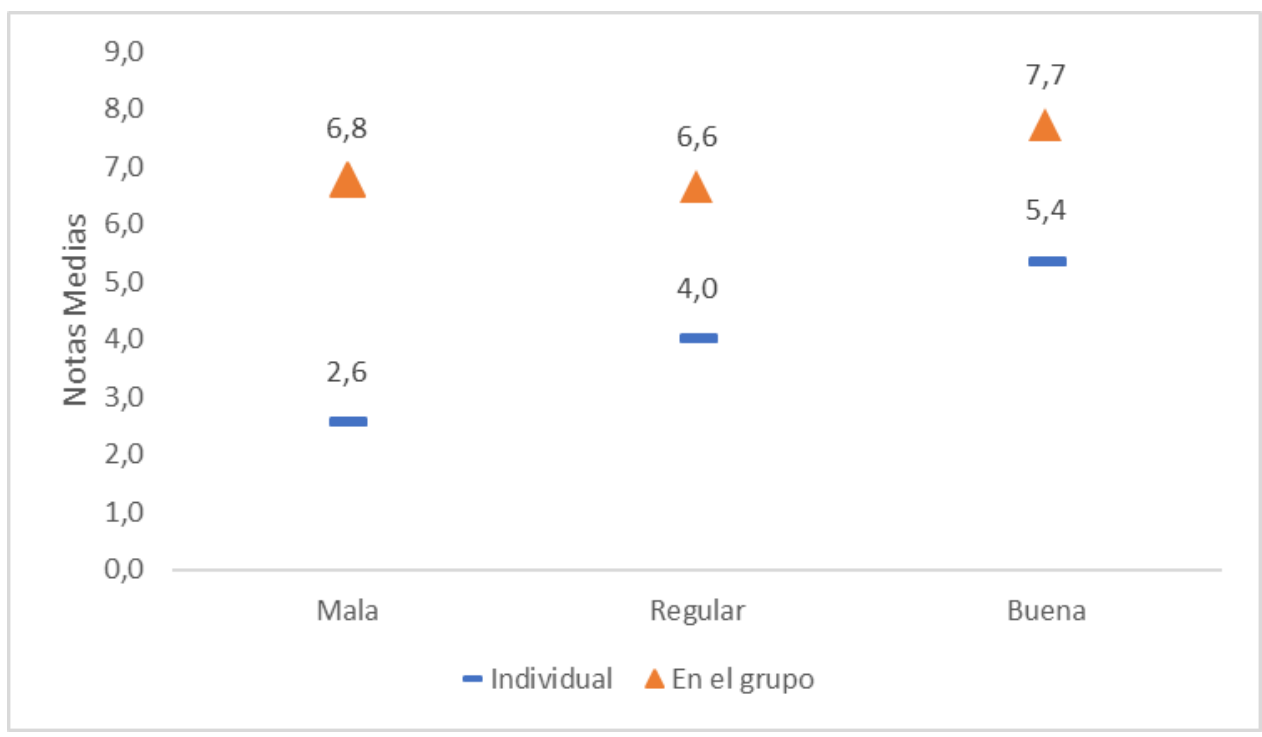

Fig. 2 Calificaciones del alumno según calidad del trabajo en grupo.

Esta relación positiva y significativa se confirma al calcular los coeficiente de correlación entre la nota individual del examen con las notas del grupo y del individuo dentro del grupo, que en ambos casos vale 0,34.

Pero para valorar el efecto en las diferencias en la nota final, se propone un modelo de regresión que explique el resultado individual a partir de los resultados del trabajo en grupo, del trabajo individual con apoyo del grupo y de sus resultados previos. Como se aprecia en los resultados del primer modelo (1) hay una relación positiva y significativa de cada uno de estos indicadores sobre el resultado individual. De manera que, descontando el efecto de las demás variables del modelo, un aumento de las notas en las que participa el grupo se traduce en aumentos en la nota individual.

$$
\begin{gathered}
\text { INDIVIDUAL }=-4,43+0,22^{* *} \text { GRUPO }+0,20^{*} \text { EN EL GRUPO }+0,97^{* *} \text { DESCRIPTIVA (1) } \\
\mathrm{r}^{2}=0.356 \\
\\
\text { * coeficiente significativo para un } 5 \% \text { de nivel de significación } \\
\end{gathered}
$$

Para percibir mejor la magnitud de los efectos se utilizará un modelo de análisis de la covarianza, en el que se propone como variable a explicar el rendimiento individual, y como variables explicativas la nota previa en descriptiva como covariable y dos factores. Por un lado, el factor grupo definido en tres categorías, y por otro lado, el factor individual con apoyo del grupo, recodificada en dos categorías, como se indicaba en la Tabla 1 de descripción de variables. Se consideran como categorías de referencia la de las peores calificaciones. Como se aprecia en los resultados del segundo modelo (2) todos los coeficientes son significativos y refrenda la influencia del grupo en los resultados individuales.

$$
\begin{aligned}
& \text { INDIVIDUAL }=-3,1+1,6^{* *} \text { GRR }+2,03^{* *} \text { GRB }+1,18^{*} \text { ENGRB }+0,90^{* *} \text { DESCRIPTIVA (2) } \\
& \text { (Modelo 2) } r^{2}=0.41 \\
& \text { * coeficiente significativo para un 5\% de nivel de significación } \\
& \text { ** coeficiente significativo para un 1\% de nivel de significación }
\end{aligned}
$$

(cc) EY-NC-ND 2018, Universitat Politècnica de València 
De la interpretación de los coeficientes estimados por el modelo se observa que, manteniendo todo lo demás constante, si el grupo es regular, la nota media en el examen individual es 1,6 puntos mayor que si el grupo es malo, y si el grupo es bueno, el efecto es aún más claro, obteniendo 2,03 puntos más en el examen final que los que de peor desempeño. De manera análoga, los que tienen buena nota individual del trabajo realizado en grupo, consiguen en media un punto más en el examen final que los que hacen una exposición pobre del problema original. Se podría decir que obtener buenos resultados en grupo, en general, ayudará a que cada uno de sus miembros obtenga también mejores resultados a nivel individual.

\section{Conclusiones}

El mundo laboral al que se enfrentarán nuestros estudiantes es cada vez más complejo y requiere el desarrollo de habilidades que les permita mejorar el acceso puestos de trabajo de calidad. Además de aprender a lo largo de su vida, se verán obligados a colaborar con otros para resolver problemas complejos y multidisciplinares, compartiendo sus conocimientos. Para preparar a nuestros estudiantes ante ese reto, este curso se han propuesto diversas actividades que promueven su creatividad y espíritu colaborativo.

El análisis de los resultados confirma que el grupo contribuye a mejorar los resultados individuales, por lo que es recomendable promover y ampliar las actividades que se realizan en grupo y darles protagonismo a ellos en su aprendizaje, animándoles a proponer y resolver problemas.

Como debilidades y aspectos a mejorar, hay que destacar que no se han tenido en cuenta las valoraciones que los estudiantes hacen de esta propuesta, más allá de los comentarios que hacen en las encuestas oficiales del profesor y de la asignatura. Tampoco se ha recogido información sobre las dinámicas que surgían en el trabajo en grupo, que quizá se pudiera haber hecho a través de la elaboración de actas virtuales en las que registren las fechas de reunión, un resumen de aspectos tratados, reparto entre sus miembros de tareas, y responsabilidades, valoración entre ellos de su trabajo en el grupo o asuntos relacionados con la gestión de conflictos en el seno del grupo.

Como reflexión final, estamos convencidos de la importancia que tiene para nosotros como profesores y para nuestros estudiantes aprender a trabajar en grupo y comunicar los resultados de manera atractiva y eficaz, como competencias imprescindibles para el futuro. Consideramos que a pesar de las dificultades y resistencias a cooperar, a pesar del tiempo que hay que dedicar a organizar y gestionar bien los grupos, a pesar de los temores que surgen por la posibilidad de que afecte a los resultados del individuo; las ventajas de aprender a gestionar los conflictos y de aprovechar las sinergias que se producen, compensan con creces esos posibles inconvenientes. Merece la pena trabajar para crear un entorno en el que profesores y estudiantes experimentemos la sabiduría que encierra el proverbio "Si quieres ir rápido, camina solo; pero si quieres llegar lejos, camina acompañado" 


\section{Referencias}

DURAN, D. (2014). Aprenseñar. Evidencias e implicaciones educativas de aprender enseñando. España: Narcea.

BARRICK, M. R., BRADLEY, B. H., \& COLBERT, A. E. (2007). "The moderating role of Top Management Team interdependence: implications for real teams and working groups”. Academy of Management Journal, 50(3), 544-557.

CHAD, P. (2012). "The Use of Team-Based Learning as an Approach to Increased Engagement and Learning for Marketing Students: A Case Study”. Journal of Marketing Education, 34 (2), 128-139.

CHAPMAN, K. J., MEUTER, M. M., TOY, D. y WRIGHT, L. K. (2010). “Are student groups dysfunctional? Perspectives from both sides of the classroom”. Journal of Marketing Education, 32, 39-49.

HETTLER, P.L. (2015). “Active Learning in Economics: Increasing Student Engagement, Excitement and Success”. International Atlantic Economic Society, Vol. 21 pp. 357-360

HULSIZER, M.R. y WOOLF, L.M. (2008) A guide to Teaching Statistics: Innovations and Best Practices. Wiley-Blackwell.

JANO, M. y ORTIZ, S. (2017a). “Aprender enseñando. Una experiencia para desarrollar la quinta competencia”. Universidad Politécnica de Valencia. Tercer Congreso Nacional de Innovación Educativa y Docencia en Red IN-RED.

JANO, M. y ORTIZ, S. (2017b). “ « Buffet libre » como experiencia de aprendizaje en la asignatura de Estadística”. REDU Revista de Docencia Universitaria, Vol. 15 (2) julio-diciembre pp. 179-192. https://doi.org/10.4995/redu.2017.6760

KIDDER, D. L. y BOWES-SPERRY, L. (2012): " Examining the Influence of Team Project Design Decisions on Student Perceptions and Evaluations of Instructors " Academy of Management Learning \& Education, 11 (1), 69-81.

LALLEY, J. P \& MILLER, R.H. (2007): "The leaming pyramid: Does it point teachers in the right direction?" Education 128(l):64-79.

https://www.youtube.com/channel/UCqkM4FQL-p9G-liqitrzgyg Canal de videos de Estadística Teórica

(cc) EY-NC-ND 2018, Universitat Politècnica de València

Congreso IN-RED (2018) 


\title{
Mala gestión del tiempo en los estudiantes universitarios: efectos de la procrastinación
}

\author{
Naturil-Alfonso, Carmen ${ }^{a^{*}}$, Peñaranda, David S. ${ }^{a}$, Vicente, José S. ${ }^{a}$ \& Marco-Jiménez, \\ Francisco $^{a}$ \\ ${ }^{a}$ Laboratorio de Biotecnología de la Reproducción, Departamento de Ciencia Animal, Universitat \\ Politècnica de València. *Autor de correspondencia: carnaal2@upvnet.upv.es.
}

\begin{abstract}
Academic procrastination is a fact related to the delay or postpone of academic work until last minute. This phenomenon is evident in a vast majority of university students, and its occurrence is increasing. In order to analyse possible causes and/or solutions, we studied if longer time for accomplishing an assignment incentives or avoids procrastination among university students. Results showed that both short and long time-frame groups tended to procrastinate in the same way. Additionally, academic grades did not revealed differences between groups, as the procrastination was the same between groups. Thus, this study shows that even with longer period of time to accomplish a task, university students tend to procrastinate, and thus seem to have a negative effect on their assignment grades. Therefore, it seems a current problem and measures should be developed in order to solve it.
\end{abstract}

Keywords: Procrastination; time manage; academic work: academic outcomes

\footnotetext{
Resumen

La procrastinación académica es un término que hace referencia a la postergación o posposición de cualquier actividad o tarea académica para el último minuto. Este fenómeno prevalece de forma mayoritaria entre los estudiantes universitarios, y su incidencia parece ir en aumento. Con el fin de analizar las posibles causas y/soluciones a la procrastinación, en este trabajo se estudió si un mayor tiempo para la elaboración y/o desarrollo de las actividades y tareas universitarias impedia o incentivaba la procrastinación entre los estudiantes universitarios. Los resultados mostraron que tanto los grupos con menor tiempo para el desarrollo de tareas, como los grupos con un mayor tiempo tendían a procrastinar de la misma manera. Además, las notas medias de las tareas no mostraron diferencias entre los grupos dado que la procrastinación fue la misma en ambos grupos. Por ello, este estudio muestra que incluso con periodos más prolongados para la elaboración de la actividad, los estudiantes universitarios tienden a procrastinar, y este hecho parece tener un efecto negativo sobre la nota de la actividad. En conclusión, la procrastinación es un grave problema en el sistema universitario actual y deberían tomarse medidas para solucionarlo.
} 
Palabras clave: Procrastinación; gestión del tiempo; trabajo académico; resultados académicos

\section{Introducción}

La procrastinación es considerada como un tipo de comportamiento de postergación o hábito de retraso de actividades o situaciones, asociados a resultados negativos (Ellis y Knaus, 1977; Silver y Sabini, 1981). En concreto, la procrastinación académica ha sido definida como la posposición de las tareas académicas (preparación de exámenes y realización de deberes y trabajos) para el último minuto (Slomon y Rothblum, 1984). Según los estudios realizados, se estima que un $80-95 \%$ de los estudiantes universitarios, o por lo menos la mitad de ellos presentan, un comportamiento de procrastinación académica (O’Brien, 2002; Ozer et al., 2009). Asimismo, este tipo de comportamiento parece ser un fenómeno que va en aumento (Steel, 2007). Además, la procrastinación ha sido correlacionada de forma negativa con el rendimiento académico (Ariely y Wertrnbrich, 2002; Wong, 2008; Kim y Seo, 2015). Estos efectos negativos se manifiestan en la nota media de los estudiantes y las notas de las areas y trabajos desarrollados por los estudiantes (Steel et al., 2001; Kim y Seo, 2015).

En el contexto académico, la característica 'procrastinación' incluye la motivación y el éxito, así como las habilidades para la planificación y gestión, disciplina, auto-control y habilidades cognitivas para el estudio (Schouwenbrug, 1995). Es por ello que la procrastinación tiene importantes consecuencias negativas en los estudiantes universitarios, como la pérdida de tiempo, mal rendimiento académico, aumento del estrés, ansiedad y depresión (Chu y Choi, 2005, Essau et al., 2008). Estos factores conducen a un aumento de la presión debido a la escasez de tiempo, lo que a su vez se traduce en una reducció en la precisión, y consecuentemente sobre el rendimiento académico (Van Eerde, 2003).

Para poder poner solución a este problema, se ha ahondado en el estudio de las causas que conllevan a la procrastinación. Son diversas los motivos que se han encontrado por los que los estudiantes tienden a procrastinar. Entre estos se encuentran el miedo al fracaso (Solomon y Rothblum, 1984) y la aversión hacia las tareas (Solomon y Rothblum, 1984; Steel, 2007). Más recientemente, Thakkar (2010) recoge la teoría de que las nuevas tencologías han generado grandes distractores como las actividades con ordenadores: la mensajería instantánea, la constante comprobación del correo, el amplio contenido mediático en la red (noticias, vídeos, música) y redes sociales; así como la televisión y los móviles. Además, también estalece un cambio en los valores de los estudiantes de la sociedad moderna (con objetivos futuros y de trabajo duro), a la sociedad post-moderna (preferencia por las actividades sociales y el placer). Frcuentemente los estudiantes se encuentran que el tiempo para la realización de las actividades académicas y de ocio es limitado, lo que conlleva a un conflicto motivacional entre las dos actividades, tendiendo a postponer las actividades académicas por aquellas alternativas de entretenimiento (Dewitt y Schouwenburg, 2002).

Por todo ello, algunas instituciones están intentando tomar medidas al respecto para intentar reducir la tendencia a la procrastinación entre los estudiantes universitarios. 


\section{Objetivo}

El objetivo de este estudio fue analizar la gestión del tiempo en los estudiantes universitarios mediante una actividad académica con distintos tiempos de entrega.

\section{Desarrollo de la innovación}

\subsection{Población de estudio}

Este estudio fue realizado en la Escuela Técnica Superior de Ingeniería Agronómica y del Medio Natural de la Universidad Politécnica de Valencia. La población de estudio fue un grupo de estudiantes universitarios pertenecientes a esta escuela. La muestra del estudio estuvo compuesta por 106 estudiantes divididos en dos grupos, denominados grupo A y grupo B.

\subsection{Prueba de procrastinación: índices de rendimiento académico}

Al inicio del cuatrimestre, el día que dio comienzo la asignatura, se realizó la presentación de la misma (26/01/2015). En este momento, todos los alumnos de ambos grupos fueron informados de un trabajo académico que debían realizar como parte de la asignatura y computaría un 5\% de la nota final de la asignatura. El trabajo consistía en un trabajo bibliográfico sobre la utilidad de una especie animal como modelo animal en investigación biomédica. La tabla 1 muestra la guía de elaboración del manuscrito, la cual fue proporcionada a ambos grupos en este día.

Tabla 1. Guía para la elaboración del trabajo del modelo animal

\begin{tabular}{l|l}
\hline Trabajo: Modelo Animal & $\begin{array}{l}\text { Trabajo bibliográfico sobre la utilidad de una especie } \\
\text { animal como modelo animal }\end{array}$ \\
\hline Tipo & Trabajo por parejas \\
\hline Estructura & $\begin{array}{l}\text { Título y autores } \\
\text { Resumen y palabras clave } \\
\text { Texto (incluyendo figuras, tablas, etc....) }\end{array}$ \\
& $\begin{array}{l}\text { Conclusiones } \\
\text { Bibliografía }\end{array}$ \\
\hline Formato & $\begin{array}{l}\text { Tamaño A4 } \\
\text { Extensión: } 5 \text { páginas máximo } \\
\text { Tipo de letra: Arial, 11 } \\
\text { Interlineado: } 1.5\end{array}$ \\
\hline
\end{tabular}

(cc) EY-NC-ND 2018, Universitat Politècnica de València Congreso In-Red (2018) 
Para poder valorar la gestión del tiempo en la preparación y elaboración del trabajo de los estudiantes, se establecieron distintas fechas de entrega para cada uno de los grupos. Para el grupo A, la fecha límite de entrega fue el 15/03/2015 (1 mes y medio después de la presentación), mientras que para el grupo B la fecha de entrega se extendió hasta el 31/05/2015 (casi 3 meses después)(figura 1). El número de días que cada grupo de estudiantes entregó el trabajo antes de la fecha límite de entrega se estableció como una medida de la variable procrastinación.

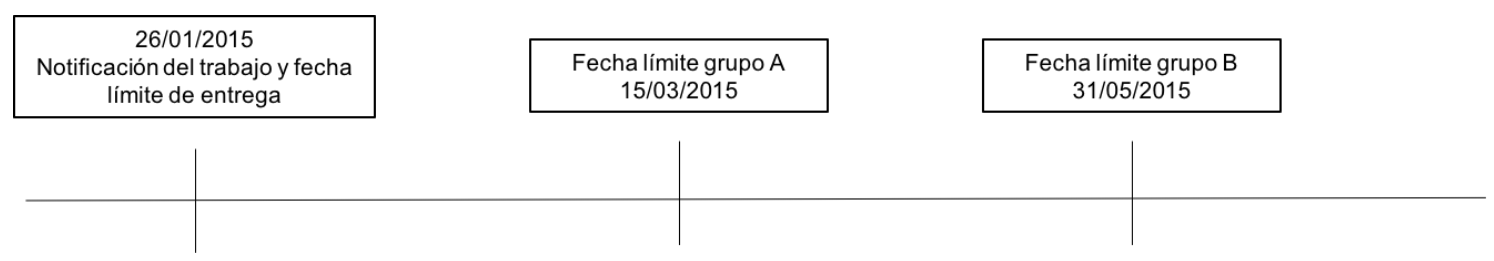

Fig.1. Cronograma del trabajo académico

Por otra parte, las notas de los trabajos de los estudiantes fueron analizadas para estudiar el efecto de la procrastinación sobre los resultados académicos. Con este fin, se empleó una rúbrica para evaluar los trabajos realizados por los alumnos (tabla 2). Esta rúbrica fue presentada a los alumnos el día de la presentación de la asignatura.

Tabla 2. Rúbrica del trabajo del modelo animal

\begin{tabular}{l|c}
\hline Contenido & $\mathbf{7 0}$ \\
Originalidad del modelo (ratón=5, caballo=20) & 20 \\
Descripción fisiológica de la especie & 20 \\
Aplicación del modelo & 20 \\
Calidad y profundidad científica & 10 \\
\hline Aspecto formal & $\mathbf{3 0}$ \\
Cumplimiento de las normas (plazos, extensión, etc.) & 10 \\
Tablas y figuras & 10 \\
Referencias & 10 \\
\hline
\end{tabular}

Por ultimo, el número de consultas que fueron realizadas durante la duración de la actividad dentro de cada uno de los grupos (grupo A y grupo B) fueron analizadas. 


\subsection{Análisis estadístico}

Como medida del nivel de procrastinación, se estudió los días antes de la fecha límite de entrega en el que cada pareja entregó su trabajo, para cada uno de los grupos (A y B). Para analizar los días previos a la fecha límite de entrega y comparar las notas del trabajo entre los grupos (A y B) se realizó un análisis mediante Modelos Lineares Generalizados. El análisis de las consultas se llevó a cabo mediante la función probit-link. Las diferencias se consideraron significativas si el p-valor $<0.05$. Los análisis fueron realizados con el paquete estadístico SPSS 16.0 (SPSS In., Chicago, IL, USA, 2002).

\section{Resultados}

En educación, el término procrastinación académica se emplea para designar la postergación del trabajo académico por parte de los estudiantes. La procrastinación académica ha sido ampliamente estudiada y se ha comprobado como tiene efectos negativos directos sobre el rendimiento de los estudiantes (Ariely y Wertenbroch, 2002; Wong, 2008; De Paola y Scoppa, 2015; Kim y Seo, 2015). De hecho, altos niveles de procrastinación hacen que los estudiantes sean incapaces de regular y organizar sus estudios para alcanzar sus objetivos académicos (Essau et al., 2008). Diferentes factores los que parecen contribuir a la tendencia de los estudiantes hacia la porcrastinación, como la falta de compromiso, la falta de constancia o una gestión inadecuada de sus capacidades (Hussain y Sultan, 2010).

Los resultados globales de este estudio nos muestran como no hay diferencias en el nivel de procrastinación ni en la nota media de los trabajos entre los dos grupos. La nota media de los trabajos no revelaron ninguna diferencia entre los grupos. La nota media de los trabajos del grupo A fue de $6.4 \pm 0.29$, mientras que la nota media de los trabajos del grupo B fue de 6.2 \pm 0.31 .

En cuanto a la variable procrastinación, la media reveló que la mayor parte de las entregas en ambos grupos se redujeron al día previo o al mismo día de la fecha límite de entrega $(0.21$ \pm 0.142 días vs. $0.39 \pm 0.146$ días, para los grupos $\mathrm{A}$ y $\mathrm{B}$, respectivamente). De hecho, el $86 \%$ de los estudiantes (84\% de los trabajos del grupo A y $87.5 \%$ de los trabajos del grupo B) entregó el trabajo en este periodo. Por ello, se observó un tendencia similar a procrastinar entre ambos grupos de estudiantes. Sin embargo, ha sido previamente publicado que periodos de tiempo más largos para la realización de una tarea promueven la procrastinación (Goode, 2008). De esta forma, la tendencia a procrastinar en los alumnos del grupo B podría ser explicada por el mayor tiempo del que dispusieron para la realización del trabajo (18 semanas del grupo B frente a las 7 semanas del grupo A). Sin embargo, resulta interesante resaltar dos hechos observados en nuestro trabajo: i) Ninguno de los trabajos del grupo B fue entregado fuera de la fecha límite, mientras que el $15.4 \%$ de los trabajos del grupo A si que fueron entregados tras la fecha límite; ii) 3 de los trabajos del grupo B (12.5\%) fueron entregados entre 3 y 4 semanas antes de la fecha límite, lo que indica la ausencia de procrastinación.

Otro punto a tener en cuenta sería si los estudiantes del grupo B podrían decidir procrastinar de forma deliberada (Kim et al., 2017). No obstante, este no parece ser el caso de nuestro

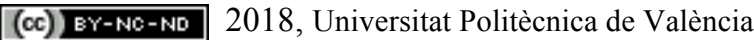


estudio dado que la fecha límite para los estudiantes del grupo B coincidió con los exámenes finales del cuatrimestre. Por ello, esto podría explicar dos de los factores estudiados: por un lado, los estudiantes del grupo B tienden a procrastinar de igual forma que lo hacen los estudiantes del grupo A, a pesar del mayor tiempo del que disponen hasta la fecha límite y la proximidad de los exámenes finales; y por otro lado, la procrastinación parece ser la consecuencia de las bajas notas medias de los trabajos de los grupos, lo que sería un indicativo del efecto dañino de la procrastinación en los resultados académicos.

En la búsqueda de medidas contra el problema de la procrastinación, Tuckman (2002) propuso que un mayor tiempo para la realización de una tarea podría ser una medida de lucha contra la procrastinación. Este autor sugirió que las tareas propuestas con tiempo y largos periodos para su elaboración podrían reducir la procrastinación. Sin embargo, nuestro estudio muestra que incluso con un mayor tiempo para la realización de los trabajos (de hasta casi 4 meses), y la proximidad de los exámenes a la fecha límite de entrega, no disuade a los alumnos de la procrastinación. Por ello, debido a que independientemente del tiempo disponible para la tarea los alumnos parecen seguir procrastinando, las instituciones académicas deberían buscar nuevas medidas contra la procrastinación de los estudiantes universitarios. Entre estas medidas, publicaciones anteriores han propuesto algunas medidas como servicios de guía y consulta universitarios (Hussain y Sultan, 2010). En este sentido, algunas instituciones universitarias han empezado a implementar medidas para adquisición de competencias, entre las que se encuentra la gestión del tiempo. En concreto, la Universitat Politècnica València ha desarrollado el proyecto de las competencias transversales, entre las que se encuentra 'La planificación y la gestión del tiempo (CT-12)'. La adquisición de esta competencia (mediante su trabajo y evaluación en distintas asignaturas durante la titulación) implica la correcta planificación del tiempo disponible y programación de las actividades necesarias para alcanzar los objetivos, tanto académico-profesionales como personales por parte del alumando.

Por ultimo, se pretendía estudiar si la procastinación estaba relacionada con el rendimiento académico, de acuerdo a estudios previos que demuestran que aquellos estudiantes que procrastinan obtienen calificaciones más bajas (De Paola y Scoppa, 2015). Sin embargo, en nuestro estudio ambos grupos registraron valores de procastinación similares, de ahí que se obtuviera la misma calificación media y no fuese posible discernir esta cuestión.

\section{Conclusiones}

De acuerdo con nuestros resultados, podemos indicar que los estudiantes universitarios tienden a procrastinar, independientemente del tiempo del que disponen para la elaboración y entrega de la tarea. Así, aquellos alumnos que aplazan la realización de la tarea hasta el periodo final de las clases reducen notablemente el tiempo que pueden dedicar a la preparación de los exámenes finales. Por tanto, la procastinación sigue siendo un problema que afectan al estudiante universitario, lo que requiere que se tomen medidas para una correcta planificación y hábitos de trabajo durante todo el curso que permiten mejorar los resultados. 


\section{Referencias}

ARIELY, D. y WERTENBROCH. (2002). "Procrastinations, deadlines, and performance: self.control by precommitment” en Psychol.vol.3, issue 3, p. 219-224.

CHU, A.H. y CHOI, J.N. (2005). "Why not procrastinate? Development and validation of a new active procrastination scale" en The Journal of Social Phychology. vol. 149, p. 195-211.

DE PAOLA, M. y SCOPPA, V. (2015). "Procrastination, academis succes and the effectiveness of a remedial program" en Journal of Economic Behaviour \& Organization. Vol. 115, p. 217-236.

DEWITT, S. y SCHOUWENBURG, H. (2002). "Procrastination, temptations, and incentives: the struggle between the present and the future in procrastinators and the punctual" en European Journal of Personality. Vol. 16, issue 6, 469-489.

ELLIS, A. y KNAUSS, W.J. (1977). “Overcoming procrastination”. New York: Institute of Rational Living.

ESSAY, C.A., EDERER, E.M., O’CALLAGHAB, J., ASCHEMANN, B. (2008). "Doing it now or later? Correlates, predictors and preventions of academic, decisional and general procrastination among students in Austria". Presentation at $8^{\text {th }}$ Alps-Adria Psychology Conference, October 2-4, Ljubljana, Slovenia.

FERRARI, J.R. (1991). "Self-handicapping by procrastinators: Protecting slef-steem, social.steem, or both?” en Journal of Research in Personality. Vol. 25, 245-261.

GOODE, C. (2008). "Effects of academic procrastination: Students procrastination affects more than grades". http://homeworktree.com/media/news-releases/academicprocrastination.

HUSSAIN, I., y SULTAN, S. (2010). "Analysis of procrastination among university students" en Procedia Social and Behavioural Sciences. Vol. 5, p1897-1904..

KIM, K.R., y SEO, E.H. (2015). "The relationship between procrastination and academic performance: A meta-analysis" en Personality and Individual Differences. Vol. 82, p. 26-33.

KIM, S., FERNANDEZ, S., TERRIER, L. (2017). "Procrastination, personality traits, and academic performance: When active and passive procrastination tell a different story" en Personality and Individual differences. Vol. 108, p. 154-157.

O'BRIEN, W.K. (2002). "Appliying the trans-theoretical model to academic procrastination" en Dissertation Abstracts Internations: Section B: The Sciences and Engineering. Vol. 62, issue 11-B, p. 5359

OZER, B.U., DEMIR, A., Y FERRARI, J.R. (2009). "Exploring academic procrastination among Turkish students: Possible gender differences in prevalence and reasons" en Journal of Social Psychology. Vol. 149, p. 241-257.

SCHOUWENBURG, H.C. (1995)." Academic procrastination: Theoretical notions, measurements, and research. In J.R. Ferrari, J.L. Johnson, \& W.G. McCown (Eds.).

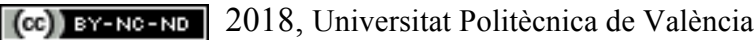


Procrastination and task avoidance: Tehory, research, and treatment (pp. 71-96). New York, NY: Plenum Press.

SILVER, M. y SABINI, J.(1981). "Procrastinating" en Journal of the Theory of Social Behaviour. Vol. 11, p. 207-221.

SOLOMON, L.J. y ROTHBLUM, E.D. (1984). "Academic procrastination: frequency and cognitive-behavioral correlates” en J. Couns. Psychol. Vol. 31, issue 4, p. 503-509.

STEEL, O. (2007). "The nature of procrastination: A meta-analytic and theoretical review of quitessential self-regulatory failure” en Phychological Bulletin. Vol. 133, issue 1, p. 65-94.

STEEL, P., BROTHEN, T., WAMBACH, C. (2001). "Procrastination and personality, performance, and mood" en Personality and Individual Differences. Vol. 31, issue 1, p. 95106.

THAKKAR, N. (2010). "Why procrastinate? An investigation of the root causes behind procrastination" en Lethbridge Undergraduate Research Journal. Vol 4, issue 2, p. 1-12.

TUCKMAN, B. (2002). "The relationship of academic procrastination, rationalizations and performance in a web course with deadlines" en Annual Meeting of the American Psychological Association: Chicago.

VAN EERDE, W. (2003). “A meta-analytic derived nomological network of procrastination" en Personality and Individual Differences. Vol. 35, p. 1401-1418.

WONG, W.K. (2008). "How much time-inconsistency is there and does it matter? Evidence of self-awareness, size and effects" en Journal of Economical Behaviour and Organization. Vol. 68, issue 3, p. 645-656.

\section{Agradecimmientos}

Este proyecto ha sido financiado por el Vicerrectorado de Estudios, Calidad y Acreditación de la Universidad Politécnica de Valencia (UPV) en el marco del Programa Proyectos de Innovación y Mejora Educativa (PIME/2017/B/010) y la Escuela de Ingeniería Agrícola y Medio Ambiente ( ETSIAMN) de la Universitat Politècnica de València (UPV). 


\title{
Elaboración y validación de materiales para la formación del profesorado de Educación Primaria, con el objetivo de que sus alumnos aprendan la competencia de Pensamiento Computacional
}

\author{
Constanza Rubio Michavilaa ${ }^{a}$ Kilian González Suárez ${ }^{\mathrm{b}}$ y María Olga Escandell \\ Bermúdez $^{\mathrm{c}}$ \\ aUniversitat Politècnica de València, crubiom@fis.upv.es, bUniversidad de Las Palmas de Gran \\ Canaria, kilian57@gmail.com, 'Universidad de Las Palmas de Gran Canaria, \\ mariaolga.escandell@ulpgc.es
}

\begin{abstract}
Programming and Robotics are some of the disciplines that have entered the classrooms with the aim of developing one of the competencies that are considered most relevant in today's education: Computational Thinking. Computational Thinking helps to structure the minds of the students, providing the necessary tools to solve problems in a precise and orderly manner. This fact has motivated the creation and validation of a proposal for learning materials which would allow to improve the way in which children develop that competence. The greatest challenge would be to train future teachers so that they are able to encourage these skills in students.

To validate the learning materials, an exploratory research was carried out using a Delphi method based on two rounds in which 10 experts from different disciplines participated, all of them with a strong technological component. The experts completed a valuation questionnaire with the objective of analyzing the strengths and weaknesses of the proposal, taking as a reference the contents, the methodology, the resources and the evaluation system. Finally, after these assessments were carried out, a consensus was reached, validating the proposal and preparing it to be applied in a real context.
\end{abstract}

Keywords: competences, computational thinking, constructionism, problembased learning, project-based learning, training, methodology, primary education.

\footnotetext{
Resumen

La programación y la robótica son algunas de las disciplinas que han invadido las aulas con el objetivo de desarrollar una de las competencias consideradas de mayor relevancia en la educación de hoy día: el Pensamiento Computacional. El Pensamiento Computacional ayuda a estructurar la mente, aportando las herramientas necesarias para resolver problemas de un modo preciso y ordenado. Este hecho ha motivado la creación y validación de una propuesta de materiales de aprendizaje que permitan perfeccionar el modo en el que los niños mejoran dicha competencia. El gran reto se encuentra en
} 
Elaboración y validación de materiales para la formación del profesorado de Educación Primaria, con el objetivo de que sus alumnos aprendan la competencia de Pensamiento Computacional

formar y acompañar a los futuros profesores para que estos sean capaces de fomentar dichas habilidades en los alumnos.

Para validar los materiales, se realizó una investigación exploratoria que empleó un método Delphi basado en dos rondas en las que participaron 10 expertos de diferentes disciplinas, todos ellos con una fuerte componente tecnológica. Los expertos completaron un cuestionario de valoración para analizar los puntos fuertes y puntos débiles de la propuesta, tomando como referencia los contenidos, la metodología, los recursos y el sistema de evaluación. Finalmente, tras dichas valoraciones se alcanzó un consenso que validó la propuesta, quedando lista para ser aplicada en un contexto real.

Palabras clave: competencias, pensamiento computacional, construccionismo, aprendizaje basado en problemas, aprendizaje basado en proyectos, formación, metodología, educación primaria.

\section{Introducción}

La humanidad vive inmersa en una transformación que radica en gran parte en el hecho digital; un hecho que todavía se encuentra en sus comienzos. Esta situación afecta a todos, no importa la edad, la cultura, el entorno o la política. Para adaptarse a este nuevo contexto, la sociedad debe educarse y formarse en base a un conjunto de competencias, que permitan afrontar un futuro volátil, incierto, complejo y ambiguo que normalmente es conocido como VUCA.

Entre las competencias vinculadas al hecho digital, a nivel macro se encuentra el Pensamiento Computacional (PC). La investigación realizada se centra en esta competencia de orden superior, ya que permite trabajar con niños, adolescentes y jóvenes, mediante el uso de recursos abiertos y motivadores que siguen pedagogías constructivistas y construccionistas, y según algunos conectivistas.

S. Papert (1991) es considerado uno de los pioneros del Pensamiento Computacional y además es autor de la teoría construccionista, inspirada en el constructivismo de Piaget, con el que trabajó en Suiza. Según Ackerman (2001), los dos definen la inteligencia como la capacidad de adaptación, la capacidad para mantener el equilibrio entre la estabilidad y el cambio. A su vez, Jeannette M. Wing (2006) es quien utilizó por primera vez la denominación actual para el PC, definiéndolo como «la forma en la que los seres humanos resuelven los problemas complejos, incorporando una serie de procesos mentales que la ciencia informática, en cierto modo, utiliza».

Desarrollar el Pensamiento Computacional es más que aprender a codificar y programar, aunque estas habilidades se pueden utilizar para perfeccionar dicho tipo de pensamiento. El PC implica enseñar a pensar, a abordar problemas y resolverlos, desarrollando la metacognición, que es básica para aprender a aprender.

Integrar el aprendizaje del PC a nivel formal puede seguir distintos modelos, ya sea incluyendo una o varias herramientas específicas dentro de una asignatura ya existente,

(cc) EY-NC-ND 2018, Universitat Politècnica de València

Congreso IN-RED (2018) 
diseñando un nueva asignatura para sumarla al currículo actual o trabajándolo de manera transversal en todo el plan de estudios. Es un área con bastantes incógnitas y líneas abiertas, que se ha comenzado a plantear ya en las instituciones educativas de todo el mundo.

Uno de los primeros pasos a dar es el desarrollo de la propia competencia en el futuro profesorado que se encuentra en las facultades de ciencias de la educación. Para que estos sean capaces de guiar a otros es conveniente que primero cultiven la competencia por sí mismos. La investigación aborda este tema de un modo general, inclusivo y para todos, pudiéndose aplicar tanto en estudiantes universitarios como en sus futuros alumnos.

\section{Objetivos}

Con el desarrollo del PC en mente, es vital que el profesorado tenga a su disposición un banco de recursos, herramientas o software, para ser utilizado en la escuela, escogiendo cada docente aquellos con los que más cómodo se encuentre y que mejor se adapten a los objetivos de aprendizaje. La importancia de las innovaciones debe situarse en las pedagogías y los procesos pedagógicos, y no tanto en las tecnologías usadas.

El propósito de la investigación ha sido elaborar y validar un conjunto de herramientas para desarrollar el Pensamiento Computacional, mediante la propuesta metodológica que tenga en cuenta las peculiaridades del mismo y que mejor se adapte. Entre dichas propuestas metodológicas se valoraron el Aprendizaje Basado en Problemas, el Aprendizaje Basado en Proyectos y una mezcla entre ambas, de modo que puedan ser utilizadas en un determinado nivel educativo formal, integrado o no en el plan de estudios, para desarrollar la competencia de Pensamiento Computacional a partir de la capacitación mediante la codificación (coding) aplicada a problemas reales del mundo físico. Es importante destacar que aunque el Aprendizaje Basado en Proyectos y el Aprendizaje Basado en Problemas comparten muchas características, se trata de dos enfoques diferentes. En el Aprendizaje Basado en Problemas prima el proceso seguido por los alumnos mientras que en el Aprendizaje Basado en Proyectos prima el producto final.

Cuando se hace referencia al mundo físico, es para recalcar la importancia de que el problema esté vinculado al mundo real de las personas, que se encuentran a cargo de la búsqueda de una solución. Todo el conocimiento y el trabajo debe estar enfocado hacia su traslado desde el mundo real al mundo virtual, para terminar volviendo al mundo real (que es tangible) con la solución, sin descuidar en ningún momento que el alumnado debe ser consciente de este proceso.

Reformulando el propósito a modo de pregunta general, se definiría la siguiente cuestión: ¿Cómo es posible estudiar adecuadamente el desarrollo, entrenamiento y asimilación de dicha competencia, mediante el uso de herramientas propias del Pensamiento Computacional?

J. M. Wing (2006) resalta que el PC es una manera ordenada de pensar, de reflexionar sobre los diferentes problemas que se puedan presentar a lo largo de la vida, tanto en lo personal (individual y colectivo) como en lo profesional. El PC ayuda a estructurar y gestionar la gran 
Elaboración y validación de materiales para la formación del profesorado de Educación Primaria, con el objetivo de que sus alumnos aprendan la competencia de Pensamiento Computacional

cantidad de información que se recibe cada día. Este proceso mental es posible gracias a las tres fases del PC, que se pueden simplificar del siguiente modo:

- Descomposición: resolver un problema dividiéndolo en partes más pequeñas.

- Reconocimiento de patrones: encontrar la relación jerárquica, analizar los datos.

- Diseño algorítmico: obtener soluciones, siguiendo una serie ordenada de pasos.

Las tres fases anteriores se encuentran implícitas en la propuesta generada para abordar el Pensamiento Computacional desde una asignatura relacionada con las TICs. Por lo tanto, será necesario el uso de dispositivos tecnológicos. En este caso, se requiere de placas y componentes de electrónica educativa además de ordenadores de sobremesa y/o portátiles, que permitan ejecutar el software controlador Snap! Dicho software permite programar de manera visual mediante el uso de bloques, que representan instrucciones y que son interconectados para llevar a cabo determinadas acciones. A este conjunto de acciones que resuelven un problema se le llama algoritmo.

Por otra parte, la profesora M. Romero (2017) ha desarrollado el modelo \#5c21, en el que se refuerza la existencia de una relación bidireccional entre el Pensamiento Computacional y otras competencias que se consideran esenciales para el siglo XXI, haciendo referencia sobre todo a las 4C's (creatividad, comunicación, colaboración, y pensamiento crítico). Quiere decir esto que mediante el desarrollo del PC también se estarían desarrollando las 4C's, y de igual modo sucedería a la inversa.

\section{Desarrollo de la innovación}

Para llevar a cabo la validación de los materiales de aprendizaje desarrollados se ha utilizado el método Delphi, una técnica cualitativa aplicable en las investigaciones exploratorias, definidas por Fernández Alarcón (2006). La técnica Delphi utiliza cuestionarios para establecer un consenso entre un grupo de expertos que son guiados por un moderador. La información no es recogida a partir de un conjunto de casos reales, sino a través de la opinión de un conjunto de personas. Esta técnica está formada por tres fases: el diseño del cuestionario, la selección de los expertos y el envío del cuestionario con su posterior proceso iterativo de retroalimentación. Es importante destacar que en esta metodología el diseño del cuestionario debe ser lo más riguroso y completo posible, aunque las preguntas pueden ser abiertas y/o cerradas, así como cuantitativas y/o cualitativas.

Según Cuhls (2003), el método Delphi es una encuesta desarrollada en dos o más rondas, en las que en cada una de ellas se incorporan a los materiales diseñados las sugerencias y orientaciones aportadas por los expertos en rondas previas. Esta investigación optó por utilizar el método Delphi convencional de dos rondas, ya que gracias a las herramientas de comunicación de las que se dispone en la actualidad, el proceso de obtención del feedback es mucho más sencillo, pudiendo contactar con los expertos mediante correo electrónico y, en los casos en los que no fue posible, de forma presencial. Según Dalkey (1972), el anonimato de los sujetos que intervienen en el proceso Delphi es un punto a favor ya que este disminuye el efecto ruido, evitando así la influencia de las respuestas de los unos en los otros.

(c) EY-NC-ND 2018, Universitat Politècnica de València

Congreso IN-RED (2018) 
Para la selección de los expertos se propuso como criterio formar un grupo multidisciplinar, ya sea por su formación inicial o por su dedicación e intereses. Al abordar el diseño de los materiales para el desarrollo del Pensamiento Computacional desde un área de trabajo principalmente tecnológica, se procuró que la totalidad de los expertos tuviese relación con el hecho digital y con su integración en la educación y formación.

De este modo, los expertos han sido personas de perfil tecnológico muy vinculado a la educación como docentes, investigadores, desarrolladores de software, profesionales de la innovación e inclusión social, formadores de formadores, expertos en aprendizaje basado en problemas y coordinadores de programas educativos.

A continuación, aparece un listado con el perfil de los 10 expertos que han participado en el análisis:

- 2 docentes de tecnología e informática pertenecientes a la ESO.

- 1 docente de ciclo medio y superior.

- 1 formador de formadores a nivel universitario.

- 1 experto en Aprendizaje Basado en Problemas.

- 1 experta en educación inclusiva.

- 1 director de área en empresa de desarrollo de software.

- 1 decano de facultad de Informática, Multimedia y Telecomunicaciones.

- 1 especialista en el desarrollo y aplicación de TIC con fines sociales.

- 1 responsable de formación y divulgación de cultura científica.

Las herramientas utilizadas para validar la propuesta se basaron fundamentalmente en un cuestionario estructurado en base a 4 preguntas de respuesta cerrada, a las que se les dio un mayor valor cualitativo, ya que incluían un apartado destinado a comentarios; y 3 cuestionarios de respuesta abierta, en los que los expertos pudieron aportar cuáles, según ellos, son las fortalezas y debilidades del planteamiento, añadiendo además un apartado final para que incluyesen nuevas ideas que contribuyeron a la mejora del mismo.

Las preguntas de carácter cerrado son evaluadas mediante una escala de tipo Likert, pudiendo seleccionar diez niveles de respuesta, donde 10 es la puntuación máxima y 1 la mínima. Las variables medidas guardaron relación con los contenidos, la metodología, los medios/recursos y la herramienta de evaluación. Una evaluación que de ser exclusivamente cuantitativa pasaría por alto muchos aspectos de relevancia; por ello la herramienta incluyó las dos vertientes, cualitativa y cuantitativa.

Las preguntas, de carácter cerrado y puntuadas de 1 a 10, fueron las siguientes:

- ¿Considera adecuados los contenidos del programa, para abordar el coding y la interacción con el mundo físico?

- ¿Considera adecuada la metodología empleada (metodología mixta entre Aprendizaje Basado en Problemas y Aprendizaje Basado en Proyectos)?

- ¿Considera adecuados los medios y recursos tecnológicos (y no tecnológicos) empleados?

- ¿Considera adecuado el sistema de evaluación del programa (la rúbrica)? 
Elaboración y validación de materiales para la formación del profesorado de Educación Primaria, con el objetivo de que sus alumnos aprendan la competencia de Pensamiento Computacional

Aunque la aplicación del método Delphi puede variar, la propuesta llevada a la práctica se considera como caso típico de dicho método. Los resultados de la ronda de valoraciones iniciales son resumidos para calcular posteriormente la media y la desviación típica. Posteriormente, esta información fue devuelta a los participantes (segunda ronda) para que revisaran las estimaciones iniciales. Normalmente, el proceso se continúa de forma iterativa hasta alcanzar un consenso. El consenso se estableció de manera objetiva tras alcanzar una nota media superior a 8 en cada uno de los aspectos evaluados.

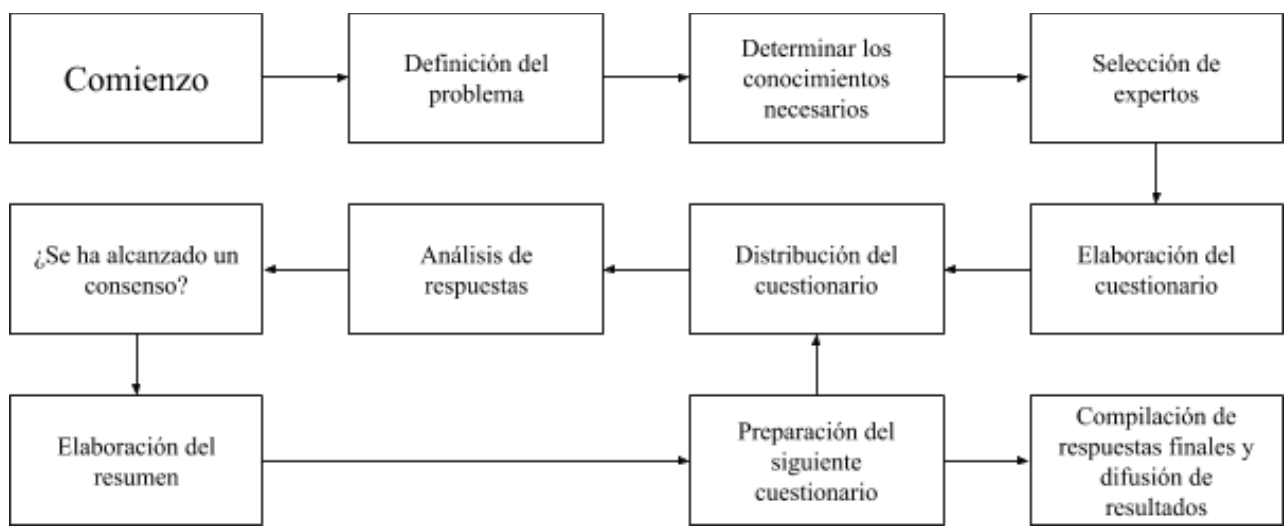

Fig. 1 Flujo estándar del desarrollo del método Delphi seguido.

\section{Resultados}

A continuación se presentan los resultados que se obtuvieron en cada ronda de valoración, analizándolos de manera independiente para iniciar la medidas de mejora propuestas por los expertos.

\subsection{Primera ronda de valoraciones}

Las preguntas de carácter cerrado arrojaron los siguientes valores cuantitativos:

Tabla 1. Medidas de tendencia central para la primera ronda de evaluación

\begin{tabular}{cccccc}
\hline & N & Mínimo & Máximo & Media & Desviación típica \\
\hline Contenidos & 10 & 7 & 10 & 8,80 & 0,919 \\
Metodología & 10 & 6 & 10 & 9,10 & 1,449 \\
Recursos & 10 & 8 & 10 & 9,40 & 0,843 \\
Evaluación & 9 & 5 & 10 & 8,22 & 1,716 \\
\hline
\end{tabular}

Se observó en los resultados que todas las calificaciones superaron el mínimo propuesto de 8 puntos, pero la segunda ronda de evaluación resultó igualmente necesaria para incorporar las opiniones de los expertos. Centrando la atención en las puntuaciones más bajas, destacan

(cc) EY-NC-ND 2018, Universitat Politècnica de València

Congreso IN-RED (2018) 
las variables correspondientes con los contenidos y la herramienta de evaluación. La desviación típica además demostró que existen irregularidades en las categorías correspondientes con la evaluación y la metodología.

Atendiendo a una explicación mucho más cualitativa de los datos estadísticos, gracias al complemento que supusieron las preguntas de carácter abierto, se resalta que, en el caso de los contenidos, las valoraciones fueron mayormente positivas, apuntando hacia la idoneidad de la propuesta en este aspecto y añadiendo como posible mejora la realización de un mayor esfuerzo en cuanto a la atención a la diversidad, asociando los contenidos con el currículo oficial y apoyando el aprendizaje mediante videos.

En el caso correspondiente con la metodología, es necesario destacar que la propuesta inicialmente solo se centró en el Aprendizaje Basado en Problemas, señalando los expertos que este es adecuado por considerar los procesos como eje principal del aprendizaje, pero la desviación típica observada señala también que algunos expertos no han estado del todo de acuerdo con el resto. Este desacuerdo fue atribuido a la preferencia que estos tenían por otro tipo de metodologías, concretamente el Aprendizaje Basado en Proyectos o de un enfoque mixto.

Respecto a los medios y recursos empleados en la propuesta educativa, todos los expertos remarcaron la conveniencia de los mismos, destacando además la importancia de generar una hoja de presupuesto que dotase al programa de mayor solidez y viabilidad. Además, a este aspecto se le sumó el entorno, la trascendencia de generar un ambiente propicio en el que llevar a cabo el proceso de enseñanza y aprendizaje.

Sin duda, la herramienta de evaluación escogida (una rúbrica) fue el aspecto en el que más estuvieron en desacuerdo los expertos, no tanto por el hecho de que se tratase de una rúbrica, sino debido al planteamiento y gradación de la misma. Estas opiniones dejaron entrever que la rúbrica requería de una reformulación.

\subsection{Segunda ronda de valoraciones}

En la segunda ronda, se obtuvieron los siguientes datos a partir de las preguntas de carácter cerrado:

Tabla 2. Medidas de tendencia central para la segunda ronda de evaluación

\begin{tabular}{cccccc}
\hline & N & Mínimo & Máximo & Media & Desviación típica \\
\hline Contenidos & 10 & 8 & 10 & 9,50 & 0,707 \\
Metodología & 10 & 8 & 10 & 9,60 & 0,843 \\
Recursos & 10 & 7 & 10 & 9,60 & 0,966 \\
Evaluación & 10 & 5 & 10 & 8,60 & 1,350 \\
\hline
\end{tabular}

En la segunda iteración de cuestionarios todas las puntuaciones sufrieron un incremento sustancial, superando el 9 en tres de los cuatro casos expuestos. El aspecto correspondiente 
Elaboración y validación de materiales para la formación del profesorado de Educación Primaria, con el objetivo de que sus alumnos aprendan la competencia de Pensamiento Computacional

a la evaluación mejoró, pero no consiguió situarse al mismo nivel que el resto de apartados; aún así la propuesta inicial se vió enriquecida a partir de las opiniones de los expertos. Los datos numéricos de la Tabla 2 se entienden desde las valoraciones cualitativas que los participantes realizaron, para cada una de las categorías contempladas, así como los puntos fuertes y los puntos débiles.

La variable relacionada con los contenidos mejoró en 0,70 puntos respecto de la fase inicial, resaltando en este apartado que los contenidos ganaron mucho valor al verse reordenados y complementados. La metodología mejoró en 0,50 puntos, destacándose la buena integración entre el Aprendizaje Basado en Problemas y el Aprendizaje Basado en Proyectos y permitiendo así que la propuesta fuese más flexible ante posibles restricciones o contratiempos. Los medios y recursos mejoraron en 0,20 puntos, ratificando lo que desde un primer momento se había planteado: son idóneos para el desarrollo del Pensamiento Computacional. Por otra parte, la valoración de la herramienta de evaluación mejoró notablemente, apuntando el panel de expertos que se trata de uno de los aspectos más difíciles en los que lograr el consenso, pues no todo el mundo comparte que un determinado método de evaluación con unas determinadas gradaciones puedan ser las más adecuadas. No obstante, esta variable experimentó una mejora de 0,38 puntos respecto de la propuesta inicial.

\section{Conclusiones}

A la vista de los resultados, se concluyó que la propuesta de materiales de aprendizaje para desarrollar el Pensamiento Computacional era válida, puesto que superó la calificación establecida como mínima para todos sus apartados; destacándose, entre otras cosas, la progresión y estructuración de los contenidos y las medidas de atención a la diversidad, que sustentan una curva de aprendizaje adecuada al perfil de cada estudiante. Por lo tanto es adecuada para el aprendizaje de los profesores de educación primaria, en su formación inicial.

La metodología mixta entre Aprendizaje Basado en Proyectos y Aprendizaje Basado en Problemas satisface a la forma en la que se ejecutaría el proyecto que deben afrontar los alumnos. Esta unión de metodologías es lo suficientemente flexible como para adaptarse a casi cualquier contexto, sobre todo si se atiende a la temporalización y a la formación docente del profesorado. La inclusión de vídeos eleva notablemente la calidad de la idea, ofreciendo de este modo un recurso atractivo que motive al alumnado y mantenga el interés de este.

A partir de la investigación realizada se abren nuevas líneas de trabajo orientadas hacia la mejora de las herramientas de evaluación, que deben ser reformuladas teniendo en cuenta cada contexto educativo concreto y creándose conjuntamente con el alumnado a partir del conocimiento del campo en el que van a ser aplicadas.

Queda pendiente la importante tarea de definir un proceso de cambio apropiado, que facilite la incorporación de estas propuestas y otras a las aulas ya existentes. El Pensamiento Computacional apunta a convertirse en una macrocompetencia esencial para el desarrollo del ser humano, teniendo en cuenta que estructuralmente será semejante y los contenidos diferentes, según la edad y capacidades de los aprendices.

(c) EY-NC-ND 2018, Universitat Politècnica de València

Congreso IN-RED (2018) 


\section{Referencias}

ACKERMANN, E. (2001). "Constructivisme et Constructionisme: Quelle Différence" en Constructivisms: Usages et Perspectives en Education. Geneva: Service de la recherche en education/Cahier 8/ September 01, Vol. 1 et 2, pp. 85-94.

CUHLS, K. (2003). "Development and perspectives of foresight in Germany" en Technikfolgenabschätzung, 2003. Vol. 12, n. 2, pp. 20-28.

DALKEY, N. C. (1972). Studies in the quality of life; delphi and decision-making. Lexington, USA: Lexington Books.

FERNÁNDEZ ALARCÓN, V. (2006). “Introducción a la investigación en ciencias sociales.” Working Paper del Departament d'Organització d'empreses de la Universitat Politècnica de Catalunya. <https://upcommons.upc.edu/bitstream/handle/2117/501/Introducci\%C3\%B3n\%20a\%201a $\% 20$ investigaci\%C3\%B3n\%20en\%20ciencias\%20sociales.pdf> [Consulta: 8 abril de 2017].

GONZÁLEZ SUÁREZ, K. (2017). Aprendizaje de competencias para el siglo XXI, mediante el desarrollo del pensamiento computacional, en alumnos de primaria: un caso piloto en Canarias. Las Palmas de Gran Canaria: Servicio de Publicaciones ULPGC. No listada.

PAPERT, S. y HAREL, I. (1993). Constructionism. Ablex Publishing Corporation, 1991.

ROMERO, M. (2017). “\#5c21 5 key skills for 21st century education” en \#CoCreaTIC, 27 de julio. <https://margaridaromero.wordpress.com/2016/07/28/5c21-5-key-skills-for-21st-century-

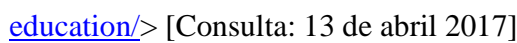

WING, J.M. (2006). "Computational thinking represents a universally applicable attitude and skill set everyone, not just computer scientists, would be eager to learn and use" en Communications of the ACM, 49, Vol. 49 Issue 3, March 2006, pp. 33-35. 


\title{
Comunicación efectiva en Lengua Extranjera a través del Aprendizaje Basado en Tareas
}

\author{
María José Gómez Perales
}

Universitat Politècnica de València, mjgomez@idm.upv.es

\begin{abstract}
Task Based Learning and Content Based Instruction approach are the methodolgical resources that nourish the present proposal. The enterprise, as transversal content, served as guide when proposing a series of tasks to the students who, with a high level of success, developed the ability of communicating effectively in German, in the context of the optional subject German B2.
\end{abstract}

Keywords: Task Based Learning, Foreign Language, German, Effective Communication

\begin{abstract}
Resumen
El Aprendizaje basado en Tareas (Task Based Learning) y el enfoque de la enseñanza de lenguas extranjeras a través de contenidos (Content-Based Instruction) son los recursos metodológicos que sustentan la presente propuesta. La empresa, como contenido transversal, ha servido de guía a la hora de proponer una serie de tareas a los estudiantes que, con un alto grado de éxito, han desarrollado la capacidad de comunicarse de forma efectiva en alemán, en el marco de la asignatura optativa transversal Alemán $B 2$.
\end{abstract}

Palabras clave: metodología, aprendizaje basado en tareas, lengua extranjera, alemán, comunicación efectiva.

\section{Introducción}

En el marco del aprendizaje de lenguas extranjeras en el ámbito universitario, la lengua alemana ocupa un lugar destacado en las preferencias del estudiantado de la Universitat Politècnica de València (a partir de ahora UPV). Así lo demuestran las cifras de alumnos que se matriculan en los diferentes niveles de esta lengua que, después del inglés, es la más demandada.

La relevancia, tanto económica como política, de Alemania en el conjunto de la Unión Europea, así como su prestigio en el ámbito de la ingeniería y la tecnología, hacen de este país un lugar de destino atractivo para los estudiantes que, no solo eligen alguna universidad alemana como destino de sus estancias ERASMUS, sino que identifican este país como el lugar en el que les gustaría desarrollar su futura profesión como ingenieros, administradores de empresas o incluso artistas. 
La asignatura Alemán B2 se oferta como asignatura optativa transversal en la UPV desde el curso 2015/2016 y el supuesto desde el que afronté su planificación partió de la idea de que la empresa, como estructura organizativa, sería con una alta probabilidad, el destino común de cualesquiera que fueran los potenciales matriculados en esta asignatura. Es decir, un futuro ingeniero industrial, agrónomo o informático trabajará en una empresa y tendrá que desenvolverse en ella. La empresa, por tanto, se convirtió en el contenido que, gracias a su carácter transversal, podía motivar a todos los alumnos. Al tomar esta decisión estamos situándonos del lado de los enfoques de enseñanza de lenguas que relegan la gramática a un lugar subsidiario en relación a los temas o contenidos que son tratados en el aula (ContentBased Instruction), que adquieren relevancia y guían el aprendizaje de la lengua extranjera (Crandall \& Tucker, 1990).

Por otra parte, la capacidad de comunicación efectiva, ya tenga lugar ésta por escrito o de forma oral, es no solo una de las competencias transversales que la UPV considera fundamentales en sus egresados, sino también, y como no podría ser de otra manera, la competencia que, según el Marco Europeo de Referencia para las Lenguas, se persigue que adquieran los aprendices de una lengua extrajera. Es importante destacar, por tanto, que a la transversalidad de nuestra asignatura, que pueden cursar estudiantes de muy diferentes Grados, se le añade el carácter transversal de la competencia comunicativa en general, que se vería concretada en nuestro caso en competencia comunicativa en alemán.

Teniendo en cuenta estos aspectos, la distribución de los créditos de la asignatura en "Teoría de Aula" y "Prácticas informáticas" se ofrecía como una oportunidad para planificar las sesiones prácticas como el eje sobre el que hacer girar el resto de los créditos, esto es, del tiempo disponible para alcanzar, en la medida de lo posible, el objetivo fundamental de la comunicación efectiva. Para ello estructuré las cuatro sesiones prácticas de las que constaba la asignatura desde los supuestos del Aprendizaje Basado en Tareas (Ellis 2003), ya que gracias a esta orientación metodológica se consigue trasladar el foco del proceso de aprendizaje del docente al discente. No obstante, hay que precisar, que estas cuatro tareas, que detallaremos más adelante, tendrían el nexo común de la empresa. Investigaciones recientes han demostrado la idoneidad de la aplicación del enfoque del Aprendizaje Basado en Tareas para la adquisición del alemán como lengua extranjera (Bosch, 2012 y 2017), si bien en un contexto más restringido que el nuestro, ya que en esas contribuciones los alumnos estudiaban todos un mismo Grado en Turismo, por lo que las tareas y las actividades conducentes a ellas estaban relacionadas con las necesidades comunicativas propias de esa actividad profesional.

\section{Objetivos}

El objetivo general de la presente propuesta consiste en presentar el desarrollo de actividades que integran habilidades receptivas y productivas en lengua extranjera - en el sentido de Input Processing (VanPatten, 2010)- conducentes a la elaboración de tareas por parte de los discentes, en las que se pretende alcanzar un nivel óptimo de comunicación efectiva. 
Atendiendo a los objetivos marcados en el Marco Europeo de Referencia para el aprendizaje y enseñanza de lenguas, presentamos actividades en las que los estudiantes han de escuchar y comprender exposiciones orales sobre temas académicos o profesionales que les son relevantes. Asimismo han de ser capaces de leer y comprender artículos e informes sobre temas que académica o profesionalmente son significativos para ellos. Por último, se pretende lograr que sean capaces de comunicarse, ya sea oral o por escrito, de forma eficiente sobre temas profesionales o académicos.

\section{Desarrollo de la Innovación}

Como hemos explicado en la introducción, nuestra propuesta consiste en cuatro tareas -a realizar por los estudiantes- que, de una u otra forma tienen, desde el punto de vista del contenido, el nexo común de la empresa. Las enumeramos a continuación, para pasar después a explicar con detalle cómo se han puesto en práctica cada una de ellas:

- $\quad$ Presentación oral de una empresa (Firmenpräsentation)

- Puesta en escena de una entrevista de trabajo (Vorstellungsgespräch)

- Video-Tutorial (Video-Anleitungen)

- Diálogos conflictivos en el puesto de trabajo (Konfliktgespräche am Arbeitsplatz)

En la primera tarea, el alumno ha de realizar una exposición oral (naturalmente en alemán) de una empresa, que él mismo ha elegido. Previamente, el estudiante ha elaborado una presentación en cualquier formato (habitualmente se elige el soporte Power Point). La gran mayoría de los alumnos optan por buscar información sobre una compañía relacionada con su posible futuro profesional. Esta presentación ha de ser expuesta oralmente al resto de la clase. Las actividades que se han llevado a cabo en el aula -lo que se conoce como pretareahan estado enfocadas a facilitar la elaboración y presentación de la empresa. Con ese objetivo, el profesor planifica actividades de comprensión oral y escrita relacionadas con esta temática, en las que a través de textos, escritos u orales, el alumno recibe un determinado input de vocabulario y estructuras gramaticales relevantes a la hora de ofrecer los datos de cualquier empresa. Por ejemplo, en lo que atañe al vocabulario, el tipo legal de empresa, es decir, si se trata de una sociedad anónima o limitada $(A G / G m b H)$; año de fundación de la empresa (Gründungsjahr); ciudad en la que está ubicada su sede central (Hauptsitz); número de trabajadores (Mitarbeiter); filiales (Tochterunternehmen), etc. En lo que respecta a las estructuras gramaticales, se hará notar en los ejemplos de presentaciones de empresas facilitadas por el profesor, por ejemplo, el uso de las adjetivaciones con la correspondiente atención a la declinación del adjetivo característica del alemán: "Wir sind ein erfolgreiches und stark expandierendes Unternehmen der Metall- und Kunststoff verarbeitenden Industrie.[...]”, "MAGNA ist ein weltweit tätiger Zulieferer der Automobilindustrie. [...]"; "Die deutsche Tochtergesellschaft in Frankfurt ist eine der bedeutendsten unserer Gruppe [...]”. (Estos ejemplos proceden del manual Präsentieren und Verhandeln. Véase bibliografía).

La segunda tarea consiste en que los alumnos, por parejas, representen una entrevista de trabajo. Previamente han elaborado este diálogo, en el que uno de los alumnos tomará el rol 
de jefe o jefa de personal (Personalleiter /In) y el otro el de candidato/a al puesto de trabajo (Bewerber/In). El puesto de trabajo al que aspira el candidato, ha sido elegido por cada pareja de alumnos de una página web auténtica ( https://www.monster.de/jobs/q-ingenieurjobs.aspx?incid=CA_FatFooter_popjob_ingenieur) en la que la oferta laboral se asemeja a la que podría interesar a los futuros egresados. Esta tarea conlleva una serie de actividades previas que el profesor ha detallado. En primer lugar, todos los estudiantes han elaborado su Curriculum Vitae en alemán (Lebenslauf), después de haber leído y analizado varios modelos de este tipo de documento durante la fase denominada Pretarea (https://www.monster.de/karriereberatung/artikel/musterlebenslauf-zum-download-30985). Asimismo, los estudiantes han de redactar la carta de solicitud (Bewerbunsbrief) para aspirar al puesto de trabajo que han seleccionado en la página web. Este tipo de documento ha sido también objeto de estudio y análisis en la fase previa a la tarea, mediante la lectura de diversos ejemplos (https://www.monster.de/karriereberatung/lebenslaufbewerbungsschreiben/anschreiben-muster). Y por último, también el diálogo típicamente característico de la entrevista de trabajo ha sido tematizado en el aula por medio de ejemplos.

La tercera tarea consiste en la grabación de un vídeo-tutorial por parte de los alumnos, en el que presenten un objeto/producto o un proceso. $\mathrm{Al}$ igual que en las tres tareas anteriores, el profesor ha diseñado una serie de actividades con las que facilitar a los estudiantes el input necesario (https://www.youtube.com/watch?v=3_IBvPsTHls) que motive la producción de un vídeo propio (output). En este caso, los ítems gramaticales que tienen un mayor protagonismo son, entre otros, el modo imperativo y la voz pasiva. Por ello, el profesor guiará la atención del alumno sobre el uso de estos dos recursos gramaticales en el contexto concreto de ese tipo de "textos" y facilitará materiales que fijen el uso correcto de ese contenido gramatical.

Por último, en la cuarta tarea, los alumnos han de representar un diálogo en el puesto de trabajo, que parte de una situación conflictiva, como por ejemplo, falta de puntualidad, incumplimiento de responsabilidades, malos entendidos, etc. Previamente, los alumnos han decidido, por parejas, cuál será el conflicto entre ambos y redactarán el diálogo con unas estrategias discursivas u otras, dependiendo de que hayan decidido que el conflicto se resuelva o no. El profesor, por su parte ha ofrecido situaciones similares por medio de actividades en el aula como trabajo previo a la tarea de los estudiantes (véase en este caso la unidad 13 "in Konfliktsituationen reagieren" del manual Im Beruf, así como esta misma unidad en el volumen de ejercicios).

\section{Resultados}

Es importante destacar que la primera y la tercera tarea- es decir, la presentación de la empresa y el tutorial- son trabajos individuales realizados por cada estudiante con el objetivo de ser presentados posteriormente al resto de la clase. Mientras que la segunda y la cuarta tareas son realizadas en grupos de dos o, en algunos casos, de tres personas. Por otra parte, hay que señalar que la presentación de la empresa y el tutorial son tareas que el

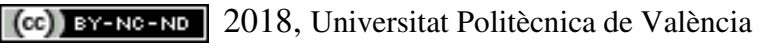

Congreso IN-RED (2018) 
estudiante ha elaborado fuera del aula; mientras que la entrevista de trabajo y el diálogo sobre una situación conflictiva son realizados en la clase. Además, se ha de destacar el hecho de que en la primera tarea el estudiante presenta su empresa en el aula, mientras que el caso del tutorial, al tratarse de un video, los estudiantes autores del trabajo, son espectadores de su propio trabajo en el aula.

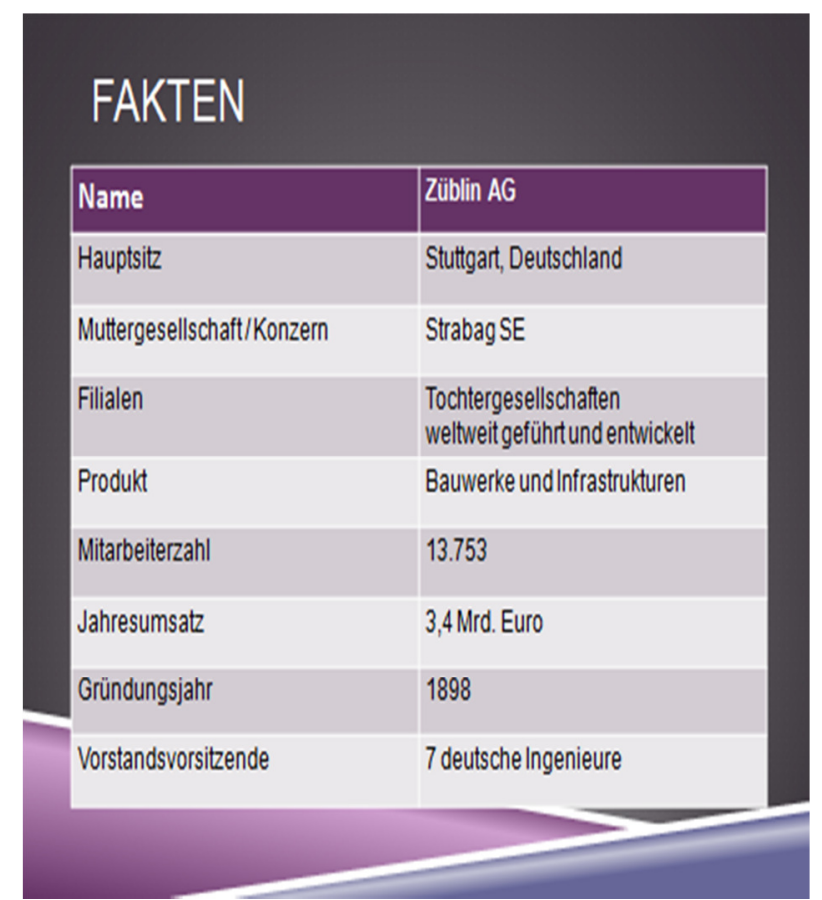

Fig. 1 Diapositiva de una las empresas

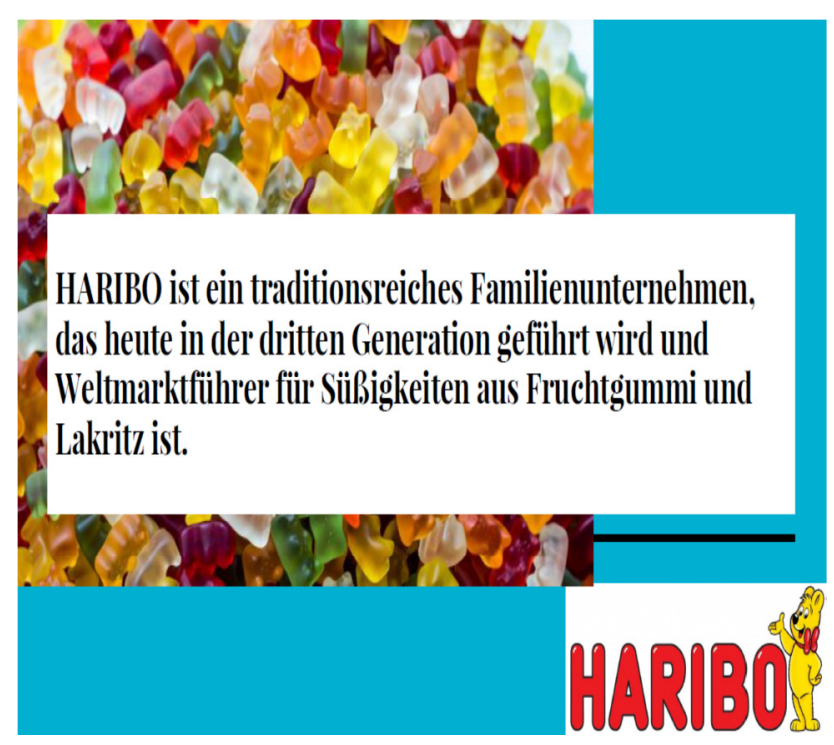

Fig.2 Diapositiva de otra de las empresas

(cc) EY-NC-ND 2018, Universitat Politècnica de València 
Los resultados de la primera tarea que presentaron los alumnos, tuvieron una extensión que osciló entre las 10 y las 15 diapositivas y las presentaciones orales una duración que, dependiendo de la fluidez y la rapidez de la dicción, se extendió entre tres y los seis minutos. Por otra parte, los vídeos tutoriales tuvieron una duración de entre tres y cinco minutos.

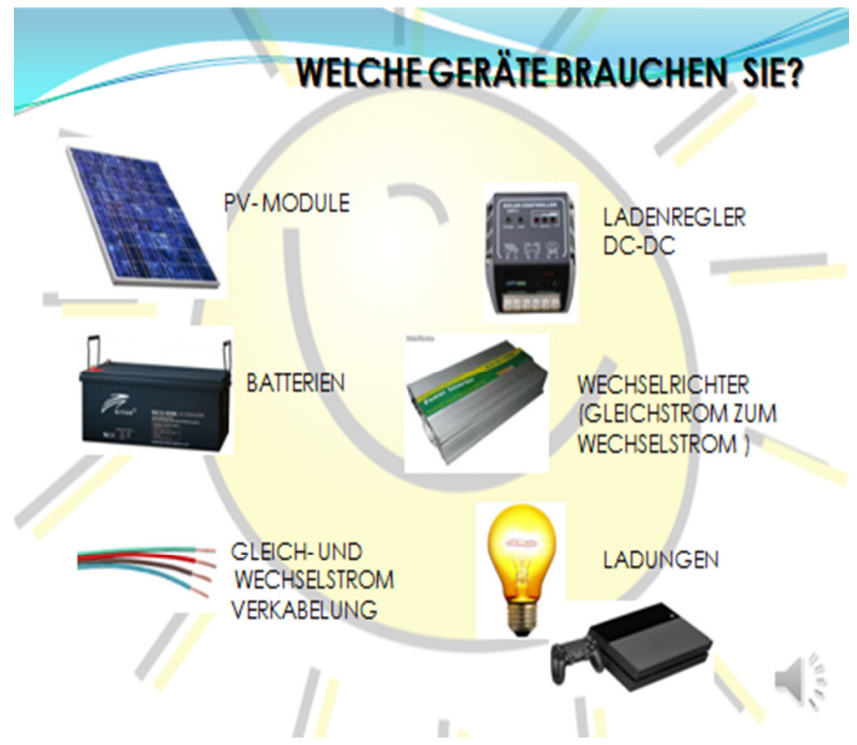

Fig. 3 Captura de una de las pantallas de un tutorial

En las siguientes direcciones de youtube pueden verse algunos de los tutoriales realizados por los estudiantes: https://www.youtube.com/watch?v=MgJG4PYbulg\&feature=youtu.be, https://www.youtube.com/watch?v=2qG-Vtc0xLk.

A continuación reproducimos un fragmento de la entrevista de trabajo redactada por un grupo de tres estudiantes. Como hemos explicado anteriormente, los alumnos han realizado un trabajo previo consistente en la búsqueda de un puesto de trabajo en una web auténtica, la elaboración del curriculum vitae y la redacción de la carta de solicitud de empleo. Todas esas actividades previas condujeron finalmente a las entrevistas de trabajo, que fueron grabadas, en este caso, como archivos de audio.

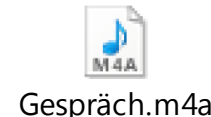

\section{*DAS VORSTELLUNGSGESPRÄCH}

P: Guten Morgen, Herr López. Mein Name ist Pablo Álvarez und sie heißt Marta Pérez. Wir freuen uns, Sie kennenzulernen.

M: Guten Mogen, wir sind für die Personalabteilung von dieser Firma zuständig. Nehmen Sie bitte Platz.

(c) EY-NC-ND 2018, Universitat Politècnica de València

Congreso IN-RED (2018) 
J: Guten Tag, ich freue mich auch, Sie kennenzulernen.

M: Haben Sie uns einfach gefunden?

J: Ich hatte Schwierigkeiten, Parkplatz zu finden aber trotzdem bin ich rechtzeitig angekommen.

P: Machen Sie sich keine Sorgen. Die Mitarbeiter haben bei uns freien Parkplatz.

J: Schön zu wissen.

M: Erzählen Sie uns bitte, wo Sie studiert haben.

J: Aus familieren Grunde habe ich in Berlin die Grundschule und das Gymnasium besucht. Dort habe ich meine Deutschkenntnisse verbessert.

P: Sie haben schon Berufserfahrung. Welche waren Ihre Aufgaben bei Dragados?

J: Dort habe ich drei Monate einen Praktikum absolviert und habe mich mit der Plannung, Herstellung und dem Betrieb von Bauwerken beschäftigt. Ich musste viel unterwegs sein.

M: Das ist aber interessant! Das passt auch zu dieser Stelle. Worin sehen Sie Ihre Stärken?

J: Ich fuhle mich gut im Team zu arbeiten und meine Kommunikationsfähigkeit mitzuteilen.[...]

Como puede observarse, hay algunos errores de ortografía (*Gründe; *fuhle, *Plannung) o de gramática, como en la flexión de los casos (*einen Praktikum), por ejemplo. No obstante, el nivel es más que aceptable y lo verdaderamente interesante desde el punto de vista didáctico, es saber que la tarea ha sido realizada por el grupo después de haber consensuado una serie de decisiones, como la de determinar quién ocuparía cada uno de los roles, así como la de decidir qué anuncio elegían de la oferta de puestos de trabajo y de apoyarse en el curriculum real de la persona que hacía las veces de candidato.

En lo que respecta a la última tarea, reproducimos también uno de los diálogos sobre una situación conflictiva en el puesto de trabajo, que fue asimismo grabado como archivo de audio:

\section{*Situation 1:}

-Herr Müller, wo ist der Jahresbericht?

+Ach ja, ich habe es schon angefangen, in zwei Wochen wird es fertig sein.

-Der Termin ist heute! Das kann doch nicht wahr sein!

+Heute? Ich habe gedacht dass es für den ersten Juli wäre.

- Ersten Juni! Das ist doch die Höhe! Wie könnten Sie den Termin vergessen?

+Es tut mir aber leid, ich hatte ...

-Das ist mir aber egal! Ich gehe jetzt zum Chef!

+ Wissen Sie was, Herr Bensalah? Dieser Bericht ist auch Ihr Job!

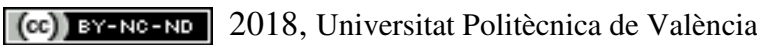
Congreso In-Red (2018) 
- Aber meinen Sie dass ich immer alles allein machen muss? Ich habe viel mehr Arbeit und Sorgen... Sie müssten nur den Bericht machen!

+ Also, das geht zu weit. Ich gehe selbst zum Chef.

$<$ Was ist hier los? Warum streitet ihr euch? Ich möchte von euch beiden nichts mehr hören! [...].

\section{Conclusiones}

Las tareas presentadas en este trabajo -realizadas por los estudiantes- muestran la complejidad que subyace en los actos comunicativos, ya sean estos presentaciones o diálogos, y también evidencian la necesidad de diseñar actividades previas -por parte del profesor- que conduzcan al éxito de la tarea. En cualquier caso, y coincidiendo con Van Dijk (2003) podemos concluir que "la teoría del contexto explica cómo los participantes son capaces de adaptar la producción y la recepción/interpretación del discurso a la situación comunicativa interpersonal-social", que en nuestro caso concreto es diferente en cada una de las tareas. Por otra parte, la relación que se establece, ya sea por parte del estudiante hacia los destinatarios de sus tareas -público que atiende a la presentación de la empresa o espectadores del vídeo tutorial- así como la relación con sus interlocutores en la elaboración y representación de los diálogos - entrevista de trabajo y diálogo conflictivoponen de manifiesto la relevancia de la interacción social como condición de aprendizaje (Suárez Guerrero, 2010).

En nuestra propuesta hemos destacado la utilidad de grabar las tareas realizadas por los estudiantes, acción que es llevada a cabo en la mayoría de los casos por ellos mismos, y que ha supuesto agregar un documento novedoso a la tarea encomendada. Los estudiantes han tenido que presentar archivos de audio o de vídeo con los resultados de sus tareas y estos documentos han tenido una doble utilidad; bien han servido para la evaluación por parte del profesor; o para la autoevaluación y reflexión propias por parte de los estudiantes.

En las encuestas de la evaluación de la docencia por parte del alumnado, la asignatura Alemán $B 2$ obtiene unos resultados bastante satisfactorios (una media de 8,75 puntos sobre 10 ), en los ítems relacionados tanto con los materiales proporcionados o recomendados (Pre-tareas); así como con aquellos relativos a la metodología empleada y las actividades realizadas. Un noventa y cinco por ciento de los estudiantes considera que las prácticas realizadas ayudan a aprender y a alcanzar un grado óptimo de competencia a la hora de comunicarse en alemán.

El desarrollo metodológico del Aprendizaje Basado en Tareas aplicado a la adquisición de la comunicación efectiva en alemán se ha revelado, por todo ello, como una herramienta útil que podría ser puesta en práctica también en el aprendizaje de otras lenguas extranjeras. 


\section{Referencias}

BOSCH ROIG, G. (2012). "Aufgabenorientierung mit proaktiver Formfokussierung als didaktisches Konzept für den Deutschunterricht im Tourismus” en IBERICA, 23, p. 157-172.

BOSCH ROIG, G. (2017). "Structured Input Activities como medio para desarrollar estrategias de Atención a la Forma (Focus on Form) en un Contexto de Aprendizaje de Alemán Basado en Tareas" en PORTA LINGUARUM, 28, P.127-140.

BUHLMANN, R., FEARNS, A., GASPARDO, N. (2003). Präsentieren und Verhandeln.Wirtschaftsdeutsch. Warschau: Poltext. Goethe Institut Internationes.

CRANDALL, J., TUCKER, R. (1990). "Content-based language instruction in second and foreign languages" en ANIVAN, S. Language teaching methodology for the nineties. Singapore: SEAMEO Regional Language Centre, p.83-96.

ELLIS, R. (2003). Task-based Language Learning and Teaching. Oxford: Oxford University Press.

HAGNER, V., SCHLÜTER, S. (2014). Im Beruf. Arbeitsbuch. Deutsch als Fremd- und Zweitsprache. $B 1+/ B 2$. Ismaning: Hueber

MÜLLER, A., SCHLÜTER, S. (2013). Im Beruf. Kursbuch. Deutsch als Fremd- und Zweitsprache. $B 1+/ B 2$. Ismaning: Hueber.

SUÁREZ GUERRERO, C. (2010). Cooperación como condición social de aprendizaje. Barcelona: Editorial UOC.

VAN DIJK, T. (2001). "Algunos principios de una teoría del contexto" en $A L E D$. Revista latinoamericana de estudios del discurso, 1(1), 2001, p. 69-81.

VANPATTEN, B. (2010). "Input Processing in SLA" en VANPATTEN, B. Processing Instruction. Theory, Research, and Commentary. NY: Routledge, p. 5-31. 


\title{
El Proyecto de Innovación SAME: el fomento de la Responsabilidad Social Universitaria en el alumnado de la Universidad de Valencia.
}

\author{
Ana Ancheta Arrabal ${ }^{\mathrm{a}}$, Cristina Pulido Montes ${ }^{\mathrm{b}}, \mathrm{M}^{\mathrm{a}}$ Esther Alventosa Bleda ${ }^{\mathrm{c}}$ y Borja \\ Mateu Luján ${ }^{\text {d }}$ \\ aUniversitat de València, (Ana.Ancheta@uv.es), bUniversitat de València (Cristina.Pulido@uv.es) y \\ cUniversitat de València (Maria.E.Alventosa@uv.es) ${ }^{d}$ Universitat de València (Borja.Mateu@uv.es)
}

\begin{abstract}
Nowadays, the right to quality education remains an aim within the international agendas. In the mission to defense this right, the Global Campaign for Education arises, as an initiative of civil and political awareness for the entitlement. Through the Educational Innovation project of the Global Action Week for Education (GAWE), which is included in this international campaign, from the Faculty of Philosophy and Education Sciences of the University of Valencia and in collaboration with the Coordination of the campaign in the Comunidad Valenciana we intend to give visibility to the fight for the right to quality education. Among the activities developed to achieve this goal, workshops are offered in the different subjects of the degrees taught in the faculty. All these actions are focused on the culmination of the main act of the campaign that takes place in the GAWE, where the educational community makes and exhibits the produced work and a manifiesto, to give visibility to said action and present it in society. The final result of all this is the participation of the students and the development of competences based on the aim of Sustainable Campus of the Social Responsibility of the University related to the partnerships with institutions and sustainability.
\end{abstract}

Keywords: GAWE, Innovation Project, Community Action, Competences, University Social Responsibility.

\section{Resumen}

El Derecho a la Educación de calidad en la actualidad, sigue siendo un objetivo en las agendas internacionales. En la misión de su defensa surge la Campaña de Acción Mundial por la Educación, como una iniciativa de concienciación civil y política por este derecho. Mediante el proyecto de Innovación Educativa de la Semana de Acción Mundial para la Educación (SAME) inmerso en dicha campaña internacional, desde la Facultad de Filosofía y Ciencias de la Educación de la 
Universidad de Valencia y en colaboración con la Coordinadora de la campaña en la Comunidad Valenciana pretendemos dar visibilidad a la lucha por el Derecho a la Educación de calidad. Entre las actividades desarrolladas para conseguir este objetivo se plantean talleres en diferentes asignaturas de las titulaciones impartidas en la facultad. Todas estas acciones están enfocadas a la culminación del acto principal de la campaña que se realiza en la SAME, donde la comunidad educativa realiza y expone el trabajo realizado y un manifiesto, para dar visibilidad a dicha acción y presentarla en sociedad. El resultado final de todo ello, es la participación del alumnado y el desarrollo de competencias basadas en el objetivo de Campus Sostenible de la Responsabilidad Social de la Universidad relacionado con las alianzas con instituciones y la sostenibilidad.

Palabras clave: SAME, Proyecto Innovación, Acción Comunitaria, Competencias, Responsabilidad Social Universitaria.

\section{Introducción}

La Semana de Acción Mundial por la Educación (SAME, en adelante) es una iniciativa de la Campaña Mundial por la Educación (CME, en adelante) como coalición internacional formada por organizaciones no gubernamentales (ONG), sindicatos del entorno educativo, centros escolares y movimientos sociales de muy diverso signo, que se moviliza para reclamar el cumplimiento íntegro de los compromisos internacionales firmados por los Estados para garantizar el acceso a una educación de calidad para todas las personas del mundo.

La CME también constituye el movimiento de la sociedad civil que trabaja para poner fin a la crisis mundial en la educación. Su misión principal es asegurar que los Estados actúen para hacer realidad el derecho de todos y cada uno de los seres humanos a disfrutar de una educación pública, gratuita y de calidad, para lo que trabaja en alrededor de 124 países (CME, 2018). El objetivo de la CME ha venido siendo velar por el cumplimiento de los compromisos adquiridos por estos países en agendas como la Educación para Todos (Dakar, 2000) y los Objetivos de Desarrollo del Milenio (ODM) del año $2000 \mathrm{y}$, aunque los avances en materia educativa han sido notables - por ejemplo, el número de niños y niñas sin escolarizar en la educación primaria se ha reducido en más de un $40 \%$ desde 1999 - aún queda mucho camino por recorrer por hacer realidad estos fines por parte de la comunidad internacional en materia educativa. En el año 2015 se cumplió el plazo tanto de los objetivos de la iniciativa para hacer efectivo el Derecho a la Educación para todas las personas. En este contexto, en el año 2015 los Gobiernos renovaron su 
compromiso con la educación, marcando la ruta a seguir en la nueva Agenda 2030 de Educación, que incluye la Declaración de Incheon (Corea, 2015) y los Objetivos de Desarrollo Sostenible (ODS). Entre ellos, el ODS número cuatro se centra en "garantizar una educación inclusiva, equitativa y de calidad y promover oportunidades de aprendizaje durante toda la vida para todos y todas antes de 2030" (UNESCO, 2016, p. 20).

En este nuevo escenario, la CME continúa su labor anterior mediante la continuación de iniciativas como la SAME como una de las principales actividades de sensibilización y movilización social en una escala mundial que la UNESCO lidera desde hace años. Este organismo internacional participa mediante la movilización de sus redes y asociados, la recopilación y el intercambio de políticas y prácticas, así como la realización de actividades en el mundo entero a través de sus oficinas internacionales. En esta semana conmemorativa y de acción global se recuerda que los esfuerzos y las iniciativas mundiales en pro de la Educación para Todos deben doblarse a fin de velar por el cumplimiento del Derecho a la Educación y exhortar

a todos los gobiernos y los asociados en las tareas del desarrollo, a todos los docentes, padres y proveedores del sector privado, a que eliminen las barreras que impiden el acceso a la enseñanza o que perduran dentro de los sistemas educativos, a fin de hacer realidad la participación plena y equitativa en la vida social de todas las personas (Bokova, 2014, p. 2).

Internacionalmente, desde el año 2001 la Campaña Mundial por la Educación celebra esta Semana de Acción Mundial por la Educación, normalmente en abril, donde los más de 124 países que integran esta campaña trabajan por garantizar el Derecho a la Educación y promover la movilización ciudadana para llamar la atención de la comunidad educativa, de los medios de comunicación, de la sociedad en general y, especialmente, de los representantes políticos sobre la necesidad de hacer real y efectivo el derecho a una educación de calidad para todos y todas en el mundo. En España, la Semana de Acción Mundial forma parte de la campaña anual que se celebra en el mundo entero y es organizada por la Campaña Mundial por la Educación con el objetivo sensibilizar a la opinión sobre la importancia de una Educación para Todos.

Concretamente desde esta experiencia, la SAME supone una semana de movilización ciudadana a la que la Facultad de Filosofía y Ciencias de la Educación de la Universidad de Valencia (UV) se ha venido sumando desde el curso 2013/14 impulsando dicha semana como una acción transversal en diferentes titulaciones de la UV (Pedagogía, Educación Social y Magisterio), apoyada en la implicación del alumnado y, especialmente, del profesorado ya colaborador de la CME, en algunos casos, en ediciones y celebraciones de la misma precedentes. En la Universidad de Valencia, durante los últimos años, se desarrolla dentro de un proyecto de innovación 
que promueve la interrelación entre esta y distintas organizaciones e instituciones de la sociedad valenciana. De este modo, el Proyecto de innovación SAME se consolida atendiendo a la LEY 2/2003 (DOCV, 2003) que recoge en su preámbulo que la Ley Orgánica 6/2001 de Universidades pretende establecer relaciones y vinculaciones recíprocas entre universidad y sociedad. Asimismo, la SAME favorece la participación del alumnado en las diferentes actividades que se realizan, vinculándose a las enseñanzas impartidas en el Grado, como se refleja en los fines del Consejo Social del artículo 2 de la citada LEY 2/2003.

El caso de la SAME es un claro ejemplo de proyecto de innovación educativa basado en el trabajo en equipo multidisciplinar, interdisciplinar e intergeneracional. El hecho de hacer confluir alumnado universitario y no universitario, profesorado universitario y diferentes agentes sociales del resto de la comunidad educativa, en actividades donde se trabajan valores y conceptos que favorezcan la adquisición de herramientas para el desarrollo social sostenible y en pro del Derecho a la Educación de todos y todas, es una manera de potenciar el sentimiento de que todas y todos formamos parte de la Comunidad Educativa. Además, como se explicará en la metodología, es un proyecto de Acción Comunitaria, ya que aglutina diversos colectivos y personas físicas, y está dinamizado por una coordinadora encargada de hacer de puente entre la campaña internacional y la Universidad de Valencia. En esta acción, como se ha dicho, se generan sinergias (procesos de vinculación y apoyo mutuo) que activan la voluntad de las personas participantes a protagonizar la mejora de su realidad (Gomà 2008). En este caso concreto, como la definen Llena y Úcar (2006) se trataría de una acción comunitaria del tipo 2, es decir, con un interés colectivo y unos objetivos predeterminados como es el acceso a la educación de calidad para todas las personas. Se trata de una acción estratégica e ideológica enmarcada en un sistema de valores, es decir, una intervención en la comunidad de aspecto socioeducativo.

A partir de este proyecto de innovación educativa se trabaja con el alumnado para desarrollar una institución universitaria democrática, sostenible y cooperativa. A la vez, que dotar de sentido crítico a las iniciativas de la institución universitaria, como principal agente de movilización social, tal y como en las Jornadas de Diálogos Universidad y Desarrollo Sostenible celebradas en la Agencia Española de Cooperación Internacional para el Desarrollo, se pondría de relieve que el espacio universitario es privilegiado para formar a las personas en todas sus dimensiones a través de diversas estrategias, entre ellas los proyectos de innovación. En este sentido, la Universidad de Valencia, mediante la aprobación del Plan Estratégico 2016-2019, persigue una serie de objetivos concretos en lo que respecta a la Responsabilidad Social Universitaria y que se fomentan a través del proyecto de innovación SAME, desatacamos especialmente el objetivo: 
- RsC02T. Fomentar los valores ligados al desarrollo humano como son la solidaridad, la cooperación, el progreso, la sostenibilidad, la excelencia y la igualdad mediante el desarrollo de su plan.

La Responsabilidad Social Universitaria según Martínez-Usarralde, Lloret-Català y Mas-Gil (2017) permite que:

se consigan beneficios a corto y largo plazo como son la consecución de una coherencia institucional integradora, una pertinencia y permeabilidad social (apertura), una dinámica hacia la innovación inteligente y transparente y una racionalización de la gestión universitaria que mejora la creación de valor social, a través, por ejemplo, de proyectos de desarrollo de la comunidad. (Martínez-Usarralde, Lloret-Català y Mas-Gil, 2017, p. 6).

A la vez, Martínez-Usarralde, Lloret-Català y Mas-Gil (2017) indican que los agentes que forman parte activa del fomento y trabajo de la Responsabilidad Social Universitaria en un nivel interno son el profesorado, los investigadores, el alumnado y el personal administrativo. En el nivel externo serían las empresas, administraciones y organizaciones no gubernamentales o sin ánimo de lucro.

De este modo, el proyecto de la SAME tal y como es descrito cumple con las características de la Responsabilidad Social Universitaria, ya que lo que pretende es concienciar al alumnado y a la comunidad educativa de una realidad que parte de la violación de un derecho que debe ser exigido por su carácter universal y democrático y que a través de la función transversal del proyecto es trabajado de manera colaborativa, en la que el alumnado es parte activa del mismo. La participación de los agentes, tanto internos como externos, comprende a todos los descritos como elementos fundamentales de la Responsabilidad Social Universitaria. La realización de los talleres previos de difusión de la campaña en las aulas y las comisiones de coordinación del proyecto son un conglomerado de todos los agentes descritos. Más adelante, iremos detallando los talleres, los agentes que participan y el carácter de las comisiones que dan sentido al fomento de la Responsabilidad Social Universitaria promocionado por el proyecto SAME en la Facultades de Filosofía y Ciencias de la Educación y la Facultad de Magisterio de la Universidad de Valencia.

\section{Objetivos}

El proyecto de Semana de Acción Mundial por la Educación, una posibilidad para desarrollar la corresponsabilidad social y educativa del alumnado y profesorado universitario se enmarca en el Programa C de Innovación educativa de la UV centrado en "Grupos estables y redes de innovación continua" y que está orientado a la constitución de grupos y redes de innovación a través de la colaboración con profesorado de otras universidades, e incluso de otros niveles educativos. Se trata, 
también, de consolidar las redes iniciadas en las convocatorias de los cursos 2015/16 y 2016/17, y profundizar en el establecimiento de otras nuevas, fruto de la experiencia acumulada con la participación en proyectos de innovación de anualidades anteriores. Desde el curso 2003/2004 la Universidad de Valencia ha realizado un importante esfuerzo institucional para impulsar la innovación educativa en los estudios universitarios y de esta manera colaborar en la mejora de la docencia en el contexto de la construcción del Espacio Europeo de Educación Superior (EEES). Durante los cursos anteriores al 2015/16, las sucesivas convocatorias han tratado de vincular las actuaciones de innovación educativa con el resto de programas estratégicos relacionados con la convergencia europea y la calidad docente de las nuevas titulaciones, sobre todo en cuanto a la utilización y exploración de las potencialidades de las nuevas tecnologías (UV, 2017). Este programa se engarza de manera sinérgica con algunas de las líneas de actuación estratégica que, sin negar la posibilidad de trabajar en otras temáticas, tienen un tratamiento preferente, toda vez que suponen aspectos especialmente vinculados a la mejora de la calidad de la docencia universitaria en la UV (UV, 2017):

- Uso de las TICs y la elaboración de materiales en abierto;

- Fomento de la participación de los y las estudiantes en la mejora de los procesos de enseñanza-aprendizaje

- Mejora de los planes de estudios, con la vista puesta en la acreditación y la obtención de sellos de calidad

- Puesta en valor y transferencia del conocimiento e investigación en materia de innovación educativa.

Aparte de la defensa del Derecho a la Educación para todos y todas, objetivo principal de la SAME, en las actividades desarrolladas se trabaja de manera práctica y teórica contenidos de la Agenda 2030 como, por ejemplo, la meta 4.7 que concretamente se centra en:

De aquí a 2030, asegurar que todos los alumnos adquieran los conocimientos teóricos y prácticos necesarios para promover el desarrollo sostenible, entre otras cosas mediante la educación para el desarrollo sostenible y los estilos de vida sostenibles, los derechos humanos, la igualdad de género, la promoción de una cultura de paz y no violencia, la ciudadanía mundial y la valoración de la diversidad cultural y la contribución de la cultura al desarrollo sostenible (punto 4.7 del Objetivo 4 de la Agenda 2030 de la UNESCO (Declaración Incheon, 2016, p. 21).

Revisando estudios como el de Barrón, Navarrete y Ferrer-Balas (2010), afirman que la formación de profesionales críticos con la manera de proceder respecto al desarrollo sostenible de nuestra sociedad actual es crucial. Ya entonces se intuía que los objetivos de la Agenda 21 no serían fáciles de conseguir, lo que lamentablemente se corroboró posteriormente. Acyalmente la UNESCO plantea nuevos retos, sin 
dejar de insistir en los anteriores, ya que se reafirma en la necesidad de la educación para el desarrollo y los estilos de vida sostenibles.

La acción desarrollada a través del proyecto de innovación de la SAME es intrínsecamente educativa por cuanto constituye un proceso de enseñanzaaprendizaje continuo, transformador y constantemente que es retroalimentado por todas y cada una de las personas implicadas, desde el momento en que se pone en marcha el proyecto, en torno a la consigna sobre la que trabajar pedagógicamente cada año, y que repercute de forma indiscutible en lo que denominamos como el proceso de "Educación a lo largo de la vida" (Life Long Learning) en el que creemos y participamos. El profesorado involucrado, docente en cuatro grados diferentes, entendemos que el proceso de elaboración de las diferentes acciones y actividades de aprendizaje que se van a ir diseñando en torno a la campaña (CME) y que se abocarán a la celebración de un acto de celebración del día de la campaña (SAME) tienen un carácter aplicado, dado que el alumnado que se involucre va a trabajar contenidos, estrategias, habilidades, capacidades y actitudes de carácter académico $\mathrm{y}$, sobre todo, profesionalizador y humanizador. Todo ello redunda en una revisión y certificación de las competencias que se ponen en jaque a lo largo y ancho de la articulación del mismo, donde los objetivos definidos para este proyecto de innovación educativa son los siguientes:

- Impulsar la Responsabilidad Social Universitaria a través del proyecto de innovación SAME.

- Explorar y aprender de la riqueza y oportunidades didáctico-metodológicas que ofrece la Campaña Mundial por la Educación (CME) y la Semana de Acción Mundial por la Educación (SAME).

- Cooperar con las ONGs, las asociaciones involucradas y los centros educativos, incidiendo en la función de responsabilidad social universitaria, fomentando las redes de participación con la sociedad civil.

- Impulsar la creatividad, el carácter propositivo y reactivo, así como los valores relacionados con el compromiso, la participación y la solidaridad bien entendida. Visualizando, de este modo, la realidad del Sur y profundizando los lazos de colaboración.

- Contribuir a la formación integral y de calidad del profesorado y alumnado universitario.

- Profundizar en la riqueza que aporta el trabajo colaborativo y cooperativo entre las diferentes personas y organismos que participan en la SAME.

- Utilizar TICs y redes sociales como medio para de difusión y herramienta de trabajo durante todo el proceso de la acción socio-pedagógica.

Para este trabajo que se presenta en concreto, dichos objetivos son los de la propia innovación, en la medida que el proyecto en sí mismo la persigue como fin. 


\section{Desarrollo de la innovación}

La metodología para llevar a cabo el desarrollo de la innovación parte de estrategias educativas que fomentan la participación, el diálogo, la negociación, la reflexión, la crítica y la evaluación. Esta metodología se viene gestionando a través de comisiones coordinadas por varias personas para facilitar el trabajo colaborativo entre la Coalición Española de la SAME y el profesorado y alumnado de la Universidad. De hecho, es una metodología relacionada con la acción comunitaria, ya que se trata de la acción desarrollada por un colectivo humano (parte de la comunidad), que en este caso se hablaría de la Comunidad Educativa, compartiendo el espacio de la Universidad de Valencia y con conciencia de pertenencia a dicha comunidad, desde la detección de una necesidad y avanzando, año tras año para encontrar una solución conjunta.

Además, cuenta con los principales elementos a tener en cuenta en una acción comunitaria, según Ricard Gomà (2008), relacionados con dinámicas participativas y de construcción de ciudadanía como:

- Autonomía y responsabilidad. Ya que existe una Coordinadora encargada de convocar y dinamizar el proceso, favoreciendo el trabajo conjunto y la construcción de soluciones.

- Confianza y respeto. Existe un vínculo entre las personas que participan y las que lo llevan adelante, que fomenta la confianza y reciprocidad, lo que favorece dinámicas de corresponsabilidad.

- Deliberación y transparencia. Se realizan reuniones informativas y de participación donde poder opinar y proponer aquello que se considere necesario. También se informa del presupuesto disponible para trabajar.

- Conflicto e innovación. Todas las propuestas son escuchadas con respeto y el diálogo es la principal herramienta para resolver conflictos, dejando aflorar la creatividad y la innovación social.

- Complejidad y articulación de redes. Como ya se ha explicado, existe una gran confluencia de diferentes agentes y la articulación de redes basada en interdependencias.

- Dinamismo y aprendizaje. Se trabaja de manera planificada y gestionada, aunque flexible, para crear dinamismo. Se revisan los procesos y contenidos para adaptarse a las circunstancias o la demanda social. Un claro ejemplo es la ampliación progresiva de actividades realizadas desde las redes sociales (TIC), para llegar a las personas más jóvenes y expandir la difusión del evento de manera óptima.

- Proximidad y dinámicas sostenibles. Teniendo en cuenta el tiempo que el proyecto lleva realizándose, es de suponer que se adapta a los recursos de los que dispone, ya sean materiales o humanos. 
Para ello, la metodología de trabajo viene siendo consensuada por el equipo que solicita y el que participa en este proyecto cada curso académico, aprovechando la experiencia en la participación de la organización de la SAME en convocatorias anteriores. El salto cualitativo de este proyecto de innovación parte de la intención de ofrecer la oportunidad a la totalidad de los agentes de la comunidad educativa de participar con su propia voz en los procesos de elaboración de la propuesta y no sólo como receptores finales. Por todo ello, se centra en erigirse en torno a la consolidación de comisiones de trabajo lideradas por 2 o 3 profesores/as junto con el alumnado participante en las mismas:

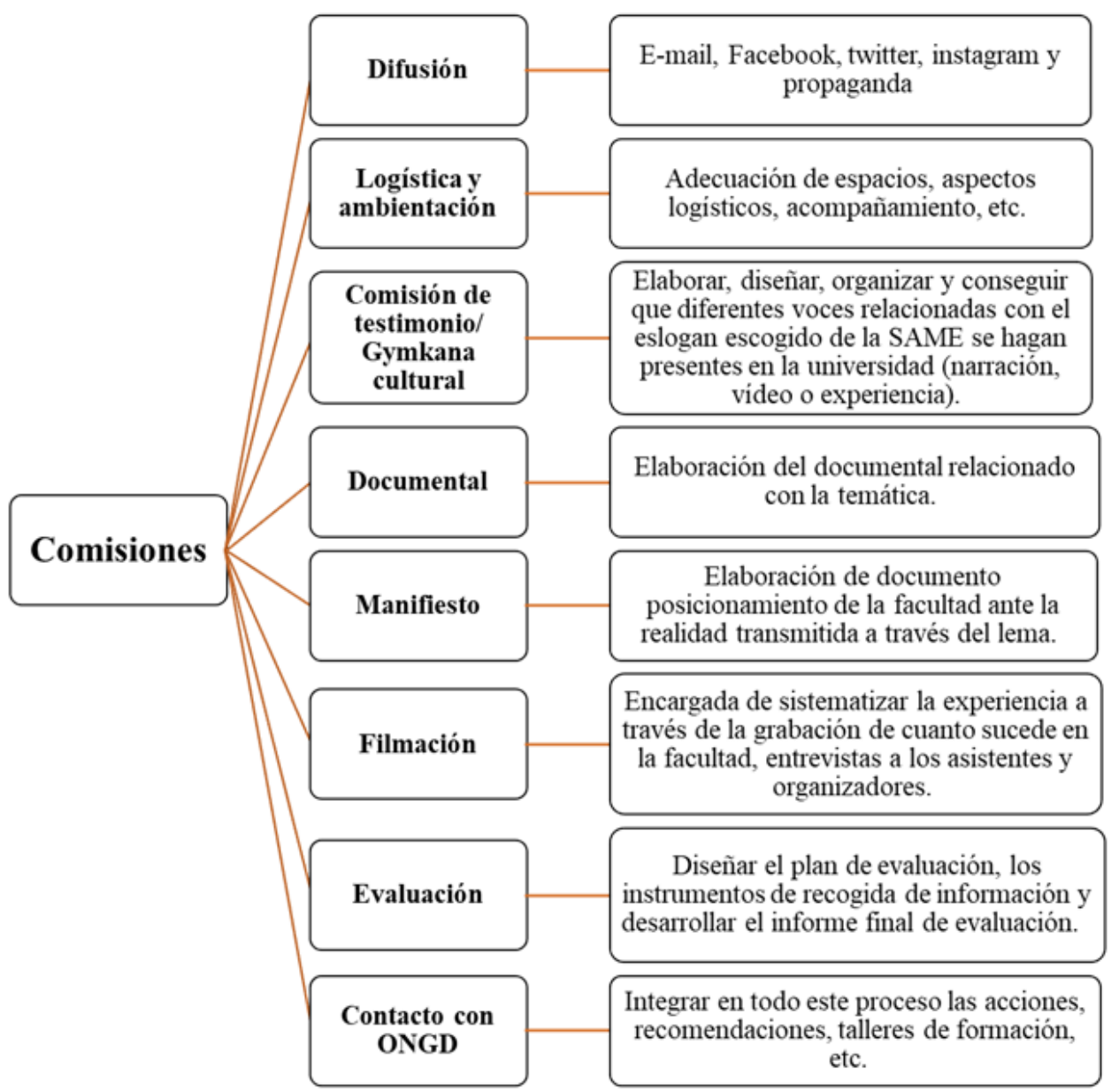

Fig. 1 Comisiones del Proyecto de innovación educativa SAME

Las Comisiones establecidas para este proyecto varían cada año en función de las necesidades, aunque las más representativas son descritas en la Fig.1. Todo este funcionamiento contribuye a que cada persona participante en el proyecto se sienta parte del mismo y adquiera el compromiso y la corresponsabilidad de llevarlo a cabo, así como la satisfacción de colaborar en el resultado final. 


\section{Resultados}

El profesorado y el alumnado de este proyecto transversal, interdepartamental e interdisciplinar están adscritos a cuatro grados relacionados con educación: Educación Social, Pedagogía, Filosofía y Magisterio. Su desarrollo e implementación ha demostrado las posibilidades pedagógicas que se abren al aprendizaje cooperativo interdisciplinar, ejercitándose en torno al proyecto de innovación generado a partir de los actos de la SAME, siendo los resultados sumamente satisfactorios tanto para el profesorado involucrado como para el alumnado, que lo ha venido reflejando en las encuestas llevadas cabo durante las ediciones anteriores de este proyecto de innovación. Consecuentemente, en aras de seguir incidiendo en esta metodología transversal, el profesorado participante se ha constituido como Grupo estable y red de innovación continua dentro del mencionado programa de innovación de la UV, posibilitando la estabilidad de la experiencia y permanencia de los vínculos de colaboración entre diversos agentes de la comunidad universitaria como del resto de la comunidad educativa valenciana. A través de los protagonistas, profesorado y alumnado de dichos grados, pero también de los expertos invitados, de las ONGD que lideran la SAME en la Comunidad Valenciana y de los colegios intervinientes, se hace patente que el éxito de un proyecto así entendido se genera desde el compromiso y del trabajo bien hecho de todos y cada uno de sus participantes. El resultado pone de manifiesto en cada acto de celebración y culminación de la SAME que el alumnado implicado está capacitado para abordar, desde su profesión pero también desde su responsabilidad como miembro de una ciudanía global, su cuota de acción profesionalizadora y ciudadana.

A lo largo de las ediciones de este proyecto realizadas desde el curso 2013/2014 hasta el actual, los resultados se han analizado en relación a los distintos modos de producción y de participación que el profesorado y el alumnado implicado, los cuales se resumen en los siguientes aspectos que se presentan a continuación:

1. Mantenimiento y actualización del blog y de la página web de la SAME de la Universidad de Valencia (http://proyectosame.blogs.uv.es/comisiones/) en el cual se presentan diversos documentos y materiales audiovisuales que documentan la experiencia y el proyecto de innovación.

2. Producciones elaboradas por todas y cada una de las diferentes comisiones de trabajo implicadas en el proyecto: trípticos, carteles, noticias en prensa y en medios de comunicación, noticias en la web de la Universitat de València, noticias en la página web de la SAME, documentales, etc.

3. Desarrollo de las diferentes actividades diseñadas para la celebración de la SAME en la Facultad de Filosofía y CC. de la Educación. 
- Documento gráfico y audiovisual sobre todas las actividades que se realizan el día de la celebración de la SAME en la Facultad de Filosofía y Ciencias de la Educación.

- Documento de posicionamiento elaborado por los estudiantes y leído por ellos durante el acto principal la SAME.

4. Instrumentos de evaluación para el profesorado y alumnado de la SAME (Anexo 1): mediante la elaboración e implementación de cuestionarios de satisfacción que se llevan a cabo durante el proceso y después de la finalización del proyecto de innovación. La valoración de las mismas se planificó para que fuera realizada tanto desde la perspectiva del alumnado como la del profesorado.

En relación a los resultados que se extraen en el proceso de evaluación destacamos aquí, de modo preliminar, las ventajas de facilitar el acceso a los instrumentos de evaluación (Anexo 1) vía on-line puesto que ello ha facilitado en gram medida la recopilación de información sobre una muestra muy representativa de información en la presente edición (de un número total aproximado de 500 participantes en los talleres y 250 en la jornada, se han recabado 278 y 114 respectivamente, representando el 55,6\% y 45,6\%). Igualmente, cabe destacar que la valoración de la realización de los talleres es realmente positiva, pues en todos los aspectos sobre los que se ha preguntado nos encontramos con medias que superan el 2,5 en una escala de cinco puntos, así como, claramente, las personas que han participado en la jornada "consideran las redes sociales útiles para una movilización social como la SAME".

Más abajo, a modo ilustrativo de los momentos más significativos del proyecto, mostramos una serie de imágenes extraídas del twitter institucional de la campaña de la SAME (2018):

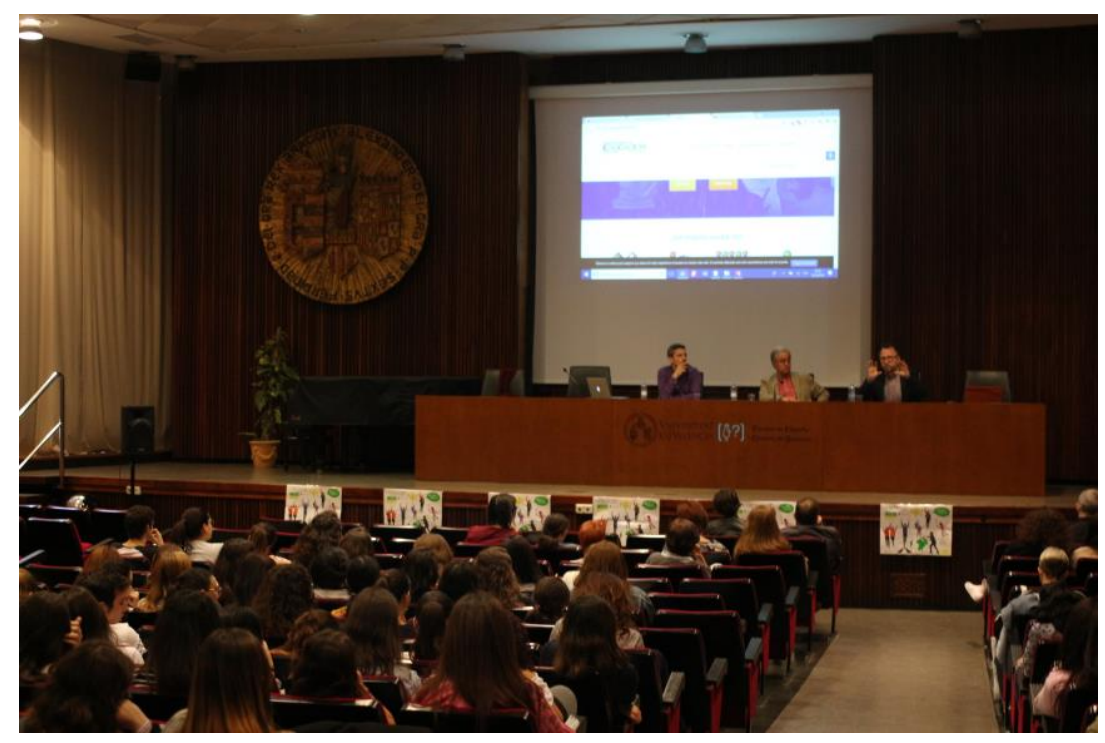

Fig. 2 Acto institucional de la SAME

(c)) EY-NC-ND 2018, Universitat Politècnica de València Congreso In-Red (2018) 


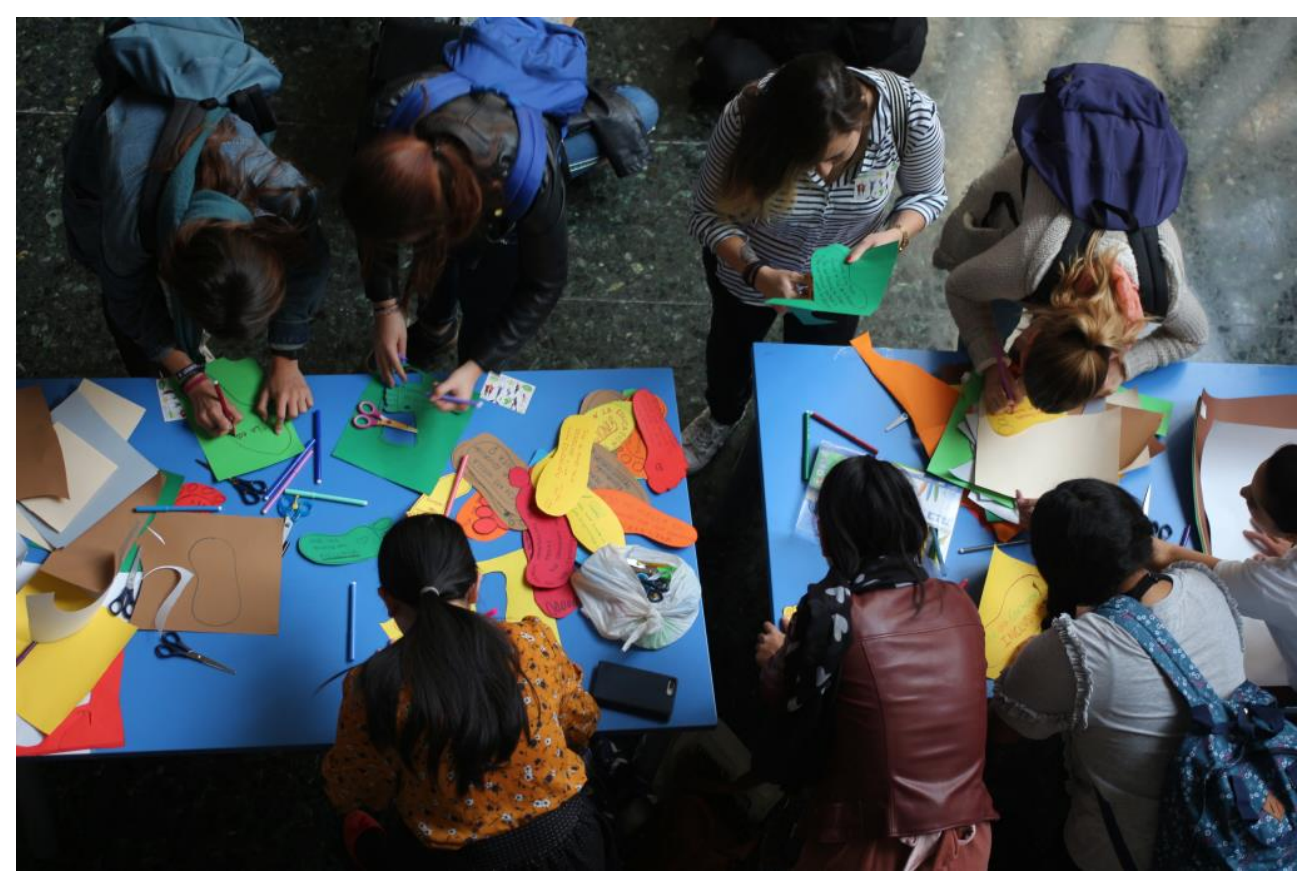

Fig. 3 Gymcana y talleres

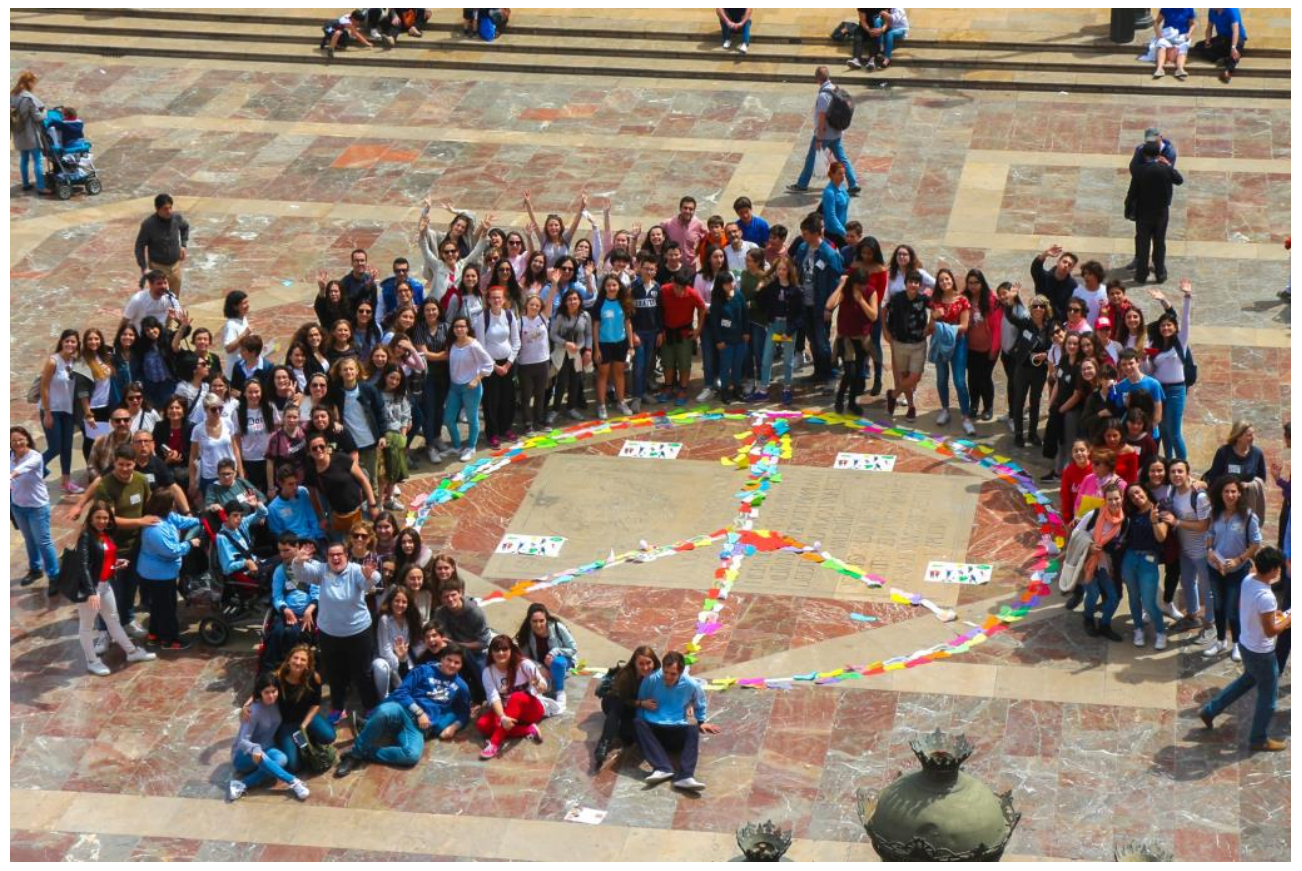

Fig. 4 Acto reivindicativo

\section{Conclusiones}

El Derecho a la Educación desgraciadamente no está al alcance de todas las personas. No obstante, desde este proyecto de innovación educativa pretendemos visualizar esta problemática y extenderla al mayor número de personas posibles para tener más 
fuerza a la hora de exigir a los representantes la erradicación de este problema y su mayor compromiso institucional para ello. Dicha realidad es una oportunidad y una obligación desde la visión de la Responsabilidad Social Universitaria, siendo conscientes de que una institución que promociona valores democráticos, unitarios, cooperativos y desde la visión del desarrollo sostenible, tiene que trabajar de manera conjunta para dotar de formación transversal en valores y compromiso ético a los agentes participantes de estas iniciativas.

Siguiendo el estudio realizado por Martínez-Usarralde, Lloret-Català y Mas-Gil (2017), a un grupo de 206 alumnos/as del grado de Educación Social de la Facultad de Filosofía y Ciencias de la Educación de la Universidad de Valencia, determinaron que estos perciben que la institución si proporciona actividades que les dan oportunidades para trabajar la dimensión ética, social y en principios que fomentan el desarrollo sostenible. Cómo críticas estos apuntaban que la coordinación y la transversalidad podría ser mejorada. Por ello, pensamos que el proyecto de la SAME por su carácter transversal, que es trabajado en el ámbito del grupo-aula en el caso de la Facultad de Filosofía y Ciencias de la Educación y mediante la semana de actividades complementarias en la Facultad de Magisterio; la participación de profesorado y ONGs en distintas comisiones, ha ido consolidando una cultura de trabajo transversal que iría en la línea de trabajo que se pretende para cumplir con los distintos objetivos, que tanto organismos internacionales, como la propia institución pretenden y desean que sean competencias basadas en la iniciativa del Campus Sostenible y del trabajo de la Responsabilidad Social Universitaria.

El éxito del proyecto de innovación que se ha consolidado en las distintas ediciones que se han celebrado desde 22013/2014 en la Universidad de Valencia, viene marcado por la coordinación de las distintas comisiones que más arriba hemos descrito. El rol de la difusión y de las nuevas tecnologías, para dar visibilidad a la campaña, ha sido fundamental para motivar la participación del alumnado de una manera activa. De hecho, este año para la celebración de la campaña se espera una gran participación a través de la red por parte del alumnado, ya que se ha erigido un concurso a través de las redes, que ya fueron un punto clave en el proyecto SAME 2016/2017. Otra de las comisiones que han sido constante en las diferentes ediciones y que ha mostrado grandes resultados en el trabajo transversal y de concienciación con el alumnado es la de la elaboración de un manifiesto crítico que se difunde en la Plaza de la Virgen de la ciudad de Valencia, esto da visibilidad al trabajo realizado en los talleres y el día de celebración de la SAME, como acto de Responsabilidad Social Universitaria a la que se le percibe un impacto fuera de las fronteras de la institución. 
Estas actividades y trabajos desde las comisiones, pensamos que son éxito y constante en las distintas ediciones por su operatividad y sentido constructivo. La diferencia viene dada por el tipo de gymkana, el foco de la campaña que modifica los talleres y las actividades que decidamos emprender con las nuevas tecnologías. Sin embargo, la conclusión más general y que dota de mayor sentido a este proyecto de innovación, es la consolidación de un grupo de trabajo y una cultura basada en la transversalidad y en la participación real que viene fortalecida por la satisfacción del alumnado con el proyecto reflejada en las distintas evaluaciones que se han realizado al término de las diferentes ediciones.

\section{Referencias}

ALVENTOSA, M. E., SENENT, J.M. y VIANA, M. I. (2018). "La formación de docentes de Primaria en las Universidades Públicas españolas. Análisis comparado de sus diseños curriculares en aspectos sociales". En II Conferência Internacional de Educação Comparada. O Professor do Século XXI em Perspectiva Comparada: Transformações e Desafios para a construção de sociedades sustentáveis. Funchal, Região Autónoma da Madeira, Portugal. P.31

BARRÓN, Á; NAVARRETE, A y FERRER-BALAS, D. (2010). "Sostenibilización Curricular En Las Universidades Españolas. ¿Ha Llegado La Hora De Actuar?" Revista Eureka sobre Enseñanza y Divulgación de las Ciencias, vol. 7, 2010, pp. 388-399. Disponible en: http://www.redalyc.org/articulo.oa?id=92013009018 (Consultada: 23 de marzo de 2018)

Bokova, I. (2014). Mensaje en video de la Sra. Irina Bokova. Directora General de la UNESCO, con motivo de la Semana de Acción Mundial 2014 sobre Educación para Todos. UNESCO. Disponible en: $\quad$ http://www.unesco.org/new/fileadmin/MULTIMEDIA/HQ/ED/pdf/GAW2014DGvideomessage-ES.pdf

CME (2018). Campaña Mundial por la Educación. CME. Disponible en: http://www.campaignforeducation.org/es/

Comunidad Valenciana. Ley 2/2003 de enero, de Consejos Sociales de las Universidades Públicas Valencianas. DOCV, 31 de enero de 2003, núm. 4430, ref. 0422/2003. Recuperado de: http://www.dogv.gva.es/disposicio-consolidadasignatura=0422/2003\&idioma=va\&L=2\&url_lista

GOMÀ, R. (2008). "La acción comunitaria: transformación social y construcción de ciudadanía". RES (Revista de Educación Social), 7. Disponible en: http://www.eduso.net/res/?b=10\&c=90\&n=251 (Consultada: 20 de marzo de 2018)

LLENA, A. y ÚCAR, X. "Acción comunitaria: miradas y diálogos interdisciplinares" en ÚCAR, X y LLENA, A. (Coords) Miradas y diálogos en torno a la acción comunitaria. Barcelona: Graó.. ISNB 10: 84-7827-447-2. ISBN 13: 978-84- 7827-447-5). Disponible en: https://www.researchgate.net/publication/282122371_Accion_comunitaria_miradas_y_dialogos_i nterdisciplinares_e_interprofesionales

MARTÍNEZ-USARRALDE, M. J.; LLORET-CATALÀ, C., y MAS-GIL, S. (2017). "Responsabilidad Social Universitaria (RSU): Principios para una Universidad Sostenible, Cooperativa y Democrática desde el Diagnóstico Participativo de su Alumnado" Archivos Analíticos de Políticas Educativas, vol. 25, 2017, pp. 1-25. Disponible en: https://epaa.asu.edu/ojs/article/view/2769/1938 (Consultada: 23 de marzo de 2018) 
SAME Valencia 2016 (@Same_UV2016).“\#Paraguada \#SAME2016 \#Valencia Gracias a tod@s por reivindicar una mayor financiación @UV_EG”.27/04/2016, 17:46, [Twitter]. https://twitter.com/SAME_UV2016 [23 de marzo de 2018:].

UNESCO (2016). Declaración de Incheon y Marco de Acción ODS 4 - Educación 2030. UNESCO. Disponible en: http://unesdoc.unesco.org/images/0024/002456/245656s.pdf

Universidad de Valencia. UV. 2016. Plà Estratègic 2016-2019. Univeritat de València. Disponible en: https://www.uv.es/uvweb/universitat/ca/pla-estrategic//pla-estrategic-2016-2019/documents-plaestrategic-2016-2019-1285972477391.html (Consultada: 23 de marzo de 2018)

Universidad de Valencia. UV. (2017). Innovación educativa. UV. Disponible en: https://www.uv.es/uvweb/servicio-formacion-permanente-innovacion-educativa/es/innovacioneducativa/convocatorias-innovacion/vigente-1285869934336.html

ANEXO 1: Instrumentos de evaluación.

\begin{tabular}{|l|}
\hline Cuestionario elaborado para la evaluación \\
\hline TALLER \\
\hline 1.- He entendido el sentido de la Semana de Acción Mundial por la Educación (SAME). \\
\hline $\begin{array}{l}\text { 2.- Con la realización del taller me he sentido motivado/a a reflexionar sobre la huella que dejamos } \\
\text { con la educación. }\end{array}$ \\
\hline $\begin{array}{l}\text { 3.- Este tipo de actividad ha sido útil para reconocer que la educación mejora a la persona y a la } \\
\text { sociedad. }\end{array}$ \\
\hline $\begin{array}{l}\text { 4.- Este tipo de actividad ha sido útil para incrementar mi actitud proactiva hacia situaciones y } \\
\text { personas que sufren la vulneración de sus derechos humanos. }\end{array}$ \\
\hline \begin{tabular}{l} 
5.- Tras la realización del Taller, tengo ganas de participar en la jornada del día 25 de abril. \\
\hline JORNADA
\end{tabular} \\
\hline 1.- Me ha gustado participar en la Semana de Acción Mundial por la Educación (SAME). \\
\hline 2.- El contenido tratado en la SAME ha sido muy interesante. \\
\hline 3.- La SAME me ha aportado una visión de cómo "la educación es el camino hacia la paz". \\
\hline 4.- La difusión de esta Jornada ha sido adecuada. \\
\hline 5.- La distribución de los diferentes actos ha sido adecuada. \\
\hline 6.- Considero las redes sociales útiles para una movilización social como la SAME. \\
\hline 7.- Volvería a participar en sucesivas ediciones en una Jornada como esta. \\
\hline
\end{tabular}




\title{
Implementación de estrategias e instrumentos para la evaluación formativa de la competencia transversal CT-08 Comunicación Efectiva (dimensión comunicación oral): Evaluación compartida y Feed-back a través de las TICs
}

\section{César Martínez Poquet}

Profesor de la Escuela Técnica Superior de Ingenieros Industriales

Departamento de Termodinámica Aplicada, Universitat Politècnica de València, cemarpo@upv.es.

\begin{abstract}
The formative evaluation of the transversal competence Effective Communication in its oral dimension has been introduced in the present teaching innovation, involving the student in the evaluation process (shared evaluation) through a rubric implemented in Google Forms, and providing an immediate feed-back with the summary of the aggregated data provided by the forms after the oral presentation.

The results obtained in the online survey made to the participants, reflected that practically all the students considered that it had been a positive experience that had allowed them to learn from their own mistakes and those made by their peers, although they certainly felt uncomfortable when evaluating as when evaluated by them. Regarding the use of ICTs through the use of online forms, most considered that these had been adequate and easy to complete.
\end{abstract}

Keywords: formative evaluation, transversal competence, feed-back, coevaluation, rubric, ICT.

\section{Resumen}

Se ha introducido en la presente innovación docente, la evaluación formativa de la competencia transversal Comunicación Efectiva en su dimensión oral, involucrando al alumno en el proceso de evaluación (evaluación compartida) a través de una rúbrica implementada en un formulario de Google Forms, y proporcionando un feed-back inmediato con el resumen de los datos agregados proporcionados por el mismo tras la exposición oral.

Los resultados obtenidos en la encuesta online realizada a los participantes, reflejaron que prácticamente todos los alumnos consideraban que había sido una experiencia positiva que les había permitido aprender de los errores propios y de los cometidos por sus compañeros, aunque se sentían ciertamente incómodos tanto al evaluar como al ser evaluado por ellos. Respecto a la utilización de las TICs mediante el empleo de formularios online, la mayoría consideró que estos habían sido adecuados y de fácil cumplimentación. 
Palabras clave: evaluación formativa, competencia transversal, feed-back, coevaluación, rúbrica, TIC.

\section{Introducción}

\subsection{Justificación}

La convergencia hacia un Espacio Europeo de Educación Superior (EEES) provocó definitivamente un cambio de paradigma en la educación universitaria mediante la adopción de un modelo de formación basado en competencias (Zabalza, 2008). Una parte fundamental de estas competencias, la constituyen las Competencias Transversales, cuyo proyecto de acreditación de las mismas se está desarrollando en la Universitat Politècnica de València (Universitat Politècnica de València, 2015).

Para la evaluación en general de las competencias en la educación superior, y en particular en las competencias transversales, se hace necesario adoptar una serie de estrategias evaluativas que favorezcan la formación y el desarrollo de las mismas. Dentro de esas estrategias de evaluación formativa se encontrarían, entre otras, la evaluación compartida y el feed-back de calidad (Fernández, 2010).

De hecho, la coevaluación incentivaría tanto el aprendizaje de contenidos como el conocimiento de los procesos metacognitivos de control de los propios alumnos (Biggs, 2005), y la retroalimentación efectiva posibilitaría la mejora tanto del proceso como del resultado obtenido.

Con el fin de implementar estas estrategias, es necesaria la adopción de instrumentos atractivos y fáciles de usar para los alumnos, que les motiven e involucren durante la evaluación formativa. Para ello, la utilización de las Tecnologías de la Información y Comunicación (TIC) desempeñaría un papel activo fundamental. No en vano, según el estudio realizado por AULATICE y el grupo de investigación "Didáctica y Multimedia" DIM-UAB de la Universitat Autònoma de Barcelona (2009-2011), el uso de recursos tecnológicos en el aula mejoró el aprendizaje en el $90 \%$ de los alumnos, mejorando un $77 \%$ de ellos sus calificaciones académicas.

\subsection{Análisis de la situación}

La asignatura "Centrales Termosolares y Fotovoltaicas” de segundo curso del Máster Universitario en Ingeniería Industrial, tiene asignado el trabajo y la posterior evaluación de la competencia transversal CT-08 Comunicación Efectiva.

Dicha competencia está integrada por dos dimensiones: comunicación escrita y comunicación oral, y la normativa al respecto establece que en el caso de que existan varias dimensiones en una CT, se podrá elegir una de ellas. Por tanto, se consensuó con todos los profesores de la asignatura abordar la dimensión de Comunicación Oral.

Para su evaluación, se estableció que los alumnos realizarán una presentación oral por parejas de un proyecto previamente requerido en la asignatura. Se elaboró para su 
evaluación una rúbrica simplificada dado el número de alumnos matriculados y el tiempo disponible para las presentaciones.

La evaluación hasta la fecha, había consistido en la utilización de la rúbrica en formato papel para obtener de forma cualitativa la calificación de la CT-08 tras la exposición de cada uno de los alumnos.

\subsection{Finalidad del proyecto}

Se pretende involucrar a los estudiantes en el proceso de evaluación de la competencia transversal CT-08 y que, a través de la misma, reflexionen y aprendan a partir de los errores de sus compañeros y de ellos mismos, utilizando herramientas visualmente atractivas y fáciles de emplear, que permitan obtener una rápida retroalimentación de todo el grupo tras su exposición.

\section{Objetivos}

Implantar la evaluación compartida entre profesores y alumnos de la CT-08, ponderando su aportación a la calificación final con el 70\% y el 30\% respectivamente, mediante el uso de las TICs, implementando la rúbrica en un formulario de Google Forms para cada alumno accesible mediante un enlace.

Proporcionar un feed-back inmediato al alumno de su exposición a partir de los datos agregados obtenidos tras su evaluación, analizados y mostrados a través de Google Forms.

\section{Desarrollo de la innovación}

En primer lugar, se acordó con el resto de profesores de la asignatura la introducción de los cambios expuestos en la evaluación de la CT-08, para posteriormente comunicárselo a todos los alumnos.

En segundo lugar, se confeccionaron los formularios implementando la rúbrica en Google Forms. Para ello, se elaboró un formulario con la rúbrica para cada uno de los alumnos a evaluar, obteniéndose a continuación los enlaces a los mismos. El conjunto de esos enlaces, que permitían el acceso a la evaluación individual, se comunicó previamente a través de los correos electrónicos de los alumnos, y mediante el uso de la carpeta Recursos de PoliformaT. 


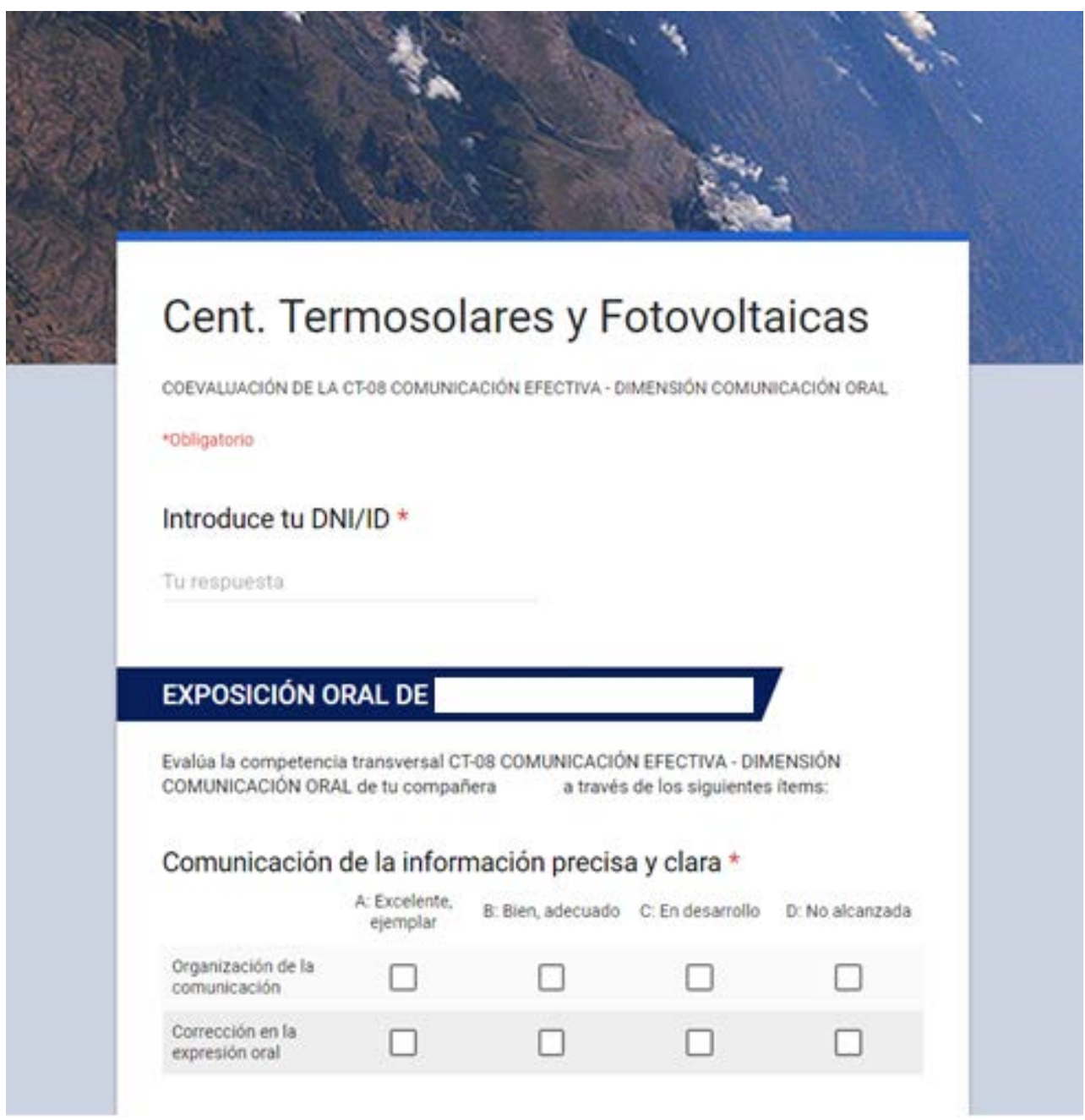

Fig. 1 Rúbrica implementada en Google Forms (i) 
Presentación de ideas clara y completa *

A: Excelente, B: Bien, adecuado C: En desarrollo D: No alcanzada
ejemplar

La exposición està

debidamente

preparada y se

ajusta al tiempo

establecido

Realiza

exposiciones

interesantes y

convincentes, que

desarrolla cuando

se le hacen

preguntas

concretas

\section{Comunicación no verbal *}

$$
\begin{gathered}
\text { A: Excelente, B: Bien, adecuado C: En desarrollo } \quad \text { D: No alcanzada } \\
\text { ejemplar }
\end{gathered}
$$

La comunicación

no verbal es

apropiada (gestos

contacto visual

con la audiencia,

ausencia de

postura

incorrecta...)

Refuerza sus ideas

con la ayuda de

medios de apoyo

Nunca envies contraseñas a través de Formularios de Google.

Este contenido no ha sido creado ni aprobado por Google. Informar sobre abusos - Condiciones del servicio Otros términos

\section{Google Formularios}

Fig. 2 Rúbrica implementada en Google Forms (ii)

En tercer lugar, el día de la exposición y tras cada una de ellas, se realizó la coevaluación accediendo al formulario correspondiente a través del enlace proporcionado, empleando para ello cualquier dispositivo móvil con acceso a internet.

Una vez finalizada la evaluación compartida de un alumno, se le proporcionaba feed-back de manera inmediata, accediendo a la visualización online del resumen de la coevaluación para posteriormente analizar los resultados obtenidos.

(c) ) EY-NC-ND 2018, Universitat Politècnica de València

Congreso In-Red (2018) 
EXPOSICIÓN ORAL DE

Comunicación de la información precisa y clara

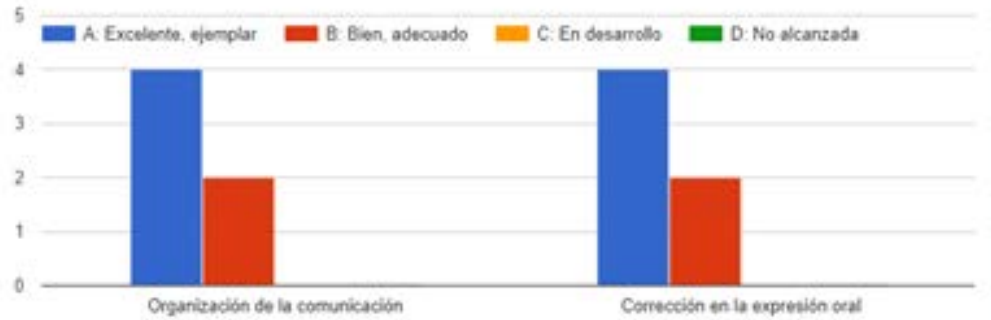

Presentación de ideas clara y completa

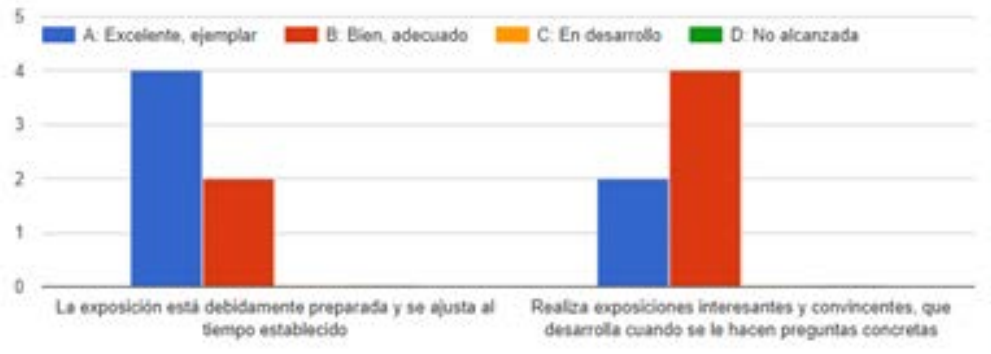

Comunicación no verbal

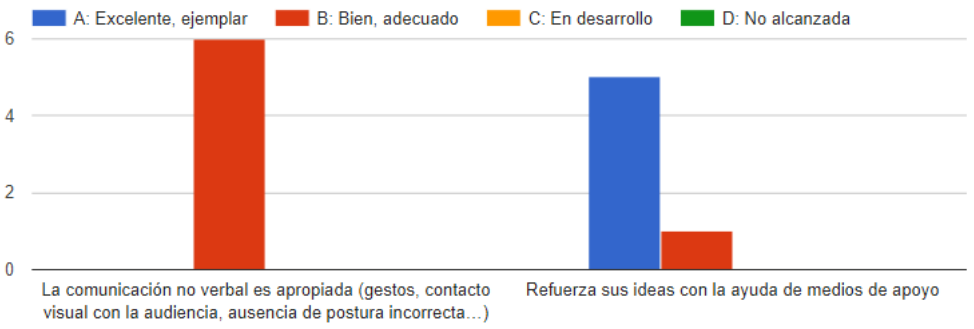

Fig. 3 Ejemplo de resultados obtenidos en la coevaluación con Google Forms - FEED-BACK facilitado

(c) EY-NC-ND 2018, Universitat Politècnica de València

Congreso IN-RED (2018) 
Finalmente, y con el fin de recopilar información sobre la opinión de los alumnos tras la experiencia vivida con la implantación de los objetivos marcados, se elaboraría un nuevo formulario online (encuesta) de preguntas tanto abiertas como cerradas (mediante el uso de una escala tipo Likert), que se cumplimentaría tras finalizar la coevaluación formativa.

\section{Resultados}

Una vez recopilada la información a través de la encuesta online, se obtuvieron los siguientes resultados:

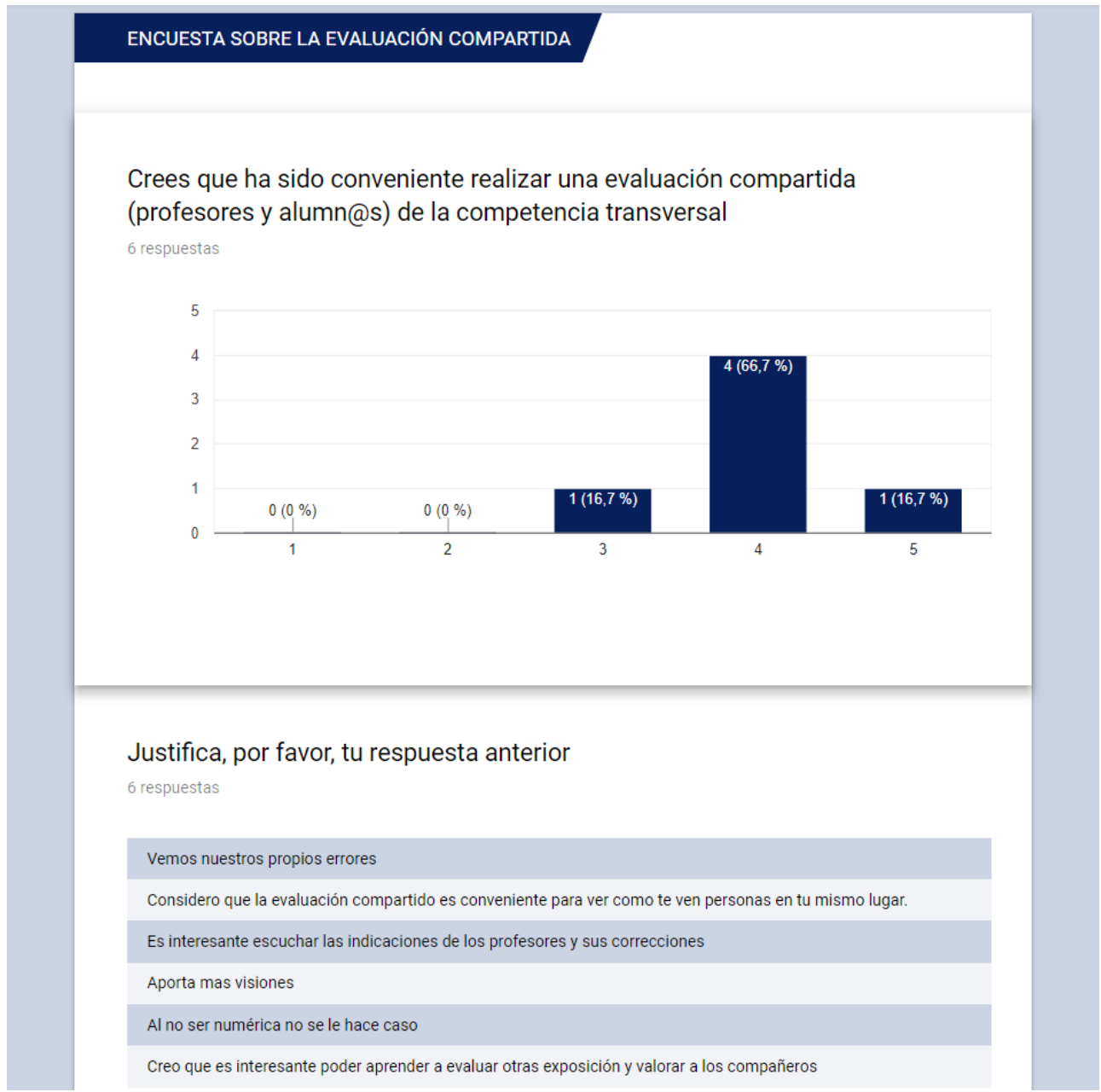

Fig. 4 Resultados de la encuesta realizada tras la implantación de la Innovación Educativa (i) 
La evaluación de la competencia transversal a mis compañer@s me ha sido útil para mejorar mi exposición oral

6 respuestas

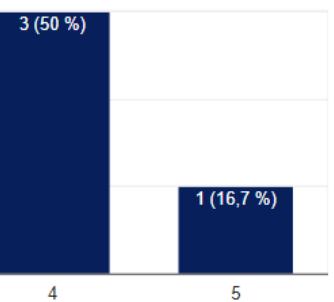

Considero que la evaluación de la competencia transversal a mis compañer@s me será útil como aprendizaje para mejorar mis futuras presentaciones

6 respuestas
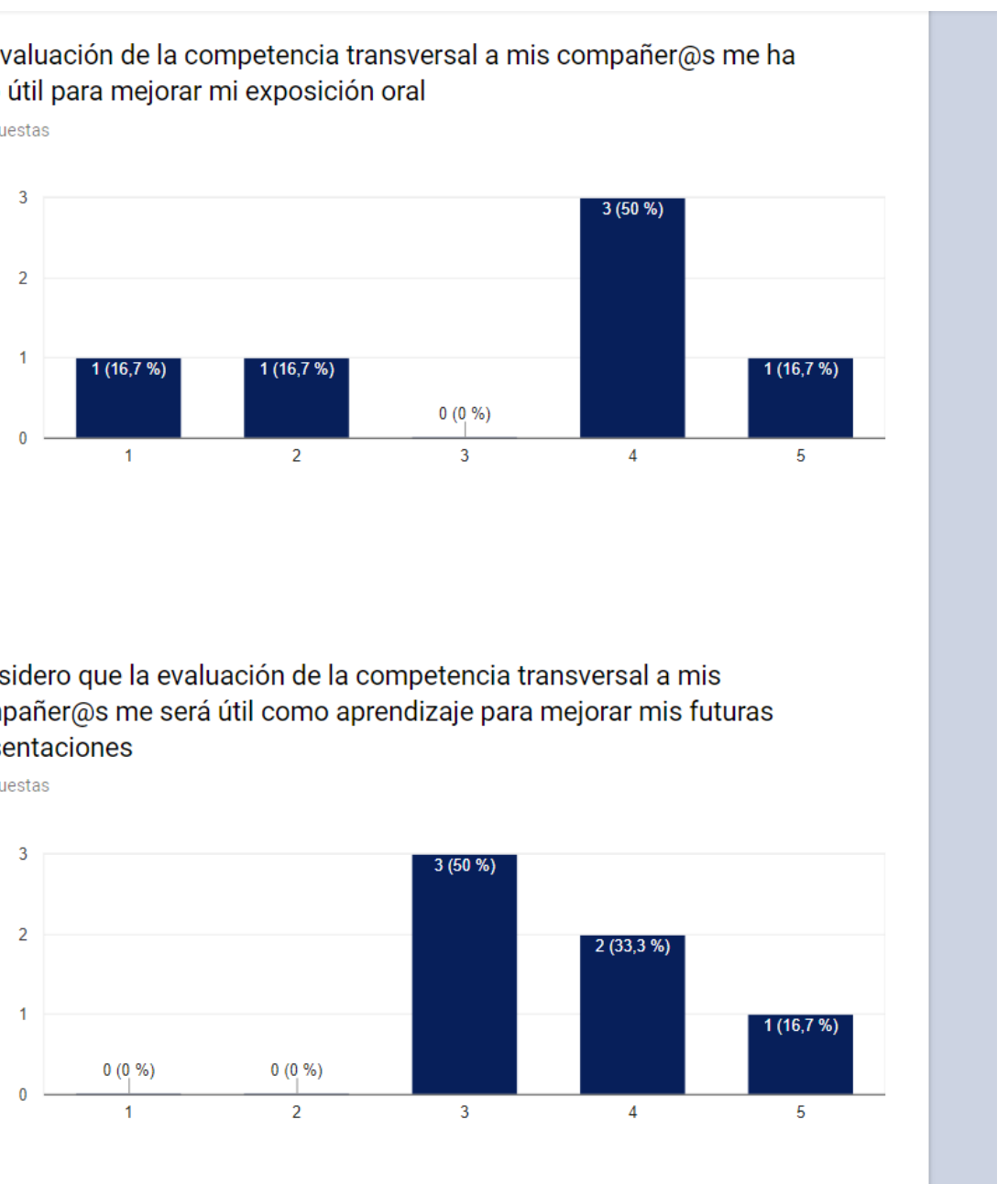

Fig. 5 Resultados de la encuesta realizada tras la implantación de la Innovación Educativa (ii)

(cc) BY-NC-ND 2018, Universitat Politècnica de València

Congreso IN-RED (2018) 
Como te has sentido al evaluar a tus compañer@s

6 respuestas

Incómodo (2)

Al evaluar eres empatico y te pones en su situación pese a ser crítico con ellos

Empática y con pensamiento crítico

Incómodo

Un poco incómodo, pues evalúas sin poder prestar toda la atención que te gustaría por estar rellenando la evaluación

Y al ser evaluad@por ell@s

6 respuestas

Incómodo

Considero favorecedor para proximas exposiciones

De la misma forma. Empática y con pensamiento crítico

Indiferente

Indeferente

Un poco incómodo

Fig. 6 Resultados de la encuesta realizada tras la implantación de la Innovación Educativa (iii)

(c) ) EY-NC-ND 2018, Universitat Politècnica de València

Congreso In-Red (2018) 
Los formularios empleados me han parecido adecuados y de fácil cumplimentación

6 respuestas

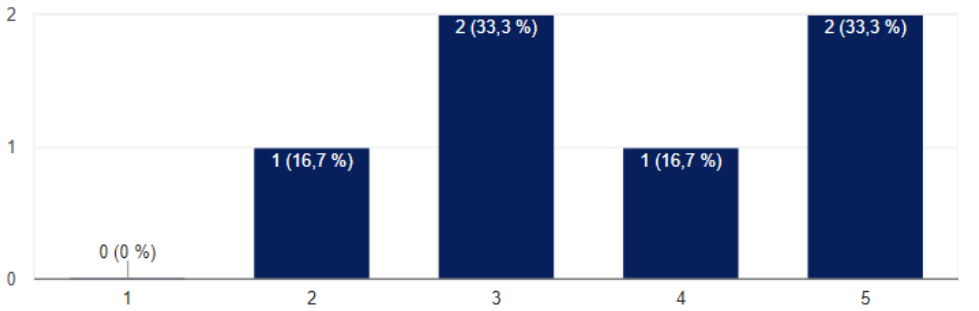

Sugerencias / comentarios adicionales

0 respuestas

Aún no hay respuestas para esta pregunta.

\section{Gracias}

Fig. 7 Resultados de la encuesta realizada tras la implantación de la Innovación Educativa (iv)

En general, aunque el número final de alumnos que contestaron a la encuesta fue reducido, prácticamente todos coincidieron en que había sido una experiencia positiva que les había permitido aprender de los errores propios y de los cometidos por sus compañeros, aunque se sentían ciertamente incómodos tanto al evaluar como al ser evaluado por ellos.

Respecto a la utilización de formularios online, la mayoría consideró que habían sido adecuados y de fácil cumplimentación.

\section{Conclusiones}

A la vista de los resultados obtenidos, creo que la implementación de las estrategias de evaluación formativa, coevaluación y realimentación inmediata, y la utilización de herramientas online para ello, ha sido un éxito en varios sentidos: implicación y aprendizaje de los alumnos, uso atractivo y fácil, corrección inmediata, ...

A pesar de esos buenos resultados, sería necesario contemplar una serie de mejoras que agilizaran la creación de formularios o el acceso a los mismos. Además, plantearía la

(cc) EY-NC-ND 2018, Universitat Politècnica de València

Congreso IN-RED (2018) 
utilización de otras plataformas (kahoot!, socrative, ...) que sean capaces de captar todavía más el interés de los alumnos y faciliten su coevaluación y feed-back.

Por último, habría que considerar, entre otros, la mejora de la rúbrica empleada con la finalidad de incentivar el crecimiento en la adquisición de la competencia transversal.

\section{Referencias}

ZABALZA BERAZA, M.A. (2008). "Innovación en la Enseñanza Universitaria: el proceso de convergencia hacia un Espacio Europeo de Educación Superior” en Educaçao, Porto Alegre, v. 31, $\mathrm{n}^{\circ}$ 3, p. 199-209.

UNIVERSITAT POLITÈCNICA DE VALÈNCIA (2015). Competencias transversales. $<$ http://www.upv.es/entidades/ICE/info/U0724624.pdf> [Consulta: 22 de marzo de 2018].

FERNÁNDEZ MARCH, A. (2010). "La evaluación orientada al aprendizaje en un modelo de formación por competencias en la educación universitaria” en Revista de Docencia Universitaria, vol. 8 , issue 1, p. 11-34.

BIGGS, J.B. (2005). Calidad del aprendizaje universitario. Madrid: Nancea. 


\title{
Desarrollo de competencias a través de la generación y desarrollo de una idea empresarial
}

Conchado, A., Pérez, V., Fernández, E. y Egea, L.

\section{Resumen}

El presente trabajo describe el planteamiento y resultados de una actividad de enseñanza - aprendizaje en el título Grado en Ingeniería en Gestión Empresarial del centro univeresitario EDEM - Escuela de empresarios. Todos los estudiantes matriculados en el título durante el curso 2017/18 participaron en esta iniciativa. La actividad se planteó como una competición multidisciplinar de generación y desarrollo de ideas de negocio. En esta actividad se aplicaron metodologías ágiles de proyectos y técnicas de Lean Canvas. Tras finalizar la competición, los estudiantes valoraron cuantitativamente cómo la actividad había contribuído a adquirir cada una de las competencias genéricas del título. Los resultados muestran que la actividad resultó un entorno de trabajo ideal para aplicar conocimientos, tomar decisiones, trabajar en equipo y comunicación oral. Los aprendizajes adquiridos en este actividad supone una valiosa experiencia para los estudiantes, pero también para el centro y los profesores implicados en su organización. Del mismo modo, es susceptible de adaptación en otros grados de futura implantación, que incluyen proyectos transversales a nivel curricular en sus planes académicos.

Palabras clave: competencias, actividad, emprendimiento

\begin{abstract}
This paper aims to describe the conditions and learning outcomes of a teaching and learning activity in the degree BSc in Engineering and Management in the university center EDEM - Business School. All students enrolled in this degree during 2017/18 participated in this initiative. The activity was presented as a multidisciplinary competition based in the generation and development of business ideas. Agile Project management methodologies and Lean Canvas techniques were applied in this activity. Once the competition finished, students scored how the activity had contributed to the development of generic competencies inherent to the degree. Our findings show that the activity provided an adequate learning environment for the application of knowledge, decisión - making, teamwork and oral communication. These results represent a valuable experience for students, as well as for the university center ans professors. Meanwhile, this activity can be applied to other degrees including cross - sectional projects in the study plans.
\end{abstract}

Keywords: competencias, actividad, emprendimiento 


\section{Introducción}

La mentalidad emprendedora se define como la predisposición a descubrir, evaluar y explotar oportunidades de negocio. El desarrollo de esta mentalidad emprendedora implica la adquisición de determinados conocimientos y competencias orientados a la creación de nuevos negocios, como contabilidad, derecho, finanzas, gestión de equipos, marketing e incluso las habilidades de venta. No obstante, los emprendedores también desarrollan un enfoque muy particular en relación a la búsqueda de nuevas oportunidades y la tolerancia al riesgo, que pueden aplicarse a otros perfiles profesionales. Como exponen McGrath and MacMillan (2000), los emprendedores se caracterizan por un estado de búsqueda permanente de nuevas oportunidades, que persiguen con disciplina. Este esfuerzo lo dedican solo a las mejores oportunidades y se centran en la ejecución de las ideas de negocio. Para ello, son capaces de comprometer a su equipo de trabajo, o sus recursos disponibles, para que den lo mejor de sí mismos en cada proyecto.

Por el contrario, la educación de los futuros ingenieros en la actualidad está fundamentada en los conocimientos científico - técnicos clálicos que constituyen la base de las tecnologías actuales. Este aprendizaje de los fundamentos matemático - físicos es clave en su formación ya que les permitirá posteriormente modelizar y resolver problemas en el entorno de los procesos industriales y empresariales en los que desarrollen su carrera profesional. No obstante, el rápido desarrollo tecnológico que se ha producido en los últimos años implica que los futuros ingenieros no sólo tendrán que ser capaces de resolver problemas ya existentes, sino de aportar valor y nuevas soluciones en las empresas donde trabajen. La generación de valor no está limitada a la creación de nuevas empresas y el desarrollo de ideas de negocio. Independientemente del área de especialización, los futuros graduados en ingeniería deberán ser capaces de facilitar el cambio de la empresa hacia nuevas tecnologías que les ayuden a satisfacer las necesidades de sus clientes, de una forma cada vez más eficiente e innovadora. Al igual que la dirección de empresas resulta una disciplina en sí misma, también existen determinados perfiles de profesionales especialistas que son capaces de liderar tecnológicamente a la empresa hacia el éxito (Drucker, 1986). Así, el intraemprendimiento constituye hoy en día una forma de emprendimiento para garantizar la supervivencia y desarrollo económico de las empresas (Trujillo, 2008).

Del mismo modo, si queremos ofrecer productos de calidad, debemos ser capaces de diseñar y producir aquello que el cliente necesita. La educación superior en ingeniería facilita la evaluación de proyectos en el ámbito del diseño, la producción, e incluso entre ambos. Pero debemos ser conscientes de que trabajar en estas dimensiones, olvidando las necesidades de cliente, puede conducirnos a una zona de satifacción exclusivamente industrial. Por ello, debemos movernos hacia la intersección de las tres dimensiones, con el fin de garantizar la satisfacción plena del cliente.

(cc) EY-NC-ND 2018, Universitat Politècnica de València

Congreso IN-RED (2018) 
Así, determinados enfoques de la mentalidad emprendedora pueden orientar y guíar a los ingenieros en el desarrollo de actividades de intraemprendimiento. Los conocimientos y competencias relacionadas con emprendimiento resultan muy recomendables para todos los estudiantes de ingeniería. No debería plantearse como una asignatura optativa reservada a determinados estudiantes con motivación personal por emprender (Bosman and Fernhaber, 2018). El principal factor motivador en la intención emprendedora de los estudiantes de ingeniería es la necesidad de autonomía en la organización y gestión de su propio trabajo (Barba-Sánchez \& Atienza-Sahuquillo, 2018). No obstante, debemos preguntarnos cuál es la forma más efectiva de adquirir este aprendizaje. Neck et al. (2014) afirman que para aprender emprendimiento, es necesario emprender. Pero cualquier experiencia práctica en emprendimiento debe estar siempre basada en una metodología que la soporte con el fin de lograr un aprendizaje eficiente.

En este proceso de diseñar un nuevo producto, o mejorar un producto o servicio ya existente, los profesionales hoy en día trabajan por proyectos. Durante esta fase de desarrollo, se aplican metodologías clásicas de gestión de proyectos inicialmente creadas para gestionar proyectos de construcción, obra civil e incluso militares. Esta forma de trabajo parte del supuesto de que el trabajo puede compartirmentarse, de modo que la ejecución del trabajo se organiza en diversos paquetes de trabajo secuenciales. No obstante, los equipos de trabajo actuales deben enfrentarse continuamente a cambios en las especificaciones y requisitos del cliente, la tecnología disponible e incluso la propia composición de los miembros del equipo. Las metodologías ágiles se han diseñado en base al supuesto de que las condiciones de trabajo pueden variar y pretenden facilitar la respuesta y adaptación a estos cambios (Ma, y Morris, 2017).

Por todo ello, las instituciones de educación superior se enfrentan al reto de formar a sus estudiantes en ingeniería en los conocimientos y competencias específicas que necesitarán en sus puestos de trabajo, al tiempo que les forman en competencias genéricas. En los últimos años, la Universidad Politécnica de Valencia está trabajando para introducir nuevas actividades de enseñanza - aprendizaje en cada asignatura, orientadas a la evaluación de competencias genéricas, en especial en las consideradas puntos de control. No obstante, cabe preguntarse en qué medida una actividad transversal y coordinada entre varias asignaturas puede contribuir al desarrollo de estas competencias genéricas. El planteamiento de retos reales y multidisciplinares, como la generación y desarrollo de ideas empresariales, puede ser el escenario perfecto para motivar a los estudiantes. El presente trabajo aborda esta cuestión y muestra los resultados obtenidos a través de la actividad en el Grado en Ingeniería en Gestión Empresarial durante el curso 2017/18. 


\section{Objetivos}

Con el fin de dar respuesta a las cuestiones planteadas anteriormente, el presente trabajo pretende analizar las competencias adquiridas por una actividad extracurricular destinado a desarrollar competencias genéricas entre los estudiantes de ingeniería en el título de Grado en Ingeniería en Gestión Empresarial. Para ello, se plantean los siguientes objetivos específicos:

1. Evaluar el grado de adquisición de competencias del título mediante esta actividad

2. Valorar las aportaciones cualitativas de los participantes como puntos fuertes y áreas de mejora

\section{Desarrollo de la innovación}

\subsection{El Grado en Ingeniería en Gestión Empresarial}

El Centro Universitario EDEM, adscrito a la Universitat de València y a la Universitat Politècnica de València, es una institución académica promovida por la Escuela de Empresarios, Fundación de la Comunitat Valenciana (EDEM) en la que se imparten estudios universitarios de carácter oficial de Grado y títulos propios de Postgrado.

En este centro se imparte el Grado en Ingeniería y Gestión Empresarial, titulación oficial adscrita a la Universitat Politècnica de València, que comenzó su implantación en 2014 con la voluntad de formar a los ingenieros del siglo XXI en conocimientos y habilidades fundamentales para la empresa, para que ocupen posiciones de gestión empresarial con orientación técnica en proyectos globales o como intraemprendedores, desarrollando nuevas áreas de negocio en una empresa.

\subsection{Participantes}

Todos los estudiantes matriculados en el Grado en Ingeniería y Gestión Empresarial durante el curso 2017/18 participaron en la actividad, alcanzando un número global de 90 participantes en la actividad. Debido a que el título se encuentra en el tercer año de implantación, estos 90 estaban matriculados en $1^{\circ}, 2^{\circ}$ y $3^{\circ}$ curso.

Cada equipo estaba formado por 5 personas, de modo que el centro formó 18 equipos. No se permitió la formación de equipos a criterio de los estudiantes. En la composición de los equipos se empleó como criterio fomentar la heterogeneidad entre los miembros. De este modo, en cada equipo se asignó al menos un estudiante de $3^{\circ}$ curso y otro de $2^{\circ}$ curso. No obstante, la actividad fue valorada por 77 estudiantes, obteniendo una tasa de respuesta del $85.5 \%$. 


\subsection{Breve descripción de la actividad}

La actividad tuvo una duración de cuatro días de trabajo. Tras una presentación inicial, los estudiantes trabajaron de forma autónoma en equipo para desarrollar una idea de negocio. Todos los equipos debían proponer un producto físico, que cumpliera la normativa legal, que fuera rentable y conforme a cuestiones éticas. Para ello, se organizaron varias sesiones de trabajo coordinadas por los profesores de distintas materias del título. El objetivo de estas sesiones era organizar el trabajo en la elaboración de sucesivos elementos entregables, que guiaban a los equipos hacia el desarrollo de la idea de negocio y la construcción del prototipo. En dichas sesiones, los profesores adaptaron los objetivos a los conocimientos de sus asignaturas, de modo que fuera posible avanzar en el desarrollo de la actividad, por medio de la aplicación práctica de los contenidos del título.

En el desarrollo de la actividad aplicamos la metodología Sprint, creada y desarrollada por Google Ventures (Knapp, 2013). Esta metodología proporciona un marco de trabajo estructurado en cinco fases que permite abordar problemas estratégicos a través de técnicas de prototipado rápido y validación de producto. Desde su creación en el año 2010, se ha aplicado en múltiples entornos como plataformas tecnológicas, por ejemplo destinadas al bienestar de personas mayores (Keijzer-Broers y De Reuver, 2016) o aplicaciones web para el análisis de datos meteorológicos (Grahl, Niklas y Söderling, 2015).

Asimismo, se ha combinado esta metodología con la técnica del Lean Canvas, para la generación y diseño de ideas de negocio. Constituye una adaptación del modelo Canvas y se centra en la identificación de problemas y necesidades del cliente enfocada a la propuesta de soluciones y métricas adaptadas. Con esta información es posible generar una propuesta de valor única, que constituye el valor diferencial y motivador para que los consumidores seleccionen nuestro producto (Maurya, 2012). Esta combinación de metodologías no es novedosa y ya se ha empleado en otros entornos, principalmente relacionados con el desarrollo de software (Nidagundi y Novickis, 2017).

Esta idea debía convertirse en un prototipo preliminar que posteriormente validaron con usuarios potenciales. Para ello se dirigieron a estudiantes matriculados en otros títulos, personal del centro y otros posibles usuarios. Con las mejoras recopiladas en esta sesión de testeo, propusieron una version final, que fue evaluada en sesión pública. Las valoraciones de cada equipo se calcularon a través de una ponderación del trabajo elaborado a lo largo de la actividad, las valoraciones de los compañeros y las valoraciones del tribunal. Asimismo, al finalizar la actividad, los estudiantes valoraron mediante una escala Likert de 1 a 5 en qué medida la actividad había contribuido al aprendizaje de las competencias genéricas (básicas y generales) del título.

\subsection{Recogida y análisis de datos}

Tras la presentación de las ideas de negocio y prototipos desarrollados por los estudiantes, los estudiantes valoraron su nivel de satisfacción con la actividad y el grado en que la actividad les había ayudado a desarrollar las competencias del título. Al finalizar, se elaboró un ranking de puntuaciones y se reconoció públicamente el valor de los equipos en 
las primeras posiciones. Estos resultados no tuvieron repercusión académica en calificaciones o implicación de los estudiantes en otras actividades. Para lograr la máxima implicación de los estudiantes, se generó un clima de competición empresarial que supone la aplicación de técnicas de gamificación en el aula (Zichermann y Linder, 2013). No obstante, la recopilación de datos sobre la valoración de competencias se realizó a la semana siguiente, tras la finalización de la actividad. Las valoraciones se recogieron de forma individual, sobre el listado de competencias del título impreso en papel. El momento de recogida de datos fue antes del comienzo de la primera sesión lectiva. Para valorar el nivel de contribución de la actividad a cada competencia se empleó una escala Likert desde 1 (Nada) hasta 5 (Mucho). La selección de competencias a evaluar fue extraída del listado de competencias generales de la memoria de verificación del título.

Asimismo, se solicitó a los estudiantes que valoraran con un enfoque cualitativo tres puntos fuertes y otros tres puntos débiles de la activdad. Finalmente se puso a disposición de los estudiantes un campo abierto de comentarios. A la hora de examinar los resultados en este apartado de la investigación, se registraron todas las aportaciones con contenido novedoso. Además, se contabilizó el número de repeticiones (frecuencias) de comentarios relativos a aportaciones anteriores. Así, fue posible trazar un análisis aproximado al histograma con el número de estudiantes que señalaron cada aportación cualitativa.

\section{Resultados}

Con el fin de abordar los objetivos planteados anteriormente, la siguiente sección expone los resultados de aprendizaje de la actividad. En particular, el análisis de valoraciones cuantitativas permitirá evaluar el grado de adquisición de las competencias del título, extraídas de la memoria de verificación, a través de la actividad.

Los resultados muestran que la actividad ha contribuido al aprendizaje de cómo aplicar conocimientos de forma profesional, transmitir información y analizar distintos elementos para la toma de decisiones empresariales. También ha fomentado que los estudiantes aprendan a reunir e interpretar datos y trabajar en equipo. Si bien los estudiantes aprenden en el título herramientas específicas para la toma de decisiones, en este trabajo se han enfrentado al reto de resolver un problema problema y asumir las consecuencias de sus decisiones.

En términos generales, es fácil observar que las competencias más relacionadas con la actividad son las de carácter genérico. Por el contrario, las competencias específicas como técnicas, habilidades y herramientas tecnológicas y económicas, expresarse en lenguajes formales, o problemas técnicos complejos obtienen los valores mínimos. Estos resultados están en línea con el planteamiento de la actividad, de carácter transversal al título. En particular, únicamente se solicitó a los estudiantes que redactaran un informe sobre las conclusiones de la investigación de mercado relativa a su idea de negocio. Por ello, no resulta sorprendente que la capacidad de expresarse en lenguajes formales haya obtenido este valor.

(c) ) EY-NC-ND 2018, Universitat Politècnica de València

Congreso IN-RED (2018) 


\begin{tabular}{lcc}
\hline Descripción competencias & Media & Desv \\
\hline $\begin{array}{l}\text { Aplicar conocimientos al trabajo de forma profesional, elaborar y defender } \\
\text { argumentos y resolver problemas }\end{array}$ & 4.03 & 0.76 \\
$\begin{array}{l}\text { Transmitir información, ideas, problemas y soluciones a un público tanto } \\
\text { especializado como no especializado }\end{array}$ & 3.99 & 0.80 \\
$\begin{array}{l}\text { Aprender a analizar los diferentes elementos que interactúan en la toma de } \\
\text { decisiones empresariales }\end{array}$ & 3.96 & 0.85 \\
$\begin{array}{l}\text { Capacidad para tomar decisiones en ambientes de certidumbre e incertidumbre } \\
\text { empresarial }\end{array}$ & 3.93 & 0.90 \\
$\begin{array}{l}\text { Reunir e interpretar datos relevantes para emitir juicios que incluyan una reflexión } \\
\text { sobre temas relevantes de índole social, científica o ética }\end{array}$ & 3.85 & 0.80 \\
$\begin{array}{l}\text { Capacidad para trabajar en equipo en entornos multilingües, multidisciplinares y } \\
\text { multiculturales }\end{array}$ & 3.82 & 1.02 \\
$\begin{array}{l}\text { Definir, resolver y exponer de forma sistémica problemas técnicos complejos } \\
\begin{array}{l}\text { Desarrollar habilidades de aprendizaje necesarias para emprender estudios } \\
\text { posteriores con alto grado de autonomía }\end{array}\end{array}$ & 3.65 & 0.74 \\
$\begin{array}{l}\text { Saber expresarse en lenguajes formales, gráficos y simbólicos necesarios para } \\
\text { entenderse en ambientes ingenieriles y empresariales }\end{array}$ & 3.62 & 0.95 \\
$\begin{array}{l}\text { Usar las técnicas, habilidades y herramientas tecnológicas y económicas, necesarias } \\
\text { para la práctica profesional de la ingeniería y gestión empresarial }\end{array}$ & 3.61 & 0.92 \\
\hline
\end{tabular}

Tabla 1. Estadísticos descriptivos de adquisición de competencias

Con el fin de enriquecer la información y conclusiones anteriores, a continuación se exponen las valoraciones cualitativas y comentarios realizados por los estudiantes. Algunos estudiantes señalaron que el tiempo estimado para el desarrollo de las actividades era insuficiente y afirmaron que les hubiera gustado tener más autonomía para gestionar su trabajo. Por el contrario, la mayoría de los estudiantes reconocieron que habían mejorado su capacidad de organización gracias a esta actividad. Asimismo, muchos estudiantes indicaron que habían mejorado sus habilidades de trabajo en equipo a través de la colaboración entre estudiantes de distintos cursos. Finalmente, también destacaron que habían mejorado sus competencias de comunicación oral, pues la presentación final ante la audiencia era obligatoria para todos los estudiantes.

\section{Conclusiones}

La actividad del Grado en Ingeniería y Gestión Empresarial del Centro Universitario EDEM ha constituido una actividad de innovación docente exitosa en la adquisición de competencias genéricas. Los estudiantes se han implicado por completo en el desarrollo de su idea de negocio y construcción del prototipo, a pesar de que los resultados no tenían implicaciones académicas en calificaciones o participación en otras actividades relacionadas con el título. El desarrollo de esta actividad ha implicado la combinación de distintas herramientas para la innovación educativa, como el aprendizaje

(c) ) EY-NC-ND 2018, Universitat Politècnica de València

Congreso IN-RED (2018) 
orientado a proyectos o las técnicas de gamificación, sin perder la orientación hacia la aplicación práctica de los conocimientos adquiridos en el aula.

Esta actividad supone un valioso aprendizaje para los estudiantes, al tener la oportunidad de desarrollar su propia idea de negocio, en un entorno controlado y guíado por sus profesores. En relación al primer objetivo del trabajo, el análisis cuantitativo del nivel de adquisición de competencias muestra que contribuye al desarrollo de competencias genéricas como entorno de trabajo ideal para aplicar conocimientos, tomar decisiones, trabajar en equipo y comunicación oral. Estos resultados están en línea con el planteamiento de la actividad, de carácter transversal al título y fueron confirmados por las valoraciones cualitativas de los estudiantes, en base al segundo objetivo del trabajo. Así, el análisis de los comentarios de los alumnos permitió confirmar la actividad es un medio de aprendizaje eficaz para las habilidades de trabajo en equipo y comunicación oral. Del mismo modo, las respuestas de los estudiantes permitió identificar la capacidad de organización y gestión de tiempo como un nuevo resultado de aprendizaje vinculado a esta actividad.

Al mismo tiempo, se ha confirmado que este tipo de innovaciones docentes contribuye al desarrollo de competencias genéricas, mientras que puede asignarse al contexto de cada asignatura la enseñanza y aprendizaje de las competencias específicas. Además, esta experiencia constituye un punto de partida para identificar a los estudiantes con orientación emprendedora, que en el futuro podrían desarrollar su propio proyecto empresiarial aprovechando los recursos. Esta actividad es susceptible de aplicación en otros grados de futura implantación, que incluyen proyectos transversales a nivel curricular en sus planes académicos. No obstante, cabe destacar que requiere un esfuerzo considerable de organización y coordinación académica por parte de los profesores implicados. Del mismo modo, el planteamiento de la actividad debe considerar el momento en que se encuentran los estudiantes a nivel curricular. No todos los estudiantes habrán estudiado los conocimientos del curso completo en que estén matriculados, y la actividad debe ajustarse a los contenidos vistos en el momento de la ejecución. En la aplicación de dicha actividad a otros títulos pueden plantearse líneas futuras de trabajo, como la generación y desarrollo de ideas basadas en problemas reales planteados por empresas. E incluso la composición de equipos de trabajo formados por alumnos de distintos títulos, que enriquecerían el enfoque multidisciplinar de las soluciones propuestas por el equipo.

\section{Referencias}

Barba-Sánchez, V., \& Atienza-Sahuquillo, C. (2018). Entrepreneurial intention among engineering students: The role of entrepreneurship education. European Research on Management and Business Economics, 24(1), 53-61 
Bosman, S. F. (2018). Teaching the Entrepreneurial Mindset to Engineers. New York, NY: Springer International Publishing.

Drucker, P. (1986). La economía empresaria innovadora (prólogo). En La innovación y el empresario innovador (pp. 11-29). Bogotá: Norma.

Grahl, N., \& Söderling, A. (2015). Design and implementation of a web interface for Axis global testing Live Sites. Ergonomics and Aerosol Technology. LUP Student Papers. Lund: Lund University Libraries.

Keijzer-Broers, W. J., \& de Reuver, M. (2016). Applying Agile Design Sprint Methods in Action Design Research: Prototyping a Health and Wellbeing Platform. In International Conference on Design Science Research in Information Systems (pp. 6880). Springer, Cham.

Knapp, J. (2013). How To Conduct Your Own Google Ventures Design Sprint. Fast Company, 24.

Ma, M., \& Morris, L. (2017). The Agile Innovation Sprint. International Management Review, 13(1), 92.

Maurya, A. (2012). Running lean: iterate from plan A to a plan that works. O'Reilly Media, Inc. UNIR Universidad de La Rioja.

McGrath, R. G., \& MacMillan, I. C. (2000). The entrepreneurial mindset: Strategies for continuously creating opportunity in an age of uncertainty. Harvard Business Press.

Neck, H. M., Greene, P. G., \& Brush, C. G. (Eds.). (2014). Teaching entrepreneurship: A practice-based approach. Edward Elgar Publishing.

Nidagundi, P., \& Novickis, L. (2017 Introducing lean canvas model adaptation in the scrum software testing. Procedia Computer Science, 104, 97-103.

Trujillo, M.-A. \& Guzmán, A. (2008). Intra/Entrepreneurship: A Review of the Theoretical Construct, its Implications, and an Agenda for Future Research. Cuadernos de Administración, Vol. 21, No. 35, pp. 37-63.

Zichermann, G., \& Linder, J. (2013). The gamification revolution: How leaders leverage game mechanics to crush the competition. New York: McGraw-Hill. 


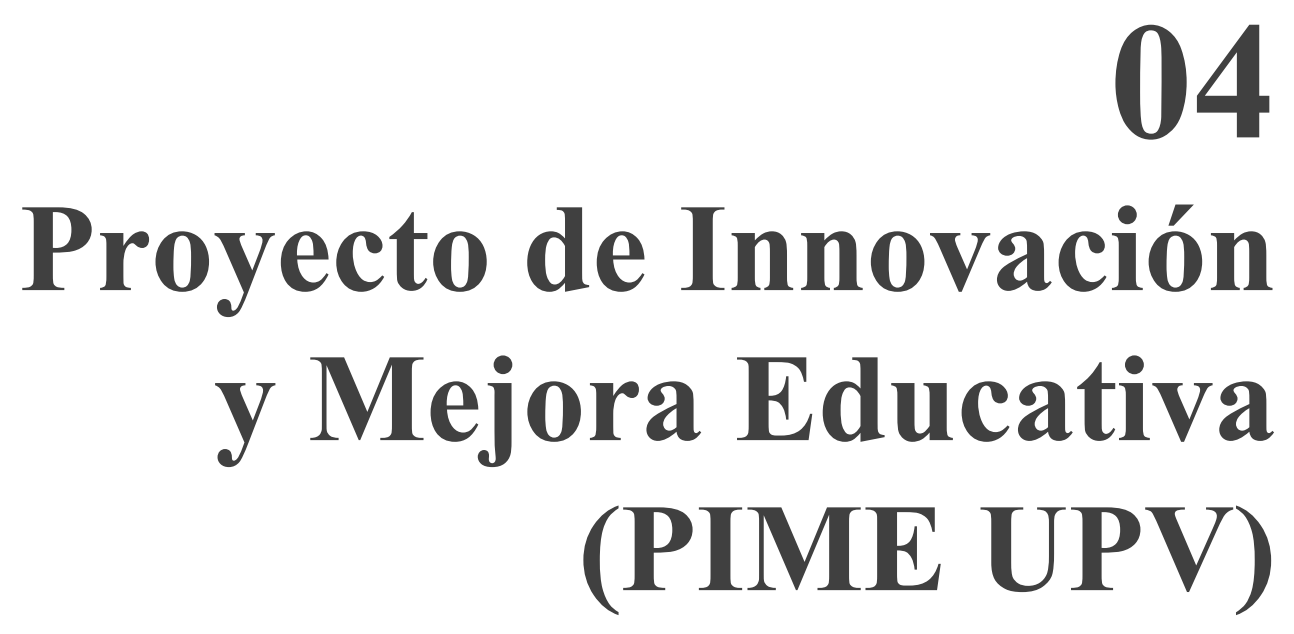




\title{
Los focus groups como herramienta en métodos cualitativos: experiencias contrastadas en docencia e investigación
}

\author{
Blanca de-Miguel-Molina ${ }^{a}$, María de-Miguel-Molina ${ }^{\mathrm{b}}$, Virginia Santamarina- \\ Campos $^{\mathrm{c}}$, y Daniel Catalá-Pérez ${ }^{\mathrm{d}}$ \\ ${ }^{a}$ Departamento de Organización de Empresas, Universitat Politècnica de València, \\ bdemigu@omp.upv.es, 'bepartamento de Organización de Empresas, Universitat Politècnica de \\ València, mademi@omp.upv.es, ${ }^{\mathrm{c}}$ Departamento de Conservación y Restauración de Bienes \\ Culturales, Universitat Politècnica de València, virsanca@crbc.upv.es, ${ }^{\mathrm{d}}$ Departamento de \\ Organización de Empresas, Universitat Politècnica de València, dacape@ade.upv.es
}

\begin{abstract}
Qualitative methods let us to obtain more precise information about the users's needs of a product or service. In order to gather this information, we can apply different tools such as focus groups. The creation of these groups is quite simple to perform in the classroom and, while students learn this tool, they can share information relevant to any aspect of their professional career. In this case, we have transferred the experience of this tool within a European Project (H2020) to an activity to be carried out in the classroom within the subject Research Methodologies. Finally, a content analysis was carried out with the transcriptions of these focus groups, and the feedback of the results was given to the student-participants and professors of the master's degree.
\end{abstract}

Keywords: research methodologies, qualitative methods, focus groups, content analysis.

\begin{abstract}
Resumen
Los métodos cualitativos permiten obtener una información más completa de los usuarios de un producto o servicio, para lo que se sirven de distintas herramientas como los focus groups. La creación de estos grupos es relativamente sencilla de realizar en el aula y, a la vez que los alumnos aprenden esta herramienta, pueden compartir información relevante para cualquier aspecto de su carrera profesional. En este caso, nosotros hemos trasladado la experiencia de esta herramienta dentro de un proyecto europeo (H2020), a una actividad a realizar en el aula dentro de la asignatura Metodologías de Investigación (Research Methodologies). Posteriormente, se realizó un análisis de contenido con la información transcrita y se dio a los alumnos-participantes y profesores del máster el feedback de los resultados.
\end{abstract}

Palabras clave: metodologías de investigación, métodos cualitativos, focus groups, análisis de contenido. 


\section{Introducción}

Conocer las necesidades de los usuarios a la hora de crear nuevos productos o servicios, o mejorarlos, no es una tarea sencilla. En ocasiones, podemos encontrar fuentes de información secundaria que nos faciliten dicha información pero, en otras, necesitamos nuestras propias fuentes de información para adaptar ese producto/servicio de la mejor manera posible.

En la asignatura Research Methodologies, del Máster Universitario en Gestión de Empresas, Productos y Servicios, les explicamos a los alumnos distintas metodologías de investigación cualitativa y las herramientas de las que se pueden servir para emplearlas. Además, sus aplicaciones en la empresa pueden ser variadas, no sólo para conocer el punto de vista de los clientes, sino incluso para conocer necesidades internas de sus empleados.

Entre esos métodos cualitativos encontramos el análisis de contenido, que Zhang y Wildemuth (2017) definen como "ir más allá de contar palabras o extraer contenido objetivo de los textos, para examinar significados, temas o patrones que pueden ser manifiestos o estar latentes en un texto. Permite a los investigadores entender una realidad social de una manera subjetiva pero científica”.

Por otro lado, en nuestra propia investigación en un proyecto europeo del Horizonte 2020, para obtener información primaria y realizar un análisis de su contenido, hemos utilizado la herramienta de focus groups. Ello nos ha permitido conocer las necesidades de una industria concreta y así poder desarrollar un producto acorde a éstas.

El focus group lo definen Berg y Lune (2012) como un grupo pequeño de discusión sobre un tema concreto, coordinado por un moderador, siendo ese tema relevante tanto para el investigador como para el grupo.

De este modo, nos planteamos que podíamos no solo explicar a los alumnos la metodología (análisis de contenido) y la herramienta (focus groups), sino que además fuesen ellos los partícipes de la actividad. Y para esto, buscamos unos objetivos en los que pudiesen participar de manera activa.

\section{Objetivos}

El objetivo de la actividad como tal, fue analizar las necesidades específicas de los alumnos del Máster para mejorar el programa, teniendo en cuenta que la mayoría de nuestros alumnos son internacionales.

Con ello, además, lográbamos otros dos objetivos:

- Que los alumnos conociesen la herramienta de los focus groups y cómo se analiza después esa información por medio del análisis de contenido.

- Que los alumnos intercambiasen sus experiencias y se creara un "debate” sobre los temas tratados. 


\section{Desarrollo de la innovación}

La actividad se llevó a cabo en diciembre de 2017 y contó con dos facilitadores, uno por grupo. Se realizó en un aula de la Facultad de Administración y Dirección de Empresas de la UPV, con una duración aproximada de una hora.

Los participantes fueron una parte de los alumnos del máster (la mitad más o menos), tanto hombres como mujeres de distintas nacionalidades. En total, 10 alumnos repartidos en dos grupos de 5. En cada grupo, además, uno de los alumnos hizo de soporte al facilitador para ir transcribiendo los comentarios de los participantes y así no ser necesario grabar la sesión. Para formar los dos grupos, el criterio seguido fue el de la lengua nativa, siendo un grupo de castellanoparlantes y el otro de distintos idiomas de lengua materna (ruso, holandés, alemán, árabe, entre otros). De todos modos, el idioma en el que se realizaron los focus groups fue el inglés al ser la lengua en la que se imparte la asignatura y conocida por todos los alumnos.

Sin embargo, en sesiones más largas o donde no se tomen notas por otra persona, es conveniente la grabación del audio (y si es posible de la imagen) para después transcribir todos los comentarios. En ese caso, es preciso entregar a los participantes un acuerdo para firmar su consentimiento sobre la grabación, siguiendo las pautas de la normativa sobre protección de datos (que, a partir del 25 de mayo de 2018, se basará en el Reglamento Europeo de Protección de Datos de 2016) (Unión Europea, 2016). En cualquier caso, la información a tratar era confidencial, sin citar en ningún momento a los intervinientes.

La dinámica se preparó con la misma base de los focus groups realizados en el proyecto H2020 citado (AiRT Project, 2017) (Imagen 1), preparando previamente un guión para ir realizando las preguntas a los participantes sobre los temas en los que se quería profundizar y así conocer las necesidades de los estudiantes de este máster.

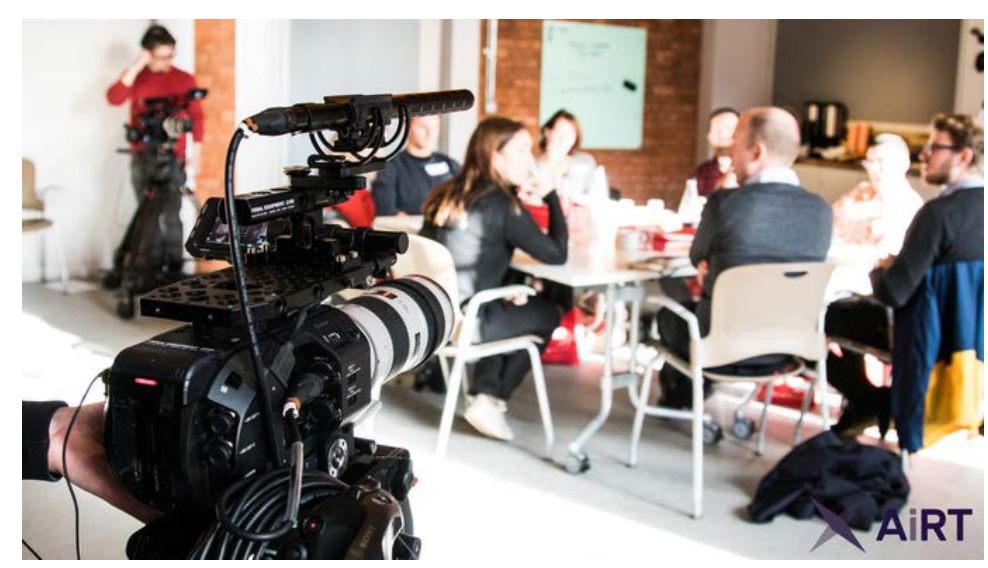

Imagen 1. Focus groups desarrollados en UK durante el Proyecto AiRT.

Fuente: repositorio del proyecto. 
Para preparar el cuestionario, se seleccionaron como temas básicos:

- La motivación de los estudiantes para escoger este máster.

- $\quad$ La experiencia que están viviendo durante su realización.

- $\quad$ Sus planes de futuro.

- Cómo les puede ayudar el máster a desarrollar su carrera profesional.

Para desplegar estos puntos, finalmente se elaboraron 12 preguntas. Estas fueron consensuadas entre algunos profesores, antiguos alumnos y la dirección del máster.

Finalizado el focus groups, se repasaron las notas entre el facilitador, el ayudante y los participantes, para comprobar que toda la información relevante estaba incluida. Posteriormente, con la información de ambos grupos, se realizó una análisis de contenido para codificar la información.

Para terminar, se elaboraron las conclusiones y se hicieron extensibles a todos los alumnos participantes y profesores del máster. Todos los datos fueron tratados de forma anónima.

\section{Resultados}

Los alumnos participaron de manera muy activa durante toda la dinámica, exponiendo sus impresiones y experiencias, lo que fue muy enriquecedor para los alumnos y profesores.

Sin lugar a dudas, el atractivo de Valencia como ciudad y el que la mayoría del programa sea en inglés, son factores atrayentes para los aumnos.

Entre los problemas encontrados, muchos están relacionados con la burocracia, especialmente para los estudiantes internacionales.

Lo que más se valora del máster es la experiencia en su conjunto, no solo por lo que aporta un título de alto nivel, sino también porque les aporta valor en su carrera profesional, destacando el entorno multidiciplinar en el que se desenvuelven.

Los resultados exactos de estos focus groups son información valiosa para nuestros competidores, por lo que no podemos detallar los resultados específicos de cada pregunta.

El guión que siguió el facilitador fue proporcionado posteriormente a los alumnos, de manera que conociesen cómo se había planificado la dinámica. Asimismo, como ya se había impartido otra sesión sobre análisis de contenido, al explicar el estudio realizado los conocimientos quedaron más asentados.

Las conclusiones se difundieron entre los alumnos-participantes y se les dio la posibilidad de aclarar o puntualizar algo si lo creían necesario.

Además, estas conclusiones se compararon con las del estudio realizado para QS por Karzunina et al. (2016), coincidiendo en varias de ellas, por ejemplo:

- $\quad$ El impacto que puedan tener sus estudios en la empleabilidad.

- Los problemas que se encuentran para acceder a determinada información proporcionada por las universidades.

(cc) EY-NC-ND 2018, Universitat Politècnica de València

Congreso IN-RED (2018) 
- $\quad$ La importancia de la posición que tenga a universidad a nivel internacional.

\section{Conclusiones}

Tras concluir esta actividad, comprobamos que todos los objetivos que nos habíamos propuesto se habían cubierto. En primer lugar, el objetivo de la actividad específica quedó completado con el análisis de las necesidades concretas de los alumnos del Máster.

El objetivo académico y principal, que era que los alumnos conociesen la herramienta de los focus groups y cómo se analiza después esa información por medio del análisis de contenido, se completó de una manera activa, siendo un tema interesante tanto para los alumnos como para los profesores de la asignatura que actuaron de facilitadores. Así mismo, el feedback continuo durante la actividad permitió que los alumnos conociesen la dinámica en caso de que tengan que replicarla en el futuro para sus investigaciones.

Por último, y aunque fuese un objetivo paralelo, los alumnos agradecieron que esta actividad les permitiese intercambiar sus experiencias y se creara un "debate” sobre los temas tratados. Al estar presentes los profesores como facilitadores, se sintieron escuchados y que su aportación puede contribuir a mejorar el programa.

De este modo, podemos concluir que existen herramientas de investigación, como los focus groups, que pueden aplicarse tanto en la docencia como en la investigación y, de esta manera, conocer una aplicación real que puede servir en las metodologías cualitativas. En definitiva, la actividad ha contribuido al objetivo final de la asignatura que es que los alumnos conozcan las bases de las metodologías de investigación en Ciencias Sociales.

\section{Agradecimientos}

Este trabajo se realizó en el marco del Proyecto de Innovación y Mejora Educativa (PIME), “La resolución de problemas a través del diseño creativo y la visualización colaborativa” de la UPV, coordinado por la profesora V. Santamarina. Asimismo, la metodología está siendo aplicada en el proyecto de investigación "Technology Transfer Of Remotely Piloted Aircraft Systems (Rpas) For The Creative Industry (AiRT)”, de la Comisión Europea (H2020).

\section{Referencias}

AiRT PROJECT. Technology Transfer Of Remotely Piloted Aircraft Systems (Rpas) For The Creative Industry. http://www.airt.eu [Consulta: 1 de febrero de 2018]

BERG, B.L. y LUNE, H. (2012). Qualitative Research Methods for the Social Sciences. New Jersey: Pearson.

Unión Europea. Reglamento del Parlamento Europeo y del Consejo, relativo a la protección de las personas físicas en lo que respecta al tratamiento de datos personales y a la libre circulación de estos datos y por el que se deroga la Directiva 95/46/CE (Reglamento general de protección de datos). Diario Oficial de la Unión Europea, de 27 de abril de 2016, núm. 679, p. L 119/1-L 119/88. 
Los focus groups como herramienta en métodos cualitativos: experiencias contrastadas en docencia e investigación

KARZUNINA, D. ; BRIDGESTOCK, L. y PHILIPPOU, G. (2016). What matters to international students. London: QS Intelligence Unit.

ZHANG, Y. y WILDEMUTH, B.M. (2016). “Qualitative analysis of content“ en Wildemuth, B.M. Applications of social research methods to questions in information and library science. Santa Bárbara, California : Unlimited Libraries.

(cc) EY-NC-ND 2018, Universitat Politècnica de València 


\title{
Desarrollo e implantación de un sistema de evaluación objetiva del aprendizaje individual en trabajos grupales en grupos numerosos de asignaturas de ingeniería
}

\author{
Y. Ye-Lin a, G. Prats-Boluda a, J. Garcia-Casado ${ }^{\text {a }}$, A. Martinez-Millana ${ }^{\text {a }}$, E. Guijarro \\ Estelles $^{\mathrm{a}}$ y J.L. Martinez-de-Juan ${ }^{\mathrm{a}}$ \\ a Universitat Politècnica de València. Departamento de Ingeniería Electrónica (yiye@eln.upv.es; \\ geprabo@eln.upv.es; jgarciac@eln.upv.es; anmarmil@itaca.upv.es; eguijarro@eln.upv.es; \\ jlmartinez@eln.upv.es).
}

\begin{abstract}
Teamwork is one of the most common teaching methodologies to achieve learning objectives in groups with a large number of students. The evaluation oriented to the group final result does not always adjust to the knowledge really acquired by each member of the team. The different instruments (diaries, portfolios) that are used to objectively assess the individual contribution of each member to group work could be a great workload for both students and teachers, especially in large groups. In this work, an evaluation system has been developed in polyform- $T$ for the objective assessment of individual student learning in group work in groups with a large number of students of engineering subjects. Although initially it represents an important effort for the implementation of this system, in the medium and long term it is highly sustainable. The evaluation by means of a test type test in polyform- $T$ is considered an appropriate technique by a large part of the students despite $55 \%$ of the students show some resistance towards the individualized evaluation of group activities. The different indicators show that the test difficulty level is appropriate, although there is a general feeling of lack of time to complete it among the students.
\end{abstract}

Keywords: individual evaluation, technological resource, group with a large number of students

\section{Resumen}

El trabajo en equipo es una de las metodologías docentes más comunes para conseguir los objetivos de aprendizaje en grupos numerosos. La evaluación orientada al resultado final grupal no siempre se ajusta a los conocimientos realmente adquiridos por cada miembro del equipo. Los distintos instrumentos (diarios, portafolios) que se utilizan para valorar objetivamente la aportación individual de cada miembro al trabajo grupal podrían suponer una gran carga de trabajo tanto para el alumnado como el profesorado, especialmente en grupos numerosos. En este trabajo, se ha desarrollado un sistema de evaluación en Poliforma-T para la valoración objetiva del aprendizaje individual del alumno en trabajos grupales en grupos numerosos 
de asignaturas de ingeniería. Aunque inicialmente supone un esfuerzo importante para la puesta en marcha de este sistema, a medio y largo plazo es altamente sostenible. La evaluación mediante examen de tipo test en Poliforma-T es considerada una técnica apropiada por gran parte del alumnado pese el 55\% de los alumnos muestra cierta resistencia hacia la evaluación individualizada de las actividades grupales. Los distintos indicadores muestrean que el nivel de dificultad del test es apropiado, aunque entre los alumnos hay una sensación general de falta de tiempo para la realización del mismo.

Palabras clave: evaluación individual, herramienta tecnológica, grupos numerosos.

\section{Introducción}

El trabajo en equipo es una de las metodologías docentes comunes para conseguir los objetivos de aprendizaje en grupos numerosos con elevado número de alumnos, gracias a que éste permite reducir la carga de trabajo y las responsabilidades, además de favorecer la motivación, la creatividad y el aprendizaje, mejoran en el desempeño, aumentan la eficiencia y la productividad (2015). Los trabajos grupales se han evaluado de forma tradicional en función del resultado final del grupo, bien por medio de memoria, una exposición oral u otro método adicional, es decir, la evaluación está orientada más al producto final grupal (Camilloni 2010). Sin embargo tiene el problema de no supervisar el proceso que conlleva la realización del mismo (Camilloni 2010). Como consecuencia de ello, se corre el riesgo de que algún miembro del equipo se aproveche del trabajo de los demás y aporta poco al trabajo común, y se beneficie de una calificación que no refleja su trabajo (Cuadrado 2012). En cambio, aquellos alumnos más comprometidos con la asignatura se enfrentan a un sobreesfuerzo realizando parte del trabajo que sus compañeros no querían realizar o asumían que su calificación se vería reducida (Sánchez 2014). Así, una evaluación grupal no garantiza que todos los miembros del equipo hayan alcanzado los objetivos de aprendizaje. De hecho en ocasiones genera una diferencia importante entre las calificaciones del trabajo grupal y de la prueba individual del alumno (Sánchez 2014). Por tanto, la valoración de las actividades grupales no debe limitarse a la evaluación del grado de cumplimientos grupales respecto a los objetivos de aprendizaje, sino conviene combinar con la evaluación individual de sus miembros mediante algún tipo de prueba que permita obtener evidencias individualizadas de sus resultados de aprendizaje (Cuadrado 2012).

Existen estrategias que permiten valorar la aportación individual a la actividad grupal, i.e, estrategia de los porcentajes. Esta estrategia consiste en la auto-evaluación del trabajo de los alumnos (Sánchez 2014), esto es, se les pide a los alumnos indicasen el porcentaje de esfuerzo que cada miembro había dedicado a la realización del trabajo. A la hora de asignar las calificaciones, se multiplicaba la calificación del trabajo grupal por el número de participantes del grupo. Luego se asigna a cada alumno el porcentaje que le correspondiese del resultado de esa multiplicación. Además de la subjetividad, Sánchez señaló que eran poco frecuentes los grupos en los cuales el porcentaje de esfuerzo no era el mismo para todos sus miembros (Sánchez 2014). Otro inconveniente de esta estrategia es que los

(cc) EY-NC-ND 2018, Universitat Politècnica de València

Congreso IN-RED (2018) 
alumnos tendían a confundir productividad con esfuerzo, es decir, los alumnos tienden a asignar los porcentajes en función de las horas trabajadas, no de los resultados obtenidos (Sánchez 2014). Otra forma más objetiva podría ser la recopilación de pruebas objetivas de la aportación individual al trabajo (Sánchez 2014, Izquierdo 2010), i.e, mediante entregas de informes sobre la planificación y organización de tareas, diarios personales o diarios de grupo, portafolio de aprendizaje, etc. Estos últimos son instrumentos muy útiles para la valoración del transcurso del proceso de elaboración del trabajo contemplando así la evolución individual de aprendizajes. No obstante podrían suponer una gran carga de trabajo para tanto el alumnado como el profesorado especialmente en grupos con elevado número de alumnos. Por consiguiente, creemos necesario desarrollar recursos que permitan obtener evidencias de los resultados de aprendizaje individual en actividades grupales debido al elevado número de alumnos de la asignatura y a la limitación en recursos tanto humanos como materiales. El desarrollo de estos recursos podría incluso aumentar el grado de motivación de todos los alumnos, puesto que favorecería una mejor valoración del nivel de aprendizaje del alumno, sin ir en detrimento de la realización de actividades grupales.

En este contexto, "Instrumentación y Control Industrial” es una asignatura troncal de 4.5 créditos de primer curso del Máster Universitario en Ingeniería Industrial de la Universidad Politécnica de Valencia (UPV). Tiene 331 alumnos distribuidos en 7 grupos de teoría y 21 grupos de prácticas, con un total de 6 profesores involucrados en la docencia de la parte de instrumentación. Aunque la mayoría de los alumnos procede del Grado en Ingeniería en Tecnologías Industriales de la misma universidad, se admiten sin complementos formativos los graduados en otras ingenierías de la rama industrial, y con complementos formativos establecidos por la ERT para otros solicitantes que cumplen los requisitos de acceso. Esto da lugar un desnivel importante en los conocimientos previos de los alumnos. Como particularidad de esta asignatura, cabe señalar que es una asignatura compartida entre el departamento de ingeniería de sistemas y automática (DISA, 2.25 créditos) y el departamento de ingeniería electrónica (DIEO, 2.25 créditos). Los 2.25 créditos impartidos por el DIEO constan de 1.2 créditos de teoría de aula, 0.6 créditos de práctica de aula y 0.45 créditos de práctica de laboratorio. Además de las competencias específicas, la asignatura tiene como objeto trabajar varias competencias transversales entre ellos el Aplicación y pensamiento práctico. En este respecto, la realización de las prácticas de laboratorio inherentemente contribuye y fomenta el desarrollo de esta competencia transversal.

Actualmente, las prácticas de laboratorio consisten en dos sesiones de prácticas 'independientes' en las que los alumnos ensayan y caracterizan distintos tipos de sensores (ensayo de impacto y colorimetría) mediante el uso combinado de sensores (emisor RGB, fotodiodos, acelerómetros), circuitos de acondicionamiento (amplificadores, filtros), bancos de ensayo (medida de aceleraciones en un ensayo de impacto) y el manejo de los instrumentos virtuales proporcionados por el profesorado para la adquisición digital y la visualización de las señales objeto de estudio. Debido al elevado número de alumnos y el elevado coste del equipamiento por puesto de trabajo en las sesiones de prácticas de asignaturas tecnológicas, los espacios y técnicos requeridos, la práctica se llevaba a cabo en equipos de 3 alumnos (con asociación libre). En cursos anteriores, se les pedía a los alumnos que realicen un estudio previo del proceso involucrado y la realización de unos 
cálculos previos que implican la comprensión de todas las etapas de dicho proceso. Antes de comenzar la práctica, cada equipo entregaba el estudio previo al profesor (uno por equipo) y éste lo revisaba durante la sesión de práctica y les proporcionaba la retroalimentación. El profesor una vez recogidas las prácticas realizaba una breve explicación de la dinámica de la actividad instruyendo a los alumnos en el manejo de los instrumentos, bancos de ensayo y equipos involucrados. Durante el resto de la sesión, además de corregir y entregar la memoria previa a los equipos, resolvía las dudas/incidencias que les han surgido a los alumnos y que han sido incapaces de resolver por sí mismos. Una vez finalizada la práctica, cada equipo de alumnos debe elaborar una memoria de la práctica que debe incluir el estudio previo, los resultados experimentales y la interpretación de los mismos. La evaluación de la práctica la realizaba a posteriori por el profesor mediante el uso de rúbricas que valoraba tanto la preparación de la práctica, el desempeño del trabajo práctico y manejo de herramientas en la sesión práctica, la consecución de objetivos y gestión del tiempo (grado de consecución de las actividades al finalizar la práctica), así como la presentación de los resultados. Finalmente se le otorgaba la misma calificación obtenida mediante la rúbrica a todos los miembros del equipo.

Nuestra experiencia a lo largo de los últimos cursos indica que la calificación grupal obtenida a partir de rúbricas de los diferentes ítems no refleja fielmente a los resultados de aprendizaje individuales de cada alumno, detectándose en un elevado número de alumnos una gran discrepancia entre la calificación obtenida en las actividades grupales y en aquellas que valoran los resultados de aprendizaje de forma individual. La realización de una memoria individual en horas no presenciales supondría una carga de trabajo que excede la asignación en créditos de las prácticas, a la vez que se corre el peligro de plagio entre los alumnos y puede que no refleje el aprendizaje del alumno a nivel individual. Además, la corrección de memorias individuales en asignaturas con un número elevado de alumnos (> 300) supone una carga excesiva para el profesorado que imparte las prácticas (3 profesores). Por consiguiente, el objetivo del presente trabajo es desarrollar recursos tecnológicos para la evaluación del aprendizaje individual de las actividades grupales mediante pruebas objetivas en grupos numerosos de ingeniería que complementen la evaluación grupal de las mismas mediante rúbrica. En concreto se pretende evaluar el aprendizaje individual de las prácticas de laboratorio la asignatura "Instrumentación y Control Industrial”.

\section{Métodos}

\subsection{Desarrollo de innovación}

Dado el elevado número de alumnos, las actividades prácticas se llevan a cabo en equipos de 3 alumnos (con asociación libre) igual que en cursos anteriores. Para ayudar una mejor comprensión de la práctica, los profesores de la asignatura han elaborado un vídeo explicativo de cada práctica (2018). Se les pide a los alumnos que visualicen las polimedias antes de la práctica. Se mantiene la elaboración de las memorias sobre el estudio previo a realizar, y la revisión de la misma por el profesor durante la sesión de práctica. Durante la sesión de prácticas cada equipo de alumnos realizan los experimentos pertinentes para la obtención de los resultados y las reflexiones de los mismos, indicando de forma específica

(c) EY-NC-ND 2018, Universitat Politècnica de València 
(tablas, figuras) los datos/señales a obtener y/o calcular y representar a la vez que incluyen cuestiones relativas a la interpretación de los resultados. Al final de práctica el profesor revisa los resultados obtenidos de cada equipo. Asimismo, teniendo en cuenta que durante los últimos 20 minutos de la práctica de laboratorio los alumnos realizarán una prueba individual objetiva en Poliforma-T (herramienta informática de la UPV comúnmente utilizada para el intercambio de información entre los profesores y los alumnos, i.e, materiales docentes, entrega de actividades, batería de preguntas para realizar exámenes), se han reestructurado las actividades de la práctica atendiendo a esta circunstancia (experimentación, cumplimentación de los resultados y prueba individual durante la sesión de prácticas).

El diseño del examen de tipo test se tuvo en cuenta los objetivos de aprendizaje de ambas prácticas: diseñar y analizar un sistema de sensado, instrumentación y adquisición de una magnitud física; interpretar las hojas características proporcionadas por el fabricante y los resultados obtenidos. Atendiendo a estos objetivos de aprendizaje de la práctica, los profesores de prácticas han preparado una batería de preguntas -prueba objetiva de tipo test- a contestar de forma individual por los alumnos. En cada práctica, se subdivide la batería de preguntas en 4 subcategorías: sensores, estudio previo, resultados y adquisición de datos. De esta manera, cada test consiste en una pregunta de cada subcategoría, siendo 4 el número total de preguntas. Puesto que en el laboratorio se dispone de 12 ordenadores en los que los alumnos pueden contestar simultáneamente el test y el número máximo de alumnos en una sesión de práctica es 24 , y que el tiempo previsto para realizar el test de cada alumnos es de unos 8 minutos, el tiempo dedicado a la realización del test se ha estimado en unos 20 minutos.

Puesto que el número de alumnos de la asignatura es elevado ello implica consecuentemente un elevado número de grupos de prácticas (21). Por tanto, la cantidad de preguntas a desarrollar debe ser vasta y variada (110 y 100 preguntas por la práctica 1 y 2 respectivamente). Téngase en consideración que las 21 sesiones de cada práctica se desarrollan durante dos semanas lectivas de manera que para evitar agravios comparativos entre los primeros y últimos grupos de prácticas las preguntas individuales deben tener un alto grado de "novedad" en cada uno de los grupos. La preparación inicial de estos recursos requiere un alto grado de dedicación y coordinación del profesorado para acordar los aprendizajes relevantes de las actividades prácticas, desarrollar las preguntas y revisarlas de forma conjunta para seleccionar aquellas que cubran todos los resultados de aprendizaje, sean variadas y con un nivel de dificultad similar.

Tras analizar las ventajas e inconvenientes que aportan las distintas herramientas tecnológicas como Kahoot, Poliforma-T para la implementación del sistema de evaluación, en principio nos hemos decantado por el uso de la plataforma poliforma-T ya que se pueden exportar directamente las puntuaciones que cada alumno ha obtenido en el test al padrino (herramienta informática comúnmente utilizado en la UPV para facilitar la gestión de notas de alumnos).

La calificación de cada práctica se obtiene ponderando la calificación obtenida en la memoria de estudio previo grupal (60\%) y la obtenida en el test individual $(40 \%)$. La 
memoria de estudio previo grupal se evalúa mediante la rúbrica que valora tanto la preparación de la práctica, el desarrollo del trabajo práctico y manejo de herramientas en la sesión práctica y la consecución de objetivos y gestión del tiempo (grado de consecución de las actividades de la práctica al finalizar la misma), siendo el peso de cada uno de los tres ítems iguales. En cuanto a la puntuación del test individual, la puntuación de cada pregunta correcta e incorrecta es de 2.5 puntos y de 0 puntos respectivamente, es decir, una respuesta incorrecta no influye negativamente sobre la puntuación final del test.

\subsection{Recopilación y análisis de datos}

Al final de la asignatura, se ha realizado una encuesta a los alumnos para conocer sus opiniones de la evaluación individualizada de las actividades grupales, el método de evaluación individualizada implantado, la idoneidad del uso la herramienta poliforma-T para este propósito y la idoneidad del test implantado ( $\mathrm{n}^{\mathrm{o}}$ de preguntas, nivel de dificultad y tiempo de desarrollo). Asimismo se ha obtenido la distribución porcentual de las puntuaciones obtenidas en el test individual de cada práctica.

Por otro lado, se ha recopilado el tiempo de dedicación del profesorado (horas no presenciales) al desarrollo e implantación del nuevo sistema de evaluación en poliforma-T incluyendo tanto la preparación y revisión de la batería de preguntas como la introducción de la misma en el poliforma-T. Asimismo, se ha recabado información sobre el tiempo de dedicación del profesorado para la revisión y calificación de la memoria final de práctica de los cursos anteriores y se ha comparado con el tiempo de dedicación a la implantación del nuevo sistema de evaluación en poliforma-T.

\section{Resultados}

Respecto al tiempo de dedicación del profesorado, en los cursos anteriores los profesores dedican un tiempo promedio de unas $2 \mathrm{~h} / \mathrm{grupo} /$ práctica para la revisión y calificación de la memoria final de práctica. Teniendo en cuenta los 21 grupos de alumnos, el tiempo de dedicación total del profesorado era de unas 84 h. En el curso actual, el tiempo de dedicación del equipo de profesores al desarrollo e implantación del sistema de evaluación en poliforma-T de las dos prácticas es de unos $82 \mathrm{~h}$, lo cual es prácticamente igual que el de cursos anteriores. No obstante, una vez implantado el sistema de evaluación del aprendizaje individual de la práctica en la plataforma, el tiempo dedicación del profesorado en los cursos posteriores se limitará al mantenimiento y actualización de 1a batería de preguntas, lo que supone un tiempo notablemente inferior. Esto es, la dedicación del profesorado al desarrollo e implantación del sistema de evaluación en Poliforma-T se amortiza en el primer año, sugiriendo una alta sostenibilidad del sistema.

En la figura 1 se muestra el porcentaje de alumnos que han obtenido las distintas puntuaciones sobre 10 de las dos prácticas. En ella se observa que la gran mayoría de alumnos han obtenido una puntuación mayor o igual que 7.5 puntos (80\% para la práctica 1 y 68\% para la práctica 2), es decir, han adquirido los resultados de aprendizaje de la práctica. No obstante, hay un porcentaje de alumnos $(<10 \%)$ que no han alcanzado los resultados de aprendizaje obteniendo así una puntuación menor o igual que 2.5 puntos. Estos casos no se podían discriminar en cursos anteriores en los que la evaluación de las

(cc) EY-NC-ND 2018, Universitat Politècnica de València

Congreso IN-RED (2018) 
Tabla 1. Tiempo de dedicación del profesorado al desarrollo e implantación del sistema de evaluación en poliforma-T de las dos prácticas.

Tiempo de dedicación (h)

\begin{tabular}{lc}
\hline Preparación & 56 \\
\hline Revisión & 18 \\
\hline Introducción al poliforma-T & 8 \\
\hline Total & 82 \\
\hline
\end{tabular}

actividades grupales se realizaba en base a una rúbrica grupal. Con ello se evidencia la necesidad de incluir un parte de evaluación individualizada para reflejar de manera más fiel el aprendizaje individual del alumno. Además, estos resultados apuntan que el nivel de dificultad del test es adecuado, además concuerdan con la observación del profesor durante la realización de la sesión de práctica: la gran mayoría de los alumnos han realizado y comprendido la práctica. Asimismo, no se ha observado diferencias apreciables de la puntuación promedio entre los distintos grupos de prácticas, lo cual indica que la variedad de la batería de preguntas es adecuada aunque el equipo de profesores pretende ampliarla en los cursos posteriores.

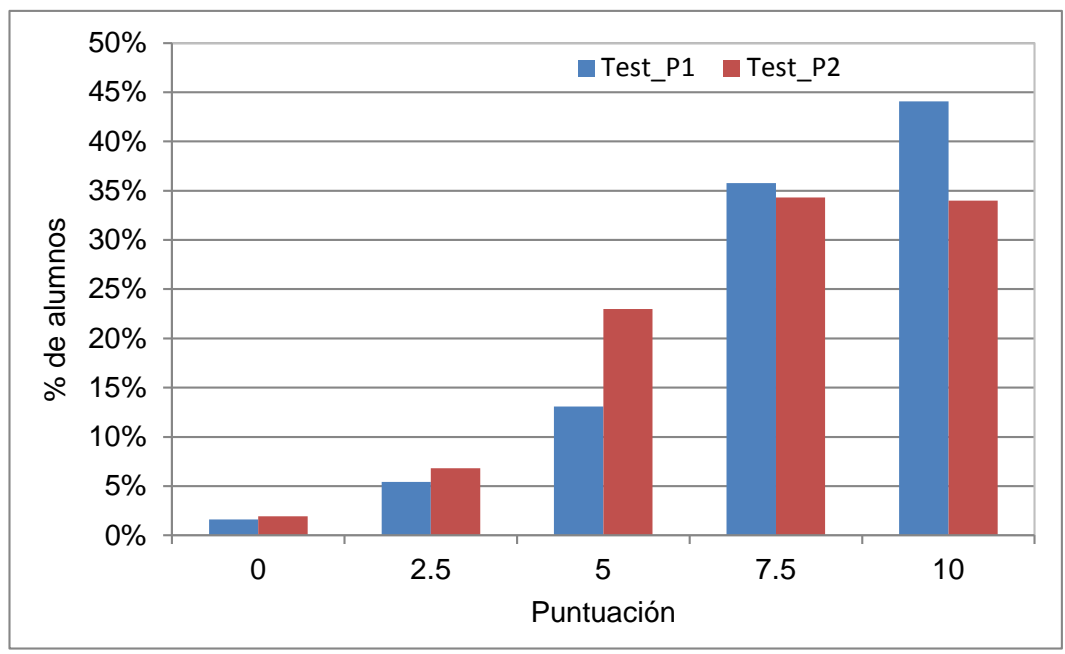

Figura 1. \% de alumnos que han obtenido las distintas puntuaciones sobre 10 de las dos prácticas.

En el proyecto participaron 319 alumnos matriculados en la asignatura. Del total de alumnos matriculados, 259 alumnos han contestado la encuesta en la última sesión de clase. Las figuras 3 y 4 muestran el resultado de las encuestas sobre la aceptación de la evaluación individualizada de las actividades grupales por parte del alumnado, método de evaluación individualizada, idoneidad de la herramienta poliforma- $T$, materiales docentes de las prácticas así como la idoneidad del número de preguntas, nivel de dificultad y el tiempo de desarrollo del test. 
Respecto a la evaluación de las actividades grupales, el 55\% de los alumnos sigue prefiriendo la evaluación grupal, siendo reacios a la evaluación individual, justificando con la gran carga de trabajo del curso académico. Tan sólo el $45 \%$ de los alumnos valoran positivamente la evaluación individualizada de las actividades grupales (ver figura 3). De los métodos propuestos (Examen oral, cuestiones cortas de respuesta abierta, examen de tipo test o memoria individual) para evaluar individualmente las actividades grupales realizadas en las prácticas, el examen de tipo test es la opción preferida del $63 \%$ de los alumnos (ver figura 4). Más aún, la herramienta poliforma-T para la realización del examen de tipo test ha tenido una gran aceptación (83\%, ver figura 3). Asimismo, el $77 \%$ de alumnos considera que los materiales docentes disponibles (memorias y vídeos explicativos) le han servido de ayuda para preparar, realizar y entender la práctica (ver figura 3).

Respecto al número de preguntas del test para valorar los conocimientos adquiridos en las prácticas, el 68\% de los alumnos considera que es apropiado o indiferente, mientras que un $29 \%$ de los alumnos creen que se debería dotar de más preguntas al test (ver figura 4). En cuanto al nivel de dificultad del test, el $28 \%$ de los alumnos han considerado que el nivel de dificultad era muy alto, mientras que el 69\% de los alumnos están conforme con el nivel de dificultad (ver figura 4). Las opiniones respecto al duración del test presentan un mayor grado de dispersión, sólo el $47 \%$ de los alumnos considera que el tiempo previsto de 8 min/práctica es apropiado, y $45 \%$ de los alumnos han manifestado su inquietud de falta de tiempo para la realización del mismo (ver figura 4). La figura 5 muestra la distribución del tiempo que los alumnos han dedicado para realizar el test, en ella se puede apreciar que el valor mediana de la práctica 1 y práctica 2 es de 8 y 7 minutos respectivamente. Entorno al $50 \%$ y $25 \%$ de los alumnos han requerido más tiempo para realizar el test que el previsto en la práctica 1 y 2 respectivamente. Estos son resultados muy valiosos para ajustar mejor la duración del test en los cursos posteriores.

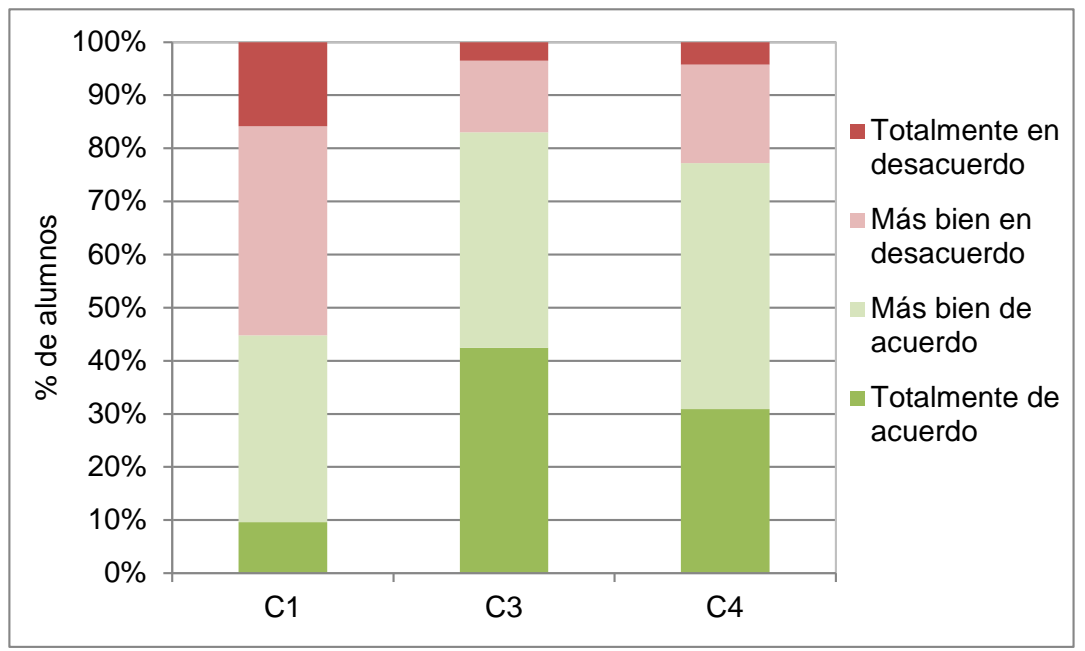

Figura 3. Resultados de las encuestas. C1: ¿Valora positivamente que la evaluación individualizada de las actividades grupales? C3: ¿La herramienta poliforma-T para la realización del examen de tipo test es adecuada? C4: ¿Los materiales docentes le han servido de ayuda para preparar, realizar y entender la práctica? 

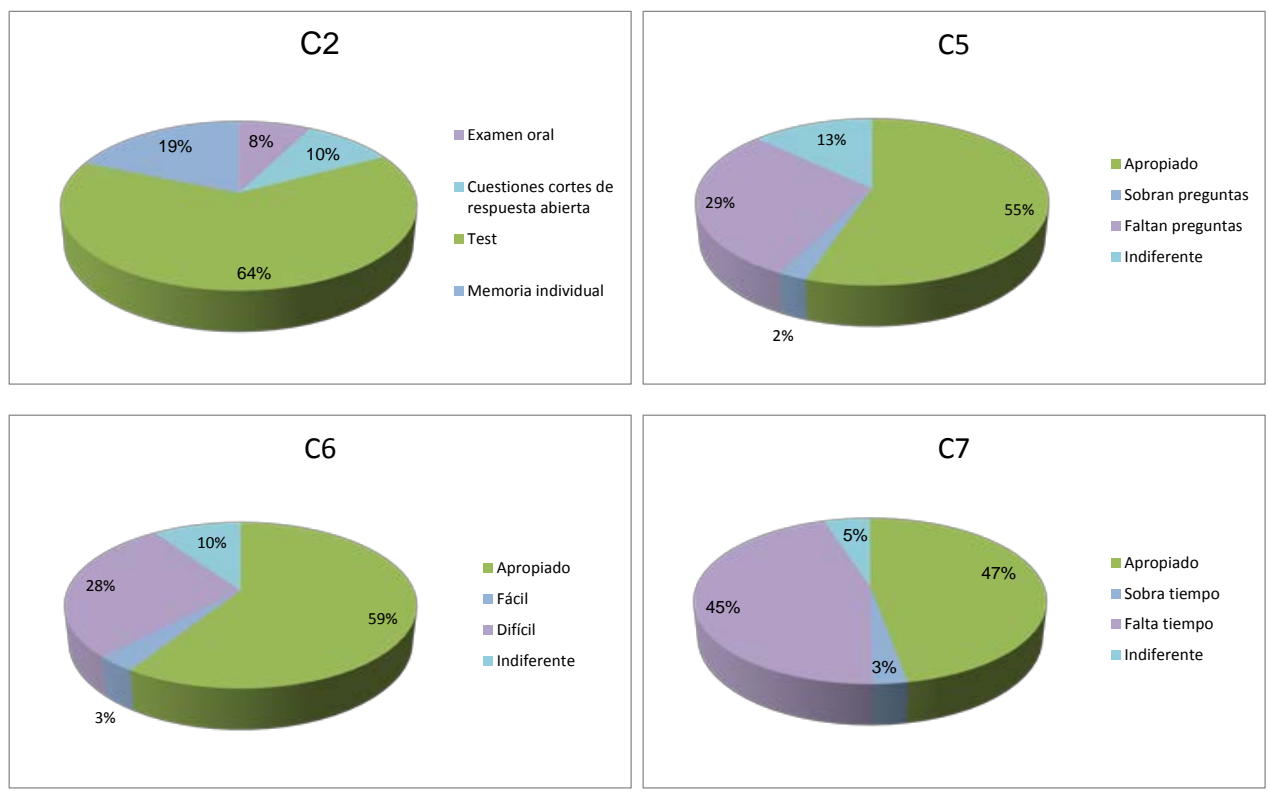

Figura 4. Otros resultados de la encuesta. C2: Preferencias sobre métodos de evaluación para la evaluación individualizada de las prácticas. C5-C7: Idoneidad del número de preguntas, nivel de dificultad y el tiempo de desarrollo del test respectivamente.

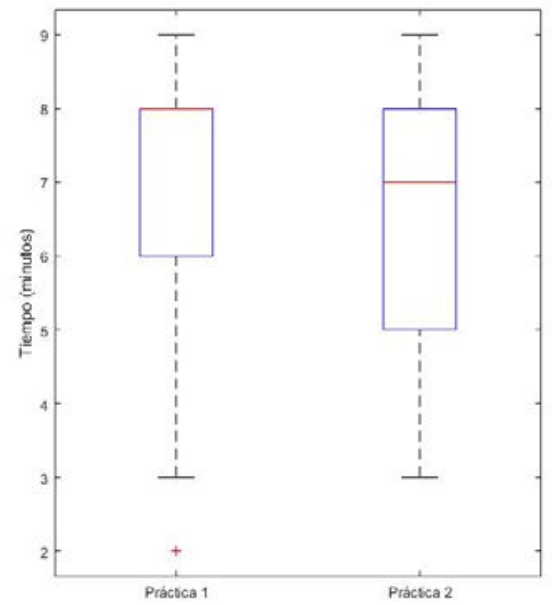

Figura 5. Distribución del tiempo que los alumnos han dedicado para realizar el test.

\section{Conclusión}

Se ha desarrollado e implantado un sistema de evaluación en plataforma poliforma-T que permite la evaluación individualizada y objetiva de las actividades grupales de modo eficiente en grupos numerosos en ingeniería. Este sistema de evaluación es altamente sostenible ya que la dedicación del profesorado se amortiza incluso en el primer año, y en los cursos posteriores sólo se necesita realizar el mantenimiento de la plataforma añadiendo algunas preguntas adicionales. Además de reducir la carga de trabajo del profesorado, la evaluación individualizada en la misma sesión de práctica reduce la carga de trabajo del alumnado al eliminar la elaboración de la memoria de práctica en horas no presenciales. 
Pese a que el 55\% de los alumnos muestra cierta resistencia hacia la evaluación individualizada de las actividades grupales, la evaluación mediante examen de tipo test en la plataforma Poliforma-T ha tenido una gran aceptación por parte de los alumnos. Asimismo tanto la puntuación en el test individual como la encuesta de los alumnos indican que el nivel de dificultad del test es apropiado, aunque hay una opinión de extensa (45\%) de falta de tiempo para realizar el test. La experiencia del presente trabajo es fácilmente transferible a otras asignaturas masivas de docencia universitaria.

Este trabajo está subvencionado por el Vicerrectorado de Estudios, Calidad y Acreditación de la UPV (PIME B04, Convocatoria 2017-2018).

\section{Referencias}

CAMILLONI A. (2010) "La evaluación de trabajos elaborados en grupo.” En Camilloni, A (Comp.) “La evaluación Significativa.” Buenos Aires: Paidós.

CUADRADO-SALINAS C., FERNÁNDEZ-LÓPEZ F.J., FERNÁNDEZ-LÓPEZ M., FERNÁNDEZ-PACHECO E., GONZÁLEZ-LAGIER D., LIFANTE-VIDAL I., MOYABALLESTER J. (2012) "Técnica de trabajo en equipo para estudiantes universitarios." En M.T. Tortosa-Ibánez, J.D. Álvarez-Teruel \& N. Pellín-Buades " $X$ Jornadas de redes de investigación en docencia universitaria” pp 3072-3086 Alicante. Universidad de Alicante

IZQUIERDO ALONSO M., IBORRA CUÉLLAR A. (2010) "Aprendiendo con la evaluación grupal: una propuesta sistémica de evaluación para procesos colaborativos de enseñanza-aprendizaje." Innovar en la universidad. Experiencias docentes. Editorial Biblioteca nueva S.L.., pp. 193-211

SANCHÉZ P. (2014) "Evaluación individual de resultados producidos por grupos: diferentes estrategias y lecciones aprendidas." en Actas de las XX JENUI. Oviedo. Pp. 41-48

(2015) El trabajo en equipo aumenta la motivación y disminuye el estrés. https://www.20minutos.es/noticia/2489660/0/trabajo-equipo/aumenta-

motivacion/disminuye-estres/,. 15-6-2015. Ref Type: Online Source

(2018) Polimedia de la práctica 1 de la asignatura Instrumentación y Control Industrial. Máster Universitario en Ingeniería Insdustrial. Universitat Politècnica de València.

https://media.upv.es/player/?id=8e34bf10-54fd-11e7-9e16-d7ba9128c149 https://media.upv.es/player/?id=932fc550-54fd-11e7-9e16-d7ba9128c149

(2018) Polimedia de la práctica 2 de la asignatura Instrumentación y Control Industrial. Máster Universitario en Ingeniería Insdustrial. Universitat Politècnica de València. https://media.upv.es/player/?id=07fd8d80-c930-11e7-9e66-91e2d42f60e2 https://media.upv.es/player/?id=15f8a780-c930-11e7-9e66-91e2d42f60e2 


\section{ANEXO I. Encuesta sobre el test de práctica del Curso 17-18}

1.- ¿Valoraría positivamente que la calificación de las actividades grupales (prácticas, trabajos académicos) se realizara a nivel individual?
A-Totalmente de acuerdo
B- Más bien de acuerdo
C- Más bien en desacuerdo
$D$ - Totalmente en desacuerdo

2.- Teniendo en cuenta la duración de la práctica, su naturaleza y el número de alumnos matriculados en cada grupo, ¿qué método de evaluación cree que es el más apropiado para la evaluación individualizada de las prácticas?
A- Examen oral
B- Cuestiones cortas de respuesta abierta
C- Examen de tipo test
D. Memoria individual

3.- ¿Considera que la selección de la herramienta poliforma-T para la realización del examen de tipo test de prácticas ha sido adecuada?
A-Totalmente de acuerdo
B- Más bien de acuerdo
C- Más bien en desacuerdo
$D$ - Totalmente en desacuerdo

4.- ¿Cree que los materiales docentes disponibles (memorias y vídeos explicativos) le han servido de ayuda para preparar, realizar y entender la práctica?
A-Totalmente de acuerdo
B- Más bien de acuerdo
C- Más bien en desacuerdo
$D$ - Totalmente en desacuerdo

5.- Respecto al número de preguntas del test utilizado para valorar los conocimientos adquiridos en las prácticas (actual: 4 preguntas/práctica), considera que:
A- Es apropiado
$B$ - Sobran preguntas
C- Faltan preguntas
D- Indiferente

6.- Respecto al nivel de dificultad de las preguntas del test, considera que es:
A- Apropiado
B- Fácil
C- Difícil
D- Indiferente

7.- Respecto al tiempo para contestar el test de 4 preguntas (actual: 8 min/práctica), considera que:
A- Es apropiado
B- Sobra tiempo
C- Falta tiempo
D- Indiferente 


\title{
El audiovisual Tutankamon como herramienta para la evaluación de la competencia transversal de pensamiento crítico y responsabilidad ética, medioambiental y profesional. Una experiencia en la Universitat Politècnica de València
}

\begin{abstract}
Francisca Ramón Fernández ${ }^{a}$, Vicente Cabedo Mallol ${ }^{b}$, María Emilia Casar Furióc, Vicent Giménez Chornet ${ }^{\mathrm{d}}$, Cristina Lull Noguera ${ }^{\mathrm{e}}$, Juan Vicente Oltra Gutiérrez ${ }^{\mathrm{f}}$ y Enrique Orduña-Malea ${ }^{\mathrm{g}}$

aProfesora titular. Departamento de Urbanismo, Universitat Politècnica de València, frarafer@urb.upv.es, ${ }^{b}$ Profesor contratado doctor, acreditado a titular. Departamento de Urbanismo, Universitat Politècnica de València, vicamal@urb.upv.es, 'Profesora contratada doctora, acreditada a titular. Departamento de Urbanismo, Universitat Politècnica de València, macafu@urb.upv.es, ${ }^{\mathrm{d}}$ Profesor titular. Departamento de Comunicación Audiovisual, Documentación e Historia del Arte, Universitat Politècnica de València, vigicho@har.upv.es ${ }^{\mathrm{e}}$ Profesora contratada doctora, Departamento de Química, Universitat Politècnica de València, clull@upvnet.upv.es, ${ }^{\mathrm{f}}$ Profesor titular de Escuela Universitaria. Departamento de Organización de Empresas, Universitat Politècnica de València, jvoltra@omp.upv.es, ${ }^{\mathrm{g}}$ Profesor Ayudante Doctor. Departamento de Comunicación Audiovisual, Documentación e Historia del Arte, enorma@upv.es
\end{abstract}

\begin{abstract}
This work presents the results obtained from a new educational innovation activity applied to two Master Degrees offered at the Universitat Politècnica de València, which consisted in using one same audio-visual (Tutankamon) to evaluate - on the student side - whether students could observe two different transversal skill qualifications: a) critical thinking, and b) ethical, environmental and professional responsibility. The conclusions we have come to is that both transversal skill qualifications have been perceived by students after the episode viewing, although with differences according to the skill and Master Degree. Additionally, a high rate of acceptance of the audiovisual in the classroom has been obtained.
\end{abstract}

Keywords:

Transversal skills, critical thinking, ethical, environmental and professional responsibility, audiovisual, evaluation, Tutankamon, Master degree

\section{Resumen}

Se presentan los resultados obtenidos de una nueva actividad de innovación docente que se ha aplicado a dos titulaciones de Máster impartidas en la Universitat Politècnica de València, consistente en utilizar un mismo audiovisual, Tutankamon, para evaluar si los estudiantes eran capaces de observar dos competencias transversales distintas: pensamiento crítico y 
responsabilidad ética, medioambiental y profesional. Las conclusiones a las que hemos llegado nos muestran que las dos competencias transversales han podido ser percibidas tras el visionado del episodio, aunque con diferencias en función de la competencia y el Master. Adicionalmente, se constata un alto índice de aceptación del audiovisual en el aula.

Palabras clave: Competencias transversales, pensamiento crítico, responsabilidad ética, medioambiental y profesional, evaluación, Tutankamon, nivel Máster

\section{Introducción}

La concesión de distintos Proyectos de Innovación y Mejora Educativa (PIME) al grupo de innovación RETAJUDOCA (Recursos tecnológicos para el aprendizaje jurídico, la documentación y la comunicación audiovisual) de la Universitat Politècnica de València, en los que se aplicaron distintos elementos audiovisuales (series de animación, ficción y documentales) para la creación de un repositorio de casos prácticos y poderlos así utilizar para evaluar las competencias transversales (principalmente "pensamiento crítico" y "responsabilidad ética, medioambiental y profesional"), han supuesto la posibilidad de realizar una nueva actividad de innovación docente pionera precisamente por considerar que la utilización del audiovisual puede resultar interesante y útil para el alumnado, superando de este modo el método tradicional del caso práctico.

Por ese motivo, se va a exponer en este trabajo una nueva experiencia desarrollada durante el presente curso académico (2017-2018), que ha consistido en utilizar el audiovisual Tutankamon en dos titulaciones diferentes (Master de Gestión Cultural y Máster en Conservación y restauración de bienes culturales), con el propósito de evaluar dos competencias transversales distintas.

\section{Objetivos}

Se ha pretendido utilizar un audiovisual de ficción, en este caso un episodio de Tutankamon para poder evaluar dos competencias: CT-07 Responsabilidad ética, medioambiental y profesional y CT-09 Pensamiento crítico, en dos asignaturas diferentes ("Marco jurídico aplicado a la protección del patrimonio y a los museos" y "Legislación del Patrimonio Cultural y creación de pequeñas empresas", de forma que podamos contrastar los resultados en los alumnos, respecto a su comprensión de dichas competencias, y determinar si el audiovisual utilizado es adecuado para ello. (UPV, 2016, y Villa y Poblete, M., 2007).

Por tanto, se persiguen los siguientes objetivos principales:

a) Utilizar un audiovisual que soporta un caso práctico elaborado y publicado por los miembros del grupo de innovación docente RETAJUDOCA, dentro del marco de los PIMEs desarrollados por el grupo. Dicha publicación se ha utilizado en diversas asignaturas para evaluar los resultados a través de la resolución de un caso práctico basado en audiovisuales. En este caso, el material elegido ha sido Tutankamon (Cabedo, Casar, Giménez, Lull, Oltra y Ramón, 2017).

(cc) EY-NC-ND 2018, Universitat Politècnica de València 
b) Comparar los resultados en dos asignaturas diferentes y de titulaciones también distintas, con el fin de conocer el grado de comprensión de las dos competencias que son objeto de innovación docente por parte de los propios estudiantes.

c) Determinar si el alumnado responde positivamente a la utilización de audiovisuales para poder evaluar las competencias.

d) Establecer si el audiovisual utilizado sirve al alumnado para ayudarle a ver la aplicación de las competencias transversales.

\section{La utilización del audiovisual Tutankamon como herramienta para evaluar las competencias transversales en asignaturas punto de control}

\subsection{El pensamiento crítico. Breves apuntes}

El pensamiento crítico es parte del proceso para la resolución de problemas, enmarcado en un entorno de aprendizaje que requiere de alfabetización informacional (ALA, 2004). Algunas veces los términos "pensamiento crítico" y "conocimiento de la información” se usan conjuntamente sin una diferenciación clara (Bryan, 2014). Es importante que en el currículo del alumnado de educación superior se fomenten prácticas interdisciplinarias y creativas que ayuden a pensar acerca de las interacciones entre el hombre y el medio que le rodea, viéndolo desde una perspectiva de lograr un futuro más sostenible. Nuevos enfoques educativos servirán para facilitar un pensamiento interdisciplinario genuino, conducente al pensamiento crítico y la capacidad reflexiva (Howlett, 2016).

El pensamiento crítico o la reflexión crítica sugiere abrir esta acción para incorporar en el proceso cognitivo aspectos sociopolíticos, un cuestionamiento de los propios valores y suposiciones, con la finalidad de generar conocimiento desde un contexto más amplio. Por ello la reflexión crítica es relevante para la educación de adultos, y particularmente la educación superior. Como señala Brookfield (1995), un pensamiento crítico es el proceso mediante el cual los adultos cuestionan y luego reemplazan o replantean una suposición que, hasta ese momento, se ha aceptado acríticamente como la sabiduría del sentido común, así como el proceso a través del cual los adultos toman perspectivas alternativas sobre ideas, acciones, formas de razonamiento e ideologías previamente dadas por hechas. El pensamiento crítico y la práctica reflexiva han ganado en los últimos años cada vez más validez en el aprendizaje y en la educación superior, en lugar del trabajo de estudio en general, particularmente en los campos de desarrollo profesional, administrativo y, también, en el de la gestión en las organizaciones (Rigg, 2008).

Es difícil llegar a una conclusión precisa sobre qué competencias se requieren para ser un profesional emprendedor, y los estudios sobre este tema coinciden en que las competencias profesionales son a menudo psicológicas o sociales, más que habilidades específicas limitadas a la rama empresarial y, sin embargo, esto no suele constar en el currículo académico. Ello ha condicionado que la educación académica superior se centre profundamente en la transmisión del conocimiento académico ignorando ayudar a los estudiantes al crecimiento de carácter psicológico o sociológico (Taatila, 2010). Sánchez (2013) define las competencias como un conjunto de conocimientos, rasgos, actitudes y habilidades relacionadas que afectan a una parte del trabajo. Las universidades están 
cambiando el enfoque del currículo de sus alumnos, especialmente en aquellos que tienen una orientación empresarial, implementando estudios centrados en estas competencias empresariales, como la creatividad, la innovación, la autoeficiencia y la orientación hacia las acciones para ser más emprendedores (Gibson, 2018). En la actividad de la gestión cultural, tanto los profesionales como las empresas del ramo, deben abordar muchas acciones diferentes para alcanzar la eficiencia, desde el conocimiento de la normativa jurídica que le compete, pasando por la gestión de proyectos, el dominio del patrimonio cultural, la sociología del público o gestión económica y presupuestaria. Para Reinstein y Bayou (1997) la educación contable - imprescindible para la gestión económica y presupuestaria - debe proporcionar a los estudiantes el conjunto de habilidades requeridas que buscan los futuros empleadores, incluida la comunicación sólida, el análisis cuantitativo y las habilidades interpersonales e intelectuales.

En el entorno educativo se han utilizado series y películas de larga duración para ayudar tanto a desarrollar esta competencia como a que los estudiantes la perciban. La organización de estas actividases se encuentran relacionadas, muchas veces, con ciertas figuras cinematográficas, especialmente en el mundo de la arqueología y los museos. Narraciones tipo Hollywood donde los arqueólogos son individuos románticos y aventureros que presentan una visión distorsionada de los motivos del arqueólogo científico, al ponerlo al servicio de agencias gubernamentales ficticias o de personas muy ricas con la misión de salvar al mundo (Argyropoulos, 2014).

\subsection{La responsabilidad ética, medioambiental y profesional. Breves apuntes}

En el caso de esta competencia se trata de que el alumnado detecte elementos de acuerdo con lo que se considera como ética, buenas prácticas en el ámbito medioambiental y dentro de su profesión de futuro.

Por ese motivo, esta competencia queda fuertamente delimitada por la titulación analizada. Por ejemplo, en el caso del Máster en Conservación y Restauración de Bienes Culturales el propósito de la actividad era que el alumnado considerase que el futuro conservador o restaurador podía realizar sus actividades conforme a las prácticas adecuadas para no dañar una obra, no aplicar técnicas que implicaran una contaminación en el medio ambiente, así como que utilizara herramientas idóneas para lograr conservar y restaurar una obra de arte.

\section{Metodología: desarrollo de la innovación en el Máster de Gestión Cultural y en el Máster en Conservación y Restauración de Bienes Culturales de la Universitat Politècnica de València}

Vamos en este punto a exponer el desarrollo de la innovación que se ha llevado a cabo en dos titulaciones de la Universitat Politècnica de València.

A) En el Máster Universitario de Gestión Cultural. Se trata de un título interuniversitario entre la Universitat de València y la Universitat Politècnica de València. Se imparte la asignatura troncal "Marco jurídico aplicado a la protección del patrimonio y a los museos". La finalidad de esta asignatura es que el alumno adquiera conocimientos sobre la aplicación de un marco jurídico exigido a las administraciones públicas y a los ciudadanos en general,

(c) EY-NC-ND 2018, Universitat Politècnica de València

Congreso IN-RED (2018) 
para la protección del patrimonio cultural y la gestión de los museos. En cuanto a los contenidos se enseñan las principales normas jurídicas sobre protección del patrimonio histórico y cultural emitidas por la UNESCO, la Unión Europea, el estado español y la Comunidad Valenciana.

Entre las competencias básicas que se deben impulsar en la asignatura constan:

- Que los estudiantes sepan aplicar los conocimientos adquiridos y su capacidad de resolución de problemas en entornos nuevos o poco conocidos dentro de contextos más amplios (o multidisciplinares) relacionados con su área de estudio.

- Que los estudiantes sean capaces de integrar conocimientos y enfrentarse a la complejidad de formular juicios a partir de una información que, siendo incompleta o limitada, incluya reflexiones sobre las responsabilidades sociales y éticas vinculadas a la aplicación de sus conocimientos y juicios.

Además, esta asignatura tiene asignada como punto de control el desarrollo y evaluación de la competencia transversal "Pensamiento Crítico". Para trabajar dicha competencia transversal se realizaron dos actividades,

B) En el Master en Conservación y Restauración de Bienes Culturales. Se trata de un título impartido en la Universitat Politècnica de València. Dentro del mismo se imparte la asignatura de "Legislación del patrimonio cultural y creación de pequeñas empresas". Se estudian como contenidos principales la legislación de protección del patrimonio cultural tanto nacional como autonómico, así como los instrumentos normativos destinados al emprendedurismo.

Entre las competencias que se impulsan en esta asignatura, se encuentan:

-Trabajar y liderar equipos de forma efectiva para la consecución de objetivos comunes contribuyendo al desarrollo personal y profesional de los mismos en el ámbito de la Conservación y Restauración de Bienes Culturales.

-Capacidad para gestionar el patrimonio histórico-artístico, determinando las actuaciones necesarias para su conservación y disfrute.

En esta asignatura se trabaja la competencia de responsabilidad ética, medioambiental y profesional.

En ambos títulos para trabajar las competencias transversales indicadas (Pensamiento crítico y responsabilidad ética, medioambiental y profesional) se realizaron dos actividades una relacionada con el estudio y comentarios de un caso, y otra relacionada con un debate a partir de la visualización de un fragmento de una serie relacionada con el descubrimiento de un tesoro y su protección jurídica.

En lo que respecta a la actividad llevada a cabo, se trataba de utilizar el caso práctico basado en la serie de ficción núm. 12 del manual Casos Prácticos basados en series de ficción, referente a Tutankamon (Cabedo, Casar, Giménez, Lull, Oltra y Ramón, 2017). Esta serie trata sobre la temática del tesoro y la regulación del mismo, así como la gestión y su propiedad, en relación con el Código Civil, principalmente el artículo 352 que especifica 
que "se entiende por tesoro, para los efectos de la ley, el depósito oculto e ignorado de dinero, alhajas u otros objetos preciosos, cuya legítima pertenencia no conste.”.

En el minuto 14 del tercer episodio de dicha serie, Howard Carter comenta a la hija de Lord Carnarvon, Lady Evelyn, el sistema de reparto de beneficios del descubrimiento según los términos de la concesión: la mitad es para el estado egipcio y la otra mitad para Lord Carnarvon.

Tras el descubrimiento del tesoro en la antecámara funeraria el reto de Carter es la gestión y conservación de las piezas. Para ello solicita ayuda externa al Museo Metropolitano de Nueva York. Sin embargo, a los pocos días, las autoridades de El Cairo deciden cambiar la legislación de forma apresurada (hecho que les afectará, pues contempla el carácter retroactivo), por la cual, cualquier descubrimiento pertenece al estado de Egipto.

\section{Resultados obtenidos en el Máster de Gestión Cultural y en el Máster en Conservación y Restauración de Bienes Culturales respecto de las competencias analizadas}

Tras la revisión de la normativa jurídica actual que afecta a la protección del patrimonio en nuestro ordenamiento jurídico, se proyecta a los alumnos un fragmento del tercer capítulo de esta miniserie. Posteriormente se inicia un debate en el aula, donde los alumnos reflexionan sobre dos épocas completamente diferentes, dando sus opiniones sobre la legalidad o no de que los extranjeros se puedan apropiar de tesoros y patrimonio artístico de otros países económicamente desprotegidos, si las leyes pueden ser retroactivas, etc.

El debate sobre la miniserie sirvió para estimular la reflexión de los alumnos a partir del conocimiento del marco jurídico de protección al patrimonio, descubriendo que es habitual realizar reflexiones del pasado con esquemas de valores actuales, que pueden dificultar la comprensión de actividades y normas jurídicas enmarcadas en una sociedad diferente.

Concluida la actividad en el aula se pasó un breve test anónimo a los alumnos asistentes para valorar el grado de satisfacción y conocer opiniones sobre la actividad. Participaron trece alumnos. Las preguntas planteadas se debían de responder con una escala de valoración de 1 a 5, siendo el uno un total desacuerdo y el cinco un total acuerdo.

Las preguntas que se les formularon fueron las siguientes:

Primera pregunta: ¿Es interesante el empleo en el aula de elementos audiovisuales para debatir el problema de casos prácticos?

Segunda pregunta: ¿Habéis detectado elementos jurídicos en el vídeo?

Tercera pregunta: ¿La actividad realizada, visualización del vídeo más el debate en clase, os ha ayudado a comprender mejor los conocimientos de la asignatura?

Cuarta pregunta: ¿El vídeo os ha resultado útil para el desarrollo de la competencia transversal de "Pensamiento crítico"?

Quinta pregunta: ¿La actividad os ha supuesto un estímulo para valorar la importancia del marco jurídico en la protección del patrimonio cultural?

(cc) EY-NC-ND 2018, Universitat Politècnica de València

Congreso IN-RED (2018) 
Los resultados en el Máster de Gestión Cultural fueron los siguientes:

a) A la primera pregunta, un 69\% están totalmente de acuerdo y un 31 \% están de acuerdo, lo que indica que consideran positivo el empleo de audiovisuales en la docencia (Figura 1).

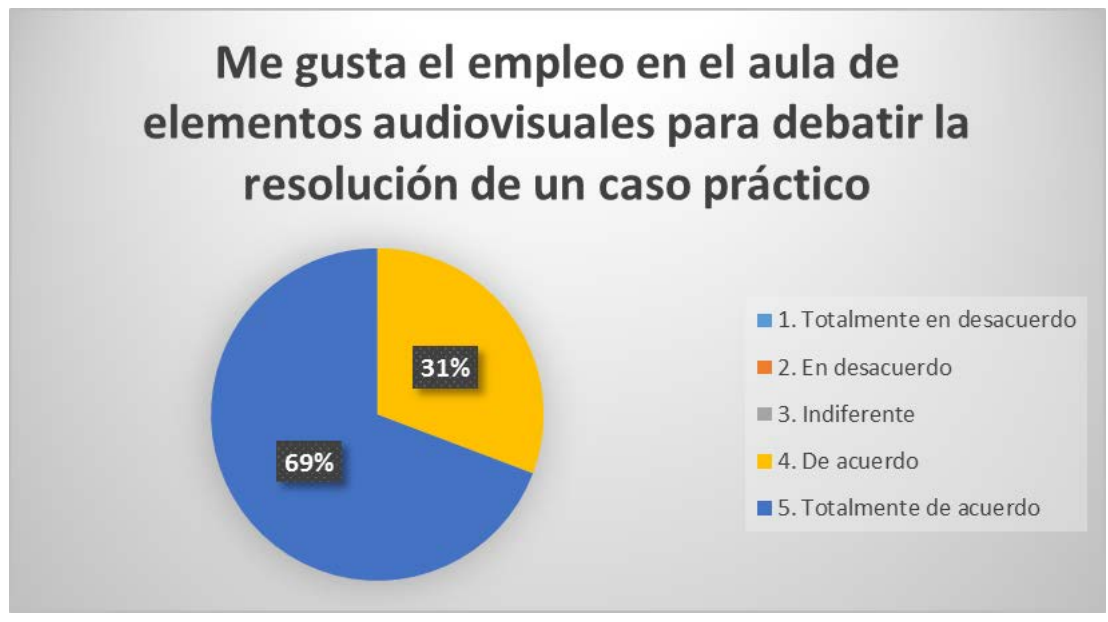

Fig. 1. Porcentaje respecto a la pregunta de "Me gusta el empleo en el aula de elementos audiovisuales para debater la resolución de un caso práctico. Fuente: elaboración propia.

b) A la segunda pregunta, un $16 \%$ no lo detectó, pero el $84 \%$ sí que ha valorado de alguna forma que en el vídeo se mencionaban elementos jurídicos (Figura 2). Se planteaba un cambio de la normaiva jurídica en Egipto a raíz del descubrimiento de la tumba de Tutankamón.

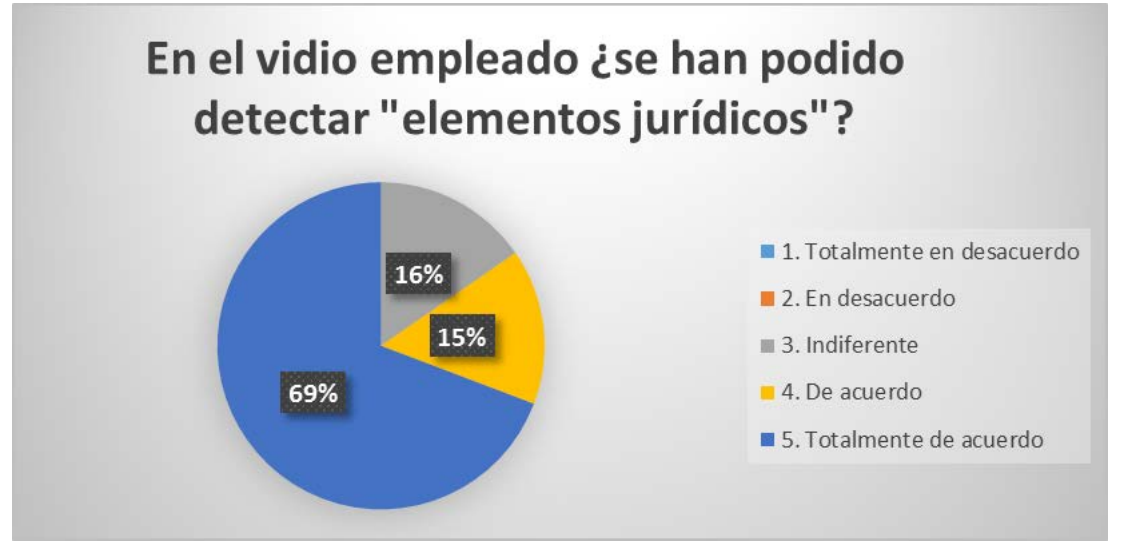

Fig. 2. Porcentaje respecto a la pregunta de "En el vídeo empleado ¿̇e han podido detectar «elementos jurídicos»”. Fuente: elaboración propia.

c) A la tercera pregunta, en general, un $85 \%$ lo considera positivo (Figura 3). 


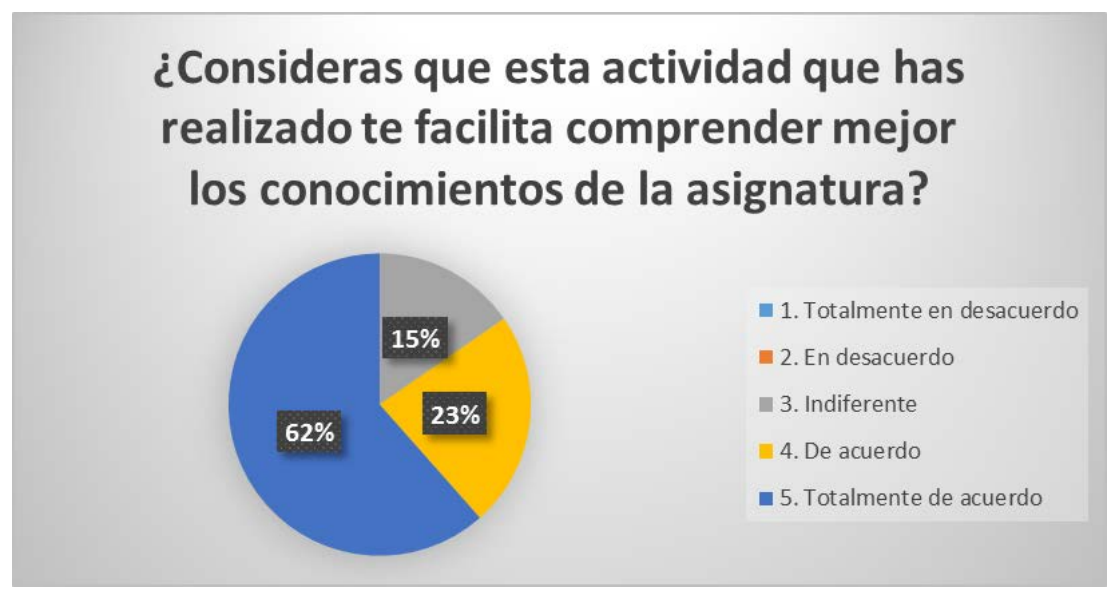

Fig. 3. Porcentaje respecto a la pregunta de “¿Consideras que esta actividad que has realizado te facilita comprender mejor los conocimientos de la asignatura?”. Fuente: elaboración propia.

d) A la cuarta pregunta, un 92\% mostró estár de acuerdo o totalmente de acuerdo, mientras que un $8 \%$ consideró indiferente la relación de este vídeo con el desarrollo de la competencia (Figura 4).

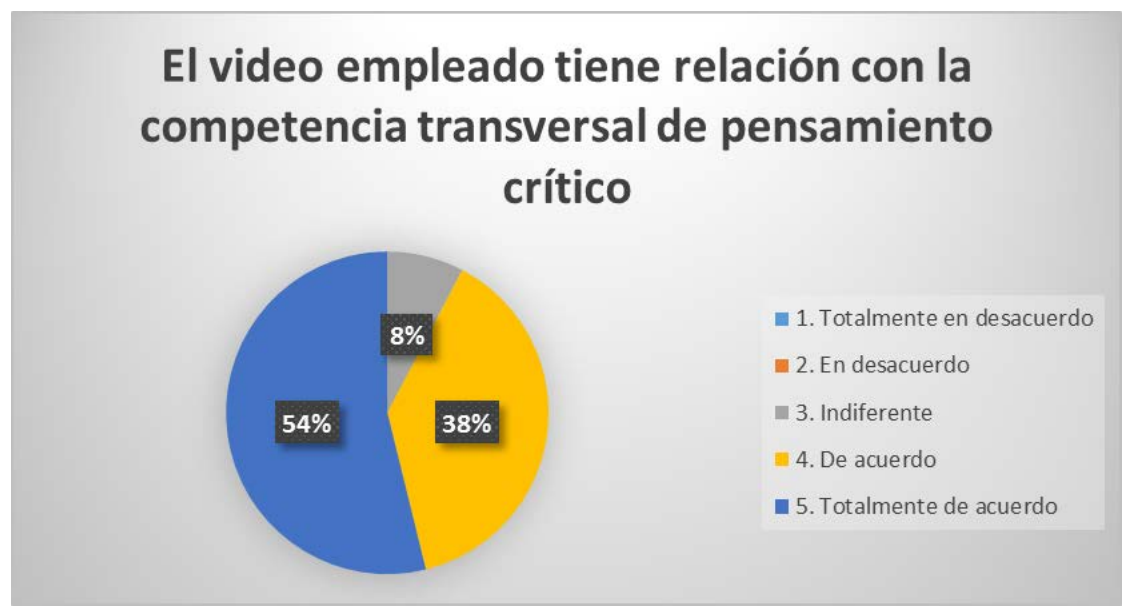

Fig. 4. Porcentaje respecto a la pregunta de "El video empleado tiene relación con la competencia transversal de pensamiento crítico”. Fuente: elaboración propia.

e) A la quinta pregunta, la totalidad de los alumnos estuvieron de acuerdo o muy de acuerdo (Figura 5). 


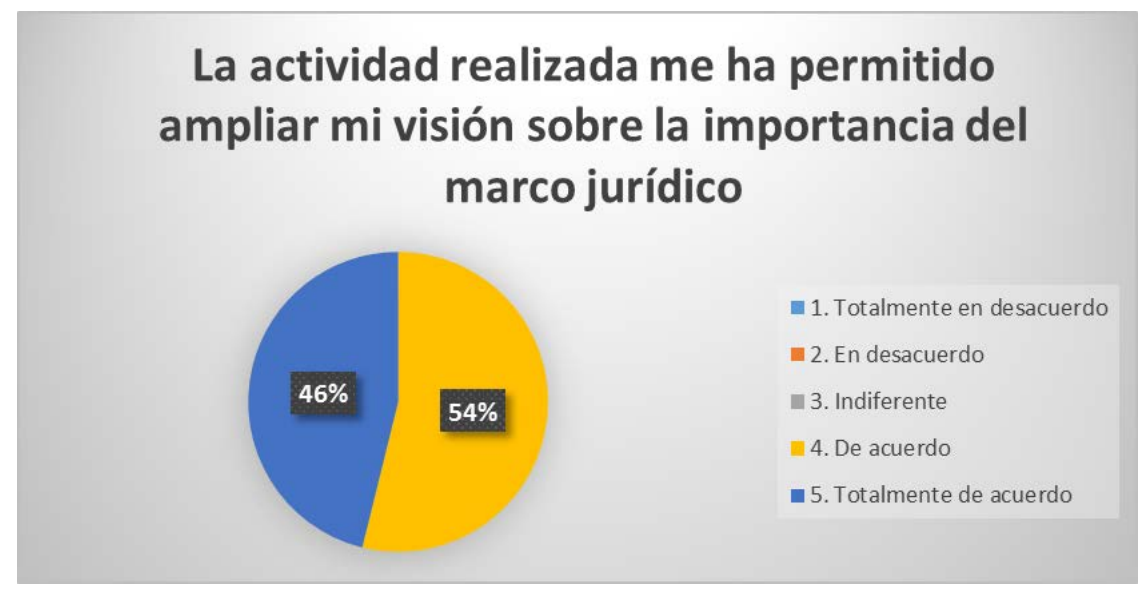

Fig. 5. Porcentaje respecto a la pregunta de "La actividad realizada me ha permitido ampliar mi visión sobre la importancia del marco jurídico”. Fuente: elaboración propia.

Por último, se les dejó a los alumnos una pregunta abierta para que diesen su opinión sobre cómo mejorar la actividad. Hubo algunas sugerencias, como poner audiovisuales de casos reales más recientes para detectar mejor las similitudes con la normativa jurídica actual; realizar grupos en el aula para posteriormente debatir en común, como forma de ampliar la participación a todos los alumnos (de lo contrario, unas cuantas personas tienen más protagonismo); algunos alumnos han coincidido en que les parece muy útil pero que ha faltado tiempo para debatir más en el aula, pudiéndose ampliar también a visualizar películas, videoclips, programas de televisión, etc.

Se formulo respecto al Máster en Conservación y Restauración de Bienes Culturales una única pregunta enfocada a detectar si el alumnado podía relacionar el episodio con la competencia transversal de responsabilidad ética, medio ambiental y profesional, y se le preguntó:

Pregunta única: ¿Puedes aplicar la competencia transversal de responsabilidad ética, medio ambiental y profesional en el episodio de Tutankamón?

Los resultados en el Máster en Conservación y Restauración de Bienes Culturales fueron los siguientes:

Se pasó la encuesta a un total de 30 alumnos de los que contestaron el 76.7\% (23 personas).

A la pregunta sobre si aplicarían la competencia transversal de responsabilidad ética, medio ambiental y profesional en el episodio de Tuankamón, un total de 11 contestaron afirmativamente que podrían aplicar la competencia transversal en la actividad que habían realizado, mientras que los 12 restantes indicaron, por el contrario, que no la podían aplicar. Tal y como se puede apreciar en la Figura 6, el porcentaje obtenido refleja una polaridad: prácticamente la mitad de los alumnos consideraba que sí podía aplicarse y la otra mitad que no. 


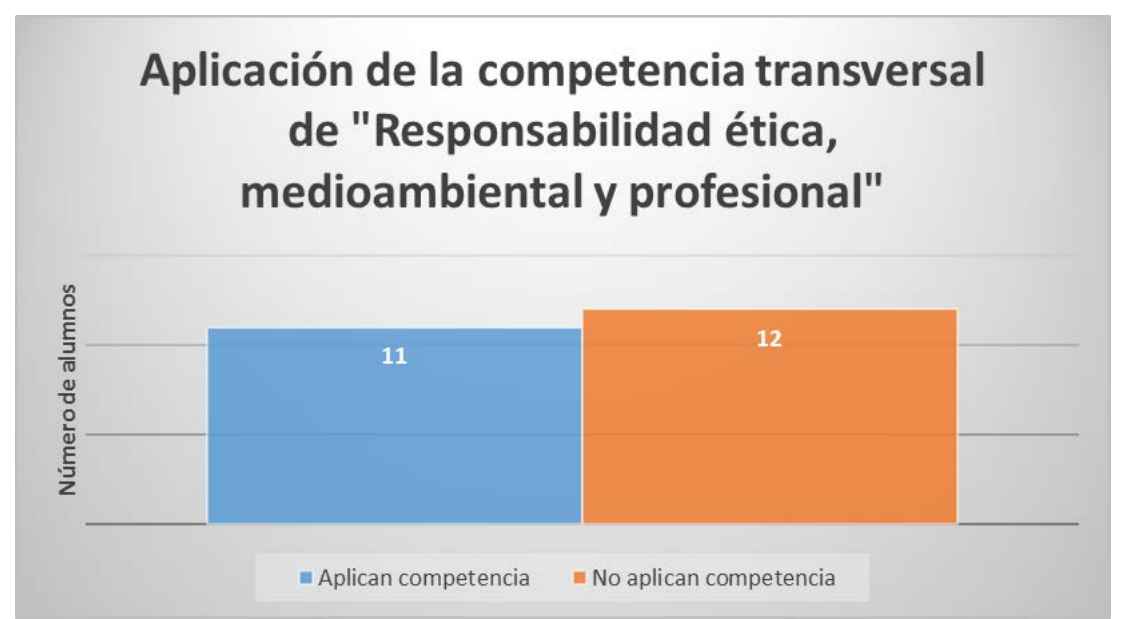

Fig. 6. Número de alumnos que consideraban que se podía aplicar la competencia transversal de "Responsabilidad ética, medioambiental y profesional" en el audiovisual Tutankamon. Fuente: elaboración propia

\section{Conclusiones}

La competencia transversal de "Pensamiento Crítico" se puede desarrollar en el aula como forma de aprendizaje en el proceso cognitivo. La actividad de visualizar un fragmento de una serie y un posterior debate permite que los alumnos participen activamente dando sus opiniones con el fundamento de los contenidos aprendidos en clase, y con sus conocimientos socioculturales actuales. La valoración por parte de los alumnos ha sido muy positiva, y les ha permitido ampliar la visión de la importancia del marco jurídico en la gestión del patrimonio cultural.

Respecto a la competencia transversal de responsabilidad ética, medioambiental y profesional, hemos observado que está muy equilibrado el número de alumnos que detectaba la competencia en el caso del audiovisual Tutankamon y los que consideraban que no se aplicaba.

Hemos podido constatar que las preguntas abiertas resultan más completas y aportan más información que las de tipo test o cerradas, aunque el inconveniente es precisamente el número de alumnos, siendo más viable en los grupos pequeños las preguntas abiertas y para los grupos más amplios las abiertas o explicativas, por distintas razones, entre ellas, la corrección de las actividades para poderlas evaluar.

También denota la influencia el alumnado respecto a su posibilidad de eplicar la percepción del episodio, que favorece a los que tienen más aptitudes de redacción, que las preguntas cerradas, que precisan de una mayor atención por parte del discente.

Concluimos que la utilización de un episodio audivisual, en este caso, de la serie de Tutankamón nos ha permitido evaluar dos diferentes competencias transversales que pretendíamos detectaran el alumnado, de tal forma que ello nos permite considerar que la experiencia de la utilización de casos prácticos basados en series es adecuado como método evaluatorio de distintas competencias. Y que aunque sea utilizado el mismo caso por 
diferentes docentes y en títulos distintos, los resultados nos aproximan a la pretensión de la utilización de este medio para permitir valorar el grado de aprendizaje de la competencia objeto de estudio.

\section{Agradecimientos}

Trabajo realizado en el marco del Proyecto I+D Excelencia del Ministerio de Economía y Competitividad (DER2015-65810-P), 2016-2018; Proyecto "Derecho civil valenciano y europeo" del Programa Prometeo para Grupos de Investigación de Excelencia de la Conselleria de Educación, Cultura y Deporte, GVPROMETEOII2015-014 y Proyecto de Innovación y Mejora Educativa (PIMEs) "La utilización de los documentales como herramienta para la evaluación de la competencia transversal CT07 Responsabilidad ética, medioambiental y profesional”, en la convocatoria llevada a cabo en la Universitat Politècnica para el curso 2017-2018, Vicerrectorado de Estudios y Convergencia Europea de la Universitat Politècnica de València. Investigadora principal: Francisca Ramón Fernández. Investigadores: Vicente Cabedo Mallol, María Emilia Casar Furió, Vicent Giménez Chornet, Cristina Lull Noguera y Juan Vicente Oltra Gutiérrez.

\section{Referencias}

ALA (AMERICAN LiBrary Association) (2004). Information Literacy Competency Standards for Higher Education .

$<\underline{\text { http://www.ala.org/Template.cfm?Section=Home\&template=\%2FContentManagement\%2 }}$ FContentDisplay.cfm\&ContentID=33553> [Consulta: 20 de febrero de 2018].

ARgYropoulos, V. et al. (2014). "Museum Education and Archaeological Ethics: An Approach to the Illicit Trade of Antiquities" en Journal of Conservation and Museum Studies, 12(1), p. 2.

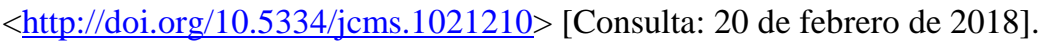

BROOKFIELD, S. (1995). “Adult learning: An overview” en International encyclopedia of education, vol. 10, p. 375-380.

$<\underline{\text { http://citeseerx.ist.psu.edu/viewdoc/download?doi=10.1.1.152.4176\&rep=rep1\&type=pdf }}$ $>$ [Consulta: 19 de febrero de 2018].

BRYAN, J. E. (2014) "Critical thinking, information literacy and quality enhancement plans” en Reference Services Review, vol. 42, issue: 3, p. 388-402.

$<$ https://doi.org/10.1108/RSR-01-2014-0001> [Consulta: 20 de febrero de 2018].

CABEDO MALLOL, V., CASAR FURIÓ, M. E., GIMÉNEZ CHORNET, V., LULL NOGUERA, C., OLTRA GUTIÉRREZ, J. V. y RAMÓN FERNÁNDEZ, F. (2017). Casos prácticos jurídicos basados en series de ficción. Francisca Ramón Fernández (coord.). Valencia: Tirant lo Blanch.

GiBSON, D., TAVLARIDIS, V. (2018) "Work-based learning for enterprise education? The case of Liverpool John Moores University "live" civic engagement projects for

(c) ) EY-NC-ND 2018, Universitat Politècnica de València 
students" en Higher Education, Skills and Work-Based Learning, vol. 8, issue 1, p.5-14.

<https://doi.org/10.1108/HESWBL-12-2017-0100> [Consulta: 21 de febrero de 2018].

HOWLETT, C.; FERREIRA, J. A.; BlOMFIELD, J. (2016) “Teaching sustainable development in higher education: Building critical, reflective thinkers through an interdisciplinary approach” en International Journal of Sustainability in Higher Education, vol. 17, issue 3, p. 305-321.

$<$ https://doi.org/10.1108/IJSHE-07-2014-0102> [Consulta: 21 de febrero de 2018].

KOVACSICS, v. (2015). The good wife: de cordero a lobo, en cinco temporadas. Caimán cuadernos de cine, núm. 35, pág. 13.

REINSTEIN, A.; BAYOU, M. E. (1997) "Critical thinking in accounting education: processes, skills and applications" en Managerial Auditing Journal, vol. 12, issue 7, p.336342.

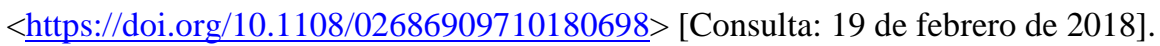

RIGG, C.; TREHAN, K.. (2008) "Critical reflection in the workplace: is it just too difficult?" en Journal of European Industrial Training, vol. 32, issue 5, p.374-384.

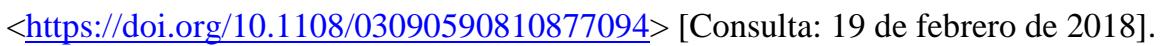

SÁNCHEZ, J. C. (2013). "El impacto de un programa de educación empresarial en las competencias e intenciones empresariales" en Journal of Small Business Management, 51 (3), 447-465.

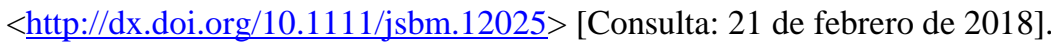

TAATILA, V. P. (2010) "Learning entrepreneurship in higher education" en Education + Training, vol. 52, issue 1, p.48-61.

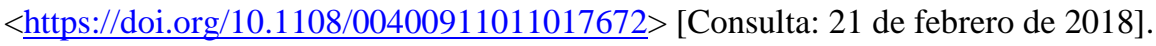

UPV. (2016). Papel de las rúbricas en la evaluación de las competencias transversales UPV.

Disponible en: <http://www.upv.es/entidades/ICE/info/U0702453.pdf> [Consulta: 25 de febrero de 2018].

VILLA, A. Y POBLETE, M. (2007). Aprendizaje basado en competencias. Una propuesta para la evaluación de las competencias genéricas. Bilbao: Ediciones Mensajero.

(cc) EY-NC-ND 2018, Universitat Politècnica de València

Congreso IN-RED (2018) 


\title{
Propuesta de evaluación alfanumérica de la competencia transversal “CT-05. Diseño y Proyecto" integrada en la evaluación la asignatura Ingeniería Fluidomecánica, asociada al PIME B24
}

Modesto Pérez-Sánchez ${ }^{\mathrm{a}}$, José Vinaches Ramis ${ }^{\mathrm{a}}$, J. Ricardo Satorre Aznar, P. Amparo López-Jiménez ${ }^{\mathrm{a}}$

a Departamento de Ingeniería Hidráulica y Medio Ambiente. Universitat Politècnica de València. mopesan1@upv.es, jvinache@upvnet.upv.es, josaaz@dihma.upv.es, palopez@upv.es;

\begin{abstract}
The introduction of active methodologies inside of the teaching is contributing to analyze the learning as a continue formative procedure of the student, neglecting the master classes partially where the lack of motivation by the student can suppose a obstacule to reach the learning results of the students. The current research describes the introduction of active methodologies in different years in the subject, called "Fluid Mechanics Engineering" that is teaching in the Escuela Politècnica Superior of Alcoi. The contribution specially shows the alphanumeric evaluation of a transversal competence, called "Design and Project". This competence is currently in the evaluation exercises of the subject.
\end{abstract}

Keywords: CT-05 Design adn Project; Fluid Mechanics Engineering; Autonomus Learning; Rubbric.

\begin{abstract}
Resumen
La introducción de metodologías activas dentro de la enseñanza está contribuyendo a ver el aprendizaje como un proceso formativo continuo del alumno, abandonando parciamente las clases magistrales tradicionales donde la falta de motivación por parte del alumno podía suponer un obstáculo al alcance de los resultados de aprendizaje de los estudiantes. En la presente comunicación se describe la introducción de metodologías activas a lo largo de diferentes cursos académicos en la asignatura de Ingeniería Fluidomecánica en la Escuela Politécnica Superior de Alcoy, haciendo especial hincapié en la evaluación alfanumérica de la competencia transversal Diseño y Proyecto como parte de los actos de evaluación de la asignatura.
\end{abstract}

Palabras clave: CT-05 Diseño y Proyecto; Ingeniería Fluidomecánica; Aprendizaje permanente; Rúbrica; 


\section{Introducción}

Desde la Educación Primaria hasta la Educación Superior, es cada vez más común poner en práctica procesos de enseñanza-aprendizaje basados en la experimentación práctica en el aula. En estos modelos, el maestro es el responsable de guiar al alumno para que pueda alcanzar su nivel máximo de desarrollo potencial aprovechando las habilidades y las aptitudes de cada niño (Wood, 1976, SPM, 2008). Este progreso académico permite reducir el número de clases magistrales para comprender las materias contenidas.

En ocasiones, los métodos tradicionales pueden ser poco motivadores para los estudiantes cuando el tema desarrollado presenta un alto grado de formalismo en algunas explicaciones. Durante la clase magistral, los estudiantes tienen que esforzarse más para memorizar la información, la cual es parcialmente olvidada posteriormente (Morales, 2004). Además, estas metodologías fomentan el trabajo individual, con el consiguiente perjuicio de no trabajar la competencia de trabajo en equipo. Para evitar la falta de motivación en los estudiantes y promoverla, los estudios universitarios pueden enfocarse como una etapa de la vida donde las adquisiciones de conocimiento son necesarias para conseguir un trabajo. Por lo tanto, es necesario buscar nuevos enfoques educativos, tales como el "Aprendizaje basado en problemas" (PBL) el cual busca conseguir que los estudiantes adquieran las habilidades suficientes para poder manejar cualquiera de las situaciones complejas que pueden enfrentarse en su etapa profesional (Benavides, 2009).

Relacionado con esa capacidad de aprendizaje, Edgar Dale (1969) sugirió un modelo sobre la efectividad de los métodos de aprendizaje, realizando una comparación sobre la capacidad de retener información de una participación activa y pasiva de los estudiantes y relacionándola con la adquisición de información, así como su influencia al generalizar los aprendizajes. Esta comparación fue presentada a través de un cono de aprendizaje (Edgar, 1969; Master, 2013) que muestra la capacidad del alumno para retener (Figura 1).

(cc) EY-NC-ND 2018, Universitat Politècnica de València 


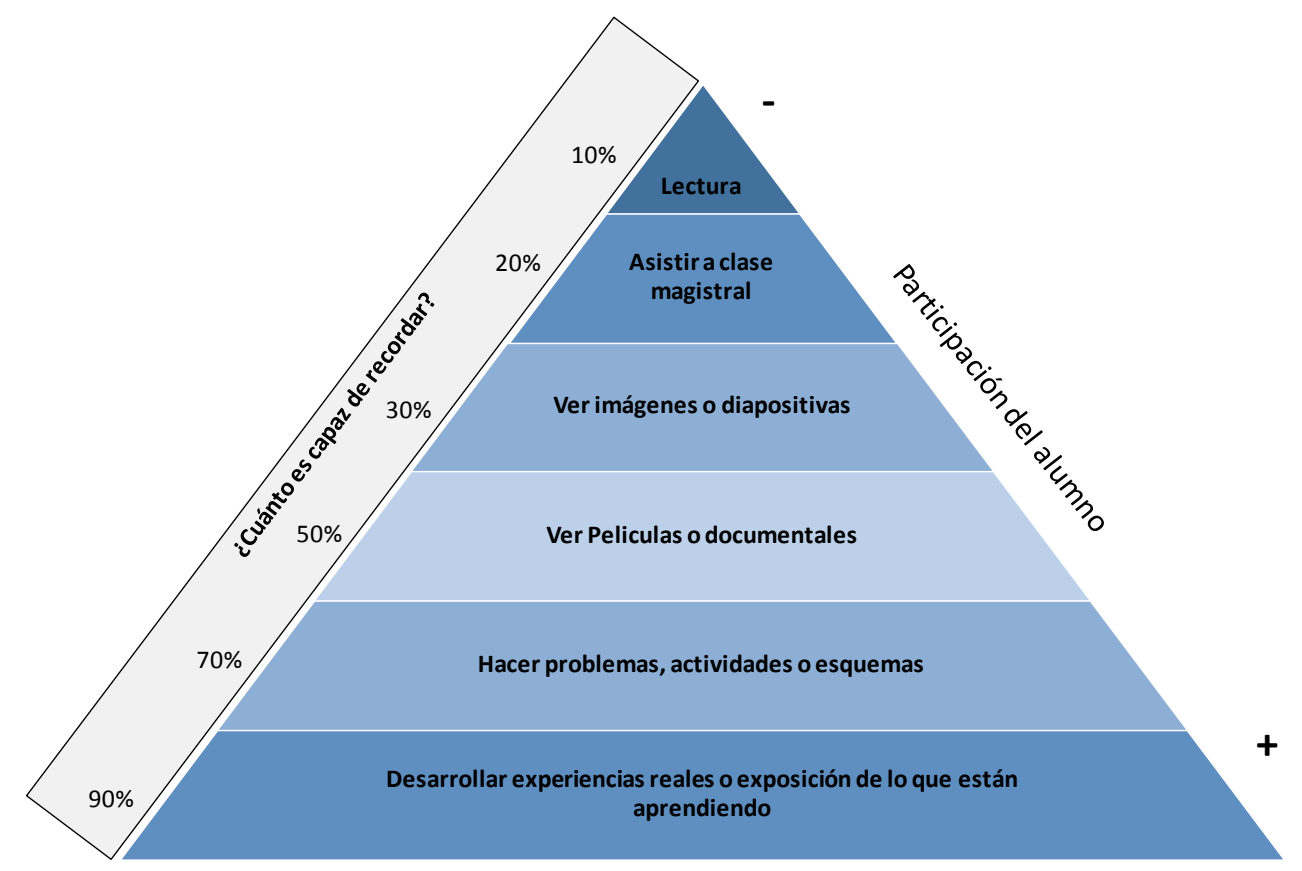

Fig 1. Metodologías vs Participación del alumno

La Figura 1 muestra el aprendizaje retenido en un alumno como función de las herramientas de enseñanza (por ejemplo, clase magistral, películas, discusión). La interacción y participación del estudiante durante el aprendizaje es crucial para promover la actitud del alumno (activo o pasivo) (Rámirez-Echeverry, 2016). Normalmente, si el estudiante solo recibe información a través de clases magistrales, clases magistrales y / o presentaciones, tiene una actitud más pasiva y el conocimiento retenido es menor (10-30\% del total de conceptos enseñados; pirámide en la Figura 1). Considerando que, si el estudiante participa en metodologías activas donde se integra en el aprendizaje (por ejemplo, resolución de problemas, experimentación, discusión), el conocimiento retenido aumenta (50-90\% del total de conceptos enseñados según la metodología educativa; parte inferior de la pirámide) en la Figura 1). La razón de esto es que PBL hace que el alumno sea responsable y una parte activa en todo su proceso de aprendizaje. En estas metodologías activas, el profesor es visto como un facilitador del proceso de enseñanza-aprendizaje, que da al alumno la oportunidad de aprender a aprender y desarrollar sus habilidades cognitivas y habilidades de cooperación como miembro de un equipo.

\section{Objetivos}

El objetivo de la presente comunicación es, por un lado, mostrar la evolución relativa a la propuesta de evaluación llevada a cabo en la asignatura Ingeniería Fluidomecánica (Iti. 2) de tercer curso del Grado de Ingeniería Mecánica de la Escuela Politécnica Superior de Alcoy por docentes del Departamento de Ingeniería Hidráulica y Medio Ambiente. Por otro 
lado, mostrar la evaluación alfanumérica relativa a la competencia transversal "Diseño y Proyecto” La asignatura de Ingeniería Fluidomecánica es troncal, se imparte en tercer curso de cuatrimestre $\mathrm{B}$, tiene una carga docente de 6 créditos y una extensión no presencial estimada de $90 \mathrm{~h}$. La asignatura se imparte una vez el alumno ha cursado los dos primeros cursos de grado, donde ha integrado dentro de su conocimiento los conceptos fundamentales de asignaturas básicas ingenieriles como son matemáticas, física, resistencia de materiales y mecánica de fluidos, entre otras. En esta situación, el alumno está cerca de escoger la mención de Grado, por lo que su visión ingenieril comienza a estar "sesgada" por los gustos o vocación del alumno. Este hecho, es importante, ya que hace que la asignatura tenga que ser atractiva ya que puede existir un gran número de alumnos que no estén interesados a priori por la asignatura ya que no la ven relacionada con la mención que consideran escoger (Diseño e Ingeniería de Vehículos, Diseño y Cálculo Materiales Poliméricos y Compuestos; Diseño y Fabricación Máquinas y Prototipos, Ingeniería de Proyectos). Aunque las máquinas hidráulicas esta presenta en todas ellas, solo los alumnos que tienen claro que cursaran la mención de Ingeniería de Proyectos ven utilidad en la asignatura, por lo que la motivación por parte del personal docente que interviene en esta materia es crucial.

Por lo tanto, desde el departamento, así como desde los docentes implicados, el hecho de cursar Ingeniería Fluidomecánica, debe conseguir alcanzar los resultado de aprendizaje establecidos en las competencias generales y específicas del título, mediante el desarrollo de estrategias que integren las competencias transversales que trabaje o sea punto de control (evalue) en Dominio II. Estas estrategias estarán diseñadas de forma que:

1. No suponga una carga de trabajo extra por los alumnos

2. Motive al alumno a llevar al día la asignatura y, por tanto, la evaluación continua cobre importancia y realismo. Esta evaluación debe ayudar al alumno a sentirse apoyado durante las $168 \mathrm{~h}$ (presencial y no presencial) de trabajo que recoge la guía docente.

3. El alumno vea la aplicabilidad de la asignatura en cualquier campo que esté presente, ya sea una bomba de engranajes recirculación de aceite de un motor, una turbina a instalar en un pequeño azud o diseño de un rodete específico para bombear un fluido con características especiales en una industria.

4. Permitan evaluar la competencia transversal que la asignatura es punto de control. Este curso 2016/2017 fue en Análisis y Resolución de Problemas, Diseño y Proyecto, Responsabilidad Social, Ética y Medio Ambiental, así como Aprendizaje Permanente.

Dentro de la presente comunicación, se centrara en la propuesta metodológica y resultados alcanzados en el curso 2016/2017 en la asignatura, teniendo en cuenta la competencia transversal Diseño y Proyecto. Del mismo modo, se presenta el desarrollo para este curso 2017/2018 de una rúbrica alfanumérica que permita la evaluación de la competencia tanto con números como con letras.

El desarrollo de esta rúbrica se encuentra dentro del Proyecto de Innovación y Mejora Docente (PIME) "Desarrollo de Metodologías de Evaluación y Diseño de Rúbricas de la Competencia Transversal (CT) 05 Diseño y Proyecto aplicado al campo de la Ingeniería

(cc) EY-NC-ND 2018, Universitat Politècnica de València 
Hidráulica (Fase II), el cual se encuentra integrado el Equipo de Innovación y Calidad Educativa (EICE) denominado Desarrollo de Metodologías Activas de evaluación aplicadas al campo de la Ingeniería Hidráulica (DESMAHIA).

\section{Desarrollo de la innovación docente}

\section{Evolución de la planificación de la asignatura relativa a la innovación docente}

La innovación docente llevada a cabo en la asignatura esta implantándose parcialmente por etapas desde el curso 2014/2015, donde se detectaron carencias motivacionales por parte del alumno, en el cual, el $65 \%$ no vea utilidad práctica a la asignatura, un $28 \%$ la consideraba útil y sólo un 7\% consideraba que la asignatura era muy útil para su formación. Este hecho, unido a la falta de demanda de TFGs por parte de los alumnos, síntoma que mostraba la falta de motivación por parte de los alumnos hacia esta asignatura.

Por ello, se estableció una implantación de metodologías activas que ayudaran a fomentar el trabajo autónomo del alumno, las cuales se han ido integrando poco a poco dentro de la asignatura que conllevará su finalización para el curso 2019/2020. La implantación de las metodologías vinieron acompañadas por el desarrollo del Plan Estratégico de la Universitat Politècnica de València (UPV), por lo que la implantación de la evaluación de las competencias transversales ha ido de forma paralela. De forma breve, el desarrollo temporal de las diferentes metodologías ha sido:

- $\quad$ Curso 2015/2016. Introducción de un proyecto de dimensionado relacionado con los contenidos teóricos impartidos, dónde el alumno pudiera relacionar la teoría con aplicaciones prácticas de la realidad. Este trabajo académico, donde el estudiante recibe los conceptos teóricos y uso de software mediante clase presencial, es desarrollado de forma no presencial y tiene un peso específico del $20 \%$ en la evaluación de la asignatura.

- $\quad$ Curso 2016/2017. Considerando el Plan Estratégico UPV, donde la asignatura es punto de control en nivel de dominio II de las competencias CT-03 'Análisis y Resolución de Problemas”, CT-07 'Responsabilidad Social, Ética y Medio Ambiental' y CT-11 'Aprendizaje Permanente', se plantea la estrategia de propuesta de tareas por revisión por pares, la cual fue descrita en Pérez-Sánchez et al., (2017b) para la evaluación de la CT-03. La incorporación de esta estrategia, supuso el incremento en la tasa de rendimiento de la asignatura, el incremento de las tutorías lo que indicaba que los alumnos llevaban una asimilación de los conceptos progresiva y continua a medida que se impartía la docencia. Al mismo tiempo se introdujeron actividades a través de PoliformaT y presenciales donde se llevaba a cabo el empleo de conceptos técnicos aplicados de la asignatura al campo aplicado de la responsabilidad social, ética y medioambiental, utilizando el debate como una de las herramientas de evaluación (Pérez-Sánchez y LópezJiménez, 2017a). Integrada en el PIME "Desarrollo de Metodologías de Evaluación y Diseño de Rúbricas de la CT-05 Diseño y Proyecto aplicado al 
campo de la Ingeniería Hidráulica”, donde el trabajo académico (proyecto) se integra para el trabajo y evaluación de la competencia transversal.

- $\quad$ Curso 2017/2018. La asignatura mantiene las todas las estrategias de aprendizaje integradas en el curso anterior, intensificando el uso de las tareas revisadas por pares e integrando la competencia transversal CT-05 dentro de la evaluación de la asignatura al evaluar numéricamente los descriptores de cada uno de los indicadores. El tratamiento de los descriptores de forma numérica y alfabética, es fruto de las reuniones mantenidas con responsables de seguimiento de la Comisión de Evaluación y Seguimiento de Proyectos de Innovación y Mejora Educativa CESPIME e Instituto de Ciencias de la Educación (ICE) del PIME actual en progreso. Durante este curso, al igual que el anterior se introduce el Proyecto Docencia en Red, donde se desarrollan un total de 23 Polimedias específicos que pueden ser usados en esta asignatura.

- $\quad$ Curso 2018/2019. Para el siguiente curso, desde el personal docente que imparte la asignatura, se optará por la integración de las tareas dentro de la evaluación de la asignatura, eliminando actos de evaluación presenciales (tradicionales exámenes y/o parciales) y sustituyéndolos parcialmente por evaluación de las tareas.

\section{Metodología desarrollada para la competencia Diseño y Proyecto en la asignatura Ingeniería Fluidomecánica}

La planificación llevada a cabo por parte del profesorado que lleva a cabo el desarrollo de la asignatura, está compuesta por 5 fases diferentes (Figura 2), las cuales se encuentran integradas dentro del PIME y son semejantes a todas ellas.

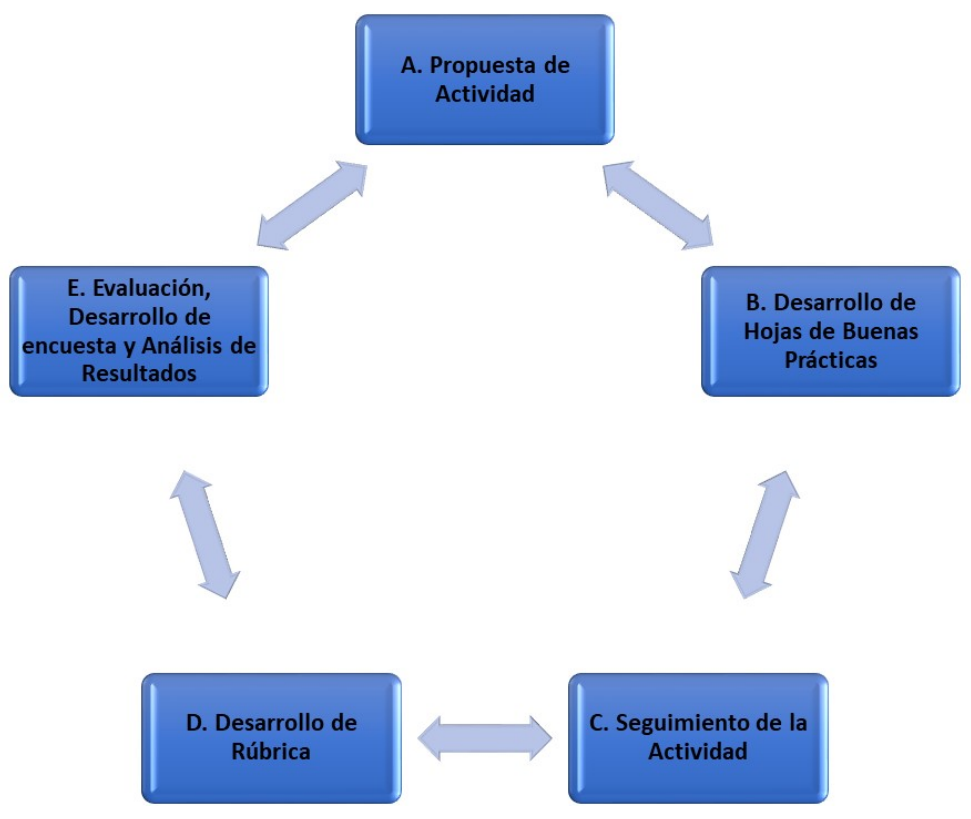

Fig 2. Planificación de la Actividad propuesta en Ingeniería Fluidomecánica

(cc) EY-NC-ND 2018, Universitat Politècnica de València

Congreso IN-RED (2018) 
A. Propuesta justificada de actividad, considerando en este caso concreto de la asignatura Ingeniería Fluidomecánica, está relacionado con la selección de bombas aplicadas a sistemas de distribución.

B. Desarrollo de la hoja de buenas prácticas de cada una de las actividades a desarrollar. Esta hoja de buenas prácticas incluye la totalidad de las actividades involucradas dentro de la asignatura. En cada actividad, se definen los resultados de aprendizaje en dicha actividad, así como para la competencia en concreto. Se elabora la estrategia de evaluación, estableciendo tipo de evaluación, peso, instrumento de evaluación, así como profesores que llevan a cabo la evaluación. En el caso concreto de la asignatura de Ingeniería Fluidomecánica, las competencias CT-03 y CT-07 utilizan rúbricas de evaluación las cuales fueron desarrolladas (Pérez-Sánchez y López-Jiménez, 2017a; Pérez-Sánchez et al., 2017b)

C. Seguimiento de la actividad. En este caso, los docentes involucrados contribuyen a dar apoyo al estudiante tanto en las fases presenciales como no presenciales. Es en este punto donde las tutorías y Polimedias, cobran una gran importancia.

D. Desarrollo de rúbrica. Se desarrolla una rúbrica "ad-hoc" para esta asignatura, la cual contempla los diferentes indicadores para evaluar el nivel de dominio II. La publicación de esta rúbrica, así como la asignación de pesos numéricos al valor alcanzado por los descriptores, constituye el enfoque principal de la presente comunicación.

E. Evaluación de proyecto, desarrollo de sondeo y análisis de resultados obtenidos. Esta última fase, es crucial ya que contempla no solo la evaluación del alumno, sino que sirve de retroalimentación para la programación de las actividades y estrategias de aprendizaje a implantar en el siguiente curso. Por tanto, un análisis correcto de los resultados, así como de la opinión del alumnado, permite una retroalimentación para la mejora de las estrategias de aprendizaje de la asignatura.

\section{Resultados}

La asignatura de Ingeniería Fluidomecánica oscila entre 130 y 140 alumnos desde el curso 2015/2016 (134 alumnos en el curso 2016/2017 y 137 alumnos en el curso 2017/2018). Los alumnos se encuentra en tercer curso en semestre B y su edad oscila a su vez entre los 21 y 27 años generalmente, aunque hay casos que esta edad es superada por alumnos que acceden de módulos de formación profesional o simplemente porque han accedido más tarde a la Universidad. Por tanto, se tiene un grupo heterogéneo de alumnos con diferentes orígenes de acceso y con inquietudes distintas, así como puntos de vista, lo que da pie a una pluralidad que enriquece el debate en las cuestiones planteadas tanto por alumnos como profesor en el aula. El curso se divide en dos grupos de teoría de 68 alumnos aproximadamente y tres de prácticas repartidos en grupos de 35-42 alumnos.

\section{Resultados de aprendizaje propuestos}

El planteamiento de la actividad tiene por objeto los siguientes resultados de aprendizaje:

1) Definir la infraestructura de regulación (depósito) a partir de los condicionante de demanda, tarifa eléctrica y sistema de distribución. 
2) Determinar la curva de consigna en situaciones de bombeo directo a depósito o bombeo inyectado a la red.

3) Seleccionar las máquinas hidráulicas necesarias en número y características hidráulicas.

4) Analizar el coste energético de la explotación del sistema de acuerdo a los equipos seleccionados, tarifa y caudales demandados.

5) Introducir al alumno el uso de software específico de simulación, concretamente EPANET.

\section{Rúbrica empleada incluyendo pesos numéricos}

En la presente sección, se describe la rúbrica empleada (Tablas 1 y 2) para llevar a cabo la evaluación de la competencia transversal "Diseño y Proyecto”.

La evaluación de la actividad contiene 6 indicadores diferentes (Tablas 1 y 2), los cuales son indicados por parte del grupo de expertos de competencias transversales desde el Instituto de Ciencias de la Educación. Dentro de cada uno de estos indicadores, se han definido 13 indicadores específicos que permiten la evaluación tanto de la competencia como la calificación del proyecto.

Como novedad, la rúbrica introduce la consideración de notas numéricas a cada uno de los descriptores, así como la distribución de pesos ponderados en función de su relación con la evaluación de las competencias específicas de la asignatura. Estas ponderaciones son descritas posteriormente.

Tabla 1. Rúbrica propuesta para la asignatura Ingeniería Fluidomecánica curso 2016/2017

\begin{tabular}{|c|c|c|c|c|}
\hline \multirow{2}{*}{ INDICADORES } & \multicolumn{4}{|c|}{ DESCRIPTORES } \\
\cline { 2 - 5 } & D. No alcanzado & C. En desarrollo & B. Bien /adecuado & A. Excelente/ejemplar \\
\hline $\begin{array}{c}\text { 1.Fundamenta el } \\
\text { contexto y la } \\
\text { necesidad del } \\
\text { proyecto }\end{array}$ & $\begin{array}{c}\text { Alude a la } \\
\text { necesidad del } \\
\text { proyecto, pero no } \\
\text { la argumenta }\end{array}$ & $\begin{array}{c}\text { Justifica la necesidad } \\
\text { del proyecto en base a } \\
\text { opiniones y juicios } \\
\text { escasamente } \\
\text { contrastados y } \\
\text { fundamentados }\end{array}$ & $\begin{array}{c}\text { Fundamenta el contexto } \\
\text { y necesidad del proyecto } \\
\text { correctamente de forma } \\
\text { correcta pero no } \\
\text { completa }\end{array}$ & $\begin{array}{c}\text { Fundamenta el contexto y } \\
\text { necesidad del proyecto } \\
\text { correcta y completamente }\end{array}$ \\
$\begin{array}{c}\text { Introducción, } \\
\text { objetivos y } \\
\text { justificación }\end{array}$ & $\begin{array}{c}\text { No existe el } \\
\text { primer punto } \\
\text { a realizar, pero no } \\
\text { justifica su necesidad } \\
\text { (o lo hace atendiendo } \\
\text { a criterios } \\
\text { equivocados })\end{array}$ & $\begin{array}{c}\text { Introduce el proyecto, } \\
\text { define objetivos, pero la } \\
\text { justificación no atiende a } \\
\text { necesidades concretas }\end{array}$ & $\begin{array}{c}\text { Introduce el proyecto, define } \\
\text { claramente los objetivos y lo } \\
\text { justifica aludiendo a } \\
\text { necesidades concretas. }\end{array}$ \\
\hline $\begin{array}{c}2 . \text { Formula los } \\
\text { objetivos del } \\
\text { proyecto con } \\
\text { coherencia } \\
\text { respecto a las } \\
\text { necesidades } \\
\text { detectadas en el }\end{array}$ & $\begin{array}{c}\text { Formula objetivos } \\
\text { sin aludir a } \\
\text { necesidades }\end{array}$ & $\begin{array}{c}\text { Formula objetivos no } \\
\text { coherentes con las } \\
\text { necesidades }\end{array}$ & $\begin{array}{c}\text { Formula objetivos } \\
\text { coherentes con las } \\
\text { necesidades }\end{array}$ & $\begin{array}{c}\text { Formula objetivos coherentes } \\
\text { con las necesidades y, } \\
\text { además, son adecuados y } \\
\text { originales para la } \\
\text { transformación de la } \\
\text { situación actual atendiendo } \\
\text { las necesidades detectadas }\end{array}$ \\
\hline
\end{tabular}

(cc) EY-NC-ND 2018, Universitat Politècnica de València

Congreso IN-RED (2018) 


\begin{tabular}{|c|c|c|c|c|}
\hline contexto & & & & \\
\hline $\begin{array}{l}\text { Introducción, } \\
\text { objetivos y } \\
\text { justificación } \\
\end{array}$ & $\begin{array}{l}\text { No existe el } \\
\text { primer punto }\end{array}$ & $\begin{array}{l}\text { Establece objetivos, } \\
\text { pero son ambiguos o } \\
\text { imprecisos }\end{array}$ & $\begin{array}{l}\text { Establece objetivos de } \\
\quad \text { forma suficiente }\end{array}$ & $\begin{array}{c}\text { Establece objetivos claros y } \\
\text { operativos }\end{array}$ \\
\hline $\begin{array}{l}\text { 3. Planifica las } \\
\text { acciones con } \\
\text { eficacia (logra } \\
\text { objetivos) }\end{array}$ & $\begin{array}{l}\text { Planifica acciones } \\
\text { no eficaces (no } \\
\text { logra gran parte } \\
\text { de los objetivos) }\end{array}$ & $\begin{array}{l}\text { Planifica acciones } \\
\text { parcialmente eficaces } \\
\text { (logra parte de los } \\
\text { objetivos) }\end{array}$ & $\begin{array}{l}\text { Planifica acciones } \\
\text { eficaces en su gran } \\
\text { mayoría (logra gran parte } \\
\text { de los objetivos) }\end{array}$ & $\begin{array}{c}\text { Planifica acciones } \\
\text { completamente eficaces } \\
\text { (todos los objetivos han sido } \\
\text { cumplidos) }\end{array}$ \\
\hline $\begin{array}{l}\text { Para cada uno de } \\
\text { los puntos }\end{array}$ & $\begin{array}{l}\text { No existe ningún } \\
\text { tipo de } \\
\text { introducción del } \\
\text { punto a } \\
\text { desarrollar }\end{array}$ & $\begin{array}{l}\text { Hace una breve } \\
\text { descripción de lo } \\
\text { contiene el punto }\end{array}$ & $\begin{array}{c}\text { Describe y justifica el } \\
\text { punto a desarrollar, pero } \\
\text { desde una perspectiva } \\
\text { académica }\end{array}$ & $\begin{array}{c}\text { Describe y justifica la } \\
\text { necesidad del punto a } \\
\text { desarrollar desde un punto } \\
\text { de vista técnico }\end{array}$ \\
\hline $\begin{array}{l}\text { 4. Planifica las } \\
\text { acciones con } \\
\text { eficiencia (usa los } \\
\text { recursos de forma } \\
\text { óptima) } \\
\end{array}$ & $\begin{array}{l}\text { No planifica } \\
\text { acciones } \\
\text { eficientes }\end{array}$ & $\begin{array}{l}\text { Planifica acciones } \\
\text { eficientes, aunque } \\
\text { visiblemente } \\
\text { mejorables }\end{array}$ & $\begin{array}{c}\text { Planifica acciones } \\
\text { eficientes, pero no todas }\end{array}$ & $\begin{array}{l}\text { Planifica de forma completa } \\
\text { acciones eficientes }\end{array}$ \\
\hline $\begin{array}{l}\text { Curva de } \\
\text { consigna }\end{array}$ & $\begin{array}{l}\text { No se realiza el } \\
\text { cálculo }\end{array}$ & $\begin{array}{l}\text { Se realiza, pero es } \\
\quad \text { incorrecto }\end{array}$ & $\begin{array}{l}\text { El resultado es correcto, } \\
\text { pero no realiza una } \\
\text { discusión del mismo }\end{array}$ & $\begin{array}{l}\text { El resultado es correcto y el } \\
\text { alumno desarrolla un } \\
\text { análisis de los resultados. }\end{array}$ \\
\hline $\begin{array}{l}\text { Definición del } \\
\text { volumen del } \\
\text { depósito }\end{array}$ & $\begin{array}{l}\text { No se realiza el } \\
\quad \text { cálculo }\end{array}$ & $\begin{array}{l}\text { Se realiza, pero es } \\
\quad \text { incorrecto }\end{array}$ & $\begin{array}{l}\text { El resultado es correcto, } \\
\text { pero no realiza una } \\
\text { discusión del mismo }\end{array}$ & $\begin{array}{l}\text { El resultado es correcto y el } \\
\text { alumno desarrolla un } \\
\text { análisis de los resultados. }\end{array}$ \\
\hline $\begin{array}{l}\text { Selección de las } \\
\text { bombas }\end{array}$ & $\begin{array}{l}\text { No se realiza la } \\
\text { selección }\end{array}$ & $\begin{array}{l}\text { Se realiza, pero es } \\
\quad \text { incorrecta }\end{array}$ & $\begin{array}{l}\text { El resultado es correcto, } \\
\text { pero no realiza una } \\
\text { discusión del mismo }\end{array}$ & $\begin{array}{l}\text { El resultado es correcto y el } \\
\text { alumno desarrolla un } \\
\text { análisis de los resultados } \\
\text { proponiendo otros modelos o } \\
\text { soluciones }\end{array}$ \\
\hline $\begin{array}{c}\text { Selección de las } \\
\text { bombas en directo } \\
\text { a velocidad fija } \\
\text { (BVF). }\end{array}$ & $\begin{array}{l}\text { La selección de } \\
\text { las bombas en } \\
\text { directo no está } \\
\text { calculada en base } \\
\text { a la nueva curva } \\
\text { de consigna }\end{array}$ & $\begin{array}{l}\text { Se realiza, pero es } \\
\quad \text { incorrecta }\end{array}$ & $\begin{array}{l}\text { La selección llevada a } \\
\text { cabo es correcta pero no } \\
\text { está justificada }\end{array}$ & $\begin{array}{l}\text { La selección llevada a cabo } \\
\text { es correcta y el alumno lleva } \\
\text { a cabo la justificación de la } \\
\text { misma, desarrollando } \\
\text { comparaciones con otras } \\
\text { posibles soluciones }\end{array}$ \\
\hline
\end{tabular}

Tabla 2. Rúbrica propuesta para la asignatura Ingeniería Fluidomecánica curso 2016/2017

\begin{tabular}{|c|c|c|c|c|}
\hline \multirow{2}{*}{ INDICADORES } & \multicolumn{4}{|c|}{ DESCRIPTORES } \\
\hline & D. No alcanzado & C. En desarrollo & B. Bien /adecuado & A. Excelente/ejemplar \\
\hline $\begin{array}{c}\text { Análisis } \\
\text { económico (BVF) }\end{array}$ & $\begin{array}{c}\text { El alumno no } \\
\text { desarrolla el } \\
\text { análisis } \\
\text { económico de } \\
\text { explotación diario }\end{array}$ & $\begin{array}{l}\text { Desarrolla el análisis, } \\
\text { pero es incorrecto }\end{array}$ & $\begin{array}{l}\text { Desarrolla el análisis, es } \\
\text { correcto, pero no lo } \\
\text { justifica. }\end{array}$ & $\begin{array}{l}\text { Lleva a cabo una descripción } \\
\text { pormenorizada del análisis } \\
\text { económico, desarrollando } \\
\text { indicadores y comparando } \\
\text { con otras instalaciones }\end{array}$ \\
\hline $\begin{array}{c}\text { Selección de las } \\
\text { bombas en directo } \\
\text { a velocidad } \\
\text { variable }(B V V)\end{array}$ & $\begin{array}{c}\text { La selección de } \\
\text { las bombas en } \\
\text { directo no está } \\
\text { calculada en base } \\
\text { a la nueva curva } \\
\text { de consigna, } \\
\text { trabajando a }\end{array}$ & $\begin{array}{l}\text { Se realiza, pero es } \\
\text { incorrecta }\end{array}$ & $\begin{array}{c}\text { La selección llevada a } \\
\text { cabo es correcta pero no } \\
\text { está justificada }\end{array}$ & $\begin{array}{c}\text { La selección llevada a cabo } \\
\text { es correcta y el alumno lleva } \\
\text { a cabo la justificación de la } \\
\text { misma, desarrollando } \\
\text { comparaciones con otras } \\
\text { posibles soluciones }\end{array}$ \\
\hline
\end{tabular}

(c) EY-NC-ND 2018, Universitat Politècnica de València 


\begin{tabular}{|c|c|c|c|c|}
\hline & velocidad variable & & & \\
\hline $\begin{array}{c}\text { Análisis } \\
\text { económico }(B V V)\end{array}$ & $\begin{array}{c}\text { El alumno no } \\
\text { desarrolla el } \\
\text { análisis } \\
\text { económico de } \\
\text { explotación diario }\end{array}$ & $\begin{array}{l}\text { Desarrolla el análisis, } \\
\text { pero es incorrecto }\end{array}$ & $\begin{array}{l}\text { Desarrolla el análisis, es } \\
\text { correcto, pero no lo } \\
\text { justifica. }\end{array}$ & $\begin{array}{l}\text { Lleva a cabo una descripción } \\
\text { pormenorizada del análisis } \\
\text { económico, desarrollando } \\
\text { indicadores y comparando } \\
\text { con otras instalaciones }\end{array}$ \\
\hline $\begin{array}{l}\text { 5. Identifica } \\
\text { posibles riesgos } \\
\text { inherentes al } \\
\text { proyecto }\end{array}$ & $\begin{array}{l}\text { Identifica algunos } \\
\text { riesgos, pero sin } \\
\text { analizarlos. }\end{array}$ & $\begin{array}{l}\text { Identifica vagamente } \\
\text { los riesgos que pueden } \\
\text { afectar a su proyecto }\end{array}$ & $\begin{array}{l}\text { Identifica los riesgos que } \\
\text { pueden afectar a su } \\
\text { proyecto sin enfoque } \\
\text { realista o sin establecer } \\
\text { medidas para } \\
\text { subsanarlos }\end{array}$ & $\begin{array}{c}\text { Identifica, analiza y } \\
\text { cuantifica los riesgos de } \\
\text { forma realista. Los prevé } \\
\text { acertadamente y establece } \\
\text { medidas para subsanarlos }\end{array}$ \\
\hline Conclusión & $\begin{array}{l}\text { No existe } \\
\text { conclusión }\end{array}$ & $\begin{array}{l}\text { La conclusión aparece } \\
\text { únicamente como } \\
\text { último punto del } \\
\text { proyecto, sin análisis } \\
\text { ni crítica de los } \\
\text { resultados } \\
\end{array}$ & $\begin{array}{c}\text { Se analizan los } \\
\text { diferentes resultados y se } \\
\text { comparan métodos }\end{array}$ & $\begin{array}{l}\text { Se analizan los resultados, } \\
\text { comparando ambos métodos } \\
\text { e identificando ventajas e } \\
\text { inconvenientes de cada uno } \\
\text { de ellos }\end{array}$ \\
\hline $\begin{array}{l}\text { Lenguaje, formato } \\
\text { y redacción del } \\
\text { proyecto }\end{array}$ & $\begin{array}{c}\text { La presentación } \\
\text { es deficiente, la } \\
\text { redacción y el } \\
\text { lenguaje } \\
\text { utilizados no se } \\
\text { corresponden con } \\
\text { el nivel académico } \\
\text { esperado } \\
\end{array}$ & $\begin{array}{l}\text { La presentación } \\
\text { es correcta, } \\
\text { aunque } \\
\text { mejorable, el } \\
\text { lenguaje y la } \\
\text { redacción no } \\
\text { son técnicos }\end{array}$ & $\begin{array}{l}\text { La presentación, el } \\
\text { lenguaje y la redacción } \\
\text { son correctas. El } \\
\text { contenido excede o no se } \\
\text { ajusta a lo requerido }\end{array}$ & $\begin{array}{l}\text { La presentación, el lenguaje } \\
\text { y la redacción son correctas. } \\
\text { El contenido se ajusta } \\
\text { perfectamente a lo requerido } \\
\text { para explicar cada uno de los } \\
\text { puntos }\end{array}$ \\
\hline $\begin{array}{l}\text { 6. Revisa los } \\
\text { resultados } \\
\text { previstos }\end{array}$ & $\begin{array}{l}\text { No se plantea la } \\
\text { evaluación de los } \\
\text { resultados }\end{array}$ & $\begin{array}{c}\text { Se plantea que es } \\
\text { necesaria la evaluación } \\
\text { de resultados sin } \\
\text { planificar como } \\
\text { llevarla a cabo }\end{array}$ & $\begin{array}{l}\text { Planifica } \\
\text { sistemáticamente quién, } \\
\text { cuándo y cómo se } \\
\text { evaluarán los resultados }\end{array}$ & $\begin{array}{l}\text { Planifica sistemáticamente } \\
\text { quién, cuándo y cómo } \\
\text { evaluar los resultados } \\
\text { mediante indicadores } \\
\text { contrastados }\end{array}$ \\
\hline $\begin{array}{l}\text { Revisa los } \\
\text { resultados de la } \\
\text { instalación } \\
\text { propuesta } \\
\text { mediante } \\
\text { simulación en } \\
\text { EPANET }\end{array}$ & $\begin{array}{l}\text { No realiza la } \\
\text { evaluación de los } \\
\text { resultados }\end{array}$ & $\begin{array}{l}\text { Comprueba los } \\
\text { resultados, pero no los } \\
\text { analiza }\end{array}$ & $\begin{array}{l}\text { Evalúa los resultados, } \\
\text { desarrolla una } \\
\text { metodología de } \\
\text { comprobación, pero no } \\
\text { desarrolla } \\
\text { comparaciones }\end{array}$ & $\begin{array}{c}\text { Evalúa los resultados, } \\
\text { desarrolla una metodología } \\
\text { de comprobación y compara } \\
\text { con resultados entre } \\
\text { compañeros u otras } \\
\text { instalaciones o indicadores } \\
\text { existentes en la bibliografía }\end{array}$ \\
\hline
\end{tabular}

Todos los indicadores pueden presentar cuatro descriptores diferentes (No alcanzado [D], En Desarrollo [C], Adecuado [B] o Excelente [A]). Consecuente a estos descriptores, se propone una matriz de pesos y ponderaciones, considerando que el valor numérico de la nota debe de discernir en el descriptor $\mathrm{D}$, diferenciando si el alumno no lo ha realizado o si la ha realizado, pero no ha alcanzado el indicador específico. En el caso de que el alumno no lo haya desarrollado, el valor numérico es 0 , mientras si no es alcanzado el valor es 3 . El descriptor "En desarrollo, C", va ligado a un valor numérico de 5. Si el descriptor es Bien o Adecuado, la nota asignada es 7 , mientras se asigna una nota de 10 para el descriptor Excelente. Con el hecho de introducir la evaluación de las competencias específicas, a cada uno de los indicadores se les da un peso ponderado, repartidos de la siguiente forma: 
1.Fundamenta el contexto y la necesidad del proyecto; se asigna un peso del 5\%, a consecuencia que en este nivel de desarrolla, el estudiante no es capaz de interrelacionar todos los aspectos que pueden conllevar a la decisión a llevar la actuación. Este indicador contiene un solo indicador especifico.

2. Formula los objetivos del proyecto con coherencia respecto a las necesidades detectadas en el contexto; se asigna un peso del $7.5 \%$. Consecuencia de que los objetivos del proyecto son expuestos parcialmente en el enunciado, y por lo tanto, el alumno únicamente debe localizarlos y relacionarlos con la teoría impartida, para poder llevar a cabo correctamente los indicadores propuestos en el grupo 3. Solamente contiene un indicador específico.

3. Planifica las acciones con eficacia (logra objetivos); se asigna un peso del $20 \%$ ya que el alumno tiene que introducir y proponer la metodología de resolución de la actividad propuesta. Este indicador contiene un solo indicador específico.

4. Planifica las acciones con eficiencia (usa los recursos de forma óptima); se asigna un peso del $50 \%$, como consecuencia que recoge los principales indicadores específicos que están relacionados con las competencias específicas de la asignatura. Contiene 7 indicadores específicos.

5. Identifica posibles riesgos inherentes al proyecto; se considera un peso del 7.5\% como consecuencia de que el alumno debe considerar los aspectos negativos o positivos relacionados con criterios medioambientales. Este indicador contempla 2 indicadores específicos.

6.Revisa los resultados previstos; se asigna un valor del $10 \%$ ya que el alumno debe revisar, analizar y ser crítico con los resultados obtenidos, en busca de posibles resultados incoherentes, fruto del uso de software que puede llevar a incluir datos erróneos dentro de su análisis. Solamente contiene un indicador específico.

Así la expresión que determina la nota numérica de la competencia transversal y de la específica, viene definida por la siguiente expresión (1):

$$
\text { Nota }=0.05 I_{1}+0.075 I_{2}+0.20 I_{3}+0.50 \frac{\sum_{I=1}^{I=7} I_{4}}{7}+0.075 I_{5}+0.10 I_{6}
$$

Con esta expresión se permite obtener un valor numérico a partir del uso de descriptores, $\mathrm{Si}$ la nota final se encuentra entre 0 y 4.5, el resultado de aprendizaje es "No Alcanzado, D". Si el valor se encuentra entre 4.5 y 6, el indicador alcanza el resultado "En desarrollo, C". Adecuado o Bien (B) se da para notas mayores de 6 y menores de 8. Finalmente, el resultado de aprendizaje "Excelente, A" es asignado para notas mayores de 8 y 10.

\section{Participación en el curso 2016/2017}

De los 134 alumnos matriculados, 100 alumnos desarrollaron el trabajo académico propuesto. De estos 100 alumnos, 74 de ellos, alcanzaron un nivel de adquisición de la competencia superior o igual a nivel B. La correlación numérica propuesta para este curso 2017/2018 fue aplicada a este curso 2016/17. Los resultados alcanzados en la competencia 
transversal Diseño y Proyecto, los cuales muestra que de los alumnos que finalmente desarrollaron el proyecto (100), 74 alumnos alcanzaron un nivel igual o superior a B, lo que demuestra que la conjugación entre trabajo presencial y no presencial, acompañado de una tutorización en paralelo, puede contribuir a alcanzar resultados satisfactorios. Si los trabajos del año anterior, se extrapolaran a la rúbrica propuesta para este año, la nota media obtenida sería 7.76 y solamente los alumnos que no presentaron el trabajo tuvieron una nota inferior 4.5. La nota promedio para el descriptor "En Desarrollo" sería 5.22, mientras que la nota media para el nivel “Adecuado" y "Excelente” sería 7.28 y 9.12 respectivamente.

Relativos a la satisfacción del alumnado, el desarrollo de sondeos internos específicos del desarrollo de la actividad en 2016/2017 establecieron que el 62\% consideraba que el desarrollo de la actividad contribuía a la adquisición de los resultados de aprendizaje propuestos en la asignatura. El 74\% consideraba que la actividad permitía la aplicabilidad de los conceptos desarrollados.

\section{Conclusiones}

El desarrollo de la estrategias de evaluación con metodologías activas dentro de la asignatura Ingeniería Fluidomecánica, está incrementando anualmente la motivación de los alumnos hacia la materia impartida, mejorando los resultados de aprendizaje alcanzados por ellos.

La inclusión de la asignatura dentro del Proyecto de Innovación y Mejora Educativa B07 'Desarrollo de metodologías de evaluación y diseño de rúbricas de la 'CT-05. Diseño y Proyecto' aplicado al campo de la ingeniería hidráulica' desarrollado durante el curso 2016/2017, logró con éxito sentar las bases de metodologías de trabajo y consecución de los objetivos en actividades de 'Diseño y Proyecto' en su nivel de Dominio II. El hecho de estar relacionadas con otras asignaturas, concretamente Mecánica de Fluidos, impartida en segundo curso y nivel de dominio I, permite al estudiante una estrategia de actuación en cuanto al desarrollo de proyectos de infraestructuras hidráulicas. La aplicación de estas estrategias está comenzando a constatar durante el curso 2017/2018 la adquisición de resultados de aprendizaje relacionados con la aplicabilidad de metodologías que muestran el éxito de la coordinación vertical.

Aprovechando el desarrollo de las rúbricas para dicha asignatura en 2016/2017 en la evaluación de la CT-05, se han propuestos pesos numéricos a cada uno de los descriptores, con el objeto de poder evaluar numéricamente la competencia. Este desarrollo ha sido fruto de las conversaciones y reuniones mantenidas entre el PIME y la unidad de seguimiento por parte de ICE y CESPIME.

Las encuestas realizadas, muestran la satisfacción de los estudiantes en relación al desarrollo de la actividad y los contenidos teóricos de la asignatura, así como su utilidad en las competencias laborales que deberán desarrollar en un futuro. Esta satisfacción, está fuertemente relacionada con la introducción de nuevas metodologías activas docentes.

Como consecuencia del fuerte dinamismo en los últimos cursos de la asignatura Ingeniería Fluidomecánica, en cuanto a la introducción de nuevas metodologías activas resulta necesario que las mismas vayan consolidándose para descubrir las ventajas e

(cc) EY-NC-ND 2018, Universitat Politècnica de València

Congreso IN-RED (2018) 
inconvenientes, con el objeto de mejorarlas y que puedan sustituir en un futuro los actos de evaluación clásicos.

\section{Agradecimientos}

La experiencia aquí descrita se ha llevado a cabo como parte de los trabajos desarrollados en el EICE DESMAHIA "Desarrollo de metodologías activas y estrategias de evaluación aplicadas al campo de la Ingeniería Hidráulica". Los autores agradecen a la UPV, y en particular al ICE, el apoyo prestado para llevar a cabo esta iniciativa. Del mismo modo, esta comunicación está dentro del Proyecto de Innovación y Mejora Docente "Desarrollo de Metodologías de Evaluación y Diseño de Rúbricas de la CT-05 Diseño y Proyecto aplicado al campo de la Ingeniería Hidráulica (Fase II) (PIME B24)

\section{Referencias}

Benavides, G.A.M., Morales, C.E.O., 2009. Laboratorio virtual basado en la metodología de aprendizaje basado en problemas, ABP. Rev. Educ. en Ing.

DALE, E. 1969. Audiovisual methods in teaching.

MASTERS, K., 2013. Edgar Dale’s Pyramid of Learning in medical education: a literature review. Med. Teach. 35, e1584-93. doi:10.3109/0142159X.2013.800636

MoralES, P., LANDA, V., 2004. Aprendizaje basado en prob-lemas. Theoria 13, 145-157.

PÉrez-SÁnchez, Modesto; LóPez Jiménez, Petra Amparo (2017a).El debate como instrumento complementario de aprendizaje en la competencia de responsabilidad ética, medioambiental y profesional. EN Congreso Nacional de Innovación Educativa y Docencia en Red (IN-RED 2017). (683 - 695). Valencia, Spain: Editorial UPV.

Pérez-SÁnchez, Modesto; M. Isabel Pérez-SÁnchez; LóPez Jiménez, Petra Amparo (2017b). ¿Puede un conjunto de tareas evaluar la competencia "Análisis y Resolución de problemas” en una asignatura de grado?. EN Congreso Nacional de Innovación Educativa y Docencia en Red (IN-RED 2017). (1322 - 1334). Valencia, Spain: Editorial UPV.

Servicio de InNovación Educativa, 2008. Aprendizaje Basado en Problemas. Guías rápidas sobre nuevas metodologías. Universidad Politécnica de Madrid

WoOd, D., BRunER, J.S., Ross, G., 1976. The Role of tutoring in problem solving. J. Child Psychol. Psychiatry 17, 89-100. doi:10.1111/j.1469-7610.1976.tb00381.x 


\title{
“Carpa de protección solar”. La dermofarmacia como herramienta para la concienciación y prevención del cáncer de piel.
}

Uriel Gallego, $M^{\mathrm{a}}$; Sáez-Benito Suescun, A $^{\mathrm{b}}$; Gómez Rincón, $C^{\mathrm{c}}$.

${ }^{a}$ Universidad San Jorge, muriel@usj.es ${ }^{\mathrm{b}}$ Universidad San Jorge, amsaezbenito@usj.es ${ }^{\mathrm{c}}$ Universidad San Jorge, cgomez@usj.es.

\begin{abstract}
During academic year 2017/2018 the project: "Sun damage protection tent" take place as a Service-Learning Methodology. In this experience, diverse agents are involved, creating an interdisciplinary space in which pharmacy students are going to participate.
\end{abstract}

This project is presented in order to motivate the students to create a didactic material, a leaflet, and a website with the awareness campaign ideas to present in the annual "Sun damage protection tent" that promotes the "Colegio Oficial de farmacéuticos de Zaragoza"(C.O.F.)and "Asociación Española Contra el Cáncer”(A.E.C.C.)

Pharmacy students are going to be the creative force of the campaign. Also, they are going to be part of the participating volunteers of the "Sun damage protection tent" and to complete the activities of the project, it will be close with the location of a "sun tent" on Universidad San Jorge's campus. There, the students can share the knowledge acquired during the experience, their communication skills and try to educate their colleagues and other member of the academic staff in sun protection.

The participation of the students will consist in the design, training, diffusion, implementation and assessment of the project. Varied innovative methodologies are used in this experience: Service-Learning and Information and communications technology.

\section{Resumen}

Durante el curso académico 2017/2018 se lleva a cabo el servicio de Aprendizaje-Servicio "Carpa de protección solar". La dermofarmacia como herramienta para la concienciación y prevención del cáncer de piel. En esta experiencia intervienen diferentes agentescreando un espacio interdisciplinar en el que van a participar los estudiantes de farmacia.

El presente proyecto motiva a los alumnos a crear un material didáctico, un folleto y una página web que contengan las principales ideas de la campaña anual "Carpa solar" que el Colegio Oficial de Farmacéuticos de 
“Carpa de protección solar”. La dermofarmacia como herramienta para la concienciación y prevención del cáncer de piel.

\section{Zaragoza(C.O.F.) organiza junto ala Asociación Española contra el Cánces} (A.E.C.C.)

Los alumnos van a formar parte de la de la campaña desde su creación hasta la participación como voluntarios en las carpas solares. Para completar el proyecto, se finalizará con la instalación de una carpa solar en el campus universitario. Los estudiantes podrán compartir su aprendizaje adquirido sobre protección solar, tanto con sus compañeros de otros grados como con el personal académico.

La participación de los alumnos consistirá en el diseño, práctica, difusión y evaluación del proyecto. Se aplican metodologías innovadoras como el Aprendizaje-Servicio(APS) y las tecnologías de la Información y la Comunicación (TICs)

Palabras clave: Aprendizaje en Dermofarmacia, Aprendizaje Servicio, TICs, Carpa Solar

\section{Introducción}

Uno de los temas fundamentales en la asignatura de dermofarmacia, es la prevención de los daños solares mediante el uso de preparados dermocosméticos y consejos farmacéuticos. Para el curso 2017/2018, se plantea el proyecto: "Carpa de protección solar. La dermofarmacia como herramienta para la concienciación y prevención del cáncer de piel”, como una metodología de aprendizaje servicio, en el que van a participar diversos agentes, generando un espacio interdisciplinar del que van a ser partícipes los alumnos de dermofarmacia. Además de tratar el tema desde un punto de vista teórico y completarlo con prácticas de laboratorio y casos prácticos de resolución en clase, se plantea el proyecto a través de la motivación al alumno a crear un material didáctico tipo blended learning, junto a un tríptico con un resumen informativo y un anuncio/cartel. Todo esto, será presentado a la campaña de protección solar que el Colegio Oficial de Farmacéuticos de Zaragoza organiza todos los años junto a la Asociación Española Contra el Cáncer. Con esta colaboración, los alumnos de farmacia de la USJ, van a convertirse en el motor creativo de la campaña del 2018, además de pasar a formar parte de los voluntarios que participen en las carpas solares organizadas en piscinas y puntos urbanos. Para completar las actividades, el proyecto se cerrará con la ubicación de una carpa solar en el campus de la Universidad San Jorge, donde los alumnos de dermofarmacia, compartirán los conocimientos adquiridos, comunicándolos e informando a los estudiantes de otros grados y personal universitario y realizando analíticas de pigmentación de piel y protección requerida mediante el manejo del equipo "dermoanalizador de piel”. La participación de los alumnos consistirá en el diseño del proyecto, la formación, difusión, puesta en marcha y evaluación del mismo. Esto va a ofrecer una visión global de cómo el aprendizaje puede situarse y aplicarse fuera del aula y ofreciendo un servicio a la población.

(cc) EY-NC-ND 2018, Universitat Politècnica de València

Congreso IN-RED (2018) 
La concienciación para la protección solar es un tema en el que el farmacéutico juega un rol fundamental. Como profesionales accesibles a la población, el estudiante de farmacia debe familiarizarse con la participación en esta y otras campañas de prevención, y que mejor forma de hacerlo que la propia intervecnción en un proyecto que combina las metodologías de docencia: Aprendizaje Servicio (APS) y la inclusión de las Tecnologías de la Información y Comunicaciones (TIC).

Las propuestas de aprendizaje servicio (APS), se situan en el marco de un modelo formativo de universidad que procura combinar aprendizaje académico y formación para una ciudadanía activa en tiempo real.

Las propuestas de APS no deben confundirse con la prestación de servicios voluntarios. Deben suponer aprendizaje académico en los estudiantes $\rightarrow$ Aprendizaje y contribuir a la mejora de la calidad de vida y del nivel de inclusión social en la población $\rightarrow$ Servicio.(Martínez, 2008)

En este proyecto se definen ambas partes:

-Aprendizaje: dermoprotección, daños solares y sus posteriores patologías, productos para la protección solar e indicaciones para su aplicación.

-Servicio: Transmisión a la sociedad que rodea a los alumnos participantes en el proyecto de la importancia de conocer los mecanismos para la prevención de los daños ocasionados de la exposición al sol. Consejos y detección de peligros de la radiación solar.

Las Tecnologías de la Información y Comunicaciones TIC han devenido incorporándose naturalmente en ladocencia universitaria obedeciendo a distintas motivaciones. El énfasis está en usarlas de apoyo en elproceso docente tradicional. Por sí mismas las TIC e Internet no educan ni reemplazan al profesor, son un recurso poderoso cuya incorporación debe considerar nuevos roles del profesor, nuevos contenidos, programas y formas de evaluar.(Vera, 2003)( Muñoz-Repiso, 2014)

\section{Objetivos}

- Reforzar desde el aprendizaje práctico y la transmisión de conocimientos, el estudio de los alumnos sobre los riesgos del sol y los beneficios de la prevención como herramienta dermofarmacéutica.

- Aplicar el conocimiento adquirido a un ámbito real. Motivar al alumno para que sea consciente de la importancia de su aprendizaje para su ejercicio profesional, y como servicio a la población.

- Diseñar un material didáctico elaborado por el propio alumno y que va a tener varios destinatarios: el propio alumno, sus compañeros y el resto de participantes en la campaña: farmacéuticos y voluntarios, pero sobre todo un destinatario final: la población.

- Practicar los recursos comunicativos empleados por el alumno, para la difusión del conocimiento a la población, tan importante en su futuro profesional como farmacéutico.

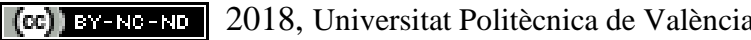


“Carpa de protección solar”. La dermofarmacia como herramienta para la concienciación y prevención del cáncer de piel.

- Involucrar al alumno como un agente fundamental en una actividad profesional y de servicio a la comunidad.

\section{Desarrollo de la innovación}

En el presente proyecto, se trata de aplicar metodologías impulsadas por la Universidad San Jorge con el fin de ofrecer un modelo educativo que proporcione "una experiencia única y transformadora de la persona” y que alcance impactos positivos en el aprendizaje de los alumnos.

Se emplea la metodología de aprendizaje servicio (APS). Se trata de que el alumno aprenda mientras participa en las diferentes fases del proyecto: en el diseño y creación del material didáctico, y en su puesta en práctica en un contexto real como es una carpa de concienciación al público, un contexto que va mucho más allá del aula.

Debido a las características del proyecto, se pretende concienciar al alumno con su contexto social inmediato; entendiendo que con su transmisión de conocimiento, está llevando a cabo un servicio a la ciudadanía, reforzando con ello su vocación sanitaria profesional.

Se trata de integrar las tecnologías de la información y la comunicación (TIC) durante todo el proyecto: creación de material didáctico, diseño de una página web, creación de vídeos, diseño de material gráfico, tipo cartel/portada para la difusión (comunicación) por diferentes medios: webs, aplicaciones móviles, redes sociales, prensa...

Se suma al punto anterior, la metodología de enseñanza de uso y aplicación de un equipo como es el "analizador de piel", con un fin concreto y aplicado, que pretende abrir la mente a las numerosas aplicaciones que se pueden conseguir con las herramientas que en su futuro profesional, el farmacéutico puede llegar a tener a su alcance, y cómo podrá utilizarlas, en beneficio del paciente.

En este proyecto, se trabaja con una asociación de pacientes, con un colegio profesional, y de la mano de farmacéuticos colegiados, futuros colegas de los alumnos. Además se trabaja para poder ofrecer una información a pacientes, a otros alumnos de su mismo y otros grados. Esto hace que dicha colaboración interdisciplinar y con otros agentes sociales, repercuta de manera positiva en el aprendizaje del estudiante de dermofarmacia, que entienda los beneficios directos de la adquisición de conocimientos. Todo ello, en una ubicación fuera del aula.

\subsection{Contextualización}

A continuación se describen los destinatarios, beneficiarios de este proyecto.

Desde el punto de vista del aprendizaje, con toda su implicación en la parte docente: los alumnos de la asignatura Dermofarmacia y cosmética; impartida en $5^{\circ}$ curso y los de Inmunología impartida en $3^{\circ}$ curso del Grado de Farmacia de la Facultad de Ciencias de la Salud. Universidad San Jorge.

(cc) EY-NC-ND 2018, Universitat Politècnica de València

Congreso IN-RED (2018) 
Los destinatarios del servicio: la asociación de pacientes de cáncer (AECC), la población en general participante en las carpas solares y particularmente los participantes del campus, compañeros y trabajadores de la Universidad.

Cabe resaltar la colaboración con el Colegio Oficial de Farmacéuticos de Zaragoza y el contacto de los alumnos con los farmacéuticos colegiados, futuros compañeros de profesión.

\subsection{Cronograma}

Todas estas actividades se llevarán a cabo según el cronograma descrito en la tabla 1:

Tabla 1. Cronograma de actividades del proyecto

\begin{tabular}{|c|c|c|c|c|c|c|c|c|c|c|c|}
\hline ACTIVIDAD & $\begin{array}{l}09 / \\
17\end{array}$ & $\begin{array}{c}10 / \\
17\end{array}$ & $\begin{array}{l}11 / \\
17\end{array}$ & $\begin{array}{l}12 / \\
17\end{array}$ & $\begin{array}{r}01 / \\
18\end{array}$ & $\begin{array}{c}02 / \\
18\end{array}$ & $\begin{array}{c}03 / \\
18\end{array}$ & $\begin{array}{r}04 / \\
18\end{array}$ & $\begin{array}{r}05 / \\
18\end{array}$ & $\begin{array}{c}06 / \\
18\end{array}$ & $\begin{array}{r}07 / \\
18\end{array}$ \\
\hline $\begin{array}{c}\text { Presentación del proyecto a } \\
\text { alumnos }\end{array}$ & $\mathrm{X}$ & & & & & & & & & & \\
\hline $\begin{array}{c}\text { Trabajo grupal en los vídeos } \\
\text { (Inmunología 3ㅇ) }\end{array}$ & & $\mathrm{X}$ & $x$ & & & & & & & & \\
\hline $\begin{array}{l}\text { Evaluación de los vídeos } \\
\text { (rúbrica) por docentes y } \\
\text { alumnos de 5ㅇ }\end{array}$ & & & $x$ & $x$ & & & & & & & \\
\hline $\begin{array}{l}\text { Trabajo grupal de creación del } \\
\text { material didáctico prevención y } \\
\text { riesgo solar (Dermofarmacia 5ㅇ) }\end{array}$ & & $\mathrm{X}$ & $x$ & $\mathrm{X}$ & & & & & & & \\
\hline $\begin{array}{l}\text { Evaluación del material } \\
\text { didáctico carpa solar por } \\
\text { docentes y COF Zaragoza }\end{array}$ & & & & $x$ & $x$ & & & & & & \\
\hline $\begin{array}{l}\text { Diseño y creación continua de } \\
\text { la página web del proyecto }\end{array}$ & & $x$ & $x$ & $x$ & $\mathrm{x}$ & $\mathrm{x}$ & $\mathrm{X}$ & $x$ & $x$ & $\mathrm{X}$ & \\
\hline $\begin{array}{c}\text { Evento: carpa solar en Zaragoza } \\
\text { y carpa solar USJ }\end{array}$ & & & & & & & & & $x$ & $x$ & \\
\hline $\begin{array}{c}\text { Evaluación del aprendizaje y } \\
\text { servicio llevado a cabo durante } \\
\text { las carpas }\end{array}$ & & & & & & & & & $x$ & $\mathrm{X}$ & $x$ \\
\hline $\begin{array}{c}\text { Evaluación de resultados y } \\
\text { difusión del proyecto }\end{array}$ & & & & & & & & & & $\mathrm{X}$ & $x$ \\
\hline
\end{tabular}


“Carpa de protección solar”. La dermofarmacia como herramienta para la concienciación y prevención del cáncer de piel.

\subsection{Evaluación}

Para el seguimiento y calificación del proyecto, se emplean diferentes tipos de evaluación, llevadas a cabo por diferentes agentes participantes. Con ello se pretende incluir la evaluación como parte del aprendizaje; por ejemplo con la evaluación dinámica, autoevaluación, o con la inclusión de los alumnos en la evaluación de los trabajos grupales.

Autoevaluación: los alumnos al finalizar el proyecto realizan una autoevaluación que permite conocer su aprendizaje y la repercusión que ha tenido el proyecto.

La forma en que los alumnos participan en la evaluación de sus compañeros es que los alumnos de $5^{\circ}$ curso de dermofarmacia, quienes ya han superado la asignatura de inmunología, realizan una evaluación de la tarea grupal de creación de vídeos llevada a cabo por sus compañeros de tercer curso. Esta evaluación se realiza mediante una rúbrica proporcionada por los docentes del proyecto, además pueden aportar comentarios a cada apartado evaluado. Los alumnos de quinto acceden a los vídeos mediante la web del proyecto. (Casanova, 2009)

Los participantes también pueden llevar a cabo una evaluación del proyecto aunque esta es opcional.

\section{Resultados}

Tal como se muestra en el cronograma, el proyecto se encuentra todavía en ejecución, por lo que algunos resultados no se encuentran finalizados.

Documentación del proyecto y productos generados:

-Website del proyecto:

Toda esta información creada por los alumnos, se recoge en web

https://sites.google.com/usj.es/carpasolar/

-Videos informativos/educativos:

Estos vídeos fueron creados por los alumnus de tercer curso y evaluados por sus compañeros de quinto curso,además de por el profesorado;

https://sites.google.com/usj.es/carpasolar/página-principal/vídeos

- Panfleto para la difusión de la campaña, ver Figura 1.-: 

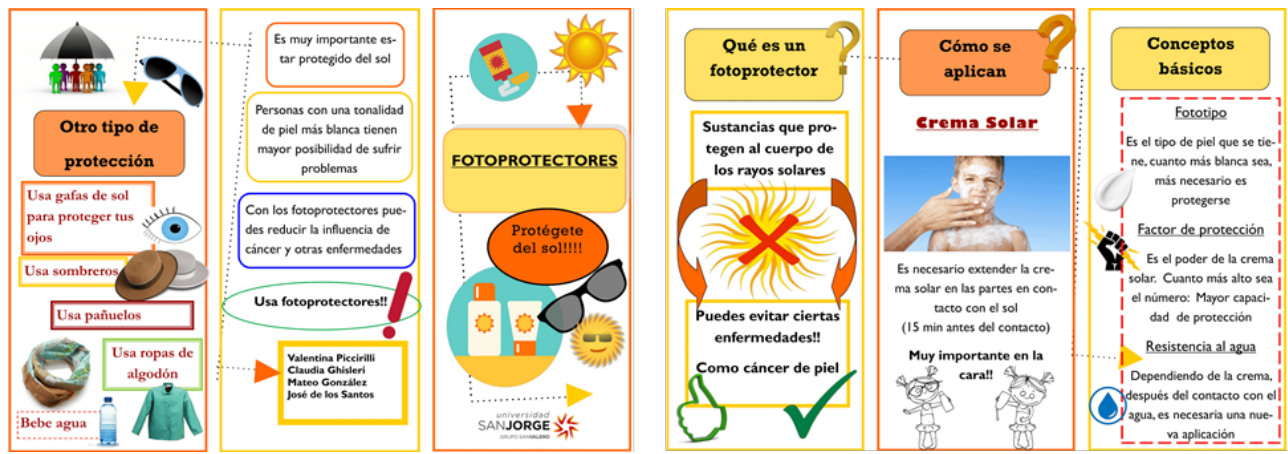

Fig. 1 Imagen de un folleto informativo creado por alumnos para la carpa solar

Resultados de evaluación del proyecto y rúbricas de evaluación.

La participación y motivación de los alumnos en la creación tanto del material, vídeos, así como de la página web es alta.

Actualmente contamos con los resultados de la evaluación entre alumnos: la que realizada por los alumnos de dermofarmacia de $5^{\circ}$ a los 13 vídeos elaborados por los de inmunología de $3^{\circ}$ recogida en la Figura 2.-

Se recogen las notas medias de dichas evaluaciones, obtenidas mediante una rúbrica creada por los docente y que los alumnos de dermofarmacia debán colgar completa con las notas y sus comentarios en la Plataforma Docente Universitaria.

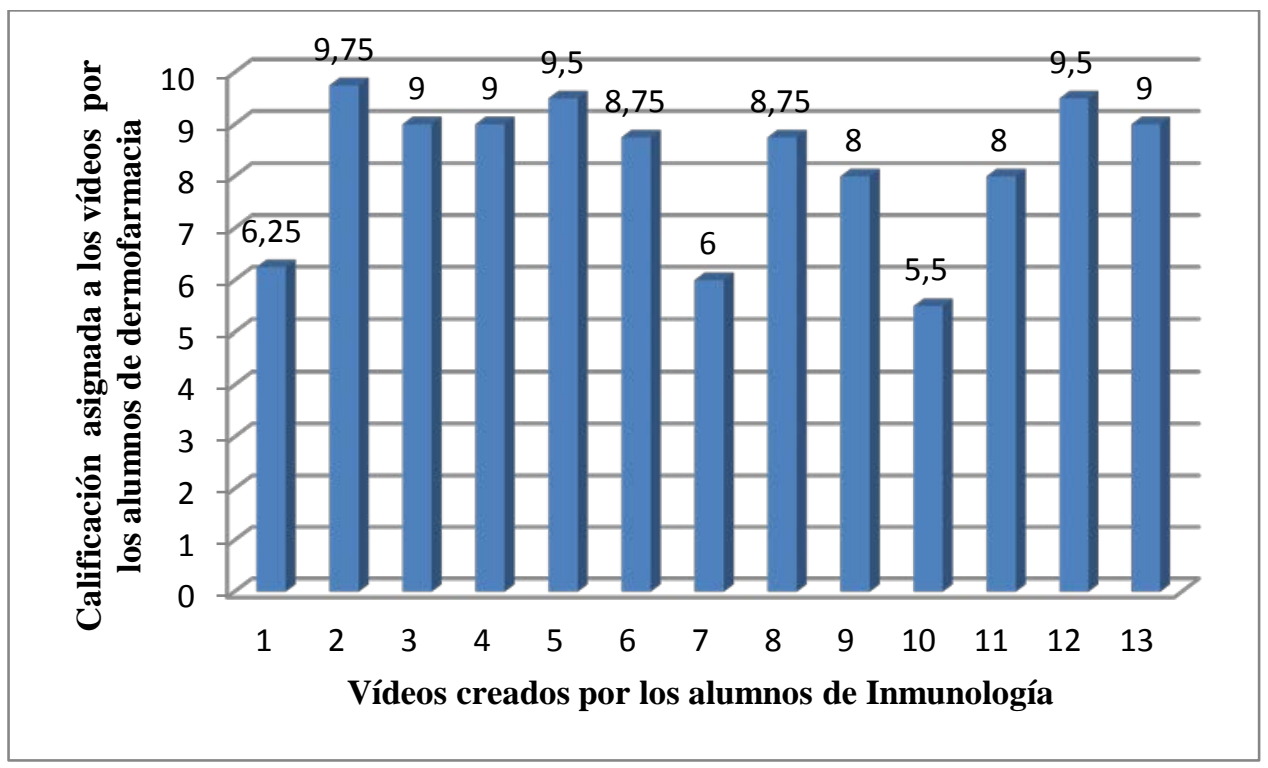

Fig.2 Gráfica de la media de los resultados de la evaluación realizada por los alumnos de $5^{\circ}$ sobre los 13 vídeos creados por los alumnos de Inmunología de $3^{\circ}$.

(c)) EY-NC-ND 2018, Universitat Politècnica de València

Congreso In-Red (2018) 
“Carpa de protección solar”. La dermofarmacia como herramienta para la concienciación y prevención del cáncer de piel.

La evaluación llevada a cabo por los docentes también se realizó mediante una rúbrica, y en el caso de la asignatura dermofarmacia, los alumnos obtuvieron una nota media de 8,8/10 frente al 6,5/10 de nota media obtenida en el total de la asignatura.

\section{Material para la difusión del proyecto:}

- Documentación en formato artículo.

- Póster o comunicación oral con los resultados del proyecto y divulgación de los mismos.

\section{Conclusiones}

Los alumnos han estado muy motivados con el proyecto y las calificaciones de las que se disponen están por encima de la media obtenidas en las asignaturas, destacamos que la nota media del proyecto en la asignatura de dermofarmacia está 2,3/10 puntos por encima de la media total de dicha materia.

Con este proyecto se consigue que los futuros farmacéuticos alcancen el aprendizaje relacionado con la protección solar y la prevención de los riesgos solares mediante su ejercicio profesional en actividades en las que practican la comunicación con el paciente, la generación de información, el análisis de la piel y el consejo dermofarmacéutico. Todo esto a su vez, genera un servicio a la sociedad y una ayuda a la asociación contra el cáncer que da el sentido a todo el proyecto. Se consigue por tanto, el ansiado tándem aprendizajeservicio que logra motivar y apasionar a todos los agentes implicados.

\section{Referencias}

MARTÍNEZ M. (2008) "Aprendizaje servicio y construcción de ciudadanía activa en la universidad: la dimensión social y cívica de los aprendizajes académicos”. Aprendizaje servicio y responsabilidad social de las universidades, 11-26.

GINNS, \& R. A. ELLIS P. (2009) "Evaluating the quality of e-learning at the degree level in the student experience of blended learning”. British Journal of Educational Technology, 40(4), 652-663.

BIGGS J., BIGGS J. B.(2006) Calidad del aprendizaje universitario. Narcea ediciones.

VERA A. (2003) "Las tecnologías de información y comunicaciones (TIC) en la docencia universitaria”. Theoría: Ciencia, Arte y Humanidades, 12, 109-118.

MUÑOZ-REPISO A. G. V. (2014) Procesos de innovación didáctica basados en el uso de las nuevas tecnologías: En Experiencias de Innovación Docente Universitaria. Ediciones Universidad de Salamanca.

HERNÁNDEZ F., GARCÍA M., MAQUILÓN J. J. (2014) "Estudio empírico de los enfoques de aprendizaje de los estudiantes universitarios en función del perfil de su

(cc) EY-NC-ND 2018, Universitat Politècnica de València

Congreso IN-RED (2018) 
titulación (profundo VS superficial) = Empirical research on university students' learning approaches depending on the degree undertaken”. REOP-Revista Española de Orientación y Psicopedagogía, 12(22), 303-318.

CASANOVA J. M., BARADAD M., SORIA X., \& MARTÍ R. M. (2009) “www. dermatoweb. net. Una web docente para el aprendizaje de la Dermatología en el pregrado”. Actas Dermo-Sifiliográficas, 100(10), 866-874.

PÉREZ V., MANUEL J., O.DELGADO QUINTANA M., GARCÍA LÓPEZ I., GARCÍA MÁRQUEZ J. A., SABORIDO CEBALLOS A., \& FERNÁNDEZ ARÉVALO M. M. (2010) Facultad de Farmacia de la Universidad de Sevilla: 4 Años de plan piloto para la adaptación al EEES. Actividades docentes realizadas para una mejora en la calidad de enseñanza y su repercusión en el alumnado. 


\title{
Impulsando el uso de los repositorios institucionales de materiales didácticos multimedia de la UPV
}

\section{D. de Andrés Martínez ${ }^{\mathrm{a}}$, C. Gisbert Doménech ${ }^{\mathrm{b}}$, E. Antonino Daviuc, J.C. Ruiz García ${ }^{\mathrm{d}}$, A. Palomares Chust ${ }^{\mathrm{e}}$, A. Peña Cerdán ${ }^{\mathrm{f}}$}

Universitat Politècnica de València: ${ }^{a} D$ pto. de Informática de Sistemas y Computadores (ddandres@disca.upv.es), bDto. de Biotecnología (cgisbert@btc.upv.es), Dpto de Comunicaciones (evanda@upvnet.upv.es), ${ }^{\mathrm{d}}$ Dpto. de Informática de Sistemas y Computadores (jcruizg@ disca.upv.es), ${ }^{\circledR}$ Dpto. de Sistemas Informáticos y Computación (apalomares@dsic.upv.es), ${ }^{\text {f } D p t o . ~ d e ~ P r o y e c t o s ~ A r q u i t e c t o ́ n i c o s ~(a n p e c e r 2 @ p r a . u p v . e s) . ~}$

\begin{abstract}
The Universitat Politècnica de València (UPV) is promoting the design and development of multimedia resources to be publicly offered under an open access policy through its institutional repository RiuNet (https://riunet.upv.es/). According to data collected from students enrolled in degrees from the areas of information and communication technologies, biotechnology, architecture and tourism, UPV students mainly use the slides professors make available through UPV's learning management system: roughly $30 \%$ of the students ignore the existence of additional resources, more than $70 \%$ massively use YouTube to locate didactic videos, and around 50\% of the students have used PoliBuscador or mediaUPV from time to time. This work presents the different actions that have been deployed, both among students and the general services of UPV, to improve, increase the visibility, and promote the use of RiuNet, UPV's institutional repository.
\end{abstract}

Keywords: RiuNet, multimedia repositories, autonomous work, transversal competences

\footnotetext{
Resumen

La Universitat Politècnica de València (UPV) promueve e incentiva el diseño y elaboración de materiales multimedia que deposita en el repositorio institucional RiuNet (https://riunet.upv.es/) y que están accesibles en abierto. De acuerdo a los datos obtenidos de alumnos pertenecientes a titulaciones de las áreas de tecnologías de la información y las comunicaciones, biotecnología, arquitectura y turismo, los alumnos hacen un uso prácticamente exclusivo de las transparencias/diapositivas que los profesores dejan a su disposición en la plataforma de gestión de la docencia de la UPV: alrededor del $30 \%$ del alumnado desconoce la existencia de material adicional, más del $70 \%$ hace uso masivo de YouTube para localizar vídeos con fines didácticos y alrededor del $50 \%$ utiliza de forma esporádica PoliBuscador o mediaUPV. En este trabajo se presentan las diferentes actuaciones que se han desplegado, tanto entre los alumnos como entre los servicios generales de la UPV, con el fin de mejorar, dar conocer y promover el uso de RiuNet, el repositorio institucional de la UPV.
} 
Palabras clave: RiuNet, repositorios multimedia, trabajo autónomo, competencias transversales

\section{Introducción}

En el año 2007 la Universitat Politècnica de València (UPV) inició el programa "Docencia en Red", para incentivar al profesorado en el diseño y elaboración de materiales multimedia educativos con el fin de incluirlos en el repositorio institucional Riunet (Universitat Politècnica de València, 2008). En este programa, que sigue en vigor, se elaboran los distintos tipos de materiales que pueden observarse en la Figura 1.

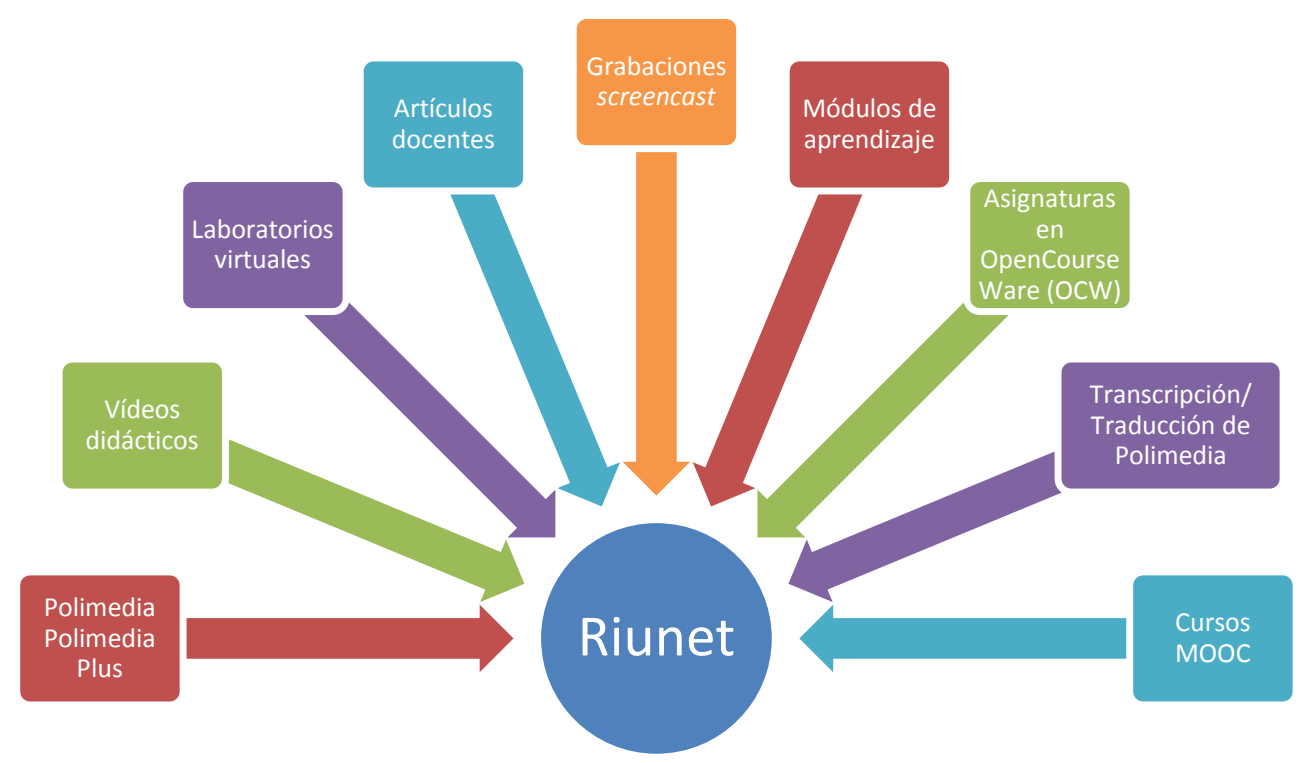

Figura 1. Materiales que forman parte del repositorio institucional de la Universitat Politècnica de València (Riunet).

No cabe duda de que todos estos materiales, que están disponibles en abierto en el repositorio RiuNet y pueden ser utilizados en cualquier momento y desde cualquier lugar, son de gran valía. Sin embargo, aunque se han realizado investigaciones centradas bien en las metodologías docentes soportadas por estos recursos (Moltó, Montserrat, Fita, \& Fita, 2014) (Argentea, García-Fornes, \& Espinosa, 2016), bien en la satisfacción del alumnado con los mismos (Jordán-Lluch, Pérez-Peñalver, \& Sanabria-Codesal, 2014), no se dispone de datos del impacto del programa "Docencia en red" desde la perspectiva de la participación del profesorado y de la utilización por parte del alumnado de los recursos elaborados por los profesores. Este tipo de análisis es de gran interés puesto que cada vez es más imperativo que, como comunidad de profesionales de educación superior, sigamos trabajando para comprender cómo aprovechar mejor el análisis de aprendizaje predictivo y compartir nuestro conocimiento colectivo (Alhadad, y otros, 2015). Por otra parte, dentro de la evaluación de

2018, Universitat Politècnica de València

Congreso IN-RED (2018) 
los repositorios institucionales se valora la existencia de actividades con el fin de promocionarlos dentro de su propia institución (Barrueco-Cruz, y otros, 2017).

Desde el punto de vista de la implicación del profesorado, el programa ha resultado todo un éxito ya que, a 21 de marzo de 2018, Riunet cuenta con 7233 objetos de aprendizaje. En cuanto a su utilización por parte del alumnado, el Equipo de Innovación y Calidad Educativa (EICE) "Tools and Strategies for Competences Assessment" (TASCA), del que forman parte los autores de este trabajo, llevó a cabo un primer estudio para analizar el impacto de este programa en el marco del Proyecto de Innovación y Mejora Educativa de la UPV titulado "Uso e impacto en la docencia universitaria del material didáctico multimedia-UPV" (PIME/2016/A/029). Este estudio, realizado durante el curso académico 2016-2017, que involucraba a asignaturas de los cuatro niveles de grado y máster en los ámbitos de las tecnologías de la información y las comunicaciones, biotecnología, arquitectura y turismo, determinó que:

- Los alumnos hacen uso prácticamente exclusivo de las transparencias/diapositivas (Microsoft PowerPoint, por ejemplo), que los profesores dejan a su disposición como recursos en PoliformaT (https://poliformat.upv.es/, plataforma docente de la UPV, basada en SAKAI). Únicamente la mitad de los alumnos hace uso de los vídeos suministrados y alrededor del $30 \%$ del alumnado declara que desconoce la existencia de material adicional más allá de las transparencias.

- Más del $70 \%$ de los alumnos hacen uso masivo y regular de YouTube (https://www.youtube.com/) para localizar vídeos con fines didácticos, mientras que los repositorios institucionales de materiales multimedia de la UPV son bastantes desconocidos. Alrededor del $50 \%$ de los alumnos declara haber utilizado alguna vez, de forma esporádica, PoliBuscador (https://polibuscador.upv.es/) o mediaUPV (https://media.upv.es/), mientras que Riunet (https://riunet.upv.es/), el repositorio institucional de referencia, está infrautilizado.

- Las grandes plataformas de cursos masivos online en abierto (MOOC), como Coursera (https://www.coursera.org/) o edX (https://www.edx.org/), no tienen prácticamente calado entre nuestro alumnado, que además declara no conocer/utilizar ningún otro repositorio de materiales como complemento a los recursos proporcionados por el profesorado.

A pesar del éxito del programa "Docencia en Red" para poblar los repositorios institucionales de materiales didácticos multimedia, el uso que hace el alumnado de estos materiales es bastante escaso. Es necesario por lo tanto desplegar actuaciones que den a conocer y promuevan el uso de estos repositorios de materiales docentes, tanto entre el alumnado como entre el propio profesorado.

Este artículo describe el trabajo desplegado para dar respuesta a esta necesidad. En primer lugar, la Sección 2 identifica los objetivos perseguidos con la actuación planteada. A continuación, la Sección 3 plantea las acciones desarrolladas entre los alumnos (a nivel de asignatura) y entre los servicios de la UPV (a nivel institucional). Los resultados obtenidos a partir de estas acciones se discuten en la Sección 4, mientras que la Sección 5 plantea las conclusiones derivadas de esta actuación. 


\section{Objetivos}

El objetivo de este proyecto es el de dar a conocer las posibilidades didácticas y promover el uso de los repositorios institucionales de la UPV, tanto entre el alumnado como entre el profesorado.

Para alcanzar la finalidad del proyecto se plantean los siguientes hitos:

- Diseñar actividades que promuevan la utilización de los recursos didácticos multimedia propios de cada asignatura, así como la utilización y conocimiento de Riunet (repositorio institucional de producción científica, académica y corporativa de la UPV), mediaUPV (portal de vídeos de la UPV), PoliBuscador (herramienta de búsqueda de múltiples recursos de información, incluyendo el catálogo de bibliotecas de la UPV, biblioteca digital y bibliografía de asignaturas), poli[OCW] (http://ocw.upv.es/, portal de materiales docentes en abierto bajo OpenCourseWare) y UPV[X] (https://www.upv.es/, portal de cursos abiertos masivos de la UPV).

- Aplicar estas actividades en cada una de las asignaturas impartidas por miembros de TASCA y determinar el nivel de conocimiento que los alumnos tienen de los repositorios institucionales de recursos didácticos multimedia al inicio y al final de dichas asignaturas.

- Definir actuaciones destinadas a i) concienciar al profesorado acerca de la necesidad de promover el conocimiento y uso de los repositorios institucionales de materiales didácticos multimedia entre los alumnos, y ii) dar a conocer las actividades desarrolladas para facilitar la progresiva utilización de estos repositorios en el seno de las diferentes titulaciones y asignaturas.

\section{Desarrollo de la innovación}

Las principales actuaciones que se están desplegando para alcanzar los diferentes objetivos planteados anteriormente se describen a continuación.

\subsection{Actividades de promoción y uso de los repositorios didácticos multimedia en el seno de diferentes asignaturas}

Dado el escaso conocimiento que los alumnos parecen tener acerca de los repositorios didácticos multimedia de la UPV, se planteó la necesidad de desplegar actividades enfocadas a dar a conocer estos repositorios entre los alumnos y promover su uso. Para ello, parece natural el plantear la realización de actividades que inviten (o fuercen) a los alumnos a utilizar, y así conocer, estos repositorios y aprendan a valorar las posibilidades que ofrecen.

Así, en las actividades desplegadas en las diferentes asignaturas involucradas en este proyecto, se ha realizado una sesión previa de promoción de los repositorios, indicando a los alumnos qué repositorios existen (RiuNet, mediaUPV, Poli[OCW], UPV[X], etc), cómo

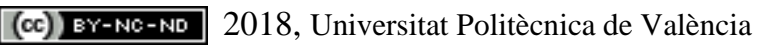

Congreso IN-RED (2018) 
acceder a ellos (buscadores propios y PoliBuscador), y qué tipo de materiales pueden encontrarse en cada uno de ellos. Para la realización de la actividad, los alumnos deben consultar estos repositorios para buscar información, visualizar un vídeo, etc., y elaborar un informe. Posteriormente, a partir de los datos disponibles en las diferentes plataformas de la UPV y el informe generado por los alumnos se pretende determinar la efectividad de estas acciones con vistas a su mejora en cursos sucesivos.

El detalle de dos de las actividades desplegadas se muestra a continuación.

\subsubsection{Mejora Genética para la Producción Vegetal (4º curso de Ingeniería Agronímica y del Medio Rural)}

El día 30 de noviembre de 2017 se accedió durante la clase a un recurso disponible en RiuNet (Fita \& Manzur, 2012) explicando cómo acceder, comentando la importancia del repositorio y visualizando el vídeo que muestra el proceso de extracción de embriones que los alumnos iban a llevar a cabo en el laboratorio de prácticas ese día. Esta técnica es de interés para salvar barreras de incompatibilidad post-cigóticas que se da en distintos cruces en programas de mejora. En esta misma práctica se indicó a los alumnos que accedieran desde casa a otro vídeo "Utilización de la citometría de flujo para analizar la ploidía en plantas" (Gisbert, 2010) que estaba relacionado con la práctica siguiente (cultivo de anteras). En este caso, no se muestra el proceso práctico del cultivo de anteras sino cómo se analizan las plantas resultantes de este proceso para seleccionar, entre las regeneradas, las plantas haploides además de explicar en qué se basa la citometría para poder determinar el nivel de ploidía. Este vídeo se seleccionó porque al ser una técnica bastante específica era más viable el poder determinar si los alumnos habían consumido dicho recurso. El número de alumnos a los que se solicitó que consultaran el vídeo fue de 39. Posteriormente entre las preguntas a puntuar para superar las prácticas de la asignatura que el alumno realiza fuera del aula se incluyó una relacionada con este recurso (periodo de realización de las prácticas de mediados de diciembre a mediados de enero).

\subsubsection{Diseño de Sistemas Digitales ( $3^{\circ}$ curso, rama de Ingeniería de Computadores del Grado de Ingeniería Informática)}

Esta asignatura actúa como punto de control (debe trabajar y evaluar) de la competencia transversal "innovación, creatividad y emprendimiento" (Universitat Politècnica de València, 2013), por lo que se decidió centrar la actividad en este ámbito. Durante la sesión teórica del 7 de marzo de 2018 se introdujo a los alumnos los diferentes repositorios institucionales de la UPV, y se les encomendó como tarea i) que definieran qué se entiende por innovación, creatividad y emprendimiento, ii) la búsqueda de materiales didácticos relacionados con esta competencia transversal, primeramente en los repositorios institucionales y posteriormente en otros repositorios, y iii) que reportaran aquellos problemas que hubieran podido encontrar al utilizar los repositorios institucionales a fin de mejorarlos. Un total de 26 alumnos entregaron la actividad 10 días después de su anuncio. Todos los informes generados han sido analizados y refundidos en uno solo, que se pondrá a 
disposición de los alumnos para que dispongan de información completa acerca de fuentes de información relacionadas con la competencia transversal. Esta actividad ha servido como toma de contacto con la competencia transversal, que se trabajará de forma específica con actividades posteriores.

\subsection{Actividades orientadas a impulsar el conocimiento y uso del repositorio institucional UPV desde la propia institución}

Los diferentes repositorios de recursos multimedia de la UPV responden al compromiso de la institución en el marco de la Iniciativa por el Acceso Abierto de Budapest (2002), su adhesión a la Declaración de Berlín (2003) y su Política Institucional sobre Acceso Abierto (2011). Por ello, parece necesario que la propia institución dé a conocer y promueva la utilización de estos repositorios tanto desde el punto de vista del profesorado como del alumnado. En este sentido se han desplegado las siguientes actuaciones.

\subsubsection{Servicio de Biblioteca y Documentación Científica (BIB)}

Durante la celebración de la conferencia IN-RED 2017, personal del Servicio de Biblioteca y Documentación Científica (BIB) mostró su interés por el artículo “¿Qué recursos didácticos conocen y usan nuestros alumnos?" (de Andrés, y otros, 2017), en el que se analiza el conocimiento que los alumnos de diversas asignaturas tenían de los repositorios institucionales UPV, en particular de RiuNet. Esta información es de vital importancia, ya que el sentido de estos repositorios, además de los ya comentados, es ofrecer un repositorio global de recursos de aprendizaje que profesores y alumnos puedan compartir y explotar libremente. El personal contactado remarcó la importancia de obtener información para mejorar la visibilidad y uso de estos repositorios, y nos emplazaron a contactar nuevamente con ellos si disponíamos de información que pudiera derivar en actuaciones futuras de mejora.

Asimismo, durante las reuniones de seguimiento de los proyectos de innovación de la UPV, se destacó la importancia de esta línea de actuación y nos animaron a contactar con el director y/o vicerrectora del área, por lo que se decidió dedicar esfuerzos para tratar de analizar qué aspectos pueden mejorarse para facilitar el conocimiento y uso de estos recursos por parte de la comunidad universitaria. Las actividades desplegadas con los alumnos pretenden recoger información en este sentido, por lo que todavía se trata de una actuación en curso.

\subsection{2. Área de Sistemas de Información y Comunicaciones (ASIC)}

Además de determinar el conocimiento que los alumnos tienen de los repositorios institucionales de la UPV, otro pilar importante del proyecto es el analizar el uso real que se hace de los diferentes materiales disponibles en la actualidad.

Información interesante del uso que hacen los alumnos de una asignatura del material publicado por el profesor en PoliformaT, la plataforma docente de la UPV, consiste en activar

(cc) EY-NC-ND 2018, Universitat Politècnica de València

Congreso IN-RED (2018) 
la opción de visualización de estadísticas. Con ello puede analizarse el número de veces que se ha accedido a determinado recurso, qué alumnos son los más activos, etc. Naturalmente, únicamente el profesorado que imaprte una determinada asignatura puede acceder a dicha información, por lo que es útil a nivel particular, pero es difícil extrapolar comportamientos a nivel global.

Para ello, puede ser de utilidad el utilizar las estadísticas de uso que proporciona RiuNet para cada uno de los recursos que ofrece. Entre otra información proporciona el número de visitas totales y distribuidas por mes durante el último año, y los accesos distribuidos por países y ciudades. Aunque es posible obtener la información para cada recurso concreto, no es posible recoger información global del total de recursos disponibles. Por ello, en julio de 2017, se realizó una reunión con personal del Área de Sistemas de Información y Comunicaciones (ASIC) con el fin de determinar si era posible realizar consultas personalizadas acerca de la información de uso de RiuNet. El resultado de la reunión fue satisfactorio, ya que se nos confirmó dicha posibilidad previa anonimización de esta información.

Después de estudiar qué información sería de mayor utilidad para realizar este estudio, se ha procedido a comunicar las consultas personalizadas que se desean realizar al ASIC. En las próximas semanas esperamos obtener los datos solicitados y proceder a su análisis para determinar el uso real que se hace de los recursos disponibles en RiuNet. Falta determinar si estas consultas pueden extenderse a mediaUPV.

\section{Resultados}

Tal y como se ha descrito anteriormente, las actuaciones encaminadas a mejorar la facilidad de uso de estos repositorios, promover su utilización entre el profesorado, y analizar en mayor profundidad el uso real que hacen los alumnos de los recursos disponibles, se encuentran todavía en fase de ejecución. Por ello, los resultados que se muestran a continuación corresponden a las actividades de difusión entre el alumnado desplegadas en el seno de dos asignaturas de diferentes titulaciones.

\subsection{Mejora Genética para la Producción Vegetal}

A pesar de transmitir a los alumnos la importancia de visualizar el vídeo disponible en el repositorio institucional como trabajo fuera del aula para la siguiente clase, el número de visitas del vídeo desde la ciudad de Valencia o municipios cercanos en la semana siguiente (y suponiendo que estos accesos corresponden a nuestros alumnos) no fue el esperado: solo 5 alumnos llevaron a cabo la actividad.

Se introdujo entonces, en la evaluación de la práctica, una cuestión relacionada con este vídeo, con lo que se incrementó el número de visualizaciones a un total de 34 (según las estadísticas de uso de RiuNet). Como puede apreciarse en la Figura 2, únicamente el $45 \%$ de los accesos al recurso utilizado en esta actividad provienen de España, y un gran procentaje proviene de EEUU y América Latina. A pesar de que pudiera darse el caso de que los alumnos de la UPV accedieran al material por medio de una conexión a través de una red privada 
virtual (VPN - Virtual Private Network) que disfrace su procedencia como proveniente de otro país, consideramos que esta posibilidad es remota.

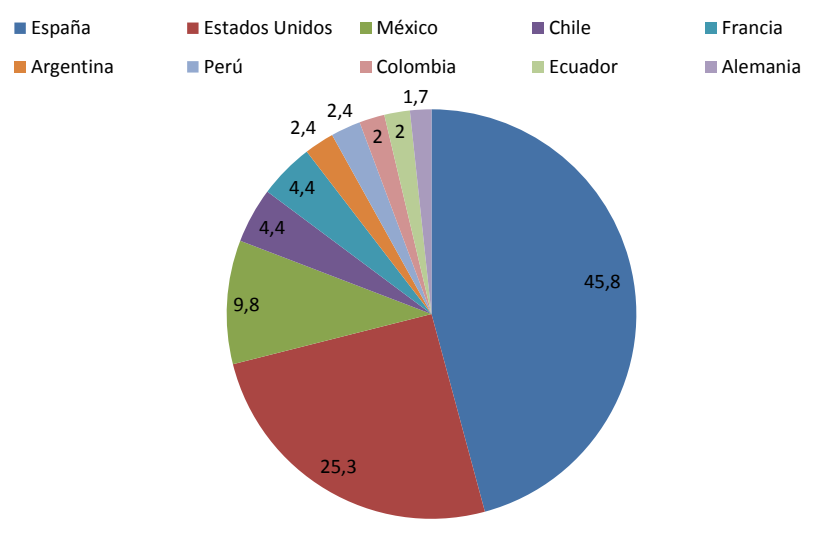

Figura 2. Porcentaje de accesos al recurso multimedia de acuerdo al país de origen (extraído de Riunet).

Asimismo, la Figura 3 muestra el número de accesos a este recurso en relación con la ciudad desde la que se produjo el acceso. Como puede apreciarse, únicamente 33 de las 1024 visualizaciones de este recurso se produjeron desde la ciudad de Valencia. Este dato parece corroborar que estos recursos despiertan más interés en alumnos extranjeros (principalmente Sudamérica, debido al lenguaje del vídeo), que en la propia UPV.

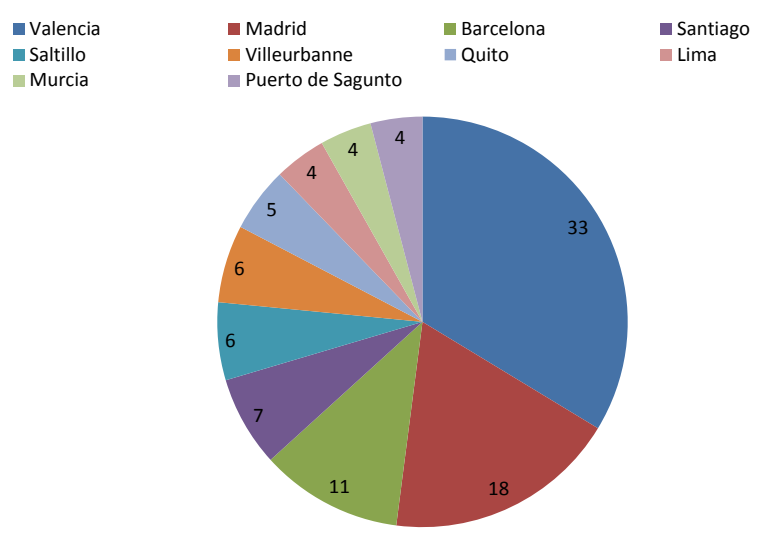

Figura 3. Número total de visualizaciones del recurso multimedia desde diversas ciudades.

Sin embargo, este mismo recurso dispone de 5667 visualizaciones en YouTube frente a las 1024 recogidas desde RiuNet. Así pues, se hace patente la necesidad de promover la difusión y uso de estos recursos en la comunidad universitaria.

(cc) EY-NC-ND 2018, Universitat Politècnica de València

Congreso IN-RED (2018) 


\subsection{Diseño de Sistemas Digitales}

Los resultados de aprendizaje alcanzados por los alumnos, en cuanto a la competencia transversal se refiere, mediante la realización de esta tarea se cuantificará con posterioridad a la realización de una actividad más específica en el contexto de la asignatura. Por ello, los datos de interés que pueden extraerse de los informes generados por los alumnos, hacen referencia a la facilidad de uso y bondades de los repositorios multimedia existentes.

Los principales aspectos de mejora indicados por los alumnos, una vez categorizados, son:

- Buscador. "Los cuadros de texto para la búsqueda son enanos en mediaUPV y en RiuNet". "El buscador de UPVIX] no muestra todo el texto al escribir una búsqueda cuando el texto alcanza cierta longitud, tiene conflictos con los acentos y con los espacios en blanco". "Probé con Poli[OCW] que tiene una etiqueta muy pequeñita que pone 'Buscar' me costó encontrarla, no sé cómo se accede para ver las asignaturas que allíse exponen, se me antojó más difícil que buscar un despacho en el edificio $8 G$ ". Los comentarios de los alumnos reflejan que la interfaz de Polibuscador resulta mucho más amigable y acorde con los nuevos tiempos que la de los repositorios institucionales. Debería considerarse la posibilidad de unificar la búsqueda en todos los repositorios a través de Polibuscador. La mayor parte de los alumnos coincide en que UPV $[\mathrm{X}]$ y Poli $[\mathrm{OCW}]$ disponen del buscador más problemático y menos amigable.

- Organización de la información. "Riunet y UPV[X] no encuentran documentos relacionados con la competencia si se busca explícitamente ("competencia transversal innovación, creatividad y emprendimiento"), se tienen que buscar los conceptos por separado". "El $6^{\circ}$ resultado que ha aparecido al buscar trata sobre cómo crear patés de legumbres". La búsqueda de información relativa a las competencias transversales, en los diferentes repositorios, no es lo suficientemente ágil. Parece ser que las etiquetas asociadas a los recursos en su creación no son lo bastante precisas y no permiten localizarlos de forma sencilla. Teniendo en cuenta la apuesta realizada por la UPV por las competencias transversales, y el interés de los propios alumnos, varios de ellos proponen la creación de secciones en RiuNet o canales específicos en mediaUPV para localizar recursos relacionados con cada una de las competencias transversales de forma cómoda y sencilla. Adicionalmente, podría utilizarse una base de datos de sinónimos para localizar información relacionada aunque las etiquetas no sean exactamente las utilizadas en la búsqueda.

- Facilidad de uso. "Prácticamente todas las páginas web de la UPV no se visualizan bien en pantallas con alta resolución y debe realizarse zoom para su uso". "Acostumbrados a entornos como netflix, youtube o twich, mediaUPV queda muy atrás en este apartado, ya que no consigue destacar los vídeos como debería". "Las miniaturas de los videos deberían representar lo que hay en el video para atraer o conseguir llamar la atención ya que parece que se generan imágenes aleatorias del video que no dicen nada, así como los títulos que quedan muy poco vistosos y con pocas palabras ya salen puntos suspensivos que no dejan leer el título completo". Debería considerarse la posibilidad de adaptar la interfaz de los diferentes 
repositorios para favorecer su correcta visualización y utilización en diversos dispositivos (como ordenador de sobremesa, Tablet, y Smartphone).

Una vez analicemos la información recogida entre los alumnos de las diversas titulaciones que comprende el proyecto en curso, procederemos a informar al BIB para que puedan tomar las acciones necesarias, si lo creen conveniente, para mejorar los aspectos clave en el acceso y búsqueda de la información en los repositorios institucionales.

\section{Conclusiones}

Con las actividades emprendidas se está transmitiendo, de manera directa, la utilidad del repositorio a alumnos de distintas titulaciones. Con ello se pretende que tomen conciencia de las posibilidades que ofrecen estos repositorios para el acceso a recursos docentes y puedan considerarlos como primera opción a la hora de buscar material relacionado con sus asignaturas e intereses. Por otra parte, los contactos establecidos con el ASIC y el BIB pretenden, por una parte, determinar el uso real que hacen los alumnos de la UPV de los recursos disponibles y, por otra parte, transmitir los problemas encontrados, y posibles soluciones, para mejorar la facilidad de uso y fomentar la visibilidad de estos repositorios.

Entre las acciones futuras posibles, en colaboración con el BIB, el ASIC y Instituto de las Ciencias de la Educación (ICE) de la UPV, se valora la posibilidad de realizar sesiones de formación e información sobre la introducción de recursos en los repositorios y su uso en la docencia, elaboración de guías y materiales de soporte, asesoramiento para los autores de los materiales y los profesores que deseen utilizarlos, acciones de fomento del acceso abierto mediante organización de eventos, presentaciones, campañas en facultades y departamentos, semanas de acceso abierto, seminarios, pósters y cartelería, utilización de los media; utilización de redes sociales, etc.

\section{Agradecimientos}

Se agradece a la UPV la financiación de los proyectos PIME/2016/A/029 ("Uso e impacto en la docencia universitaria del material didáctico multimedia-UPV”) y PIME/2017/A04 ("Impulsando el uso de los repositorios institucionales de materiales didácticos multimedia de la UPV entre el alumnado y el profesorado").

\section{Referencias}

ALHADAD, S., ARNOLD, K., BARON, J., BAYER, I., BROOKS, C., LITTLE, R., . . WHITMER, J. (2015). The Predictive Learning Analytics Revolution: Leveraging Learning Data for Student Success. Recuperado el 21 de marzo de 2018, de EDUCAUSE Center for Analysis and Research (ECAR): https://library.educause.edu/ /media/files/library/2015/10/ewg1510pdf.pdf

ARGENTEA, E., GARCÍA-FORNES, A., \& ESPINOSA, A. (2016). Aplicando la metodología Flipped-Teaching en el Grado de Ingeniería Informática: una experiencia práctica. XXII

(c)) BY-NC-ND 2018, Universitat Politècnica de València

Congreso IN-RED (2018) 
Jornadas sobre la Enseñanza Universitaria de la Informática (JENUI), (págs. 221-228). Valencia.

BARRUECO-CRUZ, J. M., ANDRÉS-RODRÍGUEZ, A., RICO-CASTRO, P., COSLADOBERNABÉ, M. A., AZORÍN-MILLARUELO, C., BERNAL-MARTÍNEZ, I., . . . PRATSPRATS, J. (2017). Guía para la evaluación de repositorios institucionales de investigación. Recuperado el 21 de marzo de 2018, de Recolector de Ciencia Abierta: https://www.recolecta.fecyt.es/sites/default/files/contenido/documentos/2017GuiaEvaluacio nRecolectaFECYT.pdf

CHAN, L., CUPLINSKAS, D., EISEN, M., FRIEND, F., GENOVA, Y., GUÉDON, J. C., . . . VELTEROP, J. (2002). Iniciativa de Budapest para el Acceso Abierto. Recuperado el 21 de marzo de 2018, de Budapest Open Access Initiative: http://www.budapestopenaccessinitiative.org/translations/spanish-translation

DE ANDRÉS, D., ANTONINO, E., GISBERT, C., RUIZ, J. C., PALOMARES, A., \& PEÑA, A. (2017). ¿Qué recursos didácticos conocen y usan nuestros alumnos? III Congreso Nacional de Innovación Educativa y de Docencia en Red (págs. 269-281). Valencia: Universitat Politècnica de València. Recuperado el 21 de marzo de 2018, de http://ocs.editorial.upv.es/index.php/INRED/INRED2017/paper/viewFile/6878/2888

Declaración de Berlín sobre acceso abierto. (22 de octubre de 2003). Recuperado el 21 de marzo de 2018, de Open Access Max-Planck-Gesellschaft: https://openaccess.mpg.de/BerlinDeclaration

FITA, A. M., \& MANZUR, J. A. (2012). Rescate de embriones inmaduros in vitro. Recuperado el 21 de marzo de 2018, de RiuNet: https://riunet.upv.es/handle/10251/16770

GISBERT, M. C. (2010). Utilización de la citometría de flujo para analizar la ploidía en plantas. Recuperado el 21 de marzo de 2018, de RiuNet: http://hdl.handle.net/10251/7781

JORDÁN-LLUCH, C., PÉREZ-PEÑALVER, M. J., \& SANABRIA-CODESAL, E. (2014). Flipped Classroom: Reflexiones y opiniones de los implicados. Jornadas de Innovación Educativa y docencia en Red de la Universitat Politècnica de València, (págs. 310-323). Valencia.

MOLTÓ, G., MONTSERRAT, J. F., FITA, I. C., \& FITA, A. (2014). Experiencias Tecnológicas de Soporte al Blended Learning en un Contexto Multidisciplinar. Jornadas de Innovación Educativa y docencia en Red de la Universitat Politècnica de València, (págs. 54-68). Valencia.

UNIVERSITAT POLITÈCNICA DE VALÈNCIA. (2008). RiuNet repositorio institucional UPV. Recuperado el 21 de marzo de 2018, de https://riunet.upv.es/

UNIVERSITAT POLITÈCNICA DE VALÈNCIA. (2013). Innovación, creatividad y emprendimiento. Recuperado el 21 de marzo de 2018, de Competencias Transversales: http://www.upv.es/contenidos/COMPTRAN/info/954818normalc.html

VICERRECTORADO PARA EL DESARROLLO DE LAS TECNOLOGÍAS DE LA INFORMACIÓN Y LAS COMUNICACIONES. (2011). Política institucional de la Universitat Politècnica de València sobre Acceso Abierto. Recuperado el 21 de marzo de 2018, de Riunet: https://riunet.upv.es/handle/10251/11342 


\title{
Innovación docente y participación ciudadana en proyectos de regeneración urbana. PIME "Desis Lab: Proyecto parques urbanos de barrio”
}

\author{
Ana Portalés Mañanós ${ }^{a}$, David Urios Mondéjar ${ }^{b}$, Juan Colomer Alcácer ${ }^{c}$, Maite \\ Palomares Figueres $^{d}$, Consuelo Esteve Sendra ${ }^{e}$ y Asenet Sosa Espinosa $^{f}$
}

a'Departamento de Urbanismo, anporma@urb.upv.es, ${ }^{\mathrm{b}}$ Departamento de Urbanismo, umdav@urb.upv.es. ${ }^{\mathrm{c} D e p a r t a m e n t o ~ d e ~ U r b a n i s m o, ~ j u a n c o l o m e r a l c a c e r @ g m a i l . c o m . ~}{ }^{\mathrm{d}}$ Departamento de Composición Arquitectónica, mapafi@cpa.upv.es, ${ }^{\mathrm{e}}$ Departamento de Dibujo cheleesteve00@gmail.com, y ${ }^{\mathrm{f}}$ Departamento de Urbanismo, assoes@urb.upv.es.

\begin{abstract}
A PIME teaching innovation project has been presented (Project of Improvement and innovation in education). It is based on improvement and innovation in education. It is an urban regeneration project of multidisciplinary nature which is currently under development. Teachers and students of different qualifications (architecture, urban planning, design, sociology and botany) take an active part contributing to the development of an overall plan. The PIME is framed within the following methodogies: $A B P$ (Project-based learning:) and APS (Servicelearning). This teaching innovation succeeded in creating a teacher Web platform for citizen participation (www.valenciaparcsdebarri.es)
\end{abstract}

keywords: service learning, project-based learning, citizen participation, urban regeneration, multidisciplinary project.

\section{Resumen}

Se presenta un proyecto de innovación docente PIME (Proyecto de Innovación y Mejora Educativa) basado en el empleo de metodologías docentes activas aplicadas a la enseñanza de una asignatura de carácter proyectual que trata temas de regeneración urbana. Este proyecto de innovación tiene un carácter multidisciplinar y actualmente se encuentra en fase de desarrollo. Participan profesores, alumnos y alumnas de distintas titulaciones (arquitectura, urbanismo, diseño, sociología y botánica) contribuyendo en el desarrollo de un proyecto global. El PIME, que cuenta entre sus antecedentes con la creación de una plataforma web docente y de participación ciudadana www.valenciaparcsdebarri.es, se enmarca dentro de las metodologías APP (Aprendizaje basado en Proyectos), y APS (Aprendizaje Servicio).

Palabras clave: aprendizaje servicio, aprendizaje basado en proyectos, participación ciudadana, regeneración urbana, proyecto multidisciplinar. 


\section{Introducción}

En la comunicación se presenta un Proyecto de Innovación y Mejora Educativa (PIME) basado en el empleo de metodologías docentes activas aplicadas a la enseñanza de asignaturas de carácter proyectual. Esta innovación se plantea en la asignatura Urbanística I de $2^{\circ}$ curso del Grado en Fundamentos de Arquitectura en la que se desarrolla un proyecto de regeneración urbana.

Coincidiendo con la reflexión: "Cuando se piensa en la regeneración urbana, se acostumbra a enfatizar la necesidad de las visiones integradoras. En los últimos años, eso significa considerar cada vez más los factores sociales, económicos y ambientales, además de físicos y constructivos" (Díez-Medina, C., \& Monclús-Fraga, J., 2017) planteamos la necesidad de establecer alianzas entre la ciudad y ciudadanía, así como con las distintas disciplinas que gravitan en torno al espacio público.

Estas conexiones entre ciudad y disciplinas relacionadas con el proyecto urbano, se pretenden trasladar al ámbito docente a través del PIME que se presenta. Así, como objetivos principales de la innovación docente señalamos por un lado, e introducir la multidisciplinareidad que caracteriza el trabajo profesional del arquitecto en el campo del urbanismo, y por otro, acercar al alumnado a la resolución de temas reales que les aproximen a las condiciones en las que podrán desarrollar su trabajo profesional.

La colaboración en un proyecto de disciplinas afines y complementarias al urbanismo, y el acercamiento a la realidad urbana, aumenta la motivación del alumnado y supone una mejora en los resultados docentes de los proyectos.

Otros pilares de apoyo en el desarrollo de este proyecto son la apertura de la Universidad a la sociedad a través del Aprendizaje Servicio (APS), la participación ciudadana y el desarrollo de trabajo en equipo. Generalmente en los proyectos de regeneración urbana de espacios públicos es habitual el trabajo en equipos multidisciplinares (arquitectos, ingenieros, sociólogos, diseñadores etc.). Este modo de trabajar se traslada a las aulas en el marco de una asignatura con una metodología de Aprendizaje Basado en Proyectos ( $A B P$ ). Así también, en este proyecto, se valora la importancia de transmitir el conocimiento e interaccionar con la sociedad, por ello consideramos necesario la apertura de la universidad a la ciudadanía. Mediante la interacción con los ciudadanos a través de una página web, obteniendo una información relevante para el desarrollo del proyecto.

El PIME se plantea partiendo de experiencias docentes previas en las que se han obtenido como resultados, entre otros, la creación de una página web de participación ciudadana www.valenciaparcsdebarri.es en la que han colaborado más de 300 alumnos y alumnas de la UPV. También cabría destacar el plan de difusion previsto para los resultados del PIME, a través de la incorporación de este proyecto dentro de la red Desis Lab.

(cc) EY-NC-ND 2018, Universitat Politècnica de València

Congreso IN-RED (2018) 


\section{Objetivos}

Partiendo de la reflexión anterior, en el PIME se plantean una serie de objetivos generales y específicos que se desarrollan a continuación

\subsection{Generales}

Incorporar a la docencia la interdisciplinareidad necesaria para mejorar el resultado de un proyecto docente en el que la temática es la regeneración urbana y la sostenibilidad en el espacio público. Para ello se impartirán clases magistrales de disciplinas complementarias a la urbanística, como la sociología o la botánica, así como clases técnicas de iluminación y accesibilidad en el espacio público.

Abrir la Universidad a la sociedad, a la ciudadanía y a las instituciones mediante la aplicación de la metodología Aprendizaje Servicio, de modo que el trabajo desarrollado por el alumnado, por un lado responda a las necesidades sociales reales y por otro tenga una utilidad para la administración pública. En este caso a través de un convenio de colaboración con l'Ajuntament d’Algemesí.

Utilizar la experiencia docente como laboratorio de diseño donde se inicien nuevos proyectos. Si un movimiento mundial hacia la sostenibilidad exige el mejor uso posible de los recursos existentes, las escuelas implicadas en el PIME, con todo su potencial en términos de entusiasmo del alumnado participante, deben considerarse como un recurso social muy prometedor: un potencialmente poderoso promotor del cambio sostenible.

Dar visibilidad a los resultados obtenidos del PIME desde los Desis Lab. Utilizar las Escuelas de Diseño, Arquitectura, Bellas Artes, Agrónomos como agentes del cambio y la web www.desislabspain.webs.upv.es para la difusión de resultados.

\subsection{Específicos}

Coordinación y desarrollo de trabajos transversales e interdisciplinares en relación a los proyectos de regeneración urbana. La incorporación de disciplinas complementarias y clases técnicas especificas ontribuye a la mejora proyectual, social y ambiental de estos espacios públicos.

Aplicar y trabajar en la docencia la competencia número 7: "Responsabilidad ética, medioambiental y profesional”, ya que el alumnado trabaja con temas que le acercan a la realidad social y medioambiental, a través del proyecto de mejora del espacio público.

Continuar y perfeccionar las metodologías docentes y de participación ciudadana iniciadas con la plataforma web www.valenciaparcsdebarri.es como antecedente a esta innovación.

Potenciar el trabajo en equipo y las aportaciones interdisciplinares.

Aportar conocimiento, experiencias e iniciativas a la red Internacional DESIS LAB

Difundir las metodologías y los resultados docentes de la UPV, a la sociedad y en el ámbito internacional a través de la red para aumentar la sinergia mediante el desarrollo de marcos y 
plataformas para conectar los diversos casos locales en los proyectos regionales más grandes.

\section{Desarrollo de la innovación}

\subsection{Antecedentes}

\subsubsection{Experiencias previas}

Como experiencias previas cabría exponer, a parte de la aplicación de la metodología ABP y APS en las ciudades de Valencia y Cullera durantes los cursos 2015-16 y 2016-17, la creación de la plataforma web valenciaparcsdebarri.es. Esta herramienta web en la que han participado alrededor de 300 alumnos y alumnas durante los cursos 2014-15 y 2015-16 surgió de la preocupación por la mejora en la toma de decisiones proyectuales en la regeneración urbana de los espacios públicos. Con el fin de ahondar en el programa de necesidades del espacio público, esta web permite obtener información de los usuarios y analizar las variables que inciden en el grado de uso y de confort de los usuarios, como calidad ambiental, accesibilidad, diseño y materialidad, entre otros.

Se trata de una plataforma web de investigación docente social y urbana que facilita el intercambio de información y colaboración entre los usuarios de los parques, el alumnado, el profesorado y los organismos públicos. en torno a los parques de barrio de Valencia. La web incluye la localización y datos básicos de los parques de barrio de Valencia y supone una ventana abierta a los usuarios del espacio público para que conozcan opinen y valoren los parques de barrio, y de este modo, favorecer la mejora proyectual de estos espacios libres.

\subsubsection{Pertenencia y colaboración del equipo con la red DESIS_Lab}

Entre los profesores integrantes del equipo que desarrolla el PIME, cabe destacar la pertenencia y participación de algunos en la red DESIS-Lab. Esta asociación sin ánimo de lucro y de carácter cultural tiene como propósito promover el diseño para la innovación social en las instituciones de educación superior, donde a través de un diseño, pueda generar conocimiento útil para crear cambios sociales significativos. Desde este punto de vista, la capacidad de difusion que brinda la red para incorporar la experiencia del PIME, será aprovechada para dar visibilidad a nivel internacional de la experiencia.

Durante la última década la innovación social se ha extendido a una gran variedad de actores sociales en todo el mundo (instituciones, empresas, organizaciones sin ánimo de lucro y, sobre todo, las redes de personas en colaboración) que se han desplazado fuera de los modelos convencionales de pensar y hacer, generando una variedad iniciativas de prometedoras que proponen soluciones viables a problemas complejos como la regeneración urbana, la accesibilidad y la gestión de la energía.

La red DESIS posee Labs en todos los continentes. Hoy en día, la innovación social está generando una constelación de pequeñas iniciativas. Sin embargo, si se crean condiciones favorables, estas pequeñas invenciones sociales, locales y sus prototipos del trabajo

(cc) EY-NC-ND 2018, Universitat Politècnica de València

Congreso IN-RED (2018) 
resultante pueden propagar para generar cambios sostenibles y sociales a gran escala. (Fig.

1)

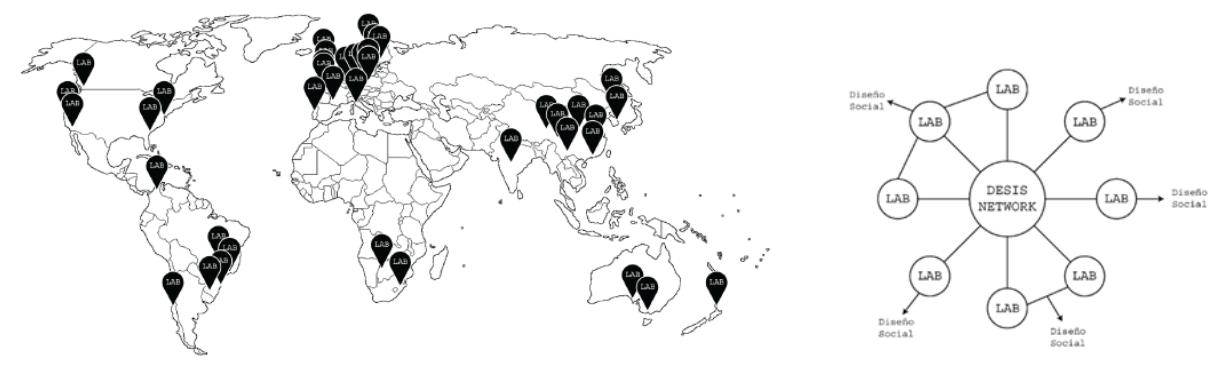

Fig. 1 Localización y esquema organizativo de la red DESIS-Lab

Actualmente el único Lab de DESIS Network en territorio español está en la ETSID/UPV. Desde la ETSA/UPV se ha solicitado el ingreso en dicha Red. El diseño para la innovación social puede encontrar en la ETSA una experiencia piloto.

\subsection{Contenido y alcance de la innovación}

El proyecto se desarrollará mayoritariamente en la asignatura Urbanística I del Grado en Fundamentos de Arquitectura en la que se realiza un trabajo docente consistente en un proyecto de regeneración urbana en parques de barrio de Valencia. El resto de asignaturas implicadas en el PIME, participarán de forma parcial, mediante la aportación de conferencias impartidas por el profesorado y trabajos específicos realizados por alumnos y alumnas que complementen a los desarrollados en la asignatura de Urbanismo. En esta asignatura (Urbanística I) se reúnen las condiciones para implementar la innovación docente, puesto que esta aportación multidisciplinar, redundará en la mejora del desarrollo de proyectos de regeneración urbana. Además, los resultados docentes de todas las asignaturas implicadas contribuirán, entre otros, a actualizar la documentación de la plataforma, y este modo abrir la Universidad a la sociedad y generar un efecto de retroalimentación entre los usuarios de la web y el alumnado.

Así en la asignatura Urbanística I, los alumnos y alumnas aprenden a conocer y a leer la ciudad en las distintas escalas. Inicialmente analizan la evolución urbana que caracteriza a las ciudades, en segundo lugar se produce un acercamiento a la escala del "barrio", como unidad morfológica y funcional dentro de las ciudades, y finalmente se desciende a la escala humana del espacio público. Es en esta escala en la que el alumnado desarrolla un proyecto urbano de mejora del espacio público, generalmente, en los parques urbanos de barrio. Así se les propone realizar un proyecto sobre estos espacios libres, públicos, de uso cotidiano, reducido tamaño y presentes en toda la ciudad.

El Proyecto de mejora de espacio público en el que trabajan los alumnos y alumnas se desarrolla este curso (2017-18) en el municipio de Algemesí. 


\subsection{Metodologías docentes aplicadas}

El Proyecto de innovación docente se basa en la aplicación de dos metodologías activas de la enseñanza, dirigidas a aproximar el trabajo que desarrolla el alumnado a la realidad profesional. Por un lado, se potencia la necesidad de realizar trabajo multidisciplinar y en equipo por medio de la metodología de Aprendizaje Basado en Proyectos (ABP). Por otro lado, se valora la importancia de trabajar en temas y contextos reales, abriendo la Universidad a la sociedad, desde la aplicación de la metodología Aprendizaje Servicio (APS).

\subsubsection{Aprendizaje basado en proyectos $(A B P)$}

Se trata de una metodología docente activa que organiza el proceso de enseñanza y aprendizaje a través de la elaboración de proyectos por parte de los alumnos y alumnas (Gülbahar y Tinmaz, 2006). El proceso de aprendizaje se produce de forma gradual mediante la implicación de los estudiantes en el desarrollo de un Proyecto, en este caso un Proyecto de mejora de un espacio público. Los estudiantes trabajan de manera activa, planificando, implementando y controlando proyectos que tienen una aplicación en el mundo real, yendo más allá del aula de la clase (Martí, 2010).

\subsubsection{Aprendizaje servicio}

El Aprendizaje Servicio (APS) implica una propuesta educativa que combina procesos de aprendizaje y de servicio a la comunidad en un solo proyecto bien articulado, en el que los participantes se forman al trabajar sobre necesidades reales del entorno con el objetivo de mejorarlo. Por su parte, para (Martínez-Odría, 2007) el APS es un método de enseñanza que enfatiza tanto el aprendizaje académico que se desarrolla en el aula, como la realización de un servicio voluntario a favor de las necesidades detectadas en la comunidad próxima.

Coincidiendo en buena parte con las definiciones anteriores, en nuestro caso el alumnado a través de sus trabajos prestan un servicio a la sociedad trabajando en temas y necesidades reales. Así se establece como emplazamiento de trabajo para los proyectos de regeneración urbana la población de Algemesí, existiendo un compromiso con el Ayuntamiento y con la ciudadanía de aportar ideas que puedan orientar a la administración en la toma de decisiones encaminadas a la resolución de problemas y necesidades de la ciudadanía en la regeneración urbana del espacio público.

\subsection{Fases del desarrollo de la innovación}

Septiembre 2017. Con el inicio de curso se desarrolla un seminario monográfico de evolución urbana de las ciudades con objeto de introducir al alumnado en la identificación de distintos tejidos urbanos. El resultado de este curso es de aplicación para la primera fase del trabajo que consiste en entender la ciudad como un conjunto, en nuestro caso Algemesí.

Octubre 2017. El mes de octubre, coincidiendo con la Semana de la Arquitectura del municipio, el Ayuntamiento de Algemesí recibió a nuestro alumnado en una Jornada en la 
que además, se realizó una visita de campo por toda la ciudad con la finalidad de obtener datos de los problemas y oportunidades detectados en el espacio público. (Fig.2/ Fig.3)
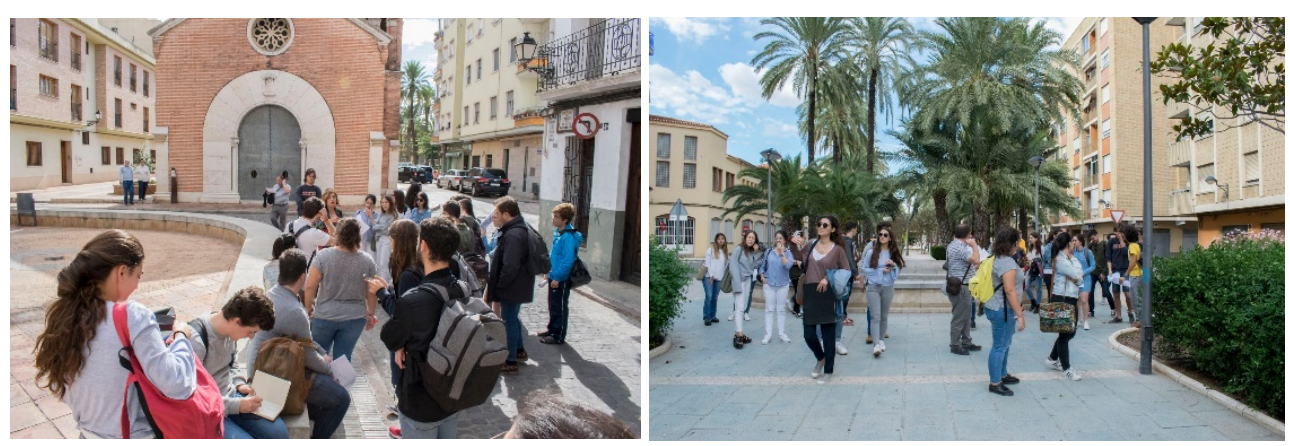

Fig. 2 y 3. Visita y reconocimiento del alumnado al espacio público de Algemesí

Noviembre 2017. El arquitecto municipal acude a la Universidad para impartir una clase magistral acerca de la evolución urbana de Algemesí. Con la toma de datos sobre el municipio y después de la clase impartida por el arquitecto municipal, los alumnos y alumnas inician un trabajo de análisis de los barrios de Algemesí atendiendo a aspectos morfológicos y funcionales, este trabajo se prolonga hasta el mes de diciembre

Diciembre 2017. Entrega del trabajo de análisis del barrio con una exposición pública de los resultados. Se realiza una valoración crítica y se detectan los principales problemas y oportunidades de intervención para la regeneración urbana.

Enero 2018. Partiendo de las áreas de interés seleccionadas anteriormente para la regeneración urbana, se inicia el segundo ejercicio práctico en equipo que consiste en el análisis del espacio público. Se seleccionan parques y rondas como elementos con mayor grado de uso por parte de la ciudadanía y que se encuentran en un estado de deterioro detectable y visible.

Febrero 2018. Los estudiantes realizan una nueva toma de datos, in situ, por medio de observación directa simple y no participante, durante un intervalo horario definido por patrones de uso del espacio público. Detectan los perfiles de usuarios y los problemas que allí se producen. Además en esas visitas, realizan una catalogación de todos los elementos que definen la materialidad de ese espacio (pavimentos, mobiliario urbano, farolas, tipos de juegos de niños etc.), por medio de fotografías y cuadernos de notas observacionales (quién, qué, cuándo, dónde y cómo de la actividad humana).

Durante el mes de febrero se producen las clases magistrales de los especialistas en sociología y botánica. En este momento se introduce la interdisciplinareidad a la asignatura. Por parte de la experta en sociología se aportan las técnicas de investigación social para el acercamiento a la ciudadanía (observación directa, entrevistas abiertas, encuestas, etc.). 
Por parte del experto en botánica se imparte una clase específica de clasificación de especies vegetales en climas mediterráneos, que les será de utilidad para la evaluación de la calidad ambiental de estos espacios.

Marzo 2018. Se entrega el trabajo de análisis del espacio público realizado en equipo y se presenta en exposición pública. En esta fase se reflejan los resultados del trabajo de análisis del espacio público, incluyéndose datos relativos a la materialidad, al uso y a las condiciones de confort del espacio público. A continuación se hace un diagnóstico y una valoración crítica del estado en que se encuentran estos parques.

Se inicia la fase final del trabajo, la realización del proyecto de mejora del espacio público. Además, el alumnado también realiza un ejercicio individual para aprender a procesar datos de la ciudadanía a través de la plataforma web valenciaparcsdebarri.es. Este ejercicio se realiza en Valencia y se complementa con encuestas in situ.

En esta fase se reflejan los resultados del trabajo de análisis del espacio público

Abril 2018. Se continua con el trabajo en equipo y se introducen clases magistrales de expertos en distintas disciplinas de aplicación a la ejecución del proyecto de mejora en el espacio público: iluminación, calidad ambiental, diseño social, intervenciones históricas, etcétera.

Mayo 2018. Al finalizar el mes de mayo, el alumnado entrega sus trabajos finales.

Junio 2018. Evaluación de los trabajos entregados

\section{Resultados de la innovación}

Los resultados de los trabajos docentes son mostrados al Ayuntamiento mediante una exposición en el municipio, abierta a la ciudadanía. Por otro lado, los trabajos serán también expuestos en la Escuela. Dentro del Plan de diffusion también contaremos con la repercussion dentro de la red internacional Desis Lab.

Aunque los resultados de este curso todavía no están finalizados, con la experiencia previa del curso 2016-17 cuyo trabajo se desarrolló en el municipio de Cullera y del año anterior en Valencia, disponemos de resultados en los que se puede valorar la aplicación de esta metodología. (Fig.4 /Fig. 5)
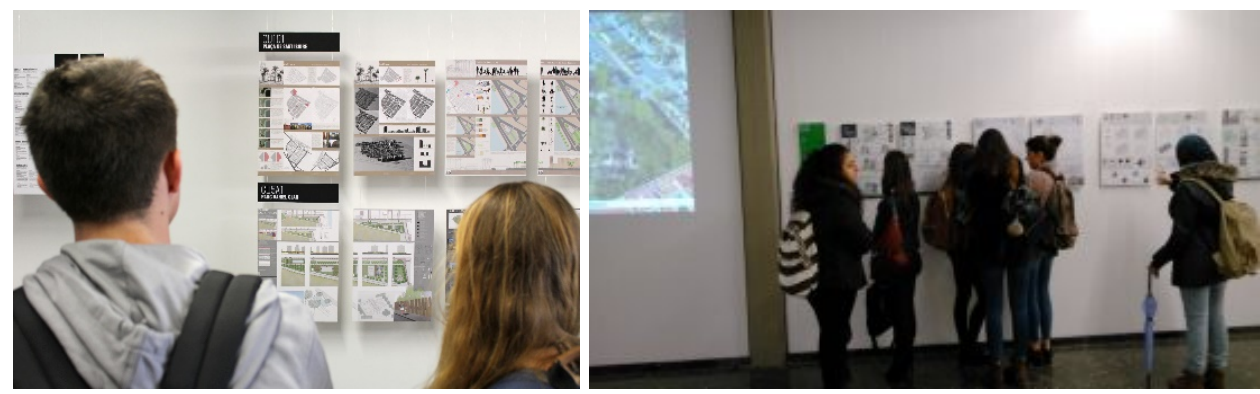

Fig. 4 y 5. Exposición de trabajos docentes en la E.T:S. de Arquitectura 2017

(c) EY-NC-ND 2018, Universitat Politècnica de València

Congreso IN-RED (2018) 
Desde el punto de vista proyectual, la aplicación de una metodología basada en temas reales, en los que se incorpora la participación ciudadana redunda en una mejora en la definición del programa de necesidades del espacio público, mejorando a nivel funcional el Proyecto desarrollado.

Desde el punto de vista de la materialidad, el análisis y la catalogación de los elementos que definen el espacio público, plantea una reflexión de la adecuación o no, de estos elementos, al espacio en el que se integran.

El diseño urbano también mejora sobre todo después de las clases impartidas por distintos especialistas en la material.

\section{Conclusiones}

Los ejercicios demuestran que el trabajo en temas reales, la cercanía a la ciudadanía y a la administración, desarrollan una motivación especial en los alumnos. La incorporación de clases de expertos refuerzan la importancia de la interdisciplinareidad en los proyectos de regeneración urbana.

Por otro lado, el trabajo en equipo de 4 o 5 alumnos integrantes, también ayuda a la toma de decisiones y acerca a la realidad del ejercicio profesional, que en urbanismo, fundamentalmente se desarrolla por medio del trabajo en equipos multidisciplinares.

Esta innovación aporta al alumnado un modo de acercamiento al espacio público que aúna la componente social con la urbana. Plantea una reflexión abierta sobre la funcionalidad y materialidad de los parques de barrio. Desde esta reflexión, surgen los argumentos para afrontar con mayor solvencia los proyectos de regeneración urbana y mejora en los espacios públicos.

Destacamos también la importancia de la difusion de las metodologías docentes activas y los resultados que generan, en este sentido la integración del Proyecto en la red DESIS-Lab aporta repercusión a esta iniciativa docente.

\section{Referencias}

DÍEZ-MEDINA, C., \& MONCLÚS-FRAGA, J. (2017). "Docencia e investigación: exploraciones teórico-proyectuales en torno a la regeneración urbana" $V$ Jornadas sobre innovación docente en arquitectura. Universitat Politècnica de Catalunya. Iniciativa Digital Politècnica. Grup per a la Innovació i la Logística Docent en l'Arquitectura. Disponible < https://upcommons.upc.edu/handle/2117/109609> [Consulta: 20 de marzo 2018.]

GULBAHAR, Y. TINMAZ, H. (2006). "Implementing Project-Based Learning and E-Portfolio Assessment in an Undergraduate Course". Journal of Research on Technology in Education, vol. 38, no3, p. 309-327.

MARTíNEZ, M. (2008). “Aprendizaje servicio y construcción de ciudadanía activa en la universidad: la dimensión social y cívica de los aprendizajes académicos”. En Miquel Martínez (ed) Aprendizaje servicio y responsabilidad social de las universidades. Barcelona: Ministerio de Educación y Ciencia 
Innovación docente y participación ciudadana en proyectos de regeneración urbana. PIME "Desis Lab: Proyecto parques urbanos de barrio"

(MEC), Secretaría General Técnica y Ediciones Octaedro, S.L..; 11-26 < http://www.ucv.ve/uploads/media/Aps y universidad.pdf> [Consulta: 14 de marzo 2018].

ODRIA, A. M. (2007). "Service-learning o aprendizaje-servicio: la apertura de la escuela a la comunidad local como propuesta de educación para la ciudadanía”. Bordón. Revista de pedagogía,Vol. 59, Núm 4, p. 627-640. Disponible https://recyt.fecyt.es/index.php/BORDON/article/view/36336> [Consulta: 14 de marzo 2018]

PORTALES MAÑANOS, A.; PALOMARES FIGUERES, M. T.; ESTEVE SENDRA, M. C.; PASCUAL-SEVA, N. (2015). "La participación social aplicada al aprendizaje en proyectos. Su desarrollo metodológico en asignaturas de diseño urbano y diseño de producto”. 23 Congreso Universitario de Innovación Educativa en las enseñanzas Técnicas. pp. 951 - 965. 


\title{
Diseño de itinerarios de aprendizaje para el desarrollo progresivo de la competencia transversal "Innovación, creatividad y emprendimiento"
}

Andrés Boza ${ }^{\mathrm{a}}$, Llanos Cuenca ${ }^{\mathrm{a}}$, Marta Fernández-Diego ${ }^{\mathrm{a}}$, Leonor Ruiz ${ }^{\mathrm{a}}$, Faustino Alarcón $^{\text {b }}$, Jose Manuel Prats-Montalbán ${ }^{\text {b }}$, M.M.E. Alemany ${ }^{\text {b }}$, Mariluz Gordo ${ }^{\text {a }}$

${ }^{a}$ Escuela Técnica Superior de Ingeniería Informática,${ }^{b}$ Escuela Técnica Superior de Ingeniería Industrial. Universitat Politècnica de València (España) (aboza@omp.upv.es,llcuenca@omp.upv.es,marferdi@omp.upv.es,Iruiz@omp.upv.es, faualva@omp.upv.es,jopramon@eio.upv.es,mareva@omp.upv.es,magormon@upvnet. upv.es)

\begin{abstract}
The level with which our students arrive with respect to a certain transversal competence is often unknown and initially presupposed by the teacher. The proposal for innovation and educational improvement presented in this document focuses on the early identification of this initial level in the transversal competence "Innovation, creativity and entrepreneurship" in order to offer learning activities at different levels to reinforce those aspects required for an adequate coverage of the competence. For the latter, it is proposed designing a map of classified learning activities. The desing of this map enables to have a broad view of the activities carried out for the development of competence, to identify overlaps of activities at the same level, and to identify levels not addressed by no activity, which encourages the development of activities that cover levels not reached by other activities.
\end{abstract}

Keywords: Learning Activities, Transversal Competences, Map of Activities, Teaching-Learning Process, Creativity, Innovation, Entrepreneurship,

\footnotetext{
Resumen

El nivel con el que llegan nuestros estudiantes respecto a una determinada competencia trasversal, es en muchas ocasiones desconocido e inicialmente presupuesto por el profesor. La propuesta de innovación y mejora educativa presentada en este documento se centra en la identificació temprana de ese nivel de partida de los alumnos en la competencia trasversal "Innovación, creatividad y emprendimiento" para poder ofrecerles actividades de aprendizaje a diferentes niveles con el fin de reforzar aquellos aspectos requeridos para una adecuada cobertura de la competencia. Para esto último, se propone el diseño de un mapa de actividades de aprendizaje clasificado que permita tener una visión amplia de las actividades llevadas a cabo para el desarrollo de la competencia, identificar superposiciones de actividades en el mismo nivel, e identificar niveles no abordados por ninguna actividad, lo que fomenta el desarrollo de actividades que cubren niveles no alcanzados por otras actividades.
} 
Palabras clave: Actividades de aprendizaje, Competencias Trasversales, Mapa de Actividades, Proceso Enseñanza-Aprendizaje, Creatividad, Innovación, Emprendimiento

\section{Introducción}

Las universidades estan rediseñando sus planes de estudios de acuerdo a nuevos perfiles profesionales que requiere la sociedad. Para estos nuevos perfiles son necesarias competencias específicas, pero también compentencias transversales, o también denominadas genéricas. (Perrenoud, 2008) define competecias como el conjunto de conocimientos, habilidades y actitudes capaces de movilizar una persona de forma integrada para responder efectivamente a un tipo de situaciones. Las competencias específicas se hubican en una determinada área de conocimiento y afectan a los perfiles profesionales que se pueden desarrollar dentro de esa área. Las competencias transversales son genéricas y transferibles en diferentes contextos personales, sociales, académicos y profesionales a lo largo de la vida (Boza et al., 2017).

De forma general, el nivel de partida de un alumno en relación a competencias no transversales puede ser conocido por la estructura de los planes de estudios previamente cursados. Así, el profesor tiene como referencia un determinado nivel en los alumnos sobre las competencias específicas que debe abordar debido al conocimiento de la formación recibida anteriormente. Sin embargo, cuando se trata de competencias transversales, ese nivel de partida del alumno no es tan fácil de identificar.

Las capacidades del alumno de hablar en público, tener pensamiento crítico o de trabajo en equipo, son, en la mayoría de los casos, desconocidas por el profesor cuando comienza su actividad docente con un grupo nuevo de alumnos. Sin embargo, un importante número del profesorado, continua actuando como con el resto de competencias no transversales, es decir, asumiendo un determinado nivel de partida del alumnado y definiendo actividades de aprendizaje para la competencia según ese "supuesto" nivel de partida.

La experiencia adquirida en anteriores proyectos ha demostrado que una actividad, para el desarrollo de competencias transversales, llevada a cabo en el aula puede tener resultados diferentes en los estudiantes. No todos se enfrentan de igual forma a la actividad, les resulta difícil, o excesivamente fácil, y surgen bloqueos o falta de motivación.

La competencia tranversal "Innovación, Creatividad, y Emprendimiento" no escapa de esta problematica cuando las actividades están más enfocadas a los indicadores de la competencia que a las necesidades del alumno. Esta compentencia esta incluida en el proyecto UPV de competencias transversales puesto en marcha por la Universitat Politècnica de València. Este proyecto incluye 13 competencias genéricas (Universitat Politècnica de Valencia, 2017).

La propuesta presentada en este artículo se centra en primer lugar en identificar el nivel de partida de la competencia de los alumnos para adecuar el proceso enseñanza-aprendizaje a los diferentes niveles encontrados en el aula, y por otro en la identificación y clasificación de actividades de aprendizaje en diferentes niveles dentro de la competencia.

(cc) EY-NC-ND 2018, Universitat Politècnica de València

Congreso IN-RED (2018) 
La propuesta incorpora al alumno como elemento clave en el proceso enseñanzaaprendizaje.

Esta propuesta se enmarca dentro de un proyecto de innovación educativa en desarrollo y lo que se presenta aquí es el diseño de dicha propuesta y el despliege que se esta desarrollando. Un aspecto clave es la intencionalidad de los autores para que la propuesta pueda analizarse desde la perspectiva de otras competencias trasversales. Así, la competencia "innovación, creatividad y emprendimiento" se presenta como soporte de la propuesta, aunque otras competencias trasversales podrían ser abordadas de forma similar. Además, la propuesta no se focaliza en un nivel de grado o master, ni para una determinada titulación al tratarse de una competencia trasversal.

\subsection{Objetivos}

Así, el objetivo general es identificar los diferentes niveles de partida en la competencia “Creatividad, Innovación y Emprendimiento” a cada alumno y clasificar las actividades de aprendizaje disponibles para dicha competencia para luego poder definir diferentes líneas de actuación que favorezcan su adecuado alcance de la competencia.

De forma más concreta, los objetivos a cubrir son:

1. Diseñar la escala para identificar niveles en el alcance de la competencia.

2. Diseñar actividades iniciales de pre-evaluación que permitan identificar la capacidad creativa, de innovación y emprendimiento para cada alumno.

3. Identificar y clasificar actividades de acuerdo con la escala establecida para construir un mapa de actividades.

\section{Diseño de la escala para identificar niveles de alcanze de la competencia}

El diseño de la escala se justifica por el requerimiento de medir el nivel de los alumnos respecto a la competencia, así como, el nivel en el que mejor contribuyen las actividades de aprendizaje al alcance de la competencia. Medir significa asignar números, símbolos o valores a las propiedades de los objetos o eventos de acuerdo con reglas(Stevens, 1951). En ciencias sociales se trabaja con conceptos abstractos que no pueden caracterizarse como objeto o evento. En este ámbito definen medición como el proceso de vincular conceptos abstractos con indicadores empíricos, el cual se realiza mediante un plan explícito y organizado para clasificar (y con frecuencia cuantificar) los datos disponibles (los indicadores), en términos del concepto que el investigador tiene en mente(Carmines \& Zeller, 1979), en nuestro caso para identificar niveles de alcance de la competencia. Para (Grinnell Jr \& Unrau, 2005) la función de la medición es establecer una correspondencia entre el "mundo real” y el "mundo conceptual”. El primero provee evidencia empírica, el segundo proporciona modelos teóricos para encontrar sentido a ese segmento del mundo real que estamos tratando de describir.

(c) ) EY-NC-ND 2018, Universitat Politècnica de València 
En este proceso, el instrumento de medición de datos tiene un papel central. Sin él no hay observaciones clasificadas. Así, los registros del instrumento de medición representan valores visibles de conceptos abstractos. Aunque no hay medición perfecta, debemos acercarnos lo más posible a la representación fiel de las variables que se van a observar mediante el instrumento de medición(Grinnell Jr \& Unrau, 2005).

Existen tres cuestiones básicas respecto a las variables que deben considerarse al momento de construir un instrumento(Hernandez Sampieri, Fernandez Collado, \& Baptista Lucio, 2014): la operacionalización, la codificación y el establecimiento de los niveles de medición.

1) El tecnicismo “operacionalización de variables” se emplea en investigación científica para designar al proceso mediante el cual se transforma la variable de conceptos abstractos a términos concretos, observables y medibles, es decir, dimensiones e indicadores(Arias, 2006). Este proceso incluye las etapas de definición nominal y conceptual de la variable, la dimensionalización de la misma (determinando sus factores, dimensiones o componentes), definir indicadores para las dimensiones y finalmente identificar, desarrollar o generar ítems o valores de cada indicador.

2) La codificación de datos significa asignarles un valor numérico o símbolo que los represente. Es decir, a las categorías (opciones de respuesta) de cada ítem o variable se les asignan valores numéricos o signos que tienen un significado. Por ejemplo, la Categoría Masculino - Femenino se puede codificar como 1 - 2, o el ítem "En esta empresa tengo libertad para tomar decisiones” se puede codificar como 5. Totalmente de acuerdo, 4. De acuerdo, 3. Ni de acuerdo ni en desacuerdo, 2. En desacuerdo, 1. Totalmente en desacuerdo)

3) Los niveles de medición más conocidos son: i) Nivel de medición nominal, donde hay dos o más categorías del ítem o la variable, y estas categorías no tienen orden ni jerarquía. (Ej. La variable “género” de la persona tiene las categorías: masculino y femenino. ii) Nivel de medición ordinal, donde hay varias categorías que mantienen un orden de mayor a menor (Por ej. Presidente es más que vicepresidente, y a su vez, más que director general, pero no se puede precisar cuánto más). iii) Nivel de medición por intervalos. Además del orden o la jerarquía entre categorías, se establecen intervalos iguales en la medición, es decir, la distancias entre categorías son las mismas a lo largo de toda la escala (Por ej. La variable "número de empleados a su cargo").

En el caso de las competencias transversales, el diseño de la escala es complejo y es dependiente del enfoque del profesor o profesores (diseñadores de la escala) quieran dar en el análisis de dicha competencia transversal y de la propia naturaleza de la competencia. Por ejemplo, la competencia transversal “Aprendizaje permanente” tiene unas dimensiones muy diferentes de la competencia “Comunicación Efectiva” tanto por las características intrínsecas de la competencia, como por los aspectos subjetivos del profesor o profesores a la hora de definir las dimensiones y los indicadores.

En el caso de la competencia transversal de la UPV "Innovación, Creatividad y Emprendimiento” la competencia se aborda como un proceso. En concreto, tomando los

(cc) BY-NC-ND 2018, Universitat Politècnica de València

Congreso IN-RED (2018) 
descriptores de las definiciones de innovación, creatividad y emprendimiento se establece un proceso a seguir, que contiene los siguientes pasos(Boza et al., 2017):

- Se analiza el entorno en busca de oportunidades

- Se proponen ideas creativas

- Se llevan a la práctica o se indica cómo hacerlo, emprendimiento, ejecución

- Se analizan riesgos y beneficios, valor de la innovación.

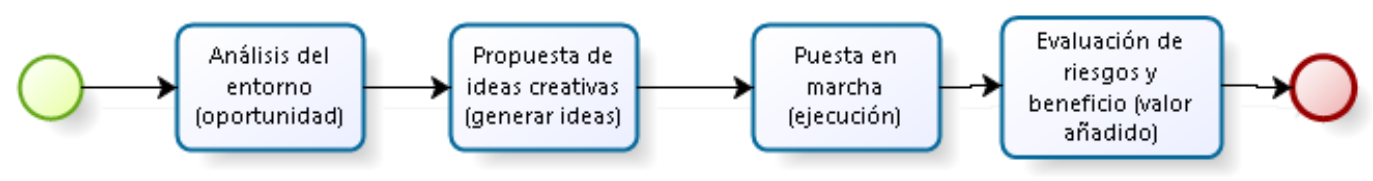

Fig 1: Proceso asociado a la competencia de creatividad, innovación y emprendimiento (Boza et al., 2017).

Así, la operacionalización de la competencia en dimensiones, indicadores e ítems se presenta en la siguiente tabla:

\begin{tabular}{|c|c|c|c|}
\hline Variable & Dimensión & Indicador & Item \\
\hline \multirow{4}{*}{$\begin{array}{l}\text { Competencia Transversal } \\
\text { "Innovación, Creatividad y } \\
\text { Emprendimiento" }\end{array}$} & $\begin{array}{l}\text { Análisis del entorno } \\
\text { (oportunidad }\end{array}$ & $\begin{array}{l}\text { El alumno se cuestiona la } \\
\text { realidad }\end{array}$ & \multirow{4}{*}{$\begin{array}{l}\text { Categorías: } \\
\text { D. No alcanzado } \\
\text { C. En desarrollo } \\
\text { B. Bien/adecuado } \\
\text { A. } \\
\text { Excelente/ejemplar }\end{array}$} \\
\hline & $\begin{array}{l}\text { Propuesta de ideas } \\
\text { creativas (generar ideas) }\end{array}$ & Aporta ideas & \\
\hline & $\begin{array}{l}\text { Puesta en marcha } \\
\text { (ejecución) }\end{array}$ & $\begin{array}{l}\text { Plasma de manera formal } \\
\text { las ideas }\end{array}$ & \\
\hline & $\begin{array}{l}\text { Evaluación de riesgos y } \\
\text { beneficio (valor añadido) }\end{array}$ & Identifica resultados & \\
\hline
\end{tabular}

Tabla 1. Operacionalización de la competencia transversal "Innovación, Creatividad y Emprendimiento".

La tabla anterior debe entenderse como una de las maneras de realizar la operacionalización de la competencia, ya que como se ha indicado anteriormente, los diseñadores de cada escala están condicionados por la naturaleza de cada competencia transversal, y su propia perspectiva. Así, para otras escalas se pueden requerir mediciones de 0 a 10 , utilizar escalas de Likert o usar diferenciales semánticos (por ej. El alumno es muy creativo --- El alumno es poco creativo). 
Respecto a los niveles de medición, para el caso que nos ocupa (identificación del nivel del estudiantes en la competencia trasversal "Innovación, creatividad y emprendimiento) se requieren al menos dos niveles. El enfoque que ha seguido esta propuesta es el establecer los niveles como un camino ordenado para el alcance de la competencia, de forma que los niveles a utilizar son el nivel de medición ordinal o el nivel de medición por intervalos.

La propuesta desarrollada en el presente artículo se enfoca en identificar el nivel inicial de los estudiantes en la competencia y clasificar actividades de aprendizaje de acuerdo a estos niveles para adaptar el proceso de enseñanza aprendizaje a los diferentes niveles encontrados en el aula. Esta es la razón por la que se require la escala ordenada. Sin embargo, para otras propuestas también se puede utilizar el nivel de medición nominal cuando se quiera poner el foco en las dimensiones en sí mismas y no tanto en su evolución (por ej. "La actividad aborda” Categorias: Innovación / Creatividad / Emprendimiento).

\section{Diseño de actividades iniciales de pre-evaluación que permitan identificar la capacidad creativa, de innovación y emprendimiento para cada alumno.}

El diseño de una actividad o actividades para la identificación temprana del nivel inicial del alumno en la competencia trasversal es un reto debido a la complejidad de la competencia al incluir elementos relacionados pero que pueden ser abordados de forma independiente.

Así, se podría diseñar una actividad que aborde de forma global los tres elementos que componen la competencia "Innovación, Creatividad y Emprendimiento", o diseñar actividades separadas para la evaluación de cada uno de estos componentes.

No hay que olvidar que el propósito de la actividad no es que sirva como una herramienta de aprendizaje para el alumno, sino que sirva como herramienta para la medición del nivel inicial de la competencia del alumno.

En la búsqueda de estas actividades nos podemos encontrar propuestas ampliamente utilizadas como the Torrance test of creative thinking (Torrance, 1974) y a su vez, críticas a estas mismas propuestas como (Piffer, 2012) que cuestiona que el test de Torrance aborde creative thinking, ya que pone el foco en el pensamiento divergente dejando de lado aspectos también importantes para la creatividad como el pensamiento convergente. Esta complejidad surge de igual modo si hablamos de innovación o de emprendimiento.

\subsection{Evaluación del nivel inicial del cada alumno}

Las actividades propuestas en el anterior paso persiguen la idenficiación temprana del nivel inicial del estudiante. En este paso se persigue el despliege de dichas actividades en el aula para realizar la evaluación.

Para dicho despliege hay que considerar dos aspectos importantes:

1. Identificación termprana. Desde el punto de vista temporal, la actividad debe realizarse en las primeras sesiones de puesta en marcha de la asignatura. Así, el profesor puede reaccionar y actuar en función de los resultados.

(cc) EY-NC-ND 2018, Universitat Politècnica de València

Congreso IN-RED (2018) 
2. Nivel de los estudiantes. Desde una perspectiva individual o de grupo, la actividad debe realizarse de forma individualizada y poder conocer los resultados de forma individualizada para poder ofrecer propuestas personalizadas a cada alumno.

\subsection{Identificar el nivel de cada estudiante en la competencia trasversal.}

Como resultado de la anterior evaluación, podemos identificar el nivel de cada estudiante en la competencia trasversal. Esto permite la agrupación de los alumnos por niveles para poder actuar de forma particular dependiendo del nivel en la competencia.

Un ejemplo puede verse con más detalle en la siguiente gráfica donde se trabaja con un grupo de 50 alumnos y se utiliza una escala de 0 a 10 respecto al nivel inicial del alumno en la competencia. Cada punto representa a un alumno:

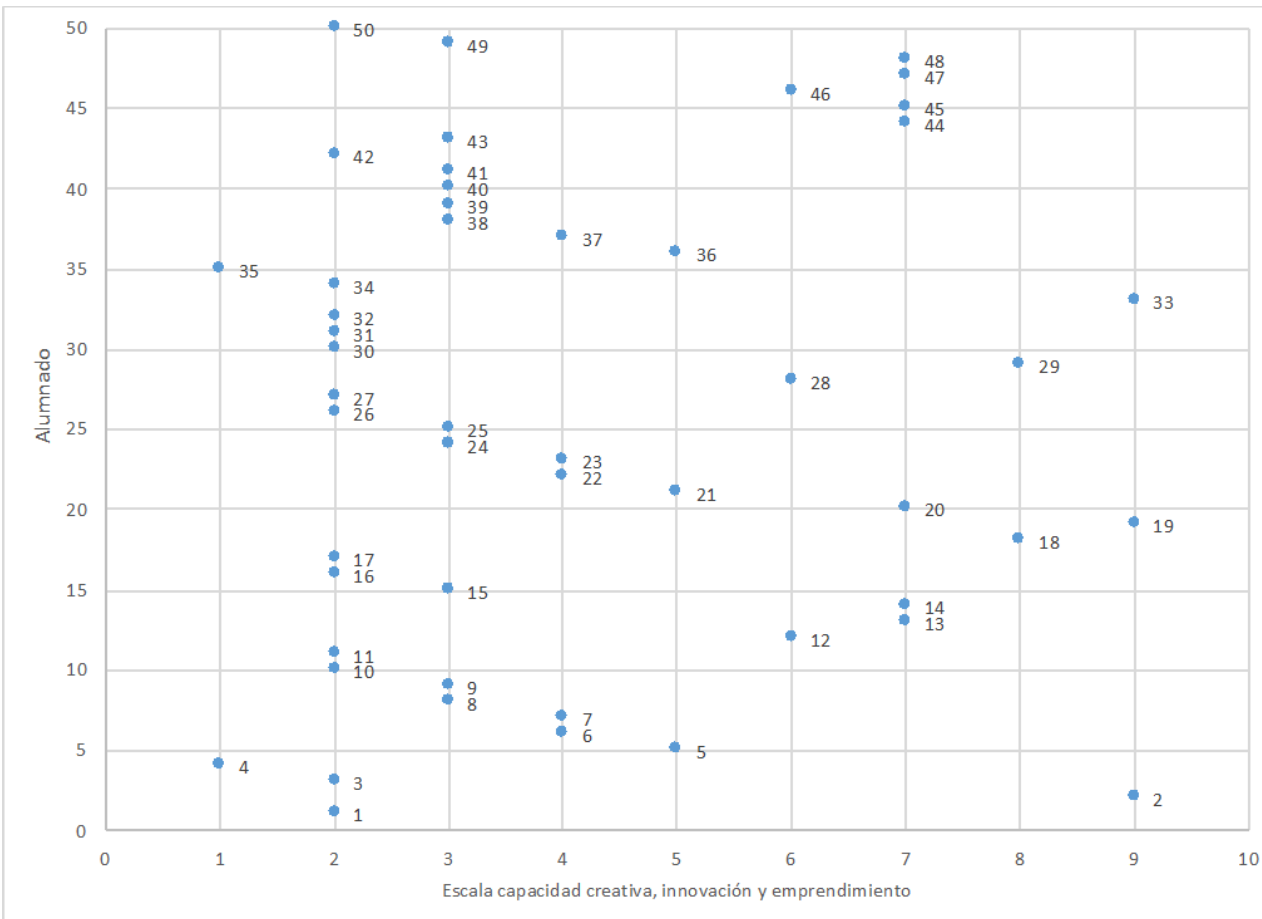

Fig 2. Nivel de la competencia para cada alumno.

La gráfica representa el diagrama de dispersión de los resultados obtenidos. Para dicho ejemplo, la capacidad creativa, de innovación y emprendimiento de los alumnos 33, 19 y 2 difiere bastante de la de los alumnos 35 y 4, por lo que las actividades para el desarrollo de la competencia a realizar en estos dos grupos de alumnos deberían ser diferentes. Así, se deberían establecer grupos de alumnos para el desarrollo de las actividades en función de su capacidad y potencial inicial. 


\section{Identificar y clasificar actividades de acuerdo con la escala establecida para construir un mapa de actividades.}

La construcción del mapa requiere en primer lugar identificar actividades de aprendizaje orientadas a la adquisición de la competencia transversal. El trabajo previamente realizado de operacionalización donde se identifican dimensiones de la competencia facilita esta labor, ya que las actividades deberían abarcar una o más de estas dimensiones. Este trabajo es más sencillo cuando ya se están realizando actividades de aprendizaje en la asignatura y ya tenemos un conjunto de actividades de aprendizaje identificadas. Si todavía no se ha trabajado con la competencia transversal, se deben buscar e identificar actividades de aprendizaje de la misma, con lo que este proceso será algo más largo.

En segundo lugar, se deben clasificar las actividades de acuerdo con la escala establecida para construir el mapa de actividades. Es decir, identificar el nivel (o niveles) para cada actividad de aprendizaje. Con ello, es posible construir el mapa de actividades situando todas las actividades en el mapa de acuerdo con la escala definida. Así, es posible identificar las actividades más idóneas para cada nivel de la escala.

En la figura 3 se muestra un ejemplo del mapa utilizando una escala de alcance de la competencia de 0 a 10 . El mapa nos muestra el conjunto de actividades de aprendizaje diseñadas para la competencia así como su ubicación dentro de la escala.

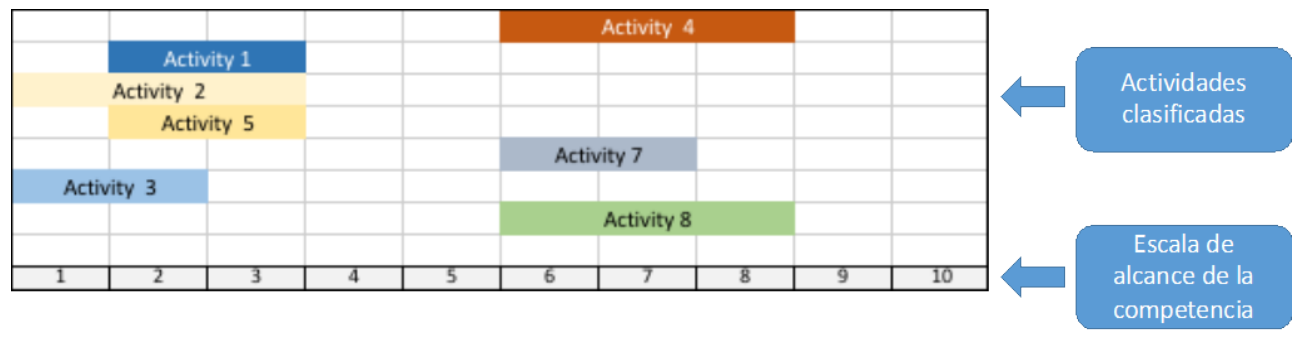

Fig 3. Mapa de actividades de apredizaje clasificadas por nivel.

La ubicación de las actividades en el mapa permite: a) por un lado identificar conjuntos de actividades que están trabando el mismo nivel, por lo que quizás no es necesario desplegar en el aula todo este conjunto de actividades, ya que con la realización de una de dichas actividades ya se tendría cubierto dicho nivel (por ejemplo el nivel 2 está saturado de actividades ya que se trabaja con las actividades 1, 2, 3 y 5). Y por otro lado, b) identificar niveles que no son trabajados por ninguna actividad. En la figura 4 se muestra estos GAPs.

(cc) EY-NC-ND 2018, Universitat Politècnica de València

Congreso IN-RED (2018) 


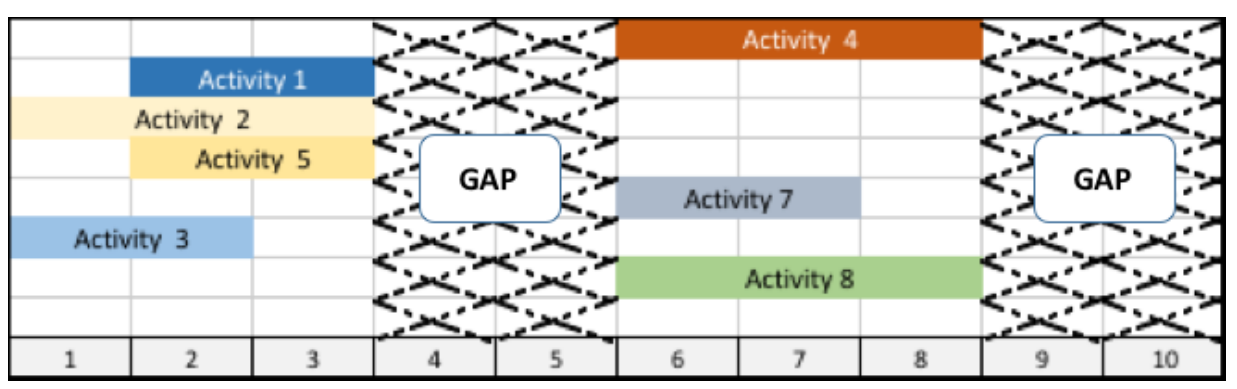

Fig 4. GAPs en el mapa de actividades de apredizaje clasificadas por nivel.

La identificación de estos GAPs permite pasar a la siguiente etapa en la configuración del mapa de actividades.

\subsection{Completar el mapa de actividades para cubrir rangos no cubiertos mediante el diseño de nuevas actividades}

La búsqueda de nuevas actividades para trabajar la competencia transversal se facilita con la construcción del mapa siguiendo las etapas anteriores, ya que sirve como guía para la búsqueda de actividades no cubiertas. Es decir, el proceso de búsqueda y análisis de actividades de aprendizaje queda dirigido por el objetivo de cubrir los GAPs encontrados. La figura 4 muestra esta inclusión de dos nuevas actividades (la 9 y la 10) para cubrir estos GAPs.

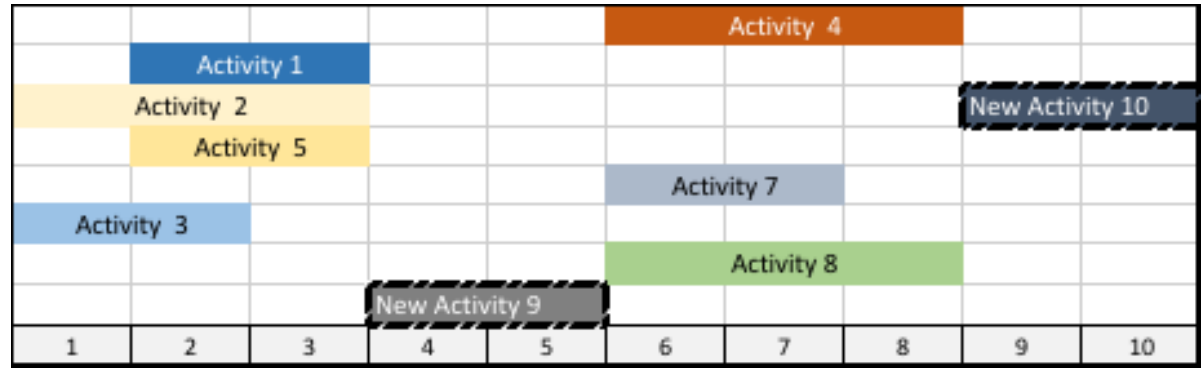

Figure 5: Incorporación de actividades para cubrir los GAPS

\section{Conclusiones}

El problema de acercarse a las necesidades particulares de cada alumno a la hora de enfrentarse y desarrollar la competencia "innovación, creatividad y emprendimiento" se ha abordado mediante la identificación temprana del nivel del estudiante en la competencia y el diseño de un mapa de actividades.

La línea seguida en este paper no ha pretendido focalizarse en una única competencia transversal, sino que se ha intentado abordado desde una perspectiva general para ser transferible a diferentes competencias transversales. Asi, como se ha indicado anteriormente, para las diferentes competencias transversales será necesario adecuarse a la propia naturaleza de la competencia, y las escalas de medición pueden estar condicionadas por el enfoque del diseñador de la misma respecto a la competencia.

(c) EY-NC-ND 2018, Universitat Politècnica de València 
Las etapas abordadas para dicho propósito con (i) el diseño de la escala para identificar niveles de alcanze de la competenciam, y (ii) el diseño de actividades iniciales de preevaluación que permitan identificar la capacidad creativa, de innovación y emprendimiento para cada alumno permiten adaptar el proceso de enseñanza aprendizaje a los diferentes niveles encontrados en el aula. Así, para adaptar dicho proceso, (iii) la identificación y clasificación de actividades de acuerdo con la escala de establecida permiten la construcción de un mapa de actividades acordes para cada nivel.

La identificación temprana del nivel del estudiante en la competencia trasvesal permite:

1. Tener una visión amplia de los estudiantes en nuestro aula sobre su punto de partida en la competencia.

2. Identificar clusters de estudiantes del mismo nivel respecto a la competencia

3. Adaptar el proceso de enseñanza-aprendizaje de acuerdo con estos grupos.

Además, el diseño del mapa de actividades de aprendizaje clasificadas permite:

1. Tener una visión amplia de las actividades llevadas a cabo para el desarrollo de la competencia.

2. Identificar superposiciones de actividades en el mismo nivel, lo que plantea la cuestión de si eliminar o no alguna de las actividades.

3. Identificar niveles no abordados por ninguna actividad, lo que fomenta el desarrollo de actividades que cubren niveles no alcanzados por otras actividades.

4. Ofrecer a los estudiantes el mapa de actividades como una herramienta para su entrenamiento.

Esta propuesta incorpora al estudiante como un elemento clave en el proceso de enseñanzaaprendizaje. Y, el mapa de actividades se convierte en una herramienta para los estudiantes, donde pueden identificar las actividades por nivel y trabajar en mayor medida en las más adecuadas de acuerdo a sus necesidades y potencial.

\section{Agradecimientos}

Esta investigación se ha llevado a cabo en el marco del Proyecto de Innovación y Mejora Educativa (PIME 2017-18 Ref. A10) de la Universitat Politècnica de València.

\section{Referencias}

Arias, F. (2006). El proyecto de investigación. Introducción a La Metodología Científica. http://doi.org/Q180.55-M4A7

Boza, A., Fernández-Diego, M., Ruiz, L., Gordo, M., Alemany, M. M. E., Alarcón, F., \& Cuenca, L. (2017). Transversal Competences as a Medium of Teaching. The Case of

(cc) EY-NC-ND 2018, Universitat Politècnica de València

Congreso IN-RED (2018) 
Creativity, Innovation and Entrepreneurship. In Strategic Innovative Marketing (pp. 3-10). Springer.

Carmines, E. G., \& Zeller, R. A. (1979). Reliability and validity assessment. Quantitative Applications in the Social Sciences. http://doi.org/10.1037/018269

Grinnell Jr, R. M., \& Unrau, Y. (2005). Social work research and evaluation: Quantitative and qualitative approaches. Cengage Learning.

Hernandez Sampieri, R., Fernandez Collado, C., \& Baptista Lucio, M. del P. (2014). Metodología de la investigación. Metodología de la investigación. Retrieved from http://www.casadellibro.com/libro-metodologia-de-la-investigacion-5-ed-incluye-cdrom/9786071502919/1960006

Perrenoud, P. (2008). Diez nuevas competencias para enseñar. Tiempo de Educar, 9(17), 159.

Piffer, D. (2012). Can creativity be measured? An attempt to clarify the notion of creativity and general directions for future research. Thinking Skills and Creativity, 7(3), 258264. http://doi.org/10.1016/j.tsc.2012.04.009

Stevens, S. S. (1951). Mathematics, measurement, and psychophysics. In Handbook of Experimental Psychology (pp. 1-49).

Torrance, E. (1974). The Torrance test of creative thinking: Norms-technical manual. Bensenville, Illinois: Scholastic Testing Services. Inc.

Universitat Politècnica de Valencia. (2017). Conoce el Proyecto de Competencias Transversales UPV. http://www.upv.es/contenidos/COMPTRAN/. Retrieved from http://www.upv.es/contenidos/COMPTRAN/ 


\title{
Diseño e implementación de una metodología autoformativa para la mejora de la "Comunicación Oral Efectiva” en el ámbito universitario.
}

\author{
Nuria Matarredona-Desantes ${ }^{\mathrm{a}}$, Raúl Oltra-Badenes ${ }^{\mathrm{b}}$, Édgar Pérez-Esteve ${ }^{\mathrm{c}}$, Joan \\ Albert Silvestre-Cerdà ${ }^{\mathrm{d}}$, Maria del Carmen Bas ${ }^{\mathrm{e}}$ y María Jesús Lerma-García ${ }^{\mathrm{f}}$
}

${ }^{a}$ Departamento de Composición Arquitectónica, Universitat Politècnica de València, numade@upvnet.upv.es ; b Departamento de Organización de Empresas, Universitat Politècnica de València, rauloltra@doe.upv.es ; ' Departamento de Tecnología de Alimentos, Universitat Politècnica de València, edpees@upv.es ; ${ }^{d}$ Departamento de Sistemas de Información y Computación, Universitat Politècnica de València, jsilvestre@dsic.upv.es; ${ }^{e}$ Departamento de Matemáticas para la Economía y Empresa, Universitat de València, maria.c.bas@uv.es ; ${ }^{\mathrm{f} D e p a r t a m e n t o ~ d e ~ T e c n o l o g i ́ a ~ d e ~}$ Alimentos, Universitat Politècnica de València, malerga1@tal.upv.es .

\begin{abstract}
The student outcome "Effective Communication" is one of the most studied competence in subjects of different degrees. An inefficient communication can lead to misinterpretations and wrong conclusions. Therefore, it is a very important competence both in the university and in the business field, since the student/graduate must know how to communicate effectively, both orally and in writing, using appropriately the necessary resources and adapting to the characteristics of the situation and the audience. Despite its importance, the disparity in the mastery of the competence between the students makes it difficult to work in the classroom through collective activities. The objective of this study is to design a self-formative methodology that allows the student to detect their weaknesses and strengths in the competence domain and propose teaching-learning formative activities according to their initial level of mastery to improve the acquisition of this transversal competence. The designed methodology has been implemented in a group of students of first course of the Degree in Fundamentals of Architecture obtaining relevant results that indicate an improvement in the domain of the competence.
\end{abstract}

Keywords: Effective oral communication, transversal competence, autonomous learning, self-formative itinerary

\begin{abstract}
Resumen
La competencia transversal "Comunicación Efectiva” es una de las más trabajadas en asignaturas de diferentes materias y ciclos. Una comunicación ineficiente puede llevar a malas interpretaciones y equivocadas conclusiones. Por tanto, se trata de una competencia muy importante tanto en el ámbito universitario como en el ámbito empresarial, ya que el alumno/egresado debe saber comunicarse de manera efectiva, tanto de forma oral como escrita, utilizando adecuadamente los recursos necesarios y adaptándose a las características de la situación y de la audiencia. Pese a su
\end{abstract}


importancia, la disparidad en el dominio de la competencia por parte del alumnado hace difícil su trabajo en el aula a través de actividades colectivas. El objetivo de este estudio es diseñar una metodología autoformativa que permitan al alumno detectar sus debilidades y fortalezas en el dominio de la competencia y proponer actividades formativas de enseñanza-aprendizaje según su nivel inicial de dominio para la mejora de la adquisición de la competencia transversal. La metodología diseñada se ha implantado en un grupo de alumnos de primero en el Grado en Fundamentos de la Arquitectura obteniendo resultados relevantes que indican una mejora en el dominio de la competencia.

Palabras clave: Comunicación Oral Efectiva, competencia transversal, aprendizaje autónomo, itinerario auto-formativo

\section{Introducción}

En los últimos años, las instituciones de educación superior han experimentado diversos cambios condicionados por las exigencias de la sociedad actual. La adaptación de los títulos de grado al Espacio Europeo de Educación Superior (EEES) es uno de los factores ineludibles que han provocado un cambio en la aplicación de las metodologías docentes y una necesidad de adaptar y flexibilizar la oferta formativa a la realidad actual. En particular, la inclusión de las competencias transversales en los planes de estudio es de especial importancia tanto para el ámbito universitario como para el ámbito empresarial. Existe un consenso entre universidad-empresa sobre la necesidad de que los futuros empleados dominen ciertas competencias de cara a su desarrollo profesional. Para el estudiante resulta muy importante adquirir y acreditar su formación en competencias en la universidad y, por otra parte, para el empleador resulta muy relevante conocer el nivel de dominio de las competencias adquirido por los egresados.

Como consecuencia de dicha necesidad la Universitat Politècnica de València (UPV) ha incluido como objetivo estratégico la evaluación de competencias específicas y transversales. La realidad es que se trabajan competencias de ambos tipos, pero debido a la reducida carga docente otorgada a cada asignatura, los profesores suelen priorizar el trabajo de las competencias específicas en detrimento de las transversales. Como resultado de esto, en muchas asignaturas no existe una alineación curricular ya que se evalúan competencias transversales que no se han trabajado en clase o que aun habiéndose trabajado no se han proporcionado actividades formativas para poder mejorar el nivel de dominio de éstas. Es por eso que este estudio se centra en el nivel de dominio de las competencias transversales y en cómo se trabajan en el aula para poder mejorar dicho nivel de dominio competencial.

Para llevar a cabo este estudio ha sido necesario definir el concepto de competencias transversales como "aquellas competencias que son claves y transferibles en relación a una amplia variedad de contextos personales, sociales, académicos y laborales a lo largo de la vida. En este sentido, constituyen una parte fundamental del perfil profesional y del perfil formativo de todas o de la mayoría de las titulaciones. Son competencias que incluyen un conjunto de habilidades cognitivas y meta-cognitivas, conocimientos instrumentales y 
actitudinales de gran valor para la sociedad del conocimiento" (ICE, 2017). Se trata, por tanto, de un saber hacer muy complejo, por lo que es necesario concretarlas en resultados de aprendizaje más específicos. Por ello, será necesario recurrir a estrategias metodológicas que propicien el cambio de roles. Ya no se puede utilizar una metodología 'tradicional' basada en clases magistrales y problemas que el profesor resuelve en el aula. Incluso las prácticas de laboratorio deben cambiar su enfoque para conseguir nuevos objetivos y lograr que los alumnos adquieran una serie de capacidades que, por lo general, antes no se tenían en cuenta ni se evaluaban, como son la capacidad de trabajo en grupo, la capacidad de realizar exposiciones orales, etc. (Oltra-Badenes y Gil-Gómez 2015). Para alcanzar las competencias es necesario realizar acciones formativas. Dichas acciones deben estar basadas en metodologías activas para la formación de competencias y en métodos de participación del alumno que generan un aprendizaje más profundo, significativo y duradero (Fernández, 2006).

El presente estudio de innovación docente pretende trabajar la competencia transversal "Comunicación Oral Efectiva" que parece ser una de las competencias en las que existe un mayor consenso respecto a la importancia que tiene para los futuros egresados. Según el proyecto institucional desarrollado por la UPV, comunicarse efectivamente significa tener desarrollada la capacidad de transmitir conocimientos y expresar ideas y argumentos de manera clara, rigurosa y convincente, tanto de forma oral como escrita, utilizando los recursos apropiados adecuadamente y adaptándose a las circunstancias y al tipo de público. Es importante diferenciar dos dimensiones dentro de esta competencia: la comunicación oral y la escrita (Universitat Politècnica de València, 2012).

El dominio de la competencia de comunicación efectiva implica la eficacia en la comunicación de ideas, conocimientos y sentimientos a través de la palabra y el escrito tanto en situaciones conversacionales/escritas y en actividades grupales como en presentaciones públicas ante audiencias más o menos numerosas (Villa y Poblete, 2007). Los estudiantes que acceden a la universidad ya han adquirido cierto bagaje instrumental de técnicas y estrategias para una buena comunicación, pero es importante que en la universidad se continúe trabajando dicha competencia teniendo en cuenta sus importantes implicaciones académicas, profesionales y personales. Desde un punto de vista estrictamente académico, las interacciones verbales y escritas constituyen la clave del proceso de enseñanza-aprendizaje, ya que facilitan la actividad colaborativa, posibilitan la interiorización del conocimiento y son fundamentales para conseguir un buen rendimiento académico. En la vida profesional resulta imprescindible saber transmitir ideas, conocimientos y sentimientos de forma precisa para obtener una mayor eficacia. Por último, desde la perspectiva personal, el hecho de poder hablar en público con seguridad y sin nerviosismo, así como la facilidad de expresarse por escrito sin dificultades comporta un incremento de la seguridad personal y refuerza la autoestima (Sayós, R., 2013).

En general, pensamos que dominamos dicha competencia debido a la necesidad que tenemos de comunicar información entre nosotros. Sin embargo, en muchas situaciones existe una gran diferencia entre lo que pretendemos decir y el mensaje que le llega al receptor. Es por ello que los alumnos se enfrentan al desarrollo de esta competencia con 
niveles de dominio muy dispares debido a las diferentes capacidades innatas y a los diferentes ritmos de adquisición de esta competencia. Además, esta disparidad se puede acentuar si los alumnos están matriculados en titulaciones y en ciclos diferentes. Por tanto, surgen distintas problemáticas en cuanto a la adquisición de esta competencia transversal:

-¿Qué nivel de dominio inicial de esta competencia transversal tienen los alumnos de distintas titulaciones y ciclos?

-¿Cómo se trabaja dicha competencia en clase?

-¿Qué herramientas de evaluación/diagnóstico se usan para analizar el nivel de dominio de la competencia?

-¿Existen herramientas de apoyo y mejora que guíen al alumno a la adquisición/mejora de la competencia?

-¿Qué actividades formativas se deben proponer para mejorar el dominio de la competencia?

En este estudio hemos abordado algunas de las problemáticas presentadas anteriormente mediante la elaboración de una metodología autoformativa que ayude a los estudiantes universitarios a la mejora de la adquisición de la competencia transversal. A continuación, se plantea el objetivo de este estudio, el diseño de la metodología con acciones que abordan la problemática anterior y la implementación en un estudio piloto.

\section{Objetivo}

El objetivo fundamental del presente trabajo es presentar la metodología diseñada en el marco del Proyecto de Mejora e Innovación Docente PIMECOE para fomentar el desarrollo mediante aprendizaje autónomo de la dimensión oral de la competencia transversal CT08 «Comunicación Efectiva» en el ámbito universitario, así como compartir los resultados obtenidos a partir de su implementación experimental en el primer curso de Grado en Fundamentos de la Arquitectura cuyo análisis permitirá generar una ulterior versión revisada de las herramientas asociadas a esta metodología.

\section{Diseño de la metodología PIMECOE}

La metodología autoformativa diseñada para la mejora del dominio del nivel inicial de la CT "Comunicación Oral Efectiva” se ha basado en 4 fases fundamentales. La figura 1 muestra cada una de las fases de la metodología y el orden de ejecución de estas. 


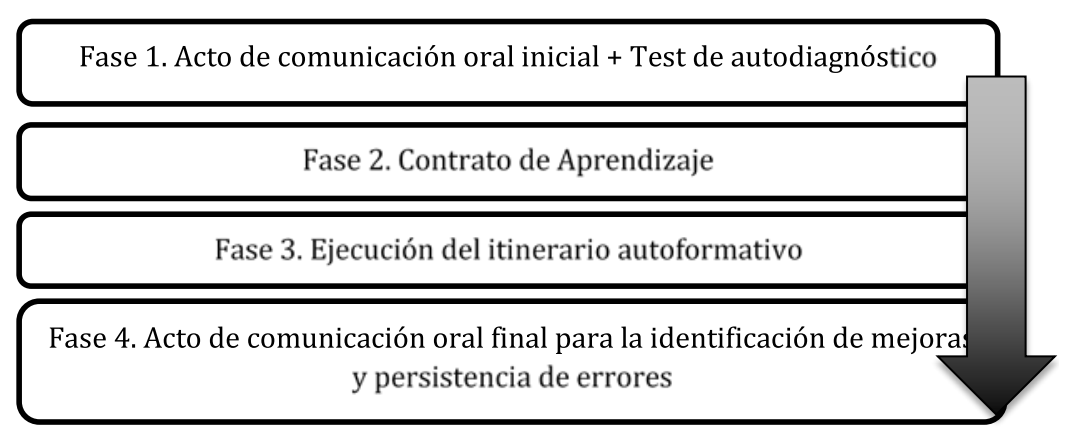

Fig. 1 Fases de la metodología autoformativa de la competencia "Comunicación Oral Efectiva"

A continuación se describe el objetivo y las acciones de cada una de las fases de la metodología.

\section{Fase 1: Acto de comunicación final + Test de autodiagnóstico}

La primera fase de la metodología corresponde a la detección del nivel inicial del dominio de la competencia que presentan los alumnos. Para ello, el profesor propone un acto de comunicación oral inicial que permite testear su nivel inicial y evaluar mediante la rúbrica de la evaluación diseñada por la UPV los indicadores de dominio de la competencia. El feedback que reciben los alumnos permite determinar las fortalezas y los puntos débiles del alumnado en relación con los indicadores básicos y avanzados que definen cada nivel de dominio de la CT.

Seguidamente, el estudiante debe realizar el test de autodiagnóstico diseñado en el marco del proyecto PIMECOE utilizando la experiencia personal del acto comunicativo inicial. La finalidad principal del test de autodiagnóstico de la Competencia transversal Comunicación Oral Efectiva no es otra que la de orientar y ayudar al alumno en la mejora de sus habilidades para conseguir una comunicación oral efectiva a partir de una serie de indicadores mensurables facilitados por el propio test. De este modo, el test persigue un doble propósito: por un lado, busca ser una herramienta que ayude al estudiante a medir y evaluar de forma general sus habilidades en la comunicación oral efectiva, y por otro, es un instrumento útil de cara a la mejora de las mismas.

Dicho autodiagnóstico será clave para que el estudiante pueda identificar aquellos indicadores que debe mejorar. Con este fin, el test se ha dividido en seis bloques atendiendo a la rúbrica de evaluación de la competencia transversal Comunicación Oral Efectiva elaborada por la UPV. A su vez, cada una de estos bloques contiene una serie de indicadores cuyo valor vendrá dado entre 1 (nunca o nada) y 5 (siempre o mucho). Atendiendo a la puntuación final obtenida en cada indicador y/o bloque, y dependiendo del nivel de dominio del estudiante (nivel I - $1^{\circ} 02^{\circ}$ de grado; nivel II - $3^{\circ}$ o $4^{\circ}$ grado; nivel III Máster), al final del test de autodiagnóstico el estudiante encontrará un conjunto de actividades a realizar para mejorar cada uno de los indicadores y/o bloques y poder conseguir así un nivel óptimo de la competencia transversal Comunicación Oral Efectiva. 
El conjunto de actividades forma el itinerario autoformativo que se destallará en su fase correspondiente.

El test de autodiagnóstico se puede encontrar en la página web del proyecto PIMECOE (Silvestre-Cerdá et al, 2017).

\section{Fase 2: Contrato de aprendizaje}

El contrato de aprendizaje corresponde a la segunda fase de la metodología. Se trata de un documento que permite ayudar y guiar al estudiante en su proceso de aprendizaje de la competencia. Según Lobato (2006) el contrato de aprendizaje se define como "un acuerdo establecido entre el profesor y el estudiante para la consecución de unos aprendizajes a través de una protesta de trabajo autónomo, con una supervisión por parte del profesor y durante un período determinado. En un contrato de aprendizaje es básico un acuerdo formalizado, una relación de contraprestación recíproca, una implicación personal y un marco temporal de ejecución”.

Por tanto, este documento nace de un acuerdo y de una negociación entre el estudiante y el profesor, ya que pactan qué, cómo y cuándo van a trabajar las actividades recogidas en el documento "itinerario autoformativo" con el objetivo de mejorar su dominio de la competencia comunicación efectiva. Es un método de trabajo autónomo puesto que la responsabilidad el proceso de aprendizaje recae sobre el estudiante. De esta forma se trabaja también el aprendizaje autónomo de los estudiantes ya que éste asume una parte importante de la responsabilidad de la organización de su trabajo adaptándolo a su propio ritmo (Ruiz, 2006).

\section{Fase 3: Ejecución del itinerario autoformativo}

La tercera fase corresponde a la ejecución del itinerario autoformativo, consistente en un documento de trabajo en el que se especifica, en función de las respuestas proporcionadas por el alumnado en el test de autodiagnóstico, el conjunto de actividades que el alumno deberá trabajar para mejorar su nivel de domino de la competencia. De forma autónoma y cumpliendo los plazos establecidos en el contrato de aprendizaje, el alumno trabajará actividades recomendadas para fortalecer los puntos débiles detectados en la guía de autodiagnóstico en la competencia de comunicación oral. El documento se encuentra también implementado on-line en la web del proyecto PIMECOE.

\section{Fase 4. Acto de comunicación oral final para la identificación de mejoras y permanencia de errores.}

En la última fase de la metodología autoformativa propuesta, se plantea la realización de un acto de comunicación oral, pudiendo ser éste el mismo o similar al inicial. El objetivo de este acto final es evaluar de nuevo al alumnado mediante los indicadores de la rúbrica de la universidad e identificar las mejoras que ha tenido en la comunicación oral y los errores o puntos débiles persistentes que no ha logrado mejorar. De esta manera, el alumno dispone de un feedback de sus resultados que le permiten analizar su evolución en cuanto a la adquisición de la competencia y detectar la permanencia de errores que continúa teniendo 
en el desarrollo de la habilidad. Además, esta última fase permite analizar si ha habido diferencias entre el pre y post análisis.

\section{Implementación experimental de la metodología PIMECOE}

\subsection{El porqué de una experiencia piloto}

El testeo de la metodología autoformativa se contempla como una fase previa fundamental en el proceso de diseño de la metodología PIMECOE. El ensayo de las herramientas en su versión preliminar permite recabar datos de carácter tanto cuantitativo como cualitativo que resultan imprescindibles para incrementar su garantía de éxito entre el alumnado universitario.

\subsection{Contexto académico}

La metodología PIMECOE se implementa de manera experimental en la asignatura Introducción a la Arquitectura (IAR) del primer curso del Grado en Fundamentos de la Arquitectura. A pesar de no ser punto de control de esta competencia transversal, la CT08 se trabaja habitualmente en el desarrollo del curso.

IARexp, acrónimo de esta experiencia piloto, se desarrolló durante el periodo lectivo de dicha asignatura que se corresponde con el primer semestre del curso 2017/2018. El objetivo de esta asignatura es el de reflexionar acerca del concepto de arquitectura y el papel que el ejercicio profesional de esta disciplina debe jugar en nuestra sociedad, así como aproximarse a los conceptos teóricos base del proyecto arquitectónico desde el análisis de nuestro entorno.

Son dos los grupos objetivo que participan en esta experiencia. El grupo C está compuesto por 45 estudiantes y su lengua vehicular es el valenciano. El grupo D, formado por 60 estudiantes se comunica en castellano.

Cabe destacar que, paralelamente al transcurso de esta asignatura, el estudiante comienza a familiarizarse con el mundo universitario y todas aquellas herramientas que le son propias lo que supone un contexto muy específico de desarrollo del alumnado.

\subsection{Cronograma}

La aprobación del proyecto "Autodiagnóstico del nivel de dominio inicial de la competencia transversal "Comunicación Efectiva” y su mejora a través de un itinerario autoformativo" (PIME/2017/B/025-14) se produce en septiembre de 2017, coincidiendo con el inicio del curso 2017/2018. Puesto que la duración establecida del proyecto PIMECOE es de un año, el cronograma del proyecto preveía el desarrollo de la herramienta durante el primer semestre de curso y su puesta en marcha durante el segundo semestre. Sin embargo, la oportunidad de realizar una experiencia piloto durante el primer semestre, a pesar del esfuerzo que supone la condensación del cronograma de proyecto, se considera una valiosa aportación para el proyecto puesto que permite que la versión a implementar durante el segundo semestre cuente ya con cierta retroalimentación por parte del estudiantado. 
El cronograma de actividades para el alumnado de IARexp vinculadas con el PIMECOE se integra absolutamente dentro de la planificación de la asignatura y refuerza el desarrollo de las competencias específicas y transversales a desarrollar.

\subsubsection{Desarrollo de la tarea "Opiniones sobre arquitectura"}

La primera tarea en la que la metodología PIMECOE se incorpora a la asignatura corresponde a la tercera tarea desarrollada durante el curso: “Opiniones sobre arquitectura”. Esta corresponde a la segunda unidad del curso dedicada precisamente a reflexionar acerca del concepto de arquitectura. Tras el debate colectivo en el aula, se invita al alumnado a conocer la idea de arquitectura que manifiestan arquitectos de prestigio de modo que puedan aproximarse al concepto desde otra perspectiva.

Para ello, cada estudiante debe localizar una definición de arquitectura que le resulte sugerente. Una vez seleccionada, se comienza a profundizar en la figura del arquitecto autor de la misma. De entre su obra construida se escoge un caso de estudio sobre el que realizar un incipiente análisis arquitectónico. Finalmente, se pretende reflexionar sobre la relación entre la definición de arquitectura y la obra realizada.

Los resultados de aprendizaje esperados evidentemente contemplan ampliar su concepto de arquitectura, pero también el familiarizarse con figuras relevantes del panorama mundial que hasta el momento desconocían. Este tipo de actividades persiguen el desarrollo de competencias transversales como el desarrollo del pensamiento crítico y la comunicación efectiva.

\subsubsection{Exposición oral "Opiniones sobre arquitectura"}

Al tratarse de un estudio individual, resulta crucial que los resultados sean compartidos entre los compañeros para lograr los resultados de aprendizaje esperados. Para ello, se diseñan unas sesiones de exposición oral a modo de foro. Estas exposiciones orales corresponden a la fase 1 del proyecto PIMECOE. Al término de las mismas, se conocerán tantas obras y autores como alumnos hayan expuesto. De esta manera, se ponen sobre la mesa diversas ideas sobre arquitectura al mismo tiempo que su iniciática cultura arquitectónica comienza a cultivarse.

Considerando el elevado número de estudiantes en cada uno de los grupos, se adopta el sistema de presentación PechaKucha para las mismas. Este dinámico formato surge en Japón en 2003 de mano del estudio de arquitectura Kein Dytham Architecture (PechaKucha:2018), y consiste en acompañar el discurso oral con 20 imágenes. Cada una de ellas permanece visible durante 20 segundos que, una vez transcurridos, dejan paso a la siguiente, siendo imposible modificar dicha transición automática. En este caso, el formato se adapta de un 20x20 a un 10X20, de manera que cada una de las exposiciones tiene una duración final de 3 minutos y 20 segundos. 


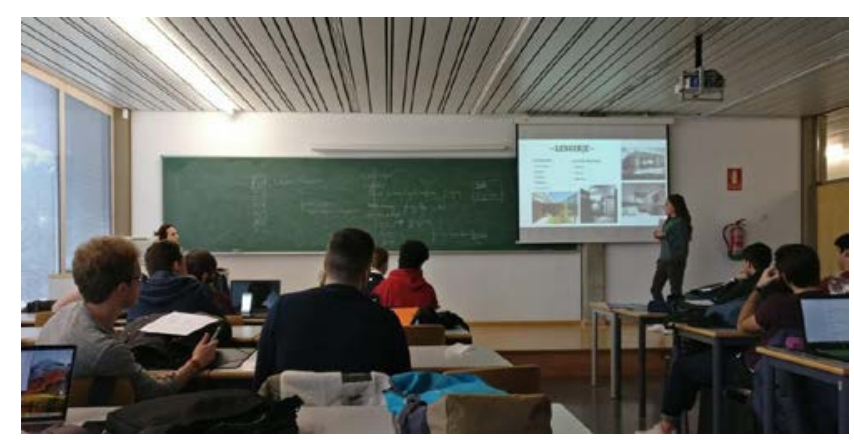

Fig 2. Estudiante presentado su tarea.

En aras de fomentar el rol activo de los alumnos escuchantes, y considerando los beneficios de la evaluación por pares, se les invita a ejercer la función de revisores. Para ello, se les proporciona una rúbrica a modo de guía con la que evaluar tanto el contenido del trabajo presentado como el desarrollo de la exposición oral. Se usa la rúbrica de evaluación diseñada por la UPV en la que se incluyen cinco indicadores y su nivel de dominio, siendo (A: excelente, ejemplar; B: adecuado, bueno; C: en desarrollo, D: no alcanzado). Los indicadores analizados son:

I1: Transmite información relevante y sabe responder las preguntas que se le formulan

I2: Las exposiciones están estructuradas de modo coherente

I3: Utiliza el lenguaje con corrección gramatical: semántica, sintáctica y ortográfica

I4: Su comunicación no verbal transmite tranquilidad

I5: Utiliza medios de apoyo de modo pertinente

Además, se incluyen dos casillas para que se valore cualitativamente la exposición y el contenido del trabajo. Junto a la rúbrica, un listado de verificación con tantas casillas como estudiantes realizan la exposición oral.

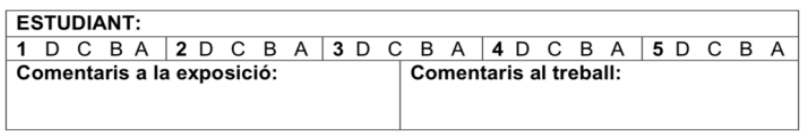

Fig 3. Listado de verificación.

Para el adecuado procesado de los datos, cada uno de los estudiantes cuenta con un código asignado que complementa su identificación con nombre y apellidos. La participación en estas exposiciones, así como el adecuado desarrollo de su función como revisores se fomenta con un incremento en su calificación final. Por otro lado, el profesorado evalúa los mismos ítems que el estudiantado. Para poder dedicar mayor atención a los contenidos, miembros del PIMECOE se dedican específicamente a la evaluación de la competencia de comunicación efectiva.

\subsubsection{Presentación de la metodología autoformativa del proyecto PIMECOE}

Una vez finalizadas las sesiones de exposición oral, se invita a los estudiantes a reflexionar acerca de la importancia de la comunicación oral efectiva y en la repercusión de una buena

(c)) EY-NC-ND 2018, Universitat Politècnica de València

Congreso In-Red (2018) 
exposición en la comprensión del trabajo desarrollado. Evidentemente, el estudiantado se muestra interesado en mejorar esta competencia.

En este momento, se presenta la metodología autoformativa del proyecto PIMECOE y se ponen a su disposición las herramientas diseñadas hasta el momento: la página web PIMECOE, el “Test de autodiagnóstico", el "Itinerario autoformativo” y el "Contrato de aprendizaje”.

\subsubsection{Diagnóstico del estado de dominio inicial de la competencia}

El diagnóstico del estado de dominio inicial de esta competencia se obtiene mediante dos vías. La primera de ellas, a través de la realización del propio "test de autodiagnóstico" ofrecido por PIMECOE, mediante el que pueden detectar su principales carencias y virtudes. Por otro lado, cada estudiante recibe mediante un informe elaborado por el equipo de PIMECOE la retroalimentación de sus compañeros que han actuado como evaluadores.

El resultado de este diagnóstico permite que cada estudiante tome conciencia de las áreas en las que debe trabajar para obtener mejores resultados en sus exposiciones.

\subsubsection{Firma del contrato de aprendizaje y realización del itinerario autoformativo}

Una vez realizada la fase 1 de la metodología correspondiente a la actividad oral inicial y al test de autodiagnóstico, el alumnado se compromete a realizar las actividades del itinerario autoformativo basándose en la puntuación del test y según su compromiso en cantidad y tiempo reflejado en el contrato de aprendizaje firmado entre estudiante-profesor. Estas actividades corresponden a las fases 2 y 3 de la metodología propuesta.

\subsubsection{Desarrollo de la tarea "La casa"}

Finalmente, los estudiantes tienen la posibilidad de comprobar su propia evolución y la de sus compañeros durante el desarrollo de la sexta práctica: “La casa”. Esta tarea corresponde a la fase final del curso y presenta un carácter concluyente, puesto que requiere de la aplicación de los contenidos trabajados a lo largo del curso a un caso de estudio. En este caso, cada estudiante selecciona una vivienda unifamiliar de entre un listado ofertado por el profesorado.

En este caso, la presente tarea se evalúa en primera instancia por los propios compañeros, empleando la herramienta de revisión por pares que ofrece la propia plataforma educativa de la UPV, PoliformaT (Matarredona-Desantes, 2017). Posteriormente, y con la misma intención perseguida en la práctica anteriormente expuesta, los trabajos son presentados oralmente en unas sesiones dedicadas expresamente a ello.

De esta manera, el alumnado termina aproximándose a un importante número de casos de estudio en tres niveles de profundidad diferente (nivel muy alto, el analizado personalmente; nivel alto, los dos casos que ha revisado a través de la plataforma y finalmente, nivel medio, aquellos presentados en el aula).

\subsubsection{Exposición oral "La casa”}

Durante las dos últimas sesiones en aula, los estudiantes presentan oralmente la tarea. En este momento se pone en evidencia el trabajo realizado autónomamente en relación con el desarrollo de la competencia transversal de comunicación efectiva y la deseable evolución en el grado de dominio de la misma. 
La evaluación se realiza siguiendo el mismo sistema descrito en la tarea anterior, tanto por pares como por el profesorado y los miembros del PIMECOE. Del mismo modo, la participación del alumnado en estas exposiciones, así como su función como revisores se fomenta con un incremento en su calificación final.

\section{Resultados}

A continuación, se muestran los resultados obtenidos de la implantación de la metodología autoformativa para la mejora del dominio de la CT Comunicación Oral Efectiva, propuesta en el proyecto PIMECOE, en la experiencia piloto en el Grado de Arquitectura. En primer lugar, se presentan los resultados cuantitativos y posteriormente se realizar un estudio cualitativo de la experiencia.

\subsection{Evaluación cuantitativa}

Los resultados cuantitativos de este estudio se basan en los resultados de la rúbrica obtenidos en la evaluación los actos de comunicación oral al inicio y al final de la metodología aplicada. De esta forma, los resultados permiten realizar una comparativa entre el antes y el después de la aplicación de la metodología propuesta (pre-test y post-test) y observar mejoras en el desarrollo de la competencia trabajada.

Para ello se cuenta con una muestra de 46 alumnos en el pre-test y 36 alumnos en el posttest de los cuales 30 han realizado ambas fases. En la figura 4 se muestran los resultados del porcentaje de los distintos niveles de dominio obtenidos para todos los indicadores evaluados en la rúbrica en el pre-test (46 alumnos) y post test (36 alumnos). Los resultados muestran que el porcentaje de "A: nivel excelente" y "B: nivel adecuado" ha aumentado en el post-test, mientras que los niveles "C: en desarrollo" y " $\mathrm{D}$ : no alcanzado" han disminuido después de implementar la metodología autoformativa.

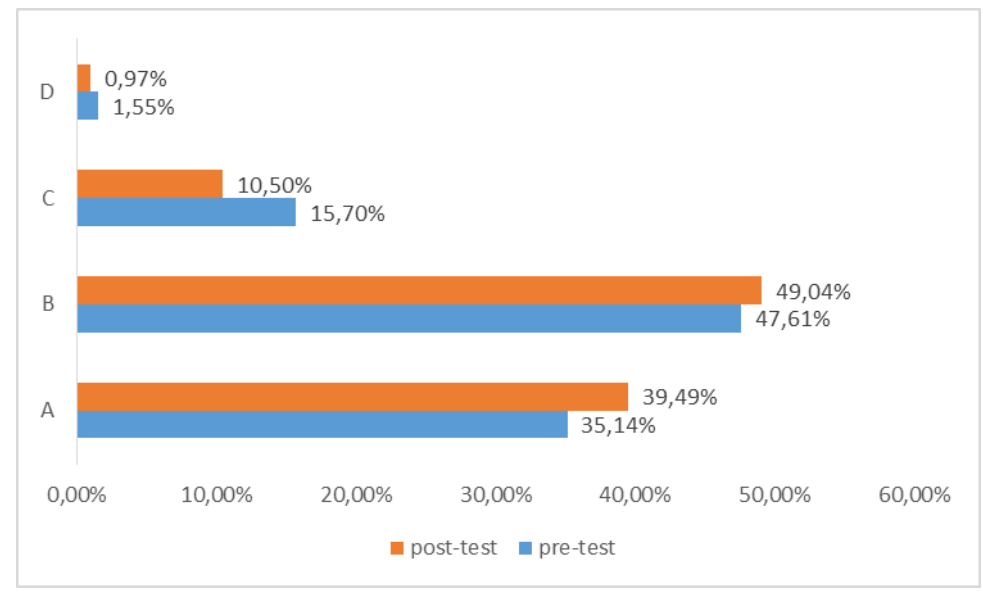

Fig. $4 \%$ Dominio en el pre-test y post-test

La figura 5 muestra los resultados del mismo análisis pero desagregado por indicadores evaluados. En general se observa que el porcentaje de "A" aumenta para todos los 
indicadores en el post-test, es decir que los alumnos obtienen una puntuación de dominio excelente en todos los indicadores una vez realizada la metodología autoformativa propuesta. De forma contraria, el porcentaje de "C" y "D" disminuye en el post-test, concluyendo, por tanto, que hay menos deficiencias en el dominio de la competencia. En cuanto al nivel de dominio "B: adecuado" de los indicadores, se mantiene aproximadamente en todos, exceptuando el "I4: Su comunicación no verbal transmite tranquilidad" en el que se observa una mejora en el post-test. Este resultado puede ser debido a la tranquilidad de los alumnos al exponerse a una segunda comunicación oral. Este resultado permite concluir que cuantas más exposiciones realiza el alumno y más trabaja la competencia, mayor tranquilidad transmite en las exposiciones orales.

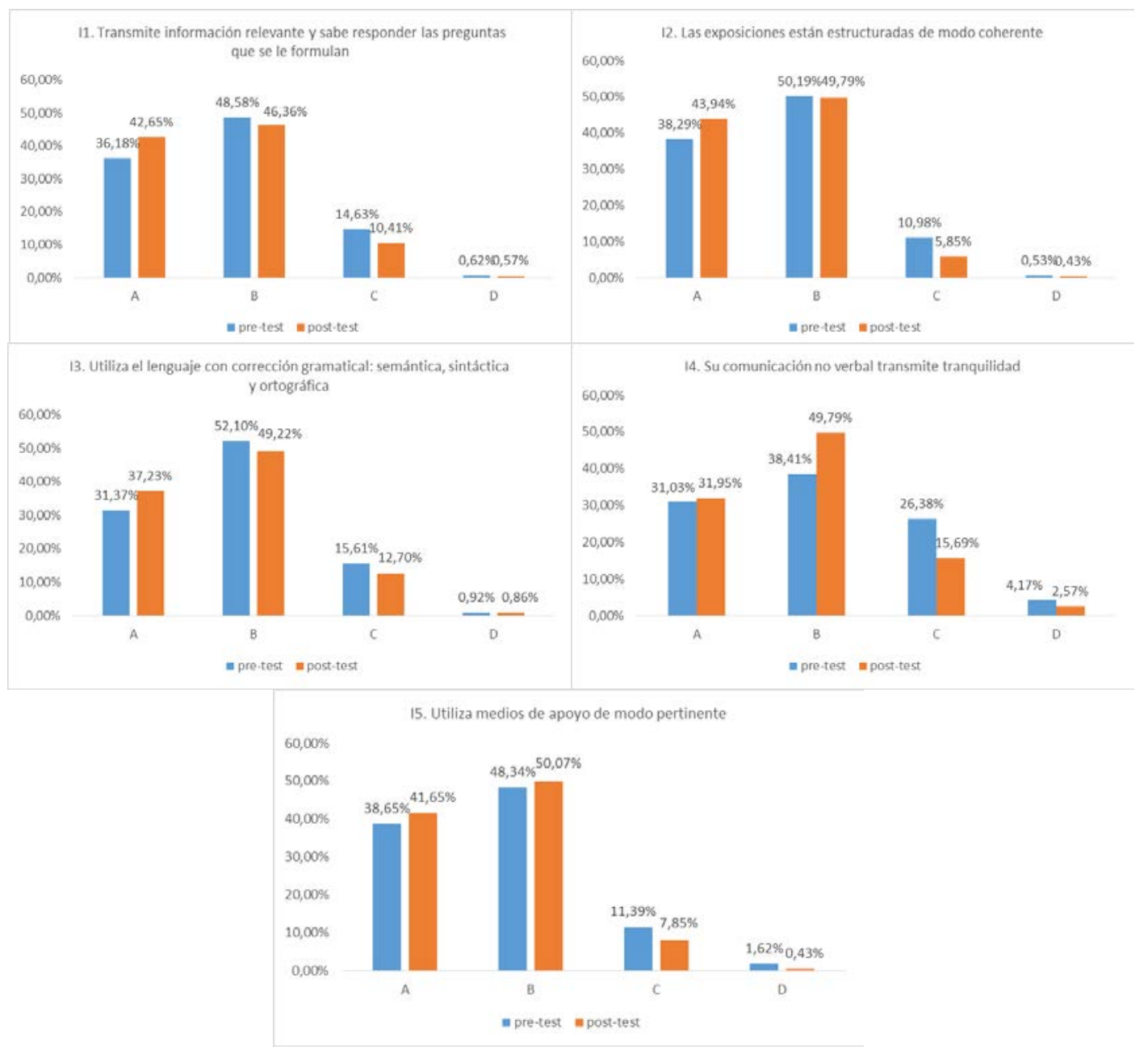

Fig 5. \%Dominio en cada Indicador en el pre-test y post-test

Finalmente se ha realizado un estudio con datos pareados centrado en los 30 alumnos que hicieron el acto comunicativo en la fase 1 y en la fase 4 de la metodología, pudiendo 
realizar una comparativa de su evolución. Para ello, se ha calculado para cada alumno el porcentaje total de cada una de las categorías de dominio (para todos los indicadores) en el pre-test y post-test y se ha contabilizado el número de alumnos en los que dicho porcentaje ha sido mayor en el post-test que en el pre-test. La tabla 1 muestra los resultados obtenidos.

Tabla 1. Resultados del estudio de evolución

\begin{tabular}{ccc}
\hline $\begin{array}{c}\text { Dominio de la } \\
\text { competencia }\end{array}$ & Nombre & \# Post $>$ Pre \\
\hline A & Excelente, ejemplar & 18 \\
B & Adecuado, bueno & 14 \\
C & En desarrollo & 11 \\
D & No alcanzado & 5 \\
\hline
\end{tabular}

Los resultados indican que 18 de los 30 alumnos han obtenido un mayor porcentaje del nivel de dominio $\mathrm{A}$ en el post-test que en el pre-test, para todos los indicadores de la rúbrica. En cuanto al dominio B, aproximadamente la mitad de alumnos han obtenido mejor porcentaje de nivel B en el pre-test y la otra mitad en el post-test. Sin embargo, sí que se observa un menor número de alumnos, 11 y 5 , en los niveles $\mathrm{C}$ y D respectivamente, que obtienen mayor porcentaje de estos dominios en el post-test y este resultado es positivo teniendo en cuenta que cuanto menor sea el porcentaje de los niveles C y D mejor para el alumno.

Estos resultados son indicativos de una evidente mejora de los estudiantes en el dominio de la competencia transversal "Comunicación Oral Efectiva" mediante el uso de la metodología autoformativa propuesta en este estudio.

\subsection{Evaluación cualitativa}

Los resultados cualitativos de la presente experiencia, IARexp, se basan en la información recogida mediante tres encuestas realizada al alumnado de la asignatura.

La primera de ellas, al término del mismo test de autodiágnostico, está formada por una sencilla pregunta abierta en la que se pregunta la opinión del alumnado acerca de la herramienta. Los estudiantes destacan como positivo el proceso de reflexión que se detona con su realización así como el hecho de que las propias preguntas del test ya desvelan ítems relacionados con la comunicación oral efectiva que desconocían. En general, las cuestiones del test de autodiagnóstico se han percibido sencillas de comprender, pero complejas de responder. Manifiestan cierta dificultad para discernir cual es el "grado de cumplimiento".

La segunda encuesta en la que el alumnado de IARexp participa no tiene como objeto principal la aplicación de la metodología PIMECOE sino que se refiere a la evaluación final de la asignatura. La valoración del PIMECOE aparece implícita en los ítems "Práctica 3", 
“Práctica 6” y "Exposiciones orales”, en los que se introduce una pregunta con respuesta abierta. En general, se manifiesta en diversas ocasiones el interés por las sesiones de exposición oral como espacios de aprendizaje que deben fomentarse. No obstante, por el contrario, al menos tres estudiantes muestran su preocupación por la comunicación oral y califican las exposiciones orales de "mal trago".

Finalmente, la tercera encuesta, sí ha sido diseñada explícitamente para conocer el grado de satisfacción general del estudiantado con la metodología PIMECOE, así como la relación entre el tiempo invertido y los resultados obtenidos. Desafortunadamente, no se han obtenido datos suficientes a través de esta vía puesto que el curso de la experiencia piloto ya había finalizado cuando se diseñó la encuesta. Hay que tener en cuenta que la primera implantación de la metodología propuesta es una experiencia piloto que se ha llevado de forma paralela al diseño de las diferentes fases de la metodología, por lo que no se tienen datos de esta última encuesta.

\section{Conclusiones}

El desarrollo de la competencia transversal "Comunicación Efectiva” y, en particular, su dimensión oral que es la que se ha trabajo en este estudio, es muy importante dentro del ámbito universitario, ya que el alumno debe expresar sus dudas, sus opiniones e incluso realizar exposiciones orales a lo largo de su carrera académica. Además, dicha competencia es muy valorada y requerida en el ámbito empresarial por lo que es muy importante que se adquiera y trabaje en la universidad. Sin embargo, debido al reducido tiempo que tienen los profesores para trabajar las competencias transversales en clase, no se suele profundizar en su aprendizaje. La metodología autoformativa propuesta en este estudio permite trabajar al alumno para mejorar la adquisición de la competencia, midiendo el nivel inicial de dominio y ofreciéndole un itinerario autoformativo para su mejora. Esta metodología no requiere de mucho tiempo de clase, sino que se trata de un aprendizaje autónomo por parte del alumno pero a la vez tutorizado por el profesor para cumplir con un contrato de aprendizaje establecido por ambas partes. Los resultados cuantitativos de la implementación de la metodología autoformativa en una experiencia piloto formada por alumnos de primer grado evidencia mejoras en la adquisición de la competencia. Además, el estudio cualitativo muestra un alto grado de interés por parte de los estudiantes de que se fomenten actividades de aprendizaje que ayuden a mejorar el dominio de la competencia. Por otra parte, este estudio cualitativo también nos ha servido para realizar una revisión en profundidad del test de autodiagnóstico y mejorar el enunciado y respuesta de cada una de las preguntas planteadas. El objetivo a corto plazo es implantar la metodología propuesta en dos másteres de la universidad y volver a analizar los resultados y las encuestas para mejorar de nuevo la metodología. Creemos que se trata de una metodología muy útil, aplicable a cualquier grado y máster de la universidad y extensible al desarrollo de la misma para el dominio de otras competencias transversales. 


\section{Agradecimientos}

El presente trabajo ha sido desarrollado en el marco del Proyecto de Innovación y Mejora Docente "Autodiagnóstico del nivel de dominio inicial de la competencia transversal "Comunicación Efectiva” y su mejora a través de un itinerario autoformativo" (Ref.: PIME/2017/B/025-14) financiado por el Vicerrectorado de Estudios, Calidad y Acreditación de la Universitat Politècnica de València a quien los autores agradecen expresamente este apoyo.

Asimismo, el equipo PIMECOE agradece a los estudiantes de la asignatura Introducción a la Arquitectura su participación en esta experiencia. Su contribución ha resultado fundamental para desarrollar una metodología con mayores garantías de éxito entre el alumnado.

\section{Referencias}

FERNÁNDEZ, A. (2006) “Metodologías activas para la formación en competencias” en Educatio Siglo XXI, vol. 24, p. 35-56.

ICE - INSTITUTO DE CIENCIAS DE LA EDUCACIÓN. UNIVERSITAT POLITÈCNICA DE VALĖNCIA (2015) Proyecto Competencias Transversales UPV $<$ http ://www.upv.es/entidades/ICE/info/U0724624.pdf> [Consulta: 27 de marzo de 2017].

LOBATO, C. (2006) “Estudio y trabajo autónomo del estudiante.” En De Miguel, M. Metodología de enseñanza y aprendizaje para el desarrollo de competencias. Madrid: Alianza.

MATARREDONA DESANTES, N. (2017) “La evaluación por pares en el ámbito no presencial.” En Sein Echaluce Lacleta, M.L., Fidalgo Blanco, A. y García Peñalvo, F. J., La innovación docente como misión del profesorado. Actas del IV Congreso Internacional sobre aprendizaje, innovación, y competitividad. CINAIC 2017. Zaragoza: Servicio de Publicaciones Universidad de Zaragoza.

OLTRA-BADENES, R. y GIL-GÓMEZ, H. (2015) “Técnicas de aprendizaje cooperativo: aplicación de metodologías activas en la asignatura de Recursos Humanos en Empresas Industriales”. En: 3rd International Conference on Innovation, Documentation and Teaching Technologies (INNODOCT/15). Valencia: Open Innovation and Coolhunting in Education. 374-382.

PECHAKUCHA (2018) Metodología Pechakucha < http://www.pechakucha.org/faq> [Consulta: 14 de marzo de 2018].

RUIZ, C. (2006) Metodologías docentes ante el EEES.

$<$ http://www.upct.es/contenido/conv_euro/ficheros/54Ponencia\%20Cecilia\%20Ruiz.pdf> [Consulta: 9 de enero de 2018].

SAYÓS, R. (2013) "Las competencias transversales en las titulaciones de grado de la Universidad de Barcelona. Orientaciones para su desarrollo" en Cuadernos de Docencia Universitaria, vol. 27.

SILVESTRE-CERDÁ, J.A., BAS, M.C., LERMA-GARCÍA, M.J., MATARREDONA-DESANTES, N., OLTRA-BADENES, R. y PÉREZ-ESTEVE, E. (2017) PIMECOE - Efective Oral Communication < $<$ htps://pimecoe.wordpress.com/> [Consulta: 11 de marzo de 2018].

VILLA, A. y POBLETE, M. (2007) Aprendizaje Basado en Competencias. Una propuesta para la evaluación de las competencias genéricas. Bilbao: Universidad de Deusto.

UNIVERSITAT POLITÈCNICA DE VALÈNCIA (2012) Competencias transversales. Blog $<$ http://www.upv.es/contenidos/COMPTRAN/info/956832normalc.html> [Consulta: 23 de abril de 2017]. 


\title{
El trabajo en equipo desde la mirada de los cuidados y la participación: reflexiones de su aplicación en el Máster en Cooperación al Desarrollo por la UPV
}

\author{
Carola Calabuig Tormo ${ }^{a}$, Álvaro Fernández-Baldor Martínez ${ }^{\text {y }}$ Sergio Belda Miquel \\ a'Departamento Proyectos de Ingeniería, Universitat Politècnica de València, cacator@dpi.upv.es \\ bDepartamento Proyectos de Ingeniería, Universitat Politècnica de València, alferma2@upv.es y Instituto \\ INGENIO UPV-CSIC, Universitat Politècnica de València, serbelmi@ingenio.upv.es
}

\begin{abstract}
The article shows the results obtained in the Master's Degree in Development Cooperation of the Universitat Politècnica de València, related to the application of the participation and care approach in teamwork competence, from the end of the 2016-2017 academic year, to current 2017-2018 academic year. The work collects what has been carried out since the 2015-2016 academic year, allowing to assess the improvements introduced and analyzing the evolution in two different groups of students. The most outstanding innovation in the last year is the improvement of the rubric for the evaluation of the competence, with the assistance of a Valencian DNGO in the assessment. There has also been a transfer of the competence to the space of external curricular internships of the master. The results continue to show the need to accompany the process, as well as to reinforce the understanding and application of some dimensions of teamwork from the adopted approaches, in order to consolidate the proposal.
\end{abstract}

Keywords: teamwork, competences, care approach, assesment

\begin{abstract}
Resumen
La comunicación muestra los resultados obtenidos en el Máster en Cooperación al Desarrollo por la Universitat Politècnica de València, relativos a la aplicación del enfoque de cuidados y la participación a la competencia transversal trabajo en equipo, desde finales del curso 2016-2017, hasta lo que lleva de avance el curso 2017-2018. El trabajo recoge lo llevado a cabo desde el curso 2015-2016, permitiendo valorar las mejoras introducidas y analizando la evolución en dos grupos de alumnado diferente. La innovación más destacada en el último año es la mejora de la rúbrica para la evaluación de la competencia, con el concurso de una ONGD valenciana en el asesoramiento. También ha habido un traslado de la competencia al espacio de las prácticas externas curriculares del máster. Los resultados siguen mostrando la necesidad de acompañar el proceso, así como reforzar el entendimiento y aplicación de algunas dimensiones del trabajo en equipo desde los enfoques adoptados, para consolidar la propuesta.
\end{abstract}

Palabras clave: trabajo en equipo, competencias transversales, enfoque de cuidados, evaluación

\section{Introducción}

Este artículo aborda el trabajo realizado en el último año por el profesorado del Máster Universitario en Cooperación al Desarrollo (MCAD) por la Universitat Politècnica de València 
El trabajo en equipo desde la mirada de los cuidados y la participación: reflexiones de su aplicación en el Máster en Cooperación al Desarrollo por la UPV

(UPV), por introducir el enfoque de cuidados y la participación en la competencia transversal trabajo en equipo. Recogiendo para ello los antecedentes de dicha experiencia.

En los estudios relacionados con la cooperación al desarrollo existe un intenso debate sobre el papel que debe desempeñar la formación de profesionales del desarrollo. Existe una corriente hegemónica, dominada por una perspectiva instrumental y poco crítica con la gestión del desarrollo (Gulrajani, 2010; Mosse, 2005), según la cual las personas dedicadas a la gestión del desarrollo deben ser "buenos técnicos", capaces de manejar los instrumentos de gestión adecuados para identificar las mejores soluciones y guiar adecuadamente el cambio en la dirección deseada (Johnson y Thomas, 2007). Como Peris et al. (2013) mencionan, esta perspectiva implicaría que los procesos formativos en gestión de proyectos de desarrollo se centren en proveer a las y los estudiantes capacidades para manejar herramientas que permitan alcanzar de manera eficiente objetivos prefijados de desarrollo mediante una secuencia lineal de pasos, o al menos mediante una planificación estricta (Clarke and Oswald, 2010).

Sin embargo, otra corriente más crítica consideraría que las personas gestoras del desarrollo deberían poner en el centro la naturaleza siempre compleja y política de los procesos de desarrollo, en los que las relaciones de poder juegan un lugar fundamental (McCourt y Gulrajani, 2010; Eyben et al, 2015). Esta visión entendería que los programas de educación superior en gestión del desarrollo deberían focalizarse en generar competencias para entender, desvelar y moverse en contextos complejos y embebidos en relaciones de poder, desde una perspectiva, abierta, flexible, colaborativa y adaptativa. Entre estas competencias, tiene un rol fundamental el trabajo en equipo, la participación y la actitud cooperativa para un trabajo productivo, respetuoso y transformador. Distintos autores del ámbito del desarrollo han apuntado que existen numerosos métodos y aproximaciones pedagógicas para desarrollar capacidades que vayan más allá del gerencialismo en la práctica del desarrollo (ver ejemplos específicos en Ortiz Aragon, 2010; Pearson, 2010; Pettit, 2006; Soal, 2010), y que van desde el aprendizaje experiencial a métodos creativos que apelan a las emociones y el uso del cuerpo.

Es bajo esta última perspectiva que se alinea el MCAD, intentando replantear las metodologías de enseñanza-aprendizaje actualmente empleadas en la gestión del desarrollo y apostando por una educación transformadora, que genere la participación activa y comprometida de todas las personas a favor de la justicia, la equidad de género y la sostenibilidad social y ambiental. Para llevar a cabo esta misión se apuesta por incorporar en la docencia diversos enfoques como el de género, el de cuidados, la participación o la sostenibilidad.

El MCAD es un título oficial de la UPV de 90 ECTS, orientado a formar profesionales de la gestión del desarrollo con competencias que les permitan una práctica crítica de la cooperación. El MCAD se desarrolla en el entorno de la UPV, una universidad técnica con una perspectiva aún muy instrumental, racionalista y limitada de las capacidades que una universidad debe desarrollar en su alumnado; muy orientada a la empleabilidad, y con un uso aún muy extendido de prácticas de enseñanza-aprendizaje poco activas. Sin embargo, la UPV ha ido generando también estrategias y espacios alternativos, para tratar de que su profesorado genere y proponga una perspectiva más amplia de la enseñanza superior y de los procesos de enseñanzaaprendizaje. Por ejemplo, está tratando de impulsar progresivamente el trabajo en trece 
competencias transversales en todas las titulaciones y asignaturas, así como en el uso de metodologías activas de enseñanza-aprendizaje para desarrollarlas.

En este artículo mostramos el trabajo realizado por el profesorado del equipo de innovación educativa (EICE) del MCAD, denominado EICE-MACODE, por incorporar el enfoque de cuidados y la participación en la competencia transversal trabajo en equipo. Se amplía de esta forma el trabajo previo realizado, disponiéndose de una contextualización más detallada de los enfoques adoptados y de la innovación, así como de los primeros avances, en Calabuig, Fernández-Baldor y Belda (2017). El trabajo realizado se enmarca en dos Proyectos de Innovación y Mejora Educativa (PIME) emprendidos desde el EICE-MACODE, uno de ellos en activo, apoyados desde el Instituto de Ciencias de la Educación y el Vicerrectorado de Estudios, Calidad y Acreditación de la UPV.

El enfoque de cuidados pone en evidencia que nuestro actual modelo de desarrollo, centrado en los mercados, es un modelo injusto, insostenible y generador de múltiples desigualdades, y en el que los trabajos de cuidados, imprescindibles para el sostenimiento de la vida, son casi invisibles, poco reconocidos, mal pagados, muchas veces relegados a que los realicen terceras personas (casi siempre las mujeres) y que tienen un desigual reparto e impacto entre hombres y mujeres (InteRed, 2017). Por ello, desde la mirada de cuidados se reivindica la posición clave de éstos en cualquier proceso de desarrollo, revalorizando los aportes que nacen precisamente del cuidado de la vida, frente a lo productivo, competitivo y excluyente de los modelos predominantes (Herrero, 2013). Así, planteamos incorporar esta mirada en el trabajo en equipo que desarrolla el alumnado del MCAD de manera que nos permita mirar la realidad teniendo en cuenta el cuidado del planeta donde vivimos (tanto a las otras personas como a la naturaleza), el cuidado en el hogar y nuestro propio cuidado.

\section{Objetivos}

La presente comunicación recoge el trabajo realizado entre abril de 2017 (curso académico 2016-2017) y el curso 2017-2018 (hasta marzo de 2018 inclusive) para mejorar y evaluar el desarrollo en el alumnado del MCAD de la competencia transversal trabajo en equipo, en tres asignaturas del primer curso del MCAD, desde el enfoque de los cuidados y la participación, siendo los objetivos al poner en marcha la iniciativa los siguientes:

- Integrar en la caracterización y variables definitorias de la competencia trabajo en equipo los enfoques de participación y de cuidados mediante la colaboración entre la UPV y la ONGD española InteRed.

- Llevar a cabo formación específica para el alumnado sobre la competencia trabajo en equipo desde los enfoques adoptados.

- Incorporar mecanismos suficientes para implementar la competencia de trabajo en equipo, desde la participación y cuidados, en tres de las cinco asignaturas del máster.

- Poner en práctica y contrastar herramientas para la adecuada evaluación cualitativa y/o cuantitativa de dicha competencia, tanto en espacios formales como informales de aprendizaje, en el seno del máster. 
El trabajo en equipo desde la mirada de los cuidados y la participación: reflexiones de su aplicación en el Máster en Cooperación al Desarrollo por la UPV

- Potenciar entre el alumnado la capacidad de reflexión sobre el proceso seguido en el trabajo en equipo, tanto el llevado a cabo de forma presencial en el aula, como fuera de ella (prácticas externas curriculares).

\section{Desarrollo de la innovación}

El propósito de la innovación educativa ha sido consolidar y mejorar el trabajo que se ha venido realizando hasta la fecha sobre la competencia trabajo en equipo en el Máster en Cooperación al Desarrollo (MCAD) por la UPV. Para ello, hemos incorporado de manera más profunda los enfoques de participación y de cuidados para trabajar la mencionada competencia, a partir de la experiencia desarrollada durante los cursos 2015-2016 y 2016-2017. A lo largo del trabajo, para la competencia será empleada la denominación Trabajo en equipo y liderazgo (código CT06), ya que está así establecida en la UPV; sin embargo, la dimensión liderazgo no ha sido abordada desde el máster hasta la fecha con la misma profundidad.

\subsection{El trabajo en equipo desde la participación y los cuidados}

Aunque la competencia transversal de trabajo en equipo es ampliamente abordada en muchos planes de estudio, proyectos y equipos de innovación educativa, aquí la particularidad ha sido que el trabajo en equipo fuera de corte colaborativo. Esta preocupación ha estado presente con fuerza desde el inicio de la titulación. La misma busca contribuir a la formación de profesionales del campo del desarrollo y la cooperación, como ciudadanas/os globales que sean capaces de ejercer su agencia individual y colectiva para el logro de modelos alternativos de mayor justicia social. Se trata, además, de que el alumnado del Máster sea capaz de trabajar en equipo en contextos de gran complejidad e incertidumbre y en los que las relaciones de poder juegan un papel fundamental (McCourt y Gulrajani, 2010; Eyben et al, 2015). Todo ello es habitual en los procesos de desarrollo. El propio alumnado que ha realizado sus prácticas externas internacionales así lo ha experimentado a pequeña escala.

Esta inquietud ha adquirido, si cabe, más fuerza durante los últimos dos cursos académicos, constatándose que debían ponerse más medios en el máster para trabajar y evaluar el trabajo en equipo como competencia indispensable en este área. Y a hacerlo desde una perspectiva más crítica, contraponiéndose a perspectivas tecnocráticas y gerenciales (se considera que éstas no contribuyen a abordar las causas estructurales de la pobreza y la exclusión sino que, al contrario, refuerzan las relaciones desiguales de poder).

Así mismo, el alumnado del máster, a través de los Comités de Seguimiento de las asignaturas, había expresado durante varios cursos la necesidad de: (i) disponer de más herramientas para entender las dimensiones del trabajo en equipo colaborativo; (ii) a poder ser acompañadas en ese proceso de aprendizaje en la práctica; (iii) y a poder evaluarlo. El EICE-MACODE decide apostar durante el curso 2016-2017, de manera progresiva y con diferentes grados de intensidad, por varias competencias transversales, principalmente CT06 Trabajo en equipo y liderazgo. Se adoptaron entonces dos enfoques específicos: el enfoque participativo y el enfoque de cuidados, combinando la experiencia y esfuerzo del personal docente del Máster con el apoyo de profesionales externas. Por un lado, el enfoque de participación ha sido esencial en la definición del enfoque pedagógico general y en la metodología de enseñanza-aprendizaje del MCAD (ver Peris et al., 2013; Belda et al., 2016),

(cc) EY-NC-ND 2018, Universitat Politècnica de València

Congreso IN-RED (2018) 
no solo porque se enseñan diferentes metodologías y técnicas participativas, sino porque el alumnado tiene que aplicarlas en sus trabajos en equipo: desde debates y discusiones grupales, juegos de rol o teatro, hasta la realización de IAP (investigación-acción participativa), ApS (Aprendizaje-Servicio) o Aprendizaje en la Acción. Por otro lado, se ha trabajado desde el denominado enfoque de cuidados, que algunas ONGD como InteRed están implementando desde la llamada pedagogía de cuidados. Como se avanzó en la introducción, este enfoque pone en el centro una combinación de la ética de la justicia y la ética del cuidado, centrándose: (i) en el reconocimiento del derecho individual y colectivo al cuidado (Carrasco, Borderías y Torns, 2011); (ii) en la dimensión política de lo personal; (iii) y en la dimensión ecológica del cuidado. Esto implica poner en el centro la igualdad dentro de las relaciones personales, desmontando jerarquías y privilegios, así como la atención de las necesidades que todas las personas pueden tener. El reconocimiento del otro/a como sujeto de derecho al cuidado lleva además a atender a la singularidad de cada persona o comunidad y a tener que dar espacio a la diversidad para que la diferencia no se convierta en desigualdad (De Blas, 2016). En general, un enfoque de cuidados supone implicarse en el bienestar de las demás personas desde posturas ecofeministas (Herrero, 2013). Supone ser conscientes de que el bienestar es una experiencia personal, vinculada a los intereses y deseos personales, a la razón, al cuerpo y a las emociones.

La incorporación de ambos enfoques, como se expondrá, ha derivado en un replanteamiento de las dimensiones que el trabajo en equipo debe tener y que debería fomentarse desde el máster.

\subsection{Insumos recibidos del curso 2016-2017}

Si bien las diversas asignaturas del máster seguirían siendo punto de control de otras competencias, se toma la decisión de profundizar en la de trabajo en equipo: garantizando una mejor coordinación entre el profesorado; buscando una mayor coherencia entre métodos empleados en las diferentes asignaturas; incorporando las demandas del alumnado fruto de coevaluaciones realizadas en los comités de seguimiento de las asignaturas (por ejemplo: precisar las rúbricas, dar más herramientas para el trabajo en equipo o dimensionar mejor el trabajo en equipo autónomo); revisando el sistema de rúbricas para la evaluación; e implicando a las ONG de Desarrollo que forman parte del Consejo Asesor del máster.

Es por ello que, durante el curso 2016-2017, se redefinieron unidades temáticas de algunas asignaturas y se realizó el esfuerzo de revisar internamente los métodos docentes y de evaluación. Se buscaba que el trabajo en equipo fuera puesto en práctica con el rigor y profundidad requeridos, así como de forma coherente con los planteamientos del máster expuestos con anterioridad. En Calabuig, Fernández-Baldor y Belda (2017) se dispone de una descripción pormenorizada de las actividades realizadas en el curso 2016-2017 y de los primeros resultados obtenidos hasta marzo de 2017. De forma resumida, se llevaron a cabo las siguientes: (a) dos talleres sobre trabajo en equipo, uno en cada cuatrimestre, específicamente diseñados para el alumnado de primer año del máster e impartido por personal especializado de la ONGD InteRed; (b) redefinición del sistema de evaluación de la competencia transversal, incorporando más espacios y actividades secuenciadas y simplificando el cuestionario; (c) respecto a los cuestionarios de autoevaluación y evaluación por pares, se decide reducir a cuatro los criterios de evaluación y no emplear un sistema de rúbricas como tal, sino aplicar una escala cualitativa de valoración (cuatrimestre A)

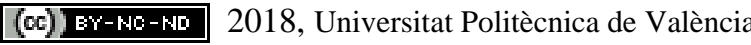

Congreso In-Red (2018) 
El trabajo en equipo desde la mirada de los cuidados y la participación: reflexiones de su aplicación en el Máster en Cooperación al Desarrollo por la UPV

y otra cuantitativa (cuatrimestre B); (d) evaluación de los mecanismos puestos en marcha al final del cuatrimestre A, tanto en el seno del EICE-MACODE, como con el alumnado del máster (en aula y a través de los Comités de Seguimiento de asignaturas).

\begin{tabular}{|c|c|c|c|c|c|}
\hline \multicolumn{6}{|c|}{ Valoración de la competencia trabajo en equipo y liderazgo } \\
\hline \multirow{2}{*}{ Criterio } & \multirow{2}{*}{ Qué comprende el criterio } & \multicolumn{4}{|c|}{ Descriptores } \\
\hline & & A & B & $\mathrm{C}$ & $\mathrm{D}$ \\
\hline $\begin{array}{l}\text { Escucha activa, } \\
\text { empatía, cuidados } \\
\text { y respeto }\end{array}$ & $\begin{array}{l}\text { En los espacios de trabajo se muestra una persona con interés. } \\
\text { Focaliza la atención en la dinámica de grupo, sin desviarse a } \\
\text { otros asuntos. Diferencia lo que son espacios de comunicación } \\
\text { relativos al trabajo del máster de los espacios privados. Da su } \\
\text { opinión sin monopolizar las conversaciones. El lenguaje } \\
\text { empleado en las intervenciones en general es inclusivo y } \\
\text { respetuoso. Es capaz de empatizar con l@s compañer@s y } \\
\text { actúa desde la cultura de los cuidados, no buscando solamente } \\
\text { un enfoque "eficientista" de la tarea. }\end{array}$ & & & & \\
\hline $\begin{array}{l}\text { Gestión de } \\
\text { conflictos }\end{array}$ & $\begin{array}{l}\text { Tiene en cuenta diferencias culturales o de otro tipo que } \\
\text { pueden dificultar un adecuado entendimiento y provocar } \\
\text { malestar. Busca integrar a todas las personas que forman parte } \\
\text { del equipo, incorporándolas a la conversación o a la sesión } \\
\text { concreta. Es capaz de aclarar su punto de vista de manera } \\
\text { adecuada frente a sus compañeras, así como reaccionar bien } \\
\text { ante visiones contrapuestas. Es capaz de aportar soluciones a } \\
\text { posibles conflictos generados entre los miembros del equipo }\end{array}$ & & & & \\
\hline Liderazgo social & $\begin{array}{l}\text { Sus intervenciones invitan a otros/as a profundizar en } \\
\text { cuestiones particulares. Valora, recoge e integra ideas } \\
\text { formuladas por sus compañeros/as para profundizar en ellas. } \\
\text { Motiva a las compañeras, promueve la distribución de roles y } \\
\text { la cohesión del grupo. }\end{array}$ & & & & \\
\hline $\begin{array}{l}\text { Responsabilidad, } \\
\text { compromiso y } \\
\text { rendición de } \\
\text { cuentas }\end{array}$ & $\begin{array}{l}\text { Se muestra como una persona proactiva en el trabajo en equipo } \\
\text { y comprometida con los objetivos a conseguir. Es responsable } \\
\text { con las tareas encomendadas y da cuentas de las mismas, } \\
\text { comunicando avances, resultados, etc., al resto del equipo. Es } \\
\text { puntual para el inicio de las reuniones. }\end{array}$ & & & & \\
\hline \multicolumn{6}{|c|}{$\begin{array}{l}\text { Descriptores cualitativos: } \\
\text { A: Ocurre casi siempre / Se da de forma ejemplar } \\
\text { B: Ocurre con frecuencia / Se da de forma adecuada } \\
\text { C: Ocurre con poca frecuencia/ Se da de forma mejorable } \\
\text { D: No ocurre casi nunca/Se da de forma claramente insatisfactoria }\end{array}$} \\
\hline
\end{tabular}

Figura 1: Tabla tipo para la valoración de la competencia trabajo en equipo durante el curso 2016-2017 Fuente: elaboración propia

La figura 1 muestra la tabla que se utilizó durante el curso 2016-2017 para evaluar la competencia. Como veremos en la siguiente sección, esta ha sufrido importantes modificaciones en el curso 2017-2018.

\subsection{Actividades realizadas en el curso 2017-2018}

Las principales actividades desarrolladas en el marco del proyecto en el presente curso académico 2017-2018, fruto de la evaluación del trabajo realizado en el curso anterior y hasta la fecha, han sido:

- Establecimiento de una mayor colaboración entre el EICE-MACODE y la ONGD InteRed, ONGD española de referencia en materia de educación para el desarrollo y educación para la ciudadanía global y que ha desarrollado una aportación propia denominada ética revolucionaria de los cuidados (InteRed, 2014).

- Taller específico para el alumnado de primer año sobre trabajo en equipo y liderazgo con enfoque de cuidados y participación (octubre de 2017), con la consiguiente generación de materiales revisados desde los enfoques adoptados. 
- Incorporación de lecciones aprendidas durante 2016-2017 a los mecanismos de trabajo y acompañamiento en el desarrollo de la competencia aplicada a tres de las asignaturas del máster (primer curso de docencia). Uno de los elementos identificados a mejorar fue el diseño de la rúbrica para la evaluación, así como los espacios para el seguimiento.

- Rediseño del sistema de evaluación de la competencia CT06 en tres de las asignaturas del máster, mediante adecuación de las rúbricas según los enfoques adoptados y a partir de diversos formatos de rúbricas aconsejados por el Instituto de Ciencias de la Educación (ICE) de la UPV. En efecto, a fin de mejorar la incorporación de los enfoques de participación y cuidados, y siguiendo las pautas del ICE, durante este curso académico se ha realizado un gran esfuerzo por rediseñar la rúbrica (ver tablas 1 y 2). En su definición han participado: el profesorado del EICE-MACODE, la ONGD InteRed y el alumnado del presente curso. La nueva rúbrica contiene cinco dimensiones evaluativas: participación; responsabilidad compartida y compromiso; escucha activa; empatía y comprensión mutua; gestión de conflictos. A su vez, cada dimensión se divide en diferentes indicadores, hasta un total de 17. El contenido y significado de cada uno de los indicadores, adaptado a la rúbrica, es lo que más trabajo ha generado al profesorado, al alumnado y a la ONGD. Para el cuatrimestre A (primer momento en el empleo de la rúbrica, más de aproximación) se ha adoptado una escala cualitativa (A,B,C y D) para los descriptores. Para el cuatrimestre B, los descriptores se han medido mediante puntuación, permitiendo de esta forma profundizar en el análisis cuantitativo.

- Generación de espacios en el aula con el alumnado, de forma planificada, para la reflexión individual y colectiva respecto al desempeño de la competencia.

- Medición del desempeño respecto a esta competencia, a estudiantes que realicen en 20172018 sus prácticas externas (segundo año del máster). Se ha llevado a cabo incorporando preguntas específicas en el guión que deben emplear para elaborar su memoria de prácticas una vez las finalizan, y a la fecha se están realizando entrevistas a dicho alumnado.

La tabla 1 muestra las dimensiones, e indicadores para cada una de ellas, que se han definido para caracterizar la competencia, enfatizando la participación y los cuidados. Para cada indicador se ha desarrollado una rúbrica, que se ha entregado al alumnado para que pudiera realizar su autoevaluación y la coevaluación. Se trata de la empleada en el cuatrimestre A, especificando más el contenido de algunos descriptores y haciendo uso de escala cuantitativa, como se mencionó anteriormente. El alumnado ha participado en este proceso de definición, aportando sus opiniones.

Debido a las limitaciones de espacio y por la imposibilidad de incorporar de forma legible toda la información, no es posible mostrar todas las rúbricas definidas, por lo que se han incluido únicamente las relativas a las dimensiones empatía y comprensión mutua y escucha activa. La tabla 2 muestra descriptores cuantitativos (se decide que una A empleada en el primer cuatrimestre pase a ser en la rúbrica para el segundo semestre una escala de 9 a 10; una B, escala de 7 a 8 ; una C, escala de 5 a 6 y una D, escala de 0 a 4). 
El trabajo en equipo desde la mirada de los cuidados y la participación: reflexiones de su aplicación en el Máster en Cooperación al Desarrollo por la UPV

Tabla 1. Dimensiones e indicadores de la competencia trabajo en equipo

\begin{tabular}{|c|c|}
\hline DIMENSIÓN & INDICADORES \\
\hline \multirow{4}{*}{$\begin{array}{l}\text { Participación: Participar y colaborar } \\
\text { activamente en las tareas del equipo, } \\
\text { fomentando la confianza y cordialidad } \\
\text { y la orientación al trabajo conjunto }\end{array}$} & Ideas propias y voz \\
\hline & Colaboración y contribución al trabajo en equipo. \\
\hline & Participación activa en la toma de decisiones \\
\hline & Respeto a las diferencias \\
\hline \multirow{4}{*}{$\begin{array}{l}\text { Responsabilidad compartida y } \\
\text { compromiso }\end{array}$} & Puntualidad \\
\hline & $\begin{array}{l}\text { Colaboración en la definición, asignación y realización de } \\
\text { las tareas }\end{array}$ \\
\hline & Corresponsabilidad y complementariedad \\
\hline & Búsqueda del bien común. Actuaciones desde lo colectivo \\
\hline \multirow{2}{*}{$\begin{array}{l}\text { Escucha Activa: Escuchar no solo lo } \\
\text { que la persona expresa directamente, } \\
\text { sino entender también sus sentimientos, } \\
\text { ideas o emociones que subyacen a lo } \\
\text { que está diciendo }\end{array}$} & $\begin{array}{l}\text { Concentración y atención al mensaje. Asertividad a la hora } \\
\text { de escuchar }\end{array}$ \\
\hline & Respeto \\
\hline \multirow{5}{*}{$\begin{array}{l}\text { Empatía y comprensión mutual: La } \\
\text { empatía es la base para una escucha } \\
\text { activa y supone ponerse en el lugar del } \\
\text { otro/a, calzar sus zapatos: ser capaz de } \\
\text { entenderle y comprenderle desde "su } \\
\text { escala de importancia" }\end{array}$} & Reconocimiento del trabajo \\
\hline & $\begin{array}{l}\text { Comprensión de las circunstancias personales, capacidad de } \\
\text { empatía }\end{array}$ \\
\hline & Solidaridad \\
\hline & Actitud positiva \\
\hline & Práctica de los cuidados \\
\hline \multirow{2}{*}{ Gestión de conflictos } & Conciliación y mediación \\
\hline & Ambiente pacífico basado en el diálogo \\
\hline
\end{tabular}

Fuente: elaboración propia

\section{Resultados}

Se recogen a continuación los principales resultados obtenidos. Por limitaciones de espacio, se centra el análisis en aquellos más significativos relativos al curso 2017-2018, tanto en estudiantes de primer año (se trata de un grupo de 24 personas), como en aquellos que durante el presente curso han realizado sus prácticas externas curriculares (se ha podido disponer de información de 9 estudiantes que ya han regresado de sus destinos). Se han tratado en el apartado 4.1, mientras que otros resultados se han resumido en el apartado 4.2.

\subsection{Resultados relativos al desempeño de la competencia}

En cuanto al cuatimestre A, algunas reflexiones llevadas a cabo por el alumnado durante los espacios ofrecidos para la reflexión individual y grupal dan muestra de que, con acompañamiento y herramientas, son capaces de darle un sentido diferente al trabajo en equipo: "pese a nuestras diferencias, creo que las asumimos respetuosa y empáticamente y conseguiremos sacarlo adelante y con buena calidad" (estudiante 1); "para mí, que un trabajo sea un buen trabajo en equipo, cada uno debería tener la capacidad de reconocer y valorar lo que cada uno aporta" (estud. 2); "lo que más me ha sorprendido es poder escuchar de manera más activa, construyendo mis ideas junto con las ideas que el grupo aporta” (estud. 3). 
Tabla 2. Rúbricas para la valoración de la competencia trabajo en equipo durante el curso 2017-2018

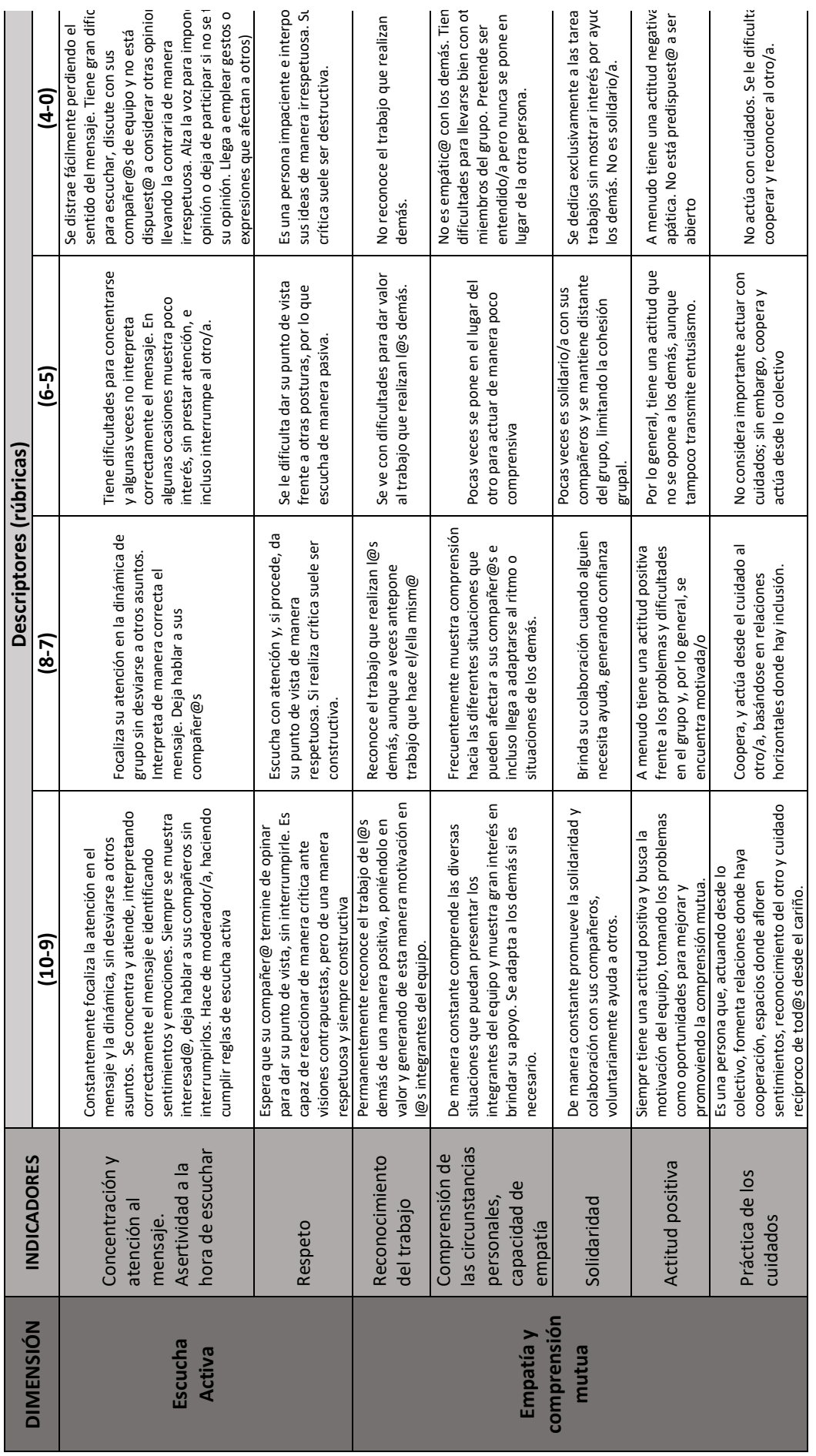

Fuente: elaboración propia

(cc)) EY-Nc-ND 2018, Universitat Politècnica de València Congreso In-Red (2018) 
El trabajo en equipo desde la mirada de los cuidados y la participación: reflexiones de su aplicación en el Máster en Cooperación al Desarrollo por la UPV

En cuanto al desempeño propiamente dicho de la competencia, ha habido diversidad de resultados, sobre una base de 6 equipos de trabajo y un total de 23 cuestionarios (sobre 24 estudiantes) de auto-evaluación y co-evaluación respondidos, relativos a la asignatura Cooperación al Desarrollo (el trabajo en equipo contribuye en un $40 \%$ a la nota final). Por un lado, ha habido equipos que han funcionado de forma muy satisfactoria, donde dimensiones básicas del trabajo en equipo como responsabilidad en la asignación de las tareas o contribución al trabajo en equipo han favorecido el buen clima y la presencia de otras dimensiones más relacionadas con el cuidado, como la comprensión mutua. Sin embargo, en otros casos, ha habido equipos que no han funcionado adecuadamente en los que el conflicto, incluso a pesar de haber sido abordado en la reunión intermedia de seguimiento, no ha sido completamente resuelto. En estos casos, se aprecia cómo las valoraciones por pares (co-evaluación) calificadas como C o D se han otorgado en indicadores como asertividad, búsqueda del bien común, comprensión de las circunstancias personales, práctica de los cuidados o solidaridad. El anonimato en el cuestionario ha favorecido la sinceridad y, aunque las valoraciones eran cualitativas (A, B, C y D), se aprecia cómo las mayores discrepancias entre lo que el/la estudiante valora de sí mismo y cñomo es valorado por sus compañeros/as se dan en los equipos en los que ha aflorado algún tipo de conflicto. También algunas estudiantes han expresado la importancia que ha tenido esta forma de aproximarse y practicar el trabajo en equipo: "Creo que este tipo de evaluacion por un lado, es importante y rompe con los escquemas tradicionales que existen en las Universidades y en diferentes lugares de trabajo, en cuanto toma en consideracion la persona con sus esencias y sus valores y no solo con lo que "produce" (estudiante 4).

En el cuatimestre B, en la Unidad Temática 1 de la asignatura Gestión del Ciclo del Proyecto (que supone prácticamente la mitad de los créditos del total de la asignatura), todo el trabajo se realiza en equipo. Además de la nota del propio trabajo, que se evalua por grupos, existe un 5\% de la nota final de la asignatura que consiste en autoevaluación y coevaluación de cada miembro del equipo según la rúbrica de evaluación mostrada en el apartado anterior. Para la evaluación, el profesor responsable de la asignatura dejó unos 15 minutos para que individualmente el alumnado leyera la rúbrica. Posteriormente, se dedicaron 30 minutos de reflexión para cada grupo, para que pudieran comentar cómo había sido la dinámica del trabajo en equipo y cómo se habían sentido. En definitiva, se trataba de comentar grupalmente cómo habían trabajado en equipos según la rúbrica. A continuación, el profesor dejó unos 30 minutos para que individualmente se autoevaluaran y evaluaran a cada uno de sus compañeros y compañeras de grupo.

De las 23 personas que cursan el máster, disponemos de 22 respuestas, pues una de las personas que ese día no asistió a clase todavía no ha entregado sus valoraciones.

La figura 2 muestra una gráfica que compara los resultados generados por el alumnado en lo que se refiere a su autoevaluación y la coevaluación. La figura muestra cómo la puntuación que se otorgan individualmente (autoevaluación), es similar a la que le otorga su grupo (coevaluación). Las principales excepciones las conforman el alumno $\mathrm{n}^{\circ} 8$, quien es muy crítico con su desempeño en la competencia (alrededor de 4 puntos frente a los casi 7,5 que le otorga su grupo)

(cc) EY-NC-ND 2018, Universitat Politècnica de València

Congreso IN-RED (2018) 
y el alumno 17, quien contrariamente se autoevalúa con prácticamente 2 puntos más que los que le otorga su equipo.

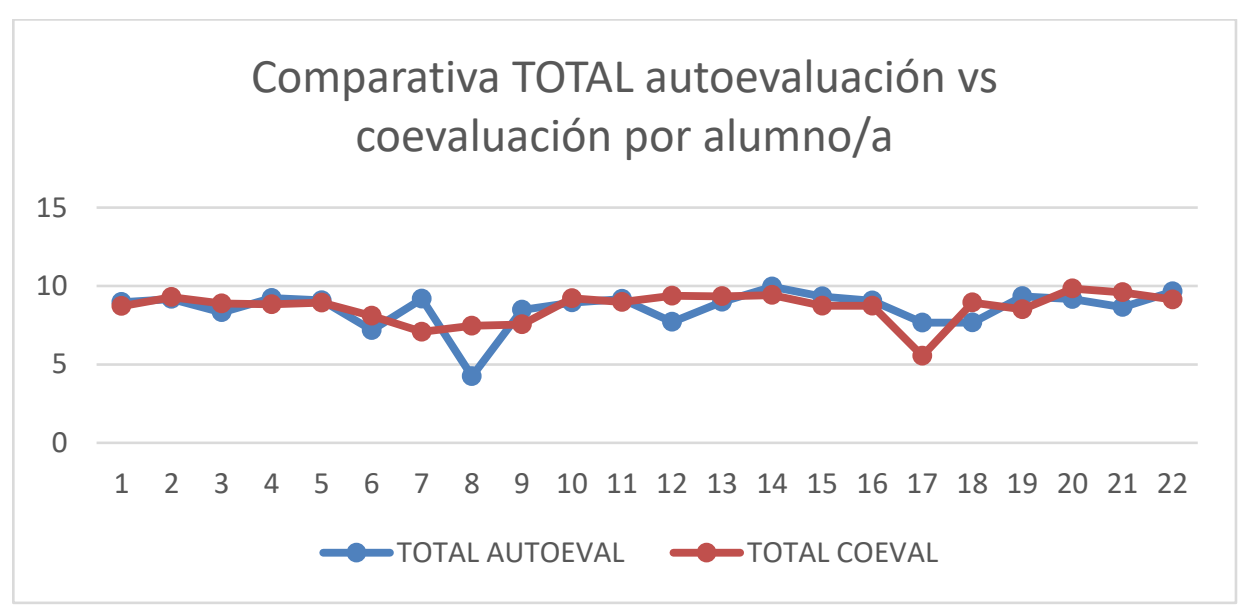

Figura 2: Comparativa entre la autoevaluación y la coevaluación para los 22 alumnos de la muestra Fuente: elaboración propia

Dejando las particularidades especificas del alumnado, y hablando de cifras medias, en la figura 4 podemos observar la puntuación por cada una de las cinco dimensiones.

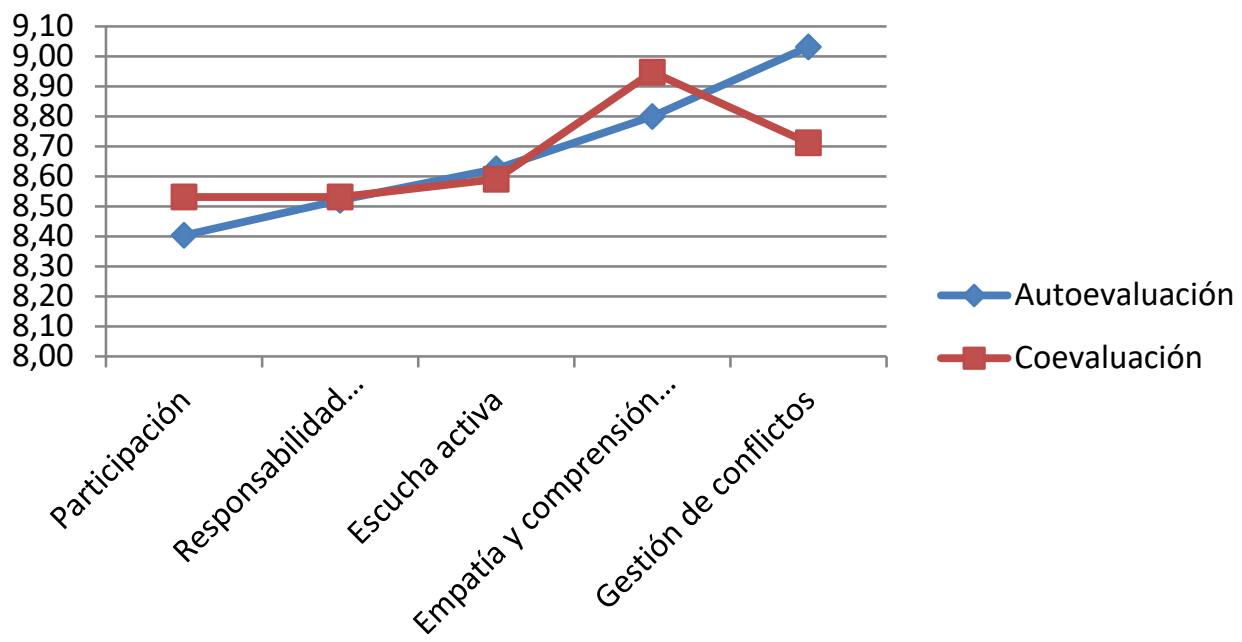

Figura 3: Comparativa de la autoevaluación y la coevaluación para cada dimensión de la rúbrica Fuente: elaboración propia

La figura 3 constata que en la dimensión de “Gestión de conflictos” es donde existe mayor divergencia entre la autoevaluación (con una media de 9 puntos) y la coevaluación (sobre 8,7 puntos). Esto nos aporta insumos para trabajar con el alumnado la empatía hacia el grupo, y el cómo nos posicionamos frente a los conflictos que surgen en los grupos durante el trabajo en equipo.

La figura 4 muestra los indicadores que conforman cada dimensión de la rúbrica. A grandes rasgos se puede ver que las puntuaciones son altas en prácticamente todos los indicadores. 
El trabajo en equipo desde la mirada de los cuidados y la participación: reflexiones de su aplicación en el Máster en Cooperación al Desarrollo por la UPV

Destacan los siguientes indicadores: respeto a las diferencias, compresión de las diferencias y empatía, solidaridad y ambiente pacífico basado en el diálogo. Todas ellas superan el 9.

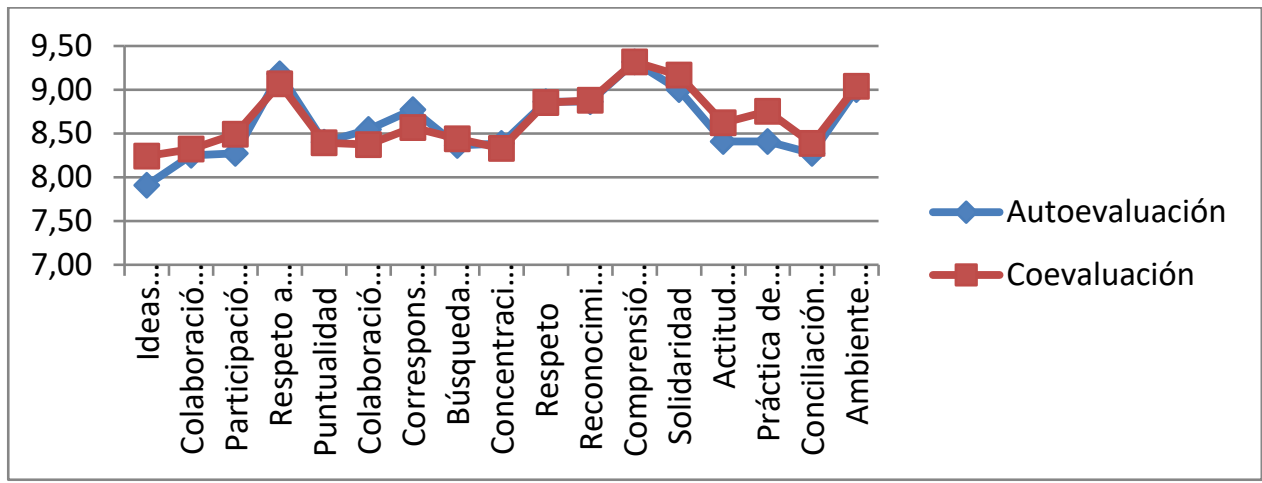

Figura 4: Comparativa de la autoevaluación y la coevaluación para cada indicador de la rúbrica Fuente: elaboración propia

En cambios los indicadores con menor nota son: ideas y voz propia, colaboración y contribución al trabajo en equipo, y asertividad a la hora de escuchar. A la luz de estas cifras son en estos puntos menor valorados donde se puede incidir el año que viene con el alumnado del curso 20182019.

Puesto que una de las novedades de esta rúbrica es la incorporación del enfoque de cuidados, a continuación prestaremos especial atención a este indicador, denominado "Práctica de los cuidados”, dentro de la dimensión Empatía y comprensión mutua.

La Figura 5 muestra el resultado de este indicador para cada estudiante, su autoevaluación, y lo que su grupo opina sobre él.

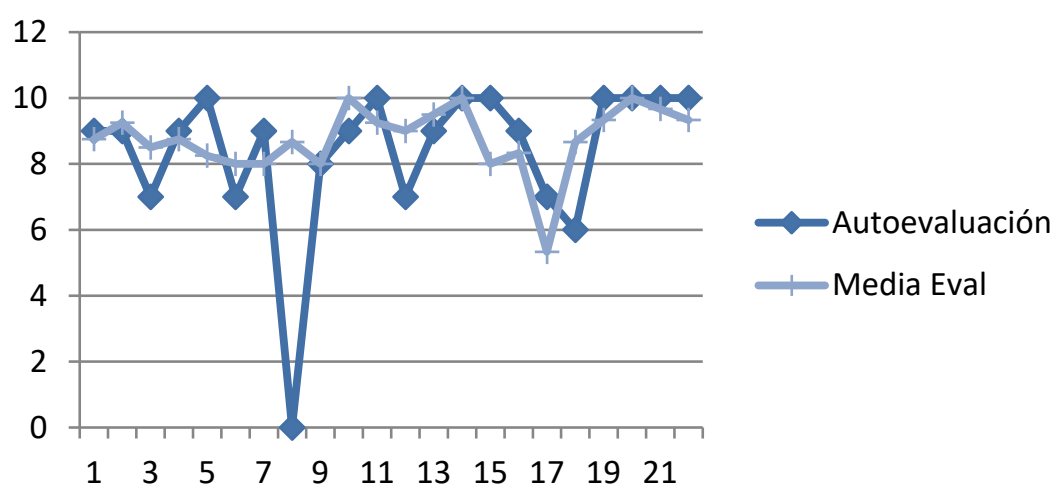

Figura 5: Comparativa de la autoevaluación y la coevaluación para el indicador "Práctica de los cuidados"

Fuente: elaboración propia

Es de destacar que un alumno opina que no practica los cuidados, mientras que la mayoría se autoevalúa con la máxima puntuación. En términos generales destacan las altas puntuaciones,

(cc) EY-NC-ND 2018, Universitat Politècnica de València

Congreso IN-RED (2018) 
tanto de autovaluación, como de coevaluación, lo que nos anima a pensar que introducir el enfoque de cuidados está colaborando a la empatía y comprensión entre cada grupo.

Finalmente, en relación a las prácticas externas, los testimonios hasta la fecha recabados no hacen sino confirmar que la introducción del enfoque de cuidados permite abordar el trabajo en equipo con una mirada necesaria, pero sin perder rigor en el desempeño de una competencia de estas características, como así lo manifiestan las estudiantes: "Creo que el máster ha producido un cambio significativo en la forma en la que las estudiantes hemos aplicado y entendido el trabajo desde los cuidados y la participación. Ha sido algo que ha estado continuamente presente, especialmente el trabajo desde los cuidados, ya que en otros espacios es un tema que se mantiene al margen y para nada forma parte de la pedagogía académica, en cambio, aquí se ha visto reforzado" (estud.5); "considero que las herramientas proporcionadas por el máster en materia de trabajo en equipo desde el enfoque de cuidados y la participación han sido de gran utilidad para las prácticas y son necesarias para el tipo de trabajo al que nos tenemos que enfrentar como futuros cooperantes (estud. 6); "He modificado algunas cosas en mi vida cotidiana y reflexionado sobre mi relación con las personas y mi entorno, gracias a los cuidados y la participación, grandes aprendizajes del máster" (estud. 7). A diferencia de la aplicación de la competencia en el aula, el desempeño del trabajo en equipo en prácticas externas se produce en entornos no académicos, internacionales la mayoría de veces, donde la complejidad y la incertidumbre son mucho mayores. Al ser una iniciativa incipiente, se está trabajando desde el máster para poder conectar mejor el proceso experimentado en el aula con las futuras prácticas, y buscando que el alumnado pueda tener también un seguimiento del trabajo en equipo en la distancia. A la fecha de cierre de la presente comunicación, se están llevando a cabo entrevistas con el alumnado que ha finalizado sus prácticas para evaluarlas, indagar sobre la utilidad del enfoque de cuidados y sistematizar la experiencia.

\subsection{Otros resultados a destacar}

Aunque el presente apartado se dirige a evidenciar los resultados de haber aplicado la competencia transversal bajo los enfoques adoptados, el proceso de elaboración de la rúbrica en sí es un elemento a destacar, dado su carácter participativo. Además, a pesar de que se deben evaluar cinco dimensiones mediante 17 indicadores (lo cual podría parecer farragoso), el alumnado ha valorado muy positivamente este sistema, por cuanto le ha ofrecido descriptores adecuados a diferentes grados de desempeño. La evaluación la han desarrollado como auto y coevaluación (por pares), por lo que era esencial lograr una total comprensión de las rúbricas propuestas.

En relación a los espacios que se han definido para llevar a cabo el seguimiento y lograr al mismo tiempo la reflexión individual y colectiva del alumnado, para el presente curso se ha buscado planificarlos mejor, aunque el desempeño ha sido desigual por cuatrimestres. En el primero, la sesión con el alumnado se produjo antes que en el curso anterior (en el mes de noviembre), permitiendo que los miembros de cada equipo de trabajo de una de las asignaturas dialogaran más entre sí y resolvieran ciertas situaciones problemáticas acontecidas. A pesar de ello, este espacio se presenta insuficiente, por cuanto el trabajo que realizan es no presencial y, por ello, hay una mayor necesidad de verse de forma intencional en el aula. Se sigue evidenciando que el alumnado en el primer cuatrimestre no se conoce todavía bien (acaban de empezar el máster) y 
El trabajo en equipo desde la mirada de los cuidados y la participación: reflexiones de su aplicación en el Máster en Cooperación al Desarrollo por la UPV

que emprender procesos nuevos de golpe les dificulta interiorizar bien lo que están haciendo (por ejemplo, la conexión entre el taller específico en octubre sobre trabajo con cuidados y su propio proceso como equipo según una rúbrica). Las lecciones aprendidas han permitido revisar los mecanismos previstos para el segundo semestre, en el cual el trabajo en aula es mucho más importante. Algunas de las preguntas a las que han respondido individual (de forma anónima) o grupalmente en los espacios para el seguimiento han sido las siguientes: ¿Cómo me estoy sintiendo emocionalmente en mi equipo de trabajo? ¿Qué es lo que más me está preocupando (si ha habido preocupación) de la dinámica de mi grupo durante el proceso? ¿Puedo identificar mi actitud y comportamiento con alguno de estos roles? ¿Qué es lo que más os está preocupando/sorprendiendo positivamente de la dinámica de vuestro equipo durante el proceso?¿Cómo está siendo vuestra comunicación? ¿Qué elementos tratados en el taller sobre trabajo en equipo creéis que habéis podido aplicar en lo que lleváis de trabajo? Cada alumno/a ha sido capaz de reflexionar y responder con sinceridad y, sobre todo, de dialogar en cada equipo a nivel interno.

\section{Conclusiones}

Los resultados obtenidos hasta la fecha, desde abril de 2017, son alentadores, por cuanto la gran mayoría del alumnado considera esencial abordar el trabajo en equipo bajo la mirada de los cuidados y la participación. El hecho de combinar descriptores cualitativos y cuantitativos, ha permitido disponer de diferentes aproximaciones a la valoración que consideramos muy útiles. A pesar de todo ello, se requiere introducir algunas mejoras, asumiendo que cada nueva promoción estará formada por alumnado diverso en cuanto a procedencias geográficas, culturales, formativas y vivenciales, que sin duda plantean un reto año tras año si se quieren tratar cuestiones que se dirigen al ámbito emocional y de las relaciones sociales. En ese sentido, el conflicto acontecido en algunos equipos procede del bajo o limitado desempeño en dimensiones esenciales del trabajo en equipo (más allá del enfoque de cuidados), como es la puntualidad, la responsabilidad y el compromiso sobre las tareas asignadas y en relación al grupo (lograr objetivos previstos y alcanzar resultados óptimos). Al introducir otras dimensiones, relativas al cuidado de la otra persona, a la atención a sus circunstancias personales o al reconocimiento al trabajo del otro/a, la visión sobre el trabajo en equipo cambia y el alumnado reconoce que no solamente es importante "lograr los objetivos marcados de forma eficiente", sino que lo es igualmente o más ser considerados/as sujetos con capacidad de participar y que no pueden eludir sus estados emocionales y personales cuando afrontan una tarea en equipo. El desafío está en cómo trabajar con el alumnado la necesidad de encontrar el equlibrio entre la comprensión del otro/a y la (auto)exigencia y responsabilidad con los compromisos adquiridos.

Finalmente, algunos elementos que deben ser revisados y mejorados serían: la dotación de más espacios presenciales para que los equipos de trabajo dialoguen; aumentar el acompañamiento desde el profesorado; dotar de herramientas para la gestión de conflictos; sistematizar las experiencias como práctica institucionalizada; valorar si es posible extender el enfoque de cuidados a otros ámbitos y propuestas del máster, como el Aprendizaje-Servicio, por ejemplo (InteRed, 2017); profundizar en la colaboración con agentes externos que desde la educación para la ciudadnía global están incorporando el enfoque de cuidados en sus actuaciones. 


\section{Referencias}

BELDA, S. PERIS, J., y CUESTA, I. (2016). "Participation for transformative learning in development management: The case of a Master in international development projects in the Universitat Politècnica de València (Spain)” en Procedia - Social and Behavioral Sciences, 228, p. 237 - 242.

CALABUIG, C., FERNANDEZ-BALDOR, A. y BELDA, S. (2017). "Una nueva mirada a la competencia transversal de trabajo en equipo desde los enfoques de participación y cuidados: El caso del Máster en Cooperación al Desarrollo por la UPV”. Botti , V. y Fernández, M.A.(Eds) En IN-RED 2017. Congreso Nacional de Innovación Educativa y de Docencia en Red.Valencia: Editorial UPV. 867-881.

CARRASCO, C., BORDERÍAS, C., y TORNS, T. (Eds) (2011). El trabajo de los cuidados. Historia, teoría y políticas. Madrid: Los libros de la catarata.

CLARKE, P., y OSWALD, K. (2010). “Why reflect collectively on capacities for change?” en IDS Bulletin, issue 41, p. 1-12.

DE BLAS, A. (2016). La revolución de los cuidados. Tácticas y estrategias. Madrid: InteRed.

EYBEN, R., GUIJT, I., ROCHE, C. y C. SHUTT (Eds.) (2015). The Politics of Evidence and Results in International Development: Playing the game to change the rules?. Rugby: Practical Action Publishing.

GULRAJANI, N. (2010). “New vistas for development management: examining radical-reformist possibilities and potential” en Public Administration and Development, vol. 30, p. 136-148.

HERRERO, Y. (2013). “Miradas ecofeministas para transitar a un mundo justo y sostenible” en Revista de Economía Crítica, nº16, segundo semestre 2013, p. 278-307.

INTERED (2014). La revolución de los cuidados. Tácticas y estrategias. Madrid: InteRed.

INTERED (2017). Guía de aprendizaje servicio con mirada de cuidados. Una aproximación desde nuestras prácticas. Madrid: InteRed.

JOHNSON, H. y THOMAS, A. (2007). "Individual learning and building organizational capacity for development” en Public Administration and Development, vol. 27, p. 39-48.

MCCOURT, W., y GULRAJANI, N. (2010). "The future of development management: Introduction to the Special Issue” en Public Administration and Development, vol.30, p. 81-90.

MOSSE, D. (2005). Cultivating development: An ethnography of aid policy and practice. London: Pluto Press.

ORTIZ ARAGON, A. (2010). "A case for surfacing theories of change for purposeful organizational capacity development” en IDS Bulletin, vol.41, p. 36-46.

PEARSON, J. (2010). "Pushing at a half-open door" en IDS Bulletin, vol. 41, p. 118-127.

PERIS, J., BELDA, S., y CUESTA, I. (2013). "Educating development professionals for reflective and transformative agency” en Boni A. \& Walker M. (Eds.). Human Development and Capabilities: Re-imagining the University of the Twenty-first Century. London and New York: Routledge.

PETTIT, J. (2006). “Power and pedagogy: Learning for reflective development practice” en IDS

Bulletin, vol.37, p. 69-78.

SOAL, S. (2010). “The more things change, the more they stay the same?”, en IDS Bulletin, vol.41, p. 128137. 


\title{
Validación y selección de indicadores para la evaluación de competencias. Aplicación a la competencia transversal de creatividad, innovación y emprendimiento
}

\author{
Prats-Montalbán, J.M. b, Ruiz L. a, Boza A. ${ }^{\text {a, }}$ Fernández-Diego M. a , Gordo M.L. a , \\ Alarcón F. b, Alemany M.M.E. ${ }^{\text {b }}$, y Cuenca L. ${ }^{\text {a }}$ \\ ${ }^{a}$ Escuela Técnica Superior de Ingeniería Informática. Universitat Politécnica de \\ Valencia (Iruiz@omp.upv.es, aboza@omp.upv.es, marferdi@omp.upv.es, \\ magormon@upvnet.upv.es, Ilcuenca@omp.upv.es), ${ }^{b}$ Escuela Técnica Superior de \\ Ingeniería Industrial. Universitat Politécnica de Valencia (jopramon@eio.upv.es, \\ faualva@omp.upv.es, mareva@omp.upv.es )
}

\begin{abstract}
The study focuses on establishing a methodology for the evaluation and selection of objective indicators based on statistical evidence, in order to determine how the scope of a given competence should be evaluated and the indicators that must be used to do so. By means of multivariate statistical models, prediction models of the mark of the competence are established from the marks of each of the indicators, as well as the degree of internal relationship between the indicators. In this way, it is possible to select those indicators that are providing information as independently as possible to that provided by any other indicator. This is a great help for the achievement of two main objectives: 1) to homogenize the items to be evaluated by each and every one of the teachers when evaluating the competence of interest; 2) increase the level of objectivity of the evaluation
\end{abstract}

Keywords: transversal competence, variable selection, validation, multivariate models, competence evaluation.

\footnotetext{
Resumen

El estudio se centra en establecer una metodología de evaluación y selección de indicadores objetiva basada en la evidencia estadística, con el fin de determinar cómo ha de evaluarse el alcance de una determinada competencia y los indicadores que hay que utilizar para ello. Por medio de modelos estadísticos multivariantes se establecen modelos de predicción de la nota de la competencia a partir de las notas de cada uno de los indicadores, así como el grado de relación interna entre los indicadores. De esta manera, es posible seleccionar aquellos indicadores que estén aportando información lo más independiente posible a aquella proporcionada por cualquier otro indicador. Esto resulta de gran ayuda para la consecución de dos objetivos principales: 1) homogeneizar los ítems a evaluar por todos y cada uno de los profesores a la hora de evaluar la competencia de interés; 2) incrementar el nivel de objetividad de la evaluación ; 3) simplificar el proceso de evaluación reduciendo el número de indicadores a los representativos.
} 
Palabras clave: competencias transversales, selección de indicadores, validación, modelos multivariantes.

\section{Introducción}

En la actualidad, la determinación (selección) de los indicadores se realiza normalmente a partir de reuniones de grupos expertos que seleccionan, entre un grupo extenso de potenciales indicadores, cuáles son los que tienen una relación clara con la competencia; estableciendo a continuación un baremo (que puede variar en función del profesor) a partir del cual se determina la nota alcanzada en la competencia evaluada.

Sin embargo, esta determinación por grupos expertos presenta una serie de problemas. Por un lado, no es posible garantizar que la selección de indicadores llevada a cabo por diferentes grupos expertos sea la misma, debido a la naturaleza intrínsecamente subjetiva (basada en el conocimiento y experiencia de cada grupo de expertos). Por otro, el establecimiento a priori de un baremo tiene como consecuencia que, cualquier estudio a posteriori de la significación estadística de la relación del indicador con la competencia de interés, se encuentre necesariamente afectada por el coeficiente utilizado en el baremo a la hora de ponderar la nota de la competencia como combinación lineal de las notas obtenidas en los indicadores utilizados.

En definitiva, es importante establecer el baremo de manera objetiva y validar que los indicadores asociados miden realmente lo que se desea medir, dando así validez a los resultados (Messick, 1996). Existen dos maneras de abordar los procesos de validación: por una parte, sobre las características del propio método de evaluación y, por otra, sobre la interpretación de los resultados (Borsboom, Mellenbergh, \& van Heerden, 2004; Brown et al., 1997). En el contexto que nos ocupa, la validación se realiza sobre el propio método de evaluación, respondiendo a la pregunta ¿los indicadores asociados a la rúbrica para la competencia de creatividad, innovación y emprendimiento han sido escogidos de manera objetiva y precisa?

La respuesta a esta pregunta hace necesario establecer una metodología de evaluación y selección de indicadores objetiva y basada en la evidencia estadística. Dicha metodología comienza con una recogida de datos, para todos y cada una de los indicadores incluidos en la batería inicial; que deben evaluarse de manera independiente a la evaluación de la competencia de interés. Sólo así es posible validar la significación estadística de la relación entre el indicador y la competencia. Una vez recogidos los datos correctamente, se hace necesario recurrir a modelos estadísticos multivariantes capaces, no sólo de crear modelos de predicción (de la nota de la competencia a partir de las notas de cada uno de los indicadores), sino también de establecer el grado de relación interna entre los indicadores. De esta manera, es posible seleccionar aquellos indicadores que estén aportando claramente información lo más independiente posible a aquella proporcionada por cualquier otro indicador incluido en el estudio. 
Asimismo, el recurso a estos modelos permite, por medio de técnicas de selección de variables determinar cuáles son los indicadores que presentan una clara significación estadística en el modelo (i.e. su relación con la nota de la competencia no es fruto del azar); proporcionando además, tras su selección, un baremo objetivo que permite predecir, una vez puesto en marcha el procedimiento, la nota de la competencia por parte de todo el profesorado a partir de un grupo reducido de indicadores seleccionado de manera objetiva en base a criterios científicos; objetivo final del presente proyecto.

\section{Objetivos}

El objetivo principal del estudio es establecer un procedimiento objetivo y basado en el método científico para la selección de indicadores asociados a la competencia de creatividad, innovación y emprendimiento, del cual se derivan los siguientes objetivos secundarios (Prats et al., 2016):

1. Definir una metodología para evaluar las rúbricas relacionadas con una determinada competencia, que se podría generalizar al total de competencias transversales de la UPV.

2. Validar y seleccionar un conjunto reducido de indicadores estadísticamente significativos, mediante la aplicación de modelos estadísticos multivariantes, que tengan una elevada capacidad predictiva del valor global de la competencia analizada.

3. Obtener, a partir de estos modelos, los coeficientes asociados a cada indicador, según el peso que cada uno tenga en la evaluación de la competencia de interés.

\section{Contextualización de la experiencia}

El estudio se ha aplicado sobre tres asignaturas de la ETSI Informática y tres de la ETSI Industrial. Las actividades definidas pueden ser transferibles a otras asignaturas y otros centros de la UPV. De esta manera, el proyecto ha involucrado a cuatro titulaciones, ocho profesores, seis asignaturas y alrededor de 300-400 alumnos. Las asignaturas involucradas, correspondientes a las titulaciones y cursos, son las que se indican a continuación.

\section{- Grado de Ingeniería Informática (E.T.S.I. Informática)}

o Fundamentos de Organización de Empresas

- Obligatoria

- Número de estudiantes: 40

- Curso: $1^{\circ}$

o Modelos de Negocio y Áreas Funcionales de la Organización

- Optativa

- Número de estudiantes: 55

- Curso: $4^{\circ}$

- Máster Universitario de Ingeniería Informática (E.T.S.I. Informática)

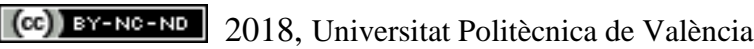

Congreso In-Red (2018) 
o Gestión y Gobierno de las TI

- Optativa

- $\quad$ Número de estudiantes: 35

- Curso $1^{\circ}$

- Grado en Ingeniería de Organización E.T.S.I. Industrial

o Métodos cuantitativos de Organización Industrial

- Obligatoria

- Número de estudiantes: 80

- Curso: $3^{\circ}$

o Gestión por Procesos de negocio. Implantación, Desarrollo y Simulación

- Optativa

- $\quad$ Número de estudiantes: 35

- Curso: $4^{\circ}$

- Grado en Ingeniería Química E.T.S.I. Industrial

o Estadística

- Obligatoria

- Número de estudiantes: 100

- Curso: $1^{\circ}$

\section{Desarrollo de la innovación}

El desarrollo del estudio fue complejo debido a diferentes complicaciones que fueron surgiendo conforme se pretendía avanzar en el mismo y que se detallan a continuación:

- Existencia de una gran cantidad de potenciales indicadores a evaluar por medio de diferentes actividades, y la dificultad asociada a la selección óptima de los mismos.

- $\quad$ Aparición de diferentes indicadores en función de la asignatura.

- Dudas acerca de la utilidad de las rúbricas a la hora de evaluar los indicadores.

- Dificultad en la evaluación de los indicadores, necesidad de determinar las actividades a realizar.

- $\quad$ Limitaciones en la cantidad de indicadores a evaluar debido a falta de recursos.

El estudio, teniendo en cuenta estas limitaciones, comenzó con la revisión y análisis de las actividades existentes en la bibliografía relacionadas con la innovación, creatividad y emprendimiento que pudieran servir de base para la adquisición de la competencia y pudieran ser adaptadas a las asignaturas.

A partir de esta revisión, se realizó una selección de una batería de 24 indicadores a partir de la fuentes bibliográficas y consultas con el Instituto de Ciencias de la Educación (ICE) de la UPV, dada la limitación en los recursos disponibles. Hay que resaltar que idealmente habría que haber utilizado todos los indicadores existentes, con el fin de que los modelos sean los que lleven a cabo la selección de manera objetiva, basada en datos. El hecho de no disponer de recursos suficientes limitó la cantidad de indicadores a utilizar en el estudio. En cualquier caso, este hecho no limita la utilidad del trabajo, el cual se centra en el 
establecimiento de una metodología objetiva para la selección de indicadores, independientemente de que se disponga o no de la totalidad desde un principio. Conocidos los indicadores, se diseñaron las actividades adecuadas para poder evaluarlos posteriormente, y se evaluaron por parte del profesorado.

La lista de indicadores seleccionados ha sido la que se indica a continuación (extraída de Boza et al., 2014, Fernández-Diego et al, 2014, Cuenca et al., 2015a, Cuenca et al., 2015b, Cuenca et al., 2016):

1. ' 'Analizar una situación dada e identificar aspectos de mejora'

2. 'Aportar ideas originales en cuanto a contenido'

3. 'Aportar ideas originales en cuanto a la forma de materializarse'

4. 'Aportar sugerencias a las ideas, situaciones, casos o problemas que se plantean'

5. 'Aportar sugerencias propias de calidad ante situaciones o problemas que se presentan'

6. 'Buscar nuevos procedimientos y métodos para hacer las cosas'

7. 'Buscar y proponer nuevos métodos y soluciones ante situaciones problemáticas reales o hipotéticas'

8. 'Disposición a actuar en contra de la tradición si esta impide mejoras en el rendimiento'

9. 'Encontrar nuevos métodos y procesos para hacer las cosas'

10. 'Expresar a otro las nuevas ideas que se han generado'

11. 'Familiarizarse con los instrumentos y técnicas de generación de ideas'

12. 'Generar ideas originales y de calidad, que se pueden plasmar de una manera formal y defenderlas en situaciones conocidas y desconocidas'

13. 'Generar y transmitir nuevas ideas o generar alternativas innovadoras a las situaciones o problemas conocidos que se plantean'

14. 'Integrar conocimientos de varias disciplinas, fuentes o ámbitos para generar ideas novedosas a situaciones conocidas o desconocidas'

15. 'Introducir nuevos procedimientos y acciones en el propio proceso de trabajo para responder mejor a las limitaciones y problemas detectados'

16. 'Plasmar de manera formal las ideas que se han generado'

17. 'Proponer ideas y soluciones innovadoras tanto en cuanto al contenido, como al proceso para llevarlas a cabo'

18. 'Proponer sugerencias y alternativas adecuadas a las necesidades de la tarea'

19. 'Reflexionar sobre nuevas formas de hacer las cosas'

20. 'Responder con detalle e integridad de respuestas'

21. 'Responder con flexibilidad (variabilidad de ideas en las respuestas)'

22. 'Responder con fluidez. Número de respuestas contestadas (fluidez)'

23. 'Responder con originalidad (rareza de la respuesta)'

24. 'Transmitir sus ideas con coherencia y eficacia' 


\section{Metodología y técnicas utilizadas para el tratamiento y análisis de los datos.}

La propia naturaleza del trabajo consiste en la creación de una metodología de recogida y análisis de datos. Dicha metodología ha consistido en la aplicación de un método de selección de variables combinado con la utilización de modelos estadísticos de proyección sobre estructuras latentes de Regresión sobre Mínimos Cuadrados Parciales, PLS (Geladi and Kowalski, 1986), a partir de datos recogidos en un proceso de evaluación por pares de actividades. Tal como explica el profesor Romero (Romero y Zúnica, 2013), "La Estadística es la ciencia cuyo objeto es la obtención y el análisis de datos mediante el recurso a modelos matemáticos y a herramientas informáticas". Por ello, si se desea obtener información a partir de los datos, éstos deben obtenerse de manera correcta. Dicho de otra manera, es improbable obtener conclusiones correctas a partir de datos obtenidos de manera incorrecta por lo que se ha puesto mucha atención en la recolección de datos, tal y como se detalla/explica a continuación.

\subsection{Recogida de los datos}

En base a los 24 indicadores seleccionados y a las actividades desarrolladas, se evaluaron por separado el grado de competencia global a partir de la actividad, y a posteriori el nivel alcanzado en cada uno de los indicadores; todos ellos de 0 a 10, por ser una escala sobre la cual (con la que) los profesores están bien entrenados a la hora de puntuar. Esta metodología garantiza que no se establece un baremo, ni interno (psicológico) ni explícito (mediante un baremo), a la hora de relacionar la nota final de la competencia con las notas asignadas a cada uno de los indicadores. Hay que tener en cuenta que el objetivo final es establecer una metodología objetiva de selección de indicadores para un conjunto general, del cual el (sub)conjunto actual no es más que una selección; a la vez que permitir que la metodología propuesta sea exportable al total de competencias.

En el momento de la realización del presente trabajo, sólo fue posible disponer de un total de 80 evaluaciones, por lo que la obtención de un baremo objetivo, se ha tenido que dejar fuera del estudio.

\subsection{Análisis de los datos}

El análisis de los datos se ha realizado a través de modelos estadísticos multivariantes de proyección sobre estructuras latentes, con el fin de manejar de manera eficiente variables (indicadores) que probablemente van a mostrar un elevado grado de correlación. Dado que se dispone de una estructura de predictores (indicadores) a partir de los cuales se pretende predecir el valor final de una variable de salida (el grado de competencia), es necesario recurrir a modelos de predicción, como es el caso de, entre otros, los modelos PLS (Geladi and Kowalski, 1986).

El objetivo del modelo PLS es explicar la relación entre dos conjuntos de variables $\mathbf{X}$ e $\mathbf{Y}$, así como la variabilidad tanto en $\mathbf{X}$ como en $\mathbf{Y}$, pero maximizando la Covarianza $(\mathbf{X}, \mathbf{Y})$. La ventaja de estos modelos estadísticos multivariantes de proyección sobre estructuras 
latentes frente a modelos típicos, tales como el de Regresión Líneal Múltiple, es el manejo de estructuras de datos con múltiples variables correlacionadas, que comprimen de manera eficiente, eliminando los problemas de invertibilidad de la matriz de varianzas-covarianzas que pueden dar lugar a estimaciones inestables de los coeficientes, y por tanto malas predicciones y/o malas selección de variables (indicadores en nuestro caso).

A partir de la utilización de modelos PLS, se ha llevado a cabo la selección de indicadores mediante la integración de un proceso de selección basado en distribuciones libres, en una secuencia de doble validación cruzada (Quintás et al., 2012). Dicha técnica consiste en los siguientes pasos:

1. A partir de una selección aleatoria del conjunto global de datos, creación de los conjuntos de Training, Validation, y Test.

2. Construcción del modelo a partir del conjunto de Training, con una variable latente.

3. Determinación del poder de predicción con el Validation set.

4. Creación de las distribuciones libres, a partir de la destrucción de la variable a predecir (nota de la competencia por parte de los profesores).

5. Eliminación de las variables no significativas del training set.

6. Volver al paso 2, hasta que no se mejore el paso 3.

7. Obtener el valor real de predicción a partir del Test set.

8. Repetir los pasos 1-7 un elevado número de veces.

9. Elegir las variables que más veces se han repetido para un determinado nivel de predicción mínimo, sobre el Test set.

\section{Resultados}

Finalmente, los indicadores elegidos de la lista analizada, a partir de la metodología propuesta, han sido:

- 'Aportar sugerencias propias de calidad ante situaciones o problemas que se presentan'

- 'Introducir nuevos procedimientos y acciones en el propio proceso de trabajo para responder mejor a las limitaciones y problemas detectados'

- 'Reflexionar sobre nuevas formas de hacer las cosas'

- 'Responder con originalidad (rareza de la respuesta)'

Como se ha comentado anteriormente, no se ha obtenido el coeficiente a aplicar a cada uno de estos indicadores, ya que se considera conveniente para ello disponer de un tamaño mayor de muestra.

Para comparar el resultado obtenido con los indicadores que actualmente se están utilizando en la rúbrica de evaluación, debemos tener en cuenta que la actividad llevada a cabo en el aula ha sido la 6-3-5 (Rohbarch, 1969; Cuenca et al., 2016b). Está actividad está más indicada para los aspectos relacionados con la creatividad y con plasmar las ideas que 
surgen (brainwriting) que en llevar a cabo un plan de acción y analizar el valor de la innovación propuesta.

También hay que tener en cuenta que los indicadores resultado de la investigación no están clasificados por niveles (N1: primer y segundo curso, N2: tercer y cuarto curso y N3: máster).

A partir de lo anterior se puede establecer una equivalencia limitada entre los indicadores inicialmente propuestos y los que ha revelado la investigación, tal y como se indica en la Tabla 1.

Tabla 1. Equivalencia entre los indicadores seleccionados por el método propuestos y los actualmente utilizados.

\begin{tabular}{|c|c|c|}
\hline $\begin{array}{c}\text { Fases del proceso } \\
\text { creatividad, } \\
\text { innovación y } \\
\text { emprendimiento que } \\
\text { se abordan en la } \\
\text { actividad } 6-3-5\end{array}$ & Indicadores previamente definidos & $\begin{array}{c}\text { Indicadores seleccionados tras la } \\
\text { investigación }\end{array}$ \\
\hline $\begin{array}{c}\text { Identificar } \\
\text { oportunidad }\end{array}$ & $\begin{array}{l}\text { N1:Se cuestiona la realidad } \\
\text { N2:Identifica oportunidades y/o } \\
\text { aspectos de mejora } \\
\text { N3:Integra conocimientos de otras } \\
\text { disciplinas }\end{array}$ & $\begin{array}{l}\text { 'Reflexionar sobre nuevas formas de } \\
\text { hacer las cosas' }\end{array}$ \\
\hline Generar Ideas & $\begin{array}{l}\text { N1:Aporta ideas } \\
\text { N2:Aporta ideas y planteamientos } \\
\text { originales } \\
\text { N3: Adopta enfoques creativos en el } \\
\text { contenido y modo de realización }\end{array}$ & $\begin{array}{l}\text { 'Aportar sugerencias propias de } \\
\text { calidad ante situaciones o problemas } \\
\text { que se presentan' } \\
\text { 'Responder con originalidad (rareza } \\
\text { de la respuesta)' }\end{array}$ \\
\hline Ejecución & $\begin{array}{l}\text { N1:Plasma de manera formal las } \\
\text { ideas } \\
\text { N2:Emplea estrategias y/o técnicas } \\
\text { creativas para } \\
\text { plasmar de manera formal las ideas } \\
\text { y soluciones } \\
\text { N3:Propone un plan de acción }\end{array}$ & $\begin{array}{l}\text { 'Introducir nuevos procedimientos y } \\
\text { acciones en el propio proceso de } \\
\text { trabajo para responder mejor a las } \\
\text { limitaciones y problemas detectados' }\end{array}$ \\
\hline
\end{tabular}

\section{Conclusiones y proyección de futuro}

El presente trabajo ha permitido validar una metodología previamente estudiada en el campo de la Estadística multivariante, dentro de otro campo con valoraciones de carácter subjetivo, lo cual aporta un grado de dificultad añadido. Los resultados son muy prometedores, si bien el presente trabajo se presenta como una primera aproximación a este tipo de datos. 
Como trabajo futuro, queda ampliar el tamaño de muestra, con el fin de validar los indicadores seleccionados en el presente estudio; así como el establecimiento de un baremo objetivo a partir de los indicadores que finalmente sean elegidos.

Uno de los aspectos clave del presente estudio es su capacidad de universalización mediante reuniones del grupo de trabajo (y de otros grupos expertos en otra competencias) con el ICE y/o Vicerrectorado. Se podría analizar la posibilidad de exportarla, con carácter general, a toda la relación de competencias transversales definidas por la UPV.

\section{Referencias}

BORSBOOM, D.; MELLENBERGH, G. J.; VAN HEERDEN, J. (2004). "The concept of validity”, en Psychological Review , vol. 111, pp. 1061-1071.

BOZA. A.; CUENCA, L.; FERNÁNDEZ-DIEGO, M.; RUIZ, L.; GORDO, M.L.; ALARCÓN, F.; ALEMANY, M.M.E.; POLER, R. (2014). "Innovation, creativity and entrepreneurship competence in higher education. Learning objectives and measurement", en ICERI2014 Proceedings, pp. 405-411.

BROWN, G.; BULL, J.; PENDLEBURY, M. (1997). Assessing student learning in higher education. London: Routledge.

CUENCA L., FAUSTINO ALARCÓNB, ANDRÉS BOZAC , MARTA FERNÁNDEZDIEGOD, LEONOR RUIZ, MARI LUZ GORDO, RAUL POLER, MAREVA ALEMANY (2015a) "Rúbrica para la Evaluación de la Competencia Innovación, Creatividad y Emprendimiento en máster”, en Congreso In-Red 2015 Universitat Politècnica de València. DOI: http://dx.doi.org/10.4995/INRED2015.2015.1610

CUENCA L., FERNÁNDEZ-DIEGO M., GORDO M., RUIZ L., ALEMANY M.M.E., ORTIZ A. (2015B) MEASURING COMPETENCIES IN HIGHER EDUCATION. "The Case of Innovation Competence”, en Peris-Ortiz M., Merigó Lindahl J. (eds) Sustainable Learning in Higher Education. Innovation, Technology, and Knowledge Management. Springer, pp. 131-141

CUENCA, L., ALARCÓN, F., BOZA, A., ET AL., (2016a). "Rubric to assess the competence of innovation, creativity and enterpreneurship in bachelor degree" en Brazilian Journal of Operations \& Production Management, vol 13(1), pp.118-123.

CUENCA, L.; ALARCÓN, F.; ALEMANY, MME.; BOZA, A.; FERNÁNDEZ DIEGO, M.; GORDO, ML.; RUIZ, L. (2016b). "La técnica 6-3-5 extendida, para la competencia de creatividad, innovación y emprendimiento”. http://hdl.handle.net/10251/68332.

FERNÁNDEZ-DIEGO M., RUIZ L., GORDO M.L., M.M.E. ALEMANY, BOZA A., CUENCA L. (2014) "Objetivos de aprendizaje para grado y máster de la competencia genérica de innovación, creatividad y emprendimiento”, en Jornadas In-Red 2014 pp.1-9

GELADI, P.; KOWALSKI, B.R. (1986) “Partial Least-Squares Regression: A Tutorial”, en Analytica Chimica Acta, vol. 185, pp. 1-17.

2018, Universitat Politècnica de València 
MESSICK, S. (1996). "Validity of performance assessments", en G. Phillips (Ed.), Technical issues in large-scale performance assessment, pp. 1-18.

QUINTÁS, G.; PORTILLO, N.; GARCÍA-CAÑAVERAS, J.C.; CASTELL, J.V.; FERRER, A.; LAHOZ, A. (2012) "Chemometric approaches to improve PLSDA model outcome for predicting human non-alcoholic fatty liver disease using UPLC-MS as a metabolic profiling tool”, en Metabolomics , vol. 8, pp. 86-98.

PRATS-MONTALBÁN J.M., F. ALARCÓN, M.M.E. ALEMANY, A. BOZA, M.L. GORDO, M. FERNÁNDEZ-DIEGO, L. RUIZ, L. CUENCA (2016) “Innovation project to validate and select items for assessing transversal competencies in higher education”, en ICERI2016 Proceedings, pp. 61-68.

ROHRBACH, BERND (1969) "Kreativ nach Regeln - Methode 635, eine neue Technik zum Lösen von Problemen". Creativo mediante reglas - Método 635, una nueva técnica para resolver problemas, en Absatzwirtschaft, vol. 12, pp. 73-75.

ROMERO VILLAFRANCA, R., ZÚNICA RAMAJO, L. (2013) Métodos estadísticos para ingenieros. Valencia: Universidad Politécnica de Valencia (Ref.: 4) 


\title{
Cómo evaluar la competencia transversal "trabajo en equipo" desde un enfoque $180^{\circ}$ en estudiantes universitarios
}

\author{
Carmen Escribá-Pérez ${ }^{\mathrm{a}}$, Tomás Baviera ${ }^{\mathrm{b}}$, Amparo Baviera-Puig ${ }^{\mathrm{c}}$ y Juan Manuel \\ Buitrago-Vera ${ }^{\mathrm{d}}$ \\ ${ }^{a}$ Universitat Politècnica de València, carespe@upv.es, ${ }^{\mathrm{b}}$ Universitat Politècnica de València, \\ tobapui@esp.upv.es, ${ }^{\mathrm{C}}$ Universitat Politècnica de València, ambapui@upv.es y ${ }^{\mathrm{d}}$ Universitat Politècnica \\ de València, jmbuitrago@esp.upv.es
}

\begin{abstract}
The general aim of this research is to assess the "teamwork ability" in university students from a $180^{\circ}$ approach. For this, we have obtained the selfassessment and coevaluation of this skill, using the CATME-BARS scale, in university students of "Marketing Management" of the Degree of Business Administration and Management at Universitat Politècncia de València. Next, we have contrasted whether this difference depends on a series of descriptive variables of the students that are being analyzed. The variables are: "Group" (morning, afternoon, English, double Degree of Business Administration and Management-Telecommunications Engineering), "Sex", "Erasmus" (if the student is Erasmus or not) and "Work" (if the student works or has worked in the last 2 years). No significant differences were found for any of them. Therefore, it could be concluded that the students analyzed have a self-perception of the "teamwork ability" aligned with the perception of their classmates.
\end{abstract}

Keywords: skills, assessment, CATME-BARS, self-evaluation, coevaluation, profile, college education.

\footnotetext{
Resumen

El objetivo general de esta investigación es evaluar la competencia "trabajo en equipo" en estudiantes universitarios desde un enfoque $180^{\circ}$. Para ello, hemos obtenido la autoevaluación y coevaluación de esta competencia, utilizando la escala CATME-BARS, en estudiantes universitarios de "Dirección Comercial" del Grado de ADE de la Universitat Politècncia de València. A continuación, hemos contrastado si esta diferencia depende de una serie de variables descriptivas de los estudiantes que se están analizando. Las variables son: "Grupo" (mañana, tardes, inglés, doble ADE- Ingeniero de Telecomunicación), "Sexo", "Erasmus" (si es Erasmus o no) y "Trabajo" (si trabaja o ha trabajado en los últimos 2 años). No se han encontrado diferencias significativas para ninguna de ellas. Por tanto, se podría concluir que los estudiantes analizados tienen una autopercepción de la competencia "trabajo en equipo" alineada con la percepción de sus compañeros.
} 
Palabras clave: competencias, evaluación, CATME-BARS, autoevaluación, coevaluación, perfil, educación universitaria.

\section{Introducción}

La Universitat Politècnica de València está desarrollando el proyecto de competencias transversales UPV (Universitat Politècnica de València, 2016) que tiene como objetivo principal acreditar las competencias transversales UPV a los estudiantes egresados en cualquiera de los títulos oficiales impartidos en la Universitat Politècnica de València. Las competencias transversales UPV, que pretenden sintetizar un perfil competencial para todos los alumnos egresados de la UPV, garantizando que se cubre el marco de referencia de todas las titulaciones, son las siguientes: CT-01. Comprensión e integración, CT-02. Aplicación y pensamiento práctico, CT-03. Análisis y resolución de problemas, CT-04. Innovación, creatividad y emprendimiento, CT-05. Diseño y proyecto, CT-06. Trabajo en equipo y liderazgo, CT-07. Responsabilidad ética, medioambiental y profesional, CT-08. Comunicación efectiva, CT-09. Pensamiento crítico, CT-10. Conocimiento de problemas contemporáneos, CT-11. Aprendizaje permanente, CT-12. Planificación y gestión del tiempo, CT-13. Instrumental específica.

En este estudio, nos centramos en la competencia 6: CT-06. Trabajo en equipo y liderazgo. Esta competencia ha sido ampliamente estudiada en diversas situaciones y entornos (McLoughlin y Luca, 2002; Ellis et al., 2005; Guitert, Romeu. y Pérez-Mateo, 2007). Salas, Sims y Burke (2005) sugieren que los componentes centrales del trabajo en equipo incluyen el liderazgo del equipo, el control mutuo del desempeño o rendimiento, la ayuda mútua, la adaptabilidad y la orientación del equipo. En cambio, Loughry, Ohland y Moore (2007) proponen otras 5 dimensiones de esta competencia: la contribución, la interacción, el seguimiento, la expectativa de calidad y la relevancia del conocimiento, capacidades y habilidades de cada uno de los miembros. A pesar de no haber un consenso, resulta obvio la necesidad de descomponer esta competencia transversal en diferentes dimensiones para poder trabajarla y evaluarla.

A la hora de evaluar competencias, existen diversos modos. Quizá los más completos sean aquellos realizados desde un enfoque $180^{\circ}$, o bien, $360^{\circ}$. Dochy, Segers y Sluijsmans (1999) proponen el uso de la autoevaluación y la coevaluación para estudiantes universitarios. De este modo, persiguen que los estudiantes sean más responsables y reflexivos al contrastar la autopercepción que tienen de ellos mismos con la opinión de sus compañeros. La autoevaluación y la coevaluación comprende el enfoque $180^{\circ}$. La evaluación $360^{\circ}$ da un paso más y cuenta con la valoración realizada por personas vinculadas al estudiante de distintos niveles (heteroevaluación). El objetivo principal en ambos casos es detectar habilidades o puntos fuertes y las posibilidades de mejora de los aspectos débiles (Cardona y García-Lombardía, 2005).

Por último, algunos autores indican la importancia de las características sociodemográficas, habilidades y rasgos de personalidad en el funcionamiento del equipo. Por ejemplo, Molleman (2005) investiga la influencia de las características sociodemográficas, entre

(cc) BY-Nc-ND 2018, UniversitatPolitècnica de València

Congreso IN-RED (2018) 
otras, en la cohesión y en la resolución de conflictos en equipos de estudiantes de pregrado. Por tanto, puede ser interesante analizar si existen diferencias entre la autoevaluación y la coevaluación de la competencia trabajo en equipo debido a características descriptivas de los estudiantes.

\section{Objetivos}

El objetivo general es evaluar la competencia "trabajo en equipo" en estudiantes universitarios desde un enfoque $180^{\circ}$. Este objetivo general se desglosa en los siguientes objetivos específicos: a) realizar la autoevaluación y coevaluación de esta competencia en estudiantes universitarios; b) calcular la diferencia entre ambas evaluaciones; c) contrastar si esta diferencia depende de una serie de variables descriptivas de los estudiantes que se están analizando.

\section{Desarrollo de la innovación}

Una de las escalas para medir la efectividad del trabajo en equipo es el CATME (Comprehensive Assessment of Team Member Effectiveness), creada por los autores Loughry, Ohland y Moore (2007). Esta escala evalúa 5 dimensiones de forma autónoma y para cada miembro del equipo: a) La contribución de cada uno o cada una al trabajo en equipo (medido por 24 items), b) La interacción con los otros miembros (medido por 30 items), c) El mantener al grupo detrás del objetivo marcado (medido por 21 items), d) La expectativa de calidad (medido por 6 items), e) La relevancia de sus conocimientos, capacidades y habilidades (medido por 9 items). Esta escala mide esas 5 dimensiones en una escala del 1 al 5, que comprende varios ítems.

Este cuestionario fue adaptado a una versión BARS (Behaviorally Anchored Rating Scale) por Ohland et al. (2012) para un contexto educativo, lo cual supuso una notable reducción de ítems, pasando de 90 a 45 items, lo que denominaron la CATME-BARS. En nuestro caso vamos a utilizar esta última versión de la CATME.

La innovación se ha desarrollado en la asignatura "Dirección Comercial” del Grado de Administración y Dirección de Empresas (ADE) de la Facultad de ADE de la Universitat Politècnica de València (Valencia, España). Esta asignatura tiene 4 grupos diferentes: mañanas, tardes, inglés y el grupo de la doble titulación ADE-Teleco. Este último grupo está formado por los alumnos que quieren obtener el doble grado de ADE e Ingeniero de Telecomunicación.

Para trabajar la competencia "trabajo en equipo", se les ha solicitado a los alumnos realizar un Plan Comercial de un nuevo producto para un supermercado. Para ello, se han organizado en grupos de 3-5 estudiantes. En el grupo de inglés, fue el único en el que los estudiantes fueron dirigidos a la hora de formar los grupos. En los otros tres, los estudiantes formaron los grupos por sí mismos. Cada estudiante se ha autoevaluado usando la escala CATME-BARS y también ha evaluado al resto de miembros de su equipo (coevaluación). 
Por tanto, cada alumno tiene su propia nota de la autoevaluación y otra nota de coevaluación, resultante de la media de las notas de todos sus compañeros de equipo.

Para analizar si hay diferencias significativas entre la autoevaluación y la coevaluación de cada una de las 5 dimensiones de la escala CATME-BARS, se ha realizado la tabulación cruzada de valores medios. Como contraste estadístico, se ha utilizado el test F de Snedecor (Santesmases, 2009). Las variables descriptivas que se han comparado son: "Grupo" (mañana, tardes, inglés, doble), “Sexo”, “Erasmus” (si es Erasmus o no) y “Trabajo” (si trabaja o ha trabajado en los últimos 2 años).

\section{Resultados}

\subsection{Descripción de la muestra}

La muestra está formada por un total de 138 alumnos. El grupo más numeroso es el de mañanas (39,9\%). Por sexo, el reparto es casi paritario, con un 52,9\% de hombres y un 47,1\% de mujeres. Sólo un 15,2\% de los alumnos son Erasmus. Por último, el 47,1\% trabaja o ha trabajado en los últimos 2 años (Tabla 1).

Tabla 1. Descripción de la muestra

\begin{tabular}{|c|c|c|c|}
\hline & & Frecuencia & $\%$ \\
\hline \multirow{4}{*}{ Grupo } & Mañanas & 55 & 39,9 \\
\hline & Tardes & 34 & 24,6 \\
\hline & Inglés & 32 & 23,2 \\
\hline & Doble ADE-Teleco & 17 & 12,3 \\
\hline \multirow{2}{*}{ Sexo } & Hombre & 73 & 52,9 \\
\hline & Mujer & 65 & 47,1 \\
\hline \multirow{2}{*}{ Erasmus } & Erasmus & 21 & 15,2 \\
\hline & No Erasmus & 117 & 84,8 \\
\hline \multirow{2}{*}{ Trabajo } & Trabaja & 65 & 47,1 \\
\hline & No trabaja & 73 & 52,9 \\
\hline
\end{tabular}

\subsection{Resultados de la escala CATME-BARS}

Tras analizar los resultados del cuestionario, se calcularon las medias de autoevaluación y coevaluación para cada una de las 5 dimensiones (Tabla 2). En autoevaluación, la nota más alta es de 3,93 y corresponde a "Interacción”. Al mismo tiempo, es la dimensión con mayor desviación estándar. Las dimensiones “Contribución” y "Seguimiento” tienen una media de 3,79. No obstante, “Seguimiento” tiene mayor desviación estándar $(0,75)$ que 
“Contribución” (0,67). “Capacidades” y “Calidad” tienen la misma media y es la más baja de todas $(3,74)$. Ambas también coinciden en la misma desviación estándar $(0,74)$.

En coevaluación, las medias más elevadas corresponden a "Capacidades" $(3,63)$,“Contribución” $(3,56)$ e “Interacción” $(3,56)$. A pesar de tener la misma media, “Contribución” tiene la desviación estándar más elevada $(0,72)$ e “Interacción” la desviación estándar más pequeña $(0,59)$. “Calidad” es la dimensión con la media más baja $(3,47)$.

Si se calcula la diferencia entre las medias de autoevaluación y coevaluación, el valor más elevado corresponde a “Interacción” $(0,106)$ y el más pequeño a “Contribución” $(-0,014)$.

Tabla 2. Valores de Autoevaluación, Coevaluación y Diferencia entre ambos

\begin{tabular}{|c|c|c|c|c|}
\hline & & Media & Desv. Estándar & Rango \\
\hline \multirow{5}{*}{ Autoevaluación } & Contribución & 3,79 & 0,67 & 4 \\
\hline & Interacción & 3,93 & 0,76 & 3 \\
\hline & Seguimiento & 3,79 & 0,75 & 4 \\
\hline & Calidad & 3,74 & 0,74 & 2 \\
\hline & Capacidades & 3,74 & 0,74 & 3 \\
\hline \multirow{5}{*}{ Coevaluación } & Contribución & 3,56 & 0,72 & 4 \\
\hline & Interacción & 3,56 & 0,59 & 3 \\
\hline & Seguimiento & 3,50 & 0,64 & 4 \\
\hline & Calidad & 3,47 & 0,64 & 3 \\
\hline & Capacidades & 3,63 & 0,62 & 3 \\
\hline \multirow{5}{*}{$\begin{array}{c}\text { Autoevaluación - } \\
\text { Coevaluación }\end{array}$} & Contribución & $-0,014$ & 0,891 & 8 \\
\hline & Interacción & 0,106 & 0,831 & 6 \\
\hline & Seguimiento & 0,028 & 0,858 & 7 \\
\hline & Calidad & 0,071 & 0,750 & 6 \\
\hline & Capacidades & $-0,028$ & 0,891 & 6 \\
\hline
\end{tabular}




\subsection{Análisis de la diferencia autoevaluación-coevaluación respecto a la variables descriptivas}

Para comprobar si hay diferencias significativas entre la diferencia de la autoevaluación y la coevaluación de cada una de las 5 dimensiones de la competencia trabajo en equipo respecto a las variables descriptivas, se ha realizado la tabulación cruzada de valores medios. Al analizar la variable "Grupo" (Tabla 3), no se han encontrado diferencias significativas entre los 4 . A priori, se podría pensar que algún grupo pudiera destacar en alguna dimensión. En cambio, no hay diferencias significativas entre ellos para ninguna de las 5 dimensiones.

Tabla 3. Tabulación cruzada de valores medios entre la diferencia de autoevaluación menos coevaluación en función de la variable “Grupo"

\begin{tabular}{ccccccc}
\hline $\begin{array}{c}\text { Dimensiones } \\
\text { Trabajo en Equipo }\end{array}$ & Mañanas & Tardes & Inglés & $\begin{array}{c}\text { Doble } \\
\text { ADE- } \\
\text { Teleco }\end{array}$ & $\begin{array}{c}\text { Total } \\
\text { Muestra }\end{array}$ & p \\
& $\mathbf{( 3 9 , 9 \% )}$ & $\mathbf{( 2 4 , 6 \% )}$ & $\mathbf{( 2 3 , 2 \% )}$ & \\
& & & & $\mathbf{( 1 2 , 3 \% )}$ & & \\
\hline Contribución & 0,05 & $-0,03$ & $-0,12$ & $-0,12$ & $-0,03$ & 0,80 \\
Interacción & 0,07 & 0,09 & 0,12 & 0,12 & 0,09 & 0,99 \\
Seguimiento & 0,11 & 0,00 & $-0,09$ & 0,00 & 0,02 & 0,77 \\
Calidad & 0,20 & $-0,06$ & 0,00 & 0,00 & 0,06 & 0,39 \\
Capacidades & 0,14 & $-0,18$ & $-0,16$ & $-0,18$ & $-0,04$ & 0,24 \\
\hline
\end{tabular}

En cuanto a la variable "Sexo", no hay diferencias significativas en ninguna de las 5 dimensiones de la escala CATME-BARS (Tabla 4). En otras palabras, no hay diferencias significativas en la diferencia entre autoevaluación y coevaluación dependiendo de si se es hombre o mujer. A la vista de las medias obtenidas (muy próximas a 0,00), podríamos decir que ambos sexos tienen una autopercepción de su competencia trabajo en equipo alineada con la percepción de sus compañeros.

Tabla 4. Tabulación cruzada de valores medios entre la diferencia de autoevaluación menos coevaluación en función de la variable "Sexo"

\begin{tabular}{ccccc}
\hline Dimensiones & Masculino & Femenino & $\begin{array}{c}\text { Total } \\
\text { Muestra }\end{array}$ & $\mathbf{p}$ \\
Trabajo en Equipo & $\mathbf{( 5 2 , 9 \% )}$ & $\mathbf{( 4 7 , 1 \% )}$ & & 0,98 \\
Contribución & $-0,03$ & $-0,03$ & $-0,03$ & 0,98 \\
Interacción & 0,09 & 0,09 & 0,09 & 0,78 \\
Seguimiento & 0,04 & 0,00 & 0,02 & 0,47 \\
Calidad & 0,11 & 0,01 & 0,06 & 0,42 \\
Capacidades & 0,01 & $-0,11$ & $-0,04$ & \\
\hline
\end{tabular}


Si analizamos la variable "Erasmus" (Tabla 5), no se han encontrado diferencias significativas entre las diferencias de la autoevaluación y la coevaluación en ninguna dimensión. Se podría pensar que el carácter español nos hace destacar o ser más humildes en alguna dimensión con respecto a los alumnos que están de Erasmus en nuestra Facultad. Sin embargo, los resultados obtenidos nos revelan que no es así. En otras palabras, tanto los alumnos españoles como los Erasmus se autoperciben de la misma manera con respecto a la competencia trabajo en equipo.

Tabla 5. Tabulación cruzada de valores medios entre la diferencia de autoevaluación menos coevaluación en función de la variable "Erasmus"

\begin{tabular}{ccccc}
\hline $\begin{array}{c}\text { Dimensiones } \\
\text { Trabajo en Equipo }\end{array}$ & $\begin{array}{c}\text { Erasmus } \\
\mathbf{( 1 5 , 2 \% )}\end{array}$ & $\begin{array}{c}\text { No } \\
\text { Erasmus } \\
\mathbf{( 8 4 , 8 \% )}\end{array}$ & $\begin{array}{c}\text { Total } \\
\text { Muestra }\end{array}$ & p \\
\hline Contribución & $-0,02$ & 0,01 & $-0,03$ & 0,25 \\
Interacción & 0,00 & 0,11 & 0,09 & 0,57 \\
Seguimiento & $-0,19$ & 0,06 & 0,02 & 0,22 \\
Calidad & $-0,19$ & 0,11 & 0,06 & 0,09 \\
Capacidades & $-0,28$ & 0,00 & $-0,04$ & 0,17 \\
\hline
\end{tabular}

Respecto a la variable "Trabajo”, tampoco hay diferencias significativas en ninguna de las 5 dimensiones de la escala CATME-BARS (Tabla 6). A priori, puede pensarse que los alumnos con experiencia profesional podrían tener una autopercepción de su competencia trabajo en equipo más alineada con la percepción de sus compañeros que aquellos que no han trabajado. No obstante, a la luz de los resultados obtenidos, no encontramos diferencias significativas entre la autoevaluación y la coevaluación de la competencia trabajo en equipo entre aquellos alumnos que no trabajan y aquellos que están trabajando o han trabajado en los últimos 2 años. Teniendo en cuenta las medias obtenidas, se podría afirmar que ambos tipos de estudiantes tienen una autopercepción de su competencia trabajo en equipo alineada con la percepción de sus compañeros. 
Tabla 6. Tabulación cruzada de valores medios entre la diferencia de autoevaluación menos coevaluación en función de la variable "Trabajo"

\begin{tabular}{ccccc}
\hline $\begin{array}{c}\text { Dimensiones } \\
\text { Trabajo en Equipo }\end{array}$ & $\begin{array}{c}\text { Trabaja } \\
\mathbf{( 4 7 , 1 \% )}\end{array}$ & $\begin{array}{c}\text { No } \\
\text { Trabaja } \\
\mathbf{( 5 2 , 9 \% )}\end{array}$ & $\begin{array}{c}\text { Total } \\
\text { Muestra }\end{array}$ & p \\
\hline Contribución & 0,03 & $-0,08$ & $-0,03$ & 0,46 \\
Interacción & 0,23 & $-0,03$ & 0,09 & 0,07 \\
Seguimiento & 0,03 & 0,01 & 0,02 & 0,91 \\
Calidad & 0,03 & 0,09 & 0,06 & 0,61 \\
Capacidades & 0,00 & $-0,08$ & $-0,04$ & 0,59 \\
\hline
\end{tabular}

\section{Conclusiones}

Se ha investigado mucho en torno a la competencia transversal "trabajo en equipo". En este estudio, nos planteamos evaluar esta competencia desde un enfoque $180^{\circ}$, utilizando la escala CATME-BARS. Para ello, dividimos a los estudiantes de la asignatura "Dirección Comercial” del Grado de ADE de la Universitat Politècnica de València en grupos de 3-5 estudiantes y les solicitamos que realicen un Plan Comercial para un nuevo producto.

Al contestar el cuestionario con la escala CATME-BARS, hemos obtenido una nota de autoevaluación y otra de coevaluación de cada alumno. La mayor diferencia entre estas notas se da en la dimensión de "Interacción" $(0,106)$, mientras que la menor diferencia se da en "Contribución" $(-0,014)$. En otras palabras, la autopercepción que tienen los estudiantes de la dimensión de "Interacción” es la menos alineada con la percepción de sus compañeros. En cambio, la autopercepción de la "Contribución” es la más alineada con la percepción de sus compañeros de todas las dimensiones de la competencia "trabajo en equipo".

Al contrastar si la diferencia de la autoevaluación menos la coevaluación depende de una serie de variables descriptivas de los estudiantes, no se han encontrado diferencias significativas para ninguna de ellas. Por tanto, podríamos decir que los estudiantes de "Dirección Comercial" tienen una autopercepción de la competencia "trabajo en equipo" alineada con la percepción de sus compañeros, independientemente del grupo al que pertenecen, del sexo, si son Erasmus o no y si no trabajan o están trabajando o han trabajado en los últimos 2 años.

Para evaluar la competencia de manera global, Ohland et al. (2012) proponen pasar la escala CATME-BARS dos veces durante el curso (al principio y al final) para ser respondida por los estudiantes. Una vez obtenidas las respuestas, proponen calcular la media de las 5 dimensiones para cada uno de los pases. Con estas dos medias, los autores calculan la media final. Este valor es considerado como la evaluación global de la competencia. En este estudio, hemos mostrado los resultados del primer pase de la escala

(cc) EY-NC-ND 2018, UniversitatPolitècnica de València

Congreso IN-RED (2018) 
ya que todavía no se disponen de los datos del segundo pase. Por tanto, como futuras líneas de trabajo, se persigue poder calcular la evaluación global de la competencia "trabajo en equipo” con los datos de ambos pases.

\section{Referencias}

Cardona, P. y García-Lombardía, P. (2005). Cómo desarrollar las competencias de liderazgo. Navarra: Editorial EUNSA.

Dochy, F.; SEgERS, M. y SLUiJSMANS, D. (1999). "The use of self-, peer and co-assessment in higher education: A review” en Studies in Higher Education, vol. 24, issue 3, p. 331-350.

Ellis, A.P.J.; Bell, B.S.; PloyharT, R.E.; HolLENBECK, J.R. y ILGEN, D. R. (2005). “An evaluation of generic teamwork skills training with action teams: effects on cognitive and skill-based outcomes” en Personnel Psychology, vol. 58, p. 641-672.

Guitert, M.; Romeu, T. y PÉRez-Mateo, M. (2007). "Competencias TIC y trabajo en equipo en entornos virtuales" en Revista de Universidad y Sociedad del Conocimiento, vol. 4, issue 1, p. 1-12.

LOUGHRY, M. L.; OHLAND, M. W. y Moore, D. D. (2007). "Development of a theory-based assessment of team member effectiveness" en Educational Psychological Measurement, vol. 67, p. 505-524.

MCLOUGHLIN C. y LUCA, J. (2002). "A learner-centred approach to developing teams kills through web-based learning and assessment" en British Journal of Educational Technology, vol. 33, issue 5, p. 571-582.

Molleman, E. (2005). "Diversity in Demographic Characteristics, Abilities and Personality Traits: Do Faultlines Affect Team Functioning?” en Group Decision and Negotiation, vol. 14, issue 3, p. 173-193.

OHLAND, M.W.; LOUghry, M.L.; WoeHR, D.J.; FinelLi, C.J.; BullaRd, L.G.; Felder, R.M.; LAYTON, R.A.; POMERANZ, H.R. y SCHMUCKeR, D.G. (2012). "The Comprehensive Assessment of Team Member Effectiveness: Development of a Behaviorally Anchored Rating Scale for Self and Peer Evaluation” en Academy of Management Learning \& Education, vol. 11, issue 4, p. 609-630.

SAlAS, E.; SiMS, D. E. y BURKE, C. S. (2005). "Is there a "Big Five” in Teamwork?" en Small Group Research, vol. 36, issue 5, p. 555-599.

SANTESMASES, M. (2009). Dyane versión 4: Diseño y análisis de encuestas en investigación social y de mercado. Madrid: Editorial Pirámide.

UnIVERSITAT POLITĖCNICA DE VALÈNCIA. (2016). Competencias transversales. <http://www.upv.es/entidades/ICE/info/U0724624.pdf> [Consulta: 15 de marzo de 2018]. 


\title{
Desarrollo de una metodología para la formación y evaluación “continua” en pensamiento crítico
}

\author{
Santiago Vidal-Puiga, Susana Barceló-Cerdáb, Ana Debón ${ }^{c}$, Ángeles Calduch-Losad y \\ Fulgencia Villa \\ Departamento de Estadística e Investigación Operativa y Calidad - UPV

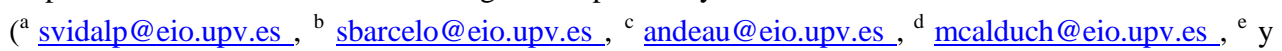 \\ mfuvilju@eio.upv.es)
}

\begin{abstract}
In this study, we shall describe a teaching experience carried out by a group of lecturers in the Statistics Department. These lecturers are involved in the training and assessment of "critical thinking" skills as part of the institutional project centred on generic skills at the Universitat Politècnica de València.

The objective of this experience was to promote the understanding, development and application of the critical thinking skills in the students. Different activities linked to the abilities involved in critical thinking are proposed to the students throughout the academic year. The activities require ongoing assessment from the formative point of view. Thus, the students are aware of their own progress. Additionally, students are evaluated in the exams with questions in different formats (PoliformaT exams, tests and peer review).

Suitable materials and activities for training and assessment of critical thinking have been developed. Finally the teaching staff and the students' opinions have been collected through surveys.
\end{abstract}

\section{Keywords:}

Keywords: Critical thinking, ongoing assessment, generic skills

\footnotetext{
Resumen

En este trabajo se presenta la experiencia realizada por un grupo de profesores del Departamento de Estadística en diversas asignaturas que son punto de control de la competencia "Pensamiento Crítico". El objetivo de la experiencia era guiar a los alumnos para que entendiesen el pensamiento crítico, lo desarrollasen y lo aplicasen. Durante el curso los alumnos han realizado actividades que trabajan diferentes habilidades vinculadas con dicha competencia. Estas actividades han sido evaluadas de tal manera que desde el punto de vista formativo, el alumno sea consciente de su progreso en la competencia. Adicionalmente se les ha evaluado en los exámenes con cuestiones bajo formatos diversos (exámenes Poliformat, preguntas en pruebas escritas y corrección por pares). Se han creado materiales y
} 
actividades adaptadas para la formación y evaluación del pensamiento crítico y a través de encuestas se ha constatado que el profesorado y el alumnado ha valorado positivamente la metodología empleada.

Palabras clave: Pensamiento crítico, evaluación continua, competencia transversal.

\section{Introducción}

De acuerdo con el nuevo proyecto institucional en competencias transversales de la Universitat Politècnica de València (UPV), los títulos de grado y posgrado han de incorporar la formación de los estudiantes en competencias transversales o genéricas, así como la evaluación de su nivel de logro. En este trabajo se explica cómo hemos enfocado y gestionado la incorporación en nuestras disciplinas de la formación y evaluación del alumnado en pensamiento crítico, tanto en las clases de teoría como en las sesiones prácticas y mediante evaluación continua. Cabe destacar que para el presente trabajo solicitamos a la UPV y se nos concedió un Proyecto de Innovación y Mejora Educativa (PIME Referencia_B10 del 2016-2017). Este proyecto se ha centrado en las asignaturas de estadística de 4 titulaciones de la Escuela Técnica Superior de la Ingeniería de Diseño (ETSID) y 3 titulaciones de la Escuela Técnica Superior de Ingeniería Agronómica y del Medio Natural (ETSIAMN) en la UPV. El número de alumnos implicados está próximo a 600 y la mayoría de las asignaturas involucradas se encuentran dentro de los dos primeros años de las titulaciones de grado envueltas.

La UPV, dentro de su proyecto institucional en competencias transversales establece 3 niveles de dominio para cada competencia transversal con el objetivo de que la adquisición y mejora en cada competencia sea progresiva a lo largo de las titulaciones. De este modo, en las asignaturas de primeros cursos de Grado se sugiere centrarse en el nivel de dominio I, con el resultado de aprendizaje, de acuerdo a lo establecido por la UPV en relación a la competencia de pensamiento crítico, de mostrar una actitud crítica ante la realidad, siendo capaz de analizar y cuestionar información, resultados, conclusiones y otros puntos de vista.

Nuestro grupo, formado por profesores del Departamento de Estadística e Investigación Operativa Aplicadas y Calidad, decidió que la manera más eficiente de colaborar en dicho proyecto era especializarnos en una de las competencias transversales para constituirnos en uno de sus puntos de control. Escogimos el pensamiento crítico por tratarse de una competencia instrumental directamente relacionada con el pensamiento estadístico (Aizikovitsh-Udi et al., 2016) indispensable para el análisis de datos y, consecuentemente, toma de decisiones de una forma objetiva y razonada. Además, siendo conscientes de que enseñar a pensar críticamente requiere mucho tiempo y mucha práctica reflexiva centrada en una amplia variedad de ejemplos, nuestro grupo decidió apostar por alguna metodología que ponga al alumno en contacto con múltiples y diversas situaciones donde las habilidades y disposiciones asociadas al pensamiento crítico se estimulen y desarrollen. Para ello, se incluyeron en nuestras sesiones de prácticas de laboratorio y en las prácticas de aula diferentes ejercicios y actividades con incidencia en el pensamiento crítico.

(cc) EY-NC-ND 2018, Universitat Politècnica de València

Congreso IN-RED (2018) 
Respecto a las distintas formas de evaluación de dicha competencia transversal, una de las cosas que más llama la atención es la falta de existencia de pruebas o test que sirvan para la evaluación del pensamiento crítico en materias específicas y, por tanto, centradas en determinadas áreas de conocimiento. Además, el pensamiento crítico es una competencia que incluye muchas y variadas habilidades y por tanto, la dificultad estriba en poder encontrar qué tipo de pruebas pueden ser las más adecuadas para formar y evaluar a los alumnos en las mismas. Para ello, aprovechando las posibilidades actuales de la plataforma educativa de la UPV, hemos decidido hacer uso de una estrategia mixta para la evaluación que utilice pruebas de tipo test opción múltiple en sus distintas modalidades (Norris y Ennis 1989) y pruebas tipo ensayo o informe de acuerdo con las habilidades o disposiciones consideradas en cada caso, siendo este último tipo de prueba el más apropiado para la evaluación de las habilidades más creativas asociadas al pensamiento crítico.

Por último, indicar que nuestro equipo considera como aspecto muy importante el que el profesorado implicado pueda alcanzar una adecuada preparación que les permita abordar la formación y evaluación de los alumnos en dicha competencia con las metodologías y herramientas más adecuadas. Agradecemos y consideramos relevante el esfuerzo realizado por el ICE (Instituto de Ciencias de la Educación de la UPV) en su ayuda de formación al profesorado.

\section{Objetivos}

De acuerdo con lo expuesto en el apartado de introducción y en concordancia con los objetivos que se ha impuesto la UPV, nuestro grupo se unió al proyecto de formación del alumnado en competencias transversales, y lo convirtió en un objetivo prioritario.

El objetivo general del presente proyecto es el desarrollo de una metodología para la formación y evaluación "continua” en pensamiento crítico en las asignaturas de Estadística de distintas titulaciones.

Dicho objetivo ha supuesto:

A) El estudio profundo de la competencia y la adopción de una definición de pensamiento crítico acorde con la asignatura de Estadística.

B) La elaboración de material y preparación de actividades contextualizadas en temas relacionados con nuestra materia específica que sean adecuados para la formación y evaluación de los alumnos en pensamiento crítico.

C) La implantación de una metodología de evaluación continua y formativa en la misma.

Dentro de los objetivos especificos cabría citar los siguientes:

1) Preparar material de información sobre la competencia transversal:

El alumno debe saber en qué consiste la competencia en la que se le pretende formar y evaluar. 
2) Preparar material de formación en pensamiento crítico para incluir en los guiones de prácticas:

- Preguntas con respuesta abierta o actividades donde se tratarán cuestiones de estadística que incorporen aspectos del pensamiento crítico.

- Resoluciones detalladas y comentadas desde el punto de vista estadístico y de las diferentes habilidades del pensamiento crítico consideradas.

- Otras posibles actividades en las que dentro de un contexto estadístico se trate de formar al alumno en pensamiento crítico.

3) Preparar preguntas para la evaluación continua en pensamiento crítico durante las sesiones de prácticas:

Junto a las posibles formas de evaluación de los conocimientos y habilidades en la materia de estadística, cada práctica incluirá adicionalmente una parte de evaluación formada por unas pocas preguntas centradas en temas estadísticos, donde se requiera de modo específico el uso de ciertas habilidades del pensamiento crítico. Estas preguntas serán cuestiones de tipo test de opción múltiple y otros formatos soportados por la herramienta exámenes de PoliformaT (plataforma educativa implantada en la UPV).

4) Preparar actividades individuales o grupales para evaluar las habilidades más creativas de pensamiento crítico y donde se puedan evaluar habilidades combinadas:

Los resultados de estas actividades se presentarán en forma de informe. Se considerará la posibilidad de incluir una evaluación entre pares, y la posibilidad de realizar sugerencias de mejoras entre distintos grupos.

5) Creación de pruebas y adaptación de las rúbricas propuestas por el ICE para la evaluación de la competencia en nuestra materia específica:

Las preguntas creadas se incorporarán a distintas pruebas de evaluación y baterías de exámenes de PoliformaT, y se realizará la evaluación final del alumno haciendo uso de las rúbricas propuestas por el ICE, adaptadas a nuestras metodologías y materias impartidas.

6) Hacer un estudio estadístico de los resultados obtenidos que nos permita validar la metodología empleada y nos proporcione posibles sugerencias de mejora.

7) Comunicar y compartir nuestros resultados con la comunidad universitaria haciendo, por tanto, una difusión adecuada de los resultados obtenidos.

\section{Desarrollo de la innovación}

En la innovación presentada se apostó por la implantanción de una metodología de evaluación continua y formativa en la competencia transversal que aumentase el contacto

(cc) EY-NC-ND 2018, Universitat Politècnica de València

Congreso IN-RED (2018) 
del alumno con diferentes situaciones donde se estimulan y desarrollan las habilidades y disposiciones asociadas al pensamiento crítico.

Para ello se han seguido las siguientes fases:

- Fase 1: Definición de pensamiento crítico

Una de los primeras tareas a realizar fue establecer la definición de pensamiento crítico con la que iba a trabajar el grupo. Todas las definiciones encontradas enfatizan la importancia de la claridad de ideas y la racionalidad, y nos inclinamos por la de Ennis (1993) "el pensamiento crítico se define como un pensamiento reflexivo y razonable y con el propósito de que la persona pueda decidir qué creer o hacer”. Ahondando un poco en esta definición, vemos que este pensamiento es reflexivo, porque analiza resultados y situaciones; es razonable, porque predomina la razón sobre otras dimensiones del pensamiento y solo los pensamientos basados en buenas razones conducen a las mejores soluciones; y finalmente tiene un propósito, porque está dirigido conscientemente hacia una evaluación de posibles afirmaciones (qué creer) o acciones (qué hacer). El pensamiento crítico incluye además aspectos creativos como la concepción de alternativas, la formulación de hipótesis y definiciones y el desarrollo de planes experimentales.

Los expertos en el tema han confeccionado una lista muy extensa de las habilidades y disposiciones necesarias para alcanzar un buen pensamiento crítico. A la vista de esta definición y la gran cantidad de habilidades y disposiciones implicadas, se puede apreciar que el pensamiento crítico incluye muchos y variados aspectos, por lo que la formación del alumnado en los mismos y su correcta evaluación se convierte en todo un reto.

El tener una definición de pensamiento crítico era un aspecto importante, dado que se requiere una definición para identificar las habilidades y elementos que son necesarios incorporar en todos y cada uno de los ámbitos (clases de teoría, prácticas, actividades...) que integran las asignaturas a impartir.

- $\quad$ Fase 2: Selección de los indicadores

Como establecimos en la justificación, nuestro ámbito de acción se centra en el nivel I de dominio de la competencia. En este nivel, nuestro grupo ha decidido considerar los indicadores de la tabla 1 para la formación y evaluación de los alumnos en pensamiento crítico. Es importante fijar los indicadores, porque consideramos que esto puede ayudar a determinar los distintos tipos de actividad a realizar y el modo de evaluarlas.

Cabe señalar que en las diferentes asignaturas impartidas por los profesores participantes en el presente PIME se ha hecho uso de materiales y estrategias de evaluación de naturaleza variada, con el objetivo de mejorar nuestro conocimiento sobre el grado de éxito de las distintas opciones planteadas. 
Tabla 1: Indicadores para medir el avance en el pensamiento crítico

\begin{tabular}{ll}
\hline \multicolumn{1}{c}{ Indicadores } \\
\hline $\mathbf{I}_{\mathbf{1}}$ & $\begin{array}{l}\text { Muestra una actitud crítica ante la realidad: se pregunta el porqué } \\
\text { de las cosas. }\end{array}$ \\
$\mathbf{I}_{\mathbf{2}} \quad \begin{array}{l}\text { Elabora un discurso argumentándolo con razones, asunciones y } \\
\text { evidencias. }\end{array}$ \\
$\mathbf{I}_{3} \quad \begin{array}{l}\text { Detecta incoherencias o contradicciones en el discurso de otras } \\
\text { personas o en un texto. }\end{array}$ \\
\hline
\end{tabular}

- Fase 3: Adaptación, creación e implementación de actividades, evaluaciones y materiales expositivos

Se han diseñado diferentes actividades para formar y evaluar, y en alguna asignatura se ha introducido algún tema de actualidad vinculándolo con la asignatura.

Entre las actividades y materiales creados cabe destacar:

- Se han propuesto ejercicios en los que se ha realizado un análisis de datos con técnicas estadísticas correspondientes a un determinado tema y los alumnos lo han examinado, rebatiendo o aceptando con argumentos bien construidos y válidos la información recibida y rehaciendo el análisis e interpretación de resultados hasta llegar a una toma de decisiones adecuada, razonada y bien fundamentada. Este tipo de actividades se evalúan bien por parte del profesor/a, o bien entre compañeros, ya que la plataforma permite la corrección por pares. Se evalúa con una rúbrica, con lo que se realiza una evaluación cualitativa del nivel de logro alcanzado en la competencia. A modo de ejemplo, la Figura 1 presenta una de las actividades utilizadas en una de las asignaturas participantes en el PIME.

- En la actividad descrita se utilizó la correción por pares. Esto nos permitió, por un lado, disponer de la corrección por parte del evaluador de la actividad realizada por el alumno, y por otro, disponer de los comentarios del evaluador que pudieron ser utilizados para calificar el indicador I3 definido en la Tabla 1.

(cc) EY-NC-ND 2018, Universitat Politècnica de València

Congreso IN-RED (2018) 


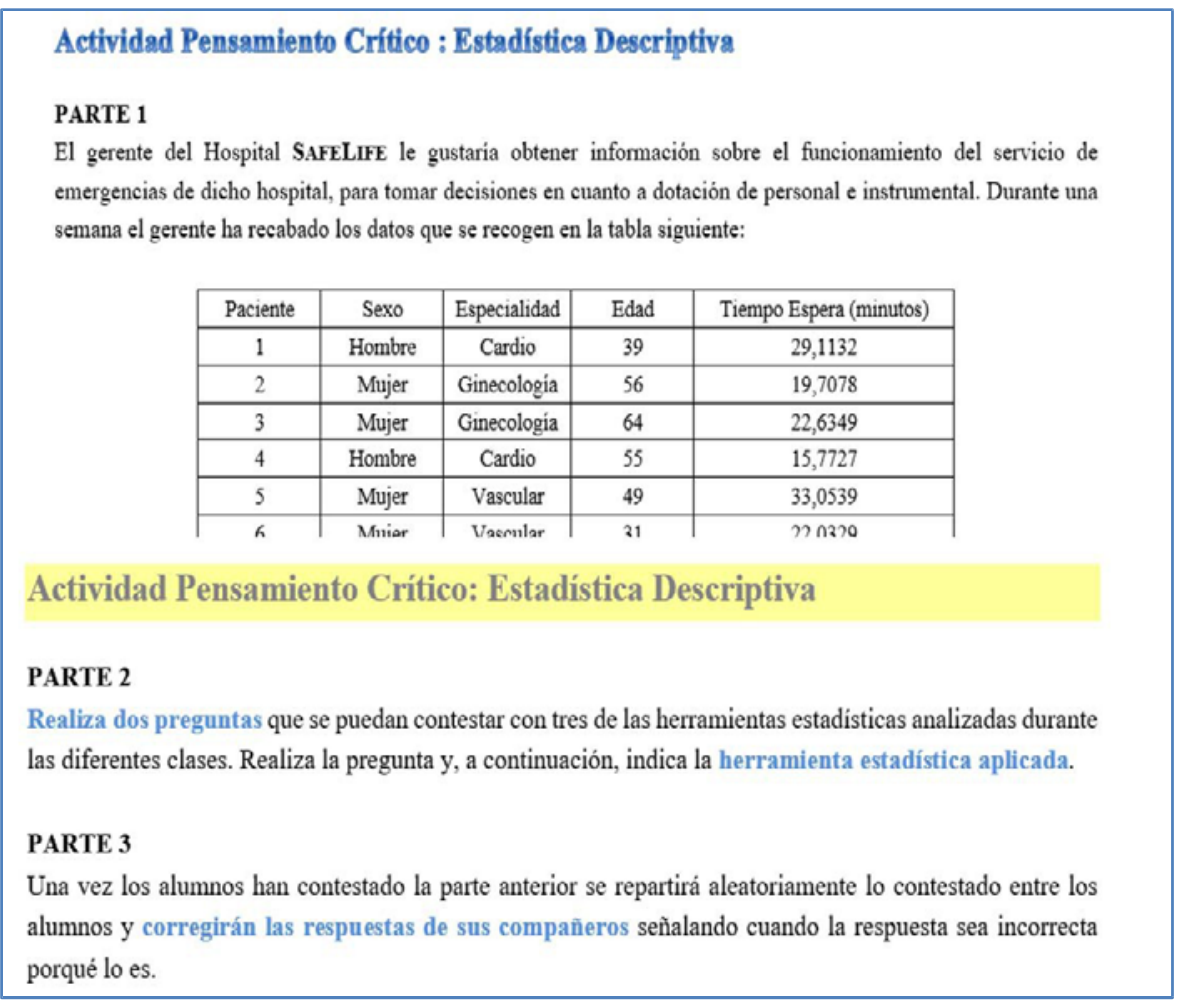

Fig. 1 Ejemplo actividad propuesta

- Pruebas objetivas: Se han realizado usando la plataforma PoliformaT con una batería de preguntas confeccionada con varias cuestiones en las que se presentan al alumno diferentes afirmaciones que pueden o no ser correctas y el alumno tiene que elegir. Estas pruebas las corrige automáticamente la plataforma.

- Pruebas con preguntas de respuesta corta: Se han realizado usando la plataforma PoliformaT y se trata de preguntas donde al alumno se le plantea un problema y diferentes posibles soluciones al mismo. El alumno realiza la correspondiente elección dando una respuesta breve que justifique críticamente su decisión. La corrección la realiza el profesor, pudiendo valorarse cuantitativa o cualitativamente con una rúbrica dependiendo de la naturaleza de la pregunta. Cabe señalar que la plataforma ofrece un entorno cómodo que agiliza y facilita la corrección.

La Figura 2 presenta una de las preguntas de respuesta corta utilizadas en una prueba de una de las asignaturas participantes en el PIME. Puede observarse también que el grupo utilizó un icono para señalar la presencia de las diferentes cuestiones relacionadas con el pensamiento crítico con objeto de que el alumno fuera consciente del carácter especial de esas preguntas. 
Con los datos obtenidos de los 97 pacientes se ha obtenido una tabla de contingencia que se presenta a continuación:

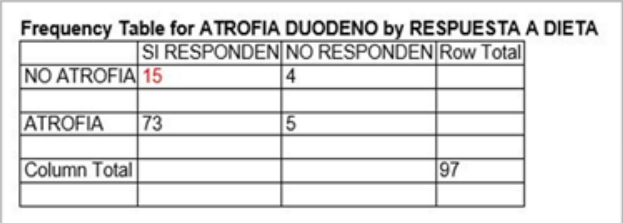

Una doctora investigadora de este estudio, al analizar los resultados de esta tabla concluye que puesto que entre los que no responden a la dieta libre de gluten hay $4 \sin$ atrofia y 5 con atrofia, la atrofia no tiene ninguna relación con la respuesta a la dieta.

- ¿Qué opináis sobre la conclusión de la doctora?

- Dad una argumentación critica y razonada sobre esta conclusión

taitar Pensamiento de Pensamiento Critico (Descriptiva)

pregunta para evaluar la competencia transversal de Pensamiento crítico

Fig. 2 Ejemplo pregunta respuesta corta

- Preguntas en los exámenes escritos: Se preguntan cuestiones o se plantean ejercicios relacionados con las actividades descritas anteriormente que se corrigen por parte del profesor/a y se puntúan numéricamente. Esta puntuación se utiliza tanto para la evaluación de la asignatura propiamente dicha, como para la evaluación de la competencia transversal.

- Tareas basadas en análisis de encuestas relacionadas con problemas contemporáneos. Por ejemplo, en una de las asignaturas, los alumnos han trabajado un tema actual como el de los refugiados como consecuencia de la guerra en Siria como sigue: en primer lugar contestaron a una serie de preguntas donde tenían que señalar su fuente de información. A continuación, tenían que contestar una encuesta relacionada con diferentes preguntas vinculadas con el tema en cuestión. Teniendo en cuenta los datos de la encuesta, aplicaban diferentes técnicas estadísticas para obtener información. Por último, se invitaron a dos chicas voluntarias en campos de refugiados, una de ellas enfermera y que actualmente sigue trabajando en ellos, que contaron su experiencia y cómo funcionan los campos de refugiados. Los alumnos pudieron hacerles preguntas estableciéndose una discusión muy interesante. Tras esta experiencia, los alumnos volvieron a contestar la encuesta inicial y aplicaron de nuevo técnicas estadísticas para obtener información. Esta actividad se llevó a cabo a lo largo del último mes de curso para que se pudieran aplicar las técnicas estadísticas más avanzadas. Además, implicaba trabajar la parte más creativa del pensamiento crítico, ya que la actividad ha estado integrada por varias fases donde la participación del alumno ha sido más activa y menos dirigida por parte del profesor.

Señalar que a modo incipiente y experimental, en uno de los grupos de la asignatura de estadística del grado de Mecánica, se utilizaron las plataformas

(cc) EY-NC-ND 2018, Universitat Politècnica de València

Congreso IN-RED (2018) 
Kahoot y Facebook para que los alumnos contestaran cuestiones de verdadero y falso por un lado y, por otro, comentaran de manera crítica noticias de actualidad relacionadas con la estadística, en las que los alumnos han detectado fallos y han propuesto cómo corregirlos.

- Respecto a las distintas formas de evaluación, una de las cosas que más llama la atención es la carencia de pruebas o test que sirvan para la evaluación del pensamiento crítico en materias específicas $\mathrm{y}$, por tanto, centradas en determinadas áreas de conocimiento. Estudios previos en el uso de la herramienta de exámenes de PoliformaT por parte de profesores de la Universidad Politécnica de Valencia (Vidal-Puig et. al., 2007; PortilloPoblador et. al., 2009; Vidal-Puig et. al., 2011 y Villa-Julia et. al., 2012) avalan el potencial del uso de esta herramienta, ahondando en las posibilidades actuales de la herramienta de exámenes de la plataforma educativa de la UPV. Finalmente, hemos optado por una estrategia mixta para la evaluación que utilice pruebas de tipo test opción múltiple en sus distintas modalidades (Norris y Ennis 1989) y pruebas tipo ensayo o informe de acuerdo con las habilidades o disposiciones consideradas en cada caso, siendo este último tipo de prueba el más apropiado para la evaluación de las habilidades más creativas asociadas al pensamiento crítico. Cada una de las actividades que se ha planteado ha sido evaluada y vinculada de acuerdo con los indicadores (entre los señalados en la Tabla 1) considerados al diseñar la actividad.

- Fase 4: Análisis del grado de consecución de las metas marcadas en las diferentes pruebas y actividades

Aunque en un primer momento el equipo se ha centrado más en desarrollar actividades y materiales, consideramos que se debe profundizar en el análisis y control de los resultados alcanzados; ya que esto nos permitirá reconsiderar algunos aspectos de la estrategia que habría que ir cambiando. Por todo lo anterior consideramos que, teniendo en cuenta la experiencia de este primer año, para los próximos cursos deberíamos mejorar los siguientes aspectos de la metodología:

- A la hora de planificar la asignatura hay que incorporar una tabla de especificaciones donde se dé la distribución de partes o pruebas que van a tener lugar y sus correspondientes ponderaciones en la nota final, de modo que se observe que la evaluación final del alumno cubre en proporción adecuada todos los indicadores de la competencia transversal considerados (descritos en la fase 2 y recogidos en la Tabla 1 ).

- La corrección, evaluación y comunicación de resultados en las diferentes pruebas y actividades realizadas por los alumnos deben realizarse dentro de unos márgenes adecuados de tiempo para que se potencie su aspecto formativo.

- La comunicación al alumno de sus resultados debe proveerles de comentarios personalizados o al menos darle comentarios generales, desde el punto de 
vista del pensamiento crítico, a todo lo observado por los profesores en la actividad realizada por los alumnos.

- La información obtenida en el propio proceso de corrección permitirá depurar la rúbricas específicas de corrección (especialmente en el caso de actividades de reciente creación).

\section{Resultados}

\subsection{Metodología y técnicas utilizadas para el tratamiento y análisis de los datos.}

Para analizar el grado de consecución de los objetivos prefijados se han utilizado los datos obtenidos a partir de tres tipos de evidencias clave: una encuesta de opinión del profesorado, una encuesta de opinión de los alumnos y los resultados obtenidos por los alumnos en las diferentes asignaturas. Para obtener la información a partir de los datos recogidos se han empleado diferentes técnicas de estadística descriptiva.

\subsection{Grado de consecución de los objetivos y resultados alcanzados}

La implantación de la metodología propuesta ha supuesto la creación de diferentes tipos materiales y actividades ya descritas en el punto 3, entre los que se citaban: actividades de análisis de un conjunto de datos sujetas a corrección por pares y discusión por parte de los alumnos haciendo uso de la herramienta tareas del PoliformaT; pruebas objetivas en sus diferentes versiones (pregunta de opción múltiple, preguntas de respuesta corta...) usando la herramienta Exámenes de PoliformaT; preguntas en las diferentes pruebas y tareas basadas en análisis de encuestas relacionadas con problemas contemporáneos.

Estos materiales creados sirven como evidencias de un nivel de logro adecuado en varios de los objetivos perseguidos en la innovación, tanto generales como específicos, que incluyen la propia elaboración de material docente, como se puede observar en la Figura 3.

En cuanto al objetivo general de estudio profundo de la competencia y la adopción de una definición de pensamiento crítico, se ha alcanzado un nivel adecuado de logro como evidencia toda la labor de documentación desarrollada por parte del profesorado implicado, la selección de indicadores, y la creación de material informativo para los alumnos (objetivo específico 1) que ha sido bien valorado por parte de estos, como pone de manifiesto la pregunta el resultado de la encuesta a los alumnos (Figura 5).

Respecto al tercero de los objetivos generales, que era conseguir la implantación de una metodología de evaluación continua y formativa en pensamiento crítico, las evidencias las basamos en tres elementos claves: la opinión del profesorado, la opinión de los alumnos y los resultados obtenidos por los alumnos.

- Opinión del profesorado

El profesorado implicado valoró en una encuesta (Figura 4) el grado de éxito de la metodología y la calidad de los materiales creados, obteniéndose un 6.69 y 7.75 sobre 10,

(cc) EY-NC-ND 2018, Universitat Politècnica de València

Congreso IN-RED (2018) 


\begin{tabular}{|c|c|c|c|}
\hline & Objetivo & Nivel & Evidencias \\
\hline \multirow{3}{*}{ 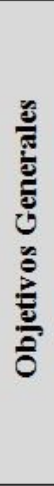 } & $\begin{array}{l}\text { A) Estudio profundo de la competencia y la } \\
\text { adopción de una definición de pensamiento } \\
\text { crítico }\end{array}$ & Adecuado & $\begin{array}{l}\text { - Selección de } \\
\text { indicadores } \\
\text { - Opinión de los } \\
\text { profesores } \\
\text { - Consecución objetivo } \\
\text { específico 1) }\end{array}$ \\
\hline & $\begin{array}{l}\text { B) Elaboración de material y preparación } \\
\text { de actividades }\end{array}$ & Adecuado & $\begin{array}{l}\text { Material creado: } \\
\text { consecución objetivos } \\
\text { específicos 2) 3) 4) 5) }\end{array}$ \\
\hline & $\begin{array}{l}\text { C) Implantación de una metodología de } \\
\text { evaluación continua y formativa en } \\
\text { pensamiento crítico }\end{array}$ & Adecuado & $\begin{array}{l}\text {-Opinión del } \\
\text { profesorado } \\
\text {-Opinión de los alumnos } \\
\text { - Resultados obtenidos } \\
\text { por los alumnos }\end{array}$ \\
\hline \multirow{7}{*}{ 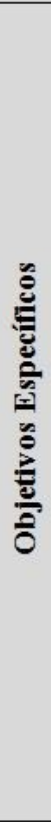 } & $\begin{array}{l}\text { 1) Preparación de material informativo para } \\
\text { los alumnos sobre la competencia } \\
\text { transversal }\end{array}$ & Adecuado & $\begin{array}{l}\text { - Documento explicativo } \\
\text { puesto a disposición de } \\
\text { los alumnos } \\
\text { - Resultados de pregunta } \\
\text { realizada en encuesta a } \\
\text { los alumnos }\end{array}$ \\
\hline & $\begin{array}{l}\text { 2) Preparación de material de formación en } \\
\text { pensamiento crítico para incluir en los } \\
\text { guiones de prácticas }\end{array}$ & $\begin{array}{c}\text { En } \\
\text { Progreso }\end{array}$ & Material creado \\
\hline & $\begin{array}{l}\text { 3) Preparación de preguntas para la } \\
\text { evaluación continua en pensamiento crítico } \\
\text { durante la sesiones de prácticas }\end{array}$ & Adecuado & $\begin{array}{l}\text { Material creado: } \\
\text { Preguntas y pruebas } \\
\text { poliformaT }\end{array}$ \\
\hline & $\begin{array}{l}\text { 4) Preparación de actividades individuales } \\
\text { o grupales para evaluar las habilidades más } \\
\text { creativas de pensamiento crítico }\end{array}$ & Adecuado & $\begin{array}{l}\text { Material creado: } \\
\text { Actividades diversas } \\
\text { creadas }\end{array}$ \\
\hline & $\begin{array}{l}\text { 5) Creación de pruebas y adaptación de las } \\
\text { rúbricas propuestas por el ICE para la } \\
\text { evaluación de la competencia en nuestra } \\
\text { materia específica }\end{array}$ & Adecuado & $\begin{array}{l}\text { Material creado: Rúbricas } \\
\text { individuales para cada } \\
\text { actividad }\end{array}$ \\
\hline & $\begin{array}{l}\text { 6) Estudio estadístico de los resultados } \\
\text { obtenidos para poder validar la } \\
\text { metodología empleada }\end{array}$ & Adecuado & $\begin{array}{l}\text { Estudio descriptivo de } \\
\text { resultados de las } \\
\text { encuestas }\end{array}$ \\
\hline & $\begin{array}{l}\text { 7) Comunicación de nuestros resultados a } \\
\text { la comunidad universitaria }\end{array}$ & Adecuado & $\begin{array}{l}2 \text { Congresos } \\
\text { internacionales }\end{array}$ \\
\hline
\end{tabular}

Fig 3 Nivel de consecución de los objetivos marcados

respectivamente. Como puntos fuertes se señalaron el conocimiento alcanzado por el profesorado en la competencia, cómo desarrollarla y evaluarla en los alumnos y la existencia de un profesorado muy implicado. Como puntos débiles se indicaron una cierta falta de tiempo y desbordamiento del profesor por las pruebas de evaluación (al menos en esta fase inicial de implantación).

- Opinión de los alumnos

La encuesta valora la satisfacción del alumnado con la metodología y actividades de formación y evaluación del pensamiento crítico. La Figura 5, donde se solicita la valoración sobre la información y documentación recibida respecto a la competencia de pensamiento 


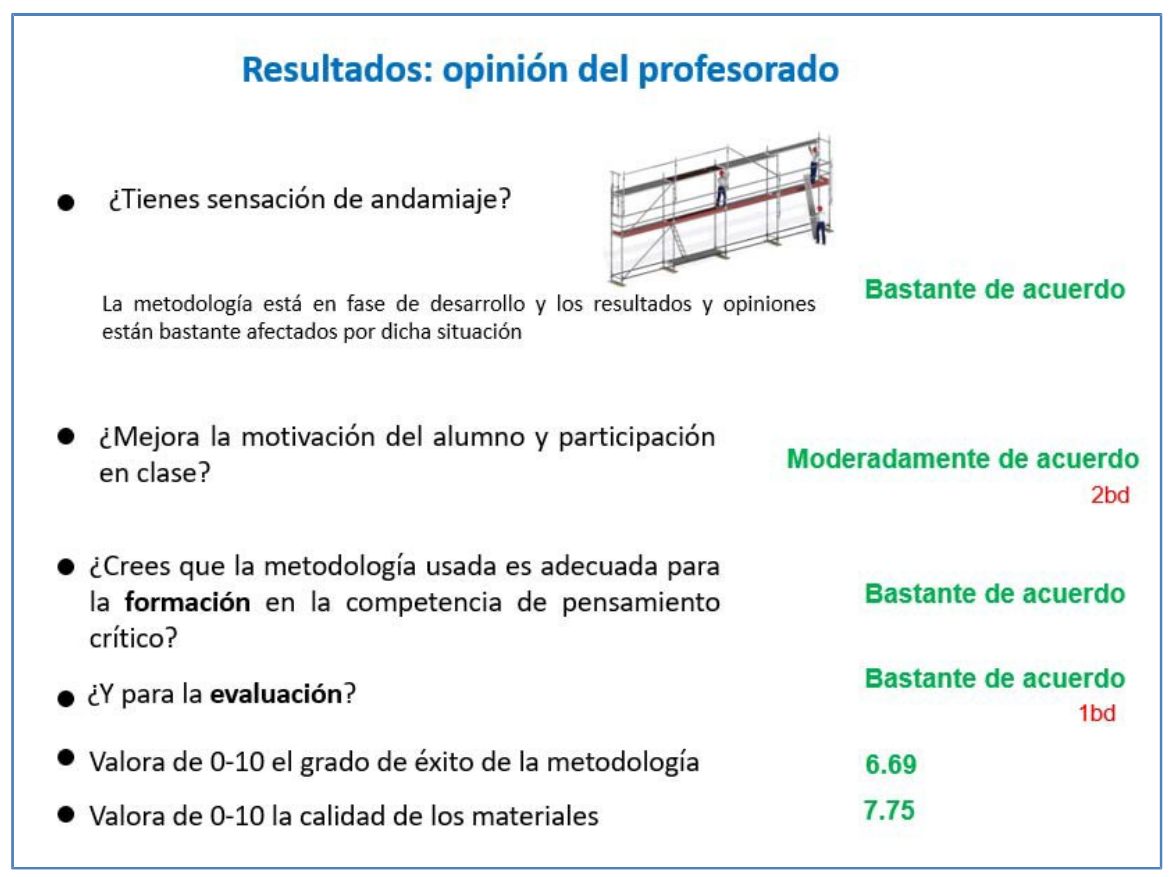

Fig 4: Opinión del profesorado sobre la metodología propuesta para la formación y evaluación en pensamiento crítico

crítico, muestra unos resultados favorables que constituyen una evidencia de la consecución de un nivel adecuado del objetivo general A y específico 1 dado el grado de satisfacción percibido por parte del alumnado.

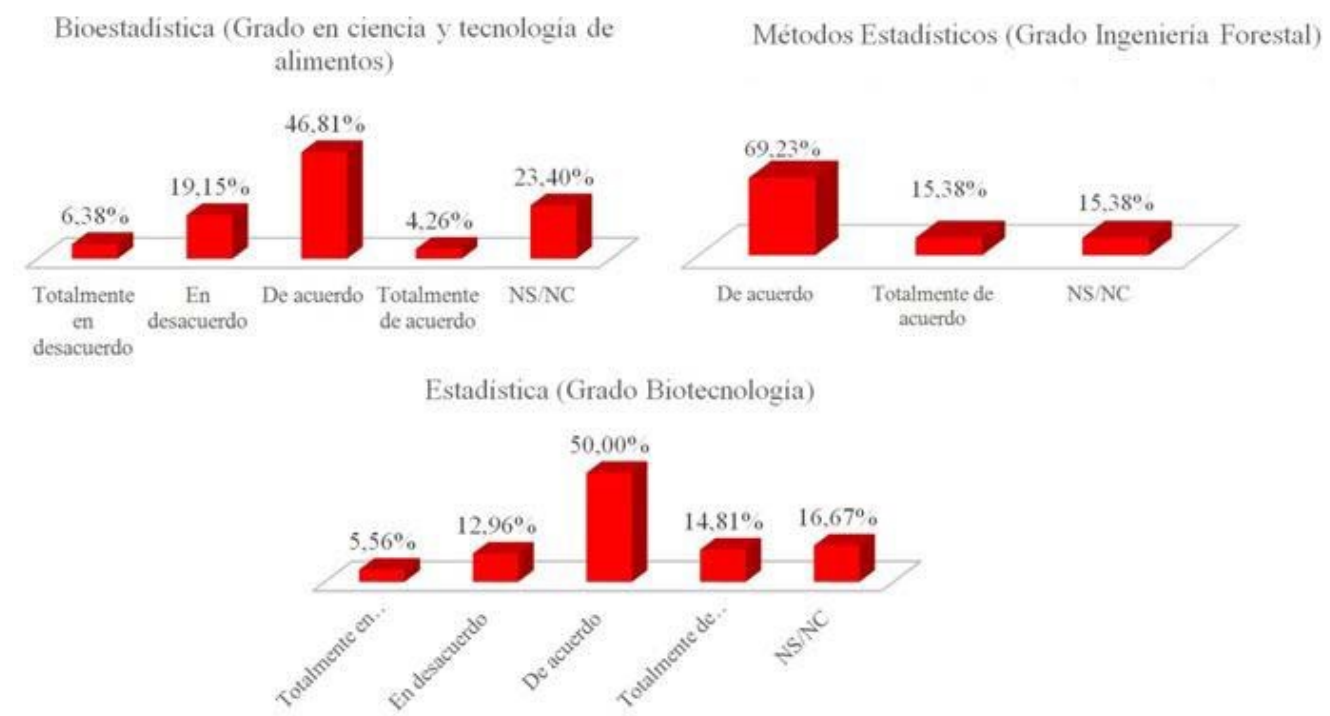

Fig 5: Opinión del alumnado sobre la información/documentación proporcionada sobre pensamiento crítico

(cc)) EY-NC-ND 2018, Universitat Politècnica de València

Congreso IN-RED (2018) 
Las Figuras 6 y 7 muestran la opinión del alumno sobre la metodología para la formación y evaluación propuesta. Los resultados son satisfactorios, pues las respuestas se agrupan mayoritariamente en un nivel medio-alto

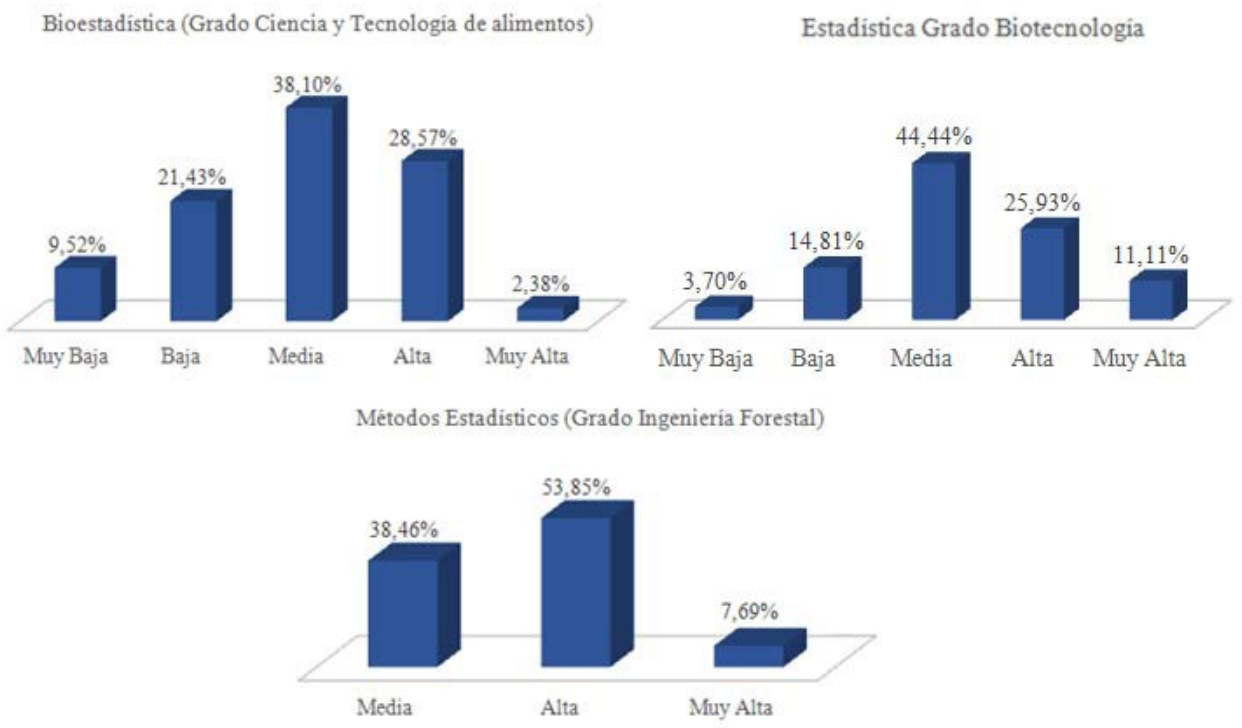

Figura 6: Opinión del alumnado sobre la metodología propuesta para la formación en pensamiento crítico

- Resultados de los alumnos

Los resultados de pensamiento crítico del estudiante varían entre titulaciones o grados, aunque hay algunos perfiles similares. Los estudiantes de los cursos de Ciencia y Tecnología de los Alimentos e Ingeniería Forestal son los grados donde mayor porcentaje de estudiantes alcanzan las calificaciones más altas, A y B. Además, estos grupos tienen los mismos perfiles de distribución de las calificaciones. Debido a que los grupos tienen un tamaño más pequeño fue posible una buena interacción estudiante-instructor. La alta coordinación entre los instructores y la retroalimentación rápida sobre la evaluación dada a los estudiantes ha sido clave para sus resultados.

Obviamente, las calificaciones no pueden ser las mismas en todos los grupos porque hay diversos factores que influyen en los resultados. El sistema de evaluación debería mejorarse para hacer una evaluación más precisa y consistente del pensamiento crítico. Hay grupos donde los resultados han sido poco satisfactorios. Sin embargo, reiteramos nuestra preocupación acerca de que mejorar el entrenamiento de los estudiantes en pensamiento crítico es esencial, pero también una retroalimentación temprana sobre el progreso del estudiante que mejore el aspecto formativo de esta metodología docente. Finalmente, queremos señalar que los sistemas de evaluación que hemos diseñado se han adaptado a grupos grandes haciendo uso de la evaluación por pares y de pruebas de corrección automática a través de la herramienta PoliformaT, que es la plataforma educativa en línea de la UPV que facilita la tarea del profesor y su comunicación con el alumnado. 

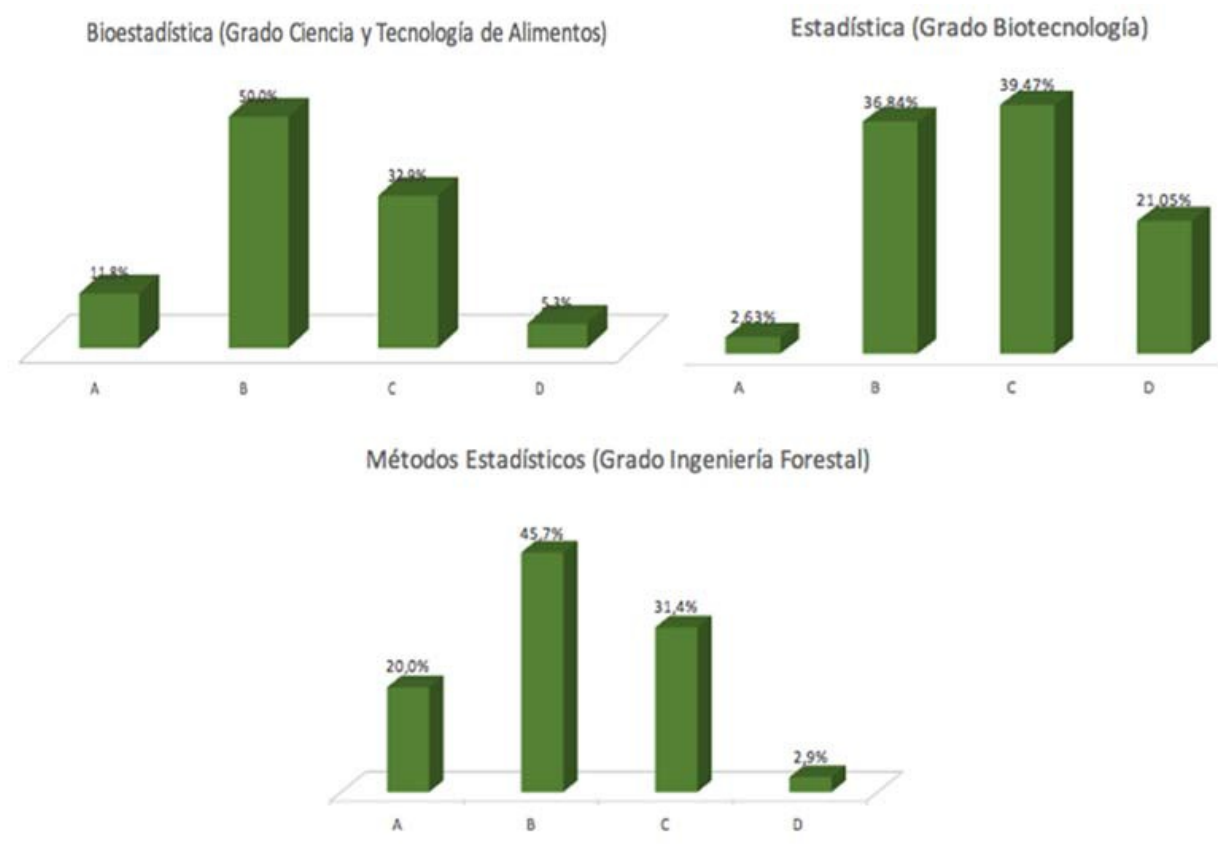

Figura 7: Resultados en la evaluación de los estudiantes del pensamiento crítico por titulación (A: Excelente; B: Adecuado; C: Desarrollandose; D: No alcanzado)

\section{Conclusiones}

Tras el primer año de implantación de la competencia del pensamiento crítico, hemos observado que se produce una retroalimentación entre el alumno y el profesor. Este hecho ayuda al docente en el perfeccionamiento y maduración de su pensamiento crítico. Por tanto, parece que este proceso lleva al docente a "enseñar aprendiendo".

La metodología en su primer año de aplicación ha mostrado una buena aceptación por parte del profesorado y del alumnado implicado, como lo han puesto de manifiesto las diferentes encuestas y los resultados obtenidos por los alumnos. Ha sido una experiencia interesante, aunque todavía está en fase de desarrollo e implantación.

Uno de los resultados importantes es que el profesorado implicado ha mejorado su aptitud para la creación de nuevos materiales y metodologías que incorporen la formación y evaluación en pensamiento crítico y lo ha incorporado a su modo habitual de trabajo. Como grupo somos conscientes de que este proyecto es complejo y debe estar sometido a continuo debate y mejora.

Otro de los aspectos a considerar es el de lograr una mejor integración en la evaluación final del alumno de un conjunto de evidencias procedentes de diferentes pruebas de naturaleza cualitativa y cuantitativa u otros aspectos relacionados con la metaevaluación.

También sería interesante la creación de herramientas estadísticas apropiadas que faciliten el seguimiento de los alumnos y permitan facilitar la retroalimentación.

(cc) EY-NC-ND 2018, Universitat Politècnica de València

Congreso IN-RED (2018) 


\section{Referencias}

AIZIKOVITSH-UDI, E., KUNTZE S., CLARKE, D. (2016). "Connections Between Statistical Thinking and Critical Thinking: A Case Study“ In: Ben-Zvi D., Makar K. (eds) The Teaching and Learning of Statistics. Switzerland : Springer International Publishing, pp 83-94.DOI.10.1007/978-3319-23470-0_8

ENNIS, R. H. (1993). Critical thinking assessment. Theory into Practice, vol. 32 issue 3, p. 179-186

NORRIS, S. P. y ENNIS, R. H. (1989). Evaluating critical thinking. Pacific Grove, CA: Midwest Publications

PORTILLO-POBLADOR, N. et al. (2009). "E-learning in teaching statistics: an application in civil engineering” en EDULEARN09 1st International Conference on Education and New Learning Technologies. (6-8 Julio 2009. Barcelona)

VIDAL-PUIG, S. et al. (2007).“New methodology for teaching statistics which allows the progressive assessment of students". International Association of Technology, Education and Development en INTED2007 (7-9 Marzo 2007. Valencia)

VIDAL-PUIG, S. et al. (2011)."Educational innovation project in teaching statistics in engineering degrees" 4th International Conference of Education, Research and Innovation en ICERI2011 (14-16 November 2011. Madrid)

VILLA-JULIA, M.F. et al.(2012) “Educational innovation project in teaching statistics in engineering degrees II“ 5th International Conference of Education, Research and Innovation en ICERI2012 (1921 November 2012. Madrid)

INSTITUTO DE CIENCIAS DE LA EDUCACIÓN UPV. Documento informativo sobre el proyecto institucional de Competencias Transversales UPV

http://www.upv.es/entidades/ICE/info/U0724624.pdf 


\title{
ECOTROPHELIA 2017: Una oportunidad para el enfoque interdisciplinar en el aprendizaje basado en proyectos.
}

Esther González Aurignac ${ }^{\mathrm{b}}$, Purificación García Segovia a , Javier Martínez Monzóa, Gabriel García Martínez y María Jesús Pagán Moreno .

${ }^{\mathrm{a}}$ ETSIAMN, ${ }^{\mathrm{b}}$ ETSID

\begin{abstract}
The present educational improvement project based on a real professional framework and developed by teams of interdisciplinary students, demonstrates that the use of active learning methodologies stimulate students motivation and their capacity for continuous learning, preparing them for the demanding of the dynamic and changing future professional world. The main objective of this teaching innovation consisted in the design of an eco-innovative food product from its concept and image to the business plan and to present it at the ECOTROPHELIA 2017 competition. The teams participating in the project belonged to two different degrees, students of ETSID (Degree in Design Engineering and Product Development) and ETSIAMN (Degree in Food Science and Technology). The interdisciplinary teamwork developed by our UPV students, was the winner of the Ecotrophelia Spain 2017 contest and represented our country in the European contest in London in November 2017.
\end{abstract}

Keywords: interdisciplinarity, projects, creativity, teamwork, active learning, critical thinking and planning.

\section{Resumen}

El presente proyecto de innovación y mejora educativa basado en un marco real y desarrollado por equipos de alumnos interdisciplinares, demuestra que el uso de metodologías activas de aprendizaje, estimula la motivación del estudiante y su capacidad de aprendizaje continuo, preparándolo para las demandadas del exigente mundo profesional actual y futuro. El objetivo principal de la presente innovación docente consistió, en el diseño de productos alimentarios ecoinnovadores desde su concepto e imagen, hasta el plan de negocio, para su presentación posterior en el certamen ECOTROPHELIA 2017. Los equipos participantes en el proyecto pertenecían a dos titulaciones diferentes, alumnos de la ETSID (Grado en Ingenieria del Diseño y Desarrollo de Productos) y de la ETSIAMN (Grado en Ciencia y Tecnología de los Alimentos). El trabajo en equipo $e$ interdisciplinar desarrollado por estos alumnos de la UPV, fue el ganador del certamen Ecotrophelia España 2017 y representó a nuestro país en el certamen Europeo en Londres en noviembre 2017. 
ECOTROPHELIA 2017: Una oportunidad para el enfoque interdisciplinar en el aprendizaje basado en proyectos.

Palabras clave: interdisciplinaridad, proyectos, creatividad, trabajo en equipo, aprendizaje activo, pensamiento critico y planificación

\section{Introducción}

\subsection{Contextualización de la experiència.}

El proceso de convergencia al Espacio Europeo de Educación Superior establece la incorporación de metodologías activas de aprendizaje (Arias, 2003), por ello entendemos que debemos realizar una reflexión profunda sobre los procesos de enseñanza-aprendizaje tradicionales y pasivos, resaltando la urgencia de innovar en el desarrollo de vías de integración de los mismos, con las necesidades reales del mundo profesional. Cada vez más las empresas son organizaciones activas y dinámicas, basadas en la capacidad de aprendizaje continuo de su personal (Edvinsson, 1997). Por ello, consideramos de gran importancia, la formación de nuestros alumnos para adecuarse a las demandas del cambiante entorno empresarial al que deberán enfrentarse en un futuro cercano y que solicita profesionales “ con la capacidad de aprender a saber, aprender a aprender y aprender a trabajar juntos” (Delors, 1996).

El presente proyecto de innovación y mejora educativa, fue encaminado a buscar un puente entre la universidad y el mundo laboral (González-Aurignac,2013). Planteamos una innovación metodológica con la que construir un entorno que beneficiase el aprendizaje (Fulla, 2002) a través de la motivación de los alumnos ante una situación real de diseño y materialización de un producto dentro de un equipo interdisciplinar.

La implementación del proyecto en el desarrollo de productos alimentarios, se realizó entre dos colectivos de estudiantes procedentes de la ETSID y de la ETSIAMN. Estos colectivos trabajaron en colaboración para desarrollar el diseño de cuatro productos alimentarios y sus respectivas filosofías e imagenes de marca, envases y logotipos, así como también los planes de negocio correspondientes a cada producto.

- Los alumnos de Generación Espontanea de la ETSIAMN: Trabajarón en el diseño de un producto alimentario ecoinnovador para su presentación en el certamen ECOTROPHELIA 2017 y el plan de negocio asociado al mismo.

- Los alumnos de la asignatura de Color y diseño de la ETSID: Trabajarón sobre la filosofía e imagen de marca del producto incluyendo el diseño de los envases, logotipos e imagenes coorporativas de cada uno de los productos alimantarios propuestos por los compañeros de la ETSIAMN para ECOTROPHELIA 2017.

\subsection{Justificación y motivación}

Para contextualizar el arranque de esta colaboración, podemos remontarnos a cinco años atrás, coincidiendo con la implantación de los nuevos grados, cuando la unidad docente de Nutrición y Restauración Colectiva, del departamento de Tecnología de Alimentos, decidió implantar la creatividad y la flexibilidad ofrecida por herramientas propias del mundo del diseño, como es el Design Thinking (DT), para abordar los conocimientos de las 
asignaturas implicadas en su unidad docente y con el fin de trabajar también, las competencias transversales de las asignaturas.

De este modo, durante el semestre correspondiente los alumnos en equipos debían, manejando las herramientas básicas del DT, diseñar, prototipar y presentar un nuevo alimento, que supusiese una innovación en el mercado. Desde esta primera iniciativa , hemos ido enviando anualmente equipos de nuestros alumnos al concurso nacional Ecotrophelia, que además cuenta con una fase europea, donde va, representando a cada país, el equipo ganador en la fase nacional. En dos ocasiones (2011 y 2015) alumnos de la UPV han resultado vencedores en la fase española acudiendo así, a la europea.

Como consecuencia de estas primeras experiencias, nos dimos cuenta de la oportunidad del enfoque interdisciplinaridad y de la necesidad del trabajo en equipo entre alumnos procedentes de titulaciones complementarias, para alcanzar la profesionalidad que demanda la sociedad actual. Constatamos que, no sólo es importante presentar un producto innovador, sino que, aspectos como la filosofía e imagen del producto, el marketing y el business plan, son fundamentales para que las propuestas fuesen completas y especialmente, para poder competir en la fase europea. Por ello, vimos la urgencia de introducir en el proceso la interdisciplinaridad en el proyecto, como solución para obtener resultados completos, coherentes y mejorados. Gracias a las posibilidades que la UPV nos ofrece, al tener titulaciones que se complementan en la vida profesional, iniciamos este proyecto de innovación y mejora educativa entre las dos escuelas, que nos ha permitido trabajar de forma activa las competencias propias de cada asignatura y en paralelo también las transversales (conocimiento de los problemas del entorno, comunicación efectiva, trabajo en equipo, responsabilidad ética y medioambiental, planificación y gestión del tiempo,....) consiguiendo crear una oportunidad para alcanzar el " aprendizaje complejo, el cual requiere comprensión, aplicación, análisis y síntesis crítica de los conocimientos" (Lave,1991). Así, se ha pretendido fomentar la formación del estudiante en una serie de conocimientos vinculados a las asignaturas implicadas y relacionados con la situación real de sus profesiones futuras (Brown, 1998), consiguiendo así un aprendizaje profundo (Bain,2005).

\section{Objetivos}

El objetivo general de la presente experiencia de innovación y mejora educativa, fue desarrollar un proyecto de diseño y materialización de un producto innovador en una situación real, propia del futuro profesional de las titulaciones implicadas en el proceso. Para ello se planteó el proyecto con equipos de alumnos multidisciplinares. Dichos equipos tenían como objetivo final la presentación de un producto alimentario eco-innovador al certamen Ecotrophelia, teniendo el rol de responsables del desarrollo del alimento, los alumnos de la ETSIAMN y el rol de responsables del pakaging, logo e imagen de marca del producto alimentario, los alumnos de la ETSID. Para la consecución de dicho objetivo se plantearon los siguientes objetivos específicos: propiciar la cooperación y colaboración entre colectivos de alumnos de las titulaciones complementarias, fomentar la puesta en común de los conocimientos adquiridos durante el proceso de aprendizaje, facilitar la 
ECOTROPHELIA 2017: Una oportunidad para el enfoque interdisciplinar en el aprendizaje basado en proyectos.

sinergia de ideas y significados, aprender a contrastar tanto la información como los conocimientos, fomentar la toma de decisiones y la planificación del trabajo en equipo .

Además, y como objetivo complementario se pretendió determinar que competencias transversales estarían asociadas al desarrollo de este tipo de proyecto de innovación y mejora educativa en vistas a la implementación de las mismas en la presentación de Proyectos Fin de Grado Colaborativos u otro tipo de actividad similar.

\section{Desarrollo de la innovación}

\subsection{Implementación de los equipos interdisciplinares en el proceso de creación de productos alimentarios innovadores.}

Esta fase de implementación se realizó entre dos colectivos de alumnos: los alumnos de la generación espontanea pertenecientes al Grado en Ciencia y Tecnología de los alimentos de la ESTIAMN y los alumnos de la asignatura de Color y diseño del Grado en Ingenieria del Diseño y Desarrollo de Productos de la ETSID.

Los primeros idearon el producto alimentario y realizaron el plan de negocio, por otro lado los segundos fueron los encargados de crear y desarrollar la filosofía e imagen tanto del producto como de la empresa. En el caso de los alumnos de la ETSIAMN se trabajó con cuatro grupos de 5-6 alumnos, mientras que en lo referente a los alumnos de la ETSID se crearon 12 subgrupos de 3 alumnos. Se organizó la colaboración de tal forma, que cada tres grupos de la escuela de Diseño trabajaran sobre una misma propuesta de las cuatro realizadas por los equipos de Tecnología de Alimentos.

La finalidad del trabajo de los alumnos de la ETSIAMN era la creación de cuatro empresas alimentarias (startup) con un producto alimentario innovador estrella para cada una de ellas.

Los alumnos de la ETSID actuaban en el rol de diseñadores de las empresas y debían crear la filosofía y la imagen de marca, los logotipos y los envases para cada uno de los cuatro productos desarrollados por los alumnos de la ETSIAMN. Los alumnos de la ETSIAMN actuaban por tanto como clientes de los alumnos de la ETSID.

El desarrollo de esta fase del proyecto se realizó en base a sesiones específicas previas independientes para los alumnos de la ETSIAMN y ETSID; sesiones conjuntas para las dos titulaciones; sesiones de trabajo de los equipos interdisciplinares y por último se desarrolló partes del trabajo de forma independiente entre los miembros de los subgrupos.

\section{1) Sesiones con los alumnos de la ETSIAMN}

El Design Thinking (DT), se define como la utilización de técnicas de exploración de un problema, buscando soluciones diversas para un posterior prototipado y testeo. De forma general el proceso básico del DT consta de cuatro pasos elementales (figura 1).

(cc) EY-NC-ND 2018, Universitat Politècnica de València

Congreso IN-RED (2018) 


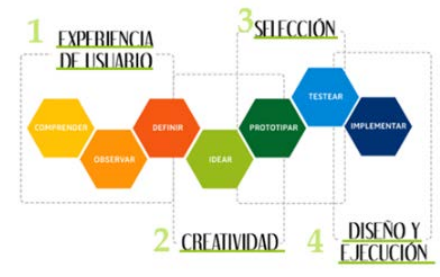

Fig.1. Esquema del proceso básico del DT (fuente: Institute Of Design at Stanfor, 2016)

La primera etapa constituye la experiencia, que incluye la comprensión y la observación del usuario, para poder definir el problema real que presenta. Este paso va seguido de la aplicación de la creatividad al proceso de como que se generan ideas. A continuación, mediante un proceso de selección de la mejor idea, se pasa al prototipado para obtener una propuesta que se adapte a los requisitos establecidos. Por último, se lleva a cabo la implementación y ejecución del prototipo.

En base a lo anteriormente mencionado se realizaron diversas sesiones de trabajo para implementar las distintas fases del DT en la elaboración de un producto alimentario, utilizándose algunas de la herramientas definidas en la guía elaborada en el marco del Proyecto Europeo Erasmus+ FoodLab, en el que han participado varios de los profesores involucrados en esta innovación docente (FoodLab, 2018) (figuras 2 y 3).

Posteriormente, también se realizaron varias sesiones de seguimiento sobre la elaboración del modelo de negocio de los productos desarrollados a través del Business Canvas.
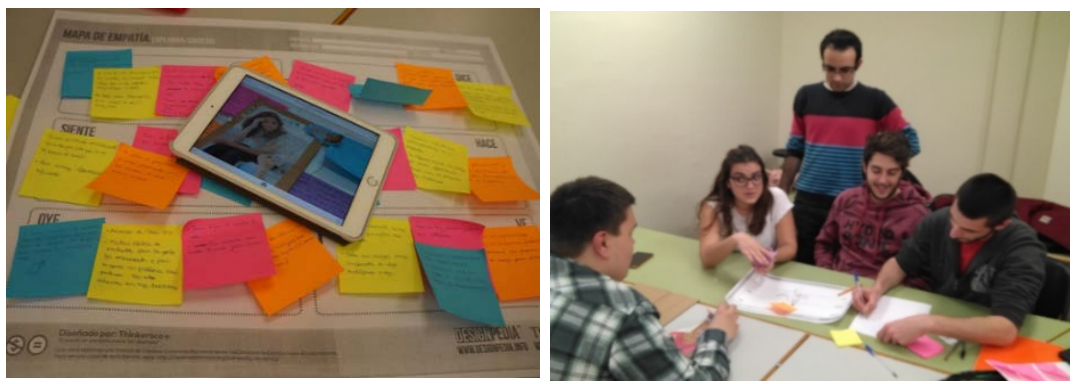

Fig. 2. Sesión de trabajo de los alumnos utilizando la herramienta EMPATIZAR
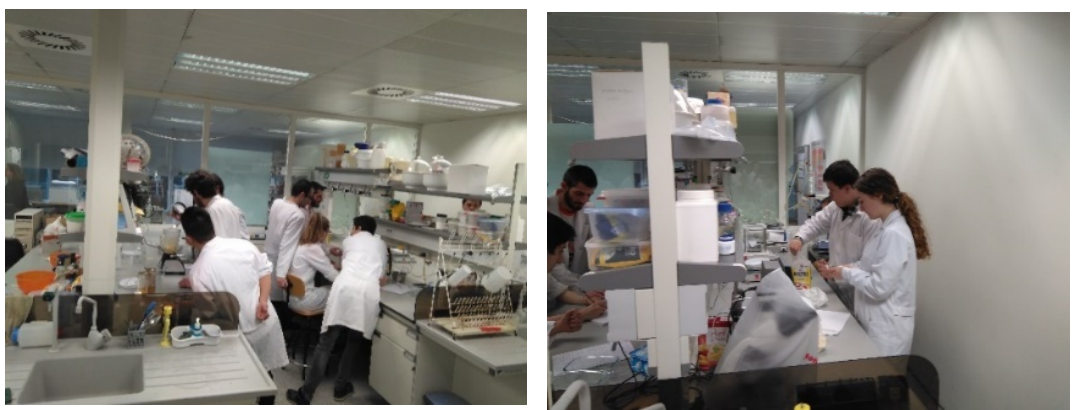

Fig. 3. Sesiones de PROTOTIPADO.

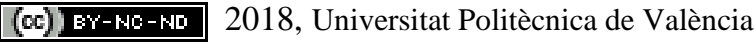

Congreso In-Red (2018) 


\section{2) Sesiones con los alumnos de la ETSID.}

Para los alumnos de la asignatura de Color y diseño del Grado en Ingenieria del Diseño y Desarrollo de Productos de la ETSID, la participación en este proyecto era la aplicación práctica de los conocimientos teóricos estudiados al inicio de la asignatura (Febrero y Marzo 2017), sobre el Diseño de productos y la fuerza de la percepción cromática para la determinación de una idea o concepto. Durante dos sesiones se preparó a los alumnos para realizar un cuestionario claro de los aspectos claves a tratar con sus "clientes" para poder definir de manera colectiva con ellos, la filosofía e imagen final del producto alimentimentario. Además, durante el proceso de creación de las propuestas los subgrupos se reunieron con el profesorado con el fin de recibir asesoramiento y apoyo.

\section{3) Primera sesión conjunta para las dos titulaciones .}

Una vez ideado el producto por parte de los alumnos de la ETSIAMN, se realizó una primera toma de contacto en una sesión conjunta, para que estos presentansen el producto a los alumnos de la ETSID (figura 4) y así, estos últimos, pudiesen proceder a definir la filosofía y la imagen de marca, incluyendo el logotipo y el envasado. En esta misma sesión y tras las presentaciones, los equipos de la ETSID eligieron en que producto alimenticio iban a trabajar. Cada tres grupos de alumnos de la ETSID trabajaría con un grupo de alumnos de la ETSIAMN para desarrollar el concepto completo del nuevo producto. Por tanto, cada producto alimentario tendría tres propuestas de diseño de dónde se elegiría una para pasar a la fase de concurso de Ecotrophelia.

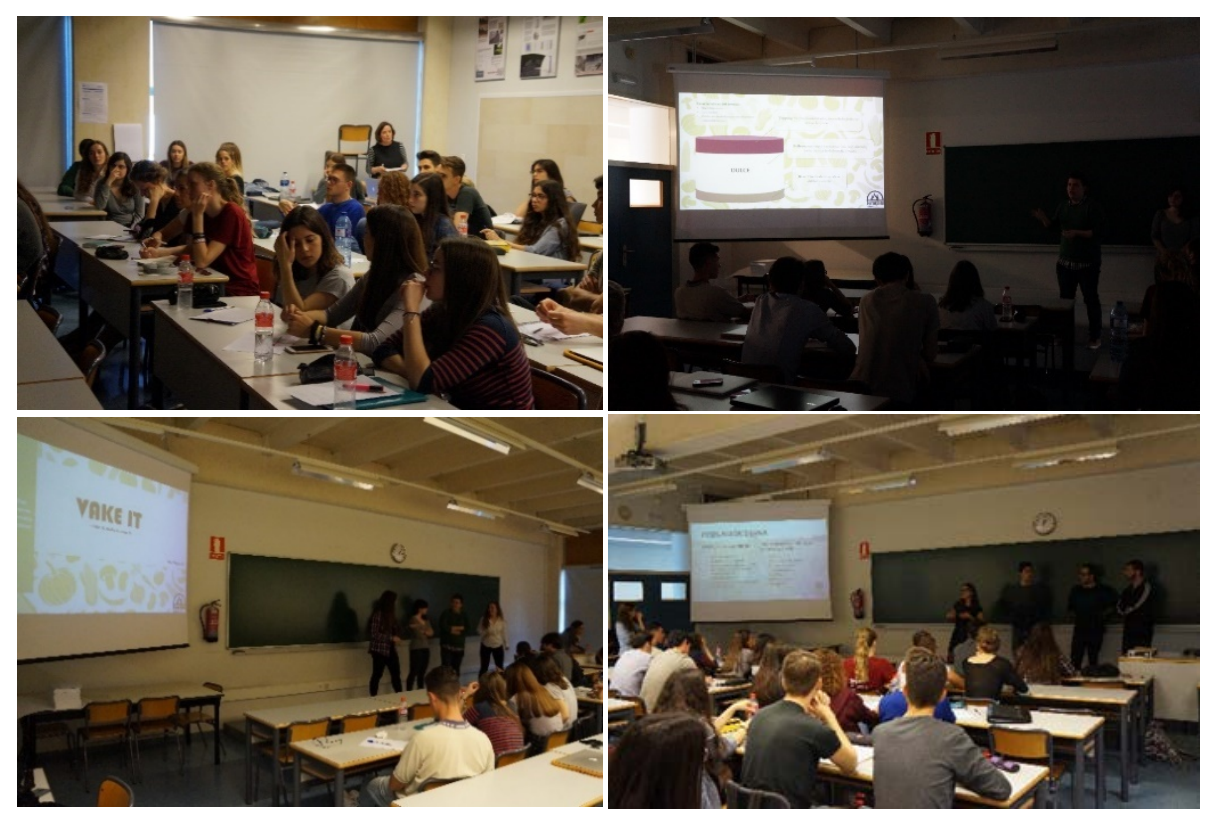

Fig. 4. Primera sesión conjunta ETSIAMN y ETSID. 


\section{4) Sesiones de trabajo de los equipos interdisciplinares.}

Durante estas sesiones de trabajo conjunto que tuvieron lugar durante los meses de Marzo y Abril 2017, los subequipos interdisciplinares de ambas escuelas se trasmitierón información básica sobre los productos alimenticios propuestos, trabajarón sobre la definición del usuario y el mercado de destino, sobre las características de conservación y la percepción del producto en el comercio final, entre otros aspectos esenciales para el desarrollo de la filosofía e imagen de la marca y de la empresa, con el objetivo común de presentar un resultado final coherente, completo y atractivo. La organización y comunicación de estas sesiones corrió a cargo de los equipos interdisciplinares, sin necesidad de la presencia de un profesor.

\section{5) Segunda sesión conjunta para las dos titulaciones.}

En la segunda sesión conjunta entre los alumnos de las dos escuelas involucradas en el proyecto, los estudiantes de la ETSID presentaron los envases, logotipos e imagen de marca para los cuatro productos alimentarios ideados por los alumnos de la ETSIAMN (figura 5). El objetivo de la sesión era la elección por parte de los equipos de la ETSIAMN, una de las tres propuestas presentadas por los subgrupos de la ETSID y seguir con ella la siguiente fase del proyecto que consistión en la presentación en ECOTROPHELIA 2017.
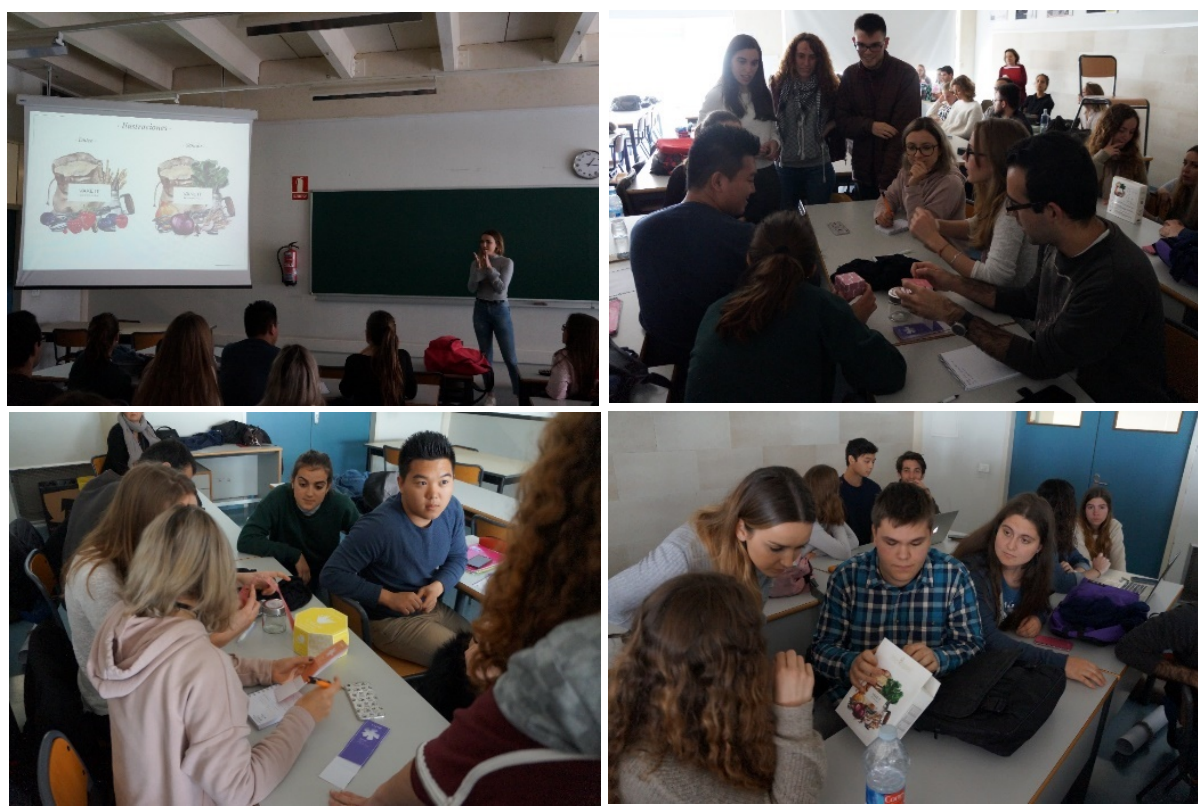

Fig. 5. Segunda sesión conjunta ETSIAMN y ETSID.

6) Presentación de los productos resultantes (producto+filosofía e imagen de marca+envase) al concurso ECOTROPHELIA 2017 (Barcelona, 22 mayo 2017) (figura 6). 


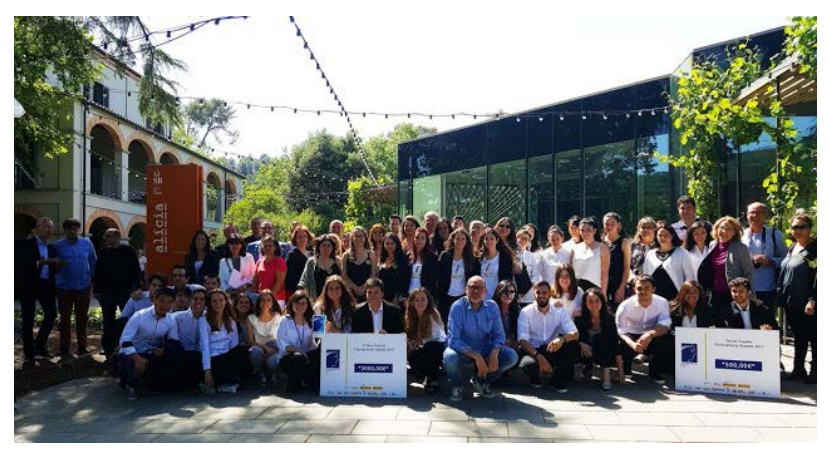

Fig. 6: participantes al certamen ECOTROPHELIA 2017.

En la figura 7 se muestra el análisis DAFO realizado por parte de los participantes en el proyecto respecto al desarrollo de este.

\begin{tabular}{|c|c|}
\hline DEBILIDADES & FORTALEZAS \\
\hline $\begin{array}{ll}\text { - } & \text { Organización compleja } \\
\text { de las sesiones por el } \\
\text { número de alumnos. } \\
\text { - } \\
\text { Dificultades de } \\
\text { comunicación entre } \\
\text { alumnos procedentes de } \\
\text { Escuelas diferentes. } \\
\text { - Tiempo y plazos cortos. }\end{array}$ & $\begin{array}{ll}\text { - } & \text { Multidisciplinaridad } \\
\text { - } & \text { Complementariedad } \\
\text { - } & \text { Trabajo en equipo } \\
\text { - } & \text { Experiencia real y activa } \\
\text { - } & \text { Motivación } \\
\text { - } & \text { Objetivos cognitivos de los } \\
& \text { niveles más altos }\end{array}$ \\
\hline AMENAZAS & OPORTUNIDADES \\
\hline $\begin{array}{ll}\text { - } & \text { Coordinación de cronograma } \\
\text { - } & \text { Organización entre escuelas }\end{array}$ & $\begin{array}{ll}\text { - } & \text { Creación de Start Up } \\
\text { - } & \text { Participación en certámenes } \\
\text { - } & \text { Creación de redes de trabajo para } \\
& \text { noveles } \\
\text { - } & \text { Creación de equipos } \\
& \text { multidisciplinares entre escuelas } \\
\text { - } & \text { Emprededurismo multidisciplinar }\end{array}$ \\
\hline
\end{tabular}

Fig. 7: Analisis DAFO del PIME.

\subsection{Definir las competencias transversales trabajadas en el proyecto.}

Para establecer las competencias transversales trabajadas en el presente proyecto se procedió a realizar encuestas a los diferentes colectivos de alumnos utilizados como grupos de control y definidos en el apartado 3.1.

(cc) EY-NC-ND 2018, Universitat Politècnica de València 


\section{Resultados}

\subsection{La implementación del aprendizaje basado en un proyecto real entre grupos interdisciplinares de diferentes titulaciones.}

Los resutlados obtenidos fueron la presentación de cuatro productos con el desarrollo completo incluyendo imagen y plan de negocio, al certamen Ecotrofelia España 2017.

- SEABITES es una gominola funcional a base de microalgas para tomar durante una actividad física aeróbica intensa (figura 8).

- LENTEYA un plato de lentejas liofilizadas que solamente se reconstituye con agua y contenidas en un envase autocalentable, lo cual resulta ideal para personas sin tiempo para cocinar por cuestiones de trabajo, o sin recursos para cocinar como los excursionistas (figura 9).

- VAKE IT es un preparado para tarta que no incluye ningún ingrediente de origen animal el cual solo necesita refrigeración para su consumo. El preparado incluye todos los ingredientes que el consumidor necesita para realizar este postre, a excepción del agua, necesaria para elaborar el relleno de la tarta, y en algunas ocasiones de la grasa, necesaria para compactar la base. Dentro de VAKE IT se presentan dos modelos: uno de tarta salada y otro modelo de tarta dulce (figura $10)$.

- CALOE es una gama de mousses a base de bebida y yogur de soja con la peculiaridad de que incluye entre sus ingredientes jugo de aloe vera y flores (figura 11).

Sobre un total de quince productos presentados en la primera fase del concurso ECOTROPHELIA España en 2017 siete parasaron a la fase final y estos tres fueron productos presentados por la UPV (LenteYa, Vake It y Caloe).

el producto

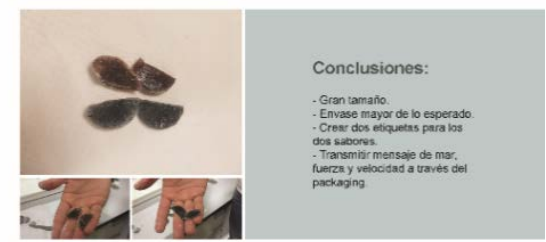

diseño de envase

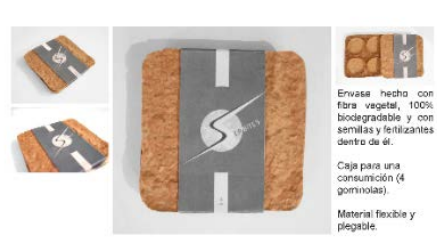

Fig.

8: 


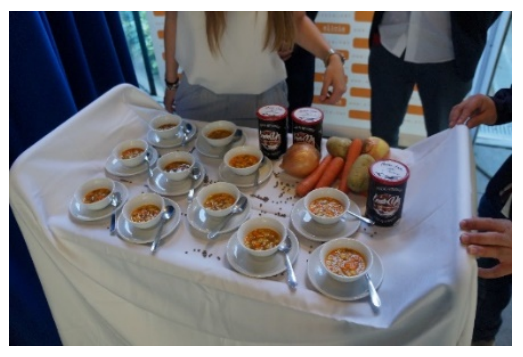

Fig. 9. LenteYa

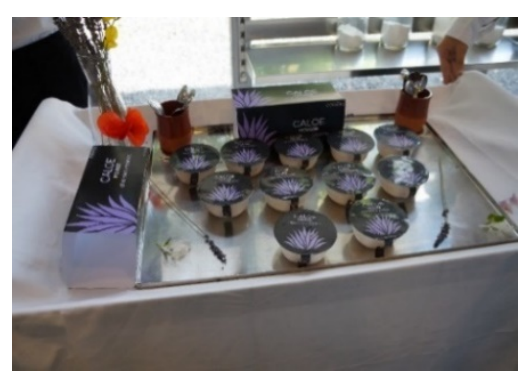

Fig. 11. Caloe

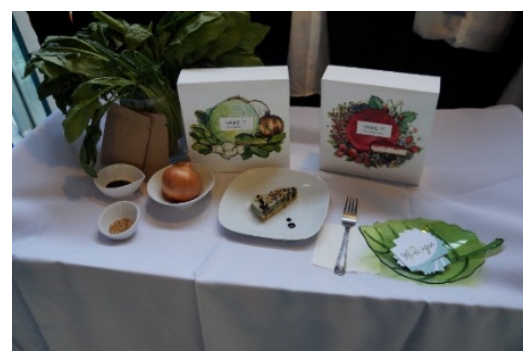

Fig. 10. VakeIt.

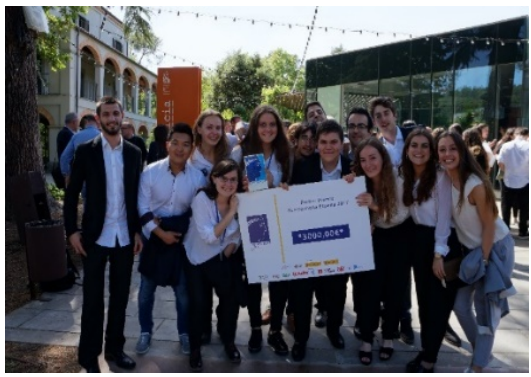

Fig. 12. Vake It ganador del certamen

En la fase final del concurso Vake It quedo ganador y representará a España en ECOTROPHELIA Europa que se desarrollará en Londres el 21 y 22 noviembre 2017 (figura 12).

Para evaluar la metodología seguida y las herramientas utilizadas en el caso de los alumnos de la ETSID se utilizó una escala a tres niveles: insatisfactorio (puntuación 1, 2, 3), satisfactorio (puntuación 4) y excelente (puntuación 5). Los resultados obtenidos se muestran en la figuras 14 . Para evaluar la metodología seguida y las herramientas utilizadas, en el caso de los alumnos de generación espontanea de la ETSIAMN, se utilizó una escala de 1 a 5 donde 1 indica un fuerte desacuerdo y 5 indica un fuerte acuerdo. Los resultados se muestranen la figura 15 . 


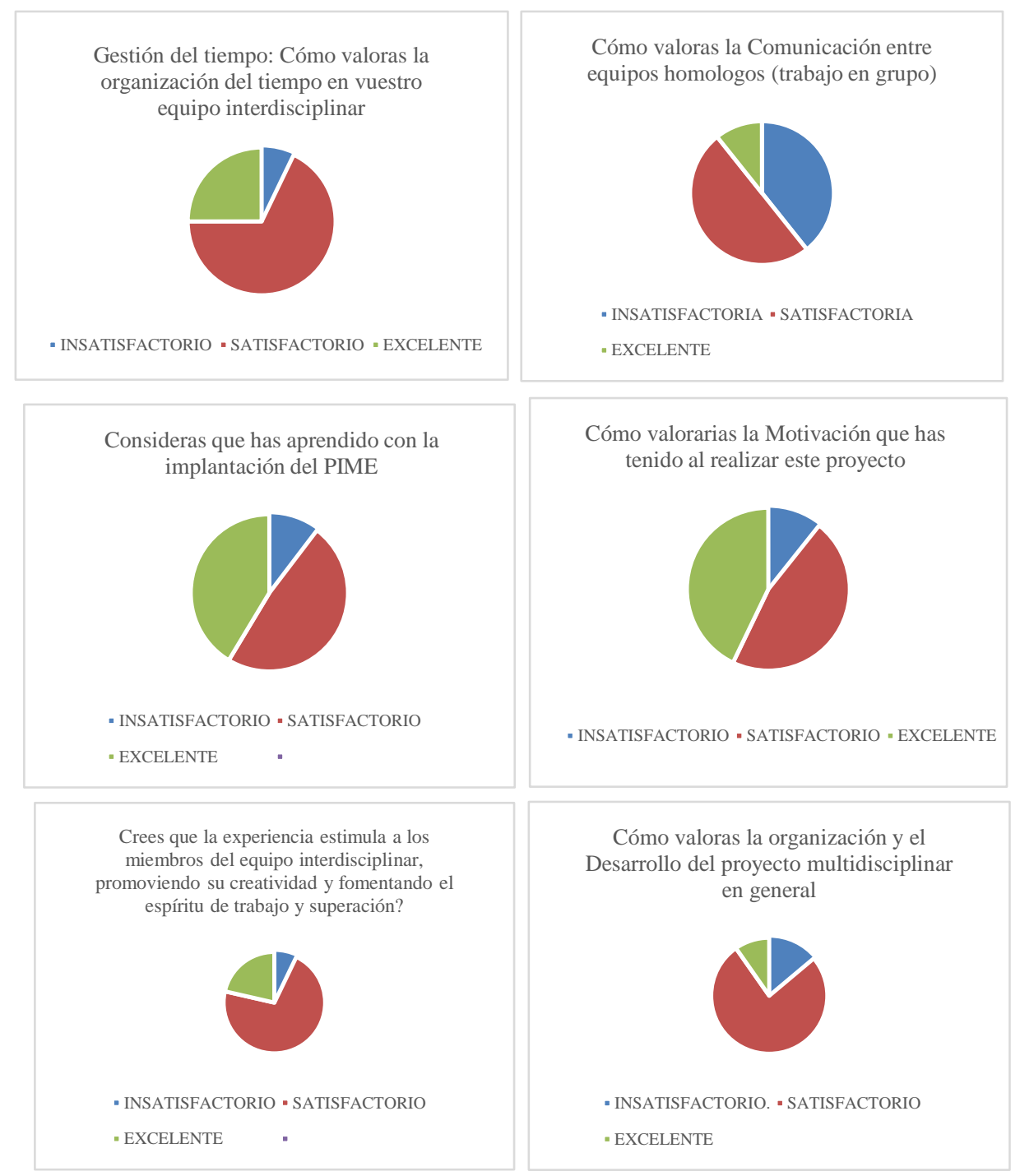

Fig. 14 Resultados de las encuestas realizadas a los alumnos de la ETSID.

\begin{tabular}{|l|l|}
$\begin{array}{l}\text { Cómo valoras los resultados del } \\
\text { proyecto? }\end{array}$ & $\begin{array}{l}\text { Cómo valoras la Transmisión de } \\
\text { información entre los equipos }\end{array}$ \\
- INSATISFACTORIO - SATISFACTORIO & - INSATISFACTORIO - SATISFACTORIO \\
"EXCELENTE EXELENTE
\end{tabular}

(cc)) EY-Nc-ND 2018, Universitat Politècnica de València

Congreso In-Red (2018) 
ECOTROPHELIA 2017: Una oportunidad para el enfoque interdisciplinar en el aprendizaje basado en proyectos.

Nueva Metodología:El proyecto te ha

servido para integrar los conocimientos adquiridos en la asignatura

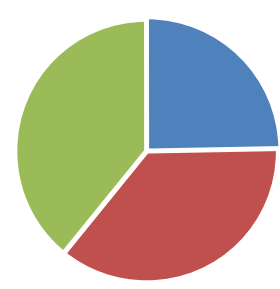

INSATISFACTORIO -SATISFACTORIO - EXCELENTE.

Fig. 14 (bis): resultados de las encuestas realizadas a los alumnos de la ETSID.

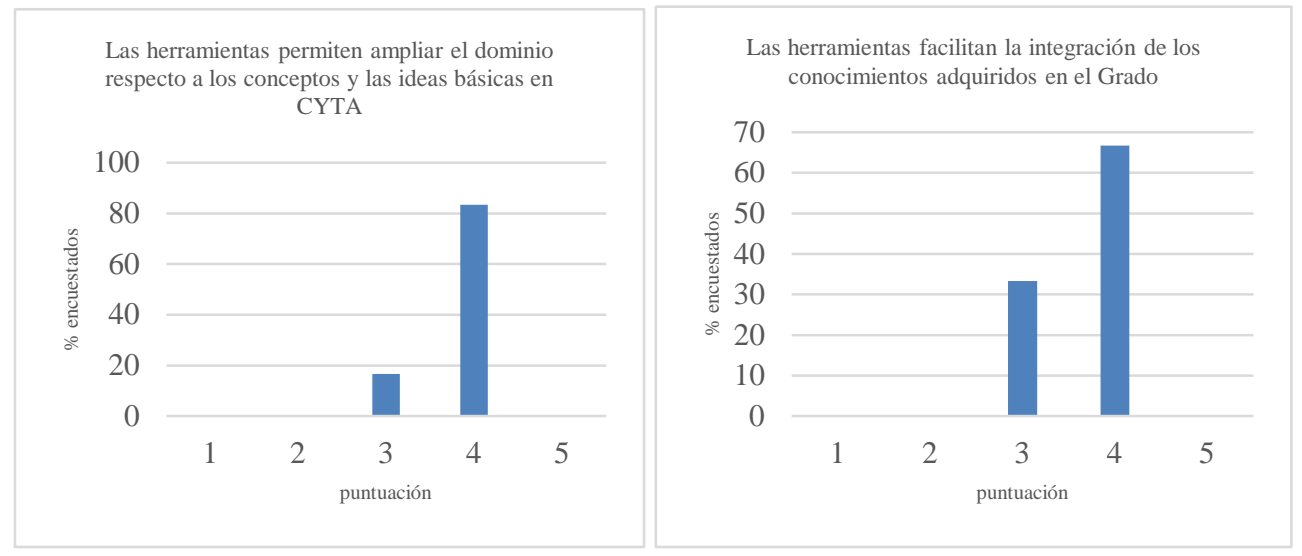

Fig. 15. resultados de las encuestas realizadas a los alumnos de la ETSIAMN

(c)) EY-NC-ND 2018, Universitat Politècnica de València 


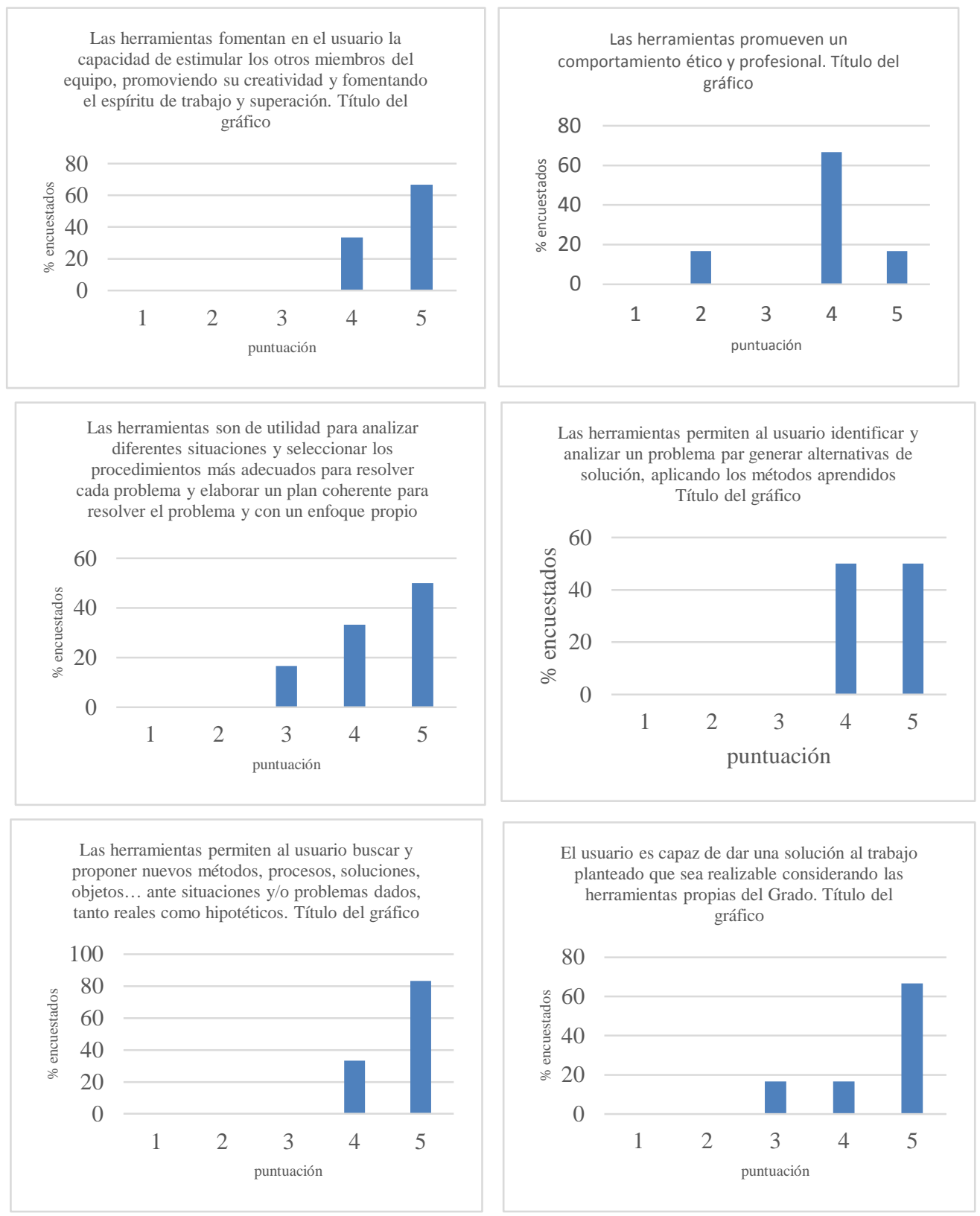

Fig. 15 (bis). resultados de las encuestas realizadas a los alumnos de la ETSIAMN.

(c)) EY-NG-ND 2018, Universitat Politècnica de València 
ECOTROPHELIA 2017: Una oportunidad para el enfoque interdisciplinar en el aprendizaje basado en proyectos.

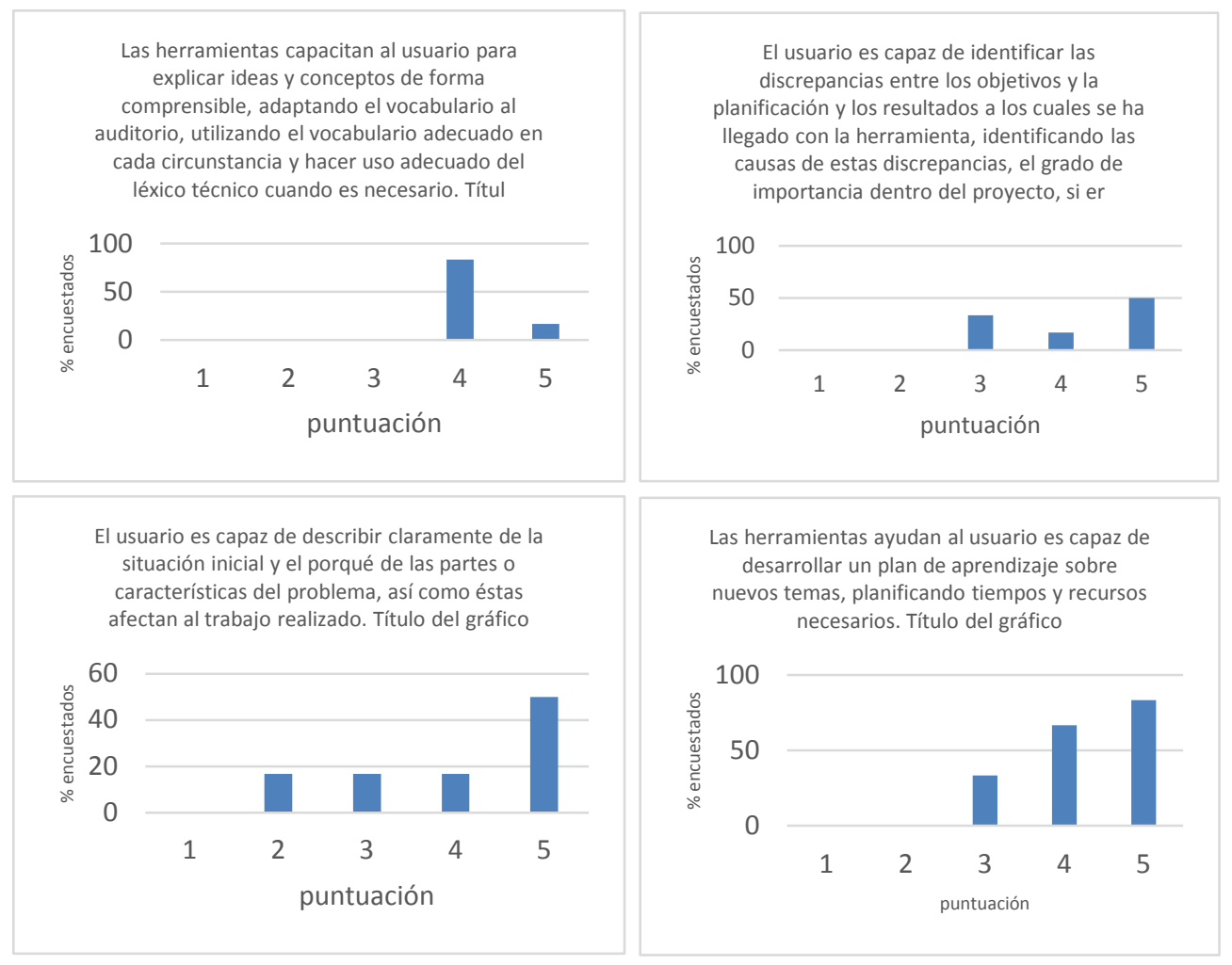

Fig. 15 (tris). resultados de las encuestas realizadas a los alumnos de la ETSIAMN.

\subsection{Competencias transversales trabajadas durante el proyecto.}

En base a los resultados expuestos en el apartado anterior se puede concluir que las competencias transversales fundamentales que se han trabajado en paralelo al desarrollo de este tipo de proyecto son todas las recogidas por la UPV:

C1: comprensión e integración

C2: aplicación y pensamiento práctico

C3: análisis y resolución de problemas

C4: innovación, creatividad y emprendimiento

C5: diseño y proyecto

C6: trabajo en equipo y liderazco

C7: responsabilidad ética, medioambiental y profesional

C8: comunición efectiva

C9: pensamiento critíco

(cc) EY-Nc-ND 2018, Universitat Politècnica de València

Congreso IN-RED (2018) 
C10: conocimiento de problemas contemporáneos

C11: aprendizaje permanente

C12: planificación y gestión del tiempo

C13: instrumental especifico

Queremos aclarar que no todas las competencias expuestas, fueron trabajadas con la misma profundidad por los dos colectivos de alumnos, debido a que cada colectivo tubo roles diferentes dentro del desarrollo del proyecto, lo cual permitió la complementariedad de los procesos, pero con ello también, el trabajo más concreto sobre diferentes competencias transversales .

\subsection{Metodología y técnicas utilizadas para el tratamiento y análisis de los datos.}

Se han utilizado tres tipos de encuestas, en función de la finalidad perseguida:

- Encuesta para la valoración de las herramientas para la creación del plan de negocio (ETSIAMN)

- Encuesta para la valoración de la metodología seguida en el desarrollo del proyecto desde el punto de vista del aprendizaje interdisciplinar ybasado en proyectos centrándonos en las competencias transversales (ETSIAMN y ETSID)

Además, en la fase 3 del proyecto, se ha contado con una evaluación externa, al estar compuesto el jurado de ECOTROPHELIA por profesionales de la Industria Alimentaria. El jurado del certamen estuvó presidido por Mauricio García de Quevedo, Director General de FIAB, y Toni Massanés, Director General de Fundación Alicia, además de por grandes expertos de la $\mathrm{I}+\mathrm{D}+\mathrm{i}$ del sector en España, desde la Administración pasando por las empresas del sector y centros de investigación de renombre nacional.

\section{Conclusiones}

Tras la experiencia y el análisis de los resultados, podemos concluir que el proyecto de innovación docente permitió al alumno llegar a alcanzar el aprendizaje completo, viniendo a reafirmar la existencia de una conexión muy intima entre conocimiento y práctica. Los estudiantes pueden cambiar y desarrollarse, no sólo por la adquisición de conocimientos, sino por el querer resolver situaciones que les resultan interesantes, atractivas o importantes, trabajando objetivos cognitivos de los niveles más altos.

A su vez, el Aprendizaje Basado en Proyectos (ABP) es una metodología de gran interés en el área de los estudios técnicos e ingenieriles. Si su aplicación trasciende a varias asignaturas de titulaciones diferentes, consideramos que sus beneficios se ven incrementados por la transversalidad, multidisciplinariedad y la riqueza del desarrollo de un proyecto completo y coherente. Sin embargo, queremos remarcar que la mayor dificultad en la actualidad para la implantación de este innovación supone todavía, la coordinación entre alumnos de dos colectivos diferentes a la hora de programar el proyecto y desarrollarlo. 
ECOTROPHELIA 2017: Una oportunidad para el enfoque interdisciplinar en el aprendizaje basado en proyectos.

En definitiva consideramos tras esta experiencia, que el logro de la excelencia universitaria pasa sin duda, por el enfoque interdisciplinar de la docencia como respuesta a la demanda futura de profesionales. Se nos exige que preparemos profesionales con competencias técnicas, pero sobretodo profesionales preparados para aprender a aprender y aprender a trabajar juntos y hemos constatado que podrán educarse de este modo siempre y cuando, seamos capaces de romper los límites entre disciplinas.

\section{Referencias}

ARIAS OLIVA,M (2003) El espacio Europea de Educación Superior: una oportunidad de desarrollo multidisciplinar a través del aprendizaje y la tecnología. Universitat Rovira i Virgili [en línea] Disponible en web: https://repositorio.uam.es/bitstream/handle/10486/680281/EM_15_3.pdf?sequence=1 [ref. 20 de Marzo de 2018].

BAIN,K (2005) Lo que hacen los mejores profesores universitarios, Publicacions de la Universitat de València, pp 229

BROWN, G \& ATKINS,M (1998), Effective Teaching in higher education .Methuen\&Co.Ltd, pp. 50-90.

DELORS, J. (1996): La Educación Encierra un Tesoro. Informe a la UNESCO de la Comisión Internacional para la educación del Siglo XXI. UNESCO

EDVINSSON,L \& MALONE,M.S (1997) Intellectual Capital, Harper Collins Publisher INC., New York.

FOODLAB, EUROPEAN FOOD INCUBATOR (2018). ((https://foodlab-eu.com/) [ Consulta: 20 marzo de 2018].

FULLAN,M (2002) Los nuevos significados del cambio en la educación, Ed.Octaedro.

GONZALEZ-AURIGNAC, E \& SAIZ MAULEON, B (2013) Innovación docente en la metodología aplicada a la asignatura Taller de Diseño I Jornadas de Innovación Docente ICE 2013, UPV.

INSTITUTE OF DESIGN AT STANFOR (2016). An introduction to Design Thiking process guide. [online], Avaliable at: http://dschool.stanford.edu/. [Consulta: 20 marzo de 2018].

LAVE, J \& WENGER E (1991) Situated Learning. Legitimate peripheral participation, Cambridge: University of Cambridge Press, pp 138 . 


\title{
El aprendizaje lúdico como estrategia didáctica: El territorio en Juego
}

Asenet Sosa Espinosa ${ }^{a}$, Eric Gielen', José Sergio Palencia Jiménez ${ }^{\text {, }}$ Yaiza Pérez Alonso $^{\text {d, María Salomé Moreno Navarro }}{ }^{\mathrm{e}}$, Rafael Ramón Temes Córdovez , Jose Luis Miralles Garciag, Maria Mercedes Trenor Galindo ${ }^{\text {h }}$

a Departamento de Urbanismo, assoes@urv.upv.es; ${ }^{\mathrm{b}}$ Departamento de Urbanismo, egielen@urb.upv.es; ${ }^{\mathrm{c}}$ Departamento de Urbanismo, ipalenci@urb.upv.es; ${ }^{\mathrm{d}}$ Departamento de Urbanismo, yaipeal@urb.upv.es; eㅡepartamento de Urbanismo, smoreno@upvnet.upv.es; fDepartamento de Urbanismo, rtemesc@urb.upv.es; ${ }^{\mathrm{g}}$ Departamento de Urbanismo, jlmirall@urb.upv.es; ${ }^{\mathrm{h}}$ Departamento de Urbanismo,. mtrenor@urb.upv.es.

\begin{abstract}
The game learning as a didactic strategy in matters of Urban and Regional Planning is the challenge of the Project of Innovation and Educational Improvement (PIME) "The territory in play". The project intend to build a teaching-learning environment that encourages students to create their own knowledge and experience, through the design of a board game. The proposal is designed to alleviate the weaknesses and threats detected, strengthen the strengths and take advantage of the possibilities of the didactic play resource, to improve learning, apply knowledge, reflect on the territory and motivate students.

The results of the first phase of the PIME are presented here, in which using a methodology based on implicative and reflexive techniques, three commercialized games are tested. The games tested propose extreme situatins: absolutely cooperative, absolutely competitive, with collaboration being a commercial instrument and sustainability a principle that is little contemplated or nullified. However, each provide elements and that, properly combined into the very model of game playing techniques interesting, may be useful for improving learning and therefore the results of students of Urban and Regional Planning, ultimate end of PIME that is presented here.
\end{abstract}

Keywords: game learning, active methodology, cooperation-opposition game, spatial planning

\section{Resumen}

El aprendizaje lúdico como estrategia didáctica en materias de Ordenación del Territorio y Urbanismo es el reto del Proyecto de Innovación y Mejora Educativa (PIME) "El territorio en juego". Se pretende construir un entorno de enseñanza-aprendizaje que estimule 
al alumnado a crear su propio conocimiento y experiencia, a través del diseño de un juego de mesa. La propuesta está diseñada para paliar las debilidades y amenazas detectadas, potenciar las fortalezas y aprovechar las posibilidades del recurso lúdico didáctico, para mejorar el aprendizaje, aplicar conocimientos, reflexionar sobre el territorio y motivar al alumnado.

Se presentan aquí los resultados de la primera fase del PIME, en la cual utilizando una metodología basada en técnicas implicativas y reflexivas, se testean tres juegos comercializados. Los juegos testeados nos sitúan ante situaciones que se posicionan en los extremos: absolutamente cooperativo-absolutamente competitivo, siendo la colaboración un instrumento comercial y la sostenibilidad un principio escasamente contemplado o anulado. Sin embargo, cada uno de ellos proporcionan elementos y técnicas de juego interesantes que, adecuadamente combinados en el modelo propio de juego, pueden ser útiles para mejorar el aprendizaje y por tanto los resultados de los alumnos de Urbanismo y Ordenación del Territorio, fin ultimo del PIME que aquí se presenta.

Palabras clave: aprendizaje lúdico, metodología activa, juego de cooperación-oposición, ordenación del territorio.

\section{Introducción}

El presente trabajo se aborda a partir de los fundamentos y claves en los que inscribe el Proyecto de Innovación y Mejora Educativa (PIME) denominado "El aprendizaje lúdico como estrategia didáctica: el territorio en juego", perteneciente a la convocatoria de Proyectos de Innovación y Mejora Educativa del Vicerrectorado de Estudios, Calidad y Acreditación de la Universitat Politècnica de València, y cofinanciado por la Escuela Superior de Ingenieros de Caminos, Canales y Puertos, correspondiente a la convocatoria de 2017 y que llegará a su fin en 2019.

El proyecto nace de la experiencia docente en aquellas asignaturas relacionadas con el área de conocimiento del Urbanismo y de la Ordenación del Territorio que actualmente se imparten en las escuelas de Ingeniería de Caminos, Canales y Puertos, de Arquitectura y de Ingeniería Geodésica, Cartográfica y Topográfica de la Universitat Politècnica de València, a lo que se une el conocimiento del profesorado implicado en el proyecto en juegos de mesa relacionados con las competencias necesarias para abordar una disciplina tan compleja y con un alto nivel de abstracción, como es el Urbanismo y la Ordenación del territorio. 
Desde hace varios años, en la universidad se está produciendo un descenso en el número de alumnos matriculados en las carreras de ingeniería que se encuentran directamente relacionadas con la obra civil y la construcción en general. Este hecho ha supuesto un descenso en la exigencia de acceso a este tipo de titulaciones, tradicionalmente elegidas por alumnos con un alto expediente académico. De este modo, se ha producido una modificación en el perfil del alumnado de nuevo ingreso de la universidad, que acceden a la misma con una nota de corte de $5^{1}$, lo que, salvo excepciones, supone que el alumnado medio actual que se matricula en estas ingenierías accede con un nivel académico mediobajo. Además, su primera opción no era el título en el que se matricula y por lo tanto, accede con una menor motivación que el matriculado años anteriores.

Por otro lado, las asignaturas de Ordenación del Territorio y Urbanismo son complejas. Se trata de una disciplina con un enfoque transversal y global, lo que supone la incorporación necesaria de un pensamiento complejo de alto nivel y de abstracción lo que dificulta el aprendizaje profundo en el alumno. Esto último constituye un aspecto de especial importancia a tener en cuenta en la propuesta educativa de esta disciplina. La problemática se acentúa aún más en los primeros cursos, especialmente en primero y segundo curso de grado, donde el alumnado no dispone del bagaje y la madurez suficiente para abordar con éxito estas temáticas. Todo ello supone una dificultad añadida al aprendizaje del estudiante, así como una escasa motivación, que se pone de manifiesto en las asignaturas troncales de los primeros cursos (71 estudiantes en la asignatura de Transporte y Territorio del Grado de Ingeniería Civil, 46 estudiantes en Urbanismo y Territorio del Grado en Ingeniería de Obras Públicas y 96 estudiantes en Urbanismo y Ordenacion del Territorio en el Master de Caminos, Canales y Puertos). Como consecuencia de todo lo anterior, nos encontramos, en los cursos siguientes, con una bajo índice de matriculación en las asignaturas optativas adscritas a esta área de conocimiento: es el caso de la optatividad en tercero y cuarto tanto en el Grado de Ingeniería Civil como en el Grado en Ingeniería de Obras Públicas, así como en el Master de Caminos, Canales y Puertos.

De la observación de esta realidad en los últimos años, nace la propuesta del Proyecto de Innovación y Mejora Educativa (PIME), cuyo objetivo es el de crear un juego de mesa como recurso lúdico-educativo para mejorar el proceso de aprendizaje en las asignaturas de Urbanismo y Ordenación del Territorio, bajo los principios de la cooperación y la competición, en el que se pone de manifiesto el conflicto y el consenso sobre decisiones territoriales. Todo esto se canaliza, mediante la asunción de roles que representan los distintos agentes sociales que, actúan dentro de un marco definido en las propias reglas del juego, que pretenden reproducir los criterios básicos de lo que supone una ocupación racional y sostenible del suelo. De este modo, para ganar, los jugadores compiten entre sí para cumplir sus objetivos, pero para ello es necesario que la "sociedad" creada alcance

\footnotetext{
${ }^{1}$ En las 2 titulaciones oficiales de grado de la Escuela de Caminos Canales y Puertos involucradas en el PIME, Grado de Ingeniería Civil y Grado en Ingeniería de Obras Públicas, según datos de Informe 2015-2016 de la Dirección General de Universidad y Estudios Superiores de la GVA
} 
ciertos niveles de "calidad y bienestar social", siendo necesario para ello que se trabajen valores transversales como la colaboración y la sostenibilidad.

El PIME se estructura en distintas fases entre los que se encuentra, en primer lugar, testear la idoneidad del uso de juegos como recurso didáctico para la enseñanza de la ordenación del territorio, como elemento motivador del aprendizaje del alumnado. En este trabajo se presentan los resultados obtenidos en la primera fase realizada por el equipo docente de 10 profesores del Departamento de Urbanismo de la Universitat Politècnica de València que compone el PIME: El aprendizaje lúdico como estrategia didáctica: el territorio en juego, el testeo de diferentes juegos comerciales.

\section{Objetivos}

El objetivo general de esta comunicación es presentar los resultados del testeo de tres juegos comerciales utilizados como recurso didáctico para la ordenación del territorio por el equipo docente que desarrolla el PIME, y que se inscribe en la primera fase de dicho proyecto. A partir de dicho objetivo general tenemos otros objetivos específicos:

1. Describir la metodología empleada en el testeo de los juegos.

2. Extraer el aprendizaje que para el urbanismo y la ordenación del territorio, nos ofrecen diferentes juegos comerciales

\section{Fundamentos y desarrollo de la innovación}

El juego didáctico es una estrategia de enseñanza y aprendizaje que se puede usar en cualquier etapa educativa. La actividad lúdica es atractiva, motivadora y capta la atención (Chacón, 2008). Además, la relación entre juego y aprendizaje es natural pues desde la infancia el juego es parte del aprendizaje. Su utilización es relativamente común en la enseñanza de las matemáticas en edades tempranas. Sin embargo, su presencia es muy limitada en el ámbito universitario (Gaete-Quezada, 2010). Esto se debe a dos motivos principales: en primer lugar, el desconocimiento de los docentes en cuanto a sus ventajas (Chacón, 2008); y en segundo lugar, por una docencia universitaria muy a menudo anclada en paradigmas tradicionales, donde el profesor tiene un rol central y el alumno y la alumna un rol pasivo (Gaete-Quezada, 2010). El juego en aula proporciona una herramienta que facilita la comprensión de los contenidos teóricos, pues la complejidad para comprender la teoría está vinculada con los distintos niveles de abstracción: lo intangible es más complejo de comprender que lo tangible. El recurso lúdico-didáctico que aquí se propone, pretende precisamente investigar cómo llevar la complejidad territorial al aula de forma tangible (Sosa y Peréz, 2014:60).

Entre los diferentes juegos se pueden establecer "tipos" relacionados con el proceso educativo (Ripoll, 2006:17-18):

- Juegos individuales: el jugador no tiene oponentes, juega superando hitos alcanzados en partidas anteriores.

(cc) EY-NC-ND 2018, Universitat Politècnica de València

Congreso IN-RED (2018) 
- Juegos de oposición: el jugador no tiene compañeros pero sí oponentes y debe jugar para superarlos.

- Juegos de cooperación: no existen oponentes, solo compañeros. Entre todos se tiene que superar un reto, buscando una estrategia común.

- Juegos de cooperación-oposición: existen compañeros y oponentes. Cada uno de los grupos juega a superar al resto buscando estrategias comunes que resulten óptimas.

El juego constituye una gran oportunidad para la mejora del aprendizaje y eso resulta particularmente interesante en lo que se refiere a la adquisición de competencias en Urbanismo y Ordenación del Territorio. Con el uso de este tipo de estrategia lúdica, se pretende poner en situación al alumnado, construyendo un entorno que estimule al estudiante a crear su propio conocimiento y experiencia (Chacón, 2008), pues permite trabajar todas las fases del proyecto; desde el establecimiento de objetivos, el diagnóstico y el establecimiento de una propuesta, todo ello, "pasando por la divergencia o generación de ideas, hasta la convergencia en soluciones prácticas. Permiten además, romper las barreras y mejorar la comunicación en el grupo y generar nuevas ideas, visiones y estrategias" (Gonzalez, 2014:4). Con el juego se aprende a hacer, lo cual permite al alumnado la adquisición de competencias para su calificación profesional y enfrentarse a situaciones diversas y trabajar en equipo, dentro de los marcos sociales y laborales donde desarrolla su vida (Delors, 1996: 34).

De este modo, el juego se convierte en una potente herramienta para abordar la enseñanza-aprendizaje dentro de disciplinas complejas y con alto nivel de abstracción como son el Urbanismo y la Ordenación del Territorio. Esta disciplina posee un enfoque multicriterio centrado en la solución de problemas, en base a un trabajo interdisciplinario, donde intervienen múltiples agentes con intereses diferenciados y, por lo tanto, propuestas de actuación también diferenciadas. Todo este proceso culmina en la toma de decisiones después de un complejo trabajo de integración y aprendizaje permanente.

Con enfoques similares, existen experiencias en técnicas de simulación y juegos para la educación ambiental ya antiguas como el "Modelo CLUG (Community Land Use Game)", diseñado por Allan Felt (1972). Se trata de un juego de tablero cuyas reglas son representativas de los factores que intervienen en la forma del crecimiento urbano, reproduciendo las interacciones en la economía y desarrollo del suelo (Taylor, 1983).

En el ámbito educativo, "Flood Resilience Game” es un juego desarrollado por "Zurich Flood Resilience Alliance y el Institute International of Applied Systems Analysis", que se ha usado en Perú para concienciar y educar a los ciudadanos que viven en zonas inundables. Existen otros ejemplos en tablero como "The Game of Urban Renewal". Sobre esta temática también existen algunas app educativas como "Move a lot" desarrollado para Android por la oficina catastral holandesa (Kadaster).

También, se han desarrollado comercialmente numerosos juegos de estrategia, que serán también objeto de análisis en este trabajo. 


\section{Metodología}

El Proyecto de Innovación y Mejora Educativa mencionado presenta una articulación metodológica por complementación encadenada, esto es, la combinación de la metodología cuantitativa y cualitativa en diferentes fases consecutivas.

Para la fase primera, en la que se inscribe el testeo de juegos, se utilizó metodología cualitativa, concretamente una técnica implicativa y reflexiva denominada "matriz de escenarios presentes y futuros” (Montañés, 2009:121). Este tipo de herramienta permite la construcción colectiva de una matriz diagnóstico que da visibilidad a los aspectos, tanto positivos como negativos, presentes en el juego que se analiza, así como aquellos que pueden mejorar o pertubar la aplicación docente del juego en materias que tienen que ver con el Urbanismo y la Ordenación del Territorio. Así se definen cuatro cuadrantes, dos positivos y dos negativos enfrentados: "lo que hay y me gusta, lo que hay y no me gusta, lo que no hay y me gustaría que hubiera y lo que no hay y no me gustaría que hubiera”.

Dicha metodología se aplicó, concretamente, a tres juegos que están en el mercado y que pasamos a tipificar brevemente.

\section{1.-Juegos seleccionados.}

La selección de los juegos de tablero objeto de análisis se realizó bajo principios que nos permitiesen abarcar diferentes modalidades presentes: de estrategia colectiva y/o individual, colaborativo y/o competitivo, cubriendo de esta forma la tipificación realizada por Ripoll (2006) y recogida en líneas anteriores.

Los juegos de mesa seleccionados y sus características básicas son las siguientes:

- Honshú (Fig. 1): es un juego de losetas (en este caso cartas), diseñado por Kalle Malmioja y editado por “Games for Gamers", que se desarrolla en varias rondas de juego. En cada una de ellas pujaremos por obtener una carta de mapa que una vez adquirida colocaremos en nuestro mapa inicial. El objetivo es ir ampliando nuestro territorio en los diferentes tipos de terreno existentes para obtener puntos de victoria al final de la partida, según la carta de resumen de puntuación multicriterio que cada uno tiene.

Se trata de un un juego individualista y de oposición. Cada participante juega solo y compite con los otros jugadores en la construcción y ordenación de un territorio sin una base previa, a través de un sistema de cartas. Su carácter es estructural y estratégico.

(cc) EY-NC-ND 2018, Universitat Politècnica de València

Congreso IN-RED (2018) 


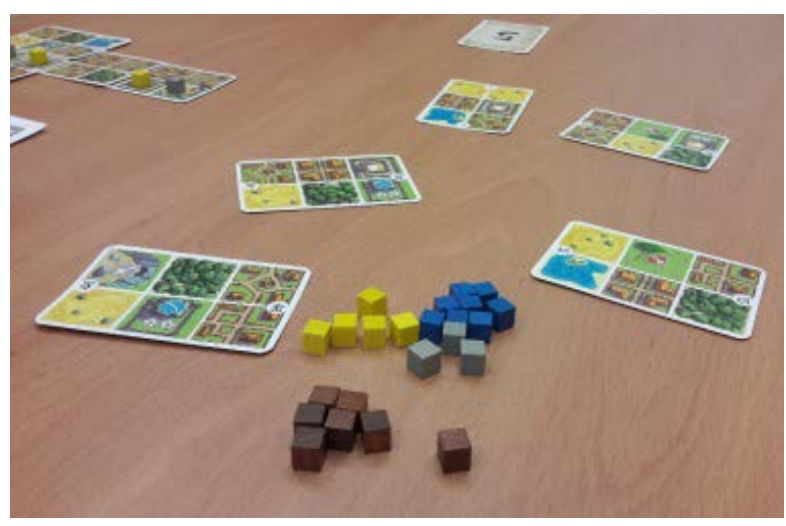

Fig. 1 Juego Honsú

- Catán en sus modalidades básica y extensión recurso petróleo (Fig. 2): es un clásico juego de estrategia alemán inventado por Klaus Teuber y editado en España por Devir Iberia donde, en su versión básica, los jugadores compiten para ver quien consigue colonizar una isla de una manera más ordenada y eficiente, recolectando las materias primas necesarias, así como negociando con los demás jugadores para conseguir esos recursos que necesitan para construir caminos, aldeas, ciudades, puertos, etc. Sobre este mismo juego, se ha desarrollado una versión no comercial y de uso libre llamada "Oilsprings". Se trata de un escenario ecológico de la versión de base donde el jugador tiene que lidiar con el agotamiento de los recursos cambio climático y otros desafíos ambientales que se producen como consecuencia de un consumo excesivo de recursos ${ }^{2}$.

Catán es un juego individualista y de oposición. Cada participante juega solo y compite con los otros jugadores en la dominación de territorio. Permite negociar con otros jugadores para la adquisión de recursos y evitar riesgo ecológico. Posee tablero que delimita el territorio. Su carácter es estructural y estratégico.

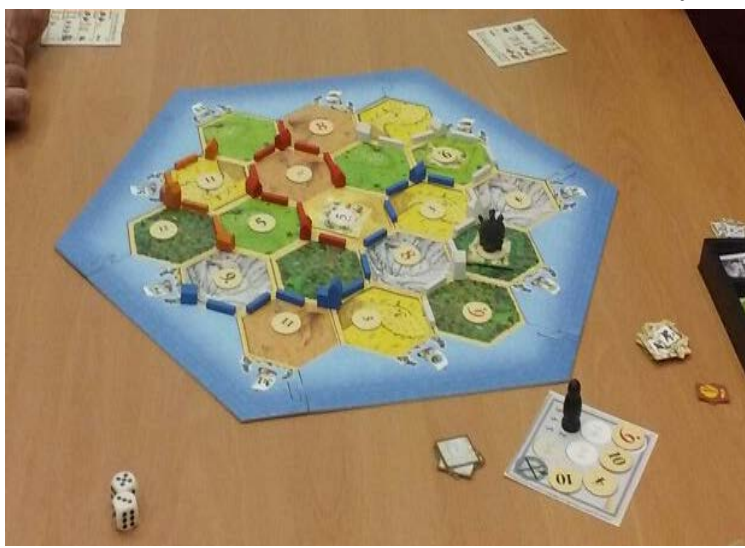

Fig. 2. Juego Catán

\footnotetext{
${ }^{2}$ http://www.oilsprings.catan.com
} 
- $\quad$ La Isla Prohibida (Fig. 3): es un juego colaborativo, diseñado por Matt Leacock y editado por Devir Iberia en España, en el que los jugadores deben evacuar una mítica isla misteriosa y para ello han de conseguir unos tesoros, necesarios para la evacuación de las personas, antes de que las aguas la inunden por completo y el territorio quede sumergido.

Se trata de un juego de cooperación, ganan todos o pierden todos, en la superación del reto (riesgo) que el propio juego establece. Posee un tablero que delimita el territorio. Su carácter es estratégico y requiere la toma de decisiones consensuadas por todos los participantes.

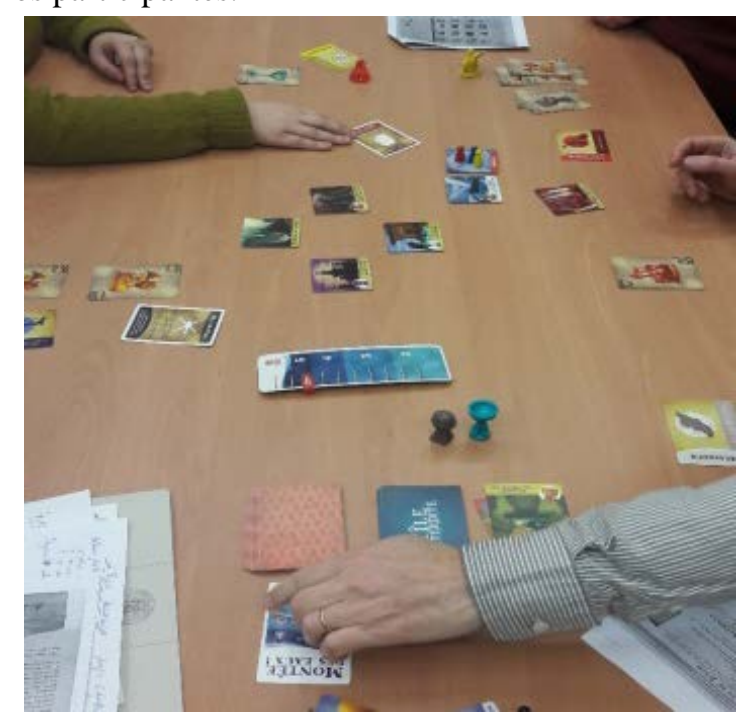

Fig. 3. Juego La isla prohibida

El testeo de los juegos, por parte del equipo docente que desarrolla el PIME, se realizó entre los meses de diciembre de 2017 y febrero de 2018, y los resultados obtenidos se abordan en las próximas líneas.

\section{Resultados}

Las pruebas realizadas a los juegos señalados arrojan el siguiente diagnóstico:

- $\quad$ El juego Honshú potencia el individualismo y la competitividad, pedagógicamente no aporta el aprendizaje de trabajo en equipo y cooperación, sin embargo, desde el punto de vista de la didáctica en ordenación de territorio y urbanismo, facilita el aprendizaje en el ámbito de la estructuración del territorio, incorpor conceptos como el de zona de valor ecológico y recursos naturales, y trabaja otros como los de de compacidad, continuidad y sostenibilidad medioambiental. Además, el sistema de puntuación permite la aproximación a la evaluación multicriterio. No obstante, es un modelo de juego sin roles ni jerarquías, lo que nos aleja de la realidad socio-territorial.

- $\quad$ El juego que más incide en las competencias transversales de trabajo en equipo, es $L a$ isla prohibida. La incorporación de esta competencia en el aprendizaje del estudiante,

(c)) BY-NC-ND 2018, Universitat Politècnica de València

Congreso IN-RED (2018) 
entronca con los principios de cooperación y colaboración, esenciales para alcanzar o aproximarnos al concepto y el hacer hacia la sostenibilidad. Además, el juego introduce el riesgo territorial como punto base, y estructura a los participantes en roles que tienen que les obliga a coordinarse en sus acciones, pero por el contrario, anula la competitividad. Con todo lo descrito también supone un modelo de juego que se aleja de la realidad socio-territorial.

- El juego Catán presenta un modelo de sociedad capitalista librecambista: control y dominio de territorios, recursos, comunicaciones y personas. Por tanto sí que refleja, en este caso, la realidad socio-territorial, afectada por jerarquías. Desde el punto de vista estructural nos enseña que la formación de poblados y ciudades está condicionada a elementos de localización y conectividad, y las vías de comunicación sólo puede bordear recursos territoriales, nunca atravesarlos. Además, permite incorporar al escenario límites al crecimiento: el recurso es agotable (petróleo) y su uso puede provocar efectos negativos (contaminación, catástrofes medio ambientales, etc.). Desde el punto de vista socio-económico la dinámica del juego sólo permite negociaciones y transacciones comerciales, no existe la cooperación, generando espacios (jugadores) segregados tanto físicamente como en su acceso a los recursos. Presenta por tanto, un concepto extremo de explotación del territorio y enseña lo contrario a la sostenibilidad.

De los resultados aquí recogidos, ninguno de estos juegos comerciales y analizados permite su inclusión completa y directa en didácticas de ordenación del territorio, puesto que no incluyen principios de colaboración y de competitividad, que nos lleven hacia la sostenibilidad. Se sitúan dentro de extremos opuestos: o cooperación u oposición; la combinación de ambos principios no se produce. Sin embargo, cada uno de los juegos testeados proporcionan elementos y técnicas de juego interesantes que adecuadamente combinados permitiría definir un modelo propio de juego que mejorase el aprendizaje profundo, y por tanto los resultados de aprendizaje, de los alumnos de Urbanismo y Ordenación del Territorio, fin ultimo del PIME que aquí se presenta.

\section{Conclusiones}

El aprendizaje lúdico como estrategia didáctica en materias de Ordenación del Territorio y Urbanismo, a través del diseño de un juego de mesa, es el reto que se propone alcanzar el equipo docente que compone el PIME El territorio en juego, de modo que se genere una metodología activa, construyendo un entorno de enseñanza-aprendizaje que estimule al alumnado a crear su propio conocimiento y experiencia, esencial para que subsuma principios y conceptos básicos de la complejidad territorial.

Uno de los primeros pasos, esenciales para alcanzar este reto, es testear los juegos comerciales que se acercan en su temática a la materia docente, de modo que podamos probarlos para extraer aprendizajes que podamos volcar en un nuevo diseño.

Utilizando una metodología basada en técnicas implicativas y reflexivas, se testean, por el profesorado participante en el PIME, tres juegos comercializados con el fin de investigar

(cc) EY-Nc-No 2018, Universitat Politècnica de València

Congreso In-Red (2018) 
cómo llevar la complejidad territorial al aula de forma tangible y lúdica. Las pruebas realizadas en juegos comercializados, nos sitúan ante situaciones que se posicionan en los extremos: absolutamente cooperativo-absolutamente competitivo, siendo la colaboración un instrumento comercial y la sostenibilidad un principio escasamente contemplado o anulado.

La creación y diseño de un juego didáctico para la ordenación del territorio deberá acercarse, desde distintos niveles, a la complejidad socio-territorial, donde cooperación y oposición pueden ocurrir casi simultáneamente entre los diferentes agentes, donde el trabajo en equipo pueda ser fundamental en la definición de estrategias y donde la concepción de la sostenibilidad en la creación, construcción y desarrollo del territorio esté presente en la simbología y códigos del juego.

\section{Referencias}

CHACÓN, P. (2008) . “ El Juego Didáctico como estrategia de enseñanza y aprendizaje. ¿Cómo crearlo en el aula?” Nueva Aula Abierta, $\mathrm{n}^{\circ}$ 16. <http://www.ehistoria.cl/cursosudla/13-EDU413/lecturas/06\%20\%20El\%20Juego\%20Didactico\%20Como\%20Estrategia\%20de\%20Ense\%C3\%B1anza\% 20y\%20Aprendizaje.pdf $>$ [Consulta: 22 de marzo 2018]

DELORS, J. (1996). La educación encierra un tesoro 2. Informe a la UNESCO de la Comisión Internacional para la Educación del siglo XXI. Santillana, Ediciones UNESCO $<$ http://www.unesco.org/education/pdf/DELORS_S.PDF > [Consulta: 20 de marzo 2017].

GAETE-QUEZADA, R.A. (2011). "El juego de roles como estrategia de evaluación de aprendizajes universitarios”. Educación y Educadores, Vol. 14, n $\mathrm{n}^{\circ}$ 2, pp. 289-307 $<$ http://educacionyeducadores.unisabana.edu.co/index.php/eye/article/view/1923/2512> $>$ [Consulta: 23 de marzo 2017]

GONZÁLEZ GONZÁLEZ, C.S. (2014). "Estrategias para trabajar la creatividad en la Educación Superior: pensamiento de diseño, aprendizaje basado en juegos y en proyectos". RED. Revista de Educación a Distancia, $\mathrm{n}^{\circ} \quad 40, \quad$ pp. $1-15$ $<$ http://revistas.um.es/red/article/view/234291/180001> [Consulta: 04 de abril 2017]

MONTAÑÉS SERANO, M. (2009). “Técnicas al servicio del proceso investigador”. En Montañés Serrano, M. Metodología y práctica participativa. Teoría y práctica de una estrategia de investigación participativa. Barcelon: Editorial UOC, pp. 127-170.

TAYLOR, J. (1983). Guía sobre simulación y juegos para la educación ambiental. UNESCO-PNUMA <http://unesdoc.unesco.org/images/0005/000569/056905so.pdf > [Consulta: 03 de abril 2017].

SOSA ESPINOSA, A.; PEREZ ALONSO, Y. (2014). "Role playing: Una buena herramienta para aprender”. En Martí Selva, ML.; Calafat Marzal, MC. (2014). I Jornadas de Investigación de la Facultad de ADE. Editorial Universitat Politècnica de València. Disponible en $<$ https://riunet.upv.es/handle/10251/43966 $>$ [Consulta: 5 de abril de 2017].

(cc) EY-NC-ND 2018, Universitat Politècnica de València

Congreso IN-RED (2018) 
Asenet Sosa Espinosa, Eric Gielen, José Sergio Palencia Jiménez, Yaiza Pérez Alonso, María Salomé Moreno Navarro, Rafael Ramón Temes Córdovez, Jose Luis Miralles Garcia, Maria Mercedes

Trenor Galindo

RIPOLL, O. (2006). “El juego como herramienta educativa”. Educación social: Revista de intervención socioeducativa. Núm. 33, pp. 11-27

$<$ http://www.raco.cat/index.php/EducacioSocial/article/viewFile/165533/373756>

[Consulta: 2 de febrero de 2018].

(c) EY-NC-ND 2018, Universitat Politècnica de València

Congreso In-Red (2018) 


\title{
Estrategia para coordinar las competencias transversales en ingeniería nuclear
}

\author{
Sergio Gallardo ${ }^{\mathrm{a}}$, José Felipe Villanueva ${ }^{\mathrm{b}}$, Sofía Carlos ${ }^{\mathrm{c}}$, Sebastián Martorell ${ }^{\mathrm{d}}$ y Ana \\ Isabel Sánchez ${ }^{\mathrm{e}}$
}

${ }^{a}$ Dpto. de Ingeniería Química y Nuclear, Universitat Politècnica de València, Spain, email: sergalbe@iqn.upv.es; 'Dpto. de Ingeniería Química y Nuclear, Universitat Politècnica de València, Spain, email: jovillo0@upvnet.upv.es; 'DDto. de Ingeniería Química y Nuclear, Universitat Politècnica de València, Spain, email: scarlos@iqn.upv.es; ${ }^{\mathrm{d}}$ Dpto. de Ingeniería Química y Nuclear, Universitat Politècnica de València, Spain, email: smartore@iqn.upv.es; ${ }^{e}$ Dpto. de Estadística e Investigación Operativa Aplicadas y Calidad, Universitat Politècnica de València, Spain, email: aisanche@eio.upv.es

\begin{abstract}
The current curricula of the European Higher Education Area (EHEA) include a series of transversal and specific competences that students must acquire at the end of the different degrees. Through the accreditation process Accreditation Board for Engineering and Technology (ABET), carried out in some degree programs at the Universitat Politècnica de València (UPV), the need to evaluate and obtain evidence of competences, mainly transversal, has been highlighted. Coordination is essential to ensure this point. However, coordination must not remain solely at the level of the entire degree (bachelor or master), but must descend to the level of the subjects. A very specific case is that related to the nuclear engineering field. The purpose of this work is to develop a methodology that systematizes the conceptual coordination of the design of activities, establishment of indicators and coherence of the evaluation of different transversal competences. In the "Results" section, the coordination of the transversal competency "Knowledge of Contemporary Problems" is shown.
\end{abstract}

Keywords: Transversal competencies, nuclear engineering, assessment, indicators.

\footnotetext{
Resumen

Los actuales planes de estudio del Espacio Europeo de Educación Superior (EEES) incluyen una serie de competencias transversales y específicas que deben adquirir los alumnos al finalizar las distintas titulaciones. A través del proceso de acreditación "Accreditation Board for Engineering and Technology" (ABET), llevado a cabo en algunas titulaciones en la Universitat Politècnica de València (UPV), ha quedado patente la necesidad de evaluar y de obtener evidencias de las competencias, principalmente transversales, que deben trabajarse en las titulaciones en cuestión. La coordinación es esencial para poder asegurar este punto. Sin embargo, la
} 
coordinación no debe quedarse únicamente en el nivel de toda la titulación, bien sea grado o máster, sino que debe descender al nivel de las materias. Un caso muy concreto es el relativo a las asignaturas del ámbito de tecnología nuclear. La finalidad de este trabajo es desarrollar una metodología que sistematice la coordinación conceptual del diseño de actividades, establecimiento de indicadores y coherencia de la evaluación de diferentes competencias transversales. En el apartado de "Resultados" se muestra cómo se realizado la coordinación en la competencia "Conocimiento de problemas contemporáneos".

Palabras clave: Competencias transversales, ingeniería nuclear, evaluación, indicadores.

\section{Introducción}

El Espacio Europeo de Educación Superior (EEES) tiene como uno de sus principales objetivos, que los alumnos adquieran una serie de competencias específicas y transversales al finalizar las distintas titulaciones (Sanz de Aceo, 2010). En este contexto queda patente la necesidad explícita de evidenciar la consecución de dichas competencias. Tradicionalmente, el personal docente no ha tenido ningún problema al establecer, trabajar, evaluar y evidenciar la consecución de las competencias específicas por asignaturas y materias en la titulación. Este proceso está completamente integrado en la forma de trabajo de los docentes y tiene, en general, una estrecha relación con la faceta investigadora de cada uno. Sin embargo, el establecimiento, aplicación y evaluación de las competencias transversales ha quedado, en términos generales, relegado a un segundo plano hasta ahora (Villa et al, 2007). En este sentido, la Universitat Politècnica de València, a través del proyecto institucional "Competencias Transversales UPV" (UPV, 2015) ha definido dos objetivos principales: a) Establecer una estrategia de evaluación sistemática de las competencias transversales, definiendo dónde se adquieren y cómo deben ser evaluadas y b) Acreditar la adquisición de dichas competencias. Los beneficios derivados del éxito de este proyecto son: a) Proporcionar a sus egresados un valor añadido diferenciador de otros egresados, b) Poner en valor la capacitación de los egresados de cara a los empleadores y c) Explicitar la adquisición de las competencias para acreditaciones internacionales. Garantizar la adquisición de las competencias no es un hecho trivial. Por ello, el proyecto institucional de la UPV propone tres vías para ello: las titulaciones, el Trabajo Fin de Grado y/o Trabajo Fin de Máster (TFG/TFM) y actividades extracurriculares (trabajo en departamentos, institutos, empresas, organizaciones, cursos de formación posgrado, etc.). Además, establece tres niveles de dominio para aumentar progresivamente el grado de profundización del alumnado en cada competencia. La UPV ha establecido 13 competencias que caracterizan globalmente el perfil competencial del egresado. Las Escuelas y Facultades han realizado una importante labor de coordinación entre materias y entre asignaturas para asegurar que todas las competencias se trabajan en los diferentes niveles de dominio a través de las tres vías mencionadas. Descendiendo al nivel de las asignaturas, resulta evidente la necesidad de establecer grupos de trabajo entre asignaturas

(cc) EY-NC-ND 2018, Universitat Politècnica de València

Congreso IN-RED (2018) 
afines para que los profesores establezcan criterios uniformes para la definición de parámetros de trabajo, evaluación y evidenciación de las competencias (UPV, 2015b). La coordinación es esencial para poder asegurar este punto. Un caso muy concreto es el relativo a las asignaturas del ámbito de ingeniería nuclear. La especificidad de contenidos obliga a redoblar los esfuerzos de coordinación para evitar solapes y asegurar un diseño, desarrollo y evaluación coherente de las competencias transversales y específicas (Gallardo et al., 2015 y Villanueva et al., 2016). La coordinación exige realizar un ejercicio de síntesis de contenidos y mostrar de forma explícita la integración de las distintas asignaturas, en este caso del campo de conocimiento de nuclear.

\section{Objetivos}

El objetivo principal de este trabajo es establecer una metodología que permita sistematizar las actividades y tareas relacionadas con la coordinación de competencias transversales en asignaturas del ámbito de la ingeniería nuclear. Con este fin se establecen los siguientes objetivos específicos:

- Puesta en común del significado de cada una de las competencias transversales para los profesores involucrados. Alcanzar una definición consensuada de cada competencia.

- Consensuar el perfil competencial del alumno egresado en materias de ingeniería nuclear.

- Obtención de rúbricas en función de la competencia, vía y nivel de dominio. Establecimiento de indicadores comunes entre asignaturas.

- Realimentación a los profesores respecto del grado de implantación y resultados de la metodología.

\section{Desarrollo de la innovación}

\subsection{Las asignaturas}

En los últimos años, se ha detectado una falta de coordinación en materia de competencias transversales en las asignaturas que se imparten en el Dpto de Ingeniería Química y Nuclear de la Universitat Politècnica de València. El presente trabajo se centra en las asignaturas que imparte la Unidad Docente (UD) de Ingeniería Nuclear. Dicha Unidad imparte docencia en los siguientes Grados: Ingeniería en Tecnologías Industriales (GITI), Ingeniero de la Energía (GIE), Ingeniería en Organización Industrial (GIOI), Ingeniería Química (GIQ) e Ingeniería Biomédica (GIB). Además, se imparte docencia en el Máster Universitario (MU) de Ingeniería Industrial, $\mathrm{MU}$ en Seguridad Industrial y Medio Ambiente y en el MU en Tecnología Energética para el Desarrollo Sostenible. La UD de Ingeniería Nuclear imparte docencia en asignaturas relacionadas con la generación y el uso de la energía (energías renovables, energía nuclear, termohidráulica, aplicaciones de las radiaciones ionizantes, etc.). En este contexto, con docencia en múltiples grados y másteres es difícil realizar una coordinación a nivel global, por lo que se ha propuesto comenzar por 
una coordinación en el Grado de Ingeniero de la Energía, ya que es el Grado con mayor número de asignaturas en las que imparte docencia Ingeniería Nuclear:

- Energía y Desarrollo Sostenible: curso $2^{\circ}$ B. Asignatura Obligatoria. Número de créditos: 6

- Tecnología Nuclear: curso $4^{\circ} \mathrm{A}$. Asignatura Obligatoria. Número de créditos: 6

- Centrales Nucleares Avanzadas: curso $4^{\circ}$ B. Asignatura Optativa. Número de créditos: 4,5

- Seguridad Nuclear: curso $4^{\circ}$ B. Asignatura Optativa. Número de créditos: 4,5

- Operación de Reactores Nucleares: curso $4^{\circ}$ B. Asignatura Optativa. Número de créditos: 4,5

- Protección Radiológica: curso $4^{\circ}$ B. Asignatura Optativa. Número de créditos: 4,5

La asignatura "Energía y Desarrollo Sostenible" es introductoria y totalmente descriptiva, mientras que las asignaturas de $4^{\circ}$ curso son muy específicas y de marcado carácter nuclear. Muchas de las asignaturas de $4^{\circ}$ pertenecen a la optatividad y cuentan con un reducido número de alumnos.

\subsection{Las competencias transversales}

Las asignaturas mencionadas en el apartado anterior son punto de control de diferentes competencias, tal y como se muestra en la Tabla 1. Las competencias con mayor peso en estas asignaturas son: Comprensión e integración; Aplicación y pensamiento práctico; Responsabilidad ética, medioambiental y profesional; Conocimiento de problemas contemporáneos e Instrumental específica.

Tabla 1. Distribución de competencias transversales por asignaturas.

\begin{tabular}{|c|c|c|c|c|c|c|c|c|c|c|c|c|c|}
\hline & 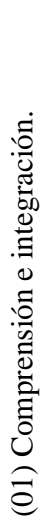 & 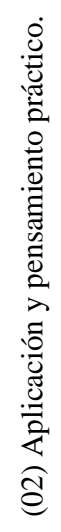 & 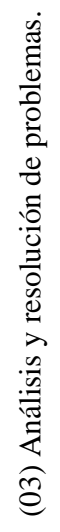 & 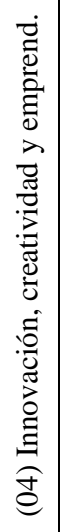 & 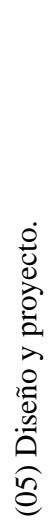 & 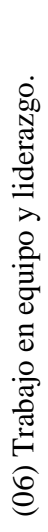 & 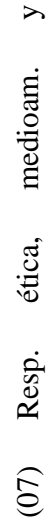 & 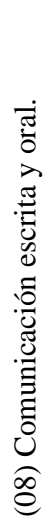 & 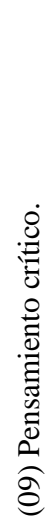 & 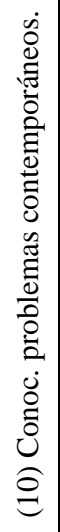 & 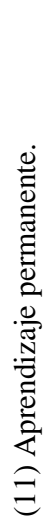 & 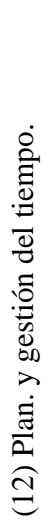 & 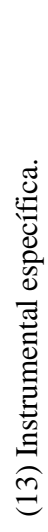 \\
\hline Energía y Desarrollo Sostenible & & & & & & & $x$ & & & $\mathrm{x}$ & & & $\mathrm{X}$ \\
\hline Tecnología Nuclear & & $\mathrm{x}$ & & & & & & & & $x$ & & & $\mathrm{x}$ \\
\hline Centrales Nucleares Avanzadas & & $\mathrm{x}$ & & & & & & & & $x$ & & & \\
\hline
\end{tabular}

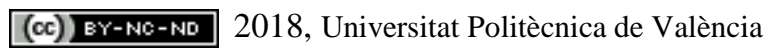

Congreso IN-RED (2018) 


\begin{tabular}{|l|l|l|l|l|l|l|l|l|l|l|l|l|l|}
\hline Seguridad Nuclear & $\mathrm{x}$ & & & & & & & & & $\mathrm{x}$ & & & $\mathrm{x}$ \\
\hline $\begin{array}{l}\text { Operación de Reactores } \\
\text { Nucleares }\end{array}$ & $\mathrm{x}$ & & & & & & & & & & & & $\mathrm{x}$ \\
\hline Protección Radiológica & $\mathrm{x}$ & & & & & & & & & $\mathrm{x}$ & & & $\mathrm{x}$ \\
\hline
\end{tabular}

\subsection{La reunión inicial}

Una vez caracterizado el escenario en cuanto a las asignaturas y competencias, es necesario entablar un debate para dirimir el significado de cada competencia. Esta reunión pretende uniformizar los conceptos de partida, eliminar ideas preconcebidas y prejuicios. Se podría pensar que el propio enunciado de la competencia es suficiente para determinarla, pero el trabajo diario ha demostrado que no todos los profesores conciben la misma competencia de igual forma, en ocasiones por interpretaciones erróneas de la misma o simplemente por desconocimiento. Queda pues patente, que es necesario planificar una primera reunión para acordar su significado. Un claro ejemplo de errores de concepto aparece cuando se trabaja la “Análisis y resolución de problemas”. Algunos profesores piensan erróneamente que esta competencia consiste en plantear y resolver problemas de una determinada asignatura y no en establecer estrategias y metodologías para resolver problemas (de cualquier tipo) de una forma sistematizada. Otro ejemplo, ¿Qué entendemos por "Conocimiento de Problemas Contemporáneos”? ¿En qué se diferencia un problema contemporáneo de cualquier otro problema? A priori, son preguntas que parecen tener fácil respuesta hasta que se realiza un análisis en profundidad. La reunión se planifica en el calendario académico antes de publicar las Guías Docentes y debe servir para establecer las bases sobre las que se va a construir toda la estructura docente. Para ayudar a consensuar los conceptos que se van a utilizar, se ha realizado una búsqueda en el Portal de Buenas Prácticas Docentes el Ministerio de Educación, Ciencia y Deporte, para localizar experiencias previas en el ámbito del trabajo en competencias transversales. Se ha encontrado diverso material que se puede categorizar en 7 Recursos de Desarrollo, 14 Recursos de Estudio, 27 Recursos de Experiencia, 5 Recursos de Innovación y 6 Recursos de Investigación. Respecto de los trabajos en innovación e investigación, destacan los realizados por Rodríguez et al., 2015 y Galván et al, 2015, En las actas de las ediciones de 2015 y 2016 del congreso de innovación docente IN-RED, se pueden encontrar distintos trabajos de innovación que profundizan en diversos aspectos de las competencias transversales, fundamentalmente en la mejora en la adquisición de alguna competencia por parte de los alumnos. Sin embargo, las únicas reseñas que hemos localizado que se centran en el problema de la coordinación de competencias transversales son: Berbegal et al, 2015 y Ochoa et al, 2015. La falta de bibliografía y referencias en este contexto evidencia la necesidad de realizar una experiencia documentada en la coordinación de competencias transversales. 


\subsection{El perfil del egresado}

Las Escuelas y Facultades intentan asegurar que los egresados de los distintos grados y másteres adquirirán capacidades en múltiples aspectos. Esta labor de coordinación a nivel de título es compleja y está sometida a revisiones internas y externas, como las realizadas en el proceso de acreditación "Accreditation Board for Engineering and Technology (ABET)”, o en las acreditaciones que llevan a cabo la ANECA o la AVAP (en la Comunitat Valenciana).

¿Qué capacidades debe tener un egresado que haya cursado las asignaturas de ingeniería nuclear? ¿Cuál debe ser su nivel de dominio? ¿Cómo se conseguirá que ese perfil sea una diferencia cualitativa respecto de otros egresados? Estas preguntas no tienen fácil respuesta.

Se ha realizado un cuestionario para determinar qué competencias serían las más adecuadas en las asignaturas de nuclear y cuál debería ser el nivel de dominio. En términos generales, la conclusión es que los puntos de control asignados por la Escuela a las asignaturas de nuclear son representativos, coherentes y se adecúan a los contenidos y objetivos de las mismas. En cuanto a los niveles de dominio, es lógico que en las asignaturas de primeros cursos el nivel de dominio sea bajo (I) y en $4^{\circ}$ de grado o en máster, más elevado (II y III, respectivamente).

\subsection{Diseño de actividades}

El objetivo es diseñar actividades que se puedan utilizar de base en distintas asignaturas, especialmente las de $4^{\circ}$ curso, tomando como referencia la asignatura obligatoria de $2^{\circ}$ curso ("Energía y Desarrollo Sostenible"). Con esta idea en mente, la coordinación se centra en aportar coherencia a los objetivos, metodología y resultados para diseñar una serie de actividades que puedan trabajarse en las diferentes asignaturas simultáneamente (teniendo en cuenta la formación inicial de los alumnos).

Partiendo de la idea vertebradora de la producción de energía eléctrica mediante nuclear, en la asignatura de $2^{\circ}$ curso de GIE se proponen diferentes actividades relacionadas para familiarizarse con conceptos básicos de la energía nuclear. En este contexto, con el objetivo de trabajar y evaluar diferentes competencias transversales, se proponen a los alumnos textos para debatir y suscitar polémica: la generación de residuos, la fiabilidad de la producción de origen nuclear, los riesgos asociados, etc. En este contexto, el alumnado además de trabajar ciertas competencias específicas, trabajan determinadas competencias transversales. Con estas sencillas actividades, introductorias al campo nuclear, el alumno realiza una primera toma de contacto. Conforme se avanza en los cursos, se incrementa la exigencia en el nivel de trabajo de las CTs. En la asignatura de $2^{\circ}$ curso se trabaja con verbos de nivel bajo según la taxonomía de Bloom (enumerar, identificar, ...), mientras que en las asignaturas de $4^{\circ}$ curso se trabaja con verbos como razonar, sintetizar, argumentar, establecer, obtener, etc.

Una vez que se realiza la puesta en común de las actividades que se realizarán en las diferentes asignaturas, es necesario definir los indicadores mediante los que se evaluará el trabajo en CTs.

(cc) EY-NC-ND 2018, Universitat Politècnica de València

Congreso IN-RED (2018) 


\subsection{Rúbricas de evaluación e indicadores}

Se parte de las propuestas publicadas en el marco del proyecto institucional de competencias transversales UPV y se procede a analizar las rúbricas genéricas de evaluación para adaptarlas a las asignaturas de la Tabla 1 . Se han utilizado entre 2 y 4 indicadores de carácter general para que se puedan adaptar a las distintas asignaturas. En las Tablas 2 a 6 se muestran los indicadores para cada competencia considerada. A partir de estos indicadores semi-genéricos, se desarrollarán los indicadores para cada actividad de cada asignatura.

Tabla 2. Comprensión e integración (nivel II).

\begin{tabular}{|l|l|}
\hline Objetivo & Relacionar e integrar conceptos en situaciones complejas en Ingeniería Nuclear. \\
\hline Indicadores & Establecer relaciones entre diferentes conceptos físicos y tecnológicos. \\
\hline & Integrar elementos de diferentes asignaturas para la interpretación de la realidad. \\
\hline
\end{tabular}

Tabla 3. Aplicación y pensamiento práctico (nivel II).

\begin{tabular}{|l|l|}
\hline Objetivo & Diseñar un plan con acciones concretas para situaciones nuevas. \\
\hline Indicadores & Establecer objetivos concretos en relación con las situaciones que se le plantean. \\
\hline & Obtener la información necesaria para abordar las situaciones. \\
\hline & Sistematizar la elaboración del plan, identificando las etapas. \\
\hline
\end{tabular}

Tabla 4. Responsabilidad ética y profesional y medioambiental (Nivel I).

\begin{tabular}{|c|c|}
\hline Objetivo & Ser conscientes de los valores a partir de los que se construye la sociedad. \\
\hline \multirow[t]{3}{*}{ Indicadores } & $\begin{array}{l}\text { Aceptar críticamente nuevas perspectivas, aunque cuestionen las propias en relación con la } \\
\text { energía nuclear. }\end{array}$ \\
\hline & $\begin{array}{l}\text { Diferenciar hechos y opiniones o interpretaciones. Identificar los fundamentos y reconocer } \\
\text { malinterpretaciones o manipulaciones. }\end{array}$ \\
\hline & Reconocer los conceptos éticos y deontológicos relacionados con la energía nuclear. \\
\hline Objetivo & $\begin{array}{l}\text { Valorar las actuaciones profesionales en cuanto a repercusión social, ambiental y } \\
\text { económica. }\end{array}$ \\
\hline \multirow[t]{3}{*}{ Indicadores } & Comprender el papel de la energía nuclear en la sociedad actual. \\
\hline & $\begin{array}{l}\text { Identificar los pros } \begin{array}{l}\text { y } \\
\text { medioambientales. }\end{array} \\
\text { contras de }\end{array}$ \\
\hline & Actuar individualmente en armonía con los planes consensuados y vigentes. \\
\hline
\end{tabular}

Tabla 5. Conocimiento de problemas contemporáneos (Nivel II).

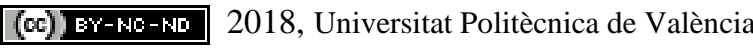

Congreso In-Red (2018) 


\begin{tabular}{|l|l|}
\hline Objetivo & $\begin{array}{l}\text { Analizar los problemas contemporáneos relacionados con la energía nuclear y sus } \\
\text { aplicaciones. }\end{array}$ \\
\hline & $\begin{array}{l}\text { Distinguir las partes que componen un problema, identificando los principales actores en } \\
\text { sus diferentes dimensiones (económica, social, ética, tecnológica...). }\end{array}$ \\
\hline & Razonar las soluciones ya propuestas para un problema. \\
\hline & $\begin{array}{l}\text { Proponer nuevas soluciones al problema que se ha planteado a partir de la propia } \\
\text { experiencia y de la información disponible. }\end{array}$ \\
\hline
\end{tabular}

Tabla 6. Instrumental específica (Nivel II).

\begin{tabular}{|l|l|}
\hline Objetivo & $\begin{array}{l}\text { Integrar correctamente las herramientas básicas del ámbito profesional de forma } \\
\text { autónoma. }\end{array}$ \\
\hline Indicadores & Manejar las herramientas básicas de forma autónoma. \\
\hline & Conocer las limitaciones de las herramientas básicas. \\
\hline
\end{tabular}

En las tablas anteriores se ha tenido en cuenta el nivel de dominio II para la mayoría de las competencias.

Con los indicadores definidos y adaptados a las actividades de las distintas asignaturas, se lleva a cabo la evaluación de las competencias. El proceso finaliza con una retroalimentación de los alumnos a los profesores y de éstos últimos al resto de profesores mediante una reunión de cierre, que establece el inicio de la siguiente interacción. En otras palabras, se lleva a cabo un proceso de mejora continua PDCA - Plan, Do, Check, Act -

\section{Resultados}

En este apartado se muestra, a modo de ejemplo, los resultados correspondientes a la competencia de "Conocimiento de Problemas Contemporáneos" (CT-10). Para el resto de competencias analizadas en la coordinación, se han obtenido resultados análogos que se omiten por motivos de concisión.

\subsection{Resultados de la reunión inicial}

Siguiendo la metodología expuesta en el apartado de "Desarrollo de la Innovación”, en la primera reunión de coordinación se realiza una puesta en común para alcanzar una caracterización consensuada de dicha competencia y del perfil del egresado.

El brainstorming realizado arroja las siguientes ideas:

- Problemas actuales que afectan a gran parte de la sociedad.

- Procesos históricos que, en la actualidad se encuentran en pleno desarrollo.

- Comprenden cuestiones sociales, económicas, medioambientales y normativas.

(cc) EY-NC-ND 2018, Universitat Politècnica de València

Congreso IN-RED (2018) 
- Tienen repercusiones importantes a nivel global.

- Generalmente, de forma indirecta tienen relación con los contenidos de las asignaturas.

- Se pueden estudiar de forma interdisciplinar.

La siguiente pregunta que se plantea en la reunión de puesta en común es, ¿cómo se transmite la importancia de esta competencia a los alumnos? Debemos conseguir:

- que el alumnado se sienta artífice de los momentos históricos que vivimos.

- trasladarles la idea de que conocer el escenario actual económico, social y medioambiental les proporciona una ventaja competitiva respecto de otros egresados.

- que se sientan que su generación "puede hacer las cosas mejor” que las anteriores generaciones.

- Q Que el alumnado sea consciente de cómo se ha llegado a la situación actual.

En definitiva, debemos ser capaces de transmitirles la ilusión por mejorar la sociedad, con todo lo que ello implica. La siguiente pregunta es: ¿cómo podemos lograrlo? Creemos que la respuesta a esta pregunta es mediante actividades que estimulen sus sentidos para que perciban el trasfondo social y humano del problema, y no se queden con la impersonalidad de los modelos, las ecuaciones y los números.

\subsection{Resultados del diseño de actividades}

Con esta idea, el grupo de trabajo ha diseñado diversas actividades para trabajar simultáneamente diferentes competencias. En este caso, se presenta la actividad que se inicia en la asignatura de $2^{\circ}$ curso y que se continúa en la obligatoria y en las optativas de $4^{\circ}$.

Actividad en $2^{\circ}$ curso.

En la asignatura obligatoria “Energía y Desarrollo Sostenible” de $2^{\circ}$ se presenta el tema de nuclear a los alumnos del Grado de Ingeniero de la Energía. El grupo de trabajo ha concluido que la mejor opción para captar la atención de los estudiantes y generar un espacio propicio para el debate es presentar el accidente de la central nuclear de Fukushima Daichi (Japón). Se trata de un suceso complejo que implica todos los aspectos que se estudian a lo largo del grado, por lo que se considera idóneo para suscitar el interés del alumnado. En la actividad se hace una breve descripción del suceso y se proporciona información que debe ser revisada por los alumnos por grupos. Revisada dicha información, el profesor plantea las siguientes afirmaciones (todas ellas falsas):

1. El accidente de Fukushima fue inevitable.

2. El accidente ha supuesto el inicio de la desaparición de las centrales nucleares comerciales.

3. En el escenario actual de España, se puede prescindir de la energía nuclear. 
4. La energía nuclear presenta más inconvenientes que ventajas.

A continuación, unos grupos deben defender estas afirmaciones y otros las deben rebatir, siempre con datos objetivos, evitando las opiniones y desarrollando un discurso coherente. Los grupos nombran un portavoz y se inicia el debate entre los que defienden y los que niegan las afirmaciones.

El debate resultante es muy valioso porque surgen de forma natural interrelaciones del problema contemporáneo de la energía con otros problemas: los residuos nucleares, el impacto medioambiental, la crisis económica, el calentamiento global (emisiones de CO2).

Al final de la sesión se elabora un listado de los argumentos más objetivos y mejor construidos. Se realizó un cuestionario al alumnado que había participado en la actividad para conocer los siguientes puntos:

- $\quad$ ¿Te ha parecido útil esta actividad?

- ¿ ¿Tenías ideas preconcebidas respecto de la energía nuclear antes de estudiar este accidente?

- ¿ ¿Ha cambiado algún aspecto de tu visión del problema de la energía?

- ¿Crees que en la actualidad la sociedad puede prescindir de la energía nuclear? En caso afirmativo, ¿cómo?

- ¿ ¿Cuál ha sido la lección aprendida de este accidente?

- ¿Crees que lo que hemos estudiado en la actividad representa un problema contemporáneo?

Los resultados del cuestionario son muy satisfactorios:

- $\quad$ Aproximadamente el 80\% del alumnado considera útil la actividad;

- $\quad$ El 55\% admite tener ideas preconcebidas;

- $\quad$ El 75\% cree que la actividad les ha permitido ampliar su visión del problema energético;

- $\quad$ El 95\% cree que en la actividad se ha trabajado un problema contemporáneo.

Actividades en $4^{\circ}$ curso.

En la asignatura obligatoria "Tecnología Nuclear" se retoma el tema del accidente de Fukushima y, gracias a los contenidos estudiados y a las competencias específicas trabajadas, se puede reevaluar el accidente y su relación con los problemas contemporáneos desde un nivel de profundidad mayor.

La actividad consiste en evaluar los costes de dicho accidente desde diferentes enfoques:

- Impacto económico. ¿Cómo ha repercutido el accidente a escala mundial en la producción de energía? ¿Ha sido determinantes para que algunos países abandonen el programa nuclear? ¿Y España, podría hacerlo en la actualidad?

(cc) EY-NC-ND 2018, Universitat Politècnica de València

Congreso IN-RED (2018) 
- Impacto medio ambiental. ¿Cómo ha afectado la contaminación radiactiva al entorno? ¿ Ha tenido repercusión mundial? ¿Se llegó a monitorizar en España un incremento de radionucleidos emitidos por la central?

- Impacto humano: ¿Cuáles han sido los efectos sufridos en algunas personas? ¿Cuál será el efecto a largo plazo?

- ¿ ¿De qué manera afectarán estos impactos a otros problemas contemporáneos?

En este caso, debido a la profundidad de las preguntas, la dinámica escogida es la elaboración de un trabajo académico por grupos y su exposición en clase.

En la asignatura optativa de 4 "Protección Radiológica", la actividad propuesta se centra en el cálculo de dosis producido por el accidente y su incidencia en aspectos biológicos. Para ahondar en el trabajo de la competencia transversal objeto de estudio, se propone comparar los efectos de este accidente con otros ocurridos en la historia, fundamentalmente el accidente de Chernobyl y el de Three Mile Island. La comparación en cuanto al escenario, las causas del accidente y las consecuencias, permiten al alumno conocer cómo ha cambiado la cultura de la seguridad en el ámbito de la energía nuclear, siendo este tema un problema contemporáneo que los profesores queremos destacar. Debido al reducido número de alumnos matriculados en la asignatura (entre 5 y 10 en función del curso académico), se considera que una exposición individual de unos 15 minutos es lo más adecuado para evaluar la actividad.

En la asignatura optativa de $4^{\circ}$ "Seguridad Nuclear", se estudia el accidente desde el punto de vista de las salvaguardias tecnológicas, los sistemas de seguridad y las probabilidades de fallo. En este caso, además de cálculos numéricos se propone estudiar cómo se ha endurecido la normativa internacional en materia de seguridad como lección aprendida. La actividad requiere un esfuerzo notable por parte de los alumnos para buscar, ordenar e interpretar cómo afectan las nuevas normativas internacionales a esta materia. Se destaca el problema de seguridad a escala global como un problema contemporáneo y las fortalezas y debilidades de la energía nuclear en este ámbito. La evidencia de la actividad es un informe donde el alumnado describe los cambios de normativa y su repercusión la vida útil de las centrales.

Por último, en "Centrales Nucleares Avanzadas", se estudian posibles escenarios futuros. La pregunta es: ¿Y qué nos espera en los próximos 30 años? ¿Es posible un nuevo Fukushima? ¿Lograrán los nuevos diseños de reactores reducir la probabilidad de accidente a un valor extremadamente pequeño? El enfoque de la actividad es relacionar los diseños de generación III y IV con los actuales diseños e identificar cómo incorporan dichos diseños las lecciones aprendidas de accidentes y fallos anteriores. La actividad es un trabajo académico con exposición en clase. De nuevo, se pone especial atención en señalar cómo se enmarca este concepto en los problemas actuales de la sociedad: el suministro de energía y la seguridad medioambiental y social. 


\subsection{La rúbrica para cada asignatura}

Tal y como se expuesto, en las cinco asignaturas se estudia el mismo caso intentando dar una coherencia y línea de continuidad entre ellas. En este contexto, la evaluación también debe ser coherente y lo más objetiva posible.

Se ha considerado que lo más acertado es adaptar la rúbrica de nivel de dominio I o II a las características de la actividad. A continuación, se muestra la rúbrica de la actividad descrita en el apartado anterior para cada asignatura (Tablas 7 a 11).

Tabla 7. Rúbrica para “Energía y Desarrollo Sostenible” - Nivel de dominio I-

\begin{tabular}{|c|c|c|c|c|}
\hline Indicador & $\begin{array}{ll}\text { D. } & \text { No } \\
\text { alcanzado }\end{array}$ & C. En desarrollo & $\begin{array}{ll}\text { B. } & \text { Bien } \\
\text { /adecuado } & \end{array}$ & $\begin{array}{l}\text { A. Excelente / } \\
\text { Ejemplar }\end{array}$ \\
\hline $\begin{array}{l}\text { Identifica y describe aspectos sociales } \\
\text { se ven afectados por un accidente } \\
\text { nuclear. }\end{array}$ & $\begin{array}{l}\text { No identifica } \\
\text { ningún aspecto } \\
\text { social. }\end{array}$ & $\begin{array}{l}\text { Identifica uno o } \\
\text { dos problemas } \\
\text { sociales. }\end{array}$ & $\begin{array}{l}\text { Identifica y } \\
\text { describe uno o } \\
\text { dos problemas } \\
\text { sociales. }\end{array}$ & $\begin{array}{l}\text { Identifica y } \\
\text { describe más de } \\
\text { dos problemas } \\
\text { sociales. }\end{array}$ \\
\hline $\begin{array}{l}\text { Identifica y describe } \text { aspectos } \\
\text { medioambientales se ven afectados } \\
\text { por un accidente nuclear. }\end{array}$ & $\begin{array}{l}\text { No identifica } \\
\text { ningún medio } \\
\text { ambiental. }\end{array}$ & $\begin{array}{l}\text { Identifica uno o } \\
\text { dos problemas } \\
\text { medio } \\
\text { ambientales. }\end{array}$ & $\begin{array}{l}\text { Identifica y } \\
\text { describe uno o } \\
\text { dos problemas } \\
\text { medio } \\
\text { ambientales. }\end{array}$ & $\begin{array}{l}\text { Identifica y } \\
\text { describe más de } \\
\text { dos problemas } \\
\text { medio } \\
\text { ambientales. }\end{array}$ \\
\hline $\begin{array}{l}\text { Identifica y describe repercusiones } \\
\text { económicas. }\end{array}$ & $\begin{array}{l}\text { No identifica } \\
\text { ninguna } \\
\text { repercusión } \\
\text { económica. }\end{array}$ & $\begin{array}{l}\text { Identifica una o } \\
\text { dos } \\
\text { repercusiones } \\
\text { económicas. }\end{array}$ & $\begin{array}{ll}\text { Identifica } & \text { y } \\
\text { describe una } & \text { o } \\
\text { dos } & \\
\text { repercusiones } & \\
\text { económicas. } & \end{array}$ & $\begin{array}{l}\text { Identifica y } \\
\text { describe más de } \\
\text { dos } \\
\text { repercusiones } \\
\text { económicas. }\end{array}$ \\
\hline
\end{tabular}

Tabla 8. Rúbrica para "Tecnología Nuclear” - Nivel de dominio II-

\begin{tabular}{|l|l|l|l|l|l|}
\hline Indicador No & C. En desarrollo & $\begin{array}{l}\text { B. } \\
\text { /adecuado }\end{array}$ & Bien & $\begin{array}{l}\text { A. Excelente / } \\
\text { Ejemplar }\end{array}$ \\
\hline $\begin{array}{l}\text { Argumenta si el accidente fue } \\
\text { evitable. iexiste el fallo de } \\
\text { probabilidad 0? Razona si hay } \\
\text { prejuicios y desinformación en este } \\
\text { aspecto. }\end{array}$ & No argumenta. & $\begin{array}{l}\text { Argumenta si el } \\
\text { accidente fue } \\
\text { evitable. }\end{array}$ & $\begin{array}{l}\text { Argumenta si el } \\
\text { accidente } \\
\text { evitable }\end{array}$ & $\begin{array}{l}\text { Argumenta si el } \\
\text { accidente } \\
\text { fue } \\
\text { evitable } \\
\text { razona } \\
\text { superficialmente } \\
\text { otros aspectos. } \\
\text { detalladamente } \\
\text { otros aspectos. }\end{array}$ \\
\hline $\begin{array}{l}\text { Establece y describe relaciones entre } \\
\text { el accidente, la tecnología nuclear y } \\
\text { otras formas de producción de } \\
\text { energía. }\end{array}$ & $\begin{array}{l}\text { No establece } \\
\text { ninguna } \\
\text { relación. }\end{array}$ & $\begin{array}{l}\text { Establece } \\
\text { alguna relación } \\
\text { pero no la } \\
\text { describe. }\end{array}$ & $\begin{array}{l}\text { Establece } \\
\text { describe alguna } \\
\text { relación. }\end{array}$ & $\begin{array}{l}\text { Establece } \\
\text { describe más de } \\
\text { tres relaciones. }\end{array}$ \\
\hline
\end{tabular}

Tabla 9. Rúbrica para “Protección Radiológica” - Nivel de dominio II-

\begin{tabular}{|l|l|l|l|l|l|}
\hline Indicador & $\begin{array}{l}\text { D. No } \\
\text { alcanzado }\end{array}$ & C. En desarrollo & $\begin{array}{l}\text { B. } \\
\text { /adecuado }\end{array}$ & $\begin{array}{l}\text { A. Excelente / } \\
\text { Ejemplar }\end{array}$ \\
\hline
\end{tabular}




\begin{tabular}{|l|l|l|l|l|l|}
\hline $\begin{array}{l}\text { Analiza y alcanza conclusiones sobre } \\
\text { los riesgos y beneficios de las } \\
\text { radiaciones ionizantes: medicina, } \\
\text { industria, energía. }\end{array}$ & $\begin{array}{l}\text { No analiza ni } \\
\text { alcanza ninguna } \\
\text { conclusión. }\end{array}$ & $\begin{array}{l}\text { Analiza } \\
\text { someramente } \\
\text { algunos riesgos. }\end{array}$ & $\begin{array}{l}\text { Analiza } \\
\text { alcanza } \\
\text { conclusiones } \\
\text { para algunos } \\
\text { riesgos. }\end{array}$ & $\begin{array}{l}\text { Analiza } \\
\text { alcanza } \\
\text { conclusiones } \\
\text { para } \\
\text { beneficios. }\end{array}$ \\
\hline $\begin{array}{l}\text { Argumenta las consecuencias } \\
\text { biológicas de las radiaciones } \\
\text { ionizantes. Identifica que las } \\
\text { consecuencias no se producen } \\
\text { únicamente por las centrales } \\
\text { nucleares. }\end{array}$ & $\begin{array}{l}\text { No identifica ni } \\
\text { argumenta. }\end{array}$ & $\begin{array}{l}\text { Identifica } \\
\text { algunas } \\
\text { consecuencias } \\
\text { pero no las } \\
\text { analiza. }\end{array}$ & $\begin{array}{l}\text { Identifica } \\
\text { algunas } \\
\text { consecuencias } \\
\text { pero las analiza } \\
\text { superficialmente. }\end{array}$ & $\begin{array}{l}\text { Identifica } \\
\text { analiza } \\
\text { consecuencias } \\
\text { razonadamente. }\end{array}$ \\
\end{tabular}

Tabla 10. Rúbrica para "Seguridad nuclear” - Nivel de dominio II-

\begin{tabular}{|c|c|c|c|c|}
\hline Indicador & $\begin{array}{ll}\text { D. } & \text { No } \\
\text { alcanzado }\end{array}$ & C. En desarrollo & $\begin{array}{ll}\text { B. } & \text { Bien } \\
\text { /adecuado } & \end{array}$ & $\begin{array}{l}\text { A. Excelente / } \\
\text { Ejemplar }\end{array}$ \\
\hline $\begin{array}{l}\text { Analiza aspectos humanos y técnicos } \\
\text { de la seguridad. Establece relaciones } \\
\text { con ámbitos sociales y } \\
\text { medioambientales. }\end{array}$ & $\begin{array}{l}\text { No analiza ni } \\
\text { establece } \\
\text { relaciones. }\end{array}$ & $\begin{array}{l}\text { Analiza algún } \\
\text { aspecto pero no } \\
\text { establece } \\
\text { ninguna } \\
\text { relación. }\end{array}$ & $\begin{array}{l}\text { Analiza y } \\
\text { estable } \\
\text { relaciones } \\
\text { razonadamente } \\
\text { (menos de dos) }\end{array}$ & $\begin{array}{l}\text { Analiza y } \\
\text { estable } \\
\text { relaciones } \\
\text { razonadamente } \\
\text { (dos o más) }\end{array}$ \\
\hline $\begin{array}{l}\text { Relaciona la seguridad de las } \\
\text { centrales con otros problemas } \\
\text { sociales (atentados, guerras, etc.). }\end{array}$ & No relaciona. & $\begin{array}{l}\text { Relaciona } \\
\text { superficialmente. }\end{array}$ & $\begin{array}{l}\text { Relaciona de } \\
\text { forma razonada } \\
\text { dos problemas }\end{array}$ & $\begin{array}{l}\text { Relaciona de } \\
\text { forma razonada } \\
\text { más de dos } \\
\text { problemas }\end{array}$ \\
\hline
\end{tabular}

Tabla 11. Rúbrica para “Centrales Nucleares Avanzadas” - Nivel de dominio II-

\begin{tabular}{|l|l|l|l|l|}
\hline Indicador No & $\begin{array}{l}\text { D. En desarrollo } \\
\text { alcanzado }\end{array}$ & $\begin{array}{l}\text { B. } \\
\text { /adecuado }\end{array}$ & $\begin{array}{l}\text { A. Excelente / } \\
\text { Ejemplar }\end{array}$ \\
\hline $\begin{array}{l}\text { Argumenta la necesidad de las } \\
\text { centrales nucleares en la sociedad del } \\
\text { futuro (a 20 años vista). Distingue la } \\
\text { tecnología madura de la no } \\
\text { convencional. }\end{array}$ & $\begin{array}{l}\text { No argumenta } \\
\text { ni distingue. }\end{array}$ & $\begin{array}{l}\text { Establece algún } \\
\text { argumento, pero } \\
\text { no lo defiende } \\
\text { adecuadamente. }\end{array}$ & $\begin{array}{l}\text { Establece } \\
\text { argumentos pero } \\
\text { no distingue } \\
\text { grado } \\
\text { madurez. }\end{array}$ & $\begin{array}{l}\text { Establece } \\
\text { argumentos } \\
\text { distingue } \\
\text { de madurez. }\end{array}$ \\
\hline $\begin{array}{l}\text { Prioriza las tecnologías nuevas que } \\
\text { pueden sustituir a las actuales } \\
\text { centrales nucleares y razona los pros } \\
\text { y contras de cada uno en el ámbito } \\
\text { del problema energético. }\end{array}$ & $\begin{array}{l}\text { No prioriza ni } \\
\text { razona. }\end{array}$ & $\begin{array}{l}\text { Prioriza, pero } \\
\text { no razona. }\end{array}$ & $\begin{array}{l}\text { Prioriza y razona } \\
\text { pero } \\
\text { superficialmente. }\end{array}$ & $\begin{array}{l}\text { Prioriza } \\
\text { razona } \\
\text { argumentos } \\
\text { válidos. }\end{array}$ \\
dando \\
\end{tabular}

Del trabajo realizado, se ha conseguido que los diferentes profesores de las asignaturas consideradas tengan una visión uniforme de lo que se pretende evaluar con cada una de las competencias transversales, mediante la realización de reuniones entre los profesores y establecimiento de las rúbricas más coordinadas en cada una de las competencias de las diferentes asignaturas involucradas en este trabajo. Además, con la definición y el 
desarrollo de una actividad, desde el punto de vista de las diferentes asignaturas, se facilita que el alumno vea un mismo problema desde ámbitos diferentes, lo que favorece que adquiera de forma más coherente y con mayor facilidad las diferentes competencias transversales.

Aunque este trabajo ha marcado las bases para poder realizar una evaluación de las competencias transversales de las diferentes asignaturas del ámbito de la Ingeniería Nuclear de manera más uniforme, coherente y coordinada, se necesita un tiempo de implementación para poder identificar posibles puntos de mejora. Queda por tanto pendiente la evaluación final y realimentación por parte del profesorado respecto al grado de implantación y resultados de la metodología planteada.

\section{Conclusiones}

La coordinación entre asignaturas es esencial para establecer las bases del trabajo competencial. El alumnado debe percibir una coherencia en el planteamiento, desarrollo y evaluación de las competencias transversales. En este trabajo se ha descrito el procedimiento mediante el cual se está realizando la coordinación de las competencias transversales en las diferentes asignaturas del ámbito de la ingeniería nuclear del Grado de Ingeniero de la Energía, en concreto con la competencia de "Conocimiento de problemas contemporáneos” como ejemplo de aplicación sin pérdida de generalidad. La coordinación debe establecer las bases de lo que los diferentes profesores van a transmitir a los alumnos y para ello lo primero realizado es el consenso en la definición de las diferentes competencias así como cuál debe ser el perfil del egresado en materia de ingeniería nuclear y se ha procedido a diseñar actividades al efecto con sus correspondientes rúbricas. Se ha intentado reforzar el mensaje trabajando una misma actividad con enfoques diferentes según la asignatura y estableciendo indicadores fácilmente medibles y transferibles entre asignaturas según el nivel de dominio. Dentro del último objetivo de la innovación, el trabajo requiere un proceso de mejora continua para subsanar las deficiencias que se detectan conforme se pone en práctica el proyecto. Como punto a destacar también por las dificultades que entraña es la conocida "libertad de cátedra" que algunos profesores alegan para evitar quedar condicionados en su materia por este tipo de coordinaciones.

Adicionalmente, se han obtenido similares productos dentro del proyecto de innovación para el resto de competencias dentro del ámbito de la ingeniería nuclear en el Grado de Ingeniero de la Energía pero cuya consecución y desarrollo es similar al analizado

\section{Agradecimientos}

Este trabajo se ha realizado en el marco del proyecto Proyecto de Innovación y Mejora Educativa, PIME Curso 2017-2018 "Coordinación de competencias transversales en asignaturas de ámbito nuclear en el Grado de Ingeniero de la Energía”, Referencia B07, del Vicerrectorado de Estudios, Calidad y Acreditación de la Universitat Politècnica de València.

(c) ) EY-NC-ND 2018, Universitat Politècnica de València

Congreso IN-RED (2018) 


\section{Referencias}

BERBEGAL et al "El portafolio digital de estudiantes como herramienta de evaluación de competencias", Red de Evaluación Alternativa en la Universidad http://www.unizar.es/real.

GALLARDO, S., CARLOS, S. (2015), "Desarrollo de la competencia transversal de "Análisis y Resolución de Problemas" en la asignatura Centrales Nucleares Avanzadas", $I N-R E D$, Valencia, Universitat Politècnica de València.

GALVÁN C. et al "Desarrollo de competencias transversales en entornos personales de aprendizaje en Educación Superior. Nuevas funciones de un sistema integrado de portafolios digitales”, III Congreso Internacional sobre Aprendizaje, Innovación y Competitividad (CINAIC 2015), Madrid, 2015.

OCHOA A. et al "Competencias en el contexto del Proyecto Mentor de una Escuela de Ingeniería, III Congreso Internacional sobre Aprendizaje, Innovación y Competitividad (CINAIC 2015), Madrid, 2015.

RODRÍGUEZ M.J. et al "Formación transversal de los estudiantes del Grado de Farmacia de la Universidad de Barcelona en un entorno de buenas prácticas", III Congreso Internacional sobre Aprendizaje, Innovación y Competitividad (CINAIC 2015), Madrid, 2015.

SANZ DE ACEO, M. L. (2010), "Competencias cognitivas en Educación Superior”, Narcea, Madrid.

VILLA, A. y POBLETE, M. (2007), “Aprendizaje basado en competencias. Una propuesta para la evaluación de las competencias genéricas”, Universidad de Deusto, Bilbao

UNIVERSITAT POLITÈCNICA DE VALÈNCIA, (2015a). "Presentación de Competencias Transversales UPV CT-10. Conocimiento de problemas contemporáneos”.

UNIVERSITAT POLITÈCNICA DE VALÈNCIA, (2015b). "Rúbrica UPV CT-10. Conocimiento de problemas contemporáneos”.

VILLANUEVA, J.F. et al. (2016), "Integración de la competencia transversal de "conocimiento de problemas contemporáneos" en Asignaturas de Grado", IN-RED, Valencia, Universitat Politècnica de València. 


\title{
Simulación de sistemas energéticos como metodología para el desarrollo competencial en la asignatura Ampliación de Energía
}

\author{
Rafael Miróa, Teresa Barrachina a, Belén Juste ${ }^{a}$, Ricardo Sanchís ${ }^{a}$, María Josefa \\ Palomo $^{a}$, Alberto Escriváa, Carlos Guardiolab, Vicente Bermúdez ${ }^{b}$, José Galindob, \\ José Javier López ${ }^{\text {, Jaime Martín }}{ }^{\text {b }}$ Ricardo Novellab \\ a Depto. de Ingeniería Química y Nuclear rmiro@iqn.upv.es, tbarrachina@iqn.upv.es, \\ bejusvi@iqn.upv.es, rsanchis@iqn.upv.es, mpalomo@iqn.upv.es, aescriva@iqn.upv.es \\ bDepto. De Máquinas y Motores Térmicos carguaga@mot.upv.es, bermudez@mot.upv.es, \\ galindo@mot.upv.es, jolosan3@mot.upv.es, jaimardi@mot.upv.es, rinoro@mot.upv.es
}

\begin{abstract}
The implementation of the New Masters for the convergence to the EHEA has led to the appearance of new advanced subjects of marked technical and professional character in the new master's degrees.

The main objective of this project has been the development and experimentation of free software, under Matlab environment, for the preparation of a portfolio for the development of the competences of the Master's degree in Industrial Engineering, as well as the transversal competences of the subject of Advanced Energy and Thermal Machines.

The development and use of free mathematical software for the resolution of professional problems of design and analysis of real industrial energy systems will facilitate the student's work by its easy availability, but needs to be oriented on the resources and time available, as well as on the use and capabilities of the developed programs.
\end{abstract}

Keywords: Competencies, Simulation, Problems, Demonstrations, software, Matlab $^{\circledR}$.

\footnotetext{
Resumen

La implantación de los Nuevos Másteres para la convergencia al EEES ha llevado aparejada la aparición de nuevas asignaturas avanzadas de marcado carácter técnico y profesional en los nuevos másteres habilitantes.

El objetivo principal del presente proyecto ha sido el desarrollo y experimentación de software libre, bajo entorno Matlab, para la elaboración de un portafolio para el desarrollo de las competencias propias del título de Máster en Ingeniería Industrial, así como de las competencias transversales de la asignatura de Ampliación de Energía y Motores Térmicos.
} 
El desarrollo y empleo de software matemático libre para la resolución de problemas profesionales de diseño y análisis de sistemas energéticos industriales reales facilitará la labor discente del alumno por su fácil disponibilidad, pero necesita ser orientado sobre los recursos y tiempo disponibles, así como sobre el uso y capacidades de los programas desarrollados.

Palabras clave: Competencias, Simulación, Problemas, Demostraciones, software, Matlab ${ }^{\circledR}$.

\section{Introducción}

El trabajo llevado a cabo formó parte de un PIME en el curso 2016-2017 y se ha realizado en la titulación Máster Universitario en Ingeniería Industrial de la ETSII, concretamente en la asignatura Ampliación de Energía y Máquinas Térmicas durante el curso académico 2016-2017.

El número de alumnos involucrados es de 298 repartidos en 6 grupos de teoria de aula. Cada grupo se divide a su vez en 3 grupos de prácticas con un total de 18 grupos.

La asignatura está dividida en dos bloques. La docencia de un bloque es responsabilidad del departamento de Ingeniería Química y Nuclear (DIQN), mientras que la del otro bloque es responsabilidad del Departamento de Máquinas y Motores Térmicos (DMMT). El número de profesores de la asignatura es 12, que es el número de profesores que han colaborado en esta experiencia.

Las acciones propuestas en este proyecto tienen por finalidad investigar, experimentar y evaluar las competencias propias y transversales en la asignatura Ampliación de Energía y Máquinas Térmicas mediante el uso de una herramienta de software abierto y libre desarrollada con el objeto de estimular su utilización por parte del alumnado y así potenciar su capacidad de autoaprendizaje.

El proyecto se articula a lo largo de cuatro ejes: i) cálculos analíticos; ii) cálculos unidimensionales; iii) cálculos acoplados de transporte de masa, momento y energía, iv) aplicaciones a casos reales en aplicaciones industriales. Estos cuatro ejes permiten abarcar un gran número de competencias tanto específicas como transversales del Máster en que se engloba la asignatura, así como en la actividad profesional de la Ingeniería Industrial.

La finalidad última del proyecto es proporcionar los conocimientos teórico-prácticos necesarios para que los alumnos desarrollen herramientas de cálculo para el estudio de sistemas energéticos de una forma avanzada, en especial los que utilizan cambio de fase, y en concreto determinar posibles problemas de seguridad e integridad, y sean capaces a posteriori de aplicar la metodología aprendida directamente al cálculo, diseño y análisis de equipos industriales, así como a la validación de resultados, e incluso al desarrollo de nuevas herramientas de cálculo, tanto para producción como para investigación.

(cc) EY-NC-ND 2018, Universitat Politècnica de València

Congreso IN-RED (2018) 
Además, se pretende introducir en las clases nuevos recursos que se ajusten al temario como apoyo en la práctica de aprendizaje de estos software abierto. Los vídeos explicativos de apoyo, screencast, laboratorios virtuales y prácticas informáticas desarrollados pueden acercar al alumno al problema rápidamente debido al impacto audiovisual que tienen, ya que no hay que olvidar que las generaciones actuales están creciendo en un ambiente en que la transmisión de información es mucho más interactiva e informatizada que antes. Por otra parte, para el docente elaborar sus propios vídeos didácticos y laboratorios virtuales si así lo desea es todo un reto ya que requiere, competencias tecnológicas, un amplio dominio de la asignatura y mucha creatividad.

\section{Objetivos}

El objetivo principal de la innovación es la implementación de software de código abierto relacionado con la simulación de los sistemas energéticos, tanto como herramienta de apoyo a la enseñanza como de usos profesionales, dotando a los alumnos de competencias útiles en su futura vida profesional.

Este objetivo general se logra a través de los siguientes objetivos parciales orientados a la minimización de los inconvenientes que presentan las plataformas de simulación de software libre y código abierto:

O1) Introducir en asignaturas de las titulaciones el uso de las técnicas más actuales de simulación en análisis y diseño de sistemas energéticos profesionales.

O2) Seleccionar las tablas de materiales y modelos físicos y matemáticos disponibles en la literatura científica y profesional que satisfagan los criterios de rigurosidad necesarios para que estas herramientas reproduzcan satisfactoriamente el comportamiento físico de los ejemplos a desarrollar.

O3) Reducir el tiempo de aprendizaje de las herramientas desarrollando Ejemplos Base de casos industriales reales que permitan la internalización de las etapas que consta toda simulación/análisis/diseño. Los Ejemplos Base tendrán un referente físico reconocible y permitirá al alumno aplicar y combinar conceptos específicos de aplicaciones industriales.

Es importante destacar que estos objetivos docentes tienen en cuenta el nivel de conocimiento y habilidades de partida de los alumnos para evitar un excesivo coste docente adicional para alcanzar un determinado nivel base para iniciar el desarrollo de los ejemplos.

\section{Descripción del desarrollo de la innovación}

Para alcanzar los objetivos del proyecto, se ha seguido el siguiente plan de trabajo:

\section{Tarea I: Selección y documentación de software}

Esta tarea ha constado de dos etapas: 
1. Análisis de los códigos disponibles

2. Desarrollo de modelos en Matlab ${ }^{\circledR}$ de problemas reales

Tras valorar el software disponible, se optó por el uso de Matlab ${ }^{\circledR}$ y Excel ${ }^{\circledR}$ por las siguientes razones:

- $\quad$ Están disponibles para los estudiantes con acceso libre desde los ordenadores de la Universidad y desde los ordenadores propios puesto que la Universidad paga por estas licencias.

- Los estudiantes han utilizado estos programas en cursos anteriores por lo que tienen el nivel requerido en este curso.

- $\quad$ Estos programas se utilizan posteriormente en la vida profesional.

Una vez seleccionado el software se ha resuelto diferentes problemas reales con diferentes datos y modelos con estos códigos. El desarrollo de la programación, es decir, la organización en funciones, subrutinas, variables de entrada y salida, se ha realizado de manera sencilla para que sea fácilmente entendible por los alumnos y por cualquiera que desee ejecutar estos programas.

\section{Tarea II: Adaptación o Creación de Materiales Docentes}

Se han desarrollado los contenidos docentes y competencias de la materia y titulación a la que se destina este proyecto. Se ha procedido a la Adaptación de Materiales cuando se disponía de un material docente.

Por otro lado, se ha llevado a cabo la Creación de Materiales con objetivo principal de desarrollar los ejercicios, casos, ejemplos de simulaciones, etc., que se han resuelto previamente con el software y que no existían previamente.

Este material se ha puesto a disposición de los alumnos en PoliformaT y se ha utilizado en clase como parte de las actividades presenciales.

\section{Tarea III: Elaboración de Guías de Software}

Las etapas generales de las que consta por lo general todo programa de cálculo son: i) Preprocesado; ii) Solver; iii) Post-procesado. Con esta tarea se pretende elaborar los materiales necesarios (manuales, tutoriales, presentaciones, animaciones, etc.) para el correcto uso y maximizar el rendimiento de las simulaciones. Estos materiales deben explicar cada una de las etapas con tal de establecer correctamente el flujo de tareas a realizar para las simulaciones.

Las unidades seguirán la siguiente estructura general:

- Objetivos de la unidad.

- Introducción.

- Segmentos de información (desarrollo de la información).

(cc) EY-NC-ND 2018, Universitat Politècnica de València

Congreso IN-RED (2018) 
- $\quad$ Errores más comunes.

- Recuerda que...

- Bibliografía relevante.

También se incluye en este apartado la elaboración de las unidades didácticas en formato presentación (Power Point) con especial énfasis en realizar una exposición clara y estructurada.

Adicionalmente, se han elaborado materiales de apoyo docente necesarios. Estos materiales son presentaciones, esquemas de resolución de los problemas, esquemas uso del formulario. Además se han elaborado objetos de aprendizaje en forma de videos screencast.

A continuación se muestran algunos ejemplos de los materiales desarrollados:

- $\quad$ En la imagen siguiente se muestra uno de los módulos desarrollados en Excel para la simulación de Turbinas (bloque DMMT):

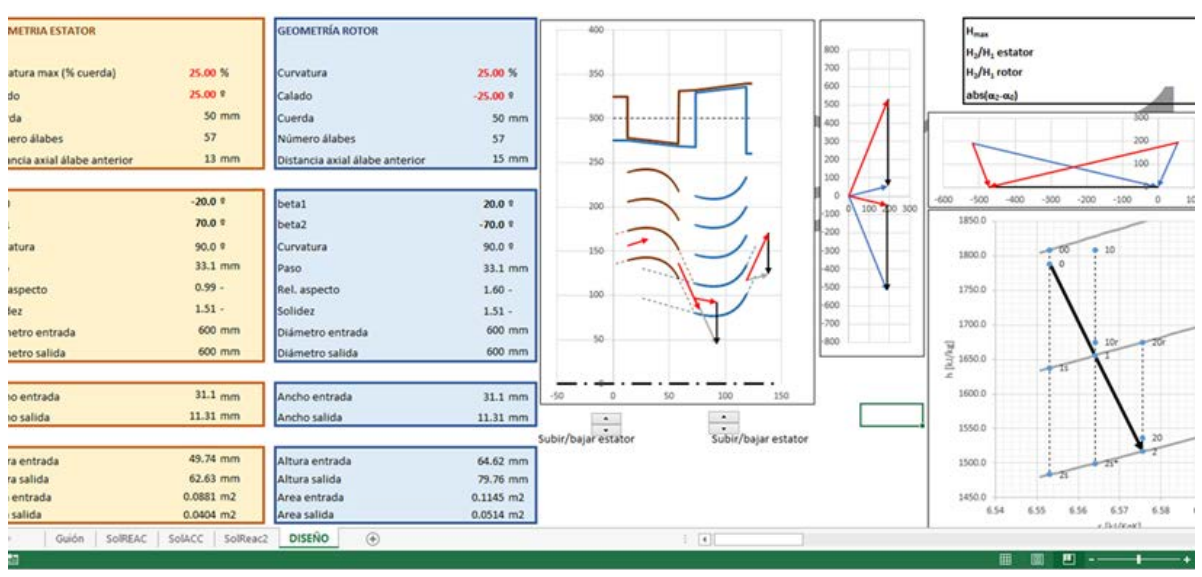

Fig. 1 Módulo en Excel para la simulación de Turbinas

- $\quad$ En la imagen siguiente se muestra uno de los diagramas de flujo para la resolución de los problemas complejos (bloque DIQN): 
Smulación de sistemas energéticos como metodología para el desarrollo competencial en la asignatura Ampliación de Energía.

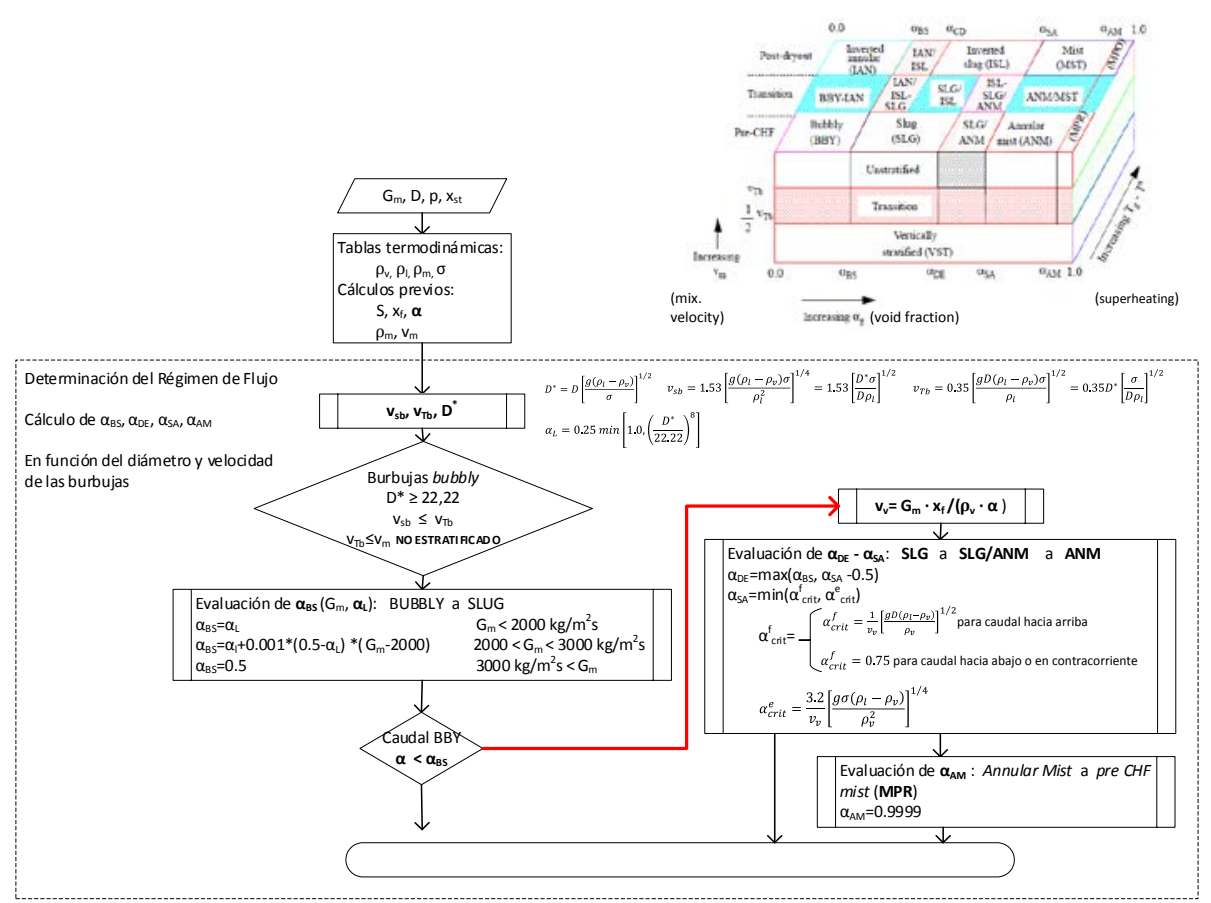

Fig. 2 Esquema del proceso de selección de régimen de caudal

- $\quad$ En la imagen siguiente se muestra uno de los programas desarrollados en Matlab (bloque DIQN):

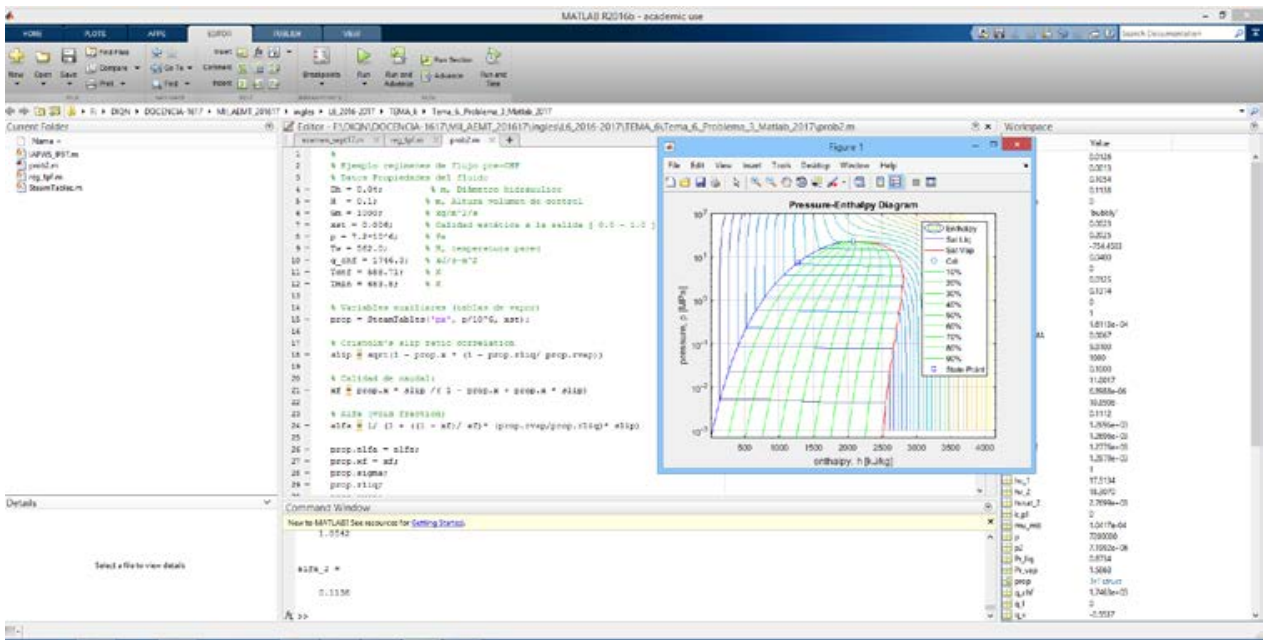

Fig. 3 Programa en Matlab para la resolución de los problemas

Además del diagrama presión entalpía, los alumnos también pueden obtener la curva de ebullición:

(c) EY-NC-ND 2018, Universitat Politècnica de València 


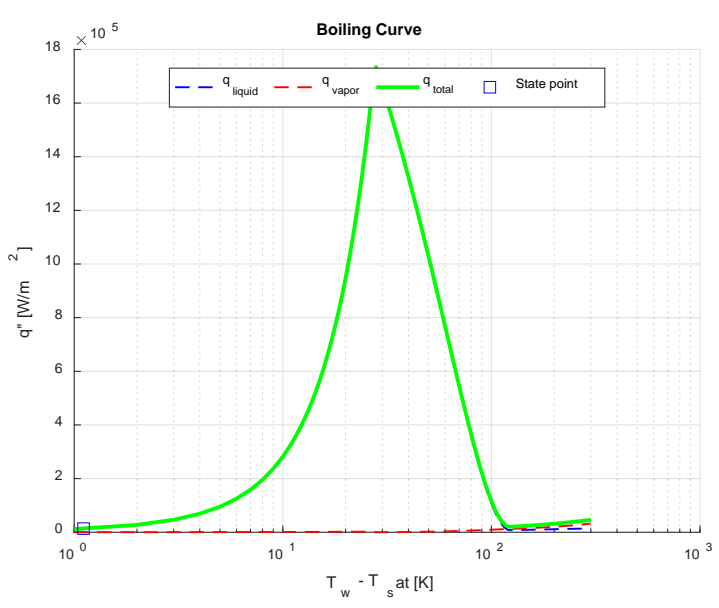

Fig. 4 Curva de ebullición obtenida con Matlab

\section{Resultados}

Se ha comprobado por testimonios de los alumnos que están deseosos de un cambio de la enseñanza con respecto a las prácticas tradicionales, y que al introducir elementos interactivos digitales en el curso, la respuesta de los alumnos ha sido muy satisfactoria.

Se han introducido mejoras de la comunicación educativa, lo que a su vez aumenta la motivación de sus estudiantes. Esto lo hemos podido constatar en las encuestas de opinión del alumnado.

Se ha constituido un factor de cambio en el modo de organizar el conocimiento de los alumnos. A través de los esquemas y diagramas de flujo, los alumnos tienen una nueva herramienta con la que interpretar el procedimiento de resolución de los problemas junto con el uso del software.

Se ha evaluado las competencias transversales a partir de las calificaciones obtenidas en los diferentes actos de evaluación. La evaluación de las CT se ha llevado a cabo de la siguiente manera:

\section{CT1 - Comprensión e integración}

Es la media aritmética de las calificaciones de las 2 preguntas de respuesta abierta de la evaluación del bloque del DIQN y de la calificación del test de la evaluación del bloque del DMMT.

\section{CT2 - Aplicación y pensamiento práctico}

Es la media aritmética de las calificaciones de las 2 memorias de las prácticas del bloque del DIQN y de las 2 prácticas del bloque del DMMT.

Las memorias de las prácticas se han evaluado utilizando una rúbrica que se adjunta al final de este documento. 
Smulación de sistemas energéticos como metodología para el desarrollo competencial en la asignatura Ampliación de Energía.

\section{CT3 - Análisis y resolución de problemas}

Es la media aritmética de las calificaciones de los problemas de la evaluación del bloque del DIQN y de los problemas de la evaluación del bloque del DMMT.

\section{CT13- Instrumental específica}

Es la calificación global de la asignatura.

Las calificaciones se han trasladado a la escala A, B, C, D dividiendo el rango de las calificaciones en cuatro partes iguales y asignando la escala A, B, C, D a cada parte en orden ascendente.

Por otro lado, la recogida de datos ha consistido en observación en el aula y testimonios de los alumnos. También se ha analizado las encuestas de opinión del alumnado y se ha comparado con años anteriores.

Los resultados de las calificaciones del curso 2015-2016 y del curso 2016-2017 se muestran en las figuras 5 y 6 :

\section{UNIVERSITAT}

POLITECCICA

DE VALÈNCIA

Estadísticas

Asignatura viernes 15 septiembre

33814 Ampliación de Energía y Máquinas térmicas (2015/2016)

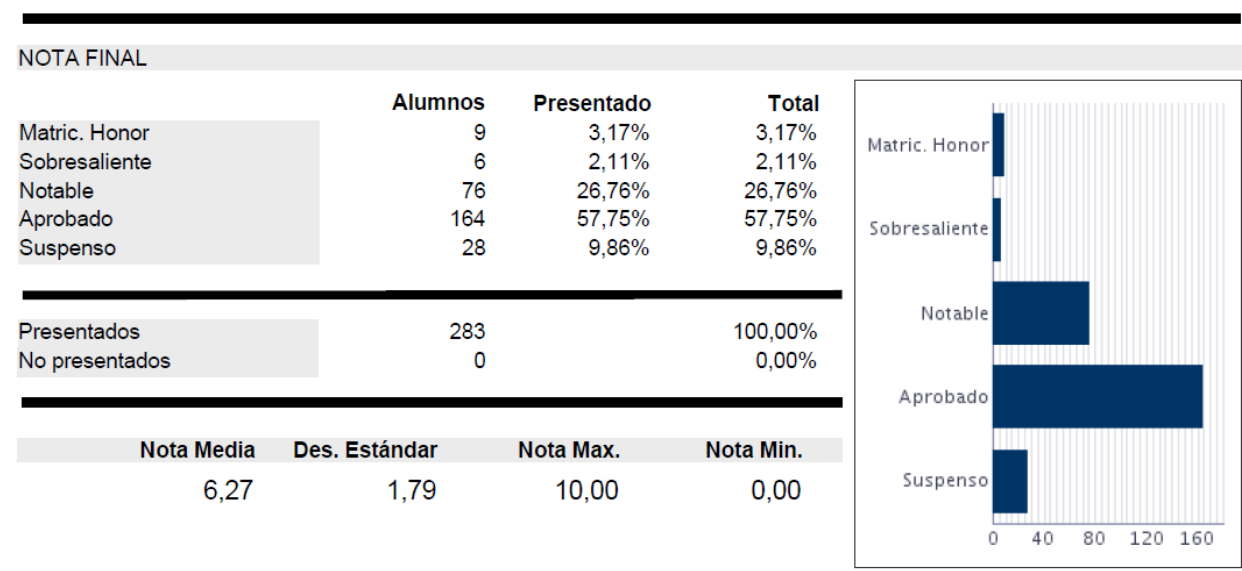

Fig. 5 Estadísticas de las notas del curso 2015-2016

(cc) EY-NC-ND 2018, Universitat Politècnica de València

Congreso IN-RED (2018) 


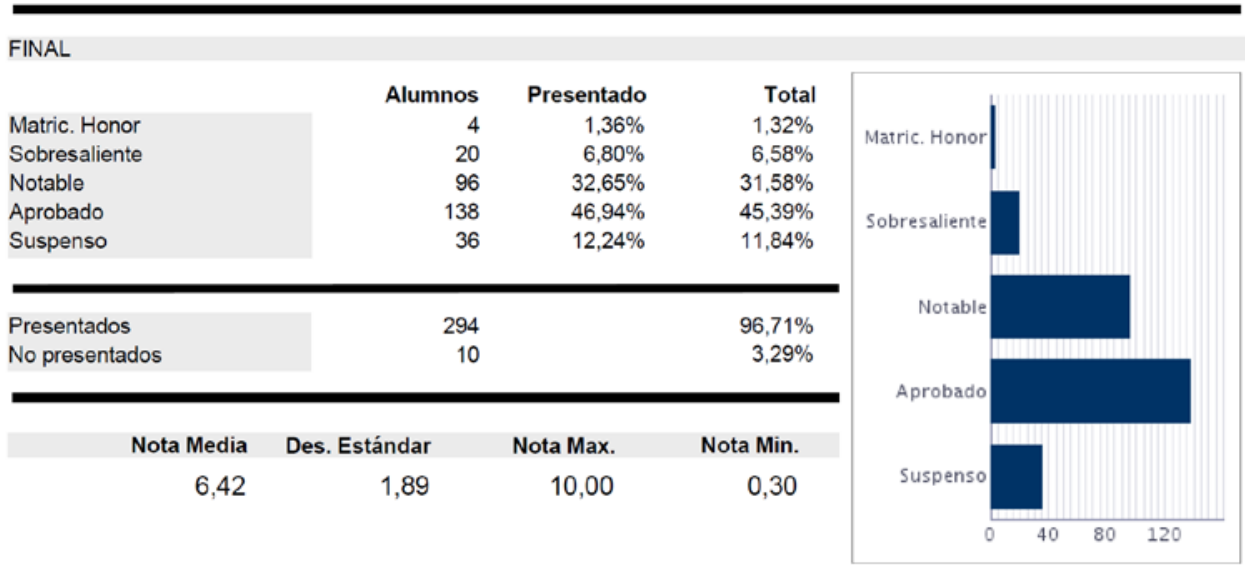

Fig. 6 Estadísticas de las notas del curso 2016-2017

Lo más destacable es el aumento de alumnos con Sobresaliente y Notable.

\section{Conclusiones}

El nivel de satisfacción derivado de la percepción positiva registrado en las encuestas junto con el rendimiento académico positivo alcanzado por estos estudiantes, avalan la utilización de las metodologías descritas.

En definitiva los resultados obtenidos han sido claramente positivos, aunque si tenemos en cuenta aspectos tales como los recursos y materiales utilizados, el curso mejorará en el futuro a medida que vayamos incorporando mejores materiales docentes (más laboratorios virtuales, screencasts, videos...) a la asignatura y el equipo docente adquiera experiencia también en el uso del software en el aula.

Consideramos además que la experiencia se puede transferir a cualquier otro contexto de la UPV, aunque nuestra recomendación es que se aplique en los últimos cursos de grado y los cursos de master, en los que el alumno ya cuenta con un determinado dominio de las herramientas informáticas y de cálculo.

\section{Referencias}

BABICH, A., MAVROMMATIS, K. (2009), “Teaching of Complex Technological Processes Using Simulations” en International Journal of Engineering Education, vol. 25, no 2, p. 209, 2009. 
Smulación de sistemas energéticos como metodología para el desarrollo competencial en la asignatura Ampliación de Energía.

CABERO, J. (2008), "Las TICs en la enseñanza de la química: aportaciones desde la Tecnología Educativa” en Química: vida y progreso. Asociación de químicos de Murcia, 2008.

IBRAHIM, D. (2011), "Engineering simulation with MATLAB: improving teaching and learning effectiveness” en Procedia Computer Science, vol.3, pp 853-858, 2011.

\section{Agradecimientos}

Los autores de este trabajo quieren expresar su gratitud al Instituto de Ciencias de la Educación y a la Escuela Técnica Superior de Ingenieros Industriales de la Universitat Politècnica de València, por su apoyo y financiación para la realización de este PIME concedido en el curso 2016-2017 (proyecto B25).

Este proyecto forma parte de los trabajos llevados a cabo por los miembros del EICE SEERI del Departamento de Ingniería Química y Nuclear.

(cc) EY-NC-ND 2018, Universitat Politècnica de València

Congreso IN-RED (2018) 


\title{
Aproximación al problema contemporáneo de la Energía y el Desarrollo Sostenible con Técnicas de Gamificación
}

\section{Sergio Gallardo ${ }^{a}$, José Felipe Villanueva ${ }^{b}$, María Lorduyc, Belén Juste ${ }^{d}$}

${ }^{a}$ Dpto. de Ingeniería Química y Nuclear, Universitat Politècnica de València, Spain, email: sergalbe@iqn.upv.es; 'b Dpto. de Ingeniería Química y Nuclear, Universitat Politècnica de València, Spain, email:jovillo0@upvnet.upv.es; 'Instituto Universitario de Seguridad Industrial, Radiofísica y Mediambiental (ISIRYM), Universitat Politècnica de València, Spain, email: maloral@upv.es; ${ }^{\mathrm{d}}$ Dpto. de Ingeniería Química y Nuclear, Universitat Politècnica de València, Spain, email: bejusvi@iqn.upv.es

\begin{abstract}
In recent years, the need to explore new teaching strategies has been proven, which encourages a more active role on the part of the students and which favors the motivation to learn. In this framework, it is worth highlighting methodologies such as gamification. In the techniques of gamification, game mechanics are applied in areas that are normally not playful, enhancing the involvement of students through rewards.

This methodology is being applied in the subject "Energy and Sustainable Development" of the Master's Degree in Industrial Engineering (MUII) of the Technical School of Industrial Engineers (ETSII) of the Universitat Politècnica de València (UPV), mainly aimed at small groups of exchange students.

In this subject, with an eminently practical approach, several gamified activities are proposed for learning of contents related to renewable energies: It is about carrying out the energy planning of an imaginary country that includes a series of economic and environmental restrictions. Depending on the results and their argumentation, "stars" are awarded, which allows students to acquire learning stimulated by reasoning and the added motivation of the game.
\end{abstract}

Keywords: Gamification, Specific competencies, Transversal competencies, Master Engineering.

\section{Resumen}

En los últimos años se ha comprobado la necesidad de explorar nuevas estrategias de enseñanza, que potencien un rol más activo por parte de los alumnos y que favorezcan la motivación por aprender. En este marco, cabe destacar metodologías como la gamificación. En las técnicas de ludificación o gamificación se aplican mecánicas de juego en ámbitos que normalmente no son lúdicos, potenciándose la involucración del alumnado mediante recompensas.

Esta metodología se está aplicando en la asignatura "Energy and Sustainable Development” del Máster Universitario de Ingeniería Industrial (MUII) de la Escuela Técnica Superior de Ingenieros Industriales (ETSII) de la Universitat 
Politècnica de València (UPV), fundamentalmente dirigida a grupos reducidos de alumnos de intercambio.

En esta asignatura, de enfoque eminentemente práctico, se plantean diversas actividades gamificadas para el aprendizaje de contenidos relacionados con las energías renovables: se trata de realizar la planificación energética de un país imaginario al que se le incluye una serie de restricciones económicas y medioambientales. En función de los resultados y su argumentación se otorgan "estrellas", lo que permite alumno adquirir un aprendizaje estimulado por el razonamiento y la motivación añadida del juego.

Palabras clave: Gamificación, Competencias específicas, Competencias transversales, Máster en Ingeniería.

\section{Introducción}

El Espacio Europeo de Educación Superior (EEES) ha propiciado la aparición y desarrollo de nuevas metodologías de trabajo dentro y fuera del aula para potenciar un rol más activo por parte de los alumnos. Este nuevo enfoque obliga a abandonar la tradicional zona de confort tanto de los profesores como de los alumnos. En el caso de los profesores se debe producir un cambio de mentalidad para renunciar al esquema actual de transmisión de conocimientos y asimilar nuevas metodologías de trabajo con el fin de proporcionar herramientas a los alumnos para que puedan adquirir conocimientos de manera más autónoma. La motivación por aprender es esencial (Romero y Pérez Ferra, 2009), ya que es una de las variables que más incidencia tiene en el rendimiento del alumnado. Los actuales resultados en los indicadores de muchas titulaciones evidencian la necesidad de explorar nuevas estrategias de motivación por parte del profesorado. Este contexto exige modificar la forma en la que se presenta la información al alumnado y, por lo tanto, implica un cambio en la relación entre los profesores y alumnos. En este marco, metodologías como la clase inversa (o flipped classroom) y la gamificación están comenzando a hacerse un hueco en la docencia universitaria.

En las técnicas de ludificación o gamificación se aplican mecánicas de juego en ámbitos que normalmente no son lúdicos (Deterding et al., 2011, Llagostera, 2012, Werbach, 2014 y Attali y Arieli-Attali, 2015). Muchos aspectos del juego y los propios juegos son muy propicios para el aprendizaje (Bruder, 2015). La gamificación en la educación pretende potenciar la acción, promover el aprendizaje y resolver problemas (Kapp, 2012). Sin embargo, hasta la fecha, las experiencias y resultados publicados sobre los beneficios e inconvenientes de utilizar esta técnica son estudios puntuales realizados en un único curso académico y con equipos de alumnos en muchas ocasiones también reducidos (Urquidi y Calabor, 2014, Ibañez, 2015, Castilla et al., 2013 y Monguillot et al., 2015).

Mediante las actividades basadas en juegos se pueden potenciar nuevos hábitos de trabajo más motivadores, potenciando la concentración y el esfuerzo (Deterding et al., 2011). ¿Cómo transformar una actividad formativa convencional en una actividad gamificada? A priori, se puede caer en el error en transformar la actividad en un juego, trivializándolo y obviando el fin último de aprendizaje. Resulta indispensable ser conscientes de lo que implica la gamificación,

(c) ) EY-NC-ND 2018, Universitat Politècnica de València

Congreso IN-RED (2018) 
cuáles son sus ventajas e inconvenientes, de qué herramientas dispone el docente para llevar a cabo este tipo de actividades y cómo debe presentar la actividad al alumnado.

En principio, cualquier actividad puede ser gamificada si se cumplen las siguientes premisas: la actividad puede aprenderse, las acciones de los usuarios se pueden medir y, existe una realimentación al mismo (Gónzalez y Mora, 2015). Las motivaciones que se pueden transmitir a los alumnos son, entre otras: recompensa, competición, reconocimiento o estatus, autoexpresión, altruismo, superación, etc. Las mecánicas también son muy variadas: avatares, insignias, puntos, colecciones, rankings, niveles, bienes virtuales, misiones y retos, desafíos, etc. (de Cea, 2014).

En buena parte, el éxito o el fracaso de las dinámicas gamificadas depende del grado de identificación del alumno con la dinámica y la actividad en sí misma. Según Valderrama (2015), hay que tener en cuenta el perfil del estudiante y programar la actividad en consecuencia: hedonistas / luchadores, exploradores / controladores, guerreros / constructores, socializadores / solitarios, etc. Personalizar los retos permite atender a diferentes ritmos de aprendizaje (Monguillot et al., 2015).

La actividad implica desafíos en todas sus etapas: diseño, ejecución y realimentación. Muchos trabajos publicados identifican como una gran ventaja de la gamificación la mejora del trabajo en grupo y la sociabilización de los alumnos: competir, colaborar y comparar logros (Gonzalez y Mora, 2015 y Riquel, 2014). Existen importantes dificultades para fijar objetivos, establecer roles, gestionar la dinámica, definir indicadores, etc. En muchas ocasiones se trata de un proceso de prueba y error. La satisfacción del alumnado y la medición de los objetivos son una buena guía para dirigir la actividad en los sucesivos cursos.

Existen numerosas herramientas que facilitan la gamificación de actividades. A continuación, se realiza una somera descripción de las más conocidas.

- Socrative: es una herramienta para conocer la respuesta de los alumnos en tiempo real mediante PCs y móviles. La aplicación es gratuita. Presenta una gran versatilidad en cuanto al formato de preguntas que se pueden plantear: de múltiple opción, de verdadero o falso, respuestas cortas, etc.

- QuizBean (Bluehouse Gruop Production, 2015) permite realizar exámenes interactivos.

- Proyecto Descartes (Proyecto Descartes, 2015), permite elaborar recursos didácticos interactivos que se embeben en páginas html.

- Kuizza (Kuizza, 2015) permite que los profesores creen un cuestionario y compartirlo con los alumnos.

En la bibliografía consultada, predomina la gamificación mediante juegos de cuestiones (Castilla et al., 2013 e Ibañez, 2015).

En el presente trabajo se describen algunas experiencias de gamificación que se están aplicando en la asignatura "Energy and Sustainable Development” del Máster Universitario de Ingeniería Industrial (MUII) de la Escuela Técnica Superior de Ingenieros Industriales (ETSII)

(cc) EY-NG-ND 2018, Universitat Politècnica de València 
de la Universitat Politècnica de València (UPV). Estas metodologías utilizadas de manera conjunta ofrecen un escenario idóneo para trabajar algunas competencias transversales.

\section{Objetivos}

Los objetivos fundamentales de esta innovación son potenciar la motivación, la concentración y el esfuerzo mediante la aplicación de técnicas de gamificación combinadas con aprendizaje basado en casos en la asignatura "Energy and Sustainable Development" del Máster Universitario de Ingeniería Industrial (MUII) de la Escuela Técnica Superior de Ingenieros Industriales (ETSII) de la Universitat Politècnica de València (UPV).

Para ello se va a presentar el diseño de las actividades, las herramientas utilizadas y la implementación en clase. Los resultados de la innovación docente, al estar en desarrollo, se basan en la realimentación inicial por parte del alumnado.

Por último, se presenta la forma en la que se ha integrado el trabajo relativo a algunas competencias transversales en el marco de actividades ludificadas.

\section{Desarrollo de la innovación}

\subsection{Energy and Sustainable Development}

La asignatura en la que se ha desarrollado la innovación docente es "Energy and Sustainable Development” del Máster Universitario de Ingeniería Industrial (MUII) de la Escuela Técnica Superior de Ingenieros Industriales (ETSII) de la Universitat Politècnica de València (UPV). Se trata de una asignatura optativa con 4,5 créditos (2,4 de teoría y 2,1 de prácticas) y docencia íntegramente en inglés. Tiene un enfoque eminentemente práctico y está fundamentalmente dirigida a alumnos de intercambio. El curso 2017-2018 es el primero en el que se está impartiendo docencia. En la asignatura se analizan aspectos del problema energético relacionados con el medio ambiente y la sostenibilidad. Las competencias específicas están relacionadas con temas de energías renovables, energía nuclear y aspectos sociales, económicos y ambientales de la generación de energía. Se intenta dar un enfoque europeo, intentando reducir en la medida de lo posible, los ejemplos relativos a España y potenciando los casos y ejemplos de otros países europeos. Además de las competencias específicas, se trabajan principalmente tres competencias transversales según el marco establecido en el proyecto institucional de competencias transversales UPV. Estas competencias son: "Responsabilidad ética, profesional y medioambiental", "Conocimiento de problemas contemporáneos" e "Instrumental específica”. La docencia se distribuye en clases presenciales de 1,5 horas, con dos sesiones por semana. En el presente curso hay 10 alumnos matriculados de diversas nacionalidades: Alemania, Suecia, Finlandia e Italia. El perfil de los alumnos es eminentemente técnico. Todos ellos son graduados: ingeniería química, ingeniería mecánica e ingeniería de la energía.

Debido al reducido número de alumnos, el carácter descriptivo de la asignatura y el perfil internacional de los mismos se ha optado por minimizar la clase magistral para potenciar otras

(cc) EY-NC-ND 2018, Universitat Politècnica de València

Congreso IN-RED (2018) 
metodologías activas a las que, por otro lado, ya están acostumbrados la mayoría de los alumnos de esta asignatura.

Este marco tan específico es, a priori, un escenario idóneo para experimentar metodologías activas de enseñanza-aprendizaje. Con el objetivo doble de trabajar competencias específicas y transversales se ha decidido realizar experiencias aplicando técnicas de gamificación y aprendizaje basado en casos.

Los contenidos de la asignatura se pueden clasificar en tres grandes bloques: energías renovables, aspectos económicos y aspectos medio ambientales.

\subsection{Planteamiento de la gamificación}

Partiendo de la idea de la gamificación y el aprendizaje basado en casos, se ha intentado buscar los contenidos de la asignatura que mejor podrían adaptarse a este tipo de dinámicas. Es cierto que la propia asignatura se presta a ello, debido fundamentalmente al tipo de contenidos y a la repercusión social, económica y medioambiental de dichos contenidos. En primer lugar, se ha realizado una revisión de los contenidos buscando aquellos que ofrezcan mayor número de grados de libertad a la hora de buscar herramientas y técnicas de gamificación. Tal y como se ha mencionado en el apartado anterior, los contenidos de la asignatura se clasifican en los bloques de energías renovables, aspectos económicos y aspectos medio ambientales. En el bloque de energías renovables se estudia la energía solar, la energía eólica, las energías del mar y la energía hidráulica. Además, este bloque incluye un tema de introducción al problema energético en el que se presentan las reservas y producciones actuales a nivel mundial y se señalan los escenarios y retos a medio y largo plazo. Desde un principio los profesores de la asignatura hemos sido conscientes de la oportunidad que representa trabajar con alumnos procedentes de diferentes países y hemos querido convertir esta situación en una ventaja de cara a plantear la asignatura.

Con esta idea en mente, se han planteado diversas actividades gamificadas en el bloque de energías renovables. La idea fundamental de la experiencia es realizar la planificación energética de un país imaginario al que se le incluye una serie de restricciones económicas y medioambientales. ¿Cómo se puede abastecer de energía eléctrica a un determinado país? ¿Qué implicaciones económicas, sociales y ambientales tiene la generación de energía? ¿Qué factores diferencian a un país de otro en este tema? ¿Es bueno focalizar toda la inversión en unas pocas fuentes de energía? ¿Qué ventajas e inconvenientes presenta cada una de las formas de energía? ¿Sólo renovables? ¿Y la nuclear? Esta batería de preguntas no tiene por objetivo abrumar al alumnado, sino hacerles partícipes de la complejidad del problema.

Los alumnos trabajan por parejas y todos parten de una "hoja en blanco" que caracteriza el país. El país en cuestión dispone de un presupuesto determinado para construir (desde cero) parques eólicos, plantas fotovoltaicas, centrales de biomasa, centrales hidroeléctricas, etc. Además del presupuesto de construcción, se proporciona un presupuesto anual para cubrir los gastos básicos del sistema (excepto los derivados de la venta de la energía eléctrica, que son sufragados por los consumidores del país). 
Los costes de inversión y de generación de estas diferentes tecnologías se han extraído del Plan de Energías Renovables (PER 2011-2020) del Ministerio de Energía, Turismo y Agenda Digital, de tal forma que se dispone del orden de magnitud relacionado con los costes de inversión y generación de cada fuente de energía.

Por otra parte, el sistema de generación de energía debe cubrir una demanda anual con variaciones diarias (con máximos en horas punta y mínimos de demanda en horas valle).

Así pues, las restricciones y condiciones del juego son las siguientes:

- Un país con una determinada demanda de energía eléctrica anual con máximos y mínimos diarios.

- Disponibilidad para construir cualquier instalación que utilice energías renovables.

- Disponibilidad de un máximo de capital de inversión.

- Se deberá tener en cuenta el coste de generación de la energía y aspectos medioambientales.

Una vez presentado el escenario, cada grupo deberá realizar la planificación del sistema energético de ese país teniendo en cuenta las restricciones enumeradas. La gamificación se extiende a lo largo de todo el curso, puesto que a medida que se presentan los contenidos teóricos de la asignatura, cada grupo aprende a estimar la energía que se produce con cada una de las tecnologías.

Al finalizar el curso, los equipos presentan su planificación energética. El grupo que mejor consigue adaptarse a la demanda, utilizando un mayor número de tecnologías con el menor coste de inversión y/o generación, gana la competición.

En una sesión final, los equipos presentan su planificación exponiendo los pros y contras de su propuesta y las implicaciones económicas y medioambientales.

La conclusión final del trabajo es que a partir de las condiciones presentadas no se puede garantizar la cobertura de la demanda a no ser que se compatibilice el uso de las renovables con otras tecnologías de carácter convencional como las centrales de carbón o las nucleares, porque no se va a poder cubrir la demanda en periodos en los que no existan buenas condiciones de viento, radiación solar, etc.

Así pues, el objetivo de la dinámica es doble. Por un lado, aprender a realizar cálculos de dimensionado de instalaciones eólicas, fotovoltaicas, de biomasa e hidráulicas y, por otro lado, hacer conscientes a los alumnos de la necesidad de compatibilizar el mayor número posible de tecnologías en aras de garantizar el consumo.

Tal y como se puede concluir, con las actividades propuestas se están trabajando diversas competencias transversales, como "Comunicación Efectiva” o "Conocimiento de Problemas Contemporáneos”, ya que, en la asignatura, el alumnado trabaja para analizar el problema del abastecimiento energético a las colectividades.

(c) ) EY-NC-ND 2018, Universitat Politècnica de València

Congreso IN-RED (2018) 


\subsection{Diseño de actividades}

A lo largo del curso, los equipos van aplicando los conocimientos adquiridos para determinar, con el presupuesto disponible, qué tecnologías van a utilizar, dónde se van a situar, cuál va a ser la energía que van a producir y cuál va a ser el coste, tanto de inversión como de generación.

A continuación, se describe someramente las actividades propuestas.

- Actividad 1: Energía eólica.

En esta actividad se establecen las bases para el cálculo y dimensionado de parque eólicos. Se explica el funcionamiento de la herramienta informática on-line “Atlas eólico” del Instituto para la Diversidad y Ahorro Energético (IDAE). Se explican los fundamentos de los cálculos eólicos y mediante el uso del "Atlas eólico" se plantea al grupo que busquen y seleccionen ubicaciones idóneas para la construcción de parques eólicos. Estas ubicaciones deben tener buenas características en cuanto a viento (densidad de potencia eólica) y en cuanto a características orográficas (disposición de cimas y cordilleras con direcciones apropiadas respecto a la dirección predominante del viento). En la Figura 1 se muestra, a modo de ejemplo, una zona concreta con sus características eólicas y orográficas.

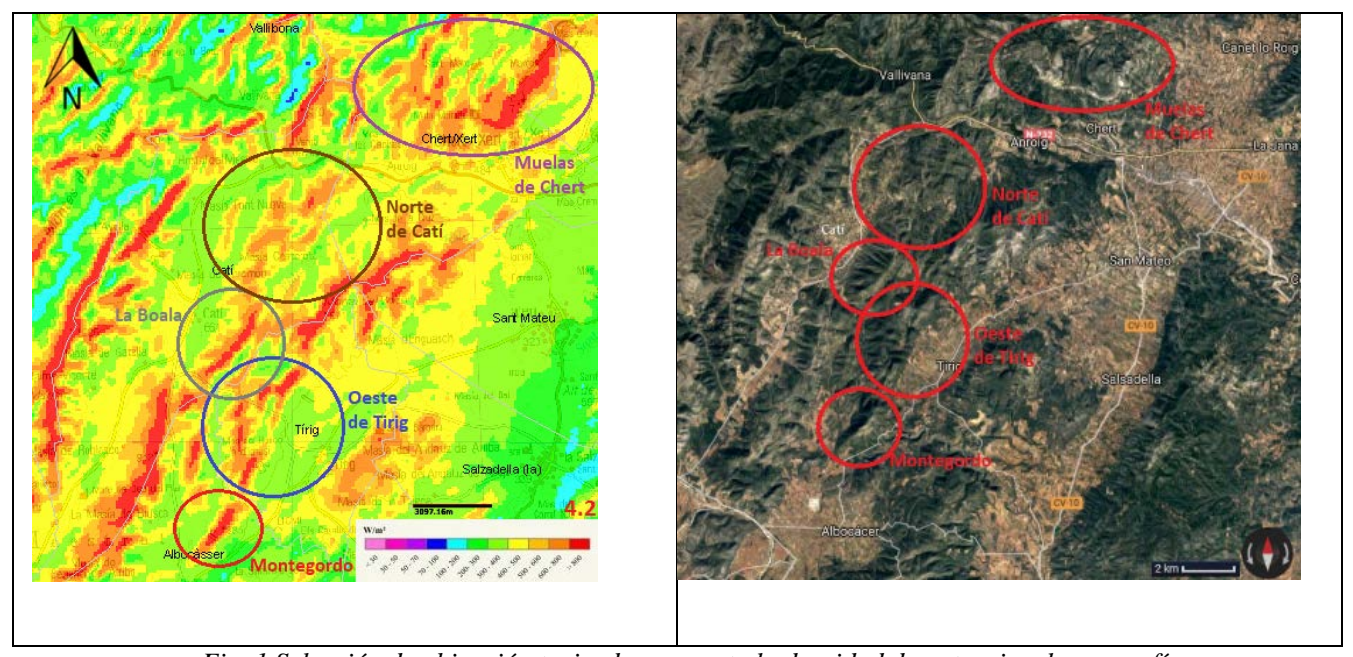

Fig. 1 Selección de ubicación teniendo en cuenta la densidad de potencia y la orografía.

Con la metodología explicada en la parte teórica, el alumnado aprende a estimar cuántos aerogeneradores y que energía podría producirse en una determinada ubicación. Con esta competencia específica adquirida, se utiliza el mapa eólico de España para que los alumnos localicen diferentes ubicaciones hasta alcanzar un máximo de potencia total.

- Actividad 2: Energía solar fotovoltaica.

Siguiendo la misma idea de la Actividad 1, se proporcionan las herramientas necesarias para calcular la energía que se puede producir mediante la tecnología solar fotovoltaica. Una vez

(c)) EY-NG-ND 2018, Universitat Politècnica de València 
expuestos los cálculos teóricos, se presenta la utilidad Photovoltaic Geographical Information Syste (PVGIS) de la Comisión Europea y se explica su uso. En la Figura 2 se muestra un cálculo correspondiente a una localización determinada en Italia. En este caso, los alumnos podrán buscar ubicaciones posibles para construir diferentes centrales fotovoltaicas hasta alcanzar un máximo de potencia instalada. El resultado del cálculo será, de nuevo, la energía capaz de producirse por dichas centrales.

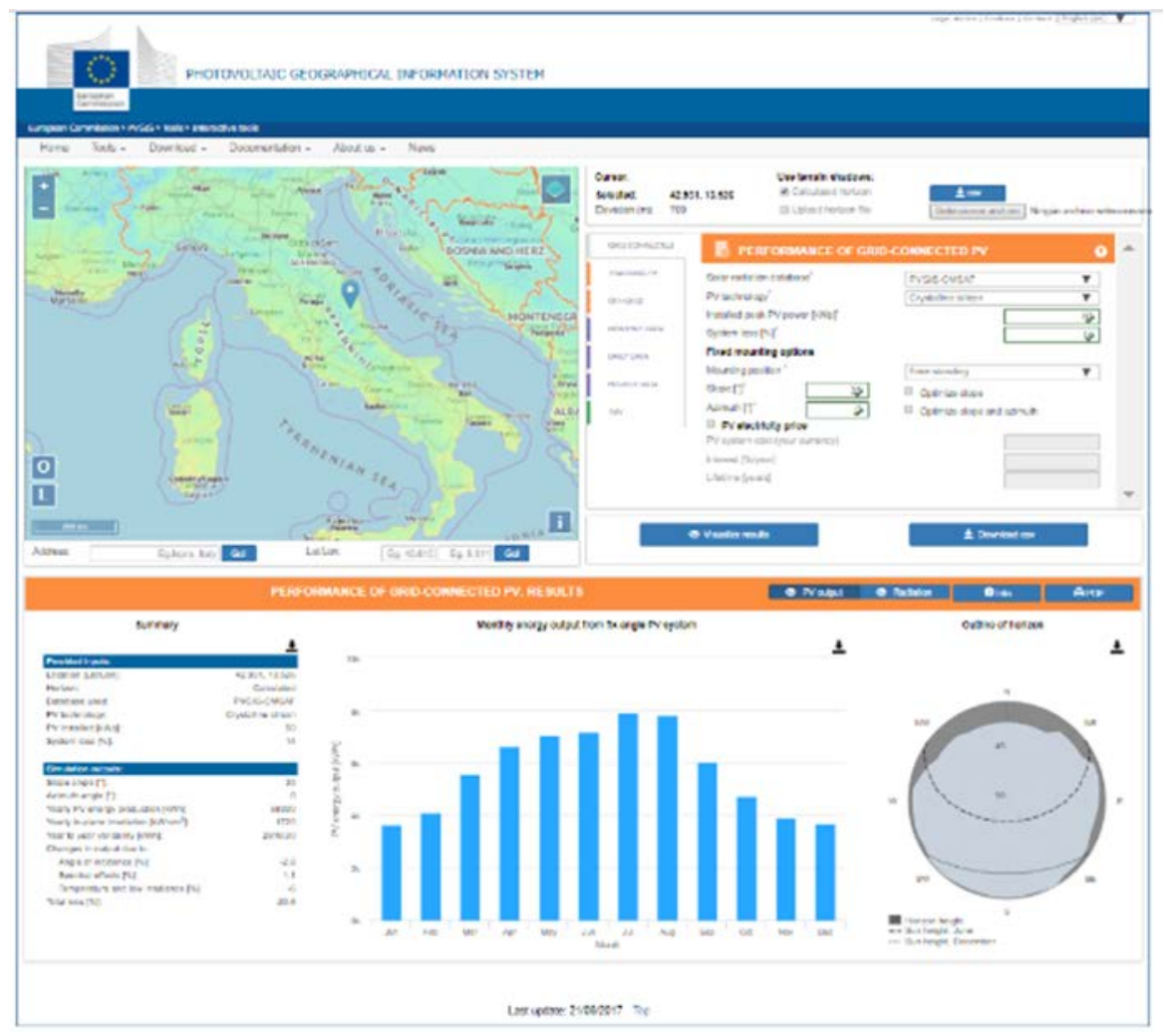

Fig. 2 Herramienta de cálculo PVGIS para estimar la energía eléctrica con fotovoltaica.

- Actividad 3: Energía hidroeléctrica.

Aplicando la misma metodología, se expone como se evalúa la producción de energía a partir del caudal de un río o de un volumen embalsado. Se utiliza el software Retscreen ( $)$ para estimar la producción energética de un determinado río, teniendo en cuenta limitaciones técnicas y medioambientales. Para el caso de aplicación del país imaginario, se facilitará el inventario de embalses de un país como España, con su producción eléctrica anual y la estimación del coste de construcción de una central genérica por MW instalado. 
- Actividad 4: Otras fuentes de energía. Energías del mar.

En este caso, debido al grado de inmadurez de las tecnologías, la exposición se limita a describir las posibles formas del aprovechamiento energético y a realizar un inventario de las instalaciones existentes a nivel mundial.

- Actividad 5. Cálculo económico.

Una vez descritas las tecnologías básicas se proporcionan las bases para realizar un cálculo económico, conociendo los costes de inversión, el coste de generación y una aproximación a las tarifas aplicables. El alumno aprende a calcular parámetros económicos como la Tasa Interna de Rentabilidad, el Valor Actual Neto y el Periodo de Retorno. Estos parámetros van a ser muy importantes para que cada grupo evalúe la rentabilidad y sostenibilidad económica de las soluciones que ellos mismos propongan.

- Actividad 6. Impacto ambiental.

Por último, se proporcionan unas directrices básicas de cómo se realiza una evaluación de impacto ambiental, qué proyectos deben someterse a tal estudio y cómo se establece un plan de prevención y minimización de impactos.

El objetivo la gamificación propuesta es obtener puntos o “estrellas” por retos. Cada tecnología (o actividad) representa un reto. Obtiene mayor puntuación en cada reto el grupo que cumple el mayor número de los siguientes criterios:

- Mayor cantidad de energía al menor coste de inversión (MW/€). Máximo 10 estrellas.

- Calidad de los resultados en cuanto a selección de ubicaciones, cálculos razonados y calidad de las fuentes de información consultadas. Máximo 10 estrellas.

En las Actividades 1, 2 y 3, se evalúan los dos criterios, y se van acumulando el número de estrellas. Las Actividades 4, 5 y 6 se puntúan mediante cuestionarios Socrative con un máximo de 10 estrellas por actividad.

En la puesta en común se pueden conseguir 20 estrellas adicionales. Esta puntuación se reparte de la siguiente forma:

- 10 estrellas por la puntuación de los profesores, atendiendo a criterios de razonamiento de los alumnos en cuanto a la idoneidad de la planificación propuesta por los equipos. ¿Se trata de una buena solución? ¿Se llega a cubrir la demanda del país? ¿Cómo se han tenido en cuenta la variabilidad de la demanda?

- 10 estrellas por la puntuación de los restos de equipos. Para ello, se facilita un pequeño cuestionario para que valoren en función de una serie de ítems, la actuación de los demás equipos.

(c) 2018, Universitat Politècnica de València 
Al finalizar la dinámica, el profesor valora el trabajo global realizado en las diferentes actividades, la capacidad de razonamiento, la disposición a entablar un debate aportando o rebatiendo argumentos, la calidad de la exposición y del trabajo en general.

\subsection{Competencias transversales}

Con esta metodología se trabajan algunas competencias transversales, fundamentales para el perfil profesional y formativo de los alumnos. Concretamente: "Conocimiento de problemas contemporáneos" permite tomar conciencia de nuestro entorno, facilitando la propuesta de soluciones a los problemas del campo profesional; "Responsabilidad ética, profesional y medioambiental” fomenta el actuar de un modo coherente y la responsabilidad en la actuación y toma de decisiones, así como la capacidad para juzgar actuaciones profesionales en términos de respeto a la sociedad y al medio ambiente. Por último, la competencia "Instrumental específica" ayuda a dominar las herramientas específicas.

\section{Resultados}

\subsection{Evaluación de la materia específica}

A partir de esta aplicación de la gamificación se evalúan varios contenidos de la materia específica de la asignatura como el diseño de sistemas, cálculos económicos y la consideración de aspectos ambientales en los proyectos de ingeniería, así como la asimilación de éstos en su argumentación y discusión. Esto se realiza a partir de diversos criterios. Mediante la puntuación subjetiva de los compañeros y del profesor en el debate, así como la puntuación obtenida en los cuestionarios Socrative y el ratio MW/€ en la gamificación, se obtiene una valoración global.

De este modo, la calificación puede ser proporcional al número de "estrellas" obtenido en el “juego”. La valoración última representa un $25 \%$ de la nota final de la asignatura en concepto de trabajos académicos y exposiciones.

\subsection{Evaluación de competencias transversales}

En cuanto a las competencias transversales trabajadas, se presenta a modo de ejemplo en la Tabla 1, la evaluación correspondiente a la competencia "Conocimiento de Problemas Contemporáneos”. Al tratarse de una asignatura de máster, se ha seguido un nivel de dominio III.

A partir de los indicadores listados en la Tabla 1, se califica los resultados obtenidos en una escala de valoración de cuatro valores $A, B, C, D$, correspondiéndose a: excelente (A), adecuado (B), en desarrollo (C) o no alcanzado (D). 
Tabla 1. Rúbrica para "Energy and Sustainable Development” - Nivel de dominio III-

\begin{tabular}{|c|c|c|c|c|}
\hline Indicador & $\begin{array}{ll}\text { D. } & \text { No } \\
\text { alcanzado } & \end{array}$ & C. En desarrollo & $\begin{array}{l}\text { B. Bien } \\
\text { /adecuado }\end{array}$ & $\begin{array}{l}\text { A. Excelente } \\
\text { Ejemplar }\end{array}$ \\
\hline $\begin{array}{l}\text { Analiza y relaciona aspectos sociales } \\
\text { se ven afectados por el abastecimiento } \\
\text { de energía a las colectividades. }\end{array}$ & $\begin{array}{ll}\text { No } & \text { analiza } \\
\text { ningún } & \text { aspecto } \\
\text { social. } & \end{array}$ & $\begin{array}{l}\text { Analiza sin } \\
\text { relacionar uno o } \\
\text { dos problemas } \\
\text { sociales. }\end{array}$ & $\begin{array}{l}\text { Analiza y } \\
\text { relaciona uno o } \\
\text { dos problemas } \\
\text { sociales. }\end{array}$ & $\begin{array}{lr}\text { Analiza } & \text { y } \\
\text { relaciona } & \text { más } \\
\text { de } & \text { dos } \\
\text { problemas } & \\
\text { sociales. } & \end{array}$ \\
\hline $\begin{array}{l}\text { Analiza y relaciona aspectos } \\
\text { medioambientales se ven afectados } \\
\text { por el abastecimiento de energía a las } \\
\text { colectividades. }\end{array}$ & $\begin{array}{l}\text { No analiza } \\
\text { ningún medio } \\
\text { ambiental. }\end{array}$ & $\begin{array}{l}\text { Analiza sin } \\
\text { relacionar uno o } \\
\text { dos problemas } \\
\text { medio } \\
\text { ambientales. }\end{array}$ & $\begin{array}{l}\text { Analiza y } \\
\text { relaciona uno o } \\
\text { dos problemas } \\
\text { medio } \\
\text { ambientales. }\end{array}$ & $\begin{array}{lr}\begin{array}{l}\text { Analiza } \\
\text { relaciona }\end{array} \text { más } \\
\text { de } & \text { dos } \\
\text { problemas } & \\
\text { medio } & \\
\text { ambientales. }\end{array}$ \\
\hline $\begin{array}{l}\text { Analiza y relaciona las repercusiones } \\
\text { económicas del abastecimiento de } \\
\text { energía a las colectividades. }\end{array}$ & $\begin{array}{l}\text { No analiza } \\
\text { ninguna } \\
\text { repercusión } \\
\text { económica. }\end{array}$ & $\begin{array}{l}\text { Analiza sin } \\
\text { relacionar una o } \\
\text { dos } \\
\text { repercusiones } \\
\text { económicas. }\end{array}$ & $\begin{array}{l}\text { Analiza y } \\
\text { relaciona una o } \\
\text { dos } \\
\text { repercusiones } \\
\text { económicas. }\end{array}$ & $\begin{array}{l}\text { Analiza y } \\
\text { relaciona más } \\
\text { de dos } \\
\text { repercusiones } \\
\text { económicas. }\end{array}$ \\
\hline
\end{tabular}

La gamificación se presta al trabajo de esta competencia porque durante toda la asignatura se realizan continuas referencias a las implicaciones sociales, medio ambientales y económicas del problema energético. Se utiliza Socrative para introducir cuestiones relacionadas con esta competencia durante la gamificación. La rúbrica de evaluación se aplica para objetivar el desempeño de los grupos en esta competencia y se utiliza durante la presentación que se realiza al finalizar la dinámica de gamificación.

\subsection{Evaluación de la metodología}

Debido al gran nivel de compromiso e implicación de los estudiantes al asumir el rol de profesional de la ingeniería, gracias al carácter realista de esta actividad, se ha apreciado una comprensión más profunda de los conceptos de la asignatura, lo que les ha permitido aplicarlos de forma correcta a las actividades. Para que esta metodología pueda desarrollarse correctamente por parte de los alumnos, habida cuenta que se emplean diferente software para los cálculos de las instalaciones que diseñan, es de gran importancia que el profesor que imparte las clases prácticas en las que se enseña el manejo de los programas, constate que se han adquirido los conocimientos necesarios para realizar los cálculos de forma autónoma. Asimismo, dado que preparan y realizan una exposición final del trabajo que han llevado a cabo, se mejora y potencia su expresión oral y dotes comunicativas, maximizándose la participación al trabajar en grupos pequeños.

Actualmente, todavía no se dispone de información relativa a la satisfacción del alumnado por la metodología utilizada, aunque si que se dispone de una realimentación informal a partir de charlas con los alumnos. La mayoría reconoce la utilidad de esta metodología siempre y cuando se compagine con otras técnicas (estudio de casos, trabajos por proyectos, etc.).

(c) B BY-NC-ND 2018, Universitat Politècnica de València

Congreso IN-RED (2018) 


\section{Conclusiones}

En los últimos años se ha visto la importancia de diseñar unas clases donde los alumnos tengan un rol más activo. Con este fin, se pensó en la metodología de la gamificación, que actualmente se está aplicando en la asignatura "Energy and Sustainable Development" del Máster Universitario de Ingeniería Industrial (MUII) de la Escuela Técnica Superior de Ingenieros Industriales (ETSII) de la Universitat Politècnica de València (UPV). Este trabajo presenta la experiencia de la implantación de dicha técnica.

Las actividades que se llevan a cabo combinan la metodología de la gamificación con el aprendizaje basado en casos. El objetivo de la dinámica es doble: por un lado, aprender a realizar cálculos de dimensionado de instalaciones eólicas, fotovoltaicas, de biomasa e hidráulicas y, por otro, hacer consciente al alumnado de la necesidad de compatibilizar el mayor número posible de tecnologías en aras de garantizar la demanda. Se premia mediante “estrellas” la obtención de unos resultados satisfactorios.

A su finalización, se defiende el trabajo ante el grupo-clase. El profesor debe valorar el trabajo global llevado a cabo por el alumno, su capacidad de razonamiento, la disposición a entablar un debate aportando o rebatiendo argumentos, la calidad de la exposición y del trabajo en general. También interaccionan el resto de los compañeros, que valoran la actuación de los demás equipos.

Con esta metodología se pretende que el alumno adquiera conocimientos partiendo de las conclusiones que adquiere de su propio razonamiento. El éxito radica, en gran medida, en su motivación.

\section{Agradecimientos}

Este trabajo se ha realizado en el marco del proyecto Proyecto de Innovación y Mejora Educativa, PIME Curso 2017-2018 "Coordinación de competencias transversales en asignaturas de ámbito nuclear en el Grado de Ingeniero de la Energía”, Referencia B07, del Vicerrectorado de Estudios, Calidad y Acreditación de la Universitat Politècnica de València.

\section{Referencias}

ROMERO, M. y PÉREZ FERRA, M. (2009). “Cómo motivar a aprender en la universidad: una estrategia fundamental contra el fracaso académico en los nuevos modelos Educativos". Revista Iberoamericana de Educación, vol. 51, p. 87-105.

ATTALI, Y. y ARIELI-ATTALI, M. (2015) "Gamification in assessment: Do points affect test performance?”, Computers \& Education, vol. 83, p. 57-63.

BRUDER, P. (2015). “GAME ON: Gamification in the Classroom”. Education Digest, vol. 80 (7), p. 56-60.

CASTILlA, G., ROMANA, M. G. y LOPEZ-TERRADAS, B. (2013) "Concursando en el aula: la gamificación mediante quiz-show como herramienta de dinamización docente” en : $X$ 
Jornadas Internacionales de Innovación Universitaria. Educar para transformar. Universidad Europea.

CEA, A. (2014) "Diseño y desarrollo de aplicaciones software para la creación de actividades docentes con elementos de Gamificación”. Universidad Autónoma ed Madrid.

DETERDING, et al. (2011). “Gamification: Toward a Definition” en CHI 2011. Vancouver. AMC 978-1-4503-0268-5/11/05.

GONZALEZ, C.S. y MORA, A. (2015). “Técnicas de gamificación aplicadas en la docencia de Ingeniería Informática”. Revista de Investigación en Docencia Universitaria de la Informática (ReVisión) vol 8, núm 1.

IBAÑEZ MORENO, A. (2015). La gamificación para (auto)evaluar las competencias léxicogramaticales en el aula de inglés como segunda lengua en el contexto de la enseñanza a distancia: un estudio de caso. Verbeia Número 0. Universidad Camilo José Cela.

KAPP, K. M. (2012). The gamification of learning and instruction: Game-based methods and strategies for training and education. San Francisco: Pfeiffer.

LLAGOSTERA, E. (2012). “On Gamification and Persuasion” en XI SB Game. SBCProceeding of SB Games. Brasilia. Games for change-Full papers. p.12-21.

MONGUILLOT HERNANDO, M. et al. (2015) "Play the Game: gamificación y hábitos saludables en educación física”. Apunts. Educación Física y Deportes vol. 119, p. 71-79.

RIQUEL, A.M., (2014) "Incrementando la motivación en la clase de ELE: el uso de la gamificación en el aula”. Universidad de Sevilla.

URQUIDI MARTIN, A. C. y CALABOR PRIETO, M. S. (2014) “Aprendizaje a través de juegos de simulación: un estudio de los factores que determinan su eficacia pedagógica”. EDUTEC. Revista Electrónica de Tecnología Educativa.

VALDERRAMA, B. (2015) “Los secretos de la gamificación: 10 motivos para jugar”. Capital Humano vol. 295, p.72-78.

WERBACH, K. (2014). “(Re) Defining Gamification: A Process Approach” Spagnolli, A. en Persuasive Technology. PERSUASIVE 2014. Lecture Notes in Computer Science. Springer International Publishing. vol. 8462, p. 266-272. 


\title{
Diseño de rúbricas para la evaluación de competencias transversales. Aplicación a Trabajos Fin de Grado en ingeniería
}

\author{
Isabel Martón a , Sergio Gallardo ${ }^{\mathrm{b}}$, José Felipe Villanueva ${ }^{\mathrm{c}}$ y Jose Ordónez ${ }^{\mathrm{d}}$ \\ ${ }^{a}$ Dpto. de Estadística e Investigación Operativa Aplicadas y Calidad, Universitat Politècnica de \\ València, Spain, email: ismarllu@upvnet.upv.es; ${ }^{\circ}$ Dpto. de Ingeniería Química y Nuclear, Universitat

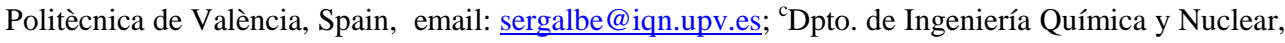 \\ Universitat Politècnica de València, Spain, email: jovillo0@upvnet.upv.es; ${ }^{\mathrm{d} D p t o . ~ d e ~ I n g e n i e r i ́ a ~}$ \\ Química y Nuclear, Universitat Politècnica de València, Spain, email: joorro1@etsii.upv.es
}

\begin{abstract}
In the Context of the European Higher Education Area (EHEA) it is necessary to guarantee that at the end of the degree the different competences have been achived, the specific skills of the subjects studied of each degree and the acquisition of another skills, so-called transversal competences.

In this context, the institutional project of Transversal Competence of the Universitat Politècnica de València (TC-UPV) carries out a classification in 13 competences, worked through three different ways (degree subjects, Bachelor's Thesis (BT)/Master's Thesis (MT) and extracurricular activities) and in different mastery levels.

BT and MT do not have a methodology that systematizes the identification, analysis and the assessment of the competences, among other reasons, for the wide spectrum of subjects studied. In this latter case, the tutor shall be responsible for performing this work.

In order to detect the main problems that students face in the development of their Bachelor's Thesis has been performed the present work. After the tutoring experience gained and through the analysis of different surveys outcomes, it was concluded that effort should be reinforced in the following transversal competences: time management, effective communication, analysis and practical thinking. So, the department has designed specific rubrics of these competences.
\end{abstract}

Keywords: Bachelor's thesis, transversal competencies, assessment, indicators.

\section{Resumen}

En el contexto del Espacio Europeo de Educación Superior es necesario garantizar que a la finalización del grado se han adquirido diferentes competencias, tanto específicas como transversales. 
El proyecto institucional Competencias Transversales de la Universitat Politècnica de València realiza una clasificación de estas, que se trabajan mediante tres vías diferentes (entre ellas los Trabajos Fin de Grado) y en diferentes niveles de dominio. Sin embargo, en TFG no se dispone de una metodología que sistematice la identificación, análisis y evaluación de las competencias, entre otras razones, por el amplio espectro de temas que se estudian, siendo en este caso el tutor el responsable de realizar esta labor.

En este trabajo, se ha elaborado un cuestionario para detectar cuáles fueron los principales problemas durante el desarrollo del TFG por parte de un grupo de alumnos. Tras la experiencia adquirida en la tutorización y mediante el análisis de los resultados del cuestionario, se concluyó que se debía reforzar el trabajo en las siguientes competencias: gestión del tiempo, comunicación efectiva, análisis y pensamiento práctico. Con el objetivo de sistematizar el proceso de evaluación, se han diseñado unas rúbricas específicas para estas competencias.

Palabras clave: Trabajo Fin de Grado, Competencias transversales, evaluación, indicadores.

\section{Introducción}

En el contexto del Espacio Europeo de Educación Superior (EEES) es necesario garantizar que a la finalización del grado se han adquirido diferentes competencias, además de las competencias específicas, propias de las asignaturas cursadas, cada titulación también debe garantizar la adquisición de otra serie de competencias denominadas transversales.

Las Escuelas y Facultades, en colaboración con los profesores, asignan a cada asignatura los puntos de control de trabajo y evaluación para diferentes competencias transversales. En el caso de los Trabajos Fin de Grado (TFG) cada Facultad y Escuela tiene desarrollado su propio programa para el TFG, en el que se especifican las características que debe reunir en cada titulación y sus criterios de evaluación. Sin embargo, en este caso no se dispone de una metodología que sistematice la identificación, análisis y evaluación de las competencias transversales, entre otras razones, por el amplio espectro de temas que se estudian, siendo en este caso el tutor el responsable de realizar esta labor teniendo en consideración las competencias transversales y específicas de cada titulación. Es por ello por lo que en los últimos años se han desarrollado algunos trabajos enfocados a la sistematización, análisis y evaluación de estas competencias transversales en los TFGs.

En (Rullán, 2010) se ha presentado una evaluación de las competencias transversales en los TFG, analizando las características que definen esta materia y los medios e instrumentos para su evaluación. En (Jaume-i-Capó, 2012) se ha realizado un estudio sobre el tipo y el número de competencias transversales establecidas como evaluables dentro de la materia TFG para 64 Grados de la Universitat Autònoma de Barcelona, agrupándolas por rama de conocimiento y diseñando indicadores para algunas de ellas, así como medios e instrumentos para evaluarlas. En (Reyes-García, 2016) se ha analizado la normativa del

(cc) EY-NC-ND 2018, Universitat Politècnica de València

Congreso IN-RED (2018) 
TFG en el enfoque del EEES, analizando si las tareas de evaluación del TFG están relacionadas con las competencias específicas y transversales de sus títulos, comprobando la modalidad de participación del alumnado en la evaluación del TFG y, además, verificando qué función cumple el feedback que se ofrece al alumnado durante el proceso de esta evaluación. En (Herrero, 2011) se propone un modelo de evaluación de competencias transversales siguiendo un esquema tipo cronológico donde se incluye una fase previa, una fase de desarrollo y una fase de finalización.

En el año 2017, la Universidad de Bilbao publicó una guía (Martínez, 2017) para el desarrollo y evaluación continua de las competencias transversales en el TFG mediante dinámicas colaborativas, fomentando la adquisición de competencias transversales tales como la capacidad de reflexión y crítica, habilidad de la comunicación oral y escrita, capacidad de trabajo en equipo o el manejo adecuado de las fuentes bibliográficas.

En este contexto, el proyecto institucional Competencias Transversales de la Universitat Politècnica de València (CT-UPV) realiza una clasificación en 13 competencias transversales, las cuales pretenden sintetizar un perfil competencial para todos los alumnos egresados de la UPV, garantizando que se cubre el marco de referencia de todas las titulaciones, son las siguientes: comprensión e integración, aplicación y pensamiento práctico, análisis y resolución de problemas innovación, creatividad y emprendimiento, diseño y proyecto, trabajo en equipo y liderazgo, responsabilidad ética, medioambiental y profesional. comunicación efectiva, pensamiento crítico, conocimiento de problemas contemporáneos, aprendizaje permanente, planificación y gestión del tiempo e instrumental específica. Estas competencias se trabajan en tres niveles de dominio: el primero se desarrolla en los cursos $1^{\circ}$ y $2^{\circ}$ del grado 2 , el segundo nivel se desarrolla en los cursos $3^{\circ} \mathrm{y}$ $4^{\circ}$ del grado y el tercer nivel se desarrolla en el máster. Además, para incorporar, evaluar y acreditar la adquisición de las CT UPV se establecen tres vías complementarias entre sí: la vía corresponde a planes de estudio, la vía 2 a TFG/TFM y la vía 3 a actividades extracurriculares. El proyecto de la UPV no ha sistematizado el proceso de la evaluación de las competencias transversales en lo que respecta a los TFGs y TFMs. En este caso son los centros los que, para cada titulación, identifican las competencias que se van a trabajar y desarrollan sus propias rúbricas. Estas rúbricas están enfocadas principalmente para facilitar la tarea de evaluación por parte del tribunal y tutor, pero no son útiles para guiar al alumno en la realización del trabajo de forma eficiente.

La innovación presentada en este trabajo se va a llevar a cabo en la unidad docente de energía nuclear del Departamento de Ingeniería Química y Nuclear de la Escuela Técnica Superior de Ingenieros Industriales, en la cual se imparte docencia en los siguientes grados: Grado de Ingeniería en Tecnologías Industriales, Grado de Ingeniería Química, Grado de Ingeniero de la Energía, Grado de Ingeniería en Organización Industrial, Grado de Ingeniería en Biomedicina y diversos másteres. En los últimos cursos académicos, en la unidad docente se han dirigido más de 40 TFGs, en temáticas centradas fundamentalmente en aplicaciones de energía nuclear, energía renovable y eficiencia energética. 


\section{Objetivos}

Los objetivos del presente trabajo son:

- Determinar los principales problemas que los alumnos han encontrado en la realización de sus TFG en relación con las competencias transversales.

- Diseñar herramientas que guíen al alumno en la adquisición de las competencias más problemáticas en el desarrollo del TFG.

\section{Desarrollo de la innovación}

\subsection{Principales problemas durante el desarrollo del TFG}

A raíz de lo comentado en el apartado anterior, se ha considerado necesario valorar en primer lugar los principales problemas que los alumnos afrontan en el desarrollo de sus respectivos TFGs en relación con las competencias transversales sobre las que serán evaluados en su grado de consecución.

Para ello se ha elaborado un cuestionario para detectar dichos problemas. En dicho cuestionario se plantearon las siguientes dimensiones como relevantes para el estudio:

- Grado de conocimiento del programa de competencias transversales.

- Grado de formación en competencias transversales.

- Importancia de las competencias transversales en la realización del TFG.

- Satisfacción en la consecución de estas en la realización del TFG.

En la Tabla 1 se muestra el cuestionario utilizado, así como la escala manejada para su medida.

La petición, instrucciones y acceso web a este cuestionario fue distribuido vía correo electrónico a la base de datos de estudiantes que habían realizado el TFG en la unidad docente durante los últimos cursos académicos. El cuestionario estuvo abierto durante un periodo de 3 semanas con dos recordatorios (a mitad de periodo y poco antes de finalizar el mismo), además de la petición inicial. Se publicó vía web mediante la herramienta "Forms" de Office365. La población estudiada fue de un total de 43 alumnos de los que respondió el $72 \%$ de los mismos (31 de los 43 alumnos).

(cc) EY-NC-ND 2018, Universitat Politècnica de València

Congreso IN-RED (2018) 
Tabla 1. Esquema cuestionario utilizado

\begin{tabular}{|c|c|}
\hline \multicolumn{2}{|c|}{ Grado de Conocimiento de las Competencias Transversales } \\
\hline $\begin{array}{l}\text { ¿Conoces el programa de competencias transversales de la } \\
\text { UPV? }\end{array}$ & Pregunta Dicotómica \\
\hline $\begin{array}{l}\text { ¿Has sido informado por parte de tu tutor de las competencias } \\
\text { transversales sobre las que serás evaluado en tu TFG? }\end{array}$ & Escala Likert \\
\hline $\begin{array}{l}\text { ¿Has sido informado por parte de la escuela de las } \\
\text { competencias transversales sobre las que serás evaluado en tu } \\
\text { TFG? }\end{array}$ & Escala Likert \\
\hline $\begin{array}{l}\text { Valora las siguientes competencias transversales con relación } \\
\text { a tu grado de conocimiento de estas y su aplicabilidad en tu } \\
\text { TFG }\end{array}$ & $\begin{array}{l}\text { Escala de Calificación } \\
\text { continua (1 a 10) (una } \\
\text { por cada competencia) }\end{array}$ \\
\hline \multicolumn{2}{|c|}{ Formación en Competencias Transversales } \\
\hline $\begin{array}{l}\text { ¿Consideras que estás bien formado para desarrollar las } \\
\text { competencias transversales? }\end{array}$ & Escala Likert \\
\hline $\begin{array}{l}\text { ¿Has recibido formación específica para desarrollar las } \\
\text { siguientes competencias transversales? }\end{array}$ & $\begin{array}{l}\text { Escala Likert (una por } \\
\text { cada competencia) }\end{array}$ \\
\hline $\begin{array}{l}\text { ¿Has recibido formación y has trabajado las competencias } \\
\text { transversales dentro de otras asignaturas? }\end{array}$ & $\begin{array}{l}\text { Escala Likert (una por } \\
\text { cada competencia) }\end{array}$ \\
\hline \multicolumn{2}{|c|}{ Importancia de las competencias transversales en la realización del TFG } \\
\hline $\begin{array}{l}\text { Valora las siguientes competencias transversales con relación } \\
\text { a su importancia para la consecución del TFG }\end{array}$ & $\begin{array}{l}\text { Escala de Calificación } \\
\text { continua (1 a 10) (una } \\
\text { por cada competencia) }\end{array}$ \\
\hline \multicolumn{2}{|c|}{ Satisfacción en la consecución de estas en la realización del TFG } \\
\hline $\begin{array}{l}\text { Valora el grado de consecución de las siguientes competencias } \\
\text { transversales }\end{array}$ & $\begin{array}{l}\text { Escala de Calificación } \\
\text { continua (1 a 10) (una } \\
\text { por cada competencia) }\end{array}$ \\
\hline $\begin{array}{l}\text { Valora el grado de información de las siguientes competencias } \\
\text { transversales }\end{array}$ & $\begin{array}{l}\text { Escala de Calificación } \\
\text { continua (1 a 10) (una } \\
\text { por cada competencia) }\end{array}$ \\
\hline $\begin{array}{l}\text { Valora el grado de formación de las siguientes competencias } \\
\text { transversales }\end{array}$ & $\begin{array}{l}\text { Escala de Calificación } \\
\text { continua (1 a 10) (una } \\
\text { por cada competencia) }\end{array}$ \\
\hline & Impresiones Generales \\
\hline $\begin{array}{l}\text { Comenta tus impresiones generales y aquellos puntos de } \\
\text { mejora }\end{array}$ & Respuesta abierta \\
\hline
\end{tabular}


Del análisis de estos resultados previos se extrajeron las primeras conclusiones

- El grado de conocimiento en competencias transversales ha aumentado con el tiempo. Esto no se podía deducir directamente del cuestionario, al que se le tuvo que incorporar datos referentes a la fecha de lectura del TFG.

- El grado de información a los alumnos por parte de las escuelas y tutores es muy limitado, comentando la existencia de éstas y que será evaluado en el mejor de los casos.

- Una gran mayoría evidencia falta de formación específica, aunque si ha recibido cierta formación dentro de otras asignaturas, aunque desde un punto de vista muy general.

- En general son conscientes de la importancia de éstas, aunque alguno no sea de aplicación en sus respectivos TFG

- Pese a la falta de información y formación, se observa que se encuentran medianamente satisfechos con el trabajo realizado en la mayoría de las competencias.

- Particularmente se muestran insatisfechos con la información, formación y desarrollo de las siguientes competencias:

o Análisis y pensamiento práctico.

o Gestión del tiempo.

o Comunicación efectiva.

Al respecto de esto último, reseñar que los TFGs son trabajos de investigación que el estudiante realiza de forma autónoma donde se tiene cierto grado de libertad, tanto en la temática como en los contenidos. Estos TFGs están enfocados para preparar al alumno para la vida profesional, por tanto, un aspecto que resulta importante es la contextualización del tema, lo cual implica un análisis y aplicación práctica del problema que se plantea, además de, una reflexión y actitud crítica. Estos trabajos se asignan al último curso del grado, donde el estudiante se enfrenta al problema de la limitación de tiempo teniendo que ser capaz de ordenar, destruir tiempos, tareas y recursos para alcanzar los resultados de una forma eficiente. En cuanto a la evaluación de estos trabajos, se realiza a través de un documento escrito y de una presentación oral, los cuales deben de ser redactados utilizando expresión clara y precisa y con un formato y estructura de contenidos definidos. Tradicionalmente, la evaluación de estos TFGs se llevaba a cabo bajo criterios de evaluación no explícitos y suelen estar basados en la experiencia del tribunal.

La importancia de estas competencias condujo a la necesidad de incorporar algún tipo de herramienta específica a las mismas que ayudase al alumno y al tutor a desarrollarlas, en especial en lo referente al TFG.

En aras de optimizar el proceso y que fuese lo más autónomo posible se ha propuesto la evaluación de las competencias transversales a partir de rúbricas las cuales están diseñadas de acuerdo con criterios de evaluación, cuantificados mediante indicadores. La rúbrica permite detallar los criterios específicos que se tendrán en cuenta a la hora de evaluar al

(cc) EY-NC-ND 2018, Universitat Politècnica de València

Congreso IN-RED (2018) 
alumno, hacer más fácil el proceso de evaluación al profesor, definir que se espera del alumno en la realización del trabajo, reduce la sensación de ambigüedad y además permite ordenar los conocimientos para realizar una evaluación equitativa. En este contexto, en (Moreno, 2013) se han diseñado varias rúbricas para los TFG en estudios de ingeniería concretamente para las competencias transversales: identificar, formular y resolver problemas propios del ámbito de la ingeniería, comunicación de manera efectiva, y el uso de técnicas y herramientas de ingeniería necesarias en la práctica profesional.

A continuación, se explica el diseño de las rúbricas propuestas.

\subsection{Diseño de rúbricas específicas}

A continuación, se presentan una sería de rúbricas basadas en los indicadores para nivel 2 del proyecto institucional de la Universitat Politècnica de València, adaptadas para su consecución en el desarrollo de un TFG.

Estas rúbricas buscan guiar al alumno en la mejor estrategia para su desarrollo y formación al mismo tiempo facilitando, en lo posible, su incorporación al bagaje propio, pero siendo suficientemente abiertas en función de la singularidad del TFG. Así mismo, también permite al tutor ayudar al alumno facilitando su seguimiento y marcando los puntos importantes a tener en cuenta.

En todos los casos se ha optado por una rúbrica con escala Likert de 4 niveles. Entre los investigadores no hay un consenso claro al respecto. Probablemente el ítem más utilizado sea el de 5 niveles, pero también se utilizan de 4, 7, o 10. Lo que se sabe es que añadir niveles redunda en unas valoraciones más diversas. La más utilizada es la de 5 puntos, pero en estos casos los encuestados suelen evitar las 2 opciones extremas, obteniendo muy poca variación (es el conocido como central tendency bias), por lo que para obtener resultados más claros se ha optado por una escala de 4 niveles.

\subsubsection{Gestión del tiempo}

Esta competencia, en lo que respecta a los TFGs, hace referencia la planificación adecuada de las diferentes actividades en el tiempo disponible, alcanzando los objetivos fijados.

La gestión del tiempo es uno de los aspectos que la mayoría de los estudiantes han detectado como más conflictivo en la realización de los TFGs. Disponer de un buen índice, donde estén definidos los contenidos y objetivos principales puede ayudar a la realización de un buen plan de trabajo, donde estén definidas las duraciones de las actividades y su jerarquización según su importancia. Por tanto, se concretan los siguientes indicadores para medir esta competencia:

- Definir el índice, contenidos y objetivos.

- Determinar las actividades y plazos a desarrollar para que sean acorde con los objetivos.

- Cumplimiento de los objetivos.

- Analizar el desarrollo de las actividades.

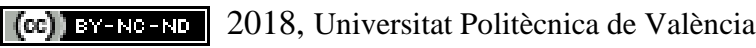

Congreso In-Red (2018) 
En la Tabla 2 se muestra la rúbrica específica propuesta para la Gestión del Tiempo en un TFG.

Tabla 2. Rúbrica Competencia Transversal Gestión del Tiempo para TFG

\begin{tabular}{|c|c|c|c|c|}
\hline & \multicolumn{4}{|c|}{ Gestión del tiempo TFG } \\
\hline Indicadores & Excelente & Notable & Suficiente & Insuficiente \\
\hline $\begin{array}{lr}\text { Definir } & \text { índice, } \\
\text { contenidos } & \mathrm{y} \\
\text { objetivos } & \end{array}$ & $\begin{array}{l}\text { Plantea una tabla } \\
\text { de contenidos } \\
\text { desde el inicio } \\
\text { acorde con los } \\
\text { objetivos } \\
\text { definidos }\end{array}$ & $\begin{array}{lr}\begin{array}{l}\text { Plantea } \\
\text { tabla una } \\
\text { contenidos }\end{array} \\
\text { durante de } \\
\text { realización del } \\
\text { trabajo siendo } \\
\text { acorde con los } \\
\text { objetivos } \\
\text { definido }\end{array}$ & $\begin{array}{l}\text { Plantea una tabla } \\
\text { de contenidos } \\
\text { durante la } \\
\text { realización del } \\
\text { trabajo no siendo } \\
\text { acorde con los } \\
\text { objetivos } \\
\text { definido }\end{array}$ & $\begin{array}{l}\text { No plantea una } \\
\text { tabla de } \\
\text { contenidos } \\
\text { desde el } \\
\text { principio } \\
\text { acorde con los } \\
\text { objetivos } \\
\text { definidos }\end{array}$ \\
\hline $\begin{array}{lr}\text { Determinar } & \text { las } \\
\text { actividades } & \text { a } \\
\text { desarrollar a medio } \\
\text { plazo, de forma } \\
\text { acorde con los } \\
\text { contenidos } \\
\text { objetivos }\end{array}$ & $\begin{array}{lr}\text { Especifica } & \text { todas } \\
\text { las actividades a } \\
\text { realizar y las } \\
\text { relaciona con el } \\
\text { índice r de } \\
\begin{array}{lr}\text { contenidos } \\
\text { objetivos }\end{array}\end{array}$ & $\begin{array}{lr}\text { Especifica } & \text { la } \\
\text { mayoría } & \text { de } \\
\text { actividades } & \text { a } \\
\text { realizar Prioriza } \\
\text { en función de su } \\
\text { urgencia las } \\
\text { actividades a } \\
\text { realizar }\end{array}$ & $\begin{array}{l}\text { Especifica } \\
\text { algunas } \\
\text { actividades. }\end{array}$ & $\begin{array}{l}\text { No especifica } \\
\text { actividades a } \\
\text { desarrollar. }\end{array}$ \\
\hline $\begin{array}{l}\text { Planificación del } \\
\text { trabajo }\end{array}$ & \begin{tabular}{lr}
\multicolumn{2}{l}{ Planifica } \\
\multicolumn{2}{l}{ adecuadamente } \\
todas las \\
actividades & para \\
alcanzar los \\
objetivos, \\
asignando \\
tiempos a \\
actividades \\
prioridades
\end{tabular} & $\begin{array}{lr}\text { Planifica } & \text { las } \\
\text { actividades } & \text { para } \\
\text { alcanzar } & \text { los } \\
\text { objetivos } & \\
\text { asignando } & \\
\text { tiempos } & \text { sin } \\
\text { priorizar. } & \end{array}$ & $\begin{array}{lr}\text { Planifica } & \text { de } \\
\text { forma errónea } \\
\text { algunas de las } \\
\text { actividades para } \\
\text { alcanzar los } \\
\text { objetivos. No se } \\
\text { asignan tiempos } \\
\text { a las actividades } \\
\text { ni prioridades }\end{array}$ & $\begin{array}{l}\text { No planifican } \\
\text { las actividades } \\
\text { para alcanzar } \\
\text { los objetivos }\end{array}$ \\
\hline $\begin{array}{ll}\text { Analizar } & \text { el } \\
\text { desarrollo de las } \\
\text { actividades. }\end{array}$ & $\begin{array}{lr}\text { Analiza } & \text { el } \\
\text { avance de las } \\
\text { actividades } & y \\
\text { propone } & \text { mejoras } \\
\text { durante ra } & \text { la } \\
\text { realización del } \\
\text { trabajo. }\end{array}$ & $\begin{array}{lr}\text { Analiza } & \text { el } \\
\text { avance de las } \\
\text { actividades de } \\
\text { forma } \\
\text { superficial, } \\
\text { proponiendo } \\
\text { algunas mejoras }\end{array}$ & $\begin{array}{ll}\text { Realiza } & \text { un } \\
\text { análisis } & \\
\text { inadecuado del } \\
\begin{array}{ll}\text { avance de las } \\
\text { actividades }\end{array}\end{array}$ & $\begin{array}{l}\text { No realiza } \\
\text { ningún } \\
\text { seguimiento y } \\
\text { análisis. }\end{array}$ \\
\hline
\end{tabular}

(c)) EY-NC-ND 2018, Universitat Politècnica de València 


\subsubsection{Comunicación Efectiva}

La comunicación efectiva, en lo que respecta a los TFGs tiene dos dimensiones, ya que los estudiantes deben de realizar un documento escrito y defender oralmente su trabajo frente a un tribunal. El alumno en los dos casos debe de comunicarse de forma clara y precisa utilizando un buen lenguaje y siguiendo una estructura y organización equilibrada. En lo que respecta a la comunicación oral, se añaden aspectos tales como la buena comunicación no verbal, el uso de medios de apoyo y el ajustarse al tiempo establecido en la presentación. Por tanto se concretan los siguientes indicadores:

- Escritura y gramática.

- Estructura y organización.

- Contenidos de la exposición oral.

- $\quad$ Ajuste al tiempo de la exposición.

- Lenguaje no verbal.

- $\quad$ Respuestas al tribunal.

En la Tabla 3 se muestra la rúbrica específica propuesta para la Comunicación Efectiva de un TFG.

Tabla 3. Rúbrica Competencia Transversal Comunicación Efectiva para TFG

\begin{tabular}{|c|c|c|c|c|}
\hline & \multicolumn{4}{|c|}{ Comunicación efectiva TFG } \\
\hline Indicadores & Excelente & Notable & Suficiente & Insuficiente \\
\hline $\begin{array}{ll}\begin{array}{l}\text { Escritura } \\
\text { gramática }\end{array} & \mathrm{y} \\
\end{array}$ & $\begin{array}{l}\text { Se entiende bien } \\
\text { lo que está } \\
\text { escrito. Utiliza } \\
\text { bien el idioma, } \\
\text { el lenguaje } \\
\text { científico y su } \\
\text { gramática. }\end{array}$ & $\begin{array}{l}\text { Necesita } \\
\text { mejorarse }\end{array}$ & $\begin{array}{l}\text { Estructura confusa } \\
\text { y difícil de leer }\end{array}$ & Ilegible \\
\hline $\begin{array}{ll}\text { Estructura } & y \\
\text { organización } & \end{array}$ & $\begin{array}{l}\text { Los contenidos } \\
\text { están } \\
\text { equilibrados y } \\
\text { bien } \\
\text { organizados. } \\
\text { Contiene los } \\
\text { apartados } \\
\text { establecidos. Se } \\
\text { centra en las } \\
\text { ideas más } \\
\text { importantes. }\end{array}$ & $\begin{array}{l}\text { La estructura } \\
\text { esta pasable, } \\
\text { falta algún } \\
\text { apartado } \\
\text { establecido. }\end{array}$ & $\begin{array}{l}\text { Los contenidos y } \\
\text { organización están } \\
\text { descompensados. } \\
\text { Faltan varios } \\
\text { apartados } \\
\text { establecidos. }\end{array}$ & $\begin{array}{l}\text { Desestructurado } \\
\text { y con } \\
\text { información } \\
\text { repetida }\end{array}$ \\
\hline $\begin{array}{l}\text { Contenidos de } \\
\text { la exposición } \\
\text { oral }\end{array}$ & $\begin{array}{l}\text { Se seleccionan } \\
\text { adecuadamente } \\
\text { los contenidos y } \\
\text { se expone de }\end{array}$ & $\begin{array}{l}\text { Se seleccionan } \\
\text { bien los } \\
\text { contenidos pero } \\
\text { se explican de }\end{array}$ & \begin{tabular}{lr}
\multicolumn{2}{l}{ No se seleccionan } \\
bien & los \\
contenidos. & La \\
presentación & es
\end{tabular} & $\begin{array}{l}\text { La presentación } \\
\text { no incluye los } \\
\text { aspectos } \\
\text { fundamentales. }\end{array}$ \\
\hline
\end{tabular}

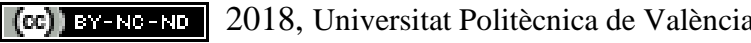

Congreso In-Red (2018) 


\begin{tabular}{|c|c|c|c|c|}
\hline & 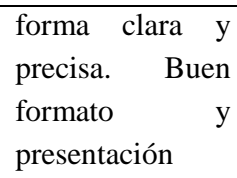 & forma confusa & difícil de seguir & $\begin{array}{l}\text { Mala } \\
\text { presentación } \\
\text { formato }\end{array}$ \\
\hline $\begin{array}{ll}\text { Ajuste } & \text { al } \\
\text { tiempo de } & \text { la } \\
\text { exposición } & \end{array}$ & $\begin{array}{l}\text { Se ajusta } \\
\text { correctamente al } \\
\text { tiempo de la } \\
\text { presentación. } \\
\text { Expone a un } \\
\text { ritmo constante, } \\
\text { notándose que la } \\
\text { presentación está } \\
\text { preparada y } \\
\text { ensayada. }\end{array}$ & $\begin{array}{l}\text { Se ajusta al } \\
\text { tiempo de la } \\
\text { presentación, } \\
\text { aunque en la } \\
\text { parte final se } \\
\text { acelera el } \\
\text { ritmo. }\end{array}$ & $\begin{array}{lr}\text { Se sobrepasa } & \text { el } \\
\text { tiempo } & \text { de } \\
\text { exposición, aunque } \\
\text { el tribunal no } \\
\text { interrumpe ra } \\
\text { exposición }\end{array}$ & $\begin{array}{l}\text { El tribunal debe } \\
\text { de interrumpir la } \\
\text { exposición, no se } \\
\text { cumplen los } \\
\text { tiempos } \\
\text { acordados. }\end{array}$ \\
\hline $\begin{array}{ll}\text { Lenguaje } & \text { no } \\
\text { verbal } & \end{array}$ & $\begin{array}{l}\text { Presentación con } \\
\text { buen tono de } \\
\text { voz, el alumno } \\
\text { está tranquilo, } \\
\text { enfatiza en lo } \\
\text { más importante. }\end{array}$ & $\begin{array}{l}\text { Presentación } \\
\text { con buen tono } \\
\text { de voz aunque } \\
\text { el alumno se } \\
\text { nota } \\
\text { intranquilo. }\end{array}$ & $\begin{array}{l}\text { Presentación con } \\
\text { mal tono de voz, } \\
\text { demostrando } \\
\text { intranquilidad e } \\
\text { inseguridad. }\end{array}$ & $\begin{array}{l}\text { Exposición } \\
\text { inaudible, } \\
\text { monótona. }\end{array}$ \\
\hline $\begin{array}{l}\text { Respuestas al } \\
\text { tribunal }\end{array}$ & $\begin{array}{l}\text { Responde } \\
\text { correctamente a } \\
\text { las preguntas } \\
\text { planteadas, de } \\
\text { forma concisa, } \\
\text { notándose que se } \\
\text { conoce la } \\
\text { materia. }\end{array}$ & $\begin{array}{l}\text { Responde de } \\
\text { forma errónea } \\
\text { las preguntes } \\
\text { planteadas. }\end{array}$ & $\begin{array}{llr}\text { Responde a las } \\
\text { preguntas } & & \text { sin } \\
\text { seguridad y } & \text { de } \\
\text { forma dubitativa. }\end{array}$ & $\begin{array}{lr}\text { No } & \text { sabe } \\
\text { responder a las } \\
\text { preguntas } & \\
\text { planteadas. } & \end{array}$ \\
\hline
\end{tabular}

\subsubsection{Análisis y pensamiento práctico}

Con esta competencia se busca que el alumno aplique los conocimientos teóricos y establezca los procesos a seguir para alcanzar sus objetivos, analice e interprete los datos para extraer conclusiones, en especial en lo referente a su TFG. Para ello se estableen los siguiente s indicadores:

- Obtener la información necesaria para abordar las situaciones.

- Evaluar la calidad de la información de que dispone para su aplicación.

- Realizar la contextualización del problema.

- Establecer la metodología y definir datos de entrada y salida.

- Elaborar un plan coherente para resolver las situaciones que se le planteen.

En la Tabla 4 se muestra la rúbrica específica propuesta para el Análisis y Pensamiento Práctico en un TFG. 
Tabla 4. Rúbrica Competencia Transversal Análisis y Pensamiento Práctico para TFG

\begin{tabular}{|c|c|c|c|c|}
\hline \multirow[b]{2}{*}{ Indicadores } & \multicolumn{4}{|c|}{ Análisis y Pensamiento Práctico TFG } \\
\hline & Excelente & Notable & Suficiente & Insuficiente \\
\hline $\begin{array}{lr}\text { Obtener } & \text { la } \\
\text { información } & \\
\text { necesaria } & \text { para } \\
\text { abordar } & \text { las } \\
\text { situaciones } & \end{array}$ & $\begin{array}{l}\text { Hay una } \\
\text { búsqueda } \\
\text { exhaustiva de } \\
\text { información y se } \\
\text { comenta }\end{array}$ & $\begin{array}{l}\text { Hay una } \\
\text { búsqueda } \\
\text { exhaustiva de } \\
\text { información, } \\
\begin{array}{ll}\text { pero no se } \\
\text { comenta }\end{array}\end{array}$ & $\begin{array}{lr}\text { Se } & \text { busca } \\
\text { información de } \\
\text { pocas fuentes }\end{array}$ & $\begin{array}{l}\text { No hay búsqueda } \\
\text { de información }\end{array}$ \\
\hline \begin{tabular}{lr} 
Evaluar & la \\
calidad de la \\
información de \\
que dispone para \\
\multicolumn{2}{l}{ su aplicación. }
\end{tabular} & $\begin{array}{l}\text { Toda la } \\
\text { información es } \\
\text { de fuentes fiables } \\
\text { y contrastables }\end{array}$ & $\begin{array}{l}\text { La mayor parte } \\
\text { de la información } \\
\text { es de fuentes } \\
\text { fiables }\end{array}$ & $\begin{array}{l}\text { Parte de la } \\
\text { información es de } \\
\text { fuentes fiables }\end{array}$ & $\begin{array}{l}\text { La información } \\
\text { es de baja } \\
\text { calidad }\end{array}$ \\
\hline $\begin{array}{l}\text { Realizar la } \\
\text { contextualización } \\
\text { del problema que } \\
\text { se plantea }\end{array}$ & $\begin{array}{l}\text { Realiza una } \\
\text { contextualización } \\
\text { del problema, } \\
\text { relacionando un } \\
\text { análisis del } \\
\text { estado actual del } \\
\text { tema. }\end{array}$ & \begin{tabular}{lr} 
Realiza & una \\
\multicolumn{2}{l}{ contextualización } \\
pobre & del \\
problema, sin \\
relacionarlo con \\
el estado actual \\
del tema.
\end{tabular} & $\begin{array}{l}\text { Realiza una mala } \\
\text { contextualización } \\
\text { del tema. }\end{array}$ & $\begin{array}{l}\text { No realiza una } \\
\text { contextualización } \\
\text { del tema. }\end{array}$ \\
\hline $\begin{array}{l}\text { Establecer la } \\
\text { metodología y } \\
\text { definir datos de } \\
\text { entrada y salida }\end{array}$ & $\begin{array}{l}\text { Elige y aplica } \\
\text { bien la } \\
\text { metodología y } \\
\text { define } \\
\text { adecuadamente } \\
\text { los datos de } \\
\text { entrada y salida } \\
\text { del problema. }\end{array}$ & $\begin{array}{l}\text { Elige } \\
\text { adecuadamente } \\
\text { la metodología, } \\
\text { pero la aplica de } \\
\text { forma parcial. } \\
\text {,Los datos de } \\
\text { entrada y salida } \\
\text { están bien } \\
\text { definidos. }\end{array}$ & $\begin{array}{l}\text { Elige bien la } \\
\text { metodología, pero } \\
\text { no la aplica } \\
\text { adecuadamente. } \\
\text { Los datos de } \\
\text { entrada y salida } \\
\text { están r mal } \\
\text { definidos. }\end{array}$ & $\begin{array}{l}\text { No realiza una } \\
\text { buena elección de } \\
\text { la metodología, } \\
\text { ni de los datos de } \\
\text { entrada y salida. }\end{array}$ \\
\hline $\begin{array}{l}\text { Elaborar un plan } \\
\text { coherente para } \\
\text { resolver las } \\
\text { situaciones que } \\
\text { se le planteen. }\end{array}$ & $\begin{array}{l}\text { Elabora } \text { un plan } \\
\text { de trabajo } \\
\text { coherente con } \\
\text { actualizaciones }\end{array}$ & $\begin{array}{l}\text { Elabora un plan } \\
\text { de trabajo } \\
\text { coherente }\end{array}$ & $\begin{array}{ll}\text { Elabora } & \text { un } \\
\text { esquema asico } & \text { de } \\
\text { trabajo } & \\
\end{array}$ & \begin{tabular}{lr} 
No & \multicolumn{2}{c}{ elabora } \\
ningún plan de \\
trabajo
\end{tabular} \\
\hline
\end{tabular}




\section{Conclusiones}

En el presente trabajo se han diseñado las rúbricas para tres competencias transversales para la realización de los TFGs, elegidas tras analizar los datos del cuestionario previo enviado a los alumnos. Estas rúbricas están diseñadas con el objetivo de que sirvan, aparte de para facilitar el proceso de evaluación de los tutores y tribunal, sirvan al alumnado de guía y de ayuda para reducir algunas dificultades durante el proceso de realización de sus TFGs. Estas rúbricas actualmente se encuentran en fase de diseño y desarrollo y no han podido ser verificadas, no pudiendo medir su eficiencia. Esta tarea de verificación se pretende realizar en el futuro con la distribución de estas rúbricas a los alumnos que previamente realizaron el cuestionario con el objetivo de poseer el punto de vista del alumnado y verificar la idoneidad de estas.

\section{Agradecimientos}

Este trabajo se ha realizado en el marco del proyecto Proyecto de Innovación y Mejora Educativa, PIME Curso 2017-2018 "Coordinación de competencias transversales en asignaturas de ámbito nuclear en el Grado de Ingeniero de la Energía”, Referencia B07, del Vicerrectorado de Estudios, Calidad y Acreditación de la Universitat Politècnica de València.

\section{Referencias}

RULLAN M., FERNÁNDEZ M., ESTAPÉ G., MARQUEZ D. (2010) “The assessment of generic competences in the final year thesis. a preliminary study on the need and opportunity to establish means and tools by fields of knowledge" Revista de Docencia Universitaria, Vol.8 (n.1) 74-100 ISSN:1887- 4592

JAUME I CAPÓ, A., GUERRERO, C., MIRO, J., EGEA A., "Elaboración de una rúbrica para la evaluación TFG y TFM de informática en la Universitat de les Illes Balears”. Actas Simposio-Taller JENUI 2012, Ciudad Real, 10-13 de julio 2012 I.S.B.N. 10: 84-695-39418

REYES-GARCIA C. DÍAZ-MEGOLLA, A.(2017) “¿se adecúa la normativa del Trabajo Fin de Grado al enfoque de evaluación del Espacio Europeo de Educación Superior? ” Rev. complut. educ. 28(4) 2017: 1285-1302, ISSN: 1988-2793

HERRERO, R., FERRER M.A., SOLANO J.P., CALDERÓN A.A., BUSQUIER S. “ Evaluación de competencias transversales en los trabajos de fin de grado”. Actas del Congreso Internacional de Innovación docente, Universidad Politécnica de Cartagena, 6-8 de Julio 2011.

MORENO, V., CARPINTERO, G., HERNANDEZ, D. (2013). "Dos casos del uso de rúbricas para la evaluación de Trabajos de Final de Grado”. III Jornadas de Innovación Educativa en Ingeniería Telemática Universitat Pompeu Fabra de Barcelona

(cc) EY-NC-ND 2018, Universitat Politècnica de València

Congreso IN-RED (2018) 
MARTÍNEZ O., MIRANDA J., SARRIONANDIA

F., TXURRUCA I. (2017). "Guía para el desarrollo y evaluación continua de las competencias transversales en el Trabajo Fin de Grado mediante dinámicas colaborativas", Servicio Editorial Universidad del País Vasco. ISBN: 978-84-9082-721-5 


\title{
Metodologías activas en asignaturas básicas. Creación de un catálogo de demostraciones experimentales o proyectos como recursos didácticos para la motivación de título (Fase II)
}

\author{
Rosario Vilaplana Cerdáa, Romina Del Rey Tormosa, Francisco Javier Manjón \\ Herrera $^{\mathrm{b}}$, Juan Antonio Monsoriu Serra ${ }^{\mathrm{b}}$, Pedro LLovera Segovia ${ }^{\mathrm{c}}$ y Constantino \\ Torregrosa Cabanilles ${ }^{\mathrm{d}}$
}

\begin{abstract}
âniversitat Politècnica de Valéncia, Escuela Politécnica Superior de Alcoy, Departamento de Física Aplicada, Pz. Ferràndiz i Carbonell s/n - 03801 Alcoy (Alicante). rovilap@fis.upv.es, roderey@doctor.upv.es
\end{abstract}

bUniversitat Politècnica de Valéncia, Escuela Politécnica Superior de Diseño, Departamento de Física Aplicada, Camino de Vera s/n - 46022 Valencia. fjmanjon@fis.upv.es, jmonsori@fis.upv.es

\footnotetext{
'Universitat Politècnica de Valéncia, Escuela Técnica Superior de Caminos, Canales y Puertos, Departamento de Ingeniería Eléctrica, Camino de Vera s/n - 46022 Valencia pllovera@ite.upv.es
}

${ }^{\mathrm{d}}$ Universitat Politècnica de Valéncia, Escuela Politécnica Superior de Gandia, Departamento de Física Aplicada, C/Paraninfo n¹ - 46715 Grao de Gandia. ctorregr@fis.upv.es

\begin{abstract}
We present the steps carried out within a PIME entitled "Active methodologies in basic subjects. A catalogue of experimental Physics demonstrations designed as teaching resources for the degree motivation" that started in 2016 and will continue until 2019. This project aims at designing a catalogue of simple experimental Physics demonstrations made with readily available low cost materials. These resources are intended to be used in theory classes and problems to demonstrate physical phenomena and their relationship to the theoretical models, thus favouring the understanding of phenomena. During this second phase of the project, the catalog of experimental demonstrations designed by the teachers has continued to be expanded. But in addition, two activities have been carried out in which is prioritized the direct experimentation with the concepts and the most practical elements by the students, so that the students take greater role being promoted in this way the studentcentered learning, the active methodologies and the small project-based learning.
\end{abstract}


Keywords: Active Methodologies, Motivation, Competencies, ProjectBased Learning.

\begin{abstract}
Resumen
Presentamos los pasos realizados dentro de una PIME denominado "Metodologías activas en asignaturas básicas. Un catálogo de demostraciones experimentales de física diseñado como recursos didácticos para la motivación del grado" que arranca en el 2016 y continuará hasta 2019. En este proyecto se está elaborando un catálogo de demostraciones experimentales sencillas hechas con materiales fácilmente disponibles y de bajo coste. Estos recursos están destinados a ser utilizados en las clases de teoría y problemas para demostrar los fenómenos físicos y su relación con los modelos teóricos, favoreciendo así la comprensión de los mismos. Durante la segunda fase del proyecto se ha continuado ampliando el catálogo de demostraciones experimentales diseñadas por los profesores. Pero además se han realizado dos actividades en las que la experimentación directa con los conceptos y los elementos más prácticos por parte del alumnado se prioriza, de modo que el alumno toma más protagonismo, promoviéndose de este modo el aprendizaje más centrado en el estudiante, las metodologías activas y el aprendizaje basado en pequeños proyectos.
\end{abstract}

Palabras clave: Metodologías Activas, Motivación, Competencias, Aprendizaje Basado en Proyectos.

\title{
Introducción
}

En este trabajo se exponen los avances en la segunda fase del desarrollo del Proyecto de Innovación y Mejora Educativa (PIME) titulado: "Metodologías activas en asignaturas básicas. Creación de un catálogo de demostraciones experimentales o proyectos como recursos didácticos para la motivación de título” y cuya primera fase ya fue desarrollada durante el curso 2016-2017 (Vilaplana 2017). Este proyecto está enfocado a la creación e implementación de un catálogo de demostraciones experimentales de Física y a promover el uso de metodologías activas en las que se mezcle la teoría con sesiones más prácticas en el aula.

La presentación de los conceptos teóricos y la deducción de las teorías son siempre positivas y necesarias, pero la teoría se entiende mejor si se conecta inmediatamente con una experiencia práctica (Freier 1996). Demostraciones prácticas del profesor en el aula pueden ayudar en esta tarea; de hecho, este proyecto tiene como uno de sus objetivos prioritarios el desarrollo cooperativo entre profesores para implementar demostraciones experimentales de física diseñadas como recursos didácticos para la motivación del grado (Vilaplana 2017). Las demostraciones experimentales de Física u otras disciplinas forman parte de la práctica docente de diferentes países y su uso está recogido

(cc) BY-Nc-No 2018, Universitat Politècnica de València

Congreso IN-RED (2018) 
explícitamente en el proyecto europeo "Tunning" de Física para la armonización de titulaciones universitarias (González 2003). No obstante, actualmente su uso en nuestro país, no forma parte de las prácticas docentes generalizadas, salvo excepciones (Ferrer 2012). En este proyecto se realizan acciones encaminadas a corregir esta situación.

Las lecciones teóricas y las sesiones de laboratorio están, por lo general, separadas por razones prácticas. Las sesiones de laboratorio son más caras que las lecciones en el aula y el tamaño del grupo para el trabajo de laboratorio tiene que ser pequeño. Como resultado, existe una separación artificial entre la teoría y la práctica que no es adecuada especialmente para la ingeniería. En general, la ingeniería es una disciplina práctica pero con un amplio contenido de contenidos teóricos (Freisel 2005). Así, el equilibrio entre la teoría y la práctica no es fácil de definir, y es una sensación muy común que la teoría ha ganado peso relativo respecto al laboratorio. Sin embargo, esta separación es artificial; y por tanto, debería haber una cooperación entre ambos campos.

Por otro lado, es sabido que la experimentación directa del estudiante con los conceptos y elementos prácticos conduce a mejores resultados en la comprensión y el aprendizaje. En muchos campos de la ingeniería, la simulación por ordenador de la situación práctica ha tomado un lugar preponderante en las sesiones prácticas. Estas herramientas de software son de primordial importancia para los estudiantes, ya que tendrán que utilizarlas en el futuro inmediato; no obstante, el contacto directo con los experimentos físicos no puede ser sustituido por instrumentos de simulación, especialmente durante los primeros cursos. Esto nos lleva al segundo objetivo del proyecto que consiste crear actividades o pequeños proyectos que permitan la experimentación directa del estudiante durante las sesiones en el aula. Para ello hacemos uso del aprendizaje basado en pequeños proyectos (Calvo 2010, Alba 2015) y llegamos a la explicación de los conceptos de una manera más natural, transformando de este modo la típica clase magistral en una clase dialogada y preguntada (Cury 2007). A este respecto, ya hemos realizado dos actividades con los alumnos en clase, en la que se prioriza la experimentación directa con los conceptos y los elementos más prácticos.

La primera de estas actividades se ha llevado a cabo con los alumnos de primero en el Grado en Ingeniería en Diseño Industrial y Desarrollo de Productos. Estos alumnos han diseñado algunas demostraciones experimentales o pequeños proyectos en grupo con la guía del profesor. Estas demostraciones experimentales se caracterizan por el uso de materiales fácilmente asequibles y de bajo coste que pueden ser diseñados sin coste, usando materiales reciclados y fácil de obtene. Con ello, se quiere fomentar la capacidad de sorpresa y articular un proceso de observación racional, algo esencial para la comprensión del método científico, en el que los alumnos emitan conclusiones en términos de los modelos físicos que se estudian en el ámbito teórico de asignaturas básicas como la Física. También se pretende trasmitir a los alumnos de esta titulación, el hecho de que aquellos diseños que incluye ciencia, cobrán un valor añadido. Ejemplos claros de algunos diseños que existen y que cumplen con estas características son las lámparas de lava o las macetas o lámparas que levitan.

La segunda actividad en esta línea, se ha realizado con los alumnos de segundo año de Ingeniería Civil y de Obras Públicas y de Ingeniería Química en la materia de 
electricidad. La actividad ha consistido en mezclar la teoría y las sesiones de laboratorio en el aula por medio de la implementación de un laboratorio portátil en el aula durante el tiempo asignado a una lección (Llovera 2015). La solución propuesta para la mezcla de teoría y sesiones de laboratorio en el aula, requiere resolver algunas cuestiones: a) el despliegue y la colección del laboratorio necesita un mínimo de tiempo, normalmente, al menos 10 minutos, b) el laboratorio tiene que ser seguro, c) el peso total del equipo que se traslada a las aulas ha de ser tan bajo como sea posible, d) no deben ser equipos que supongan gastos adicionales, sino que contengan equipos disponibles en los laboratorios tales como multímetros, fuentes de alimentación, cables, etc.

\section{Objetivos}

El objetivo original del proyecto es generar recursos útiles y prácticos que ayuden a mejorar y motivar las prácticas docentes en las asignaturas de primeros cursos de Física y Electricidad de distintas Ingenierías. Trascurrido un año y medio del proyecto, los objetivos han ido evolucionando y quedan reflejados del siguiente modo:

1. Seguir desarrollando el catálogo o banco de experimentos disponible para el profesorado que imparte docencia en asignaturas de Física, y continuar de este modo con su uso en las clases de teoría y problemas. Esto conlleva seguir desarrollando los materiales asociados a estas demostraciones tales como fichas, vídeos y cuestionarios.

2. Continuar con la experiencia de trabajar en forma colaborativa los profesores que participan en el proyecto de modo que se generen tres prototipos por cada demostración experimental siempre que sea posible.

3. Involucrar a los alumnos en algunos de estos diseños experimentales en el aula, haciendo así uso de metodologías activas basadas en la realización de proyectos sencillos.

4. Mezclar la teoría y las sesiones de laboratorio de Electricidad en el aula por medio de la implementación de un laboratorio portátil en el aula durante el tiempo asignado a una lección.

5. Hacer especial hincapié en la evaluación de tipo formativo. Lo que hemos comprobado es que los alumnos valoran muy positivamente que se les retroalimente; esto es, que se les de feedback. Así, el desarrollo de competencias se convierte en un fin en sí mismo y dejan a una lado la evalución como una mera herramienta que calificar.

6. Crear rúbricas adecuadas para evaluar los proyectos desarrollados por los alumnos así como los conocimientos y competencias que adquieren.

7. Pasar una encuesta de valoración de metodologías activas a los alumnos con el fin de que muestren su grado de satisfacción y que al mismo tiempo reflejen si ven útil esta práctica docente. De este modo estamos obteniendo información que nos sirve a los profesores no sólo para evaluar el proyecto, sino también para reconducirlo.

(c) B EY-NC-ND 2018, Universitat Politècnica de València

Congreso IN-RED (2018) 


\section{Desarrollo de la innovación}

El desarrollo de la innovación se lleva cabo de modo que:

Cada profesor elabora algunas demostraciones experimentales, desarrollando las correspondientes fichas descriptivas y el posible material asociado, de modo que sirvan de guía a los otros profesores que quieran utilizar dichas demostraciones en clase.

A continuación mostramos en la figura 1 algunas de las demostraciones experimentales desarrolladas por los profesores.

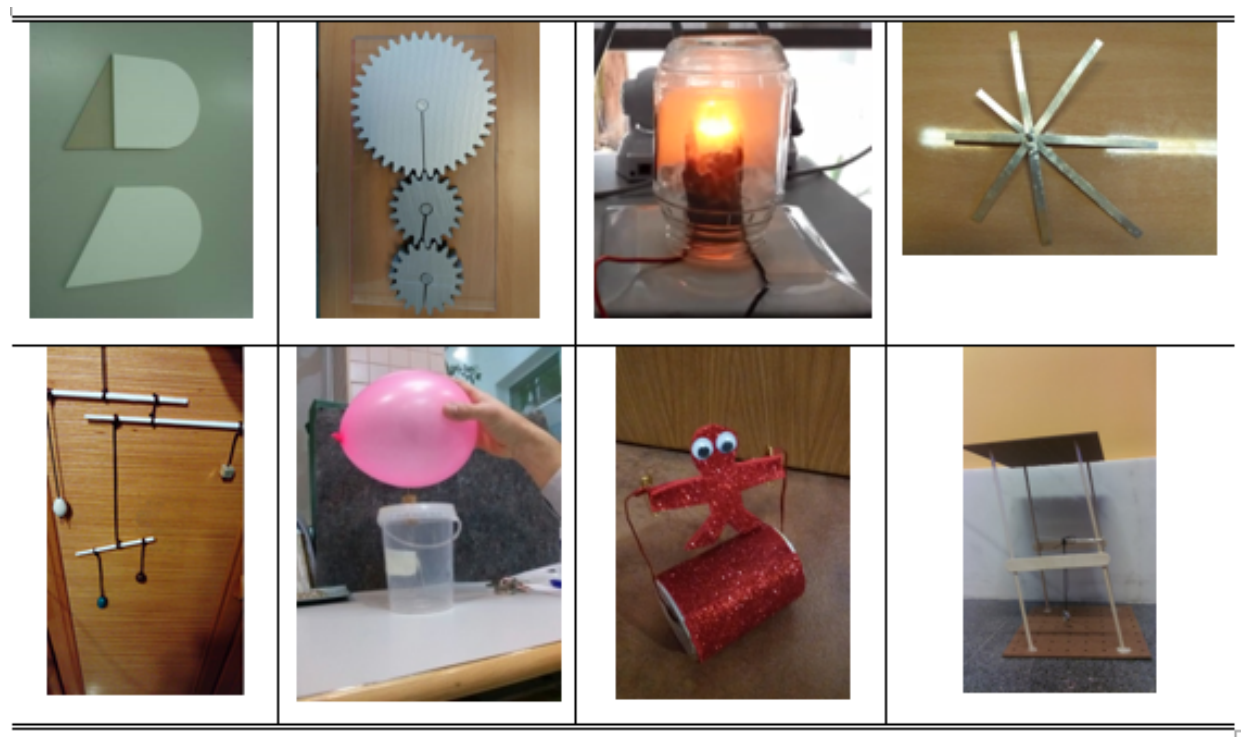

Fig. 1 Ejemplos de demostraciones experimentales desarrolladas por los profesores.

Cada profesor siempre que sea posible genera tres prototipos de cada una de demostraciones experimentales, así los profesores de cada campus puueden disponer de un prototipo.

Seguidamenete describimos como es la ficha estándar a rellenar.

\section{TITULO}

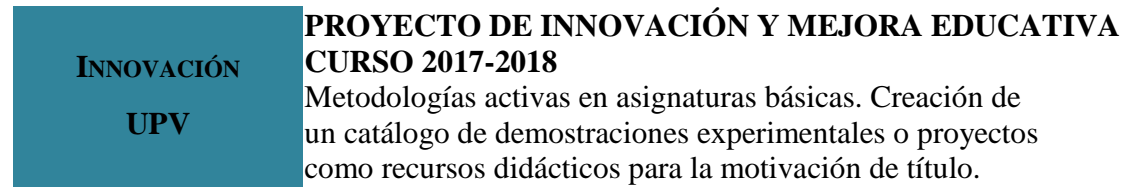

\section{MODALIDAD}

Demostrativa: 


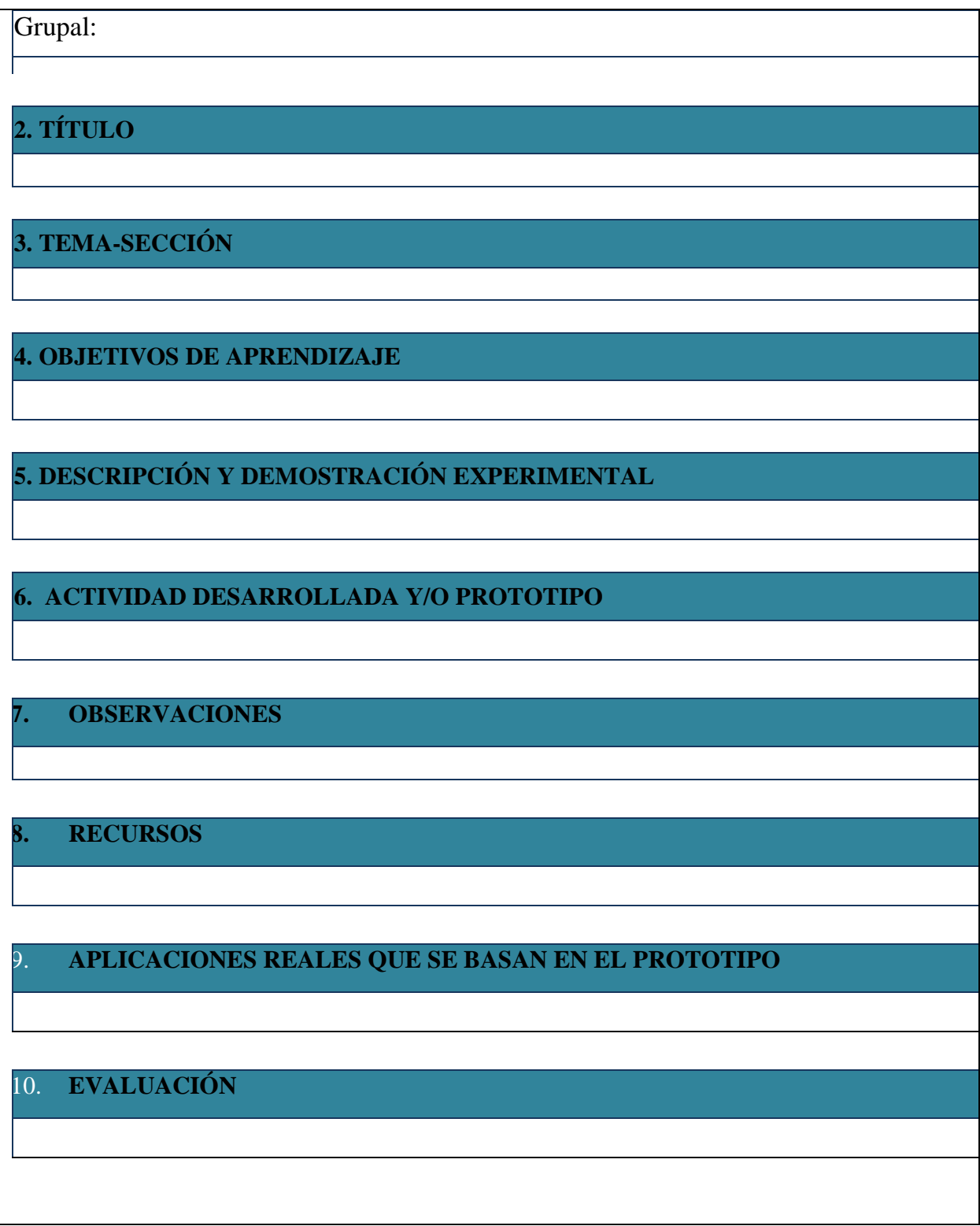

En cuanto a involucrar a los alumnos en alguna de estas demostraciones experimentales, los estudiantes del Grado en Ingeniería en Diseño Industrial y Desarrollo de Productos han desarrollado este año tres pequeños proyectos en grupo con la guía del profesor, a saber: una pieza en 2D para diferenciar el centro geométrico del centro de gravedad, una catapulta y un sistema en equilibrio de varillas con masas colgantes. La figura 2 muestra las imágenes de algunos de prototipos diseñados por los alumnos.

(cc) EY-NC-ND 2018, Universitat Politècnica de València

Congreso IN-RED (2018) 


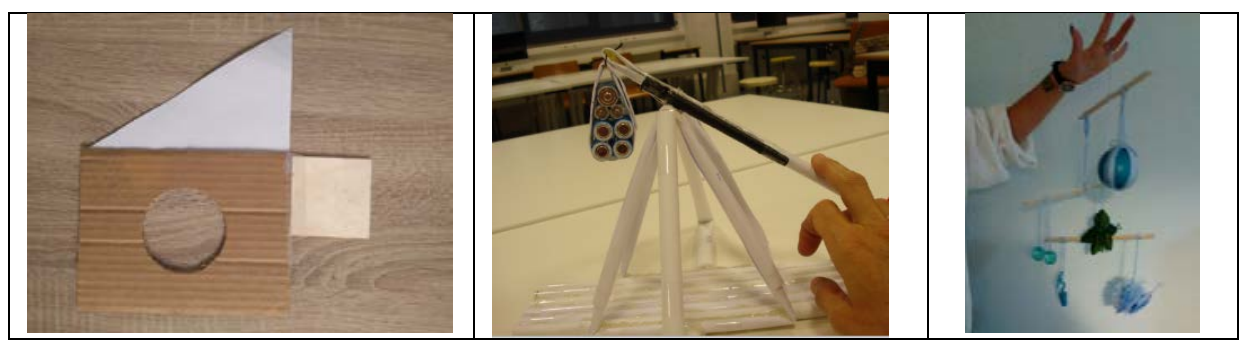

Fig. 2 Ejemplos de los pequeños prototipos desarrollados por los alumnos.

La figura 3 muestra a los alumnos durante una de las sesiones en el aula mostrando los prototipos diseñados por ellos.

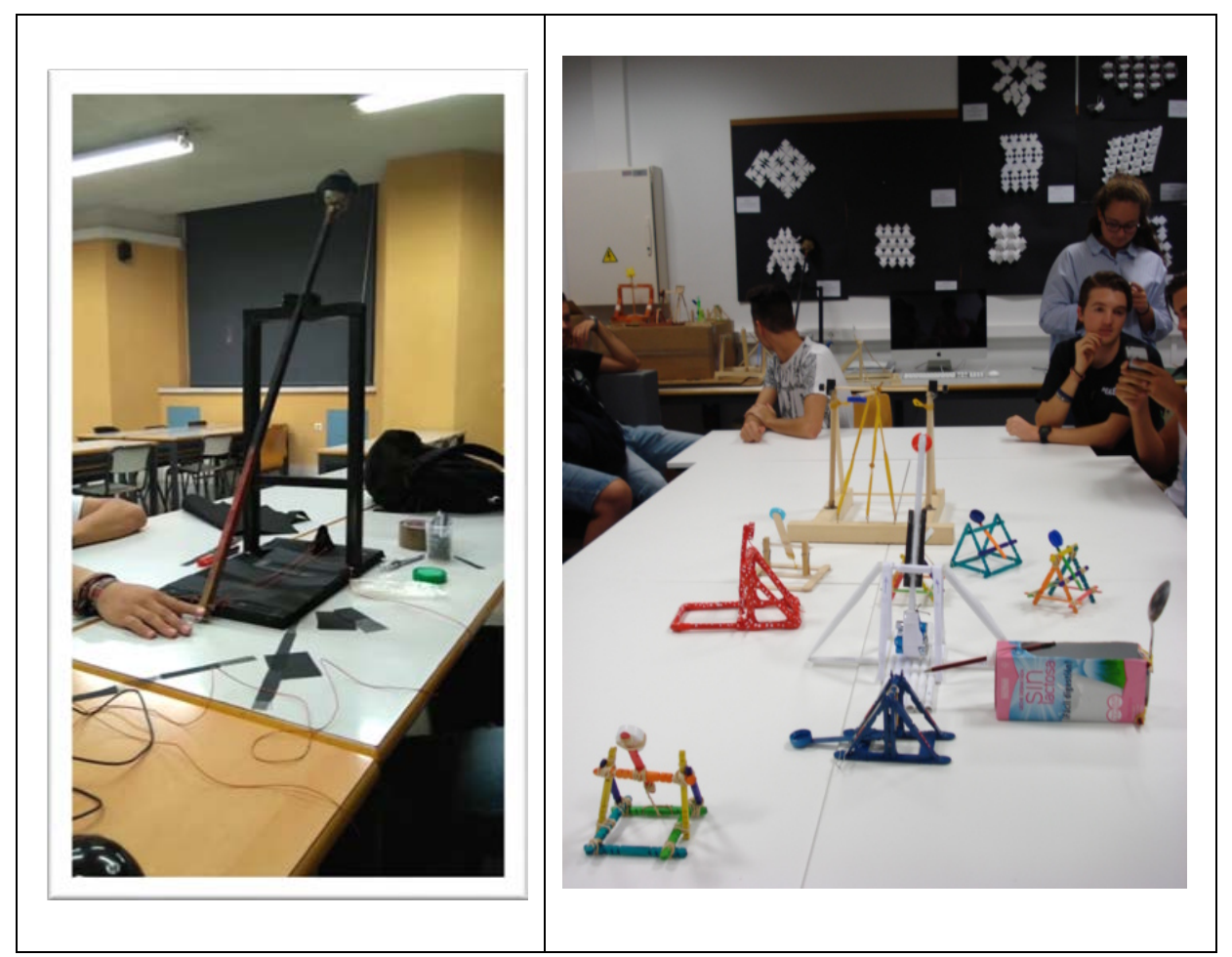

Fig. 3 Los alumnos en el aula durante las demostraciones de sus prototipos.

También se pretende con estos pequeños proyectos que la motivación de los alumnos hacia el aprendizaje de determiandos conceptos físicos sea una consecuencia natural de su experimentación con los prototipos y su diseño. A posteriori, en alguno de estos diseños se les pidio al alumno que resolviese algún problema numérico relacionado con el prototipo y que buscasen ejemplos reales de diseños en donde el prototipo ayudase a la comprensión de su funcionamiento. En la figura 4 se muestra un ejemplo para el caso de las varillas en equilibrio y las masas colgantes. 


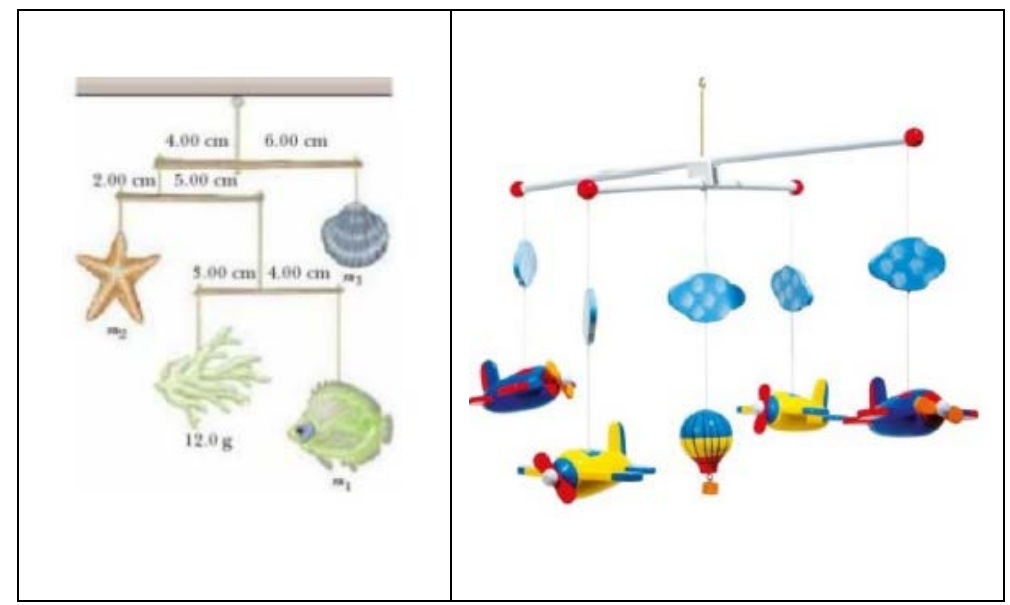

Fig. 4 Problema a resolver y objeto real basado en el equilibrio entre varillas y masas colgantes.

En cuanto al prototipo de la catapulta, además de haber servido para introducir conceptos tales como el tiro parabólico, conservación de energía, momento de inercia de un sólido, teorema de Steiner, etc..., mencionar que fue modelado con el software Matlab (el Matlab es introducido a los alumnos de esta titulación en la asignatura de matemáticas). A partir del modelado hemos observado que ayuda al alumno a identificar los distintos parámetros del mismo y como éstos influyen en su funcionamiento. Entre otros, por ejemplo, les permite calcular la velocidad con la que sale lanzado un proyectil una vez están fijados los otros parámetros modelo (longitud de la barra, peso de la masa lanzada, peso del contrapeso y las longitudes del brazo mayor y menor).

Por último, en relación a la actividad relacionada con la mezcla de la teoría y las sesiones de laboratorio de Electricidad en el aula por medio de la implementación de un laboratorio portátil durante el tiempo asignado a una lección en el aula, se muestra en la figura 6 el kit de trabajo diseñado y a los alumnos trabajando durante una sesión en el aula.

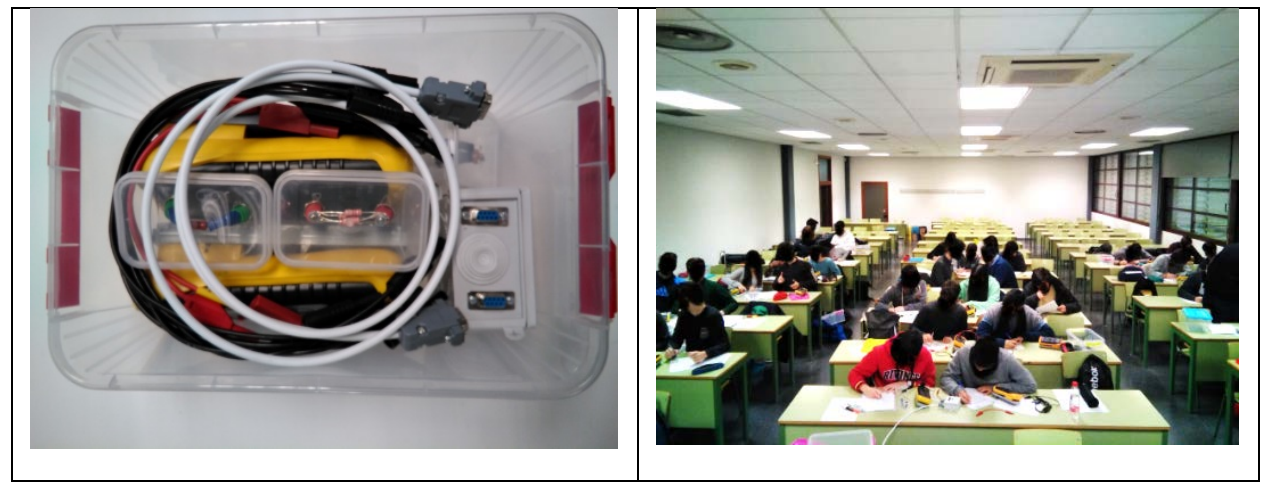

Fig. 6 Kit de cada estudiante y los alumnos trabajando en el aula durante una sesión.

(cc) EY-NC-ND 2018, Universitat Politècnica de València

Congreso IN-RED (2018) 


\section{Resultados}

Algunos de los profesores han pasado una encuesta de valoración para conocer el grado de aceptación por parte de los alumnos de la metodología aplicada.. Se ha considerado interesante utilizar la encuesta que enmarca la valoración a nivel global de toda la Universitat Politécnica de València sobre otro tipo de metodología activa, la docendia inversa (http://docenciainversa.blogs.upv.es/el-proyecto/proyecto-clase-inversa-upv/) . A continuación, mostramos los contenidos de la misma.

\section{Encuesta valoración Metodologías activas en asignaturas básicas: Creación de un catálogo de demostraciones experimentales o proyectos como recursos didácticos para la motivación de titulo}

(Título de la demostración experimental).(Asignatura donde se pasa la encuesta)

Parte de la docencia de esta asignatura ha sido impartida a través de demostraciones experimentales como material de apoyo en las clases de teoría. Se han elaborado unes fichas descriptivas para que los estudiantes pudieseis ver y pensar en fenómenos físicos que explicados desde el punto de vista puramente teórico pudieran quedar "más alejados” de vuestro interés.

Con esto, el profesorado hace uso de las metodologías activas para involucrar a los alumnos en el desarrollo de estas demostraciones experimentales. Se busca que los alumnos tomen iniciativa y protagonismo, desarrollando por grupos, sus propias demostraciones experimentales tutorizadas por el profesor.

\section{EN LAS SIGUIENTE PREGUNTAS VALORA DEL 1 AL 5, TENIENDO EN CUENTA LA} ESCALA:

\section{1: TOTALMENTE EN DESACUERDO... 5: TOTALMENTE DE ACUERDO}

1.- Con la aplicación de estas demostraciones experimentales en clase muestra tu grado de acuerdo con las siguientes afirmaciones:

- Ha contribuido a aumentar mi implicación en la asignatura:

- Me ha resultado gratificante:

- Ha requerido mucho tiempo por mi parte:

- Ha fomentado el trabajo en grupo:

- Me ha ayudado a llegar mejor preparado a los exámenes:

2.- Lo que más te ha gustado de la aplicación de esta metodología en esta asignatura ha sido:

- $\quad$ Los materiales facilitados por el profesor:

- El trabajo realizado en clase:

- El trabajo realizado en casa necesario para llevar a cabo la demostración:

- La relación con el profesor, más cercana y de trabajo conjunto:

- La relación con mis compañeros:

- $\quad$ El sistema de evaluación empleado:

- $\quad$ La preparación de la asignatura por parte del profesor (todo organizado y planificado):

3.- Estoy muy satisfecho con esta experiencia/metodología:

4.- Recomendaría esta experiencia/metodología a mis compañeros de otros cursos y titulaciones:

5.- Me gustaría que esta metodología se aplicara al resto de asignaturas:

6.- Indica dos aspectos positivos y 2 negativos que destacarías de esta metodología:

Positivos:

(cc) EY-NG-ND 2018, Universitat Politècnica de València

Congreso In-Red (2018) 
Negativos:
7.- Añade alguna observación si lo deseas:

En la figura 5 se muestra el resultado de algunas de las preguntas de la encuesta de valoración teniendo en cuenta que la escala de puntuación va del 1 (Totalmente en desacuerdo) al 5 (Totalmente de acuerdo).

\section{RESULTADOS DE LA ECUESTA DE VALORACIÓN}

Te ha ayudado a comprender mejor los conceptos de la asignatura involucrados

Se ha visto favorecido el trabajo en grupo

A supuesto mucho tiempo por tu parte

Te ha sido gratificante este modo de trabajo

Ha contribuido a aumentar el grado de satisfacción con la asignatura

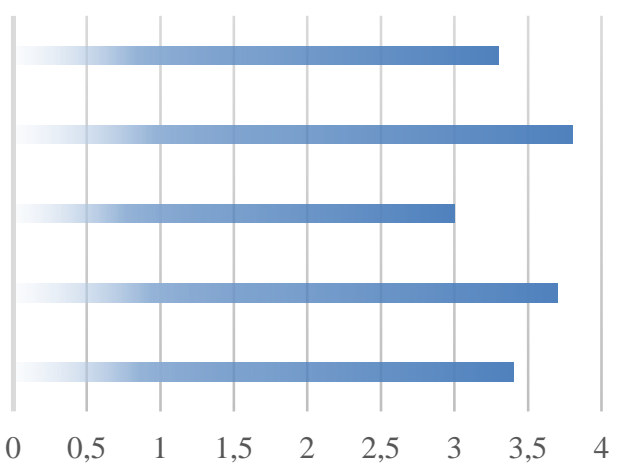

Fig. 5 Resultados de alguna de las preguntas de la encuesta de valoración.

\section{Conclusiones}

Después de un año y medio de proyecto, podemos hacer un breve análisis. En primer lugar, podemos decir que es una experiencia muy positiva y motivadora tanto para estudiantes como para docentes; principalmente, porque ha permitido generar herramientas útiles para involucrar activamente a los estudiantes y acercarles a la asignatura desde la experimentación en el aula. Hemos definido una ficha estándar y sus secciones para completar para cada una de las demostraciones experimentales o proyectos desarrollados por cada profesor. También hemos decidido generar tres prototipos de cada demostración experimental, uno para cada campus. De esta manera, el presente proyecto se estructura como un proyecto de enseñanza Intercampus. Hasta la fecha, todos los participantes en el proyecto ya tienen su primer prototipo desarrollado y los correspondientes tres prototipos. Dicho de otro modo hemos visto que es posible multiplicar los recursos de enseñanza con la creación del catálogo o banco de experimentos mediante un esfuerzo colaborativo entre profesores. Todo este esfuerzo se realiza a coste cero con el objetivo de motivar a los estudiantes y mejorar su aprendizaje. Asimismo, los profesores han encontrado una forma de trabajar a distancia utilizando Google Drive para facilitar el trabajo colaborativo entre diferentes campus. Esto nos está permitiendo generar una cantidad de recursos educativos con un esfuerzo razonable. 
En relación a la implementación de prototipos por parte los estudiantes del Grado en Ingeniería en Diseño Industrial y Desarrollo de Productos, hemos observado y comprobado a partir de los resultados de la encuesta de valoración que la experiencia les resulta gratificante y que les ayuda a asimilar los conceptos de la asignatura de un modo más ameno. También les hace ver que la asignatura de Física puede ser más útil en el diseño de productos, de lo que en general la consideran, lo cual redunda en su mayor motivación a la hora de estudiarla y aprenderla, ya que pasan a considerarla útil.

Por otro lado, la experiencia de mezclar la teoría y la práctica de la asignatura de electricidad en el aula ha sido muy positiva. En particular, la explicación del uso del multímetro en el aula permitió ganar tiempo en las sesiones de laboratorio, que son más cortas y escasas. Los estudiantes estuvieron muy activos y tuvieron con una actitud muy positiva durante la lección. Los comentarios de los estudiantes destacan que el método es agradable y les gusta a asimilar la asignatura.

Como aspecto negativo de estas dos últimas experiencias, hemos observado que la clase puede llegar a volver muy ruidosa; y que por lo tanto, es fundamental tenerla muy bien planificada.

\section{Referencias}

ALBA, J., TORREGROSA, C. y DEL REY, R. (2015). “Aprendizaje basado en proyectos: Primera experiencia en la asignatura de Física del Grado en Ingeniería de Telecomunicación, Sonido e Imagen”. En IN-RED 2015. Valencia: Universitat Politècnica de València.

CALVO, I., LOPEZ-GUEDE, J.M. y ZULUETA, E. (2010). “Aplicando la metodología del maprendizaje basado en Proyectos en la docencia de Ingeniería Técnica en Informática de Gestión”, Revista de Formación e Innovación Educativa Universitaria. vol. 3, № 4, p.166-18.

CURY, A. (2007). Padres Brillantes, Maestros Fascinantes. Ed. Planeta.

FEISEL, L.D. y ROSA, A. J. (2005) "The role of the laboratory in undergraduate engineering education”. J Eng Educ. vol. 94, issue 1, p. 121-130.

FERRER, C. (2012) Demostraciones experimentales de Física para el aula. $<$ http://fisicademos.blogs.uv.es/?page_id=29> [Consulta: 26 de marzo de 2018].

FREIER, G. D. y ANDERSON, F. J. (1996). A demonstration Handbook for Physics $3^{\text {rd }}$ Ed. American Association of Physics Teachers. College Park MD.

GONZÁLEZ, J. y WAGENAAR, R. (2003). “Tuning Educational Structures in Europe. Informe Final” - Proyecto Piloto, Fase 1, Bilbao, Universidad de Deusto.

LLOVERA-SEGOVIA, P., SIMÓN, J. y FUSTER, V. (2015). "Uso de las demostraciones prácticas en las clases de teoría para mejorar el aprendizaje de la Electrotecnia” en 23 Congreso Universitario de Innovación Educativa en las Enseñanzas Técnicas. Valencia. Disponible en $<$ https://innovacioneducativa.upm.es/node/2910> [Consulta: 26 de Marzo del 2018]

VILAPLANA-CERDÁ, R. I., DEL REY-TORMO, R., MANJÓN-HERRERA, F. J., GOMISHILARIO, O., ALBA-FERNÁNDEZ, J., CUENCA-GOTOR, V. P y MONSORIU, J. A. (2017). "Metodologías activas en asignaturas básicas. Creación de un catálogo de demostraciones experimentales o proyectos como recursos didácticos para la motivación de título”. Innovación en la educación superior. PIMES en la ETSID 2016/2017. Valencia: Escuela Técnica Superior de Ingeniería del Diseño. Universidad Politécnica de Valencia. p. 81-86.

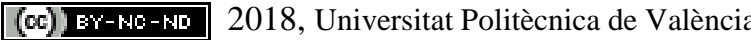




\title{
Aplicación de una metodología de trabajo ágil y colaborativo (SCRUM) en el Master Universitario en Dirección de Empresas (MBA) para la mejora de las competencias transversales
} Josep Capó-Vicedo, Josefa Mula, Manuel Díaz-Madroñero y Pau Vicedo Departamento de Organización de Empresas, E. Politécnica Superior de Alcoy, Universitat Politècnica de València, pepcapo@doe.upv.es, fmula@doe.upv.es, fcodiama@doe.upv.es, pavipa@upv.es

\begin{abstract}
The adaptation of the university to the European Higher Education Area is leading to the achievement of substantial changes in many aspects related to his pedagogical model, for example incorporation of active methodologies oriented to learning and integrated in the dynamics of the classes. In this sense, in this work are presented the results of incorporating a methodology of work (SCRUM) in which are applied a set of best practices to collaboratively work, in teamwork, and obtain the best possible result of a project, in diverse subjects of the Master's Degree in Business Administration (MBA) of the Universitat Politècnica de València. The development of this Project of Innovation and Educational Improvement (PIME) has involved the formation of students and professors in this methodology, by means of his practical application and integrated in the classes along all the course. This has been translated in an improvement of the academic performance and the better acquisition of transversal competencies, mainly analysis and resolution of problems, teamwork and leadership and time management and planning.
\end{abstract}

Keywords: Transversal competencies, Scrum, collaborative work.

\section{Resumen}

La adaptación de la universidad al Espacio Europeo de Educación Superior está llevando a la realización de cambios sustanciales en muchos aspectos vinculados a su modelo pedagógico, por ejemplo, la incorporación de metodologías activas orientadas al aprendizaje e integradas en las dinámicas de las clases. En este sentido, en el presente trabajo se presentan los resultados de incorporar una metodología de trabajo (SCRUM) en la que se aplican un conjunto de buenas prácticas para trabajar colaborativamente, en equipo, y obtener el mejor resultado posible de un proyecto, en diversas asignaturas del Master Universitario en Dirección de Empresas (MBA), del Campus d'Alcoi de la Universitat Politècnica de València. El desarrollo de este Proyecto de Innovación y Mejora Educativa (PIME) ha implicado la formación de alumnos y profesores en esta metodología, mediante su aplicación práctica e integrada en las clases a lo largo de todo el curso. Esto se ha traducido en una mejora del rendimiento académico y en la adquisición y mejora de competencias transversales, principalmente las de análisis y resolución de problemas, trabajo en equipo y liderazgo, y planificación y gestión del tiempo.

Palabras clave: competencias transversales, SCRUM, trabajo colaborativo. 


\section{Introducción}

El Espacio Europeo de Educación Superior (EEES) ha supuesto cambios sustanciales en la universidad, principalmente en su modelo pedagógico, donde la labor del docente se está trasladando hacia una mayor atención a lo que tienen que hacer los alumnos para aprender (Padilla-Carmona y Gil-Flores, 2008). Estos cambios han influido, sin duda, de forma significativa en diferentes aspectos como la planificación de la enseñanza, la metodología, el diseño de actividades, las tutorías y la evaluación del aprendizaje. Así, en esta misma línea, Fernández-March (2010) señala que la adaptación al EEES introduce nuevos elementos en los planes de estudio, cuya principal finalidad es el desarrollo de competencias como resultados de aprendizaje en la formación, la renovación metodológica y la utilización de la evaluación como estrategia que debe influir positivamente en el aprendizaje.

Se define una competencia como "un atributo latente, conocimiento, actitud, destreza y facultad para el desarrollo de una profesión, puesto de trabajo o actuación académica, ejecutando adecuada y correctamente las actuaciones y actividades laborales o académicas exigidas" (Ibarra y Rodríguez, 2010: 450-451). Una competencia, por tanto, integra recursos variados e implica la combinación de recursos complementarios y sinérgicos. Así, en el marco de una formación, es fundamental reflexionar sobre qué nivel de desarrollo debe ser alcanzado por los estudiantes al finalizar su formación para que puedan ser profesionales autónomos, con capacidad de reflexión y ética, y cómo continuar con su desarrollo durante su vida profesional (Fernández-March, 2010). En este sentido, la Universitat Politècnica de València (UPV) ha establecido el Proyecto de Competencias Transversales UPV, el cual tiene como objetivo principal acreditar las competencias transversales UPV a los estudiantes egresados en cualquiera de los títulos oficiales impartidos en la Universitat Politècnica de València. Este objetivo se concreta en otros más específicos, entre los que destacan el de incorporar las competencias a la formación de los estudiantes utilizando diferentes vías o estrategias, el diseño de procesos de evaluación y acreditación de las competencias transversales que sean flexibles e innovadores y el dar visibilidad de los resultados adquiridos por los estudiantes a la sociedad. Con todo ello, la UPV pretende proporcionar a sus egresados un valor añadido que pueda diferenciarlos de otros egresados y, en consecuencia, hacer más atractivos los estudios ofertados frente a ofertas similares de otras universidades, así como poner en valor la capacitación de nuestros egresados de cara a los empleadores (UPV, 2017).

En el caso concreto del Máster Universitario en Dirección de Empresas (MBA) de la UPV, se ha creado en el mes de abril de 2017 un Consejo Consultivo del mismo, integrado por alguna de las empresas más representativas de su zona de influencia, con el objetivo de abrir el master a las necesidades reales de su contexto empresarial. En la primera reunión del mismo se detectó la necesidad de que los alumnos del master adquieran competencias transversales, adicionalmente a los conocimientos teóricos impartidos en el mismo. Se hizo especial hincapié en la necesidad de adquisición de competencias relacionadas con la resolución de problemas y el trabajo en equipo. En base a lo anterior, desde la Comisión Académica del Máster, se planteó la opción de utilizar una metodología de trabajo en equipo y resolución de problemas de manera ágil, de manera transversal en varias asignaturas del mismo, de tal manera que los alumnos y profesores pudieran reforzar estas competencias específicas.

Analizadas las distintas opciones existentes, se decidió utilizar la metodología SCRUM, que es un marco de trabajo en el cual las personas pueden abordar problemas complejos adaptativos, a la vez que entregar productos del máximo valor posible productiva y creativamente (Schwaber y Sutherland, 2016). Este marco de trabajo de procesos que ha sido 
usado para gestionar el desarrollo de productos complejos desde principios de los años 90 no es un proceso o una técnica para construir productos; en lugar de eso, es un marco de trabajo dentro del cual se pueden emplear varios procesos y técnicas. Esta metodología muestra la eficacia relativa de las prácticas de gestión de producto y las prácticas de desarrollo de modo que se pueda mejorar. Este marco de trabajo consiste en los Equipos SCRUM y sus roles, eventos, artefactos y reglas asociadas. Cada componente dentro del marco de trabajo sirve a un propósito específico y es esencial para el éxito de la metodología y para su uso. Las reglas relacionan los eventos, roles y artefactos, gobernando las relaciones e interacciones entre ellos.

En SCRUM se realizan entregas parciales y regulares del producto final, priorizadas por el beneficio que aportan al receptor del proyecto. Por ello, SCRUM está especialmente indicado para proyectos en entornos complejos, donde: se necesita obtener resultados pronto; los requisitos son cambiantes o poco definidos; y la innovación, la competitividad, la flexibilidad y la productividad son fundamentales (Proyectos Ágiles, 2017). En SCRUM un proyecto se ejecuta en bloques temporales cortos y fijos (iteraciones que normalmente son de 2 semanas, aunque en algunos equipos son de 3 y hasta 4 semanas, límite máximo de feedback y reflexión). Cada iteración tiene que proporcionar un resultado completo, un incremento de producto final que sea susceptible de ser entregado con el mínimo esfuerzo al cliente cuando lo solicite.

La finalidad del Proyecto de Innovación y Mejora Educativa (PIME) presentado ha consistido en la aplicación de esta metodología en las asignaturas implicadas en el mismo. De esta manera los alumnos trabajan en equipos auto-gestionados, donde cada uno tiene claro su rol en el mismo, realizando entregas periódicas de los trabajos de las asignaturas, cumpliendo siempre los requisitos consensuados por ellos mismos, los profesores y las empresas implicadas. Si se producen desviaciones en los requisitos y/o necesidades de los clientes se puede reaccionar, ajustándose a los nuevos requerimientos. De esta manera, se pretende que los alumnos sean capaces de trabajar en equipo, resolviendo problemas reales de las empresas en tiempo real, y ajustándose en todo momento a las necesidades y requerimientos de las mismas.

El resto del artículo se ha estructurado de la siguiente forma. En primer lugar, se contextualiza el MBA de la UPV. Seguidamente, se explican las características principales de la metodología SCRUM, así como su aplicabilidad en procesos de gestión, en general, y en educación en particular. A continuación, se detallan los objetivos principales del PIME desarrollado en alguna de las asignaturas del MBA. Posteriormente, se describe cómo se ha aplicado esta metodología en las asignaturas objeto de estudio, así como los resultados principales conseguidos, problemas encontrados y soluciones propuestas a los mismos. Para finalizar, se explican las conclusiones principales obtenidas de la aplicación de esta metodología, así como las propuestas de líneas futuras de trabajo.

\section{Antecedentes}

En este apartado se contextualiza el MBA de la UPV, la metodología SCRUM, el PIME desarrollado en el máster, así como las asignaturas participantes en el mismo, en las cuales se ha aplicado la metodología. 


\subsection{El Master Universitario en Dirección de Empresas (MBA) de la UPV}

El objetivo principal del Programa MBA de la UPV es la formación de futuros directivos y empresarios capacitados para la dirección y el liderazgo de organizaciones en los entornos globales actuales, caracterizados por su elevada complejidad, dinamismo e incertidumbre. Con este MBA se pretende que los estudiantes adquieran los conocimientos globales de la dirección de empresas en un entorno internacional que les permita desarrollar las habilidades directivas imprescindibles para liderar diferentes proyectos empresariales en todo tipo de organizaciones. De este modo, con el MBA se intenta dar respuesta a las necesidades reales y actuales del mundo empresarial.

El MBA pretende dotar a los alumnos de conocimientos para que sean capaces de analizar y resolver, de forma creativa, situaciones complejas en el ámbito de la dirección de empresas apoyándose en el desarrollo y uso de herramientas teórico-prácticas, metodológicas y de análisis de la información. En concreto, y de modo específico, se pretende que el estudiante alcance conocimientos avanzados tanto teóricos como prácticos en los siguientes campos: organización, dirección de empresas; contabilidad; finanzas; marketing; liderazgo, habilidades directivas y trabajo en equipo; fiscalidad empresarial; análisis del entorno; estrategia de operaciones y herramientas de gestión para la toma de decisiones.

Además de la formación en aspectos técnicos, se considera también importante transmitir a los alumnos una mayor sensibilidad por los aspectos éticos de la función empresarial, para valorar las empresas no sólo por su dimensión económica sino también por su dimensión social y medioambiental.

El MBA tiene una duración de 3 semestres con una carga lectiva de 90 ECTS, repartidos como se indica en la Tabla 1.

Tabla 1. Asignaturas del MBA de la UPV.

\begin{tabular}{c}
\hline \hline SEMESTRE 1 \\
\hline Entorno Legal Internacional (4,5 ECTS) \\
\hline Entorno Económico Internacional (4,5 ECTS) \\
\hline Herramientas Estadísticas para la Gestión (4,5 ECTS) \\
\hline Dirección de Marketing (4,5 ECTS) \\
\hline Técnicas Avanzadas de Dirección Financiera (6 ECTS) \\
\hline Estrategia de Operaciones y Tecnología (4,5 ECTS) \\
\hline SEMESTRE 2 \\
\hline Management Estratégico en Entornos Globales (4,5 ECTS) \\
\hline Besarrollo de habilidades directivas y gestión de equipos de alto rendimiento (4,5 ECTS) \\
\hline Sloque Intensificación Marketing o Banca y Sector Financiero (18 ECTS) \\
SEMESTRE 3 \\
\hline Bloque Intensificación Dirección Corporativa y Emprendimiento o E-Business (18 ECTS) \\
Trabajo Final de Master - TFM (12 ECTS)
\end{tabular}

\subsection{La metodología SCRUM}

Schawer y Sutherland (2016) definen SCRUM como un marco para el desarrollo y mantenimiento de productos y proyectos complejos que aborda de forma adaptativa su desarrollo al mismo tiempo que entrega productos del máximo valor posible. SCRUM se basa en la teoría de control de procesos empírica, es decir, se toman decisiones basándose en 
lo que se conoce y, para ello, se definen tres pilares que soportan la implementación del control de los procesos empíricos: transparencia (se comparte un lenguaje común), inspección (detección de variaciones indeseadas) y adaptación (si un proceso se desvía de límites aceptables debe realizarse un ajuste).

Tabla 2. Componentes de la metodología SCRUM.

\begin{tabular}{|c|c|c|c|c|}
\hline & Sprint Planning & Daily Scrum & Sprint Review & $\begin{array}{c}\text { Sprint } \\
\text { Restrospective }\end{array}$ \\
\hline Frecuencia & Al inicio del sprint & Diaria & $\begin{array}{l}\text { Una al final del } \\
\text { sprint }\end{array}$ & $\begin{array}{l}\text { Una al final del } \\
\text { sprint }\end{array}$ \\
\hline Duración & Máximo de 8 horas & $\begin{array}{l}\text { Máximo de } 15 \\
\text { minutos }\end{array}$ & Máximo de 4 horas & Máximo de 3 horas \\
\hline Asistentes & $\begin{array}{l}\text { Todo el equipo } \\
\text { SCRUM }\end{array}$ & $\begin{array}{l}\text { Equipo de desarrollo } \\
\text { y, opcionalmente, } \\
\text { SCRUM Master }\end{array}$ & $\begin{array}{l}\text { Equipo SCRUM } \\
\text { más stakeholders }\end{array}$ & Equipo SCRUM \\
\hline Input & $\begin{array}{l}\text { Definición de } \\
\text { "done", capacidad y } \\
\text { velocidad del equipo } \\
\text { de desarrollo, } \\
\text { product backlog, } \\
\text { conclusiones del } \\
\text { sprint retrospective }\end{array}$ & $\begin{array}{l}\text { Tareas realizadas el } \\
\text { día anterior }\end{array}$ & $\begin{array}{l}\text { Items del sprint } \\
\text { backlog terminados }\end{array}$ & Desarrollo del sprint \\
\hline Proceso & $\begin{array}{l}\text { Análisis, evaluación } \\
\text { y selección de los } \\
\text { ítems del product } \\
\text { backlog, } \\
\text { descomposición de } \\
\text { los ítems en un plan } \\
\text { de acción }\end{array}$ & $\begin{array}{l}\text { Contestar a tres } \\
\text { preguntas: ¿Qué hice } \\
\text { ayer para conseguir } \\
\text { el objetivo del } \\
\text { sprint? ¿Qué voy a } \\
\text { hacer hoy? ¿Qué } \\
\text { impedimentos } \\
\text { encuentro? }\end{array}$ & $\begin{array}{l}\text { Se demuestra el } \\
\text { trabajo terminado } \\
\text { (incremento), se } \\
\text { discute sobre el } \\
\text { desarrollo del sprint }\end{array}$ & $\begin{array}{l}\text { Inspeccionar cómo } \\
\text { fue el último sprint } \\
\text { en cuanto a } \\
\text { personas, relaciones, } \\
\text { procesos y } \\
\text { herramientas. } \\
\text { Identificar y ordenar } \\
\text { los elementos más } \\
\text { importantes que } \\
\text { salieron bien y las } \\
\text { posibles mejoras }\end{array}$ \\
\hline Output & $\begin{array}{l}\text { Sprint goal y sprint } \\
\text { backlog }\end{array}$ & Plan para el día & $\begin{array}{l}\text { Se obtiene el input } \\
\text { de los stakeholders } \\
\text { y se proyectan las } \\
\text { fechas de } \\
\text { finalización en } \\
\text { función del } \\
\text { progreso obtenido }\end{array}$ & $\begin{array}{l}\text { Crear un plan para } \\
\text { implementar las } \\
\text { mejoras a la forma } \\
\text { en la que el equipo } \\
\text { SCRUM despeña su } \\
\text { trabajo }\end{array}$ \\
\hline
\end{tabular}

Los componentes principales de SCRUM son (Tabla 2):

\section{Equipo SCRUM:}

- Product owner: optimiza el valor del producto y maneja el product backlog.

- SCRUM master: maneja el proceso SCRUM, elimina impedimentos para que el equipo de desarrollo se centre en sus tareas, coaching.

- Equipo de desarrollo: equipo multifuncional de entre 3 y 9 personas Artefactos: autogestionado, es el encargado de crear incrementos.

- Product backlog: inventario de las tareas pendientes que se tienen que realizar. El product owner es el propietario.

- Sprint backlog: son los ítems del product backlog a desarrollar durante el sprint además de un plan para entregarlos. El equipo de desarrollo es el propietario. 
- Incremento: es la suma de todos los elementos del product backlog completados durante el sprint. Este incremento debe proporcionar un producto potencialmente utilizable.

Eventos:

- Sprint: Es la base de SCRUM, un período de tiempo determinado de un mes o menos en el que se crea un incremento de producto "done", utilizable y potencialmente desplegable. Un sprint comienza inmediatamente después de la finalización del anterior. El sprint contiene el resto de reuniones también consideradas eventos.

\subsection{El Proyecto de Innovación y Mejora Educativa (PIME) desarrollado en el MBA}

Los proyectos PIME que contempla la convocatoria 2017/2018 de la UPV han de tener un carácter esencialmente realista, práctico y sostenible. Así mismo, los productos de estos proyectos deben ser útiles y aplicables dentro de la comunidad universitaria. Se propicia su difusión dentro de la UPV para que los resultados de los proyectos se compartan, debatan y sirvan de ejemplo y de estímulo a otros nuevos proyectos.

El PIME concedido al MBA tiene como título "Aplicación de una metodología de trabajo ágil y colaborativo (SCRUM) en el Master Universitario en Dirección de Empresas (MBA) para mejorar competencias transversales", una duración prevista de un año y participan en él 9 asignaturas (Tabla 3), con un total de 12 profesores. Este PIME se encuadra en el ámbito temático de la experimentación en metodologías activas y en el de experimentación de instrumentos o estrategias orientadas al aprendizaje e integradas en las dinámicas de las clases. La principal finalidad del proyecto es la mejora de las competencias transversales de análisis y resolución de problemas, trabajo en equipo y liderazgo, y planificación y gestión del tiempo, de los alumnos del MBA, mediante la aplicación de la metodología SCRUM. Los objetivos específicos del proyecto son los siguientes: Formación de alumnos y profesores del máster en la metodología SCRUM; aplicación de manera continuada e integrada de dicha metodología en las clases en general, y en los trabajos realizados en las asignaturas en particular; y comparación de los resultados obtenidos aplicando esta metodología con los obtenidos en años anteriores. En la Tabla 4 se puede observar el cronograma previsto para la ejecución del PIME.

Tabla 3. Asignaturas del MBA participantes en el PIME.

\begin{tabular}{|c|c|c|c|c|c|}
\hline Código & Nombre & Carácter & ECTS & $\begin{array}{c}\mathbf{N}^{0} \\
\text { estudiantes }\end{array}$ & Dpto. responsable \\
\hline 33621 & Dirección de Marketing & Obligatoria & 4,5 & 25 & Organización de Empresas \\
\hline 33622 & $\begin{array}{l}\text { Técnicas Avanzadas de } \\
\text { Dirección Financiera }\end{array}$ & Obligatoria & 6 & 25 & Economía y C. Sociales \\
\hline 33623 & $\begin{array}{c}\text { Estrategia de Operaciones y } \\
\text { Tecnología }\end{array}$ & Obligatoria & 4,5 & 25 & Organización de Empresas \\
\hline 33624 & $\begin{array}{c}\text { Herramientas Estadísticas } \\
\text { para la Gestión }\end{array}$ & Obligatoria & 4,5 & 25 & $\begin{array}{c}\text { Estadística, Investigación } \\
\text { Operativa y Calidad }\end{array}$ \\
\hline 33626 & $\begin{array}{c}\text { Management Estratégico en } \\
\text { Entornos Globales }\end{array}$ & Obligatoria & 4,5 & 25 & Organización de Empresas \\
\hline 33627 & $\begin{array}{c}\text { Desarrollo de Habilidades } \\
\text { Directivas y Gestión de } \\
\text { Equipos de Alto Rendimiento }\end{array}$ & Obligatoria & 4,5 & 25 & Organización de Empresas \\
\hline 33629 & Marketing Internacional & Optativa & 4,5 & 25 & Economía y C. Sociales \\
\hline 33638 & $\begin{array}{l}\text { Herramientas de Business } \\
\text { Intelligence }\end{array}$ & Optativa & 4,5 & 15 & Organización de Empresas \\
\hline 33639 & Resp. Social Corporativa & Optativa & 4,5 & 15 & Economía y C. Sociales \\
\hline
\end{tabular}


Tabla 4. Cronograma de ejecución del PIME del MBA.

\begin{tabular}{|c|c|c|c|c|c|c|c|c|c|c|c|c|}
\hline & & \multicolumn{11}{|c|}{ Curso 2017-2018 } \\
\hline Fases/Tareas & RESP. & Sep & Oct & $\mathrm{Nv}$ & Dic & Ene & Feb & Mr & Abr & My & Jun & Jul \\
\hline $\begin{array}{l}\text { 1. Formación inicial en } \\
\text { metodología SCRUM }\end{array}$ & $\begin{array}{l}\begin{array}{l}\text { Todo el } \\
\text { equipo }\end{array} \\
\end{array}$ & & & & & & & & & & & \\
\hline 1.1 Formación profesores & & $\bullet$ & & & & & & & & & & \\
\hline 1.2 Formación alumnos & & & $\bullet$ & & & & & & & & & \\
\hline $\begin{array}{l}\text { 2. Aplicación metodología ler } \\
\text { cuatrimestre }\end{array}$ & $\begin{array}{l}\text { Todo el } \\
\text { equipo }\end{array}$ & & & & & & & & & & & \\
\hline 2.1 Aplicación metodología & & & $\bullet$ & $\bullet$ & $\bullet$ & $\bullet$ & & & & & & \\
\hline 2.2 Reuniones seguimiento & & & & $\bullet$ & & $\bullet$ & & & & & & \\
\hline $\begin{array}{l}\text { 3. Revisión resultados primer } \\
\text { cuatrimestre }\end{array}$ & $\begin{array}{l}\text { Todo el } \\
\text { equipo }\end{array}$ & & & & & & & & & & & \\
\hline 3.1 Revisión problemas & & & & & & $\bullet$ & & & & & & \\
\hline 3.2 Propuesta mejoras & & & & & & $\bullet$ & & & & & & \\
\hline $\begin{array}{l}\text { 4. Aplicación metodología } 2^{\circ} \\
\text { cuatrimestre }\end{array}$ & $\begin{array}{l}\text { Todo el } \\
\text { equipo }\end{array}$ & & & & & & & & & & & \\
\hline 4.1 Aplicación metodología & & & & & & & $\bullet$ & $\bullet$ & $\bullet$ & $\bullet$ & $\bullet$ & \\
\hline 4.2 Reuniones seguimiento & & & & & & & & $\bullet$ & & $\bullet$ & & \\
\hline $\begin{array}{l}\text { 5. Revisión final, aprobación } \\
\text { y difusión }\end{array}$ & $\begin{array}{l}\text { Todo el } \\
\text { equipo }\end{array}$ & & & & & & & & & & & \\
\hline $\begin{array}{l}5.1 \text { Revisión final por } \\
\text { alumnos y profesores }\end{array}$ & & & & & & & & & & & $\bullet$ & \\
\hline $\begin{array}{l}5.2 \text { Aprobación y difusión del } \\
\text { resultado }\end{array}$ & & & & & & & & & & & & $\bullet$ \\
\hline
\end{tabular}

A continuación, se van a detallar los aspectos principales del desarrollo del proyecto a través de las asignaturas de Management Estratégico en Entornos Globales y Estrategia de Operaciones y Tecnología.

\section{Desarrollo del proyecto}

En este apartado se explica cómo ha surgido y se ha desarrollado el PIME hasta la fecha, así como los principales resultados obtenidos.

\subsection{Experiencia Piloto en el curso 2016/2017}

En el curso 2016/2017 se llevó a cabo una experiencia piloto, utilizando la metodología SCRUM en una de las asignaturas del Máster. En concreto, se aplicó esta metodología en la asignatura "Management Estratégico en Entornos Globales". Esta ofrece formación respecto a las principales funciones de dirección, centrando el interés en la formulación e implantación de la estrategia como un elemento determinante del éxito de la organización en un entorno globalizado. Con el aprendizaje de esta materia se pretende que el estudiante asimile y aplique el significado que adquiere la dirección estratégica en el contexto actual, en el que el desarrollo de la estrategia puede contribuir a la superación de los retos del entorno y a que la empresa sea competitiva.

Con la utilización de la metodología SCRUM se buscaba obtener una mejora del rendimiento académico de los alumnos de la asignatura, así como la adquisición y mejora de competencias transversales, principalmente, las de análisis y resolución de problemas, trabajo en equipo y liderazgo, y planificación y gestión del tiempo, mediante su aplicación práctica e integrada en el trabajo de la asignatura. Para conseguirlo, a lo largo de la asignatura se aplicó la metodología SCRUM sobre la propuesta de nuevos modelos de negocio innovadores para cuatro empresas pertenecientes al Consejo Consultivo del MBA. 
En concreto, se trabajó con una empresa del sector plástico, una del sector de alimentación, una dedicada al marketing electrónico y una emisora local de radio, perteneciente a una cadena nacional líder en el sector. Se buscaba así que los alumnos se implicasen en realidades muy diferentes, tanto a nivel de sector y tamaño, como de problemáticas a resolver. Todos los alumnos de la asignatura visitaron las cuatro empresas, con lo que después podían valorar y ofrecer realimentación sobre las propuestas de cada grupo, implicándose mucho más en el desarrollo de los proyectos.

Los aspectos a trabajar en cada una de las empresas fueron los siguientes:

- Empresa del sector plástico: esta empresa no planteó una problemática concreta, sino que solicitó que los alumnos analizaran su modelo de negocio actual y que propusieran alguna línea de negocio innovadora que pudiera complementar las que ya tenían en marcha.

- Empresa del sector alimentación: esta compañía requirió que los alumnos analizaran su utilización de las redes sociales y que les propusieran mejoras en la misma, ya que lo consideraban uno de sus puntos débiles principales.

- Empresa de marketing electrónico: esta empresa pidió que se analizara una de sus líneas de negocio, en concreto, la de servicio de bases de datos a otras empresas, con el objetivo de plantear alguna variante novedosa en este servicio.

- Empresa de radio: en este caso se trataba de una empresa con una gran historia y experiencia, pero que necesitaba urgentemente modernizarse y trabajar su imagen de marca.

Se dividió a los alumnos en cuatro equipos auto-gestionados intentando que fueran interdisciplinares, teniendo todos ellos miembros de distintas titulaciones, intentando compensar los que venían de ingenierías con los que procedían de estudios relacionados con la administración de empresas.

Se planteó un índice general del trabajo, dividido en cuatro SPRINTS a trabajar, en concreto, los siguientes:

- SPRINT 1: Análisis DAFO de la empresa y planteamiento de su modelo de negocio actual mediante la herramienta Business Model Canvas.

- SPRINT 2: Elaboración del cuadro estratégico actual de la empresa y planteamiento de nuevas posibilidades a partir de la aplicación del esquema de las 6 vías de la estrategia del Océano Azul.

- SPRINT 3: Elección de un nuevo cuadro estratégico, análisis de los niveles de no clientes y análisis del mismo mediante la secuencia estratégica.

- SPRINT 4: Planteamiento de un nuevo modelo de negocio innovador para la empresa.

Cada componente del grupo tenía claro su rol en el mismo en base a la metodología SCRUM, ocupándose el Product Owner de la comunicación con la empresa correspondiente, el SCRUM Master de la coordinación interna del grupo y, dado el carácter académico todos ellos formaban parte del Equipo de Desarrollo encargado de la realización de las tareas encomendadas.

En cada uno de los SPRINTS cada grupo presentaba al resto sus avances, produciéndose después un turno de preguntas, comentarios y realimentación por parte del resto de grupos. Estas sesiones fueron especialmente productivas, ya que, al conocer todos los alumnos las problemáticas de las cuatro empresas, podían opinar con conocimiento de causa, realizando 
sus propias aportaciones. Una vez realizadas estas por parte del resto de grupos, los profesores también opinaban al respecto, con lo que cada grupo obtenía un importante feedback desde varias fuentes para mejorar el trabajo para las siguientes entregas. La sesión terminaba con una reunión de cada grupo en la que se analizaban los resultados obtenidos y el grado de cumplimiento personal de los objetivos de cada miembro del grupo, proponiéndose acciones de mejora y repartiéndose las tareas para el siguiente SPRINT.

Finalmente, se realizó una sesión pública de presentación de los resultados a las empresas y al público en general. En ella cada grupo expuso su propuesta a la empresa correspondiente, produciéndose posteriormente un debate sobre las mismas. La satisfacción por parte de las empresas fue muy elevada, llegando incluso a contratar alumnos en una de ellas para poner en marcha las soluciones propuestas.

A partir de esta experiencia piloto se consideró la opción de ampliar a otras asignaturas del máster, planteando para ello el PIME tratado en el presente artículo. Se ofreció participar a todas las asignaturas del máster, accediendo a ello nueve de ellas, seis del primer semestre y tres del segundo.

\subsection{Realización del PIME en el curso 2017/2018}

En el curso 2017/2018, y tal y como ya se ha comentado en apartados anteriores, se ha aplicado esta metodología a nueve asignaturas del máster. A continuación, se presenta la dinámica de funcionamiento seguida.

En el primer cuatrimestre participaban en el PIME las siguientes asignaturas:

- Estrategia de Operaciones y Tecnología.

- Herramientas Estadísticas para la Gestión.

- Dirección de Marketing.

- Responsabilidad Social Corporativa.

- Técnicas Avanzadas de Dirección Financiera.

- Herramientas de Business Intelligence.

Antes de empezar el curso se realizó una sesión de formación a los profesores responsables de las mismas en la metodología SCRUM. Esta sesión la realizó un SCRUM Master certificado, el cual está participando durante todo el curso en labores de apoyo y asesoramiento a todas las asignaturas participantes.

Posteriormente, en la primera semana de clase, se realizó un seminario de formación en la metodología a los alumnos. Este seminario se realizó dentro de la asignatura "Estrategia de Operaciones y Tecnología", aprovechando una sesión práctica, en la cual se empezó a aplicar la metodología directamente para explicar de manera práctica la forma de funcionar. En los cursos anteriores, la asignatura se basaba en el desarrollo de dos casos prácticos y un trabajo teórico-práctico final desarrollados en grupo. Sin embargo, en el presente curso se ha reestructurado la parte práctica de la asignatura de forma que los alumnos tengan que desarrollar un proyecto de estrategia de operaciones a partir de un conjunto de tres entregas parciales que coinciden con los sprints a realizar según SCRUM. En concreto, los alumnos han trabajado en grupo para diseñar la estrategia de operaciones de una empresa o modelo de negocio de nueva creación a través de las tres entregas parciales y del proyecto final elaborado a partir de estas. Para cada sprint correspondiente a las entregas parciales y el proyecto final ha sido obligatorio elaborar un informe escrito y una exposición oral asociada. 
A finales de noviembre se realizó una primera reunión de seguimiento con todos los profesores de asignaturas participantes en el primer cuatrimestre. En esta reunión cada profesor expuso su experiencia, así como los problemas detectados y las acciones que estaban llevando a cabo, las cuales se resumen a continuación:

- Estrategia de Operaciones y Tecnología: los profesores de la asignatura indicaron que los alumnos en un principio no estaban del todo contentos con la metodología, puesto que les implicaba un mayor trabajo y un mayor esfuerzo de coordinación, pero que ya estaban cogiendo el ritmo de trabajo y empezaban a valorar los resultados. En cada sesión se ha realizado un acta con los resultados de la misma, siendo revisadas por el SCRUM Master.

- Herramientas Estadísticas para la Gestión: el profesor responsable indicó que, inicialmente, hubo problemas de coordinación, ya que la metodología era nueva para profesores y alumnos, pero después de una reunión adicional y particularizada para la asignatura con el SCRUM Master se encauzó la situación, mejorando significativamente. De hecho, el profesor valoró especialmente la realimentación que obtienen los alumnos en cada entrega, tanto del contenido del trabajo, como de la propia dinámica de funcionamiento del grupo. Desde su propio punto de vista, el profesor incidió en que la aplicación de la metodología le ha permitido tener un mayor orden en las entregas y tener por escrito mucha más información. Utilizan una plantilla en cada sprint en la cual se resumen los principales resultados del mismo y se aprovecha para poner las principales correcciones.

- Dirección de Marketing: al igual que en el resto de asignaturas, los alumnos inicialmente eran reacios a aplicar una nueva metodología que les implicaba una mayor carga de trabajo, debido a las entregas parciales en cada sprint, pero poco a poco fueron asimilando y aceptando la nueva forma de trabajar. En cada sprint se está dando realimentación por parte del profesor, lo cual les está ayudando a mejorar los resultados.

- Responsabilidad Social Corporativa: al ser una asignatura optativa, con únicamente seis alumnos, se hicieron dos grupos de 3 , uno de los cuales funcionaba bien, mientras que el otro presentó problemas, lo cual llevó en este momento a plantear la opción de trabajar con un grupo único que aglutinara a los dos anteriores.

- Técnicas Avanzadas de Dirección Financiera y Herramientas de Business Intelligence: en estos dos casos, los profesores correspondientes no aplicaron la metodología, por lo que abandonaron el PIME. Las razones aducidas fueron de falta de tiempo para implantar una metodología docente nueva.

A partir de esta primera reunión de seguimiento se estableció la conveniencia de coordinar mejor para el siguiente curso la dinámica de funcionamiento, aplicar la metodología en menos asignaturas a la vez, para no saturar a los alumnos, e incluso intentar hacerlo con un proyecto de trabajo común e interdisciplinar entre las asignaturas participantes. Se decidió hacer la siguiente reunión de seguimiento al finalizar el cuatrimestre, juntando a todos los profesores participantes en el proyecto, de tal manera que los correspondientes al primer cuatrimestre pudieran explicar a los del segundo las dificultades con las que se habían encontrado, y las soluciones que les habían dado. En febrero, una vez finalizado el primer cuatrimestre, y antes de empezar las clases del segundo, se hizo la segunda reunión de seguimiento de la manera indicada en el párrafo anterior.

Los profesores del primer cuatrimestre indicaron que los alumnos habían acabado un poco saturados por la carga de trabajo, que no habían tenido en algunos casos muy claros los roles de cada uno en los equipos de trabajo, y que las entregas en las distintas asignaturas no estaban bien coordinadas. Para subsanar estos problemas y mejorar el funcionamiento, en el 
segundo cuatrimestre se ha optado por coordinar mejor las tres asignaturas participantes, de tal forma que se han fijado los mismos equipos de trabajo para las tres, establecidos por el profesor responsable de la asignatura "Desarrollo de habilidades directivas y Gestión de Equipos de Alto Rendimiento". Adicionalmente el rol de "Product Owner" ha sido asumido por los profesores responsables de las asignaturas, para coordinar mejor a todos los equipos. En estos momentos las tres asignaturas están en fase inicial, pero observándose una clara mejora en el funcionamiento de los quipos respecto al primer cuatrimestre, siendo la valoración de los alumnos más positiva. Este hecho se quiere refrendar de manera objetiva, para lo cual se les pasará a finales de marzo un cuestionario para que indiquen su percepción en la aplicación de la metodología en el primer cuatrimestre, comparándola con aquellas asignaturas que no han funcionado son SCRUM, y este mismo cuestionario se pasará a final de curso, para ver si se ha mejorado su percepción, resultados y rendimiento respecto al primer cuatrimestre y a las asignaturas no SCRUM.

\subsection{Principales resultados obtenidos}

En cuanto al grado de cumplimiento de los objetivos planteados en la asignatura de Management Estratégico en Entornos Globales durante el curso 2016/17, se obtuvieron los resultados que se describen a continuación. Referente al rendimiento académico, la nota media de los alumnos matriculados en la asignatura utilizando la metodología SCRUM es de 8,7 sobre 10 , mientras que la nota media en los cursos anteriores, en los que no se aplicó la metodología era de 7,6 sobre 10, con lo que se ha aumentado el rendimiento en más de un $10 \%$. En cuanto a la mejora en las competencias transversales se ha observado una mejora significativa en las tres competencias analizadas, tal y como se explica a continuación (Fig. 1), sobre una clasificación de adquisición de competencias que sigue la siguiente escala: $\mathrm{A}$ Excelente; B - Adecuado; C - en desarrollo; D - no alcanzado.

- Competencia de análisis y resolución de problemas: con la aplicación de la metodología SCRUM se conseguía que, si se producían desviaciones en los requisitos y/o necesidades de las empresas, se pudiera reaccionar, ajustándose a los nuevos requerimientos. De esta manera, se conseguía que los alumnos fueran capaces de trabajar en equipo, resolviendo problemas reales de las empresas en tiempo real, y ajustándose en todo momento a las necesidades y requerimientos de las mismas. En cuanto al nivel de adquisición de la competencia, la media de cursos anteriores era de un $22 \%$ de nivel A y un $78 \%$ de nivel B, pasando en este curso a un nivel del $53 \%$ A, $47 \%$ B, siendo la mejora muy sustancial.

- Competencia de trabajo en equipo y liderazgo: el hecho de asignar roles específicos a cada uno de los componentes de los grupos, realizar sesiones de autocontrol y planteamiento de mejoras en el funcionamiento interno de los grupos, dentro de las especificaciones de la metodología SCRUM ha supuesto una mejora en la adquisición de esta competencia muy alta, en concreto se ha pasado de un $0 \% \mathrm{~A}$, $95 \%$ B y $5 \%$ C a $74 \%$ A, $26 \%$ B.

- Competencia de planificación y gestión del tiempo: la realización de entregas periódicas, la planificación de las tareas individuales y grupales en cada entrega y las reuniones semanales de seguimiento que implica SCRUM han supuesto aumentar el nivel de adquisición de esta competencia desde una media en cursos anteriores de $22 \%$ A, $67 \%$ B y $11 \% \mathrm{C}$ a unos valores de $63 \%$ A y $37 \% \mathrm{~B}$. 

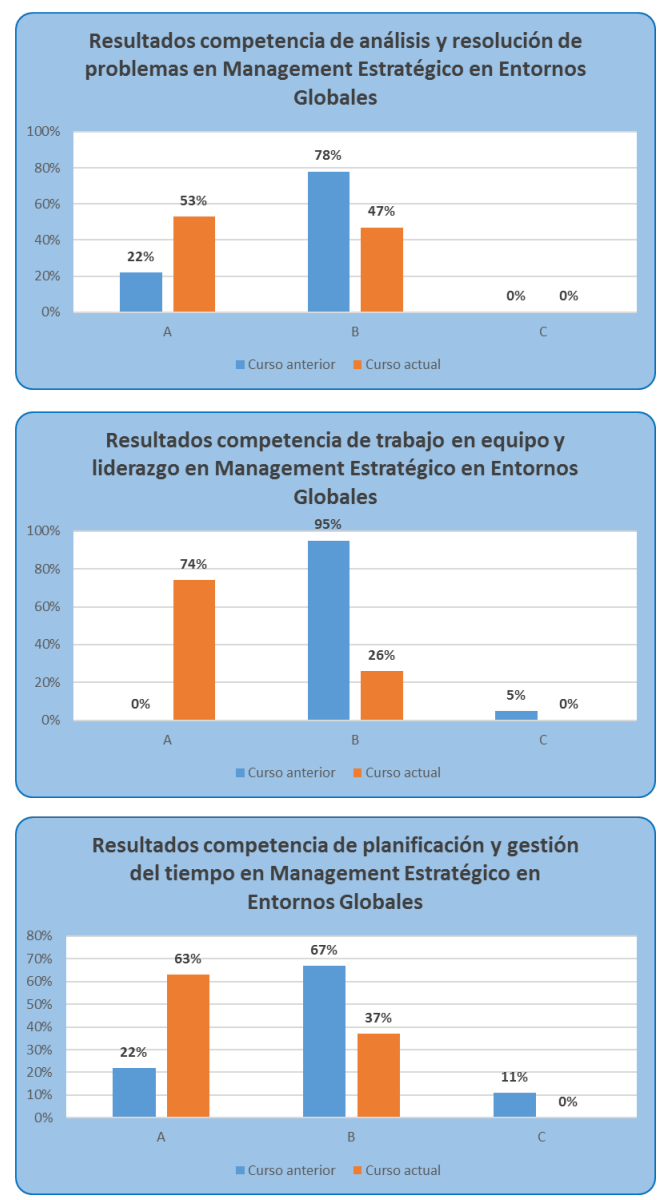

Fig. 1 Comparación de competencias en la asignatura Management Estratégico en Entornos Globales

Por otro lado, se destacan seguidamente los resultados obtenidos en la asignatura "Estrategia de Operaciones y Tecnología", comparándolos con los obtenidos en años anteriores, en los cuales no se aplicó la metodología, cabe destacar que el rendimiento promedio se ha situado ligeramente por debajo del obtenido en el curso anterior. Concretamente, la nota media final de la asignatura ha correspondido a 7,2 puntos, mientras que en el curso anterior fue de 7,7 puntos. La Fig. 2 muestra el grado de adquisición de competencias transversales, obteniendo para "Aplicación y pensamiento práctico" una calificación de A en el 20\% de alumnos y de B en el $80 \%$ restante; para "Diseño y proyecto" un rendimiento de A en el $20 \%$ del grupo y una calificación de B en el resto; y para "Planificación y gestión del tiempo" una calificación de A para el $68 \%$ de los alumnos y una calificación B en el 32\% restante. Estos resultados son ligeramente inferiores a los obtenidos en el curso anterior, en el que no se aplicó SCRUM. En este caso, el rendimiento asociado a la competencia "Aplicación y pensamiento práctico" se situó en 30,43\% para la calificación A y en un $69,57 \%$ para la calificación B. Referente a la competencia "Diseño y proyecto", se obtuvo una calificación de A en el 47,83\% de los alumnos y de B en el 52,17\%, mientras que para la competencia "Planificación y gestión del tiempo" un 91,30\% obtuvo la calificación de A y la calificación de B el 8,70\% restante. Se considera que las causas asociadas a esta diferencia de rendimiento en la aplicación de SCRUM se corresponden a un mayor grado de complejidad del proyecto de estrategia de operaciones a realizar en comparación con el trabajo teórico-práctico del curso anterior, y según las opiniones de los alumnos, principalmente, a la carga de trabajo que les ha supuesto 
la aplicación de SCRUM de forma simultánea en la mayor parte de las asignaturas. Con todo, según la encuesta confeccionada por la dirección académica del MBA, la satisfacción del alumnado con los contenidos y metodología de la asignatura se ha incrementado un 23,26\% respecto al curso anterior en el que no se aplicó dicha metodología.
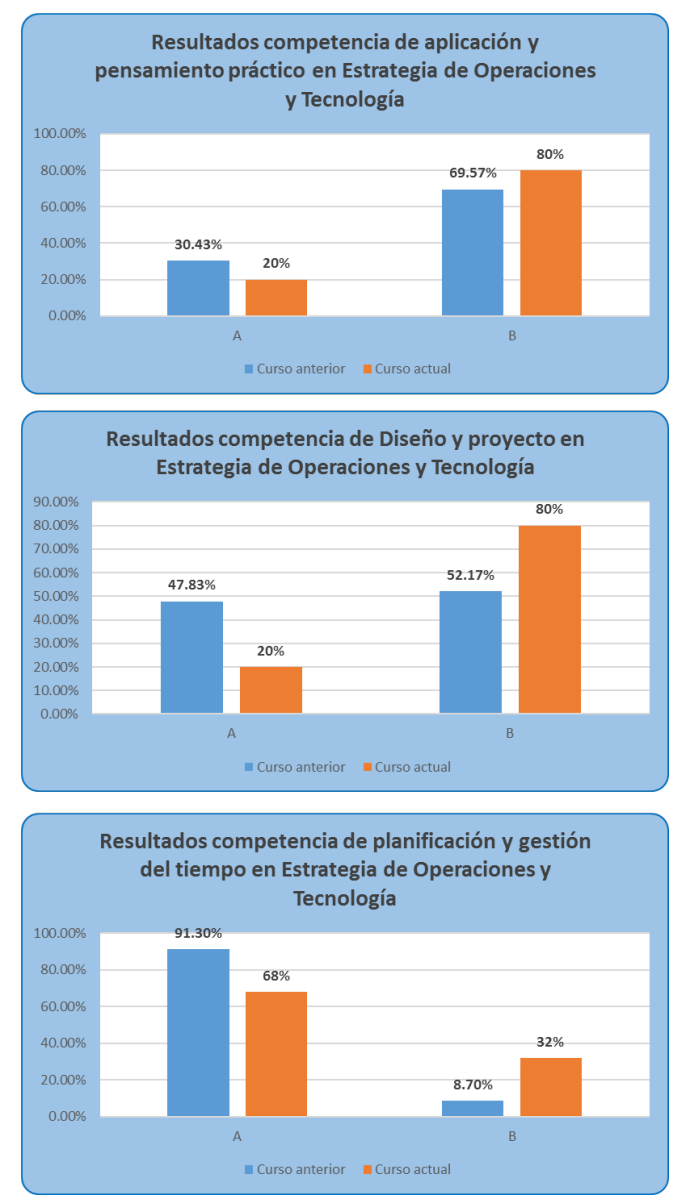

Fig. 2 Comparación de competencias en la asignatura Estrategia de Operaciones y Tecnología

\section{Conclusiones}

En este artículo se ha presentado el desarrollo del proyecto PIME titulado "Aplicación de una metodología de trabajo ágil y colaborativo (SCRUM) en el Master Universitario en Dirección de Empresas (MBA) para mejorar competencias transversales" del Campus d'Alcoi en la UPV durante el curso actual 2017/2018. Para ello, se ha enmarcado el contenido del título de máster objeto de la innovación docente presentada así como las características principales de la metodología SCRUM que se propone como un marco de trabajo activo y colaborativo para la mejora educativa.

Seguidamente, se ha descrito la dinámica de funcionamiento del proyecto destacándose las limitaciones identificadas en la aplicación de la metodología, que se refieren principalmente a una percepción inicial de una mayor carga de trabajo por parte del alumnado o a una falta de tiempo para la aplicación de una metodología docente nueva por parte del profesorado. En cuanto a los resultados principales obtenidos cabe destacar el incremento del rendimiento 
académico y la mejora de la adquisición de las competencias transversales de análisis y resolución de problemas, trabajo en equipo y liderazgo y planificación y gestión del tiempo. Como ejemplo de esa adquisición se puede mencionar cómo los alumnos solucionaron los problemas que les fueron surgiendo durante el desarrollo de los proyectos de una forma colaborativa y sin intervención de los profesores. Cabe destacar que en uno de los equipos los problemas no se solucionaron con la autogestión y el equipo docente resolvió el conflicto con la reasignación de los roles SCRUM a otros miembros del equipo.

Por último, cabe destacar la necesidad identificada a lo largo del desarrollo de este PIME de llevar a cabo la aplicación de la metodología SCRUM de forma conjunta y coordinada por parte de un conjunto de al menos dos o tres asignaturas proponiendo un proyecto único. Se propone la extensión del actual PIME en uno nuevo que contemple dicha línea futura de trabajo.

\section{Agradecimientos}

El presente trabajo es fruto del PIME “Aplicación de una metodología de trabajo ágil y colaborativo (SCRUM) en el Master Universitario en Dirección de Empresas (MBA) para mejorar competencias transversales", de la convocatoria de Proyectos de Innovación y Mejora Educativa del Vicerrectorado de Estudios, Calidad y Acreditación de la Universitat Politècnica de València.

\section{Referencias}

FERNANDEZ-MARCH, A. (2010). "La evaluación orientada al aprendizaje en un modelo de formación por competencias en la educación universitaria“. Revista de Docencia Universitaria, 8 (1), pp. 11-34.

IBARRA, M.S. y RODRIGUEZ, G. (2010). “Aproximación al discurso dominante sobre la evaluación del aprendizaje en la universidad“. Revista de Educación, 351, pp. 385-407.

PADILLA-CARMONA, M.T y GIL-FLORES, J. (2008). "La evaluación orientada al aprendizaje en la Educación Superior: condiciones y estrategias para su aplicación en la docencia universitaria“. Revista Española de Pedagogía, 241, pp. 467-486.

Proyectos Ágiles (2017) <https://proyectosagiles.org/que-es-scrum/> [Consultada el 27/04/2017]

SCHWABER, K. y SUTHERLAND, J. (2016). La Guía de Scrum.

$<$ http://www.scrumguides.org/index.html $>$

UPV (2017) <http://www.upv.es/contenidos/COMPTRAN/info/955689normalc.html>

[Consultada el 27/04/2017] 